

\section{MEDICAL LIBRARY}

\section{LOANED BY}

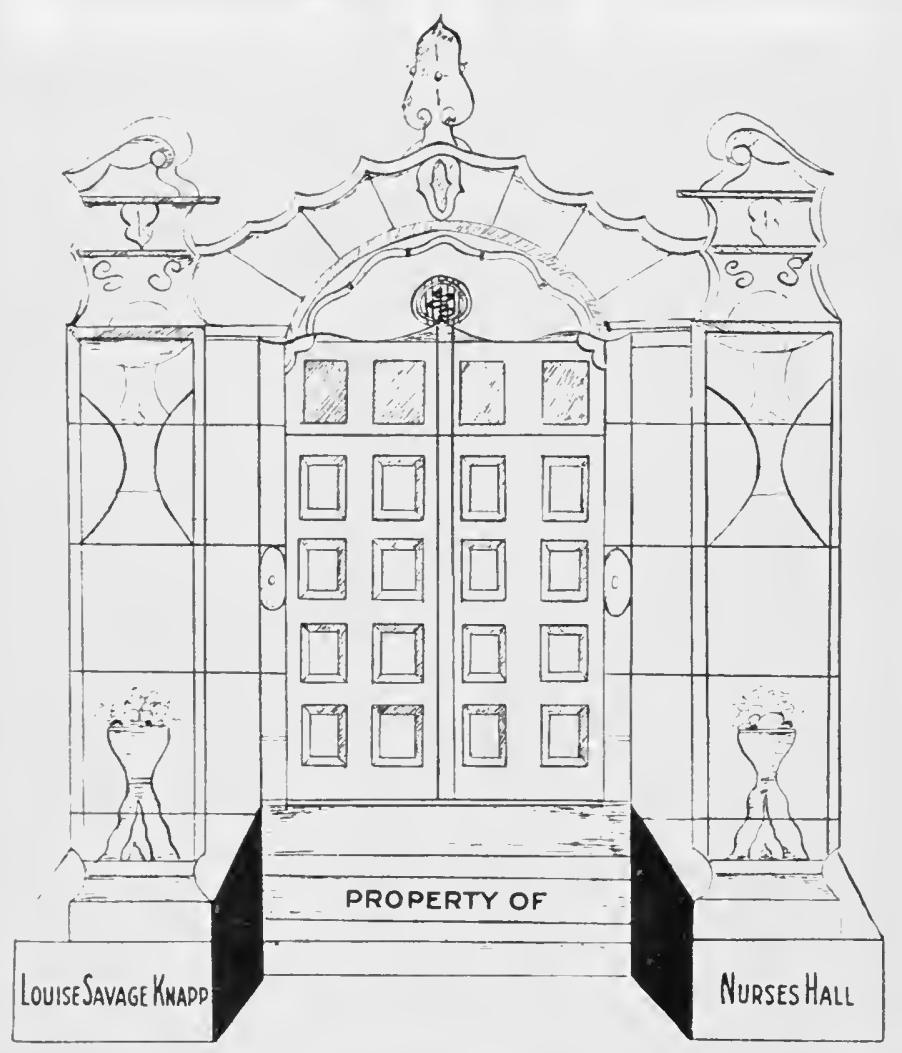





\section{Digitized by the Internet Archive in 2007 with funding from Microsoft Corporation}




\section{HIS'TORY OF}

\section{AMERICAN RED CROSS NURSING}




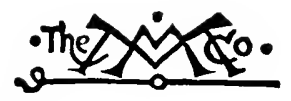

THE MACMILLAN COMPANY

NEW YORK - BOSTON - CHICAGO - DALLAS atLaNTa - SAN FRANCISCO

MACMILLAN \& CO., Limited

LONDON - BOMBAY - CALCUTTA

MELBOURNE

THE MACMILLAN CO. OF CANADA, LזD. TORONTO 



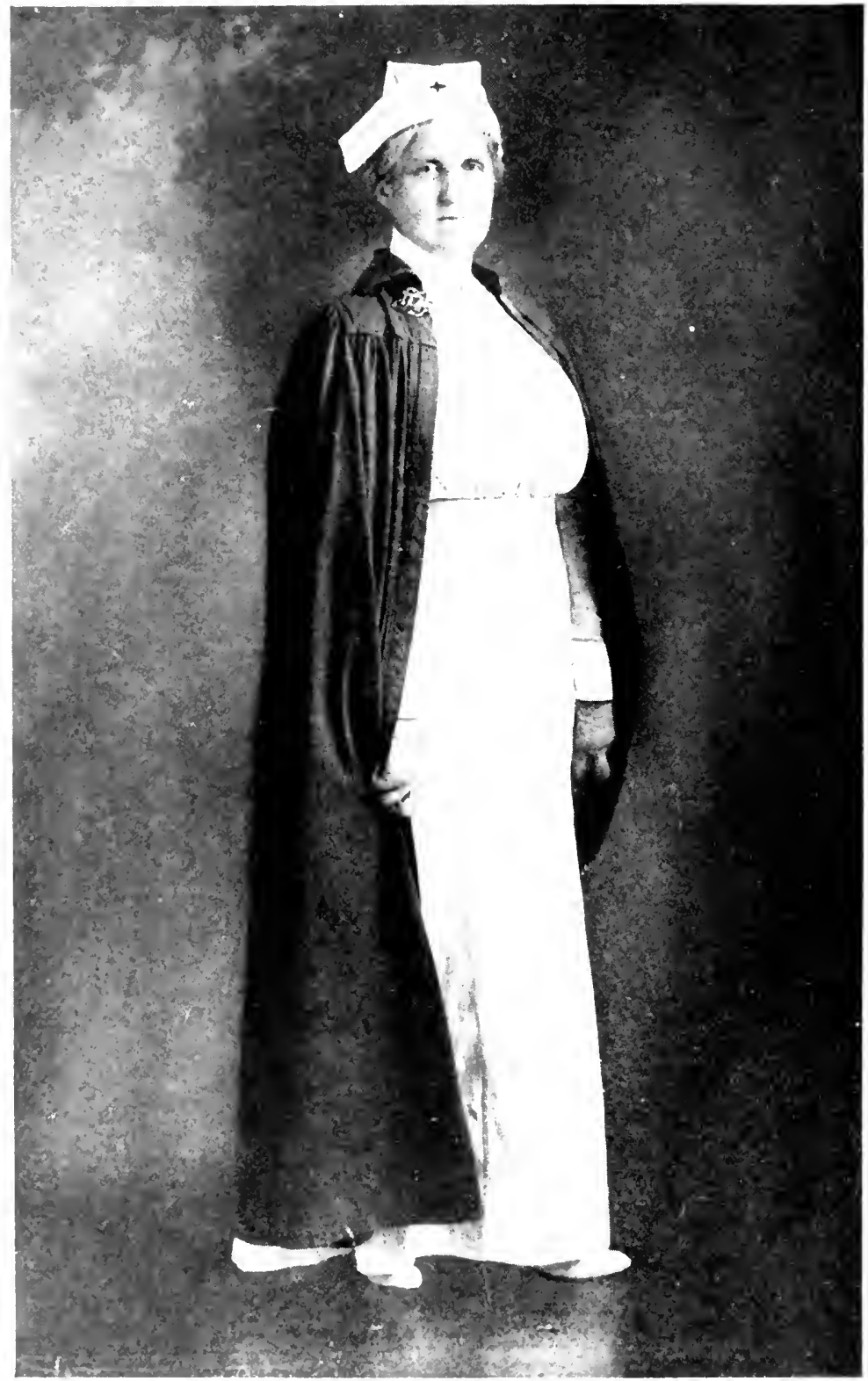

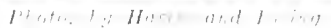

Jame 1. Jelano 


\title{
HISTORY OF AMERICAN RED CROSS NURSING
}

\author{
BY \\ LAVINIA L. DOCK, R.N. \\ Former Secretary, International Couneil of Nurses
}

SARAH ELIZABE'TH PICKE'T'T, B.A.

Former Assistant to the Director, American Red Cross Nursing Service

\section{CLARA D. NOYES, R.N.}

Former General Superintendent of Training Schools, Bellevue and Allied flospitals, New Fork ('ity; Former President, National League of Nursing Education;

Former President, American Nurses' Association; Director, American Red Cross Nursing Service

FANNIE F. CLEMENT, B.A., R.N.

Former Superintendent, American Red Cross Town and Country Nursing Service

ELIZABE'TH G. FOX, B.A., R.N.

President, National Organization for Publie IIealth Nursing; Director, Imerican Red Cross Pullic Health Nursing Service

ANNA R. VAN METER, B.A., M.S.

Former Professor of Ifome Economies, Ohio State Fniversity; Former Assistant Director, American Red Cross Nutrition Service

ILLUSTRATED

Prw Park

TIEE MACMILLAN COMPANY

1922

All rights rescrved 
Copyright, 1922,

BY THE MACMILIAX COMPANY.

Set up and electrotyped. Published Deccmber, 1922.

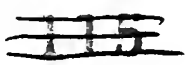


To

AMERICAN RED CROSS

NURSES 



\title{
CON'TENTS
}

\section{CHAPTER I.}

Early Growth

Origin of the Red Cross Idea-Florence NightingaleNursing in the ('ivil War-Clara Barton.

\author{
Larixia L. Dock
}

\section{CHAPTER II.}

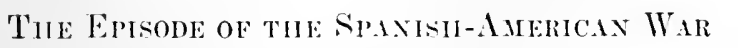

Organization of the Red Cross in 1898-The Red Cross Sisters-Nursing under the Government-Red Cross Auxiliary No. 3 .

\section{Lavinia L. Dock}

\section{CHAPTER III.}

Afpiliation of tule Anerican Red Cross with tile Nirses' Assoclation • • • • • • . • . . .

The Army Nurse Corps-Reorganization of the Red Cross in 1905-The American Federation of Associated Alumna Aecepts Affiliation with the American Red Cross-Derelopment of the Nursing Service-Participation in Disaster Relief.

\section{Livisia L. Dock}

\section{CHAPTER IV.}

TiIE MerCY SHIP

The S.S. Red Cross Sails-Paignton, England-Pan, France-Kief. Rusia-Gileiwit\% (remany-Kosel, Germany-Vienna. Austria-Budapest. Hungary-Belgrade, Serbia-Gevgeli, sorbia-l'vetot, France-La l'anne,

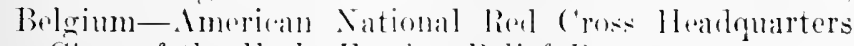
- Close of the Early Fureign Relief Promram. 


\section{CHAPTER V.}

\section{Mobilization}

National Headquarters Reorganizes-The National Committee on Red Cross Nursing Service-The Committee on Nursing of the Council of National Defense-Special Courses-Special Groups-The Army School of Nursing -The Nurses' Drives-Surgical Dressings-The Nursing Surveys.

Lavinia L. Dock and Sarah Elizabeth Pickett

\section{CHAPTER VI.}

Tile Relation of tire Nursing Service to tife Army .

Organization of Tnits-Base Hospitals-Hospital Units - Emergency Detachments-Training School UnitsSpecial Units-Cantonment \%one Service-Mexican Border Service-Equipment and Insignia.

\section{Sarail Elizabeth Pickett}

\section{CHAPTER VII.}

The Erropeax War

Cantonments of the New Armies-Embarkation-With the American Expeditionary Forces in Great BritainWith the British Expeditionary Forces in France-The Zone of the Base, A.E.F. in France-The American Red Cross Commission for France-Nurses' Equipment Shop, Paris-With the French service de santéEmergency Hospitalization, A.E.F. in France-The Zone of the Advance, A.F.F. in France-With the American Expeditionary Forces in Italy-With the American Expeditionary Forces in North Russia.

\section{S.arai Elizhbeti Pichett}

\section{CHAP'TER VIII.}

Service with the NiYy

()rgunzation of Inits-Iniforms and Insignia-Navy

Nursing Service in the Inited States- Nary Nursing survice at Foreign stations-Detaled Service of Nary Nurses. 


\section{CHAPTER IX.}

Nursicig Service to tuf Civiliax Population of the Allies • • • • • • • • • • • • • • •

The Children's Bureau in France-The Refugee Bureau in France-The Tuberculosis Bureau in France-The Conmission for Italy-The First Commission for Roumania-The Commission for Palestine-'The Commission for Siberia.

\section{Saliar Elizabetil Pichett}

CHAPTER $\mathrm{X}$.

At National Headquiters

Auxiliary Nursing Service-The Summer Months of 1918-The Influenza Epidemic-The Armistice is Signed.

\section{Sarail Elizabeth Pickett}

\section{CHAPTER XI.}

DEMOBILIZATION

Miss Delano's Death-The Close of the Military Program Overseas-Bureau of Information for NursesNursing Service. I. S. Public Health Service-Casualties among Nurses-Memorials to Nurses-Red Cross Aides-Educational Projects-Military liank for Army Nurses.

\section{Sarail Elizabecit Pickeft}

\section{CHAP'TER XII.}

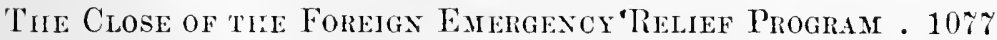
'The Commision for Europe-The Commission for Poland-'The ('ommission for the Balkan States-'The Contraction of the llar (Oruanization.

\section{S.ARAu Elizhabti Pickett}

\section{('IAPTER XIII.}

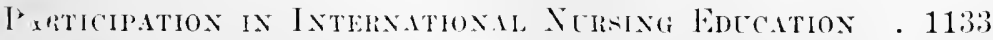

league of lied Cross societies-sidhools of Nursing-

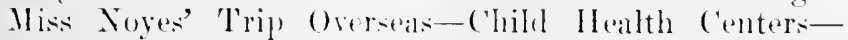
Nursing detivities in Insular and Foreign lossessions of ther [niter] Sitates. 


\section{CHAPTER XIV.}

From Rural Nursing to time Public Healti Service . 1211 Outline of Early Growth-Requirements for Applicants -Affiliation Principles Adopted-Growth of Central and Branch Units-Early Affiliations-The Interruption of War-Scholarships.

Lavinia L. Dock and Fasie F. Clement

CHAP'TER XV.

Red Cross Public Healtil Nursing after the War • . 1293

Elizabeth G. Fox

CHAPTER XVI.

Class Instruction for Wouren . . . . . . . 1352

Lavinia L. Dock

CHAPTER XVII.

The Dietitian Service . . . . . . . . . 1375

Class Instruction in Home Dietetics-Red Cross Dietitians' Service in the European War-The Nutrition Service.

Axsa R. Vha Meter

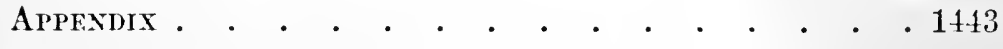




\section{ILLUSTRATIONS}

Jane A. Delano . . . . . . . . . . Frontispiece

A Group of American Red Cross Sisters who Served at Siboney during the Spanish-American War . . . . 28

Indoor Lniform, Gray Dress, Apron, Brassard and Cap, of an American Red Cross Nurse . . . . . . . . 104

Insignia . . . . . . . . . . . . . . . 116

Clara Dutton Noyes . . . . . . . . . . . . 232

Outdoor Uniform of an American Red Cross Nurse . . . 358

American Red Cross Nurses Washing Their Clothing in an Improvised Laundry Set up at American Red Cross Evacuation Hospital No. 110, Coiney, France . . . 366

(Above) A Recreation House Built by the American Red Cross for the Nursing Staff of the U. S. Army Base Hospital at Fort MeHenry, Maryland. (Below) Xurses' Mess, ('amp Devens, Massachusetts . . . . . . 398

A Nurses l'arade Held in Chicago in 1918 to Stimulate Enrollment for Military Duty . . . . . . . .

(Above) Nurses on the Balcony of the Ameriean Red Cross Nurses' ('lub, London, Overlooking the Gardens of Buekingham Palace. (Below) Colebrook Lodge, a Convalescent Ifome for American Army, Nary and Red Cross Nurses Established at Putney, near London, by the American Red Cross. . . . . . . . . .

Nurses of a C. S. Army Base IIospital Marehing off the Dorks at Brest, France. . . . . . . . . . 486

An Airplane liew of savenay Inospital Center, Medical Corps A.E.F. in France . . . . . . . . . 512

1 Corner of a Surgical Ward of Ameriean Red Cross Military Inospital No. 1 at Tenilly. France . . . . .

(Ahove) Ameriman Red ('ros Military Hospital No. 5) at Anteuil, near l'aris. (Below) The Interior of a Tent Ward at Anteuil 
A Poster by Robert Reid, Planned by the American Red Cross to Stimulate the Enrollment of Nurses for Military Service but Withheld from Distribution at the Request of the War Department

A U. S. Army Hospital Train

U. S. Army Evacuation Hospital No. 6, at Souilly, France 622

The 112th Field Hospital, A.E.F., Cohan, France, August 12,1918 .

(Above) Stretcher-Bearers Bringing in a Wounded Soldier to a First Aid Station. (Below) First Aid Station, 168th Reg. Infantry, A.E.F.

636

$6+4$

656

(Above) Looking Across the Frozen Dvina River to the American Red Cross Hospital at Archangel, Russia. (Below) Two Types of Ambulance Used by the American Expeditionary Forces in North Russia . . . . . 68?

The U. S. S. Relief .

An American Red Cross Child Welfare Nurse with Her Charges in the Grounds of the Orphanage and Convalescent Hospital, Château des IIalles, near Lyons, France 664 702 680

(Above) A Group of Patients at an American Red Cross Children's Dispensary in Paris. (Below) An American Red Cross Children's Dispensary in a small Town in France

(Above) A Tuberculous Refugee Child Who Died in an Ameriean Red Cross Children's Hospital in France. (Below) A Child Who Lived

(Above) Ozpizio Marino, an American Red Cross Hospital for Children Suffering from Bone Tuberculosis, at Taldoltra, near Trieste, Italy. (Below) A Patient of the Ozprizio Marino

Refugees Waiting at the Doors of a Relief Station in Jerusalem

(Above) American Red Cross Nurses and Surgeons En Route to Vladisostok. Siberia, Visit the Iyersan Temple. Nikion. Japan. (Below) Nurses of the siberian Commission (io Shopping at a Market of Manchuria Station

Sick Nurese Quarters, I. S. Nary Rase Hospital No. 1. Brest. Erance 
(Above) A Ward of the Vilna Military Surgical Hospital, Vilna, Poland. (Below) The American Red Cross Orphanage at Liskow, Poland

(Above) An American Red Cross Nurse, Jeannie Frasier, Instructing 'Two Pupils of a Little Mothers' Class in Elementary Nursing Procedure, Podgoritza, Montenegro. (Below) An American Red Cross Nurse and Her Interpreter Giving a Lesson in Home Hygiene and Care of the sick to a Group of Refugees in Tirana, Albania

(Above) The Open Sewers of Tirana, Albania. (Center) An American Red ('ross 1)ispensary in Albania. (Below) A Mosque of 'Tirma . . . . . . . . . . . . 1110 Three Types of Ambulance in the Balkans . . . . . . 1122

(Above) Roumanian Refugees Living in Mud Dug-Outs in the Devastated IVar Zones. (Below) An American Red Cross Nurse Serving Somp to Roumanian Refugees . . 1126

(Above) First (las: of the School of Nursing, Warsaw, Poland, Established by the American Red Cross. (Below) Exterior of the School of Nursing, Warsaw, Poland . 1162

Cray Dress, Cape and Straw Hat Worn by American Red Cross Nurses . . . . . . . . . . . . 1212

An American Red ('ross Public Iealth Nurse on Her Rounds 1340

A Rural Red Cross C'lass in Home Hygiene and Care of the sick Ciathers at a Cross-Roads Meeting-Place . . . 1372 



\section{FOREWORD}

Perhaps of no other figure in American tradition have there been more stories written, pietures painted, songs sung than of the American Red Cross Nurse. She has personified courage, sympathy and gentle strength in eontrast with the brutality of war. Yet of her actual eharacter and work little is generally known.

Here is her own story. The experienees of many thousands of nurses, selected from personal letters, reports and official correspondenee and recorded in this history, make it both a souree book of vital professional significance and a profoundly humin document. For the first time there is properly characterized and deseribed the magnifieent contribution of American nurses in aid of human suffering, not only on the battlefield but in all the heretofore hidden places where humanity was miserable because of war.

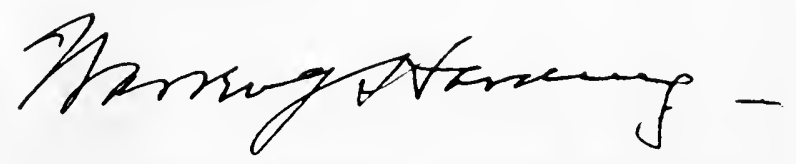

President, Ameriean National Red Cross.

The White House,

Washington,

Nov. 1, 1922. 



\section{INTRODUCTION}

Since its establishment in 1909, the American Red Cross Nursing service has been the grateful reeipient of considerable interest from the nursing profession and from the laity. Maur requests have come to National Headquarters for data regarding its origin, its purposes, its organization and accomplishment. To the answering of these requests, Miss Delano and her assistants gave especial eare, feeling that the Nursing Sicrice could repay this interest only by courteons and intelligent aequiescence. Nevertheless, the gathering together of such lata involved the frequent repetition of painstaking research and correspondenee.

Inring and after the European War, such requests were greatly multiplied. Nurses and laywomen in increasing numbers wrote to Headquarters to ask for information needed for preparing papers for elub meetings, specehes or personal narratives. Orcanizations compiling war records asked for histories of Red Cross nursing accomplishment; chroniclers of the War l)epartment called upon the Red Cross for extensive chapters to include in the Govermment's records. Then, too, the national offirers of the Red Cross shared with the Nursing Service the opinion that a comprehensive history of Red ('ross nursing service, of which no adequate account harl hitherto been written, should be eompiled for the nse of individuals and ('hapters. Thus the molertaking whieh now reaches fmition in the publication of this book, was lannched in 1919.

The outstanding aditorial policy in shapine this rompilation was the desire to have an anthentic history which woukl recount the methods of work as well as the work itself. By far the grealest amomit of material previous to the European War lay in Red cross arehives, in the Library of Congress and in that

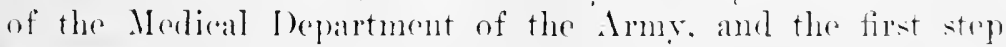
taken was to engage an expert in resoardi, to assemble. analyze and elassify the rolmminoms records. Beatries copley (now Mrs. Ralph (hatpman). M...., of the Tniversity of Illinuis.

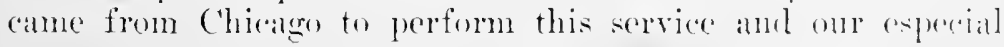
sivii 
thanks and recognition are due to her for the admirable way in which she earried on her task.

It was felt that the nurses who had made history in the field should be the ones best fitted to edit this book which records the work done. Early in 1919 an editorial committee whose membership was largely that of the National Committee on Red Cross Nursing Service was invited to read and criticize the material. No one refused to share the responsibility. The members of the eommittee are: Mabel T. Boardman, Anna C. Maxwell, M. Adelaide Nutting. Annie W. Goodrich, Dora E. Thompson, Julia C. Stimson, Lenah S. Higbee, Lucy Minnigerode, Martha M. Russell, Carrie M. Hall and George B. Chadwick.

As the writers to whom the different chapters were entrusted eompleted their pages, each seetion was submitted to those of the Editorial Committee who had been most elosely related to the work under disenssion. While they in no way directed the treatment of material, they gave it most eareful eritical readings and their suggestions were helpful in the extreme. Their corrections and revisions were for the most part serupulously incorporated in the text and thus the Ameriean Red Cross is able to guarantee the fidelity of this text to the truth in so far as it is humanly possible to interpret it.

The efforts of the anthors have been met by an intelligent and enthusiastic spirit of helpfulness from innrses and laywomen alike. To Miss Boardman, who as secretary of the society was designated by the Central Committee to read and judge the manuseript in its entircty, we are deeply and sincercly grateful for much paticnce, encouragement and aid. From 1)r. Anita Newromb MaGee we have received especial assistance in the matter of verification of official fortnotes and of details tonching mon her relation to the War Department in the Spanish-Ameriean War. To Mary S. Fergusene, a member of the National Hoadquarters editorial statf and a woman of searelinge intelligence and keen powers of eriticism, whose work on this history was interrupted early in $192 \mathrm{~g}$ ly death. we areknowledger on affertionate and heart folt gratitmle. To Mr. Chatwiek, whose editorial aid followed the history through its many fages, thromeh complexities of securing a publisher and through num official "red-tape," we express our many thanks.

Miny oflues have given us editorial assistance, conspicuous 
among whom are Dr. Anma IIamilton of France, Mrs. Riehard Aldrich, Miss Lamra Drake Gill, General Merritte W. Ireland, Dr. 'Taliaferro Clark and Dr. Albert Ross IIill.

In giving us data from correspondence and from their wealth of personal recollection and nemories, we acknowledge our indebtedness to Mrs. Whitelaw Reid, whose seeretary, Mr. Trving Blake, by her direction opened to us her war nursing records, to Dr. Monae Lesser, Mr. Allen Wardwell, Jr., and many nurses. We also owe recognition for valuable assistance in supplying records to the Librarian of the Library of Congress and to the Army Medical Library. In gathering our illustrations we were helped by the Signal Corps, U. S. A., the Air Service, U. S. A., and the Information Section, Naval Intelligence, Nary Department.

To the humdreds of 1111 ses who have answered our requests for information and material and to those whose written experiences constitute the original sources of this history, we offer this rolnme as our best endeavor to thank them adequately for their services in this as in all enterprises of the Nursing Service.

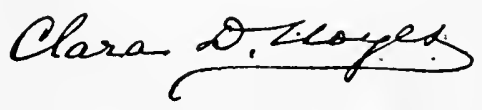

National Teadquarters,

Chairman, Editorial Commtee.

IVashingtom,

November 11, 1922. 



\title{
HISTORY OF AMERICAN RED CROSS NURSING
}

\author{
CHAPTER I \\ EARLY GROWTII
}

Origin of the Red Cross Idea-Florence Nightingale-Nursing in the Civil War-C'lara Barton

T

HE Red Cross spirit, the motive prompting the work of the International Red Cross, is simply the instinct of compassion and mercy in a pure form. Such a spirit might be traced down from the beginning of history if a genealogical lied Cross tree were desired. In every age illuminating instances of direct or collateral relationship conld be found. It is possible, however, to wander too far atield in a search of this kind and a slight sketeh will suffice to introduce the history of the American Red Cross Nursing Service. We need not go farther back than to the Good Samaritan, who typified all the classic characteristics of the Red Cross, the spontaneous, voluntary helpfulness of the private citizen; compassion and aid extended freely on the sole ground of common humanity; practical skill and intelligence in binding up the wounds of the thieves' rictim; efficient relief work in leaving the wounded man to be nursed at the imn and in paying for him there.

Though Red Cross nursing was first developed in comnection with war, not all war nursing in history wan be looked upon as rudimentary lied cross service. It has often been solely for the furtherance of military projects. The presence of the inpersonal spirit of pity for and the desire to relieve alike both friend and foe is the esential characteristic of the lied cross idea, as it is also the true ideal in mursing. There i. 3u assmpance that the heroic women of the Gaelic and Teutonic tribes, 
skilled as they were in medical and surgical nursing, who always followed their men in war to bind their wounds, would rescue as readily a stricken enemy,-though it may be that it was so. Haldora, the Dane, in the year 1000 A.D. stands forth as a true forerunner of Florence Nightingale and Henri Dunant, for she assembled the women of her household after a fierce battle and said to them, "Let us go forth and dress the wounds of the warriors, be they friend or foe." 1 She herself, it is recorded, found the enemy ehieftain desperately wounded and tended him long and skillfully until he was healed.

In the medieval orders of the Knights Hospitallers with their women's branches, are to be found the first organizations on a grand scale for nursing and relief work of the Red Cross type and it is quite possible that their practice and principles may have become familiar to Isabella of Spain, who was the first on record among queens to take an intelligent interest in the sanitary and hygienie eare of her nation's soldiers.

Those knightly orders, too, imprinted their influence on the German women, who in the War of Freedom (1813) formed the first modern women's societies for organized war-relief work by volunteers. The armies of Napoleon, on their side, had the nursing service of the Sisters of Charity of St. Vineent de Paul-the first trained and diseiplined nurses of the later medieval period to be officially assigned to the care of sick and wounded men in war.

All the heritage of the past and the promise of the future met in Florence Nightiugale, whose career was opened to her by the Crimean War. Not only did she there give a complete pattern of the many branches of service later developed under the Red Cross, but also by what she did she inspired Henri Dunant, the founder of the International Red Cross Committee, to his far-reaching achievement. Then by her later efforts she ereated the modern army of skilled, seeular, professional women from whose ranks the Red Cross Nursing Service is now drawn. It will be essential, therefore, to preface this record of American lied Cross mursing by recalling in some detail the demonstration given by Miss Xightingale in the Crimea.

Ther first efforts were of course for the organization of an emerency nursing sorrice. For this she had a nixed enmpany-at first of forty women, some of whom were Sisters of Religions Nursing Orders and others hospital-taught women of

1.Mrs. Norrie in "A History of Nursing," Vol. II, p. 313. 
the old sehool, not trained in the modern way, but experienced. In all, abont two hundred nurses belonged to Miss Nightingale's staff, - a small group compared with the thousands of nurses mobilized during the recent World War, but a group historically potent and unique.

The mursing service having been appointed in its place and assisted by orderlies and convalescent patients, Miss Nightingale next organized a laundry service by renting outside buildings and employing soldiers' wives for the lanndry work. Diet kitchens arose under her hand from which, for the first time, the wounded men were served with nourishing food, and throngh her efforts the entire kitehen department of the arny hospitals was systematically remodeled by the famous Soyer. The disorganization and inefficient management had been such that to Miss Nightingale fell the task of purveying much of the daily supplies and clothing of the patients under her care. In a letter to Mr. Herbert, she wrote (Jan. 4, 1555): "I am a kind of general dealer in socks, shirts, knives and forks, wooden spoons, tin baths, tables and forms, cabbage and carrots, operating tables, towels, soap, fine tooth combs, precipitate for destroying lice, scissors, bedpans and stmmp pillows." ? Presently, because kits had been thrown away during a mareh, she reclothed a large part of the English army. To provide for an expected intlux of wounded at Scutari, she undertook on her own anthority to remodel some abandoned wards, engaged two hundred workingmen, paid them out of her private resources, outfitted the wards and had eight hundred additional beds ready when the need eame. To have done this throngh military chamnels, at that time, and under the system then in vogue, would have taken months. Miss Nightingales biographer tells us that this particular feat, more than any other one thing that she did, electrified the "red-tape men" and spread a sensational lecend of the "Nightingale Power." She was both fiercely" criticized and greatly praised for this daring piece of initiative, but Parliament later refunded the money it had cost, thus, in effect, endorsing her action. Miss Nightingale urged and planned in minute detail the sanitary engineering works later carried out in the hospitals of Seutari. She herself considered this her best piece of work, for hospitals which had formerly been deathtraps, were thereby put on a level with the best, in ventilation, drainage and cleanliness. These sanitary reforms,

- "Life of Florence Nightingale," by Sir Edward T. Cuok, Vol. I, p. 200. 


\section{HISTORY OF AMERICAN RED CROSS NURSING}

in conjunction with her other improvements in nursing and in the hospital dietary, reduced the army death rate from 42 per cent to 22 per thousand of cases treated.

Though Miss Nightingale dared greatly on her own initiative when life and death were in question, yet her habitual order of discipline was strict in the extreme and she was punctilious, as a rule, in allowing her private stores to be used solely on the requisition of the medical officers. Her funds for supplies came from her own income, from other private sources and from the Royal Bounty. The needs of the allied armies were not overlooked by her. She sent wines and other supplies to the French Sisters of Charity. When the Italian Sisters suffered a loss of their stores through fire, Miss Nightingale dispatched a consignment of supplies to them. These were friends. Did Niss Nightingale also help the foe? The rules of war often set a limit to the merciful impulse, but we may surmise what her spirit was from the story told of the Russian boy prisoner who was under her care and who, when asked where he would go after death, replied confidently, "I shall go to Miss Nightingale."

In social service, Miss Nightingale opened new paths, hitherto as wholly untrodden in the army as had been those of her hospital reform. Her nurses' families at home were systematically visited and helped by her friends at her request. She brough about reforms in the pay of invalided soldiers, and kept in her hedroom much of the officers' moner, because if they offended the purveyor or the commissary, they were likely not to get it. She established reading rooms for the convalescent patients; opened a post oftice and encouraged the men to send their money home. She combated drunkenness, to the great derision of the military chiefs. To counteract it she opened a cottee house for the men and set on foot reading and class-rooms for them. She had school-masters sent ont from England to teach and lecture, and provided maps, books, papers and games. It was said of her that she was the first person who ever taught officials to treat the soldiers as Christian men. Nor did she forget the soldiers' wives, many of whom had follower the army. She organized a lying-in hospital and secured work for them, rhoosing friendly visitors to go among them and help them as needed.

The war orer, Miss Nightingale, as all the world knows, with the gift in money made to her by the grateful British public, 
founded the Nightingale Training Sehool for Nurses at St. Thomas' Hospital which was the parent of the modern system of nursing. From her, therefore, we may well date the story of the nursing service of the American Red Cross.

After the World War a woman of national prominence who had worked through the Civil War was asked to point ont the greatest difference between the two wars in the methods of participation by the civilian population; her answer was: "In tho nursing." This was Louisa Lee Schuyler, whose part in the organization of the School of Nursing at Bellevere Hospital in 187:3 lends a special interest to the following extract from a letter written by her to Miss Clara D. Noyes on the eve of the entrance of the United States into the World War:

In these days, at the age of seventy-nine, when I ean not do very active work, my thoughts go back to the early lays of the Civil llar and of what we are trying to do and did do then on a very small seale compared with today. We wanted nurses for our wounded and sick and there were none to be had. There were no trained nurses in those days, as you know. In our New York Branch of the Lnited States Sunitary Commission it was as easy to get supplies as it is with the Red Cross today. They poured in from all over the country. Our receiving and shipping business was enormous. Many a time did our loaded wagons take the boxes on short notice on Sunday down Broadway to a steamer starting for a southern port. We were notified by the Sanitary Commission of battles to come that hospitals and hospital supplies might be ready. Alas! no trained nurses to be had. Our doctors, Elizabeth and Emily Blackwell, provided one month's hospital training for 100 selected women who rolunteered to go as nurses. It was most elementary but it was better than uothing and many of them turned out finely and did magnifient work later on, and now the Red Cross! so much to be thankful for if war must come. ${ }^{3}$

Not only had the Enited States no trained nurses during the Civil War, but even the luternational ('ommittee of the Red ('ross did not ret exist. It was in 1sia: that IIenri l)unant la irl his proposals for a relief society before the society of Public I tility of Genera and in 1sitt that the Articles of

${ }^{3}$ Annual Report of The National League of Nursing Eilucation, 1917, 1P. 2.27.2.25. 
Convention touching the treatment of the wounded in war were signed at Geneva. To this convention, known as the International Red Cross Treaty, the United States Government gave its accession in 1882. In the meantime, however, the name Red Cross alone was lacking during the Civil War, for in the work of relief carried on by the United States Sanitary Commission a demonstration of efficiency in civilian aid in wartime was given, which was nothing less than extraordinary for a young nation waging its first war on a grand scale. Stille in his "History of the Samitary Commission" gives the credit for originating Civil War relief work to women. "It is hardly necessary to say," he writes, "that the earliest movement that was made for any relief was begun by the women of the country."

The Enited States Sanitary Commission grew out of a mass meeting held in Cooper Union, New York City, on the 26th of April, 1861, which had been called by the Ladies' Relief Committee. This committee was the work of Dr. Elizabeth Blackwell, who had held an informal meeting of women and men at the New York Infirmary for Women and Children. The local New York group took the name "Women's Central Association of Relief" and was, in effect, during the whole war the most powerful and important branch of the Sanitary Commission. Its leading executive officer was Lonisa Lee Schuyler. One of the purposes of the association was "to open a bureau for the examination and registration of nurses."

Dr. Blackwell was personally intimate with Miss Nightingale and through her friendship she had a clearer idea, perhaps, of what a nurse might be than others had at that time. She labored derotedly in selecting and sending numbers of voluntecr nurses to Bellevie Hospital for a month of such training as they could get there. As the training school for nurses was not ret founded, that experience could have had but slight value, yet about one hundred of those hastily trained women entered the army hospitals and grave nseful aid, many of them continuine in the service throughout the war. Miss Nightingale was in close correspondenue with l)r. Blackwell and others on the Sanitary ('mmmission and gare them bomtifully of her counsel and adviere. She, indeerl, in private letters expressed a desire to come persolully and help flem: but this her fragile health prevented. A lettor written to the Secetary of War (May 18, 1861) by the "Women"s ('entral Assonation of Telief for the 
Sick and Wounded of the Army, acting in conjunction with the Advisory Committee of the Boards of Physicians and Surgeons of the IIospitals of New York and the New York Medieal Association for Furnishing Hospital Supplies in aid of the Army" speaks of nursing as follows:

The committee represent that the Women's Central Association of Relief have selected and are selecting out of several hundred candidates one hundred women, suited in all respects to become nurses in the general hospitals of the Arny. These women the distinguished physicians and surgeons of the various hospitals in New York have undertaken to educate and drill in a most thorough and laborious manner and the committee ask that the War Department consent to receive, on wages, these nurses, in such numbers as the exigencies of the campaign may require. It is not proposed that the nurses should advance to the seat of war until directly called for by the Medical Burean here, nor that the government should be at any expense until they are actually in service.

In this letter it was stated that the Commission for whose recognition the combined associations were pleading, would, among other things, "inquire into the organization of military" hospitals, general and regimental, and the precise regulations and routine through which the serviees of the patriotic women of the comntry may be made arailable as murses." Is a result of this eorrespondence and of the efforts of a delegation sent to Washington to represent the associations, official mistrust of eivilian rolunteer aid, which at first had been obstinate, was allayed: the Surgeon General's attitude of opposition was altered to one of reluctant coipperation and the formal organization of the Sanitary Commission proceeded. For nursing. the serviens of religions Sisterhoods, which were promptly volunteered, were the first to be acepted. There were numerous convents of sisters of Charity, Nisters of Merey, Nisters of St. Vincent and others where emerencer hespitals were opened, and from whose staff's Sisters and IIother superiors were supplied. Throughout the war a great deal of hespital service was borne by ('atholir. Sisters, among whom, as espeeially distinguished, were Mother Anthony ()' 'onsuell of ('incimati, Mother Francis of ("hicago, Mother Nugelat of Mommet ('ity and Mother Gonzaga of Philadelphial. The Holy ('ross 
Sisters, an Anglican order, conducted important hospital work at Annapolis and Chester and Sister Adeline Taylor had a war nursing record of great variety.

Much light is thrown on the condition of hospital nursing during the war by the following intelligent commentary taken from Katherine P. Wormeley's small book on the "Sanitary Commission." As one who served with the Commission throughout, Miss Wormley has written:

And here a few words may be said on the work that might, -we dare to say should-belong to women in general hospitals. If women comprehended their true work and had the patience to show that they do comprehend it, the deep prejudice against them, in the minds of the Army surgeons, would be removed. Indeed it has been removed in many instances. But women have not as a general thing, seen their place or their duty. It is hard, perhaps, to do so. It is hard to realize that even benevolence must be obedient. And it is for this reason that Sisters of Mercy, so far, have been preferred as nurses by the surgeons of the Army. It could, however, be shown that the work of women belonging in the world would be more useful than even the work of the Sisters if such women could learn their true place. And if they learned it and kept to it, the result wonld be that in the end they would have all the power of benevolence that even they would ask. For here it may be said, in deep conviction of its truth, that the surgreons of the Army of all grades are, as a rule, desirous of doing well by those under their eharge ... they are conscientious and faithful men. It is believed and is perhaps (apal)le of proof that if a lady (by which is meant a gentlewoman holding a certain social position) and one fitterl for the work conld be placed in charge of what may be called the women's department in a hospital . . namely, the nursing of the rery sick men, the special dict and the linen departmont, with a body of nurses under her charge, a benefit to the hospital wonli follow, and the surgeons, far from complaining of it would in the end welcome it with sincerity.

As to the puality of women's work as a whole, Dr. Bellows, president of the Sanitary Commission wrote:

The distinctive features of women's work in this war were magnitule, system, thorough röperativeness with the other sex, distineturs of purpose, business-like thoroughness 
in details, sturdy persistency to the close. . . . Everywhere started up women acquainted with the order of public business: able to call and preside over public meetings of their own sex; act as secretaries and committees, draft constitutions and bylaws; open books and keep accounts with adequate precision ... enter into extensive correspondence, coöperate in the largest, most rational plans. . . .

During the progress of the Civil War nursing assumed two general types: one, a fairly systematic rontine under government direction; the other, an original spontaneity of action which took its own eourse and obtained, usually, first the acquieseence and finally the help of the Govermment. Of the former type Dorothea L. Dix was the official head, having been appointed as Superintendent of Female Nurses by Seeretary Cameron in Jume, 1861. Of the latter type was Clara Harlowe Barton, the founder in after years of the Ameriean Red Cross.

It is said that Miss Dix was one of the first to do actual war nursing, as she took eare of some of the soldiers who had been womded in the Baltimore riots. Her long and remarkable eareer as a reformer of prisons, almshouses and insane asylums (as they were then ealled) throughout the entire country and her lofty character, made her seem, probably, as preeisely the one woman to direet the war nursing, as Miss Nightingale had so seemed in England. Miss Dix, however, was not a nurse, nor had she had experience in mursing administration and her work in this episode of her life was not on a par with her earlier distinguished labors. As her charaeter and personality have been described, she seems to have been in many ways like Miss Nightingale. She was slight, delicate looking, graeeful, had been in her youth beantiful and had a soft musical voice, with winning manners. It was said that her gentle and persuasive tones had a remarkably eontrolling influence over the fierest maniacs. She was exceedingly quiet and retiring in her deportment and her success with legislatures was due to gentleness and mildness covering an unyielding persistence. She eared nothing for praise or fame. She preferred not to be talked about. She had private means, which she lavished on her work, and her labors for the Government were throughout unpaid. Her standards were exeeedingly rigid and her individualism was intense, alienating many of those with whom she had to work in a field where almost everything depended upon suasion. For 
our Govermment gave Miss Dix, at first, duties but insufficient authority and when later her authority was extended, no penalty was attached for disobedienee. Many of the surgeons resented her position. They called her arbitrary, opinionated, severe and capricious. Without a doubt she was somewhat severe. She mistrusted the young and it was said that a woman must be "mature in years, plain almost to homeliness in dress and by no means liberally endowed with personal attractions, if she hoped to meet the approval of Miss Dix."

The second type of Army nurse has been thus described by Dr. Bellows:

Of the labors of women in the hospital and in the field . . . this sort of service eamnot be recorded in the histories of organized work. For, far the largest part of this work was done by persons of exceptional energy and some fine natural aptitude for the service, which was independent of organizations, and hardly submitted itself to any rule except the impulse of deroted love for the work ... supplying tact, patience, and resources. The women who did hospital service continually or kept themselves near the base of armies in the field, or who moved among the camps, and travelled with the corps, were an exceptional class ... as rare as heroines always are, a class representing no social grade, but coming from all . . . but in all cases women with a mighty love and earnestness in their hearts . . . a love and pity and ability to show it forth and to labor in behalf of it, equal to that which in other departments of life distinguishes poets, philosophers, sages and saints, from ordinary men. ${ }^{4}$

It would be a congenial task, if it were possible, to summon before our readers the army of Civil War nurses. There were in all abont two thousand, of whom only a few have been recorded with nanes and histories.

One of the most appealing was Helen Louise Gilson, of Boston, who was so young, girlish and lovely that Miss Dix refused to areept her, hut who, nevertheless, through family influenee, followed the Army of the Potomae through all of its battles save the first and who displayed abilities that remind one, often, of the young Florence Nightingale.

The most nearly aphroathing in her training to the Red Cross nurse of tolay was Emily E. Parsons, of Cambridge. At

" "Women's Work in the Civil War," p. 60, Introduction. 
the outset of the war Miss Parsons entered the Massachusetts General Hospital for experience and remained in it for a year and a half. 'There was as yet no school for nurses there, but through her social connections she was able to receive speeial and careful instruction from the medieal men and surgeons.

The story of Maria M. C. Hall, of Washington, and her sister, is peculiarly illustrative of the voluntecr character of mueh Civil War nursing. Like Miss Gilson, Maria Hall was rejeeted by Miss Dix as being too young. She then went to Mrs. Fales, who had gained an independent position in Washington hospitals. Her importunity finally won Mrs. Falles to throw open the door of a ward, saying as she did so: "Well, girls, here they are, with everything to be done for them. You will find work enongh." The "girls" stuck to their job, with no comntenanee from the surgeons. When a general order was sent out for the removal of volnnteers from the wards, Maria enrolled as a "murse" and drew Army pily, which she gave to the men. She kept on in this way for a year "with no recognition from any official sonrce"!

As a contrast to this breezy volunteer there was Sarah Edson of Now York, who stremously attempted to found a home and training sehool where nurses might be prepared for the field. She labored untiringly for this purpose, brought it before the Sanitary Commission, went to the Surgeon General and even had a bill embodying her plan brought to a senate eommittere she may rightly be considered as the first to eonceive the idea of an Army school for Nurses. That she was mable to bring her plan to fruition in the intense atmosphere of war does not diminish her distinction. The Sanitary ('ommission regarded a training school as mmeessary, thinking that the hospital experience itself was the best training and that the urgent needs of the moment did not admit of delay sufficient to prepare the amatenr murses who were so imperatively called for. The surgeon General seemed at first farolably impressed with Mrs. Edson's idea, but finally discomraged it and signitied his disapproval to the Senate committer who harl her hill in chatrece.

Every section of the comntry had its famons murse. The Confederaer acelaimed Ella $K$. Newsom as "I)ixic"s Floremee Nightingale." She was a wealthy and beantiful widow when the war broke ont, and spent her fortme in hospital and relief work and nursine.

P'rliaps of all the murses of whom reeords alle left, the most 
pieturesque figure and the most widely known is "Mother" Bickerdrke. Truly amazing stories are told of her enduranee, her remarkable mursing and purveying abilities, her bold denunciation of rich "slackers" who withheld their money from war work, and her high hand with officials whose standards were less disinterested than her own.

Finally, none was more elosely linked with the present time than Anclia Barlow, whose work inspired Captain James Scrrmser to take the initial steps that brought about the building of the beautiful National Red Cross Headquarters at Washington.

The hospitals of the Civil War were sometimes temporary adaptations of buildings at hand, sometimes struetures hastily ereeted for the purpose, sometimes public buildings taken over for the oceasion. The Capitol at Washington was once so used and hundreds of wounded were distributed in the Senate, House and Rotunda. Hospital ships originated in the Civil War. Coast and river steamers were used. Many such vessels plied on the Ohio and Mississippi rivers with their freight of wounded men.

In spite of the utmost endeavors of the women volunteer nurses, Civil War hospital standards were far below those that would be acecpted today. The warks were overerowded, primitive in equipment and meager in provisions for operating and for dressing eases. It has been estinated that during those four years approximately six and one-half million men were admitted to hospitals and of them more than $6,000,000$ were medical cases, no doubt largely presentable, had prevention then been nuderstood. Only $+25,270$ eases were surgieal.

After the war the Army nurses formed an assoeiation which had its headfuarters at Getysburg. They were wont to meet at the reminons of the Cirand Army of the Republic and some of their number survived the war of 1914. A roster of the names of the members hangs in the present Red Cross National Headyuarters building at Washington.

Their wall work renderl, the women of the Sanitary Commission went their valions ways home and, inspired and strengthcued by their experience, many of then threw themselves with enerey inte the work of reformation in civil hospitals and other instintions. What they had sern had made plain to them the need of instrueted, disciplined nurses and aguin with the help and comborl of Miss Nightingale; women and mon in Now York 
City, Boston and New Haven simultaneously established (1873) schools for training nurses in three large hospitals: Bellevue, the Massachusetts General and the New Haven. Smaller pioneer schools already existing in this country and Canada were strengthened by this morement and hospitals generally followed the example set them.

Whilst the new profession of nursing was thus taking form, one of the volmnteer workers of whom I)r. Bellows had written the characterization quoted on a previous page went abroad for travel and there arepuainted herself with the work and organization of the Red Cross. This was Miss Clara Barton, a woman of New England family, whose fixed purpose it then hecame to bring about the adherence of the United States to the Geneva Convention. Upon her return to her own country she was instrumental in forming a Red Cross organization which was incorporated in the Iistrict of Columbia, under the name of "The American Association of the Red Cross" and of which she became the first president. As this country had but a small army and was considered to be on the whole a peaceful nation, it was anticipated that the chief activity of a National Red Cross would be on lines of relief and succor in times of disaster or natural calamity. Two such calamities, the yellow fever epidemic in Florida (1888) and the Johnstown flood (1889) brought American nurses for the first time into contact with the Red Cross and one of these nurses was the woman who was destined to become, in later years, the lead of the Red Cross Nursing Service.

It is hardly possible today, for nurses who only know of vellow fever as a preventable and almost extinct discase, to realize its appalling character before the research and selfsalerifice of scientific men had discovered its mode of transmission.

A suspicion of the mosquito had, indeed, been put forth as carly as 18ts, by Ir. Josiah Nott of Mobile, Mlabama, but no "xperimental work had followed his sugerestions." The writines of I)r. Charles Finlay, of Mavana, Cuba (18s1 and 1s-6), adranced afresh the relinioal evidence against the mospuito and with so much original foree that a Yellow Ferer Commission was appointed, which bromeht its investigation to a climax at the time of the Spanish-Ameriean War. Major Walter limed was its head. Ender his direction, at an experimental station

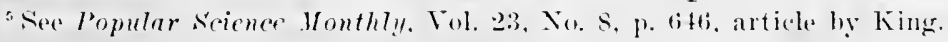




\section{HISTORY OF AMERICAN RED CROSS NURSING}

in Cuba, the tests of 1900 were carried out by Dr. Jesse W. Lazear, Dr. James Carroll and Dr. Aristide Agramonti, which proved the rôle in yellow fever of a special variety of mosquito, the Stegomyia fasciata. In those tests Dr. Lazear sacrificed his life, but as a consequence of that work, Havana, other parts of Cuba, and, later, the Canal Zone were freed from yellow fever and it was shown that, with proper sanitation, the tropies could be made safe for white men.

But these truths were still unknown when Miss Barton's aides went to the help of the ferer-stricken South in 1888. In every epidemic of yellow fever, scenes were enacted in Sonthern cities like those of plague times in medieval Europe. The only hope of safety of medical men and attendants lay, it was believed, in the immunity of acclimated persons, or of those who had survived an attack. It was also believed that negroes were especially immune. It seemed therefore at that time wise and reasonable that, when the Red Cross Society of New Orleans was formed (1883), it should have been ruled that no unacelimated persons, nor any non-immunes, should be used as assistants by the Red Cross. Miss Barton's writings refer to the well known "Old Howard Association" of New Orleans that carried on heroic service in epidemies in earlier days under Colonel F. R. Southmayd and that had united with the National Red Cross Committee. When the call came from Jacksonville for help, Miss Barton expected to supply it. She wrote :

It was arranged that the Southern states, through this society [the New Orleans Red C'ross] should provide all Red Cross nurses for yellow fever, and that the northern part of the country should raise the money to pary and provision them. We felt this to be a security, and an immediate provision which the comtry had never before known. Fearing that this might not, at its inception, be fully understood, I ralled at once on Dr. Inamilton. then in charge of the Marine Inospital, explaining it to him, and offering all the nurses that conld be required, even to hundreds, all experienced and organized for inmediate artion. Perhaps it was not strange that a provision so new and so unknown in the sat history of plagues and epidemies should have seemed utopian, and as such have been brushed aside as not only uscless. hut selfsceking and obstructive. Like the entire organization of which it was a part, it has to wait and win its way against anstom or cwen prejulice. . . Yot realizing the opposition 
there might be to our nurses, we called upon their old-time leader, Colonel sonthmayd, to enlist a body of murses and take them at once to the fever district. He enlisted thirty, both men and women, white and colored, and took a part with him, the rest following next day. ${ }^{6}$

Friction developed between the corps of volunteer nurses raised by Colonel Sonthmayd and taken to Jacksonville and a little place called MacClenny, and the local boards of health with which the Marine Hospital Service was coöperating. 'The clash between the older system of dealing with epidemics and the newer, more seientific methods of the Federal and municipal health officers was inevitable and Colonel Southmayd was withdrawn. These untrained volunteers, of whom there were about thirty, some of whom were of the Negro race, were the first Red Cross murses in the United States.

It would go far beyond our limits to tell the story of the Jacksonville epidemie. In the daily press of that time the general picture of distress, terror and death was outlined. 'Through the scene moved many figures brought there by the great need,-many of them ministering in faithful unselfishness according to their knowledge, others preying upon a stricken commmity. The personal recollection of a worker in that emergency is that a strangely debased type of adventurer came to Jacksonville,-immoral, abandoned women and unprincipled men. Many such persons were on the lists as nurses and there were Northern volunteers among them. The Red Cross idea had been seized by the popular mind and the glamour of the brassard made itself felt. Many actors in those scenes made and wore on their arms or shoulders the emblem to which they had no right whatever. It wonld, therefore, be unfair to judge the status of Red Cross nursing even in that formless period, by the individuals who claimed to be Red Cross workers.

The loeal health board very properly deported objectionable characters to a detention and quarantine camp (Camp Perry) in charge of I)r. (initeras, the rellow fever specialist, and items of this kind oecasionally appeared in the New lork palpers:

For very good reasous another nurse will be forwarded to Camp lerry tomorrow, ... the action of the Board of в."The Red cross." hy Clara Barton, p. 147-148.

"New York Tribune, Feptember 2:, lssis. 


\section{HISTORY OF AMERICAN RED CROSS NURSING}

Health in regard to incompetent and immoral nurses. . . . Two other nurses [their names were printed] are at Camp Perry, sadder if not wiser women.

Dr. J. Y. Porter, who was in charge of the Government relief measures, also had eharge of Government nurses. Few of these were trained as we count training today, but the "Bureau of Nurses and Medieal Attention" answered, in all, over seven hundred calls for help. Many of the aides thus supplied were men who had served in various eapacities in hospitals and were not unfamiliar with scenes of disease and death. The theory of immunity seems then to have been waived and this was especially so at a temporary hospital on the pavilion plan which was erected for the epidemic energency on the sand dunes outside of Jacksonville. It was ealled the Sandhills Hospital and as early as the 20th of August was in charge of Dr. Sollice Mitchell, brother of Neal Mitehell, then president of the Jacksonville Board of Health.

It is at this time that Jane $\mathrm{A}$. Delano, who later takes so important a part in this history, first enters its pages, though not through Red Cross channels. Dr. Sollice Mitchell had been a Bellevue interne. He had had his surgical service in the ward where Miss Delano had been head nurse and through his knowledge of her abilities she was asked to eome as superintendent of the Sandhills Hospital, a position which she filled with distinction during her two months' stay. Two of her classmates followed her there as volunters, Wilhelmina Weir, a Canadian, and Larinia L. Dock, a Pennsylvanian, each of whom had charge of a ward in the hospital.

Miss Ielano's later distinguished service in the Red Cross gives a special interest to this, her first public service after her training. She had been one of the youngest of her class (18si) and had gome through the hospital so mobtrusively and with so maffected a quiet and reserve that fow of her classmates dreamed of the munsual abilities she later displared, althongh all her hospital work had becn well and easily dome. One of the vounge internes of that day, who rose to the position of Surecon General of the Inited States Navy (Rear Admiral IV. ('. Braisted) reralled "a singularly dear keen intelligenere, an abiding sense of duty and an innate resoluteness of charactrer" as among leer characteristies.

Miss Delano was born in Watkins, New York, in 1862. 
Her family was a substantial one of New England stock. Her father had died in the Civil War and though she was too young to remember him personally, his memory remained with her and animated the intense interest that she felt, later, in the soldiers and nurses of another war. In appearance Miss Delano, at Jacksonville, was pleasing withont being beautiful. She was tall and of a very calm, self-contained bearing, blueeyed and brown-haired, with good teeth and a soft fine complexion. She was quiet and serious in manner and spoke but little. She wore the Bellerne uniform of blue and white seersucker with the cap, which increased her youthful look and, by contrast, made her poise and quictude seem the more impressive. She was a disciplinarian, and fearless.

The hospital on the Sandhills was not long needed. After a comple of months the epidemic abated and the Northern nurses and physicians were quarintined and returned to their homes. A legend has arisen that Miss Delano, in advance of medical knowledge, insisted on the use of mosquito sereens in the hospital. It was, indeed, thoroughly sereened, and this may have heen her doing. It has been pointed ont, however, that Dr. Finlay's writings two years before had sounded a warning which donbtless made medical men also suspicious of the mosquito.

After this emergency Miss Delano had twenty years of varied experience before she came under the Red Cross flag. She spent some time in a mining camp in Arizona, persuaded to go there by Ir. Darlington, later Health Commissioner of New York City, who was an old family friend. For five years she was superintendent of nurses in the Lniversity of Pennsylrania IIospital with Miss M. E. P. Davis as head of the hospital. She was one of the first among nurses to take the special Course in Philanthropy founded by the Charity ()remization Society of New York City, and she followed this by two rears' work as head of the Girls Department in the Ilomse of Rofuge on Ramballs Island. In 1902 she was called to be the heat of the training school in Bellevere, her almat mater, and held that position for four rears. Then for several real's her time was broken by the ill health and death of her widewed mother. Alworbed in these eares Miss l)clano was, from 1!noti to 1908, soplestered from artive nursing associattions. Ilor friends in the later lied cross work, howeror, know that in the otadisonville experienee she had reathed a clear 


\section{8}

HISTORY OF AMERICAN RED CROSS NURSING

conviction of what a nursing reserve under the Red Cross might mean and of the great usefulness it might have, and they believe that her special feeling for the Red Cross dated from that time.

At Johnstown much of the relief and all the nursing work was carried on under the Red Cross. Philadelphia had a Red Cross Society affiliated with the National Association and this group sent a staff of medical men and nurses to work in the tent hospitals which were used for ill and injured persons. The nurses in this corps were rather of the "Staff" Nurse, Old Style" than of the ultra modern school. They were, however, well disciplined and accustomed to working under the direetion of the physicians who had selected them. Before they arrived Bellevue Hospital had again sent a volunteer nurse, Lavinia L. Dock, who remained until the others came. Miss Barton took a part in the work of relief, leaving the hospital management to the phrsicians in charge. After this episode a number of years elapsed without any special awakening of nurses to Red Cross aims.

On the eve of the war with Spain, which prepared the way for the present Red Cross Nursing Service, it may be well to give our readers an impression of the advance of nursing after 1873 and of the main lines npon which it had progressed, with some touches of the personality and characteristics of nursing leaders.

The women who had entered the pioneer field of regenerating lospitals and opening schools of instruction for pupil murses were women of strong fiber and intense practical idealism. They entered a special world,-the old-time hospital world, where internal conditions of dirt, disorder, immorality anong attendants and among paticnts, bad nursing, coarseness and vulgarity were often hidden behind imposing structures and fine ontward appearances. Even among those of the best class, where respectable attendants and a good tone were found, reforms were difficult enough lecause of the grotesquely long hours, - from twelve to eighteen; the strange survival of srstems of duty handed down from the Middle Ages, where nursing attendants rotated from the wards to the washtubs; the total absence of teaching and training, and the generally widrspread state of satisfartion of medieal mon and hospital directors with thrir domains; with the resulting resistance, often intense and obstinate, to innovations, even though brought in the nane of 
Florenee Nightingale. It has been said of these pioneers and their adventures in reform:

"The women who plunged into this publie housecleaning were so alsorbed in it that to them, for a time, the outer world reased to exist. It was quite as adventurous, quite as exciting, as walr nursing. Nurses from different parts of the country met as veterans meet-no other introduction necessary than their identity of experience. When order had been restored and time came for constructive work, they, with one accord the country over, took up the problem of giving their pupils ampler teaching and a more careful preparation than they themselves had had. It may be conlidently asserted that never in a modern comntry has a more disinterested and useful civic service been performed by women than this regeneration of hospitals by women's boards and nurses during the last three decades of the Nineteenth C'entury. In all estimates of the value of skilled nursing by women of education only half the subject is considered if the immense moral uplift that they have given to institutions be forgotten or ignored. ${ }^{8}$

A number of the early nursing superintendents had been teathers,-for instance, Mary Snively, Lonise Darche, Irene Sintliffe, Isabel Itampton and Luey Drown. Others were representative Southern women with a eapaeity for driving work lefore them, snch as Lystral Gretter and Miss Caroline IIampton, Wade Hampton's nieee. By far the most were women who had never before mndertaken eareers outside of the family life in which they had been schooled by circumstances.

Every section of the country was represented among the clders in mursing and many of the strongest fignres came from ('illada, of substantial English stock, indomitalule, progressive and serving well the country in which they found opportmity to derelop their talents. T'ine methods and strstem of training and instruction in their hands had been steadily rising since 1s:3. From the course of two years' lonspital work, with instruction limited to the first pear, modeled upon Miss Nightingale's pattern in St. Thomnas' IIospital, Ameriean superintendents graddually extemded elasses and lectures thromghout the comrse, provided pest-graduate work in special lowpitals,

s.A History of Nurwing." Vol. III, p. 117. 
arranged for affiliation between two or more institutions in order to insure well-rounded experience, lengthened the two years' course to three, shortened hours as compared with the system of 1560 , fixed more exacting entrance requirements and made every effort to raise the ethical and professional plane.

Organization on a wide seale began in 1893 with the formation of the Society of Superintendents of Training Sehools for Nurses. The superintendents at once began forming graduate nurses into alummæ societies (only two such societies had been organized prior to 1893) and these in turn were brought together under the name "The Nurses' Associated Alumnæ of the United States and Canada." Their first regular convention was held in Baltimore, February, 1897. There were then two hundred and twenty-one ${ }^{9}$ training schools in the United States and Canada that were regarded by nursing leaders as being already good schools giving a general training, or as building steadily toward that end. They were sending out, yearly, several thousand trained and taught women.

The Associated Alumne had at first been formed in a eonservative way by the graduates of twenty of the foremost schools, but it rapidly beeame inchusive of all on a broad general level. The main subject of those early conferences was the protection and maintenance of good standards. For progress was by no means uniform and continuous. Even worse than the direet confliet with the old system, was a swift commercial exploitation of the new one. Opposition had sometimes given place to an imitation skillfully clothed in the appearance of reality. The attractive uniform, the plausible showing of a well-graded course of instruction in print, and the "diploma" were sometimes eleverly used to disguise purely money-making institutions, or those of one specialty only, lacking in equipment and teaching. The methods of the eorrespondenee sehool, well enough adapted perhaps to some lines of educational preparation for self-support, were beginning to reach into the nursing ficld and thus thirty years and less after the opening of the large training schools, there were already almost as many" different measurements by which to test the "trained nurse" as there were classes of institutions. Problems of this kind bronght nurses to consider two principles as hasic; first, that

"Tane Hodson's book "IIow to Pecome a Trained Nurse," listed 29? (1s97), not including foreign or post-graduate schools. 
the minimum training must be general (i. e., ineluding medical, surgical, gynecological and obstetrical experience); next, that mursing education and administration must be directed by murses. These principles have controlled the nursing profession in all its subsequent history.

Absorbed then in educational and diseiplinary problems and in the extension of their related branches, the nurses of the comntry had not yet been called upon as an organized body for any public service, nor had they met any national emergency up to the time of the war with Spain.

In her stay abroad after the Civil War, Miss Barton had absorbed the European system of Red Cross nursing and war relief work and had aceompanied the German ambulances during the war of 1870 . So deeply impressed was she that on her return to her own country, she hoped and planned to establish that system here. It emphasized the volunteer aid, as shown in these Artieles:

IV. In time of peace the committees and sections shall train and instruct rolunteer nurses.

$V$. In the event of war, they shall organize and place volunteer nurses on an active footing.

VI. The committees shall send volunteer nurses to the field of battle.

In 1893 a branch of the Ameriean National Red Cross was organized in New York City and throngh its efforts a small hospital was opened which, Miss Barton hoped, would be the first of many similar institutions and would prepare Red Cross Nisters on the European model, for service under the Red Cross flag. This little foundation, at first located in a small rented house, was formally opened in 1893 in Miss Barton's presence and under her direet auspiees. To carry on the hospital work and the teaching, Miss Barton had the aid of Mr. 1. Monae Lesser and his wife, who shared her enthusiasm for the Red Cross nursing of (rermany. 1)r. Lesser was a skillful surgeon: his wife, Bettina IIofker lesser, who was familiar with foreign nursing srstems, Was also an American trained nurse, having graduated from Mt. Sinat Hospital School for Nurses, New York City, in 1s!?:3.

The cirenlar showing the organization plan of the Red Cross Hoppital is a real treasure from the historical viewpoint. 
Red Cross Hospital \& Training School for Sisters, New York, 233 West 100th Street

William T. Warkwell, President, A. Monae Lesser, M. D., Executive Surgeon.
Under the direct auspices of

The American National Red Cross,

Rt. Hon. Clara Barton, President, Washington, D. C.

In order to become a Sister of the Red Cross the applicant must be of unquestionable character and qualifications. Further, she must-

1. 'Take the regular two years and three months' course of training at the Red Cross Hospital; or

2. Present certificates from some reputable training school for nurses, and take six months' post graduate in methods specially applicable to war or other national calamity. At the expiration of the course, upon giving satisfactory evidence of requisite fitness, the candiclate is graduated as a Red Cross Sister and can thereafter act as such either at home or abroad.

In eases of emergency nurses may be enlisted for the special need upon presentation of their certificates and without taking the six months' course mentioned in 2 ; but it should be understood that at the close of the service in question their relation with the Red Cross ceases, until they can be graduated in the regular way. In this comnection, however, credit will be given for character of work done during the enlistment.

The certificates above mentioned are:

a. A certificate of health and character.

b. Certificate (or a true copy thereof) of graduation from training school.

c. The enclosed blank properly filled out.

Candidates must have no ideal that there is any romantic or sentimental attractiveness in the stem demands of war, pestilence or famine. The emergencies of the service are often trying, sometimes involving privation and danger, and only those realy for such work ran be of real use.

The sisters are required to be within all at all times. ready to respond to any order anthorized by the President of the Amerian National Red Cross. The institution is absolutely nentral and non-sectarian, not in the sonse of ignoring, but of respeeting every nationality and all religions. The Red Cross is a volunteer institution, guided by and 
practising regular military taetics. The Sisters are required to devote their entire attention during the period of their service to the work to which they are assigned, and must cheerfully obey the instrnctions of their directors.

No salary is paid, but during actual service the best available provision is made for the support and requirements of the sisters.

Information when and where examinations for ranks may be made will be sent upon receipt of signed application. Should at any time one be found unfit for certain service in the field changes will be made as found proper.

These regulations are made for the purpose of rendering best aid to the sufferer, best assistance to the physicians and surgeons and to those who derote themselves to attend the sick and wounded.

By order of the

Rigift Hon. Clara Barton,

President American Tational Red Cross.

BETTINA A. Hofklir-Lesser,

Sister-in-Chief, led Cross Hospital.

(For male applicants, read Male Attendant instead of Sister)

In 1870 , when Miss Barton saw German nursing, it was by no means model. The deaconesses were then the best trained and Red Cross nursing in war time was largely in the hands of titled anateurs. 'Twenty years later, when the New York Red Cross Hospital was opened, a number of excellent training schools for murses had indeed been developed in German Red Cross hospitals, but the whole system on which their nurses were maintained and controlled was foreign to American ideas. The founders of the Bellevue school had affirmed the principle of econonic and professional independence for nurses after completing their hospital conrse and this was tenacionsly held to by the romng profession. Miss Barton and the lessers did not perecive how much at variance were their nursing ideas with those which had been firmly established aromd them. Their hospital oreanization was destined to fail,-not because it was of small beginnings, but beanse what they were hoping to do had already been done in a different and more enduring wav.

In 1s:3 when the Red Cross hospital in 100th Street was opened, there were all around it in the latre training schools of the city, the very women who later took important parts in 


\section{HISTORY OF AMERICAN RED CROSS NURSING}

the Spanish-American War work and still later helped to perfect the present Red Cross Nursing Service. But Miss Barton was apparently oblivious of the army of nurses ready trained and eager to serve. Older women, whose memory reached some years back, recalled the fact that even before war was thought of, but as some incident or published word brought the Red Cross to the front, nurses had often applied individually to know how they could "join the Red Cross" and were invariably disappointed at finding no response.

Yet with the oncoming of the Spanish-Ameriean War, the New York Red Cross Hospital with pathetic inadequaey stood forth to meet the emergency. We do not know how many Sisters it had trained, nor how mueh it was prepared to do in fitting civilian nurses for war work, but it is clear that its resourees must have been but slight, for in a later report Dr. Lesser wrote:

During the last four years, from the time Sister-in-Chief Bettina had introduced the idea of training led Cross nurses in this country, we had labored with the desire of having an adequate number of trained Red Cross Sisters, well known to us and upon whose efforts and capabilities we night rely: unfortunately we met with but indifferent success, there being no thought of war to stimulate the undertaking. ${ }^{10}$

As the prospect of war nursing came nearer and nurses offered their services in various directions, some to the War Department and others to the Red Cross, the Red Cross Hospital enrolled all those of attested character who applied to it, listing some as fully trained, some as partly trained, and others as untrained but eapable and intelligent volunteers, and the earliest contingents sent out from it represented all of these groups. A great advance over the chaotic conditions that had prevaled in the yellow ferer epidemic was even then obvions. It has been said that there was "only one adventuress" in the first large nursing expedition of the Spanish-American War that was recruited almost entirely by the Red Cross Hospital, and on the other hand that group included a number of professional and volunteer women whose effective services in aetion soon became well and widely known.

10 "Conduct of the War with Spain," Vol. V, p. 2384. 


\section{CHAPTER II}

TIE EPISODE OF TIE SPAXISH-AMERICAN WAR

Organization of the Red Cross in 1898-The Red Cross Sisters-Nursing under the Government-Red C'ross Auxiliary No. 3

W

HEN the year 1898 opened, the officers of the American National Red Cross were: Clara Barton, president; George Kemnan, vice president; Stephen E. Barton, Executive Committee member; David L. Cobb, counsel; Dr. A. Monae Lesser and his wife Bettina, who were, respectively, executive surgeon and chief of hospital work. Before the United States deelared war on Spain, Miss Barton hatd gone to Cuba with relief for the reconcentrados. With her was a staff of workers, among them being four Sisters from the Red Cross Hospital. In March, the Cuban Relief Committee chartered the steamship State of T'exas and loaded her with food, clothing, medicines and hospital supplies for the Cubans. She was a true Red Cross Relief Ship, sent under the Red Cross flag and in conformity with the articles of the Geneva ('onvention, to be turned over to the Ameriean National Red ('ross. Miss Barton went to a Florida port to meet the ship and go with it to Cuba, but her plans were frustrated by the declaration of war (April 25, 1s98) and the state of Texas did not reach Cuba until she went with the trinsports conveying the Cnited States Army, and entered the hartor of Sintiago. Instead of aiding reconcentrados Miss Banton hald to meet the desperate cmeregeney of aiding ill and wounded Ameri("an soldiors. So far only as the mursing story goes, her efforts will be recorded here, but in any estimate of the charaleter and extent of the mursing work it must be remembered that this talsk wals al very different one from that which $\mathrm{Ml}$ is: Baarton had been authorized to undertake, and that mueh of the critieism put forth at that time arese from an imperfecet understanding of this fillet. 
At first the Red Cross Hospital functioned as its directors had hoped and meant it should do. At a meeting of the Board of Trustees on April 23, 1898, a committee was appointed to be responsible for a supply of nurses for the war. Sister-in-Chief Bettina (Mrs. Lesser) had a seat on this committee, which began at once to plan for calls for nurses. We may fairly say, therefore, that the Red Cross Nursing Serviee was historically anticipated at that meeting. by that eommittee. Soon afterwards its services were formally placed at the disposal of the Government by Dr. Lesser.

At the same time a wide reorganization and enlargement of Red Cross eireles was under way in New York City. This was initiated by Mr. William Wardwell, president of the Red Cross Hospital and director of the New York Red Cross Soeiety, who, foreseeing the progress of events, brought about the formation of a larger committee ealled the "Ameriean National Red Cross Relief Committee." This new committee was entrusted by Miss Barton with the task of inviting and promoting the coöperation of similar committees throughout the country. Mr. William Wardwell was one of the vice ehailmen of the enlarged body and Bishop Potter was its ehairman. The Seeretary of State ( $\mathrm{Wm}$. R. Day) then marle it known that the Ameriean National Red Cross would be reeognized as "the proper and sole representative in the Lnited States of the International Committee," 1 thus fixing the official status of the Red Cross. Secretary Day also stated that Congressional action would protect the insignia of the Red Cross from use by any manthorized person. This protection had not previously been aceorded by the Lnited States Government. ${ }^{2}$

The early reports of the Relief Committee gave on the title page the names of Miss Barton and other national officers, followed by those of the new group in New York City.

The Ameriean National Red Cross Relief Committee as its first step had appointed a "Women's Committee on Auxiliaries" charged with the duty of organizing similar auxiliary commit-

\footnotetext{
Letter from the Secretary of State to the War Department, quoted in "The Red Cross in Peace and War." p. 377.

${ }^{2}$ Congress did not take the action promised by Mr. Iay until 1900. See Congressional Discussions and Aetions upon Various Measures of the Incorporation of the hed cross and the Protertion of its Insignia, lset to 1910. eompiled by Gen. Georore W. Davis with his Notes on same. Red Cross libriry. National lloadguarters. Washington, 1). C.
} 
tees of women throughout the United States. Almost one hundred such anxiliaries were formed, each one taking up some one special responsibility. They were designated by numbers. The New York group was known as Auxiliary No. 3, but also took the name "Red Cross Society for Maintenance of Trained Nurses." Besides organizing the others it beeame the central agency of relief and also through a committee on nursing, it took over and finally controlled the whole Red Cross nursing service in New York and influeneed materially the general service during the war.

Reference will be male again to the new anxiliary's activities after following the Red Cross nurses in Cuba and tracing the early steps in nursing which were taken by the Government.

Dr. Lesser's official report, written after the events, says of the first steps taken:

Immediately after the declaration of war with Spain, I received the order from the president of the American National Red Cross to the effert, "that the Red Cross Hospital Department shall be ready for service in the war." By the direction of the president (Miss Barton) all applications for enlistment and communications relating to this service were sent to the New York Red Cross Hospital. A certain standard of experience and character was established as necessary for enlistment on our staff. A number of applications from physicians, nurses and other assistants were received ... and those whose qualifications and recommendations seemed satisfactory were chosen and placed upon a list for further investigation and final selection. From the large number of names of trained and other nurses the Sister-inChief and I had selected men who we helieved would be physically able to carry wounded soldiers, also trained nurses and gentlewomen who seemed least snsceptible to disease, ....3

When Miss Barton reached the Cuban shore she took her ship to siboney, where there was need of supplies and aid, and her representatives made their way to the Army hospital. 'They'

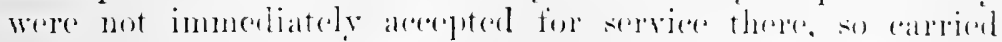
their offeres to the (aihan hospital. where they were gratefully.

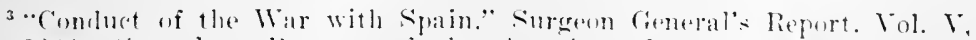
p. ezst. Siere also "lieporte of the Ameriean lied cross Relief Committore." p. 1it. 
aceepted. Presently their assistance was asked for by Major La Garde of the American forces, in a hospital designated by him, and was given.

The Red Cross Sisters, foreign fashion, were called by their first names. Mrs. Lesser, who was Sister-in-Chief, was Sister Bettina. She and Sister Mimnie were in clarge of the tents; Sister Annie with a volunteer assistant, Mrs. White, was in the Red Cross Hospital; Sister Isabelle and Sister Blanche helped with operations. The need of nurses was already acutely felt. Dr. Lesser said at this point in his narrative:

News of another battle was expected. Finally it was agreed to request more Red Cross aid by telegraph. A call for one hundred Sisters was suggested and Mrs. Lesser was consulted in the matter. We had fifty trained nurses and assistants on our lists, also women to art as matrons to distribute nourishment, etc., whom we hoped we could rely upon. We promised to send for that number immediately, as we had sent for twenty-five already. ${ }^{4}$

The call for the twenty-five nurses here mentioned is of interest, as it gave their names and was signed by Miss Barton. It was sent to Stephen Barton and transmitted by him to the Auxiliary No. 3, or to the Red Cross Hospital. As it arrived in New York it was written out as here shown:

Playadeleste,

Barton, New York,

July 2, 1898.

William Street.

Siboney-Send nurses muttell coffin shaw sisters lavinia eva card is gardner rutty bouligney Amma muessing medora allen strom fleigge hilda olsen edith abrams margaret meguir doctors nums gill rogel two hundred fifty equipped bed linen towels rothes.

B.hitox. 5

Before completing the story of the adventures of the little group of sisters thus canght aceidentally, as it were, in the war emrent, it is necessary to retmrn to the larger events in

" Conduct of the War with Spain." Surgeon fencral's Report. Vol. V. P. 37.

${ }^{5}$ Files of the Rent Crose Society for the Maintenance of Trained Nurses, May to July, 1898 . 


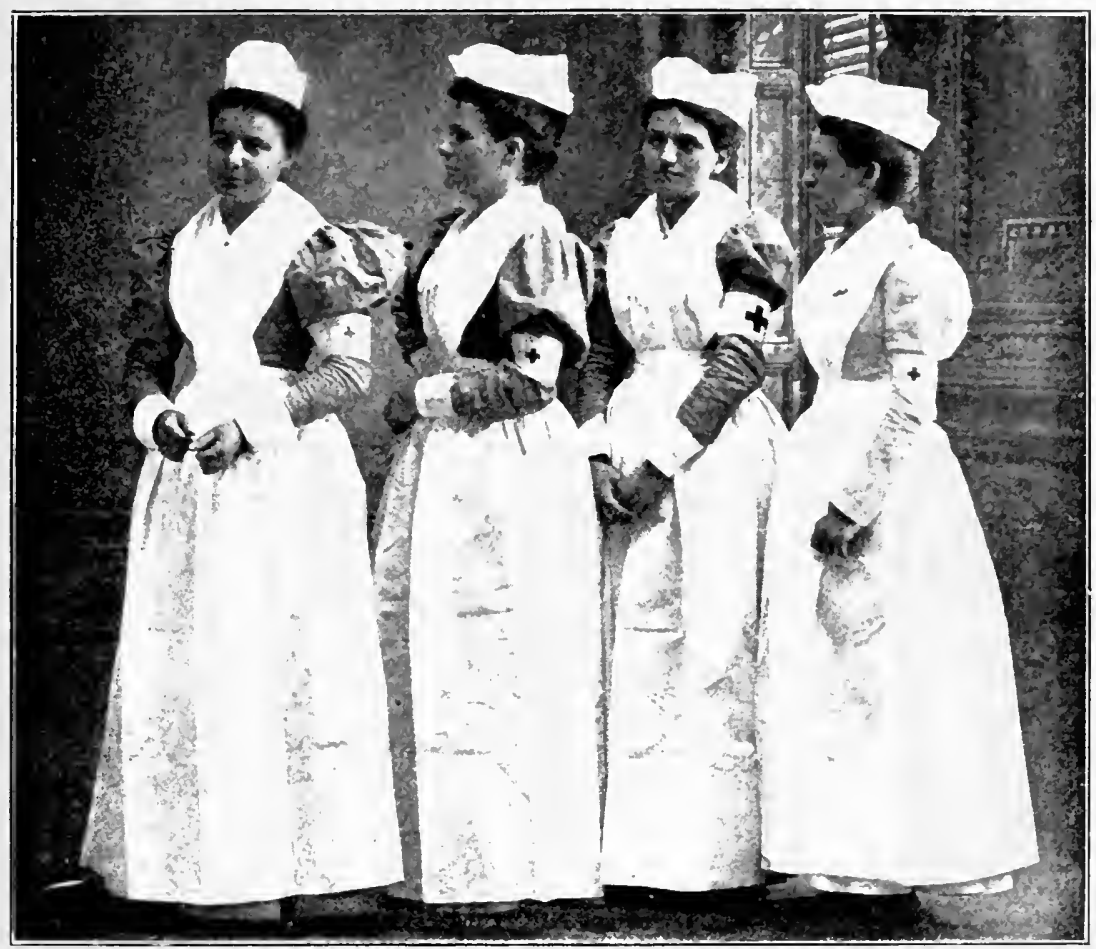

Copmeright. 15?s, l,y Clara Barton.

1 group of American Reul Crose Sisters who sorved at Siboney during the Spanish-dmerican War. 
. 
Red Cross activity which affected the Red C'ross IIospital service, and to trace the steps which had been taken by Miss Barton's officers in preparation for war nursing.

In .June, 18:98, the Iepartments aecepted the offer of services made by the lied Cross. Dr. Lesser wrote:

After the Department of War had approved and acepted the services of the Red Cross to supplement the work of the Army Medial Department in atse of need, I alled, in the (aparity of Surgeon-in-Chief of the American National Red Cross, upon surgeon General Sternburg of the Inited States Army. I was arcompanied by the Sister-in-Chiel. We asked the Surgeon General for information in regard to fiehl service -in his opjinion a hospital ship would be the best service that we might render. He, however, referred us to Colonel Greenleat", who, he said, would have charge of the field. After a short interview the colonel said that he felt there would he a land service and that it would be wise for us to be prepared. ${ }^{6}$

The story now returns to the place where the Red Cross Sisters were left at work with Dr. La Garde. The need of nurses had grown steadily more urgent and finally, as already recorded, a number were eabled for. Dr. Lesser wrote:

That morning Miss Barton, with George Kennan and several of her stalf, had gone to the front and before leaving Miss Barton instructed her secretary, Mr. C. H. H. Cottrell, in the presence of Mrs. Lesser and myself, that at our request he should cable in her name for such persons and material as should be needed in the hospital department. Since it was the wish of the surgeon of the amp. we cabled first by name and then by special list for fifty nurses, ten assistants, a number of immine physictans and complete bospital equipment to make at least five humdred patients comfortable. The wombled continued to arrive for four days. Surgeon Major La ciarle die! me the homor of consulting me in reagal to the mursing and I suggested that some of the sisters leave the operating tables and take charere of the patients in the tents. The rews of tents were then placed in her (Mrs. Leseners) rhare and she portioned the work of aring for them amoner the sisters assisted hy hospital arpomen.'

${ }^{6}$ lieports. Ameriean National Red Cross Relief Committees. P. 177. "Combles of the Itar with spain." Surgeon Generat's Report. Vol. V.

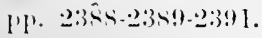


In the midst of this arduous work, July 15, Dr. Lesser and all his nurses were stricken down by yellow fever. It was supposed that their little Red Cross hospital, which had been construeted in a Cuban dwelling, was infected. At the time much controversy went on as to who was blamable, but since the mode of transmission of yellow fever was then still undemonstrated, the criticism and hard f(eling engendered by those disputes were futile. Meantime Dr. La Garde waited impatiently, in great need, for the expected reënforcement of nurses. 'Still they did not come. They had, however, been dispatched from New York by the Auxiliary No. 3. Dr. Lesser's story tells us:

In the meantime word from Assistant Surgeon General Greenleaf was received at Siboney, stating that forty-five Rer Cross sisters, surgeons and other assistants had arrived at Guantanamo, waiting to come to us, and as we returned the same day from the fever camp, Surgeon Major La Garde telegraphed and telephoned repeatedly for them to come, but he received no reply. Feeling that under existing circumstances, and exhausted from work and illness, we could not continue to work without more assistance, I applied for our return. ${ }^{8}$

Dr. Lesser and the Sisters went north on the steamship Concho from Siboney to New York (about August 24), but no record of the Sisters' subsequent activities have been found. Concealed at first by the absence of surnames, it is quite possible that they returned into war work under their ordinary titles.

The Red Cross hospital had already begun losing its precedence because of the larger organization growing up around it. At the time of Miss Barton's entrance into Cuba, Dr. Lesser had urged that twelve Red Cross Sisters and several others selected by Sister Bettina should be sent on the Strate of T'Pras.s to join the four who were awaiting them in the South, but for some (undoultedly valid) reason they were not sent, to his great chagrin. At this point the opening first appears of that transition process in the nursing srstem of the Red Cross which led from the little gromp of volunteer Sisters to the highly modernized Nursing Service of $1917,{ }^{9}$ and such periods are

" "Conduct of the War with Spain." Surgeon Greneral's Report, Vel. V, p. 2393.

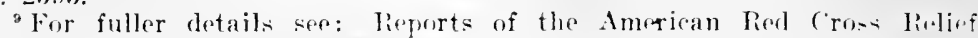

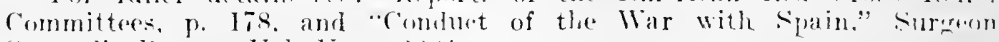

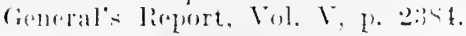


painful to those who find themselves displaced. One cannot but feel that the Lessers did not have a "good chanee" and that Sister Bettina might have administered easily the larger staff of murses that she vainly tried to secure.

'l'o return to Dr. La Garde; the failure of the murses so eacerly awaited and so much needed, to reach him, had its explanation in the nuwillingness of the Surgeon General's office to send nurses into Cuba who were not known to be imnume to yellow fever, for Dr. Stemberg was very careful on this point. Other reports of those strenuous days confirm Dr. Lesser's story and among several references to the nursing situation of that time that are to be found in the report of I)r. Charles R. Greenleaf, Chief Army Surgeon in the Field, one explains why Dr. La Garde did not receive his reënforcement of nurses:

On the 1sth of July we proceeded to Guantanamo Bay, the renlezvous for the P'orto Rican experlition. At this place we found a detachment of doctors and female nurses on board the steamship Lampasis that had been sent to work with the Red Cross Association. As they conkl not go into Cuba or land from their own ship, I determined to use them in the Porto Rican expedition, and subsequent erents demonstrated the wisdom of this action, since the increase of typhoid ferer cases on board the steamship Fale was very large. requiring the transfer of some eighty odd to the ship on which these unres were quartered, which I converted into a quasihospital ship, notifying the medical officers in charge of the varions transports to send their sick to it, and with them descriptive lists. complete transfer lists, and sufficient quantities of medial supplies and rations to last during the return royage to the states. ${ }^{10}$

Later in the summer a report on this expedition was sent to the American Reel C'ross by one of the party, Miss Rutty, who had been placed in dircet charge of the trained nurses. She was not a murse, but had been efficient and practical and showed gifts of managenent. Her report is included at this point, becanse it is a connecting link between the licd cross Hospital war work and that of the Anxiliary No. :8. Addressed to Nister Bettina, as still holding the position of sister-in-( hief, the reports of the Anxiliary to be given later show that the Lampasas

"...conduct of the War with Spain," Report of the Surgeon Cemeral, Vol. I, Pp. $6336-638$. 
party, though made up chiefly at the hospital, was merged in the general department of administration of the auxiliary.

\section{Repont of the Red Cross Expedition Aboard THE S. S. Lampasas}

\section{To Bettina Hofker Lesser, Sister-in-Chief, American National Red Cross}

Left New York July $t$ in charge of nine nurses, one surgeon and two assistant surgeons, under orders to conduct party to Cuba. Miss Anna Boligny according to orders joined us at Washington. At the Port of Tampa we joined Miss Gill and her party, and under instruction from Mr. Stephen Barton put up at Tampa Bay Hotel, and waited for transportation. The condurt of the nurses while at Tampa was especially commended by the officers of the Army and Nary with whom they ame in contact. On the night of July 7, Major Carter of the Divisional Hospital, General Snyder's Camp, Picnic Island, asked for murses for typhoid nursing. For this service two night nurses and two day nurses were detailed for luty during our stay in Tampa. July 8 we boarded the S. S. Lampasas, and on July 12 sajled from the Port of Tampa, Miss Gill having given into my hands all matters pertaining to the finances of the combined parties. Arrived at Key llest evening of July 1t. At Mr. Cobb's request I went ashore to cable to New York for funds. Ship sailed before answer came. We were instrueted to remain on board the Lampasas at Santiago until Red Cross orders came. Sailed into harbor of Santiago morning of July 19. Colonel Black having gone ashore for orders, reported that nothing could be learned of the Real Cross authorities; that on account of the presence of yellow fever. anchor woukt be weighed at once, and all communication would he eut ofl. As we were under orders not to leave the ship until so instructed, we sailed to Guantanamo. On the morning of the oflth gave orders that the Red Cross party was to be ready to leave the ship at noon. Orders from Cieneral Viles that we go on loard the Oregon and return to Sintiago. An interview being had with cieneral Viles, he authorized us to remain on board while awaitine orkler's anel such orders failing us sald he would gladly utilize us at the front. In additional order eame from fincral lliles that all immme nurses shomld be detailed for work at siantiago. Mrs. Bull, the only immune in our numbere was trans lerred] to the ()regon in empany with 11 is: Wheeler who had sperial 
permission to join her father. Colonel Black kindly put me ashore, where I rabled to Mr. Stephen Barton explanations, and asking for funds and supplies. Colonel Greenleaf had stated that the supplies at hand were only adequate for the needs of their own surgeons. Rumor reached us at this time that I)r. and Mrs. Lesser were very ill with yellow fever, and II is Barton having failed to respond to a message sent by Mrs. Nutall in charge ol the party on the Nueces and no word reaching us from 1)r. Barton, we sailed for Porto Rico. Having learned that it was absolutely necessary for our future usefulness that an organization be formed, the nurses and doetors hedd a mass meeting on July 220 and elerted me chirector and Sister-in-('harge. Sailed into Guanica of uly 25 and on same afternoon received sixteen patients from Comanche. Following morning fifty-seven came from Yale. Anchored off Ponce, evening of :8. Quarantined by Dr. D. R. Burns on account of three cases of measles and pemphigus. Removal of quarantine on 31st. On July 31 we were asked to proceed north with our patients. Colonel Greenleaf did all in his power to assist us and requested me to proceed to Washington to report to Surgeon General Sternberg at the earliest posiblo opportunity. Sailed August 1st leaving Miss Chanler and Miss Boligny at I'once at their special request, and with General Miles' sanction. According to instructions we landed our one lumbled and two patients at the general hospital, Fortress Monroe, August \%. From Fortress Monroe I proceeted to Washington and delivered Colonel Greenleaf's letter to surgeon General sternberg, going thence to Sew York and reporting to Red Cross authorities on August 9. We now await further orders. Special mention should be made of Mary E. Glarlwin, whose management of the diet kitrhen merits the greatest redit and appreciation on the part of those who worked with her and also of the National Red ('ross. Beatrice Von Ifomrigh was most eflicient in systematizing the nursing on a plan which has been placed on file.

Respertfully submitted.

ISABELLE: E. RITTTY,

sister-in-e tharere.

Miss Shaw, a yomme Belleve trained nurse who had applied at the lied cross Itospital, was included in this group and her rexollections are lively enongh to deserve more space than we can give them. She satid of the stay in Tampa:

Typhodid forer was raging there and the nurses wished to care for the sitk nem, but there was great difliculty in getting 


\section{3\$ HISTORY OF AMERICAN RED CROSS NURSING}

permission to do this, as there seemed to be no organization. One never knew what would become of one next. All one's service seemed haphazard.

Miss Shaw told how the nurses were repeatedly transferred from one location to another, "always obeying the last order, no matter how conflicting with the preceding one."

Her recollection was that an engineering corps was about to leave for Cuba on the Lampasas and that the murses, on their own motion, persuaded the eaptain to take them also. To gain his consent they had to agree to relinquish temporarily the protection of the Red Cross and accept all the hazards of war on a war ship sailing under military orders in hostile waters. When they arrived in Santiago Harbor, the sailors on the ships in the harbor turned spy-glasses on them and shouted "Skirts!"

This pieturesque but somewhat adventurous expedition of the Lampasas in the early, elaotic period of the first war conducted by this country since 1864 , though mueh eriticized at the time, ent a path for later Red Cross nursing service and won many friends for nurses. Dr. Charles R. Greenleaf, Chief Surgeon in the Field, wrote:

The service rendered by the nembers of this detachment of Red Cross people has been invaluable, and they are entitled to great credit for their derotion to duty, their zeal and their unremitting eare of the sick under circumstanees that were peculiarly trying. I shall be glad indeed to welcome them, should they return, and I can always find suitable work for them in the loase field hospitals. ${ }^{11}$

Later in the summer Dr. Greenleaf wrote to Dr. Sternberg:

Porto Rico, August sith.

Cabled you to-day for Mliss Rutty and thirty nurses. I know her to be a good administrator and valuable woman and if she can bring with her the nurses who were on the lampasas I shall be much pleased and you will be sure of good service. ${ }^{12}$

With this episode the immediate comnection of Miss Barton's staff with war nursing ends and no further records are available of the intrepid little group of Sisters and Sister-in-Chief Bettina. I nursing report written by the latter and covering

"1" conduct of War with spain," Vol. I, p. 576.

"Itirl., Vol. I, p. 603. 
the whole period of their service is alluded to in several documents, but camnot be found. It must be concluded that it was not preserved, an oversight that, from the historical standpoint, must be deeply regretted. For some little time I)r. Lesser contimned to enroll nurses at the Red Cross Hospital, until the complete organization of Anxiliary No. 3 eentered all Red Cross nursing activities in its committee.

1 few lines are needed for the final history of the Red Cross Hospital. Is the war went on, its staff was depleted and its regular work interfered with, but it kept on in the face of difficulties and a certain number of applicants passed through it, some of whom made their way direetly into the army serviee, while others were listed by the Auxiliary No. 3. After the war was over the original New York Red Cross Soeiety endeavored to earry on the hospital aecording to its first plans. In 1903 a special corporation was formed to manage it and in $190 \pi$ the building at 99th Street and Central Park West was erected and contimued for several years as the New York Red Cross Hospital. Agreements with the National Red Cross at Washington were made (1903) by which the New York Society was to have two members on the hospital board and the hospital was to be regarded as an affiliated body under the general jurisdietion of the National Red Cross. It was still hoped, in some quarters, that the National Red Cross might extend the work of developing its own hospitals for the training of Red Cross nurses, but with the gradual abandonment of this idea, as the greater possibilities were pereeived of building up a nursing service by the help of the professional forees already existing, the relationship of the Red Cross Hospital to the Xational Committee ceased to have any vital significance, and in $191+$ this relation was finally severed by mutual consent. The hospital (hanged its name and beeane the Park Hospital.

It the same time that the Red Cross was organizing for aid, the Lnited states (ooremment was preparing an ofticial nursing staff in the event of war and becanse of the close relationship of the Irmy Nursing service to the Red Cross, in this as in every enmery, it is important for us to follow here its main lines. The seope of this work does not pernit a detailed presentation of the Army Surse Corps and its activities at that time, hut compels us to pass orer much of interest and rahe that belenges properly to a history of a general, rather than of a sperialized kind. 
As early as Felruary, 1898, officers of the Government began to receive applications from women who wished to serve as nurses during the approaching war and all those letters and papers found their way to the files of the surgeon Generals of the Army aud Nary.

So wrote the medical woman who became the official head of the trained nurses employed by the goverument in Army nursing during the war with Spain, and whose nursing staff developed into the Army Nurse Corps.

Anita Newcomb McGee, M. D., was the daughter of the distinguished astronomer, Simon Newcomb, and inherited intellectual powers. Her medical studies were taken in the Columbian (now George Washington) and Johns Hopkins Universities.

She was a woman of strong personality, attractive in appearance, small, with dark hair and dark blue-gray eyes, of very quick movements and keen, rapid mental processes. Her social and scientifie position naturally brought her into elose aequaintance with Washington's notables and before war was declared she had conversed with the Surgeon General of the Army, General George MI. Sternberg, upon the use of trained women in Army work. It was his purpose if war came, to employ women as nurses, but it was Dr. MrcGee who dwelt upon the importance of having them professionally well trained and who succeeded in carrying this principle into the service. She was a Vice President General of the Daughters of the American Revolution and this society at her suggestion formed a "Hospital Corps Committee" of which she was the chairman, with Mrs. Amos G. Draper and Miss Mary Jesha as her chief assistants. Dr. MreGee offered the Government (April 27) the services of this committee and the offer was aceepted. In July at the request of the Surgeon General Congress had anthorized the employment of contract nurses "regardless of sex."

Dr. Sternbercis official reports and papers give the following account of the creation of the Army Nurse Corps and a picture of the deficiencies existing in the pre-war Army nursing system:

The oricinal purpose of the Medical Department was to have all the nursing and other work of the hospitals. including the rerial and diwensiry work, done by trained members of the Hospital (orps: liut the Art approved April $\because .2$, 1898, providing for temporarily increasing the Military 
Establishment, failed to include Hospital Corps privates for the volunteer regiments. The great majority of the Hospital Corps men secured by enlistment and transfer had little or no proper training as murses and as a consequence were largely ineflicient. At the outbreak of the war nursing in the Army was done entirely by the men of the Hospital Corps; but the emplosment of contract murses, recardless of sex, was anthorized by Congress in March, $1898 .{ }^{13}$ Before the 30th of April alnost a thousand applications had been received from women who wished to serve as nurses but no examination of these alplicants harl been possible. On April 28 the National soriety of the Laughters of the American Revolution offered its services to the Surceon General of the Army in the "aparity of an examining board for female murses and this offer having been acepted, the following day all applinations from women were reforred to it for examination. The status of this organization rendered it peculiarly suitable to modertake this work. it has headquarters in Washington ('ity and twenty-five thonsand members living in every state and territory of the Inion and as it had no affiliations with any hospital or borly of nurses it is entirely mprejudiced in its juclgment. Mrs. Anita Newcomb McGee, II. D., a physician in good and regular standing and Vice President (ieneral, National Soriety of the Daughters of the American Revolution, was designated as director of the "Danghters of the American lievolution Hospital Corps" and placed in charge of this work. Her statement regarding the nethod of selection is as follows: "In accordance with directions from the surgeon General, only graduate trained nurses

${ }^{13}$ The Congressional authorization above mentioned was asked for in April, and obtained in July. Special anthority for the employment of women nurses in 1he Army appears in Sections l:38, 1239, 1277, and 1279, Revised statutes of the inited States, providing compensation at forty eents a day and one ration. These date from the time of the Civil liar and are the onterowth of that war.

No women nurses ware employed in the Army from the time of the Civil War ment the Sianish American War. Encler elate of April 28,

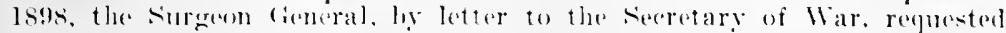
attherity to employ by entrate as many nurses male or fomales as might he repuired dioring the war with Spain at the rate of thirty dollars a nontle with a ration. The secretary eranted the authority asked for

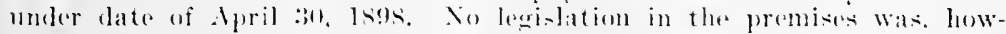

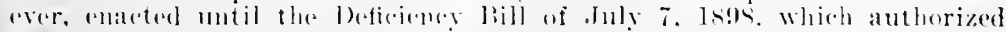

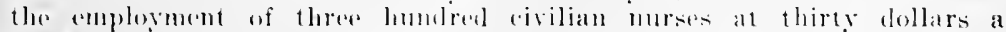
month (30 stats. 7193). ltems for the gay of rivilian nurses without any

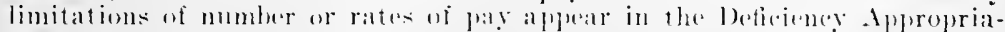

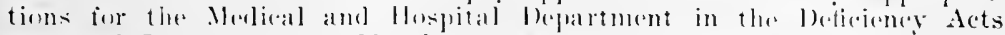

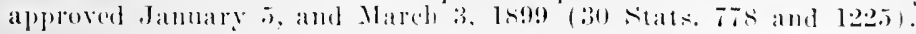


were accepted by the Daughters of the American Revolution as eligible and they were required to fill out blanks like the one appended hereto. In judging a nurse, three points were considered: First, professional ability: as evidence of which endorsements from physicians were usually submitted. In all cases the superintendent of the training school from which the nurse graduated was asked for endorsement, and when this was refused, the nurse was not accepted. A few women physicians in good standing were also accepted as nurses. Second, character: to establish which the endorsement of a Daughter of the American Revolution was requested (though never exacted). In lieu of this, the signature of any lady of known standing was accepted. Committees of 'Daughters' were formed in all large eities and in many small ones and rendered admirable service in securing suitable applicants. 'Third, health: as eridence of which a physician's certificate was required. In certain cases, however, where the need for the nurse was too urgent to admit of delay and where there was no reason to doubt her health, this certificate was not filed. Originally the nurses were required to be between thirty and fifty years of age, but the large number of desirable trained nurses who were under thirty caused that limit to be disregarded. The evident necessity for and importance of the limitation of appointments to trained nurses, was neglected only in the sending of nurses to Santiago. As it was essential that they should be inmune, it was impossible in all cases to require graduation. The assistance of all organizations that desired to recommend nurses was gladly welcomed and applicants who conformed to the standard were accepted without regard to creed. Almost fire thousand applications were examined by my associates and myself and about onefifth of that number were accepted as eligible for appointment." This arrangement with the Daughters of the American Revolution continued until September \%, since which time Dr. McGee, having been appointed acting assistant surgeon, United States Army, has been on duty in the War Department, in charge, under my immediate direction, of matters pertaining to female unrses.

In adilition to the contract nurses, selected as above stated, Mrs. Namah Curtis was, on . July 13, sent Jy direction of the Surgeon General, to New Orleans and other cities to secure the service of colorel immune women as nurses at santiago, and thirty-two were sclected by her. At the amps at Ilontauk and Jacksonville the rhief surgeons were authorized to contract with nurses who might apply to them, and at each place a small number were enrolled in this way. The nursing 
at a few of the Army hospitals has been done by volunteers, with whon no contracts were male. ${ }^{4}$

Though in the quotation above, "directions" are attributed to the Sinrgeon General, it was really Dr. McGee who defined the standards and ained at maintaining them, for she was deeply interested in the suceess of women nurses in the army. Being a woman, she was solicitous for the prestige of women nindertaking a new responsibility and as a professional woman herself, she was eager to uphold the professional worth and dignity of the army nurses. The directions aetually given by General Sternberg were, that nurses should be ehosen from all parts of the United States, if practicable, and that "political pull" should be entirely ignored.

In view of the novelty then of trained women nurses in Army service it is interesting to know how Dr. MeGee arrived at her decisions in selecting her nurse corps. Although the first printed regulations did not qualify the words "a training school for nurses," yet in fact the best known institutions were always first applied to. In listing them, Dr. MeGee eonsulted Tane Hodson"s book "How to Become a Trained Nurse," and advised with Georgia M. Nevins (then head of the Garfield Hospital, Washington), Isabel M(Isaae, superintendent of the largest training school in the West, the Illinois Training School for Nurses, Chicago, Sophia F. Pahner, then chairman of the Danghters of the American Revolution committee in Roches-

1s "Conduret of the War with Spain." Reply of the Surgeon Feneral to the Committer. The Selection of Fenmale Nurres. Vol. I, 1p. 725-726.

The question blank sent to nurses was as follows:

Name in full.

Adeleses and nearest telegraph station.

Do yon desire appointment in Army or Xay?

llow soon after receiving an appointment can you leave home?

Itabe you had yellow fever?

Are you a grabluate of a training school for nurses?

If sol. What sehool and what your?

What other hospital experience have you had?

llave you nursed contimunsly since grabluation?

If not, what has been your oceolution?

What experience have you had in invalisl aokery?

What is your age?

('olor":

Height?

1)ate and place of birth?

Are you single, marricel or willuwed?

linght?

Are you strong and healthy and have you always heen so?

Hawe you a tembency to any disease?

llave ?ull been succesisfully vateinated and when?

What is your legil residenete" 


\section{HISTORY OF AMERICAN RED CROSS NURSING}

ter, New York, and other superintending nurses of note. As the war went on, periods of great emergency arose, when women possessing every qualification were not available in sufficient numbers and at those times, the less well-equipped graduate nurses had to be called upon.

The first volunteer offers made to the Government had come from individual women. On the declaration of war these were followed by groups, or organized bodies, of which there were in all, as Dr. MeGee has recorded, no less than eighteen. Among the earliest were the National Emergency Assoeiation of Women Physieians, Surgeons and Nurses, of Chicago, whose president was Gertrude G. Wellington; the Graduate Nurses' Protective Association of New York State through Miss Enright; an association of the Connectieut Training Sehool through Mrs. John Kerrigan; the Metropolitan Nurses' Club through Mrs. Mary Hateh Willard; St. Barnabas Guild Club of Nurses, and many Catholie orders.

The Associated Alumnx (whose formation has been deseribed) requires special mention, for this body subsequently became affiliated with the Red Cross and later broadened into the Ameriean Nurses' Assoeiation. In April, 1898, it was in session in New York City for its first regular eonvention after organization had been effeeted and it there offered its services to the Surgeon General. The president was Isabel Hampton (Mrs. Hunter) Robb, whose eontributions to nursing edueation and to organization are so important and so elosely interwoven with our history that we must pause here to bring her before our readers. Isabel Hampton was a Canadian of English parentage, of a fair and stately trpe of beanty. Her presence was both imposing and winning, for a special graciousness and ardor shone in her blue eres and gave her sweet English voice a vibrating, electric quality. Miss II:mpton had graduated from Bellevue when still below the usual age of admission. She lad held two important hospital positions, first as head of the Illinois Trainine school, then of the Johns IIopkins School for Nurses, which she oreanized and directed until her marriage. She had been foremost in advaneing numsing education and in promoting nursing organization. Marriage did not lessen her devotion to her profrusion and she was, until her death, its chice spokesman in its varions causes and undertakings. Her co-officers in the organization at the time of the war were IIelena Barnard (.Johns Hopkins), Mrs. Hawley (Miss Horner from 
the Nightingale School in England), Tamar Healy (Brooklyn City Hospital) and Jean A. Iopkins (Bellevue).

Mrs. Robb brought the war situation beforn the convention and the following telegram was sent to Surgeon General Sternberg:

The Associaterl Alumnan of Trained Nurses of the United States and ('anada, including two thousand graduates of twenty-four training schook, offer their sorvices for any work which the Medieal Department of the Army may demand of them in connection with the war with spain. City,

By direction of the delegates now in session in New York (signed) IsABel Hampton Ronb, President.

By an error in transmission the word "nurses" was written "musie" and Mrs. Robb's name was misspelled. The reply received was the usual courteous form of declining with thanks. As a result of this misunderstanding the convention took no further action, for the time of its adjommment had come, and thereafter its members entered the war service as individuals, many through the War Department, and others through the Red Cross Auxiliary No. 3. Mrs. Robb, however, went to Washington and saw Dr. Sternberg and Dr. MeGee. They warmly weleomed the offer of coïperation, but a definite mutual agrecment was not finally arrived at, becanse of different points of view as to mothods. Mrs. Robb, with lee intimate knowledge of training selools and murses, would lave urged a somewhat exchusive standard of requirements, which i)r. MeGee, from her nore extensive acepraintance with the War Department's probable nexds and what it would do officially, eould not promise. The Govermment's plans were already formulated and well under way.

On May 10, 1sis, contracts were signed with the first group of six Army nurses. lerom this date, then, one may informally reckon the beginning of the present Army Nurse ('orps, while its purely ofticial date will be met with a little later. Two of

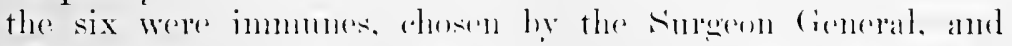
with whom I)r. Mrefier hate nothing to do. The other four were: Johnetta B. Sanerer and M. Agnes lease. loth of the . Johns Inpkins: Nioe l'. Lyon of the bronklyn Homorpathic: and Marearet E. Schatfer of the Philadelphia ILospital. ${ }^{15}$

2.5 Army Nurse Corps Index. Sulteon General's otliee. A. X. C. Div. 
They were selected by Dr. McGee for Key West but were not sent there immediately.

The relation of the nurses to the Government and Dr. MeGee, during the time of her work as Director of the D. A. R. Hospital Corps, is indicated below. The excerpt given also shows how the formal appointment of Dr. McGee to an army position on August 28, 1898, was made. This began the official existence of the Army Nurse Corps:

During the summer all applications from women, whether addressed to the President, the Secretaries of War and Navy, or the respective Surgeon Generals, were sent to us for examination and reply. We were, therefore, more closely associated with the Gorernment than any other rolunteer organization; but, on the other hand, the limits of our responsibility had always been sharply defined by the Surgeon General of the Army. We had no official relations or communications with the surgeons, and our official connection with a nurse ceased absolutely when she, having been accepted, signed the army contract. But when a large body of nurses had entered the service many questions arose, necessitating official action in the Surgeon General's office, such as the receipt of reports from surgeons and ordering of transfers between hospitals. As I was the person having the greatest knowledge of this work, and as it was impossible for a rolunteer to conduct it, the Surgeon General appointed me as arting assistant surgeon. He then believed that the contracting with fresh nurses was about at an end, and therefore, on September 7 the Daughters of the American Rerolution were relieved, with thanks, from further duty in connection with this office. Since that time I have been on duty in the War Department, my orders immediately on appointment having been to Yew York and Montauk. ${ }^{i 6}$

The nurses who signed contracts with the Government were classed as the "Nurse Corps (female)," with Acting Assistant Surgeon Anita Nowcomb IleGee as their superintendent. These titles were used officially by Dr. Sternberg in his reports of that time to the War Department, but in signing papers Dr. MeGee wrote herself "In charge, Amny Nurse Corps." The Corps was ralssifiod as consisting of dhief nurses, nurses and reserve nurses. After they entered the Irmy the title 3173.

${ }^{19}$ Dr. MrcGee's testimony, "Conduct of War with Spain," Vol. VII, p. 
"Nurse," formerly applied to the enlisted men on ward duty, was restricted to the women. The regulations governing their appointment and defining their duties, pay and privileges, were issued from the Surgeon General's office.

$\Lambda$ fter .June 20, 1898 , the printed regulations speeified "two years residence in hospital training school" for applicants to the Amy Nurse Corps, thus defining what had been the actual practice. In the late summer, with the ealls for the typhoid camps, the rules had to be sometimes relaxed and nurses were then accepted from small or speeial hospitals. There were also four large camps where, during the heaviest emergency, the ehief surgeons had been authorized to secure women nurses without regard to training. This method did not commend itself as one to be approved.

In round numbers the nurses in serviee were listed as follows:

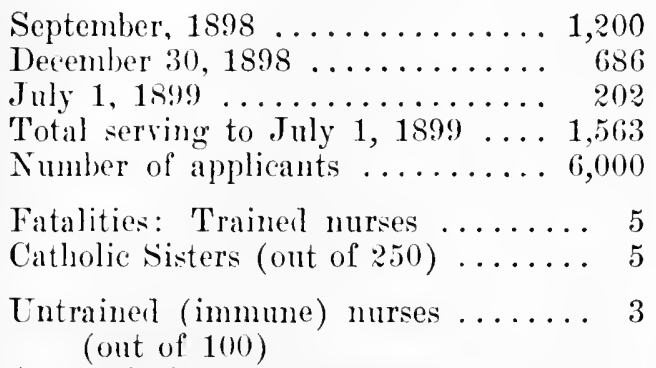

All deatlss but two were from typhoid.

After the war was over Dr. MrGee gave interesting testimony before the Congressional Committe, from which a brief section is taken:

Q. How many of those nurses proved to be thoroughly well-trained nurses?

A. We arepted only graduates of training solools who were endorsed by the superintendent of their schools. Therofore less than a dozen that we sent were afterwards fouml to be undesirible.

(2. Ilid they prose to be eflicient in the rarions lospitals:

A. Very. We have receibed rery satisfactory reportis fom all lospitals.

Q. So far as pou know. has the experienes in this war shown that fomale mores may be properly emploged in military hospitals: 
A. Yes, sir, decidedly so.

Q. How near to the front have female nurses been sent; in other words, how near to the moving column have there been female uurses in military hospitals?

A. Female nurses went to Santiago in the middle of July.

Q. As a result of the experience in the months just past, do you think it adrisable that female nurses should be employed in military hospitals?

A. Yes, sir, decidedly.

Q. Has such opinion been expressed to you by the authorities in the Medical Department?

A. It has been expressed to me by a large number of surgeons who have been in Washington.

Q. The nurses, then, numbering about one thousand, their actions being satisfactory to the medical authorities of the hospital and satisfactory to the organization that selected them, is there any reason, think you, for hesitating to employ female nurses in any military hospital other than that in the immediate vicinity of the firing line, where I suppose no female nurse can go?

A. I should judge their presence was extremely desirable, as they had a better training than the rast majority of the men arailable for the Hospital Corps. This is the chief reason. They were employed in foreign armies and are a permanent part of the British army, where their services have been very satisfactory. You spoke in a recent question of one thousand nurses. In giving this number I was speaking only of those accepted by the Danghters of the American Revolution.

Q. To what extent have the religions orders been called upon?

A. To the full extent of their offer.

Q. Will you tell us what that extent was?

A. The sisters of (harity furnished a few over two humbed of their sisters: the sisters of Ilercy of Baltimore. thirteen: the sisters of the Holy Cross, eleven; the sister: of st. Joseph, eleven: the Congregated American sisters. which onsists of Intian women from South I)akota, five: the sisters of st. Marnaret. which is a Protestant sisterhooul. two: the rit. Bammabis Cinith, which is also an Episongl orsanization. quite a number. We accepted the nurses regardless of their roligions helief if they filed their applicafions in the uslat way, and all those Sisters filled ont the applieation hianks furnished he the Danghter's. and cortified their qualifintions individually and all were under contract and receivel pay "sactly as the other nurses. 
Q. As to those less than three hundred furnished by the various orders, have the reports of them been satisfactory to you?

A. Some of the surgeons prefer them to the other nurses and some prefor the others.

Q. 'To what extent have female murses been employed in diet kitchens in the various hospitals, either as superintendents or occupied in the work of the diet kitchen?

A. They have been employed in a considerable number of hospitals in (harge of diet work. I have had several calls lately for women to supervise that work.

Q. Ilave the reports that you have received from the diet murses of those oceupied in the care of the diet kitchens been satisfactory to you?

A. Yes. ${ }^{17}$

\section{About the routine of assigning nurses Dr. McGee said:}

The original procedure was, when the Surgeon General received requests from surgeons for nurses, he sent over to me representing the Daughters of the American Rerolution, with my associates, for a certain number of nurses to go to a rertain place. I and my associates selected the number and sent the names and addresses to him. His clerks then made out the contracts and mailed them to each nurse with a transportation order. She then went to the hospital to which she was ordered. ${ }^{13}$

Dr. MreGee's testimony also makes clear in an interesting way the record of the nurses and throws light on complaints that were numerous at that time, of undesirable and unsuitable women who entered in irregular ways through individual heads of camps; but it is needless to enter into these mimutio.

Sirrgen General Stermberg should be more than a name to murses and our readers may be refered to his biograply for the details of his life. ${ }^{19}$ ilis recognition of women in their professional cataleity was very striking indeed, in comparison with the gencral militiry reluctance of that time to admit women into war nursing, and the moreso, as his own lone drmy training hat make him anservative and arerse to imovation. Ile had little knowledge of what women eould do and at first

17 "Conduet of the War with Spain." Vol. 7, pp. 316s-3180.

${ }^{28}$ Ibid., pe. $3173-3174$.

13.. A binglaphy of Cenrege Miller Sternbere," by Martha L. Sternberer. 


\section{6}

HISTORY OF AMERICAN RED CROSS NURSING

anticipated placing them only in base hospitals. He appeared an austere man, not easily approached nor readily persuaded. He was entirely free from political opportmism. "Pull" 'was odious to him and this was of the greatest importance to the nursing service. After the war, Dr. MeGee said of him:

The Surgeon General har of his own initiative and without suggestion from anyone asked from Congress and received an appropriation for the payment of contract nurses, either male or female. Had he not done this, the Nurse Corps could have had no existence, and so it should never be forgotten that however much the Surgeon General may have been assisted by others, the first and fundanental action towards the recognition of women murses in the army was taken by Surgeon General Sternberg.

The work that Dr. MeGee herself did was pioneer effort of an original and difficult kind and in its execution she eommands the appreciation and recognition of the nursing body for breaking the ice of military routine and opposition to women nurses in the Army and for the care and regard she had for good professional standards. She bore the brunt of heary initial responsibilities and difficulties, with the usual eriticism that pioneers meet, and so made it easier for those who followed her. Nlany nurses of the finest quality first cutered the war uursing through her office, women who becane distinguished and who still hold important places in the Army. Nary and Red Cross serrices. She was staunch and loyal to them, fair, kind and helpful in her personal relations with them and had their strong regard. ${ }^{20}$ One who knew her said of her:

Her friends were deroted to her; those who were hostile were equally strong in their feelings. Her ability as an organizer was consicterable: her ability to carry her point was remarkable; she keje in touch with her (hief nurses. writing often to them. She had great influence with prominent

${ }^{20}$ In the winter of 1898.99 . Dr. Meree and the mombers of the Army Turse Corps founded the Society of Spanish-American War Inrses. and Dr. Nefiee was for six rears its jrevilent and later it honorary presilent for life. The other officers in its first years were: vice presidents. Dr.

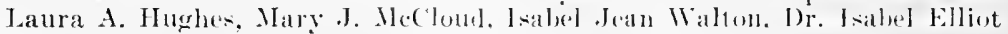
Cowman, Annie A. Robbins. Rose Meiselbath, Mary E. Dreyer, Anna Elizabeth Mclixoy, Ysabella B. Waters and klizabeth Porteons: recording secetary, leca il ilson: treasurer and corresponeling secretary, Harriet Camp Lomsthry. 
politicians and all the nurses believed that she had done much to help pass the Army and Navy bills after the war.

In the autumn of 1900 , when the Army reorganization bill, to be referred to later with more detail, was in preparation, J)r. MeGee at the renuest of the War Department wrote the seetion which made the Nurse Corps, as it lad been organized, a permanent part of the Army. This marked the end of the pioneer work and brought a climax of suecess, long hoped for, to the first chapter of the story of the Army Nurse Corps. Dr. MeGre then tendered her resignation, which took effeet December 31, 1900, and selected Dita H. Kinney, one of her ehief nurses, as her successor.

If, as has been said, the present Red Cross Nursing Service was foreshindowed by the Red Crose Hospital Committee on which Sister Bettina sat, it is even more certain that it had an advance demonstration of a prophetic character in the mursing work of Anxiliary No. :3, known also as the Red Cross Society for the Marintenane of Trained Nurses. On the auxiliary were women who had always been familiar with the hospital and nursing conditions of $\mathrm{A}^{\prime} \mathrm{w}$ York City, such as Mrs. James speyer, president of the anxiliary and of the Red Cross Hospital, Mrs. Bayard C'utting, Mrs. George II. Shrady, Mrs. William shetticld Cowles (Theodore Roosevelt's sister) and Mrs. Lamman Bull. Two women of exeeptional charaeter bore the dircet responsibility of the Committee on Nursing. One of them, Mrs. Whitalaw Rieid, by her charitable interests was already closely identified with the hospital and musing worlds: the other, Mrs. Winthrop (owdin, had not been in eontact with mursing matters up to that time. Mrs. Reid, who was also the anxiliary's secretary. Was the first dhairman of the Committer on Nursing. An old friend $" 1$ who worked intimately with her through those days has since written of her:

Elizabeth llills lieju is an exceptional woman, a possessor of larere wolth and of long yous of social and diptonatic experience rsperdilly during the time when her hushand. Mr. Whitelaw Rovil. was Anerican Minister to Franee and Ambasiarlor to Fugland. She is a woman gifted with the virtues of -implieity, of simpathy and of loyalty to her videals

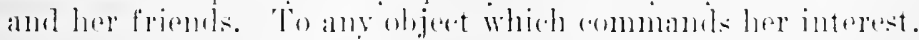
she has bronght pratiral husines ability and unlerstanding 21 Miss Mainel lomardman. 
combined with elear vision and whole-hearted devotion. She has given not only of her wealth but of herself to the great eauses for which she labored, prominent among which have been the American Red Cross, the hospitals she has built and aided and the public health nursing service she has done so much to support.

Another of the Spanish-American war workers ${ }^{22}$ of the Red Cross wrote of Mrs. Cowdin:

Lena Potter Cowdin, in succeeding to the ehairmanship of the Nursing Committee, brought to it excellent administrative ability and some executive experience in Civil Service Reform work. She had had neither previous special interest nor experience in nursing matters. She had, though, the broad human sympathy of her father, the Rt. Rev. Henry Codman Potter, and very unusual qualities of mind and spirit. Her good method, superb grasp of problems and power to inspire loyalty and enthusiasm in her staff made her a rare executive. Personally spirituelle and eager, she resembled, to her friends' eyes, a "flying Victory."

These women naturally came at once into close touch with the leading superintendents of New York City. Foremost among the latter was Amna C. Maxwell, at the Presbyterian Hospital, eminent by reason of her great gifts and abilities, her compelling personality, stately presence and uneompromising ideals of nursing. Anna Caroline Maxwell was by birth a New York State woman, whose Seotch clergrman father endowed her with the strong qualities so notably blended, in her charaeter, with a great charity of judgment. She became interested in nursing and with a "love of difficult tasks" took the course of training in the early days of the Boston City Hospital School. Following this she was for a time Matron in the New England Hospital for Women and Children; and later was called to the position of superintendent of murses of the training school, Montreal Gencral Iospital, an exreedingly difficult task at which she did not remain long. Later she was superintendent of murses in the Massachusetts General IIospital for seren vears. She was called from there to St. Luke's Hospital, New York City, where she reorganized the school of nursing and where she remained for three years. Then she was invited in 1891 to establish the School of Nursing of the ${ }^{2}$ Miss Laura D. Gill. 
Presbyterian Hospital, also of New York, where she spent thirty years,-an unusual record in this country,-and where she built up a school of fine traditions, of interuational fame, distinguished for the high eharacter of its training and ideals. She was always deeply interested in the Red Cross and from the first an untiring worker in its activities. It may be truly said of Miss Maxwell, that no appeal for help that it was possibly in her power to grive, was ever made to her in vain.

Another of the New York nursing leaders who took an important part in the war nursing under Red Cross auspices was Mrs. Lucy W. Quintard, at that time head of the school of St. Luke's Hospital. Mrs. Quintard had graduated from the Connectient training school in New Haven in 1890, with special honors (the "Red Seal" indicative of an excellent record). Immediately afterwards she was appointed superintendent of nurses there and remained at the head of her alma mater until November, 18:5, when she was ealled to New York. Mrs. Quintard had, during the war, one of the most diffieult posts, that at Camp Wikoff, Long Island, and fulfilled its duties with great tact and ability. After the war she was ealled to assist in the reorganization of the civil hospitals in Cuba. Later she devoted herself to the Visiting Nursing Association in Philadelphia, where she died. Mrs. Quintard was exeedingly aarnest, gentle, but firm in discipline and deeply religions. "To her, the war work was a cross.

At the New York Hospital was Irene H. Sutliffe, whose whole professional life was identified with its history. She was trained there, was made Directress of Nurses and only left it for the short period of war nursing, until the time cane when she finally retired from active service. During her many vears of anthority there and afterwards. when she went into residence at the 'Now York Nurses' Club, she had a special hold on the atferetions of her pupils. Of massuming manner, great kindness and simpathetic insight, her professional career was perenliarly one of persomal influence. Other Xew York superintendents, all women of ability and character and who shared in the responsibilities of that time, thongh less directly drawn into the war work than the three especially nentioned,

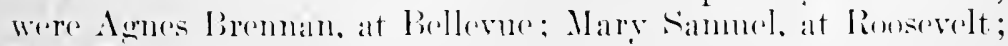
Miss Revert, at the Post-Graduate: Katherine Sanborn, at St. Vineent's: Mrs. l)an, at Mt. Sinali, and Mary S. (Gilunomr, at 


\section{HISTORY OF AMERICAN RED CROSS NURSING}

the New York City school. With these nursing leaders the women of Auxiliary No. 3 formed a strong alliance.

In the early part of the anxiliary's activities Dr. NeGee went to New York to talk over with its members the Government's plans, and was later elected an officer of the anxiliary. The anxiliary agreed to use the application form of the Danghters of the American Revolution (afterwards the Government's) and to adopt the Army requirement of training, while Dr. McGee promised to give official appointments to all the nurses recommended by the auxiliary. It was then arranged that all the New York superintendents might direet nurses to enter throngh the anxiliary for war work and thereafter the Washington office made no further investigation of the qualifications of nurses thus supplied.

The work of recruiting nurses for Anxiliary No. 3 was organized by Miss Maxwell. An informal committee composed of the New York superintendents established eorrespondence with training school heads of prominence elsewhere asking them to choose nurses who should hold themselves in readiness for service. Of women thus carefully selected, one hundred and fifty at a time were bronght to New York and suitably honsed, there to be in instant readiness if calls came. So uncertain and so imperative were these ealls that the reserve nurses were, praetically, almost prisoners in their rooms, for little more than an hour could be allowed between summons and departure. Katherine $N$. Pieree, head of the Samaritan Hospital in Troy, New York, gave her vacation to start this recruiting work and after that it was entrusted to Mary E. Wadley, a Bellevne unrse. Miss Wadley was a New England woman of great energy and resourcefulness. Fair and sumyfaced, she was attractive and most eapable. She was already snecessfully conducting a large registry for nurses at 6 East $42 n d$ Street and the war nursing service was brought in to hor headquarters. The srstem was quickly reduced to a smoothly rumning rontine. Telegrams from Washington would call for so many unrses to go at once to - While Laura D. Gill, the auxiliary aide, flew to the station to buy tickets and make reservations, Miss Wadley smmoned by telephone the waiting reserves. Immediately when they were oft, calls went to the hospital superintendents on her list to fill up the numbers that had been sent ont. This method worked exceedingly well. It was expensive to maintain the waiting nurses in New York, 
hut this was a part of the work of the auxiliary, whose resomres were mintinted. For speed the auxiliary bought all railroad tickets and these funds were reimbursed by the government.

The Woman's Auxiliary No. 3 had a visiting agent of speeial ability and tact in Mand Cromelien, a murse from the Massachusetts General Hospital. In the late summer when typhoid fever hecame epidemic in the eamps, reports made by Miss Cromelien, who had been sent to the camps to offer the services of the Red Cross, and the powerful influenees brought to bear, as a result of these reports, by Mrs. Cowdin and Mrs. Reid on public ofticials, finally won ont over the Army eonvietion that women should only serve in base hospitals, and Auxiliary No. 3 had the immense satisfaction of supplying trained murses from its staff for the first time on an organized system to field hospitals. Miss Cromelion considered that this marked an epoch in the history of nursing, as indeed it did. When this important work was undertaken a number of New York superintendents went themsclyes to the camps at the head of mursing staffs. Miss Maxwell, who had written many personal appeals to the Surgeon General to allow murses to enter the eamps, was sent to the Stemberg IIospital at Camp Thomas, Chickamanga Park. Miss Sutliffe went to Camp Black and Mrs. Quintard to Camp Wikoff at Montank Point. Their reports are full of interest but ean he only briefly quoted. Miss Maxwell's report, sent in to her Board of Hospital Managers, follows in part:

$$
\begin{array}{r}
\text { Sternberg U. S. Hospital, } \\
\text { October } 31,1898 .
\end{array}
$$

To the Boaril of Managers of

The Prestiterian Hospital,

New Jork ('ity.

Gentlemen:

On Angurt 1. Mrs. Whitelaw Reid and Mrs. Winthrop Cowdin, menbers of the American National Red cross, Auxiliary No. 3 for the Mantenance of Trabed Nurses, asked if the (ommittee of our 'Training Sichool would grant

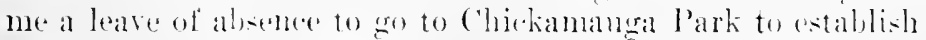
the work of nursine in a Field Ilespital at (amme Thomas.

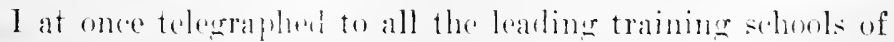

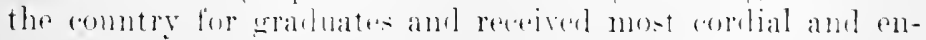

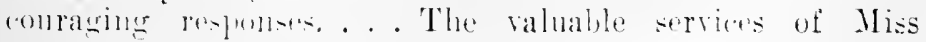


Frances A. Stone were secured as assistant superintendent and we left New York on August $\%$.

On August 12 we went to the Sternberg U. S. Field Hospital, to begin the work we had set out to do. This hospital .. . was designed to hold one thousand patients. The supplies were coming in slowly, but for the first patients, who numbered one hundred and thirty-six, the only things ready for use were the tents and beds. The supplies that were on hand had neither been unpacked nor verified and we were helpless to pay the sick soldiers the necessary attention. It was impossible to borrow any considerable number of utensils from the neighboring camps and late in the evening I went to the Quartermaster and told him I should stay there all night, or until the supplies were unpacked. Tired as we all were we put our "shoulders to the wheel" and before midnight we had given out sufficient material for the night and had drawn on our own resources for milk, ice, medicine, brandy, hypodermics, thermometers, sponges, basins, ete., provided by the Red Cross. I was informed that it was a military law that the soldier, sick or well, must be on the spot before rations can be drawn, hence the supply of food did not arrive until the following day.

As the tents were prepared and supplies provided, more patients were admitted; often two hundred in a day. In many instances they were brought long distances, driven through a broiling sun at midlay, and had to lie in the ambulance from two to three hours before they could be moved to their beds. When you consider that of ten as many as four men were crowerl into one ambulance, suffering with thirst and heat, scarcely able to move in the cramped and narrow space allotted to them it is no wonder that many suffered from shock, exhaustion and convulsions.

I am glad to say that we fouml some of the officers who demanded an ambinlance and camvas cot for each serionsly sick soldier, but the comdition of the majority showed plainly how meager had been the nourishment and rare they hail rexeived. It was certainly a most harrowing sirht to see the long narrow cots filled with what had been strons. splendid men, hollow-eyed, emaciated, muttering in the delirium of fever, sores in which deat flies were incrusted filled their months, making swallowing almost imposible. Their bones protruting through their skin and bed sores sereral inches drep were not uncommonly found on hipe. hack, follows and often on the head and wars and it was here that all the energics and resouress of the trained nurse were called forth 
in making the lives of these men less wretched and in restoring them to health.

'The conrse of our work was often impeded and marle difficult by such stumbling blocks as sanitation of the most primitive kind, insuficient disinfections, water supply and accommodations for washing utensils, irregularity in furnishing the details of soldiers so that our work could not be done in a consecutive way. Occasional lack of medicine, milk, ice and other supplies. The dearth of orderlies more than anything else handicapped the work. Those we had were chinged too often or were physically incapacitated for work. Add to this the heat, the dust, the moisture and the flies and you have the picture complete.

I cannot say enough in praise of the liberality and thoughtfulness of the auxiliary of the Red Cross Society in supplying us with eight (lormitories, a bathhouse, store rooms, kitehen, dining room, houscheeper, servants and not only the necessities but nuany of the luxuries of life.

The Govermment sent us one hundred and fifty-two nurses and a dietitian. In this number seventy-five training schools from all parts of the Union were represented. Several of our nursing statf were infected with typhoid fever and one, Miss Greenwood, died. 'The total number of patients received between Angust 15 and September 10, the date on which I left, was nine hundred and thirty-six. Four hundred and seventy were furloughed and sixty-eight died. ${ }^{23}$

'The good nursing' and the admirable diseipline of the staff under Miss Maxwell eompletely altered the Amuy officers' point of view and Dr. Hofl" said to her: "I woudered when yon came what we would do with you. Now I do not know what we would have done withont you."

Mrs. Lounsbery (before her marriage, Harret Camp), who followed Miss ilaxwell, has written commentaries on the mursing statf that may be of interest to Army murses todar. whe had graduated from the Brooklyn Homeopathic Hospital and had hedel for six var's the position of smperintendent of the training school. l)uring her stay both hospital and school developed ereatly. She was the earliest anthor of professional books among her New York rontemporandes and wote on "Nursing Ethics" and on "Malking (iond in Private Jutr." After

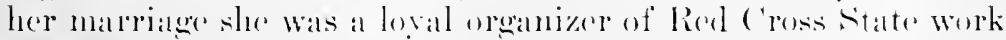
in llest Virginial, np to the time when this reard was written.

${ }^{33}$ In the files of Auxiliary No. 3. 
She had been married five years when she volunteered in the Spanish-American war. She wrote of Chickamauga:

It is very amusing to remember how ignorant we all were of Army ways when we first went into camp. I think I am right in saying we all were influenced by the purest patriotism in going. I know it seemed to me a wonderful thing that my country really needed me and I joyfully went, anxious only to help. I knew nothing of the best way of getting into Army work. As I happened to be in Washington, I went to Dr. IIcGee's office, signed the contract and was sent off. The contracts came for the nurses a few days after I had arrived in camp. Most of the nurses had come from the North and Northwest and had never heard of any contracts. They did not know why they should sign such elaborate papers. They had come to nurse the soldiers, they were doing their best and were very successful. At last they grasped the idea that the contract only meant that the Government wished them to be regularly recognized as a part of the Army and most of them signed.

The thought that upon their conduct and efficiency then and there would be based the action of Congress as to whether women should or should not be regularly employed as army nurses, be looked upon as part of the Army hospital equipment, was urged upon them again and again and most of them seemed to feel this responsibility and governed themselves accordingly.

It was curious and interesting to see representatives of so many training schools working together. There was always much pride manifested in one's alma mater and school badges were, of course, very much in evidence. Nothing would bring a nurse more quickly to a sense of her duty than to ask if in her training school she had never been instructed as regards this or that. The different uniforms were also interesting; most of them were blue, blue and white stripes, checks, plaid, plain luhe, but pink was not absent. There were with us nurses from ninety-one different schools and but two wore pink. The caps were as diverse as the uniforms. Every kind was to be seen, from a tiny square of lawn to quite an imposing erection of starched linen and quilled rumles. It sexmed to me that the dainty "Rerl cross" cap furnishen by Auxiliary No. 3 was the nost universally becoming. ${ }^{24}$

\footnotetext{
24."Reminiscences of Sternberg IIospital," American Journal of Nursing, Nosmber, 19(1).
} 
The text of the official report of Auxiliary No. 3, as filed after the war in the Red Cross records, shows very clearly the characteristic quality of Red Cross organization. It did not wait to be asked, but pushed forward looking for work and reiterated its offers until they were accepted. There is a very important difference here between the official etiquette of a military hierarehy and the informality of a civilian body. The former is essential for its purpose, but may be carried to extremes. The latter may be at times inconvenient, but there is in it a life-saring power that is precious. The report of the auxiliary is not long, but can only be quoted here in brief, omitting much interesting material, some of which has already been used, and touching only the few outstanding lines:

\section{REPORT OF AUXILIARY NO. 3, March 1, 1899}

Shortly after the organization of the Society, the president appointed a Committee on Nurses consisting of Mrs. Whitelaw Reid, chairman, and Mrs. W. Lamman Bull, to select nurses and arrange for their transportation and to make all final decisions as to the relations of the Society with the Govermment in respect to nurses. On July 21, Mrs. Winthrop Cowdin was added to this committee. With the abandonment of the plan for the hospital ship, the scope of the Society's work was much enlarged, as it was then decided to place trained women nurses in the Army hospitals. It was not possible to follow the Red Cross rule of volunteer service. Competent trained women nurses were unable in most cases to work without salary, many having others dependent upon them for support; but they all gave evidence of patriotism in being willing to serve for much less than they would ordimarily receive... When the first call came from santiago on Jume 30 , the committee was ready to respond.

'The first party of murses sent by the society went to 'Tampa a few days later maler the charge of Miss Laura I). (iill. It consisted of twelve trained nurses, one immune nurse and one assistant. A second and third detachment followed, consisting of fire physicians, forty-three nurses and six orderlies. ['This was the lampusws party already described, sent in answer to lor. Lescer's and lir. La Ciarde's request. Its wanderings have alroady been told.l

'The following letter from colonel charles li. Cireenleaf will show how edlicient were the services of these nures and how much aplereciated: 
Miss Rutty,

$$
\begin{array}{r}
\text { Headquarters of the Army. } \\
\text { Office of the Chief Surgeon, } \\
\text { Ponce, Puerto Rieo, } \\
\text { July 31, } 1898 .
\end{array}
$$

In charge Detachment of Nurses

from National Red Cross Association,

Dear Miss Rutty:

I desire to express to you, on behalf of the Medical Department in the field, my thanks to you and through you to the ladies under your charge, for the services you have reudered and are still rendering to the sick soldiers on board the Lampasas. No words of mine can express my appreciation of the self-sacrificing efforts you have each and all made and your unflinching devotion to duty. It is a source of deep regret to me that you should have been surrounded by so many discomforts and have had so little material to work with, but you are fully cognizant of the circumstances under which we have been placed sinee our sick were put aboard the Lampasas and it is unnecessary for me to say any more regarding it. Wishing you and the noble association of women you represent every success and hoping if my duties are continued that I may see you again at this post, I am,

Tery respectfully,

Your obedient servant,

(signed) Charles R. Greexleaf, Colonel,

Chief surgeon of the Army.

As no more nurses were able to go to Cuba on account of the outbreak of the yellow fever there, the forernment only arcepting immunes, the soefety folt that the next greatest want was for good nurses in our home camps and Army hospitals. The appeimance of typhoid and other fevers was so sudden and orerwhelming in the rliferent regimental and division hospitals, that the orderlies were unable to give adequate service. while in adlition many sick men were being brought home from (uha on the different transports. It was deemerl neesesary therefore to get into closer relations with the frovermment. in order that our nurses might be accepted in these hospitals. (O) July 15 a special ('ommittee, conconsisting of Mrs. Whitelaw Reirl, Mrs. Winthrop Cowdin and Mr. Joward Townsend, was sent to Washington to confer with the anthorities on this matter. P'resident Mr.Kinley considerately granted the rommittee an immediate interview and wry kindly arrangerl a conference at the White House, 
with the Secretary of War and the Surgeon General. At this conference, the committee was assured of the coöperation of the Government. (ieneral Sternberg agreed to meet the ladies again in New York the next day; at this meeting results were reached which were stated in a letter from General Sternberg to Mrs. Reid as follows:

"I take pleasure in confirming by letter the arrangements made at our interview in New York on the 17th instant. I am quite willing to employ female nurses rouched for by yourself as Secretary of the Red Cross Society for Maintenance of Trained Nurses. I had previously made very satisfactory arrangements for the emplorment of trained female nurses through a committee of the Daughters of the Revolution. As I said to you during our interview, I recognize the value of trained female nurses in general hospitals and we expect to make use of their service to such an extent as seems to be desirable. But I do not approve of sending female nurses with troops in the field, or to camps of instruction. It is the intention to transfer the seriously sick men from our field hospitals to the general hospitals as soon as practicable; and we wish our enlisted men of the Hospital Corps to take care of the sick in the Division Field Hospitals and in camps of instruction, so that they may be fully prepared to perform the same duties when the troops are in active operation.

Among these privates of the Hospital Corps who constitute the Red Cross organization of the regular military service and who are non-combatants in accordance with the terms of the Geneva Convention, we have many medical students and even graduates in medicine. I lave made an exception with reference to sending female nurses to Cuba, in view of the outbreak of yellow fever at Santiago, and I am now sending immune nurses, both male and female, for duty at the yellow fever hospitals. In accordance with our agreement, you are authorized to send ten female trined nurses, selected by yourself, to the Leiter IIospital at Camp Thomas, Georgia: ten to the Lnited States General Hlospital at Fort Monroe, Virginia, and two to the hospital at Fort Wadsworth. New York, the understanling being that those at Fort Ionroe and at Fort Wardsworth shall be boarded and lodged outside of the lospital.

Thanking you very sincerely for your arnest efforts in behalf of our sick and woumded soldiers. I am,

Yours very truly,

(igolige M. Atthisberg. 
A second letter enclosed the following request from Charleston:

To the Surgeon General, U. S. A.,

Washington, D. C.

I would recommend that twenty nurses be ordered to this station for duty in St. Francis Xavier's and city hospitals. Impossible for hospitals to obtain sufficient help.

\section{Clayton ParkHill,}

Major and Chief Surgeon, U. S. A.

First Division, First Corps.

In answer to this last order, twenty nurses went to Charleston, South Carolina, on July 24, under Miss Martha L. Draper who showed great ability in arranging for the nurses and seeing them started in their work in the different hospitals, which were very much overcrowded.

In addition to this, three men nurses, graduates of the Mills Training School ${ }^{25}$ at Bellerue, were sent to the Marine Hospital at Staten Island; and Miss Marjorie Henshall went with three women nurses to the Post Hospital at Fort Wadsworth. Additional nurses were sent to Fort Wadsworth as the need became greater, till their number finally increased to forty-one, and Miss Ienshall had two hospitals under her care. In recognition of her admirable work she was chosen as the head of the party of nurses afterward sent to Manila.

The rest of the nurses left at Tampa awaiting orders were now sent to the Leiter Hospital, near Chattanooga, and accomplished good work there, though the service was very exacting. Miss Maud Cromelien was sent to inspect their work anil reported that Major ('arter, the surgeon in charge. said that "the nurses were indispensahle to him." While there she visited (hirkamauga Park to examine the Division IIospitals at Camp George II. Thomas and reporter] as follows: "One glance was enough to convince me that trained nurses were greatly neederl to are for the sick, most of whom were suffering from typhoid ferer. The majority of patients were in a wretched condition and needed skilled nursing to give them even a chance to recover. I called upon Colonel.J. V. R. Itofl, Chief Surgeon in the Field, and stated to him that "the Red cross is ready to put nurses in at least

${ }^{25}$ The scloos for training men as nurses, then housed in a fine luilding grion to Bellevue by Mr. I). (1). Mills, Mrs. Reid's father, has since leeen discontinued. 
one division hospital; to erect the tents needed for nurses and to defray all expenses, such as provisions, etc, and to provide them with a competent matron; and all to be subject to whatever orders or discipline the surgeon in charge advises.' At first it was not consillered wise to expose women to the hardships of life in a field hospital. However, in the end the exigencies of the situation prevailed and C'olonel Iloff was kind enough to recommend my statement to General Sternberg, surgeon Ceneral of the Army."

The following letter from Major R. E. Griffin, Surgeon in Charge, to Mrs. Reil is a statement as to the work done by the Red Cross nurses at Chickamauga:

"Dear Marlans:

The Red Cross Society for the Maintenance of Trained Nurses can truly say 'Veni, vidi, vici,' for without them I would have been mable to have stayed the dread discase that has been raging in our eamp. Their helping hand came in the hour of need and the inistory of the future shall record each and every member of the Red Cross Society as the guardian angels of the Sternberg Hospital. My experience of years of hospital work has enabled me to jurlge of the abilities of nurses, and I am prond to say that this corps of murses under the excellent supervision of Miss Maxwell has never before been equalled.

As to the untiring efforts of Miss Cromelien and her success after knocking at the door of the department for days to be allowed to admit your society, words can never express the praise due her. IIiss Cromelien was here on the ground the tay I put my first tent at the hospital and immediately began building parilions for the nurses. . .."

Miss ('romelien said: "The work begm as an experiment has proved beyond doubt the ability of women to work as trained nurses in the field hospitals and the small anount of sickness among us certainly shows that we have the phrsical enturance needed for such work under such peculiarly trying (irremimstances."

T'on nurses wore at first sent to the General Mospital at

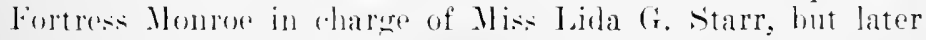
others followed and at one time the number naintained there by the soretety was as latre as forty-five. Miss stare remained at Fortres Monme until late in oanuary. when she was resalled to Xew York to take rharese of one of the parties of nurstes sent to Manila. 
In August when the Government bought the Missouri for a hospital ship, trained male nurses were offered to Major Arthur, the officer-in-charge. 'These men were chiefly selected from the Mills 'Training School and a few with the assistance of Dr. Fisher, of the Presbyterian Hospital. They fully deserved Major Arthur's commendation and on the second and third trips their number was increased to fifteen.

Much good was also done by our representative at Fort Hamilton. There the work was in charge of Miss M. E. Wood.

Soon after the first party of nurses had been sent to Fortress Monroe and Leiter Hospital, Dr. Anita Newcomb MeGee, director of the 1). A. R. Hospital Corps, visited New York to consult with the Committee on Nurses as to the best means of coöperating with the Government in regard to the distinction between Government nurses and nurses sent out by the Society for the Maintenance of Trained Nurses. It was agreed that the Society would coöperate with the Government in every way and to make everything absolutely clear, Mrs. Cowdin, for the Committee on Nurses, visited Washington. After her consultation with the members of the Hospital Corps, a fund of $\$ 500$ was placed in the hands of Mrs. Amos G. Draper, the treasurer, to pay for immediate transportation expenses for nurses, as Congress had not appropriated any sum for this purpose. In all $\$ 5,425.80$ were so disbursed by the Society, until the Government assumed all further transportation charges on September 6 . It was also agreed that the Society would allow the nurses to sign Govermment contracts when so required, the Society to pay their maintenance and transportation in some cases, in others only transportation.

A field nearer home was opened at Montauk. By the courtesy of the Managers of St. Luke's Hospital, Mrs. Quintard, their superintendent, was given leave of absence, so that she was able to take charge of this department. . . .

Miss Young representer the Society at the Detention Hospital at Camp Wikoff, with fifty women under her. . . .

In all, Mrs. Quintard and Miss Young had ten thousand pationts under their care.

The following is a summary of the nurses, partly or wholly maintained by the society:

Fort Walsworth: Forty-one nurses were maintained and paid by the society.

Charleston: 'Twenty murses.

Leiter Ilospital: 'T'en nurses. 
Governor's Island: Six nurses.

Tampa: Five nurses.

The ('onvalesint Home for Nurses, Rowayton, Connecticut: One nurse.

Atlantic llighlands: Five murses and one surgeon.

On hospital cars: Fonr nurses.

(amp) Black: Salaries and laumdry bills of forty-two nurses were pail by the society; the Ciovermment provided army tents and rations.

Fort Ilanilton: Salaries and laundry bills of twenty-three murses were paid by the soeicty; the Govermment provided army tents and rations.

Fortress Monroe: Salaries of forty-three nurses were paicl by the Govermment; the Society provided maintenance for these, and salaries and mantenance for two Rerl Cross nurses.

Hospital ship Missouri: Salaries of fiften men nurses wore partially paid lyy the society; these murses were maintained by the Government.

Bedloe's Island: (One murse was paid by the Society and rereived army rations: There was also one vounteer Red ('ross nurse who received army rations.

Portsmonth: Six men nurses were paid by the Society. They received army rations, but their transportation was assumed by the Society.

General Hospital, Montauk Point: Almost all of the one hundred and fifty nurses under Mrs. Quintard's superintendence signed the Government contract. Mrs. Quintard's salary continued to be paid by the society, and large supplies of all kinds for the nurses were selented by Auxiliary No. 3 and their expenses to Montauk paid.

Sternberer Hospital, Chickamauga : Sixty-four nurses sent by the society received Government pay and rations. Additional maintenane and supplies for these and for ninety-six other nurses ortered there by the Govermment, were fumished be the soriety.

Long lsland ('ity Relief station: 'Twenty-nine nurses and two sureans were paid by the society and maintained ly the Rirleel sitation.

In the tents, Montank station: One merse was paid hy the society and one voluntere murse was mantamed hy the Reliefle ('ommittore

One nurse was supported in Mliso ('hanler's hospital.

Nastall llospital and Innex, Hompetead: 'T'wenty nurses were paid by the society and maintained hy the Hospital. 
Home for Convaleseent Soldiers, Sag Harbor: Six nurses were paid by the Society and maintained by the citizens of Sag Harbor.

Convalescent Home for the 8th Regiment at Hunter's Island: Two nurses were paid by the Society and maintained by funds raised by Miss Chauneey.

U. S. Transport Lampasas: of the twenty-nine nurses on this transport, many were volunteers, and the salaries of some and maintenance of all were borne by the Society.

Nurses were also supplied on emergency calls to the Eighth and Ninth Regiment armories. ...

With the necessity of reinforcing our troops in the Philippines came a new opportunity which the society was glad to grasp. Knowing that General Otis had asked for nurses for Ianila and hearing that they were greatly needed there, the Executive Committee decided to apply the funds remaining in the treasury for this purpose and after a consultation between Mrs. Reid and Secretary Alger, the suggestion of sending nurses to the Philippines was favorably received by the Government. While awaiting the official orders from Wrashington, a Committee on Nurses was appointed by the President, consisting of Mrs. Whitelaw Reid, chairman; Mrs. William S. Cowles, Mrs. Charles B. Alexander, Mrs. Edmund L. Baylies and Mrs. James Speyer, ex-officio. A formal offer was made by the Society to send nurses to the Philippines, and on January 8 the following letter from Adjutant General Corbin was received by the chairman: . . .

"We have determinned to take three transports from here to Manila, abont eighteen humlred men on each. The Secretary of IVar approves your sending four nurses on each. The first ship will leave the 15th, the other two before February $1 . "$...

No time was lost in completing arrangements which had alrearly been carefully planned, so that though for the first party the notice was short. it was possible to semel the nurses properly equipped and provided for. The latter were most carcululy selected, many of them having alrealy done raluable work for the society during the past summer. They were peronally instructed in every ase by members of the committee, as to their duties. The transport was insperted hy the rhairman and her committee, letters of introrlution from prominent mon weresonerl for the nurses and everythiner possible was deme for their comfort and suceese on the experfition. All signed contracts with the society for six 
months' duty in Manila and on the transports to take care of the sick in the hospital.

Miss Henshall sailed on the Grant January 19, with Miss Dowling, Miss Torne and Miss Ridley. Miss Henshall was not only in charge of this division but was the superintendent of the entire party of twelve nurses. Miss Starr sailed on the sherman, February 2 , in charge of the second detachment, taking with her Miss Betts, Miss Sara Shaw and Miss Agnes Shaw. The last transport, the Sheridan, left February 19 with Miss Cladwin in charge of the party of nurses, who were Miss Stirk, Miss Mount and Miss Holmes. ${ }^{26}$

The report of the eommittee, with the financial statement for which MIrs. Speyer justly deserved espeeial eredit, was cordially commended by President MeKinley in letters to Mrs. Speyer in April, 1899.

Among the names mentioned in the Report are those of several volunteer aides of special ability and uscfulness, and two, whose work began with the Lampasas expedition, not only accomplished excellent things in the general field of auxiliary service bnt eommanded the speeial regard of nurses for the strong influence they lent in support of the professional nursing staff.

One of the first women to register at the Red Cross Hospital

${ }^{26}$ Ameriean National Red Cross Relief Committee Reports, pp. 4I-59.

The contract signed by murses in the Philippines ran as follows:

TIIS CONTRACT, entered into this ...... day of ........ I899, at New York City, in the State of New York, hetween the Red Cross Society for Maintenance of Trained Nurses Auxiliary No. 3, and Miss $\ldots \ldots \ldots$ of $\ldots \ldots \ldots$ in the State of $\ldots \ldots \ldots$ wituesseth : That for the consideration hereinafter montioned, the said Miss ....... promises and agrees to perform the duties of Nurse on Lnited States Transports, or in the Plilippines. The minimum term of service shall be six months in the Philippines in addition to the time of transportation, mbess otherwise determined by the Military Commandor, or by the Red Cross Suciety for llaintenance of Trimed Nurses Auxiliary No. 3, as represented by the Superintendent of Nurses. The said Rod Cross Society for Maintemanee of Trained Nurses Auxiliary No. 3 promises and agrees to pay, or cause to be paid to the sad Miss .......... the sum of stio per month, and to furnish Maintenance, Laundry, Medical Attendance during her term of service, and the assurance of means for a suitable return home.

A.N1) IT IS IERTIEROLE AGREEI) that the said Miss . . . . . . . shall receive transportation whils on duty. and on departure from and return to her place of legal resiclence. from the Government. She shall agree to rocugnize the anthority of the superintendent of Nurses appointed by the Auxiliary.

signed. sealed and delivered in the presence of $\ldots \ldots \ldots \ldots \ldots \ldots \ldots \ldots \ldots$ 


\section{HISTORY OF AMERICAN RED CROSS NURSING}

for executive service was Laura Drake Gill, a daughter of the New England Pilgrims and Puritans. She was a college woman of broad training and was placed in general charge of the Lampasas party by Mr. Wardwell. Later, she was sent to Chickamauga to place the nurses in the Leiter Hospital and at all other times, had charge of all the transportation of nurses to and from New York, meeting and dispatehing them by day or night.

Another prominent aide was Margaret Livingston Chanler, of Knickerbocker circles, who after the war, married Richard Aldrich. Both of these aides gave strong support to the post-war campaign of placing nurses permanently in army hospitals.

Our space allows no full detail of the many nurses who deserve mention for their part in the Spanish-American War episode, but a few names must be taken from the Army Nurse Corps Index. Some of these became distinguished in other ways later on. Not a few reappeared in subsequent Army and Navy nursing and Red Cross orgnization. Two members of the Lampasas party, Beatrice Von Homrigh and Mary E. Gladwin, will be met more than once in later pages.

Esther V. Hasson, who served in 1898 on the Relief, became Superintendent of the Nary Nurse Corps (1908) and Dita Kinney, as already told, of the Army Nurse Corps.

There were women of eminent distinction in training school work then and later,-among them Nancy Cadmus, whose administrative eareer in hospitals was unbroken for years, except for the war service; Frances A. Stone, associated with Miss Maxwell at the Presbyterian Hospital and Mrs. Lounsbery, with others already mentioned.

Especially distinctive was the work of the group of women who, after the war, carried out the organization of inodern training schools in the reivil hospitals of Cuba and Porto Rico, Lney Quintard, Sarah S. IIenry, M. Eugénie Hibbard, Mary $A$. O'Donnell, Amy E. Pope and others. ${ }^{27}$ Mary .J. McCloud organized a school in the military hospital at Mexico City. Elizabreth stack tanght the hospital eorps men mursing and dieteties at Angel Island. On the Army Nurse Corps Index, too, one finds Yssabella G. Waters, whose later compilation of public health nursing agenejes in the Inited States, kept rearly up to rate, has become a classic of its kind; Lydia JIolman, one of ${ }_{27}$ "History of Nursing," Vol. III, Chap. VI. 
the earliest pioneers in rural nursing; Jane Hodson, author of the well-known book previously mentioned; Isabel sean Walton, a New York Hospital nurse since then identified with St. John's Floating Hospital and other public health nursing work.

Some of those no longer living must be named. Clara L. Maas was a young Amy nurse who during the investigation of yellow ferer transmission in 1900-1901, in Cuba, insisted on being allowed to volunter for the experimental service. She was aceordingly bitten by an infected mosquito and died as a result of the too-perfect demonstration. She was buried with military honors and is mentioned with respect in several official records. Louisa I'arsons, English born, and a Spanish-American war nurse, died in the British Army service in 1915. Emma Duensing, German born, died in the same year in the service of Germany. Rose Kaplan, who had beeome head of a hospital in Jerusilem, died while earing for refugees in 1917. A little group of Spanish-Ameriean war nurses lived to serve throughout the World War. They were: Samantha C. Plummer, Edith Rutley, Helen M. Piekel, M. Estelle Hine and Carrie L. Howard.

After the war there were many testimonials to the usefulness of the Army nurse. It may suffice to repeat here the eonelusion reached by the Congressional committee appointed to inquire into the conduet of the war. In its report, among other recommendations was this one: “. . . Needed by the Medical Department in the future; a Reserve Corps of seleeted trained women nurses." 28

Its estimate of the nurses ran as follows:

In the last twenty years the rahe, the efliciency and the arailability of well-trained women nurses has been demonstraten and it is much to be regretted that this fact was not fully realized by the medinal otiders of the army when the war commeneofi. It is to be remembered, thomigh, that in military hospitals in the field women had been empleyed as nurses, if at all, only ter a sery limited extent, and there was good reason for questioning whether a tield hospital with a moving army wals any placor for a woman. Our recent experiene may justly he helel to lave shown that female nurses, properly trained and properly selected. wan be duly ared for and ale of the greater value. Those who have been serving under contract in enr military hospitals, and there have been

* "Conduct of War with spain," Vol. I, J. lsi. 
about fifteen hundred of these, have with scarcely an exception done excellent work and it is to the high credit of the American soldier that not a single complaint has been made by any nurse of personal discourtesy. ${ }^{29}$

26 "Conduct of War with Spain," Vol, I, p. 171. 


\section{CHAPTER III}

AFFiliATION OF TIL LMERICAN LEU CROSS WITI THE NURSES' ASSOCIATION

The Army Nurse Corps-Reorganization of the Red Cross in 1905-The American Federation of Associated Alumne Accepts Affiliation with the American Red C'ross-Development of the Nursing Service-Participation in Disaster lielief

THE war was not yet orer when the idea of seenring the existence of the Army Nurse Corps by legislation was 1 agitated by various war workers. In December, 1598, Dr. MeGee went to New York to suggest to Mrs. Quintard and other murses with whom she had been in close touch, the wisdom of attempting such legislation. While she, as a subordinate of the War Iepartment, could not initiate it, she would, she promised, do everything in her power to obtain Congressional approval of an art that should not be too great a departure from the methods and ideas of the Army.

At almost the same time Mrs. Robb went to New York to lay a similar proposal before nurses and Auxiliary members, all of whom received the suggestion with enthusiasm.

In view of the Army Nurse legislation of 1920 , a full aceomt of that first campaign would be interesting, but we must limit ourselves to a brief summary of its main features.

A committee of women, many of them of national distinetion, with prominent nurses, promoted the bill. Mrs. Winthrop Cowdin was its first chaiman and among these who, in the course of its duration, served on the "Committee to Seenre by let of Congress the Emplorment of Women Nurses in the Hospital Serviee of the Enited States Army," were Lonisa lee Schure ler, veteran of the Sanitary (ommission of the Civil War: Mrs. Willian Osborn and Mrs. Joseph Hohson, two of the oreanizers of the Bellevue School for Nurses: Mrs. Ames (i. 1)raper, prominent in the laughters of the Ameriean Revolution; Mrs. 
Whitelaw Reid, unfailingly helpful in nursing matters and lavish of her influenee and means; Margaret Livingston Chanler and Laura Drake Gill, who had been two of the most hardworking of the volunteer aides; Mrs. W. N. Armstrong, of Hampton, Virginia; Mrs. Bayard Cutting; Mrs. C. K. Meredith, Mrs. Harriet Blaine Beale, Mrs. John S. T. Hull, Mrs. Hawley (the English nurse, mentioned earlier as Miss Horner and afterwards married to Senator Hawley of Connecticut), with Anna C. Maxwell, Irene H. Sutliffe, Isabel Hampton Robb, Ellen M. Wood, Linda Richards, M. Adelaide Nutting, Mary F. Wadley, Georgia M. Nevins and Luey W. Quintard. Miss Nutting was the ehairman of the eommittee of nurses and direeted the work of informing the rank and file of the points at issue. She was then superintendent and principal of the Johns IIopkins training school where she had entered as one of Miss Hanpton's first elass and in which she had risen to the position of head of the school on Miss Hampton's marriage. Born in Canada, Miss Nutting's brilliant mind and untiring energy turned witl special attention to edueational nursing problems and she will be met in the forefront of such eireles of activity, as we go through these pages. Her work at the Johns Hopkins was so original and effective that she was ealled thence to direet the Department of Nursing and Health at Teachers College, where she surrounded herself with ardent young enthusiasts and made an international reputation for her department. In the work for the Army Nurse Bill her exeeutive ability was for the first time shown outside of the hospital, for there was then no mursing jonrnal, no elose network of eentral and local associations to facilitate communication. She said, later:

One of the things that makes that correspondence stand ont in my memory is the fact that for the first time in training school work I had some help from a stenographer. The New York women insisted npon my nsing such assistance, which I rather timorously diid to a small degree.

This was the first time nurses had approached Congress. Miss Nutting wrote:

One incident which stands ont rather clearly was a hearing by the Military (ommitter of the House or Senate. I forget which, where I hal to smmmon by telegram Mr's. Isabel Robb, Miss McIsaac, Miss Maxwell and various others, inchuling, I 
think, Dr. Billings, who gave us constant help and adrice. At the beginning of the hearing in Washington, in walked Mrs. Joseph Hobson, who had heard of it and wanted to give her point of view on the importance of good nursing. 1 remember what an ordeal it was, because as chairman 1 had to introduce each member ant explain who he or she was and why his views and opinions would be entitled to respect and when it came to Dr. Welch, who was there and spoke splendidly for us, I felt paralyzed.

Powerful yet intangible opposition to the bill was met with. It seemed to be especially direeted against the professional requirements asked for and the stipulation that the head of the Army Nurse Corps should be a nurse. The committee and the entire nursing profession back of them regarded these requirements and the elaim for a nurse superintendent as fundamental. In the process of overeoming the opposition, Margaret Chanler volunteered no less a service than to make a trip to the Philippines, to investigate persistent unfriendly rumors that appar-ently came from Luzon and were brought to members of Congress in depreciation of the morale of women nurses in the Army.

There had indeed been some unfortunate selections made in the early part of Philippine war nursing, when western Red Cross societies had unwittingly recommended several women of unsuitable trpe, who had been sent home in disgrace. But when Miss Chanler visited Manila (summer of 1899) there was only the earefully chosen staff of seventy-five nurses sent out by the Auxiliary No. 3, working under Colonel Greenleaf, who was their staunch friend. It was clear that the hostility of the opposition did not then emanate from Manila, and mysterionsly enough, with Miss Chanler's visit it was effectnally siloneed.

The bill sponsored ly the committee was bromght np in Congress on January 24, 1899, but failed to pass. Resolute in their determination, the committee rontinued their work through 1900. 'They had at first asked for a "Nursing Service Commission" and edurational repuirements alike for the entire staff, i.c. "Creneral hospital training of not less than two vears." There vears' training was then established in reptain large schools and was being rapidly extended. Many nurses, tom, were taking posteraduate comrses.

The contest ended in a rasomably satisfactory compromise, 
for the committee finally agreed to aceept a section in the $\Lambda \mathrm{rmy}$ Reorganization Bill of 1900-1901. This was the seetion previously referred to, drafted by Dr. MeGee, at the request of the Surgeon General, on what seemed to the War Department aceeptable lines. The committee obtained the insertion of an amendment to it specifying in part, for the superintendent, the edueational qualifications they had wished to secure throughout the staff. 'Thus amended, Seetion 19, as it was numbered, read (omitting nuessential details):

That the Nurse Corps (female) shall consist of one superintendent, who shall be a graduate of a hospital training school having a course of instruction of not less than two years, and of as many chief nurses, nurses and reserve nurses as may be needed, provided that they shall be graduates of hospital training schools and shall have passed a satisfactory professional, moral, mental and physical examination. $^{1}$

The bill was signed by the President on February 2, 1901, and the nurse seleeted by Dr. MeGee to be her successor was duly appointed.

Mirs. Dita H. Kinney, the new head of the Army Nurse Corps, had had active service during the war, chiefly in the West and Southwest. She was a New York State woman, trained at the Massachusetts Gencral Hospital (class of 1892.) Her experience before the war had been varied and responsible and she had carried on some pioneer work in teaching the elements of mursing to mothers of families on social settlement lines. Mrs. Kimey had earlier shown her eourage by making the first attack in print on bogus schools for unrses.

${ }^{1}$ Army Reorganization Act of 190I-February 2, 1901, Sec. 19, Vol. 31, U. S. Statutes at Large. 1). 748 .

The "Special Committer in Charge of the Bill" during the stith Congress were: Miss Margaret livingston Clanler. Mrs. Harriet Blaine Beale, Mrs. Joseph Holson, Mrs. William Sheffield Cowles. Mrs. Joseph R. IIawley, Mrs. Amos G. Draper, Mls. Joln S. T. Hull. Miss Georgia Nevins.

The Navy Nurse Corps soon followerl. It was organized definitely in 1901; the first effort to pass a lill in Congress was made in 1903: final passage of the Bill came in lons. Nary Appropriation Act of May l:,

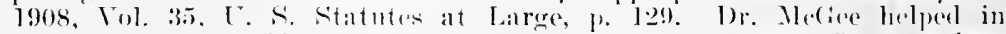

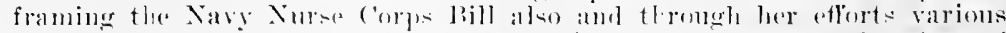

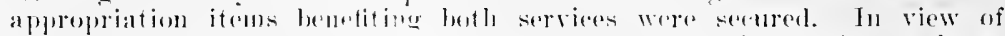
the later bestowal of "Rank" on Army morses, it is interesting to know

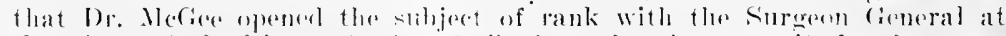
the time of drafting ".seretima 19?" diut the Amy attitude then was immovably opposed fo any surely imnovation. 
The first few years after the war were full of reorganization plans, both in the Annerian Red Cross and in nursing socictices. The lessons of the war were not forgotten and women in New York and rlsewhere, who had been at the head of relief and nursing work, held to the lied Cross, hoping to continue the efficient system they lad done so much to develop. In that period also, the two nursing societies, the Superintendents' Society and the Associated Alumna, had joined in a free aftiliation for international purposes, under the name the Ameriean Federation of Nurses, each one retaining its corporate identity.

At a meeting of the Superintendents' Soeiety (October, 1903), a resolution had been adopted giving its comncillors power to act for the society in any publie fuestion that might arise during the year. This action had been specifically taken with a view to future union with the Red Cross, for which they cherished a desire. The Associated Ahmme were exually alive to this possibility, one of the great questions of that day, and a concerted effort to open up a way of aftiliation with the Red Cross was made in the winter of $190+$ by executive ofticers of the two societies. The American Journal of Nursing said in April, 1904:

On February 23, a number of well-known women in the nursing profession ame together in New York and quite informally a group of Xew York women met with them in the evening to discussion questions of importance to murses.

The out-of-town members present were Mary M. Ridlle, president of the Associated Almmme: M. Arelaide Nutting, president of the American Federation of Nurses; Isaliel Mrelsaac, president of the Amerion Jourmal of Nursing ('ompany : Sophia F. Palmer, estitor of the dmerican. Jourmal of iurving. and the five Chicago members of the class in llospital Eomomics at Teathers college.

() the well-known tew York women there were present Mis: Maxwell, Miss Melano, Miss Milson of St. Luke's;

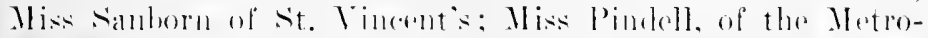
politan: Mrs. Mcin. of Mt. Sinai: Mise Gilmour. of the Vew Sork city school: Mise llaly li. Thornton, sencetary of the Ascortateil Alummar and others.

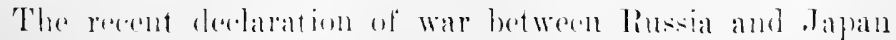

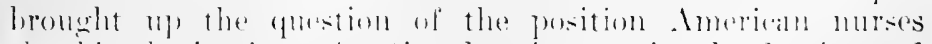

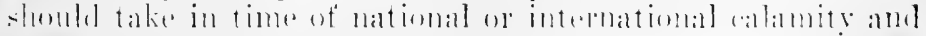
it wats arrent that -ome artion shoukl be taken that would 
place American nurses always in an attitude of readiness when their services were nceder, either at home or abroad.

In a diseussion the following points were brought out:

1. American nurses, to be at all times in a position to render aid to suffering humanity, regardless of nationality or ereed, should be affiliated in some way with the American National Red Cross.

2. Such affiliation should be consummated through some one of the existing nursing organizations.

An informal committee was appointed to ascertain whether the American National Red Cross had so far contemplated its reorganization that it could consider a proposition for such attiliation if made through the proper official channel.

The editorial added:

The Soriety [Red Cross] is now in a condition of reorganization and this reconstruction period would seem to be a very proper time for American nurses to endeavor to obtain some form of aftiliation which would identify them with the Red Cross.

At this point Miss Delano reappears in our history for the first time since the yellow fever episode. She had not entered the war service, but had remained at her institutional work. In 1902-1904 she was at the head of the Bellevue sehool. There she was in elose association with Mrs. Whitelaw Reidwhose family had long been identified with large gifts to Bellevue and who was one of the Board of Managers--with Mrs. W. K. Draper and others who had been members of the Red Cross Auxiliary No. 3. Whilst the war activities were going on Miss Delano hat joined the New York State Red Cross Branch and had become deeply interested in bringing a large enrollment of nurses into it. So keen was this interest, even when the war was orer and reconstruction not ret begun, that one of her assistants in the school, Mary 1 . Clarke, wrote later:

During that perion we often discussed the work of the American lixt C'ross nurses, and even then it seened to me that of all the nurses in the Tniter States Miss Delano was the one woman caplable of taking hold of the nursing service and promoting it for areater development.

From that time en Miss [nelams devotion to the Red Cross gradnally berame paramemut with here. 
The next advance toward affiliation was taken by the national association in 1904. At the Associated Alumma convention of that year the president, Mary M. Riddle, a Pennsylvania woman, trained at the Boston City Hospital, who had held excentive positions there and in other Massachusetts hospitals and who had been for years a stroug figure in nursing affairs and in Red Cross organization in that state, said, in part:

We have in this country an organization known as the National Red Cross, with whose name at least we are familiar, but whose plans for work we do not always comprehend. Our idea would be to ally ourselves with this national body for practical purposes.

So strong was the conviction that nurses should be awake to their opportunities and responsibilities in this direction that an informal committee visited last winter in Washington members of the Red Cross Association in higl official position and placed the matter before them. The suggestions of the committee were welcome and it was adrised to make preparations for the work, with the promise that an opportunity would be given the murses for rendering their service whenever the demind for such service should arise.

The appeal is made to you to consider the advisability of getting into form for such work. It is made to you because you are the rank and file of the nursing profession in this country and without you nothing can be done, upon you must the dependence for service be placed.

Disenssion followed and then action:

The President: I would like to ask if it is your pleasure to refier any question of alliance with the Red ('ross Society to the Exerutive ('ommittere and Board of 1)irectors?

The seeretary: I would like to move that sines Miss Riddle has alrealy conferred with ladies on the Board of loirectors of the Red cross fordety, she be empenwered to associate with her two, three or four people whom she knows to be interested in the matter and proced in such manner as the committee thus formed may decide.

secouded and rarried.

The committer formen amprised llise Riddle, rhairman. Miss Jaxwell and Miss Jamor."

The Superintendents' Society them appointed a similar committee with Miss Nutting as chairman. to meet ame anter with

"I'roceedings Annual Convention of the Associated Alumnax, 1!nt. 
Miss Riddle and her associates and together they approached representative women of the Red Cross in New York and Washington with their suggestions. While these steps were being taken the reorganization of the Red Cross by Act of Congress had been completed.

The American Journal of Nursing said (March, 1905):

The plan of the reorganization of the National Red Cross Society is of special interest to nurses in view of the fact that a committee was appointed at the last meeting of the Associated Alumnæ to arrange, if possible, for some form of affiliation with the Red Cross, so that the great nursing body of the country might have a recognized place in the Red Cross work. At the first annual meeting, held under the new charter, William H. Taft, Secretary of War, was elected president. The Executive Committee inclurles Surgeon General Wyman and Miss Mabel T. Boardman.

It is planned to have a committee of twelve in each State to work for the upbuilding of the Red Cross and make it more national in character and it would seem a very natural conclusion to reach that nurses, who will be depended upon to do the hard, practical work in caring for the sick and wounded in time of national calamity, should ... have representation on these committees.

In Miss Boardman the nurses were to come into elose working relations with a strong and judicions friend, a woman whose abundant common sense and keen pereeption were of the greatest support and value in building up a Red Cross Nursing Service.

Mabel Thorp Boardman was born in Cleveland, Ohio. Her family later moved to Washington and made it a permanent liome. In 1,000 when the American Red Cross was incorporated by Act of Congress, several persons who had worked in the Red Cross during the Spanish-American War asked Frederick H. Gillett, who was in charge of the bill, to insert Miss Boardman's name as one of the incorporators. She was active in the reorcanization in 196.:. In those carly days there was but one paid cmployee,-the serepetary, and Miss Boardman freely deroted leer time and resoneres to the work at home and abroad. She traveled orer this wouter organizing Red Cross Chapters and went throngh Enrope and to . apan studring lied Cross organization. In 1907 she was a delegate to the Eighth International 
Conference in London and in 1912 to the Ninth held in Washington.

At a very early moment $\mathrm{M}$ iss Boardman realized that a nursing service should be one of the most important departments of the lied Cross. She made it a point to become acpuainted with heads of training schools and assure them of her eonviction that nurses themselves must take eharge of the nursing department as they best understood mursing problems, duties and qualifications. With this olject she made a visit to the Johns Hopkins Hospital and met Miss Nutting and Dr. Hurd. In April, 1906, she spoke before the American Society of Superintendents of 'Training Schools on "The Red Cross 'Nurse" and in October, 1907, wrote in the Red Cross Bulletin:

There is no doult that this important department of the Red Cross work will greatly dcrelop as the nurses themselves take the matter in hand and assist in tinis development.

After its reincorporation by Congress, the American Red Cross issued the following circular. It was reprinted in the American. Journal of Tursing in July, 1905. In this circular the Red Cross Central Committee outlined its own plan of organization and ideas as to the recruiting of nurses as follows:

Am axp Propose of Mmbiche National Red Cross

The International Conference which met at Genera, Switzerland, August ?:. 1sist, agreed upon a treaty for the purpose of mitigating the evils inseparable from war. This treaty has becu ratified ly forty-four nations, including the Inited states. The conference recommended "that there shall exist in every country a rommittee whose mission shall (onsist in coipperating in times of war with the hospital service of the armies by all means in its power." It also recommended the atoption and use of a distinctive flag and arm ballue....

The (harter granted hy Congress in Jamary. 1905, to the American Xational lied ('ross declared the purpose of the corperation to bee: "'lo furnish voluntere aid to the sick and wombled of armies in time of war, in alcomelane with the spirit and comblitions of the comeva comvention. ..."

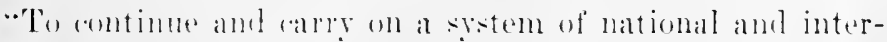
national reelief in time of peace and aply the same in

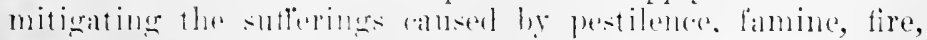

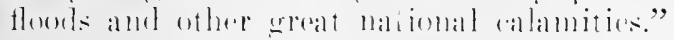


Congress considered the importance of the work so great that the charter granted in 1905 provided for Governmental supervision.

The charter conferred on the Board of Incorporators and the Central Committee the power necessary to carry into effect the above provisions.

In pursuance of this authority the Central Committee proposes to organize in every State and Territory of the United States, branch societies, to enable every person who desires to do so to become a member of the society and to awaken in this country the same interest in the objects of the organization that is so markedly manifested in every other nation having a National Red Cross Society.

The necessity of being prepared for emergencies has been too often demonstrated to require argument. The object of the Central Committee is to have in each State and Territory a branch society that will be ready to act at once in time of war or disaster, and so strong in its personnel that it will command unicersal confidence.

Each branch will act as a unit in the organization and take charge in case of any great ealamity in its State. Its Exeeutive Committee or a special committee will enroll doctors and nurses for Red Cross service in time of war or great disaster in the State or its immediate vicinity. Reports as to the number of doctors and nurses enrolled by each branch will be made anmully through the Central Conmittee to the Army Nedical Department. . . .

The secretary of each branch will keep informed as to the number, names ant addresses of the doctors and nurses enrolled for artive service. This service may be given either without compensation or for the same salaries as those paid by the War Department,--namely, one hundred and fifty dollars for medical officers and for nurses, forty dollars a month for service in the [nited States and fifty dollars a month for service outside of the United States. The seeretary will alio keep informed as to where hospital and relief supplies an be obtained at shortest notice. ${ }^{3}$

At the time the cirrollar was issued, plans for organization by states were aldeady woll meter way. The District of Columbia had the first branch. New York perhaps made the best showing of the States, althongh ('alifornia was also strong. Miss Delano was Seceretary of Enrollnent for New York State and Miss Paluner, of Iiochester, editor of the American Journal of

${ }^{3}$ In the Rinl Croses Archives. 
Nursing, reached nurses at large; Miss Maxwell, eminent in the hospital field, and Miss Wald, head of the Nurses (now Henry Street) Settlement, who led in soeial movements and altruistic work growing out of the visiting nurse service, all bent their best energies to stimulate interest, membership and enrollments. Mrs. W. K. Draper received the applications for New York membership and Miss Delano sent out an urgent appeal for every murse in the State to join and enroll. Two other nurses, Beatrice Ton Homrigh Stevenson and Mary A. Gladwin, both of whom we met first on the Lampasas expedition, were especially untiring in their efforts to gain new members.

By beeming paring nembers at a moderate fee, nurses as well as others would have had a vote in the management of Red Cross State societies and it was then thought that in this way murses conld help to direct the details of nurse enrollment and their service in war or other ealamity. The mere enrollment for such service was a different thing; it alone would not confer a voice in management; membership must also be held. But nurses did not come forward for membership or enrollment. As states organized and fell in line, state nurses' eommittees were, therefore, formed to promote enrollments and select women of the neeessary qualifications from among those who applied. It beeame evident that nurses wonld follow none but their own leaders and so it was hoped that eommittees of unrses in the varions states conld bring the rank and file into the enrollment lists.

The Imerican Journal of Nursing lost no opportunity of giving publicity to Red Cross events and information to its readers.

In February, 1906, it explained editorially the reorganization of the lied cross and the features of the new eharter. It also stated the restrictions on the use of the brassard and the cmblem, which had been indiseriminately and improperly used, salying:

The arm piece or "brassard," consisting of a white band with a Red cress. may only be worn when on duty under the officers of the lied ('loss. So murse has the right to wear it on any other oreasion. nor has any other borly the right to

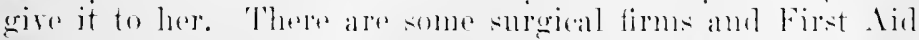
corperations which have in fermer yeals lexally serember the

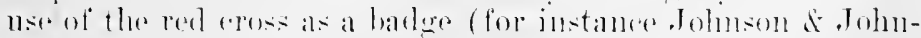
son) and from these it amnot be taken awas: but no one in 
future ean ever obtain this privilege. The laws of all countries rigidly protect the use of the Red Cross as an emblem reserved to the national societies and their workers on the battle field, or in the camp or hospital in time of disaster.

Miss Boardman, too, was untiring in her efforts to make plain the purposes and plans of the Red Cross. In her travels over the country she spoke before many gatherings of nurses. She dwelt upon the importance of the nurse's place in the reconstructed Red Cross, emphasized the high standards that would be required and told her hearers that it was agreed by the Government that, in ease of war, the Red Cross uurses would be the Army Reserve.

At these meeings she explained the two forms of agreement then existing, one for paid, the other for volunteer service. The latter did not signify amateur service, but presumed that fully trained women might sometimes be in a position to give their aid without compensation.

\section{Volunteer Nurse}

I hereby agree to hold myself in readiness and to enter the service of the American National Red Cross when and where my services may be required as a nurse, without compensation except transportation and subsistence.

\section{Paid Nurse}

I hereby agree to hold myself in readiness and to enter the service of the American National Red Cross when and where my services may be required as a nurse, with compensation at the rate of forty dollars per month when on duty in the Tnited States, and fifty dollars per month when without the limits of the United States, in addition to transportation and subsistence.

She also set forth the rules that had been agreed upon for the enrolhment of paid and mupaid nurses. As there was, then, no nursing rommitter at the Washington headquarters, these rules had been framed by her in consultation with the New York State and I)istrict of Columbia members.

1. All nurses enrolled for service under the Ameriean National lied ('ross slabll be required to show a certificate of recistration when concolled in states or territories where 
registration is required by law. Nurses enrolled in states or territories where recristration is not required by law shall show a certificate or diploma of gractuation from a recognized training school for nurses requiring a course of not less than two years.

2. No nurse under twenty-five years of age shall be enrolled for active service.

3. All applicants shall be required to give a physician's certificate of somnd health and unimpaired faculties, which certificate shall be renewed every two years.

4. The moral character, professional standing and suitability of applicants for enrollment as nurses shall be determined in such manner as the branch society may prescribe. ${ }^{4}$

At that time New York State had one of the first and best nurse registration acts and the Red Cross State Committee had laid down these additional stipulations:

1. All nurses enrolled in the State of New York for Red Cross service shall be required to show a certificate of registration with the Regents of the University of the State of New York.

2. All applications must have three signatures, vouching for their moral character, professional standing and suitability to this special work-two from nurses of good standing and the third from the president of the subdivision.

3. ...

4. All applicants must appear before a member of the Nurses' Committee for examination, and must present to the committee with their other papers, the endorsement of their applications by that nember of the committee.

$5 . .$.

The District of Columbia Branch was the first to arrange special lectures designed to attract nurses to the Red Cross work and also to enlarge their information. The Red Cross Bulletin, April, 1907, has the following record of this effort:

The District of Columbia Branch is preparing to give to its enrolled nurses a special course of lectures with practical demonstration of field hospital work under the auspices of the Median Department of the Army. These lectures will be given at the Washington Barracks.

Article hy Miss Boardman, American Journal of Nursing, August, 1906 , Vol. VI, p. 810. 


\section{A syllabus of the lectures follows:}

I. General outline of the organization of the Army in time of war and of its medical and sanitary service. II. The regimental hospital. The ambulance section. The field hospital. The base hospital. Other hospitals and stations. III. Medical and sanitary service of camps and on the march. IV. Service in battle at the front. V. Service in battle at the rear.

One afternoon will be devoted to the practical demonstration of the field hospital. 'This will be done at the conclusion of the course as detailed above. An opportunity will then be given to examine the equipment and working plan of the organization.

One of the subjects brought forward and exciting warm discussion in the early formative period, before the final affiliation of the Red Cross with the nurses' association had taken place, was that of the desirability of giving elementary instruction in nursing to women of the lome under the Red Cross anspices. The District of Columbia Chapter had pioneered in holding classes of this kind and Beatrice Stevenson, attracted by their example, initiated similar work in Brooklyn (1908) in a set of talks on Hygiene, Sanitation and the Emergeney Care of the Injured.

This new departure elicited, at first, considerable opposition among nurses, who feared that the American Red Cross might perhaps follow the eximple of European societies in promoting a superficially trained volunteer nurse corps, which would in the event of war or other disaster, cause confusion and difficulty. A meeting of the New York County Nurses' Association was held in the Bellovere Nurses' Club, in April, 1908, where the allied questions of uurses' enrollment in the Red Cross and the evolution of teaching under its banner were warmly disenssed. It now seruns obvions that the very concern felt over such possible development, brought home to nurses a sense of their own duty to the Red Cross. The two questions were introduced together by Miss Pindell, who stated that the Alumme of the New York city Training School for Nurses had sent a communication to the Nurses' Committee of the New York State Red Cross branch, asking for recognition as an association desirons of affiliation with the Red Cross Nurse Corps. Miss Pindell read the answer received, also the rules of the committee in regard to the enrollunent of nurses. 'The syllabus of 
the course of lectures on Home Care which had been given in Washington under the anspices of the Red Cross, was also read and Miss Damer was asked to open the discussion. A Bellevue woman (1885) and a Canadian, she had long held responsible positions in nursing associations. She had been one of the ehief builders of the Associated Alummæ and State nurses' societies. She now said, with the strong eommon sense which was her leading characteristic, that she felt that the nursing profession had not been doing its duty by the Red Cross, for as the latter had shown its readiness to eonform to the murses' standards, the nurses shonld either have enrolled in force or stated why they were not willing to do so. If they took no action in the matter they must expect that the Red Cross would take other steps to provide nurses for its work.

Miss Gladwin and Mrs. Stevenson, who knew that the purposes and plans of the Red Cross were not directed toward the creation of a short term nursing corps, spoke in defense of the Home Nursing teaching and what they said has been amply justified by time and by the nltimate coöperation of nurses as a body in guiding the direction of classes for women of the home.

Mrs. Stevenson spoke of the new policy in the Red Cross, of guarding health, and mentioned the international resolution of London (1907) to the effect that Red Cross societies might take a share in the warfare against tubereulosis. ${ }^{5}$ She quoted Major Lynch's address at the ammual meeting (1907) of the New York State lied Cross Branch, in which he had said that, in order to get members and to keep up their interest in the Red Cross, opportumities should be seized to show individuals that they had a part to play in Red Cross work and that universal instruction of people in the laws governing sanitation would seem to be a peculiarly appropriate field of work for nurses. Miss Gladwin spoke to the same effect. ${ }^{6}$ An article written later by Mrs. Stevenson said in part:

It has been said that social efficiency depends upon a sense of social responsibility. . . It was this spirit of social responsibility which prompted the Red Cross to untertake a campaign of health education with reference to the pre-

- The American Red Cross opened its first Day Camps for Tuberculosis in June, loos. Miny others followed and brouglit nurses into contact with the Red Cross.

S'se 1 merican Journal of Nursing, May, 190\$, p. 603. 
vention of disease and accidents, and the highest degree of social efficiency of both societies, the Nurses' Associated Alumnæ and the Red Cross, can best be reached by the affiliation of the nurses with the Red Cross and the hearty cooperation of both in the furtherance of this public health work.

The registered nurses have been asked to coöperate with the Red Cross in this work by delivering these addresses. Two reasonable objections have been offered, one, that the majority of nurses know nothing about teaching and are not accustomed to speaking in public; the other, that as time means money to the majority of nurses, it will be impossible to do any effective work unless the Red Cross can have salaried teachers. It is probable that for some of this work the Red Cross will arrange a definite course of instruction with salaried teachers, but in a movement which it is hoped will become as wide-spread and far reaching as this, some of the pioneer work must be voluntary. ${ }^{7}$

After the first doubts of the nurses were allayed, it is ecrtain that to most of them the prospect of peace activities under the Red Cross was more attractive than war work. Those especially who were absorbed in teaching and training for lives of constructive usefulness became greatly interested in the class-work plans. For some years this interest ran parallel with "affiliation" and will be shown briefly in that way during the early stages of growth, while the details will be presented fully in the section on class work and teaching.

The calls made upon the reorganized Red Cross in its early years, by the calamities of the Japanese famine and the San Franeisco carthquake and fire, gave the nation striking lessons which it was not slow to learn, but the nursing reserve was then not well enough organized to make a reeord and individual nurses eame forward as volunteers in San Francisco in response to telegrams from headquarters. The American Journal of Nursing pressed home the lesson by saying:

We urge upon all nurses enrollment in the Red Cross Society, as working nembers if posible, as contributing members without fail. This is one of the obligations of citizenship or residence in this prosperous country. ... Will the nurses of this country learn a lesson from this greatest national calamity?

: See 1 merican Journal of Nursing, June, 1908, p. 701. 
Impressed by these events, the Red Cross and its nurse members redoubled their efforts to build up enrollment and membership, but weak spots presently appeared in the professional requirements of state units. The standard of the Regents' examination set by New York was not aceeptable to others. Pennsylyania, for instance, desired to make exceptions, as in the following elause:

Nurses who have graduated in less than a two years' course must have served at least three years at nursing after graduation and be recommended by two doctors as to efficiency as nurses.

To this ambiguous proposal Miss Boardman replied with great clearness and decision. All questions of this kind then came to her for final answers and it is fortunate for the Red Cress Nursing Service that her administration was so able and wise. She wrote (July, 1908):

The rule that all of the American Red Cross nurses must be graduates of recognized training schools with at least two years' training in the course is of first importanee and a rule that cannot be omitted. The Army makes this one of its regulations and we cannot be less particular, not only on this account but for many other reasons. At the time of the late war. the - state branch of the Red Cross sent out a number of nurses to the Philippines whose characters were of such a nature as to foree the United States to require their recall. . . . Iater when MIrs. Whitelaw Reid had charge of surh matters for the New York Red Cross the nurses were selectend for their character and ability and as a result most excellent women went. We can run no risk of repeating the . . experience by taking in as Red Cross nurses women whose character, training and ability have been guaranteed by no one. I would rather have no murses at all than run any such risk. . . Quality must come first, quantity second. ... Certain regulations must he observed; if they are not willing to ohserve them in Philatelphia we will get our nurses from elsewhere. Aceording to these rules any nurse who hat received one of those six weeks training courses and conld get two phrsicians to testify to her efficiency. after she had been prateticing for three years could become a Red Cross nurve. As a result we would promptly lose our best nurses and supply ourstres with a second rate and poor lot of women. Sot only is the two years of study and training 
necessary to make a good nurse, but the discipline that these schools provide is of great value. We pay far too little attention to this.

To the officers of the Pemsylvania Branch, all of whom were men, who wrote asking:

Who appoints the Committee on Nurses, and could the committee consist of the president and secretary of any State branch?

\section{Miss Boardman replied:}

A Committee on Enrollment might be appointed by the chairman of the Execntire Committee or the president of a Branch. ... There is no reason why the presichent and secretary of a Branch should not be nembers of the committee for the enrollment of nurses. It would scem advisable, however, to have as a third member of such committee the superintendent of some training school of unquestionable standing.

The above material selected from among other examples illustrates the firm, intelligent support given by Miss Boardman to the ideals of good nursing and shows her part in maintaining standards in the Red Cross Nursing Service. Such examples recur from time to time, but this one will suffice to make the point.

An excellent plan now devised for the Nursing Service of the Red Cross State Branclies was one whereby the superintendents of training schools might be sccured, if neessary, to take command in time of need, such as war. The American Journal of Nursing, December, 1906, said of this:

A meeting of the New York Committee for the enrollment of nurses for Red Cross service was held at the house of Mrs. William K. Draper, on October 19, 1905. It was decided to enroll two classes of nurses for Red C'ross service; the regular private nurses for field work and hospital nurses for administrative work, the conditions of salary, houlth rertificates, etc., being identical for the two. This will make it possible for many of the older women holding positions at the head of hospitals or training schools, to enroll for lied ('ross duty and will insure to the Red Cross the serviges of traned exerative heals if, in emereneies, temporary hospitals have to be entablisherl. Dy this provision also. there would be no age limit, as many of our most valuable workers, 
who would not feel physically able to give field service in emergencies, will enroll with the prospect of being able to serve the country as supervising nurses.

The New York Rid Cross committee deeided in 1907 to enroll dietitians for hospital service and Miss Corbett, dietitian of the Department of Charities in New York City, was placed on the murses' committee to draw up proper rules for such enrollments.

In 1907 the Executive Committee of the Ameriean National Red Cross issued resolutions explaining the protection of the Emblem by international treaty and requesting that all hospitals and commereial firms give up its hitherto widely exploited use. The latter resolution follows:

Be it Resolved: That the Executive Committee of the American National Red Cross request that all hospitals, health departments and like institutions kindly desist from the use of the Red Cross created for the special purpose mentioner above, and suggests that for it should be substituted some other insignia, such as a green St. Andrew's cross on a white ground, to be named "Hospital Cross" and used to designate all hospitals (save such as are under the Medical Department of the Army and Navy and the authorized rolunteer aid society of the Government), all health departments and like institutions, and further,

Be it Resolved: That the Executive Conmittee of the American Sational Red Cross likewise request that all individuals or business firms and corporations who employ the Geneva lied ('ross for business purposes, kindly desist f'rom such use, gradually withlrawing its employment and substituting some other distinguishing mark.

This request was generally heeded; thus Robert W. Hebberd, then Commissioner of Public Charities in New York City, substituted for the lied Cross on the sleeve of the white miiforms in the eity hospitals, the staff and serpent of Aesenkipius.

In that year (1907) oecorred the tirst instance of a Comity Nurses society joinime a lied ('ross State Branch as a body, in the atfiliation of the Siln Franciseo ('ounty Nurses Association with the C'alifornia sitate lied ('ross. Another and different early gromping was shown in the atfiliation of the I )istriat Xursing . Asocolation of Tror, Now York, with the Red cross.

In the antum of 1907, the Amerienn fournal of Susing

slinutes of Central Exentive committer. Vol. 1, p. 10: 
established a Red Cross Nursing Department, for the purpose of spreading knowledge more widely among nurses and stimulating their interest by giving reports from all sections of the country. It was at first edited by Miss DeWitt, editorial assistant in the Journal office. With this department a systematic and complete history of Red Cross nursing growth and activity appeared regularly month by month. In that year also, the International Red Cross had resolved to take a part in the crusade against tuberculosis and it was realized that this would need the services of many more nurses. But with all these efforts, it became clcar that nurses were not elosely enough approached and that they were hanging back. Between the Red Cross Central Committee at Washington, the State societies with the nursing committees and the individual nurse, there was too lengthy a line of communication. Perhaps leading nurses felt this even more definitely than did the Central Committee of the Red Cross. They were aware that the nursing service was too loosely knit together to hold well in a dire emergency. They then made the suggestion that instead of State nursing committees within Red Cross State societics, the State Associations of Nurses, by that time strongly dereloped throughout the country, should themselves be the bodies responsible for emrollment and shonld coöperate in this work with State Red Cross socicties. Several states had actually brought such an arrangement into being. Miss Damer, president of the Associated Alumme, pointed this out in her address at the Tenth Aumual Convention in 1907. She said:

Another matter in which we have made the discovery of the need of coöperation is the Red Cross work. . . The Red Cross calls upon us nurses in its work in many ways. . . . It has been suggested that we ask the state (nursing) associations to coopperate in this matter. to form auxiliary societies among their members or have committees appointed who will enroll nurses for the Red Cross work. Ohio is very well organized in that respect, and California has recently started an auxiliary.

In $190 \mathrm{~s}$ came the first serere test of the efficiency of the Red Cross Nursing Reserve, with the calls for help from immdated scctions of Mississippi, following the tornado and floods that oceured in April of that rear. By dint of great coffort, the noed was met. but the mathinery creaked, as explained with (ander by the American Jourmel of Sursing (Junc. 1!os). 
After reciting the incidents of mustering the required nursing reserves, it said editorially:

Judging from these facts, one receives the impression of prompt and efficient serrice, but knowing the inner side of the story, the nursing profession is given some cause for serious reflection. ... .

The question before us is how to bring all of our forees so into coöperation with the Red Cross that prompt and efficient service may always be at the command of that society without unnecessary clelays.

All other considerations in comnection with the Red Cross are secondary to this one of efficient enrollment. It should be taken up by every local organization and carried into our state and national tonrentions until the problem has been satisfactorily threshed out. Otherwise the Red Cross will be forced to train its own workers.

So far all the steps taken toward providing a Red Cross Nursing Reserve had proved to be but tentative and opportunistic and did not satisfy the nurses themselves.

The genuine attiliation of organized nursing bodies with the Red Cross which finally took shape, began with the work of Isabel Hampton Robb in 1908-1909, though her plan did not then earry in its original form. The story is fully told in Mrs. Robb's words at the second convention of the Federation of Nurses. This body, it is to be remembered, was composed of the two societies, the Superintendents and the Associated Ahmne in joint meetings.

At the Superintendent's Convention in April, 1908, Miss Nutting, its president, had asked Mrs. Robb to serve as ehairman of a Red Cross Committee and to enable such a committee to confer with the Central Committee of the Red Cross for the purpose of finding out whether any arrangements eould be made whereby a settled Red Cross Nursing Service might be established. The following women were selected to serve with Mrs. Robb): Miss Damer (representing the Alumna), Miss Nutting (the Federation), Miss Nevins (the Superintendents" Society) and Miss Maxwell, who had had great experienee in the Red Cross work of the Spanish-ineriean War, as member at large.

On June 13. 190s, Mrs. Rubb wrote to Miss Boardman telling her of the murses wishes and of the existensere of the committee. Mliss Boardman replied on Jnly 20, 190s, saring: 
I was very glad to receive your letter and am delighted. . . . This spring there were created three Red Cross Departments on, first, War; second, Emergency, and third, International Relief. A Board is at the head of each Department. General O'Reilly, Surgeon General of the Army and a member of our Central Conmittee, is the chairman of the first Board and I am chairman of the second. At the time of our annual meeting in December, the 8 th and 9th, there will be meetings of these two Boards and there will also be a meeting of the Emergency Board in Washington the first part of October and probably also a meeting of the War Board about the same time.

If you are near Washington at that time and could meet these Boards it would be very useful as they are the Boards which will have active charge of those relief measures in which we would probably need the nurses' assistance.

Mrs. Robb and Miss Maxwell went to Washington in October and had an informal conference with Miss Boardman and Mr. Bickncll. They returned to New York and met the other committee members, no definite conclusion being arrived at. Mrs. Robb next summed up the substance of their conference with the Red Cross officials in the following letter to Miss Boardman :

Cleveland, October 15, 1908.

My dear Miss Boardman:

I beg to submit to you in writing the substance of the conversation Miss Maxwell and myself had with you on October t. to the cfiect that the Fefleration of Nurses. which ... numbers about 15,600 memiers. appointed a sperial committee to confer with the Central Committee of the Red Cross to find out if it might be possible to make suitable arrangements whereby all nursing and allied work required by the Red Crose society might he lone throngh the Federation of Nurses under proper oreanization. Inless some such organization is effected the majority of nurses feet that the most efficient nursing work annot he attained, nor the proper selection of nurses male. and that in consequence all members of the profesion are subject to unnecesiry anlwerse rriticism. The nurses also feel that suitable recongition should be afeorded them as a body of professional women and the interrity of their work shomil be maintained. To those of us who have erien the matter careful thoment. it would seem that a satisfaretory anreenent to hoth the lied Cross and the Federation of Nurses might he rearhed through 
affiliation, whereby a nursing department carefully planned in every detail might be organized that would cover all branches of Red Cross nursing, including that of the Army and Navy. This would not necessarily mean that women for appointment to any branch of the Red Cross nursing work must be a nember of some nursing organization, but that she should have the qualifications now considered essential for a nurse in good and regular standing. If the Central Committee of the lied ('ross is willing to consider this affiliation proposition, then it will be necessary to lold a conference to decide upon what grounds such an affiliation can be best worked out.

Very truly yours,

(signed) Isabel Hampton RobB.

To this Miss Boardman replied:

My dear Mrs. Robb:

Your letter of the 15th has been forwarded. . . . I feel confident that a plan satisfactory to all can be worked out. I shall be at my office in Washington on 'Thurshay and then will gro into the matter at length. I want you on the War Relief Board and as a meeting of the Board will be held soon after my return to Washington, your appointment will then be arranged for. The Red Cross presiclent, Mr. Talt, makes this appointment.

Yours sincerely, (signed) Mabel T. Boardan.

A week later Miss Boardman wrote again to Mrs. Robb:

There las not yet been a meeting of the War Relief Board, but I think one will be helel next week at which time your letter will he presented to the Board and at the same time your appointment as a member of that Board to represent the Trained Nurse part of the Red ('ross and as a representative of the Federation of Nurses, will be made. I feel sure that this proposed affiliation with the Federation of Nurses can be brought about in a way satisfartory to all.

l'lease let me know when you expect to be and so that a merting of this Board an be held during that time. A meeting of this Board will also be held about the time of the regular anmual lied cross meeting, Berember 8 . It the meeting next week or thereabouts, I will read your ketter to me of October 15 .

In order that Mrs. Robb might obtain a seat on the War Relief Board, Mlis Boardman generonsly resigned her own, 
thus creating a vacancy which Mrs. Robb was appointed to fill, January, 1909.

Having conferred with her committee, Mrs. Robb attended the War Relief Board meeting in Washington (March 25) and there submitted the plan of aftiliation as agreed on by her committee. The plan was, with but a few modifications, the same as one drawn up by Mrs. Robb herself, earlier in the winter, which had been informally discussed at Red Cross Headquarters and which is now in the Red Cross archires. This historical detail explains dual allusions in Red Cross official material to "Mrs. Robb's Plan" and "Mrs. Robb's Committee's Plan." Both were essentially the fruit of Mrs. Robb's ideas. The plan presented follows:

To the Red Cross Board of Control of War Relief :-

The committee appointed by the Federation of Nurses to derise a plan whereby the Red Cross might enter into atililiation with the Federation of Nurses for nursing purposes, begs to suggest the following plan for your consideration.

Whereas it has been proven that volunteer service by the individual nurse is not a success owing to the fact that it is impossible to count upon her services in emergency:-

It would seem advisable to form a regular nursing department of the Red C'ross. That a permanent Chief Nurse having the requisite training, experience and organization ability be appointed to the head of this department. That the department be subdivided into four lare sections, that of the North, South, East and West, and that a permanent Head Nurse be placed over each of these. That the Federation of Nurses be asked to atfiliate with the Red Cross for the purpose of supplying the main mursing force. This force to be composed of its members speedally selected, and in consideration of this, the Federation would request the following privileges:

That its nursing force be drawn upon first for active service; that this nursing force have the privilege of wearing the Red ('ross brassard on nursing service of any kind; that an exerutive rommittee from among its members shall be appointed by the Federation comneil to act with the War Relief Board of control: that the Federation be represented at the Red ('ross anmal meeting by one or more clelemates seleceted from the Fendration.

The soure of supply shall he drawn from the ranks of the Fonderation. from other qualifixd nurses not mombers of the Federation, from sisterhouli and from so-called "experi- 
encel nurses." It is further suggested that in order to insure a ready supply of nurses the Federation of Nurses be asked to form a central clirectory in all the large cities of the Tnion and the head nurse in charge of these directories be put on the permanent staff of the Red Cross Nursing Department subject in emergencies to orders from the national head nurse.

Dutics of the Chief Nurse:

To organize the nursing force in detail in coopperation with the Executive Committee and Board of Control and the sectional head nurses. To keep corrected lists of all nurses on the sectional registers. 'T'o visit and inspect the various sections from time to time. To arrange for special courses in emergency training throughout the country. To arrange for IIome Nursing courses in the various sections. To talk upon Red Cross nursing matters wherever and whenever desirable. To study Red Cross nursing organizations of other countries with a view of improving that in America. The Nursing I)epartment of the bulletin to be edited by her. Duties of the Sectional II ead Nurse:

To make lists with records of all trained nurses in their sections:

1. Number of Federated Nurses.

2. Number of Grarluated Nurses not in the Federation.

3. Number of sisterhoods-available.

4. Number of experienced nurses-available.

5. Lists of nurses on directories.

6. Lists of all available nurses.

7. Represent Red ('ross work by at least one lecture before students in training schools. To arrange for and oversee courses on emergency and first aid nursing. Also to give courses on home mursing. To coöperate with other Red Cross work where possible.

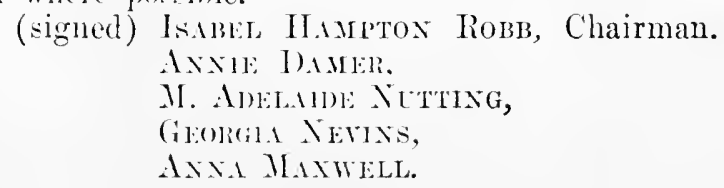

There were present besides Miss Boardman, Surgeon General Torney, I)r. Wise of the Nary, and Major l)aris. Exeeption was taken (quite properly) to the point enemerning the nse of the brasand (a matter which enuld have heren easily arranged) and to the expense the seheme would entail. Thio members

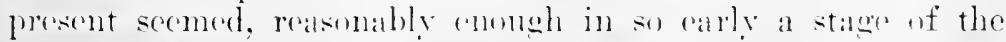
organization, nuready to aceept so considerable a plan, as there 
would not always be a need for a great many nurses. Mrs. Robb suggested, in answer to this, that they might be used in nursing people of moderate means, but that, it was thought, was outside the Red Cross province.

The meeting then adjourned. The plan was talked over further by the Red Cross officers, who thought it elaborate and complicated, and a little later they sent the following statement in regard to it:

At a meeting of the War Relief Board held March 25 at the National Headquarters in the War Department the suggested outline of plan for the affiliation of the Federation of Nurses with the Red Cross. prepared by Mrs. Robb at the request of the Board and after consultation with the Federation of Nurses' committee on Red Cross nursing, of which Mrs. Robb is chairman, was presented by Mrs. Robb and informally discussed. The Board considered the plan carefully studied out and containing valuable suggestions, but that as the carrying ont of such a plan would involve a large expenditure of money from the Administration Fund of the Society, the Board felt that it would be impossible under present conditions for it to undertake any such elaborate plans. Mrs. Robb thought that it would involve an annual expenditure of from nine to ten thousand dollars to carry out the proposed plan.

As experience has shown that for both war and emergency relief, the services of a number of nurses have very seldom been required for strictly Red Cross work, the Board questioned as to whether at any time it would be justified in such a large anmual expenditure for the proposed plan unless some continuous beneficial use within the led Cross sphere of work could be made of this atliliation.

The Board hoped that for the present a plan for some limited afliliation may he bronght about that will involve little or no expense tis the Red ('ross. It is desirous of obtaining the interest, suppurt and assistance of the Federation of Nurses in Red ('rosis work so that the trained murses of onr comtry may be able to take their part in the patriotice and humane service of the tiofiety in time of war or clisaster.

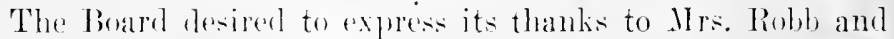

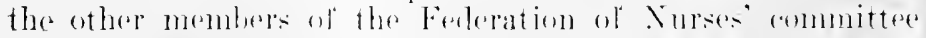
on hed crose nursine for the are and thenght griven the propesed plan and recent that the finanedal question makes its adoption moler existing virenmstances imposible.

Chaiman, Ried Cross War lielief Board. ${ }^{9}$

- Miinutes, Meeting War Relief Board. Mardi 25, 1909. 
Thus the first negotiations failed, but, in the light of later history, it is interesting to pause a moment and consider how the Red Cross Nursing Service has actually developed, along the lines of the plan presented by Mrs. Robb. The Iepartment of Nursing was evolved for war purposes almost exactly as she recommended and gave striking testimony to Mrs. Robb's vision and foresight.

The decentralization of the service, as suggested by her under four sections, was rapidly effected after the declaration of war (1917) but instead of four it was necessary to create fonrteen dirisions, in each of which a full time, paid mursing director with a staff has been required. ${ }^{10}$ The Executive Committce of her plan exists as the present National Committee on lied Cross Nursing Service.

The provision to include Sisterhoods was carefully considered (1914) and found of much practical value. For example, the nursing personnel of Base Hospital No. 102, from New Orleans, was directed by Sister Chrysostom Moynahan and ineluded ten other sisters. Practical nurses were utilized. rspecially during the influenza epidemie in 1919-1920, when miny humdreds of women were needed.

The suggested directories as centers for enrollment were not ntilized to any extent but, instead, local committees of nurses attarleed to state associations were organized and they eolleeted credentials, passed upon the professional qualifieations of applicants and finally forwarded all papers to National Headquarters where they were filed. The duties of the chief nurse as indialed loy Mrs. Rohb are almost identieal with those of the l)irector of the lepartment of Nursing. Time has shown that luer general plan, while a little startling when first submitted to the $\mathrm{War}$ leelief Boarel, and probably as a begimning ton claburate, was gratually accepted and that a still further elaboration, on an even nuore generous basis, soon beeane necessary. It was fortmate that this was so, for upon the declaration of war in Ipril, 1917, there were to(o) nurses enrolled under the lied fors and so woll oromized were its state and local commiters that this enerollnent was easily inereased with ereat rapidity.

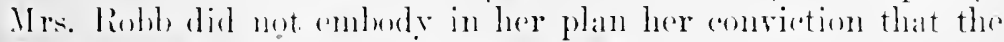

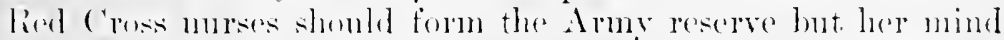
was rlate on this point. Finally her hope of seeing IIome Norsing relasses dopeluperd on a national scale has been fultilled,

"This number under grace conditions was reluced to eight. 


\section{HISTORY OF AMERICAN RED CROSS NURSING}

beyond, perhaps, even what she foresaw as possible, as we shall learn in another chapter.

The Central Committee of the Red Cross, disappointed in their first attempt, took counsel among themselves and planned another way of solving the nursing question.

In May, 1909, the War Relief Board proposed placing the Red Cross Nursing Department under a special subcommittee and sent to Mrs. Robb the following resolution passed by them on May 7 to that effect:

Resolved, That the subcommittee on Red Cross Nursing Service s'uall consist of a chairman and fourteen other members, five to constitute a quorum. The chairman and five members to be members of the War Relief Board, to be appointed by the chairman of the Board; six members to be appointed by the chairman of the Board from a list of trained nurses submitted by the Nurses' Federation, and three persons to be appointed by the chairman on recommendation of the Board.

The chairman and two other members of the committee to be selected from trained nurses, members of the War Relief Board. Of the three other members one should be a surgeon of the Army, one a surgeon of the Nary, and the third some other member of the War Relief Board. This will give a membership of nine trained nurses on a committee of fifteen. ${ }^{11}$

The resolution was read by Mrs. Robb as a part of her report at the annual convention in Minneapolis (1909) and discussed. Mrs. Robb was keenly disappointed in that the work and thought she and her committe had put upon their plan seemed to lave been lost, and she feared that the hope of satisfactory affiliation had faded. But her intense idealism and lowe of perfection perhaps led her to forget how new and nutried, as yet, was the American Red Cross organization. It is ease to see, now, how formidable and binding the plan must have seened to the lied cross exeentives. Other nurses realized this at the tine and beliered that it wonld be better to begin in a smaller way and to build up little by little. The sugested committe of fifteen seemed to them a sensible compromise and Miss Palmer arose as the spokesuman of this gromp. She spoke of lexing an ofticer in the liochester branch, reviewed the general conditions of lied Cross state work and offered this motion :

"Winutes, War Relief Roard, May $7,1909$. 


\section{REORGANIZA'TION AND AFFILIA'TION}

Resolved, That the American Federation of Nurses afliliate in a body with the Nationai Red Cross Society and that nurses be nominated by this association to serve with the National lied Cross Committee as outlined by the National War Relief Board.

Miss Ielano had gone to the Mimneapolis meeting with a hope of seeuring the assent of the Federation to the proposal made by the Red Cross. Miss Palmer wrote later:

I know from my close association with Miss Delano in those early days ... that she had very definite plans for the derelopment of the service. . . Although I submitted the resolution for affiliation it was really Miss Delano's resolution, as she had it written out in ink before the meeting and, sitting next to me, asked me to present it. ${ }^{12}$

There was an animated discussion and the resolution was adopted, but with an amendment to make the Associated Alumne the affiliating body, as all the superintendents belonged individwally to it. After the ammal meeting of the Red Cross in December, 1909, the War Relief Board named the following National Committee on Red Cross Nursing Service, and Miss Delano was made chairman ${ }^{13}$

\section{Froni ITar Relief Boird}

Mrs. Whitelaw Reid, New York City; Mrs. Isabel Hampton Robh, ('leveland. Ohio; Miss Jane A. Delano, Office of the Surgeen General, War Department, Washington, 1). C.; Miss (ieorgia Nevins. Washington, D. C.; Major Charles Lynch, I. S. Army, Washington, D. C.; Surgeon W. L. Bell, U. S. Nary, Washington, D. C.

\section{From Ealergency Relief Board}

Miss Maliel 'T. Boardman, War Department. Washington, D. C.; Mrs. Milliam K. INaper, New York City.

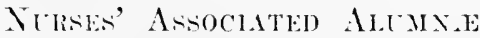

Miss Sophia F. Palmer. Rochester, New York: Miss Emma M. Nichols. Boston ('ity Hospital, Boston, Mass. Miss Limna

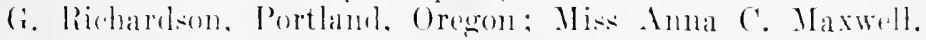

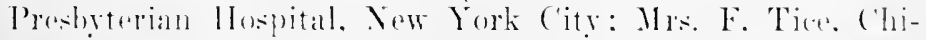

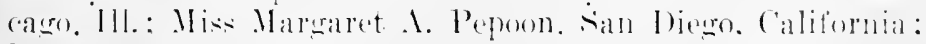
Mrs. I arriet ('amp) Lombhury, Charleston, West Virginia. 


\section{The American Journal of Nursing said editorially:}

By the appointment of this committee, with the majority of its members nurses, the responsibility of the nursing department of the American National Red Cross is placed upon the shoulders of the members of the Associated Alumnæ. . . .

So far, the nurses of the country have not responded to the call for enrollment in the Red Cross as they should, the reason frequently given being that such a department under the direction of laymen could not be conducted on a practical working basis. This excuse can no longer be advanced,the work of organizing a Red Cross nursing service is now in the hands of nurses. With the concentrated strength of all our national and local nursing societies it can be made a practical working force. ...

The action of the Associated Alumnæ brings the nurses of this country into distinct relationship with the War Relief Board and gives to them a very influential place in the administration of the strictly nursing side of the work of the National Red Cross. It is an opportunity which has never been ours and one which must receive the most intelligent coöperation from all the affiliated sorieties in order to prove our worthiness of the confidence which has been shown us.

After the meeting at Mimneapolis, Miss Delano had gone abroad for a short trip but was suddenly recalled by receiving the appointment to the post of Superintendent of the Army Nurse Corps, as indicated in the list given above. Her selection for this responsible work had been made on Miss Boardman's recommentation. The Surgeon General had gone through Colonel Lynch to Miss Boardman for advice and she knowing that Miss I)elano was then free (her mother having some tine before passed away) and feeling confident of her ability, had counseled them to seene her if possible. Miss Boardinan believed this appointment wonld mify the Red Cross and the Army Nursing work and Miss Delano shared this foeling. for she once said to Miss Boardman, "one of my reasons for taking this (the Army Nurse Corps) is my interest in Red ('ross nursing and I believe the Army Nurse Corps and the Red Cross Nursing Service should work in harmony."

The Red ross: Bulletin of October, 1919, said of Miss Delano's appointment:

By this arrangement the whole system of the Regular Armix Nursine corpes and the lied Cross Xursing Corpe will he placed moler onc head, io that in case of war the plans 
for Red Cross nursing assistance will fall into complete accord with the demants of the Army Medical Service. Miss Delano will, therefore, be not only fully adrised as to the regular nursing strength of the Army Corps, but will know exactly the status of the volunteer aid of the Red Cross Nursing Corps.

On a later oceasion, when narrating the steps by which Miss Jelano went on to hor long volunteer service in the Red Cross, Miss Boardman recalled the incidents of that time. She wrote:

... At the time of Miss Delano's appointment to the Army Nurse Corps she was asked by the Red Cross to aceept the chairmanship of its nursing committee. In consenting to do so Miss Delano said that one of the motives which influenced her in taking the Army position was the opportunity it would give to bring about a close relationship between the Army Nurse Corps and the Red Cross Nursing Service. . . . At that time there were not more than twenty nurses reporting regularly as members of the Army Nursing Reserve and Miss Deluno concluded that the best way to secure an arlequate number of reserve nurses was to do away with this branch of the Army Nurse Corps and to have the Red Cross authorized to provide this service. The Surgeon General agreed to her suggestion. . . Devoting herself to the serious duty of reorsanizing and improving the Army Nurse Corps Miss Delano quietly and carefully studied it. . . . The pay of the Army nurse was so low that it was impossible to obtain graduates of the best training schools and to correct this Miss Delano ureed the increase of the pay in an Army appropriation hill. The surgeon General's office approvel her suggestion and induled in it an inerease in the pay of the superintendent of the Army Nurse Corps, which was also inadequate. When this amentment was submitted to Miss Delano she promptly struek it out so that she should be untrimmeled hy any alparent self-interest in her efforts for the benefit of the nutres.

After two reale als superintentent of the Army Nurse

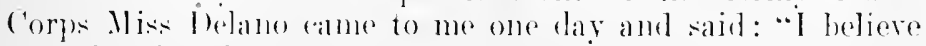
now the time his emo when I an grve up my position in

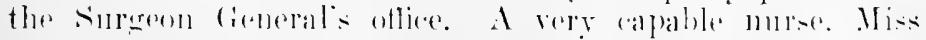
Melsale, will he appointef to sureecel me. I have a little means of my own and I would rather live on a remst and serve the lied crose than to anything ole in the world. I

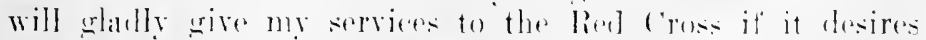
them, to oreanize and cherelep its Nursing leghartment." 
It was a very wonderful gift ... there never was a gift given in a nobler spirit. ... ${ }^{14}$

The official correspondence touching Miss Delano's resignation as head of the Army Nurse Corps follows:

\section{War Department}

Office of the Surgeon General

Washington

To the Surgeon General,

March 11, 1912.

United States Army, Sir :

In aceepting the position of superintendent of the Army Nurse Corps I did so in the hope of developing in connection with the Ameriean Red Cross an adequate nursing personnel which would in the event of war be available as a reserve for the Army Nurse Corps.

The organization of this nursing service is progressing most satisfactorily, but in addition to my duties as superintendent of the Army Nurse Corps the work has grown beyond my eapacity. Believing that the maintenance of this Red Cross reserve is as necessary to the Army as the Nurse Corps and that Red Cross work should be as far as possible volunteer service, I have the honor to submit my resignation as superintendent of the Army Nurse Corps, to take effect April 1, 1912.

Ny only object in resigning is that I may have the time to devote to the development and maintenance of an efficient, reserve of lied Cross nurses for the service of the Army.

Very respectfully,

$$
\text { (signed) Jane A. Delaxo, }
$$

Superintendent, Army Nurse Corps.

1st Indorsement, War Department, Office of the Surgeon General,

Marrh 11, 1912.

Respertfully forwarder to the Arjutant General of the Army, resommending that Miss Delanos resignation be acrepterl to take effect April 1. I view with great regret Miss J)clano's smparation from the Mediral Departunest of the Army. She acopted the position of superintendent of the Nurse ('orps in August, 1909, with the understanding that she would remain in wfice for only sufficient lenesth of time to put the virse forps on a thoroughly satisfactory basis. This she has done in an ardmirable manner.

14 Red Cross Bulletin, May 12, 1919. 
When she came to this office there were only 80 nurses on duty in the Army Nurse Corps and there was no eligible list from which appointments could be made. In acldition to this armirable work Miss Delano has had charge of the enrollment of Red ('ross nurses and has now on her list nearly 3,000 well solerted nurses that will be available for service in the Medical l)epartment in case of cmergency.

In view of the success which has attended Miss Delano's work as superintendent of the Army Nurse Corps in preparing that organization to meet fully its obligations in the event of war, it is recommented that the Secretary of War in accepting her resignation place on record his appreciation of her services.

(signed) Gro. II. 'Tonxer, Surgeon General, U. S. Army Approved:

By order of the Secretary of War, (signed) Leosind Woon,

\section{Major General \\ Chief of Staff.}

Affiliation was now firmly rooted, but before following it further a brief final glanee should be taken at the evolution of the Army Nurse ('orps as part of Miss Delano's work. Mrs. Kimmer had effected improvements in the Army Nurse Corps, though in her time the War lepartment had ent down very materially on all expenses. She had gained saloon mess for the nurses at sea and helped greatly in improving from the professional and social standpoint the position they had.

She did, probably, as much as anyone could have done in those early months, but there was still progress to be made when Miss 1) lano took charege. The Sureon General had planned a Nurse Reserve which he alled the "liligible Voluntece Corps," 15 but in this he had not been sneeessful. Early in 1904, the Surgeon General had issued the following regulations, which the Journal of Nursing published.

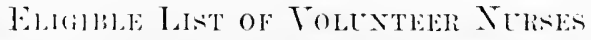

The surgeon cieneral has deemed it advisahle to open in his ofliee what shall he known as the Eligrible List of Yolunteer Furses. 'The names of aceeptable graduate nurses who are willing to serve in time of war or national emorerency will (anstitute this list and the repuirements for enrollument shall be as follows: Applicants must have erraluated from al training-sehool for murses which gives a thorough professional ". Imerieten fournal of lursing, March, 1004. 


\section{HISTORY OF AMERICAN RED CROSS NURSING}

education, both practical and theoretical, and which requires at least a two-years' residence in an acceptable general hospital of not less than fifty beds. Graduates from special hospitals and from insane asylums and private sanatoria will not be considered unless their training has been supplemented by not less than six months in a large general hospital.

Application for enrollment must be made to the surgeon General and before being accepted the applicant must submit to the following: (1) A statement of her physical condition filled out in her own handwriting and sworn to by a notary public. (2) A certificate of her health from at least one reputable physician personally acquainted with the applicant. (3) The name of her school and date of her graduation. (4) A certificate concerning the moral, physical and professional qualifications of the applicant as shown by the records of the hospital must be furnished by the superintendent of the training school from which the applicant graduated. If she was trained under a former superintendent of nurses, her endorsement is also desirable. Blanks for these purposes will be furnished by the Surgeon General.

Approved candidates will be placed on the eligible list for appointment in erent of war or national calamity.

Each nurse must agree to enter active service as she may be needed in time of war or national calamity. On the first of January and the first of July of every year she shall report to the Surgeon General, giving her address and enclosing a certificate from some reputable physician showing the condition of her health at that time.

When called into active service these nurses will be subject to all established rules and regulations and will receive the pay and allowances of murses of the Army Surse Corps as set forth in General Orders No. 54, War Department. Norember 16, 1903.

Nurses did not enroll, however, in large numbers in the Volunteer Corps. In the September, 1905, issue of the Journal, Miss Palmer, the editor, wrote:

Another rear is drawing to a close and at the beximning of Anerust the "Eligible List of Volunterer Nurses" stands. since the tirst appeal in Mareh, 1901: nmmber of applieants for blanks. 1\%. (If these the pe have been returned to: not reeommenelof by her superintendent. 1: total number on the list. 41. Of these the momber who have been or who are at present in the Arme are lis. thes leaving the mmber of ontside grabluates on the list an twenty-three. If this means anything. it means that enly forty-one murses out of oser thirty 
thousand desire to serve their country in its time of need. But we know that if an energency arose the nurses would rise to meet it and we would have a repetition of the confusion and dissatisfaction which we were so rearly to criticize and rebuke seven years ago simply because we are more selfish than patriotic.

Our faults are not the faults of nurses alone, for we only reflect the signs of the times and our own people, who love the glare of notoriety and excitement and are fickle and inconstant until misfortume and disaster overtake, when their inborn courage and faithfulness come to the front and save the day. Neanwhile we cry aloud, "How longr, O Lord, how long?" with this record of our indifference standing as a public rebuke upon ns?

Through Miss Delano's influence, the Red Cross Nursing Corps became the Army Nurse Reserve and the Eligible List of Volunteer Nurses was finally discontinned. Miss Delano secured for the Army Nurse Corps additional pay; cumulative leave; lamidry of miforms; first-class transportation for all nurses and improved quarters and in all of this the coöperation of the Red Cross had been most effective.

Miss Boardman has said that Miss Delano's influence with ofticials of the Army was most marked. She gained their confidenee by her sober, solid judgment and by her willingmess to consider opposing viewpoints. She was usually able to get her recommendations through.

Her sucressor in the Army Nurse Corps, Isabel MeIsaac, was one of the most widely known and beloved murses in the eomtry. A graduate under lsabel Hampton liobb, of the Illinois Trainine School, she had risen throngh every position there to the superintendeney; had been prominent in all nursing associations, had met thomsands of nurses intimately as inter-state seretary and had written popular textbonks. Very attractive in appearance, with a personality expressine ereat sincerity, loe Seoteh aneestry wals always evident in al rertain dry and numfailing humor. Her views were broad and tolerant and her

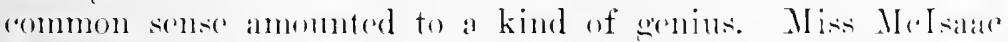
threw all here gifts inte the Army work and also her lifre. for she died "in harmes." at the Wilter lined Hospital, Washington, 1). C., on september $21,1911$.

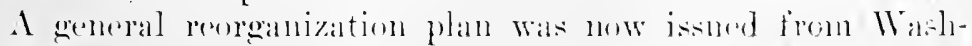

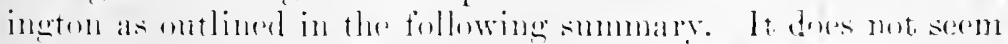




\section{HISTORY OF AMERICAN RED CROSS NURSING}

to have applied directly to nursing enrollment, but instituted the "Chapter" which from now on becomes a familiar word.

The Central Committee at Washington has found it necessary to make certain changes in the form of the state branches and in a letter to these branches, under date of November 1, 1909, the reasons are clearly set forth. Briefly stated, these are distances which prevent representation from all parts of a state, with a tendency to concentrate officers and members at some central point, absence of state officers, jealousies, . . . conditions detrimental to the best interests of the Red Cross. Moreover, experience has taught that in case of disaster within the state the governor is the one who makes the appeal for assistance to the rest of the state, or to the President of the United States if national help is necrled. Therefore, that the national headquarters with its artive working force may be in immediate and close touch with all its branches when relief is needed, new regulations have been adopted by which local branches, hereafter to be called "Chapters," will be in direct commmnication with hearquarters at Washington, retaining fifty cents on the annual dues, instead of twenty-fire, for local use, and each Chapter may have the privilege of sending one relegate to the annuai meeting at Washington. The state boards will assemble only in case of war or serious disasters.

The charter, by-laws and regulations for state boards and Chapter: have been issued under date of January 1. 1910, ropies of which may be obtained from Major General George II. Davis, chairman Central Committee, American National Red Cross, Washington, D. C. ${ }^{16}$

At the first meeting of the National Committee on Red Cross Nursine Service, held on Jannary 20, 1910, at the home of Mrs. W. K. Uraper, New York, Miss Delano's appointment was ratified and she was asked to take the chair. Miss Georgia Tevins, learl of the Garfield Inspital, was appointed seceretary but as she was not present Mrs. Draper was asked to act as sereretary pore tem. Miss Jorano then submitted the list ot suggestions drawn up by her committce and herself:

Ontline of I'lan for the Enrolment of Nurses Aropterl by thr. National (ommittor on lied Cross Nursing Pervice.

I) uties of Vitional committee:

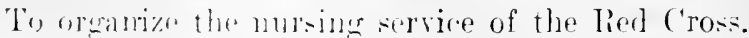

"Charter, By-Laws. and liculuations for State Boards and Chapters,

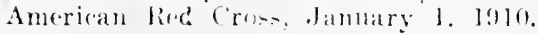


To make uniform rnles for the enrollment of nurses throughout the country.

'To arrange for the establishment of state and local committees on Red C'ross Nursing Service, and to specify the duties of all such committees.

To appoint annually state committees on Red Cross Nursing Service of not less than five or more than ten nurses who are members of organizations affiliated with the Nurses' Associated Alumne of the United States, lut where a state nurses' association exists whieh is affiliated with the Nurses' Assoriated Alumna, appointments mmst be marle from names submitted by the executive committee of such murses' associations.

'To issne to local committees on Red Cross Nursing Service the necessary blank forms for application of nurses for enrollment.

To receive and file in the central office of the Red Cross in Washington the application blanks and required credentials of all nurses who have been accepted by local committees for enrollment as Reel Cross murses, and to issue cards of appointment and Red Cross badges to all such accepted applicants.

To appoint, as headquarters, registries for nurses or other offices recommended hy local committees as suitable places for filingr lists of curolled nurses.

'T'o keep in the National oflice of the Red Cross in Washington card catalogues of all state and lowal committees and of all headquarters for enrolled nurses with the approximate number of nurses arailable at each.

To ascertain and keep on file the varions somrees of volunteer service available, intluding sisterhoods and members of other orders.

To arrange for courses in home nursing, hygiene, and first aid under the lirestion of the lied ('ross, utilizing as far as possible for this instruction enrolled lied Cross nurses.

'To arrange for lectures on the relation of nurses to the Red Cross, and to eneourage the presentation of the sulpject to graduating claseses of nurses throughont the comntry.

To stuly the mursing servie of the lied cress in other comtries, with the object of improving that in Americal.

In corperation with the medical departments of the army and nave. to provite instrution for enrolled nurses in the special chuties which would be required of them in time of will.

All matters relating to the services of nures muler the lien! cross will he refered to the chamman or secrotary of 


\section{HISTORY OF AMERICAN RED CROSS NURSING}

the National Committee of Nursing Service, and in coöperation with such other members of the committee as may be necessary they will be responsible for all assignments of nurses to duty, and when two or more nurses are sent out together one shall be placed in charge or authorized to act as head nurse.

The National Committee on Red Cross Nursing Service shall hold regular semi-annual meetings, one in Washington at the time of the annual meeting of the Red Cross, and the second at the time and place of the annual meeting of the Nurses' Associated Alumnx.

Special meetings may be held at any time at the call of the chairman.

Full reports shall be presented at the semi-annual meetings. ${ }^{17}$

\section{Jane A. Delano.}

The form of application, as prepared by Miss Delano's committee was submitted and with one or two slight changes was approved, as follows:

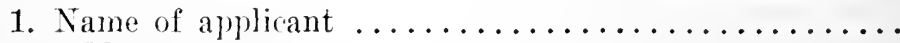

2. Address

3. Date of birth.

Place of birth

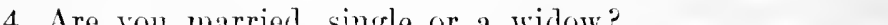

5. Are you a citizen of the United States?............

6. Have you any physical defects?..............

7. Eduation and orcupation before entering training

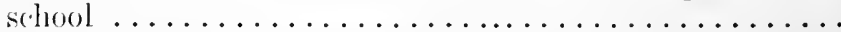

8. From what training solool did you graduate?........

$9.1 \mathrm{~s}$ it connected with a general, special or private

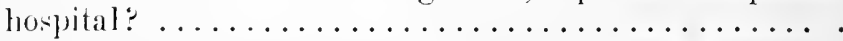

10. How many beds in hospital at time of graduation?.....

11. Tate of grarluation........ Length of course........

12. Name and address of superintendent under whom you were trained

13. Of what nursing organization are you a member?.....

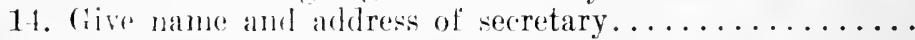

15. Ar you a registered nurse?..... In what State?.....

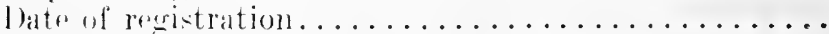

16. How have yon been employed since graduation?.......

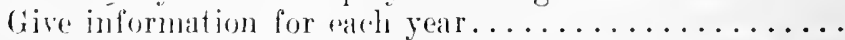

17. Give name and permanent aldress of nearest relative... Signature............

Date...............

${ }^{17}$ A merican Journal of Nursing, February, 1910, p. 303. 


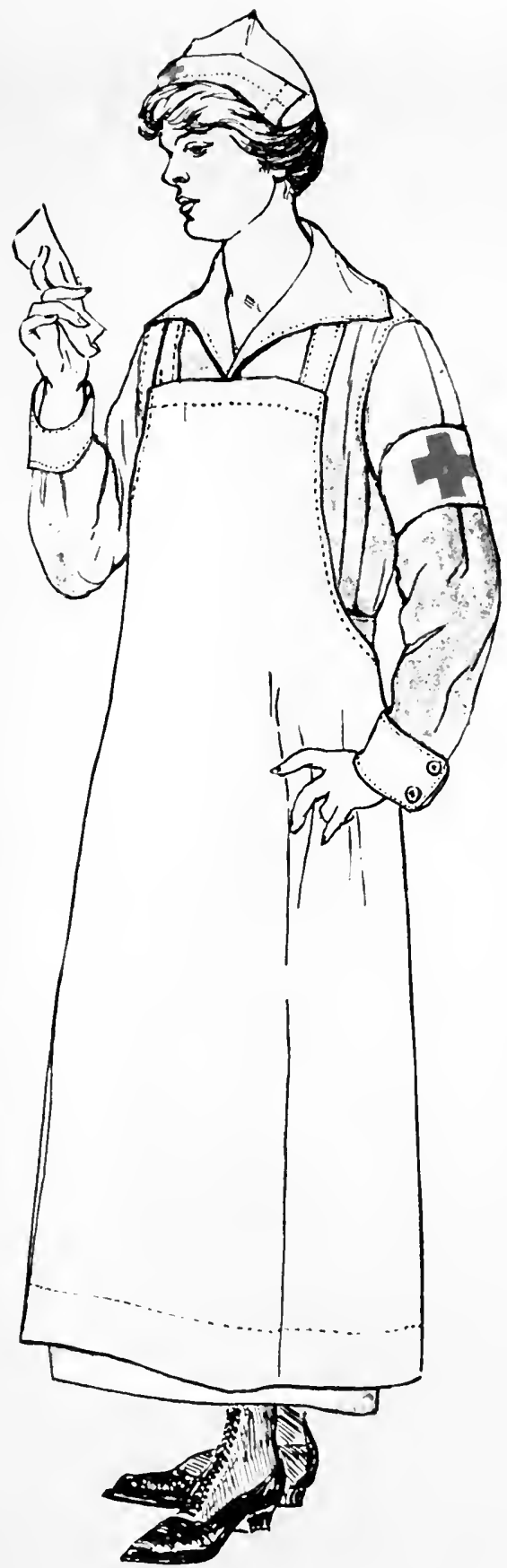

Indoor miform, gray drest. hrassard and cap, of an Amerion Pent

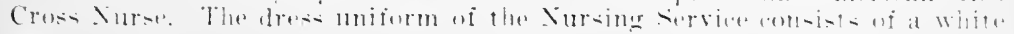

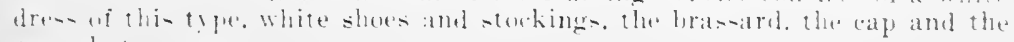
("alue. hut nu ipron. 

The chairman then presented suggestions to be filed as referenee for the applicants-this blank to be entitled "Credentials from Training Schools." After a short discussion of the above title, and one or two slight changes in the text, the blank was accepted as follows:

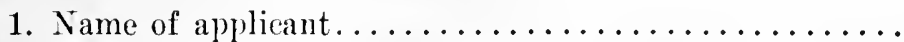

2. Name of training sehool..........Address........

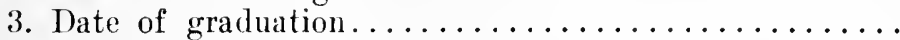

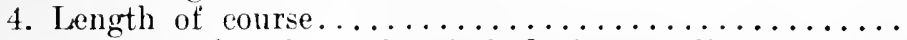

5. Number of beds in hospital during applicant's train-

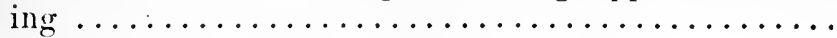

6. Character of hospital:

General........ Special........ Private......

7. Are pupils sent out for private duty?.............

8. What, if any, position of responsibility did applicant hold

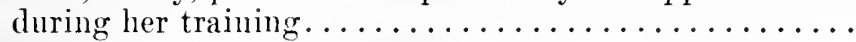

9. Was her record satisfactory in regard to the following:

Work?

Health?

Coulduet?

10. Was she employed in your hospital after graduation?

11. What has been her standing as a nurse and woman sinee graduation?

12. Are you willing to recomment her for hed Cross

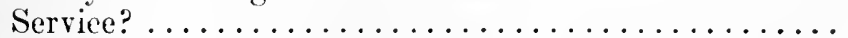

Superintendent of Training School

............ Hospital

Graduate of

Name and address of superintendent under whom the applicant was trained:

Remarks

Date

It was moved by Miss Palmer and seconded he Mrs. Robb that the form of applieation and credentials from training sebools be arlopted. 'These were as nearly miforme as possible with these nsed by the (rovernment, so that in time of wall they

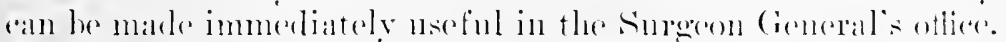

The rules gorerning the enrollunent of murses for service under the Ameriean Red cross were adopted, as follows:

1. All nurses curotled for service muler the American National Red crose must have graduated from a sotool for nurses which gives a thomomarh profosional exhuation, both 
theoretical and practical, and which requires a residence of at least two years in an acceptable hospital. In states and territories where registration of nurses is required by law, graduates of schools not acceptable to Boards of Registration will not be considered eligible for enrollment as Red Cross nurses.

2. All applicants for enrollment must be endorsed either by superintendents by whom they were trained, or by a nursing organization which is a member of, or affiliated with, the Nurses Associated Alumne of the United States; or must submit such other evidence of moral, professional and mental qualifications as may be required.

3. All enrolled nurses shall receive a physical examination before being assigned to service, if required,-such examination to be made at most con renient point by a physician authorized by the Red Cross.

4. No nurse under twenty-five years of age shall be enrolled for active service.

5. All nurses called on for service in time of war will be required to take the oath of allegiance.

Mrs. Robb mored that this committee recommend that the Red Cross Nursing Corps enroll for paid service. This motion was seeonded by Miss Niehols, and after a short disenssion was carried.

The plan for carrying on the work of enrollment was then discussed by the committee and the following motion made by Miss Cooke and seconded by Miss Palmer was unanimously adopted :

That the Central Committee on Red Cross Nursing Service should ask each state Nurses' Association to instruct their executive committee to appoint a Red Cross committee, of not less than five members, to organize local committees throughout the State for the purpose of enrolling nurses. The local committees to be seven in number-five nurses and two lay mombers. representing the local Red Cross; these committees to have charge of enrollment. The application blanks and credentials of the nurses, as accepted by this committee, to be sent to Washington for filing; and a card catalogne, giving the name, address, telephone number, school of graduation and late of crarluation to be kept ly the local committer for roference- the local committe alon having the responsibility with the approval of the State Nurses Red C'ros: Committer, for arranging with some registry, training school or oflice to take change of these cards, and be respon- 
sible for the immediate notification of these nurses in case of an emergeney eall.

\section{AMERICAN NATIONAL RED CROSS . Branch ${ }^{18}$}

On recommendation of the Committee on Nurses of the .......... Branch of the American National Red Cross your offer of scrvice is hereby accepted for assignment to duty when and where your services may be required.

When assigned to duty your compensation will be at the rate of forty dollars per month when on duty in the United States and fifty dollars per month when without the limits of the United States, in addition to transportation and subsistence.

This acceptance to hold until your services are no longer required, or until your resignation is accepted.

Very respectfully,

President...... Branch, ${ }^{19}$

American National Red Cross.

To

The correspondence between Miss Delano and her co-workers at that time tecms with suggestions and comnter-suggestions. The letters are full of interest and many tempt one to include them, but their length precludes all but brief illustrative exampl's.

Mrs. Ifolen F. Draper to Miss Delano:

I agree with you that as a general thing it is wiser to limit the number of persons to serse on a committee. In this particular instance, however. Where we are not starting out on a new basis, but reoreanizing a former plan. I think that local conditions have to he taken into consideration. It wombl seem to me wiser, as in Brooklyn and New York, to rontinne the former committees as far in possilile. I therefore think that rour sugesetion in rearid to state Committes is anoul"It shall he the duty of the Xational ('ommittere to ampoint State committees of at least five nurses who are members of

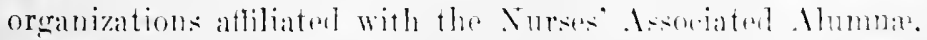

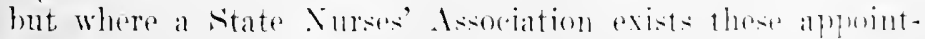

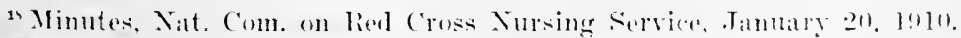
${ }^{19}$ llidel. 


\section{HISTORY OF AMERICAN RED CROSS NURSING}

ments must be made from names submitted by the executive committee of such State Nurses' Association." I, also, agree to the suggestion in regard to the appointment of local Red Cross committee by the State Committee on Nursing Service.

In regard to the annual appointment of committees, I think if this is done, it slould be done only with the idea that two members only should come up each year. I would personally prefer a permanent-but if the majority of the Central Committee on Red Cross Nursing Service feel that a varying committee is wiser, I would be willing to vote for one where two members were changed each year.

The manifold details of bringing affiliation plans into shape and of uniting on some definite lines of activity for peace times are suggested in the following letter from Miss Delano which touches on all the problems then pressing for solution. Of these one of the most significant was that already mentioned as having arisen in 1908, of earrying instruction into the homes of the people.

My dear Mrs. Draper:-

March 15, 1910.

At last we have the first installment of the Red Cross matter ready, and it seems to me that it would be possible to begin on the formation of the State Committees while we are at work on the other data. In the meantime the State Committees can be planning out their work and locating the branches. After talking the matter over a number of times we decided that it would be better to publish all the data in a little book about the size of the Constitution of the Rerl C'ross so that every one interested will know all of the steps from the duties of the National Committee down to the actual enrollment of murses. Miss Boardman thought that it would be well to have a little outline of the Red Cross at the begriming and the cirrmmstances leading up to the affiliation of the Nurses Asociated Nlumne, which arcounts for the littl, "foreword" I am sonding you. Some changes may be neersary in the "lutins of the National Committre," anr we hopk you will rriticize and suggest any changes yon think noersiry. Aftrer murh discussion and many letter it seemed wise to leave the size of the State ('ommittee with the various State. Do you approse of the paragraphs relating to "sources of roluntere servine", "the courses in home nursing," "livgiene." "firstail" (these were among Mrs. Roblis sug(restions) and prosicion for lectures on Red Cross subjects? Mis: Boardman wisherl to leave the matter of assignment of 
nurses to active duty to the National Committee, and the paragraph referring to this was added at her request. . . In talking with Miss Boardman and Miss Nevins in regard to the appointment of the committees it was suggested that it would be almost impossible to keep track of the members going out at varying periods where there are so many eommittees to consider. 'The idea of the annual appointment was that, as a matter of course, all members of the Committee should be reappointed, unless for some reason it seemed best to make a change. If we make any provision for reappointment with so many permanent committees all over the country, there seems more or less danger of having a certain number of inative people on the committees with difficulty in regard to placing them. This would make it possible to reappoint all of the changes without hurting anyone's feelings.

To the reference in this letter to the home nursing plan Mrs. Draper replied with suspended judgment, as she thought it was too soon to branch out in new directions. What the subsequent developments of this department were will be dealt with in a special section.

In April, 1910, Isabel Hampton Robb was suddenly removed by death from the manifold activities in which she took so eager, intense and inspiring a part. In the American Journal of Nursing of May, we read:

The shock of her death is so great that it seems impossible yet to (ollect one's thought sufficiently to look bark over her long service to the nursing profession-she was still in rlose touch with all its artivities. One ramot think of a movement of importance of which she was not one of the moring spirits. organizer, supporter; the superintemlent's Society, of which she was presilent only last year; the Asoctated Alumbar. of which she was presilent for the first five rears and at whose mectings she was almost always present; the

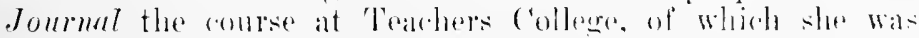
onc of the lecturers: the International Aseoriation to which she was a delenate last smmmer: the liod cross. of whose ('entral commitere she was a member. All of these will misher sally.

The Minutes of the ('entral committee said of her':

We recoprl with momb sorrow the tragic death of Mrs.

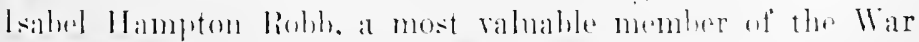

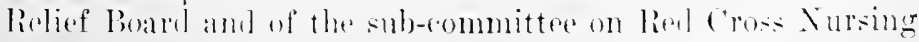




\section{HISTORY OF AMERICAN RED CROSS NURSING}

Service, a woman of large insight, warm sympathies and broad experience, to whom we are indebted more than to any other person for the derelopment and perfection of nursing organizations which has made the work of this committee possible.

By early summer Miss Delano presented the following encouraging report on affiliation and enrollment:

\section{Americax Red Cross Notes}

The National Committee on Red Cross Nursing Service announces with pleasure the completion of the plan for the enrollment of Red Cross nurses. The first step neeessary is the formation of State Committees on Red Cross Nursing Service in accordance with the following provisions.

"The National Committee shall appoint State Committees on Red Cross Nursing Serrice of not less than five nor more than ten nurses who are members of organizations affiliated with the Nurses' Associated Alumne of the United States, but where a state nurses association exists which is affiliated with the Nurses' Associated Alumnæ appointments must be made from names submitted by the executive committees of such state nurses' arsociations. Unless changes in personnel become necessary, it is desirable that a majority of the members of State Committees he reappointed annually."

The following state Committees on Red Cross nursing service have already been appointed.

West Virginia: Mrs. 11. C. Lounsbury, Charleston; Mrs. Mary G. Carpenter, Wheeling; Miss Vernon, Fairmont; M. Virginia McCune, Martinsburg; Mrs. M. Lingenfelter, Hinton.

Illinois: Adda Ehdredge, (hairman. Chicago: Mary ('. Wheeler, Quincy; Adelaide M. Walsh, Chicago; Ellen Parsons, Chicago; Mrs. Tice, Chicago: Helena M. Mcllillan, Chicago; Benna M. Henderson. ('hicago.

New York: Elizabeth Dewey, Chairman. Brooklyn; Beatrice T. Sterenson, Brooklyn; Mrs. C. T. Twiss, Tew York City: Elsie Patterson, New York City ; Anna ('harlton, New York ('ity; Mrs. Ernest (i. H. Schenck, Tew Jork (ity: Mrs. Jarsey I). Burrill, Syracuse: Soplia F. Palmer, Rochester: Marie T. Phelan, Rochester: Rye Morley, Buffalo.

To facilitate the formation of these committees the following states have been ascigned to members of the National Committer and state secretaries are earnestly ureed to rommunicate with their orerinizine menber of the National Committee for information and advice. 
Enmma M. Nichols, Boston, Mass., Maine, New Mampshire, Vermont, Massachusetts, Rhorle Island, Connecticut.

Anna C. Maxwell, New York City, New York and New Jersey.

Georgia MI. Nevins, Washington, D. C., District of Columbia and Maryland.

Mrs. II. ( C. Lounsbury, Charleston, W. Virginia, West Virginia, North Carolina, South Carolina, Georgia, Kentucky and 'Tennessee.

Mrs. Frederick Tice, Chicago, Illinois, Michigan, Iowa, Minnesota, Missouri, Arkansas, Lonisiana.

Linna G. Richardson, Portland, Oregon, Washington, Oregon, Idaho, Montana, Wyoming.

Margaret A. Pepoon, San Diego, Calif., California, Nevada, Utah, Arizona.

States unassigned will eommunicate directly with the Chairman of the National Committee on Nursing Service, State, Wall and Navy Building, Washington, D. C.

$$
\begin{gathered}
\text { (signed) JANE A. DeLixo, } \\
\text { Chairman National Committee } \\
\text { on Nursing Service. }
\end{gathered}
$$

States which were not yet organized were summed up thus by Miss Delano:

To myself, as chairman of the Committee, came the mother"s share, all those states which did not seem to fit in any locality, many of them without state organizations. I am sorry that I am not able to show a better report of my own work.

Pennsylvania has begun its organization. Delaware has not been communicated with. Mrs. Lounsbury is going to ronsult with Virginia to bring about an organization, while the delegates are here. Florida has no state organization. Texas is at work and I hope will very soon be orwanized. North Dakota and South Dakota have no state oreanizations. Nebraska has, and has a delegation here, and we hope to have something done betore it goes back.

Kansas has no state organization. Colorato has. New Mexico has none. Mabama has none. Miscissippi has none. Ohio is organized with Mis. Johnson, who is in wharge of the district murses in clevelant. as chairman. Indianal is organized with Miss Elizaheth Johnson of Indianilpulis, dhatirmaln. Wisensin. one of the two states admitter this sescion. is organized. With true western spirit they hat their com- 


\section{HIS'TORY OF AMERICAN RED CROSS NURSING}

mittee all appointed in ease they were accepted, so there was very little trouble, and Miss Matthews is chairman.

I think you will agree with me that this is a good showing for a very few weeks' service.

Within a couple of months the results of the labors of the National Committee members to whom had been entrusted the seetions of the country above named, were recorded in Miss Delano's notes, together with an outline of her own coast-tocoast tour of speech-making before audiences of nurses. She wrote:

The response from various sections of the country has been most gratifying and already the following State Committees have been appointed and are at work organizing Local Committees: Massachusetts, chairman, Mary M. Riddle; New York, chairman, Elizabeth Dewey: District of Columbia, chairman, Anna .J. Greenlees; Maryland, chairman, Mary C. Parkard; West Virginia, chairman, Mrs. H. Camp Lounsbury; Georgia, chairman, Mrs. A. C. Hartridge; Tennessee, chairman, Lena A. Warner; Illinois, chairman, Adda Eldredge; Michigan, chairman, Mrs. L. E. Gretter; Iowa, chairman, Helen Balcom; Louisiana, ehairman, Emma L. Wall; California, (hairman, Moselle Richie; Oregon, chairman, Jennie V. Doyle; Ohio, ehairman, Matilda L. Johnson; Indiana, chairman, Elizabeth Johnson; Wisconsin, chairman, Stella S. Mathews. . .

The following letters show how the work of tying up State socicties of nurses with the Red Cross was completed:

$$
\text { December 2, } 1910 .
$$

General George H. 'Torney, Chairman, of the llar Retief Buard of the

American lien Cross. Sir :-

In arcordanfe with the provision of the By-Laws of the American lied Cross. Article 15, paragraph f, page 21, which reads as fellows: "societies of Nurses. The Central Committee shall have authority to establish a rlass of membership into which may be invited permanent State or Territorial soreties of nurses. When accepterl into membership by the C'entral Committer any surb soriety shall be cutitled to delegate representation in the annual mecting of the American Pierl cross under terms and resulation prescriberl by the

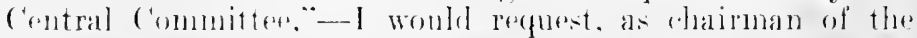
Committee on Red cross Nursing Service, that membership 
be allowed all State Nurses' Associations organized for the enrolhment of Red Cross nurses.

If this suggestion meets with the approval of the Central Committee of the American lied Cross, the following State Nurses' Associations would be eligible for membership: (alifornia; District of Columbia ; Georgia ; Illinois; Indiana; Iowa; Louisiana; Maryland; Massachusetts; Michigan; Nebraska; New Jersey; New York; North Carolina; Ohio; Oregon; Pennsylvania; 'Tennessee; West Virginia; and Wistonsin.

$$
\begin{aligned}
& \text { Very respectfully, } \\
& \text { (JaNe A. Drano) }
\end{aligned}
$$

Chairman, National Committee on Red Cross Nursing Service.

\section{To Miss Delano:}

$$
\text { December 5, } 1910 .
$$

.. That the plan in general, as outlined in report submitted by the (hairman of the Subcommittee on Red Cross Nursing serviee, is approved and the Chairman is requested to transmit the same to the Central Committee for its consideration and action.

\section{(signed)}

\section{TORNEY.}

An example of the letters sent throughout the country is this one of Mrs. Lomishmry.

$$
\begin{aligned}
& \text { The Americhe Natoxil, Red Cross } \\
& \text { Washington, 1). C. } \\
& \text { National Hearlquarters, } \\
& \text { Room 311, State, War and Nary Building }
\end{aligned}
$$

Miss

Presilent State Nurses Association.

Jear M.......

The National Red Cross Nursing Sorvice has been thor-

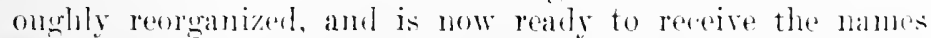
of murses who wish to be enrolled for service. The plan of the Xational (ommittee is to enlist the aletive sympathe ant

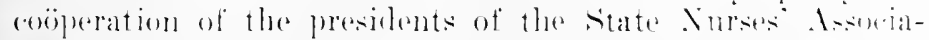
tions and through them to reach the individual nurses.

lon are ordially inviten to assist in this ereat work, and to aret as the distributing enenter for - I emelese a looklet containing the rules and resulations for the Imeri-

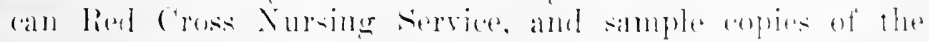
application for corolhment, the ard for filing in Warhimgtum 


\section{HISTORY OF AMERICAN RED CROSS NURSING}

and the card for the endorsement of applicants by State or Alumnæ Society.

IVill you kindly let me know if you will assist us in this great work, which seeks to place in the hands of the Red Cross in Washington the names and addresses of graduate registered nurses, who can be called upon in time of war or national calamity.

Will you send me the names of four responsible nurses of who will assist you, acting as a State Committee? An early reply will be much appreciated.

sincerely yours,

(signed) Harriet Camp Lounsbury, R. N. Mrs. George Lounsibry.

We must pass over Miss Delano's trips to the West in the summer of 1910, primarily to inspect the Army Nurse Corps. It is more relevant to give, here, some glimpse of how the Red Cross enrollment went on, as recorded by Mary A. Clarke in her personal recollections of Miss Delano:

On her return to Washington about December 1, 1910, she asked me to come to assist her in the work of enrollment. . . . Miss Delano was just getting settled in a cozy home. . . . She was essentially domestic in her tastes. . . The American Red Cross offices were then in the State, War and Nary Building, but Miss Delano, expecting to do her Red Cross work betore and after her day at the War Department, made her office in her home.

Her largest room was fitted up for Red Cross work. . . . Applications and letters were gone over daily. A vast number of trpewritten letters of instructions and large packets of circulars were sent east and west, north and south. . . . Every application was carefully gone over, first by me and then by Mliss Delanlo. . .

When the mursing service was reorganized it was found that about 950 nurses had heon enrolled under the old dispensation. Through the Jourmal Miss Delano sought to locate them all, list names and adrossos, number of their balges, date of enrollment and ascertain how many were still arailable for service. . .

Stealily as time went on, qualifications for enrollment berome more stringent. Training shools arrwhere were anxions to come up to the requirements, some insisting upon nore extensive pleliminary eduation on the part of their apphicants, others lengthening their (ourse of instruetion, and some superintendents adling bels to the hospital's former "apacity in ordere to meet the fifty-bed requirement. . . 
It was soon evident that the more the enrollment of nurses was restricted the more eager uurses were to join. By July, 1911, applications were coming in at the rate of 200 a month. . . .

Miss Delano was single minded in her determination to enroll only those women who, in addition to professional efficiency were well recommented personally both by the hospital superintendent and the president of the alumma association. . . She was tenacious of her point as to the personality of the nurse because she felt that the women chosen for Red Cross nursing must be of such uprightness of character, purity of life and good judgment, that they could be relied on to do the discreet and right thing wherever placed. ${ }^{21}$

The home-loving phases of Miss Delano's many-sided personality, to which 1 liss Clarke made referenee, were further described by a close friend who later made her home with Miss Delano:

I grew to love her dearly, not only for her goodness to me but because of her personal charm, her interest in all that pertains to home life, her love of animals and flowers, her almost (hild-like enjorment of the simplest pleasures. I strong sense of humor arricel her through many trying situations and she loved both to hear and to tell a good story. She was rarely idle, rest to her meaning only change of occupation. She worked deftly and swiftly, making every moment count, and she played, when not overburdened as in the last year, with the sime thoroughness. In excellent houselseeper in methods familiar to New England, she was interested in the smallest dotails of her homsehold. . . . It was a pleasure to watch the motion of her hands, they were so capable and eflicient. She was very orderly as to her belongings, but at the same time delightiluly inconsistent, for she would allow her pet dog to talie liberties which to most people would have been annoying. lle alored her and from the moment her ar turned into our street he was at the door with a rapturous greeting.

She professed to have formotten how to murse, ret I shall never foreet an illness whom she arried me hodily to her home, put me to bed and areel for me herself with wonderful tenderness skill and resourefulness. . . .22

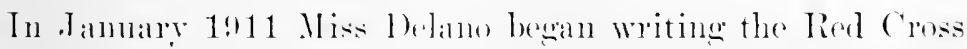
Thepartment of the Ameriend Joumul of Sursing, a responsi-

st Memorandum in Rerd (rone Arehives.

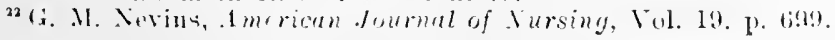




\section{HISTORY OF AMERICAN RED CROSS NURSING}

bility which she carried until her death. In her first notes she wrote:

At a meeting of the Central Committee of the American Red Cross held on Monday, December 5, 1910, the following resolution was arlopted:

That each State or 'Territorial nurses' association organized for the enrollment of Red Cross nurses be admitted to membership in the American Red Cross with the right to send a delegate to the ammal meeting. . . .

[The names of the states arlmitted to membership followed; they have alrearly been given.]

IVe will confine this report more especially to the activities of the Committee on Red Cross Nursing Service. 'The importance with which this work is considered is shown by the official report of Surgeon General George H. 'Torney, chairman of the War Relief Board, which was read at the annual meeting and from which we quote the following:

"Probably the most important accomplishment of the War Relief Board during the year has been the organization of two departments, the First Aid Department and the Nursing Department. It was realized that the importance of these two rlasses of work had become so great and demanded such close supervision that it was essential that two departments be created. The wistom of this decision has been proved by the outrome. The work of the First did Department and of the Norsing Department will be described by their respective chaimen. I ferl, however, that I can allude to the importance of the work of these departments with more grace than can these rhairmen." . .

Since some of our nurses can be relied upon only for organization work, and realizing the inmortance of this, either in time of peare or in the event of war, it was resolver "that all nurses. members of Red Cross Committees. he askerl to enroll even thongh unable to respond to a call for active service.

The first suggestion of Rural Nursing was made in 1910 at the anninal moreting:

A letere from Mjes Wald to Mr. Sehiff was then read hy the rearman. Mise Mald sot forth the neerts of the rural anmmunities for mursing and wished to know if the Red ('mos might not ronsider taking up such a work. While the faret was recosnized he the committere that effort shomld be

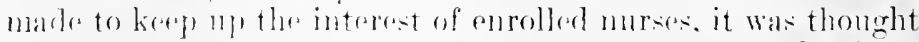
that prepalation for war. and enerencency work in the form 

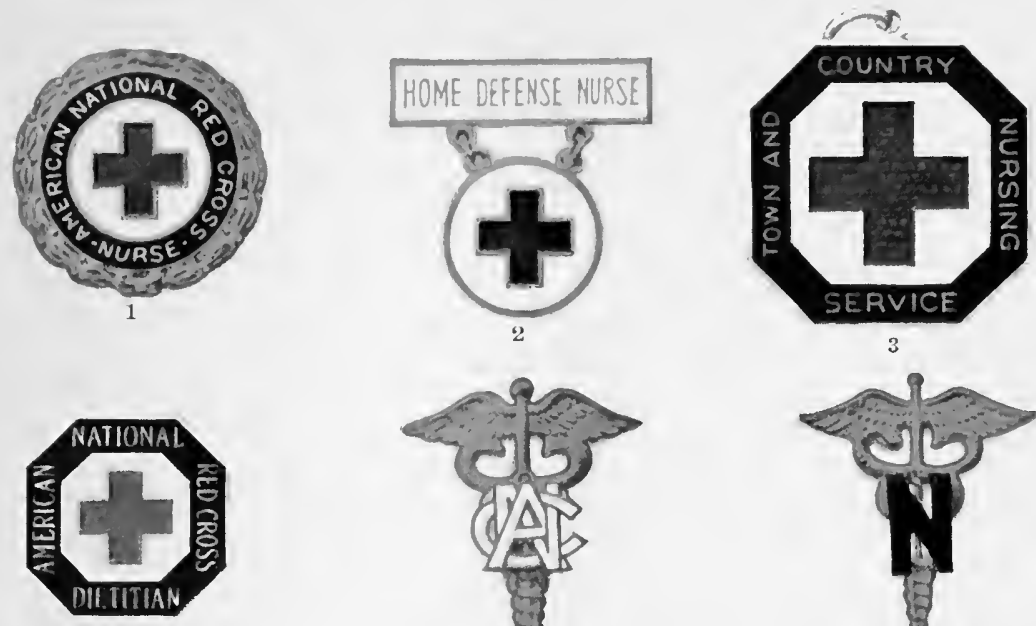

4
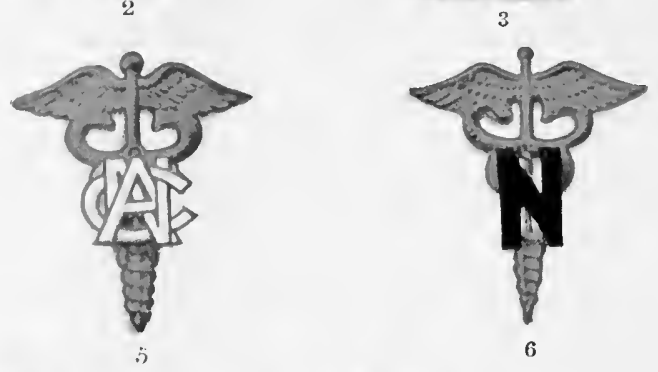

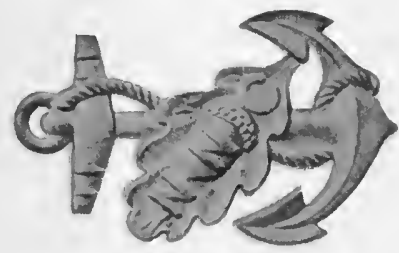

7

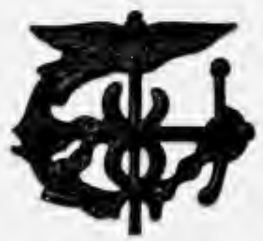

8

\section{Tusinnil (arllial -ize)}

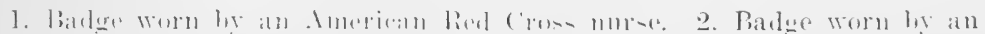

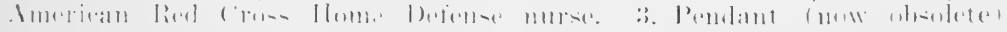

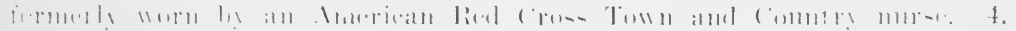

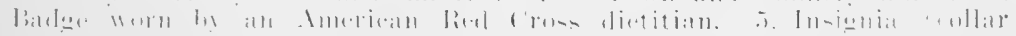

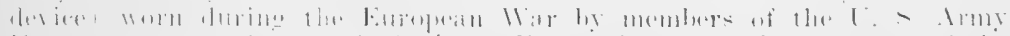

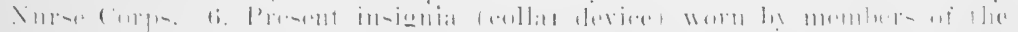

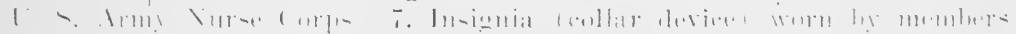

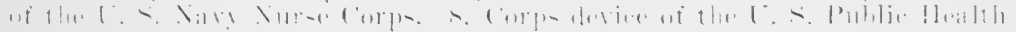

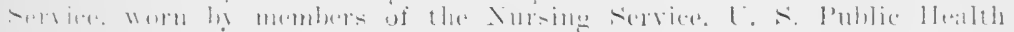
S.Mil i 
of lec ures from army oflicers, if possible, and later perhaps, the formation of home nursing classes, were preferable to any 6 her nursing work by the Red ('ross at present.

IIrs. Draper strongly urged that the lied Cross direct its attention for some time to come to the subject of thorough organization. Mrs. 'Tire mosed that a committee including Mrs. Mraper, Mr. and Mrs. Glenn, and Miss Maxwell be appointed to confer with Miss Wald. This was carried.

Mrs. Draper then brought up the question of assistance to the rhairman of the Red ('ross Nursing service. The small oflice of the superintendent of the Army Nurse Corps was wholly inatequate and she was no longer able to do the constantly increasing work of this committee maided. Major Lynch moved that the Red Cross be asked to appropriate a sum not exceeding $\$ 1: 00$ annually for salury of a clerk and room rent. It was carried.

A paper was read at the same meeting on the "Coordination of Social Agencies," by Annie Laws, secretary of the ("incinnati Chapter. Miss Laws, as Miss Wald had done, brought larger social problems forward. She said among other suggestive things:

The question has arisen in the minds of many as to whether the great Amerian Red ('ross, pledged to help homanity in so many directions, might not extend its fostering eare, through the visiting Red cross nurses, to others needing help quite as haldly as tuberoulosis patients, in some cases more. Also, whether the laret that the lied cross with its insignia being so alsolutely identified at christmas-time with a more limited organization, and yot heing bromght so prominently forward, does not tend to confuse the minds of many people and obseme the lareer signifiane of the lied ('ross. and make it appear ats an aljunde rather than as the great international and national omhlem. . . ..23

This paper and Miss Wald's letter eontain tle initial sugegestions of important sulseguent work of the Red e rose for pullice health which will torm the subjeret of later chatpters.

The year 1911 saw the first nusement of the Tnited States

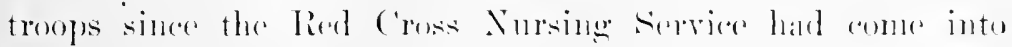

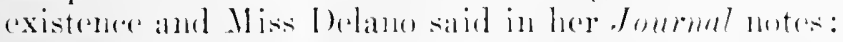

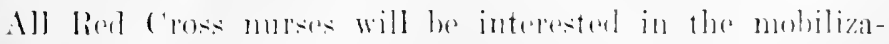

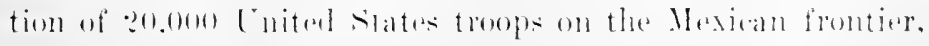

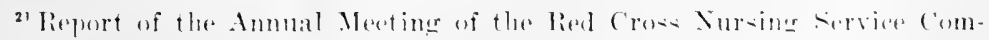
mitter. December 7.1910 . 


\section{HISTORY OF AMERICAN RED CROSS NURSING}

and over 2000 marines in the Gulf of Mexico, for never before in the history of the country has such a large body of soldiers been brought together in time of peace. .. . Should a sudden need for nurses arise, there stand ready to coöperate with the National Committee on Red Cross Nursing Service, 141 nurses on 24 State Red Cross committees, and 233 more on local committees. These committees, with nearly 1300 enrolled nurses, are a guarantee to the nation that neither the stress of calamity nor the turmoil of war will ever again find us wholly unprepared.

The National Committee on Red Cross Nursing Service has in contemplation a plan for providing instructive leetures to be given by medical officers of the army to assemblages of nurses in different parts of the country. Two of these have already been given by Colonel L. M. Mans, Chief Surgeon of the Department of the Lakes; one in Illinois, the other in Wisconsin, at the meeting of their respective State associations. ${ }^{24}$

A letter to Mrs. Reid from Miss Delano at this time gives a personal touch to the activities of each:

May I thank you for your most generous contributions toward the work of the National committee on Red Cross Nursing Serrice and tell you something of what has been accomplished during the past year:- . . .

IVe have a special Red Cross Department in the Journal. of Nursing. and the interest shown by nurses all over the country is most gratifying. We send to each nurse enrolled the usial badge and an appointment card like the enclosed, which is really a card of identification in case the batere is lost. I am sending by separate mail copies of our various blanks, which may be of some interest.

I have boen houing all winter that we conld arrange for a reception for enrollell Red ('ross nurses in Boston at the time of the meetings of the Asorciated Alumme in June and just when I was wombering how it rould be managed your contribution ame thomgh Mrs. Draper. Sothing. I am sure, would more stimulate interest in our Rod Cross work than bringing the enrolled nurses together. I have talked this over with Mrs. Draper and Miss Boardman and they both feel sure that you womld approve of our using a portion of this last antribution for the expenses incurred in griving this roxption. Wr will send an invitation to each enrolled lied cross nurse in the Inited states (we have now

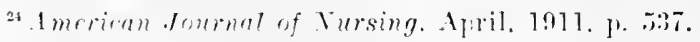


nearly 1600), and hope that many of the Alumne Associations may send them as delegates to the Boston meetings. Mrs. Draper, Miss Boardman, Major Lynch of the Arny and Dr. Elliott of the Nary have all promised to assist in receiving, and Major Lynch has suggested that we invite all the plyssicians in Boston who are on the Army Medical Reserve list.

It was suggested at the meeting of the Associated Alumnæ last year that it would be a great adrantage to have a wellknown nurse attend the rarious meetings of State Societies, Alumna Assoriations, ete., and speak to the nurses in regard to the purposes of our larger organization, the educational value of the Journal of Nursing, and the responsibility of individual nurses toward the Red Cross. We selected Miss Isabel McIsaac, for many years superintendent of the lllinois Training School for Nurses, for this work. She was employed for six months, receiving $\$ 100.00$ a month, and made a complete tour of the various states. All of her traveling expenses were met by the nurses themselves, leaving only her salary of $\$ 600$ to be shared by the American. Journal of Nursing, the Red Cross and the Assoriated Alumnx. Your contribution of last year made it possible for the Red Cross to do its part, and I feel sure that we have been more than repairl by the interest aroused in all sections of the country.

This is a hopelessly long letter, but I am sure you will forgive me, for I feel that I must tell you again how thankful we are for your interest and help. "To have your name on the Committees means much, and 1 really want you to know just what progress we are making.

Believe me,

$$
\text { Yours sincerely, }
$$

The .Tume Meeting of the Associated Alumne in Boston, 1911, was made a special Red C'ross nursing event. A Red Cross reception was held at the Hotel Brunswick, and letters of grecting and congratulation were read. 1)r. Torney wrote:

War Department.

Othice of the sureon (ienerial.

Washington. П. С.. Мay 25, 1911.

Dear Misi Delinno:

It is with ereat gratification that I learn that nearly ?000

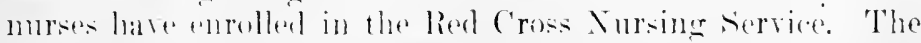
Molical bepartment always looks won these nurses as its resere in time of war. and this laree anrollment is the most pheoularing information I hase receiven in a longer time with 
reference to our efforts to prepare the Department for its work in time of emergency.

I hope you will take occasion at your Boston meeting to express my appreciation of the patriotism shown by the State and Local Committees and the nurses throughout the country in respondng to the call to join the Red Cross Nursing Service.

With a large enrollment of Red Cross nurses, the difficulties that have been experienced by the Medical Department in obtaining a suitable nursing service will be impossible in the future.

Miss Delano wrote, after this meeting:

Nothing has so stimulated interest in the Red Cross as the bringing together of Red Cross nurses from different sections of the country during the meetings of the American Nurses Association.

In August, 1911, the President issued a proclamation relating to the Red Cross service. Its text follows :

By the President of the United States.

A Proclamation.

WHEREAS, the American National Red Cross having been incorporated by an act of Congress, January 5, 1905, "To furnish volunteer aid to the sick and wounded of armies in time of war, in aceordance with the spirit and conditions of - . . the "Treaty of (ieneva of August 2.2, 186t," and

WHEREAS, it is desirable definitely to state the relations that shall exist hetween the American National Red Cross and the Military departments of the government in event of war:

NOH, THEREFORE, I, WILLIAM H. 'TAFT, President of the Cnited states, by virtue of the authority in me rested. to herdy derlare and proclaim-

1. That the American Vational Red Cross is the only voluntere society now anthorizod by this government to render aid to its land and naval forese in time of war.

2. That any other cociety desiring to render similar assistane ran io so only through the American Sational Red Cross.

3. That to amply with the requirements of Article 10 of the International lien Cross Convention of 1906 (revision of the 'Treaty of (imesa), that part of the Ameriean National Rerl cross rendering aid to the land and naval forces will constitute a part of the sanitary services thereof. 
4. That if it should be desirable in time of war, or when war is imminent, for the War Department or the Navy Department to make use of the services of the American National Red Cross, the Secretary of such lepartment is authorized to communicate with the President of the Society, sperifying the waracter of the services required, and designating the place or plares where the personnel and material will be assemblecl.

5. That when any momber of the American Sational Red Cross reports for lluty with the land or naval forces of the United states, pursuant to a proper call. he will thereafter be sulject to military laws and regulations as proviled in Article 10, of the linternational Red ('ross C'onvention of 1906 , and will be provided with the necessary brassard and certificate of iclentity.

6. That except in ases of great omergency the personmel of the American National Red ('ross will not he assigned to duty at the lront. but will be (onfined to hospitals in the home comintry, at the lase of operations, on lospital ships and along lines of commnuication of the military and naval forces of the Cuited states.

IN WITAES WIEREOF I have hereunto set my hand and caused the sal of the ['nited states to be affixed.

Done at the ('ity of Washington, this twenty-second day of August, A. I). one thousand nine hundred and cleven, and of the Independence of the Inited States of America, the one humdred (Seal) and thirty-sixth.

WM. H. T.MFT.2"

Miss Delano's notes in Oetober return to the educational outlook :

It is with much sratification that we announce the formation of Rorl cross committees in all states having a siate

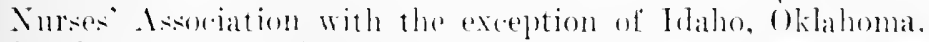
South (arolina and 11 yominge. It is hoperd that hetere the next montlis issme of the formerme we may wolome these states to onr National Branch of this world-wile work for humanitr. . .

This makes in all :31 State Committers. while one lomal Commiteres. With the allition of sureh state ('ommittees as are acting as lomal committone number is. . . .

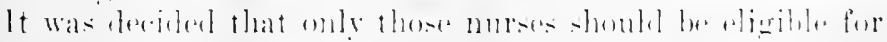

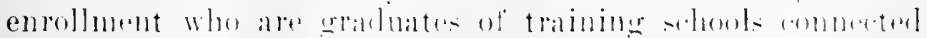

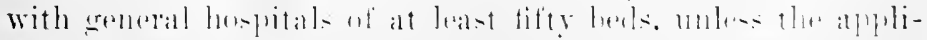

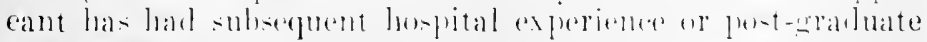

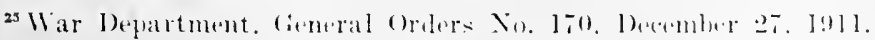




\section{HISTORY OF AMERICAN RED CROSS NURSING}

work. Graduates of training sehools connected with hospitals for the insane must have had at least six months training in a general hospital. . . .

A special committee was provided for, to outline a course of lectures for enrolled Red Cross Nurses. Mary E. Gladwin, superintendent of the City Hospital, Cleveland, Ohio, was made chairman of this committee, with the privilege of selecting her associates. ...

\section{Lectures for Red Cross Nurses \\ Object of Lectures}

1. To keep alive the interest which alrealy exists, and to bring to the attention of the young graduate the desiralility and importance of being identified with the Red Cross Nursing Service.

2. To be a means of education and preparation for future work, either in time of peace or war.

3 . To give enrolled nurses more knowledge of the history, aims and achievements of the Red Cross, a better understanding of relief problems in general, and of the modern humanitarian movements which so closely concern nurses.

t. To furnish a pleasant and useful pretext for bringing enrolled nurses together in loealities where it is seldom possible to provide military or Red Cross speakers. To give to nurses in such places a community of interests which shall make them more valuable to the Red Cross.

5. To have these papers printed, but not published until after they have been well distributed and used. To furnish them to Local and state committees, part of whose duties it shall be to see that they are regularly and properly used.

\section{Slggested OtTlise}

I. History of Relief and the Red Cross.

(a) Before the Crimea.

(b) Floreuce Nightingale.

(c) Solferino and Henri Dunant.

(d) Modern Red Cross.

II. San Francis(o J)isaster.

(a) The Ilisaster.

(b) Immediate Relicf.

(c) Rohabilitation and Reconstruction.

III. The Italian Eisthruake.

(a) The Ilisiliter.

(b) Relief Itork-Road Making. thoemaking, rete. 
IV. Chinese Famine.

(a) Description of Country and Cause of Famine.

(b) Famine Camps-Material Lsed for Food.

(c) Newpaper C'riticism, i.e., Futility of Frequent Relief Inless steps Are Taken Towarks l'revention.

V. Spanish-American War.

VI. Military Hospitals.

Vll. The Red ('ross in Other Countries.

VIII. Notable Medical Achievements of U. S. A.

1X. Forest Fires, Mine Disasters.

X. Relief Work for Celebrations and Parades. ${ }^{26}$

The full committee on the lecture conrse were: Mary E. Gladwin, Mabel T. Boardman, Major Lynch, Ermest P. Bicknell and Miss Delano, ex-officio.

Important details of perfected organization were referred to by Alss Delano in her report of 1912:

At the last meeting of the National Committee, held in Washington, December 4, 1911, it was decided that every nurse enrolled for service under the Red Cross must be a member of an organization affiliated with the American Nurses' Assoriation.

Believing that in order to do effective work, there must be coibrdination of the rarious lied ('ross artivities. it was suggested by the Yational Committee that there shonld be appointer in the Red ('ross reliof committee of earh institutional member an enrolled hed Cross nurse to represent the nursing service.

In the notes of April, 1912, there comes the anticipation of the beantiful bilding in which the Red Cross is now housed:

Mention was made in the November Journal of the proposal to erest in the r.ity of Washington a national monument to the memory of the brave women of the Civil War. At that time no sligerestions had heren offered as to the form which this memorial should take. but it wemed a grancions trihute to the work of women many of whom hat served as nurses during the four years of war. It is now proposed that the monmment to be ereretel shall take the form of a buileding to be given as headenarters to the Ameriean liesl ('ross in perpetuity. It some must alpropriate that the hmmatarian work of the Amprian lied ('ross in all the years to rome

2n. Tournal Department, Oetoher, 1931. 


\section{HISTORY OF AMERICAN RED CROSS NURSING}

should be carried on in a building commemorating the zeal and devotion of the patriotic women who inaugurated the Sanitary Commission, raising millions for relief work and who braved the dangers and discomforts of fever stricken camp or crowded ward to lessen the suffering of the sick and wounded.

Can we wonder that a memorial to them has appealed to the public conscience and finds favor with all who shared in the sorrow and anxiety of those years?

In the summer of 1912 the Ninth International Red Cross conforence was. held in Washington,-the tirst outside of Europe. The sessions were held in the Pan-American Building. The Secretary of State selected four murses as official delegates. These were: Misses Maxwell, Nevins, MeIsaac and Delano. The Red Cross Nursing Service committees were also represented, for there were present Mrs. Gretter of Michigan; Miss Giberson of Pennsylvania; Mrs. Tupman of Georgia; Miss Robinson of Illinois; Miss Stuff of Nebraska; Miss Rommell of Minnesota; Misses Black and Fletcher of Virginia; Misses Gladwin and Echols of Ohio; Miss Wilkinson of Connecticut and Miss Perry of North Carolina.

At that meeting the momorial to Miss Nightingale was agreed upon of which Miss Delano wrote in her August notes:

The Red Cross societies of the world agreed to raise a fund to be known as the Florence Nightingale Foundation. $A$ special committee was appointed to make recommendations concerning this fund with Sir John Furley of the St. John's Ambulane Association as chairman. II iss Boardman and Miss Delano were asked to serve on this rommittee. It was agreed that a medal, accompanied hy a cortiticate on vellum, to be called the Florence Nightingale Medal, should be instituted and that six such medials, to be increased to the number of twelse in the erent of a ereat war, should be available annully: that they should be sranted only to trained murses who inaly have especially distinguished themselves by great and exceptimal desotion to the sick and womeded in peare ol war. So country may propose more thall one andidate for this medal amualiy. The dinal award is made by

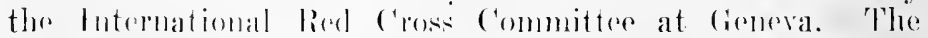
awardiner of these medals to murses will be akin to the be-

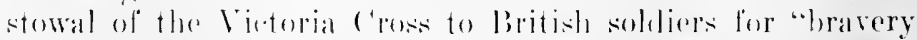
in action" and will br the highest honer which "an be paid to any nurse. A most fitting memorial to one "who rescued 
from obseurity and shanc a noble profession," may this Nightingale Medal prove ever an incentive to higher and higher stanlards of duty among us.

At that time Miss Delano did not enlarge upon the discussion held over the Florenee Nightingale Medal, but later (1918) she told something of lier part in it, and as it illustrates very interestingly leer tact in mecting the foreign viewpoint in nursing, we include here her subsequent narrative of the difficulty of limiting a Nightingale Medal to a nurse trained on the Nightingale system:

I was placed on a committee to decide as to the awarding of the Nightingale medal for service in time of war: and I assure you it was no easy task for me to convince the other members of the committe- (I believe I was the only member representing this country, but at any rate I was the only one that spoke for nurses alone) - first that it should be given only for the actual (are of the sick and wounded; and second, that it should only be awarded to women who could qualify as graduate nurses. We were in session for part of two days before I convinced them that I was right that this medal, the Florence Nightingale Medal, should be given to graduate nurses for service in the actual care of the sick and wounded. That eliminated abolutely from any possibility of securing this medal women who were engaged in organization work in any of the comntries of the world. It eliminated any woman who might contribute large funds to the organization of the nursing servios in the time of war. It pinned the award of that molal down absolutely to a graduate murse. At that time wr ande only sugrest one and l sugrested Mary $E$. Gladwin, and I hope that eventually she will receive the Florence Nightingale medal. ${ }^{27}$

Miss Delanes cefort in thus restricting the medal was heartily soronded hy Miss boardman, who was fully in aceord with her view.

At the ammal meeting of 1912 Miss lolano, who had been a member of the War Rolief Boald since the oreanization of

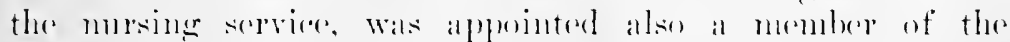
National Relief lional. The tirst intimation of an apperatehing wat theal is given in the committer reports of that mereting.

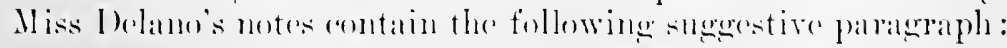

\footnotetext{
${ }^{n}$ Proceedings Xational League for Nursing bolucatiom, 1918. page ltil.
} 


\section{HISTORY OF AMERICAN RED CROSS NURSING}

At its annual meeting in 1912 the American Medieal Association authorized the appointment of a committee whose duty it should be to confer with the Ameriean Red Cross with a view to establishing a comprehensive system of coöperation between the Red Cross and the physicians of the United States. This coöperation is expected to be effective in providing prompt and adequate medical and surgical attendance on the occurrence of great disasters and also to afford a reserve upon which the Red Cross may draw for a medical personnel in the event of war. It is probable that a system of enrollment will be adopted which will eventually build up a large force of Red Cross physicians representing every section of the country. The committec representing the American Medical Association in this matter consists of Dr. Gcorge M. Kober, Washington, D. C., (hairman; Colonel F. A. Winter, of the Army Medical Corps, and Surgeon E. M. Blackwell of the Nary.

The American Journal of Nursing in Febluary, 1912, made this commentary on the situation indicated in the sentences just quoted :

No department made a better showing of work done during the year than that of nursing service as presented by Miss Delano. The medical department of the lied Cross is murh less well organized, although the American Iledical Associaton has now taken the matter in hand and working through a committee will enroll a corps of physicians for Red Cross service and to act as an army reserve in time of war.

In April, 1913, there recurs in Miss Delano's notes the intimation of impending war. She wrote:

A special committce has recently been appointer] [of which Miss Delano was a member] to formulate plans for the organization of a Red cross persomnel to be called un on for service, either in time of lisaster or with the military forces in the event of war. . . It is proposed as an experiment to crganize at varions solected points huspital columns mare up of the following: One director. three assistant directors, who shall be physidians. six rhief nurses and forty-five nures. It is intended that these physicians and nurses shall be brought together for sperial instruction in the duties which would be required of them when called unon for service under the Red Cross.

It has been estimated that in the eyent of war with a first class power nearly half a million volunter troops would be 
needed at once and four thousand nurses for the Army alone, with an additional thousand nurses for the Nary. It is impossible to estimate the future demands but with our experienced committees of nurses and the ever increasing enrollment we feel sure there would be no failure on the part of the Nursing Service of the Red Cross.

From this time on there were ehanges preparatory to war service. The National Committee on Nursing Service had some of these changes. Miss Delano's notes say:

Owing to his transfer to the Philippines, Major Charles Lynch, Medical Corps. U. S. A., has resigned from this committee and in his place Major R. U. Patterson, Medieal Corps, U. S. A., has been appointed. Miss Georgia Tevins, who had served on the rommittee since its creation has also resigned and Mrs. Lena s. Highee, superintendent of the Navy Nurse Corps, has been appointed by the War Relief Board as her successor. Miss Julia C. Stimson and Miss Mary E. Gladwin have also been appointed to fill vacancies on the committee. The full committee is as follows:

Miss Jane A. Delano, Chairman.

Miss Mabel T. Roardman,

Mrs. William K. Draper,

Maj. R. L. Patterson,

Dr. T. IV. Richarets,

1)r. Wm. II. Weleh,

Mrs. Frederick 'Tice,
Miss Emma M. Nichols, Miss Alma E. Wrigley, Mrs. Whitelaw Reid, Miss Anna Maxwell, Miss Isabel Mr.Isaac, Mrs. Lenah Higbee. Miss Mary E. Giladwin, Miss Julia S. Stimson.

As the conrolled Red Cross nurses form the reserve of the Army the surgeon (ieneral of the Army has detailed a member of the Army Nurse Corps. Miss Ama Reeves, to assist in the recort work of the lied ('ross ofrice. This will add to the efficiency of the service and give the chairman more time for constructive work.

There has been a satisfactory increase in the number of enroliments, and even more discrimination and areful selertion of nureses on the part of the Local ('ommittees. We now have over 4.200 enrolled lied cross nurses, and have Loual

29 Though in praction this had heen aceepted for a long time the order

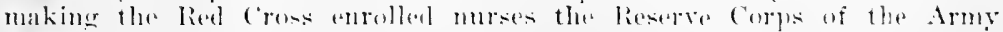

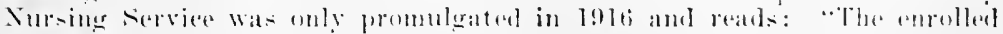
murses of the Amerian lied (ross Nursing Survice will antitule the lieserve of the Army Nurse Corpls, and in time of war or ot her emereneney

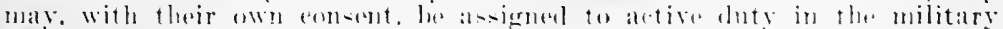

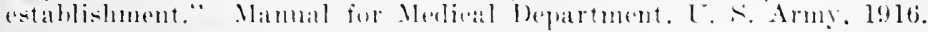




\section{HISTORY OF AMERICAN RED CROSS NURSING}

Committees in practically all of the large nursing centers in the United States.

The committees appointed primarily for the enrollment of nurses have responded with enthusiasm to all demands made upon them. In organizing our rural nursing service, we have sought their advice and assistance. In the development of our classes of instruction for women we shall rely upon them to suggest instructors and examiners from among the Red Cross nurses. ${ }^{29}$

\section{Early in 1914 Miss Delano reported:}

Late in April the National Committee on Red Cross Nursing Service was instructed by the War Relief Board to communicate with all Local Committees asking for a list of nurses a vailable should it be necessary to call on our Red Cross personnel for service in Mexico. The response was so prompt and enthusiastic that we felt secure in urging all nurses not to begin preparations for service or give up their present positions unless definite instructions were received. It seemed wise, however, to have a small group of Red Cross nurses ready, and a few Loral Committees in nearby cities were asked to prepare eligible lists. These nurses were then requested to present themselves for physical examination. antityphoid treatment and vaccination for smallpox.

On May 9, a call came from the Surceon General of the Uniterl States Army for three Red C'ross nurses to go to Vera Cruz, and the following Washington nurses were selected from among those on the arailahle list: Kathrine Domnelly, Luhu T. Floyd, Nannie B. Hardy and Nice B. Harrey. These nurses reported at once to lied Cros: Hearlquarters, and in a few hours all necossary preparations for their leparture had been made. They left Washington on sumdar aftermoon, May 10, in charge of Miss Elizabeth Reed, a member of the Army Nurse Corps, who has been assigned as rhief nurse for Vera Cruz.

A circular of information giving definite instrurtions conrerning uniforms and equipment has been prepared in the hole that our nurses may a void the common mistake of carrying useless lugerage and leaving at home the things most needed. A special fiekd uniform of blue-gray had been adopterl. of surh material and style as to launter casily and park in small sure, the wap, collar and apron of which can be laundered without starch; while most suitable for service in a warm country the uniform is still neat and attructive.".

* Reports, National Committee on Nursing Service, December, 1913.

30 Ameriean Red rooss llagazine, July, l!14. 
This note of July, 1914, reeapitulated what scemed later to have been a game of child's play, faintly foreshadowing the terror about to deseend on the world.

In this section of this history no attempt will be made to do more than compile in very brief form the share of the Nursing Service in those instances where nursing was required to supplement the general work of relief.

The San Francisco fire, following the earthquake, brought out nurses as voluntecrs. Affiliation had not taken place, but there was a local Red Cross socicty, with a committee on nurses. The ehairman of that eommittee, Mrs. L. L. Dunbar, wrote:

There was no further need of the Red Cross Society in San Francisco until 1906. In 1905 when Congress made the society national, an organization was effected in San Francisco with Judge Morrow as president. There seemed no hurry and Judge Morrow was a busy man and no committees were appointed until April 17, 1906, when a meeting was called, and Judge Morrow appointed the committees on nurses and physicians. Then the very next day came the earthquake and fire. I had been appointed chairman of the committee on nurses, but I was out of the city at the time and rould not get back into it for a week. IIeanwhile our nurses hat responded to the need, and though without organization had done much. As soon as I was able to get back to the city and some organization could be effected, conditions greatly improved. ${ }^{31}$

The eall to send nurses to the scenes of the Mississippi floods (April 1908) has been mentioned as the first such demand that was made on the Washington Headquarters after the interest of nurses in the lied ('ross had led them to join local and state Red Cross societies in fairly large mumbers. Fighteren numses were sent from New York, Pennsylvania, and District of Columbia Branches of the Red Cross, and emereney hospitals were established. The work eentered in Mattiesbure, Mississippi. IIalt an henr after the wire came to Philadelphia, asking for nurses, the nurses were on their way. The eharacter of the serviee rendered is slown in the report of the New York Branch, from which the following brief portion of the narrative as told by the nurse in wharere is taken:

at Red Cross Magazine, January, 1908. 


\section{HISTORY OF AMERICAN RED CROSS NURSING}

We arrived in Hattiesburg, May 17.

Previous to the coming of the Red Cross nurses the local relief committees had sent to New Orleans for six Charity Hospital graduates and were paying them at the rate of $\$ 25$ per week for relief work in the two hospitals. Three of these nurses were discharged soon after the arrival of the first detachment of Red Cross nurses, and the remaining three after our arrival. Three of our nurses were assigned to night duty, two to day duty, and I was to act with Major Simpson and Captain Ashford in coördinating the food, medical supplies and repairs, also clothes, equipment and the names of discharged patients who were entitled to transportation, etc. ... My duty was to go each morning to the hospitals, army tents and Red Cross relief stations; and collect and inspect all requisitions, when needful make suggestions and eliminate all requisitions not provider in the list of medical and commissary supplies provided by the Relief Expedition. These requisitions were then taken by me to the official offices to be approved and signed, then to the storehouse to be filled and delivered. All complaints from either superintendents. patients or head nurses regarding supplies, etc., were furnished me in written signed complaints, to be adjusted by the officials in whose department they were. As the buildings were from one-quarter to one-half mile apart and as I went mostly on foot, my first week was a pretty busy one, until I had learned to systematize my work.

May 29, 1908.

(signed) Gexoveva PetTit. ${ }^{32}$

The Dallas floods occurring in the summer of 1908 created conditions that called for nurses. The service was supplied entirely by the Texas Red ('ross State Nursing Committee. Its president, Mary Sherman Allen, wrote of the experience that she and her staff had there:

As many people in the larger camps were sick, from exposure and the terrible experience they had passed through, some being days in tree-tops before rescued, it was thought adrisable to stablish emercency hospitals in ('amp) Hay and Camp Ferris. We, therefore, istued a call for nurses and nearly all of our conrolled nurses responded to the call, and

3a The American National Red Cross Society, at its meeting held last Nowember. decorated Elizabeth M. Hewitt and .J. Peatrice Buwan. both of the Nurse Corps. Inited states Navy, with a serviee bar for volunteer work dome under the liewl cross at Ilattiosbure. Miss.e after the erolone of last spring. The bar is of hrone and on its face are the words, Hattisaburg, 1908." Americen Jonemal of Nursing. September, 1908. 
immediately we established a large field emergency hospital, fully equipped with drugs, sanitary dressings, cots for the sick and all appliances to care for those that needed the attention of the Ped ('ross. 1)octors Stoval, Furgeson, Black and Davis had charge of the medical department; Miss Mary Emisson, charge of the lospital work, and the Misses Annie Swinsky and Ailrian Palm, trained lied Cross nurses, charge of nurses' department. Our Emergeney Hospital stood at the head of a broad avemue of tents. The camp presented a beautiful picture and the Vinited States flags and Red Cross flags floating above our hospital tents could be seen for miles around. Sanitary (onditions and perfect order were maintained during the entire time. Our doctors and nurses were kept busy earing for cases of fever and other diseases caused by exposure.

Our doctors and nurses cared for many eases of destitution and sickness in both (amps, as well as in all parts of the eity where needed, and it has been the miversal expression that the prompt, efficient and systematized work of the Red Cross did much in preventing an epilemic of fever. ${ }^{33}$

No nurses were sent from America by our Red Cross at the time of the earthipuake in Sicily (1908), but three or four Ameriean nurses were in Italy at that time and volunteered their services. It is interesting to know that one of these was Aliee Fitzgerald, a dolns IIopkins nurse, whose later important position as chief nurse of the commission to France and still later as director of the nursing service of the Leagne of Red Cross Soejeties, will be fully told in another chapter.

When a building collapsed in Philadelphia, July, 1909, a single Red ('ross nurse, Margaret B. Sinon, was the heroine of this aceident, and for her work sher was commended by personal letters frem the Mayor of Philadelphia, and from the (then) President 'Taft.

At the time of the ('herry Mine disaster, nurses, though ready, were not sent be the Washington office, as the Visiting Nurses' Association of ('hieago had conough of its staff to fill the resunied servine.

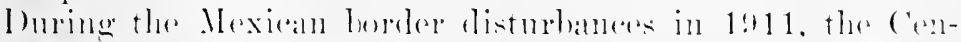

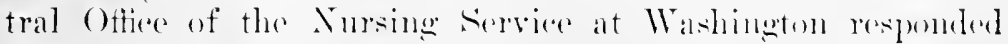

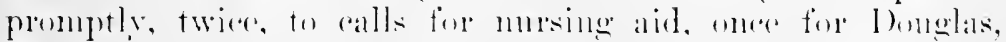

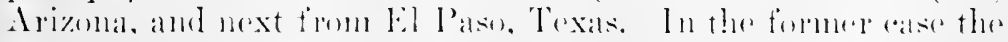
experted mensity did not alrise, alled in the lattere, two Aneri-

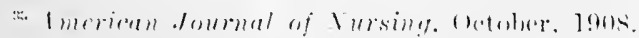




\section{HISTORY OF AMERICAN RED CROSS NURSING}

can Red Cross nurses began to organize work, which was then taken over by the Mexican Red Cross.

When the Anstin Dam broke in 1911, the Red Cross Service stood readr to provide numses, but they were not needed, as the State of Pemnsylvania provided pliysicians and nurses.

In the floods of early summer, 1912, Mississippi and Louisiana being the chief sufferers, the Red Cross Nursing Service organized relief for the sickness which resulted from the floods and the hot weather. A staff of nurses was mustered by the Kansas City Local Committee on Red Cross Nursing Service at the request of the Washington office, to be sent to Mississippi, leaving New Orleans nurses to supply Louisiana. Camps were formed for the refugees and the nurses were stationed in these. Thirteen nurses were assigned to duty. Miss Delano wrote: ${ }^{34}$

In each case the response to our call was prompt. Too much cannot be said in praise of the splendid spirit shown by the nurses.

The Omaha cyclone occurred in March, 1913. In the American Red C'ross Magazine for July, 1913, Miss Delano wrote:

Soon after the April number of the Red Cross Magazine went into print we were alled upon to face a series of disasters such as this comutry had never before experienced. The efficiency and preparedness of the Nursing service of the Red Cross were well tested and the nurses were found ready to meet all the demands made upon them.

As soon as the new of the Omaha disaster was received in Washingtom rommmiration was estahlished, through the courtesy of the [nited Press, with Miss Lillian B. Stuff. Acting ('hairmin of the Nobraska Committee on Red Cross Nursing sorvice, and anthority was given her to call out Red Cross nurses and to organize such relief as lay in her power. An emoreney hospital of one hundred and fifty beds was established in a local grmulsium where they ared for the injured and homeless.

Mis. stult. in here report. al's. "We did not wait for" alls to eome to us. but makle a house to hemse canvalss as many

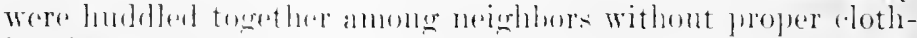

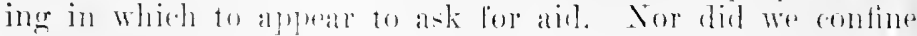
our efforts entirely to mursing. but gave whatever help was neereled."

34 1 merient Journal of 1 ursing, Soptember, 1912. 
A hospital of one hundred fifty beds was established and eight Red Cross nurses were continued in service there for some weeks after the disaster.

Two days after the Omaha cyclone, vague rumors came to us over press wires of the Dayton horror. Telegram after telegram was sent to our Local committees on Nursing Service and on March 20 a message (ame throngh from ('incinnati concerning the assignment of their own nurses to duty and asking that one hundred alditional nurses be sent to them at once from adjoining cities.

'The chairman of the National Committee on lief Cross Nursing Service and ten Red Cross murses left Washington with Miss Boardman on Friday, March 28 , at midnight on a special relief train sent out by the Washington l'ost. 'This train reached Cincinnati Sunday morning and found the most perfect coopperation between the lowal Chapter, nursingr committees and various relief agencies. ${ }^{35}$

In her Ammual Report, Miss Delano said:

During the first forty-eight hours following the Ohio flood, which occurred March 25, seventy-seven unses were assigned to duty by the Cincinnati Local Committee, and in response to telecrams sent from Washington one humberl and thirty-six nurses from other cities rearhed the flooder area during the next forty-eight hours. These nurses were sent from Chimago, St. Lonis, Detroit, Am Arbor, Cleveland, and Akron, while ten went from Washington and Baltimore on the "l'ost Sperial" with the rhairman of the Nitional Committee. Rerl cross nurses were assigned to the following cities in the flooded arat:

Columbus, Dayton. IIamilton, Midlleton, West Carrolton, Portsmouth, Miamisburs. Cilenlale, Peru, shawnertown. Catletsburer. Marsille, Point Pleisinnt.

The number of nurses assinged to duty at any one place and the lengtlo of service depended npon lenel comblitions.

He were fortunate in having an artice hod ('ross ( haptere in

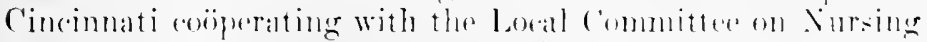
Service, and through the prompt action of llise Anuie laws,

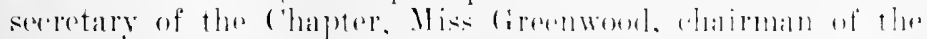

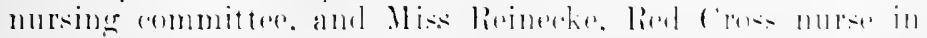

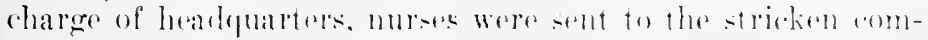

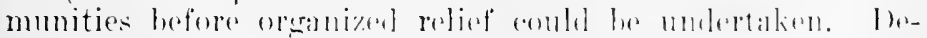
tailed reperte of the work done hy our nurses under the supervision of Miss Mary kE (ilatwin, hairman of the ohio

"Rod Cross Magazine, July. 1!) I3. 


\section{HISTORY OF AMERICAN RED CROSS NURSING}

State Committee, and in charge of the nursing relief in Dayton; Miss Ella Phillips Crandall, of Teachers College, New York, responsible for about fifty nurses doing sanitary inspection work under the direction of Major T. L. Rhoads, Medical Corps, United States Army; Miss Mary C. Wheeler, superintendent of Illinois Training Sehool for Nurses, Chicago; Miss Emily MeLaughlin, superintendent, Harper Hospital, Detroit; Yiss Julia C. Stimson, in charge of social service work in St. Louis, Mo., Miss Jennie L. Tuttle, superintendent, Tisiting Nurse Association, Columbus; Miss Mary B. IVilson, and Miss Abbie Roberts, of Cincinnati, have already appeared in the Red Cross Magazine. These nurses and many others were relieved from responsible positions, and in some instances substitutes were employed in order that they might meet their obligations as enrolled Red Cross nurses.

In describing the work of the Red Cross nurses in Dayton, Miss Gladwin wrote:

They may be found serenely picking their way around wrecked furniture, sodden mattresses, ruins of porches and sheds; wearing rubber boots, with skirts kilted high, wet nearly to the waist; sending sick people to the hospitals, inspecting plumbing, back yards and cellars; superintending all sorts of work from feeding the baby to the digging of trenches. Through all parts of the flooded city nurses go on similar errands, inspecting nearly nine thousand homes and reporting conditions found.

Through the activity of Mrs. H. C. Lounsbury, clairman of the Mest Virginia State Committee on Red Cross Nursing Service, most efficient relief was rendered at Point Pleasant. West Virginia. Mrs. Lounshury and two other Red Cross nurses "went down the river on a boat loaded with supplies furnished hy the ritizens of Charleston and the neighburing towns." They found little sickuess at Point Pleasint, and devoted their efforts ahiefly to the distribution of clothing and supplies and the establishing and maintaining of sanitary conditions. ${ }^{36}$

The murses were on duty for four weeks, and it is reended that in Inatom alone they ared for over two thousand cases of illuess or alecident. This was the sererest test ret given to the lied Cross Nursing serviee. and the way in which it was met

\footnotetext{
an Iiport of the Sational committe on Red Cross Nursing Service 1913.
} 
was justifiably regarded as a triumphant proof that organization was now in perfeet rmning order. ${ }^{3 i}$

When a terribly destructive fire in Salem made thousands of people homeless the Boston Loeal Committee on Red Cross Nursing Service took eharge of nursing relief. Stations were appointed and Red Cross nurses assigned to each. A Maternity Hospital with a Milk and Baby Hygiene Station was organized and a Contagions Hospital established. The work of the nurses was largely preventive and was well and thoroughly done.

The Eastland disaster which occurred in 1915, was reported as follows:

On July 24 one of the large excursion steamers, which had been chartered by the employees of the Western Electric Company, overturned just before the boat was ready to leave the dock. 'There were about twenty-five hundred people on board and of this number over nine hundred lost their lives. The accident occurred about seven o'clock in the morning. The chairman of the Local Committee on Red Cross Nursing Service, Miss Minnie Ahrens, heard of the catastrophe on the way to her office and started at once with another nurse for the scene of disaster. She telephoned immediately for additional nurses, not only to headquarters of the enrolled Red Cross nurses, but to the registrar of the Central Directory and all Public II aalth Nursing organizations. Nurses responded quickly and reported on arrival to the chairman of the Committee for instructions. By one o'clock at least one hundred nurses were on duty. They worked in the pouring rain wherever the rescued were carried, and many taken from the water before nine oclock were resuscitated. About noon shelter was provided in the Reed Murdock Wholesale Grocery Building, and artificial respiration, hot applications and other emergency treatments were continued as long as there was the slightest lope. When nothing more could be done for the injured, a morerue was established at the serond lecriment Armory where relatives could identify their dead. Five heal ('ross nurses were assigned to duty in an emergenty hospital at the morgue to grive such care and confort as miglit be posible to those who were bereaved. 'This emergency hospital wat continued with relays of Red ('ross nurses until

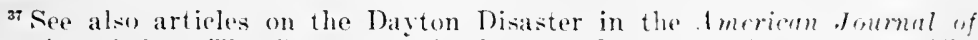
Nursing. 19l3. The Red ('rosis in Dayton, ly Mary E. Giadwin. The Work of the cincimati bocal lied cross Nursing Service committon, hy Mary II. Greenwood. lieport sent to Miss Delano ly Ella Plillips Crandall, etce 


\section{HISTORY OF AMERICAN RED CROSS NURSING}

Wednesday, July 28, all serving gratuitously. In closing her report Miss Ahrens, who had charge of the work and who rendered most efficient service, said: "It is at such a time that we realize and appreciate the value of our Red Cross Nursing Service. Without organization it would have been impossible to have had such coöperation. ${ }^{38}$

The year 1917 had a number of calls for nurses in times of disaster; six were called to New Castle in Indiana; nineteen to New Albany, Indiana; four to Chester, Pennsylvania; eight to Atlanta, Georgia; thirty-four to two Illinois towns; five to Hickman, Kentueky ; three to a Missouri town ; one to Springport, Michigan; five to East St. Louis; one to Clay, Kentucky. The crowning disaster of 1917 was the explosion at Halifax, Nova Seotia.

The terrible calamity resulting from the explosion of war munitions in the harbor of Halifax, on the 6 th of December, 1917, will long be remembered. Amidst the many forms of relief and suecor ealled for by the unparalleled destructiveness of the disaster, nursing aid was needed. From this eountry a number of nurses were reeruited in desperate haste by Red Cress committees and hospital authorities of the New England states, as being the nearest to the scene.

The Providence Local Committee on Red Cross Nursing Service sent fifty nurses in charge of Grace L. McIntyre, Chief Nurse; various hospitals sent physicians and nurses; the Committee of National Defense and the Public Safety Committee formed units of physicians who chose their own murses, and thus the New England Hivision Headquarters of the Red Cross was not called upon to supply nurses.

Miss Delano was kept informed of the movements of nurses and on December 17 wrote to Elizabeth F. Sherman, of Providence, who had been prominent in eollecting Miss MeIntyre's staff:

December $1 \%, 191 \%$.

May I thank you for your very satisfactory report of the Halifax activities. It is our desire that Red Cross Committees shall cöpperate in every way possible in relief work of this kind withont waiting for orders from IIearlquarters. as the important thing in disaster relief is to meet the need

${ }^{34}$ Annual Report of the Committee on Red Cross Nursing Service, 1915. fee also the Rere cross. by Mimie Abrens. Imerican dournal of Nursing, (rother, 1915. 
as quickly as possible. I am more than glad that you were able to secure the nurses, and appreciate greatly your untiring efforts in the matter.

In this brief summary of special emergency mursing episodes there has been no attempt made to cover purely local, isolated instances where Red Cross nurses have eome forward. Nor can the numerous list be included of such preparations for nursing eare as were made, for instance, at the time of the Veterans' Reunion at Gettysburg, and similar remions; still less the long list of such oceasions as might be covered by the term "Dress Parade." For events of this kind the report of a typical year will give sufficient idea, as follows:

\section{Axyua, Report, 1917. \\ Relicf Actiritics.}

The following relief activities have been conducted during the past year by our Local Committees:

\begin{tabular}{|c|c|c|c|c|}
\hline \multicolumn{2}{|c|}{ Date } & Town or City & Oceasion of Service & $\begin{array}{c}\text { Red Cross Nurses } \\
\text { on Duty }\end{array}$ \\
\hline \multirow{3}{*}{\multicolumn{2}{|c|}{$\begin{array}{l}\text { January I } \\
\text { Mareh } 4 \\
\text { March } 5-10\end{array}$}} & Pasadena, Calif. & Tournament of lioses & 2 \\
\hline & & Waslington, D. C. & Inauguration & 19 \\
\hline & & Clevelanel, Ohio & $\begin{array}{l}\text { Central Armory } \\
\text { Colebration }\end{array}$ & 10 \\
\hline “ & 12 & New Castle, Ind. & Cyclone Disaster & 6 \\
\hline •. & $2: 3$ & New Albiny & Tornado Disaster & $\begin{array}{l}10 \text { from Indiana } \\
5 \text { " Cincinnati } \\
4 \text { " Kentucky }\end{array}$ \\
\hline \multicolumn{2}{|c|}{$\begin{array}{l}\text { April } 10 \\
. . \quad 16 \text { to } \\
\text { May } 26\end{array}$} & $\begin{array}{l}\text { Cliester, P'mna. } \\
\text { Washington, D. C. }\end{array}$ & $\begin{array}{l}\text { Edelystome Disaster } \\
\text { lincimpment, Nary } \\
\text { league }\end{array}$ & 4 \\
\hline \multicolumn{2}{|c|}{ May 21} & Atlanta, Gia. & Fire Disaster & $\begin{array}{c}\text { S Bloomington } \\
\text { Ill. }\end{array}$ \\
\hline “" & 25 & $\begin{array}{l}\text { Charleston. IIl. } \\
\text { Mattoon, Ill. }\end{array}$ & $\begin{array}{l}\text { (yolone bisaster } \\
\text { (yelone bisaster }\end{array}$ & 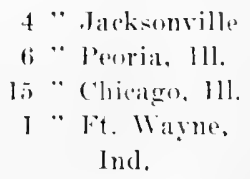 \\
\hline “ & $2 ?$ & Hickman, Kentucky & ('yolunu )isistrer & 5 \\
\hline " & 10 & Brooklyn, N. Y. & 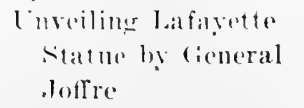 & 4 \\
\hline
\end{tabular}




\begin{tabular}{|c|c|c|c|}
\hline Date & Town or City & Oceasion of Service & $\begin{array}{c}\text { Red Cross Nurses } \\
\text { on Duty }\end{array}$ \\
\hline May 30 & Briclgeport, Conn. & $\begin{array}{l}\text { Memorial Day Exer- } \\
\text { eises }\end{array}$ & 8 \\
\hline $\begin{array}{l}\text { " } 31 \text { to } \\
\text { June } 30\end{array}$ & Mineral Point, Mo. & Tornado Disaster & 3 \\
\hline June $2-9$ & Washington, D. C. & Confederate Reunion & 20 \\
\hline “ 9 & Springport, Mieh. & Tornado Disaster & 1 \\
\hline " $17-22$ & Atlanta, Ga. & Rotary Convention & 4 \\
\hline " $3 \cdot 6$ & East St. Louis, Ill. & Race Riots & 5 \\
\hline July 4 & Phelps, N. Y. & Military Maneuvers & 3 \\
\hline " 4 & Newport, R. I. & Parade & 1 \\
\hline $\begin{array}{l}\text { " } 28 \text { to } \\
\text { Sept. } 3\end{array}$ & Brilgeport, Conn. & "Lordship Park" & 1 \\
\hline August 4 & $\begin{array}{l}\text { Clay, Kentueky } \\
\text { Albany, N. Y. }\end{array}$ & $\begin{array}{l}\text { Mine Disaster } \\
\text { State Federation of } \\
\text { Women's Clubs }\end{array}$ & $\begin{array}{l}1 \\
9\end{array}$ \\
\hline $\begin{array}{l}\text { Septem- } \\
\text { ber } 10\end{array}$ & Grand Rapids, Mich. & $\begin{array}{l}\text { Union Depot for } \\
\text { troops passing } \\
\text { through }\end{array}$ & 2 \\
\hline
\end{tabular}




\section{CHAPTER IV}

THE MERCY SIIIP

The S. S. "Red Cross" Sails-Paignton, England-Pau, France-Kief, Russia-Gileiwitz, Germany-Kosel, Germany-Vienna, Austria-Budapest, IIungary-Belgrade, Serbia-Gevgeli, Serbia-Yvetot, F'rance-La Panne, Belgium-American National Red Cross Headquarters-Close of the Early Foreign Relief Program.

WHITE ship banded with searlet, with a Red Cross
flaming on her fumnels, weighed anchor in the sunlit
waters of the Hudson River and with the bells and whistles of ferries and tug-boats, the salute of liners and the throaty roar of men-o'-war to voiee the God-speed of a nation, steamed out to the gray $\Lambda$ tlantic, bound on a rare mission to warring Europe. The day was September 12, 1914.

Against the lower rail of this good ship, the Red Cross, was banked a line of women, who watehed Manhattan fade away and knew not what horror of war might be theirs before they saw that broken sky-line again. The white eaps, the gray miforms, the line of searlet as the fresh sea wind blew back the active serrice capes, proclaimed their identity. The Red Cross Nursing Service, eoneeived in the suffering of the Civil and Spanish-American wars, brought into being br the affiliation of the Ameriean Nurses' Association and the American Red Cross, murtured and dereloped through five rears of intensive organization by Miss Delano and the National Committee, fared the most formidable test of its hitherto dormant powers. With its present resourees untried, its potential strength unguessed, it was shouldering its first burden of nentral humanitarian service to the Allied and Centril Powers.

At a joint meeting of the International and War Relief Boards held on Angust 5. 1914, the Ameriean Red cross roted to charter a ship to earry trained persomel and hospital 


\section{HISTORY OF AMERICAN RED CROSS NURSING}

supplies to the countries involved in the European War. The story of the immediate consequences of this action was told by Miss Boardman in the Red C'ross Magazine of October, 1914:

A committee consisting of Mr. Bernard N. Baker, of Baltimore; Surgeon General William C. Gorgas, U. S. A.; Surgeon General William C. Braisted, U. S. N.; and Chief Constructor Richard M. Watt, U. S. N., was appointed to secure a suitable ship. To American ressel was available, but two ships were most generously offered free of charge by the Hamburg-American Line and by the Austro-Ameriean Line. The committee insperted both ships and finally selected the Ilamburg, of the former company, as best suited to the purpose.

By special Act of Congress [then in session], the ship flies the American and lied Cross flags, has a temporary American registry and has changed her name to that of the Red Cross, sailing from New York. According to the colors designated for such a ship by the treaty of The Hague, she was painted white with a broad red band.

Major Rohert L. Patterson, Medical Corps, U. S. A., Chief of the Red Cross Medical Bureau, soon secured his corps of surgenns. Miss Delano, rhairman of the National Committee on Red Cross Nursing Service, through the coöperation of her Local Committees, selected from among volunteers from our five thousant lied Cross trained nurses, those best fitted for this special service. [Niss Helen Scott Hay was general superintendent of nurses of the Red Cross ship.]

Almiral Aaron Ward, L. S. N., retired, who was in Europe, accepted by cable the request that he take charge of the expedition, joining the ship in Encland. Armiral Plue, of the Navy, lent his aid to secure the rest of the officers. Captain Arnistrad linst took (f)mmand of the ship and with him are ascociated other retirel offieers, Commander E. H. Delany, I. S. X. as rhief enginerer; Commander J. S. Dodtridere, T. S. .., and lientemant Gilfort Darst, I. S. N.; Mr. Rirohard 1). L. Mohmo is the paymaster. Captain Jarka, superintemdront of thi line gave invaluable service in the roling and provicioning of the ship. The painters hung along hor sides and busily plied their brushes the moment the roaling was over.

The S. S. Leed Crose was loaded from warehouses in Brooklyn, the nes of which were donated by Mr. Irving Bush. Colone] S. L. I). Sluenun, I. S. A., retired, was in command of the loading of hospital and othere supplies. Four hundred thou- 
sind pounds of cotton, two hundred and fifty thousand meters of gauze, fifteen thousand pounds of bandages, thirty gallons of iodine, two thousand ans of ether, rubber gloves, vaseline, rocoa, tobaceo and other' comforts and necessities for' the care of the siek, filled the hold of the liner. Be'anse of this argo and because of her passengers, the lied C'ross reeeived the name of the "Merey Ship" from the friendly press.

The professional persommel of this relief expedition was made up of ten mits, cach composed of twelve murses and three surgeons. Lnits $A$ and $B$ were assigned to Pan, France; D and F to Paignton, England; C and II to Kief, Russia; $G$ and I to Germany; $K$ to Anstria and $\mathrm{E}$ to Budapest, Hungary. A Serbian mit, of which Pr. Elward IV. Rvan was director and Mary E. Gladwin, ehief nurse, had proceeded five days before the saling of the Merey ship on the merehant liner Ioannina bound for the Mediterranean and Nish.

The superintendent of murses of the S. S. Red Cross was Holen Seott Hay. The assignment to the Merey Ship which brings her for the first time into this history was in keeping with her sulsequenty romantic and brilliant career in Red Cross service. She was graduated from Northwestern Academy in 1889 and received her B.L. degree from Northwestern Lniversity four vears later. Further theoretical phases of her broad education were completed in 1900 at the University of chicago. She had entered the Inlinois Training School for Nurses in 15!:3 and following her graduation beame associated in executive eaparities of varying types with the sonthwestern lowa llospital for the Insane at ('larinda, Iowa, and with private sanatoria in Los Angeles, California. She was superintendent of murses at the County lnstitute for the Insane and Indigent at ('hieage and later superintement of the hospital and tranine school of the Pasadena IIospital, Pasadena, California. Private duty nursing elaimed her attention at intermittent periods. In interesting break in her professional atreer is marked hy a rear as principal of the Silvanmah Iligh Sichool,

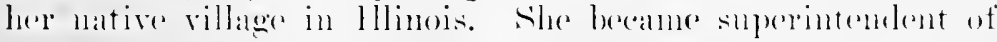

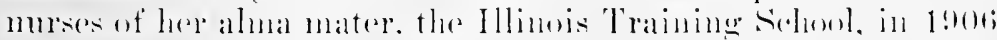
and remained there mitil 1912 . After eightern monthe spent in travel, she nudertook the oremization of the West suburban Hospital and Sichool for Nurses at Oak P'ark. Illimois, and ror mained theresix months, resigning to anerpt her first lied cross service. 


\section{HISTORY OF AMERICAN RED CROSS NURSING}

Miss Hay's early war service was elosely interwoven with a project of nursing edueation which first linked the American Red Cross with the development of foreign nursing. Before the declaration of war, Queen Eleanora of Bulgaria had appealed to National Headquarters for advice and assistance in establishing a training school for nurses in Sofia in accordance with American standards. In the Red Cross Annual Report for 1914, Miss Delano stated this prospective plan of the keen-risioned Queen:

She wished to secure an American superintendent to organize a training school and to send to America four Bulgarian young women of education and promise who coukd fulfill the requirements for admission to one of our best schools for nurses. These pupils were to enter the Presbyterian Hospital School for Nurses in New York City. Miss Helen Scott Hay was selected by the Red Cross to establish the school in Bulgaria. The Red Cross assumed the responsibility for her salary for three years and she was to have sailed for Bulgaria [August 4, 1914]. The derlaration of war made it necessary to abandon our plans temporarily, rendering it possible. however, for us to assign Miss Hay to duty on the Red Cross Ship.

In organizing the nursing staffs of the ten units, Miss Delano and Miss Hay were guided in their assignments by the prineiple that graduates from the same school and section of the country would work advantageously together. An earnest spirit characterized these surecons and nurses bound on their crusader's mission during that memorable September of 1914. In a leading editorial the American. Journal of Nursing voiced the sentiment of the Red Cross: "Our nurses have been sent not to lead others or to show how Red Cross work should be done, but to supplement the existing relief work, to piece in where there is no one else to serve."

Individualism also gave way before the Red Cross ideal of nentrality. Althongh all the nurses were native-born citizens of the [nited states, many of their names were distinetly ("ontinental. After a first moment of astomishment, they acreed to follow the European custom and to be known only as "sister Doma" or "Sister ('harlotte," titles appropriate indeed when it is remembered that the old Sanskrit word for "sister" meant "comforter."

The one hundred and twenty-six nurses saling on the Merey 
Ship had been assembled through the Local Committees of Manhattan, Boston, Brooklyn, Philadelphia, Baltimore, New Hampshire, New Jersey, Rochester, Buffalo, Detroit, Albany, Chicugo, Kansas City, Cincimnati, Akron, Cleveland, Columbus, Connecticul and Washington, I). C. A diary written during the quiet days at sea, presented a vivid picture of this swift mobilization:

\section{On board the S. S. Red Cross, September 22, 1914.}

Almost a month has passed since a telegram came from Miss Delano salying, "Report Wednesday in New York for Red Cross service in Europe." As I read over that telegram, a queer feeling come into my throat. Then with pencil and pad I was soon busy making out lists of necessary articles. Il urried shopping followed in the morning. Constant telephone calls from friends brought varied questions: "Why are you going!" "It won't be any fun!" "How I enry you the opportunity!" "Please send me postcards every week, won't you :" "1 have a consin in Germany-give her my love." "We hiave just finished a bushel basket of bandages for the Allies we want you to take over."

T'o have only forty-eight hours in which to adjust your affairs and to get rour mind into a realization that all things of your former life are to cease and an entirely new and very real existence is to begin is no easy task. I can still hear my mother's "Yes, you should go," though the look in her eyes belied her words. My brother"s "Be a good soldier, sis!" is all mixed up with "duffel hagrs" and "war zones" and the prescribed number of flannel night-gowns to be taken.

On Wednesday evening, September 2, nurses began to arrive in Now loork from all parts of the comntry. In view of the fact that many nurses were on their vacations, their mobilization within two days after their "travel orders" were recoived, was remarkably swift. They were entertained at the Central ('lub for Nurses, it East 3 thl Strect. This was eonveniently near the $\mathrm{New}$ York Comuty Chapter, where they were equipped with the regulation miform upon their arrival. Gray uniforms, white alprons, (aps with a small Red Cross in front, soft collars, a nary bhe cape lined with searlet and with the lied ('ross on the left side, a dark blue felt hat, a water-proof duffel bage of brown canvas delnesed with a bar and lock and conspienonsly marked with a lied ('ross encireled by the words. "Aneri-

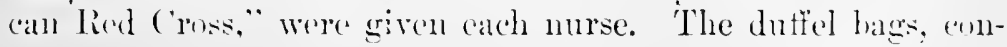




\section{4¥ HISTORY OF AMERICAN RED CROSS NURSING}

taining three additional bags, one for shoes, one for laundry and one containing seissors, needles, cotton, buttons and a piece of the uniform material, were the only luggage allowed, except a suit case or hand bag. Gray sweaters were also furnished. Warm storm coats were later added to this equipment. An slive green blanket, with a Red Cross woven in the center was presented to each member of the expedition, to be used as a steamer robe or extra bed covering in the hard and unusual places of war where they soon might find themselves.

The pleasant hours on board the Mercy Ship was busily taken up with elasses. The daily routine resembled more elosely that of a training sehool than an ocean voyage. The nurses breakfasted at eight o'eloek and spent the morming at lectures given by the surgeons on such subjeets as First Aid, languages, contagious and infeetious discases, anatomy, anrestheties, bandaging, the metric system, field surgery and allied subjects. At eleven-thirty, they exercised in the gymmasium. After luneheon they practised nursing technique for an hour and a half. At four o'eloek, they attended elasses in French and German. They dined at seven. Prayers were condueted by Sister Helen Seott Hay at eight-thirty and the nurses retired at ten o'eloek.

The grim realities of war horered near the staunch S. S. Red Cross as she plowed her way through the heary seas. Letters and diaries of the nurses recounted the eventful days in the war zone:

Monday, September 1t. About 3 A. M. the searchlights of the British eruiser, Ex:ex, found us. After our flags were rm up and our illuminated Red Cross had flashed baek our inlentity, we were allowed to proceed. As this is my first ocean trip, my lappiness will not be complete until there are "shots across the bow" and I see a whale.

They found three stowaways, two of the old erew; sighted four ships, ordinary trading vessels.

'Tueshay, September 15. Another lesson on bandaging at $9: 30$. Passed sonth of the banks of Newfomdland at noon. The soa is still romoh, the sum warm, a strong wind blowing. Huge waves come braking over the decks. We are taking the eastern conre direct.

Werdnestay, September 16. A beautiful, warm, bright moruing. They found two more stowawas who looker as if they harl been makine their home in the roal boxes. Had a very interesting talk on solutions, preparations for aspirating, renous sertion and lumbar puncture. It is dark and 
cloudy and looks very much like rain. The Lusitania sent a wireless at $8 \mathrm{P}$. II. saying we were coming to a storm. Everything is being tied fast and tacked down.

Friday, September 18. Such wonderful weather and the sick chirping up. Our class this morning was on the care of the wounded in the field. Then in the afternoon we were shown the engine room. I thought my time had surely come; we went down, down, down. It was the cleanest but also the oiliest place that I hat ever seen. There is one fact which penetrated my brain aur remained there: the stokers are not the miserably unhappy mortals one is likely to imagine. The one I saw was blissfully smoking a pipe and singing. Then after I had smiled sweetly (and no doubt patronizingly), great was his joy when I put my hand on a rod covered with tar. He langhed ontright and so did I.

Monday, September 21 . Major Patterson received a wireless this morning from I)r. Ryan of the Serbian unit, stating they have had bad storms for five days. I really think we are all feeling the depression of this awful fog. It is just the feeling that one would have after being put in a cold pack and then forgotten by the nurse.

'Tuestay, September 22. Another heart-to-heart talk with our superintendent has bronght home to us that neither the best bandage nor the deft handling of a wound will win for us a place among those we hope to assist; the keen and realy sympathy that we show them will make or mar our mission.

Weduesday, September 23. Bishops Hearlight has just blinked a welcome. Land at last! One war vessel at anchor in the harbor sent the following message by wireless: "God bless you and good night.",

With her flags unfurled to the brilliant glare of searchlights from land and from battle craft in the harbor, the $s$. S. Red C'ross lowered anchor on the evening of September $2: 3$ in the Bay of Falnouth, England. Surgeons and nurses of four units were to leave her at this port, $\mathrm{D}$ and $\mathrm{F}$ to report to the American Ambassador in London for assignment to service with the British; $\mathrm{C}$ and $\mathrm{H}$ to proeecd north by way of sicotland and Sweden for Petrograd, Russia. The remaining six mits destined for serviee in France, Germany and Austria were to remain aboard for dobarkation at other ports.

Anomg the low hills of sontheast Fingland lay Paignton.

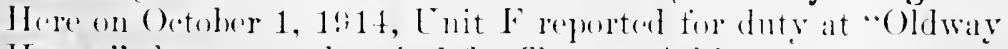
House," the'n a war hospital for l'omme Atkins. 


\section{HISTORY OF AMERICAN RED CROSS NURSING}

"Oldway House" was formerly the country estate of Paris Singer, of New York, and had been loaned by him for hospital purposes to the Committee of the American Women's War Relief Fund. This group of American women, then resident in England, included among others, Lady Arthur Paget, Lady Henry, the Duchess of Marlborough, Lady Randolph Churchill, Mrs. Whitelaw Reid, Mrs. John Astor and Viscountess Hareourt. Sir William Osler, Baronet, serred as consulting physician and Lieutenant Colonel R. C. Gunning, Royal Army Medical Corps, as military commandant. To this beautiful place with its spacious parks facing the Channel, its broad terraces and columned façades, its marble stairways and tapestried walls, came Unit $\mathrm{F}$ with Sister Mabelle $\mathrm{S}$. Welsh, a former superintendent of nurses at Peter Bent Brigham Hospital, Boston, as supervisor and Dr. Howard W. Beal of Worcester, Mass., as director.

In the meantime, Unit D with Dr. Robert W. Hinds, of Buffalo, New York, as director and Sister J. Beatrice Bowman, of the Nary Nurse Corps, as supervising nurse, had been sent to the Haslar Royal Naval Hospital, near Portsmonth. This unit remained at Haslar for six weeks before it was called to Paignton to supplenent the staff at "Oldway Honse." A brief deseription of the Haslar hospital is therefore given before the work at Paignton of Lnit F and the combined work of Units $\mathrm{F}$ and $\mathrm{D}$ is detailed.

Sister Beatrice of Lnit D wrote:

From owr hotel windows overlooking Falmouth Harbor, we saw the Channel and the fied ('ross as she steamed out. and the s. s. Tennessee as she swung into her place.

At ten o'clock on the morning of October 3. we started for ciosurt. Even the roals and foliage seemed old-world and cuaint. Lady Hotham says that Americans are not considered foreigner's here and indeed they do not treat ns so. One wonkd think we were some near relative turning up after years of separation.

This is the lareset hospital, naval or military, in Eneramol. with a capacity of two thomsand and six humdred heds, and a possible enerency one of seven thonsand. Farb of the ninety-nine wark has twenty-eight to thirty patients.

Pircturespuely sca-going was the langnage at Haslar. The floor was "the deck;" "upstairs "top-side," and downstairs "be- 
low." The nurses' office was the "Sister's cabin," the operating" room "the theater," the Ilospital Corps "the sirk berth staff." small wonder that the American nurses gasped to hear the British Nayy Sisters refor solemuly to a critically ill patient as "that jolly sick man just gone below!"

But it was neecssiry to supplement the staff at "Oldway Ilonse." 'Thus after six weeks of absorbingly interesting work at the Naval Hospital, the order came for Unit D to proceed to Paigutou.

The Matron of "Oldway IIouse," Gertrude Fleteher, was an Anstralian woman whose long experience during the Boer War had holped prepare her for the delicate task of directing the work of the English and American murses. When Unit D arrived on November 12, they found that Unit F had previonsly been given the care of a ward of sixty-seven beds, one-third of the entive house. 'This responsibility was continued, but shifted so that Sister Mabollo Melsh of Enit F became Matron's first assistant on day duty and Sister Beatrice Bowman of Unit I) was appointed general night Matron. Other mentbers of Cnit D were assigned to ward, night and operating room duty.

In interesting analysis of the first 1000 cases treated at the American Women's War IIospital at Paignton showed that 445 patients were wounded, while 520 snffered from miscellaneous injurices, such as abrasions, burns, dislocations and contusions. One hundred and serenty-nine operations, under general anastlesial, were performed. Of the results of the treatment, ouly 12! of this first 1000 were pronounced "nnimproved," $62: 3$ were completely cured and only 3 died. "On January 4," a nurse wrote. "we reecedred one hundred new cases, coming direct from the treneles through Bonlogne. One yomg man had lost both eyes: others had terribly frosted feet: two came in with perfertly elean wombs, the first we have had; one has right bullet womels in one leg, another throngh the shoulder, and a salure cut on the arm, the only ease of this type in the hospital."

It the relose of their six months' serviee, four of the Ameri-

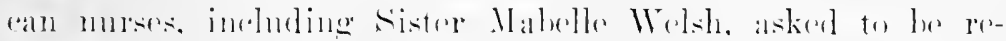
lieved from duty on aceomt of the lightmess of the work. In a

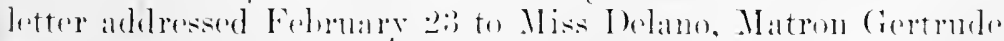

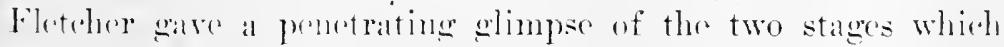
every morse in antive sorviee soon underenes: 


\section{HISTORY OF AMERICAN RED CROSS NURSING}

War nursing as a whole is a demoralizing experience. As long as the work is heary, all is well, but when long periods of waiting arrive, even the most level-headed of women are apt to become lacking in judgment to a degree that astounds one. The work begins with such stirred up emotions and enthusiasms, and one can never quite tell where that will lead. This is why I regard the second stage of war nursing as the test. I have gone through it all before, so it becomes like nursing a familiar disease.

At Miss Fletcher's request, National Headquarters appointed Sister Louise Bennett and Sister Elizabeth Weber as supervisors of their respective units. With fifteen English sisters, seventeen probationers and twenty-six American graduate nurses, the mursing staff at "Oldway House" had been experieneing difficulties of seniority and Miss Fletcher felt that better diseipline could be secured by having the remaining Americans work under their own leaders rather than under British nurses.

During the spring, the work grew heavy. Three additional nurses and two doctors from the United States arrived April 5, 1915. Miss Fletcher expressed her relief in the following letter:

The whole of England seems to be preparing for heary times ahearl, and nurses apparently are going to be difficult to get. Soldiers and everybody else can see no other possibility than that we must have an immense amount of sickness when the summer sets in. The men say that even already while the weather is so cold, the odor from the dearl horses alone is drearlful. and whenever they start to dig a fresh trench they come upon the dead. Therefore, it can be nothing short of a miracle that will prevent a summer of sickness and disease.

However keen may have been the disappointment of the Amerian nurses that they were not ahars busy to the utmost raparity of their strength, or lowerer dolicate the relations between probationer, sister, supervisor, Matron and rlirector, the work with Tommy Atkins "'imself" was intensely satisfying. Sister Beatrice wrote:

Our patients had great fun at our expense on Washington's Birthelay. One of onr probationer's, a girl from Vircinia. sent to lousdon for somer artificial wherries which she passed among all of us Americans and which we wore, creatly to the anjoyment of our thirty-two romalescents. When I came 
on duty the next morning, I found every man Jack of them had tied abont his neck on a string an apple, or an orange, or a banana. When I asked what the decorations meant, I was greeted with this answer: "Well, yesterday being George Washington's birthday, we thought we'd celebrate Adam's and Eve's today!"

To the white beds filling the reeption halls and guest rooms of that stately palace-hospital came soldiers from the Seven Seas. Princess Pat's trooper lay beside "those blark Gurkhas, a fine lot of men they be." Blackwateh and Patriot sumned themselves on the terrares, or limped through the gardens. The paticnts delighted to write poems which they presented to the nurses. Among the popular subjects was "Frozen Feet":

Tingle, tingle, little toes,

Them wot's at 'em only knows

Nothin's pleasant, nothin's sweet,

'Bout a pair of frozen feet!

Standin' in trenches wet an' "old

Is wot is (allsed 'em, so I'm told,

They throb all night. and burn all day,

lut are cured by friends from U. S. A.

They work all day and watch all night,

T'o do their bit to get (haps right.

A Corporal of the King's Own Regiment.

Spring eame over the Devonshire hills, bringing splendid ('anadian troeps to Paignten, some of them blinded, others choking with poisen gats, and the horror and weariness of war grew harder to bear. "We donlt say much abont it," wrote Sister Lonise, "but we are all heartily sick of this endless anelty and wickeduness." The monotony of ten months' continuons duty was broken by vacations and short trips about England.

The Ameriean Ambassidors in the varions belligerent ammtries reecived word Angust 1 that the Anerican Red ('ross wals withdrawing its forreign mits on (October 1, owing to lack of funds. With a record of 190.5 aldmissions during the period the American Women's War Inspital was operated by Ameriran lied ('ress, Inits F" and I) withdrew September 30 . 1915.

Early in the spring of 1915, the Ameriman Red Cross had atsigned two mits to the Bergian (onvermment to assist in the care of their womeded at Lal Panme. Belginm. The persomel

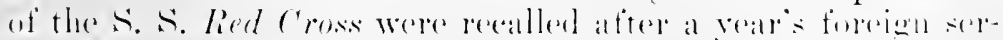

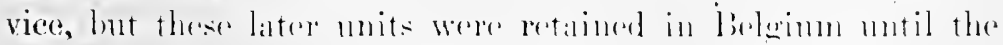




\section{HISTORY OF AMERICAN RED CROSS NURSING}

completion of their entire twelve months' duty. Several nurses of the Units D and F were accordingly transferred by Miss Delano to La Panne. Five other nurses remained at the invitation of the British War Office at Paignton. Other members of the units returned eventually to the United States.

In a sunny valley below the Pyrenees lay the city of Pau, France. The French units A and B of the Merey Ship Expedition were detailed for duty at this famous winter resort. Dr. Reynold M. Kirby-Smith, of Sewanee, Tennessee, and Margaret Lehmann, of Philadelphia, were in charge of Unit A; Dr. Roades Fayerweather, of Baltimore, Maryland, and Alice Henderson, of Baltimore, were in charge of Unit B.

On their arrival, Oetober 3, 1914, at Pau, the American surgeons and nurses were greeted by the mayor and residents of the town and by many Amerieans then living there. "Pau is a prosperous little city," wrote Sister Alice Henderson, "every one seems quite well-off and prices on food and elothing have advaneed little, if at all. Were it not for the soldiers on the streets, one would never know that a war is raging." Since the hotels were all liable to be requisitioned for the soldiers, the Pulais d'Ifiver, a pleasure-designed casino, was secured and equipped as a hospital.

The Winter Palace had formerly been the center of the great gayety of Pau and its rooms and corridors were large enough to accommodate 166 patients. In the center of the palace was a palmarium; the Americans put long tables down the middle of the room between the palms and blossoming vines and the convalescents had their meals there in the warm sunshine. Every window of the Winter Palace commanded a view of the white Pyrenees which loomed above Pau.

Although the nurses were all Ameriean-born, some of them had names of Teutonie origin and the French felt and even expressed some doubt as to their sympathies. This was one of the reasons why the units were assigned to southern France, instead of to Paris, where professional nurses were greatly needed. Paris was the headquarters for the Government and the Army. During the first weeks of their stay at Pan, the Americans received few patients. However, they som earned the eonfidence of the local authorities. "We are not only wanted," wrote Sister kmma, "but we are needed. I do not think that we will be moved nearer the front," she added. "it is easy to understand now why we were sent to Pau. As indirid- 
uals on our own resources, it might have been possible for us to work at the front but as an organization representing a neutral government, this appears to be quite out of the question."

Finally in the last days of November, many wounded were sent to the Palais d'Ifiver. Arabs, Belgians, Moroceans, Algerians and French were unloaded from the hospital trains. "One has little idea of what this war really is," wrote Sister Alice, after a convoy of 110 wounded had arrived, "until you see a train of wounded come from the front, the men so dirty, so ragged, so tired, so sick, ret not one of them ready to admit that he is either hungry or exhausted or that his wound is more than a serateh!"

Christmas in France during this first year of the war was a time of anxiety and suffering. The drive on Amiens was in progress; every provinee was sending its men to the defense of la douce terre de France. As Pau was a recruiting eenter for the surrounding country, the streets swarmed with soldiers of every class and type. From her busy operating-room, Sister Emogene E. Miles wrote on Necember 20:

This past week has been sad. Our ears are filled with the sound of drums, of bugles, of marching men. They are mobilizing all the avalable recruits for the January drive, calling boys eighteen years old, though volunteers of sixteen are accepted. Dr. Kirby-Smith was absent one day last week and he tells us that at every station on his way home were mothers bringing their sous to the train. After it had pulled out, many of those poor youngsters wonld weep, their heads bent, yet mashamel.

Tan has tremendous barracks, now filled with men and boys getting into miforms, drilling and being sent off to the Army at once. 'They are in sore need of more men. When the soldiers go to the train, their friends meet at the barracks and thrnst a bonquet into each gon.

A train loaded with wounded eame to Pau on Decenber 21, direct from Amiens. Before the arrival of these gronds blesses, a notice hat been posted from the chiset medical officer in the Department-Basses-Pyrenees, stating that in future consignments all seriously wonnded men were to be sent to the American Ihoppital. 'These patients had truly mulergone the rignrs of trench warfare. (One man's nund-saturated clethes hore ont his statement that he hall heren standing in water-filled tremelese for three werks. Yany of the pationts aming from cowated hespi- 


\section{HISTORY OF AMERICAN RED CROSS NURSING}

tals further up the line, had slonghing bedsores. A desperate ease of tetamis, which required special nursing day and night for several weeks, recovered, to the vast surprise of the French. Althongh the First Aid dressings were uniformly exeellent, the majority of the wounds were badly infected. This infection was caused by mud-soaked uniforms full of bits of straw touching the wounds before the dressings eould be applied.

The hospital at Pau occupied a geographieal position which inereascel the professional diftienlties of the Ameriean units. Althongh they were near enough to the front to reeeive patients forty-cight hours after injury, often with only First Aid dressings on their wounds, they were also far enough back in the zone of the base to be the eynosure of many tourists' eyes. Sister Alice wrote:

We must always be on dress parade. The seores of English, French and American visitors who come to visit us each week make it necessary that we keep the hospital ready for inspection at any moment. At the present time. I am satisfied that we are doing all that we could handle efficiently. Were we in some isolated place, or at the line, we could easily take care of many more patients. As it is, however, we seem to have made a lasting impression on the French in demonstrating the value of trained nursing as opposed to volunteer effort.

The American units found their French patients courteous, appreriative and simple, with the mairete of children of the soil. Robert IIrrick, then Ancriean Ambassador to France, wrote that "the proular nicknamo of poilu, the mushaved, has an intimate significance. 'The little French soldiers arr not parade soldiers, but (onmon, plain men, careless of appearance." 1 Barbusse described in Le Feu the characteristies which so endeared their patients to the American murses:

They are not solliners, they are men. They are not artventurers, warriors for masalere, butchers or driven rattle; they are flemohnm and lahorers, easily recognized als such muler theip uniforms. They are up-rooted avilians. In their silene. in their immobility, in the masks of superhuman calm on their fares. reffertion and four and longing are visible. Thery are not the sort of heroes they are popularly supposed to be. but their anerifier is moler than these whe have not seren them will "sere be able to divine.

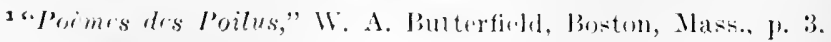


Sister Emma wrote on December 31 that a man in her ward, the father of four babies, had received not one word from his wife sinee the war began. Another young man, she wrote, seemed dazed after his thirty-two days in the trenches, where he had slept only in suatches, always drinking black eoffee to keep awake. "He returus very soon. It is dreadful to hear him say with a shrug of the shoulders: 'Eh bien, I shall som be dead,-I go for France.' We see only mourning on the streets. The women do all the work, driving oxen and mules, plodding throngh mud and rain drawing loads of produce to the eity, delivering bundles of wood and sweeping the streets. Every day more men go to the front." Always grateful, always respectful, always appreciative of the slightest attention, never forgetting their merci beaucoup, never failing in their sympathy for their fellow wounded, the French soldiers were the wonder and inspiration of all couners. Sister Margaret wrote: "It was always a beantiful as well as a most touching sight to wateh the eonvalescents weleome the new blessés. They hail them hilarionsly, telling them of the good eare they are to reeeive, assisting us in making onr French understood and helping generally in making the newcomers feel comfortable and at home."

When a soldier died at Pau, it was the eustom for one surgeon and two murses to attend his funeral. First marched the reterans of the little eity, old men searred in former wars for France, then the slow chanting priests, then the military escort. As very few poilus conld be attended to their last sleep by members of their immediate family, the American doctor and the two murses walked slowly before the flag-draped easket. Sister Vashti Bartlett wrote: "All along the way, the black dressed women and chilelren stood at attention. Even small boys of five and six would drop their playthings and remove their caps. As we walked slowly down the road to the burial ground, I thought of the thousands of dead on the battle fields, denied "ven this last poor homage."

It was a sad day both for patients and nurses when a soldier was dismissed frem the American Hospital. Every one soon knew erery one else in this smill fanily of theirs. In a letter to Miss Delane, Sister Vashti emumerated her patients:

No. I having been a waiter in London. spoke English; No. II, Laderee always ready to help. comes from northern

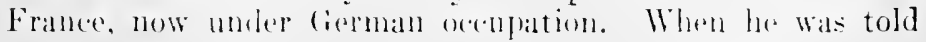




\section{4 HISTORY OF AMERICAN RED CROSS NURSING}

that he must leave Pau, he had no place to spend his preeious eight days' leave before returning to the front. As French soldiers receive only one cent a clay, when one's family could not send one money. c'est dommage, n'est-ce pas?

No. III. ('huzel, the baby of Salle D, holds the reeord for having killed sixteen Germans.

No. $\mathrm{T}$, a twenty-one year old sergeant, is a veteran in hospital experience. "Jou know, Sister," he said solemnly, "to be wounded twice means to be wounded thrice, and then one is killed and goes-who knows where?"

As the busy winter months slipped by in the daily routine of hospital life, little if any word from the other Red Cross units seattered over Europe eame to the American Hospital at Pau. A cablegram from Major Patterson, at National Headquarters, brought in the latter part of February, 1915, however, serions news of Serbian Lnits 2 and 3. A severe epidemic of typhus was sweping Serbia. Every member of the commission at Gergeli save five had been infered. Lntil additional assistance could arrive from the Lnited States, wonld not one surgeon and three nurses from Pau report immediately at Xish?

Every one of the American family volunteered. Dr. KirbySmith, the senior director, Sister Margaret Lchmann and Anna V. Lofring, of Philadelphia, and Sister Rebecea Watson, of Baltimore, were chosen and left Pau in Mareh to sail on the calidomen from Marseilles for their destination in Serbia. After their departure, I)r. Roades Fayerweather took charge of the Palais dilliver as senior dircetor, with Sister Alice IFenderson as supervising nurse. As other vacancies ocenred, surgeons and nurses were assigned to fill them from Washington or were transferred from Paignton.

With a reoord of having trated sas patients to a conchusion, the Palais d'Itiver was closed on September 16, 1915. During their twolve months of duty at the Palais d'lliver mere than 2.25 major, as well as innmerable minor operations, were performed. Throughnut their stay at Pau, the Ameriean suregens and murses were greatly assisted by the miting enutesy and couperation of Mayor Alfred do Lassence and his danghter, Mune. de cabrole. Mrs. IIenry Hntton, Mne. de Arizemin and Margaret Porter, Aneriean women living in Frances. hat Whatge of the sering renm of the hospital and did splendid work. Mrs. Leonarid brown. Mlrs. Wadsworth lingers. President of the comite des lomes. Mrs. Iohn ('nshing and Mr. 
George A. Bucklin, Jr., the Ameriean consul at Bordeaux, greatly furthered the work of the American units through their personal service and interest.

Kief, which was a clearing-house for thousands of Russia's wounded, is situated on the Bnieper River, with the Black Sea to the southward and the Carpathian mountains to the west. This Rinssian eity was the destination of Units $\mathrm{C}$ and $\mathrm{H}$ of the Red ('ross Merey Ship lielief Expedition.

Units C and II left the S. S. Red C'ross at Falmouth IIarbor for London on Wednesday, September 30, 1914, and started the next day on their long journey for Petrograd via Scotland and the North and Baltic Seas.

When the erowded little steamship Balder docked at Gottenburg, Sweden, the Americans were met with the cordial weleome which wats to characterize their reception all along the way to Kiof. A brief stay at Raumo, Finland, was made pleasant by the cordial hospitality of the population. This Finnish village, then used as a port of landing for refugees, boasted no hotel. The women prepared food, howerer, for the passengers of any ship which eame to their wharves, and on many days fed more refugees than the town had inhabitants. The American surgeons and nurses breakfasted in small groups at different houses.

A representative of the Russian Red Cross escorted the units from Rammo to Petrograd. At the eapital eity of Russia, the Honoralle George T. Marye and his wife and Mr. Winship of the Anncrican Embassy, aeted as hosts. Her Majesty, the Dowager Empress Marie Fendororma, who was the head of the Russian Red ('ross, received the Amerieans at the lllagen Palaec. Lest the field miforms of the Ameriean Red Cross, not then as familiar as they grew to be in later years of the war, should fail to be recognized and the work of the nuits areordingly hindered, the American surgeons were given high rank as medical officers in the Russian Amy and the nurses were presented certificaltes ats Russian Red ('ross Sister's.

At list on Oetober 2s. Lnits ( and II set out for their final destination, Kief, al five dars' trip of nine hundred miles. The special trowpe train on whish they traseled drew freight ars containing furniture, linen, kitchen and lanndry supplies for a torthed lonspital and four calr londs of Ameriean hed Cross merlical supplies from the Luited states.

Dr. William s. Magill Wils sernior direetor of the Russian

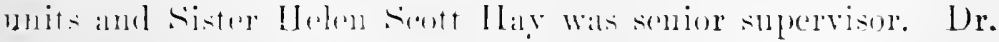




\section{HISTORY OF AMERICAN RED CROSS NURSING}

Phillip Newton, of Washington, D. C., was director of Unit II and Sister luey Minnigerode, one time superintendent of the City General Hospital, Savannah, Georgia, and later of Columbia Hospital for Women and Children, Washington, D. C., was supervising murse. Dr. Edward Egbert, of Washington, D. C., was director of Unit $\mathrm{C}$ and Sister Charlotte Burgess was supervising murse.

During November, the units set up an American Red Cross hospital in a wing of the Polyteehnie Institute, which crowned the erest of a hill just outside the eity of Kief. On the first floor, they established administrative oftiees, pharmaey and living quarters. The second and third stories were utilized as operating and dressing rooms and as wards. In the basement, large rooms were given over to the reception of patients; and an effieient srstem of baths, which awakened the interest of many other hospitals in Kief, was set into operation. All incoming patients received a bath, a haircut and a shave from the saniturs before they were admitted to the wards upstairs. Seriously wounded and helpless cases were sponged off by the nurses in rooms adjoining the main baths.

To transform this school into a hospital required not only equipment but genuine hard work. The rooms where the wards were established were large, with high ceilings and many windows; the amount of scrubling necessary was consequently great. On one oecasion the Red Cross officer who purchased supplies for Kief, sighed when he saw sister Helen Seott Hay's shopping list. "Holy fathers!" he ejaculated, "I think that Sister Helen actually eats scrub brushes! I've bought about all there are in Kief now!" In our of her letters to Miss Delano, Sister Helen told to what use these articles had been put: "I wish you might have seen your Amerikan spii cestritza serub! Some say we have lost fale thereby: but what our twenty-four nurses did to those dirt-littered wards is a poem in itself and a subject risht worthy for epic or knighthond!"

After a month spent in preparation, the hospital was formally opened in llecember, 1914 . The majority were sent up from the Austrian Front, the (arpaths, as they called it: Siberians, Great and Little Russians, Poles, Tartars, Bessaralians, Cruzins ant Cossacks from the lon and from the Caneasus lar in

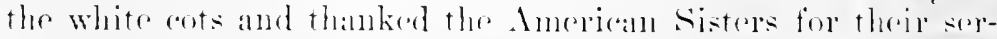
vires with simple. andems. heartfolt expressions of gratitude. sister luey limnigerede wrote: 
They tell us stories of the war, but never speak of their experiences as a hardship. One man described having been wounded at a place the soldiers call "the mountain of death." He lay among the bodies of his company on the field for five days, griving himself First Aid, before the firing lifted enough for anyone to bring him in. Another owed his life to a peasant woman, to whose shell-rifled hut he hal crawled. A third was buried in a trench for dead, lut managed in three days to dig himself out. ${ }^{2}$

The American Christmas, with its carols and tree, and thirteen days later the Russian holiday, celebrated by a second tree and a vandeville show for the patients, came and went in the busy routine of hospital life. The big Polytechnical Institute Hospital was operated under a nursing schedule of nine hours' day duty and ten hours' night duty, of two weeks duration for the American nurses, and ten days duration for the Russian Sisters.

The coming of many visitors to the American Red Cross Hospital at Kief made necessary the same "dress parade nursing" as at the P'alais d'IIver in Pau. A large medical school nearby sent its students in groups of twenty and thirty to see the work of the American surgeons and nurses. Visiting Army officers of high rank came to inspect the institution. One asked if the Sisters were good to their patients. A soldier replied: "Not good,-donble good!" A ranking general inquired how soldiers managed with nurses who conld not speak their language. A big cossack answered him: "What need to speak, Excellency? "They do everything for us without asking!" Sister Lucy wrote of the confidence with which the Russians regarded the Americans:

The patient: themselves were quick to realize the difference in the nursing servieg given them in the American and in the Russian hospitals. Xeither patient, sanitar nor linsian sister would have been willing to return to the way of aring for the wounderl to which they harl heen alemstomed. Lenters from ex-pationts testify to their appreciation : to their willingness to help als far as they were able: to their patience under terrible suffering and aftor months of extreme hartship: to their unsolfishness with ath other and their aratitude for any service rembreml.

" "Experiences of lnit C at Kirr. Russia," Luer Minnigerole: Red Cross Departulent, Imeriean fournal of Vursing. December. 1915. Vol. XVI, p. 2.23 . 


\section{HISTORY OF AMERICAN RED CROSS NURSING}

Of course, many indiridual cases of special interest developed. The top sergeant who had part of his jaw and all of his tongue shot away and who lingered between life and death for many weeks, finally recorered and remained in the hospital to teach others, wounded in like manner, how to feed themselves and to keep the mouth properly cleansed. The first blind soldier, who with the aid of his comrades' direction learned his way about the hospital, taught others, blinded like himself, low to heep themselves and find their way about without assistance. Courage, endurance and a blind determination to get well were potent aids toward recovery.

The organization and personnel of the units underwent important changes following the termination of the first six months of service. Ir. Magill had been relieved from duty, November 7, 1914, and the units had been without the guidance of a general medical director. A more satisfactory unity of command was secured upon the arrival in April, 1915, of Dr. H. H. Snively, of Columbus, Ohio, as senior director. Six of the original nursing staff had left Kief in March, 1915, to return to the United States and eleven relief nurses arrived with Dr. Snively. Further vital changes oecurred in Jume. Sister Helen Scott Hay left Kief on June 2 to investigate the school of nursing project in Bulgaria. Sister Minnigerode with two other members of Lnit C returned to the United States in June by way of the Paeific; mines in the North Sea and submarine warfare endangered the shorter route. Sisters Charlotte Burgess, Alma Foerster, Rachel Torrance and Alice Gilbourne were transferred from Kief to the Serbian units.

The remaining surgeons and nurses settled down to a summer of stremons activity. Sister Mabel Rich became supervisor of Init C, Sister Sophia Kiel, supervisor of Unit H. The hospital was inereased on the first of July from 400 to 500 beds. The anticipated activities on the Polish Front did not take place, howerer, and the ominous lull gave opportmity for the tired surgeons and nurses in Kief to take weleome varations.

Of the aceomplishment of the units at Kief, statisties show that the mortality rate of the American Red Cross Hospital was three and seven tenths (3.7) per eent. ${ }^{3}$ l)uring the nime months in whieh this hospital was maintained nuder American manage-

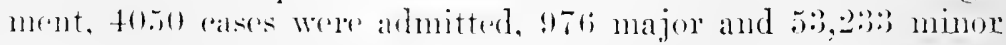
operations and dressings were performed.

Imerican lied (ross Anmual Report. 1915. p. 18. 
When the American Red Cross recalled its foreign units in October, 1915, the American family at Kief separated into small groups, each going its own way. Several of the surgeons and nurses returned to the Lnited States. 1)r. Phillip Newton took charge of a flying field hospital in the Russian Army. Dr. Snively, with Dr. Brown MeClintic, Dr. 'T. Lyle Hazlett, Sophia Kiel, R. Lee Cromwell, Florence Farmer, Edwina Klee, Mary Hill, Aurel Baker, Margaret Pepper, Clara Barndollar and Eleanor Soukup nudertook service with the Russian Red Cross. They were sent in Norember, 1915, to establish a 200 bed hospital for Russian soldiers at Khoi, Persia. In this ancient eity seventy-five miles from a railroad, with its narrow arched streets and its curious bazars where merehants, with long beards dyed red, squatted on rich carpets and cried their wares, the Americans set up a Red Cross hospital. The building they used was a low adobe strueture in which eamel drivers had housed their caravans. On February 12, 1916, the Americans left Khoi for Kasbin, Persia, where both a military and a Red Cross hospital hat been established. While here, Sister Fileanor had a rare opportunity to learn something of Persian customs :

'The Persian house was a mass of mud walls with a flat roof, built around a compound and surrounded by a tern foot mud wall which exchules all view of the yard or harem. Entrance was through a strong wooden gate in the wall, always attended loy a keeper.

The patient was placed upon two narrow tables in a damp, coll room. and a casarean section performed in the midst of her entire family and a molla who prayed all the time. As tables. (hairs and beds are not found in Persian homes, when the operation was over, the patient was put into a bed consisting of a narrow mattress laid upon the floor. Every family, whether rich or poor, posseses many exquisite rugs:

Presuming that all water was brought from the woll, I harnt given this muel thought. but one day when groing to the house, I notieed at the small stram rumning through the midlle of the street (sareely wide enomerh for a teim of horses). a woman washing elothes hy beating them with a (lub: further down a mother was bathing her whikl and yet further on a yomeg girl (leaning the heal of a sheep for some future mol. When I arrived at my destination. the servant was dipling up in an earthen urin water for cooking and drinking. This shows how rapidly epidemics may sprearle as we salw later when rholelal broke out. 
We had another patient, a Persian woman recently married, who had made an attempt at suicide by taking large doses of opium and strychnine. After sereral days she recorered enough to tell us that her husband whipped her. She resented it rery much. He, however, was present and sail he beat his wives once a month whether they needed it or not just to show them their place. He divorced her the next day by commanding her to go away with her dowry. ${ }^{4}$

Again on March 24, the Americans moved, this time to a hospital established in a carpet factory in Hamadan. A speeial detachment, consisting of Dr. MeClintic, Eleanor Soukup and a Russian Sister, started in April to Kermanshah for surgical work at the front, but the advance of the fierce Kurds in June drove them back, after many adventures, to Kasbin. The further record of the work of these Amerikanskii Cestritza in the Persian desert, colorful, vivid, full of the swift dangers and sufferings of guerrilla warfare, became no longer that of an American Red Cross unit, but was merged into the record of splendid achievement of the many men and women who carried on individually their service for the wounded in the European War.

The smoky eity of Gleiwitz, situated in the wealthy provinee of Silesia, that thick finger of Prussia which extends southward between Austria and Russia, was the destination of Lnit I. Unit G, the second of the two detachments assigned to Germany, was destined for nearby Kosel.

The Red Cross Relief Expedition of 1914, it will be remembered, was comprised of ten units, two of which had been assigned to each of the five belligerent nations. The detachments destined for England and Russia had left the Merey Ship at Falmonth. From the decks of the S. S. Red Cross as she lay in the vellow waters of the Gironde River, France, the units destined for Germany and Anstria watehed the surgeons and nurses discmbark for Pan, Franee. So, with four remaining units, the Red ('ross weighed anchor October 4 for Rotterdam, her final port of entry. At last the Merey Ship steamed up the Mas River, throngh level Holland fields. The Amerian murses as they leaned along the rail, exclaimed with pleasure at the picturesegue serne, the windmills and the children who rattered along the banks in their wooden shoes pointing with delight to the great Red ('ross on the ship's white sides.

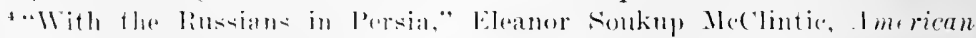
Journal of lursin!. Vol. XVIll, page 39 . 
The four units were formally welconed at Rotterdam, October 10, by the Prince Consort, president of the Dutch Ried Cross. I)r. Henry van Dyke, American Ambassador, and the German and Austrian ministers at The Hague paid visits. Sister Anna Reutinger wrote of the refugees pouring down across the frontier into Holland a few hours before the fall of Antwerp:

From painting and histories we had visualized war as a struggle between manly foes, both victors and ranquisher displaying heroic qualities that stimulated the inagimation and sent the blood coursing rapidly through the reins. That was the false and artificial glory of war. Now we began to see its real, ugly, hideous features. Here were aged men driven from their country, their faces reflecting their misery and despair; here were desolate women whose fathers, husbands, sons and brothers were held as hostages or shot as suspects by a relentless conqueror; here were children emaciated, gaunt and hungry,-all homeless outcasts.

Under the personal guidance of Count Helie de TalleyrandPerigord and of Baron Goldsehmidt Rothschild, the four mits entrained Oetober 10, 1914, for Berlin. There Units I and G parted company with the Austrian units and started on their trip across Germany to Gleiwitz.

At noon of October 17, the long supply train earrying the Red ('ross surgeons and nurses pulled into the grimy station of Gleiwitz. As they had neared their destination, the nurses had exclaimed at the smoke and coal-dust which hung in a blue haze over the pine and bireh forests of the heavily-wooded comntryside; and now that they arrived, they looked about with eurious, delighted ayes on this busy eity of 70,000 . the aenter of the rich mining and manufacturing interests of southern Prussia. Here [nit ( $\mathrm{r}$ left Lnit 1 and proceeded forty miles further to Liosel.

The proverbial German system was at onee in evidence at Gleiwitz; the Anericans were immediately escorted on an inspection tour of the public buildings available for hospital purposes. The military anthorities allowed the Americans to choose the location of their future Lazaret. The aity theater, which eould aceommodate sixty-two patients in the downstairs lobly and sixteen in an uppere reereption room, sermed to contain the best possibilities for development and was taken over by the unit. 


\section{HIS'TORY OF AMERICAN RED CROSS NLRSING}

Unit I went on duty October 18. Dr. Charles H. Sanders, of Calvert, Texas, was direetor and Sister Anna L. Rentinger, formerly Directress of Nurses, Lying-in Hospital, New York City, was supervisor. Sister I)omna Burgar described her impressions of that first morning in the wards:

The theater was a living picture of the tragedy of war. The stage, the boxes and the galleries were there just as you would see them in any theater at any time, but there were no chairs nor seats for patrons. In their places stood low slatted iron berls corered with straw ticks, a single straw pillow and a blue checked bed cover. Nearby stood plain pine tables, one for every two beds, in which the last bare necessities of maintaining life of man were kept; the dark bread, the daily allowance of butter, the knife, fork, spoon, tobacco, soap, pocketcomb and an occasional toothbrush and always a much worn picture of the wife, the children or sweetheart. . . .

If we did not see orchestra chairs, neither did we see the ordinary theater-goers, dressed comfortably and well, intent on pleasure, with laughter in their faces and joy in their voices. In their place we saw many weary soldiers in worn, muclstained, torn miforms, with dark dried blood stains telling the tale of wounds of hours and days before. ${ }^{5}$

Within a few days Cnit I had an opportunity to witness the remarkably swift and thorough "turn-over" of patients which characterized the entire German sanitary service. Sister Anna Reutinger described it:

A few days after our arrival an order came at $8 \mathrm{~A}$. M. to prepare sixty-five patients for discharge in two hours. IIithin an hour after their departure, we admitted sixty-eight new stretcher cases. The arrival of a transport of serionsly wounded is an indescribable scene. Their bloodless and hagrarl faces reflected the agony they were suffering. Womuled five dars previonsly in a battle many miles from the railroal, their first enverances were springless farm wagon: and crude home-make arts. In these they traveled twentyfour hours, without food or drink and were then packed in frejuht ars with little straw to lie upon. getting no slefp and a limitel amount of ford. Their dresings. not chaned during four days. were stiff and foul. One of our patients hat heen liffert from the lattlofield, placerl with three others in a watgon, jolten orrer rough roads all night long. The dis-

5..In Gileiwitz." Donna G. Burgar, 1 morican Joumal of Tursing, Tol. $\mathrm{XV}:$ 1. 11191. 
rovered at dawn that his comrade had passed away in the darkiness, probably from hemorrhages and exhaustion.

'They lay on the hard floor of the foyer, since they could not be taken into the wards mutil the vermin-overed uniforms and boots were removed-those sarl-looking uniforms, a few rlays before so spotless and clean, now mul-calied, bulletpiereed and hlood-stanexl, with here and there an arm or legr missing. On arrival they received a cup of hot coffece and a samiwich. The miforms were put into bags and sent to the garrison hospital for fumigation. The boots, helmets, belts anl knapsan'ks were kept in separate bags. Often the soldiers' feet were so swollen it was necessary to ent the boots to remove them. Baths were given in bed since we were handicapped by having no bath tub or available place to install one. Fortunately whenever large transports arrived, the neighbors brought in buckets of hot water and in such c.ircmustances they were of great value. The first consignment of men had worn their uniforms eight weeks without once removing them.

At the end of their second week in Gleiwitz in addition to their duties at the Vihtoria Theater, Unit I was placed in charge of two private kliniken. These annexes each accommodated twenty-five officer patients and were luxuriously equipped and furnished. The twelve American nurses were distributed so that one day and one night unrse was always on duty in each klinit. They were assisted by young German women of geod family, Ilelferinnen, who also arcted as interpreters. The sistem of volunteres worked well in Germany; because of the strict military discipline, an order given in a military establishment was obeged in erery detail. Lnder an American granluate muse's constant supervision, the wounded received excellent "are in the face of many emergencies. "Always hemorrhages!" wrote sister Amna.

Gleiwitz was an important military center. Sister Ama told of the shitting movenents of the Russian and German alruics:

At one time the Russians were supposed to be within thirty miles of ciluwit\%. Their gums were heard all night. Ilou and hoys from fourten to twenty-one were oreterest to the interior. Aremulationd hy sorrowing mothers they matreded

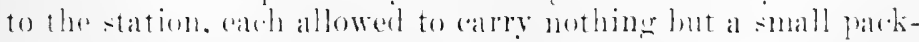

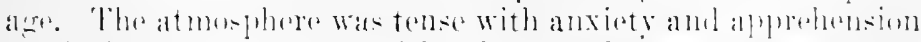

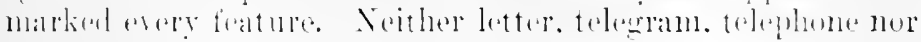


person was permitted to leave the city for seven days. We were notified to be prepared to depart within an hour's warning. Gloom and fear had seized the people. 'The troop trains were now moving at fifteen minute intervals. They continued to pass for five days and nights, two million men, with big and small guns, horses, supplies and all that go to make up an army transferred from West to East. It this time Austrian-Hungarian soldiers appeared before homes at midnight, begging for lodging. Twelve applied at a private clinic that had been turned over to us and the poor fellows, fagged and footsore, dropped on the cellar floor, the only vacant spot, and were sound asleep before we could bring them straw to lie npon. The Germans were again driving the Russians back; and again the freshly wounder were poured into the rity.

Gleiwitz being a garrison town our attention was frequently directed to squadrons of Lhlans leaving for the front, in full war equipment with splendid mounts and uniforms, their banners unfurled and decorated with roses, the mounted bands on dappled greys. They were magnificient bodies of men, full of buoyancy, patriotism and eagerness for the fray. What a contrast to the unfortunates who returned to us wounded, vermin-covered, helpless, crippled and maimed for life, with faces paled and pinched from loss of blood and with hands and feet frozen, arms and legs missing. eyes shot out, bones crushed, muscles, tendons and nerves torn, all heaping pain and agony upon the sufferer!

Sister Amma made brief comment upon the mental attitude in which the patients arrived:

Their lingering death and bodily injuries can be moderated to some extent, but what about scars of a sonl seared or brutalized by this awful lust of blood: I (ite one of many similar histories of a young university student, twenty-two years of acre. I dicovered him sitting alone and apart on several ocasions in an apparently melancholy mood. He told me finally that he had bayoneted a Russian in a charge attack: "It was either he or I and I rewret exceedingly that he did not get nue. I still fool my hayonet going through him. I will never knowingly kill again."

The Ameriean nurses described their wounded as strong, relem, halthỵ men, patient, courageous, frugal and childishly apprediative.

Fonr numses sailod in Fobmury, 1915, from New York to reliere members of I'nit I, who wished to return to the Enited 
States at the end of their six months' service. 'The war zone was then full of danger; one of the relief nurses, Edith Wood, described her passage in the following letter to Miss Delano:

The acdident to the s. S. Toumine furnished us with excitement for two days. Of the fourteen ressels receiving her S. (). S. we were the first to rearch her, turning back in a dense fog eighty miles from our course. Our eaptain harl to reduce speed onc-half to allow La Touruine in her crippled condition, to crawl slowly behind us. Sunday afternoon, two French (rnisers, called by wireless, came up), swung about and one before and after, escorterl our charge away toward Le Havre. We congratulated ourselves that we were not on a burning ship carrying 400,000 rounds of cartridges and in momentary langer from German torpedo boats!

All night long we have lain at anchor in Dover. Torpedo boats and destroyers patrol up and down near us, and grayhulled battleships slip in and out through the fog. Our life boats have been swung clear on the davits, from the time of our entrance in ('hannel waters. The Rotterdam has her name in three great rows one below the other on each side, in large letters about four feet square, composed of electric lights. As we mored out toward the North Sea this morning, the wreck of a liner drifted past us.

Upon their arrival at Gleiwitz in Mareh, the four new nurses found that Unit I was in sore need of rë̈nforcements. From the Vilitoria Theater, the American Red Cross IIospital had becu moved to a concert house nearby, which aecommodated 140 beds, an inerease of sixty beds over the capacity of the theater-hospital. Unit I retained, moreover, the two Kliniten. Sister Anna was extremely loath, in view of the pressure of work, to allow two of the four new nurses to go on to Kosel, but they were needed equally and had to go there.

Although Sister Amua's letter's to Miss Delano were persistently cheerful, the Gleiwitz Cnit was not without its difficulties. One hundred and seventy-three beds, always full, taxed the strength of eleven murses. 'The ten hours' dinty and the lack of a common langmage and of recreational facilities made the serviee more severe. The presenee of the $M$ elferinuen in the wards further complicated matters. Sister Amma wrote:

The first duty of our German $/ 1$ eiferinnen is to write and knep histories. and to assist when possible with ward work. I am determined to get on with them in this (ierman military hospital! 


\section{HISTORY OF AMERICAN RED CROSS NURSING}

What we need are conscientious, skilled nurses who are willing to accept without nurmur the routine work of making helpless patients comfortable, bathing them, making beds, dusting, using our improvised equipment and accepting cheerfully the general discomforts of war. Peace at any price has been my first consideration.

The Aneriean Red Cross Lazaret Konzerthaus was closed September 13, 1915, with a record of 1527 cases and the staff of Luit I received their reeall with regret. Several members returned immediately to the United States. Ten nurses and one surgeon joined the group which I)r. Snodily, senior direetor of American Red Cross units assigned to Austria, was organizing for the German Government, to render relief to German and Austrian prisoners of war in Noseow and Siberia.

The closing days of the Konzerthaus were as busy as had been the first days. Sister Amm's last report from Gleiwitz to Miss Delano described how the patients contimued to arrive:

Vermin-covered as they are, exhausted and hungry, with their womds undresied for five or six days, to bathe and care for these patients is the most soul-satisfying work I have erer done.

We are busier at present than ever. The arrival of a large transport is dramatic. When all else fails, I am prepared to manage a night lunch counter! Recently thirty ravenous, womnled, tired sonls arrived well after midnight. When we had finished scrubbing them, I stole some bread and with the jam on hand and seventy huge mugs of hot tea, those weary men declared this old Konzerthaus Heaven on earth!

Parting with the soldiers was hardest for me. We left many seriously wounded from our last frightful convoy; their eyes, full of feverish pain, haunt me.

The ancient warrison town of Kosel lay forty miles from Gleiwitz in German silesia. Here in a military hospital of

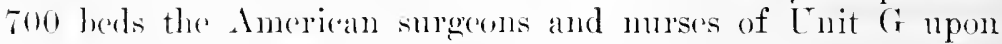
their arrival on Oetober 17, 1914, were given the charee of the main Lasuret.

Vnit (a quidely won a place for itsolf in Kosel. Dr. Bial F.

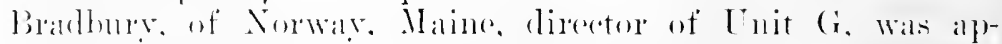
pointed in shert order general consulting sureeon of the entire military hospital. I)r. R. ll. Newman, of Kunxville. Tenunessee, was made general operator. Within a fow woeks of their alrrival, a stat jou of fifty herls was opened in a public school near- 
by and assigned to 1). John Laneer, of New York, thereby making a total of 1:30 beds to be cared for by Unit G. Sister Frances H. Neyer, of the New York City Ilospital, was supervisor of Unit G. A German Red Cross sister was assigned to the Amerian Red ('ross Lazaret to interpret for the surgeons and to record histories.

The even tenor of their days at Kosel was interrupted on January 7, 1915, when J)r. Bradbury was ealled home by the critical illness of his wife. Four nurses returned to the United States at the termination of their six months' duty, Marels 3. As the Garrison Lazaret was transformed in March into a central operating station for Kosel and as all major cases remained five or six days under the care of the Americans before they were returned to their own wards, the work was heavy for the nine remaining nurses. Dr. Gilbert $A$. Bailey, of Chicago, appointed to suceced Dr. Bradbury, arrived in Kosel March 12 with one relief nurse, Sister Caroline Baner. Dr. Newman succeeded I)r. Bailey as director on April 2.2 .

Two relief nurses destined for Kosel sailed in July on the S. S. Noorden. With them was the first IIarvard Unit of 150 surgeons and nurses, which has been assigned independently of tha American Red Cross for service under the British Expeditionary Fores. To these two nurses, after days of danger in the war zone,- the Noordam with her life-boats swung out above huge electrie letters which proclaimed leer neutrality to German submarines,--the quaint town of Kosel, set anong fields of waving grain, seemed peaceful indeed.

When the Garrison Lazaret was (losed on September 15, 1915, 750 eases land been treated to a conclusion and 275 major operations perforned. Only a few of the surgeons and nurses returned to the Lnited States. 1)rs. Newman and Lien with Sister Franees and seven of her unit joined 1)r. Snoddy's group in Berlin for duty among German prisoners in Moseow and Siberia.

Init K of the s. S. Leed ('ross arrived on ()etober 14, 1914. in Vienna, Anstrial, the garest capital dity of Europe, to estall)lish Reserve IIospital No. \& for Austriats wounded and were

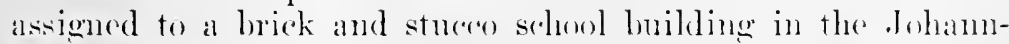
IIoffmann Platz. Ilere they set up a military lonspital of -100 beds, splendidly expuipped thromgh the gernervisty of the Austrian lied ('ross. 1)r. ('iry A. Sunddy, of Knoxville, T'munesee,

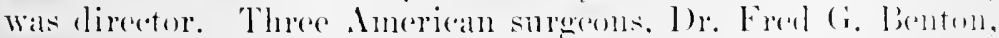




\section{HISTORY OF AMERICAN RED CROSS NURSING}

of Owego, New York, Dr. Walcott Denison, of St. Louis, and Dr. P. A. Smithe, of Enid, Oklahoma, composed his staff. Sister Ixda IV. Anderson, of the Illinois Training School of Nursing, Chicago, was supervisor of nurses.

Wounded soldiers coming by train from the front were received in the school gymmasimn, which had been equipped with beds, benches, bathtubs, showers, diet kitchen, dressing room and steam sterilizer. Dr. Snoddy described to Major Patterson the arrival of a transport:

Ambulances drive to the door of the receiving department, which is capable of handling thirty bed and seventy sitting patients at one time. Here hot nourishment, stimulants and medical attendance are given inmediately. The spectacle is one of suffering, exhaustion, discouragement and filth.

Next to the physician and dietitian in the receiving line is the barber, and then the chemist comes with his lice-killing applications. The bath stewards are ready with tuls for the sitting patients and tables for the prone cases. The record writer is Jusy. Surgeons and nurses stand by in three operating rooms. one for aseptic cases and two for septic. The ward nurses are at their posts with beds prepared. Patients are handled at the arerage rate of twelve per hour.

The American Red Cross hospital needed efficient organiza. tion and high professional skill as its work was subject to constant comparison with the best organized clinies of Enrope, such as that of Eiselberg in Viema and Dollinger in Budapest.

Sister Lyda's report of November 24 to Miss Delano bore testimeny to the case with which the Americans cared for the wounded :

This afternoon we are enjoying a little lull after a heary night and morning's work. We received a message yesterlay now that a transport would arrive at nine P. if. today. They did not come until midnight, but we had them hathed and their womeds dresed by three o'clock this morning. This is our third transport, about ninety wounderl in all. They have not been severe ases. but all filthy with dirt and vormin. Many have not had their rothes off for weeks, nor have they oren had their faces washed.

It is the rreater gratification to see them in their comfortable besh: 'Though srubbing from thirty to sixty men makes us feel we have really done something. the work so far has not been in stremusom: but that we have been able to do it thoroushly. liool and generous equipment makes the work 
convenient and comfortable. We no loubt have harder days in store for us. Our greatest difficulty lies in compromising on methods and in adjusting ourselves to military regulations.

Home-sickness was a potent foe with which all the units had to combat. "Like cool water to the thirsty, is the somnd of his mother tongue to a man in a far country." Few of the nurses spoke German, however, and Sister Jyda urged the members of her mit to meet with tact and diplomacy situations that constantly arose because of the laek of a common language. $\mathrm{Al}$ thongh they were not in simpathy with the extrenely practical and sistematic habits of the Ameriean graduate nurse as opposed to the more sentimental point of view which Europeans cntertained toward the care of their wounded soldiers, two Viennese volunteers of high social standing gave much time and energy towards making the Amerieans comfortable. They suceeeded well. "Our meals are late and long but very good indeed," wrote Sister Lyda to Miss Delano. "Personally I like the life here in Europe, though to be sure it is abnormal now. Wien is not the happy eity I visited several years ago. It is in sack-cloth and ashes. They are begimning to resume their gayety to a small degree. The Royal Opera and the eoncert halls are open again." Sister Lyrla's description of the bread lines alone, served as an index to conditions:

The husbandry of fookstuffs was more carefully considered as time went on. Bread was issued at bakeries, restaurants and hotels only upon presentation of breal tickets. These cards allowed one a week supply. Flour was obtained in the same way. This law was rigidly enforeed. On Theslays and Fridays ne meat could be purthased. ('ream rould not be taken from the milk. P'asints harboring their erop of meal were all requires to grive it in to the general supply for common distribution. Bread hines formed, extending the whole lenerth of the block. forenoons and afternoens. at the sereral hundred stations in the city people waiting hours for their allotment of hread. This was a heary. blate hread marle from potato flour principally, and eould he prepareel so as to be quite palatable, but when made very eheaply. Was heary batk and sogrgy. Foodstufls had more than trebled in price during our vear in Vienna.

Supplies of all kinds. so murb wanted hast winter. will be much more neesterl this winter. Some monthe hadek they issued a call in Viema for all the old linen to he used. when frayed into ravelingrs as a substitute for absorbent cotton. Hobse- 


\section{HISTORY OF AMERICAN RED CROSS NURSING}

wives were required to give up all copper and brass utensils to be melted and sent to ammunition factories. Some splendid heirlonens, beautiful Ruscian samovars and oriental urns were sacrificed. An especially designed iron finger ring worn by anyone signified that this person had thrown a jewel into the cotter and arcepted this war decoration instead. ${ }^{6}$

One year later, horse-flesh was selling in Vienna at fifty-six cents a pound!

I). Snoddy gave Major Patterson an interesting analysis of the effectiveness of projectiles as shown by the first thonsand case's which cane to Reserve-s'pital No. 8. He judged that the high valocity rifle bullet was the most destruetive from hand weapons. Distinguishing features of the German, Austrian and Scrbian bullets were lead cores, ogival heads and flat trajectories which deformed easily. The Russian bullet, conicalpeinted and of smaller calibre, was generally less harmful. The French bullet, large in size, of solid brass with high penctrating power, did not easily deform. Shrapnel shells were by far the most effective of projectiles from artillery. The octagonal iron balls used in French shrapnel were more destructive than the lead or alloy balls of the other nations. German bombs fired at short range from mortar guns threw many fragments of shell when exploding and literally swept the enemy down. $^{7}$

The American nurses found the German-speaking Austrian soldier particularly appreciative, quiet and obedient. Sister Lyda wrote:

The Austrian soldier accepts the war sulmiscively, as the inevitable, neser questioning for what he is figliting, or whether the sacrifice of his precious life is adding to the crlory of his conntry or is fulfilling anything of value to the world. Seroine troep after troop of the best men of the country, as fine as the world has to offer, talented men often of grout minds. marding ont daily, few to return and these fow maimed and nosles ritizens, one wonders that it did not stir allarchistio feerlings. ${ }^{8}$

B"Experienees of l'nit $K$ at Vienna. Austria," a paper read by Jyda IV. Andersons at the Eleventh Annual lleoting of the American Red cross. 1)

"..Vutes on the European War," Cary A. Snoddy, Red Crose Archives.

"laper rand ly lyda Andreron before the American Red Cross Ammal Mecting. 1915. 
Although Unit $\mathrm{K}$ was amoug the most successful of the units sent abroad on the Red ('ross Ship, Sister Lyda had to confess that even in this detachment, there were moments of discouragement:

I must admit that this position of supervisor has caused me more anxiety than other positions I lave held of far more grave responsibility. 'That a number of graduate nurses who have lived an independent life for several years are not going to adjust themselves to new and unnsual eonditions, suth as we found here, or eome under authority (even though the supervisor tries not to make this authority felt cnough to arouse antagonism) is a natural condition. It has taken a great deal of thought on my part to try to know each individual.

In listening to the nurses of the different groups who have visited us on their way home, it has seemed to me that the one stumbling block has heen that the individual conld not forget herself for the good of the whole. Is this disinclination toward united effort a weakness especially of our profession, or just a natural human instinct? Shall we depend on a few strong leaders to control the number or should the individual be educated to appreciate more fully her personal responsibility?

With a record of only five deaths among 20:50 eases treated (althongh they had received largely only lightly wounded patients), the American Red Cross IIospital No. S closed its doors September 18, 1915. Sister lyda with several nurses returued inmediately to the United States. At the request of the German Government, Dr. Snoddy with two surgeons and nine nurses of Unit $K$, as well as additional American lied Cross persomnel from Budapest, Gleiwitz and Kosel, went to Petrograd to care for German prisoners in Russia. Sister Ixyda described with considerable amusement ineidents of their departure which were in sharp contrast to the eordiality of the reception given the nuit upon its arrival one year lefore:

Of the thoroughness of any system instituted by the German forernment. there and be no question left in the minds of travelers who have crossed her border the list few weeks. The only thing one "an think of which they might but didn't do. was to apply the X-ray!

Your clothes are removed and every garment is oxamined. for was not a woman just the day betore. who hast rome in with a presumably broken arm, fomml with paturs concealed 


\section{HISTORY OF AMERICAN RED CROSS NURSING}

in her bandages? Your body is examined, for in the week past a woman was found with her back tattooed, showing the plan of the army. The soles of your feet are scraped; there is the possibility of papers being plastered there by adhesive. Your tooth paste is squeezed out of the tube, your candy pieces are broken, your pow der boxes are emptied. You feel when you are through, that your very soul had been ransacked, that they know your innermost thoughts. All papers, books, printed and written matter are held over for more careful reading and are mailed to you later if you leave the money for postage. If you remain in any German city longer than is neressary to change trains, you are required to report to the police department when you arrive and when you leave, giving a short sketch of your life each time, assuring them of your legitimate business and leaving your finger print. Any war souvenir such as bullets or anything used in the field by the soldier, maps or diaries, they retain, giving you the promise that they will be sent you after the war. For the civilian they have no regard; he is a trouble to them in their serious business of war. ${ }^{9}$

In the rich plain of Humgary on the main rail and water rontes from western Europe to the Balkans, lies Budapest. Near the beantiful Vares Leget in this eity, Unit E of the Amorican lied cross Rolief mission established Military Reserve-s'prital. No. 4 of 20 (o-bed (apacity, in a modern brick and conrrete structure which had shortly before been built as an asylum for the blind.

As with the other mits of the Red Cross Ship seattered in the several colners of Europe, so with this group of surgeons and murses at Budapest did the geographical location and the attitude with which the military authorities regarded the Anerienans, entirely determine the number and condition of the wounded assigued to the strangers' are. Budapest boasted fifty military hospitals, which gave a ratio of one soldier paltient to every cheren civilians. As the city was splendidly located, from a stratenic point of view, on the Dambe River, the womblel anme from many points, first from the Sorlian

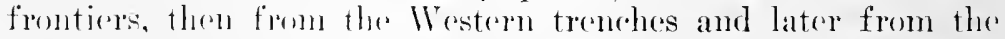
('arpathian and ltalian battle-heights. Unit E ronsidered itself fortunate indered to be assigued to the Inumgarian capital, which watr hald malde a center of hospitals.

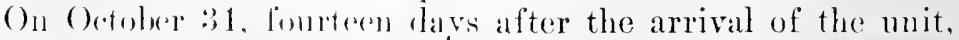

"Paper reath hy Lyda Anderson before the American Red Cross Annual Heting, 1!n15. 
Dr. Charles Mar.Ionald, of Salem, New Jersey, director, and Sister Alice Beatle, of Cleveland, Ohio, supervisor, opened the door's of the American Red ('ross Ilespital. 'The first alswignment of patients was made up of soldiers desperately wounded during the Austrian drive on Belgrade. It is signifieant of the nentrality of the lied ('ross that its mits should lind up the womnds of both Hungary and Serbia in the capitals of these countries that were fighting each other. Within ten days, Enit li had received 1355 streteher eases. Sister Katrina Hertzer described the condition in which the patients arrived:

Serbs, Albanians, Hungarians, Croatians, Austrians, Miontenegrins and Russians began their long journey from the front on stretchers, ox-carts and hay wagons to the nearest railroad, where hospital trains brought them filthy. hungry, exhalusted to us. Many of them had their faces blown away; pus flowed down their chests and on the beantiful new lied Crows blankets. As they arrived with their first dressings still on their wounds after fifteen days travel, it was almost imposibible to protect the beds. We dressed nuany cases three and four times a day.

Ilideous mutilation was the rule, not the exception. It was a frightful thing to take off foul dressings and see below the shattered, yellow flesh, the labored inspiration and expiration of the exposed hung. The thought of what pain these mon were sulfering used to sicken me.

Baron Armin Popper, General Staff, was military commander of the Red ('ross Hospital at Budapest. Many former Ameriman citizens residing in the eity opened their houses to the members of Lnit E. Countess Sigraly, the danghter of Marrons Maly, of Now York, and Comntess Zichy, formerly Miss Malmel Wright of Buston, took a keen interest in their com-

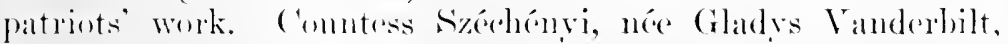
presented lonit E with a beantifully complete X-ray apparatus. 1)r. Inertzog, military eommander' of the Budalest hospitals. often made romuls with his staffi at No. 4. P'rofessor bulius Dollinger invited the surgeons and sister Nlice to attend his famons alinicr.

Between the lines of Sister Aliee's small leather diary appeared a brief story of the tirst month's work:

Octoler 30. 191 - Supplies arriving all day were listed am

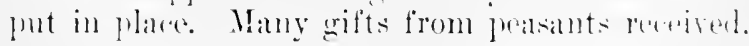




\section{7t HISTORY OF AMERICAN RED CROSS NURSING}

October 31-Hospital turned over to American Red Cross by II err Oberstubsarzt Hertzog; forty-two wounded soldiers arrived.

November 4-Nurses dresed rases until 2 A. M.; two leg amputations. Arrhduchess called again.

November 10-Twelve patients from Galicia, badly frozen; heary work.

November 11-Nurses had cholera vaceine.

Norember 13-Twenty-two wounded from Serbian Border141 patients in all.

November 24-Profescors from Lniversity visited us.

November 55 -Fortress Przemyzl in Poland has fallen!

November :28-Twelve patients ardmitted; $17 \%$ in hospital.

November 2 !-Mrs. (ierard from Berlin visited us.

December 1-Eighteen Budapest hospitals quarantined because of typhus.

The work proved absorbingly interesting. Sister Alice wrote of the different nationalities which sifted through the American Hospital :

Moravians, Slovaks, Dahmatians, Magyars, Germans, Ruthenians, Poles, Roumanians, Italians, Croatians, Helvetims, Turks, Serlss and Rusians come to us, and somehow we manage to find out their wants and make them comfortable: Quite frequently we find a man who speaks English. A few days ago I saicl to a new arrival: "And so you speak English, do you?" "Well, jus' tol'able, Miss."

The IImugarians take excellent rare of all wounded they receive and are very elever at improvising hospitals in sehoolhouses. theaters, the stock lixchange, art gallorise, warehonses, private homes, rlubs and sub-stations of banks. The women do a tremendous anount of work liere, of a type never essayed before. The wives and rhildren of soldiers must be aired for: plates must be provided for the hlind and (rippled whose asylums are now being used for hospitals, and cmployment must be found for thousands. This requires genuine oremizing ability.

The loniger I taly here the more deeply am I impresord with the faret that the women who undertake forejon service for the Amerian Real coss must be fine women before they

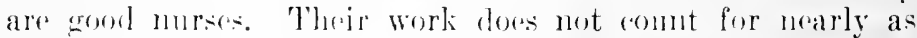
much as does their general bearing and conduct, both in and out of the hesipital.

Althemgh the nembers of the Budapest Tuit were far re-

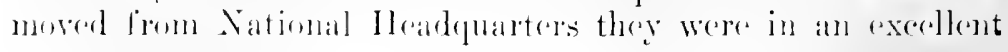


position to receive wisps of information regarding the other Ameriean Red Cross persomel. Sister Lyda from nearby Wien wrote of the interesting work accomplished at Gleiwitz and Kosel. Sister Helen Seott Hay, writing from Kief, assured Sister Alice that the Russian soldiers were quite the nicest patients she had ever seen. A New York newspaper woman brought tragic word of Serbia. Political jealousy, intrigue and cumning ran high in the Hungarian eapital. "Small wonder," wrote Sister Alice, "that they term Budapest the whirlpool of modern Europe." During the early spring of 1915, the city became a maclstrom throngh which gray hordes streamed. down to the Carpathian and Italian frontiers. Sister Alice wrote on March 11 to Miss Delano:

You have read in the papers about the morement of German troops to Galicia, Serbia and Transylvania? Those millions of men keep marching past our hospital, week in and week out. Troop trains constantly go by night and day, loaded with soldiers and ammunition. Army wagons, ambulances, artillery, automobiles, ox-carts and aeroplanes form a never-ending proression. All types of vehicles from an imperial coupé to a Fifth Arenue motor bus are used.

The German soldiers are always singing. At almost any hour of the night when one awakens, we can hear "Die Wacht am Rhein" or "Morgenroth." As they swing past our hospital in the daytime the infantry smartly salute the Stars and Stripes above their heads.

Hot summer months brought no cessation of work to Unit E. Sister Alice's letters reforred repeatedly to the unselfish helpfulness of the wounded. When it became erident that he eould not recover, a critically ill soldier was removed in July to a hospital nearer his home. His eomrade in the next bed, who had helped care for him constantly, eame to Sister Alice the next day and asked if his cot might not be placed by the side of sone other very siek patient. "Die schuestern have taught me how to be gentle," he said, "and I would help."

When the Ameriean thag and the Red cross banner were lowered for the last time, September 20, 1:1., the Red Cross hospital closed its dewr's with a record of 1.r.3 eases and 313 major operations. The death rate was less than one and one-

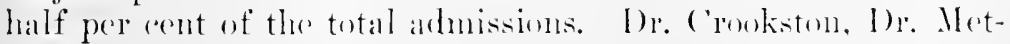
("alf and 1)r. Miller, with eleven nurses, joined Dr. Shoddy's unit for sorvice among (iorman prisomers. 


\section{HISTORY OF AMERICAN RED CROSS NURSING}

When the American Red Cross had offered its ten relief units in August, 1914, to the belligerents of the European War, the detachment of twelve nurses and three surgeons destined for duty in Serbia, had not been sent upon the S. S. Red Cross, because of the expense that would have attached to an extended trip of the ressel down through the Mediterranean for just these fifteen. Thus a dingy merchant vessel instead of the white Merey Ship brought Unit No. 1 to Saloniki for its destination further north, at the time the first overwhelming tide of.suffering and disease incident to the Serbs' gallant part in the war rushed across the sunny agricultural lands of the little Balkan principality.

The Serbian people had always been a nation of farmersoldiers. Pride in ownership of field and cattle-herd had bred a fierce national love of independence. Manual toil, shared alike by rich and poor, had developed a fine, upstanding democracy. The people had clung desperately through years of internal and external warfare to the hope of a great Jugo-Slavic kingdom. Sinee the dawn of European history, the Balkan penimsula had constituted the natural trade-gates to the East and its control had been the goal of ambitious world-powers since the dars of Alexander the Great. Exhausted by two previous wars, Serbia chose to submit to the terms of Austria's ultimatum of July 2:3, 1914, rather than to endure her powerful neighbor's "punitive experlition." But in spite of Serbia's humble agreement to right of the ten Austrian demands, Austria declared war July 28 on the scemingly defenseless little kingdom to the south. History records the resultant action of linssia, Germany, France, Great Britain, Italy and the United States.

Serbia swiftly mobilized leer five million population. An heroie hand of 500 modical men marched away with the new Army. Serbia had only one doctor for every 5500 of her sturdy peasant-soldirs. The goverument immediately accepted the offors of sanitary assistance which were extended her by the Red Cross societies of several then neutral nations.

Amone these contingents of surgeons and nurses was the Anerican Red C'ross Sirpian Lnit No. 1, of which Dr. Edward II. Ryan of Seranton, Pennsylyania, was director and Mary E. Gladwin was supervising murse. Miss Gladwin's share in Leel Cross nursing in the Spanish-American War has already been mentioned. She was graduated from the Boston City 
Hospital, was in turn superintendent of nurses of the Woman's Hospital, New York City ; of the City Hospital, Cleveland, Ohio ; and of the Akron (Ohio) Visiting Nurses' Association. At a Japanese base hospital during the Russo-Japanese War, she had received expericnee in the lonely, monotonons, exhansting school of war nursing. As chief nurse, she had directed the relief work of many American Red Cross nurses during the Dayton flood.

Upon the arrival of Unit No. 1 at Nish, Crown Prince Alexander asked the Americans if they were willing to report to the Military IIospital at Belgrade. The Austrians were at that time bombarding the eity. Unit No. 1 acepted the ehallenge with alacrity and on Oetober 15, 1914, took over this excellently equipped institution, then filled with wounded Serbs.

The Military IIospital at Belgrade eonsisted of nine modern stone pavilions, erected in 1907 by the military authorities. The main building had two wings in which were two large operating-rooms, a laboratory, a main office and four wards of fifty beds each constructed aceording to modern standards with white-tiled floors and ample windows. Adjacent to the main building were medical and surgical pavilions of one hundred beds each. Nearby were the administration building, the kitchen, laundry, chapel and morgue. A magazine and trenches plainly visible from the windows of one pavilion brought home to the Americans their closeness to war.

Grave difficulties confronted this unit of three American surgeons and twelve nurses. During the first seventeen days of heroie house cleaning, they cared for approximately one thonsand lightly womnded Serbs. IDr. Ryan's responsibilities were greatly increased by his appointment on November 25 to the general directorship of the military and civil hospitals in the entire eitr. His and Miss Gladwin's professional and administrative duties were further complieated by the fact that they oould communieate with National Headiuarters, Washington, I). C., only through the already overtaxed ables of the State I department. Nedical supplies could not be obtained in Belgrade. Food for the pationts was monitable and inadequate. Overhead shrieked the Mustrian shells. Miss Gladwin described the bembardment of the city:

There was no time during the first six months that some of the grums were not fired. My room was a little white-washed 


\section{HISTORY OF AMERICAN RED CROSS NURSING}

one. Every time one of the big French guns would fire, for example, it would show the flash on my wall. It would illuminate the wall and then, in a second or two, I would hear the boom of the guns. That kept up night after night. ${ }^{10}$

At two o'elock on the morning of November 30, the Serbian authorities notified Dr. Ryan that they were evacuating Belgrade because their supply of ammunition was almost exhausted. They left one hundred of their seriously wounded in his care. Of the taking of the city, Dr. Ryan wrote Major Patterson:

No anthorities were left. As there were many robbers about, stores were looted. . . . Many people were being held up in broad darlight and it was necessary to do something for the poor who harl no food. As we had not enough for the patients at the hospitals, I sent men into the country to bring in all the fuod they could lay their hands upon. But before their return the Austrians arrived and forty-eight hours after the first troops, their wounded.

We worked day and night until we conld no longer continue. We had wounded men everywliere. Starting at six oclork in the morning we would dress wounds all day. About nine oclock at night we would start to operate and work until five or six in the morning. Many nights we got no sleep and never more than three hours. Halls, floors of wards and every place a man could fit in, we had filled. Te had in this hosital for several days three thousand wounded and one lay we had nine thousand in the grounds. I was then forced to beg the Austrian officials to send some of them to the hospitals in IIungary.

During the Austrian oceupation, the American Red Cross furnished food, conl and wood to all the hospitals in Belgrade and supplied six thomsand loaves of bread daily for the poor. Somp, a little meat, a few beans, and an allowance of two hundred and fifty grams of bread, comprised the rations for patients and statf of the Military Hospital.

An insupportable burden of work confronted the nurses. The Austrians bromght hundreds of cases of frozen hands and feet, dyentery. renerent ferer, typhus and typhoid to the American lied ('russ Jospital. Other patients suffered from every type of rifle, shrapuel, erenade and bomb wound. Ox-carts and hay

${ }^{10}$ Pagwe read he Mi-s Gladwin lefore the Nineteenth Anmual Comvention of the Ameriean Nures Asonciation held at New Orleans. La. 1916: later published in the Amerien Journal of Nursing, June, 1916, Vol. XVI, patere 
wagons had transported some of the patients, often without even First Aid dressings on their wounds, from remote mountain towns. Gangrene set in and the exhansted nurses, on their slow rounds to minister to those who possessed at least a fighting chance for life, had to pass by the doomed men. Miss Gladwin wrote of the pitiful eries of the dying:

There was a ward next to mine, with a door leading directly into it. I could hear every sound in it and I used to tumble into bed at two or three o'clock in the morning and hear those men in the ward. They begged and prayed in all languages for help. They swore, they tore their bandages and the nights: when I got up (it took all my strength of mind to stay in bed), I kinew exactly what I would find when I went in,--the men in their agony tearing off the dressings, the dark streams of blood on the floor. ${ }^{11}$

In the meantime the Serbs had received a fresh supply of ammunition from the French. They rallied and advanced on the too-eontident $A$ ustrians with a fury which drove them completely out of Serbia. The order to evacuate Belgrade eame as quiekly to the Austrians as to the Serbs. Cammon began to thunder afar during the carly dawn of Deember 13. At eleven o'elock, Serbian and French heavy artillery had found the range and were pounding the slopes of the eity. Dr. Ryan wrote:

$\mathrm{By}$ one o'clock, the battle was raging on the ontskirts. At dark, shells were bursting everywhere. The streets were jammed with cannon. soldiers, supply wagons and horses going toward the bridges that would take them across the 1)anube and sive rivers to safety. They continued the retreat until the next morning, when the Serbians destroyed the bridges, leaving those who had not gotten across, as prisoners on this side. About five hundred Austrian wounded were left in our care.

The following days brought lighter work to the big military hespital. The care of the Serbian wounded was not so heary. "The work has been indescribably hard," wrote Miss Gladwin to Miss 1)elano, "hut it has growi much lighter during the last two weeks. The numbers are beenning a little rested, in readiness for the Next Thing. whaterer that may be."

The Next Thing was typhus. Horeles of refugees pouring

1 Paper read hy Mise Gialwin hefore the Ninetrenth Annual Convention

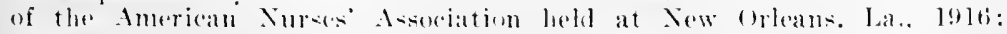
later published in the Ameriean Journal of Vursing. June. 1916, Vol. XYI, page 911.5 . 
down from the frontiers, a shortage of adequate food and the total dearth of Serbian doctors and nurses favored the contagion nutil it swept the little principality. A graduate of Roosevelt Hospital, then in Nish, wired National Headquarters: "Typhus raging throughout country. Mortality high. Cholera foared later. Help urgently needed, especially doctors, nurses with hospital isolation equipment, disinfectors for typhus elothing." Mr. Bicknell, National Director of the American Rod Cross, then in Europe with the Rockefeller Commission, cabled: "T'yphus overshadows everything else." Dr. Ryan's report for February gave fuller details:

During the month we added to our number about 800 patients, totaling 1850 in all. Typhus has overrun Serbia. In Nish alone there are one hundred deaths a day and I believe at least fifty a day here, though Belgrade is better off from a sanitary standpoint, than any city in Serbia. Typhoid rlaims its share. Nany die also from relapsing fever. There are always shells passing over us, as the Austriaus retaliate on Belgrade the French fire on the City of Semlin across the river, now exceedingly ligh. This precludes the possibility of military aetion for some time to come. Fortumately it will give us a chance to try to get rid of the typhus upon us.

Until April, 1915, at the height of the typhus epidemie, Unit 1 had worked entirely alone as the only group of American suregens and nurses in northern Serbia, bnt circumstances outlined below then dew to them nembers of two other Aneriean Red Cross mits which had previously been assigned to duty on the sonthern frontier at Gergeli. During the autumn of 191t, following the sureess of Cnit No. 1, the Serbian Government had requested National Red Cross Headquarters to send additional surerons and numses to assist them in earing for their sick and wombled. In response, two mits had been sent to Serbia in Inerember, 1914, and had been assigned to a large military hospital and prison eamp at Gergeli, fifty miles inland from the Greek lorder. 1)r. Ethan Flageg Butler, of Washingtom, I). ('. Was direstor of Serbian Unit No. 2; I)r. Eruest Pembleton Vaermere of the same aity, was director of Serbian Init No. 3: Mathilde Krurger, of Detroit. Michigan, was supervisor of the twolve murses who comprised the mursing staff of the two muits. A detailed account of their struggles at Gevgeli will follow. 
While Dr. Ryan and his associates were endeavoring to check the spread of the typhus epidemic in Belgrade, word eame during the last day of February, 1915, to the American consul at Nish that the najority of the members of Units Vo. 2 and 3 had been infereted with typhus at Gevgeli. He immediatcly commminieated with Dr. Ryan and with National Red Cross Headquarters. Major Patterson cabled Dr. KirbySmith at Pan to sond one surgeon and three nurses of the French units to the aid of the stricken Americans, and instrueted 1)r. Ryan to investigate immediately the situation at Gergeli. Epon his arrival there, Dr. Ryan found that only four nurses of the stafti of twelve and two doctors of the original number of six had esciped infeetion. These six Americans still on duty were, howerer, taking good care of their own sick. Dr. Ryan suggested that Lnits 2 and 3 withdraw from Gergeli to Saloniki as soon as the health of the patients permitted. II then on Mareh 3 returned to Bolgrade and resumed his efforts to combat the typhus which was hecoming epidemic in Belgrade.

For the next three weeks, 1)r. Ryan was the only American surgeon in the big Military Hospital. His two assistants had returned to the United States, Mareh 3 , in eompany with three nurses of Unit No. 1 whose strength had not been equal to the strain of the Austrian oceupation. The depleted mit tried gallantly to meet its responsibilities. "Life is rather monotonous," Miss Gladwin wrote Miss Delano, "we go nowhere and see few people, but we get along surprisingly well. I am as usual well," she continued, "a little thin perhaps and acquiring gray hairs steadily, but happy and content to be in Serhia and glad to have escaped the fuss, feathers and festivities which seem to have overtaken some of our mits."

In the montime, Inr. Kirby-smith and the nurses from Pau had arrived at Saloniki and there hand fommd sereral romvaldescent mombers of Serbian l'uits No. 2 and $?$. Laving the murses there, he had then gone on to Geregeli and fomel that the pationts were progeresing well there and that the remaining

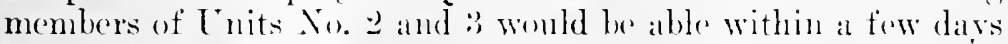
to witheraw entirely from that ill-fated serbian hospital camp.

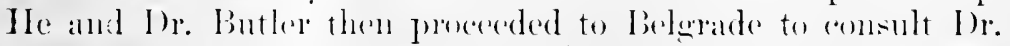
Ryan reanding the next mose. They arriod at the Military.

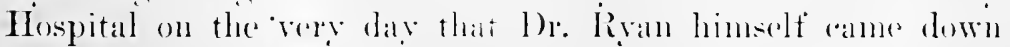
with typhus. Mliss Ciladwin wrote of her cmotions when she first silw them: 


\section{HISTORY OF AMERICAN RED CROSS NLRSING}

I went back to the sterilizing-room and as I entered I looked up. There in the doorway stood two men in the uniforms of American Red Cross surgeons. I rubbed my eyes, because I thought that my wish for help was making me see visions, but I went forward and found Dr. Kirby-Smith and Dr. Butler. It seemed the merest arcident which had brought them there, but 1 shall always believe it was in answer to prayer.

The contagion swiftly overtook other members of the unit at Belgrade. On March 28, Miss Gladwin wrote Miss Delano that Ida Lusk, a Bellevue nurse, was desperately sick with typhus. Dr. Ryan had developed pnemmonia. "It is pitiful," Miss Gladwin added, "to hear him in his delirium going over and over again the details of the work."

Immediately upon his arrival, Dr. Kirby-Smith wired to Dr. Magruder at Saloniki for which reënforcements from Lnits 2 and 3 as might safely be spared. Then with Dr. Butler, he set to work. In that over-crowded hospital shelled by enemy fire, with an exhansted nursing staff and a stricken director, Miss Gladwin and the remaining seven nurses faced the rounds of duty with cheerfulness and equanimity. Fear held their hearts in a grip of iron, but the discipline of their profession steadied them and sent them about their duties, which was soon to inchude the care of other desperately ill nurses and the burial of one of their lorst-loved surgeons. With the almness of the experienced sanitarian, I)r. Kirbs-Smith reported to his superior officer at National Headquarters:

The typhns situation: It the time of my arrival, the epidemice was at it: height, with nine hundred rases under treatment in the typhus pavilions. These buiddings were not umler our administration. Our own wards were overcrowded, and pationts had neessiarily been arlmitted in such large numbers that there was uo (hance to give them careful examination. The result was that tyhus became epidemic in onr pavilions. livan probably contracter the disense by working in the warkls. 'This may also be sald of Miss Lowk, although

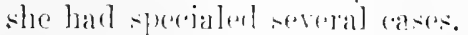

1)r. Matgunder arrived in Betgrade March 31. The had fever of $10+$ deweres within a fow homrs, in fart he harl not bren

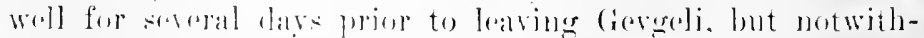
standing thice he enutimed his work of arranginer transportation for his party and supplies, worling hard at a time 
when he should have been in bed. During the first lays of his illness, his comblition did not give us undue alarm, but thirty-six hours before his death, he was surldenly overwhelmed by poisons of the disease. He died April $s$ and will be buried here in the Civil Cemetery.

Miss Helen Kerrigan, of Brooklyn, New York, was taken suddenly ill April 13. 'Typhus was positively diagnosed a few days later. She evidently contracted the disease from work in the wards.

Mis: Helen Smith became ill April 18. She had specialed lliss lusk and had not been on duty in the wards for a month.

Mliss Rebecca Watson (from l'an) developed severe typhus May 5.

The nurses have been mored to a part of the hospital especially cleaned and disinfected for their ocmuney. Only orrasional ases now develop in our wards, and it is believed that we will soon have the disease entirely stamped out of our parilions. (of conrse, there remains the rhance that onr persomnel may be bitten by an inferted louse, conditions being such that we hare not entire control over every one with whom we rome in contalet.

The routine of the hospital now runs smoothly. Dr. Butler with Dr. Downer as his assistant is in charge of the surgical pavilions, and the encosed list of operations gives an idlea of the work being ancomplished faveraging five daily|. I)rs. Kirkpatrick and llagler each have a large pavilion. My duties are largely administrative, but l have given my persomal attention to the members of our party stricken with typhus. Inr. Ryan is making a good convalescence, and I hope soon to turn over to him the management of his hospital. I will at once start for home, with Miss Lehnamn and Miss Lofving [May 9, 1915].

While the routiue work of saving life and warding off death to the last moment of resistanee, went on as nsual within the Ameriean Ilospital, spring "ane to Belgrade with soft winds and vivid sunsets. ('loar balmy days brought ont the eomvalesonts in wheel-chairs to wateh the French aviaters aireline the eity on their way to and from sonting expeditions across the bamube and the sare. Though the enemy made ready to renrw his ascanlt, all Serlia drew a vast sigh of reliof and fared the summer with hope. Typhus was gone, thanks larewy. to that hand of forte-soven sanitarians moler l)r. Rielatrd l'. strong, which the Rockefeller Fonndation and the Anerian 


\section{8t HISTORY OF AMERICAN RED CROSS NURSING}

Red Cross had sent during the dark days of early spring. ${ }^{12}$ And no longer did the menace of cholera fill man, woman and child with paralyzing fear.

Upon the arrival, April 13, of six relief nurses and two surgeons, better days came quickly. Following their convalescence, Miss Smith and Miss Kerrigan were transferred to an American Red Cross hospital at Yvetot, France. When tired members from all three nnits were invalided home in June, Miss Delano sent others to fill the gaps. Miss Gladwin's letter of July 7 to Miss Delano differed greatly from those short notes written in previous months:

You are cordially invited to a tea at the American Hospital at four-thirty o'clock. You will have no difficulty in finding us, as our flag on the clock tower is visible from many parts of the city. The sentry at the gate will let you through the archway. Come along the drive under the tower. As you open the front door leading into the big, cool hall, you will see Old Glory again, colorful and splendid against all our whiteness. giving you a sense of protection and security.

Come straight down the corridor to double-doors opened wide in welcome. A great, white-tiled room, with enormous window spaces; a long writing-talsle covered with green blotters; a newspaper table; and a tea-table gay with bright chintz, a bunch of blue and white larkspur, another of purple tenweeks stock, red and white geranimms in pots and begonias cosered with coral blossoms,- - that's our tea-room where you may find on any afternoon a warm welcome and many eups of Sir Thomas Lipton"s "hest."

Yon will like the Red Cross family. You know all my girls, lut you havent seen them in their gray wowns as they come from their work in the wards. Ton will like the way they look, a little tired and worn, perbaps, but contented and happy. womm who have male a name for good beharior and hard work sleth as heloness to no other mission in serbia.

Jon may not know the men so well. Though he may be (alled alwiy hefore his second cup is poured, our I)irector will (ome. The serond-in-('ommand will drink his tea with great enjorment. 'The Professor will hear' in his hands a potted gerninum which he arries from room to room seeking sunny winkms. limmor lath it that he sings a lullaby to it erery nightit!

The l'hotographer with his lig pipe in the corner of his

13 For an account of the work of this commission see "Inder the Red Cross Flag," Mabel 'T. Boarchman, J. B. Jippincott Company, 1915. 
mouth and his hands dripping "hypo," will hurry across from the dark room to show you his latest picture of the marketplace. C'ome see our Student, our Atheist, our Demoerat and our Boy for yourself!

Delay in the long-expected advance of the Russians and Serbs upon Budapest lightened materially the work at the Ameriean Hospital during the summer, but tried the nerves of officers and privates alike.

During the hot summer months, the immaculate hospital on the hill maintained an average of six hundred patients. Quiet days brought the Amerieans weleome opportunity to beeome better acquainted with their simple-hearted, generous, appreciative soldier charges. One sister wrote of her orderly:

The linen closet on my floor was not rean enough to suit me. After I harl spent an entire afternoon on it, one of the "bolachi" (as they call the men who help us), came into the ward clapping his hands and beckoning me to follow. I dicl so, thinking that he lat seen the linen closet and approvel. When we both got to the door, he clapped his hands even more delightedly and motioned me to open it. To my astonishment out flew two white pigeons. He hat arranged a cozy nest for them among ny immaculate sheets! At intervals he would come and get ne to gro with him to see his pets fly ont and light on his had. When they were banished, he seemed almo:t heart-broken.

Every time an Austrian bullet is removed from a Serbian's wound all the patients get around his bed and sing the Serbian national anthem. I harl a boy of seventeen who had hat a bullet remover from his foot. On his return from the oferating-room he was still half under the anasthetic and I left lim for a few minutes to gret a hypodermic. I returued to fiml him sitting up in bed, completely surromuled by other patients, all whooping lustily!

The second Anstrian offensive, long experted by the French and Sorlian armies, was lamehed against bederade in septemberr, 1915. The Amerian lied ('ooss llospital quickly filled with womeded. Althomgh the Aneriom lied ('ross formally recalled their foreign mits on ()otober 1, 1915, the serbian Minister of $W^{2}$ ar, in the name of their Kins. beged the Anerirams to remalin, assuring them that the serbian (iovermment wonld gladly defray expenses. Bulgaria was on the verege of 


\section{HISTORY OF AMERICAN RED CROSS NURSING}

a declaration of war. One hundred and twenty thousand German troops were massed across the River Save. Dr. Downer deseribed how the Anstrians captured the eity:

From our vantage point we conld witness every more in the desperate undertaking. The broad river lay beneath us and to the right rose the Kalenegdan, the old Belgrade fortress, with its white tower and its white walls, dating from the days whell the Turks were masters of the city. Just across the river the combined Austro-Hungarian and German heavy artillery were hurling their great projectiles, searching for the Allies' artillery positions. Allied artillery were ilropping shell in semlin, trying vainly to reach the guns that were slowly battering down their own defenses. 'The Austrians' thirty-point-five mortars were throwing entire houses into the air, leaving great craters fifteen feet deep and thirty feet in circumference. Adled to this, the city caught fire and at night was a most wonderful sight.

In this wild scene we could see thin battalions of Hungarians, lying with their feet still in the river on the Belgrade side of the stream, held in check by a murderons rifle and machine gmm fire from the old walls of the Kalonecglan and the trenches along the Danube; the damaged pontoons full of dearl men floating down stream with the swift ('urrent; the Germans making their bloody struggrle to cross over the Gypse listand and finally the combined Austro-German rush from the river to the trenches and the fearful hand-tohand fighting with bayonets, knives and (lub-guns.

After that came the strect fighting, the rally of the Serbs from Porlock Heights lack into Belgrarle, in which heary infantry and artillery fighting rager aromel the gates of our hospital all night, mntil finally in the morning the serbs retreated for goorl. And then we heard the distant booming of the ramon at . Irile, showing that the Serbs were resisting to the last the terrible onrush of the Austro-German fores. ${ }^{13}$

Luder that smombl of merey which they had worn so woll,

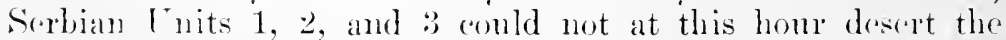
"rowded henpital. They remained at their posts of duty when the dusty, glay hordes again swamed the streets and they kept the doress of the Military Hospital open alike to Anstrian, ling garian and Sorbian wounded. After six werks of stress, ther turned orer the managenent of the hospital to the Ans-

"..The Thrice-Capturel Capital," I)r. Earl 13. Downer, Ameriean Red resse Magraine, l!nti, Vul. XI, p. is. 
trian military authorities and entrained November 28, 1915, for Viema. From Vienua, in groups of three and four, the surgeons and nurses went their several ways homeward to merited rest.

On the single railroad which in 1914 cut direetly nortl and south across Serbia, lay the isolated depot of Gevgoli. In this dreary town near the Greek frontier, American Red Cross

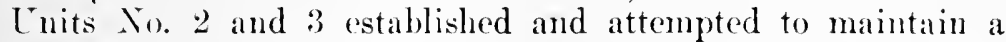
military hospital under conditions which made their brief stay a disastrous ret heroic incident of American Red Cross service during the first year of the European War.

During the last weeks of December, 1914, American Red Cross Inits No. 2 and 3 arrived in Saloniki and were assimned by the Serbian Govermment to the Military Base Ilospital and Prison Camp which had been opened in Gergoli to supplement the already overerowded hospitals seatterod throughout the central part of the small principality. 1)r. Ethan Flagg Butler, of Washington, I). C., was director of Tnit No. 2; 1)r. Ermest Pendloton Magrnder of the same eity, was in eharge of Unit No. 3; Mathild Krueger, of 1)etroit, Michigan, was supervisor of the twelve murses.

So highly developed were the medieal departments of the armies of the Allied and Central Powers at the outbreak of hostilities, that sanitary eonditions existing in the Balkans seemed at first mbelievalble to the pioneer surgeons and nurses who went there in 1!14. Native standards of living, primitive to a decree astomding to Amoricans, were lowered ly the lack of food and other supplies of every deseription, by the shortage of labor and by the absenee of a native medical and nursing persomel.

Emily Lounise Simmonds, a graduate of the Roosevelt Sehool of Nursine. New York ('itr, who mulertook scrvies under the Serhiam lied cross, wrote of her impressions of three military hospitals in serbia during the winter of 1914:

Ciecereli is the first serhinu town across the Greek frontier: it really represents a station depot and a cigarette faretory of four stories. smmounderl hy a commmity of squalid little huts.

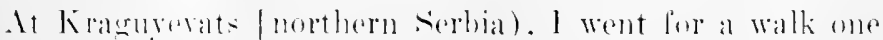

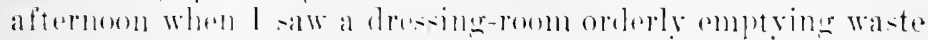

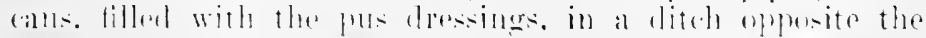
main building. He answered niy question hy stating in a 


\section{HISTORY OF AMERICAN RED CROSS NURSING}

surprised roice that they had never burned them and it seemed muecessary to start now.

Of 2500 Austrian prisoners at Usknb, 1000 are dead, 200 are on their feet and the rest are down with wounds and typhus. llere their hospitals are in long, low-roofed barns with two-foot windows on one sicle only. Beds are often pushed together so that three men lie on two cots, with 200 in each barm, dyiug at the rate of forty a day.

One of their buildings was on a steep hill and the orderly used to empty the dressing-ans over the wall where they would blow abont in all rirertions. The 'Turks (Lskub was 'Turkish two years ago) used to pick these over, taking the cleanest ones to line their wadded waistroats. I don't want to be discrusting, hut I do want to make you appreciate that this may he the beginning of an epidemic and is an instance of what is happening all over the country. If any help is coming it must come at once and must be of drastic measure.

The American Red Cross Units Nos. 2 and 3 were placed in charge of an inprovised hospital located in the cigarette factory described by Miss simmonds. It was without heat, water, or drainage and it sheltered under its leaking roof 1200 surgical patients. Two days after the arrival of the muits, 560 additional wounded raised the quota to well over 1700 sick and dying men. Ilospital exuipment consisted of straw mattresses laid on the tobaceo-littered thoor. Every drop of water had to be brought from a distance. All waste and excreta were earried to a cesspool several hundred rods from the building. The basement was filled with an aermunlation of soiled elothes and linen over which thonsands of body lice crawled. When Saints' lougs did not forbid, three 'Turkish women came to wash a few sherots and pajanas in small (rib-shaped tubs similar to American rhopping-bowls.

Geregeli was a small commmnity. Serhian offiecrs ocenpied the few wretelued lodging-honses. (2uarters in private houses rould not leseserored. The nurses had to be assigned to a mative hotel in roms appoxinately twelve fert sfuare, without light or heat,- there woment to a romm. The beds comsisted of straw

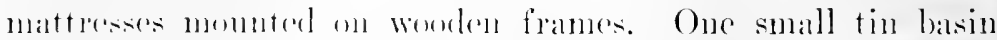
and a water jug were the onle torilet aleommondations furnished

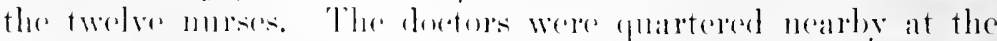

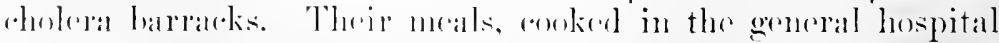
kitchen and serverl in the staft dining room, were adequate, 
except perhaps the traditional Serbian breakfast which consisted of tea with lemon and toasted black bread.

Miss Krueger stated the spirit in which the Mmerican units started to work:

In this unsanitary location, the building crowded to its doors, with vermin and filth on every hand and no prospects of obtaining vitally neederl equipment for promoting better sanitary conclitions, we went to work, not optimistice nor sanguine of results, but with a determination to do our best. . . .

A stalf of two hundred murses would have been inadequate. For four days we spent our entire time getting all seriously womded into one ward, areraging four hundred dresings a day. Barly inferted wombls were the rule. not the exception. Many had not heen dressed since temporary First Aid on the fiekl ten days to two wereks previous. Every day we realizerl more and more how pitifully inadequate was our force. Conditions grew more disheartening with each week. ${ }^{14}$

The tobacco factory was so dirty that the American surgeons did not dare attempt there the heary surgical work imperative for the recovery of the patients. Dr. Butler accordingly secured, Jamury 1, 1915, a large tobace shed for use as a temporary surgical hospital. At the cost of much time and discouragement, the Sorbian Government finally furnished a small amount of equipment, inchuding windows, a most important item. On the day of the first operation, Jamuary 1:3, the Amerian flag was bravely hoisted over this warehouse. A sifting process of secking out operative cases in the tobaceo factory and of scrubling, shaving and clothing them lofore transportation to the warchouse for operation, soon filled the so-called "American Hospital" to over-capacity. Miss Krueger continued:

Most tragie of all was the meager and unsuitable food supply. Two meals a day consisting of veuretable soup and coarse brown breat was the allowane for all pationts. They were ferl on this diet and then treatod for dyentery. typhoid and other intertinal disonses with a wislom equal to that of the sage who dipped up water in a sieve. Posibly some notes

" laper prepared ly Miss Krutger for the enuention of the American

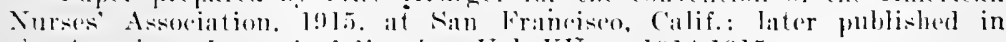
the American Journal of Nursing, Vol. XV, p. 1014-1015. 
taken from my diary give a better picture of things as they were:

January 7-All the wards of the tobacco factory very cold; patients suffering; food very scarce; impossible to get milk or eggs. No clean clothes for the patients or beds, no laundry done for four days, being holiday week.

Nurses all have bad colds and begin to show strain of work, which is fatiguing, depressing and disheartening. I insist on their having one afternoon and half Sunday to get out in the air and sunshine.

January $20-$ New cases of typhus, pneumonia and smallpox developing daily. Four hundred cases of recurrent fever, many of them among Austrian prisoners who have been our only helpers. Sanitary conditions indescribable.

January 28-Medical wards almost hopeless, so many desperately sick patients, very little food and no orderlies to help with the work. One of sour doctors and two American nurses off duty with temperatures 103 degrees; probably typhus. ${ }^{15}$

The fight at Gevgeli had begun against overwhelming odds. On their arrival Lnits Nos. 2 and 3 had found the sick and wounded in so pitiful a condition that common humanity had prompted the Americans to assume charge immediately, without taking the time necessary to render their own living conditions at least reasonably safe. Massed against them were lack of equipment and supplies, orerwork, a strange language and that potent ally of typhus, the body louse.

The members of Lnits Nos. 2 and 3 went down one by one before the ferer. Tr. Lane was mable to report for duty January 28: Clara Tulloss, January 29 ; Clara Slusher, January 30 ; and Dr. King, February 7. Anna Lockerby wrote Miss Delano:

On Monday, February s. Miss Krueger did not feel well, but was on duty all day until four o'clock. 'Two hours later her temperature was 10 ? degres. Wednesday, there was no doubt that she hat pneumonia. Wilhelmina lievhing did not feel well yesterlay. Fobruary 12: tolay she had a temperature of 104 decrees: tiphus. of course.

We are very much eripled in our work. Dr. Butler says we must come fir-t. Our dresings: are holding out. What

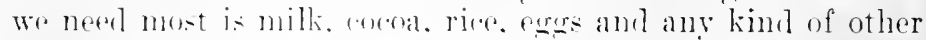

1s Paper prepared hy llise krueger for the convention of the American

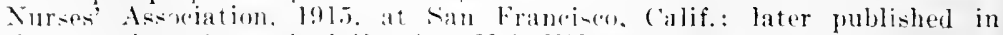

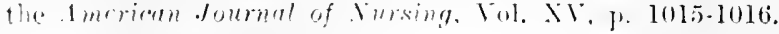


food. All diet we give our patients is cabbage soup. Sir Thomas Lipton and his murses stopped to see us on their way to Nish and left us such food as he could spare from his ship. Dr. Butler has worked hard to get a place at last where we can have our cook and buy our own rations.

Teresa Curley was the next member of the units to become infected. On February 18, Dr. James F. Domelly, of New York City, eame down with it; the following day, Maude Ellis; the following day, Mary Siehrs; on February 21, Mary D. Cox. The next day Mliss Krueger developed typhus following pnemmonia. Of the original eighteen comprising the units, four murses and two doctors remained on duty. Miss Lockerby wrote Miss Delano:

In two rooms we have three nurses each and across the hall, two others, all typhus, some cases three weeks old and one eleven clays. Misses Fry, Tetrault and I care for them; Mliss Canfield is nursing Drs. King and Lane during the day. Drs. Magruder and Butler have done everything in their power to help. When the crises came, they wanted to stay up all night so we four could sleep.

There have been so many things besides the sick nurses. I was the second person in Dr. Ionnelly's room and helped the doctors. None of the nurses know of his death yet. That was a very harl day. Something has come up concerning Dr. — - which required a firm stand from the director. 'The nurses were quite excited at first. I said they must obey or go home and they remembered what you had said in New York to Miss Krueger. I folt sure that in her illness you would want me to make the same stand. Dr. - __ has left the unit.

February was a dark time for all Serbia. "We have ourselves lost one humdred and tive doctors," calsled the Serbian Red Cross to American National lied C'moss Headquarters. Four of the British lied ('ross Enit died at I'skub. 'l'wo sureeons and throe nurses of the linssian lied ('ross sureomulod at Nish. So trateic were the losses in the lontele and (irock contingents

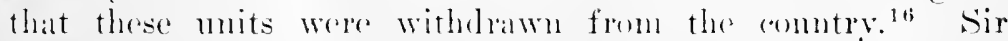
Themas lipton, whe land hromeht over the British Ried Cross units on his galcht Livin, salil in cable dispatehes: "One cau

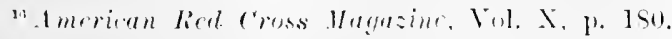




\section{HISTORY OF AMERICAN RED CROSS NURSING}

scarcely imagine the terrible ravages of typhus, far worse than typhoid and even the Black Plague." Only with diffieulty was Serbia able to bury her dead.

Drastic measures were imperative. When Dr. Ryan came down from Belgrade, a consultation was held between the American surgeons and two doctors of the Serbian Red Cross and it was deeided to withdraw Units Nos. 2 and 3 from Gergeli to Saloniki, Greece, as rapidly as the condition of the sick would permit, for reeuperation and reorganization. Dr. Kirby-Smith, with three nurses from the French units, were on their way to Saloniki from Pau. He and his party, including Dr. George W. Mellon, of Beaver, Penmsylvania, who volunteered his services when he heard on shipboard of the desperate need, reached Saloniki on March 18 and found Dr. Butler and several eonvalescent members of Units Nos. 2 and 3 in a third-elass hotel, the only one in the Greek seaport which would receive the infected Americans. Leaving the three nurses there, Dr. Kirby-Smith went with Dr. Butler to Gevgeli where Dr. Magruder was taking eare of the remaining members of the two units. Miss Lockerby's report of Mareh 19, to Miss Delano told of conditions at Gevgeli:

I am so happy I am almost afraid to write. All of our sick were able to sit at table for dinmer. I could hardly keep the tears bark,-I felt sure this day wonld never come. Seven of our convalescents are in Saloniki. Dr. Kirby-smith came down tolay learing his three nurses with them there.

Now the days grow warmer and the quaint native women come out in their bright dresses to gossip as they stand knitting by the roadside, clicking their tongnes as fast as their needles. ... .

This week we were able to do a little hospital work. I gave chloroform for twenty-one operations. Sometimes this meant that I dimt get to Miss Krueger, whom 1 am caring for, until five o'clock. She is very anxious for us to get back on duty.

Major Patterson eabled Dr. Kirby-Smith to eonsolidate the units, as the health of the individual members permitted, at Belgrade. Gradually strength returned to the eight convales(ent nurses and to I)r. King and I)r. Lane at Saloniki. enabling them to return early in April to the Enited States.

On Narch 25, 1)r. Kirby-smith and Dr. Butler had gone 
to Belgrade to interview Dr. Ryan about bringing the uninfected nurses and doctors to Belgrade. After wiring Dr. Magruder to bring up what reanforeements he could spare, they remained at the Military Hospital to take care of Serbian Init No. 1. 1)r. Magruder with the three "surviving" nurses reported at Belgrade, Mareh 31. "At last our wishes have come true and what is left of [nits Nos. 2 and "3 are here!" wrote Miss Lockerby. Their joy was short-lived. On April 18, she wrote again: "All our time since Jamuary has been a strain, but it seened almost more than we conld endure to have to bury I)r. Magruder. You will never know how much he helped us," she continued, "he was sick before we left Gevgeli, but he wouldn't give up, nor at Saloniki. He died after five dars' illness here and was buried in the Civil Cemetery."

Here ends the separate history of Serbian Units Nos. 2 and 3. Subsequently they shared the experiences of the Americans at the Military Hospital in Belgrade.

Just as the subsequent history of the three Serbian units merged into one, so has the record of individual experiences, massed together in the arehives at National Headquarters, been merged into an awesome whole. The terse calble messages, the short letters written in fear and exhanstion which recount the fortumes of the gallant mits at Gevgeli and Belgrade, picture war surgery and war nursing with terrible reality. Filth, monotony, hunger, peril, agony, dishonor and despair were there; so also were comrage and faithfuluess unto death. Let the faret that human strength faltered once or twice show the intense strain of those diys! For one man who left his post of duty at an hemr of need, there were eight surgeons for whom pestilener held no tererer. For one murse demoralized by ntter exhanstion, there were twenty-two others brave and stroing and sime under the lingering shadows of death. Florence Niglitin-

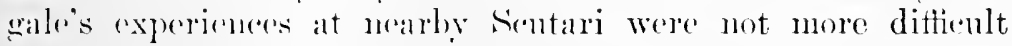
tham those of these lied ('ross murses.

ln far (ieraceli, a white stone cross marks the iry-covered

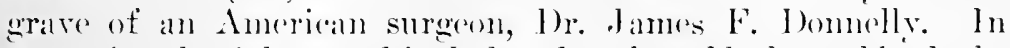
an ancent hurial-ground in Bulgrade, where black marble shafts point skward among dark endars, another Rod Cross physeian, 1)r. Ermest P'. Magrmder. rested quietly motil cessation of hostilities permitted the return of his body to his mative soil.

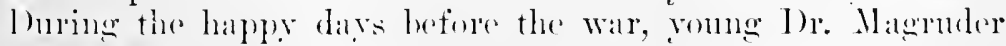

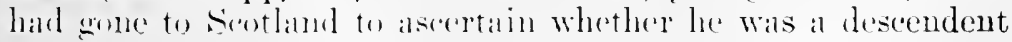




\section{HISTORY OF AMERICAN RED CROSS NURSING}

of the famous MacGregor Clan. There he had met and married the daughter of Lord MacGregor of Edenehip, Valquhider. $A$ letter written by his widow from her father's home during the first days of her loss bears testimony to the spirit of sacrifice with which the Red Cross moves forward:

Realizing as I do how immense are the claims on the funds of the American Red Cross, I have already written Miss Boardman to acknowledge $m y$ appreciation of the action of your committee in making an allowance to me and my little son. I hope it will enable me to keep my small boy with me.

It is my great consolation to know that my husband laid down his life in the service of others. I feel I should like to express to you the admiration,- the deep admiration,-I have as a Britisher for the noble spirit that actuates the American Red Cross.

In these days when all Europe is in anxiety and mourning and when a dreadful spirit of hate has raised its learl above our boasted civilization, one sees in the selfless derotion of Americans, in no way bound to share our suffering, a ray of real comfort and hope and a glory far greater than any won upon the battlefield.

Here ends the experiences of the units which had sailed upon the Merey Ship for service in Enropean theaters of war. Three other units were assigned, however, by National Headquarters during the winter of 1914-1915; one of them went to Yretot, France, and the other two to La Panne, Belgium. A bricf aceount of their experiences belongs in this chapter which summarizes the service of the Ancrican Red Cross to the Central and Allied Powers before the entrance of the Lnited States into the World War.

The first your of the war had been marked by the establishment of many hospitals under organizations of varying types and aims. Thronghout the first six months, wounded had come bark from the Marne and from Ypres in increasing hordes. The existing raparities of the sanitary services of the Allied Jowers had heen greatly orertaxed by the influx of patients, and their derelopment retarded by shortage of supplies. persomed and transportation falcilities. By serving on committees intresesed in the establishment of anxiliary hospitals and convaleserent homes and ly antributing lavishly to the support of sucl $l_{1}$ institutions, nuen and women in every station of life, loth in bingland and in the l nited States, seized aridly the oppor- 
tunity for dissipating their own emotional tension and for genuinely aiding the wombded soldier.

At Iretot, France, on the River Seine, within easy reach of Ronen, one of the prineipal military bases, the French Government placed at the disposal of the Committee of l'IIopital de l'Alliance Fondation Inglaise et Iméricaine a large monastic school for bors, left raeant eight years before by the separation of Church and state, - this structure to house a military hospital for the care of British, French and Belgian soldiers. The hospital was supported by volunteer eontributions from industrial workers in Great Britain and America. The aim of the committee, whose chairman was l)r. F. S. Pearson, Bishopsgate, E. C., was to afford other industrial groups, particularly those engaged in the manufacture of govermment supplies and munitions of war, an opportunity to give "their bit" for something tangible. Backed by the influential London eommittee and by many Americans of wealth, the hospital was in a splendid position to seeure equipment and persommel. It was later ranked second to the Ameriean Ambulanee at Paris, coneeded to be an ideal institution of its type. Dr. Ralph Fitch, a Bostonian, was direetor of the Alliance Hospital. Ite had practiced his profession in Rochester, New York, and was an orthopedic surgeon of brilliant powers. Before saling for France in December, 1914, where both he and his wite gare prodigally of their wealth and services, Dr. Fiteh had requested nursing assistanee of the American Red Cross, should the need be areat enough to justify the expenditure. After his report of eonditions existing at Rionen, France, National IIeadquarter's confirmed his appointment as a Red Cross surgeon, in order that Red Cross nurses might be assigned to the Alliance Hospital, and dispatehed on the Rochambern February $2: 3,1915$, a mit of nire nurses, with Mary M. Fletcher, of charlottesville. Virginia, as supervisor.

Lpon their arrival at Yretot, II arch 2, 1915, the Ameriean nurses found a woll-epuipped institution with ahapel, adninistration building, balcteriological laboratories and six large wards of tifty beds rach. I separate wing of the building contaninge one hunded and righty beds, which was operated by the Fremele liad cross. bromght the total anacity of the

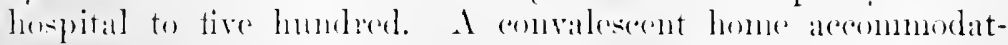
ing letweren thirty and forty patients was maintained at nearby lonille-les-linses. 


\section{HISTORY OF AMERICAN RED CROSS NURSING}

Alliance Hospital was governed by a Board of Administration consisting of the chief medical officer, Dr. Dudley D'Avergne Wright, of London; Dr. R. R. Fitch, Captain T. J. C. Warren, of New Zealand, and Mr. George S. Taylor is business manager. Two English surgeons and two students or "dressers" completed the medical staff. Sixteen English Sisters including Matron Adelaide $\mathrm{A}$. Wood and ten probations, with the ten Americans, eomposed the nursing staff. Eighteen infermiers, French soldiers unfit for duty at the front, served their military term there under a French $\Lambda \mathrm{d}$ jutant. To supplement these orderlies, six young English and American men acted as stretcher bearers and ambulance drivers and did general repair work. To volunteers from Great Britain and the United States was delegated much of the routine hospital detail such as the care of the lamdry, the kitehen, linen rooms and the vestiaire. Baron Rothsehild's chef was major domo in the kitchens.

During the first weeks, the nurses at the Alliance Hospital experienced the same inactivity which taxed the cheerfulness of the American mnits at Paignton and Pau, but as the winter of 1915 dragged on, the Americans gradually won the confidenee of the English and French authorities, so that the care of large numbers of patients was entrusted to them. Two of the American nurses were placed in charge of one of the wards. A third was appointed night superintendent, aeting in Matron's place when she was absent in England for several weeks. "We have tried very hard indeed," wrote Miss Fleteher, "to remember not to spill our efficiency over onto the aprons of the English sisters and probationers."

The work at the Alliance Hospital was almost entirely surgieal. Many bone ases repuired plating, and all womds had to be drained frocely. After a winter in the trenchess, with nerves pommled throad-bare by shelling and "wind" shortened by contimnal rigarette smoking, the soldiers were in poor condi-

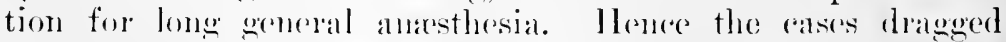
ont while the sureeons waited for wounds to heal before attempting seroud and third operations. Mary K. Nelson, in charge of I)r. Fitele's operating-room, described the patients arriving from Ypues as wretrobedly womded, their mud-soiked muiforms a torturing, rxhanstive burden.

The American murses fonnd a certain deep satisfaction in aring for anses which they rearived from hospitals further 
up the line. In writing to the Princeton Chapter, which paid the salaries of several of the Pau and Yvetot nurses, Miss Fletcher said:

To get cases which have been unavoidably neglected in an overcrowded hospital lor from two days to two months, may seem uninteresting and perhaps not cuite fair from a professional point of view. It foes, however, present a wonderfully humanitarian opportunity to give them scientific surgical care. Since it is not our comntry which is at war, we camnot all expect to be at the front.

The English 'Tommies are mardhing through under my window, with an unending proesssion of lorries, transports and yellow-brown ambulances, on their way to Amiens and Nismes.

About every ten days splendid young, fresh men go through on machine gums from IIave straight for the front. They are usually abont forty at a time and are called the Sundry Brigade. They are all sure of death. When they stay over night at Yretot, the hospital has an impromptu concert. Any one whom the others think can sing even a bit is sent up to perform. You always feel that these boys who ean cheerfully undertake to entertain this company must have nerve enongh to do anything. They are always given coflee and rakes and are so appreciative and rheerfin it makes your heart arhe. You know almost all of them will go down.

One of our patients, a man of thirty, has lost both arms. Yesterday his wife, who had not seen him for months eame into the ward. His face was heart-breaking to look at. He tried so hard to keep the tears back, but they would come and she had to wipe them away.

August, 1915, brought many ehanges to the Allianee Hospital. Of the ten muses, one felt it necessary to return to the Lnited States. later Miss Fleteher turned over her supervisory duties to Miss Nelson.

"Remembering what you said about the one thing you would insist on,-_no foolishness," wrote Miss Floteher to Miss 1)elano, "it is pretty hard for a supervising murse to have to confoss she is engaged."

"Sever your" comneetion with your mit at once," answered Miss 1)ebino: "nnder present eonditions, there is no renm in the hed ("ross for sorviere and romanee at the same time."

Areompanving this official messager, howerer. Went a personal 


\section{HISTORI OF AMERICAN RED CROSS NURSING}

letter: "I am delighted to hear of your engagement, my dear," wrote Miss Delano, "and hope most sineerely that he is worthy of you and will make pou happ.."

'To fill the two vacincies caused by Miss Fleteher's resignation and the return of the other nurse to America, Sisters Smith and Kerrigan were transferred to Yvetot from Belgrade after their recovery from typhus. The greatest change came, howerer, on Angust 15, 1915, when the French Government requested 1)r. Fitch and the American nurses to take charge of Military Hospital No. 43 bis, at St. Valery-en-Caux, a little Norman fishing town on the Channel, between Dieppe and Le Harre.

The nurses at once fell to work house-cleaning their new hospital. Strenuous dars and nights followed. Only two of the murses were independent of their salaries; eight of them, however, decided to remain on at St. Valery-en-Caux withont remumeration after the lied Cross had reealled its foreign units on Oetober 1. Miss Delano cabled that the nurses might retain their Red Cross equipment. Miss Nelson acknowledged this gift and in the same letter described how heavy their work had become:

With our constant influx of seriously wounded men directly from the front. it was almost impossible for us here in this little village on the coast to obtain uniforms and aprons immuliately. Over at home such a supply is a simple matter, but here it is very different. You will appreciate that our entire thonght, time and energy has been riven to the work itself. to the care of the wounded and the management of the hospital.

It is now long past midnight and common sense reminds me that at leat six hours of sleep are necessary. Te all seem to hare wrown arenstomeel very easily to longer hours of duty. At last we have the work we hoped to find?

J)ring the antumu, 1515, Miss Nelson hilt up a strong nuring stafi at Lit. Yalory-en-Canx. To supploment the eight

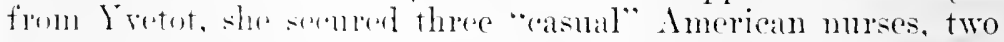

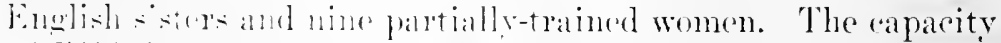

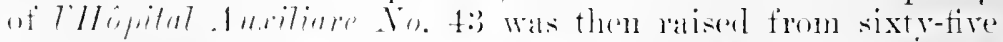
to onr lommlend and sixtrone leds. Besides direeting the

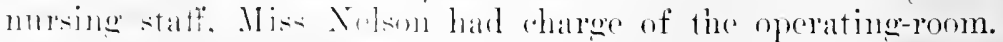
The smpgieal departmont had been greatly strengthened by the 
acquisition of a portable $\mathrm{X}$-ray plant, with an electric generator, from the French service de Santé. With the inereased nursing strength and with this exeellent equipment, Dr. Fiteh's hospital received a monthly average of one hundred and fifty patients. In a letter written October 26, to Miss l)elano, Miss Nelson told of the pressure under which they worked:

I scrubbed up shortly after three P. MI. and had my gloves off only about half an hour for a bite of dinner in the sterilizing-room about eight that evening. It was four-thirty the next morning before we finished, only to begin again that afternoon. As ever so many of our grands blessés are bad joint wounds, the work in the wards does not lighten.

The nurses have borne up remarkably well under the strain. Dr. Fitch is very considerate. He planned no operations today and placed his big car at our disposal. The four night nurses went driving this morning and six others will get the air the rest of this a fternoon.

[ntil we have more nurses, it seems unwise to take more patients or to open our convalescent hospital of thirty beds at Veuille-les-lioses. We need it thourh. for it is hard to start these boys away to other hospitals for their ronvalescence just when they begin to pull up. Such wounds as I have never seen before and I thought I'd seen horrible ones,shattered lips, knees and shoulders all ealling for expert nursing care.

Whenever there eame a lull in military operations l'II ôpital Auxiliare No. 4:3 bis drew patients from the surrounding country, or nursed the saddened Belgian refugee children in nearly orpinanages. Three of the Amerian nurses returned to the States during the spring but Miss Nelson, IIelen Kerrigan, Josephine C'lay, IIelen Spaulding and Marion M. Rice remained.

IIere, during the summer of 1916, ended the letters and records which tell of the erents of the Yveotot [nit. The little

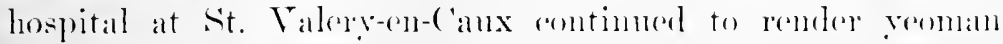
serviee during the erucial winter of 1!16-1!17. Nearly Amiens was the IIeadquarters of the British Expeditionary Forees. The enemy was massing his strength against Vordim, while

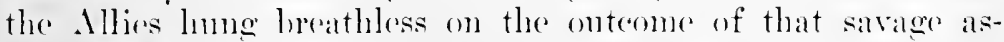
santt. Pomnded by erory type of artillery fire, shattered by

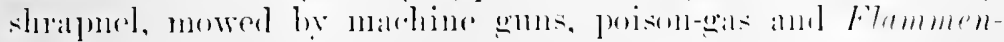
werfer, France during these months wats holding the heights 


\section{HISTORY OF AMERICAN RED CROSS NURSING}

of Verdun at a total cost of 550,000 casualties among her picked soldiery, some of whom lay unburied among the craters on the shell-plowed slopes, while others came straggling back through casualty clearing stations to the French and Allied bases. How gallant a part the American staff of l'Hôpital Auxiliare No. 43 bis played in later Red Cross endeavor will be found in a subsequent chapter.

When the American Red Cross had first offered its medical and nursing units to Europe following the deelaration of war, Belgium had asked only for supplies. The Belgian Red Cross mobilized with Albert's Army, but no sanitary organization eould cope with the wounded which flooded baek to the eoast towns of the Chamnel and the North Sea. By February, 1915, Albert with his forty thousand Belgians held a strip of land forty miles long and ten miles wide from the Yser to Holland. Directly in the path of the Taubes, at La Panne, Belgium, the Beigian Red C'ross was reorganized and from this mneonquered territory on February 21, came their appeal to the American Red Cross :

We need about twenty or thirty nurses, four or five surgeon:, one thonsand beds complete with sheets, covers and rubber sheeting, tents for housing one thousand beds; tents for persomnel and large quantities of surgical dressings, tetanus serum.

$$
\text { (signed) DePage. }
$$

Antoine DePage, a surgeon of Brussels, and LieutenantGeneral Melis, Inspector General of the Health Serviee of the Belgian Army, headed a eommittee appointed by King Albert to organize Belgian Red Cross field hospitals. While Dr. 1) Page was building the parilions of l'Hopital de l'Océan on the sand-hills four miles above Nieuport, Madame Marie DePage, his wife, made a Hying tour of the prineipal cities of the Enited States to raise funds to support this medical eity of twelve linndred beds. In response to lier solicitation, the American Red Cross plodeded itself to support two mits, of three suremens and twolve Red Cross murses each, at La Pamne, as it had don in $191+$ for Fngland. Franee, Russia, Germany, Austria and Serbia. National IJadyuarters also donated two complete ficld hospitals and $\$ 20,000$ for their maintenanee. On April 17. 1918, lielevian luits Tos. 1 and 2 sailed on the S. S. St. Lomis for liverponl. I)r. Albert R. Cioodman had 
been appointed senior director of the two units, but was obliged in London to return to the United States and I)r. Robert Hinds, of Buffalo, suceeded him there. Dorothy M. Ferree, of the Ilenry Street Settlement, New York City, and of Phipus Institute, Philadelphia, was general supervisor of the twentyfour nurses.

Under the shadows of war, the Belgian units were delayed three weeks in London. Already l'Ilopital de l'Océan was being shelled and it was deemed unsafe to send additional personnel there. Dr. DePage came over to England in May to consult with the director of the Belgian units and to welcome his wife on her expected return from the United States with drafts for $\$ 100,000$ which she had raised for Belgium's soldiers. Her eagerness to reach La Panne had made her disregard Germany's warning to the passengers scheduled to sail on the Lusitania on her last fatal trip. The giant liner was sunk and the body of Marie DePage was recovered and was brought in to her husband on the docks. Payment of the lost drafts was cancelled and the fruits of her labors were later sent over by a more fortunate courier, but the American nurses in London were not soon to forget that earnest, intelligent, eager little woman who had waved good-by to them in New York with her smiling farewell: "I am here so that you can be there."

Dr. DePage brought his wife's body to La Pame on May 20. The Belgian Lnits Nos. 1 and 2 had left London the day before for the beach-hospital. Fron l)ieppe to Xieuportles-Bains, they found themselves veritably in the war zone. At Forges-les-Eaux, where they spent a night at a hospital which sheltered three hundred wounded, they fonnd hotels, busses and trains operated entirely by women and convaleseent soldiers. Calais was in total darkness. A Fenchman guided them with a small pocket flashlight to motors which earried them to a sehool-house; there ther spent the night on iron hospital eots which now filled every arailable building. Miss Ferree deseribed the fifty-mile ride in ambulanees to Lat Pame, May 19 :

The roads are well guarded excruwhe: thirten sentries stopped us to see onr passports. It noon we drove straight through the ruins of Dunkirk.

La Panme has one lone strect into whide run soreral smaller ones. The honses appear to have been set down eare- 


\section{HISTORY OF AMERICAN RED CROSS NURSING}

lessly in the sand. The beach and sea are beautiful, but all else is desolate among the ruins of shelled villas.

The streets swarm with soldiers in from the trenches. The population seems to have swollen overnight from two thousand to ten thousand. Here too, all lights are put out at night and curtains tightly drawn.

Marie DePage was buried among the sun-bleached dunes of the shining beach near l'Iloppital de l'Océan. Between double lines of soldiers moved the Hower-eovered easket, followed by American. British and Belgian murses. Dr. DePage, accompanied by his two sons, who had come in from the trenches for their mother's funcral, marched with officers, Belgian nobility and foreign medical mits to the lonely grave, then returned with resolute comntenance to carry on the work for which his wife had given her full, joyous life. The first year of the war did not allow Belgimm's eitizens the luxury and comfort of prolonged grief,- there was too much to be done.

As viewed from the sea, l'Hojpital de l'Océrn rose high above the white sands on the sloping beach. A summer hotel hat been eonverted into the main building. Four large temporary parilions, lightly construeted of wood, with corrugated iron roofs on which hnge Red C'rosses had been painted, had been ereeted aromnd it to form the wards. Surgeons and nurses were puartered in summer villas, taken over by Dr. DePage. "The hospital is very complete," wrote Dr. Hinds, the director of the two Red ("ross mits, to Major Patterson, "it has two steam lanndries, a bacteriological laboratory, a small steam sterilizer, and an instrmment-naker who manufactures from steel strips excellent operating-knives and even nickels them afterwarts." A newly-installed bath system of twentr-four tubs batled tive hundred soldiers a day who came in relays from the front. One reximent was alwilrs ynartered at lal P'ame: after serubbing up, the men received elean underelothing and their miforms wore de-lonsed and mended.

Miss Winell, an linglish murse of tact and exerutive ability, was Matron of the hospital. Her statf consisted of well over

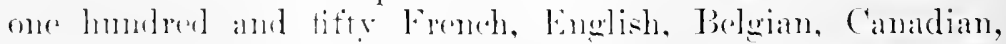
American, l)anish and swiss nurses, speaking many different languages, and trained under different enstoms. 'The hours of duty were from - I.M. to > P'. M., with two hours off, besides ample time for meals and fomr oideck tea.

la Panne lay in the moved mat to Calais which commanded 
the control of the Chamel beyond. Three lines of defense stretched their barbed wire entanglements and sand bulwarks between l'llopital de l'()éan and the enemy. No one conld wholly understand during the summer of 1915 just exactly why the Germans did not blow the hospital-city entirely off the shell-eratered beach. Some said the eneny would not harm Elizabeth of Belginm, whose days were spent among the wounded.

It was quite a formal occasion when the Queen of the Belgians visited the parilions. Nurses and all patients whose strength permitted, remained standing while Elizabeth distributed checolate and cigarettes. Dr. DePage carried "the snokes" and Miss Ferree the eandy. A lady-in-waiting always followed the Qneen from ward to ward. Dix, a sparrow which one of the boys had brought from Dixmunde, had little understanding of court etiquette. It perched first on Miss Ferree's stiffy-starched lied Cross eap and persisted in remaining there until she shook it off. It flew to Dr. DePage's head, then back to its vantage ground above Miss Ferree's neatly brushed hair, where it sat in dignity mil the general langhter of the ward startled it again and it flew to eling with cold thin claws to Que'n Elizabeth's hand. "It is remarkable how happy every one is here," philosophized Miss Ferree in her reports to Miss Dolano, "and how soon one gets over momentary fear."

Eleren nurses of Bolgian L'nits Nos. 1 and 2 returned October 1, 1915, to the 'Enited States after six months' service at La Pamne, and their places were tilled by murses whom Miss Delano transforred from Paignton, England, and Pau, France. Sister Vashti Bartlett took Miss Ferree's place as supervisor: Dr. W. T. Fitzsimons, of Kansas City, Missonri, suceeceded Dr. Ilind as senior director of the Belaian mits.

The Annericans from Paignton and Pan fomnd life at La Panne vastly more exciting than that among the Devonshire hills or the smmey villeys of the Prrenees. A fragment of a German shell tore up the bath-rem thor of the Albert and Elizaloth pavilion. Another killed nine and injured forty rivilians in the street ontside. Off-shore the British flect lay thundering a tremendous response to the long-range Commin gmons. Ilalf with plasure and half with dread, the nurses watehed the great white geresers thung up by enemy shells, suspenderl for a moment like phantom sails drifting on the blue level of the water. At night they lay awalke and listened to the 


\section{HISTORY OF AMERICAN RED CROSS NURSING}

"coo-ey" of big Berthas singing through the air over their heads. Their own windows were zealonsly curtained and only a dim candle flickered in the long, silent wards. The nightnurses often paused to wateh like summer sheet-lightning, the flashes from the trenches a few miles away. The glow of an occasional star-shell often silhonetted a belated fisherman coming home across the lonely, glistening beach.

Throughout the winter of 1915-1916, Taubes and Zeppelins released their hombs on La Panne as they returned from raids on the Channel ports. Sunday seemed a popular day for bombing because sunshine brought out the crowds on the beaches. The American murses were not soon to forget the horror that one or two well-placed bombs made. The anti-air craft guns were as noisy as the Taubes, but doctors and nurses no longer left their busy wards to see how many victims the bombing parties caused. Fortunately the weather often kept the air eraft behind the German lines. The clinging white fog of the Flanders eoast chilled the nurses' heatless rooms. The cold rains and harsh winds sweeping down from the North Sea sent them shivering about the loosely-constructed pavilions. Lydia Shrope could not throw off a lingering cough. When Dr. Fitzsimons told her that she had developed tubereulosis, she returned with Grace Bentley to the Cnited States in February, 1916, bitterly disappointed in having to leave the Belgian service. After a gallant struggle at a private sanatorium and later at Fort Bayard, New Mexico, where the Red Cross had sent her, she died at Fort Bavard, July 14, 1918.

L'Moprital de l'oréan reerived only Belgian soldiers and the work was largely surgiral. Sister Emogene Miles, who had bren in charge of the operating-room at Pau, found the service at La Panne exactly as difficult, as splendidly worthwhile as she hard antie.ipated that war nursing near the front would loe. Sixteren beds in a sureical ward which received only seriens operative cases were assigned to her. An English giri areded as her aide. There Brelgian doctors were in reharge of the ward. "They snrely work hard to save these "xhausted

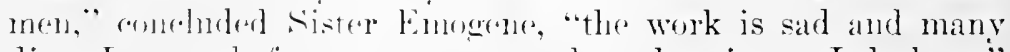
die. I never before gase so many hyodermies as I do here." Gas cangrene with its forte sweetish odor, was ommipresent.

During the early Flanders spring, National Headquarters

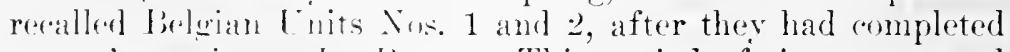
a year's scrvice at la l'anne. This period of time was equal 
in duration to that which the units of the Mercy Ship had spent in service to the other belligerents. The nurses of the Belgian units left La Panne in May, 1:16. Some joined the American Ambulance at Paris; others did further war nursing in England; but the majority returned to the United States, where ominous elonds were gathering. On the Western Front, France, Belgium and England faced the "hlood bath of the Somme."

Between August, 19)14, and May, 1916, Miss Delano alone held in her powerful hands the strands of policy and administration which extended like light steel wires from Washington to the fifteen supervising nurses located in England, Russia, Germany, Austria-Hungary, Serbia and Belgium.

National Headquarters of the American Red Cross was then located in a three-story red brick house on the corner of Seventeenth and H Strects. The Nursing Service ocenpied two medium-sized rooms and a hall-way on the second floor. The finane's of the Red Cross did not permit spacions oftices, nor had the beautiful memorial building, furnished by contributions from the government and from public-spirited citizens, been completed. Miss Delano shared a single, bare, highcoilinged room with her stenographer and her assistant, Anna Reeves. A rusty leather conch stood against the wall on one side; her oak desk ocempied a coruer. At the back of her swivel chair was a commonplace oak bookcase. Jirectly in front of her desk was a huge, high-backed wicker chair. By reason of the smulight slanting in from the windows to the left and behind her, Jiss Delano held the advantage sought by many astute executives, of being able to see every change of expression about the eves and mouths of the nurses, Army offierers and voluntecrs who faced her during the inummerable ronferenees held in that buss office.

Iliss Reeves lated leen detailed hy the Surceon General of the Army on Novemuler 17, 1! 1:?, for duty in eonneretion with the selecetion of nurses for the lied ('ross heserve. She was a graduate of the Plidadolphia General llospital and had joined the Army Nurse ('orps in 1910. Cpou her assigmment to the Red ('poss she assisted Miss l)elano with the enrollment and helped to reeruit and to equip the murses for the 11 erey ship. Her desk and the trperwiter table stood on the other side

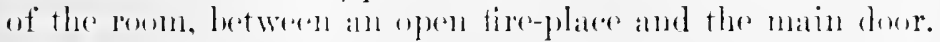

Adjoining 11 iss belanos oftion was the hall in whieh Marion

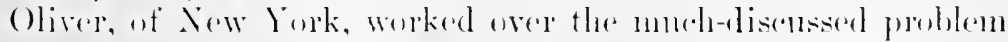




\section{IIISTORY OF AMERICAN RED CROSS NURSING}

of the mobilization of lay-women for war service. At Miss Boardman's request, Miss Oliver had come to National Headquarters in 1915 to organize groups of nurses' aides similar to the Vohuntary Aid Detachments of the British Red Cross. She was appointed a member of the National Committee on Red Cross Nursing Service in December, 1915, and continued a member of Miss Delano's family until the Red Cross decided that the service of nurses' aides, if snch beeame necessary in the event of war, should be directed by a Red Cross nurse.

The Red Cross Town and Country Nursing Service occupied the second room; here Miss Famnie Clement and her assistants held sway until the removal of this section in July, 1916, to the Mills Building. In a small attic room upstairs, the files of the National Committee, then containing the names of six thousand enrolled nurses, were handled by a Washington nurse, Lily Kanely, of the New Haven Hospital Training School, who also assisted Miss Oliver in the details of examinations and certificates of Red Cross instruetion in Elementary $\mathrm{H}_{\mathrm{y}}$ giene and Home Care of the Sick.

Equal simplicity existed in other departments at National Headquarters. Miss Boardman was the guiding spirit of the organization. Major-General George W. Davis, U. S. A., retired, was chaimun of the Central Committee. Mr. Ermest P. Bicknell, formerly of the Chicago Burean of Charities, was national tirector; his duties kept him in Europe the greater part of 1914-1915. In a large room on the first floor Major Robert L. Patterson, Medical Corps, T. S. A., detailed by the Surgeon General of the Army to the Red Cross, was chief of the Burean of Medieal Service. Mr. Clarles I. Magee was seeretary of the organization and also acted as disbursing officer for the treasurer, the Honorable. John skelton Willians. The pay-poll for the entire National Headquaters, including the clerical staff and a single messenger, eontained barely fifty names.

Miss 1)elano's official fanily mumbered ten members and an effieient ret informal group it was. Althongh she was thronghout her lied Cross labors a full-time volunteer. Miss l)amo appeared every morning at nine o'cloek; often her arms were full of flowers and bright leares for the vases on her desk and bookease. II re singular gracionsness of personality pervaded the dingy rooms and roked from her statt an interest in the Nursing service which prompted them to work checrfully after 
office hours and during holidays if need existed. "When you'd once really seen her hig heart underneath," said one of her assistants, "you never noticed afterwards how impatient she got with you, or how late she asked you to stay." "She often brought her "live stock" to the office. On such oceasions her secretary took complete charge of her parrot, bequeathed Miss I) lane by her mother. Polly could not be left alone in the apartment on Biltmore Street, when her mistress was on one of those flying trips to New York, nor could Patrick, an Irish terrier, then on an indefinite visit to Miss Delano, though the property of an intimate friend. Patrick often sat in the wicker chair, watching the Momnt Pleasant cars swing up Comnecticut Avenue from II street, or erawled across the rugless floor to lick the shoe polish from the glistening boots of Army officers who eame to interview his hostess.

Warmth of personality characterized Miss Delano's attitude toward every one with whom she came in contact. Her letters to her supervising nurses brimmed over with cordiality and a boundless interest in their welfare. At the time the Red Cross Ship sailed, she equipped with her own hands all members of the varions mits. She made innumerable visits to the offices of foreign eonsuls and representatives that the nurses' passports might be viséed. She held earnest, protracted conferences with her supervisors, warning them with almost prophetic insight of the troublous days ahead of them. A phase of her many-sided personality was shown in a letter (May 4, 1915) from Helen Fidelia Iraper, herself a staneh friend of the Nursing Service:

I expect it may have seemed almost too much of an effort for you to come to my homse last Friday afternoon. I felt this especially when I saw you dressed in "your best party clothes." l. too, feel repail each time we welcome the nurses and send them ofl with a hearty Codspeed.

For many nurses who sailed in intervals during 1915 as well as for those of the Red ('ross ship, Miss Delano's handsome tigure as she wared geosl-hy from the docks ar from the deck of a tue-hart, was often their last definite impression before distanes or perhaps a mist of tears hlured their vision.

That her "lambs" were now far removed flom her immetiate solicitoms care, dismayed Miss Delano not a whit. She and Miss liecess and her secretary packed on the leather conch 


\section{HISTORY OF AMERICAN RED CROSS NURSING}

in her office the big wooden Christmas boxes which she sent to all the foreign units. With her own money and an even greater expenditure of thought, she bought the artieles which went to fill them. The eontents of one such box are enumerated in her letter to Vashti Bartlett, at La Panne: four dozen cans malted milk; six dozen eans condensed milk; four dozen cans cocoa; four dozen cans coffee; one thousand beef eubes; four dozen cakes sweet chocolate; two dozen cakes toilet soap; two dozen tubes tooth paste; two dozen toothbrushes; one dozen sweaters. Not content with this, she wrote to the families of the nurses then in active serviec that the Red Cross would gladly send their presents through official channels lest they be lost in the unsettled shipping conditions.

Many of the nurses' salaries (sixty dollars a month) were met through the generosity of Chapter and individual members of the American Red Cross. Letters written by Red Cross nurses to these donors formed one of the strong personal bonds by whieh Miss Delano endeavored to unite ardent supporters at home with Red Cross workers in the field.

Two hundred and fiftr-five nurses inchding the one hundred and twenty-nine of the original units and the additional one hundred and twenty-six others who relieved them, were engaged in war nursing between August, 1914, and December, 1915. Miss Delano rigorons] y denied in a letter written April 9, 1915, to the editor of The Survey, the rumors of atrocities current at that time:

I am indeen glat to reassure ron that so far as we have been able to determine. no lied Cross nurses from any country have met with the nutilation spoken of so frequently. Of the treatment experieneed by our own units. there is absolutely no trith in any suld reports.

One of our mits was in Belgrarde when that rity was captured lis the Austrians: thomsands of soldiers poured into the hospital and were ared for in the samo wards with the Serhians alreacly there. The city was recaptured acain hy the serbian trowps. aqain ly the Austrians, and the American Red cross remained inviolate.

Miss Inelano folt an intense personal responsibility for the nurses' health. She was ereatly distressed that their rooms were so often withont leat, as a letter of thanks written January 26, 1915, to the (iraduate Nurses' Association of Charles- 
ton, West Virginia, showed. When eables arrived telling of the typhus epidemic at Gevgeli, her anxiety expressed itself in an inmediate, wholly characteristic recommendation to Major Patterson: "May I ask," she wrote, "that six dozen nightgowns, two dozen bath towels, four dozen hand towels, four dozen boxes talem powder, be ordered for the use of the sick nurses in Scrbia and delivered as soon as possible to Red Cross Headquarters, New York, addressed to me, so that I may pack them in a trunk to go over with the next unit of murses?"

To Miss Krueger she wrote: "I am more than grieved to hear of your illness and that of the other murses at Gergeli and am so worried for fear yon are not able to get any kind of suitable food. Were it not for fear that there would not be enough nurses to take care of those who are ill," she added, "I shonld not send other murses into this danger, but with this thonght in mind, we shall probably send additional ones by the first steamer. It often seems to me that I must go abroad at once, if I did not realize so completely that my place is here at Headequarters."

To Miss Gladwin she wrote:

I am sending over with the unit sailing March 16, garments for the nurses to wear when caring for vermin-covered patients. Te have evolved these garments with the arlvice of people who have lived in these countries. While they are not esperially beautiful, I do beheve they will lessen the danger of infection.

'Tle skirt is made like Turkish trousers, has little extensions to fit in the top of the shoes, tying tightly around the ankles. The waist has no opening through which rermin could galu aleress to the boxly except at the neck and sleeves. These are arranged to tie tightly as you see.

Her extreme practicability, which expressed itself by having these garments made for the murses, provoked conisiderable langhter at her expeense, in which she wonld have modonltedly joined more heartily had she not been so distressed. "The

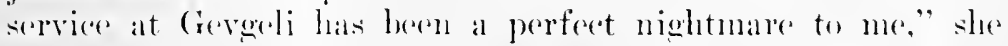
wrote to Mliss Giadwin on April 17 . "and I have been actually" af fraid to read the rables as they come in. . . I have notitied the filnilies of all the sick nurses, as it seems to me they hatre a right to know the onditions. I am simply hearthroken to think that trphus has "xtended to your mit at belgrade." 


\section{HISTORY OF AMERICAN RED CROSS NLRSING}

This intense maternal solicitude did not in any respect, however, imply indulgence. Miss Delano was a stern disciplinarian. To her supervising nurses she wrote:

Do you think the foreign authorities are pleased with the service our murses are giving? The only thing that worries me is the possibility of conditions becoming a little lax if our units are not fully occupied. Will you impress upon the nurses the importance of dignified and professional conduct both on and off duty?

Please do not hesitate to write to me quite frequently if you have any worries. Should any unexpected complications arise, cable me. If you think it necessary for the good of the service to relieve any nurses from duty, be assured that I am ready to support any action you may take, even to the extent of sending nurses home. We have many others anxious for European duty, so I do not believe it would be worth while to temporize much slould there be any breach of discipline.

Three principal defects in the organization of these pioneer Red Cross units were apparent to National Headquarters in 1916 , a realization of which was to save much confusion and unhappiness when the Red Cross organized a medical and mursing personnel a year later upon the entry of the Lnited States into the war. First, when the Merey Ship sailed, the anthority of the chief nurse and the relation of the medical directore to the nursing staff hath not been defined. Second, some of the nurses thensedves did not seem to possess imagination enomgh to perecive that this condition was due to the speed with which the mits were dispatched to Europe and therefore alled for even greater exerceise of their professional ideal of lovalty to their immediate superior than would have been necessary at home. Instrad of endeavoring to live up to this ideal, which was one of the foundation stones of nursing ethics, they toek allvantage of the geregraphice separation of the supervisor from the Nursing Survier at National Headpuarters and were the means of partially discupting the discipline and lowering the morale of the contire medical and nursing stafts. Third

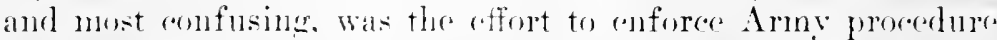
upon groups of perople nutrained in its emplexities and wholly ignorant of its neses. als were the surgeons and nurses of the S. S. Red Cross.

The first manifestation of an absence of esprit de corps 
presented itself in an open disloyalty between several nurses and their supervisors. 'This was due in part to a lack of support given ly the medical director to the supervisor and in part to the attitude of a few nurses who seemed to regard their foreign assigmment as more of a sky-larking expedition than a disciplined war service. Perhaps Miss Delano and her supervisors in their jealousy for the reputation of the American Red Cross Nursing Service abroad, may have set up more rigid standards than graduate murses, long since freed from the severe diseipline of training school days, would brook. At any rate, individual nurses eomplained to the medical directors of varions mits and the directors, some of them young men whose service as internes had been eompleted only a few years before, undertook to aljust this ticklisl problem with the supervisors.

But these women had enjoved many prerogatives and had borne grave responsibilities at home as superintendents of hospitals and training schools. They resented the interference of the routhful medical men in disciplinary matters relating purely to the mursing staff and accused the directors of lack of eoiperation and the tale-bearing nurses of disloyalty. The directors then reported their views to Major Patterson, while the superrisors laid their cases before Miss Delano. Lively discussions ensucd at National Headquarters. To secure effirient nursing serviee, Miss Delano maintained, as did her supervising nurses, that the same srstem of discipline prevailing in every well organized hospital should exist also in the Red Cross organization, that all matters relating to the discipline of the nursing staff should be handled by the supervising nurse thromgh recommendations to the medical officer of the unit and to the (hatrman of the National Committee on Red Cross Nursing serviee at Washington, D. C.: and that the director of the mit should support the authority of the supervisor as long as her servies were satisfactory. ifter thorough investigation, Major Pattrison in January, 1915, issued the following letter of instructions to all directors for foreign units:

All of rour healings with the nurses should be through the senjor supervisor. . . Your stregenss should be justructed to refer all requests for detail of nurses, orders, complaints. of other matters regarding the nurses to gou to be actal on by you at rour discretion. Whan these units were originally sint to linropes, the suregens- were instructed to this effect. In other works, if any of the doctors desired 


\section{HISTORY OF AMERICAN RED CROSS NURSING}

to have instructions given to any of the nurses or to make complaint, such matters were to be brought to the attention of the senior director, who would transmit the same to the supervising nurse, who in turn would give the necessary instruction to the nurses.

The matter of assignment to duty of nurses and their general supervision shonld be left entirely in the hands of the senior supervising nurse. These instrnctions do not mean that doctors working with nurses should not give them the usual instructions and orlers common between ward surgeons and the physicians and nurses working with them. . .

If in the opinion of the supervising nurse, any of the nurses under her eharge are deficient in condurt or unsatisfactory to her in any particular and she so recommends, you should return such murss to the Cnited States, merely obtaining sullifient information from the supervising murse to satisfy yourself that there has been no miscarriage of justice.

As long as the supervising nurse is satisfactory to you, you should sustain her authority on all occasions. If at any time her services are mustisfactory, she should be reliever from further duty, a temporary supervisor appointed in her stead and this office notified by cable.

A letter written to one of her supervisors, April 28, 1915, outlined Miss 1)elano's interpretation of these instructions:

It seems to me eonsistent and necessary for discipline that the director have the power of removal of the dortors serving under him and of the supervising nurse of the mit. So long as the supervising nurse remains in rharge of the nurses in the unit, any recommendation made by her should, I think, be arepted by the medial director without question. All the dealings of the medical corps with the murses, except in the matter of orders for patients, should be absolutely throngh the supervising nurse and she should be helit responsible for the discipline and maintenance of order of the nurses moler her. Iny recommendations for the removal of a nurse should. howeser, be made by the smpervising nurse through tho mediand director, unless he should rofuse to forward this rexommmlation. Lunler these circumatances, I think the supervising mure would be quite justitied in communisating with mo direct, although every effort shomb be marle to ionse to and arerement with the merlical director in regard to the recommendation so that after artion was taken, the supersising nurse could be sure of his support and approval. 
Miss Delano was undeviating in her support of the supervisors, even recommending the immediate recall of individuil murses whose complaints had first brought about the loss of harmony. The following statement of Miss Delano's reasons for her support of the supervisors was contained in a letter written by her to the supervisor of several murses who had been relieved from duty at the end of six months:

1 think they were a little surprised to find me waiting for them on the dork, but in spite of that they seemed grlad to see me. I asked them to report to Red Cross II adquarters as soon as they had atranged for the inspection of their lugrgralge.

Thloy came quite willingly. I asked them to tell me exactly what their diffieulties had been. No one seemed particularly anxions to talk and it was only after more or less questioning that they began a discussion of the matter. I was really surprised at the little they had to say. I explained to them my idea of the relation which should have existed between murses and the director and that the supervisor represented as far as they were concerned the authority of the Red Cross, acting in my place.

I also told them that I felt under obligation to support to the last any supervising morse moless sone definite charges could be brought against her, that it was not a question of the individual but of the principle and that I should have supported any one of then with equal willingness had they been selerted an supervising murse. This seement to appeal to them as reasonalhe and just and I an hoping that they went home with rather a different idea of their relation to the Red C'ross Nursing Service.

Of the seven nurses who were relieved from duty for insubordination, she wrote: "I have not seen Miss___ nor do I intend to do so nutil you are in this eometry. Nothing will be done albout disenrollunent until both sides of this question are healrd." $\quad$ l letter to a murse, a close friend, who differed radically in opinion from the medieal directer of here mit. ilhnstrated dliss loclane's impartiality, a quality which commanded the respect of all who knew her well:

1 wish, howerer. to tell you exartly what I sald to Major Patterson. \&o that you maly understand my position. of

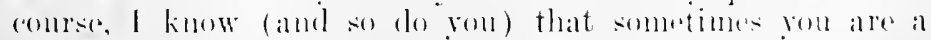

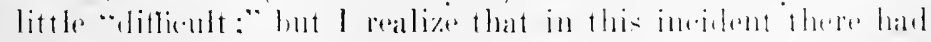




\section{HISTORY OF AMERICAN RED CROSS NURSING}

been great provocation and I think that you know me well enough to feel sure that I have only the good of the service at heart, even though this meant the sacrifice of my dearest friends. I have sail that I would not consent to your return, except on your own request. until the arrival of the new medical director. If. when he has looked all the ground over, he feels that your relief will be a benefit to the service, I shall be willing to accept his recommendation.

Had there been time on the part of National Headquarters to establish a definite plan of organization and communication before the mits sailed, much disconragement and mulppiness would have been aroided when the units found themselves face to face with these difficulties in the far corners of Europe. Miss Delano appreciated keenly her share of this responsibility. In a particularly trying instance, she wrote to one of her simpervisors with singular tenderiess and sympathy:

I do not wish you to feel in any way that your work has been in vain. I am most unreconciled that things have been allowed to drift along to such a futile ending, but if you have had difficulties in - - - I certainly have not been free from them at this end. Never for one moment have I faltered in my support of you and your policy. nor have I doubted for one nuoment that all would have been well if you had received from the beginning the support due you, not only profesionally but personally.

Your letter of discouratgenent maties me feel as if I had failed you. I lave taken the liberty of realing the parangapli of your letter, in which you ask to be transferred to another country as one of the "rank and file" to Miss Boardman. It may comfort you a little to know that she regrets as much as I do all the unpleant experiences you have met.

Two vears later, Miss Delano said to Miss Hay, then returned from Enope. "No one will ever know the difficulties I had in trying to suppert poul supervising nurses, nor what Miss Boardman has dome in trring to serure for nulses the proper relationship and anthority which she felt was due the Nursing Serviere in the Led crose oreanization."

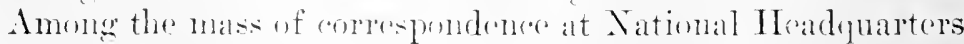
which contains the history of the Merey Ship, there alppears

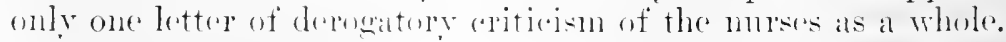
"This estimate was given by a british llatron and it will be 
appreciated that she was prejudieed to some degree by national differences in training, preecedent and temperament which placed the Ameriean nurses working under her in a strange environment, at grave disadrantage: "I think few of them have the real nursing instinet or love of hmmanity about them," the British nurse wrote, "they are keen on their own comfort. Their theory, I thought, seemed better than ours, but their practice not nearly so tinished as that of a good English nurse. Their discipline was nowhere and their independence too awful."

Miss Delano responded: "I am always glad to hear both sides of a question and will take up the matter with the supervisors in charge of these mits. The service at - has also tried the very sonls of onr murses."

National II addquarters realled fourteen of the foreign units October 1, 1915. Beleian Lnits Nos. 1 and 2 remained at La Panne mitil the completion of a year's service. The Yvetot Unit was no longer nuder the Ameriean Red Cross. In the Anmual Report for 1915, Major Patterson stated the reasons for recalling the stirgeons and nurses of the Mercy Ship:

As the war had been in progress for nearly a year, it was felt that the sanitary service of the various belligerent countries, as far as personnel was concerned, should be well organized and that with few exceptions they were in such a position that further assistance of surgeons and nurses from the Anerinan lion ('ross was no longer greatly needed. This was not true. howevor, regarding supplies, which it was felt would stearlily diminish. These would be increasingly difficult to obtain ant, therefore, would continue to be needed in varvine amounts by all warring countries.

'The money that otherwise would be recuired for the payment of salaries travel and other necesary expenses would be siver and the funds thes released would be available to continue the purchase of medical, surerieal and other hospital supplies for the lied ('ross socicties of the belligerents for many muntlis.

Although she had axpresiod a fervent hope that the nurses shomld return inmendiatele to the Enited States. Miss Delano's interest and eneonraging letters followed many of them through their further servies in Enrepe. Fonl mirses remained on

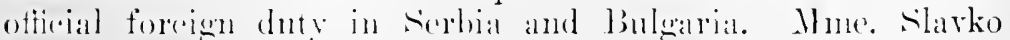

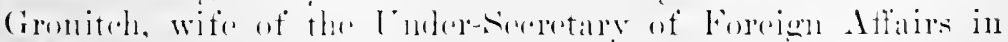

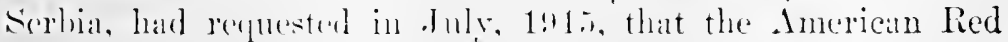




\section{HIS'TORY OF AMERICAN RED CROSS NIRSING}

Cross organize a unit of two doctors and two nurses to establish in Nish a hospital for infants and young ehildren. Funds raised by Mne. Grouitch were turned over to the Red Cross to defray expenses. With 1)r. Lonise Taylor Jones, of Washington, I). ('., as direetor. 1)1. Catherine Travis, New Britain, Connecticut, as assistant, Mrs. Maud Metealf, of Bellevue Hospital, and Miss Grace Ctley, of Hahnemann Hospital, New York City, as the nursing persomel, the Mabel Grouitch Baby Hospital was opened August 20, 1915, at Nish, Serbia, there to exist for a few brief erowded months.

Dr. Jones had started the dispensary under canvas. The main building was opened Oetober 1. Nme. Grouitch described this first Serbian baby hospital:

The Serbian Gorernment has given us a really nice building. the former Old Peoples' Home. Orer three hundred cases have been treated in the dispensary during these first five weeks. Women walk all night from remote villages to bring their children. It is heart-breaking to see the wretehed, absolutely starred little bodies and the fearful eases of hernia due to the poor mother and baby haring been uncared for at birth.

The white enameled cribs and beds are the delight and wonder of all. The diet kitchen with its stove and special arrangements. was marveled at with almost religions awe by the peasant women who heard for the first time of the necessary are in the preparation of their children's food. The strire-room was riewert with that respect always given to abundance by very poor people.

In September, 1915, after the hospital and elinie were well established. Inr. Jones returned to the Lnited States, leaving Dr. Travis in rleilrece.

In addition to heing a hospital center boasting eleven military and ejvilian institutions, Nish was the seat of the serbian Govermment. In noarby Kromyevatz were located the arsemals. A member of the Grovitch Baby Hospital described the movements of the serbian troops:

For ten dars the trains have heen constantly transporting soldiers to the Bulderian frontior. train after traill. day and night. Vhites of men malrh thomeh Xish. I hare wared to them from the hill where ontr elinic is sitnaterl and they answer with a shout. At tive oidock one morning, in the 
pouring rain, a train filled to the guards passed by with soldiers standing in straw on open freight cars, all singing at the top of their lungs: "There is my Serbia; There is ny home!"

If the wounded are brought back to Nish, our Baby Hospital will at once be turned into a military one. I know we shall take eare of the grown-ups with as much zeal as we give the babies. Even if we have soldiers in every bed and on straw starks in the halls, we will keep the clinic going for the mothers.

The Austrian-Bulgarian offensive was hurled against Serbia early in October, 1915. The Mabel Grouiteh Baby Hospital became a field ambulance October 1:3 and with members of the sanitary commission hastened to the front. Grace Utley described the flying squadron of mercy:

For ten days we were on the firing line, giving First Aid to the wounded on the field. This sometimes meant immediate amputation of a limb, operation on the brain, emergency surgery of all kinds. The liravery of the men was magnificent; for some, one prayed for swift death.

IVe saw the big guns silence two batteries. The cannonade of the Austrians and Germans was a solemn thing to hear. We evacuated hefore the on-coming enemy; moving back a station, we set up our tents anew for the wounded, so that our "Front" was a constantly ehanging one.

We now await here in Nish the arrival of the Bulgars, the 'lurks, the (icrmans. Nany places arount us have fallen; our turn comes soon. The Baby Hospital under the Stars and stripes and the Red Cross flag goes on until we are called acrain to the front: or until the floosls of wounderl turn this into a military hospital; or until the Bulgars shall order us on our walk with thousands of other refugees to a port where a ship will take us home; or until we shall be taken prisoners of war.

Of the lawlessness whieh broke out in Nish immediately before the Bulgarian oreupation, Itiss ltley wrote:

The storchomses not under. American jurisdietion in Nish

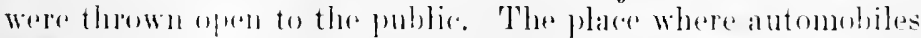
were kepte as well as any othere thinges that would he of use to the chemlny. were burned np. ('arks of wine were broken

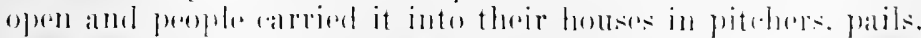

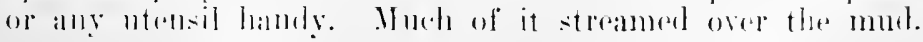




\section{HISTORY OF AMERICAN RED CROSS NURSING}

Even little children were drunk in a short time. Some of the people broke the windows of their own shops and earried away things without discrimination, or simply destroyed them. The powder magazines were blown up at one o'clock in the morning of the fourth of November. Add to the terrifie explosions the constant crackling sound of the flames as they lickerl up the gmupowder; the sight of mighty towers of solid flame here and there and at intervals a fresh explosion! One can realize fully how it might affect men who were ill and weak and helpless. For a short time we had almost a panie within our compound.

\section{Of their sole protection, Mand Metcalf wrote:}

Upon our return from the front, we were requested to take orer a military hospital filled with wounded Serbians. We went out to its crowled wards one wet dreary afternoon and by the next morning all the officials had left, leaving us with 1100 patients. We were not the most cheerful people in the world. To onr dismay, moreover, we found that we were left withont an American flag.

I walked three miles to a village to find all the stores closed and their windows tightly boarded up. After a great deal of talk, a shop-keeper pulled down one board and let me in. I bought some red and white sateen and a little square of blue cloth. Back I hurried to the hospital and we proceeded to make a flag. the other memhers of the mit cutting out stars while l sewed the stripes together. All of us wondered what our fate wonld he. I sat up all night to finish it and in the morning we ('ut off a limb of a tree for a pole, nailed? the flag to it, fastened the pole to a window frame and there it humg through sunshine and storm for five months while we stayed at our post.

At half-past ten o'dock on the night of November $7,191 \%$, the Bulgars and Turks aptured Nish and on the next day the Germans cane in, bo,0oo strong. The military hospital, flying the American and hed cross thags, remained muharmed and the murses and suremens anded withont diserimination for the wounded of both the Mllied and the ('entral Powers.

National Headequarters abled the recall of the Mabel Cronitch Baly. Wolfare L'uit in Novemulure 1915. Maud Motralt reported in Inecomber to Ifelen Seott IIay in Sotia. Grace Ltley and the other . Annericans returned home during 1916 after many delays. 
During the summer of 1915, Helen Scott May and Rachel Torranee had molertaken in Sofia, Bulgaria, nuder gracious (Qneen Eleanora's protertion, the organization of the training school first proposel in 1913. Before taking up the details of this project, it is of interest to read Miss Hay's characterization of its sponsor:

What Queen Elizaineth was to Humgary, that was Eleanora to her adopterl country, - a woman whose constant thought was for the help of her people. But for her wislom and incomparable strongth and farlessness, the small though convincing demonstration of good nursing methods in hospitals and in home would not lase been possible in Bulgaria in 1915 nor probably for long years to come.

Of the German house of Reuss and brought up near Tienna, her family, father. brotlers and sisters. were all noted for their kindiness and gencrosity. Her concern for the sick began when the parish priest tanght her the simple remedies which she applied in wre of the sick poor of the neighlorhood. In the Russo-d apincse War, she had good opportunity to learn the value of skilled nursing. During the Balkan Wars. she as Quen was head of the Bulgarian Red Cross and then indeed the lack of good nurses and good nursing sehools was impresed upon her. That she at once began to plan how this defort might he remedied is characteristic of her sympathetic desires for her people and of her indefatigable purpose. ...

In her manner. she was simple and without ostentation and repeatedly surprised even her best friends by her sound wistom and good sense. There was nothing of the dilettante about her. In quentions of curriculum and discipline, she would have been a helpful speater in any group of nurse instructors. . . No detail was too insignifient for her attention if it meant somerones happines: or added comfort. A village werlding. an insane soldier. the ambition of an orphan girl for an education,--everything that would help she did at once. Schoris for the deaf and dumb. help for the blind. "are and cure of the tubercular. a thousand interests bier anel little were leres and of her strenerth and hor means she gave to the utmost. . .

Two other wonen instrumental in the orenization of the

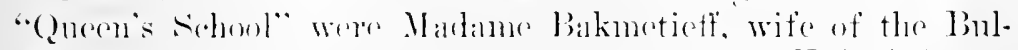

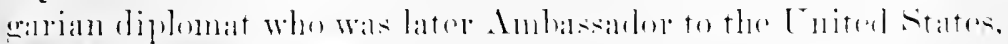

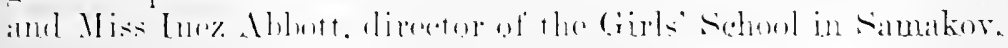




\section{HISTORY OF AMERICAN RED CROSS NURSING}

Miss Hay wrote of her assignment to Bulgaria and her reception there:

To Kief early in 1915 came Mr. Bicknell from Bulgaria, where Queen Eleanora hard discussed with him her ardent desire to see the School established, even though the times contimued unpropitions. As I was then ahout to return to America. Mr. Bicknell felt that I should go to sofia and acquaint myself with comditions there; so early in June, 1915, I went to Siofia with the understanding that my mission was only to inform myself of conditions such as would be helpful should the sidnool project be resumed later.

From the moment of my arrival in Sofia. the Queen was most hospitahle.... During the weeks which followed, I visited the Alexander. Red C'ross and Clementina Hospitals, met numerous men and women favorable and unfarorable to our plan and had many conferences with the Queen. At this time Bulgaria seemed to me to be singularly peaceful compared with the military liussia I had just left. True, she was still weary from the Balkan Wars and who could tell what the King. Cabinet or Minister might do when faced witl the increasingly complicated situation due to the European Nar?

Srarcely had my first week in Bulgaria passed before I fomm that the Qurem was arriving at the same conclusions I held: that the neer? Was beyond question and that the time was as offortume as it was ever likely to be. "You are here," sle sidl, "and we should hegin at once. There will be big difliculties and nuch opposition but my shoulelers are broad.'.

The plans proposed months before in Washington were that the Alexamble (tho (iovernment) Ifospital of 1000 beds shomlel be nsod for the pracetical trainine and that in turn the

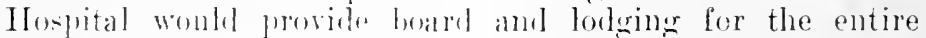

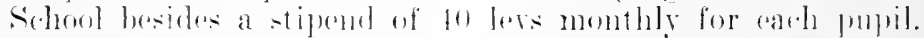

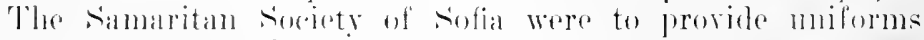

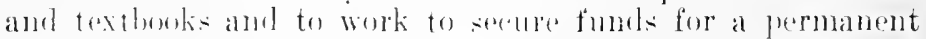
nurses home. lint tines hal abunged and interest shifted

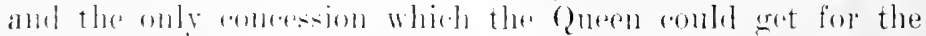

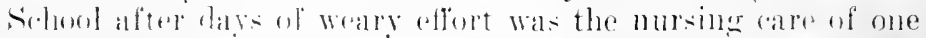
batilon amb that withont rotorn of any sort. I private

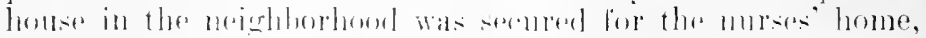

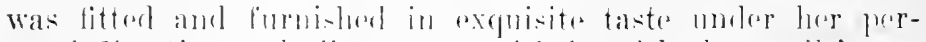

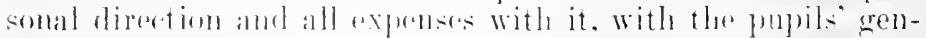

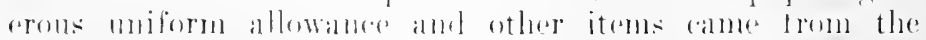

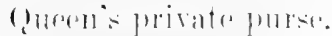


On September 15, the School was opened with Miss Hay as Director and Rachel Torrance as assistant. The pupils numbered eight; one of them had had full college training; two had had two years in college; two others were graduates of high schools and the rest had had some years in high school. All were Bulgarian and all but one spoke Euglish. A course of study covering two years and corresponding to the "Standard Curriculum" had been adopted by Miss Hay.

Of the fortunes of the School, Miss Hay wrote:

On the very first morning of elasses, the Queen brought us the news that Bulgaria was on the eve of mobilization, having thrown in her fortunes with Germany and Austria. We must therefore place our pupils at once, she said, in the Alexander Hospital to assist in caring for the soldiers. I begged for a few weeks, even a few days, for preliminary training and we were able to give almost a montl to it. In the excitement of a nation going to war, no wonder we found our pupils unusually apt! Dll day long they made beds and ponltices, gave each other baths and simple treatments to the music of a military band or of fife and drum that in the parade ground hard by was continually welcoming troops of war-weary veterans and exuberant recruits pouring in from all quarters of the kingdom.

Then fighting began off to the West and North and we made ready our pavilion at Alexander Hospital. As a good nurses' school, we must stand for the highest standards of cleanliness and order. Scarrely was the last yard of paint scoured white, the last toilet made spotless, the kast bed benzined, however, when the (ierman Red Cross witl doctors. nurses and vast supplies began arriving in Sofia to take over the direction of all military hospitals in Bulgaria. To Alexander Hospital came the chief, Dr. Goldammer, and his assistants. With our pupils we were left the nursing care of our pavilion. But not for long were we allowed to enjoy our rean quarters. A nurses school meant to the (ierman direction undesirahle complieations and (most olnoxions:) division of anthority and they wonld have none of that. So with thank-yous and good wishes all aromul, our sichool was transfered to Fotenoff Ilospital nearer the center of the (ity.

Foternoff Hospital was muder the Queen's control and was directed hy a sinuathetic bulgarian physiedan, 1)r. Michael-

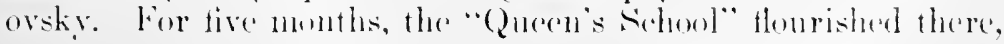




\section{HISTORY OF AMERICAN RED CROSS NURSING}

but early in 1916 Dr. Michaelovsky grew ill and a German physician was put in charge and German Sisters were installed in the operating-room. Miss Hay wrote:

These were the days of increasing animosity between Germans and Americans. Moreover, German methods of training are wholly different from ours. And again arose the question of divided authority. Sad it was but unquestionably true that the building up of a good nurses' school under American methods was not then feasible. The Queen, too, came to the same conchusions, probably on account of the increasing opposition of the King and Prime Minister to her giving any longer her faror and protection to Americans. So the transfer of the pupils of our school was made and back they went to the Alexander Hospital. . . .

However, the Queen was not the one to relinquish easily a project as dear to her as was the introduction of American nursing methods in her country, so she begged MIiss Torrance and me to remain in Bulgaria so that the School might he resumed speedily as soon as the war was orer. Even if the Germans did not further desire our serrices, there were many Bulgarians whom she felt we might assist. And was it not to help these that we had come to Bulgaria? And so it was decided that we could help most effectually in the care of the refugees. In Philipopolos. second city of Bulgaria in size. with a normal population of 60,000 there were a large number of refugees, some the remuants of other Balkan Wars, others just arriving from the Greek and IIacedomian fronts where fighting had already begun.

National Headquarters cabled its approval to the change in assignment and anthorized Miss Hay and Miss Torrance to spend their small balanee of five humdred dollars in general relief work. Miss Hay wrote:

The plan was that we should work in coupperation with the American missionaries nuter the Ameriman Boart: their long residenes mate them familiar with local needs. We were attarher to a lowal women's organization, the samaritans. which ondeavered to find the meediest sick and supplied them with milk and egrge. The women in this gromp nutler

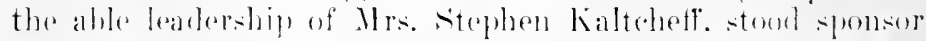

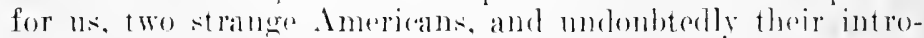
duction went far to arouse for ns feelings of respect and confidence. 
In the disorganization of war days, there were virtually no other social agencies with which to coopperate. During our stay in Philipopolis, a moion was effected of soreral groups representing the several religions of that cosmopolitan rity,-Jew, P'ravo-slar, ('atholic, Armenian, Protestant, Mohammedan, - and funds were collected, though our work really harl little help) therefrom. Intentions were of the best but the ideas we stood for were new to the Oriental mind which could not be expected to act upon such short notice.

In Philipopolis, there were two physicians for the eity poor, but with enormous clinics daily and with the work of sanitary officers for a prodigious area, they could give little, very little, individual attention to anyone and the person too ill or otherwise mable to drag himself weary miles up the hill to the clinic must get along without the assistance of a physician. Therefore, after the city had been divided into six main parishes, each of us undertook to cover three of them as best we could. Through the "poor lists" supplied by the mayor's oflice, the advice of the parish priest, rabli or Mohammedan hodji, we were able to find and to assist many of the most needy. At first we sought them. Soon they sought us and after that the question was how much we could manage to grive to all who needed help.

The needs and problems were legion and it took careful plaming to make our efforts most effectual. The distances were long: there were no streetears or Fords and the Turkish cobblestones or foot-deep mud was wearisome. Our clientele was a motley one,- - as raried as the patches in our" 'Turkish latimah's ragred and roluminous trousers. Resilent Bulgarians. Spanish, Jews, Greeks, 'Turks and gypsies: refugees from Macedonia. Greece. Turkey. Serbia. liommania, eath holding himself still a good Pulgarian but marked in dress. in eustom and often in religrion by the land of most recent sojoum. The Wallachian nomals with their floctis and herds were frequently in our district, always knitting knitting, on horseback, or walking or standiner grosiping with their neighbors. . . To know and become a necful thomerh a very small part in the lives of all these kindly, nowly folk was an experience interesting indeed hegoml my purer to tell.

Every scasom sormed to hring forth its special diffienlties and its sperial cone of "miseries." Miss Hay" contimmed:

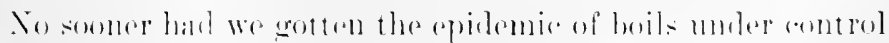

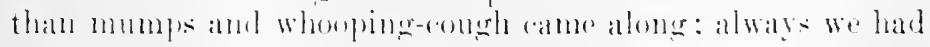




\section{HISTORY OF AMERICAN RED CROSS NURSING}

scabies and malaria; and starvation that showed in the waxy ashen faces everywhere. Rations were becoming more and more scarce and with the cold months, the great need of soup kitchens was evident. And then came to us from our blessed American Red Cross the sum of five thousand dollars, a princely gift indeed! At once we secured and salted down three big hogs, bought up potatoes, onions and beans and began to unwind the endless meters of red tape necessary to procure through the military authorities flour for our bread to be served with the soup. Securing kitchens and needed equipment was well under way when came a thunderbolt,we were recalled to America. Facing the inevitable, funds and the soup kitchens were put in the hands of a strong committee who were able to extend their usefulness over the worst of two winters. Visiting nursing was given over to three Bulgarian young women, one of whom had acted as our interpreter and assistant. Two of our old pupils from Sofia assisted for a time and were succeeded by others from the Sofia School for two years or more until lack of funds made necessary the closing of the activities.

Looking back over our work in Bulgaria certainly we saw it not as we had planned; it seemed unfinished and sketchy, the field too enormous for satisfactory accomplishment. But we had helped in a time of great need and that which we had done in the Nurses' School and in our demonstration of visiting nursing was to create a desire in the minds of the people for American methods of skilled nursing.

\section{Of the resolute Queen, Miss Hay wrote:}

To Queen Eleanora, it was a sincere grief that war conditions interrupted the development of the sichool. Still more disappointing was it when we were recalled; for as long as we were in Bulgaria, she felt that we conld resune the School as soon as the war was over. Her optimism and tonsuming wish speak ont in the last letter received from leer: "(iod grant that the work established by you may grow and remain in good form, til in better times helpful American hamb: may work at it again!"

ln a beantiful garden beside an ancient church on the slopes of Vitosla, guardian mountain of Sofia, lies the good Queen, watehing perhaps as she said she would, over her dear Bulgarian ehildren. 'Truly the memories of her alms and her good deeds arise like sweet ineense to immortalize the name of Eleanora of Bulgaria. And as one who gave the impetus to andequate nursing standards in Bulgaria. she de- 
serves a worthy place in a history of nursing accomplishment.

Many other nurses had remained in Europe after their official recall in 1915. Thirty-seven volunteers from the units at Vienna, Budapest, Gleiwitz and Kosel went into Russia and Siberia at the request of the German Government to distribute relief to German prisoners. The Russian Government had a similar projeet under consideration to send Ameriean Red (ross personnel to care for Riussian prisoners but the plan did not materialize. "No higher tribute," stated an editorial in the American Journal of Nursing (October, 1915), "has been paid to the service rendered by our Red Cross workers than this request from two warring countries for a continuance of their services for the benefit of prisoners in exile."

Sister Anna Rentinger was supervising morse of the German prison units. Dr. Cary $A$. Snoddy and eight American surgeons eomposed the medical staff. Before this detachment was relieved during the spring of 1916 , they had visited and distributed medicines and supplies to German prisoners at Moseow, Ugresh, Ryazan. Penza, Saratov, Astrakhan, Samara, Orenbure, Omsk, Novo-Nirolaiersk, Tomsk, Irkutsk, Tashkent and Kasan. Sister Amma described to Miss Delano the kind of work accomplished:

Of the uninjured in transit, we gave comfort and relief to 1734 officers and 11.271 soldiers; of the recently wounded and ill, bedriden and helpless, we aider 788 officers and 24.466 privates; of the incurables we aided 78 officers and 8436 solliers.

The evaruation hospitals where invalids. were concentrated were the school buildings. The recitation rooms and halls were overerowled with rietims of advancel tuberculosis, their beds closely rangerl side hy side. It was stimated that cighty per cont of the exchange prisoners were affected by this disease, the White lague indeed! I am never forget their

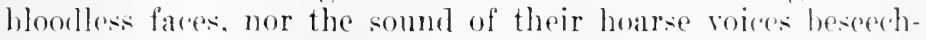
ing in whispering tones: "Sister, do gou think I shall live to reach home: I want only to live one day at home alsain in Hungary." and then the skeleton hand and arm wonld steal from winlernoath the bed rethes in an attempt to take me hand and hise it for the solace and aommiseration offered.

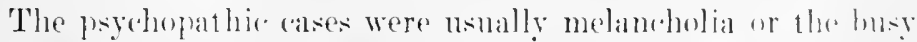
ahatering type, the subject of their mania being invariably the horrors of war. 


\section{HISTORY OF AMERICAN RED CROSS NURSING}

Scurvy worked great haroc among the captives. We aided 856 victims of this disease whose teeth had fallen out and who were unable to walk from stiff and swollen joints. In fact, it seemed that every sickness known to civilized man found here a ready prey. A major general suffering from nephritis told me that the lieutenant general to whom he had surrendered was a prisoner in his country and on his return to his home he would endeavor to have his captor released and sent back to Russia. "We are two broken men," he said, "with only perhaps a few months more, which should be spent with our families."

We can readily comprehend the depths of their despondency, returning blind. crippled and ill, many of them to destitute families and many of them to endure in pain and poverty a living, lingering death. We often wondered if our twentieth century civilization was but mockery, or if it had only endowed barbarians with more efficient and ruthless weapons and methods of slaughter. Where, we asked, is the culture, where the loving message of Christianity, where the humanity that can countenance such savage and infamons cruelties? The only answer from this gruesome slaughterhouse of hopes and desires was the pathetic prayer of the sufferers for peace.

Although by Christmas, 1915, the Red Cross had closed its foreign program, Miss Delano, as chairman of the National Committee on Red Cross Nursing Service, was in an excellent position to gain a bird's-eve view of almost every phase of war nursing. She saw the American Ambulance which had been established in September, 1914, at Neuilly, France, by the American Ambulance Committee of Paris. Here many American Red Cross nurses were stationed with Margaret Dumlop of the Pemsylvania Hospital. Philarlelphia, as chief uurse. She saw the first Harvard Unit serving with the British Expeditionary Forees at General Hospital No. 23. The Me(Xill Lniversity and the Chicago Medical mits were their alow. neighbors. From personal letters witten by Red Cross nurses seattered with other organizations in all parts of the world. she gatlered wisps of information abont the nursing situation. Two members speaking for the American Ambulance might well have voiced the forelings of other nurses serving in the war:

We never saw the flashing lattle-line, that arch of bright steel that stretehes 300 miles between France and Ciemany, we did not hear the cannon or long lines of men cheering as 
they swept into artion, or the dying horses scream; we saw none of the pageantry of war; but we lid get a glimpse behind the senes of its most real, its most lasting part. We saw the long ambulanee trains, those "rivers of pain" ranning bark from the lines; we saw strong men sobbing with agony like children; we saw them crippled, dying: we saw their women struggling alone against anxiety and poverty, pale women with that look in their eyes which comes of sleepless nights and unshed tears; we heard little children erying for the father's love they will never know again. All these things are the necessary routine of war. We have seen and we ean never forget. ${ }^{17}$

At the close of this first early chapter of American Red Cross participation in the European War, Miss Delano summed up the value of the service which had been rendered by the American Red Cross nurses:

Two hundred and fifty-five nurses have been sent to Europe. When we think of the vast number of sick and wounded, the thirty thousand patients cared for by our units seems pitifully small. I do believe, however, that we have established in European countries, where modern training schools for nurses have not yet been organized, a definite standard of nursing, which will surely produce results later.

Our nurses have had a valuable experience which should be of henefit to our own country. They have learned how to are for large numbers of patients all weary, ill, hmory and cold and to make them comfortable in the shortest possible time without disturbing the rontine of the hospital.

lle have loamert that women an be mobilized without confusion; that their chances of ilhess when arefully selected seen to be no wreater than men s: that they face danger with equanimity. We have learned also the special type of nurse most desirable for service of this kind.

Out of this experience we should be able to do a splendid piece of constructive work for our own country. We should be able to grablantee a satisfactory nursing persommel not only for national reliof in time of calamity. but for eflicient servire shomld our country be confronted with that greatest of all disilstors- IIar. ${ }^{1 *}$

For the American lied Cross, the first enthusiasm of world sympathy had spent itselt. But an all-shadowing responsibility

17. Imerieten Journal of Vursing. Vol. XV. p. sist.

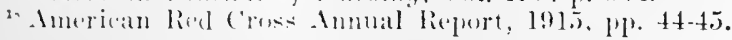




\section{HISTORY OF AMERICAN RED CROSS NURSING}

loomed ahead. Although popular inclination clamored for peace, men and women at National Headquarters stood looking ahead to a day not far distant, when American men might wait in a welter of sand, mud and flesh as the trenches about them crumbled under enemy fire; when American boys might lie in casualty-elearing stations under a Mexican sky or in a Flemish farm-house, tearing at wounds in blessed delirium or biding their turn in stoic consciousness of physieal agony.

War, dimly visible through diplomatic and economic events of 1915 and 1916, was hurling at the American Red Cross the challenge of its charter obligation: Look to thine own! 


\title{
CHAPTER V
}

\author{
MOBILIZATION
}

National Headquarters Reoryanizes-The Naiional Committee on Red C'ross Nursing Service-The Committee on Nursing of the Council of National Defonse-Special Courses - Special Groups-The A rmy School of Nursing-The Nurses' Drives-Surgical Dressings-The Nursing Surveys.

The International Conference of Geneva in 1863 reeommended "that there exist in every country a committee whose mission consists in coüperating in times of war with the hospital service of the armies by all means in its power." Succeeding to all the rights and properties of the earlier organization, the American Red Cross was reincorporated under Govermment supervision by an Act of Congress approved January 5,1905 . In the charter of that date under which it still acts are enumerated four purposes of its creation, three of which deal with relief to the sick and wounded of the Military Establishment, as follows:

First. To furnish volunteer aid to the sick and wounded of Armies in time of war, in arcordance with the spirit and conditions of the Conference of Geneva of October, 1863, and also of the treaty of the Red Cross, or the treaty of Creneva. of

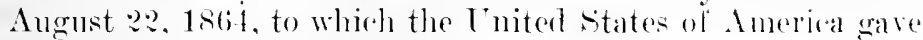
its adhesion on March 1, 188?.

Second. And for said purposes to perform all the duties devolved upon a national society by each nation which has acceded to sais treaty.

Fourth. To aet in matters of roluntary relief and in accord with the military and naval anthorities as a medium of communieation betwern the perople of the lenited states of Amerixa and their Army and Nary and to alet in such matters betwom similar national soridies of other governments through the "Comite' Interuational de secours" and the (ior- 


\section{HISTORY OF AMERICAN RED CROSS NURSIYG}

ernments and the people and the Army and Nary of the Lnited States of America.

For two years before the declaration of war, April 6, 1917, the Red Cross underwent a period of tensely active but silent mobilization. The experiences of the foreign units, which had wituessed the initial collapse and subsequent reorganization of the sanitary formations of the belligerents, had made clear to the American Red Cross that it must be ready to meet its responsibilities shonld the United States enter the conflict. Even a rear carlier, namely in April, 1914, Miss Delano had begun making plans for an enlarged enrollment. At a meeting of the National Committee on Red Cross Nursing Service held April 24, she requested the State Committees to send to her lists of all training schools in the respective states which fully met the Red Cross requirements; also additional lists of those meeting the requirements only in part. She asked further for lists of nurses who were especially well fitted to serve as (1) superintendents; (2) head nurses; (3) clinie nurses; (t) dietitians.

Lnder a revision of the By-Laws of the American Red Cross adopted by the Central Coimmittee at the anmul meeting in December, 1915, the National Committee on Red Cross Nursing Service, which had been a subcommittee of the War Relief Board. was thenceforth to be appointed direetly by the Red Cross Central Committee and to work under its direction. In 1)ecember, 1915, the members of the Central Committee were: Willian H. Taft, chairman; Gen. Charles Bird; Mabel T. Boardman; Admiral William C. Braisted; John WT. Davis; Robert Wr. DeForest: Gen. William C. Gorgas: John Bassett Moore: Judge W. IT. Worrow: (harles 1). Norton; James Tanner: John Skelton Williams. At a meeting of the Central Committee on Inexember 1:, 1916, the Surgeon Generals of the Amur. Navy and Public Health Service, the presidents of the there national oreanizations of nurses and a number of other officials designated hy title were made ex-officio members of the National Commitese on Red Cross Nursing Service. In Fobruary. 1!17. the Saltunal Committee, on its own recommondation to the ('entral ('mmittee. was increased to forty-six members by the appointment of twentr-thee additional representatives from the there national socicties of nurses.

The three relief lwards, i.e., War, National and Interna- 
tional became advisory boards. All aetivities were grouped under two main departments: Civilian Rolief and Military Relief. Ernest P. Bicknell, who had been national dirertor of the organization from his appointment in 1908 became $\mathrm{Di}$ rector General of Civilian Relief and Colonel ondrerson Randolph Kean of the Medical Corps of the United States Army was made Director General of Military Relief.

Col. Kean ontlined the scope of the Department of Military Relief in the Red Cross Annual Report of 1916, as follows:

It has supervision of all the work of the chapters relative to the various branches of military relief work, such as European war relief, assistance to our own soldiers, instructions in First Aid and Hone Care of the Sick, ete.

It deals dirertly and without the intermediation of the Chapters with the military units such as base hospitals, ambulance companies, hospital units, surgical sections, supply depots and naval and emergency detachments of nurses which are organized with the approval of the Medical Departments of the Army and Nary to reinfore these services in case of war. It atministers also all agencies of assistanfe to the sick and wounded soldiers of foreign countries and to prisoners of war.

These manifold activities were conducted through three bureans: Major Robert U. Patterson of the Merlical Corjes of the Cnited Ntates Army, who had been Director of the Burean of Medical service from its creation in $191+$ was rontinued as Director; Mr. Theodore W. Richards, Lnited States Nary, was in charge of the Burean of Supplies; and from September, 1916, Clara I). Noyes was the l)irector of the Bureaul of Nursing Service. L'pon the last-named, newly-organized Bureau was placed the responsibility for all work in connection with the selection of nurses for enrollment and the organization of mits of nurses for service, the assignment of nurses to duty and all details relating to the comrses of instruction muder

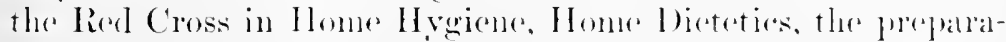
tion of surgial dressings and hospital galments:- "worthing, in short, except the public health nursine (then the Town and Country Nursing sirvices).

The rush of work of erery kind during 191 is indi ated in the Anmual lieport for that roatr. It shows that member-

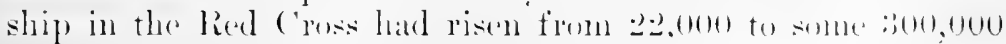




\section{HISTORY OF AMERICAN RED CROSS NURSING}

odd and even that was only a beginning. The appointment of Miss Noyes as Director of the Bureau of Nursing was of great moment to the Service. To take up this task of infinite detail, untold anxieties and extreme responsibility, she resigned one of the foremost nursing positions in this country, that of General Superintendent of Training Sehools for Nurses, eonnected with Bellevue and Allied Hospitals, New York City.

Clara Dutton Noyes had had long experience in the administrative work of her profession. Born at Port Deposit, Maryland, she eame of Conneeticut parentage. Her father had served, as had Miss Delano's, in the Civil War. Miss Noyes was graduated from the Johns Hopkins Training School for Nurses in the class of 1896 , where she served for a year after graduation as a head nurse. She was for some years superintendent of nurses at the Hospital for Women and Children, Boston, and later superintendent of St. Luke's Hospital and School of Nursing, New Bedford, Mass., leaving there in 1910 to accept the general smperintendency of Bellevue and Allicd Training Schools. From 1913 to 1916 she was president of the National League of Nursing Edueation, and president of the Board of Directors of the American Journal of Nursing from 1911 to 1918. As a result of her broad and many-sided interests she brought to the Red Cross a keen appreciation of nursing problems. Professional elaims were never ignored even in the intense absorption of her Red Cross work. She became president of the American Nurses' Association in the spring of 1918, serving thus through the trying days of war and demobilization.

On April :3, 1916, Miss Delano first approached Miss Noyes, who was at that time also chief murse of Base Hospital No. 1. Bellevue, the first unit to complete the organization of its nursing personnel. Miss I) elano had hurried to New York to eonfer rearding the Bellevie and Presbyterian units of murses, then being detailed with their respertive base hospitals. On her return to Washington, she wrote to Miss Noyes:

Ever since I saw you at Miss Maxwell's, I have been wondering if rou really would consider coming to the Red Cross.

There is no doult in my mind that there is wonderful opportunity to decelop for this country a service such as we never dreamed of in the beginning. It is a piece of work which needs ronstant thought and $I$ should be very happy if 


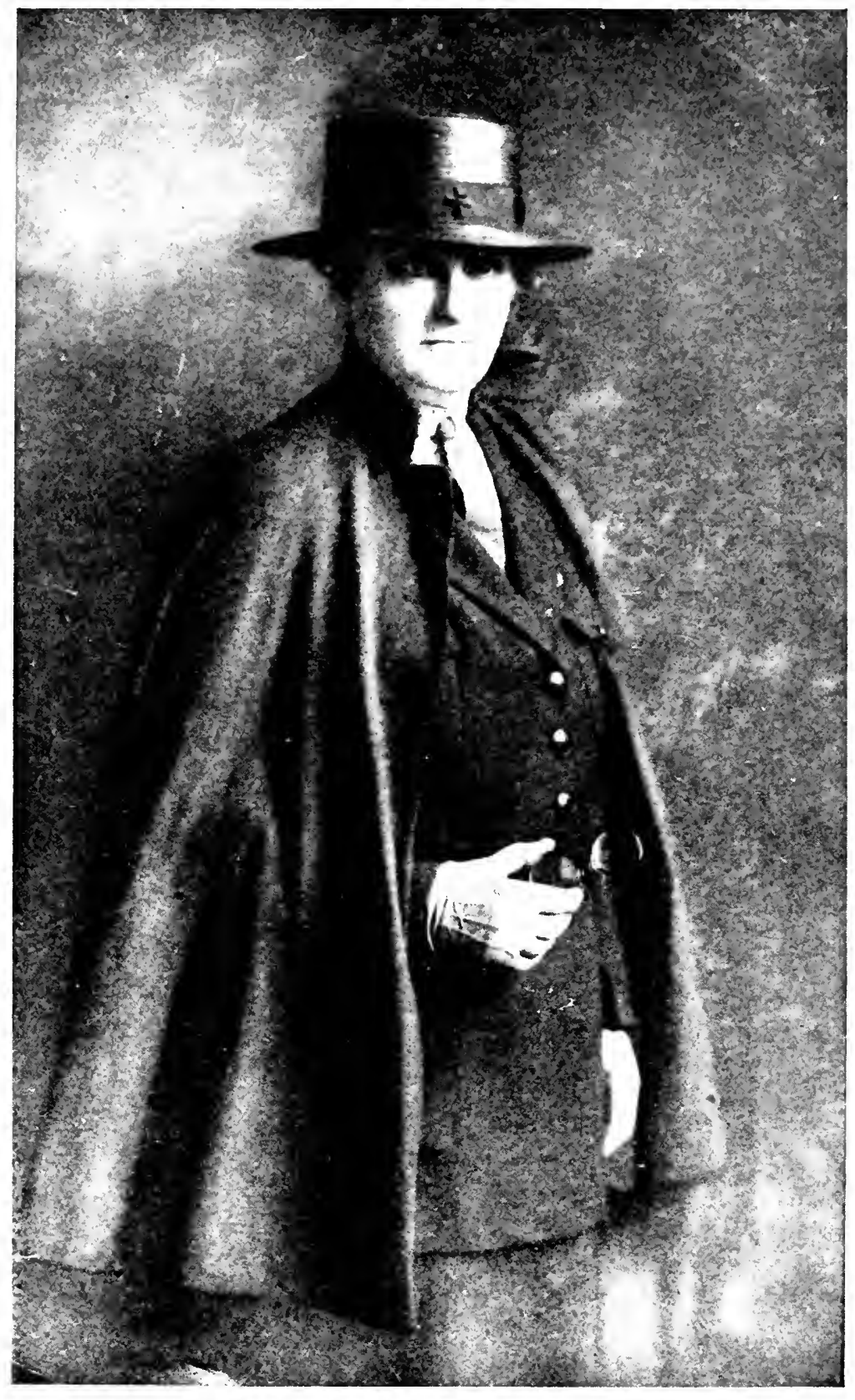

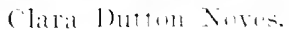



by any chance you are willing to consider coming to Washington.

The Director General of Military Relief, Col. Jeflerson R. Kean, has under his department two bureaus,-Medical and Nursing Service. Major Patterson is chief of the Medial Bureau and you would be chief of the Nursing Bureau. I should still be chairman of the National Committee on Red Cross Nursing Service, but this committee would become advisory and could be called upon if needed.

For several years Miss 1)elano had been hoping to free herself from the confining office life which she had led since 1909. Her resignation from the Army Nurse Corps in 1912 to devote her attention undiridedly to the Red Cross had been the first step toward this relinquishment of executive detail. Her wish was to establish a capable director of the Nursing Service at National Headquarters and to continue holding her own position as ehairman, thus releasing herself from excessive routine. She dreamed, also, of a little home in the country to he prepared for her later years, for she had inherited a love of rural peace and quiet from her New England ancestry. The war pressure now gave impetus to her plan for the office, but banished that for her own future.

Miss Noyes, however, was not at first disposed to give up the work at Bellerue, with its large braneh hospitals at Harlem, Fordham and Gouverneur, and its specialized sehools of midwifery and of male attendants. On June 1 Miss Delano took up again with Miss Noyes the need existing at National Headquarters for an able organizer and exeentive. She wrote:

I am still hoping that you will be able to come by the fall and it would be my idea to build up a definite gromp of nurses who would really lie assistants to the "Chief of the Nursing Bureau" or "Superintendent of Nurses" or whatever the new position may be ralled. This would relieve the Mashington Offiee of many details and would divide the work so that local interest would be maintained, still laving the direction and final word at Red Cross Headquarters.

We must have a strong woman in Washington! There is too much at stake now to take any rhances amel l foel in my wry soul that you are the person for the place. Mliss Boardman adds her persulsion to mine.

A letter written five days later gives a more vivid pieture of the press of work at Headiparters, and shows that Miss 


\section{3ł HISTORY OF AMERICAN RED CROSS NURSING}

\section{Noyes was giving grave consideration to Miss Delano's urgent}

appeals :

I am hoping that it may not be necessary for you to come until you can do so with an easy mind concerning Bellevue. It is an awful wrench eren at the best to give up such an important work and I am willing to do my share. Things were pretty bad here when the rush first came, for it was difficult to get extra stenographers,-at least good ones. So many of them had gone from the Departments to "the front." -in this case over to Fort Meyer. We are getting on better now and the feeling that you are arailable if a great need comes makes it all much easier.

The can surely wait throngh July unless new conditions develop in Mexico and if I keep well, perhaps even longer. so that you too may have a vacation. I am so tired I can scarcely writc. Was at the oflice all day yesterday and sumlay as well.

Miss Delano ontlined the. new work more definitely in a letter written on the serenth:

Instructions for enrolled nurses as members of hospital units should be prepared. Outlines are needed for chief nurses who are to undertake the practical instruction of nurses aides.

Some methor shonld be developed for the inspection of classes of instruction to women so that incapable instructors slould not be allowed to continue.

There will be a new course in Dietetics ready in the fall, which will make supervision more than ever necessary.

I believe there is a distinet menace to onr nursing standards in the development of this lay persomel unless it is carefully directed and supervised and that at this time no work in the entire comntry compares with it in far-reaching results or importance. I simply (annot do it alone but will help in every way in my power and as I have said before. am perfectly willing as (hairman of the Sational Committee to support rou to the nttermost in any policy which you may think desirable.

Miss Noyes amme to Washington on Jume 13 to interview

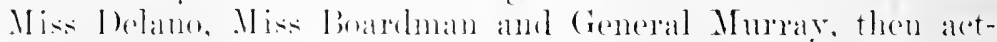

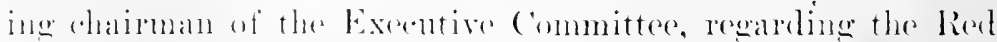
('ross appointment. ( 11 . Inue 24 a short note from 11 iss I)elamo to Mliss Noyes gives a second pieture of National Ileadequarters: 
You ean imagine how busy we are and how interesting it is! We have just opened another office arross the street [I and 17 th f for volunteer workers. . . They are addressing envelopes and sending out hundreds of form letters. The Chicago Cliapter has agreed to employ a nurse and New York is also ready. 'There is a tremendous piece of organization work to be done and your country certainly needs you!

I am trying to be patient, for I am sure you will do what is best, but you cannot know how many times a day I long for your cool judgment and wise counsel.

Miss Noyes aceepted the directorship of the Bureau of Nursing July 24 and came to Washington September 10, 1916, to devote her whole time and all her powers to the lied Cross. A woman of elear judgment, of excellent organizing ability and jealously ambitious for her chosen profession, she was wholly relied on by Miss Delano, with whose more intense and dramatic nature the exceeding reserve of Miss Noves was in striking eontrast. Under the eool poise of her ontward bearing there was a naïveté and warmtl of personality, only appreciated by those who knew her well. Like Miss Delano, she was tall and of commanding presence. Like her, too, her gray hair beeame snowy white during her Red ('ross labors.

The nursing staff now numbered five, not including the Rural Service. Besides Miss Delano, Miss Noyes, Miss Reeves and Josephine Johnson, Katrina Hertzer, a nember of the Navy Nurse Corps, who had served with Unit E at Budapest, was detailed on September 20, 1916, by the Bureau of Medieine and Surgery of the Department of the Nary to act as liaison offieer between the Navy Nurse Corps and the Red Cross, at that time organizing Nayy base hospitals and detachments. Miss Hertzer was born in Ohio and was a graduate of the Illinois Training School for Nurses. Before her assignment by Surgeon General Braisted to the Red Cross, she had been superintendent of murses of the ('ity and ('ounty Hospital. St. Panl, Minn., and chief nurse, U. S. Naval Hospital, Chelsea, Mass.

On the 25th of January, 1917, the Red Cross Headquarters organization moved from its old location to the beantiful building on Seventeenth Street farcing Potoniar Park, which was ereceted as a memerial to the "IJ and dedicated as the administration headefuarters in perpetuity of the Aneriean hed c'ross. In anmon with the other de- 


\section{HISTORY OF AMERICAN RED CROSS NURSING}

partments the Nursing Service had completely outgrown its old quarters.

Singularly appropriate is this Georgian-Colonial strueture of Vermont marble, set opposite the ellipse of the White House, the second in that fine chain of buildings which extends down Seventeenth Street to the Tidal Basin. On its left is the Coreoran Gallery of Art; on its right, Continental Memorial Hall, belonging to the Danghters of the American Revolution, and just beyond that is the Pan-American Building. Its history goes back to the Civil War, to two of Lincoln's volunteers of 1861, Francis Barlow and James Scrymser. Sergeant (later General) Barlow was wounded at Antietam and again at Gettysburg. His wife, a member of the Sanitary Commission, went to the battle line to nurse him, there contracted typhus and died, 1864. To her husband, she typified the spirit of women in war time and in 1896, not long before his death, Major General Barlow prophetically said that some day the nation would build a fitting monument to the women of the Civil War. His friend, Captain Serymser, heard his words and was afterwards one of the guarantors for the amount pledged for the building. The story of how the memorial was assured and built mar be read in Miss Boardman's book "Under the Red Cross Flag."

On the first floor to the left of the stairway Miss Delano and Miss Noyes shared two spacious rooms, green-tinted, with books and photographs, soft-toned rugs and dark solid furniture, all in malrked contrast to the scarred oak desks and worn floors of the II street oftices. Miss Delano then matched her one wicker chair hy others equally comfortable. She often received contributions from friends who were interested in the Nursing Service and these went into a special fund for equipment, books, or other things connected with the welfure and eomfort of lied cross nurses.

The volume of routine work of the Nursing Service at this time was ontlined by Miss Helano in a letter written on Angust :31, 1!14i, to . Miss Boardman :

The only thine that troubles me is the question of room in the new bulding and I am wondering if by any ehance it will be possible to have the sulall room which rou had planned to give to Miss Oliver for Miss Reeves and the nurse from the Nary if she romes. I shall have to put a part of the rlerks in the rom where the files are. We have two permanenty 
for the class work and have been obliged to employ a third to help out with the additional work. It takes the time of one clerk for the surgical supplies and patterns, and should need a second clerk but for the fact that wo lave been able to use volunteers in that oflice. It takes the ontire time of one clerk for the work of the base hospital units and emergency detarhments, with occasional help from others when the pressure of work comes in. l'nless the work decreases more than I have reason to expert, I do not see how it will be possible to get on. We shall have more people, judging from present indieations, than the top floor will arcommodate. I am greatly worried and only wish you were here so that I could talk it over with you.

To the third floor, nevertheless, went the Town and Country Nursing serviee, the clerical foree, class instruction and the files of the National Committee. The paraphernalia of surgical dressings was ensconced on the balcony overlooking the Assembly Room. Even this stately conference chamber had been divided into offices, one of which Miss Hertzer at one time ocenpied. 'Temporary partitions shut off the Tiffany memorial windows and stenographers from every corner of the Lnited States flocked daily to their erowded desks there, while waiting for better locations. Thongh the Nursing Service retained the two large oftiees on the first floor, the attachés and clerical foree, in turn, moved from the attic to the basement, from the basement to the First Annex, from the First Ammex to the Third and tinally bronght up in 1919! in its present home in the permanent Fomrth Amnex, before its mushroom growth rould be aceommodated.

To aid Miss Noves in the assignment of murses and the standardization of sureical dressings, Vashti Bartlett, of Johns Hopkins, came to Xational Headquarters in Mardh, 1917. Miss bartlett had begmu her lied Cross sopve doring the Dartom fleod: she was a member of ['nit $A$ at P'an, and of the Belgian mits at La P'anme. Hor reply to Miss Norese request that she ande to Washington. Lremght a smile to the lips of the overworked Direwter of Ninsing.

"Will you answer a Macedonian call!" Miss Noves had wired.

"I will have to onsult my family," replied Miss Bartlett,

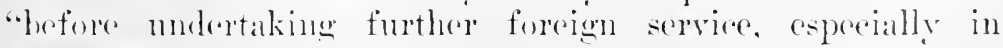
Girecen!" 


\section{HISTORY OF AMERICAN RED CROSS NURSING}

On April 6, 1917, the United States entered the World War. Immediately Red Cross Headquarters was flooded by correspondence. Stimulated by events, murses from all comers of the United States were volunteering. Immense development took place in every branch of Red Cross work. On the 10th of May, 1917, President Wilson had appointed a War Council for the American National Red Cross. ${ }^{1}$ Their first task was to raise the rast sum of money needed.

The persommel of the Ninsing Service was now greatly enlarged. Anna W. Kerr, who had been one of Miss Delano's classmates, eame to Washington to take over the examination of all applications for enrollment. Miss Kerr had been assistant at Bellevue when Miss Delano had been superintendent of nurses there. For eleven vears she had been director of nurses of the Burean of Child Hygiene, Department of Health, New York City. Her derotion and great faithfuhess to Miss Delano did not end with the death of her life-long friend.

Agnes G. Deans, well known to American murses as a former seeretary of the Ameriean Nurses' Association, came, on June 11. 1:17, to the oftice of the chaiman of the National Committee. Her knowledge of nursing organizations and training sehools throughout the eountry was of the ntmost value to Miss Delano in the first lied Cross nursing survey. A graduate of the Farrand Training School for Nurses, IIarper Hospital, Detroit, Ifichigan, IViss I teans was a pioneer public health nurse, having done visiting mursing in Jichigan and Minnesota. She was assistant to the director of the l)epartment of Nursing until July 1, 1920: six months later, she became direcerer of the Social Siervice Inepartment. Washington Tniversity. Sit. Lonis. A devoted friend of Miss Delano, Miss Ieans was an able executive and a loyal upholder of the best ideals of her profession.

The oreanization of the base hospitals included a dietitian and her assistant. Public opinion in all parts of the nation demanded general instrutetion in the elementany principles of home diceteties and food conservation, of vital importanes to a nation at war. Elya Anne Georege, a graduate of P'ratt Institute, came to the Burran of Nursing on July 27,1917 , to

"The original mombers of the War (omncil were: Henry l'. Davison.

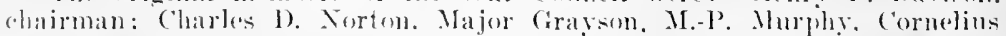

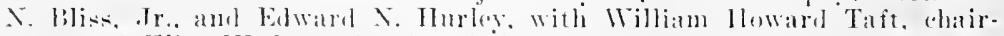
man. and Eliot Wadsooth. vice chairmam of the Contral Committere exotlicio. 
take charge of the mobilization of dietitians for the base hospitals and to supervise class instruetion for women in the Red Cross course of Home Dieteties.

Helen Scott Hay was the next nurse to join that strong group brought by Miss Delano to National Headquarters. She and Rachel Torrance had had an eventful trip home from Bulgaria, following the declaration of war by the United States. The organization of the base hospitals, which called for twentyfive nurses' aides for each one, had given great impetus to the class work in Elementary Hygiene and Hone Care of the Sick. Miss Noyes' duties in the selection and assignment of nurses were multiplying to dimensions beyond the control of one individual. Miss Hay aceordingly eame to Washington in July, 1917 , as director of the newly-created Burean of Instruetion.

In Jamuary, 1918, Miss Hay resigned from the Nursing Service to undertake at the request of the Surgeon General some special work for the Army Nurse Corps and Harriette Sheldon Douglas, a graduate of the Roosevelt Hospital, New York City, became director of the Burean of Instruction. At this time, the scope of this Bureau was broadened to inelude the assignment of nurses' aides to foreign services and the name of the Bureau was enlarged to that of the Bureau of Nurses' Aides and Instruction.

With Miss Donglas there came an interesting link with the Civil War days, for she was the danghter of the late Dr. John Hancork Douglas, attending physician during General Grant's last illness, who was also one of the three associate secretaries and Chief of Inspection of the Sanitary Commission during the Civil War. Though she had not been engaged in active nursing for some rears, Miss Douglas voluntecred her services to the Red Cross in the early winter of 1917. Her appointment to the Burcan of Nurses' Aides and Instruction was a particularly happy one, in that she combined the viewpoint of both the livwonan and the nurse. Slender and spirituelle. a flame of ardor in earnest eyes lit the view Miss I louglas had so alearly of the human ereature in every lonely and neglected patient. Is a sister of Bishop IIarding of Wislingtom, she was also in a particularly fortunate position to brine to the support of her work the interest and enthusiasm of many. Washingtom women.

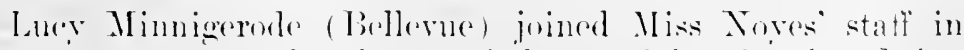
Angust, 1917. to take ehalew of the special mits then heing 


\section{HISTORY OF AMERICAN RED CROSS NURSING}

organized for the War Department and for Red Cross foreign commissions. She too had sailed on the Merey Ship, serving in Kief; she too was intensely devoted to Miss Delano. She eontinued her Red Cross work until December, 1918, when she undertook a supervisory tour of the U. S. Public Health Hospitals, later becoming superintendent of nurses of the U. S. Publie Health Service. Absolutely fearless, impulsive and outspoken, devoted to her friends, resolute toward opponents, in Miss Minnigerode were found many attributes of the typieal pioneer.

The Town and Country Nursing Service had as its Director Fannie Clement and later Mary S. Gardner and Elizabeth Fox. An aecount of this Service and its leaders will be given in a subsequent chapter.

Other nurses who assisted Miss Delano and Miss Noyes at National Headquarters at various periods during the war were Lyda Anderson, Florence Patterson, Virginia Ward, A. Maury Carter, Adeline H. Rowland (Mrs. Robert Gourlay), Josephine Johnson, Sarah Addison, Barbara Sandmaier, Lulu J. Justis, Charlotte Brewer, Adelaide Tennant, May Claypool, Charlotte Garrison, Elsbetli H. Vanghan and Marie Roder.

In that memorable summer of 1917 , thousands of letters inundated National Headquarters. Many were deeply touching in their genuine desire to help; others were full of war-hysteria ; some were shoeking in their unconsciously displayed reversal to the frame of mind of the massed audiences at thrilling moments of the gladiatorial combats of the Coliseum:-all effervesced with "patriotism." One woman stated as her chief reason for volunteering that "her family had always taken an active part in disturbanees of the nation." Another wrote:

Will yon arept my services as an mprofessional nurse? I am a woman 3.5 years old, lave a quiet disposition, a clean character and always keep my nerve under some very tryine rirenmstanees. I work every day on a milk wagon, so you see I an strong and not lazy.

$\Lambda$ commercial firm wrote:

Kindly furnish us with lists of names and ardresses of the nurses who are members of your organization.

I pon reecipt of your reply, we will he pleased to send you a full-sized hottle of our best grade of malted milk for your trouble. 
The flood of letters had, indeed, begun even a year before, and was stemmed very largely at first by the steady work of volunteers. Of the first staff of faithful volunteer helpers, Miss Delano had written :

During the summer of 1916, there was such an enormous increase in the correspondence coming to the office of the ('hairman of the National ('ommittee on Red Cross Nursing service. that it was found impossible to conduct the work withont a great increase in the office force. Believing in the desirability of utilizing vohnteer workers for hed Cross service, we asked loor the assistance of varions groups of women who had had our "surwe of instruction in Elementary II ygiene and Ilome 'are of the sick and others interested in lied Cros: work.

Among the first to volunteer were Miss Joan Ohls and Mrs. Callan ('laughlin, why (ame to us when the pressure of work was greatest, and helped us to conduct a mailing bureau through which thousands of letters and circulars were sent out. Both Miss Ohls and Mrs. O'laughlin ame to the ofliee daily through the greater part of the summer.

Mrs. (i. s. Meloy and lls. Richard Wetherill, of Lanham, Daryland, cane regularly for several months, giving to the Red C'ross an entire lay each week. They were of the greatest assistance, as they helped in many letails of office work requiring a high degree of aceuracy. 'They were assisted from time to time by Mrs. F. N. Wells, Mrs. Eilgar Brown, and Miss ('ross, also of lanham. Marrlant: the Mlisene stemalrt. of Washington. 1). ('.. and Miss Engenie J. Cuthbert, of ('hery Chase, Maryland.

IIr. Robert Waleott Weeks devoted practically the entire summer to linel ('ress work in the oflice of the chairman of the National committere on Red ('ross Nursing Service, roming als regularly als ally other member of the office staff, assisting in erery way posible.

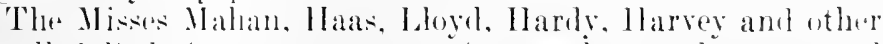
enrolleal heal ('ress nurves ame frequenty as volunters and

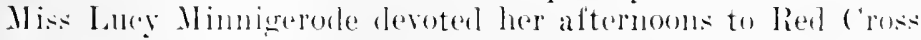
work, taking als her spectal taks the semelinge out of appeintment earels and batgers to enrolled Red ('roses nurses.

Volunteer secretaries of this callihere were regularly arailables throngh the crisis and many were called upon.

By september, 1917, more than 5,000,0(1) people had been

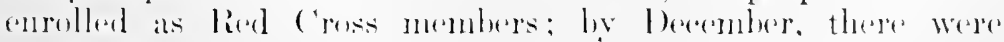

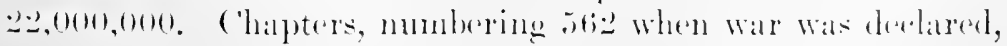




\section{HISTORY OF AMERICAN RED CROSS NURSING}

totaled 3,700 one year later, with a quota of 8,000,000 volunteer workers, a man-woman-and-child power such as no other organization in the world conld claim. This brought, however, an inealculable anount of detail to National Headquarters, which would have been entirely "swamped," had not the War Comncil created the new organization plan called "deeentralization, with Division offices." National Headquarters had maintained a branch oftiec in New York City as early as 1912, the budget appropriations for which were contained in the Minutes of a meeting of the Execntive Committee held Decmber 30 of that year. As the need for Red Cross disaster relief increased, the following action was taken by the Executive Committee, meeting October 31, 1913:

Mr. Bicknell then presented to the rommittee a sncrestei plan for the extension of the atministrative eflicieney of the Red Cross in organization and emergency relief. The plan, as outhined, involved the employment of four Division directors or superintendents, to be stationed in each of the following prints: San Francisco, Denver, Chicago and New York or IIashington. . . A Ater some discussion by members of the committer, (ieneral 'Tormey moved that the tentative plan submitted by Mr. Bicknell be authorized. Motion seeonded by Mr. Tammer and adopted. ${ }^{2}$

When imperative need for greater administrative machinery arose in 1917, the new "decontralization plan" elaborated this principle through thirtern instead of fom districts. It was described by Mr. Davison as follows:

The word "derentralization" in this rase resolved itself into the partitioning of the Inited states into thirteen divisions, each division a smalter lied ('ross, with all its departments and bureans under a divisional chief and a force complete in every drail with the varions lines of endeavor firmly and clearly outlined. When once the foundation was (omplete, the Il'ar ('omncil had 110 more to do with the ('halpters or any of their activities, alve in the way of judging the needs, devising metheds and fixing standards. The ('hapter's busines was regulated in the department to which it belonged by the divisional offierers. The Division manager was . . . to his divison what the general manager in Wakhington was to the contire organization. Washington Headquarters was now free to prowent with the hamblling of the larger problems ${ }^{2}$ Mluntes of the Execution Committen, Anerican led Cruss, page 368. 
which were daily growing to greater magnitule and importance. $^{3}$

Miss Delano and Miss Noyes appointed in each Division prominent murses who handled all nursing details in their immediate states. Only vital questions of policy were referred to National Headquarters. This group of "l)ivision l)irectors of Nursing," representing as it did strong women of reeognized standing in their districts, comprised the very backbone of the Nursing Service. Through their hands passed all applications for enrollnent received from Local Committees, all management of class instruction, publie health nursing, early surveys and other details. (On their shoulders rested the ultimate responsibility of recruiting the many thousands of murses requisitioned by the Surgeon General. To them came, too, the wellnigh overwhelming demands for nurses for the inthenza epidenic.

Miss Delano ontlined thus the relation of the nursing representative to the Division manager and the Bureau of Nirsing at National Headquarters:

As the sucess of the Nursing Service and our alitity to secure the nurses in the large number likely to be needed during the period of the war depends entirely upon maintaining the interest and enthusiasm of the cratuate murses throughout the country, it seems to me of primary importance that the person in charge of the Division Burean of Nursing Service should be a lied Cross nurse and should be in truth the representative of the Nursing service. She shonld be appointed by the chairman of the Sational committee on Fied ('ross Yursing Service, subject, of course, to the approval of the Division manager.

Furthermore, since the direction of all the artivities of the Bureau of Nursing Sorvice within the jurjsoliction of the Division will be in charge of this person. it is highly important that we secure the services of murses who, by reason of their education, experiencer, profesional standing, exerutive ability and knowledere of enditions in the Divison. will he highly qualified to fill these imporiant positions. I beliese that this

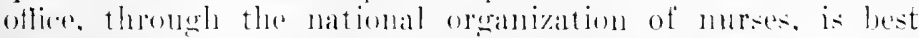
prepatres to serelle the qualified presonnel.

Ill professional phates of the work of the Division Director

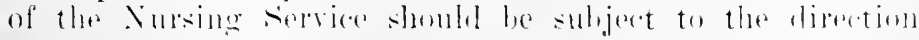
s."The Ameriean lied cross in the cireat War," pages lo-17. The Macmillan C'omlyam!. 19!!?. 


\section{HISTORY OF AMERICAN RED CROSS NURSING}

of the Bureau of Nursing Service at National Headquarters, for only in this way will it be possible to maintain the necessary standards and uniform policies of the Red Cross Nursing Service.

It will be necessary for the Division Director of the Nursing Service, in administering her Bureau, either personally or through her functional assistants, depending upon the extent of the activities in her Division, to:

(1) Supervise Chapter work as related to nursing activities and advise Chapters on matters of policy and practice pertaining to nursing service as preseribed by National Headquarters.

(2) Supervise instruction of personnel within her Division and coöperate with Chapters and committees on Red Cross Nursing Service on matters relating to enrollment of instructors.

(3) Supervise the organization and administration of Chapter instruction in Elementary Hygiene and Home Care of the Sick and in Home Dietetics.

(4) Adrise and coöperate with Chapters on matters relating to class equipment.

(5) Study and advise on methods of promoting enrollment in classes.

(6) Coöperate with Local and State Committees on Nursing Service in promoting enrollment of Red Cross nurses.

(r) Summarize periodic reports relating to activities under the Nursing Service as received from Chapters and compile Division reports of these activities for the Division manager to transmit to National Headquarters.

(8) Perform such other duties as may be designated by the Bureau of Nursing Service at National Headquarters.

In the December, 1917, issue of the Journal, Miss Delano reported the appointment in Oetober of these Division representatives. Elizabeth Ross, a graduate of the Newton Hospital, and a public health nurse of high standing, served in the New Fingland Division, which included Maine, New Hampshire, Vermont, Massachusetts and Rhode Island. Miss Ross had organized the Nursing Center of the Woman's Municipal league of Boston and had also acted as supervisor of the Forwood Civic Association.

Carolyn ('. Tan Blarcom (Johns Hopkins) resigned as seeretary of the Illinois suciety for the Prevention of Plindness to represent the Nursing sivice in the Atlantic Division, which inchuded New York, Connecticut and New Jersey (exeept 
Camden). Of Dutch descent, she was possessed of keen organizing ability and of brilliant proeesses of thought and expression. At varying periods of her useful career, she was assistant superintendent of murses at lier alma mater, then superintendent of nurses, St. Luke's llospital, St. Lonis, superintendent of the New Bedford luberulosis Sanatorium and secretary of the National Committer for the Prevention of Blinduess. Uंpon her arrival in June, 1917, at Atlantic Division Headquarters, New York City, she immodiately set up the organization of a nurses' equipment division for the base hospitals then embarking for France and to her acumen was largely due the establishment of the efficient svstem which characterized this important detail of mobilization for foreign service. Another conspicuous piece of her work was the reeruiting of hundreds of Red Cross and Army nurses then in New York who marched in the historic first Red ('ross parale of the antumn of $1: 117$. During the later part of that year, Miss Van Blareom undertook a speaking tour of the United States to interest nurses in emrolling for war service, after which ill health necessitated her resignation from Red Cross service.

Florence Merriam Johnson followed Miss Van Blareom in January, 1918, as director of nursing of the Atlantic I)ivision. A graduate of Smith College and of the New York Hospital, she had been commected with the Cornell University Medical Dispensary, New York: had done social service work for the New York Association for the Improvement of the Condition of the Poor; and for the Harlem Hospital. She later became a member of the filculty of the Department of Nursing and Health, Teachers College, Columbia Lniversity. Her remarkable serviee in faldiliting the embarkation and debarkation of nurses in foreign serviee bronght her the Florence Nightingale Medal of the International lied Cross. A woman of poise, intelligence and great charm, she combined swnpathetic warmth of personality with firm exerutive ability to such an extent as to make her one of the most "alpathle and well-loved murses of the "yomnger generation" which the war bromght forward.

The Pennsylvania lovision, which included the Korstone State, Delawile, and ('amelen, New dersey, was represented by Susan Francis (Roating Hospital, Pennsylrania). She was linge associated with state orgatnization work and with arly

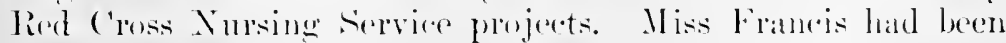




\section{HISTORY OF AMERICAN RED CROSS NURSING}

superintendent of nurses of hospitals in the City of Washington, in New Orleans, and in Philadelphia.

Georgia Marquis Nevins came to the Potomae Divison (District of Columbia, Maryland, Virginia and West Virginia) after twenty-three years of service as the head of Garfield Memorial Hospital, Washington. Her name has appeared more than once since an early point in our text, in comnection with professional progress and growth. She was one of the first class graduated under Miss Hampton at the Johns Hopkins. An ardent sponsor of the Army Nurse Corps and also of the bill for registration of nurses in the Distriet of Columbia, she was at one time president of the National League for Nursing Education, then known as the American Society of Superintendents, and for many years was secretary of the American Nurses' Association. Her Red Cross service began in 1909, as secretary of the National Committee on Red Cross Nursing Service. A New England woman, she represented a type of all the sturdy virtues of that section.

Jane Van de Vrede (Milwaukee County Hospital, Wauwatosa, Wisconsin) was the nursing representative for North and South Carolina, Florida, Georgia and Tennessee. Miss Van de Trede was for nine years assistant bacteriologist of the Department of Health, Savamah, Georgia. As secretary of the State Board of Examiners of Nurses for Georgia, and as viee chairman of the Savannah Red Cross ('hapter, and secretary of the Local Committee on Red Cross Nursing Service of that eity, she brought to her duties a wide, extremely practical knowledge of southern nursing resources.

The Gulf I)ivision, to which I. Agnes Daspit ('Touro Infirmary, New Orleans) was appointed, included Alabama, Mississippi and Louisiana. Miss J)aspit had long been associated with the Red Cross Nursing Serviee, as chairman of the lonisiana State and Iocal Committers. She was at one time president of the Lomisiana State Nurses' Association and ehairman of the Advisory Board of the State Board of Examiners.

The Sonthwestern 1)ivision, corering the immonse distance of Texas, Missouri, Kansas, Mrkansas and Oklahoma, was fortunate in secoring so able and timeless an organizer as Lydat II. Anderson, alreaty known to reader's of this history as supervisor of I nut $K$ of the Merey Ship.

Mary M. Roberts (Jewish Mospital, Cincinnati) served as moning representative in the lalke D)ivision, embrating Ohio, 
Indiana and Kenturky. Both as superintendent of nurses in the Savannah Hospital, and assistant superintendent of murses of the Jewish Ilospital in Cincinnati, she had had long experience in administrative work. As a former president of the Ohio State Association of Graduate Nurses and a member of the State Board of Nurse lixaminers, she too was excellently fitted for the tasks before her.

$A$ child welfare nurse of national reputation, Minnie $H$. Ahrens (Illinois Training Sichool for Nurses; Teachers College) directed Red Cross activities in Illinois, Wisconsin, Iowa, Nebraska and Michigan, the states comprising the Central Jivision. Thongh Miss Aluens' name had been long associated with high standards of nursing education, she was perhaps best known as an organizer and the first superintendent of the Infant Welfare Society, of Chicago.

The Northern .Division, Minnesota, North and Sonth Dakota and Montana had as its nursing representative Edith $\Lambda$. Barber. A graduate of the Garfield Park Hospital, Chicago, IIiss Barber was at one time superintendent of nurses of the Green Gables Sanatorium, Lincoln, Nebraska, and a nember of the training school statf of the University of Minnesota.

Lettic G. Wrelch (Illinois Training School) was appointed to the Mountain I)ivision including Colorado, Wyoming, New Mexico and Utah. Formerly superintendent of murses of the City and ('omnty Hospital, Denver, she had served for several vears on the Colorado state Committee on Red Cross Nursing service.

Tillian L. White (Protestant Episcopal Hospital, Philadelphia), also long associated with nursing education, gave up her position as assistant superintendent of nurses of the University of California, to represent the Red Cross Nursing Service in the Pacitic I)ivision, (mul)raeing Nevada, Arizona and California. Miss White lad at varions periods of her career been superintentent of murses of the Knoxville (Temessee) General IIospital: of the Merritt ILospital, Oakland, California, and head of the Bally. Hospital of that city.

Including Washington, Idalıo, Oregon and Alaska, the Northwestern llivison lad as its mursing representative Mar $\therefore$ Lommis (Illinois Training School). She was a surgical nurse of long experience. ('hairman of the Washington State committer on Red cross Nerring Servies since 1915, she gave "P her position as supervisor of nurses at the City IInspital, 


\section{HISTORY OF AMERICAN RED CROSS NURSING}

Seattle, to accept the Red Cross appointment. Miss Loomis was for several years presiclent of the Washington State Nurses' Association.

Following the establishment of the Divisions, the Exeeutive Committee voted on December 6, 1917, to ereate the Department of Nursing, combining moder one exeeutive all phases of the nursing program. Miss Delano beeame the director, her rision of a lightened responsibility and a country home relinquished for the time, and the representatives in the Division offices were given the title of Dirision Directors of the Department of Nursing. 'This organization was put into effeet in the spring of 1918. Miss Noyes, who had been on a speaking tour sinee December, 1917, returned to National Headquarters in February, 1918, and beeame director of the newly ereated Burcau of Field Nursing, through which the selection and assigmment of all murses for war duty, either military or civilian, were carried out. Some of the ehanges then ocemring have already been mentioned. The reorganization of the Town and Country Nursing Service will be spoken of under its own chapter heading.

With the National Committee on Red Cross Nursing Service acting in an advisory capacity, with the strong Headquartrers' organization at Washington and with eorresponding Departments in all l)ivisions, the Red Cross Nursing Service now faced the greatest mursing needs of Ameriean and world history. From its inception in the satatered efforts of the Civil and spanish-dmerican wars, its peale time development from 190! to 1917, one step toward more eomplete oromization had followed fast on the herels of another, until the creation of the lepartment of Nursing marked the final perfection of this great "marebine." so refliciont and withal so silent and unobtrusive, that fow indecel realize how vital and far-peaching were its workinges and low great its results in the alleviation of human suffering.

The National ('ommitter on lind Cross Nursing serrice guiderl the policies of develepment of Ameriean Red Cross mursing serviee. The members of the National Committee who served at the outhreak of the war were Jane $d$. Delano, chairman: William ('. (ioreats. Sureenen General of the Army: IV. C. Braisted, Surem General of the Nary: Riupert Blue, Surenon General of the Pnhlir Ilealth service: Amnie Goodrich. president, American Nurses' Association; S. Lillian Clay- 
ton, president, National League for Nursing Education; Mary F. Beard, president, National Organization for Public Iealth Nursing; Colonel Jefferson R. Kean, Director of Military Relief, American Red Cross; W. Frank Persons, Director of Civilian Relief, American Red Cross; Hajor C. H. Comnor, Director, Bureatu of Medical Service, American Red Cross; Dr. T. W. Richards, Director, Burean of Naval Service, American Red Cross; Clara D). Noyes, Direetor, Bureau of Nursing Servier, American Red Cross; Fannie F. Clement, Jirector, Bureau of 'Town and comntry Nursing Service, American Red ('ross; Emma II. Gunther, chairman, Committee on I)ietitians; (appointed for three years) Nabel 'T. Boardman; Mrs. Wm. K. Draper, New York City; Mrs. Wm. Chureh Osborne, New York ('ity; Mnna C. Maxwell, Presbyterian Hospital, New York City; Mary E. Gladwin, Akron, Ohio; Mrs. Frederiek M. 'Tiøe, (Hicago; Lillian I). Wald, New York City; M. Adelaide Nutting, New York City; Auy Hilliard, BeHlevue Hospital, Now York City; Susan C. Franeis, Philadelphia; Louise M. Powell, New York City; Jane E. Nash, Baltimore: (appointed for two years) Julia Stimson, st. Louis; Emma Nichols, Boston City Hospital ; Dora E. Thompson, head of Army Nurse ('orps; Lenah S. Iighee, head of Nary Nurse Corps; Ella Phillips Crandall, New York City: Georeia M. Novins; Anna L. Rentingere, New York City ; Elizabeth (x. Fox. Visiting Nurses' Association, Washington : Iarricet Lecote. Clevelandel. ()hijo; Amme II. Strong; Simmons Colleace, Boston : (appointed for one yoar) Alma E. Wrigley. Pasarlena, Cal.: Carrie .1. Iall, Peter Bent Brigham Hospital, Buston; Lucial Jalepuith, Memerial IJospital, Woreester, Malss.; Annal ('.

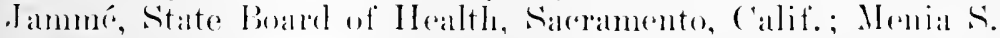
Tre, Sparks Momerial Ilospital, Jt. Simith, Ark. Emmal.

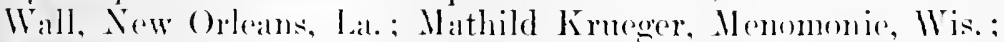

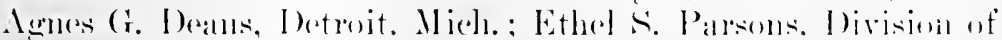
Health, San Antonio, Texas: Mary C'. Wheoler, Hlinois Train-

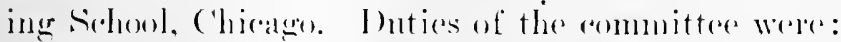

1. 'T'o oremize and supervise the Xursing Service of the

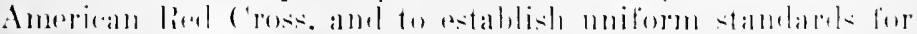

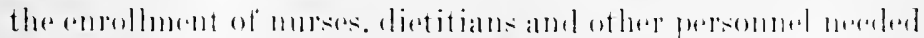

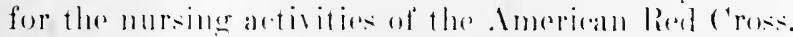

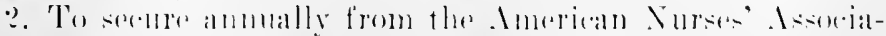

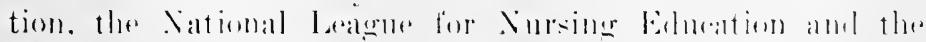

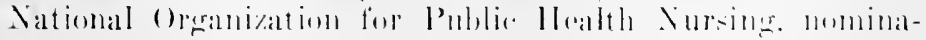




\section{HISTORY OF AMERICAN RED CROSS NURSING}

tions to fill vacancies as they occur in the National Committee on Nursing Service and to submit these nominations with recommendations to the Central Committee for appointment.

3. To appoint, annually, State Committees on Red Cross Nursing Service, of not less than six members, who are enrolled Red Cross nurses from names subnitted by the executive committee of State Nurses' Associations. When possible, the nurses selected should consist not only of members of the American Nurses' Association, but of training school superintendents and public health Nurses. In order that the work of committees may not be interrupted, a complete change should be avoidect.

4. To appoint such committees, not otherwise provided for, as may be neceswary to supplement the work of the National Conmittee, and to specify the duties of all committees.

5. To issue the necessary instructions, circulars of information and blank forms of application for the enrollment of the Red Cross personnel of women.

6. To appoint loral headquarters recommended by Local Committces where lists of enrolled nurses and other personnel may be kept on file. Such headquarters should be preferably registries for nurses, or training school oflices.

7. To pass upon all applications for enrollment forwarder to Red Cross llearquarters and to issue cards of appointment and lied Cross badges or pendants to nurses meeting the requirements, to issue cards of appointment to approved dietitians and to anmul the appointment of any member of the Nursing Service for caukes which it may deem sulfieient.

8. To keep a carl catalogue of all committees and of local nursing headquarters with a list of all murses and other persomel on file with each.

9. 'To keep on file lists of Sisterhoorls and other orders, and women volunteers avalable for lied c'ross relief work involving the are of the sirek or wounded, either in time of war or ealamity, the names of lied Cross nurses employed by chapters, other Red ('ross organizations or those anthorized to use the Red ('ross insignia, together with the names of members of the Army and Nary Nurse ('orps who are aloo enrolled lied choss nurses and to refor the latter to Local Committes when their term of service expires.

10. T'o provide, in erojperation with the modial departments of the Army and Nary, instruction for curolled nurses in such special dutios as wonld be required of them in time of war.

11. To adont courses of instruction for women other than nurses, which will ald in the alo of the sick in their own 
homes and prepare them to render assistance, as required under the superrision of the Nursing Service of the Red Cross.

12. 'To study the Nursing Service of the leed Cross in this and other comntries; to report on the efliciency and needs of our own services and make such recommentations to the central committee as the exigencies of the service may indicate.

13. 'To adrise conceming the administration of the Town and comntry Nursing service, to interest nurses in this phase of lied Cross work, and to aid in securing opportmities for the sperial preparation necessary to qualify for Red C'ross Service as public health murses.

14. 'To make recommendations to the Central Committee of the American Red ('ross in regard to the selection of Directors of Bureans of the Nursing Service, and other nurses employed at lied cross lleadquarters.

15. 'T'o share with the Direstors of Nursing Bureaus the responsibility for the assignment to enty and supervision of all personnd included in the Red Cross Nursing Service.

Details of the time of ammal meeting and other routine matters completed the sehedule. The duties of State Committers were thus defined:

16. State Committees consist of not less than seven members, appointed by the National Committee, from names submitter by the exerntive eommittee of State Nurses' Associations at the time of their ammal meeting, such members to be enrolled lied ('ross nurses.

1\%. 'To appoint anmually such Local Committees on Red Cross Xursing service as may be needed for the enrolhment of nurses in their own state and to designate the chaiman of each eommitter. . .

19. 'To hare general supervision orer Local committees and to stimulate interest in the Red cross Nursing service.

?0. 'l'o report all local ('ommittees appointer, and racancies filled, to the ehairmam of the National (ommittee. giving the nomes and adldesses of all members, and indieating the ehairman and seretary of each Committere

?1. |'This reane dralt with moetings and reports.]

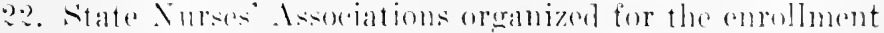

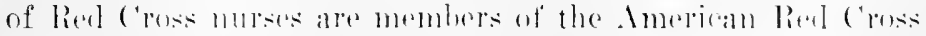
and entitled to he pepresented hy one delecalte at the Amoual Aleeting of the liowl ('ross.

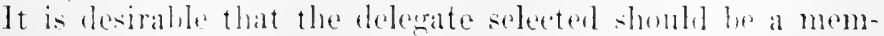




\section{HISTORY OF AMERICAN RED CROSS NURSING}

ber of the State or a Loeal Committee on Red Cross Nursing Service.

Local Committees consist of at least six nurses appointed by State Committees on Red Cross Nursing Service.

The duties of Local Committees on Red Cross Nursing Service were:

23. To make recommendation to the National Committee as to the appointment of hearquarters, where a list of en rolled nurses and other persomnel of the Nursing Service may be kept on file, such healquarters to be preferably registries for murses or training school offices, as it is important that a place shonld be selected where nurses may be seeured at all times day and night.

24. To issue circnlars of information and blank forms for enrollment to appliants, and to decide whether applicants fulfill the requirements and are desirable.

25. To receive applications for the enrollment of nurses and to secure the required credentials except from nurses interested in the Town and Country Nursing Service, whose applications should be forwarded direct to Red Cross Headquarters, Washington, D. C., where credentials will be secured. ${ }^{*}$

Of the numbers and activity of the Committees Miss Delano said, in the Annmal Report for the year ending December 31, 1917 :

In addition to the National Committee, we have fortycight State conmittees and one huncled and two local Committees on Red Cross Nursing Service, four state and thirty-four local Committees having heen appointed since Jannary 1, 191\%. About one thousand nurses are serving the Red Cross gratuitonsly on these committees.

After the war she wrote of the work of the State and Local Committees :

To the State Committees on Red Cross Nursing Service, and the Local committees representing local nursing organizations, the Nursing somine of the Red Cross owes much during the past years. The laree murolhnent of Red Cross nurses was due in a sreat part to the actirities of these committers. Approximately one thomsand graduate nurses are serving cratuitoms as members of State and Local Com-

A. R. C. 159, July 12, 1917. 
mittees on Red Cross Nursing Service, and the value of their services cannot be overestimated. During the period of the war, these committees held frequent meetings to pass on the application of thomsands of murses and salerifiend their racations, and often their positions, in order to do this rolunter work of the Red Cross. When the need for nurses for active service became pressing, during the perios of the war, the Nursing Service of the Red Cross appointed on its local (ommittees those women especially who were mable to acept active service, but who had given generously of their time and money to arry on this important part of the hed Cross work. These Local ('ommittees in this way prepared thonsands of nurses for active service; advised them in regard to their home conditions and their release from positions; and it was only throngh their coöperation and assistance that the work at National Headquarters was made possible.

The size of the National Committee on Red Cross Nursing Serviee and the widely-separated locations of its members made it imperative to have a small but efficient Executive Committec. ()reanized .Inly 2:3, 1917, this was composed of any members the'n stationed in Mashington, with the presidents of the three national societies of nurses. This small committee shared the responsilility of the problems of the Red Cross Nursing service as they arose day by day.

Soon after the appointment of the War Comneil by President Wilson on May 10, 1917, its chairman, Mr. Henry P. Darison, arranged special conferences designed to bring the different Red cross l bepartments together to eonsider nursing problems and to make recommendations in regard to the Servire. On this committee there were representatives of the IVar C'onncil; the Red Cross Committee on Coüperation; the Red ('ross Medical Advisory Committee; and the National Committe on Red ('ross Nursing Service. I)r. Simon Flexner, Chairman of the Red ('ross Medical Advisory Committee presided at a meeting of this conferenee which was held at Ifead(puarters, July 2:), 1917. A nmmber of members of the $X_{\text {il- }}$ tional committere an Nursing Servier had been invited to atterd. 'Therse present were: (from the Red C'ross National

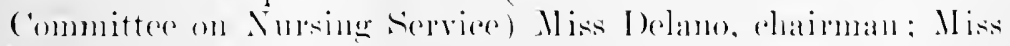
Noyes, Director, Burean of Noming Serviee: Miss clement,

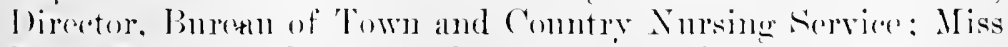
Iay, Director. Burean of Instruction for Women: Miss Haills: Mrs. William K. Mraper : Miss Nutting: Miss Good- 


\section{5+ HISTORY OF AMERICAN RED CROSS NUURSING}

rich; Miss Beard; Miss Clayton; Miss Wald; Miss Hilliard; Miss Thompson; Mrs. IIigbee; (from the Red Cross Committee on Coöperation) Judge Robert S. Lovett; Messrs. A. D. Hodenpyl, George Wharton Pepper, Edward D. Butler, John F. Moore, and L. K. Frankel; (from the Red Cross Nedieal Advisory Committee) Doetors Biggs, Chapin, Flexner, Kerr, Rose, Rran, Rosenan, Smitl, Pearee and Richards; (from the War Council) Messrs. Davison and Wadsworth.

The entire field of mursing needs and desirable standards of nursing qualifications for Red Cross war enrollment was thoroughly gone over. It was agreed that there was no immediate shortage in well-trained nurses and that the Red Cross was adding to its available rescrves in every way that foresight could dietate. It was found that the real erisis of the nursing situation lay in the future and that while present needs were being met the war demands would inerease rapidly and it was of the greatest importance that well educated women should be urged to take the nurse's training. At the end of the conference the chairman (I)r. Flexner) was directed to appoint a small conference committee to meet on a later day in that same week and settle finally, if possible, the war nursing policy of the Red C'ross in regard to the standards for enrollment and to report its conchusions to the War Council.

Dr. Flexner appointed Miss Melamo, Miss Nutting, Miss Beard, Dr. William H. Weleh, Dr. Herman M. Biggs and Dr. Winford II. Smith.

On Friday, July 27, all exeept Dr. Weleh and Dr. Biggs who were mable to be present, met at Red Cross IIeadquarters. Dr. Flexner took the chair and Dr. R. M. Pearce (of the Iedical Adrisory Committee) acted as secretary. The conference eommitte examined its nursing problems in a frank and thoromgh-gning way and in due time its report was laid before the War Comneil and aecepted by that body. The questions considered were:

1. Size of hopitals in which nurses are trained, i.e., arerage number of patients per day.

$\therefore$ Ine limit at the time of enrollment.

3. Early graduation of clasese in (a) three year, (b) two year shools.

4. Short training rourses for ailes. 
5. Public health nurses-should they be urged to decline service with hospital mits abroad?

\section{Hospital training schools.}

The committee discussed first the Red Cross requirements for enrollment in its nursing service with such modifications as have been foumd necessary to meet war conditions. The chairman of the National ('ommittee on Red C'ross Nursing Service reported that in coöperation with state Boards of Registration provision has been made for the acceptance of graduates from schools recommended by the Boards as giving sufficiently thoronglu training to qualify such graduates for War service. This molification has been made, she reported, without a definite requirment as to the size of the hospital. It is estimated that approximately five hundred training schools will be adkled to the acceptable list through this change.

\section{Age limit of enrolling nurses.}

The chairman of the National Committee on Red Cross Nursing Service also reported that the age limit for enrolling nurses has been reduced to twenty-one years and extended beyond forty years. depending upon the qualifications of the individual murse in each case.

\section{Early graduation of nurses.}

The question of an earlier graduation of the pupils already in training in orler to increase the supply of nurses, was discussed. It was the opinion of the sperial committere that schools giving a three year course of training might later, should the exigencies of war make such action necessary, be requested to ad value the date of graduation.

Miss Xutting submitted a report of the elforts now heing made by the committee on Nursing of the Comeil of National l)efense to increase the output of the training schools. In coopperation with the Red Cross it has addressed an appeal to college women and to graduates of technical schools. high and private schools, ureging them to enter training schools as student murses in training, and thus aid in meeting the need of ejvil hospitals as woll as supply a large bofy of women of exeptional ability trained for the reconstruction work which will follow the war.

The chaiman of the National committere on lied ('ross Nursing service reported that provision has been mate for a complete listing of the morsing sistorhoods thromerhout the Inited states. I questiomatere is to be sernt to there si-terhoorls to determine the approximate number of nursing sis- 


\section{HISTORY OF AMERICAN RED CROSS NURSING}

ters and lay Sisters trained in their hospitals who are available for Red Cross service. Provision has also been made to utilize colored nurses for service in caring for colored troops in base hospitals and the Red Cross will enroll such nurses as needed. It was also reported that the Red Cross has organized committees for the enrollment of nurses in Hawaii, the Philippines and in France, in order to utilize American nurses resident in those regions.

4. Training of nurses' aides.

The system of training nurses' aides was considered. The chairman of the National Committee on Red Cross Nursing Service reported that authority has already been given to forty-five hospital centers around which base hospitals have been organized to provide practical hospital experience to women volunteering as nurses' aides. These hospitals will be urged to complete their lists of twenty-five aides each on first call; and to carry a reserve of twenty-five or more. This will give approximately twenty-two hundred and fifty aides available for service.

A questionnaire is being prepared to send to these volunteers in order to determine how many of them are ready for service, in either the military or civil hospitals in this country. The course in Elementary Hygiene and Home Care of the Sick forms the basis of selertion for admission to this service. and some idea of the possible resources may be gained from the fact that about thirty-four thousand women have completed this course of instruction.

5. Public health nurses.

The question of ntilizing publie health nurses for service both in this comutry and abroad was considered. The rhairman of the National Committee on Rod Cross Nursing Service reported that in order to utilize public health mires to the best advantage a special enrollment has been provided exempting them from ofleer service. Tnder this enrollment publix. health nurses will be held arailable for service in and about military cantomments in this country and for service in activities in Europer.

Summary.

In submitting the foregoing report, the Special Committee on Nursing appointex by the Red Crosis War ('ommeil desires to express its approval of the general plan of enrollment of nurses as adepted by the National Committee on Red ('ross Nursing Sicriae. 'Tlie modifirations included in this plan may be smmmarized as follows: 
1. That the lower age limit for Red Cross nurses be reduced to twenty-one yoars; that the upper age limit be left indetinite, to be dealt with separately in each mase according to the character of the service and the physical qualifications of the applieant.

2. That the requirements governing training schools be modified so as to qualify for Red Cross enrollment the gradnates of sehools which are recommended by state Boards of Registration as giving courses sufficiently thorough to prepare nurses for lied Cross service.

3. That in order further to increase the supply of nurses, the sehools giving a three year conrse of training be requested to adrance the date of graduation of pupil nurses, should the exigeneies of war make such action seem desirable.

4. That in addition to the steps already taken to supply volunteer nurses' aides, which the committee approves, it is recommended that the period of practical hospital experience for these volunteers be increased to one month of eight hours' service each day under the supervision of the Red Cross, and that the Rerl Cross volunteer aides be used for service in our own country only, and that women under twenty-one years of age shall not be selected.

In view of the provision already made for the instruction of rolunteer aides in commection with Base Hospitals and the large number of women who have completer the required course of theoretion instruction and whose names are on file in Washington, the rommittee believes that the immediate extension of this service is not pressing, but approses of the anthorization of aivil hospitals to give this instruction to nursese aides as ueded. subject to the approval and under the direction of the American Rerl Cross. and recommends that only those hospitals approved by the state Boards of Registration of Nurses shall receive such authorization.

5. The committee ajproves of the plan alopted by the National Committee on Red Cross mursing for a special enrollment of public health nurses who shall be held available for public health work under the Rod Cross either in this country or abroad.

This program las bem approved by the oflicers of the Red Crose Nursing sorvios: by officers of the Committes on Nursing of the Council of National Defonse: by Annie Coodrieh. president of the Imerican Nurses Asociation: Wary F. Parard, president of the National (Oranization for Public 


\section{HISTORY OF AMERICAN RED CROSS NURSING}

Health Nursing; S. Lillian Clayton, president of the National League for Nurse Edncation; Amy Hilliard, formerly inspector of training schools in New York State; Dora E. Thompson, superintendent of the Army Nurse Corps; Lenah S. Higbee, superintendent of the Nary Nurse Corps and by the Red Cross Medical Advisory Committee and the Red Cross Committee on Coöperation.

The members of the Red Cross departments were gratified by this endorsement and by the letter that had been written a little earlier by Miss Nutting, here reproduced, for the anxiety and responsibility of executive work often formed an almost crushing burden for Miss Delano and her eo-workers, who, desirous on one hand of maintaining high professional requirements, were on the other under the obligation of meeting every instant necessity in the matter of a supply of nurses, no matter how difficult.

Teachers College, Columbia University, July 16, 191\%.

Miss Jane A. Delano, Chairman,

National Committee on Red Cross Nursing Service, Washington, 1). C.

My dear Miss Delano:

At the last meeting of the Committee on Nursing of the General Medical Board, of the Conncil of National Defense, a motion was passed expressing our approval of the methor of enrollment adopted by the Nursing Service of the Red Cross.

I am very glad to transmit this motion to you and to add that those of us who have watched the careful, thorough work of the past seven years which has gone to building up this important branch of the Red Cross, feel that a rery great national service has been rendered. For not only has there been reated a large body composed of trained, skilled and competent nurses to form the Nursing Service of the Red Cross, but the establishment and maintenance of proper requirements for enrollment in this service have acted as a valuable stimulus to hospitals and training schools in uroring them to improve their standards of training in order that their graduates might be eligible for such enrollment.

In no other conntry in the world has the Red Cross surh a reord. On the entrary, its effort throughout history has cenerally tended to weaken instearl of to strengthen gruod nursing standards, and consequently and inevitably to impair 
the efficiency of its nursing service. It is our hope that you may be able to maintain the high stanclarils you have set for your life-saving work and that our great dependence for nursing the sick and wounded men of our army may continue to be placed upon skilled and capable workers.

Faithfully yours,

$$
\begin{aligned}
& \text { (signed) M. Anelane Nutroxa, Chairman, } \\
& \text { Committee on Nursing, the General } \\
& \text { Medical Board of the Conncil of } \\
& \text { National Defense. }
\end{aligned}
$$

The immediate steps taken during the early part of the summer of 1917 by the National Committee on Red Cross Nursing Service and its smaller executive group were directed toward the one main purpose of inereasing enrollment. To this end, all State Boards of Examiners were urged to amnounce more frequent examinations of graduate murses desiring to register under state aets and to pass upon examination papers with the utmost dispateh so that murses might enroll without delay. State Boards of Registration were asked to furnish the Red Cross with three elassified training school lists, giving in one the names of all those sehools which mot the Red Cross requirements, in another those on the border line and in the third those which were below. Lowal ('ommittees were written to and asked to select nurses for serviee. Letters were sent to a selected group of women in close touch with National IIeadquarters, urging them to take the nurse's training. A special committee of nurses in Now York ('ity, all of whom were Red Cross members. and who afterwards hecame leading figures in the Committer on Nursing under the Comneil of Nittional Defense, muderteok to aronse oducators and educational institutions espevially and so to direct large mumbers of applicants to training schools.

With the end of the war the exeentive committen of the $\mathrm{Ka}$ tional Committer an lied ('russ Nursing Serviee summed up its meetings and recommendations as follows:

Eight meetinge of the perentive enmuttes of the Sational Committer on lime ('ross Xursing service hase been beht since its anthorization.

Artion was taken on the following questions. in arch in-

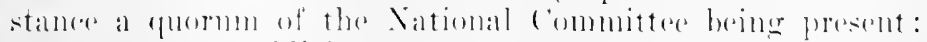

1. Pan for publicity campaign-begimning with a sydi-

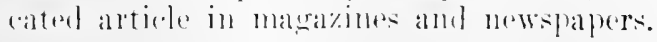


2. Definite request to be made to the American Red Cross for an expert publicity man to assist the committee.

3. Resolution adopted and sent to the president of Vassar College on establishing a preparatory course in nursing for college women (Vassar Plan).

4. Letter submitted to the Surgeon General's office requesting that some action be taken to combat the rumors of nurses returning from Europe pregnant.

5. Nurses not eligible for active military serrice and in charge of training schools for nurses to be enrolled as recruiting agents.

6. "Special enrollment" for nurses through Divisions for Home Defense (physically unfit for military service, over age, married and those holding important positions who should not be disturbed).

\%. Cniform of Dictitians.

8. Recommendation that receipts from the Metropolitan Life Insurance Company for Town and Country Nursing be paid to the organizations supporting nurse, rather than to Headquarters.

9. Pecommendation that Miss Clement, Director Town and Country Nursing Service, draft all recommendations with her personal opinion regarding the further development of rural nursing.

10. Service Flag.

11. Coöperation with the Toman's Committee of the National Council of Defonse in their campaign on Infant Welfare, as far as possible.

12. Plan to secure rank for nurses.

13. Circularize Poards of Recristration for Nurses and State Associations: circularize the superintendents of training schools for murses: armalarize the sisterhools: arenlarize the non-reristered nurses: aromlarize the sulseription list of the Amerian. Journal of Vursing.

14. Prepare plans for publicity campaign and lameh as soom as the committere on publicity (consisting of thairman of National committere on lierl ('ross Nursing Service and representatives from the thres national organizations) derederd it was practical and if posible immediately following the drive for loiberty Bumls.

The most important details covered ly some of the above resulutions will le dealt with in later pages.

Of all the subjects named in the list above as taken up by 
the National Committee on Red Cross Nursing Service, none was more perplexing than that one alluded to in paragraph four. Elusive whispers of scandal touching lied C'ross nurses and gruesome tales of mutilation suffered by them, reached the Nursing Service early in 1917, persisting thronglont the war and ren after the Armistice. "The Red cross files have an extraordinary series of lotters written to Miss 1)(elano or sent to her by the reeipients, with her answers. The letter's, usually written by friendly loyal persons, related with indignation yet often, too, with misgivings the alarming rumors. Fifty such letters, analyzed for the purposes of this history, may be thus summarized. The rumors foll under throe heads. First,that Red Cross nurses abroad lad beeme victims of forcible ontrage by enemy soldiers, or even by Allied officials, and that numbers of them (the numbers, always mentioned, varied from fifty to several hundred) had become pregnant and were being brought home to be cared for in American hospitals. Names of hospitals, especially two well-known ones in New York City, were sometimes specified. Second,-that Red Cross murses, as a result of forrible ontrage or personal immorality, or both, had become infected with renereal disease and were quarantined at a French port, usually named. In this legend also the numbers ran high; the writer personally heard that nine hundred such victims, all murses, were behind stockades at a locality in France. Third,- that Red Cross uurses had come back to their homes witl eyes gouged out, tongues slit, or hands and toes cut off.

It soon became elear that these rumors ennstituted a definite propaganda, arising from an unknown source. This might have had one of two purposes; one, to add fuel to the flames of hatred against an enemy; two, to retard the enrollment of nurses in the Red Cross and thus endearor to ront off' at its souree the supply of nurses to serve in military hospitals.

The Committee on Nursing Service conchuded that while both purposes were served, the latter was the one directly aimed at and indeed, while enrollment was not prevented, its andse was often made infinitely difficult by the pepular reaction to the rumors.

The Nursing Serviere, desirous of avoiding publicity in the daily press as tending to assist the propagandists, took up each report separately as it reached IIeadepuarters. Surh worl nsially rame in from some mure or Red ('ooss member' indignant, 


\section{HISTORY OF AMERICAN RED CROSS NURSING}

shocked and incredulous, ret having at hand no way of making anthoritative denial. They were then given a categorical denial by the Nursing Service and were requested to obtain and forward to Headquarters the names of persons from whom the rumor was heard, with dates and names of places involved. Every such elue was painstakingly followed up and invariably ended in nothing.

It was, however, learned that the mode of starting the rumors on their way was this: On a railway train of some small railroad, in a remote or provincial region, a well-appearing woman traveler, getting into conversation with other travelers, would modestly mention herself as a Red Cross worker from abroad and would then with deep feeling relate most confidentially the horrid tales, presently alighting at some small town, there to disappear withont trace. Or again, travelers in a far distant locality, again on the railway, would be attracted by the sight of two apparent invalids, so licavily bandaged as to be practically invisible and would learn from a kindly woman or man in charge that they were Red Cross nurses whose eres had been put out, tongues slit, or hands chopped off. In no instance did any one see beneath the bandages.

As these tales were whispered from one to another they sometimes got into local papers and were often given eredence by well-meaning but ill-balaneed persons. Statements based upon them were occasionally recklessly made at public meetings, sometimes even at local Red Cross meetings. An embarrassing detail in connteracting them was that members of another national society of the highest standing more than once disseminated these absurdities, as proving the need of their own ministrations and of the enlargement of their own facilities in the war zones.

The rumors were dealt with almost entirely by the Red Cross. In serral instances the I)epartment of Justice was called on for assistance. One quite prominent woman phrsician was callecl heefore a federal jury and reprimanded and in another case a man was fined $\$ 1000$ and costs. Similar rumors wre set on fout regurding ('andian nurses and forermment rireles in cimadat had the same difternlty in denomeing them. Ther tales were nellally repeated with no malicions intent and were wedl known in nursing eireles, lout there, naturally, were not believerl. The following lettre witten by Miss Delano is a type of the many that she wrote in this comnetion: 
My dear Mr.

December 4, $191 \%$.

Your letter addressed to ..... has been referred to me for reply.

Similar rumors have come to this office from time to time, and I can only assure you as emphatically as possible that there is absolutely no truth in the statement. We have altogether about four thonsand nurses, about three thousand of these in service in France. They are definitely assigned to base hospital units muler military authority, or under the direct supervision of the Red Cross. Of all our nurses in France only two or three have returned, and it would be impossible for any large number to be brought back in the condition mentioned in your letter without the Red Cross being fully informed of the matter.

Would it not he possible to take up quite definitely with T... F..., who has circulated the report, this matter, compelling him to give the source of his information and as a lawyer interested in Red ('ross activities take such stejs as may be necessary to prevent the repetition of this untruth in your conmunity? I can well understand that you would hesitate to do this without definite information from Hearlquarters.

I may assure you that there is no foundation for the rumor. A similar rumor is being circulated concerning Canadian nurses and I wrote to the I)epartment of Militia and Defense, Ottawa, Canala, for a rlefinite statement, which was promptly receired, denying absolutely all foundation for the rumors. It secms evident that it is a definite propacranda which should be mot as promptly as possible. We have tried to aroid any newspaper publicity, as it would only spread the rumor.

I shall appreciate greatly any further information you may secure, and hope for your coöperation in branding such rumors as malicious falsehoods. Appreciating greatly your having written to the lied ('ross direct,

Believe me,

Sincerely yours.

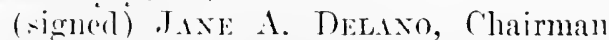

National Committee on Red Cross Nursing service.

As the magnitude of the war tarks became plain, extensive systems of eoördinated coffort were woven into the social fabric and the energices of nurses, lent to the support of the hed cross

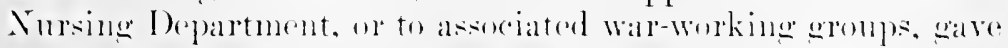
results that are distinctive in international lied Crose mursing 


\section{HISTORY OF AMERICAN RED CROSS NURSING}

history, not only for the bold and original methods adopted, but also for the proof that, even in war emergency, an extensive inerease in nursing personnel is possible, without seriously lowering the hard-won standards of professional competency.

Early in June, 1917, an Emergency Committee on Nursing was organized by Miss Nutting and Miss Wald in New York City to include a number of prominent nurses, all of whom were members of the Red Cross National Committee and one of whom was Miss Delano, as also several prominent physicians, with Miss Julia Lathrop, Chief of the Federal Children's Bureau. The purposes of the Committee were: "to devise the wisest methods of mecting the present problems connected with the care of the sick and injured in hospitals and homes; the educational problems of nursing; and extraordinary emergencies as they may arise."

The founders of this Emergency Committee had been fearful that under the great excitement of war, the usual objects of their care might be neglected and they planned to guard those objects; i.e., the daily mursing of the sick in the homes and hospitals and the teaching and preparing of nurses for their ficlds, while the Red Cross, officially charged by the government to be directly responsible for war nursing would naturally be absorbed in that immense obligation. With the formation of the Conncil of National I)efense (composed of the Secretaries of War, Nary, Interior, Agriculture, Commerce and Labor) an Adrisory Commission of seren speeialists was nominated and appointed by President Wilson. Dr. Franklin Martin, as one of the seven, organized the General Medical Board and this Board took over the Emergency Committee and made it the National Committer on Nursing of the Council of Na-

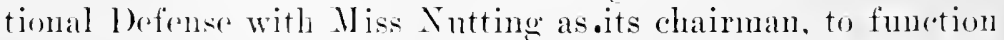
muler the direction of the ehairman of the Gencral Merlical loard. Mr. Martin himself heing chairman of the Committee on Medicine and Sanitation of the Board, came into close correspondener and professional contact with the murses on all the committers. There was also under the Conncil of National I)efenser a subermmitter on Public IIralth Nursing and a committee on Inome Nursing. Miss lelano had a place on each and her sperial part in their eonferenees was to prevent as far as presible overlapping and dupliation of effort, as from her

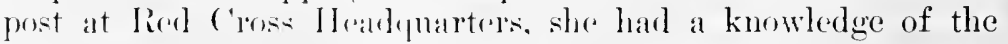

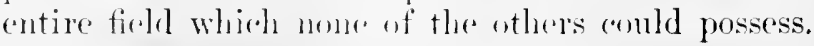


As the national pace speeded up, frictional reduplication of activities was not always preventable and it may be reasonably concluded that the single task of nursing during the war would have evolved more smonthly and expeditiously had the Nursing Committee of the Council of National Defense organized itself for its special interests under the Red Cross (as a subcommittee of the National Committee) and this the more as they were all Red Cross Nurses and the majority of them members of the National Committee on Red Cross Nursing Service.

Miss Nutting's committee, as it was informally ealled, had from the begimning a special "oneern for the underlying educational factor in nursing and to its leaders it could not have seemed otherwise than that they were specially responsible for that trust, for elearly the Red Cross alone, as then organized, could not have cultivated the educational field in addition to its vast administrative domain, but its readiness to coöperate and contribute show that the sceond committee would have had equally wide seope had it been a special Red Cross committce. Miss Nutting's committee stood elose to the educational world and its activities bore the impress of her original and boldly resoureeful mind. Her suggestions and plans gave great impetus to those intensive ret educationally sound courses opened for murses in women's eolleges, in comeetion with hospital training, of which Vassar gave the most highly perfected example, to be presently described and known as the Vassar Plan. In the recruiting of pupils for the training schools, in the movement to induce schools for nurses generally as a war duty to admit eollege women for training on a two-rear instead of three-vear basis. and in the inception of the drmy sichool Miss Nutting's "ommitter did original and distinctive work. Of permanent value to nursing literature are the committec's nine pamphlets, most of which were prepared by Isabel Maitland Stewart, a professor in the lepartment of Nursing and Health at Teachers ('ollege. Their studies of war mursing problems should make them uscful to the lied cross societies and nursing associations of otheremutries as well als to our own.

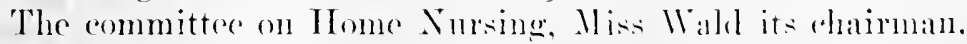
was elosely tied to the Department of Labor and coneerned itself primarily with all alsperts of industrial nulsing. so called, especially in those industries which were engitged in war work, and with strengthening public health nursing in industries and in the homes. 


\section{HISTORY OF AMERICAN RED CROSS NURSING}

The purposes of the subcommittee on Public Health Nursing and some parts of its plans are told in the following excerpts :

This committee was created by Surgeon General Blue for the purpose of relating the work of the public health nurse to the many problems of hygiene and sanitation brought into prominence by the war. These problems are suggested by the names of the other sub-committees of the Committee on Hygiene and Sanitation, for example, the Committee on Alcoholism. the Committee on Venereal Disease and the Committee on Drug Addiction.

The public health nurse must be the instrument which will make preventive medicine effective. It is wise, therefore, to create a body, the function of which shall be to study the changing conditions produced by the war and to be ready to recommend to any given community a plan for establishing a public health nursing agency whenever these changing conditions demand it. First: The purpose of the committee is: To collect and edit material relating to the disastrous effects of the last three years of war on the community health of the European nations at war. Second: To procure information of the present status of community health work in this country and of the extent to which such work is endangered by a state of war, and, further, to procure information as to the need of the greater extension of it by a state of war.

Community health work in areas about the cantonments must be undertaken by public health nurses. Therefore, the Nursing Burean of the Red Cross is asking the help of this committee in enrolling all public health nurses for public health mursing service either here or in Europe, and is further turning to the secretary of this rommittee to alet in an arlvisory capacity for the selection of public health nurses for these areas. 5

This subcommittee aathered important data bearing on public health activitics; made a special census of public health resonrees, agencies and nurses at home: assisted the Red Cross in securing nurses for the sanitary zones surroundiug eantonments; initiated at Teachers College, with the help of Miss Nutting and through sobolarships donated by the Red Cross, the educational preparation for ten nurses necessary in the campaign against veruereal discases rondueted by sureon General Blue; gave impetus to the long-discussed plan of intro-

${ }^{5}$ Report of Subcommitter on Public Health Nursing. November, 1916. 
ducing preliminary public health instruction into the senior vear of training schoels for nurses and was especially prominent in urging that public health nursing should be accepted as the equivalent of artive military duty.

Miss Delano wrote of mursing groups coöperating in mobilization:

The Red Cross is working in close coöperation with the American Nurses Aroriation, an afriliated body with which it has for many year's enjoyed intimate and harmonions relations. I'ractivally all of the curolled Red Cross nurses are inchuded in the membership of this association.

Another organization with which the Red Cross is 1.0operating is the National Committee on Nursing, recently appointed by the Council of National Defense with M. Adelaide Nutting as chairman and Eila P. Crandall as secretary.

The Red Cross is roöperating with this committee in a movenent to enlist joung college women in nursing as a patriotic service. As the Red cross sees it, the big problem is not only providing for the present nursing needs but safeguarling against the possible needs two, three and five years from now. Therefore, it is urging the young women of America to prepare themselves for the most efficient work as nurses by submitting themselves to the training courses of high rlass schools of nursing. Several of our learling schools have agreed to almit graduates of approved colleges, who are otherwise aceeptable as cantilates for nursing, to special courses which will srant them credit for one academic year.

The Red ('ross will rely upon the thonsands of Red Cross Chapters, branches and auxiliaries. the Women's ('ommittere of the C'ouncil of National Defense, and similar organizations of women to supply lists of volnnteer workers when needed. These organizations are already compiling lists of volunteers in the varions communities.

To give a complete list of all the groups and associations that aided the lied Crose Nursing Service would mean, in effect. listing almost all those engaged in war service, but three names that must be esperially mentioned, aside from the national nursing eroups. as coriperating ageneies entitled to special appredation were: the Ameriean Comede of Eduration; the Assoriation of Collergate Almmux: the Enited States Food Administration.

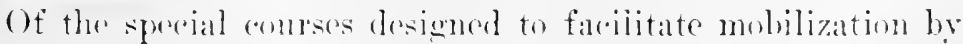
shortening the prodod of hospital training and giving instruc- 


\section{HISTORY OF AMERICAN RED CROSS NURSING}

tion under college auspices, that at Vassar was the first and set the most excellent example to others. The generous intention of the college to offer its ample facilities during the summer of 1918, "as a training school for young women for patriotic service in whatever lines of work offer the greatest opportunities or present the greatest needs" had been declared by resolution at a meeting of the Provisional Alumnæ Couneil on June 9, 1917. The committee who recommended the nursing comrse as finally established were: Mrs. John Wood Blodgett, chairman, Frank R. Chambers and Frank L. Babbitt. To this decision Miss Nutting's commsel had largely contributed, and toward the suceess of the course Mrs. Blodgett's brilliant serviees were inestimable.

The course offered pupils twelve weeks instruction in anatomy and physiology, bacteriology, chemistry, hygiene and sanitation, elementary materia medica, mutrition and dicteties, the psrchology and sociology of nursing, nursing ethies and history, elementary nursing procedures with models, and special lectures. This was combined with a diseiplinary régime and phrsical training. It was followed by two rears of work in selected schools of mursing connected with hospitals. Those consenting to join in the plan were ealled Coöperating Schools and Hospitals.

The Leagne of Nursing Education gave three of its nembers, Isabel M. Stewart, A. M., professor of Nursing, Teachers College, Columbia University ; Elizabeth Burgess, B. S., State Inspector of Training Schools, New York, Edneation Department, and Anne Strong, A. B. (Bryn Mawr), assistant professor of Public Health Nursing, Simmons College, Boston, as an advisory committee to arrange the curriculum in coöperation with the Vassar faculty members. The expenses were also coïperatively met. The Associated Almme of Vassar bore the cost of the publieity and recruting campaigns: the pupils paid moderate fees and the hed Cross War Conneil on January 9, 1918, appropriated $\$ 5$ is,000 for the general expenses.

By the time the Amistien was signed nearly tifty eolleges, as reported by Miss Nuttinges committee, hase completed thrir plans for opening similar comrses to student murses, if such shomld have been made neressary by the eontinnance of the war. Conrses in eight colleges had been formally approved by the Surgeon General.

An cneampment for lay women was that of the Women's 
Seetion of the Navy League next to be mentioned. Its official leaflet gave the following statement of its plan:

The National Service Sichool, Ine., was organized by the Women's Section of the Nary League in 1916, to train American women for the duties which come to them in war times and in other national disasters. The first National Service School was helıl at (hery Chase, Maryland, in May, 1916. Nearly one thomsand students were trained there and the Amerian Red cross, the Army, the Nary and the Marine Corps coopperated in the instruction and running of the school. Thus the instruction and methods used were standard and official and had been worked ont by experts. Since May, the following National service sehools have been held: second National servie School, The Presidio, San Francisco, Cahifornia: Third National Service School, lake Geneva, Wisconsin; Fourth National Service School, Narragansett Pier, Rhode Island.

There were three conrses, any one of which might be selected at the preference of the student. They inchded First Aid; making surgical dressings; signal work; wigwagging and semaphore; knitting and plain sewing; bicyeling; plain telegraphy and wireless; houschold hygiene and home care of the sick.

The question of the instruction of Red Cross murses' aides is rooted in the arly history of the Nursing Service. After the Red Cross became aftiliated with the American Nurses' Association (190()), there had been no mention until the year 1!) 1.2 of the vohutere aide so familiar in Europe. Then, following the Ninth International Red Cross Conference in Washingen, there was a movement to form Women's Detachments on the European plan. This step was questioned by Miss Delano, as shown in the following letter written by her at that time. (Lotter from Miss belano to Miss Boardman, September 27, 1912):

.. I I fo fend that the outline of instruction gives a wrong impresson of the object of the roulse and ratl only repeat what I silial this altermen in regard to the posible dallgers.

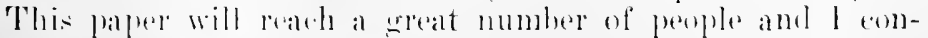

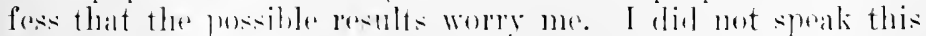

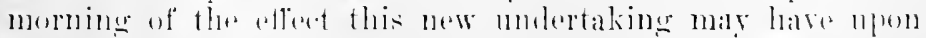

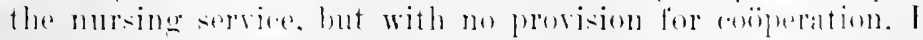

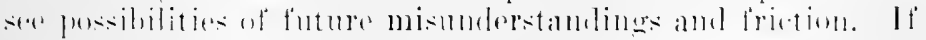


we have Red Cross nursing committees located in various cities and towns throughout the country, working as we hope in coöperation with the Red Cross Chapters, the institutional members and the committees appointed by the American Medical Association, would not this detachment of women working apparently independently, be a source of confusion and misunderstanding? How could one be sure that work would not be duplicated with inevitable friction and misunderstanding? I know so little of the details of this present organization that my opinion may be valueless. but I see nothing to indicate coöperation or definite supervision. In organizing the Red Cross enrollment of nurses and in planning for the rural nursing, it has always scemed most important to me to have the adrice and support of physicians. In the same way, I can scarcely imagine the organization of courses on home nursing without the eoopperation and interest of nurses.

We can scarcely compare the conditions in this country with those in France. The training given their nurses is most inadequate.

In the written schedule of work I am in doubt whether the term "nurse" refers to graduates or to members of the women's detachments. If the latter. I am wondering how it will be possible to teach aseptic surgieal technique in the time allowed for First Aid and home nursing. I do not mean to make diffieulties. I am sure you will believe this, but thinking only of the ultimate good, my mind is filled with doubts and misgivings. I have spent three years in building up the Red Cross enrollment, and have always believed that the success of the Red Cross and its activities depends primarily upon the coördination and the coöperation of all its departments.

Miss Delano brought this subject before the Ameriean Nurses' Convention in 1912 and on November 1t, of that rear, the members of the National Committee on Nursing disapproved the plan of a separate Women's Detachment, but gave unqualified approval to the organization of classes of women for instruction in First $A$ id, home care of the sick and alliced subjects designed to aid women in the care of their own families, and pledged the coopperation of murses for such teaching. ${ }^{6}$

It was subsequently agreed by the Red Cross that independent Women's Intachments should not be organized; that classes for women (except those in First Aid) should be directed by the Nursing Service and that a volunteer service

¿.1merican Journal of Tursing, December, 1912. 
of women, if such should ever be required in war, should be under the direction of the Red Cross Nursing Service.

The classes for women in Home Care of the Sick and Home Hygiene, which later dereloped widely, thus partly arose from the relinquished plan of Women's Detachments. With the threatened warfare of the Mexican border, 1916, and the establishment of base hospitals there, the National Committee on Red Cross Nursing Service, at a special meeting during the Convention of the American Nurses' Association at New Orleans, 1916, had agreed that the nurses' aides, if needed, should be a responsibility of the nursing profession, which they would not evade, provided that their teaching and duties were justly defined in relation to the actual eare of the sick.

"Yolunteer nurses' aides" were, in fact, ealled for in 1916 and their status was thus defined by Colonel Jefferson Randolph Kean, Director of Military Relief:

Tolunteer Nurses' Ailles. Provision has been made for the assignment to our base hospital units of a limited number of women who are not nurses by profession. They will serve without pay but may be furnished with transportation, lodging and subsistence, when the unit to which they are attached is called into artive service. Nurses' aides will be prepared for duty under the supervision of the nursing service of the Red Cross and will be required to take at least the course of instruction in Elementary IIygiene and Home Care of the Sick and pass a satisfactory examination in the same. It is also desirable that they take such other courses of instruction as may be provided by the Red ('ross. The chief nurse of the hase hospital unit will be responsible for the selection of all nurses aides attached to her unit and will, if necessary, arrange for their instruction. When called into service they will serve under the direction of the chief nurse of the unit.

To this explanation Miss Delano added:

Practical experience as nurses or partial training as such (annot be acepterl in lieu of our course in Elementary Hyriene and Home (are of the sick, as one of the chief adrantages of this instruction given by a lied cross nurse is to enable the Red cross by observation to judge of the qualification of those taking the course and their probable fitnes for service.

"Miss Delano in 1 moriman Journal of Tursing, September, 1916. 


\section{HISTORY OF AMERICAN RED CROSS NURSING}

While most lay women volunteering for service imagine themselves giving aid on the battlefields, as a matter of fact they will not be assigned to duty within the zone of military operations. 'Their chief sphere of usefuhness will be iu supply roonı, linen rooms, diet kitchens, laundries and the wards of base hospitals located considerably in the rear of military operations. Assignments to duty both of nurses and nurses' aides will, in all cases, be made through the Red Cross Headquarters, Washington, D. C. ...

As the organization of Red Cross base hospitals progressed, the National Committee on Red Cross Nursing Service, at a meeting held in New Orleans in April, 1916, recommended that practical instruction for nurses' aides be limited to seventy-two hours a month, for three hours daily in the morning in consecutive days, Sundays and holidays excepted. This training was optional with the parent hospital anthorities and these volunteer aides formed no part of the eivilian hospital staff except when as a base hospital unit they were ealled into active service. The following guide to practical instruction which was prepared by Miss Noyes as one of her first duties in the Nursing Service in September, 1917, was recommended by the National Committee:

Service in Wards: Sweeping and dusting; cleaning lavatory utensils; (rleaning, airing and making beds; care of soiled linen; are of rean linen, blanhets, rubber groods: sorving trass, feeding helpless patients; serving water and nourishments: washing nourishment dishes; preparing patients for the night; (are of heads: bed baths.

Service in Surgical Supply Room: Preparation of surgical dresings. mending rubber gloves; preparation of goods for sterilization.

Service in ('outral finen Room: Folding, examining and stacling linen; sewing on buttons, tapes; assisting with exchanges.

Service in comnection with Operating-Room: Asorting and folding linen; dusting and rleaning: cleaning rubber gloves and instruments; admision to operations not approvert.

Service in hict Kitchen. Sewing looms and Laundry ma be arranged for such nurses aides as have indicated special preferemere for work in these departments.

Additional singerestoms. (areful records as to hours and duties performed, interest displayed and attitude toward 
the service shonld be kept. As service with a base hospital in time of war is a serious one, it is important that the aides solected to accompany such should be women of dignity and purpose. In order to maintain interest, the practical work may be repeated earh year. Conlerences with appropriate talks or lectures inight be holl during the interval between practice periods. Iermanent vacancies which mily occur should be filled from the reserve list and under these circumstances the muster roll may be signed by card.

When the United States entered the World War the National Committee on Red Cross Nursing Service on April 28, 1917: "recommended that courses in practical work for lay women shall be given in hospitals selected by the Nursing Service and that such courses shall be on the same basis as plamned in connertion with base hospitals" and the following regulations were agreed upon:

The term "Red Cross nurses' aide" is applied to those women who have voluntarily pledged themselves to service after meeting the following definite requirements of the Red Cross:

First: The satisfactory completion of the course in Elementary IIygiene and Ifome Care of the Sick, anthorized by the Red ('ross (A. R. C. 70).

Second: Selection for service and eight hours daily of practical hospital experience for one month (this was later extended) in a hospital authorized by the Red Cross.

\section{Selection}

Women who have had the course in Elementary Iygiene and Home Care of the Sick may be recommended for service as nurses aides by the chief nurse of a batse hospital unit. ly the superintendent of the training shool of the hospital aromel which a mit may have been organized, or by a Ilivision I)irector of Nursing. The final derision rests with the Department of Nursing, American Red Cross, Washington, D. C.

\section{Qualifications for Service}

1. Age. Preferably between twenty-five and thirty-five. $\therefore$ Freetom from home ties which might intertere with unintermated serviee. Inmarried women or widews will ho given proferenes in assignment to duty.

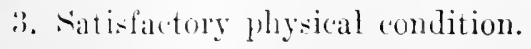




\section{HISTORY OF AMERICAN RED CROSS NURSING}

4. Adequate education and credentials.

5. Special fitness for such work.

Exceptions to these general requirements may be made by the Department of Xursing in the case of candidates possessing special qualifications. ${ }^{8}$

In midsummer, 1918 , the direetions relative to nurses' aides were sent ont by the Department of Nursing as shown in the following letters:

To

From Director, Department of Nursing,

Subject: Placing Nurses' Aides in Service.

It has been decided by the War Conncil that the Red Cross should, through its Divisional officers, midertake at once the training of a sufficient number of nurses' aides to meet the needs of the Red Cross in Europe. This personnel is not intended in any way for service in military hospitals, but to supplement the work now being carricd on abroad in the care of refugees, infant welfare work, and similar activities conducted under the anspices of the Red Cross.

The assigmment of nurses' aictes as provided for in this letter and the accompanying instructions must in no way interfere with the enrolling of Red Cross nurses for service under the Army and Nary, or under the iled Cross. The War Department has asked us to increase our assigmments of nurses to one thousand a week, and it is most urgent that the greatest effort be directed to meet this requirement.

Each Division Director of Nursing should arrange immediately to recommend two hospitals located in the Division, to be selected as schools for instructing applicants for this work. In making this recommendation it is, of course, essential that you consult and secure the approval of your Division manager. In order to avoid duplicatien of work, it is suggested that hospitals at which this experience is now griven, be recommended. Only hospitals having training schools for nurses, which are on the accredited list with the state Boaris of liegistration and are in other respects acceptable, will be considered. If necessary, in order to reach a conchusion, final decision in the selection of the hospitals where this experience is to be given may be requestel from National Headquarters.

You should secrire the service of a capalile lay woman and any necessary alditional ascistants (also lay women), to assist

${ }^{8}$ A. R. C. T07, Instructions for Nurses' Aides. 
you in the supervision of the selection of nurses' aides. It it is expected that nurses aides will be recruiterl largely from women who have taken the Red Cross course in Home Care of the Sick. A part of this assistant's duties, therefore, could inclucle the development and stimulation of interest in this instruction course.

In each of the two hospitals in your Division, there should be under instruction continuonsly twenty-five selected candidates for nurses' aides. Only women should be selected for such experience as give promise of being desirable for assigmment, and otherwise meet the requirements preseribed.

The aceompanying instructions for the livision Bureau of Nursing provide the necessiry procednre for recruiting and supervising the instruction of candidates.

After receiving the required hospital experience, eandidates will be enrolled for foreign service under the direction of the Division Burean of Norsing and the Division Bureau of Personnel will participate in the enrollment and assigmment of murses' aides in the manner prescriber by the aecompanying instrutions.

'T'en copies of the "Memorandum Routine for Placing Nurses" dides in service" are forwarded herewith and an initial supply of forms is being forwarded by express to the Division office. A complete copy of the Routine should be transmitted immerliately to the Division Bureau of Personnel. Tery truly yours,

(signed) JANE A. DELixo, Director, Department of Nursing.

Approved: G. E. Scott, Acting General Manager.

To Division Directors of Nursing.

August 29, 1918.

In my letter of August 6, I stated that the War Council desired the selection of two hospitals in each Division to give practical experience to women who have lad our course of instruction in Home Care of the sick and who are willing to arepet service as needed. I realized that there might be difficulty in securing the admision of twenty-five pupils to each of two hospitals. and that it would probably be easier to use a larere number of hospitals. arimitting fewer pupils. 'The decision in regard to two hospitals was. however, based on a refuest from the surgen cienerals office. Satisfartory arrangement: have recently been made to allow for a change of plan. leavine the bivision l)irectors of Nursing. in consultation with the Division managers. free to make such selections of hospitals as they think most desirable, without 
reference to the number of hospitals admitting pupils. It is, however, understood that fifty women will be admitted each month for the required period of hospital experience, making six hundred women to be prepared as nurses' aides each year in your Division. While the Red Cross wishes to have this number arailable for serrice through the Division offices, it is impossible to guarantee assignment to duty.

As they will be used for service abroad under the auspices of the American Red Cross, largely in France, they should have a conversational knowledge of French. It is, therefore, suggested that as far as possible a tentative selection of desirable women be made, even before they begin the course of instruction in Home Care of the Sick, and that they be urged to review and perfect their knowledge of French in order that they may be eligible for admission to the hospitals for practical experience, upon the completion of the course in Home Care of the Sick. It is the desire of the Surgeon General's office that we should admit for practical experience in hospitals only such women as have a conversational knowledge of French.

Yours very truly,

\section{(signed) J ANe A. Delayo,}

Director, Department of Nursing.

The orders coming from the War Department regarding nurses' aides were variable. Aides were first called for, then countermanded, then called for again. They were not, however, in the end placed in military service through regular channels either at home or abroad. When the Red Cross organized its extensive civilian relief service in France, many aides served there as secretaries, interpreters, friendly risitors, etc., with great acceptability. In all, up to July 1, 191s, fifteen hundred nurse's aides enrolled and were assigned to active duty with the Red Cross. Their motives and spirit were excellent and as most of them spoke French and were gently reared women of social tact, their nsefulness was often very great.

As the cantonments of the United States were developed. a tide of popular emotional demand for voluntere "nurses," with a short course training, marde itself frelt and was difficult to stem. It was finally comteracted by the plan for an Army School of Nursing to be described in another section.

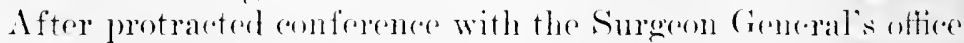
during the carly summor of 1918, the Red Cross Nursing 
Service made an attempt to organize a group of Reconstruction aides, women especially trained to give remedial exereises, cither in physio- or ocenpational therapy, preseribed for the care of patients in hospitals and other sanitary formations of the Amy. Lists of nurses expert in this specialized work were first collected by Miss Noyes. A tentative plan of the Red Cross embraced the training of college women in these branches. Josephine Samulers, of New York, was finally given an appointment in the Sureon General's oftice to develop these groups entirely within the War Department, but the Red Cross cooperated with the Amy in mobilizing them, as is shown in the following description of these aides and their field of work:

At a meeting of the War Council held .Tune $2 \%$. 1918, the following rote was passed and communicated to Miss Delano:

VOTED: That Appropriation No. - - for the purchase of equipment. including miforms for the outfiting of nurses he, and it is herewith amenled to cover Reconstruction aides (female) who are being ordered for service overseas by the Surgeon General's office. with the understanding that the Director of the Department of Nursing shall confer with the Otfice of the sinrgeon General of the Army as to the necesiary uniform and equipment.

The War Department wrote to Miss Noyes:

I am enclosing a rircular sent to Reconstruction aides regarding orerseas and domestic equipment. Please let me know if this ments with yomr alploroval.

I am having mineographed a signed anthorization without which no aide shomld he allowed to purchase equipment at cost from the lied cross.

\section{(signed) Fraxk B. Gisinger.}

Through the Burean of Nurses' Equipment in Sew York City,

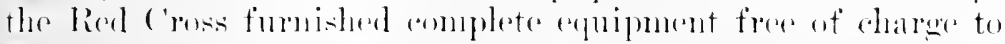

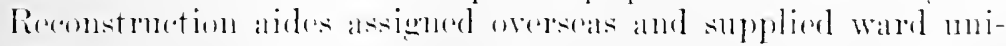
forms at ant to aldes cmployed in drmy hospitals in this romitry.

loaders and assistants in recrational theralyes a highly expert and speredalized form of aid to invalided soldiers. hath

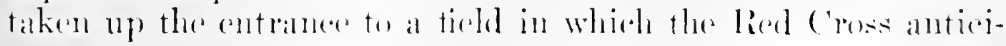




\section{HISTORY OF AMERICAN RED CROSS NURSING}

pated developing an extensive and useful service. These plans wero, however, terminated with the Armistice and subsequent reconstruction of the Army hospitals.

On April 23, 1917, the Red Cross Committee on Nursing Service considered the whole aspect of the public health nursing service in its relation to the war and at subsequent meetings throughout 1917, the exemption of public health nurses from military service always called forth lively discussion. A subcommittee of the National Committee on Red Cross Nursing Service was accordingly appointed, which recommended a plan by which various groups of nurses then performing essential service were placed in a Special Service group.

There were already certain groups of nurses who were regarded by the Red Cross as exempt from active military duty, i.e., those at Red Cross Headquarters and in Division offices; Chapter supervisors; members of the Red Cross State and Loeal committees; members of the Red Cross Town and Country Nursing Service, and those holding important positions in hospitals, training schools and public health organizations.

The Special Service group as now defined gave public health nurses, as well as those serving in hospitals, a recognition similar to that accorded the nurses who enrolled for war nursing. Such reeognition had been asked for by the subcommittee on Public Health Nursing of the Council of National Defense (Miss Beard's eommittee), on May 28 when it reeommended to the Committee on Hygiene and Sanitation the advisability of seeking to obtain, from the Council of National Defense, a "pronouncement" recognizing public health mursing as a war service.

Brief extraets from the correspondence between Miss Delano and Miss Beard give the elearest statements of this special enrollment. Miss Delano wrote, September 12, 1917:

In riew of the probable demand for public health nurses for work in the zones surrounding the military cantonments and possibly for public health work in France, the National Committee on Red Cross Nursing Service has provided for a special enrollment of publit health murses exempting them from other service. as has already been done for the nurses enrolling as instructors.

It would seem desirable, however, that a communication he sent from the subcommittee on Public Tealth Nursing or the General Medical board of the Council of National Defense, 
bringing the importance of this service to the public health organizations' attention, and urging that they release a certain proportion of the nurses upon their staffs for enrollment with the Red Cross for this service. I will in turn communicate with our Loral ('ommittees authorizing them to enroll nurses for this special service.

In response to this letter Miss Beard sent to the various organizations for public lealth nursing a questionnaire, and an appeal, in which she said:

So pressing is the immediate need for carefully selected nurses for public health duty that the Red Cross has asked this committee to send out an appeal to public health nurses to enroll in a special ('lass exempted from all other service. 'This does not mean that a public health nurse may not enroll for other duty.

It will be a high mark of patriotism to serve in our own country. It may even become the supreme test of devotion to remain at one's regular post of duty. It is certain that the greatest discrimination must be exercised in the "selective draft" in order to avoid disrupting or seriously depleting the home work while providing. from the already inadequate ranks of public health nursing, our full proportionate quota for war duty wherever needed.

This committee urgently requests you to answer the enclosed questionnaire within three days of receipt and begs that your decision he made in the light of the nation's two great equal needs, i.e.: first, to guard the health of our soldiers and sailors and those of our allies; second, to protect our home defenses in the face of new dangers and increased demands. ${ }^{9}$

The regulations framed and issued by the Red Cross Nursing Service in regard to this special group were these:

1. A nurse shall be eligible for enrollment in the Special Service eroum, providing she is an enrolled Red C'ross nurse. eligrible for active duty, yet holling a position in which in the opinion of the Red Cross she is more raluable at present than

- A. R. C. file. September 15. 1917: also Reports of Miss Nutting's committee. The questionnate askerl for: 1. Name of organization. 2. Names of staff members indispensable lorally. 3. Members who conld be spared and when avalable. 4. Clatrater of serviee rondered by each. 5. Names of members then in active dnty with the Red cross. 6. Names of those enrolled. 7 . Those who had applied for enrollment. S. Those intending to apply for enrollment. 
in war service. Nurses physically or otherwise disqualified for active war service are not eligible for this enrollment. . . .

4. A committee appointed by the Division Director, Bureau of Nursing Service, shall act upon applications and shall issue a chevron to each nurse whose application has been approved.

5. The names of all nurses in the Special Service group will be forwarded to the American Red Cross, Department of Nursing, at Washington, in order to prevent the assignment of these nurses to active war service.

6 . The Special Service enrollment of a nurse relates to the position she holds at the time the cherron is issued. If a nurse changes her position, the person, organization or institution which employs her shall immediately inform the Bureau of Nursing of the change of status and shall also return the cherron. Nothing shall prevent the filing of another application should the nurse assume a new position in which she may be essential to a community.

Before making application for nurses in the Special Service group which entitles them to the chevron, ronsideration should be given to adjustments with the view of conserving graduate unrses, i.e.:

1. For utilization of student nurses wherever possible for positions as head nurses, social service and visiting nurses.

2. Consideration of other assistants to graluate nurses, such as Home Defense Nurse, and attendants.

The Sipecial Sorvice ('herron is to be issued by a committee appointed by the 1)ivision director to such enrolled Red Cross nurses as are fit for active service but are fulfilling important responsibilities in their present positions.

After the committee has granted a chevron 10 call for active military service will be sent a nurse, without consultation with the Board by whom she is cmployed. By establishing this "Cherron sieprice" the hed cross hopes to give nurses and organizations a freedom to deselop the most important teaching in training schools and in public health renters in order to eonserve the health of our own enututy.

If a nurse is not physifally fit for active serrice or has personal responibilities that make it improsible that she should go, she should apply for enrolment in the Home Defense.

The form of the letter sent by the Department of Nursing to public health asiociations was:

In view of the very great demands for nurses for military service and considering the many nurses disqualified for this 
serviee, the committee respectfully recommend that every institution prepare now to meet the even greater need in the future and wherever possible, a nurse eligible for military service and now exempt from such service be substituted by one who is not qualifired for such serviee. Our mursing resources being limiterl surh readjustments will be absolutely neeessary.

II ith the assurances that the Department of Nursing of the American Red Cross has the interest of your institution at heart, I beg to remain,

$$
\begin{gathered}
\text { Very truly yours, } \\
\text { (signed) Jane A. Derano, } \\
\text { Director, Department of Nursing. }
\end{gathered}
$$

The form of the letters sent to murses entering the special service group was:

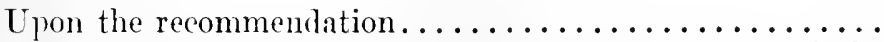
you have been placed in the Special service group of the American Red Cross Nursing Service and you are temporarily exempt from artive military service. You are herely privileged to wear the enclosed cherron until such time as you are released for active service. I am,

With good wishes for the suecess of your present work,

Very sincerely yours,

(signed) Jaxe A. Delano,

Director, Nursing service. ${ }^{10}$

The form of the letter sent to nurses eligible for a special service eherron was:

I note that you are holding an important position at present and since it is the wish of the Nursing service of the American Red ('ross to disturb as little as possible the work of organizations such as yours, I am writing to learn if it is your wish to be onsidered for exemption from artive military service at present?

We wish to ascociate all our good nurses definitely with the Ameriman lied fross and are therefore placing nurses holding important positions in al special service eroup, is-ming to them a chesron to wear clenoting their exemption from active military service temporarily.

I juldere from your appliation that this is your desire but sincer we and inly ronsider such requests upont the recommendation of the heal of the institution. I will ask you to ${ }^{10}$ Special servien group. Xo. 5. 


\section{HISTORY OF AMERICAN RED CROSS NURSING}

forward the enelosed to your president. When this blank is properly filled out and returned to us, this recommendation will be acted upon by the Committee on Exemption and you will be duly notified.

The Red Cross assumes that the president of every institution and every nurse keeps in mind the fact that with many nurses disqualified for military service, readjustments must be considered whereby every nurse eligible for active military service is substituted for by a nurse not so qualified.

Awaiting your attention to this, I am, Sincerely yours,

$$
\begin{aligned}
& \text { (signed) JAxE A. Defano, } \\
& \text { Director, Nursing Service. }{ }^{11}
\end{aligned}
$$

An interesting example of the response met by these letters is the answer of Arehdeacon Hudson Stuck, Fort Yukon, Alaska:

September 18, 1918.

... In accordance with your suggestion of August 18 addressed to our one remaining nurse, Miss $N-$ at St. Stephen's Hospital at this place, I make request that a "Special Service chevron" be granted her.

This hospital, located a mile above the Arctic Circle, is the only place where medical relief can be obtained in something like fifty thousand square miles. The nearest physician up the Yukon is at Dawson, three hundred fifty miles distant, the nearest one down the river is at the Army lost Fort Gibbon, another three hundred and fifty miles away. Ind in all the wide winterland, northward to the Arctic Ocean and southward to Fairbanks, there is no nurse. The explorer Stefansson, lying ill at Herschel Island, had himsclf hauled four hundred miles by dog-sled to reach our little institution.

Niss $X$. has been urged by her conscience and by some of her friends to give herself up to war work. She would, however, be fortified in her resolve to remain here, I feel confident, did your organization distinguish her from mere slackers and absentees by the award of your "Special service chevron."

- Another special group mobilized by the Red Cross was that of the Home Defense nurses. The most important details of their enrollment plan are given:

1. Purposes of Enrollment:

The lied ('russ I lepartment of Nursing recognizes that in every commmuity there are graduate nurses who for some "Special Service group, No. S. 
reason are not eligible for military duty but who are able to renler valuable service in connection with emergencies, inchuding local disaster, all forms of visiting and instructive nursing, institutional work, and as instructors in Elementary Hygiene and Home ('are of the Sick. A special enrollment for such nurses has been authorized with the designation of Home Defense nurse. This enrollment is not intended for those who meet the regular requirements for enrollment as Red Cross nurses.

... Division Bureaus of Nursing have the responsibility for the enrollment of these nurses.

... An applicant must hold a diploma from an accredited school of nursing in the State from which she was graduated and he a member of the American Red Cross, and able to render some regular service.

... Approved appliants for enrollment will receive a membership badge with a bar bearing the title "Home Defense Nurse." which will be issued by the Inivision Director of Nursing.

. . Nurses who have married or are beyond the age limit, physically disqualified or otherwise ineligible for military duty or other active service, will be conrolled by the Red Cross Division Department of Nursing for their territory under the special classification of Home Defense nurses.

The Red C'ross instituted the Home Defense nurses' enrollument because it believed and still maintains that the skill and experience of every woman who has had a nurse's training must be made available to the nation in some direct way. ... ${ }^{12}$

Miss Delano made special appeals for the Home Defense Service and her prevision was borne out by the experiences of the influenza epidemic. To neet that emergency, married, old, and retired nurses came forth and, as was often declared hy a Red ('ross leeturer, I)r. Thomas E. Green, helped greatly' ti) save the day.

The Army fichonl of Nursing, though not originating with the lied cross, was a prominent feature of the mobilization of nurses for war and in its ineeption and growth was closely woren tegather with the processes of Red Cruss enrollment and assignment for sorvioe. The eonstructive idea which gave rise to the Army Shehowl was Miss Goodrichs, for she had been delegated by the surecon General as rhiof inspecting nurse, with an assistant, also a nurse, to risit and inspect nursing in

13. L. R. C. Lorm 49.5. March, 1915. 
the cantonments. Their appointment had been made in response to a recommendation of the Committee on Nursing under the Council of National Defense and a similar proposition offered by the Hospital Division of the Medical Department of the Council of National Defense. The report made by Miss Goodrich after the inspection included these words: "It is therefore recommended that an Army sehool of Nursing be ereated and that we be permitted to present a detailed plan relating to the same."

The report and its recommendations were considered at a conference of Medical and Army officers and nurses, the latter being Miss Delano, Miss Thompson, superintendent of the Army Nurse Corps. Miss Clayton, president of the National League of Nursing Education, Miss Burgess and Miss Goodrich. Miss Goodrich submitted full plans to the Surgeon General, March 24, 1918, but for reasons of space only a part of her outline can be here given:

A plan whereby through an Army School of Nursing the most complete nursing (are may he provided for the sick and wounded soldiers at home and abroad, for the period of the war and for as long thereafter as the Government may decree. ...

The plan to provide for an easy, constant and almost mlimited expansion of training fields and consequent increase in student and graduate nurses. in order that the arising demands of the service may he fully met.

Through the provision of the stimlent horly to have in the process of training large groups becoming inc reasingly compertent therelsy mabling the release of the most experienced nurses for the foreign and other demanding fields without lowering the officiency of the hase hospitals.

To raise immerliately the stanclarl of the nursing eare of the sirk in the hase hospitals hy the provision of an increased number of jertoms to romder silch are.

The plan an fresented provides that the shool. to he known as the Army sichoul of Nursine shall be lecaterl in the oftiee of the sinrexon General. Through this oflice the enrollunent of the students will take place and all matters relating to the eroneral management of the relhool shall be dealt with. The facolty presider over by the lean of the sehomb is to detemine all questions relating to the comrse of instruction; the eneneral ardministation of the shombl beine cutrusted to

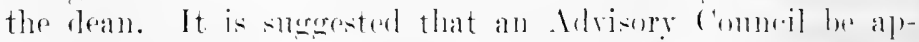
pointerd amposed of members of the Iledical Doplartment; 
the superintendents of the Army and Navy Nurse Corps; the Director of the lepartment of Nursing, American Red Cross; the presidents of the American Nurses' Association, the National Leagne of Ninsing Education and the National Organization for Publie llealth Nursing; the dean of the school of nursing and other members of the mursing profession conversant with the problems of nursing edncation, to make recommendations concerning the appoint ment of the faculty, the relations between the military and civil hespitals and other matters relating to the general policy of the sehool.

In order that the school may come into immediate existence and that as large a group of students as possible may be obtained before the heat of the summer, the committee makes the following recommendations: (1) The immediate appointment of a dean or arting clean of the school. ( $(\%)$ l)etails. (3) That the Reel ('russ Department of Nursing be asked to issue to those who have successfully completed a course in Elementary llygiene and llome Care of the Sick the application blanks and announcement in order that should these applicants desire to enter the Army school of Nursing and should they meet the requirements for admission they may be immediately enrollet. (4-5-6. Details). (7) That the dean be anthorized to recommend for appointment a director, an assistant direetor, a full time instructor, and one or more part time instructors in addition to the regular nursing staff of each base hospital selected as a branch of the school of mursingr.

That the dean be authorized to confer with the commanding oflicer and the chief's of the medical and surgical staffs of such base hospitals as are selected concerning the appointment of medical lecturers and instructors. . . .

The Seepetary of War approved the plan on May 2t, 1918, and the surgeon Gencrial appointed the advisory committee:

\section{War lepartment \\ Oflice of the sureon General \\ IVashington.}

Office Order No. is.

June 5, 1918.

The Ahisury commeil of the Army Sehool of Nursing is herehy alpointent. the members of which shall be ats lollows:

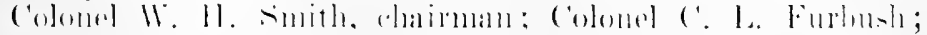

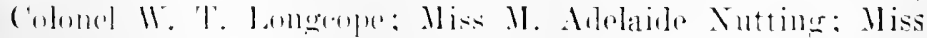

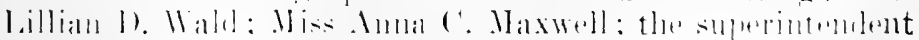


of the Army Nurse Corps; the superintendent of the Nary Nurse Corps; the director of the Department of Nursing. American Red Cross; the president of the American Nurses' Association; the president of the National League of Nursing Education; the president of the National Organization for Public Health Nursing; the dean of the Army School of Nursing.

By direction of the Surgeon General, (signed) C. L. Funbesir, Colonel, Medical Corps, N. A.

At its second meeting, February, 1919, the advisory council recommended placing the school on a permanent foundation by. Act of Congress and submitted this their resolution, together with an outline draft of a suitable aet, to the Surgeon General for his approval. Miss Delano, Miss Goodrich and Miss Thompson were appointed a committee of three to present the plan for the proposed school, but its outline and details as completed followed Miss Goodrich's suggestions.

The Army School of Nursing was made a Division in the Surgeon General's office. On May 27, 1918, Miss Goodrich was placed at its head with the title of Dean and was directly responsible to the Hospital Division.

In a meeting of the Committee on Nursing, Council of National Defense, September, 1918, it was deeided "that a committee be appointed by the chair to develop a program for the participation of the civilian hospitals in the training of pupil murses or hospital assistants for army service in affiliation with the Army School of Nursing." The members of this committee were: Jane A. Delano, Amie W. Goodrich, Lillian Clayton, Ella P. Crandall, Dr. S. S. Goldwater, Colonel IV. II. Sinith.

The first meeting was held on September $20,191 \mathrm{~s}$, and the minutes for that meeting embody the coördination plans arrived at between the Red Cross and the school. From them have been taken only those details which illustrate this adjustment for smooth working and the aroidance of duplication:

\section{Minutes of the Special Committee}

Appointed to develop a program for participation in civilian hospitals in the training of pupil nurses or hospital assistants for Army Service in alliliation with the Army School of Nursing. Conncil of Tational Defense. Washington. I). C., $10: 30$ A. $\mathrm{I.}$ 
September 20, 1918.

The chairman stated the purpose of the meeting and asked for suggestions from thove in attendance. Upon request, Miss Coodricll, l)an of the Army School of Nursing, presented a suggestive plan of affiliation of civilian schools with the Army Sichool of Nursing. . . Miss Delano urged the importance of enrolling afliliated students for military duty through the Red ('ross only and not directly into the Army Nurse ('orps in order to secure a permanent registration of future unrsing for(es; she also urged the enrollment in the licd ('ross of all senior classes peuding graduation, subject of course, to the individuals who wish to be enrolled.

IIss Delano raised the question of enrolling hospital assistants through the hal Cross. While this matter was generally felt not to be pertinent to the main jssue and should therefore be left for consileration with other details of development, the chairman ruled that in the absence of objections. Mis: I) lano's urgent request for its consideration at this time would be granted.

Dr. Foldwater moved as follows: "Resolved that civil hospitals which have the necessary facilities be encouraged to arrange for the training and use of hospital assistants according to the plan ambl qualifications of the Army School of Nursing that such horpital assistants should be enrolled through the Amerian lied ('ross with the understanding that they will arept service as required either in hospitals in which they are trained, with the Amerian Red ('ross, or in the Army Hospitals." The motion was seconded by Miss Nutting and rarried unanimonsly.

Mis: Dolano mored that the students in schools for nurses contemplating attiliating with the Army School of Nursing be griven an opportunity to enroll as Red Cross Student Nurses, such chrollment to constitute graduate enrollment mon completion of this course. and the rerommendation of the dean of the Army hospitals. The motion was seconded by Miss Nutting and carried.

Mi:- Nutting male the following motion: "Having heard from apploxinately three hundred training schools of the (wuntry and appoximately two hundred haring expressed a desion to afliliate with the Army school, this committere alyproves in weneral the plan of atlitiation as presented hy Miss Geoulrieh. Dean of the Army stehool of Xursiner. with the mulerstanding that it is subject to purther moditications as later experience may make advisahle." The motion was seronded ly .thiss (lilyton and arried. 
To provide for the public health nursing instruetion of students of the Army school at Henry Street Settlement, Now York City, the Red Cross through the New York County Chapter contributed $\$ 40,000$ for each of the sehool years of 1919 and 1920. A provision of $\$ 6000$ was also made by the Ameriean Red Cross in San Franciseo with the University of Califormia for the Amy School at Letterman General Hospital. The full details of these gifts are found in the Ammual Report of the American Red Cross for the year ended Jume 30, 1921.

In compliance with a request from the Surgeon General of the U. S. Army, the Executive Conmittee of the American Red Cross on January 13, 1921, authorized the chairman to make available for the New York County Chapter funds not to exceed $\$ 40,000$, or such part thereof as might be necessary to cover assistance through the New York County Chapter to nurses in the Army School of Nursing taking the course in public health nursing at the Henry street Settlement and Teachers College, New York City. This was in continuation of assistance which harl been given through the same channel and under the same conditions during the previous year and was to come, if feasible, from funds which har been set asile by the National Organization for financing the work of the New York County Chapter by special arrangements with this Chapter. Lp to December, 1920, eighty students had taken the course. and serenty-nine more to .June, 1921.

Scholarships amounting to $\$ 16000$ for $1919-20$ were given to Major Julia ('. Stimson. Dean of the Army Nurse Corps to be used for thirty stulents of the Army School of Nursing at the Letterman (iencral Hospital for incidental expenses in comnertion with the course in public health nursing at the Eniversity of California : $\$ 9.90$ were griren in March. 19:2. and $8 \cdot 280$ in August, $19 \cdot 21$, for the same purpose.

The Army school laad an immediate and pronomerel suecess. The foremost rivilian training schools for mmrses atfiliated with it and lye the date of the Amistice, it had 10!ns students on duty in twenty-five hospitals, stit more awaiting assignment and a total of 10.6s:t applications filed. One of the valued pieces of work anemplished by the Red Cress Burean of Information for Nurses, cstablished during clemolilization, Was to refor to rivilian sehools of mursing these atit acerpted caurlielates for the Army soluod. 
Following the plans for the continuance of the Army

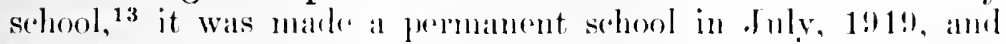
Miss Goodrich then returned to her work at T'andhers College. She was suecerded by Julial (atherine Stimson als deant.

By the carly part of 1918 the Surgeon Gemeral's oflice hat grive'n out the word that fifty thousand graduate and student murses must be enrolled and available during the period up to Jammary, 1!)19.

The Red Cross Nursing Service had already taken definite steps toward enrolling a cluota of five thousand nurses that had been asked for by the sureseon General's office for the period ending Jume 1, 1918. On March 14 Miss Delano reported these steps as follows:

A letter to the superintendents of 2000 or more training schools urging them to increase the supply of nurses for immediate scrvice by ardvancing the date of graduation.

A letter to the boards of registration urging carly examinations and as prompt action upon papers as possible. (The provisional curollment has been anthorized to accept nurses pending the return of the result of their exanination.)

A sperial letter to the State 'Nurses' Assoriations explaining the necessity of elose coöperation with the Divisional directors.

A circular letter was also sent to the ten thousand subscrilers of the Jourmal calling attention to the need of nurses, the Wiar Risk Insurance and the necessity of registration.

A mall enrolluent leaflet las heen sent ont in the exeneral correspoudenese of the livisional direstors and also in the correnomilenee of the American Jourmal of Nursing and to the subseribers.

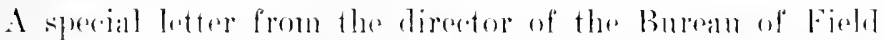

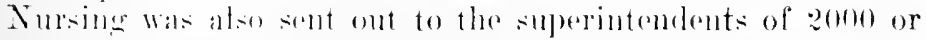

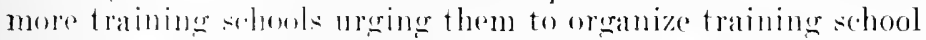

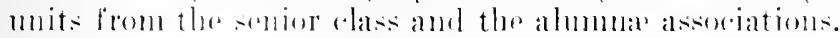

Now in view of the everatly increased rempisitions the Red

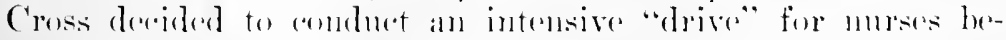

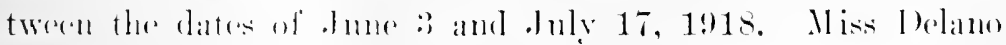
wrote in tpril in the Jourmul:

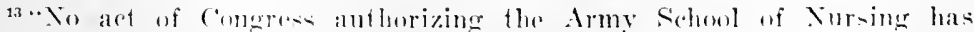

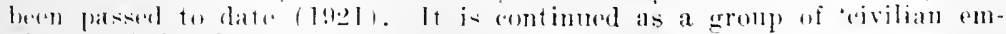

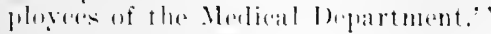

.J. (․ Stimsox. 
The survey which has recently been made [by nursing societies] indicates that there are not more than 65,000 registered nurses in the United States. If we are to meet the needs of the Army and the Nary with registered nurses alone, it will be neeessary to withdraw not far from fifty per cent of the total number of registered nurses. Even though we inelude all graduate nurses who are not registered, placing the total at about one hundred thousand, at least thirty-three per cent of the entire number must be secured, if we are to provide nursing care for our Army and Nary.

In view of these figures it seems evident that a special campaign for the enrollment of nurses must be undertaken, not only to bring to the nurses the great need, but to insure the coöperation and assistance of the public and physicians of the country as well. It does not seem fair to place upon the nurses the entire responsibility of a decision. We believe that the community must share with the nurse the responsibility for her withdrawal from the community and protect her as far as possible from too great a financial sacrifice. The Red Cross is therefore taking steps toward organizing a definite campaign which we hope to undertake in the early spring.

A special committee has been appointerl by the chairman of the National Committee on Red Cross Nursing Serrice, representing the three national organizations of nurses, to aid in preparing the publicity material and in carrying out this special campaign. The representatives of the three organizations are Katharine Dellitt, secretary of the nurses' association and assistant editor of the Americun Journal of Nursing; S. Lillian Clayton, president of the National League for Nursing Education; and Ella Phillips Crandall, executive secretary of the National Organization for Public Health Nursing and of the Committee on Nursing of the Council of National Defense. ${ }^{14}$

The Surgeon General himself wrote an appeal to the Red Cross in behalf of the drive. He said:

$$
\text { Мay } 25,1918 .
$$

I am informed that on the third of June it is the intention of the Ped ('ross to start a Drive for Nurses for the Army.

The American Red Cross is a great recruiting acency for Army Nurses and through this agency I wish to appeal to the murses of the country to enroll for service in the Nurse Corps of the Army.

"Red Cross Department, American Journal of Tursing, April, 1918. 
The need of a great number of nurses is acute, and any assistance the Red (ross can render the War Department in obtaining for the Army Nurse Corps the number of nurses required will be a service to the country.

$$
\begin{aligned}
& \text { (signed) Willim E. Gorgas, } \\
& \text { Surgeon General, U. S. Army. }
\end{aligned}
$$

The machinery used for the drive was very largely the organization of the Red Cross Chapters, which had taken on vast dimensions nuder the war stimulus. In August, Misy Delano summed up the methods used for, and the results obtained by, the drive:

It was decided to call upon the Chapters of the American Red Cross to coöperate in securing the required number (it may not be cenerally known to the nurses of our country that the Red Cross now has a membership of more than $22,000,000$ adult members and 9,000,000 junior members, with 3885 ('hapters, 14,208 chapter-branches, and auxiliaries) : in order that the vital need of our country for nursing service might be brought to prectically every graduate murse in the country. It was understood, of course, that the formal applications for enrollment should come in through the nsinal committees on Red Cross Nursing Service and the Division officers.

This was a new departure, and the results have confirmed us in the belicf that our nursing service will be greatly strengthened by this close contact with the general membership of the American Red Cross. We have found the Chapters throughout the United States most coöperative and anxions to assist, and we fecl that the Nursing service of the Red Cross will be permanently benefited by the relationship which has been established in this way. ${ }^{15}$

Results of the "Nurses' Drive" can best he appreciated by a brief comparison of enrollments during the fiseal year of 19171918 and the subsequent five months terminating November 1, 1918. No method for determining the exact returns of the drive was attempted, but the umparalleled increase in enrollment over previous months was due in large part to this publicity campaign and to the unceasing labors of local Chapters and enmmittees on Reel Cross Nursing Service.

During the fiscal vear of 1917-1918, 11,21:3 nurses were curolled, an average of 817 a month. The impetus of the 15 Miss Delano in 1 merican Journal of Nursing. August, 191s. 


\section{HISTORY OF AMERICAN RED CROSS NURSING}

"nurses' drive" was first felt in June, 1918, when enrollment inereased from approximately 900 to 1500 murses. During July 2664 nurses were enrolled and in August 2700, the highest figure reached during the war. For the five months beginning July 1 and ending December 1, 11,118 nurses joined the Red Cross reserve, an average of 2220 nurses a month-an inerease of almost 300 per cent over previous months and a number equal to the entire enrollment in 1917.

By the autumn many Division directors reported that they had reached and passed their quota, but the cessation of hostilities then made it needless to enroll further members. In speaking before an audience of nurses a year later, Miss Noyes gave some interesting details of the immense and fatigning labor involved in the enrollment and the intensive "drive." Alluding to Miss Delano she said:

Working with her at National Headquarters for over two years, it was my privilege to see something of her devotion to the canse which she served. Many times when we reached the end of a weary day's work and the pressure seemed ahmost more than human power could stand I have heard her say, when asked if she were tired, "Well. I suppose it is no harder for us to die at our desks than for the boys to die in the trenches."

When the Armistice was signed the papers of six hundred nurses were in the War Department ready for assignment and several thousand more had given their date of arailability between that time and January 1, 1919. With the addition of those who had entered the Army (3000) and the Nary Nurse Corps (500) direct, the total number of nurses in service at the time the Armistice was signed was, as nearly as it is possible to estimate. about ?:5,000.

The Army harl asked for the phenomenal number of 25.000 nurses by .January 1. 1919, and $50 .(0) 0$ by the first of June, 1919. Cireat anxiety had been felt on the part of those who were working elose to the seene, as to the posibibility of meeting this demand and at the same time meeting the civilian needs of our Allies and of our own country.

Figures speak for themsetres. The response hy the nurses to the rall of the (o)lors is a (o) ln lusive refutation of any criticism that ther failed to meret their war obligations. It

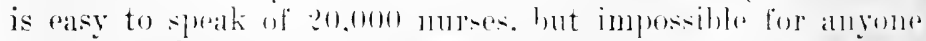
to pieture the trementons amount of work in connestion with the enrellnent and assignnent of these to sorvice. The or- 
ganization at Red Cross IIealquarters had to be developed with the utmost regard for complete coöperation.

In order to prepare a mure for duty with the military establishment it was frequently necesiary to send many communications both by letter and telegram lack and forth before the nurse berame sulliciently stable to refor her papers to the War Inepartment. 'This was necessaly lest some arcilent oceur whereby the transportation which was issued from Washington might go to an aldress at which the murse andel not be found. To prepare a murse for service directly under the Red cross was even more dillieult, as the proratutions adopited by the State and $\mathrm{War}$ Departments before a pasiport could be issued were extremely complicated. Invertigations through the llilitary lutellimence l bepartment for loyalty were required for evergone, and it frequently took weeks and even months to secore the passport of a nurse for overseas chaty with the rivilian population in those romtries that were turning to the Red ('ross for help. I mention thus hriefly. some of the purely rontine procedures that held the individuals in charge of the varions bureans under the Department of Nursing at their desks from early morning mutil late at niglit, holidays and sumdays, from the time diplomatic relations with (iermany were broken until several months after the signing of the Armistice. ${ }^{16}$

The Student Nurse Reserve campaign, like that for the creation of the Army Selool, was stimulated eleetrically by the

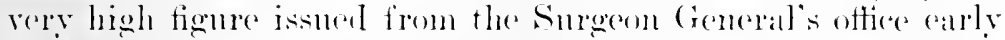
in 1918, in estimating the prohalble need for muses and assistants. A formal statement of the launching of the campaign is fomm in a letter from 1)r. Franklin Martin, member of the Advisory Commission, (omneil of National Defonse to Mr. Henry P. Iavison. It was dated June 27, 1918, and ended with the words:

... Immediately following these reports. Miss Patterson. director of the lloman's Committee. ('ommeil of Xatimal Defense, presented an outline of at amtation, as extensive

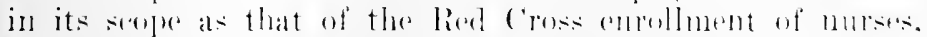

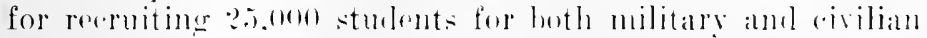

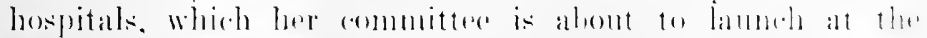

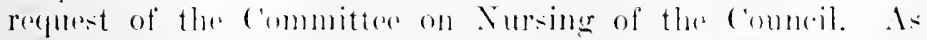

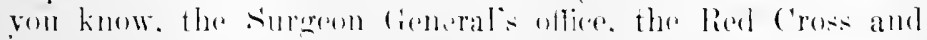

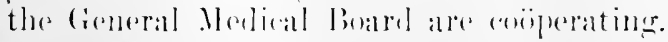

19 The Reel cross Nursing serviee. Twenty-tifth Annual Report. Xat. tional Leagur for Nursing bibeation, 1919. 


\section{HISTORY OF AMERICAN RED CROSS NURSING}

The Red Cross eoöperated by eircularizing all of its Chapters, by opening Chapter offices as recruiting centers and by assigning Red Cross workers to help carry on the campaign. The publicity material was the work of Miss Nutting's committee and was submitted for approval to the Publicity Department of the American Red Cross. An example of the material follows:

The Gorermment is now ealling for 25,000 young women to join the Cnited States Student Nurse Reserve and hold themselves in readiness to train for service as nurses.

Age: The call is for women between the ages of nineteen and thirty-five.

Qualifications: Intelligent, responsible women of good education and sound health are wanted - the pick of the country. A college elucation is a raluable asset and many hospitals will give credit for it. Credit will also be given for a special scientific equipment or for preliminary training in mursing, such as that given in special courses now being conducted by varions colleges and schools.

Enrollment: Women will be given an opportunity to enroll in the Lnited States Student Reserve in any one of three ways:

1. As engaging to hold themselves in readiness until April 1, 1919, to accept assignments to nurses' training schools in civilian hospitals.

2. As desiring to become candidates for the Army Nursing School recently established by authority of the War Department, with branch schools in selected military hospitals.

3. As engaging to hold themselves in readiness until April 1, 1919, to accept assignments to either a civilian training school or the Army Nursing School.

The Student Nurse Reserve campaign was a work of infinite detail and in its course many puzzling and exceedingly complicated obstacles of an educational or ecomomic nature were met with. Its results shed light upon our own profresional problems and may even be found helpful in other countries. For this reason some parts of the final report are here given:

The ontire program as outlined was dependent upon keeping up a larce. stanly smply of canclidates of smperior quality for both oul avil trainine sehorls and the Army seloonl, and it was som evirlent that the batter would aromse great interest and attract luany de-irable applicants. . . .

There are nany ranetical rlifficulties to be overeome. For example miny arammar shool graluates are not eligible 
in the state in whieh they enlisted, and they may be unalsle to bear their expenses even to an adjacent state. 'Thus while racancies still exist and applicants await aplointment, it is often impossible to ac'ommodate either. The large number of reassignments are due (hicely to three causes, i.e.: (a) Latch of information on the application forms regarding denominational preference. (b) Inability of the camdidates to meet the expenses of travel and expipment. (c) Direct recruiting in localities, in many instances, into their own schools instead of through this committee.

Disappointing delays have arisen, dne largely to four causes, i.e.: (a) Incomplete application forms. (b) Incomplete and often inacenrate information regarding age and educational requirements and the number of students needed. (e) An utter lack of precedent for or experience in such a piece of work. (d) lnadequate staff of workers.

Ilowever the fact remains that, whereas in June, July and Angust, many hospital training schools were suffering for lark of sturents, there are now thirteen states (this number was later increased to seventeen), in which needs of all schools have been met.

As the need for large numbers was urgent and immediate, and as fourteen state laws called for only grammar school elucation, the committee thought it necessary not to axilule such applicants in the first drive. Later two years of high school was made the minimm requirement. By common ronsent, the thomsand and more inclicrible candirlates were urcerl to accept positions as attonlants or to enter for training as attemclants in bospitals for the mentally sick, rhildren's orthoperlic hospitals and tuber'ulosis sanitaria, institutions in whirh an almost tragic need of workers existed. Many letters from these institutions have expressed the greatest appreciation of and cratitude for the committec offer of assistance. Cnfortunately very few of these young women were willing to arcept surh service.

A little les: than thirty-three per cent of the andiantes were roferred to the Arny school of Sursing and the re-

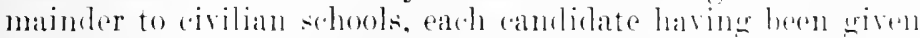
the privilege of rhoosing which she would enter. Even though many states failed to reeruit the necessily numbers to fill all

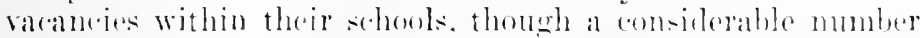
of eamlichates proved ineligible. and though there have heen

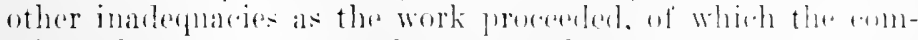
mittere has been constantly aware. there is anple eridence that the almpaign met a very great need at a time of heth

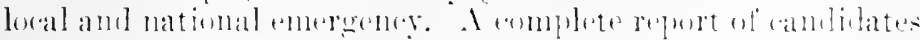




\section{HISTORY OF AMERICAN RED CROSS NURSING}

recruited and assigned has been prepared by states and by schools and copies sent to each state. ${ }^{17}$

The campaign was closed on December 15, 1918. Some 14,000 or more applications were dealt with and of these, 13,800 odd candidates were enrolled for entrance into schools for nurses. Those who met all the requirements numbered 5380 and were assigned to the Army school. To the civil schools of nursing 5185 were directed. The others were on a waiting list. Much was learned of the hospitals. In one state alone, for example, twelve hospital training schools were dropped from the accredited list, as undesirable for the training of Student Nurse Rescrve candidates.

The instructions and demonstrations to volunteers for making surgical dressings for the Army were first given by Red Cross nurses. As the work spread over the country, it was standardized by regulations from the Nursing Service in consultation with Army surgeons. It was estimated that $8,000,000$ women working in Red Cross Chapters made 253,000,000 surgical dressings between $A_{\text {pril }}$ 6, 1917, and October 1, 1918, while for twenty months encling February 28,1919 , the number was 306 ,966,759 . There were more than 30,000 workrooms, where aseptic conditions were maintained as in the surgical workrooms of a hospital. In addition to the dressings, many millions of other articles of clothing and hospital equipment were marle.

When the Mercy Ship sailed at the outbreak of the war, a small group of Washingtonians went immediately to work to prepare surgical dressings for the Red Cross. Admiral M. E. Mason, chairman of the loistrict of Columbia Chapter, appointed a committre composed of Abbie B. and Edith M. MeCammon, Amic Power and Mary Randolph to develop this activity. In a little shop on Eleventh Strect, donated throngh the generosity of Mr. M. A. Leese, they opened on December 1, 1914, the first official Red Cross workroom--the parent of hundreds of supply depots, later set up in libraries, railroad terminals, departmint stores, clubs, Sunday School rooms and remote country schoolhouses.

At a mecting of the National Committee on Red Cross Nursing Srrvice, hodd Junc 20, 1917, in New York City, Miss Delano described the work of this first committee on surgical drossings:

${ }^{17}$ Report of the Committer on Nursing, General Medical Board, Council of National Defense, $A_{\text {pril, } 1919 .}$ 
A circular was issued in 1915 and distributed generally to Red Cross ('hapters. This was used as a basis of work until the publieation early in $1 ! 16$, of a seconml pamphlot intended for United States llar liclicl. At this time, the standard boxes were also adopted and their contents defined. In order to maintain a delinite standard for the preparation of these dressings, we realized that a course of instruction must be adopted. A plan was arordingly worked out and appointment rards authorizing their recipient to art as instructors, were issued to those recommended for this work loy the committees in charge of our surgical dressing workroom.

During the spring of 1916, dlasses were organized not only in connection with our ('hapters but in coopperation with the Woman's Section of the Sary League. It may he interesting to state the method followed in the adoption of standard dressings. In coöperation with the Supply Department of the Red Cross, I visited rarions hospitals in Boston and elsewhere, such as the Boston City Hospital and the Preshyterian and Bellerne IIospitals in Few York City, and selected samples of their various dressings, operating-room gowns, helmets, ete. Wo then serured complete sets of iressings from the Army and Nary Hospitals, so that we had typieal dressings from about twelve different hospitals.

A conference was then held between surgeons and nurses from the Army and Nary. Red ('ross personuel and several nurses who had had experience in Europe. The various dressings were examined and those which seemed common to a majority of hospitals wore selected. A sample box was prepared and submitted to directors of units such as Dr. Crile of the Lakeside llospital in Clescland. Slight changes were made on their surgestions, and the so-called hed C'ross dressings were adopted.

In Septomber, 1916, the responsibility for hospital supplies was turned orer to Miss Noyes. She and Jr. Richards, a representative of the Sary, revised the supply circular, but no radical changes reemed necessary.

Throughout the winter months of 1916 and 1917 , the interest of women in all parts of the Enited States in the preparation of surevical dresinges dereloped berond the rapacity of a central office at National IInadquarter's to handle. Miss Noyes had prepared a special romrise in the making of these

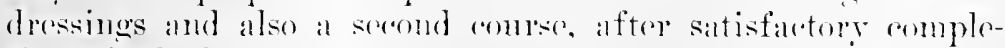
tion of which the sturlent was rertified as beine allo to alet as an instruetor for otlure rassies in the preparation of dressings. 


\section{HISTORY OF AMERICAN RED CROSS NURSING}

Hundreds of certificates, one for the general course and a second for the instructor's course, went out under Miss Noyes' signature to all sections of the country and became the keystone over which the Red Cross workrooms sprang up in schoolhouses, ehurches, clubs and industrial centers.

Before a woman was certified as an instructor, she was required to submit a sample box of the various types of surgieal dressings. No sooner had Miss Noyes examined and eleared her desk of these samples than the Mail Division would send up a hundred more. The top floor of the "Narble Palace" billowed with eotton and gauze. Vashti Bartlett was the first nurse to assist Miss Noves; later, volunteer nurses from Washington lightened the burden of the overtaxed director and her assistants. Among these was Mrs. Charles Silliman (Mary V. Lee, Johns Hopkins). After examination, these innumerable white pads and neatly-folded bandages were passed on in clothes-baskets to Mrs. Theodore W. Riehards, who sorted out the perfect articles and packed them into complete model boxes to be returned to Chapter workrooms.

To zealous women waiting impatiently in Red Cross Chapter and Branch headquarters for their certificates, the Nursing Service may have seemed over-exacting in their insistenee upon perfect dressings. Sharp adherence to standards resulted, however, in great economy of materials and time. Overworked nurses in evacuation and base hospitals, moreover, could not stop to refold a pad whose ravelled edges might result in discomfort and danger to their patients. Great pressure was being brought to bear at this time upon the Nursing Service to change the trpes of dressings to suit the preferenees of individual surgeons. The aim of National Headquarters had always been to prepare a trpe of dressing which anyone could use. As this standard had been reached after eonference with leading authorities of the Army, the Navy and eirilian institutions, Niss Nores turned a polite but deaf ear to protesting physicians who came to interview her. After the Nursing Service lad given orer this work to the Women's Bureau, a special committee went to Europe to study the entire question, and the Red Cross models were later changed.

On June 23, 1917, Miss Noyes wrote as follows to Col. Kean:

Since Tanuary 1, the work of the Surgical Dressings and Farment: Division of the Bureau of Nursing Service has expanderl with great rapidity. Thousands of inquiries are com- 
ing to us from Chapters, branches of Chapters, auxiliaries, groups of workers and individuals who are interested in the preparation of surgical dressings and hospital garments. Every new (hapter and anxiliary at once desires this particular work. Although circulars of information and detailed directions are sent concerning the organization of (lasises and the manufacture of dressings and garments, questions are constantly arising which must be referred to an anthoritative head.

We have divided the country into eight districts-Boston, New York City, Philadelphia, Baltimore, Cleveland, Chicago, Colorado Springs and San Francisco, for distribution of sample boxes of dressings, patterns, emblems and information. As the pressure upon these Chapters has increased, it has seemed desirable to authorize other distributing centers and the following are preparing to qualify as sucli-Atlanta, New Orleans, St. Lonis, Mimneapolis and Seattle.

It would be safe to say that workrooms have not only been established in all of our cities, but towns and country districts have developed in the same direction. The following workrooms stand out conspicuously as models of efficiency:

New York City as developed mider Mrs. Belmont Tiffany.

Chicago as developed under Mrs. John Glass.

Washington, D. C.. as developed under Mrs. T. W. Richards.

Baltimore as deseloped under Mrs. Thos. s. Cullen.

Cleveland as developed under Mrs. E. S. Burke.

There are many others equally proficient.

The statistics appended show the status of the work at the present time:

Since Derember 15. 1916.

No. of completed surgical dressings dasses........ 330

No. of pupils qualified.................. 4799

No. of enrolled hed cross nurses qualified......... 156

No. of lay instructors qualified.............. 36 fi3

No. of simple boxes sent from this oflice......... tis

You will note that 1 sif Red Cross nulses have heen qualified? and enrolled as instructors in this course. but we believe that the instruction and management of workroms could safely be entrusted to our qualified workers and lay instruetors. Red cross nurses are required for the more important work of caring for sick and wounded soldiors and salilors.

To provide administrative ehamels thromgh which this transfor combl be effereterl, the Execoltive Committer astablished

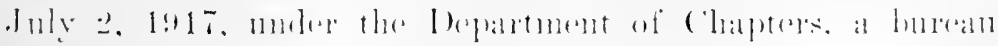




\section{HIS'TORY OF AMERICAN RED CROSS NURSING}

through which all women's activities for the Red Cross (other than professional nursing) should be recognized and developed. The vice-chairman also appointed a Woman's Advisory Committee, eonsisting of the following members: Mrs. William K. Draper. chairman; Miss Mary Goodwillie, vice-chairman; Miss Mabel T. Boardman, Mrs. Joseph M. Cudahy, Mrs. Frank V. Hammar, Mrs. E. H. Harriman, Mrs. George Wharton Pepper, Mrs. Leonard Wood, Miss Lavinia H. Newell, Mrs. William H. Crocker, Mrs. Preston S. Arkwright, Mrs. August Belmont, Mrs. .J. Randolph Coolidge, Jr. To the Woman's Bureau, of which Miss Florence M. Marshall was director, was immediately delegated all work connected with surgical dressings, hospital garments and refugee clothing.

In the Red Cross Ammual Report for 1917, Miss Delano summarized the benefits derived from this transfer:

This reorganization served two purposes; it released a large number of nurses. who have been acting as instructors in surcical dressings and hospital supplies, for other serrice, and it marshaled the forces, not only of women rolunteers, who were fitted to become instructors, but of the great army of volunteer workers throughout the country just when the emergency demanded such a realignment. It left the Nursing Service free to deal with its purely professional duties.

During the period in which the United States was at war, several survers of the nursing profession were made in order to obtain a working estimate of tle nursing strength of the country. Immediately after the declaration of war by this country, the National Committee on Red Cross Nursing Serrice, as a first step. arriced ont a preliminary classification of its own formllal membres moder the heads of nursing specialties. Miss 1)ano wrote: ${ }^{18}$

With the Herlaration of war, there was a decirled increase in tho anpliation of nurses for enrollment with the Red

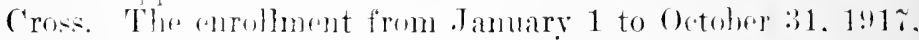

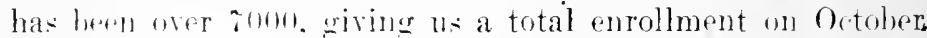

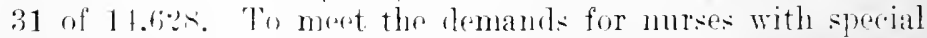
training. a clasifient list of the entire enrolment has reently

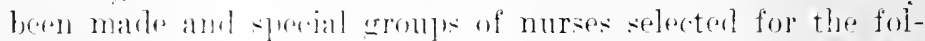

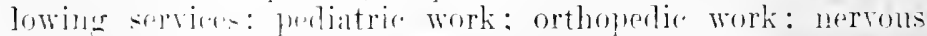

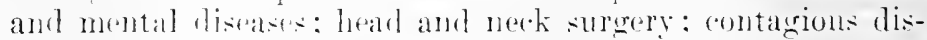
eases pultir health work: oye and ear work.

${ }^{18}$ Eighth Annual Repert. American Red Cross. December, 1917. 
Further than this, the first census of the entire nursing resources of the country was set on foot early in . ?une, 1917, by the Nursing Iepartment of the Red Cross. This eonsisted of an exhaustive survey of all the hospital training seloots in the United States. It was Mliss Delano's own idea and was carried ont entirely under luer direction by Miss Ieans, whose exceptional knowledge of training schools and nursing standards made her an unusually alpable worker on such lines. This survey was complated hy August 18, 1917.

The survey was conducted by first writing to the Boards of Examiners of the diflerent states, to ask for complete lists of all accoedited and non-aceredited training schools of the state. The Boards of Examiners replied with promptitude and aceuracy to this request and the survey was theol pushed further by sending a questionmaire to all the training schools thus listed, asking for eareful and detailed statements of their educational standards, practical services and nursing resourees. An alphabetical list by states was then made showing all the hospital training sehools by name and address. From the replies received to the questionnaire the training schools were classified under six headings.

Prior to the war, the Red Cross Nursing Service had simply listed training schools whose graduates were eligible for lied Cross enrollment; where supplementary training was necessary, this information had been placed upon the file card. But now the classification was as follows:

Class A. Schools which meet Red Cross requirements.

Class B. Schools whose graduates are of a high grade and the training general in character, including men, but daily arerage number of patients below fifty.

Class C. Schools which are small hut training good as far as it goes.

Class 1). Shelowls romected with privato hospitals having aftiliation with general hospitals.

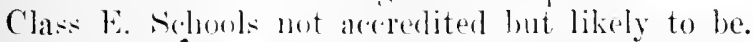

Class li. siduods which are undesirable.

The ane and thoromgluess with which this survey was conducted. als woll as the helptul readiness of Miss l belanes ottiee

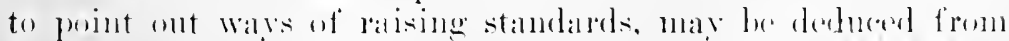
the following illustrative solections frome the loteres sent ont from and received liy the lopartment of Nursing: 


\section{HISTORY OF AMERICAN RED CROSS NURSING}

\section{(Letter Sent to Boards of Examiners) :}

The Red Cross is making every effort to anticipate the demands which will be made for nurses not only in Europe, but in our own country should the war be of several years' duration.

With this in view we are asking for the coöperation of the American Nurses' Association, state associations of nurses, State Boards of Exanniners for Nurses and hospitals to assist us in meeting all emergencies which may arise.

We are enclosing a list of schools accredited by your State Board of Examiners, together with a questionnaire to be used in supplying the information we require, also a copy of the requirements for enrollment in the lied cross.

Would it be possible to conduct special examinations, as many nurses are eligible as soon as graduated, but have to wait sereral months to take this examination? The Red Cross would greatly regret the necessity of lowering its standard for enrollment without this requirement of registration.

Could you furnish us with a list of nurses as soon as they have pasiod their examinations, in case there should be an unavoidable delay in issuing their certificates?

It is absolutely essential that we have definite information on file of all the nurses in the country, and believe there is no one in a better position than the Board of Examiners to furnish the probable number of nurses arailable in its state.

It may be necessary to supplement the nursing service both in military and civil hospitals with women who have had at least the course in Elementary Hygicne and Home Care of the sirck. This theoretical instruction should be supplemented by $2: 2$ hours in a carefully sclected group of hospitals and we shall appreciate your interest in suggesting training schools which (an be safely entrusterl to give this instruction.

Assuring you of my sincere appreciation of your efforts in behalf of the Red Cross, believe me, to be,

\section{Yours very truly,}

(signed) JaNE A. DrLano,

\section{My dear Miss}

August 4, 191\%.

I appreciate greatly your letter received this morning and your willingness to talke for post-eraduate work some of the registered nurses who are graduates of the hospitals somewhat under our required average.

We are interproting this requirement a little more leniently and have deciderl to acespt sehorels recommended by Boards of liegistration as giving a suffiriently thorough training to 
qualify its graduates for Red Cross service. A number of other schools have expressed their willingness to provide some post-graduate work for their nurses, and we shall be very glad to accept the four montlus' experience in your hospital for such nurses as you may recommend for service.

Assuring you of our sincere appreciation of your service, believe me,

\section{Yours sincerely,}

(signed) Jane A. Delano,

My dear Miss

August 29, $191 \%$.

Your second list of the small schools in with other information reccived for which I thank you.

We have a large number of applications from nurses graduating from small schools who might be eligible for enrollment, provided they have some subsequent experience or training and $\mathrm{I}$ should he glad to have the names of the schools in which offer post-graduate work for nurses.

We are urging these nurses that do not meet the requirements to take this subequent training and recently have heard that the IIospital of and the Ilospital of —— are offering special post-graduate work to graduates who do not meet the requirements of the American lied C'ross.

Thanking you again for your helpful information, I am, Yours very truly,

$$
\text { (signed) Jane A. Delaxo, }
$$

December \%, $191 \%$.

In riew of the tremendous demands now being made upon us for nurses in the cantonment hospitals, we are wairing the requirement of alliliation with the American Nurses Association. I feel sure that this requirement ean be far better sacrificed than that of registration, or the character of the school from which the nurse graduated.

Will you therefore forward to I)ivision office at once any papers which you are holling pending affiliation, securing at the same tine their physical examination blanks together with a reliable address and a statement concerning their arailability for service? Will you also annomnce to the murses in your commonity that the applications of those meeting other requirements except atliliation will be considered and forwarded to Washington, thus stimulating increased enrollment? 


\section{HISTORY OF AMERICAN RED CROSS NURSING}

I would suggest, in view of the fact that practically all of the cantonment hospitals need additional nursing personnel, that you request each member of your eommittee to secure at once the enrollment of as many nurses as possible. Kindly ask the nurses sceuring these enrollments to write their names and addresses at the top of the applications, so that as the papers come in we may be able to give due eredit on a chart which we are preparing, to the various individuals and committees.

The organizations of nurses in this country have assumed a definite responsibility for service in time of war, a far greater responsibility than rests upon any other group of women, and I feel sure that if the need is brought to them clearly, they will not fail at this time. If they do, we shall be responsible for any breaking down of nursing standards which may follow, and do inestimable harm to the schools and nurses of the country.

May I ask that you send me a telegram on the receipt of this letter, assuring me that you are taking the matter up promptly and vigorously? I would also suggest that applications of desirable nurses should be forwarded, even though not meeting our age requirements.

Yours sincerely,

(signed) Jane A. Delanio.

Brief mention of this survey and its results was made by Miss Delano in the following lines taken from her Annual Report: "Through the coöperation and assistance of State Boards of Registration, a classified list of all the training sehools in the comntry has been secured."

With the formation of the Einergency Committee on Nursing in New York C'ity, a nursing census was planned by it to be carried out on national lines aceording to a method which had been developed in a nursing survey of Greater New York by Miss Gondrich, a member of the (then) Emergency Committee on Nursing, for what was known as "The Maror"s [Maror Hrlan] Committee of Women for National Dofense." When that committe of nurses evolved into the National Committee m Nursing under the Council of National Defense, its census plan was eontinued on a national seale during the summor of 1917. The machinery used was that of the American Nurses' leseration and its state hranchess. The assoedation marle itself responsible for collecting the information asked for by Miss Nutting's committee and Miss Goodrich, as president of the 
American Nurses' Association, directed the survey and commumicated the results to the respective committees eoöperating in war service. ${ }^{19}$

That census, carried out entirely, as it was, by unpaid volunteers, all of whom were in active nursing work and making no elaim to be expert statisticians, was a creditable piece of work, of substantial practical value. While not a scicutifieally perfect survey, it was approximately accurate and sufficed for the immediate purpose. In contrast to the first Red Cross surver, which was a survey of training sehools, this one was a census of individual nurses.

The information asked for was: (1) the total number of registered nurses; (2) the total number of graduate nurses, not registered; (3) numbers of pupils in registered or accedited training sehools; (3a) in non-aceredited training schools; (4) the total number of pupils graduating in 1918; (5) the total number of pupils that could be enrolled in the fall classes; (6) the total number of pupils that could be emrolled during the year.

The census figures showed that there were 66,017 registered nurses and 17,758 murses not registered, making a total of $83,75.5$ murses. From the 1579 aceredited schools, 13,288 murses had been gradnated in 1918, and from the 414 non-aceredited schools, 109:9 had been graduated, making a total of 14,387 of the 1918 elasses, which brought the total number of graduate nurses available at the end of 1918 to 98,162 .

As to the mumbers of student murses, 38,938 were in aceredited schools, while $: 36: 33$ were in non-aceredited sthools, making a total number of 42,571 student nurses in the United States. No figures were obtained from three states where State nurses' associations did not exist. The census was completed in Mareh, 1918.

Early in 1918 Congress inquired into the nursing reserves of the nation:

Mr. Trammell sulmitted the following resolution (S. Res. 185), which was read, considered by manimons consent and agreed to:

RESOLVED: That the Sonate Committee on Military

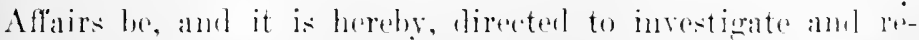
port to the somate at the earliest practicable late the alvat${ }^{20}$ See Report of Committee on Nursing (Comncil of National befense) July 29,1917 . 


\section{HISTORY OF AMERICAN RED CROSS NURSING}

able number of trained nurses for service with the United States Army; and whether or not this present available number will be adequate for the needs of the Army when increased by the anticipated future increments, taking into consideration the increased demand when the Army shall more largely engage in active conflict; and to investigate and report on the advisability of at once establishing training sources or schools for nurses for future service with the Army Hospitals; and to investigate and report what, if any, provisions have been made to this end by the War Department. ${ }^{20}$

As the summer wore on and the Red Cross continued to draw nurses from institutional fields for the Military Establishment, Miss Noyes was confronted by the imminent possibility of breaking down completely the efficiency of the nursing systems in already overerowded civilian hospitals. General Gorgas in August, 1915, was calling for one thousand nurses a week. The civilian population eonstituted, however, the second line of defense. Their health might be seriously undermined by this exhaustive drain upon the supply of physicians and nurses. "We have only one graduate nurse left," wrote superintendents of smaller schools of nursing to Miss Noyes, "and if you call her into service, we shall be forced to close our doors." Some institutions had already done so.

To secure scientifically aceurate data by which the Nursing Service might be guided in its withdrawal of nurses from eivil establishments, Miss Dolano and Miss Noyes suggested early in the summer of 1918 to the War Department and to officials at National IIeadquarters that the Red Cross make a complete survey of the mursing resourees of the nation. On August 27, 1918, the Surgeon General wrote to Mr. Davison, chairman of the War Comeil:

Because of the increased military programs it is necessary that there should be immediately arailable definite information as to the number of graduate nurses arailable for military service: also supplementary morsing persomel. trained hospital attendants. and all others who are qualified to render aid under the direction of graduate nurses in the care of the cirilian population.

As the Red ('ross is the agency for recruiting nurses for the Army Nurse Corps I wish you would take immediate ${ }^{20}$ Congressional Record, January 16, 1918, p. 967. 
steps to make a nation-wide survey of the nursing resources in order that a sufficient number of graduate nurses may be withdrawn for military service with the least interference to the possible needs of the cirilian population.

$$
\begin{aligned}
& \text { (signed) Wididan C. Gongas, } \\
& \text { Surgeon General, U. S. Army. }{ }^{21}
\end{aligned}
$$

Immediate steps were taken for complying with Dr. Gorgas' request. The Minutes of the War Conncil meetings for the 119th meeting, held September 26, 1918, give a full account of what was done:

. . under date of August 29, 1918 (D. R., p. 1469), the chairman had replied to the above letter of the Surgeon General of the Army, stating that the lied Cross deeply appreciated the importance of the work suggested, and that the acting gencral manager had been instructed to set up special machinery at Headquarters under expert guidance, to manage the survey which will be conducted through Red Cross Chapters.

The chairman further stated that a comprehensive plan had now been submitted (1). R., p. 1538) by the assistant greneral manager for the making of such a survey; that questionmaires had heen prepared which would be sent out through the Chapters, through which rery comprehensive information on the mursing resources would be made arailable; that, moler this plan, an exentive manager of the muring survey. Mr. Frederick C. Munroe, had been appointed, and a sperial organization had been set up at National Headquarters, at the Divisional Hleadquarters, and thence to every Chapter and branch in the country; that the work of canvassing the field to secure facts abont every nurse would involve a homse to house canvas in many parts of the comntry, and hence would require large forces of workers: that it all the facts that wan be neful are to he gathered from this surver, the tabulation work would be very ereat: that the number of questiomaires that would be sent to National Iloadquarters to be rassified and analyzerl is estimated romehly at 300.000 : that tabulation of this great number of questionmaires an he done only by merhanical means. and that plans were now being comploted to use the so-alled "Hollerith srstem." which would involve ma-

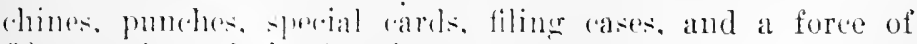
fifty or sixty arkis for about two months.

${ }^{21}$ Documents of Recorl, pp. 1465-69. 


\section{HISTORY OF AMERICAN RED CROSS NURSING}

He further stated that a request for an appropriation of $\$ 60,000$ had now been received from the director of the Department of Nursing, approved by the assistant general manager, to cover the.cost of making this survey, including the printing and distributing of questionnaires, Headquarters' expense for machines, punches, cards, filing cases, and clerical hire, and Division expenses for clerks, traveling and publicity. [The appropriation was granted. ${ }^{22}$ ]

The statistical division was under the direction of Mr. C. S. Quinn.

In a letter sent to all the Division directors, Miss Delano said in part:

The survey is quite apart from the enrollment of Red Cross nurses and will be conducted more nearly like a census than an enrollment, and for this reason it will be necessary to secure the assistance of people who have had experience in conducting surveys and compiling statistics. Mr. Munroe, of Boston, who is an expert along these lines, has been placed in charge of the work at Red Cross Headquarters. I have already appealed to the State nurses' associations, who made the former survey, urging their coopperation and we are adrising with the Committees on Nursing of the American Red Cross and the Council of National Defense and the Surgeon General's office. . .

We are anxions to secure definite information concerning all the mursing resources of the community. induding not only graduate nurses, registered and unregistered. but pupil nurses, practical nurses, trained attendants, midwives, etc. This places the whole work on a different basis from any previous survey and will make available the information so greatly needed at this time to meet military necessities and protect the welfare of the communities.

Definite plans outlining the work will be issued as soon as possible.

The coming of the Armistice with its welcome relief from high tension had an inhibiting effect on the processes of the surver and when, in the spring of 1:19 the Burean of Nursing Sinvey reported that field activities were drawing to a close, it had received but 57.9\% of the expected returns. The questionnaires filled out in sufficiently complete form to be

22 See Minutes of the 119th Meeting of the War Council, September 26, 1918 , pp. $1556-1557$. 
utilized showed 155,918 women broadly classed as nurses, and coming under all the various headings indieated in the letter quoted above, from Miss I laluo to the l)ivision directors. From the averages it wis computed that the whole number of nurses of all grades, in the country, would be about 269,288 , but the minute classifications could not be pushed to a conclusion, nor was the final completion of the survey as a whole possible, after the return of peace. 


\section{CHAPTER VI}

RELATION OF TIIE NLRSIXG SERVICE TO THE ARMY

Organization of Units-Base IIospitals-IIospital UnitsEmergency Detachments-Training School Units-Special Units-Cantonment Zone Service-Mexican Border Service -Equipment and Insignia.

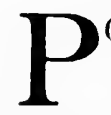

OPLLAR opinion has made of the American Red Cross nurse a romantic embodiment of personal beauty, of steadfast courage and sympathy, of womanly sweetness and gentle strength. It has, moreover, pictured her at the forefront of war, set high above the ugliness and stench of combat, unperturbed, serene and holy by reason of this beauty of person and character, a shining ideal toward which the dying soldier turned his glazing eyes.

Among the eighteen thousand American Red Cross nurses who served with the American Armies during the European War, sentimentalists eould have foind scarcely a single woman who fulfilled in outward appearanee at least this radiant conception of the angel of the battlefiglds. Instead of the flowing white reil and the immaculate uniform of popular fance and postered fame, the Red Cross nurse wore the utilitarian eap of the graduate nurse and the practical gray uniform of the field: sometimes she was muffled np in slicker, with storm boots on her feet and solu'wester pulled down orer her eyes; or again she had drawn a sagging, weather-beaten sweater about her shivering loody. Instead of a seraphic-faced girl, she was far more frequently a woman of mature rears, long familiar with the seamy side of luman relationships, long arcunainted with the sadness born of working day and night with the two sup rene realities of hnunan wistenee. Life and Death. She land little opportmity for gerntle specech to the wounded in monernts of stress, only time and strength to utter brief words of instruction to corpenen and stretrlier-bearers who assisted her. Highlytrained instrument in the "are of the siek that she lerrelf 
was, she could manifest no reaetions of her own personality or of her own emotions. 'Though her throat might ache with sympathy, her mind must be alert, her eyes must be clear, her hands steady for the performance of her manifold duties.

As the personality of the individual woman was lost in the efficiency of the expert nurse, so was the identity of the Ameriean Red Cross Nursing Service lost in that of the Army Nurse Corps. So elose was its relationship, so whole-hearted was its coöperation with the United States War Department that its nurses, during the last months of the duration of hostilities, checrfully laid aside the Red Cross, that symbol of humanitarianism which had led them to pledge loyalty and service to an ideal of patriotic altruism, that they might conform in all particulars to the regulations of the Military Establishment.

How the individualistic humanitarian instincts of the relief worker during the Civil and Spanish-American Wars erystalized into the Red Cross ideal, how the affiliation of the American nursing profession brought this shadowy vision of the care of the sick and wounded of armies in war from the realm of vague aspiration into that of definite actuality, how this germidea developed into the offieial reserve of the United States Army and Nary Nurse Corps, has already been shown. Into this complex patteru of American war nursing, the lives and accomplishmests of many women have been woven. Among the seven who in turn have stood at the head of the Government's musing forces,-Dorothea Dix, Anita Newcomb MeGee, Dita Kimney, Jane Delano, Isabel MeIsaae, Dora E. Thompson, and Julia C. Stimson-the World War brought into sharp relief the last two as superintendents of the Army Nurse Corps.

By training and temperament, these women were both minuely fitted for the work each accomplished in the Amy Nurse Corps. Miss Thompson was a reteran nember of this organization. After post-graduate work in operating-room methorls at her alma mater, the City Hospital, Blackwell's Island, New York ('ity, she did privite duty nursing for four years in New York City. She was cnrolled as a nurse April $22,1 !(12$, , in the then infant Amy Nurse Corps and was appointed as a ehief murse in Lugust, 190.5. Service followed at letterman General Hospital, where her work as chief murse during and atter the Siln Franciseo earthinake was highly anmended, Latter, she wats sent to Manilat to serve als chief 


\section{HISTORY OF AMERICAN RED CROSS NURSING}

nurse of the Division Hospital. In May, 1914, she became a member of the American Red Cross Nursing Service. During the same year, she was appointed Superintendent of the Army Nurse Corps, following the death of Miss McIsaac. In this capacity, she served until December 30, 1919, when she tendered her resignation. She then took extended leave of absence, at the expiration of which she was appointed assistant Superintendent of the Army Nurse Corps and at her own request was assigned to duty in the Philippines.

Painstakingly faithful to minutix, Miss Thompson possessed that type of mind often described as the first prerequisite to genius. Hers was an infinite eapacity for detail, which made her invaluable in the performance of her sharply defined duties in the Surgeon General's office. Iron-clad regulations handed down by the high officials of the War and State Departments controlled to the last detail the complicated process by which an American Red Cross nurse was assigned to active Army service. Miss Thompson piloted the Army Nurse Corps through these narrow channels with a faithfulness characteristic of the "Army mind." Beneath a certain cold reserve of mamner born of her exacting tasks, she possessed gentleness and sweet restraint. She was absolutely free from what may be termed the politician's instinct.

The meteor-like ascendeney of Julia Catherine Stimson offered sharp eontrast to the unobtrusive rise of her predecessor. In the blinding light of war, her dominant personality stood out in the same bold outlines as did her Amazonian phrsique. Her regular, hovish features habitually wore a thoughtful expression, which brought to the observer an impression of dignity and power. Her well-trained mental processes, clean-cut often to the point of brusque speech, were as direct in their focus as were her keen blue eres.

The danghter of a New York elergyman, Miss Stimson was graduated from Vassar College and from the Srhool of Nursing of the New York Hospital, New York City. For three years she was superintentent of nurses at the Harlen Hospital. She went to St. Louis in Oetober, 1911, to do social service work in Washington University and in the St. Lonis Children's Tospitals, and later becime superintendent of nurses of the Washington University Training Sehool for Nurses. She voluntened in 1909 for patriotie serviee under the Red Cross, when enrollment of nurses was being under- 
taken through Red Cross Chapters. Her first opportunity for active duty under the Red Cross flag came in 1913) during the Ohio flood.

When the Red Cross I)partment of Military Relief authorized the organization of Base Hospital No. 21, within the Washington University Medical School, Julia Stimson was appointed rhief nurse. She served with distinction during its subsequent assignment to the British Expeditionary Forces. Her sncerssful work in the Washington University School of Nursing, as well as the fact that she was an alumna of Vassar, eaused her name to be brought forward during the spring of 1918 as a natural selection for the head of the preparatory course of the Vassar training school project. The ('hief Surgeon, Anerịan Expeditionary Forces, however, assigned Miss Stimson in April, 1918, to the office of the American Red Cross in Paris at the request of the Red Cross commissioner to serve as Chiof Nurse of the American Red Cross in France. On November 15 of the same year, General Ireland, who thronghout his service as Chief Surgeon of the American Forees in France and later as Surgeon General, United States Army, had been a stanch friend of the Red Cross Nursing Service, appointed Miss Stimson Director of the Nursing Service of the American Expeditionary Forees. In July, 1919, Miss Stimson returned to the United States to succeed Miss Goodrich as lean of the Army School of Nursing. Secretary of War Baker appointed her Superintendent of the Army Nurse Corps five months later.

The special relationship between the Army Nurse Corps and the Ameriean lied Cross Nursing Service was defined in a paragraph drafted by Miss Jelano when she was superiuteulent of the Army Nurse Corps and was printed in the (1!16) Mammal of the Ilodical Department, United States Army. The paragrabli follows:

102. The enrolted nurses of the American National lied C'ros Sursing service will comstitute the reserve of the Army Nurse corps. and in time of war or other emererency may with their own consent he assigned to artive duty in the

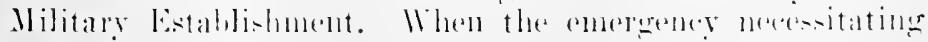
the empleyment of reserse nurses is imminent. the sureront

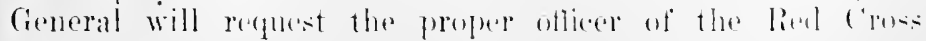
Society to nominate from among the enrolled morsts ynalified for the work to be done als many as the sillewen lieneral 


\section{1* HISTORY OF AMERICAN RED CROSS NURSING}

may deem necessary to cnable him to choose those for assignment to active duty.

(a) When called into active service they will be subject to all the established rules and regulations for the govern. ment of the Nurse Corps, and will receive the pay and allowance of nurses on the regular list.

(b) I reserve nurse will not be relieved from actire service except by order of the Surgeon General. Except in case of misconduct she will, if she so desires, be furnished travel orders to her home before the order of relief shall take effect. ... .

(c) When a reserve nurse is assigned to actire service the Surgeon General will by letter promptly arlise the proper officer of the Red Cross Society to that effect. Then she is relieved from active service he will communicate that fact likewise by letter, stating the cause of her relief and whether her services have been satisfactory. ${ }^{1}$

On December 18, 1916, ${ }^{2}$ Secretary Baker issued Regulations Governing the Employment of the American Red Cross in Time of War, which contained the following paragraph: "10. The Red Cross units organized for service with the Army or for the purpose of training personnel therefor are: 1, ambulance companies; 2 , base hospitals; 3 , hospital units; 4, surgical seetions; 5, emergeney nurse detachments; 6 , sanitary training detachments; 7 , information service; 8 , refreshment units and detaclmonts; 9, supply depots: 10, general hospitals : 11, convalesent homes."

Efficient and friendly coöperation of the closest type existed during the European War between the Army Nurse Corps and the American Red Cross Nursing Service. By letter, by telephone, by special messenger, Miss Thompson and Miss Delano and Miss Toyes kept in tonch with each other. Calls went from the Sureon Gencral's office, first located in the Mills Building and later moved to temporary offices flanking the Botanical Gardens at Eighth and B Streets, to National Red

1 Manual for the Medical Department. C. S. A., 1916, p. 47.

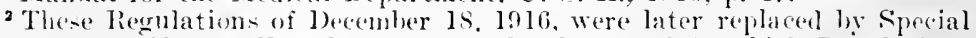
Regulations, Xo. 61. War Department, Oetober 8, 1917, which Regulations "include and are identical with the Remulations Governing the Employment of the Amerien lierl Cross in Time of War (1)ecenter 18. 1916) and Foneral Orders No. S2. War bepartment, 1917." Special hegulations No. (al formed the otlicial guide-bork of the Ameriean lied Cross duringer the remainder of the participation by the Enited States in the Eurepean II ar. 
Cross IFeadquarters; Miss Noyes in turn sped these demands to Division offices and Local Committees; while the Red Cross publicity organization spread the appeals broadeast over the length and breadth of the land, until on November 11, 1918, the United States Army Nurse Corps totaled the largest body of professional women ever mobilized for patriotic service.

Far removed, however, from its final war strength of 21,480 members was the Army Nurse Corps on April 6, 1917. Only 235 regular and 165 reserve members constituted the Govermment's nursing forees when the United States declared war.

Military scienee decreed that the sanitary personnel within the armies of civilized countries shonld constitnte ten per cent of the strength of the forees. Secretary Baker eonfirmed this opinion by his orders of Jume, 1917. The General Staff, American Expeditionary Forees, finally agreed that the total sanitary personnel, otficers, nurses and enlisted men, shonld be seven and sixty-five hundredths per cent $(7.65 \%)$. The Chief Surgeon in a letter submitted August 11, 1917, to the Chief of Statf stated that for an army of one million men, 22,430 murses would be required. He added that "it is believed that if this calculation is crroneous, the error will be on the side of eonservatism." 3

The Army estimated that the ratio of one nurse to every ten hospital beds was a safe one. In a memorandum prepared in February, 1918, by the Surgeon General's office for Secretary Baker, the following statement was made:

The ten-bed-to-one-nurse ratio is almittedly a restricted allowance, offering scant margin of safety to take up a serions epidemic. As shown on the tabular sheet, the present actual ratio in the [nited States is one nurse to 15.8 beds. To meet an epidemice emergency, additional murses must be requested after the need has appeared, making at least temporary inatdequacy inevitable. ${ }^{4}$

The assignment to active duty of fifty base hospitals organizod lye the lied cross in 1916 and $191 \%$ for the Irmy formed the skeleton of the hospitalization of the Lnited States Medi(al I department in France. When these massive colmuns were

a "History of Nursing Aetivities. A.E.F. on the Mestern Front during the

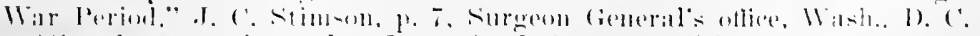

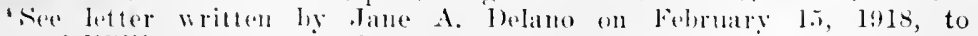
General Willian C. (iongas; lied Cross Archives, Wath., 1). ('. 


\section{HISTORY OF AMERICAN RED CROSS NURSING}

ordered overseas during the summer of 1917 and to the cantomments of the National Army, Surgeon General Gorgas authorized the organization of fifty additional ones, beginning with Number Fifty-four. These base hospital units were to be organized on a basis of five hundred beds, with a nursing persomel of sixty-five members. The Surgeon General's office stated that they did not believe that these units would be ordered into the field, however, until after the original fifty base hospital units which the Red Cross had organized and equipped had been called into active service. ${ }^{5}$

The first branches of the American Army to see foreign service were six base hospital units which were assigned to duty with the British Expeditionary Forees several weeks after the United States declared war. Upon arrival in France, these units were placed in charge of six British general hospitals, of from fifteen hundred to twenty-five hundred bed capacity, which were located in the Rouen and Le Tréport areas. The original nursing staff of sixty-five members was found to be inadequate, so the Surgeon General's office called for additional nurses in sufficient numbers to raise the staffs to one hundred nurses each. Nurses from Red Cross hospital units were used for this purpose and "casuals" were also sent over. The organization of all future base hospital units was undertaken on a basis of one hundred nurses rather than sixty-five.

On February 21, 1918, Miss Thompson wrote Miss Delano of the first change in method of assignment of reserve nurses to active service from the former system of unit organization. The Surgeon General's office suggested that, in the future, the nurses who were enrolled by the Red Cross should not be assigned to specific base hospital units, as had been done with the first fifty, but that they should be held as a general nursing reserve, to be called upon as available and as needed. "The advantage of this procedure," wrote Colonel Winford Smith, then in rharge of the Base Hospital I hivision of the Sureon General"s office, "would be that it would not be necessary to keep track of specific groups which might have to be withdrawn from serviee at some place to go with the base hospital to which they had been assigned, nor would it be necessary to hold nurses on the inactive list beranse of their

\footnotetext{
${ }^{5}$ See letter written by Dora E. Thompson to Clara D. Noyes, October 8. 1917 .
} 
assignment to base hospitals not yet in sorvice. If the murses are enrolled in a general reserve, they can be alled as needed and assigned where they are needed most." " Luder this plan, the Surgeon General's office hoped to develop a reserve supply in the cantonnent lospitals, from which nurses would be drawn when a base hospital was to be organized for service in Great Britain or France.

'The method by which the Surgeon General's office adrised the Nursing servies of the needs of the Arny is well illustrated in two repuests for nurses which were received in the late winter and alrly spring of 1918. On February 28, 1918, (olonel Simith wrote Miss Delano that the Surgeon General would reguire approximately five thousand nurses between March and June, in addition to those already assigned to base hospital units. Miss Thompson partially echoed this request in a letter written to Miss Noyes on March 4, in which she asked that the lied (ross "nominate as soon as possible 450 nurses needed for immediate assigmment, in addition to the one humbled murses" a month which the Red Cross was mobilizing during Jamuary, February and March for immediate assignment to the Anerican Expeditionary Forees.

D ming the middle of 1)ecmber, 1917, Miss Noyes had experieneed difficulty in comvincing nurses that the time had arrived for them to relinepuish their civilian affiliations and to mudertake arotive military service. The Red Cross enrollment, then of eight thousand nurses pledged to active service upon all, was at this time wholly unclassitied. Two methods of utilizing this nursing reserve confronted Miss Noyes; on the one hand she might weed out from the general files of the Nursing servere by detailed and tedions correspondence the names of all womeni who met the eitizenship and physical requirements of the sureoon General's offiee and who were, moreover. willing to respond to an immediate all: on the other land she might present the military need to the mursing profession ly speaking personally to large groups of nurses in all parts of the comntry. Sle finally decided to take a speaking

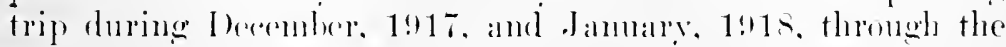

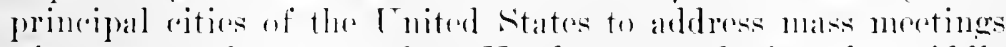
of mulses. She returned to IIeadipuaters during the middle of February, $1 ! 18$.

"Spe letter written by Dora E. Thompson to Jane A. Delano, Pebruary 21. 1918 . 


\section{HISTORY OF AMERICAN RED CROSS NURSING}

Hardly had she begun when she found out the reasons why nurses were slow to volunteer for the additional base hospitals and the groups of "casuals" for which the War Department was then pressing the Red Cross. To her appeals for nurses for cantonment hospitals in this country, members of her audiences responded with the statement that three thousand murses were known to be listed upon the muster-rolls of the fifty base hospitals then awaiting assignment to active duty, and that several hundreds of these very women had been marking time for weeks at the port of embarkation, Ellis Island. Their transportation was delayed on account of orders to hold all non-combatants and to rush the combatants overseas, but this information, of course, was not given out to the public for obvious reasons; nor was it known in the Surgeon General's office when the nurses would be sent orerseas. Notification as to accommodations on the transports was often sent but a few hours before sailing. As long as the services of these women remained unutilized, argued Miss Noyes' listeners, the demands of the cantonments could not be so urgent. Direct foreign assigument, moreover, appeared far more picturesque, more desirable. On the other hand, the Surgeon General's office held to the policy that the nursing staffs of base hospitals should not be scattered among the cantonments at this time, as the sailing of their units was imminent and it was thought that their assionment and almost immediate withdrawal would add to the already heary burden at the eamps. Miss Thompson and Colonel Smith, naturally, knew that an initial experience in military routine in the cantonment hospitals for nurses as well as for officers and enlisted men would heighten their efficieney, so in order to correct the general misunderstanding that the Red Cross was in no great need for nurses for the Army, the nurses of the various units were finally sent to the cantonments and Army general hospitals throughout the country for duty pending the sailing of their units. Niss Thompson wrote Xiss Delano on Mareh 8, 1918: "In order to meet the need for nurses in this comntry, the entire group of nurses attached to base hospitals not rect ordered out, will he ordered into service upon receipt of their names in this office. It is thought advisable, howerer, that no more than ten (10) nurses from any one base hespital he ordered to any one cantomment hospital, lest we cripple the hospital when the nurses must be withdrawn." 


\section{RELA'TION OF NURSING SERVICE 'TO 'THE ARMY 319}

By the late spring of 1918, the Surgeon General's office had estimated the number of nurses which the Army would require of the Red Cross reserve. In a letter written II arch 8 , Colonel Smith stated that "the number of nurses estimated for our requirements up to January, 1919, including those now in service and the 5000 asked for by June 1, is 25,000." Early in the summer of 1918, this number was greatly increased. On July 27, Brigadier General Robert E. Noble advised the Direetor General of Military Relief that at least 2500 additional nurses would be needed between that date and September 15 . On Angust 1, 1918, Surgeon General Gorgas issued to the Red Cross his historic appeal:

I call upon your organization, as the chief nurse recruiting arency of the Army, to employ every possible means to increase the enrollment of nurses for immediate assignment to duty.

With the contemplated increase in the Army both at home and overseas. there must be a proportionate increase in the number of murses in the service. The Army tolay is growing finster than the Nurse Corps is increasing, and as the Armies overseas enter the front line trenches in greater numbers, the greater will be the need for nurses in the Army Nurse Corps.

I, therefore, urae upon the American Red Cross, through its agencies, to bring to the attention of the trained nurses of the country, the neressity of immediate offer of service, ant then enrollment in the Army Nurse Corps.

I hesitate to leal in concrete nmmbers. but I desire to emplatise the fart that I need torlay a rery material in(rease in the Army Xurse ('orps, anil desire this increase in the ratio of at jeast a thousand a week for the next two months.

Thesc requests, together with the assistance which the American lied Cross was giving the Women's Committee of the commeil of National I) fense in recruiting student nurses for the Army Sichool of Nursing and for civilian hospital schools, ${ }^{7}$

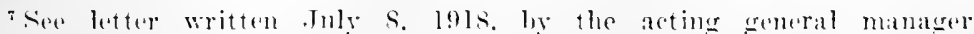

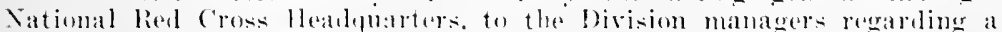

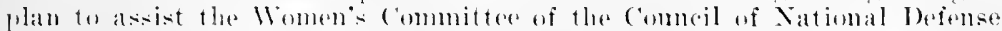
11) recruit student nurses for the Army seboel of Nursiner ant rivilian

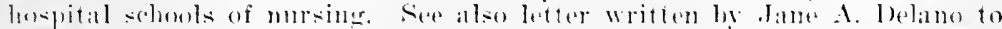

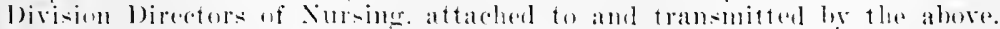

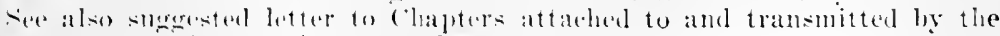
abere letter of the aloting general manager. 


\section{HISTORY OF AMERICAN RED CROSS NURSING}

brought, by July, 1919, the total needs of the Army to fifty thousand graduate and student nurses. Fifty thousand graduate and student nurses! This was the responsibility which fell to Miss Delano, more than to any other woman. As chairman of the National Committee, the American Red Cross and the American nursing profession had entrusted to her vision the development of Red Cross nursing service. If now at the supreme moment, this organization which her brain and hand had created and nurtured, failed to meet the obligations which war laid upon it, to her more than to any other woman would belong the overwhelming catastrophe and despair of its failure; and in crowded wards of base hospitals and evacuation stations, American men would have to endure the agony of modern battle casualties, unalleviated by adequate nursing care.

A definite problem of supply and demand confronted the Red Cross. On one side of the equation were the nursing resources of the country, distributed in the fields of private duty nursing, in institutional work, in public health nursing and in the adranced classes of schools of nursing. On the other side were the needs of the Military Establishment. The responsibility of the Red Cross was to select from these fields nurses sufficient in number to meet war needs, yet to withdraw them in such a way that the health of the civilian population would not be jeopardized.

According to the Regulations Governing the Employment of the American Red Cross in Time of War, which Secretary Baker issued on December 18, 1916, the four types of unit through which the Army secured nurses from the Red Cross were base hospitals, hospital units, surgical sections and emergeney nurse detachments.

After steps had been initiated to meet the general demands, groups of nurses expert in the care of special diseases were organized by the Nursing service for duty in four special hospitals of the Mredical Corps, the Orthopedic; the Fracture: the Eye, Ear and Throat; and the Psychiatric Hospitals. Public health nurses also were ealled for lye the U. S. Public Health Service for duty in extra-cantonment zones.

Paper charts and pamphlets outlining the requirements, purpose and probable future service of each trpe of unit were sent out to Local Committees on Red ('ross Nursing Service and to civilian hospitals from National Headquarters and later to the same Local Committees from I)irision utfires. With 
unrenitting energy, the field workers set out to fill the units. Individual nurses were approaehed with the suggestion that they undertake military service in some one of these units. If they met the requirements of the Army, they were enrolled in the Red Cross Nursing Service and their names checked off against given positions in the organization charts of the units. When one of these structures was entirely eomplete, its musterin-roll or personnel-list was sent to the War I)epartment. The Surgeon General then ordered the nurses into active service; travel orders were issued to each nurse. The proeedure by which the majority of nurses serving in the European War were mustered into military duty is well illustrated by the detailed steps taken in the case of a member of an emergency detachment.

"Mary Brown," a nurse engaged in private duty nursing at Cascade, Iowa, desired military service. She had previously learned that the Red Cross Nursing Service was the reserve of the Army Nurse Corps, so sle wrote to the nearest Local Committee on Red Cross Nursing serviee. The chairman of this Loeal Committe opened correspondenee with Mary Brown, or in a personal interview, required by the National Committee if possible, gave lee the necessary application papers, told her that an emergeney detachment was then under process of organization in her locality and advised her to join it. Mary Brown expressed her willingness, filled ont her application papers and in due time moderwent a complete physical examination and immmnization for trphoid and paratyphoid. (This inoculation was later given at cantomnent hospitals.) The chairman of the lonal ('ommittes in the eity neals Cascade entered Mary Brown's name on the lists of one of the emerenency detarbments tor which the committer was responsible, secored her training selool credentials, her certitieates of examination and inomatation, her latest address and luer date of arailability and sent them all to the director of the bepartment of Xursing. ('entral l)ivision, who passed upon them and forwarded them to National lenaldualters. Miss Nores then wired Mary brown and in a telexraphed answer received confirmation of the statement in her enmollnent palpers that she would be avalable for assigmuent on . Ime it at Cascade. Inwa. Mliss Noyes then sent this last yollow tolegram, together with the other pilpers. to Miss Thompson. The surgeon Generall: order followed within a few days: 


\section{HISTORY OF AMERICAN RED CROSS NURSING}

Mary Brown, Reserve Nurse, Army Nurse Corps, now at Cascade, Iowa, will proceed without delay not later than June 6, after having taken the oath of office, to Camp Dodge, Des Moines, Iowa, and will report to the Commanding Officer, United States Army Base Hospital, for assignment to duty.

Travel is necessary in the Military Establishment. ${ }^{8}$

This task of loeating and stabilizing nurses which devolved upon Miss Noyes and her associates was fraught with tedious and troublesome detail. In addition to professional credentials, immunization and physical examination certifications, it was necessary that the enrollment papers of every nurse show the address at which she might be reached within a certain period of time. To this location, within a preseribed number of days, the Surgeon General sent instruetions, as has been shown before, bidding the nurse take oath of office and proceed to her post of duty. If the nurse was not at this given place at the time specified in her papers, the order for her oath of office and her transportation had to be revoked and a corrected one issued. Nurses often could not understand why travel orders could not be forwarded to another town like personal mail. The War Department, overburdened with clerical detail, for its part failed to see in the call for an issuance of new orders anything but carelessness and ineffieieney on the part

- In addition to the requirements for enrollment in the Red Cross Nursing Service, the Surceon Gencral set up the following regulations: "Citizens of the United States, native or naturalized, are alike lialle to service and no discrimination should be made as far as the manner in which the eitizenship was acquired is concerned, if the loyalty and fitlelity of the individual is unquestioned.

In casc of medical units or individuals intended for service directly with or under the forces of our allies, eare should be taken not to assign to such units or detail for such service persons who are naturalized eitizens of alien enemy origin."

Married nurses were not eligible for service with the Army Nurse Corps.

The length of service was coverexl in the following regulation: "Reserve nurses assigned to active service during war will be expected to serve as long as they may he needed. A nurse who desires relief from aetive service may apply therefor by letter to the Surgeon General, through the proper chimnels, stating her reasons in full. If the reasons are sufficient in the judgment of the surgeon General her reguest may be granted. Return transportation will not be authorized to nurses who have. served less than obe year, inless the need for their services ceases to exist. or to those who are cliscliarged for misconduct. A nurse who is found to be unsuited for the service physically, professionally or temperimentally. will be furnisled transportation to her home for relief from active servied without regard to lemeth of scrviee." 
of the Red Cross in giving an inaecurate address in the first place. Hence arose the necessity for establishing the rule that a confirmation telegram be received from the nurse before her papers were sent to the War Department. An idea of the correspondence which was carried on between National Headquarters, Division offices, State and local Committees and individuals before a nurse could be assigned to active service, may be gained from the following letter written October 12, 1917 , by Miss Noyes to all nurses organizing units for the Army:

Organizing nurses will please bear in mind the following points to make the service more efficient:

First: Do not report to Red Cross I Ieadquarters a nurse as "ready for duty" before communicating with her in order to letermine this fact. Information upon this point two or three weeks old is many times found to be inaccurate.

Second: l'lease determine from each nurse her latest accurate address.

Third: Communicate with each individual nurse immediately before sending her name to this office in order to make definitely certin her date of availability and her accurate address.

Fourth: Impress upon the nurse that except in case of grave illness it is impossinle to release her from her promise to answer a call when once her name has been sent to the War Department.

Fifth: When a nurse is reported to the Surgeon General's office as "readr." assignment to duty, oath of office and transortation will he forwarled by that Department. If. by any chance, this is forwarded to an incorrect adluess. it is not only a very serious inconvenience to the War Department to revolie these order's. but a reflection on the efficiency of the Red Crosis Nursing Service.

Sixth: In all (ases when the nurses live in an adjacent town. it is arlvisable to have them assemble at their own expense at the liarer point where the detarhment has been oreanizerl. In this way. the can proced together to their point of destination. It this is not posible. inclividual transportation orders may be iswed to each nurse from her own home.

Equipment oceupied the last phase of the manifold duties develving upon Mlist Noyes and here assoriates. Dfter Mary

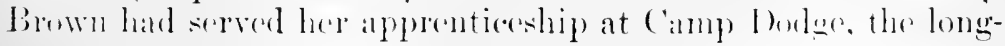




\section{HISTORY OF AMERICAN RED CROSS NURSING}

coveted orders for foreign assignment were forwarded her throngh her ehief nurse and off she went to Ellis Island with instructions to report as soon as possible to the director of Nursing Service, Atlantic Division, Ameriean Red Cross, regarding equipment. In New York City, the Bureau of Nurses' Equipment supplied uniforms, blankets, sou'westers, boots and other conforts to soften the harsh living conditions of these nurses of the American Expeditionary Forees.

The middle span of eantomment service was omitted for the members of the first base hospital mits. Their orders read for them to proceed direct to the port of embarkation and Europe. As was often the ease with the soldiers, many nurses waiting patiently in cantomment wards never received foreign assignment.

These units through which nurses were mobilized by the Ameriean Red Cross were not only eomplex in detail, but dissimilar in purpose. Consequently, each form of organization would be treated separately.

In modern warfare, with its enormous armies in the field, its fleets of eapital ships at sea and its instruments highly perfected in the science of killing, it is imperative that the Army and Nary be supplemented by organized volunteer aid. Sir Frederick Treves summarized this need:

In time of peace, no army medical service can be maintained on a war footing. There is involved at such times an elaborate scheme for expansion in war; but one prominent and inevitable feature of that scheme is the enrollment of a rast body of doctors, murses, orderlies, motor drivers, clerks, cooks, dispensers and the like. In such a work, a civilian society can act with greater ease and promptness than can a huge organization like the Mar Office, and thus it is that in the supply of personnel, the Red Cross societies have undoubtedly rendered sterling service. ${ }^{9}$

In the Red ('ross Ammal Peport for $1916,{ }^{10}$ Colonel Kean outlined the zones into which the military service for the resene of the wounded of armies in the field were divided:

'The Medical Riesord. Vol. 90, page 466.

10 "The Amual Repurt of the American National Red cross is published yearly in two forms, the first a full report published by the chaiman of the central committere the second a somewhat ablireviated report published as a Dormunent of Pexord of the House of Representatives. The quotations and page reforences which are used in this history are taken from the full Anmal licport published by the American Red Cross, the so-called "umotfirial reprert," rather than the Comeressonal Document. 
The medical service of the zone of the front is one of first aid, temporary shelter and transportation of the wounded to the rear. It is mammed by trained sanitary soldiers of the Army and requires for its service nearly the cutire personnel of the peace establishment. The Red Cross mits and personnel are not admitted to this zone.

The medical service of the second zone, the military base, consists of sick transport trains and base hospitals and is largely manned by a persommel from aivil life, recruited either by the Red ('ross or the Medical Department of the Army. Its base hospitals are the first true hospitals encomntered by the wombded man in his journey to the rear. Here for the first time he finds a good bod with a mattress, instead of a cot; trained nurses instead of sanitary soldiers; and the highly traines and specialized practitioners from civil life. Here he finds quiet and rest and the conditions suitable for recovery.

The third zone, that of the home country, receives the overflow and the convalescents from the base hospitals near the theater of war. In it the civil hospitals of the country are called into use in addition to such seneral hospitals as the medical department may establish. Its medical staff are, with the exreption of a few trained administrative officers, physicians and nurses drawn from civil life.

Of this structure, the base hospital is the central span and the most important contribution which the Red Cross can make for the safety and comfort of the wounded. It is immediately and uroertly needed as soon as war is declared, vet beranse of its numerous personnel and massive and costly equipment, it has never heretotore been provided in time of peace. Yet so large and romplex an organization cannot he improvised. Its varied and specialized personnel when brought togrether, reguire time and training to fall into orderly adjustmont and eflicient operation. A chance agroregation of feretors and murses an no more elaim at first to he an efficient hospital than a thousind men collereded irom the street: an be reganded as an edlewtive roriment. likewise, its olahorate cquipment ammot be purdisenl in a lay, or a week, nor yet in a month, esperially in time of war.

It has already been shown that ly Presidential Proclama-

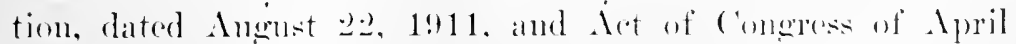
24,1912 , the Red ('mos persennel eonstituted in tine of war

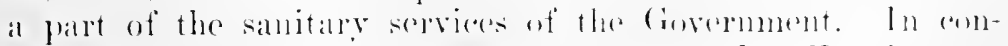
formity with this ediet and these statutes, the Mar lepart- 


\section{HISTORY OF AMERICAN RED CROSS NURSING}

ment, upon the recommendation of George A. Torney, Surgeon General of the United States Army, issued on September 10, 1912, Cireular No. 8, which contained the following regulations:

2. When the War Department desires the use of the services of the Refl Cross in time of war, or when war is imminent, the Secretary of War will communicate with the president of the society, specifying the eharacter of the services required, and resignating the place or places where the persomnel and material will be assembled.

3. When any member of the Red Cross reports for duty with the land forces of the Tnited States pursuant to a proper call, he will therefore be subject to military laws and regulations as provided in Article Ten of the International Red Cross ('onvention of 1906, and will be provided with the necessary brassarl and certificate of identity.

4. Except in cases of great emergency, Red Cross personnel serving with the land forces will not be assigned to duty at the front, Junt will be employed in hospitals in the home country, at the base of operations, on hospital ships and along lines of communications of the military forces in the Tnited States.

5. Red Cross organizations will not establish independent hospitals or other institutions, but will assist military sanitary formations at the places above indicated.

6 . Before military patients are assigned thereto, separate establishments maintained by the Red Cross Society will be placer under the immerliate direction of a medical officer of the Army. Such officer will be held responsible for the management, discipline and records of the institution; he will regulate admissions and discharges and see that the interests of both the Government and the patients are conserverl.

\%. No rolumms, sections or individuals of the Red Cross Soriety will be acerpted for service by the War Department unless prerionsly inspecterl by a morlical officer of the Army and found qualified for the service expected of them.

8. The lied ('ross Sordirty may be called upon in time of war, or when war is perrling. for the following columns of persommel: (1) physicians and surgeons; (:) dentists; (3) pharmarists; (1) murses ( (5) rerks; (6) rooks: (7) litter bearers drisers and of here transport peromuel; (s) laborers.

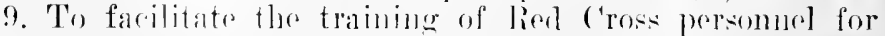
the ruties it mal le ralled mpon to perform in time of war, it is dirided into three clasises: Class (a) those willing to 


\section{RELA'TION OF NURSING SERVICE 'TO THE ARMY 327}

serve when needed; (b) those willing to serve in home country only; (e) those willing to serve at place of residence only, etc., ete.

10. The Red Cross service at the base, along the line of communications of in a military district, will be under the supervision of a clirector general who will conduct the service under the direction of the chief surgeon of the field army or expeditionary foree.

11. For service at the base and along lines of communications Red Cross personnel shall be organized into (1) field columns; (2) hospital columns; (3) supply columns; (t) information burea sections, etc, ete. ...

The greatest single contribution of the Ameriean Red Cross to the welfare of the sick and wounded American soldier lay in its organization and equipment of fifty base hospitals for the United States Army. The germ idea of a medical unit organized from the staff of a large civilian hospital for war service in the zone of the base had been conerived in 1914 by In. George W. Crile, of Lakeside Hospital, Cleveland, Ohio. The project of organizing such units for the Army was brought forward for diseussion by Dr. Crile as follows on October 25, 1915, at the symposium on military surgery, Climical Congress of Surgeons of North America:

When our distinguished American Ambassador, the Honorable Myron ' $T$. Herrick, asked me to take a service in the American Ambulance, I suggested that it might be better to form a unit among the men at Lakeside IIospital and take complete charge of a given number of patients. This proposal was (abled to the American Ambulance and a facorable reply returned. This was the beginning of the university unit plan of organization for service at the American Ambulance.

This plan worked out so excellently in France that it has occurred to me that at least for the base hospitals. it would be a workable plan for our American Medical heserve Corpls. After an informal disension with the Sureen fieneral of the Army, he surerested that to stimulate further discolsion, I shomli outline a plan for a unit to take charego of a five hundrod bed has hospital. . . .

'Theso mits will be more officient if they are marle up of

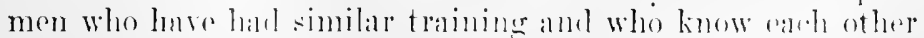
well, and if ther halse assoriated with them a mursing stalf familial with there methouls. 'This suegersts thalt the fir:t 


\section{HISTORY OF AMERICAN RED CROSS NURSING}

units be made up from the staffs of large well-organized hospitals, especially teaching hospitals, and that they be distributed according to population among the states of the Union.

In making such an organization of the Medical Reserve Corps we must be guided by three fundamental principles. First: each man should be assigned to the service for which he is best qualified. Second: the mobilization of the Reserve Corps should be country-wide. Third: standard materials should be stored so that we may not be caught by a shortage at a time when industries are paralyzed.

A few days previous to this meeting, the Red Cross had taken up with Dr. Crile the question of the organization of such units. Adelaide McKee, chairman of the Cleveland Local Committce on Red Cross Nursing Service, wrote on October 16, 1915, to Miss Delano that "circulars and applications have been sent to graduate nurses in this city by Miss Allison, the superintendent of nurses of the Lakeside Hospital, asking them to join an organization composed of a body of nurses and doctors for service at home and abroad. This circular states that Dr. Crile has been asked by the United States Government to organize a society, salary to be the same as that of the Red Cross Nursing Service, and that the Govermment has promised to equip a hospital of five hundred beds for Dr. Crile in ease of emergeney."

Miss Boardman telegraphed Dr. Crile on October 18, informing him that according to Regulations issued by the War Department and by Presidential Proclamation, all voluntecr aid must go throngh the American Red Cross, and requesting further information regarding his plans. "Great confusion now exists," she concluded.

Dr. Crile in a letter written October 31 explained that in view of the mupreparedness in offering organized aid to wonnded soldiers which had been experienced by France and Fngland and which many American surgeons had witnessed when in foreign service in 1914 and 1915, it was felt that "the preparation of om comtry for offensive and defensive manenvers in time of war shonld include pre-organized plans for medical and sureical service. This is a work," he added, "which belongs prinarily to the Govermment. With this understanding, at the sugerestion of Crenelal Gorgas, a tentative plan is now in progress of formation. . . ."

25 Surgery. Ciynecolon!y and Obstetrics, January, 1916, pp. 68-69. 
In her reply addressed to Dr. Crile October 23, Miss Boardman explained that so much confusion already existed among the nurses that wnless it eould be cleared up Miss Delano might dissolve the Red Cross Nursing Service, in which she had enrolled between six and seven thousand of the best trained murses in the eomntry. There conld not be two organizations undertaking the same enterprise independently of each other without leading to great confusion.

The Regulations of the War Department, Miss Boardman argued in this letter of October 2:, provided that the Red Cross should form exactly the same type of mit as that under organization by Dr. Crile. A National Medical Committee was already appointed to take up this work. Dr. Crile's name, as well as that of $\mathrm{Dr}_{\mathrm{r}}$. Harvey Cushing, Dr. Lambert and Dr. George Brewer, was among the list of members. Should any or every hospital in the comntry that desired to do so undertake the organization of hospital units independently of the Red Cross, which muler its charter was the official volmuteer ageney of the Government for the relief of siek and wounded in war, then the Red Cross would go ont of existence.

When in time of war, continned Miss Boardman, the War Department asked of the Red Cross hospital formations, they were to be turned over to the office of the Surgeon General just as it was now proposed to turn over these surgical mits. Therefore, there appealed to be no valid reason why the organization of these mits shonld not be undertaken through the medium of the Red Cross, in the place of these proposed mits. Miss Delano was ready to issue regulations that wonld make the nurses of these mits able to enroll as Red Cross murses, provided that they anme up to the recpuirements of the Army Nurse Corps and of the lied cross.

Dr. Crile replied on Octoler 30 to Miss Boardman that "this is a matter which pertains to the Medieal Resorve Corps of the Army, of which I am a member . . " and that "I have reread with "are Cirenlar No. S of the War I department and find nothing therein to indiate any eontliet betwern the Red cross Association and the oreanization of lospital mits." IJe went on to say that "the Red cross may be "alled mpon in time of war for erertain serviens at the diseretiom of the War Department. The Mrediual lieserve ( orps is a part of the Army and therefore is, of course, subject to its allo."

On Norember 2, 1915, Miss Boarduan wrote Jr. Crile: 
A number of years ago, the Surgeon General's office started an Army nursing reserve. At first, there were some two or three hundred enrolled, but in time the interest died out and finally it was reduced to less than twenty nurses who reported yearly. In the meantime, the American Red Cross had initiated its enrollment of nurses, under Miss Delano's remarkably able executive management. I will not go into details of development, but after three or four years, the Army decided to give up its nursing reserve and to take the American Red Cross nurses as a reserve. The plan is working very satisfactorily. We have between six and seven thousand of the best trained nurses of the profession enrolled; between seven and eight hundred of the most representative nurses in the country are serving as members of Local Committees. We can and have mobilized our nurses on short notice. We have spent thousands of dollars on this work and it would have cost several thousands more, if Miss Delano har not given her services without remuneration. I have spoken at many nurses' meetings to aronse their interest. Next year (the work has grown so), we will probahly give Miss Delano an assistant. She also has an Army nurse detailed to her office and two or three stenographers to assist her to maintain this efficient enrollment.

Suddenly without any word to the Red Cross, varions doctors are communicated with and the request is made that they form hospital units and enroll murses in a reserve corps. In several cases our own nurses have been applied to, not only to enroll but to secure nulses for this Army nurse reserve. This, of course, is lealing to great confusion. It is breaking up our nursing reserve. The plan of the Surgeon General's office cannot be kept up except by an organization such as the Red Cross, as was evident from past experience.

Miss Delano has aìrearly been to New York, has seen the superintendents of some of the large hospitals there and a plan is being worked out to form units or hospital columns, for hospitals of five hundred heils, securing the murses from each hospital for a hospital mit or column. The head of such a column wonld be a member of the Irmy Nerlical Reserve Corps and the nurses would be from the same hospital ancl those with whom he was arenstomed to work. In this way, the Red Cross will be able to build up around varions members of the Nedical Reserve Corps complete nospital wolmms or units. It is, furthermore, making arrangements for special instruction for other personnel. such as women to run linen rooms and other hospital work and 
plans to enroll cooks, ete., so as to have a whole unit and a complete one.

Many other points I will not now attempt to discuss. I have explained the situation, trusting that the matter can be worked out in fairness to the Red Cross.

Miss Boardman and Miss Delano then interviewed the Surgeon General of the Army, only to find that it was the opinion of General Gorgas and Major Robert E. Noble that the organization of base hospital units was an undertaking for the Medical Reserve Corps rather than for the Red Cross. This interview resulted in the deadloek which Colonel Jefferson IR. Kean of the United States Army found upon his arrival, January 6, 1916, at National Headquarters.

At the request of the Red Cross Executive Committec, Colonel Kean had been detailed by the War Department to act as Director General of the newly-ereated Department of Military Relief of the American Red Cross. A former president of the Association of Military Surgeons, Colonel Kean was an early and enthusiastic sponsor of the Medical Reserve Corps. He was an alummus of the University of Virginia. His Army record included thirty years' active service at Fort Sill, Fort Robinson, St. Augustine, Key West, Fort Warren, Cuba, Washington, D. C., and Fort Leavenworth. He had received the Campaign Medal for service in the Indian wars and was chief surgeon of an Army Corps during the Spanish-American War. He brought to the Red Cross a thorough-going knowledge of Army personnel and methods of procedure, also tact and a tremendons faith in the opportunities for Red Cross service. Itis ability, his lively humor, his keen vision brought him many friends, both within the Army and the Red Cross.

Colonel Kean's first constructive work resulted immediately in a more complete understanding of the relation of the lied Cross to the Army. On January 24, 1916, eight days after his arrival, he wrote to Colonel Merritte W. Ireland, Medieal Corps, then stationed at Fort Sam Houston, Texas. Colonel Ireland, like Colonel Kean and Colonel Francis Winter, was one of that brilliant gromp of romeng officers, sinee risen to generalship in the Medieal Corps, who had known and csteremed Miss lolano when she had shared with them in 19 lo the limited desk-spane of the sureeon General's oftice. In his letter to colomel Iroland, colomel Keam stated: 
The military preparedness side of Red Cross organization has nerer been dereloped and the consequence is that I have a new and untilled field in which nothing has yet been done except in the two bureaus-the First Aid which [Colonel Charles] Lynch developed, and Miss Delano's reserve nurses with which you are entirely familiar. Miss Delano has at present between six and seven thousand of these and you know her well enough to know how well she has them in hand.

The first thing I had to do was with reference to the proposed organization by the Surgeon General of surgical units. ... I discussed the matter with the Surgeon General and his associates. I admitted that he had the right to go outside of the Red Cross reserve to employ nurses if he chose to do so, and that he also had the right to let his Reserve Corps officers undertake to get up units, although these would have no official existence. But I pointed out that while this was an abstract right, ... it would much discourage the nurses' reserve and the Red Cross would be very nearly inhibited from any successful effort to carry out the provisions of Circular No. 8, 1912, in organizing sanitary units. I proposed that the units which he had already authorized should be enrolled and inspected by me, both as a representative of the Red Cross and as his assistant under a letter of instructions from him. The three so authorized are Crile in Cleveland, Swan in Rochester, and Cushing in Boston.

My proposition would enable the Surgeon General to make use of the assistance of the Red Cross, whereas if he rejected it, he would have no place in time of peace to get the pecmuiary assistance which the Red Cross stood realy to offer. Existing orders already provided that when these units were ralled into artive servire, they ame under the orders of the War Department, and by plaring a regular medical ofticer in command of each hospital, it became absolutely under the control of the Surgeon (ieneral.

On Folmury 7 , 1916, Colonel Kean wrote Dr. Crile that "with reference to the base hospital which you were authorized by the Sureeren General to enroll for service in war, it has been decided after ronference between the Surgeon General and the National Red croses that the enrollment will be made through

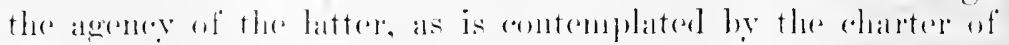
the Anerican National lied Cross and existing War Department orders." 
In a second letter written February 16 to Colonel Ireland, Colonel Kean reported further details of the new project:

I am starting out now in a few minutes to New York, Boston, Rochester and Cleveland, to organize base hospitals. We have three alrearly in process of organization in New York, one in each of the other eities. There is so much enthusiasm abroad that I believe we can organize one in connection with every big hospital in the country. My present scheme is to have Red Cross Chapters aceumulate the money to buy the equipment for each hospital and store it when at hand. It will cost over $\$ 20,000$ for each hospital, so you see there is nothing small about my scheme!

With characteristie briskness and zeal, Colonel Kean and Miss Delano set about their gigantic task in the early spring of 1916. By personal interview or letter, Colonel Kean placed his project before the president of the Board of Directors, or the 'Trustees of each hospital. After they had signified their willingness to undertake the organization of a base hospital composed of the personnel within their iustitution, a director and chief nurse were immediately appointed to undertake the enrollment of the other members of the unit. While these busy individnals were interviewing their eandidates and looking into past records, Colonel Kean took up with the local Red Cross Chapter the problem of equipment. This meant buying, storing and having "ready for instant transportation everything necessary for the surgieal, medical and nursing care of five hundred sick and womnded soldiers, from the beds they lie upon to every kind of bandage and operating instrument." 12 This non-perishable equipment, the finest which could be purchased, was estimated to eost approximately $\$ 25,000.00$ per unit; this equipment was "found to cost ipwards of $\$ 5 \pi$,000 " for each nut before the work was completed. ${ }^{13}$ The Comptroller's Report for the period July 1, 1917, to February 28, 1919, the months during which the operations of the American Red Cross were directed by the War Council, stated that "the Chapters of the Red Cross spent, in round figures. \$:;,

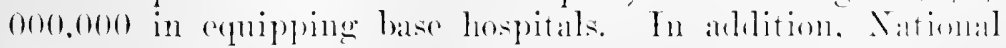
IIcadpuarters made a number of appropriations to meet special needs." 14 The equipment of each mit repuired the nise

${ }^{12}$ The surle! Fohrmary 7. 1917. Vol. 37. p. 38т.

"Anmal Report. American lied Cross. 1917. p. 2.2.

14 "The Work of the American Red Cross during the War." p. 41. 


\section{HISTORY OF AMERICAN RED CROSS NURSING}

of seven freight cars to transport its beds, bedding, ward furniture, drugs, dental and surgical instruments, laboratory supplies and equipment, mess gear, sterilizers, ambulances, touring cars, motor trucks, motoreyeles, complete $\mathrm{X}$-ray plant, kitehen and disinfectors. The initial supply of surgical dressings and hospital garments was at first furnished through committees of Women's Auxiliaries of the parent hospital and the cost amounted to $\$ 8000$ for each base hospital unit. After National Headquarters had built up its surgical dressings department, the Red Cross assumed entire responsibility for these articles.

The relation between the local Red Cross Chapter which furnished the funds for equipment and the base hospital unit was, in Colonel Kean's words, "that of a big sister, close and cordial, but without parental authority." ${ }^{15}$ In view of the great pecuniary assistance which was expected of the Chapters, the question of whether they should not have a controlling voice in the selection of officers and in other details of organization, had naturally arisen, but National Headquarters had not felt it wise to authorize this because the military and professional personnel of the units would naturally demand that direct control be of a military and professional character.

A base hospital first included a personnel of 265 souls, with "such subordinate adininistrative personnel as may be necessary" and "such Red Cross volunteers as may be authorized by the Director General of Military Relief, upon the approval of the Secretary of War." 16 The original number of nurses was placed at fifty, but was later inereased to sixty-five and then to one hundred and the rest of the personnel raised proportionately. The personnel of a base hospital as originally anthorized ineluded twenty-three doctors (later raised to fifty); fiftr nurses (later raised to one hundred); twenty-fire murses' aides (never called out) ; fifteen reserve nurses (later raised to twenty-five); and twenty-five reserve nurses aides (nerer called ont); and other personnel necessary to care for a firehundred-bed hospital (later raised to one thousand beds).

In the Regulations Goveruing the Emplorment of the American Red Cross in Time of War, anthorization for the nursing staff was contained in paragraph twelve, viz., that "the

\footnotetext{
15 See Annual Report. American Red Cross. 1916, p. 41.

${ }^{19}$ Reternlations Govmung the limplowment of the Anerican Red Cross in Time of War, December 1s, 1!li.
} 
organization of a base lospital will be . . . fifty nurses, members of the Red Cross Nursing Service, one of whom shall be chicf nurse and one of whom may be a dietitian. Twenty-five rolunteer nurses' aides."

To the chicf nurse, in consultation with the director of each hase hospital was delegated the selection of the nurses, the dietitian and the nurses' aides. All members of the mursing staff thus selected were required to be enrolled in the Red Cross Nursing Service. To save unnecessary correspondenee and to hasten appointments, Red Cross application blanks were scut to chicf nurses, who secured the training school (redentials of each nurse not already enrolled. The blanks were then sent to the Secretary of the Loeal Committee on Red Cross Nursing Service. The nursing staff consisted of one chief nurse; one assistant chief nurse; one night chief nurse; one charge nurse, operating-room; five assistant murses, operating-room; one charge nurse or dietitian; ${ }^{17}$ one assistant nurse or dietitian; one charge nurse, linen room; thirty-eight nurses for medical and surgieal wards; fifteen reserve nurses not on the muster-roll. It was suggested that at least three of the murses should have had some practical experience in the care of contagious discases.

As muster-rolls of the base hospitals lengthened and as the Chapters purchased and stored the equipment for each unit, the eagerness of laywonen to share in this type of war service erew to such dimensions that the Surgean General and the Red ('ross deeided to include among the personnel of the base hospitals twenty-five nurse's' aides, with a reserve of the same number. This group included for each hospital four diet kitchen aides, four aides to be assigned to the linen room, two aides to the nurse's' quarters and fifteen to the wards. Like the nurses, these aides were required to enroll in the Red Cross and to mulergo a thorongh physical examination. Their instruction in the care of the sick has already been set forth in a preceding section.

Theoughout the strained summer of 1916 the organization of hase hospitals proceseded. A rivid pieture of Miss Iolano remained in the menory of one of her seceretaries at National Inadquarters. At the ilese of an oppressively warm sunday's

17 Full information exncerning requirements for service als hed crom dictitians may be fommt in the ehapter relating to the Red Cross Sutri. tion Service. 


\section{HISTORY OF AMERICAN RED CROSS NURSING}

work, the chairman of the National Committee was on her knees on the floor sorting out nurses' papers. Her seeretary reached over to a file-ease and the string of beads which she wore eaught on a corner of the drawer, broke and scattered about the floor. With a sigh of relief, Miss Delano said: "You go on with the papers and I'll gather up the beads. I'm so tired I can't keep my mind on the work."

After the personnel of a base hospital unit had been enrolled, the nurses and enlisted men were required to sign in duplieate the muster-roll of the unit. This early system of requiring nurses to affix their signature to the muster-roll was later discontimued. Sinee nurses were members of the professional staff, the Surgeon General decided in 1917 that this troublesome detail might well be eliminated.

The American Red Cross entered into a definite contract with every parent institution which had undertaken the organization of a base hospital unit. The following contraet illustrated this relation:

The parties in this agreement hereinafter referred to as the RED CROSS and as THE HOSPITAL shall refer to the American Red Cross and to the Lakeside Hospital, Cleveland, Ohio.

The Hospital does hereby agree to assemble from its staff graduates, nurses, employes and friends, a trained personnel for a five-hundred bed Army base hospital, and to keep the specified posts of such a personnel filled, in accordance with the specifications as made and from time to time revised, by the Surgeon General of the United States Army. It also agrees to keep in the officiai muster-roll and ready for service, this persomnel and at the call of the Red Cross, immediately assemble such persons for transportation under the Government orders. From time to time as racancies oeeur, they shall be filled lyy persons nominated by the Hospital Trustees and the Director, and those so nominated shall be appointed to such racant posts, provided they conform to the prescribed regulations. At a call from the Red Cross for the services of this mit, the smperintendent of the Hospital is hereby anthorized and is instructed by the Trustees of the IIospital to release and send, wherever and whenever ordered, the enlisted personnel of this unit, and with the Direstor. to select substitutes for any who are unable to go.

The employess sent with the Hospital unit shall not remain on the Ilospital pay-roll during absence. but no $\mathrm{cm}$ - 


\section{RELA'TION OF NURSING SERVICE 'TO 'THE ARMY 337}

ployec of the Hospital shall be dismissed from the Hospital service, or fail in reinstatement at the close of such service, becanse of absence on account of the call of the unit to active service.

In consideration of the maintenance of the above personmel by the Hospital, the Red Cross anrees that the above mentioned unit shall constitute a part of its reserve medical organization and be known by the name of the IIospital as well as by its oflicial nmmber. It is understood that after the calling of this unit it will be out of the Rel ('ross reserve organization and controlled entirely by the Government. It is also unclerstool that, whenever this Ifospital Unit is called ont by the Red Cross or Govermment, that its entire expenses, including transportation from Cleveland, are to be paid either by the Red Cross or the Government.

Eliot Wadsortir, Acting Chairman, American .led Cross. Sameel Mather, President, Lakeside Hospital.

To the Lakeside Unit belongs the honor of being the first base hospital to complete its muster-roll, and also to be mobilized into active service. Colonel Kean in a letter written Dr. Crile on July 31, 1916, gave the Lakeside Unit the designation of Red Cross Base Hospital No. 4. He stated that while National Headquarters had originally intended to give numerical designations to base hospital units in the order in which the completed muster-rolls had been received, this plan had not been possible on acrount of mexpected delays encountered in completing the muster-rolls, especially in the column of male administrative persomel. "The purchase of equipment," concluded Colonel Kean, "therefore began before the rolls were completed and it hecame necessary to give number's to the base hospitals in order that areounts might be opened with them in this office for the purchased property and in order that the equipment so purchised might be duly marked."

On August 1. 1916. Colonel Keam transmitted to the ehairman of the Red Cross Central Committee the completed musterroll of Ameriean Ried ('ross Base IIospital No. + (Lakeside) with the recommendation that "this nuit be enrolled in the oftiee of the Sureen General, L. S. A., nuder Paragraph 16, Circulir No. S, .'. ( . O. September 10, 1912." On the same day, Major General Arthur Murray, C. S. A. Retired, then chainuan of the Central Committee forwarded the muster- 


\section{HISTORY OF AMERICAN RED CROSS NURSING}

roll and Colonel Kean's letter to the Adjutant General, for transmittal to General Gorgas. On August 5, the Surgeon General informed the Red Cross that "the receipt of muster-in roll of Base Hospital No. 4 (Lakeside) Cleveland, Ohio, Dr. George IV. Crile, Direetor, is acknowledged. The same has been placed upon the records for future referenee." Thus in complete readiness for immediate mobilization upon future need, the first one of that subsequently long list of Red Cross base hospitals was entered among the reserve personnel of the Cnited States War Department. A list of these units may be found in the Appendix.

In addition to these first fifty base hospital units, the Nursing Service supplied twenty nurses to serve on the staff of Base Hospital No. 55 which was organized by Dr. Baleh, of Boston, Mass. Jessie Grant was chicf nurse of this unit. Two other units, which were designated as Supplementary and as Replacement Hospitals, each had their full complement of one hundred nurses furnished by the lied Cross, but these units acted as a reserve in furnishing nurses for other hospitals and so were not regularly organized as Red Cross base hospitals. Another mit, ealled the British Base Hospital, had its nurses furnished by the Ameriean Red Cross with the definite destination of scrvice in England in view.

After the completed muster-rolls of several base hospitals had been filed in the War Department and the equipment for rarch had been stored in warehouses provided by the Government and the lied Cross, National Headquarters desired to see how these "amned hospitals" would meet the test of actual mobilization. The National Committee on Red Cross Medial Sorvice at a meeting leeld June 15, 1916, reguested the American Red Cross to order ont on October 29 one of its base hospital mits in Philadelphia. Colonel Kean stated that "the purpose of this mobilization was primarily to demonstrate that the organization existing on paper was a practieal and servicealle one; secondly, to ascertain what difficulties would stand in the way of such a mobilization; and thirdly, for the instruction in medical prepareduess of the great body of surgeons who would be in Philadelphia at that time, in attendance upon the Clinieal Congress of Surgeons and the American college of Surgeons." 18

Pase Hospital No. 4 was selected for trial mobilization. On

${ }^{25}$ American Red Cross Annual Report, 1916, p. 30. 
the brow of picturesque Behnont Plateau, Fairmont Park, Philadelphia, P'a., Base Iospital No. 4 mobilized on October 28, 1916, under cighty-five dum-colored Army tents. 'Twentyfive nurses, with (irace Allison as chief nurse, reported, but no murses' aides were present, owing to a decision not to call them out. The camp, covering twelve acres, had been erected by a detachment of the Medical Department sent over from Washington, I). C., under the command of Major Harold W. Jones. 'Twenty-four hours after the arrival of the nurses, all wards were in readiness for patients.

Tents are not the most satistactory housing equipment for "so large and sedentary an organization as a base hospital." On exhibition at Faimont Park was a splendid model showing the arrangement and materials of an ideal base hospital, ereated under the supervision of I)r. George E. Brewer, of New York, and his assistant, I)r. Sidney R. Burmap.

Colonel Kean summarized the benefits derived from the trial mobilization of Base Hospital No. 4:

The mobilization of this hospital marks an epoch in Rerl Cross development as concerns its obligations to assist the medical service of the armed forces in time of war. It is the first practical and concrete demonstration of the ability of the lied ('ross to do this. It takes the scheme of Red Cross military mits as a part of the Medical Service out of the domain of theory into that of accomplished fact. The cost of this mobilization was in all $\$ 5035.75$. The freight on cquipment and incidentals, $\$ 355.15$, was paid for by the New York County Chapter. ${ }^{19}$

During the fall of 1916 and throughout the vear 1917, Miss Noves carried practically alone the work of organizing the mursing stafts of the first fifty base hospitals, a task fraught with extensive detail.

In the organization and equipment of its base hospitals for the Army, ineluding a total persomel of $4: 397$ murses, the Red Cross aneomplished the groatest single projeet of medieal and nursing preparedness in history. The amonnt of time repuired to purchase the expipment of Base Hospitals Nos. 1 and 2 in New York in time of peace, without any restrictions of funds or military "ped tape" amounted to four months. Adrocates of preparedness folt that reonnmic conditions existing in a

${ }^{10}$ Ameriean Red Crons Anmual Report, 1916, p. 30. 
nation at war would greatly increase the period necessary for these mechanical arrangements. "Therefore," argued Colonel Kean, "if we are to have base hospitals ready to take care of our soldiers when war comes, we must equip them in time of peace." Theoretically, it was undoubtedly the duty of the Government to provide base hospitals. The fighting branch of the Army had always lacked many things, however, which perforee had to be asked for in preference to base hospital equipment. "Rifles, cannon, munitions, tentage, clothing, transport service have to be provided before we can have an army and naturally take precedence over provision for the care of the siek and wounded." 20 Here lay a supreme opportunity for the American Red Cross, unhampered by lack of funds, possessed of flexibility of organization, blessed with popular appeal.

Only the larger civil hospitals in the principal cities of the United States maintained staffs of sufficient size and specialization to permit the organization of a base hospital. Many small institutions, however, were also eager to organize Red Cross units. To accept their offers of assistance which came directly to the Red Cross or were referred thereto by the War Department, and to utilize the hospital facilities of the entire country, the War Department authorized the organization of smaller units of about one-half the size of a base hospital, to be known as hospital units. The Regulations Governing the Employment of the American Red Cross in Time of War (December 18, 1916) stated in Paragraph Thirteen that "hospital units are intended to supplement and assist established military hospitals. Sections of hospital units may also be assigned to duty on hospital trains and ships and to other military sanitary organizations."

The staff' of a hospital unit was made up of "a director"; an adjutant; two chiefs of service: four staff physicians; one head nurse; twenty nurses; three clerks, who may be women; and such numbers of orderlies as may be necessary."

The method by which hospital units were organized was similar to that used for their ligger brother, the base hospital. The equipment of hospital units inchded only instruments, medical and surcical supplies, basins, cushions, brushes, huckets, fracture apparatus, splints, and similar artirles. Is the purpose of these nuits was to supplement rstablished institutions, all ${ }^{20}$ See A. R. C. Annual lieport, 1916, p. 31. 


\section{RELATION OF NURSING SERVICE TO THE ARMY 341}

permanent articles such as furniture, refrigerating and delousing plants and X-ray apparatus were omitted. lied Cross Chapter's in the cities where hospital mits were organized, provided and stored their equipment and prepared their quotas of surgical dressings. P'erishable supplies were often purchased from the stock of the parent institution when the hospital unit was ordered into active service. Complete equipment for a hospital mit was estimated to cost approximately $\$ 2.500$.

National Headeuarter's organized ninetren hospital mits which wore assigned to artive service with the Enited States Army during the European War. The nursing stafis of these units were composed of 3!19 American Red Cross nurses, who served as reserves of the Army Nurse Corps. A complete list of these mits may be found in the Appendix.

Although surgical sertions were a type of mit which Secretary Baker anthorized the Red Cross to organize in the Regulations Governing the Employment of the American Red Cross in Time of War (I)ecember 1s, 1916) only one such mit was organized by National Hoadquarters. It was designated as Surgical Section No. 1 and was organized under Dr. E. MI. Quain, of Bismarck, North Dakota.

Emergency dotachments, made up solely of nurses, were the smallest and the most numerous of the three early Red Cross mits. As early as .June 2.2, 1916, Miss Delano wrote to all State and local Committees on Red Cross Nursing Service, explaining the purpose of emergener detachments and charging the state and Loeal Committee nembers with the responsibility of developing one or more of these mits. The Regulations Croverning the Emplorment of the Amerian Red Cross in Time of War (Iecember 18, 1916) stated in Paragraph Fifteen that "enerenery detarhments of nurses are organized to meet sudden alls from the sanitary service of the Army, or other emeremeise. Tley will be used to supplement the nursing service of military hospitals already estalblished, or be assigned to duty on hospital ships, hospital trains, or any service where gromps of nurses may be needed. . . Each detachment," combluded the paragraphli, "oomsists of ten murses, one of whom may he designated as head nurse and alets als such

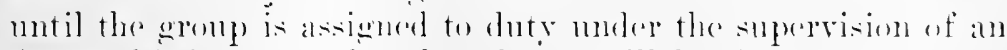
Army dhe murse, when her duties will be the same as those of entler memblers of the detarehment."

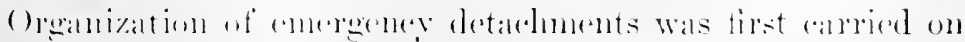




\section{HISTORY OF AMERICAN RED CROSS NURSING}

by direct eorrespondence between the Bureau of Nursing at National Headquarters and Loeal Committees on Red Cross Nursing Service. This procedure continued until the fall of 1!17, when the thirteen Red Cross Division offices were created; the Divison Directors of Nursing then took over the details of reeruiting which had previously been handled by Miss Noyes and her assistants. ${ }^{21}$

With its absence of equipment, its ease of mobilization, its ability to respond immediately to duty upon the receipt of its orders into active service, the emergency detachment proved one of the most valuable methods through which nurses were seeured. The first of these groups was ordered into duty on the Mexican border in July, 1916. Many other's were assigned during 1917 and the early months of 1918 directly to the British and Amoriean Expeditionary Forees. Later, however, nurses from these units were sent to cantonments where they were prepared for overseas duty. Red Cross emergeney detachments supplied 11,470 nurses to the War Department, half the entire strength of the Army Nurse Corps. No more brilliant proof than this ean be found of the soundness of the Red Cross Nursing Service committee system, nor of the untiring patriotism of these nurse-members, who, although already overburdened with tasks of maintaining with inadequate personnel hospitals and training schools and other trpes of work, served as volunteers during every available moment on the Local Committees which brought these eleven thousand nurses into the military service.

The youngest members of the nursing profession to serve with the American Armv during the European War entered the Army Nurse Corps br joining training sehool units which the Red C'ross organized within the senior classes of hospital schools of nursing. An unusually attractive group they were, young, adventure-loving, a brave and eager company of whom almost all were of recognized dependability and skill.

Red Cross base hospitals and hospital units, made up of the members of statts of major civilian institutions in all parts of the comntry. laarl drawn, during 1917, hundreds of nurses of distinguished positions from the institutional field. Iocal Committers on Red cross Xursing Service wre combing graduate nurse's' associations, clubs, registries and other agencies

${ }^{21}$ Se letter written November 1, 1917. ly (. 1). Noyes to all State and Local committees and organizing murses. 


\section{RELATION OF NURSING SERVICE 'TO 'THE ARMY $3+3$}

for private duty murses to serve especially in emergency detachments. With these fields of supply almost exhausted in the spring of 1918, Miss Delano and Miss Noyes appealed to members of the Jume graduating classes of hospital schools of nursing, urging these yomigr women also to join that continuous procession of reserve nurses filing into the Army Nurse Corps through the American Red C'ross.

Miss I latuo presented in a letter written March 12, 1918, to all superintendents of sehools of mursing, the first step of the lied Cross plan to utilize the services of young graduates for the Army:

We have been definitely asked by the Surgeon General to supply five thousand nurses by June 1, 1918, for the Army alone, and it is estimated that probably not far from thirty thowand adlitional ones will be needed by January $1,1919$. ... It seems evilent from the recent surveys which have been marle of the nursing resources of the country that there are not more than sixty-five thousand registered nurses in the United States. ...

We believe that training school superintendents are most anxions to aid in every possible way to secure the number of nurses needed. One of the most practical methods of increasing the arailable supply of nurses is to adrance somewhat the date of graduation in training schools giving a three years course of training, provided of course that only such inurses shoukl be graduated as are willing to enroll promptly with the Red Cross and accept service at once with the Army or with the Sary. . .

I should not feel justified in urging this shortening of the regular three voars' course. if I did not believe that the experience in military hospitals woukl supplement their recular training and give them not only experience which will he of ralue to them in their career as moses, but would give them as well the satisfaction of having served their conntry in time of need.

On March 13, 1918, Miss Toyes followed up Miss Delano's letter with a personal communieation addresed to all superintendents, in which she nrered them to mulertake the organization of at least one training schonl nuit.

The underlying principle of oremizing such mits was a recognition of the elan instinet. War semed less formidable when a nurse conld go wat with a former room-unate or a friend who had heon trained in the same wards. 


\section{HISTORY OF AMERICAN RED CROSS NURSING}

Each training school unit was numbered, the designation beginning with a high number to avoid confusion with base hospitals and hospital units. The first training school unit was formed at Sara Elizabeth Hospital, Henderson, North Carolina, and was designated T. S. Unit No. 500 ; the second, from the Methodist Episcopal Hospital, Brooklyn, New York, as T. S. Unit No. 501. Nurses other than the graduates of a given school which had formed a unit might join the unit of that institution if none existed in their own school, or if satisfactory reasons were presented, but this was seldom done.

During the spring and summer of 1918, 1362 nurses volunteered for war service in 307 training school units. A list of the units is given in the Appendix.

Immediately following the declaration of war by the United States, General Gorgas organized within the Medical Corps of the Army, dirisions of Mental Diseases, Internal Medicine, Orthopedics and Opthalmology, the directors of which were experts in these different branches of medical practice. These directors were charged with the responsibility of organizing such base hospitals for service in the United States and abroad as the treatment of such cases as might fall under the above classifications, required.

The medical and enlisted personnel of these units was organized entirely within the Surgeon General's office and the equipment was supplicd by the Gorermment, but the Army Nurse Corps called upon the Red Cross to supply the nurses. The first step in seeuring nurses qualified for this serrice lay in the establishment of a classified list of murses specially trained in pediatric, pstchopathic and orthopedic nursing and in nursing mental diseases, contagions diseases, head and neek surgery and ere and ear work. After the establishment of this list, the procedure was eomparatively simple. From time to time. Miss Thompson notified Miss Foyes of the formation of special hospitals and she secured the nurses throngh correspondence with those whose names appeared on the classified lists.

The develnpment of phrsio-therapy, one of the signal developments which the war indirectly brought to medical science, created a drmand for expert masseuses. Miss Noves prepared a formu letter in Xorember, 1917, to be sent to nurses wher repuested information of this type from National Headgliarters, or to murses whose enrollment slowed special training. 
Regulations concerning enrollment as an expert masseuse were as follows:

Applicants should be graduates of a recognized school of massage.

The service is entered for the period of the war. It is to be performed in the wards of the reconstruction hospitals under the supervision of the head nurse of the ward.

Applicants should be preferably between the ages of twenty-fice and forty-five.

Applicants should be endorsed by the principal of the school of massige from which she received her diploma.

Members of the service are expected to respond promptly to a call for service coming from the Bureau of Nursing of the lied Cross.

A masseuse will be paid $\$ 50.00$ a month, with maintenance and transportation.

[Here follow the same passport and physical examination instructions as apply to the Red Cross Nursing Service.]

The Nursing Service assigned 193 murses expert in the care of special discases to the Army Nurse Corps for service in the following special base hospitals of the Medical Department: No. 11t, Orthopedic (assigned to service in the United States and later to foreign duty); No. 115, Eye and Ear (assigned to service in the Enited States and later to foreign duty); No. 116, Fracture (assigned to service abroad) ; No. 117, Psychiatric (assigned to service abroad); a mobile operating mit under Major P'. R. Turmure, M. R. C. of New York City.

As the Selective Mraft brought thousands of recruits to the cantonments, which had sprung up overnight in rows of mpainted barracks like clusters of enormons gray mushrooms. a problem in santation arose which presented an opportunity to the Thed Cross for vital service to the enlisted man. Within the military boundaries of each cantomment, sanitary measuress were directly moder the charge of Amy Medioal offieers. In the regions immerliately surromding the military distriet, this

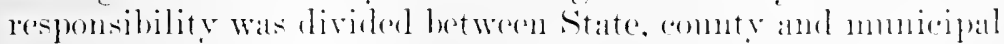
health departments. The physial well-hedies of the new armies was intinately related, howerer, to these extrateantonment zomes. Through the ereiperation of the Wall and Treasury Departunents, the Inited States Public Hoalth sirvice had

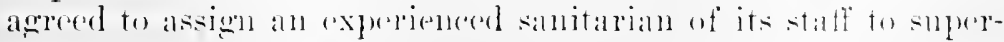
vise health mealsures alunt eateh eantomment. This oflierer was 


\section{$3+6$ HIS'TOR I OF AMERICAN RED CROSS NURSING}

duly invested with such powers as the State and Local Boards of Health would transfer.

Neither the Federal P'ublie Health Service, nor local agencies possessed, however, suffieient funds to employ an adequate persomnel to help this officer. Legislative action would have consumed valuable time. The Red Cross accordingly set aside an initial appropriation of over $\$ 10,000$ to organize a Burcau of Sanitary Service under the Department of Military Relief and supplemented this appropriation from time to time to the amount of approximately $\$ 750,000$ in the aggregate.

Dr. Taliaferro Clark, Surgeon, United States Health Service, and one-time director of the Red Cross Burean of Sanitary Service, stated in the Amnual Report of 1917, the method under which this bureau operated:

Assistance is giren only on request from a State and on recommentation of the Surgeon General of the Unuted States Public ITealth Service, under whose direction a sanitary surrey is being made in the vicinity of each rantonment.

Upon receipt of a report from the Public Health Service stating the ronditions in a district and establishing the need for ait, the Red Cross promptly furnishes this supplementary assistance by assigning to the district bacteriologists. sanitary inspertors and lied Cross public health nurses, with an appropriation sufficient to provide equipment, transportation and maintenance.

Miss Noyes wrote on August 6, 1917, to chief nurses of all units and inetarhments, stating that the National Committee on Red Cross Nursing service had roted the week before in faror of a sperial enrolment for publie health nurses, exempting them from active military serviee, if they desired, so that they might mulertake antomment zone work. Miss Noyes suggested that all nurses who were enrolled in base hospital and other units, rot who hy training and experience were fitted for camtomment zone servie, shomk be withdrawn from the mits then being oreanized for the Army and should be transterred to cantomucht zone service.

This particular platse of war nursing suremeling the cantomments consisted in sanitary work in ennection with the publie and private water supply: the disposal of sewage and garbage; the drainage of mosquito-infested swanps; the in- 
spection of food supplies; and the control of communicable discases. Miss Ella Phillips Crandall, executive secretary of the National Organization for Public Health Nursing, assisted the Red Cross in the selection of public health nurses for this serviee, one hundred and fifty-four of whom were assigned to twenty-nine sanitary zones at the following localities: Alexandria, La.; American Lake, Wash.; Amiston, Ala.; Atlauta, (ia.; Augusta, Cia.; Ayer, Mass.; Charlotte, N. C.; Chattanooga, Temn.; Chillicothie, Olnio; Columbia, S. C.; Des Moines, Iowa ; Manhattan, Kansas; Fort Worth, Texas; Greenville, S. C.; Hattiesbure, Miss.; Houston, Texas; Jacksonville, Fla.; Leavenworth, Kansas ; Little Rock, Ark. ; Louisville, Ky. ; Macon, Ga.; Montgonery, Mla.; Newport News, Va.; Petersburg, Va.; Portsmonth and Norfolk, Va.; San Antonio, Texas; Spartanbure, S. C.; Waco, Texas; Wrightstown, N. J.

By vote of the National Committe on Red Cross Nursing Service in May, 1918, the name of the Red Cross Town and Comitry Nursing Service was changed to that of the Burean of Public IIcalth Nursing Service. To it were delegated during the summer of 1918 the responsibility for public health nurses assigned to extra-cantomment zones.

Sceond in military inportance to American combat troops in France were the essential war industries in the Lnited States, which furnished supplies to the American Expeditionary Forees and to the Allies. For ten miles aloig the Olio River, in whose dark, swiftly-flowing waters were reflected at night the graring throats of a thousand furna ses, steted the Lnited States Ammunition Plant at Nitro, in ine Sest Tirginia hills. From Muscle Shoals, Mlabama, eame the nitrate for high explosives. Tarions other centers for manufacturing essential war supplies were located in different parts of the comtry and employed many thousands of workers. The health of these men and of their families was of paramount importanee, -for upon their labor depended the output of these manufacturing renters-aso the (iovernment established base hospitals to eare for anecident anses and illuess which oceurred there.

The Sureen Goncral of the Cnited States Prublie Health service, modere whose department these hospitals were maintained, agreed to utilize for this servied nurses who had been

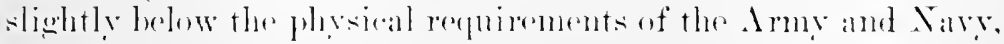
or these slightly abore the maximum age limit. or married nurses whos hoishands wore in military servere, a gromp which 


\section{HIS'TORY OF AMERICAN RED CROSS NURSING}

was barred from joining the Army Nurse Corps. Eighty-eight nurses were assigned to this service.

To Marine Hospitals and to special institutions maintained by the United States Public Health Service for the care of pellagra, trachoma and other contagious diseases, fifty-four Red Cross nurses were assigned before the Armistice. The development of the Nurse Corps of the Public Health Service is treated more fully in a later chapter.

The first field service which American Red Cross nurses experienced as reserve members of the Army Nurse Corps was on the Mexican border. This type of duty began in 1911. In the spring of 1914, the Punitive Expedition was dispatched to Vera Cruz and oceupied the eity. Army nurses accompanied the military forces. Early in 1916, the Villesta forees killed several American miners and the United States Government demanded reparation. On Mareh 9, 1916, Villa invaded Columbus, New Mexico, killed seven troopers and several civilians and fired many buildings. President Wilson then ordered a punitive expedition under "Black Jack" Pershing to eross the border in pursuit of Villa, but to respect serupulously the sovereignity of the Mexiean Republic. Pershing, with the aid of Carranza's troops, drove Villa into the hills, but the chaotic state of anarchy existing in Mexico continued.

In June, President Wilson changed his policy of "watchful waiting" to one of border defense; in a note of .June 2, 1916, sent to all factions, he warned them that they must adjust their differences and "aet promptly for the relief and redemption of their prostrate country" or else the Lnited States would be "constrained to decide what means should be employed to help Mexico save herself." On June 12, two troops of U. S. eavalry (colored) approached the town of Carrizal, requested permission of General Gomez to pass, stopped at his sugegestion to confer and were fired upon by the Nexican forces. A number of coldiors. including the officere in command, were killed and twentr-four were taken prisoners. President Wilson immediately demanded that Carranza define his attitude and surrender the prisoners. On June 1s, he called out every militiaman in the Inited Sitates to strengthen Pershing's line of 12,000 Rirenlars which extenderd gon miles directly sonth to Namiquipa. Sixtern batsleships stemed to the Meximan coast. congress officially anthorized the President to draft the Na- 
tional Guard into Federal service and voted $\$ 26,000,000$ for the energeney. Carranza then yielded and returned the prisoners. Notes proposing diplomatic settlement of the differences between Mexico and the United States were exchanged in July. At this juneture, Villa ennerged from among the hills and the "cat and monse" warfare that had been going on before began again.

With over 200,000 Regulars and Militiamen in the field in August, 1916, the United States Army established during the smmmer five base hospitals, five eamp hospitals and one eantomment hospital along the Mexiean border." ${ }^{2}$ Kathrine Donnelly, Lulu T. Lloyd, Alice B. Harvey and Nannie B. Hardy, reserve members of the Army Nurse Corps, had been in service with the border troops since 1914 . When the relations between Mexico and the United States became strained in the spring of 1916, Colonel Kean, then acting chairman of the Central Committee of the American Red Cross, wrote May 15 to the Surgeon General, offering the serviees of "such a number of nurses, not exceeding forty, as may be needed." The Red Cross at the same time offered to pay the salaries of these nurses and to furnish transportation for them to the place of service, but the Army to furnish maintenance. "It is presumed," concluded Colonel Kean, "that after July 1 these nurses ean be paid from the Army appropriation if their services are still needed." Red Cross records show no evidence of a written reply to this offer.

Colonel Kean took up the question again in a letter addressed July 28 to Colonel Birmingham, then Aeting Surgeon General. This letter contained interesting arguments of the three wars in which the number of nurses available for the Medieal Corps might be inereased. The first way was to inerease the number of nurses in the Regular Nurse Corps. The second way was to eall reserve nurses, namely, American Red Closs nurses, into active service in the Army Nurse Corps. The third way was to employ eontract nurses "who may or may not be enrolled Red Cross nurses," stated Colonel Kean, "but who are paid out of the Medieal and Hospital Appropriatimi."

The first methed, that of increasing the number of murses in the liegulatr Nurso ('orpes. Was tlem being nsed to secoure nurses for the Army base hospitals on the Mexicam berder.

${ }^{2}$ Report of the surgeon (ieneral. C. S. A., 1917. p. 2:3. 


\section{HISTORY OF AMERICAN RED CROSS NURSING}

"I do not know," argued Colonel Kean in his letter of July 28, "what advantages it has which have led to its adoption in preference to the second method, in an emergency which is of a more or less temporary nature, but $I$ think it is clear that it has the disadvantage of being much slower than ealling out the reserve nurses. I understand that only 190 out of the more than 400 which are now authorized, have been obtained during the number of weeks since an increase was authorized. Also, I do not believe," he continued further, "that the best nurses in the country are as easily seeured for a permanent engagement in the Army Nursing Service as ean be secured by the selection from the Reserve. In the latter, as you know, a very large number is available from which to select, and there is the appeal of patriotic service which is not so much in evidence in the Army."

Colonel Kean's argument next dealt with the third method, the employment of nurses by eontract. In his opinion, it had several disadvantages. "In the first place," he stated, "the term 'contract nurse' is one which was brought into diseredit during the Spanish-American War by the employment in this way of untrained nurses and of women for matrons and other purposes than special nursing, and the term 'contract nurse,' like 'contract doctor,' is itself not an attractive one. Also, the fact that these nurses are paid out of the Medieal and Hospital Appropriation, which is never too large, rather than from the appropriation for pay of the Army, is a serious disadvantage. I think, therefore," he declared, "that this method of securing nurses should not be eonsidered."

After a diseussion of the probable number of nurses needed, which Colonel Kean estimated would ultimately be one thousand, he proceeded with directness to his conchusion: "I am writing to suggest that the additional nurses needed in the present emergeney, due to the calling out of the National Gnard and the mobilization of the Army on the border, be furuished from the nurses' Reserve, as is contemplated by the Regulations, and that this office be taken into the confidence of the Surgeon Creneral's office as far as possible and notified as nuch in advance as may be practicable of the ealls which nay bo made upon it for nurses."

On July 2!?, 1916, the Sureon General replied to Colonel Kean, reciuesting that "this office be furnished with the names of forty reserve nurses in groups of about ten, who are willing 
to be assigned to active duty in the Military Establishment and who "an respond to an immediate call." In this letter, the Surgeon General also stated that the physical examination repuired by the Red cross for enrollnent would be satisfactory, but he repuested that the credentials of each nurse assigned to meet this call should be sent to his office.

Insight into the reasons why the War Department did not alecept carlier the offer of lied Cross assistance was contained in a letter written by Miss Delano August 10 to Mrs. William li. Hraper:

The Red Cross offer, to send forty or fifty nurses to the border, went to the War Department and after much discussion it was decided by the Secretary of War, l believe, that the Army could not accept this contribution from the Red ('ross except when war was actually declared. Their appropriation for additional nurses is now arailable and we have again offered to send nurses as they are needed.

I believe that at present there is some question concerning quarters, but at any rate the nurses are ready. I began some time ago the development of what we call emergency detachments of which we now have a good many available. (Our base hospitals are well developed, nearly ready for servicr. I thank Ileaven every day that we were fortunate enongh in begimning the organization of the Nursing Service (o) long ago that now there need be no delay as far as the nurses are eoncerned.

Four dilys later, Angust 1t, the Surgeon General called upon the lied cross for one hundred nurses, instead of forty, for border sorvice. As this was the first call of sizable dimcisions which the Red ('ross Nursing service had received, the rules and regulations handed down by the Surgeon General are of importance, in that they constituted the precedent which later geverued the assignument of Ameriean lied Cross nurses to the Army Nurse ('orps during the participation of the Lnited states in the Eurepran War. In his letter of Angust 1t, the Simperen (imeral stated that reserve murses must be citizens of the Inited states. Colonel Kean in his reply of Angust 16 wrote:

$\because$ The requirement mentioned in your letter, which is a

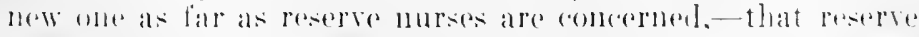

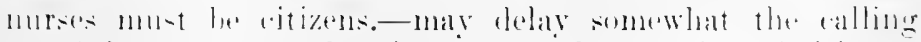

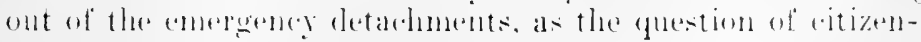




\section{HISTORY OF AMERICAN RED CROSS NURSING}

ship has to be put to each individual nurse. The War Relief Board, of which the Surgeon General of the Army and the Surgeon General of the Nary are members, have considered the regulations for enrollment in the Red Cross Reserve and have not considered this requirement necessary for reserve nurses, whose service is of a more or less temporary character, although it is required of members of the Army Nurse Corps. 'They have always, of course, been required to take the oath of allegiance. This requirement seems somewhat at variance with the neutral and international character of the Red Cross.

In his letter of August 16, Colonel Kean next dealt with two questions of only temporal importance. He suggested that nurses assigned to border duty be permitted to serve for a period of only six months, if necessary, so that they might return to positions which were being held open for them. He also requested that several reserve nurses from various base hospital units be assigned to the border, so that they might become familiar with Army paper work and other conditions peculiar to Army nursing. The last point made in this letter was one of vital importance. Colonel Kean wrote:

5. As the question of insignia for Red Cross nurses when on active duty has not been authoritatively settled, it is requested that a ruling be made that they shall wear the Reserve cap with the Red Cross on the front and the Red Cross cape which is issued to them gratis. This is considered of importance on account of the international and well-accepted character of this insignia and its value in maintaining esprit de corps.

In a letter written August 18, the Acting Surgeon General, Colonel Birmingham, answered these points in the following order and mamer:

1. Your letter of August 16 is herewith acknowledged.

2. As there appears to be no law requiring the reserve nurses assigned to active duty in the Military Establishment to be citizens of the United States, so much of letter dated August 1.t as pertains to this need not be regarded, though citizens, or those who have made declaration of intention to become such, will be given precedence.

3. You are anthorized to inform reserve nurses volunteering for active scrvice that they may on request, be reliever from active duty and given transportation, to the place from 
which they started, at the end of six months' service, unless in the meantime, the need for their service ceases to exist or in case of misconduct.

4. In the case of murses assigned to active duty, and who are enrolled for base hospital units, every effort will be made to transfer them to the unit of which they are a part, should the mit be called out, provided the Red Cross will nominate other nurses to replace them.

5. There is no objection in this office to the use of the led Cross cape and eap by reserve nurses.

Immediately upon receipt of Col. Birmingham's answer, Miss Delano called out emergency detachments which had been oreanized by Loeal Committees in Alabama, Colorado, Georgia, Nebraska, Iowa, Lonisiana, Maryland, Minnesota, New Jersey, New York, Ohio, Pemsylvania, Texas, Virginia and Washington, D. C. One hundred and forty-four nurses were first assigned to Camp MeAllen, Fort Sam Mouston, Eagle Pass, Laredo, Llano Grande, Brownsville and Fort Bliss in Texas; to Nogales and Douglas, Arizona; and to Deming, New Mexico.

Nurses were also assigned to United States Army base hospitals from the base hospital units organized at Bellevue, the Presbyterian, the New York City, the Post Graduate, Mt. Sinai and the German Hospital, of New York City; at the Boston City, the Massachusetts General and the Peter Bent Brigham, of Boston; at the Lakeside, of Cleveland; at the Rochester Hospital, of Rochester, New York; at the Harper Iospital, of I)etroit, Michigan; and at the Washington Unirersity Medieal Sichool, of St. Louis, Missouri.

Reserve nurses who went to the borter were almost unanimous in their expression of enjoyment of the service. The chief nurses were Regulars of the Army Nurse Corps. An eight-hour day are the nurses ample leisure. The work in itself was liglit, hut the lieserves fomml unending interest in the routine of an Amy (oneral IIospital. "The Military is so different." they wrote Miss Inelano.

At Fort Sam Homston, Sill Antonio. Texals, the hase hospital of one thomsand berls was alwars full. "The patients are mostly trphoirl and operative eases and soldiers suffering from exhanstion due to the hot smo," wrote Ada Hayton, of the Washington, I). ('., emereney detachment, to disis Delano.

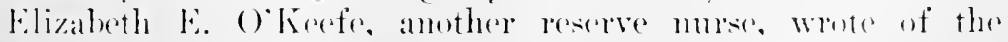
attitute with whinh visitors and patients regarded the Reserve: 


\section{HISTORY OF AMERICAN RED CROSS NURSING}

We are quite amused at the terms applied to us by the soldiers and their visitors to designate us from the Army' nurses. A young woman visiting one of the wards, stopped me to say "I want to ask you a question, and if you are not allowed to answer it, why just say so, won't you?" I nodded. Imagine my surprise when she drew a long breath, screwed up her courage and whispered confidentially: "You Red Cross nurses aren't really all graduate nurses, now, are you?"

A patient said to one of the Reserres, as she was giving him a bath: "Do you find this work very hard to learn"?" "What do you mean?" she asked. "Why," he replied, "aren't you one of those society women who are doing this for fun and the good of humanity?"

At Fort Bliss, Texas, the Army base hospital cared for an average of five hundred patients, the majority of them aceident eases. Here as in other bases, the nurses were at first somewhat uncertain as to their exact dutios. "After we get better acquainted with the Army," wrote Ellen Thomas to Miss Delano on September 12, 1916, "I think we will be busier. The Corps men have done all the work until June of this year and it is now rather difficult to know where their work stops and ours begins."

Overlooking the low brush and eacti of the Mexican shore, directly on the bank of the Rio Grande, stood the Brownsville Hospital. In a letter written September 28, 1916, to Miss Delano, Edith L. Wood, reserve nurse, deseribed their "quarters":

We are fairly comfortably situated here in a low frame building, just boards, with two of us in each room. Everything is screened against mosquitoes and we sleep under nets. Though the heat is intense during the day, the wind off the Gulf of Mexico, twenty miles away, makes our nights very comfortalle.

All the buildings are of the same construction. The wards accommodate about fifty patients each. They are so quickly and easily assembled that they secm to spring up orernight like mushrooms. A month ago there was nothing here but dust, sandfleas, cacti and heat. Now it looks like a small village.

No sperial disease prevails. The have something of everything. quite a bit of malaria, and a ferer called "dengue," which the merry mosquitoes give us. 
One of the five camp hospitals which the Medical Corps maintained on the border was located at Lano Cirande, Texas. A reserve nurse who had seen service with the British Expeditionary Forces during the early years of the European War wrote of the work at Llano Grinde:

Our experiences are quite different from those in an English camp hospital in France. We were much disappointed at first to find our hospital so poorly equipped. Camp life in France was so very fascinating and the nurses were treated with great respect by the British Tommies. . . .

We were later transferred to Fort Sam Honston, where everything is well systematized, with supplies in abundance. Here we found our boys quite as appreciative as the English and French and so full of fun!

The camp hospital at Donglas, Arizona, consisted of tents and wooden barracks. "Nurses' quarters," wrote Harriet Hankins to Miss Delano on August 27, 1916, "are separate and are bnilt of wood, with exeellent floors, plenty of sereened windows, rmming water, in fact are wonderfully comfortable. Each nurse has a bed, a burean and a built-in wardrobe." Miss Delano's reply was reminiscent of her own early experiences in the West: "Soon after my graduation," she wrote, "and almost my first work was in the mining camp at Bisbee, Arizona, not far from your present assigmment. In those dars, the Apache Indians were usually on the war-path and we never dared stir out without a revolver. I imagine things are more avilized nowe."

The wooden hildings and tents at Douglas, which were comfortalile enongh during the summer of 1916 , were meager protection acainst the raw fall rains and the bitterly cold winters. The nurses stationed there then experienced more of the rigors of open camp life, for a letter written by a member of a local committer on Red Cross Nursing service to Miss Drano gare a diflerent pieture:

Their quarters were a small tent shared by five nurses. There was no way of heatiug it; the weather was very cold. The nurese in the shacks had foul hankets and a store. IIhen it rained, the water would run nuder the cots. The flocring of the tonts was arth. One very cold night the wind hese up the top of the tent and the nurses gatherend up these hankets and rothes and spent the rest of the night win the 


\section{HISTORY OF AMERICAN RED CROSS NURSING}

floor of the dining-room. They used to stand on their cots to dress so they would not have to put their feet on the cold earth. ${ }^{23}$

This first field service with the Army which reserve nurses experienced on the Mexiean border was of great value in acquainting Ameriean Red Cross nurses with military discipline. In her letters in reply to complaints which the nurses sent to National Headquarters, Miss Delano emphasized again and again the unofficial connection which she held to Red Cross nurses after they had once been assigned to the Army Nurse Corps. The Red Cross could in no way interfere with the discipline of the Army and Navy and no one appreciated this fact more than did Miss Delano. To eomplaints, her answers were almost invariably as follows:

In the first place, Red Cross nurses when assigned to duty in a military hospital become temporarily members of the Army Nurse Corps, subject to all rules governing that service. It is impossible for me to take up this situation officially. Any statement should be sent through the chief nurse and the regular military channels.

May I urge, howerer, that you keep the nurses from diseussing this matter and ask them to accept without question any decision of the chief nurse? Be patient for a little while. You know how deeply interested I am in everything concerning Red Cross nurses, but when it comes to a question of military authority, I am quite helpless. I can only count on you to do your best to keep things ruming smoothly.

Though only a minor skirmish in comparison with the titanic struggle to come, the Mexican border service of 257 reserve nurses remained an illuminating and, for most of them, a worth-while memory.

Both from a utilitarian and from an asthetic point of view, the uniform of the Anserican Arny nurse on active duty during the European War differed greatly from the costmmes worn by nurses in previons wars. Volnnteer and professional nurses of the Spanish-American War had gome to their posts of duty garber in eivilian dress or in the miform of their sehool of mursing. The appeantance of the Civil War nurses, in erinoline and shaw, is familiar to stmlents of American military history.

${ }^{2}$ Red Cross Archives. National Ileadquarters, Wash., D. C. 
The deseription of the "grey tweed wrapper, worsted jacket with eap, a short woolen cloak and frightful scarf of brown holland" ${ }^{24}$ of Miss Nightingale's murses calls up an awesome image.

The uniform of the American Army nurse was both useful and attractive. It consisted of blue norfolk coat with the bronze letters U. S. and the eaduceus of the Army Medical Corps with the initials of the Army Nurse Corps superimposed upon them, the short blue skirt above brown shoes, and trim sailor hat, or the white, one-piece dress worn with the scarlet-lined blue Red Cross cape and the winged white eap. A war correspondent once asked a doughboy from a Penusylvania mining town, who had been brought into an Anncrican base hospital with a shattered leg, what he thought of the reserve Army murses there. "It gives me," replied the Pennsylvanian, "benefieient shellshock to look at 'em!"

The distinctive uniform of the American nurse was, however, a gradual evolution. The Manual of the Medical Department, 1906 , the edition in which first appear regulations regarding the uniform of Army nurses, stated that "the miform of the Army Nurse Corps shall consist of a waist and skirt of suitable white material, adjustable white cufts, bishop collar and white eap, according to patterns and specifications in the oftice of the Surgeon General." 25

At the first meeting of the National Committee on Red Cross Nursing Service, which was held in New York on Jamuary 20, 1910, a committee which consisted of Miss Delano, Miss Boardman, Miss Nerins and Major Eynch (then in charge of Red ('moss First did instruction) was appointed to draw up a cirrular of information: regarding enrollment in the Nursing service. This circular was printed by the National Headquarters on April 1, 1910, and contained the following regulations:

\section{Uniform and Badge}

Tnless otherwise authorized, nurses alled upon for service under the lied cross will weal plain white uniforms with bishop rollars and aps. the gitterns of which will he provided by the American lied ( ross on application to the chairman of the Sational committer on lied ('ross Xursing Service. . . LAdress follows.

24 "Memories of the Crimea," Sister Mary Aloysins, p. 17.

${ }^{2}$ Manmal of the Medical bepartment, ling; j. 31. 
At the time of appointment each nurse will receive a badge with lier name and the number of the badge engraved on the back and a reeord of the same will be kept in the National office of the Red Cross in Washington.

Under the Act of Congress incorporating the Red Cross, this badge camnot be legally worn by any other than the person to whom it is issued, and is owned by the American Red Cross. It should be worn on the front left-hand side of the collar. In case of withdrawal from enrollment, the badge and certificate of appointment must be returned to the (hairman of the National Committee on Red Cross Nursing Service. . . [Arddress follows.]

In the event of war, the Red Cross will provide all nurses called upon for active service with blue capes-bearing the insignia of the Red Cross.

Miss Delano, with a rare sense of the dramatic and an appreciation of the power of sentiment, designed the eape referred to, which has since become perhaps the most distinguishing nark of the American nurse on active service during the European War. It was a circular garment of medium length, made of nary blue flamnel and lined with searlet, and it was usually worn flung back over the left shoulder. On the left side was a lied Cross and by reason of the high ideal of conduet which Miss Delano set for the enrolled nurses and the vivid appearance of the garment itself, nurses grew to honor and love the eape and to wear it with soldierly pride. It symbolized for them the romance and the saerifiee of war nursing.

The use of the lied Cross brassard was ontlined in the original Treaty of Geneva and was defined in the revised Treaty of Geneva, which was signed July 6, 1906:

Article 20. The persomnel protected in virtue of the first paragraph of article nine and articles ten and eleren, will wear attarhed to the left arm a brassard bearing a rod cross on a white ground, which will be issued and stamped by compotent military authority, and accompanied by a certificate of identity in the rase of persons attached to the sanitary service of armies who do not have military uniform.

In the Rerulations ronorning the $\Lambda$ meriean Red Cross Norsing Servier, as artopted by the Executive Committee Decrmber 20, 1912, which supersedred the Circular of Information issued April 1, 1910, the following sentence was ineor- 


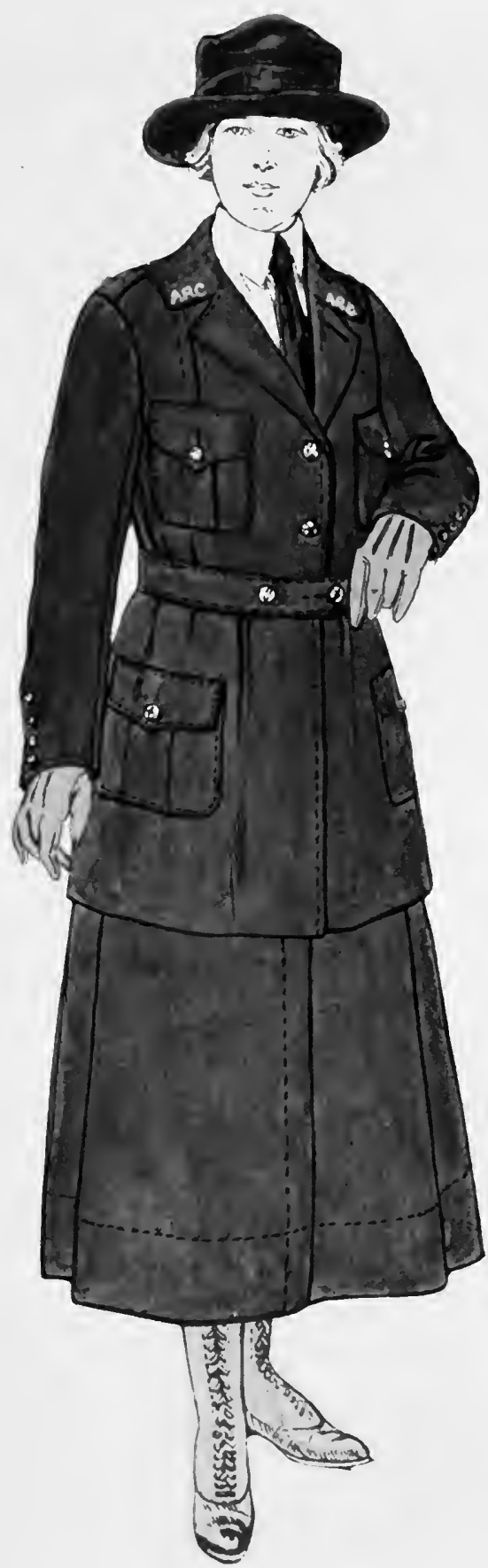

Outdoor uniform of an Ameriean litel crose nurwe This miform was

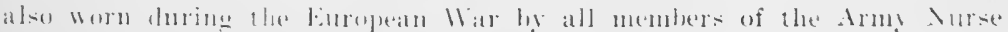
corps, with the insignia of that corps. 

porated into the seetion defining the Red Cross nurse's uniform: "Nurses are not at any tine allowed to wear Red Cross brassards without special authority from the American National Red Cross."

The next mention of uniforms is to be found in the Minutes of a meeting of the National Committee on Red Cross Nursing Service, held December 9, 1913, at which "it was decided to adopt a murse's uniform for the Red Cross Nursing service if a suitable material could be found. . . . Miss Delano was asked to get information about gray cotton erepe material, the cost, width, etc. and to send this information to all Local Committees."

At a meeting held at the Planters' Hotel, St. Lonis, Mo., on April 24, 1914, the National Committee again diseussed the question of equipment and miforms and "it was suggested that patterns be distributed by Loeal Committees and that Local Committees be ready to help with details in any way in order to relieve the Washington office. Samples of the uniform material were distributed, so that the murses might begin their preparation. ... The meeting was crowded with earnest, dignified, enthusiastic nurses ready to prepare for work which might come." 26 When within four months, the first eall for the mobilization of Red Cross nurses on a large scale sounded in the organization of the Merey Ship Expedition of 1914, the nuiform was thus practically agreed npon. The nurses of the Merey Ship, as it has been explained in Chapter IV, wore the gray eotton erepe uniform, with white collars and enffs, a navy b) ue ulster and the Red Cross cap and eape. National Headquarters allowed them to wear also the Red Cross brassard.

In the meantime, certain small changes had oceured in the uniform of the Army Nurse Corps. In 1912, the Surgeon General had anthorized nurses on duty in the Philippines and in the Hawailan Department to wear low collars. In 1913, he issued regulations changing the "waist and skirt" to a onepiece dress similar to that worn by Army nurses during the European War. When Army nurses were ordered with the P'mitive Expedition to Vera Cruz, Mexieo, the question of lanully arose and Miss Mr. Isata, then superintendent of the Army Nurse Corps, decided that gray erepe uniforms wonld solve the problem. One of the nurses ordered there was sayes L. Milliken, who later became assistant superintendent of the ${ }^{20}$ Minutes of the National committee, Vol. T, Pp. 83-5.5. 


\section{HISTORY OF AMERICAN RED CROSS NURSING}

Army Nurse Corps; she wrote, "I supplied myself at my own expense with gray crepe uniforms, made exactly like our white ones, touched off by white collars, cuffs and aprons. This uniform, however, was so unbecoming and washed so poorly that the nurses wore them only a few weeks and then, by special permission from Miss MeIsaac, went back to the white uniform."

As for the Red Cross nurses, the gray uniform for ward duty and the white uniform for dress wear, which were both worn with the Red Cross cape, remained the only distinctive uniform of the Red Cross nurse until 1916. Then National Headquarters undertook the organization of base hospitals and other units for the Army and the question of uniforms arose again. Miss Delano was strongly in faror of using the gray uniform, because she thought it was highly practicable, but the Surgeon General's office did not share this opinion and Miss Delano was forced to coineide with their decision to continue the use of the white uniform, since nurses of base hospitals and other units, when turned over to the War Department, became members of the Army Nurse Corps and as such would be required to wear the uniform of that Corps.

On June 26, 1917, Miss Delano telegraphed Miss Noyes, then chief nurse of Base Hospital No. 1, that "to save purchase of additional miforms, it has been decided that members of base hospital units may wear the miform of their school, except caps. Brassards, eapes and caps will be supplied without cost by the Red Cross upon assignment to duty." Formal authorization of the change from the gray to the white uniform was requested by Miss Delano in a letter written July 17, 1916;, and addressed to General Murray, then acting-chairman of the Central Committee; this letter was returned approved by General Murray, Colonel Kean and Mr. Bicknell under the same date.

While the American Nurses' Association was holding its Twentieth Ammul Convention in Philadelphia, National Headquarters wired Miss Noyes April 29, 1917, of the impending mobilization of six base hospitals for service with the British Expeditionary Forees. Miss Noyes returned post-haste to Washington to look into the question of an ontdoor uniform. The Army had not standardized an ontdoor miform for its Nurse Corps, but the Surem General's office concurred in the opinion of the Red Cross War Comncil that nurses of the mits assigned to the British Expeditionary Forees should be distinctively 


\section{RELATION OF NURSING SERVICE TO 'THE ARMY 361}

garbed as United States military personnel. Miss Noyes telegraphed Miss Van Blareom, then the representative of the Nursing Service in the Atlantic Division headquarters, New York City, to call together a eommittee composed of the chief nurses of base hospital units organized in the larger civilian hospitals of New York City, to consider the selection of a suitable ontdoor uniform. Iliss Maxwell, of the Presbyterian Hospital, and the other members of this group had sample garments and prices ready to submit to the committee by the time Miss Nores got over to New York. The committee selected an ontdoor uniform consisting of a one-piece blue serge dress of distinetive military ent, a heary blue ulster and a blue velour hat of campaign style and Miss Noyes immediately placed orders for a large number of these nuiforms with a New York manufacturing clothier.

Base Hospital No. 4 (Lakeside) arrived at the port of embarkation, however, before the uniforms were ready. 'The nurses of the unit sailed in eivilian elothes, with only such aceessories as eapes, blankets, eaps and other articles then in Red Cross supply rooms, but their measurements were taken so that the next unit seheduled to sail a few days later might take over their equipment. The Peter Bent Brigham Unit (Base Hospital No. 5) also embarked withont miforms. The third column to be ordered ont was the Presbyterian Unit, and the nursing staff not only went completely uniformed but took with them equipment for the Likeside and Peter Bent Brigham units. So hurried had been the embarkation of these three pioneer eolumms that many of the nurses, especially those who lived at a considerable distanee from New York City, went directly from the trains to the doeks and Miss Noves, Miss Van Blareom, members of the New York Comuty Chapter and the tailors' assistants, followed them in taxis and private limonsines piled high with boxes of dresses, hats and other articles.

The Now York Comnty Chapter, which had repuipped the nurses of the Merer ship, arted as agents for Nitional Headquarters. Mrs. John s. Thateher, Franees Anderson and Mary Ilagoun brown boluntereed their servioes. The Chapter assumed the immeliate responsilility for the parment of the elothiers' bills mutil National II ad liparters eould serome a derision from the War I lepartment that the Govermment wonld

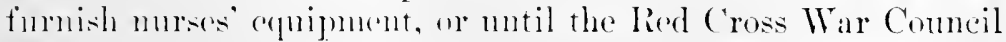
(onld apperepriate funds for this purpose. 


\section{HISTORY OF AMERICAN RED CROSS NURSING}

Miss Noyes notified the manufacturing tailor on Jume 1, 1917, to prepare to equip Base Hospital No. 17, of Detroit, and four additional Army base hospitals. Her letter also gave an important change in procedure; Miss Thompson had consented to issue nurses' sailing orders several days in advance so that the nurses might have opportunity to be measured and fitted for uniforms after their arrival in New York. This was a great advantage over the former system by which the chief murse had endeavored to secure and forward the murses' measurements to the manufacturing tailor before the unit had left its home eity.

The Minutes of the National Committee on Red Cross Nursing Service, which met. June 16 at National Headquarters, recorded this action:

The chairman stated that in order to equip Red Cross nurses assigned to duty as expeditiously as possible, it was necessary to appoint a special committee on uniforms, who would be responsible for selecting the uniform and issuing the equipment. As the time was limited, the chairman appointed this committee as follows: Mrs. John S. Thatcher. chairman; Miss Charlotte Stillman; Miss Frances Anderson; Miss Anna C. Maxwell: Miss Mary M. Brown.

The chairman asked that this action be ratified, as this Committee should be appointed by the National Committee rather than by the chairman. [IIotion to this effect made and carried.]

Mrs. Thateher immediately began to look about for a suitable place in which to estahlish headquarters for the equipment division. She visited the newly-established headquarters of the Atlantic Division, then located at To. One, Madieon Arenue. and conferred with Miss Yan Blareom, who as the representative of the Nursine serviee in the Atlantic Division was an exofficio member of the Committee on Equipment. It was then decided to bocate the equipment work there. Miss Van Blareom at the same time seemend the serviees of Mande G. Moody to assist Mrs. That here in the husiness details of the work. "IIrs. Toody has been recommended to us," wrote Mrs. Thateher to Miss Nores on June 14, "as an musually capal)le woman, of gond exreutive mind, tactful and of pleasing personality."

Mrs. Mooly wrote of the expansion of the carly division of nurses' equipinent : 
In June, 1917, the Atlantic Division took offices on the thirty-second floor of the Metropolitan 'Tower, and the linreau of Nurses' Equipment was soon in actmal operation there. On the twenty-eighth floor we hat a little storeroom where our stoek of all articles, excepting the ulsters and dresese, was kept. We earried tan gloves, aprons, ete, for the murses to purehase at cost.

Army Base llospital No. 15 (Rooserelt Ilospital) was the first unit equipped by the bureau. As we had no assembly room to which the murses conld come, we conveyed the equip)ment to them at the hospital. T'o transport those mans packages, Mr. John Niexer of the Manhattan Storage and Warchouse Company offered us the use of his vans. Ellis Island in the meantime had been designated as the murses mobilization station, and it was not unusual to see the vans backing up at the ferry-house discharging their argo of humlreds of boxes of all sizes, to he transferred to the waiting baggage trucks which husky corpsmen hustled aboard the ferry. Perilous indeed were those trups from Island To. One to Island $N_{0}$. 'Three, when we dashed from one truck to another trying to keep that precious equipment from falling moler the wheels! Once safe in the large many-windowed assembly room of Islant No. Three, the hold-ills and boxes were arranged alplabetically and given out to the bong line of waiting nurses, who signed their ards, had their hats fitterl and went off laden with burdens almost too great to (arry.

Following the establishment of the Burean of Nurses' Equipment at Atlantic bivision headtuarters, the next step in hinileing up efficiont organization was the transfer of all responsihility

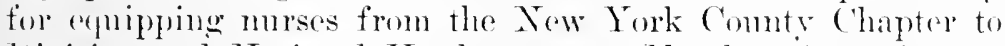
livision and Tational Headquarters. Mr. Leo Arnstein was then l)irector of Military Relief of the New York Comnty Chapter and he was loath to surrender responsibility which he fielt belenged in his department. Miss Noyes ammomeced this transfer in a letter written June 15 to Mr. Jiarsey D). (ribsom, then elatirman of the Exerative Commitere of the Xer Vork (omint. Chapter. "This arrangenent," ammented Miss Voyes. "will centralize all nursing atfairs at a given point, an alrangerment neree hefore possible owing to the fact that we halve mot had a direst representative in Now York mutil Miss Vam liar-

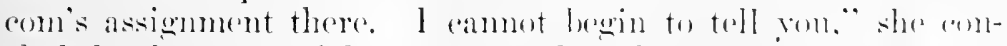

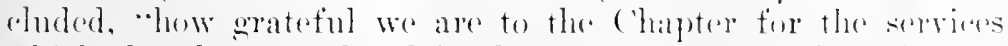
which they have rendered in the past. We must have bern a veryereat trial at times." 


\section{HISTORY OF AMERICAN RED CROSS NURSING}

The cost of equipping these first units of nurses was increasing by leaps and bounds and National Headquarters had already foreseen that financial responsibility for this work would far exceed the resources of the New York County Chapter and would soon become a matter for decision between the War Department and National Headquarters. Miss Noyes submitted a memorandum to the War Council in July, 1917, which recommended outdoor uniforms for nurses at an estimated cost of $\$ 35,580$ per thousand nurses. "The War Comneil," stated the minute corering a meeting of the War Council held July 4, 1917, "decided to refer the matter to Colonel Kean, with instructions to present it formally to the War Department. As the nurses, on going into service, come immediately under the War Department, it would seem that the War Department should decide upon the uniform and pay for same."

At a meeting held July 10, Mr. Wadsworth again brought up the question of nurses' equipment. Mr. Davison stated that it was the policy of the War Council that Red Cross nurses assigned to service in Allied countries should always be uniformed. The War Council accordingly voted that the "Chapters sending Red Cross units shall provide uniforms for nurses, that nurses whom Chapters are unable to miform shall be uniformed by National Headquarters, and $\mathrm{Mr}$. Wadsworth is directed to make arrangements accordingly with each Chapter."

Early in .July, Colonel Kean was placed in charge of the Ambulance Service of the Ameriean Experlitionary Forees and was sent immediately to France. John D. Ryan, of New York Citr, was elected Director General of Military Relief. Colonel Vinford Smith, late superintendent of Johns Hopkins Hospital, was detailed on July 18, 1917, to represent the Surgeon General at Tational Headquarters and on Angust 31, he was clected Ibirector Ceneral of Military Reliof, following the appointuent of Mr. Ryan to membership on the War Council.

While the War lepartment, National Red Cross Headquarters and Local lied c'poss Chapters were considering who shonld pay the lills for moses equipment, the fortmes of war took a

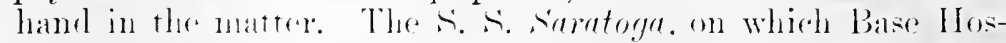
pital No. S harl wnbalked for Franee, collided on July 30 in New York Iatrles with the City of Panama. The minses had gone to their stateromss, han removed their heary nuiforms on accomnt of the intrise heat and in kimonos and night gowns 
were resting or sleeping. Following the collision, all hands were ordered immediately to the life-boats. The murses canght up capes and coats, flung them over their seant garments and, with atmirable sacoir faire, toek their places in the boats, abandoning not only their nuiforms but other articles of elothing and their money as well.

The suratoga sank eighteen mimutes after she had been struck. The life-boats containing the nurses were rowed some distance from the accident and held there for further orders. The men of the rescuing erews spread their coats over the shoulders of the murses to protect them from the glare of the July sum. After a tedions delay, the nurses were rowed to Ellis Island. The interned Germans and agents detained on the Island crowded to the wire fences to watch the American women eome ashore. Wet and insufficiently clad, with their arms and faces burned and their nerves tiut from a harrowing experience, the nurses, when they heard the jeering words of the enemy, conducted themselves according to the best traditions of Ameriean womanhood. $\overline{\mathrm{U}}_{\mathrm{P}}$ went their heads and they marched proudly to their dormitories with langhter on their lips.

On August 1, Miss Van Blareom telephoned Miss Noves that the murses of the mit were stationed on Ellis Island without adequate elothing. Miss Noyes went immediately to the offiees of the War Council; the members were holding one of their customary morning meetings. Miss Noyes presented the facts of the (ase and asked the War Conneil to appropriate funds sufticient to reiennip the murses, - an appropriation which she estimated roughly at $\$ 14,000$ or $\$ 200$ per nurse. A member of the War Comneil suggested that Miss Noyes call the War Department to ascertain whether any Government fund was available for such purposes.

Miss Noyes was refereed to Colonel Birmingham, then Acting surgeon Ceneral of the Army. He stated that the only pessible way in which the War lecpartment conld reëquip these murses was hy special Aret of Congress!

Miss Noyes again went to the War Comncil and within two hours after the time when Miss Van Biareom had tirst tele-

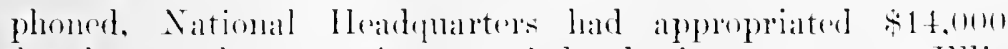
for the eomplete reapuipunent of the lestitute murses at Ellis Island and Jliss Noyes had instrueted Miss Vam Blarenm ly teleplone to begin the sedertion and purchase of the varions articles. 


\section{HISTORY OF AMERICAN RED CROSS NURSING}

When the nursing representatives of the Atlantic Division went over to Ellis Island to confer with the nurses regarding their needs, they found a ehaotic eondition. Mrs. Moody described it:

Ellis Island showed us "stay-at-homes" to a small degree at least what war meant. Island No. 3 looked like a refugee camp in a war-ridden country. Spread over the lawn were water-soaked army lockers, stained and muddy clothing, here a white uniform streaked with the red of a cape which had lain near it, there a pathetic-looking shoe ruined beyond repair. Too much cannot be said in praise of the courage displayed by these women who after a narrowing ordeal during those torrid summer days met us with a joke and a smile.

In the meantime, the six American base hospitals assigned to the British Expeditionary Forees had arrived in Franee. None of the British General Hospitals where they were detailed for duty were equipped with laundries and the nurses soon discovered that they would have to wash out the white uniforms after they came off duty if they were to present a neat and professional appearance. Members of several base hospital units even joined groups of French women who were pounding their elothes clean in eonvenient brooks! "The white uniform is most unpractical," wrote Miss Stimson at Rouen, France, to Miss Noyes. "The night nurses put them on with aprons and eaps, then don raincoats and rubbers, earry an umbrella in one hand and a lantern in the other and start on their rounds from one tent or but to another. By morning you should see the eaps of those who have not brought rubber hats, after ther have ducked in and out of the tents, and their white skirts, after they have gone splashing through the sticky yellow mud!"

I)r. Pichard H. Harte, director of Pase Hospital No. 10, which was stationed with the British at Etretat, stated in a letter written to Miss Delano on June 17 that in addition to the impracticality of the white muiform, the nurses" equipment was sadly inadequate. "Each nurse," he declared, "should have a good pair of rubber boots, a mackintosh, and a rubber hat, preferably the ordinary solv wester worn by sailors. Anything less will he blown off by the terrifie winds prevailing here. It is also terrifically cold."

Colonel Robert E. Noble transmitted August 9 to the Di- 


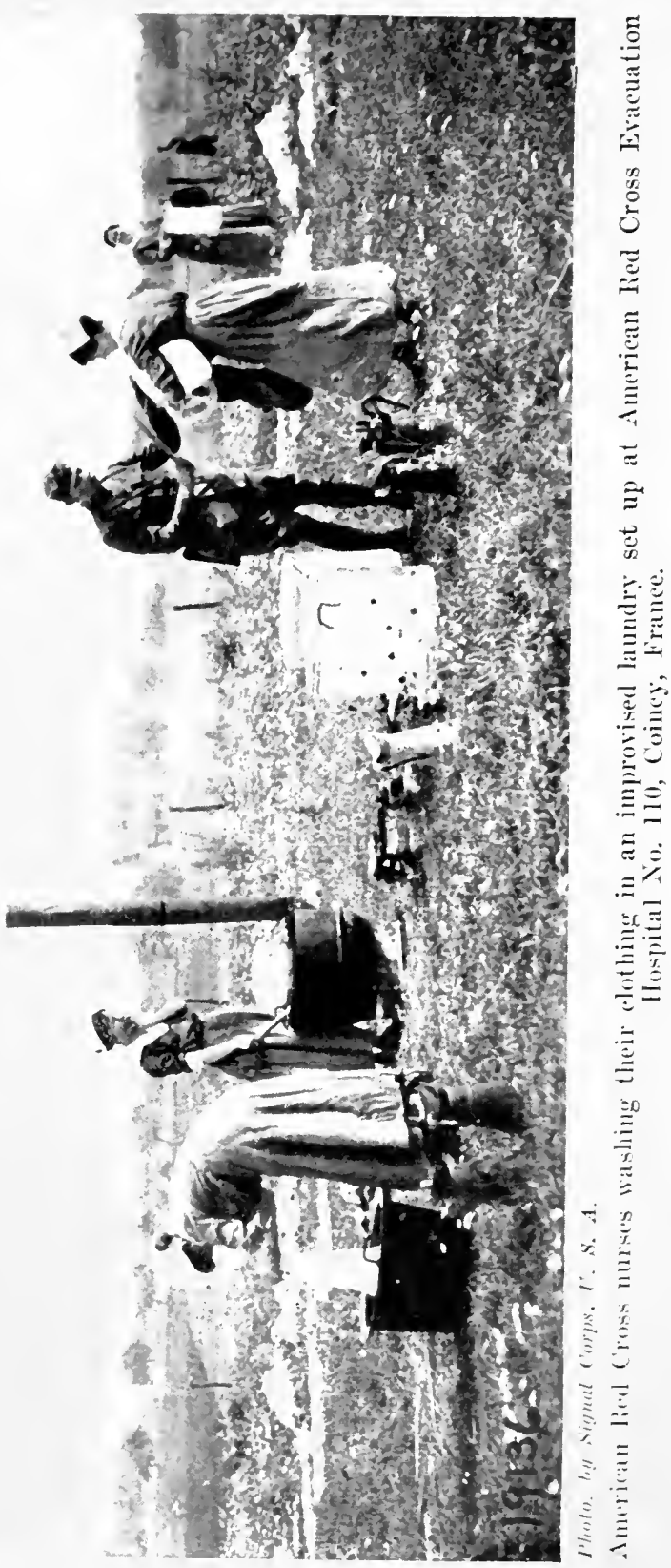





\section{rector General of Military Relief a copy of the following regu- lation:}

Referring to information received in this office that the white uniform now used by members of the Army Nurse Corps is not practionble for service in Europe, I am directed by the surgeon General to inform you that the use of a medium gray uniform and white apron has been anthorized to be made in aceordance with specifications enclosed herewith. This information is furnished so that reserve murses going to Europe may have their miforms makle to conform with these instructions. 'This authority has been forwarded this date to the commanding ollicers of the United States Army hospitals now in Europe.

A certain amount of well-behaved humor appeared in the Minutes of the War Council for Angust 8, 1917:

The chairman stated that in preparing Red Cross base hospitals for service abroal, the white miform for nurses was insisted upon by the Medial Department of the Army; that it now appeared that owing to lack of laundry facilities, white uniforms are impranticable in France and the surgeon (ieneral's oflice has decided to adopt the gray uniform; that there are sixty-five nurses in each of the six base hospitals with the British forces in France, all equipped with white nuiforms purchased at the expense of the individual nurses, the same being true of the nurses in the six hospitals with the American troops in France: and that no doulst many nurses of the hospitals not yet alled have supplied themselves with the white uniforms formerly required.

The chairman further stated that these nurses could not he expected to go to additional expense in buying more uniforms: that the estimated ast of the gray uniform being about $\$ 16$ it would require about $\$ 1040$ to equip the sisty-five nurses of each mit: and on the recommentation of the Department of Military Relief, he advised this appropriation. Whereupm it was, on motion

Toted: That from the Red Cross Mar Fund the sum of $\$ 14.000$ be and is hereby anpropriated for furmishing yray uniforms to the unses of the twelve hase hospitals servinis with the British and Amerian troops in France.

Miss Noyes thom sot alont furmishing the gray dress to all nurses of hace lospitals and other mits, both in this amontry and overseas, thromeh the Xew lork bimean of Surses Enuipment and throngh the oftioe locited in P'alris of the whict number. 


\section{HISTORY OF AMERICAN RED CROSS NURSING}

American Red Cross in France. The diffieulties of sending the gray uniform to all members of base hospital nuits then with the British and American Expeditionary Forces was greatly heightened by submarine warfare. Twice the enemy sunk merehant steamers in which gray uniforms had been sent. The following quaint deseription of the Scurs Américaines, appearing in a French newspaper, recorded their final metamorphosis :

The American nurses, notres dames grises, we see leaving the hotel where they are lodged and note that almost every one is tall and stately in stature, wearing short gray skirts and laced brown boots. The waist has a large white collar and the white apron is worn in a crosswise fashion in the back. The head is coquettishly crowned with a little white cap, which rests softly on the knot of hair, dressed in a style much like the arrangement used by our own women. Jiany of them wear large romd eye-glasses, which make them retain their youthful appearance and look as if they were sehool girls going to their class.

The question of the insignia to be worn by reserve members of the Army Nurse Corps, the cause of patient and prolonged disenssion between the Surgeon General's ottiee and the Red Cross, had first arisen in August, 1916, following the assignment of Red Cross murses to United States base hospitals on the Mexican berder. One year later, on Angust 27,1917 , the War Department made its first move toward the militarization of Red Cross nurses: Acting Surgeon General Birminghim then wrote to the Director General of Military Relief:

In reply to vour letier of Angust 18, relative to the wearing of the brassard by the reserve nurses. Almy Nurse Corps, mulese the nae of the brassard by members of the rexular Military Establishment is indicated. its me by members of the Reserve is not ansidered necessary. Also. the wistom of wearing the hrassard in Europe has been questioned on aecount of its eonspiemonsmess.

It is requesterl that hereafter the outdoor nuiform of the reserve murses. which is furnished by the lied ('ross. be made to anform in all resperets to that which has been approved by the Secretary of Wiar for the Irmy Nurse Corps (diagram and information enclesed). Owing to the confusion which has been created in the minds of the murses hy the nese of the Red Cross on the "ap and eape, the anthority given in letter 


\section{RELATION OF NURSING SERVICE TO THE ARMY 369}

from this office dated Angust 18, 1916, for the use of this emblem on these articles is hereby revoked.

With this letter, specifications were sent for an outdoor uniform, Arny Nurse Corps, consisting of blue serge norfolk coat and skirt. This uniform replaced the Red Cross serge dress and was to be worn by all $A$ rmy nurses in foreign service. At the same time, the Surgeon General's office adopted a new white uniform of distinctive type, to be worn by nurses while on indoor duty in military hospitals in the United States and wherever practicable in foreign service; the use of the gray uniform was retained, however, for general ward duty overseas.

For nurses volunteering for foreign service, this ruling made necessary the purchase of entirely new indoor and outdoor uniforms. For the Red Cross Nursing Service, these regulations meant the banishment of the cap and cape, beloved symbols of an ideal of pure altruism. Following protracted conferenees between the Red Cross and the Surgeon Gencral's oftice, Colonel Birmingham wrote september 11, 1917, to the Director General of Military Relief: "Referring to letter from this office dated August 27, relative to the miform of the reserve nurses, Army Nurse Corps, upon further consideration the use of the Red Cross cap is hereby authorized. The nurses may also continue to use the present "ape, but withont the Red Cross upon it."

Banishment of the well-loved Red Cross badge was ennfirmed on October 10, 1517, in a letter addressed by Miss Thompson to Miss Delano: "In regard to the ruling of the Red Cross pin, it was decided some time ago that the Red Cross on the cap was to be used to indicate that the wearer was an enrolled Red Cross nurse and that the pin was not to be worn with the miforms."

Following the anthorization of the new indoor and ontdoor muiform for members of the Army Nurse Corps assigned to foreign service, the lied Cross felt even more strongly than they had at the time of the embarkation of the Red Cross base hospitals, that the Govermment should furmish miforms and equipment for nurses assigned to military service. The l)irector (ineral of Military Relief bronght this question to the attention of the Surgeon General on Augnst: $: 0$ : he in turn reforred it to the Sorerotary of War, Mut Mr. Baker did not share the opinion of the Red Cross. Colonel George E. Bushnell. 


\section{HISTORY OF AMERICAN RED CROSS NURSING}

Acting Surgeon General, Medical Corps, wrote on September 26,1917 , to the Director General of Military Relief, National Headquarters :

Relative to the clothing allowance for nurses ordered to Europe, this question was taken up with the Secretary of War and a letter sent from this office recommending an appropriation be made for this purpose.

The recommendation was returned disapproved, with the remark that it was not the policy of the Wrar Department to make clothing allowance during war.

In riew of the expense of this equipment, which in the opinion of this office is too heary to be borne by the individual nurse, it is requested that the War Council of the American Red Cross make some provision for the nurses ordered to Europe.

It is also requested that the allowance be made to members of the permament Corps as well as to the reserve nurses who may be ordered abroad for duty.

The War Council was at this time considering the equipment and uniforms of members of the Red Cross foreign commissions. On Septemler 20 they had appropriated an allowanee not to exced two hundred dollars $(\$ 200)$ for each member of such units. Following the receipt of Colonel Bushnell's letter, they authorized the Nursing Service to recommend a list of equipment necessary for all murses assigned to foreign service. Closen with care and economy as befitted the expenditure of Red Cross founds, ret with full insight to future needs, and given with the same generosity of spirit which had led Miss Delano to buy and parek hoxes of comfort for her "lambs" of the Merey ship, the list of articles as finally workerl out by Mise Noyes comprised: hat; outdoor mniform; coat or heary ulster: cape: gloves; shirtwaists, two, white; shirtwaists, colored flamuel (two if snit is used) : gray wash uniforms, four: aprons, six or eight: cuffs and collars, six sets; caps: sleere links, 2 pairs: "adneeii, one set: ['. S. letters, one set: black woolen tights, 2 pair': steamer blanket, one; slecping bag, one: sweater, gray, one: puncho, or rubber shect, one: blanket roll, wne: raincoat, one: rain hat, one: rubber boots, one pair; morcasins, one pair; shoes ${ }^{27}$ : stockings ${ }^{27}$ : heary underwear ${ }^{2 \tau}$ : pajamas. ${ }^{27}$

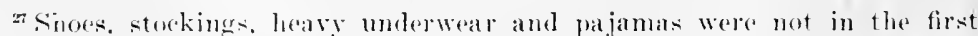
list of equipment furnished by the Red Crose without aost. These articles had to be supplied by the mirses themselves (A. R. C. Fil. Denerember 31, 1917 1. Later. howerier, they were all adderl (september 18. 1918). 
The Bureau of Equipment at the Atlantic Division now settled down to the long pull aliead. Mrs. Thateher hard resigned in September, 1917, the chairmanship of the Uniform (ommittec. The efficieney of the oreanization of the hurean murler Miss Van Blareom and Mrs. Moody had relieved Mrs. Thateher and II iss Brown, the two most active members of the committee, of the heary responsibilitios which they had bravely borne since Mav, 1917. Mrs. Thateher wished to turn her enthulsiasm and energy to more active expression than the chairmanship of an Advisory C'ommittec on Uniforms permitted. Nurses will long remember with gratitude, however, her courteous, faithful assistance during the stremous spring and summer when the base hospitals were enbarking for France.

Miss Noyes wrote on October 16 to Mr. Harvey D. Gibson, by this time general manager at National Headquarters of the Red Cross, ${ }^{2 s}$ recuesting the first of the several extensive appropriations made from time to time by the War Council to sustain the Bureau of Equipment: "I should be grateful," she stated, "if the War Council would vote an appropriation sufficiently large to enable us to carry an adequate supply in our store-room, viz., five hundred sets at two hundred dollars a set. We find it exceedingly diflicult to secure sleeping bags, steamer rugs, rubber boots and slickers on short notice. We now lave four units waiting in New York for sleeping bags. All their other equipment was given by Loeal Chapters before they left home. To avoid such situations as this, it seems highly important that an adequate supply be kept on hand." The War Council appropriated on October 30, 1917, one hundred thonsand dollars "for the purchase of equipment for Army and Nary nurses, it being understood that in the case of hospital units, ete., which would ordinarily be outfitted by Chapters, the amount so spent shall be collected from the Chapter wherever possible." This attempt to have the local Chapter include nurses' equipment in its appropriation for base hospitals was never satisfartorily worked out and was later aompletely giren up.

In order that Red ('ross publie health nurses working in the sanitary zones which the Enited states P'ublic Inealth sorvire had drawn abont the eantomments, might be preperly miformed,

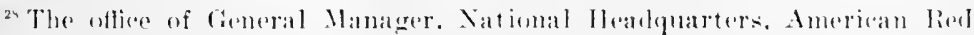

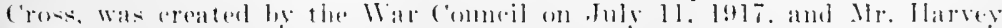

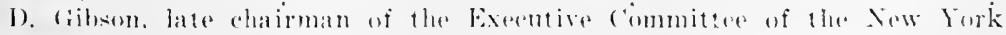
Comber chapter. Was apluminted to the pusition. 


\section{$3 \% 2$ HISTORY OF AMERICAN RED CROSS NURSING}

the War Council also appropriated funds to furnish uniforms and equipment to them. The following statement appears in the pamphlet, Information for Nurses Called Upon for Active Service (A. R. C. 702, December 31, 1917):

Nurses assigned to sanitary zones under the Red Cross for public health or other forms of service will be provided, free of cost, with the following articles: one or more outdoor uniforms of dark blue serge; detached waist with high collar; one blue ulster; one cape, dark blue, lined with red, insignia on left side; one hat, dark blue velour; eaps; three gray uniforms. These articles will be issued upon the arrival of the nurse at her destination.

When the Army was mobilizing its Psychiatric and Orthopedic Base Hospital Units, No. 117 and No. 114, Miss Thompson in a letter addressed on March 4, 1918, to Miss Delano, asked if the Red Cross would supply equipment to the eivilian employees and the reeonstruction aides of these mits. National Headquarters ultimately shouldered the responsibility for equipping, through the Bureau of Nurses' Equipment in New York City, all nurses, dietitians, clerical workers and aides for all types of foreign serviee in the Army, the Nary and American Red Cross commissions.

On January 15, 1918, Caroline Van Blareom, who had represented the Nursing Service at the Atlantic Division since the early summer of 1:17, resigned and Florence Nlerriam Johnson was appointed as director of the Department of Nursing there. The Bureau of Nurses' Equipment was maintained as a branch office of National Headquarters, but Miss Johnson, representing Miss Delano and Miss Noyes, had general supervision of its activities.

Now in March, 1918, began that long proecssion of women, which day after day passed in ever-increasing numbers throngh the port of cmbarkation for Europe. Mrs. Mloody described the expansion that had been going on of the Bureau of Equipment:

In Ortoher, 191\%, the Atlantic Division moved across the street from its former home and our new storeroom seemed enormons. Only too soon dirl we onterrow it and packing cases lined the erriblors. The oversas units beran mobilizing thick and fast and we found it necessary to secure more 
trucks. The Peter Doelger Brewing Company aame to our rescue and many were the smiles of amusenent from bystanders when three bright yellow brewery wagons wonld begin to disgorge their Ried ('ross boxes.

It became necessary now to revise our previous method of issuing equipment, both beranse of the many articles and also beallse of the great numbers of personnel sailing earth week.

When a base hospital or unit arrived in New York, Miss Johnson appointed a day when that group should report to her at the Atlantic Division headquarters. After her glaphic: and inspiring talk, the nurses came to the Bureau of Furses' Equipnent (we hald nowert to the New York Branch of National Hearquarters at :2.2 Fourth Arenue and now hat half an otlice floor, none too much space). Here cards were distributed to each nurse. On these carls were listed all the articles to be issued and the nurse, after filling in her name, unit and badge number, designated on the card the sizes of the garments which she needed. Perhaps here she first appreciated the hardships of war. She was destined to have her uniform hats tried on without being allowed even a peep at a mirror.

To every nember of the group we gave an order for shoes and rubber boots and the next lay the unit went en musse to the one tailor to be fitted for suits and coats, then to the other for gray service uniforms and raincoats and then on to the shoe-shop. When the necessary alterations had been completed, these hoxes were picked up by our truck. It next rollected holdalls. arefully packed at the Burean of Equipment. These holdalis containing the rest of the nurse's articles, were tagged with her name. By this sritem both boxes and holfalls were delivered to the various hotels where murses were staving.

So crowded did our quarters become that we fomnd it necessary to have the units asisemble for equipment at rarions halls loaned to us by different organizations in the ricinity of Madison Fiquare. In the meantime, ons stork had increared to carry numberless articles not included in the equijument issmed. but which the morses needed and which we sold to them at ast. . II throment that smmere of $191 \mathrm{~s}$. the line of

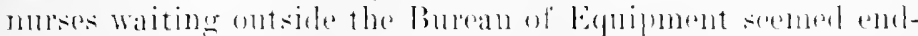
less. stretehing form the deviltors down the longe hall to the

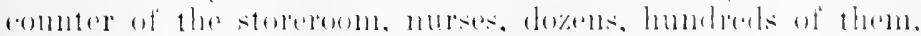

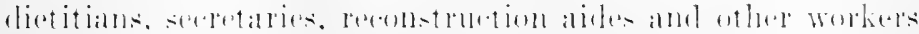

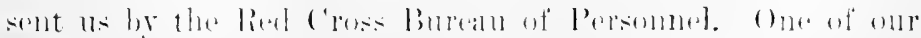

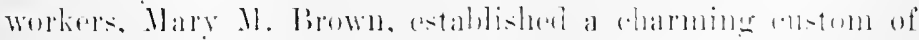

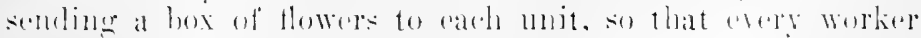




\section{7t HISTORY OF AMERICAN RED CROSS NURSING}

going overseas could have at least one blossom as a tiny personal message, a word of greeting and a Godspeed.

For nurses serving directly under Red Cross commissions to the Allied Powers, Mliss Delano and Miss Noyes had adopted the same uniform as that of the Army and Navy Nurse Corps. Of the equipment of these nurses, Mrs. Moody wrote:

Before they reported to the bureau for equipment, Miss Johnson saw individually every nurse sailing under the Red Cross flag. How interesting it all was for us when a unit was being sent to so romantic a country as Palestine or Porto Rico and how eagerly we revised and planned their equipment to meet these particular services!

A nurse on active duty with Red Cross foreign commissions wore upon her hat band, upon her shoulders and upon the lapels of her coat, the symbol of the organization. Withont consultation with the Army Nurse Corps or with National Headquarters, the Red Cross Commission for France adopted in 1915, upon the authority of the Chief Surgeon, American Expeditionary Forees, a distinctive emblem made by placing an enameled Red Cross upon the caduceus of the Medical Corps. The bronze letters "U. S." were worn with this device and insured for the wearer recognition and protection in the foreign theaters of war where the American Armies were operating.

Previous to August, 1918, nurses serving in Army hospitals in the United States had been permitted to wear the uniform of their school, provided it was not extreme in cut, when on duty, but when off duty, they had worn civilian elothes. Following an increase of salary for the members of the Army and Nary Nurse Corps from fifty dollars $(\$ 50)$ to sixty dollars $(\$ 60)$ a month for domestic service and from sixty dollars $(\$ 60)$ to seventy dollars $(\$ 70)$ for overseas duty, the Surgeon General authorized that all members of the Army Nurse Corps shonld wear the outdoor uniform. On July $2: 3,1918$. Colonel Winford II. Smith transmitted to the general manager of the Anneriean Red Cross, for the attention of the Nursing Service, the following regulations issued by the Surgeon (ieneral, regarding uniforms:

Nurses who enter the service at this time are permitted to wear such white miforms as they may have, provided that they are not extreme in any way. When it is nesescary to 
replace these uniforms, they must then be obtained in accorelance with specifications, with this exception: 'The uniforms of all reserve nurses must conform in all respects to that of the Army Nurse Corps.

The use of the outdoor uniform is considered advisable and it is further directed that all members of the Army Nurse Corps, including the reserve nurses, purchase the suit, hat and necessary waists within three monthe after they enter the service. This uniform will be worll at all times when not on duty.

'The overcoat should be purchased if and when the weather requires its use.

On August 15, 1918, the following ruling was sent by the Surgeon General of the Army to the commanding officers of all military hospitals in the United States:

1. I am directed by the Surgeon General to inclose herewith specifications, eap pattern and other data concerning the indoor and outdoor uniform of the Army Nurse Corps. Nurses who enter the service at this time may be permitted to wear such white uniforms as they may have, for a period of six months after their 'ntry into the service, provided they are not extreme in any way. When it is necessary to replace these uniforms, those made aecording to specifications must then be obtained. With this exception, the uniforms of all nurses, including the cap, must conform in all respects to that of the Army Nurse Corps.

As the use of the ontdoor uniform is considered advisable at this time, it is further directed that all members of the Army Nurse Corps now in the service, purchase the suit, hat mil necessary waists within three months, and all those who enter the service hereafter purchase these garments within three months after their entry into the service. Before ordering these garments, however, those nurses who are physically or otherwise unfit for the service should be informed to that effect in order to avoid placing them under any unecessary expense in the purchase of these garments. This uniform is to be worn at all times when not on duty in the hospital. The overoat should be purchased if the weather requires its use.

?. The American Rod Cross will omit from the equipment of nurses ortemerl overseas the above mentioned articles. but will antinue to issue to these murses exceptional aguipment. Fonr monthe howerer, will be allowed for adjustment. 'The

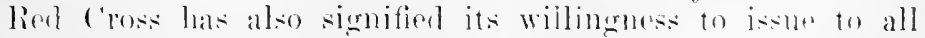
members of the Irmy Furse ('orps on duty at lome or abroad 
a dark blue cape lined with red, the use of which is hereby authorized. The insignia of the Army Nurse Corps and the letters "L. S." may be worn on the collar of the cape. The chief nurse should notify the director of Nursing Service, Atlantic Division, $4+$ East 23d Street, New York, in regard to the number of capes needed by the nurses at the hospital from time to time, giving their names. If sweaters are required for additional warmth, gray ones shonld be obtained.

Several months before, when the question of the Red Cross cape had been under lively discussion, the Surgeon General's office laad contended that this garment when worn by reserve nurses of the Army Nurse Corps tended to differentiate them from the Regulars and thus to break down the esprit de corps of that body. When National Headquarters offered to furnish the cape, without the Red Cross upon the left side, to all members of the Army Nurse Corps, its offer was immediately accepted and the traditional blue garment with its scarlet lining was issued to all nurses assigned to foreign and home service.

The ruling of August 15, 1918, which removed the Red Cross from the reserve nurse's cap, was made in the interest of discipline, but evoked regret among the nurses. The following letter is typical of many received at Red Cross Headquarters:

I am so glad we are to wear ontdoor uniforms. We've always hoped that it would be so. but we who came into the service through the Red Cross are di-appointed and hurt to be deprived of all possible sign of the fact. It is not that we have any objection to the new cap; it is nice and neither gives nor takes anything from us as murses. It is simply that we loverl to be kinown as Red Cross nurses. We rolunteered for that organization and would have liked to retain something to show our association with it.

A question of iutermational Red Cross policy presented itself in reference to the habit and insionia of Catholic Sisterhoods. One of the spereifir duties of the National and Local Committers on Red Cross Nursing Service, was "to keep on file lists of sisterhoods and other order's and women volunteers, available for Red Cross reliof work inwlving the care of the siek and womedod, rither in time of war or calamity."

During the smmmer of 191 s, the lied ('moss was especially anxions to ntilize the scrviess of Sisters of Charity. who had always held an hromed phare in military mursing. They, too, 


\section{RELATION OF NURSING SERVICE TO THE ARMY 377}

earnestly desired to serve. Miss Delano wrote on .June 10 to Miss Thompson stating that some time before, she had seeured a list of the Catholic Sisterhoods in the United States, but had never written to them asking for the probable number available for servire in time of need. "I shall be very glad," concluded Miss Delano, "if yon will tell me if you think it desirable for me to send ont a letter requesting this information." Miss Thompson replied on .June 18:

Relative to the use of Roman Catholic Sisters in Army hospitals, I have referred this matter to Colonel smith of the Hospital Invision with the result it is believed advisable to place on file the resourees of the Sisterhoods of the country, provided they are graduate nurses and eligible for enrollment. Should it be necessary to use these Sisters, your office will be so informed at once.

It is believed there might be some trouble in regard to accommorlations for the Sisters. Many of the nurses are obliged to live in dormitories. Furthermore, in many hospitals. the murses are obliged to wear a large white apron over their miform. as well as a mask over their faces. This woukd be ditlieult for the sisters. They are obliged in all cases, I mulerstand, to wear the habit of their order.

After some slight misunderstanding, Colonel Smith wrote on July 3, 191s, to Miss I) lano that "indeed there is every reason why enrollment shomlel be made of all such nursing Sisters who are eradnate numes. It should be understood, however," he added, "that if ordered to active duty, they will come in on exactly the same terms and under the same regulations as to conduct, miform regmlations, ete, as all other members of the Army Nmres (orps."

The matter stood thes mil the mobilization of Base Ilospital No. 10:2 which hald among its nurses ten Danghters of Charity. A special ruling was then made which pernitted these Sisters to wear the arart of their order lut the surgem (ien-

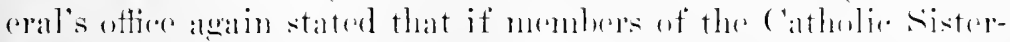
hoods were assigned in the future to the Amy Nurse Corps it would he with the moldestanding that they wear the regulation

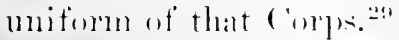

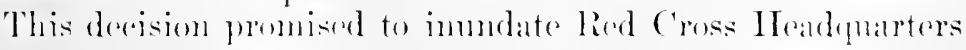

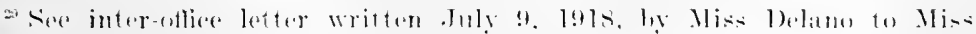
Kerr. elirector of the limean of Enrollinent. 


\section{HISTORY OF AMERICAN RED CROSS NURSING}

with criticism from the Catholic Press similar to that of 1917 , before Sisterhoods clearly understood that the Surgeon General's oftice and not the Red Cross Nursing Service was debarring them from active duty. Colonel Smith, however, wrote M[iss Delano on August 3, 1918:

Seferring to your recent letter relative to the admission of Catholic Sisters to the Army Nurse Corps, I am directed by the Surgeon General to inform you that a recommendation has been made to the secretary of War to the effect that should the Sisters be adnitted to the Corps, as graduate nurses. they must, when on duty in the wards, wear the uniform of the Corps, with the exception of the hearl corering, which may be a modification of the nurse's cap which will satisfactorily meet the situation.

It is further recommended that, when on the street, they be permitted to wear the habit of their order. Cntil a reply has been received from the War Department, a definite decision

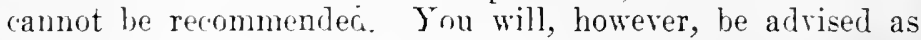
soon as the reply has been received

Service in the Army Nurse Corps was made possible for the Sisterhoods on September 10, 1918, in the following order transmitted by Colonel Smith to Miss Delano:

Your attention is invited to the recent decision of the Adjutant Cieneral as quoted below.

1. Orders are being issued directing that Arny Nurses who are members of ('atholic orders, whose vows require the wearing of a distinctive garb, are authorized to wear the garb of their order while traveling on land in this conntry without troops and while traveling on transports.

¿. You will prescribe a suitable derice to be worn with this religious garb. which will clearly mark the wearer as a member of the Ariny Nurse Corps.

:3. Tou will aloo prescribe a rap to rover the entire head which shall be wern by them while on duty.

The revien rofurerl to in paragraph ? will be the regular insignia of the Army Nurse Corps: the letters T.S. and the batge or ralurens with the gilt letters "A.N.C." superimposed. This insignia will bre worn on the Sisterhorod sarb at such times when it is approved that they be worn. The superintendent of the Army Nurse Corps will prescribe the cap to be worn.

By direction of the Surgeon Gieneral. 
On Angust 1, 1918, the Surgeon General of the Army requested the American Red Cross to make preparations through its New Jork Burean of Equipment to fit out completely one thousand nurses a week for overseas duty. The staff of the Burean of Nurses' Equipment then numbered twenty-two persons. "Mrs. Moody and all her assistants," wrote Miss Johnson to Miss Noyes on Angust 8, "are as anxious as we are to have the nurses really, even thomgh the Army may not be able to send them over as rapidly as we "an equip them." Men and women who were doing war work in Washington and in New York during the oppressive heat of August and September, 1918, will appreciate in part the intense strain under which all branches of the Government were laboring.

While the Now York Burean was struggling with the problem of equipment, the Chief Surgeon of the Ameriean Expeditionary Fores notified the American Red Cross Commission in Paris that the Nurses' Equipment shop there would probably be called upon during the early autumn to replenish at cost wornout articles of clothing for ten thousand nurses and to furmish extraordinary equipment for nurses assigned to the zone of advanee, especially those of forty mobile hospitals.

The early base hospital units assigned to the British forces had sailed hefore the American Red Cross made its generous appropriation for ecpuipping murses. The London Chapter had sent them graly uniforms, aprons, boots, rain hats, rubber sheets, woolen knickerbockers and other necessities. Great need existed, however, in Frane for some central agency through which inequalities in the initial supply of and replenishment of wornout articles conld he adjusted.

Through the efforts of Martha M. Russell. first chief nurse of the Ameriean lied ('ross Commission to France, more adequate winter dothing and shoes had been forwarded to nurses in bases of the British and American fores during that first lleak winter of antive serviee. But the Red Cross had never undertaken to rë̈puip nurses free of charge, nor was it then doing so. In a letter written November 16, 1917. to Miss Rusicell, Miss Noyes stated that the Red Closs "could hatrdly" mulertake the replianenent of worn-ent artieles in any wholesile way. As nurses are on a salary." she pointed ont, "there would serm to be no reason why they shomld not provide such additional artieles as ale required in the same way that they womld blo were they in this commery." 
An interesting comment on the equipment question was contained in a letter written June 13, 1918, by Miss Russell to Miss Delano:

The equipment now given the nurses is generous and suitable. I think there is some feeling among the nurses that they should be clothed all the time that they are in the service and I think that Major Perkins thought I was a stingy person because I stood by the statement we had when I first went to France, that the Red Cross furnished initial equipment and then the nurse attended to her own needs afterwards. I believe that there is a rertain pamperizing effect in giving equipment. 'The British give earh nurse a sum of money and require her to present herself with the regulation outfit for inspection. Now onr way results in greater uniformity, but I hare heard so much complaint that I would like to see each nurse made to feel more personal responsibility about her equipment.

As to salaries, in the general emotional upset due to war conditions, it is highly difficult to adjust money matters. The service the nurses can render is priceless; yet I believe that every one who goes into the service really believes in her heart, as one of them said to a man who aslied her if she was to get a bigger salary than she had been receiving in civilian work: "It is my privilege to serve my country and the allowance is sullicient for all my needs." I really believe that the nurses' pay of sixty dollars a month and maintenance is not so great a reduction in income for the private duty nurse, if taken in the average, unless of course she is depending on "gifts" as too many do. For a school nurse there must be a decided advantage in the sixty dollars salary and five hundred franes maintenance. However. the nurses romplain now and then to the men in Paris, men whose wealth makes them think the sixty dollars is barely enough for an evening's entertainment. and they pity the nurses and encourage them to ask for further gifts in the way of equipment. . . .

If the lierl cross could make possible a systematir, intelligent development of esprit de corps in the Amerisan military mursing service, it would be a far greater gift to the mures themelves and to the profession than any amount of fur trench coats and pianos for recreation houses. . .

Early in the spring of 1918, the Red Cross Commission for France felt that the establishnent of an equipment renter in Paris where murses conld sceme articles of clothing and equipment to replenish worll-out ones at cost, of nearly ant, would 
be a great eonvenience. The War Department and National Headefuarters coneurred in this opinion and a Nurses' Equipment shop was developed and mantained at the Paris Headquarters, muder the chicef murse of the American Red ('ross in France. A report of these activities will be found in a subsequent clapter.

The first detinite movement of the Government to furnish equipment for Army nurses was made in August, 1918. General Pershing then cabled to the War Department, repuesting that forty-three thousand pair's of shoes, rubber's, raineoats, summer underwear, norfolk jacket snits in regulation sizes, coats, hats, cte., should be sent to France at Govermment expense, a request which argued towards the possibility that the Ameriean Expeditionary Forees rontemplated the establishment under their own direction of a department for the replenishment of murses' equipment and miforms.

At the erisis of the nursing situation, when the War Department was ealling for fifty thonsand graduate and student nurses by July, 1919, Colonel Winford Smith, Medieal Corps, took up again in a letter written November 6, 1918, to the General Nimager of the Anerican Red Cross, the old question as to whether the Red Cross or the Army should pay for nurses' equipment :

I am directed by the Surgeon General to acknowledge the receipt of a recent letter from the general manager of the Red Cross, stating that inasmuch as the IVar Comncil of the Red Cross understands that the Government is to provide for the equipment of nurses for overseas service, the lied Cross is preparing to disband its organization which has had this phase of work in hand.

The Surgeon (ienera! has again requested that the Covernment equip the nurses, but at this writing we have no assurance that farorable artion will be taken on this request.

Inasmuch as we bolieve that it would scriomsly interfore with the recpuiting of nurses who are so urently needed, if the Red cross stops issuing equipment and the Ciorernment fails to provide for it, it is hoped that mutil definite arrangement: have beren made by the dorernment. the hed ('ross will feel like continuing its custom of equipping the nurses as heretofore.

General Peytom C'. Mareh, Chief of Staff, issued on December

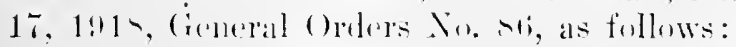


In order to enable them immediately to comply with regulations requiring the wearing of uniforms, a single initial uniform ontfit is hereby authorized for issue to members of the Army Nurse Corps upon their first entry into the service, as follows: One nary blue norfolk suit; one navy blue overcoat; one nary blue flannel waist; one nary blue velour hat for winter; one nary blue straw hat for summer; two sets insignia, United States; two pairs insignia, badge of Corps.

When members of the Army Nurse Corps are ordered to duty overseas with the American Expeditionary Forces, the following articles will be issued to them: six gray cotton uniforms; one gray woolen sweater; one gray woolen muffler; one raincoat; one blanket for use on transport; one sleeping bag; one steamer trunk.

2. Nurses who have been enrolled for service during the existing emergency and who have not been supplied with uniform ontfits by the American Red Cross without cost to themselves, will be entitled to the issue herein authorized. The Quartermaster General will supply the necessary articles ố uniform for issue and sale at cost price, when issue is not authorized. The details of material, make and design will conform to the specifications prescribed by the Surgeon General and no change therein will be made without his authority. By order of the Secretary of IVar.

The American Red Cross at its New York Bureau Nurses' Equipment equipped between April 7, 1917, and December 31,1918 , the following personnel for overseas duty:

ARMY

10,519 Nurses at an average of $\$ 180$ each. . . \$1,893,420.00 266 Civilian employees at an average of $\$ 180$ cach ................ $4 \%, 880.00$

134 Dietitians at an arerage of $\$ 180$ each. . $\quad 24,120.00$

365 Reconstruction aides, at an arerage of $\$ 180$ each............... $65, \% 00.00$

$$
\mathrm{TAYT}^{30} \$ 2,031,120.00
$$

334 Nurses at $\$ 180$ each. . . . . . . \$ $\$ 60,120.00$

${ }^{2}$ These figures are included here to grive an idea of the proportion of service rendered by the Red Cross to the Army in comparison to that given to the Navy and to Red Cross foreign commissions, also to give in one table a complete smmmary of the activities of the Bureau of Nurses' Equipment. 


\title{
RELATION OF NURSING SERVICE TO 'THE ARMY 383
}

\author{
Red Cross (Foreign Aetivities) \\ 573 Nurses at $\$ 180$ each. . . . . . . . \$103,140.00 \\ 351 Nurses' aides at $\$ 100$ each . . . . . . $35,100.00$ \\ 4 Dietitians at $\$ 180$ each........ 720.00
}

$\$ 2,230,200.00^{31}$

Of the equipment, Miss Noyes wrote in her request to the War Council for an appropriation to cover these expenditures:

A maximmm amount allowed for equipment was $\$ 200$ per individual, but only in a few instances was this amount given, while in many other instances it fell below the $\$ 180$. The average cost per nurse for the equipment was $\$ 180$ each.

The equipment for the nurses' aides was approximated at $\$ 100$ each. Some of them were given entire equipment, others partial, while in a great many instances the equipment was provided by the nurses' aide.

These figures do not include the equipment issued to the nurses in home service, which consisted of the cape; neither does it inchude the equipment issued to the nurses in the sanitary zones, as this is provided from a separate appropriation. The approximate amount of money spent for capes at the present time was $\$ 280,000 .^{31}$

The Red Cross appropriated more than three million dollars for equipment for murses, nurses' aides and dietitians. The estimates which Miss Noyes gave above were based upon the ratio of $\$ 180.00$ for each nurse. Equipment required for some nurses exceeded this amomt and required the expenditure of $\$ 200$, the maximum which the $\mathrm{War}$ Council allowed for an individual. P'rices of materials and labor varied from time to time and these conditions caused equipment to exceed three million dollars. ${ }^{32}$

('lara l). Noves, Caroline Van Blareom, Florence Johnson, Sophie Kiel, Mary Magoun Brown and Maude (r. Moody stand ont preäminently among the group of Red ('ross women whose interest and tireless effort made smooth the rubarkation of those thousands of overseas workers. Sophie Kicl (Nt. Luke's Hospital, X. Y. ('ity) was Miss Van Blareom's and Miss Johnsons assistant in the Atlantic l)ivision. Following her

${ }^{31}$ See American Red Coms War Commeil Request for Appropriation No. 998 , February 14, 1919.

34 "The Work of the Ameriean Red cress during the Mar," p. 33. 


\section{HISTORY OF AMERICAN RED CROSS NURSING}

return from Khoi, Persia, in 1916, she organized one of the Red Cross detachments for the Navy. Though her status continued as that of a $\mathrm{Nary}$ chief nurse, the superintendent of the Navy Nurse Corps released her from active service to assist in the Atlantic Division until August 22, 1918, when she was assigned by Mrs. Higbee to the U. S. Army Transport George Washington.

The attitude of mind which characterized the Red Cross executives and their assistants who handled the often vexatious details of equipment was described by Miss Brown, herself a member of Miss Johnson's staff. "As I reeall those busy dars," she wrote, "one outstanding point remains freshly in my memory. Miss Johnson and her associates drew so much vivid interest and enthusiasm from the new groups of nurses coming from all parts of the country, all fired by the same ideals of service, that they themselves seemed forever ummindful of personal fatigue and genume labor and inconvenience." Mrs. Moody wrote, "Armistice Day found the Burear of Equipment with an organization of thirty more than willing workers, a staff which knew no hours of service,-its inspiration gained from that long line of nurses who, with never a thought of self, just marking time mit their aetual work overseas might begin, had come and gone before us."

National Headquarters provided other comforts for the welfare of American nurses in Army service orerseas and mention of them may be included in this chapter. The Minutes of the War Council, which record all appropriations made from the Red Cross eofiers, briefiy mention two other items. On March $19,1917, \$ \tau 7,500$ was appropriated, "of which so much as may be necessary shall be expended for the purchase of 'safety suits' for the use of nurses and members of hospital staff's, with the understanding that should the War Iepartment wish to reimburse the Red Cross for these suits, it should be permitted to do so." 33 The high seas were alive with L-boats. In addition to keeping a pereon afloat for an indefinite time, these particular safety suits aflorded protection from exposure, "a canse of many of the deaths," stated this minute of the War Conncil, "following the sinking of ships."

Before the "leclaration of war on Germany by the Lnited States, the War I lepartment had allowed forty cents per day for food for Army nurses and patients. This allowance could

35. Minutes of the War Comncil, Vol. 1II, pages 787-789. 
not be changed without Congressional action. 'The Surgeon General acoordingly asked the Red Cross to assume the responsibility of providing the difference between the legal allowance and seventy-five cents, which was coneded to be a proper amount of subsistence. For a period of eleven months, these thirty-five pennies given daily for food for every Army nurse and every sick or wounded soldier in Europe amounted to well over \$155,007. "Colonel Ireland," rexorded the Minutes of the War Comeil for May 18, 1918, "stated that ample provision has now been made by the Government for the sick in hospitals and for the nembers of the Army Nurse Corps."

The Red Cross furnished laundry allowance for nurses serving on the Mexiean borker, but did not make similar provision for nurses on duty during the European War in the eantonments or on foreign assignments beeause of the vast amount of elerical detail that would have been required.

Whatever the Ameriean Red Cross did for the war nurse, were she of the Army or Nayy, the U. S. Public Health Service or the Red Cross, was giren back indirectly in service by her to the American soldier. His eomfort, often his very life, depended upon that gray-uniformed nurse who from time to time accommodated her own personality to the needs of her patients; she was sometimes eheerfully frivolons; she was sometimes seemingly eallous and unsympathetic; she was sometimes the very reinearnation of that woman who sixty years ago walked, lamp in hand, among the wounded at Scitari. That nurses themselves were grateful for the gifts which American generosity enabled the Red Cross to make them, is shown in this one letter chosen from among many of similar content:

\section{American Experlitionary Fores,} France, september : $2,1918$.

Everywhere we look, everywhere we go, there ariso evidences of your consideration and love. The wartrobes you gave us hest mimifest this.

It is hard to determine which of the articles you chese are the most nichul and attractive. Whan we notice how the peasant women ege us. We think it is onr smart jackets and skirts. When the weather gets cold and om ulsters tit inmerly about our throats, we are sure we need these great coats uno than anythine olse. When it rams the next hay, we watm.

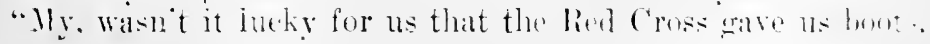


shickers and raincoats!" When we crawl into bed at night with hands and feet numb with cold, we bless you for giving us warm pajamas and sleeping bags. But when the gray morning comes all too soon, then our wool underwear certainly feels best of all!

Many times when I have been lonely, heart-sick, soul-weary, the sight of my equipment and the thought of why it was given to me has brought me new courage, has made me into a better soldier. 


\title{
CHAP'TER VII
}

\author{
THE EUROPEAN WAR
}

Cantonments of the New Armies-Embarkation-With the American Expeditionary Forces in Great Britain-With the American Expeditionary Forces in France-The Zone of the Base, A. E. F. in France-The American Red Cross C'ommission for France-Nurses' Equipment Shop, ParisWith the French Service de Santé-Emergency IIospitalization, A. E. F. in France-The Zone of the Advance, A. E. F. in France-W'ith the A. E. F. in Italy-With the A. E. F. in North Russia

7 HE United States entered the European War on April 6, 1917. Twenty days later the American Nurses' Assoeiation met for its Twentieth Annual Convention in Philadelphia, with a record attendance. The Red Cross session was held on Monday evening, April 30, in the Academy of Musie. Every one of the 3000 seats was filled and all available standing room oceupied. In the red, white and blue of the Red Cross miform, nurses sitting in the orchestra, the baleony and the galleries formed line upon line of color, splendidly vivid against the somber-hued furnishings of the auditorium. Their faees nnder the winged Red Cross eap were tense and expectant. Realization of the responsibilities soon to be placed upon them hushed the idle conversation which nsually runs lightly through an andienee before the program begins. On that night, the very air seemed charged with patriotic ardor.

Miss Noyes, Dr. Wirren P. Wilson, of Columbia University, and Eliot Wadsworth, acting chaiman of the Red Cross Contral Committee, were the speakers of the evening, Miss Delano presided. Her introduction of Miss Noyes was prefaced in part by the following words:

It is eight vears agro this month since I stoon hepore the Amerian Nurses" lsweciation and berged of them to ratify the affiliation which the Red ('ross had oftered to us and to 


\section{HISTORY OF AMERICAN RED CROSS NURSING}

pledge themselves to the organization of a Nursing Service which 1 believed we should organize for the benefit of our country. At that time, so far as I know, all the nations of the earth were at peace. We began this work with no thought that within a comparatively short period, eight years, we should be called upon to meet the needs and service of the greatest and most horrible war that the world has ever known. ${ }^{1}$

After giving an outline of the development of war nursing, Miss Noyes voiced the responsibility confronting the American nursing profession:

As I stand facing you to-night, sister nurses, under the shadow of war, we know not what we as nurses shall be called upon to do. We know, however, that our Red Cross Nursing Service exists but for one purpose,- the reserve of the Army and Nary Nurse Corps in time of war. You may be called upon to give fully, to make great personal sacrifices, but we know you are prepared, we know that you are realy, we know that we can depend upon you to carry the spirit of Red C'ross service, as well as its banner, wherever our Army and Navy may be sent, whether to the Pacific or Atlantic coasts, to the cantomments. to the frontiers of France or Russia, or to fardistant Mesopotania. It must le written upon the pages of history for all time that our Red Cross nurses were prepared, that in this war our soldiers at least were not neglected and that they were properly nursed.2

Following an address by Dr. Wilson on Rural Nursing, Eliot Wadsworth, acting chairman of the Red Cross Central Committee, spoke in part, as follows:

In these days of alarm and excitement. when the whole country is thinking of war and when at every cros-road and in every railoar train the people are debating as to the extent to which the rountry is prepared . . I lave come here really to say a word of appreciation for what the nurses hase done by their sestematic oreanization. and what they will be alled

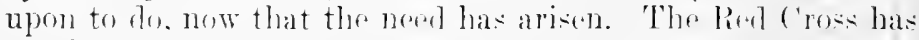
enrolled for servier more than senof murses whose qualifications are knewn, who have taken all the stepe repured by the Army Mrefieal (orpes to permit their inmediate enlistment in :23rd Annual Report, National League of Nursing Education, 1917, p. 2.23.

Ibid. 
this service.... And as a result, the Red Cross Nursing Service is ready at this hour, more ready than perhaps any branch, official or unofficial, of the United States. ${ }^{3}$

As Mr. Wadsworth concluded, the vast body of $A$ merican women rose as one and pledged themselves "to give our best serviee to the nation wherever ealled upon to render it, either in home or foreign field, in the daily routine of eivil or military hospital, or in the equally great effort to conserve, protect and strengthen the health and cinduranee of the civilian population, the men, women and children at home in our land."

Even then, the eall to the colors had sounded. Orders for the immediate mobilization of six Red Cross base hospitals for duty with the British Expeditionary Forees had been sent the day before, April 29, by the Surgeon General. One after the other, these and other Red Cross sanitary mits were assigned to active foreign service, while at home the building of future American Armies, of which nurses were to form a vital part, began.

History was swift in the making during that memorable spring and summer of 1917. Congress in special session passed the Selective Service Law on May 19 and the first registration on June 5 brought thousands of recruits to the cantonments of the new Armies. The building of sixteen eamps for the $\mathrm{Na}$ tional Guard and sixteen cantonments for the National Army had been authorized in May; the last site for these temporary gray cities was secured on July 6 . Aecommodations were ready on September 4 for 430,000 men. This eapacity was shortly increased to provide for the eare of 750.000 men, an average eapacity per eantonment of 48,000. Divisions of the Regular Arny were trained both in camps and cantonments and at various Army posts. Training schools for the Artillere, Ariation. Engineer, Tank and Quirtermaster Corps and for ('hemieal Warfare were cetahlished, with proving gromuls and testing fields. Embarkation camps were built at Now York and Newport News and afforded housing aecommodations for more than 300,000 men. $^{4}$

Each of the thirty-two camps and cantonments included as part of its organization the development and maintenane of a

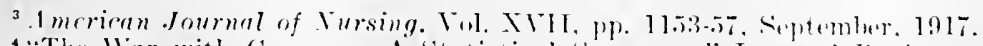

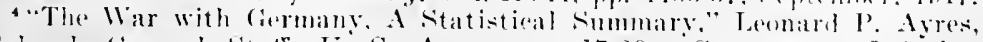

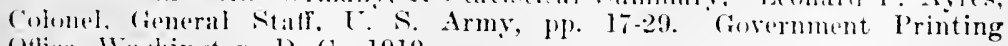
(Ollice. Wishingrton, 1). C., 1919. 


\section{HISTORY OF AMERICAN RED CROSS NURSING}

hospital of one thousand beds. The nurses of these hospitals were seeured largely from Red Cross emergency detachments. In a letter written September 22, 1917, to all Local Committees on Red Cross Nursing Service, Miss Noyes stated that "we are being asked for many hundreds of nurses for cantonment duty. ... Will you not 'round up' as many as possible for this work? The phrsical examination of each nurse will, of course, have to be on file in this office before she can be assigned to duty, but it will not be necessary for her to complete immunity treatment."

The Surgeon General also asked the Nursing Service to nominate chicf nurses for several of the cantonment hospitals. Susan Hearle, Alice Beatle, of the Merey Ship Relief Expedition, Mary Roberts, Estelle Campbell and Sophia Rutley were appointed. "Each chief nurse," wrote Miss Noyes in the Red Cross columns of the Journal of Nursing for November, 1917, "has been asked to organize groups of nurses as a nueleus for her personnel, but should she not be able to seeure the required number hy the time the cantonment hospital is ready for occupaney, it is expected to fill the deficit from emergency detachments."

As rapidly as barracks could be erected in the cantonments, they were filled with reemits from the Selective Draft. Base hospital construetion, including the ereetion of nurses' quarters, was deferred until after the barracks were completed. The need for medieal and nursing service increased, however, with each new assigument of men to the cantonments. Immediately upon their arrival, the "rookies" were inoculated for various contagious diseases and many of them beeame ill. Others, long aecustomed to more sedentary and luxurious habits of liring and to food different from Army rations, were slow to beeome acelimated to the rigors of military life and so fell an easy prey to disease. Thus came about the acute need for nurses in the camps and eantonments, which Miss Noyes set forth in a letter written October 30 to all Local Committees on Red Cross Nursing Service:

We have juit received a definite all from the War Department for nearly ion murses for immediate cantonment service.

The National rommittee feels very strongly that this seri. ous need shomld be homent rery forcibly to the attention of individual menles: of the Red Cross Nursing Service. It is far from patrictic. far from the purpose of the Red Cross to 
have nurses continue to refuse home service where the need is urgent, in favor of foreign assignment, where the demand is not so great. Nurses whom the committees consider available for cantonments and who continue to refuse service should be reported at once to National Headquarters.

The need is indeed pressing. There are from 600 to 800 desperately ill men in sereral of these hospitals, with an average of ten nurses on duty.

Nurses themselves held back from volunteering for eantonment serviee beeause they felt that foreign service would be more attractive, more interesting. In the January, 1915, issue of the American Journal of Nursing, 1 iss Palner, the editor, soundly rated the nursing profession in an editorial bearing the title: "Are we slackers ?"

Appeals are being made constantly from Red Cross Headquarters for the enrolment of murses for home service. The situation is rendered difficult for the reason that nurses who are enrolled in base hospitals are being held back to some extent for foreign service, while many others are failing to respond becanse they are hoping for a chance to go abroad and desire to do that rather than volunteer for service in the cantomments in their own country.

The waving of one of the requirements for enrollment in the Red Cross, that of membership in the American Nurses' Assoriation, will make large numbers of nurses eligible who have been debarred up to this time. We wish to call the attention of our readers again to Miss Delano's report in the last issue of the Journul, which showed that during the war period the age limit is abolished so that older women who are in rigorous: heilth may be enrolled for home service. It is going to be possible. alio, for nurses from the smaller hospitals to be recognized muler certain conditions.

One reason given by nurses of all ages for not enrolling is that their families object to their sorving. We want to say that if any woman is old enough to be ont in the world supporting herself amb perhaps helping her family. she is old enough to decide such questions for herself.

Returns which are coming in from the survey of nursing resurece being marle thromghout the combtry show that a complaratively small proportion of the renistered nurses in the twenty states that have reported. are encolled with the lied

- cross. The berentiges vary from one and throu-fourths. which is the lowest recerved, through soren and eight, which 


\section{HISTORY OF AMERICAN RED CROSS NURSING}

are the most common, to thirty-two and forty-one, the last being to the credit of the Distriet of Columbia.

Do not let it go down in history that when the young men of our country were called into service in defense of the democracy of the world, the nurses held back, because of financial reasons, or because they shrink from the hardships of war service.

Among letters of sharp eriticism which eame to National Headquarters was one which had been written by a registered nurse fifty-eight years old. After roundly upbraiding younger nurses who refrained from offering their services, she asked for assignment in the Army Nurse Corps. In replying to her on February 28, 1918, Miss Delano gave the following reasons for the existing shortage of nurses:

In the first place, camps were erected before the hospitals were built and I believe the hospitals took precedence over the nurses' quarters. Bringing hundreds of thousands of young men together in camp life made it possible for an epidemic of contagious discases to develop, which came on in a great flood before adequate preparations had been made for their care.

In some cases, quarters for nurses were not available. In other instances, there was temporary diffieulty in securing an arlequate number of nurses to meet an emergency. This was due to various (auses, (hief among them, I believe, being the fact that we had several hundred nurses mobilized and waiting for service. 'This fact was generaily known throughont the country. It was, therefore, diffienlt to convince nurses at large of the extreme neel when they knew that at the same time we had several hundred nurses mobilized at Ellis Island who were not alled upon for cantonment duty. It was difficult to explain to nurses at large that these gromps at Ellis Island might recoive sailing orders at any moment.

We have met all the demands of the Navy and the U. S. Public Ilealth service ancl, I believe, are meeting satisfartorily today the needs of the Army. This is, I think, proven by the faret that we are corolling over a thomsand nurses a month and are sending large mumbers into immediate service, both at lome and overseas.

I agree with you, howerer, that if we as a profession are to meet the oblingtions that this war has thrust upon us. the rank and file of the nursing profession must realize that not ing is more important than the are of our soldiers here $n$ oir ow1 country. 
After the adoption of the ruling that nurses should be "sent to cantonment hospitals in this country to determine their professional and physical titness for overseas service," many nurses from the staffs of base hespital units were assigned to cantonment duty. But the need for nurses in this branch of the service still continued. On May 16, 1918, Miss Thompson wrote Miss Noyes that "in view of the fact that 550 'easuals' are to be rushed to Europe in addition to the base hospitals now awaiting transportation in New York, the eantonments will be in urgent need of nurses, I fear, in a short tine. . . . Therefore, will you not do all within your power," she eoucluded, "to nominate as many nurses as possible for immodiate duty? One thousand could be placed today without difficulty."

Cantonment service was full of the hubbub, the change, the excitement of armies in the making. Emergencies made up the very fabric of the nurses' crowded days. Rachel Golzar, Reserve Nurse, A. N. C., wrote from Camp McClellan, Anniston, Alabama:

A few months ago, this region was a stretch of wilderness. The first division of men worked this place through to what it is at present. 'The lospital is perched on a hill-top' and below the hill are the elrill gromds and tents. The camp ground occupies some seventeen thousand acres. The base hospital, extending over sixty-two acres, has at present thirty-two warks: more are in process of construction. Surcrical warets, a medical and dental department, X-ray room. nose, ear and throat seetion, aye clinice, contagious and tuberentosis divisions; one ward for mental cases and one warl for sick oflicers, comprise our line-up. Each warl is a barracks hy itselt. We have now between six hundred and seven humdred patient: and a wite variety of cases, perhaps more than in any large hospital of a city.

When we seven arrived, we found ourselves the first group of nurses that ever trotted these gromnls. We were not expected so soon nor was anything ready for us. So department store in New York, howerer, dolivered things more rapiblly than the (quartermaster ('orps bromsht us berls, furmishing: and other eomforts.

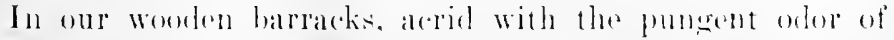

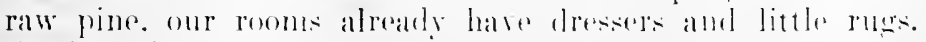

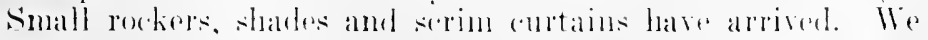
expect our own cook and two maicls hater to attend to the murses' home. 


\section{HIS'TORY OF AMERICAN RED CROSS NURSING}

The American Journal of Nursing published in May, 1918, a speeial Military Number, which was made up of articles which had been written by nurses in various types of war nursing and which deseribed their personal experiences. As Miss Delano took a large part in seeuring these articles, extracts from them are quoted as primary sourees in this history.

Of the eantonment near Boston, at Ayer, Massachusetts, Jane G. Molloy (City and County Hospital, San Franeiseo) wrote:

Camp Devens, named after General Devens of Civil War fame, is in the Northeast Division. Its development, spread over ten thousand acres, is a feat of engineering. Twenty miles of road were laid; four hundred miles of electric wiring were done; sixty miles of heating pipes were connected, all in less time than is ordinarily taken to erect our municipal buildings.

It is a small world that you must see for yourself. The hospital itself is a little town. Its corridors measure three and one-half miles. They are enclosed and each is named as are streets in a well haid out village, each ward numbered as are houses in a eity block.

Patients who filled the wards of cantonment base hospitals during 1917 and during the spring and summer of 1918 were generally medieal and contagions and aecident eases. Soldiers wounded in active serviee in France had not yet begun to come back to the United States. However, the nurses who were assigned to cantomment duty worked very hard, especially during the epidemic of contagions diseases to which Miss Delano referred in the letter of February 28, 1918, quoted above. The virulence of this epidemie and the need which it cansed for expert nursing service was deseribed by Eleanor Hall, Army Nurse Corps, in a letter written from Camp Taylor, Louisville, Kentucky:

On April 1, 1918, I was assigned to day duty on "yC," a pneumonia ward. We seem to work in a treatmill here; we rush from morning till night and yet, in spite of all we can do, the boys get sicker and sicker and we have had several deaths. The other day we lost one, measles, bronchial pmemmonia and meningitis. It sermed as if his head was filled with pus which oezed from his eyes, his ears, his nose and month. . . . When one gets meastes here, it is serions, for the infertion which causes mobsles also anses absersed eyes, ears, throat infections, and then it anes to the lungs and we have pueu- 
monia, bronchitis, erysipelas (there are four cases in the ward now) and pleurisy. Between the last day of health till the first day of "at the point of death" is sometimes only thirtysix or forty-eight hours.

Ethel Haigitt (St. Michael's Hospital, Toronto, Canada), rescrve nurse, wrote in the Military Number of the Journal of her work at Fort Riley, a Regular Amy Post, near Junction City, Kansas:

They were very busy on the wards, so we were asked to be ready for duty by nine o'clock. The large gray stone buiklings, which had been previously used as barracks, band quarters, prison, mess hall, etc., were fast being cleaned, painteil and remodeled; also a very good plumbing system was being put in. As we walked along ('avalry l)rive with the chief nurse, she requested us to wait for her while she took one of our number into one of these buildings known as sections, where she assigned her to duty. So we passed on until it came my turn and I was ushered into a section marked "C," "Isolation," "Measles."

Here I found two nurses and a head nurse, but the one whose place I was taking was to go on night duty. This section, though full of patients, probably $1+0$, had only had nurses there for about two weeks; there were none to put there before. Ilere, as in other sections, the carpenter's and plumbers were at work.

As you may judge, we were very short of nurses through all the Fort. We deciled to put all the sickest patients and those requiring the most treatment in one large warl, thereby saving time and steps. We found the warl masters and corpsmen invaluable helpers, many times willing to do things out of their province. During the first two weeks I must admit I was very tired and the hed looked good to me at night. IVe, the day staff, had only eight-hour duty; that usually meant four hours on and four hours off. The night nurses worked twelve hours.

When I hat been in this section three weeks. the chief murse informed me that she wished to open another building (by that she meant to place nurses in it) and wanted me to take charge of it. Being still short of nurses. she could wive mo only one. but promised more as soon as they could he obtaned. When l left. I had nine nurses for day and threes for night duty. So you sce she kept her promise. . . .

Within a fow works, the epidomic was worked and the pressure of work lightened projortionately in the antonment 


\section{HISTORY OF AMERICAN RED CROSS NURSING}

hospitals. Then the nurses enjoyed an eight-hour day, which gave ample opportunity for rest and recreation. Jane Molloy wrote of the facilities for recreation at Camp Devens:

Do not believe that a nurse is always "over-worked" in the Army. When she leaves the wards, she is completely and gloriously "off duty." This total freedom from all responsibility means an opportunity to relax and enjoy the interval between hours of duty, rarely possible in other vocations.

Nor is there dearth of entertaimment. Something is going on at all tinles. Though it is work for the company to drill, it is entertaimment for the observer. I have yet to see a comedy staged that can compare with the "Awkward Squad." Many of the best plays of the season have been produced at our camp theater. 'The Boston Symphony Company gave one of its fine concerts here during the winter; and the movies are always to be seen.

And abore, around and behind all this, the great, stupendous work goes on - the training of brawn and muscle, of mind and will. The Army changes no one; it simply proves what we are.

In its professional phases, military nursing differed greatly from institutional or private duty mursing. In a letter written from Camp Taylor, Louisville, Kentucky, Eleanor Hall described these aspects:

The nursing experience we get here is invaluable. We learn much in rarious lines which is not essential in private duty nursing but which is rery necessary in Army service. The nurses have come from all types of schools, from all states and from all walks of life. They are thrown together here and must quirkly accustom themselves to the Army discipline. Length of service at a given post. and that alone, puts one nurse ahove another. The head nurses for the wards are selerted entirely from among the nurses who have been longest at ('amp, Taylor. In a ward. the head nurse rules, except that earh nurse is free to do her work aceording to her training. provided. of course. that she does it correctly. When a question arises howerer, the nurse who has been on duty for the greatest length of time in the ward has the greatest amount of autherity. We must learn to aceept this. . . .

We niust learn to elose onr eyes to many things which we would like to do and stick instead to the essentials. We must refrain esperally from doing anything or everything that the orderlies or the prationts can do, because there is so much to 
be done that a nurse alone can handle, such as hypodermics, medicines of a dangerons nature, treatments and general supervision, that a nurse has no right to waste her time and energy doing non-essentials.

One of Miss Hall's letters contained the following romment upon the Medical Corps mon:

I never saw college boys work the way our orderlins do. (Most of them rome fron excellent families and are of grood education.) 'They get up at 4 A.M.; walk three miles to their breakfast; (ome on (luty at (; A.M.; swee), mop), scrub), lift, carry heary loads and help the nurses in every possible way; take "bossing," complaints and fanlt finding from the dortors, nursess and pationts and have no "comeback"; have one half hour off for lunch ; and go ofl" duty again at six o'clock, drill and march three miles home again. Some of the very young ones are dears, gentle and sweet, courteons and patient, yet not sissy or goodly-good at all. . . .

The Red Cross provided many little comforts for the nurses in military service in the Inited States. In thirty-six camps and cantomments, the nse of the Red Cross motor cars was extended to murses for shopping trips or for recreation. 'Temis courts were built and maintained. louring the intense heat of 1918 , awnings and poreh curtains were provided and electric faus, to cool the dormitories and moss-halls. At Fort Mcollherson, (ieoreial, a committee of women from the Atlanta ('hapter did mending for the nurses. At Fort l)oniphan, (Oklahoma, a cottage in Ilediejur Park, about seven miles forom camp, was rented and theres nurses at a time were taken there by the Red ('ross Notor ('orps for short racations. When a fire at Camp Iodece. Iowa, destroped the personal belongings of the numsinge staff, the lied ('ross supplied muiforms and elothing within two lomes. Ialus were mate to murses whose resomeres hand been completaly exhamsted.

C:mup life with its bustle and its constant noises ranging

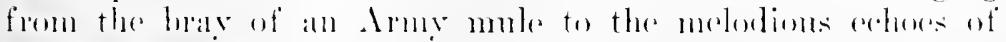
the bugle alls, was vatsty wearisome and the nurses sulely

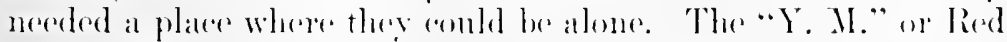
cross huts were alwals arewded with visitors and the sight of

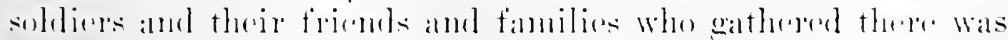
ancenge the last things which tired nurses wanted to soe after

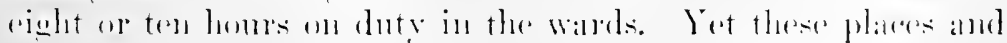




\section{HISTORY OF AMERICAN RED CROSS NURSING}

the rooms in the nurses' quarters, shared by others with nerves equally taut, were their only refuge until the Red Cross built special recreation houses for nurses. The following letter from a nurse at Camp J- is quoted to show the need for these buildings:

... If we could in our hearts wish you such luck, we would wish you were here; for our sakes, though, and not for yours. Miss — - who has been in the service for about a year, is our chief. At first we hoped for some sort of home life. ... Our quarters are built probably like those at every other cantonment. As you enter, there are small rooms on either side of the hall. Our chief nurse insists that there is no provision for a sitting room in these quarters for nurses, though the rooms are not yet all filled. I told her that I never would believe that anybody neant to set fifty nurses down in the woods without sone place to receive a guest. Several people have called whom we could not invite in and several more have asked to call. It hurts my feelings to have to say "no." We have five hundred patients and work on the wards goes smoothly. When we get off duty, we go to bed to get warm and because there is no other place to go.

The Army deplored the lack of recreation rooms and other facilities and in almost all cases later supplied attractively furnished living-rooms for the nurses, but in the interim the Red Cross recreation houses filled a great need.

At a total cost of $\$ 245,000$, the American Red Cross built these recreation houses for the exclusive use of the nurses in thirty-seven camps, cantonments and training centers. 'Though outwardly these structures resembled in their monotonous grayness an ordinary barrack, within there was quiet and comfort. Each had a laree assembly room, bright with cretonne hangings; at one end of it wicker chairs stood cozily about a deep-throated fire-place. In the rear of the building was a small kitchenette, in which the nurses might prepare afteruoon tea for their friends. Nearlyy was a laundry. I balcony encircled the assembly room and afforded the nurses a sewing room and small alcoves where they might read, write letters or serve supper. There was a library and many of the books brought woleome rolaxation to nurses wearied of bandages and the care of sick men.

Encircling the military boundaries of the cantonments were arcas in which the many types of perple who follow an army, 


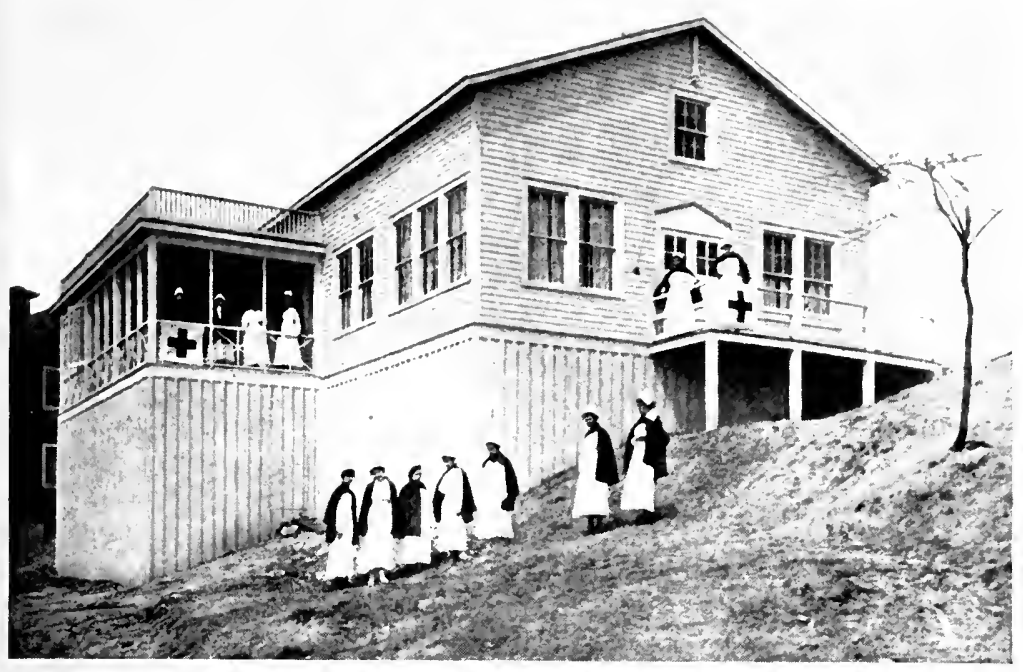

A hecreation llowse built by the American Red Cross for the nursing staff of the U. S. Army base Hospital at Fort Mchenry, Maryland.

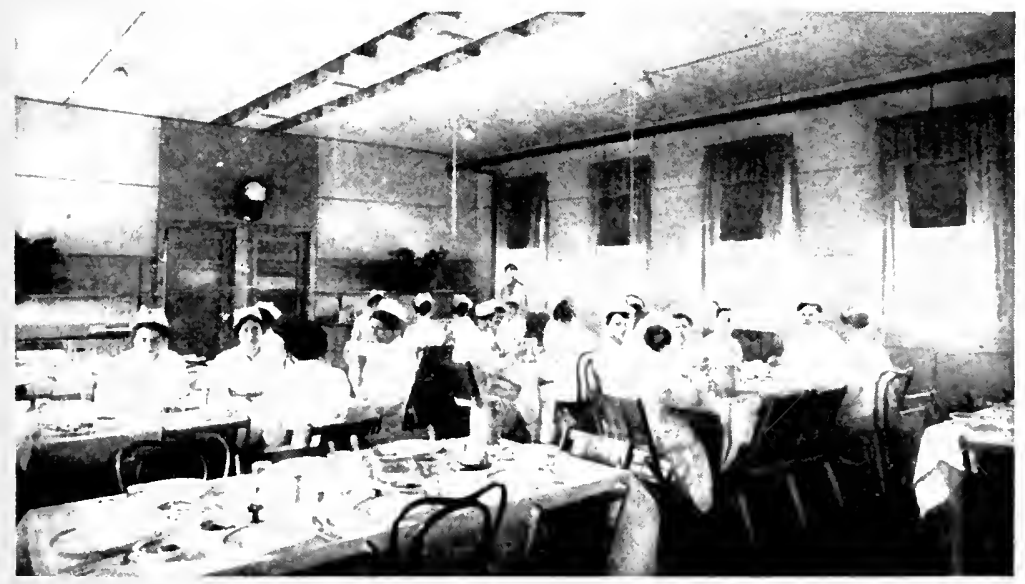

Nurses Mer.. Camp Devens, Matsachusetts. 

gathered to ply their trades. The sanitary eonditions prevailing in stalls where food and soft drinks were sold, in dance-halls, in shooting galleries, in motion-picture theaters and in houses where soldiers, eluding the sharp discipline by which the Army endeavored to check such practices, met immoral women, directly affected the fighting strength of the now Armies. The Inited States Public Health Service, therefore, drew cordons of sanitary protection around the camps and cantonments, ('alling these outlying districts extra-cantonment zones, and, in coöperation with the Amy and with the Red Cross, assigned trained sanitarians and public health nurses to these areas to safeguard the health of the soldiers by bettering the general health conditions in these localities.

While sunitary officers of the U. S. Public Health Service supervised the drainage of malaria-infested swamps and ditches, condemned the venders of dirty or tuberculous milk and rigidly ferreted ont the carriers of communicable diseases, Red Cross public health murses assisted in clinies, dispensaries and isolation hospitals, or "followed up" eases into homes surrounding the military areas. Varied and interesting indeed were the duties of mirses assigned to these health zones. A nurse wrote in the Nilitary Number of the Journal:

Our district, covering a territory of five miles about a camp, consisted of the rity of Spartanburg, Sonth Carolina, of about twenty thonsand inhabitants in normal times, but now of at least double that number. In the numerous cotton-mill villages outsiule the city, the population comprises about twentyfive hundred. There were a few farms with small groups of negro laborers and tenants.

Our unit was part of the T. S. Publie Health Service. The director and the lareer part of the unit was L. S. Publie Health Service persomnel. but we know no difference save that of the miforms. We had a ear for the use of the nurses.

The city had a board of health, a full time director of health and one public health nurse who acted as quarantine oflicer and rlerk: she investigated rases of ilhness and gave instructive care. There was no county health officer. no free hospital hols or dinic farcilities. I local phrsician marle charity calls on a fere hasis. There were good schools with an enrollument of alwnt pour thousand ehildren. No sestematic: nedial inspertion of sohools was being done, but volunteer inspertion had been made. No follow-up work had been undertakis'n. 


\section{HISTORY OF AMERICAN RED CROSS NURSING}

During the second week after the arrival of this unit, several cases of typhoid fever were reported in nearby cotton villages. The Red Cross public health nurses immediately visited the cases and gave instructive care. The sanitarians investigated the water and milk supply. The water came largely from shallow wells, all of which were found to be contaminated, some to the extent of ninety-eight per cent bacillus coli. The director of the unit immediately closed the most dangerous wells and initiated other forms of health protection, with such success that neighboring villages also having typhoid cases, asked for similar service.

How effective the mnit was is shown in the nurse's short statement of accomplishment:

Before we had been in the field two months, we had as our nursing staff the supervising nurse and assistant, paid by the Red Cross; a school nurse, paid by the U. S. Public Health Service; and the city health department nurse. This coordinated all the nursing service in this zone. We organized a council of social agencies and had regular monthly meetings. Mary E. Lent, supervising nurse for the U. S. Public Health Service, suggested rules which were approved by our medical director.

Often the work was of the most primitive type. Mary Pritchard (Poli-clinic, Chicago) wrote in the Military Number of the Journal, the following account of her work in the cantonment zone at ('harlotte, North Carolina:

When I rame here on short notice six months ago. I harl visions of doing general visiting nursing. Cpon arrival they informed me that I was to do tubereulosis work. The one visiting nurse in town, who was supported by the churches. gave "are to hedridden ases when she hat time. An industrial nurse lowked after insured cases. I had to cover a city of fifty-five thomsand inhabitants, hesides the mill villages. We often walkerl ten and twelve blocks at a stretch to make a all. Cutside the healt of the eity some of the districts do not know whal a sirlewalk or a bit of parement is; the soil is red, sticky (lily. Show, rain and mud makes you stick anut slip and sink over your rubbers, ford creeks, climb up embankments and hurdle ditches.

The population included mill-hands, foreign and native, white and colored. Miss Pritchard's report continued: 
The colored districts have small separate houses or cabins, usually old and dilapidated. Alout half of these have no sewer comnections and those which have are rery poorly equipped with the outsile flush toilets, so often out of orler. 'The only means of heating in most cases is the old-time fireplace. . . When a murse wants hot water, all she has to do is to set a pan of water into the fireplace.

The mill houses minally have four or five rooms: they are better (onstructed and kept up) than the houses built to rent, but are terribly cold in winter. Only one of the olesen mill villages has sewer comnections. Two mills have put in aseptic. tanks for the outsile toilets; the others will be compelled to do so this spring on acrount of the amp being here. We have the problem of the lodger, both male and female, in the mill homes as well as among the colored people.

\section{Miss Pritchard described some of the difficulties under which the unit set to work:}

I first called upon the local physicians. Three had their office girls inquire very arefully if I were soliciting funds for the Red ('ross before they would consent to see me.

Iost of them thought that there was a great deal of tuberculosis here which was only being reached by the physicians after the hopoful stage was past. The state sanatorium had such a long waiting list that such patients as wonld consent to go so far away from home usmally died before there was a beel for them. As there was no system of lollow-up work, home "are had proven very unsatisfin.tory. The aslored physieians were lecply interested, sperating espectally of the problem of house inderetion. One tuberenlous fanily womld move ont and a healthy one nowe in only to become inferted. and this process would be reperated orer and over. Susceptibility, poor living conditions and the fact that patients wereso bath to artmit that they had the disease, as it liept them from gerthing (mployment, malle their nork most discouragingr.

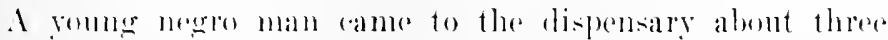

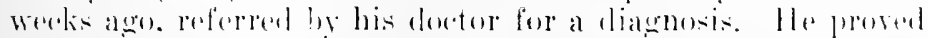
to be all olen rase of tuberedulesis and sermed intelligent and

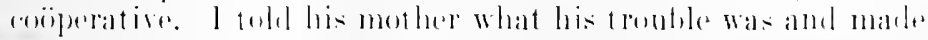

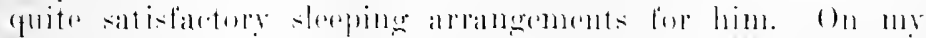

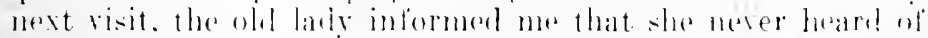

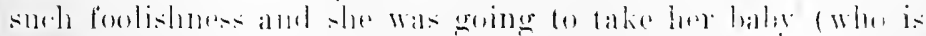

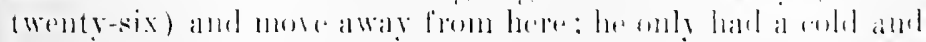

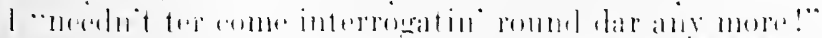




\section{HIS'TORY OF AMERICAN RED CROSS NURSING}

Contact between carriers of communicable diseases and the soldiers in nearby cantonments was often direct. Miss Pritchard wrote:

This work, done primarily to protect the troops, has brought out some interesting facts. Two colored women came to the dispensary, one an old lady going blind and the other with a cough of long standing. One was found to be syphilitic and the other an open case of tuberculosis. Both had been doing soldiers' washing. In another squalid home I found the mother of two tuberculous children ironing the soldiers" clothes and putting them on a filthy bed.

I was also assigned to the venereal clinie, maintained by the U. S. Public Health Service. Two physicians of this service are in attendance. A nurse, formerly comnected with the medical social service department of a large city hospital, was assigned by the Red Cross to do dispensary and "followup" work. A male nurse assists in the elinie. It is estimated that forty per cent of the colored people, who comprise onethird of the population here, have venereal infection; the percentage is almost equally high among the whites.

Emily C. Snively (W. C. A. Hospital, now Jemnie Edmonson Memorial Fospital, Comncil Blufts, Lowa), supervising muse of the Red Cross Sanitary Unit No. 5, wrote in the Military Number of the Journal:

When necessity demands, as it did in our extra-cantonment zone when a typhoid epidemic was raging, the l'. S. Public Health service or the American Red Cross sends a laboratory (ar all equipped to take care of all bikteriological work until the local laboratory (an be established.

The laboratory test is the only positive proof of diphtheria. .. . The taking of throat and nose anltures by the mulse is a very important part of her work, both in diphtheria and meningitis. The artual knowledge that is obtained in regard to milk is invaluable. Samples of milk are collected regularly from the local dairvmen while on their rontes and sustematio examination is made in the laboratory to determine the chemi(al and bacteriological contents and value for infant feesling. Examination is also made to detect any adulteration. preservatives or coloring matter. which are so detrimental to the health and life of imocent babies. . . It did not take longr to "onvict a man for adding formaldehyde to his milk. when the baly of the chice of police was ill from that anse. May the day be hastened when those who are in power will lie as 
interested in protecting the babies of the unknown mother and father as they are their own!

The analysis of specimens in the laboratory ear, which led to the diagnosis of vencreal disease, was one of the most important phases of extra-cantonment zone work of this type. Iliss Snively wrote:

In the sanitary zone, liquor, vice and disease are the three foes which are fought. The liquor problem is handled by the police, but vice by both police and health departments. Any prostitute can be taken by the police to the health ofticer . . . ancl in a very short time it is known positively whether that girl is discased. If / the reaction is | negative, she is released; if positive, she is put away so as to safeguard the soldier. The farm arljoins our city, so the deputy state health officer . . . defincs the farm as the place of isolation. Medioal treatment is criven and no one is released until three smears are taken which prove negative. A splendid woman is superintendent of this farm and these girls are surrounded with such good wholesome enviromment that many have more home life than they have had for years.

When the War Comncil of the American Red Cross went out of office in Fibluary, 1!1!), its chairman published a report giving in statistical form the finanees and accomplishments of the soriety during the period when it was operated by this boly, May 10, 1917 to Feloruary 28, 191!. This report states that Red Cross public health murses assigned to sanitary zones paid a total of $34: 3,943$ nursing visits. The number of new patients visited were $5.3,618$; the nursing visits were 90,602 ; the instructive visits were 104,818 ; the school visits were $21,09-4$ and the "follow-up" visits were 73,811 . In the field of school modieal inspertion, inspertion work was done in 562 schools; $2.29,0: 30$ rhildren wore examined : $81,98.3$ children were found to be defective and 438 s corrections were reported to have been made.

Public health nurses in extra-cantonment zones rendered reoman service in the pandenice of Spanish influenza which swept the country during the antumn and winter of $1918-1 ! 19$.

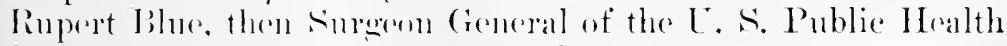
Service, eited seraral heroic examples:

At Muscle shouls sinnitary listrict, on the night of October :" a lind ('ross public: health nurse. assisted hy two ent- 


\section{HIS'TORY OF AMERICAN RED CROSS NURSING}

listed men, received and cared for one hundred and thirty-nine patients, among whom there was only one death in three days. In another instance a public health nurse worked for twentyeight hours, though herself ill, and after five hours" sleep returned to duty. In still another instance, a public bealth nurse was on dinty forty-eight hours with only two hours' sleep. This same nurse paid nine hundred visits in Florence, Alabama, in the period of one week.

Within military bounds, the situation was equally desperate. Conditions at (amp l)odge, as reported by the Red Cross Field Director, Department of Military Relief, were typical of other cantonments. On September 2!), the total number of patients in the base hospital was 1264 , with 245 murses on duty. On October 10 , there were $786: 3$ patients, with seven deaths and 442 nurses on duty. Six days later 5000 patients had been admitted, 56 had died and 595 nurses were on duty. An increase of one hundred and fifty per eent in the eantomment nursing staff was significant of the great activity on the part of the Red Cross in securing nurses for such service at a time when the Army was also endeavoring through Red Cross effort to send overseas one thonsand murses a week. The nurses were mobilized for Camp Dodge through a nurses' registry in Des Moines and were brought ont to the eamp in vehicles of the Red Cross Motor Corps. They were housed in the nurses' domitories and in the Red Cross recreation house.

Many of these nurses had been sent from the Department of Nursing at Red Cross Central l)ivision hearlyuarters, Chicago. Miss Ahrens described the exodns: "At a few hours" notice, one thousand nurses, old ones, young ones, Red cross nurses and nurses not enrolled, nurses available for service later on and nurses who womld nerere be eligible for permanent cnrollnent, parked thrir kits, boarded the trains and proceeded like soldier's to thre ramples."

The official smmmar prepared by Coloned Leonard P. Ayres,

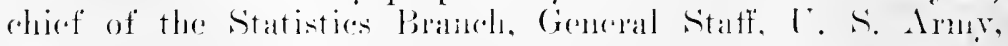
stated that "the hospital apaleity in this cometry (112,2.20) beds) was exceerted only during the influenza cpidenine, when it became necessary to take over barracks for hospital purposes.". The faret that four deaths per themsand soldierse oecenred cach week in the Lnited States during October and

s"The War with fermany," I'P. 199-130.

"Itidl. p. 126ti. 
November, 1!)18, shows the virulence of the disease. This loss of life was, inteed, a tragie aceompaniment of war.

An interesting experiment in the assignment of colored murses to a military cantomment hospital was developed at Camp Sherman, Olio, during the inthenza epidenice. The question of utilization of colored nurses had been the canse of prolonged discussion between the Surgeon General's offiee and the Ameriem Red Cross. At a meeting of the National Committee on Red Cross Nursing Service, held in Continental Ilemorial IIall of the Damghter's of the Aneriean Revolution on lecenber 5, 1911, the following action was taken regarding the emrollnent of colored nurses:

The question of the enrollment of colored nurses was discussed at length and in the meantime a conference had been held with the surgeon (ieneral in regard to the appointment of colored nurses ats members of the Army Nurse (orps. Owing to the impossibility of securing proper quarters for them, it has never been the policy of the surgeon (ieneral's office to consider the appointment of colored mirses.

In view of this lact it was noved by ilrs. Draper and seconded that for the present, at least, colored nurses should not be enrolled for service under the Red Cross. The motion was (a)riced. ${ }^{\top}$

The Ninutes of the National Committee on Red Cross Nursing service for a neeting held Jume 16; 1917, recorded a motion made and carried which approved "a plan for the utilization of colored nurses in eonnection with base hospitals, if such were organized for colored troops alone." This plan was modified at the next neeting of the National Committee, held on June 20,1917 :

The chaiman stated: The next question is the arsignment of colored nurses to duty. The understanding was that we shombl not open a general enrollment for colored nulrses. lunt if the surgenen (ieneral finds a way to nese them (ats serms possible in lowa) we will enroll them for that special servioe.

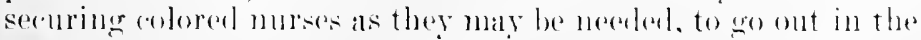

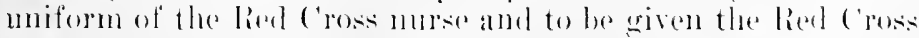

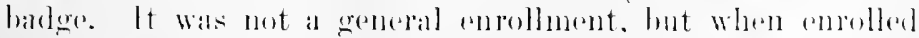
they would be on the same footing njon alsignment to duty ats were other nuress.

"Minutes of the National committere on Red cross Nursing Sirvice, Vol. 1. I'1. 4.j. 1 \%. 


\section{HISTORY OF AMERICAN RED CROSS NURSING}

After some general diseussion, the resolution in regard to colored nurses, offered at the meeting on June 16, was changed by the insertion of the words: "Wherever there is opportunity for assignment of colored nurces for duty, they be enrolled for that service and assigned to that duty." Motion carried.

On Deeember 18, 1917, Miss Delano asked Miss Thompson regarding the probability of the Surgeon General assigning colored nurses to duty. Miss Thompson replied the following day that there was no immediate prospect of calling upon them, but she stated that she thonght it would be advisable to enroll them "with the understanding, however, that their assignment is an uncertain proposition."

During the influenza epirlemic, the base hospital at Camp Sherman, Ohio, asked the Local Red Cross Chapter on October 10 to supply it with additional nurses. Among those responding to the call was a registered colored nurse whose serviees were refused. Catherine L. Leary, then chief nurse at Camp Sherman, wrote November 21, 1918, to Miss Thompson, giving the reason for this refusal:

The evening this colored nurse arrived at Camp Sherman for duty, the response to the appeal through the Red Cross had been actol upon so quirkly that we had many nurses at the time. I therefore had to refuse a number that ilay, among whom was this attractive and intelligent young colored woman.

She seemed much disappointed after having come all the way from Columbus. I offered her a bed for the night, which she accepted and hater refused. deciding to return to Columbus: as her services were not needed. I felt very surry that she shomld have to go away disappointed. so I pait her fare to and from Columbus to the camp. telling her that when our quarter: for colored nurses were ready, we would be glad to have her when we needed her services.

An emergency detarhment eonsisting of nine colored nurses from Fresdman's Hospital, Washington, T). ('., and of one murse from Battle ('reek. Michigan, was assigned during the early part of lecomber to Camp Sherman. Aileen B. Cole, rescrve murse, wrote beanlere:3 of their reception:

We first interviewerd the ehiof nurse. who recoived us very cordially. Ite then wisited the colored hostess house l)r. 
Amanda Gray, of Washington, who is chief hostess there, introduced us to the guests. We also attenderl the colored Y. M. C. A. services that evening and it warmed our hearts to see how thoroughly glad those boys were to have us with them and to hear them weere!

Whe are accepting conditions exactly as we find them. We have met with indivilual prejudice, but, generally speaking, every one so far has been exceedingly kind.

\section{Clara A. Rollins, reserve nurse, described their quarters:}

Eacll nurse has her own room and everything to make her feel at home. Our living room is to have a piano, Victrola, desks, chairs and many other comforts to break the monotony of camp life.

'The work is very interesting. Our boys are in the same wards with the white soldiers. Members of our unit have been assimed to the accident and wounded from overseas ward; surgical, ear, nose and throat ward; the psirehiatric; the observation and contagious wards: and medieal wards of various types. Miss Ball is the only masseuse in the hospital and they were very glad indeed to have her.

Mary M. Roberts, chief nurse of Camp Sherman at the time when the detachment of colored nurses was ordered there, wrote:

Clara A. Rollins I hope I shall never forget, because of her splendidly cooperative spirit shown throughout her service at sherman. No matter what problem arose in recrard to the colored group. I (ould always depend on Miss liollins to think the matter through with me and to coöperate with any solution I might have to offer. She was so well loverl by the boys in a surgical ward that I never changed her from her first pesition. I recall one amusing instanes which oxedured when a change of persomel in the ward seemed logical and inminent. I request. signed hy every man in the warl, was sent to my office beeringer that Miss liollins be not taken from them. The bors always alled her "the llajor" and the day hefore she left ramp they had a sperial ceremomy and made her a "lientemant colonicl." . I I recall that gromp of patients. there were vere fow colored men in it.

Of the livine eonditions and social life of the colored nurses, Mjes lioluerts wote: 


\section{HIS'TORY OF AMERICAN RED CROSS NURSING}

They had their own quarters with its dining room and kitchen. We very early made connection with the colored " $\mathrm{Y}$ " in camp and such other arrangements as we could for a reasonably normal social life. After their conference with me, they agreed that they would not expect to share in the social activities of the white nurses. It was to be understood that they were most welcome at all the "program" affairs. We were areful to resorve the Red Cross recreation hut for their use occasionally, as we reserved it for other groups for special occasions such as parties given by the aides, the students or the graduate murses.

Of the value of the work rendered by the unit as a whole, Miss Roberts wrote:

I do not mind saying that I was quite sure, when orders came for the colored group, that I was about to meet my Waterloo. My feeling now is that it was a valuable experience for them and for me. They really were a credit to their race, for they did raluable service for our patients and it was a service that the patients appreciated. I now find myself deeply interested in the problems of all colored nurses and helieve in giving them such opportunities as they can grasp for advancement. . . .

The War Department reported that the services of seven members of this detachment of colored nurses were satisfactory in erery respect. Two were recorded as "Grade 2." This was highly creditable in view of the fact that the detachment was the first one of colored nurses in the service.

A second detachment of colored nurses was organized and assigned early in l)ecember, 1918, to service at Camp Grant. Of this group, Ame Wiltiamson, then chief nurse of Camp Grant, wrote:

In the latter part of the year, 1918, our commandine officer. (obomel I1. C. Miehie, received dofinite information that we were to have a contingent of colored nurses at ('amp Grant. Aretion to construct quarters for their accommodation was immediately taken and by the time that nurses arrived their home of abont twenty ronms was in realiness.

A colored rook and a maid were assigned to this group. One murse was appointed lomsekepper. ordered supplies. planmerl the meals and muler the direction of the ehicf nurse conducted the homsehold affairs. 
The first nurse reported for duty December 3, 1918, and within a few days about thirteen nurses had arrived. Several of the nurses were from the Lincoln Hospital, New York City, one from the Freedman's Ilospital, Washington, D. C., and several from Providente Ilospital, Chicago.

since the white and colored patients were not assigned to separate wards, these nurses were assigned to the general wards under the direction of the head nurse. They were serious-minded, quiet, business-like young women, well qualified to take clarge of wards, had our colored patients been segregated. For a time, colored troops were stationed at Camp Grant and the nurses had opportunity for quite a bit of social life. They gave several dinners and dances, entertaining the officers from the troops mentioned. I believe that one nurse sulsequently married an officer whom she had met at the camp.

Colored nurses served with distinction during the influenza epidenic at Canp Sevicr, South Carolina. Sayres L. Milliken, who wals at the time chief nurse at Camp Sevier, wrote:

At the peak of the influenza epidemic at Camp Sevier, South (arolina, about fifty per cent of the nurses were off duty, sick, and the hospital contained about 3000 patients. It became necessary to employ locally every nurse who could be secured. A meitical officer on duty at Camp Sevier who was from that section of the country said that there were several grood colored nurses who could be secured in the vicinity of Spartanburg, South Carolina. The idea of securing the services of colored nurses did not immediately meet with enthlusiasm. as fully seventy-five per cent of the nurses were women of sioutheril birth and hat very positive objections to working with rolored nurses. The need was so imperative that it was derided to employ them, furnishing them quarters and a mess separate from the white murses.

About twelse reperted for duty. They were assigned to the wards in the hospital in subordinate positions and with the exteption of onfer or two who were not young ('nongh to adapt themestres to the truing tomditions under which orery one was

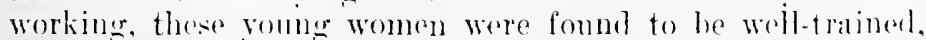

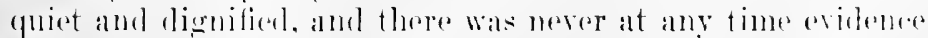
of friction betweess the white and eolored nurses. They serwed for a periend of posibily three weoks. . . I should say thatt. although these nurses bath no epportunity to display exerentive ability, they did and can fill a raluable place in the mursing profossiont. 


\section{HISTORY OF AMERICAN RED CROSS NURSING}

Four types of assignment characterized war nursing service in the United States. At the base of the military pyramid were the barrack wards of the eantonments where the recruits of the Selective Draft were trained. The National Guard did not need so thorough a schooling, military theorists argued, and it was housed under canvas. Sometimes a murse found herself in the shining tiled corridors of Walter Reed or Letterman U. S. Amy General Base Hospitals, permanent establishments of the Regular Army. Fortunate indeed was the nurse whose orders took her to an embarkation encampment! Stella Godard, reserve nurse, wrote in August, 1918, from Camp Stuart, Newport News, Virgina:

After the preliminary business of arrival and reporting myself to the chief nurse, I was taken over to a long barrack-like building and found a bed allotted to me in a dormitory with about fifty other nurses. I must admit that this, for a first impression, was rather daunting. The place was littered from end to end with elothes, trunks and grips. Fven the beds themselves were oceupied, some by night nurses trying to sleep, others by day nurses, reading, writing, sewing and resting. I could see no possibility of the faintest trace of privacy for the undressing and the dressing hour. Neither was there any and later I learned there was no water for any purpose nearer than the main building. We had rough wooden shelves to put our things on and a few nails on which to hang our clothes. To get a bath we had to walk outside to the main building, two blocks away. At all times of the day, nurses were to be met à la negligée passing to and from their ablutions. When it stormed, the rain leaked down npon us from the roof : when it blew, the sand whirled in and almost buried us. and the flies were a reritable plagne.

But all this was. I am glad to say. only temporary disconfort, for now we have rery nice quarters, all branil new and rean. I of ten look back and langh to think of my chagrin and realize that it was not so bad as it seened after all.

Here in Hampton Roads were the shifting sights and sounds of maritime traftic. Miss Codard wrote:

The hospital warks are built facing the fine water front. Both day and night its ever-changing heanty refoshes and rharms one. Doring the day, we sore the ships that come and so to and from the huse jorts aromed here. Tramsports, 
battleships, coaling vessels and innumerable other craft lie at Hampton Roarls, a great air of indomitable purpose and mystery surrounding them. Then when night falls, stillness comes over the water and the long road of silver light made by the moon shimmers up to meet the stars. 'Then, too, there are the little birds that live in the reeds and long grasses by the water's elge, that all night long make weird, restless little noises, neither a song nor a call, but a sound that fills one with inexplicable longings.

The romance of war, now doubly potent because of the neeessity for absolute secrecy, enveloped the constant movement of the troops. Miss Godard wrote:

The troops are continually entering and leaving. For a few days the camp will be crowded with men busy about their drills, parades, exercises, a continually moving mass.

Several times I have come off night duty to see a regiment leaving in the early morming. The colonel addressed his men in a few brief worls, poignant with pride, hope and high courage. The cmotion which he would have hidden was evident only in the deep vibration of his voice. He saluted his men, his officers, then stepped up to the head of his regiment. The band struck np, the order rang out and they all swung forward with brisk tread, enthusiasm like a glory shining from their faces.

When you stepped out on the front porch that morning, you would find the long rows of barracks. the water front and the camp streets empty, deserted and silent, a deathly and haunting stillness over all, where only a few homrs before there had been morement and laughter, song and banter, the playing of bands and the shrill call of bugles. From two hundred to two thousand men had been literally spirited away during the night on to the transports and it will be many a long day before the tramp, tramp of their marching feet will be heard upon this camping ground again.

By nown, however the vacated barracks and parade grounds would be filled again. At the main gate new regiments would come marching in, fine borlies of men, neat and trim, their overseas raps set smartly on the sides of their heads. Following them would come carts, wagons, trucks laden with paraphernalia for horses and men, magnifient and inspiring. soldiers and equipment alike the best Imeria has to offer.

Twelve thousand, seven hondred and ninety-three nombers of the Army Nurse ('orps, reculars and reserves. serverl in 


\section{HISTORY OF AMERICAN RED CROSS NCRSING}

military cantomment and camp hospitals in the United States during the European War. A certain amount of gossip was whispered about regarding the diseomforts, the unreasoning discipline, the overwork, the monotony and the loneliness of this branch of the service. In shalp contrast to the few nurses who complained bitterly yet humanly of their assignment to cantonment duty, there were many who looked behind the surface annovances and inconveniences of eamp life, the tedium of nursing aceident cases and minor ailments and the lack of eonsideration on the part of some of their superior officers and saw the real meaning of cantomment duty, sensed its tremendously vital part in the war plan and aceepted their assigment like the good soldiers that they were. This sportsmanlike and altruistic spirit was well expressed in the following letter written by a reserve nurse:

$$
\begin{aligned}
& \text { U. S. Army Base Hospital, } \\
& \text { Camp- May 25, } 1918 .
\end{aligned}
$$

And so the summons eame and I answered. I am one of the one humdred and forty-eight nurses at Camp_-an atom. For as I write, there march before me sixty thousand fighting men. undaunted, ready and supreme. Here we stand together. one hundred and forty-eight nurses and sixty thousand of the routh of America.

'The number on my Red Cross pin is - In Oetober, 1916. haply in safe ambitions, in a gay loyalty to an idea which sprouts in "aldets" training. I enrolled in the Amerian Red Cross. I still have a eireular letter, dated Mareh 18. 191s. It is an appeal. almost a prayer to sixty-five thousand registered numes of onr nation. it asked for volunteers.

And tomb there are one hundred and fortp-eight nurses to sixty thomind men in (amp _ _ _ trying to accomplish the work of twie their nmmber and more. Tomorrow they journey on the great adventure and their footsteps must be folkowed by other women to whom the war means more than knitting soreks and sweaters and using wheat substitutes.

It seems to whe that this titanic military strugere has become a test for our profesion : a test of its faith in silerifier: a test of woman's willingress and ability to share hardship: a test of womanl s right to be heard in the councils which shall create new ideals from this holocaust of war. 
From hospitals and from private homes, from eamps and from cantonments, American nurses on their eager way to foreign service went to New York and to Hoboken, the imbarkatien port for the Ameriean Expeditionary Forces. From there they sailed when transportation could be seconred.

The attitude of the embarking murses offered an interesting psychological demonstration of the value and efferet of disciplined training. Nurses are tanght to suppress their personal reactions and emotions. They are primarily ministers to others in time of erisis and snffering and it is not for them to show feelings of fear, of hysterical sympathy, even of joy, when they are working in a professional capacity. This principle of nursing ethie's is well illustrated by an incident which oceurred during a recent disaster. The mutilated bodies of the dead were lving in an improvised morgne, awaiting identifieation, and relatives were passing down the line. $A$ number of Red Cross murses were on duty. $\Lambda$ s an attendant lifted the sheet which covered a body, one of the yominger nurses grew dizzy at the sight. She tumed to the nurse in charge and said, "I am going to faint."

The older woman leaned toward her and whispered sharply: "lon't you dare! Other people have a right to faint. You haven't."

The young murse bowed her head for a moment, pulled herself quickly together and went on with her work.

This professional poise, which is attained only throngh discipline and experience, is the first prerequisite of the gond nurse. Cnder it, however, must lie a fountain-spring of sympathy and altruism, without which no woman could stand the sights and render the services expected of murses. Warr tomened these cmetiens and stirred them deeply, but the disripline of training led nurses to eover their real feelings with

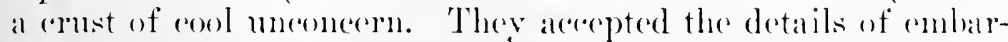
kation with a saloir faire which some observers called "hatrdboiled indifference." So the ten thonsand nurses went down to New York, donned their miforms and hoarded the transports with an anazing quicetness impossible of achievement

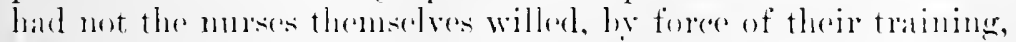

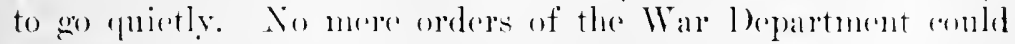

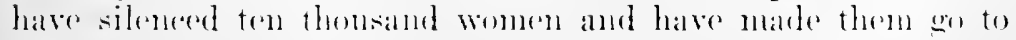
Franere to nume the wounded under the conditions prevailing in $1: 117$, withent aron a ripple of pullic acclaim. 


\section{HISTORY OF AMERICAN RED CROSS NURSING}

Embarkation was a tedious, a bewildering and a somewhat disappointing experience for these nurses, so many of whom had eherished sinee girlhood the hope of nursing the wounded in war; for indeed the name of Florence Nightingale had led more women into schools of nursing than had the remmerative phases of the profession. During long hours of night duty in city hospital wards and later in isolated cantomment bases, nurses had lived in anticipation again and again the day when they should at last set out for war service. Stories of physical hardships and exhansting work, stories told by American nurses who had served on the Western Front during the early days of the war, rumors of submarine attacks and reiled suggestions which were eireulated in 1917 of atrocities committed on nurses, did not help to dispel any natural apprehensions which these women might have felt when embarking upon a service as precarious as war nursing. For most of them the old life, the old sheltered life within hospital walls, ended once and for all time. The Great Adventure, long-antieipated, had begun, but like all experiences which have been lived nany times in anticipation, the actual going-out, though picturesque enough in itself, was less colorful, less dramatic than had been their conception of it.

The first eontingents of the Ameriean Army to sail for Europe in May, 1917, were the six American Red Cross base hospitals which General Gorgas assigned to the British Expeditionary Forees. The embarkation of the first two units was so hurried that the nurses were not even allowed to wait in New York mitil the newly-adopted Red Cross onteloor miforms conld be completed. They sailed instead in civilian attire, having reeeived only such articles of equipment as were then immediately available in Red Cross storerooms.

United States Army Base Hospital No. 4 (Lakeside) which had had a trial mobilization in Fairmont Park, Philadelphia, in the fall of 1916, was remobilized in Cleveland, ()hio, thirty days after the Lnited States deelared war, for immediate service overseas. Grace Allison, ehief nurse, described the sailing of the unit:

Sixty-two nurses from various parts of the T'nited States assombled on llay fi with the general unit at cleveland and entrained for an unknown destination. Arriving in New York, we were quietly transferred to the cmuard liner. Orduna. Here Miss loyes distributed our capes, caps and 
other equipment. Miss Nutting, Mrs. Helen Hartley Jenkins, Mrs. Draper, Mr. Samuel Mather, president of the Board of Directors of the Lakeside Ilospital and many others barle us Codspeed before ropes were loosened llay 8 and we moverl down the harbor.

Lnited States Army Base Hospital No. 5, of Peter Bent Brigham, Boston, Massachusetts, sailed on May 11 without the scrge dress, ulster and velour hat which had just been standardized as the ontdoor miform for rescrve murses of Red (ross base hospital units assigned to foreign service.

The sixty-five nurses of the Presbyterian Lnit, U. S. Army Base Hospital No. 2, which embarked May 14, were miformed and equipped by the American Red Cross. On May 19, three other units, U. S. Army Base Hospital No. 21 (Washington University Medical Sehool, St. Lonis), U. S. Army Base Hospital No. 10 (Penusylvania IIospital, Philadelphia) and U. S. Army Base IIospital No. 12 (Northwestern Lniversity Medieal Sichool, Chieago) also sailed with outdoor uniforms and more complete equipment. Miss Noyes in the August issue, 1917, of the American Journal of Nursing deseribed the spirit in which the nurses of these pioncer units accepted foreigm service:

It is an inspiring picture to see the mursing personnel of a base hospital realy to embark. The dignified uniform of lark bue roth, the sorlet lining of the rape, the radureus and the lutters "I". S." on the collar, emphasizing the "lose reJationship to the Medieal Corps of the Army, are significant and impresive. Complete molerstanding of the nature of the miscion is expressed in their faces. There is no laughing or joking, yet there are no tears. Courage is written on each (o) mentence and service wherever required is their purpose.

During May, 1917, Miss Noyes made as many as three trips a week to Now York, going over at midnight to sere a mit sail the following day, returning again at night to be ready for work the following morning on the lists of persomel of other mits then awating assigment. By these trips. Miss Noves started the practier. whieh was hatre abried on by Mliss Johnsom, of explaining to the nurses sailing for Europe their new relation to the Irmy or the Xary and the lied ('ross, and a little of the tryes of service which they might ment and the 


\section{HISTORY OF AMERICAN RED CROSS NURSING}

responsibilities they might be expected to shoulder. She impressed upon them the fact that they were privileged, above all other women, to work in the closest and most appealing relationship with the American soldier, the relation of wounded man and nurse, and she urged them always to remember that their conduct would not only bring honor or discredit upon the American Red Cross and the American nursing profession but as well upon American womanhood.

Early in June, 1917, the Army established a mobilization center for nurses on Ellis Island. Edith Agnes Mury was chief nurse. A Californian by birth and parentage, Miss Mury was graduated from the Waldeck Hospital Training School in San Francisco. Following institutional work in western and Philippine hospitals, she served three rears in the Navy Nurse Corps and was transferred July 18, 1916, to the Army Nurse Corps. Later she was appointed assistant superintendent of the Corps and served in the Surgeon General's office for some time. In June, 1917, while she was on duty on the Mexican border, orders eame directing her "to proceed to New York and report on arrival there to the Commanding General. Eastern Department, at Governors Island, for duty as chief nurse of a molilization station for nurses to be established at Ellis Island, New York Harbor." MIina Keenan, a regular of the Army Nurse Corps, was also assigned to Ellis Island as Miss Mury's assistant.

Three large buildings on Ellis Island, which had been used as hospitals ly the Immigration Iepartment, but which had been empty since 1914 owing to the decrease in immigration sine the beginning of the war, were turned over to the Army Nurse Corps. "On the day of our arrival," wrote Miss Mnury, "we were faeed with these three huge, empty buildings and with a telegram stating that sixty-six murses would arrive the next day. . . Beds, bedding and al fow aceessories were hrought by Quartermaster tugs from the Supply I Jepot in Now lonk. Infantromen from (fovernors Island cleaned the watrds and set up the furniture. When those sixty-six nurses arrived the next diay, ther hard elean white hospital beds but little else. ... For a while it seemed as if we were not to eat," Viss

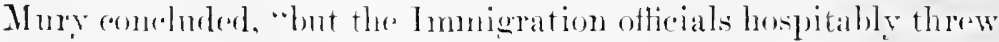
"pen their comployeses' rining rom to us."

Within a few weeks. Miss Mury and Miss Keenan had dereloped a smonthly-runing organization. Miss . Mnre wrete: 
With the hely of a female eivil service stenographer and men from the Hospital Corps, I handled the oflice work while Miss liechan managed the housekeping and looked after the comfort of the nurses in their respective quarters. Our accommolations at first were only for two humbred and filty nurses. later we took over a tourth building and could then accommodate five hundred nurses at one time.

'The wards were converted into dormitories. The beds were placed close together down the sides of each room. There were no clothes resets and the nurses lived practically in their small steamer trunks. Although they were so crowded, we heard remarkably few complaints.

The procedure by which nurses joined the Army Nurse Corps throngh the Red C'ross Reserve has already been described. After the nurses of a base hospital or other type of mit had received their travel-orders, they exeeuted their oath of office at home and served an apprenticeship in the hospital of a camp or cantomment, then went to New York for foreign serviee. The first base hospitals, however, reported directly to Ellis lsland and there the Amry absorbed them completely. Miss Mury wrote:

When we were informed of a unit's arrival in New York, men of the Ilospital corps who had been detailed to our station for miscellanems duty met the murses at the depot and esorted them to Ellis Island. Men with Army trucks obtained the bagerage and sent it to us by boat. When the nures arrivell. they ame single file thromgh my office. where a sergeant. the stemorapher and I reeded their papers and secured such information as was necessary for our records. Mis: Kienan then took them in waree and they were given beds and mess asidenments at the Immigration dining room.

Every morning at ! A.M. roll call for all nurses of every unit at the station was held. Permision was never griven to a

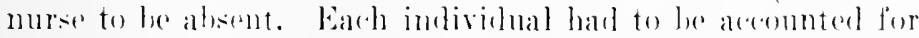
once a day. After roll call, shore leare was granted to any one until midnight unless a unit was hesing hohl under siliner orders. If a $110 \mathrm{w}$ unit had arrived the las hefore, thes were hele alter roll all for an explanation of their new dutien the Army remplations to which they would now have to adluere. the fecal rules of the mobilization station and somethine of the tratitions of the Army of which they were now an interral part.

The next step in the preparation of a unit for sabing was 


\section{HISTORY OF AMERICAN RED CROSS NURSING}

the procuring of passports, which in the early days of the war were necessary.

Of some of the details by which nurses secured their identification cards and passports. Glenna L. Bigelow wrote in the Military Number of the Journal:

We went this morning to Hoboken, where we are to get our identification cards and finger prints. I surely feel as if $m y$ "fate was hung around my neck" now.

After this episode, we all filed into another room, small and stuffy, where were a glaring electric light and a huge camera. A fleissige Berthe would not have been more formilable. However, each one in turn sat down before the drearlful object while two dozen companions uncompromisingly criticized her camera expression. Then. "Smile and look at me." said the operator; click, and the thing was done. In exactly seven minutes the picture, aripping from its acid bath, was finisherl, developerl and printed. And as the Scotch woman said when she saw her first photograph, "It was a humblin' sight."

Equipment was the next business in hand. Miss Bigelow described from the point of view of the individual nurse this phase of embarkation:

Tueslar. February - -1918 . Trit — went en masse to the tailors to be measured for unitorms. The wonderful system of outfitting the crowds of nurses, ranging all the way from "small thirty-two" to large "forty-four." seenls perfect. The fitters were verr amiable until about lunch time when one of them insisted that a certain ceat was all right. IIis client (a sorial service nurse who had picted un some stray phrases of the (ihetto), spote to him in Yiddish and then he discovered that it was all wrong and marked it up and down and all over with his chalk. ...

Friday our equipment arrived on the ferry boat. oreat lyackages anil hoxes from New Fork. We stoon in line alphabetically to rurese onr ronsignment and marveled alt the order and thepatch with whild that ereat pile of thing- wadissipaterl. Every persont: name was on exartly the risht hox. in exactly the right place. so that there was no con-

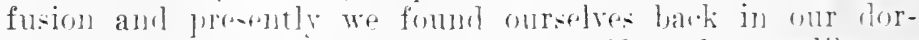
mitore. stagerering inder our logel of eifts. It was lihe an indivithal christma- trese all aromml and we were immonely gratroful. Wr realize what rwally hasd work it is and how monotonous the practing of those kits must become after the 
novelty has worn off. It is true that we nurses have the excitement, the change, the danger perhaps, while they are getting the dull, stay-at-home part. W'e bless them, every one, for these numumbered comlorts which will smooth our way over there. ...

Saturilay night. The dormitory is the most amusing place in the evening, when all the nurses come back from town. It is a reritable Grand street, with all the coats and dresses hung up on frames over the beds and bundles strewn about. Artides are bought, sold and swapped, appraised and depreciated. Shylock would find some hindred spirits in our little lialto and his glittering eyes would certainly approve our spirit of bargaining. By the way, we have a feminine IIarry lauder among us, whose Scotch burr caresses the ether with a subtle touch. She is the most optimistic of people and when the conversation hovers about U-boats, her only concern is whether Providence or sticking plaster keeps the sailors' caps on their heads!

After the nurses had received their passports and identification tags, after they had domned their ontdoor miforms and packed away the other articles of equipment, they entered into the most trying period of embarkation. Until July, 1918, troops and supplies for the American Expeditionary Forees were given right of way to France and the nurses were often kept waiting on Ellis Island for wecks at a time until the transportation officer would supply sailing accommodations for them. During the tedious day's of waiting, an Army sergeant drilled them in the rudiments of military formations. Ellis lsland in 1917 presented a martial appearance. "As our buildings were on the sea wall directly in front of the chamel to the orean," wrote Miss Mury, "all the activities of a harbor given orer to war went on in our front yard. Also there were a thomsand interned Germans and imprisoned German agents moder heary guard on Ellis Island and their presence prodnced rather a shadow of apprehension."

Flora 1. Graham (. Mlhany City Hospital, New York), a nurse member of Base Inspital $\mathrm{No}$. 33, wrote in the Military Number of the Journal of the recreation facilities:

On Island No. 1 there is also an immense hall where the Y. If. ('. A. provides ammsoment throe times each week for soldiers and salors and . Irmy nurses. These ammsements (onsist of motion piotures. lectures. popular amel patriotice 


\section{HISTORY OF AMERICAN RED CROSS NURSING}

songs and are largely attended and appreciated. On one occasion I noticed that the boys were especially enthusiastic over the song, "Mother, Bid Your Baby Boy Good-bye." 'The screen picture that night was "Tom Sawyer" and it gave us all great pleasure.

The chief murse of base hospitals spent many hours in trying to master Army paper work. "Chief nurses from civilian hospitals," wrote Miss Mury, "had had no opportunity to become familiar with the special duties of an Army ehief nurse. It was my duty to instruct them in the methods of keeping reeords and preparing ofticial reports pertaining to the Corps. I fear that the methods of rontine that had taken me years to learn," concluded Miss Mury, "I often expected those ehief nurses to aequire in a single day."

In December, 1917, the old Colony Club building in New York City was offered to the War Department by Mirs. Genevieve Walsh for use as a mobilization station for nurses awaiting transportation overseas. As the space on Ellis Island was limited, the offer was accepted at once and proved a veritable Godsend, as one hundred and thirty murses eonld be accommodated there at one time. Its central location was an added advantage. Mary E. Shechan was the first chief nurse there and was followed hy Minnie Winslow. The building was used until the spring of 1918 .

From the nurse's mobilized in New York were drawn hundreds who participated in the Red Cross parades which were held during 1917 and 1918. Leed by Miss I telano, Miss Noyes, Miss Thompson, Mrs. Higbee, Miss Van Blareom and other national cxecoutives, colmun after columm of murses, some clad in white with their scarlot-lined capes flung hack, others marching row upon row in the smart lolue nuiforms of the Army and Nayy, swmen down Fifth Avenue in that first historic parade of Ótolere 9, 1917, the most spectacnlar pageanty of wemen mobilizel for watr that New York City had erer witnessed.

The delaty in the embarkation of murses from billis Island was due principally to the areute shortage of Aurrican and Alliod tommage. The transportation of Ameriam combat tropss and supplies was meressarily givers the pight of way orer that of medieal persommel and hespital supplies, especially after the Cerman offensive of Mareh, 1918. "The Lnited States par-

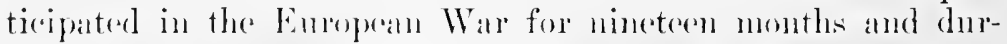
ing that perion more thatn 2.000,000 Ameriean soldiers wernt 


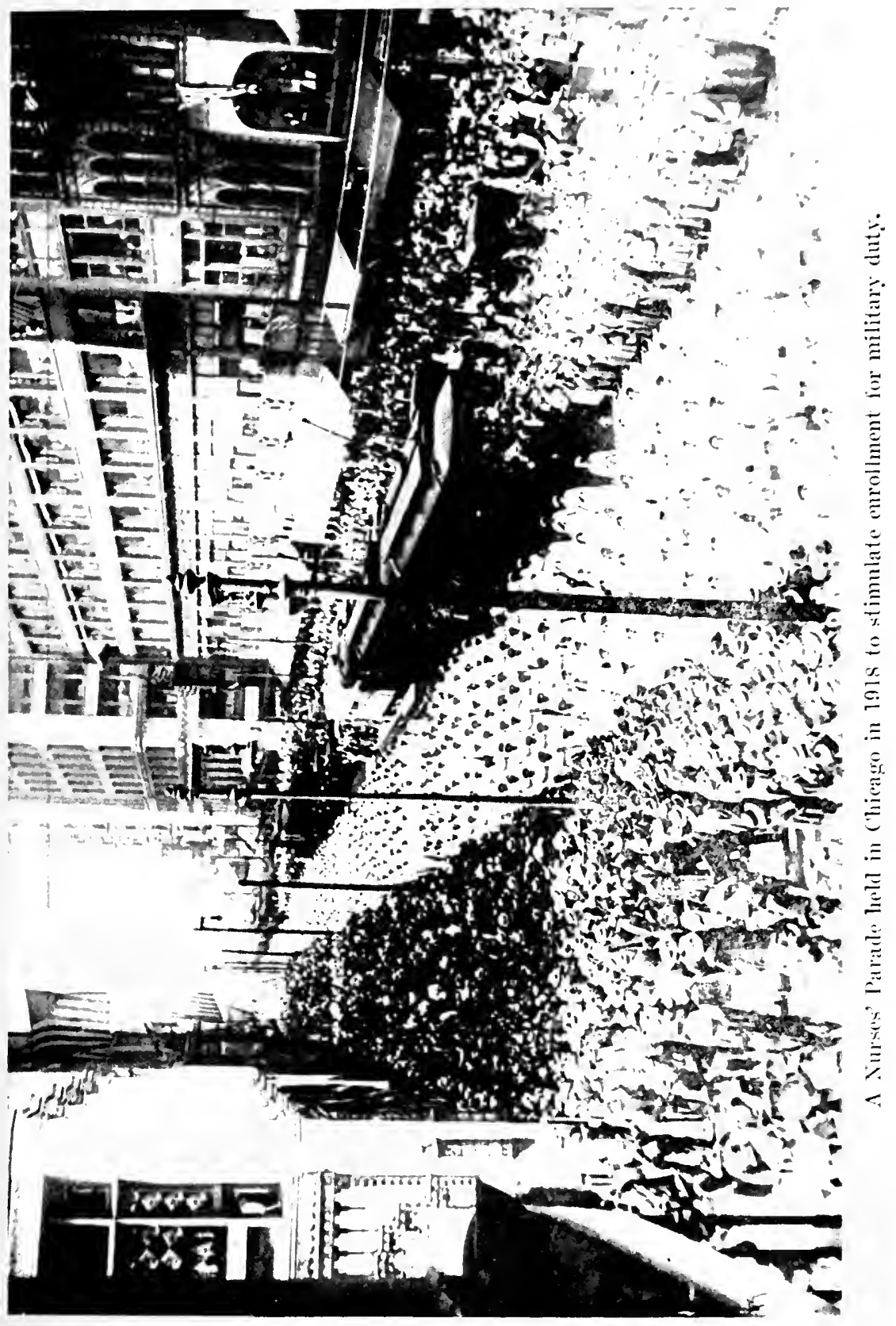



to France, 500,000 of them during the first thirteen months and 1,500,000 during the last six months. At first, the Army had only a few American and British troop ships which they chartered directly from the owners, but during the winter months of 1917-1918 the German liners which had been seized were brought into use and the movement of troops erradually increased. Early in 1918, the British Govermment anreed to assign three of its large liners and four smaller troop ships to the Ameriean Army and an increase of 5779 men in March, 1918, over the preceding month resulted. Also in Mareh oecurred the disastrous l'ieardy l)rive, with results which threatened to and in German vietory. "Every ship that conld be secured," wrote Colonel Ayres, ehiof of the statisties Branch of the Ceneral Staff, "was pressed into service. The aid furnished by the British was greatly inereased. . . . In II ay and in the four following montlis, . . . the transportation miracle took place. The number of men carried in llay was more than twice as great as the number for $A$ pril. The Jume record was greater tham that of May and before the first of $\mathrm{Jul} y, 1,000,000$ men harl heen embarked." s

In Jnly, over 306,000 Ameriean soldiers were carried to France and by Oetober 31, 1918, 2,000,000 had sailed from the United States. Doring many weeks in the summer, 10,000 men embarked every tay for Europe. "Among every hundred men who went over," wrote Colonel Ayres, "forty-nine went in British ships, forty-five in Ameriean ships, three in those of Italy, two in French and one in Russian shipping nuder British ("ontrol.".")

In the late spring of 1918, the $\mathrm{War}$ Department found it necessary to use the buildings on Ellis Island for hospital purposes, so the Knott chain of hotels in Now York ('ity was taken over by the Army and nurses were mobilized there. An administration center was established at Hotel Mlbert. Mary C. Jorecensen followed Miss Alury as ehief nurse of the mobilizattion station in New York. She wrote:

Soon the daily reports showed nearly one thonsand nurses housed in twenty difforent hotels, stretihing from Wishington square to sorenty-second sitreet. There. in Amerials largest rity. it was no easy task to keep an eye on them all.

s..The llar with Germany." HJ. 3i-38.

"Ibid., p. 41. 
Confusion was necessarily present to a great degree. The corriflors and the none-too-large offices provided in the hotels commandeered for mobilization stations seemed overflowing with swarms of women asking all sorts of questions dealing with equipment, War Risk Insurance, allotments and pay. All were so truly eager to be of service that the objective was the proper functioning of the great machine centered in Washington. Units prided themselves on the correet wearing of the uniform and on proper drilling and a spirit of friendly rivalry existed between the various groups as to which were the better soldiers. As each unit became equipped, its members, earnest and intensely eager, with trunks packed, waited on the qui vive for orders to sail. The most serupulous precautions laad to be exereised in giving out sailing dates; only the chief nurse was told when her unit would go.

The greatest single problem eneountered during the entire period of mobilization was the arrival of the five hundred and fifty "casuals" who were withdrawn from the cantonments in May for immediate assignment overseas. Their arrival in New York extended over a period of several nights and days and they were housed in seven different lotels. They had no chief nurse to assume responsibility. "They seemed," wrote Miss Jorgensen, "to be in a chaotic state of disorganization. Finally they were all assembled at the 71st Infantry Armory," she continued, "one of their number was designated as chief nurse and she appointed five assistants. Conditions improved to a considerable extent."

The six hundred odd Red Cross nurses sent overseas to work directly under Red Cross foreign commissions, found less routine in embarkation than did those attached to the Army. They were mobilized at the house of Joseph A. Auerbach on West Tenth Sitreet. This house, which had been loaned to the New York County (Chapter, was more than just a beautiful place for nurses to stay in mint the Red Cross secured their passports and passage. It soon becane a meeting place for Army amel Nary besorves as woll as for nurses destined for strictly lied cross foreign service. After roll call in the morning, $\mathrm{M}$ is Fohnson usually gathered together the different units of murses sailinge each woek and explained to them their new relation to the Armer or to fhe Navy and to the Red cross, her resolute, human philosophy of service often being the last message which the murses received lofore they embarked. 
Solemn indeed for the nurses was the long anticipated hour when they boarded ship. 'Though her official duties concerned only murses enrolled in the Red Cross, Miss Johnson saw almost every American murse off for Europe. She deseribed the docks :

Sometimes we'd crawl out of bed at three A.II. and drive down to the East liver or over to Hoboken to meet the murses on the rlocks. Often it wonld be raining torrents. Again the cold sleet numbed us. Our arms were always piled high with every conceivable kind of bundle. We lied ('rossers had great difficulty in getting supplies to the other side, so every murse en route to the P'aris office, went laden down with bundles and resembled an immigrant at Ellis Island.

When our nurses went over on an Irmy transport we'd find the docks crowded with troops. The hoys invariahly had a friendly greeting for the nurses. The Red Cross Canteen women were there, too, no matter how hot or cold, how early or how late it might be. Sometimes we'd wait hours on sweltering dorks, so hot that the pitch oozel out of the cracks and the boys, panting with heat and fatigue, would lie down to sleep as best they could.

The "dazzle painting" of the liners and transports further leightened the sensations of weird unreality which the nurses experieneed as they waited on the docks. 'This type of painting, popularly termed "amonflage," made it more difficult for a submarine commander, pering through a periseope for only a few seconds at a time, to determine the course of a vessel so decorated. "The Carpathia," wrote Priscilla J. IInghes, Army Nurse Corps, chicf nurse of Eracuation ITospital No. 22, "had the most fearful and wonderful camoutlage, the design of which was supposed to represent large teeth encireling her bow and stern to show that she had sumk a submarine-so they told us! Each ship of our convoy of fourteen had a different fantastic pattern.'

Miss Mury summarized briefly the spirit of the ten thousand nurses who embarked throngh Ellis Island for service with the Anerican Expeditionary Forees:

When sailing orders were received for a unit, shore leave was stopped, no communication with friends or molates was allowed: truntis were inspereted and locked and the unit stomed by for the tuge which was to take theme to the transpurt. (On arrival of the tug. the (ommand "Fall in ". Was erirent, fol- 


\section{HISTORY OF AMERICAN RED CROSS NURSING}

lowed by "Forward Mareh!" and sixty-five silent, blue-clad, white-faced women with ehins well up and eyes to the front marched down the dock and on to the tug in soldierly formation. Usually as the boat shoved off a lilting song came drifting back. "Pack up your troubles in your old kit bag and smile, smile, smile." One knew, however, that the wonderful spirit of American womanhood strengthened by hospital training enabled those nurses one and all to face so bravely the joumey across the submarine-infested sea and the further unknown dangers of military hospital duty in a warstricken foreign land.

To the nurses watching and awaiting their turn, the departure of a unit was full of tense emotion. Miss Bigelow wrote:

The sky was blue and the sun shone brightly on the little procession of fifty nurses. so dignified and smart in their dark blue uniforms. They emerged from their quarters, marched silently along the quay of lsland To. 3 and over the bridge to the chapel on lsland No. 1, when we lost sight of them for a moment. Soon they came ont and marched, two by two, toward the tenter which was to take them out to their ship. Their leader carried the flag. 'That mass of color crushed in her arms ... seemed like a dart of flame, an imprisoned thing seeking freedom.

It happened that a company of sailor boys, out for morning drill, was drawn up at "attention" right at the gang plank when the unit embarked; their presence added tremendomsly to the impressiveness of the picture. But the silence was terrible, - no fanfare of trumpets, no admiring friends, no flowers, only the grimness of parting. The little boat shrieked ont a warning, warped away from the pier and silently disipleared around the Island.

Great Britain, the gateway through which passed one-half of the two million Aneriean soldiers who served at the Western Front during the European War, was the scene of extensive American lial cross numsing service in the fielul.

Early in 1:14, it will be remembered, a group of American ritizens resident in bingland had desired to experess their s.rmpathy for the Allied canse and especially for England by the establishment and maintenander of a wat hospital. The Anerican Women's War Relief Fund was raised and the Committee responsible for its dishursement opened "Oldway House" Hos- 
pital, Mr. Paris Singer's estate at Paignton, Dewonshire. When the Amerian Red Cross offered two medical mits of the Merey Ship to the British Government in Angust, 1914, the War Office assigned Unit F and later Unit D to Paignton and they remained there for one year. After their recall, the committere continued the maintenance of "Oldway Honse" Hospital and also established a small officers' hospital at Lancaster Gate, Hyde P'ark, London.

Upon the entry of the United States into the European War, members of the Ameriean rolony in England desired to take a more active part in war relief work than was afferded them in the maintenance of these two hospitals. They aceordingly petioned National Headequarters to grant them a charter as an American Red Cross Chapter. Thus on May 24, 1917, eame into existence the London Chapter of the society.

Mr. Walter H. Page, then Ameriean Ambassador, was the first honorary president. Mrs. Page and Mrs. Robert P. Skinner were honorary viee-presidents; Mrs. Whitelaw Reid was (hairman; Mrs. Irwin Laughlin, vice-chairman; Boylston A. Beal, honorary seeretary; and Robert Grant, Jr., honorary treasurer. W. II. Buckler served as administrative director.

Six base hospitals organized by the Ameriean Red Cross were, it will be remembered, the first branches of the American Army to go overseas. The nurses of these columms were eordially received in London by members of the London Chapter. As other base hospital mits arrived in England on their way to service with the American Expeditionary Forees in France, urgent need developed for a large central elub where transient nurses might be housed and entertained. A committer of the London C'halpter was organized, with Viscomntess Harrompt as chairman and this eommittere established in .June, 1917, the Ameri'all Nurses' ('lub, at No. to Grosvenor Place. 'This club soon became so popular with Army, Navy and Red Cross murses on their way to France or on brief holiday in London, that the Chapter furnished an ammex to it on a floor of Forbes IIouse. the home of the ('omntess of Granard in IIalkin sitreet. Mrs. Cavendish bentinck opened an extensive suite of rooms in her

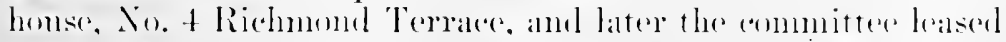
another building. No. tis Grosicnor Platee. Agnes Birtles, an Ameriean Red ('ross nurse on duty in Great Britain, wrote that "10 one who hats not beren a stranger hersolf in London atu realize what it has meant to us to have an attractive place to go 


\section{HIS'TORY OF AMERICAN RED CROSS NURSING}

to in a strange eity. Everything, even to serving our breakfasts to us in bed, was done for our comfort."

In the fall of 1917 , two long-pending developments of the Ameriean military situation brought about an urgent need for more extensive American Red Cross operations in Great Britain than conld be handled solely through the London Chapter. The first of these was the deeision to brigade American troops with the British Armies in northern France; this brought with it the certainty that Ameriean sick and wounded would be sent to Great Britain for eare and treatment. Ameriean hospital facilities in England for these men would, therefore, be necessarv.

The second derelopment was the enormons inerease in the numbers of Ameriean soldiers who were being landed on British soil while en route to France. Of the 2,000,000 American soldiers who served on the Western Front, 1,025,000 of them were carried across the Atlantic in British ships. Early in the spring of 1918, the British Government assigned three of its big liners and four of its smaller troop ships to the use of the American Army. These ships tonk on American soldiers at Quebee, Montreal, St. John, Halifax, Portland, Boston, New York, Philadelphia, Bạltimore and Norfolk and diseharged them at Glasgow, Manchester, Liverpool, Bristol Ports, Falmouth, Plymouth, Southampton and London. After a short time spent in Ameriean rest eamps established by the Ameriean Army near these ports, the soldiers were transported to France by means of the Cross-Channel Fleet.

Following the decision of the War Department to send American troops to France by way of the British Isles, the Seeretary of War established in October, 1917, in England, Enited States Army Base Section No. 3 and placed Major General George T. Bartlett in eommand. Brigadier General Francis Winter was assigned as (hief surgeon of the Anerican Armies in Creat Britain. His office did not at this time include, however, a representative of the Army Nurse Corps.

Wherever branches of the Ampriean Army were sent during the European War, representatives of the Ameriean Red Cross followed to offer them the service which its charter of 190 . authorized the society to give. Tyon the arrival in Creat Britain of large numbers of American troops, the need for Red C'ross service increased to proportionate dimensions. This serrice entailed the purchase and distribution of rast quantities of 
supplies to the American Army and the establishment, if the A rmy DIedieal Corps so desired, of Red Cross hospital facilitics for American sick and wonnded soldiers. Although the London Chapter was organized in May, 1917, it was the policy of the War Comneil to eonduct activities of this nature through foreign commissions sent out from National Headquarters. Local Chapters, if such existed in the foreign ficld, laeked both the funds and the knowledge of national and international Recl Cross poliey to administer the diversified aetivities. The War Council appointed the members of each commission, appropriated from the Red Cross General Fund the moneys neecssary for their work and directed their activities entirely from National Headquarters.

The first of these eommissions, the American Red Cross Commission for Europe, as will be recounted in a subsequent seetion, arrived in Parris early in June, 1917, and set up its headquarters at No. 5, Rue Francois 1r. Marjor Grayson II.-P. Murphy, of New York City, was the eommissioner. Among the seventeen men who formed his staff was William Endieott, of Boston, Massachusetts.

Early in July, a need was felt both by National Headquarters and by the Commission for Europe for an American Reel Cross representative in London. The War Comeil voted on . July 12, 1917. "That a Commission for Great Britain be immediately organized." The need for a "direct representative in London" was echoed again in the Vinutes of the War Comneil, meeting August 7, 1917, and on August 22, "Edgarr II. Wolls was recommended and appointed as deputy commissioner for (ireat Britain."

During . Tuly and Angust, the Commission for Enrope was experiencing its initial diffienlties in securing supplies in Franec. Major Endicott was aceordingly dispatched to England to act as "purchasing agent" for the Paris office. Ho hung up his (ap september 10, 1917, in a reom at the Chapter hemelyualrters on Crosvenor Gatrdens which was haned to him by the London Chapter, and in this office six wecks later, the Ameri-

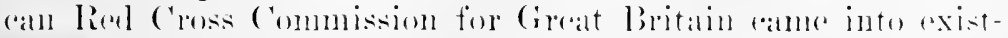

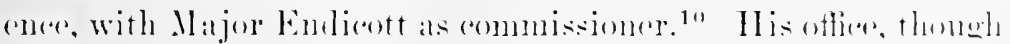
mumberingeresen persons, did not at this time inchude al representative of the Ameriem lied ('ross Nursing Sorvine.

The first work of the Commission wals the cistablishment neatr

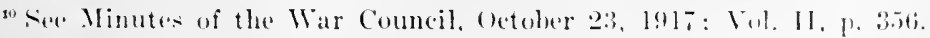




\section{HISTORY OF AMERICAN RED CROSS NURSING}

Liverpool of American Red Cross Military Hospital No. 4. On November 19, 1917, Major Endicott leased an English country estate, Mossley Hill, which was located within fifteen minutes by motor from the docks. The Red Cross immediately began the renovation and equipment of the fine old mansion house as a war hospital.

Small numbers of American troops were then being sent to England in the available passenger space on commercial liners. They were concentrated at the United States Army Rest Camp at Winchester and the first Ameriean Army hospital in England was opened there. It was located on the crest of Mom Hill, two miles from the eity and was designated as Cnited States Aimy Camp Hospital No. 35. It was opened for patients on December 15, 1917. Nine Army nurses, with Ada J. Allan as chief nurse. were assigned to duty there on February 22, 1918. The capacity of the hospital was gradually increased to 600 beds and the nursing staff raised to thirty members. ${ }^{11}$

On January 9, 1918, Ameriean Red Cross Military Hospital No. 4, Mossley Hill, received its first patients. Its capacity then included only forty beds, but eight barracks were soon eonstructed within the spacious grounds, which brought up the total caparity of the hospital to 500 beds. An officer of the [nited States IIedical Corps was placed in charge. The Nursing Service at National Headquarters, Washington, supplied the nurses. Marion Weller (New York Hospital) was chief nurse; she was installed by Major Enclicott previous to the opening of the hospital and she and her nurses worked with great devertion to transform the old mansion into a hospital. One of these was Agnes C. Birtles. She wrote:

My first aswignment to duty upon my arrival on December 1. 191\%. at Liverpoul. was to a new Red Cross hospital then being prejurest for the reception of Amerion trespes talien ill

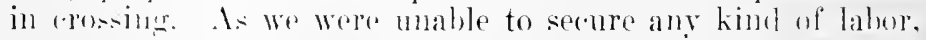
we soven nurses sot to work cleaning, scrubling. painting floors. unjoldking furniture and putting up beds. 'The beantiful old house liall been empity for al long time.

I shall never forget onl first patients, these ill, homesick boys whe anme to ns from other hospitals or direstly from the dorks. Some hat been taken to Enerlish hospitals where

\footnotetext{
${ }^{11}$ Sere liepure of the Hirector of Nursing Service, American Expeditionary Forces. p. 27.
} 
they had received the best of care, but English people, kind as they are and English surroundings, clean and of ten luxurious, were not American. Our bare wards seemed like home. New buildings were soon ererted and never a bed was empty. More than once we put our patients on mattresses in the halls while the erection of new barracks was speeded up.

In July, 1918, this hospital was transferred from the Red Cross Commission to the American Expeditionary Forces in England and was stafted by reserve nurses, Army Nurse Corps. Hospital Unit "T," which had been organized by the Red Cross for the Army, was transferred from Sarisbury Court for duty at Mossley Iill. Nellio Brookbanks was chicef nurse. The capacity of the hospital was later raised to 500 beds, with a permanent nursing statf of forty-five. ${ }^{12}$

The Red Cross Commission for Great Britain next took over three hospitals in England which had previonsly been conducted by the American Women's War Relief Committee and by the London Chapter. The Commission assumed financial responsibility for these already sncessful hospitals, greatly extended their activities to meet the new demands, centralized the management and brought about economy of personnel and funds.

The largest of these three hospitals was "Oldway House," Paignton, which the Ameriean Women's War Relief Committee tumed over on January 1, 1918, to the Ameriean Red Cross. It was designated as American Red Cross Military Hospital No. 21. Its sixty rooms accommodated 250 patients. By the acquisition of other bnildings on the estate and of the Redeliffe and the Esplanade Hotels in Paignton, the Commission raised the bed capaleity of the hospital to 700 . Like other Red Cross military hospitals in England and France, officers of the Enited States Army Medical Corps were in command. A British Matron was in charge of the nursing statf which consisted of Enerlish sisters, mumerons V. A. I). members, and Ameriean Redel cross nurses of the Merey Ship, who had elected to remain at "Oldwily Homse" affer the reeall of the mits. (On Angust 17, 1918, twenty-five reserves of the Army Nurse Corps. who hat gone oversoas as members of Base Hospital No. fo. were assigned to temporary duty at l'aigntom and all others were released. Mary Murphe a graduate of the Cammer Hospital, Somth lostom. Was chicef momse.

${ }^{12}$ See Report of the Director of Nursing Service, Ameriean Expeditionary Foreses, p. 28. 


\section{HISTORY OF AMERICAN RED CROSS NURSING}

The other hospital formerly administered by the American Women's War Relief Committee was a small institution at Lancaster Gate, IIrrle Park, London, which the committee had opened in March, 1917, for British officers. The American Red C'ross C'ommission for Great Britain took over this hospital, gave it the designation of American Red Cross Military Hospital No. 22 and expanded its original capacity of fortyeight beds so that it nltimately accommodated approximately 150 American officer patients. The nursing staff was made up of English Sisters and nursing members of Voluntary Aid Detachments of the British Red Cross. A British nurse was Matron. The presence of three American Red Cross nurses added an American tonch during the spring and summer of 1918 , but they were recalled by antumn. The success of the Lancaster Gate Hospital was due largely to the efforts of Viscountess Harcourt.

The third hospital to be taken over by the Commission was St. Katharine's Lodge, Regent's Park, London. In June, 1917, Mrs. William Salomon, of New York, had offered her house, a rambling two-story lodge built by George IV in four acres of roval parks, to the London Chapter of the American Red Cross to be used for hospital purposes. The London Chapter accepted the gift and St. Katharine's Lodge was first maintained as an anxiliary of the British Military Orthopedic Hospital at Shepherd's Bush. Upon its transfer on Jamury 1, 1918, to the Commission for Great Britain, it was designated as American Red Cross Military Hospital No. 23, but its thirtyeight beds continued to be used for the care of British officers. It was staffed by eleven Anerican Red Cross nurses, with Isabelle F. Carson as ehief murse. In midsmmmer of 191s. St. Katharine's Lodge was militarized and became an Imerican officers' ward of Tnited States Army Base Hospital No. 29, at Tottenhan, near London.

So snecessful was St. Katharine's Lodge as an officers' hospital that Mr. ('hester Beattr, an Ameriean mining engineer, and his wife offered in Jannaly, 1!18, the use of thoir london residenere, Baroda Homse, for hospital purposes to the lied Cross Commission. Major Endicott aceepted the gift and on March 20, 1918, Tharoda TIonse was opened as Ameriean Red Cross Military IIspital No. 2t. Mr. and Mrs. Beattr contributed the funds repuired for the maintenance of the hospital and the Amorican lied Cross Commission supplied the 
professional staff, the orderlies and the medical and surgical supplies. Five Ameriean Red Cross nurses and four V. A. I). nembers, were assigned to dnty there.

In location and in execution, Baroda House was eharmingly suited for use as an officers' hospital. 'Though in the center of London, it adjoined Kensington Palace Gardens and was removed from traffic,- a quiet and soothing place. Its founder had been an Indian prinee, the Gaekwar of Baroda, and the spacions, square, high-ceilinged rooms still contained in their furnishings a quaint and Eastern flavor. Tall windows on the ground floor opened direetly upon lawns and a garden where convalescent patients in wheel-chairs and on beds, drowsed through the sumny afternoons.

American Red Cross military hospitals in Great Britain thus on March 20, 1918, consisted of No. 4, Mossley Hill, Liverpool; No. 21, Paignton; No. 22, Lancaster Gate, London; No. 23, St. Katharine's Lodge, London; and No. 24, Baroda House, London.

The development of hospital activities in England, both of the Army and of the Red Cross, was greatly accelerated during the spring and summer of 1918 by the aid which the British Government gave the United States War Department in the transportation of American troops. The movement of American troops for Mareh showed an inerease over Febriary of almost 6000 men. During the same month, the disastrous Picardy offensive oecurred and every available British ship was immediately pressed in service to transport American reinforeements for the almost-exhansted Allied armies holding the Western Front. The number of men transported to France in April showed an increase over Mareh of 33,000 and in Mar, the number transported was more than twice as many as in April. By July 1, 1,000,000 men had been embarked and a great number of them passed through England.

This increase in the number of American troops passing through England bronght about a need for more extensive hospitalization in Base Seection No. 3. The establishment of new hospitals requiring large staff's of murses created a need also for a representative of the Army Nurse Corps to serve on Gen-

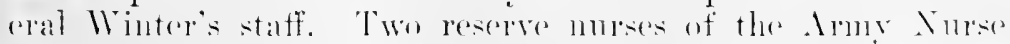
Corps. Nollie E. Merovern (Manhattan State Hospital, New York (ity) and Nollie V. Brookhanks (Bellerme Jlowpital) were assigned on Fobruary $2.2,191 \mathrm{~s}$, by the Chief surgeon, 


\section{HISTORY OF AMERICAN RED CROSS NURSING}

American Expeditionary Forces in France, to the office of the Chief Surgeon, American Armies in Great Britain, and into their hands was placed responsibility for the conduct of the Army Nurse Corps in England.

During the early spring of 1918, General Winter established a camp hospital at Liverpool and an Army base hospital at Hursley Park, Winchester. The first of these, U. S. Army Camp Hospital No. 40, was located at Knotty Ash, Liverpool, and was opened on March 26, 1918. It drew patients from the big Ameriean Rest Camp at Knotty Ash, which then accommodated 10,000 troops. The initial bed capacity of Camp Hospital No. 40 was 250 , but it was raised during the summer and fall of 1918 to 500 beds. Twenty-one nurses of Hospital Unit "W," which had been organized by the American Red Cross for the Army, were assigned to duty there on May 28; Amanda Metzger, a graduate of the Springfield (Illinois) Hospital, was chief nurse. The strength of the nursing staff was later increased to forty-five members and was maintained at this number by the assignment of nurses from various base hospital units to temporaly duty there. ${ }^{13}$

The first United States Army hospital in England, No. 204, opened its doors April 23, 1918, at Hursley Park in southeastern England, five miles distant from Winchester. The British War Office turned over to the American Army Medical Corps wooden barracks which they had built for the hospitalization of their own troops and Base Hospital No. 204 opened its doors to patients on April 23, 1918. The nursing staff was composed of twenty-two members of Hospital Unit "I". Lora B. Roser, a graduate of the Culver Union Hospital, Crawfordsville, Indiana, was chief nurse. The capacity of the hospital was later raised to eight hundred beds and the strength of the mursing staff to fifty permanent members. ${ }^{14}$ Hursley Park Ifospital was repaired and rë̈quipped by the Red Cross.

The Rerl c'ross Commission for Great Britain was permitted to take an important part in the establishment of the next hospital for Amerion troops in England. In the spring of 1918 , the American Army Riest Camp at Winchester overflowed, so the Anerican Army in Encland took over a second eamp six miles away at Romsery. Nurses will remember that one of the

${ }^{13}$ Sese Report of the Director of Nursing Service, American Expeditionary Forces. p. 27.

1t lbirl. 
Nightingale estates was situated near Romsey, in Hanpshire, and the young Florence Nightingale especially enjoved the summers spent there.

The camp at Romsey which the American $\Lambda$ rmy took over had formerly belenged to the British Army and had accommodations for seven thousand troops. Its hospital facilities consisted, however, of a row of tents along one of the (amp strects. These tents were equipped only with straw ticks laid upon boards raised about six inches from the floor. During the pleasant English summer, these quarters had been confortallole enough for the British sick and wounded to spend a few hours in before British ambulanees transported them to nearby bases. A different situation confronted the American Army. They had only the one base hespital, at Inursley Park. 'Thus forr the raw English winters, they needed permanent hospital facilities at Romsey. The Chief Surgeon ealled upon the Red Cross Commission for Great Britain to eonstruct a permanent hospital of at least two hundred and fifty beds.

The commission immediately undertook the work and Major Endicott set about the discouraging task of securing supplies and labor. While he was searrehing for wood or eoncrete or stone or any building materials, not necessarily the most desirable but those aretually to be had, an Army lientenant seenedred an option for some brieks and he turned it over to Major Endientt. 'The neecissary lumber was sawed by small portalble mills in the New Forest and was swiftly transported by Army trucks to Romsey. Working squads of the Anerican Armies were assigned to brieklaying. Sometimes the hospital construetion progressed minterruptedly for as long as three weeks. Then the troops were ordered to Plymouth or Sonthampton, the transports steanned ont into the Chammel and the hospital walls, half-raised, stond undisturted in the quiet camp until the next detachnents amme swinging down from Liverposl and andstruetion leagan again. By June, 1918, the neat little hospital with houg smuny wards, completely appointed operating and X-ray romens, dient kitchens, milk palstenrizing plant and gats

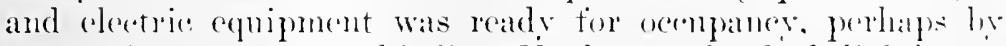
some of those s:me whistling Yankers, whe hatd lighthentedly latid a briek in the walls of this hespital in lingland againat the day when there or their "buddires" might he sent back in mortal newd of herepital are from the troundes which they were then so rager to reath. 


\section{HISTORY OF AMERICAN RED CROSS NURSING}

The hospital at Romsey was designated as United States Army Camp Hospital No. 34. Ten nurses, "casuals" and members of various base hospital units with Nellie McGovern as ehief nurse, were assigned on August 4, 1918, to this hospital. The permanent staff was later raised to seventeen nurses.

The next institution to be opened by the Red Cross Commission for Great Britain was a convalescent hospital for American officers. This was opened June 1, 1918, at Lingfield, about thirty-five miles from London, on the country estate of Colonel Spender Clay and his wife, who was the daughter of Lord Astor. This eonvalescent hospital was designated American Red Cross Convalescent Hospital No. 101. The house aecommodated more than one hundred patients.

Previous to May, 1918, the American Red Cross Commission for Great Britain had not included a representative of the Nursing Service. Many Ameriean Red Cross nurses were on duty, however, in the five Ameriean Red Cross military hospitals then heing conducted by the commission for the Medical Corps. Also many reserve nurses of the Army Nurse Corps were in active service in England. On May 14, 1918, Major Endicott wrote Miss Delano:

Miss Carrie Hall, who has lately been the Matron at General Hospital No. 13. British Expeditionary Forces, Boulogne, is our newly-appointed chief Nurse of the American Rerl Cross in (ireat Britain, assigned to the position by the Chief' Surgeon, Anerian Expeditionary Forees [in France]. She will have entire chare here in Great Britain of the enrollment, assignment and direetion of Red Cross nurses. We have asked her to report directly to the Burean of Xursing Service of the American Red Cross in Washington.

This appointment was made withont conference with Miss Delano and Miss Noyes. I precedent for such action had already been established $b y$ the Anerican Reel cross Commission for Enrope and a detailed discussion of the polieies involved will be found in a subsepuent seretion.

A few weeks latere, the chief Sureon, American Expeditionary Forees in Fance, notitiod General Winter, ('licef Surgem of the Ameriean Armies in England, that a permanent

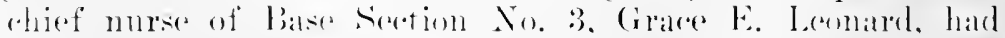
heen appointed. With her assistant, Anme C. Porter, Miss

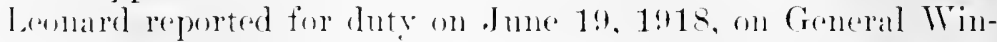

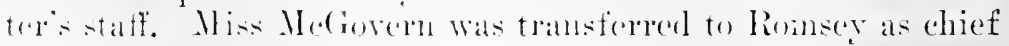


nurse of Camp Hospital No. 34 and Miss Brookhanks to Mossley Ilill as ehief murse of Ameriean Red Cross Military Hospital No. 4.

The appointment of a chief nurse for the American Expeditionary Forees in England and the appointment of a chief murse for the American Red Cross Commission for Great Britain marked the beginnings of an authoritative and permanent mursing service in England.

In her first report to Miss Delano regarding the Red Cross nursing situation in England, Miss Hall wrote on June 6:

Plans are under way for opening here in London a hospital of about sixty beds for sick and wounded American murses. . . .

There are now in England six hospitals nominally under the American Red Cross. At least two of these are responsible directly to the British War Ot?ice and with regard to them, I propose no interference, except perhaps to withdraw slowly snch Amerian murses as are now in them, replacing them with English nurses and so leaving the nursing statl entircly English in character. By using the American nurses to fill in the galps in other more distinctly Imerican hospitals, we can thus attempt to have complete American staff's and American methods in these later institutions.

We shall need a good many nurses in England for our own Red Cross work, apart from those assigned as reserves to the Army Turse corps. Major Endicott informs me that some time ago he asked for fifty nurses: I hope they will be forthcoming during the next few weeks. I am recommending to him today that he apply through the proper channels for fifty additional ones.

Tpon the antlorization of the Nursing Service at National Headefuarters, Miss Hall organized a Local committee in Lomdon to nudertake the emollument in the American Red Cross Nursing Service of Ameriman murses then in Great Britain. Mlisis Mall estinnated that orer one hundred murses were curolled thus themgh the Lomelom office.

One of the most important things which Miss IIall aecomplished at Lomelon Hoadpuarters was the establishment of a burlget system and an epripment section. Miss Ilall wrote:

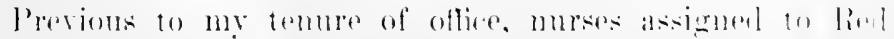

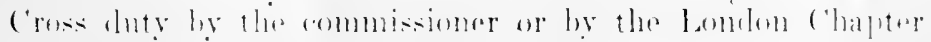

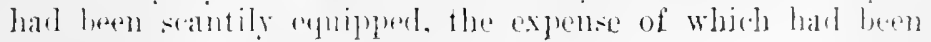




\section{HISTORY OF AMERICAN RED CROSS NURSING}

charged to the hospital where the individual was assigned to duty. I stated the case to the comptroller, showing that nurses should be enrolled and equipped who were not assigned to any hospital in England but might be transferred to the Red cross in France or to the Army in England. He saw the need for a separate budget for the nursing department and immediately secured it. That enabled me to establish means for supplying equipment in London which was parallel to the equipment supplied to nurses sent from home.

In June, July and August, 1918, 870,98s American soldiers were landed in France. A large portion of these troops passed through England. l)uring this period, General Winter established another camp hospital and four additional Army base hospitals in Base Section No. 3.

Enited States Army Camp Hospital No. 36 was opened July 1, at Sonthampton, the principal port of embarkation for France. This institution had a capacity of eighty beds but was capable of expansion to five hundred beds.

United States Army Base Hospital No. 33 was assigned to Portsmouth, England. This base hospital had been organized by the American Red Cross at the Albany Hospital, Albany. New York. Sally M. Johnson, superintendent of the Albany Hospital School of Nursing, had organized the nursing staff of the mit, but Mattic M. Washburn, her assistant, led the nurses into active service.

Base Hospital No. 33 had waited two months at Ellis Island hefore embarkation. The unit sailed April 22, 1918, on the S. S. Carmania, which also carried the entire 2 Sth Division. Epon the arrival of the unit at liverpool on May 15, the murses were temporarily billeted at United States Aimy Base Hospital No. 204 at IInrsley Park. On June 1 they entrained for permanent quarter's at Portsmonth and were finally assigned a the Portsunouth Borough Asylum, three miles from the eenter of the eity. This institution had been built and maintained hy the Board of Asylum ('ontrol of London. It rousisted of me main building of morlern hrick and stone construction and of several detached villas surrounded by eight acres of farmlind.

The American nut trok possession on July s and immediatcly began the tedions and irksome task of changing the asylum to a hospital. Like Miss Nightingale's supplies which, 
buried under ammunition, had gone up the Bosphorus past Scutari, the equipment of Base Ilospital No. 33 had been carried to France. The distressed unit was able to secure only the most essential articles from the generous stores with which the Local Red Cross Chapter at Albany had supplied them. The asylum authorities, the British War Office and the Admiralty and the American lind Cross Commission donated materials until the bed capacity of Base Hospital No. 33 numbered three thousand with an additional emergency expansion of one thousand patients. The Red Cross erected a theater, seating an andience of twelve hundred, and built temnis courts and the best bascball diamond in England.

Miss !̣ashburn wrote of their first patients:

Surgical casnalties which had arrived on hospital ships at Southampton were bronght to us July $2+$ by motor ambulances and hospital trains within thirty-six hours from the time they had been wounted.

On September ?.: we had seven hundred patients. Worl was then received that the S. S. Olympic, with six thousand troops on board, the greater number of them suffering from influenza, had come to jort in Sonthampton. Sixty-six tents were immediately serdured from the British to set up in the court yard of Base Hospital No. 33. ('onvalescent patients and members of the detirchment were immediately transferred to these tents and the wards were cleared for the reception of influenza pationts. Within one week seven humdred and ninety-seven (ases had ("ome to us. one hundred and fortyfour of whom were nurses and fenale members of the signal Corpls. Both puemomia and moningitis developerd. Of our one humdred and twenty-nine deatlis among these patients, eleven were nurses and one wils a dirtitian.

United States Army Base Hospital No. 87, the largest Ameriean military hospital in kingland, arowned the erest of a hill at Dartford, tiftern miles from Lomdon. It was located in wooden barracks and in briek buildings of a former con-

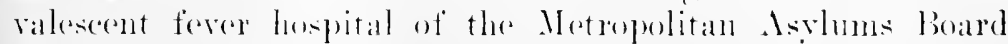

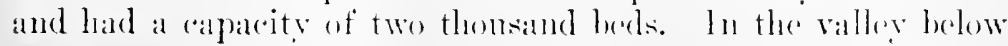
was a large werefluw henpital where the british Ame eared

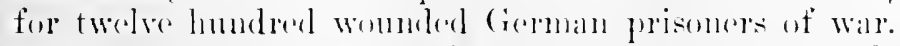

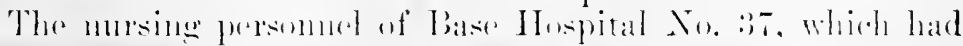

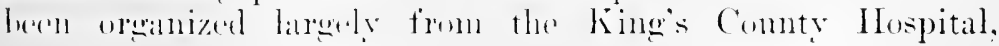




\section{HISTORY OF AMERICAN RED CROSS NURSING}

Brooklyn, New York, with Annie F. Mack as chief nurse, had arrired in England on May 31, 1918, and had been assigned to temporary duty at Hursley Park. On June 10, they were transferred to Camp Efford at Plymouth, but as the hospital there was not then completed, they were seattered on temporary assigmments among various other hospitals. The entire unit of ninety-nine nurses was collected on July 18 and was assigned to permanent duty at Dartford.

Meantime in the outskirts of London, at Tottenham, United States Base Hospital No. 29, organized within the Medical Sehool of the University of Denver, Colorado, had established a permanent base in buildings taken over by General Winter from the Metropolitan Asylums Board. The nursing staff of this unit, which was composed of one hundred reserve nurses, was assigned to duty there in July. Laura A. Beecroft was chief nurse. Tottenham Base was one of the largest American military hospitals in Great Britain and had a capacity of fifteen himdred beds.

During the summer of 1918, the American Red Cross Commission for Great Britain established two additional convalescent homes and one base hospital for the American Armies in England. One of these homes was located in Putney, London, at Colebrook Lodge, the estate of John T. Rran, of Toronto, and was used as a convalescent home for Army, Navy and Red Cross nurses and other American women workers in the Military Establishment. Colebrook Lodge was a threestory modern building, constructed on the threc-hundred-rearold foundations of Putney Manor and the murses thoronghly enjoyed their stay there, their walks among the gardens and orer the downs of Putney Heath and Wimbledon Conmon.

The Red Cooss ('ommission took over on August 1.5 the estate of Percy Chulb at Winbledon, which the British had maintained as a convaleserent home for British officers. The Commission designated this homse as American Red Cross Convalescont Hospital No. 102 and maintained it for the British Army with the modrestanding that it should be used exclusively for convalescent Anerion officers, if such a need shomld arise. Its raparity was serenty-five beds.

The final and nust ambitions project which the Commission undertexk for the Aneriean Expeditionary Forees in England was the preparation for oecupancy of United States Army Base Ifospital No. 40 at Surishry Comrt, near Southampton. 

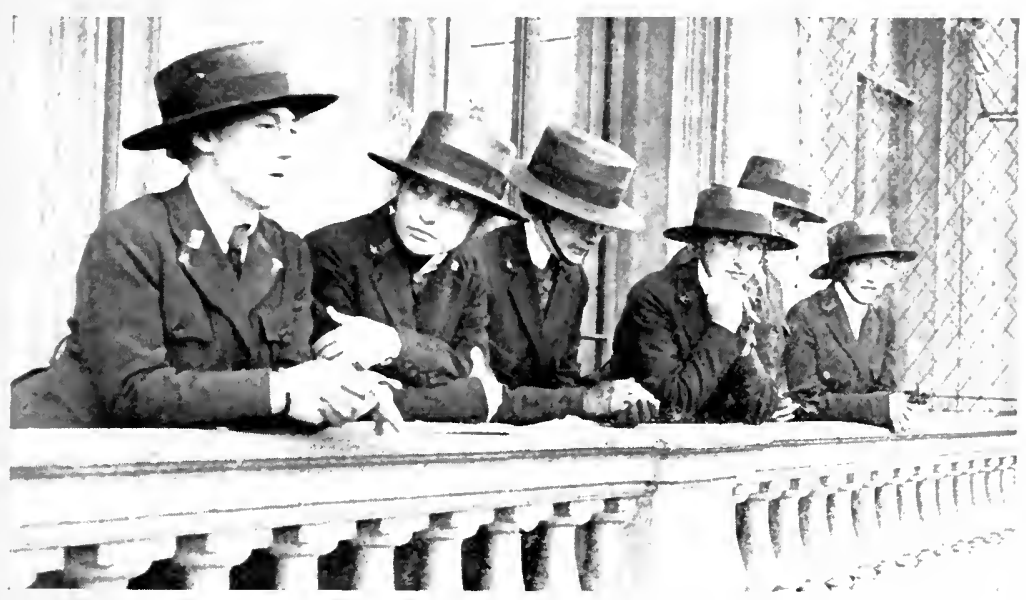

Nurses on the baleony of the Aneriean Red Cross Nurses' Club, London, overlooking the Garlens of Buckinglam Palace.

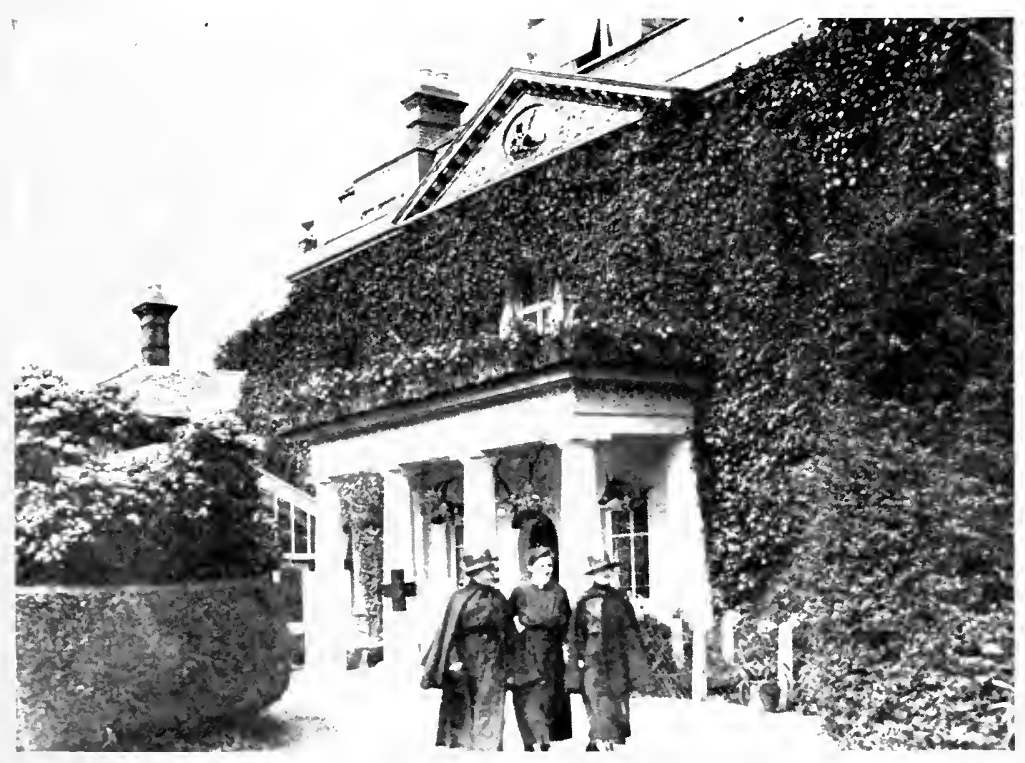

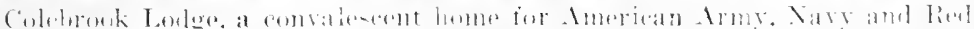

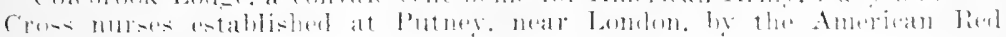
(roms. 

The report of the Commission for Great Britain described the establishment of this base:

In April, 1918, the Commission for Great Britain commenced negotiations for the purchase of a large estate in Hampshire between Southampton and P'ortsmouth, known as Sarisbury Court. . . .

The estate lies in the bend of the Hamble river, sloping down to the water on two silles. 'The manor house, a massive three-story building of severe Tudor architecture, stands on high ground and its tower is visible on a clear day from points twenty miles distant. Though built twenty-five years ago, the house provided an excellent nucleus for a hospital. Acres of hut wards, quarters for nurses, doctors and men, an administration buldling and store houses were immediately planned and construction was begun to raise it to its estimated capacity of three thousand beds.

speed was essential. American wounded from France were already pouring into England. The difficulty in obtaining lumber made necessary the establishment of saw mills on the property, so that timber from the woodland pastures could be utilized. Concrete for the wards was mixed in little factories from sand and gravel found on the estate. 'To supplement the ward buildings in emergencies seventy large tents, double-roofed and with windows, were also erected. . . . ${ }^{15}$

The problem of cows for the hospital farm was solved by the generosity of the people from the little islands of Jersey and Guernsey, located a few score miles ont of Sonthampton in the Engli-h channel. Sixty cows of their fine herds were offered as a gift to the American base. . . .

The mursing persomel of Base Hospital No. 40 had been organized at the Good Simaritan Hospital, Lexington, Kentucky, and upon arrival in England on July 20, 1918, consisted of one hundred and seren members. Elizabeth MeCormack Bogle was chief nurse. The nurses of the Good Simaritan Tnit were first stationed at Sarisbury Court, but as the hospital was not then ready to receive patients, they were distributed on temporary assignments among other American military base and eamp hospitals. Five of them were sent to Base TIospital No. 1.; in France; seven other's, "casuals" who hat been attached to the mit only durine the triple orere, went on to France. When Sarisbury Court was ready for patients on

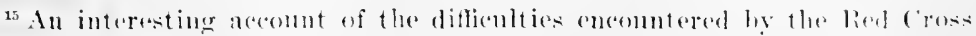
in the estahlishment of this base may he found in "The l'ascine lectoms." by Ceore Bnchanan life, pl. 202.211; The Macmillan Compang, 1920. 


\section{HISTORY OF AMERICAN RED CROSS NURSING}

September 4, the nurses of the original Good Samaritan Unit were returned there for duty.

Base Hospital No. 40 rendered yeoman service during the last week of September, 1918, when the influenza epidemic was at its height. The liner Olympic, with four hundred cases of influenza aboard, docked at Southampton on September 29 in a cold, raw mist. The six thousand troops which she had brought overseas cane from southern states and were keenly susceptible to the change of chimate. The medieal authorities hesitated to assign even the well men, exposed as they had been on shipboard to the influenza, to Southampton Rest Camp, where they would lave to sleep in entless tents on floors consisting of a layer of thin boards a few inches above the wet ground.

The troops were detained aboard the Olympic for a few dars. The influenza then became so virulent that the soldiers were finally disembarked and taken to Southampton Rest Camp. Pneumonia developed among full one-third of the men who had contracted the influenza on shipboard.

Although Sarishury Court was not yet equipped to receive a large number of patients, the Commission swiftly made arrangements so that the hospital could accommodate about three hundred men. Som of the personnel of Base Hospital No. 40 had already arrived there but many of the surgeons and nurses had been seattered on temporary assignments to other bases. They were quirkly recalled and they worked day and night withont respite mitil the epidemic was checked.

During the summer of 1918 , an important change of poliey was adopted by the chief simenen, American Expeditionary Forees in England, which ereatly diminished the need for extensive Amorican lied closs modical and mursing service in Great Pritain. Mis: II all wrote Miss Toyes on Angust 2:

The eneneral poliey of the Army here in England at the present time is that all hespitals shall be directly moler the Army. The lied ('rose will therefore establish wo further hospitals as separate lied cross institutions. I hope, however. that wo will still he able to staff the ones alleady in existrones with lierl comse nulses. but many of these will be transermerl to the Army hesere. If work as rhef nurse of the Amerian lied Crose in Great Britain now becomes (puitr secondary to that of the chief nurse, Army Surse Corps. Base Sertion To.?. 
On September 18, Miss IIall commented again upon the cessation of Red Cross activities:

The whole situation in England has undergone great changes during the summer months. In the early spring, the policy of brigalding our troops with the British in France bronght forth a ligig hespital building policy in lingland. In pursuance thereof, much work has been done in starting . Irmy hospitals. Then the ('hief surgeon continned comsistently to take over these institutions, with the result that so far as hospital and nursing work are concerned, there will be no further developments in England for the American Red ('ross.

It has been decidecl that I am to go to Paris the latter part of this month to help ont in Miss Stimson's oftice.

Miss Stimson, at this time rhicf nurse of the American Red Cross in France, was in need of an assistant at the Paris Ifeadquarters of the organization and Miss Hall was assigned to duty there on September 28, 1918. After Miss Hall's departure, Rachel Torrance, whose name is familiar to readers of this listory in connection with Miss Hay's work in Sofia and Philippopolis, beeame Chief Nurse, American Red Cross in Great Britain. On Oetober 1, 1!)18, fifty-seven nurses were on duty directly under the Ameriean Red Cross in Great Britain.

By November 11, 1918, the American Red Cross Commission for England hat estallished six hospitals and three convalescent homes for the use of sick and wounded members of the Amerim Military Establishnent in England. ${ }^{\text {ti }}$ At the signing of the Armistice, the Chice Surgeon, Batse Seetion No. 3 , was eonducting fire lase hospitals and four camp hospitals for the service of the Americall Armies in England. ${ }^{\text {ti }}$

Of the number of Ameriem Army nurses, regulars antel roserves, on active duty in Base Section No. 3, in October, 1918, Miss Leonard wrote:

The largest number of nurses on duty at any time was five

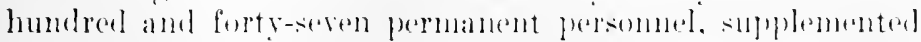

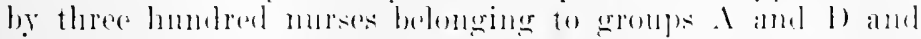

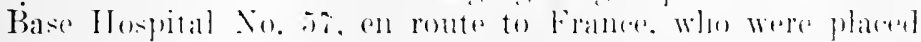

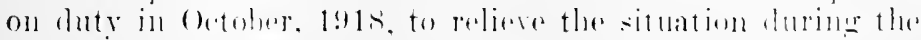

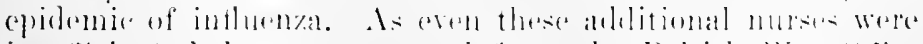

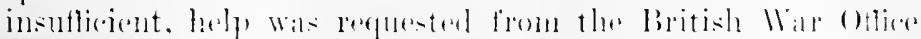

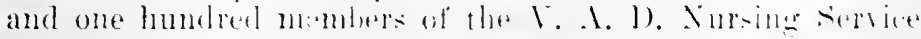

${ }^{16}$ For a list of these hespitills. sere Appemelix. 


\section{HISTORY OF AMERICAN RED CROSS NURSING}

were immediately placed at our disposal. During this time, there were more than one thousand emergency beds in use and every hospital was taxed to its utmost capacity.

'T'wenty-four nurses, largely British subjects trained in America, have been transferred from the American Red Cross to active service in the Army Nurse Corps through this office.

Miss Leonard reported November 15 to the Chief Surgeon in 'Tours to serve as assistant Director of the Nursing Service, American Expeditionary Forces in France. Annie G. Porter followed her as Chief Nurse, American Forces in England.

Immediately following the declaration of war by the United States, the British Government sent the Balfour Mission to Washington to confer with President Wilson regarding the coördination of the fighting strength of the two nations. One of the members of this mission was Sir John Goodwin, Colonel, Royal Army Medical Corps, and sinee 1918 Surgeon General of the British Army. He had been detailed by the British War Office for duty in the Surgeon General's oftice, United States Army. Upon the arrival of the Balfour Mission in Washington on April 22, 1917, General Goodwin requested that the Surgeon Gencral assign immediately, if possible, six Ameriean base hospitals to scrviee with the British Expeditionary Forees in Franee. The German submarine hlockade, then tightening abont the British Isles, made it inadvisable for the British War Oftiee to attempt the transportation of their sick and wounded to England and this decision ereated pressing need for additional British hospitals in France. Moreover, some of the nurses and surgeons who had seen three years' continuous service on the Western Front, were encatly exhausted and asualties from disease were growing more frequent anomg their ranks. General Gorgas called upon the Aneriean lied ('ross to muster into active duty six of the twenty-five base hespitals which were, on April 6,1917 , practically complete in organization, equipment and personnel.

The Lakeside Init, Base IIospital No. 4, on Ipril zos was sent notifieation of impending molsilization. 'Tlhe Sureon General did not rall ont the nurses' aldes who had leen attached to the base hospital mits, but anthorized that fifteren additional nurses shomld be selected from the reserve nurses alleady anthorized and shomled go forward in their place. All nurses were instructed to report either to the lakeside IIospital or to 
Red Cross headquarters in New York City, if they were then located nearer the port of embarkation than Cleveland.

The reasons as monderstood by the Nursing Service of the Surgeon (Eeneral for not assigning the twenty-five nurses' aides attached to cach basc hospital unit to active serviee were given in a letter written by Miss Noves August 9, 1917, to Major Fred T. Murply, director of Base Hospital No. 21:

'The decision against the use of our nurses' aides in France was remlered | by the representative of the English Gorernmont. Their argmments appeared to us well-grounderl. Briefly, they amomuted to this: although the utilization of lay women of lirench and English bith was necesary he(ailse of the lack in France of a professional nursing body and an inadecpuate supply in England and although they had performed good servire in many instances, their assignment had bech considered upon the whole an unsatislactory way of moreting the situation. Constant rhanges were necessary. Many of the nursese atiles, unused to hardships and long hours: of work, hat to be returued home. As the hospitals were not far removed from either (ireat Britain or the aides' homes in France, this was not difricult. It became, however, a different problem when the nurses' aides would need to be transported over three thomsind miles of orean. This, briefly, is the reason for the decision as rendered by our Government upon the atrice of the French and English.

The chief nurse of Base Hospital No. + Was Grace Allison and this history is indebted to her for an excellent report of the experiences of her unit. Miss Allison was born in Port Anstin, Michigan. Following her graduation from the Lakeside Traning School for Nurses, Cleveland, Ohio, she was for one vall superintemlent of the North l'aleifie sanatorimm, Portland, ()regon. In 1!90!), she matrienlated at Teachers College, Now Jork, hint interrupted her work there from 1!l10 to 1911 to take the pusition of assistant principal at the Lakeside

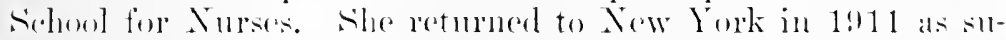

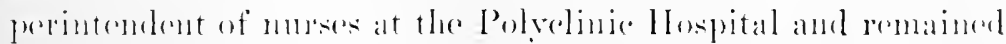
in that pesition for two years. In $191:$, she again took up her

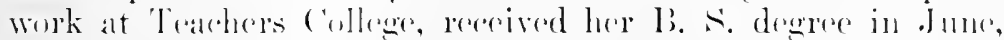

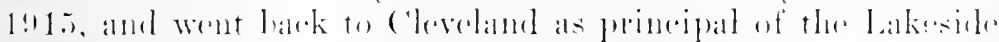
Shaool for Nurses. From this position, she was ordered with

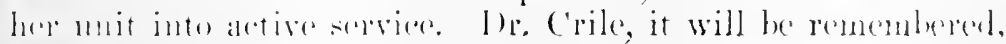
Was the direcetor of this mut. 


\section{HISTORY OF AMERICAN RED CROSS NURSING}

Base Hospital No. 4 embarked May 8; Miss Allison reported the arrival of the unit in France:

From Southampton we were transferred to the hospital ship Western A ustrulia. Morning came and we lay at anchor in the Seine River. The fog liad disappeared and the sun shone brightly. ...

Up to this time war seemed remote. As we passed small villages or lonely, thatched cottages with their groups of aged peasant folk with perhaps one or two young children or infants, we realized keenly how the three and one-half years of warfare had deprived them of their sons and fathers. Young women had gone forward to munition plants and factories. From a German prison camp hundreds of soldiers gazed with interest through a barb-wire fence upon us but I doubt if they comprehended the significance of the entrance of America into the war. Later one remarked, when seeing the insignia of the United States upon the uniform of an American officer: "America! And are you with us at last?"

At the rlose of the day, May 26 , we approached Rouen. As the ship steamed toward the dock, great throngs of people crowded to the wibarf. Women dressed in mourning and children, with pale, emaciated faces and black aprons, presented a sad picture. 'Their cries of "Vive l'Amérique!" we will not soon forget.

After debarkation came a two mile march through the deepening twilight, then a trip in dusty ambulances and the unit finally reached its destination, No. 9 General Hospital, British Expeditionary Forees, Rouen, France.

To. 9 General IIospital was located in twenty-five long brown-stained wooden huts and many dun-colored tents lying in paralled streets. The buildings were surrounded by neatlytrimmed lawns and regetable gardens. Near the administration building was a flag pole from which, upon the arrival on May 27, 1917, of this first contingent of the American Expeditionary Forees upon Allied soil, the Stars and Stripes floated for the first time with the Lnion Jack and the Rerl cross flag.

No. 9) General llospital was of twenty-two hundred and fifty bed caparity, with an amerenery expansion which allowed for three hundred and fifty additional pationts. The medical di-

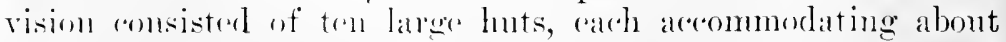
forty beds. Pestateses were planted betweren the parallel rows of bown wooden buldings. This regrotable was hard to secure 
in the French markets. The administration buildings, the operating-room pavilion, the patient's recreation and mess halls and the Quartermaster's department oceupied the center of the hospital grounds. To the right was the surgieal division, sitnated in fonrteen tents and in ten huts similar to those of the medical division.

The wards differed from those of the American military hospitals chiefly in the type of furniture and supplies. Miss Allison wrote:

The iron beds are painted black with a short head and foot piece so attached to the legs of the bed ats to permit their being doubled under, making a flat surface which may be conveyed easily from place to place.

The sheets' are one hundred and five inches long. They are turned back orer the blanket at the top of the bed and also folded upermost at the foot of the bet for twelve inches. When a sheet is soiles at the top from coming in rontact with the patient's food, it may be reversed, to provide a clean space at the head of the bed and prevent the soiled part, still turned uppermost at the foot, from coming in contact with the patient's feet. This device is necessary, not always because of the shortage of linen, lont becanse of the great laundry problem. In many places in France, laundry is done on the stones adjoining a reek. Ifot water seemed almost impossible to procure on account of the lack of fuel. Our soiled linen had to be transported forty miles by two large Army trucks.

The British Red Cross Society equipped the reereation hall with reading-tables, books, desks, newspapers, magazines and games; patients constructed a stage and painted the "urtains and several "sets." The British Red Cross supplied soap,

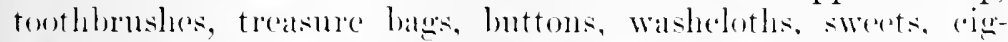
arettes, soreks, gowns, hinders, stationery, smatl pillows and other necessities to "Tommy Atkins." I Muring the spring of 1919, American tronse were brigaded with the british and the wounded of both nations were alike sent dewn through british bases for mediand and mursing are. As Ameriean wounded

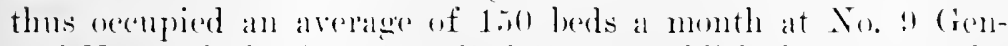

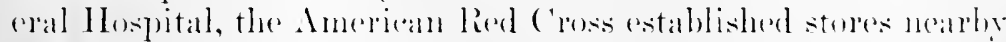

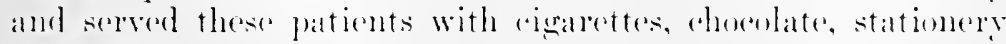
and other comforts and huxuries furnished be the Aneriean

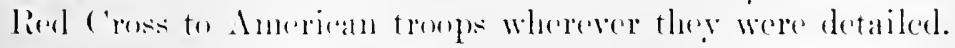


After a few days during which the Americans were learning the well-established rontine of No. 9 General Hospital, the British sisters were withdrawn. On the morning after their departure, the bewildered Ameriean murses found of the furniture which had formerly been in the nurses' quarters only a few boxes and some neatly-stocked bedding. It was their first intimation that the eamp kit which the British War Office supplied each of its nurses was carried by them from one post of duty to another. This kit was eomposed of three army blankets and a large canvas bag containing a folding eot, a cork mattress, a washstand, a small table, a chair, a canvas pail in which to carry water, a lantern, an enameled plate, a drinking eup, a knife, a fork and a teaspoon. The practice was different in the United States. The Anerican Army furnished the quarters of the nurses, rather than issued the articles direct to each nurse. But General Pershing's First Division harl not yet landed in France and there was no one to furnish the quarters of these first American nurses assigned to British bases. However, the British Government came immediately to the rescue and supplied the neessary articles for the American nurses both at No. 9 General Hospital and at the five other bases to which American nursing personnel had been assigned. Mrs. Whitelaw Reid, of the London Chapter of the American Red Cross, sent each nurse articles of personal equipment, notably aprons. The practice of the British Army and the great need in the harsh elimate of France for extra articles such as boots, son'westers, ponchos and sleeping bags were important factors in eonvineing the $\mathrm{W}$ ar Council that the American Red Cross should issne complete equipment to nurses assigned to active serviee overseas.

Miss Allison eommented upon the comfort and cheerfulness of their newly-furnished quarters:

They ronsisted of five long wooden buildings. earbly acommolating eighteen nurses, and several small (anvas-covered Armstrong huts. The night nurses" hut or "resl-r'urtained hut" hat crimson hangings eleverly arranged to shut out the light and to serve as partitons. In our cheerful living room, with its rhintz-coseren widker furniture piano and abundance of fresh flowers, afternoon tea was served daily.

"Nurses" Vres." where we breakfasted usually on sardines, breal. butter, jam and coffee, was much more attractive than one might suppose from the bare woolen walls and ross-beam 
ceiling. The floors were covered with plain brown linoleum. light large windows with pretty areton draperies and large white covered tables contributed much toward the checrful appearance of the room.

The mursing staff of Base Hospital No. 4 was rë̈nforced in July, 1917, by the arrival of additional nurses. A second detachment of seventeen nurses from Cleveland, Ohio, joined the unit in September of that year.

When the rigorous winter set in at No. 9 General Hospital, patients, surgeons and murses suffered from the bitterly cold weather. Miss Allison wrote Miss Noyes Janmary 7, 1918:

Our water pipes have all frozen and for three days we had no water, except that which could be carried from a distance of a quarter of a mile. Our huts are only summer buildings and there is scarcely a room that the outside cannot be seen through many 'racks in the walls. In the murses' quarters we have provided o:l stores and in the mess hall we have two coal stoves.

Ile are now on fifty per cent rations of oil, which means only a pint a day for each stove. This provides only about two honrs of heat for our rooms out of the twenty-four hours. During the warmest part of the day, the temperature in the ward: varies from thirty-two to forty degrees. The nurses are sulfering from chilblains.

The work at No. 9 General Hospital followed the theory of military procedure as set forth in preceding sections. The wounded were carried on stretehers from the trenches to the nearest First Lid dressing station, which was located in as sheltered a spot as possible just back of the firing-line. After they had received treatment there, motor ambulances transported them to the nearest casualty elearing station. These stations were lowated from four to ten miles behind the first line trenches and usually eonsisted of four separite hospitals grouped near one another, each with its own complete organization. Patients whose womds showed upon examination that inmediate attention was mot inperative, were rushed at onee to the nearest base: others repluiring immediate aid or operation were eared for at once at the calsualty clearing station by surgical trims

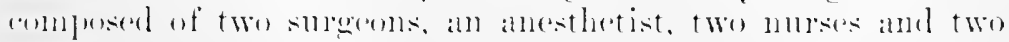
orderlies, sent np from the varions base hospitals nearest the station. 


\section{HISTORY OF AMERICAN RED CROSS NURSING}

From the casualty clearing station, hospital trains conveyed the wounded sixty to one hundred miles to the zone of the base. Ammunition trains, however, had the right of way, so that the wounded were often completely exhansted upon their arrival. Ronen was the clearing center for eleven British hospitals in its immediate vicinity. Here the depnty director, Medical Service, received information regarding all ineoming cases, allotted as many new patients to each of the hospitals in his zone as their free beds wonld accommodate and informed each base of the type and number of cases they might expect within a given time. The reception of patients was described by Miss Allison:

When the ambulance trains arrived at the station, they were met by automobile ambulances, to which the wounded were hurriedly transferred and taken to the particular hospitals to which they were assigned. The main roadway was often lined for a distance of three or four miles with anbulances coming and going. The procession continued for hours.

The convoy bugle call at the hospital announced the approath of the ambulances. Old sight-seeing cars, such as we formerly saw in our cities before the war, were usually the first to appear and were filled with the walking wonnded. These patinnts, assisted by those less seriously wounded or by orderlies, hobbled out anid were assigned to regular quarters as "walking convalescent patients." The aressing of their womnds was flome in a separate department. With the assistance of orderlies and convalescent patients, 300 dressings a day were often done by three nurses.

The arrival of stretcher cases necessitated intense activity on the part of nurses and orderlies. Miss Allison continued:

From the admision hut, the patients were quickly despatehed to the wards, where they were earefully placed on the beds. orer which convoy blankets had been spread. These

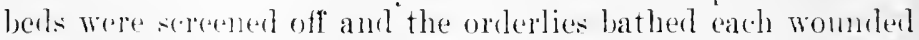
man. Ifot liquin nourishment was then providerd. though the patient often hand to be awakened from the sleep of utter exhantition.

Nurses ant down all dressings for the inspection of the surgical stali". Sionne pationts. whe hat lain in shell holes withont mextimal attention. (ance with wounds inferted with magrots: wheres were admitted who had lost beth leags, while 
still others were found with great pieces of muscle and flesh toru away by shell and shrapnel. . . .

With eyes swollen and discharging, the body covered with blisters and apparent lisemplort in the respiratory tract, the gassed patients prosented one of the sandest sights. 'They expectorated quantities of blood and nearly all were unable to speak above a whisper. In a single day, seven hundred came to our hospital.

A warl ofter achitted as many as twenty new stretcher patients at one time. 'Two nurses were usually assigned to the metical service and perhaps three to the surgical division of each hut.

One of Miss Allison's deseriptions brings up the picture of another woman who sixty years before at far-away Scutari ministered to England's wounded:

Nursing at night was extremely difficult; few lights were permitted, owing to the frequent air raids. The night nurse inspected the dressings, groing from bed to bed with a lantern shaded to prevent the light from being seen through the windows. One nurse leterted eight hemorrhages in a single night. Not one patient at this base has met death for reason of lelay in recognizing a hemorrhage. One instance occurred where the life of a Tommy was saved by a nurse who made constant pressure with her bare hand buried decply in the wound until assistance arrived.

Evacuation of convalescents occurred almost nightly. Each patient was given clean linen, warm eovering, fresh dressings and hot food before his stretcher was hoisted into an ambulance for "Blighty." Bat the closing of the ('hamnel to elear it of mines sometimes dismpted this smoothly ruming process by which England ared for the wounded coming back from Ypres, Ilouge, Loos, Amiens and the Somme.

Never at any time was the work light at No. 9 Creneral Hospital. dir raids added to the strain of rowded wards and semingly endless anvoys. Miss Mllison deseribed the bombing of the British bases:

As the firing line drew uearer, we often experienced five sucessive night rajds in one week. When notien of an ap-

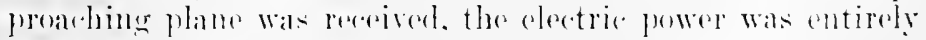
shut off. Evon smoking and the use of torehes was strietly 


\section{HIS'TORY OF AMERICAN RED CROSS NURSING}

forbidden in all areas. The wailing siren or pop of an antiaircraft gun was usually the first signal.

All nurses were required to dress quickly and remain in quarters as a protection from the falling shrapnel, until ordered to the abris. Rouen was well fortified with antiaircraft guns and they contributed deafening sound during a raid.

Often we were obliged to go to the abris dug for our protection. Only twenty-five per cent of our personnel were issued trench or steel helmets. Those having none sought the use of water pails, wash basins or similar derices, as a head covering. When we arrived muddy and wet in the trenches, there was nothing to do but wait. watch and listen. In looking above and around the city, we could see in the distance pairs of sausage balloons suspended at different heights in the air. Between each a cable was stretched, cleverly devised to catch the wings of a plane which, if entangled, would drop to earth. Amid the sound of the anti-aircraft guns we could distinguish the destructive roar of an exploding enemy bomb. Each plane usually carried six bombs, so it was comparatively easy to follow its general direction. Occasionally a rocket illuminated the ground for a wide area. At other times incendiary fires in the petroleum tanks, thought to be the work of spies, burned for twenty-four hours.

Some murses did not even have the protection of a waterfilled trench. Night nurses and officers remained on duty throngh all air raids to assist in any emergency. Each hut was barricaded with sand bags which protected it effectively in case a bomb dropped between the buildings. 'The sand bags were of no use, however, in case of a direct hit. Miss Allison wrote that "it was surprising to find how little fear was felt during the apparent danger. One learned to become a fatalist and to hold oneself in readiness for any happenings."

As increased activities in the zone of the adrance made neeessary the presence of additional surgeons, murses and sanitary soldiers in easualty clearing stations and evacuation hospitals at the British Front, mobile hospitals and professional teams were organized from among the personnel of base hospitals in the rear. Happy indeed was the nurse whose skill sent her forward to the line! Miss Allison described this type of service:

During the summer of 1917 , Nobile Tnit No. 5), collsisting of about ten officers. twenty nurses and thirty corpsmen, was 
temporarily detacher from Base Hospital No. 4 for service nearer the front. Betty Comnelly, of ('leveland, was dhief nurse. 'This mit, with its complete equipment for a five hundred bed hospital. was transported from place to place by trucks especially designed for the purpose. At one time this smpplemented the bed alpacity of an over-erowled hospital and at another maintained itself as an independent institution near the firing line.

Canvas tents wore stretwhed over a steel framework, which not only held the structure securely, but offered the advantage of having no center posts which so often obstructed the passage way. Each hed was apportioned a $155^{\prime \prime} \times 155^{\prime \prime}$ window. The warls were comnceted by anvas-covered corridors, which also joined all neressary departments of the hospital. The sterilizing plant was maile stationary on a truck which formed one wall of the operating-room. Permanently fixed on this truck was a fire box, a boiler and instrmment and dressing sterilizer. A small room adjacent was fully equipped for the necessary X-ray work and permittel the patient being wheeled in on the operating-room table and out again. 1 laundry was also established on two arljoining truks. On the one was the firebox, boiler. washer and extractor and on the trailer was the dryer with a small stove in the rear.

Hospitals are primarily places of life and death. The work of caring for the dead was as inexorable as that of caring for the living. Miss Mllison described the burial of soldiers who died at No. 9 Gencral Hospital:

At the far cormer of the base was situated a small building in front of whith was a mound surrounded by flowers and an jey vine whin elimbed up over the winlows. I narrow pathway led into a small mortuary. Against the white board walls resterl a flower-elected altar.

Many of onr Tommies and American boys fouml here rest after the lass of hattle. Burial services were comducted in the small rhapel within the enmetery gromeds. Every atternom rough antins were arried there upon the shoulders of eight British or . Imeritan soldiers and boweded into a deep trench, there allins, one upen another. Often a single redative had arrived from England and stood alone in her errief

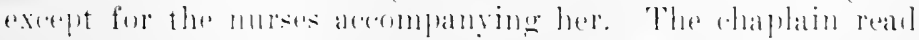

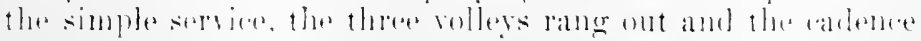

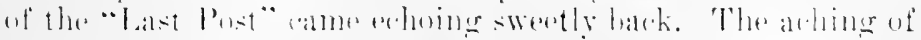

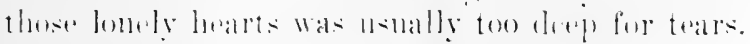




\section{HISTORY OF AMERICAN RED CROSS NURSING}

During the first twelve months in which Base Hospital No. 4 was stationed at No. 9 General Hospital, 82,179 patients were cared for by the Americans. The largest single day's work was that of Mareh 27, 1918, when 1125 patients were convoyed in and out.

Overlooking the English Channel, midway between Calais and the month of the Somme, lay the French village of Dannes Camiers, the destination of United States Army Base Hospital No. 5, organized at the Peter Bent Brigham Hospital and at Harvard Medieal School, Cambridge, Mass.

The second of the Red Cross base hospitals to go overseas, this mit has been termed both the Peter Bent Brigham Unit and the Second Harvard Unit. It will be remembered that the first Harvard Unit had been organized without assistance from the American Red Cross and had been assigned during the spring of 1915 to service at No. 23 General Hospital, British Expeditionary Forces. To avoid confusing Base Hospital No. 5 with the first Harvard Unit, it will be designated in this history, when its military appellation is not used, as the Peter Bent Brigham Unit.

Dr. Harvey Cushing had organized this unit and was its director. Colonel Rolert Urie Patterson, formerly chief of the Red Cross Burean of Medical Service at National Headquarters, was detailed by the Surgeon General as commanding officer of Base Hospital No. 5 after it was mustered into the Medical Corps and he led the mit into foreign service. Carrie M. Hall was chief nurse. Following her graduation from the Massachnsetts General Hospital, Miss IIall was superintendent for four yars of the Margaret Pillsbury General Hospital, Concord, New Hampshire. She then entered Teachers College for a course in training school administration. In 1912 she hecame superintendent of the Training school of l'eter Bent Brigham Hospital, of Boston, and remained in this position mutil as chief nurse she was ordered with the Peter Bent Brigham Enit into active sorvice.

The personmel of Base IIospital No. 5 mobilized in Boston on May 6 and sailed from New York five days later. Tpon their arrival at l)ames ('amiers on May :31, they took over No. 11 General Ilospital, British Expeditionary Forees, a well-established British hase of two thonsand beds.

In organization and in work, No. 11 General Hospital (dosely resmbled the trpe of institution which has been de- 
scribed in the section which recounts the experienees of the Lakeside Unit. No. 11 General Hospital was housed, however, chiefly under eanvas.

Of the ten thousand Ameriean nurses who served with the American and British Expeditionary Fores during the European War, only three were wounded in line of duty. One of the three was Eva Jean Parmelee, a member of Base IIospital No. 5. She described the air raid which brought the first mortalities to the Americans at Dames Camiers:

On a bright moonlight night, September 4, rame our initial experience with bombs. It was $10: 30$ P.M. and my two long tents were absolutely quict. Our lights, rontrolled by a central switeh, had no sooner winked out than the siren of the eement factory blew its air raid warning. My orderly, Oscar Tugo, came rumning from his supper; I met him in the roat in front of our two tents. Suddenly abose us we heard the hum of the planes, saw a sputtering streak of sparks drop from the sky and 'Tumo (ried out, "Why, they re here!"

After a deafening report. I found myelf in the ditch. The choking, sulphurous smell and the noise mate me feel as if I were being stirred up in a great bowl of reeking gunpowiter. Four more reports followed and I said to myself: "We're done for-they're wiping us out!"'

Then I heard the calls of the womded: "Sister-Sister!" I jumped up and flashlight in hand (for we clung to our lights) ran to the tent foor. A glance showed the nearest man to be bleeding badly. Doctors, nurses and men with stretchers were arriving. . . . I rossed over to the other tent and found the whole front sertion had been blown up. berls, lockers, floor and all. Not a patient was in sight. 'Though wounded. howorer, they were all living and had been plated in other wards. In the officers quarters and the reception tent. seven of the rommand lost their lives and several were gravely wounderl. 'T'ugro. my orderly, harl been killext. I escaped with two tiny face wounds and a blatek eye, thourd shrapnel had torn my skirt and apron and cut away my wrist watch so that only the strap remainerl.

The Peter Bent Brigham Cnit was transferred November 1, 1917, to Boulogne-sur- Vler to take over No. 1:) Cirueral Hospital, British Experlitionary Forees. Hore during the spring and summor of 1918 , they shared the hard service which all the British hospitals experienced. 


\section{HISTORY OF AMERICAN RED CROSS NURSING}

On the great cliffs above the fretful Channel at nearby Etretat, U. S. Army Base Hospital No. 2, organized as the Presbyterian Hospital Unit, New York City, took over on June 10, 1917, No. 1 General Hospital of the British Expeditionary Forees. In. George Emerson Brewer was director of the unit. Miss Maxwell had organized the nursing staff but Janet Christie, her assistant, accompanied the unit as chief nurse when it was ordered into the field. Mrs. Christie was a graduate of the Presbyterian School of Nurses and for thirteen vears had served in various executive eapacities at this institution. She was among the first hundred nurses who had been enrolled in 1905 in the Ameriean Red Cross.

Etretat, the Hamlet of the Setting Sun, had been a favorite resort for artists and authors, beeause of the beauty of its ereseent-shaped beach and its high eliffs overlooking the Channel. The many hotels and villas were requisitioned during the war for use as hospitals. No. 1 General Hospital was loeated in the Casino and in various hotels. A large private house formed an officers' hospital. A newly-built villa, charming both in architecture and in location, was fitted up by the British Army as a home for sick murses.

During the German offensives of March-July, 1918, this hospital reeeived between sixty and seventy British and American nurse refugees. As the German lines were advaneed, many of the easualty elearing stations and evacuation hospitals of the Allies were bomber and shclled completely out of existenee. The nurses and surgeons had been working night and day to eare for the greatly-increased numbers of wounded and when the lines broke under savage assaults of the enemy, the nurses fell back to Etretat in a state of almost total collapse.

Enited States Army Base Hospital No. 2 sent forward operating teams during 1917 and 1918 for service at easualty rlearing stations on the British Front. Anne Penland, who had been anesthetist at the Presbytrian Hospital, was sent up with the first team and held the honor of being one of the first, if not the first. nurse andesthetiste to go officially to the British

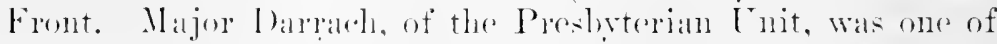
the sureones to tako up a team and he told the incident by which Mise P'enland won the anfidenere of the British ofticers. When they arrivel at the "asualty relearing station, the British

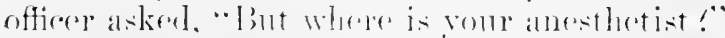

Ma jor lourarh indirated II iss I'enland, a small, quiet woman. 
"But often there are eight or ten patients at onee, big ehaps," expostulated the Britisher, "And they struggle!"

"Wait and see," promised Major I Marrach.

During a lull in the work which followed, the British officer came back to Major Darrach, praised Miss Penland's work and concluded, "But she always seems to draw the quiet, peaceful chaps."

"Come and see why," suggested the Ameriean surgeon.

They approached the table where Miss Penland was anesthetizing a broad-shouldered Tommy who seemed inclined to fight the ether. Miss Penland leaned over and murmured soothingly:

"There, dear, it won't hurt you a bit,--there,-there."

At the sound of her low, distinctly feminine, southern voiee, the Tommy looked up in surprise, then grimed with perfeet confidence and "went under" withont a struggle. So suceessful was her work that the British deeided to train their own nurses for this service and thus relieve several hundred doetors for medieal and surgieal work. Several hospitals in the Ronen and Le Tréport areas. among them No. 1 General, were chosen as training eenters for these British nurses.

Other operating teams were sent forward during the winter and spring of 1918. Twenty-three nurses of Base Hospital No. 2, with Jane Rignel as chief nurse, were detached from the stalf at No. 1 General Inospital at Etretat and were sent forward to the Ameriean Front to form the nursing staff of Mobile Ilospital No. 2, Ameriean Expeditionary Forees.

No. 1 General IIospital drew patients largely from the Third Army Sector of the British Front and evacuated them by ambulance through Le Havre. Freneh, Italian, Colonial, East Indian, Arab and Portuguese wounded, and Ameriean wounded after the First I livision had entered the lines. fommd rest and eare in the seven hotels which the British Army had equipped as hospitals. The persomed of Base I Lespital No. 2 were always busy. In transmittinge a communication to Sational Headdenarters, Mrs. Christie smmmarized their work in a fow words which peinted to the most worth-while service that war nurses "all give: "() nur experiemeses were not spertalenlar in any way. Wo oceatsionally heard gmos and got our warninges lint the greater part of the time we simply had steady, harrl work."

Thongh the Presheterian ['nit was lowated well hechind the

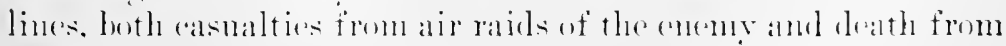
overwork and expositere loronght to its members a realization of 


\section{HISTORY OF AMERICAN RED CROSS NURSING}

the sadness of war. Beatrice Mary MacDonald, a member of this unit, was the first American nurse to be wounded in the European War. She had been sent forward as a member of a detached team to No. 61 Casualty Clearing Station, near St. Sixte's Convent, Belgium. Seven surgical teams, five British and two American, were on detached duty here during July, 1917; the two American teams had been organized from the Presbyterian and the Pennsylvania units. Helen Grace McClelland, a nurse serving with the Pennsylvania team, described the air raid of which Miss MacDonald was a victim:

Miss Mac.Donald and I had been relieved at 4 P.M., August 17, 191\%, and were expected to report for duty again at twelve. We had been asleep and were awakened by the humming of German motors. I looked at my watch to see if it were time to go on duty, but it was only $10: 15$ P.M. Then the bombs began to drop. We reached for our tin hats which we always kept hanging with our gas masks on the cot. I put mine on the sille of my head and corered up again. Miss MacDonald was slightly raised on her elbow when two bombs struck the cook honse nearby and a piece of shrapnel came through our tent wall and penetrated her eye; another piece struck her rhcek. Two English murses were also wounded and the nurse in the tent next to ours was thrown out of bed by the concussion.

Our tent was about twenty-five or thirty feet from the place where the bombs struck. In the field alongside our compound, there was a row of five holes where they had dropped their bombs. Even with my eyes closed I had seen the flashes from the explosions. The concussion was terrific and things came flying through our tent, tearing great holes out of it. The cook. who had just returned that day from leave in England, was blown to pieces.

The officers. who had been in their mess tent when the bombs struck. rame over at once. calling: "Are any of the Sisters hurt:" I answered. "Yes," and two of them entered with flashlights. Mlis MacDonald was then placed on a stretcher and taken to the operating-tent for a more thorough examination. As there was an ambulance train on the track then being loader for the zone of the base, she was put on it and it was orrlered to Bonlogne. the ophthalmic center.

Althongh Miss Marl) honald lost the sight of her right eve, she returned to duty at boulogne and remained in service with her mit mutil two numblhs alter the Armistice. 
Fourteen base hospitals served during the winter of 19171918 in France; six of then were attached to the British Expeditionary Forces and eight to the American forces. All of the nurses found the rigorous climate and the heavy work a more severe test of their stamina than the bombs of enemy raiders. First one nurse and then another, among the staff of one hundred in each hospital, grew sick during tle blrak winter months and here and there in the British and Ameriean bases, a nurse died and was buried with military homors. The following aceount of the funeral of Amabel S. Roberts, a nurse and a member of the Presbyterian Unit, was published in the Military Number (May, 1!18) of the American Journal of Nursing:

At $6: 15$ P.M. on Thursday, January 17, 1918, Amabel S. Roherts, reserve nurse, Army Nurse Corps. . . No. 1. General Hospital, Etretat. France, gave up the life she had devoted to the service of others. Her illness, one of the most deadly of infections, had lasted barely three days.

... The services were to be held at the Blanquet, the nurses' quarters, and in a moment the narrow street was choked with troops who formed in a long double rank on either side of the street leading to the gate. For fifteen minutes the men stoor at attention while the simple services were being held inside the Blanquet and then the leaden casket was bronght out and placed on a stretcher carriage covered with flags. The carriage moved slowly down the street lietween the two ranks of men who uncovered their heads as it passed. As it reached the end of the lines, the files telescoped on themselves and fell in behind.

It was an impressive procession. ... The masses of flowers that buried the rasket flamed arainst the somber batkgromut. . . The dark hlue miforms of the murses blended with the blue and leather of thisese of the ambulance drivers and both were relieved by the flowing white head-dresses of members of the V. A. Ws. Ant then wame the olive drab as the officers marched past, heading the solid ranks of mon in a long column of fours. with the herizen blue of the prilus following. One felt sure, somolnow, that whe would have been glan to know that the poitus were there. They were all wounded and some of them hoblhed along on sticks white one or two gave an arm to a "ommate who had risked his strength to inme. . .

More khaki as the British marched and then the patients. Some of them wore uniform roats, hut most of them were in 


\section{HIS'TORY OF AMERICAN RED CROSS NURSING}

blues, that strange ill-fitting garb of the convalescent. After these came all Etretat, women and old men unfit for service... in clumping wooden shoes, some leading little children, the lame, the halt and the blind, the old and the weak,they knew of bitter experience and they could sympathize. It was not an impersonal sorrow that the French gave. They had known her. ...

Some of us have felt from time to time that in this old world we have found only a land out-worn, devitalized and cold, but as the funeral procession of our sister passed through the narrow streets between the rows of Norman houses with their gabled roofs, that feeling changed and there was comfort in the change. One felt a sense of sheltering protection, the promise of a mother old in the ways of pain,- that she would care for that which we bequeathed her until such time as we could claim our own. Through the outskirts of the town the column went, past the old Norman ehureh with its strong, restful lines, and into the cemetery.

There. beyond the civilian portion with its crowded tombs and quaint head stones, upon a little slope above the rest is a phalanx of black wooden crosses which mark the resting places of those who have died that a better world might come into being. Here the procession halted. A grave had been dug in the center, between the two larger plots. Far off in one corner of the cemetery lay a German, a prisoner of war, and one felt that in the great democracy of death, all war had been forgotten.

At the foot of the srave stood Padre Johnston; at the head and on the upper side were grouped the nurses. Further up were the officers and behind them and extending down behind the nurses were the enlisted men of all nationalities. The sun shone warmly and a soft wind came up from the sea. The beantiful service of the Church of England was read through. ... At last the pall bearers stood clear and the bugler's stepped forward. Taps were blown for the first time in Etretat over an open grave. We har become so used to the "Last Post" that we had almost forgotten the real beanty" of Taps but now its piercing sweetness struck home. . . "Go to sleep. Cio-to-sleep." It was an end and a beginning.

A plain wooden eross will mark her grave, a cross differing in nowise from the crosses which surround it, except in the name painterl in white upon its arms. It was sugrested that some more elilorate memorial might be fitting but surely none could fit so well. It is a soldier"s cross for one who died like a soldier. 
No. 16 General IIospital, British Expeditionary Forees, was located at Le 'Tr'port, linance, an hour's journey by motor from Dieppe, and was the destination of U. S. Army Base Hospital No. 10. The persommel of this unit had been chosen from anmong the alumne and the staff of the Pennsylvania Hospital, Philadelphia, Pa. 1)r. Richard H. Harte was the director and Margaret $A$. Dunlop was the chicf nurse.

Miss Dunlop was a veteran in war service. The daughter of a Connectieut clergyman, she was educated at Normal College, New York City, and at the Presbyterian Hospital, Philadelphia, Pa. For ten years she was assistant directress of nurses at the Presbyterian IIospital. She became Matron and superintendent of nurse's at the Pennsylvania IIospital in 1909. Immediately following the declaration of war in August, 1914, the Ameriean Ambulance called her to Paris as chief nurse. Upon her return to the United States in 1916, she organized the nursing staff of Base Hospital No. 10. Her strong, energetic personality, her initiative and her ready humor made her admirably fitted for war nursing.

The Pennsylvania Lnit mobilized on May 6, 1917, in Philadelphia and sailed on May 19 from New York with the St. Lonis Unit on the S. S. St. Paul bound for Liverpool. Miss Dunlop marshalled her nurses in orderly formations which would have done eredit to a veteran sergeant of the United States Regnlars. The nurses of the unit were divided into different groups, each with its group leader who received all orders for the nurses in her section directly from Miss I)unlop and who was responsible to Miss Dunlop for the promptness of the murses of her section, for the appearance on time of the baggage and for all other matters which related to her section. "Never during the many dars of travel," wrote Miss Dunlop, "were we hampered by unpunctuality or disobedience."

The P'ennsvivinial and St. Louis muits were the third and fourth branches of the Ameriean Army to arrive in London and the reception whirh the British gave them was cordial inderd. Hospitable londoners took the nurses sight-secing in the day time and asked them to the thealters esere nieght. P'adestrians notired the nursis' miforms on the strext, stopped them to point ont places of historieal interest and insisted on taking

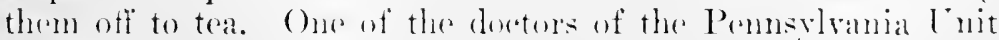

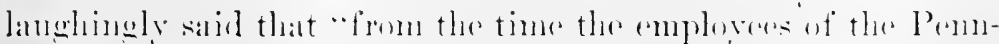

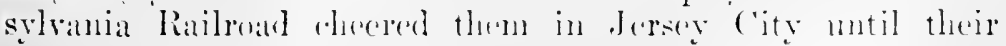


arrival in France, the whole journey was one long glorification for the nurses!"

This cordial reception helped greatly to unify the British and American groups. Miss Dunlop wrote that "the period in London seemed to us at first a wonderful joy ride, but later the wisdom of the scheme was understood. It brought the American units who were to work with the Allies into a bond of kinship and good feeling which perhaps could not have been produced in any other way."

The Pemnsylvinia Unit left London on June 8, bound for Sonthampton and Frince. They arrived at Dieppe at one o'elock in the morning of June 11 and found waiting for them British "chauffeurines" with their ambulances. The Americans were driven through the mud and rain to Le Tréport and arrived at two o'clock at No. 16 General Hospital, British Expeditionary Forees. Miss Dumlop wrote Miss Noyes that "the Matron was one of God's own; she and her nurses turned out and gave us their beds. We were a sorry lot, without even hand luggage."

No. 16 General Hospital was composed of eight low huts which comprised the nurses' quarters, thirty-six long brownstained wards, nine huts and seven tents called barracks where walking cases were housed and numerous temporary buildings of the isolation department. As it was located in one of the most forward points of the British Zone of the Base, it was always busy. During the first week the Americans were in charge, the hospital with a staff of sixty-five nurses and eighteen members of V.A. ls. received tourteen humdred patients, many of them heary sureical and mustard gas cases. The gassed soldiers eroked the kerest sympathy. Miss Dunlop wrote:

These pationt: were horrible pictures of misery. They poured upon us in wreat numbers, six hundred in less than forty-eight hours. ankl their sufferings were pitiful to see, but their hravery. unselfishness and fortitude stiffened up our own courage at this our first soul harassing introluction to the indescribalhe losharity ly which was is inflicted upon the individual soldine. Feing montrained to the handling of such large numbers of wombled and not yet inured to the immensity of the work, it was a tremendous strain on the minds, hearts and horlios of the medical and of the nursing staff. Of nexesity, the nurse had many dresings to do. They soon grew exprert. () ur patient: one answer, when we askeil eren 
the desperately wounded if they were in pain was always: "Not too bad, sister."

During that summer of 1917 , we had our baptism of horror and work, but alter a few months the whole unit settled down to the inevitable. As we grew more efficient in handling large numbers of wounded, we grew less fearful that we would not prove equal to the tasks demanded of us.

Late in July, 1917, the surgical teams, each composed of a surgeon, an anesthetist, a nurse and an orderly of Base Ifospital No. 10 were sent forward from No. 16 General Hospital for duty in casualty clearing stations at the British Front. Holen Fairehild ${ }^{17}$ and Ielen Grace MeClelland were the nurses chosen for this coveted assignment. The team left the base at six o'clock on July 21 in ambulances driven by British "chauffeurines." Their first stop was at Abbeville; they then proceeded on to Hesden where they spent the night at a hotel which had formerly been a hunting lodge of one of the Bourlons. The V. A. I)'s. who drove the British ambulances were not allowed to go to the front, so the surgieal teams proceeded forwird the next morning with new drivers. Miss MeClelland wrote:

After we had left Hesden, the ambulance ahead of us had some tire tronlle so we stopped on the arest of a high hill leyond the forests and saw miles away a pufï of blue smoke from one of the bigr guns and knew before long that we would see some of the destrution and agony which they were (ausing.

We had dimer at Steenwoorde. The town was filled with Belgian troops and we soon (anght up on the roal beyond with great numbers of Portuguese soldiers. From this point on, we saw more and more of the tremendous numbers of men amb the vast amomnt of material which are demanded by war. Jere were thousands of ponton bridges for nse in the drive to rese the canal at lpres; here were British Tommies with that tired. questioning look on their faces. that look whire we salf later in the reges of atl those who had bitterly rome to know, as the T'onmies saicl, that "a bit o" war was on."

The trattic now berame more rongested and we were al-

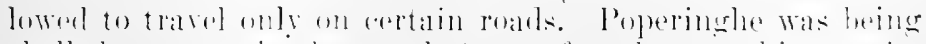

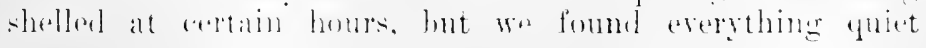

${ }^{17}$ Dien in line of duty: sere Appendix: Deceased Nurses. 
there. We proceeled on to Proven and finally reached our station, near St. Sixtes Convent in Belgium. Miss Fairchild went on with her train to No. 4 Casualty Clearing Station, and I to No. 61 Casualty Clearing Station. The next afternoon Miss MacDonald, of the New York Presbyterian Unit, arrived. From the way we greeted each other, the British sisters thought we were old friends, but we had not known of each other's existence until we met there at the front.

Surgical teams usually went up to casualty elearing stations for duty lasting about forty-eight hours. The nurses eared for men injured in a particular drive and then returned to the base. They were, therefore, instructed to travel with as little baggage as possible. Five weeks passed before the American nurses were able to get more than the forty-eight hours' supply of clothing which they had brought with them. During these weeks, they did their own washing after they came off duty and hung it to dry on tent ropes. The commanding officer happened one day to notice what was happening and sent a special car to the base to get additional clothing and the nurses' mail.

Miss McClelland deseribed the work at No. 61 Casualty Clearing Station:

There were seven surgical teams, five British and two American, besides the regular staff of officers and sisters. Four teams were assigned to day duty and four teams went on at night until a "push" began, when the schedule was changed and the teams would work for twelve hours, go off for eight and come on again for twelve. There were tive operating tables in a Nissen hut and two others in a large marquee. The two American teams were on duty at the same time and our tables stood next to each other in the luut.

When the first big arive came on, no one folt lilie going off duty while the men were still pouring in on us. One day we worken for twenty-four hours. stopping only for something to eat. After cleaning up our tables, we went to berl at 2 A.M., but were back on duty at 4 A.M. for another twelve hour shift.

We who were new to the front were greatly impresser at the efficient way in which the work was arried on during the drives. Those needing operation went directly to the presoperating tent: those suffering from shock were sent to the resuscitation tent; rhest ases to their section: oflicers to their tents... 
During a drive there were always ambulance trains on the tracks waiting to be louled. Only the worst ases were brought into the clearing stations; the others were taken directly onto the trains, which carried a certain number of cot rases and a rertain number of "walkers." As soon as its quota was complete, the train was sent down to the base.

Bairnsfathers picture of a casualty clearing station, showing the men on stretchers, most of them asleep, is very goorl. Even those who were horribly wounded slept the sleep of utter exhaustion.

I shall never forget those men; they never had a word of complaint. When you asked them if they were suffering much pain, they woukl answer: "It's drawing a bit, Sister." When a lad would say to the doctor who was examining him, "Do you think it will be a Blighty, sir?" the hope in that boy's eyes made your heart ache,-you knew how bally he winted to get back home, away from filth, agony and destruetion for a little while at least.

Miss MeClelland and Miss MacDonald worked together at No. 61 Casualty Clearing Station until Miss MacDonald was wounded August 17, 1917. After the latter had been sent back to Boulogne, Miss MeClelland was the only American nurse at No. fi1. She wrote of the consideration which the British nurses showed her:

As soon as Miss MacDonald left, our team began work again. I missed her a great deal and it was several weeks before another murse from her unit came to take her place. The Natron in charere of Xo. 61 was most kind and thoughtful to me. She would say every day: "Well, Miss America, havent you had enough and don"t you want to go back to gour hase?... I learned to molerstand and lore the English. My previous inteas of them hat been formed purely from Amerian history of the Revolutionary period. I shall never for'get the unselfish devotion of those British sisters to their work ant their lindness to me.

In the moantime, the nursing staft at No. 16 Creneral Hospital at Le Tréport had heen angmented on September 22.2 . 1917 , by the arrival of thirty nurses moder the leadership of Marie Edene Miss lomblep wrote that "durine the winter months, the intenes work slatekened, the atmies sitting tight in the tremehes with only desultery tighting, and the mumlere of patients in the hospital ran down as low as cight hundred on 


\section{HISTORY OF AMERICAN RED CROSS NURSING}

one day." The nurses then turned their attention to the amusement of their patients.

After the Treaty of Brest-Litorsk had been signed on March 3, 1918, the German High Command came into possession of huge quantities of material and large numbers of men which conld immediately be transferred from the eastern to the western theaters of war. As a skeleton for the new divisions to be formed from the troops released from the Russian frontiers, the German High Conmand withdrew from Russia all the soldiers between the ages of twenty-five and thirty-five and formed them into approximately sixty new divisions of 12,000 men each. This gave the Germans on the Western Front a numerical inerease of about 700,000 men.

The German High Command selected for the initial attack the point where the British and French lines joined in Picardy, between Mareoing, near Cambrai, and the Oise River. The British had taken over this battle-front from the French at the beginning of the year 1918 and were endeavoring to hold a line of about fifty miles in length with the British Fifth Army, which totaled about $170,000 \mathrm{men}$. With approximately 750.000 men, the enemy struck a supreme blow here at five o'elock on the morning of March 21, 1918. The line broke and the Allied cause hung in the balance while the fresh German divisions the following dars swept down along the road to Péronne and Albert, along the direct route from St. Quentin to Amiens and down the Oise River valley along two roads, one of which led to Paris and the other to the south of Amiens. On Mareh 24, the enemy took Péronne and crossed the Somme; on March 2.t, he captured Bapaume, Nesle and other villages; on March 26, he crossed the old hattle-line of 1916 in sereral places and captured Noron, Roye and Lihon. The next day saw the first pereeptilile signs that the German adrance was slowing up, but by the 2sth of March, the Germans had established a thirty-five mile salient towarls Amiens, thr Britisl base of supplies. Some sixty miles directly south lay Paris.

With the Germans cight miles from Amiens, the situation of No. 16 General Howpital becanne threatening. The big base was erowded with patients, the great majority extrencly serions casces. On one night, when there were 159 patients on the "dangerously-ill list," an rvacuation oceurreel whicl may well serve as a splemdid example of modern medical and nursing skill. Miss Dunlep wrotr: 
... With $2: 200$ patients crowded in the hospital, we were notified that a train which would bring down $3: 0$ patients would be expected to take away 300 others. This meant removing many ill patients from bed, placing them on stretehers and getting the beds ready for the incoming $3: 20$. At midnight with rain coming lown in torrents, with the floors of the wards eovered with the stretchers of the 300 ontgoing patients, with orderlies filing in with the first neweomers, with the friends of the 159 dangerously-ill patients arriving from lingland and with the lights suddenly going out all over the camp, our wards presented a scene never to be forgotten.

By the dim glow of lanterns, in this chaotic time when order seemed to be an imposibility, through the steady, quiet routine of ollicers, men and night nurses, the camp grew quiet, order was restored and the work was accomplished by three oclock, a feat that would have seemed appalling to us the previons year. 'Things that seem to stand out in my memory of that night are the fortitude and bravery of the severelywounder coming down; the patient, uncomplaining attitude of the sirk men suldenly taken from their warm beds and sent out into the rain; the efficient handling of the numbers of patients ly the men and the nurses; the quiet, repressed attitude of the friends of the dying.

On March 21, 1918, Base Hospital No. 10 sent forward Casualty Clearing Station Tcam No. 28, of which Isabelle Stambangh was the nurse member. After a hasty evacuation of the team from No. :2. Casualty Clearing Station at Marchclepot, near Péromue, Miss Stambangh was assigned for temporary duty at No. 42 Stationary Hospital at Amiens. Here on Mareh 2:3, 1918, she was severely wounded by a piece of shrapuel during an air raid. The attack was described by the officer in command of her team, Captain Elward B. I'odge. who wrote as follows:

We went hack to the hospital. Captain Mokenzie of the Canadian team with us, as we hall lealled that our murses, Miss Stambaugh and Miss Patterson, hat been working there

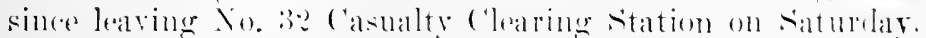

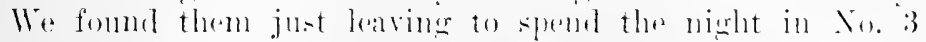
braneh. . . "'he first hombing flight had been ofer and it seened a goosl time to mose. The Mat lon herselle wats groing. White walking alenge a broal beulevand about half way to one destination, more bombers ande over and dropleal four bembs in our hisek. 
After we had extricated ourselves from the fallen glass and plaster, we found every one had a wound in leg or foot, except Captain McKenzie. At first we feared that he was killed, he was lying so quictly in the gutter. Later it appeared he was only stunned. An ambulance took us back to the place we had just left. The chaplain gave up lis room to the nurses, whose wounds were the most serious, and we found a place for Captain Dillard in a ward. Major Hodge arranged for remoral of our casualties by ambulance convoy next day to Abberille. The nurses were later evacuated to England. . . . ${ }^{18}$

Meantime in the Le Tréport Area, orders had come for transfer of all patients at Base Hospital No. 10 to Rouen. Miss Dunlop wrote:

This meant the evacuation of over ten thousand men in two or three days. As many of the patients had but small chance of living under the best of conditions, it seemed a heart-breaking thing to do. However, orders must be followed and irrespective of condition, they were sent back, though nine died en route. An order came at ten one morning that forty-five nurses should be ready. bag, bedding and baggage hy twelve o'clock to be sent out of the area. Fifteen mider Mrs. Eden were sent to the Cleveland Cnit at Ronen and fifteen under Miss Gerhard went to the st. Lonis Lnit also at Romen and fifteen under Miss M( Neal fell back to the New York Lnit at Etretat. After much hurry and bustle and much exeitement, not knowing whother we should meet again or what might lappen during their absence, they got off.

The remainder of the nurses were ordered to be packed up realy to cranate with heary baggage, light baggage or no baggage. Anxicty was in every heart but we marle little ontward slow. Time went on and the Germans were he'd. After two werks' suspense, a few patients were sent to us and we were toln to arry on without equipment. Little by little more patients (ame, more equipment was opened up until we were rmming full aparity agrain. (Onr nurses soon returnen and a new peare (rept into our hearts. The tide harl turned and the fationts coming down were no longrer silent. . . . Even the badly wounderl seemed in the best of spirits.

March 26 had been the decisive day of the Second Battle of

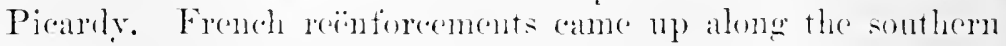
front and mited with the British at Moreiul. The same day saw the oreanization of a new British Army, under General

18 "Ilistory of the Pennsylvania Hospital Cnit in the Great War," p.

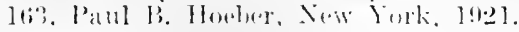


Sandeman Carey. 'This Army was composed largely of laborers, sappers and engineers and it was flung immediately into the trenches to hold the gap made by the Germans. For six days, it fought over unknown ground, with officers in charge of men they had never seen betore, until reënforeements could be brought up and the line marle permanent. The action continned during the first week of April, but the Germans failed to smash the sides of the Amiens salient and the Seeond Battle of Picardy ended with the German plan in the main frustrated and the British and French still united in strong defensive positions.

Out of the disastrous Second Battle of Picardy and ont of the subsefunent demoralization and almost complete defeat of the Allies came the mity of command of the entire Allied and Amerienn forces under Marshal Foeh,-for the first time in the European War, the Allies were in a position to present, in the words of Painlevé, "a single front, a single army, a single nation . . . the program repuisite for future victory." 1!

1)ring July, 1918, the Pennsylvania Unit received its first Aneriean patients, men of Pershing's First IVirision, who had been brigaded with the British. From that time on, Base Hospital No. 10 shared in the heavy work incident to the Allied offensive.

United States Army Base Hospital No. 21, organized from the staff of the Washington University Medieal School and several other hespitals of St. Lonis, Missouri, arrived in Ronen on . June 10, 1!)17, and took over No. 12 General Hospital, British Expeditionary Forees, a British base hospital which had been established in Ingust, 191t, ontside Ronen.

The ancient eity of Ronen was the eenter of the sonthern line of British base hospitals in France and the Rouen area supported fonlen hospitals and convaleseent eamps which maintained a total of twenty-five thousand beds for the British Experlitionary Forece. No. 12 General and two others of these hases, Xo. 1 Anstrilian and No. 10 General, were located on the race track two miles from the eenter of the eity. No. 12 Goneral Inspital, which the St. Louis Lnit took over, was the laregest of this group.

Mr. Free T. Murphy, of st. Louis, was direetor of base

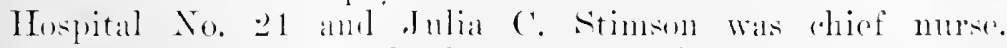

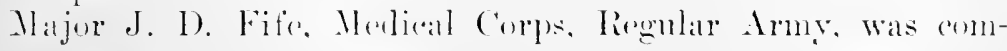

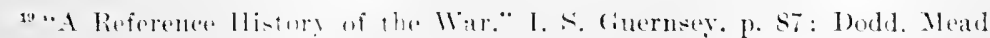
and compray, Sew York ('ity, l9:20. 


\section{HISTORY OF AMERICAN RED CROSS NURSING}

manding officer. The original nursing staff of sixty-five members was augmented in August, 1917, by the arrival of thirty additional nurses and in April, 1918, by Hospital Unit "D," which had been organized by the Red Cross in the City Hospital, Louisville, Kentucky. One hundred "casual" American Army nurses, sent overseas during the early months of 1918 for temporary assignment as need arose in British bases and evacnation hospital in the area between Bonlogne and Tronville, had their headquarters at Base Hospital No. 21 and the records of assignment, the reports and the expense accounts of each nurse while on various assignments were kept there.

British soldiers of the Imperial and Overseas troops constituted the patients of No. 12 General Hospital. The number of British wounded, light during the summer of 1917, increased swiftly during the Flanders offensive on Passehendacle Rirlge in October of that year. While the English Armies doggedly held the muddy Somme trenches during the winter of 19171918, medical cases filled the wards. The German drive on Amicns in Mareh, 1918, placed intense strain upon the nursing staff and Miss Stimson wrote of the heavy service:

We were all so hard pushed physically that Major Murphy wired for help and we received a mobile unit from the American Expeditionary Forees. The fifteen nurses were soon lost in the shuffle. They were all young, inexperienced, little things from Kentucky, who had not seen a patient since they had landed. Some of them were only twenty-one years old, fresh from small hospitals. It seemed a heart-breaking thing to thrust them into this mbelievable hell of a hospitil. . . .

A little later I had occasion to go down the lines and I looked in one of the huts to see how one of the little new nurses was coming on. Just before I got to the hut, a procession had come out of the door. two men carrying a stretcher eovered with the Inion Jack, then a second stretrher also covered by a flag, then our supervisor accompanying them to the mortuary. People along the line stood rigilly at attention and saluted as they passod. I went into the hut. The odor was terrifice for most of the cases in this hut have penetrating dhest womnds which drain. The little nurse was standing hy the stove stirring something in a cup. She was green-white and looked utterly nauseated. I dirl not dare to speak to her, for fear she would lose what control she had left. 20

m "Finding Tlemselves," Inlia ('. Stimson, 1). 215-216; The Maemillan (iv., 1915. 
In July, 1918, Mobile IIospital No. 4 was organized from the persommel of Base IIospital No. 21 and went forward with the advancing armies thromgh the St. Mihiel and ArgonneMense offensives of September and Oetober. A unit of twenty nurses with Ruth Morton as chief nurse comprised the nursing staft. Other nurses were detached from the big hospital on the race course and were sent forward for duty at casualty cloaring stations.

1)uring the eighteen months that Base Hospital No. 21 served at No. 12 General Ilospital, 21,543 patients were admitted. Of this number only 2833 were American casualties and they came from the 27 th and 30 th United States Divisions which were attached during September and October, 1918, to the British Fourth $\mathrm{Army}$.

Enited States Army Base Hospital No. 12, which had been organized by the Ameriean Red Cross from the nurses and sureens of the Northwestern Lniversity Medical School and of Cook County Hospital, ('hieago, was assigned to No. 18 General IIospital, British Expeditionary Forees.

Hr. Frederick Besley, attending surgeon in 1916 at Cook Comity Hospital, was director of the mit. Daisy 1). Ureh was chicf nurse. As was true of many other women holding executive positions in the nursing profession, Miss Ureh had been edueated an a school teacher. For nine vears she had been principal of a publice scheol in Munising, Michigan. She entered the lllinois Training sehool for Nurses in 1910 and after craduation was rengaged in private duty mursing and later institutional work at cook comuty Hospital. This history is indrobed to her for the reports which give the experienees of Basce IIospital No. 12.

Miss I rell wote of the embarkation of the Northwestern Unit:

The entire mit sailed Saturdar, May 19. 191\%, at 2 P.MT. on the s. s. Mongenlid. Thepe were the nsual precantions, no lights. Boat drill with lifre preservers. assignment to life loats. In spite of unrestricted submarine warlare, arery one was in crood spirits.

Sumlay moming worel went thromen the boat that a gun

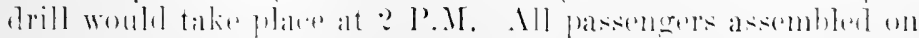

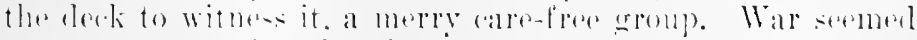
remote. "xerpt for the three grim sons on the Vongolia, silent and mukgled in the sumshine on the walm sat. 


\section{HISTORY OF AMERICAN RED CROSS NURSING}

A target was throin overboard and the drill began. Suddenly a defective shell exploded prematurely. Edith Ayres and Helen B. Wood were instantly killed. Emma Matzen received two serions flesh wounds.

The nurses showed presence of mind and self-control; there was no confusion, no hysteria. Enough nurses to take eare of the immediate situation helped carry our dead and injured into the nearest cabin. The others kept quietly out of the way.

Instructions by wireless for the Mongolia to go back to New York to exchange the ammunition made it possible to send our dead ashore. Miss Matzen was taken to a hospital in New York and two monthe later rejoined the unit in Franee.

The Mongolia sailed again on Tuesday, May 22. Except for a submarine attack at noon on June 1, the trip was uneventful. From London, the unit entrained June 11 for Folkestone. crossed the Channel and from Boulogne traveled by lorry to No. 18 General Hospital, British Expeditionary Forces, at Dannes Camiers.

No. 18 General Hospital was located on a hillside in Picardy, within a quarter of a mile of the British base then being maintained by the Peter Bent Brigham Unit, and was housed largely under canvas. Of its total capacity of eighteen humdred beds, only one hundred were placed in wooden huts. Units of four large tents, marques, grouped together to form a ward aceommodating forty-four patients each, housed the balance. Both the tents and the huts were lighted by electricity, but running water was available only in the kitehens, operatingrooms and wooden buildings. i single telephone served for the entire camp. Cinder paths bordered by neat rustic fencess led from one tent to another. The "Swiss Xiary" of the British Army, comparalle to the Fatigne Squad of Tncle Sam's tromps. kept the gromends in order, pruned the old-fashioned binglish rose bushes and cultivated extensive regetable gardens. In the wards, the Ameriean nurses preforred Secoteh orderlies berause . Tock made a more careful and srstematic helper than did 'lommy ittins.

The irrepressille British soldiers were, however, a constant source of ammorment to the Ameriom nurses. Miss Lerch gave in a regurt lits if the dialogute between the langhter loving patientis and nurses: 
Tommy: "Sister, your brogue is rippin'?"

Sister: "Oh, I thought it was you who had the brogue!"

Tommy : (after listening to a long dissertation on how to win the war) "Yes, you Americans will win, all right. You'll talk Fritz to death."

From the records available at National Red Cross Headquarters, this general deduction may be drawn about the British soldiers: they keenly enjoyed writing verse. This tendency may be attributed to the fal that they possessed either more natural talent for rhymed expression than did the wounded of other nationalities, or less reticence in showing the fruits of their ready pens. Miss Urch's report contained the following example:

Who put me in my little bed, Then placed nice dressings on my head And "Ha re sweet dreams tonight," she said?

The Sister!

Who talks to me in cheery tones

'Till I forget my aching bones,

Until 1 cease to utter moans?

The Sister!

Who tries with all her might and main

To make me strongr and right as rain,

That I may fight the IIm again?

The sister!

The location of No. 1s General Hospital possessed many advantages. The sloping hillside afforded exeellent drainage. the wards were wedl ventilated and the riew, moreover. was one of great beanty. On one side were the sand dumes and the ('hamel, on the other, the orehard-studded hills and rich pasture lands of Pieardy.

In the winter, however, this location was less pleasing. The patients and the personnel of So. 18, leonsed under canvas, were mereilessly exposed to the eold winds and rain of the harsh

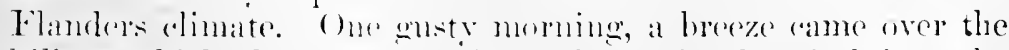
hilltop which threatenes to hlow the entire hospital inte the

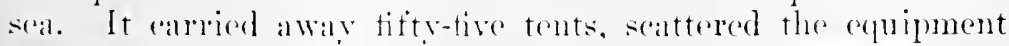
broadeast and expered the siek and wounded to the drenching 


\section{$4 \% 2$ HISTORY OF AMERICAN RED CROSS NURSING}

rain. "In their zeal for their patients," wrote Miss Urch, "the nurses seemed endowed with superhuman strength. I saw one, single-handed, drag bed, patient and all over the rough ground to the nearest shelter."

The location of No. 18 General Hospital possessed a second grave disadvantage, thongh the nurses were not prone to regard it as one. The big British hospital camp was only forty miles from the front and enemy aviators often visited it. Miss Ureh wrote of the air raids:

In the early spring of 1918 , persistent disquieting reports of the Boche's intent to destroy our camp were afloat. Great preparations for such an attempt were made. "Abris" in the shape of trenthes were dug by German prisoners. The tents and huts were sandbagged. Special instructions were given as to what to do in case of a raid. Upon signal all helpless patients' beds were to be lowered to the floor by folding under the legs of cach cot. One medical officer wrote in the order book, "Flatten all helpless patients." Other wounded, nurses and men were to go into the nearest abri. One nurse stayed with her patients who were so tied up to frames that their beds could not be lowered. When the hum of Boche engines and machine-gun fire plainly indicated that they were overhead a Tommy with a fractured femur and one broken arm called, "Sister":" She hastened to his side. He pleaded with her to go to a place of safety. When she assured him she was not af raid, he tried with his one good arm to push her under the adjoining bed.

Many of the nurses sat on the hillside at Damnes Camiers and watched the destruction of nearby Etaples. No member of Base Hospital No. 12 was, however, injured.

Before summarizing the value of the service rendered by the six American balo hospitals assigned to the British, it mar be of interest to include a statement of the size and strength of the British military nursing service, both professional and volunteer. The official nursing strength of the British Empire during the World War was divided between three organizations: Queen Alexandra's Imperial Military Nursing Service; the Territorial Fore Nursing Serviee; and Queen Alexandra's Naval Nursing serrice.

Florenee Nightingale may well be ealled the first British Ammy nurse. Following her historic overthow of military mursing traditions during the Crimean War, the War Ottice 
employed trained women nurses in the Boer War and in military hospitals at home and abroad in time of peace. The Govcriment nursing organization in which these women served was called the Army Nursing Service.

In 1!(). , the Army Nursing Service was reconstituted as Queen Mexandra's limperial Military Nursing Service under a Nursing board of which the Matrons of two civilian hospitals and the Matron-in-('hicf of the Queen Alexandra's Service were members. The grades were Statf Nurse, Sister, Matron, Prineipal Matron and Matron-in-Chief. Candidates were required to be within twenty-five and thirty-five years of age and to hold the usual three years' certificate of training, althongh the wording of this clause made this certiticate not absolutely compulsory; a candidato might be admitted withont certificate provided the Matron-in-Chief satisfied the Nursing Board that this applicant was fitted as regards edncation, character and social status for admission. Before Nisters could be promoted to the grade of Matron, they were required to pass an examination and to give practical evidence of administrative and teaching ability. Pensions were granted to nurses of the Service after twenty years' nembership or at the age of fifty years.

In time of war, the membership of the Queen Alexandra's Imperial Nursing service was increased both by its own Reserve and by a Civil Iíspital lieserve. Previous to the declaration of hostilities in 1914, the War Office laad approached the civil hospitals throughout the Kingdom and had asked each institution to employ a cortain number of trained nurses who would

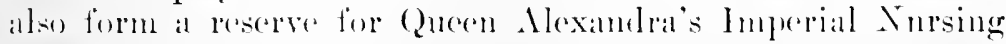
service. These nurses were called into the field in Angust, $191+$ and were later dratted into the ofticial Rieserve.

The Territorial Foree Nursing Nervie was formed in 1910 primarily for home servioe in the twenty-there territorial areas of the lipitish Empire. Nurses in cateli of these localities had pherlged themsedres to serve when their mative territorial fores wore molhilized. This mustreroll wats revised anmually so that upon the onthreak of wald, the numbers were really for inmediate mobilization. When it was reosgnized during the tirst month of antliet that (2uren Alexaludral's Imperial Mlilitary Nursing Servier was insufiedent in mumbers to mest the demands that womld he made upon it, the War ()tilee permitted

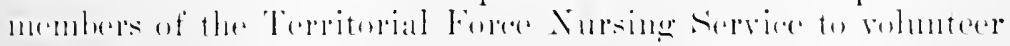

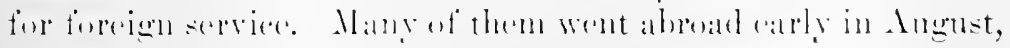


1914, and their places at home were supplied by new reeruits. The Territorial Nursing Service was directed from the War Office in London and had its own Matron-in-Chief. It also had a Principal Matron for each territorial area, who was responsible for the recruiting of the staff and for the conduct of all territorial corps which might be opened in her district.

Queen Alexandra's Naval Nursing Serrice was a small standing service, with approximately a hundred nurses in times of peace. These Sisters acted as superintendents of nurses and trained corpsmen for sick bay attendants. This organization was augmented during the war.

Dame Ethel H. Becher, G.B.E., R.R.C., was Matron-in-Chief of Queen Alexandra's Imperial Military Nursing Service during the European War. Her headquarters were located at the War Office in London and she worked in close coöperation with the Director General of the Medieal Department of the British Army, Sir Alfred Keogh. Her position was one of dignity and power and at public and Court functions when visiting nurses were presented to Royalty, Miss Becher in her bonnet and searlet cape was a commanding and pieturesque figure.

Dame E. Mand MeCarthy, G.B.E., R.R.C., was Matron-inChief of the Q.A.I.II.N.S., British Expeditionary Forees. She was considered a member of the IIeadquarters staff and her offices were in elose proximity to the headquarters of the Director General of the Ifedieal Department, I3.E.F. All orders for movements of nurses went forward signed by her and counter-signed by the Jirector General. She was furnishen with a private car and in it she malle supervisory visits from one hospital to another, lunt in the case of the six American base hospital mits assigned to the British Army, she did not take up disciplinary or professional problems miless they were connected in some way to British Army regulations. In a letter dated March 1, 1918, to Miss Delimo, Marthal Rumsichl, then chief murse of the American Red Cross in France, wrote:

The position of Natron-in-Chice, B. E. F., is one of great

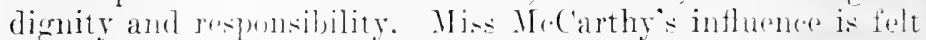

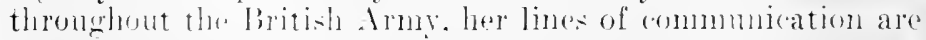

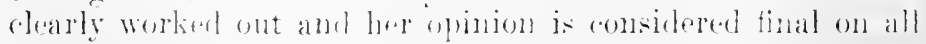
matter's relatiner (1) the nursine situation. 'lhe british have maintainen a hige surve for on loner that they have onterown many of the diftenttine with which we are now strugerling. 
On August 1, 1914, (Queen Alexandra's Imperial Military Nursing Service had numbered only 463 ; its effective strength on November 1, 1918, numbered 7710 members, an increase of tifteen hundred per cent.

The Territorial Forec Nursing Service numbered in August, 1914, 2783 and in November, 1918, 5059, an increase of one hundred per cent.

During the European War, 7710 regular members of Queen Alexandra's Imperial Military Nursing Service saw active duty, over 3000 of them at home stations and 2000 others in France. The remainder sored at stations in Italy, Gibraltar, Malta, Saloniki, Egypt, East Africa, Mesopotamia and India."

The regular members of the Territorial Foree Nursing Service on dinty during the European IVar were distributed in proportionate nmmbers and in locations similar to those of members of Queen Alexandra's Nursing Service."21

In ardition to these 12.769 members, both the official nursing organizations for the British Army employed partially trained and nutrained women whom the Wiar Otfice designated as Military Probationers. They were recruted by the War Office and after a short experience in civilian hospitals, were assigned to assist British Sisters in military establishments both at home and abroad. They totaled 10,s!) $t$, over two-thirds of whom served at hone stations. ${ }^{21}$ Including regulai and reserve members of Queen Alexindra's Imperial Military Nursing Service and of the 'lerritorial Forees Nursing' Service, and including partially trained and untrained women employed in these organizations, the muncrical strength of these two govermmental mursing serviees during the European $\mathrm{W}$ an approximated $2: 3$.titit women. Miss MreCathy commented upon these numbers:

These figures deal with Queen Mexandra's Imperial Mili-

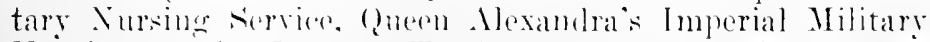
Nursing servie lieserve. Territorial Forese Xursing service and untrainel and partially trained women attached to the

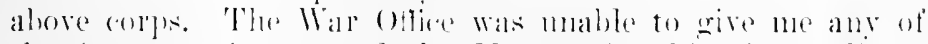

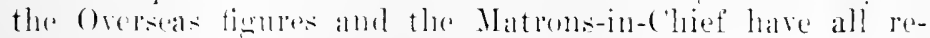
turned to their lominions.

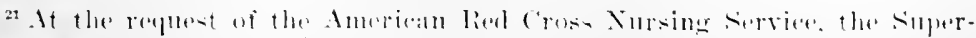

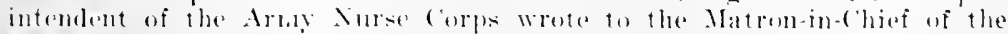

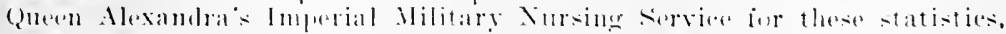

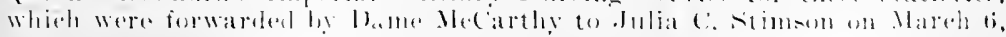
$1 ! 1311$. 


\section{HISTORY OF AMERICAN RED CROSS NURSING}

The British Red Cross had large numbers of nurses, both trained and untrained, in the United Kingdom and in many of the theaters of war. ${ }^{22}$

The British military nursing system also included, a large service, both professional and volunteer, which was conducted by the British Red Cross. The trained nurses employed by this society were not members of the two official services, but did war nursing in hospitals and convalesceut homes established by the British Red Cross and the Order of St. John of Jerusalem in England. In the matter of assignment of unrses, the British Red Cross and the St. John's Ambulance served in somewhat the same relation to the British Army Medical Department as did the American Red Cross in France to the Chief Surgeon, American Expeditionary Forces. At the outbreak of the war in 1914, both the St. John's Ambulance and the British Red Cross began to enroll nurses for work in France and Belgium. When the Joint War Committee, under which these two organizations were united for war service, cane into existence, the two Nursing I)epartments were put under one head and Dame Sarah Swift, late Matron of Guy's IIospital, was appointed Matron-in-Chief. A Principal Matron, Nora Fletcher, was shortly appointed in France and all nurses proceeding to France for service under the Joint War Committee were sent to her and were assigued by her to various hospitals and homes. ${ }^{23}$

The repuirements for services as uurses under the Joint Committee were set forth in the Reports by the Joint War Committee and the Joint War Finance Committee of the British Red Cross and the Order of St. John of Jerusalem in England:

\section{Rules for Nurses}

1. You must hold a rertificate of three vears' rensecultive training of a (immeral Ilospital of not less than 50 berls and must be woll porommentad by your Matron.

2. Nurses not up to the required standard of traininge ob-

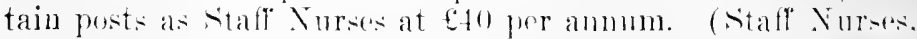
that is, those with two rears training, women's and bhil${ }^{22}$ Sine letter written by E. M. Ifecartly to J. C. Stimeom on March 6. 1920.

2" Sere Represts ly the foint War Commitere and the . Toint War Finanee

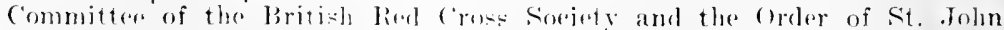

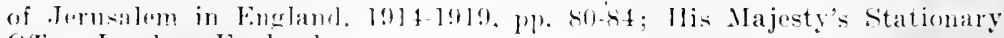
Office, Lomblon, Enerland. 
dren's hospital and fever training, were paid at the rate of $\mathfrak{f} 40$ per alumm.)

3. If your hoilth rertifioate and roferencos are satisfactory, you will be registered on the list for either home or foreign service. For forngign service, a grood knowledge of French is desirahle. All murses must be equally willing to serve on night or day duty at homo or abroad.

4. If youl are aceepted, it will be necessary for you to be inoculated agriust enterie and also to be raccinated, if not done within the last seren years.

5. Yon will be required to sign an agreement to serve in a home hospital for a period of six months at a salary of one guinea per week, insurance, outdoor miform, laubdry at rate of : is. 6ol. por woek (unless otherwise provided) ; travelinge expenses from Lombon. board and lorlging will also lo provided. You will be loclged at a hostel between engagements.

6. You must provide your own indoor uniform. blue cottrom (or use what you have) and when on duty must wear the barlege. which will be provided.

[Here follow further details regarding salary, sick leare. application forms. ete. $\left.\right|^{24}$

After the candidate had filled out the "Form of Application," she was reguived to appear lefore a Selection Board. After a personal interview, here referenees were looked up and if sho had filsod all repuirements satisfactorily, she was engaged by the Mitrom. At this time. each murse was given the option of signing a contract.

Trained murses to the number of filss served during the European War undere the Joint Committere of the British Red ('rose and the () relare of st. John, 4730 of them in home service and the others in hespitals in France, Bolgim, Egrpt, Russia. Siberia, Serbia, Montenegro, Rommania, Italy, Holland and

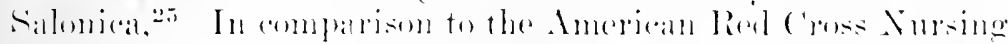
Serrifere it is interesting to note that :3f.s of this total mumber of diso were assigned to the Qnecu Alexandrats Imperial Mili-

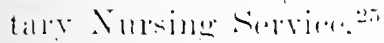

The greatest mumerieal strength of the British lied Cross

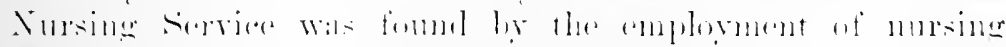

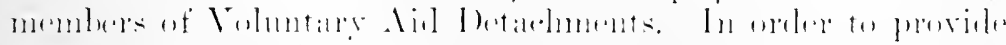
fursomel to supplement the military medieal oreanization of

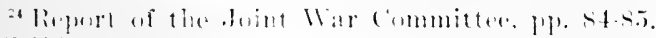

$\because$ Mrir... p. 93. 
the 'Territorial Force on home service, the War Office had in 1909 issued a "Scheme for the Organization of Voluntary Aid in England and Wales." It was suggested that Voluntary Aid Detachments be formed, to consist both of men and women. The Women's Detachments were to be employed in forming railway rest stations, where meals and refreshments for sick and wounded could be prepared and served; and in taking temporary charge of severe cases unable to continue their journey." 28

In 1910, a revised issue of the "Scheme" was authorized and shortly afterwards the Voluntary $A$ id organization was extended to Scotland. Women members of these Detachments were taught First Aid, lome nursing and in many cases hydriene and cookery. They "practised the work of a hospital ward; they earmarked buildings suitable for temporary hospitals and learned the methorls of improvising or obtaining the necessary equipment and supplies.

On October 14, 1914, sixteen Voluntary Aid Detachment members, drawn from two London detachments with two trained umrses in charge, were sent to France with the sanction of the War Office. Dame Katherine Furse was in charge of the group. At Bonlogne, they organized a rest station, took over three wagons and two passenger coaches and eonverted them into a dispensary, a kitchen, stores and quarters: within twentyfour hours they had received and fed one thousand wonnded with such success that the experiment marked the beginnings of the broad and extensive later developments of the British lied C'ross oversras muder Voluntary Aid Detachments.

After about three months at Boulogne, l)ame Furse returued to London and took charge of the Voluntary Aid lepartment at bevoushire House and Dame Rachel Crowdy suceeseded her in France, later becoming Principal Commandant of Voluntary Aid I)etachnents in France.

r. A. I). nursing members were employed in hospitals establishod by the British Red Cross and the Order of St. John and in base hospitals maintained by the Modical Irepartment of the British Army. On February 1, 1915, the War Offire wrote that "in view of the faret that a largely inceresed supply of fully trained nurses will be repuired for the mecessary rixpansion of military hospitals at home and abroad, it is sug-

${ }^{26}$ Report of the Joint War Committee, p. 189.

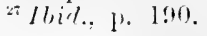


gested that members of recognized Voluntary Aid Detachments might advantageously be employed and so enable us to release a number of fully trained nurkes for duty in new Ilospitals." 28 At this time, the War Office made the following suggestions as to the conditions of employment of nursing members of Voluntary Aid Detachments:

1. The selected members must hold the certificates for home nursing and First did and must be thoroughly recommenderl.

$\therefore$. They will be required to work under fully trained nurses and will te under the direct control of the officer in charge and the Matron of the hospital.

3. They should be between twenty-three and thirty-eight years of age.

4. They should be required to live in quarters provided for the nursing stati of the military hospitals under the control and supervision of the Matron.

5. They will be required to allhere strictly to the time tables in force in military hospitals and to the regulations and standing orders for Q.A.I.M.X.S.

6. They will have at all times when on duty to wear the washing uniform of their Detachments.

7. They will be appointed for one month on probation,then if recommended. they will be required to sign an agreement to serve for one year or for the duration of the war.

8. The engagement of Voluntary Aid letachment memhers may be terminated at any time if found unfit in any respect for service.

On February 19, 1.215, a second letter was sent by the War Office which sugerested that nursing members of Voluntary

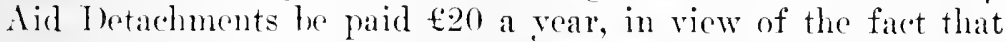
fully trained certificated Staff Nurses received $\mathfrak{E} 40$. This latter added that "arrangements will be made for aceommodation and an allowance for board and washing for each member," with E'1 per cpuarter for the upkeep of uniforms. ${ }^{29}$

The Reports by the Toint War Committee and the Joint War Finance ('ommittere of the British Red Cross and of the Order of St. John for 1!14-191! state that the total number of nurs-

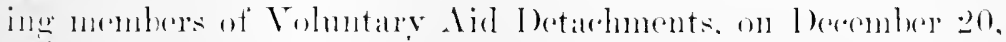
1919, was 17,367. (of this number. seti were homorally mentioned in dispatehes and 320 roceived nursing decorations. One

" Repurt of the Joint War Committee. p. 192.

$=$ Hirl.. 1. 19:2. 
hundred and twenty-eight of them died in line of duty and "it is known," state the Reports, "that over one hundred other V. A. D. members, not working directly under the V. A. D. Department, also laid down their lives." 30

During the summer of 1916, Miss Maxwell and a personal friend, Irene M. Givenwilson, who later beeame curator of the Red Cross Musem at Tational Headquarters, risited sixty-seren French, British and Belgian hospitals situated in Paris, in England, in Belgium and at rarious places near and at the Western Front. Miss Givenwilson had taken the nursing diploma of the German Red Cross at Bonn, Germany, a course of elementary nursing in Holland and another in England; from November, 1914, to March, 1915, Miss Maxwell had allowed Miss Givenwilson to work in the wards of the Presbyterian Hospital, New York City. With her previous knowledge of foreign languages, of the voluntary nursing services of Europe and of the nursing profession in the Lnited States as she had seen it at the Presbrterian Hospital, Miss Givenwilson was in an excellent position to evaluate volunteer nursing abroad. Moreover, Miss Maxwell edited both the report and the diary which Miss Givenwilson submitted to National Headquarters at the close of the trip.

Miss Girenwilson's report included the following statement regarding the nursing members of Yoluntary Aid Detachments:

We marle many inquiries as to the efliciency of the T.A.D. nures at British Red Cross Healquarters and also of the Matrons in charege of the military and auxiliary hospitals. The unanimity of opinion on their nefulness and willingness to work under any conditions impressed ns as remarkable. . . . There was only one criticism offerent.-that a presions training of six months in a civil hospital is under all rircumstances rery desirable and woukd render the nursing members more useful and aphble of arcepting some responsibility in the wards. 'The Army nures are already so overworked that they are mable to train their subordinates in the wards. This lack of trainine leads to two difliculties: firet. the members find it hard at first to arlapt themselves readily to the necessarily striet disedpline of military and auxiliary hospitals in time of war: serond. through inexperience. they are apt to consider the whole prative of nursing romsists in the dresing of wommls and that whon this has hecen mastered. they are of equal proficingey with fully trained nurses.

${ }^{3 n}$ Report of the Juint War Committee. p. 203. 
These difliculties could be easily overcome by a regulation enforcing a definite periorl of training in a civil hospital for any member of the lied Cross who aspired to be a nurses' aide in a military hospital in time of war. ${ }^{31}$

With this total strength of well over 40,000 trained and untrained women, it may readily be appreciated that the 600 Aneriean nurses who served in the british base lospitals at Ronen, Dannes ('amiers, Etretat and le Tréport made slight addition to the numerieal strength of the British mursing forces. The institutions which they staffed did, however, ocenpy highly important positions along the southern line of British hospitals in France and the American nurses and surgeons eared for approximately 300,000 British and Colonial soldiers. Moreover, the arrival of these six mits in England and France during the third month of the participation of the United States in the Workd War disl much to raise the morale of the British and French Armies, in that the eflieient personnel and the splendid equipment of these pioneer base hospitals were a timely guarantee to the weary dllies of the reeinforcements soon to come.

The experience of the Ameriean Army reserve nurses who sorved in these British bases was an illuminating one and fortmate indeed did these American Red Cross nurses count themselves. The disadrantages of assigmment to the British Expeditionary Forees were of minor nature. Miss Stimson summarized them:

C'hief marses of these muts had the doulle difireulty of functioning as an important part of an American Army organization without previous experience or knowledge of Army Ways and at the same time had the ditheolty encontered in taling orer aftor a few days apprenticeship. the position of Ilatron of a british hopital in full operation. and from which the British nursing personnel was withelraw almost

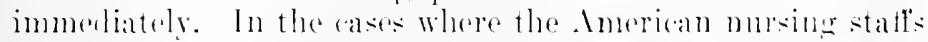

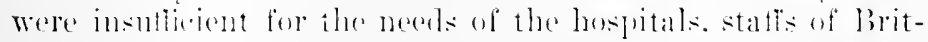

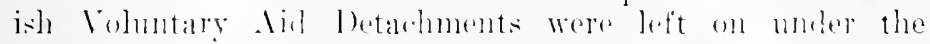

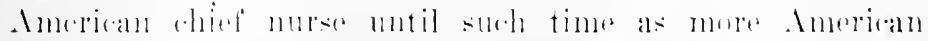

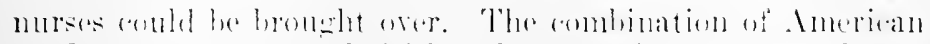

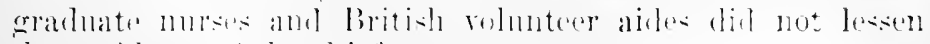

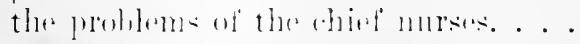

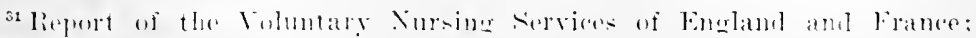

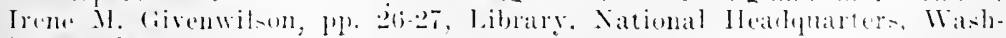
ing(1)1, 1). (. 
Our second difficulty was lack of "camp kits," without which no English Sister nor V. A. D. goes anywhere. When they withdrew, completely barren rooms confronted the dismayed Americans. A combination of British courtesy and generosity on the part of the War Office and the American Red Cross Chapter at London came swiftly to our rescue and supplied us the necessary articles. ${ }^{32}$

Perhaps the greatest difficulty which the Ameriean nurses met during the first months in the field was the absence of an authoritative head of the American Army Nurse Corps in France. Questions arose as to the replenishment of uniforms, the issuance of more adequate equipment and such other matters; to disciplinary problems such as transfers, resignations and the conduct of nurses when off duty. Neither Miss Becher nor Miss MeCarthy could undertake to settle them. Martha Montague Russell had joined the American Red Cross Commission for France in August, 1917, as the official representative of the Nursing Service at National Headquarters, but her only possible relation to the members of the Army Nurse Corps then in France with the British and American Expeditionary Forces was of a purely unofficial nature. She termed herself a "maiden aunt" rather than a mother invested with parental authority. The Surgeon General accordingly assigmed to the staff of the Chicf Surgeon, A. E. F. in France, Bessie S. Bell, of the Army Nurse Corps. Miss Bell was a graduate of the Boston City Hospital and had been chief nurse of Walter Reed Hospital. Washington, D. C. She arrived in Paris in November, 1917, and for a ycar served as Chief Nurse of the American Expeditionary Forces. She was largely engaged in organization work incident to the assignment of nurses to American base hospitals, evacuation and mobile hospitals and forward professional teams of the C. S. Medical Department in Franee, so she did not have much time in which to visit the well-established and smoothly-ruming British bases then staffed by American nursing persomel. Moreover, the American Expeditionary Forces did not furnish the Chief Nurse special transportation facilities during Miss Bell's incumbeney of the office. The chief nurses of the Aneriean hase hospitals assignerl to the British Experlitionary Forees were thus thrown larely upon their own resomeses as regards the nursing sirvice. Howerer, they were in the main

"History of the Nursing Activities on the Western Front during the War Period," Julia C. Stimson, p. 5. 
strong women and were well able to meet with sound judgment the different situations which arose.

As to the advantages of service in the British Expeditionary Forees, nurses assigned to these mits experieneed none of the idleness and monotony born of light work which nurses of the American Expeditionary Fores encountered during their first summer in the field. The British troops ocenpied, during 1917 and 1918 , important and almost constantly active sectors of the Western Front, so both the surgical and medical cases were of great professional interest. The American nurses assigned to the British bases shared, moreover, many privileges aceorded the British Sisters, which had not yet been granted the younger Ameriean eontingents. Miss Stimson summarized them:

Advantages of leave; are during sickness at splendidlyequipped "Sick Sisters" Hospitals" and convalescent treatment on the coast was given to the American nurses. Althongh the ['nited States Army paid the nurses' salaries, the British put them on the same mess allowance as their own murses and many were the hours during which ehief nurses struggled with board at twenty-five shillings a month, laundry at six shillings a week, field allowance and other perplexing prohlems.

This mess allowance, although it entailed considerable extra paper work for the chicf nurses, proviled the hospital dietitian with availahle funds with which to purchase green vegetables and other artieles not included in general rations.

British nurses oceupied a position of great dignity and respect. The position hold by Ameriean Army nurses as reagrds rank will be treated in detail in a subsecpuent chapter, hit the following amment npon the status of the British nurse, which was malde by Miss IIall, bears directly upon the British military nursing sistrm and is therefore included:

The British mores did not have rank as officers of the British Army. They dicl, howerer, have a place in the British Amy which was dienified and enviable. . .

In erery arra preseled over by a Deputy Director of Medical serviee, there was a I'rincipal Jatron whese area inchemen all the morses in the area corered by the bejuty

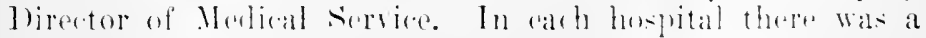

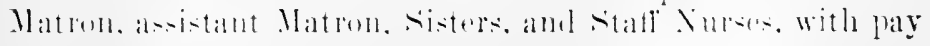




\section{HISTORY OF AMERICAN RED CROSS NURSING}

and allowances according to their status as just named. In the hospitals, a definite number of non-commissioned officers and men were assigned directly to the Matron to act as ward masters and orderlies. She had entire control in the assigning of them to huty, arranging their time, eic., and the position of the Matron and those under her was so strong that there was never disobedience or disrespect towards them. In all matters of living. travel and social functicns. the British nurses were given all the respect and rights of officers; sometimes even given preference over officers. ${ }^{33}$

On June 13, 1917, three weeks after the arrival of United States Army Base Hospital No. 4 at Rouen, Colonel (later General) A. S. Bradley, the first Chief Surgeon of the American Expeditionary Forees in France, opened in the Rue Constantine, Paris, the hoalduarters of the United States Army Medical Corps in France. With him were Colonel Francis Winter and Colonel Merritte $\mathbb{W}$. Ireland. On the same day, the Ameriean Red Cross Commission for Europe landed in Bordeanx. In view of the parallel development of the medical serviees of the Ameriean Expeditionary Forees and the American Red Cross, it is of interest that these organizations arrived in Paris at practically the same time and began their development anid the sime difficulties.

War mursing with the American Expeditionary Forces in France consisted of duty in the zones of the base and of the advance of the Lnited sitates Armies. In the zone of the base. to which this portion of this history relates, murses serverl in base hospitals ratablished along the principal lines of communication. Comnecting the zone of the base with that of the alvance were the hospital trains of the U. S. Army Modical Corps in France: murses served on these sanitary trains. In the forward areas, murses served in evaenation and mobile hospitals and on profesional teams. Further, sick and womded soldiers of the Annerion lixpeditionary Forees were aned for in military lospitals astablished by the Ameriean Red Cross,

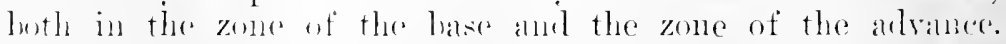
Moreover, American lied Cross nurses were evon detailed to dutr in hospitals of the Freneh servies de simté in order that Aneriann womederd of the divisions which General Pershing

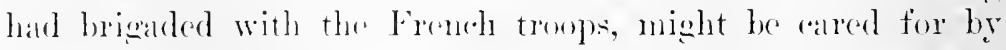

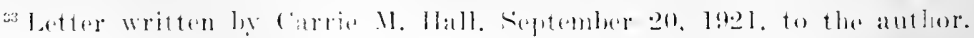


Aneriean murses. As these several types of assignment differed greatly, they will be treated eatch one in separate sections of this history. This section will set forth the arrival of the early Red Cross base hospitals in France and will deseribe the experiences of reserve murses in tle zone of the base.

Inring the first cight months of the participation of the United States in the Europealu War, April through Norember, 1917 , only eight base hospitals were on duty with the American Experlitionary Forees in France. The American Army was expected in 1917 to ocenpy the sontheastern sectors of the Western Front, the area lying roughly between Toul and Belfort. The American line of comminications was developed to extend from Bordeaux and St. Nazaire to Dijon and Is-surLille and from these eenters to radiate up through the areas established for divisional training near Neufchattean and the Toul-Belfort seetors. The Chief Surgeon aceordingly located the hospitals of the American Expeditionary Forees along this line of communieations. II assigned the first base hospitals to Bazoilles. Chanmont, Vittel and Contrexéville as forward eenters of the zone of the base; to Limoges. Dijon, Vichy and Sarenay as bases in the rear; and to Bordeanx and St. Nazaire as embarkation centers from which sick and wounded soldiers were to be returned to the United States.

In diffienlties met and in aceomplishment, the experiences of the first eight Ameriean base hospitals in France were so nearly identical that a detailed pieture of the first mits will serve for all. In collecting the source material for this seetion, National IIeadquarter's sent a request, oftentimes repeated, to all chiet nurses of hase lonpitals, asking them for a summary of the experiemeses of their mits. Some of the chiof nurses failed to reppond: others sent in reports of numsnial interest and marked historical value. In exeerpts from these reports, to be anoted later in this portion of this history, may clearly be seene the generial pollicies of the Aledical Corps in France. The efferet of these poliedes npon the mursing situation in the Lnited States will alon le set forth.

Inited Stattes Army liase I[nepital No. 18, organized at

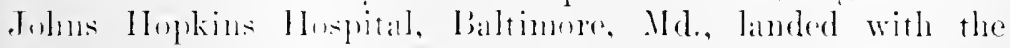

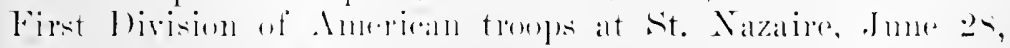

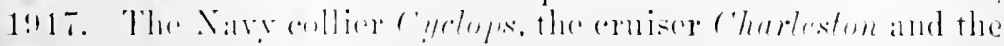

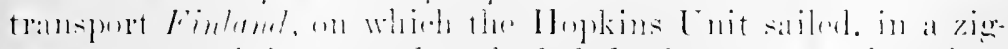

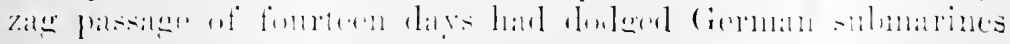




\section{HISTORY OF AMERICAN RED CROSS NURSING}

which were on their mettle to catch the first American contingent.

Dr. Winford Smith had organized Base Hospital No. 18, but the Surgeon General elaimed his services at Washington. Dr. John M. T. Finney led the unit into the field. Bessie Baker was chief of the sixty-four nurses and of a second unit of thirtyseven "casuals." Miss Baker was born in Maryland. Following her graduation from the Robert Garrett Hospital for Children in Baltinore, she entered the School of Nursing at Johns Hopkins Hospital. She later became assistant superintendent of nurses at the Women's Hospital in Baltimore. She returned to Johns IIopkins in 1912, as first assistant superintendent of the training school. Although much of her life had been spent in Maryland, her brisk humor, reflected in her twinkling brown eyes, her energy and her enthusiasm ealled to mind the Westem rather than the Southern temperament.

Miss Baker described the reception of Base Hospital No. 18 at St. Nazaire:

During the afternoon we received a visit from the general then in commant of the Medical Corps of the American Expeditionary Forces [General Bradley|. He remarked that up to twenty-four hours before he lad not been aware of our existence, much less our expected arrival. An immediate survey of the surromding country was necessary, if he was to find a place whereon we might lay our heads.

'The following morning brought the parting from the 18th Reginent, our companions of the royage. It was hart to say the last word. Many of them we knew we shonld never sce again, unless they were brought to us wounded and miserable.

'To their cheers, we filed down the gang-plank to the station and entrained for the village of Savenay. 'The quiet peacefulness of that first glimpse of the French countryside, with its old windmills and rharming peasant homes: The wild flowers were riotous, (rimson poppies, purple heather, yellow and white daisies.

Thitil war made it a garrison of hospitals, the little village of Saremay, lowated on the orrhard-covered hills of Brittany, had led a drowsy and peaceful existence. The persomel of Base Hospital No. 18 was temporarily assigned there until a permanent lospital eomld be seemred for them neatrer the

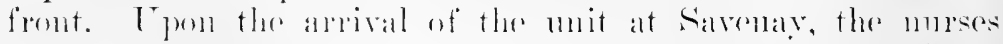
were billeted in a domintory of a large nomal sciluol for boys. 


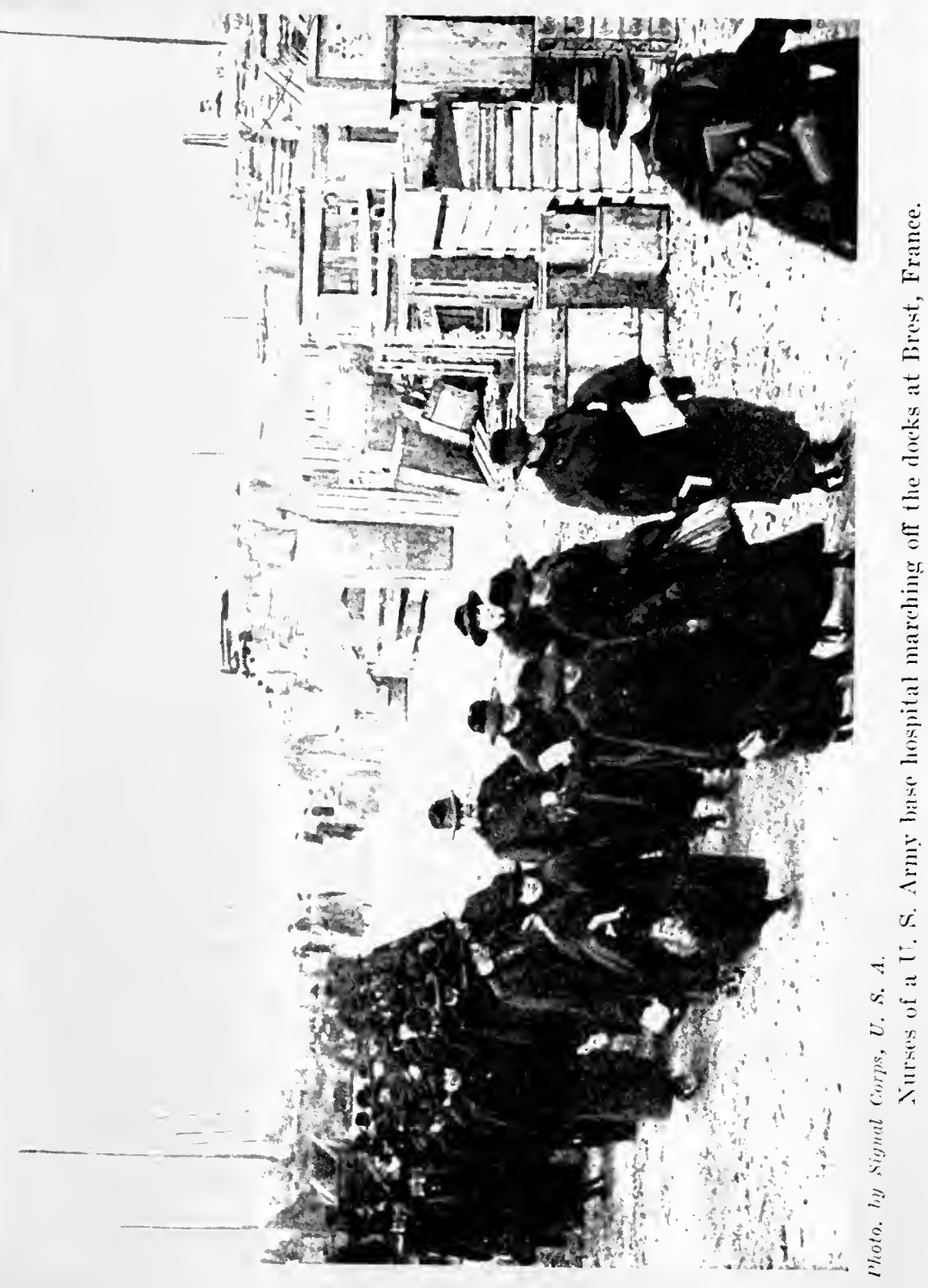



The democracy of field service soon established itself. "In our single public wash-room," wrote Miss Baker, "high and low, those who had 'run' hospitals and those who had been 'rmul, scrubbed erepe garments side by side." Miss Baker's report contained the following description of Army "chow":

On our way over, we had inwardly pitied the enlisted men with the tin plates and knives and forks and the long wooden tables. First mess-call at savenay told us that we too were in the Army. There was war bread in heavy slices, there were onions and bacon. Ieary tin-ware adorned our clothless table and backless benches supported us while we fed. How we langhed!

Unless you sat near the end of the bench, you had to be a high stepper and hop over. Black coffee came around in huge galvanized buckets, which we drank humbly from receptacles ranging from a pint tin cup to a quart capacity dish-pan. Onions were with 11, morning, noon and evening. What we could never puzzle out was why we were destined to eat in a few weeks all of that delectable dish meant to serve the entire American Army during the period of the war.

Fifteen of the thirty-seven nurses who had eome overseas with the Hopkins Unit were ordered back to St. Nazaire on July 5 to stalf a small hospital which the French transferred to the American Army. Here were received acute cases of the infections diseases that lad attacked troops of the First Division on their way overseas. This hospital, first known as Lnited States Army IIospital No. 1, American Expeditionary Forces, was later designated as Base IIospital No. 101 and as such functioned until the end of the war. Members of the medical and nursing staffs of the original Johns IIopkins Lnit who had been detailed to St. Nazaire, were returned to Base Iospital No. 18 before winter.

The nurses and surgeons waiting at Sarenay for the completion of the hespital which they were soon to oecupy, spent the days in attending French classes and in drilling. The routine of Army life and the discipline of divisionsl training sumetimes proved irksome. Miss Baker wrote of these experi(nuces carly in July:

It was hard to gon to bed at 10 P.M. when the sun had just slipped bedow the horizon. From oms latele wimlowe the coun-

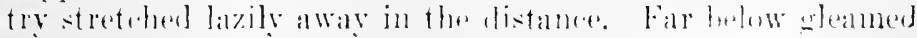


the lights of St. Nazaire. The green vineyards sloped to the river Loire and on every hillside the quaint old mills now turned leisurely at their task, now stood silhouetted against the pastel sky, with a wee erescent moon and a lone star standing guard above. Never could we have imagined a scene more symbolic of peace than this, our first experience of war.

As the days rolled on, we struggled with our hopelessly poor drills. In vain did the Major endeavor to make us military women. He finally gave us up in despair. Many mornings, however, we spent in the old hay fields watching the men mop and drill and drill and mop in the hot July sun. The skylarks flitted up into the blue sky and an occasional Zeppelin horered in the distance far beyond us. . . .

After a month at Sarenay, the persomnel of Base Hospital No. 18 entrained for their permanent quarters. Miss Baker wrote of the trip across France:

Every inch of this wonderful country seemed under eultiration. Hillsides were covered with vineyards. Buckwheat, rye, red clover. yellow mustard, asparagus and alfalfa carpeted the rolling country. Quaint little villages peeped out from the valleys or topped the hillsides.

We left the windmills behind us orernight and ame to great hillsides of rock, with houkes dug ont of them. Te passed groves of chestnut and willows and stately spruces, "fox-tail" and oak. The poplars lined the fine white turnpikes and, like tall sentinels standing on guard for miles and miles, crowned the crests of the distant hills.

They arrived July 26 at Bazoilles, a village of two hundred inhabitants, situated on the headwaters of the Mense River, in the I)epartment of the Vosges. In this little town, the châtean and out-buildinges of a private estate, supplemented by barracklike wooden wards, had heen made into a hospital of one thousand beds. Tleres hnildines were located on both sides of an avenue which streteled up a hillside. The aremure was roofed orer and rurlesed and throngh apertures in the sides, the murses saw below them as they went to and from the wats, a beantiful valley theraded by sulall streams and beyond the foothills of the Voseres.

Base Hospital No. 18 reecived its first patients on July 81, 1917: it served as a amp hospital durimg the smmmer for several divisions of American troops then in training in nearby 
areas. The work was light, so between assignments to duty the nurses had long intervals of leisure which gave them opportunity to go on sight-sering trips. Some of them went to Nenfehâtean, four miles distant, others to Domreny which Miss Baker described:

The valley blazed in a shimmer of blended color, the wild mustard tawny in the sunlight, the winding Meuse, the mearlows brichit with daisies, gentians, poppies. . . In that humble chamber where Jamne didre first saw the light three hundred years acro, I could not help thinking today of the thousanils of women. French. English, American, going to war for France, thomgh not to the fanfare of trumpets that cheered the Maid to Orleans and Rheims.

The rainy season set in about Bazoilles towards the end of September. 'The American troops were macenstomed to tho exeessive dampness and the medical wards of Base Hospital No. 18 were soon filled to eapacity with patients suffering from colds, sore throats, bronehial ailments and pneumonia. A nurse of the Hopkins Unit wrote of her charges:

They are mostly boys from little towns and from every walk in life. On a warl of ten, we have an Irish policeman; an Austrian harber: a Philadelphia steam fitter; a marine with an lrish mother and Italian father; a trap drummer from the movies of (hicago: a big six-foot farmer boy from New England: a lan of fifteen years who ran away from school in Indiana: a presser from a tailor's establishment in Ohio; and a farmer from Missouri. So it goes, often a college man next to a tramp. 'To us they are just sick and lonely boys, whose life we coukd make a lit more cheery.

The winter eame early in Norember with raw winds and rlinging fogs. lark of firel acentuated the diseomfort which the prolongerd dampmess produred. Tpon their arrival at bitzoilles. the Amerienes had heen told grim tales of patients who had beren fomed frozen to death in bed the winter bofore. "There ame a tinue." whete Miss Biker. "when we began to fore that there nuight he sone truth in these stories." On many

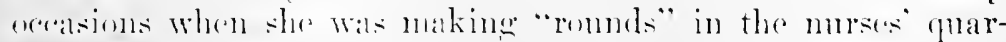

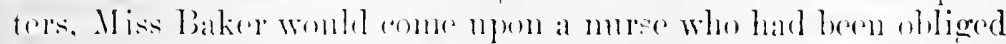

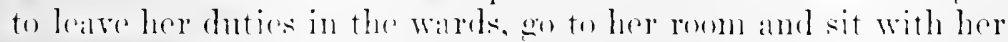
munbed foet in ien water to relieve their aldhing enomoh to permit 
her to go on with her morning's work. "There was talk," contimed Miss Baker, "of starting a Chilblain Club, but such rivalry for the presidency arose between one of the surgeons and the assistant chief nurse that it had to be abandoned."

Lighting also offered difficulties. The nurses were expected to provide their own lamps, but no sooner had they secured them than the kerosene gave out. As it was too cold to sit up, the nurses retired to bed to read by the light of a single candle stuck with tallow on the head of their cots. The picture suggested by Miss Baker's descriptions, of a shivering, blue-lipped woman wrapped in sweaters, ulsters and blankets is indeed a true picture of the American war nurse as she appeared many times when off duty during the harsh French winters.

Of the work of the Hopkins Unit, Miss Baker wrote:

Day by day our wards filled up rapidly with soldiers. At the same time the nurses began to fall ill in large numbers. We started with an eight hour day, but with many patients on the wards and sick nurses in the infirmary, the periods we spent on duty became as many hours as one could stand.

At no time did the nurses work any harder than during these cold, dark days between Norember and January, 1918. But the joy of being there ready and waiting to give to our incoming patients the comfort that good nursing alone will bring to a sick man! Here we meant mother, sister and sweetheart to those shivering, lonely, homesick boys. What confidences we received! One romgster, just a wee lad, told his nurse that if he ever got back to his mother she wouldn't have to beg him to eat the pie she had baked for him.

On a dull. cray simday afternoon early in Norember we received our first Imerican wounded. the victims of that first French raid, 16th Jufantry boys who had been holding the Toul Sector.

In commenting on the many delicacies with which the nurses supplemented rations for the soldiers, Miss Baker wrote:

How like Mis. Nightingales experience with regard to diet. entertaiment and many other mcidents, was our own: "Preposterms luxuries!" one of the old doctors of her day. contempturusy alled? the results of her hereulean efforts to furnish an andequate diet. To have recreation huts and the additional comforts and dainties which the lied Cross and the nurses smpplienl the soldiers may have been "spoiling the brutes" in the Imm remarular, lint it undoubtedly saved the 
morale of our soldiers in 1917 and 1918, no less than Miss Nightingale's efforts in the Crimean War. One commanding officer of Base No. 18 remarked: "These men don't need all this fenlale nursing, - they haven't been accustomed to it!"

While we sat swathed in blankets around those miserable little French stoves and breathed upon our numbed fingers and waited for the monotonous hours to drag by, we nurses tried to puzzle out the meaning of war, of those sick boys on the wards, of our own ridiculous plight.

We couldn't get very far with most of our discussions, but there was real comfort. to us at least, in one doughboy's words: "The last thing 1 knew, I was out and over the top. ... I opened my eyes and there above me was a nurse with a small Red Cross on her eap. I just turned over and went to sleep, because I knew then that everything would be all right."

The New Year brought better times for the overworked nurses of Base Hospital No. 18. The medical and mursing staffs were supplemented in January, 1918, by the arrival of Hospital Unit "A," organized by the Ameriean Red Cross at the Presbyterian Hospital, Philadelphia, Pa. Katherine Liddle, of Wilkinsburg, Pa., was chief nurse of the twenty-one nurses who composed this mit. Toward February the weather at Bazoilles changed from penetrating dampness to sharp cold; and nurses and doetors alike found relaxation in winter sports. Oreanizad recreation was developed by Oolah Burmer, a secretary of the Young Women's Christian Association, who arrived in Feluruary. William Preseott Wolcott, the Red Cross representative at Base Hospital No. 1s, suceeded in seeuring a nurses recreation hut. A small nurses' intirmary, which later drew patients from surromding posts, replared the bare wooden barracks in which many Hopkins nurses hald spent days of siekness during the winter.

During the early spring of 1918, the American Expeditionary Forees tirst shouldered the heary responsibilities of loulding a portion of the Western Front. The entranee of American soldiers into the French and British tremehes made necessury

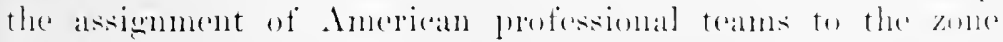

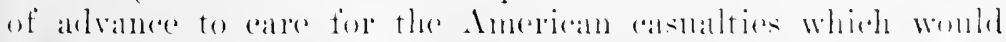

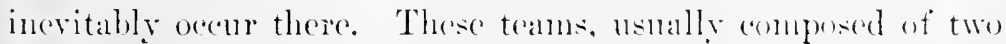

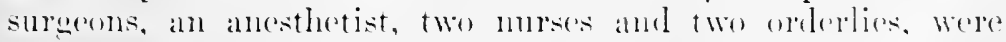
organized from andene the persomed of hate luspitals in the 


\section{HISTORY OF AMERICAN RED CROSS NURSING}

rear and were sent forward for temporary duty in evacuation, mobile and field hospitals.

The nursing strength of Base Hospital No. 18, at times entirely inadequate to cope with the rolume of work in their wards, was further reduced by the formation of these surgical, splint and shock teams. These units were often absent from the base during some particular drive,-just at the time when the greatest number of patients were being sent to the base hospital,- and the depleted staff of nurses at No. 18 were sorely overworked on such an oecasion. The "gas convoys" were particularly distressing. One night after eleven o'clock, ambulances discharged over two hundred and fifty blindfolded men, dressed in torn and dirty horizon blue miforms, some of them stumbling along with their hands on their buddy's shoulders, others quiet on stretchers. "We thought ther were French," a Hopkins nurse wrote in her diary, "but they proved to be our own men who had been brigaded with the French,-great stalwart chaps now groping their way like small children, blinded, the tears ruming down their cheeks, their faces blistered and burned." Of corridors and pre-operative rooms crowded with wounded, Miss Baker wrote:

As the long line of stretchers continued to be moved in hour after hour, each one holding what seemed to be a case more helpless than the last, we conld only pray for the end of such brutality. As we went around the wards, stepping over the stretchers, bending down to the floor with a hot drink. or with a match to light a cigarette for an armless man, we were almost ready to ery "(puits" at any rost. How savage, how inexpressibly futile has become this light valuation of human life!

One of the early projects of the Ameriean Red Cross in France was the establishment in the Voseses of a dispensary service for the benefit of the civilian population. The aims and general nature of this service was described by Ruth Weir, an Imorican lied Cosss nurse assigned to duty at Neufehatean, the headquarters:

In November, $191 \%$.. I was assigned to the American Medical service for the civilian population. which hat its

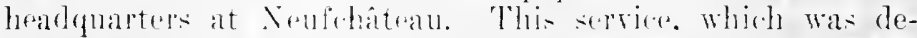
reloped under colonel II. H. Younger rhef nempolegist of the Anerioan Expenditionary forces, had two great ends, to aid 
the poor people deprived of medical care and to prevent epidemies in localities where our troops were billeted.

The work was carried on in dispensaries located in all the ontlying villages. A doctor and a nurse visited these dispensaries every two or three days and called on very sick people in their homes. In this way we successfully uncovered stray cases of scarlet fever, meningitis, diphtheria and other diseases and treated them, thus nipping in the bud the sprearl of contagion. Later on we had a perfectly-equipped hospital at Neufchâteau where patients requiring special care and surgical cases were treated. From the moment of its opening, the sixty beds of this hospital were always occupied. 'The people flocked to us for treatment and also, it must be confessed, to hear les Américaines speak French. They were most grateful and loaded us with kindnesses.

The second Ameriean Army base hospital to arrive in France for service with the American Expeditionary Forees was No. 15, organized by the Ameriean Red Cross from the alumne and staff of the Roosevelt Iospital, New York City. Mary L. Francis, a graduate and assistant superintendent of nurses of the Roosevelt Hospital, was chief nurse.

The Roosevelt Unit arrived in France early in July, 1917, and established a base hospital of three thousand beds at Chaumont, in the Department Haute-Marne. During their first four or five months of service, they cared largely for French wounded, but later Ameriean siek and wounded soldiers came to them from all the surrounding sectors. ${ }^{34}$

Bordeaux, destined to become the principal sonthern hospital eenter of the United States Medieal Corps in France, was the destination of United States Army Base Hospital No. 6, the third of the Red Cross columns to be called into active service with the American Expeelitionary Forees. This mint tork orer late in July, 1917, l'IIopital Complémentaire No. 25, in the Lyere de Talence, sitnated in a beantiful park outside the city.

Base Hospital No. 6 had been organized at the Massalchusotts General Hospital, Boston, Mass. Saral E. Parsons was rhief nurse. Miss Parsons wats a graduate of the Boston Training School of the Massarhusetts General IIospital. After long executive experience in varions New England institutions, she rounded out a broad education gained in this institutional work

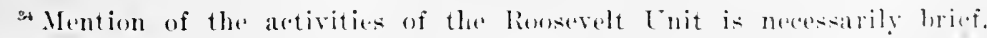
leeranse at the writing of this history Miss Francis did not have access to her papers and data menalding the ixperieness of her unit. 


\section{HISTORY OF AMERICAN RED CROSS NURSING}

and by foreign travel, by post-graduate training at Teachers College. She was in 1907 and 1908 superintendent of the Shepard Pratt Hospital of Baltimore and in 1909 returned to the Massachusetts Cieneral Hospital as director of the Boston Training School. She enrolled in the Red Cross Nursing Service in 1910. She was a woman of practical and energetic temperament, with snapping gray eyes and a strong mouth, which bespoke humor and fearlessness.

The nursing staff of Base Hospital No. 6 arrived at Talence on July 29, 1917, and were immediately installed in wards from which wounded Senegalese and French soldiers had been evacuated. The first patients to eome to the Massachusetts Unit were sent in September from the nearby training areas of the American Expeditionary Forces. Hospital Unit "O". of Charlotte, North Carolina, arrived March 10, 1918, at Bordeaux to rë̈nforce the nursing staff. Heary work for Base Hospital No. 6 began the following July and continued until the end of the war. On November 11, 1918 , there were 4319 patients in the hospital with ninety-nine nurses on duty, an average of fortyfour patients to each nurse. Miss Parsons wrote of the outstanding features of the life and work of the nurses during their eighteen months in the field:

A universal enjoyment of actual belside nursing characterized the attitude of the nursing staff. Although thirty-eight of the original unit of sixty-four nurses had held executive positions before joining Base Hospital No. 6, they were always glar to take subordinate positions where they could work directly with the patients. Never did our nursing staff suffer from too many executives, a complaint of some other units. For were the nurses too tired or too busy to do extra kindnesses for the patients. The hours off duty were spent making eandy, pies, ice-cream for the boys. . . Most gratifying was the spirit of motherliness which pervaled the atmosphere and the respect which the nurses eommanderl.

To sum up my impresion, the allantage of knowing one's persomel is trementons. Woth from a profesional and a physial point of riew. Some of onr most valuable women will do exeellent work in an molerstanding and sympathetiv envirnment. but conld never stand the strain in an uncongenial situation.

Bijon, below ('hammont in rentral rastern France, was the next hospital eenten to be established during the early summer 
of 1917. In this city, Luited States Army Base Hospital No. 17 on July 29 took over from the French military authorities l'Hopital T'emporaire. No. $\%$.

This fourth Red Cross mit to see serviee with the Ameriean Expeditionary Forees in France, Base Hospital No. 17, had been organized at the Harper Hospital, Detroit, Michigan. Emily 1. McLanghlin was chief nurse. Miss Melanghhlin was educated in eonvent schools of Brooklyn and Detroit and was graduated from the Farrand Training S'hool, Harper Hospital. During the Spanish-imerican War, she served at Lexington, Kentucky, at Columbus, Georgia and at Matanzas, Cuba. She remained in military serviee nutil November, 1901, when she returned to the Farrand Training School as night supervisor. In 1909, she became prineipal of the training sehool there and remained in that capacity until she was again ealled into military mursing as chice nurse of Base Hospital No. 17.

The Harper Unit arrived at Dijon on July 29, 1917, and was, with the exeeption of an Ameriean bakery, the first branch of the American Expeditionary Forees to invade that aneient city. A French military hospital, l'Hopital Temporaire No. 7 , was assigned to them. The main building had formerly housed the School of St. Ignate and was a four-storied, ell-shaped structure. Fonrteen wooden barracks of from thirty-five to forty-five bed capacity were later erected immediately behind the larger building. The normal capacity of Base Hospital No. 17 was eightern hundred beds, but it was eapable of an emergency expansion to two thonsand beds. The mursing staff was billeted in houses loeated in various parts of the city.

As was the ease with the sulgeons and murses of other base hospitals assigned to the then embrvonic Aneriean Expeditionary Forees, the personnel of the Ilarper Lnit experieneed at first the tedimn of having too few patients to oceupy their time. Lnits of murses were sent carly in August to Paris to help ont at the Imeriean lied cross dressing station, which was then drawing on American bases for persomel. Others were ordered

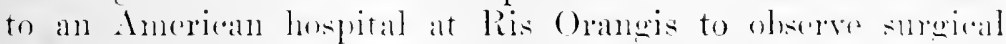
mothods. On sereral exeasions these at I)ijon assisted in serring hot food to the French bleseses as their hospital trains passed

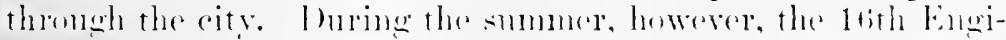
neers and later the bie ('amontlage ('amp, the lonited states Army laberatery and the tirst traninge billets of the and bivision were situated near loijon, and these branches of the 


\section{HISTORY OF AMERICAN RED CROSS NURSING}

American Expeditionary Forces sent many medical and accident cases to Base Hospital No. 17.

Hospital Unit "S," of Nashville, Tennessee, of which Katherine G. Sennott was chief nurse, arrived at Dijon in February, 1918, to reënforce the nursing staff of Base Hospital No. 17 . During the German offensive of March-July, 1918, heavy casualties occurred among the American and Allied Armies then holding the Western Front and many patients came to Base Hospital No. 17. Miss MeLaughlin wrote:

Our first big convoy of over three hundred Americans who had been brigaded near Soissons with the French arrived on March 16. From that time on, there was little respite for us. We functioned sometimes as an evacuation hospital, retaining our patients only a few days.

We were told May 29 that a hospital train had arrived with about two hundred patients. This proved to be a train of nearly twelve hundred British soldiers from the Soissons sector, six hundred of whom were received at our base. Many were badly wounded; the only one we could not save was a terribly woundel scotch laddie, sixteen years old, who kept crying: "I want tae gae hame tae ma mither!"

On the 18 th of June a convoy of our own terribly mangled and gassed men was received from Château-Thierry, coming to us direct from the field hospital. Many of these were Marines who had taken part in that memorable fight and had done much in stemming the tide at this point.

United States Army Base Hospital No. 8 was the fifth Red Cross column to cmbark during the early summer of 1917 for service with the American Expeditionary Forces in France. This unit had been organized at the New York City Post-Graduate Hospital. Amy Florence Patmore, who since her graduation from the parent institution of this unit had conducted a private sanitarim in $\mathrm{N}$ ('w York City, was chief nurse.

Base Hospital No. S sot ont on July 30, 1917, on the S. S. Saratoga. Miss Patmore wrote:

Passing Staten Island, the S. S. Saratoga slowed up and finally dropered anchor off Tompkinsville. The day was desperately hot and after luncheon most of the nurses removed their heary unforms and were kolling about in their cabins in

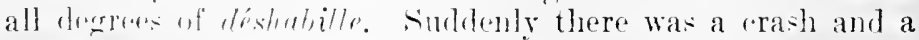
terrific shock,- the s. s. I'anama had rammed into the sara- 
toga, tearing a thirty-foot hole in her side. The ship immediately began to list and orders were given to aluandon ship at once.

'There was no hysteria among the nurses. Ialf-clad as they were, they took their places in the boats. All the smaller craft in the harbor rushed to our assistance and we were picked up and taken to various large boats scattered about the Bay. A Government boat finally collected and carried us back to quarters on board the finland, which was then lying at her dock in Hoboken. We learned that seventeen minutes after the last person had left the ship, the saratoga sulmmerged. With her went not only our own personal belongings but our entire hospital equipment.

We were not allowed to hold any communication with friends on shore. . . We were taken back to Ellis Islanck. The nurses of Base Hospital Unit No. 9 were mobilized there awaiting orders to sail and they opered up their luggage and divided their wearing apparel with our little band of refugees.

The rë̈quipment of Base Hospital No. 8 has already been detailed in an earlier seetion. Eight days after the sinking of the S. S. Saratoga, this mit reëmbarked on the Finland, which was one of a convoy of five troopships. Rigid diseipline was maintained on board. All passengers were drilled every day and were ordered to be fully dressed and ready to go on deck at 2,3 and $+A$. M. every night. The utter blackness of their own ship and the huge dim shapes of other ships of the eonroy slipping along beside them in the darkness bronght to the murses realization of the danger of submarine attack. "For the last three nights," wrote Miss Patmore, "we were not allowed to remove our clothing and our life preservers were alwars close beside us."

German submarines in search of Allied ships lound for St. Nazaire combed the waters near Belle lsle, just off the coast of France. Sieveral of them sighted the American romory and attacked the Finland. Miss Patmore elescribed the encounter:

Suddenly about nine o'dock on Monday morning. the signal canes sis shent hasts and the firing of a anmen. baleh

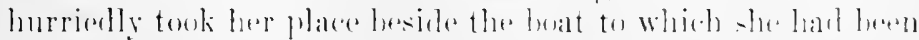

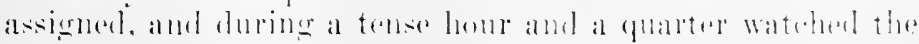
hattle. 'The roar of anume and the sheres of denth hombs brought to us a grim realization of naval warfare. Out of the 


\section{HISTORY OF AMERICAN RED CROSS NURSINĞ}

five ships of the convoy, the Finland seemed to have been the target. Six torpedo destroyers and two aeroplanes came to our rescue.

We were off the cost of France when the attack occurred. After the submarines had been ronted, we proceeded on our way to St. Nazaire. When we arrived there at seven in the evening of August 20 , the populace, who had heard the news of the battle by wireless, was waiting to bid us welcome and we docked amid round after round of cheers.

The persomel of Base Hospital No. 8 was permanently assigned to the same normal school building at Savenay, in the Loire Distriet, in which the Hopkins Unit had been temporarily billeted two months before. Juring the first winter, the New York Post-Graduate L'nit cared for large numbers of medieal cases sent in from training centers of the American Expeditionary Forees. Base Hospital No. 8 expanded during the spring of 1918 to a capacity of $: 3470$ beds. Large tuberenlosis, isolation and psechopathic departments and a school for blinded soldiers were organized. Classes in administration of anestheties were conducted for nurses. A diet kitehen was later dereloped which served 2200 patients each day with deligacies and speciallyprescribod articles of diet.

Hospital Cnit "F," consisting of twenty-one murses from the Harlem Hospital, New York City, arrived February 6, 1918, to supplement the mursing staft of Base Hospital No. 8. Even with these rëuforeennents, Base IIospital No. 8 suffered from the shortage of nurses felt throughout the early summer of 1918 liv throther base hospitals attached to the American Expeditionary Fores. Patine came to Savenay from all parts of France. Miss Patmore wrote that during the major offensives patients sometines were receired from as many as three hospital trains in thirty-six hours. carh train hringing botween six and seven humdred wounded, fully onchalf of whom were streteher cases. On one "pork day" the Now York Post-Gradnate Enit had 5010 patients in the hospital and only eighty-four unrses to care for them, a ratio of se.s patients to each murse. Overflow rases were housed in huildings whieh later becane Base Hospital No. 69. "Inring those hectic months of the summer and antumn of 1918," wrote Miss Patmore, "we found time for little but real life-sereing service. Perhaps the most wearing work of all was nipht duty in the psychepathic departnent and in thro wards where the patients were running high fevers. 
In their delirimu, these men lived over again the battles they had fought, went over the top, killed the enemy or fell back wounded on the firld, all of which was nerve-racking to the most experienced of nurses."

By ()etober of 1918, the bed capacity of Savenay IIospital ('ruter had reached 14,000 and even this number proved inadequate to cope with the influenza epidemic. Miss Patmore wrote:

"Hu" first broke ont in the prison (amp at Savenay where over cighteen humdred German and Austrian prisoners were stockaded. 'The rery sick ones were brought into our metical wards. ('aring for those poor souls was one of our tragic experiences of service. With raging fever, glaring eyes and purple faces, in their delirium they too were back again in "No Man's land" or on furlongh going home.

(m Ortober !, 1918, we received a large envoy of our own bors from the hoats at St. Nazaire. They had been exposed to the contagion at amps in the Inited States and were stricken on ship-board. Many of their comrades had died and had been buried at sea.

The New York Hospital Unit, Base Hospital No. 9, had sailed on the Finland with Base Hospital No. 8. This muit was assigned on September 7 to Chateanronx, Indre, which lay midway between Bordeaux and Paris. The French Governnent turned over to the American Expeditionary Forees new concrete buildings erected in 1914 as an asylum for the insane. base IIospital No. 9 immediately set up an excellently equipped hospital of five hundred beds.

As with all the American bases, Base Hospital No. 9 soon trebled its original capaleity. Mary Vroom. we time superintendent of the Greenwich Hospital Association, Greenwich, commetient. Was chict nurse of the Now York Hospital linit and she wrote that "immediately after the arrival of the Cuited states Engineers, barrarke spring up like mushrooms." When she was "makine romuls" one moming at nine o o.lock, she saw sone timbers and planking ling in a valeant spane botween two

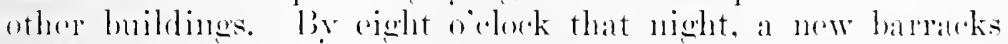
hatd heen completri. the wards fumished and tiftrefour beds matly made with white sherets and blankets folded harek. before noming arery bed was tilled.

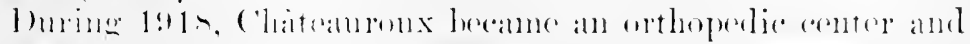

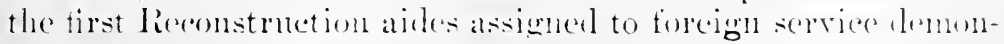




\section{HISTORY OF AMERICAN RED CROSS NURSING}

strated there the value of occupational therapy as an aid to rapid convalescence.

The next American base hospital unit to go overseas was No. 27, which had been organized by the University of Pittsburg Medical School. Blanche S. Rulon was chief nurse. Miss Rulon was a graduate of the Women's Hospital of Philadelphia and since 1913 had been superintendent of the Eye and Ear Hospital, Pittsburgh. The nurses of Base Hospital No. 27 came from six hospitals in the same city.

Base Hospital No. 27 sailed from New York on September 27, after a delay at Ellis Island of five weeks. The early expeliences of the group of nurses connected with this unit illustrated the entirely unforeseen kind of ability which Army chief nurses had to develop during the European War. When the unit arrived in Liverpool, the officers and men were separated from the group and the nurses were left to proceed to their destination alone. Without the help of any officer belonging to their formation and without any preliminary instructions or arrangenents, the chief nurse saw to it that the members of her group with all their baggage were conducted in Liverpool from the hotel to the station, then later across London and aboard a train. for Southampton, in spite of the fact that the station master had told her that this could not possibly be done. After an unheralded and unprepared-for arrival at Southampton, she got them on to a transport and across the Channel, although they had to spend the night in ehairs in the corridors or two in a berth on the lower decks. After five days at Le Havre, the men of the mit arrived and the whole organization was put aboard a special train which took them to Angers where they arrived without the loss of a single nurse or of a single piece of luggage. Only those who have been through similar experiences will understand how this feat was aceomplished, without anthority, without large sums of money and without knowledge of the French langrage.

The Jittsbure Medieal School Lnit set up permanent quarters in the Mongazon, in Angers, in buildings which had formerly honsed a sominary and in Ameriean-made barracks huts which were erected abenit the heantiful older structures. Base IIospital No. 27 held the record of being one of the most satis-

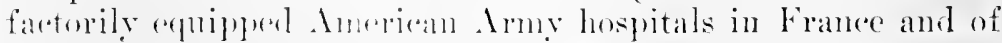
caring for the lanesest number of patients in any one single day in any of the American lases. The first murses to be sent 
for duty on a hospital train, Helen Burrey, Grace O'Donnell and Edna Cooper, were members of Base Hospital No. 27.

Vittel, a little town of the Vosges, thirty miles behind the line and forty-five miles from the German frontier, was the destination of United States Army Base Hospital No. 36, organized within the Detroit College of Medicine and mobilized into active service in September, 1917. Dr. Burt F. Shurley was director and Mrs. Betsey Long Harris was chief nurse of this mit. A New Englander by birth and ancestry. Mrs. Harris was graduated from the New York Infirmary for Women and Children. She was for some years superinteudent of murses of the Episeopal Hospital at Brooklyn, New York. At the completion of post-graduate work in Teachers College, she served as an instructor in Harper Hospital and in 1914 beeame superintendent of the Children's Free Hospital in Detroit. she resigned from this position to go with her unit for active service in France.

The persomel of Base Hospital No. 36 mobilized in Detroit on September 6 and sailed from New York seven weeks later on the S. S. Orduna for Halifax, where they joined a convoy of seven other ships. They arrived at Vittel on November 18 and spent the first three weeks in putting five large summer hotels of this resort in shape to receive patients. "With no stoves and little fucl to burn in the few tiny tire-places," wrote Mrs. Harris, "it was a bleak time for all of us."

1 glimpse of the manner in which the rigid climate affected the raw American troops who were in training nearby was given in the diary of one of the nurses of Base Hospital No. 36. Twelve of the wit hat been sent to Vaneouleur's on I)ecember 1, 1!)17, for service with the 42nd Division, and one of them, Jennic A. Abranson, wrote:

December :: Major Fairchild took us through the hospital, situated in two portable buildings and in an old rhateau built in 1.5.). We found about seventy-five rases of mmmps and meases in the loft of the barn. The French cots were very rlose together and the air was foul. A smoking stove arded to the (leseness but the boys said they dicht mind the smoke as much ats the cold.

lowember s: Wresent seventy-five cases of mumps ant meales to Vittel tolay. In this raw elimate, our soldiers.

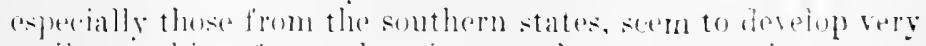

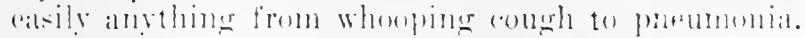


By the end of November, 1917, the eight Ameriean bases located at Bazoilles, Chammont, Bordeaux, Dijon, Savenay, Chatteauroux, Angers and Vittel, and the Yale Mobile Unit at Limoges, comprised the only Ameriean Army hospitals with the United States Armies in France. The nursing staffs of these nine units then numbered approximately sixty-five nurses each, these six hundred women thus comprising the entire nursing strength of the Ameriean Expeditionary Forces in France.

The nursing personnel of the six Red Cross base hospitals assigned to the British Expeditionary Forces, reënforced by numerous hospital units, also numbered about six hundred nurses.

The chicf nurses of these early units had had little, if any, experience in Army administration before assignment to active duty. The mobilization station for nurses at Ellis Island had not been established when the six base hospitals embarked in May, 1917, for service with the British Expeditionary Forees, and Miss Mury had little opportunity in the erowded summer of 1917 to instruet in Army paper work the chicf murses of the nine units assigned to the American forces. Each chief nurse was responsible to Miss Thompson in Washington for the conduct and diseipline of her unit, but the standards of one chief nurse differed from those of another ehief murse and, moreover, Washington was separated by zealous censors and many miles of ocean from nurses on active duty in France.

Duriug the summer of 1917, the oftice of the Chief Surgeon, Ameriean Expeditionary Forees, was located in Paris. On September 1, it was moved to Chamont and all the reeords of the Anerican Amy nurses then in France were kept there. No nurses served, howerer, on the Chief Surgeon's staft. As the winter of 1917 apperaded, the twelve hundred American Army nurses in France needed new and warmer articles of rlothing and of equipment. Requests for transfers from one base to anothere and from the zone of the base to that of the arlvance, came to the Chief sinereon's office and made necessary the keeping of valoms new rexerds and accounts. Mroreovere, disciplinary problems regarding the conduet of murses, both on and off duty, constantly arose and a need was felt for an antloritative reperesentative of the Army Nurse ('orps in

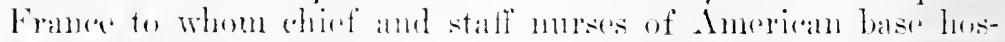

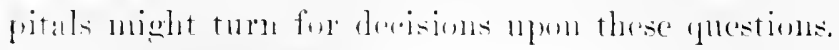


On November 13, 1917, Bessie S. Bell, who had formerly been chief nurse of Wralter Reed Hospital, Washington, 1). (... arrived in France on orders from the Surgeon General to act as Chief Nurse of the Ameriean Expeditionary Forces. Ama E. Coffer, Army Nurse Corps, acempanied her as her assistant. Mliss Bell's oftice was placed in the Bureau of Personnel, of which Colonel E. M. Welles, Jr., was in command, and she and her assistant hamlled all mursing matters. The office of the Chief Surgeon was moved in Jamuary, 1918, to Tours and the headquarters of the Army Nurse Corps in France was established there. ${ }^{35}$

Between Inecember, 1917, and the lannehing of the German offensive on March 26,1918 , less than nine hundred additional nurses were sent overseas. Many of these were members of Red Cross hospital mits which were assigned to rë̈uforee the stafts of already-established base hospitals. Others were "casuals" who were assigned to fill various vacancies caused by transfers, illness and death among the original stafts of base lospitals then on duty with the American and the British Expeditionary Forces, or to duty in new base hospitals and other sanitary formations organized by the Surgeon General withont the assistance of the Ameriean Red Cross. Inring this period. Red cross archives record the arrival in France of four alditional base hospitals from among the fifty original columms which the Red ('ross had undertaken to organize for the suremen (ienerial's office.

The teuth Ameriom Red Cross base hospital to arrive in France was the Buffalo Lnit, Enited States Army Base Hospital No. 2:?, which had been organized from the almme and staffs of varions recistered hospitals in Buffalo, New York. 'The personnel ambarked November 22, 1917, from New York and upon their arrival in France, were assigned to duty near Base Hospital No. 36, in the rapidly-dereloping hospital "enter at Vittel. Lawrie L. Phillips, a graduate of the Buffalo Gencral 1lespital. was chiof nurse. Doring the summer of $191 \mathrm{~s}$.

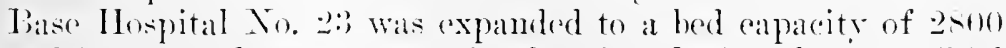
and it operated as an evacuation hospital doring the Sit. Mihiel drive.

Contrexerille, a well-known French watering-place in the Vosges, served also ats an Anerican hospital center during the

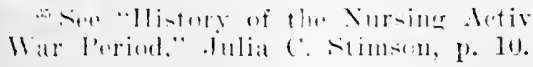




\section{HISTORY OF AMERICAN RED CROSS NURSING}

European War. United States Army Base Hospital No. 32 arrived there on Christmas Eve, 1917. This unit had been organized at the Indianapolis City Hospital, Indianapolis, Indiana. Florence J. Martin, a graduate of the Pennsylvania IIospital, Philadelphia, was chief nurse.

Contrexéville possessed famous mineral springs; it owed its reputation especially to the Pavilion Spring, the waters of which had been preseribed for King Stanislas of Lorraine. It was a favorite place for soldiers on leave and Miss Martin wrote that during the summer of 1918 the town "was thronged with French infantrymen in horizon blue, chasseurs in dark blue tam o' shanters with gold bugles embroidered upon them, Algerians with scarlet fezzes and gold creseents, Czecho-Slovaks, British Tommies and Scoteh kilties, Italians. Chinese, Hindoos and an Egyptian or two, to say nothing of the men in green with P. W. stamped on their backs, who marched to and from their work with an armed donghboy following them."

Contrexéville was splendidly equipped from a sanitary standpoint, in distinct contrast to the meager provision at some of the other American bases. Miss Martin wrote:

At our enormous bath-house, with its hundreds of tubs rented by the Red Cross, dazed-looking, slightly-wounded doughboys lined up in the colonnade on dozens of benches waiting their turn for the warm, refreshing water. Here, where formerly only kings and the wealthy people of the earth bathed, any doughboy who could walk or limp enjoyed the bath to its fullest extent.

On the American line of communications almost midway between Dijon and Bordeaux lay the city of Limoges, the destination of the United States Army Base Hospital No. 24, of Tulane University, New Orleans, Louisiana. This mit took over on March 18, 1918, the buildings occupied since September, 1917, by Base Hospital No. 39, the name by which the Yale Mobile Unit was known until it was sent in the spring of 1918 to the forward area when it became Mobile Hospital No. 39.

Ethel A. Holmes (Johns Hopkins) was chief nurse of Base Hospital No. 24. 'The nursing staft' was composed of graduates from twenty-six training schools located in all parts of the south. 
Bellevme Hospital, New York City, had been the first institution to complete the organization of its nursing staff and had been given the designation of Base Hospital No. 1, but this unit, male up of persomel of the big municipal hospital, did not arrive in France until March, 1918. They were assigned to the eity of Vichy, in the Fepartment of Cantal, destined to become one of the principal hospital centers of the American Expeditionary Forees. Beatrice Bamber, chief nurse of Base Hospital No. 1, wrote of the arrival of the unit:

We reached Vichy about midnight of March 12, the pioneers of the subsequent American invasion of this ancient city. Quarters and wards were immediately established in the larger hotels. Until the arrival of Base Hospital No. 19 [Rochester, X. Y.] in June, 1918, we maintained alone a hospital of six thonsand beds. The University of California [nit established in May their base in the IIotel Royal and in August, the New York Eye and Ear Hospital took over the Ruhl Hotel as Base Hospital No. 115.

Previous to March, 1918, the American Expeditionary Forees hald taken little part in active hostilities on the Western Front. The War Department, it will be remembered, had been oceupied chiefly in the training and transportation of troops and the shipment of supplies. Combat troops and supplies, it will also be remembered, were given right of way over medical persinnel, consecpuntly an acute shortage of nurses cxisted in the Anerican Expeditionary Forees. Previons to March, 1918, the mevement of American troops had been comparatively slow, but the Army planned during the early summer to land an army of over two million soldiers on Allied soil and did send during the last six months of hostilities over a million and a half soldiers to France. Swift and substantial increase in the medieal and nursing persomnel during the spring and summer of 1 !) 18 was paramomt, if this contemplated arme of two million men was to have adequate medical and nursing ("are.

In her report as director of the Nursing Serviee of the Ameriam Expeditionary Forees, Miss Stimson stated that on Mareh :3), 1!)1s, there were 20 os murses in France, of whom apposinately 700 were on duty with the British kxpedition-

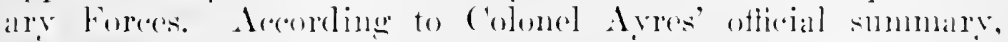

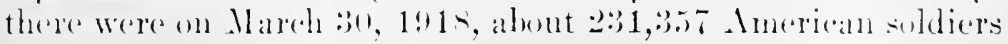




\section{HISTORY OF AMERICAN RED CROSS NURSING}

in France. ${ }^{36}$ The ratio of nurses to soldier was thus 110.8. In aceordance with the estimate agreed upon in July, 1917, by General Headquarters, that the sanitary personnel of the Army should constitute 7.65 per cent of the total strength of the forces, it is evident that a considerable shortage of murses existed during the spring of 1918. In her report, Miss Stimson fixed this shortage at 100 nurses. ${ }^{37}$

By the middle of April, approximately 300,000 American soldiers had been landed in France and the shortage of murses was then estimated at $1121 .^{37}$ "About this time," wrote Miss Stimson, "the statement was made that 'a breakdown in medical service was threatened' and on May 3 a cable was sent asking for the immediate dispatch of 555 nurses."

This was the request, it will be recalled, which stripped the cantomments bare of nurses in May, 1918. It resulted in the immediate dispatch of many base hospitals, the nursing staffs of which had been scattered among the cantonments.

Among these mits was Lnited States Army Base Hospital No. 20, organized at the University of Pennsylyania. The murses of this Red Cross columm had been stationed during the winter of 1917 in rarions cantonments; the chief nurse. Eilith B. Irwin, had been assigned to Camp Taylor. The entire personnel of Base Hospital No. 20 was mobilized on February 18, 1918, at Ellis Island. Great was the disappointment of the nurses to learn that, instead of sailing at once, they were detailed to take over the Immigration Hospital in New York Harbor. However, overseas orders finally came on April 20 and Base Hospital No. 20 sailed four days later on the Leviathan for Brest. E pon the arrival of the mit in France. they entrained for ('hattelgnyon, in the south-central part of the country. Miss Irwin wrote of the travel conditions:

There were six murses in each compartment. At nisht we put our suitcases in the renter and slept croswise. There was no water on the train and two or three times a day wo would stop, sometimes long enough for us to wash up a bit. On the seronl day of the trip. the train stopped at a plare where one hydrant and soreral tubs of water had berm prepared for us. Armerl with salp. towels and tooth-hrmshes. everybody got off. The mon shaved and the girls combed; it really was a very funty sight.

: "The llar with Germany." p. 37.

${ }^{3}$.. History of Nursing Artivities on the Westem Front during the War Prorod," Julia C. Stimson. 1) T. 
Châtelguyon was a famous health resort; its thirty-three mineral springs, which yielded daily one million, two hundred thousand gallons of water varying from seventy to one hundred degrees falnenheit, had made it a center for invalids and tourists from all parts of the world. Upon the arrival there of the University of Pemsylvania Unit, Base Hospital No. 20, it was estahlished in thirty-two buildings, largely summer hotels and pensions. The IIotel du l'arc, with a bed capacity of three hundred and seventy-five, was selected as the chief surgical building. Less serions non-ambulatory eases were established in the Intels siplendid, Nourel and liégence, because of favorable mess facilities. Ambulatory, slightly wounded and convalescing patients were quartered in the Hotels Castel-Regina, ('astel-(iuy, D)' France, Elizabeth, Bon Accueil, Medeah and Thermes. Medieal patients were first eared for in wards of the IIotel du P'erc; later the two Thermalias, the Front Hermitage, the Bengeres, the Chrysenthemes, and wards of the splendid, Nonel and liégrnce Ilotels were used for medical patients. The nursing staff was permanently quartered in the Ilotcl International, the ofticers in the IIotel des Princes and the enlisted men in the Fillas Florence, Trinnon and Palais Royal.

In spite of their pretentions names, these summer hotels had meiger heating, lighting and plumbing facilities and limited equipment. It required hereulean labors on the part of the persimunel of Base Itospital No. 20 to clean and equip them as a base hospital. Seren hundred thousand feet, more or less, of floors, walls and ceilings of quarters previously oceupied by eight hundred sick Myerian soldiers were cleaned by the enlisted personuel of the Buffalo Unit and "after the men had reaned the premises to suit the male mind, the murses literally: gont down on their hands and knees and with rag and brush, hroom and mop, recleaned these floors, walls, wood-work and ailing.."

Here as in other Ameriean sanitary enters in France, the acute shortage of nurses greatly overtaxed the enduranee of the nursing statt. "Wo never had more than the original sixtytive murse," wrote Vliss Irwin, "and at no time after the oreanization of the hospital did we have even that number. When we were husiest with twenty-two hunded and seventy patients, wo had only fortr-nine nurses on duty" No "easual" murses

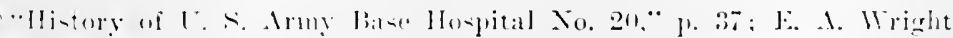
Sompany. Philadelphia, Pa.. 1!20. 


\section{HISTORY OF AMERICAN RED CROSS NURSING}

were assigned to Base Hospital No. 20. The original number did all the nursing at No. 20, staffed Camp Hospital No. 44 and furnished nurses for various medical and surgical teams at the front.

United States Army Base Hospital No. 46, organized at the University of Oregon, Portland, Oregon, embarked for France in June, 1918. Grace Phelps, chief nurse, and the other members of the nursing staff had seen service in eantomments in the United States. Upon its arrival in France Base Hospital No. 46 was assigned to supplement the bed capacity of Bazoilles Hospital Center. From the little peasant village which the Johns Hopkins Unit had found upon their arrival there in July, 1917, Bazoilles had developed by July, 1918, into one of the most important sanitary outposts of the Medical Corps. Eleanor Donaldson, a member of Base Hospital No. 46, wrote of the line of communications which passed below the nurses' recreation house at Bazoilles:

One of our doorwars faced a panorama of wood crowned hills, a river and three of the great roads in France. One road was tree-bordered, a silver line where trucks and motors passed up and down endlessly. The second was the railroad on which our bors went to the battlefields, singing, waring and cheering, and on which they returned to us silent, broken but undaunted. There was a special train known as "old 56 " and when it was missing from the tracks, we knew the errand on which it had gone and anxionsly watched for its return. It used to come around the hills so slowly that one could scarcely see it move, or he sure it halted until the three short whistles that meant "conroy in!" called us to our posts in the wards. The third road ran just a few rards from om' tent door, with the river beyond, the last road of all for the boys we left in France. It was a short road, ending in a plot at the foot of the hill where the sunset light tonched the white crosses, row on row.

Enited States Army Base IIospital No. 13 arrived in France in June, 1918, and Wals assigned to Limoges to raise the bed alpalcity of that center. This mit hat heen organized from the staff and alumne of the Presbyterian and Cook County Inspitals. Chicano, Illinois. Mabel K. Arams, chiof nurse, had already served in the European War with Dr. I. B. Murphy's Lnit whirh was attarhed in 1915 to No. 2:; General Hospital, British Expeditionary Forees, Etaples, France. The 
other nurses of Base Hospital No. 13 had seen duty at Camp Dodge, Iowa, and Camp Pike, Arkansas, before their mobilization for foreign service.

Base Hospital No. 13 set up a hospital in the Champs de Juillet, Limoges, and immediately received patients who had been wounded in the German offensive of June, 1918, upon Paris. Miss Adams wrote:

In the long, low receiving ward, rude and bare, they were lifted from the floor onto the tables and their history was taken. "Kind of a rough ride, eh, Buddie?"

Next came the "up cases," with their uniforms torn and caked with mud, their faces haggard and worn. Some of them still chtched a few precious souvenirs tied in a handkerchief or in an old rag. Many were so exhausted that they slept while they waited in line to be registered.

Finally the last ambulance was mloader, the last patient entered, the night supervisor had gone to the wards to help, the day nurses hal turned the work over to the night shift, the secretaries, tired and stiff, left their typewriters and the oflicer of the day had started his night rounds. With a distant rumble ancl a final honk, the trucks and ambulances were through for the night and the drivers and stretcher bearers crawled into their wooden bunks. The early morning hours found the (amp) very quict, with only the guards trudging back and forth on their lonely posts.

The rapidity with which combat troops were sent overseas in June, 1!18, has been deseribed in a previous chapter. Large numbers of medical and nursing persomel accompanied these troops. On the Baltic which sailed June 4 were Base IIospitals Nos. 19, 22 and 26, eomprising three hundred murses. The envoy of nine vessels, of which the Battimore was one, with destrovers, acoplanes, hydroplanes and sulmanine rhasers, carried thirts thonsand men and twelve hundred officers for the Amerian Expeditionary Forees.

Base Hospital No. 19 (Rochester Homeopathic [nit) reported at Vichr. Base Hospitals Nos. 115 and 119 which sailed later in June, were also assigned to Vichy. Base Hospital No. 2s (Kinsas ("ity) sailed during the last weeks in June and wats assigned to duty at Limogers.

July 15, 1918, saw the failure of the last German offensive on Paris. The enomy hard attareked simultaneonsty on both sides of Rheims but his path was everrwhere hlocked hy the 


\section{HISTORY ON AMERICAN RED CROSS NURSING}

Freneh and Ameriean armies. Three days later, July 18, Marshal Foch seized the initiative which passed from General Ludendorff and launched the great Allied offensive, which was destined to break the Hindenburg Line and result in the final collapse of the German Army.

Eighty-five thousand American troops of the Forty-second, the Third and the Twenty-eighth Divisions had been engaged in the battle of July 15 which cheeked the German advanee across the Marne. In the counter-offensive of July 18, the First, Second, Third, Fourth, Twenty-sixth, Twenty-eighth, Thirtysecond and Forty-second Divisions, together with selected French troops, went into action.

At the begimning of the Allied offensive, July 18, 1918, the Medieal Corps, American Expeditionary Forees, was maintaining forty-five base hospitals in France and England. Thirtynine of these were units which had been organized and equipped by the Ameriean Red Cross.

Ifiss Stimson summarized the nursing needs of the Ameriean Expeditionary Forces in France at this erucial time: "On July 27 , reports stated that the recent fighting has been so severe that the resources of the Medical Division have been practically exhausted in so far as personnel is concerned." On August 10, General Headquarters, A. E. F., sent a cable which requested absolute priority for medical organizations, including 2312111 rses. $^{39}$

This shortage had been foreseen by the Surgeon General's office and General Gorgats had issued an order on Angust 1 . 1918, that one thousand murses should be sent overseas each week for a period of eight weeks. The Surgeon General requested the Ameriean Red Cross to prepare to equip these nurses as they came down to New York for embarkation. Moreorer, he called upon the Nursing Service, as the reserve of the Army Nurse Corps to curoll one thousand murses a week for the same period of eight weeks to fill the racancies which wonld be cansed in the eantonments by the withdrawal of nurses for foreign service.

Bro the early summer of 1918, the Medieal Corps had finished the establishment of the principal sinitary centers of the Aneriean Expelitimary forees alloing the Ameriean line of eommunications. The alditional base hospitals which arrived

as History of Nursing Activities on the Writern Front during War Period," Julia C. Stimonn. p. S. 
in France between $\mathbf{J} u n e$ and November were assigned to these already established enditers to raise the bed capacity of the Medical Corps at that given point. The new nuits did not lose their identity in that of the original base hospital located there, but they formed instead individual units of a gromp of base hospitals. These groups were designated as lospital centers.

One thousand nurses arrived in France in August. Among these was the staff of Base Iospital No. 14, organized from St. Luke's and Michacl Reese IIospitals, Chicago, which reported August 16 at the hospital center at Mars-sur-Allier, to relieve murses of Base Hospitals Nos. 48 and 68 , then detached from their own mits at Ilesves. Base Hospital No. 44!) (University of Nebraska), which had sailed August 26, was ordered also to Mars-sur-Allier. As other base hospitals which had been organized by the Surgeon General's oftiee or the Reel cross reported for duty in France in August and September, 1918, they were housed in wooden barracks and thus developed the great hospital centers of the Ameriean Expeditionary Forees at Allerey, Bazoilles, Beau Desert, Mars, Mesves, Le Mans, Nantes, Savenay, Toul, Vichy, Kerlunon, Pan, Commerey, Orleans, Beanne, Tours, VittelContrexéville, Clernont-Ferrand, Limoges, Rimaneourt, Langres, Vannes, Angers, Perignenx and the hospitals, largely convaleserent, of the livieral district.

At the signing of the Armistice, the Modieal I)ivision of the American Expeditionary Forees was maintaining one hundred and fifte-three base huspitals in Franee and the nurses on active duty in these formations suffered in varving degrees from inconvenience and discomfort cansed by cold, erowled and often meigerly equipped gutirter's. A difticult honsing problem confronted the clief surgeon of the Ameriean Expeditionary Forecs. Coloncl sanford II. Wadhams, representative of the

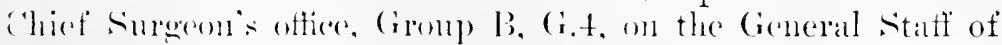
the Ameriean Expeditimary Forees, wrote:

Buildings accuired from the Freme hefore it was possible

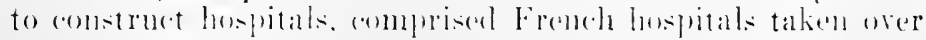

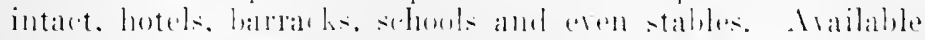

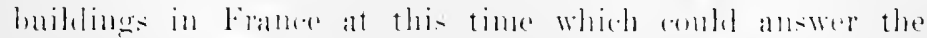

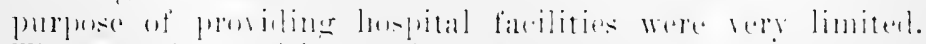

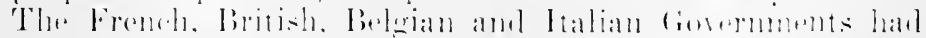

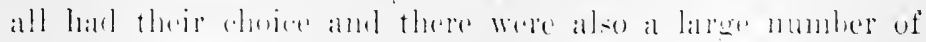




\section{HISTORY OF AMERICAN RED CROSS NURSING}

hospitals maintained by volunteer aid societies from different parts of the world. Consequently the buildings obtained were generally of a most unsatisfactory character, very expensive to maintain, difficult to administer and usually required an excessive number of personnel to operate them properly. Few school buildings had running water, sewer connections, or toilet facilities. The hotels taken over were largely summer hotels, without heating facilities and with insufficient water and very limited plumbing.

This shortage of suitable buildings which could be secured for hospitalization purposes and the dearth of building materials in France made necessary the erowding of many nurses into limited quarters. Colonel Wadhams' report continued:

Soon after starting their construction program, the General Staff faced the prospect of being unable to have transported to France, or to obtain there, sufficient building material to carry on the many construction projects confronting these forces. The first change in the plans prescribed by General Headquarters was to reduce the space in the living quarters allowed to efficers, nurses and enlisted men (G. O. $46,191 \%$, A.E.F.). The Chief Surgeon's office was willing to make sacrifices as regards officers and enlisted men, but strenuonsly opposed, without success, reducing the modest allowances that had been prescribed for the nurses in these units.

Despite our protestations and as adopted, the order prescribed that our nurses slecp in double-tier bunks, with scarcely sufficient floor space to get aromnd. This subjected these wortly women to considerable hardship that seemed unwarranted. 'This inconsistent attitude on the part of the anthorities who reviewed our plans was later changed, largely due to the individual effort and critical reports rendered by the Inspector Gencral of these Forces. As amenderl, the nurses eventually were giren living quarters and the same allowance as was prescribed for junior officers. ${ }^{40}$

In many cases the exment floors of the barracks were constantly wet and trunks, lages, shoes and anything left on the floor inildewerl immediately. Often the roof and walls of the barracks let in wind and rain. The most satisfactory trpe of building was the rewulation brick or wood barrack with

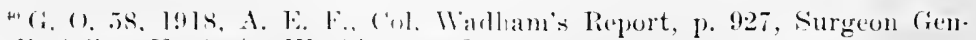
eral's Oflice, C.S. A. Witshington, I). C. 


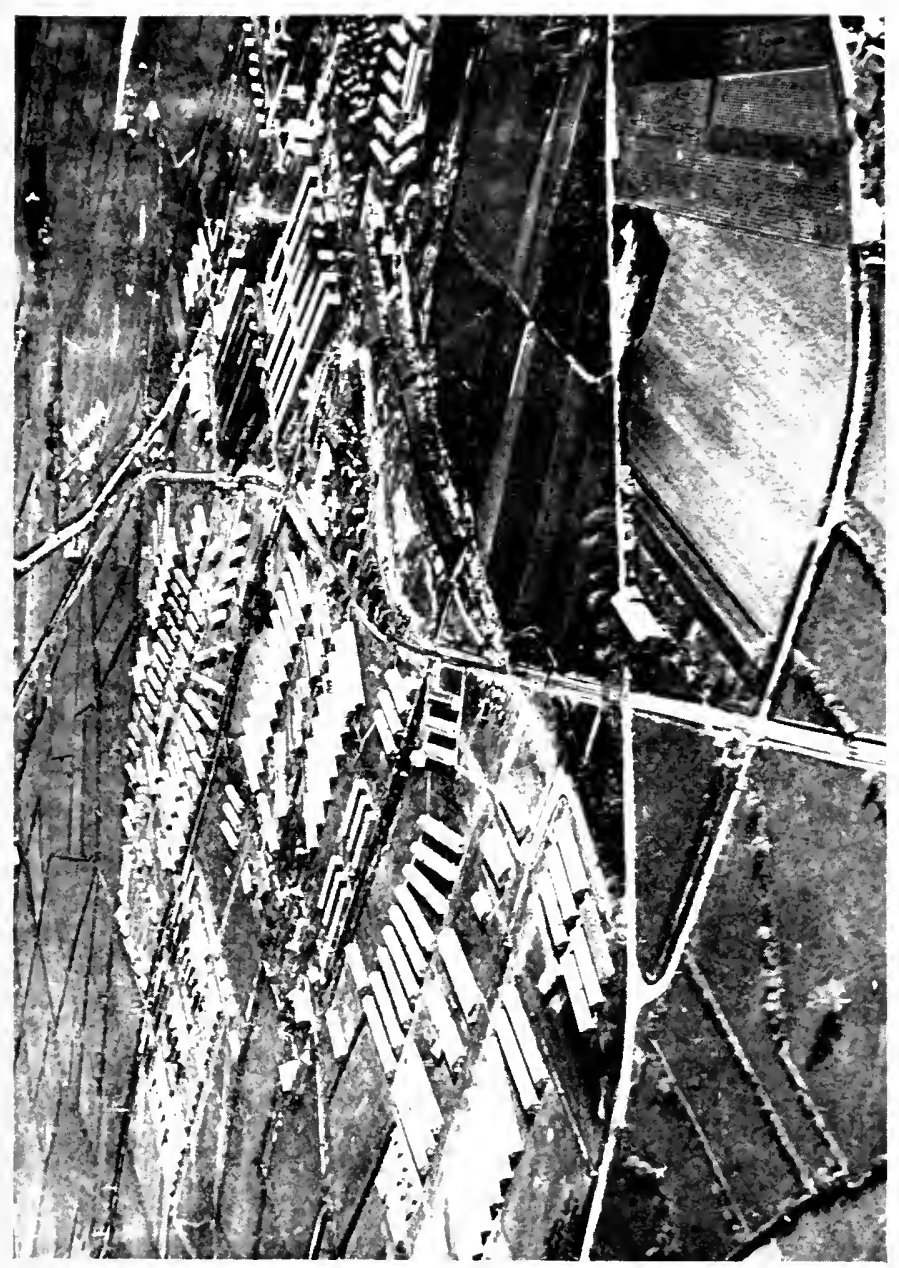

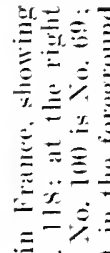

$\therefore \dot{\bar{O}} \equiv$

$\therefore= \pm$

$\div \div$

恣焉

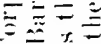

$\because \equiv$

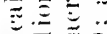

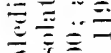

$\div$ 画

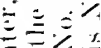

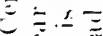

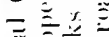

产要

原:

$\equiv \equiv$

菃引三

栗三

$\div \overline{\bar{x}} \equiv$

$\therefore \div$

$\underline{\Xi}=$

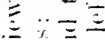

$\overline{\frac{1}{二} \equiv}$

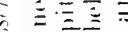

$\therefore$ 三人

․ㅡ三三

$5=\overline{3}$

$\equiv \equiv \bar{\equiv}$

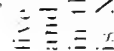



separate entrance for every four rooms and with indoor toilet facilities and rumning water. A stove sufficiently large to heat all four rooms was located in each hallway. Generally not more than two nurses were quartered in each room. "The comfort of these quarters," wrote $M$ I iss Stimson, "eompared to the large, bare, cold dormitories in French buildings which had to be used by from twenty to fifty women, which had no convenicnees and most inadequate toilet and washing facilities, was really all that could be hoped for in the field."

Rations for Army nurses were the same as those allowed for patients and were on the whole varied and ample. Previous to 1917. Congress had allowed forty cents a day for food for patients and Army nurses, but experienee proved this amount to be inadequate in view of the greatly inereased cost of supplies during the war period. The Surgeon General aceordingly asked the American Red Cross to make an additional daily provision of thirty-five eents for each patient and nurse, bringing the allowance to serenty-five eents, an amount conceded to be satisfactory, until Congressional aetion could be passed affixing the legal allowance at seventy-five cents. The Red Cross appropriated funds for this purpose until May, 1918; the amount expended for food for patients and Army nurses was well over $\$ 185,000$. "Coloncl Ireland," reeorded the Minutes of a meeting of the Red Cross War Couneil, May 18, 1918, "stated that ample provision has now been made by" the Government for the sick in hospitals and for members of the Army Nurse Corps."

The mothod in which nurses' meals were cooked and served depended largely upon loeal conditions. Sometimes nurses stnod up in the "chow-lines" with their mess-kits, as did the donghboys. Sometimes they messed with the officers of their unit. In base, evacuation and eamp hospitals, the staffs of which were large enough to make such an arrangement practieable, a separate nurses' mess was considered by Miss Stimson to be the most satisfactory plan. An excellent combination was to put such a mess muder the direction of a nurse "whose duty it was to coïperate with the regular mess officer and in addition to give her personal attention to the eooking and sorving of meals," and to cmploy Army cooks to cook them and French women to serve them. ${ }^{41}$

"HIlintory of th" Xursing Activities. A. F. F.. on the Western Front during the "Iar P'eriod," Julia C. Stimson, p. 13. 


\section{HISTORY OF AMERICAN RED CROSS NURSING}

Perhaps the greatest single continued discomfort which nurses experienced on active service with the American Expeditionary Forces was the doing a large part of their own laundry work. Some hospitals maintained their own establishments; others were able to send the nurses' laundry to commercial firms in nearby towns. But in the large proportion of hospitals, the nurses were obliged to wash their uniforms and other articles of clothing themselves, because there appeared to be no other way of getting it done. "Particularly during the times when the actual physical strength of the nurses was taxed to the very utmost in their care of the patients," wrote Miss Stimson, "this was a great hardship." A nurse wrote: "Washing elothes at night after mursing all dav wore us out."

If recreation in a cantonment hospital in the United States was difficult to get, it was well nigh impossible at an isolated base in France. Mud and sleet made walking practically ont of the question during the winter months. The nurses' quarters were usually so crowded that the nurses found little relaxation there. The Red Cross soon constructed in the principal base hospital centers reereation huts for the patients and the libraries in these huts, as well as motion picture programs and other performanees which were provided there, were open to the nurses. American Red Cross eanteen and recreation hut workers were assigned to duty and nurses had reason to be grateful, indeed, to them for many services faithfully and sympathetically rendered.

The American Red Cross also built in many hospital centers special recreation houses for the nurses and upon the reconmendation of the Army chief nurses, invited the Young Women's Christian Association to send secretaries to act as hostesses at these houses. The suecess of this work was due in large part to the tactfulness and administrative ability of Margaret $S$. Morriss, who resigned from the faculty of Momut Holvoke College and went orerseas in December, 1917, as a Y. W. C. A. Fecretary. She was first assigned to Base Hospital No. 27 at Anerers. where the value of the service which she had come to render to nulses was proven beyond a doubt. In the early summer of 1 ! 18 , she was sent to the Headquarters of her association in l'aris and there took charge of this phase of the work of the Yomng Wonn's ('hristian Association in all the hase hospitals of the American Expeditionary Forees to which secetaries were atsignesl. 
Far more discouraging than the crowded quarters, the sometimes unsavory food, the lanndry problem and the lack of recreation was the exhanstive burden of professional work which the general shortage of nurses in the American Expeditionary Forees placed npon the Army numses on duty in the zone of the base. This shortage hats been emphasized in previous paragraphs but it should be noted that it still continued, dne to the transportation sitnation and the dire military need for giving combat troops and supplies the right of way over medical persomel. To stimulate murses to enter military service, General Ireland, then Chief surgeon of the A. E. F., cabled National Headquarters on September 4, 1518, "that the Ameriean Expeditionary Forres need at present four thousand murses. We will need," he continned, "one hundred murses with each additional base hospital and there are four to each division; forty murses with each evacuation hospital and there are two to each division. In addition to this, we need a great number of nurses for eamp hospitals and emergency calls we reeeive daily."

The War I)iary of September 9 , 1918, stated that "base hospitals have been stripped of every axailable officer and murse for the purpose of forming surgical teams and in the event of extreme alctivity of our troops at the front, there undoubtedly will be the greatest diffienlty in taking care of patients sent balck to the base hospitals in the s.' O. S. The sitnation," ("onltinued this rntry of the Ilary, "was sared only by the selfsacrificing spirit of officers, murses and men. 1)uring the period from July in to Normuler 11, the anomut of work done was such that no praise would be great enongh. It was not at all uneommon for nurses to work fonrteen to eighteen hours a day for weeks at al time. . . " +2

Statisties of the "peak days" at hospital centers showed sharp contrast between actual conditions and the estimated ratio of ten-beds-to-one-nur'se which the Walr I lepartment felt in 1917 would be a safo matrein on which to rection the mursing necels of the Amere lot the six hospitals at IIars, there wats on Xo-

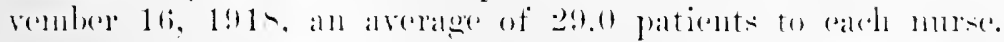
In the seven lespitals at Toul, there wals on Novemlere an

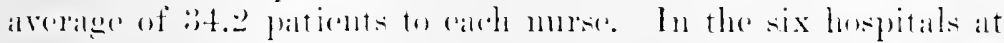

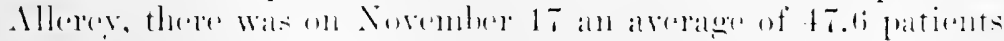

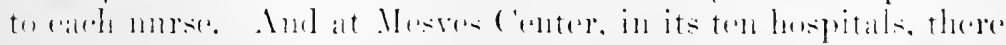

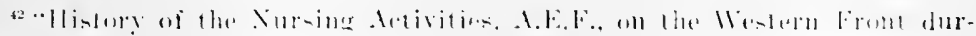

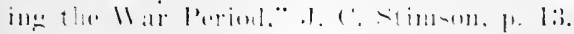




\section{HISTORY OF AMERICAN RED CROSS NURSING}

\section{was on November 16 an average of 51.2 patients to each nurse. ${ }^{43}$}

Like cantonment duty in the United States, field service in base hospitals in France lacked the horrible yet stimulating pageantry of nursing at the front. Periods of intense strain characterized the service both in the forward areas and in the zone of the base, but the duration of such periods in the base, observed Miss Stimson, averaged a longer period than did the most severe periods in evacuation and mobile hospitals. Nor was there present in the zone of the base the excitement of real emergency and the thrill of danger to challenge the nurses' imaginations and spur them to heroic moments. There was only continued, patient, monotonous, exhausting work.

Colonel Wadhams wrote of the base hospitals that "it is unfortunate but certain that the Army and the people at large will never be able to realize the debt of gratitude which they owe to the persomnel of these units. . . . Surgeons and nurses literally dropped at the operating-tables from fatigue." 44

And the morale of the 10,061 American Army nurses, regulars and reserves, who served in the zone of the base with the American Expeditionary Forces in France? These women had gone to France with high hopes for rendering heroic service but with extremely vague conceptions of what this scrvice would in actuality consist. When they arrived, they were quietly absorbed in the Sanitary Service and were sent to bases far behind the lines, to lonely and remote French villages where living conditions were prinitive and social customs strange. Instead of the assignment, immediate or later for most of them, to the fighting zones which they eoveted, the zones where they had imagined themselves as rendering spectacular service, they were sent to the rear of the Armies and scrubbed floors in dirty and dilapidated French buildings or in rude wooden barracks, set up wards, made beds and nursed contagions cases. During 1917 and the carly part of 1918, physical discomfort, manual toil, loneliness and monotony was the order, not the exeeption, of their day. In addition to bearing the responsibility of housework which should have been done by orderlies and convaleseent patients and to performing comparatively minterest-

"3 "History of the Nursing Activities. A.F.F., on the Western Front during the War Periorl." I. (C. Ttimson. p. 8.

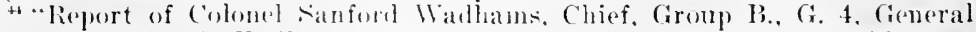
Statf, (i. H. (2., A. E. F." Surgern Genral's Oflice, C. S. A., Washington, 1). $\mathrm{C}$. 
ing professional duties, they were under the strain of endless inspections and criticisms of conditions beyond their power to remedy.

A last straw for most of them was the formation of forward professional teams. Iuring the spring and summer of 1918, nurses to the numbers of 2662 were detached from the staffs of the base hospitals and sent to the zone of the advance, leaving to the 7000 nurses remaining in the bases, greatly increased duties and the poignant disappointment of not having been chosen to share in the most romantic and spectacular phase of war nursing.

'Then during the early summer of 1918 , the pendulum swung, eren in the zone of the base, to the other extreme and the nurses in the base hospitals were called upon to shoulder a task as difficult as was that at the front, a task, however, which lacked the features which made front line service heroic and, therefore, more easily endurable. American troops went into action at Chatean-Thierry and the wards of all American sanitary formations were erowded with wounded men. Nurses, surgeons and orderlies, as has been stated before, worked until they could work no more. Discouraged by apparently futile efforts to improve conditions, exhansted by the herculean labor demanded of them, in many cases harried by constant bombardments and bewildered by the sight and suffering of the disfigured men, the nurses were sobered and numbed by fatigue and horror into silence and disillusionment. War no longer appeared to be a fine, a brave, an heroic thing.

All of them sobered, many of them sileneed, a few of them embittered, ther nevertheless did efficient work and did it at loast as gallantly as women have met crises before-and even though this may sound contradietory when the disillusionment and bitterness is considered, they did rise spiritually to their task. They eould do no less, for they had only to look about them in the wards to find examples of fortitude and cheerfulness which shamed their eomplaints into silence and sent them al wont their work. "The wounded are so brave." wrote Saral Parsons, herself an Army nurse as well as a veteran in nursing cdueation and administration, "that no woman with a heart, as lome as she has strength to stand on her feet and keep going. romld ricld to disonmeanement and depression."

Even though the mures had little time for the expression of their sempathy and admiration for the wounderl, eren though 
many of them may have been short at times in patience, even thongh a few of them broke under the strain, none who know conditions as they actually existed, may say with truth that their work was not bravely and well done! Much has been written in eulogy of the war nurse, but to nurses, the thoughtful and well-weighed sentences of one who knew, William S. Thaver, are praise enough:

Only tried women are suitable to go out into nursing, and especially into army nursing. No better proof of this can be found than the prejudice which existed in 1898 among many excellent medical officers of the Army, against the introduction of the trained nurse regularly into the Army service. These offcers could not conceive the presence of attractive young women among the somewhat rough boys of the Army without complications and scandal. This prejudice still persisted among some Army officers after twenty years. . . .

I remember well the conditions of the Spanish War. I remember the fine work done by nurses; but I remember also the difficulties, the anxieties and the obstacles in the way of those who endeavored to maintain the standards of the service and to show to the Medical Corps what nursing in the Army might and should be.

Twenty rears later... nearly eleven thousand regular and reserve nurses served in France alone. The anxieties and the danger of the royage these women bore as calmly, and often more so, than the men. To their work in France I can testify as one who was among them. I saw them under all conditions. In the hurriedly improrised camp hospital of the crowded base port, and in isolated points in the base sections; in spots remored from all that was interesting and stimulating. where, at times, refined women had to sleep crowded together, twenty or thirty in a rough. open ward. without privacy, whth the crulest and most insuiticient sanitary arrangements. exposed continually in damp rainy weather, with mul so deep that ono conth narigate only in rubber boots. I saw them in half-finisher base hospitals in the Tosges, moler like ronlitions. in the hitter northern winter. where with fingers and tous numb and hanched with cold, one nurse had almost to lare for a whole. ill-heated warl. I saw them work day in and tay ont without rest. without recreation. in the darkenot wards be night, and the fon and rain by day, and hear the strain esery hit as well as men. . . They serred without par. without flimehing. without romplaint. But one mormur did I hear. and this a murmur and not a complaint. 
a regret that it might not be given to them to share more fully the duties and the responsibilities at the points of greatest danger. Wherever they went they brought order and cleanliness, and system and contentment and peace. Ask the doughboy what it meant to him to find himself at last in a ward presided over by a nurse. Try to say a light word about a nurse to a doughboy who has been under her care! ${ }^{45}$

While the United States Medieal Corps was organizing sanitary units in the zones of the base and the advance, the American Red Cross Commission for Europe was setting up a supplementary medieal and mursing service to take eare of emergeney demands which the less flexible structure of the Military Establishment conld not meet. The Ameriean Red Cross in Franee served as an emergency arm of the Medical Department of the American Expeditionary Forces and the Nursing Service formed a vital phase of this service. An account of its development and accomplishments constitutes a dramatic and conplex chapter of military nursing history.

The Ameriean Red Cross Nursing Service in France may well be compared to a small and sturdy ship in strange and troublous waters, a ship on which many masters strove for command, a ship buffeted about by ehanging winds of European and American public opinion, threatened by perilons shoals of fundamental professional nursing, military and lay policy and strained by emergencies which demanded service in proportions such ats have nucver before been demanded of women. That this ship came at last gallantly to port speaks well indeed for the stanina of those who formed her crew.

To gain a true understanding of the nature and value of the nursing service rendered by the American Red ('ross in Franee, an appreciation is necessary of French mursing progress. of Frenela and Aneriean social enditions, of Ameriean Army and Ameriean Red (ross organization and of the military situation whicle eonfronted the Allies in 1917 and 1918. Earde of these determining falctors will be treated in turn.

The French fird cross muted the prominent women of France in volunterer work in tine of war. This organization

4s "Nursing and the Ant of Medicine": An address delivered hy I)r. W. S.

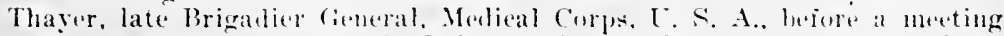
held in memory of Jane A. Delamo, Philatelphia. Yay 7 . 1919: later

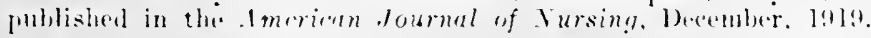




\section{HISTORY OF AMERICAN RED CROSS NURSING}

was divided into three societies as follows: (1) Société Française de Secours aux Blessés Militaires; (2) Union des Femmes de France; (3) Association des Dames Françaises.

Each of these three societics had its own organization and direction and arranged for its own finaneing. The Société Française de Secours aux Blessés Militaires was direeted by a committee of men, but the other two societies were managed entirely by women, with men serving only as consultants at board meetings. The three societies were united through a Central Committee which alone possessed the authority to maintain official relations with the International Committee of the Red Cross at Geneva and with foreign Red Cross societies. ${ }^{46}$

The Société Française de Secours aux Blessés Militaires was created in June, 1864, and was reeognized to be of public utility on June 23, 1866. It was estimated that in April, 1917, this society was maintaining eight hundred hospitals with a total capacity of seventy thousand beds. ${ }^{47}$ The nurses for these hospitals were all members of the Société Française de Secours aux Blessés Militaires and had received instruction in nursing offered by the soeicty. The course of studies was given at a large dispensary school in the Place des Peupliers, covered five months and led to the first diploma, or Diplôme Simple.

During the summer of 1916, Miss Maxwell and Miss Irene Givenwilson made the inspection tour of sixty-scven French, British and Belgian military hospitals, whieh has been described in a preceding scetion. A report of this tour submitted in Oetober, 1916, by Miss Givenwilson to Miss Delano contained the following statement:

All members of the French Red Cross belong to the upper and midlle classes and the whole service is voluntary for the love of country and humanity. There are about thirty thousand members at present enrolled as murses. Some of these, owing to adverse circumstances, may require pecuniary assistance and this is granted ont of the funds of the society. but it is never looked upon as remuneration for services rendered.

The rociéte de śprours aux Blessés Mililaires is the largest of the three ascoriations. . . The training school in Paris is known as the Ioprital-Ecole and is presided over by Mlle.

4"See "Report of the French Pind Crose," written ly William r:. Sharp, Ambassador to France, to the L. S. State Department, April 27, 1917, filecl Library, National lleadquarters, Washington, D. C.

${ }^{47}$ Ibid. 
Genin. Here all aspirants to membership undergo a strict training daily for five months before they can present themselves for examination and receive the first diploma which admits them to the society. To acquire the mental attitude necessary for service in time of war, three prineiples are strongly impressed upon the pupils during their training: (1) unity of action; (2) unity of thought; (3) unity of submission. ${ }^{48}$

The training offered by the Société de Secours aux Blessés Militaires was described as follows by Mme. Edouard KrebsJapy, in L'Infirmière:

\section{Schools for Training Red Cross Nurses:}

A. The Society for Assistance to Wounded Soldiers:

I. Hospital School in the Square des Peupliers, Paris (XIII). Directrice, Mlle. Genin.

Prerequisites for admission: The applicants must be twenty years of agre, must bring responsible references, must belong to the Society for Assistance to Wounded Soldiers and must promise to serve in case of war or public calamity.

The subjects are arranged as follows: (a) A five months' period of instruction, entitling the applicant to appear for examination, for the purpose of obtaining a primary diploma conferring the title of nurse to the society. The nurse is entitled to a service book and may be assigned to medical or surcical sanitary units, ciril or military, in case of war. (b) A second nine months' period of study and theoretical instruction will be required for obtaining the second degree. Only nurses having the primary diploma and who are from twenty-five to forty-five years old may be admitted to receive this supplementary instruction. 'The final examination will allow the applicant to obtain a second degree diploma, entitling her to be known as a head nurse or supervisor. . . .

II. In the provinces, the society trains its murses in its numerous dispensary-schools. ${ }^{49}$

Miss Givenwilson's diary contained the following enment rearding a visit made by Miss Maxwell and herself to the llopital-École:

"4 "Report of the Voluntary Nursing Serviees of England and France:" I. M. Givenwilson, pp. $7-9$; Library, National Headquarters, Washington, I). $C$.

5 Lnfirmiire; Mme. Felouard Krebs-Jayy, pp. 60-61, Librairie Armand Colin, 1921, Paris, France. 
Miss Maxwell and I then set out for the Red Cross Training Hospital for Nurses in the Place des Peupliers, of which Mlle. Genin, Chevalier of the Legion of Honneur, is the directrice.... We had a most interesting talk with Mlle. Genin. She has a wonderful personality and the fine commanding head and features of a leader.

... The training school had been transformed into a military hospital of about seventy or eighty beds. We were conducted over the whole building by an infirmiere major and we were struck by the perfect cleanliness of the whole building and its equipment. What, however, struck us disagreeably was the closeness of the atmosphere and the number of flies which worried and distressed the poor wounded. It is a characteristic of the French hospitals to keep nearly all the windows closed; their aversion to fresh air is remarkable. . . . 50

The second societr, Union des Femmes de France, was recognized to be of public utility on August 6,1882 . It was estimated that this branch of the French Red Cross was maintaining in April, 1917, 363 hospitals with a total bed capacity of $30,000 .{ }^{51}$ The official circular issued by the Union des Femmes de France set forth the following information regarding the annual courses:

Assistant hosprital-attendant's certificate: Pupils desirous of obtaining this certificate must take the theoretical course in anatomy, minor surery. hyciene, care of the sick, pharmacy, bantages and practical exercises, in one of the different training centers, and pass the examination.

IIosprital-atlendant's certificale: To obtain this certificate, one must take the theoretical courses designated above; after reaching the are of $1 \mathrm{n}$. take a practical probationary term of three months (three attendances per week) in a dispensary school or outside consultation office of a civil hospital; and pass the examination. (X. B.) A term either in a consultation office for habies. in a lay-nursery or in a baby home. completed by practical instruction in puericulture, is strongly recommended to pupils until it hecomes obligatory.

Iliplome for hospitul alfendant: After obtaining the infimarians certiticate, one must take the theoretical courses,

so "Diary of My Visit to france, June-Angust, 1916," I. M. Givenwilson, pp. $20-21 \div 41$.

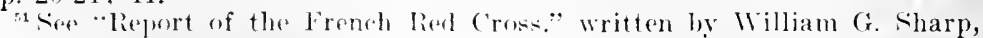
Ambasiaror to France. to the L. S. State le prartment, April $2 \bar{i}, 1917$. 
and, only after reaching the age of 21 , take: (1) $A$ three months' term in the training hospital; (\&) A three months' term in theoretical and praetical massare; (3) A three months' term in a civil or military hospital; (4) 'Take the conrees in military administration and pass the different tests in each branch.

The third society, Association des Dames Françaises, was recognized to be of public utility on April 23, 1883. It was reported to be maintaining in April, 1917, 281 hospitals with a total bed capacity of 17,207 . The instruetion which it gave its nurses resembled that offered by the two other societies of the Freneh lied C'ross.

As to professional nursing service, only one school for nurses organized npon British and American standards existed in France: L'École Professionale des Crardes-Malades Mospitalieres at Bordeaux, known as the Nightingale School, with the sanction of Miss Nightingale's executors).

As to the nurses in French eivil hospitals, Miss Givenwilson wrote in her official report to National Headquarters:

The professional nurses are comparatively few and do not receive the same exhaustive training as our own. 'They are drawn for the most fart from the ranks of the religions sisters, or from women of the lower classes trained in the civil hospitals of the Assistance Publique. . . .52

The following aecomnt appeared in Miss Givenwilson's diary:

July 18, 1916. We went to visit the old eivil hospital of St. Lomis this afternoon. It was built in the dith century as a bospital for the plague and was separated from the ait $y$ he strong turreterl walls and a moat. Some of the ancient bailiings still remain. hut the moat has disappeared and small

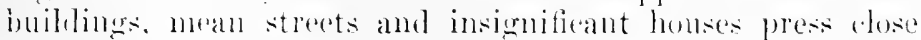
upon the olfl walls. It is now the ehief hospital in the aity | Paris/ for skin diseases and contains a lamous library on the subjert. . . .

The Frencle murses are seen at their worst here. . . I think that this war will impress upon the Froneh the nexessity of training unses of higher soedal standing and ereater intelligenese for their hospitals. The gart of the horpital 1. 12.

s2 "Report of the Volunter Nursing Service of England and Franee," 


\section{HIS'TORY OF AMERICAN RED CROSS NURSING}

which looked the most carefully tended was the beautiful old garden with its magnificent trees and neat flower beds. . . .53

Of the mobilization and service of the nursing members of the French Red Cross, Miss Givenwilson wrote in her report:

On the declaration of war, all the members of the three societies of the French Red Cross were immediately mobilized and dispersed throughout the country wherever they were needed. And to their honor be it said that all nobly responded to the call, leaving comfortable, often luxurious homes, to experience the rigid discipline and heary responsibilities of a French military or auxiliary hospital for the duration of the war. For it has to be remembered that very few of these women are trained nurses, although they are often given the supervision of a ward of seriously wounded soldiers with only orderlies to assist them. This is the great defect of the nursing system in France ... and this war has demonstrated the urgent need in France for the estallishment of training schools for nurses on the same lines as those that exist in England and America. . . .

The training of the French Red Cross for its first diploma ... renders their members very capable "nurses' aides." But they are called upon to accept responsibilities far beyond their knowledge and this they do with a courage and devotion which is truly admirable. They are tireless in the accomplishment of their arduous duties; they take no hours off for recreation or ammsement; their free time, if they have any, is spent in making their wards more attractive by simple decorations manufactured by their deft fingers from the morlest means at their disposal. They are full of cheerfulness and compassion and in the eyes of the wounded under their care is to be read the appreciation of these noble women, who have voluntarily sacrificed all with glad heart at the eall of patriotism and humanity. ${ }^{5 t}$

Of the French military hospitals, Miss Givenwilson wrote:

Hôpital ('entral at Bar-le-Dur:: This hospital ar(commodated three thousand beds and is situated in some barracks which were approaching completion before the war broke out and were rapidly transtomed into a hospital. . .

We first visitinl thre surgiral side, whose wards appeared to sz "Diary" 1. M. (iivenwilum, Pl. 7273.

" "leport of the Volmutary Nursimg Service of England and France," pI. $11-13$. 
be beautifully kept, although there is only one nurse to each. This is one of the points that has struck me forcibly; the French or Belgian nurse accomplished much more than the English or American one, in sheer mannal labor. Her technical knowledge is murh less and her pationts suffer in consequence, but she had a lar larger number of heds nuder her charge withont anxiliary help and yet she manages to keep her wards neat and cladn. Everything in French hospitals is on a simpler scale and the French poilu is neither given nor demands as much as the British 'Tommy. In this huge hospital of three thousand beds, there were only fifty nurses and about one hundred orderlies and the wounded looked well cared for. ...

There is a terrible plague of flies throughout this whole neighborhood, in spite of all preeautions to get rid of them. They swarm in thousands everywhere and the most seriously wounded have to be protected by pieces of gauze over their heads. There are camps of soldiers and horses everywhere, so it seems impossible to eradieate the pest. . . .55

Miss Maxwell and Miss Givenwilson visited the French military evacuation hospital at Revigny. Miss Givenwilson wrote in her report to National Headquarters:

The work of this great hospital was in full swing when we arrived early in the morning. The establishment consists of an evacuation hospital of eight hundred heds which is even now being increased to one thousand. The womded are brought here straight from Verdun by a little branch line of railway and it is here that the triage or sorting of the wommled takes place. Over one humdred thomand have passol throngh the cracmation hospital since the beginning of Mareh.

A colony of huts has been erected in a convenient situation arljoining the main line from Paris to Bar-le-Ino. Toul and Nancy. The evacuation hospital is practially contisuons with the stationary hospital but is a complete imit in itsolf and possesses its own kitehen, ofluese, operating and dresing rocollis.

There are four catenories for the wounded: (1) Those serimsty wombled. who annot he tramsported further with-

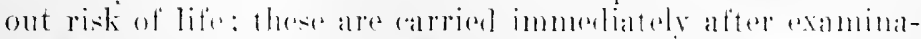
tion to the aljoming stationary hospitat (small compared to

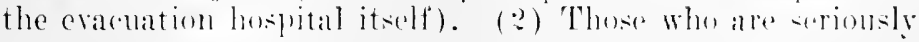

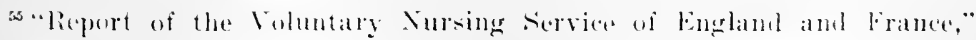
P1. 4.5. 


\section{HISTORY OF AMERICAN RED CROSS NURSING}

wounded and can be transported are taken by ambulance cars to the hospitals of Jean d'II eurs or to the British hospital of Faux Miroir, both situated a few kilometers distant. (3) Others who are less seriously wounded are sent by ambulance train to Paris or hospitals in the interior. (4) All those who are only slightly wounded are sent to hospitals within the Army Zone, so that on recovery they can be immediately returned to their companies. They are seldom absent for more than a week or a fortnight.

The town of Rerigny itself is a mass of ruins and the hospital is situated on the outskirts, among the fields. ${ }^{56}$

The following description of the evacuation hospital at Revigny appeared in Miss Givenwilson's diary:

August 4, 1916. We started for Revigny early this morning. . . . The work of the great hospital was in full swing when we arrived. . . We visited all the huts of the stationary hospital and found them filled with very sick men. The mortality here is very great. . . .

I shall never forget the ghastly sights in the wards in which the septic and gangrenous cases were lying. An attempt was being made to treat these by constant irrigation, but the awful diseomfort of the men was horrible to look upon. They had no proper mattresses and those parts of the body not being irrigated were supported only by pillows and sacks. Yet such is the heroic endurance of these men, that no complaints were to be heard. only the restless, moaning delirium of those who were almost past help.

The mises were a nice set of cheerful, hard-working women, though their life is full of hardship and toil. . .

The surgeon-in-chief proposed that we should witness the arrival of the Verdun ambulance train which was shortly due. We went to the little roadside station to find that the train was alrearly there and was slowly unloading its ghastly burden. Shillful arm: were there to receive the shapeless masses huddled on the stretrhers and they were swiftly borne to the hospital.

Soon the little therating-room berame a shambles, the floor bloodstained. the pails orerflowing with soiled dressings, the atmosphere thick with the smell of bleod. disinferetants and human sweat. Itoctors and murses worked without pause. the only sounds being the click of the instruments and the low moans or shary exclamations of pain of the wounderl. One

so "Report of the Voluntary Nursing service of England and France." J'1. 4s. 1!). 
by one they lay exposed to the keen eye of the surgeon,-men with limbs fractured and hattered to a pulp, with faces mangled beyond recognition, with huge rents torn in their bodies. .. And in the faces of all these wounded was a lumb look of wonderment that such things should be and an infinite trust in the skill of those in whose eare they now were. . . .57

From the report and diary submitted by Miss Givenwilson, which bore the endorsement of Miss Maxwell, it may readily be appreciated that in a modern system of nursing, the French nation was far behind the United States, where practically every town of over ten thousand population possessed, at the time of the Lnited States' entry into the war, a hospital maintaining a professional school for murses founded on the Nightingale System. The heroism with which murses of the French Red Cross cared for their wounded needs no further eulogy here, but it is equally self-evident that the professional attainments of women who have had only five months' theoretieal instruction gained through semi-weekly leetures and dispensary training, are not to be compared with those of women who have undergone two or three ycars' training as nurses while resident at a modern general hospital. In addition to the inhibitory influence of the French Red Cross, French social eustoms were potent factors in limiting the development of a Freneh mursing profession comparable to that of Great Britain and the United States. To give a man a bed-bath was considered by nurses of the French Red Cross to be menial labor of a degrading nature; to remain on duty all night was, to them, an unheard-of breach of convention. Before taking up in detail the Paris situation, it must be understood that in a country where any woman who cared for the sick was ofticially rated as a nurse, public opinion would have little understanding and appreciation of the meaning and value of American mursing standards and ethies.

A second deternining factor of the mursing situation as it developod in the Paris Headquarters of the American Red ('ross was the natural zeal of Ameriean larwomen then in France, the wives, dalughters and relatives of prominent Red ('ross oftheials and other influential American women who rendered distinguished serrice to the Allied and Ameriean troops in Francen, to share in mursing the womnded. The point of riew of the Ameriean laywoman was natural and easy to understand.

s; "-1)iary." I. M. (Givenwilson, pp. 151-156. 


\section{HISTORY OF AMERICAN RED CROSS NURSING}

It may be said that since the beginnings of war, women have been urged by sympathies based on the maternal instinct and the tendency of womankind to venerate that which is strong and courageous, to desire to minister to the wounded. This principle may certainly be called one of the foundation-stones of the Red Cross ideal and in the twentieth century, the Red Cross nurse was, to the general public, the crowning symbol of the Red Cross organization, the fullest expression of this ideal; hence the desire on the part of the laywoman to serve as a Red Cross nurse. Further, American laywomen argued, why was it so necessary for a woman, before she could go into the wards of a military hospital, to undergo a long training based on some elusive idea to which nurses constantly referred as "professional standards?" Leaders of the nursing world had admitted that the number of trained women was limited. Better a partially trained woman in a ward than that men should die unattended! Why should not they themselves be allowed to go immediately into this spectacular, this most appealing branch of Red Cross endeavor?

The point of view of the American professional nurse-and it has been shown that the American Red Cross nurse was the highest exponent of the American mursing profession-was equally natural and easy to understand. It has been stated in a preceding chapter that one of the basic principles of the nursing profession was that "nursing education and administration must be directed hy nurses." The welfare of the patient was the fundamental reason for this principle. Nurses contended that an executive murse, alive to the opportunities of nursing service by reason of her own personal familiarity with nursing theory and technique and her knowledge of the primary importance of discipline, could judge the needs of the patient and the work of the nurse lietter than conld a laywoman, who knew little, if anything, of this theory, this technique and above all this discipline.

In addition to the principle of the welfare of the patient, another determinime social factor of the Paris situatim, a fartor which leaders of nursing womld probably not have admitted at the time, was the natural desire of the professional nurse to reap the fruits of a hard won struggle. Previous to the decelaration of the European War, a professional nurse did not hold so enviable a position as was acoorded her immediately after the declaration of war, when to nurse the soldiers was the 
romantie, the spectacular serviee to render. The American Army authorities permitted only professionally trained women in their hospitals and the Ameriean nurses in these instances reaped the reward, in this opportunity to serve, of long years spent in training and longer years spent in the practice of their profession. Through the American Red Cross in France, however, another opportunity for war mursing presented itself and to this more yielding avenue of approach, laywomen flocked, there to eome up against the bars of "professional standards," the only bars with which nurses could strive-for murses in the majority have not wealth and social position-to hold that which they considered rightfully their own.

Conditions outside the Red Cross, as well, played a part in this controversy. The English system of Voluntary Aid Detachments; the presence of untrained helpers in the wards of hospitals established by various other American relief ageneies and later taken over by the American Red Cross, notably Military Hospitals Nos. 1 and 2 ; the dictum of the French government that any woman who eared for the siek was officially rated as a nurse, all fimned the flame of volunteer zeal to such heights of enthusiasm that an American Red Cross Nursing Service established in France on a professional basis seemed in the early days of $191 \%$ likely to be eonsumed therein.

The organization of the American Red Cross in France constituted another shoal upon which the Nursing Service threatened to go aground. On May 9, 1917, Henry P. Davison eabled to Herman II. Itarjes, of the banking firm of Morgan, IIarjes and Company, Paris, who wats then head of the Ameriean Red Cross in Franee, regalrding the anticipated appointment and persomel of the War Comecil of the Amerixan Red Cross. After outlining the proposed campaign for the first Red Cross War Fund, Mr. Darison's message continned:

We now contemulate immediately after our organization having one of omr commed, Murphy, proceed at onere with a personal staff to Paris, where he will go with full authority from the War ('ombeil to undertake and do smeh things al: may serm to him wise. he being neresarily governesl hy anditions obtaining here from time to time.

Grayson M-P'. Murphy is a West Point graduate, was in the

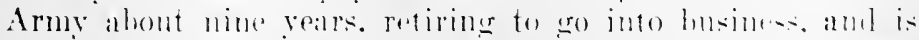

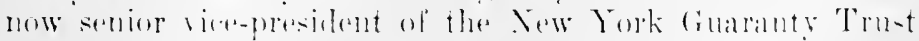

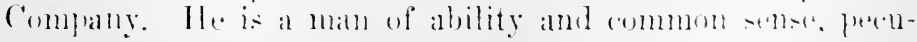




\section{HISTORY OF AMERICAN RED CROSS NURSING}

liarly free from personal ambition. . . . It is expected he will receive the line commission of major in the United States Army. He understands that you are at present the head of the American Red Cross in France and desires, as we all do, that your relations to this organization shall not only be maintained but strengthened. ${ }^{58}$

This cable went on to outline the coopperation of the American Red Cross with Alexander Ribot, Premier of France, and with relief organizations then in France. It was contemplated that Major Murphy should be commissioner for Europe with his headquarters in Paris. On May 13, Mr. Harjes eabled, at the suggestion of the French Ministry of Foreign Affairs and General Petain, that "a competent man be sent at once, invested with the necessary authority as high commissioner who would be the effective representative of our Government and Army and the link between the French and American Governments so as to make known at once and aceurately what our friends here desire."

On May 10, 1917, President Wilson announced the appointment of the War Council of the Ameriean Red Cross. A few days later, this body "recommended to the Executive Committee of the Central Committee that Grayson M-P. Murphy, a member of the War Council, should be appointed the representative of the American National Red Cross in Europe and that a commission, of which Major Murphy would be the head, should accompany him to Europe for the purpose of carrying ont relief work in France, Belgium and other European countries ..." This action was later formally ratified by the Executive Committee at a meeting held Jume 15, 1917, and was spread on the Minutes of the War Council at a meeting held August 16, 1917.

In the meantime, Major Murphy had selected a strong staff and the new Commission for Europe had sailed June 2. Major Murphy was commissioner'; the deputy ammissioners were James H. Perkins, of New York; William Endicott, of Boston; Carl Tarlor, of New York; George B. Ford, of New York; Ernest VIr.Cullough, of Boston; A. W. Copp, and Eruest 1'. Birknell, I)irector (ieneral of Civilian Relief of the Ameriean Red Cross. Others who alerompanied the rommission, but whose names are not listred as deputy eommissioners on the

ssee Red Cross Arehives, File No. 241. 
Minutes of the War Council of August 16, 1917, were Frederick S. Hoppin, Reverend Robert Davis, Reverend E. I). Miel, F. R. King, Panl Rainey, Frederick IIoffman, Ralph Preston, Phillip Goodwin, C. G. Osborne, R. J. Daly, John Van Schaick and Thomas H. Kenny. The War Department detailed Mr. Alexander Lambert, Major, Medieal Reserve Corps, U. S. A., to join the commission as liaison officer between the American Expeditionary Forees and the American Red Cross.

The Ameriean Red Cross Commission for Europe arrived in Paris on June 1t, 1917, and set up the headquarters of the organization at $\mathrm{No} .5$ Rue Francois $1^{\mathrm{r}}$. 'Ten days later, the War Department appointed Major Murphy to membership on (icneral Pershing's staff. By this appointment, members of the Red Cross Commission for Europe who were soon to become directors of important branches of Red Cross service, were placed in a position where they could easily consult offieers of the American Fxpeditionary Forees who were heads of those departments in the American Armies in France which were particularly affected by Red Cross operations.

The first work of the commission was aceomplished throngh the generosity of relief organizations already existing in France. Ir. C. C. Burlingame, then Captain, Medical Corps, I. S. A., who was later the director of Hospital Service, Ameriean Red Cross in France, wrote:

At the time the Red Cross stepped into the field, the American Relief ('learing House was already functioning to furuish efficient relief and avoid the duplication of varions relief ayencies. The director general of this orcranization was at the time 1I. (). Beatty; I. H. Jordian was the chief operating manager. Alliliated with the Clearing House were Ralph Preston. IJerman Harjes. J. Ridgely Carter, James R. Barbour and others. Ascociated with the Clearing House wre such organizations as the Norton-Harjes Ambulance servioe and the American I istributing Service, organized by Mr. ancl Mrs. Robert W. Bliss, of the Lnited States Embassy in Paris. 59

The Committee of the American Relief Clearing House turned over to the American Rod Cross their organization,

$\therefore$. Military Itistery of the Ameriean Red cross in France." (. C. Bur-

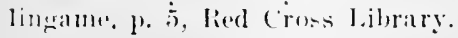




\section{HISTORY OF AMERICAN RED CROSS NURSING}

their equipment and their personnel, which immediately gave to the commission a "rumning start" for its new task.

In September, 1917, Major Perkins was made commissioner for France; Major Murphy was foreed to spend much of his time traveling in Belgium, Italy and the Balkans, preparatory to the initiation of Ameriean Red Cross activities in these places.

The early days of the summer of 1917 were spent in establishing contact with the American Army officers then in France, with the organizations already existing there for the relief of the civilian population and with the French anthorities. The conferenees which took place in July, August and September were attended by high offieials of the American Army and the Red Cross Commission for Europe. Among the consulting offieers were General Pershing, Colonel Bradley, Colonel Sanford Wadhams, Major NIurphy, Major Lambert and Captain Burlingame, and recognition was given by these officials to the relationship, already provided for by law and Army regulations, that the Ameriean Red Cross should serve as an emergeney arm of the Medical Corps in the field.

Of the early organization of the American Red Cross in France, Major Perkins wrote:

Within a few weeks after our arrival. Major Murphy and I discussed with General Pershing the work which lay before us. .. . He folt that it would be many months before his Army would he an effective fighting force and that the Rerl Cross must during those months carry the American flag in Europe.

With this idea in view, we organized two departments: one. the Department of ('ivil Affairs, whose duty it was to take up all the relief work in France. the need for which hat been created by the war: the other. the Department of Military Affairs, shonld lamelle our lied Cross work with both the French and American Armies. ${ }^{60}$

Dr. Alexander Lambert was straightway appointed director of the Reed Cross Mediral and Sireical Serviee, under the Departmont of Military Aftairs.

American lied cross medical and surgieal service to Amerian and Allied troops embraed two distincet types of hospitals.

whe First Vear of the American Red Cross in Fance," p. 4. 
The first of these were designated as American Red Cross military hospitals and were established primarily to care for Anerican soldiers. Of this type Commissioner Perkins wrote: "Whore the hospital is known als a Red Cross military hospital, it means that we have installed the hospital and that its business aspeets are managed by us, but that its medieal direction is turned over to the Army, which employs its own persomncl."

Captain Burlingame defined American Red Cross military hospitals :

The term "American Red Cross military hospital" was used only by direction of the Chief Surgeon, A. E. F., a number being assigned only by his office. The word "military" in the title of a Red Cross hospital was never inserted except upon his order. It was for this reason that certain hospitals known as American Red Cross hospitals were operated nuder the same general plan as American Red Cross military hospitals but not under that name.

Again, certain personnel organized as base hospital units were moved into American Red Cross hospitals and operated on the same basis as the American Red Cross military hospitak. It seemed unwise to change the name of a base hospital unit even when operated on this plan.

American Red ('ross military hospitals were operated jointly ly the lied Cross and the Medical Corps. In each instance there was some reason why it could not be operated to adrantage by the Inited States Army independent of the Amerinan lied ('ross. These reasons were varied: for example, when America first entered the war, Paris and its environs ware not opened by the French to the L. S. Army for hospitalization purposes. It was possible, however, for the lied ('ross thromgh various agreements, some of them informal. to talie over or establish hospitals in and about l'aris. It should he remembered that Paris was then out of the Anerican and in the heart of the lerench Army Zone.

As rapidly as conditions ahanged, making it posible for the lied ('ross to withlraw. formations operating as Ameriean Rerl ('ross military hospitals were a ompletely turned over to the Merlical corpis to be operated as regular Army formations. . . . ${ }^{61}$

o1 . Military History of the American Rerl Cross in Prance," Pp. 26-27:

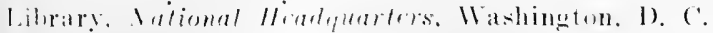




\section{3+ HISTORY OF AMERICAN RED CROSS NCRSING}

In a letter addressed December 27, 1917, to the Judge Advocate General of the Army, the Surgeon General of the Army asked

... for the opinion of the Judge Adrocate General specifically on (a) Base IIospital No. 39 "attached to and rendering service to the French Army;" (b) on personnel of "American Red Cross Military Hospitals, Nos. 1, 2 and 3 (formerly the American Ambulance, the Hospital Bénévole 21 bis-Blake's Hospital and Mrs. Reid's Hospital), the personnel of which are partly commissioned or enlisted in the U. S. Army and are partly cirilian, whether American or foreign not of record; and (e) on personnel of Red Cross hospitals maintained in France for civil relief only. ${ }^{62}$

\section{The Judge Adrocate General replied on December 29, 1917 :}

When American Red Cross officials have been accepted by the United states and are performing in France service for any of the Allied forces. they are, to use the words of Article of War 2, "persons accompanying or serving with the Armies of the United states in the field," and hence American Rerl Cross officials with the hospital described in paragraph 1 , sub-paragraph (a) are subject to the military jurisdiction of the United States. The hospitals described in sub-paragraphs (b) and (c) are not, in a strict sense, military hospitals, as they furnish aid to rivilians: but, nevertheless, as the Army of the Cnited States is operating quite as much for the benefit of the civilian population of France as for the benefit of the military population, the persomnel of these hospitals must be held to be subject to American military jurisdiction in case the persons in question have been in some formal or informal way recognized by the Army of the Cnited states-otherwise not. What is important is neither what these persons are doing. nor where they are doing it. but what description of persons they are. If they are "persons accompanying or serving with the Armies of the Cnited states in the field" there is military jurisdiction under the words of Article of War 2. (Gre Cienera Convention of 1906, Article 10. and Rules of Laml Warfare, prars. 13:3-136.) ${ }^{63}$

American Red Cross hospitals, the second type of institntion established by the Commision for Franere, arlmitted luth

${ }^{62}$ Legal Matters Reelatiner to the American Red Cross: Army and Vary orders: Appendix No. VI. Ineument l102. Library, National Headquarters.

a Mbirl. Doenument Xio. Ho:?. 
American and Allied wounded. They were defined by Major Perkins: "In what are known as Ameriean Red cross bospitals we supply all materials and install the hospital. We also furnish nurses and pay their salaries. Doctors and orderlies are partly loaned by the Army and partly supplied by us."

In working out a poliey of coördination, the American Red Cross acepiired, during the summer and fall of 1917, hospitals then being maintained in Franee by varions American relief ageneies. The first of these was the American Ambulance at Nenilly. Of this institntion, American Red Cross Military Hospital No. 1, W. S. Patten, then direetor of the Department of Military Affairs, American Red Cross in France, wrote in his report of the medical division during its first six montlis in France:

American Red Cross Military Hospital No. 1 was originally the American Ambulanee and has now been put under the Lnited States Army and the American Red Cross. This hospital contains between five and six hundred beds, which are at the disposal of the French Army. It also operates a complete dental clinic for the free service of the French soldiers, members of the Inited States Army and personnel of the American Red Cross. In rommection with this hospital, we have an ambulane sorvice which earries the wounded for the entire Paris district, viz.. it evacuates lirench wounded to all the hospitals in Paris, a very valuable service in itself and a useful medium through which to help our Allies. We have, furthermore. establisherl a sanitary train for the French which goes to the Front and brings back the wounded. The American Rid ('ress has the entire mediral and surgical management of this train. In agreement under which the hospital and its asworiated undertakings are directed gives us authority over them, but an Imerican Army officer is assigned to the directorship of the hospital.

American Red Cross Military Hospital No. 1 was the first Ameriean institution in Franee to be operated under the special relationship which has been defined abowe by the oludge Adroate (ieneral and others. It was also a stronghold of lay influenee. It had been oreanized early in 1914 by a eommittee

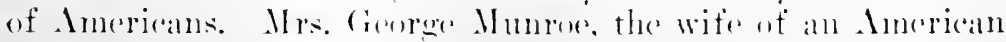
banker who had for many vears made his home in Paris. was one of the principal spensenrs for and contributors to its mainteIlatll'(') 


\section{HISTORY OF AMERICAN RED CROSS NURSING}

At this point it may be well to interpolate a word as to the method adopted by the American Red Cross in developing its foreign activities. When a commission entered a foreign country, it first established contact with the members of the American Embassy and Americans then resident there who had already won the confidence of the local authorities, and made them the spokesmen for the American Red Cross until the officers of the commission had won local confidence. Mr. George Munroe was boln in France and both he and Mrs. Munroe were known to Parisians. Mrs. Munroe spoke fluent French, knew the conditions in French hospitals in and about Paris and was a staunch war worker, so she was in an excellent position to advise the commissioner about the development of women's service.

The American Ambulance had been developed in 1914 and in the absence of Ameriean nurses in Paris, American women resident there had done the pioneer work. Mrs. Mrunroe was one of these; Mrs. William K. Yanderbilt was another, and she made the first bed at the Neuilly Ambulance because, as she afterwards stated to Miss Boardman, there was no one else to do it. After these American women had once become interested in the work, it was only human nature that they would desire to continue it. An incident will serve to show the absolute dearth of professional murses. The Duchess of Rohan converted her Paris residence into a military hospital for French wounded and she and her friends did the nursing. They had neither resident sureen nor ehief murse becanse they could not get either; a single doctor came in once a day to make rounds. The Duchess and her friends had had only the most elementary instruction in mursing, yet they were forced by necessity to eare for grands blessés. "The anxicty we felt in trying to eare for these gravely wounded men, many of whom had just eome off the operating-table," the Duehess said to Miss Boardman, "was our greatest trial. When we had air raids, they begged us to take them down to the abris but we could not tell whether the moving of them would be fatal or not. If we moved them and they died, we would be responsille, ret if they were not moved, they might be struck and again we would be responsible."

As the work at the Ambulanes got under way, a unit of American murses, among them many Red Cross nurses, was sent over from this conntry to form the mursing staff. Margaret 


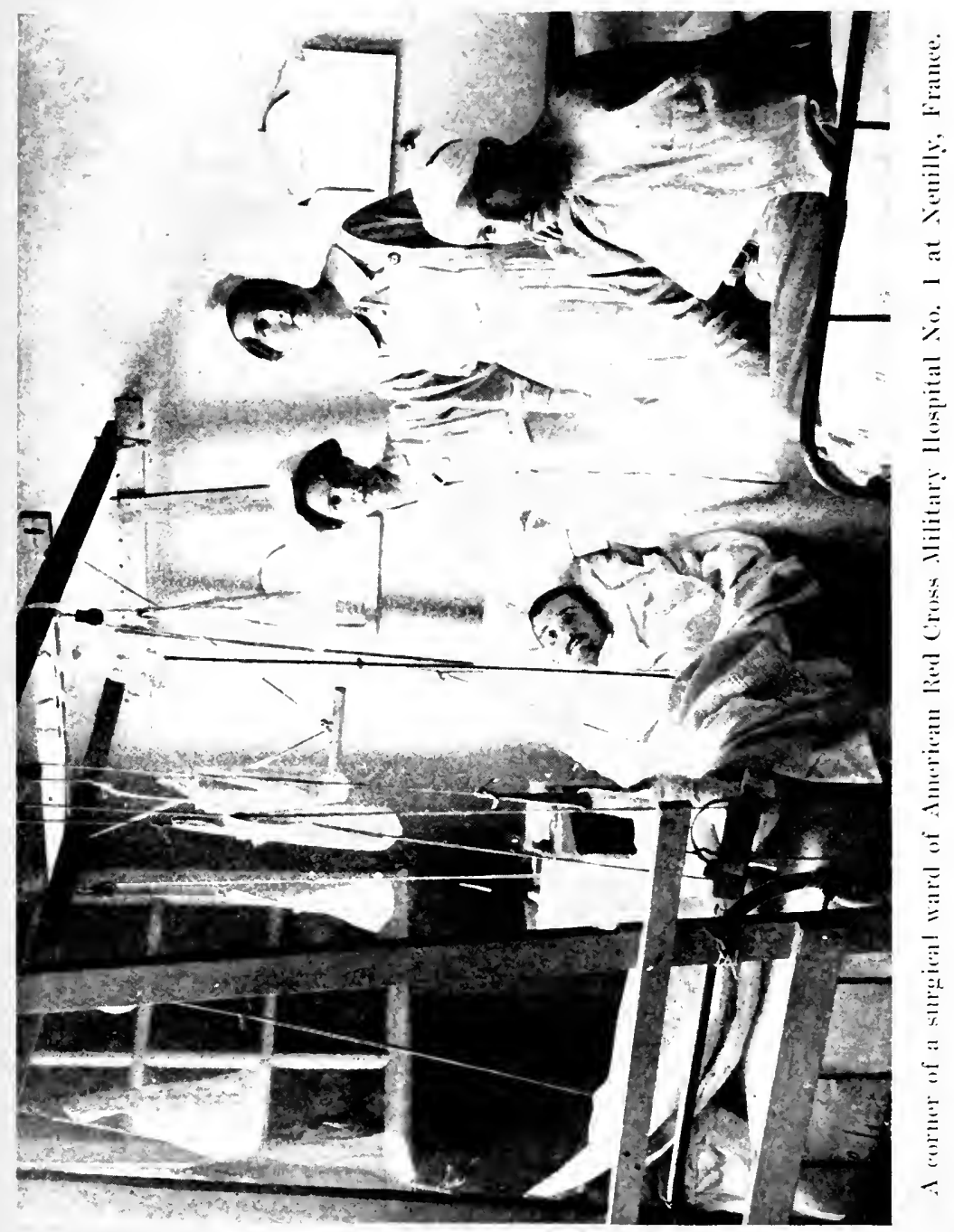



Dunlop, of the Pennsylvania School, was the chief nurse. She and several of the original unit, however, returned in 1916 to the United States. $\Lambda$ s the needs for the Ambulance were increasing with every year of the duration of the war, the nursing statf was enlarged by the assignment of whatever nursing persomnel was available in Paris-several British nurses, a number of the American Red Cross nurses who had elected to remain in foreign serviee after the recall of the Merey Ship units, and especially untrained Ameriean volunteers who were then resident in Paris and who were zealous to serve.

In the summer of 1917 , the Ameriean Red Cross took over the Ambulance, enlarged and militarized it and assigned numerous American lied Cross nurses to duty as reserves of the Army Nurse Corps. Differences of opinion arose between the old and the new rigime. Esther V. Hassan was the first superintendent of the Sary Nurse Corps. Later she was assigned als head murse of a hundred Army "easuals" who went overseas in June, 1917 , for duty in various American and British hospitals then in need of reinforcements. She drew a significant comparison between eonditions existing in the English bases and at Ameriean Red Cross Military Hospital No. 1:

The fact that I was in charge of the unit on the way over and during these wonderful eight days in London came nigh to ruining an otherwise perfectly good nurse, for to be "Matron" in England is quite the most blissful experience that has ever come to me. I never knew before what a very important person "Matron" is. We have all come to love the British mightily. Their hospital administration is quite remarkable.

We foumd the British officers very nice also. They saluted whenever they ame into the wards and when we met them outside and their attitude was just what it would be to al brother oflicer, but, alas and alack, here we are once more eating humble pie with our own countrymen! The work wis harl in the british bases but always interesting. We nurses

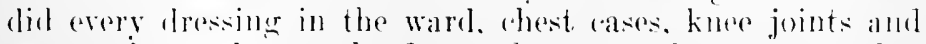
amputations, whereas the doctor does eren the tiny sratubes here, with forteps and all the pomp and fuss of the most extreme eivil hospitils.

Just at present this whole hospital is heing reoramized and you will have to inamerine what that means. We are trembling for the mursing standards. Lut hope that thinges will turn ont better when the moke of hattle clears away. I would like to 


\section{HISTORY OF AMERICAN RED CROSS NURSING}

tell you more of the conditions here, but upon studying the posted rules of our energetic young censor I have decided to follow the counsel of one of our humorous publications which gave as advice to the young man about to marry, the single word, "Don't!" Of course, you must expect that we Americans, young in this game of war, would go to many extremes.

Martha St. John Eakins was chief nurse of the Ambulance Hospital and Frances B. Latimer, one of the nurses of the Mercy Ship Expedition, was her assistant. The hospital was of one hundred and fifty bed capacity. Later it was enlarged.

The second institution taken over by the Red Cross Commission for France was the surgical hospital established in 1915 by Dr. Joseph A. Blake, of New York City. This hospital, which was subsequently designated as American Red Cross Military Hospital No. 2, was used largely for fracture cases. Of this institution, Mr. Patten wrote:

Military Hospital No. 2 contains three hundred beds, of which one humdred are reserved for French wounded and the remainder for members of the American Army and the personnel of the American Red Cross. In this hospital is situated our Research Laboratory No. 1. where a corps of bacteriologists are making valuable records for the benefit of the medical profession working with the Army. During the past months, we have arried on in this laboratory a careful investigation of some of the auses of trench fever. By means of the work of this laboratory we are making it possible to grasp more thoroughly the original auses of maladies common to soldiers. There has been no lack of attention given to the severely womnled. Through such information as our research biboratories have giren us. injuries and sickness which in the rush of war seem less important because less visible, can be watehed in the first stages when they are more quickly and more easily ared.

A third institution which the commission took over early in the summer of 1917 was the oftices' hospital established in 1915 he Mrs. Whitelaw Revil in the Rone de Chrvense, in the building which had formerly housed her Club for Girls. Miss Eleanor R. White, a reserve murse, Army Nurse Corps, wats the chief nurse; Miss Agnes F. Jamues, Army Nurse Corps, was her assistant and was also chief nurse of Anorican Red Cross Military Hospital No. 112, an orerflow hospital. Mrs. 
Reid's hospital was designated as American Red Cross Military Hospital No. 3.

Additional hospitals previously maintained by individual Americans were also taken over during the summer and fall of 1917 by the commission. Of these, Mr. Patten wrote:

In the interests of the Freneh, the Red Cross assists four other hospitals situated at Amel, Cugny, Erreux and Soissons. It also supplies part of the persomel for these hospitals to which we have given ambulances, beds, instrmments and other medical and surgical materials. The hospitals at Annel, Cugny, Erreux and Soissons were existing institutions and are operated for the French soldiers.

The hospital at Evrenx was staffed by murses of the original Yvetot Unit which National Headquarters had sent in February, 1915, to the Alliance Hospital. Dr. Ralph Fitch had been director and Mary M. Fleteher, supervising nurse of the unit. In August, 1915, Miss Fleteher hat resigned to marry an Englishman and Xary K. Nelson had been appointed in her place. During the same month, the Service de Santé had requested that I)r. Fitch and the nurses take charge of Mlilitary Hospital No. $43^{\text {bis }}$ at St. Valery-en-Canx.

National Headequarters recalled its foreign mits on October 1, 1915, but 1)r. Fitch, Miss Nelson, Tosephine Clay, Marion M. Rice, Ielen Spaulding and Helen Kerrigan elected to remain as volunteers at St. Valery in the serviee of the French. 1)uring the following months Miss Nelson built up a strong mursing staff, emposed of Ameriean and English nurses and murses' aides. In September, 1917, the French Govermment moved the mit from St. Valery to Evreux and placed them in eharge of l'Hôpital Complimentaire No. 2, of six hundred beds.

When the Ameriean Red Cross Commission for France adopted its polieg of coürdination of existing relief agencies, it offered financial aid and supplies to Dr. Fiteh's hespital. The work was largely orthopedic. Doris Petrola, an Anerican Red ('ross nurses' atdo as rigned to duty at Evrenx, wrote:

The two wards on which I an stationed have 38 French blesses and perything looks weird at night. There is no light exeret that frem the waning moon and from ous lantern covered with a towol. Arms and lews ale strung up! in $5 \%$ 


\section{HISTORY OF AMERICAN RED CROSS NURSING}

varieties of angles and one's imagination may distort them into anything, according to the degree of indigestion one has from the cooking. . . .

Shortly I will hear a blessé ealling "Mees!" It is almost time to give the "squirts" as they call Dakin irrigations. We do everything but drink Dakins here. . . . I am told that the wounds here are very bad. I have no means of comparison, but I do know that a man injured at home like the least seriously wounded here would be considered extremely ill and would be surromled by doctors and nurses. . . . Aides were badly needed, so we were welcome and it is a great pleasure. Often the blessés will say "That makes beaucoup travail for you, Mees"; and I can always say and mean it in my heart "Ce n'est-ce pas beaucoup de travail parceque c'est un plaisir."

The assumption of financial and executive responsibility for these hospitals immediately ereated a need for an exeeutive nurse to dircet from the Paris headquarters of the Commission for Europe the nursing service in these institutions. At this early date the question of lay control of professional nursing service arose, a problem to persist until after the signing of the armistice. The Commission for France desired to place Mrs. Mnuroe in charge of American Red Cross nurses in France. Through the efforts of two influential American Red Cross nurses then in France the point of view of American Red Cross murses and their desire for professional direction was presented to the commissioners and Mrs. Mmmroe was given the direction of the nurses' aides, which were known in France as auxiliares. Major Murphy cabled Mr. Davison on July 10: "(Cable No. 119). Please have Miss Delano seleet a trained murse to act as head of our nursing activities in France. This woman is needed immediately. She should have tact and experience and be thoronghly subject to eommand of ofticers in charge."

Miss Delano ackmowledged receipt of this message under date of July 19. Among the muses of the New York IInspital Unit, U. S. Amy Base Hospital No. 9, then expipped and ready to sail, was Martha Rinsorell. Miss Delano on July 17 requested her to come to National Headquarters and upon her arrival offered her the appointmont as chief nurse of the commission. Miss Rusicell aneepted the position. Miss Delano wrote on July 18 to Major Murphy as follows a letter 
of introduction: "This letter will introduce Martha Russell, who has been seleceted at your repuest to act as a representative of the Nursing Service nuder your direetion in Franeer. Miss Russell has had a good dral of executive experience and is, I beliere, well qualified for the work." Similar lotters were written to Colonel Ireland and to Colonel Winter and full information concerning Miss Russell's appointment was reported rerbally to Mr. Wadsworth, then acting chairman of the Red cross and ex-officio nember of the War Conncil, and to other interested offieials at National Headyuarters. Miss Noyes wrote on July 21 to Mr. Norton, of the $\mathrm{W}^{+}$ar Conneil: "Will rou kindly able to Major Murphy that Martha Russell is leaving New York to-day as the representative of the Nursing Service in France?"

An important change of personnel, which was to lave direct bearing upon the situation relating te the appointment of a ehief murse, American Red Cross in France, laat taken place some dars before in the Department of Military Relief. The Mimites of the War Comeil, meeting July 11, reeorded the fact that "the War Comeil has been informed by Major General Gorgas that Colonel Jefferson R. Kean has been plaeed in elarge of the entire ambulanee serviee in Franere and has therefore been withdrawn from the Red Cross." The same Mimutes stated that the War Comeil had reemmended to the Executive Committer that John 1). Ryan, one of its members, be appointed as l)irector General of Military Relief. On July 1:3, Mr. Rvan wrote to General Gorgas, requesting that Major Winford II. Simith, some time superintendent of Johns Hopkins Hospital, who was then on dnty in the Surgeon Cieneral's ottiee, be detailed to duty at National Headenarters as assistant loirector (ieneral of Military Relief. General Bliss, then aloting ('hiet of Staft. T. S. A., muler speedial Orders No. 1tir, dated July 18, detailed Major Smith to National Meadepuarter's.

Major Smith arrived at National IIeadenarters at a time of stress and becanse of the mobilization of lied Cross hase hospitals into actios serviee, fomme a heary hurden of work awaiting him. Ile orempied an offiee on the first thoor of the main hilding, dimetly aresos the hall from that which was

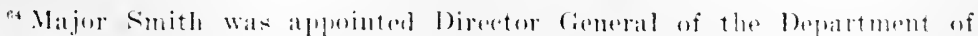
Military Relief at a meeting of the Exeentive Commitlen held Angu-t 31 , 1917. 


\section{HISTORY OF AMERICAN RED CROSS NURSING}

used by Miss Delano and Miss Noyes. After hours, on the night of July 20, while Major Smith was endeavoring to get his work in hand, the following cable arrived at National Headquarters and was referred to him:

$$
\begin{gathered}
7: 40 \text { P.M. } \\
\text { July 20, } 191 \% .
\end{gathered}
$$

19,686. Please communicate the following to H. P. Davison :

Cable No. 196. Please communicate the following to Annie W. Goodrich, Teachers College, Columbia University: quote: Doctor Lambert says necessary to have someone competent to take complete management of Red Cross nurses in France under him. You must undertake this and report at once to him in Paris. End quote.

(signed) M[LRPHY-HARJEs.

Major Smith, apparently not realizing the importance of consulting the Nursing Service before taking any action on the above cable, that night sent a copy of it rerbatim to Miss Goodrich, with the following letter of transmittal:

My dear Madam:

$$
\text { July } 20,191 \% .
$$

Mr. H. P. Davison, chairman of the War Council of the Red Crcss, is in receipt of the following cable. What shall we reply?

$$
\begin{aligned}
& \text { Yery truly yours, } \\
& \text { (signed) W. H. Suntr, Major, M.R.C. W.S.A. } \\
& \text { Asst. Director General, Mil. Relief. }
\end{aligned}
$$

Thus at the beginning of the war period the personality of Annie Warburton Goodrich leaped into the arena of hed ('ross nursing history and remained an active and complex factor thromehont the tense and sometimes hysterical months which followed. Hitherto, as one of the members of the Sational Commitee on lied Cross Nursing Service, she had from the begimning helped to shape the policies of the serviee.

Miss Coodrich ame from pure New England stock. She was of slender build, quick in her movements, with alert gray ress and a highly oreanized nervous temperament. Iner brilliant mental powers were expersed in instantaneons reartions and in a flashing, rapier-like wit which often held a satiriv flavor. Ambition, forvid sincerity and staunchuess blended 
to form a character highly complex and not easy to understand. She was a contimed pacifist. Hers was a practical idealism, best seen in the working ont of difficult problems. She had a penchant for administration which amounted almost to genius.

Her professional career was as brilliant as that of any American nurse. She was graduated in 1892 from the New York Hospital Sichool for Nurses. For seven years, she was superintenclent of the training sehool and Matron of the Xew York Post-Graduate Hospital. In much the same way that a strong administrator is alled from one high post to another in the business world, Miss Goodrich was called first to reorganize the training sehool at St. Luke's Hospital, New York City, then to the New York Hospital and then to Bellevue and Allied Hospitals. She then went to Albany, to be inspector of training schools under the Board of Regents of New York State. From that position she was called to Teachers College to instruct in the theoretical phases of public health mursing affiliated with Henry Street Settlement. In 1917, at the request of the Surgeon General, she made an inspection trip through the eintomments in the Enited States and returned to the Surereon General's office in Washington and organized the Army School of Nursing. In 1905, Miss Goodrich was president of the Superintendent's Society and from 1915 to 1918 was president of the American Nurses' Association. From 1912 to 1915, she was president of the International Couneil of Nurses.

At the time. Inly, 1!17, when the correspondenee between Major Smith and Miss Goodrich took place, the Nursing Servior was reopiving an overwhelming number of telegrams and calles every day. In due course of office routine, a copy of the Lambert-Croodrich cable, No. 196, was sent to Miss Noyes' desk. She juterpreted the eable as a request for Miss Giondrich s a id in obtaining a proper chief nurse and as Miss Rinssell had already sailed when this cops of Cable No. 19ti came to her desk, she latid it aside, regarding the question as a closed one and neither she nor Miss l)elano broached the subject with Miss Goodrich.

Mis: Inelano, as she later stated, did not then see a copy of Cable No. 19ti. ()n the marein of a copy of this cable, in the lied cross Nursing servide files, there now appears in Miss lebanos hamelwiting the words "never saw this." No date is given as to the time when Miss lolano wrote this phratse upon 


\section{HISTORY OF AMERICAN RED CROSS NURSING}

the copy, but from events which later took place, it is probable that she saw it for the first time in October, 1917.

Some time between July 21 and July 24, during one of the many conferenees which took place daily between Miss Noyes and Major Smith, Major Smith asked Miss Noyes if a director of nursing for the Paris office had yet been seleeted. Miss Noyes replied that Miss Russell had sailed on July 21. Most unfortunately Major Smith did not mention to Miss Noyes the matter of his letter to Miss Goodrich, either then or later, else the sequel might have been different.

On July 24, Miss Goodrich wrote to Major Smith:

I beg to acknowledge your communication of July 20, relating to the message received by Mr. Davison from Dr. Lambert. This letter only reached me this morning, owing to my absence from the city.

In order that there may be no misunderstanding, I am writing to say that I understood you to tell me over the telephone that Miss Martha Russell had already been sent to take the management of Red Cross nurses in France and therefore the matter was closed.

Major Smith replied on July 27 to Miss Goodrich: "Your letter of the 24th is at hand, in which you say you understood Miss Martha Russell has already been sent to take the management of Red Cross murses in France and that the matter is therefore closed. Your understanding is correct."

At the time of this correspondence between Major Smith and Miss Goodrieh, Miss Russell, in eomplete ignorance that she was embarking upon a task for which another woman had been requested, had already sailed for France. Martha Montague Russell was born in Pittsfield, Massachusetts, and was an alumna of Mount IIolyoke College. She reeeived her training as a nurse at the New York and Sloane Hospitals, New York City. She was for some months a head nurse in the Manhattan Hospital, New York (ity, and later in the Norton Intirmary, Lonisville, Kentucky. She afterwards did publie health nursing at Ifenry street Settlement. She then berame assistant superintendent of the Providence Lying-in IIospital. Providence. Rhode Island, and later director of murses of the ITest Penu IIospital, P'ittshnregh, Pa. She then went to the Sloane Maternity I [ospital, New York ('ity, als superintendent of nurses and remained there for twelve vears, nutil she alcerpted 
Red Cross service. Her enrollment, however, dated back to the year 1908. Her nine months' service in the pioneer work of establishing the American Red Cross Nursing Service in Franee brought her the Florence Nightingale Medal of the International Red Cross.

Mliss Russell arrived in Paris on August 12, 1917. The following day she wrote Miss Delano:

After a very pleasant interview with Major Murphy, he handed me over to 1)r. Lambert, who is in charge of the medical and surgical work of the Red Cross, inchuding the nursing. Dr. Lambert said the French ruling was that anyone who eared for the sick is a nurse. I do hope our nurses will be able to show that our Red Cross pins mean a whole lot more. Dr. Lambert said: "Do not question that I am with you in upholding the standards to the limit."

Dr. Lambert took me down to Army Headquarters and I met Colonel Bradler, Colonel Ireland and Colonel Winter. I gave vour letters to the last two gentlemen, and they were both delighted to hear from you and spoke with cordial appreciation of the work your courage and wisdom has accomplisherl.

In this section will be set forth American Red Cross nursing serviee to the siek and wounded of the American Expeditionary Forres. Red Cross numing service to the civilian population of Enrope will be found in a subsequent ehapter.

Miss Russell first mulertook a survey of the Amerioan Red ('ross hospitals them existing in France. She fomend that the staft's of these hospuitals were all in need of additional nurses and that the standards of morsing servie existing in each was varied and differed from that which the National fommittee demanded shonld exist in Amerioun Red couss hospitals. She immediately beran an athort to standardize these services and

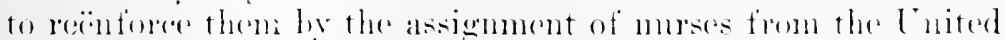
States. Inder ('ommissioner Murphy's or Major l'orkins'

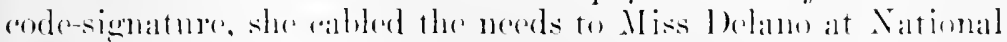

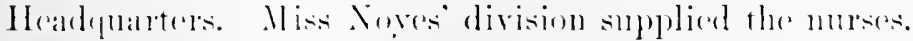

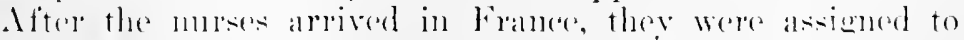

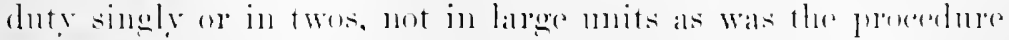

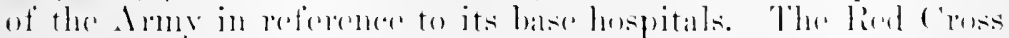

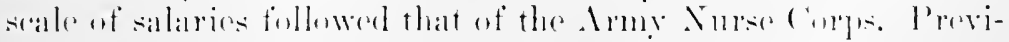

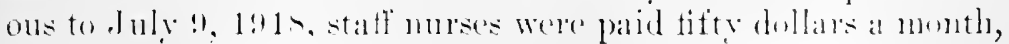




\section{HISTORY OF AMERICAN RED CROSS NURSING}

with ten dollars monthly inerease for foreign service. Chief nurses received thirty dollars in addition to this base pay. By Aet of Congress, July 9, 1918, the salaries of all members of the Army Nurse Corps were increased ten dollars a month and the Red Cross followed this ruling with reference to the nurses serving directly under its auspices overseas.

In addition to pressing demands for graduate nurses, Miss Russell faced an insistent demand, from Red Cross officials, for nurses' aides. The assignment of nurses' aides to foreign service offered, however, opportunity for many differences of opinion in the War Department, at National Headquarters, among the members of the Paris office and among phrsicians and nurses in foreign service. The decision of General Gorgas rendered immediately before the mobilization of the first six base hospital units, definitely barred untrained women from the military hospitals of the American Expeditionary Forees. This decision was repeated in a second ruling transmitted September 20, 1917, by Colonel G. E. Bushnell to Miss Noyes:

The Surgeon General directs me to state that in view of the large number of graduate nurses available and the additional large number which are now being trained, it is not thought necessary to inaugurate any measures for the training of volunteer nurses at the present time.

The views of General Bradley, the chief surgeon of the American Expeditionary Forees, seemed to correspond with those of General Gorgas in the desire to exclude nurses' aides entirely from military hospitals. General Ireland had faith that their services, if properly directed, might result in great benefit both to patient and nurse. In a letter written Iecember 10, 1917, Miss Russell reported General Winter's attitude:

Just a line to tell you that at a meeting of the medical committee this evening. your old frient, Colonel IIinter. quashed the plan that the people here had been concorting for getting airles for convalecent hospital work over here. He said that one good nurse who knew her business was worth twenty aides and. with the orderlies and convalescent patients to help her, would take better are of the patients than the airles. If sairl they could use them in the antomments if they wanted to, but that they dirl not want them in France for the soldiers moles it was much more important than it appeared at present. 
The first important development of the aide problem appeared in a cable (No. 456) dated August 21, 1917, in which Commissioner l'erkins requested that a bureau to pass on all auxiliary hospital workers to be assigned to overseas service be established at National Headquarters moler the director of the Woman's Burean. On September 12 Major Perkins cabled again that the Nursing Burean in France had been divided, "Miss Russoll taking graduate trained nurses and Mrs. Munroe auxiliary nurses not graduates of training schools." This plan of organization contemplated that Mrs. Munroe's burean shonld be a sub-burean of $\mathrm{II}$ iss Russell's department.

The responsibility for the training and direction of nurses' aides had been intristed, it will be remembered, to the National Committe on Red Cross Nursing Serviee. Miss Delano and Miss Noyes therefore considered that the ereation of this subburean with an mutrained woman as director, would present opportunity for possible division of authority and they made vigorous protest against it to the War Comieil. After some further discussion by cable, Mr. Davison on September 17 sent the following message drafted by Miss Noyes:

Burean Nursing feels strongly inadvisability separating hospital auxiliary workers from Nursing Service. Establishes precedent wntriry to Red Cross regulations and policy of Surgeon Generals. Sursing Service recommends Martha Eakins, chief nurse of American Ambulance, if acceptable to Ilisi Rusede as head auxiliary bureau. Believe that this will accomplish purpose desired and insure efliciency of hospital service.

The discussion then dragged along by letter and eable until Major Prerkins sugesested on October 15 that the whole vexiltions puestien le "tabled" for the present.

ln the meantine, Miss Russell was organizing a Local Committer on Red Cons Sursing Service in Paris, which would nndertake npon anthorization from National Ieadeparters the enrollment in the American lied Cross Nursing serviee of Aneriean murses then in Europe. The work she was doing inrluded distribution of extra winter equipment to nurses of the lind cross hase hespitals, then militarized and in sorvice with the liritish and Anerican Expeditionary Forees: the weleoming of nurses coming abroad for assignment to the T. S. Mediral corps: and assistanes in the development of Ameriean lied 


\section{$5 \$ 8$ HISTORY OF AMERICAN RED CROSS NURSING}

Cross relief to the civilian population of France and Belgium. In the bulletin published on November 13 by the Paris commission appeared a notice stating that fourteen chief nurses from base hospitals of the British Expeditionary Forces, the American Expeditionary Forces and the Red Cross attended Miss Russell's conferences.

In addition to the American Red Cross military hospitals and American Red Cross hospitals, the Commission for Europe also established and maintained dispensaries to serve the American Expeditionary Forces. As United States troops were landed in France in increasing numbers, they needed dispensary service and the Medical Department requested the commission to supply it. The first dispensaries were established at the ports of debarkation, Bordeaux, Brest, Lorient and St. Nazaire and along the line of communications at Nantes, Neuilly and Paris. A full list of these dispensaries may be found in the Appendix.

An interesting srstem was worked out at Neufehâtean whereby traveling dispensaries attached to a central hospital served United States divisions then in training centers in the surrounding districts. Of this service, which resembled the extra-cantonment work of the Federal Public Health Service in the United States, Mr. Patten wrote:

Our dispensary service is one of the most valuable services developed by this division. With its center at Nenfchâteau, where we have established a hospital in connection with it, the work has been planned to cover the surrounding territory wherever the French civil population required medical attention. Nost of the french doctors are in the service of the Army. so that in some of the smaller town there is no native doctor or at hest one too old to care for all the inhabitants. Towns where there were sufficient native doctors and equipment were passed over in ormanizing our routes.

kecping this pulieg in mind, we drew up different itineraries so that onr ambulances could visit the various dispensaries at least one "rery other day. We have now forty of these dispensaries and a corps of cleven Amerion Red ('ross nurses in this serviere. The loctors are assigned he the Enited States Army and work under the direction of the American Red C'ross.

Infirmaries for American troops at rest stations and at two ariation amps wore also establisherl and maintained by the 
Commission for France. Convaleseent and rest homes comprised another type of American Red Cross medical service to American troops. At these homes, officers, enlisted men and Army nurses found agreeable surromendings and healthy recreation. One of these was established in the Hotel liegina at Biarritz, overlooking the sea. Here there was golf, teminis and bathing and owners of neighboring villas extended their hospitality to convalescents, or to war-weary men and women on their precious fourteen days' leave.

As the Ameriean Red Cross in France developed this extensive military program and the even more elaborate program of civilian reliet and child welfare work to be described later, the officials at Paris headpuarters grew more and more insistent in their demands for nurses. If large numbers of graduate murses were not available, they argued, then send us the partially trained aides we have already recommended. They had already in many cases cabled directly to these women. On Norember 13, Major Perkins cabled to National Headquarters for thirty aides to be sent over as rapidly as possible, to be used in conncetion with Red Cross eivilian relief in France. Again Miss Delano and Miss Noyes tried to strengthen Miss Russell's position and sent the following reply, Cable 6099, which was transmitted by Mr. Davison to Major Murphy:

Nursing Service asks that Red Cross nurses and nurses' aides, paid or volunteer. be requested through Martha Russell as needed. In coöperation with prominent public health nurses, groups of pullic health workers have al realy been organized. We maintain list of relected and caretully preplared aidles.

It will be remembered that the aides trained for the first fifty lied ('ross base hospitals were enrolled at National Heandquarters. The decision of the War Inepartment mot te utilize theje services had already bronght mmele derogatory ariticism

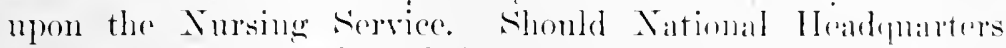

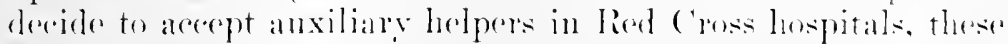
nurses aides should in justien be the first to be sent ont. Memhers of the Commision. however. abled insistontly for individnals whom they persomally knew. Mr. Mavison attempted to rloar up this and other asperets of the situation in al cable (No. dilt) of Norember 1!, drafted ly lliss Noyes: 
We are receiving cables from you for nurses and nurses' aides requested through various sources. Highly important that these should be secured through Red Cross Nursing Service at Washington or their representative in Paris. In commection with base hospitals here and in France, a large number of women have been prepared who meet established Red Cross requirements and are arailable for duty if needed. Agreement with State Department confines requests for passports to Red Cross workers who have been fully investigated. As we are held responsible for all workers, it seems hardly fair to them or to nurses' aikles whom we have enrolled to ask for passports unless we make selection through our Nursing Service. If Miss Russell is not capable of assuming this responsibility, she could be replaced. We have been assured that she is worthy of your entire confidence. Mrs. Munroe and others who have been doing splendid work in France could no doubt be helpful as an advisory committee.

The office of the chief nurse now became the subject of a cross-fire of eables and letters. Miss Russell, instead of being a member of Major Murphy's immediate staff and a member of the Commission for Enrope, a position which would have given her administrative freedom and access to all bureaus and departments of the commissions for France, Italy and other comtries, had been assigned to Major Lambert's staff, in the Department of Military Affairs of the Commission for France. However, she was expected to provide nursing service for eivilian as well as military relief in all parts of Europe, yet her contact with the commissioner and with directors of the other departments was thromeh the chief of her department, Major Lambert. Miss Delano and Miss Noyes at National Headquarters had direct personal contact with the members of the War Commeil and heads of important services and they naturally thonght that their representative in France, Miss Russcll, had similar freedom and prerogatives. They held Miss Rinssell responsible for the development of a service, for which she larked the anthority to makr such a development possible. The oreanization of the Nursing Sorvice at Paris headquarters in 1917 was thus manifestly unsonnd, and on Derember 13 Miss Riussell reommonded to Major Lambert that a reorganization he effereted wherele the Nurses' Bureau would he transferred from the lepartment of Military Affairs to the administrative staff of the Commiscioner for France, where it would be in a position to sorve all departments and bureaus. Cufortu. 
nately, Major Lambert was on receipt of this letter on the point of starting on a field trip, but he assured Miss Rinssell that on his return her recommendation would be put into effect. "On his return," wrote Miss Russell to Miss Noves, "his power was gone." Dr. lambert in January, 1918, became director of the Medical Department of the commission and l)r. (. C. Burlingame, with Dr. W. E. Clark as his assistant, suceceded Major Lambert as chief of the medical and surgical divisions of the Military Affairs Department.

The entire situation, both in Washington and Paris, was swiftly approaching serious misunderstanding, as may be seen in a letter written Decomber 16, 1917, by Major lambert to I)r. R. M. Pearce, then chaiman of the National Medical Board at Red Cross Headquarters.

.. If I ask for nurses Norember 9 and six weeks later find the national department in Washington still asking questions as to what I want nurses for, it strikes me that something is wrong with the Washington end. Will you not use your endeavor to make them realize that we ale not asking for people here mless we need them and we are not asking for nurses unless we need them as nurses to do nursing work?

It is a growing conviction with Commissioner P'erkins, myself and all concerned that we must have a rescrve of nurses to supply those who are sick and convalescing and to meet varions demands that we camnot foresee. Therefore, please make a serious request to the national department in Washington that they cease to block the supply of nurses that come here.

The first urgent need of the commission, as it has been said before, was for nurses to undertake the many projects, both civil and military, of the Ameriean Red Cross in France. The pioneer Americain Red c'ross pediatric mit which had sailed for France early in August, 1917, had included in its persomnel only one murse, Elizalbeth Ashe, who later became chief nurse of the American Red cross Children's Bumean. The sorond pediatric unit had included among its persomel ten Americam led Cross murses esperially trained in elild welfare work; it embarked in september for Franee. A third unit of about fifteen public health nurses had sailed a aly in Novenubur and a fourth nuit of apploximately twenty-tive ehild weltare nurses was muler process of oreanization in Forembere at the time when 


\section{HIS'TORY OF AMERICAN RED CROSS NURSING}

Major Lambert's letter to Doctor Pearee, as quoted above, was received at National Headquarters. Miss Noyes and her coworkers were then combing the country for nurses to supply these and the military needs. The Army alone was asking for nurses to staff fitty additional base hospitals over and above the nurses of the first fifty base hospitals, was calling for hospital units and emergency detachments and large numbers of "easuals"; the Navy and the United States Publie Health Service were looking to the Red Cross for their reserves.

An extremely important responsibility confronted the Red Cross: If nurses should be recklessly drawn into military serviee from civilian hospitals and publie health nursing organizations, these civilian hospitals and public health nursing organizations would be forced to close their doors and to discontinue their visiting nursing, with the result that the health of the civilian population would suffer. War conditions were already taxing the strength of the civilian population, yet upon them depended the manufacture of war supplies, the finaneing of war loans and the general economic stability of the United States and Europe. Unfamiliarity with nursing conditions in the United States led Major Lambert to use, in his letter to Dr. Pearee, the words "please make a serious request to the national department in Washington that they cease to block the supply of nurses that come here," but the words brought a certain ironical amusement to Miss Melano and Miss Noyes when the letter was referred, to them. In a letter addressed November 22 to Miss Russell, Miss Noyes hat already protested against the extravagant demands for nurses which the Paris oftice was makiug:

We realize that you will have a great deal of work to do in organizing your forces, and please do not hesitate to call upon us for assistance when needed. We are securing nurses and nurses' aides, solecting them from the base hospitals which had prepared groups for service, as rapidly as possible. I hope the licel Cross Commission for France is not experting ns to supply murses for all the French eivil hospitals, for there is no mursing serviee in the world which conlel meet sueh a demand as that. We can, however, as we told you before you left, meet the military needs in France and in this eountry and supply public health and welfare workers, organizing nurses and those for base hospitals, but I do not see how we could possibly supply an unlimited number of nurses to civil hospitals. 
May I state here that we liave thirty-two cantonment hos. pitals in this country, each one calling for a stafl of from sixty-five to one hundred nurses, and these we are supplying at the present time. In addition we have all the regular Army posts and the base hospitals on the horder. The more you know about conditions over here and the strength of our Reel Cross Nursing Service at home, the better prepared you will be to meet conditions abroad.

On December 26, Major Perkins cabled Mr. Davison: "Situation makes it imperative Miss Goodrich of Nursing Serviee be sent to France as soon as possible."

Two montlis before, Miss Delano had learned for the first time and under embarrassing conditions that Miss Goodrich's serviees had been requested as ehief nurse of the Ameriean Red Cross overseas. During a meeting of the National Committee on Red Cross Nursing Service held on October 26, 1917, at the Atlantic Division headquarters in New York City, Miss Maxwell brought up a leading question regarding the appointment of the chief nurse, Ameriean Red Cross in France. Miss Delano replied that this appointment was a Red Cross administrative matter, not a problem of policy which belonged to the National (ommittee. ${ }^{65}$ Brisk discussion followed, during the course of which one member asked why Miss Goodrich had not been sent, espeeially in view of the fact that her services as chicf nurse had been speeifieally recunested by 1)r. Lambert. Miss Delano and Miss Noyes looked at rillell other in blank bewilderment. Miss Delano was in emmplete ignorance of the entire situation. Miss Noyes had wholly failed to identify ('able No. 196 as a request for $M$ iss Goodrichl's personal serviees as whief nurse. Further, she hat mot seen a eopy of the callue mutil after Miss linsell had sailed.

Miss Lillian Wald renarked that it was self-evident that neither Miss [Delano nor Miss Nores knew anything about a

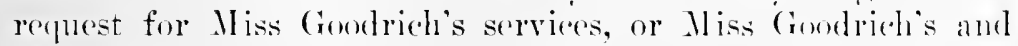
Major Smith s correspondenee, and she acerdingly told them the varions fanets in the case. Miss Goodrieh hrirelf stated at this meeting that she had first interpreted the cable, just as Mliss Noyes diel, to be al request for her holp in nominating the chice mirse, not a refuest for her personal serviees. She later wrote that ". . . as I recall the disenssion at the enm-

ar For this reason, no record of this discussion is to be found in the Minutes of the National committere on this meeting. 


\section{4 HISTORY OF AMERICAN RED CROSS NURSING}

mittee meeting referred to, the question was not so much as to why I was not appointed, but why the selection of the appointee for this important overseas position was not brought to the Red Cross committee on mursing for suggestions . . ." 66 But it may be stated that the wording of Cable No. 119 was so peremptory that, even if Miss Melano had agreed that the appointment was a matter for the National Committee, she would have hesitated to delay it long enough to get in touch with the membership of this body. The Advisory Committee of the National Committee was not organized until two days after Miss Russell had sailed. However, Miss Delano and Miss Noyes, had they previously been in possession of all this information, would have had little reason to believe that Miss Goodrich would be interested in a more or less subordinate administrative position with the American Red Cross in France. She was then director of nurses at Henry Street Settlement, associate professor in the Department of Nursing and Health, Teacher's College, and president of the American Nurses' Association.

Miss Delano and Miss Noyes had returned to National Headquarters, considerably chagrined that nurses outside the Red Cross organization should have known more about Red Cross arministrative correspondence than did they. After some deliberation, Miss Delano on November 20 wrote Miss Goodrich and asked her if she wonld consider going to Franee as clief nurse of the American Red Cross. Lnder date of December 11, Miss Goodrich wrote Miss Delano:

It scems to me important that you should have as clear a statement as possible of my attitude towards the matter concerning which you wrote me November 20 , and that I discussed with pourself aud Mr. [George] Soott [then director of division oronization at Tational Headquarters] in Washington last week.

I beg you to helieve that I deeply appreciate the honor of being askirl by the lied c'ross to gro to France in this capacity, but as I consider the matter. and I am sure you will understand that I have given it the deepest ensideration. I ramot feel that I shomled he justified in severing lines of work. the important hearing of which on the present situation I to not believe I exaggerate, to assume for an indefinite period the Noyes. 
work in France as you present it in your letter, or even in its wider asperts as presented by Mr. Scott. I appreciate that a survey of the situation is important to enable a wise determination of the policies of the Rod ('ross relating to the nursing are to be rentered by our women in France, hut surb a survey, I am envinced, would be of limited value if it did not include a study of the mursing situation in our hospitals on the other side as well as the public health field. I believe that only under the inghest governmental authority woukt the task be possible. In the survey conld be matle under such authorization and it is felt that $I$ am the person to be entrusted with so important and difficult mission, I should, of course, be ready to go.

Upon receipt of Major Perkins' request of December 26 for Mliss Goodricll's assigmment to the Paris office, Miss Delano immediately submitted to Mr. Srott Miss Goodrich's letter, quoted above. To a general statement of the situation, Miss Delano added the following recommendation: "I would suggest that a letter be sent the Surgeon General, inchding this statement of Miss Croodrich's, thus placing upon him the responsibility for a decision."

However', the Rod cross did not ask the Surgeon General to cmpower 11 iss Goodrich with governmental anthority to make a surver of military and lied C'ross hospitals in France. Miss Delano stated the following reasons in a memorandum prepared January :1, 1!18, for Mr. Soott:

Some time ago I requested Miss Goodrich to accept service in France as the representative of the American lied cross Department of Xursing. At the time she stated to me that if she were to gro she wonlel not wish to assmme Miss Rnssell: responsibilitios and should desire that either she or someno else remain in the Paris ofliee. She expresed herself ats willing to go ower to make a survey of the nursing situation gencrally, including the military hospitals.

I requested II iss (ioodrich to send me a statement in resalrd to the matter and an sembling with this her lotter. I have

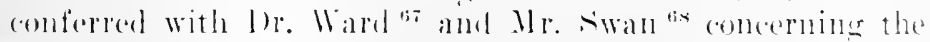

oz Dr. Folwin St. Tohn Ward, an asistant surgeon in the Departmont wi

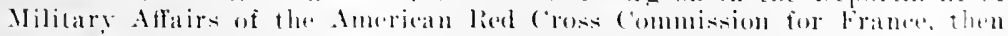

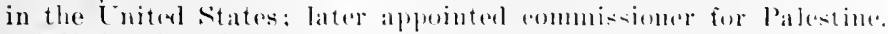

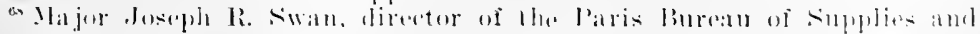

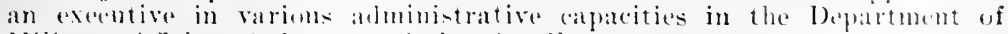
Military Affairs of the ('mumi-sion for Fiance. 


\section{HISTORY OF AMERICAN RED CROSS NURSING}

duties required of the representatives of the United States in Paris, and they both agreed that supervision or inspection of the nursing service in military hospitals was not contemplated. I have also consulted with Dr. Pearce as to the desirability of suggesting such supervision to the Surgeon General's office and he too thinks that it would be undesirable at this time.

Under these circumstances and in view of Miss Goodrich's evident unwillingness to go to France for Red Cross work alone, I would suggest that a caible be sent, stating Miss Goodrich's position in the matter.

We have recently sent Blanche E. Eldon to act as Miss Russell's assistant. This fact might also be noted in the cablegram. I feel sure that both Miss Russell and Miss Eldon would be willing to accept any decision reached by the Red Cross.

I have hesitated to select another nurse in this country for service in France, as 1 know of no one at the moment who would be in any way familiar with the situation. I am wondering if you might not think it desirable to suggest to Major P'erkins that he request Mary Nelson's release from Dr. Fitch 's hospital. She has been there since 1914 as chief nurse and is spoken of very highly by people returning from France. Mr. Swan has met her and can give you further information regarding her ability. It is possible that Miss Russell or Miss Eldon might be acceptable to Dr. Fitch as her substitute.

Mr. Davison cabled to Major Perkins January 11, 191s: "Nursing Scrvice suggest you obtain release if acceptable to you of Mary Nelson of 1Mr. Fitch's hospital to relieve Miss Russell who might be acceptable to Inr. Fitch to replace Miss Nelson. Unable to obtain services of Anuie Goodrich."

To Miss Goodrich, Miss Delano wrote January 12 :

I have had sereral conferences with members of the Red Cross commission who have recently retumed from France, in regarel to the special matter in comnection with our work there.

It roes not serm desirable at this time for the Red Cross to ask the surewn lisueral's oflice to confer upon their representative in France drefinite anthority in regard to the military hospitals.

I greatly regret that you do not fecl justified in going to Europe for the lind ('ross alone, but the members of the 
commission who have recently been here assure mo that the duties which they have in mind for this position do not involve any anthority in connection with the military hospitals and that any attempt to secure such authority would probably not be areepitable.

legretting that it has not been possible to make satisfactory arrangements and appreciating greatly your interest in the matter, believe me, ete.

On Jamury 19, 1918, Dr. Lambert cabled directly to Miss Goodrich: "Have repeatedly cabled for you in last three months. Is there anvthing to prevent your coming? Answer me personally."

Miss Goodrich eabled to Dr. Lambert on January 21: "Work here for civilians and soldier's too important to justify abandonment unless given govermment anthority to inquire into and report upon nursing situation there military as well as Red Cross. In November expressed willingness to go under these conditions."

On January 22, Miss Goodrich wrote to Miss Delano:

I had dictated a brief letter of acknowledgment to your communication of . Junary 12 , but in the interim between the dictation and transcription of the letter, a message has come from the other side that seems to indicate that my services are still desired. I am loath indeed to refuse to go, bnt I am also firmly convinced that I can only effectively render the sorvice thes have in mind through a governmental recognition that will clearly define my position and make my opinions in matters relative to nursing anthoritative. I appreriate that this is a great deal to ask, hut I helicve that my experience in nursing, the importance of the work I shall be forced to relinquish and. above all, the problems I may be called upon to solve, justify this request.

In order that there shatl be no confusion or misumberstandiur I an writing to Miss Thompsom and Mrs. Highere and am enclosing a copy of my letter. I and alor enclosing copies of my letter of lexember 11 and this letter to them.

l am loaving to-nimht for Cincinnati and shall hoper to be hack by sumdals. If for ans reason som thonght it desirable. I could returtu by the way of Washington if you telengraph me to doso....

The follewing letter was sent the same day to Miss Thompson ly Miss Gendriell : 


\section{HIS'TORY OF AMERICAN RED CROSS NURSING}

Some time ago I was asked by the Red Cross to go to France. I expressed my willingness to do so under certain conditions that are set forth in a letter dated December 11 that I am enclosing. The matter hung for some time in abeyance, was (losed, but may possibly be reopened for the reason that my letter to Miss Delano of Jannary 2:2 will explain. As head nurse of the Army, I desire youl to know exactly how $I$ feel in the matter in order that you may be in a position to express your opinion upon the question should it come to your attention. May $I$ add that I am sending a similar letter to Mrs. Higbee.

The Nursing Service files show no record that Miss Delano replied to this letter from Miss Goodrich.

It will be readily appreciated that an assumption on the part of the American Red Cross of any responsibility in connection with the conditions existing in and the conduct of United States Army hospitals would lie far outside its charter obligations and wonld, moreover, be contrary to all precedents and regulations of the highly organized and sharply disciplined Military Establishment.

In this serious and unfortunate controversy, one of the most regrettable which appears in connection with the nursing history of the war, both Miss Delano and Miss Goodrich were motivated by high though opposing ideals of duty to the sick. It is to be doubted if elements of personal interest were guiding factors on either side of the case, for both Miss Goodrich and Miss Ielano were at this time holding positions which set them above the need of self-seeking. Miss Goodrich earnestly believed that only through complete comprehension of the entire situation both in military and Red Cross hospitals could she formulate sound polieies for the Red Cross Nursing Servive abroad.

Miss Delano had scen the failnre of the Tolunteer Corps which the Surgeon General had tried to organize in 1905. She felt that the Red Cross lieserve was the only practical instrumentality through which a large group of nurses might be held in readiness for the Ammy. However, her one aim was to serve the Army, even thongh it meant the total celipse of the Red Cross Nursing. Scrvice. "The rhief aim of the Nursing Service," Miss l)elano hard said again and again to Miss Noyes and here other ro-workers, "is to serve the Army." For the Red cross to put itself in the position of asking of the Army 
any authority over the military hospitals in France would have been an offense to Miss Jelano's sense of elean-cut organization. Moreover, her knowledge of the $\Lambda \mathrm{rmy}$, gained through the years when she was head of the Army Nurse Corps, had taught her the futility of asking for such authority, even if she herself had been in sympathy with Miss Goodrich's point of view. Miss Delano regarded this secthing Paris situation as essentially an administrative problem and consequently saw no reason for taking it up with the National Committee. Differences in the outward expression of fundamental war nursing principles undoubtedly existed among the other members of the National C'ommittee on Red C'ross Nursing Service, as well as between Miss Delano and Miss Goodrich.

While the controversy was still going on, Miss Russell contimned her efforts to maintain a professional nursing service in France in face of the persistent tendencies toward lay control. On January 23, 1918, she wrote Miss Noyes:

I think that it is desired to have a laywoman in charge of the women's activities, including nursing with the canteens, ete. 'This is rather vague and I trust will not materialize, but, between military and lay control, we have some reason to wonder how nurses can manage to hold the position they need in orler to fulfill their responsibilities. I do not want to write discouraged letters. War is a savage state of society and it strikes at many things we have cherisherl. I really hare faith in the nltimate outcome, though I think that we must be really to go through a black period at first.

Of lay eontrol, Miss Russell alluded again in a letter to Miss Delano, January 2!), 1918: "I confess to a very strong feeling that our standing as professional women is hard-pressed these days. They want our hends but not our heads for the work. Perhaps 1 an too tired to be hopeful to-day and I am ashamed to speak to vom, who hav labered so valiantly for vears."

After Miss Goodrich had refused to go to France as chief murse of the Ameriein lied Cross nloue. Miss Delano, as has beren stated, had nominated Mary K. Nelsom, then ehiof nurse of American Reel c'rose llospital No. 109 at Evrenx, of which I)r. Fitch was in amminud, als a possible surecessor to Miss Rinssell. Since Angust, 1915, when Miss Nelson had suceeeded

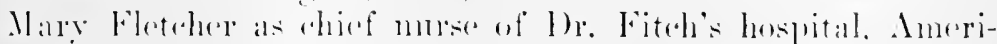
ean lied Cross nurses and lay assistants had worked together 


\section{HISTORY OF AMERICAN RED CROSS NURSING}

\section{both at St. Valery-en-Caux and at Evreux in great harmony under Miss Nelson.}

In February, 1918, Miss Morgan and Dr. Lambert requested that Miss Nelson come to Paris for a personal interview. Miss Nelson described the conference at the Paris headquarters:

... The date was between the 18th and the 28th of February. ... Dr. Burlingame telephoned our Chief and gave him to understand my experience with nurses' aides was the reason why I was needed in Paris to do it on a bigger scale. That same day Miss Morgan wrote me a very casual note in which she assumed I was seeking another position and invited me to lunch with her where we might talk over some work in which she thought I would be interested. . . .

Immediately Dr. Fitch by telephone to Dr. Burlingame demanded an explanation. Then it was arranged that I report in Paris to Major Lambert and Dr. Fitch was assured that he was releasing me for a more important need.

On entering Major Lambert's office, where I found with him Miss Morgan and Dr. Burlingame, the atmosphere did not seem clear. They gave me the impression of not being quite ready for me. I was surprised to find Miss Morgan assuming direction of the conference. The first question, after the usual greetings, was something to this effect: "Tell us just how, when everyone else is having so much difficulty with aides, you seem to have no trouble?"

Very quietly I went orer the gradual growth of our group, - how each aide knew from the beginning which nurse was responsible for her work and how with the spirit of the work paramomnt, it just workerl wetl and seemed most natural. To this Miss Morgan shook her head. My methods were too simple: they wonld not serve for Paris. Then followed a brief discussion, where 1 calmly insisted on the necessity of clear lines of responsibility. Dr. Burlingame appeared to agree with me: he had visited us in Evreux and had seen it all in operation.

It was then Mis Morgan's turn to describe Mrs. Mnnroe's difficulties and how they had hoped I might have rome to help her, but with such definite irleas of professional relations, it would perhaps be wiser to think the whole matter over before going any further.

Wheremon I fomd miself being ushered out with some hazy plan of a future meeting which even then seemed a mere pretext. . . I nurer dreamor of anyone's even thinkingr of ronsidering my replar.ing Miss Russell. ${ }^{69}$

${ }^{\infty}$ See letter written September 23, 1921, by M. K. Nelson to the author. 
The situation came to a climax on February 20. Miss Russell wrote Miss Delano:

The responsibility that I feel for the standards and the accomplishment of our profession are so involved with conditions here and at home that I am afraid I have not been able to keep als elear a head as is needed for the situation and evidently from your letter you are bewildered as to our nects:

First: I will tell you about the demands brought to me yesterday and that may help you to see why the requests I send seem indefinite. P'art of it is the "war" atmosphere and the way we must expect to work. I had told you they were discussing convalesent plans, but I had no definite request till yesterday. They then told me that they would want ten or twelve nurses to io visiting nursing in two rities, Biarritz and Royen, where they had taken rooms in hotels for convalescent men, one hotel for fifty to one hundred oflicers and beds in earlh city for one to two hundred men. Their plan is to have the nurses live by themselves in some hotel and risit the patimits when necessary. They saiu they wanted the nurses to go in about ten days. It seems to me that this calls for women of munsual dignity and character and I tremble lest they demand that aides be placed there to help.

Then a little later, a telephone call came asking for four or sis murses to be sent to help in some of the French Army hospitals at the front. I begged that a conference be held before embarking on such a new departure, as I did not feel that we could aceept an obligation like that without eonsideration. The ('ommisioner said that they must be sent at once. I suppose l did not protest wisely, but while I wish we could take care of all the sick, I wish we eonld also have a little clearer idea of our responsibility before we embark upon so new an undertaking. IIowever, we have Florence Bullard, who (an leat the expedition, and we will see who else can help. You will note that we asked in a cable for thirty nurses who could be here on call for emergencies.

Second: The question of the use of aides is very acute, as I have presions ly written. It is probable that the situation will not be allowed to remain in our hands ats completely al: we wish.

War conditions in Paris were at this time grave. Air raids

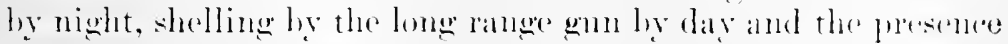

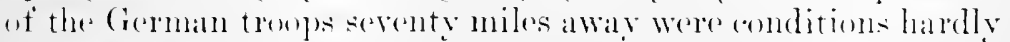

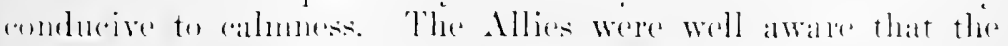

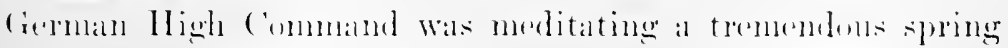




\section{HISTORY OF AMERICAN RED CROSS NURSING}

offensive, using the troops and supplies released by the collapse of Russia from the eastern theater of war.

On February 20, Major Perkins cabled Mr. Davison:

Cable 2414: Our whole relationship to Nursing Service here dependent upon competent leadership. We are losing our position with mursing profession, which, as you know, is one of our greatest assets. Believe head of our service should be possessed of great personality, eharacter and recognized leadership. This one position so vital that no job at home should stand in way. Neither Miss Delano nor Miss Noyes considered just the person. Please select new head for our service, but before deciding finally wire name for our confirmation.

To this eable Mr. Gibson, of the War Council, responded (Cable No. 6979):

Dr. Clarke ${ }^{70} \ldots$ just sailing has long story which desire you to consider, either cabling ns further thereafter. If question so rital impossible [to] wait his arrival, cable us more in detail regarding just requirements of position. Strongly advise however seeing Clarke first.

Miss Russell in the meantime was eontimuing her work as best she could. She wrote Miss Delano, March 4:

A lease has been signed for Pension Galilee, for use as a nurses' ('lub for the duration of the war. The French propriétuire rontimues to run it as her own business proposition, the Red Cross undertakes to back the scheme by paying rent and a certain bonus to hold the house and each nimrse will probably pay eleven francs without lunch, or fourteen francs with lunch. Before the price is absolutely settled, further conference with Colonel Ifinter is necessary. This amount will be covered for any nurse on detailed duty and that seemed a fair standarl to me.

The house is in the pleasantest residential district of Paris, near the Alma and Etoile stations of the "metro." and is a most attractive building with light roms. eachs with hot and (n)d water, a fair mumber of baths and numerons balconies. One of its great charms is a garden opening from the saloon, where tea (if there is any) may be served. This will be a

${ }^{70}$ Dr. William E. C'larke sailed April 13, 1918, with rank of major, American lied Cross Commission for France. 
restful, pleasant spot when one comes in after work. I think the nurses who eome on leave will enjoy it very much. We do not plan to try for much emphasis on the social side, as the nurses always want to spend most of their time here sightseeing and resting.

The I'nsion Galilee was entirely self-supporting. Nurses were aceommodated there at the rate of 14 franes a day and for this rasomable charge were given among other things sugar, butter and plenty of hot water and heat, luxuries almost injossible to obtain at the average hotel in Paris during 1918.

To linth Morgan, a member of the Finance Committee of the ('ommission and a woman of numsual business acumen, nurses owe the establishment of the Pension Galilee. Miss Morgan was the daughter of Mr. and Mrs. William D). Morgan, of New Furk City, and had for many years taken a prominent part in philanthropic work there. She had served on the training school and social service committees at Belleve Hospital and had shown keen interest in hospital and civic reform. For many roars she was president of the New York Colony Club. She spoke fluent French and was familiar with eonditions existing in P'aris. As she was the only woman to serve on the Finance Committee, she held a position of much influence and authority at Paris headeguarters.

Early in Mareh, 1!18, the nursing situation at Paris headfuinrters eame to the crisis which had been imminent for some months. On March 9, Miss Rinssell wrote personally to Miss Delano:

Since I wrote you March 6, matters are practically in strth quo. I have learned that the plan is to have a dejartment of hospital women, with Miss Ruth Morgan at the head, and that they have abled for Miss Coodrich to head the nurving part of it. I lo not know if she will come or whother they wonlit give even to her adequate anthority to aceomplish thinges.

When I ram I was told by sereral of the commision that nurses were realy to tell how much they rould do, but never ready really to work. I folt that it was wiee to go quietly and monstentationsly ahent the businese of learning what the

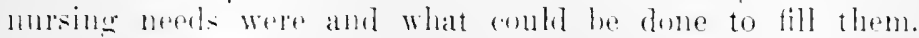
Evidently I waldiel it. for the powers-that be have of late

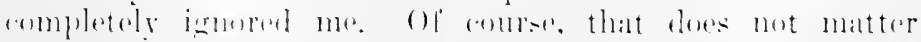

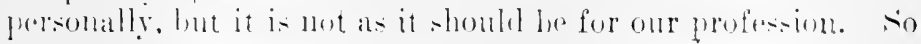




\section{6+ HISTORY OF AMERICAN RED CROSS NURSING}

many fine, intelligent women are here. But defeat of one person is not necessarily disaster for the whole profession, and I still have hope for you and them, through the deroted determination among the nurses that they will let no personal grierances hinder them from giring our men the care they need. I shall continue to do what I can unless I am orlered to ranish.

In a personal cable sent on March 13 to Miss Delano, Miss Russell reported: "Resignation given by request of Commissioner."

National Headquarters responded under date of Mareh 19: "Sending suecessor to Russell on first available steamer." On the following day, however, Major Perkins wrote to General Bradley, then chief surgeon, A. E. F., requesting the assigument of Julia Catherine Stimson, then chief nurse of General Hospital No. 9, British Expeditionary Forees, as chief nurse of the Ameriean Red Cross in Franee. He did not, however, advise Miss Delano of this fact. On the same day Miss Delano offered Miss Russell foreign assigmment in Italy or elsewhere in Europe, but Major Perkins answered on Mareh 25: "Miss Russell will report to you about April fifteen. Lay control desired here." On the following day, he cabled again: "Sueecssor to Miss Russell selected here. Miss Julia Stimson has been assigned by the Army for this purpose."

Major Perkins cabled National Headquarters April 2 of the reorganization of the American Red Cross Nursing Service in France: "Further modifieation of organization of Military" Affairs Department takes Nursing Service out of this Department and makes it separate burean under administrative bureans for general service to entire organization."

This cable meant that the Nursing Service, instead of being an independent department such as existed at National Headquarters, was to be a sub-burean of the Women's Burean of Hospital Service, of which Miss Morgan was the director.

Information as to Miss Morgan's position may he gained from the following personal letter written by her on March 27 to Miss Russell:

There sems to be an implession in your mind that there was a usurpation intunded by mo of inuses functions- - in fact, that you have alreaty registored a protest in this belief. I am taking on direset lied ( poss responsibility and author- 
ity precisely as IIajor Fosburgh [Director General, Army and Nary bepartment, American lied ('ross ('ommission for France | and Mrs. Whitelaw Reid | a momber of the Red Cross commission for Great britain| have done and this anthority conde be transfered at any moment to a lied Cross man if it was the sontiment of nurses in general that no woman should represent the hed Cross to them. I think the general ause of women would suffer by this riew.

As I have said to you, I consicler that the chief nurse of the lied cross has been unduly hampered in two resiects: One, becanse she was suborlinated to one section of one department of the Refl Cross; and the other, that she hat no relation or means of communicating with the Army.

This being her position. I think the whole position of the nursing profession is suffering, and considering that it is giving the biggest service rembered by women in the war and is only seconcl to the men in the fighting line, this is a matter of deep regret. My plan purposed a more independent nursing burean in the Red Cross with comnection through me to the commissioner and direct relation through the chief nurse to the Army.

I have already put up the greatest effort of which I am capable to bring these things about, but have no personal interest in the matter so long as it is accomphished. I have deeply appreciated your difliculties and your disinterested patience.

The Paris interpretation which put the Nursing Bureau in the Womens: Bureau of Hospital Service had one general theoretical aremment in its favor, i.e., nurses were women and therefore mursing service belonged in the Burean of Women's Ilospital service. This interpretation was in reality, however, a direet blow at fundamental principles held by the mursing profession that professional "mursing cducation and administration shomld be directed by murses." Trun, the organization provided that Miss stimson shomld be dhicef nurse. but that Miss llorean should be direcetor of the department in which 11 is stimson and her burean functioned. This fandty oreanization

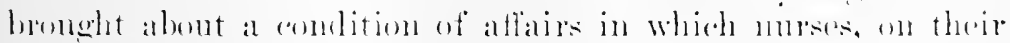
part, ware not prepaned to take kighlly the aflopts of Mis: Morwan on there hehalt, and in which all larworkers interested in

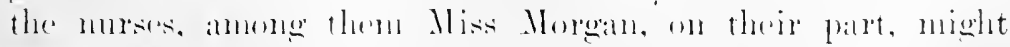

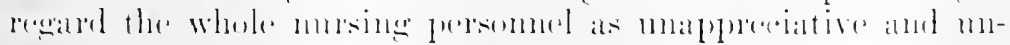
Eriateitul. 


\section{HISTORY OF AMERICAN RED CROSS NURSING}

When these questions of poliey and administration were submitted at a later date to Miss Morgan, she wrote:

The position occupied by the chief nurse before the organization and formation of the independent nurses' bureau caused her to be dominated by the whole hierarchy of the Medical Department and Military Affairs, including the subordinate of these departments.

No doubt there is a series of protests in the records of the Washington Burean of Nursing against this domination.

The profession of nursing is the greatest of women's professions and was founded by a woman. It was my opinion that there was danger that the professional dignity would go unrecognized and the professional opportunities for service be lost. 1 am quite content that any judgment in the matter be left to a history of the results.

The reorganization of the Nursing Bureau in France presented opportunity for a general analysis of the misunderstanding existing between the Paris office and National Headquarters, and Miss Noves wrote on April 4, 1918, a strong letter to Mr. Case, of the War Comeil, a letter which enumerated in detail the six problems upon which confusion had resulted. All of these problems were of an administrative nature. A copy of this letter was immediately sent by $\mathrm{Mr}$. Case to Commissioner Perkins and resulted in a much better understanding between the two offices.

The office and anthority of the chicf nurse, American Red Cross Commission for France, was finally outlined by Majos Perkins in a cable sent April 16 to National Headquarters:

Bureau of Hospital Service is new burean in American Red ('ross which is responsible directly to general manager [Paris ollice] and commissioner. It concerns itself only with nurses and nurses addes and inchules plans for their holiday, convalescent are. hotel and club accommonations, equipment, recreation, ete. Ruth Morgan is director of $\mid$ this: burean. This burean has separate budget and power to requisition. Julia ('. Stimson js newly appointed ehiof nurse of the Amprican liod cross in France, assigned to this position by sureon General of the Amerian Expeditionary Forees, and will in iddition perform all duties heretolore per-

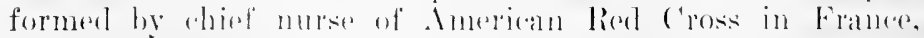

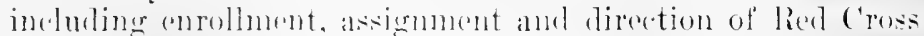


nurses. She will report lirectly to Bureau of Nursing Service of American Red Cross in Washington.

Julia Stimson's first letter to Miss Delano, written April 16, 1918, explained the circumstances which led to her appointment :

A little over a month ago, Major Alexander Lambert, chief surgeon of the Amerian lied ('ross in France, telegraphed to me to go to l'aris for a conference. I came and one of the first questions that. I was asked was, could l explain what was Wrong with the present position of the chief nurse of the American lied Cross. I told him that there was a very great difficulty which had been olvious to many of us for a great many months past, and that was that they expected the chief nurse of the American lied Cross to undertake very difficult duties with her hands tied behind her. They asked me what I meant by such a statement and I said that so long as the position of chief nurse had no official relation to the Army Nurse Corps, it wonld never have the authority, responsibility and dignity that it should have. After a considerable talk with Major Lambert and Miss Morgan and Commissioner Perkins, they asked me to put in writing my ideas on the smbjoct. I prepared them at night and presented them the following mornmg, in the form expressel on the aceompanying sheet. . . I left that paper with them and returned to Ronen.

1 must say that it was explained to me that Miss Russell was relurning to America and I was askerl what I thought of the position for myselt. I told them very frankly that I was an Army nurse and muter Army orders and that the scheme that 1 was proposing for the position was not made in reference to mycelf in any way, as I could consider nothing that lid not come as an Army order. I lave sunce learned that the seheme which I had left with them was enterely approved by the lied Cross officials and was taken at once to Irmy licarquarters and anepted by Gosoral Bratley and Colonel

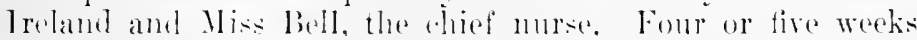
later. I respivel an order from the oflice of the Surgeon (ieneral as follows: "itis. I. ('. Stimson, R. .., A. X. C.. is relieved from further luts with Base IIospital No. ?1 and is ordered to report to the chief sureson of the Amerioan Red

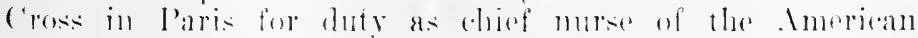
Rerd cross in France." sines I have been here I have learned

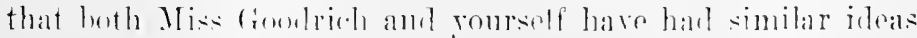

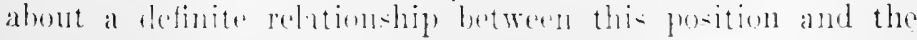




\section{HISTORY OF AMERICAN RED CROSS NURSING}

Army Nurse Corps. It is too soon to know how the arrangement is going to work, or what snags we shall meet, but I am perfectly sure that the way is opened for a far greater cooperation and understanding than was possible before.

I wish very much that I might have seen Miss Russell before she left and could have explained to her my understanding and synpathy with her in the difficulties she encountered and my admiration of the spirit she showed in circumstances that made her position intolerable. She has been through a most difficult time and gave of her very best, and anything that $I$ am able to do will be but building on the foundation that she has laid.

Herewith is quoted Miss Stimson's conception of the position as referred to above, a conception which was prepared, it must be remembered, after twenty-four hours' study of the situation from a point of view outside the Paris office:

I. The chief nurse of the Ameriean Red Cross (in France) should be nominated by the Red Cross and approved by the Army. She should be given by the Army (if not aheady so graded) the grade of army ehief nurse in charge of the American Red Cross Nursing Service in France.

II. She should be subordinate to the chief nurse of the American Expeditionary Forces.

11I. Duties. Supervision and control of all nursing artivities which have been or may be assigned by the Army to the American Real Cross.

A. Present anctivities: (1) assistance of nurses on leave; (2) supply of rquipment; (3) assistance of nurses ordered hack to the Cuited States; (t) establishment and control of a burean of American Red Cross nurses not in the Army.

13. Proposed activities: (1) formation of plans for the establishunent and control of an American Red Cross nurses' aide sorere in France; (2) establishment of an authoritative informatom hureau for morses, authoritative because it represents the rhich uurse of the $\Lambda$. E. F.

Realson for the need of an $\Delta$ rmy chief nurse in charge of the Amerian lied ('ross Nursing Service in France: that a more efficiont renation may be marle possible by having in anthority a chice mure reengrized by the Army and cognizant of Army nursing mattres and ronditions in military hospitals.

In her answer written May 8 to Miss Stimson, Miss Delano said: 
There are certain points which to me seem absolutely essential in working out any basis of coöperation with National Headquarters. . . .

The first is that the representative of the Department of Nursing should be definitely in charge of Red Cross nurses and nurses' aides, responsible for their assigmment to duty in France and for their supervision. She should make recommendations in regard to their release from duty and other complications which might arise concerning their health and conduct.

This insistence that an executive nurse, subject to the joint policies of the American lied Cross and of the mursing profession, as represented by the National Committee on Red Cross Nursing Service, shonld control the destinies of Ameriean Red Cross nurses on active service, was the old contention, it will be remembered, over which the supervising nurses of the Merey Ship Expedition had struggled in 1914. Noreover, it was the keystone upon which the Nursing Service had been erected. The Anerican nursing profession had in 1909 acepted aftiliation with the American lied Cross upon the definite understanding that the National Committee on Red Cross Nursing Service, which was to be composed of a majority representation of nurses and was to have a nurse as chaiman. shonld possess advisory powers in the dotermination of the polieies governing the service. This basic understanding implied a guarantee of professional leadership to all nurses who might enroll in the service and Miss Delano and Miss Noyes had explained this organization and indirectly implied this professional guarantee when they had ured numes to enroll. This was another powerful reason why they both felt under undeviating obligation to protest against liy control of the American Red Cross Nursing Serviee in Franee.

In the sanc letter, Miss Delano wrote:

I was, however, greatly surprised at your appointment without conference with this office. Fortmately l am ontirely satistied, lunt I an imagine circumstances imfler which I would not have heren willing to plate in the hands of a prersom who had neither leen nominated nor selerted by nes. the

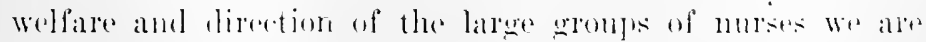
semding orer. I am telling vou this not with an idea of raising difficulties now. hut tis explain te you that the lient

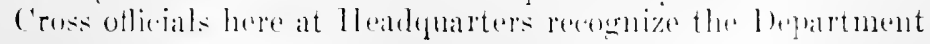




\section{HISTORY OF AMERICAN RED CROSS NURSING}

of Nursing as definitely in charge of Red Cross nursing activities wherever we are located and would have naturally expected that no formal appointment would be made without consultation with me.

I had not anticipated that the chief nurse of a base hospital unit released for this service would have continued in the grade of Army chief nurse, receiving her salary from the Government. I can see no objection to this, lowever, if it seems more acceptable to the Army.

In commenting on Miss Stimson's outline, Miss Delano continued:

I shall be very glad of further information in regard to the duties designated and the reason for omitting ${ }^{71}$ from these duties all reference to the nurses' aides which we have from time to time sent to France. The selection of nurses' airles for service has been placed definitely under the Department of Nursing at Red Cross Headquarters. It, therefore, seems inconsistent that requests for nurses aides should come to us through others than the representatives of the Department of Nursing, or that we should be expected to assign nurses' aides through any other channel, either to hospitals or directly unter the Red Cross.

More than five years ago. the instruction, preparation, selection and superision of women diesiring to rolunteer as nurses' aides in case of war was placed under the Department of Nursing and all correspondence relative to such appointments came to this oflice. I unlerstand the complications in France and realize that as far as the American Ambulance is concerned. Mrs. Munroe has for some time been in charge of the selection of aides for this hospital and could apureciate Miss Russell's mullinguess to interfere with a plan which had actually been in existence for so long. If this arrangement annot be modified for Army Hospital Xo. 1, I should certainly think it most molesirable that the plan be extended to other hospitals or positions and that a dual responsiljility should be reated.

We shall, therefore, expect that in sending requests for nurses and nurses' aides to II arlquarters, (ablegrams should indicate that these requests meet with your approval. It also seems decirable that as far as possible, a definite statement should lo malle in regard to the special serriae for which the nurses or nurses" ailes are desired.

"In writing this letter. Miss Delano overlooked Point P. III. of Miss Stimson's ontline of dutios. 


\section{Miss Delano summarized the criticism which the Red Cross Nursing Service was then meeting:}

It naturally leads to dissatisfaction to send a nurse to France with a good deal of experience along certain lines and find that she is assigned to some routine duty without special reference to her qualifications. There is a good deal of opposition throughout the whole Cnited states to the withdrawal of so many experienced nurses from important positions, both in hospital work and public health service. 'The Red ('ross must, therefore, ensiler the needs of the whole comntry as well as the military service and our work in France. We camnot afloril to tear down existing organizations and ruthlessly withlraw nurses from communities unless we can justify ourselves hy a convincing statement that the nurses are needed for a more important piece of work.

Miss Delano's letter closed with a characteristic personal message to her new representative:

I am much pleased over the news in the morning papers of General Ireland's appointment as Chief surgeon General in France. I feel sure you can rely on his sympathetic: interest and eoöperation, for I have fouml him at all times a tower of strength, with great ability and absolute sincerity of purpose.

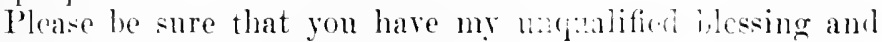

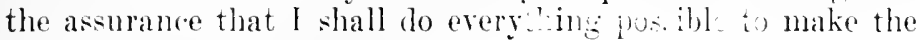
work in France a success.

Miss Delano wrote Miss Noyes on Jamuary 18, 1919, after a careful study of the Paris offiee, when she was on that foreign inspection tour which was her last work for the service which slse had built up and loved:

There is no loubt that Miss Morean was the nominal heal of the Norsing Service in France. Apparently the question

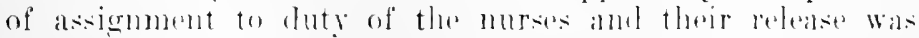
left to the nurse in waree. but theoretically there is no dembe that their line of ammmonition with the higher antherities was through lliss lloreran.

I do not know whether this situation axisted when Mins

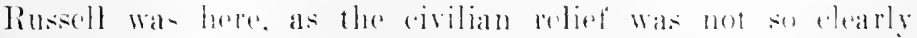

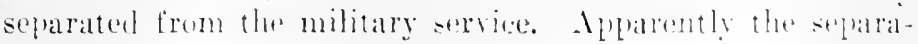




\section{HISTORY OF AMERICAN RED CROSS NURSING}

tion is still quite distinct, although nominally under the same jurisdiction.

Miss Noyes wrote regarding the organization of the American Red Cross Nursing Service in France:

The Nursing Service at National Headquarters consisted of an independent department which supplies nurses for all branches of military and public health nursing service, both within the Government and the Red Cross. Miss Delano and I had personal contact with the various members of the War Council and we could make recommendations directly to them regarding the conduct of the service.

The organization of the Paris office consisted of a Nurses' Bureau within the Nomen's Bureau. Miss Stimson had the title of chicf nurse, American Red Cross in France; however, the organization made Miss Morgan the official channel of communication between the Nurses' Bureau and the Commissioner.

Miss Delano interviewed Dr. Lambert while he was on a trip to this country during the spring of 1918, regarding the nursing situation in France. I was present. Dr. Lambert denied that the Nursing Bureau was under the direction of a laywoman. I asked: "Did Miss Stimson have the power to make recommendations to the Commissioner for the conduct of the Nursing Service in France, or did these recommendations have to go throngh Miss Morgan's hands?" He replied: "They had to go through Miss Morgan."

Why a nursing service. wholly different from that which existed at National Headquarters, should have been set in Paris, was not clear to National Healquarter's or to murses in foreign service and it cansed great anxiety and considerable criticism among the Red Cross nurses overseas, thus lowering their morale to an appreciable degree. The nurses themselves fully understoor that the Nursing Service in Washington was directed by nurses who had easy arcess to the members of the War Council and needed no intermediary. They were suspicions of the l'aris organization aml many personal letters and personal protests to that effect were received hy us. They well knew that the organization at National Ileadquartors han already proven itself capable of administering the problems arising from the mobilization and rquipment of many thousands of murses, whereas the Paris onlioe at this time dealt only with a few humdrets. Why shonld not an alle nurse in the Paris oflice. they arened, have attended to the horimesis details of the Nursing Sirvice 
in France, just as the Department of Nursing at National Headquarters attended to the business details of the Nursing Service in the Inited States, even to the expenditure of thousands of dollars for equipment alone?

Nurses were quite willing to roncede that a women's bureau with a laywoman in charge, was essential in Paris, in order that the groups of non-professional workers might have full ronsideration. But they contended that a nurses' bureau, quite independent and on an equal plane should also have existed so that plans and recommendations involving the work and welfare of murses might be presented directly to the commissioner through their representative, the chief nurse of the American Red Cross in France.

While information regarding the organization of the American lied Cross Nursing Service was in their hands, it is possible that in the pressure of the time, the commission did not appreciate that they were setting up an organization in Paris which was directly contrary to that which had existed for many years at National Headquarters. ${ }^{i 2}$

The last word in this controversy belongs in chronological sequence to Miss Stimson, who thus defined her own position:

After the reoranization accomplished by Miss Morgan, Miss Stimon's position was entirely different from that occupied by Miss liussetl. Miss stimion was not in any way subordinate to the Medical Iepartment or the I)epartment of Military Afrairs and she did have direct access to the Commisioner. It must he remembered that Miss Rinssell had been responsible to the ('hief Surgeon and his assistant and also to the Director of Military Allairs. At the time Miss Stimson was appointed rhief nurse, Miss Morgan was artually the liation ofticer between the mursing artivities and the rommision, as a member of the Finance and Exerntive rommittess and later of the commision. She was not known as the hearl of the nursing bureau but held a somewhat unofficial position.

The chicf nurse's responsibility through a member of the commision freed laer from the demination of the Medial Department and atsured her the hatking of the ammision and of the (hice sureren of the Army and thel not in any way prevent here dired acesess to the commissioner when she desired it. Iny number of instances an be enumerated to prove that fact. For example. there was no intermediary : Menorandum written by (lata 1). Noyes, september 12. 1921, to the althor. 


\section{HISTORY OF AMERICAN RED CROSS NURSING}

between her and the Chief Surgeon of the American Expeditionary Forces, a thing unheard of under the former régime and a fact which should also prove (if any proof other than her word is necessary) her freedom of aecess to the Commissioners. ${ }^{33}$

While this much diseussed reorganization of the Nursing Service in France was taking place, the enemy had launched the first of their five major, offensives of 1918 and during the entire spring and early summer, the fate of Paris hung in the balance. With the constant air raids and the shelling as well, it was not a time conducive to cool and judicious deliberation. When she first aceepted the appointment, Miss Stimson knew little if anything of the standardized organization of the Nursing Service in the United States, which Miss Delano had been building up for eight years. Later the military situation gave her little opportunity to try to bring the organization of the Nursing Service in France in line with the organization of the Nursing Service at National Headquarters. Thus it may be stated that she aceomplished her work not beeause of the organization but in spite of it, for fortumately she and Miss Morgan worked well together and she found Miss Morgan at all times an enthusiastic and sympathetie helper.

This whole subject of organization may be compared to an imperfect tool. Miss Russell tried to reshape the tool to the pattern upon which she knew Miss Delano and Miss Noyes were insistent; Miss Nelson stated her opinions about the tool so definitely that it was not offered to her; Miss Stimson took up the tool and worked with it as it was as well as she conld and with her nurses accomplished a brilliant piece of work.

Miss Russell was at this time returning to the United States, greatly discouraged and in ahmost complete physical exhanstion. However, it may be seen that her nine montlis' work in France was not without far-reaching results. Miss Russell had organized, upon anthority from National Headguarters, a Local Committe for the enrollment in the American Red Cross Nursing Serviee of Ameriean nurses then overseis. She had furnished extra articles of ecpuipment to murses serving with the pioneer lied Cross base hospitals of the British and Ameri-

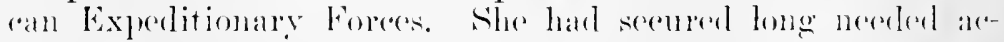
commodations in Paris for Ancriean murses. Further, the

zatter written March S, 1922, by J. C. Stimson to C. D. Xoyes. 
development of a mobile serviee by which Ameriean Red Cross nurses could be sent immediately upon call from the American Expeditionary Fores to any energeney, and the first plans for later Red Cross coöperation with the Fench Service de sunté had been initiated during lier term of office.

This situation has been set forth in some detail, not only in justice to the persons and principles coneerned, but to show to the nursing profession that the Red Cross Nursing Service was not without its internal problems.

To Miss Stimson and her associates during the summer of 1918 came the opportunity to develop brilliant projects of military nursing service. Her first work was the establishment of a more complete system for supplying nurses with equipment. The first step was to secure and distribnte to all the nursing statfs of the American base hospitals then in France such articles as had been omitted from their initial equipment. A seeond important step was to supply nurses who had been enrolled in Europe with the standard Red Cross equipment. A third step was the establishment in Paris of an organization through which nurses both of the Ameriean Red Cross and of the Army and Nary Nurse Corps could replace at eost worn-out articles of equipment. Inother phase of the equipment problem which derolsed upon the Nurses' Bureau was to supply the norfolk suit, after the Army Nurse Corps had adopted it as its regulation outdoor uniform, to the murses who had been equipped with the serece elress, the original type of outdoor uniform supplied lyy the Red cross.

Marie B. Rhodes reported April 22, 1918, to the Chief Nurse of the Commission to Franee and was temporarily placed in eharge of nurses' equipment. Of her, Miss Stimson wrote:

One day Miss Rhodes appeared at the oflice and asked how she coukl get into the Army Xurse ('orps, stating that she was a lind ('ross murse and had come to France with a womenls mit which had been disorganized. She was tols] low to apply for admission to the Army Surse corps and her papers were forwarted to the oftice of the chief surgen at 'Tours. In the meantime. While awatine artion on here alpli"ation, she askinl if she comld he of any nse and was told that

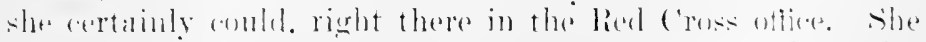

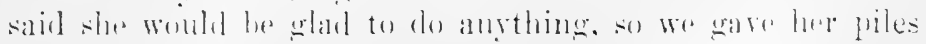




\section{HISTORY OF AMERICAN RED CROSS NURSING}

of correspondence and reports on the subject of nurses' clothing.

She started to put them in shape, making tables of the equipment the nurses' units had already received and what they were asking for, to show what each unit should have to meet the minimm standard equipment which had then been worked ont. The way in which Miss Rhodes undertook this extremely complicater task and compiled accurate tables and statements from which the Red Cross Commission could order thousands of dollars worth of contracts for clothing, proved her efficiency to such an extent that before her papers came throngh from the Chief Surgeon's office at Tours, the Chief Nurse of the Red Cross telegraphed to Tours, asking that Miss Rhodes be assigned to the Red Cross office in Paris.

From that time until May, 1919, Miss Rhodes did a magnificent piece of work in charge of the equipment bureau and therefore made possible the efficient functioning of literally thousands of nurses, because through her efforts these nurses all over France were supplied with equipment which was an absolute necessity for their physical welfare.

A graphic description of the pleasing manner in which Miss Rhodes met nurses and supplied their needs was given by Sophia M. Burns, chief nurse of Mobile Hospital No. 9:

I have always believed that an efficient operating-room nurse would make a good business woman and in the Red Cross office I found proof that I was right. At her desk, Miss Rhodes was directing three orderlies, speaking French to a rather trying maid, answering an insistent telephone and dexterously meeting the demands of many visitors.

She spoke to me briskly: "So you all are Mobile No. 9? That completes our chain of medical organizations. Hare a chair and tell me what equipment you have and what you need."

The result of our conference was that each nurse was completely ontfitted with a trench coat. two jersey uniforms, rain hat, rubber boots, sweater, mittens with wristlets, two snits of genuine all-woolen underwear, black jersey tights, hose, woolen kimono, trench (ap) or bonnet de police, set of dishes consisting of (up, saucer, plate, folding linife. fork and spoon, rot pillow. four blankets, bed sorks. wash rothis. bath and hand towels, duffle bag with padlock (trunks wore forbidden) and the sleeping bag which we had brought from New York. 
In Miss Rhodes' report of the Nurses' Equipment Shop appeared a paragraph with which many nurses and many men in all branches of the service will sympathize, in that it reflects their own experiences:

We were very busy and happy, but I felt that I would like to he at my own work. $\Lambda$ great many requests for anesthetists came into headquarters. I offered my services at night and for two months went into the different hospitals in Paris where they needed help. At two o'lock in the morning the commanding oflicer sent me home by ambulance so that I got to bed by three-thirty. This was the reason why I never got down to the office in the morning lefore ten o'clock. I met so many people in the hospitals whom I knew and liked helping our boys directly so much that I found it hard to stick to jersey dresses and trench coats, but every time 1 said anything about leaving, my Big Chief was kind and yet positive that I must jersey dress and trench coat a while longer. We hild so many hurry calls for them that we got the idea that these jersey dresses and trench coats were winning the war!

The dress was made of gray jersey and in style resembled tho gray cotton ward miform; it was warmer and eould be worn for a longer period without being lanndered. It was issued by the Nurses' Burean in Paris, withont consultation with National Headquarters and was not in conformance with Army regulations, but because of its practicability, no objections were raised.

Of ronditions at the line, Miss Rhodes wrote:

We had many demands from the front. The only way to get them there was to deliser the things myself. by amion. I made many trizes up the line. It always semed one of the most worth-while things I could have done. Many of the nurses were up there without their lugarage: others had never seen theirs since they left the States. One time I remember

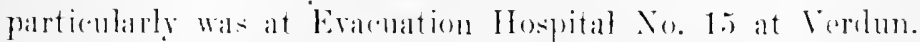
Here were twenty nurses with only hand logerage. (alriug for thomands of patients. It was very cold and living conditions were most uncemfortable. When we fitted wh those nurses from onr amion, they almost ariod for joy:

I visited all the hospitals in the forward aleas several

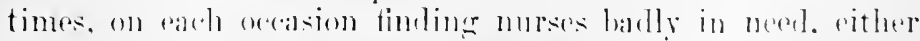

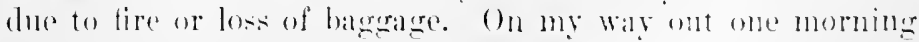


to Mobile Hospital No. 8, where I had an emergency call, I met a hospital train on which were three nurses. I never have been so welcome anywhere. One of the coaches harl burned, including most of their clothes, and we were able to fit up those nurses right there on the track.

From May 1, 1918, to December 31, 1918, the Nurses' Equipment Shop supplied articles free of charge to 9,300 regular and reserve nurses, Army Nurse Corps, 800 Red Cross nurses, 100 American aides, 75 French aides, and 130 officers and clerical workers of various Red Cross foreign commissions.

The staff of the Paris Nurses' Equipment Shop numbered ten people in October, 1918. A Red Cross captain was in charge of the buying and eash sales. Besides Miss Rhodes and her two nurse assistants, there were shippers, packers and a chanffeur for their camionettes. This division contimued to sell reequipment articles during the spring of 1919 until their records show transactions amounting to over 7,500,000 francs before the Quartermaster's Corps assumed these responsibilities. A statistical summary is as follows:

Donations (May 1, 1918-May 1, 1919) . . . .3,401.189.85 frs.

Cash sales " " " "

Stock on hand, May $1,1919 \ldots \ldots \ldots \ldots \ldots 218,060.15$ "

Purchases (May 1, 1918-May 1, 1919) ...3,445,47.2.50 “

Stock purchased prior to May $1,1918 \ldots \ldots$. $292,200.00$ “

Now during the spring and summer of 1918 eame the crucial days of the European War, days and weeks when the German High Command struck again and again on the Western Front and the Allies, united at last under Marshal Foch, resisted savagely until the fury of the five German drives on Paris had been spent. Then on July 18, the Allied Armies took over the offensive and during the following months drove the enemy out of France and Belgium.

The first German offensive of 1918 , it will be remembered, hard been launched on March 21 at the junction of the French and British lines noar Cambrai. Of this engagement, the Second Battle of l'irardy, Colonel Ayres wrote:

The (ampaign of 1918 opened with the Germans in posseswion of the offensive. In a series of five divives of unpre- 
cedented violence. the Imperial Great General Staff sought to break the Allied line and end the war. . . . The first drive opened on March 21 on a fifty-mile front across the old battlefield of the somme. In serenteen days of fighting the Germans atvanced their lines beyond Noyon and Ilontelidier and were within twelve miles of the important railroal center of Amiens with its great stores of British supplies. In this battle, also known as the Pieardy offensive, approximately. twenty-two hundred Imerican troops serving with the British and French were engaged. ${ }^{74}$

Immediately after the Germans struek near Cambrai in this Seeond Battle of Pieardy, General Pershing offered the small number of Ameriean troops then in France to the Allied Armies, to be nsed either as an independent mnit or to be broken up and brigaded with the Freneh and British Armies. The latter method of using these soldiers was employed and they were brigaded all along the Western Front. When these soldiers became sick or wounded, they were cared for by the British and French sanitary services in exactly the same manner as if they had been British or French soldiers.

One of Miss Russell's last reports to Miss Delano, that written Febmary 20, 1918, had mentioned the possible assignment of Aneriean Red Cross murses to military hospitals of the French service de S'enté, to eare for American sick and wounded who had been sent bark to these mits. The demand for nurses to render service of this type increased in proportions dependent npon the numbers of American troops brigaded with the Freneh and the military activities which ocenred rluring April, May, Jume and July. This type of assignment finally formed one of the most brilliant and appealing phases of military nursing servie during the European War.

Of the position held by Ameriean Red Cross supply mits at the beginning of the Second Battle of Pieardy, Major . James 1). A. Foshmeh, Direster (Feneral, Army and Navy l)epartment, Amerian lied cross in France, wrote:

A: is well known, all the plans of our Army were prediated npon the orenpation by the Ameriean Expeditionary Forees of the seretor lying roughly between Toul and belfort (1913). The line of eommunications was taken orer immediately and deseloped to extern from borteanx and st. Savalire to Dijon and ls-sur-Lille. and from there rambating ".."The Wiar with Cermany," p. Hoti. 
up through the area established for division training in the country about Neufchateau and adjacent to the Toul-Belfort sector. The hospitalization provided by the American Expeditionary Forces was entirely located along this line of communications. Large units were located at Bazoilles, Vittel, Contrexéville as forward bases, and at Dijon and points further toward the interior. In the entire area from Toul to the Channel, however, the other Allied authorities had specifically excluded all American hospitals.

With the knowledge of the divisional training and hospitalization plans of the Army, the American Red Cross located the bulk of their warehouses in the Toul-Belfort area, at Dijon, Neuichâtean, Langres, Châtillon, to serve the divisional area, and at Bar-le-Duc, Toul, Nancy, Rambervillers and Belfort, to serve the troops actually in the line. Fortunately as it subsequently dereloped, the bulk of our stores was centered in Paris.

On March 21, the first of the series of German offensives started in the neighborhood of Noyon and Nan and with great rapidity the German forces overran the country lying to the south as far as Montdidier, sweeping aside the French and British forces occupying that sector. 'This resulted in the appointment of Marshal Forh as Generalissimo of the Allied Forces. General Pershing . . . turned over to General Foch certain American divisions with the melerstanding that they would in all respects be cared for by the French.

On or about May 1, the First Division was moved across country from Toul to a point in the line just to the east of Montdidicr, about forty kilometers north of Beaurais. While the division was on the move, we were adrised in a general way of their destination and immediately took steps to secure a warehouse at Beanvais. We were told that they were moring with only their field hospital equipment and that even this material was lacking in certain essential requirements. We therefore sent in advance to Beauvas two large domblewalled Bessonneau tents with all the equipment for a small field hospital, also two Red C'ross nurses and other persommel with diet kitchens. etc.

From long experinnce with French hospitals, we knew that those institutions to which our men would be sent would Jack many items of equipment and supplies which Anerioan practiee considered esintial for the proper are of the wounded. Before the arrial of the division. our French hospital smpply service had sent their inspertors to visit "alch French hospital in the area aromed Branvais to see that they were provided with nerded smpplies. . . 
Another provision was the assignment of American Red Cross nurses and interpreters to these hospitals. Within a week after the First loivision had gone into the line, American wounded appeared in fourteen French hospitals. Had not American Red ('ross nurses gone immediately into these institutions, some of those boys would have died without ever being able to speak to anyone who understood them. ${ }^{75}$

On May 6, 1918, Miss Stimson made a supervisory tour of the Beaurais area, which served the Noyon-Montdidier sectors. Of this tour she wrote:

About half-past nine that night we arrived in the pouring rain at Beaurais. Some Rel Cross men took us to a little hotel, one of the glooniest places I have ever seen in my life. All the electric lights had been painted lark blue. so that no one eould possibly read. The hall and little salon were crowded with officers of all sorts, wanlering disconsolately about. Our room upstairs was so dark we lit andles. Even the glass in the windows was painted deep blue against II un avions.

The next day we visited nine hospitals, some with our American nurses and aides, others with no English-speaking persons except the few American soldier patients. In every case where there was one, I talked to the infirmiere major. Each one said how glad she was to have the American nurses. Our women told us they were receiving every consideration. They all spoke of the wonderful derotion of the French nurses and nums and were deeply touched by the eagerness of the French to learn American methods. Our nurses appreciate that the years of voluntary self-sacrificing service which these French women have given deserve great respect. If they, our murses. are tactful and gracious enough in their dealings with the French nurses to be asked to teach these splendid women some results of the professional advantages so freely given us, then indeed no greater reward nor highar tribute could be ours.

()ur nurses looked shadowy-eyed and white-facel from their long hours. The Amerieans were pitifully grat to have them. The surgical are which our men get in these hospitals is excellent.

During the serond weok of May, 1918, the following permission for and instructions reandeding the assignment of trams

is Report of llajjor Foshurgh to II. I'. Davison: Red (ross Arehives. 


\section{HISTORY OF AMERICAN RED CROSS NURSING}

of one American Red Cross nurse and one nurses' aide to go into every French military hospital where American troops were being cared for, were issued:

From: 'The Under-Secretary of State for the Service de Santé Militaire.

To: The Chief of the Service de Santé of the First Army by order of the General Commander-inChief.

I have received from the American Red Cross acting in connection with the Medical Department of the American Expeditionary Forces, a request for permission to detail American Red Cross nurses to French hospitals of the Zone of the Interior and of the Army Zone which have admitted for treatment sick and wounded of the American Army.

I consider that our desire to make it possible for our Allies to find English-speaking personnel in our hospitals makes us accept this proposition.

I have, therefore, decided that nurses of the American Rert Cross in groups of two may be sent to all hospitals where French nurses are already present and which will have been reported to us as having received, or as expecting to receive. sick or wounded of the American Expeditionary Forces.

To carry out these instructions, you will notify me at once by telegram sent to my central office Service de Concours Etrangers as soon as the hospitals placed under your authority have received or expect to receive soldiers of the American Army. You will notify me also in the same manner when the services of these nurses are no longer requiral.

All nurses on duty in the Army Zone will be militarized: that is, they will possess the "red workers' permit" granted by the Adjutant General of the American Expeditionary Forces. In addition to this, the laws regulating the armission of this personnel into the Army Zone and as well as its stay there are those set forth in the Instruction 3993.SBA.1 of the 2 sil, $191 \%$.

During their stay in French hospitals, the nurses will be plareel under the direct orders of the médecin chef who will assign them to duty with their countrymen or with the French wounderl, if the cmergency arises. The nurses will not he under the orders of the infirmieres principales, but they will live with the other infirmieres under the same conditions and will conform to the same rules and regulations which govern the French peromenel.

In ase of serions discegard of rules, you will notify me ly wire in order that I may communicate with the American Red 
Cross and request the urgent removal of the nurse who has beeome undesirable and arrange for the detailing of a nurse to take her place.

\section{In a report of May 28, Miss Stimson wrote:}

The Service de Santé has asked [allowed] us to organize twenty-five teams of nurses and nurses' aides. I have appointed Alice Fitzgerald to prepare and supervise these units. She speaks fluent French and is, as perhaps you remember, a Hopkins nurse of wide executive experience.

Now that the offensive lias commenced with renewed fierceness, this part of our work is bound to inerease tremendonsly. We have had to take nurses from the Department of Civil Affairs as it is impossible to get Army nurses for this work. The Army officials, though heartily in favor of our work with the service de santé, state that their nurses are needed, or soon will be, in the places to which they have been assigned. Among the last group of nurses many possessed very specialized training, but when they heard of the real military necessity they were eager to be used wherever needed. Heads of Red Cross departments have been equally fine about giving over to this work nurses assigned to their specialized services.

Alice Louise Florence Fitzgerald's first executive work with the American Red Cross was in the development of this service. The daughter of an American scholar who made his home in Florence, Italy, Miss Fitzgerald early gained knowledge of the language and peoples of France, Italy and Germany. This international background, coupled with her wide professional experience, commanding presence and native charm of personality have made her a romantic figure in American Red Cross nursing listory.

Miss Fitzgerald was graduated in 1906 from the Johns Hopkins School of Nursing. Two vears later during the earthquake which devastated Messina, Italy, she did emeroency reliof nursing in that city. In 1911, when a reorganization of the operating-room system at Bellevele Hospital was effected, Miss Noyes, then superintendent of murses, had chosen Miss Fitzwerald as head nurse, a post repuiring the exercise of umusual tact and exeentive ability. After the new system had been firmly established, Miss Fitzererald left New York to become superintendent of nurses at the ('ity Hospital, Wilkes-barpe, Pennsylyania. She later became superintenelent of the holert 


\section{HISTORY OF AMERICAN RED CROSS NURSING}

Long Hospital, University of Indiana. In 1913 she enrolled in the American Red Cross Nursing Service. She was sent overseas in February, 1916, as the Edith Cavell Memorial Nurse from Massachusetts and she served as a member of the Queen Alexandra's Imperial Military Nursing Service Reserve at Boulogne-sur-Mer and at the British Front. In December, 1917, Miss Fitzgerald desired to join the American forces, so the committee of prominent Bostonians which had sent her overseas provided a substitute and Miss Fitzgerald reported on December 13 to Miss Russell at Paris headquarters of the American Red Cross. She was immediately assigned to answer an emergency call for nurses at Rimini, Italy.

In February, 1:18, she was recalled to Paris. She wrote of her subsequent work:

On Febrniary 18 I was sent down to Bordeaux where I was attached to zone headquarters. My work consisted chiefly of supervising the existing American Red Cross activities and of looking around for possible sites for future projects. Among other duties, I took over that of meeting the incoming boats and welcoming our nurses as they landed in France. I have heard many of them say that it was a great relief for them to see a fellow-nurse standing on the dock waiting for them.

On May 16 I was recalled to Paris and given charge of the work with the Serrice de Santé. This type of service consisted of placing American nurses in French hospitals to care for American sick and wounded; it had begun in a rery small and unollicial way as far back as March, 1918, when nurses were sent to Soissons to care for our men in French hospitals. ... The formal agreement with the service de Santé hiul just been signed when I took charge of the service in IIay. . . .

Florence M. Patterson assisted Miss Fitzgerald in this phase of American lied Cross mursing service. Born in Wisconsin, Miss Patterson reecived her A.B. from Northwestern Lniversity and was graduated in 1907 from the Johns Hopkins School of Nursing. She wats for some time assistant superintendent of murses of the Allegheny General Hospital, Pittshurgh, Penna. After extensive post-graluate instruction at 'leathers ('ollege. New York, and at the ('hicago School of Civies and Philanthropy, she did mediend sorial scrriee work and public health nursing in ('hiergon and Buston. In June, 1917, she joined the 
staff of Miss Noyes at National Headquarters, but was released the following month to act as chief nurse of tho American Red Cross Commission for Rommania. The Rommania muit was realled from the Balkans in .Jume, 1918, and Miss Patterson was then assigned to the Paris headquarters to assist Miss Fitzgerald.

Ot the conditions which confronted the first Amorican nurses who were assigned to French hospitals, Miss Stimson wrote Miss Delano on May 28, 1918:

You already know that American troops have been placed with the British and the French forces. It has followed that when they were sick or hurt, they have been cared for exactly as were the British and French troops. With the Britisli, this, of course, was a very simple matter; the American wounded were sent right fown through the British bases. With the French, the problem has been quite different because of two things; the difference in standards of nursing and the difference in language.

In one hospital I saw a French sign in the corridor which said "All rolunteer nurses will please leave their names and addresses in the office." In this institution. I was told there was no head nurse. I should tell you further details, were it not that I think it unfair to put in writing observations about women whose self-salrifice and endurance have heen so deroted but whose professional opportunities so limited.

As for language difliculties, a large number of . Imerican boys soon came to French hospitals, where there was not one English-spealing person. When this was discovered, the Red Crosis reecived permission to put a fow American nurses into these hospitals. Since so few of our nurses speak lirench, a French-speating nurses aide was sent with her in almost every instance. "Tho reports that rame hark on the work ol' these trams were most satisfactory. I wish I had time to toll yon individual stories of our boys. who motil an .meriean nurse spoke to them. had thomght they might be in the hamks of the Ciermans. and of "ases where ammontations late to he done when it was imposible to explain to the boy beforehand what was going to take place. . . .

some lay the story will be written of the spirit of these few nurses who went out into hombed aras.s. into enweled French hospitals where they shared guarters with Feneh sol-

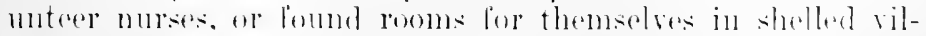

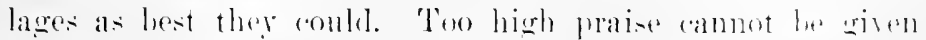
them. Some day perhaps these Amerian boss themselves 


\section{HISTORY OF AMERICAN RED CROSS NURSING}

will tell what it meant to them to have an American nurse when they were so badly hurt, and were in the midst of strangers with whom they could not communicate and under conditions the misery of which they cannot exaggerate.

\section{Miss Delano commented in the Red Cross Bulletin of August} 26, 1918, upon the heart-appeal of this service:

The sound of the mother tongue in a strange land has always been considered the sweetest sound on earth. A letter from a led Cross nurse in Roumania tells of being assigned to a ward containing a Hungarian, a German, a Bulgarian, a Prussian and a 'Turk. "The 'Turk had his leg in a lissian splint but he certainly did smile when 1 asked him for the first time if something was 'Choke ginsel' ('Turkish for 'very' good')," the letter reads, "and was equally delighted when I counted for him in his own language." If the unspeakable Turk can smile with delight at the sound of his own language, what must it mean to our American boys to have someone near who understands when he refers to "Dad" as a "good old scout;" New York as the "Big Town;" who knows that a "eop" is a policeman; a "hobo" a tramp; that "Howdy" means "how do you do ;" and "look out!" means "be careful!" Medical men call it the striking of a normal balance, the destroying of the abnormal condition produced by unusual complexity of emotion and the sudden acquisition of almost a lifetime of experience in a few months.

Sara R. Addison, an American Red Cross nurse assigned to duty in a French hospital, wrote of her service:

Morale does not apply to the fighting men alone, but to the soldier who has fought, is wounded and is "down and out" for the present. I firmly believe that many a man wonkl have felt it casier to die than to try to make his wants understood. I remember one incident, amusing after it was over. but intensely painful to the lad while it lasted. He had had both lears and one arm broken by an Army truck which had struck him. When he ame to the French hospital where I was assigned. I happened to be off duty. As I rame on again I was met by a Fench patient gesticulating wildly toward "le blessé diméricain." I was distinctly alarmed to find six Frenchmen and one French nurse surrounding his boel. Hemorrhare collapse. death entered my mind. The real facts were that he had sneezed while asleep and in some way 
twisted one of his broken legs. The French nurse immediately ran to him and sueceeded in getting the leg in a more confortable position but he could not make her understand it us easier. She continued to change its position, with excruciating results. To understand his relief upon my arrival, one had to see his face. llis only exclamation was: "lior God's sake, tell them I'm comfortable!"

Of the nature of this serviee, nurses' letters speak for themselves. Annie s. Rathbone wrote:

I was one of a group of nurses assigned in June, 1918, to February 3, 1919, to the care of Anerican soldier's in French hospitals. The presence of Ameriean women, as well as the more familiar methods of nursing, seemed to sooth s them greatly. One boy, weak and near his end, said: "No, I dont want anything. Please talk to me. I like to hear you talk American."

Particular scenes stand out vivilly, but it is sometimes the simple and less romantic details that one lores best to remember. Perhaps my most precious memory in all those stirring times was that of half-delirious, dying boys calling me "Nother." This was by no means merely a nickname; but it occurred so often in isolated calses as to quite astonish me, for in my nursing work at home it had never happeneel. I hearl two other lied Cross nurses ay that their experienees had been the same and they treasured the remembrance as 1 do.

Of course as nurses in the war zone, we had the nsulal bombing raids. Sometimes (as at ('reve-Cocme-le-(irand) it seemed. when bombs dropped all aromel omr hospital, quite ly itself in the open fields, and when window grlase was shattered orer the patients' beds. that the memy was really using the hospital as a tareset. We nurses gemerally fombl these raids more endurable when it was our turn to be on night duty with the patients than when we had to sit passirely throngh long hours in the shelter of a care.

The Amerioan Red Cross supplied many articles of repuipment and numerons luxuries to Mmeriean sick and womndad in French hospitals. Miss Fitzgerald wrote of this phase of the service:

Our nurses dial not simply go ont to grive the pattine the nursing calde he required. They went to lowk after his general 


\section{HISTORY OF AMERICAN RED CROSS NURSING}

welfare. They provided for him the food which was not obtainable in the hospital, the companionship which he missed, the small luxuries which our men were very apt to call necessities and in other words, anything or everything which the Red Cross could give. As soon as nurses left for a particular hospital, I put in a request for certain standard supplies such as pajamas, socks, cigarettes, chocolate, games, writing-paper, magazines, books and newspapers. Wherever the hospital was not too far, I have taken these supplies out by motor.

The average French hospital has very little equipment and it is surprising that the results are as good as they are. In all cases, we have been given all that there was to give and if any partiality has been shown by the French, it was in favor of the Americans. It has been necessary to greatly supplement the food. clothing, bedding and equipment in order to approach the standards which we have set for ourselves in America.

In one particular instance in a French hospital in Betz when I arrived there on a tour of inspection shortly after the nurses, l found that a room, in which ordinarily we would have placed two beds, then contained ten beds. In eight of these, very seriously wounded men were lying. In the other two beds, men had died but a short time before. The beds were so close together that you conld not have stood between them. The nurses were absolutely at a loss through lack of equipment and the men were so sick that even then it seemed impossible for many of them to survire the night. I made a list of the supplies that they needed and at the same hour the next diy. I had all these supplies out there and the gratitude of the nurses and indirectly of the patients was a joy to behold. . . .

Miss Fitzorerald made many trips of inspection. The following extracts were taken from reports written by her after these trips:

June 1S. 191s: I left Tours for Saumur. Here I found our murses on duty in a rontagious hospital in a wonderful old (hatean werleoking the Loire. Teither moat nor drawbrilge were lacking. . . The nurses are living in a private house just outside the chatean walls and are rery happily situated. Our pationts semed contented and well cared for. . .

June :00: Miss lithel swope /Connectieut sthool for Nurses, New Havan. Conn. I is working in the Hoprenl Aufjedi. the alest hospital in France except the original Hôtel Dieu. 
She is caring for the contagious. On arrival there, she found a colored man suffering from a very severe case of small-pox and his condition was so desperate and repulsive that he harl practically been abandoned to his fate. Many were afraid to go near him. His joy at seeing an Ameriean who could understand him was quite pitiful. The first thing which he asked the nurse to do was to write to his people that they would never see him again and that his one regret was that he was dying before even having been in battle. Miss swope cared for him until the end and the man was given a most impressive and dignified military funeral, his eoffin draped with the Stars and Stripes.

June 28: Argentan-sur-Orne: Some of the patients were in another hospital in the city and the surgeon had them bronght to the Hopital Wixte in order to have them all together. This removal caused much flutter among the French Red Cross nurses who are very anxious to keep our men. . . .

A very ill patient is now being eared for in this hospital. He is lying on a hammork suspended to a wooden frame and with the help of many pillows is being made comfortable. A water mattress has been asked for him and was shipped immediately. Miss Adeline Rowland [Johns Hopkins School of Nursing], who has charge of this case, has been extremely devoted. She has bought food and dainties and the patient himself told me of a delicious chicken which lasted three days and of which he often thinks. It is a question if his life ean be saved. T asked him what I could send him and his answer was "pies!" I fear" it will be difficult to fulfil his desire, as there are $n 0$ anteens nearer than Angers, but I will semd timned fruits and other delicacies from Paris. . . .

Of the pressure under which the French hospitals operated during the last great German offensive, Katherine Williams, a St. Luke's (New York City) graduate assigned to l'llopital Militaire, Chalons-sur-Marne, wrote:

Paris, July, 1918: . . . That memorable holiday, July 14 , I had dimes with some of the canteeners and went to a conreet afterwarls, returning home and getting to bed about 9:30. T'welve midnight-Bang-with so greal a concusion that it prantically threw us both ont of bed, and we were sure a bomb hal struck the house. The sky was blazing from horizon to horizon an! the thundering roar of guns was so dose and terrifie that it made my blood run cold. 'That first bang on the whe of midhight was a long range grme that planter a shell rery elose to our house every five minutes 
regularly for two days and nights. ... By the time this letter reaches you it will be no secret that the Huns had their eyes and plans fixed to drive through Chalons again.

When it began, one of the first things we did was to pack up everything, ready to flee at a moment's notice. Of course we dressed and went over to the hospital and about $6: 30$ A.M. the first French grands blessés began to arrive. I shall never forget the sight of that hall, litters from end to end, men blown to atoms but still pitifully hanging to a thread of life; no noise, a sickening silence as the ambulances were unloaded, a litter lifted down to the ground, only to find that the journey had been too much and that in that lonely, ghastly ride one more soul had been released.

We both turned to at once, to cut the clothing off the men and get them ready to go to the operating-room. In the midst of this, the chief surgeon, M. Tardary, asked me if I would operate with him; they were short on doctors and his assistant must work another room so that they could keep' going two at a time. The French surgeons are marrelous. He asked me during the day if I were fond of surgery and added "But this is not surgery; it is butchery."

... About noon that day we were told that we were going to receive Americans; there had been a dandy little field and mobile hospital unit established nearer the line, but they had been bomber and shelled almost out of existence and were forced to move back. . . Four barracks on the lawn were set aside for the American unit when it should arrive and about 2 A.M. the patients began to arrive. . . Sister Jean and M. Houlie, the eye, ear, nose and throat doctor, who was not very busy at the time, picked out the rorst rases and pemper them full of camphor or morphine. Mirs Robins it too was splendid; how thankful 1 was to lave an aide who had had sixteen months of war work, who was possessed of a level head and a tactful French tongue!

About five that afternoon, two American surgical teams, four loctror's, two anesthetists, five nurses and several orderlies arrived. . . We established a triage, as the French call it, or a sorting-out hospital on the lawn and as the ambulances arrived, one doctor was stationed to keep those men who were in so shorkent a condition they could not go further (eight kiloneters on was a large Ancrican hospital ready for a large number of men) and to send the rest on. The new arrival. were put in one barrack and as soon as possible were carrient over to the main hospital building for operation and then bark

"Margaret Robins, of Pliladolplia, an American Ped Cross nurse's aide who served with Miss Willians at Chalons. 
to a post-operative barraeks. All this went on under Boche bombs tumbling trom airplanes, that five minute long range shell and anti-aircraft shrapnel falling like hail all ower the place and much the most dangerous timng of all. Surely God, in his protecting divineness, must have seen and felt onr sufferings that week, for happily no one was hurt or killed in our particular hospital all those terrible days. I've saved the piece of shrapnel that glanced off my tin lid.

During nights such as these, the French and American nurses repeatedly came face to face with death and the memory of the agony which attended the last struggle burned itself into their conscionsness and left scars which were to remain there for many nights and days to come. Miss Williams wrote:

Miss Robins, two of the Sisters and myself stayed in the barracks on the lawn. There were five nurses in the operating-room. I conld never tell you about that night,-it is burned into my memory as a horror never to be forgotten. Men died, it seemed to me, every five minutes; every case was either abdominal or head and therefore practically hopeless. I did not know death could be so pitiful. All I've ever seen of death has really been a mereiful release for some soul strugghing against disease when the eourse of life was nearly complete, but God! how hard it was for these strong young lives to give up, such a ghastly waste of human vitality, thought, happiness, everything worth having, smuffed out under the most exquisite suffering! And nothing to be done about it but try and make it bearable and thank fool few knew they were groing to die. That is the worst of all. . . .

Friday night enemy aviators came again, so the patients were taken down to a cave which served as an abri. Miss Williams described the bombing:

At nine-thirty the Huns arrived. They hombed until $: 3: 45$ A. M. aromol and aromel the hospital. blew open every iron shutter on the winlows. cane within ten yards of the iontagions bulloling so that all the contagions patients were forred

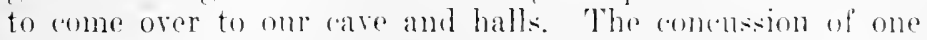
homb was so terrifie that it broke the lece of captain M.. one of onr oldest patients, whose two breaks had nicely knittent.

The terror of the pationts was simply pitiful; these hrawe larks who hat gone over the top so unthinkingly, foumel it almost impossible to hear the radent when they were bound 


\section{HIS'TORY OF AMERICAN RED CROSS NURSING}

helplessly to a bed. I kept thinking the next will surely get us, but evidently they were just warning us to get out, for their aim was perfect and they just went around and around us all night. We started at 4 A.M. to evacuate (that was Saturday) and after all the patients had gone we went over and packed.

We started for Paris at 5:30 P.M. Saturday and it wasn't until we got into that train that we realized we had not been undressed, to bed, or off duty sinee Sunday at midnight when the fracas began, and during the whole week I counted up four and a half hours sleep [in 137 hours' duty]. We got to a little town about midnight, where we had to ehange. There we had something to eat and although we were half-starved we would fall asleep between mouthfuls. After that we sat on our bags on the platform until $6 \mathrm{~A}$.M. waiting for the train to Paris, which was supposed to come throngh about 2 A.M. We reached Paris at $1: 30$ P.M., Sunday, went to the Pension Galilee, had a grand lunch in our rooms and by $2: 30$ we were sound asleep and never woke up until the following morning around 5 A.M.

\section{Of each day's routine in those French hospitals, a nurse wrote:}

Some years ago, a wild youth, the son of a titled family in Brittany, ran off to America. He had no money and helped to unload bananas at the docks in New York as his first job. Later he was a waiter and almost everything else. In the course of twenty years he became very prosperous in iron and steel and was completely Americanized.

Then when the war broke ont, he rolunteered in the French Army. For monthis he seemed to bear a charmed life. But after a while in one of his dare-devil voluntary services, he lost a leer near the thigh. 'The surgery was skillful but gangrene had made headway. There was just one thing to do, long frightful baths of iodine. Those baths were my sererest duty in this war. The agony afterwards, too! With his fare drawn and ghastly, he would joke in American slang. His strengtl was so wasted that his surgeon told him he must conserse it "wen to the axtent of not changing his position. Watching the r.lock, he would lie on one side for five minutes, the extreme duration possible, then on the other for five minutes. With surth a mighty force of will to live, he porformed for a while the miracle of living.

They toll his mother from Brittany, whom he harl not seen for twenty years, that she could come if she would smile all 
the time she was there. The frail little gentlewoman bowed. "I will come smiling," she said. She did. And in the days that followed, through the dressings, through the iodine baths, she sat near him, knitting and smiling.

Then one day we brought him other news, the two supreme messages of his life. This French-American or this American-Frenchman, hal been cited. . . . It the appointed time, the doctors, the murses, the directors came in. Then the General cntered with his staff, to which were attached military drummers. The ceremony begins with the drums rolling a rertain beat, never used except to announce this decoration. We stood at attention, the patients of the wards held themselves at silute, the General tonched with his sword the shonlder of the trembling, uniformed man in bed, saluted his rheeks and attacher the Médaille Militaire on his breast. The drums rolled thumderously.

The surgeons didnt talk for a while. They knew. And we nurses cropped things and were awkward for the rest of the d.y. And the frail little mother kept smiling, with energetic nods over her knitting. She knew.

Miss Fitzgerald had ample opportunity to see the French hospital and nursing service in operation. The reports of her inspection trips mention again and again the courtesy of the French surecons and the willingness of the French nurses, handieapped by inadeguate training, to do what they could for the Amoricans. Miss Fitzgerald wrote:

August 3: I visited the H. O. E. 18 at Meaux. Here I found one of our nurses in charge of the trage, or sortingstation. In one corner of this great armission tent, she hand established a little diet kitchen of her own and in her odd time she made broth, porridge and such diets for the piatients in that hospital and in the other hospital at Mloux whom she thought would be henefited by such food.

lo the hosplital, the modecin chef spote in ereat aldmiration of the murses. 'lhe thing that struck him espertally was the faret that our nurses actually washed and deamed the partients themsolves and that they said they enjoyed doing this. This remark might serem strange to anyone who did not un-

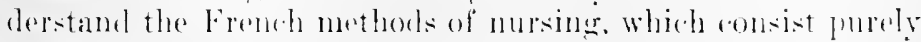

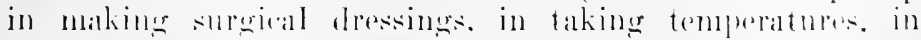
griving the medicines and (arrying out the treatments ordered

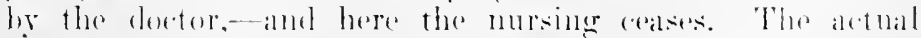
are and clandiness of the patient and of the buditing falls to 


\section{HISTORY OF AMERICAN RED CROSS NURSING}

the lot of the servant class, no matter how ill the patient is. The result is that a patient goes unwashed until he is well enough to get up and ambitious enough to do this for himself. ...

August 22: Went to the H. O. E. 13 at Château-Thierry and found one of the nurses had been called for by a French General in his own car to go and care for an American lad in a French formation nearby, who was not expected to live. Time proved this to be true and the man died very much the happier for having had.an American nurse with him who was able to take his messages and send them to his people at home. The courtesy of this French General should be much appreciater; it was a very humane act on his part to go himself and get the nurse whom he knew would provide the care and consolation which the boy needed.

Molly B. Smith, an American Red Cross nurse transferred from the Children's Bureau to a French hospital, wrote:

We found ten severely wounded American boys at the Hospital Betz. The French moved them into a separate ward and put them entirely in the care of my aide and me. Four of the boys were delirious and two died almost immediately, the other two a few days later. The French at once sent four very ill poilus to fill the four vacant beds. At first we could not unlerstand this, as there were still racant beds in the French hospital, but we learned that they had sent us their worst cases because they had noticed the nursing eare which we had been giving our boys and realized what it might acconplish with their own desperately wounded cases.

The in turn marveled at the kindness and the attention which the French doctors gave every man, regardless of his rank and the nature of his wound. And the hours that they were able to kecp groing, in a work which to them was already a very old story! This was also true of the poilu orderly, so polite and so efficient.

In September, 1:15, Miss Fitzorald inspected twenty-six French hospitals to which American Red Cross nurses had been assigned. She wrote:

Most of the formations that I risited at this time were barrack formations and some of them were extremely well oreanizel and anministered. I found several of them being taken over by the Americans, who naturally were adch day 
taking over more in this particular region. The situation in a hospital which is changing hands is really rather curious: the médecin chef finds himself very much at a loss because he has no iclea of his own personal status. All he knows is that he has lost a hospital and that the Americans hare gained one and as our methods are so very different from the french, he does not quite understand at what stage of the game he is. The Americans arrive rather suddenly with a grout many cars and conveyances and apparently need more space than the poor French ever had in four years of war, hut after a while things settle down and nothing could interfere with the perfectly good fecling between the French and the Americans.

I found that the American formations did not have any nurses with them. E pou asking the reason for this, I was told that an Army order had forbidden the presence of any woman in this area mint the first gun should be fired, as the white eap and white miform were considered to be too conspicuous. The roads presented an endless stream of convoys going in a direction north of Verdun and this endless stream continued for twenty-four hours out of the twenty-four. It did not seem possible that so many Americans could be in France!

Two hundred and five American Red Cross nurses and nurses' aides were assigned during the spring, summer and autumn of 1918 to the French hospitals of the Service de Santé. Miss Fitzgerald wrote:

Our nurses have been in 151 French hospitals. The total number of the American Expeditionary Forces ared for is difficult to estimate, becanse the American wounded came in in such varying-sized groups, from 4 patients to as many as 600 patients. A fair average gromp, I think, would be abont 20 pationts to one hospital. It least 3000 American sick and wombled have been wred for in all by the Ameriom Red Cross nurses. When there were not enomgh of the American Expeditionary liores to need all of a murses time. she helped among the french wounded.

Perhaps the most spectacular serviee which the Ameriean

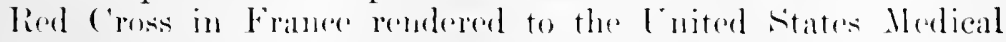

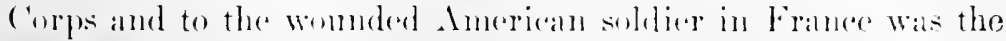

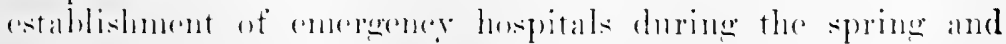
smmmer of $191 \mathrm{~s}$ for the Anerian Expeditionary Forees. It

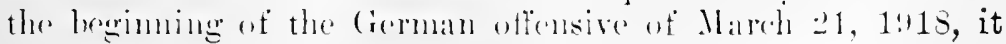




\section{HISTORY OF AMERICAN RED CROSS NURSING}

will be remembered that the sanitary formations of the U. S. Medical Corps were located behind the Toul sectors in the eastern and sontheastern part of France. In the third offensive, the German High Command chose to strike, however, at the French trenches along the center of the Western Front. Of this blow, Colonel Ayres wrote: "For their next attack (May 2 7 ) the Germans selected the French Front along the Chemin des Dames north of the Aisne. The line from Rheims to a little east of Noron was forced back. Soissons fell. . . ." The First Division was at this time brigaded with the French in the Noyon-Montdidier trenches. On May 28 the Americans captured and held the town of Cantigny and the casualties were sent back to Beauvais for evacuation to Paris. How the American Red Cross medical service fitted into this emergency is shown in Major Fosburgh's report:

We consulted with the Army authorities and found that by agreement the French had promised hospitalization of our men and that for diplomatic reasons it would then be impossible for our Medical Corps to establish an American eracuation hospital back of our own troops in the French sector. If the American Red Cross could accomplish this, however, it wonld be welcomed by the Army.

The French service de Santé was approached on the subject. The American Red Cross proposed that they establish and operate an Allied hospital at Beaurais with the understanding that if American troops were in the neighborhood, their wounded would be sent here. The proposal was inmediately accepted and the French hospital located in L'Ecole Professionelle at Beaurais was turned orer to the American Red cross. It was our understanding with the French service de sante that the hospital would be transferred to us fully equippert. Onr inspectors reported. however, that the existing equipment was deficient, so we made arrangements prior to the actual assumption of the hospital to re-equip it expecting in the meantime to nse temporarily the equipment of the French.

Of the organization of the nursing staff for this hospital, later designated as American Red Cross Hospital No. 104, Miss Stimson wrote:

A special meeting was held May 29 in the office of the ceneral manager who in the absence of the commissioner for 
France called the arting head of the Department of Civil Affairs, the rhief nurse of the Children's Bureau, the director of the Women's Burean of IIospital service and the chief nurse of the American Red Cross in France. After the discussion of the need for nurses to take are of American soldiers not only in Paris but in hospitals noarer the line, this meeting roted that the Department of Civil Iffairs should immerliately call in at least forty nurses for reassigmment by the (hief nurse to the Department of Military Affairs. This number was later raised to sixty.

By three ordeck the next aftermoon twenty nures, most of them specialists in bahy welfare, tuberenlosis and other forms of public health mursing, left for Beaurais while twenty others were sent to prepare the hospital at Anteuil. Three doctors, the nurses and two orderlies were crowded with many supplies into two trucks.

We reached Beanvais after 10 P.M. The town was so dark that we could hardly keep the roarl; French sentinels at intersecting streets were the only human beings visible. Two American military police guided us to Red Cross headquarters. On the way, they pointed ont the wreeded buildinge in which many of the sixty civilians, killed the night before, had met death.

Red C'ross heakluarters was in total darkness. When I told Captain backson that twenty nurses and Bishop M(-Cormick had arrivel, we got vigorous response. 'Tlurough the streets now dark and compested by Army trucks heavily laden with tromse we threaded our way to L'Ecole Profescionelle. As we drowe into the eourtrard we saw the lim outline of a quablangh-shaped building. Some voices were heard and several people came out with exelamations of welcome. By this time, the siren was sommling and the gums boomed theip reply.

We nurses wore hurried across a choster-like corridor into a pitch blark reom. It was impossible to see the fares of the

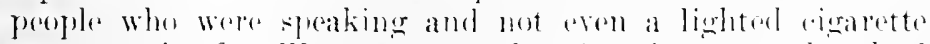
was permited. Whe soon got the sitnation: two humberl

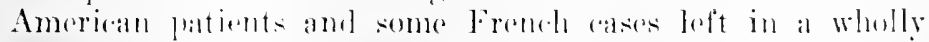

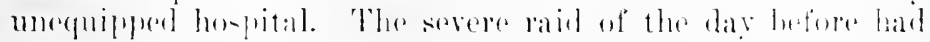

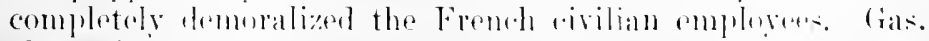
electricity and water mains hat berent put ont of commisione.

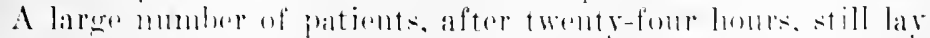

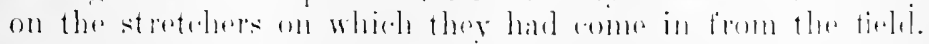

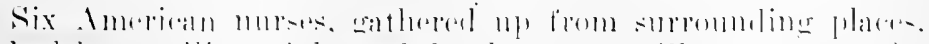

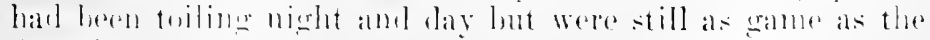
Ameriean ofticers in rhatrese. 


\section{HIS'TORY OF AMERICAN RED CROSS NURSING}

They asked for eight volunteers from among the new arrivals. Every one of the twenty moved forward. The first eight whom we touched in the larkness were put to one side and the rest groped their way to an empty ward containing nothing but bed frames with metal slat-springs. In spite of two air raid alarms, they went immediately to bed. One adventurous soul happened to look out of the window at 2 A.M. and saw in the courtyard our other truck containing their baggage. Out she went for bags and holdalls and those nurses at least had uniforms in which to go on duty.

The eight nurses took off their hats and coats and went into the unlighted wards filled with heavily wounded men. What a tired group they were next morning, with their hair disheveled, without caps, with their faces and dresses covered with dust from their trip, with stained towels pinned up across the front of their cloth dresses:

One of the eight nurses who were selected for night duty was Anna J. Johnson. She wrote of her experience:

Miss [Dorothy] 'Turnbull, the chief nurse, led the way through the darkness and we followed as best we conld. Miss [Margaret F.] McLeod and I were taken to wards on the top floor; we thought we would never reach the top. as we had to feel our way up winding stairs and through dark halls. We were told that there were about sixty new operative cases and were instructed to watrh for shork and hemorrhage. "Do not strike a match or turn on a flashlight," were Miss 'Turnbull's parting words.

The barrage continued throughout the night. the Boche planes hovering alove us and the shrapnel falling like rain on the roof: When there was a lull, we could hear our paltients moaning but we could not always find them. It $3:(10$ A.1I. the moon came out and we condd see after a fashion. It dawn, we discovered that we had had patients and beds and dirt. but prastically nothing alse. We had only one centigrade thermometer, three glasses, one basin, no towels, 110 wash-clothes. . .

Miss 'Turnbull took us to breakfast in a huge hall whero Italian and Fromch orderlies were soreaming at each other. There were a number of long lark marble tables. Breakfant consisted of French military bread, hate 1915 on the loaf. Each person wit his or her bhumk off : there was a streak of mold ruming through it. but one picked off the grood bread and ate it. There were large granite pitchers of colfee. . . 
The capacity of the Beauvais hospital, originally two hundred and fifty beds, was immediately expanded by the use of Bossominean tents to four hundred, a number large enough to make necessary the establishment of a special evacuation train serviee running between beauvais and an emergeney base hospital established on the Antenil race course near Paris. During the entire time that the First livision was in the IIontdidier sector, American Red ('ross Ilospital No. 104 received and evacuated American wounded. Miss Stimson reported the conditions on the morning following the arrival of the emergency unit :

Patients were immediately evarnated and others admitted. Nurses in charge of the wards soon began to bring comparative order out of rhases. Boxes of supplies were opened and equipment of all sorts distributed. A number of the members of the Smith college Lnit were flying about on all kinds of errands. Some made beds, some went in their camions for food, others washerl dishes. The kind of work they had been doing for days has been beyond all praise. Left alone in wards full of seriously injured men, they had nothing but instinct and common sense to guide them in their are.

In learing the hospital, the French had taken a great dea! of their equipment. Red Cross supplies from the warehouse in Beaurais were rushed over within a few hours. A Red Cross plumber and electrician appeared. Soon all the departments of a smoothly ruming evacuation hospital were getting into line.

"Tell thom in l'aris," said the Army Major in charge, "that we are marching on."

"T"l] them." sair the nurses, "this is what we have come for. this is exactly what we have had all our preparation and all our training for, and we can't say how glad we are to be here!"

Barek in Paris on the Champs de Course at Antenil, just as splendid a piese of work was being done in the emerereney

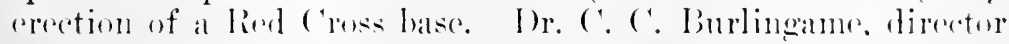
of hospital ardministration of the enmmission, reported (onnrerning the estallishonent of this hospital, American Red Cross Military Hospital No. $\therefore$ :

On . Aprit s. 1918, Colomel S. R. Wadhams. Medical Corps. presented to the lied (ross the posible noed for anditional 


\section{HISTORY OF AMERICAN RED CROSS NURSING}

hospital beds in Paris; that the Army was forbidden to acquire them; and asked for a tent hospital in the Bois de Boulogne. This request was later confirmed in writing in the name of the Chief Surgeon.

The Red Cross undertook the establishment of a hospital capable not only of caring for convalescents, but to be used for general medical and surgical work. The construction was commenced on May 6 . 'Twenty-one working days later, on Memorial Day, this hospital received its first convoy of one hundred and sixty-nine patients. At the beginning it was a five hundred bed hospital, but grew rapidly to twenty-five hundred beds. This tent hospital became the great sponge which absorbed all the overflow patients during the German drives toward Paris.

American Red Cross nurses composed the entire original nursing force. When the emergency arose, they were swiftly withdrawn from the Children's Bureau, the Tuberculosis Bureau and other Red Cross civilian relief activities. Never was there a better demonstration of the resourcefulness of American women than in this instance. Perfectly green in the military game, they filed in, formed a nursing force of an extremely active military hospital and accomplished their task as if they had been there all their lives.

Harrict L. Leete, of the Red Cross Children's Bureau in Paris, an American public health nurse of ripe experience and great native ability, was chief nurse of the Anteuil Tent Hospital, American Red Cross Military Hospital No. 5. Miss Leete was a graduate of the Jakeside Training School for Nurses, Cleveland, Ohio, and was for many years superintendent of the Babies' Hospital dispensary of that city. Hex first affiliation with tho American Red Cross came in 1907, when she voluntered through the Rochester Chapter for service as a murse. She was one of the charter members of the National Committee on Red ('ross Nursing Service and was an enthusiastic sponsor of the service during the early days of oreanization and thronghont the periond of war and demobilization. She went overseas as a nember of the L. S. Amy Base Hospital No. 4 (lakeside). Hut was transfered from her nuit on september 15, 1917, for duty with the American Red Cross Chil-

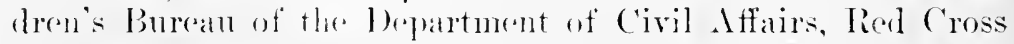
Commission for Franer. In her work with the Children's Bureau, she rendered brilliant service until her transfer to military duty as rhief nurse of Xu. . 
Miss Leete had as her assistants at the Tent Hospital, Susan Apted; Blanche Gilbert and Grace Kellerhouse. 'T' Mrs. Apted (Connecticut Training School, New IIaven, Connecticut) was entrusted responsibility for setting up and equipping the varions tent wards, as the hospital was expanded during the summer to meet emergency needs. Blanche Gilbert (Lakeside) had charge of the placement of nurses in the different divisions of the big batse. Grare Kellerhouse (Methodist Episeopal Hospital, Brooklyn, New York) was the head nurse of a unit of twenty Nayy nurses which was assigned in August, 1918, from Nary Base Ilospital No. 1 at Brest to Auteuil, to relieve the nursing shortage at the Tent Hospital. Miss Kellerhouse was placed in charge of the training of the orderlies at No. 5. She was giren anthority over the sergeants and by reason of this important concession, as woll as because of her native tact and ability and her previous experience in the Navy Nurse Corps-for one of the chice duties of Navy nurses is the instruction of hospital attendants-Miss Kellerhonse did brilliant work at American Red Cross Mlilitary Hospital No. 5.

At the height of the summer offensives, the nursing staff of the Antenil Ilospital numbered nearly three hundred nurses. The hospital orecupied a position of great strategie importance. Nurses who had arrived in France without any experience in military nursing were assigned to temporary duty at No. 5 and were there instructed in war-time surgery by Inez Cadell (Johns Inopkins), a surgical nurse familiar with the most modern phases of war mursing technique. After this introduction to military mursing in the Tent Hospital, where conditions somewhat resembled those to be encountered later in the field, the nurses were sent on up the line to forward American Red Cross and Mredieal Corps units.

Of the recreational phatses of American Red Cross Military Hospital No. i, Dorothy Lewis Kitehen, who had aided Miss Delano in the preparation of nursing publicity at Kattonal Headquarters until her assignment overseas as a hospital recreation hut worker, wrote:

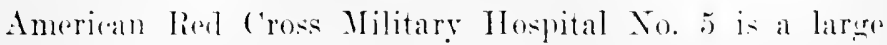

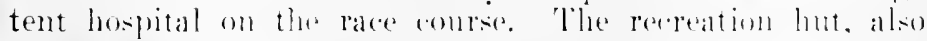
under (auras. contabins writing tables, al piano and victrolia

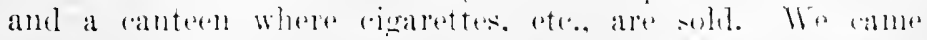

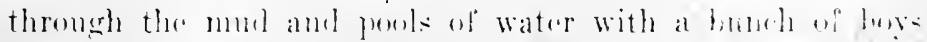

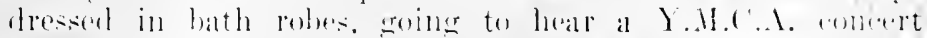




\section{HIS'TORY OF AMERICAN RED CROSS NURSING}

there. The gassed cases are the hardest. Any man would prefer a heary wound. These boys have a queer yellow-white color, are very thin and cough in a peculiarly rasping voice when they've had it in their lungs.

The tent was jammed with soldiers. The concert singer, one I'd heard in vaudeville in the States, got them to singing. It's queer that they seem to adore the rather sad, sentimental songs like "Just a Baby's Prayer at 'Twilight" and "Homeward Bound." She singled out a little darkey from 'Tenuessee who ragged the piano, another doughboy who also played and several who whistled excellently. The audience really brightened up to hear one of their own crowd perform.

Going back we passed the windows of the tent wards; heads came popping out and they called:

"Gee, real American girls!"

"Anybody there from Missouri?"

"Ain't California swell?"

Some inside who couldn't lift their heads smiled at us through the windows.

Elizabeth Creadick, an American Red Cross nurse who was at one time assigned to duty at No. 5, wrote:

The little comforts and luxuries furnished the boys at Autenil made a tremendous inupression ujon them. One night while on duty in a stable which had been improvised into a semi-hospital, I overheard a boy say he hoped he would go to Red ('ross Hospital No. "5 in Paris because "you got ice cream there and it was some hospital, besides!" 'The other boys, all grievously wounded and lying on blood-soaked stretchers, forgot their suffering for a moment to dispute such a fairy tale. The lad got his wish beeause I went to see him at Hospital No. 5 a month later.

During the first six months after its establishment, American Red Cross Military Hospital No. 5 received 11,401 American patients and maintained 18:3,7:3:3 hospital days.

The Boanvais and Autruil hospitals were areated ont of the dire emergency autused by the enemy's possession of the Soissons Line. The noed for lied Cross cmergency hospitalization for Amerian troops antimud. Colonel Ayres reported the contimation of the third great offensive of the German divisions massed on the Western Front:

... Soissons foll and on May 31 the enemy harl reached the Marne Valley, down which he was alvanding in the direes- 


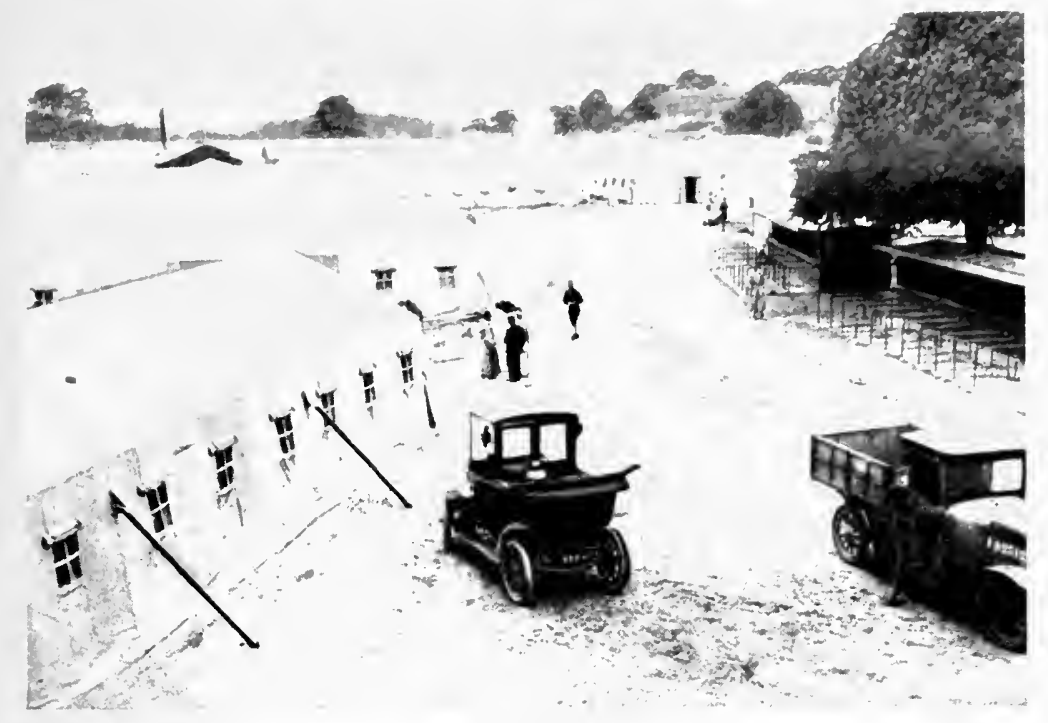

American Red Cross Military llospital No, 5, at Autenil. near Paris. To the right appear the old betting-booths under the trees.

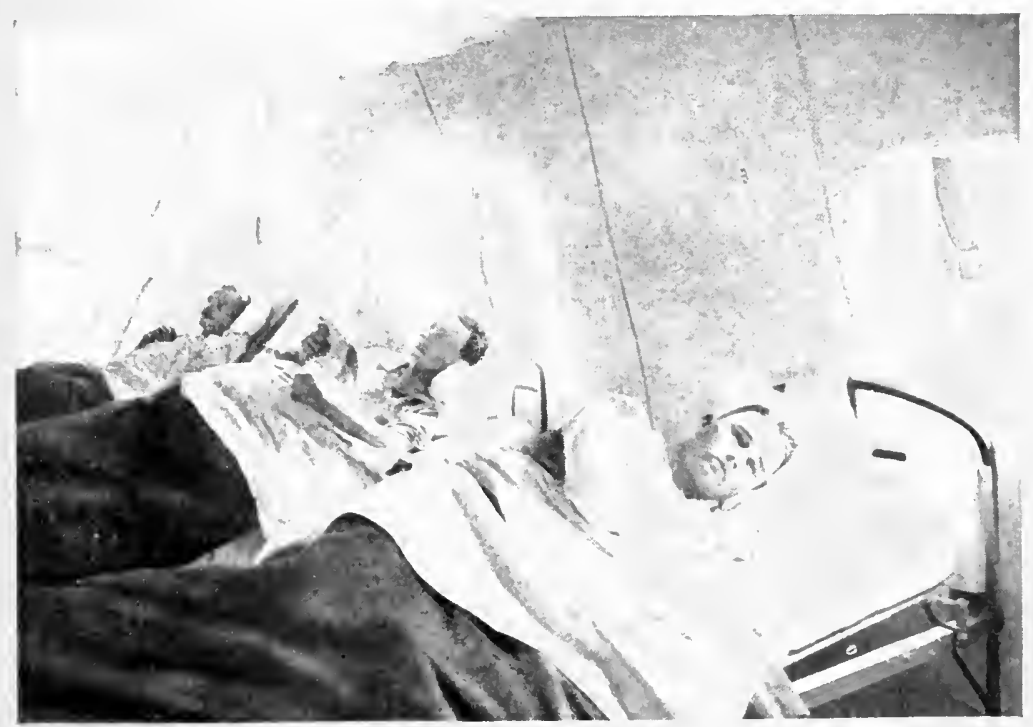

The interior of a tent ward at dutenil. 

tion of Paris. At this eritical moment, our Second Division together with elements of the 'Third and 'Twenty-eighth Divisions were thrown into the line. By blocking the general allance at (hâtean-Thierry, they renderel great assistance in stopping perhaps the most dangerous of the fierman drives. The Sccond J)irision not only halted the enemy on its front but also captured from him the strong tactical position of Bouresches, Belleau Wood and Vaux.

Major Fosburgh summarized the sanitary situation of the Second l)ivision as it moved into the line at this grave crisis:

It was reported to us that in the expectation that the French would provide all hospitalization, the Second Inivision harl left in the Toul area everything except their reginental medical chests. Furthermore, because of the suddemuess of the drive between Soisons and Rheims, the French had been mahle to salvage any of the hospitalization in that area and had lost in excess of 5 s.000 beds. They were totally mable to make provision for the needs of the Second Division.

The lay after their arrival in the Meaux area, Resl Cross inspection of their equipment found their entire hospitatization to consist of two field hospitals. One of these, located in a cow barn, had five stretchers and a small assortment of drugs anl dressings. The second one, located in a small schoolhouse, hat twelve stretchers and a larger collection of dressings and expipment. Back of these so-called fiekl hospitats, the clivisional surgeon was attempting to establish at Jeanx. a distance of twenty miles behind the lines. in a wrecked chattrau, an evilcuation hospital, using tentage and equipment previomsly loaned to the division by the American Red C'ross. Bark of Meaux, not a single hed was in rearliness for the recoption of wombled. hourly expected. until Paris could be reached at a further distance of approximately thirty miles.

The divisional medical oflicers and (onsultants apyealerl to the Red ('rosis for assistance. It was apparent that a hospital for eracoution purposes must be established at once and arrangements were condented over night for taking over the

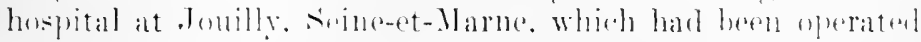

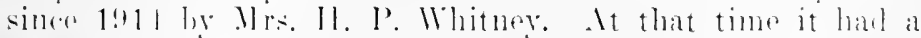

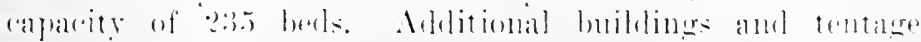

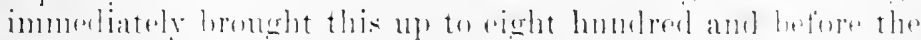

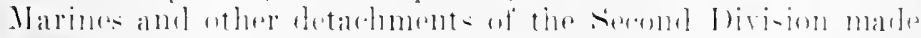

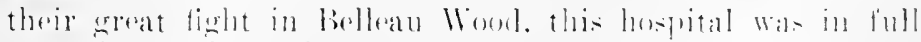

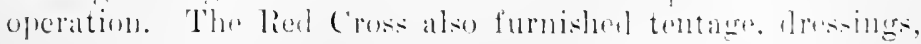




\section{HISTORY OF AMERICAN RED CROSS NURSING}

instruments, drugs and other supplies to the division for their field hospitals. Everyone of the eighty-five hundred casualties in a single week in Belleau Wood were brought down through American Red Cross beds to Paris. ${ }^{77}$

Colonel Burlingame's report included the following comment upon the work accomplished by the little unit at Jouilly, Seine-et-Marme:

Colonel Ilorrow, chief surgeon of the Second Division, suggested that the Red Cross take over the Jonilly hospital and that transportation of patients be made by ambulance from Mcaux to this point. With no formality at all, the hospital was taken over and on the same night, June 3 , it was filled. Within a few days its capacity was increased from two hundred and eighty to one thousand beds. On June 8 the Red Cross personnel was angmented by the assignment to duty at this formation of personnel from United States Army Evaruation Ilospital No. 8.

During the lays of its enlargement, installation of electric lights. ete.. it received a continuous stream of supplies from Paris and at the same time was caring for its maximum capacity of patients. On July 6 and $\%, 1700$ patients were handled by this small unit and 118 were evacuated to l'aris. The persomnel of Evacuation Ilospital No. 8 was withdrawn and for a time some of the persomel from a newly-arrived Army base hospital were assigned to duty there.

The removal of American troops from this sector resulted in the withliawal of the Medical Corps from this formation and this mit was therefore disontinned as an American Red cross military hospital to function as Anerioan Red Cross llospital No. 105 for the French womded. ${ }^{88}$

The hospital at .Jouilly, Seine-et-Marne, was used as a medical and sureical "enter throughout the summer of 1918, while Anerican tronss were in the vicinity of Châtean-Thierry. Anma Johnson was assigned to duty there on August 22. She wrote:

This hospitil is located in an old college and the buildings have heen used at three different times in history as military

7 A further aceount of the work at. Jouilly. Seine-et-Marme. appears in Chapter VIIL.

7M.Military Ilistory of the Ameriean Red Cross in Franee," p. 44. Library, National Headputaters. 
hospitals. . . I was put on night duty; influenza patients were coming in very last from a veterinary (amp) at Jouilly. I had two tents about one half a block apart. One orderly was on duty in one tent and another in the other tent and all night long in the pouring rain I plowed back and forth through the mud between the two tents.

'The men were desperately sick. On the fourth night, the theater of this old college was opened to arcommorlate the great numbers. There were 63 new patients that night, besicles the ones in my two tents and in the theater. I was told that at midnight nore murses would arrive to help me. Four of the doctors stayed on. 'The men were the sickest I lave ever seen. They looked like gassed patients but none of them had ever been near the front and they had only been in France three weoks, taking care of gassed horses. If ever doctors worked with patients, those from Base Hospital No. 57 certainly did. but those boys in spite of all our efforts simply died. One night 13 were carried out of my ward. It was discouraging beyond all words to see those splendid specimens of manhood just pass out without a struggle. They were all big Western tellows; many of them had never had a sick day in their lives before.

The last week in May, 1918, found General Ludendorff in possession of two wedges thrust toward Paris, that in the northeast with its point at Cantigny and Montdidier and that in the southeast with its tip at Chatean-Thierry. In his fourth great offensive, he somght to smooth these wedges ont into a single continuous front. Of the threatened blow which fell in Jume upon the French and Ameriean troops holding the NoyonMontdidier trenches, Colonel Ayres wrote:

The enemy had by his offensive established two salients threatening laris. He now solght to convert them into one by a fourth terrific how delivered on a front of twenty-two miles hotween Ilontdidier and Noyon, The reinfored French Army resisted firmly and the attalck was halted after an initial alvame of about six miles. Thromeghout this operation (June 1-15) the extreme left line of the salient was defended by our lirst Division.

During the first week of Jme, 1918, Ameriean lied Cross Military llospital No. 107 was organized at July-sur-Murin. (of its establishment, ('olonel Burlinganer wrote: 


\section{HIS'TORY OF AMERICAN RED CROSS NURSING}

It will be remembered that in the first week in June, 1918, two American Divisions were in action around ChâteauThierry. Action, and quick action, was necessary for hospitalization. Fifty thousand hospital beds had previously been captured from the French in the German drive. It had early become evident that the greatly diminished hospital resources of the French, combined with their own urgent need for beds, would make it impossible for them to carry out the agrement to lospitalize wounded from American divisions loaned to and fighting with the French.

Word concerning the conditions was received from Colonel Paul C. Hutton, Medical Corps, who was representing the Chief Surgeon of the Army east of Montdidicr where American troops had been brigaded with the French. A camion train of supplies, together with persommel, was started on the road in the general direction of Montmirail. The Director of the Burean of Hospital Administration and the Chief Nurse preceded this convoy, getting in touch with Colonel Hutton. Hurricel conference between the head of the Merlical Service of the French Army and Colonel Hutton resulted in the Red Cross taking over a chateau at Jouy-sur-Morin, which had just been evacuated by the withdrawal of a French formation. Watchers along the road diverted the camion train to the point which was to become American Red Cross hospital No. $10 \%$.

Thongh never designated as an American Red Cross military hospital. No. $10 \%$ was operated as such, with personnel furnished jointly by the Army and the Red Cross.

In a letter addressed June 5 to her family, Miss Stimson wrote of the difficulties which the nurses faced in establishing the hospital at Jouy-sur-Morin:

It is no small job to take over a French institution together with part of its force and man it with two teams of officers who have before seen each other and a crroup of nurses who had nover worked together cither with each other or with the doctors in command. Iost of them speak no French and all of them are nurses sperializod in child welfare or tuberculosis or social service work. Fortunately they are all Rerl cross murses. which mons that once upon a time before they speralized in welfare work, they had had good general trainmo. so they are instantly transformed back to surgical nurses.

'The nurse in rharese. Linda K. Veirs. harl never seen most of bre statl before. She had reently come back from work 
in Roumania and hat heen in Paris only a few days before I sent her to this hespital.

Everything out at Jony looked so impossible to-rlay that after mueh talk we got a good many arrangements about servants, rations, supplies and relation to the freneh and American oflicials straightened out and then I)r. Burlingame deeided that the sooner we disappeared the sooner would they work out their own salration, so we returned to Paris....

Miss Meirs' Red Cross service had begun on the Merey Ship, had extended through assigmment to Kief and later to the Ameriean Red C'ross Commission (1917) for Rommania; it finally bronght her the Florenee Nightingale Medal. Of her conduct at Jouy-sur-Morin, Miss Stimson wrote Miss Noyes (July 19) :

Miss Meirs has done splendid work here at American Red Cross Hospital So. 10\%. The commanding officer tells me that on the night of the heary raid (July 15) she could not have been finer. It was a terrible experience. One of the hospital corps mon was killed outright: another man had his leg so bally hurt that immediate amputation was necessary. Several other orderlies as well as patients were wounded.

I stayed at the hospital during a raid on the following night. After what they hat had the night before, the terror among the patients. pirticularly those suftering from shellsherek, we shall nerver formet.

Miss Patterson, formerly rhiof nurse of the Commission for Roumania and in 1918 assistant to Miss Stimson and Miss Fitzgerald in the Paris headeuarters, wrote of Miss Meirs:

.. Her commanding officer has said that she is the finest nurse he knows and her nurses, her ades and every person connected with the plare have been nustinted in their praise. Her corjemen eall her "("olonel" and would do anything for her. In short. her wonderful sperit has dominated alway-hor absohte moselfishness and kemmess to serve at any julare or anylody whe needs help. It is not surhe tremendolls axecortive alility whide she has, but she is so tre-

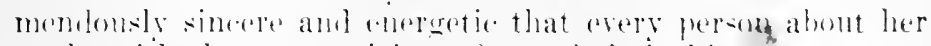
works with the same spirit als far as it is in him. . .

At Jour-sur-Morin, on the night of .July 15, Inne ofeffery,

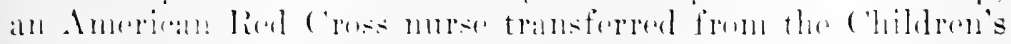




\section{HISTORY OF AMERICAN RED CROSS NURSING}

Bureau, was severely wounded. A French dispatch contained the following comment:

Located in a quiet, remote spot three kilometers from the railroad, the hospital at Jouy-sur-Morin not only bears the distinetive marks of the sanitary service, but on a nearby grass plot there has been spread a huge eross made of white towels, its arms measuring thirty meters. Shortly after the inauguration of the hospital, one of the Allied planes flew over the spot taking photographs to show that the cross was plainly risible from a height of many thousand meters.

During the night of July 15, two German aviators flew above the American hospital; volplaning, they descended to within a few hundred meters of the buildings and dropped four bombs. It was midnight.

In the operating-room, the surgeons were at work. At the moment when the first bomb struck. Major McCoy held in his foreeps the femoral artery of the patient on the table. The lights went out. two more bomiss fell, the third failing to explode. In one room, an orderly was killed as he was giving a drink of water to a patient. Nine were wounded, . . . one of whom was an Amerian Red Cross nurse.

We remember that recently sixty German prisoners were treated in this hospital at Jouy-sur-Morin. where they received from perhaps the very nurse whom they have wounded the same care and attention which she was giving our soldier.s. ${ }^{i 9}$

\section{Miss Stimson wrote Miss Noves on July 19 :}

Miss Jeffery was on night duty attending her patients when a fragment of shell struck her. She showed great spirit and was only concerned hecanse she felt she was causing more trouble to the already oferworked statf of doctors and nurses. When I told her the next day we were going to bring her into a hosplital here in Paris, she was greatly disappointed. She had hoped to be able to go on duty again in a few days.

On July 31 the Paris Bureau of Nursing rushed twelve new arrivals up to Jolly-sul-Morin to mënforec Miss Morirs staff. Among these muses was Edith Ambrose, a nurse especially trained in psychiatric work. Of her experionees, she wrote:

79 Translated by the Amerixan Red c'ross Department of publicity, from Tablettes tes liner-horente. July 23, 1918. 
Upon our arrival at 10:30 P.M. three of us went immediately on night duty. Inst as we were about to go to our tent assignments, Fritz was announced by a siren. We happened to be in the corridor of the chateau which is hearlquarters for the staff and operating-rooms for the hospital. Fritz's calling cards roared as they struck and bang! bang! bang! (ame our welcoming response. ()ur exchange of amenities lasted for perhaps half an hour. When it was over, I tried to analyze my sensations, rhiefly disappointment at not being outsile to see what was going on and certainly amusement at our different attitudes. A timid roice whispered out of the darkness that she "wouldn"t be so afraid if someone would only hold her hand!" Every one must have grabbed for it, for I found both of mine firmly held until after the last gun was fired.

They led us out in the darkness to the tents where each of us were given a candile and explicit instructions to shield it carefully. The tents had no floors, but by morning we had every bed full. In an evacuation hospital like this we did as much as we could to make the boys comfortable for a few hours hefore they go on to the base. Morphine of necessity became the standing order. We tried to give them a lath, something hot to eat and fresh dressings.

In my tent was a lad from North Carolina with both lungs pierced. As he was hemorrhaging quite frequently, we moved his bed ontside to give him all the air possible. He sairl to me: "Ilould you tell me a fils if I asked you if I was going to die?" 1 answered. "Well, you are a good enomgh soldier to know what a fighting wance means and you mustn't think for a minute contre going to lose." ILe groped for my hand in fear that $i$ shomla leate him alone to fare the weakness: coming over him. Presently, l asked him if he would like me to write to his mother. "No," le said. "she"s so sared now shrid die to sere a strange handwriting." After a little while he said again, "You all are certainly next to having her here herself."

A hospital whioh had previously been maintained in part by private Amorican philanthropists and in part by subsidies from the American liod cross, was taken over entirely by the

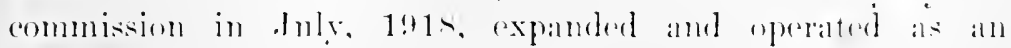
Amerioun Rod (cose hospital: this formation was l)r. Fitch"s

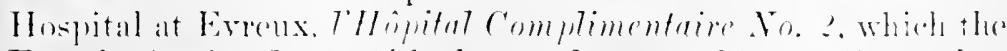

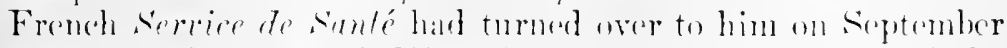
4, 1917, after he and Misi Xelson and other murses of the 


\section{HIS'TORY OF AMERICAN RED CROSS NURSING}

original Yvetot.Unit had been transferred from St. Valery-enCaux. Dr. Fitch's hospital at Evreux was given on July 21 , 1918, the designation of American Red Cross Hospital No. 109 , was greatly enlarged and was run by the commission until after the Armistice. The nursing staff was reënforced from time to time by additional nurses from Paris headquarters. Leila Halverson, an Ameriean Red Cross nurse transferred from the Children's Bureau to Dr. Fiteh's hospital, wrote:

About May 1, the hospital had a capacity of 300 , but soon four fifty-bed barracks were built and afterwards ten tents, containing from ten to fifty beds each, were put up. Most of the wounded were French, but we also had Americans, English, Colonials and Boche prisoners. . . .

The work done in this hospital was almost entirely orthopedic, with a great deal of bone plating and bone grafting. We were terribly rushed at times and were very short of nurses and aides. After the arrival of one American convoy, the surgical staff worked steadily for 42 hours, stopping only long enough to eat the meals that were serred in the sterilizing room, then slept for four hours, then operated again for 20 hours. ...

From September 4, 1917, the date on which Dr. Fitch and Miss Nelson first took over l'llopital Complimentaire No. 2 at Evreux until Jamuary 1, 1919, 2194 patients had reeeived eare there from American Red Cross surgeons and nurses.

Early in .June, 1918, the use of gas by the Germans was increased to a eonsiderable extent; this increase brought about the need for a hospital in Paris which could be used exelusively for the treatment of gassed patients. The Red Cross Commission for France accordingly leased the Pavillon Belleve, at. beautiful St. Cloud, near Paris, and on Jume 18, 1918, opened a hospital of 600 beds, which was designated as Ameriean Red Cross Military Hospital No. 6. This institution was originally intended as a conter where both French and American phrsicians might study gassed eases, but the acute military need for beds for Amerieans wounded in the German offensives of Jume and July, 1918, and the subsequent Allied offensives resulted in the use of the Bellevene Hospital solely by the American Expeditionary Forees.

American Red Cross Military Inspital No. 6 was staffed 
wholly by forty American Red Cross nurses and twelve nurses' aides, who had been recalled from hospitals of the Children's and Tubereulosis Bureans and reassigned to help meet the military needs. Lily B. Crighton (lllinois Training school for Nurses) was chief nurse of this hospital. She wrote:

On July 10, I was assigned to a new gas hospital which the Red Cross started at Bellevue, st. ('loud. It was a very beautiful place and rommanmled a bird's-eve view of Paris. . . .

Our hospital was supposed to be of 500 bed capacity but during the rush, we hat well over 600 patients. The Red Cross sent us generonsly supplies of all kinds, so we could put cots in the halls on short notice. . . We were also equipped with an electric blower and "amberine" sprays. . . The men would come in with hifleous blisters extending from their shoulders down. The nurses would (lip away all this blisteren skin, elean the then raw surface with antiseptic solution, dry it with the electric blower and spray on the "amberine." Burns treated in this manner healed in an incredibly short time. . . .

Colonel Burlingame stated that American Red Cross Military Iospital No. 6 during the six months ending I)ecember 31, 1915, maintained 61,360 hospital days and admitted 3052 patients.

Paris was the receiving base for American soldiers womded in the German offensives, but, as has been stated before, the sanitary mits of the L. S. Medical Department were net then admitted to the Fromeh Amy Zone, of which Paris was the "enter. Thus all Amprican Red c'ross hospitals in and near the rity were cousded to capaleity during the smmmer of $1 ! 1$ s.

The Amorican Ambulance which was greatly enlarged and two smaller speceial hospitals which had been established in comertion with it. were utilized for the womeled. Early in 1918. a need had arisen for hospitalization facilities to care for siek persommel of the Aneriean lied cross and of other Ameri"aln welfare oreanizations thes operating in burope and of womene emploveres of thr. Ameriean Armies in and about l'aris.

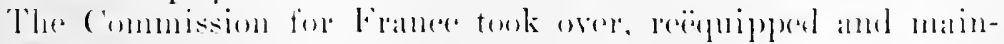

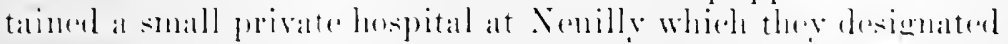

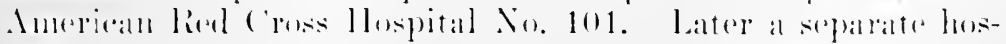

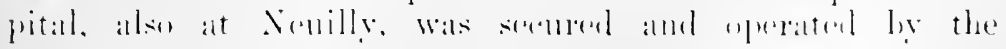




\section{HISTORY OF AMERICAN RED CROSS NURSING}

American Red Cross for auxiliary personnel of the American Expeditionary Forces. It was designated as American Red Cross Hospital No. 103. When, in June, 1918, the military situation became acute and the Germans seized Soissons, with the subsequent loss of French hospitalization, the beds of American Red Cross Hospitals Nos. 101 and 103 were used to care for overflow patients from the Ambulance, Military Hospital No. 1. Thus during the six months ending December 30, 1918, Red C'ross Military Hospital No. 1, with its allied hospitals Nos. 101 and 103, admitted 7437 patients and maintained 175,873 hospital days; 5553 operations were performed during this period.

Red Cross Military Hospital No. 2 admitted during the period from July 1, 1918, to December 31, 1918, 2283 patients, performed 1294 operations, and maintained 64,478 hospital days.

American Red Cross Military Hospital No. 3 during the last six months of 1918 , admitted 1524 patients, of whom 27 died. The hospital maintained during this period 31,491 hospital days.

The operation of this emergency hospital service in the zone of the base in such places as Paris and Evrenx, and in forward areas such as Beanvais, Jouilly-Seine-et-Marne and Jouysur-Morin called for extensive leed Cross organization to furnish personnel and supplies to the mits. To meet the calls which they had reason to expert would eontinue thromghout the summer as the Allied offensive was developed, the Red Cross Commission for Europe hat built up by June, ls1^, an organization similar to that existing in the Cuited States. In Jannary, Major Murphy had resigneel frem the American Red Cross War comeril to modertake serviee in the Aneriean $A$ rmy and on Fobruary 5, Major Perkins was appointed enmmissioner for

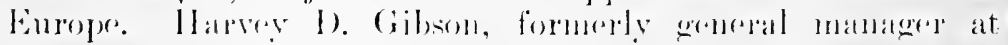
National Hearlquarters and later a member of the War ('omncil,

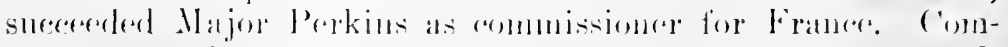
missioner Gibern divided France inte nine genes, with headquarters at Paris, Boreleanx, Brest, St. Nazaire, Ilavre, Mar-

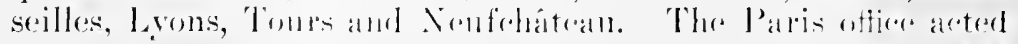
in relation to these \%olese in moreh the sane. way as did National IIeadquarters in Wa-hington to its divisions. The twenty artivities of the rommision ware arministered by seven departinerits : 
I. Department of Requirements, which dealt with supplies, transportation, manufactures, personnel, permits and passes, construction.

11. Medical and Surgical Department, which dealt with hospital administration, nursing, tuberculosis and public: health, the childrens's Bureau, reconstruction and reeducation.

III. Medical Research and Intelligence Department, which dealt with research, medical information, the library bureau and publications.

IV. Department of Army and Nary Sorvice, which dealt with canteen, home and hospital, outpost and Army fieht service.

V. Department of French Hospitals, which dealt with requisitions from and supplies for French hospitals, the burean of risiting.

VI. Department of General Relief, which dealt with refugees, soldiers' families, war orphans, agriculture.

VII. Department of Public Information, which dealt with news service plotographs and motion pictures descriptive of Red Cross activities overseas.

I Juring the summer of 1918, the Nurses' Bureau established and maintained nmmerous homes in and near P'aris and at other hospital centers where Army and Red Cross murses who were being held on temporary assignment in these renters, who were on leave or who were convalesernt from siekness incurred in line of dutr, were entertained. () f these homes, ('arrie 1 . Hall, who in Norember, 1!18, followed Miss Stimson as chief nurse of the American lied C'ross in France, wrote:

The combaleseent home at Le ('roisice, which was openes] in July, 1918. offered areommolations for 100 nurses on convalesernes or on iave. Le croisic is an attratetion little fishing village on the Brittany roats and the convalesent.

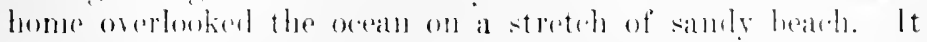
mate an isloal restingeplase for murses amel workers worn with

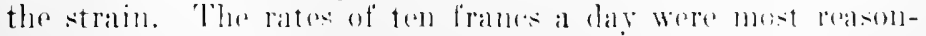

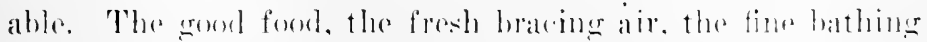

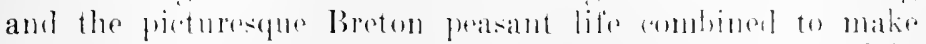

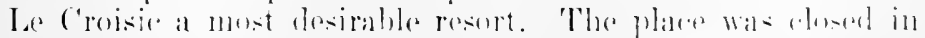

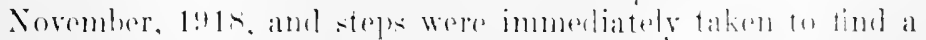
suitable sulstitute in the south of France. I lenations at

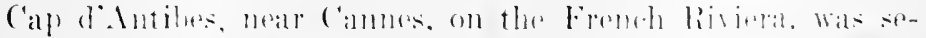
cured and on talluary ti. 1919, the hotel wal- taken over. 


\section{HIS'TORY OF AMERICAN RED CROSS NURSING}

Plans were made to receive 200 convalescent women personnel of the Red Cross and five murses were sent to assist the nurse in charge, Mrs. Katherine Hough. The Convalescent Bureau provided all information and secured transportation and reservations. The personnel who were sent down on convalescent leave by arlvice of a doctor, were kept there free of all expense. The personnel on leave were charged reasonable rates, which they could not have obtained at any other hotel in this very fashionable neighborhood.

Miss Morgan took a vivid interest in the establishment of the convalescent home at Le Croisic and did much to secure the funds necessary for maintaining it and the other murses' homes in and near Paris. A list of these nurses' homes may be found in the Appendix.

The later weeks of June were comparatively quiet while General Iudendorff massed his forces for what proved to be his last offensive. Colonel Ayres wrote:

On July 15, the enemy attacked simultaneously on both sides of Rheims, the eastern corner of the salient he had created in the Aisne Drive (May 27). To the east of the city, he crossed the Marne but made slight progress. His path was everywhere blocked. In this battle, eighty-five thousand American troops were engaged, the Forty-second Division to the extreme east of Champagne, and the Third and Twentyeighth to the west, near Chatean-Thierry.

The turning-point of the war had come. The great German offensive had been stopped. 'The initiative now passed from Ludendorfi to Marshal Foch and a series of Allied offensives began, destined to roll. lack the German armies beyoud the French frontier. The moment chosen by Marshal Foch for launching the first comnter-offensive was .July 18, when it was (lear that the German Champagne-Marne drive had spent its force. The plare chosen was the uncovered west flank of the German saliont from the Aisne to the Marne. The First. Serourl. Thirr, Fourth, Twenty-sixth, Twentyeichth, Thirty-ceromd and Forty-second Anerican divisions, together with selected French troops, were employed.

At the initiation of the counter-offensive of July 18 , the Medieal corps had recerved permission from the French to bring up their own "ralcuation hospitals, so that the Red Cross lospitals subseduently deroleped areted in a supplementary eapacity to Army formations. A small unit at Chantilly was, 
however, an exception and was described by Colonel Burlingame as follows:

Just before the great counter-offensive on July 15 the American First and siccond divisions were withdrawn from the Beauvais seetor. It was generally believed that their destination was to be Meanx, where they were to have a muchneeded period of rest. Less than twenty-four hours before the actual attack began on the morning of July 18, it was learned that the destination of these divisions had been abruptly changed and they were being swing toward the line south of Soissons.

On the line of evacuation from this sector existed no American hospitalization. It so happened that the Ambulance St. Paul, then being operated in coöperation with the lied Cross, was then located at Chantilly on this very line. With but twenty-four hours, the Ambulance St. Paul was selected as the meeting place and an emergeney formation created to function as an annex to this little one hundred and fifty bed French unit. Wight surgeons, sixteen nurses and twelve enlisted men were detached from American Red Cross Hospital No. 104 at Beaurars and directed to proceed to Chantilly, where they were met by additional Red Cross persomel from l'aris. Tents, operating equipment and all things neecssary for a three hundred bed eval'uation hospital were rushed from Beauvais and Paris to meet at Chantilly.

The nursing staff at Chantilly was made up of fifteen murses who were withdrawn from American Red Cross Hospital No. 104 at Beaurais and twenty Army nurses who were sent up from Paris.

Mary A. Burgess, formerly in service with the Red Cross Children's Bureau, wats ehief murse. One of the murses withdrawn from Beanvais, Elizabeth E. Cherry, wrote:

On July 18. Major Moorehead heard from Paris Headquarters that murses and supplies were needed at chantilly, that many French and Imorican womuled were expected there at any time. In less than twelve hours, he had split our persomel, leaving a part in Beanais. With the remainder of the persomnel and with what suppiies could be spared. we started for ('hantilly. 'The lied ('ross was also sending us more nurst's and supplies from Paris.

When we arrivel, we fomml that the tents lad already been put up. Mlle. St. Pand | fommlar of the Ambulanee sit. 


\section{HISTORY OF AMERICAN RED CROSS NURSING}

Paul] had managed to save them in the retreat from Soissons. . . .

This unit remained at Chantilly for thirteen weeks and during this time received $136 t$ patients, many of them wounded men from the United States Marine Corps. The unit cared also for French wounded.

One of the largest of the Red Cross evacuation hospitals to be established for care of the wounded of the American Expeditionary Forces was set up early in August at Coincy, north of Château-Thierry in the Vesle sector. Colonel Burlingame wrote:

When the Americans were near Fere-en-Tardenois and Fismes, urgent need existed for an evacuation hospital. American Red Cross representatives went over the devastated area, found a pump capable of furnishing the water supply, ordered materials from five different points to be assembled at this pump, with a piece of charcoal designated it "American Red Cross Hospital No. 110" and stationed a man to guard it. Within three days materials were on the spot and within a week patients were being received.

Of special interest was the method in which the supplies of this emergency evacuation hospital were assembled at Coincy. Colonel Burlingame stated:

A part of this equipment was taken from the American Red C'ross hospital at Beanvais, a part from the American Red Cross formation at Chantilly, a part from the American Red Cross hospital at Jouy-sur-Morin. with other articles from Paris warehouses. At one time, these materials met at Coincy and hecame American Red Cross Hospital No. 110. a permanent and complete mobile unit.

An extract from the report of the commanding officer, Lientenant-Colunel .John .J. Moorehead, gave a vivid picture of this evacuation center:

The loration was chosen primarily because of the water, becalse thr roarl pasing our doors was the main artery to the not distant frunt and because a railroad soon to be repaired was not far from us. The farm buildings used for oftices and store-rooms were wrecks. the sround on which we pitched our teuts was full of shell holes. discarded anmunition and 
other accontrements of war. Great piles of refuse and débris made it a hreeding place for myriads of flies. Not far away, enemy dead lay unburied. 'The only pleasing outlook was the view from the hill-top, a wide sweep encling in a range of hills beyond which the sounds of war told us that the line was not far clistant, told us also that in this sector there was need of a hospital.

To this forbidding site we brought from (hantilly nine surgeons and twenty-nine nurses. Soon we were provided with an ambulance company with one lunched and ten enlisted men and the actual preparation for our new home began.

After the American troops moved out of this sector, the Chief Surgeon, American Expeditionary Forees, ordered No. 110 to Villers-Daucourt for the Argome offensive. During the four months ending November 30, 1918, this hospital admitted 17,446 patients and maintained 23,179 hospital days.

Another emergency evacuation hospital was American Red Cross Hospital No. 111, of which Lieutenant-Colonel J. C. MeCoy was eommanding officer. Colonel Burlingane wrote of its establishment:

At the request of the Army, American Red C'ross Hospital No. 111 was estahlished in the Hotel Dieu at Châtean-Thierry in August, 1918. The builling was for the most part still intart, thomgh at first (ierman, then Freneh and lastly Amoriean shells had somewhat pommed it to pieses. For a fow days it hat been the home of a mediand formation of the Thited States Irmy division which had withdrawn. As the hospital at Jomy-str- llorin was no longer actire practically all the personuel from that formation was moverl to this new

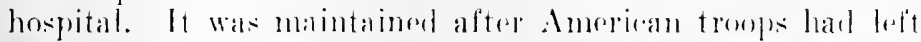

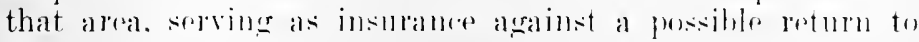
that secetor. Doring the lour months onding Noventher 30 .

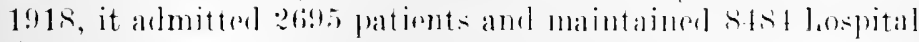
days.

The following report reatrling the omeremer assignment of Red Cross murses to lowpritals aring for wombled of the Imeri"an Expeditionary Forers during the military arisis of May, June and July, 191s, was submitted ly Miss Stimson:

All the following repuests were mot within forty-eiglat hours and in many alsos within twenty-aterht hours. 


\section{HISTORY OF AMERICAN RED CROSS NURSING}

Beaurais: Since April 12, 59 nurses and aides have been sent to Beaurais and the vicinity. The first groups were assigned under the Red Cross representative to French hospitals where there were American men. On May 29, seren of these were assigned to the hospital which had just been put under the eare of the American Red Cross and on May 30 twenty more were sent to relieve the urgent condition in that hospital. All the nurses and aides in this area can be moved about from hospital to hospital as the need for their services varies from day to lay.

Jouy-sur-IIorin: On June 4, twelve nurses and aides were sent up to get this hospital rearly for patients who were received within three days after the nurses' arrival. On June 18, eight more were sent up to help in the hospital, which is now rumning as an active evacuation hospital of 300 berls.

Auteuil: To American Red Cross Military Hospital No. 5, 40 nurses and aides have been assigned to take care of patients who have varied in number from 100 to 712 . The first patients arrived on May 31. The Army nurses who were askerl for did not arrive until June $1 \dot{14}$

Service de santé: Beginning May 25, 21 teams of one nurse and one aide have been sent out at the request of the serrice de sianté, which has given us not more than twenty-four hours' notice at any time.

A. R. C. Hospital. $4 t$ Rue Chaureau, Neuilly, asked for temporary airt to assist in the care of American soldiers beginning llay 30 . Five nurses have been sent for varying perions of time.

A. R. C'. Military Hospital No. 2: Five nurses have been sent here.

Evroux: Major Fitch askerl for help and on April 27 ten nulses and aides were sent there.

Ris Orangis: A nurse and an aide were sent in response to an emerencen call.

Etc., Etc. . . .

In a report written by Miss Hall, later ehief nurse of the American lied c'ross in France, appeared the following comment regarding the work of Miss Eildon:

During the ('hiteau-Thierry the St. Mihiel and the drive north of Verdum, all fererish times at Paris Ieadquarters. the Nursine Burean owerd much of tts stability. its apparent farility in answering urent (alls for help and its good judg- 
ment in sclerting nurses and aides to the assistant to the Chief Nurse | Miss Eldon|. . . It was no unusual thing to find her at her desk in the morning with a blank list of waiting nurses and aides in one hand and a request for perhaps twenty or thirty for inmediate assignment in the other. This meant the necessity of checking up every hospital in the neighborhood and asking for the release of as nany nurses as it was possible to get, and before evening the necessary number would generally be produced. . . . ${ }^{80}$

Of the intense strain under which the Ameriean Expeditionary Forces and the Ameriean Red Cross were then laboring, Major Fosburgh wrote Mr. Iavison:

The work referred to was done at the most critical period of the war, when Paris, it would seem, was almost in the grasp of the enemy and when everyone was working under the greatest pressure, both physically and mentally. For periods as long as three weeks our offices were dosed neither day nor night. Divisional representatives, messengers from division surgeons, headquarters medical consultants of the Army were coming in at all times to beg additional help or report progress. During one night between the hours of midnight and eight A. . . over fifty requisitions were received and the goorls sent out.

To Dr. Burlingame (U. S. A. Medical Corps) is due a major portion of the eredit for what was done. His assistant, Mis: l'reston, by her unquenchable good spirit and enthusiam, kept the whole organization going. Captain 1 . A. Rice, supply officer, unknown probably ontside the department, workenl withont thought of food or sleep. Miss stmmson, Chief Xurse. who used and re-used, shifted and changed our small persomel in such a way as to mect every real emergency. mate pessible the establishment and operation of all these hospitals. Mrs. Moorehead. Tarnowsy and Mec'oy. in charge of individual emergency hospitals. equipped and operated eflicint hoppitals with probahly more limited material and in a shorter space of time than had perhaps been done in this war. IPr. II Coy, during the bombing of his hospital at Jouy-sur-1Joru, standing above a serious ablominal operation calmly holding with forreps a soreped artery until andles conld be bromght by which to amplete the operation. is no more striking than mumerous other instances of this kind. gerformed by our persomnel during this past great :ummor.

so "Report of the Nursing Burean": Carrie M. Hall; Red ('row Archives. 


\section{HISTORY OF AMERICAN RED CROSS NURSING}

The difficulties under which the entire Paris headquarters' staff were laboring were indeed very great. Forty desks extended down a large eentral offiee space and at each desk, the harried officials of each service administered their particular duties among the pandemonium of typewriters, dictation, local and long distance telephone calls and always outside the intermittent roar of Big Bertha as the shells exploded. There was no time for protracted conferences. "It was as if each of us was working in an isolated tank," Miss Stimson once said. "In the interior of our particular tank, we were eut off from the other tanks and we were working under tremendous individual pressure and strain, yet we were all forging ahead in the same general attack and toward the same general goal."

Of this mobile nursing service operating for the American Expeditionary Forces from the Paris headquarters of the American Red Cross, Miss Stimson first wrote Miss Noyes, June 12:

I wish it were possible for you to be here even for one day to get a glimpse of how we are trying to meet the calls for murses constantly coming to us. These demands come for nurses to care for American soldiers not only here in Paris, where the already established hospitals are overflowing and to whom we are sending every possible kind of nurse or aide we can secure. but also to the new hospitals the Red Cross is opening in order to relieve this urgent military situation. High Army ofticials come here every day to confer with the Commisioner about new ways in which the Red Cross an assist the Army. These requests in almost every instance imply the help of nurses who can easily be moved from place to place and (an he hrought up to meet emergencies behind the lines more quidkly than Army nurses can be moved.

Later in the smmmer, the moving of any personnel other than that of the American Army hecome so dittienlt and took so long to acenuplish, that this situation was almost entirely reversed. Army nurses conld then be moved more readily and with less dolay than lied Cross murses, so many nurses who had heens serving before meler the commission for France, were enrolled as reserves of the Army Nurse Corps, hut continued to serve in Amerioin lied ( ross samitary units.

late in . Inly, the American lied Cross Commission for France submited the following estimate of persomnel needed by the Nursing Burean lexwern Angust and January 1919: 
Nurses and nurses' aides are used for two purposes: First, they are the only nursing personnel available to take charge of Red ('ross emergency hospitals until they become the responsibility of the Army; also they are placed in French hospitals under the service de Santé in order that our soldiers in those hospitals may have the care of some one who can speak their language. Second, they are nsed in connection with the emergency work being done for the civilian population of France, particularly the children and the tuberculous.

Up to the present time there have been about four hundred and seventy nurses and nurses' aides brought to France. They constitnte an emergency force that can be mover from place to place as the need exists. In order to earry out our program of being able to assist the Military Establishment in whatever emergency may arise and in order to discharge the responsibility which we have assumed toward the civilian population of France, it will be necessary to import up to January 1, 1919, the following persomel: Nurses, 250; nurses' aides, 300 .

Dietitians are used for organizing diet plans in American Red Cross hospitals, for assistance to American Expeditionary Forces' hospitals and for general use as mess officers. The Red Cross assigns then to such work and pays their salaries. They are also used to teach and work with the French civilian population and in French military hospitals. At the present time, notwithstanding the great use that could be marle of the services of dietitians, only two bave been brought from America and there is no supply of them to be secured in France.

\section{On July 31 Miss Stimson wrote Miss Noyes:}

The Red ('ross is constantly being asked to take new hospitals for the Army. Into some of these, Army nurses are sent at once; in a good many instances, however. we have to take "are of the emergency before the $\mathrm{drm}$ " nurses arrive. Some of these nurses assigned by the Red cross are of ten left on the stalf with the Immy nurses. You will he interested to know that the ('hief surgeon. American bixpentitionary Forese has assigned tifty Army nurses to the hed ('rose heallose of this very need for noving nurses quidily in just.

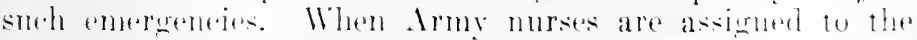

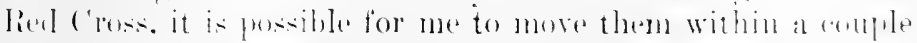

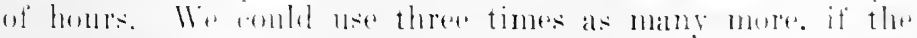

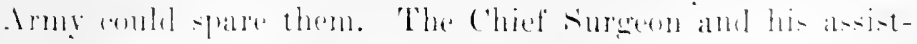




\section{HISTORY OF AMERICAN RED CROSS NURSING}

ants are continually in our office and in the past two or three months they and the Red Cross officials have worked together as though they were one organization.

The last Red Cross hospital to be organized for American troops in action at the front was American Red Cross Hospital No. 114, which was established at Luxembourg, Toul, in the Asile C'aserne, a former hospital and orphanage which had been maintained since December, 1917, by the American Red Cross Children's Burean for French refugee children. The buildings consisted of typical French wooden military barracks. The children were evacuated in August to Nenfchâtean, Nancy and Lyons, the hospital was enlarged from ninety beds for children to fiftcen hundred beds for American wounded expected from the St. Mihiel drive. Martha S. Clark, an American Red Cross nurse sent up from Paris to help reëquip the Asile Caserne as a military hospital, wrote:

. . On September 11, a Red Cross mobile unit of about 100 doctors and 45 nurses, with Major McCoy as commanding officer and Linda Meirs as chief nurse, arrived and we began to set up the wards for patients from St. Mihiel. That day we made twelve hundred beds and almost within twentyfour hours they were filled; a few days later we had 1800. As this was an evacuation hospital, we only kept them for a few hours' rest after re-dressing their wounds. . . .

Henrietta R. Reed, another Red Cross nurse on duty at the Asile Caserne, wrote:

On the night of September 12, our first wounded arrived. By dawn abont 1000 men had come in and Major McCoy's unit had twelve operating-tables running at full speed. . . . II first assignment was to a ward containing 63 wounded Boches, both officers and privates. They were covered with filth from hearl to feet and almost all of them were badly wounded. They were all undressed, bathed, given new pajamas and put to bed between the clean Red Cross sheets and new blankets. They stayed with us five days. . .

The hospital consisted of seutions which were lettered from A to K. Each section was made up of seven wards containing twenty men each. There were four private rooms to each sertion; men who were lying or who could not live for ts hours were placed in these rooms, thus sparing the other wounded the sight of a dying comrade and griving to the unfortunate man himself quiet and privacy to the end. 


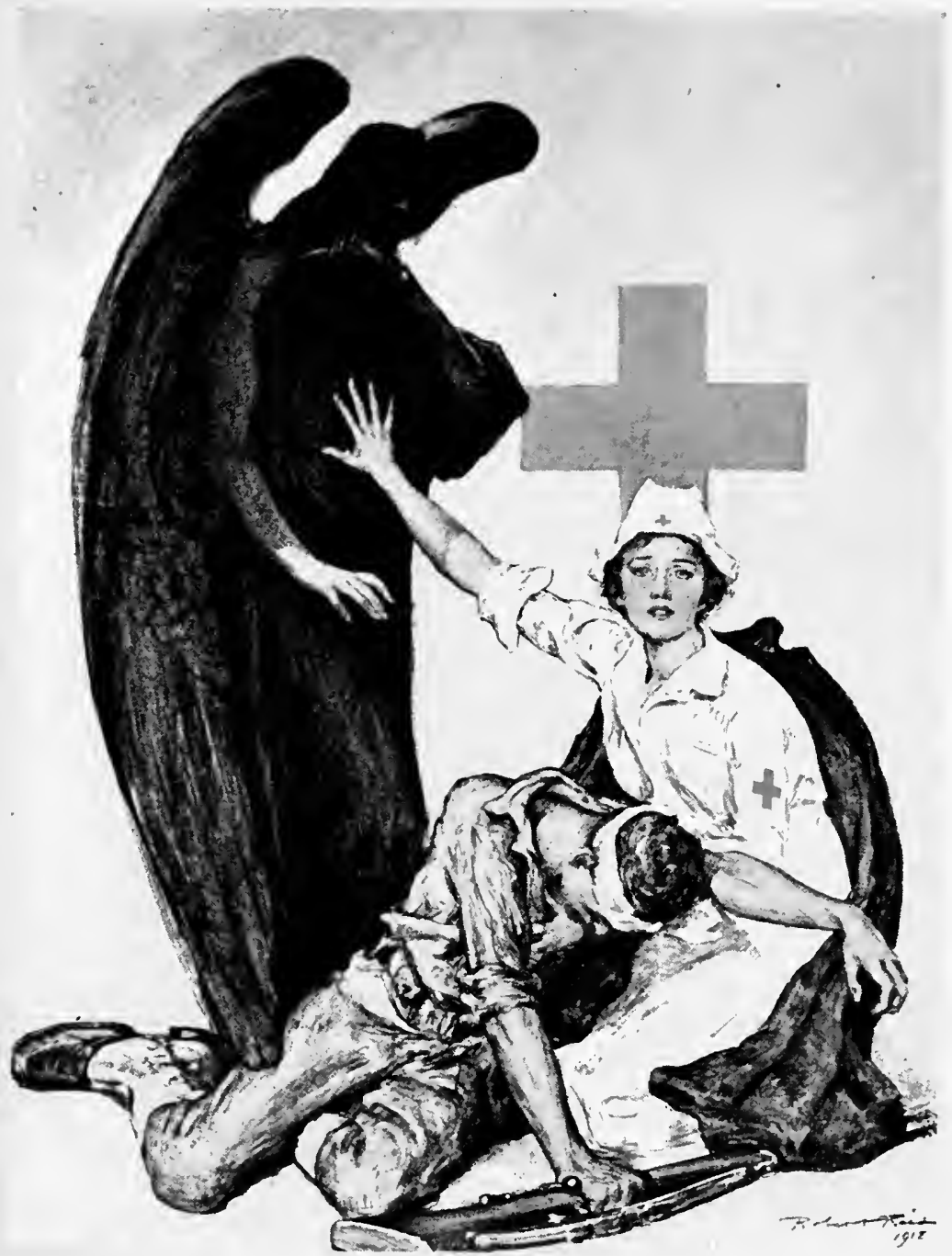

Miligimal in Red C"russ Mus um

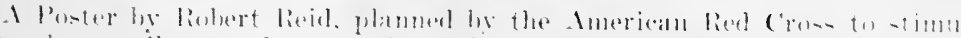

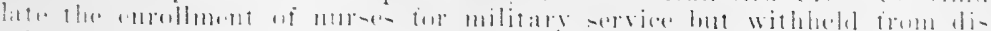

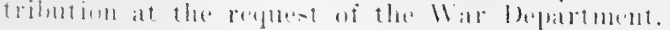




$$
\text { - }
$$


American Red Cross Evacuation Hospital No. 114 was in operation at the Asile Caserne de Luxembourg from September 12 to September 23. The American troops then advanced north of Verdun, so Major MeCoy's unit was ordered to follow them as far as Fleury-sur-Aire. United States Army Base Hospital No. 82, which had recently arrived from the United States with surgeons and corpsmen but without nurses, was ordered to duty at the Asile C'aserne de Luxembourg and the original child welfare murses, "easuals" who had been sent up from Paris and several of Miss Meirs' original unit remained there to constitute the nursing staff. Colonel Burnham was commanding officer of Base Hospital No. 82 and Sarah M. Morgart (Conemangh Valley Memorial Hospital, Johnstown, Pa.) was appointed as ehief nurse; she had formerly been Miss Meirs' assistant. Henrietta Reed, who had remained at the Asile Caserne, wrote:

On September 23, Base Hospital No. 82, with Colonel Buruham in rommand, arrived and the following day the ambulances hegan rolling in again, this time with 500 gassed and "flu" cases from the Fourth, the Seventh, the Ninety-first and other divisions. It one time I had charge of 176 men with mumps, pneumonia and influenza. . . .

Gladys H. Porter, a public health nurse who had been at the A sile ('aserne since its establishment in December, 1917, and who remained there throngh its metamorphosis as Evacuation Hospital No. $11 t$ and finally as U. S. Army Base Hospital No. 82, wrote:

After Major McCoy's mit had moved up to Fleury, we suddenly found ourselves being entirely reëquipped by the Amerian Red ('ross and converted into a hase hospital of 2000 beds. Melical and surerial cases (ame so quickly that we had to resert to cots in the corridors and finally teints on the gromols. ()ur surerical warks had so many frames and so much fracture apparatus that the boys called them farmum and Bailes eircus i iness, or "trollev-ars" and urged all visitors to take stork in the new corporation.

In the meantime. Major Mre 'oy's unit had gone on to Flenry-sur-tire. Bessie 1. Copolin, one of the nurses, described the trip up: 


\section{HISTORY OF AMERICAN RED CROSS NURSING}

We traveled in 35 ambulances, each one running twenty minutes apart. No one was allowed to stick her head out, as we were in constant danger of being bombed or shelled.

On our arrival at Fleury, we found that our corpsmen, who had gone on two days before, had everything in readiness. On September 25, the wounded began to come in and we evacuated from 1200 to 2000 a day.

At Fleury, Major McCoy's unit was taken over by the Army. Colonel Burlingame wrote:

This transfer of No. 114 to Fleury was largely a movement of personnel with but a small unit of equipment. Although financed for a time by the Red Cross, they were largely equipped by the Army. On their arrival at Fleury, the formation became known as Evacuation Hospital No. 114 and was eventually taken over entirely by the Medical Corps, with the exception of certain Red Cross nursing personnel, who continued with the formation until the end. 'To quote from a letter of September 24 from the Red Cross (addressed to the Army): "In view of the fact that the movement of this unit is one of personnel alone, it seems to be a hindrance rather than a help to the Army to operate it as an American Red Cross unit and we therefore propose to turn the persomnel of the unit to the United States Army." A few weeks after its resignation as American Rerl Cross Evacuation Ilospital No. 114, it disappeared from Red Cross history.

For the thinty-two days of its Red Cross existence, the hospital recoived 14,771 and evacuated 13,809 patients.

Another hospital, formerly maintained by the Children's Burean of the lepartunent of Civil Affairs but later transferred to the lepartment of Military Affairs to scrve the Aneri"an Expeditionary Forres, was the Hospital Violet, at L crons. It har been established in the spring of 1918 as a rontagions hospital for refugere rhildren but when the influenza epidemic: broke ont annong American soldiers in ranes near Lyons, the children were evarnated from it and the medical and mursing staff rared contirely for American soldiers taken sick with the influcnza. Susanno Hoskins, an American Red Cross child wolfare nurse, wrote:

In Octolere 1918. I was transferred to the Hospital Vislet, which had just been taken orer for the are of American boys. Ily first week there was most monapy; we lost three 
of our finest boys with the flu. It broke one's heart to think of all that these boys had been through at the front,- - some of them had seen nine months in the trenches,- - and then to have them come back of the lines to rest and tie like that. Our first patients were all from La Valbonne, an officers' training camp just ontside lyons. Most of them were sergeants in line for commissions. Later on, we had many "casuals," boys passing through Lyons and getting sick in the hotels and even the railroad stations. Hospital Violet was also used to evacuate the boys from French hospitals. . . The American Red Cross hospitals seem to give the boys the touch of home they crave.

No incidents illustrate the flexibility of Red Cross organization better than do these transfers of American Red Cross Hospital No. 114 and of the Hospital Violet. Hospital No. 114 was formerly a mobile mit but when need arose, it was established at the Asile Caserne de Luxembourg as an evacuation hospital to serve the wounded; Hospital Violet had been a ehildren's hospital, but it too was commandeered for the care of sick American troops. Through the summer of $191 \mathrm{~s}$, efficient fulfillment of the neods of the American and Allied Military Establishments became the primary aim of the Paris hadquarters, even though this meant in large part a loss of identity of the American Red Cross Nursing Service in France. It has already been shown that nurses who had come over to work primarily with the civilian population were "militarized" as necessity arose. Miss Stimson explained some of the reasons for this transfer:

At the time when the Red Cross murses in France who came for work witls the civilian population were placed in hospitals moler military control during the great emereneng of the smmmer of 1918 . they were all grisen an opportmity to become definitely attached to the military service. I mumber of them were sworn in as reserve nurses, trmy Xorse (inpss. ant were batil he the Army. . . It is doubthil whether at the time, which wals ome of great confusion, it was explainesl to these morses that it they diet not hecome a part of the Army they would not be entitled to compensation and henetits shombl they berome disabled. It that time such bernetits were not generally kmown, if they had been anthorized.

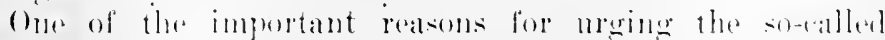

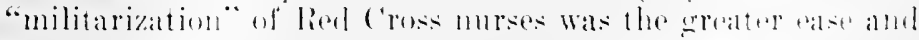
speed in movinge them from platere to place atcerding to the 


\section{HIS'TORY OF AMERICAN RED CROSS NURSING}

need, than was made possible through Army orders. It frequently required ten days to secure the necessary papers to move Red Cross nurses not in the Army. Permission to move all non-Army personnel had been obtained through the French, but American Army transfers could be made in a few hours.

This absorption into the Military Establishment of nurses as assigned under the American Red Cross involved an important question of Red Cross policy. Miss Stimson wrote Miss Tayes:

I am very sorry if in our work in Paris we embarrassed you in ally way by allowing Red Cross nurses, i.e., nurses assigned to the Rer Cross Commission to France, to join the Reserve Army Nurse Corps. We did not urge them to do so, but we felt that when they wished to we had no right not to allow them. Many of them said they had not had an opportunity to join in the States and were even so misinformed as to think that when they signed up for the Red Cross Nursing Service they were joining the Army Nurse Corps. I did not realize the difference in paper work in preparing the two groups. As a matter of fact, the total number of Red Cross nurses who joined the Reserve Nurse Corps over here did not exceer forty-five. At the present time most of these are being given permanent assignment with various Army formations, as the emergency needs to which the Red Cross deroted their services no longer exist. ${ }^{81}$

Here lay the crux of a situation which caused both Miss Delano and Miss Nores embarrassment because of the position in which it placed the Red Cross in regard to the group of murses who served with ereat loyalty and self-sacrifice in the eantomment hospitals in the Lnited States throughout the war. Miss Noyes answered this point as follows:

There was no nurse who left this country who did not have a formal rommuniation from me sayng that it was definitely understool that she was arecpting service under the Reil ('ross and that transfer to the Army would not he permitted. Some of these morsestood out agrainst acrepting service in the military amps in this comntry. this being a preliminary preparation for overeas duty with the Army. I should never have assigned some of these women to France at all, except "1 Mis Stimson to Miss Noyes. Denember 2, 1918. 
that the need for nurses was so great that we could not ignore any source of supply, but we considered them unpatriotic.

If military traming in this country for oflicers and soldiers in the "antonments was a prerequisite for overseas duty in the Army, then no patriotic nurse should have held out against the assignment to a military camp in this country. In their anxicty to get overseas in the shortest possible space of time, they would arept service directly with the lien ('ross. It was marle plain, however, to these women, not only by me but invariably by Miss Johnson in New York, that this: service was not for the Army. I fear the same traits which many of them showed in refusing service in the camps have been the controlling fartor in lading you to believe that they were not informed concerning the military service.

There is one thing l camnot quite understand, whether, for instance, Jiss Eldon and others need have gone into the Army Nurse Corps when they were to be loft in the Paris offiee, which u'as a lied Cross office. I mention this point, as many of the nurses who are returning to this country are speaking reritically of the militarization of the Paris oflice and resent what they call the elimination of the Red Cross. ${ }^{8: 2}$

The Nursing Service in France has already been compared to a small ship in strange and troublous waters. If lay control in Red Cross administrative matters may be called the Seylla which threatened her on the one quarter, then the absorption of the Nursing Service by the Army, as set forth above, may surely be called the Charybdis! This interesting and vital point of poliey, bearing directly on the relationship of the Red Cross to the Army, may thus be summarized: Mlany persons might hold that by proclamation of the President and by reanlations of the War Department, every enrolled Red Cross nurse is a reserve nurse of the Army Nurse Corps, provided she is willing to serve. When such a nurse has been detailed hy the Red Cross to a militarized establishment sueh as the Red Cross ('ommission for Franer, operating in the theater of war monder an Army chief nurse, it beeomes a matter of interpretation of Article 10 of the Revised Treaty of (ienera, Iuly 6, 1906i, as to whether she is "assimilated to the persomel chared with the removal, transportation and treatment of the sick and womberd."

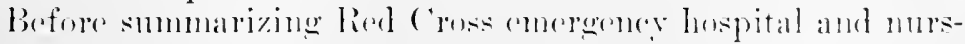
ing servie to the Ameriean Expeditionary Foreese it is well to inchule at this point a statement of .lliss Stimson's appointment

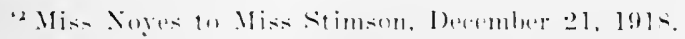




\section{HISTORY OF AMERICAN RED CROSS NURSING}

as director of the Nursing Service, American Expeditionary Forces. As early as July 31, 1918, her report to Miss Noyes mentioned the over-lapping of her duties as chief nurse, American Red Cross, with those of the Chief Nurse, American Expeditionary Forces:

During the great activity of our forces, we have placed almost the entire emphasis of our work on the military phases. Iy own position as an Army chief nurse, directly representing the Chief Surgeon, has had to be greatly developed. Tot only are there countless numbers of Army nurses coming to our office for various kinds of assistance. but the Chief Surgeon has asked, since the Red Cross supplies free transportation by automobile, that I inquire into the welfare of Army nimres at the front. It is very easy for me to combine my visits to the two groups of nurses and I have been able to be of considerable assistance to Army nurses in evacuation hospitals and on surgical teams. I am able to see that needful equipment from the Red Cross is supplied quickly and I can also be helpful by acting as a go-between with groups of nurses to their own chief nurses at the bases, or with the Chief Nurse of the American Expeditionary Forces. I am also able to communicate rery quickly with these nurses through our ambulances and automobiles which are constantly going between Paris and the front and this, since the mail service is so slow and difficult, is useful.

It is because of the increasing importance of such duties as these that I have cabled to ask if Florence Johnson can be sent over to assist me. It is very necessary that I visit all the base hospitals to explain to the nurses what the Rerl Cross is doing and what it stands ready to do for them. I feel that I could do no more important piece of work than to explain to the large numbers of Army nurses now in France the details of the work of the Red Cross here. I was utterly ignorant myself until I was appointed to this office and I foel sure that many of the moses in France are as unknowing as I was. You will remember that Miss Johnson was a rlass-mate of mine at the Now York Hospital and is a rery dose friend. she wonld bre exactly the person to under-study me and to share some of the tremendous hurden and responsibility of the Paris office. I would not ask to have so valuable a person. were it not almost imporsible to find her equal here.

When Miss Johnson was approached upon the subject. she dreided to remain in New York. National Headquarters cabled to Miss Stimson: 
[Cable No. 10.0?\% | Miss Johnon is doing most important work in New York. Enjoys very close and harmonious relations with hiof murses stationed there representing the Surgeon General's oflice. Ilas full rharge of efuipping. interviewing and directing all Army and Red ('ross nurses sailing from New lork. looks after their comfort and morale, advises them of their duties and responsibilities and we feel that her removal at this time would result in serious dislocation of the entire service.

This cable reeommended other nurses then serving in the Paris office who were, in Miss Dolane's opinion, well fitted for this work. Carrie M. Iall, at that time chief nurse of the Ameriean Red Cross in Great Britain, was finally transferred to Paris to assist Miss Stimson.

Miss Stimson's dnties during August and September brought hor in more and more close touch with the nursing serviee of the Ameriean Expeditionary Forees. In her last offieial letter to Miss Delano, written on November 6, Miss Stimson announced her appointment as Direetor of Nursing, American Expeditionary Forces:

By this time, you probably know that General Ireland has appointed me director of the Army Nurse Corps. I am not definitely taking up the work, however, until November 15. I do not know how to explain to you how all this development has taken place. for the situation is so absolutely different from what anyone so far away can imagine. or from what any of us lave experienced before. Cieneral I reland will be able to explain to you better than anyone else why he thought I could he of more use in this position than I am here. Misis IIall hats a very complete understanding of the situation here.

1 cannot tell you how strongly we all feel over here that you should rome and sere just what is happentung. At the period

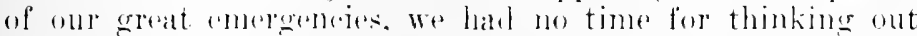
policies: but now ats we fare ancether winter of harel work we are greatly in nemb of inspiration.

In hor report als direcotor of the Nursing sorvice, 1. E. F., Jiss Sitimson wrote:

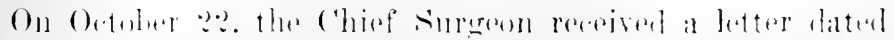

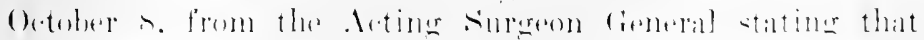

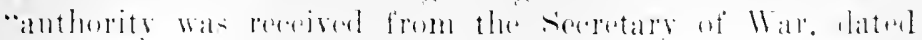




\section{HISTORY OF AMERICAN RED CROSS NURSING}

September 5, 1918, for the appointment of one director and two assistant directors of Nursing Service in France and the same in England." Miss Stimson reported to the Chief Surgeon in Tours, November 15, 1918. Miss Bell returned to the United States, December 2, 1918, and became assistant to the Superintendent of the Army Nurse Corps in Washington.

During its first eighteen months in France, the American Red Cross established nine Ameriean Red Cross military hospitals in France; these institutions had an estimated bed capacity of 6727. During the same period, the commission also established twelve American Red Cross Hospitals to serve the American and Allied Military Establishments; these institutions had an estimated bed eapacity of 4331. Other formations included L'Hôpital des Alliés, at the Châtean d'Annel, near Campeigne; Ambulance Chirurgical St. Paul, the temporary formation at Chantilly; the Daly Unit; and the L'École de Légion d'Honneur at St. Denis. All these units were assisted by American Red Cross funds, personnel and supplies. A list of all sanitary units organized by the eommission to serve the American and Allied Military Establishments may be found in the Appendix.

Colonel Burlingame's report of the work aceomplished in twenty-four of the twenty-eight military hospitals operated by the Red Cross for the twenty months ending February 28, 1919, summarized Ameriean Red Cross medical and nursing service to the American Expeditionary Forces:

$$
\begin{aligned}
& \text { Hospital days } \ldots \ldots \ldots \ldots \ldots \ldots 1.154,854 \\
& \text { Patients adimitted } \ldots \ldots \ldots \ldots \\
& \text { Patients died } \ldots \ldots \ldots \ldots \ldots \ldots \\
& \hline
\end{aligned}
$$

Of the 89,539 patients almitted to Red Cross hospitals during the last six months of 1918, s6,is\% were from the American Expeditionary Forces.

It should be borne in mind that the Chief Surgeon of the American Expeditionary Forces intended that this coöperative effort of hospitalization between the Red Cross and the other parts of the Ilerlical Corps should be primarily an emergency measure. How well the intent of the Chief "surgeon was carried ont appears in the graphice chart attalded, which shows a drope of two-thirds of the total days of hospitalization "are within one month after the signing of the Armistice. 
On November 11, 1915, the American Red Cross Nursing Service in France had (i)t of its nurses at work directly under its own anspices in both militury and civilian activities of the American Red Cross Commission for Europe. Five humered and fifty-three American Red Cross aides were also in active service at this time. Of this number, 233 were sent to France from the Lnited States; 320 others were women who had been trained for service as aides with the first fifty base hospitals organized by the Red Cross for the Army. When the Surgeon General debared them from active service in hospitals of the Military Establishment, they volunteered for Red Cross service overseas as canteen, recreation hut and surgical dressings workers and were sent to France in these eapaeities. During the military erisis of the smmmer of 1918 , with the attendant acute shortage of nurses, these aides registered with the Bureau of Nursing at the Paris ()ffice and were assigned to duty in French lospitals of the service de santé and to emergeney hospitals of the Americin Red Cross.

How well the American Red Cross in France served as an emergener arm of the [nited States Medieal Corps may be seen by a brief statistical summary. The total number of battle casualties of the Ameriean Expeditionary Forees during the European War was 289,330 . Of this number 34,180 were killed in action: 14,72 !) died of wounds: $230,07 t$ were wounded in varying degrees: 2 !)1:? were reported "missing in aetion"; and 4434 were taken prisoner. ${ }^{\dot{x}}$ During the twenty months ending February 2s, 1919, twenty-four of the twenty-eight military hospitals which were operated in Franee by the Ameriean Red Cross eared for 86,787 patients of the Ameriean Expeditionary Fores. These men were largely wound cases because the hospitals where they were treated were organized for the speeifie purpose of earing for American soldiers wounded in the principal German and Allied offensives. 'Thus the American Red Cross, in addition to organizing and equipping the fifty base hospitals which forment the skeleton of the hospitalization of the Medical Iepartment in Franee, may also be said to have provided, throngh this emergeney hospital serviee as developed

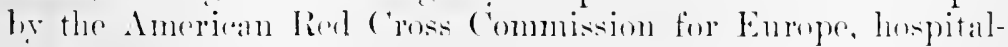
ization to mone than one thind of the Anerican battle calsualties of the European War. 


\section{HISTORY OF AMERICAN RED CROSS NURSING}

The greater flexibility of the Red Cross organization as compared to the necessary stability of the Military Establishment, the tremendous resources placed at the immediate and complete disposal of the American Red Cross in France through the generosity of the American public as compared to the governmental routine of Congressional appropriation and expenditure, and the unofficial position which the society oceupied in relation to the French Government, permitted the Ameriean Red Cross in France to render this signal serviee to the wounded of the American Expeditionary Forees. Thus the early policy which had been adopted by the Ameriean Army and the Commission for France that the American Red Cross in France should serve as an emergency arm of the Medieal Corps was developed beyond even the most earnest and enthusiastic hopes entertained by the society for the alleviation of the suffering of siek and wounded American soldiers.

With the exception of the Red Cross evacuation hospitals described in the preceding section, the Medical Corps of the Ameriean Expeditionary Forees organized all Ameriean sanitary formations operating in the immediate zone of the advanee. In these formations, however, many reserve members of the Army Nurse Corps served at the front during the Allied offensive of the summer of 1918. To appreciate as a whole the general type of scrvice of these nurses, a brief summary at this point of the forward operations of the American Expeditionary Forees will throw light upon the fragmentary accomits of their experieneses given later by murses.

Immediately following the failure of the German offensive of Mareh-,July, 1!18, Marshal Foch lannehed his first comnterattack on fluly 18 mpon the merovered west flank of the German salient from the Aisme to the Marne. By this operation, eompleted August fi, the Allied line ran from Soissons to Rheims along the Vesle. I frow dars later, the British Armies began their offensive on the Somme salient, which lasted until the date of the Armistice. With these troops were elements of three American divisions. Of the next movement, Colonel Ayres wrote:

In the meantime, simultaneous assaults were in progress at other points. ()n lugust 1s. (ieneral Mangin began the (lise- tisne phase of the ereat Alided oflensive. I day later. the British launehed the first of a series of attacks in the 


\section{THE FUROPEAN WAR}

Ypres sector, which continued with some interruptions to the time of the Armistice. [With these troops were four American divisions. |

With the organization of the American lirst Army on August 10 under the personal command of Cieneral Pershing, the history of the Anerican Expeditionary lorces entererl a new stage. 'The st. Ilihial (September 1:-16) and the Mense-Argonne (Neptember 26 -November 11) oflensives were major operations planned and executed by American generals and American troops. . .

Two comparisons lectween this operation at St. Mihiel and the Battle of Gettyshurg emphasize the magnitude of the action. About five hundred and fifty thousand Americans were engaged at St. Wibiel; the Union forces at Gettysurror numbered approximately one hundred thousand; St. Nihiel set a record for (uncentration of artillery fire by a four-hour artillery preparation. consuming more than one million romels of ammmition. In three days at Cettysburg, laion artillery fired thirty-three thomsand rounds. The st. Mihiel offensive cost only about seren thousand easualties, less than one-third of the Inion loses at Gettysburg. . . . st

The Mense-Argonne cimpainn saw the collapse of the German Fifth Army. Of this engagement, Colonel Ayres wrote:

"The objoct of this offensive." sain General Pershing in his report of November :0, 1!) 18, "was to draw the best cieman divisions to our lront and to consune them." This sentence expresses better than any long description not only the object but also the onteome of the battle. Every arailatide. Imerian division was thrown agrinst the eneny. Every available German division was thrown in to meet them. At the emel of forty-seven days of continnous battle, our divisions had ansumed the German divisions.

The goal of the Aneriean attark was the sedan llowiopes railroad. the main line of supply for the German foress on the major fart of the Mistern Front. If this line were rent. a retirement on the whele front would he foreed. This retire-

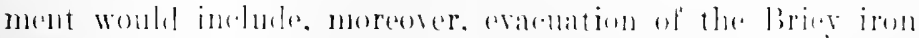

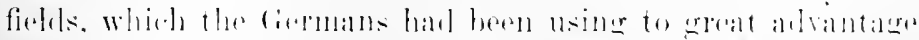

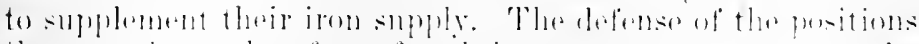

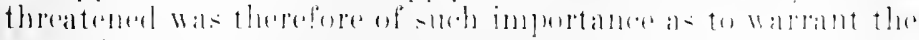

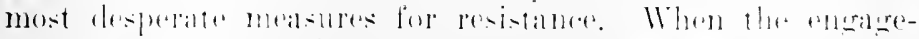
ment was ardently impending. the anmmandep of the lierman filth druy sent word to his forres. alling on them for s".The War with (anman!." pp. 109-110. 


\section{3+ HISTORY OF AMERICAN RED CROSS NURSING}

unyielding resistance and pointing out that defeat in this engagement might mean disaster for the Fatherland. . . .

On the first day of American action, the 26th of September, and the next day or two after that the lines were considerably advanced. Then the resistance became more stubborn. Each side threw in more and more of its man power until there were no more reserves. Many German divisions went into action twice and not a few three times, until through loss they were far under strength. All through the month of October the attrition went on. Foot by foot the American troops pushed back the best of the German divisions. On November 1, the last stage of the offensive began. The enemy power began to break. American troops forced their way to the east banks of the Mense. Toward the north, they made even more rapid progress and in seven days reacher the outskirts of Sedan and cut the Sedan Mezières railroad, making the German line untenahle.

In the meantime (October 2 to 28) our Second and Thirtysixth divisions had been sent west to assist the French who were advancing in Champagne, beside our drive in the Argomne. The liaison detarhment between the two Armies was for a time furnished by the Ninety-second Division. ${ }^{85}$

From Châtean-Thierry to the Sedan-Mezières railroad, the forward sanitary formations of the Medical Corps, American Expeditionary Forees, followed the advaneing American armies. From the Chice Surgeon's office, moved in Jamuary, 1918, from Chammont to Tours, Miss Bell directed the nursing service of the Anerican Expoditionary Forees, assisted until June 13, 1918, by Anma E. Coffey, Army Nurse Corps. Upon this date Miss Coffey was transferred to another station and Nina Shelton was ordered from Base Hospital No. 24 to assist Miss Bell until Miss Stimson's appointment took effect on November 15.

Three types of assigment,-(1) to hospital trains; (2) to evacuation and molile hospitals; (3) to professional teamscharacterized the nursing servie of the zone of the alvanee. The following sections deal separately with these, the most forward positions held by any American wonen during the Einroperall llar.

Linking the font with the base were the hospital trains of the L. S. Army Medical Corps. In her definition of this branch of the mursing service of the American Expeditionary Forecs, Miss Stinson wrote:

$$
\text { ss "The War with ciermany," p. } 111 .
$$


Hospital trains, not originally intended for operative or other treatment, are designated for evacuation of the sick and wounderl. Each train is a complete unit under the command of a selected medical officer. The regular staff consists of two medical oflicers, three nurses and thirty-six enlistel men, inchuding a registered pharmacist, a clerk, a mechanie, two cooks, two assistant cooks, two men for each ward car and one man detailed to the staff coach.

Of the assigmments of women nurses to this branch of the service, Miss Stimson wrote:

For the most part, these groups of two officers and thirtysix men were organized in the United States as hospital train units. On Trains Nos. 50 and 51 they were formed from casuals of the American Expeditionary Forces. None of these units, prior to the summer of 1918 , inclucled women nurses. On July 13, 1918, three murses were detailed from Base IIospital No. 27 for temporary duty on Hospital Train No. 37 and a trial trip was made by them a few days later. Several officers of the Medical Department were present on this first trip to observe their work and to judge the advisability of having them assigned permanently to this service. Three nurses of Base llospital No. 47 were sent on August 4 to Train No. 5: and three others to Train No. 61. Base Hospital No. 8 supplied otlers on August 5 for 'Trains Nos. 53 and 54 , while Base Hospital No. 9 sent forward three to Train No. 55. As new trains came into the service additional nurses were assigned.

Becanse of the munsual natme of this serviee, General Instructions issued to the officers of trains are herewith given, although they belong rather in a history of the Army Furse ('orps than in that of its Reserve:

buties of traincel nurse: The senior of the three nurses assigned to the train will act as matron. Nurses will arry ont the orders of the medical officers and are to be obered next alter them.

(Guarters: Vurses will have quarters assigned them within the statl enath and they will not use other compartments. Xin visitors sabe women will enter their quaters. (1nly the necessary personal articles will be kept on trains: all heary hageanere will be kept at the nurses home.

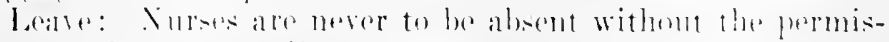
sion of the commanting otlieer of the train. 'l'hey are not 


\section{HISTORY OF AMERICAN RED CROSS NURSING}

allowed more than two hours away from the train and permission to be absent is never given within the zone of the advance. One trained nurse must always be present with the train, whether it is lialted at a station or garaged on a siding. When trains are laid up for prolonged repairs or are otherwise delaved for a considerable period, nurses will not be kept on the train, but will be reported to the senior matron of the section, who will make use of their services temporarily. They will be returned upon the request of the commanding officer of the train.

Helen T. Burrey, reserve nurse, Army Nurse Corps, a graduate of St. Francis Hospital, Pittsburgh, Pa., and a member of the nursing staff of U. S. Army Base Hospital No. 27, was one of the first three nurses to be assigned to hospital trains of the American Expeditionary Forces. She wrote:

Base Hospital 2\%, located at Angers, France, received the first official order dated July 14, 1918, to supply Army nurses for this service. Until this time, the Medical Corps attached to hospital trains were caring for the wounded. Through Miss Blanche Rulon, chief nurse of Base Hospital 2\%, Edna Cooper, Grace O'Donnell and I were detailed to Hospital Train 5\%.

When told that we were to leave the next day to board this train which was then stationed at Port Boulet, France, we were certainly filled with a spirit of adventure. We arrived at Port Boulet. July 15, found our train and made ourselves known to the commanding officer, Captain Goodwin, who had knowlerlge of our coming. He received us very kindly and immediately slowed us to our quarters.

We were agreeably surprised at the modern equipment. In our coarh there were three compartments which consisted of a dining room and two steeping rooms and a laratory (triangular in shape) containing a small wash bowl and commode. The sleeping rooms were made up of a private room consisting of one herth and a wardrobe and a second room whicle containerl a lower besth and an mpper berth. Of course. we all wanter the private room. but since it conld not be private among three, we resolved to take "turns about" and rotate from i]per borth to private room. The rule was one werk in the private room and the next week in the lower berth and the thind week in the unper herth. As we had five montlss of this life. we har plenty of time for the private room. The dining room, which was also used as a living 

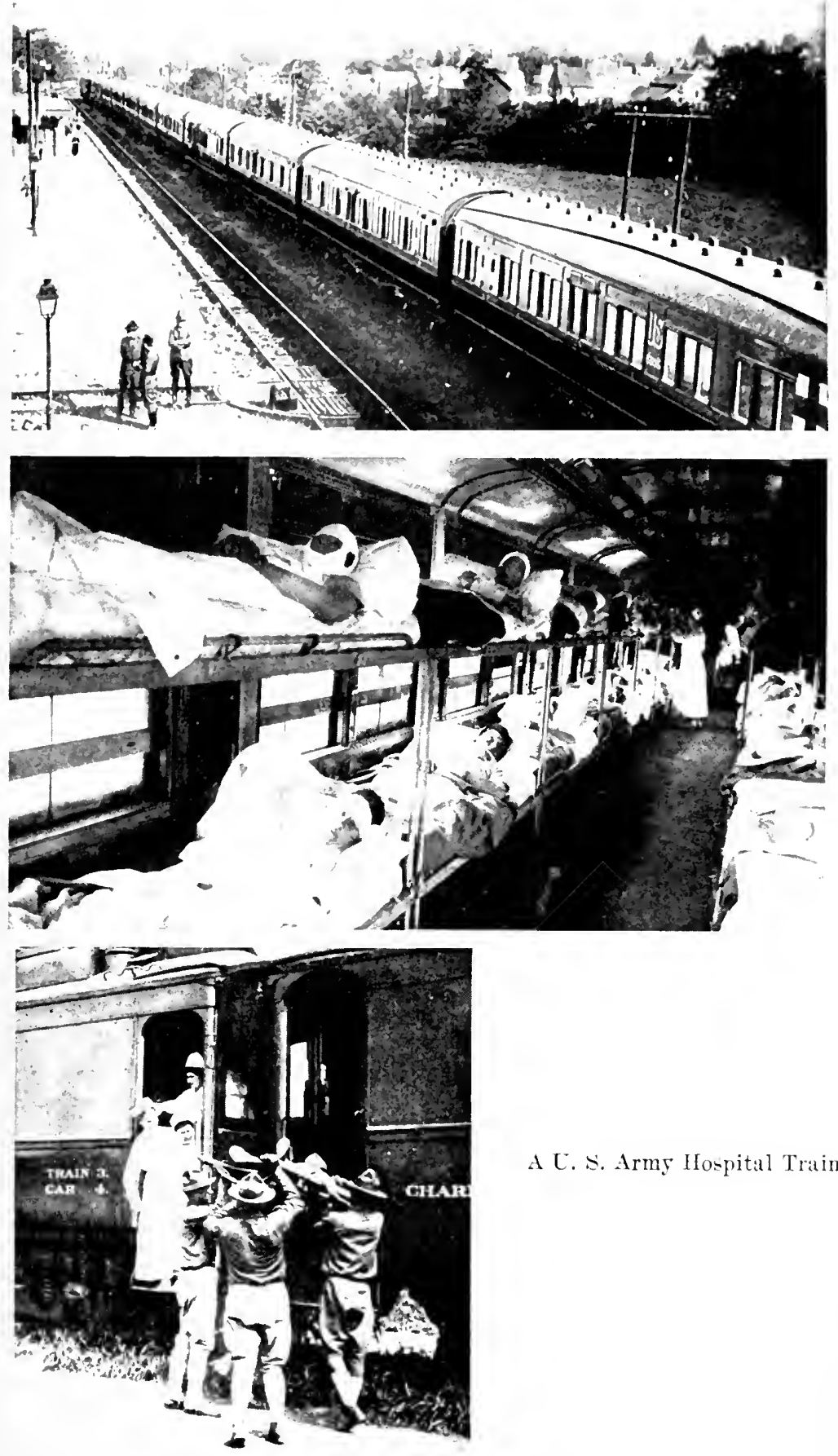

A C. S. Army Hospital Train. 

room, contained a table and two chairs and a side seat fitted to the wall.

\section{Miss Burrey deseribed the aecommodations of Hospital Train} No. 57 :

T'he rest of the train consisted of sixteen coaches, including one infections car which carried eighteen bers; one stafi rar which carried eight beds; one kitchen and sitting sick officers' car which arried three beds and twenty seats; eight ordinary lying ward ears which carried 288 beds; one pharmacy car; one infections wase sitting car which carried fiftysix seats and fourteen upper berths; one kitchen and mess car with three beds for cooks; one persomnel car with thirty beds and one train crew and store car; the total capacity of the train was thus 400 beds.

Each moving hospital was equipped with electric lights. steam heat, electric fans, lavatories and racks for personal belongings and even ash trays for the patients' indulgence. There were eight ordinary ward cars for patients containing thirty-six beds arranged in tiers of three. These could easily be converted into seats to accommodate patients who were able to sit up; they could also be used for stretchers in emergency cases or folded against the sides of the coach when the cars required cleaning.

Miss Burrey wrote of the trial trip of Train No. 57, when for the first time American Army nurses were officially assigned to train service:

Our first trip was to evacuate patients from different hospitals who were able to be moved to a point of embarkation for the Uniterl States. Since we were the first nurses, Colonel Howard Clark. who was then in charge of the train service, mare the first trip to these different hospitals; this was also the first trip for transporting badly wounded patients from the hospitals noar the front to the hospitals near the point of embarkation.

We started Iuly 17. passed through Tours. Boureses. Nevers. Dijon, ('haumonit, Teuf(hâtean, Contrexéville, Toul and Savenay, stoppiner at several base hospitals and filling our train with wombled who were to be taken to Base Hospital No. S at silvenay. Ifter soping our work. Colonel clark congratulaterl us and recommendod that all the trains be supplied with three nurses.

Wir worked day and night with those pationts: the pathetic condition of onr boys who were very badly wombded male us 


\section{HISTORY OF AMERICAN RED CROSS NLRSING}

realize that being wounded was hard enough to bear, without the jolts, noise and dirt connected with traveling on a train. 'These patient: were in our care for two nights and three das: before they were unloaded at Base Hospital No. 8. I remenber two patients: who had broken backs and had horrible be I sores. You "an picture the special rare such a rase would require, but onr time with each patient was limited and we gave the best attention possible. We also had many patients who had amputations of legs, or arms, and many other wound: that caused much pain and constant attention from doctors and lluries.

One of the dhief discomforts which we noticed that the patients met was ansed by the tightening of bandages due to the restless position of the patient and by the moving and stoppin of the train. This condition was also aggravated by the inferted wombl: and the patients were constantly calling for relief from the bandages.

Anue P. Hill (nixe Peck), reserve nurse, who was assigned in August, 1!18, from L. S. Army Base Hospital No. 9 to hospital train service, described the routine of taking on patients:

Our first trip was one which we would have chosen,- - to Chatean-Thierry. We arrived ahout ten oblock that night, took on four limelend and fifty badly womnderl and gasso: patients and at midnight started back for Chatelguron. . . .

Iot soup, coffee, leans and bread were prepared for the patient: while they were being assigned to varions cars arcording to their rondition. The commanding olficer tried to arrange all serons ases in the alr adjoining the pharmaty ear, for that was most convenient for emerefency treatment.

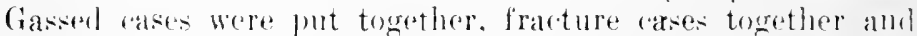
so on. The oflicers directed, the arpesmen carried in the: stretchers and holperd the wommled te their cots. and twe murses assisted in makine them amfortable, whilo the other

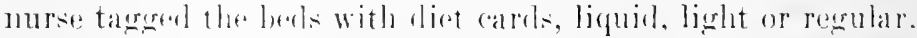

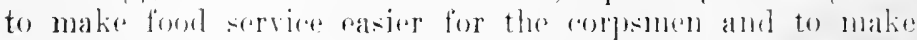

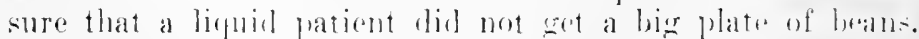

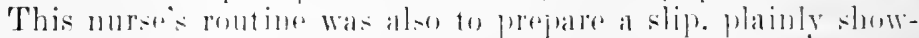
ing the exald loration of serionsty womeded patients or those

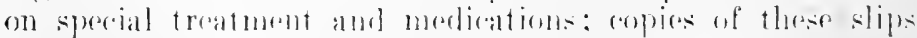

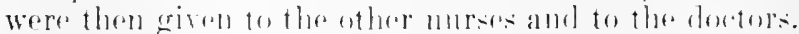

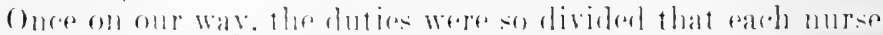

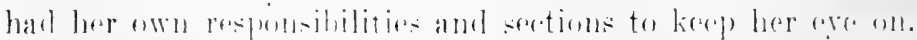

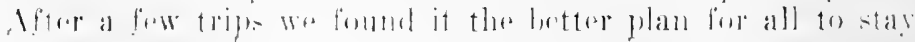


on duty during the entire trip il there were many serious or uncomfortable patients on loard; on the trip back to the front, our time was our own and we would then rest, do our laundry, or write and reat.

There is much to contrast in the careful movement of these wounded and the mutilated Serbian, Italian and Austrian wounded who were bronght down to Vienna and Budapest in jolting ox-earts during the carly days of the war.

Dnring the drives which eentered in the Chatean-Thierry sectors, work on all hospital trains of the American Expeditionary Forees was heavy. Miss Burrey wrote:

During the drive at Château-Thierry a great number of the hospital trains were molilized at Pantin, a suburb of Paris, for dnty into ('hâteall-'lhierry. From Paris to Châtean-'Thierry was about three hours' ride and 'Train So. $_{0}$ 57 was ordered to make the trip. The train was sent to evacuate patients from 1 lospital No. 7 , a molsile unit. 'These patients had received First $A \mathrm{id}$; major operations were cared for. Some hat hardly reacted from their anæsthetic ant most of them were in a pitiable state. . .

In the station and surrombling it were litters covered with boys; mul-spattered and torn were the miforms they wore. They were patiently waiting to be taken, they did not are where, but some plawe where they conld be given proper are. Aiter we received our train loail, about toi) patients, one of the things that hothered both patients and nurses most were the countles numbers of flies that infested our train. The olors from the woumb that had no wre cammot be described but slatl live in the menory of the nurses and orderlies. We made thee trijes to (hat tean-Thierry. The third one was to a small town outsile of château-Thierry. It was after dark when we got there and we inmediately started to load wur train with pationts that hat been gased. At the height of our work. we hat an alarm of the enemy alrplanes which meant all lights out and we had to work in the dark genting as many patients moler shelter as possible. We bated onde train without kerepinge roment of the patients that would walk. After the train pulled out and we got to a plater of safoty. the lights were tumed on and we foumd we had patients arerywhere, in the herths. on the seats and redowed in the alise.

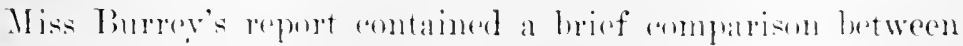
the Anerican. British and Fenell hespital trains: 
We also had opportunity to see the hospital trains belonging to the English Government. They were very much like our own as ours also were mate in England. The English trains had nurses, whom they addressed as Sisters. . . .

The French hospital train was an ordinary box-ear fitted up with litters for patients. To pass from one car to another you had to wait until the train stopped to get out and on to the other car. There were no nurses on the French trains. The French soldiers cared for their wounded while on these trains.

Both the French peasants and the soldiers of the Allied Armies evinced great euriosity regarding the hospital trains. Mrs. Hill wrote:

The arrival of an American hospital train ereated as mueh interest anong the French people and the U. S. men encamped nearby as would a circus parade in a small American village. Our train was usually held on a siding with a platform on one side of it, and as we slept later than did the French we were greatly disturbed and embarrassed the first few mornings by heing awakened between five and six oclock by voices exclaiming over the grandeur of the train and by heads coming even inside our compartment windows. i guard was then ordered to promenale the platform until the nurses had awakened, removed curl papers and drawn the shades.

Hospital train service formed one of the most adventurous and interesting branches of war nursing. Miss Burrey wrote:

T'o get to a cortain base hospital. which was in a mommtainous district. the train had to be divided: the angine (onld not pull the entire train up the momntain. We got no instructions as to the splitting of the train, so it was just huck that all the murses were not in one part of the train. I found myself on one hall of the train, caraged in a railroad rard with about two hunded patients; the other half with two murses was starting up the hill. While they were gone, an encrine was attaleded hy mistake to our train and soon we were rapidly moving away. Wo traveled about eight hours before we firally found thre rest of our train. He wore surely laplys to seo thim anain, for they happened to have the supply and the kitchen ("alr.

Mrs. Hill wrote: 
The middle of August found us traveling through the lovely country of loijon and ('hammont. At Chaumont, we got unexpected orders to gal'age at Vaucouleurs, south of Toul, and a wait further orders. We had passed through Bazoilles, where Base Hospitals Nos. 18 and 116 were stationed. They were picturesquely spread out on the hillsides in barracks and tents on either side of the tracks, most conveniently arranged for the reception of the wounded.

We arrived at night at Vaucouleurs to the humming of aeroplanes and learned that the village had been bombed the night before. wounding many of the peasants. Occasional signal lights went up into the black sky from the German air-dromes over the hill in the distance and oreasional barraging made us thrill with the nearness to the activities of war. Our train, however, stayed in this little village for nearly three wecks before receiving orders. . . .

Soon came orders to go to the Argonne and from then on we were very busy making trips from the first evacuation hospitals to the bases. On these trips we saw a great deal of the paraphernalia of war, hig gums, tanks, thousands of soldiers going to the front in camouflaged cars. These cars were chalked in every available space with all sorts of jokes.

Some niglits, when we were side-tracked near the front or when we were taking on wounded, were full of the sights and sounds of war. The constant roar of the guns and the intermittent whir of the Boche planes as distinguished from the French or Ameriann souting-planes over us filled us with excitable expertaney. When we had time during the daystops at the front line or eranation hospitals, we were sometimes allowed to insperet the hospitals. They were all splendidly equipped and systomatized, hut to step out from a barrack of men, whe thomen hadly wombled were so grateful for the eare they were receiving and who wre trying so hard to he eheerful, to the nearby hillsile of hastily made crosess was tragie. Even now when the sulpject of war is hrought up. ] do not pireture the horrors or suffering or hear the some of the gruns, hut sere those hay patches of (rosses where Amerians were buried and those seattered graves on the open hillsides marked ly a solitary cross showing where a French soldier had fallen.

Hospital trains were often side-tracked to make way for combat troops and supplies. Mrs. Hill wrote:

During our first fow trips. we were very impatient berause it took there or four times lonerel to get our wounded 
to their destination than through service would take in ordinary times. Some were so badly wounded and were made so extremely uncomfortable by the jogging of the train that we wondered how they lived or endured it, but they did, and with the greatest patience. He soon discorered that this slow service was a part of war, that the trains coming away from the front had to be side-tracked to permit the rushing in of troops and ammunition and supply trains. At no time were there sufficient tracks to take care of the greatly enlarged train service.

Miss Stimson stated tersely the difficulties which the nurses experieneed in this precarious branch of the service:

The most obvious were the constant motion, the restricted space which made it necessary for the nurses to walk long distances to get needed articles, the great irregularity of the hours and the uncertainty of the time of arrival and departure from the station. 'These trains could not be operated on any fixed schedule or over any regular route. In times of heary fighting, even hospital trains with wounded must give precedence to men and supplies on their way to the front. It was, therefore, necessary to send the trains by roundabont ways or to hold them on sidings until arrival at their destination was greatly delayed. Extra meals had to be provided and dressings changed. Though the average duration of a trip was about forty hours. it was often necessary to serve Army rations to as many as six hundred patients for from two to four days.

\section{Miss Burrey wrote:}

When the train was empty and we were moring, the scenery and the wonderful views of France thrilled us. but when the train stopped, we were garaged in some railroal yard and we might stay there an hour or mayle two days before our train was ordered to move. You can picture the average trainyard in Imerica: picture it in Fance in war times!

When we nurses would get off the train to stretch our legrs. we were greatly amused at oursolves. We felt like three geese walking along. for we noticed we trailed one another. Did you ever see geese walking one in the lead and the others following: Wo nesel to do that till we realized we were not on the train any ]onger but out in the street. and then we would rhuckle to oursolves. One reason for doing this was that the aisle in the train was so narrow that we had to walk singlefile. 
That only murses of high mental and moral caliber were suecessful in hospital train service is self-evident. Miss Stimson stated the needed qualifications:

Great professional skill and an ability to meet every kind of emergency were, of course, primary requisites. lixwptional physical endurance and a willingness to abandone if need be, the msual ideas of a rontined. ordered life are alin necessary. These requirements are not hard to fill and no diftienlties would be encomntered in having the most desirable type of nurses on the trains if the work was always heary. But since there must be times when work is very liglit and the waits in garage must be long and tiresome. other qualities in trained murses cannot be orerlooked. 'The restricted area of living quarters and the elose association of officers and nurses, the isolation from other groups of workers and from the diversions possible in hospitals also make this luty a severe test of the tart. arlaptahility and character of all in the service. It is greatl; to thejr credit that there have been so few lailures. In those which have occurred, the principal reasons appear to have been due to error's in selecting the inclivilualis for the work and to a lack of larmony and an nuwillingness to coöprorate with others.

On November 11, 1918, sixty-three murses were on hospital train duty.

The hospital train service was operated to transport sick and womeded from the evalenation hospitals in the zome of the advance to the hase nuts in the zone of the hase. Evaenation hospitals were dereloped entirely by the Lnited States Army Medieal Corps, with the axerption of the American Ried Cross enereney hospitals al ready outlined. To eateh division of combat trospes was attarhed two evacuation eolumms. Evacuation Hospital No. 1 was loceated at Selalstopol on the Lorraine Front. At Baceatrat, Xo. 2 ocerupied a hillside above the village of Nancy. Priseilla .J. Hughes, Amy Nurse Corps, described the ever changing paleantry of the fiont:

From le llare we went to Paris and from Paris to Bhois. the mulitimation center for " "alshals." From Bhois I wats sent in a detardument of nurses to livaruation llospital lo. at Bacearat in the Lorraine sector. The hospital was partly

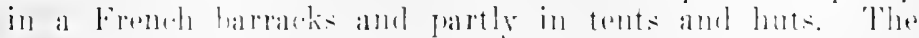

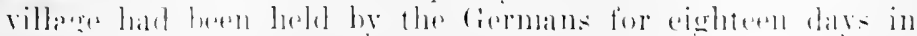
1911 and was mow partially in ruins. 


\section{HISTORY OF AMERICAN RED CROSS NURSING}

We were about six kilometers from the line. The Fortysecond Division had just left and the Serenty-seventh Division was coming in when we first reached there. When the Thirty-seventh Division relieved them later in July, the Boche certainly kept us on the jump. Sometimes when there was a quiet interval, we would steal to the window to watch the planes flying around, their ligints like big stars and the sky ablaze with signals sent up from below and also dropped from the planes. The sky seemed as bright as if the sun was shining and the moon was the biggest and clearest I have ever seen.

All through the night we could hear the men marching to and from the trenches, the rumble of the ammunition and supply wagons and ambulances coming and going, the noise of the motorcycles carrying dispatches. It certainly was wonderful that there were not more collisions. We used to fall asleep listening to the guns and awaken to their voices. The flashes from a barrage lighted up the walls of our dormitory. Onr windows and doors were camonflaged. On dark nights, however, all out-door's seemed like the bottom of a deep well.

Miss Hughes described the general type of service:

As we are in a comparatively quiet sector, the patients were not evacuated as they otherwise would have been in twenty-four hours. We had some excellent surgeons and a well equipped operating-room and X-ray apparatus, so the men were given every chance possible. Juring July, August and september the Boche grew active again. As onr patients were fastened up in slings and all kinds of surgical appliances and therefore quite helpless, the night rails were very lard on them and their distress worried the nurses quite as murh as dirl fritz.

Ahent the first of October the whole "Wild cat" Division (at least so it seemed) ane landing on us. One day we admited four hundred and the next fay about six hundred, all siek, onld. hungry and certainly m moed of mursing. They had mumps, moasles, puemuonia and moningitis. There were only thirty-two nurses all told on the stalli, so ambulaneses were semt to bring hack the twelve that had been sent away on temperary duty. I have had seven and eight boys delirious at the same time, some of them doing "grlard duty" and the oflur poor follows answoring: ofluers were at home talking with "Whether" or "lhatl." "They were neaty all southern bose. When one of them would start singing ohl 
darkie chants, you may imagine the effect it had on the whole ward.

Located near a shell torn wood at Eeury, Evacuation Hospital No. 4 formed a center for surgical teams and wonnded during the German offensive of July, 1918. Holen Pratt, reserve nurse and a member of Base Hospital No. 20, reported a few of the difficulties encountered here:

The night of July $1 . t$ was stifling; with blankets and pillows, the nurses went into the open whent fields. All the next day, the wounded boys came back to us. That night heary rain churned the broken soil into mud and a tornadolike wind blew down many of the smaller tents. At such times the reneer of one's disposition rubs off and you sce the stark outlines of your own and your coworkers' (haracters.

The day shifts and the wounded were tortured by flies. Each morning the orderlies broke off larere boughs from the neighboring woods and tried to beat them from the tents.

A night and a day at Evaenation Hospital No. 6 was described by Daisy Pirie Beyca, a reserve nurse and a member of Base Hospital No. 24:

In an open wheat field, with an ammunition dimmp on one side and the artillery on the other, whike the boys were throwing a pontoon bridge across the Marne in front of us, we began to get things in order for the drive beginning in forty-eight hours. Oh, the flies, the dear horses and the learl Germans! At three A. x. the barrage started. Then the word ame down the line: "The boys go over the top at five!" A flash of light, the roar of the gums and then the very earth rocking under our feet as we lumbled with our helmets and gas masks. Crash after rash followed all day long until five, when the ambulaness began pouring in. 'The tents were overflowing. but still the ambulanes's linesl the roads. l)arkness came, lit erery fow secomls with an explouling shell. Jpirers shouted instruetions: trucks lumbled past to the front and above the incidental noises roared the hary gillis.

Mrs. Berea deseribed the stretchers and their blanketed oe('upants :

Vow and a gain you hear, "Fasy there. Bulds. I entess that leg is about ofl." I roice from moler my foet called up): 


\section{HISTORY OF AMERICAN RED CROSS NURSING}

"Got a match, Sister?" A stretcher passed, the lad on it still under ether. screaming: "At 'em, boys!" And always the ambulances coming in, until we had three thousand before the night was over.

Lights were on in the operating tents, nurses and doctors were working faster and faster. The strain grew intense. Suddenly above the din, a peculiar sound struck the air, the sound of a motor. once heard, never forgotten. Then the ery : "Lights out! The Boche!" Piteh blackness, then the explosions outside. A muffled shout from the surgeon across the table: "Someone bring a candle, I've got an artery here!" and then to me: "Nurse, can you hold the patient under?" "Yes, Major." Then a yell, "Everybody flat on your faces, they're right over us!" "Hell," growled the IIajor, "we haven"t got time!" There was a roar above, then "After 'em, boys-it's the pursuit!' Back came the lights and the work went on.

Maude S. Crawford, a reserve nurse and a member of Base Hospital No. 7 , wrote of her experiences at another evacuation hospital :

We left Paris at 1100 n for a destination whose name will bring a shurder to the nurses who were there in the awful days of July. We reached Chateau-Thierry about five o'cloek and waited an hour at the station until our officers found the evacuation hospital to which we were assigned. Finally we arrived at a camp of yellow tents, pitched on a recent battle field in "No Man's Land" near what was left of a railroad station. Behind the station lay a town in ruins.

Here we hecame acquainted with "bully heef," "goldfish," moldy black lrear and black roffee. Most people are familiar with the discomforts of ordinary camp life, but try and imagine tents pitcher on ground that an army has left, the dear not all buried, shell holes and trenches, mud and rain. Imagine alwar the sound of artillery, air machines and no sounds or signs of normal life. Our initiation into the adranced zone was made in fly time. It really seemed as if we rould stank anything if the flies conld be lessened.

Oh. the meme that shome ahove Châtean-Thierry those August and september nights: The searchlights that swept arross the sticus ontried any Aurora Borealis that ever flamed above the horizun. "Jory" "ame over every night. Before we rould distineruish the hurr of his marhine. we heard: "All lights out!" We sut in darkness until the bombing ceased. Xight in these tents is unlike any other experience. 


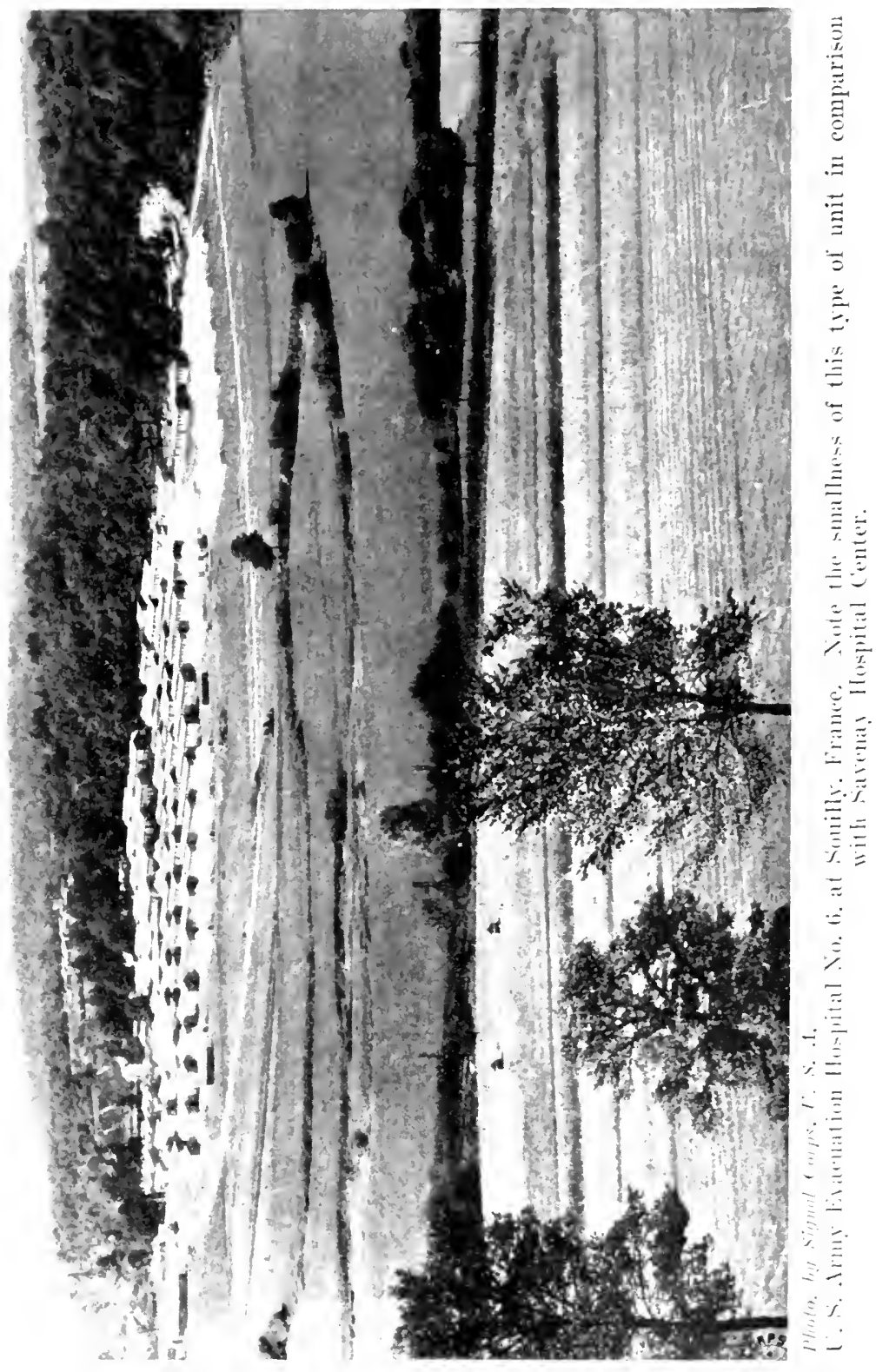




\section{.}


The cots were so low that the blankets drabbled in the mud. Down the center of the tent were loose boarts. They never seemed so narrow as when the stretcher-bearers carried in their lurdens by the light of a smoky lantern. P'oor as the accommodations were. the men were always glad to get under shelter and in bed. The devotion of these doughboys to ear.h other was the only heantiful thing that we saw. If they hal seen their comrades fall, they wept for them; if they were uncertain as to their fate, they worried and fretted.

How cold it was in September! There were no fires in the damp tents, but there were plenty of blankets for the patients and always hot-water bottles. When the railroad track was put into commiscion and the first hospital train came in, "Jerry" kept watch for that train and we were always anxious until it got away. Evaruation nonally took place at night, quietly, with rery little light, the patients lying on the ground on stretchers waiting to be put on hoard. They woudd have cocoa and sandwiches from the Red Cross tent, chocolate and cigarettes. The murses who were able to do so woull leave their posts and come down to say good-by and good lnck. Very often the train would leave about three in the morning. It was always a comfort to see the three "rerl eyes" at the end of the train wink and disappear in the darkness. It seemed strange to us that the boys never wanted to go. 'They were perfertly satisfied to stay where they were, in their first bed, with American women to care for them.

As the troops moved forward, the evacuation hospitals moved forward with them, keeping several miles in their rear. The murses were sent to a nearby base and when their outfit had been set up again, rejoined it. Weird moments of the trips forward during the night have etched their fantastie ontlines upon the memorics of many American nurses who waited throngh the long hours in the rain by a railroad track, watching weary plateons stmmble from beliated trains, while fresh empanies as silently climbed aboard. After combat troops had been moved. the sanitary mits went on up throngh the sodden grarness of dawn to the eracuation hospital with its shambles. Miss Crawford's report continned:

We had something to cat and got into uniform. How murcal that oprerating-room seremed! The tahles were plawed

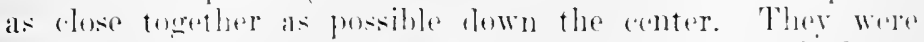
never empty, one patient waiting until the suremen had fin-

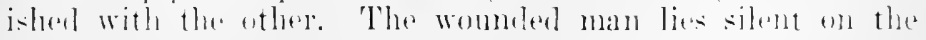


table. The nurses are too busy to do more than give hin a smile or an encouraging pat as they pass by. The anesthetist has a better chance.

I remenber a midnight luneh beyond St. Mihiel. The kitchen was situated in the woods, well out of sight. It had been part of a German eamp. The night was cold; it was raining and the mud was the best of its kind. There were no lights to show us the up-hill way. When we had pulled our feet throngh the stickiness and reached the cabin, it looked as if we had reached the lower regions. The oil lanterns tied to the tent stakes ast grotesque shadows. Dark figures flitter about with cups and plates in their hands. Officers and nurses were laughing away the discomfort and the wretched food.

Anna J. Johnson, an American Red Cross nurse who was loaned to the Army by Paris headquarters, wrote:

On Octoher 6, 1918, I reported to Evacuation Hospital No. 9 at Vaubecourt, near Verdun. The chicf nurse, Ruth Golden, assigned me to a tent full of desperately sick pneu. monia patients. We worked hard for them, but they died sometines as many as four in less than an hour. . . .

Vaubecourt was a frightful place. It rained every day and was very cold. We lived in wooden barracks; fifty of us nurses were in one of the large rooms which had been divided into apartments eight feet square. Two Army cots and a rongh table were in each apartment. There was noise and mud everyhere, but we were glad to get into the barracks after our former quarters in tents. One night our tent hal come down in the rain and the whole place had seemed like tents and cots in a soi of yellow clay mud.

We took care of many patients with very little to do with. We got towels and pajamas from the Red Cross. Dr. Clark, the Red cross representative, establisherl a diet kituhen with Miss Elizabeth 11 itter in charge. She prepared cereals, custards. toast, jollies and many other dishes for our sickest patients. She did splendid work.

Enolugh annot le said in praise of the young women who did the lied Cross anteen work in this frightful place. They worked rarly and late. night and day, many times in the pouring rain in mul up to their knees. When the hospital trains were loalded. they were always there with hot drinks and hankets for the loys. We all worked hard and there was very littlo sleep at night: ereryone talked or conghed. The whole thing wis depresing. . . . 
Pare de Prince, near Paris, was the mobile hospital training eenter of the United States Army Medical Corps. Here each unit was stationed for several weeks before their assignment to the ficld. Sophic M. Burns, Army Nurse Corps, of Mobile Hospital No. 9, described this period of training:

Here we had opportunity to familiarize ourselves with the features of an efficient tent hospital. The corridors comnecting the ten wards, the (omplete operating-room, the hot and cold ruming water, the camion sterilizer and the well equipped laundry all provoked appreciative admiration. The beautiful level grounds of the park afforded admirable space in which three molile hospitals might practice setting up tent hospitals at one time. The officers found need for all the knowledge of architecture they possessed, for there are many different ways of putting up a hospital. Each way is the best way in some particular energency. In the meantime we nurses were completing our preparation, making operatingroom supplies enongh to last at least three days and going through gas mask drill.

Mobile Hospital No. 9 was sent forward into Belgium to serve American divisions participating with the British in the last stages of the Ypres-Lys offensive. Miss Burns described the trip up the line:

Our train consisted of thirty-one cars, coaches for nurses and officers and hox cars for the enlisted men. We were on our way to the front at last and every one of us was thrilled at the prospect. The British, thromgh whose sector we passerl, rather dampened onr enthusiasm: they were so thoroughly aremstomed to this war husiness and so heartily sick of it. We molerstool their attitude better bater on.

After passing through Etaples and Calais, we reached Dunkirk, where we received new orders to proceed to staden. On the way up we met some American resiments who shouterl at us chereful, comrately questions: "roing to the fount:" "Weve just finishert the Argone!" "Anvboly from (Ohio:" "What town?" "My hrother lives there." The next morning

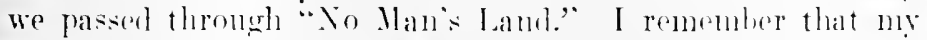
first imperesion was not of shell holes or devastatent liands. but of Amerianu soldieps sitting before deftry propleed trench mirrors, shaviug with eroat enjorment. diany of the boys

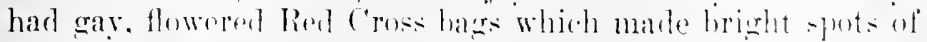
wolor on the eneneral drab-hued seene. 
Miss Burns' report contained a graphic description of the swiftness with which these mobile units could be set up:

The pulled in close to a site where the French labor battalion was busily constructing a French eracuation hospital. Before nightfall eight Bescomneau tents were up in the shellriddled fields and accommodations for two hundred patients were in readiness. We had ample time to prepare for the drive. Two Bessonneau tents together formed the admission tent and pre-operative wards. In the admission tent a nurse, acting as dietitian, serred hot coffee to all the incoming patients and prepared special diets. Patients were first carried here on stretchers and their dressings cut down; then they went to the $\mathrm{X}$-ray room and thence to the pre-operative ward of fifty heds where they were bathed and at last to the operating-table. After the operations, the patients were again lifted. still on the same stretchers, and carried to beds in any one of the six wards, which were connected by corridors. i short time later. the operating teams arrived and in three days we were in working order. When the drive came, we evacuated a daily average of a hundred patients.

The speed with which a mobile hospital conld strike camp and move back is described by Violetta C. Mercer, reserve nurse of Base Hospital No. 2, in an accomst of the eracuation on the evening of July 25, 1918, of Mobile Cnit No. 1, American Expeditionary Forces:

The barrage scemed about as nsual until 11:30 P. M. We were watching the fire-works when at midnight the alarm of a gas attack sounderl. All uurses were immediately ordered to the dug-onts. While ory smen began to clear the wards of patients. Ilown I went arompanied by the other night mures. With a sigh of relief IFajor Barclay and Colonel Brewer. standing at the dowrway, saw us safely" in. 'They harl been counting nures noss and ours were the last.

Let me aly a word ahont this place of safety. It was a huge atfair. lined with strel, like a ereat tumnel. supposed to hold a thromand people. We had stayed here about two hours when amblandre after ambulane of wombled began to arrive. They decident to begin operating at once. Those who were ordered unstairs. Were glad to gro. To wear a tin hat and a respirator Anrine an opwation. howerer. is not the pleasintert thiug in the worlul.

The attack lexran arain about six ocelork that morning and we all wont to the dugout acrain. There the Hun pelterl 
us for two hours. I shall never forget that scene underground. Stretcher after stretcher was brought in, the poor men in hideous romdition. We did our best, which was very little, but two died down there in the close darkness. About eight o'clock an order came for general evacuation. We weren $t$ allowed to go back to our quarters. The corpsmen threw everything we owned in sheets and tied them up and so they traveled. Absolutely nothing was lost. We had breakfast ant were parked into lorries, following the evacuation of the patients. We feel now we know the meaning of "an orderly retreat." After us ame the rest of the personnel as fast as they conld be loaded in the motors.

In the meantime, the equipment of the mobile unit had gone on ahead. Within twenty-four hours they were again ready for their nurses. Miss Nercer continued:

It seemed like heaven to arrive in this nice, clean, open field and see our own tents gromped together in one adorable little hospital and our officers and men so glad to see us and welcome us home. We certainly camped out,-the officers' mess by day was their sleeping quarters by night and we all mess together. That very afternoon we received patients and did so all night until our place was full, but everything went like a breeze, the patients got immediate operation and good care, rest and food, even while the hospital was being put together :

They were, however, an easy target for bombing planes. Miss Mercer's letter gave a grimly amusing incident:

I forgot to tell you that in the area we were in there was much aeroplane activity. The night before our convoy started, the colonel of the division was on his way to see our commanding officer. After three hours he finally arrived with the astombling story that he hat been chased liy a Hun plane and had harl to hide in a ditch, making three different attempts to get away. lut each time being pieked up again by this II un highwayman. who immediately turned his machine erun on the and. At the end of three hours. the llun grew weary and colonel F. crawled ont and hurried to us.

Within five days they moved again. Miss Mereer wrote:

Wo hat to evacuate erery patient. pull up saless and he ready to move in twolve hollts, but there wats some delaly in 


\section{HISTORY OF AMERICAN RED CROSS NURSING}

the arrival of our convoy so we did not get off until five o'elock in the afternoon. We started the whole circus parade again. We stopped on the road at seven and had cheese and crackers, which was dinner. It was a heavenly night, full moon and not a light to be used. We drove until one $A$. M., when orders came to stop, so we slept for two hours on the side of the road wrapperl in beaucoup blankets. Sharp at three the whistle blew and we were soon on our way; we continued without further interruption until we arrived at a French châtean with a nice park in which many troops were sheltered. It looked like heaven to us after the awful flat, dusty country we had come from. The next morning loright and early, our patients began arriving and are still coming: our stay here has only lasted a few days; the future is a sealed order. It may be months before we move again.

Miss Stimson's report stated that at the signing of the Armistice there were sixty-eight camp hospitals functioning in the Nedical Corps of the Ameriean Expeditionary Forces.

Coveted above all forms of assignment within the Medical Corps was the professional service at the front, made up of "officers, nurses and enlisted men especially selected for their professional attainments and formed into surgical, 'shock' and gas teams, so mobilized as to permit them to be sent fully equipped on short notice to any part of the front where their services were needed." 86

Of these units the most numerous were operating teams organized from base hospitals. Two hundred and forty-four existed on December 31, 1918. The prevailing shortage of medical personnel in the zone of the base prevented, however, the withdrawal of all these units, so that less than two hundred teams actnally saw service at the front. Ninety-five additional operating teams we organized from among "casnals" of the American Expeditionary Forces.

An operating tram usnally consisted of one surgeon, one assistant, one anesthetist, two murses and two orderlies. Of the nature of the sorvior, cigrid II. Jorgensen, reserve nurse, of Base Hospital No. 15, wrote:

On July 11 our trows were making the first big offensive

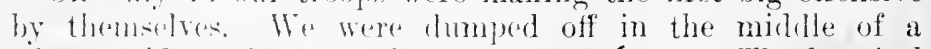
wheat fichl outsile a small trwn called Ecury. The hospital

sepert of the Direntor of Nursing Service, A. E. F., p. 16, Surgeon General's Oflice. 
[Evacuation No. 4] consisted of ten Bessonneau tents, a dozen large khaki tents and numerous smaller ones. This whole hospital was just twenty-four hours old when we arriverl and from the time the drive began the day before they had admitted over a thousand wounded. A dozen tired but cheerful nurses greeted us.

Our operating-room was the usual Bessonneau tent connected with a smaller tent which served as sterilizing and supply room. Four tables were arranged down eacli side. The night teams relieved the lay teams. There was no stopping for explanations. The faces of the wounderl all around us on the gromml, on the tables, everywhere we looked, seemed to say: "When will my turn come?"

About eleven o' $\cdot$ lock that night the shelling of Châlons, about four kilometers away, began. Now and then the machine gruns would be peppering about us trying to get the Boche planes. The next night the Boche came about tenthirty and after (ircling about the amp a few times, dropped a large bomb about twenty feet from the nurses' tent and played about with his macline gun. Many of the boys whose nerves were pretty well shattered, wanted to get away. We newcomers did not know enough to be scared.

The work of the teams was the usual round of heavy surgery. Miss Jorgensen continued:

Sometimes we were fortunate enough to have two tahles: for one team. which meant that we were able to prepare and anesthetize one patient ahead and in that way we could wat on without stoplinge. By addling one extra surgeon and one anesthetist during rush blays, a team like this could handle from sixty to pighty minor cases or thirty mixed cases on on cighteen-hour shilt.

Sixteen or twenty hours in the operating-rom is hard work. If we went ofl duty, thomegh, it meant that for every

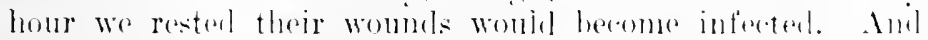
such brarery as those hoys displayed! I remember one young

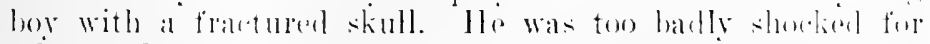
other and so the nperation was perturmed moler local anatsthesiat. For hugre siull wommls. drills and all sorts of uther

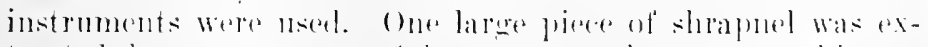
tracted hy a sery pewerful magnet and nerer a whimper from the hoy: When we pratised his mhere he told 11 - that anyone whe could stand the life in the trentehes an it hat beren for the past week roukl stand anything. 


\section{HISTORY OF AMERICAN RED CROSS NURSING}

Another youngster about eighteen years old had gone to sleep on the table, waiting for his turn to come. Suddenly his roice rang through the operating-room: "Why, hello, it is an age since I've seen a woman like you!" The surgeon wanted to know if he was a friend of mine. Poor little chap, he was brare enough for anyone to be proud to claim him. I went up to examine his wound and found one hand completely blown to pieces and asked him what he would do if it had to be amputated. "Do?" he joked. "Do without it, I guess." I told him not to look at it lest it make him sick. He raised himself up, eyed it and said, "Why, there ain t none!" I asked him how he could be so cheerful. "Why, nurse," he said, "it might have been the right one. 'This time it was only the left!" And his childish langhter rang through the tent.

Ruth Cushman, reserve nurse, of Base Hospital No. 18, described the bombing of Châlons:

Up until the night of July 14 everything was quiet sare for the barrage which rocked our barracks. We were awakened at midnight by a shell exploding in our midst and the immediate order of "gas alerte."

As the patients were pouring in, the night force went on duty in the operating-room and wards. The rest of us remained in abris and dugouts. By six o'clock that morning, part of the hospital had been demolished, two patients lilled and some of our personnel injured. Orders to evacuate came at eight o'clock from Headquarters.

We rode for several hours (and the memory of the real refugees journeying along the roadside still remains). Some of the nurses slept on the floor of the trucks. We soon found ourselves attar.hed to an evacuation tent hospital in a large open field. Our own team, however, was ordered back to Châlons to operate that night on the more serious ases which had been left behind.

from our hospitals we watched the brilliant display made by the signals and shrapnel from the anti-aircralt guins. In the bright monlight, we could see the Boche planes flying low, then the terrific explosions of the bursting shramel. Personnel and patients alike sought the what finds and to my dying day l believe a field of grain will hold a certain fascination for me.

Our hospital train of over a thousand trucks moved ly: night, so our way along the main roals was lighted by huriing ammunition dumps sat off by enemy bonns. Wie led a 
gypsy life constantly in evaeuated territory of the once beautiful Marne Valley about Chateau-Thierry. 'The devastated country lying stark in the brilliant moonlight grew to have a natural aspect, town after town in ruins, fields plowed with shell holes, roadsides lined with ammunition and graves. ${ }^{87}$

\section{From Écury the teams moved forward. Miss Jorgensen continued:}

Soon Soissons had been taken and the Germans were driven back about thirty-five miles. On August 6 we were on our way, only this time it was quite different seenery to which we were introdnced. Everywhere along the road we saw ruins, torn trees, dead horses, shelled roads, trenches and wire entanglements in every direction; but through all this misery we did not see one sad face; we were all going forward.

Our entrance to Chateau-Thierry was five days after the Germans had left. The eity must have been very beautiful before the attack. Such wonderful architecture and such scenery orer the hills and the Marne! Now almost every house was shelled to pieces; furniture littered the torn streets. No civilian inhabitants remained. One beautiful home with damask curtains and tapestries attracted our attention. We peeked in and there were our boys peacefully asleep on the most comfortable divan.

Olive I. Thompson, also reserve nurse of Base Hospital No. 15, deseribed the historic advance:

Our team with a number of others was moved after five days to Viller-sur-Marne, where we were stationed with Field Inospital Yo. 148 in Mme. Huarde's château. The thoracic team on night duty at this hospital was called during the day only for cmerency ases. As all of the boys had lain ont on the gromel for twenty-four hours hefore they were picked up, they were in very bad shape when they were brought in. Delay in reaching the base was due to the fact that the oneway road was congested by the traflie of the adrance.

Inuring the lull in the oflensive. we went with the surgeon in charere of our team to Paris to oltain supplies and instruments from the Reel cross. Returning, we overtook our hospital on . Iuly :31 at château de la Forret. The operatinerroom here wis in an old hunting lodge. 11 aromml the room were stutfol animals. Which we were not allowel to toudh as

si Regort writton by Ruth ('ushman for the Johns Hopkins Alumne

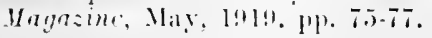




\section{HISTORY OF AMERICAN RED CROSS NURSING}

it was feared that they had been wired by the retreating Germans. The flies were horrible and a foul stench arose from dead men and horses which still littered the ground.

Anne E. Schncider, reserve nurse of Base Hospital No. 6, wrote of Field Hospital No. 27 :

Monday, July 29 , found us again on the move, this time in the direction of Château-Thierry, where we made our home in a deserted châtean with spacious grounds. Team $7 \%$ to which I belonged was placed on night duty, for which I will always be grateful. Our stay was destined to be a lively one. Early in the game $I$ diseovered that it was much easier to be busily engaged with one's mind on one's patients than to lie quietly in bed trying to figure out just where the next bomb was going to land.

Here during our leisure hours we explored the surrounding country, visiting the dugouts so recently occupied by the enemy, made comfortable by the looting of the homes of Chatteau-Thierry; crossing the river on the pontoon bridges thrown across by our brave engineers in that bitter struggle across the Marne; climbing Hill No. 204 with its countless shell-holes: stopping by the way to examine a broken plane resting by the grave of its fallen hero; viewing from its height the beautiful valley of the Marne, at its base the utter destrurction and ruin of a once-thriving city ; through Bellean Wood where hardly a tree remains unscarred; through many a valley where no stone remained unturned; and back through the poppy fields of France in all the glory of their brilliant hues.

We watched the return of the refugees in groups and in single file by erery train or wagon. Into Château-Thierry they rame. some on foot with the old family row and the faithful shepherd dog close on the heels of the baby arriage, heaper with all their pitiful worldly possessions. While the somnd of the gurss was still to be heard. these people returned to recistablish their homes and to rebuild the eity and with their coming we acain joined the mighty caravan of the road.

Of the simultaneous arrival of varions types of forward sanitary formations of the Ancrican Expeditionary Forees at a given point of evacuation, Katheryn A. Levorman, reserve nurse of Base Iosputal No. 4ti, wrote:

From Field IInspital No. 27 we were taken to Red Cross Hospital No. 111 then at Châtean-Thierry to remain over 


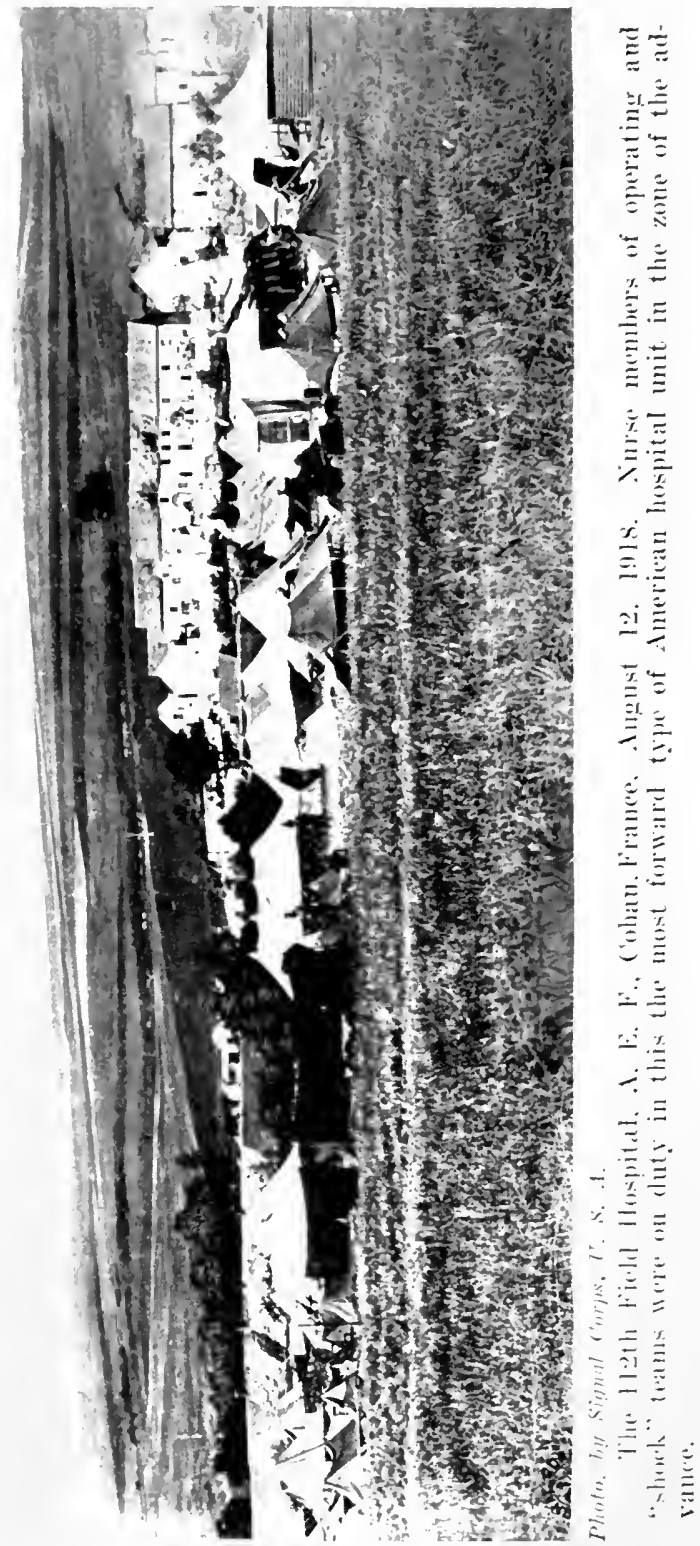



night, expecting to return to our base. After scrubbing all morning in our new quarters, we received our orders. While waiting for the ambulance to take us to the station there came a call for more nurses up the line. We were hastily shoved into ambulances and there followed a wild ride to Crezancy, where Evaeuation Hospital No. 3 was stationed.

Arriving at Toul one night, we were taken by anbulance to Eracuation Hospital No. 1 which was permanently located at Sebastopol, a good distance from Toul. Aiter resting here for a day we moved on again, this time oexupying a large French military barracks barely outside of the city. A number of tents were also set up and one of the large Bessonneau type was fully equiphed for operating, containing eight titbles for that purpose. with two extending the entire length on one side to be used for sterile supplics. Other hospitals were arriving daily and all were stationed around this neighborhood and were designated the "Justice Group." I cannot now rerall all the diflerent numbers, but one was for gassed ases only, another for medical, one for the slightly injured and we were to take only the seriously wounded. It was here that Captain Cutler, our surgical direstor, organized the work so that this partieular hospital handled an enormous number of ases during the St. Mihiel Drive.

Those of us who worked in the tent still shiver when we think of those cold September nights, when we were sterile nurses for several operating teams, our hands in wet gloves constantly, standing within a small spare. handing out sterile supplies and setting up instrument tables. Although this organization was wonderfully equipped, there was no oversupply of aproms. or other articles, so we had to be especially eareful. Eateh operating team had a "floating nurse." who was kept so busy that she did not feel the cold quite so much. There were just two of us to handle the sterile supplies for those eight talles and we did not dare to move outside of our own little sphere. About four A.Ml. we felt more like wooden idols than human beings and oln! how ummercifully cold it roullel grot!

After the st. Miliel I) rive we went on to Fleury. where we worked with hed C'ross . No. 114 for one week and were then ordered to the ('hampagne leront. When we arrived at ('uperly in the ('hampagne secter carly that Octuber morning. the gromul was white with frost. (O) hespital tents were pitebed alcoss the railroal track from the Ilt. Frenet Fronch hospital harracks. . . It was in this sector that we had to wear rubher boots so much and we rall a terrille risk of losing them ompletely. I really dont know of anything that has 


\section{HIS'TORY OF AMERICAN RED CROSS NURSING}

the stick-to-itiveness that French mud has. The most popular costume those days were raincoats over either a jersey or gray crêpe uniform, rubber boots and sou'wester hat. Our boys told us we looked like the advertisement of codliver oil. No wonder the mademoiselles asked our soldiers: "Are all American women so homely?"

\section{Of their last stand at Fromerville, Sigrid Jorgensen wrote:}

It was hardship, sacrifice and toil from the day we came there. Something seemed to tell us that this our last fight was to be the end. The tents were pitched on the top of a hill overlooking the ruins of the villages. The mud, alive with the filth of war, grew thicker in the cold rain. Insteal of uniforms with such trimmings as white collars and caps, we nurses then wore high rubber boots, trench coats and rain hats and sweaters in several layers.

Verdun, pounded by German guns, was about four kilometers from us, but we never dreamt for a minute that they were after our little camp. On November 3 they got our range and threw orer thirteen shells. Healquarters was shelled down completely; some shells struck the tents and the shrapnel flew in every direction. Everyone rushed to the help of the wounded. Some carried stretchers, others went about with bandages and dressings and still others did their best to cover the boys up.

Thirty "splint teams" were organized by the Medical Department for service in the zone of the advance. The serrico which the personnel of this type of unit saw, closely resembled that experienced by the personnel of operating-teams. These "splint teams" are of especial interest to members of the American Red Cross, because at the request of the Army and withont any expense to the Military Establishment, the American Red Cross supplied more than 294,000 splints to soldiers of the American Expeditionary Forees.

"Shere" work at the front represented the most forward branch of American military nursing service during the European War. Serenty-eight "shock teams" were organized. From a professional point of riew, their work demonstrated unequivocally the value of expert mursing technique in the immediate zone of the advance. Elizabeth (iomules Sitrode. resere murse, of Base Hospital No. 20, described the nature of their work : 
"Shock" is produced by loss of blood, destruction of tissue, exposure and privations of every kind. latients had often lain mudiscovered in the cold and wet for days in shell holes or some other exposed spot, under constant fire, where it was impossible to conduct rescue work. Life was sustained only by water from mud holes. Many others, desperately wounded. after recoiving first Aid, were moved rapidly back of the lines for further treatment. Owing to the great necessity for haste, the ambulances covered the distance in the shortest time possible so that the jolting over romgh roads had further adderl to the suffering and devitalization of the men.

If the pationt's condition warranted it on arrival at the hospital. we removed soiled clothing, bathed him and supplierl cloan clothes before taking him to the wards or operatingroom. We were on constant gnard to keep the wards as free from "eooties" as possible. Those suffering from extreme shock were admitted to the "shock wards" with none of the horrors of war removed. In most cases we eould only wast the hands and faces of these men for many days before their condition enabled us to remove fully the blood, mud and filth of the trenches caked on them.

The treatment consister first of giving heat. Clothing was cut away, the patient put immediately on a warm stretrher [mounted sometimes on trestles] and surrounder] by hot-water bottles or anteens. If very cold, he was given a walm air bath by placingr over him a large wire cradle covered with hlankets. following the method formerly used in civil hospitals for giving vapor baths, but giving diry insteal of moist heat. Warm air was supplied by means of a pipe ruming under the cralle from a small kerosene stove at the foot of the cot. The blood pressure was then taken to determine the degree of shock. The "T.P.R." usually showel suhnormal temperature, feeble rapid pulse and inareased respiration.

In addition to extreme shock, many patients were dying from ars barilli infertion. The suffering ansed by this infection was so acolte and the effects on dearlly that our most vigorons reflorts to save life were of little avail. Indiotions for active treatmont were first, hemorrhage: second. Hood presure below ninety; third, blood pressure that falls rontinumsty.

Following rest and the application of heat came active treatment. P'anline I. Siturk, reserve nurse, of Base Hospital No. 1o, continued a deseription of the work: 
If the man was conscious and not an abdominal case, he was given hot coffee on admission with a teaspoonful of bicarbonate of solla to counteract acidosis. The soda was repeated in all their hot drinks which were given every two hours. A quarter of a grain of morphine was given if the patient was suffering or restless and large doses of atropin if he had lost much fluid through perspiration, a loss of which was frequently as proportionately great as the excessive thirst. The stimulants used were strychnia and caffein sodium benzoate.

In cases where it was imperative to get fluids into the system at once, sterile salt solution with six per cent gum acacia was given intravenously. The theory advanced was that the salt solution with gum acacia was less liable to be lost by osmosis than plain salt solution. But after all, blood transfusion, when the blood could be obtained, proved to be the most satisfactory. The blood was usually taken from the gassed patients, who were really better for it. When the situation was explained to them, the boys were very good about offering themselves as donors and were always greatly interested in the recipient and whether the blood had helpeil him. It was remarkable how quickly the patient would pick up, as a rule, after such a transfusion. Of course, many times it was only temporary, but frequently he would improve enough to warrant operation. ${ }^{88}$

\section{Of further treatment, Miss Strode wrote:}

Special diets of milk, eggs, etc., were issued for patients whose condition permitted it. The Red Cross gave daily con tributions of cocoa. chocolate. small cakes, anned milk and. at times, fruit. Everything possible was done to alleviate the terrible suffering but only those working under existing conditions realized low stupendous was the task of smplying comforts so close to the lines. As many patients were in a dyiug condition when admitted, the mortality was exceedingly high. The daily seenes in the shock wayl truly illustrate the lorrible cruelty of war, with its ghaslly waste of life. its inexpressible acrony.

Gertrude Buwling, reserve murse, who with Miss Stock hat been sent forward from Base Hospital No. 18, wrote of experiences in Château-Thierry :

as Report written by lauline. Stock, Johns Hopkins Alumner Hagazine, May, 1919, Pp. 70-71. 
For a comple of hours we jogged along a road pitter on either side with shell holes, the tell-tale wrappings of a First Aid packet, or a bit of clothing beside them. 'Throngh the shell wrecked, half demolished villages of Vaux and Esson, nakerl, forbidding skeletons in the summer lusk, we were held 11 p by ammunition trains going up or empty camion convoys returning irom the front.

Less than a week after its evacuation by the Huns, we entered Châtea-'Thierry. The dead were still mburied on the battleliekds. Ruins of the great bridges blown up by the Boche were still in evidence, as was the pontoon bridge thrown over the Narne by the victorious lirench and Ameri(an troops. IIotel Dien, where we joined the 11:th Fiekl Hospital of the esth I)ivision, was filled with shell holes and without a pane of grass.

Wanton destruction, indescribable devastation and filth were everywhere manifest. Houses, churches, public buildings in ruins, here and there whole sides stripped off of homes showing intimate details of family life rudely interrupted, a piano with music still open upon it, a victrola with record: scattered about, a table partially set, a baby carriage or cralle just as the inhabitants had left it,-one could not but wonder what hand become of them. At our own hospital, furniture, tapestry, bedding. china, broken and trampled, were strewn on the floors and in the court yards. Piles of everything from candlesticks and fine linens to hospital supplies were maksed in heaps in the cellars and about the grounds. From these we gathered equipment for our new warl. Through our paneless windows and the ranged shell holes in our wall, the flare from the big gums and their boom kept us awake. ${ }^{89}$

The following day, shock work began again. In Miss Bowling's account, as in the motes of other nurses at the front, appeared a total disregard of the passing of time. Days and nights became only a blur of exhansted yot mosurrendering 'ndurance.

You fores many things: you had heen taught. Youl only remembered to roll up gour sleeses and die in. It wis work,

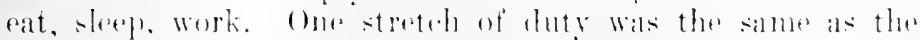
next. lou formet the lays of the werk: you thought only of how many gon andu keepi from dying.

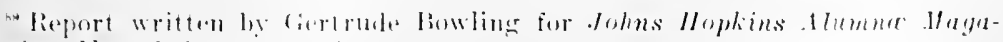

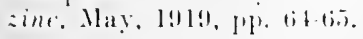




\section{HISTORY OF AMERICAN RED CROSS NLRSING}

Never will I forget some of the faces, wonderful, physical types of American manhood, and the spirit, sometimes in mere slips of boys, well,-superhuman! 'They were a gante lot. Dust-raked, bloody, often wet, they eame to us sometimes too fast to handle. One little second lientenant, badly smashed, grimed from ear to ear: "Boys," he said, "I got my seven Boches hefore they got me!"

Another dark-luaired, broad-shouldered chap of twenty, with both legs amputated almost to the hip, his face and body peppered by bits of shrapnel, lay helpless in our ward. "Tell," he told us, "I was studying to be a dentist, but now that is impossible. At one time I learned to make artificial teeth. When I go back I think I can be able to make a living with that as my trade."

The dumb, long-suffering look in the eyes of a lad who came to us after lying for three days in "No Man's land" before being found, still haunts me. His back bore huge shrapnel wounds alive with maggots. Words cannot do justice to the gruesomeness of those erawling things in human flesh.

After two weeks at Château-Thierry, the American ficld hospital moved up to Cohan, five miles across country from Fismes. Miss Bowling wrote of her anxiety lest in the darkness she could not get her unconscious patients into their gasmasks in time. She described the nightly bombing:

At such times a piece of roof is a certain satisfaction. Even the hest eanvas seems thin. No sooner did the moon show her face than the buzz-buzz, with its peculiar singing whine, was overheal. Many bombs exploded near us. 'Two that proverl to be "duds" fell just back of our tents. Harl they exploded quite a few of us, to use the parlance of the boys. would have been saying "Good morning, St. P'eter." Later we learned that a woman spy had signaled the planes with a flashlight from the top of the hillside on which our tents were placed. She was a midlle-aged French womar and pretended to speak no linghish. unt her condemination was pronomincel.

Of the shelling, Miss Bowling wrote:

Suddenly one momine we heard over our heads a new

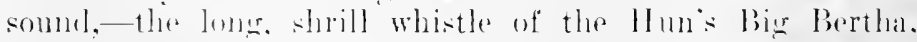
followed in a few seronds ly the rash of explosion at the

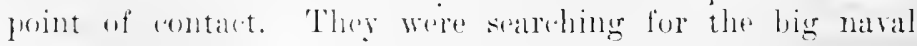


guns just back of us. All my life I have read of the whistle and whine of shells. The vacum left over our heads as the shells semed to pass lower and lower, was so vivid to our minds, we felt we could reach up and touch it with our hands.

\section{One of their stations was in an old cow stable. Miss Bowling continued:}

Open to the air only by one small door which we kept blanketed at night to hide the candle by which we worked, we set up our "shock-warl" near the manger, with the dusty cobwebs clinging to the rafters. The stable itself was at the mouth of a wine cellar ruming fifty feet underground, under a hill. Here we carried our patients for shelter in necessity. When not on duty, we slept npstairs over the little $\mathrm{X}$-ray and operating-room. When "Jerry"s" shells began to whistle with the regularity of clock work about ten P.A. and again at four $1 . .11 .$, we repaired in pajamas, raincoats, tin hats and gas masks to the wine cellar until it was over. It was at this place they brought us one night a l'ittsburgh boy an hour after he had been wounded. He was at the key-hoard at a general's chateau when a piece of shrapnel cauglit him, severing an artery. He came to us with a tourniquet made of a blue bandana handkerehief and a wooden spoon.

I might tell you many, many incidents of the brave boys who passed through our hands; of the way some of them died; of the things all of them endured; of the rats, huge as guinea figs:; of the thirst and the mul; of the swarming flies, the fleas, the "rooties" that tormented them; of the periods of intense suspense not harder to bear than the kong days of monotony and great physical exhanstion that of ton followed. But 1 could never really picture things as they were.

Of the Sit. Mihiel Drive, Alice A. Kelly, Army Nurse Corps, of Base Hospital No. 49, wrote:

Our team ensisting of a raptain of the Menlical Corps.

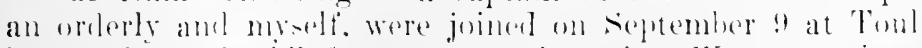
by another "shexk" from a liwereia unit. We were giten

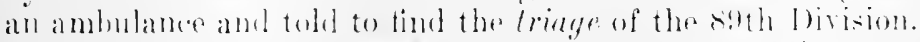

In the arly morning of september 13 we were riding over territery which our forces had left the day before. (Our driver lost his way. At one time we were ricling aheal of the artillery of one of the divisoms on its way to the fan alvameiner line. Wo saw oserghthe from deall horses up, camoutlaged 


\section{HISTORY OF AMERICAN RED CROSS NURSING}

guns beside the road, everything bearing the look of hasty departure. Several times we were obliged to stop and inquire the location of this triage. Whenever the boys saw us, they stared. I heard one man say: "My God, it's a woman!"

We stopped in a rery much ruined little village where parts of one division were having a hasty breakfast before they pushed on. Excitement was everywhere. Of course, the boys cheered and told us that we were the only two girls around that section and it did please them to see "some really and truly American women."

A triage has been defined as the sorting-station immediately behind the First Aid dugout in the field. Of this one, Miss Kelly wrote:

It consisted of about ten canvas tents; one of them was an extremely large one which was used as a receiving ward. The boys were evacuated almost as soon as they came in, remaining only to be redressed. Though there were many eases that needed transfusion, we did not have the supplies to do much work there. To apply heat we improvised a hood to be placed over the stretcher and used lanterns.

As for our living conditions, our one and only trouble was the mice. Often I woke up with them running orer my cot. At first we could not sleep on account of the barrage each night. but finally got accustomed to it. I remember late one evening hearing a steady beat, beat, beat. I got up and peeked out of the tent to see a steady line of soldiers marching to the front in the gorgeous moonlight. As these boys swung on, not a sound was heard except the tread of their feet. I watchel them pass for ten full minutes. . . .

We harl arrived in time for the Argonne Irive, September 26. We were immodiately put in charge of a regular "shockward." the two teams relieving each other on the day and night work. And there the real work began. We got everything. but had more shrapnel wounds than fractures. Throse were hosy times. It was discouraging to brine back some of those frichtful ases only to have them die later with ga: bacillus inferetions.

Of the cost of the Arenno victors, Miss Bowling wrote: "It is no new story, the frightful "arnage of that hard-fought ground. The dead sometines waited thres and four on the wards with

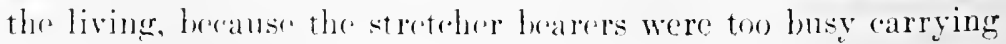
the wombed and the dead eould wait." 
Approximately four thousand officers, nurses and enlisted men comprised the professional team service of the American Expeditionary Forces. Of this number, two thousand, six hundred and sixty-two were nurses. Miss Stimson deseribed how these more fortunate ones were regarded by nurses serving in the zone of the base:

The work in the hospitals at the front, with all its trying conditions, was the prize and goal for which every nurse of the Amerim lixpeditionary lorces longed. No special aredit should be given the nurses who achieved it, even when recognition of their skill, their courage and their uncomplaining willingness to adapt themselves to all the hardships entailed, is made. 'The work was its own rewart. Each nurse knew that she was fortunate indeed to be there and that waiting to take her place. may, only too eager for the chance, were literally hundreds of other nurses.

Attached to the 332nd Regiment from Ohio, brigaded with the Italian Armies, was Lnited States Base Hospital No. 102, of one thousand beds, organized by Dr. Joseph A. Danna within the Medieal School of Loyola University of New Orleans, Lonisiana. Althongh this unit was not ordered into the field until August of 1918, its experiences as the most forward base hospital operating on the Italian Front, comprised a most pirturescune section of war nursing history.

Born in Bisalepuinto, in the provence of Palermo, Italy, Dr. I anna at the age of seven eame with his parents to the United States, and subsequently made his home in New Orleans. When the American lied ('ross suggested the organization of a base hospital from the staff of Loyolal University Medieal School, he was appointed director. ('hrresostom Noynaham, a Daughter of ('hilrity of St. Vineent de Panl, was chiof nurse. Sister Isaldellat, another banghter of Charity, was delegated by Sister Chrresstom to compile the reports describing the activities of Base llospital No. 102 as guoted in this section. She wrote of her chief:

Sister ('hryostom was horn in Ireland and came to this country at an sarly age with her parents who settled in

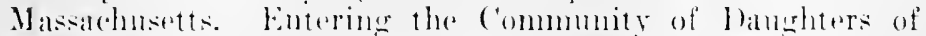
('harity of st. Vincent de Paul at l'mmittebure. Marvland. their Ilother llowse in this comutry. she was sent at the ex- 


\section{HISTORY OF AMERICAN RED CROSS NURSING}

piration of her seminary term, January, 1889, to Carney Hospital, Boston. This Community opened here its first training school for murses in 189.2 with Miss Emily Stoney as superintendent. Sister Chrysostom was one of the graduates of this first elass. the term then being two years. She then transferred to St. Mary's IIospital, Evansville, Indiana, where she remained mutil 189s. At the ontbreak of the SpanishAmerican War. she was called with nine others of this Community to Washington preparatory to being sent to Santiagro to nurse fever patients. The day previons to their departure. President Mekinley requested that no Sister be sent to ('nba who was not immune. As Sister Chrysostom was the only exception. a sister from Providence Hospital, Washington, who had had the fever, was hurriedly called and Sister Chrysostom was sent to Providence Hospital to replace this Sister. Some months later. however, she was detailed to Portsmouth, Tirginia, to help nurse the Spanish who had been injured by the buming of the Marie Theresa and on recovery of these patients, Sister Chrysostom was transferred to Fort Thomas, Kentucky, where sle helped to are for fever patients nutil February, 18.99. From here she returned to Eransville, indiana, and was thence sent to Birmingham. Alabama, where she later built the beautiful St. Tincents Hospital.

From 1899 mntil 1918, Sister Chrrsostom was in charge of this institution, receiving while there, in Jannary, 1918, her appointment as chief nurse of Loyola Base ILospital Lnit No. $10 \%$.

Sister Chrysostom was the first registered nurse in the State of Alibama.

Ten Daughters of Charity from representative hospitals in the South held executive positions under Sister Chrysostom upon the mursing statf of base Hospital Xo. 10.2. These women were the only nums who served with the Ameriean Amy in the European War. They were Nisters be Sales Loftus. Lueia bolan, Agatha Mulekon, (atherine Coleman. Angela l)rendel, II. David Ingram, Mariana Flrom, Valeria lorn and Florence Means. Their order, however, had long hefore blazed the way to the moderu womans part in the alleviation of suffering among the wounderd of armies. Sister Isabella wrote:

The I anghters of Charity of St. Vineent de Paul were the forerumers of the Red cross, operating on the hattefield in the wars of Gustarus . Molpluns. Their Community numbers 
thirty-five thousand subjects. They are found in every country in the world, their works being well known in China, the Philippine lsands, through South America, in the Levant, Constantinople and the Turkish possessions, Jerusalem, Northern Africa, Madagascar and all over Europe.

When they were first sent out in 1654 and 1655 by Vincent de Paul, their Fonnder, to the battlefields of Sedan and Arras, it was a world wonder, for women had never before engaged in this work. 'They were the first religions women of any Community to brave the dangers and hardships of the battlefield.

Florence Nightingale visited the Daughters of Charity in their Mother Ilouse in Paris, for the purpose of learning their methods and she acknowledged that her own work would have failed without their coöperation. Thus from the day when the Turk christened the Daughters of Charity the "White Swallows of Allah" have they continued their errands of mercy, reaching, perhaps, the climax in their recent faithful service to the dead and wounded in Belgium. It is recorded of several Daughters of Charity, following the French Army back from Belgium, that for twelve days they went without changing their garments and upon reaching shelter, such was their soiled and disheveled condition, that they were not recognized as sisters, but had to prove their identity.

Since the begiming of the war five thousand members of the Mother Ilouse of this Community in France have been doing field work.

The remaining ninety nurses who formed the mursing personnel of Base IIospital No. 102 canc larecoly from training schools in all parts of the United Sitates conducted by the Daughters of Charity. Sister Isabella wrote of their mobilization:

Twenty-two nurses were from New Orleans, twelve from Birmingham, six from Montgomery. five from Mobile, five from ('hicatro, ten from lil Palso, ten from los Angeles, eight from san Franciseo and live from sit. Louis, several from Austin, Texas. and several others from various southern cities. Arting upon official orders, for several months previous to mobilization, the nurses were detailed to bifferent cantonments.

The equipment of Base Hospital No. 102, costing $\$ 100.000$, was purchased hy funds contributed cutirely by Mrs. John 


\section{HISTORY OF AMERICAN RED CROSS NURSING}

Dibert, a New Orleans philanthropist. Its assignment to Italy was in part determined by the strong sympathies of Dr. Danna for his mother comutry and by the need for a sanitary unit to serve with the 392 nd Regiment of the American Expeditionary Forces, brigaded in the summer of 1918 with General Diaz' troops.

Early in July, 1918, the nursing staff of Base Hospital No. 102 mobilized in New York. Nurses and Daughters alike received complete equipment for foreign service from the American Red Cross. The nuns, however, were permitted by special ruling to wear the dark blue cloth habit, the white collar and the cornet of their order. The embarkation of the unit was made the oceasion for ceremonials of a deeply religious character. An eloquent flag blessing at St. Stephen's Church, delivered by Chaplain George T. McCarthy, July 23, was the first public Catholic demonstration of this kind given in New York City. A last High Mass was held at three o'clock Sunday morning, August 4, and Major Chaplain Joseph P. Dineen sent the unit forth with an inspirational blessing. The Reverend Godfrey P. Hunt, a Francisean from the monastery in Washington, D. C., accompanied Base Hospital No. 102 into the field as rhaplain. Sister Isabella wrote as follows of their embarkation :

Sunlay. August 4, at 2 A.M. under cover of darkness, the Sisters and nurses marched in file. four abreast, full uniform and hearled by Ioieutenant MeCarthy, to St. Stephen's Church.

The nurses then returnod to the hotel, got suitrases and arossed in the ferry to Jersey ('ity. Here darkened roaches awaited them. The train was composed of first-class rars and before starting, the Lisutenant turned them over to a secret service man. The train pulled out at one P.M... rearhed Baltimore and went straight to the wharf, where the s. S. Cmbris awaited it.

The I mlere an Italian boat built in 1901 and for the past three years used as a freight steamer, had had a through overhauline in proparation for this trip. It was small for the mit and in many reperts rery incomenent. but it had a

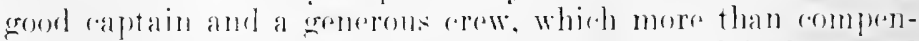
sated for all shortromings. On arrival of (haplain-lioserend Hunt from Washington, I). C., the I mbria started on her royage. 
The first morning out, the S. S. Umbria pirked up a black speck on her left. It proved to be the lifeboat of thr American oil tanker Jennings, containing the survivors of the Jennings which had been torperesed twenty-four hours hefore. The lifeboat was re-provisioned and with its passengers ralried back until it was within sight of Cape IIatteras. This caused a delay of six hours to the I mbria.

Of their approach to Gibraltar, Sister Isabella wrote:

Until August 17, the Umbrin was without convoy, but on that day, a great English man-o'-war came out to escort her through the strait and into the harbor. It had been in search of the limbria all night, but could not locate her until the following morning. 'This convoy was more than welcome, as on the previous aftermon fourteen messages had been received by the officers warning them to be on the lookout for submarines.

While the ship was eoaling at Gibraltar, the nurses were given shore leave. American jackies, many of whom had not seen an American girl for three voars, came alongside and took the nurses ashore. The United States Naval Hospital entertained them for tea. The Imbria lay under the Rock for three days hefore she sailed under convoy August 21 for Genoa. A murse's diary deseribed their conroy as follows:

As you know, the Gulf of Gibraltar and the Mediterranean were a nest of submarines. We sailed Tuesday afternoon and such a sight 1 shall neter forget. twonty-nine beantiful boats leaviug the old Rock! The sea was ralm as a tub and we moved out singing a hymn to our Blessed Wother and also a crood-by to ciliraltar. the latter to the air of "Tipperary."

We had a beatiful Freneh man-o-war in front of 11 , whose duty it was to look out for mines and to serro as our pilot ship: the Admiral of the fleet was on this maln-o'-war. In the rear was a laree Italian man-o'-war, which we calloul our "bull dog." herause their bow reminded us of a hull deres nose. This is the largest ship in the fleet and and get alomm the fistest. - she was constantly aromel the fleet. sumetimes would almest ge out of sight. on the lookout. l'hen we had there small gum-hoats, one ear.h. Fuglish, Imeriran and lablian: we ralled these the "efists." as there kept themselves alround the sides and ran ahead and belind our 


\section{HISTORY OF AMERICAN RED CROSS NURSING}

fleet looking for something at which to strike. The other boats were earrying oil and provisions.

The spent most of our time watching the ships do their silent talking. Our Umbria seemed to be the pet of the fleet, she was put in the center, - this no doubt because she was the only one carrying women. Every Ally's flag was taken down shortly after we left the Rock and only the signal flags were used. Each ship had her own peenliar camouflage paint. The pilot ship received all wireless messages and sent them to us. They had boat drills twice a day--a sailor gave a signal, our boat whistled and all the other boats answered, then centered around us at rest, or ehanged the course of position of their ships.

One day we passed a large school of porpoises taking a sun bath. We saw flying fish in droves and it was almost impossible to believe they were not black-birds. Another day one flew in on the lower deck; it was rery pretty and after a while we threw it back into the water. Several times our pilot ship swung around and made a smoke screen through which we passed. We will never know just what the men in the crow's nest saw to make them so cautious. One morning just at daylight, two imnocent looking fishing sailboats were seen at our left. Our "bull dog" put out her signal flag and not getting the satisfactory response signal. she made for them. We do not know what happened but suppose the crew were taken prisoners and the boats sunk. We learned later they were supply boats for submarines. The night of August 26, a neighbor boat came up near enough to call out: ".s. S. Umbria, put out your light on aft side." An officer investigated and found that one of the ship's crew had lighted a cigarette and was smoking.

Of their safe arrival in Genoa, August 27, a member of the unit, Blanche Asher, wrote:

We awakenel one sunny morning in the harhor of this ancient port and I am sure our heartfelt thanks at Jass that morning. in riew of Columbus' native city, were no less devout than were his at sight of our own native land. Columbus braver unknown hazards (ignorance is bliss!) lut we were one and all well aware of the danger, which through the grare of find. we nassed safely and every member of our narty attributed our safe voyage to onr invisible convors. the many prayers which were offered for our safe and happy journey. 
A young officer remarked, a few evenings ago, while we were disconsing the wonderful way in which we were protected: "I tell you I wanted to pray too, sometimes, but I didn't know how, so when the rest of you prayed. I just smoked like the diekens and thanked God I had grot into such good complnany?"'

\section{Miss Asher wrote of their first billet:}

The Enited Sitates military band met us at the docks and Inited States ambulances conveyed us to this quaint but beautiful old building, which until recently was a ronvent. Sisters are in wharge here now, assisted by returned eripples from the front; poor fellows, they look thin and old, but are rheerful and courteons and do not invite pity. In fact, nothing about the town or its inhabitants suggests war much more than in our own comntry. We were awaiting orders to proceed to our hospital and artive duty, but in the meantime, the officers and Father arranged us in sight-seeing groups.

Finally on Septrmber 5 Base Hospital No. 102 reached its destination, Vieconza, Italy, in the provinee of Venice, abont fifteen miles from the tiring line. Italian Sisters turned over to the Aneriean mit the hospital established in the Rossi Industrial School. As the work increased, a second hospital intended exchusively for Italian medical cases was opened in an orphan asylum, the "Misericordia." At the outbreak of the inthenza cpidemic six American nurses from this unit were furnished to a French hospital in Vieenza. Several teams consisting of officers and mlisted men, but no nurses, were sent to the First Aid stations.

Of the Rossi Ilospital, Sara M. F. Babb wrote Miss Delano as follows:

The ith of tieptember we were ordered to the war zone and the week following an Italian hospital was turned ovor to ns. It prosent we have several hundred patients. Italians, Amerians and a few British. We have also had the priviluge of aring for three British Red Cross nurses. Who were doing work in our little city. in the civilian department of the British heol cross. Vie have a ereat many mellial (asces,

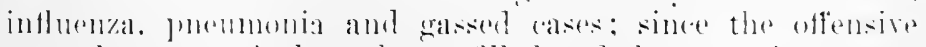

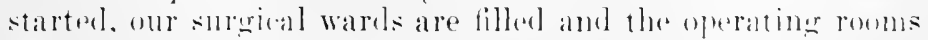
are busy. The lepench hospital here askenl for help motil their nimses. for whom they hat wiresl, combl reath theme. 


\section{HISTORY OF AMERICAN RED CROSS NURSING}

Six of our nurses were lent. In the immediate future, two other hospitals will be taken over. It is evident we are going to have all the work we can do and our capacity will be taxed to the utmost.

But I think you are most interested in our living conditions. We are quartered in an old house in which Sir Walter Scott would have loved to put his heroines. The entrance is severe and forbidding, great heavy oaken doors, with iron gratings in front of which is stationed the patrol. The courtyard is paver with coblle stones and a beautiful rose bush and a wisteria vine have climbed to the top of the high gray walls. Lnder broad overhanging eaves, hundreds of doves make their home. In the tower there is a winding marble stairway and rooms into which the sunlight never falls. To reach ny room I have to go up four stories, through a narrow hall, up another flight of steps into another hall, out on a small stone terrace, down another flight of steps ans then into my room, which I have dubbed the "Crow's Nest" because it hangs out on the side of the house and is such a splendid post for observation. I have one tiny casement window into which the (ireat Bear peers at night, with the smile of a familiar friend. Aeroplanes fly low over the "Crow's Nest" and from the stone terrace I look across to snow-rovered mountains, over which the smoke of battle hangs like a cloud. The roar of big guns is like thunder in a far-ofl storm.

Although we are the nearest nurses to the Italian Front, we have many of the comforts of morlerns. The tomb of Romeo and Juket is almost near enough for us to make pious pilgrimages, for the sake of all the old loves we have left behind. We have moonlight nights such as Shakrepeare conceived and browning loved to decribe. We have aloo elecetric lights, three bath tuls and a shower and an abundance of rold running water. The American Reel Cross in lione sont us a generous shipment of silver, china, glassware, table linesn, trays. (hairs and many other areustomed home appointrnent. for our lining-room, which we also use as a recreation rom This room is our special pride, a great ball-room splendilly lightex], with high Venctian windows that open out uposs (harming laternies. The floor is inlaid in beantiful design with bits of marble from the Mosque of Santa Sofia in Cosstantiusple.

He have no lark of recrention, our Dibert Club has put on two shows; the Y. W. (C. A. gives us moving pirtures and the band of a fanous british regiment, stationed near us, whus 
over to play for us. We have also been invited to the British camp for four o'dock tea. The wife of the American consul in P'alermo on her return from the trenches, where she had gone to sing to the soldiers, came by to sing for us. We have had a great cartoonist, a minstrel show by the enlisted men and an inspiring lecture by Professor Clark of Chicago University who gave us "The Latest News From Home." For thrills we have had a few air raids. It is very unpleasant to be wakened in the middle of the night and made to run for your life down winding stairs in the dark. On the way I wonder which is worse, to be blown up or to die of a broken neck.

On October 24 the Allied offensive, composed of fifty-one Italian, three British, four French and one Czccho-Slovak division and one American regiment, was hurled against the Austrian Armies. Vicenza felt the answer of Austria's shells.

Sara Babb wrote Miss Daspit, Director of Nursing of the Gulf Division, as follows:

I shall never forget the opening of the great Italian Drive. At midnight we heard the most terrific explosion, our old stone house that has stool for several centuries was shaken to the fomdation and the guard on duty at our door was thrown to his knees. We thonght we were in another air raicl and the nurses began to run down stairs for the refugie, sure that the first bomb had struck us. The camnonading was like thumder in one of our terrifie storms. Next day the wounded begin to rome in, bringing news of the battle. When the victory was won the people were wild with jos, held areat demonstrations and the ehiklen went through the strects singing. "Viva la lace!" Several of our doctors have gone to the dressing stations at the front. None of the nurses lave beon allowed, as yet, to go in spite of their pleatinger.

The vidury has hrought to us a feeling of security. We are grartually emptring our air raicl bags. I lamighed at breakfias this morninger when one of the nursese bexan to

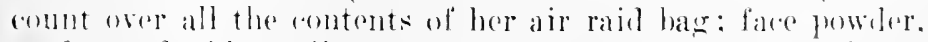

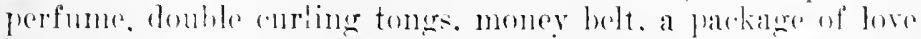

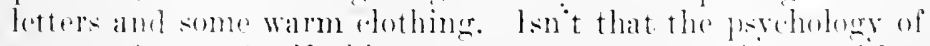
women for you: Suthing so stroner as our vanity.-neither

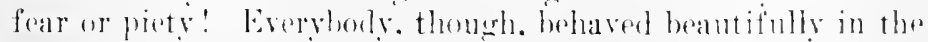
air raik. 'Thore was no panic, only a little ermmliting for being awakenes in the mithle of the nieht amb mate to wet up out of a warm bed and run for life down a dark, winding stairway. 


\section{HISTORY OF AMERICAN RED CROSS NURSING}

\section{A nurse's diary reads as follows:}

October 30. Many more thousand prisoners taken. Artillery fighting heard. An eighteen-year-old Ardite stopped at our hospital this evening, said he was on his way to the front. His regiment and four thousand Americans were going over the top. The regiment is made up of eighteenyear-old boys who are known as "Little Devils." They carry a bomb under each arm, a knife in the mouth and a gun at their side. The lad seemed to be nervous,- - said he did not feel well, complained of a sore throat and cold, but said that it was a small matter-when he got to running that would disappear.

November 3. At 11 P.M. a crowd of Italians was heard below our windows shouting and cheering the Americans. The official bulletin which announced that all firing on land, sea and air was to cease at 3 P.M. tomorrow, was read to the patients. The poor Italians were beside themselves with joy. One little Ardite hopped out of bed to the mirldle of the floor. The nurse led him back to his bed and told him to stay there. A few minutes later he was in the farthest corner of the room on a high bench waving the American flag and shouting "Tiva l'America!" Another lad with a drainage tube in a badly infected arm, pulled out the tube and getting out of bed, danced around. Only these poor Italians themselves know what they have gone through within the last three years.

Norember 18. This evening at 6 o'clock, fourteen Austrian Red Cross nurses were brought to our hospital by the Cnited States Ambulance Corps. They were prisoners; they askerl for something to eat and a night's lodging. 'They were given their supper, but permission to keep them over night was refused our commanding officer. Orders were given to watch them rery closely. They were taken to the Italian Sisters' hospital, about ten minutes' ride from here, two Italian officers guarding them. They were not allowed to open their bags for anything.

December 1\%. We are the nearest field hospital to the Front and the only one that has trained nurses. Fow that the war is over, I may give you military news. Our American Ambulance Corps (O)hio boys) brought us the patients from the first dressing station. After the drive our officers twh turus of three or four in going to the relief of the First . Aid station. They say it was a terrible sight.- dead men. horses ant wounder everwwere, mostly Austrians. Among the primeners was an Awstrian Red Cross nurse and we had her 
here four days as a guest. She told us she had been an Italian prisoner of war, but was treated as a visitor. She has vohmteced to remain with four Austrian soldiers who were dying when the Austrians retreated.

\section{Of the Italian people, Miss Babb wrote Miss Delano:}

The spirit of the people of Italy is inspiring. In the faces of the old men, the women and the little children who kneel with great devotion in the churehes, there is the look of the early (hristian martyrs,-patient, uncomplaining resignation. Italy, today, is worthy of her glorious past. Since ('oming here, I understand why great souls of other 'ountries have loved her and lived and died for her.--not only because of her beanty and her old-world charm, but because of her heroic soul and $I$ read in these lines of Browning a deeper meaning:

Open my heart and you will see

Graved inside of it, "Italy."

Such lovers old are I and she:

Here, as everywhere, the hardest task of the Red Cross will eome with peace. The need for work along public health lines, is appalling.

During the summer of 1918 , the Allies landed military forees in North Russia to operate against the Bolsherik anmiess which were then folt to be strongly pro-German. The situation has bern described:

The reports conceruing the activities of the Czecho-Slovak troops and the Allied forees, which were landed at Murmansk. Archangel and Thadivostok, were very meager and (ontlicting throughout the war. Reports given out by the soviet government of liussia and the various governments of siberia differed widlely from and often contradieted those griven wut by Allied governments. Therefore the material contained in this suction annot he strietly vouched for. The methou of obtaining it was to gather, as far as possible. material from Enropean and Ameriean sources and then to compare it and kerep that matter which seemed to be founded on fiact. . . .

Alter the bulsheviki had made peace with the ('elutral lowers, their attempts to pacify that part of Rossia which remained in their hands were lather unsuressful. 1 ron- 


\section{HISTORY OF AMERICAN RED CROSS NURSING}

siderable army of Czecho-Slovaks were roaming around the central part of Russia, attempting to reach Vladivostok and and rejoin the Allies in order to down their hereditary enemies, the Germans and Austrians. These men had deserted from the forces of the Central Powers and had fought with the Russians against their enemies. When the Treaty of Brest-Litovsk was signed and Russia retired from the war, they received permission from the Bolsheviki to cross Siberia and rejoin the Allies. For some time, their relations with the new rulers of Russia were very friendly. Then, presumably at the request of Germany, the Bolsheviki ordered them to be disarmed, but the Czecho-Slovaks resisted and conflicts oeeurred between them and the Soviet forces. The first battles began in the latter part of May and continned throughout 1918 and $1919 . \ldots{ }^{90}$

The reasons for the assigument of Allied forces to North Russia and their subsequent activities there have been described :

When it beeame known that the treaties of peace between Germany on the one hand and Finland, Russia, Roumania and the Ukraine on the other were to be used by Germany as a means of making these countries subservient to Germany, the Allies determined upon a certain amount of military intervention in order to try to save something from the chaos that existed in Russia. The Allies first seized the region around the Murman coast, with the cities of Murmansk, Kola and Kem (July, 1918). The purpose of this was to prevent Germany from obtaining submarine bases on the Arctic Ocean and from seizing control of the Murman railroad which might have resulted in the cutting off of Petrograd from the rest of Russia. There were also rast quantities of war materials there which liar been ordered by the old Russian Government and which had never been paid for. From April to July, 1918, the Germans and their Finnish allies were plamning an attack on the railroad and even went so far as to build a railroad across Russia from Finlant to the neighborhood of Kem. Consequently in July, 1918. Mltied forres, including Americans, were lamed at Thumansk and were welcomed by the anti-Bolsherik inhabitants. who almost immediately serefled from Russia and establisherl an inlependent government. The Allies advanced at once along the railroad and seized Kem.

on "A Peference History of the War," I. S. Guernsey, p. 141, Dodd, Mead and Company, 1920 . 
On Alyust 4, 1918, it was announced that the Allied troops had taken possession of Archangel, after ineffectual resistance by the Bolsheriki. 'The Allies (inchuling Americans) now controlled the entire coast from Archangel to Murmansk. ${ }^{91}$

Following the assignment of American troops to North Russia in July, 1!18, the American Red Cross organized a commission to take a shipload of foodstuffs and other articles to Rnssia on a boat which would be under the protection and control of the Enited States Government. The personnel of this commission included a commissioner, a doetor, a sanitarian, two nurses and two execntives with knowledge of storage and distribution of supplies.

Ahma E. Foerster and Beatrice M. Gosling were chosen as the two nurses of the Aneriean Red Cross Commission for North Russia. Miss Focrster was the daughter of a Chicago relergyman. Following her graduation from the Presbyterian IIospital, Chicago, she did public health nursing with the Infant Welfare and Jewish Aid Societies there. She was later in charge of the Out-Patient Obstetrical Department of Rush IIedical College. She was enrolled in the Ameriean Red Cross Nursing Service in November, 1911. Two vears later, she did disaster relief work in the Ohio flood. She sailerl upon the Merey Ship in 1914 and saw service in Kief, Russia, and later in 1917 and 1918, with the Red Cross Commission in Roumania. Of that sturdy temperament which regarded hardships and emerenencies only ats a challenge to greater resonreofulness and more persistent good humor, lliss Foerster proved herself an indefatigable worker and an alle executive. Hor heroie work at Arehangel romuded ont Red Cross service which covered four vears and which hronght hor in 1919 the Florenee Nightingale Iledal of the International Red Cross.

Boatrice M. Cosling, of Milburn, New Jersey, was gradnated from the Prospeet Heights Training Sehool, Brooklyn, Now York. Slle did publie health nursing at IJemry Street Sottlement. New lork ('ity, and was for some years engaged in social serviee work with the Xew York Association for Improving the Condition of the Pour. Iler first lied cross service was with the (ommission for Rommania in 1917 .

Major ('harles T. Williams, of Baltimore, Marrland, forma1 "A Reference History of the War," Pl. 142-143. 


\section{6\%8 HISTORY OF AMERICAN RED CROSS NURSING}

erly in 1917 American Red Cross Commissioner for Roumania, was appointed Commissioner for Russia. Major William D. Kirkpatrick, Medical Corps, U. S. A., of Bellingham, Washington, was his deputy; Major Kirkpatrick had served at Dr. Rvan's hospital in Belgrade in 1914, and later with the American Red Cross Commission for Roumania. Eight other men, inchuling a motion picture eamera man, Lientenant Harold M. Wrekotf, formed Major Williams' staff. Mrs. Aurora N. Merriman, of Minneapolis, Minnesota, secretary to the Commissioner, was the only other woman besides IFiss Foerster and Niss Gosling to accompany the party of eleven.

The mit moliblized during the last week of August, 1918, in New York City. Transportation for the personnel and for their four thousand and two hundred tons of food and medicine, valued at one million and a half dollars, was seeured on a merchant steamer, the Ascutney.

Miss Foerster described the spirit in which the unit cmbarked, Angust 30, 1918, and their subsequent reversal of feeling upon arrival a month later at Archangel:

Tou remember on what an indefinite mission we started, how nseless it seemed to send two nurses when there would be no nursing for them? What we found was more work than we could possibly handle.

Our ship. only a fire thousand ton ressel, was a rery smooth sailer. They tirned the wheel house into two cabins for us women. The erew and the gun-rew seemed to appreciate having us on board. After five weeks on the Ascutney, whose engincs were constantly giving $u s$ much diffieulty and worry, we finally reached Archangel. September 29. Here on the quay we were astonished to see Ameriean soldiers. With tears in their ever. those lonesome, homesick boys breathlessty told us how glad they were to see and talk with American women. how they har been there only a month but it seemerl a yrar to them. how disappointed they were to have heen sent there rather than to France, how already sixty-eight of their number har diert of influenza.

Major Milliams summarized the military situation in North Russia :

The whole Arehangel district is more or less under military control. There are approximately twelve thomsand

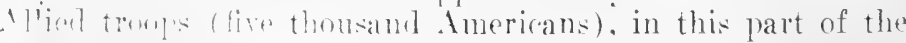


country. They were landed here early in September but not until the Bolsheriki had been able to remove southward or else destroy most of the vast quantity of ammunition and stores, which were here last year. I have within an hour returned from Bakaritza, which twelve months ago was the great Russian military depot. Today it looks like another place. In lieu of airplanes, guns, steel rails and limitless piles of ammunition and supplies either for the Russian Army or Roumania, there are now only those of the British and American Armies. . .

The Bolsherik forces in which German elements are found from time to time, are facing the Allies, Americans, English and French, on a battle front approximately one hundred and twenty-five miles south of Archangel. Along this line, there is almost continual fighting and practically every day wounded Americans and others arrive in Archangel. Up to two weeks ago, General Poole, of the British Army, was Commander-in-Chief of the Allied Forees. He has since gone to London and there are intimations that General Ironsides will sueceed him.

In regard to the civil situation, there is bound to be suffering in the remote districts as soon as the ice eloses in. We are arranging for sled service and expect to be able to do what we can for emergencies. While we are now able to get only about one hundred and twenty-five miles to the sonth, there is a rast region east and west, occupied by people whose needs, ac'ording to reports, must be great. Since our arrival in Archangel, we have been deluged by requests for assistance. ${ }^{92}$

Miss Focrster wrote of their first days in the bleak northern port: "It was very muddy indeed and it rained contimually. There were no hotel aecommodations so we remained on shiphoard. In Oetober, howerer, it began to snow and the ugliness of the little town was blanketed in white."

Major Williams wrote:

Archangel is just about as crowded this vear as last. British and Imerian solliers are evertwhere. Our dounhlogs patrol the stresets... .

The 'Troitsky l'rospect on which the American lied cross hearlquarters is located is Arehangel's cireat White llay. except that Broadway has no cobblestones. lese mul and shis

${ }^{22}$ leport written Oet. 15. 1918, by Major Williams to Georese b. Case, IVar (ommeil. National Headquarters. Washingtom, D). ('. 


\section{HISTORY OF AMERICAN RED CROSS NURSING}

and no drainage system which inclines from the sidewalk to a trough of mud in the middle of the street. Here and there the houses have been torn by Bolshevik bombs. Dame Rumor is not helpful: "Wait till we are frozen in and the Bolsheviki are coming through from the south on the ice and drive us into the White Sea!"

There were only nine American women in Archangel. Miss Foerster enumerated them:

There were five Y. I. C. A. girls who had been working along the Volga River with the Russian girls but left Petrograd when the diplomats did. They came back from Stockholm to Archangel with additional $Y$. M. C. A. men and established a hostess house, visited American boys in the British hospitals and worked in the Y. II. C. A. canteens. Then there was Mrs. Davis, the wife of a consul, and also a young woman employed in the Embassy. Mrs. Merriman left us in December, so we nurses make up the nine.

Of the first work of the commission, Miss Foerster wrote Miss Delano, October 5 :

We immediately saw that our social service work was out of the question. This proved a greater disappointment to Miss Gosling than to me because I don't mind hospital work especially when we can care for onr own boys. They do need us. We are less than a drop in the bucket. They still come to us in relays to tell us with tears in their eyes how glad they are to see us... .

We two are the only trained nurses in all Northern Russia now ofeupied by the Allies. There is an English girl who visits the soldiers but no British nurses. There are three hospitals, one of them a small Russian hospital which we have not yet been able to locate. the Interallied Base Hospital of thres humlred beds: and a little American Red Cross hospital of thirty beds. The British doctor in charge of the Interallierl base was in command of one of the hospitals in Roumania hefore the Red C'ross took it over, so we have met an oll friencl. There are abont fifteen Russian sisters of Charity in his institution: almost starring, they asked the authoritiss to feed them in return for their are of the troops. In the warls American, British and French orderlies assist several Amerian Army doctors.

I wish you could see the little American Ret Cross hospital! 
It is lorated in a small Russian chapel and has twenty beds in the church proper, two beds at the altar rail, and eight along the two sides. A long table ciown the center serves for reading and dimer table. There are two small rooms on one side with abont six patients in them and another cubby hole in the front with three oflicers in it. A little reception room on the other side serves as an operating and ilressing room. It is really only a small convaleseent home, but my? how our boys do love this little place! Soldiers off duty come here and you should hear them brag about this tiny spot of the U.S. A.!

This hospital later beeame the "Annex."

The first work of the Ameriean Red Cross Commission for North Russia was the establishment of a hospital for American sick and wounded soldiers. These eases had previously been cared for at the Interallied Base, which was maintained largely by the British. Miss Foerster wrote of Miss Gosling's and her work during the interval while Major Williams endeavored to secure a suitable building for the future Red Cross Military Hospital :

Our entire plans had to be changed immediately to "Americans first." Miss Gosling did such civilian relief work as was absolutely necessary. With Captain [Daniel O'Connel] Lively, she visited the sehools and taught how cocoa should be prepared. From our supplies they furnished cocoa, sugar, condensed milk and a little hard-tack biscuit, for the emaciated (hildren. By April 1. one hundred and seventy-eight schools had been risited and thirteen thousand youngsters supplied with eight hundred thousand lot school lunches.

In the meantime. I helped in the small operating room in the "Annex." . . . Some hours each day I spent at the ronvalescent depot. al'ommodating about one hundred and fifty light (ases. 'The Red Cross also supplied this place with extra food. We had British rations, and our own supplies, so we were not starving as in Roumania. How good our white bread and beef and bacon tasted!

Through the coöpration of Ambassador Francis and of President Tehaykovsky, Major Williams secured, ()ctober 15, for hospital purposes, a bufleling previously used as a scheol by the local metenrologioal department. Major William H. Ilenry, of the Medical Corps, was assigned by the ('hief sureeon of 


\section{HISTORY OF AMERICAN RED CROSS NURSING}

the American Expeditionary Forces to duty as commanding officer of the American Red Cross hospital established in this school. Major Williams cabled for ten nurses to staff the hospital but the British Government would not permit National Headquarters to send them. Miss Foerster's report contained the following comment:

The reason we had no relief nurses sent us is very plain now, but it did seem eruel then when we needed them so badly. The British, in charge of the situation up there, would not visé any passports for women to Archangel. It was true that the ships from England to Murmansk were very bad but we nurses during this war have put up with many inconreniences and I know any murse wonld have felt clonbly repaid when she found out how much she was needed.

Our American Red Cross Hospital was located in an old but fairly clean, white building on the quay street, overlooking the Drina River. With my little Russian rocabulary, I was able to direct the maids in cleaning. We also had four washerwomen. We almost despaired of ever getting linen dry before it froze.

It was hard work for me at first alone. Miss Gosling was naturally more interested in the public health work which she had come over to do. . . . Later, however, she supervised the work of the Army orderlies. Her mechanical turn of mind expressed itself cleverly in little improvements, such as woolen trays for the bed patients, wood boxes in the halls, inprovised rosets, extra tables and chairs.

Major Williams placed me in charge of the operating room as well as of the lospital. As in the Amnex I did any sterilizing in the hasement on the kitchen stove until Major Kirkpatrick conceived the happy idea of building a brick stove under our big linen sterilizer.

In addition to their own stores, the American Red Cross Commission for North Russia received generous hospital supplies from the Rod C'ross ('ommission for Great Britain. Miss Foerster deseribed some of these articles:

We hat nice iron cots, good mattresses, plesity of linen, majanas, socks and towels. Fortunately we had brought from Now York a number of extra things which we foared minht he hard to serole in Russia. Amoug these was a sewing marhine. I sonresl a derer Rusian woman and showed her how to make operating gowns, caps and masks. 


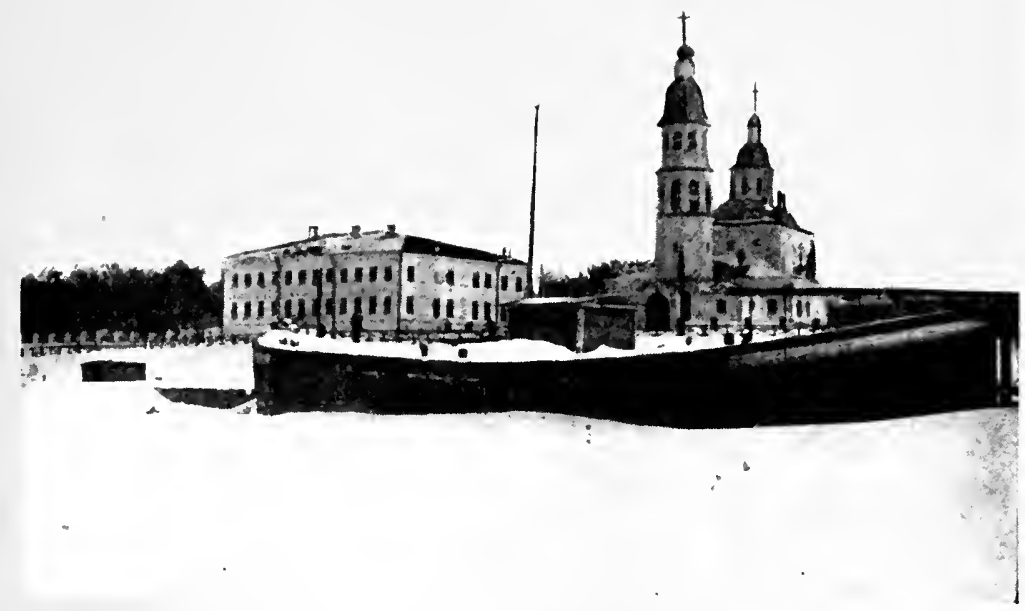

Looking across the frozen Drina River to the American Red Cross Hospital (left) at Archangel, Rinssia.

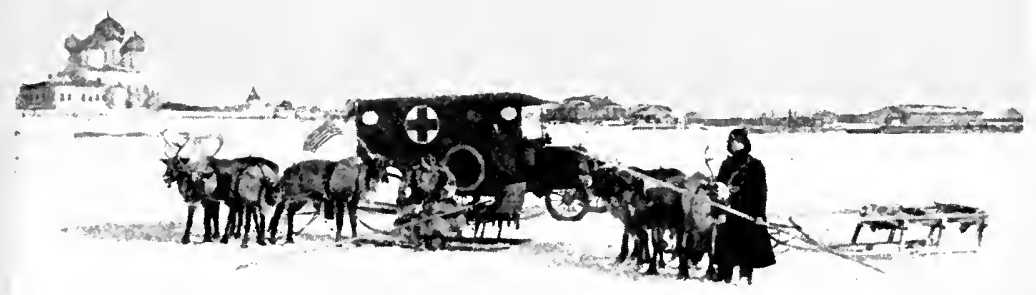

Two types of ambulanee $1-4$ hy the Ameriean Expeditionary Fores in Nortl Rusia. 

We never had to look about for help; the Russians were only too eager to work for us in return for the gooed food wo gave them. Fortunately, too, for us was the asigmment to our hospital of Amerioan Army cooks. I made the agrnoges and did the necessary invalid cooking myself. Eiggs were one dollar each, but for one egg we traded a pound of lied Cross rice, costing us about six rents. . .

\section{Miss Foerster wrote of their living conditions:}

Our hospital accommodated seventy patients, but about twenty of the persommel also slept there. Our wards were very light and had an average of ten beds. Major Hanry, in (harge of the hospital, hat a room upstairs, as also dis Iliss Gosling and I. We covered what had formerly been the coit rack with blankets and hung our clothes on it. This improvised closet really separated our room into two parts and gave us considerable privacy. Our meals were served here.

Our coldest weather was thirty-seren degrees below. We managed nicely to keep warm with our twenty-two stoves. Major Williams bought us black coats lined with sheep skin, and we wore brassirds on the sleeve. Knitted (ap)s protected our ears. We got out into the fresh air almost every day. Miss Gosling enjoyed particularly the skating. Our engineers had also built a tohoggan slide and there were reindeer sled rides, and we took a trip to Murmansk by dog train.

The patients at the American Red Cross Military Hospital at Arehangel were modical and lightly wounded surgical cases from among the soldiers of the Anerican North Russian Expeditionary Foree. Allied fighting had increased in the Archangel district in the fall of $1 ! 18$. The military situation at that time has been summarized as follows:

Many towns along the l)wina River were ocempied by the Allied and American troops. Kadish, in the province of

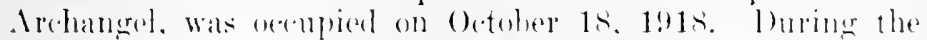
latter half of () tober and in early Sorember. the tightimer

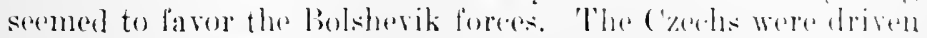
from samara and reperted that without immediate as sistance they would not he able to hold ont much lonerer. The

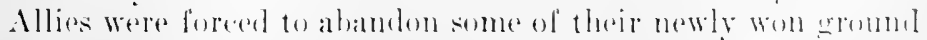
along the Drina (Kadish) but sureected in driving the Bulsheriki anerese the Finnish border from karelia.

The signing of the Amistice with liemany, contrary to 


\section{HISTORY OF AMERICAN RED CROSS NURSING}

the expectations of many people, did not bring to a close the hostilities in Russia. No official declaration of war had ever been made against the Bolsheviki and consequently a legal state of war did not exist, although fighting continued. . . . The Allies advanced up the Onega River in the Archangel distriet, for a distance of fifteen miles on December 30 and recaptured Kadish and made their rather precarious position more secure.

During 1918 and 1919 the whole situation in Russia and Siberia was still unsettled. Arguments were rife in Allied countries as to what should be done. Some contended that a large force should be sent into Russia and Bolshevism crushed, while others maintained that the armies should be withdrawn and Russia permitted to work ont her own salvation. The question was for the Peace Conference to decide. ${ }^{93}$

The Ameriean North Russian Expeditionary Foree was reealled in the spring of 1919. The Ameriean Red Cross Hospital was closed in April and Miss Foerster and Miss Gosling returned to the United States as soon as the ice broke and the Aretic Oecan was open again to navigation. Moreover, eighteen British nurses had arrived for duty at the Interallied Base and the sick and wounded among the Amoriean troops were sent there until the Ameriean Foree was withdrawn.

The Ameriean Red Cross Hospital at Archangel had a reeord of six hundred and twenty-two patients. Four hundred and thirty-eight of these were medieal and one hundred and eightyfour were surgical cases. Seventy-two operations were performed. Only three American soldiers died at this hospital just below the Aretic Cirele.

93 "A Reference IIistory of the War," p. 143. 


\section{CHAPTER VIII}

SERVICE WITII THE NAVY

Organization of Units-Uniforms and Insignia-Navy Nursing service in the United States-Navy Nursing service in Foreign Stations-Detached Service of Navy Nurses

$\mathrm{F}$

OUR outstanding accomplishments of the American Navy during the participation of the United States in the European War were the successful escort duty furnished to American troops and supply ships in home and foreign waters; American mine and patrol activities in the North Sea; the re-fitting for transport duty of the interned German liners; and the accomplishments of the Marine Corps in France. For the combatant Navy, the most formidable dangers were German submarines and mines; in addition there were the risks of collision and the natural perils of winds and sea. As for the Marine Corps, it faeed and ehecked the advaneing enemy divisions in the Bois de Belleau during the third German offensive of May 30, 1918, on Paris; its accomplishment on that occasion and in the subsequent Inter-Allied offensive of July 18 to November 11 needs no further comment here.

The aceident and casualty list of the American Navy during the period beginning $A$ pril 6, 1917, and ending November 15, 1918 , numbered 117 offieers and 893 enlisted men; that of the Marine (on'ps totalled 201 officer's and 508t enlisted men. ${ }^{1}$ Responsibility for the siek and wounded of the Marine Corps and the combatant Nary in home and foreign waters, and for medical and aterident adses of the Nary persommel in training in the Conited states wasts rested in the Burean of Mredicine and Surgery, Nary lepartment.

${ }^{2}$ Report of the Serertary of the Navy, 1918, pp. 212.255; $310-322$. 


\section{HISTORY OF AMERICAN RED CROSS NLRSING}

By Act of Congress, ${ }^{2}$ during the year 1908, the Navy Nurse Corps eame into being as part of the Bureau of Medieine and Surgery, of which Rear Admiral William C. Braisted was then Surgeon General. Esther Voorhees Hassan was its first superintendent. Though of New England ancestry, Miss Hassan was born in Maryland. Following her graduation from the New Haven Training School for Nurses, she served both as staff and ehief nurse in the Isthmian Canal Service, Army Nurse Corps. Her name has appeared previously in this history in connection with the Spanish-American War. Katrina Hertzer, who represented the Navy Nurse Corps at National Red Cross Headquarters during the European War, wrote of Miss Hasson:

When the Tary Nurse Corps was established, Miss Hasson was given the appointment as Superintendent, August 18, 1908, on account of the splendid service she rendered under the Army during the Spanish-American War on the United States S. S. Relief.

When the Corps was first established no public quarters for nurses nor an appropriation to finance them were available. The nurses were allowed commutation for quarters and subsistence. Miss Hasson leased, furnished and financed quarters at $5+1$ Twentr-first Street. X. W., Washington, D. C. These were the only quarters arailable in Washington until the present quarters on the Naral Medical School Reservation

${ }^{2} 601$. Establishment of the Nurse Corps. (Act of May 13, 1908). "The Nurse Corps (female) of the Cnited States Nary is lereby established and shall consist of one superintendent, to be aplointed by the Secretary of the Nary, who shall be a graduate of a hospital training school having a course of instruction of not less than two years. Whose term of office may be terminated at his discretion and of as many ehief nurses, nurses, and reserve murses, as may be needed: Prorided, That all nurses in the Nurse Corps shall be appointed or removed ly the surgeon General with the approval of the Secretary of the Nary. and that they shall be graduates of hospital training schools having a course of instruction of not less than two years. The appointment of superintendent, chiof murses, nurses. and resurve nurses shall be subject to an examination as to their professional. moral. mental and physical fitness. and they shall be eligible for duty at naval hospitals and on board of hospital and ambinance ships and for such special duty as may he deemed necessary by the surgeon General of the Nary. Reserve nurses maly be assigned to active duty when the necessitifs of the service demand and when on such duty shall receive the pay and allowances of nurses: Provided. That they shall receive no compensation except when on active dutg. The superintenclent. (duice nurses, and nurses shall, respectively. receive the same pay, alluwances, emolumonts and privilesges as are now or may hereafter be provided lyy or in pursuance of law for the Nurse Corps "( female) of the Army." 
were completed in 1910. She managed the quarters so well that when they were disposed of after the completion of government quarters, the nurses realized from them not only all they had put in but a eonsiderable bonus.

Miss Hasson designed the indoor uniform and the insignia of the Navy Nurse Corps. During her incumbency as superintendent nurses were assigned to the Naval Ilospitals in Washington, New York, Norfolk, Amnapolis and Mare Island, California.

She resigned from the Nary Nurse Corps in January, 1911.

Lenah Sutelitfe Higbee was the second superintendent of the Navy Nurse Corps. She was born in Chatham, England, but received her training at the New York Post Graduate Hospital, New York City. Later, she beame a citizen of the Lnited States. Before joining the Nary Nurse Corps, she was engaged in institutional nursing in Bellevue and Allied Hospitals (Fordham). Her enrollment in the Ameriean Red Cross Nursing Service dated from May, 1912. She was a woman of strong, quiet personality and her native English reserve was impregnated with a keen sense of justice and of proportion which areatly endeared her to the members of her Corps.

Requirements for 'nrollment in the Navy Nurse Corps were set forth in the Cirrular of Information for Persons I)esiring to Enroll in the Lnited States Naval Reserve Forces as Nurses:

A candidate for enrollment as nurse is first examined for enrollment in the provisional grade of nurve. Tnited states Reserve Force. Ifter her enrollment is arcomplished, should she so desire. she may make request for active duty for confirmation in grale aird after the completion of a minimm perion of three months, active service. she is again examined and if fomd qualified is confirmed in grade.

A member nunst he a citizen of the Enited States.

1 member enrolls or re-enrolls for a term of four vears.

The minimum active service required for maintaining the effiejency of a memher (Naval Coast l)efense Recerve). is three mionths duringe each term of enrollment. 'This active service may he in one period or in periods of not less than three weoks and year.

A member receives retainer pay of $\$ 1$ ? per anmum white ('nrolled in her provisional grade. provided she makes sub

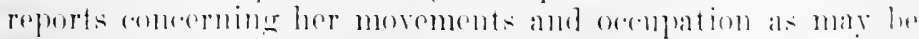

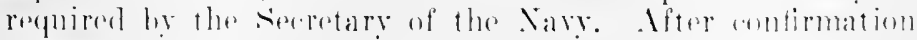
in grade. Her anmul retained pay is two monthe bas pay 


\section{HIS'TORY OF AMERICAN RED CROSS NURSING}

of nurse in the Nary. Retained pay is in addition to any pay to which a member may be entitled by reason of active service. As noted below, numbers of the Volunteer Naval Reserve do not receive any retained fee.

Enrollment of persons shall be made in the Naval Coast Defense Reserve, Class 4, or Volunteer Naval Reserve for duty in the Naval Coast Defense Reserve, Class 4, U. S. Naval Reserve Force. (Members of Volunteer Naval Reserve receive no retainer fees or uniform gratuity in time of peace, but when on active duty receive the service pay of their grade and service.)

A candidate for enrollment as above, must be between 22 and 44 years of age, and a eitizen of the United States and unmarried. She must be a graduate of a reputable training sehool ronnected with a recognized general hospital giving not less than two years continuous training. Candidates for enrollment from states where State Board laws are operative, are required to be registered.

A certificate of enrollment in the American Red Cross will be aecepted in lieu of the above (professional) certifieates. ${ }^{3}$

In three respects the Navy Nurse Corps set up requirements of no little embarrassment to its reserve, the American Red Cross Nursing Service.

First, it was required that a eandidate for the naval services be a woman of the highest professional training and of mature judgment, because she was expected to have entire charge of the nursing education of the hospital apprentices of the Navy. When in the exigeney of war the Red Cross Nursing Service let down its enmollment bars to admit young graduates of smaller institutions, the Nary Nurse Corps refused to accept these murses, on the gromed that they lacked the experience and the years which make for profieient instructors.

The scrond print rovered plyysical condition and was described in a circular letter sent in .June, 1917, by Miss Noyes to all Committees on Red Cross Nursing Service:

Perfect physical condition is escential. Orerweight or imperfect eyeright. unlese corrected by glasses. will dohar a nurse from inrollment. A rhest expansion of not less than two inches and freedom from organic diseases of any hind is imperative.

3. Nav, 375, March 31, 1917, Government Printing Offier, Washington, i). C. 
The requirement eovering eyesight proved particularly troublesome. Miss Noyes once remarked to Mrs. Higbee: "Does the Navy contemplate making sharp-shooters out of your murses?"

But the most formidable requirement of the Corps was that its members be of American eitizenship. However, when the pending shortage of murses was foreseen in 1917, the Navy lowered this requirement. A statement eovering this change was giver in a postscript written by Miss Delano and attached to a letter written by Iliss Noyes in June, 1917, to chairmen of State and Loeal Committees on Red Cross Nursing Service:

Since writing the enclosed letter we have been advised that a law has recently been passed making it possible to enroll nurses who have taken out their Declaration of Intention, providing they were horn in the comtries of the Allies. 'This holds good only for nurses who are expecting to sign the certificate of enrollment for the Voluntary Naval Reserve, but does not apply to those nurses who would wish to come into the Reserve.

Nurses a re requested to submit to this office an affidavit to the effect that they have taken out their Declaration of Intention in orler that we may forward it to the Navy Department for their files.

The Superintendent of the Nary Nurse Corps has also advised us that nurses will be given the privilege of enrolling in the Saval Recerve Fore or they may come into the Nary through the Volunterer Reserve. This latter enrollment dores not carry with it. however, the definite alvantages to the nurses as deses corollment in the Naval lieserve Foree. Nurses are experted to serve as long as the emergency exist:-

As was the ease with the Army, the relations of the Red Cross Nursing Service and the Navy Nurse Corps during the war were at all times intimate and cordial. In september, 1916 , General Braisted assigned Katrina Hertzer, a rhicof nurse of the Nary Nurse ('orpes and ome of the members of the Merey Ship Expedition of 1914, to represent the Xary Nurse (inps at National Headguarters. Miss Hertzer was attached to Mliss Delano's statf; she aided in the enrollment of nurses and was linison oftieer between the Nursing serviee and the Nary Nurse ('orps.

Some months before Miss Hortzer's assignment to Siltimal

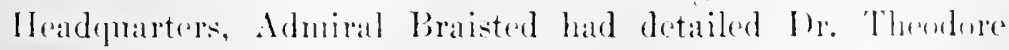




\section{HISTORY OF AMERICAN RED CROSS NURSING}

Riehards, Medical Director, U. S. Navy, to act in a similar eapacity between the Bureau of Medieine and Surgery and the Department of Military Relief, National Headquarters. Dr. Richards also served as assistant Direetor General of the Department of Military Relief, of which Colonel Kean was Director General. On August 30, 1917, the War Council created a Bureau of Naval Affairs within the Department of Military Relief and Lieutenant Commander Richards was appointed as direetor.

As international events during the year 1916 pointed more and more to participation by the Cnited States in the European War, the Red Cross was authorized to undertake the organization of sanitary units for the Navy as well as for the Army. Dr. Richards summarized the need of organizing and equipping Navy base hospitals in time of peace for service in war:

Although navies in general, our own included, are commonly said to be always on a "war footing." the statement obvionsly onits from consideration the well-known fact that enormons expansion of the personnel will occur coincident with or immerliately subsequent to the outbreak of hostilities. It is furthermore apparent that such expansion must take place with sreat rapidity, since active naval operations, so far as concelns the [nited States, might be appreciably deferred pending the transportation of large bodies of men overseas. Step by step with enlistments in the naval service come demands for hospital facilities and unless these have been prepared in excess before the outbreak of war, great ditficulty will be encountered in keeping pace with the growing demands.

turder peace conditions, our naval hospital facilities have been necestarily limited to current needs. Public opinion in this country. as reflected in Congress. has never countenanced the expenditures which would be involved by hospital construction and equipment in excess of such requirements. It was foreseen, of course. that at any time upon the ontbreak of war foverument funds would be arailable in ample amount and that the problem which would then confront the Merdical Department of the Army and Nary would he. not the lack of money, hut inability to expand it rapidly. Is a matter of fart. exartly this condition prevailed last spring and summer (1917) when it was fonml that the availahle markets of the world would not immediately suffice to procure in sufficient amount medical and surgial equipments which might have been urgently neded. Fortunately. the international situa- 
tion was surh that opportunity was afforded to meet the more pressing demants as they arose.

Of the initial call whith the Navy Department made upon the Ameriean Red Cross, I)r. Richards wrote:

Under the nomination of the Surgeon General of the Nary, I was assigned to duty in charge of the Burean of Caval Affairs, American Red ('ross, for the sperial purpose of organizing five Nary base hospitals which the surgeon (ieneral considered desirable. $11 y$ connection, therefore, with this undertaking dates back to Jnly, 1916, at which time no equipment for any of the hase hospitals had been procured. As there was then a serious shortage of personnel at Red ('ross Headquarters. the supervision of this work for both the Army and the Nary hospitals was temporarily turned over to me.

Nay hase hospitals differed from those of the Army chiefly in size. Housing at a naval base or station was at all times a serions consideration. In view of this problem, hospitals of 250 bed eapacity were determined upon. Further, it was believed, in consideration of the small size of the Nay in parison with the Aruy, 2.50 bed hospitals would fully meet the needs of the Naral hases; certainly they conld be more 'puickly set up than io() bed hospitals. The personnel of these first Naval base hospitals inchoded ten doctors (later raised to twentr-eight), forty nurses (later raised to fifty); fonrteen murses aides (later raised to twenty-six); twenty reserve nurses (later changed to fifteen reserve nurses and twenty-five reserve nurses' aides); and other personnel, approximately ninctyeight, necessary to care for a two hundred and fifty bed hospital (later raised to five hundred).

As a guide to chleef nurses in solecting a statf, Miss Noyes sent ont eirenlars of information which defined the different divisions of exeentive and other professional details of the

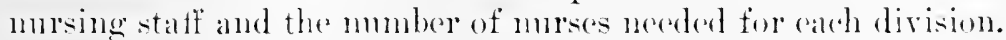
she recommended that at least three of the forty murases should

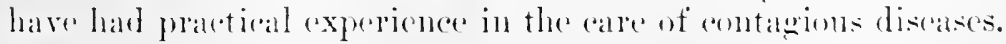
similar ontlines redating to the musese aldes were also issued.

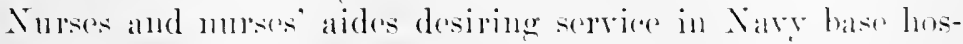

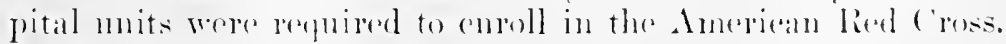
Lecal chapter's mulertonk the raising of fouds by means of

' $l$. s. ratal Bulletin. April, 1!18, p. 184. 
which equipment for Navy base hospitals was purehased and stored.

After the declaration of war by the United States, the Navy called upon the American Red Cross to organize three more base hospitals in addition to the five original ones organized in 1916.

Between April 4, 1917, and November 11, 1918, the Ameriean Red Cross Nursing Service assigned 339 nurses to the eight Navy base hospitals organized by the Red Cross. A list of these columns will be found in the Appendix.

$\mathrm{Up}$ and down the long coast line of the Atlantic seaboard were located numerous Naval stations. Upon the declaration of war, these were in need of Naval hospitals. Admiral Braisted in June, 1917, authorized the organization of ten naval station hospital units. $A$ circular letter issued at that time by Dr. Richards gave more complete information:

At the request of the Surgeon General of the Navy, the Bureau of Naval Affairs, American Red Cross, has undertaken to organize a new group of units to be known as "Navy station hospital." These units are for the purpose of supplying in part the personnel for a number of new hospitals now being erected at various naval stations along the Atlantic Coast and at one or two points elsewhere within the United States, for care of the rapidly expanding naval personnel.

With a view to drawing as lightly as possible upon the civilian profession, only five medical officers will be required for earh mit. Additional nembers to fill the complement will be furnished by the Surgeon General from young oflicers already enrolled in the Naval Reserve Force. No equipment will be required, but if funds are available for the purchase of X-ray or dental outfits, anbulances, etc., such donations will be gladly accepted.

Naval station units called for an initial staff of from ten to twenty nurses, one of whom was authorized to act as head nurse until the unit was called into service. The same requirements of enrollment, physical examination and immunization existed for this service as for other military units.

In size and purpose, Naval station units corresponded in many respects to hospital units for the Army. As did their sister formations in the Army, these nuits of organization proved exceedingly popular with smaller institutions, the staffis 
of which eould not provide the specialization or stand the drain of personnel necessary for such elaborate organizations as base hospitals.

There was swift expansion of the Navy immediately after April 6, 1917, and the Burean of Medicine and Surgery found it expodient to anthorize the organization by the Red Cross of ten additional Naval station hospital mits. Twenty-one units in all were thus organized by National INeadquarters and 180 Red Cross murses were assigned to active service in the Navy Nurse ('orps through these mits. A list of them appears in the Appendix.

The smallest and most mmmerous of the three types of nursing units whieh were organized by the Anericam Red Cross for the Navy was the Nary detachment. As early as October 6 , 1916 , Miss belano wrote to all superintendents of schools of nursing in the United States:

... It is now our intention to develop Navy units from among the graduates of varions schools which have not already been called upon to organize base hospital units, and have selected your school as one of the mumber to be responsible for maintaining such a unit for service with the Xary in the event of war. These units will be called upon only in time of war and may I suggest that you consult with your Board of Maningers and secure their permission to maintain at all times a "Nary detarhment of nurses" in connection with your sehool.

While it is probalile that Nary detadhments will he assigned to duty in their own locality in hospitals establishert by the Nary, they should be willing to aceept service elsewhere. Proference should be griven to nurses under forty years of age and to citizens of the linted states. Whenever possible these units should consist of twenty nurses including the head murse. The majority of the morses should be axperieneed surgieal nurses with one or two anesthetists. If absolutely unable to maintain a mit of twenty murses in con-

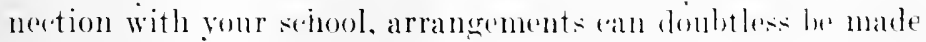
to authoriza a smaller number. There will be no medical personmel attached to these mit.... .

Folkwing the soveranee of diplomatic relations with Ger.

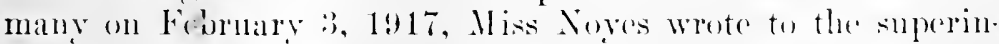
tenelents of fifty training schools then organizing Xilvy de tilchurents : 
Under the present uncertain conditions, we believe that we should rush the completion of our Navy detachments as rapidly as possible. Should our country be so unfortunate as to become involved in war the Nary would probably be the first engaged. Under such circumstances large numbers of reserve nurses would be required. In anticipation of these needs you were asked to enroll a group of selected nurses around your school.

Will you kindly notify me preferably by telegram what progress you have made, the number of nurses enrolled and their names? The enrolled Red Cross nurse has always answered the call for service willingly and promptly. Let us not be found unprepared should our country need us now!

Five hundred and forty Ameriean Red Cross nurses were assigned to active duty in the Navy Nurse Corps as members of Nary detachments. A list of these units appears in the Appendix.

Of the 1500 Ameriean nurses serving in the Navy Nurse Corps at the time of the signing of the Armistice, 1058 of them had been mobilized through the American Red Cross Nursing Service. This number was sixty-six per cent of the total strength of the Nary Nurse Corps.

When the United States entered the Enropran War, the Nay Nurse Corps, like that of the Army, had no distinctive ontdoor miform for its nurses. American Red Cross nurses assigned to the Nary Nurse Corps, when on duty in the wards of Navy hospitals, wore the white wash uniform of their school, with the Red Cross cap, brassard and cape. When off duty they wore civilian clothes.

The first Navy nurses to serve overseas were those attached to Lnited States Nary Base Hospital No. 1. This formation had been oreanized by the Ameriean Red Cross. When its murses arrived in New York arly in september, 1917, for embarkation overseas, they were furnished with the blue sorge dress, the ulster, the velour hat and other articles of expipuent which the American lied cross was then issuing to Army base hospitals assigned to foreign service.

The following instructions were issued by the Surgeon Creneral and were forwarded November 16, 1917, by Mrs. Highee to Miss I) lano: 


\section{Outdoor Uniform for Members of the Navy Nurse Corps}

Skirt and coat of heary lark blue serge. . . .

Wash waists, cotton cheriot, dark blue flannel, dark blue silk. .

Top coat: dark blue heary roating, smooth finish, similar to Nary "cap cloth." ..

C'ape: ${ }^{5}$ heary long "ape of cap cloth. . . . Light cape, navy blue serge lined with flannel.

Sueater of any weight desired; color, dark or nary blue or gray.

Rain coal: Coat of tan cravenette, or rubber, and rubber hat. Hat: Nary blue velour. ...

Boots or shoes: Black, heels not higher than "Cuban;" heary soles; under certain ronditions the Surgeon General may authorize tan boots for heary walking.

IIosiery: black with black boots or shoes; tan with tan boots or shoes: white with white boots or shoes.

Rubber orershoes.

High rubber boots.

Corps Insignia: to be worn on duty always with wash uniforms and on waists of outloor uniform, when such mniform is ordered. Collar tevice for outdoor uniform:The letters I'. S. for members of the liegular Nurse Corps, and I. S. R. for reserve nurses and Nurses' Reserve Force: to le worn $3 / 4$ inch from collar openings on collar of coat or suit, top coat or heary eape; Corps device to he worn $3 / 4$ inch from letters i S. or T. S. R.: collar derices shall not be worn except when in full outdoor uniform or when top eat and heary cape are worn over wash uniform in hospital reservation.

Nurses in the Enited states are not obliged to obtain the entire outdoor miform except when so ortered by the surgeon General. No part of this uniform shall he worn on duty in hospital or hospital reservation, mess so orleres by the surgeon cieneral, exept that the top coat, heary rape or light cape or rain eat or authorized sweater, shall be worn over wash uniform for protection and warmth; and no other garment sha!l be worn with mitorm.

$$
\text { (rigned) W. C. BRALTED. }
$$

The collar device referred to above eomsisted of al gold acorn on a gold mak-leaf, which wats superimpused num the characteristic gold anchor of the Nary lepartment. The letters K. N. C. in gold appear upon the oak-leat and acorn. limserve nurses who had entered the Nary Surse (orps thromgh

antional for dut! owerats. 


\section{HISTORY OF AMERICAN RED CROSS NURSING}

the American Red Cross Nursing Service were allowed to wear the Red Cross cap and the Red Cross cape from which the emblem of the society had been renioved.

Specifications for the indoor uniform of members of the Navy Nurse Corps were transmitted by Mrs. Higbee to Miss Delano on November 21, 1917 :

White uniform: for members of the Navy Corps, Navy Reserve Force and Reserve Nurses, U. S. Navy, who are not already equipped with uniforms, shall consist of a one-piece dress, ${ }^{5 a}$ as illustrated, with attached soft collar and attached belt. . . .

When authorized by the Surgeon Gencral, the wash uniform shall consist of a gray chambray, one-piece dress, as illustrated, supplemented with white collars and cuff's, as illustrated, and with an apron of approved style. . . .

While the Surgeons General of the Navy and the Army had been working out, during the early autumn of 1917 , the specifieations for the distinctive outdoor uniforms for their respective Nurse Corps, the American Red Cross War Council had had under consideration the equipment of all Red Cross personnel for foreign service. As has already been stated in Chapter VI, National Headquarters felt that it was the responsibility of the Government to equip Red Cross nurses assigned to Federal service but the recommendation to this effect of the Surgeon General of the Army to Secretary Baker "was returned disapproved, with the remark that it was not the policy of the War Department to make clothing allowances during the war." 6

Upon the request of the Surgeon General of the Army, the Red Cross undertook the complete equipment of both regular and reserve members of the Amy Nurse Corps at an individual cost not to exceed $\$ 200.00$ per nurse. This ruling was extended to embrace all nembers of the Navy Nurse Corps who were assigned to foreign service. Limited artirles of equipment also were given to nurses assigned for duty on hospital ships.

Early in Angust, 1918, a change in the insignia to be worn by members of the Navy Nurse Corps was made. Creneral Braisted on August 9, 1918, sent Miss Delano a print of the

${ }^{5 a}$ The gray ehambray uniform must be included in equipment for duty overseas.

- See letter written Sept. 26, 1917, by the Acting Surgeon General. U. S. A., to Col. Krean, Chap. VI. 
new design. "The device is supplied in pairs and is to be worn on either side of the collar of coat or suit, top coat and cape, the anchor to be horizontal with point toward and one inch from opening of the collar. 'The use of the letters ' $U$. S.' and 'U. S. R.' as a part of the collar device of the Nurse Corps is herewith conntermandod." In a letter written Angust 24, 1918, to Miss Delano, General Braisted pointed ont that "the elimination of the letters 'U. S.' and 'U. S. R.' materially reduces the amount expended on the Collar Deviees of the Navy Nurse Corps."

In August, 1918, after Congress had raised the pay for members of the Army and Navy Nurse Corps from $\$ 50$ to $\$ 60$ a month for service in the United States, and from $\$ 60$ to $\$ 70$ for service overseas, the Surgen General of the Navy authorized all members of the Navy Nurse Corps on duty in Navil hospitals in the United Sitates to wear the outdoor miform which had hitherto been worn only by Navy nurses in foreign service. General Braisted on August 30, 1918, sent a copy of this ruling to Miss Delano:

1. The miform approved by the Secretary of the Navy for members of the Nary Nurse Corps will be worn by all members of the Nary Niure Corps assigned to aldive duty; and instructions have heen sent to the Commandirg Officers of Naval hospitals, Nival stations, hospital and ambulance ships and Naval transports, that there shall be no distinguishing marks in the uniforms of nurses other than those which renote their oflie ial status.

2. It is alpureciated that the alue, which is issued by the Equijment Burean to the nurses who have entered the Siaral serviee through the American Red Cross, is a satistanctory and desirable garment to be worn over the wash minforms. In order to promote contentment and efficiency, howerer. it is

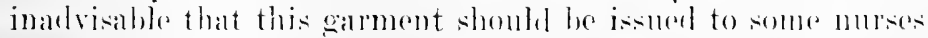
who alre onl duty and not to others. It is sugerested. there-

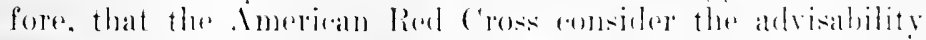

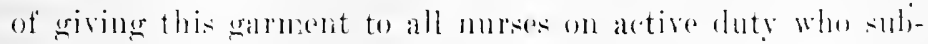
mit a reguest for the eape.

This rulinge as did the moling made Augnst 15, 191 a by the

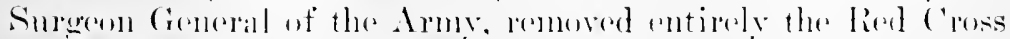
emblem from the miform of Amorican lied c'ross moses assigned to Naval inerion. 


\section{HISTORY OF AMERICAN RED CROSS NLRSING}

Three hundred and thirty-four (334) members of the Navy Nurse Corps were furnished full equipment for foreign service by the American Red Cross through the Bureau of Nurses' Equipment, Atlantic Division Headquarters, New York City, at a total cost of $\$(50,120.00$. Nurse members of Navy base hospitals which had been assigned to foreign service before the full list of equipment had been authorized on Oetober :30, 1917, by the War Council, were furnished the supplementary articles due them under this later ruling, through the office of the Chief Nurse, American Red Cross in France. Navy nurses in foreign service were allowed to replace worn out articles of wearing apparel by purchases made at cost from the Nurses' Equipment Shop, which was maintained at Paris by the Red Cross.

On April 6, 1917, the United States Navy numbered 65,777 enlisted and enrolled persomnel and had a eomplement of one hundred and ninety-seven ships in commission. Hospital facilities for this peace-time Taval foree had been provided by the erection and maintenance of permanent base hospitals situated at the principal Taval bases along the Atlantic and Pacifie seaboards and in insular and foreign waters.

After the Lnited States declared war, the Navy Department underwent an immediate and unparalleled expansion by the utilization of personnel of the Naval Ifilitia, the National Naval Voluntecrs and the Lnited States Naval Reserve, and by the construction of new ships and the conversion of pleasure and commereial craft to war uses. On November 11, 1918, the Sary bepartment numbered 497,030 men and women, with a (omplement of $20(0) 3$ ships.

The training of this enlarged Nay took place in camps in the various Naral distriets in the Lnited States and at sehools for specialists. The Naval Academy at Amnapolis was chlarged; "officer material schools" were hastily improvised. Such a school for officers of the Pay Corps was restablished at Princeton, N. J. Deck and engineer officers for the merehant. type ships were trained at a sperial sehool which was located at the Naval Traning Camp, Pelham Bay Park, New York City, and at branches of the school in Chicago, Cleveland and at Stroens Institute, Moloken, New Jorsey. Officers for the Flying ('orps wrere trained at the Nary Ground Schools at the Massachusetts Iustitute of Technology, the Tuiversity of Washington, Dinwoody Industrial Institute at Minneapolis and the 
Naval Training Station, Great Lakes, Illinois. Flight officers received post-graduate instruction at Naval air stations at home and abroad; submarinc ofticers at the Submarine Base, New London, ('omnecticut; torpedo officers at the Naval T'orpedo Station, Newport, Rhode lsland; turbine-engine officers at the Naval Turbine Enginerering Sohool, Carnegie Institute, Pittslourgl, l'a.

Seamen, firemen and rertain elasses of petty officers and specialists were trained at the four Regular Saval training stations which had existed prior to the war. The total capacity of these stations which had originally housed six thousand recruits, was increased to well over one hundred thousand. To supplenent these four principal stations, a new training camp was established in each Naval district, either at Naval stations or on land loaned on nominal lease to the Nay Department. Special schools for trained mechanics, artisans and cooks were also established. Naval training units, which offered college students "opportunity to contime their education along the usual chamnels, at the same time clecting Naval subjects and receiving military drill and instruction, were established in over ninety educational institutions of collegiate grade." 7

To care for the sickness which inevitably occurred among these large groups of men brought together under new and often more stremoms habits of living than the mon had been nesed to, the Burcan of Medicine and Surgery increased the hospital capacities of the Sary from three thousand to seventeen thensand beds in the Enited States alone. Of the fifteen hundred member's of the Xary Nurse Corps who saw active scrviere durine the European War, approximately eleven humdred of them served in Saval hospitals in the Énited States. There hundred nurses, the mursing staffs of the first five hase hospitals oreanized and apuipped by the Amorican Red Cross for the Nary lepartment, were assigned to serviee in foreign water's and a briaf aceonnt of their experiences will be griven in a subseguent seretion.

Previons to April. 1917. the Burean of Mredicine and SurErery, Navy lepartment, had established and maintained Naval lespitals at the fonr permanent Naval training (ampse at Naval

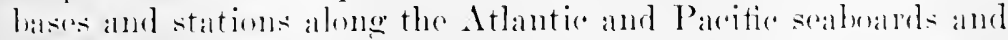
amone insular and foreign posessions of the [nitud states. Following the decelaration of war, the Xary lepartuent ereatly

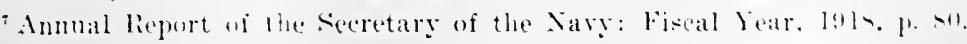




\section{HISTORY OF AMERICAN RED CROSS NURSING}

enlarged the eapacity of these permanent Navy hospitals and erected additional ones in the varions newly established Naval training camps and stations. In the Annual Report of the Secretary of the Navy, for the fiscal year, 1917-1918, Josephus Daniels wrote:

As an illustration of the hospital expansion in the naval service may be cited the case of the Naval Hospital, Norfolk, Va., which during one quarter of the year preceding the war, had an average of two hundred patients and during the last quarter of 1917 had 1,100 patients. In May, 1918, this hospital was raring for thirteen hundred eases, of whom five hundred were in a fully equipped camp of more than twenty buildings, complete in all matters of heating, lighting, water supply and sewerage. ${ }^{8}$

Elizabeth H. Dwyer was one of the nurses assigned to the Norfolk Navy Hospital. She wrote:

Norfolk Naval Hospital, curiously enough, is situated in the town of Portsmouth on the Elizabeth River, which separates the two cities and the hospital is styled Norfolk in order to save confusing it with the P'ortsmouth, N. H., Naval Hospital. It was the first U. S. Naval hospital to be built and it was rompleted in 18:8. Previous to the period of the European IVar, the hospital could take care of two hundred patients but during that time its capacity was increased to accommodate approximately three thousand patients.

The Naval IIospital was beautifully situated among old trees. In the rear was a wide court and on eitler side of it were large sleeping porches. A circle of bungalows stood beyond the court and were nsed as convaleseent wards.

The pepulation in and about the Norfolk Naval Base increased during the war to one hundred thousand people. Little building was done, so the housing problem was an acute one. The Eilks Club leased their elubhouse to the Government and the majority of the murses were culartered there. The elul was loceated at a twenty minutes' walk from the Naval Hospital.

Oue of the most interesting events in the routine of a Nary murse at Norfolk was the arrival of the hospital ships. Miss Dwyer wrote:

${ }^{8}$ Annual Report of the Secretary of the Navy, p. 87. 
Often before we had been notified of her arrival, we would see the good ship Mercy lying in the harbor, the lied Cross on her side symbolic of her mission. 'The Herey was the hospital ship we knew best. She usually brought us about seventy-live cases of mumps, the disease which had perhaps always the largest gromp of sufferers; numeroms measles (ases and smaller groups of medical and surgical patients.

Whenerer the Merry visited our shores, some few nurses always took alvantage of the chance to visit her and see her in operation.

A hospital ship is truly a work of art. Arrangement is made for good are and every possible space is used to such good alvantage. One would almost think they were in a shore hospital. wave that the besk are in the style of berths rather than beds. The operating-room condl not be better equipped or look more real in a shore hospital; there is plenty of room, the sterilizers are large and everything immaeulately white. Afternoon tea was usually served during our visit.

Farly in May, 1917, Dr. Harriss offered the Navy the use of his yacht surf. It was aceepted by the Navy, was reerpuipped as an Aneriean Red Cross ambulance ship and was used to transfer siek sailors from battleships in Atlantic.waters to Nary hospitals. Three Ameriean Red Cross nurses were assigned to duty on the Surf in July, 1917; others were supplied to fill vacancies which ocenred from time to time. Nurses remained on duty on the ambulance ship until the use of the surf was discontinued late in 1917.

Navy nurses were assigned late in 1918 to several of the large transports to assist in the care of sick and wounded Anerican soldiers being returned to this country.

Another permanent $\mathrm{Naval}$ hospital to mulergo tremendous (xpansion was the Naval Station Hospital at Gray's Ferry Road, Philadelphia. One of the first lied ('ross mints to be mobilized into active service was the Philadelphia (ieneral I nit and the murses were assigned to the Gray's Ferry Xaval Hospital. Mary C. MeNolis, one of these nurses, wrote:

Inmediately after our country declaled war we were sent

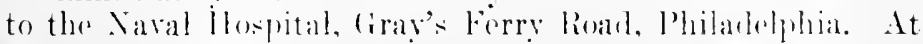
this hospital wo had trying days and the memory of them will last as long as life. The work in itself was hard, and the difficulties seremed harder because the work was so strange. . . 


\section{HISTORY OF AMERICAN RED CROSS NURSING}

At the outbreak of the war this hospital was the only Naval base in Philadelphia and we saw this base of less than one hundred patients grow, in a few days, to one with more than six hundred patients. Many of these men were, like ourselves. new in the service. Add to this, the naval discipline which insisted upon sick call at 9 A.M., all medications, nourishments and treatments on time and everything in readiness for inspection at $10 \mathrm{~A} . \mathrm{M}$. This was usually made by the exeeutive officer accompanied by the chief nurse. Captain's inspection with all its details occurred every Saturday morning.

Miss MeNelis wrote of the instructive phases which made nursing service in the Ameriean Navy different from Army or civilian nursing service:

We were employed not so much as nurses but as instruetors and supervisors of the hospital corpsmen. These men were to serve aboard ship. They were to be the nurses in time of distress. and we had to work with this thought always in mind. Often when haste was imperative it would have expedited matters to have done the work ourselves; for example, to give a hyporlermic. But no. we had to supervise the corpsman while he gare it: otherwise present expediency, we knew, might interfere with a terrible future contingency. This reminds me that as yet no pen has been so facile as to describe in true worth the hospital corpsman.

They were not at all children as one is sometimes led to believe. They were citizens, young men who immediately leaper to the defense of country and to them the Draft was ail too slow. They knew no fear. The sea, perilous by nature and marle more perilous by the machinations of man, did not trouble them.

They came from every walk of life. At one time I had two lawyers, a seminarian and a registered pharmacist working with me. All longed to be off to war. To such as these we harl to explain that working in the hospitals "at home" was vital particization in the war. 'To their credit. be it said they acrepted our explanations eheerfully. worked industriously but longed patiently for other things.

During the summer of 1917 , an epidemic of contagious disrases broke out in the training ramps and stations of the Navy. Miss MeNelis wrote:

In the summer of 191\%. Wr had elirlemies of moningiti-

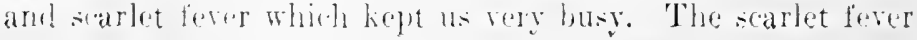



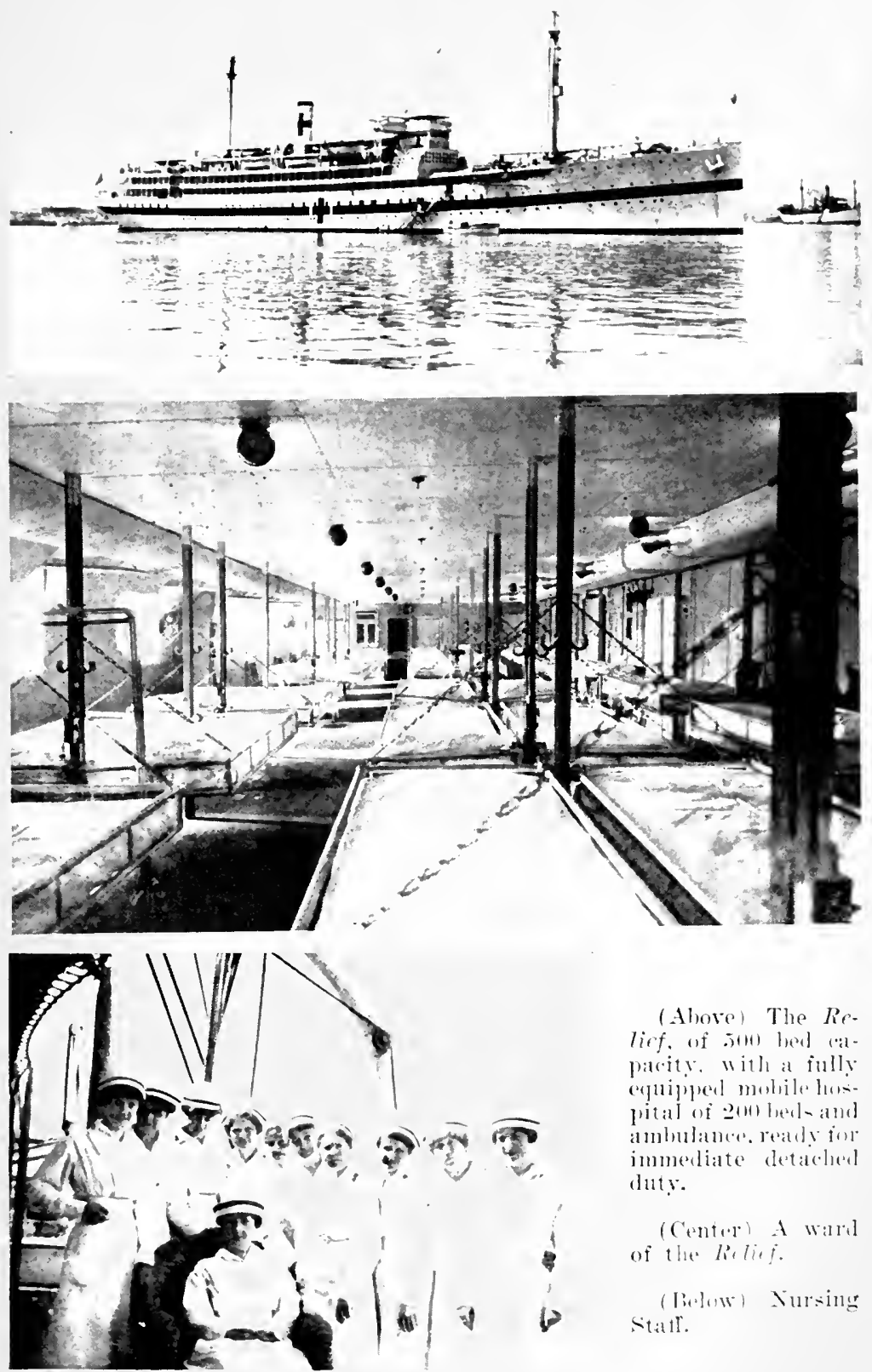

(Ahove) The Re.

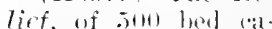
pacity. with a fully expipiped molile herspital of 2011 texth and ambulance. reats ion immerliate detalehed dinty.

(Center) A wirrel of the lititi.

([i, low) Nursing Statl.

Phetess, by Worly In purtmet 

cases were transferred to the Municipal IIospital for Contagious Iniseases at l'hiladelphia, and details of nurses and (orpsmen were sent to take "are of them. Now, if you wish my idea of hard work, picture a nurse surrounded by men in quarantine for about six weeks. The comntry is at war, the patients are sailors, cager for the allurement of war. It was almost more than she could do to maintain military discipline and impross upon these men that "They also serve who only stand and wait."

i respite from many ases was obtained in the summer of 1918 by the establishment of naval hases on the reservation at League Island and at the Medico-Chirurgical Ilospital.

An early opportunity for assistance to the Navy presented itself to the Anerican lied Cross in comnection with the hospital at Philadelphia. The Mimutes of a Meeting of the War Council held on Iuly 2t, 1917, recorded the following action:

The chaiman stated that in Philarelphia the MedicoChirurgical Ho:pital owned by the rity hat been condemned in order that a boulevard might be (ont thromgh; that the hospital containcel about two hundred and filty beds and that its use had been ollered to the lied cross for an indefinite term without rental. hy the Mayor; that its usefulness was not serionsly interfered with by eutting through the boulevard, as it only nexessitated teariving dewn some of the ontholdelings that honse the lamelry and refrigerating plant which most therefore las moved to at new location.

1he further stated that it was proposed to use the hospital for the Nary at the present time and reemmended appropriation for making the neesesary changes in the hospital ame for its maintenanes which had formerly (ost the rity ahout $\$ 1.5 .060)$ a month. Wherempon it was on motion roted that from the lied ('rose War Find the sum of $\$ 1:$ onen be and it is herehy appopriated for alterations and recomstruction of

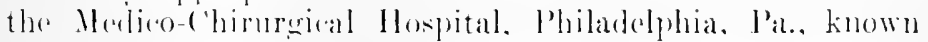
as lied crosis (ineral llospital No. 1.

Funds for the mantemame of this hespital were also roted at

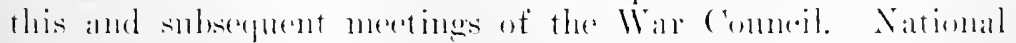

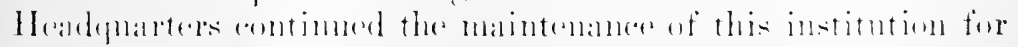

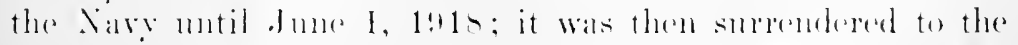

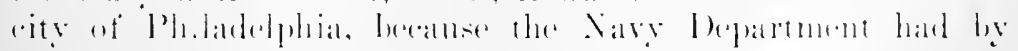


this time so increased its hospital accommodations at Cape May and at Philadelphia that assistance from the Red Cross was no longer needed.

Nursing service in permanent Naval hospitals in the United States during the period of the European War was full of interest. The nurses had comfortable quarters and interesting work. Elizabeth Hoag, a nurse member of the Springfield (Massachusetts) Navy Hospital Unit, wrote:

Early in May, 1917, sixteen of us nurses received orders to report to the U. S. Naval Hospital at Newport, Rhode Island. We found a warm welcome awaiting us. The hospital was then overcrowded with very sick boys and there were not enough nurses to care for them. I was assigned to Ward D Medical for duty; I found seventy-six patients, most of whom were very ill with measles. A number of these patients had already developed pneumonia, while others had developed ear complications. One nurse had the supervision of this ward and the nursing care of these patients. She had as her assistants six hospital corpsmen. These hospital corpsmen had been carefully trained in the care of the sick and it was really wonderful to see how well most of them performed their duties and how kind they were to their "ick buddies," as they called them.

I remember so well one young boy, about seventeen, who was very ill with pneumonia. He said to me, "Nurse, won't you put some lard and turpentine on my chest? If I was home, that is what my mother would do and I know it would help my pain." I astert permission of the dortor to grant his request. 'Two days later he left us--forever.

Another ase that comes to my mind was a boy of eighteen, whose parents were missonaries. This boy ran away from home and joined the Nary under an assumed name. Ile gave as his nearest relative the name of an aunt, whom he sairl he? lived with and who later proved to be his own mother. When the todegram arrived saying her son was seriously ill, this mother hurried to his herlside. lout did not arrive intil after he hal pasted away. It was then we learned the sarl story of this heart-broken mother and how she had searederd months for her only (hild without avail; almost the first thing she asked was, "I)idl he leave me any mestage:"

Miss Hoag was later assigned to Ward C, the "pus surgical" division. She wrote: 
Here we had fifty-six bed patients, suffering from empyema, gangrenous appendices, infected arms and legs and crushed hands and feet. Some of these patients had been in the hospital for months and had grown thin and pale, but still seemed happy and cheerful.

... During the spinal meningitis epidemic, we had one building with thirty-six beds; it was divided into two sections by a glass partition. In one half we lad our bed patients and in the remaining half we had what were called carrier patients. These earrier patients had never had spinal meningitis, but they were arrying the germ in their nose and throat and transmitting it to other people who sometimes hal the disease in its severest form. When the epidemic broke out and cultures were taken of every man's throat at the training station, these men were sent to the hospital for isolation and treatment. In some cases the germ could be killed in six weeks, while in others it took three months. Dr. $\mathrm{K}$., who speeialized in this work, had the eare of these patients and was untiring in his efforts. He was just as cheerful when called at three A.M. to do a spinal puncture, as he was when ealled at three o'clock in the afternoon. His labor was well rewarded when in twenty-four hours after starting treatment, he wonld watch them come ont of their delirium and in three weeks time, leave the hospital to finish their convalescent period at home. Upon their return at the end of four weeks, they were well and strong again.

Newport was a quaint and historic town and the view from the ocean eliffs one of great beauty. The nurses derived much pleasure from walking through the narrow crooked streets and along the cliffis overlooking the rolling surt.

Early in July, 1917, a gromp of nurses firom the Naval Hospital at Newport were sent to the City Hospital at Providence to take a two weeks' course in the technique of caring for contagious cases. Mimnette Butler, a reserve nurse at Newport, wrote:

This course was a great help during the months of epidemics which followed. In July a humbed ases of diphtheria deseloped within one weeh anomer the rivilian population at vewport. Faring that the (ontagion might spreali to the training station, our eommanding officer offored to assist the eity health department. These ontedals furnished cars and a piast ascistant surgeon. a nurse and a corpeman were detailed to visit cory lotel. bikery, ice cream parlor, 


\section{HISTORY OF AMERICAN RED CROSS NURSING}

restaurant and dairy in the city and take cultures of all people handling milk. The authorities had reason to suspect that the trouble was coming from the milk supply.

After the city had been "cultured" in this way, they made the rounds of farms outside the city and visited ninety families. In a Portuguese cottage, a seventeen-year-old boy, with a heavy membrane in his throat, was found ill in bed with diphtheria. His mother was caring for him; she also milked the cows and was sending a supply of contaninated milk to niany city houses. A constable was placed on the grounds to see that all milk was buried. No new cases dereloped but had it not been for the prompt and efficient work of the Naval culture squad, an epidemic might have developed which would have proven to be a real crisis.

Fate, however, could not let Newport rest, it seemed, because a terrific explosion oceurred soon afterwards at the Torpedo Station. It caused many deaths and maimed, burned and blinded many others. . . .

The permanent Naval Hospital at Chelsea, Massachusetts, was located in broad-winged buildings which crowned the crest of a hill rising from the water-front. Nora M. McQuade was one of the nurses assigued to duty early in the fall of 1917 there. She wrote:

My first detail was to a busy surgical ward with a staff of one regular Sary nuirse and six hospital corpsmen. It was a shock to me to see those young men doing the things I had been brought up to believe were the sole duty of a trained nurse. I felt sure the men were being neglected; still. they looked happy and the ward was beautifully clean. I deeided to refer judgment for a little while and it took but a short time for the nurse recruits to absorb the Nary spirit and to realize low important and far-reaching our work really was. Ipon the elegree of skill with which we tanght the hospital corpsmen to are for the patients in our wards depended the degree of skill with which they would in turn nurse the sick men on the ships at sea. It was impossible to have women nurses except on the largest transports.

The expansion of the Naval Hospital at Chelsea was similar to that at Philadelphia and Newport. Miss McQuade wrote:

Day hy day we watched new pavilions going up on the reservation. 'They were hadly meeded. Then ame the strike 
and building was held up for weeks. Finally it was settled and the neen went back to work. None were gladiler than the nurses. The first weeks of our participation in the war found the hospital with an average of 180 patients. Within a year the number had reached $9: 0$, with $3: 7$ of them assigned hospitals outside the rescration. Extra beds were put in and then ents on which the men were eared for until space was available in the out-ide hospitals and they could be transferred there. All during the winter of $191 \%$, patients were transferred in this way ats soon as the acute stage of their illness had passed. 'This srstem male the nursing service difficult all the time; we always had acutely sick men.

During that first winter "Trpe $t$ " premmonia with the romplicating organism, hemolytic streptococcus, which proved so fatal, was prevalent. Many of these patients who survived this infertion, later developed (minyema and were in the hospital for months at a time. These men required infinite care and patience. Their apletites needed coaxing, their minds needed diverting,-for they fretted against the length of inactivity,-and their hodies, especially their poor backs, neeled and received constant attention. If we conld have had the same corpsmon with us all of the time it would have been easier for us, but we were conducting a training school. As soon as we trained corpomen to be very useful, they were sent to sea with the next draft.

The Naval Hospital at Chelsea received patients from the transports, from the smaller Xaval craft operating about the big Boston Harbor Yard and from the varous training stations near Boston such as the Radio School at Cambridge and the Ariation Sichool at the Massachusetts school of Technologr. "One of my tirst troubles was with Nary regulations and parlanere," wote Miss Mre(kuade. "The Nary "paper work" was a new and diffienlt task and the language bewildered us. How were wo to know that "spuil gee the deck' meant to polish the ward floor !"

Onteloor wards were upened at Chelsea on . June 1, 1918, and

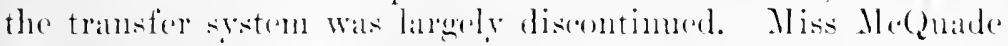
wrote:

'The summer montles were bus ones. The Xarr men who

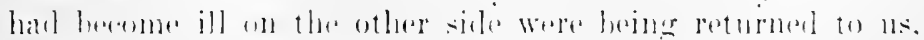

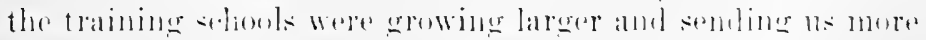
flatients and the military stuation in Europe was daily 


\section{\%08 HIS'TORY OF AMERICAN RED CROSS NURSING}

becoming more critical. It was an anxious as well as a busy time for all of us.

Ona day toward the last of August we were told an epidemic had broken ont among the men of the receiving ship. It was influemza, they said. The word did not mean much to us that lovely August afternoon as those of us off duty made beds in an empty ward. That night, during which sixty-seren sitk men came in, was the beginning of the influenza epidemic that has become history. We worked as we never worked before. The influx of patients, the calls for extra nurses, the illnesses of the staff, the deaths, all were repeated later in other hospitals but to those of us who experienced the initial outbreak when the disease and its treatment were unfamiliar to all, this trying period has left a memory that will not fade for many years.

Navy nurses were assigned in November, 1918, to the Marine Station at Parris Island, South Carolina, to nurse influenza patients. Mrrtle Gilmore Chandler, head nurse of the Naval Station Unit No. 11, wrote:

Parris Island is the most interesting one of a large group of islands in Port Royal Sound, South Carolina. It is a long narrow strip of sea-sand which is held in the wild rice and reeds. Bleak and desolate it looked when we ten nurses arrived at the dilapidated dock; a few scattered buildings, thousands of tents and rough clay roads, with a covering of oyster shells, greeted the eye.

The Naral Hospital, which was a rambling, white, twostoried building on the water's edge, had had only corpsmen in attendance upon the patients and medical officers to direct their work. Being the first murses ordered to this lost, we naturally felt it was quite an adventure and tackled the work with enthusiasn.

Our first patients were suffering from influenza. After some werks the epidemic abated and we then had many surgical rases. ...

During the spring a large addition to the hospital was built; aros's the street the nurses' new quarters was completed and it was a joyous day when we moved in. Instead of sharing a dormitory. each nurse had a delightful room to herselt. . . Numerons large barracks were opened, many officers' quarter's and recreation huts were built, anong them a very fine Red ('ross building nicely arranged for reading, games, music and dancing. It reemed as if a veritable small city had sprung up ahnost over night. 
Paving of the roadways was one of the most appreciated improvements. "The lslind was so near the sea-level," wrote Miss IIcQuade, "that previous to the road-making, small creeks had oozed their way here and there with every rising tide and they left us no choice but to wade through thens. Then when the tide reeeded, the mud was alive with a huge army of small crabs."

Of the permanent Marine Barracks, Miss McQuade wrote:

The Marine Post har in 1919 a large main station, a quarantine (amp), a training eamp, an aviation fiekl and school and a sea-going depot, with thonsands of Marines in training there. There also was maintaned a large Naval disciplinary barracks.

Parris Island was a place of great beauty in the spring and summer. Miss MeQuade wrote:

The winter storms subsided and spring announced itself by covering the once barren and bleak island with a carpet of emerald swamp grass; here and there in profusion grew lovely swamp violets and lilies and later the wild honey-suckle trailed over the fences in masses of perfume. We explored the farther end of the island and found an inleal spot where palms and palnettos grew under the luge spreading oaks and the light gray Spanish moss hung and swayed in graceful festoons from the wide branches. We often had pienies here on summer days.

Beaufort, the palatial old Southern town famous before the Civil War for its hospitable people and beautiful homes, still retains it: old time hospitality. Is it was only forty minutes by notor boat from the istand, we spent many delightful hemrs there. We had many diversions of our own,tea at (ieneral Pondleton s every Frilay: dancing and motion picture shows: temis, for the larines harl hromght elay in barges and built a court hehind the nurses quarters: swimming and horsehatek rides along the hard. white sand beaches. It one side of the island the covernment had set aside a tract of land for the negroes who had previonsly ben seattered about. Here they lived in their abins amidet the eotton fields. As we antered lis ons horroblate during the Sonthern twilight, we oonle] hear the thrumming un the banjoes and the nexpo melodies floating ont wh the still air.

At the Naval Training ('amp. Great lakes, lllinois, was lowated one of the largest Navy hase hospitals in the lonited 
States. Beatrice Bowman, supervising nurse of Unit D of the Red Cross Merey Ship Expedition of 1914, was chief nurse of this Nary base. She wrote:

This hospital went into commission in May, 191\%, but drew its quota of patients from a comparatively small number of men at the training stations. Since last summer, however, it would seem that an electric button had been touched and as a result many units sprang into existence, over farms and the great plain. P'rior to August $26,191 \%$, one large brick building and a group of tents in which the sick were cared for, filled the park in front of the hospital; in January. a village of more than fifty building units was in full working order. Twenty-nine of these mits are each a complete hospital. with quiet rooms, diet kitchens, offices and lavatories. In addition to the hospitals proper, modern laundries, nurses' quarters, hospital corps barracks, civilian employees' harracks, garages for ambulances, trucks and jitneys, a complete water and sewage system and many miles of cement roads have been built.

Bernice D. Mansfield was assigned in July, 1917, to duty at Great Lakes. She wrote:

Eleven of us arrived at Great Lakes about midnight on July $\%$, and found that they had been looking for us for some few days, but had only that day succeeded in finding a place to quarter additional nurses. . . At that time there was the one hospital huilding, just as there had been before April 6 . 191\%. As the training station was rapidly increasing, the hospital was kecpinw pace and new buildings going up all about but as yet were in a state of nncompletion. To accommollate the number of patients, all available space in work shops had been utilized and tents were in use all about. It hal been a cold rainy spring and mud was very much in eridence aromml the tents. as roads $u$ p to that time had not been completed.

In one building which was later nsed for an ice plant, the patients had cots but no whairs or lockers or bedside tables. The first thing we saw on entering was the men's clothes lying among the sputum boxes and pus basins. just as they hat been droppend when taken off by the wearers. "Where shall I begin!" was the murse's first thought. "The patients called to It: " "( )h, nurse. I am so glanl you have (onne, we havent had any nurse hefore. Can I have this? Will rou get me that?" "The first thing we did was to have the wothes folderl and tied tomether. labeled with the patients name and 
tied to the head of his bed; when the clothes were all off the floor, the room looked as large again and we felt as though we could reach the patients to do something for them.

An epidemie of contagious diseases broke out at Great Lakes during the summer of 1917. Miss Mansfield wrote:

Into our already overcrowded hospital, we took in two hundred additional patients in twenty-four hours. . . A new colony of tents went up "on the front lawn" and the main hospital was empticed and marle ready for the new comers. As long as they were in bed, we laad no trouble but as soon as they were convalencent, eternal vigilance was refuired to see that they did not gret out and into other camps with which the main building was surrounded. Many of the horpital corpsmen were young and inexperienced and certainly the patients were young and inexperienced too!

In the meantime, new hospital buildings were being finishet and equipped. Is soon as one ward was ready, patients were moved from tents into it.

Evidently the infections diseases of dhildhood had never gone throngh that borty of recruits before they entered the training station, for there were continually epistemics of measles, chicken-pox and mumps. The tent colonies grew to aecommodate the increasing number of patients. One group of tents was put up just opposite the remetery. It'first there were no lights about the gromds here and the nurses on night duty would stumble orer the ropes from tent to tent, keeping one eye on the remetery. Even the bravest ones foumd it a bit lonely in a dark isolated camp with a spot light the only source of illuminition.

The sewerage in the amps was taken care of as rapilly as possible, but muless a murse has sone through the experience of caring for infertions diseases in a temporary camp where there is no sewerage and flies are abundant, then the hats somethine to look forwark to! In the mese tents, there was an electrie plate which was med to heat water and nourishments, but the task of washing dishes for forty or fifty ment who were ill with an infections diseate and only an electrie rlate to heat the water. seemed at first to be beyond accomplishment.

Great Lakes Training Station increased from a pealere ca-

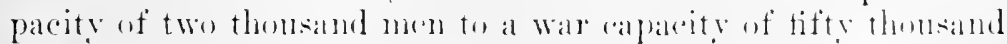

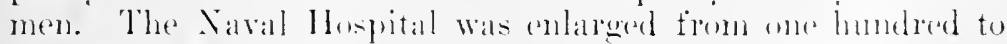
twelve hundred led alpateity. 


\section{HISTORY OF AMERICAN RED CROSS NURSING}

The Bureau of Medicine and Surgery maintained four Naval Hospital Corps Sehools. The one located at Great Lakes was the largest of these; it had a normal capacity of three hundred, with an emergeney eapacity of three times that size. The greatest number of students registered at one time was 2200 . The three other schools were established at Newport, R. I., San Franciseo, Calif., and the Naval Operating Base, Norfolk, Va.

The Burean of Medicine and Surgery received offers of assistance in the training of hospital eorpsmen from various universities and three of these were accepted. A four months' course for one hundred men at the Medical and Dental Schools, University of Minnesota; a six-weeks course for three hundred men at the College of Pharmaey, University of New York; and a three-months course for one hundred and fifty men at the Philadelphia College of Pharmacy were given. Willard Comnely, a nurse of the United States Naval Reserve Foree, who was on duty at the University of Mimnesota, Minneapolis, Minn., wrote:

It is a new experiment for sailor students to be admitted to a medical college, as it is a new and essentially valuable war work for nurses to assist in training these Nary men. . . .

For the first month of the four months' course, the teaching is confined to the medical school, including the institute of pathology. the college of dentistry and the institute of anatomy. There are lectures and recitations, then supplementary experience in the laboratories and dispensaries. It is held that this preliminary knowledge is indispensable if the corpsmen are to grasp comprehensively the fundamentals of pratical nursing as given at the Lniversity Hospital during the three final months. During this time, the men have a course of lectures and experiment action in pharmacentical chemistry, minor surrery and first aid, anatomy (with weekly practice in diswerting), physiology, and hygiene, bacteriology, and the principles of dentistry in normal conditions.

Whan the nursing instrution begins the andanced cor relative training in the foreroing subjects is griven ehiefly irs the mornings. While one wre more divisions of the sailors (five divisions of twenty minutes eath) are engaged in hospital work. Throughom the afternoms this teathing is direded hy Lomise M. P'owell, superintendent of nurses, by Marion linnier, alsistant supervisor, and Gertrude Thomas, die- 
titian. They are aided by a staff of head nurses and undergraduate nurses, and the latter also help at the medieal school clinies where the sailors obtain practice in diagnosing and treating cases in dermatology and eye, ear, nose and throat.

The fourse in bandaging, "onducted by Miss Powell, is in six lessons, each lesson covering one ant one-half hours. . . In a room at the University Hospital, Miss Vannier grives ten demonstrations in practical nursing. After observing each Monday the methods employed, the corpsmen put in the rest of the week in the dass rooms or wards where, in sections of five or ten, they receive individual supervision, at the hands of the assisting head nurses. The demonstrations are given before fifty men at a time, in periods of one and one-half hours duration, and after some ground has been covered, demonstration quizzes too are held, to eheek up the work which has been carried on in the wards.

The ten lessons in practical nursing ineluded instruetion in the theory and teehnique of the simpler methods of nursing procedure. The lessons were thorough and together with the practice gained in the wards of the University Hospital, gave future corpsmen an exeellent working knowledge of the treatment to be given for all the common ailments and for emergencies arising on shipboard.

Graee Kiline, a nurse on duty at the Naval Training Camp at Charleston, South ('arolina, wrote that one of her pupils had said, on completion of a detail given him to clean up a ward: "Gee, I'm glad my mother can't see me now, or she"d fire the hired girl when I get home!"

On the Patrific (oast a laree Naval station was located on Preget Sound and anotler at Vallejo, Mare Island, California. Annir Miller was one of the murses on duty at Mare Island Naval Hospital. She wrote:

The sm was shining as it shines in few places ontride of California, when from the deck of the forrybat, on a Iune morning, 191\%, we aught our first glimpse of the shores of Mare Island.

At Vallejo we left the ferry. I llarine grnard lookent ower our orders and allowed us to hoard the tug for the $i$ itaml.

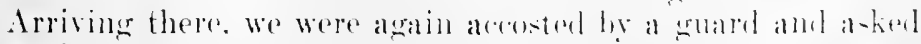

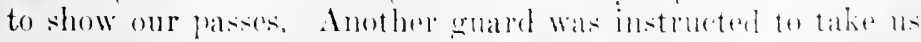
to the oflie of the commlandant. I remember thinking how nice of them to gro with us and show the way insteal of simply 


\section{HISTORY OF AMERICAN RED CROSS NURSING}

pointing it out. After having lived on the island awhile and grown more aceustomed to the military routine, it dawned upon me that the guards had no thought of being "nice" to strangers, but we were simply under guard until passes could be secured for us.

Arriving at the nurses' quarters we were shown to our room. Yes, I mean it in the singular. We had four other roommates besides. The room har once been used as a gymnasium for the nurses; but after war was declared the expansion at this station had been rery rapid and all available space had to be pressed into service to accommodate the overflow.

So we dubbed our room "the tenement" and while nurses are supposed to be exacting, I have always been rather proud of the fact that we proved we conld live together in those close quarters, not only amicably, but very pleasantly.

During the European War, nurses rendered many types of service which differed greatly from the medical and surgical nursing they had expeeted to do. Miss Miller's assignment was no exception to this rule; she wrote:

I was told to take the place of housekeeper at the murses' quarters. The rest of the nurses in the detachment with me seemed to find this quite amusing and to this day I am still addressed as "Housekeeper" by some of them.

My experience with servants had been confined only to the colored ones of the South, so that I approarhed the Chinese here with considerable trepidity. I found them rery willing to work. but also found they hard to be handled with care. Old Lonie, the cook, had a disconcerting way of saying, "No sarry, no sary," when it was to his adrantage not to understand the point under discussion.

One Sunday we had plamned. as a part of the menu. plain ice cream to be served in cantaloupes. I had tried to instruct Louie and while he pretended to understand. I had an meany feeling that all was not well. so came back later to investigate. Not finding the cantaloupes in the refrigerator. I alled to Loule to know where they were. "In the lice cream." he almly repliest. It was true. He had in some way contrived to reduce those cantalonpes to a pulp and combine them with the cram in such a way that it was smooth as relret and deticions. After that, antaloupe ice cream was a farorite with us. In Lonier's own remacular, it was "more better" than ordinary ice crean. 
Though housekecping on Mare Island must often have seemed only a monotonoms routine of uninteresting details compared to front line nursing in France, life on Mare Island was not without the thrill of danger. Miss Miller wrote:

The day of the explosion of the black powder magazine stands ont rividly in ny memory. It occurred at eight in the morning, just as the day nurses had gone on duty and the night murses were being relieved.

T'he rhief nurse and I had gone into the kitchen to instruct as to the menu lor the lay. I think I was more puzzled than frightened, even as I felt the floor rock under my feet and saw the swaying chandelier and falling plaster; for at that time, even if I knew there was a magazine on the island, I did not grasp the possibilities of what might oecur.

Lonie canght hold of the table and began crying and, I presume, praying, in his own language. The chief nurse turned to me with an expression I have never forgotten and simply said, "The magazine!"

We ran to the door, but finding it completely jammed. rushed to another and out into the yard, to see only a thoul of dust and smoke in the direction of the magazine that told the story. Everyone, inchuling afternoon and night nurses. hurried to the hospital to render what aid they conkl in caring for the injured. Only I had to remain behind and try to keep the frightened Chinamen at their work. All that long morning I helped Huey, the house man, whose work that day was more than one person could have accomplished. I swept fallen plaster and broken glass, while he shoveled it up and carried it away. And together we picked up and replaced books. pictures and other fallen articles and suceeded in eleaning the house, that the tired nurses who had done the actual work with the injured, could rest when they came to luneh.

California is a long way from France, but even there one could have the satifaction of knowing that their small hit was helping in the strugrgle. Often when we went down to the docks to watch a detarehment of marines leaving. murses would recognize among these salor-soldiers who were alterwards to malie history on the fiekts of Fiance. boys whom they had helped batek to health.

The rigid entranere recpuirements of the Xary Nurse Corps, the limited size of the Nary and the responsible nature of the

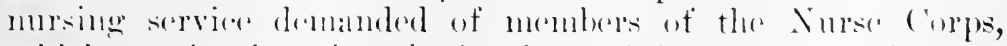

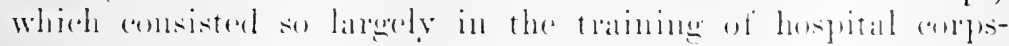




\section{HISTORY OF AMERICAN RED CROSS NURSING}

men, tended to promote an excellent morale and esprit de corps among the nurses of the Navy. However, in many isolated naval stations life for the nurses was undoubtedly monotonous and lonely just as it was in the case of Army nurses at cantonment and camp hospitals remote from recreational facilities. A ruling that nembers of the Navy and Army Nurse Corps should not associate with enlisted men-a regulation issued in the interest of discipline-was the cause of many complaints. The following letter was written by an American Red Cross nurse in Naval service on the Paeific Coast:

Everyone here likes the work, but we have no recreation except the mories or a trip to-(the nearby eity). Of course that rosts so much that we ean't go very often on a $\$ 60$. a month salary.

When you work only eight hours, you have got to do something the rest of the time. I read and knit and sleep but that gets rather monotonous. If we could only play tennis or swim or do something! We had a court but they built new wards on it. They are going to build us another when they get a round to it.

We are so entirely out of everything here. Of course, we are never allowed to go to anything where there are enlisted men. and the officers' families won't have us at their parties. We don't mind this, but we certainly would like to talk to some one who wasn't a nurse. Our chief nurse is rery good to us and gets up little parties where we dance and sing with the same girls we work with all day. I have thought if I had happened to be a stenographer, I conld have served my country at Washington and still not have been a social outcast.

There is such a grind of petty detail on the ward that we lose sight of the fact were at war. We were invited to a big Christmas dance where even the commandant took his family. lut we (oull not go berause nurses must not assoeiate with enlister men. I an twenty-eight years old; I wondre how the vounger girls just ont of training sehool stand it: Wo lasent wen thought of doing something romantic to kecp us going. There's nothing leroir in earing for monstes and mumps.

Now I'm met anding to resign. I'll stay here or any other plare where I an needed just als long as 1 am wanted, but norer in my life have I boen so blue and lonesome. Everyone is so nilu to the "boys in the service." Why do they never think of the erirls:

- Amerienn Red crome bureau of Archives. 
Reasons for this ruling were set forth by Miss Kline, an American Red Cross reserve murse in service at the Charleston Navy Yard:

The status of the nurse, officially, is that of a head nurse in a civil hospital. Professionally and socially she is rated as an officer. It is difficult for the nurse to understand the justice of this ruling at first, when some of the finest timber of our young manhood is of the enlisted personncl. Her own brother, friend and sweetheart may be among them, and why, when she has no rank, shoukl she be subjected to officer's regulations? When she considers that the mere restriction is a recognition of rank, though ever so meager, she usually realizes that it is of too much professional value to treat lightly. In ciril life an intimate friendship is not desirable with one's patients; so in military circles, reserve is a safeguard. Most of the patients are of the enlisted persomel. Cordial relations are desirable and possible, and the nurse is the confidant and advisor. The men are responsive creatures, sensitive to their environment, though stoical when "balled out" and appreciative of the least interest evinced in their welfare. The opportunities for personal influence are enormous and the nursing care is often a minor part of the nurses's duty. ${ }^{10}$

A fine devotion to duty, evident even in the letter of complaint quoted above, prevailed at the Naval hospitals. For almost all the murses in the Navy Corps, war service meant far more than the mere routine of daily hospital duty and the nurses gave willing, skillful and patriotie service. Conscionsly and unconsciously, they derived inspiration from their surroundings. The infections eagerness for ocean duty which was shown by the young boys who made up the greater part of the new Nary, the sight of gray battle craft anchored in the harbor at sunset but which went ont again perhaps in the turning of a tide, the play of srarchlights on the water, the hum and the crackle of the wireless, the very patients who came back sick from exposure to the rigers of the open seat, gave meaning and purpose to the life of Naval training camps or station hospitals. Josephine Trippett, Naval Reserve nurse in serviee at P'ollann Bay 'Training Station, New York, wrote in the Alilitary Number of the fournal:

. . And then there are times when one is deeply mored and is brought to al realization of the meaning of this and so 1 meriean fournal of lursing. Nilitary Number. p. diTl. 
all other places of its kind. Watch the sailors being shipped. They pass out of the gate, their sea-bags on their backs. No one speaks; their hearts are too full. We listen to the muffled sound of many feet marching solemmly along the road. For a mile one can see the wide, dark line and hear the rhythm and jangle of the rifles.

On May 4, 1917, a destroyer and patrol fleet of the American Navy, under the command of Rear-Admiral William S. Sims, arrived in a British port. Admiral Sims had been appointed as the commander of American Naval operations overseas and this destroyer and patrol fleet was the first unit of the American Nary to go abroad. Later, five thousand officers and seventy thousand enlisted men saw active service in foreign waters.

During the spring and summer of 1917 , the losses of merchant ships by reason of German submarine activities became so great that, at the suggestion of President Wilson, the Lnited States adopted the convoy system of transportation. This meant that large numbers of troops and supply ships were gathered together and sailed at regular intervals along established sca-lanes, under naval protection. Armed cruisers, smaller cruisers and later old battle ships, accompanied the convoys to protect them from raiders; destroyers went along to protect them from submarines. Of the $7,500,000$ tons of cargo earried to Europe, the Army lost only 200,000 tons and no American troop transport was sumk on its voyage to Emrope.

The destrover, with its depth bombs, proved to be an effective craft in anti-submarine warfare. A submarine attack which took place in July, 1918, was described by 1)r. Howard Kennedy Hill, of Philadelphia, Pennsylvania, a surgeon who served under the American Red Cross in France:

We were told that we would pick up destroyers at a certain hour. Exactly on the minute, although it was foger and rough. we saw a little American flag emerge through the fog and we later comnted seventeen destroyers in all, two of them the fast t:-knot type.

The next day at three oclock in the afternoon. when the sea was as sminy and quiet as a millpond, we sudlenly silw a tremendons explosion some four miles to the south and immediately folt the (ondesion of a bomb atrainst the side of our boat. likis the pushing in and out of a tin pan. The destroyers them began a systematic dropping of depth bombs 
which are supposed to at least injure a submarine if within a radius of four humber yards. The rumor immediately spread through our boat that the destroyers had sunk five submarines. We were all sure that we saw one black mass rise in the air. 'That evening the British Admiralty officially' confirmed the destruction of four.

American destroyers and submarine chasers had their bases at (Queenstown, Ireland. Battleship I)ivision Six was based on Berehaven, Ireland, in readiness to meet and escort transports and supply ships. A submarine patrol off the west and south coasts of Ireland was also maintained from Berehaven.

A second major enterprise of the American $\mathrm{Navy}$ was its participation in Allied Naval activities in the North Sea. Battleship Division Nine of the Atlantic Fleet under the command of Admiral Rodman, constituted for nearly a year the sixth Battle Squadron of the British Grand Fleet, which was directed by Admiral Sir 1)avid Beatty. A mine barrage was laid by the Allies from Scotland to Norway. By thus closing the North Sca, the Allies denied enemy submarines free access to the Atlantic Ocean from German bases. Secretary Daniels wrote:

More than 50.000 American mines have been laid in stratecrical areas in European waters. The Navy has taken part in and actively laid so per cent of the great mine barrage 230 miles long, from Scotland to Norway ; a total of 56.439 mines have been laid, all of which were designed and manufactured by the Inited States and transported and laid by the Enited States Nary.

Rear Admiral Strauss was in eharge of the Ameriean mining activities in the North Sea. Two mine bases were estahlished orerseas and a personnel of over $6700 \mathrm{men}$ were engaged in mining activities.

Conveniently near the Sixth Battle Squadron and the Mine Bases was the American Naval coaling base at Cardiff. Wales, from which coal was secenred for the Atlantic Fleet and for the Ameriean Expeditionary Forees in France.

There were other Amerioan Naval activities in foreign waters. A foree made np of destroyers, gunbuats, cruisers.

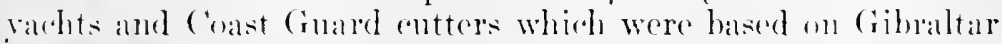
performed twenty-tive pere ant of the orean eseort duty letween Cibraltate. Franeer and Italy, and serenty per cente of the ocean 


\section{HISTORY OF AMERICAN RED CROSS NURSING}

escort duty between Gibraltar and England. A temporary American Naval base for submarine flotillas was established at Ponta Delgada in the Azores.

The American Navy maintained four thousand hospital beds in Europe for the care of its personnel engaged in the various activities briefly mentioned above and also for the care of the United States Marine Corps in Franee. The major portion of these beds were furnished by the assignment to foreign service of the five base hospitals which the Ameriean Red Cross had organized and equipped for the American Navy. Two of these hospitals were assigned to duty near Edinburgh, Seotland, a third at Queenstown, Ireland, and the remaining two at Brest, France. Small hospitals and dispensaries were established in Great Britain and in France by the American Red Cross and were later taken over by the Navy. Other hospitals, dispensaries and siek-bays were staffed by Navy surgeons and hospital corpsmen at Plymouth, England; along the French and Irish coasts; at Ponta Delgada, Azores; at Gibraltar; at Corfu and at Genoa, Italy. This brief mention is all that will be made in this history of these dispensaries and sick-bays, as no American Red Cross nurses saw aetive service in them.

Five American Naval hospitals were maintained in Great Britain during the Enropean War. Three of these were United States Navy base hospitals and the other two were institutions established by the American Red Cross and later turned over to the Naval authorities. Similarly as with the Army, the American Red Cross in Great Britain formed an emergency arm of the American Nayy; its nurses rendered service to the first American soldiers to be torpedoed by German submarines.

On the evening of February 5, 1918, His Majesty's troopship, Tuscania, with convoy and escorting destroyers, approached the entrance of the North Channel. A German submarine piereed the ring of destrovers, fired on the Tuscania and the torpedo struck her on the starboard side. She immediately listed doeply. The 2500 American soldiers who were aboard were ordered to the boats and the British destroyers and patrols of the North Channel stood by and many humdreds of her company were resened by them.

The life boats on the Tuscrinie's port side had been nuinjured, so other American soldiers rowed away in them as she sank. The swift ont-flowing tide and the bitterly cold wind (anght the boats and life-rafts and drove them toward the 
rocky shores of the Isle of Islay. The bodies of 182 of the T'uscania's company were thung ashore.

Many of the lifeboats, however, were brought saf foly to land but the survivors were in a desperate plight from exposure. Along with other Red Cross persomel, a detachment of Red Cross murses from American Red Cross Military Hospital No. 4, Mossley IIill, Liverpool, were inmediately hurried to Islay to eare for these patients. This detachment arrived in reeord time, tended the soldiers and finally accompanied them to the Army hospital at the American Army Rest Camp in Winchester, England.

Soon after the sinking of the Tuscania, United States Naval Balse I Lespital No. 2 arrived in England; on Mareh 1, 1918, it opened a Naval base hospital of six hundred beds at Strathpeffer, Scotland. ${ }^{11}$ This Naval mnit had been organized by the American Red Cross from personnel of the Lane Hospital, San Franciseo, California. Dir. Stanley Stillman was the director, and E. Elizabeth Hogne, the chief nurse. Miss Hogne was a gradnate of the California Training sehool for Nurses, Los Angeles, California. After extensive excentive experience in several California institutions, she became in 1914 superintendent of the School of Nursing of Lane Hospital. Two years later she organized the mursing staff of Nalval Base Hospital No. 2 , and in the antumn of 1917 went with her mit into naval serviee in the Lnited states. Foreign assigmment followed.

The location of Nay Base Hospital No. 2 was in a picturesque spot, for the little seotch town of strathpeffer lay in the anvirons of Inverness at the head of the long fingerlike ('romarty Firth. Nary Base IIospital No. 2 received patients from Mine Bases Nos. 17 and 18, and from the Sixtl Battle Siquadron.

The second Ameriean Naval hespital to be established in Great Britain wils placed in London by the American Red ('ross for the eare of officers and nuen of the Ameriean Nalval II add fuarters at bondon and of naval eraft form the inmediate

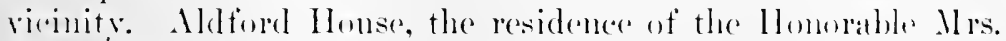
Frederiek (inest, was taken overe by the ('ommission to Cireat

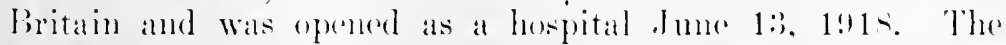
honse, which eorered an entire rity block in Park Lalne. had formerly: been used ats al hospital for British wounderl and had

". "lieport of the A. R. C. Commission for Cireat Britam. Part I. Haspitals:" l. l.2. 


\section{HISTORY OF AMERICAN RED CROSS NURSING}

a capacity of fifty beds. A Navy surgeon and staff were assigned to duty there and shortly afterward the Navy took over its entire management, raised the bed eapacity to seventy-five and maintained it as a Naval Hospital.

Miss Hall, one time chief nurse of the American Red Cross in Great Britain, wrote:

Catherine Taylor, a Canarlian woman, an American Red Cross nurse and a graduate of St. Luke's Hospital, New York City, was chief nurse of Aldford House and remained in charge there until the hospital was taken over by the Navy and staffed with a mit sent out from America by the Nary Nurse Corps on september 10, 1918.

The third American Naval hospital to be established in Great Britain was L. S. Nary Base Hospital No. 3, which was assigned to duty at Seafield Leith, near Edinburgh, on the Firth of Forth. Like Nayy Base Hospital No. 2, this unit had been organized by the Ameriean Red Cross from the personnel of a western hospital, the California Hospital, Los Angeles, California. Dr. Rea Smith was the director and Sue Soplia I)auser was chief nurse.

Miss l)anser was graduated in 1914 from the California School for Nurses, and for two vears was head murse on the surgieal department. Ame A. Williamson, superintendent of nurses of the California Hospital, had organized the nursing staft of Nary Buse Hospital No. 3, but Miss l)anser, after instrurtion at the Naval Training (amp at San l)iego, led the nursing mit into foreign duty. She wrote:

Inited States Navy Base Hopital No. 3 mobilized at Philadelphia during the month of Hecember, 1!1\%. Cutil August 1, 1918, the nurses diel temporary duty in and near Philadelphia. ()n Augnst 1. 1918. we embarked from New York on the British transport H. M. S. Mandingo for IIalifax. where we joind a British convoy of twenty-one ships. Seven of these ships were transports earrying troops; the rest rarried freight.

We arivel at Liverpool, Alugust 15, 1918, and by train arriced at Edinhourgh. Sirotand, eally the next morning. "The hospital we tork over had been inder the British Admiralty for four years. In antioipation of the chance, the British Lemiralty transfereel all the onlisterl men fationts to (ilasgow, but there remainen abont tifty oflicer-pationts. 
The buikling in pre-war days was a poorhouse. It was well buitt and so arranged as to adapt itself most conveniently for a hospital, and aflorded ample room for sesen humdred and fifty patients. 'The British hospital equipment was established in the buthling and all of our own equipment had arrivel there before us. We installed our own and aceepted enough of the old to enable us to earry about seven humbled and fifty patients. We found our own equipment more conrenient. For instance, our heds were the high white hospital beris: the old ones were low black iron cots. We also had enough white paint with us to paint the walls, which had formerly been liriglit and striking colors.

The mirses of Nary Base Hospital No. 3 were assigned to comfortable and attractive quarters. Miss Dauser wrote:

The nurses lived in a building that in pre-war days had bean one of the best hotels in the suburbs of Eelinhurgh, and was about three miles distant from the hospital. A large bus, similar to the Fifth . Nenue buses, New York, male regular trips betwen the hospital and nurses' quarters. 'This stretch of three miles was considered one of the most beautiful drives from lidinburgh. We were, as we always put it, "loaned to the British Almiralty" and in spite of four years" hardships in England and sootland, they seemed willing and eager to give us the best of the comtry in appreciation of our services to their wounded.

Enited States Nay Base Hospital No. 3 was located in Ealinburgh to take care of patients sent from the Grand Fleet, which was then oprerating in the North Sea. Miss I)anser werte of the siek and womnded who were sent to this big Amerian base:

The hospital was open to the four military oreanizations, the British Xary and Army and the Ameriean Xary and Army. The majorits of Saval pationts were influenza castes. lut biluejackets were only a small pere cent of the number ol

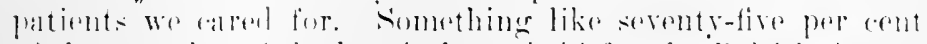

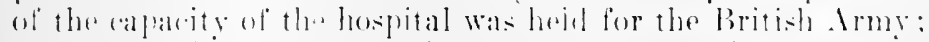

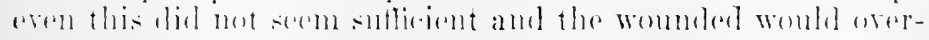

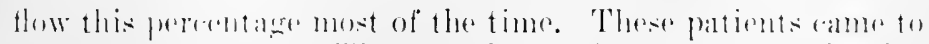

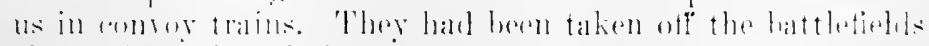

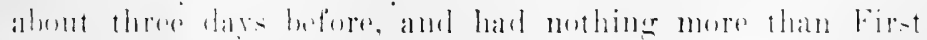

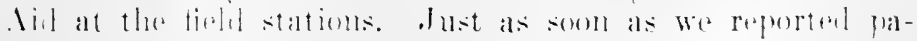




\section{HISTORY OF AMERICAN RED CROSS NURSING}

tients on the convalescent list, they were transferred to some convalescent home, and the space given to new patients arriving from the channel ports.

During the entire stay of United States Navy Base Hospital No. $\tilde{5}$ at Edinlburgh, Scotland, we were extremely busy. Every nurse of the entire nursing staff seemed to completely lose herself to her ward and ward-work. The spirit of the wounded was a great inspiration. I do not remember of ever having heard a complaint, no matter how trivial, from a patient.

The Naval coaling base for the American Navy in foreign waters and for the Ameriean Expeditionary Forees was established at Cardiff, Wales, as has been stated in this ehapter. Seventeen American colliers carried Welsh coal taken from the mines near Cardiff to the Atlantic Fleet in the North Sea; eighty-two other American govermment ressels which were known in the Nary as the "Suicide Patrol" beeanse of their eonstant trips through the mine-infested Channel, carried coal from Cardiff to Brest, Bordeanx, Nantes, and St. Nazaire for the use of the American Expeditionary Forees in France: Over two thousand bluejackets were based on Cardiff. To care for cases of influenza and pucumonia among these sailors, the American Red Cross established on October 7, 1918, a hospital and dispensary in Park Place, Cardiff. Three houses adjoining a large disused acroplane factory which served as a Red Cross Club and dormitory for Ancrican sailors, were fitted up. Six American Red Cross nurses were detailed to serviee there and with a Navy surgeon and several hospital corpsmen. eared for a daily average of forty bed pationts and one hundred dispensary cases. The following summary of their activities has been given:

So active was the port of Cardifl that while the Rowl cros: was on duty there. more than 100,000 Ameriean bhejackets and Naral officers enterest, pased through. or were attarhen to the base. Of these, the Amerian Red Cross gare servine of some tyle. to more than eighty per cent. It aroul for $3 i$ it patients-on of them "fh" "ases-in its own hospital, only

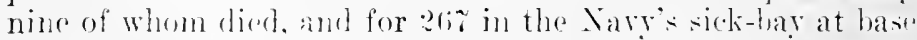
hearlequarters. It the hed Cross dispensary 36006 saitors receiven treatment. ${ }^{12}$

13."The Passing Lexions," (i. li. Fife, p. 2999. The Nacmillan Co. 
The American Red ('ross IIospital at Cardiff, Wales, was taken over by the American Navy a few weeks after its establishment. Its capacity was raised to two hundred beds and it was maintained as a naval hospital as long as Cardiff was used as a roaling hase.

The last American Naval hospital to be established in Great Britain was Enited States Nary Base Hospital $N^{2}$ o. 4, wheh had been organized by the Anerian Red Cross from personnel of the Rhode Island Ilospital, Providence, R. I. I)r. George A. Ilattingly was director, and (irace MeIntrre was rhice nurse of this mit. Miss MeIntyre was graduated from the Boston Lying-In Hospital and for twelve years did private duty nursing. She was a student of the i)epartment of Nursing and Health, Teachers College, for two years, and then returned to her alma miter as superintendent of murses. She later be"ame assistant superintendent of nurses of the Rhode Island Hospital and was subsequently appointed ehief nurse of Naval Basc Ilospital No. 4.

After service in varions naval training camps and stations in the Enited States, the nurses of Navy Base Hospital No. 4 were mobilized September 12, 1918, in New York. Miss Macintyre wrote:

We sailed reptember 23 on an English ship, the Briton. The persomnel on bard consisted of 2:?00 troops and of 60 women, inchuling our nurses and a group of Red Cross workers. A dirigille halloon and a group of airplanes areompanied us ont of the harbor until we met our consoy which consisted of fourteen troop) ships, one aruiser which went aheal of us. one battleship which guarded our roar, four de. troyers and oight or ten submarine dhasers which left us the sedomel day out. 'This anvoy arried about 30,000 troopss in all.

The position of the ships was interesting. During the dar

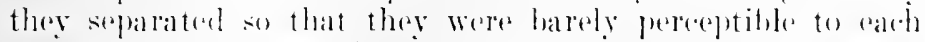
other. lut at retreat they ame together like al hen with a hroos of rehickerses.

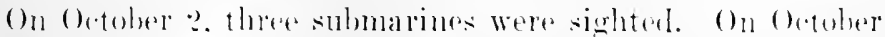

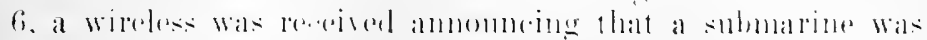
after the liritom. While at dinner that exominge we reserived

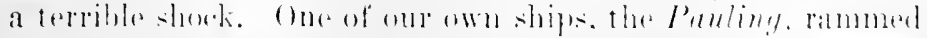

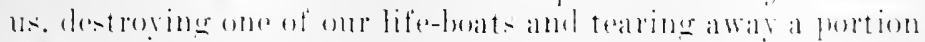

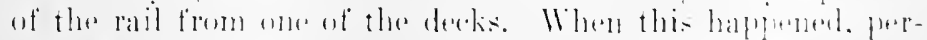

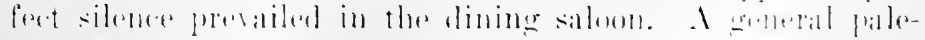




\section{HISTORY OF AMERICAN RED CROSS NCRSING}

ness was on ereryone's face, as we all felt that we had been torpedoed. Our ship soon righted herself and happiness permeated the room again.

Spanish influenza broke out anong the troops on the Briton and the nurses of Navy Base Hospital No. 4 volunteered their services. Miss Macintyre wrote:

... The medical officer in charge of the sick men invited me to inspert the patients, men from the 319 th Regiment of Engineers, from ('alifornia. On the promenade aft deck were about thirty sick men, lying on the deck with nothing under them but a canras hammock or a blanket serving as a mattress. They were so close together that one could hardly pass between them.

Within forty-eight hours, one hundred and sixty cases had developed. Some of these men were ruming high temperatures and many of them were in great pain. At first the very sick patients were cared for in the sick-bay, but were later taken to the decks of the ship where fresh air surrounded them and where more room was arailable. As the royage lengthened, the weather grew more severe and the sea more rough. The decks were often washed by the wares and our sick men drenched to the skiu. The patients were then moved into the officers' smoking saloon and into the main salown of the ship, where we were able to make them more comfortable.

Colonel Otwell, in command of the 319th Engineers, wrote:

The sick report of the troops on board .. . jumped from 6 to 160 in forty-eight hours. Seeing the danger. Miss MatIntyre and her (u-workers . . volunteered their services, with the result that what was chaos (there being practically no accommorations or facilities on board to care for such numbers) was handled in what I consider a most admirable manner muter the rircumstances. They have worked niont and day in the ond and hamp, on decks that were being washed by seas. without any lights whatsoever. exposed to the dangers of rontagion with a deadly malady and they have rendered these services most cheerfully. . . . ${ }^{13}$

The docking at Liverpool was impressive. Miss MacIntyre wrote:

${ }^{13}$ Report written Octoher 7. 191s, hy C. W. Otwell. Commanding Troops on Board H. M. T. Britom. to the Commanding Otlieer. L. S. Nayg base Hospital, No. 4. Queenstown. Ireland. 
As there were twenty-one miles of docks, it took us several hours. We passed ships of men in our familiar khaki uniform who exchanged enthusiastic greetings. Many pleasant acquaintances had been made during our troublesome royage, (aused by the illness of our men and by the extremely rough weather. (olonel otwell called our group together and spoke most feclingly regarding the work of the nurses, and when he har finished, . . . the ship rang with applanse from officers and men.

At Liverpool seven nurses of our unit were detached and sent to Leith, Sicotland, and four others to Cardiff, Wales. The rest of us soon entrained for Queenstown, Ireland. . . .

Our hospital was epenel thirty hours after our arrival, to meet an emergency cansed by the Aquitania, which cut the Shau, a destroyer, in half. Several men had been killed and about twenty, I think, injures. ${ }^{14}$ Dr. Carpenter, our 'ommanding officer, was much pleased with the manner in which the nurses threw themiselves into the work after their strenuous royages, both across the Atlantic and the Irish Sea. He said: "They all rebounded like rubber balls."

\section{U. S. Nary Base Hospital No. 4 was established at White-} point, one of the most beautiful and pieturespue spots along the Irish coast. The hospital buildings were the familiar barrack hut which had becon brought from the United States. The caparity of the seven wards wals two hundred and fifty beds.

The patients which came to Navy Base Hospital No. 4 were largely influenza eases. Miss Macintyre wrote:

Our patients wame from the torpedo base just across the harbor from us. from the dir Station at Aghacka, thirty miles from Queenstown. from the Passage Barraks two miles north. from the Air Station and Pigeon Carrier Station at Widdy lstand. cighty miles away, and from our own ships in tho harbor. There were two large ships. the llirie and the Metrille, and many smaller boats stationed in the harbor near us doring our stay in (queenstown.

Throngh the worst palt of the epromine. we loaned a few of our nurses to the British Xaval llospital areros the harbor at [Homllowline. They hand a hospital of eighty heds and omly two erratuate nurese. Howerer. they had twolve splemelit

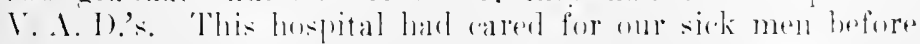

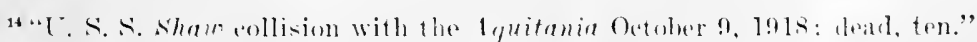
lieport of the sereretary of the Nity. 1915. p. 249. List of injured not giverle. 


\section{HISTORY OF AMERICAN RED CROSS NURSING}

we had arrived and we were only too glad to be able to be of service to them. We also sent two of our nurses to Widdy Island eighty miles away, to care for a few patients who were too ill to be brought to us at Whitepoint. ...

Three American Naval hospitals, in which Red Cross nurses, and regular and reserve members of the Navy Nurse Corps served, were established in France during the European War. The first of these to arrive in France was United States Navy Base Hospital No. 1, which was attached to the United States Marine Corps. When the Marines were brigaded with Pershing's divisions in the autumn of 1917, Navy Base Hospital No. 1 was assigned to duty with the Ameriean Expeditionary Forees at Angers, and later at Brest, France. The seeond Navy hospital in France was United States Navy Base Hospital No. 5, which served the American Navy based on Brest. The third was established by the American Red Cross Commission near Bordeaux for the care of patients from the Naval forces operating in the waters near the southern port. Sick-bays and dispensaries, staffed entirely by Naval Hospital corpsmen, were located at Lorient and Panillae and at various Naval air stations along the coast of France.

Navy Base Hospitals Nos. 1 and 5 were mobilized in September, 1917, and embarked for foreign service within a few weeks of each other. Although Navy Base Hospital No. 1 was the first to arrive in France, the experiences of Nary Base Inspital No. 5 will be recounted first because No. 5 was more typieally a Naval hospital. As the sanitary mit of the Marine Corps, Nayy Base Hospital No. 1 became part and pareel of the Ameriain Armies when the Marines were assigned to land duty in France.

Lnited States Navy Base Hospital No. 5 was established in October, 1917, in Brest. The professional persommel of this unit was eompesed largely of murses and physicians of thr Ifothodist Episcopal Hospital, Philarlelphia, Pa.; Ir. Robert LeConta was director, and Alice NI. Garrett was chief nurse.

Miss Garrett was graduated from the Pennsylvania IIospital, Philadelphia, and held various executive positions in the surgical watds there, as head murse of the operating room and as assistant to the superintendent of nurses, Miss l) mulop. Miss Garrett became superiutendent of nurses of the Methodist 
Episcopal IIospital in Philadelphia in 1906. She was enrolled in the Ameriean Red Cross Nursing Service in 1911 and served as head murse of the Ricd Cross fichd hospital at the Fiftieth Amniversary of the Battle of Gettysburg, 1913. Three years later, she organized the nursing staff of Navy Base Hospital No. 5.

The mursing staff of this unit were mobilized in Philadelphia in September, 1917. Miss Garrett wrote:

On O(tober 15, 1917, we were ordered to New York by special train. We went directly to the S. S. St. Louis and sailed the same afternoon at is P.MI.

We reached Liverpool, ().tober 24, 1917; at 3 P.M. we left for South Hampton... We reached Le Harre without accident and entrained for Brest, onr destination. We spent two nights and one and a half days making this trip which usually takes a few hours.

Navy Base Hospital No. 5 was set up early in November, 1917 , in an old Carmelite convent, at Brest. Miss Garrett wrote:

The building, which was not adapted to hospital use, was divided into many small rooms. The plumbing was of the most primitise kind; water was often a missing quantity. There was no beanty and little comfort in the cold. damp place, yet the patients were happy, appreciating their care and treatment, and they mostly made good recoveries.

With tents and huts in the grounds surrounding the hospital, there were arommodations for six hundred patients. the sick and injured of the Xavy. We eared for the men composing the cress of the transports, destroyers. mine swecpers and Vaval men stationed in and around Brest. It was the Naval llospital in France. . . .

The work of the Nary Nurse Corps was perhaps not as spectacular as that of the Army, but it was nevertheless just as needful. ()ur batiente were survivors from terpentoed boats or lads whe were hurned from explosions. or were almost physical wrecke from the hard lives they spent on the smaller cralt meed as destroyers and comserse It was alwaye a pleasure to minister to them: their bravery and their arati-

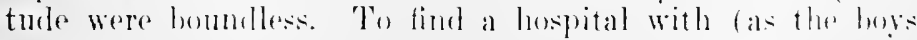
expressed it ) real Amerian murses meant more to them than ther could tell.

ilthough there wass always enough to de. the work was 


\section{HISTORY OF AMERICAN RED CROSS NURSING}

harder at times than at others. Whenever we heard of a boat being torperloed, we prepared for the survivors; our Naval Base was the best equipped on the French coast. Every time the bors went out they never experted to return, so the smaller ressels were i ightly called the "Suicide Fleet."

Miss Garrett's report contained the following extraet from the diary of one of the nurses of Navy Base No. 5.

April 18. 1918: This morning we had emergency call, sixteen burned cases. The Florence $/ I$. a small freight boat belonging to the - Steamship Company, was reported to have been torpedued. The accident (which is now generally believer was causer by a time bomb placed in the engine room ) happened one himdred and twenty miles out to sea. The boat had anchored on account of the fog. The cargo consisted of over five hundred tons of ammunition purchased by our second Liberty Loan. The entire crew was lost with the exception of thirty. ${ }^{15}$

These survivors were frightfully burned; some of them had the ends of their fingers drop off. All were burned on the face, che t and hands. Alout six are so ill that the doctors give little hope. It is a sal sight to see them all in surch horrible pain. The explosion hajpened at ten oclock at night, and the erew which brought the survivors in said the explosion lit up the sky like daylight.

July 1t. 191s: To-night tweity survivors were brought in from the llostorer. lour were wombled and the rest were shorked and in a bad condition generally. The boat. "arrying munitions, stexel, hospital supplies. locomotives. ambulances. etr., was makine her mailen trije. She was with a consoy but one of her engines became disabled and she was foresel to las behind, an mos target for Cirman ['-boats. Twice the

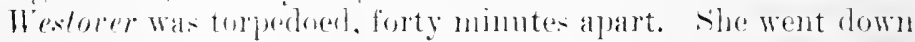
at one after thesesend shot.

The erew tork to lifoloats and were afloat from Thurselay morning. July 11. when they were struck, until sumblay night. July 11. When they arrived at our hase. They wore four

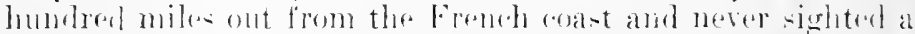

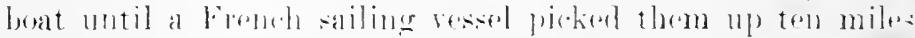
off shore and bromelst theme in. The captan of the llestoper

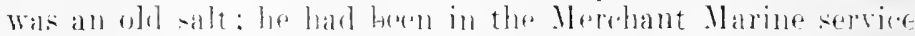
thirty-one veats and in the first life boat he had wnided them ly the stars.

is Serentern men of the "rew of the S. S. Florene H. were lost. Report

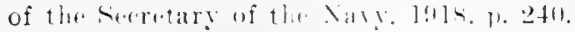


They had a little hardtack and a small amount of water, but as they did not know how long they might be at sea, they used very little of this supply. It had poured rain for two nights and days, and they had no protection whatever. They sang all the way "Pull for the shore, sailors, pull for the shore." They arrived at Brest, cold and wet to the skin and nearly starved.

We fed them hot coffee, eggs and toast, gave them each a hot shower and put them in clean beds. Several had had scalp wounds which needed attention, two had been severely burned on the face, hands and feet, and one with a fractured hip had suffered intensely. 'Two were given antitoxin serum as they ran a risk of getting tetanus under the circumstances. Many were given sedatives for shock. Poor lads, it was surprising how cheerful they were. There are still three life boats missing; the destroyers have gone out for them at once.

July 15: This afternoon fourteen more of the Westover survivors came in, and to-night fifty more, now making eightyfour in all. The entire crew, with the exception of about twelve, ${ }^{16}$ which were lost in the explosion, are now accounted for. We had to discharge a number of the survivors of the transport Corington to the receiving station to make room for them. It was well past midnight before we had them settled down.

The mascot was sared and he was brought to the hospital and eared for. They would not leare the faithful dog behind. They were cheerful in spite of their wounds and so grateful for all we did for them. These last survirors were almost five days in the life boats. They will be fitted out with new clothing by the Red Cross and when ready for duty will go back again at the old post.

A second American hospital to be established in France for the eare of sick and wounded of the American Navy was American Red Cross Hospital No. 100, which was cstablished in Jannary, 1918, in the picturesque Château Beaucaillon, on the Gironde River, near Bordeaux. Lientenant Colonel C. C. Burlingane wrote:

Among the earliest of the hospital formations of the Red ('roses wils . Imerican Red ('rose Howpital No. 100, installed in

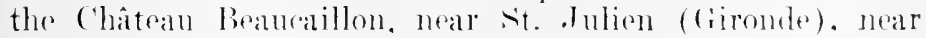
enough to Bordeaux to be easily arressible to the Nary. This

${ }^{1 n}$ Fight men of the erew of the S. S. Westorer were lost. Report of the secretary of the Xary, 1915. P. 2.t.2. 


\section{HISTORY OF AMERICAN RED CROSS NURSING}

hospital was operated for the Navy, which supplied the actual medical personnel, exclusive of nurses. . . . So great was the need and so effective the work done here that it was later expanded to one hundred and fifty beds by the erection of tents on the grounds, to take care of an epidemic which occurred among the Nary personnel.

A summarized report of this hospital for six months ending December 31, 1918, is as follows: Hospital days, 22,864; Patients admitted, r03; Patients evacuated, 197; Patients returned to duty, 440 ; Patients died, $295 .^{17}$

Convalescent patients of the American Navy were admitted to the American Red Cross convalescent homes already described in Chapter VI. Bluejackets were entertained largely at Convalescent Home No. 1, located in the Château de Beychéville, at St. Julien, Gironde; at Convalescent Home No. 2 which had been established in the Hotel Regina, Biarritz; and at Convalescent Home No. 3, which was located in the Hotel de la Source, Morgat, near Brest.

Navy nurses were assigned to duty in Guam, an insular possession of the United States which was located on the direct water path between the Hawaiian and Philippine Islands and they experienced unusually interesting and picturesque service. Frederica Braun (Columbia Hospital for Women and Children, Washington, D. C.) wrote, in the Nilitary Number of the Journal:

The Naval Hospital in Guam differs from any other hospital in the Naval service. Otficers and their families, civilians, enlisted men, and the natives of the islands. all depend on the United States Medical Corps and nurses for medical care. There is a small private hospital. "Susanna," in part endowed and also supported by fees from the patients: a ward for enlisted men and two native wards, one for men and boys over ten. and the other for women and children.

The hospital is situated in a beantiful part of Agana, the capital of the lstand. With a population of five thousand natives and about one hundred Americans. The nurses' duty is varied and interesting and is an excellent field for the nurse who has or desires experience in public health and welfare work: there is also experience in nursing tropical diseases. From thirty to forty children are always having the treatment; as fast as one set is ready to go out another comes 17 "Military History of the American Red Cross in France," p. 60. 
in. The treatment lasts from ten days to three weeks, and while the children are there they are examined very much as we would sthool children in the States.

When the Americans first took over the Island in 1898 the mortality from ehilkbirth and among infants was appalling. A training school was started by the IIeclical Corps for native nurses: since the Navy Nurse Corps was established part of the duty of Nary Nurses in Guam is to train these young women as midwives. They do remarkably well in this line, and if anything abnormal occurs they rush their patient at once to the hospital, sometimes by automobile, sometimes on a streteher, very often in bull carts, oecasionally in fish nets.

As a race, the chamorros are superstitious and have been taught that an evil spirit will get them if they leave window or door open at nierht. As the houses are most primitive, having usually but two rooms, with the entire family sleepingr on straw mats on the floor, tuberculosis claims many victims.

There are queer acrident rases; such as injuries from being gored by earaboas and falls from cocoanut trees causing unusual fracture complications; also there are serious infections from fish bites.

Nay murses stationed at Guam found ample opportunity for recreation. Miss Bramn wrote:

For amusment there is tennis, swimming, antomobiling, walking, dancing anel moonlight pienics. Every afternoon, madhines run from Igana to Piti for swimming: the water at Piti is deep and still. Dances at Dorn Hall are held every week, with music by the Marine Band. The piconics are the best kind of fun, with the moonlight shining on the white bearle and the seal somnding on the reef. . . The darkness comes quickly in the tropies, with no twilight, like a curtain let down. In the natives houses appear andle lights or tiny lampes, and the white roaks and beaches gleam against the dark palms-a fairy land. . .

()n night duty, one hears the sea all the time and every other sound is stilled : early in the morning. betore it is light. the natives so slip-slip to rhureh, a never-ending prosession. Then quickly connes the splendid sunrise.

As was previonsly stated, the first and largest Naval hospital to arrise in Frande was Enited states Nary batse Inopital No. 1, which was attahed to the Enited states llarine corps. 


\section{HISTORY OF AMERICAN RED CROSS NURSING}

This unit was also the first base hospital which the Red Cross organized for the Navy Department. Its parent institution was the Brooklyn Hospital, Brooklyn, N. Y. Dr. William C. Brinsmade was director, and Franees F. Van Ingen, chief nurse.

Following her graduation from the Brooklyn School of Nursing, Miss Van Ingen did private duty and institutional mursing in Ohio and Minnesota. She was a nember of the Yvetot Unit which National Headquarters assigned to duty in February, 1915, at the Alliance Hospital, Yvetot, France. She returned to the United States in April, 1916, and as superintendent of nurses of the Brooklyn Hospital, organized the nursing staff of Nary Base Hospital No. 1.

Navy Base Hospital No. 1 was ordered to mobilize on September 11, 1917. Miss Van Ingen wrote:

At noon on September 11th, while I was stationed at the United States Nary Hospital, Brooklyn, the commanding officer told me to have forty nurses reacly to sail for France in two days. It's still hazy in my mind just what did happen during those two days. Kind people helped me phone, others loaned their antomobiles or ran errands themselves, the Rerl Cross stretched forth its mighty arm and the full equipment, including the uniforms, appeared.

On September 14, 191\%, the mit Jeft Grand Central Station. It was early enough in the war for our miforms to be new to the public. A regular officer of the Nary, Dr. L. S. Von Wedikind, with Dr. Vickery, took charge of the unit. Our destination was the Xary Yard at Philatelphia and we walked from the train to the U. S. S. IIenderson. It was the first time officers and crew had ever had women traveling with them and the nurses found things as interesting as the crew found 11 .

The following Sunday evening, the Sixth Division of Marines ame aboard, abont 1500 men moler Major Hughes. Comparatively few of this division lived to come back. 'Twothirde of the officers were killed. After the Armistice colonel Hughes passed through our hospital on crutches on his way back to the l'nited states, a mere shadow of his former vigrorouss self.

Momlay morning we slipjed from onr moorings out between the nen-ei-war. On arery sicle (endel be heard the music of two or three hands, the shrill. whistles of Sary and harbor craft, the deering of the edakics... 


\section{Miss Van Ingen wrote of the trip across:}

In our convoy was the Cruiser san I)iego, ${ }^{18}$ with its great observation balloon which was up most of the time; two destroyers; a tanker: and two transports, the Finland and the Aritles, which was sunk on her return trip.

I was told one morning to assemble all nurses in the mess hall for "Invpection." Every one was to be in dress uniform, which included hats and gloves. At the appointed hour we cathered together very solemmly and proceeded to wait. Alter two hours, the inspecting party approached. All the officers were dressed in blue and white and gold, with swords burkled at their sides, and white gloves on their hands. They filed through one door, took a searching look at us, and eachi, according to his rank, filed through the other door and out of sight. It was awe inspiring! I don't know what became of those swords and white gloves; they never graced another inspection. We surely took ourselves serionsly at first. We had "Quarters" at 9:15 A.M.; "Abandion ship" at $9: 30$; deck drill at 10; with "Sick Call" at the same time for those not feeling well.

The IIenderson docked at St. Nazaire, France, on Oetober t, and the persomel of Lnited States Navy Base Hospital No. 1 proceeded the next day to Angers in the Department Ilarne-et-loire, Frince.

The Marines, to whom Nary Base Hospital No. 1 was attached, were lorigaded in the fall of 1917 with the Ameriean Expeditionary lores and the mit, thomgh still monder the anmmand of a $\mathrm{X}$ avy otticer, was taken over by the Army. Hence this Naval mit was tomporarily assigned, until the end of Norember, 1917, to staff the Ilongazon, a future Army hatse hospital at Angers. Of their arrival there, Miss Van Ingen wrote:

It was extremely weirl in that station at mirnight. We

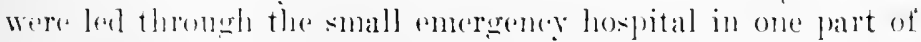
the holdener. whero dim lights slowerl us soldiel's and nurses in the French mifurms: arerything arme and rather dirty. The only means of beaching our destination, two mike ontside the aty. was hy walking. So we tiled through the dark. narrow strees of Ingers. and the shut tered hollses and silent streets left a dram-like impresion with me-so unreal from the bustling Angers by day.

"Hater sunk he a dicrman submarine. 


\section{HISTORY OF AMERICAN RED CROSS NURSING}

We were given a great building, the Mongazon, formerly an old school for priests. The buildings and grounds were ideally situated for the splendid hospital it was afterwards made into.

We nurses were apportioned to the top floor of one of the wings of the Mongazon. Here forty nurses found forty French beds, forty small bedside tables, forty chairs in one large dormitory, and c'est tout. A small room was given me. Across the hall from it was a wash-room with a stone floor, a long narrow tin trough down the center and a pipe with ten tiny water taps suspended above it. And again c'est tout. As I made my rounds, my heart froze within me. How could forty grown women, the sprightly and the silent, the tidy and the thoughtless, the tranquil and the turbulent, room here together? In answer to most of my requests, it was either "Now you must remember that this is war," or "I hardly think that the nurses RATE that."

Not that there was much complaining, however; the nurses were really very game and sporty. Baths were our greatest difficulties. On the ground floor at the extreme end of the building were two small rooms with a tin bathtub in each and a hot water geyser over one; this geyser was expected to supply hot water to both tubs. Everyone was warned to follow directions of operations very closely and all went well for two weeks. Then a nurse mismanaged, there was a loud explosion and the geyser was a wreck! Ifter that we walker about two miles to Angers with our own towels and soap, waited half an hour or so at a public bath and had a clean comfortable bath and walked back again.

During the last week in November, 1917, the personnel of Navy Base Hospital No. 1 was ordered to permanent quarters at Brest. The Pittsburgh Lnit, United States Army Base Hospital No. 27, had been assigned to the Mongazon at Angers and desired to take over their permanent quarters. Horeover, the twenty additional nurses of Navy Base Hospital No. 1 who had bern loft in the United States when the majority of the mit sailed, arrived on the U. S. S. Von Steuben and the mursing staff of Nary Base Hospital No. 1, thus re-mnited, proceeded to Brest. Miss Van Ingen wrote of their arrival:

I will never forget my fechings when we marched to the hospital which was to be ours for aleven months; it so chosedy resmbled the liaymond street jail in Brooklyn. . . The building had been used originally as a school for bogs, the 
Petit Lycée. Since the war the French hat used it for a hospital and their evacuation to make room for us was delayed until a young liench lad made complete his great sacrifice for France.

The buildings covered alyout two hundred square feet and had been erested about two courts in which we afterwards put up tents and barracks to increase the number of our beds. The main part of the building had four floors above the grounl floor. Besides isolation tents, sick officers' and sick nurses' quarters, we had seren warls in all, which accommodated from ten to one hundred beds each.

The 11 rses of Navy Base Hospital No. 1 aceepted their new quarters with the same good humored sportsmanship which they had shown at Angers. Miss Van Ingen wrote:

In the far corner of the larger court, with its windows overlooking the court d'Anjon and the Bay, I was given a few rooms for nineteen nurses. Seven were in three unfinished attic rooms, with dormer windows. The other rooms held from one to two each.

The lower part of a Convent, three blocks from the hospital, which included a large chapel, five fairly large bed-rooms and two or three small ones had been rented for the remainder of the murses. Twenty-two nurses were crowded into the chapel, four and five in each of the bed-rooms, that should have held only two. The Red ('ross helped us out wonderfully in adding a fow comforts: they provided easy chairs, a number of screens, to furnish a little privacy, three wash basins and a bath tub, hot water heater, gas stove, sash curtains, hand basins and pitchers, a few mirrors, china dishes to replace the tin ones we were nsing, and a little later a piano. The pleasant, free way in which the Red cross grave to us came as balm: never ond" was it said that we did not "rate" these comforts. but rather "Is there anything alse that you need "."

The nurses were wonderful about making the best of trying situations and there were many of them. First and worst was the question of heating. . . Another distresing circumstane were the night prowlers-cats, mice and men. Our rooms were on the ground floor. 'The windows opened right

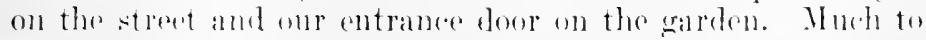
the horror of the people of Brest. we refused to sleep bethind those window shutters made of solid wool. Lattice whields were put half way up the windows. but they failus to keep out the "ats, who walked ofl with delertable "eats." or to prevent the Fronchmen from elimbind to the window ledges 


\section{HISTORY OF AMERICAN RED CROSS NURSING}

and attempting to scramble over. The garden entrance was rather more of a menace, for we many times had actually to turn out of our hall and bed-rooms intoxicated soldiers and sailors. Nothing even approaching a serious situation ever happened; they were in fact often more ludicrous than alarming, but I never retired at bedtime that I did not hope the night would pass without someone being dreadfully frightened. The mice and rats are, of course, a part of French housekeeping. An oecasional shriek or squeal would be heard at night in the room next to mine, induced by the travels of some mouse across the pillow of a nurse or a too venturesome one getting lis feet tangled in her hair.

Our garden was our chief joy. It was a really French one, with all that implies, hidden behind a thick wall ten feet high with fruit trees and rose vines trained against it, winding paths around rather neglected flower beds, splendicl trees that gave shade or shelter and a little screen door that opened on to an unpared lane. ...

Nurses and hospital corpsmen of the Brooklyn Lnit immediately undertook the renovation of their new hospital. However, Paris headquarters on Deember 20th ordered thirty nurses on detached duty to Camp Coetquidan, then the largest American artillery training eenter in France. Anna Burges was ehosen head nurse.

Of the heary work which confronted the depleted nursing staff at Navy Base No. 1 at this time, Miss Van Ingen wrote:

The demand on our unit to send these thirty nurses to Camp Coetquidan came just when our hospital was filling rapidly with stevedores and men from the transports, all, of conrse, medical ases. The States were sending orer many of their colored regiments, and, as all the stevedores were of that rare, two-third: of our beds har black faces on the white pillows. The wards were not yet fully equipped, many very necessary articles were still inpacked in the store rooms: the galley was in need of stoves; half the nurses were doing detarbed duty and we had an average of ten sick in murses' sick quartors. Adt io this a hospital full of black men, sick with mumps, noasles, meningitis. . .

Our most sorions ases were the measles and moningitis. esperially the measles ases coming from the transports. The transporting of them from the ships to the hospital proved fatal to many. They were arried from the ship to the lighter, from the lighter to the dork, from the dock to 
ambulance, from ambulance to hospital. It sometimes took from six to eight hours to accomplish this. At this time these lighters were uncovered boats, mere bareses, so that these sick boys were exposed for hours to the cold and rain.

The work of the nurses and corpsinen was made exceptionally hard through the lack of elevators, dumb-waiters, toilet facilities and rumning water. The city of Brest had nearly three times its normal population to supply with water, so there was constantly a fear of a water famine. Sometimes, without the slightest warning, the water would be shut off for days. We would have to send out relays of French women and corpsmen with great varieties of pitchers and tubs to bring back all they could from remote public fountains. On each floor we larl bath tubs placed near a tap, so that when the water was turned on by the city at night we could collect some and have it for the morning toilets and cleaning. It seemed the irony of fate that with the sky constantly pouring down water on our heals that the eity pipes should be so of ten dry-abont the only thing dry in Brest.

Our sorond greatest difliculty was the lack of good plumbing. Brest does not possess sewage; eath building has its own cess pool. These had to be emptied by the city at our own expense: generally not until we had notified the authorities many times anl waited until the cess pools were overflowing and the toilets were backing up and out of use, would they pay the slightest attention to our demands.

W'hen this happened, and it seemerl to be happening all the time. it male neessary the arrying down from the upper floors of all excreta. I am sure few corpsmen worked any hariler than ours. All the stretcher cases had to be carried up and down the one, two or three long flights of stairs. Food. water. (nal and refuse had to be taken ware of in the same way. By comparison with the men in the trenches. their work was child play, but for most of the boys with us the work wals such as they had never done before and it was hard and not very pleasant.

During the spring of 1918 , the American transports began to take laak to America the "Class I)" men and Nayy Basc Hospital No. 1, which was then the only Aneriean hespital in Brest serving the American drmy, was erowded with paticuts. An Army amp on the ontskirts of Brest was opened in April, 1!15, and later another was established at Kehumon, a town near Brest, and later several of the laresest baso hospitals of

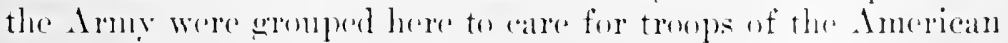




\section{HISTORY OF AMERICAN RED CROSS NURSING}

Expeditionary Forces returning to America after the signing of the Armistice.

During the summer of 1918, Brest and its environs were crowded with American troops. Over 300,000 American soldiers, it may be remembered, were earried to France in July, 1918. At the same time that the wards of Navy Base Hospital No. 1 were filled with medical and accident cases among these troops, the German drives on Paris were greatly overtaxing the medical and nursing faeilities of the Army and the Red Cross. Nurses were at a premium, both in the zone of the base and of the advance, so operating teams were organized from Navy Base Hospital No. 1 and sent to Orleans, to Paris and to the front.

Of the work which confronted the depleted nursing staff at Navy Base Hospital No. 1 at Brest, Miss Van Ingen wrote:

It was during these months, when we were so short of nurses and corpsmen, that our work was heaviest. American troops were pouring into Brest from May to November. Forty thousand were camped in and around Brest in the early part of June, 1918. Consequently our beds were filled with sick. If it had not been that nurses were being sent over on these transports at the same time, we would not have been able to keep up the high standard of nursing we harl set ourselves. These transient nurses were detailed to help us while they waited for further orders. As it was, the lours were long. These transient nurses would just about have learned the routine and have gotten into the swing of the work, when their call would come and they would go, leaving us to face twelve, fourtren or sixteen hours without time off.

In September we began to gret the "flu" cases from the States. Men brought in off the loattefields shattered and bleeding were not as tragio to me as these that ame from our own ships. In with the pallor of death on their faces, labering for air. yet begeging for food, their lips and tongues so grlued together they comdd hardly articulate. and hefore we conlel are for them they wond be out of their agony. begond the want of form and water. Many dien on their way to hospital or as they were put on their beds. . . I think we all agerd with the aw fulness of it, and have our nights haunted with the memories of those weeks.

The first detalment of nurses who were sent from Nav Base Hospital No. 1 left Brest April 6, 1918, for service with 
the French at Orleans. Anne Burges was among the four nurses who saw service there and she wrote of their experiences:

Upon the arrival of Dr. Brinsmade, his assistant and a few corpsmen (at Orleans), a parilion accommodating 16s patients was assigned to him. This pavilion had been entirely equipped by the American Red Cross with the one exception of beds. ...

When a convoy of wounded were brought in, the system adopted was excellent. Everyone expected to work and did so until all the men were cared for. . . .

After the first two months the nurses did all but the most serious dressings.

The ward mursing was done by volunteer French nurses, with chambermaids to keep the wards clean. Nearly all of the volunteer workers had been nursing since the outbreak of the war. 'They never seemed weary of doing for their brave men. They were on duty at eight A. M., and stayed until eight P. x., none coming late or leaving early. The greatest care was taken by then to see that any American wounded received especial attention, as so few of our boys rould speak French and make their wants known. As there was no regular night nurse, the day nurses had to take each her turn, about once a week.

Army Base Hospital No. 202 was opened about the mirdle of July. On August 1 th this detachment from Nary Base No. 1 was transferred from the French hospital to help them. for the American wounded were coming back in great numbers. . . The morning after they had reported for duty they were each assigned to a large surgical ward, to take charge of dressings. . . They were returned to Brest on October $21,1918 \ldots$

In addition to this medical and nursing detachment, an operating tean composed of two surgeons, two nurses and several corpsmen, all from Nary Base Hospital No. 1, was sent on Jume 1. 1918, to the front. I)r. Joln Long was in eommand; Mary Elderkins and Katherine Mac'arthy were the nurses. Of their experiences, Miss Elderkins wote:

About Fubuary, 1918. Mis. Me Carthy and I were selereted for operating tam ervioe. . . It lant definite orters ar-

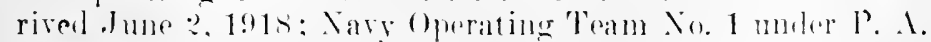
Surgeon John H. Long was to proceed immediately to American Ambulance "B" Ioully for temporary duty. . . For 


\section{$7+2$ HISTORY OF AMERICAN RED CROSS NURSING}

equipment we took only such articles as would enable us to set up an operating-room wherever we might be sent. It was surprising how little would answer the purpose when necessary. A few instruments, a handful of sterile goods, an alcohol lamp, some ether and iodine, a little suture material and a needle, at times seemed bountiful. For about three weeks we were operating in field hospitals, doing some of the most serions work of our whole trip, such as extensive laparotomies, chest wounds, head cases and the like when our supply of needles consisted of a few large curved cutting edges, one poor dilapidated "Mayo" and one intestinal needle. The crown jewels were nerer guarded more carefully than they. ...

Brittany was at her loreliest as we left, the early June twilight lingering until ten P. x. We did not dream of the change of scene twenty-four hours would bring.

The destination of Navy Operating Team No. 1 was Ameriean Red (ross Hospital No. 7 , loeated in the hospital at Jonilly, Seine-et-Marne, which had been operated since 1914 by Mrs. Harry P. Whitney for the French wounded. Miss Elderkins wrote of their journey there:

While on the platform of the Gare de L'Est, it began to dawn on us that there was something unusual in the air. The place was filled with Americans in miform, mostly officers and mostly juniors, and all going in the same direction as ourselves. Three Harine officers shared our compartment when we boarded the train. . . We soon learned the reason for that tensity of feeling which seemed all about us. 'The Amerieans were at last in action; these men were being rushed back to their outfits from the Otficers' School at Grandecourt. from furlough, from convalescent amps, from wherever they might have been at the time. They did not know where their companies were; all they knew was that they were to proceed to Meanx, that there had heen heary fighting, that the (iermans had been making definite progress and had apparently not yet been stoppert. It Meaux we began to gret an inca of the serionsness of the sitnation. In Amerian onticer there told us the ciermans were only abont nine miles awa: that the divil popmlation of Mean had been evacuating all the previons day; that refugees from tows nearer the fighting were pouring into the eity.

We had some time to wat in making train eonnections and thought it wise to have lunch. No one at the station coukl 
direct us to any place where they thought we could obtain anything to eat. After walking a few blocks, we understood why; all the shops and eaf'és were closed. It would seem that everyone had turned the key in the lock and fled. The few who remained eyed us suspiciously. The Naval uniform was not a familiar one inland at that time, nor was the uniform of the American nurse recognized as quickly as it was in the months to follow. We might have been Germans for all the information we could gather from the one or two civilians we met; and I believe they half suspected we were. . . .

We went back for our little toy train to take us to Jouilly, and after leaving the city could see the French preparations for retreat all along the road leading back from the front. It was not exactly reassuring!

An amusing incident occurred at one of the stores. Five German prisoners were being put aboard under guard of a French soldier. He had them safely on the train when he remembered a large basket some half dozen yards away; he gave his gun to one of the prisoners and dasher back for the basket. We expected the Boche to hold up the train, but he simply waited patiently for the return of the guard.

Warm, travel-worn and hungry, Navy Operating Team No. 1 arrived at their destination, Jouilly, Seine-et-Marne, at six o'elock in the evening and went directly to work. Miss Elderkins wrote:

Captain Mixter took us to the operating-room after supper. On our way there we could see the courtyard filled with ambulances and stretehers containing wounded Americans. The corridors were filled with stretchers; a long line of them extemled down the center of the ward through which we passed, and when we reached the operating-room the floor of the ante-room was parked and the four operating-tables in the room each had a patient on it. Poor bors, they were sorry looking follows, as they lay there. waiting for their turn. but as "erame" as they could be. The murses and dortors operating had been at it most of the time for the past three days.

Before going further I would like to give rou an inlea of what the American Ambulance "B" was and the eomditions: when we arrived. In 1914 Mrs. Iarry layne Whitury hawl established this hospital in the wing of the iollexpe of . Donilly for the lineneh blextes. The work was taken ware of he liext

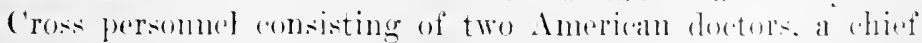




\section{HISTORY OF AMERICAN RED CROSS NURSING}

nurse with twenty nurses under her, of various nationalities....

During those days of fighting in the vicinity of Belleau Woods, this little hospital was all that stood between the fighting and Paris, thereby cutting in two the long ambulance journey for our mutilated boys. It was only equipped with two hundred beds, but the faithful workers kept up their supplies for the possible emergency that they were always watching for after their four years' experiences, and if it had not been for their well stocked sterile lockers and the instrument cabinets, we would have been greatly handicapped.

About the time we were receiving our orders at Brest to proceed June 2 to Jouilly, they got a message saying there had been heary casualties among the American troops and asking if they could care for some. Before they had time to answer, ambulances began to arrive, and they had been coming in ever since and continued to do so for many days. The divisional surgeon had been giving what help he could, but the combined efforts of all seemed like but a drop in the bucket. with hundreds of wounded men pouring in. An additional operating-room had been improvised, so our team took over the original and the other surgeons opened up the new one. Work went on both night and day for the next ten days.

We operated all through that first night and I don't believe one of us had ever imagined men could be so absolutely "shot to pieces." Many of them were the Marines who had crossed with us on the U. S. S. IIenderson and seemed a bit closer to us for that reason. Five Marine officers whom we knew were in the hospital as patients that night. The following night one of the young officers who had shared onr compartment from Paris to Meaux came in severely wounded, giving an idea of how quickly those men had gotten into the "thick of it."

About 11 P. x. some one from the office announced that there were twenty enemy planes over head. We were barely conscious of the bombing, so intent was every one on the work at hant. The receiving of patients and care of them in the wards was all done in the dark or by the wee flare of a candle: the operating-room was the only place where lights were allowed. The windows were hearily blanketed and black curtains hung over them.

I cannot describe those nights,- the long hours spent at the sterile table. or in griving anesthetics or in doing the many tasks about the room: the intense suffering of the wounded; the ghastly sights and nauseating smells when gas gangrene was present. 
Some days after the arrival of Naval Operating Unit No. 1, reënforcements from the Paris headquarters of the Ameriean Red Cross in France, and United States Army Evacuation Hospital No. 8 were brought up to Jouilly, Scine-etMarne. Other operating teams arrived also and the little châtean-hospital was greatly enlarged and beeame the principal evaenation center from Belleau Woods to Paris. Miss Elderkins wrote:

Instead of two hundred patients, there were at times close on to one thousand, these being evacuated as quickly as possible to make room for the fresh cases coming in. I do not remember the exact fignres, but over three thousand patients passed throngh the operating-rooms during the Belleau Woods and soissons Drive.

We remained at Jonilly during June and July, going over to Meaux to help out in a rush for few days. An evacuation hospital had come up there but was hardly ready for work when a convoy of wounded arrived.

On June $\tau$ a second operating team had been sent forward from Navy Base Hospital No. 1. Dr. James Watt was in eommand. Lcola Steward and Florence Missimer were the nurses. The team left Brest on June 7,1918 , and after varions temporary assigmments were detailed to duty with Jlobile Hospital No. 1 at Evacuation Hospital No. 7 , near Coulommiers. Of the artillery fire there, Miss $\mathrm{Ml}$ issimer wrote:

Big Bertha was also sportive in this section, she plowed up great holes: in moarly fields. One night a Boche dropped a lunge bomb in a field right in front of the hospital and wased a small earthqualie: we and the chattean trembled tograther. 'To the right of 11, , the French hal an anti-aircraft station. with their big isis (m)stantly in action.

We were five weeks at this station. doing twelve-homir duty either day or night, and occasionally it would be twenty-four hours at a stretch and occasionally a like time off.

On the twenticth of July, we retired at night very tired. having been on dut; all the night belore. After an hours sleep orders came for us to report to the esth Division. Stangering ont of bed. we dressed. shosed our few belongines into

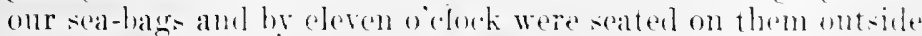
the chitean, waiting for transportation. Here we nodled and 


\section{HISTORY OF AMERICAN RED CROSS NURSING}

dozed until one-thirty, when a French ambulance rattled up and all, including luggage, was bundled in and the journey begun.

The weather was extremely hot and the dust so thick that our lungs seemed choked with it. We were supposed to reach headquarters for the 2Sth Division in two hours. Every mile scemed to take us nearer real activities. Not a civilian was to be seen, but we passed continual streams of soldiers on horseback and on foot. Large ammunition trucks rumbled by. The soldiers we met seemed indifferently puzzled, as if they wondered what we were doing there. It was not long before we, too, wondered.

Carde, a little village, at that time only three miles behind the firing line, was a mass of ruins, deserted except for an oceasional sentry on duty, the roads almost impassable witl fallen bricks and stones. On beyond this village we came upon big Naval guns swinging back and forward in action. Still further on was the artillery earefully camouflaged in the woods. Time and again we met whole regiments of American and French soldiers trudging along in a mechanical way, an unforgetable expression on their worn faces, desperate through utter exhaustion. On either side of the road, men had dropped out. throwing themselves on the ground, unable to go any farther. We found out later that these were men who had just been relieved from the firing line.

With high explosives whirring past us, we sped on past trench after treuch, actually seeing our own boys, with guns to shoulder, rearly for the words that would send them over the top, and came finally to a bridge where we halted for Dr. Watt to ask where we were and where were Division :8: headquarters. An officer rolunteered to take him to a dugout where he rould telephone; we then found our French chauffeur had taken us miles out of our way. While we were waiting for the return of Dr. Watt, we had no difliculty in engaging the bows. doing sentry duty at the bridge, in conversation: they had not seen a woman in weeks. They told us that under the bridge was enough dynamite to blow up a whole division of Germans. We delved into our sea-bags and found several hoxes of crackers. which we passed over to them. hating onrelves for the smalness of the gift.

When In. Wilt appeared. the Major was with him. He pointul out the German lines. which were just over the hillside, and arderl that we were in the first line reserve trenches. a gas soution. Is the Germans had been sending over gas shells all dar, he begered we would hurry our leave-taking. We did, tout de suite. 
Dr. Watt's team was finally ordered to Field Hospital No. 109 and reached there at $10 \mathrm{l}$. $\mathrm{m}$. that night. Howevere, the end of their journeying had not yet come. Miss Missimer wrote:

Here at Field Hospital No. 109, a unit under Major Schaffer, was just getting settled in a lovely château, with most attractive grounds. 'The Major was very attentive anl kincl. So far we were the only women in the persommel. Brfore dawn of the second night there, orders ame for us t, move on, first to Field Hospital No. 10:3 at La Ferté, then to Field Hospital No. 33, and at midnight four days later we were sent by motor to Field Hospital No. 11: at Château'Thierry.

Field Hospital No. 112 was located in a building, one end of which had been entirely destroved. All the windows were gone. . . Pontoon bridges spanned the Marne and they and the ammunition trucks rumbling over them were a constant target for enemy bombs.

Our stay at Field Hospital No. 112 was for two weeks only. Dr. Watt's health broke down and we were returned, Anguit 18th, to Brest.

While Dr. Brinsmade's detachment was at Orleans and Tary Operating leams No. 1 and No. 2 were at the front, twenty additional Nary nurses were called from Nary Base IIospital No. 1 at Brest for service at Paris. One of these nurses, IIelen Halward, wrote:

On July ?\%. 1918, we left Brest for Paris, where right of us were assigned to Ameriean lied cross Hosplat No. ?, in Paris, and twelve to Ameriban Red Cross Honsital No. i. at Anteril.

Ameriean fied Cross No. s was sitnated on the race trateks of the Bois de boulogne and was entirely moler lied cross

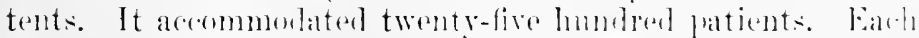
ward ronsisted of from one to throe tonts. with from borty to seronty-eight beds. Ile went on duty the following mornines.

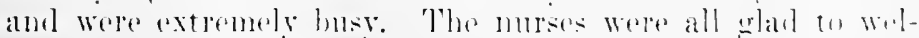

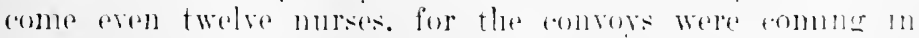

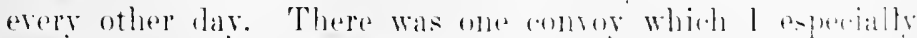

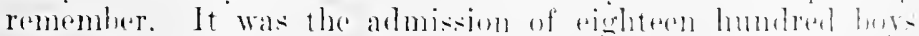

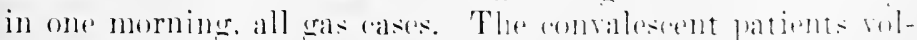

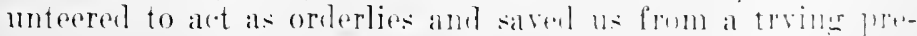
dicament: we were at the time short of corminum. Thirir 


\section{7\$8 HISTORY OF AMERICAN RED CROSS NURSING}

fine spirit of comradeship for the inen worse off than themselves was shown in such a splendid way, for before we had time to ask we had numerous offers of help. A bad gas case is absolutely helpless. It is surely the most cruel weapon of warfare; there is so little one can do for them and they suffer so dreadfully.

The "Bertha" was shooting over the hospital and of course we had the usual air raids at night when the moon was bright.

The spirit around the hospital was wonderful. Everyone helped the other. There never was any umpleasantness. Of course we did a lot of pioneer work, for we did not have the conveniences or the things to work with that we had at our home base, but the boys seemed happy and certainly recovered rapidly.

Of the experiences of the eight Nary nurses assigned to American Red Cross Military Hospital No. 3, Mary Caldwell wrote:

At seven $\mathrm{A}$. x. the next morning we were each detailed to different wards and encountered a very decided change of work. Here we had patients from generals down to lieutenants, the anes nearly all surgical, the officers mostly suffering from explosive wounds and compound fractures. No more great black stevedores, with mumps and measles! The majority of our patients belonged to the 1s1st, end and Foth divisions. Many of them were prominent Americans. Some of our beloved Miarines from the s. s. II enderson, whom a year before we had last scen marching away from the ship well and hapys. (ame bark to us shattered and miserable. to be nursed back to a poor resemblance of their former stur? selves. . . .

The other Nary Base hospital in France which furnished nurses for detached duty at the front was No. 5. Elizabeth Dewey was one of these murses and she wrote:

As wo were gromer off ciuty the erening of July 19, 191s, we four hurws. Miss Faye Fulton and Miss Deriey anesthetizars. and Jise Mlow IJurst and Miss Caroline Thompon, were told to be ready to feave for the front at is A. $\mathrm{x}$.

We met the others of the two operating teams at the station the next morning. Hre. (reorege Ross and John Jones were in

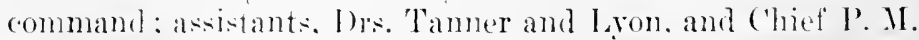
Shank and P. II. Steel. Niable and Homsburger were the other mombers of the teams. 
We reached Paris about 8 P. M., and reported at Dr. Blate's hospital. . . About 3 P. M., July 20 , we started off in 12 new Ford ambulanc's, with a sergeant, on a motoreycle, to act as ronroy. Wie passed the fortifications and wire entanglements, huge airdromes and encampments and later several hundred cierman prisoners hoddled in a farm yart. We heard the gums and saw the line of observation balloons above the trenches. The roal was a solid mass of trucks and artillery and everything was veiled in the dust. Our Fords had to get off into a field every little while to cool, and we tried to remember where c'répy was, for all signs pointed to C'répy. When we reached there some soldiers gare us hot colfee and lard tack.

About dusk we sighted a castle on a hill, a fairy-tale castle. almost too beantiful to be real. We male a turn and were in the square of a small town. We stoplenel before a white gate. and in front of us, behind $1 \mathrm{~s}$ and on both sides of the road were stretchers, each with its lurden of wounderl. Some were very still, some gruaning, some muttering in delirimm. One man ranght my coat as I passed and begged for water. to we entered lillotel des liuines at Pierrefonls, where Fiedd Ilospital No. 1? was borated.

In about a hall hour both teams were working in the hotel parlor, a nedimm-sized room reached by a hallway three stretchers long, and wide enongh for the streteher-bearers to walk besile alde onher. The lone Freneh windors of this room were (dosel : blankets were nailed up ontwhe the shutter: to hide the light. The lurniture was gone. In its place were two operating-tables and a plank on chothes-hories male a third. Pictures and mirrors deeorated the walls, stronger electtric drop lights hung orer the tables. fancy stands hold instruments, allhesise strips were stuck on mirrors and windows. A pile of hoorl-soalied. filthy dothing grew in one corner of the porm and milloms of thes rose and huz\%d when an adelition was male to the pile. As a patient was carried out, the stretebere nearet the door was bronght in and another shesed in at the fall and liom the erenom ontsile. The work

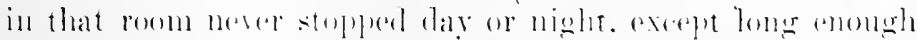
in the morning to selape ont the filth of the night work. almel

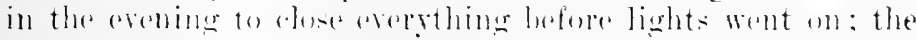

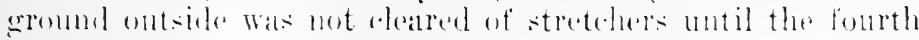
dars.

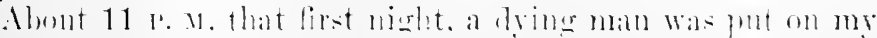

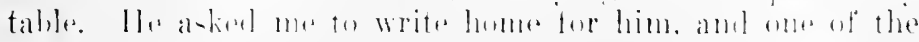

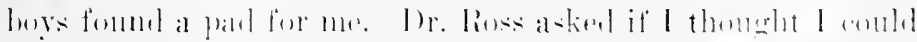

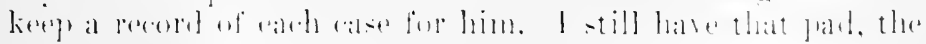


first entry being the address of the only man who died on our table, though the record covers over two hundred cases.

The next morning other teams arrived and the tired Navy nurses were told to find a place where they could get a few hours' sleep. They stumbled to the nearest house. Miss Dewey wrote:

On the second floor were two adjoining rooms with double beds, the bedding thrown back as if people had just gotten out of them. We four nurses got into those beds and pulled up the covers.

Miss Dewey's team went on duty again that night. She wrote:

The night of July 21 a bomb exploded in a garden about 20 yards from us and blew open the windows. Chief Shank stepped away from one, remarking, "That's too close, but thank God they let in a little air." Only the most urgent cases were operated at No. 12. The others were sent on to where facilities were better. Some of the wounds contained maggots and nearly all were gas gangrene cases, and the stench of that room was beyond words.

The pluck of the men kept us at it. Most of them were conscious and told us they had the Germans on the run. One boy whose leg had to come off, said, "All the fun I had lying there in the mud was seeing the Germans beat it. Our boys couldn't get to me any sooner than they did." Some asked if we thought they could get back, because "I got to get a Boche for this."

The night of the 24 th we operated on some Srotchmen, who had come up to relieve our 1st and end divisions. By morning their medical corps had come up and we were sent back. reaching Paris at $9 \mathrm{P}$. x. that night. Over 3500 wounder went through No. 12, between July 18 and July 24. About 300 non-transportable cases were operated upon there and the Navy teams performed about 160 of those operations.

On July 29 Dr. Ross's team, with Miss Dewey and Miss Hurst, was ordered to join Field IIospital No. 6 at chateanThierry. When they arrived they found that the hospital had not yet come up, but were told to report temporarily for duty at the College Jean Mace where some operating was under way. They were promptly set to work there. Miss bewey wrote: 
Miss Hurst was asked to hand instruments for three tables and during the night har three abdominal cases going on at the same time anrl, as I)r. Ross said, "got away with it without a hitch." It was a wonderful piece of work. How she managed to get all those neelles threaded and with the proper sutures is more than I know, but she did.

'The following day we joined Field Hospital No. 6 and Mobile 1, which was being put up in a field near ChâteauThierry. We were taken there in a truck, crossing the Marne by a pontoon bridge. This was a large tent hospital wonderfully equipped and the operating there, after Pierrefonds, seemed almost ideal in spite of the fact that we were bomber and fired over. We operated every day, and part of some of the nights, ending wth a stretch of twenty-four hours. . . .

The other operating team from Navy Base Hospital No. 5, under the command of Mr. Jones, with Miss Fulton and Miss Thompson as nurses, had been detailed to Field Hospital No. 7 at Coulommiers. Miss Dewey wrote of the type of service which this team had seen:

Field Hospital No. 7 was located near a small château, about a mile from the town. Tents filled the woorls back of the châtean and eight beds were in a tent. The first few days after their arrival the work was very strenuous, and they hat long hours and little sleep, then more teams arrived and the work was better regulated.

One night while they were working all the lights in the operating tent went ont. and they had to finish their ase by flash light. That was during one of the severe air raids, of which they had several.

Both teams returned to Brest on August 15. Miss Dewey was commended ${ }^{1: 5}$ as follows by the Commander of the L. S. Naval Forces in France:

She is a splendid nurse and a woman of fine character and exceptional executive ability. Her services while on duty with the operating teams at the front were extremely valuahle. She acted as anestletist during most of her service there, in arldition to which, when relieved from that duty.

${ }^{10}$ It is not the polieg of this history to puhlish indivinual ritations: spare does not fermit it. A list of mirses who have heen decorated for grallant and devoted conduct may be found in the Appendix. This ritation is. howerere, griven in the text as an index to the general type of citation receivel hy numeroms marses Inring the European II ar. 


\section{HISTORY OF AMERICAN RED CROSS NURSING}

she did extra duty in assisting the nurses in the care of the wounded with their dressings. On one occasion, under extremely unsatisfactory surroundings, sle gave anesthetics steadily for fourteen hours without leaving the table, and after this strenuous labor she visited the cases which had been operated upon.

Following the return of Dr. Watt and his team members to Brest in August, 1918, Navy Operating Team No. 1 of Base Hospital No. 1 with Dr. Long commanding, was sent up to replace Nay Operating Team No. 2, at Field Hospital No. 112, Châtean-Thierry. Miss McCarthy, the second nurse on Nary Operating Team No. 1, had been ill and Jeannette MeClellan, one of the Nay nurses of Nay Base Hospital No. 1, who had been on detailed duty at Paris, was sent forward to take Miss Mer'arthy's place.

Navv Operating Team No. 1 set out on August 11 to find Field IIospital No. 112, which had been moved that morning from Chatean-Thierry twenty miles closer to the fast advancing Anerican Front. Miss Elderkins wrote:

Twelve nurses attached to Field Hospital No. 112 were also waiting for ambulances to be sent to take them up to the next site. An officer coming down from there said he feared it would not be posible for any of us to go on that night, as the Borhes were sholling the roarls and also sending over a great many gas shells in the vicinity of the hospital. Nevertheless, the ambulance came and Iliss Mrclellan, the other murses, sexton and Brady and l started up. We were provided with leelnets and gas masks.

That was a wild ride. We passed through village after village where not a house han been spared, and the only signs of life were the military cruards. Ammunition trucks were raring in both directions, and as no lights were allowed, the traffice was rather porilous. About a half hour before we radcherl ramp, we wore stopperf and told that all masks wre to he worn in the "alert" pesition. We had no more than adjusterl thems so, when the real gas alarm rame.

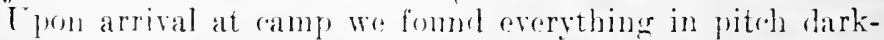
ness. . . Wr gropexl our way to the last tent, where fonr orenpant: were stepling. (oots wore brought for us . . but we didnt sterle.

Gas alarme somoled continuously. You would hear the

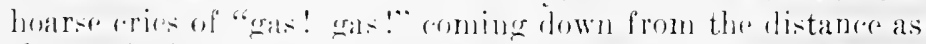

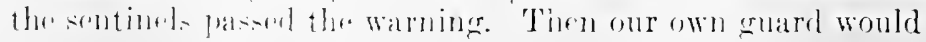




\section{SERVICE WITH THE NAVY}

take it up, five pistol shots would be fired and some one would start beating a huge shell strung up on a tripod. To hear the horses whinuying across the road, where some cavalry troops were spending the night, was pitiful. 'They also had to have the masks on and ronld not seem to understand it.

In the morning. we found ourselves in a little town called Cohan. 'The hospital was at the foot of a hill; from the top' you could get a good idea of where the fighting was taking place. Fismes was only four miles away, and the Germans occupied the town on the opposite side of the river. At night it seemed like the battle was being fought just outside our tents.

Army nurses have described the severe service at Cohan, and Miss EIderkins' report repeated some of the things which made that post of duty so arduous. She wrote:

Our location was poor; we were right in the midst of things most desired by our enemy. The work here was not especially heary, but conditions were such that erery bit of reserve force was needed. The days were intensely hot and the nights bitterly cold. The flies were unbearable. We hall air raids night after night, with no opposition, for there were no anti-air craft nearby and seemingly very few French or American planes.

When we were not operating at night, we spent the time from darkness to dawn in a cellar twenty feet under gromml. It just held seven cots and thirteen mures were suppesed to sleep there. If we sat erect on the cot our head struck the rough stone above. Water drippert on us all night leng. Huge black bugs araled about and after we quieted down we could hear the rats. We, ourselves. folt like rats in some trap). for in (alse of a dired hit our chances of getting out were slim. I would have preferred the dugouts, or "irrabe" as we called them. that l)r. long and the corpsmen had dug under our cots in the tent.

'The morning of the tenth day the Germans had found our range. 'Thery opened fire on us. or rather on their ohjoetions about us. ligth shells falling all about us, we went back that night three miles.

Then followed a series of moves. first to Earuation Hospital No. $\pi$. outsile of chateatu-l'hierre then aldoss the

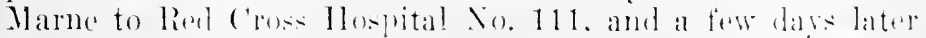

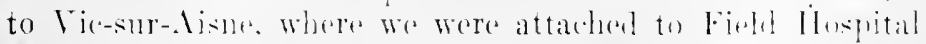
Yo. 1:a of the :3end livision, who were serving with the French under Cieneral llangin. 


\section{HISTORY OF AMERICAN RED CROSS NURSING}

The casualties were heavy. We worked a twenty-hour shift, which really became a twenty-four hour shift, and under the most trying conditions. The furnishings of the operatingroom were of the crudest kind. Packing boxes were used for instrument tables and seats for the anesthetist, a stretcher on two carpenter horses was the operating-table, while we had to put our solutions, ete, in tin cans, cooking utensils or stray bits of china ware. A pie plate made a splendid container for our alcohol sponges for "scrubbing up." I think it is pretty generally known that only non-transportable cases were cared for in the field hospitals, which meant all major cases, abdominals, amputations, severe hemorrhages and head cases.

When the 32nd Division withdrew, we went baek with them, and by another series of moves and short stops at various field and evacuation hospitals eventually reached Base Hospital No. 15 situated at Chaumont.

At Chaumont, Dr. Long's assistant, Dr. Pierson, was given a team of his own, composed of Miss McClellan and Hospital Corpsmen Brady. Dr. Long's team, with Miss Elderkins as the only nurse, was ordered, on September 24, 1918, to report to Evacuation Hospital No. 8, then near Souilly, seven miles from Verdun. Miss Elderkins wrote:

It was noon of September 26 when we arrived after a fortyhour trip with no sleep and little to eat. . . .

When I went to the operating-room to inquire about the baggage, I found Dr. Long already "scrubbing up" and he asked me to start the anesthetic of the patient upon whom he was preparing to operate. It was necessary to continue giving them until 9 P. M., so I did not have an opportunity to get into my gray uniform.

I do not believe there was a better organized operating room in the American Expeditionary Forces than that at Evacuation Hospital No. 8. It kept the sterile nurse on the alert every moment. for at times an operation would be in progress on all the tables. I remember one night there was a bad chest wound and a laparotomy on the first two of my tables. At the next Dr. Hanson was removing a piece of shrapnel which had entered through the skull and was lodged somewhere near the ethmoid, while the other three tables contained minor cases.

Again. I have seen six surgeons all working on the same (ase. where a long anesthetic was counter-indicated. Earh surgeon would take a section of the body and the multiple 
wounds would be cared for very quickly. Practically all the work was done by specialists in their own particular lines. Colonel Lilienthal of Mt. Sinai Hospital did most of the (hest work; a I)r. Hanson of Minnesota was a wizard at brains; Dr. Long (hil all of the abrominal work and took over the chest cases when Colonel Lilienthal left, and later the hearl cases.

We worked twelve-hour shifts, changing from night to day and vice versa, about every two weeks. ..

At the signing of the Armistice, two hundred and ninety mombers of the United States Navy Nurse Corps were in service in Great Britain and France. 


\section{CHAPTER IX.}

NURSING SERVICE TO TIE CIVILIAN POPLLATION OF TIE ALLIES

The Children's Bureau in France-The Refugee Bureau in France-The Tuberculosis Bureau in France-The Commission for Italy - The First Commission for lioumaniuThe Commission for Palestine-The Commission for Siberia

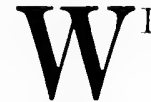

HEN Major Murphy and his staft of seventeen men, who formed the first Ameriean Red Cross Commission for Enrope, sailed for France in June, 1917, they went with the purpose, as supplemental to the nilitary responsibilities of the commission, of expressing in relief work the sympathy of the Ameriean people for the civilian popnlation of the Allies. Upon its arrival in Paris, the commission thus immediately created two departments: the Department of Civil Atfairs and the Department of Military Affairs, the organization of which has already been given in Chapter VI. This chapter will give an account of Ameriean Red Cross mursing service in connection with the civilian population in France and Belgimm, Italy, Roumania, Palestine and Siberia, as it was administered through Fational Headenarters and throngh the American lied Cross Commission fur Europe.

France, the hattle gromnd of the war, was the theater of the most extensive redief work of the Ameriman Red cruss almoad. Of the eighty-six departments into which the French liepublic was divided, in the Xorth one wats whelly in the enemy sossession and nine others were partially so. The Varue, the

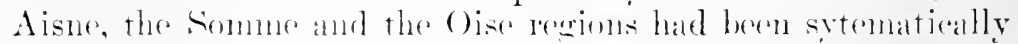

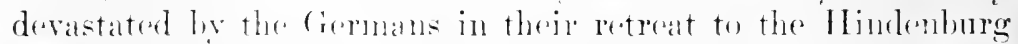
Line. A million and at half refogers from these previnese in 1917 were scatterenl in the contral and sonthern parts of

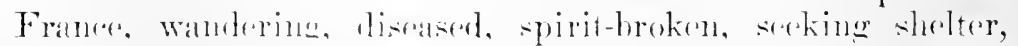

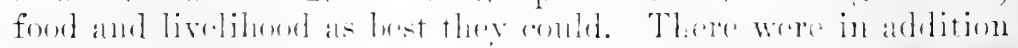
three millions in the oeconpend torritore, the women and children 
who had stayed in their homes and those who had been deported to Germany but who from lecermber, 1916, on were flung lack to France at the rate of from one hundred to twelve hundrod a day.

The work which eonfronted the Department of Civil Affairs of the American Red C'ross in France fell into five principal classes: chilll welfare work; the establishment and maintenance of hounes for refugees, rapatriés and other exiles of war; participation in a well rounded and comprehensive plan for the prevention of tubereulosis throughout France; assistance to civilians returning to the devastated areas and training of mutilés to enable them to carn their own and their family's livolihood. The Commission for France created within the Department of Civil Afriars five bureaus to deal separately with these five problems-the Children's Bureau, the Bureau of Refugees and Reliof, the Burean of Tuberenlosis, the Bureau of the War \%one and the Burean for the Reëdncation of llutilés.

Homer Folks, of New York City, joined the Paris headquarters in July, 1917, as director of the bepartment of ('ivil Atfairs. He had previously been engaged in social serviee and child wolfare work in the lnited States and was the anthor of a history and varions pamphlets dealing with these subjects. Mr. Folks upon lis arrival in France appointed experts as diresetors of the valuious bureaus of his department and relief work was immediately started.

Perhaps the ontstanding misfortume which eonfronted Franee, a nisfortune which, if not remedied, would penetrate inte her future and rumbuner her existence as a capital nation, was the condition of here orphaned, homeless, sick children, her balies whose devitalized nothers were angaged in war industries. her lowered hirth rate. Assistanee to the rhildrem and

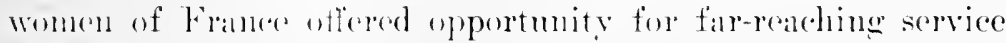
of a type which apperaled immediately and instinetively to the sympathy of the Americall perple, whese alvatal the American

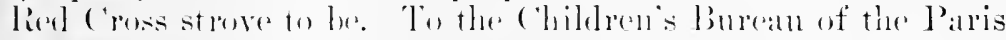
other wase entrusted this respensibility.

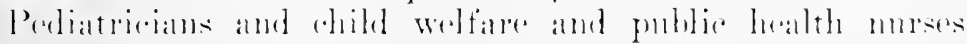

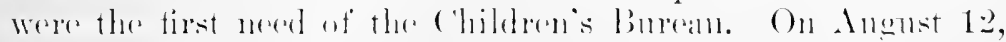

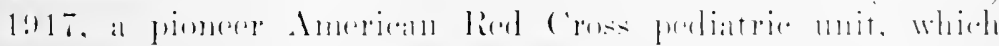

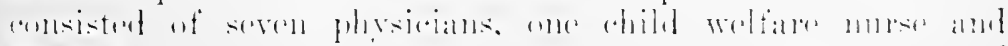

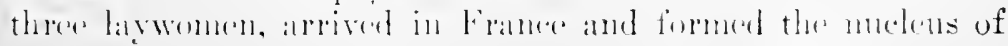




\section{HISTORY OF AMERICAN RED CROSS NURSING}

personnel of the Children's Bureau. Dr. William Palmer Lucas, professor of Pediatries of the University of California, was director; Elizabeth Harwood Ashe was chief nurse. The other members of the unit were Mrs. Lueas, Dr. and Mis. .T. Morris Slemons, Dr. J. P. Sedgwick, Dr. J. I. Durand, Dr. N. O. Pearce, Dr. John C. Baldwin, Dr. Clair F. Gelston and Rosamond Gilder, executive secretary of the Bureau. Miss Gilder, the daughter of the American poet and editor, Richard Watson Gilder, afterwards wrote the most comprehensive report of the activities of the Children's Bureau to be found in Red Cross archives, a report which this history will from time to time quote.

Before sailing for France, Dr. Lncas had asked that the personnel of his mit should include twelve public health murses, but the Nursing Service at National Headquarters advised Dr. Lneas to wait until his arrival in France, as it was felt that among the many American nurses already in France an ample number would be available for this tye of work. A memorandum which was prepared by the Nursing Service for Dr. Jucas before he sailed, gave the names and addresses of Alice E. Henderson, formerly supervising nurse of the Freneh units of the Nerey Ship Expedition, then in Paus Mary K. Nelson, Helen Kerrigen, Marion McCune Riee, Josephine Clay and Emma J. Jones, then at Erreux: Margaret Inulop, then thought to be in England; Grace Barelay Moore, at Dr. Blake's hospital in P'aris, and Caroline Hatch, at Ris Orangis.

Immediately following the arrival of the unit in France, Dr. Lueas undertook a complete surver of the child weltare sitmation. He found that eities, towns and villages had been drained of medical personnel hy the exedus of physicians and surgeons from civilian practice to military service. Twentyfive to fifty per cent fewer physicians were available in the larger cities in 1917 than in 1914. St. Etienne, with a population of 180.000 in 1914, had had the serrices of 120 phys: cians: in 1917, with an increase of population to 2.00 .000 . it had the services of mly $1 t$ phrsicians. France possessed no group of professional nurses comparable to that which existed in the British Empire and in the Lnited States.

Before the outhreak of the European War, the birth rate of Franee had exeeded the death rate hy a marein just enengh to keep hor total perpulation at a slight increase. Two falcturs developed during the war and caused the birth rate to fall 
materially-the presence of the men in the trenches and the entrance of women into industry. Previous to 1914, only five thousand women had been emploved in factorios; in 1917 eiglit hundred thousand wre so employed. In the meantime, war casualties had increased the death rate to unprecedented proportions. "With this increased death rate and with the incritable diminution in birth rate," wrote Dr. Lueas, "the result to-day is that the birth rate is forty per cent lower than the death rate, a figure which no country has ever reached before except as it began to pass out from among the group of first-class nations..."1

Franee, herself, was making heroic efforts on behalf of her (hildron. I)r. Lucas summarized the maternity and child welfare legislation:

... Certain definite steps had been taken to ameliorate the concition of women in the factories, most noteworthy among them being Paul Strauss's law of August, 1914, which allowed an allocation of one franc a day for a mother one month before the birth of her child and 1.5 francs per day for four weeks after the birth of the child. This had a powerful influence in increasing the birth rate and it was one of the objects of our eampaign to see that this law was put into force throughout the country. The conditions of the Roussell law making it mandatory for factories to have chambres d'allatement and creches for nursing mothers and babies, and the creation of factory inspectresses to see that these laws were carried out, showed the earnest intent of the govermment to right as far as posible the deplorable conditions created by the war.

In the Academy of Medicine throughout the whole period of the war. the disenssion rolating to infant mortality and the lowered birth rate thed and flowed. Every one is familiar with Pinards firm stand arainst the employment of women in factories. . . To save France. thr women hal to work and the Ferench mother preferred to work, although it jeopardized the future to sibe the pressit. . . In conjunction with the ligue combe le Morlulite Infunlile ant the federal govermment of the lesartment of the luterior. the service de simte. the childrens: Burean of the Amerian lied Crose worked out a definite program. In the ligne are the foremost representation of the medical profeston in Francen

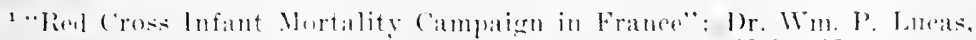

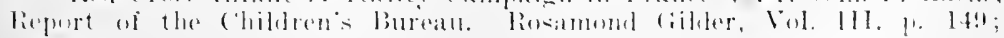

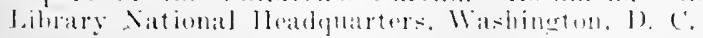


interested in women and childhood, as well as the most intelligent social workers, philanthropists and educators. Senator Paul Stranss, author of the beneficent law referred to above, is its president. Dr. Marfar, of international reputation as a pediatrician, is its first vice-president; Dr. Le Sage, another well-known pediatrician, is the secretary of the Ligue.

With the advice of these experts, Dr. Lucas adopted simple but fundamental policies to govern the development of the Children's Bureau. He believed that preventive measures were far more forceful in lowering infant mortality than curative measures and that "these preventive measures must start in the prenatal period and must reach every mother a long enough time before the birth of her child to insure as nearly as possible a normal pregnancy and a healthy child." He felt that "every baby should be followed up so as to prevent illness." 2

Preventive measures for the infant had originated in France in 1891, when Budin had first established Nourrissons Clinies. In 1917 many of these clinies existed throughout France, and one of the first duties of the Red Cross Children's Burean was to offer assistance to those in operation, to help reopen those which had been closed during the war and to assist in starting new ones where they never had existed. To secure a persomel to carry on the "follow-up work" which Dr. Lneas felt to be imperative, the Children's Burean undertook to recruit and train groups of health visitors by giving short intensive courses of instruction to French women who had been working in French military hospitals and who had had Red Cross training of various types. With these policies to govern constructive child welfare work and with unlimited funds and supplies with which to render emeroncy relief, the Children's Bureau settled down in septemlier, 1917 , to its gigantic ret elusive task.

Miss Aslee the chief nurse of the Children's Burean, was born in California. Immediately following her graduation from the Preshyterian School in Sew York City, she retmmed to her native state and hecame director of the "Telegraph Hill Neighborhond Association in Sian Francisco.

Miss Ashe was a woman of strong personality and resolute will and had had many arlvantages of hirth and colucation. In her mannere sle was direct, blunt, fearless and often impatient

zailder Repert, Vil. III, p. 1.it. 
-always so of what she ealled red tape. She held the interests of the needy elhildren of France and Belgium close to her big heart and she went about her work of alleviation with a swift, foarless and brilliant power which entitled loer to a goodly share of the eredit which the Aneriean Red Cross mursing serviee in the Children's burean deservedly earned.

Doring the pioneer montls of 1!17, the organization of the Nursing Service in France, as had been said before, was imperfect. Miss Russell, clicef nurse of the Ameriean Red Cross in France, was in the Department of Military Affairs and Miss Ashe, chicf nurse of the Cluildren's Burcau, was in the Departuent of Civil Atfairs. The two departments had difterent chiefs and difterent policies. The division in organization tended to separate the military mursing service from the public health nursing service, yot Miss I)lano and Miss Noves regarded II Ass Ashe's burcau as a subdivision of Miss Russell's burcau. All American Red Cross murses sent orerseas for military and civilian work were instructed to report to $\mathrm{Miss}$ Russell; she in turn assigned them to $\mathrm{M}$ iss $\mathrm{Ashe.} \mathrm{M}$ iss $\mathrm{Ashe}$ folt that this organization was unreasonable and incfficient and made vigorous protrist regalding it to the Nursing Service. ${ }^{3}$ Miss Nores explained to Miss Ashe that "it seems only good and logical administration for us to send our murses and imrses' aides to the Paris Il aldeluarter's to repert, as Miss Russell is the representative of the Nursing servere in Franee and as ablulegrams for nulses ame thromgh Paris Headquarters. By assigning the nurses to the Paris office," she adeled, "there is one plater in which a romplete reeord is maintained of the atrival and assignument of all nurses to Europe."

As hals herus slegersted. Miss . Ashe wals hampered in the developunent of her service by a shortage of public licalth nurses, but throughout the antmon and winter of $1: 917$, and the spring and summer of $191 \mathrm{~s}$, National Headpulater's sent mits of

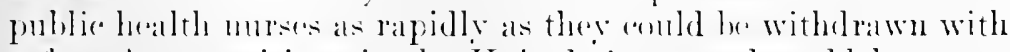
salfety form postions in the Lniterl Sitates and eould be trans-

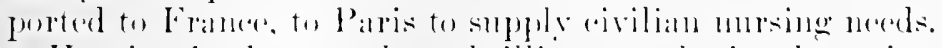

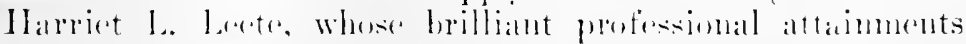
hase heren ontlined in the soretion which relates to here serviee

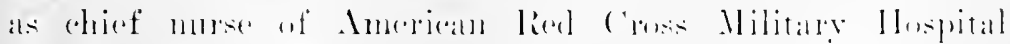

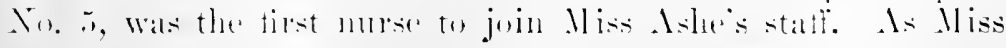

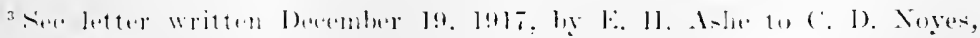

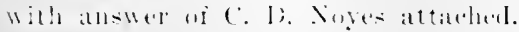




\section{HISTORY OF AMERICAN RED CROSS NURSING}

Ashe spent much of her time in the field, Miss Leete was assigned to the Paris office and upon her derolved the routino work of directing the public health nursing activities of the commission during the fall of 1917. The most authoritative nursing report of the Children's Bureau which Miss Delano and Miss Noyes saw until after the Armistice, was sent by Miss Leete to Miss Russell, under date of December 3, 1917, and was in due time forwarded by Miss Russell to National Headquarters. Early in 1918, Miss Leete was placed in charge of the instruction of visiteuses d'enfants at Paris. In May she became chief nurse of the Tent Hospital.

Marie T. Phelan and fifteen public health nurses of prominence in the United States sailed for France on September 16, 1917. Mliss Phelan was head nurse of this unit. She was a graduate of the Rochester City Hospital, Rochester, New York. She did public health and tuberculosis nursing in Rochester and was later assistant superintendent of the Child Welfare Society in Chicago. She was a woman of mature judgment and excellent exceutive ability and was recognized as one of the pioneers of the public health nursing movement in the United States. Her affiliation with the Red Cross had come through the Rochester Chapter in 1907.

National Headquarters sent a second mit of child welfare and public health nurses to the Paris headquarters in Norember, 1917. Dr. J. H. Mason Knox, of Johns Hopkins University, Baltimore, who later became associate director of the Children's Bureau, was in charge of this group. A third unit arrived in Paris in December. From time to time during the following ten months, National Headquarters sent over additional groups of public health nurses.

Manifold difficulties attended the selection and assignment of nurses for service with the Rerl Cross Commission for Europe. Miss Delano and Niss Noyes were combing the country for nurses for the Army, the Tary and the L. S. Public Hoalth Service. The exodus of nurses from hospitals, training sehools and public health nursing organizations into military service, placed in jeepardy the health of the eivilian population of the Enited States. The Nursing Sorvice was loath to alsk pullic health nurses to volunteer for civilian relief work in Franer or Italy or the balkans when the need for their services was so grealt at hrome.

The exerutives and physicians of the ('ommission for Europe 
controlled the polieies of the American Red Cross in Europe and they were zealous of doing everything in their power to aid the Allies. Civilian relief was an immediate and natural expression of this desire and public health nursing was acknowledged to be an efficient instrument in civilian relief. The War Council at National Headquarters was resolute in its determination to support the Commission and to carry ont, as far as possible, all its requests; they thus brought pressure to bear on the Nursing Service.

Miss Delano's opinion carried great weight with the members of the War Couneil. She strongly questioned the wisdom of withdrawing large numbers of nurses from American institutions to assign them to extensive eivilian nursing service in France. After the nurses arrived overseas, local conditions often did not permit their immediate assignment to the highly specialized phases of nursing service for which they had been sent to France. Miss Delano appreciated, however, that since she was not in the ficld, she must accept the recommendations regarding the development of public health nursing of those who were in the field, even thongh her knowledge of the public health situation in the United States led her to question the somndness of these recommendations. She felt that she could not go overseas and see for herself, because the chief duty of the Nursing Service was to secure nurses for the Army and she felt her presence was needed in this comtry o complish that

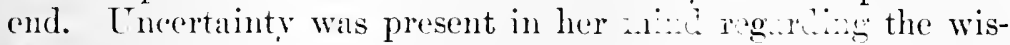

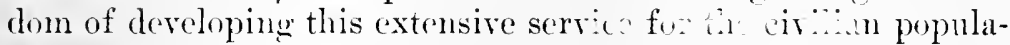
tion and the resulting anxiety formed ne oi the great burdens which weighed upon the shoulders of $\mathrm{Y}$ is lolino and Miss Noyes.

The War Department established passport rulings which materially inereased the diffieulties under which the Red Cross was already laboring to secure nurses. ${ }^{*}$ Notable among these

I Inder date of Felmury 23, 1918. the Secretary of State wrote to National Headquarters: " " deem it important to eall vour attention to the fact that this Department, "lpon request of the War and Navy lepartments. has for some time been eleclining to issue patsiports for bureper to near female relatives (this is. wives. dangliters. mothers and sisterse of Army and Nary oflierers. The bepartment enteiders it advisable to follow the same pelieg with renger to the is-mance of passperts to near female relatives of persens whe are sent to burepe for the lied cress."

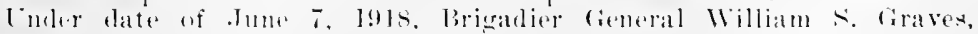

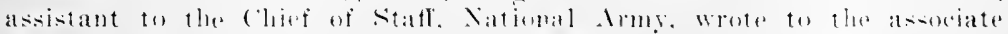

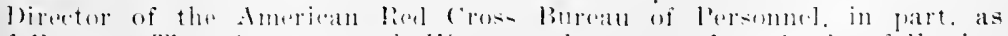

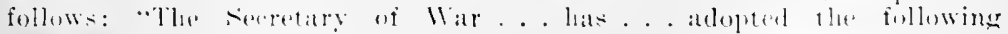




\section{6+ HISTORY OF AMERICAN RED CROSS NURSING}

was the so-called "brother ruling," which forbade the issuance of a passport to any nurse who had a brother in military service. In one group of thirty umrses ready to sail eleven were held because they fell under this regulation. During the summer of 1918 the "brother" restrietion was removed and the Nursing Service was able to send many more murses to Franee.

National Headquarters also sent over nurses' aides for service with the Children's Bureau. Thirty aides were ealled for by Dr. Lueas in November, 1917, for work in eomnection with children's hospitals and orphanages and the first group of them arrived in Paris on Deeember 15. Other units were subsequently sent. Nurses' aides were required to be able to speak French fluently and to have volunteered their services. MI any also paid their own expenses. National Headquarters also required that they undergo the training and pass suceessfully the examination for nurses' aides which has been outlined in a preceding chapter. They were instructed to report upon arrival in France to Miss Russell and to work nnder professional direction. They were usually housed with American Ied Cross nurses in the various children's hospitals, dispensaries and other establishments maintained by the American lied Cross in Franee. On the whole, ther rendered excellent service. "Lp to August 1, 1918," stated the Gilder Report of the Children's Burean, "not one moral question had arisen in relation to any aide in this service nor had any eomplaint been received from any nurse or doctor as to the poor work or lack of discipline of any aide. The Nursing Service at Washingtom should receive the eredit for the high state of efficiency of this branch

rules: 1. Ender no circumstances will the War lepartment approve the issuaner of pasiogerts to go to Europe for the wives. mothers. si-ters or laughters of the following classes of persons: Offeers or enlisted men of the Enited States Mitilary Forres: nule civilians employed with the Red Cross, Young Moni- Chri-tian Association or other organizations of a similar nature, that mas he in Enrope: civilians employed or attacherl to the Ameriean bxpenlitionary forces.

..2. Auy of the female relatives emmerated in paragraph l. who hase reeently been to Gurope but at present are in the lonted states for any reason whatsocver, are now included in the restriction impored hy paragraphl 1 abure.

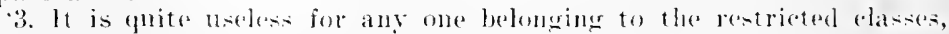
rianl abore, to reppest an "xwption in her ato as no exceptions will be matrle.'

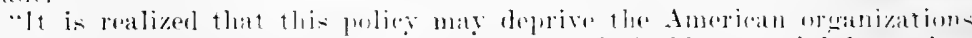

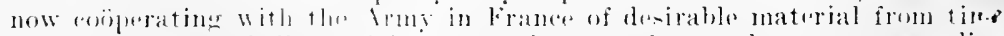

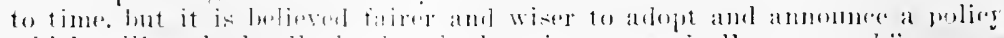

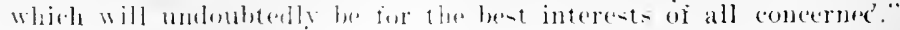


of the service, as it was the result of their areful selection. ... Untrained women as they were, the majority of them coming from haxurious homes, they never murmured at any task . . and the murses were mustinted in praise of them.'

The activities of the Children's Burean looped France, from Toul somburd down the valley of the Rhone, from Marseilles on the Mediterranean to Bordeaux on the Bay of Biscay, and northwards throngh Blois, Corbiel, Paris and Ronen back to the derastated regions of the Marne and Aisne valleys. To recount all the alctivities of the Children's Bureau in the many diverse forms of child weltare work would lie ontside the provinee of a history of the Nursing Service; only the projects in which nurses participated have a definite place therein. However, this was no small part, as will be shown in the following pages.

The first eall which eame to the Commission to Europe was a children's call, from the Jépartement Meurthe-et-Moselle. The rich grain fields surrounding Nancy and the city itself, where mills were humming with essential war industries, wore under fire from (ierman asphyxiating bombs and shells. The peasants wore gas-masks and reaped the harvests but the children were too young to wear the masks and had to be cared for elsewhere. Thery were gathered together and taken to Toul, which lay immediately to the southwest of the Naney distriet.

(On July 26,1917, M. Mirman, then profet of the Meurtheet-l/oselle, telegraphed to the ('ommittee of the Ameriean Fund for French Womnded that three hundred and fifty clisdren had suddenly been put in his charge and that he had nothing but a tomporary shelter for them in some old barracks at Toul. He askerl for assistanere at once. Mrs. lsabel Lathrop, president of the Committer for the Anerican Fund for French Wounded, to whom the telegram was addresed, lrought it to the newly-

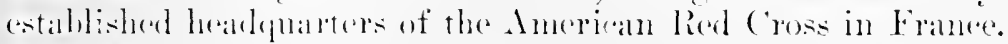
Major Murphy asked 1)r. Rebert l)avis to answer the call.

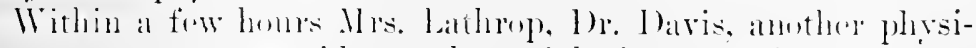
cian, a nurse, two aldes, a baldeterologist, an administrative director and two womento lexk after supplies were on their

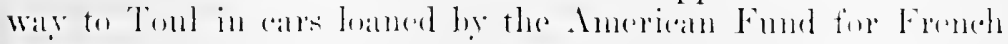

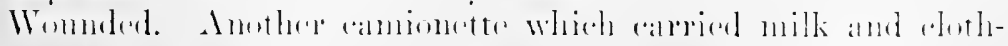

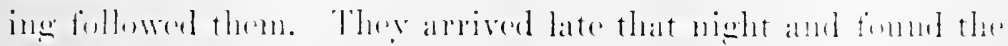

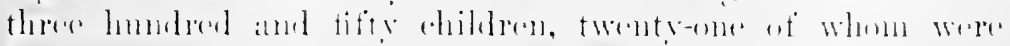

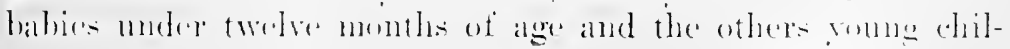


dren less than eight years old, huddled together in an old barracks, which was dirty and practically unfurmished, with no sanitary arrangements whatsoever. "The sick children were erowded in with the well ones," wrote Mrs. Lueas, wife of Dr. Lucas. "Skin diseases were prevalent and vermin abounded."

On the following day Prefet Mirman and the representatives of the Ameriean Red Cross set up a temporary organization. M. Mirman stated that the French Govermment would furnish new and sanitary barracks constructed of brick and cement, of a capacity for housing 800 persons; would provide lighting, coal, water and food in the government rations furnished to all refugees; would assign soldiers to do the heary work and employ the neeessary unskilled women's labor, and would supply beds, bedding and clothing and all transportation of supplies from Nancy or Toul. The Ameriean Red Cross agreed to take over the complete direction of the center, to furnish doctors, nurses, drugs and all hrgienie equipment, all extra diets and all supplies and equipment necessary for the recreation of the children.

From this beginning the "Toul projeet" of the Children's Bureau developed, with the coopperation of Prefet Mirman, the Committee of the American Fund for Frenel Wounded and the Ameriean Friends' Unit, into a children's home known as the Asile Caserne de Luxembourg, with a capacity of 500 ; a Children's Hospital; a Maternity Hospital: a dental department; a sustem of dispensaries, and a second refugee asile at Fellering, in the Tosges. At the ehildren's home, the Asile Caserne de Luxembourg, the Red Cross set up and maintained a diet kitehen and the French Government established schonl and ehurch services.

Dr. John P. Sedgwick was first in command of the Asile Caserne de Luxembourg; on December 1, 1917, Dr. Maynard Ladd, of the Harrard Medical school, was placed in charge of the work of the C'hildren's Bureau in the Meurthe-et-1Moselle. "Miss Phelan," wrote Miss Leete to Miss Russell on December 3,1917, " is in eharge of the group of nurses at Toul and has been doing remarkable work under most tring conditions." Six Army nurses on detaehed duty and three Americin lied C'ross nurses, Engenia L. Aceredo, Helen 7. Gill and Lanra E. Kreamer, scrubbed and painted the long. dirty harracks, set up and made the small white beds and got the hospital ready for their roung patients. It was opened late in October, 1917, 
and in the next two months admitted over 150 cases of measles alone. At first the hospital had only one operator, one assistant, two etherizers, one set of instruments, one stove ("very French," a nurse described it) and no ruming water. Later the Red Cross supplied excellent equipment. "In nine months," wrote Gladys H. Porter, one of the nurses later assigned to duty there, "we operated on about eight hundred cases, a record of which the most modern hospital might be prond, much more one in the war zone. Our first big rush was a drive on tonsils."

In a letter addressed to the American Journal of Nursing, Miss Phelan wrote of Toul:

This is an old walled rity and is wonderfully interesting with its crooked streets and narrow passages leading back to interesting looking courtyards. There is an old cathedral here, some parts of which date back to the twelfth century. 'The C'userne is located on a hill outside the city and was formerly used for birracks. I eame up here to take charge of the nurses and my first commission was to prepare one of the long, ugly buildings for a hospital. It looked discouraging five weeks ago, but to-day it is really attractive.

We never conld have done what we have if the Friends had not sent us five young men. The Friends are loing some of the best work that is being done in France. These boys are all rollege men, but they can do anything and everything and do not hesitate to undertake the most menial labors. We are having an epirlenic of measles just now; we have fifty patients to-rlay. There is very little ac ute illness. Most of the rhildren have sabies, impetigo and heads, just the conditions we find in some branches of public health work at home."

After the perind of pionecring was over, Miss Phelan returned to Paris and the direction of the nursing activities of thr. lsile ("useme was assigned to Josephine Ellet. Miss Ellet wats gradnated from the Johns Hopkins Sehool in May, 1917, and had been in chargere of a ward of the pediatrice department there mutil she salled in Tovember for France. She was a Virginian by birth and was a young nurse of intelligence and alility.

In Jannary the Childrens IIospital opened a sureicall wanl for prasint women from the surromding neighberhod.

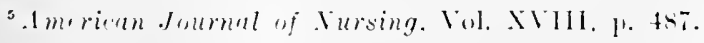




\section{HIS'TORY OF AMERICAN RED CROSS NURSING}

Exhausted from manual toil in the fields, privation and the sufferings of the past four years, these women were in great need of medical attention and the surgical division of the Children's Hospital averaged six major operations daily four days each week. Helen 7. Gill was head nurse. The hospital at the Asile Caserne received 1042 patients, of whom 12 died. Six hundred and forty-eight operations were performed.

A Maternity Hospital was opened on March 1, 1918, at the Asile C'aserne. The Germans had bombed a maternity hospital at Nancy the day before and Prefet Mirman telephoned to Major Ladd to ask if the Red Cross would take care of the expectant mother's and other patients. Major Ladd consented and several of the nurses, two French women and the Quaker orderlies converted one of the barracks of the Asile Caserne into a hospital in six homrs. "At four o'clock that aftermom," wrote Miss Ellet, "the patients arrived and our first baby was born two hours later."

The Red Cross furnished clothing, if it was needed, to the mother, and supplied lavettes for the babies. If a pregnant woman had children at home and if her husband was at the front, she was allowed to bring her ehildren during leer confinement to the isile C'aserne, where they too were cared for mitil she was well enough to go home. Before leaving the hospital, each mother was tanght to bathe and care for hor rhild and was shown proper methods of fecding it. If the mother was mable to morse it, a supplementary fording was provided and given under sterile enditions. When the mother was woll roongh to go home, she was given written instructions regarding the retre of the child and was ureed to report at regular intervals to the American Red C'ross dispensary nearest her home to have the baby examined.

This dispensary service which radiated ont from Toul through the Meurthe-el-Moselle and the Vosges was an im-

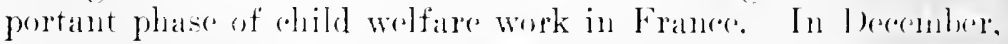
1917, the Aneriean Fund for Fremeh Wommded and the Ameri-

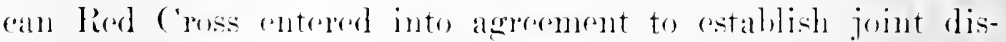

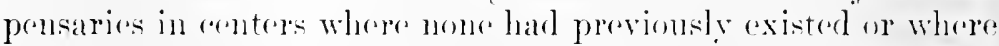
there was a deartle of loral medical care for the rivilian populat-

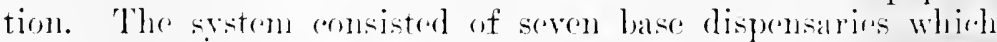
operated twonty-six snb-dispensary units and two ereefles. The persommel of a lase dispensary mit nsmally romsisted of a dere-

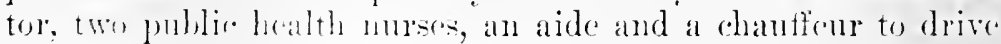


a camionette. The doctor and the nurses established headfuarters at the base dispensary and then made the rounds of the sub-dispensaries in the camionette. Dr. Karlton G. Percy was the medical director of the system.

Base dispensaries were located at Toul, Nancy, Lunéville, Nenve Maison, Gerbéviller, Epinal and Fong. The Naney group, which included seren sub-dispensaries, was entirely financed by the town of Winetka, Illinois. The Lnneville group of six sub-dispensaries was finaneed in part by the Destitute Babies' Aid Societr; the Gerbéviller group was supported by the Ameriean Fund for French Wounded; Epinal by citizens of Baltimore, Maryland, and Minneapolis, Minnesota; Neuve Maison by citizens of st. Panl, Minnesota.

The dispensary service worked in close coipperation with the Asile Caserne de Lurembourg. When children or women in need of operation or prolonged medical care were found in the radius of the sub-dispensaries, they were sent to the Children's Inspital or to the surecical or maternity wards.

Early in March, 1918, a colony of nine hundred refugee children from the Nancy district were sent under the patronage of Prefet Miman to llinard, where the warm sum on the beaches and the fresh salt air helped to drive tubereulosis from their emaciated bodies. They went under the chaperonage of French teachers and principals from the Nancy selools. Dr. Karlton G. Perey, rhicf of the Red Cross dispensary system in the Weurthe-et-liosolle, and several Red C'ross murses aceompanied the comory from Toul to Linard and remained there nutil a permanent statf was sent up from Paris. Mary C. Nelson, a nurse who had gene to France in Norember, 1917. with the Rorkefoller Tubrerenlosis ('ommission, was one of the murses and she remained at l)inard as supervisor. Dr. May Mllen was the medieal director.

Dinard was pratetically deserted during the war. The Mritel Roynd was taken ower for the girls and the boys were honsed in another hoted at st. lonnaire, on the seashore tive miles west. Buth of these hotels hat been used he French troops and the military anthorities hand left some bedeling. beds. dishes and other erpuipment. The walls were damp and in maluy plateres the paper home in tattered strips. hut the thors wele comparat-

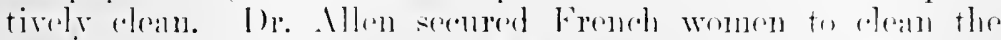

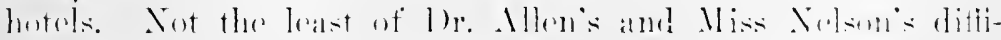
rulties was the problem of lanndering some laree heary and 


\section{HISTORY OF AMERICAN RED CROSS NURSING}

exceedingly handsome sheets which wealthy residents of Dinard presented to the colony.

The Children's Bureau established a dispensary with a small infirmary at Dinard and treated from forty to fifty children every day, furnished all sick and anæmic children with nourishing food and provided elothing, linen and drugs as needed. The children suffered from tuberculosis and diseases due to malnutrition. Their hands were covered with sores, "which in many cases went as deep as the bone." ${ }^{8}$ Some had scabies and at first vermin were a veritable plague to them all. During the month of May, 1918, the total attendanee at the clinies was 2540. Eighty-one children were cared for in the infirmary. At this time threc American Red Cross nurses and six aides were on duty at Dinard.

A second colony which consisted of 110 girls was installed in a château at Damarie-les-Lys near Melun and the Children's Bureau supplicd medical and dental treatment.

Thronghout the spring and summer of 1918 the Toul project expanded and flourished under the happy coöperation of Prefet Mirman, representing the French Government, Mrs. Lathrop, representing the Committee for the Amcrican Fund for French Wounded, and Dr. Ladd of the American Red Cross Children's Bureau. In September, however, the military needs engulfed the work for the eivil' population; American troops went into action at St. Miliel and the Asile C'aserne de Luxembourg was converted into an eqvaenation center for American wounded. In Angust the children were sent to Nenfchattean, Nancy and Lyon. The Asile Caserne with its lospitals was transferred from the Department of Civil Affairs to the Department of Military Afficir's and was expanded in a week to a one thousand bed military hospital. The nurses already at the Asile ('aserne were taken into the military service and "easuals" were rushed up from Paris Headquarters. An American Red Cross mobile unit with Major MeCoy as enumanding offieer and $\mathrm{M}$ iss Meirs as chief nurse, took possession of the Asile C'aserne on September 11 and estallished Ameriean Red Cross IInspital No. 114 and at dawn two days later one thonsand American wounded had eome lack from St. Mihiel. The lsite C'aserne with its hospitals and clinies thus disappeared from the reports of the ('hildren's Burean.

\footnotetext{
"Sien Report of I)r. Allen. Weekly Report of the Children's Bureau ending Jume s, 1918, p. 6.
} 
The American Red Cross elosed its dispensary service in the Meurthe-et-1/oselle and the Vosges on January 1, 1919. Some of the dispensaries were taken over by the Women's Overseas Hospital Lnit, others by the American Fund for French Wounded, still others bỵ private organizations which were given financial assistance by the French government. I)r. Iadd, rhief of the Toul project, wrote that "we have had 33,2:32 dispensary consultations since the American Red Cross came to the Meurthe-et-. Woselle; 29,307 of these consultations have oceurred since January 1, 1918; 9797 of these represent new cases."7

During the fourteen months in which the Toul project was maintained, the following division of responsibility existed between the Committee for the Ameriean Fund for French Wounded and the American Red Cross: One-half the number of notor cars which were used were supplied by the Ameriean Fund for French Wounded, one-half by the Ameriean Red Cross: one-third of the graduate nurses and aides were furnished and their salaries paid by the Ameriean Fund for French Womnded and two-thirds by the American Red Cross; over five-sixths of the total expense was borne by the American Red Cross, the remainder by the Ameriean Fund for French Wounded; all medieal service and all supervision and administration was provided by the Ameriean Red Cross. ${ }^{8}$

A secend northern provinee to know the work of the American lied cross was the lepartment of the Somme. On Angust 15, 1917, the (hildrens Bureau reecived an appeal from Nesles and seven villages in the immediate vicinity. The plight of these villages, Matigny, Croix, Moligneanx, Mesnil, St. Nicaise. Romy-le- (irand and others, was pitiable. They had been captured and ocempied by the Germans in the early years of the war and had been reciptured by the French in Miareh, 1917. The retiring Germans hald sent the strong, able-bodied women and children to Gemany and had systemationlly looted the comntry whel they were evacuating. From the little farms the ruenye tork furniture, bedding. cooking utensils and all film inplements. Orehards were leveled and isolated houses hombed or burned. In some of the villages no homse remalined intart. Y'ot among these bleak ruins still existed many old women and men and approximately twelve hundred 


\section{HISTORY OF AMERICAN RED CROSS NURSING}

young children, many of them suffering from ringworm, impetigo, scabies and blepharitis. "They looked stumned and sullen," wrote Mrs. Lueas, "and no smile eould be teased from them." 9

The village of Voyemnes had formerly had a population of nine hundred souls, but in 1917 only four hundred and fifty remained. 'The mayor and the school teacher begged above all else for bathing facilities. During the German oceupaney each civilian had been required to take a shower-bath once a week, but upon the enemy's retirement all bathing facilities had been destroyed and since MIarch the civilian population had suffered greatly. One hundred and serenty children had been collected in this village and were going to school. "One wonders at the poise of the little French child," wrote Mrs. Lueas, "or is it just the eternal elild, eager to learn, that seuds these siek children to sehool in the midst of devastation and within hearing of the guns? And in all the villages are the old, old people," she added. "They are so terrorized, so heart-broken there is nothing more that life ean do to them. They do not seem to be asking for a place to live in but a place in which to die undisturbed."

The Children's Burean sent Dr. John C. Baldwin, of Baltimore, to establish rhild welfare work in Nesle. The French offered the Ancrican lied Cross a small tuberenlosis parilion in the grounds of the Hetel Dien and with the assistance of two American Red (Cross murses, Mary A. Brogan and Susan 1). Potts, and two aldes. I)r. Baldwin established a clinice at Nesle and a weekly dispensary serviec throngh nine outlving villages. Dr. Baldwin wrote of the pioneer work:

\section{Weekly Report. October :5- Norember 3. 1912.}

The situation whieh confronted us upen arrival at Teste

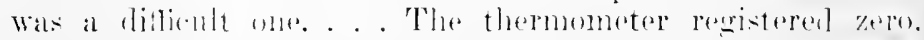
Sone one hart removed the litte iron stere from the parilion and our only means of heilting was a buteh oren with a breken stevepipe. The water works had not been repaired.

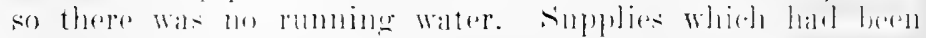

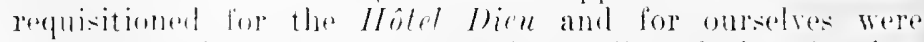

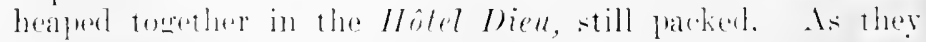

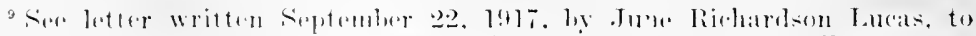

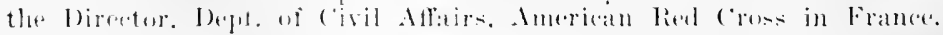


were identically marked, we had to unpack all of them to disener the things we neederl for the night. l)arkness ame soon and we used the lamps from the anto. . . .

Sunday passed rapidly in an attempt to shovel and sweep the mul aud dirt out of the parilion. Walls and reilings in some of the rooms were serubbed. Monday and Thesday cleaning was continued and a semblance of order created in the drug room, supply room and stafl quarters. Signs are being painted by a local artist for our building, which has been christened "I avition Jofire."

The spirit of the murses in meeting the real hardships of the periot of invasion has been splendit. No one has grumbled at wet feet and bame shoulders. Noses have been red at brakfast, but weve aten it standing and jugreded our enffee glasses (we have no eups yet) from hand to hand as we hopped about to kecp warm.

The little American dispensary nestled down behind the high and forbidding wall of the ILotel Dieu. Every morning an average of twenty children came through the ancient pertal or the grille gate belind the garken in the rear and were treated for skin diceases and other ailments resulting from malnutrition. Miss Brogan and Miss Potts ran a small hospital of twelve beds. "The work was very gratifying," wrote Miss Potts, "not only because all but two of our patients recovered, lut becanse the hospital was so small that we came to regard the children as our own little family and they in turn grew responsive and aflectionate."

Nosle was c.lose to the British front lines and the Red Cross relief work for the eivilian population there was greatly limited hy war restrictions. Passes conld be secured only with great diffieulty and it was impossible to circulate in the Nesle distriet without passes. Giasoline could not be procured and so mom of the dispensary work which hatd heen well oreanized in many neighboring towns had to be given up. Yet reeords of

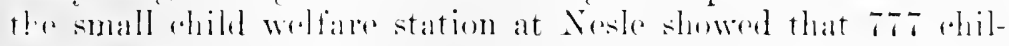
dren were eximuined be the Anerican lied Cross during the munth of Fobruary, 191s.

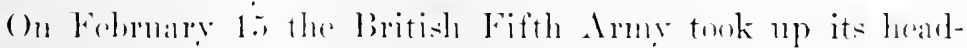

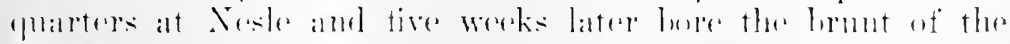

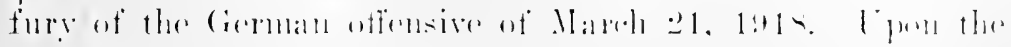

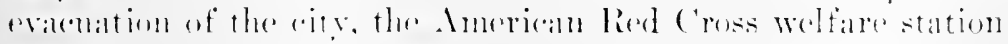
was alandoned. Miss Potts wrote: 


\section{7\%4 HISTORY OF AMERICAN RED CROSS NURSING}

On March 23, the Germans for the second time adranced with lightning speed and a few days later left little Nesle a heap of ruins. On that twenty-third day of March we evacuated very hastily in a large camion with a hand-bag each and with what supplies we could gather together. We took with us an eight weeks' old baby, a girl of fourteen who had tuberculosis, several burned and several convalescent eases and hurried to Roye, southwest of Nesle.

'The noise of battle was quite as terrific there as it had been at Nesle and we soon evacuated again, with refugees from Ham, Nesle and villages all along the line. We started by amion for Montdidier, but progress was slow through the congested traflic of terrified refugees, carts, cattle, dogs, geese and pigs.

Miss Brogan and I went to Amiens, to find the mother of our eight weeks' old baby Daniel. He had been fed at $7 \mathrm{~A}$. $\mathrm{x}$. but we could not find food for him until three that afternoon; an infirmière at a hospital at Amiens then gave him a little milk. . . Dirty with camion and train dust, jostled and jolter, hungry, tired and slecpy, he had never whimpered through the journey.

Complete records of the Red Cross child welfare station at Nesle were lost in the evacuation of the city.

At Amiens, as at Nesle, the work of the Children's Bureau was destroyed almost before its complete initiation. In August, 1917, a public health nurse, Amnie A. Rathbone, had begun to do visiting nursing under the auspices of the Secours 1 méricrines jontr les liefugées. Her expenses were at first paid by Major Richard A. Cahot, but soon afterwards the work was supported by the American Red Cross and Miss Rathbone was attached to Miss Ashe's sorvice. Miss Rathbone's duties at Amiens consisted in risiting from house to house among the 11,000 refueres. Cntil such time as the Red Cross could arrange to assign a pediatrieian to permanent duty at Amiens, she distributed food and assisted at a clinie which was condueted by a French phrsician. The long antieipated arrangements wore finally completed arly in 1918 and l)r. Baldwin, of Nese, ledel his first elinic abent the middle of March. A second nurse, Miss Flanagan, was sent up to assist Miss Rathbone.

Hewerer, at dawn on March 21, the enemy lanuelied his offensire at the junction of the French and British lines near Cambrai and the prosesion of Aniens lung in the balance 
while Gough's Fifth Army, cut off from the British at Arras and the French at Le Fire, struggrled in chaotic disorganization until French and British reënforcements came up on March 26, filled the gap at Moreiul and slowed up the German drive. Amiens did not fall, but the eivilian population fled from the eity on the sixth day of the offensive. Miss Rathbone, Dr. Baldwin and the nurses from Nesle, the members of various Ameriean eolleges and the Friends' mits fell bark in the general evacuation to Montdidier and Beanvais and thenee to Paris. Records of the Ameriean Red Cross child welfare station in Amiens were lost in the evacuation of the eity, an account of which appears later.

Evian-les-Bains, the gateway throngh which the Germans flung back to France inhabitants of the occupied northern provinees, who were too old or too young or physically unfit for military purposes, was a town with a normal population of about 2000 , situated in France a few miles from the Swiss border on the slopes of the hills which rise above the sonthern shores of exquisite Lake Geneva. Nearby were the French villages Amemasse and Thonon; the snow-capped ranges of the Bernese Oberland rose in the east. In peace times Evian had been one of the smartest and most expensive of the Freneh watering-places. Howerer, in 1917 and 1918, its two Ritz hotels, its easino with theater, gambling rooms, restamrant and music hall, its alkaline springs and bathing establishments, its parks and boarding honses were daily the seene of a woeful influx of rapatriés.

The reception which the French Govermment extended to its rapatrié citizens was a cordial and efficient one. Representatives of the Minister of the Interior established in the Evian Casino a smoothly ruming system of reception, entertainment and distribution to other parts of France of all rapatriés who cutered Evian. 'Two convors, atrving about six lundred and tifty people cach: arrived daily, the first at six ocelock in the merning, the serond at four o'eloek in the atternoon. Two French nurses and a French physician attalehed to the gurernment serviere boarded the tratins at Bomberet Station and res-

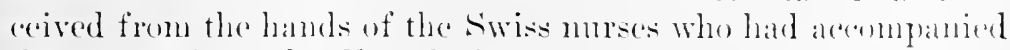
the repatriés to the French frontior, a list of all the sick, infirm and old on the anvoy who merded attention.

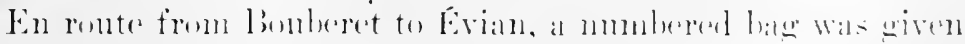
to each family and the rametries were instructed to put their 


\section{7ซ6 HISTORY OF AMERICAN RED CROSS NURSING}

belongings in them. They were then given eheeks and the bags were stored at the station at Evian until the owners claimed them upon leaving the city. A list of all the people in the convoy was also made out, to be given to the Commissuire Special upon arrival at Évian.

With flags flying and a band playing, all Exvian met the convoy trains. Sometimes a train was made up of third-class carriages; again it might be composed of cattle cars, but as it came winding slowly around to the station the windows or the apertures were black with outhrust heads and waving arms. On the platform nurses, ambulance drivers, rapatriés, government officials and local committee members cheered and waved their flags in response and as the train drew in, stretehed out eager hands to help the weary rapatrie dismount.

Some cheering and singing, others with the easy tears of age running down their eheeks, still others dazed and silent, the old women and men, the sick mothers, the thin, curions-eyed children set foot again on Freneh soil and marched down the narrow street to the Casino, with the band playing bravely at the head of the straggling line. In a big cheerful room of the Casino hot food was served to them and the prefet of the District weleomed them home. The band struek up the Marseillaise and they sang, haltingly at first, then with a great cry "Marchons, irarchons!" that rang to the flag-draped ceiling. ${ }^{10}$

The next step was that of identification. A card was given each rapatrie which cuabled him to draw allocation and an effort was made to get in touch with his relations. If clothing was needed, it was issued. Medical examination followed; carriers of parasites were segregated and treated; those too ill to go on were detained at Evian for hospitalization. Those who were in good health, who had means of sulsistence and who did not desire enovernment assistance in traveling, were allowed to go, at their own expense. to whaterer locality desired, exreptions bering Parris and the war zone. Those who had been clained be relatives and desired to travel at government expense were hospitalized at Evian for the moment but were allowed to leave withere by the first convoy ont or to go individually as semen ats arangements conld be made. Those who were waiting to lwe chinmed by relatives were cared for by

${ }^{19}$ For an exomllent deseription of the arrival of rapatrie train- in Evian. sere "The children of Frane. and the lied (rose" hy June Richardson

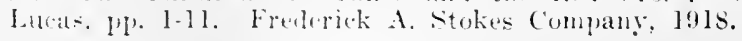


the govermment at Evian or at Thonon or Amnemasse. Those who were not clained after a due period of waiting were sent to rapatrié centers which were maintained by the government.

Early in September, 1917, Dr. Lneas went to Evian to aseertain if assistance from the ('hildren's Burean would be needed, and it so, aceeptable. He fomd that only thirty-five beds were available in the entire region for the hospitalization of ehildren. Moreover, no systematic medical examination was given to the children as they passed throngh Evian, to find ont if they were in fit condition to continne on their way, and already complaints had becmu to come from various parts of France that rapatrié childron were bringing in virulent contagions diseases.

On September 27 Dr. Luras took Dr. C. F. Gelston, of San Franciseo, a member of the original pediatric unit, and $\mathrm{Mr}$. IV. ('. Stronson, an administrator, to Evian. A conferenee was held the following day between officials of the French Department of the Interior, the service de's liapatries of Evian, the C'omite aux Rapatriés de Lyon and the three Amerieans. It was decided that the Anerican Red Cross shonld establish a medical service at the Casino for the examination of overy rapatrié ehild immediately after its arrival in Evian and a hospital nearby to take care of the ehildren who were not in condition to continne on their way ${ }^{11}$

In an aleove of the main hall of the Casino Dr. Grolston set up his eximnining booth. The equipment was simple, three chairs, an electrie light, a table with tongue depressors, a stothoseope. All the rapalries tiled through this hall of the Casino and as the line noved forward an Imeriean Red Cross aide stepped all children moder sixteen and led then over to the booth. Here another aide assisted the Ameriean doctor while he examined the child's throat. A nurse stood by to take statisties and remarks on eareh ohild as they were called off lix the phesician. After examination another aide tagered the child for treatment at the Ameriane dispensary, at the dentist is or at the Childeres Itespital. Ilealthy ehilderen were allowed to (w) on immediately with their parents or guadians to other parts of Fince.

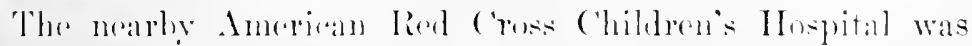

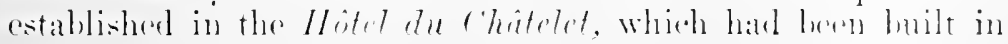
p. 1s.

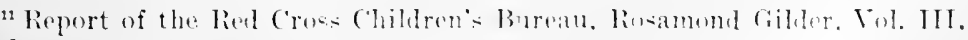




\section{HISTORY OF AMERICAN RED CROSS NURSING}

a handsome park on a sloping hillside above Lake Geneva. Several private villas nestled among the rose gardens and flowering shrubbery and these were utilized for various purposes, one as a dispensary where both dental and medical work was done, another as a temporary orphanage, a third as nurses' quarters. The Hotel du Chatelet itself had many open balconies and long windows, so the large, high-ceilinged rooms were flooded with sunshine and fresh air.

On October 19, 1917, nine child welfare nurses, with Miss Ashe in charge, went up to Evian and opened the Children's Hospital. Fifty children were admitted and twenty-one discharged during the first week of its maintenance. The maladies from which these patients suffered included measles, chicken-pox, scarlet fever, diphtheria and tuberculosis. Some of the skin diseases resulting from undernourishment were in advaneed stages and very repulsive.

Following Miss Ashe's return to Paris after the first days at Evian, Miss Helen King, a laywoman, was placed in charge at Evian. She became ill and a Red Cross nurse, Susanne Hoskins, was put temporarily in charge. In December, 1917, Helen Almy Bigelow, a Massachusetts nurse, arrived at Paris Headquarters and was immediately assigned to Evian as chief nurse. Miss Bigelow was a graduate of the Children's Hospital, Boston. She had done publie duty nursing in that city and had had institutional experience in the Cleveland City Hospital. She later was supervisor of the pediatric service of the New York Nursery and Child's Hospital and resigned from this position to undertake work with the Children's Bureau.

The number of nurses at Evian varied. On December 3, 1917, there were twelve. For the major part of the time the number was maintained at a stremeth of fifteen graduate nurses, fonr American airles and ten French aides. The enployment of Ameriean aides on a enmprehensive seale was soon found to le inpracticalble. Their lack of training in the care of contagious discases made them of little use and, moreover, they were constantly rontracting the diseases beeause they did not know hew to take care of themsolves.

1)r. E. .J. Lappere of Portland, Oregon, was medical director of the chatteleot IJospital until January 15, 191-; he was then transfereed to Nesc and I)r. (relston took over the direction of the children's Inspital in addition to his work in exanina- 
tion of ehildren at the Casino. Dr. Florence Child was the resident physieian at the Châtelet Hospital; 1)r. Horothy Child was the dispensary and laboratory doetor; Dr. Raymond Mixsell, of Pasadena and Dr. E. K. Armstrong, of (hicago, later were in turn médicin-chef of the Châtelet IIospital. Mr. W. C. Stevenson was in charge of administration.

The rapatrie children who filled the sumny rooms had known to the full the hardships of existence in a comitry occupied by the enemy. Many of them came to the hospital with their stunted little bodies clothed in rags. Their eyes, which peexed out big and black from pinched eheeks, were full of a wisdom and a hunger that greatly endeared them to the American nurses.

The Germans closed their frontiers on February 26, 1918, and the convoys stopped, but on May 21 they began again and continued uninterruptedly until August 3, 1918. Between October, 1917, and August, 1918, 65,801 children were examined at the Casino; 1809 of them were eared for in the American hospital, 1824 were treated in the Red Cross dispensary and 2597 were treated in the dental dispensary. ${ }^{12}$ The convors were resumed again on September 16 and continued until November, 1918.

The Germans in November ceased to return the rapatriés through Evian. The convoys were then sent thromgh llollami and 1)r. Gelston was instrueted to organize at Dieppe a scrice sinilar to that at Evian. Eighty thousand rapatries were returned to France in November and leecmber, 1918, throneh Holland and 1750 (hildren were examined at Dieppe. Fiftyone of them received hospital care at a small pavilion which the II ijpital Vixte loaned to the American lied Cross. ${ }^{13}$

The work of medieal examination and hospital care, both at

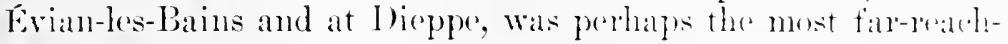
ing in its professional phases and the most appealing in its human aspects of any of the projects mulertaken by the chil-

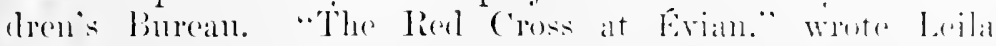

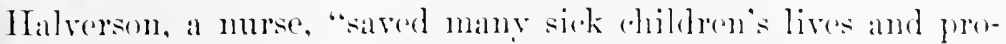

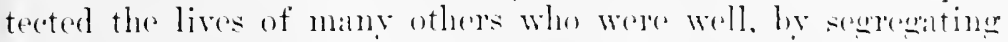
the sick from the healthy before they had had oppostmity to spread the contagion."

2 Giller Report. Vol. III. p. 22.

13 lbid., lp. $41-4.2$. 


\section{HISTORY OF AMERICAN RED CROSS NURSING}

Sonthwest of Evian lay the large industrial city of Lxrons, which during 1917 and 1918 beeame a stronghold of Red Cross child welfare work in France. Evian was primarily a center of evacuation. The French authorities insisted that the rapatriés be sent on to other localities as rapidly as possible so that this small border town would not become congested. The Children's Burean was foreed to look elsewhere for a site on which to establish a convalescent home for children eoming from the Châtelet Hospital at Evian. Dr. Lucas took over for the purpose the C'hateau des IIalles, at Ste. Fov l'Argentière, thirty miles from lyons. Later, the Children's Burean developed and maintained two large convalescent homes, two contagious hospitals and an extensive dispensary service in the Lyons district, all an outgrowth of this first orphanage at Ste. Foy l'Argentière.

Chateau des IIalles had been the eountry estate of Monsieur Mangini, a French engineer who built the Riviera railroad. Upon the death of Madame Mangini he had presented the estate to l'Hospices Civils de Lyon upon eondition that it be used as a convaleseent hospital for children. L'Hospices Civits de Lyon was one of the oldest charitable organizations in Europe. It had been founded about 900 A. D. by Queen Hiltrud and had been in contimons existence ever since. "It is heavily condowed and is very well managed," wrote Dr. Howard Kennedy Hill, a pediatrician of the Children's Burean, "and all the hospitals of lyous are under its control."

Lillospices Civils de lyyon offered the use of the Chateau des Halle's to the Children's Burean free of charge, provided that the American Red Cross would leave it equipped as a hospital after the war was over. It wals then being operated by 1)r. Ellen Corer of Siln Antonio, Texas, Mrs. Mrekinnon of Oklihomal (ity and Mliss Louise Brbee. It stood high upon a hill, heavily wooded with old cedar's, pines and redwoods. It was surrounded by a fillm which furnished milk, butter, eggs and fresh veogetables in almundanes. The ('hattean had been built in 1str. with modern monvenienees, hut the Red ('ross had to enlarge the heating and lighting facilities to hospital dimensions. Mnch of the beantiful anred furniture was left in the

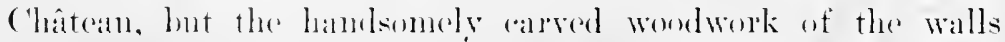
was corered for protertion. Ilowerere, the murals, the white

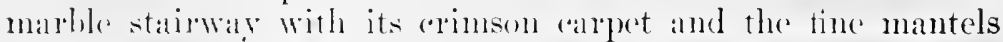
still galse to the interiore of the ('hittean dignity and charm. 


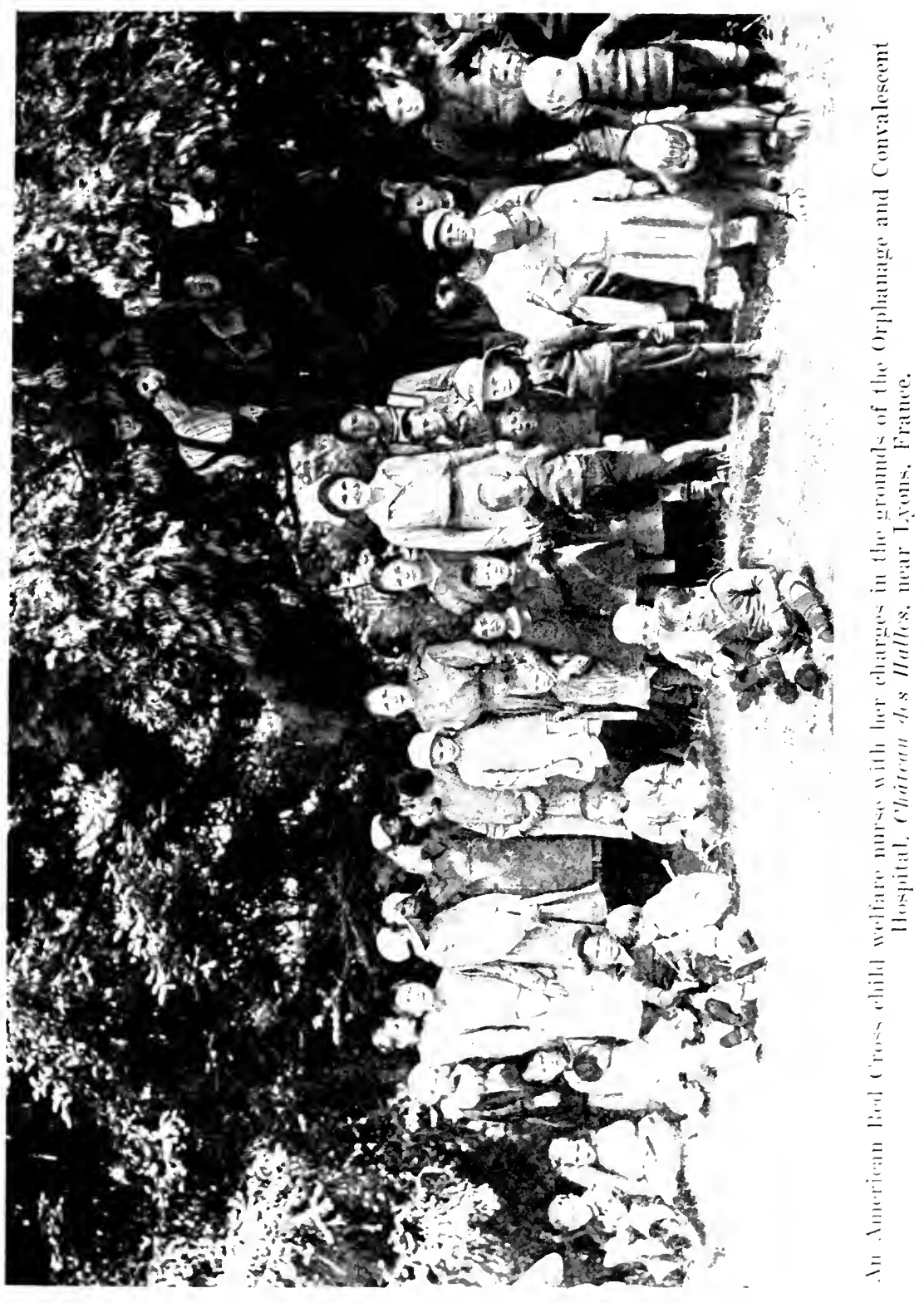



During the first days of November, 1917, a detachment consisting of a director and four lied Cross child welfare nurses were sent up from Paris headepiarters to prepare the C'hatenu des Halles for occupaney. 1)r. Franees O'Neill, one of the physicians of the second pediatric mit under I)r. J. Mason Kiox, was in charge; Sophic ('. Nelson was chicf nurse. Miss Nolson was born in Copenhagen, Denmark, but was a naturalized citizen of the United states. She was graduated from the Waltham (Massachusetts) Training Sehool for Nurses. In April, 1916, she undertook infant-welfare work for the board of health of Cambridge, Mass., and later became superintendent of the Public Health Nursing Association, Louisville, Kentucky. With this experience as a background and with a fluent knowledge of French, Miss Nelson proved herself an able organizer and executive. Moreover, she was possessed of an unusually wiming personality.

Frances 13. Areher, Elmira W. Bears and Mary P. MeCandlish were the other nurses. Mrs. Florence Lee Holtzman, of Washington, I). C., a laywoman of initiative and business aenmen, first had charge of the financial details at the Château.

By November 22 the nurses had eleaned the wards and set up rows of small white eribs in readiness for the arrival of ten children from Evian. Other detalhments were som sont in rapidly until there were serenty patients in the chattran in February. The nursing staft, though reënforeed by several aides, was limited and the heating facilities were very poor, so I)r. O'Neill did not dare for the time being to take a larger number of patients. The Chatean had some sixty rooms whicll were at first heated only by wood fires. The fall of snow around lyons was heavier in the winter of 1917 and 1!) 1 s than it had been for forty years. "The enormonsly thiek stone walls

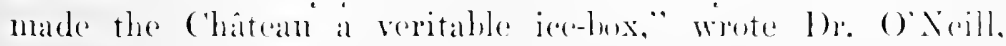
"and I have often wondered how these Ameriean nurses and aides stoud the cold. Smrely they must hatre sutfered."

The professonal work at the chatean des Malles differend very little from that at othere hospitals of the childrens binreaiu. Here were the same siek bahere, the same thin, wist ful romig children to murse and foed and hatle. "A depmenting thing." wrote I)r. () Neill, "wats the inability or persibly foill

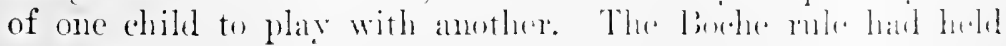
them down so lome that they wonled simply sit where they hat

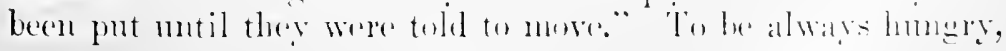




\section{HISTORY OF AMERICAN RED CROSS NURSING}

to be sick and frightened, to have scen their parents, their brother's and sisters killed, to have watched their homes burn down with "mes affaires," which means everything to the French child, seemed to have cloked the play instinet within them and they sat motionless and dumb.

"To me perhaps the saddest sight," continued Dr. O'Neill, "was the little Boche babies abandoned by their mothers as soon as they reached French soil again. I have seen several families where part of the children had French fathers and part had had Boche fathers."

As soon as the children were fully recovered they were sent to the societé de Secours aux Rapatriés at Lyons, a well established French organization under the leadership of Nadame Gillet-Motte; she maintained two establishments in Lyons, one for boys and the other for girls, and a barracks where children suspected of exposure to contagious diseases were placed for observation. The Societé de secours made efforts to return the rapatrié children to their parents or relatives.

The chateau des Halles had originally been intended for use as a conralescent home for children, but on account of the great number of children examined at Evian and the lack of space there in which to house children for the proper period of observation, contagions cases slipperl by to Lyons and were then taken to the Chateau, which caused it to be quarantined frequently. Another disadrantage was the location of the Chattean thirty miles from Lyons; the railroad service from Lyons to Nite. Foy l'Arecuticre was poor and the transportation of patients and supplies berame a difticult problem. For these reasons the Chatem did not antirely meet the need for comvalescent beds, so about May 1, 1:18, the policy which governed its maintenanee was changed. I)r. O'Neill was transferred to Paris, the nurses were reassigned to other more vital service and ('hateau des Halles was nsed as an orphanage where children were sent for smmoner ontings. It was then filled to eapacity.

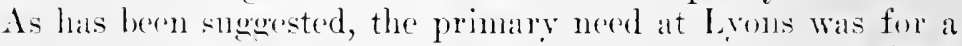
general hospital for children which would care for cases from l, rons and mpatriés who slipped through Evian. On Felonary 6, 1918, 1)r. Clifford Grulee, of (hicago, had arrived at I'aris headeluaters for work in the Childrents Burean. Dr. Girulere had leen assistant profesorer of Pediatries at Rush Mredieal Colleger and attendiant perdiatriedian at the Presbyterian IIopital and the IInme for l bestitute ('rippled ('hildren 
and his book on Infant Feeding was regarded as an authority throughout the United States. Upon his return in 1918 from France he became professor of Pediatries of the University of Chicago.

Early in February, 1918, Dr. Grulee was appointed medieal delegate of the Children's Burean for Lyons and he immediately went there to develop the work. Sophie Nelson, hitherto chief nurse of the Chateau des Ilalles, was appointed as chicf nurse of the Lyons district and she and Dr. Grulee undertook the establishment of a contagious children's hospital in Lyons, Hospital Violet; a convalescent home, La Chaux; a dispensary service, and some months later a special general hospital, Hospital Holtzman.

Before outlining the development of these institutions at Lyons a short statement of the educational work of the Children's Bureau is necessary, for to this phase of Red Cross cudeavor was undoubtedly due in large part the success which atteaded the establislment of these hospitals and homes. The need in France for a strong public interest in child welfare work was vital; in a country where two adults were dying for every child born, the life of that ehild beeame doubly precions. In eonjunction with the Edncational Service of the Rockefeller Commission for the Prerention of Tuberculosis in France, the Children's Bureau undertook an edueational eampaign early in 1918 to awaken public interest in saving the lives of babies and ehildren. Philip s. Platt was the tirst direetor of the Educational Service of the Children's Bureau. Ellen C. Babbitt, an Anerican social worker, expert in preparing whild wolfare exhibits, joined the Children's Burean on March 26, 1918, and assisted in the preparation of the exhibits. Health literature was published and distributed in large quantities. Two traveling exhibits were set up and sent through seven departments of France. Larere child welfare expositions were oreanized by the Ameriean lied Cross in eöiperation with the French Ministry of the Interior and the Infant Mortality League and

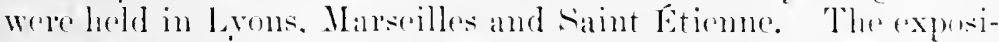
tion at lerons was, howerer, the first and laresest of these.

A detailed aecount ${ }^{14}$ of this expesition lies ontside the provinee of a history of the Ameriean Red cross Nursing service.

"For such sere Report of the children"s burean. Vol, 111, Infant Weltare (ampian. Rosamond (ibler. Library, Xational Ileadluarters, Washington, D). ('. 


\section{IIISTORY OF AMERICAN RED CROSS NURSING}

The exposition was opened in a large pavilion on the Place Bellecour, on April 9, 1916, by Senator Herriot, then mayor of Lyons. Healtlı plays enacted by puppets, lectures, motion picture shows and charts illustrating all types of child welfare work formed the principal material of the exhibit. Among these were a series of some eighteen posters drawn in color by Anna Miles Lpjohn, an American portrait painter. Demonstrations of dental hygiene and of the hygiene of the nose, ear and throat were held in separate booths. In the center of the pavilion on a platform surrounded by glass to keep it warm Susame 13. Hoskins denonstrated the proper eare of a baby. "While the Freneh people whom I met personally were very pleasant to me," wrote Miss Hoskins, "and used to crowd around to see the jolly, kicking baby plunged into the tub of warm water... they said we were foolish in coming over and trying to teach them how to eare for their children. My answer was: "We are only trying to show you our way.",

The exposition at lyons lasted from April ! to $A$ pril 30 and during these twenty-two days 173,155 people attended it, onefourth of the population of the Lyons district. ${ }^{15}$

On April 1 the doors of the Children's IIospital at Lyons were openerl. Dnring the early summer of 1914 I)r. Violet, a French physician, had started a private hospital at 142 Cours Gambetta, Lrons, but upon the declaration of war he had been mobilized inte the military service. His hospital, Hospital Violet, had beren closed. The modern hospital luilding in which it had heren loceated was unocenpied until March, 1918, when the Amerian lied Cross rented it for use as a general hospital for rhildrens.

Inla F. Butler was ehief nurse of the Iospital Violet. With Miss Butlor's assigmonent to war nursine sorvice in France rame an interesting link with Civil War days. Iner father, of Now Eneland sterek and northern sympathies, was severely womeded in Vireinia and was bronght to the old Armory signare Inepital in Waslineton, W). ('. Whilo on duty as a volunteer nurse in this hospital, lda de M. Fazio, a Washingron girl of Castilian deserent and sontleren srmpathies, met hine and they were malried at the and of hostilitios. A direct link between

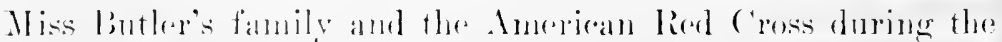
Eumperan Wall was thromeh leer brother, who as president of a laree American insurane company, made possible the gen15 (iiller lieport, Vul. III, p. 158. 
erous arrangements by which the American Red Cross was able to insure the health and lives of its overseas workers.

Miss Butler was a graduate of the IIartford Training School and was for twelve years head of the maternity aml gronecologieal department of the Hartford IIospital. She then became supervisor of probationers. By temperament, she was direct and fearless, with a rivid and droll gift of expression and an intense lovalty for luer friends. Above all else, she was conscientious, a good nurse who never forgot the old-fashioned ethies of the relation of murse to paticnt.

Hospital Violet was opened on April 1 and drew patients from thrce principal sourees. "Refugees from the north who had been sent to the two Red Cross orphanages, Chateau des Halles and La Chaux," wrote Mliss Butler, "and rapatrié children coming from Evian were our emergeney eases. Our constructive work was done in connection with children sent into the hospital from two Red Cross dispensaries established in l. yons."

The first of these dispensaries had been opened at 42 Aveme Berthelot in March, 1918, by I)r. Virginia Murray, of Sam Francisco. The dispensarv treated rapatrié elildren then living in Lxons, and also children who had lived there since infanery but who beranse of the dearth of French phrsicians were in need of medieal eatre. By July 1, 1918, this dispensary had treated over 1960 new eases. A second dispensary, located at 2 Aremue de la Bibliotheque, was opened on July 22.

As Miss Butler stated, these dispensaries were one of the principal sourees through which pationts were sent to the IInspital Violet and a great number of them were nose, throat and dental eases. I)r. William E. Wiggin of Lowell, Mass, Was chief of the nose and throat department; his wife Laural Wiggin, a nurse, was lis assistant and anesthetist. Dr. Rilymond II. Watson of Waltham, Matss., Was rhief of the dental department and trated from thirty to fifty children daily fom times a work.

Following the rstablishment of the Ifospital Violet in April, 1918, a convalescent heme, La ('haur, was opened early in II lay.

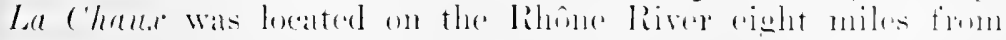

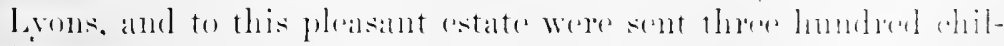

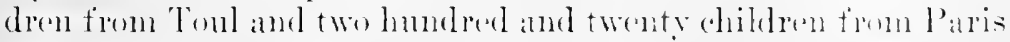

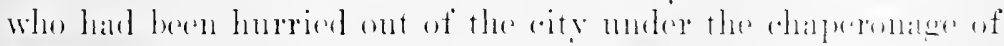
Paris solumel tabelers during the spring bombandunents. Two 


\section{HISTORY OF AMERICAN RED CROSS NÜRSING}

nurses, Susame B. Hoskins and Kathryn Flanagan, opened the old chatean late in April and set up the several hundred beds for the reception of the children. "The little brown cots neatly spread with the charming, vari-colored afghans made by American Red Cross Juniors," wrote Miss Flanagan, "surely were a joy to see. The entire châtean was surrounded by a terrace banked with wistaria, then in full bloom, and when those tired roungsters arrived from Paris, the first thing they saw were these vivid afghans and beyond the open windows, the fragrant flower-hung terraees." The children at La Chaux lived largely in the open air. Classes, drills and games were held and even meals were served on the terraces and in the gardens.

Neither the two orphanages, Chateau des Halles and La Chaux, nor the Hospital Violet, nor the dispensaries afforded exactly the specialization which the Lyons situation demanded, so on June 11, 1!18, Dr. Grulee converted the Hospital Violet into a purely contagious hospital and sent Miss Butler to organize a hospital for aente diseases of children in the former German Consulate, 37 Boulevard des Belges. This was called Hospital Holtzman, in deference to Madame Holtzman's tireless efforts at des IIalles. The nose and throat department was transferred from the Hospital Violet to the new hospital, but the dental department was attached to the main dispensary in the Avenue Berthelot.

The German Consulate, a "magnificent example of German ornate extravagance," had been built with the idea that the Kaiser wonld reside there whenever he chose to visit Lyons. It had seren bath-rooms, "each one finished in marble and onyx," wrote Miss Butler to Miss Noyes. "It makes the finest kind of serviere rom. The old rose lialls and the grand salons, now eovered with brown paper to proteret them," she continued, "are wards for children aged from two to four and the brilliant light from the mienitionent glass chandelier dazzles therir little eves. The library is still full of valuable books; the shelves have beren bordedel nu and sealed and the room is used as an infants ward." I) rothy Cox, of Terre IIante. Intliana, was business manager: she had assisted Miss Bablitt in the development of the Lyons Child Welfare Exposition and remained at Lyons after the exposition was elosed.

The IIoltman Ilopital had a total caparity of one hundred and fifteren beds, but owing to the searreity of nureses and aldes due to the military neds, it athitted an arorage of only sixty 
cases. L'ntil July, Miss Butler's staff had ronsisted of four American Red Cross nurses, three Ameriean aides and numerous French aides, hut by the middle of July, only one other murse was left. (One of the four had been taken ill and Miss Ashe had recalled two others and the Aneriean aides for assignment to the Inepartment of Military Affairs, so Miss Butler and the fourth American graduate nurse, a French nurse from the Nightingale School at Bordeanx and ten French aides did all the mursing at the IIoltzman Hospital. "At present we have nine bone cases," wrote Miss Butler to Miss Noyes on Inly 30, "and fifteen daily dressings,--little fingers and toes just slonghing away. Te also have several cases of pulnonary tuberenlosis and feeding cases with complications of all kinds." In August, 50 per cent of the vommo patients at Hospital IIoltzman were tubereular.

The policies of the Children's Burean included, it will be remembered, the training of French women to do "follow-up" work in the homes. These women were called risiteuses d'enfants and the value of their service depended almost entirely upon the type of woman selected and the intensive instruction given them by the lied Cross. A eommittee was formed which consisted of five influcintial women of Jyons and of Miss Nelson, chief nurse of the children's Burean in the Lyons district. Lectures were delivered to the risiteuses d'enfants by prominent French phrsicians of the city. American Red Cross nurses at the Hospital Violet gave them elinieal instruction in the wards. 'Tw'nty-tive women were chosen. The general arrangements were mado by Elizaheth Mitchell, a murse from Newport. Rhorde Island. The course began in the middle of April and lasted mutil the first of June. It consisted of forty lectures, one of which was given each day. The practical instruetion in the wards of the Inspital Violet and at the lied

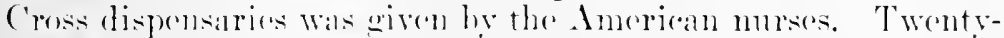
ome women passod the examination sueressfully and were allibe to give material help in the Red cross campaigu against infant mortilits.

In addition to the maintemance of the two orphamages, the contagions hespital. He hespital for alente diseases and the two

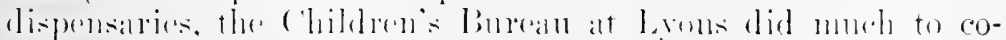

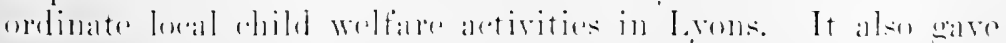

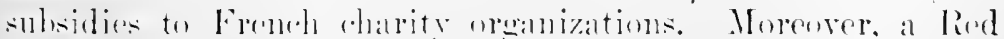

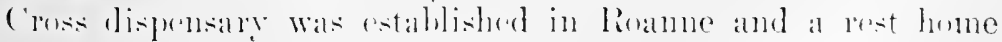




\section{HIS'OORY OF AMERICAN RED CROSS NURSING}

for pregnant women and a pouponnière at Vienne, both outlying villages near Lyons.

When the American Army planned its drive on St. Mihiel in Angust, 1918, the military anthorities asked that the Asile Caserne de Luxembourg at Toul be converted into a military hospital. The five hundred children who were being cared for there were sent on September 2 to Lyons; three hundred and forty of them were taken to La Chaux and the others were distributed in various hospitals in the eity. Even Lyons, how ever, was to share in the great need for hospital beds for the American troops during the influenza epidemic. A large reserve officers' training camp of the American Expeditionary Forces was located at La Valbonne, fifteen miles north of Lyons. Late in October, when the influenza epidemic became virulent, Colonel Morrow, L. S. A. Medieal Corps, asked the Red Cross to find 10,000) hospital beds for American soldiers in and near Lyons. La Chaur was converted into a military hospital, as has already been stated, and military wards were opened both at the Hospitais Holtzman and Violet to eare for influenza cases.

Twenty miles below Lyons on the Rhone River was situated the industrial city of St. Etienne,- "the Pittsburg of France," Dr. Richard Cabot called it. Both within the eity districts and in the outlying villages, the normal population was doubled by the influx of refugees from the North, many of them the rapatriés who had passed throngh Evian. Only fourteen physicians were available in 1917 to eare for the medical and surgical needs of these 250,000 people.

Early in November, 1917, eitizens of St. Etienne asked the Children's Bureau to send them a pediatrician to undertake child welfare work. 1)r. II. S. I3. Simith and Eva Lonise Simpthe were sent from Paris Headquariers and opened a Red

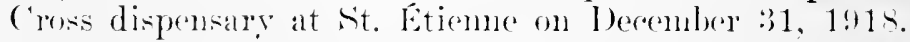

Eva Lonise Smythe lad had wide experience as a public heralth nurve. She was born on the Island of St. Helena. She Was graduated from the Massachusetts Training Sichorl. Mal-

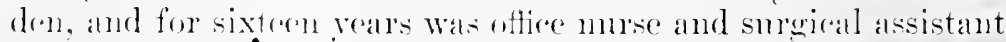
to a Malden phesician. She then took up sehool nursing in

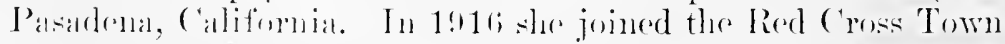
and comntry Norsing Sorvice and for nine months did ruml mursing in Deslestown, Pa. She went overeas with the first

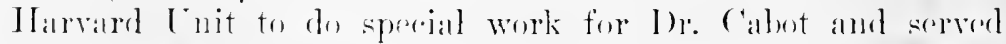
with the Brition lixporditionary Forees. She joined the Chil- 
dren's Bureau in October, 1917, and was sent immediately to St. Etienne. She was a woman of strong personality, an exeentive who did not shirk responsibility; she was honest, direet, sometimes to the point of bluntness, and possessed of good judgment.

'l'he mayor of St. Etienne donated a room expipped with eleetrieity, gas, water and modern dispensary equipment; the American Red Cross furnished personmel, medicines, clothing and other neeessary supplies. During the first months of her work at St. Etienne Miss Smythe assisted at the elinies held every afternoon at the dispensary and did visiting nursing in the momings. Gradually I)r. Smith extended his work to the neighboring villages and established Red Cross dispensaries at La Talaudière, St. Chamond and at Roame.

$\Lambda$ s the dispensary service developed, the need for a ehildren's hospital at st. Etienne beeame more and more evident. Arrangenents were effected whereby the Ameriean Red Cross appropriated $\overline{1} 75,000$ franes for the purpose of establishing such an institution, and the eitizens of St. Etienne raised a similar amount.

'Tli is hospital, which was called Chantalonette and which was of 100 bed capacity, was formally opened on .Jamury 21, 1919. The American Red Cross turned it over entirely to the city of St. Etienne on Mareh 20, but during the two months of Ried Cross administration 267 cases were treated there and 231 operations were performed. Refugee ehildren comprised 3.5 per cont of this number ; the others were elildren from St. Etienne and the surrounding villages. ${ }^{16}$

'The mursing persomel for these dispensaries and for the Chantalonette IIospital was recruited and trained entirely by Miss surthe. Miss Ashe summarized Miss smythe's work in the Weekly Report of the Children's Bureau ending July 6, 1918:

Miss Simythe went to St. Ftionne eight months ago, alone. She has nerer atked us for help and she has oreanized there a group of :2 f Fench girls. I asked her where she sot them.

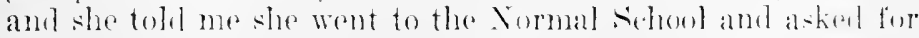
rolunteres who (o)uld speak English to help her. 'Twontyfome women, all volunteres. responded and she has tanght them. and right straight along these girls have gone with her and have hat splenticl training. She asked for an Amerian "Giller Regent. Vol. 111. p. 43. 
nurse to do the work at the child welfare exhibit, and I have sent her one nurse. I think that for a woman coming over alone, without a word of French, to have developed a situation like this is really quite remarkable.

Miss Snythe expects to get from her class enough nurses to put into the children's hospital about to open at St. Etienne, without asking us for American nurses. There were some school teachers of St. Etienne who came to Miss Smythe outside of school hours for the training.

One of Miss Smythe's first steps was to organize a little boys' club. St. Etienne is a manufacturing city, and is very dirty and crowded at the present time. The refugees have gone into abandoned houses, which in many cases are simply filthy holes. By putting up a prize of a pair of rubber boots, Miss Smythe aroused competition among the boys, and got these dirty streets and alleys cleaned up. She also started sewing classes for the girls, and they made necessary articles for the dispensaries.

St. Etienne was one of the three large industrial cities to be visited by the child welfare exposition of the Children's Burean. The exposition was held in the Bourse de Travail between July 11 and July 28, and 80,000 people attended it. Margaret Frances McLeod, the single American nurse Miss Ashe wrote of who was sent by the Children's Bureau to assist Miss Sinythe, deseribed the attendance:

The hall was filled; over 5000 people attended the opening. The next day 1 think the entire city, or at least it seemed that many, risited the exposition and displayed intense interest. School teachers ame not once but several times and brought their elasses. 'The French girls from the best families in the city donned the Red Cross gown and cap and acted as interpreters and assistants for the doctors at the different clinics. Literature was distributed and educational posters displayed everywhere. I have never seen such real enjoyment and appreciation anywhere clse and it was genuine.

My small part in the exhibition was to bathe the baby and dress it in the Amerixan way. I don't think I ever enjoyed anything more than that in all my nursing experience. You really folt the people were taking an interest.

The dortor and nurse at St. Etienne have accomplished more good in public health than any place in France. 'Their coojueration with the prominent aity officials and the people of St. Fitime wis truly remarkable. . . . 
Directly below Lyons and St. Etienne lay the eity of Marseilles, the sontheastern gateway to France. Like its sister industrial cities in the north, its population had doubled. The housing facilities which had accommodated 600,000 in 1914 were wholly inadequate for the 1,000,000 and more who thronged the eity in 1917. The war had practically inhibited new construction.

The population of Marseilles was a transient, cosmopolitan one. Soldiers, refuees and merchants of every race elbowed each other in the dirty, picturesque streets. A colony of Greeks and a colony of 120,000 Italians had settled there. Althongh unique among French eities, this population resembled that of many American eities and in this respect did not offer a social service and public health nursing problem unusual to an experienced American persomel.

Both the native and the refugee ehild suffered at Marseilles and would have suffered more lad it not been for the efforts of some sixty local philanthropic institutions, of all types, which existed in the eity and which expended in 1917 over $\dot{8}, 000.000 \mathrm{frs}$. for child welfare. The Children's Bureau as well undertook extensive work at Marseilles.

In Jamary, 1918, Dr. and Mrs. Lueas, Dr. Osear H. Sellenings, of Columbus, Olio, and Miss Elizabeth Wallace visited the eity and made a swift survey of conditions. Two facts brought ont by this survey were: first, the need for relief work for the children; secondly, the need for infinite care and tact in developing this work, beeause of the large number of already organized oeures.

On February 6, Dr. Sellenings was assigned to Marseilles to develop child welfare work there.

On Marell 1 a meeting was held, at which representatives of between 40 and 50 institutions agreed to form an oftice central which would act ats a "clearing house" for child wolfare work at Marseilles. This oflice was established at the lieadeguarters of the Children's Burean, 3:; Bonlerard de la Liberté, and the American lied cross contributed the services of a secretary to this oremination.

Emily Ifammond Smith arrived in Marseilles on March $t$ to assist l)r. Sellenings in the derelopment of the dispemsary and milk station, and to develop publie health nursing. Miss Smith was a graduate of the (hildren's Hospital, Bustom, Mass. she was for two seatons superintendent of the North shore 


\section{HISTORY OF AMERICAN RED CROSS NURSING}

Babies' Summer Hospital, Salem, Mass. She later became assistant superintendent of the Children's Hospital, Boston, and resigned to enter Red Cross service early in 1918.

The Red Cross children's dispensary at Marseilles, which was called the Maison d'Enfance, was located in the Rue Tregance within the walls of old Roman ruins. On a rainy Saturday afternoon, Mareh 16, Dr. Sellenings and Miss Smith opened the doors of the elinic and found the ante-room packed with mothers and babies.

Clinies were afterwards held on Tuesdays and Saturdays from 2 to 7 P.M., and the average attendance was 40 eases. Dr. A. M. Gove was in charge of the dispensary. Only children under 2 years of age were admitted at the Maison d'Enfance. A canteen for nursing mothers was conducted in comnection with the dispensary. IIilk formulas for bottle-fed babies were prepared there, and follow-up work in the homes was done by the nurses.

One of the principal aims of the Children's Burean at Marseilles was to furnish assistance to Nourrisons Clinies. Mr. Gove, the American nurses and the French nursing aides gave medical and nursing eare to babies at three such elinies; this particular service was only for well babies. The Children's Burean also furnished a doctor for the Dispensaire des Enfants Malades, Rue St. Sebastian and for another local dispensary at No. 22 Roncas Blane. Other miscellaneous activities ineluded the establishment and maintenance at Anbenas, for three months of a dispensary for intluenza cases, which was finally turned over to French plysicians on their return from the front.

During its 14 months at Marseilles, the Children's Bureau made formal donations amounting to 106,500 francs to eight local charities: Entre-A ide Feminine; Art et Charité; Asile St. Louis; Asile st. Joseph; Abri Matemal; Dispensaire des Infants Maludes; lide anur leures; and five creches. ${ }^{17}$

Following the establishment of the dispensary service, the Chithren's burean hedd a child welfare exposition at Marseilles from Dlay 27 to June 9 at the Maison de la Mutualité. In this building were the oftioes of seme s.: loceal oeveres, so the exposition was held in the very center of organized charity work of the rity. It was arrangerd for by Miss Balblitt and her assistant, Dorrother Baldwin, and :32,2:3 1 perple attenderd. One hundred and sixty-one motion pirture shows were given and 296,250

${ }^{17}$ Giller lieport, Vol. III, Ip. 48-49. 
pieces of eliild welfare and anti-tubereulosis literature were distributed.

Marseilles supported only one local institution which hospitalized children under eighteen months of age. Children were boarded out and "in one institution not manifestly inferior to many other's in managenent, locale or equipment," wrote Miss Gilder, ${ }^{18}$ "the death rate was 49 per eent." The loeal oeuvres were net at that time prepared to provide one, so the Children's Burcau established a temporary hospital and preventorium in some barracks on the seashore ontside the eity. The Barrack Hospital, as it was called, was opened on September 6, 1918, with a capacity of fifty beds. At the same time, a convaleseent home for boys, at St. Louis, to which the Children's Bureau had contributed both persomnel and funds, was opened. During the summer, the staff' of the Children's Bureau at Marseilles also rendered assistanee in relieving an epidemic at St. Maximun, and to two nourissons elinies.

Early in October, 1918, 1)r. Sellenings returned to the United States and 1)r. May Agnes Hopkins took over the direction of the work at Ifarseilles. A general reorganization of the ehild welfare aletivities was brought into line after the Armistice and, under the leadership of the local organization, the Art et Charité, the citizens of Marseilles formed a special committer on child weltare, which was called the Franeo-American C'ommittee and which agreed to act as a central elearing house for chilel welfare atter the withdrawal of the Ameriean Red ('ross. This emmitte took orer the dispensaries, the risiting nursing and the nourissons clinies; in addition, they had a nineran's laise on a renralescent home for children, San Joseph, which was loeated just outside the city.

In November, 191s, the American Red Cross appropriated

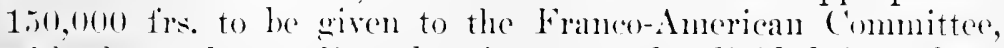
with the mulerstanding that it was to be divided into thee

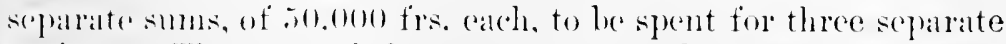
projeets. The first of these smms was to be need to maintain a permanent eomvalesernt home for infants and rhildren up to

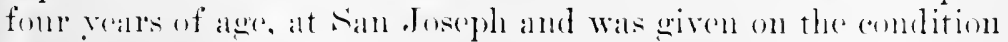
that "an refual smu be guaranted to make a permanuent fund of 100,000 firs. for the rumbing and managenent of the san Joseph convalesernt llome for childerne, for a period of at

"ciilder liepurt, Vol, !ll, p. 45. 


\section{9ł HISTORY OF AMERICAN RED CROSS NURSING}

least three years." 19 A second provision of this bequest was that the Home should be directed by a graduate nurse experienced in the care of children; that she should have a staff of trained assistants; and that the Home would be used as a teaching center for the training of visiteuses d'enfants.

The second sum of 50,000 francs was to be used for the dispensary for infants and children at No. 1, Vieille Tour, and it was also given on condition that the eitizens of Marseilles raise an equal amount, thus guaranteeing a prineipal foundation of 100,000 franes. One of the special purposes for which this bequest was made was for the development of health visiting and visitors in the dispensaries and in the homes of the children who attended the clinics. Like the Convaleseent Home at San Joseph, this nursing service was to be under the direction of a graduate nurse experieneed in ehild eare and the dispensary was to be used as a teaching center for visiteuses d'enfants.

The third sum of 50,000 franes was also given under eondition that a similar sum be raised by the French, with the understanding that the total sum of 100,000 franes should be used for a school of risiteuses d'enfants. The course of training was outlined by Dr. Lueas:

The course of liealth risitors to cover a period of at least six months: three months are to be given in practical work at some (hildren's institution such as San Joseph, or some other institution controlled by this committee and by the modical and nursing staff apjointed by this commitice to carry on the theoretical and practical training of these health visitors. 'The other three months are to be given to tear-hing home visiting, using Dispensary No. 1, Vieille Tour, as a base, and the special district as the training place for praetical home care of mother and child.

It is not intended, of course, to limit the places of training to these two institutions. San Joseph and the dispensary at No. 1, but simply that these two be nsed as the hasis for practical and theoretical training, and, further. that a course of 36 lectures at least be arranged, covering the suljects of pre-uatal care, nursing and general hrgiene, and feeting of the rhild. to be griven by members of the medical poofrsion (-hosen by this Committee, engaged especially with qualifications and training for such teathing. ${ }^{20}$

${ }^{19}$ Gilder Repert. Vol. IIJ, Jp. 52-53. Sese letter of Dr. W. P. Lucas, andirased Novamber e? 1918, to the Franco-American Committee for Child Welfare in Marseilles.

2"lbirl. 
On February 1, 1919, the Children's Burean turued over its activities to the ()flice Central and withdrew from Marseilles. The loeal organization, Art et Charite, took over the dispensary in the Rue Tregance. The Red Cross pledge of a gitt of 150,000 franes for the subrention of the School for Health Visitors and the endiwment of the St. Joseph Convaleseent Home for Boys and Girls, was fultilled.

Toulomse lay midway between Marseilles and Bordeaux and here the American Red Cross held the last of its large child welfare expositions. The exposition was opened in the Halle aux (imins on Ootober 20, 1918, and lasted until November 10. Eighty thomsand people attended it. At the health clinies, 608 children received medical examination, 1362 were given dental treatment and 79 attended consultations on corrective grm nastics, making a total of $21+7$ children treated. Mary C. Nelson, the Imorican lied cross nurse who had been eharge nurse of the Children's Colony at Dinard, was assigned to Toulouse and spent a month there doing pre-natal and child welfare work in connection with the exposition.

A group of interested people in Toulouse formed a Children's Committee for the purpose of training French girls to serve as ehild health visitors. The Ameriean Red Cross offered to assist the Committee in the development of the course, but the offer was not accepted.

Bordanx was the principal southwestern seaport of France. Here the eonditions of ehild health were as critical as at Marseilles. The birth rate at Bordeanx in 1913 was ten thousand and the infant mortality one thousand: two rears later the birth rate had fallen to fire thousand and the mortality remained at one thomsund. Where the eivilian popmation had had in 1914 the services of twenty-two physicians, in 1919 there were only six.

Althongh the American lied Cross developed an extensive program of emerencer rolief and left a foundation for constructive wolfare work at bordeanx, no murses were alsigned to duty there motil ()otoluer, 1!18. The military sitnation was too pressing in the smmmer of 1 !n 1 for them to be spared for work with the rhilelreil. 'The medical work there hat tirst been intiated by IOr. Philip Van Buren dohnson, whom the

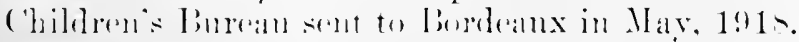

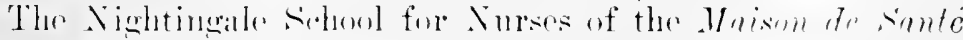
Protestmente, which wats the one professional schenl uf nursing 


\section{HISTORY OF AMERICAN RED CROSS NURSING}

in France, was located at Bordeaux and Dr. Hamilton had developed there a course in public health nursing. In Angust, 1918, Dr. Johnson recommended that the Red Cross present two seholarships to the Nightingale School in order that the services of two of Dr. Hamilton's pupils might be available for earrying on the activities of the Children's Burcan. These scholarships and eight additional ones were subsequently granted ${ }^{21}$ and Dr. Johnson thus had the service of ten French nurses in the development of the relief activities of the Children's Bureau.

The emergency relief at Bordeaux was eonsiderable. Late in Jume, Dr. Johnson established a twenty-five-bed hospital in the Bastide quarter near the Maison. du Bébé. At Bagatelle, an estate belonging to the Maison de Santé Protestante, which afterwards became the site of the Ameriean Nurses Memorial building of the Nightingale Sehool, a barrack hospital for ehildren was established by Dr. Johnson and 405 eases were treated there in July, 1918. In August, a preventorium was developed at Sonlae. A new dispensary at the Maison. du Bébé was opened in September and twelve beds at the.Maison de Santé Protestante were secured by the American Red Cross for permanent use by Bordeaux children suffering from acute diseases.

When the time came for the Red Cross to withdraw in 1919 from Bordeaux, the Children's Bureau established a foundation of 10,000 franes to be used for constructive ehild welfare work at Bordeaux. A permanent nursing organization entitled L'A ssociation. Franco-A mérieadne pour les Infirmières Tisitenses was organized. Its aim was to "establish in the eity of Bordeaux an organization to coöperate with the training schools for nurses at the Maison. de Sante Protestante and the IIopital Tondu (and other similar training sehools as may be subsequently decided upon) with the object of providing a special course of six months practical training in public health work particularly as applied to children." 22 The Boald of Managers of the Association included Dr. Hamilton, Evelyn Walker, Nadame Gommonilhou. M. Charles de Lnze. L.t. Colinel Charles Cazalet, treasurer, and I noctem Momssean. The plan of oreanization specified that the superintendent of the Association

\footnotetext{
${ }^{21}$ See Minutes of the Finane Committee of the Commission to France, Septrmber 17. 1918. p. .74 .

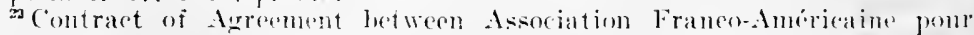

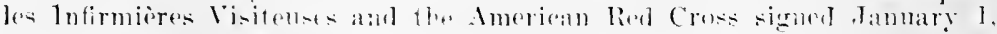
lol!!. See ribler liepert, Vol. III. p. 5s.
} 
shonld he an American graduate murse; Evelyn T. Walker was appointed in October, 1!1s, to this position. Miss Walker was a medical social service nurse of experience and ability. Born at Cork, I reland, of I rish parentage, Miss Walker was educated at private selools in Cork and London. Her professional training was obtained at the Fast London Iospital for Children and 1) ispensary for Woncu; she took a post-graduate course in medical and obstetrical work at Bellevue Hospital, New York City, and in 1914 attended lectures at the New York School of Social Work. From 19(0) to 1911 she was in charge consecutively of the tubereulosis, the male medical and the children's division at Bellerue Hospital and later organized and directed the maternity social service work. Subsequently, she became supervisor of the Department of Edueational Niursing and Frosh $A$ ir of the Association for Improving the Condition of the Poor. She wont overseas for work with the Children's Burcan in fuly, 1!1s, did military nursing at American Red Cross Military Inospital No. 1, and on October 9, 1918, went to Bordeanx, where her knowledge of French, her pleasing personality and her professional attainments led to her appointment as superintendent of nurses of the distriet nursing association.

On a direret line between Bordeanx and Paris lay the ancient aity of Blois, in the valley of the Loire. Blois was another of the French eities which in 1918 were crowded with refugee children and the hed Cross opened a dispensary there on Fobruary 21, 1!)18, and continued its maintenance for ten montlis. 1)r. Bertha B. Stuart, of Portland, Oregon, was in change of the activities of the Children's Burean and with the aid of specialists who came down from Paris, she organized eve, ear, nose and throat and dental clinies. Mrs. Margaret P. Churrele, an Anerican lied Cross nurse, assisted in the dispensary and gave anestloetics. Mr's. C'hurrele was a graduate of the lere l'rivate Ilespital. Renchester. New York, and had had post-graduate work at St. Luke's IIospital, New York City. She joined the statf of the ('hildren's Burean in Fubruary, 1919. and instructed risitenses ofenfunts attending the Paris

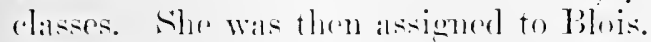

The visiting nursing at libis was at first done ly risitenses denfants. In her monthly report for Jume, 1918, I)r. Stuart wrote:

At the diepencisy. we have grems we now have over ano

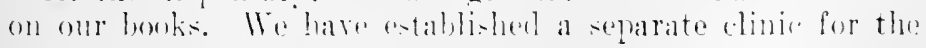


fecling cases; each Saturday morning, the mothers bring in the babies, have them weighed and have their feeding superrised. . . . We have a French risiting nurse, a rolnuteer who does nothing but look after the small babies. She has a list of all babies horn since January, 1917; she visits the homes, tells the mothers of the clinics and gets them to promise to bring their children. If the mother does not report the following Saturday morning, she goes again to see why she did not conre. ...

Miss Zimmerman, an "enfant risiteuse" from the May classes in laris, has been added to our staff and she is doing fine work both in the risiting nursing and in the social work. . . .

Early in the summer of 1918, the Red Cross established a pleasant summer home for children in a house loaned by the Marquise de Poitou, in the village of Chitney, just outside of Blois.

In August, 1918, Miss Ashe assigned Agnes R. Lenihan (Elizabeth General Hospital, Elizabeth, New Jersey) to Blois to assist Mrs. Church. Miss Lenihan did general visiting nursing and educational work. Early in August two risiteuses denfants from the Paris classes also were assigned to Blois.

There was need in Blois for a children's lospital, but the Ameriean Expeditionary Forees had taken over all the hospitals in the eity and all vacant buildings suitable for use as temporary hospitals. However, offieers of the Army Medical Corps were generous in aiding child welfare work and withont their assistance the Children's Bureau could have acemplished little. "They took the X-ray pictures," wrote Miss Gilder, "did the laboratory work, operated on the general surgieal paticnts, assisted with the orthopedic cases and loaned ambulances and (amions." 23 The establishment of a permanent ehildren's hospital at Blois was made possibie, howerer, in 1919, by Ameriean generosity ; the War Servie Committee of the American Medical Women's National Association donated through the American Iied Cross a sum of $\$ 25,000$ which was used to erect a permanent rhildren's hospital.

A quaintly interesting and typical demonstration of the work of the Children's Burean was dereloped early in 1918 at Corbeil. a small mannfactming town situated some twenty miles sonth of Paris on the sieine River. Here as in other cities,

${ }^{23}$ (iibdur lieport. Fol. III. P, 6I. 
a dispensary was the entering wedge; it was anthorized by the Children's Bureau on Fobruary 6. Mr. Margaret W. Farwell, whose original and energetie personality was reflected in breezy reports to Dr. Lneas, was placed in charge. Dr. C. I). Mosher, one time assistant professor of IIrgicene at Leland Stanford University and in 1918 one of the staff of the Children's Bureau, and Mrs. Farrand, wife of the American health specialist, 1)r. Livingston Farrand, took an important part in the development of the Red ('ross child weltare work at Corbeil.

The begimings of the dispensary service are pleasingly recomited in the following report written by Marion Posttethwate Greene, of New Fork City, an assistant to Dr. Farwell:

... We walked about the streets of the quaint little town, gathering groups of mothers and children on the street corners to listen to simple talks on hygiene, to invite them to come to the dispensary when in need of help and to urge them to bring their babies there for weekly weighing and inspection.

'The dispenary was opened on May 20 and there was never a moment when it was idle. Nearly all the French doctors had been molilized: the few who remained were overworked .. . and the poor of the town were in misery and despair. News from the front was always bal: air rails harased Paris by night and "Bertha" dropped her messages of death by day. Shortly after the dispensary was opened, Corbeil sulfered an air rail and six people were killed and several wounded.

()ne American murse was assigned to ns. but stayed only a week before sle was alled to the front. For come time 1)r. Farwell and I workerl on alone, I igmorant of nursing but doing what I conld under her instruction. We soon hat another murse.

The first murse to go to Corbeil was Amy F. Lowe, whose later work at the milk station at Marsoilles has already been mentioned. Sine arrived on Maly 2 but was recalled on May 30 for work at the Trent llospital at Antenil. Molly B. Sinith (chicago Baptist Training sedool) was the second nurse mentioned above. She wrote:

. . I was as-igned to the lied Crose Dispensary at Corbeil. where my work comsisted in loing visiting nursing among the civilians. There were only two oll alentors in the

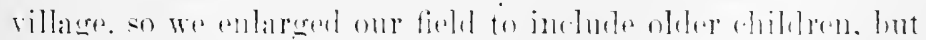

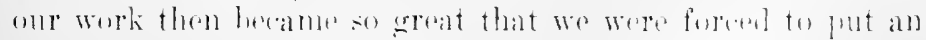




\section{HISTORY OF AMERICAN RED CROSS NURSING}

age limit on children, admitting only those below sixteen years of age. The town itself had about 20,000 , but we also nursed in five other villages nearby. Our clinie had begun with only one patient, but it soon became so famous that we had sixty-five cases in an afternoon. We emphasized three vital points : fresh air, personal lygiene and daily washing of the hands and face. At night we took walks and noted the windows that were or were not opened and spoke of it the next day. ...

We encouraged bobbing the children's hair. It facilitated cleaniug the children's heads from scurry and other diseases. We did not emphasize its use as a prophylactic measure, but it beeame the style and was called the Jeanne d'Arc cut.

\section{A further extract from Miss Greene's report follows:}

We soon had another nurse, organized a "Baby Day," earried on two afternoon clinics a week, did dressings every morning from ten to twelve and between times visited from house to house preaching the gospel of fresh air and simple hygiene, rhecring disconraged and war-weary women and trying to put a little joy into the drab-hned lives of the children, born and brought up under the shadow of war.

Frequent visits to the dispensary from the poilus on leave, to thank us for our work, male us always fresh and eager to do more and more, regardless of fatigue and long hour:. "We fight with more conrage now that we know you are taking rare of our chilkren." said one sollier in farled bhe. And a mother who had carried her baby many kilometers on a sufforating August day saje trustingly: "The babies of Corbeil to not die any more since the American ladies came, so I bring mine to be cured, too."

The dispensary treated refugess and rapetries on presontation of their cards of jontity; these cards were the ones which

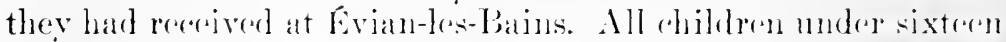
years of age and all prasons who presented a special card issued by the maver of combeil were also admitted. Dnrine the months from . Junce thromeh October, 1918, 11,988 consultations were held. Eight risitenses d'enfants were aventually assigned to Corbeil to carry on thre home visiting and clinies wore opened

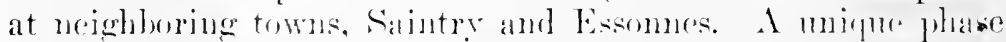
of the corbeil dispensary work dealt with the care of Ameriean soldiers from the Amerian Coffere Pant at Esemues: whem-

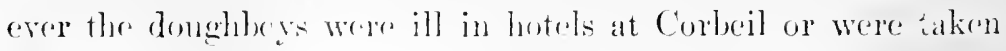


sick at the station, as frequently happened during the influenza epidemic of Oetober, 1918, they were brought to the Red Cross dispensary.

Another appealing outgrowth of the service was the Red Cross playgronnd which Aliss Greene organized in the fair grounds outside the city; play afternoons were held twice a week. In some of the districts of Corbeil, the houses were built directly on the streets and the children had no place where they might play except on the cobblestones. "After school elosed," wrote 1)r. Farwell in an Angust report, "we spent most of our mornings picking pieces of tlint and gravel out of the hands of small bors and bandaging the legs of small girls who had lost much epidermis through falling on stone-paved streets." Miss Greene wrote of the playground:

Our sole equipment was three rubber balls and boundless enthusiasm. A "gouter" was served, which consisted of a piece of bread and a tiny bit of chocolate or a handful of raisins. At that time children under thirteen were allowed only 200 grammes of bread a day. Dr. Farwell and I each had four liundred and we were abje to save about one hundred a day on our allotunnt and we begged tickets from any and every Red ('ross acquaintance we saw and were able to accumulate the necessary number of tickets from Thurselay to Thursilay. A friendly haker often gave me more bread than my tickets called for, asking me to say nothing or "the whole town would be upon my back!"

Paris was the heart of the Ameriean Red Cross in France and it sent life-giving aid to the Army in the form of supplies and medical, nursing, hospital and social service; to refugees in the form of frod, clothing and temporary shelter; to mutiles through reeiducation: and to so many other types of war workers and war sufferers in so many different forms that its orcanization webhed France like a capillary sustem. Paris was also the heart of rhild wolfare work and inneriean Red cross molieal mursing and social serviee was woren into the falmie of existence in many of the arrondiswements of the cits.

In addition to its normal permlation. Paris in the winter

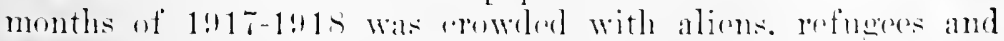
industrial workers hronglat there in the wake of war. The native population of the pororer alasses suffered nost from this inthe

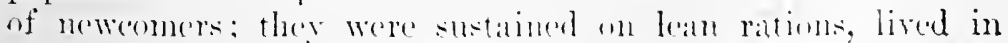


cramped quarters, often worked beyond the point of exhaustion, were harrassed by shells in the day time and by air raids at night, suffered discase and death from natural and war causes and were disheartened by the grave military situation on the Western Front. The children of this population were least able to withstand the strain of these conditions, so the Children's Bureau worked out an extensive program of medical and nursing service in an effort to save their lives. Pre-natal and infant welfare work was also undertaken. "It seems the custom has been to send babies to the country for the first few months of their lives," wrote Mary B. Ross, a child welfare nurse of the Bureau. "There they are nursed by a wet-nurse or given a bottle. This allows the mother to go out to work. And many babies die."

The aim of the Children's Burean to "save the babies" found expression in the establishment and maintenance of fourteen dispensaries in Paris. In these dispensaries were conducted consultations in pre-natal care for mothers; clinics for the care of tubercular children and those in contact with tuberculosis; dental, nose and throat clinies; a diagnostic clinic; a children's hospital; an organization for the care and protection of the new born; and a social service center.

Dr. John B. Manning, of Seattle, Washington, was the first chief of the Paris dispensary work. In a report written May 1, 1918, I)r. Manning stated the method by which the Children's Bureau set to work:

The first plan was one of coöperation with the Rockefeller Commission in the 19th Arrondissement.

We began by operating dispensaries jointly with it. The medical work in those cinis is sumplemented by courses in which French women are trained as home risitors by American nurses. It soon became evident that owing to unaroidable difficulties in securing labor under existing conditions, it would take months to carry out this program in the 19th Arrondiscement. The Bureau then looked to other parts of Paris. from which numerons urent requests for aid in the form of dispensarise had already come. Without in any way interfering with the Tiochefeller commiston, "areful consideration was eriven to these pequests with an intar of placine dispensaries, as far as posible, in established French oevers where no dismensary had provionsly existed, or where hecause of the mobilization of its staff a dispensary had been abandonerl. 
What we hoped to accomplish in our Paris work was: first, to supply equipment and persomnel, doctor's, nurses and nurses aides, drugs and surgical dressings for these dispensaries; second, to establish relations as far as possible with competent French nursing women and competent dispensary management; thirdly, to develop a system of medical social service, including i program which has as its object the demonstration that competent visiting in the home in connection with thoromgh-going dispensary work is absolutely essential in any attempt to lower the rate of infant mortality.

Marie Phelan was head nurse of the Paris dispensary system. Hor staff consisted of pullie health murses from the United States. I)r. Mamning wrote in his May (1918) Report:

The steady grind of the work of our doctors and murses gives no opportmity for spectacular service, but I an firmly. convinced that it is bringing renewed hope to hundreds of poor homes in Paris and is laying a permanent foundation of health and hroiene for the future of the city. Too much stress cannot be lail on the value of the work of home visiting by the nurses. Their tact and sympathy have brought to many homes the peare of mind and cleanliness of living that are the first aids to health. ...

The first dispensary was opened on December 5, 1917, in connertion with a sottlement house in Levallois, a large munition district just ontside of l'aris. 1)r. Mabed II. Bancroft was in charge of it. I're-natal care was an important phase of the Levallois loispensary work. The murses visited the home, instructed the experetant mother in the care of hersedt and in the preparation of a layete and recommended that the lied Cross supply various necossitios. I)r. Bancent wrote:

We have had some very delighteul rosults, espectally in families where there have been al number of previons cleathe among the babies. In all alses. I somed them to the hospital. thes arobling the anuplieation of the milwife. whith is a

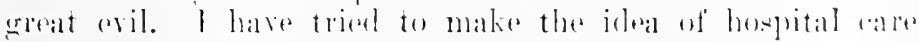
pepulial....

Conere a werk I have a conference of mothers. An arerager

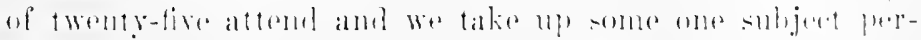

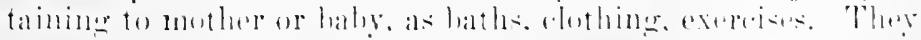

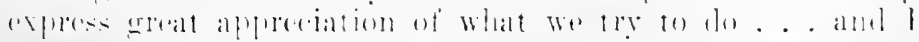

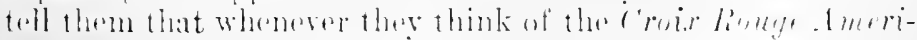


caine to think "open your windows and nurse your bahies!" I have a feeling that we have been very close to these simple folk and they have received open-heartedly our attempts to make life brighter for them.

The next Red Cross dispensary to be opened was the Grenelle Dispensary, 17 Rue de l'Avere, in the 15th Arrondissement. Quarters were offered the Children's Bureau by the MeCall Mission, a social settlement which had been conducted for some years by a group of American women. The American Red Cross took over the parsonage, reëquipped it as a dispensary and on December 1 received the first patients.

Nellie Reed (Garfield Memorial Hospital) was a public health nurse assigned to the Grenelle Dispensary. She wrote on March 6,1918 :

. . Madame Gallinlau, the wife of the minister who formerly ran this McCall Mission but who is now at the front, carries on his work. She has organized a Mothers' Club of 150 members. from among whom I hope to get my babies. .. I had my first baby conference to-day.

"Follow-up" work is not so simple as it sounds. The French are so formal that there is no casual dropping in to see a baby. Every visit is almost a ceremonial; there are alwars two or three to receire us and it seems as if $I$ spend most of my time shaking hands. All school children must and will shake hands and their little fists are like all other little fists. Some of the homes look imposing from the windows: almost all of them have the loveliest lace or scrim curtains, but behind, just what we find at home. except that the setting is usually more artistic. I am entirely truthful when I say that I like the work rery much and especially the French. The babies wear about the same kind of rothing that ours do aud the mothers manage with little or mueh as the case may be.

Marrh 13. This letter was interrupted by a raid. The Borhe planes come frequently now, and when they are not actually here we are expeeting them, so it is rather much the same thing. Naturally the prople are very much frightemel and they literally pack themselves like sarlines inte the cellars. I think the average cellar is more dangerons than the second or third floor. There is murh discension upon this subject and we hear nothing else. "The raids arre very upset-

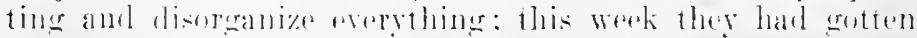
the whole di-pensary into a very nerrous state. 


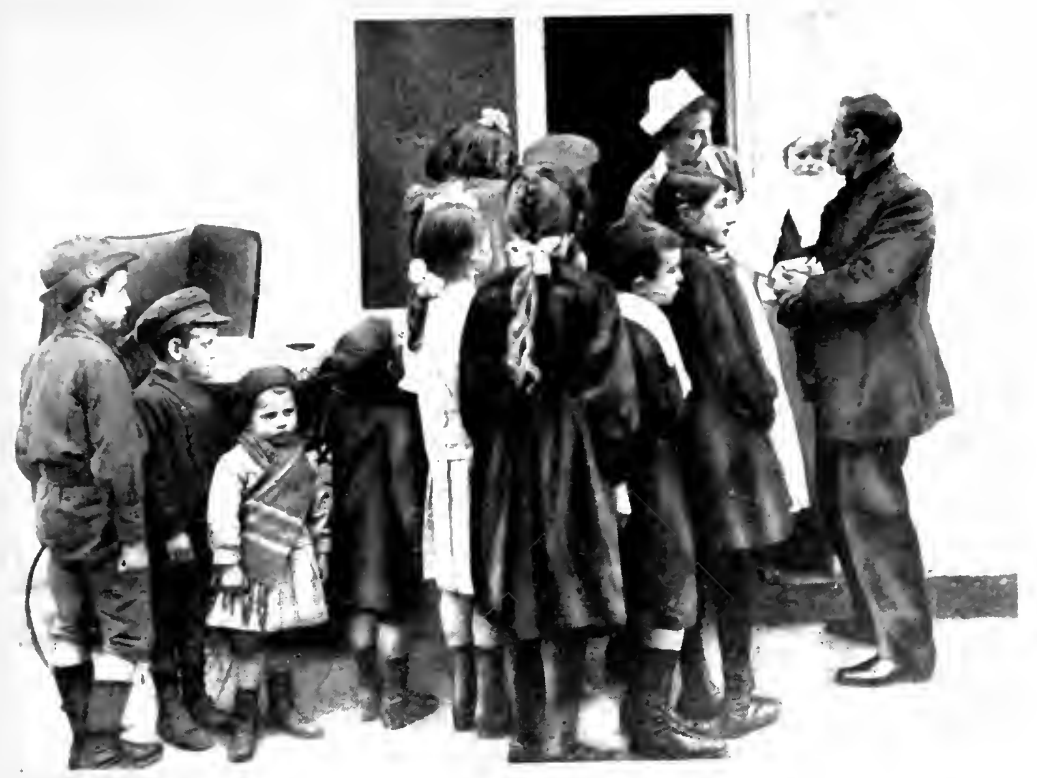

A group of patients at an American Red Cross children's dispensary in paris.

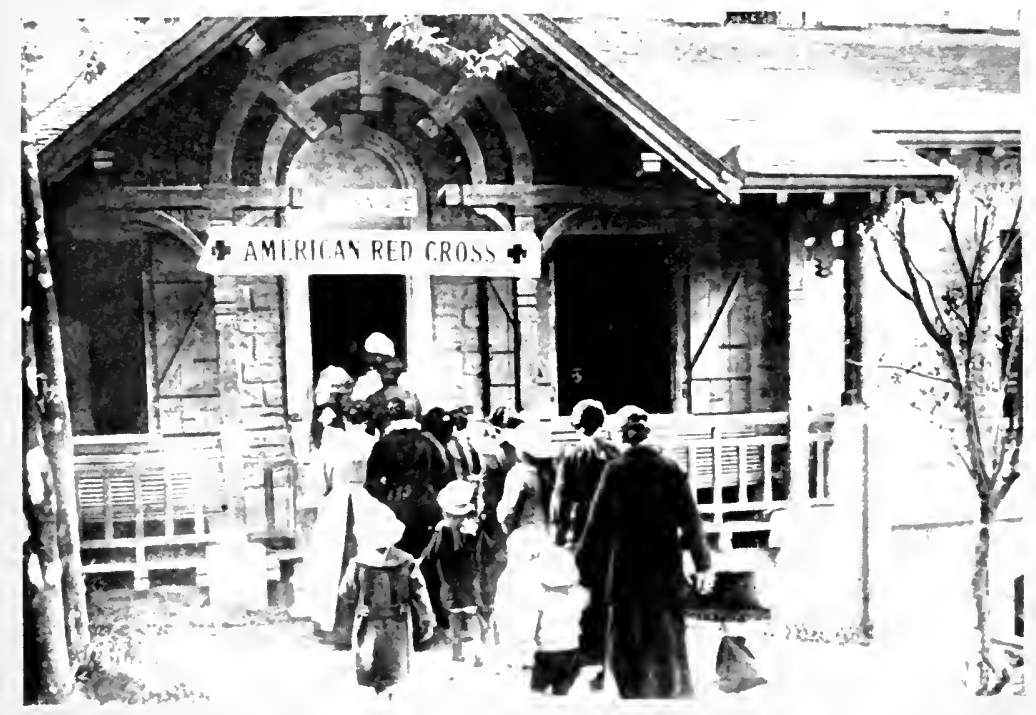

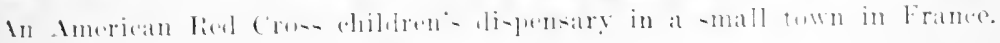





\section{NURSING SERVICE TO CIVILIAN POPUIATION 805}

The Grenelle lispensary developed extensive coöperation with French welfare organizations. Frances S. Hoppen, a volunteer who had helped to organize the dispensary, wrote:

... Patients neerlingr special treatment were sent to Red Cross chinies for tuberenlosis, throat and rentistry work and to the French IIopital de's Enfunts Malades and other French institutions. Our mursery ared for the ehildren who needed special feeding. We hal such satisfactory results that the work increased to such an extent that we added an American volunteer aide and two excellent French ones (paid) to the staff.

We worked in complete harmony with the local French authorities and (harities, the maire, the Protestant Mission, the Catholic sisters, Irs. Marfan and llomdre from the French Children's Hospital and about fourteen other homes and institutions and mot everywhere cordial help and (ooperation. The inlea of a neighborhood house and district nursing in conncetion with dispensary work greatly interested the Frende doctors. We trained two social workers for the children's Ilospital and had many French risiteuses d'enfants sent to us to observe and learn. . . We gave little money directly; our cutire expenses, inchuding the salaries of the French aides and the servants, came to about $\$ 300$ a month.

On Deermber 20, 1917, the third American Red Cross dispensary was opened at 20 Rue Censier, in the oth Arrondissement. This dispensary, which was known as the Censier I)ispensary, was established in response to a request from lllle. de liose, who had for some vears maintained a large private charitr there. 'Thre setflement romsisted of a home for workine girls, a school for children and a large apartment house for families. Froda 11. Cattin (French ITospital, New York City) was assigned to duty thror. She wrote:

... Mr. Malir was in eharere and Miss Phelan was heal

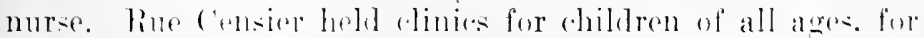
women and also two nieght rliniss for working girls and

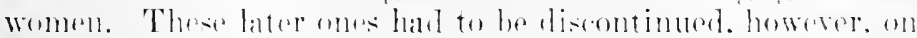

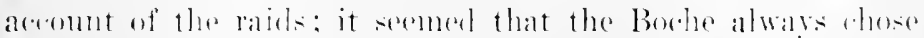

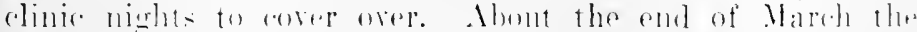

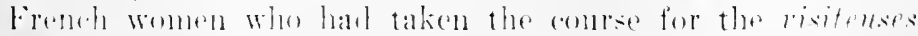
denfonts bean to arrive. two at a time. for in-truetion in

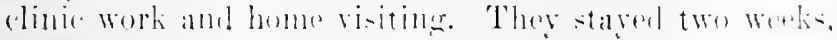




\section{HISTORY OF AMERICAN RED CROSS NURSING}

Another American Red Cross public health nurse on duty at Rue Censier Dispensary was Margaret F. MeLeod.

$A$ fourth dispensary to reeeive aid from the Children's Bureau was La Courneuve Dispensary, which had been maintained for some time by the Mutualité Maternelle, an extensive and powerful French charity organization, which was deseribed by Dr. Manning in his monthly report, February, 1918:

Mutuatité Maternelle de France gives to women, in return for three franes a day, care during confinement and other aid in the form of a woman to do housework for nine days, also laundry, milk at reduced rates, layettes as needed and medical service both to mother and child. They have thirty-two stations in Paris, forty-three in the suburbs and others throughont France. They have 50,000 babies in their Consultations de Nourissons-and there is the explanation of our baby free clinies. Mr. Pronssineau was extremely willing to coöperate with the Children's Burean and assured us we could in turn do nothing in Paris without their assistanee, which we know to be true.

An American doctor and nurse were assigned to the Dispensary at La Courneuve and the Children's Bureau finally built a temporary barracks to take the place of the old, mouldy building. Dr. Reed, the physician then in charge of the La Courneuve Dispensary, wrote in the Weekly Report of the Children's Bureau ending August 31, 1918:

Most of the equipment is now in place and the walls are covered with pictures explaining child welfare work. Notwitlistanding the holes in the roof and the racks in the floor. some good work will be done here within the next month or six weeks. In the old dispensary, there were from eighty-five to ninety women and children each week; here there should be at least a third more than that. We have permission to go to the factories and tell about the dispensary.

Many children came to the various Red Cross dispensaries who were in need of operative work. On Jamuary 18, 1918,

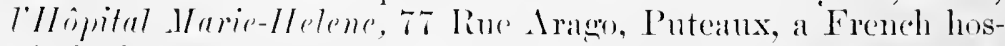
pital of twenty-seren leds which hatd been elosed since 1914 on aleonut of larek of funds, was leopened and patients neerling "peration weresent there from the dispensaries. The Ameriean 
Red Cross paid five-eighths of the rumning expenses. An American surgeon did the adenoid and tonsil work there and an American dentist conducted a dental elinic.

A seeond small French hospital to receive aid from the Red Cross was l'IIopital Bicetre, 19 Rue du Pasteur. An Ameriean Red Cross nurse was assigned to this small municipal hospital and later, when the French doctor who directed its management was called to the front, an American doctor took his place.

The Rockefeller Commission for the Prevention of Tubereulosis in France and the Ameriean Red Cross opened their first combined dispensary on February 15, 1918, at the corner of the Rue des Mignottes and the Rue des Solitaries in the Quartier d'A mérique of the 19th Arrondissement. The rate of infant mortality in this section of Paris was 350 per every 1000 births, the second highest rate in the eity. This joint dispensary, which was ealled the I)ispensary des Mignottes, was opened late in February, 1918.

Another French oeurre to receive assistance from the American Red Cross was Dispensaire Marie-Lannelongue, 129 Rue de Tolbiac. This dispensary held consultations for nursing mothers each week under the direction of a French physician, and the Children's Bnrean assigned to it two public health nurses to aid in the elinies and to do visiting nursing. In the Report of the Children's Burcau, for March, 1918, Dr. Manning wrote:

This dispensary received daily assistance from our Burean during the winter in the form of contensed mik for 40 bottle-fed habies and food for forty mothers who are nursing their habies. Once a week. (6) babies are bromeght to this (linic and weighed. alwout 30 eath (dinic day. Those who are ill or underwight ane seen ly the French physician in tharere.

bach tay the milk is sterilized at the dispensary and griven in bottles to the mothers. It a conference hedil this week. the presilent of the (bomere ensented to bermit our nurses. provided they wombl take orer the hambling of the halies. to go into the homes and try to teach the mothers haby hygiene. . .

The Mutuatite Maternetle had maintained a dispensary in

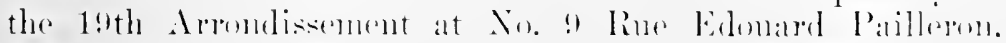
which was known as the Edonand Pailleron llispensiry. The Children's binran tonk orer its maintenanee in lpril, 1!1s. and held weekly ansultations for nursing mother's. 
The next Children's Bureau dispensary was opened in April 6, 1918, at 41 Rue de Poteau in a settlement house maintained by Mlle. Doillard. It was ealled the Poteau Dispensary. A special phase of this institution, which had been established by Freneh women, was the garderie scholaire, where children of working women were kept between sehool hours and the time when their mothers retnrned from the factories. The Potean Dispensary came in direct contact with some five hundred ehildren.

The dispensary located at 40 Rue de Pre-Saint Gervais, also in the 19th Arrondissement, which was maintained by the Assistance Publique, was one of the largest of the dispensaries aided by the Children's Burean. One of the Ameriean Red Cross nurses assigned to this dispensary, Juliet Snyder, deseribed the nature of the work:

This dispensary was conducted entircly by French personnel and it was in the nature of a concession that we were allowed to attend the clinies. At first we took names and addresses of only the worst cases and risited them, trating skin diseases and doing general public health and social service work. The dispensary was admirably conducted from a melical point of riew.

After sereral weeks, the French physician, who was at first not at all interested but always polite, began to ask us to risit rertain homes and do special things which he recommended. After a few more weeks, he requested us to risit and instruct all new cases arlmitted, as a matter of daily routine. . . After four months. the French physician declared that, to him, the work of the nurses was indispensable.

Loeated in the Rue de l'Argonne, 19th Arrondissement, was one of the pionecr dispensaries of the Rockofeller Commission. Here Dr. Mamning eonducted clinies for children. He wrote in his report for the week ending Jannary 5, 1915, that the ontlook is depressing muless the Red Cross is in a position to establish and maintain, together with or independent of the local school authorities, cantecus for these ehildren. "They need food, not tonics." This recommendation of Dr. Mamining's was the beginning of a projeet by which the American Red Cross supplied a supplementary daily feeding to 27,812 sehool children. Nany French mothers worked all day in the factories and the noon meal, the most substantial, was given to the rhildren at seloog cantecns. But it was not anple, so the 
Children's Bureau supplied extra food to the amount of 35,873 kilos each month to the canteens. "In the arrondissement where 9050 children eat daily in the school canteen," wrote Dr. Mamning, "fifty per rent of the food is supplied by the Red ('ross."

The American Red Cross cö̈perated with the Rockefeller Commission and on september 23, 1918, a joint dispensary was opened at 21 his, rue d' Argonne. This was also used as a teaching center for students who were taking the conrses for risiteuses d'enfants which the Children's Bureau conducted.

The work of the Children's Burean in the 19th Arrondissement thus included in the winter of 1918-1919 the maintenance of three large dispensaries,-at Rue des Mignottes, Ruc Eelomard Pailleron and Rue d'Argonne and the Social Service ('enter at 3 Rine Clarel. I)r. William J. French had been appointed director of the work in this district in September, 1918, and Nellie Reed supervising nurse. One of the nurses on her staff wrote that "Miss Reed proved an agreeable and capable head, welding the work and the persomel together into a good whole."

The child welfare program as finally worked out in the 19th Arrondissement ineluded clinical work, instructive nursing in the homes, school nursing, pre-natal work and social service. Olive Simons, Helen M. Spalding, Juliet Snyder, Jcanette Inays, Katherine L. Mackenzic, Donalda Lanctôt, Anna M. Sundbere, Florence M. Peters, Lotetta C. Quinn, Edith Young and Miss Foarn formed the mursing staff. 'They were assisted by two Anerican nurses' aides, Katharine D. Exton and Alma i. Clark, and ummeroms French visiteuses d'enfants. Social serviere work was done muler the direction of Franees Stern, of Buston. Mlle. A. M. Codet, sceretary to Dr. Freneh, rendered enthusiatic service. I)r. French wrote of her, "Always my tongue and ears when dealine with the French people, Mlle. Godot has frepuently heen my mind as woll and her judgment has beon morringe."

The last Anurean Rod Cros dispensalry in Paris was opened

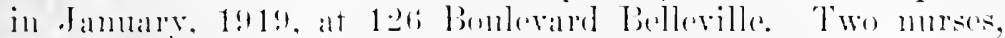

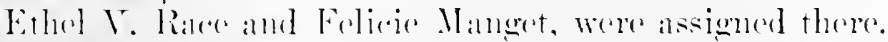

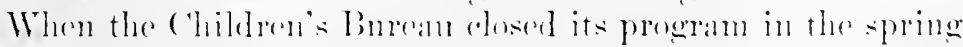

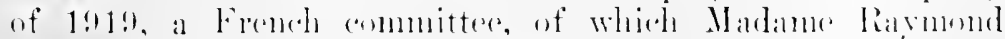

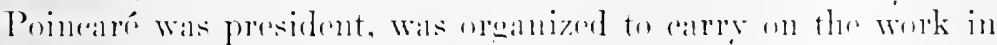

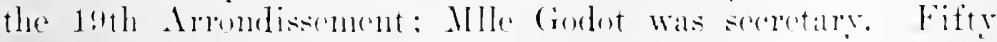




\section{HISTORY OF AMERICAN RED CROSS NURSING}

thousand franes were subscribed and the basis of the French organization established.

A large dispensary to which the Children's Burean furnished personnel and supplies, was located at Bobigny, Seine, some miles from Paris. Cora Kinney, the nurse assigned to duty there, wrote:

My aide, who acted also as an interpreter, and I were taken December 6 in a Red Cross camionette to Bobigny. . . . The people are rery poor . . . but the dispensary has been a dire necessity and there are many to be cared for. They are factory people and laborers and owing to the extremely high cost of living they have barely the necessities of life. Their honses are made mostly by themselves of wood, mortar and canvas; some have no windows or floors but are resting on the bare ground. In rainy weather, of which there is a plenty, the place is so deep in mul that they have to wade in it. IIost of them have no water nearer than the canal, which means that some of them have to carry it as far as a half a mile.

Our hours are from nine to twelve in the morning and from two to five in the afternoon, but our dispensary more often than not keeps us until about one oclock at noon. In the afternoon we call at the homes to instruct mothers in general hygiene and the care of children. We were warned when we first came to be very tactful if we made calls, as the people would countenance no interference and we might be rebuffed. so we have not made a house to honse canras but have selected our calls and tried to gain their confidence. . . . Now they come to us for advice many times.

The statisties for the Paris dispensaries show that their time of greatest activity was in the early spring of 1918 . During Jamuary, only 500 eases were treated and in February a few more than a thousand, but in March the eases treated in the fourteen principal dispensaries numbered 2383 and in

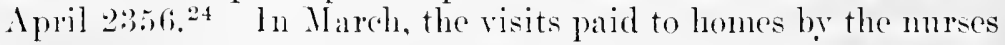
totalled 7922 ; in April 1264, an musually high figure in view of the fact that home visiting had to be diseontinued for two weeks. ${ }^{24}$ These were the days when the Germans were shelling Paris in the daytime and making raids with bombing planes at night. Moreorer, it was a time of intense activity on the Western Front.

${ }^{24}$ (iilder Report. Vol. III, p. 114. 


\section{NURSING SERVICE TO CIVILIAN POPULATION 811}

In this history it is impossible, from lack of space, to list all the French oeuvres to which the Children's Bureau gave assistance. The dispensaries described above were the prineipal units of the Paris child welfare program. Full details, however, regarding these and allied projects, may be found in the Gilder Report.

One of the most constructive and enduring phases of American Red Cross child weltare work in Paris was the training of French women as risiteuse's d'enfants. Mention has already been made of similar courses offered in Lyons, Marseilles and Bordeaux, but those given at Paris were the most numerous and the most extensive.

Miss Leete organized and developed the first courses of instruction in Paris. On May 1, 1918, she was, however, assigned as chief nurse of the Autenil Tent IIospital and Miss Ashe took over the general direction of this work. Mademoiselle Marie Diemer, a French woman, was asked by the Children's Burean to serve as directrice des Tisiteuses d'Enfants. In her final report to Dr. Lucas, she wrote:

The risiteuses d'enfants were part of a big scheme claborated lyy I)r. Lutas to insure children's welfare in France. 'They were to have their first experiences under American murses especially trained in home visiting and then to carry on the work.

Let us remember that, although for many centuries Sister: of charity have taken care of the poor and sulfering, the "visiting nurse" aml "health visitor" as known in America or England are quite new in France.

I fow months lefore the war, I had been one of the promoters in France of visiting nursing and with Mlle. de Montmort created the Infirmines Tisitense's de France. In the spring of 191\%, I helped to organize l'Ecole sociule des surintendantes d.l'sines-the surintendantes or "ladies" superintendente" having in ware the health and welfare of women employes in factories, more especially in muntion facteries. I have also during four months acted ats exerentive

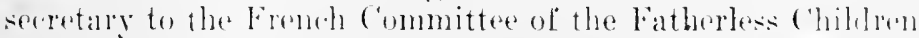
of limere, which I left for the more artive work entrusterl mo ly the Ameriean lied cross.

The French women who applied to take the comses were

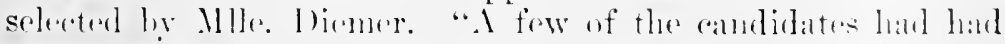

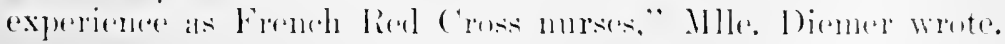




\section{HISTORY OF AMERICAN RED CROSS NURSING}

"Others had already taken care of young children. Several had suffered from the war, being refugees, war orphans or war widows. All were eager to do their best and were grateful to the Croix Rouge Américaine which enabled them to earn their living as well as to help the suffering babies of their own country."

The first lecture of the first course was given on February 20, 1918, at the Fondation Budin, the memorial ereeted to the founder of child welfare work in France; the lecturer was Dr. Lesage, then executive secretary of the Ligue contre la Mortalité Infantile. Twenty-six candidates had been aceepted. The course consisted of lectures, all given at the Fondation Budin, on maternity by Dr. Devraigne, Dr. Weill-Hallé, Dr. Lesage, Dr. Dora Mantoux and Dr. Loude; on children's hygiene, tubereulosis and contagious diseases by Dr. Guinon and Dr. Besson; and on social laws and social charitable organizations for mothers and children by Madame Weill-Raynal, Dr. Lesage, M. Emile Leven, Mlle. Bassot and Mlle. Diemer. These lectures were given in the afternoon. The following outline of the lectures, an outline which appeared in the syllabus issued by the Children's Bureau, gave the general scope and subject matter of the lectures:

History (one hour) : Brief review of child welfare conditions and influences ancient and modem, showing the rhanging attitude towards the child; infant mortality, its callses and remedies. ...

Motherhood (seven lessons): Pregnancy; lactation; conferences with practical demonstrations.

Simple Anatomy and Physiology (two hours): A study of the parts of the body and their functions. . .

Infants (seven hours): (a) 'The normal infant, its rest, exerrise and food; lactation; bathing and clothing; proper handling; weights; special symptoms, their recognition and treatment; (b) the alnormal infant, diseases of respiration ... and intestinal disturbances... are of excreta, ear, nose and throat complications; brain ant nerrous system. . . .

Children (seven hours): (hild life, the need for examination, guidanee, protection, reereation, food and rest . . . special disenses of importance, contagions infections. ...tulurenlosis . . venereal . . respiratory . . of sperial oremstis.

IIygiene and sintilution (four hours). . . . 
Sockal Legislation (two hours) ... Oeuvres d'Assistance; Lois d'Assistance.

Sorial Oryanization (one hour)....

I'ractical sociology (three hours). . . .

Ilousehold Économic: and l)ietelics (three hours). . . .

Practical Inemonstration in the preparing of artificial foods; varieties of artificial foods; milk and control of milk supply; milk modifications and mixed feeding.

Statistical Methorls (three hours)....

Child Welfare (three hours)....

Praetieal instruction was given by American Red Cross public health murses at French institutions and American Red ('ross dispensaries. These nurses were Marie Bamrle, Mary E. Bailey, (Mrs.) - Margaret P. Church, Marie C. Ells and Elizabeth (i. Mitchell. Eanch of these nurses had under her eare five.or six pupils. Mlle. I)iemer wrote:

The pupils went in groups to l'Ilôpital des Enfants Maludes, Crèche de Convalescence des Infirmières-Vi.vileuses de France, Dispensuire de la Nouvelle Etoile, Jardin d'Enfants de l'Amélioration des jartin oeutres and others. During the third month they went to the American Red Cross' own children's dispensaries and accompanied the nurses in home risiting.

An examination followed the conrse of lectures and practical instruction. Of the twenty-six candidates who entered the first course, seventeen were gradnated. Three of these joined the Association de's Infirmières de France and eleven entered the serviee of the Children's Bureau and were assigned to duty at Porelefontane, Plessis-Piquet, Levallois, Bieetre, Blois and the American lied ('ross l)ispensary in the Rue des Mathmins. The names of these first visitenses d'enfants to be entered as French aides on the rolls of the Amerien lied cross were Helene Deshons, Mlle. Devingtmuid, Mlle. Duprat, Mne.

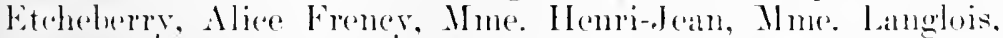
Edme PJenelist, Marie 'T. Plenehol, Jamme Kinmerman and Hlle. Nonchet.

The farcilities for the practical instrution of the risitenses had not heen wholly satisfactory, so early in April, 1!ls. the childrens burean effected an arrangenent wherele part of

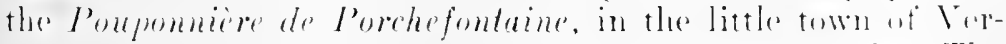
sailles, was seenred as a teathing renter for the pupils. The 


\section{HISTORY OF AMERICAN RED CROSS NURSING}

Pouponnière was a large French sanatorium to which unmarried mothers were sent for treatment and eare on the eondition that each of them nurse her own child and an orphaned baby as well. Many difticulties attended the maintenance of the Pouponnière. Versailles was in the heart of the bombing belt and was also under fire from "Big Bertha." There were no modern conveniences such as Anericans were accustomed to, in the builkings. The stables where the cows were kept, were connected with the house. Because of the scareity of food and the resulting exorbitant prices, the diet for the mothers was hardly ade(quate and the babies were as a result anemic and sickly.

Marie Baurle, one of the nurses who had instructed visiteuses d'enfants during the first course in Paris, was sent out to Porchefontaine to take charge of the pavilions secured by the Children's Bureau as a teaching center. Of her work there, Miss Ashe wrote:

Miss Baurle, a graduate of the Boston Children's Hospital and one of the few nurses of the Bureau who spoke French fluently, was put in charge. When Niss Baurle took orer the management of these two honses, each contained twenty-eight babies and seventeen wet-nurses. The conditions were most discouraging. The babies were colorless and flabby and though they were bathed regularly they were not kept clean. ... The windows were never opened and the odors in the building almost unbearable. Miss Baurle found children as old as eighteon months being ferl from seven to nine times a day on soup and dibuted milk.

The rifficulties of bringing about a rhange in this régime were great . . lont Miss Baurle was able to rhange the diet, open the windows and get the babies out of doors. The imIrovement in their appearance after a short time was quite remarkable. They practically lived outdoors and had a fine, rosy robust mien which rejoiced one's aye and heart to sec!

Ilis: Baurle was not able to bring about one very necessary roforn which she felt was vital to the well-heing of the babies. She believed that the nursing mothers were not properly ferl. Each one of these women who was an unmarried mother nursed one bahy hesides ber own and the food

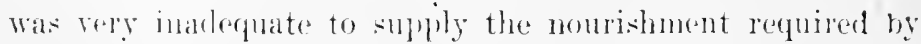
two babis. Intil Miss baturle took possesion, nothing whatreser was being done for the montal or latoral betterment of these women. She met with a goest deal of opposition when

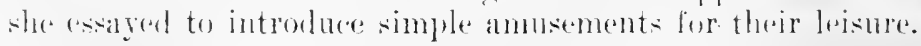


... From a teathing point of riew, the experiment at the l'ouponnière was thought to be a great success.

Later, the American Red Cross took over the entire management of l'orchefontaine. 'The divided responsibility had made malny difticulties, so on September 1t, 1918, an agreement was cutered into between the Poupomière of Porchefontaine and the American Red Cross by which the American Red Cross assumed the complete control of and responsibility of all expenses in ruming the institution for three months after the cessation of hostilities. The Red Cross also agreed to provide medieal and nursing service. In Norember and December, the diet for the nursing mother's was improved and the general hygiene and sanitation at the P'ouponnieve bettered. Of particular value were the services of a group of Quakers. The establishment was turned back to the French authorities on April 2, 1919 .

To return to the visiteuses d'enfants, the second course was opened on May 1, 1918. Owing to the fact that the Fondation Budin was then under fire by Big Bertha, the lectures were given at the Lyeemun Club by Mrs. Devagne, Drs. Weill-Halle, Lesage, Aviragnet, Renanlt, Guinon and Besson and by Madame Budin, M. Leven, Madame Devonge and Mlles. Bassot and Diemer. The five American Red Cross nurses who had had charge of the practical instruction had been ealled into military service, so a French nurse, Mlle. Oelker, acted alone as monitrice. Fifteen visiteuses were graduated: thirteen of these entered the Children's Burean and were assigned to Red Cross rlild wolfare institutions.

A third course was organized to hegin early in July, but owing to the military crisis was postponed until October. This proved to be a large elass; there were twenty-cight eandidates. Professor Pinard, I) pe. Weill-ILallé, Guinon, Méry, Collin, Bresson and Donet, and Mne. Derouge and Mlles. Rianb and llemer gave the theoretical instruction. Practical demonstrations took place at Porrelufontaine. I pon eraduation, nine visiteuses entered the serviee of the Children's Burean.

In evaluating the work of the Anerioan lied C'oss in Paris, the preparation of these visiteuses deenfonts stands ont at a major acomplishment. The thirty-two spraduates who entered

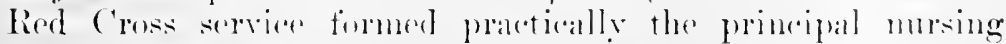
strength of the childern's burean at the time when the military 


\section{HISTORY OF AMERICAN RED CROSS NURSING}

crisis made necessary the withdrawal of American Red Cross nurses from civilian work to engage in care of the wounded of the American Expeditionary Forces. Moreover, these courses introduced the idea of public health nursing, as developed by the American nursing profession, into France. The last phase of aceomplishment was summarized by MHe. Diemer:

In creating the "visiting of infants" the Children's Bureau not only secured trained health visitors who proved useful in American Red Cross organizations, not only helped to save the lives of babies in poor crowded towns or among the refugees, but gave a living, an aim, to French girls heartbroken by the war. I have seen some of them who had looked once so despairing, come back in their blue uniforms, with rosy cheeks and brilliant eyes, happy to talk about their babies, eager to tell of the welcome they found in dark lodgings and suburb huts.

Some of the risiteuses d'enfants have learned more than the lessons their four months' course could give them. They have learned from "their American family" the great lesson of social work; work that requires not only good abilities and special training but the utter gift of one's self.

During the German offensives of the spring of 1918, the city of Ronen, northwest of Paris, was erowded with refugees from Belgium. The condition of these refugees and especially of the children was pitiful, so the Children's Bureau sent up a physician and nurse to organize a dispensary where acute eases might be treated. The maire of Ronen donated a building and the Ameriean Red Cross held elinies there where from twenty to forty children were examined daily. Social service work was extensively developed. The dispensary also established cooperation with the syndicate de sage Femmes and periodie instruction on questions pertaining to child-welfare was given to midwives.

Dijon, in the Départment C'ote d'Or, was the location of the Camonflage Camp of the 40th Engineers, American Expeditionary Fores. Many French women, howerer, were employed here; they spread the rards of burlap out on the grome and applied the water colors with lrooms. The strips of burlap were then earried into long sheds and hung on lacks to dry. "The ground, the workers, the buildings, the very sky itself," wrote Mrs. Lneas, "secmed covered with green, yellow, brown, 
yellow and green mixtures, terrible stuff to work with, so wet, so messy and so smclly." 25

At the Camouflage Camp the need for a crèche where mothers could nurse their balbies was very great, so the Children's Bureau ('stablished one there in July, 1918, and sent an Ameriean Red Cross nurse, Mary E. Mather, to run it. Miss Ashe wrote:

The crèche was a simple affair, but it was made wonderfully attractive for the children by camouflage artists who donated their sunlay rest to the decoration of the walls with marvelous Ilother (ioose figures. The American boys stationed at the ('amouflage ('amp took the greatest pride and interest in the babies and were joyful whenever a case of tiny garments or toys arrived."

The criche had a capacity of one hundred and fifty babies. Miss Mather wrote:

The babies and children rarying from one week old to eight years were brought to us at seven in the morning and were taken home at seven at night. During the day they were clothed and fed at the crèche or nursed by their mothers. For the older children we had first grate school. I had nine French aides to help.

Some time during August the hospital at Dijon became overcrowderl and was unable to take any more patients. The boys at the (amonflage C'amp began to "ome home ill with influenza, so with the permission of Mr. Walsh, the American Red ('ross representative at Dijon, I made a hospital of part of the criche. Hlere we ared for sick boys from the Camp. We lad one hundred heds and our total number of patients was over t50. To make room for the rhildren I had three more rooms built on to the crèche, so we were able to take (are of everyboty.

The derivation of the French word creche is a pleasing one. The word originally meant "manger" and crèehe is now srmbolie of the rude arib in which the Infant Jesus lay in Bethlehem.

Early in 1s17, the War Council appointed the American Red

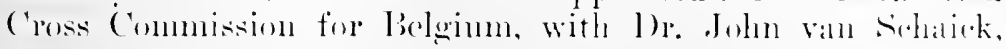
whe of Major Muphyes original stalff, als commiscioner. Hr.

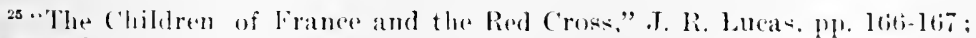
Frederick A. Stukes ('omprum. New York C'ity. 1918.

${ }^{20}$ (iilder lieport, Vil. III, i1. 11 . 


\section{HISTORY OF AMERICAN RED CROSS NURSING}

J. Mason Knox, associate chief of the Children's Bureau at Paris headquarters, was appointed by the Commission for France as medical ehief and Miss Ashe, chief nurse of the Commission for Belgium.

The children of Belgium suffered much during the war. One of the earliest projects which the American Red Cross undertook in 1917 to alleviate their pitiable condition was to furnish nursing service to a colony of Belgian refugee ehildren at Le Glandier, in the Département Corrèze, in centralsonthern France. This colony, which was called l'École de S. M. la Reine was under the special patronage of Queen Elizabeth of Belgium. Dr. Charles Neeleman, an eminent Belgian child specialist, was medical director.

In October, 1917, the Commission for France sent two Ameriean Red Cross nurses, Martha Hower and Sara Jane Boyle, to Le Glandier to assist Dr. Neeleman. Miss Hower later became head nurse of the colony. She was a Pemnsrlvanian by birth and was graduated from the Jefferson Medical College School for Nurses. She did public health nursing in the Stock Yards District in Chicago and later was superintendent of the Louise Home for Babies, Pittsburgh, Pa.

Miss Boyle wrote of the establishment of the colony at Le Glandier:

On October 26, 191\%, I was sent to Le Glandier, Corrèze, to are for Belgian (hildren. An old monastery had been assigned to us, but as it had been unoceupied for twelve rears, it was in a fearful state of decadence. Sanitary conditions were absolutely nil. 'The water supply was poor and unfit for drinking purposes. No fuel was to be had near or in Le Cilandier.

Our first dars were devoted to cleaning the monastery. Our next problem was beds. These had to be made of strijs of wowl and eantas. This proved quite a task. as there were only Betgian women and us two murses to make them. By the end of three weeks we had made a thonsand beds and mattress.s the latter of ticking filled with straw. Then what a time we hat finding spare where ne could put theme all: When worl ame. howerer. for us to procecl to Erian-lesBains to mert the children then on their way to us. everything was in reatiness.

Ten bergian women, Hiss Hower and I went to Evian. The ehildren arrived there at four A. Ir. It the (asine they

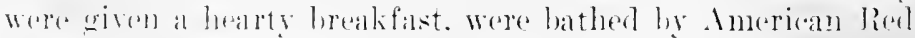


Cross murses and then exmmed by American Red Cross doctors. All were pronounced able to proceed on their journey to Le cilamelier.

The following afternoon twelve coaches were provided and each of us women tork charge of ad coach. 'They were very crowded. 'The trip took tifty-six hours and it poured rain all the time. The children were fed en route at each station by ranteen workers. At the end of the journey two cases of diphtheria and one of starlet fever had developed.

Upon the arrival of the convoy at Pompadour, the nearest station to Le Glandier, whiddren were taken in Red cross wirs to the monastery. When they reached their destination they were instructed to remove their old clothing and new Red Cross garments were provided. The sick children were taken immediately to the small Red C'ross infirmary previonsly equipped for such an emereney.

In spite of all these precautions, an epidemic of measles developed. Iliss Borlo wrote:

Almost in every instance these cases developed into pnenmonia. We soon fomml it neressary to have an ardition to the infirmary. As lliss Hower and I were the only murses there, we worked night and day, until two other nurses [Freda Caffin and Irene Jennings arrived from Paris in response to our wire for help. They took care of the children in the general hospital. Not haring sulficient medicines or equipment for the worti. I)r. Ia Bonte went to P'aris and returned in a few dass with some medicines, equipment and, to our great jos, two addes (Hazel Mallory and Marjory Vaudling). Tpon thoir asigmment to duty, I was able to take my first night's sleep in fourteen days. We had. howerer. fought the disease derperately and been able to save all but one child.

Irene Jemnings, one of the relief nurses sent down from Paris wrote of the pressure of the work:

Le Cilandier was in the midst of a meates enidemis when we arrivel. some of the ehildem were axtremely ill with

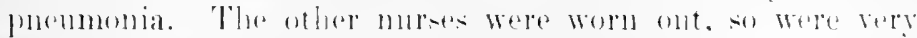
glad to sere llis- latlin and me.

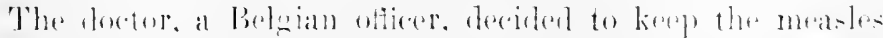

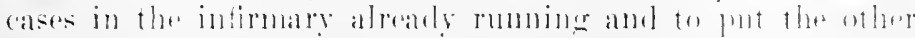

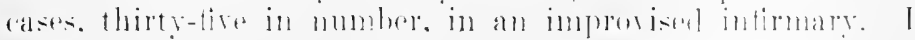

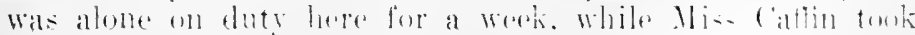


night duty. It was mighty hard work to take care of thirtyfive children in so many different rooms, with a scarlet fever case thrown in. I went on duty at six in the morning. Miss Caffin stayed on until about ten o'clock, so that we eould have the rooms half way fit for the doctor's morning inspection. After she came on at night, I would wash towels and such other things as any woman with such a family has to do. The diet was also a problem, but with all the dressings on frozen feet and sore eyes, to say nothing of new patients, possibly nine at a time, all of them having to be bathed before they could be put to bed and their elothes tagged, it was "right smart" work for one pair of hands, without extra cooking. Anyone who has ever tried to boil a bucket of water on those French stores which refuse absolutely to do anything but smoke, will appreciate how we felt!

The ehildren at Le Glandier numbered about seven hundred. As soon as the measles epidemic subsided, Miss Caffin was reealled to Paris, but Miss Jennings was assigned to a nose and throat elinie which was opened in the permanent infirmary. Dr. Wiggin, who was later assigned to Lyons, operated for tonsils and adenoids, and his wife, Mrs. Wiggin, gave anestheties. An American Red Cross physieian, Dr. Lillie A. Arnett, was also on duty at Le Glandier. She wrote of the dispensary there:

Each morning we began work at $\%: 30$. There was a daily average of about 65 or $\% 0$ patients. Many of them were old ulcer cases, the results of frozen feet or hands, others were indigestion, aural abscesses, skin diseases of different sorts, afflicted scalps and scabies. It was necessary to finish with the children who attended morning school hy nine ochock, and care for the children after nine who attended afternoon school. After we had finished with all the children, we treated members of the personnel who were ill. Nearly every day two or three peasants from the neighborhood would cone to the dispensary for consultation, and often there would be alls to be made in their homes, perhaps three such visits a week.

The life at Le Glandier was pleasant. It was very interesting to live with the Belgian people and to know them intimately. They realized and often said that withont doubt had it not been for the American Rerl Cross many of the six hundred children of the colony would have diext; instead they now promise to develop into healtly and useful citizens. 


\section{Mrs. Laura Wiggin wrote of the children:}

They tell me many little stories about their homes and in their turn ask questions about America. 'Two asked me today if the savage red men with plumes on their heads lived in the woods near my homse. 'They had seen Buffalo bill in a circoss at lieger and thomght America still full of Indians. They know of Butlalo Bill's death and spoke of it with regret.

Bread rast upon the waters, or a rumor of it, came back to me when one little erirl announeed that she would not return to Belgium after the war" "because," she said, "I had not enough to eat. Madiame." she confided, "we hat but three hmolred grams of bread ench day, with no butter mor confiture, and for dinner we had buit potatoes or turnips, with ahmost alwars no meat nor bread. For supper we had soup, but it had not moch in it, only the soup and nothing else. But les A méricains, Marlame, they sent us milk in ans, so that children might have a cup extra each clay, and in the afternoon at the end of sehool they served a muj of chocolate with the milk to ear.h child. Wais, it was goorl"' Herempon the children ehimed in with smacking of lips and rubbing of stomachs and began to sing a song: "Tivent les A méricains." Many of the children have reforred to the fact of Americans sedrling them gifts and food and the proulest thing any of them an seem to procure is something with a Red Cross upon it. Some of them have cut Red C'ross from envelopes and paprers and have pinned or sewed them to their elothes in ronspicnoms places.

In Jamury, 1919, the colony of children was returned to Belgimm. From Norember 25, 1917, to . Tumary 13, 1919, 1336 child wen were ared for by the American lied Cross at Le Glandier. When it anme time for them to be sent home, Queen Elizabeth asked that Miss Ilower low allowed to aseort them

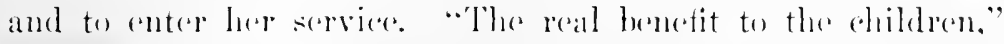
wrote Miss Hower, "enuld be sen upon their arrival in their home rity, Liege. They had rosy rbeke and were well and

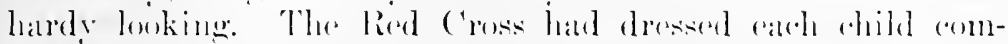
fortably and eiven it an extral supply of alothing.

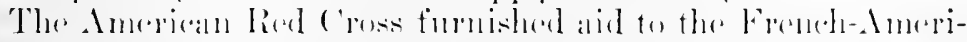

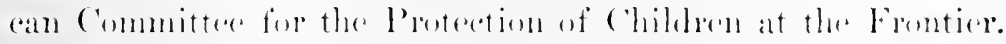

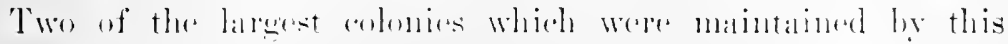

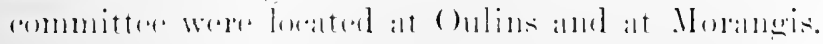

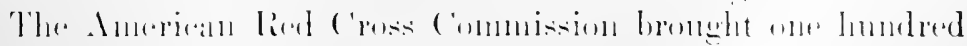




\section{HISTORY OF AMERICAN RED CROSS NURSING}

and thirty-two ehildren from Switzerland and sent them to their parents or relatives in various parts of France.

The Commission for Belgium developed extensive publie health mursing and dispensary service for Belgian refugee ehildren at Le Harre, in the Salle Franklin. Mabel I. Wileox was ehief nurse. Miss Ashe wrote:

In January, 1918, Dr. Edwards Park was put in chaige of the medical work at Le Havre. Miss Wilcox and an aide who acted as interpreter accompanied him. This work with the Belgian refugees was so much appreciated that the French Refugee Committee asked them to extend it to the French ehildren.

The Salle Franklin was an old theater which was converted into a hospital and dispensary. They had in August, 1918, a twenty-bed hospital and a large out-patient department. Fxcellent social service work was done here, and a small class of Frenclu women were trained as public health visitors.

On Angust 1, intensive work against infant mortality was begun in the poorest district of Le IIavre. The maire reported each day the births in the quarter. The visiting nurse immediately called and the baby was kept under close surveillance until it was a year old. ${ }^{2} \mathbf{T}$

The Report of the Work of the American Red Cross during the time the soeiety was operated by the War Council stated that at Le Havre a total of 14,610 patients were treated at the dispensary, 252:3 honse visits were made by doctors and nurses and 195 hospital patients treated.

At Lille and at Cambrai, the Ameriean Red Cross undertook extensive projects in sehool nursing for the benefit of ehildren who had been hiving in these areas through the German oceupation and whose health had suffered. Miss Fitzgerald made a trip from I'aris headepurters to these cities in June, 1919, and she wrote:

The work here has been the establishment of school canteens and the maintenane of public health nursing for the ehildren in these areas. In Lible. Elmira Boars. the nurse in charge. has done a remarkable piece of organization work. There were about sixteren thousand shool rhildren in the eity and when I was there nine thonsand of them had already been eximinert.

${ }_{27}^{27}$ iilder Report. Vid. HI. p. 92. 
The methorl followed is that employed in America. The children receive a thorough examination which is given in cooperation with the Frencli, who have entered into the scheme most wholo heartedly. 'The chihlren needing convalescence are sent to the seashore, or to momtain resorts, throngh the help of different committees: those needing hospital ('are are sent to the hospitals in the locality wherever posible.

The cantem work consists in serving corom to all children and a meal to those needing extra food. This meal is served in the afternoon, after school hours, and consists of soup, meat or fish, veretahles and fruit. The ('ommission for Relief in Belgium and Northern France has endowed this work to the extent of nine million francs, which will enable the French people to arry it on.

One very interestilig part of the work consists in the care they have had to give to the many children suffering from scabies. They have been able to secure a portion of the public baths of the rity, and here from arly morning till late at night the children are bathed and scrubled and treated; they now have the situation well under control.

At Cambrai, Miss Baurle is in charge of similar work and has agrain shown herself to be most efficient and competent.

In the previous chapter it has been shown how during the spring of 1:1s, the needs of the American Expeditionary Forees engulfed Aneriean Red Cross activities for the French civilian population. Miss Ashe wrote:

Following the first all for help from Military Mlfairs in March, 1918, the strain on the mursing force was very severe. ... Within the next two weeks. forty nurses and ailes wore loaned to the Department of Ililitary Affairs hy the children's Burealu. A hospital was opened at Beamais, the personmel of which was composed entirety of nurses fom the Department of ('ivil Mffairs. In July, the nursing force was

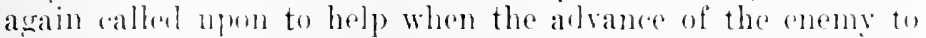
the Marno entibly disupted for a time the Medical sorvion

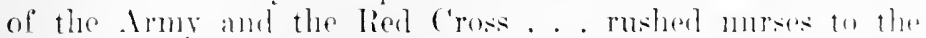
front. A linepital was establisher at Joney-sur-llorin, with

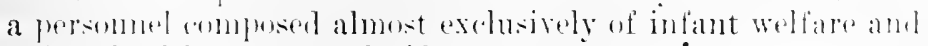

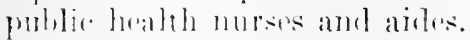

The andputality of these nurses to war needs was a surprise to erergone. "Their training in the pour homes where

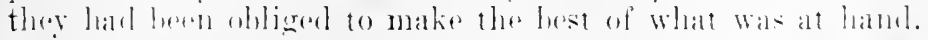

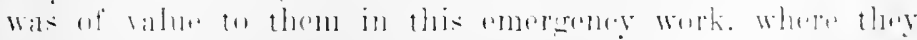

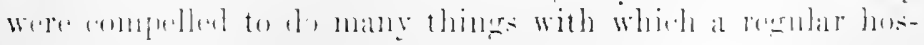




\section{HISTORY OF AMERICAN RED CROSS NURSING}

pital nurse is not accustomed to work. The Children's Bureau felt much pride in them and great happiness in that it had been able in the time of need to make vital contribution to the care of American wounded. ${ }^{28}$

August, 1918, marked a erueial month in the history of the Children's Bureau in France. Dr. Knox, Dr. Manning and Dr. Baldwin, three of its strongest pediatricians, returned to America. The organization of the entire Paris headquarters was also effected and the Children's Bureau became a part of the newly-created Medical and Surgical Department of which Colonel Fred Murphy was director. September and October were months spent in definition of future policies and readjustment of present activities of the Children's Burean.

Miss Gilder in the ofticial report of the Bureau, summarized the close of the work:

By the middle of Jamuary, 1919, the personnel of the Bureau numbered 228 against $5+1$ of the preceding August, the highwater mark of the staff. This was approximately the minimum with which the Bureau could operate and was only slightly reduced before the final wind-up of the work on May 1. This was to occur after the hospitals at Limoges and at St. Etienne were turned orer to the French: after the dispensaries at St. Etienne, Blois and Corbeil were taken over by French dortors who were demobilized; and after the permanent child welfare organization in Paris was completed.

On January 1, 1919. Dr. Lucas received a cable from Red Cross Headquarters confirming a gift of $\$ 100,000$ from the American Junior Red Cross to the children of France. The gift eame as a memorial of the sympathy that expressed itself in small gifts, the dimes and quarters out of rhildren's pockets. and was nood to endow a hospital and health renter in Paris, to be inseribed "From the children of America to the Children of France" and to be arministered by a French Committee composent of the Medical Faculty of Paris and of represmatives of the leading child relief and child welfare organizations of France.

On January 1, 1919. the Children's Burean completed a little orer sixteren months of work in France. It hat in this perion griven ascistance, in medical service. money and relief materials to at least :50.000 (hildren. . . .

When the childrens: Burean alosed its books on May 1, 1919, it left behind it four permanent hospitals, in St,

* Gilder Report, Vol. III, p. 92. 
Etieme, Foug, Ronen and Paris, and four important FrancoAmerican chilel wellare organizations whose object it was to carry on the training school for nurses which the Bureau had inaugurated, and to do general child welfare and public health work. It had established at least twenty-eight permancut institutions; and by turning orer the equipment, supplies and "grood will" of its dispensaries to French management it had naturally helped and made lasting its work in 71 other medical establishments. ${ }^{29}$

A list of these principal hospitals and dispensaries may be found in the Appendix.

In the lieport issued by the War Council on the Work of the American Ried cross during the period begiming May 10, 1917, and ending Fobruary 28,1915 , it is stated that the Children's Burean operated 2.5 hospitals and convalescent homes for children and in them treated 16,346 patients; operated 99 dispensaries and clinies and in them treated 189,111 patients; served 32,000 children in school canteens; tanght 27,000 children how to play (in organized recereation centers); held 7 child wolfare expositions which were attended by a total of 625,000 people and aided 51! (hildrens institutions or societies. ${ }^{30}$

And the comfort and happiness which this phase of American lied Cross nursing and general relief serviee bronght? "The women and rhildren who came to our clinies," wrote Mar garet Wood, an American Red Cross nurse, "liave had little glory, yet they endured almost unbelievable hardships without a murmur. Poor, little, neglected, underfed and silent children, whose sermingly small ailments had gone meared for during years, were at last able to be treated through the American Red Cross." Miss Leete summarized as follows this mursing serviee of the Children's liurean: "Onr nurses tonched all parts of France, deft tender fingers seeking out and easing pain."

One of the tive major opportmities for service which oftered themselves to the Amerienan lied Cross in France in July, 1!17, was, it will be remembered, work for the alleviation of the suffering of Fremell and belgian refugeres. This serviere was

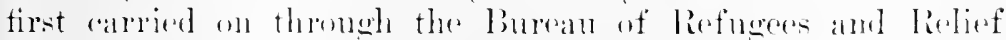
in l'aris, one of the tive primeipal burramx of the lopplotment of ("ivil Affails. Margaret ('urtis, of boston, was its tirst

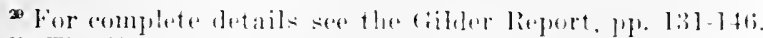

30."The Work uf the Ameritan lied crose buriug the Whar: I statement of Finances and Acomplishments." p. (63). 


\section{HISTORY OF AMERICAN RED CROSS NURSING}

director and she initiated varied phases of social service work for the refugees in Paris. In September, 1917, Dr. Edward T. Devine, of New York, was appointed ehief of the bureau and directed the service work for refugees throughout all of France, except the war zone and Paris. Dr. Devine had been professor of Social Economy at Columbia University, director of the New York School for Philanthropy and for twenty years seeretary of the New York Charity Organization. He had done emergency relief work for the American Red Cross during the San Franciseo fire and the Dayton, Ohio, floods.

The French Ministry of the Interior stated that the number of destitute refugees in Mareh, 1917, was four hundred thousand. The problem of furmishing housing faeilities and means of earning a livelihood to these numbers was one with which many French and American charity and war relief organizations had been working since 1914. 'The American Red Cross Commission for France early adopted a policy of coöperation ander which substantial gifts of funds, supplies and personnel were donated to these already-existing organizations and they were urged to continue and further develop their own machinery for relief work. "Do all the work you can in an efficient manner," the American Red Cross practically said to these organizations, "and we will provide the funds." 31 In addition the Bureau established and maintained hospitals, dispensaries, colonies and homes for refugees and developed a strstem whereby a trained soeial serviee worker was sent as an American Red Cross delegate to the different départements where large numbers of rofugees had been placed.

The Pritish and Amorican Societies of Friends blazed the way in Franee for relief work among the refugees. The British Society of Friends lad hegun volunteer relief work in the Marne in September, 1914, and the Ameriean Society of Friends had given them generous antributions of funds and rothing. In June, 1917, a unit of one hundred American Friends went into training for foreign service at a camp at Haverford, Pemservania, and the society sent two representatives to Frame to make a ficld surver. 'These men sailed on the same ship as did Najor Murphy and his staff and were appointed to membership in the American lied ('ross ('ommission for France. The plan of coupperation which was later developed is stated in the Repert of the First Your of the American Red Cross in Franee:

ste "The First lear of the Ameriean Rod Cross in France", p. 13. 
Ender the original plan of work, it was decided that American Friends desiring service in France shomld not form a new mot but shenld muite themselves with the British organization which alrealy had been in the fiedd nearly three years. 'The result was a compart group uncer the control of a single execontive committee with a common treasury. The Amerieans, however, became members of the American Red ('ross, while the British Friends retaned their connection with the French lied cross. . . To the common treasury of the Ameriean and British friends the Ameriean Red Cross domated money, transportation and equipment; it farilitated the movement of workers and the shipment of goods and supplies. The Friends, on the other land, presented plans for extension of their work and new developments to the hed ('ross for apj)roval, thus enabling their persomel to coöjerate dirertly with lied ('ross workers.

This plan was put into effert early in September, $191 \%$ The Amerian liriends arriving then found that the British Fiends alrealy had established three medical relief institutions for refugess in the department of the Marne at Châdonssur-llarne, where there was a maternity hospital of twentyeight berls: at Bettancourt, where a convalescent home was being operated for fifty (hildren, and at Sermaize, where there was a chidtren's and local hospital of twenty beds.

Early in the fall of 1917, the numbers of volunteers among the American Friends began to exceed the immediate needs of the British Friends: so a seeond mit was formed which worked independently of the British Society. This mit was designated as T'nit No. 2o while the earlier unit was known as Lnit No. 1. ()n September $2 !$, 1!)17, a burean called the Burean of Friends was established in the lepartment of Civil Affairs of the Commission for France and .l. Henry Scattergood, one of the two representatives who had gone to Frane to make field survey for the Amerienn Friends. was appointed direretor and ('harles

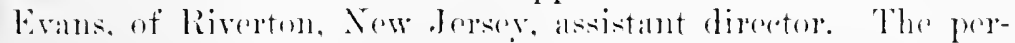
sommel of T nit Xo. 2 worked entirely under the direction of the

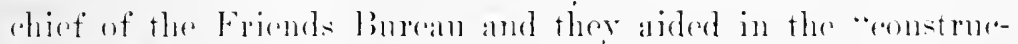
tion of hospitals. the refitting of buildinge for dispensary pur-

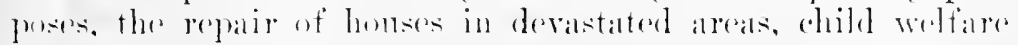

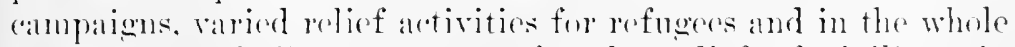
Ameriean lied cons program for the relief of eivilians in

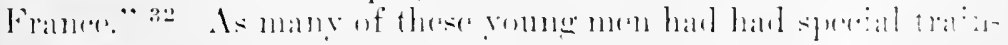
sa whe First Gear of the funerican Rad cross in France," p. th. 


\section{HISTORY OF AMERICAN RED CROSS NURSING}

ing in antomobile work, carpentry and agriculture and as their attitude toward service was one of earnest enthusiasm, it may indeed be said of them that no task was too hard, no emergency too trying to chill their unfailing cheer and good-will.

After some months, Mr. Evans became chicf of the Burean of Friends and in the First Ammal Report of the American Friends Service Committee, Bulletin No. 18, he wrote:

We now have one hundred and fifty-cight men and the twenty-six women in Unit No. 1 and eighty-three men in Unit No. 2, making a total of two humdred and forty-seven American workers. At least one hundred and fifty more men have been favorahly passed upon for this service by our Philarlelphia Committee and will sail as soon as passports and sailing ac'onmonations are avalable. In giving these figures it seems appropriate to mention the loan of workers to other Bureans of the Ameriean lied Cross, quite apart from the plan of Unit No. 2. In ardition to the work of on! Mission it has been our pleasnre to coöperate with various bureaus in the Ameriean hed Cross by lending temporarily to them men and women whose qualifications clearly fitted them for the work desired. We mention the following instances: Belgian Commission, one; Italian Commission, four; Children's Bureau, Lanéville one, Toul two; Bureau of Refugees and Relief, Aube (delegate) one, Eaux Bonnes four, Fure and Maycme three; Bureau of the War Zone, two (chauffeurs); Buraun of Reëducation of Mutilés, one; Jistorial and Editorial Division, two ; Manufacture of Artificial Limbs, one.

American Red Cross nursing service for refugees was carried on ehicfly under the dirertion of $M$ iss $A$ she; althongh she was called rhiof murse of the Children's Burran, she also served as ehief nurse of the entire l)epartment of Civil $A$ ffairs, in that pullic health nurses assigned to her by Miss Russell were sent to do tuberrulosis and infant welfare work and visiting mursing among the adult civilian population of France as well as among the rhildren.

Early in the fall of 1917 , the (ommussion made a grant of $993,00(0)$ frames to the Friends' Society and with part of this fund a hospital home for sick habies was opened at ('hâlonssur-Marne, in eomection with the Friends' Maternity IIospital ahready established there. This homo was horated al St. Rémy"n-Bonzenont, Marne, and "was needed," wrote Mr. Fuans in his First Anmal lieport, "for babies lorre at the Maternity 
Hospital at Châlons-sur-Marne whose mothers were incapahle of taking eare of them. A suitable house to the south of Vitryle-Francois was offered rent free. The cost of fitting and equip)ment has praetieally all been paid by the American Red Cross." Miss Ashe assigned nurses and aides both to the Maternity Hospital and to the Babies' IIome.

A similar baby hospital was established at Châlons-sur-Marne and rent and equipment expenses were met by the American Red Cross.

A general surgical hospital was next opened at Sormaizeles-Bains. Dr. James H. Babbitt, a member of the Friends' Unit, was director. The French civilian hospital at Bar-le-Dne had been evacuated on aeconnt of severe air raids and the women and ehildren of the district in need of medieal eare were left in dire straits. The American Red Cross hospital, which was called the Chatean IIospital, had at first a capacity of sixty beds, but by the spring of 1918 this was raised to one hundred beds. Several barracks were erected to house contagious cases and to afford acconmodations for the staff; electric lights, improved water supply, a drainage system and X-ray and other apparatus were installed. "Practically the whole expense of this hospital," wrote Mr. Evans in his First Amnual Report, "has heen carried by the Ameriean Red Cross."

The Châtean Hospital was partially staffed by Ameriean Red Cross nurses and aides. Dr. Babbitt's report for the week ending May 11, 1918, showed that an extensive surgical service was maintained here for the Sermaize-Châlons district.

The report of the past week will be given as combined report of the two hospital staff physicians and will thus inchude the ont-patient service at the somre Hospital. Bettanrourt and ('hammont. as well as the general visits in the villages. There are forty-two patients in the Chatean Ilospital and twenty-three operations have heen performed there this week. The staff has seen or visited seventy now bationts. and the combined out-patients serviec mumbers one humdred and thirty-nine ases. On May first there wore twonty-eight. patients in La soures Hospital and fifty-three at Bettaneourt. Since foremher $2 \pi$. We have performed three humered and seventy-nine operations.

Refuger reliof work in Paris fell under two prineipal heads, eonomir rebalibitation and medial social serviee. The latter 


\section{HISTORY OF AMERICAN RED CROSS NURSING}

phase of work (and the only one of which an account belongs in this history) was first developed in 1917 under the AccueilFranco-Américain, with Dr. Richard C. Cabot as director. The development of this service was described by Julia B. Norton, a nurses' aide and social service worker:

December 1, 191\%, found me in Paris, starting medical soeial work under the great master, Dr. Richard C. Cabot, Major. L. S. II. R. C., who had been loaned to the American Red Cross to start a program of good medical social service in connection with a refugee dispensary. Medical attention for the refugees was greatly neeled. The out-patient clinics of the Paris civilian hospitals were so overcrowled that for the most part the refugees had little attention. The need for a central dispensary to which all refugees conld go and be welcomel was very apparent.

Litecueil Franco-Américain had starter in a small dispensary at 12 rue Boissy d'Anglas to take care of the medical eases which presented themselves along with general relief cases. Dr. Cabot took over this dispensary and started it on a much larger scale with the following statf: one children's specialist, one tuberculosis specialist, three general medical men, one dentist, some six or seven nurses and as many more social service workers. . . The dispensary grew from seventy-five to one hundred cases a week and when it was moved to its new home at 32 Rue Mathurins, to six hundred cases a week. The new location was more or less ideal, central, quiet and conveniently divided as to space into small consultation roms, each with natural light and good air. and a few big reception rooms.

The dispensary was escentially a temporary proposition. started as a temporary service to fill in chinks where the French lackerl founds or personnel. so it will naturally be closed on March 1. 1919. with the return of the refugees to their former homes.

There was a great amomut of actual relief done through the dispensary. Besides free medical consultation and free medicine fancl pullic. health nursing servicel for tubercular andmir patients. we gave extra food, the kind of food ('ontaining arbohvelrates and oils which they rould not get for themselves and for which there was absolutely no existing French organization to supply them. Clotbes we gave and modial appliances and furuiture ton. hut only after thorough home investigation throush antral orurese of the Ameriean lied (rose astahlisboul to till indivinual needs. Besjles the six huntred medienl cases a woek. we gave material aid to 


\section{NURSING SERVICE TO CIVILIAN POPULATION 831}

about two linndred others a week. . . Let me cite an example. On Norember 18, 1918, a delegate of the Croix liose caule to the dispensary and asked for two hundred and fifty kilos of medical supplies to take up in a camion to destitute Lille. Lille hat then plenty of doetors but no medicines. The Amerienn lied Cross had the medicines but no transportation from Paris to lille for the moment. The Croix hose furnished the camion, the American Red Cross the medicines and within two days the doetors of Lille were at work.

The Burean of Refugees through its departmental delegates undertook extensive relief work for the refingees in eentral and sonthern France. Food and elothing were issued in large quantiti's, farming implements were supplied and positions seeured for trained workmen.

The entire refugee problem was dependent upon the military situation. On Marrh 21, 1918, the Germans launched the first of their five major offensives and the refugee problem immediately assumed enormous proportions. Amiens did not fall, hut the eivilian pepulation of the city and the surrounding villages and countryside thed. Amnie s. Rathbone, the American hed C'ross murse stationed at the child welfare station at Amiens, wrote:

For five uights previons to the evacuation of Amiens. the enemy had systematically tried to break the eity"s morale by air-raids. lleanwhile, leed (ross workers am members of the Friends and the sunith (oollege units kept coming in from point: further rast. I)r. Ballwin brought three small sick children from the Rod Cross Hospital at Xesle, whom he hal not been able to return to their parents. . . .

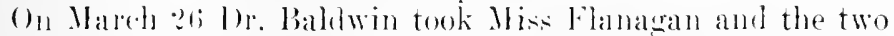
Noster dhildren to Paris: they were afterwards renuited with their parents. I starterl areros the city to return the Amiens. baby to it: mother. In Amerian solitier warried her. I som

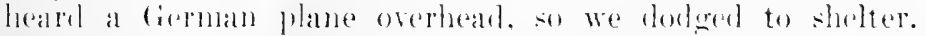
latter. we tried again. 'The night was beantiful, with a phacil full moon. We calve the balor to her mother. who was halfmad with anxirty, supplied her with money and condensed milk and dorluged hatck.

The next morning I mate rounds among my sick. Some

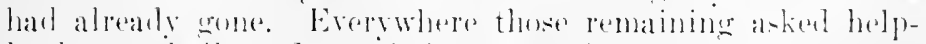
lessty: "shall we fly or shall we stay " In my" inmorane of

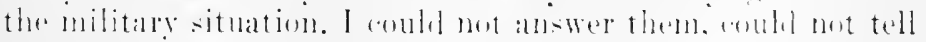




\section{HISTORY OF AMERICAN RED CROSS NURSING}

them whether to risk death from the German shells or from exhaustion on the road.... The streets were already jammed with refugees staggering along under the weight of their bundles. . . .

At noon, shells began to fall on a distant part of the city and it was time to go. While waiting at headquarters to get off, we women distributed Red Cross chocolate, condensed milk, cheese, biscuits and blankets to some five hundred British soldiers who had lost their equipment. As the only nurse in our party, I was given the care of a young French girl who had an extensive shell wound in the lumbar region. She had come from the east, fleeing with her mother in front of the advancing Germans. Girls of the Smith College Unit had found her. I packed her in a stretcher with rolls of material and used ny umbrella as a sort of splint for her body.

The actual evacuation of Amiens was a tremendous sight, a city of 100,000 emptying itself frenziedly in one direction. The road to Poix was packed with refugees of erery age and condition, tottering old people and young girls; women with babies and children scarcely able to walk hanging to their skirts; automobiles, wheelbarrows, smart equipages, donkey carts and baby carriages; animals of all kinds, cattle, sheep, dogs, poultry and rabbits; domestic possessions of infinite variety, carried in an infinite variety of ways, a swollen stream of traffic which formed a dark unending line of misery over the unconscious smiling earth.

Beauvais lay immediately south of Amiens, on the direct route to Paris and to this bombed and congested city the refugees fled. Miss Rathbone wrote:

Late in the evening we pushed on our journey and reached Beaurais, where the sisters at the Hotel Dieu took charge of our wounded and inviten us to rest that night in their delicionsly clean hospital beds. We women workers from Amiens and those who had joined us from points further east filled two wards. It was the first night's sleep we had had ferr nearly a week.

In the morning. Captain Van Kemen of the American Red ('rows arranged for the me of a freight shed near the Beanvais station. There a canteen was starterl at one end by the Sinith ('ollege ['nit: mattresses thrown on the sandeil floor at the wher end serres] as resting places for the sick and wayorn. Later in the day. we nurses were joined there bx other nurses alld doctors sist from l'aris heallpuarters and two days lator wo moved into a house. This was the begin- 
ning of the Emergeney Hospital for Refugees, which was carried on for about two months. Then the nurses and equipment were transferred to the Red Cross military hospital later established in the town / American Red C'ross Ilospital No. 10.t: Lícole Professionale 1.

One of these nurses sent up from Paris headquarters was Anastasia Miller, who became head nurse of the Refugee Hospital. She wrote:

During the spring offensive . . the refugees were pouring in from Amiens, Arras and the surrounding villages. 'They' suffered not alone from malarlies but from shock and injuries received from shell fire before reaching places of safety. Families came in with one or two of their numbers missing; a child was brought to us who had been found in a cellar where she had stayed three days without food, her dead mother, who had benn killed before her eyes, lying beside her. Horrors such as these we had to cope with, so it required a great deal more than nursing care.

The food for the refugees was prepared by French soldiers and consisted of the usual boiled meat, with rice or potatoes in the grary and a piece of hard bread. We undertook to supplement this by what we could cook ourselves on a twoburner gas plate. The Red Cross had supplied us abundantly with craporated milk, sugar, cocoa, rice, oatmeal, dried prunes and figs, gelatine, rggs and fresh vegetables. With these extra rations, we managed to keep them nourished and happy, although many a night $\mathrm{I}$ was cooking when the alerte of an air roumd sominded.

For a month we antinued the work andisturbed. We held dispensary abuis ary morning from ten to twelve, treating principally chiblen. 'They were infected with scabies, vermin or inpetigo. We heame adepts in hot haths given in a tin washtub and followed hy sulphur inmotions, softening and removing the erusts of impetige with the suljeret almost in spasms meanwhile and the envelopment of humberls of hearls in kerosene with shampoo followinge. It was all 50 worth-while! To see habies' faces aming ont pink and soft from umer the moightly arusts of impetige and the soft flutfy hair arain free of bermin. with the attendant relief in those little ones eves, brought all the satisfaction in the world.

Towasts the end of May. the Cantigny l)rive. in which Americans tirst ligured. beran and simulanomsly the Cirrmans sarted to himb, beaturas. The Amerian lied Cross 


\section{HISTORY OF AMERICAN RED CROSS NURSING}

military hospital which was then being equipped to receive the wounded was not yet ready for occupancy; the medical and nursing stafl a vailable for it consisted then only of three nurses and three surgeons. The wonnded were then on their way to Beauvais from the front, so in order to help over the energency I sent down from the Refugee Hospital all the nursing help I had, prepared myself a corner in the ward and stayed with my refugees on ahmost twenty-four hour duty for another month. Owing to the bombing which took place during this time, not a piece of glass was left in our windows and the low tongue-and-groove partitions which separated the beds were knocked apart by the concussion. I gathered up a candy box of shrapnel in the wards after the raids were over. Aside from slight glass wounds which I dressed after each raid, there were no injuries, a remarkable thing because the majority of patients were mable to go to the cave for shelter. One night a dog went mad during a raid and bit several people, tearing one man's hand severely. These I dressed by the light of a taper while a priest held a blanket up to block off its rays. Without windows or shntters, any spark of light was a risk.

Finally, as the German advance continmed, it was thonght wise to evacuate our refugee hospital in the Ecole Tormale, so the refugees and patients were moved further sonth.

Paris was the next stop for the refugees on their journey southward. The American Red Cross established rest stations in the railroad stations of the city and gave the refugees food, clothing, medical and nursing care and a night's lodging and in the morning sent them on their way to the Midi. Dr. Mabel H. Bancroft wrote of the general phases of this work:

We assisted with the refugees who in April and May were pouring in at all times at the rarious gares. Sometimes they woukl come in all night long, ohl people, children, mothers with habies, many ill and half "lothed, all hungry and tired and heart-sore. We gave a little medical attention to the most urent ases, but what was most needed was food and rest. We fitted oursulves into any work which came to hand. whatever the need happened to be.

I often wished that those at home who have worked so hard for the Red cross and given so liberally conld have seen the lient eome into these fortorn faces when they heard that it was the Ameriean lied Cross that was taking are of them. They wanterl to give rou all that they harl, their pet hen or goose which they hail picked up in their hasty thight. the 
most precious thing they possessed. We sent those who were too ill to travel further to hospitals and put on the train those who, in hope of finding friends, lodgement and work, were going further sonth. The number of names on our books were about twenty-three humbred.

Le Gare du Nord was the seene of the first extensive Red Cross relief activity of this type. Katharine W. Ilolmes, a graduate of Sinth ('ollege and of the Newton (Massachusetts) IIospital School for Nurses, was one of the first Red Cross murses to be assigned to duty at this station. Miss Holmes had done nursing at Henry Street Settement and for seven years before her assigmment to France, had been in charge of the boarding-out department of the New York Nursery and Children's Hospital. After her return from France, she became assistant to the direcotor of the Publie Heatth Nursing Service at National Red Cross Headquarters. Miss Holmes wrote of the Gare du Nord:

The last of March the refugees began to come through Paris in great trainloals. One day late in March, after our work in the Chiluren's Burean was over for the day, Mrs. William II. Mill an! I went over to the ciare du Nord to see if the Red cross could be of any use in handling the large numbers that were pouring in. We fomm the directrice of the Fronch Military ('anteen distracted by the double care of the French soldiers on the main floor and the hordes of refugers who hat no place to go except to a dark basement once vised als a freight depot.

Hundreds were straming down the narrow stairs from the croweded trains. with their children, bagage and animals. evervthing that they and take with them in their hurried fliglit from thoir homes. Some of them hat leen frightfully hurt by ciemalu bombs. ('hildren were brought in strappoul

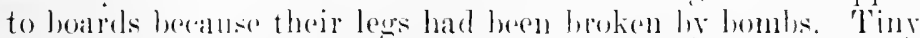

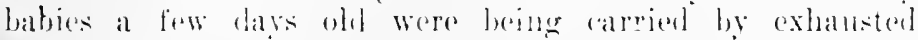
mothers. ()hd old peento had walked sometines on kilo-

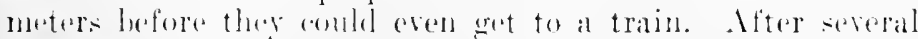

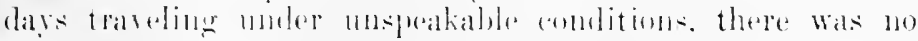

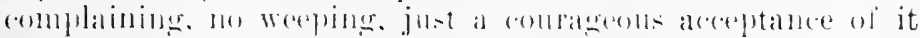

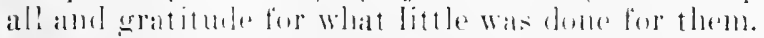

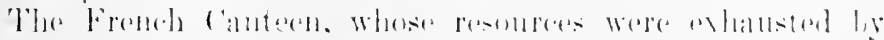

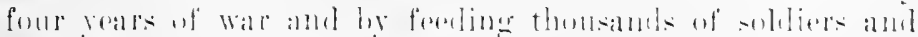

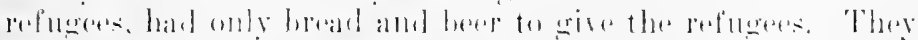

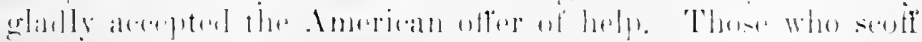


at the cumbersomeness of a large organization like the Red Cross would have done well to have been present at the Gare $d u$ Nord and to have watched the establishment of that emergency canteen.

Through Mrs. Hill's initiative, Red Cross trucks were immediately sent to the warehouses for supplies and a complete personnel of volunteer workers was secured. In a few hours time, the refingees were receiving steaning hot chocolate and coffee, American corned beef and their own beloved sausage, cheese, figs, beer, milk, sandwiches, egrgs for the delicate and best of all, sterilized milk in sterilized bottles for the babies who up to that time had had only the choice of water or beer.

Medical are for those who neerled it was given under the direction of I)rs. Lucas, Knox, Manning; between professional ministrations, they washed cups and passed sandwiches. I shall not soon forget the face of I)r. Knox, usually so dignified and at times almost austere, then shining with happiness over the menial task of washing tin eups in a basin on the top of an upturnerl beer harrel!

That night, two thousand refugees passed throngh the station and all of them were fed. Those who needed changes of clothing were given it. The lied Cross personnel was divided into night and day shifts; everyone gave as much time from their owm particular work as possible. Everyone wanted to help in the ranteen. We harl workers from the Friends, the Y.M. C.A., the Amorican Fund for French Wounded, British cantemers and many othors. The seeond night, five thousand refugees went through and the Emergency Canteen became a fixture of the Gare du Nord.

A temporary barrack was built to house the Emergency Red Cross Canteron at the Ciare du Nort. It took only right days to crect, equip and put it in ruming order.

Great need existed for tomporary puarters in which the refugeres conld sperind a night. They comld not all wait in the stations. longenges and hotel areommondations in Paris were well nigh impossible to sorane thromglomt the period of the war. Morecoser, purjoes wore cxomlitant.

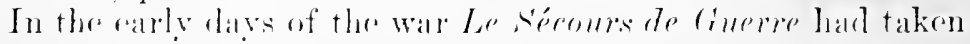

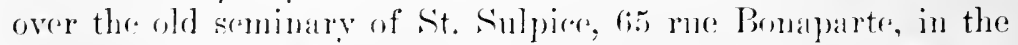
Sixth Arrondissement and the poliere offieress anderepted it into

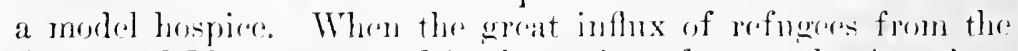

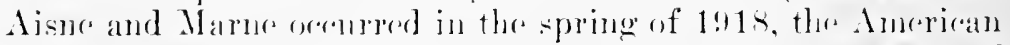
Red Cross offered tho Fronch polire assistance in the form of 
supplies and personnel. Doetors and murses and vast quantities of limen and food were sent to St. Sulpiec; beds were set up in every corner; halls and anditoriums were nsed for dormitories, nurseries and information burcans.

In his report for Jume, 1918, regarding the artivities of the Department of Civil Afrairs, Mr. Homer Folks wrote of Saint Sulpice:

The difficult problem of lodging refugees who had to remain in the city overnight was solved by aiding Saint sulpice, which since the onthreak of the war has been used as a stopping place for soldiers en permission and as a refuge for Belgian and French families male homeless by the war. Beds, blankets and other supplies in large quantities were hurried from the warchouses, increasing the accommodations so that 2500 persons could be housed it a time. . . A hospital infirmary of twenty beds was installed and also a special infirmary where babies, besides receiving medical treatment. were bathed and fitton out with clean new clothing. Here an average of seventy children were cared for daily.

Emergency canteens were also established in the stations at the Ciares de l'Est, Orléans, Montparnasse, and d'Auterlitz and Miss Ashe assigned teams of nurses and nurses' aides to duty there.

After a night's rest and refreshment in Paris, many of the refugees continned on their way southward. Limoges was the next large eity where they stopped, cither for rest or to seek quarters and cimployment intil they eould return to their former homes in the invaded northern provinees. I)r. May E. Watker condureded a dispensary there during the smmmer of 1918 for refugees, but great need also existed for a children's hospital. A project to establish an institution of this type was undertaken jointly in July, 191s, ly the Childrens and Rofugess Bureans, but difliculties in eonstruction delayed its opening mutil loncember. 1)r. Walker was plateed in eharge of it and Venal M. Woods, an American lierl ('ross nurse, was sent down from Paris as supervisor. She wrote:

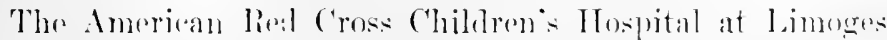

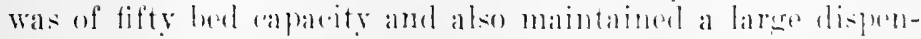

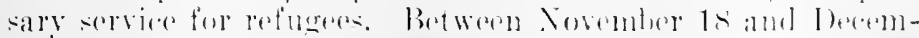

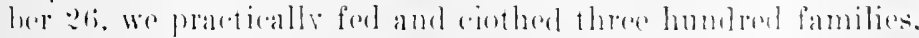
litte children hlue with rold and siek from huner. The city 


\section{HISTORY OF AMERICAN RED CROSS NURSING}

could not care for all the refugees and had it not been for the quickness with which the Red Cross furnished first aid, many would have died.

Our hospital was ready on December 26 and then our real work began and rontinued until April 1, 1919. The American Red Cross then gave 50,000 franes and the city of Limoges raised 50.000 , the hospital building was purchased and was operated as a Hospital for Children. The building was four stories high and was fully equipped-for instance, three hundred chillren's dresses, two hundred and fifty gowns, one hundred and fifty complete layettes, three sheets and other supplies in like proportions. Thus the work done by American mothers through the American Red Cross will not stop but its influence will be felt for years to come. ${ }^{33}$

Not only was our work in Limoges done for the benefit of French and Belgian refugees, but we supplied hundreds of sweaters, mufflers. socks and other articles to American boys returning from the devastated districts. Men of the American Expeditionary Forces were constantly coming in and we never had a meal withont some of them joining us. . . .

Southwest of Limoges was the eity of Angonleme in the Charente I) partment and here the American Red Cross established and maintained an extensive dispensary service for the many refuges who erowded the eity. Dr. Lillie Amett, the American Red Cross phrsician who had formerly been on duty at Le Glandier, was transferred to Angoulême. She wrote of the establishment of the dispensary:

On August 20. I arrived at Angouleme and met the refugee delegate. Mrs. (ioodale. who had been in the city since Ipril. The same day Drs. Knox, Mamuing and Baldwin stopped in the city a few hours on their way to America and Dr. Kunx gave ine his nsmal brief instructions: "Open a dispensary the following Monday." It was then Wednestay. I returned to Le cilandier. packed, said goorl-by and reached Angombene again Friłay mon.

Mrs. Cenolate had requisitioned a splemeld residence in the best lowation of the city. hut the house was absolutely empty. A rorps of serub women reanerl it up. but my hopes of opening on Wombre were batsed beraluse the women were then in

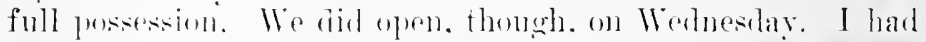

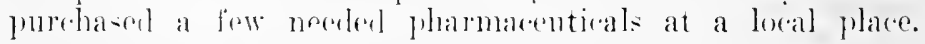

${ }^{23}$ For details of aureenent between the eity of Limoges and the tmeriran Rinl Cross regarding the (hildren's llowital, see the Gilder lieport, Vol. III, pp. $79-80$. 
Mrs. Goodale sent in a tahle, chairs, towels, etc., and I had my own instruments, so Mlle. LeGrand, my French nurses' aide, and 1 went to work and had seven patients on our first day.

'The dispensary was conducted in a beantiful sun-parlor about fifty feet long. with a mosaic floor and great windows which gave us idcal light. Each day saw an increase in the attendance.

On September 20, we took in our first hospital patient, a baby very sick with indigestion and auto-intoxication. (Other patients came and our household increased. Each morning I went about the city making calls and every afternoon conducted the dispensary service. Our maximm daily attendance was thirty-four. In all, we cared for fifty patients in the hospital. We tried to keep a caid system of the dispensary cases. but $I$ could not always get the names of my morning calls recorded. Our cards showed 575 patients.

Sonth of Angonleme, Limoges and Lrous lay the provinees rich in agrienltural and industrial activities. To these provinees the French Government sent large convoys of refugees to live and work until the military situation permitted their return to the Somme, Aisne and Marne Valleys.

Many of the refugees who were assigned by the French Governmeit to these southern provinees were the rapatriés whose reception at Evians-les-Bains has alleady been deseribed. The pscrchology of the rapatrie, an important factor in the refugeo problem, was described in a French jourual:

After those of the arrival at Evian who are fortunate enough to have friends or relatives awating them and those who are sick and feeble are disposed ol, there still remains a crowel varying from four hundred to six humeled persons who are absolutely without resources. plans or any ability whateoever to help themsolves. They are sent by a separate comvoy into the interior. The alrival at Evian brines to eareh train the joyous certanty that it is France that awaits them. that they will be able to sueak their nation tongue again and to greet their henthers. The secome stane of their journeythe arrisal in an moknown provinere-coften works a reartion,

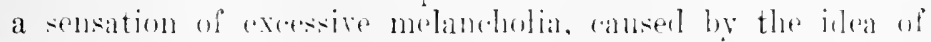
being alone in their own country, so near and yet so far prom their homes.

The refutries are people from the lowlands of the morth.

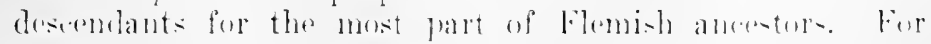

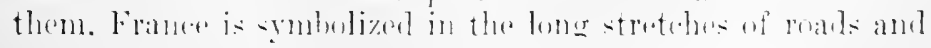




\section{HISTORY OF AMERICAN RED CROSS NURSING}

highways of commerce, populous villages and fields of wheat and beets, the ground rich in iron, the mines, as dear to them as the little Breton port into which come red-sailed boatsthe vine-covered hills of Touraine or the Pyrenees Mountains. ...

The arrival of these people for whom Germany has no use ... has been for the French communes, impoverished by the drain of forty-two months of war, a heary burden. Two episodes of the villages of the Midi will show this: La Gis a little village composed of a score of thatched cottages situated far from the main highway. The mayor is a "reformé." . . When the first dozen rapatriés arrived in his commune and saw the land, encircled by low hills and traversed by deep valleys with here and there small pieces of fertile ground, threaded with rocky roads along which ambled on market days droves of cattle and sheep, they returned at once to the eity from which they had been sent. The mayor declared to a Red Cross delegate that they had only glanced at the banquet that the little village had prepareil for them. No one was to blame. They had done what they could. The rapatriés had decided that there was nothing for them to do there and that idleness would never help them forget even for a moment their incurable homesickness for the plains of Flanders!

At $\mathrm{T}$ and of courteous manners. . . Since the beginning of the war. T- has organized five ambulances, has supported the French Red Cross in the way of gifts of sheets, clothing, bed linen, etc.. and now came the rapatries and the refugees. When the milyor found this new duty thrust upon him, he could not sleep for eight dars. No place to put them, no work to grive them! 'The only place available was a hospital ward filled with beds without covers! ${ }^{34}$

In nearly all the principal cities of the southern départements the Bureau of Refugees and Relief sent delegates to establish headguarters for refugee relief. Sometimes these delegates were mures who had had social service training but they were generally social service workers. During the summer of 1918 there were more than to delegates and assistants and their work coverexl fifty-eight of the sixty-six uninvaded depprtements in France. The nature of the service rendered by them was described by Katlarine Holmes:

a la Croir-Ronge Imorianine of la Population rivile Franeaise, Journal des Ourages de llemes. (Hotoler 1, 1918. Pf. 198-199. 
On May 1, 1918, I went as delegate for the Bureau of Refugees to the I)epartment of the l)rome in southern France, where twelve thomsand refugees hat been placed. 'The refugee work in that department had already been musually well organized by Miss Dewson, who gave up that department to become zone delegate. 'There was a warehense well stocked with all the different kinds of furniture neeted by the refugees in starting new homes-beds, talles, whairs, butlets, blankets, sheets, quilts, stoves, mattresses, pillows and garelen tools and seeds.

Cordial relations already existed with the preffets du police and the mayors and various committees of French volunteers which had already been started in many of the bigger towns. Coal was being given ont to the needy and knitting to mothers who wished to make money at home. Plans were on foot for the establishment of an American dispensary which was much needed.

My work for the last eight months has been to carry on this work so admirably begun and to meet new situations and needs as they arose. About two hundred families a month have been provides with the furniture necessary for the establishment of a new home. This has meant that they have also had each one the friendly counsel and visits in their home of one of our committees in whatever part of the department they lived. One huntred and fifty-three volunteer French "home visitors" whom we have trained help us in the Drôme.

Two Amerien dispensaries have been started, one at Romans and one at Valence. . . They are run by I)r. Wright of ('alifornid and two Red Cross nurses, Miss Freda M. Caflin and IIiss $0^{\circ}$ ('ommell. They have a staff of French assistants who help with the home risiting and dispensary routine. Ahout forty people are treated at rach day"s clinic and very careful work is done by the aides in following nu work for all wases. On the dector's oreler we furnish extra food for all those whose physial andition demands it. We send each month ten of the most anemic ahildren to Miss Frick's eountry home at chanay in the mountains of Ain.

'Three playcrenmels were started in the smmmer. two at Talence and one at lomans, a cromed center for shoe manufacturers. This idea, new to France. . was taken up enthusiastically by the French.

One of our most satisfartory artivitios was in finting spobrate folgrines for families who hat heon hepded together in the big "entres de tringes" where the French wepe fureed to

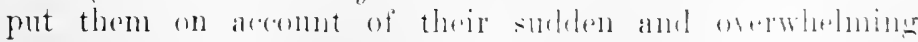
arrival. The French enmmitters in the different towns would 


\section{$8+2$ HISTORY OF AMERICAN RED CROSS NURSING}

hunt up the empty buildings, we would pick out the families most needing a separate home, see that they got permission to leave from the préfet and then send on furniture ${ }^{35}$ in arlvance so that their home would be ready for them. On their arrival, our representative met them, helped them with their luggage, took them to the mayor to secure bread tickets, and other services of like nature.

The development of playgrounds, a projeet new to the French, was carried out at Valence. Six American normal sehool graduates were sent to Lyons for an intensive course and then assigned to different Valence schools. So suceessful was their work that when the American Red Cross withdrew the French sehool authorities retained the services of two of these workers permanently.

Miss Caffin wrote of the establishment of the Red Cross refugee dispensary at Valence:

On May 22 Dr. Wright and I arrived at Talence and found nothing. In twenty-four hours a building was located and arrangements for having it painted and having plumbing installed were begun. On May 31 we received our first patient, a young girl of twenty who had tuberculosis.

Our chinies were held on Monday and Thursday mornings from nine to $10: 30$ for children; on Mondays and Thursdays from 6 to $7: 30$ for tuberculosis patients and men from Talence; on Tuesdays and Saturdays from $1: 30$ to 3 for women. The infirmières made 2492 home visits and visiter 110 patients in the cantonments.

On August 29 the second dispensary in Talence, at Bourg

${ }^{35}$ This single item of furniture illustrates one of a wealth of interesting incidents which from lack of space must be omitted from this history? When the refugees were pouring inte Paris and the southern provinces, Dr. Devine askef the Finanee Committee for some two million francs with whicls to buy furniture. The members of the Committee responded with the statement that he would not be able to buy furniture in Fance and that lack of tommage made impossible its importation from the Lnited States. Jle answered that the refugees could not begin to build even temporary homes without bers and ehairs and asked for a provisional appropriation with which to buy furniture, provided it could be secured. This provisional sum was granted him.

Dr. Devine then turnerl the entire problem over to Martha Spence, of Cloveland. a layworker, and she and leer assistants combed the small shops all over France. buring leere a half dozen chairs, there a bed or two. A fabrigue ton small to minufaeture war essentials yet large enolugh to offer some facilities for the manufacture of simple furniture, was taken over and it torned out many tables and chairs. From this central supply. the departmental dolegates drew furniture for the refuges. This incident is also a pleasing example of woments ingrnuity, espeeially in the face of men's dictum that "it could mot be done." 
de Péage, was opened. This dispensary was for all poor chilaren under the age of sixteen. ... On "losing the Ameri(an Red C'ross work at Bourg de P'éage the French Red Cross took orer the work of the dispensary and are continuing it along the same lines. Arrangements have also been made whereby the socielé de s'ecours aux Blessés. Milituires will take over the dispensary at Valence, thus leaving our work in sympathetic hands. 'The Chilılren's Bureau in coöperation with the Bureau of Refugees maintained a small hospital of 25 beds for children of Valence.

The nursing sarvice of the Burean of Refugees was, like that of the Children's Burean, limited and largely curtailed in the late spring and summer of 1918 by the nursing needs of the American Expeditionary Forces. Public health and child welfare nurses were recalled from refugee dispensaries and assigned to Red Cross military hospitals. During the twenty months between Mar 10, 1917, and February 28, 1919, the American Red Cross in France aided 1,726,354 refugees; provided 996 dwellings; operated 67 hospitals and dispensaries where 190,575 refugees received medical and nursing service; operated five dispensaries jointly with the French, in which $66,+19$ refugees were eared for; opened 8 refugee eanteens and in them feal $66,+19$ refugees, and operated 68 workrooms. ${ }^{36}$

The third major phase of the work undertaken by the Commission for Franee for the civilian population-and the last one of which the nursing scrvice formed a substantial and vital part-was the work done by the Burean of Tuberenlosis. Mueh has been writen reanding the tuberenlosis situation in France during the European War, so the treatment of this subject in this history will be brief. Only such phases of it as touch upon Ameriean Red Cross nursing service will be included.

Tuberenlosis was a potent foe of all the Allied armies in France. In 1916 the Ameriean press published nany stories, some cxalgerated, others rearejons, of the decination of the French forees by this disease. Other armies sulfered in much the same way, thomeh little was said regarding them save in technical publications. ${ }^{37}$

3n..The Work of the Ameriean Red Cross During the War: A statement of Finances and Accomplishment.." p. 62.

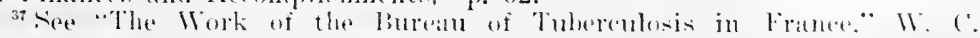

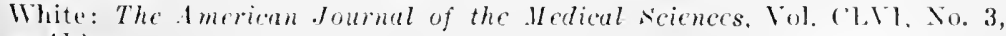
p. 416 . 


\section{HISTORY OF AMERICAN RED CROSS NURSING}

At the beginning of the twentieth century the French Department of the Interior had formed a permanent committee charged with the problem of controlling tuberculosis. The French form of government divided France into departments, each department with its several arrondissements; in every arrondissement was loeated at least one large eity supporting a general hospital of considerable size. Many of these hospitals had speeial wards or pavilions for tubereulosis cases.

Following the deelaration of war, these and all other existing facilities for the eare of tubereulosis patients were immediately utilized for tuberculons soldiers and new and beneficent laws were passed to supplement these provisions. After a year of war, the French Government established a new and more powerful central committee to collect and distribute funds to care for diseharged soldiers suffering from tubereulosis and also to coördinate the work of the departmental committees which had direct eharge of these soldiers after they had been released from hospitals of the Army and the Department of the Interior. In the third year of the war, the Service de Santé established numerous special hospitals for soldiers suffering from tubereulosis; these were largely private sanatoria, convents and sehools which were requisitioned and equipped as hospitals. They were ealled Hopitaux Sanituires. In the fall of 1915, the Department of the Interior established a fund from which thirty Stations Sanitaires were maintained to receive soldiers discharged from the Ilopitaux Sanitaires of the Army. This fund was also used to assist the departmental committees in the home care of patients who had been diseharged from the Stations Sunitaires.

This extensive federal organization was supplemented by a private organization known as the Tuberculeux de la Guerre. Mrs. Edward Tuek was the president, Mrs. Edith Wharton the vice-presibnt and $11 \mathrm{r}$. Blatir Fairchild the secretary. The special aim of the Committee was to provide sanatoria for soldats reformés.

Late in 1:11; the Rockefeller Foundation sent Dr. Herman Bigges, Health Othicer of New York State, to France to investigate the tuberentusis situation and to report whether or not the Foundation should undertake an anti-tuber'onlosis campaign in Franee. I)r. Rigiges report resulted in the formation of the Rockefeller Comminsion for the Prevention of Tuberenlosis in France, with I)r. Livingston Farrand as director and Dr. 


\section{James A. Miller and Dr. Selskar M. Gunn as associate directors.}

The members of the War Council and of the Commission to France had early felt that one of the vital phases of service which the American Red Cross could render lay in the eare of tuberculous soldiers and civilians. Upon the ereation of the Department of Civil Affairs at Paris headquarters, Mr. Folks appointed on August 13, 1917, as chief of the Red Cross Bureau of Tuberculosis, Dr. William Charles White, who had eome to France several months before to serve as director of the Tuberculeux de la Guerre. Dr. White was also appointed as an associate director of the Rockefeller Commission.

Elizabeth Crowell was chief nurse of the Rockefeller Commission for the Prevention of Tubereulosis in France. Early in the fall of 1917, a nursing committee consisting of Miss Crowell, Miss Russell, Miss Ashe and Miss Leete was appointed by the Commission to eoordinate the nursing activities of the Rockefeller Commission and the American Red Cross.

Dr. White wrote of the subsequent aligument of work:

The first task was a division of labor between the Red Cross and the lockefeller Foundation, so that their efforts would contemplate a miformity of results. The Rockefeller Commision umlertook a study of the conditions existing. the provision of dispensary service, an elucational campaign and the selection of two units-one an arrondissement of Paris and another a department of France-in which it would provide a morlel or cranization to be used as an object lesson in Ameriean methoils.

The lied ('ros: Bureau of Tuberculosis undertook the more immediate fiekls of the work. such as the provision of hospitals, imporements of comditions in temporary hospitals, assistance to Fench organizations dealing with tubcrenlosis and a roreful sturly of the whole tuberonlosis situation in France. which might be used in eonjunetion with the Fommlattion:s work for a permanent program and lasting evilene of the work of Americalo

Clara L. Shalekford was the first supervising murse of the Burean of Tulnerenlesis. A graduate of the Eniversity of

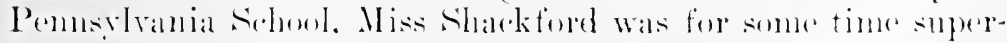
intendent of murses of St. Lonkes Hospital, St. Lomis, and

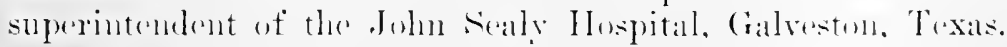

s4..The Work of the Burean of Tubereulosis in France," p. 417. 


\section{HISTORY OF AMERICAN RED CROSS NURSING}

She went to France in December, 1917, and was appointed as exeeutive nurse of the Tubereulosis Bureau. During the spring of 1918 she developed tuberculosis, returned to this country and spent some months at Saranac; there the disease was arrested, and in November, 1918, she entered the Army Nurse Corps and was assigned to Camp Devens.

For some months Miss Ashe carried the work of the Tubereulosis Bureau and in October, 1918, Sarah Adams Crawford was appointed as supervising nurse. Following her graduation from the Framingham (Massachusetts) Training School, Miss Crawford had had executive experience in various New England institutions and for three and a half years was superintendent of nurses and also dietitian of the Massackusetts State Sanatorium for Tuberculosis. Although she was enrolled in 1911, Miss Crawford's first work for the Ameriean Red Cross began in 1917, when she taught elasses in Home Hrgiene and Care of the Siek. She went overseas in the summer of 1918 and upon her return in 1919 to the United States did school nursing under the Visiting Nurse Association at Wilmington, Delaware. She was later appointed as a Red Cross public health nurse for the Wilmington Chapter. She died there on February 7, 1920, from double pneumonia contracted in line of duty.

Both Miss Shackford and Miss Crawford typify the great rank and file of Red Cross nurses, women who have given the best vears of their lives in mobtrusive service to others and many of whom have died in harness.

The nursing staff of the Tuberculosis Bureau numbered about sixty nurses. They were chosen by National Headquarters by reason of special training and experience. Upon arrival in France they reported to the chief nurse of the commission and were by her assigned to tubereulosis work. Miss Ashe in her capacity of chief nurse of the Children's Bureau had general supervision of this phase of nursing service to the cirilian population; Miss Stimson's time was almost entirely occupied with the military service.

One of the earliest expressions of the Red Cross anti-tubereulosis program lay in the provision of new beds in existing French institutions. In 1914 the French had undertaken the construction of a model sanatorium at Bligny, Briis-sonsForges, near Paris, and had completed buildinges in which two hundred patients conld be cared for. The declaration of war 
arrested further construction and the timbers and structural iron still lay on the grounds in 1917 where the workmen had left them three years before. The Bureau of 'Tuberculosis arranged for a grant fin the American Red Cross by means of which the other buildings of the samatorium were completed during the spring of 1918 and some three hundred and fifty additional beds were thus made available. The new pavilions of the Bligny Sanatorium were staffed for a time by American lied Cross nurses and aides.

The Board of Managers of l'IIopital St. Joseph, which was located in the Fourteenth Arrondissement and which was one of the largest and most progressive hospitals in Paris, had purchased a convent adjoining the hospital buildings, which they planned to reconstruet to hospitalize men and women suffering from tubereulosis. An arrangement was finally made whereby the IIopital St. Joseph contributed 208,000 franes and the American Red Cross 255,000 franes for this reconstruction work and some two hundred and fifty additional beds were thus secured in Paris. The American Red Cross later made an additional grant.

The tubereulous soldiers and reformés presented a picture of gemine pathos. "Nothing is sadder," stated the Anmual Report, 1918, of the Tubereulosis Burean, "than a ward of tubereulous reformés. A young soldier told us that he was alone in Paris; that his parents had remained in invaded territory; that he reeeived no letter, no remembrance from anyone. He asked earnestly for some clothes. In giving this assistance to him, we know that he will never have the strength to put them on-his hour had eome-but we hope to see in his already dim eves a loneing satisfied." In the same report a reforme wrote, "We are plague-stricken-nobody comes to see us. If only we had lost an arm or a leg, then we should have a lot of perple around ns. Wo are the badly wounded of the war."

The Assistance l'ublique of Paris had construeted seren sets of barrateks in connection with large hospitals and almshouses of the city. with a potential rapacity of 10.52 beds, hut only $17 t$ of these beds were in eneneral inse. The Ameriean lied Cross completed neessary eonstruction. added diet kitehens

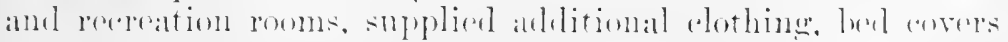
and thowers and brightencel up the general alspeet of the wallst: the number of pattents was als al pesult incereacel to fist. Ameriean Red Cross muses were assigned to duty in these barrarks 


\section{HISTORY OF AMERICAN RED CROSS NURSING}

and the non-professional phases of the work were directed with marked suceess by Mlle. Moufflard, a French woman. In addition to affording an increased number of beds for reformés, these barracks also afforded hospitalization to tuberculous rapatriés and refugees.

Hôpital Bénévole $19^{\text {his }}$ was a small hospital of twenty-eight beds which was operated in Paris by the American Red Cross for French soldiers in the incipient stages of tuberculosis.

Financial assistance was given by the Bureau of Tuberculosis to many other French institutions. On April 15, 1916, l'IIopital Ormesson, a hospital for tubcrculous children, had undertaken the care of 150 tuberculous soldiers. The Service de Santé in return for this hospitalization gave the institution an allowanee per patient of three franes a day, but a deficit of nearly 10,000 franes a month had resulted from this arrangement. L'Hôpital Ormesson consequently notified the French Army that the beds would have to be discontinued. This fortunately did not happes, as the American Red Cross agreed to appropriate the necessary funds.

Assistance of this type was also given to Mlle. Chaptal for the development of a hospital of forty beds for tubereulous women. To the Sanatorium Lege, the departmental institution of the Gironde, two hundred thousand franes were given. To the rocieté de Secours aux Blessés Militaires a similar gift was made which was added to a fund of one hundred and fifty thousand franes furnished by this organization; the aggregate sum was used to purchase a property at Tours for a departmental sanatorium of the Indre-et-Loire. A total of $8+7$ institutions for the care of tubereulosis cases were aided by the American Red Cross during the European War and a total of 2675 new beds were added to already existing organizations. ${ }^{39}$

Early in the summer of 1917 the organization Les Tuberculeut de ln Guerre had undertaken to remodel the (hitenu de la Fontaine Bude at Yerres, near Paris, as a tuberculosis sanatorium. When the American Red Cross took over the artivities of this oremization, it carried on the work contemplated at Yerres and there maintained so beds for French men eivilians in the early stages of the disease. Nary C. Ewing, a social

53."The Work of the Ameriean Red Cross during the War: Finances and Accomplishments." p. 6it. For a list of these institutions, see Annual Report. July 1, 1918. of the Bureau of Tuberculosis, p. 22, Chart 4, supplements 1-10. Red Cross Library. 
service worker and a nurses' aide, organized the sanatorimm at Yerres. She arrived in Paris in November, 1917, to work under the anspices of Le's Tuberculeux de la Guerre and was immediately sent up to Yerres. She wrote:

In this hospital, we eventually had ten French nurses and the original plan was to make it as nearly like a French hospital as possible. All our patients were Frenchmen. save for a few American soldiers. The hospital was opened the midelle of January, but from about Derember 12th l thad heen the only American there, so you might well say that 1 assisted in the equipment of the hospital and in establishing the routine which was afterwards carried out.

Miss Ewing was next assigned to Miss Lecte's staff at the Tent Hospital, was later placed in charge of the various nurses' homes in and near Paris and finally went to Romnania with Miss Patterson. Her service, a long and responsible one, is trpical of that of many American lavwomen who served in a semi-nursing and execntive eapacity with the Ameriean Red Cross Nursing Service in Franee, but who were classed as aides beause they were not professionally trained nurses. Of Miss Ewing, Miss Leete wrote: "She came to No. 5 before it was opened and she remained there until the line was far enongh removed from us so that the responsibilities were not so great. She first took charge of the kitehen and when that was turned over to the Army eook she took charge of the diet kitehen and later of the nurses' home and the doctor's quarters. When off duty she went into the wards. She rendered umusually effective service, fitting herself into any department which required assistance."

Even greater than the need for hospitalization for tubereulous soldiers was that for tuberenlons rapatriés, refugees and members of the French civilian population. All the private sanatoria and wards of the Assistence Pullipue wore being utilized, it will be remembered, prineipally for tuberenlons soldiers and reformés. The Burean of Tubereulosis chose the two largest eities in Francer, Lxoms ame Paris, as the theater of activities in thoir hehalf and estahlished in each of these cities laree hospitals and sanatoria for tubereulosis patients.

Lvons, inmediately behind Frian-les-bains. Was the first stoppineplate of the repatries. The General Hospital buard

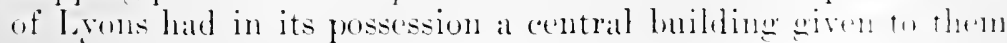




\section{HISTORY OF AMERICAN RED CROSS NURSING}

by the Empress Eugénie and they turned it, and five newly ereeted barracks adjacent to it, over to the American Red Cross early in the fall of 1917 for use as a tuberenlosis hospital for women and children rapatriés. The Hospital Board provided all equipment, linen, food and other artieles and factors of maintenance; the Ameriean Red Cross paid a per capita rate per patient to the Hospital Board, for which the French Government partially reimbursed the Ameriean Red Cross. The Bureau of Tubereulosis supplied all medieal and nursing serviee and medieal supplies. The hospital, which was called the Asile Ste. Eugérie, was opened on December 5, 1917, and on the first of April, 1918, was maintaining beds for one hundred and twenty-eight patients. This hospital worked in close coöperation with the children's hospitals and convalescent homes developed at Lyons by Miss Nelson, Miss Butler and Dr. Grulee.

Madelaine Evans was the first chief nurse at the 1 sile Ste. Eugénie. She was loaned to the Tuberculosis Bureau by the Army, but only for three months, and was reealled to her unit, Base Hospital No. 2, early in March, 1918. Amne Carney was then placed in charge of the nursing service at the Asile. Her statf consisted of one American nurse, three Swiss nurses and one French aide. Lient. (later Major) G. L. Bellis, who had been transferred in September, 1917, from Colonel Winter's staff, was in charge of the hospital and later direeted an extensive dispensary service at Lyons for tubereulons rapatriés and refugees.

The headlpuarters of this dispensary serviee was at 57 Cours Gambetta. Lillian Bell Stuff was the public health nurse in charge and she was assisted by a Swiss nurse and an American murse. An idea of the coöperation which existed between all bureans of the American Red Cress organization in Lyons is contained in the following statement written by Miss Stuff:

Our daily routine ronsisted of dispensary duty. of visiting sick refugres in their homes and instructing them in sanitation. of furnishing heip where needed for beelsirle care in advanced (asces and of arranging for ambulances to take them to hosplats if hospitalization was considered necessary. When patients woro foumd poorly nourished, the physician in (harese of the dispensary ordered food supplies such as cocoa, sugar. prumes, rice. fanterl milk and mancaroni and these were furnisled by the American Red cross. Lnsuitable housing 
conditions were reported to the Bureau of Refugees and cooperation with all other departments of Red Cross service was establisherl wherever it was needed.

This dispensary was transferred on Deeember 1, 1918, to the Rockefoller Foundation. Like many other Ancriean Red Cross hospitals and dispensaries, it also served individual soldiers of the Ameriean Expeditionary Forees.

At Plessis-Robinson, six miles from Paris, the Tuberculosis Burean established the largest of its institutions, the Edward T. Trudeau Sanatorium. Previous to 1914, the Department of the Srine had purchased two chateamx, Hachette and Malabry, which were loeated just outside the eity: on these estates, houses for working people were to be constructed under a plan known as the "Ganden (ity Plant." The deelaration of war arrested the development of the project, but its originator, Henri sicllier, was so interested in the tubereulosis problem that he offered the two estates, rent free, to the Bureau of Tuberculosis.

The two chiteanx and their adjacent buildings and grounds rovered one hundred and fifty acres. Reeonstruction work was begun in November, 1917, by a group of British and Ameriean Fiends working under the direction of Dr. James L. Gamble, of Johns Iopkins Hospital. Four additional houses of considerable size were secured in the vicinity and on Christmas 1)ay the first patients were admitted-three refugees suffering with tuberculosis. The institution was named after the pioneer "xpert in tuberculosis, Dr. Trudeau, an Ameriean of French origin whose name. the Commission hoped, would help establish a boud of mity and smpathy between the two nations.

The Trudean Sanatorimim was soon developed into a model project for the treatment of tuberenlosis. Dr. White wrote:

The futuro blans enr this whole poperty contemplate the following lifforent grompingers of people: a sanatorium for women: a detention homse for entering children; a hospital for tulereulous rhilalen: a preventorimm for rhiblen of tuberoulons parents: a colony for fambies with a tubereulous: momber from which the sick one camont be separatert. With the rompletion of the project. appereximately two thomsand

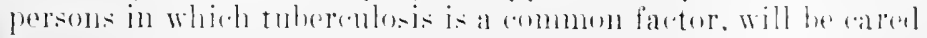

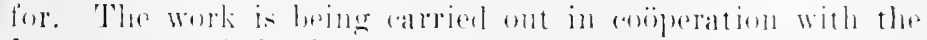
Jepartment of the Interior of the Fromely (iovertmente the 


\section{HISTORY OF AMERICAN RED CROSS NURSING}

dispensary service is of the Rockefeller Foundation and our own Hospital Admission Bureau. ${ }^{40}$

Inez Louise Cadel, a Johns Hopkins graduate, was head nurse of the Trudeau Sanatorium, until the military erisis in May, 1918, made necessary her assignment to the Auteuil Tent Hospital. In March, 1918, the nursing staff at Plessis-Robinson numbered five Ameriean Red Cross nurses, one graduate English nurse, one graduate Australian nurse, one French nurse and two Ameriean Red Cross nurses' aides.

The Women's Hospital aceommodated some eighty patients, the Children's Hospital about seventy. Miss Crawford, second supervising nurse of the Tubereulosis Bureau, wrote of the observation hospital:

The patients are assigned to us through the Paris dispensaries. About thirty children are admitted at a time to a building quite distant from the hospital and there they are kept for about two weeks. During this time they receive the necessary attention from our lentist or our throat specialist and they are under the constant observation of the doctor and nurse. At the end of two weeks, they are either transferred to the Children's Hospital or to the Preventorium and thirty more children are brought in to the Receiving Hospital. We have children of all ages at the hospitals, babies and children to ten years of age, but the older ones are transferred to the Preventorium as soon as possible.

In some cases we will have the mother at the Women's Sanatorimm and her children in the Children's Hospital and in the Preventorium.

One of the American Red Cross nurses who was assigned to the Children's Hospital was Laura Blanche Bingham. She wrote:

I went to Châteaux Ifachette-Robinson on August 16, 1918. for general duty at the Children's Hospital. 'There our work was arluous. bit we were all willing to do our bit for those half-starverl suffering children of France. We began bathing chiltren at eight $\%$ clock in the morning; next came merlical treitment. surgiral hressings. irrigations, massage and handaging. Then all patients were carried outdoors.

w "Work of the Bureat of Tuhereulosis in France." Dr. White. The A merican Journal of the lledical seirnces, Vol. CLVI, No. 3, p. 423. 


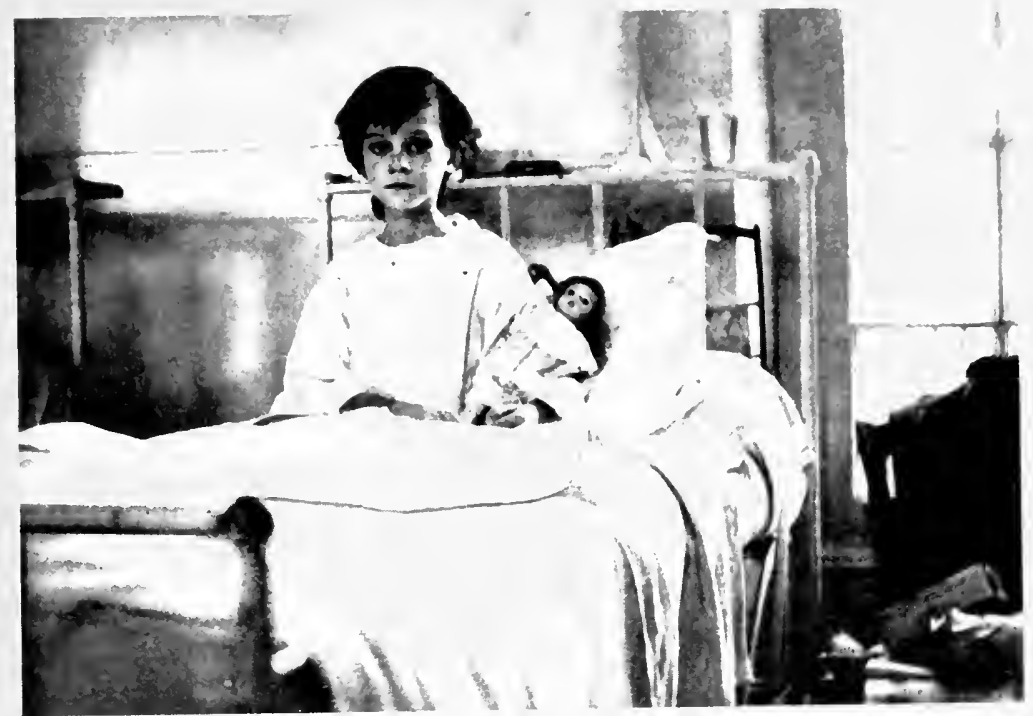

A tuberculous refuree child who died in an American Red Cross children's hospital in France.

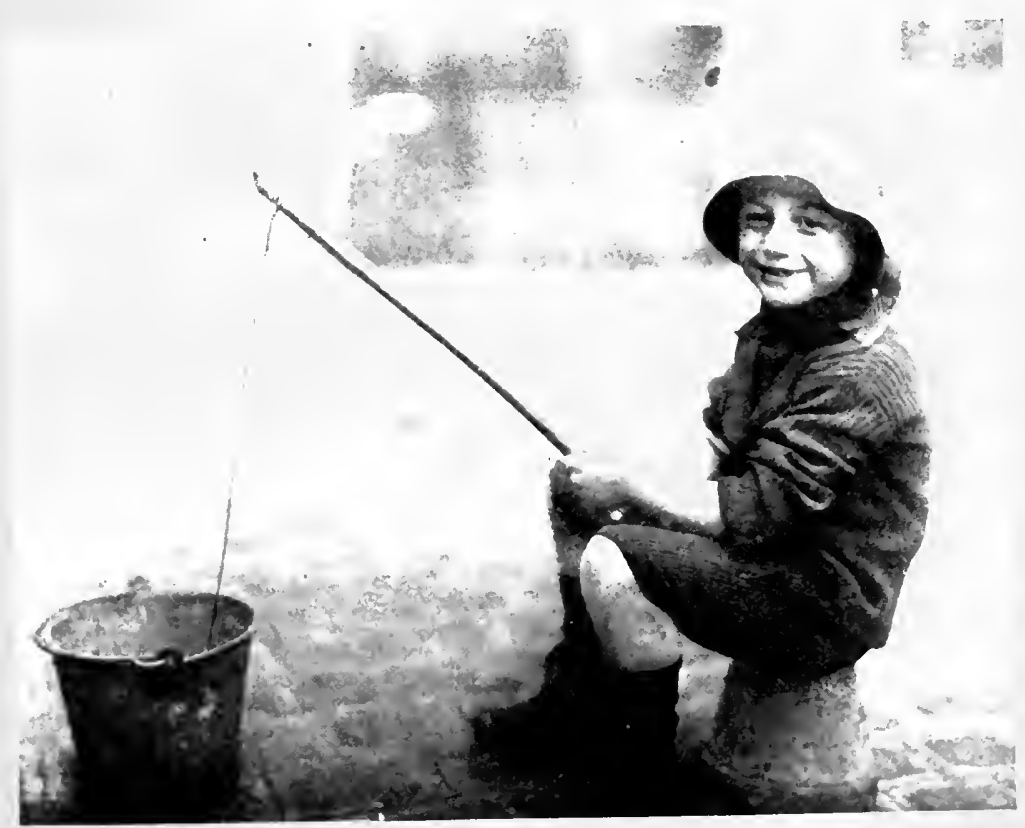

A rhilıl who liverl. 

some on their beds, others in chaises-longues. We nurses were assisted by lirench maids.

We had right bottle-fed bahies, each of whom had six bottles apiece, so forty-eight bottles to be sterilized every day is quite a task. We were terribly understafferl all summer and the work at times seened overwhelming, but we loved the children. During those strenuous months of August and September, bombing raids were of daily occurrence and the effert of them on those little mites was terrorizing. One night we had a tremendous thunderstorm. In one moment, it was pandemonium let loose; they thought the thunder was the Boche again. The panic among the little ones during our last hideous raid in september was pitiful.

Sonth of Paris lay the old eity of Blois and here the Tubereulosis Bureau established a small Women's Hospital, of seventeen beds. A large Franeo-American dispensary located here was also maintained by I)r. White's buream.

To summarize, the Môpital Bénévole, 19 bis, at Paris; the Edith Wharton Sanatorium at Yerres; the Asile Ste. Eugénie at Lyons; the Edward Trudean Sanatorium at Plessis-Robinson near Paris; and the small Women's IIospital at Blois were the hospitals maintained by the Burean of Tuberenlosis for the civilian population. These hospitals provided 6075 beds and maintained 172,942 patient days. The two Ameriean Red C'ross dispensaries for tulereulosis were those loeated at lyons and at Blois.

The Burean of Tuberenlosis developed extensive cö̈peration with the Rockefeller Foundation in its two model demonstrations. The joint dispensaries of the two organizations in the Nineteenth Arrondissment in Paris have been deseribed. In the Hepartment Eureet-loir, the Rockefeller Fonndation with assistance from the Amerian lied Cross mantaned tuberenlo-

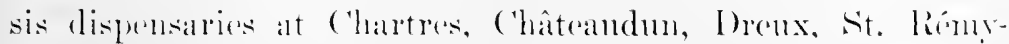
sur-Arre and Sogent-le-kotron. The Burcan of Tuberenlosis proviled hospital fareilities at Dreux, at Chattrandun and at Charters for advaneed cases.

The two oreanizations also earried on an extensive antituberenlosis and infant welfare ampaign. There traveling equipes were oromized and sont ont through the varions de-

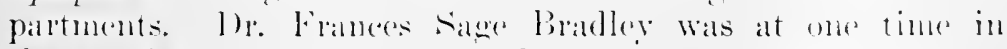
chatre of one of these nutits. She wote: 


\section{HISTORY OF AMERICAN RED CROSS NURSING}

This equipe consisted of an advance agent who arranged dates and suitable publicity, secured a building, hotel accommodations, ete.; a speaker from each organization; a young woman who gave practical demonstrations of bathing the baby; a mechanician. The exhibit material inchuded sereral cinema on tuberculosis and the care of children; a series of panels on each subject; a small model of tuberculosis dispensary and a life-sized baby doll used for the bathing demonstration; and much literature for distribution.

American Red Cross nurses were assigned to this publicity work until the military crisis of 1918 made necessary their withdrawal and reassignment to Red Cross emergency hospitals. Then visiteuses d'enfants or French nurses carried on the nursing demonstrations.

The Bureau of Tuberculosis undertook extensive relief work for tubereulosis patients among the colonies of Serbian refugees in France. The American Red Cross also provided hospitalization for acute cases among the American Expeditionary Forces.

The fourth principal bureau of the Commission for France was the Burean of the War Zone, which provided material relief of civilians still living in the fighting zones and assisted in making possible the return of refugees to the devastated regions and the areas evacuated by the forward-moving Allied troops. The fifth and last burean of the Paris headquarters was the burean for the Rë̈ducation of French Mutiles. The American Red Cross Nursing Serrice did not share in the activities of either of these two bureaus.

Italy declared war on Anstria-Hungary on May 23, 1915. The American Red Cross immediately offered to her the scrvices of a unit of surgeons and nurses, as it had to the other belligerents, but the offer was declined. George B. MeClellan, one time maror of Xew York City, described in a personal letter addressed May 27, 191.5, to Miss Boardman and Miss Delano, the popular feeling then prevalent in Italy:

There seem to be very few trained nurses (in our sense) in the comntry. Since the war began last Iugust. most of the Italian women have taken. . e conres in nursingr. All are ralled lied ('rose nurses and are very enthmiastic and willing.

The work at the actual front is to be lone by men. hat the hosprats bethind the lines and in the hase are to be statled hy the few rall trained nures there are and ly these amatems. 
... I have talked with a great number of I talians and with a few Amerians who know Jaly. With one accord, they have all disconraged the idea of sending American and English nurses to Italy at the present time. 'The Italians do not want our help. They are convincel that they are quite able to take care of themislies and do not want ns to send them either nurses, surgeons or advice. All agree that supplies will be welome.

The musing system in Italy resembled in many respects that which prevailed in France and other continental countries. The Sisterhoods had many nursing members. These nuns were seldom trained according to the Nightingale system, but long experienee had made them able administrators and skilled murses. They gave medicines, assisted in the operating rooms and had general supervision of the wards; but they did very little bedside mursing and they rarely nursed men.

The economic advantages of this type of nursing service were summarized by Mary S. Gardner, a pioneer American public health murse who in 1918 undertook a special mission, to be described later, for the American Red Cross in Italy:

Their emplorment offers a number of advantages; perhaps most important is the fact that the spirit of servece actuates their work. It is also an inexpensive and convenient form of nur'ing service, for if a religious order staffs a hospital the management is at no further trouble. There is manally an adequate sumply and if one num is sick another appears to take her Mlace inmediately. The complete laicization in Italy would moloubtedly be a calamity. It would seem wise to ofler a better and more general training to nums. Even though a secular body of trained nurses may later be dereloper. the muns must continue to occupy an important place in the nursing enomy of the country.

llonke also are for the sick. ${ }^{41}$

The actual bedside nursing of the patient was left to untrained attendants of the sorvant type, alled infermiere. Of this type of murse Miss Garelner wrote:

This group, a laren one, presents few posibilities for improsement. Ilours of work are too longr. living anditions: too harel and sillaries too low to attract a fine tyle of whman.

"feneral lieport of the Commistion for Tuberculosis. American lect Cross in llaly. He. 49-50. 


\section{HISTORY OF AMERICAN RED CROSS NURSING}

nor does the work stimulate ambition. The doctors give most of the treatments usually given by nurses in England and America and little attempt is made either to increase the skill of the infermiere or to secure a type of woman capable of such improvement. It may be generally stated that few infermiere would be capable of receiving a nurse's training, eren were requirements reduced to the lowest possible minimum. One unfortunate custom also prevails which is demoralizing to the infirmiera's ethical standard and which does much to prevent a uniform and disinterested care of the sick. In many hospitals fees are taken by infermiere, which inevitably leads to neglect of the poorer patients who are unable to "tip" their nurses. The infermiera may perhaps have a place in the economy of hospital management, but she can be looked upon as nothing but an unmixed evil, if regarded as a substitute for a graduate nurse or pupil of a well administered training school.

Nursing is also done by men infermieri, who are of about the same type as the women. ${ }^{42}$

The infermiere were organized into a "union" called the Associazione Nazionale Italiana tra Infermiere, with headquarters at Rome.

Midwifery was in a much more advaneed stage in Italy than in the Lnited States. Every midwife was required by law to have had two rears of training and one year of practice bofore she was permitted to follow her profession. "In some of the small towns, particularly in Tuscany," wrote Miss Gardner, "midwives act as operating-room murses."

The modern profession of mursing, as developed to a high degree in the British Empire and in the United States, was mon-existent in Italy. Very few foreign-trained murses were there and practically no modem training schools had been established. Potent eronomic and social factors were at the bottom of this sitnation.

"Many have said," Miss Noyes often affirmed, "that thirty rears ago in the Inited States girls entered schools of mursing for three prineipal reasous: to forecet personal sorrow: to better their matrimonial prosperts; or to earn their living in the only way then open to women except school-tearhinge."

Three similar reasons, howerer, ramot be said to have influeneed Italian gipls to herenue porofessional murses. As for Miss Noves' first reason, Italian women who wished to foret

* General Roport of the Commi-ion for Tuburoulouis. p. 50. 
personal sorrow in altruistic service entered the nursing Sisterhoods. As for Miss Noyes' second reason, Italian girls did not consider becoming murses to better their social eondition through advantageons marriage because the social position of infermiere was inferior to that oecupied by student nurses in American sehools of nursing. Infermiere were classed as servants and young Italian physicians were not apt to chose their brides from annong them. In the United Sitates, student nurses oecupied a status which placed them on social equality with the internes in the hospital. As to Miss Noyes' third reason, nurses in Italy received a wage similar to that of the servant classes, not the thirty-five dollars a week and more which American nurses reeced for highly trained service.

These economic and social eonditions which existed in Italy greatly inhibited the development of a professional nursing persomel. In addition, "the hospital authorities," wrote Miss Gardner, "are not hospitable to the training-school idea. It is considered too expensive a form of nursing and a woman superintendent with proper authority is thought undesirable. Even were plenty of pupils arailable, few hospitals are ready to open sehools to receive them. ..." 43

Italian military nursing service was largely intrusted to the volunteer murses of the C'roce Rossa Italiana, the Scuola Samaritana and similar patriotic organizations.

The Italian lied Cross maintained a large body of volunteer nurses whose training covered intermittently a period of three years. Miss Gaudner described the courses:

In the first rear not less than twenty lessons and at least one month in the hospitals with eight hours daily duty are requirel. In the second year not less than twenty lessons and at least one month in the hospital or ambulatorio are required. 'The third year is a repetition of the second. The second and third vear may. muler cortain conditions, he conbined. Iniplemas are given after theoretical and practionl examinations. Nurses holding diplemas most hate at lobst two months" experiene in a hospital eateb reals, otherwise their grade is lost. . . .4t

The Sruola Semaritana offered two eourses, one in First Lid. which was composed of thitty leseons and coreded a preriod of

someral Report of the commision for 'luberenlosis. p. il.

"Ibial., 1. 52. 


\section{HISTORY OF AMERICAN RED CROSS NURSING}

two months, and another in nursing the sick and wounded, which included fifty-four lessons and covered six months. 'The instructors who gave these courses were volunteers and any person, either man or woman, could take them upon the payment of a small fee.

The Italian volunteer nurses were both devoted and able, as may be seen from a letter written February 4, 1918, to Miss Noyes by Sara E. Shaw, then representative of the American Red Cross Nursing Service in Italy:

The people of northern Italy are very capable and their organization is really wonderful. They are proud-and justly so- of what they have done, but their nurses are also keenly interested in new methods. . . The Italian women make splendid nurses. The volunteers really work and after two years of steady service are almost "trained nurses." A definite time schedule is kept for each rolunteer on duty so they give really long hours of service. Their hearts are in the work.

It is very important that our nurses who come here should not be critical. We need most capable women for this service, nurses who can do not only the technical skilled work but women of good personal appearances. Our nurses are watched with critical eyes. . . Knowledge of Italian is almost imperative.

Three hospitals maintained upon the British and American system were mentioned in letters and reports to National Headquarters from American Red Cross murses in Italy. One was at Florence and was directed by an English nurse, Miss Baxter. A small American hospital had also been organized and financed at Florence by an American teacher, Miss Sheldon. The third was the Ospedale Iolanda at Milan, which had ten pupil nurses.

Previous to 1917 the American Red Cross conducted practically no relief activities in Italy. I)uring the summer of that voar the collapse of Russia permitted the transfer of many German divisions from the eastern to the western and southern theaters of war. On Octoher 21,1917 , the Austrian forees, reönforeced by the Germans, struck at the Italian lines on the northeastern bomendaries of Ttaly, broke through at Plezzo and Tolmino, took Tdine on Octriber 30 and were advaneing on to the Venetian plains. The Italian Army withdrew to the Tiave River and there during Norember and becember dog- 
gedly held strong defensive positions in some of the bitterest and most gallant fighting of the European War.

The Italian Retreat to the Piave River in the fall of 1917, caused, however, the evacuation of the civilian population from the entire northeastern thumb of Italy. Half a million refugees fled in complete demoralization to the central and southern provinees and to sicily. From the invaded territory went 208,213 refugees; from the areas cleared for the new fighting zone went 87,552 others and from the distriets in constant danger from enemy air raids went 131,009 more. Among these homeless, sick and often wounded old men, women and children was opportunity for the Ameriean Red Cross to render assistanee which was needed.

During the summer of 1917 the American Red Cross had sent a commission to Italy under George F. Baker, Jr., of New York Citr, to ascertain whether or not American relief would be weleomed. 'This commission returned to Washington in October with a report which the military situation rendered out of date almost before their boat landed.

When word of the Piave Retreat reached Rome, Mr. Page, then American Ambassador to Italy, eabled to the War Council and wirel Paris headquarters for help. National Headquarters immediately placed half a million dollars at his disposal and Major Murphy, commissioner for Europe, dispatehed to Italy an emereney commission under Major Carl Taylor, one of the original deputy eommissioners for Europe. This commission immediately undertook temporary relicf measures; in the Lnited States the organization of a permanent commission which had already been initiated with Colonel Robert P. Perkins, of New York City, in command, was speeded up.

American Red Cross relief to Italy was confined ehiefly to hospital, ambulanee and canteen service to the Italian Armies at the front and to the relief of refugees from the Venetian plains. To the Military Establishment the Italian Commission distributed 951,000 articles of supplies, ineluding ten complete field hespitals and more than one hundred field ambulanees and drivers. Thirty-there canterens wore operated in Italy for the henefit of Italian and Allied troops. In the field of eivilian relief, five refuger eolonies were established in which $27 i t$ persons were cared for: three hospitals and three dispensaries were maintained: ss workrooms were operated in which 9057 persons were given emplovment and $1,+11,10$. 
garments were produced; 50 food kitchens were set up and an average of 28,664 rations were daily served from them. Uncooked food supplies were furnished to 424,600 persons. This work extended to 141 Italian towns and to thousands of villages from the Alps to Sicily. ${ }^{45}$

American Red Cross nursing service in Italy was confined chiefly to work of an educational nature. Even if Italy had welcomed emergency nursing relief, the supply of American nurses was too limited to have rendered possible any extensive development of such a service.

Early in November, 1917, the temporary commission called upon Paris headquarters for "an executive nurse for Italy" and Niss Russell assigned Pauline Jordan, then in Paris awaiting a problematical assignment to Roumania. Miss Jordan was a graduate of the New York Hospital and had served as anesthetist with the Carrel Mission to Roumania early in 1917, an account of which will appear later.

Miss Jordan arrived at Rome on December 2, 1917, and five days later wrote Miss Delano:

From the nursing standpoint there is nuch work to be done. This includes the manufacture of surgical dressings and the opening up of new workrooms for this purpose; a certain amount of hospital and day nursery work; the establishment of a hospital at Rimini for refugees threatened with varions mild epirlenics; canteen work and visiting nursing among the refugce population.

I expect to leave at once for Florence and Genoa to open surgical dressings workrooms. I have been allowed to telegraph to Paris for two nurses to take charge of these and we expert them in a few dass. Whether we shall be sent to Rimini in connection witli the establishment of the Refugee Hospital remains to be seen.

The policy of the acting American Rerl Cross officers is against the introduction of American nurses. I $\mathrm{I}_{\mathrm{p}}$ to the present time, the policy has been to donate money and supplies to the rarious Italian women who are the nominal hears of Italian organizations.

Alice Fitzererald, whose name has already appeared many times in this history, was sent from Paris to open the Rimini Refugre Hospital. She wrote:

${ }^{45}$ For further details sefo "The Story of the Ameriean Rerl Cross in Italy." Charles M. Batkewell, The Macmillan Company, 1920: also "The Work of the American Rod Cross During the War: A Statement of Finanees and Aceomplishments," PI. 6S-7.2. lied Cross Lilorary. 
On December 19, with three other nurses, I started for Rome. Eight days later another nurse and I proceeded to Rimini, a town on the Arratic ('oast where the American Red Cross was carrying out an interesting experimental piece of work among the Venetian refugees.

The broal general lines of this work consisted in trying to keep families, relatives and friends togetler as much as possible and to remore with them their tools, looms or whatever equipment or implements were necessary to their particular means of earning a livelihood. These people were to be settled in such a way that they could continue as nearly uninterruptedly as possible their work-as if they were still at home in Venice. When the military situation was so altered that they could return to their home, they would thus not have lost touch with their families, relatives, friends, and particularly their work.

Tumerous rommittees had this scheme in hand and distribution of food and rlothing was being made to them. The care of the sick was just beginning to take form and the Commission for Italy planned to start at Rimini a health center from which rare could be sent to outlying districts either through visiting nurses and doctors or by the estabhishment of small dispensaries and infirmaries. My particular mission in the city was to help organize and start the American Red Cross Hospital for Venetian Refugees.

When we arrived in Rimini in the early morning, the snow was thick on the ground. ${ }^{46}$ The next morning we were driven out to the hospital which we found had been established in a large building on the seashore. This building had been erected as a summer home for tuberculous ahildren from the mountain regions of Italy . . . and was nothing but windows and boors. The cold poured in from all sides. There was absolutely no means of heating the rooms, either by stoves or fireplaces, and the patients already in the hospital were actually blue with rold in their beds. Hot-water bags did not remain hot long enough to take off the chill and the piling on of blankets sarcely adled to the comfort of the sick man or woman or dhild. Conditions were indeed desperate and our very first effort was to obtain stowes and have them put up in as many of the warks as we rould. The one other nurpe was wonderfully plueky and did not complain, but I know she suffered as much as all of us did.

"This tremendous and for the Allies providential snowfall closed the open winter which had greatly aided the Peutonic offensives, impaired the German lines of fommunitations and prevented the enemy from eapturing vital new passes and emptring their armies onto the Venetian platins through strategie positions already held. 
Little by little conditions adjusted themselves. The hospital ran to full capacity and our work spread to many miles around. On February 13, 1918, I was recalled to Paris. . . .

The Rimini Hospital, which was known as the Ospizio Comasco, had a capacity of one hundred and fifty beds. American Red Cross nurses served as supervisors and fourteen Italian girls who had been employed in the Venice Civil Hospital for some months acted as aides. Five male infermieri were on duty in the men's wards. On May 1, 1918, the professional staff was increased to seven American Red Cross murses and a nurses' home was opened in the Villa Tonti. The Rimini Hospital had many acute cases, especially during the influenza epidemic, and about one hundred and fifty patients died. During the year of its operation, Ospizio Comasco received 1533 patients.

The permanent Commission for Italy arrived in Rome on December 20, 1917. Colonel Perkins had appointed Sara E. Shaw to membership on his staff. She had been in charge of the tuberculosis division of the social service department at Bellevue Hospital and he wished to utilize this previous experience in comnection with giving temporary relicf in Italy. However, the Nursing Service at National Headquarters was loath to allow a murse to serve at this particular period in any but a professional eapaeity, so Miss Shaw was appointed chief murse of the Italian Commission and Miss Jordan was reealled to Paris headquarters and assigned to duty in France. Miss Shaw was a graduate of the Bellevue School and had served as a Red Cross murse on the Lampasis.s Expedition and also six months in Manila during the SpanishAmeriean War.

In a final letter of instructions written November 28, 1917, to Miss Shaw, Miss Noyes outlined the polieies which were to govern the development of American Red Cross nursing serviee in Italy:

Italy is a hig country . . and we do not know how rou will approareh a study of nursing conditions with a riew towarl makiner perommendations to us in this comntrs. You must lear in mind. howerer, that the demands now facing the Red ('row Nursing servite-to med all the military needs of the hase bospitals in liance the cantonment hospitals in this country and the public bealth work we are doing in for- 


\section{NURSING SERVICE TO CIVILIAN POPULATION 863}

eign countries, with the least possible disturbance to civitiun hospritals and other forms of nursing work in this country, puts no small task upon our shoulders. It would be quite impossible, of fourse, for the American Red Cross to assume the mursing in rivilian hospitals in foreign comntries. They minht take up a definite piece of public health work, in connection with directors and supervisors of institutions, but thore are not enough nurses in America to supply other countries of the workl with a professional nursing staff.

During the first weeks of January Miss Russell sent nine murses to assist Miss Shaw in Italy. National Headquarters organized a mnit of sixteen others and they sailed from New York in April. Katlerine C. DeLong, a Canadian woman and a wraduate of the Johns Hopkins School, was head nurse of this detachment. Previous to the Italian assigmment, Miss DeLong had filled many executive positions at the Johns Hopkins Hospital and had becn superintendent of residence both at the Johns Hopkins and at the Bellevne Schools. Other murses were sent to Italy from the United States and Paris Headquarters mitil Miss Shaw's staff finally numbered thirty-seven mirses.

Miss Shaw's first major project in Italy was the establishment of a Nurses' Center in Milan. On April 22, 1918, she wrote Miss lioyes:

My activities have been raried. I have risited many military hospitals and have been very cordially received. The Marchesa (astelnuovo, who is at the head of the Italian Red ('ross for this section of the comntry, has been a gooul friend and advisor to me and so also have some of the Italian medi(al ofticers.

The need seemed to be more for hospital sipplies than for nulses. 'The volunter nurses are well orcanized and are really doing excellent work. There seams no place suitable for our trained women to render definite emergency sorvice. This is the reason for our plan of a Nurse's c'nter and I have serenred a pensione which is now in the throes of being relenet and remodeled for this murpose.

In one sparate division we have fifteen private hespital

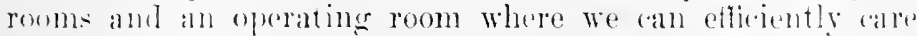
for one own Ameriean fores or where we an late fareilities

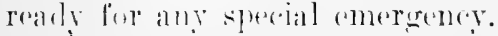

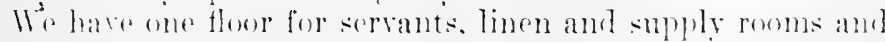
a beantiful cellar where food can he stored. Cunother thom 


\section{HISTORY OF AMERICAN RED CROSS NURSING}

is nsed for the nurses. We have a reception room, lecture hall and library, demonstration room and dining rooms. There are balconies on each floor.

We do not say we are establishing a training school; this would be objectionable to Italians who were prone to organizing work like this lefore the war. But the idea of conferences appeals very much, so we are to have conferences and lectures by prominent doctors. The Italian women who are supervisors and heads of each hospital will come to the conferences. 'The demonstration room will always be open for demonstrating various American methods of caring for the sick.

This plan for conferences will aid in the distribution of hospital supplies. Many things of which they do not understand the use are made in our workrooms and we will demonstrate the use of these dressings. By this plan it seems to us that we can be of greater help than if we were lost in one little hospital.

The American nurses at Milan undertook many other types of war service in addition to that at the Teaching Center. Miss Shaw described them in her letter of April 22:

There is also big work to be done in the distribution of hospital supplies. We have cleaned up several rooms in a famous old palace and there seventeen Italian women sort dressings and fill hospital requisitions; two of our American Red Cross nurses are on duty here. Each of our numses is now preparing a suitcase of sterile dressings and necessary instruments and if a call comes for nurses for an emergency service, they can pick up their case and run. Tone of us have wasted time waiting for work; we have certainly found plenty to do. We make up gift packagres and distribute them in hospitals and every month we meet the prisoners of war returned on exchange from Austria.

The uniforms of the American nurses were a source of keen interest to the Italians. The nurses had white tailored dresses made after the pattern of the one-piece serge dress and wore them with the eape and eap for dress parade, a combination which greatly appealed to the color-loving Italians. "Onr borts," wrote Miss I MeLong to Miss Noyes, "seem an mending somere of ammsement to the natives and they cross the strects to read the lettering on onr brassards." 
From the Nurses' Center at Milan, the infiuence of Miss Shaw and her nurses extended to other parts of Italy. In view of the attitude of the Italians and the limited number of American nurses, they were placed only in hospitals and dispensaries where they would have a wide radius of influenee.

The Commission for Italy established and maintained six hospitals, two of them for refugees; the Nurses' Center and Hospital at Milan; a hospital of twenty beds at Padua for the Air Forees of the American Expeditionary Forees in Italy; and an American Red Cross Hospital in Rome.

The first refugee hospital which was established at Rimini, has already been described. The other was situated at Canicattini Bagni, in Sicily.

This drowsy old town of fifteen thousand inhabitants was situated fifteen miles from Syraeuse and received, as did all the eities and villages of Sicily, immediately following the Piave Retreat, large numbers of refugees from the Venetian plains. Need had arisen for a hospital, so the mayor of Syracuse asked an American woman physician, the wife of an Italian surgeon then at the front, to take charge of it. She moved into the improvised building, named it the Martha Washington Hospital and on March 1, 1918, the institution came under the dircetion of the commission. Additional equipment was given, the director was appointed as the Ameri"an hed cross representative for that district and the commission maintained it for a year, during which time two hundred and serenty-two patients were received. No American Red Cross nurses were assigned, however, to the hospital.

The Ameriean Red Cross Naval Hospital at Genoa was situated in a villa at lido d'Albaro. Four American Red Cross murses, three muns and seven naval hospital attendants were assigned to duty there. Early in September, 191s, the lospital was talien into the Military Establishment. Doring the period of its operation as a Red Cross hospital, fortr-nine patients were reereived.

The Ameriean Red ('ross at Padua, which was operated for Ameriean aviaters from the valrous camps near Pallua, was situated in a wing of an old moiversity building. Miss shaw sent a murse to oreanize and operate it in Oetober, 1!15, but the influenza beame virulent in the camps and six arditional nurses were plated on duty to are for the hundred patients sent in from the aviation centers and the 3332 nd liegiment of 


\section{HISTORY OF AMERICAN RED CROSS NURSING}

the American Expeditionary Forces. The hospital was operated until April 1, 1919, and received a total of one hundred and thirty-two patients. Additional American Red Cross nurses were detailed to service in aviation and hydro-aviation eamps at Foggia, Bolsena and Porta Corsini.

The American Red Cross Hospital at Rome was established to care for all American workers in Italy who needed hospitalization. It was beantifully situated on the two upper floors of a large building fronting the Pincian Gardens, and had a thirty-five bed eapacity. Four American Red Cross nurses and two Italian aides composed the nursing staff. During the three months of operation following its opening on August 22, 1918, fifty-six patients were admitted.

A convalescent home for sick ehildren with a capacity of twenty-eight beds was established at Taormina and was known as the Casa dei Convalescenti. It was staffed by American Red Cross nurses and Italian aides. A local Italian physician attended to the medieal needs.

The Commission for Italy operated nine dispensaries which were nuclei for public health nursing serviee and ehild welfare work. These dispensaries were located at Cesanatico, Bellaria, Chioggia, Genoa, Florence, Naples, Avellino, Villa San Giovanni and Taormina. In the establishment and maintenance of these dispensaries the American Red Cross worked entirely through loeal Italian eommittees. Each of the members of the Dieci per Uno, the organization which sponsored the dispensary at Genoa, assumed responsibility for the eare of ten children. At Florence, the dispensaries took the form of three Aiuti Materni. American Red Cross public health nurses were in eharge and did-district visiting, distributed eggs, milk, broth and layettes. ${ }^{4 \tau}$

In June, 1918, the Italian Armies, strengthened by reënforcements from the British and French, lamehed a comteroffensive against the 'T'eutons which resulted on November :3 in the complete collapse of Austria-Ilungary. With the changing fortunes of war eame a substantial lessening of the need for emergency relief. The American Red Cross Commission for Italy then looked ahead toward the formulation of a more constructive prosrame.

${ }^{47} \mathrm{For}$ a complete list of the various assignments of Ameriean Red Cross nurses in Italy, see "Reports of the Departments of Military and Civil Affairs, American Red Cross in Italy, Jannary, 1918-April, 191!," Rerl C'ross Jibrary. 

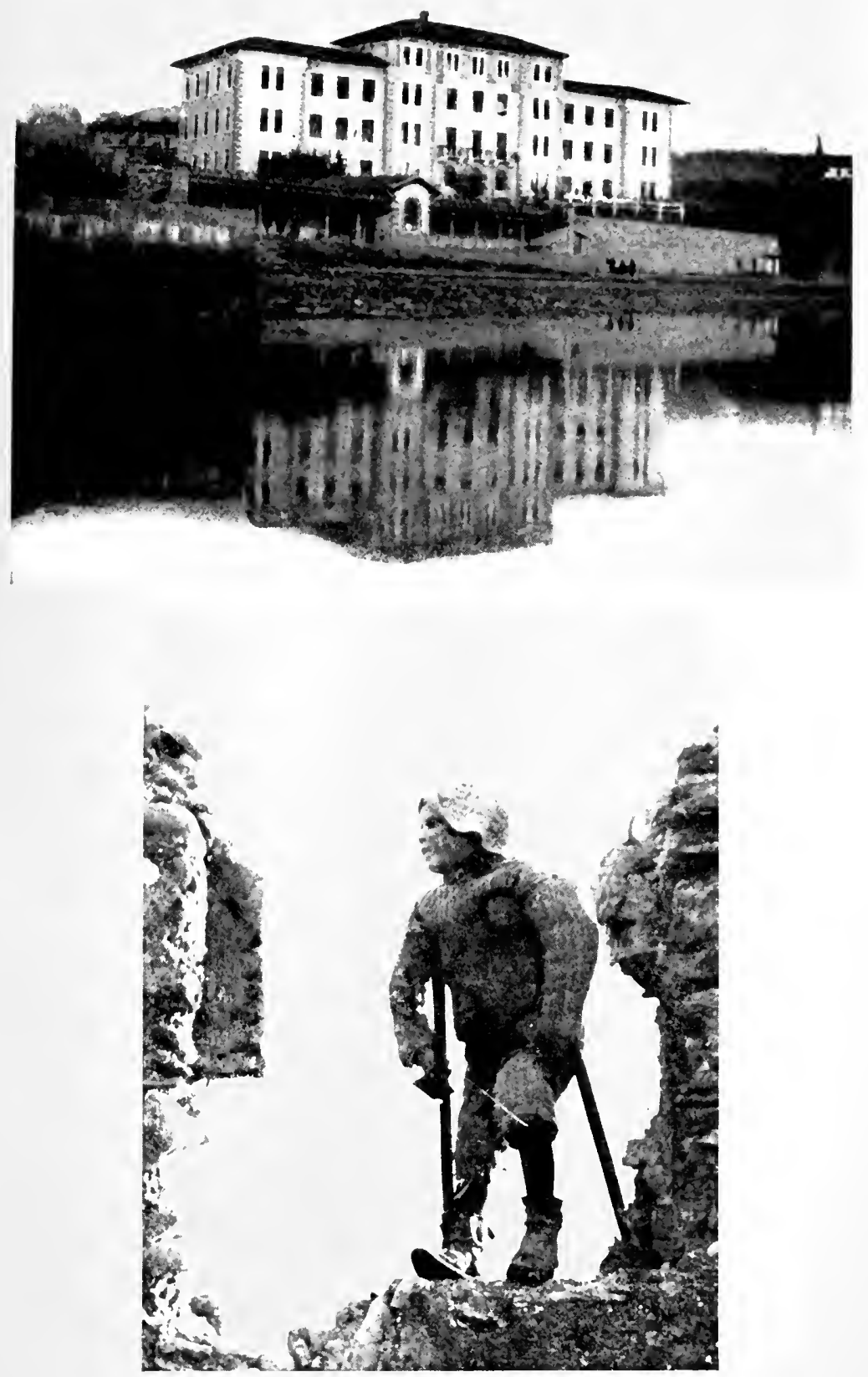

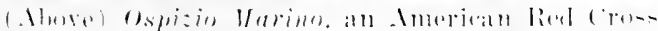

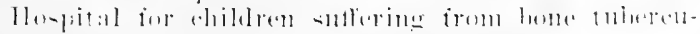

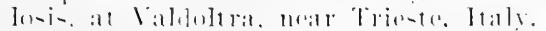

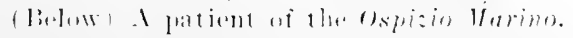




$$
\text { . }
$$


During the epring of 1918, Dr. Farrand, director of the Rockefeller Conmission for the Prevention of Tubereulosis in France, and I)r. William ('harles White, director of the Tuberenlosis Bureau, Anerican Red Cross in France, made a health survey of Italy with a view toward the inauguration of an anti-tuberenlosis campaign in Italy similar to that undertaken in France. Also Dr. Joseph Collins, Major, Medical Corps, U. S. A., and director of Iledical Affairs of the (ommission for Italy, made an independent study of health conditions. As a result of the recommendations of these men, $\mathrm{Na}$ tional Ifeadquarters appointed in September, 1918, the American Red Cross Committee for Tuberenlosis, with Dr. White as the director and II ary S. Gardner as chicf of the Section of Public Health Nursing.

Miss Gardner needs no introduction at this point in this history. Full biographical material regarding her signal contribution to the Anerican mursing profession may be found in the chapter on American Red Cross Public Health Nursing Service-a more appropriate field for such an account than this section, which deals primarily with American Red Cross military nursing serviee. However, the military program in Italy was closed by the demonstration made by Miss Gardner of American methods of public health nursing service.

Miss Gardner and fifteen public health murses sailed for Italy early in September and initiated a special educational project. The emergeney nursing activities, such as the operation of hospitals, surgical dressings workrooms, were gradually bronght to a conclusion. Miss Shaw, Miss JeLong and many of the first detalehments of Ameriean Red Cross nurses in Italy returned to the Enited States during the spring of 1919.

The specialized phase of nursing service known as public health nursing was a derelopment, purely, of the British and Ameriean mursing professions. It did not exist in Italy. In the supplementary Report on Nursing, General Report of the Anerian Red cross Commission for Tuberculosis in Italy, Miss Gardner wrote of the Italian situation:

Home visiting is done to a small extent by nums and in some instances nursing are is given by them to the patients in their homes. Fonally surh rare is male secomelary to the dispensing of material relief and the giving of spiritual (omfort or instruction. Home visiting is also arried on from a number of dispensaries hy groups of rolunterers, many of 


\section{HISTORY OF AMERICAN RED CROSS NURSING}

whom do excellent individual work. Knowledge and skill are, however, gained only by experience and in all these efforts which have been studied the usual limitations of rolunteer work have been erinced: namely, an insufficiency of time spent, an absence of training and a lack of work caused by the call of other duties. In one group dealing with tuberculosis patients, all work stopped during the influenza epidemic (a time when an added vigilance was required), not because the workers themselves were ill but because, being mothers and wives, it seemed mwise to run the risk of contagion for themselves and their families.

The general policy of the Commission for Tuberculosis was that it should work only with Italian committees and only upon request from Italian communities and organizations desiring American coüperation. The Section on Public Health Nursing followed this policy. Italian and American public opinion hung on the outcome of the Peace Convention of Versailles. Although enthusiasm for America and American ideas then ran high in Italy, the entire situation was one of extreme delicacy and continued so until the elose of the Italian program.

"The problem," wrote Miss Gardner, "seemed two-fold, the creation of a desire for the work and the creation of a group of workers. The former involved the stimulation of groups of Italians to a conseionsness of the need for public health work, a stimulation which must be earried to the point of formation of committees. The latter involved the training of a few carefully selected Italian women to act as pioneers and teachers in the new ficld."

In the selection of these Italian women who should aet as pioneers, three fields of supply were open to the Commissionthe muns, the infermiere and the Italian Red Cross and samaritanu murses.

Among the volnnteer nurses then being demobilized after a war service of from one to three years, however, there were many women who hat loved their work as nurses and who were gland to continue it upon a remmerative basis.

Miss Gardner summarized the work involved in the training of these women:

In the first place an enlightened Italian committee must be formed. willing to work hard and capable of sulfirient elasticity of thought to permit the grasping of mumiliar 
ideas; a committee also from whom permanency of work could be expected. A single eourse offered by American nurses, with no hope of successive courses, would avail but little.

In the second place a gromp of workers must be found possessed of the pioncer spirit and the type of ability likely to insure success.

In the third place Italian doctors and other lecturers must be secured and intereted in the new ilea.

In the fourth place a field for practical instruction must be developed by the American nurses under wholly Italian auspices.

In the fifth place the market for the produet must be stimulated that positions might be ready for the newly educated workers.

Under these plans, three courses were initiated, the first at Rome through a committee organized under the anspices of the Federation of Women's Clubs; a second at Genoa through a sub-committee of the Lega Antitubercolare della Provincia di Genova; and a third at Florenee. The sehool at Rome opened on March 17, 1918, with sixteen students and the sehool at Genoa on April 2 with fiftecn. A plan for a school at $\mathrm{Pa}$ lermo was initiated but later was given up. The sehool at Florence was begun on November 10 but the eourse was not completed.

The instruction covered a period of four months. The first three were given up to lectures and to field and practical work; the last month was spent entirely in field work. Miss Gardner described the nature of the instruction given:

One Amerixan nurse is in charge of each school while six others in each city act as instructors in dispensary work, school and home visiting. All the eincational work is under the direction of one colucational head. Lectures are given by Italians, though American doetors also lecture through an interpreter. Conferences are held by American nurses. I)ieteties and invalid cooking are tameght by both Amerioan and Italian teachers. the Italian teacher being lont by the Ministry of ludustry. The courses of study differ somewhat in the different rities, but the following subjerts are tanght in all: history of puhlie health nursines theory and methods. of public health work; tuberemlosis nursing: ehils welfare nursing: solhool hygiene nursing: dietutics: obstetrical murving: diseases of the skin, of the eye of the ear, 


\section{HISTORY OF AMERICAN RED CROSS NURSING}

nose and throat; sanitation; housing, with one or two lectures on Italian mortality and morbidity statistics.

... In Rome the course is held in two simple rooms formerly stores, and in Genoa at the Tuberculosis Institute and at the University. ...

An interesting comment upon the courses in Rome was contained in the following letter, written by Winifred Terni de Gregory, president of the Lombard Branch, National Association of Italian Nurses, which was published in the open columns of the British Journal of Nursing:

... Usually foreign Red Cross societies, while giving their nurses excellent scicntific training and a great deal of practice in operation theater and surgical wards, have so far never given real systematic teaching in the art of practical nursing.

What our excellent Italian Red Cross nurses know on the subject. they have found out for themselves or learned from English books, never having had professional Matrons or Sisters to teach them, and until lately the subject of practical mursing was not included in the Red Cross curriculum. Now I am happy to say, a new curriculum has been compiled at Red Cross Headquarters which gives a prominent place to the teaching of practical nursing. But most foreign nurses (except those trained in English training schools) know very little on the subject and when a public health course for Italian Red Cross and other nurses was arranged in Rome by the American Red Cross, at my suggestion a great many lessons on bed-making, washing of patients and other mursing details were inchuded in the conrse, with great benefit to the students and ultimately, I hope, to the patients.

The possibility of developing publie health nursing in the small Italian hill towns was a project in which the American Red Cross took keen interest, owing to the pioneer work done in the Inited States in this field by Miss Clement, Miss Gardner and Miss Fox.

A study was made of two typical Italian towns, Sezze and Piperno, situated fifteen miles apart above the Pontine Marshes. Miss Gardner summarized the results of these studies:

If Sezze and l'iperno are at all typical of other small Italian town-and we have reason to bilieve that such is the case - it sems jortable for the small tomens of laly, 
That the services of a good public health nurse would be warmly welcomed by the people.

'That there is great need for such service for bedside nursing, for dispensary and school work and for general home instruction on health matters, also for assisting the people to obtain for themselves more modern health adrantages along various lines:

That it is going to be diffieult to induce an Italian uurse to accept the limitations and discomforts of small town life.

That the community as a whole woull probably be quite as rearly as the more backward American towns to coöperate in the nurse's efforts for improvement, thongh in this statement an understanding of the difference between Italian and American standards must, of course, be taken into account. The doctors will, as in America, prove the importance of the personal equation. Some will be found coöperative, the others the reverse.

That the average small town will not readily understand the necessity of paying a sufficient salary to secure the right type of woman for public health nursing work.

As may be seen from these results, the possibility of developing rural public health nursing in Italy in 1919 was not a promising one. "For the moment probably the most effective expenditure of money and effort for public liealth work," concluded Miss Gardncr," "will be in the citios and larger towns. Later the small town work in Italy can modoubtedly be developed as has been rural and county mursing in England and Ameriea, bush nursing in Australia and back block nursing in Now Zealand. Mcamwhile, nothing can be done without the worker. The heart of the diftionlty would, therefore, seem to be in the problem of nursing education."

In June, 191!), Miss Gardner returned to the United States and Edna Foley took her place as chief nume of the Ameriom Red C'ross 'Tuberenlosis Commission for larly. Mise Foley was released from the superintendeney of the Instructive Visiting Nurse socicty of (hileago to midertake this foredgn serviee. As a member of the National Committere she had for many yoars taken a kecu interest in Ancrioan lied cross numing service.

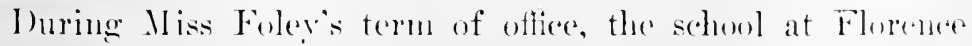

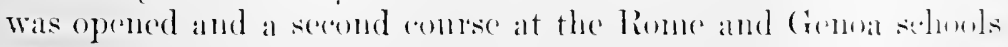
was completed. Poublic health nurses were assigned to duty in

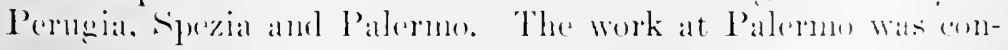




\section{HISTORY OF AMERICAN RED CROSS NURSING}

dueted by the Lega Antitubercolare, a local society organized by Dr. White's commission. Mary Gallagher and Isabelle Hall were on duty at a tuberculosis elinie there. "Dr. Lazzaro, the chief of this clinic," wrote Miss Foley in her report of September 12-October 25, 1919, to the Commissioner, "said he considered the work of these two Red Cross nurses the biggest gift of the American Red Cross to Sieily." Miss Foley's report contiuued:

Late in August Miss Hall succeeded in establishing a clinic for well babies. . . . There were more than forty babies the opening day and a large attendance at every clinic. Miss Hall left a young lalf-trained Italian girl in her place. She was much afraid that the clinic would not survive, for its Committee, like all other organizations for social endeavor, is poor. We have seen porerty all over Italy, but that in Palermo seems to haunt the streets. The babies are particularly starved and sickly looking.

A visiting nurse was employed in a country district near Perugia and her round of duty covered three small villages.

The American Red Cross completed its nursing activities in Italy on December 31, 1919, and withdrew from the country. A final gift of 36,000 lire was made to carry on the sehools; 9000 lire each was given to the Scuola Infermiere Visitatrice at Rome, the Lega Antitubercolare della Provincia di Genora and the Scuola Infermiere Visitatrice at Florence; 4800 lire to the Lega Antitubercolare di Palermo and 2400 to the Lega intitubereotare dell' L'mbria at Perugia.

In a letter addressed on November 11, 1919, to the American Red C'ross Commission to Europe, Miss Fitzgerald, then ehief' nurse of the Commission to Europe and herself a resident for many years in Italy, summarized the schools of nursing which were organized by the American Red Cross:

The work done by Miss Foley and her staff ronsisted of (arrving on the course of instruction established by Miss Gariner for the purpose of training young women in visiting nursing and the arm of patients suffering from tubereulosis. It has bern fory np-hill work to obtain the coöperation necessary for sucessifully carrying on these courses. particularly from the mention profession, which in Italy is still opjosed to the higher enduration of nurses. 


\section{NURSING SERVICE 'TO CIVILIAN POPULA'TION 873}

Committees of prominent women have been formed in Rome, Florence and cienoa and these have fulfilled their obligations . . . to the extent of providing alass rooms for the conrse and interesting themselves gencrally in the work. However, this interest is not strong enough to influence the medical profession subliciently to obtain for these sturlents the field work necesiary to complete their training. Sonte dispensaries have been willing to take these students for a cortain number of lays a week, but the doctors have refued to allow the nurses or the students to do any follow-up work or to visit the patients in their homes. 'This the doctors rlaim would never be tolerated by the people, but as a concession they admit that later on an Italian nurse might be allowed to do the visiting work.

This lack of coöperation from the doctors necessarily limits the scope of the training and this has been conspicuous in Rome. In Genoa the doctors have been more helpful and the graduates of the first course have found positions in dispensaries, clinies and schools. . .

From Octoler, 1918, we have had in Italy Miss Gardner, Miss Thompion and Miss Foley, all three of them women who rank high in our nursing profession and who are specialists along public health lines. They have worked hard and have been deeply interested in their work. I feel, however, that educational work of this kind has not found appreciation in Italy, but I hope 1 may be mistaken in this. so far the work has resulted in educating less than twenty women ... and the great difficulty is to obtain positions for them after their stullies are completed. The medical profession is not ready for assoriates of this kind and naturally the demand for such workers must cone from them.

Miss Fitzgerald summarized the long struggle whieh had taken place in Italy for the higher edueation of unuses:

The history of the attempts to educate nurses in Italy is one of great discouragenent. . . Attempts to rum training schools along the lines of Ameriean and britisle trainine

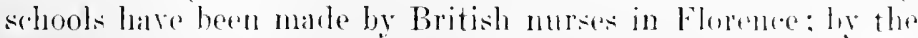
Queen of laly herselt. at a higr hospital in lome where sereral wards were given over to an Eselish-trained nurse: hy a graduate of the John: Hopkins School, in Naples; and hy the

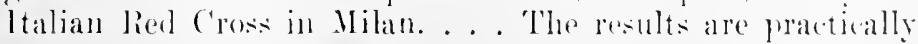

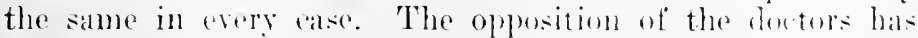
continued: to this has been acklent the ill will of both men and women of the servant class of nurses who now do the nursing 


\section{HISTORY OF AMERICAN RED CROSS NURSING}

in Italian hospitals; and the well-established control by nurses. This opposition is represented by a very large body of people, none of whom wish the reform as each one fears a personal loss of prestige and privileges.

It has been suggested at different times that the approach to the nursing problem in Italy and in France should come through the religious body. It is interesting to note that this was attempted in Florence; two muns were sent to the training school in Rome for the full three years' course. Upon their return to Florence, they immediately took sides against the trained women and went back to the opposition, thereby showing the uselessness of this mode of approach.

The only ray of hope I can see is in the Italian Red Cross, which, I believe, intends to start training schools and has already placed on a salary basis nurses who are now acting in an official capacity for that organization. This is alrearly a step in the right direction, as the Italian Red Cross formerly insisted that all nursing should be voluntary and in no wily did the society recognize the necessity for trained and salaried persolnel. line.

It is very apparent that Italy needs no help from us in this

Thus was ended the work of the American Red Cross in Italy. The seed of modern nursing which the American Red Cross attempted to plant in Italy at great cost fell into barren soil, but may in the future take root and bear fruit. Promise of this future development is contained in the following notice which appeared in the Foreign Department of the October, 1920, issne of the American Journal of Nursing:

The three courses in public health nursing estahlished by the American Red Cross Tuberculosis Commission in Italy are meeting with well-deserved success. When the American nurses were withdrawn in January, people prophesied that the courses might be closed, but the farrully selected and organized Italian committees have proved themselves more than able to meet any emergencies and the shorter courses in Rome and Florence are hoth to be repeated. A new course is being opened this month in Nilan by the Italian director of the Rome course and the more anbitious ten months' course which is being oflered in (ienoa (doses this October. Letters from Italy tell us that the graduates of all three conrses are in such demand that there ore constantly more positions than candidates. The murses who saw the hardships of the primitive 
life in the southern part of the peninsula will be interested in knowing that one nurse has been placed in Calabria, three in sicily and more will be sent south as soon as they have completed the special training. . . .

Miss Gardner epitomized the Italian situation: "Italy must work out her own nursing salvation and it must be an Italian salvation worked out by Italians in an Italian way."

Roumania perhaps suffered more during the European War than did any other nation, with the exceptions of Serbia and Siberia. She was faced on the sonth by the Bulgarians, who were smarting under the outcome of the Second Balkan War and desired to recover the lands of Dobrudja lost under the Treaty of Bucharest; on the west by powerful Austria-Hungary : and on the north by Russia, an ally in whom Rommania hat little confidence. For two years she had remained an island in a whirlpool of war, but on $\mathrm{A}$ pril 28, 1916 , she joined the Allies.

The kingdom of Rommania then oceupied the ereat plan which sloped from the Carpathian Alps to the Black Sea, a plain covered with rich alluvial deposits similar to the famons Russian "black carth." The shape of the country resembled the letter "I." The provinee of Dobrudja oceupied the leg of the letter and fronted on the Black Sea. The principality of Wallachia formed the left arm and extended westward. "The principality of Moldavia formed the right arm of the letter and extended north between Austria-1Inngary and Russia.

The eountry was chictly agricultural. In 1900 Rommania was the third laresest grain-growing nation in the world. She possessed rich oil and roal deposits and iron, coppere lead, nirekel, mereury and other metals in quantities sufficient to make mining protitable. However, the Romminan tomperament did not incline toward industrial life. The oil tiolds of Wallachia had been developed to considerable extent lye foreign apital. Rommaniar's chiof expolts were timber from the oak, pine and berel forests of the ('arpathian momutain slopes, potrolenm and grain. She inported notals. malchinery, textiles and other mamufactured necessitios of medern life.

In 1:11t the population of Rommania numberel apploximately seven and a half million people, of which six million

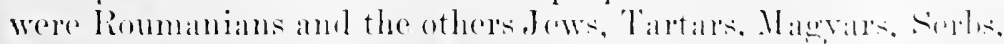
Bulgars and Armenians. The Rommanian clement was sharply 


\section{HISTORY OF AMERICAN RED CROSS NURSING}

divided into two elasses: the wealthy land-owning aristocracy who possessed a eulture similar to and largely derived from the French, and the peasant group who were made up for the most part of simple unedueated folk who tilled the grain fields and herded the flocks. A middle-elass industrial or merehant group similar to that in the United States did not exist.

In 1914 Rommania found herself in an extremely diffieult politieal position. She had gone in 1877 to the resene of Russia, then hard pressed by the Turks at Plerna, but was rewarded by the deprivation of the provinee of Bessarabia and was given a part of worthless Dobrudja as eompensation. Roumania's independence from Turkish sovereignty was, however, established, and in 1881 the country was proclaimed a kingdom. Prince Charles of Hohenzollern-Sigmaringen was erowned King under the title of Carol I. During the thirty years' reign of Charles and his poetess-queen, "Carmen-Syivia," the era was one of national prosperity and economie and civil development.

During the first Balkan War of 1912-1913, Roumania remained nentral. When peace negotiations were begun, Ronmania claimed that she was entitled to territorial compensation from Bulgaria for her neutrality and demanded eession of the town of Silistria, realignment of the frontier of Dobrudja and cession of a strip of eoast territory on the Black Sea to permit her to develop a naval base. The Second Balkan War was declared before these claims had been settled. Roumania put her armies in the field, occupied Silistria and by July 1:3, 191:s, had approached within twenty miles of the Bulgarian eapital. An armistice was then signed and by the Treaty of Bucharest, Rommania obtained what she had claimed but also the enmity of her sonthern neighbor, Bulgaria.

When the European War broke out, King Charles desired to join the ('ontral Powers, lut Rommanian public opinion was in srompathy with the Allies, so the comntry remained nentral. Kine (harles died on Octoher 10, 191t, and two rears later, his queen died. The suceessor to the throne was Ferdinand, a nephew of charles and a romuger brother of Prinee William of Hohnenzollern-Aignaringen. Ferdinand had married Marie, daughter of the lonke of Saxe-Colnurg and Cotha and granddanghter of (2uexu Vietoria, a woman of umsual heanty and strength of ("laraceter who had won the love and svinpatly of the Roumanian penple. 
Roumania declared war in April, 1916, and in the summer her First Army invaded Transylvania, captured Kronstadt and Hermannstadt and by September 9 were holding nearly onefourth of Transylvania. General Von Hindenburg with 450,000 veteran troops was then sent by the German IIigh Command to crush Roumania. The opposing armies met at Hermannstadt and in four days of fighting the Roumanian First Army was annihilated. General Von Falkenharn made a rapid enveloping movement, came np in the Roumanian rear and ent off their retreat through the Red Tower Pass. The Roumanian forees were thrown into disorganization and retreated in eomplete disorder and with great losses.

On the south the Bulgar and Gorman fores were also pressing forward. General Von Mackensen entered the Dobrudja. Russian reënforeenents failed to arrive and Roumania was then "like a nut in the jaws of a nutcracker." 48 Von Falkenhayn was pushing down from the north and Von Mackensen up from the south. By Angust, 1917, the Tentons were in complete possession of all of Rommania except Moldavia.

In little more than a rear Rommania had lost her two richest provinces and at least two hundred and fifty thousand men, forty per cent of her original army. Mnch of its equipment and ordnance had been captured by the enemy.

Government and Arny Headquarters and the Court evacuated Bucharest and tled to Jassy, the former eapital of Mboldaria. This eity wats also the headquarters for the Russian Armies operating on the Remmanian Front. Jassy had normally a population of about seventy thousand; this in 1917 was more thin doubled. As also the refugees from the two oecupied provinces had fled to Moldavia, this least rich of the Roumanian provines's thus was alled upon to support the Cosernment officials, the Rommanian Army of four lundred thousand. the refugees who numbered about half a million and the Russian Army which at me time aggregated about one million men.

The winter of 1916-1917 was one of the most severe on record: the the mumeter often registered thirty degrees below zero. Cattle. hersese and sheep died for want of food. People were found deat from starvation and expesure in the strects of the cities and ind duguts, stables and huts in the contutre. In December, typhus began to spread among the devitalized popu-

".A Reference History of the War," I. S. Cuernsey, p. 162. Dodil. Mead \& (o., New York, 1920). 


\section{HISTORY OF AMERICAN RED CROSS NURSING}

lation. During the winter and spring 230,000 persons died of disease and by the summer of 1917 Rommania had lost from war casualties and diseases seren per cent of her entire population.

Both from an economic and professional point of view, Roumania was not prepared in 1916 to give to her sick and wonnded soldiers and to her typhus-ridden civilians sanitary serviee comparable to that which prevailed in the British Empire and the United States. Three types of hospitals existed in Ronmania: those established by the Roumanian Red Cross; those by the Rommanian Army, and those by Queen Marie.

The hospitals of the Roumanian Red Cross maintained the highest standards in earing for the wounded. They were usually of five hundred bed capacity and were generally located in a school building which had been taken over for use as a hospital. The equipment was the most liberal and the food the most adequate of any hospitals in the comntry. This superiority was due to the fact that the Rommanian Red Cross was a wellestablished and generonsly-supported organization. Also, the most prominent surgeons were associated with this group of hospitals. The nursing service was rendered by Red Cross volunterer nurses, untrained according to the English and American standards, but deroted and tireless in their ministry.

The hospitals established by the Rommanian Army were generally located in newly-constructed wooden barracks. The beds were of wood, the mattress of straw and one sheet and two blankets were furnished to each patient. The capacity of the hospitals locited at important strategie points ran as high as 2000 beds. No women nurses were emploved in this group.

The hospitals of Regina Maria were usmally to be found in the smaller villages and towns. They had been established and were supported by the resolute Queen Marie.

In september, 1916, a French medieal mit under the direction of Dr. Dehelley was sent at the request of the Rommanian Goverument to Jassy, to demonstrate the Carrel treatment of wounds. One of the nurses was Pauline Jordan, the Amerivan Red C'ross nurse who was later sent to Italy; she had been on duty since 1914 at the American Ambulance at Nenilly. The Carrel Mission arrived in Bucharest in the fall of $1: 16$ and a letter written ly Miss Jordan on April 22, 1917, to $\mathrm{M}$ iss Delano, gave an 'xecellent picture of conditions existing in many liommanian hospitals: 
We were given a pavilion of the best hospital at Bucharest but it was hardly ready for patients when the city was evacuated. Arriving at Jassy, we were placed in a Roumanian hospital.

There were no "murses" here, only ladies who came in to see that the domesties did their work properly. l)uring the six weeks that we were in the Rommanian Ilospital at Jassy, we did most of the dressings under great difficulty. 'The dressing room was rowded with sisters of Charity, boy scouts, medical students and many young girls. As we had over six hundred patients and about four sets of instruments and only one alcohol stove, the work was never completely finished.

There was no heat and the food was very poor. Our prin(ij)al diet was corn meal mush and goats' cheese, black bread and oexasionally beans. Once a day we had tea and twice a week meat. During the winter we cared for patients. whose feet had been completely frozen while lying in bed.

The Carrel Mission was soon moved into their own hospital, a building formerly used as a school for orthodox priests. Miss Jordan wrote:

We found it umbelievally dirty and with the poorest of sanitary arrangements. The wounded were alive with vermin and we had no supplies. When the severely wounded came in we had almost nothing to work with. They lay on straw mattresses withont rubber sheets and the straw quickly became contaminated with pus and blood, but we hat no fresh straw A great many of them died from exposure and septic infection. I remember the amputation of the arm of two patients. Which was caused by bandages applied too tightly before they ame to us.

There are one or two huge Roumanian stoves in each warl, but we have had almost no wood or coal to burn in them. We have hal biting Russian winds and ieides hung from the windows in the wards all winter and the wombled used to ary to us: "Give us a fire, we are freezing, we are dying of cold!:" We have operated for days when onr breath almost conguled in the cold air. Of course we have had a great many cases of pneumonia. There rarely was ever more than one blanket to each bel.

There are no hasins for the patients to wash themselves in, no towels and they have been withont nightgowns for weeks. There simply int anything in the comtry and the supplies which have been ordered have either been sunk or lost in 
Russia. The food for the patients consists of thin soup twice a day, black bread and occasionally beans. From time to time we have had a little condensed milk and macaroni for the sickest patients. Our food is the same, with the addition of potatoes and meat twice a week. As French offieers, we are permitted to buy meat once a week. The Queen sent us some rice, macaroni, sugar and tea and the American Legation has been very kind to us indeed so we have managed to live through the winter. The patients are all suffering from malnutrition.

No doubt you have read of the frightful typhus epidemic. The hospitals are full and at present the autlorities are building rude barracks on the outskirts of the city for them. People have died by the thousands and all the hospitals are overcrowded. . . .

Upon admission, the blessés are bathed, shaved and rubbed with petrol. When they eame to us, they received a second petrol bath on the streteher before being put in bed. 'The floors are washed with petrol onee a week and beds and mattresses scrubbed regularly, but on account of the dirty maids and militia, one never feels safe. Life here is a continual fight against the vermin. In spite of precautions we find them occasionally on our clothing. They are absolutely. colorless and have tiny black erosses on their backs.

In a letter written to Miss Delano on August 5 from Jassy, Miss Jordan commented again on the nursing situation in Roumania :

The Roumanian offensive has started brilliantly, but has been forced to stop owing to the Russians. . . Hospitals have been organized all along the line of the prospective offensive, some of them only five kilometers from the trenches. . . .

There alre five of us graduates now and we sit day after day making surgical supplies . . mattresses all neatly turked in. envelope-fashion, while many other hospitals have neither the supplies nor the people to make or use them. This is our great trial. A mit will come ont and take over the direction of a hospital of one hundred to three hundred beds. In that one hospital, everything will be as nearly perfect as existing conditions will allow, down to the smallest compress. while in the rest of the country the very essentials of life and death are orerlooked and all is confusion. We have so often recretted having been able to do so little goorl in a country where the need is so great. 
The greatest lack seems to be nurses. There seems to be none except a few who have come out with special units and cannot leave them. In these Roumanian hospitals, practically any woman who wears a cap is allowed to do surgical dressings and operating-room work. All other work is ronsidered uninteresting and is left to servants. One wishes that the nurses could be scattered about where the need is greatest.

The Roumanians seem to have a profound respect for our training and look upou us as a new sort of doctor.

The intense cold from which Roumania had suffered had been replaced by equally intense heat. Miss Jordan's letter eontinued:

At the present time, the lieat is almost mulsearable, 107 degrees in the sharle yestorday afternoon at five o'clock. There has been an epielemic of dysentery and many people, enfeebled by disease and naluutrition, have died. 'Typhus has practically disappeared and the body-louse also, but the flies have taken their place and are an abomination.

Of the hospitals established in Roumania by foreign units, Miss Jordan wrote:

We have been ahle to visit some prison camps, also a few well-equipped lospitals. One was managed by a French doctor who designed and arranged a splendid mechanotherapy room, also a home-made sterihzer made of cement and heated by wool, for quilts and mattresses. The British lied Cross has a very good hospital at loman. Nearly all their furniture, beds tables. chairs and sandals have been made by convalesent pationts under the doctor's direction. It the present time his patients are building a sort of rough swimming tank. He was far-seeing enough to plant a garden in the spring and now their own table is well supplied with green vegetables, a rare luxury.

Of the military situation in August, 1917, Miss Jordan wrote:

For the past week. we have heen ready to leave on an hour's notice. The Russians are refusing to tight and are rapilly retreating from Bukuvina. which endangers our line of rommunication to kief and l'etrograd. The rest of Roumania will then be aiftures, we fear. A train left resterday with the Eanglish civilian colony and one is learing to-norrow 


\section{HISTORY OF AMERICAN RED CROSS NURSING}

with the French. The legations and the Court expect to leave in three or four days. We have received the order to stay on for a few more days and will evacuate with the Army, by rail if possible.

The authorities have begun to give us the food supplies for distribution to the population. The greater part of the civilians have decided to stay in the country, preferring to be prisoners rather than to live with the Russians. . . .

To such a situation, the American Red Cross sent its first Roumanian relief unit in September, 1917. The American Red Cross Commission for Rommania had been under process of organization in the United States since early that summer, under the leadership of Lientenant Colonel Henry W. Anderson, of Richmond, Yirginia. Dr. Francis Peabody, an expert on internal medicine, Bernard Flexner, a sociologist, Dr. Gideon Wells, a pathologist, Dr. Robert C. Bryan, an expert in surgery, Dr. lioger G. Perkins, a sanitarian and Arthur G. Glasgow, an engineer, were the principal new members of the commission. It was the intention of the War Conneil that these men should make a survey of Roumania and then return to the Lnited States with a report on which to base future Red Cross relief work.

The medical and nursing unit was to remain in Roumania for emergeney relief work. Dr. Kirkpatrick, who served with Dr. Ryan at Belgrade in 1915, was the director. Florence M. Patterson was chief nurse. Miss Patterson's name has already appeared in this history in connection with American Red Cross nursing service in Great Britain and France, but her Rommanian assigmment marked the begimning of her subsequently long and vahuable field service.

The nursing unit was composed of eleven nurses in addition to Miss Patterson and contained among its members many remarkable women whose names stand high upon Red Cross rolls-Thachel Torrance, Linda K. Meirs, Katherine Olmstead and Alma Fuerster. Other nurses of the unit were Adelaide Rowland, Mary Mrolntire, Beatrice Gosling, Alice Gilbourne, Mary Brownell and Jenuie Donald.

The Rommanim Commission mobilized in Chicago on July 2s, 1917, and sailed from Vaneonver five dars later for Yokohama, Japan. From Japan the muit proceeded to Vladirostek, thenere to Harbin and westward by special train orer 
the Trans-Siberian Railroad to Moseow and thenee to Jassy. They arrived in the Rommanian capital on September 16, 1917, after a journey of fifty-two days.

Supplies were sent by the Ameriean Red Cross via the Pacifir ronte and a second considerable consignment to Arehangel, Russia, for shipment sonthward to Roumania.

After a month spent in survering Moldavia, five of the commissioners returned to the Lnited States and submitted detailed reports to the War Council of the economic and sanitary situation of Romminia. ('olonel Anderson and the members of the eommission who remained in Jassy immediately nullertook emergency relief work. This fell into five general groupshospital serviee, public health and sanitation, civilian relief, transport service, and nuiscellaneous relief. Carloads of food were brought down from Archangel, Petrograd and Noscow and were distributed to the Roumanian population. In Putna, Tekuehin and Bocan, 40,000 persons were fed daily by the American Red Cross, and a canteen was opened in Jassy where for two months meals were daily given to 2000 persons. ${ }^{49}$

The Commission for Roumania maintaned a hospital at Roman and dispensary service at Roman and at Jassy. The hospital at Roman was the former British Red Cross IIospital described by Miss Jordan and was known as the Prince Mereca Iospital. Major Kirkpatrick, dircetor of the medical mit, gave the following realsons why the commission took over this institution :

Firstly, the hospital equipment that we expected from Ameria by way of Archangel had failed to arrive and we were unalie to equip a new hospital with the limited emergency supplies we himl brought with us across siberia.

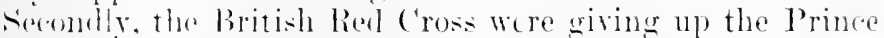
Mereea llospital heabe of an overworked staft. 'This hospital was equiflued sufficiently for good surgical service. . .

Thirelly. Romann was so loceated in relation to the armin: that the hueprial drew from a harese section of the fromt, with a minimum of delaty in transportation of the wounded.

Fonrthly. we covild begin work at once.

In her final report to Miss Noyes, Miss Patterson weote of their experionces:

6..The Work of the American Red Crose luring the War: A Statement of Finances and Acemplishments," p. so. 
We took orer the Prince Mercea Hospital on October 6, 1917, and until March 8, 1918, we were always sitting on the edge of a volcano which never erupted. We had to be ready to move within an hour provided the Huns came or if the Russians signed peace or (much more probable) if the Bolsheviki attacked us for food supplies. We had, as you know, no offensive after we arrived but when we took over the hospital from the British Red Cross, we "inherited" about 400 patients and from then until we left we had between 380 and 500 cases. Most of them were wounded who had been evacuated from hospitals nearer the front (an entirely imaginary term as far as the Eastern Front is concerned!). Also, we har civilians and even women and children when we had empty beds.

As we had inherited the hospital from the British, it was more or less well equipped and, indeed, we should have had a sorry time except for the unstinted way in which the British and Russian Red Cross helped us out all along. The equipment which was shipped from the American Red Cross reached Roman the latter part of November and even then was quite inadequate for any sort of a hospital.

The nurses lived in two small wards of the Roman Hospital. Miss Patterson wrote:

The nurses all considered their quarters quite comfortable, although they had nothing except their beds and one or two small tables and several chairs. The beds were boards with straw mattresses, but not at all bad.

Of course the food proposition was much the most difficult. for there was nothing to be purchased in Roumania. Fortunately the potatoes were splendid and we were able to get a good supply stored away for winter. We were able to get no meat after lecember 1 and had no canned meats. but in true Roumanian fashion. we had a small farm in our back yard, which we sturked in the fall with sereral pigs. ('onsequently, we went on marl debanches sereral times by having a pig killed, but we always ate it with the foar that we minht need it worse bater on. We had macaroni. rice and plenty of butter whirh "ame from the Russian lied Cross and roffee from the I. S. A. which seemed really to save our lives.

There was practically no milk in the onntry because there was no forkter for the rows and during the last few months we had about ten quarts daily for the entire bospital and some days nome at all. We probably had an averaere of two dozen egers for the cutire hospital. The patients had meat 
twice a weok but in almost infinitesimal quantities and fearfully bar, simply starved animals. 'The other articles of food were heans, ahliagr and potators. How those patients managed to recover on that dint is still a puzzle to us-loor we harl nothing else eren for the desperately ill men. It is quite imposible to tell how alsolutely destitute the country is, with neither fool nor alothing.

For the peasants we have the utmost sympathy. They are splendid and are the one hope of Rommania, except queen Marie, who is womlerful. She and Princess Marie had Thanksuring dinner with us at the hospital . . . and when we left she asked us in trals to tell the women of America how she had tried and how she would continue to fight to the end: "We English never give up."

Early in January, 1918, the commission started an outpatient department at the Roman Hospital. Miss Patterson wrote:

Our most interesting work was the out-patient department for civilians. We did general relief work in comection with it and ato some nursing in the homes, an unheard-of thing there. The starvation diet and complete absence of soap among the civilian population, together with the general prevalence of renereal diseases, soon made our clinics known as the S. S. S. (soap, sulphur and salvarsan).

I should say that erery child and about 85 per cent of the patients had salbies. lie distributed soap in small pieces, but of course the whole effort was futile nuder existing conditions. The peasants had practically nothing to eat except cornmeal, which (onstitutes a large pirt of their normal diet. so you can imagine the amount of resistane to disease they had. When a patinut would semingly he doing well. he would without any apparent reason rin a fearful temprerature and just go all to prieces. Sho we really never knew until

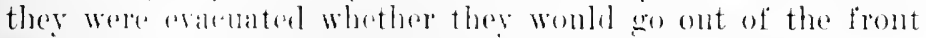
door or be arried ont of the hardi:

Within three days at ('hristmas time, we had list hernia ases come in lor operation (1 never dial make ont whether or not it was an epidemiar). but these were pratetieally the only "lean atses wo saw while there and many of these weren't

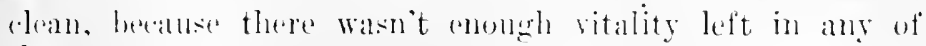
them.

Late in 1917 the armmission devoloped plans for astallish-

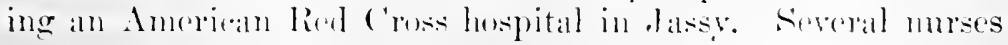




\section{HISTORY OF AMERICAN RED CROSS NURSING}

of Miss Patterson's group were sent from Roman to organize it in a building loaned by the Government. Before it could be equipped, however, the Government decided to utilize it for military quarters. "That project was ended before it began, fortumately for us," wrote Miss Patterson, "for to be perfectly frank, there was no equipment in sight!"

The typhus epidemic in 1917 and 1918 was thought to be somewhat less violent than during the preceding years. Though the conditions faroring it-overerowding, filth, lice, exposure, starvation and lowered vitality-persisted, the winter was less severe and this one factor saved many lives. The body louse continued to be a trying pest. "Bathing facilities in a Roumanian village," wrote Major Kirkpatrick, "are alnost nonexistent. If you ask one of the peasants whether he has lice, he will probably look at you in surprise and say: 'Am I dead, that I should have no lice?" "

In Oetober, 1917, the Russian Govermment under Kerensky was overthrown and the Bolsheviki eame into power. The Russian Armies in Roumania collapsed and in December negotiations were opened between the Central Powers and the Russian authorities with a view toward a separate peace. Roumania was violently and persistently opposed to a separate peace but national amihilation faced her. An armistice to continue for sixty days and to be terminated by seventy-two hour's' notice was signed on December 9. By Mareh 1, 1918, the Russian Army had gone out of existence. With her own small forees Rommania conld not hope to hold her extended battle-front. General Mackensen then delivered two nltimatums to Roumania: either to enter into a separate peace or to be overrum by the German Armies and complotely destroyed as a state. On Narch 8, 1918, Roumania signed a preliminary treaty of the humiliating peace which was subsequently forced upon her.

One of the terms of this preliminary treaty was that all Allied reliof missions should leare Roumania: they were to be given three days' time for departure. On Marcli $\dot{9}$ the American Red Cross Commission started, in a train composed largely of second-class sleeping cars, on their long journey from Jassy to Murmansk. Huring the thight northward, which lasted four weeks, and the time-three weeks more-at Murmansk waiting for a ship to "arry them to England, the exeellent morele of the nurses never Hageret. They did all the eooking, the cleaning 
and washing and met the situation with equanimity. Miss Patterson wrote:

Onr experiences sound much worse than they really were, for we had the nicest people in our car, Colonel Anderson and Major Kirkpatrick and our nurses. . . We have lived in a peace and harmony which makes any hardship tolerable and erery one has seren something funny in it all. We have had a wonderful service and incidentally a splendid schooling in adapting ourselves to an entircly new system of raluation, a sivtem which has tanght us that one can be healthy, haply and more or less sane with very few of the commonlyaccepted necessities of our normal American life. . . It has been, however, most disheartening to sit by and wateh the stearly breakdown of the Eastern Front and at the same time to get very little authentic news of the Western Front and none from the Lnited States.

The commission arrived safely in England in April, 1918, and the majority of the nursing members remained for duty there or were transferred to France. Miss Patterson wrote:

We are all feeling quite like Rip Tan Winkles, vet it is certainly nice to be back in civilization and above all else to find some of our Allies with the bit in their teeth. Many people here sem to feel that they are in rather lesperate straits lut to us the whole of England is a fairy-land and the Fuglish sem to realize it and are making little complaint. Their spirit is splendid and gives one an entirely new backbone after living with Orientals for so long.

Mary MeIntire, another nurse of this unit, wrote Miss Noyes:

I (annot realize I an hack where we have plenty of food. English literature and "green gras growing afl aromul." It was womlerfut to see our boys reviewed in Lomden, to wateh the enung of twenty-three Ameriean ships on the high seats. to see the leneh dirigibles horering over us. Neser have I loved the frion orek so much as when we saw those destroyers speceling out to us in the North siea.

This is a terrible time to live and the whole world seems: just nue ereat heartarhe. yet it is a womlerful time Whon we lankleal in Enerland. We were struck by the silent and parnest ethiciency of every man and woman. Rusia and Romminia were 
Syria, the key to the East and the Turkish province in which Palestine was situated, occupied in 1914 the long strip of comparatively habitable land lying between the Mediterranean Sea and the Aralian Desert. On the sonth it tonched Egypt, on the north and on the east the Turkish provinces of Aleppo and Mesopotamia. For almost seven centuries Syria had been ruled by Turkish masters though they had always remained hated strangers to the polyglot Syrian population.

Syria in 1914 was peopled largely by Arabs, Armenians, Maronites, Druses, 'Turks and Jews. The Arabs numbered some three million sonls and occupied the whole of the comntry except for a few mountainous districts. By religion, the Arabs were followers of Islan and had absorbed into their faith numerous mongrel tribes. The mountainous regions of Syria, especially Lebanon, were held by some three hundred and fifty thousand Maronites. They were Christians and as Christians reconciled with Rome, had for some centuries been under the protectorate of France; they had thus absorbed much of the French culture. Parts of the Lebanon and Damascus regions were occupied by the Druses, a fierce and predatory Moslem sect numbering perhaps two hundred thonsand. The Jews were to be found in Palestine.

Syria was comparatively a poor country, the soil outworn, the hills cleforested, the rainfall meager, the heat intense. She was poor in minerals and water power and the native industries of textile-making had been practically swallowed up by the importation of cheap Enropean-made products which had also destroyed the foreign market for the Syrian textiles.

North of Sirria lay Kurdistan, inhalited by wild and lawless semi-named tribes, Mohanmedans by religion and shepherds and robbers by trade. North of Kurdistan were the lofty monntain ranges and plateans, rich in mudeveloped mineral products, and the fortilo hill slopes and valleys of Armenia.

Ammenia I'ropere, as this monntainous platean was called, was bonnded on the north by the Black Sea and Transeancasia, on the east by Persia, on the sonth by Mesopotamia and Persia and on the west by Asia Minor. The Armenians were in prehistoric ages a short, lark, non- Aryan race. In modern times this strain still formed the hasic peasant type, though Aryan conquerors had long since impressed their language on the country and their blood upon the upper classes. The true Armenians were mostly peasants and artisans, possessed of in- 
telligence, adaptability, marked commercial aptitude and a strong instinct for mantaining their racial integrity. In 1914 the Armenians living in the Cancasian regions numbered about one million two hundred thousand, those living in P'ersia abont fifty thonsand and those living in Asia Minor under Turkish rule about one million.

The Armenians had suffered from massaeres by the fanatical Turks since 1s:\%). In 1914 the Turkish Goverument adopted a policy of wholesale massacre and deportation of these people to the coast cities of Syria. In addition, thousands fled to these cities-Aleppo, Beirut, Acre, Jaffa, Jerusalem and Port Said. Syria, a poor land, conld not support them and they died in great numbers from exposure, disease and starvation. At the same time the native population suffered to an almost similar degree.

Turkey declared war on Russia on October 30, 1914, and on England on November 5. Turkey occupied a position of strategic importance in that as long as the Central Powers, of which she was one, controlled the Dardanelles, the Allies would be unable to get supplies to Russia from the south. Military actirities in the southeastern theater fell into five principal campaigns-the Turkish offensive in the Caucasus, the Gallipoli Campaign by British and French forces, the Turkish attack on the Suez Canal, the British advance on Mesopotamia, and the collapse of 'Turkey. Early in 1917 the British began a "ampaign from Eeypt northeastward through syria. (On lecember 10, 1917, General Sir Edmund Allenby, in command of British, Indian and "Anzac" troops, entered .Jerusilem.

In 1915 Dr. Edwin St. John Ward, formerly of the Medieal Department of the Sirrian Protestant College at Boirut, was asked by the 'lurkish Govermment to make a survey of the Jerusalem lostrict and the harren regions to the somth as far as Beershelal. Ile and his party fomed the (o)untry pratetically destitute of professional nodical and mursing serviee. The importation of foreden products had practionally arased and the resourees of the combery were insuffiedent to support the treenendonsly intated pepriblation. Slow starvation fared both the native and refuene popmlation, espereially in Palestine.

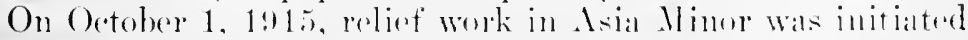

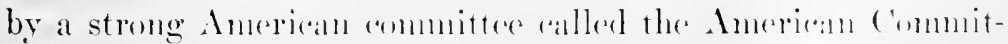
tee for Armenian and sirian lielief. This rommittor appealed 


\section{HISTORY OF AMERICAN RED CROSS NURSING}

to the American Red Cross during the early summer of 1917 for financial aid and the minutes of a meeting of the War Couneil, July 23, 1917, record the following action:

The chairman stated that in a letter dated July 18, 1917 (D. R. P. 56), Mr. R. S. Lovett, chairman of the Committee on Coopperation, had presented an application from the American Committee for Armenian and Syrian Relief, dated July 5, 1917 (D. R. P. 59), asking that the Red Cross War Council appropriate to that committee for its relief work in Western Asia, the sum of $\$ 300,000$ per month for the remaining six months of the calendar year.

He further stated that the American Committee for Armenian and Syrian Relief had during the period, October 1, 1915 , to April 1, 1917, raised $\$ 3,400,000$ to carry on its work and that as its administration expenses were met privately, the committee was mable to derote to distinctly relief work one hundred cents on every dollar received for the purpose; that at a conference held last February attended by $\mathrm{Am}$ bassador Morgenthau and the foremost authorities on IVestern Asia, figures were presented showing that there were no less than $2,1+4,000$ persons in Western Asia whose death could be prevented only by direct and continued help and that on a minimum allowance of ten cents per day for foor, $\$ 6,000,000$ per month would be required to support these people until they could be restored to their homes on a self-supporting basis.

He further stated that Ambassador Elkus had reported that the lied Cros: was not allowed by the Turkish Government to arry on relief work itself within the Turkish Empire and that the American Committee for Armenian and Syrian Relief was the only organization ontside of the Red Crescent (controlled by the Turkish Government) in a position to administer relief to the starring Armenians and syrians and certain portions of the Greck population in the Turkish Empire; that Imbastalor Elkits had ascertamed from the state Department that there was apparently no danger of interferene by the Turkish Govermment for the present at least. with the work of the American ('ommittee for Armenian and Syrian Relief, and that in order to safeguard its interests the former assistant treasurer and three member's of its ('onstantinople Commistion laal been made attaches of the swerlish Lecration now representine American interests in Turkey.

lle further stated that the rharman of the committee on Coöperation explainded that the discrepancy between the amomit resuired. nimely, $\$(6,000,0000$ per montl. and the 
amomit asked for of $\$ 300,000$ per month was due to the fact that many of the necdy people could not be reached and the realization that demands would be made npon the American Red ('ross for so many other worthy objects. 'The rhairman of the ('ommittee on ('vöperation further recommended that the grant of $\$ 300(0000$ per month to be made from month to month at the pleasure of the War Council insteal of for the remaining five months in the calendar year as requested in the application, as there was a possibility of the Committee's work being interrupted. . . .

At this meeting the War Comeil voted that the sum of $\$ 300,000$ should be appropriated for the month of July, 1917, for use by the American Committe for Armenian and Syrian Relief. Sinilar appropriations were made each month for the remainder of the year 1917 .

During the period from July, 1917, to February 28, 1919, the Ameriean lied Cross contributed to the American Conmittee for Armenian and Srrian Relief $\$ 4,500,000$ in money and $\$ 1,4+4,032.54$ in supplies. ${ }^{50}$

The taking of Jerusalem by the British in December, 1917, opened Palestiue to the Allies and remored in the portions of Srria then moder British military control the restrictions which the Turkisl: Covermment had plaeed upon independent Ameri('an Red Cross activities.

In a letter addressed to the War Comncil on Jamary 23, 1918, the American Committee for Armenian and Sirian lieliof stated that "a considerable sum of money had recently heren contributed to the above committee from Sunday schools for nse in Palestine and that in view of the advantages that would acerue from having the work behind the British Lines conducted in coüperation with or under the name of the Anerican Rod C'ross, an carly conference with that society was requested to eonsider some plan whereby the best results could be seeured in relief work in Palestine and other countries." At a meetine of the War Comeil held on .Jamary 2!! this letter was discussed and plans were approved for somding an Amerian hed ( ross anmmission and modical mits to l'illestine muder the loadership of lir. St. dohn Ward, then serving as a member of the Aneriean lied ('ross ('ommission for France at Jaris headpuarter's. The Commission for l'alestine, with

so."The Work of the Amerien lied cross during the War: A statement of Finances and Acomplishments." p. si. 


\section{HISTORY OF AMERICAN RED CROSS NURSING}

Dr. Ward as deputy commissioner, was appointed by the War Comneil at a meeting held Mareh 7, 1918. On April 17, 1918, Dr. John H. Finley was appointed commissioner for Palestine.

The persomel of the commission numbered fifty-four people; ten of these were American Red Cross nurses, six were surgeons, three were sanitary engineers and the rest were social service workers, teachers and assistants of various types. "Twenty-three members had been either missionaries, teachers or persons with some previous experience in the near East," stated the Anmal Report, 1918, of the Palestine Commission, "and sixteen had been stationed in Syria, Palestine or Egypt."

The nursing staff was solceted by the Nursing Service at National Headquarters. Edith Madeira was chief nurse. Miss Madeira was a graduate of the Hopkins Sehool and a woman of wide travel and broad interests. She had gained administrative experience in her profession as superintendent of nurses of the Howard Hospital in Philadelphia and at the Mountainside Hospital, Montclair, New Jersey. Morenver, she was a publie health uurse and had served as Superintendent of the Visiting Nurse Associations at Harrisburg, Pennsylvania, and at Waterbury, Connectient.

The nurses of the Palestine Commission were Ellen M. Hamilton, Edith M. Maslam, Katherine Macklin, Frances Mr.Quaide, Anne L. O’Malley, Jessie G. Paterson, Olive Ranger, Jillian M. Spelman and Enma M. Wood. In September. 1919, five additional murses who had all had service in the Near East and spoke Arabie, joined Miss Madeira's staff. They were (Nrs.) I.illian Cole Sewny, Beatrice Areher, a graduate nurse whom the British Reel Cross lomed to the erommission; Ruth Edly, Sara Faisermann, a grouluate of the College Hospital, Beirut, and a Mrs. Abramson, another British nurse.

Relief work in a comntry as primitive and destitute as Syria in $1: 117$ offered diffirulties not to be eneountered in eountries where Oceridental nuetlonds of travel and standarts of living prevaled. In addition to the peralation expipment for medi-

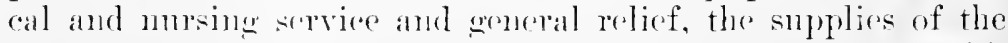
l'alestine (omminseion included twenty motor transpent rehireles, complote madlinery for road-making, trantors, stram pumper refrigrating and hoisting machines, plumbing, air-

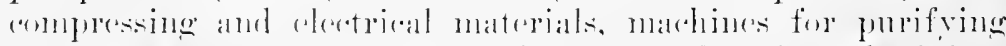
watel and thominuls of feet of galvanized and stcel piping, 
sewing machines, plows, hand-cultivators, hoes, rakes and shovels.

The Commission for Palestine sailed from Now York City on March 13, 1918, on their long journey around the Cape of Good Hope to Cevlon, then areross the Arabian Sea and north throngh the Red soa and the suez Canal. They arrived at Port Said on Imne 11 and entrained for Jerusalem.

General Allemby made his headquarters in June, 1918, at Ramleh, thirty miles west of Jerusalem. General sir Arthur Money, formerly chicef of staff under General Mande at Bagdad, was chief of the Oecupied Enemy 'Jerritory Administration and Colonel Ronald Storrs was military governor of Jerusalem. Colonel Storrs turned over to the commission the old Russian Hospital with its annex and half the large Men's IIospice within the Russian Compound and also a large residrnee, the "Lord Bute IIonse," which was located just outside the south gate of the ('ompound. These buildings had been used by the Turks as military hospitals but had been noeeupied since the British captured the Holy City.

The nembers of the commission arrived in Jerusalem on June 18 and literally "dng into" the aceumulated filth of their new quarters. The "Lord Bute House" was used for administrative lieadquarters and the former Men's Hospice for the living quarters of the personnel of the commission. "This is a picturesque old building," wrote Miss Madeira to Miss Noyes, "and has gardens and lovely corridors."

The Russian Hospital was opened on Angust 22 after heroie labor. The angineers of the eommission had been fored to go down into the sewer drains themselves to show the amateur plumbers how to work; the skilled mechanies in Jerusalem were then serving with the Turkish Army. Workrooms were established in the andens and native women wereset to work pulling ont the stuttinge of the mattresses for disinfection, then restutfing and resewing them. The nurses direseted the work of scrubbing and whitewashing the wares of the hospital. In a report sent to Miss Noyes on September 20, Miss Madeira wrote:

The hospital hulding is two stories high and has huge halls rumbine the full bength of the bulling with hierh,

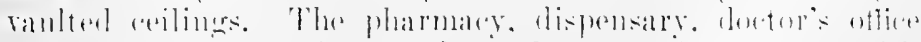
and a lihrary are on the first flore, also two private rooms with 
bath and a large bathroom where all patients receive their initial scrubbing on admission to the hospital On the first floor are also the operating, sterilizing and dressing rooms. Wards accommodating fifty patients occupy the second floor. Altogether it is an up-to-date hospital and is being run as such.

Miss Mequaide is in charge of it. Miss Eddy, Miss Kaisermam and Mrs. Sewny are head nurses. Miss Wood has the operating-room and Miss Archer is night supervisor. There are eight native nurses and three orderlies.

The work of the Russian Hospital was almost entirely surgical. Many of the native farmers and the refugees engaged in agricultural work in the Jerusalem District were injured through the accidental explosion of shells lost or left by the armies in the open warfare which was earried on in Palestine. This method of warfare as opposed to trench tacties, prevented close salvaging of the battleficlds. During the seven months of its existence, the American Red Cross Surgical Hospital in Jerusalem treated a total of 668 patients, of whom 402 were surgical and 266 medical cases. The death rate was 3.7 per cent. One of the most complete and valuable phases of this hospital service was the bacteriological department, of which Naney Hamilton was in charge.

The British Forces had laid out extensive plans for the American Red Cross commission, eren before Dr. Finler and his staff arrived. The work dealt entirely with the civilian population. One of the first projects undertaken by the commission was the assigmment of an American Red Cross nurse to the Turkish Municipal Hospital, of 65 bed eapacity, at Jerusalem. Miss Macklin was detailed to duty there on June 24 and she gradually brought order out of chaos. Miss Madeira wrote:

Miss Marklin found disorder and filth to be the principal difficulties. Exery hall and corner was packed full of rubbish intermixed with a thin layer of useful things that har? to be sorted ont. The equipment was meager but has been supplemented slightly by requisitions and larely by the reelemption of pitchers, hasins. (oups, plates and similar artickes picked out of these rubhish heaps.

The lambly was reported to be a week hehind with it: work, lut it took more than a month and three lanulresses to orertake that "week." This laumlly should be seen to be 


\section{NURSING SERVICE TO CIVILIAN POPULATION 895}

appreciated. It is a room in the basement. There is a device for drawing water and a curious depression where water accumulates. The work is lone by women sitting on the floor with huge, flat copper tubs, like round Engrish bathtubs, in front of them. II ere they dabble the clothes around in a little water and, from all alpurances, have never been in the habit of rinsing them. Miss Macklin has greatly improved conditions here and the clothes are assuming a less dusky hue.

Cleanliness reigns in other departments, too, and the patients are naturally responding. There are eight native nurses, with no training to speak of and no irleas of responsibility. Miss Macklin has found them ambitious to learn and very teachable. A native doctor is in charge of the hospital.

Extensive dispensary and publie health nursing service was maintained in Jerusalem and the outlying regions. Early in July, Red Cross phrsicians were assigned to visit the different deserted convents and other buildings where the refugees had taken shelter. Miss Ellon Hamilton, one of the nurses, was assigned to go with one of the doctors on his rounds, and together they established the begimnings of a traveling dispensary service. 'This service was given at the Carmelite Convent on the Nomnt of Olives: the Franeiscan Monastery on the road to Bethany; the Bueharlea, which often had six hindred inmates at one time: the Creck Hospital and schools; the Convent of the Holy Cross; the Russian Convent; Bishop Gobat's school, and David's Tower.

Miss Marlicra described the manner in which this service operated :

The Mukhatar, or head man of the place or of the particular siroup of refugese gathers together all the sick at a time and place designated by the doctor. When he and Miss IIanilton antive, he examines them and preseribes treatment. She treats the eyes, makes the dressings and assists him. so that the service is just like that griven in a dispensary. Any persons who ale too sick to come to the appointed place are visited by the ductor and murse.

The Burblartea. a large group of buiblings in the . Tewish Quarter, is one of the principal centers of this type. As it seremerl in a worse endition than the other's and was overcroweled. we malertexk intemsive work there. Two roms:

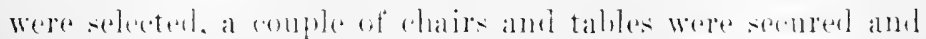

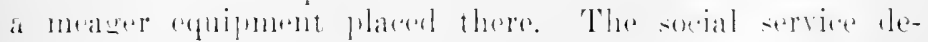

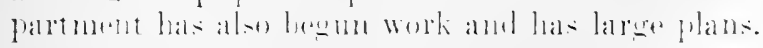


The medical and nursing service provides in addition to the dispensary service, a place where milk can be prepared and fed to babies. thus preventing the father from drinking it himself or selling it. Miss Haslam has been appointed to serve here on full time. She has a native helper who also interprets for her. She distributes quinine, treats eyes, prepares milk and sees that the babies consume it.

At the Franciscan Monastery the dispensary service was held outdoors. "There was no suitable place inside," wrote Miss Madiera. "In one room four goats and a donkey were found living contentedly with a large human family."

One of the most ambitious undertakings of the commission in Jerusalem was the establishment in a building formerly occupied by the Russian Consulate of a general dispensary, a children's hospital and a home for native nurses. 'The Children's Hospital was opened late in September and was of twenty five bed capacity. Miss Spelman was placed in eharge of it. The daily attendance at the dispensary ranged from forty to one hundred patients, largely ehildren suffering from malaria, measles and diseases due to malnutrition. Of the 2331 cases treated 1401 were Moslems, 618 were Greek Orthodox, 138 were Latin Catholies and the remaining $17 t$ were divided almost equally between Armenians and Jews. Of the seventy-three patients who died, forty-three succumbed to malaria.

Dental elinies were maintained at the Children's Hospital and by January, 1919, twelve liundred cases, including every type of patient from British Army officers to the most emaciated Moslem child, were treated there. A diet kitchen was established and milk and food given to babies and undernourished ehildren.

The final report of the Children's Hospital gave a vivid account of the types of patients treated:

When the American Red ross rame to Palestine in the hot, dusty days of .June. 1918, it was evident to the workers that a seronct slanghter of the innorents was going on in the land of the lufant ('hrist . . . so a small room was fitted out as a clinic for chilulren of five years and uncler.

The sun blazed down on the open court which the waiting patients thated with fifty women who were emptying and disinferting a learary of Turkish mattrestes. Earbh ione forenoon a crowl of war-worn mothers came to us. There were 


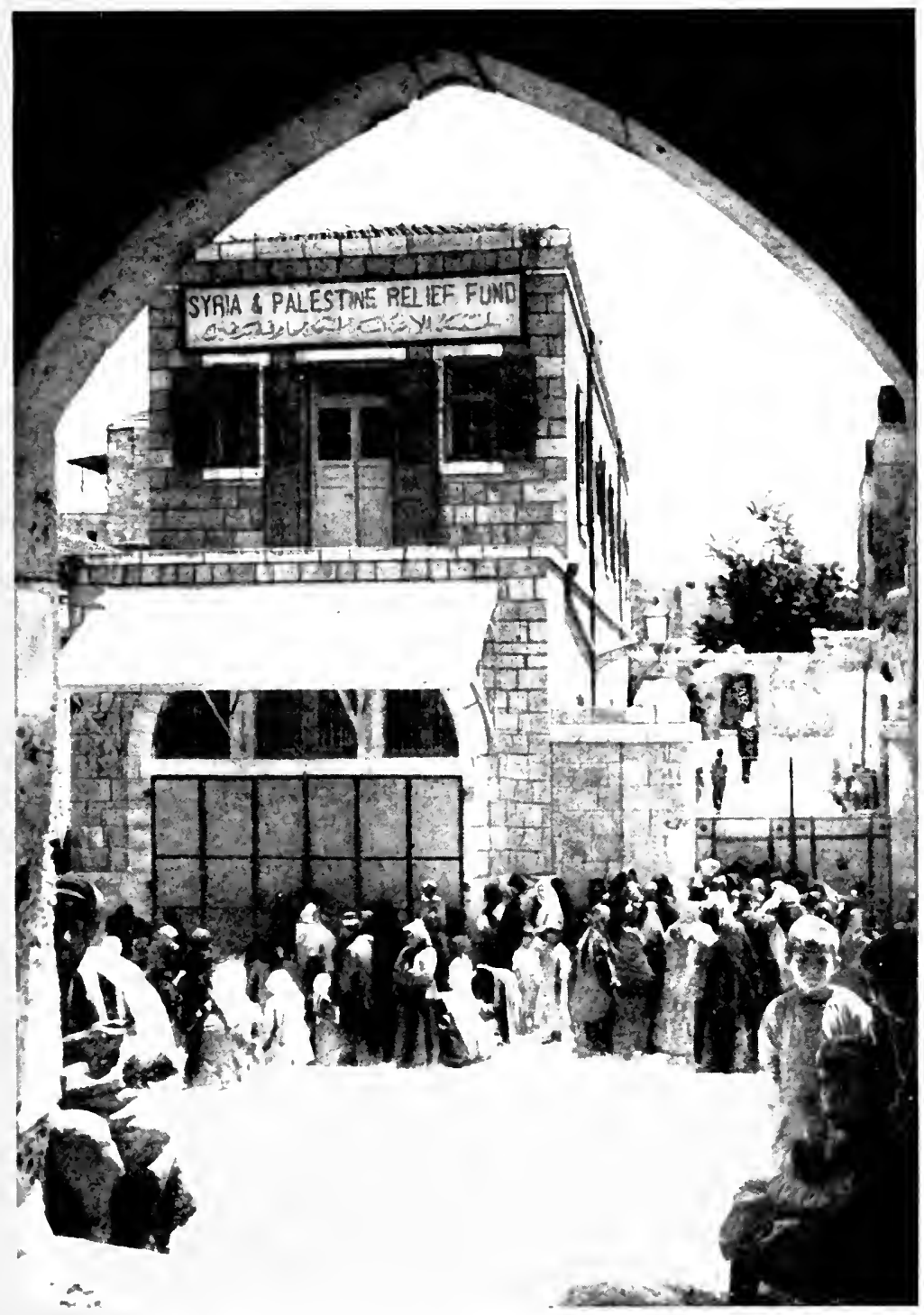

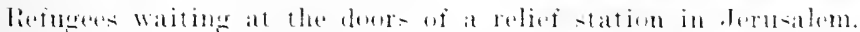



wives of Turkish soldiers who hat vanished in the retreat; there were wives of once thrifty artisans and tradesmen now penniless in their vain eflort to ward off the draft; there were beggared refugress from "beyoud Jordan" and "up Nabulous way" and there were peasant women in ragred, quaintlyembroilered costumes, women hunger spent and exhausted from a three-mile walk along stony, dust-choked roads, their forehads chafed raw with the rope of the saddle-bag in which were arried their sick rehildren.

These mothers, gant from starvation and malarial poisoning, would lie at length on the paving, taking what comfort they could from the loot stones when the ague-fit shook them. The children and bahies also shivered and burned, strangled in paroxysms of wheoping-cough, squirmed under the teasings of skin diseases or burrowed their tiny skull-like faces against the mother's empty wrinkled breasts in fruitless search for food.

In all Jerusalem, the color of war prevails-on the dustpeppered olive trees of the gray and dusty city, in the haze which envelops the lorries, the cavalry, the infantry always on the move northwards, on the thomsands of camouflaged tents and the uniforms of the Tommies and over the bare parched hills and sterile valleys.

All of Palestine, the land across which the chariots of Alexander's warriors lad swept, and which in turn had been the provine of Rome, the Holy ground on which the Crusaders had pitched their graly-hued silken tents, the stronghold of the Turk. was again in 1917 the battle-ground of the East and the West. Miss Madiela wrote:

The whole country is a camp and war the main business, ret in spite of the faret that we constantly hear the guns and that airplanes fly orephead, we seem to lave lost all sense of the reality of war. The paraphernalia of war seems just a part of the daty's work in this barren land of stones and dust and we no loneres think of it. Of rourse. We do not see any of the womberl-only the civil population, but in traveling about from one station to another ontside of Jerusalem, one is again and again impresed. almost overwhelned. with the fact that the business end of morlern warfare is tremendous.

In addition to the rolief work in the Moly City, the British Forces had induded in their plans an extension of Ameriean Red Cross work southward as far as Port siad and later northward as fall as the advaneing font permitted. 


\section{HISTORY OF AMERICAN RED CROSS NURSING}

The Refugee Camp at Wadi Surar was one of the first places outside of Jerusalem to which American Red Cross nurses were assigned. Miss Madiera wrote:

Our next renture was to take over the Tent Hospital at Warli Surar, where the refugees, driven from their homes near the firing-line, and the Armenians were concentrated. When we first saw the camp, about 3500 people were there, half of them Armenians. Wadi Surar acted only as a detention camp for Armenians; here they were placed under observation and if found free from infectious diseases, were sent on to the Armenian Refugee Camp at Port Said.

All the refugees at Wadi Surar were living in bell tents and sleeping on the ground, as is their custom, even with the sick. The first impression of Wadi Surar was of sand and tents; tents and sand, with a wonderful view of the hills beyond. This riew and a fine breeze redeems the situation, for it is hot and cheerless otherwise. Among the tents are shelters where the refugees in their picturesque rags assemble to cook and eat. Everything is very primitive.

Lillian Spelman and Olive Ranger, both of them nurses, were sent to Wadi Surar on July 9 and found that the camp was being run by a young English doctor, "in appearance not more than seventeen rears," wrote Miss Madiera, "but naturally he is much older and is doing splendid work." There were three other officers and the American nurses took with them three capable native women and two orderlies, also tents and full camp equipment.

The Camp Hospital was composed of bell tents set up a little distance from the camp proper. Miss Madiera wrote:

Here patients left at will, babies arrived without merical assistance which did not eren seem to be experted: people died without the doctor being sent for. The hospital equipment was poor: there were no elean clothes or linen and very few utencil.. Egrptian tomargies had previonsly done whatever nursing had existed but they were discharged before our nurses arrived.

The work was divided. Yiss Spelman encentrated on the so-called Hospital and Miss Ranger took rare of the patients with minor ailments who did not need hospital eare. In the Hospital. native nurses were instructed in proper bathing and the care of the patients. with special emphasis upon gentleness. Soon the hinder care made the hospital much more 
popular. With the advent of the sorial service workers and their supplies, the refugee women were given sewing to do and more andeguate linen and garments for the hospital were supplied. 'Then "ame the larger tents and the whole hospital was movel to a better site and was endosed by a barbedwire fence with one opening at which a guard was placed. Ile prevented the continuous risiting and mingling of sick and well.

The prevalent diseases throughout the Palestine area were malaria, dysentery, ophthalmia, trachoma and skin diseases due to the starvation dict.

In September, 1918, the Armenians at Wadi Surar were sent ('n misse to Port siald. Military aetivities in the north were resumed and as the British Forees pressed on some refugees returned to the recaptured territory. Others sent to harvest the figs and grapes which were ripening in the groves near Jorusalem. Thus the population of the Camp on the sands diminished to eight hundred sonls. Howerer, the Hospital continued to draw its average of one hundred patients, "due largely to the kind eare they receive," wrote Miss Madiera.

Northwest of Jerusalem on the Mediterranean slore was situated the seatown of Iafla. During the first vears of the war the population of the city was about 76,000 . In March, 1917, the 'lurks had ordered the entire civilian population to evaruate Jaffa, on the gronuds that it might suffer from British lombardnent. The Turkish and lentonic military anthorities loaded the poorer people into ralihoad trueks and started them somth towad Iloms, Ramleh and Ludd. Inst of the refueres remained in these neighboring town but some of them fled ats far cast as Jermsalenu. Damaseus and the small Palestine villages. Of the entire civilian population of Jaffa, the Turks allowed some seren shopowners to remain to run their stores and the owner of an orange prove to stay on his pleperty. This orange grove served als a places of refuge for two humdred others. With the eity empty, the ememy stripped the homses and stores of timber and iron for defensive works further south. Lanting wals rife.

On November 16, 1917, the British touk fattil and in a

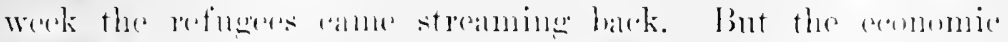
and santary renerery of the eity was show. The British an-

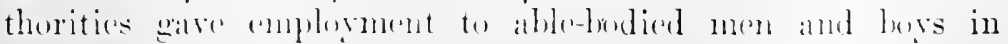




\section{HISTORY OF AMERICAN RED CROSS NURSING}

road-making and set some of the women to work at laundering and mending and at making mattresses. The British also supplied food to the destitute until they discovered that at least 14 per cent of the recipients were professional beggars. Then they ceased and turned the situation over to the American Relief organizations.

The Commission for Palestine undertook extensive social service work and medical relief in Jaffa. On July 2 Miss Paterson was sent from Jerusalen to Jaffa to take orer the Infections Disease Hospital. The building had been used by the Turks as a quarantine station and was located on the beach. Motors could not get to it on account of the deep sand. Miss Paterson waded through the sand to the hospital and found there the usual dirty buildings and tents. Miss Madiera wrote:

The institution was absolutely without system. Meals were never prepared at a regular time and the dirty dishes lay around from one meal to the next. The washing was done at the pleasure of the laundresses. When patients were discharged, the bed linen was not changed mnless it was unspeakably dirty and the blankets were never sterilized or aired. And this an infectious hospital!

There was not a single elock in the whole place and no one had a watch that kept time. Patients were admitted in a very crude way by the ward maid or male servant. Two young and midy Jewish girls acterl as murses. The employees slept in any vacant hed in the wards and ate their meals in any part of the hospital.

Miss Paterson mored into the hospital as soon as a room could be furnished for her. purchased a clock and started in. The laundreses were prevailed upon to wash five lays and mond one. The hospital was cleaned and the kitchen reorganized. Patients were admitted by the nurse. and kept in tents motil definite diagnowis hat been made. A time scherlule was arringed so that all employees were getting one-half day f) ff duty a week and two hours daily. Compotalse sleeping quarters were provided for them and a dining room for the nurses. Whe were tanght simple mursing are. Every one was given dedinite work and was held responsible for that work and that alone.

On September 19, when Miss Paterson was recalled to other werk, she tmrned over a well-oreanized rstahlishment to her suceesser. The question as to how long it wombl remain so was 
one of the genuinely discouraging questions which all Occidental workers experienced in the Near East. Nurses' letters record that the efliciency of the professionally-trained American nurses throughout Palestine was a sonrce of amazement and incomprehension to the Oriental mind.

East of Jaffa lay Ramleh, the first stopping-place of the refugees. The ('ommission for Palestine sent a medical unit to Ramleh on July 15, 1918. 'They pitehed their tents in a dustgray olive grove behind the Crusader's Tower and went to work among the refugee and native population of Ludd and Ramleh.

Emma Wood was the nurse of the mint and she took orer the direetion of a small hospital of twolve beds at Ramleh and a dispensary at Lndd, both of which had been started by the Medical Iepartment of the British Ocenpied Enemy Territory Administration. Miss Madiera wrote:

The hospital deserves deseription. It is a roof, with a number of rooms around the onter edge, which are used for patients, nurses, operating-room, kitchen, lamdry and storerooms.

The dispensaries are most interesting places. A room which was needed for one of them had been the lodging-place of an untidy but very contented donkey. At first the dispensaries were hard to manage because the crowds. eager for care, were disorderly, hut eventually srstem was establisherl and they now draw patients from hamlel. Judd and many surrounding villages. The natives lay their sick at the doors. One man dying of tuheroulosis was found lying aress the threshold in extreme exhanstion: he had walked four miles to get there, as he had heard there was a great healer there. It was too late: he died that night.

North of Jaffa was the seaport of Haifa, where on Oetober 14 the Anerican Red cross opened a hospital for civilians. The building was the former German Ilospital which had been used, previous to its ocempation by the Amorican liod croses staff, by the French. Miss Paterson and Miss Rameer were in charge of the mursing activities and the emeral reäynipnent of the hospital. (of the type of rases treated at IIaifa. Menry S. Iluntington, a Rad Cross worker assigned there, wrote:

The head doctor piekest up the lamp after supper to grive

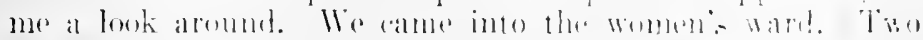
women were sitting up in bed, one of them an atietionate- 


\section{HIS'TORY OF AMERICAN RED CROSS NURSING}

faced. hunch-backed Jewess suffering from tuberculosis and Bright's disense, the other a bomb case. In another bed was a woman and her ten-year-old son; they had walked to Haifa from Beirut, one hundrel miles away, and arrived here filthy and covered with scabs and sores. The mother's diet had to be limited and she cuffed her boy one day because he refused to give his food to her. We have to keep them in one bed-no room for a children's ward.

In the men's ward, we found men suffering with "amobic dysentery." the doctor called it, cases of influenza and pneumonia, wounded with their arms shattered by hand grenades.

An out-patient elinic was maintained at Haija where an average of one hundred and fifty cases a day were treated. Mr. Huntington wrote:

Before the door was opener, the patients had gathered there, mothers with gaunt, paper-gray babies; children with red-rimmed eyes sore with the world-wide diseases of bad parentage; Armenian refugees; malaria patients by the dozens: people with handaged hands or feet. The costumes were mostly half European, but of course, it all takes one back nearly nineteen hundred years to other clinies held in Galilee. Jew and (ientile and Samaritan were still here in effect.

In the busy room where the Greek loctor, himself a nominal prisoner of war, prescribes for the patients and our Red Cross nurse attends to the dressings while the young Armenian clerk enters the aises on his cards, we picked out a man or woman to talk with. One family were Maronites from a Lebanon village formerly of one thousand people. Half of them are now dead of starvation. "Do you want to go back to your home country" we asked. "There is nothing there," the man answered. "We had a hotel. One regiment rame and took a little. another regiment rame and took a little; so it went. It is heantiful here compared to what it was there."

Another nuan to whom we talked was Balthasar Artin of Mara-h. He awated his late with ralmmess. "If you kill us." he sald, "rom kill us. If you save ns alive, we live. Te are your proprety." Xer him was a chiled who sat down on the flow and reried. for the prin in his foot. As his mother talked. the flins gathered on the dressings of the child's sore. The mother, tore. harl a fincere to he treated. Her hushand diexl in the army. Tlo hushands of a quarter of Haija wives are deat or misine.

There alse wer bark-veiled Mostem women who nursed their bahos at they waited, women wearing gold bracelets 


\section{NURSING SERVICE TO CIVILIAN POPULATION 903}

and variegated necklaces made in Beirut out of gold coin. They pay their fee of five piasters (twenty-five cents) and nurse their babies as they sit waiting. . . .

In one corner were a llohammedan husband and wife. His name was Victory-of-Ciod Brass, as translated. She was an orphan. He had married her at the beginning of the war, dowerless though she was, in order to avoid military service; here was the Turkish law for the protection of women. How ever, the Turks took him as a soldier just the same and he came back from Damascus with dysentery and hid about here to avoid going back to the army. . . .

"Why do you think we come here?" we asked a Mohammedan woman carrying a baby whose head was covered with sores and from whose small ears heavy gold rings hung. "Berause we needed a good doctor here and God willed it," she answered.

Across the bay from Haija was Acre. There the American Red Cross established a hospital and clinieal service in the former Bab's honse which overlooked the old moat built by the Crusaders. The staffi at Haija did the work at Aere until additional doctors and nurses arrived in 1919.

On September 23, 1918, General Allenby's forces took Tiberias. Several days later cholera broke ont in the eity and the Oedupied Enemy Territory Aeministration ealled upon the Ameriean Red Cross commission to assist in fighting it. Miss Madiera wrote:

On October 4, Colonel Ward, Miss Ellen Hamilton and I went up to Tiberias. We were only a few days behind the advancing troops; the dead lay unburied; the shattered lorries were standing just where they had been bombed; papers and débris were eserywhere.

We went first to Nablus and then on to J-_, where we stopled in an empty house in which one of our doctors lad been working. We impacked our cots and made them up, mosquito netting and all, and in the morning rolled np our bets again and were otf. The Turkish and (Ferman prisoners were pouring in and while our things were being loaded on our truck wo wathed them receivine their rations. Then on we went to Xalyaleth, where we stomped at the Church of the Annumbiation: it was smolay and we were present at the first servicas since the ocrupation. Then on to Thiberias.

such serenery rou do not often see. The eolor was matrniffent and the blue sea of Thiberias truly beantiful. The 


\section{HISTORY OF AMERICAN RED CROSS NURSING}

heat was intense; Tiberias is 680 feet below sea-level and a siroceo was blowing.

We went at once to the Governor's and he asked us to luncheon. He had been there three days and his table equipment and furniture were distinctly sketehy. The [British] doctor had been there two days and had had a [British] nurse one day.

In the afternoon we went to see the hospital. Such a state of affairs! Men, women and children lay on the beds or mattresses or on the tile floors, all mixed up and all halfnaked. The filth was indescribable and there was no linen, no plumbing, no water supply.

The next morning we took charge, sent for nurses and supplies. had water carried in, locked up the brandy which the attendants had been consuming and worked like dogs. . . .

Miss Madiera took over the reorganization of the hospital and Miss Hamilton assisted Captain Clark, the British military surgeon who was then spending all his time giving saline injections which is the first treatment for cholera.

Modern sanitary provisions at Tiberias were critically inadequate. "The king of the fleas and all his court," an Arabian proverb ran, "live in Tiberias." Supplies of all kinds were meager. The British governor commandeered dishes and other essentials for the patients and told the Red Cross workers to "go down to the German dump and help rourselves." Out of these stores came tables, eupboards, more dishes and basins. A lorry was sent to Jerusalem for Red Cross linen, but when this linen had been put to use in Tiberias, it began to disappear; finally a valuable ring was found missing. So a search was made of the patients and nuder the loose Oriental clothes the missing sheets, pillow eases and towels were found wound about the patients' waists.

The British themselves took active steps to break the epidemie. One of the first measures was to forbid the use of the lake water and a 'Tommie was stationed to guard each of the streets that led down to the sea. "Part of the people approved," wrote Mr. Ifuntingtem, "part of them sighed and by night went down and stole the water, but most of them walked nip to the new taps or to the places where safe well-water was pumped up to the roadside and awated their turn for the chlorine water. Whenever the mmnicipal doretor on his daily rounds discovered a case, the stroteher-bearers bronght the patient to the Red 
Cross Hospital and the inspector's gang disinfectrod the house, burned up wooden dishes and replated them with iron, destroyed old clothing unfit for further wear and disinfected the rest." City-wide vaceination was also carried on.

Within five days after the arrival of Colonel Ward's first unit, the cholera was almost in hand and when a work later the hospital was turned over permanently to the Zionists, not a single case existed.

On her way back from Tiberias to Jerusalem, Miss Madiera visited the two Amerifan Red Cross nurses who were then working in Es Salt, an isolated hill-town east of the Jordan River. Es Salt was greatly overerowded with refugees and its population was serenteen thousand people. Health conditions existed there similar to those at Acre, Iaija and Jaffa, so the Commission for Palestine had sent two American Red Cross nurses and a doctor on October 17 to establish a small hospital and dispensary. Mrs. Sewny was the nurse in eharge. Miss Madiera wrote:

The trip to Es Salt was a very beautiful one-down by Jericho and across the Jorkan and up the mountains for a six hours' (limb. Although Es Salt was conquered by the British with the help of the Hejez troops, it lies outside of the Occupied Enemy' 'Territory Zone and is in the possession of the Arabs. It is situated on the steep sides of two high hills. Cp to the very top the paths rmo and down to the valley below, through which a strean flows briskly along.

Many of thr rofugese we have had all summer in Jernsalem came from lis salt and I saw numerons old iriends there. Many of the houses have no roofs, wintows or any woodwork. T'The timber has been arried away by the enemy and userl for defensive works.] the hospital is high upon the hillside and is reached hy walking over the roof of the chureh. Doors and windows are heing made for it and it is the craziestlooking place imaginable. Lamber ls so soaree that the prices are prohilitive, so doors. windows. shelves. tables and other pieces of furniture are being marle from sorans. The bedside tables are old German music stands with pieces of wood for the top. I painted the tops of such tables and shelves for the operating-room.

Many of the women who came to the clinies at Fs Salt were of the spirited Arabian trye. In. Lanmenee, one of the Red Cross physicians, wrote of them: 


\section{HISTORY OF AMERICAN RED CROSS NURSING}

The Salt women are tall and upstanding, with a lithe swing and well-cut features outlined by close Madonna-like head draperies. They are ornately tatooed in indigo, a heary trellis on the chin and neck, a cross between the eyes and beanty spots scattered over the cheeks. Their beyond-Jordan Arabic is quaint: "Our bread is bitter "" "the Turks have toasted us like meat on a spit;" "the age of this ehild is the count of my fingers" (five years) ; "he was born in the year of the visitation of the locusts;" "I live near the gate of the Pillar (I)amaseus) under a fig tree." Indeed, the writing of addresses never becomes monotonous, as they are apt to be the Mount of Olives, the Prison of the Christ, the Via Dolorosa.

The British advance had opened up the way for American Red Cross general relief-and medical service, where urgently needed-in the villages north of Jerusalem, villages oceupying historic and often Holy ground. Red Cross work was undertaken in twenty-two such towns: in Beit-In which was ancient Bethal; in Beit-ur-el-Foka whieh was the upper Beth Heron; in Yalo which was, wrote Lientenant G. C. Hunter, a Red Cross worker, the Ajalon "of the ralley down which Joshua hid his men, where Gallus in 66 A. D. met defeat, where Richard the Lion-Hearted gained the heights and where the last great crusader of Richard's race drove back the Turks and won Jerusalem." Of the refugees from the north, who in the winter of 1918 crowded these villages, Lieutenant Hunter wrote:

They are the most homesick lot imaginable. The authorities provided a splendid camp for them with abundant food and water and they stuck it ont there mntil the time of the big harrest. Then they driblbled awar, a hundred in a night, some on donkeys but most of them on foot. and came as far north as the white stones which mark the line orer which they may not cross. In the little stone towers of the grape and fig orchards on the momutain sides, they sit and look off toward their homes in the north where the shells break and all the British tents are camouflaged.

During October, 1918, Ceneral Allenby was pushing northward thromgh Siria and at the same time the British Forees nuder Fenoral Marshall were adraneing northwest along the Tigris River from bagdarl. With the rapture of Kaleh sherwhat, which cut thr 'Turkish-Tentonic line of communications 
with Mosul, and the fall of Aleppo, the chief base of supplies of the Turkish-German Armies in Asia Minor, supreme disaster faced the Ottoman Empire. On October 30, Turkish representatives aceepted the British terms of peace, which were practically of unconditional surrender. Thus ended the brilliant Srrian and Mosopotamian Campaign and the seven-eentury old mastery of the Turk in the IIoly Land.

Following the British victories in Asia Minor, Turkey in Asia and Cancasian linssia, where thousands of destitute men, women and children were existing as best they conld, were opened to Allied relicf organizations. The problem was too large for the Aneriean lied Cross alone, and, moreover, the Anerican Commitee for Armenian and Syrian Relief had been longer in the field and had no other responsibilities such as those confronting the Ameriean Red Cross. Extensive plans for relief in the Near East were undertaken early in 1919 by the Ameriean Committee for Amenian and Syrian Relief. One of the first steps was to bring about its incorporation by Act of Congress when it became known as the American Committee for Relief in the Near East. It ultimately absorbed in 1919 and 1920 the activities of the Ameriean Relief Administration and the American Red Cross and to quote from its Anmual Report for 1921 , was "the only Ameriean relief agency" operating extensively in Constantinople and the adjoining territory in European Tirker, Thrace, Anatolia, Armenia, (Cilicia, Kurdestan, Srria, Palestine, Mesopotamia, Persia and TransCancasia (Rissia) inchuding Russian Armenia."

This committee called upon the American Red Cross Nursing Service to supply nurses to work under its own anspices in the Near East. A mit of fifty-four murses was supplied with Anma E. Rothrock as chief nurse, and sailed on February 16, 1919, for Asia Minor. Eight others, among them Emma Wood of the original Red Cross Commission for Palestine, sailed on February 29, 1920, and four more on March 16, while small units of from two to fom nurses also accepted this service throughout 1919 and $19 \cdot 20$.

Stimulated loy an appreciation of the needs which had brought about the axtension of the work of the Aneriean Committee for Armenian and Srrian Reliet, Colonel Finley had gone to Paris in l)erenuber, 191s, and there hat recruited from amone the workers then beine released be the dininution of the French program, a large muit for service in Palestine. This 


\section{HIS'TORY OF AMERICAN RED CROSS NURSING}

unit proceeded to Jerusalem in February, 1919. Among them were twenty nurses and Miss Noyes was under the impression that they had gone out to work under Miss Madiera or a possible successor to her, for early in December, 1918, administrative difficulties had developed among various members of the Palestine mit. 'Through correspondence with Miss Madiera, Miss Noyes gained the impression that the organization was somewhat weak and that the status of the nurses was not clearly defined. Colonel Ward was then making his plans to return to his former work at Beirut and was closing the affairs of the medical service of the commission. On December 4 , he wrote Miss Noyes:

.. Fundamentally there has been disagreement between Miss Madiera and the commission as to her services. . . She came out with the idea that she was to direct a nursing unit and that all her work would be administrative.

Even before we reached Palestine it seemed unwise to keep all the nurses together in a distinct section as we would have in serrice. Perhaps if we were more thoroughly under military discipline, this would have been the natural thing, but with a large nmmber of social workers, secretaries and others, we felt it much better to mix up the various members of our larger mit. treating them all on a par. I supposed that that was the truly American, democratic way of looking at things. At any rate, after we ame to Palestine and began to realize the nature of the work expected of us, we saw that the ten nurses would have to be distributed among the various hospitals and dispensaries scattered mp and down the conntry. It was impossible for Miss Madiera to control all this work and it therefore seemed wisest to himit her functions to the general functions of a nursing burean and not to give her control of the mursing service in the field.

In this capacity, she male many trips here and there ant? did excollent service in helping to organize the work in varions hospitals. For a time we gave her the complete respensibility of directing the district mursing and dispensary service in and about Jerusalem, but this has gratually diminished until practically all of our nurses are in hospital work.

Miss Madiera has folt repeatedly that there was not scope for her activities and we have folt repeatedly the difficulty of giving her that sope evon when it ame to the matter of nurses quarters. . . I In fact, there seems no place here for a director of nursing service. Our work is too small and is 
organized on an entirely different plane from that in France. We would have place for a murse who wonld be a chief among the nurses, doing regnlar nursing service like any of the others. ...

Before the twenty additional nurses from Paris headquarters arrived in Jerusalem, Miss Madiera had left the city and was on her way home. When they arrived, they were seattered under the system already referred to by Colonel Ward to varions dispensaries in the Beirut, Aleppo and Gaza districts and they served without a chief nurse or nurse representation of any kind on the Cimmission for Palestine. Miss Noyes endeavored to serure information regarding their work and the possibility of appointing a new chice nurse, but on April 11, Major Storer, then one of the new commissioner's for Palestine, cabled National Headeuatrers: "Offire of chief murse abolished with Madiera's department; statistical report following by post." Miss Noyes continued to remain in ignorance of the nursing activities in Palestine and of the general welfare and efficiency of the murses.

Thus ended organized American Red Cross mursing service in Srriat. The nurses continued to work under the direction of the varions doctors but finally returned singly or in groups of one or two during the summer of 1919 to the United States or andertook service with the American Committec for Relief in the Near Fast.

During the period hegimning . Inly 1, 1:18, and ending February 28, 191!), the American Red Cross in its twelve hospitals and sixtern dispensaries in the Jernsalem 1)istriet treated 127.000 men, women and elithren, furmisled milk to 9500 methers for womeng habies and cared for 685 children in orphan-

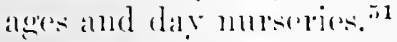

On Nareli s, 1!1!, a plan was worked out hy the Amerian Commitere for lielief in the Near bast and the Anerican lied cross commission for Palestine wherely the American Commitere for lielief in the Neall East took overe the relief

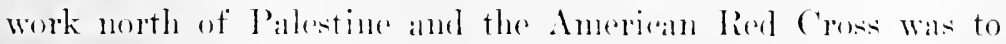
continue its work in l'alestine mutil lluly 1, 1919, when all its activities and montilized supplies an haind were to be tumed over to the American ('ommittere for lielief in the Sear bist.

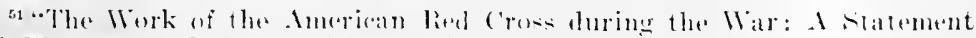
of Finamees and Areomulishments." L. si. 


\section{HISTORY OF AMERICAN RED CROSS NURSING}

Thus in the summer of 1919, American Red Cross service in the Holy Land was closed.

Siberia, a land of magnificent distances held together only by a slender thread of rail and telegraphic communication, with a population swollen by the influx of refugees from Russia, harassed by guerrilla warfare between the Red Guard and the remnants of a Czech and native Army and devitalized by famine and disease, was the seene in 1918 and 1919 for extensive, albeit at first somewhat disorganized, relief operations by the American Red Cross.

The political situation in Siberia was the determining factor of American Red Cross activity there. After the Treaty of Brest-Litorsk had been signed in December, 1917, a considerable number of Czecho-Slovak soldiers who had been fighting in the former Russian armies against the Central Powers and who were anxions to reach Vladivostok and rejoin the Allies on the Western Front, gained permission from the Bolsheviki to cross Siberia. The actual number of this Czech Army has never been definitely determined, but a conservative estimate placed the number at about fifty thousand men. ${ }^{52}$ Early in 1918, presumably at the instigation of the Central Powers, the Bolsheriki ordered the Czechs to disarm. This the Czechs refused to do and immediately aetive hostility to the Bolshevik régime broke ont in the region of the Ural Mountains and later spread eastward along the line of the Trans-Siberian Railway to the eastern provinces.

The Anti-Bolsherik armies were led by General Semenoff, Admiral Kolchak, General Gaida, Colonel Orloff and others. In addition small groups of native soldiers joined the forees of these leaders or operated independently.

In May, 1918, the Bolsherik forces ocenpied the TransBaikalia and thus ent the Czech armies, leaving some forty thousand of them scattered along the line of the Trans-siberian Railway from Irkutsk westward to Samara and about fifteen thousand others in Vladivostok, awaiting transportation to Franee. The situation was extremely precarions, because a Bolshevik offensive in the west was daily expected and the divided Czech armies fomd themselves, with only the most meager supplics of food, ordnance, ammunition and sanitary

sa "A lieference History of the War," p. 142. 
service, facing this offensive and, within a few months, the severe Siberian winter.

The Allies "determined upon a certain amount of military intervention in order to try to save something from the chaos which existed in Russia" 53 and forees of Allied troops were sent in the summer of 1918 to Murmansk, on the North Russian Front, and to Vladivostok, on the Siberian side, to reёnforce the Anti-Bolshevik armies.

The reasons for the despatch of American troops to Siberia were contained in a statement made by President Wilson on July 25, 1919, in reply to a Senate resolution concerning the American Expeditionary Forees in Siberia:

... The decision to send American troops to Siberia was announced to the press on August 5, 1918, in a statement from the Acting Secretary of State.

This measure was taken in conjunction with Japan and in concert of purpose with the other Allied powers, first of all to save the Czecho-Slovak armies which were threatened with destruction by hostile armies apparently organized by, and often largely composed of, eneny prisoners of war. The second purpose in view was to steady any efforts of the Russians at self-defense, or the establishment of law and order in which they might be willing to accept assistance.

'Two regiments of infantry, with auxiliary troops-about 8000 effectives-comprising a total of approximately 10,000 men, were sent under the command of General William S. Graves. The troops began to arrive at Vladivostok in September, 1918.

Considerably larger forces were dispatched by Japan at about the same time and much smaller forces by other of the Allied powers. The net result was the suecesful reunion of the separated ('zecho-slorak armies and the substantial elimination in Fastern Siberia of the active efforts of eneny: prisoners of war. A period of relative quiet then ensued. ${ }^{54}$. .

The determination of the Enited States Government to send Ameriean troops to Niberia opened up the way for the Ameriean Red cross. In fact, representatives of the socicty arrived in Vladivostok and beann relief operations there previous to the arrival of American troops.

53 "A Reference Ilistory of the War," p. 142.

"See "Amerien Ascistane in the Operation of the Trans-Siberian Railway, husian Sirius No. 4." p. T: Department of State, Goverment Print. ing Oflice, 191!? Washington, D. C. 


\section{HISTORY OF AMERICAN RED CROSS NURSING}

The war organization at National Headquarters included, it will be remembered, the Foreign and Insular Division, the socalled Fourteenth Division. This division was then eomposed of Red Cross Chapters in all parts of the world outside of the United States and Europe; among these Chapters was a strongly-organized Chapter with ample resources at Honolulu, the Philippine Islands, and another at Tokyo, Japan. Officials of these Chapters were in constant communication with J. Otis Cutler, manager of the Fourteenth Division at National Headquarters, who kept the War Council informed as to developments in the Far East.

On July 22, 1918, the American Ambassador called a meeting of the members of the American Red Cross Chapter in Tokyo, Japan, to discuss the question of furnishing aid to the Czecho-Slovak Army in Siberia. Four days later, a formal conference was held between the Ambassador and the Executive Committee of the Tokyo Chapter, and Dr. R. B. Teusler, a Virginian, who was then superintendent of St. Luke's Hospital. Tokyo, was authorized to go to Vladirostok to inrestigate conditions and report personally to the Tokyo Chapter the situation in Siberia and the opportunities for relief service.

In company with two American business men who were also representatives of the Tokyo Chapter, Dr. Teusler left Tokyo on July 16 and upon arrival in Vladivostok, investigated conditions in that city and along the Trans-Siberian Railroad as far east as Nikolsk. After discussing the situation with representatives of the Czech Amy and of the Ameriean Navy and State Departments there, he returned to Tokyo and organized a unit of J apancse doctors and nurses from St. Luke's Hospital for emerencer service in Vladirostok.

The nurses were under the direction of Alice St. John, an enrolled American Red Cross nurse who was then superintendent of nurses at St. Luke's. Mrs. St. John was graduated from and later lecame superintendent of the Hackensack ( New Jersey) IInpital. She was a Canadian but had married a New York phrsician, Dr. St. John, and after his death, had gone out to Tokyo. Ilrs. St. John was a woman of serene and gracious personality. She served as rhicef nurse of the Ineri"an Red Cross ( ummission for Siberia from the early inception of the work witil the reses of the program.

Of the situation in Vladivostok in the summer of 1918, Mrs. St. John wrote Miss Noyes: 
Early in June, the 15,000 Czech troops collected in Vladirostok harl five dortors and seven trained nurses to care for all their wounded and they were entirely withont medieines, hospital equipment and surgical supplies. Owing to the blockating of the remainder of the Czech Army west of Irkutsk by the lied cinard, the Czech authorities in Vladirostok decisled in .July to send their contingent of 15,000 ('zechs back over the Trans-Siberian Railway to arive out the Bolsheriki from the Trans-Baikalia. Definite appeals for military and material assistance were sent to the American (ioverument by the (zechs. . . .

(In June 25 , street tighting broke out in Vladivostok between the Czeds and the local Red Guard and several were killed on both sides. The fight continued west of Vladivostok at Nikolsk and Lsuri in early July. There were no hospital facilities in Thalivontok for the care of the wounderl, so emerency shelter was provided in a storage shed at the disposition of the U. S. Cruiser Broolilyn. 'This shed wals temporarily fitted up by the ofticers and men of the Broolilyn to rale for about one humdred patients.

On July 20, a building capable of aceommodating two humdred aind fifty patients was secured on Rinssian Island, at the entrance of the Vladivostok harbor. Supplies and equip)ment were sent orer from Japan and China by the Ameriean hed ('ross amd a unit of fifteen Japanese nurses and seseral doctors from st. Juke's in Tokyo were sent to staff the Russian lstand hospital. Dr. Gill, senior surecon of the Broolilyn. Was director of the hespital and l reported on August 1? for luty as chief nurse. The Czorho-slorak woundenl who had been in the Brooklyn's warehouse were transferod to Rusian lsand and several Fronch and British soldi(rs, also wombled in the Ussuri campaign, were brought to $11 \mathrm{~s}$.

Russian Island IIospital was thus the first American Red Cross hospital in silueria and the Japanese nurses, in the face of nurager epuipurent and personal privations, kept it in eperation

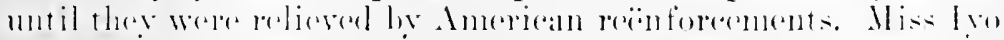
Araki, for tiftern rairs head murse at St. Lake's, was the lealder of the dipathese mit.

In addition to the Russian Island Hospital, the Anerion Red ('rose in siberial assisted in the equipment of the ('zoeds

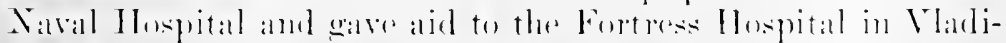

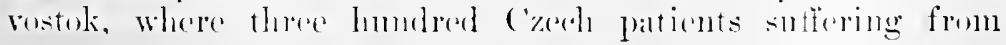




\section{HISTORY OF AMERICAN RED CROSS NURSING}

venereal diseases were being eared for under the joint managemeni of the loeal Russian authorities and the Czech leaders.

Early in August, the Czech Army in Vladivostok planned to attack the Bolsheviki at Manchuria Station with a view toward driving them out of the Trans-Baikalia. They asked Dr. Teusler to furnish surgeons and nurses and to assist in organizing samitary trains. Mrs. St. John wrote of the sanitary transport situation facing the Czech Army:

At this time, many of the wounded were being brought down from Xikolsk and Usouri in filthy box-cars with no provisions for their care. Owing to the disorganized railroad service, the journey as a rule required two or three days. The wounded were fed with food purchased from the peasants at stations along the way and were withont the service of either surgeons or nurses during the two or three days' trip. The Czechs had one small improvised hospital train made up of third and fourth class (ars and several freight cars, but the train had practically no equipment for handling the wounded and was without drugs and surgical dressings. These the Red Cross supplied and at once began preparation to commission two more hospital trains for service on the Tssuri and Manchuria fronts. The trains were to be supplied with American doctors and nurses and the first train, intended for service in the Trans-Baikal provinces, was ready late in August. The second was to be commissioned by september $15 . .$.

Early in August, 1918, Dr. Teusler sent telegraphie appeals to the superintendents of Anerican mission hospitals in ('hina and Japan, asking surgeons and nurses to volunteer for service in Siberia and to mobilize ly Angust 20 at Ilarbin, the nearest point of safety to Manchuria Station.

The response of the nurses was immediate. The first group of Ameriean nurses to arrive in Harbin was organized from among the staff of the Iluman-Yale Hospital at ('hangshial, China. One of these was Gertrude P. Carter, a granduate of the Hartford (Comnecticut) Sichool and formerly night supervisor of the pediatrie department of Jolms IIopkins Jluspital. inother group was organized from st. Luke's I Iospital, Shanghiai, China, and included Florenoe Fanmer, a Canatian nurse who had been a member of thit $\mathrm{C}$ of the lied Cross Merey ship Expedition in 1!91. She hat seren serviere at Kief and hater at 
Khoi, Persia. After her release from Red Cross assigument late in 1916, Miss Finmer had remained in China and had done private mursing duty among the English colony at Peking and Shamghili.

Another murse of the Shanghai mit was Katherine Steelman, a graduate of the Johns Hopkins School. Among Miss Steelman's papers is a "opy" of the original mobilization telegram sent to Nit. Luke's Hospital, Shanghai, by Dr. Teusler and it is of interest in that it shows the conditions which prevailed in this pioneering period:

Dr. Tucker, St. Luke's Hospital, Shanghai.

Vladivostok.

Uraent all. Ploase report with 1)r. Lee to American Consulate, Harmin, not later than August 10. Our unit leaves that day. Bring fifty pairs of blankets, sheets, pillows, two hundred towels; also warm dothing for own use; our klaki minform with legrengess or puttees; amned food for personal service. Also local Red Cross (hapter to advance cost to be repaid later. Bring two or three American nurses with you if possible. This is important. Have full authority Washington

(signed) Teusler.

The unrses anc surgeons reported in good time at Harbin. Fight of the murses were assigned to a surgical parilion in the Harbin Military IIospital; the other seven were sent to Buchaloo, a small village about ninety miles east of Manchuria Station. The only buildings available were Russian military barracks, which were not at all suited for hospital purposes; but with truk American ingenuity the nurses organized a hospital of two hundred bed eapacity. Later, the Buchatoo Hospital was maintained as a convaleseent hospital for Czerb soldiers suffering from tuberenlosis.

Tho political situation was highly msettled so the murses were kept marking time. Gertrude Carter wrote of the Buchaloo Hospital:

From IIarhin. we had gone for an eighteen hours ride up the raileatel to Buchatoo and hat established a hespital there. lut only resivel ahout thirty patients in all. Fifteren of these

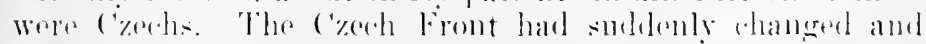
all tronge were moved on to the lat louldan recrion. Through monferesen reasons. we did not mose with them. . . 


\section{HISTORY OF AMERICAN RED CROSS NURSING}

In a report submitted June 30, 1919, to Miss Noyes, Mrs. St. John described what had happened:

Early in September, 1918, General Gaida with a few thousand Czechs completed his remarkable campaign through the Trans-Baikalia from Irkutsk eastward to Chita and with his staff came down to Olivinnaya. This expedition completely cleared out the Bolsheviki in the Trans-Baikal provinces and reëstablished rail communications between western and eastern Siberia. The expected campaign between Manchuria Station and Irkutsk vanished with the collapse of the Red Guard resistance and the entire Trans-Siberian Railroad was thrown open from Vladivostok to the east-Russian fronts near Samara and Perm, nearly, five thousand miles away. Every station along the railway was in the hands of the Czechs and they were then the masters of the situation in Siberia. This campaign of General Gaida brought to an abrupt end the arrangements for First Aid and evacuation hospitals in eastern Siberia and made necessary complete readjustment of all American Red Cross plans.

At this juncture, the question arose as to whether the American Red Cross was justified in undertaking assistance on the east-Russian fronts beyond the Ural Mountains. The definite policy of the United States Govermment stated that it should assist the Czechs only to leave Siberia and aid them to get to France, but not to give them military or other support along an east-Russian front.

With the approval of the War Conncil, the representatives of the Red Cross in Siberia decided to give medical assistance to the Czechs in western Siberia and to investigate the vivilian refugee situation beyond Lake Baikal. During the development of these plans, the nurses and surgeons were held in Harbin and thus closed the early phases of the pioneer period of American Red Cross service in Siberia. . . .

The second period in the development of American Red Cross Nursing Service in Siberia began in Noventher, 1918, and was rharacterized hr the development of civilian relief work as well as medial serviee in the Vladivostok district and tentative expansion of Red Cross activity into western Sibcria.

The first task was to evaruate the wounded Crechs to Prague. The journey was a long one, so the sick and wounded men were sent from Vhadivostok to St. Inke's Ilospital, Tokyo, where a ward in a building belonging to the hospital had been 
prepared to reecive them. This ward was staffed by two Japanese nurses and two aides, with an American Red Cross nurse, Marion Doane, as head nurse. On September 17, 1918, sixty patients were received and from time to time others came. On April 9, 191!), the convalescent Czechs were evacuated on the s. S. Wadras to go via the Indian (Ocean and the suez Canal to Trieste and thence by rail to Prague.

Eight thousand destitute refugees were known to be living in Vladivostok in the summer of 1918 without medical or nursing attention of any kind. To care for the easual sick among these refugees, the American lied Cross took over No. 7 Marine Barracks, a building formerly a part of the Russian Submarine Base at Vladivostok, and equipped it as a hospital of two hundred and fifty bed eapacity. It was opened on November 15 and was statfed largely by Chinese murses who worked under the direction of Ameriean physicians and nurses. Mary Hood, a graduate of the Scarritt Bible and Training School for Nurses, Kansas ('ity, was chief nurse; she had gone out to Foochow, China, to serve in the Mary Blaek Hospital, had been transferred to shanghai, and had subsequently joined the Commission for Siberia.

Thus in the fall of 1918, the American Red Cross was maintaining in Vladirostok Riussian Island Hospital, the Refugee Hospital and, in 'Tokyo, a large ward at St. Luke's Hospital. In the Harbin distriet, the eommission was maintaining a sureieal pavilion in the Military Hospital and the hospital at Buchaloo and had muder proeess of organization extensive relief antivities for westeril siberia.

In ()etober, 1918. five of the American Red Cross murses who were stationed at IIarbin were started westward on Sanitary Train No. 1 to establish a hospital in the West-Siberian provinees. Jiss Fanner was in charge of the mit. The trip was a longe one and durine the jomrney the murses hand ample opportunity to ser the destitute comditions axisting throughout the interiol.

Siberia was a beintiful eomutry and to the murses, as the sanitary train arrying them moved westward throngh Manchuria and the Thans-Baikalia and stopped at the different terminal rities alome the line, the seremery semed to grow nure lorely, but the gurermuent more mustalie and livine ronditions more weteland ly antrast. Matranding bands of Polsheriki,

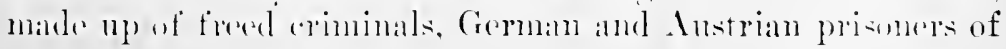




\section{HISTORY OF AMERICAN RED CROSS NURSING}

war and the ficree Mragyars held up the hands of the loeal Red Guard. Confiseation and re-division of property and livestock had taken place and production under the new régime had not begun. The educational and legal systems seemed paralyzed and starvation and disease, especially typhns, was abroad in the land.

In November, 1918, the menace of a typhus pandemic beeame so threatening that an Inter-Allied Typhus Commission was formed by the Allied Armies in Siberia and a complete anti-typhus train, consisting of seven ears devoted to apparatus for bathing persons and disinfecting clothes, of twolve box car's carrying supplies and three personnel ears, was sent out along the Trans-siberian Railway to eombat the spread of the disease. The train was furnished by the American Red Cross and its business manager was Rudolph Bukeley, of Ifonolulu. Captain F. A. Dallyn, of the Hydrological Corps, Canadian Expeditionary Forces, was direetor of the expedition and commanding officer of the train. Captain Bukeley later wrote a report now on file at National Headquarters, from which extracts are quoted in this history to show the environment in and the conditions under which the nurses worked. Of the famous tumnels of Lake Baikal, Captain Bukeley wrote:

Now we are going throngh tumnel after tumnel; I beliere there are forty-nine of them, mostly short ones, so we have had good opportunity to see the beaity of this Lake. On our left are the slate rocks through which the track has been cut and blasted; below us and to the right is the Lake. at this point some eighteen miles wide; ahead of us as the roadway winds and twists we can see the next tumnel. To our right stretches the long expanse of ice, snow swept and wind driven, and on the other shore the undulating mountain range, beantiful beyond words and of all sorts of colors, with a grayish purple predominating. ...

In the trancuil winter landscape, the paraphernalia of war seemed incongruous. Captain Bukeley wrote:

... At Terkhne-Tdinsk. I saw my first armored train: first comes a that car proterten on each side ly armor-phate:

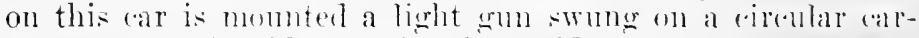
riage so as to be able to swing from side to silde. Then comes the engine, also armor proterted. two prosenger rars and 
finally a box car, reënforced in the usual manner, with openings on each sile for rapid-fire gums and above holes for rifle shooting.

Incidentally, General Scmenofi. from what I can gather, must be of the picturesque bamlit type and one who is doubtless worshipled hy his soldicrs. . . Ile was formerly the colonel of a (ossick regiment which made him a general. Now he trarels in style. . in his privite car and is absolutcly his own law as far as life and property are concerned. Tsually he rides in his train le luxe with an armored train in front of him and another behind him, ... dominating the countryside from Ilarbin and Chita. ...

Of the conditions and methods of travel which prevailed along the Trans-Siberian railroad, an American engineer wrote:

... This Chinese Eastem Railway is the eastern end of the Trans-siberian sytem and has a good permanent way and good ties. with conerete bridges and tumnels, all built as only they built in liussia under the Czar. . . The station buildings all along the line are stone, or brick and stone, substantial and of good appearance; the platforms of gravel with cut stone curbing: the station house situated at about the centers of the platlorm, at each end of which is a so-called toilet. The station house has the Chinese architectural roof, pleasing to the eyeon the exterior but unspeakable within. . . . Then there is a buildiner in which is a great kettle full of boiling water: from this the pasengers fill their ever-present teapoti. . . In Siberia, time is no object. There is also at most stations a larken or small selling store, where you can get the usual necessities, the rhief of which is rodka. . . .

Every station has also a military barracks and at every one hundred versts are lome military unloading platforms and

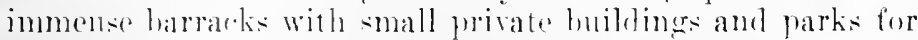
the otlicers. and aren now an lo seen evilence of the jorous life which existed here in the dars of the Czar and military predominanee. At present they are all going to ruin... and the former trim parks are now the rendez-rons of the village piers. . .

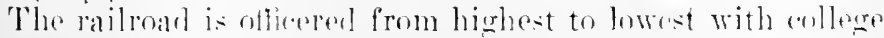

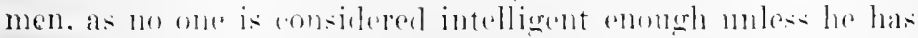

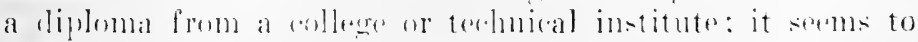
matter little what he hats stmlied. se loner as he has his diploma. Which is a surt of oral mexlal and is always worn on the mans breat. The traveline enerinere is often a cralluate 


\section{HISTORY OF AMERICAN RED CROSS NURSING}

of the Naval college; the master mechanic may have a degree in philosophy; the chief executive is often a general. In fact they seem to be everything except railroad men. All are so scientific that they are overtrained. . . This is coupled with supreme ego and the remark: "Wre do it so in Russia."

The Trans-Siberian Railway was in 1918 and 1919 the artery through which the demobilized soldiers and refugees from the Lral Mountains and the western provinces flowed eastward to Irkutsk and Amur. Captain Bukeley wrote:

Siberia has almost unsurmountable conditions to face; her towns to-day have increased in population more than fourfold, so there is no means of housing the people except by the use of barracks, concentration camps and box cars. . . This enforced crowding; the climatic conditions which make necessary the use of heary, lice-carrying clothing; the impossibility of providing sufficient bathing accommodations; the paralyzing of her railroad so that she is unable to import from Vladivostok, all help to make Siberia's problem a despairing one.... We feel as if we are trying to put out a fire by means of a teacup of water. . .

Every day trains come in with released war prisoners returning from German prison camps, gray, gaunt and feeble from the privations they have suffered. . . They are traveling onwarl. always onward, trying to find the loved ones they left hehind and who to-day are suattered somewhere in siberia. Their homes are gone, their families disappeared without a trace, and on they go themselves from station to station lowking and searching everywhere, no longer soldiers but plain men again, worn ont and aged in the service of the most ungrateful employer of all, one"s own country; fathers seeking their rhildren and wives; sons secking aged parents; young men looking for the grirl whom once they had hoped to make their wife.

And the rofuges: those countless thonsands who at the approach of the war fled on a moment's notice. some juet as they were: others arrying in a bundle their all, a kettle, a piliow or somer other rommant of their former worllly treasures. . . Their past life has ranished, their future.-hopeless days of wanflering, tired, frozen and worn ont; dazed, broken and spiritles.

With the exwarionsuese of the human heinge, they herd togetluer. in lox ars. those fow who are fortunate in finding one; they arow the fourth-chass wating rooms of the sta- 
tions. The sides of the box ars-the very walls of the stations' toilets-are covered with messages of all descriptions, in some instances only a name, in other cases a message, -simple cries flumg out by a father to his wife and daughter, by a mother and chiln to the father. written in the hope that some day the loved one may pass through that station and read the message.

Individual suffering in Siberia, to judge from the reports on file at National Ilealyuarters, was more acute and on a broader scale than that which the American Red Cross found anywere exeept in the devastated areas of Serbia and Rouminia and France. One of the most tragic cases which eame to the attention of Ameriean Red Cross representatives in Siberia was that of a train of twenty-one hundred political prisoncres from Samara, nen, women and children, who had been parked into box cars in september, 1918, and had been shunted batek and forth along the Trans-Siberian line for two montlis. They were so crowded in the cars that they often had no room in which to lie down; they were moder heary guard and were not allowed to leave the cars. For food, they were largely dependent upon the charity of the peasants in towns through which the train passed. No water for washing themselves was fumished the prisoners, nor brooms for sweeping ont the cars, and the only sanitary provisions in alch war was a hole from six to eight inches in dianneter which had been eut in the floor. Captain Bukeley wrote of this train:

I have seen men lving on the floor of the cars, with the death rattle in their throat, half naked. with lice and vermin crawling over them. visible to the naked ere, with matted, knoted hair, mkempt, filthy berond description.

othor: I have seen, just lying there on the boards, half naked. in a semi-conscious stupor, and yet otbers. . who holk out rlawlike hands, with a whining ingratiating grin an!

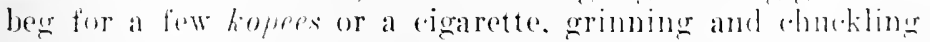
... upun wersing the one or the other and making horrible. theraty semble of glece, as they snatehed their prize. . .

The women are bettre trated than the men, elcren wemen in one (ar. war the guards" ar. . .

This melniber we were fold be the guards that throe me? had dew doring the night. As we watked ne the string of

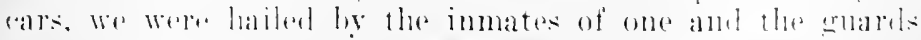
intormed that there were deal withen. We insicted on the 


\section{HISTORY OF AMERICAN RED CROSS NURSING}

door being opened. Lying across the threshold was the body of a dearl boy, not over eighteen or nineteen years old, no coat, merely a thin shirt in such rags that his chest and arms were exposed. and for trousers a piece of jute sacking pinned around him, nothing more in this bitter siberian cold. . . .

Of the twenty-one hundred, on November 21 only thirteen hundred and twenty-four were alive; the other eight hundred had died of typhus, dysentery, blood poisoning and starvation. The officers of the Inter-Allied Typhus Train held up the prisoners' train as long as they could, bathed and gave medical and surgical treatment to as many as possible and furnished food and clothing, but the train was finally shunted along on its way castward.

In March, 1919, the officers of the Inter-Allied Typhus Train met another such train, this one of thirty-two box cars filled with Red Guard prisoners. Captain Bukeley wrote:

Some of these men have been prisoners for months, but the greater part of them were captured on the l'erm front some six weeks ago. 'The box cars are indescribably filthy, as well they may be, not having been eleaned in any mamer for six weeks. (In the two tiers of wooken planks. without mattresses or blankets, wrapperl in their greasy, lice-covered furs, lie these poor wretrhes. dying of typhus, dysentery, pnenmonia, without drugs or medicine. . . .

Yon can pass within twenty-five yards on the little sleightracked road with its tumble-down shacks and the train appears to be an ordinary string of empty box ars: there is no sign of life or morement. all doors are closed, as though the hinssians had left it there and forcotten its existence. . . .

As far as 1 can ather, the men are fairly well fed with broar. moat and water for their tea: the focd is brought to within a short distance of the end of the train. Here vom wan wateh a man. in throes of fever, with ehattering teceth and limbs halt naked through his rags. stagerering on betweren the cars with some linel of a container in his hant, perhaps a rusty jam (an. to get some of the foorl left at the emol of the train. Every few steps he stops and leans against a bux rar until ho (an erather enomgh strength to rawl on a lew more yarks.

Two sights of this train particularly affected me. One was that of a man who hal loft his box rar in somb of foot and

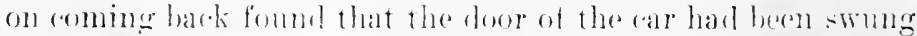
to. owinir to the rolul: there he stoorl leaning arainst the car 
and beating fecbly on the door with his hands, trying to attract the attention of those inside. He was too weak to open it himself and his cries, mere throatish mutterings for help, could not be heard ten yards off.

The other sight was of a man waiting for his turn to get into our batle-ars. Il is comrades had gone inside and, as the ar was then full, he had to wait for the next contingent; there he sat on the steps of the bath-car, the tears of weakness and disappointment coursing down his checks because he feared that he was too late and would get no bath or nnderclothes. Brok / the Russian sanitar and I promised that he would not lose out and gave him a few cigarettes to help him forget the waiting. . . .

To return to the American Red Cross nurses who had started westward in October, 1918, under Miss Farmer's leadership: These nurses went as far as Tumen, a small border-town under the Cral Momentins on the West-Siberian frontier. There the American Red C'ross representative, Dr. Lewis, took over a large school building and the murses and sanitars converted it into a hospital of two hundred beds for the Czech soldiers. "We all like the Czech soldiers very much," wrote Miss Farmer to Miss l)elano, "and we hope that they ean soon go back to their families again. Some have not received any word from their families for over a year."

The question of equipment for the Tumen IIospital-and for that matter all hospitals-was one which eansed the executives of the American Red Cross in Siberia much weariness and rexation of spirit. Mrs. St. John wrote:

All hospital equipment, drugs and supplies for the Tumen IIospital . . had to he purchased in China and Japan and shipped to Vladivostok, forced through the congestion of the harber and the disorganized eustoms and lamed in our warehouses. One by one freight rars were ferreted ont in railroad vards. on sidings. in roundlwheses and machine shogs and the supplies loaderl in them. After a sufficient number of cars had been eoflected and loaded. endless wire pulling was required to get an engine to pull the train. Then began the fonger journey of tive thousand miles orer a dilipudated road. exposed much of the way to attands by the Bolsheriki and dependent all along the line to the whims of station rom-

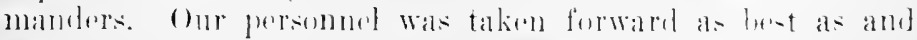
whenever we could, both supply and personnel trains being 


\section{HISTORY OF AMERICAN RED CROSS NURSING}

always sent out under the protection of an American military guard.

The nursing unit included five American nurses, two of whom were enrolled in the American Red Cross, Miss Farmer and Nettie Grace McBride. During the second week in December Miss McBride eame down with typhus, and on December 23, she died. "Six American soldiers," wrote Miss Farmer to Miss Delano, "carried her body to its last restingplace, in a small Russian cemetery where the Czech soldiers who had died in our hospital, are buried. It is a beautiful place, like a small woods. She was buried in her Red Cross uniform, with the American flag across the casket."

Several of the American nurses at Tumen returned in January, 1919, to their mission posts in China, and General Powell, of the British Expeditionary Forees in Siberia, assigned five British nurses to the American Red Cross Hospital at Tumen. Miss MacGregor, of the British Red Cross, a veteran who had served both in France and Nesopotamia, was in charge of them and of several Russian Sisters.

The American Red Cross hospital at Tumen was maintained until July, 1919. On April 28, Miss Farmer wrote Miss Delano:

We expect to increase our hospital shortly to 410 beds. Just now we have a Russian mit working with us. We still have some ('zech patients but the majority now are Russians, -mere boys. I still like them as much as I did in Kief and, I suppose, always will.

Of the Russian temperament, Captain Bukeley, who was at this time in the Ural Mountain area on the Inter-Allied Typhus Traill, wrote:

Russia is essentially a singing country. On all possible occasions, the linswans sing: when they are tirent. to rest them: when they are miscrable, to help them formet their troulbles: when they are happs. beeanse they are happy. . . Their folk song are beantifully simple. often with a minor melody rmuning throngh the refrain. The bors and grirls each have their own folk songs and it is delightenl to listen to them. The wirts, now that spring has eome. Wander thromerh the village with their arms intertwined and sing of flowers 
and spring and love; and the boys gather around one or two of their companions who play the balalaika, a wooden stringed instrument. . . .

To return again to the American Red Cross uurses who were being held in Harbin in October, 1918: A second mit under Gertrude P. Carter was started westward at this time on a sanitary train and went to Onsk, which was loeated forty-eight hours castward from Tumen on the Trans-Siberian Railroad. Of this city, Captain Bukeley wrote:

Onsk is a strange and ugly eity situated some seven versts away from the milin railroad station. Omsk would have a normal population of say one hundred thousand, but to-ray there are five times that number. The barracks are crowdeil with ('zech, liusian and other troops and there must be twenty-five thonsand German-Austrian prisoners in barracks and concent ration camps.

There is no transportation, no importation of goods except what is smlngeled in by passengers and provodnyiks. There are many beantiful stores but their stock would shame a little comtry store. . .

In the Irtish River lie all kinds of boats, icebound for the winter. The arerage man has no ilea of these siberian rivers. the Irtish at Omsk, the Volga flowing south. and the Ob, the Yenise, the Amur, the Dvina flowing through virgin. unexplored lanel to the frozen North. On the other side of the bricline spanning the Irtish at Omsk is a large space kept free and swept lor stating and in the afternoons you see wonderful exhibitions of the sport. Sobody seems to worry ahent poserty or the fact that a typhus epilemic is ragines: the skating rink is crowled. In the one restaurant l visited, a laree orehest ra wils playing.

Then from the vity you drive back to the station oser fields and hare wastes covered with snow which a hiting wind drives inte your eyes. At the station you walk alonger the tracks to where vour train is lying in the vards, surromment by trains of hox cars, all very dirty, with all kimes of pefuse lying alkout and with refuerees wandering around and locking very cold dirty and hungry . . the women wsully with an old shaw thed anomed their head and shonders. the mon in

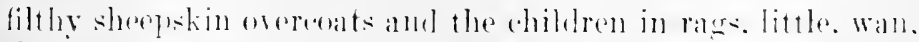

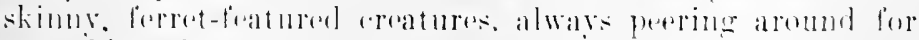
something that some one hat thrown away. . . 


\section{HISTORY OF AMERICAN RED CROSS NURSING}

The American Red Cross established a hospital at Omsk and maintained it for some months. On January 11, 1919, Miss Carter wrote Miss Noyes:

Our unit arrived in Omsk on November 10. By this time, the Czechs had started their hospital in Ecteunburgh ... and all they wished from us were drugs and supplies. ... They did not seem to need women nurses; in the field they use sanitars from the ranks of Austrian prisoners. . . .

We had some difficnlty in finding a building in Omsk suitable for a hospital. After eight weeks, the Agrienltural College was turned over to us to use as a hospital for the Czechs, but it was grudgingly given. In fact, they immediately put 186 Bolsheviki into it for safe-keeping, but by December 30 we had our beds made, our scanty equipment in place and were ready to receive patients, and four French patients arrived and ten days later, two hundred Russians. . . .

Our hospital capacity at present is two hundred and fifty patients. The building is large, but is chiefly corridors. However, it is a fine building, but is located six miles from the city and about twelve miles from the railroad station. Of course the present unsettled conditions account for much delay, but . . . this is the way things go in Siberia. . . .

In addition to the large hospitals at Tumen and Omsk, the Ameriean Red Cross maintained smaller ones at Novo-Nikolaersk, Omsk, Petropavlosk and Cheliabinsk for the treatment of typhus eases. On aceount of the limited number of Ameriran nurses, these hospitals were staffed by Russian nurses, but the result was not highly satisfactory. In her report of June 30, 1919, Mrs. St. John wrote:

My experience with the Russian nurses has convinced me that one of the serions obstacles to their efficiency is their own lark of knowlerlge of personal protertion. Many go about in bare feet, exposing themselves needlessly to inifection: as a result, the perentage of nurse infection is very high and the mortality proportionate. In a Ruscian hospital which we were ascisting at Ekaterinburg. five nurses and three dos.tors died of typhus fluring the first two months of its operation.

Thus an opportunity for far-reaching service presented itsclf to the Ancrican Red Cross in the training of a corps of linssian nurses. 


\section{NURSING SERVICE TO CIVIIIAN POPULATION 927}

The first experiment in the field of mirsing edneation was made at the Vladivostok Refugee Hospital. In February, 1919, Miss Hood returned to her mission post in China and Janet lewar sueceeded her as chief murse. Miss Dewar was a California murse who had since 1909 served as superintendent of the Kanikeolani Children's Hospital at ILonolulu, Hawaii.

() 1 pril 1, 1919, a simple eourse of nursing was established by Miss lewar and twelve Rnssian girls, all of them nineteen years old and over and graduates of high school, were registered as pupils. In a report addressed April 30, 1919, to Najor finerson, then acting nedical director of the commission, Miss l)ewar wrote:

The curriculum includes weekly three classes of two hours each on both the theory and practice of nursing, also five lectures weekly from members of the medical staff of the hospital. 'The hours of work in the wards are from $7: 30$ A.Mr. to $r: 30$ P.x., with the usual time off duty, and the work is done under the direct supervision of the American murses. 'The stulents are classed as nurses' aides and receive $\$ 30.00$ monthly in addition to maintenance. We do not aim to give complete training such as is given in a good hospital in the States, but we do aim to give these girls thorongh groundwork in the thenry and practice of nursing.

We have found these students more satisfactory help than the Russian nurses who have had more or less experience at the front. 'They are intelligent and loyal when once their (onfidemes has heon gained. They are not to be driven but are ansily antrolled by kindness. They are willing to do the hard monial work of nursing but they seem to lark physical reserve strmeth. . .

The eonrse was given up on June 20, the date when Miss Dewar returned to hare former position in Honoluln.

"The politial sitnation in siberia in the spring of 1919 faromed the development of an extensive American relice presEram. In Fulnary, 1919, it will be remembered, the Allies decoded to assume responsibility for the relubilitation and direetion of the Trans-Siberian Railway. In his reply addressed July 2.5, 1!19. to the Sernate resolution mentioned abose, l'resident Wilson wrote:

In Fahruary 1919. as a conclusion of negotiations begun

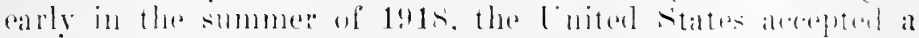




\section{HISTORY OF AMERICAN RED CROSS NURSING}

plan proposed by Japan for the supervision of the Siberian railways by an international committee, under which committee Mr. John F. Stevens would assume the operation of the Russian Railway Serrice Corps. In this connection it is to be recalled that Mr. John F. Stevens, in response to a request of the Provisional Government of Russia, went to Russia in the spring of 1917. A few months later he was made official adviser to the Minister of Ways of Communication at Petrograd under the Provisional Government.

At the request of the Provisional Government and with the support of Mr. John F. Stevens, there was organized the socalled Russian Railway Serrice Corps, composed of American engineers. As originally organized, the persomnel of this corps constituted fourteen skeleton division units as known in this country, the idea being that these skeleton units would serve as practical advisers and assistants on fourteen different sections of the Siberian railway and assist the Russians by their knowledge of long-haul problems as known in this country and which are the rule and not the exception in Siberia.

Owing to the Bolsherik uprising and the general chaotic conditions, neither Mr. Stevens nor the Russian Railway Service Corps was able to begin work in Siberia until Mareh, 1918. 'They have been able to operate effectively only since the railway plan was adopted in February, 1919. The most recent report from Mr. Stevens shows that on parts of the Chinese-Eastern Trans-Baikal Railway he is now running six trains a day each way, while a little while ago they were only able to run that many trains per week.

In accepting the railway plan (in February, 1919) it was provided that some protection should be given by the Allied forces. Mr. Sterens stated frankly that he would not undertake the arduous task before him unless he could rely upon support from American troops in an emergency. Accordingly, as provided in the railway plan, and with the approval of the Inter-Allied Committee, the military commanders in Siberia have established troops where it is necessary to maintain order at different parts of the line.

The American forces under General Graves are understood to he protecting parts of the line near Vladivostok and also on the sertion around Verkhne-Tlinsk. There is also understood to be a small body of American troops at IIarbin. The exact location from time to time of American troops is, howerer, subject to change by the direction of General Graves.

The instruetions to General Graves direct him not to interfere in Russian affairs, but to support Mr. Stevens wherever neessary. The siberian Railway is not only the main artery 
for transportation in Siberia, but it is the only open aecess to European Russia to-day. The population of siberia, whose resources have been almost exhausted by the long years of war and the chaotic conditions which have existed there, can be protected from a further period of chaos and anarchy only by the restoration and maintenance of traffic on the Siberian Railway. . . .

The Russian authorities in this country have sneceeded in shipping large quantities of Russian supplies to Siberia and the Secretary of $\|^{\circ}$ ir is now contracting with great coöperative societies which operate thronghout Enropean and Asiatic Russia to ship further supplies to meet the needs of the eivilian population. The Kolchak Government is also endearoring to arrange for the purchase of medical and other Red Cross supplies from the War Department and the American Red Cross itself is attempting the forms of relief for which it is organized. . ..55

\section{Partial responsibility for the care of American engineers} and certain speeified medical aid to the Russian Army was rested in the American Red Cross. Moreover, there was imperative necessity of more adequate organization and additional personnel if the maintenanee of the hospitals already established was to be rontinned. The leave of absence which had been granted the original physicians and murses of the early commission by their mission hospitals had expired and they wore obliged to return to China, Korea and Japan. With their departure ended the pioneer period of Ameriean Red Cross service in Siberia,-a period marked by sterling service in the face of gigantic needs, a chaotic political situation and general latek of organization.

In Mareh, 1!1!, while on a train in eentral-western siberia. Mrs. St. John met with an accident which made necessary her return to the Enited states for treatment. At the same time, 1)r. Temsler plamed to come to National Headquarters to lay before the lixerentive Committe plans for the derelopment of further Aneriean Red Cross activity in Siberia.

In Fubutry, 1919, the Siberian Commission hatd cabled to Sational Inoidyuarter's, asking for the assignment of one houdred and thirty nurses and fifty nurses aldes for sorvice in siberia. (Other tyees of persomel which were repuested

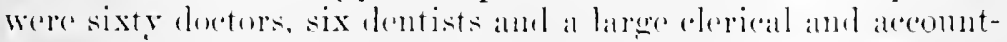

ss."Russian Sirries No. 4." pp. 5.ti. State Department. 


\section{HISTORY OF AMERICAN RED CROSS NURSING}

ing staff. The total number of persons reeruited from America during 1919 exceeded six hundred, of which one hundred and fifty-six were American Red Cross nurses and forty-three were nurses' aides.

The first contingent of nurses and aides, with Grace Harrington in charge, arrived in Vladivostok on April 24, 1919, thirteen days before Mrs. St. John left for Ameriea. Miss Harrington was appointed aeting chief nurse of the Siberian Commission and for the first time the status of the Nursing Service was defined. Hitherto, the nurses had had no representation on the Finance (the governing) Committee of the commission; they had been assigned to service by the doctors and had had little voice in the determination of nursing policies. Upon the occasion of Miss Harrington's appointment, the general supervision of nurses and their assignment to duty was delegated to a separate Department of Nursing, of which Miss Harrington was made acting dircetor. She was given a place on the Finanee Committee and powers and facilities to organize the Nursing Service along the same general lines of office detail and administration prevailing at National Headquarters.

Miss Harrington was a graduate of St. Mary's Hospital, Milwankee, Wisconsin, and had done public health and industrial nursing in Seattle, Washington, previous to her Red Cross assignment.

A second group of nurses arrived in Vladivostok on June 5, under the leadership of Ethel Pinder, a young and able nurse who after graduation from the Atlantic City (New Jersey) Hospital School, had had experience in medical social service at Bellevue Hospital and in public health nursing at Henry Street. Cpon her arrival at Vladivostok, Miss Pinder was assigned to duty as Miss Harrington's assistant; she promptly established the records of duty and correspondence files for the nurses of the commission, in conformity with the srstem prevailing at National Headquarters.

On June 26, Anma L. Tittman and a unit of twenty-five murses and seven aides arrived in Siberia. Miss Thittman hatd been seleceted by Miss Noyes as a nurse executive who would be particularly valuable in straightening ont the organization diffieulties in Siberia. She possessed a penchant for details and with it a keen and well-balaneed mind. She was graduated in 1906 from the Sipringfield (llinois) Shohool for Nurses and had had post-graduate work at the Johns IIopkins and liellerue 


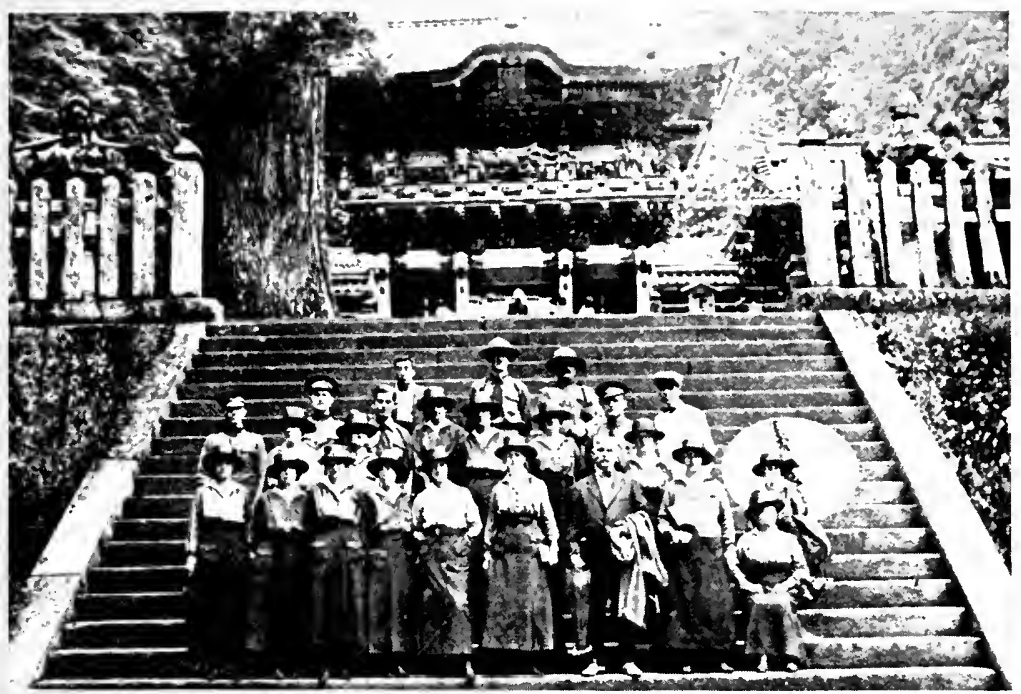

Ameriean Red cross murses and smeons en romte to Vladivostok, Siberia. visit the tyeysan Temple, Nikko, Japan.

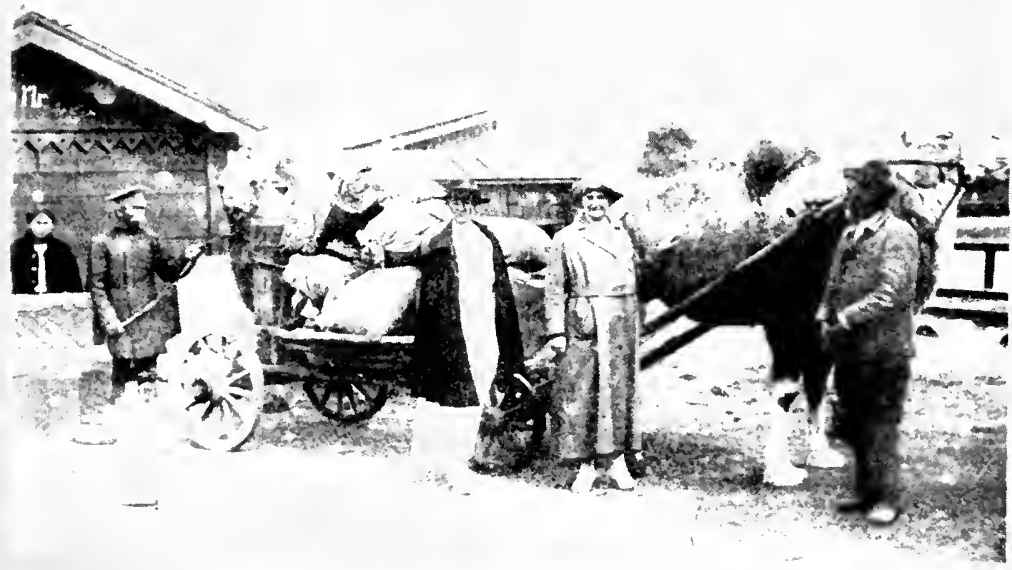

Nurses of the Siberian Commission go shopping at a market of Manchuria station. 

Hospitals. She later organized public school nursing in Springfield and was for some years secretary and treasurer of the Hllineis Board of Nurse Examiners.

The activities of the reorganized Commission for Siberia included medical and general relief in three principal zones: the Eastern IDivision which included the Vladivostok Distriet and extended westward to Manchmria Station; the far-Western Division, which included the territory extending from the Ural Momtains to Krasnovarsk; and the Central Division, which included the provinees of Irkutsk and the Trans-Baikalia. The aceomt of the Anerican Red Cross nursing activities in these three zones will deal first with events which transpired in the Eastern Division, then in the far-Western and Central 1)ivisions.

Vladivostok was the port of entry for all Ameriean Red Cross personnel of the commission and relief supplies in Siberia; all files were kept there and all reports of its activities cleared through the Vladivostok office to National Headquarters. The nurses and aides of the reënforced eommission were lonsed in the Russian Barracks, "an international compound," wrote Miss Pinder to Miss Noves, "where Japanese, Chinese, French, Italian and British soldiers are billeted in the surrounding buildings." As the needs for their services developed in western Siberia, nurses were sent into the interior on Red Cross trains. Nurses and aides assigned to service in Vladivostok continned to live at the Russian Barracks or, if conditions premitted. were furnished puarters in the hospitals to which they were assigned.

The first work of the Nursing l)epartment in the Eastern 1)ivision was the reorganization of mulsing activities in all led ('ross hospitals in this zone. This reoreanization, with its inprovement in the quality of nursing eare given the patients, had not leern possible before because of the limited number of nurses and the shertine of supplies.

Russian lsland Hospital was the first institution to modereo. the rendernization. Mary Marey. formerly superintemelent of the IIonse of Merey Ilospital at Pittsfield. Massachusetts, was

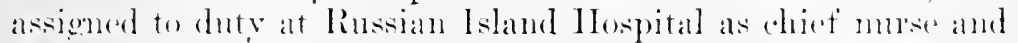
a large detail of Anerican lied Cross nurses wores stationed

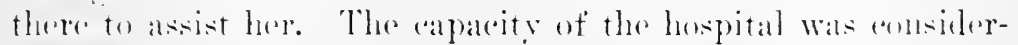
ally ratised and its seope broadened. In a letter alderesed on

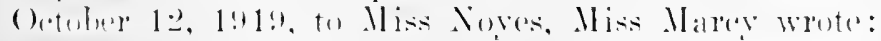




\section{HISTORY OF AMERICAN RED CROSS NURSING}

In the summer, Russian Island is a place of great beauty. It is about seventeen miles long, has many inlets and is hilly and covered with small, rather stunted trees and quantities of wild flowers (we counted forty varieties at one time). We are a thirty minutes' boat ride across the bay from Vladirostok.

The hospital itself is situated on a cliff overlooking the bay and consists of three one-story buildings. When I first came here in July, there were only Czech soldiers here, but since it has been changed into a general hospital, our patients represent about ten nationalities. Our staff is made up of two American and two Russian doctors. fourteen American nurses, two Czech aides and eighteen Russian Sisters. . . .

Next to the Russian Island Hospital was an American Red Cross children's colony. In the summer of 1918, a committee of Petrograd parents, organized under the sanction of the Department of Education of the Soviet Govermment, had sent a large colony of Petrograd children, with their teachers, to western Siberia on account of the food shortage in Russia. Starvation and disease, however, had overtaken them in Siberia and finally the Russian woman in charge of the colony, Madame Vera Qvanowna Kutchenakaiga, appealed to representatives of the American Red Cross then in the Ural Mountain regions for aid. "She told us," wrote Captain Bukeley, "of the suffering of these children who had trekked their way from European Russia, traveling many hundreds of miles on foot. . . . Many of them became little frightened animals who ran away at the sight of human beings who wonld have helped them, ran until they were free from pursuit, when they would eat grass and roots until exposure mercifully let them sleep without awakening."

Two huided and seventy-two children were gathered together lyy the American Red Cross early in 1919 at Lake Turgoyal and werestated in July upon their long journey eastward. (Others were collected from adjoining towns and rillages: three hundred arrived in Vladivostok in Angust and seren hundered more sereral weeks later. The entire colony of over nine hundred was established in barracks next to the American Rerd ('mose Hospital on Rossian Island. Two nurses. Mirian lewis and Mande li. Mondry were the first nurses assigned to

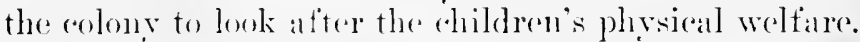

The Viadivestek linfuger Hospital niderwent the same gen- 
eral reorganization and expansion as did the Russian Island Hospital. Mary II. Bethel, a capable and energetic former chicof nurse in the Nay Nurse Corps, was assigned to duty there, first as dietitian and assistant chief nurse, later as chief nurse. A large and active elinie yas organized at the Refugee Hospital ; Iosephine Albright was placed in charege of public health nursing and medical social service work in eonnection with it.

Owing to the influx of Russian refugees into Vladivostok in the fall of 1919, an influx duc to victories of the lied Guard in the West, the ammission took over on November 1 seretions of the Morskoi (Naval) Ilospital. Red Cross wards hald a capacity of 220 patients and treated principally surgical casces. The mirsing stall consisted of twenty-eight Smerian nurses and twenty Rinssian aides. Miss Bethel was chiof nurse, a responsibility added to hor duties at the Rofugee Hospital.

() November 1s, strect fighting broke out in Vladivostok between the upholders of the Kolchak Government and local Bolsherik sympathizers, and muncrous eivilians were wonnded. An emerecincy hospital was established in twenty-four hours' time ly the commission in American Red Cross Barracks No. 7. Miss Tittman wrote Miss Noyes:

During the revolution in Vladivostok, everyone at Barracks No. \& worked ladrd and long. Our Red C'ross mon showed spirit and contrage in picking up and bringing in the wounderl. The varioty of our patients (there were sfi admitted to the emergency lospital) exemplified the true principles of Resl Crose nesitrality. There was a Korean who harl been picked 11) from his simpan: two Japanese: (iemeral Gaida's woman rowk. who bad been beaten with the butts of soluliers' guns: a Rusian priest : a British oflicer; soldiers of all the factions: involved in the fight; railroal men; innorent bystanders; and pren an Amerian sailor.

By Nowember 19. practically all the sictims of the street fighting had ben transfored to other Red ('poss and Rusian hospitals or to their homes. Most of the military alses were taken to the IIorstoi Ilospital. ...

In November, 1919, Mrs. St. Tohn and Colonel Tensler returned to Vladivostok. Mrs. St. Lolne resumed her duties as

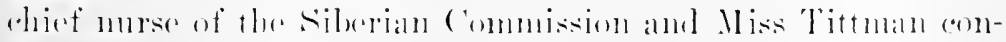
tinued as rhiet nurse of the Fastorn loivision. 


\section{4 HISTORY OF AMERICAN RED CROSS NURSING}

In addition to the maintenance of the hospitals deseribed above, the Nursing Service in Siberia took up again the edueational project initiated by Miss Dewar in April, 1919, and Helen L. Bridge was made responsible for its development. Miss Bridge had taken her B. S. degree at Teachers' College, had been an instructor at the St. Luke's (New York City) Sichool for Nurses and had later served as superintendent of the Washington University School for Nurses at St. Louis. In a report submitted to Miss Tittman on December 17, 1919, Miss Bridge wrote:

On August 4, 1919, a four months' course of study was initiated for Russian women serving as nurses' aides in the Ameriean Red Cross hospitals at Russian 1sland and Tladivostok. 1)uring the course it was planned to give sixty-four hours" instruction in elementary nursing and hygiene, inchding bandaging; discussion of the commoner medical and surgical emergencies and forty-eight hours' class work in English.

The object underlying the course was to improve the standard of the nursing service in the Ameriean Red Cross hospitals by giving the pupils a systematic training which could be coördinated with their practical work in the hospital warls. . . In addition, it was felt that the organization of class work for Russian girls offered a splendid erlucational olportunity in itself; a national characteristic of the Russians is their passion for study.

Two classes were organized, one at Russian Island Hospital and the other at Tladivostok. . . During the past four months, the theoretical instructor has taught four hours a day for three days a week on Russian Island and three hours a lay for three dars each week in Vladivostok. .. The warl instructors. . . have supplemented the pupils classroom instruction with bedside teaching. As there was no nursiner texthouk in linsian procurable, a digest of the textbook of Home Hreriene and Care of the sick was transiated and later zublished in linssian: the transtator also served as interpreter during the elassroom work.

For the Finglish instruction, no books were available until within a for werks hofore the conclusion of the enurse. Then a supply of Besheturians" "Foreigners' Guide to English" was received from Naniła.

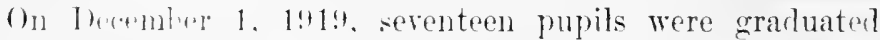
from the Rosian Liand alass and eleven others from the Thalivostok class. 
A third elass was organized on November 6 and was composed of Russian girls of over eighteen years of age from the Petrograd Children's Colony. Fifteen students entered this conrse and reeeived their practical instruction in American Red Cross wards of the Morskoi Naval Hospital.

These three clementary comrses had been initiated as an experinent to determine whether or not it would be feasible for the American Red Cross to attempt to develop in Vladivostok a permanent training school for nurses under the Nightingale System. Miss Noyes had been anxious for the Department of Nursing to establish one but to Miss Tittman and Miss Bridge it had seemed wiser not to attempt it for the following reasons, which were contained in a letter written December 8, 1919, by Miss Bridge to Colonel Teusler:

1. The preliminary education of candidates is too uneven to allow definite methods of instruction or the giving of prescribed courses.

2. 'There is an inadequate number of candidates with satisfactory preliminary edueation.

3. Applicants come to us not because of a deep-rooted interest in nursing and a desire for training but beeanse they are forced to earn their livelihood.

4. American murses cannot teach withont more of a working vocabulary of Ruscian than they could arquire in the time spent here. It is not wholly satisfactory to teach through interpreters. The pupils, although eager and quick to learn English, would not be able to use English textbooks. There are no satisfactory Russian textbooks arailable.

In addition to the courses offered to Russian hospital aides, Miss Bridge also orounized, with the coöperation of the Russian Red cross, enorses in Home Hygiene and Care of the siek for laywomen. The first class was started on Derember 10; Vasheti Bartlett was the instructor. During the progless of this comrse a teaching center was opened at No. 10 Peter the Great Sitrect and during I)ecmber, 1919, and Jamary, 1920, five additional daseses of Vladivestok women were instructiod there. Anether class was started in lecember which inchuded airls of the Petrograd childron's Colomy fifteen rears of age and ower.

An interesting phase of the edueational proseran hand taken place in August. Miss bridge desceribed it in luen tinal repurt: 


\section{HISTORY OF AMERICAN RED CROSS NURSING}

During the month of August, the Department of Nursing was requested to provide instruction to a group of Korean women in the eity of Vladivostok. The Red Cross agreed to do this if an interpreter could be secured. It was necessary to send to Korea for one and she did not arrive in Vladivostok until December. A further delay was encountered by the necessity of preparing a Korean translation of the textbook in Home Hygiene and Care of the Sick. After having overcome these difficulties, the classes could not be given owing to the imminent withdrawal of American Red Cross nurses from Siberia. It was suggested, however, that the courses be given anyhow. the theoretical instruetion by a liorean woman who is a graduate of a mission school for nurses in Seoul, and the practical demonstrations by a Russian nurses' aide who served as interpreter to Miss Bartlett and assisted in the conduct of the classes for laywomen.

An effort was made to extend the class work and the instruetion of nurses' aides to western Siberia but the military situation in the summer of 1919 made the devclopment of such a project impossible.

When the American Red Cross closed its program in Siberia in the spring of 1920, fourteen classes had been organized, ineluding the three for nurses' aides, and 216 pupils had been enrolled. Of the elose of the educational program, Miss Bridge wrote:

A plan has been formulated to continue the Teaching Center under the direction of Sister Selma Chepposova, a graduate liussian nurse who will be assisted by Valentina Alexandrof, interpreter to Miss Bartlett. Miss Farmer, the American Red cross nurse in tharge of the Petrograd C'hildren's Colony, will continue the classes among the girls of the Colony.

As to the textbooks in hand, .. . the "Foreigners" Guides to English" have been turned over to Miss Farmor for use in the chilitren's ('olony. The liussian text of Home Hygiene and care of the sick was received from the printer early in February. Siome of these will be used by the children's ['olony and the 'Teaching Center and others will be turned over to the Russian elucational authorities and public officials.

Tmmediately west of Vadivostok in the Manclumian province of China lay the rity of Marbin. Here in August and september, 1919, cholera was epidemic. Five American Red Cross 
nurses of the Siberian Commission were assigned in August to assist Annerican Red Cross doctors in their efforts to check the discase. The head nurse of this detachment was Vashti Bartlett, who needs no introduetion here to readers of this history. On September 2, Miss Bartlett wrote Miss Noyes:

The five of $u s$ arrived here in Harbin on the morning of August 26 and spent our first day being taken on a surver about the city. Ilarbin is livided into three principal districts; each district is a distinct city in itself. One is occupied by the Chinese, another by the Russians and a third by the Jews.

Our first morning was spent in the Chinese city. There we met many people wearing masks. Lime is sprinkled everywhere and we saw coffins in the streets waiting to be hauled off. We were told that in the beginning of the epidemic the bodies were thrown in any clump of tall grass, but that has been stopped. Now coffins are given to anyone who asks for one; the relief societies and the American Red Cross here put asile a sum of money for this express purpose.

The Chinese City Jospital has a most capable Chinese doctor in charge of it, Dr. Wu. Our Anterian Red Cross doctors were also working here; on the following day, two of our nurses reported there to help with the transfusions. The cause of death from cholera, it seems, is dne to the fact that so much of the fluids of the body are given off in the almost constant romiting and stools that the blood cannot flow for lark of fluid. 'Thus transfusions supply the needed fluid, and under this treatment the death rate is lessened fifty per ent. Indeed. I have soen men brought in monsongons and half an hours later I have seen them walk ont. One of the whef ditficulties in treating the ('hinese is to keep them long enough for the two or the transfusions needet.

No one who lail not been here am imagine the mumbers of flies which swarm over the patients. It rour approath. a black choud of them will riso from the pationts who lie abent waiting their turn. As soon as the Imerican doeters and nurses and get it done. straw sheds were male and the doors

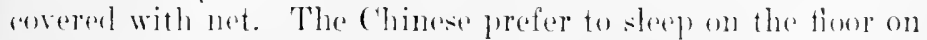
straw, which is afterwards burned. Other than this. we really did repy little but give the transfusions. becallose the pattents are soun ahle to look after themselses. I lent know what we

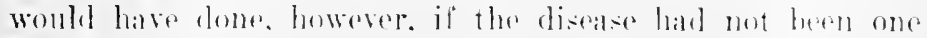
from which its vietims reovered quickly after treatment. als the epidemire was spreadling from the ('binese ('ity to the other sections. 


\section{HIS'TORY OF AMERICAN RED CROSS NURSING}

In the Russian section of Harbin, the situation was even more desperate. Miss Bartlett wrote Miss Noyes:

Our nurses are now working in two Russian hospitals and a building of the Central Hospital has been turned over to us. This building houses about a hundred patients. In a Russian hospital, things are not done as we do them. For instance, I was in a warl to-day with three Russian doctors and several nurses: a patient was sick and they let her romit three times and made no motion to get a basin or to clean up the floor, but did after the fourth time. The Russian nurses go on duty for twenty-four hours and then go off again for forty-eight hours. Men and women are put in the same room in beds next to one another and I have yet to see a screen. No attempt is made to keep the patient corered and as likely as not the orderly will wait upon a woman patient and the nurse upon a man. I have seen them bring a patient the length of the building on a stretcher without anything on him; now they seem to know, however, that I insist upon a sheet.

Patients used to be brought in, placed on any racant bed and transfused right there with friends and other patients looking on. As I have not yet seen a rubber sheet, the beds were always wet and bloody. Now we have a room with three long tables in it and the patients are laid on them and transfused there. I often lead them by the hand back to their relatives or friends. Things appear to be going excellently. ...

By the end of Oetober, cholera had been stamped out in Harbin and three of the murses, among them Miss Bartlett, were recalled early in November to Vladivostok. The other two remained to assist in caring for American engineers in the hospital of the Russian Railway service Corps. This hospital had been started early in 1919 and had then had a uursing staff of two American Red Cross nurses, (Mrs.) Ciertrude C. Brandon and Mabel E. Doub, two British Red Cross nurses and one British aide. In November, Niss Tittman visited the R. R. C. S. Hospital, the Central Hospital, the City Hospital, the Chinese 1 Iospital and the Russian Red Cross Ĺospital, all of them places in which Ameriean nurses had been stationed. Miss Tittman wote Miss Noyes on November 15 that she was "again inplessed with the weak organization and meager equipment of Rinsian hospitals in Siberia. The Russian Red cross IIoppital gives a two rear course of training to nurses." she 
added, "and I made an effort to secure data on their cowrse of instruetion but received only vague comments."

The educational projects and the mursing service which was maintained in the hospitals established or aided ley the commission in Vladivostok and Harbin, eonstituted the mursing activities of the Eastern Division. Extensive civilian relief was also given in the Vladivostok District and throughout western Siberia. Barracks were ereeted to house the refugees and meals were served to them. Sewing rooms, a weaving and a tailoring shop was opened. Boots, pajamas, sheepskin coats, shirts, socks, sweaters and underwear to the number of 880,000 articles were distributed by Febrlatry 28, 1919.56

The mursing activities of the American Red Cross in the western and eentral provinees of Siberia were manifold and the service itself diffieult and franght with many hardships and considerable peril. To return to the summer of 1919 and the reorganization of the Nursing Service: Upon Miss Tittman's arrival at Vladivostok late in June, Miss Harrington had been appointed chief nurse of the Western Division and in company with Major F. P. Manget, then acting-commissioner and manager of the Western Division, had gone west in June to Omsk to supervise the establishment of an office from which nursing personnel eould be distributed in western Siberia. It will be remembered that at this time the American Red Cross was operating a large hospital at Tumen, of which $\mathrm{M}$ iss Farmer was chief murse: another at Onsk, of which Miss Carter was chief nurse; and typhus hospitals at various other towns and cities in western Siberial. Colonel Teusler and Mrs. St. John, it will also be remembered, had gone to the United States and Miss Tittman and Major J. N. Strong were left in rharge in Vladirostok during their albence.

Among the Red Cross persomel who went west with Miss Marrington and Major Manget was a merry-spirited nursese alde, Edith Barnett. On July 3, she wrote from Omsk to Miss l'inder:

I wish I could arlequately describe this sweet spot in whith we ale wating for onl assigmments. The hesplital itself is

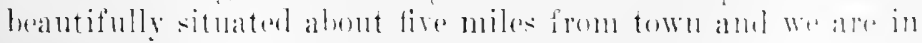

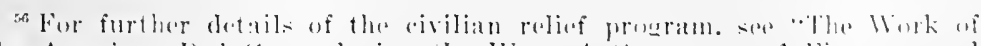

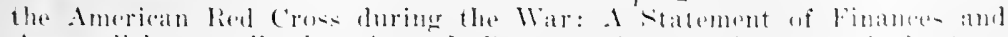

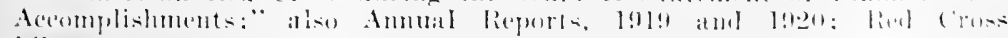
Libritry. 


\section{HISTORY OF AMERICAN RED CROSS NURSING}

a real Russian log house set in a grove of birch trees. The song birts awoke us this morning and we lay on our cots on the summer sleeping porch and looked out through the quivering birch leaves to the cobalt sky-for the sky can be bluer in Siberia than anywhere else, it seems.

We had a most beautiful trip on the train. We came by freight and stopped at all the wood piles and watering tanks. The scenery and wild flowers were indescribably beautiful. On the upgrades some of the men would jump off the train and gather flowers that filled onr compartments ant dining rooms. We were in a bower of purple iris, marigolds, yellow lilies, peonies, lilies-of-the-valley, blue columbine and wild roses. . . .

On July 9, Miss Harrington with six American Red Cross nurses and three aides arrived at Cheliabinsk and found that the American Red Cross had taken over the Perecelenchesky Punkt, or Government Immigration Station, two weeks hefore, but that they were not yet fully established. Miss Harrington wrote Miss Noyes:

We gradually took possession of the buildings as they were freed from rermin, whitewashed and made sanitary. Eleven of the sixteen buildings were soon in our possession and our wards filled with patients delighted with the lungless beds and the fresh sheets and Red Cross pajamas. We had inherited three hundred surgical and serenteen typhus cases. Stephanie Pohle is rhief nmrse.

A goon-sized landry and hig bath were in the process of being made sanitary, also five other buildings to be used for patient:. In arlation, there was a good-sized Ambulutoryah or clinic where during a four days' observation five hundreal rases were treatef. When the hospital was first taken over. there was a larce percentage of hand and foot or self-inflicted wounds. [ndtre our régime, these ases were refused hospital rarr but allowed treatment at the Ambulatoryah.

Takine it in all, the Punkt was an irleal loration for a lowpital. 'Prainloals of womnded from the front could be barkent juto the rards and nuloarled with little effort: the gromull. though newlectorl. ronld have been marle highly attractite. anel the builianes nable.

In a letter written Miss Noyes on July 2.3, Miss Marring-

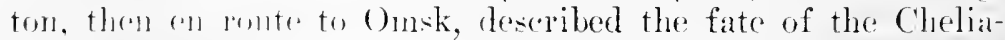
binsk Hospital: 
After we had been at Cheliabinsk for two days, we learned that the Bolsheviki were making rapis progress and that diflerent Russian regiments which had been sent to the front had vanished in thin air. Major Manget, arting commissioner, decided to push on to Miass to interview (ieneral Surolf regarding true conditions, so our car was attached to an outgoing train heavly guarded by Russian soldiers and we marle lliass in about eight hours. 'Thus Major Manget was advised to evacmate castward the Red Cross persomnel at ('heliabinsk and the Petrograd Red Cross Children's ('olony then at Lake 'Turgoyal, about sixteen versts from the station at Miass. We three women, one an interpreter and the other a publicity woman, started ont for the colony in the rain and arriced there about two o' lock in the morning.

'The next morning, a beautiful one, the whildren gathered with thair treasures and . . finally all were gotten starterl on their way eastward. We finally reached Cheliabinsk and were there for a day, then pulled out one train behind that carrying the Children's Colony.

The conditions here seem hopeless now. The latest news from Cheliabinsk is sorious and Ekaterinburg is in the hands of the Bolsheriki. Nothing in the world can prevent them from swopling lown on Onsk and where the front will be in three weeks is a matter for conjecture.

On July 26, Miss Harrington wrote Miss Noyes from Omsk regarding the evacuation before the victorious Red Guard:

We arrived at Omsk on July 2 \& and were astonished to find that om Amerian personnel had already been moved down the line. Ekaterinburg is also evacuating, so Major Manget after a consultation with American ('onsul General Ilarris and our Army oflicials, felt that it would be well to gret our persomel ont before tratfic is paralyzed and our people bottled 11) here indefinitely.

The complete personnel from Tumen will be mosed to Tomsk to opent a :moo-hed hospital there. The rest will go on to Irkntek to await burther orders. . .

All our phans for the four monthe intensive training for Russian alides have hall to be given up. It is discouragring

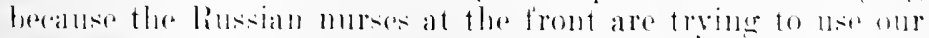

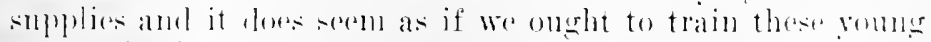

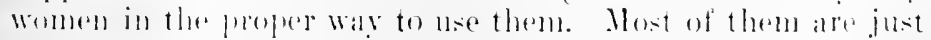

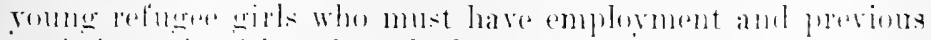
to their werk with u- hase hat no tratuing of any kind. 


\section{$9+2$ HISTORY OF AMERICAN RED CROSS NURSING}

A second train earrying our personnel starts eastward this afternoon. There will be left only seren nurses in Omsk and they will evacuate with other American personnel on Consul General Harris' train when he feels that the proper time has come. We are sar, indeed, over the sudden change of affairs and we can only hope that within a short time we will be back in Onsk and even in Cheliabinsk.

The suceess which had met the advance of the Red Guard in the Cheliabinsk district continned and on July 29, Najor Strong, in charge of American Red Cross activities in Vladivostok, wired Colonel Teusler, then in Washington:

Owing to Bolshevik advances, Cheliabinsk and Tumen have already been evacuated. Omsk is being evacuated and the nursing staff has already left. 'The supply trains going west are being returned east. Irkutsk wiil have a three hundred bed hospital, but further extensions or storage impossible on account of the overcrowded conditions of the city. We are arranging store depots at Terkhne-C dinsk and Harbin as the most advisable western points for warehouse space.

The personnel will be housed at Buchaloo mitil the situation clears. Further incomers are being stopped at Japan, as there is no space in Vladivostok.

Tomsk was the next large eity loeated east of Omsk on the Trans-Siberian Railway and for some weeks it became the headquarters of the American Red Cross in western Siberia. Miss Harrington detailed nurses and aides to the American Red Cross hospital which had been established in 1918 with the coöperation of the Faculty, in one of the twenty-nine buildings of the Tomsk University. No Ameriean nurses had been assigned to duty there in 1918, however, beeause they conld not be spared, and, indeed, their stay in the handsome Lniversity IIospital during 1!) 19 was short. The city of Tomsk possessed the beanty traditional to Russian and Siberian cities. The streets were broad and well kept and the stores large and, previous to 1!)1t. well stocked with luxuries of all kinds. The Eniversity, where Motchnikoff had performed some of his remarkable experiments, had made Tomsk the center of Siberian art, seience and letters. It had also been the seat of the Kolehak Govermunent.

11] Amerian Red Cross women personnel were evaeuated from Tomsk late in Angust and got out safely, all except Edith 
Barnett, who had died of typhus on August 15 and had been buried several days later at Verkhne-Udinsk.

During the month of Septemher, 1919, only three American Red Cross lospitals were maintaned in the Western Division, the first at Omsk; the second at Novo-Nikolanvsk; and the third at Tomsk. Ameriean Red Cross physicians were still in charge but no Ameriean Red ('ross nurses were on duty in any of them. The thousand-bed hospital whieh had been started in 1918 in the agrieultural suhool at Onsk, was staffed by Russian Sisters, with Helen Domersehikoff in eharge. Other Russian Sisters and Rinssian nurse's aides were on duty at Novo-Nikolansk and 'Tomsk.

The eity of Irkutsk, some miles west of Lake Baikal, became in September the center of Ancriean Red Cross activity in the Siberian interior. Previous to 1914, Irkutsk had been perhaps the largest commereial eenter in Siberia and with its many stores, musemm, the university and a military barracks eapable of honsing thirty thonsand men, was still regarded in 1919, in spite of paralyzed trade, as the metropolis of Siberia.

Upon his return to Vladivostok from the United States, Colonel Teusler had proceeded west to Irkutsk to confer with Major Manget regarding the reorganization of the Western Division. Epon his arrival there in the fall of 1919, a third Division was ereated and its headquarters established at Irkutsk. Miss Harrington was appointed acting chicf nurse.

At Irkutsk, the commission established fom large hospitals. One of the first of these was described by Miss Harrington in her September Report:

The American Reel C'ross Hospital on Namanskaya Clitza, with (hristine kemp in charge of it, is now caring for :2.)3 pratients, most of whom are wounded soldiers brought rown from the Western Front. As the shortest time in which we have reseived them after they have started from the front is four weeks, the condition of some of them upon arrival is appalling. Even their bandages are alive with rermin and their garments in an unthinkable state. The surgical work done here (and our agreement with the lansian military anthorities provides that we take only surerial cases) (nmsists principally of re-amputations, amputations and clrainage surcery of all kinds.

The new (hapel ward of th-bed "apacity is resersed solely

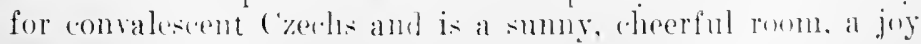




\section{HISTORY OF AMERICAN RED CROSS NURSING}

to these men who deserve the best. . . . The American ward, reserved for male members of the American Red Cross personnel, the American engineers and the Y. M. C. A. and those of our Allies, holds an average of two or three patients, all grateful indeed for the homelike surroundings and the familiar medical and nursing methods.

A second American Red Cross hospital at Irkutsk was Division No. 2 of the Russian Military Hospital. The commission supplied here persomel and hospital supplies to carry on the clinic where 300 hospital patients and numerous out-patients had their wounds dressed daily; it also operated a surgical ward of sixty-two beds and a medical ward of twenty-six. Stephanie Pohle was chicf nurse and Harriet Hunt in charge of the clinic. But it was up-hill work; in a report submitted on October 11 to the Finance Committee of the Central Division, Miss Harrington described the conditions existing in the Russian Military Hospital :

On entering the hospital each morning, it is not the greatest inspiration to be greeted by the sight of dead bodies; then passing up the stairs and through the corridors thick with smoke and heary with odors. to arrive at a floor where 300 patients are being houserl. Ninety are in Red ('ross wards, but two hundred and ten others receive hit-and-miss care; some of these have been lying for days without change of clothes on the floor in the same clothes which they had on over a month betor at the front. Infected with typhus, (arring vermin as they are, they ronstitute a serions menace to the Rinsian and Ameriran personnel.

After heroir labors, Miss Pohle and her nurses rid the Russian Military Ilospital of vermin and established more sanitary conditions.

The third American Rerl Cross hospital at Irkutsk was maintained for the benefit of wounded soldiers from the CzechoSlovak Army. Lillian C'raig Clark, an curolled American Red Cross murse, and three Coch aides formed the nursine statf.

The fourth lospital was located in five barracks at Military City, an encanpunent which lay some tive rersts from Irkutsk. Mabel Clare Blacknor, the former chicef nurse of the shortlived Omsk Ilospital, was chicef nurse. The Military City Hospital, as it was called, was of fom hundred bed capacity and 
cared for the patients who were being constantly sent eastward from the west Siberian provinees before the on-coming Bolshevik armies.

An emergeney dressing car was equipped at Irkutsk and set up in the main railroad station where from eighty to one hundred wounded soldiers and civilians en route eastward had their wounds re-dressed each day. Katherine Steelman and a Russian nurse were later assigned to duty there.

Dircetly opposite the main station at Irkutsk was established a large Red Cross dispensary, of twelve rooms, including a wating-room, a small operating-room, a reeovery room and an emergency typhus infirmary. Eva Smythe, the nurse who had organized Red Cross child welfare work at St. Etienne, France, was thief nurse and was aided by four other American Red Cross nurses.

As the Bolsheriki pressed eastward from Omsk in their fight for the control of the Trans-Siberian Railway, train after train filled with wounded and typhus-stricken Czech and Russian soldiers and refugees pulled into Irkutsk. On August 10, an American engineer stationed at Lrkutsk wrote one of the nurses of the Siberian Commission:

As a nurse, you will be interested in the Russian sanitary trains which run through this town at the rate of from three to six a lay. Each train carried fully five hundred wounded or sick soldier's in a few sanitary and many box cars. From personal observation, I know that five young Russian girls took care of this number of sick and wounded on one train. Many of the men suffer from tuberculosis, typhus and ehronic dyscintery. 'Through an instinct of cleanliness, must cases of the latter disease try to leave the cars at every stop and are then so wak that they faint, falling under the cars, and have to be assisted aboard again. Every train takes off deal at earh terminal. The supplies are so scarce here that not even a rag or a piece of paper can be spared to cover the fares of the dearl. It is needless to tell you that sureb a state of affairs has been brought about by unsanitary conditions in the amps and the lack of suitable nourishment for the men.

The linsian sanitary trains have no actual funds with which to buy supplies or foodstulfs and the oftiecers have to rely entirely on the crenerosity of the publia all along the line. The puhlic has nothing to give. We are located in the very heart of the famine belt and sere homery men and lots of them. It's not plasiant to rene face to face with this sont of thing, 


\section{HISTORY OF AMERICAN RED CROSS NURSING}

but it's tougher to see hungry women and it's plain hell to see hungry ehildren. . . .

One of the first projects of the American Red Cross in Siberia had been the equipment and maintenance of sanitary trains for the Czech and Russian forces. At Irkutsk, an interesting experiment was made in 1919 in the assignment of American Red Cross nurses to one of these trains. In her September Report, Miss Harrington wrote:

Ameriean Red Cross Sanitary Train No. 1 operates between Omsk and Verkhne-Udinsk ant is made up of twenty-three cars. Two of our murses, Tera Allen ant Katherine Steelman, and ten Russian Sisters composed the nursing persomel on its initial trip. They carried nearly three hundred cases and did forty major operations en route. Some of the patients were unloaded at Irkutsk and the others at Verkhne-Tdinsk and the train made the return trip to Omsk and the front without the American nurses.

The military situation, in Colonel Teusler's estimation, did not permit reassignment of American nurses to this precarious type of service.

Irkutsk was loeated on the western shore and TerkhneCdinsk on the eastern shore of Lake Baikal. At Irkutsk were stationed some twenty-fire thousand Czech soldiers and at Verkhne-C dinsk about 500 versts away, were numerons companies of Japanese troops and the 27 th U. S. Infantry, which then numbered abont eighteen hundred men. Since August, Irkutsk had heen the dead-line for American Red Cross women persomel and, inderd, there were few of them there. The majority had been sent east through the tmmels of Lake Baikal to Verkhne-tolinsk. There was a possibility that the Red Guard might any day blow mp the tmunels and cut the line of communication between the East and West. Ot the military situation in the West, Miss Harrington wrote Miss Noves in her October lieport, dated, howerer, November 28:

Since last week, the Western Division has ceased to exist. Omsk has fallen and the Red ciuard has obtained a great deal of ammunition and supplies of all kinds. All of onr Rod Crose supply trains are now on this side of Noro-Nikolansk. Coudition- luere at lrkutsk were nost serious last week and 
we have evacuated as many of our women as we can possibly spare, in oreler to grot them eatst of the Baikal tumels. 'Thirtynine murses, ables and alerioal workers went east to VerkhurLdinsk on a lied ('ross special train and we have retained only enough here to arry on our work until the liussian Sisters arrive from Omsk. Consul General Ilarris and his statl are now at I lkutsk. Ilis presence here reassures ns, for he has his finere on the pulse of the politionl situation and now that colonel 'Teuster has been called back to Vladirostok, he (an arluise us.

'Typhus is the areat problem and peril here. One of our interpleters informenl us that 25,000 ases of typhus had been registered amony the soldier's alone in Innokentivskaya. just ontside of Irkutsk. It is generally known that it was typhus among the white army that gave the Reds their victory at Omsk.

With large supplies at Terkhne-Udinsk and a considerable number of nurses and sureideal rases, the commission in August estahlished a hospital and a dispensary there. The Ameriean Red cross Hospital was located in a one-story building which had formerly honsed a department store. It was originally of two humbed and fifty bed capracity but was later increased to

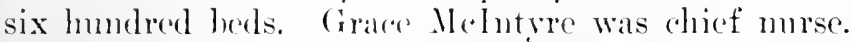

In addition to Mise Mrelutre's Hospital, the American Red Cross in Vorkhne-links tomk orer and maintained the Provost Guard Hospital and astalslished an emergency typhns hospital of 1600 beds in twentredeht waredonses. "General Seminoff," wrote Miss Harrington in her October lieport to Mliss Noyes, "wired that we rould halve the warehomeses porided that we would take infections casess. Trphus is everywere." Florruce Farmere was chief nurse of the Barracks Hospital for typhus patients.

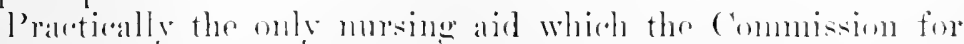
silneria gave to the American lixpeditionary Forees in siberia

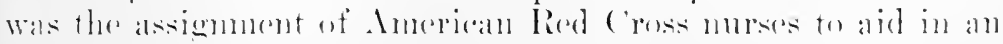

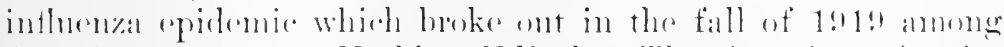

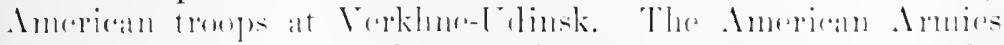

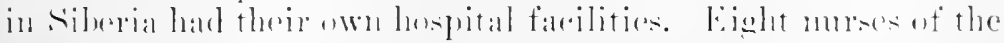

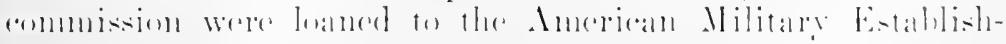
ment for duty at the l. S. Army Fiedel Inopital al Verkhe-

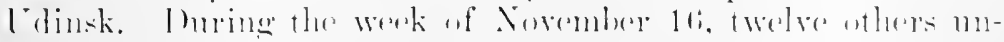

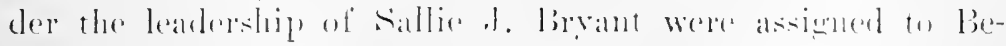




\section{HISTORY OF AMERICAN RED CROSS NURSING}

rosvka, the winter quarters of the 27 th U. S., and served there in U. S. Army Evacuation Hospital No. 17, of which Major Robert E. Parrish, Medical Corps, was then in command and Katherine C. Hannan, chief nurse. Of the work of Miss Bryant's detachment of nurses, Miss Harrington wrote Miss Noyes on December 16 :

At Berosvka, just outside of Verkhne-Udinsk, the nurses found two hundred very sick boys and managed in less than twenty-four hours to transform the hospital. Young inexperienced corpsnien had been in charge. The boys seemed to regard the arrival of the Red Cross nurses as a gift from Heaven, and under their eare the epidemic was soon checked; not, however, before twenty-eight of our men had died. These new men are very young! One little fellow of fourteen eried so hard for his mother before his death.

Throughout the fall of 1919 , the Red $\Lambda$ rmies had been gaining in the West and were pushing eastward toward Vladivostok. The Ameriean Armies were withdrawn from Irkutsk in December and with them went all American Red Cross persommel. Miss Harrington in her Report to the Finance Committee for the week ending December 30, 1919, wrote:

On December 23, the Execntive Committee informed the heals of all departments that they were to make preparations for the (omplete evar'nation of their persomel. No definite time was set, but it was understood that we were to be proparel to lave within twenty-four hours. A communication was immediately sent to the American Red Cross IIospital on Namanskaya I litza and the Station where our personnel were on duty on the Emergency Dressing (ar and Dispensary.

The Divisional Manager stated in a communication dated Derember et that Rinsian Sister's who so desired would be taken on lied ('ross evacuation trains as far east as Verkhnelansk or ('hita if tiney could prove that they had friculs or relatives in either plate, but that they must be off the traius, with all haggalge, two hours after arrival at either station.

Christmats hay found us all momentarily expecting the storm to break but endeavoring to maintain a holiday spirit heroming to fordigners in this land which has sutfered beyond deseription. As you entered the brilliantly-lighterl rhapel wards of the lrkutsk llospital and saw the trees, the gilts for 


\section{NURSING SERVICE TO CIVILIAN POPULATION 949}

everyone, the festooned walls, the three Czech aides who were Santa Clanses, it was hard to realize that ontside in the city proper there was neither electrie light nor water, and that it was doomed to fall. . .

On lecember 26 evacuation began at 9:00 A.M. All American Red ('rosis moring artivities at Division No. 1 of the Russian Military Ilospital, at the Czecho-Sloramska Ilospital and the Czecho-surenical Hospital were brought to a dose.

Baggage other than hamel bags had already been sent to the trains in order that our departure might wase as little comment as possible among the Russian people, who were nearing the "panicky" stage anyhow. As the day drew to a close, only sixteen of our personnel had time to cross the pontoon hridge over the Angara, hecause of darkness, the rapid current and the huge cakes of ire brought down from the Baikal. . . .

December 2\%: The rest of the nursing personnel were evacuated to-day. As the last boatload of lied Crossers pulled out from the western shore of the Angara, the battle around the telegraph station in Irkutsk, just back of our former persomnel house, began. . . .

For seven days, however, the American Red Cross evacuation trains waited in the Irkutsk Railroad Yards for final word from Consul General Inaris to cvacuate castward. "The atmosphere was tense and rumors wild," wrote Miss Harrington in her Weekly Report ending Jannary 7, 1920, "the yard workmen and railway employees had all been armed. Red Cross women personnel were repuired to stay near their own track and compé, for at the least provocation a volley of bullets would eome and might prove fatal to those imoeently taking an airing. The murses busied themsehes," added Miss II inrington, "in sewing curtains for their compés."

On Jamury :, the Americans evacuated Irkutsk, Consul General IIarris' train went first, preeeded by a 'zech eschelon,

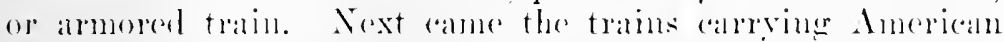
persmunel. Ealeh train left the valds at twenty-minnte intervals

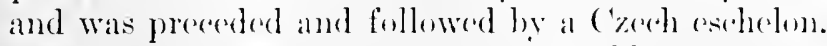

The nurses did not stay long at Verkhne-Ldinsk. Miss IHarrington wrote:

There we met Mrs. St. John. who hat ame up on colonel

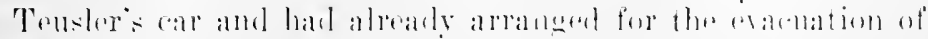

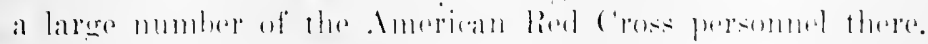
.. Plans were immediately mate to eranewate the whers. 


\section{HISTORY OF AMERICAN RED CROSS NURSING}

They left on January 6 , the nurses under the leadership of Florenee Farmer. The others came later. . . .

On January 7, Mrs. St. John wrote Miss Noyes from Verkhne-Udinsk, just before the departure of the last train:

The complete dissolution of any stable form of government in Siberia has made it impossible for us to carry on successfully any Red Cross work other than the distribution of warm clothing and relief supplies; with the growing military activities east of Baikal and the withdrawal of American troops from this section, it is impossible to keep our nurses or other women personnel east of Manchuria Station. This practically concentrates our work in Vladivostok, so far as the nurses are concerned. Because of this, 1 am instructing all the nurses from the west to prepare for early transportation home and have written Miss Tittman to ask that passage be secured for all excepting those needed for replacements in Vladivostok.

You will be interested to know that apparently the Social Democrat movement in Irkutsk has been largely fostered by the Czechs and almost surely they are in more or less sympathetic contact with the somewhat modified Bolsherism of western Siberia. Here in Verkhne-Udinsk we are surrounded by Bolsheviki and this is true all the way east to the Amur Basin.

With such conditions, the opposition offered by the Cossacks cannot be effective much longer and probably by the time this letter reaches you either Social Democracy or Bolshevism will rule siberia to the environs of V'ladivostok. You can easily see that for at least the next few months it would be impossible for the lied ('ross to operate here successfully.

The people will see us leave with real regret, but we will withdraw at a time when the Russians will have the least reason to criticize us for this attion, and I am grad, if the work has to be discontinned in Siberia, that the break has come now.

The next terminal castward from Terkhne-Cdinsk was Chita and here the Anerican Red Cross evacuation trains were held long enough for the personnel to distribute the supplies which had been brought inte the eity from the west on Train No. 27.

Ilargaret l. Matthew, then acting director of the lhepartment of Civilian Rolief in the Central 1)ivision, was in eharee of the work, with MIs. St. John and Miss Bridge as her assistants. Madane Semenoff placed at the disposal of the lied 
Cross an old café, with shelves along the walls and counters rumning around the room; behind the eafé was a large courtyard which was well adapted for warehouse purposes and which could be easily guarded. The distribution began on January 16 and lasted until the 29rd. "The entire American Red Cross staff," wrote Miss Matthew, "volunteered to help in the distribution,--doetors, nurses, elerical workers and even the Railway engineer's and the American Guard." The militia was called in to police the crowds but even they could not control ihem. "The strect became a secthing mass of humanity," wrote Iliss Matthew, "and they erowded so as to endanger the glass windows of the eafe. It was then deeided to allow the military to give ont every day in each district headquarters fifty tickets for each of the six districts of the town, thus making three hundred tickets in all. This department gave out in the seven days 39,313 garments to 11,355 persons."

A carload of goods was distributed to the Railroad employees at Chita and a considerable amount of general supplies furnished to German, Austrian and Hungarian prisoners then interned at three camps nearby. Private lists numbering 253 needy fimilies, which were sent in for Madame Semenoff's approval, were also filled. "Madame Semenoff," wrote Miss St. John to Miss Noyes, "is utterly fearless in visiting the typhus hospitals and prisons and when she finds orphaned and destitute rhilden, she adopts them until they are claimed. She has a home for orphaned children opposite her own and when I visited it, I found it elean, well ordered and the children happy and, of course, devoted to her."

On January 2:3, the trains pulled out of Chita, and thus was resed the work of the American Red ('ross in the Western and ('outral l)ivisions of Siberia. The persommel had started out rieh in supplies, plans and enthusiasm. hut had been able to areomplish ittle in comparison with the true needs of the comitry. 'The mures had had scant opportmity to do the work for which they had gone out, hut they had net the changing situations with repanimity. "You would have been prond of them," wrote Mist Ilarrington to Miss Noyes, "if rou hat seen their spirit and aheortul willinguess to work thromeh the upheaval, when the resolutionary foress were steadily pushing us eastward in ware after wave of evaruation amonge the nomdescript mixture of eomviot, typhus and the so-called sanitary trains and the hurdes of resugeres." 


\section{HISTORY OF AMERICAN RED CROSS NURSING}

By the first of April, 1920, practically all American Red Cross personnel had left Vladivostok, which was then under frank Bolshevik rule. Of the closing of the program Mrs. St. John wrote Miss Noyes on March 4:

Two weeks before the Morskoi (Naval) Hospital was turned over to the Russians, the American nurses were withdrawn and it was then staffed entirely by Russian nurses and aides trained by us. I inspected the hospital during this period and found it well kept and reflecting in a satisfactory manner the training received under Miss Bethel's able administration. This hospital has been thoroughly equipperl and is much improved since the Red Cross took it over in November, 1919.

The American nurses in the Russian Island Hospital were withdrawn February 1 and the Russian nurses and aides are carrying on the work. . .

Miss Farmer has been appointed assistant to Dr. Coulter, chief of the Petrograd Children's Colony. She will probably be the only American Red Cross nurse from the commission who will remain in Siberia. . . . I think the transfer of these children back to their homes in Moscow and Petrograd one of the important questions with which the commision has to deal. Plans are ready to be developed to give them safe transportation proviled conditions in central Russia make their return advisable. [This transfer was arromplished in the summer and autumn of 1920 muler the anspices of the American Jumior liert ('ross.]

Mis: Ifarrington and her nuit arrived from Harbin on February o on C'onsul Ceneral Ilarris' train and the majority of the nurses went immerliately to the U. S. transport, which took them home. Mis: Tittmin left on Feburury Ds, but will remain in (hina and Iapan for a few weeks. I will see her in Tokyo and ask her to bring ron the final records and efliciency reports: she will an immediately to Washington. I expect to leave Ylarlirostok in about four days.

The contimution under Russian auspices of the Teaching Center and exheational phases of the nursing service program has already been described.

Thus was relosel Ameriean Reel C'ross nursing service in Sibrria, a gallant attement, alleeit somewhat rbantie and shortlived, to implant in a land not yet ready to receive and nurture them, the stamblarls and traditions of modern American nursing service. 


\section{CIIAPTER X}

A'T NATIONAL IEADQLARTERS

Auxiliary Nursing service-The Summer Months of 1918The Influenza Eipdemic-The Armistice is signed

$\mathrm{U}$

NIER the main facts of history lie the human relationships of the participants and these relationships may be called the background against which the actual events stand ont like the principal motif's in the design of a Persian rug. This backgronnd, when viewed in a changeable and uncertain light, often appear's blurred and even distorted to different observer's and aich observer sees the details aceording to his own pesition and his own mothods of observation. Yet the background as a whole forms a vital part of the pattern and must be taken into consideration if the pattern is to be described. Hence this chapter of this history will deal largely with these homan relationships and their bearing upon the nursing sitnation of the European War. Yet it must be remembered that the true pattern of Ameriean war mursing, as developed and seen in the minds of American mursing leaders, was often blurred and distorted ly war psycholing.

"War is a salvage state of socicty and it strikes at many things we have elherished," wrote an American lied Cross nurse serving in France. "I realty latre faitl in the nltimate onteome, thenght I think that we muist be ready to go throngh a black period at first." For the Nursing serviee, this black peried began to loom up early in 1918 and continned mutil the signing of the Armistice.

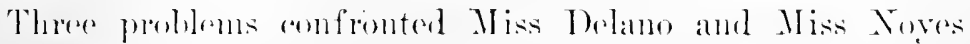

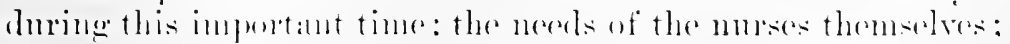
the needs of the Military Establishment: and nltimately, the needs of the rivilian jeprotation.

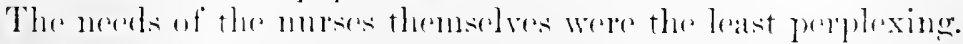

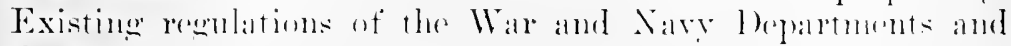

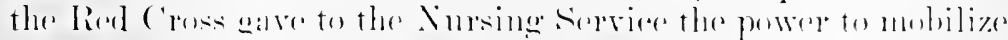

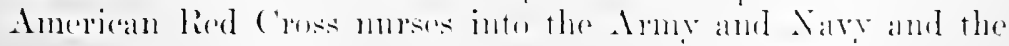




\section{HISTORY OF AMERICAN RED CROSS NURSING}

War Council appropriated the funds necessary to equip them; after this had been accomplished, the responsibility of the Red Cross ceased. For nurses in foreign service directly under the Red Cross, Miss Delano and Miss Noyes were concerned with organization difficulties previously described.

The second and the genuinely distressing problem was the military nursing needs and in certain aspects of this question Miss Delano stood alone, facing on the one hand the professional group of which she herself was a member and on the other, the untrained women of America who clamored for opportunity, through the American Red Cross, for war nursing service.

As the war progressed, the nursing needs of the Military Establishment and the available supply of graduate murses grew more apparent to Army, Nay and Red Cross ofticials. The numbers of men in the Military Establishment were increasing to grigantic figures; the activities of the enemy and the resulting numbers of casualties to the Allies, were also increasing to an alarming degree, especially after the German offensive of Narch 21. During the spring of 1918, public, professional and military opinion upon the nursing situation crrstallized into two groups: those who felt that the Military Establishment should include only professional nurses, and those who felt that the Military Establishment should inelude professional nurses and assistants or aides working under protessional direction. On Feluruary 9, 1918, General Gorgas wrote to the Dirererer (ieneral of Military Relief of the Americum Rerl Cross that "in my opinion it is highly advisable that measures be taken by the Ainerican Red Cross to carry out the plans already formulated by them to provide a large number of nurses' aides who may be used to supplement the nursing foree in military hospitals should need arise. . . The aides will he classed as civilian employees of the Medieal 1)epartment at large and will be given a saliry of $\$ 30 \mathrm{per}^{\mathrm{r}}$ month, with quaters. subsistene, the lanndering of their miforms while on duty in hoppitals and the neeresary traveling expenses when traveling under orders."

On Monday moruing, Fohruary 18, Miss Goodrich assumed her duties in the sureon General's ottice. Late that week, she heard abont the plan for ntilization of lied c'ross aldes in militalry hospitals and she immediately took up the matter with Colonel Winford Sunth, then chiof of the IIospital Division on the Surgeon firmerals otfier, with the result that Colonel smith asked the Red ('ross to withhold the annomeement re- 
garding aides until Miss Goodrich and her assistant, Elizabeth Burgess, had had "time to study the situation in base hospitals and conld make recommendations." 1

On Fobruary 20, 1918, Colonel smith wrote to Miss Delano:

Referring to the request recently sent to you from this oflice requesting that steps be taken to inaugurate short conres for the training of murses' aides or attenlants, 1 am direded by the Surqeon General to request that for the present no steps be taken to put this plan in actual operation in the hospitals: in other works, it is desired to withhold announcements and circulars for a brief time until a report has been make as to the possilility and desirability of modifying this: plan, or of accomplishing the same purpose in a different manmer. It is expected that this report will be available within the next two weoks.

This is not to be considered as a definite abandonment of the policy as indicatorl by the previous request, but is merely a delay in its execution nutil additional data are arailable.

Out of the study and recommendations of Miss Goodrich grew the plan for the Army School of Nursing and the question of ntilizing the fifteen hindred aides already trained as persomel of the base hospital plan, and others to be trained by the lied Cross, was again "tabled," in spite of Miss Delano's efforts.

The proposed plan for the Army School evoked many differenees of opinion within the medical and nmesing professions. l)iscrssion on this subjret eame to a head in the Twenty-fourth Ammal convention of the National League of Nursing Education, which met at Cleveland, May 7-11, 1918.

Three gromps were represented at this convention: the nursing eromp, fealous for the maintenance of hard-won professional standards; the advorates for the supplementary volunteer mursing sorrive: and the volmuteres themselves, anxions to share in war mursing. 'The rank and file as woll as the leaders of nursing represented the first group. I). S. S. Goldwater, superintendent of Xt. Sinal ILespital and ehaiman of the Committere om Inspitals of the Comeral Medial Board of the Comed of National lofenter. Was spokesman of the second geromp. In summing np the ansention, Miss Palnuere wrote in the editorial colmuns (.lume, 1!1-) of the American Jourmal of Tursing: 1918.

1 Sere Twenty-fourth Annual lieport of the League of Nursing Education, 


\section{HISTORY OF AMERICAN RED CROSS NURSING}

The two papers which were of greatest importance were those presented by Colonel Winford Smith in which he submitted plans for an Army School of Nursing, and by Dr. Goldwater. entitled "A Nursing Crisis," in which he adrocated the employment of nurses' aides as they have been trained for the past three or four years through the education committees of the Red Cross. . . .

As the organization of the Army School of Nursing has already been set forth in a previous chapter, Colonel Smith's paper will not he given herewith. Dr. Goldwater told of the Surgeon General's plans for three hundred thousand hospital beds, stated that during the past year, the Army and Navy, with the help of the Red Cross and the active support of hospitals and nursing organizations, had been able to secure only one-fifth of the number of nurses needed and marle the statement that "the country cannot spare the number of gradnate nurses that the Army requires, nor can the training schools produce new graduates in sufficient numbers to satisfy the needs of the military and civilian population." 2

After detailed discussion of the possibility of seeuring an adequate supply of graduate nurses from those already trained; of increasing the supply of student nurses in schools; of utilizing "practical murses" in the Army; and of the establishment of the Army School of Nursing, Dr. Goldwater made the following recommendation:

I come finally to what appears to me to be the safest and best way out.-in fact. the only way out, namely, the training of a large number of non-professional, voluntary, war nursing aides, enlisted for the period of the war only and romposed of a class which will not talie up nursing professionally under any riremetances. but which is willing to give gratuitous hospital service during the emereency. . . The women I have in mind heloner wholly or almost wholly to the lejsure class. They are now contributing nothing to the eflionene of the nation or to the suceess of the war: yet they are strong. healthy. patrintic and willingr. They are the ouly lathor reserves that the country poscesses and they ran be bronght into the mursing fietr? willout lessening the arritable supply of urotiers for an! escontinl industry. . . .

"Twenty-fourth Ammal Report. N. L. N. E.. pp. 132-133.

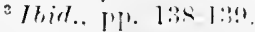


On the following day Miss Delano addressed the convention on "the Red Cross Aide Versus the Short-term Course" and her words are significant to every student of military nursing service, both professional and volunteer. She said that the idea of Red C'ross serviee had developed out of war experienee: that the "aim of Red Cross societies was primarily to coïrdinate and develop the volunteer service of the world;" that the Anerican Red Cross had chesen to develop a professional nursing service thinking that this service would afford the most efficient nursing eare to the American Military Establishment; and that the development of this professional mursing serviee had been entrusted in 1909 to the American nursing profession.

The Ameriean Red Cross Nursing Service thus stood alone among the nursing services of national Red Cross societics and this professional fommlation evoked, it may be frankly admitted, considerable eritieism. Miss Delano continued:

I confess that this attitude of the American Red Cross was viewed with more or less suspicion by many of the countries signatory to the cionera Treaty. It was an innovation.

Ahout five years ago [1912] there was held in the city of Washington an international conference of the Red Cross organizations of the world. I had the honor to be a delegate to that anrention. Nursing questions were diseussed more or less throughout the entire convention. because the supplying of the service of nurses in time of war was always reengnized as the chief function of the Red C'ross. . . The fact that we hilt the sorvice up entirely on professional service, which is of necessity expensive and whirh is restricted in certain ways as it deprives the women of the comntry of the service which they have considered from time immemorial their right, this plan of ours was riewed with more or less suspicions. experially hy the women of France. who bolieved that their plall was far superior to ours. . . In this international eonferenere the Amerion Red Cross--not the nursing departunent hut the Ameriean Red Cross of the Inited States,-arkind itolf whether it had done all that it should do to provide for the needs of war. ...

Here followed in Miss Itelano's words a deseription of the project which has heren brietly alluded to pleviously, with

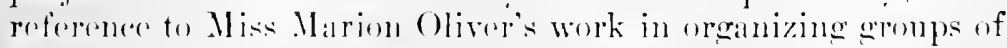
lay workers, resembling the British system of Volmutary did Detalluments. Miss lolano continued: 


\section{HISTORY OF AMERICAN RED CROSS NURSING}

An officer of the Medical Corps of the Army then assigned to Red Cross service was sent to Europe during the summer following the International Convention to study the nursing service of the European countries, especially England. $\mathrm{He}$ came back in the late summer to recommend to the Executive Committee of the Ameriean Red Cross that an organization of women should be built up in this country along the same lines as the Toluntary Aid Detachments in England. The course was plammed ont. a circular concerning this work was printed and the whole plan was laid out, to be put into operation in this comintry.

I felt that our nursing standards were absolutely threatenel, that our Nursing Service would be of no avail with these groups of women mrelated to us, organized by physicians, taught by physicians, serving under their guidance, their own leaders . . . that our Nursing Service was seriously threatened and that our nursing standards might all go by the board. ...

Miss Delano then explained how she had called the National Committee together (on November 14, 1912, in New York City) and had laid the situation before them. Miss Maxwell, Mrs. Tice, Miss Nevins, Miss Nutting, Miss Goodrich, Miss Nichols, Miss MeIsaac, Miss Palmer and Miss Wald had been present. ${ }^{4}$ Ifiss Delano recounted the results of that meeting:

The whole question of the organization of the Voluntary Aid Detachment was discussed at length and I stood then positively opposen to it. I told the lied Cross that if this plan were put through that I shomld at once sever my comection with the liml Cross; that I believed that every member of the National Committee and every member of the State and Local Committees would go out with me. That. to the Red Cross at that time, was an manswerahle argument and it wa: I aswure you. . . . a difficolt thing to anvince them that this: plan shomld be set aside and they should turn it over bodily to us to devalop. We fook from them that day the responsibility for the levelomment of the auxiliary nursing service of the American Tied Cross.

I consiler that practically a plertge. a promise. and for five vears we have developerl that amxiliary service. We have built up every step of the way. Antail after detail. We never

- For further details, sop Minates of the National committer on Rerl Cross Nursing Services also the tmerican Journal of Tursing. Derember, 1912. 
had one single interference or one word of suggestion from the Red Cross regarding the work. Absolutely no pressure has been brought to bear upon us to motify or to change or to alter one iota or one tittle of the plan. It has heen our plan. It was indeed the plan of the Red Cross and in every step that I took in the development of the service I was guided absolutely by the National Committee, representing first the American Nurses' Asociation and second equal representation from the three national ormanizations of nurses. Even the name ... Volunteer Nurses' Aide, was selerted by the Committee after careful discussion . . . but more than that, the women of this country acopted our leadership."

Miss Delano then explained how the course of instruction in Home Hrgiene and ('are of the Siek had been used as a basis of selection for the gromps of laywomen and how the hospital training of nurses' aides for the base hospital mits, had been the next step. At every move, the plans for the development of the service were disconsed with leaders of the mursing profession then serving as nembers of the National Committee on Red Cross Nursing Service. Miss Delano said further:

I hold no brief for nurses' aides as such, but I do hold a brief for your obligations and griving your word and then standing by it. For I am absolutely in sympathy with any plan that will help meet the needs of the country to-day. The Red Cross stands roaly to cöperate, in any way posible, in any plan which the Surgeon General adopts to meet the needs of the military hospitals to-day. . . But I do not believe that any plan suggested now would reliese us of the obligation which we definitely assumed five vears ago and I believe that the nursing profession will stand reproarbed by the people of America if they repudiate the responsibilities which they foumbl to serme.

I have expressed myelf as entirely willine to put all the resouress of the Red Cross. -and the resources of the Red Crose to-day are not insignificant.- . . at the disposal of the Army, to "oöperate in any plan that the Surgeon General brings forward. Wo shall gro forward with just as murb zeal and help in serenring a staff for training sehools if this should be thonght nowesiary to be done. as we were in trying to provide aides for this service. . . It is not at all a question for us of one thing as against the other. We are willing to

5 Twenty-fourth Annual lieport of the League of Nursing Faluation, pp. $11+2-11 ; 3$. 


\section{HISTORY OF AMERICAN RED CROSS NURSING}

help in any way we can, in any way we possibly can. But I shall never, so long as I stand at the head of the Red Cross Nursing Service, repudiate the solemn obligation we have assumed. ${ }^{6}$

\section{Miss Delano then stated her opinion of the proposed Army} School of Nursing:

Personally, I do not believe that the establishment of a training service will meet the needs. I do not believe it can be put into operation quickly and promptly enough to meet the need when our troops, who are now in service, are brought back to this country. I do not say by that that I disapprove of the idea of a training service or of trying it. I think it is worth while to try anything that will meet the emergency when it comes, because it is surely coming.

If it be schools. in carefully selected places, I say let's try and get students for them. I feel that it is for the Nurses' Association and those who are more familiar with the influence of training schools to-day to decide whether this question of the Army training schools is going to be a greater menace than the selertion of the nurses' aides for training. I do not pass on that. It is a technical question. . . . But I do feel that there is a place in the small hospital for hands and for feet more or less trained. . . .

Although Miss Delano was primarily a nurse and regarded herself as the representative in the Red Cross of the American Nurses' Association, she presented at this meeting in part the continental point of view and thus sponsored the canse of the larwoman. "To help win thr war and to give adequate care to the sick and womnded," wrote Miss Pahmer in the Journal, "was her religion from the day that war was declared. Soxt to that eane her aspiration to have the rank and file of the American Nurses Aseociation satisfied with her work as their representative in the Red Cross. . .

Miss Delanos next words expressed, in part, this intense and carnest patriotism which lighted her whole Red Cross service:

What I want to-day is for the nurses of the country to forget everthing except the importance of the need at this

- Twenty-fourth Anmual Report, X. T. X. E., p. 165.

"Ilid.. P. 166. 
time. If we can neet it one way, let's move heaven and earth to meet it that way. If that is not enough, let us be broadminded and meet it any way we can.

\section{Miss Delano then diseussed the possibility of securing enough} graduate nurses; the possibility of seeuring transportation overseas for these nurses; the wisdom and necessity of holding these nurses in military base hospitals in France, where they might perhaps be idle for months in order that when an unexpeeted drive oceurred and the wounded were sent back to the bases, they might be on hand and prepared to murse the men. She next brought up the utilization of soldier-orderlies in hospitals. She said:

No one speaks of the able-bodied men in the hospitals. Nobody tells you that to-day there are 115,000 able-bodied, strong men in the Arny hospitals alone, doing work for which they are not in any way fitted or trained or prepared,115,000 able-borlicd men domg very hard work in military hospitals, running and waiting on patients more or less efficiently. We are talking about 10,000 nurses whom we have in the Army hospitals but we forget that for the 10,000 women we have 115,000 able-bodied men. The surgeon General in my office the other day spoke about that very question. He said he was anxions for the number of able-borlied men serving in military hospitals instead of ont learning to fight. And these men are the piek of the nation, all young, able-botied, strong, ambitions nom, like a lot of ruming horses tied down to drawing rarts. It is not right.

Those men. I heliese, shonld be replaced by women. . . Now, l say, fot us provirle the supervision of the finest women we ran find, and let us supplement that fore with women traines or in proesses of heing trained. so that these 115,000 men, or at least a larege proportion of them, an be sent ont to traning and commissions. Doesn't that sound reasonable?...

For I ammot believe that we should use at this time the services of our graduate murses to sit down and feed our helpless men in the walr: I believe that women of common sense or juclgment, a student or aide or whaterer she is. could ho those services aneptahly and that a very grave responsibility will rest upon us if ultimately we prefent from drawing inte the hospitals a sufbeint mumber of women. trained students or aides, to meet the military needs."

s Twenty-fourth Annual heport, X. L. X. E.. pp. 16i-169. 


\section{HISTORY OF AMERICAN RED CROSS NURSING}

Miss Delano closed her address with a plea for the lay aides:

As far as the Red Cross is concerned, we have nothing to recommend. We stand ready to coöperate with any plan brought forward by the Surgeon General. The only point that I think important, and 1 will make, is that we are not fair to the women of this comntry if we say absolutely after five years of building up a service for them and they are not yet accepted to-rlay,-if we say, "we will have none of you."

I think we have prejudiced our profession in the minds of the public by this attitude more than by anything that has ever happened. I have heard things that might never come to the ears of others and I know that there is underneath, in the spirit of the women of this country. a feeling that they have been dealt with most unfairly; and I assure you that I will not take part in anything that eliminates absolutely the women of this country whose lored ones are serving in France. $^{9}$

Miss Delano left the platform and immediately the president of the National League of Nursing Edueation called upon Miss Goodrich to present her "Plan for the Army Sehool of Nursing." Miss Goodrich spoke with her usual brilliant powers. The chairman then ealled for disenssion and a spirited rebuttal took place. Finally Miss Nutting threw her influence as a well-lored and trusted leader toward the aceeptance of Miss Goodrich's plan.

The nursing profession may well be said to have stood, on this IIay morning, at the cross-roats. Miss Goodrich beekoned at one fork for them to follow her, Miss Delano at the other. The tension of the necting had grown very high. After further discussion, the chairman put the question to a rote. Miss Powell moved "that the Army School of Nursing as plamed by Miss Goodrich be endorsed by the three organizations," the motion was amended to read "as planned by the committee" and was passed. This endorsement of the Army Sehool by the three national organizations of nursing was sent to Washington, the Secretary of War approved the plan on May 24, 1915, and the developinent of the sichool was immediately begun. ${ }^{10}$

- Twenty-fourth Anmual Report, X. J. X. E.. p. 169.

in On liay 10, 1918, a meetiner of the National Committee on Red Cross Nursing Service was held in C'leceland and this whole glestion was again discussed. The Minutes of the meeting record that Miss Sinting moved "that the members of the National Committee give their support to the 
On June 8, 1918, Miss Delano wrote to Miss Palmer, editor of the Journal:

'The discussions concerning the Army Sthool for Nurses' Airles seems to have developed into very much of a feud . . . with folonel sinith, Miss (ioodrich and followers representing one side and I)r. (ioldwater and his followers, largely the American Jlospital Association, on the other side. I an kept busy trying to steer my aralt between the breakers, believing as I do that both sides are right and both sides are wrong. IVith your mulerstancing mind, you will know what l mean.

I believe the school inlea a good thing to try ont and one more way to help meet the need and if carried out along fretty definite lines and with definite alfiliations with civilian schocils, ought not to dismpt the training schools of the (onintry.

()n the other hand, I believe we are ontirely justified in using women who are past the age for armission to this school for minor positions in military hospitals. surel as the are of linen rooms. sorving diets, foeding of patients and a thousand and one details which our graduate nurses have no time to do....

\section{On July 22, 1918, General Gorgas wrote to Mr. Davison:}

Enderstanding that Goneral Soble told you when at Cimpr Mearle the oflere dily something of our recently establishard

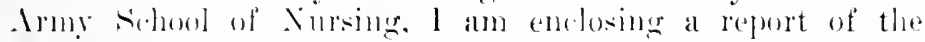
(ommitte appointed to preplare the plan of the school, which may interest you. With eomparatively little publisity a very grreat interest has heen aroused and we have not only recoived

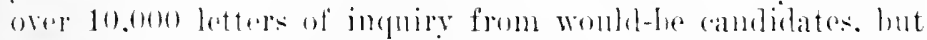
have actually on file orer 1000 (ompleted applingtions a larges majority of which ment our recpurements for ahmission.

May I say that 10 are indebted for this enrollment in no small moasure to the varions lied ('rose bivisions and ('hay-

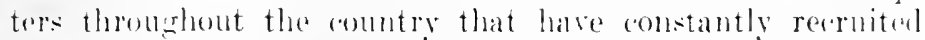
for us. It is my belief that this hearty respones to the alpual

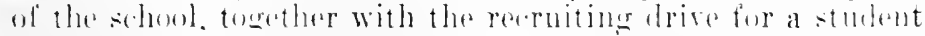

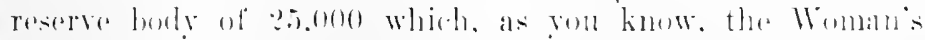

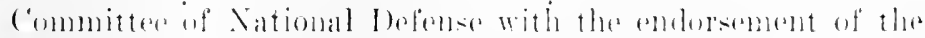

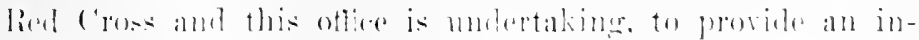

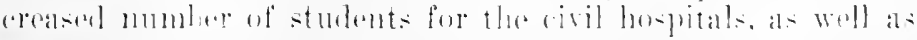

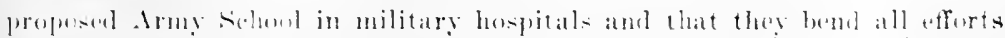

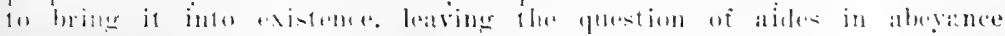
until this is sedlede" This motion was seronkled and carried. 


\section{4 HISTORY OF AMERICAN RED CROSS NURSING}

the military, will meet our arising needs and that we need not further consider the preparation of aides through shorter and more superficial courses. It is obvious that should the supply of graduate nurses prove inadequate for the overseas service, this student group will render the most satisfactory service and will be the next to go.

I understand that you are preparing aides to supplement the work of the public health nurses in France and Italy. In order not to deflect desirable students from the more constructive and comprehensive preparation provided through the Army School of Nursing, and also to avoid any misunderstanding and disappointment on the part of the young women taking these courses, may I ask you to direct those in charge of this branch of work, especially those who are concerned with the publicity, to make it clear to these students that these courses will not lead to a nursing service in the Army.

By November, 1918, the Army School had 1099 students on duty in twenty-five military hospitals in the United States, 567 more waiting assignment and a total of 10,689 applications filed.

The rejection of her proposal for the utilization of Red Cross aides, as contained in the endorsement of the Army Sichool by the American Nurses' Association at the Cleveland meeting, may be said to have marked the erisis of Miss Delano's professional career. For the first time, the rank and file of nurses had not followed her. Unquestionably, pressure had been brought to bear on the Red Cross from influential groups outside of the organization. Miss Delano's words show that she felt that the nursing profession, in its continued rejection of lay assistance, was not true to the trust which the National Committee had assnmed. In this meeting, Miss 1)lano had carried her canse into the open, had defended and lost it.

On the other hand, the strong professional group may have thought they saw in Miss l)anows rhanpionship of the layworker a desertion of the fundamental principles of the nursing profession, a bending before the winds of Red Cross opinion. The prineiple of the sentimentalist versus the trained workere, an old as Ameriean war nursing, had lanised its head again and nurses may have thomght they saw in Miss l)elano a reently won but powerful ally of the traditional influenee of the ente-

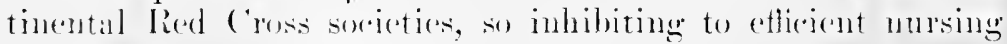


service. Miss Nutting and Miss Goodrich had spent their lives in trying to better the standards of nursing education; their words spoken at the May meeting show that they did not possess sufficient knowledge of the military and nursing situation overseas to recognize the serionsuess of the existing shortage of murses, a shortiage which was then estimated at 1121 nurses. This was the time when the statement was made in the

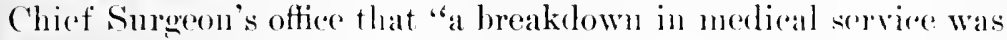
threatened" and on May 3 a cable had been sent to the War Department asking for the immediate dispatch of 555 murses, but even with these reënforeements, it is hard to conceive how the War Department could have thought that a nursing service overseas of some twenty-five hundred murses would be able to care for the casualties of the then elearly anticipated offensives of May, June and July.

Because of the Surgeon General's call for fifty thousand nurses by June 1, 1!19, Miss Delano felt that it was highly unsafe to trust to a slow, constructive up-building of an educational system like the Army Sehool; she felt that it was even then a time for emergency action. On the other hand, Miss Nutting and Miss Goodrich did not think the military crisis as imminent as it really was and in view of their long strnggele for nursing advancement and standards, it can readily be understood how they should have continued to lay the greatest emphasis upon phases of nursing education.

As for Miss Delano, the (leveland meeting marked her last public appearance before the nursing profession and in the memories of thousands of murses her inager as she appeared that day was indelibly stamped. For the remaining eleven months of her life, Il iss I Melano kept her own councils. However, it was not during these last months that she was first ealled politie. She had always been a silent woman, talking little to her sister murses regarding her hopes and plans. Among them, howerer, a strong fraternal spirit of inter-rediance and conti-

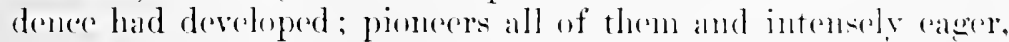
they had shared their hopes and the stories of their stringertes with each other, but .1 iss belano had nevere taken them fully into her eonfidenere. Beranse they did not know her well. per-

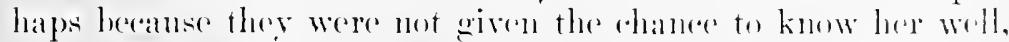
they distrusted her te some cextent. Ilowerer, it is mudoubtedly true that the nursing and general publir did nut serm to appreciate, in the spring and summere of 1914 , the real and inpera- 


\section{HISTORY OF AMERICAN RED CROSS NURSING}

tive need for immediate reënforcement of the nursing service as Miss Delano appeared to know or at least to sense it. The War Department could not make public the true sanitary situation in France in May and June of 1918. Miss Delano, however, had been for ten years a student of sanitary theory and practice and with that uncamy gift called vision, she was able to look ahead and visualize the conditions which later existed in military hospitals in the zone of the base and the advance, conditions already described in preecding chapters. Many of her listeners that May morning in Cleveland must have felt that she was taking an unduly pessimistie view of the situation. Yet on that May morning she was like a proplet erying in the wilderness - with roice not heeded.

To the student of history the whole controversy well illustrates the irony and even the tragedy of war. On the days when the nursing profession was preparing to argue these theories at the Cleveland meeting, the Germans had struck their seeond great blow on the Western Front, this time in the Armentières sector; they had advaneed seventeen miles up the Lys valley, had finally been repulsed and during the first three weeks of May were massing their forees for their third major offensive, an offensive during which the fate of Paris and the Allied eause hung in the balanee. Knowledge of the extreme military erisis, however, was then not fully known or made publie, and indeed neither student nurses nor Red Cross aides nor all the graduates then in civilian hospitals in the United States eould have relieved the nursing shortage existing late in Mlay and early in June in France-for there were no ships avalable to earry them overseas. Throughout the last year of the European War and especially during the summer of 1918, many hundreds of nurses were kept marking time at Ellis Island, because precedenee in transportation was necessarily given to combat troops and supplies.

"We'll do it another way!" Miss Inlano declared after the Cleveland mecting had adjourned. Following the aceptance of the Army Sichool as a substitute for her plan of utilizing Red Cross aldes to supplement professional military nursing serviee, the recruiting of a sufficient number of graduate nurses to meet the military nereds sermed to Miss Delano the only way out. This was the first duty of the Red Cross Yursing Serviee and Miss Delano knew that the exerutives at National Headquarters would put no obstacles in the way of her purposes and 
plans. She knew that she possessed the complete confidenee of the War Council, for once Mr. Davison had said: "Do as you think best, Miss Delano. Keep us informed of your general plans and of the money you need, but go ahead yourself. Even if you make mistakes, you know more about Red Cross mursing than any other woman or man we conld get to handle it."

Miss Delano and her associates returned to Washington and to Division headquarters and during the torrid summer months flung themselves into the recruiting of graduate nurses. She and Miss Noyes built up an office force at National Headquarters of over one hundred persons. The I)ivision staffs were enlarged and the entire lied Cross Nursing Serviee, with its State and Local Committees, bent its energies almost solely to securing graduate nurses.

The total number of nurses needed was divided into thirteen parts and a quota, based upon the nursing resources of each locality, was giren to each Division Director of Nursing and she was charged with the responsibility of securing her quota. The following statistical table is of interest:

\begin{tabular}{|c|c|c|c|c|}
\hline & \multicolumn{3}{|c|}{ AssignuENTs } & \\
\hline & First & Assignments & Allotment & \\
\hline & Allotment & to 1 ugust 1 & still Due & \\
\hline Atlantie & $5 \% 08$ & 2600 & 3108 & $45 \%$ \\
\hline Central & 3940 & $2: 311$ & 1629 & $58 \%$ \\
\hline (iulf & 864 & $3: 4$ & 540 & $3 \% \%$ \\
\hline Iake & $27+8$ & 1205 & $15+3$ & $4: 3 \%$ \\
\hline Mountain & 264 & 221 & 43 & $83 \%$ \\
\hline New Fingland & 3318 & 1360 & 1958 & $+1 \%$ \\
\hline Northern & 1165 & 598 & 567 & $50 \%$ \\
\hline Northwestern & $6+11$ & 386 & 25.5 & $60 \%$ \\
\hline l'areifice & 10.36 & $8 ! 19$ & $18 \%$ & $8 \% \%$ \\
\hline l'(xmsylrania & 2151 & 1302 & 852 & $60 \%$ \\
\hline Potomiar & 1366 & $26 i t$ & 602 & $56 \%$ \\
\hline Southeru & $1: 3 \% 1$ & $38:$ & 989 & $28 \%$ \\
\hline Southwestern & 2425 & 995 & 1430 & $41 \%$ \\
\hline
\end{tabular}

The effects of the "nurses' drive" have been griven in a previous chapter. For the five months begimning July 1 and conding December 1, 11.118 murses were enrolled. an average of 2.200 murses a month. In one month alone of that historic smmmer, the Amerienn lied Cross soremed and assigned to the Military Fatablishment orer twiee as many gratuate nurses as there 


\section{HISTORY OF AMERICAN RED CROSS NURSING}

were students supplied by the Army Sehool during the entire period of hostilitics.

In .July, 191S, the Comptroller of the United States Treasury rendered to the Seeretary of War a decision of injustice to Army nurses. Information as to this ruling and its possible effect upon the nursing situation was contained in the following letter of protest written on August 31 by Miss Noyes, as president of the American Nurses' Association, to the Honorable W. W. Warwick, comptroller of the U. S. Treasury:

On July 16, you rendered a decision to the Secretary of War to the effect that members of the Army Nurse Corps who may be taken as prisoners of war are not entitled to pay during captivity.

I feel sure that you were not familiar with the history of the organization of the Arny Nurse Corps and its legal relation to the Army, when you rendered this decision. As president of the American Nurses' Association, which is affiliated with the Red Cross and assumed with it the responsibility of organizing the graduate nurses of this country as a reserve of the regular Army Nurse Corps, I was filled with dismay when I read your decision.

Rendered at a time when the Government was appealing for a thousand nurses a week for service with the Army, your derision could not help but be destructive to their enrollment. It is therefore a vital blow at the welfare of our soldiers.

Approximately fifteen thousand nurses are in servire with the Army and Xary. These nurses who have already entered the servied and these abont to enroll shonhl have every assurance that the govermment is ready to protest them in their hazardons work and safeguard them in their statutory rights. Will you not be willing to give them this assurance?

On September 27 a decision was rendered by the Comptroller of the Treatsury which reversed the ruling of July 16 . It was addressed to the secretary of War and contained the following paragraphs :

In view of unusual conditions that have arisen. I am of the opinion that from the time any member of the Army Nurse Corpe is a prisonere of war held by the enemy. without fault on her part as to here anture, her absene from duty should be excrused as mavoidable and she be treated as in a full pay status. 
The derision of July 16,1918 , is modified arcordingly.

As to fichd rlertss and member's of the Army Nurse Corps reported "missing," my decision is similar to that given in the "ases of oflicers and enlisted men reported "missing" (25 Comp. Dee., 36 ) and is as follows: Xo definite meneral rule that shall cover pay of field elerks and members of the Army Nurse Corps rejorted "missing" in action or otherwise missing shall be formulated. "Their pay should be witheld until their status an be dofinitely ascertained. In ase no information establishing their status an be obtainod, individual ases must be considered on their merit and determined upon such evidence as may he ohtainable." 11

Another trying condition which Miss Noyes met was the refusal of wealthy chronic patients, some of whom were in health good enough to permit them to go to their offices every day, to give up their private nurses. Another minor difficulty was eneountered in the protests of doetors who refused to release for military scrvice office nurses whom they wished to retain to hold their practice together while they themselves went into the Army. Protests also eame from owners of small private hospitals, who refused to give up their graduate special nurses. In this respect, however, many small private hospitals were patriotic enongh to close their doors entirely for the period of the war.

On August 1 the Surgeon General issued his historic call for a "thonsand nurses a week for a perpiod of eight weeks." The strain at National Iradquarters gerew intemse. Moreover, Washington was owererowded and was suffering from reordbroaking heat. In a letter addressed September 5 to Miss Do Long in Italy, Miss Noyes wrote:

The work at National Ileadquarters has never heen so diffirult and is now orepwlobming ns. The demamel for one thousand nurses a week hy the surgeon fiencral has made it necessary for evryone to burkla down to work from one and of the Inited siates to the other in order to rout out every possible murse from her hirling plate.

We have dene a tromendous piene of work. Vesterilay we sent the papers of $1: 2$ nurses to the War longatment. the day before 132 . and they areraere at per day. There will he no nurses loft in civil life if we kerep on at this rate. . .

"Decisions of the Comptroller, L. S. Treasury, Army lind Clerks, A. (1. 1). 2.21.51: p. 6. 


\section{HISTORY OF AMERICAN RED CROSS NURSING}

There seems to be an impression abroad that the war may end in 1919.

At this eritical moment an unfortunate newspaper article had a definitely inhibiting effect on recruiting. A personal interview with the chaiman of the Committee on Nursing of the Comncil of National Defense was so written as to sound official and unduly optimistic. Lest the impression given by this article should deter nurses from entering military service, the Acting Surgeon General of the Army issued a public statement of the actual nursing conditions and also stated it in a letter written September 7 to Major Franklin Martin, then chairman of the Medical Board, Council of National Defense:

At least 25,000 graduate nurses will be needed by January or as soon as they can possibly be obtained. 'There are at present somewhat over 16,000 graduate nurses on duty at home and abroad. This number by no means meets the need of the present situation, owing to the fact that large numbers of troops are being sent overseas weekly. The Red Cross reports that over 9000 additional graduate nurses must be enrolled before Ianuary 1 to meet this need. In the Atlantic Division alone, which includes New York City, 2452 additional nurses must he enrolled to complete their quota. It will be impossible for the Army School of Nursing to be of any great assistance in solving the mursing problem of military hospitals during the present year. Only $2: 1$ students have as yet been assigned to seven $(y)$ cantonment hospitals and 105 atditional are under orders to proceed, but they camnot be relied upon to take the place of graduate nurses, as they are expected to serve a four months probation with only a limited number of hours in the wards of the hospital during this probationary period.

It is repnested that such artion as may be necessary be taken to correct this statemont, in order that the public and the murses may be informed of the true situation and that the work of recruiting murses shall not be interfered with. . . .

This incident was also of some importance in that it illustrated the danger of mismuderstanding which may arise when two national rommitters such as the Committee on Nursing of the Commel of National I) fense and the National Committee on Red cross Nursing Serviee were both operating in the field. In the fall of 1ols the nursing needs of the civilian popula- 
tion engulfed the American Red Cross. Late in August, Spanish influenza broke out among the men of the $\mathrm{Navy}$ Receiving Ship in Boston Harbor and swept across the United States during September and October. The first eall for Red Cross assistance came on September 14 from the United States Public Health Serviee, for mursing persomel for the Quarantine Station, Boston Harbor. Almost simultaneously, calls began to come in from all parts of New England and from Washington, I). C. Within a few weeks the infection had beeone pandemic in the eastern eantomments and spread from the soldiers to the civilian population and thence westward. One thousand nurses, it will be remembered, had been withdrawn from the eantonment nursing staff's and had arrivel in Angust in France. True, the American Red Cross had sent the papers of 2700 additional murses to the Surgeon General's oftiee in August alone, but it took some time to assimilate these nurses into the Military Establishment. On September 7 the Army School had only 221 students on duty in seven eantonment hospitals, according to the Acting Surgeon General's letter of September 7 addressed to Dr. Martin. These students were "green probationers" and it was estimated that it would take four months of training before their services would be of material value. The truly desperate condition which existed in the cantomment and Naval hospitals during that memorable Septrmber and ()etober of 1918 has ahready been deseribed. Colonel Ayres wrote:

More than 40,000 died of pnemmonia. Of these, probably 25,000 resulted from the influenza-pnemmonia pandemic which swept through every (amp and cantonment in this country and ansed thonsands of deatls in the Expeditionary Forces. l'p to september 14, 1918 , only 9840 deaths from disease had oceurred in the Army and the death rate for the period of the war up to that time was only 5 per year for cach 100() mene.

During the eight weeks from september 14 to the sth of November, 316,0s! wases of influenza and 53.4t9 of pnenmonia were reported anomer troops in this comutry. The explosice charater of the epridenice ss shown in diagram sti: fs.3.6\% of the total deaths were from pnemmonial. It reached its high point the serenel week in october. When four out of every 1000 troops moler arms in this comitry died. . . .12

12 "The War with Gemany" pp. 10.5-126. 


\section{HISTORY OF AMERICAN RED CROSS NURSING}

The situation among the civilian population was equally critical and responsibility for aid was rested in the United States Public Health Service and the Ameriean Red Cross. At National Headquarters a meeting was called at which were present representatives of the Surgeon Generals of the Army, the Nary and the Public Health Service and of the Red Cross and a prelininary plan for affording unsing relief was formulated. Nliss Delano was then in Atlantic City attending a meeting of the Ameriean Hospital Assoeiation, so Miss Noyes drew up the plans for the mobilization of nursing resourees and throughout the pandemic carried all national details regarding nursing relief.

National Headquarters was of course the center to which the nursing needs of the entire country eame. National morale was already under a heary war strain and the confessed lack of medical knowledge regarding the nature of the disease fanned the flames of publie alarm. Many hundreds of nurses in eivilian and military service themselves came down with the disease and the calls for nurses inereased proportionately. $\mathrm{By}$ long distance telephone, by telegraph and personal interviews with Niss Noyes, State health ofticials, Army ofticers, heads of eivilian hospitals and particularly men in charge of industries, importmed National Headquarters: "If you eamot send us murses," they aftirmed, "our men will all eome down with the flu and production will stop."

On Septrmber 24 Miss Noyes wired the Division Directors of Nursing to moljilize all Home Defense nurses for emergeney dnty to meet the situation. The assiomment to inthenza work of nurses who were being mobilized for military service was to be aroided as long as possible. No Dirision was permitted to recruit nurses from other Divisions without conferring with National IIndeluarters. Nurses not enrolled in the Red ('ross Nursing Serrier, attendants, practical nurses and laywomen volmuteres who had taken the Red Cross ronrse in Home Iregiene and Care of the Sick, were to be assigned to duty unker the direetion of enrolled Red Cross nurses. All Local Committes an Ried Cross Nursing Service were to be called upen immediately for reseruiting nursing personmel. In "very l)ivision lepartinent of Nursinge, additional ederical assistance was to be serenred and nuaks malle in the Chapters for no in Ampy (ambumment hospitals. Complete records of all assignuesits were alon to le kept. 
The need for nurses daily grew more imperative. On September 27 Miss Noyes telegraphed to all Division Directors of Nursing:

We should like you to organize in your Division one or more mobile units of ten to fifteen mursing personnel to be sent to other localities if necesary. Place competent Ilome l)efense nurse in charge and authorize her to sec'sure assistants, undergraduates, attendants, or nurses' aides and prepare them for instant service.

Several days later the general manager appointed a National Committee on Intluenza, which was composed of the direetors of the departments at National Headquarters, with W. Frank Persons, then Director General of C'ivilian Relief, as chairman. On October 1, Rupert Blue, Surgeon General of the U. S. Public Health service, vested in the Red Cross the following responsibility :

In order that all arailable resources may be utilized to the best alvantage in rombating the present epidemic of influenza, I have the honor to make the following recommendation in regard to the participation of your organization in this (ampaign :

1. That the Red ('ross assume charge of supplying all the needed nursing personnel and pay the salary and other expenses connected with the detail of such persomel for work during the present epidemice.

2. That the lied ('ross furnish emergency supplies, when it is fombl that local anthorities are mable to furnish such supplies with the promptness required by existing circumstances.

On the same day, the War Council appropriated $\$ 575,000$ for influenza relief and the entire Red C'ross organization, in Wishington and in the field, set to work to comlat this most virulent of anv pandemic which had hitherto attacked the conutry.

The eoiperation between the Federal Public Hoalth Serviee and the Anerican lied Cross was ontlined in the following l'lan, issued October :3:

1. That the Rerl Cross should assume charge of supplying needed personnel and will pay salaries anul other apentises 


\section{7t HISTORY OF AMERICAN RED CROSS NURSING}

connected with detail of such personnel for work during the present epidemic.

2. That the Red Cross will furnish emergency hospital supplies when local authorities are unable to furnish such supplies with the promptness required by existing circumstances.

3. The United States Public Health Service will gather facts about the spread of this disease and the adequacy of existing resources and will determine when and where to send additional nursing persomnel and emergency hospital supplies and to what person the nursing personnel shall report and such supplies be delirered.

4. The Public Health Service will decide when any such nursing personnel and supplies have served the emergent purpose and may be transferred to some other place for further duty.

5. The Nursing Department of the Red Cross will have full charge of enrolling and assigning all nursing personnel as requested by the Surgeon General and will also determine their salaries and other compensation. In this connection it is important to add that the widespread call for nurses and the obligations of the Nursing Service to supply nurses also for the Army and Nary render it imperatively necessary that the Nursing Departmcnt shall. through its own officers and committees under the direction of the head of the Department, be and remain in full charge of this part of the program.

6. The United States Public Health Serrice will conduct all necessary dealings with the state and the local boards of health concerning all the above matters and the Divisional offices of the Red Cross will act in providing nursing persomnel and in furnishing supplies only upon the request of the Federal Public Health service.

7. The Lnited States Public Health Service will mobilize all needed doctors.

8. The Lnited States Public Health Service will from time to time ask the Red Cross through the usual channels to distribute official statements issued by the former concerning means of prevention and methods of care of this disease.

9. All general publicity concerning the part of the Red Cross in this program and all general directions concerning the use of the Red Cross resources except the enrollment and assignment of nursing personnel will be issued by the chairman of the Red C'ross National Committee on Inthuenza. 
Development of this general plan for further mobilization of the Red Cross for emergeney relief was authorized during the next few days. Each Red Cross Chapter was instructed to organize immediately a Chapter Committee on Influenza, consisting preferably of the chairman of the Chapter, a leading physician, a representative of the Local Committee on Red Cross Nursing service where one existed, the chairman of the Chapter Committee on Nursing Aetivities, the chairman of the Home Service Section, and such additional members as were deemed neecssary. This eommittee was instructed to work in elose coöperation with the local public health officer, making a survey of available nursing personnel and hospital supplies within its jurisdiction. Only at request of the local health officer and in consultation with the Division office, however, were these nurses and supplies to be mobilized to meet loeal needs.

A Division Committee on Influenza was also appointed, made up of the Division Manager, the Division Directors of Civilian and Military Relief, Nursing, Supplies, Accounts and Chapter Produetion. After issuing this general plan for mobilization of all Red Cross resources, the National Committee on Influenza left its further developments, excepting. where questions of policy arose, to the judgment of the Division and Loeal committees. The educational campaign was developed largely by the Lnited States Public Health Service.

The medical and nursing relief afforded by the Red Cross to the eivilian population in large eities, industrial centers, small towns, and rural and isolated communities was probably as extensive als hats erer been offered by any Red Cross society in any country and is therefore of interest.

The efforts of the Red Cross in the larger eities in the United States is well illustrated in the work done in Washington. I). C. In eöperation with the Enited States Publice Health Service, the Local Chapter equipped and maintained an influenzal hospital on F street. When it beeame evident that this hospital woukd be inalequate to care for the increasing number of pationts, a second hospital was opened by the L. S. Public Ilealth Service at Eighte'nth and Virginia Arenues. Lucy Il innigerode rendered conspienous serviee in organizing the F Street hospital and Rathel Independenee Albangh. whose name will appear numerous times in post-1 rmistice sections of this history, handled details of equipment. 


\section{HISTORY OF AMERICAN RED CROSS NURSING}

The U. S. Public Health Service divided the city into headquarters and four main divisions, each of which was then subdivided into districts. Each district had a headquarters to which all calls for influenza relief work should come. A central reeruiting station for nurses was opened by the Red Cross Chapter at Fourteenth and F Streets, for the purpose of securing additional nursing personnel. In this the coöperation of the school teachers proved of great value. As the schools throughout the country were closed during the most virulent periods of the epidemic, many of the teachers volunteered as assistants to the nurses and rendered efficient service. The work of lay volunteers, especially that rendered by women who had had Red Cross elass instruction, was of great value.

An enrolled nurse who had once taught classes in Home $\mathrm{Hy}$ giene but who had had to give up active service on account of ill health, rallied to duty again during the pandemic. She wrote:

Owing to my semi-nvalidism, I was not officially under the local organization, but my former students had enrolled with me and I caller on them. We did what we could where we ourselves knew the need to be great and we were able to earry several hundrerl homes through to safety with only one death. Many refused relief, but we srstematized our work so that the inexperience of the rolunteer aides would not work hardship either on patient or aide. I sat at my phone day and night, backing their orders with advice and instruction. It was the sweetest thing in the world to hear their responses rome back when I called on them, "Why, yes, of course I will do what I ('an to help."

To return to the District of Columbia, the District Chapter Cantern Service organized a kitchen in each of the four divisions, where food was prepared for those who ronld not secure it in other ways, berause of the illness of members of their families or berause of the rewded conditions existing on acconnt of thr housing probloms. From this kitchon in each division a hot lunch was daily served to dortors and uurses to save their time. The I)istricet Chapter IIotor Corps put its ambulanees and other ears with their drivers to vahable use in carrring pationts to the hospital and in transporting the nurses abont the rity.

The organization which was developed in industrial towns 
is well illustrated by the work at Wilkes Barre, Pennsylvania. Mrs. Gertrude Williamson, the Red Cross nurse in charge of the emergency hospital, wrote:

For two days, volunteers mostly from Red Cross classes in Home Hygiene and ('are of the sick, worked like beavers, cutting (lraw-sheets, making up the Army cots, serubling hatracks to serve as linen shelves and cleaning (amp chairs to be used as bedside talles. The Armory was serubled from roof to basement and four wards were partitioned off with beaverboard and lavatories and sinks were installed in the only available rooms.

The Rerl C'ross Canteen Service took entire charge of the basement kitchen and, with a few paid employees, but mostly rolunteers, served all the food to the nurses, the physicians, the orderlies and the members of the National Guard who were always on duty, besides sending out food, broths mostly, to over 150 families daily, who because of the "flu" had no one well enough to prepare their meals.

In small towns, where there were rarely any hospital facilities of any kind, the emergency was met in an equally effieient way. In Watkins, New York, the Red Men offered the use of their hall to the Local Red Cross Chapter as an emergeney hospital. This offer was immediately aceepted. The problem of equipment presented a grave diftienlty but each housewife sent whaterer she conld spare-a eot, a pair of sheets, a blanket. In the same way, the kitchen was supplied and the principal of the High sichool, released for the period of the eontagion, took complete eharge of the preparation of the diets.

In rural communities, where no hospital facilities existed, the Local ('hapters established temporary ones in schoolhouses or churches. Iliss Barber, Direetor of Nursing of the Northeru Division, wrote:

The houses are often half a mile or more apart from each other. so we used the rural and village silhoollowses for emergency hospitals, wiring them with electricity in many

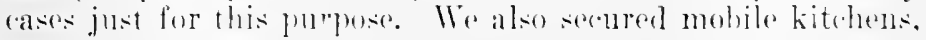
which hand presinusly been used in the harvest fietels, and attisched them to the shoulhouses for cantern service. The result wals highly saltisfactory.

To the most isolated country districts. we ansigned nurses" 


\section{HISTORY OF AMERICAN RED CROSS NURSING}

aides who remained in the houses of their patients as long as the need for nursing care existed.

A nurse assigned to influenza relief work in Denio, Oregon. wrote:

Our patients are mostly families of sheep herders; they live in miserable cabins scattered in most inacessible places, a house to a hill and each hill from twelve to fifteen miles apart. There is no food. no bedding and absolutely no eonception of the first principles of hygiene and sanitation or of nursing care.

I have taken over the hotel as a hospital'and the Big Boss, who employs the sheep herders, is haring all who are not too ill to be moved, brought in here. The men are willing, some are intelligent, but most are sick, and if it were not for the grit and brains of the nurses who have been working here before and for the women of the community, God help us :

I am writing by fits and starts, as I can snatch a minnte off to jot down our needs, hoping that the situation may be clear to you and that you will be able to get us some supplies before we get snowed in for the winter. Our greatest need (next to fruit and malted milk) is feeding cups and drinking tubes, which we can't get at Winnimucea, our nearest town. We also need lots of gauze or eheesecloth and cotton for pneumonia jackets; also rubber shceting and quantities of oll rags. to be used and burned, also gallons of formaldehyde. if we are to stamp out the disease; everything is thrown on the groumd and will thaw out next spring and release all these germs again, if we do not take precautious against it.

Annie L. Colon, a Red Cross public health nurse on duty in Lnce Connty, northern Michigan, wrote:

Some of our patients lived miles back in the woods in the logging (amps where not even a road could reach them. We would go after our patients in hand cars, mounted on the logring trains, and so saved many lives. We had gasoline engines on the most modern type of hand cars and we hitcherl a flat (ar to eacllo one, newally with wire, put a board thoor on it, laid mattresses over that and with a canras cover to hreak the wind we arried our patients fifteen or more miles to a decent bed and a rhance to live.

IVitly this equipment, we rode usually at night through the deep woods and over the rough roadbeds to the camps. Many 
times we would find thirty or forty cases, sometimes ten people all with fever over 104 degrees, huddled together on two or three beds in a tiny cabin, too sick to remove their clothes.

Assigmments of Red Cross nursing personnel (ineluding enrolled nurses, Ilome Defense nurses, pupil nurses, practical nurses and laywonen who had taken the Red Cross conrse in Home Hygiene and Care of the Sick), which eovered only the first wave of influenza that swept across the country from sicptember 14, 1918, to November 7, 1918, totalled 15,000 women.

On Norember 2, 191s, the United States Public Health Service reported that 115,000 persons had died from influenza and pueumonia. The battle deaths of the American Expeditionary Forees were 48,900 , less than half the influenza deaths, and the pandemic was not yet under control. The contagion continued to spreal and Red Cross relicf was earried on until late in the spring of 1919. In round figures, the number of civilian deaths from influenza and pnemmonia totaled 150,000 persons.

During the influenza epidemic, National Headquarters had opportunity to test the efficiency, as an emergency relief agency, of Red Cross national, division and local organization to an extent mequaled even by the opportunities for service coincident to the European War. Moreover, National Headquarters learned bevond doubt that this organization could-and didfunction efficiontly.

The influenza epidemic impressed upon the general public realization of two vital needs. The first of these was the need for organized public health mursing activities in every community. "'lhe only aond which could possibly eome out of an rpidemic which has carried off a great number of our best as well as our pourest reitizens," wrote Katherine La Prade, chairman of the Nursing ('ommitter of the Vietoria ('Texas) Red ('ross ('hapter, "is the prouf to the public of the need and value of organized publie health nursing servie and also the absolute necessity for a connty hospital in exery rural commmnity."

A second nered was that of health education. In many places a four of the inthereza prevailed which was akin to the troror of the Middle Ages regarding the Blarek Plague. Amy l'otts,

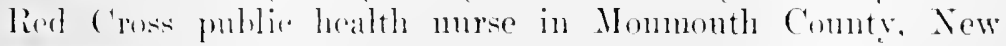
Jerser, wrote: 


\section{HISTORY OF AMERICAN RED CROSS NURSING}

One poor woman had nursed her husband and her three boys through serious cases of the flu and then came down with it herself. All she begged was to be left alone,- - she was so "tired." Her husband got up and tried to do his best. Not one of the neighbors would conve in to help. I stayed there all night and in the morning telephoned to the woman's sister. The sister came and tapped on the window, but refused to talk to me until she had gotten a safe distance away. Finally I managed to pull her into the house and convinced her that she had to stay. When she heard that her sister's recovery was doubtful, she was ashamed, but we could do nothing for the woman after midnight, except send for the priest.

The influenza epidemic and the resulting call for nurses came at a time when the entire Red Cross Nursing Service staff was already overburdened with the needs of the Military Establishment. At National Headquarters, Miss Delano and Miss Noyes had long since begun to show the effects of the responsibility and work they had been carrying. These were trying days, also, for Miss Kerr and Miss Deans, for the patience of these two-perhaps Miss Delano's closest friends at National Headquarters-was often tried by their harassed and exhausted lady-in-chief.

As August and September had passed with crowded, oppressively hot dars and breathless nights, the contrast of temperament between Miss Delano and Miss Noyes had daily grown more apparent. Dark cireles deepened under Miss Delano's eyes, her usual kindliness of manner gave way now and then, deep lines appeared about her resolute mouth. But at no time in her entire Red Cross service was she less confident, less splendid in her sure and brilliant strength.

If Miss Delano earried the major responsibility for the policies and ways and means of proeedure, Miss Nores carried the actual responsibility for and details of reeruiting and assigning nurses to militiry and influenza service. As her burdens increased, Niss Noves grew more silent, more poised, in appearance more cool. IIer moliakable control, the result of temperament and eircumstances, seemed to render her impervious to rexations detail. Looking neither to the right or left, sermingly indifferent at times even to Miss Delano's extreme urginge for haste, she forged ahead on the given task that was hers.

Early in the antumu of 1918, General Gorgas went overseas 
and Merritte W. Ireland, Chief Surgeon of the Ameriean Expeditionary Forces, was reealled to the United States and was appointed as Surgeon General. General Ireland was probably more familiar with the actual mursing shortage existing in the Medieal Department in France than any other man and one of his first moves was to eall upon the American Red Cross to recruit fifteen hundred nurses' aides for immediate service overseas. This request involved the initiation of an extensive drive for aides and plans were developed for seeuring then through eöperation with the Danghters of the American Revolution, the Association of Collegiate Alumne, the Professional Seetion of the Women's Employment Serviee of the Department of Labor and other organizations which were in touch with women who would qualify as candidates.

The eall for aides seemed like the "last straw." However, the beginning of the end was in sight. On November 6, a United States Army hospital train on which three reserve nurses were serving stopped at the station at Sommielle, France. One of these nurses was Anne P. Hill; she wrote:

An officer in charge of the schedule of trains passing through Sommielle told one of our officers that a special train was then on its way toward Verdun and that this train was carrying the principal Allied war generals to meet a delegation from Germany.

'The new's spreall like wild-fire through the train and greatly excited patients and murses alike. It four oclork on the afternoon of November 8 , a special train drew up to ours on the next track and on it were those same war generals returning from negotiating an armistice with the Cermans. All the country-side, too, seemed to sense that the end of the war was in sight. . . .

The first word that an armistice had been signed and that firing had ceased, came to Washington and to Red Cross IIeadquarters at cleven oblock on the morning of November 10, but was a false report. A conference was leeing held in Miss Delano's ottiee when Annie, the small messenger girl, burst in, clapping her hands and erving: "Peace hals been signed. Miss

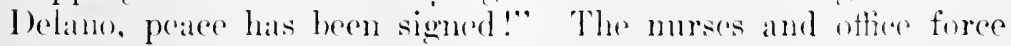
rushed ont to anfirm the report. for newspaper buse were calling the extras. Miss Delano and Miss Xoves steod looking at each other in the deserted, sunshine-thented romm. 


\section{HISTORY OF AMERICAN RED CROSS NURSING}

An hour later Washington had gone mad with joy. Government elerks, soldiers, young stenographers, business men, officers, had rushed ont from the government buildings and swept in a sereaming, waving hysterical mass to the closed and guarded gates of the Executive Office of the White House. Until late in the night, the celebration continued.

On that same night in an Army tent of Evacuation Hospital No. 8, which was located at Souilly, near Verdun, France, a group of tired American Army nurses gathered about the stove in complete discouragement. They knew that the firing had not ceased, beeause they could still hear the sound of the guns. Among them was a Nary nurse on detached duty, Mary Elderkins. She wrote:

Rumors of peace had kept drifting in, but we really had little faith in them. The false armistice report made but a slight impression, as we conld still hear the fighting going on.

The night of Norember 10 we were sitting in my tent around the stove in utter dejection. We regretted that the hopes of those in America and of the rest of the world were being raised only to be disappointed, so sure were most of us that there would be 110 armistice. It 3 A.M., Norember 11, we were awakened by the most terrific barrage we had had in weeks. Someone cynically remarked, "That sounds like peace!"'

At 9 A.M. the message came that the Armistice had been signed. At eleven all ears were strained to see if the firing would cease. It did:

We operated all day long and received wounded men as late as eleven that night. but the msual ceremony of putting up the blark curtains at five ordock was omitted and for the first time we looked out on a camp ablaze with light. 


\section{CHAPTER XI}

\section{DEMOBILIZATION}

Miss Delano's Death-The Close of the Military Program Oerseas-Bureau of Information for Nurses-Nurse Corps. U. S. Public Health Service-Casualties Among Nurse-s-Memorials to Nurses-Red Cross Aides-Educational Projects-Military Rank for Army Nurses

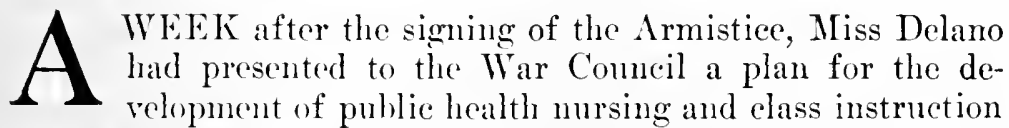
throughout the Lnited states and had won its approval. Full accounts of these projects may be found in subsequent pages. This chapter will relate the closing of the military program, the return of nurses from military to eivilian fields, postArmistice activities and the final termination of American Red Cross war emergeney relief in Europe.

The shutting-dowin of the military nursing needs was immediate. Three dalys after the Armistice had been signed. the Superintendent of the Army Nurse Corps hald notified all murses awaiting assignment that "muless sueh steps had been taken by them toward entering the serviee as to make it inconvenient and a financial loss if they did not do so, they would not be given serviee in the inmediate future." 1 The lowering of the standards for service in the Army Nurse Corps on accomnt of the urgent need for murses, was inmediately rescinded and all numses whose applieations showed that they did not meet the former peace-time repuirements, were informed that they were not eligible for appointment. Four hundred of the murses then anwating transpertation overseas at the Inobilizations Station in Sew York-and there were on Noventer 1.5 some fonteren hundred of them-were sent to France as soon ats transportation conded be sereured to relieve the shortage existing there.

On Norember 15 . Miss Thompson wrote Mirs Delano:

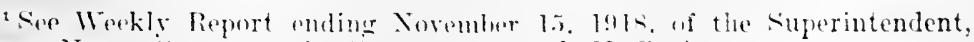
Army Nurse corps, to the Surgeon cieneral, L'S. A. 


\section{HISTORY OF AMERICAN RED CROSS NURSING}

Since the signing of the Armistice within the past week, the need for the assignment to active duty of more nurses has ceased, at least for the time being, as it is thought there is a sufficient number for the present need. This office has received instructions to assign no more nurses to active duty and to notify the Red Cross to that effect. It is thought wise, however, that the recruiting of nurses be continued in the event of a possible future need.

In all probability, nurses' aides will not be called, either for duty in this country or abroad, but there seems to be no reason why the Red Cross should not continue with the training of these aides in coöperation with the civil hospitals, but it should not be with a definite understanding that they are to be called into service as soon as they have completed their training.

\section{On November 23 Surgeon General Ireland wrote Miss De- lano:}

The war being virtually over, I desire to take this occasion to express my appreciation and that of the Medical Department of the Army of the splendid service which you and your organization have rendered the government in supplying practically eighteen thousand nurses to the Army Nurse Corps alone.

The group of women now serving in the Corps is, I believe, one of the largest organized groups of professional women in the world, and it is largely due to your efforts and that of the nurses of your organization that this has been made possible. The service of the lurses have been efficient in the highest degree and their work both in this country and abroad has been very highly recommended.

I desire also to express through you, to the directors of the different Divisions of the American Red Cross and their assistants, my appreciation of the remarkable service which they rendered the government during the influenza epidemic in supplying the military hospitals with hundreds of nurses and nurses' aides for temporary duty at a time of acute need.

A statistieal summary of the nurses in military service showed that the Army Nurse Corps had on duty on November 15, 1918, approximately 21,344 nurses. Of this number, some nine thousand were serving with the American Expeditionary Forees in Grat Britain and France: fourteen hundred others were in New York City awaiting transportation overseas; the remaining eleven thousand were on duty in military 
hospitals in the United States. The papers of five hundred more were in the Surgeon General's office, these nurses awaiting at home their travel orders.

Of this total maximm strength of the Army Nurse Corps of 21,480 nurses, 17,931 were reserve nurses-nurses recruited and assigned to the Military Establishment by the American Red Cross Nursing Service. Thus more than four-fifths of the members of the Army Nurse Corps were American Red Cross nurses.

Of these 17,931 reserve nurses some 4400 had joined the Arny Nurse Corps as niembers of base hospitals; some 400 as members of base hospital units, some 11,500 as members of emergency detachments, about 1400 as members of training school units and approximately 200 as members of special units.

During the nineteen months in which the United States participated in the European War, the Ameriean Expeditionary Forces suffered 286,330 battle casualties, of which 48,909 were of men killed in action. In the American Army 56,991 men died from disease and 6522 from aceidents. Thus the total number of lives lost in the Army, inching the Marines attached to it, from April 5, 1!17, to May 1, 1919, were 112,432. Five ont of every six men who were sent to hospitals were eured and returned to duty.

In the toll of battle deaths of the European War, the United States stamls third from the bottom of the list of belligerents, as the following table will show:

Russia
Germany
France
Great Britain
Austria
Italy
Turkey
Serbia and Montenegro
Belgimm
Roumania
Bulgaria
Lnited States
Cirope
Portugral

'Total
$1,700,000$

$1,(600,000$

$1,38.5,300$

900,000

800,000

330.000

250.000

1.5.000

10.0000

100.000

100.000

48.900

. .0100

2.0010

$\overline{\%, 4.519 .201)^{2}}$

2"The Mar with Ciermany." p. 119. 


\section{HISTORY OF AMERICAN RED CROSS NURSING}

While the European War was undoubtedly the bloodiest in the history of warfare, the disease rate among the American forces was remarkably low. Nineteen out of every thousand men of the Expeditionary Forces died of disease. During the Mexican War, 110 per year of every thousand men had died of disease; during the Civil War, 65 out of every thousand men, and during the Spanish-American War, 26 out of every thousand men. The causes of this remarkably low disease death rate among the American forees in the European War was due to (1) a highly trained medical and nursing personnel; (2) compulsory vaceination of the entire Army against typhoid fever; (3) thorough camp sanitation and control of drinking water; (4) adequate provision for hospital facilities. ${ }^{3}$

On November 11, 1918, the total strength of the Navy Nurse Corps was approximately 1500 nurses. The maximum number of nurses actually serving in the Navy was reached on Oetober 19, 1918, when 1460 murses were on duty. Fortythree others had signified their willingness to undertake navy nursing service, had executed their oath of office and were awaiting travel orders but later resigned on aceount of the lessening of the needs for nurses due to the signing of the Armistice. Of these 1503 regular and reserve members of the Nary Nurse Corps, 1058 had been reeruited and assigned to the Corps by the American Red Cross Nursing Service. Thus more than two-thirds of the nembers of the Navy Nurse Corps were American Red Cross nurses.

The total number of deaths in the Nary between April 5, 1917 , and $\mathrm{llay} 1$, 1919 , was 10,068 men. Thus the cost of life to the Ameriean Military Establishments during the Enropean Wa was 122,500 men."

The Anerican lied Cross Nursing Service assigned 18,989 of its enrolled nurses to the Military Establishments and in addition assigned 284 to the hospitils and cantonment zones of the Inited States Public Inealth Service and 604 other's to foreign service under Ameriean lied C'ross commissions to the Allies. Thus the total number of American Red Cross murses in military serviee during the Enropean War was 19,457. The total number of American grabuate nurses who scrved in the European War was $2: 3,869$.

3"The War with Germany," p. 125.

4 Ibid., p. 123. 
Since 1912 Miss Delano had not left the United States, as she had felt that her place was at National Headquarters. She had long desired, however, to see the enditions under which nurses were working in Europe; the War Conneil also wished her to go overseas. On December 15, 1918, Miss Noyes was appointed acting director of the Department of Nursing, and Miss Delino left Headquarters and Washington to make a trip of inspection in France.

In France the signing of the Armistice had arrested the flow of fresh casnalties into American Army and Red Cross hospitals, but influenza patients and the numbers of men wounded in the Argonne, St. Mihiel and Verdun offensives crowded the wards to such an extent that the "peak days" for the hospital eenters occurred late in November.

The pressure of work quickly lightened, however, in the zone of the advance. After the casualties of the pre-Armistice drives had been evacuated to the zone of the base, no more patients eame in and the nurses had ample time to look about at the paraphernalia of war. Priscilla J. Hughes, chief nurse of Evacuation Hospital No. 2, wrote:

Five days after the Armistice, we went up to the trenches and across No-Ylan's Land. climbed in and out of the shell holes and through the terrible barbed-wire entanglements into the German trenches. It was quite apparent that the Boche had at least thought he had come to stay. The dugonts were like summore hungalows: some had beds and others had bunks with chicken wire for springs and really soft mattresses. The walls were covered with a blue fibre material resembling burlap, and booksases and cupboards had been built. The windews were of gliss and opened on hinges.

We salw one of their "pill-boxes," mate of concrete and iron. I small narrow gange railroad ran right up to the doors of the huts. Outside were little rustic walks and steps and hridges. In one of the dugrouts we fouml rolfee in steins and hrearl still on the table. brend which quite answered the description we hard heard that it was made of sawdust and chicken feathers. It rertainly bolied it! They also had carpenter shops fittert ont with all kinds of tools.

By Noventer 15 the first released war prisoners hegan to stragede batek to the Ferende and Ameriean lines and many of them were brought to Ameri"au hospitals. Miss IInghes wrote: 


\section{HISTORY OF AMERICAN RED CROSS NURSING}

On Norember 15, some of our corpsmen were down in the village and they ran across two Tommies who had just wandered into Baccarat on their way back from a German prison somewhere in Alsace. Our men practically carried those boys to the hospital, gave them good showers, dressed them up in U. S. A. O. D. and sat them down before the first good meal which they had had since they had been taken prisoners last March.

Each day the boys would come back to the hospital with more Tommies in tow and by means known only to the doughboy, had them admitted. To the credit of our C. 0 . and the officers and the joy of the nurses, nothing was said until finally the French sent us word we were not to interfere with the British prisoners and that they were to go to the French barracks. Then our boys fixed up cans of C. S. A. coffee, sandwiches and all the cigarettes, tobacco and chocolate they conld lay their hands on, carried them down to the French barracks and bribed the guards with some of the food to let them pass the rest through the railings to the British boys.

These Tommies were simply in rags. They told us that the Germans ... had practically starved them, which was quite evident. Three hundred and thirty of them had been set at liberty from this particular prison and guards had gone with then for about thirty kilometers, then left them to find their way back as best they could. Over thirty of them had died by the road. How some of them ever managed to walk, especially across To-Man's Land, is a wonder, they were so sick and weak.

On November 30 the German High Command telegraphed Paris headquarters of the American Red Cross that anthority had been granted "for the American Red Cross to send at once to Trives, food, clothing and necessary supplies, with a minimum of personnel, to handle the distribution of same to the Allies' wounded in the Military Hospital at Treves." Six molile anits, cach consisting of two doctors, four American Red Cross murses, one camion of food supplies, one camionette of medical and reaning supplies and a touring ear and ambulance for transferring the personnel and their baggage, were organized and started on their way. "The plan," wrote Colonel Burlingame, "was to mobilize these six units near the border to precede the Army als soon as permission was granted. They were to nove into Croman lospitals and carry on until such 
time as the Medical Corps was allowed to advance and take over the patients." "

These six mits left Paris at dawn of December 1, and during their trip into Germany had an extraordinary opportmnity to view conditions in the devastated regions. One of the imits was composed of Dr. (i. R. Wiseman, Dr. Baldwin and Rachel Torranee, Elcanor Beatrice Brown, Mary Irene Kelly and Henrietta Altman. Dr. Wiseman wrote:

Sunday, December 1: Tp at dawn. At eleven-thirty wo left the Rue de Riroli for Cermany. The old applewoman at. the Porte gives me two apples and "God bless the ('roix Rouge A mericaine." Over the mudly roads to Meaux; then the rolling country-side, beautiful in the glinting autumn sunlight. The big trucks break down. We lunch at lleaux and the nurses talk of chatean-Thierry and the Champagne and Evacuation No. 3. The gun lientenant with the Taval guns hails us: "Ilello. Americans!" The cold hotel, the cathedral against the gray sky, the dim old square with the movie filled with French poilus, the American military police on guard the endless sound of horns of passing motors and Army transports-Meanx.

Monday: Vanx and the graves of the Marines on Hill 20t, wet in the mist, the colors on the wooten croses. The sandbags in the torn and bloody woods, ('hâtcan-Thierry and the smashed loridge aress the Harne, in the valley ororlooked by the heights the Germans beld as the engineers built the pontoon we ross on now, a pontoon built then muler shell and machine grun and anrplane fire, with a rashing city behind them. In the twilierht and darkness I walk alone the river with a nurso who han once served in the Hotel de Dieu Mospital areros the river. The questions of the wounderl to earhe other come bak to her and reconstruct the fight: "Hollo, Buddy! Did they get you along the damn railroad ". "You got rours in that hellish river lual ?" The shork murse talls of the eheerfuluess of the wommled in the Aremone. . .

I huy allsige and heer breal from an . Irmy mese for dinner and on we eno the white lights of the ars throwing into erhostly relief the stark ruins of l)ormans, where the (iemalls

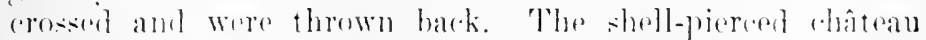
walls. the ent tress the renular piereing hits be the artillers on the stome femes: over the river the hills loom in the darkness, silont now.

s.Mflitar History of the Ameriean hed crens in France." p. Ino. 


\section{HISTORY OF AMERICAN RED CROSS NURSING}

We reach ruined Épernay and filthy cots in a French convent.

The raw French winter was elosing in and the units went forward under chilling mist and rain. Dr. Wiseman continued:

Tuesday: Smashed Epernay, where we breakfasted in a dark stone cellar room with French privates. Rain! Rain! Rain! Along the rolling hills, then past endless French cavalry and convoy columns into busy Châlons, with its German prison camp. The Boche give us gasoline and we roll slowly by the bomber houses in the square, where twilight is settling down like mist. Darkness, and we start for St. Menehould behind the Rheims Front. The rush of motors in the dark, muddy streets, the crowds of poilus, the Americans, the retnrning refugees! We camp in the trucks, overlooking the lights of Châlons. On the wet breeze the sweet torses of the cathedral chimes steal up out of the misty valley to the Champagne plains.

Wedneslay: Dawn and the crows in the cold trees. Past great shanties of the rear area camps; tremendous hangars, black and brown; old emplacements beside the road-all in the early morning mist banks. Breakfast in an old stone house across the creek where the Red Cross anteen serves in the muddy rooms. The blazing fire, the Victrola, the tired doughboys sleeping on the cots or writing home. All day in the rain we fix the trucks in the narrow muddy street while the armies pass. . .

Thurstay: It noon we climb the rolling hills again. On either side of the road, the long loarbed wire vineyards point like spear heads at the dark road ahead. Dusk comes early and we see more and more American instead of linench truckis. We climb the hill through runed ('lermont with its fantastic assemblage of Imerican merhanical genii-aterpillars, tractors. Fords, giant trucks and motors lining the road thromer the shattred homses and rowding every inch of the muldy field beside the orchard where the gasoline station is fomm. No more gas until the Third Army is readled in Germany now. We Toarl up and start for Verdum.

The Verdun roal, a subway of lamplight tumneline the valleys on the straieht camonflaged roads! The lights of a ramp flash by and the strains of an Amerion band reach 11. Green flares show ons trucks the proterted roarway. pitchblack again in an instant, a roadway flanked by the great hill- 
sides, the blinking (amps, the black mist and mud. We come out on the level road around Verdun by the hospital, once Evaeuation No. 3.

Two o'dock now and we run along beside the re-won railroad where an American engine pulfs heavily. We go through the great high modent gate into ruined Verdun; past the enormons, bastioned, monstrous walls, the ghostly shattered stone houses, the hanging blinds and torn floors, the barricades, the fire in the ruined corner house on the Rue Étain where we ask three watching doughboys the way.

The convoy refiles through the Porte St. Paul and elatters out towards No-Man's Land. Still the enormons hills, the headlights on the shell-torn fields, the fog. 'The convoy forges ahead and we are left alone on the lioad of Ghosts. At last we fix our tires and push on, now at dawn we see the riddled muddy fields, glimpsed through endless eamouflage stretched from one blastel tree to another. The concrete towers and the able defense against the allied tanks stretch along the barbed-wire-filled meadows, the zigzag trenches and pulverized farmhouscs. At last we reach destroyed Étain, with its German signs. A negro regiment is encamped here and the bugle call in the misty desolation speaks breakfast to our hungry crowd. 'The nigger jazz band serenades us as we pass out through the ruins. It is another day and we have forgotten to sleep.

The eonvoy had now penetrated behind the former German lines into the territory of great strategic importance, where the Amoricans harl soized the Metz railway and had thus broken the German line of communieation. Dr. Wiseman's report eontinued:

Frilay: Igain we saw the endless barbed wire entanglements. thro reared plains etched with trenches now empty ant cleared be the desperate battle in the forest of the Argoine to the northwest: now we saw lines of negro troopers on the mudly romls: a salvage engineer train on the Met\% railroal with Amerian lesomotives: a bombed station: the cierman road signs and orders: the barrels of rum and the darkies reatly (mpes: the vast piles of thares and hand grenades and enemy materials: the re-named streets. the Kron brinz Strase: the silent own now deserted: on the hills old graves

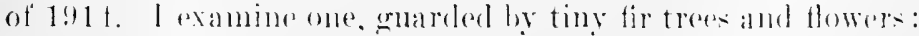

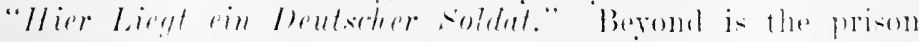
(amp), with it- rough, heary barbed wire walls: be the kitchen. 


\section{HISTORY OF AMERICAN RED CROSS NURSING}

the potato peelings are still fresh in the barrels; litters of filthy clothes still lie on the two-tiered plank bunks. Haste had risited here.

Before us at last stretched the road to Esch and Luxembourg. The long hills are passed in the starlight and we reach Esch with its flaring mills, its factories roaring with energy and life. Little girls, with odd accents and infinite charm, crowd our camionette. Then we ride past the great beautiful residences of Luxembourg into the lighted, crowded town and park, finally in the statued square. About us gather curious erowds, friendly faces, and we hear the German tongue. In the Clesse Hotel we sleep for the first time since Wednesday, to dream of the road of black towering trucks with locomotive headlights, erushing our little Ford camionette on the heaps of stones by the roadside. . . .

On Saturday morning the convoys started out on the last leg of their six days' journey. Dr. Wiseman wrote:

Through incredible, romantic, eastled Luxembourg we go, across the great bridge over the Moselle, a bridge now crowded with the grim, matter-of-fact divisions of the American Army. An endless chain of huge, mud-splashed trucks, of easy-riding cavalry squadrons; of trains of mules drawing eanvas-eovered wagons; mess outfits, kitchens; ammunition; tired infantrymen in brown steel trench hats-all moving stearlily across the stone bridge and up into the giant, green and black forest with its maroon carpet of autumn leaves rovering the towering hills. Below and beyond, we saw the green of winter wheat; the neat dainty houses; and far down the valley of the Noselle, the eindless, slow-moving convoys of canvas wagons marking each river roarl on both banks. Along the roardside the faces of old men stare at us through the windows and doorways as we cross into Germany.

Chiblren, first, thousands of rhildren, wearing Fritzie's renbanded cap, offering I ron ('rosses for sale, saluting, asking for chorolate, cigarettes! Through the outskirts of Trères we drive until we strike C'mar's old arch and the Itotel Porta Negra. I luy dinner for the nurses and we get a-plenty: Anit for seren marks apiece! I meet some friends and in the hotel bar below we drink weiss llein.

Outside ganes the servile populare. Like the doughboy, we all find diflonlty in changing from the French to the German languages still we moet no hostility. 'The doughlose smiles realily: the (hildren are ricliculous: the obl people are friemelly: warese are low. The domerhboy likes (iomany: 
I go to bed, aware of an appalling anti-climax. My mind still pictures tired, frugal, denying Frante.

At Trèves the six mobile units were not sent forward as had been originally planned, but were fitted in for service wherever need existed. Units Nos. 1, 3 and 4 were assigned to duty at U. S. Evacuation Ilospital No. 3 at Trèves; Lnit No. 5 was sent to Montmedy to take over a civilian hospital where men of the Fifth Division were ill with influenza, pneumonia and dysentery; Lnit No. 6 went to Stenay to care for forty American men left behind with a detachnent from an $A$ rmy field hospital; Unit No. 2 was sent to Vitron. These units stayed in Germany until late in January, 1919, when they were recalled to Paris.

In the ineantime the Army of Oceupation was pushing on from Trères and with it went Evacuation Hospital No. 2. In this eolumn were many regular and reserve Army nurses. Miss Hughes, the ehief nurse, wrote:

From Trèves began the most wonderful and historic part of our journey through the beautiful valley of the Moselle. To those who do not know it: Imagine a valley with a broad silver river winding in and out among pieturesque hills grouped on either side in many shapes and heights but with wonderfink symmetry, hills covered with grape rines arranged with the most methodical exartness, not a single one out of line. Ilere and there were tiny pathes of gartens in greens and reds and browns, which reminded one of a picture puzzle arefully placed together. Some of the hills seemed almost perpendirenlar and one would think that the peasints must have been suspended by their eyebrows to plant and are for the vines. Ilere and there towering ligh above the hills were the ruins of ofd Roman fortifications and medieval astles and at their feet nestled cosily quaint little villages, with never a sign of the havoe and desolation only a few kilometers away.

The railroads and bridges were all guarded by our own Amerian solliers: with fixed bayonets, they stowd at interrals alonge the right of way. As we pasied through the Kaiser's 'Tumber, we distingmished the flash of bayonets as we speed along in the dark.

Then out wo (ame into a part of the ralley where our train ran aleng in the eenter and we had a full view of the valley. 'There on either side marched our troups into (iermany, the Stars and stripes and the lieginental ('olors flyine at the lead of the columns, the sun shining on the enthuiastic fares of our bors and flashing on the loras instruments of the bands. 


\section{HISTORY OF AMERICAN RED CROSS NURSING}

In the center went our train, with "Our Flag" on the pilot of the engine and a German engineer at the wheel. Surely we women of America had been given many privileges, but I do not think, in the history of women, that there has been a precedent to this experience given the nurses of Evacuation Hospital No. 2.

On Wednesday afternoon, December 11, 1918, the train earrying Evacuation Hospital No. 2 pulled into Coblenz, but as the Army had not yet eome in, it was switehed back to Guile, a village on the eity's edge, to wait until the arrival of the Army. Miss Hughes wrote of their reeption at Guile:

The children of the village came down to the train and our boys were soon wearing Iron Crosses which they had traded for hard tack and "corned willy." The chillren said that the Prussian soldiers marehed into their homes and took anything they wanted. They also told us that there had been riots in Coblenz three days before.

Meanwhile the troops had caught up with us and on Friday morning, December 13, went marehing by into the city. We elimbed up on the banks and stood at attention as the advance guard swung past. And on Saturday our train moved on into the Coblenz Station and we were ordered to a hotel before going on to Ems to establish our hospital. We left the station and started for the street car and how the fraus and frauleins stared at us and everybody stopped in the strects to turn and gaze after us.

All day long Sunday, Monday, Tuesday and Wednesday the American Armies continued to stream into Coblenz. Miss Hughes wrote:

Men, horses, mules, field kitchens, ammunition caissons, trucks, ambulances, motor-cycles! The children swarmed like flies. If the Germans had had any doubt as to the numbers of Americans who had crossed the ocean, they certainly seemed to lare their eyes opened during those days. They stoor and stared and stared at the seemingly endless American Army with a bewildered, stolid expression.

During these dars Evaeuation Hospitals Nos. 9, 14, 4 and 6 came into Coblenz, and buildings were assigned to them all. No. 2 was given an old German barracks, of which Miss Hughes wrote: 
It had been left in an almost impossible condition and was inhabited by everytining from cooties to dead horses' heads; the Bothe had apparently been living on horse meat. Helmets and bayonets, some like saws with teeth half an inch long, littered the place. We nsed the bayonets to poke up the fires. In the attics were pied smashed furniture of all types, and an extensive library full of books and charts and maps of France, England, America, and Palestinc; apparently they had been tearhing the soldiers all aibont the world which they had experted to orrupy. . . .

Here we are now, located on a beautiful little island right on the Bhine with the famous fortress of Ehrenbreitstein just across the river from the hospital and the Stars and Stripes flying atop and alnost reaching the sun!

During the days when the American and Allied Armies were coming into Coblenz, Miss Delano was preparing to leave Washington for her inspection trip overseas. On Deeember 15 she left National Headquarters and went to New York to await transportation to France. She dreaded the ardnons trip ahead of her and seemed to be filled with foreboding and a depression foreign to her usual equanimity. She was very tired.

Miss Noyes areompanied her to New York. Miss Deans was already there on special duty with the Atlantic Division and she and Miss Delano stayed at the same hotel. The Surgeon General had secured sailing for Miss Delano on the Leviathan for Decenber 24, but delay resulted. Finally arlangements were made that she should sail on the George Washington, which was dne to leave New York on Deeenber 31. On the night before she sailed, she and Miss Deans were dining at a large hotel and an Amy offieer wearing the ribbons of sereral foreign decorations eame over to their table, talked with Miss lolano and passed on. Miss Deans looked at Miss Indano's outdoor uniform and asked her why she was not wearing some of her own decorations. Miss Delano langhed:

"What do those ribbons mean to me? All I want is the love of the murises."

Miss Delano went aboard the George Washington at two orlock in the afternoon of December :31 and the transport sated the next noming. General Jefferson Randolph Keam, a great friend of her's, was on board, and IJiss Indano's diary recounts the pleatsant passiger: 


\section{HISTORY OF AMERICAN RED CROSS NURSING}

I was given a confortable room to myself on the upper deck; it had a dressing-room adjoining it. General Kean found that he had a room-mate, General Emnis, whom he knew slightly. At the same table with us was a Miss Poe, on her way to Rome for some work connected with military intelligence. Te had discovered many mutual friends.

On Jamuary 10 the George Washington docked at Brest. Admiral Wilson had been advised of her arrival and sent a Navy laumeh to take Miss Delano and the two Navy nurses assigned to the George Washington ashore. They went directly to Navy Base Hospital No. 1. Of Miss Delano's reception, Miss Van Ingen wrote:

I was finishing some paper work when a message came from the C. O's office that Miss Delano had arrived. 'Taken very much by surprise and thinking that the Red Cross had secured rooms for her at the hotel, I decided to go order some flowers sent as a welcome from our hospital. Before I could reach the street, she was at our door. We made her as comfortable as we could. The weather was especially bad at that time, sleet, snow, rain, and the penetrating cold that seems to belong just to Brest. . . .

In her diary Miss Delano wrote of her first day at Brest:

Dr. Brinsmead, the medical director of the Brooklyn Unit, said he would take ine wherever I wished to go in his ar. It was arranged that Hiss Van Ingen should accompany us and that we should leave at once for the army base hospitals near Brest.

We went first to Arniy Base Hospital No. 65 at Kerhuon, which is known as the Kerhuon Hospital Center and has connected with it Army Base Hospital No. 105 which operates in part as a separate hospital but is under the general direction of the hospital center. Bree S. Kelly is chief nurse of the center, and Maud Parsons, of Base No. 105. The hospital is built on the barrack srstem and at the time of my visit all the wards were comnected by board walks, which are shipped in sections and set up as needed. Before these board walks were placed. there was the nexessity for the nurses to wear rubber boots when on duty as the mud at this time of the year is more than ankle deep.

At present there are 240 nurses in the two lospitals. I visiter? nearle all the wards nurses quarters and the charters 
for sick nurses. The nurses seem to be given excellent (are and so far as I could judge were well contented and satisfied.

The hospital has a total of 3000 patients and bed caparity for even more. The Red (ross han built a comfortable recreation house with a young dietitian in rharge... . The nurses were called together here and I spoke to them and told them of our appreciation of the splendid work they are doing. We then went to a little sitting room off the general recreation room and had tea. . . .

Miss Kelly assured me that the nurses' mess was condurted by the commissary department rather than as a separate mess, but this plan seemed to work quite satisfactorily. I visited the kitchen and found that they were to have for dessert that night real American pie which looked excellent.

On Saturday morning, Jamuary 11, Miss Delano started rounds at Navy Base Hospital No. 1 at Brest. In her diary she wrote:

The dormitories open on verandas where the patients ean be moverl in pleasant weather. All French people injured by Amerieans are carel for in this hospital, also the Army anil the Marines. I saw one Frenchman who had been run over by an Army truck and who had unfortunately lost both legs. Two or three French women were also ill and were oceupying the same infirmary as the sick nurses.

There is a great lack of quarters here. . . The water supply is most inalequate, practically no ruming water during the day. . . . There is very little heat in the nurses' dormitories aud none in the room where I slept. The nurses seem aceustomed to the difficulties and do not complain. . . .

On the same morning Miss Delano went out to Camp Pontanazen. She wrote:

Miss Jones, chief nurse, was at Nice on her vacation. so Miss llelm met me and we male fairly complete romuls of the wards. They have $14 t$ nurses living in what are known as inside and outside quarters. The inside portion of the hospital is lowated in the old French harracks and the nurses assigned to duty inside live in a convent, a most attraletive old building. with a crarden, which is attached to the harraks hospital. The outsele quarters were built on the barracks ulan by our Army and ath nurse is given a separate cubiefo with convendent shelus amb a gond hed. . . The tormitories are 


\section{HISTORY OF AMERICAN RED CROSS NURSING}

comfortably heated by a large stone at each end with space for sitting room around each stone. Seats were built in and eomfortably eushioned.

As many as eighty thousand troops have been in this eamp at one time with a water supply for only twenty thousand. To meet this emergeney, large quantities of wine casks were purchased and water was hauled to the camp. Inadequate preparation scems to have been made for the care of the troops at Brest, but in spite of the diffienlties, about a million men have come into France through the port of Brest and probably a large proportion of the army will be re-embarked from this port. . . .

The mud was overpowering and only a few board walks have been built. In some parts of the camp, it was almost impossible to get through even in the automobile, so one wonders how the nurses have been able to get from ward to ward. In almost all the wards, I saw the nurses actually earing for the patients.

The spirit of the nurses was excellent. In one ward, I met Miss Lord, one of the older Red Cross nurses. She has had a great deal of training school and hospital experience. She told me that never in her life had she found more satisfying work and that she was very happy to have been able to be in charge of a ward and able to take care of the soldiers herself.

At noon that day Miss Delano spoke to the nurses of Navy Base Hospital No. 1. Miss Van Ingen wrote:

She told them how her heart had been with each one, how she wished she might have shared all their discomforts, that she welcomed the bad weather she was encountering as it gave her a better idea of what those in France had had to endure. It was a talk such as one comrade would have had with another, not a hint at (riticism or supervision, just encouragement and approbation... .

Saturday afternoon Miss Delano left Brest for Paris. The Roosevelt party had chartered a special car and Mrs. Linosevelt asked Miss Holano to join them. In Paris Miss lelauso was taken to the Hotel Wagram. Monday morning sle went down to Paris headepuarters and found that Miss Mall, who had snceceded Miss Stimson as rhiof nurse of the American Red Cross in France, was absent at Tours. Miss Delano was given an office and a stenographer and spent most of the day dictating 
letters, making out reports on the hospitals at Brest, and writing her diary. "l met many nurses both on the street and at the oftice whom I knew," she wrote.

During the next two days Miss Delano made plans for extensive trips to the varions anxiliary hospitals in France. On Jamuary 1:3 Walter 1). MaCaw, Chief Surgeon, A. E. F., wrote the following letter of introduction:

To: Commanding officers of all hospitals, A. E. F.

Subject: Inspection of nursing serrice by Miss Delano.

1. Miss Delano, chief of the nursing division, Ameriean Red Cross, who has organized the nursing reserve of the U. S. Army, has come to France with the approval of the Surgeon General, U. S. A., to visit and inspect the nursing detachments of the hospitals of the Army.

2 . It is believed that her visit will not only result in obtaining information which will be of value to the Medical Service, but will also be of much benefit to the morale and esprit de corps of the nursing service.

3. The Nedical Department of the Army is under deep obligations to Miss Delano for her patriotic and arduous serrice in organizing the nursing reserve. It is reqnested that commanding otficers give Miss Delano all possible facilities and assistance in the performance of her mission, and issue such instructions as will be necessary to secure this object.

On January 15 Miss Delano went to American Red Cross Military Hospital No. 2, and on the following day to No. 1, the former Ameriean Ambulanee. On the next day she went with Miss Hall to inspeet Lnited States Army Base Hospital No. 57, which was maintained by the Ifemphis (Temnessee) Init. Miss Delano was delighted with the establishment. She wrote:

I was greatly pleased over Margaret E. Thompson, the chicf nurse, and the general condition of the hospital. The wards were orderly and clean; this is the first hospital I lave seen where all the beds had white covers. She had utilized sheets whith had heen re-josted to her from some of the hospitals which have been closerl. Ilere I fomm for the first time an attempt to oil the ward floors. Mr general impersions of this hespital were axeellent: the discipline among the men was goosl. the patients became quict on our entry into the wards and the eorps men were quite willing to respond to Mis: "lhempsons orter of attention. 


\section{HISTORY OF AMERICAN RED CROSS NURSING}

From there we went to American Red Cross Military Hospital No. 3, Mrs. Whitelaw Reid's hospital for officers, which is located in her forme: Club for Girls. The building is probably better suited for a convalescent home than for seriously ill patients.

We returned to the office about two o'clock and went at once with Miss Ashe

Here Miss Delano's diary broke off. It was never finished. However, on January 18 she wrote Miss Noyes a long and confidential letter about various administrative questions. Three days later Miss Hall wrote Miss Noyes:

In case you may hear of it from some outside souree, I am writing you that Miss Delano is at the moment sick in hospital. I know that she has no idea of letting you know and I think she is not sufficiently ill to send a cable and so perhaps stir you up on the subject. On Saturday afternoon, she said she had a slight sore throat and was feeling it in her ear; later in the evening she had very severe pain and at eight o'clock the ear drum ruptured. We called an ear specialist from American Red Cross Military Hospital No. 1 to see her and she was taken at once to No. 101, where Miss Jones is giving her most splendid care. We are all disturbed and anxious, for after all it is a little diffieult to come into this French climate in the middle of winter, particularly after one has been through so many months of strenuous life as Miss Delano has.

Miss Delano was soon up and out again-too soon, many thought.

She went on with her trips of inspection. On February 14 she visited Base Hospital Fo. 27 at Angers and her report is of interest. She had had an outline stenciled, and when she visited a hospital she wrote in, in longhand, her comments.

From Angers Miss Delano went sonthward. A nurse wrote that she harl seen her standing on a windy station platform near St. Nazaire, her muttler held up to protect her face and ear from the penctrating rold. But she did not make any more inspeetion risits as she was soon again troubled by severe pain. She was taken to Sarenay Hospital Center, twenty miles from St. Nazaire, surecesfinlly muderwent a mastoid operation on Febuary 21 and a seeond one on February 24.

Sarroy Hospital Center was in the spring of 1919 a barrark rity: in right hase hospitals ten thousand American sick 
and wounded were being eared for. Miss Delano had a small, bare, pine-boarded room on the ground floor of the nurses' barracks, adjoining the nurses' sitting room. For the operations which she underwent at Savenay this sitting room was converted into a perfectly equipped operation theatre. In this, the scene of hor last effort, her fight for life was characteristically determined. "It was thought at all the operations that her ease was practically hopeless," wrote Colonel Conlter, the commanding ofticer of Savenay Hospital ('enter, to General Ireland, "but she rallied each' time and her life was not despaired of until the last operation. . . ."

On March 4 Miss Hall wrote Miss Noyes:

While Sarenay is perfectly hare and rheerless in many ways, Miss Delano is in a place where she can have every possible medical, surgical, and mursing care. Colonel Coulter was in the Surgeon fieneral's office and has put every resoure in the center at her disposal. . . She has three special nurses, all of whom she likes, and they are giving her splendid care. The officers of the Red Cross are much distressed and have placed all the facilities of the Red Cross through the zone officers at her disposal. . . . The nurses all over France are much distressed about her illness and there have been countless inquiries for her and quantities of flowers have been sent to her.

During the first three weeks of March Miss Delano's health mended steadily. She celebrated her birthday on Mareh 12 and asked to have a eake made. "She invited a number of her friends to come have tea in her room," wrote Miss Hall to Miss Noyes, "and during the tea she told them it was her birthday and that she was having a party. She seemed to enjoy herwelf very much. On Monday, Mareh 17, she went for a short motor ride in a large closed car and seemed to enjoy that a great doal."

On March :31 Miss Hall again wrote to Miss Noyes regarding Miss Delano:

Colonel Coulter started on Saturday, March :1, in a motor to find the best man available for brain surerery. At lantes. he found (aptain l'Tauter. a youmg man who has hat I)r. (ushingrs nenrologinal serviee at the brigham llospital and who has since speeralized in hrain surererg a very ahle and aroful

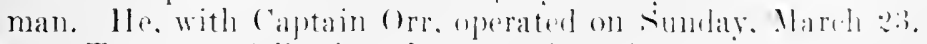
.. Two days following the operation, the temperatum was normal and her mind guite clear. . . 
I talked with her Saturday morning, March 29, for about twenty minutes, when she had quieted down from her dressing. She told me to tell you that it would be at least another month before she is able to start for home. She further said that she felt she would not be able to do any work during the coming summer; that at the present time she is not able to dictate any letters; that she reads only a few, or has them read to her becanse it tires her to concentrate her mind on these matters. She selects the personal letters and lets the others go. She also said that in any questions that need deciding, you must go ahead and not depend on her for suggestions and advice becanse it will be a long time before she is able to be a holp and she feels that there are many things which must not wait.

When I saw her on Mareh 21, I felt much depressed abont her and found her four physicians also very much discouraged. At that time, I thonght she would not live to return to America. However, on March 29, the whole picture has changed and I believe she will rally and be able to go home, perhaps not in a month but surely in a reasonable time, considering the three operations and all she has passed through.

I do not know what you will decide over there to do abont having Miss Kerr or some close personal friend come over. Over here, we feel, have felt, that we wanted to leave nothing undone that would in any way add to her comfort or happiness during this period of illness. Miss Delano does not know that we have asked to have some one come over, but I feel sure she would be delighted to see some one who stands in the relation of family to her, for after all she is among most unattractive surroundings, although as I have said before, she is having everything that ran possibly be done for her from the surgical, medical and mursing standpoint. There are now five nurses assisting in her care; three of them are the original three, on an eight-hour schedule of duty. . . .

Anma Kerr, Miss Delano's closest friend, arrived in Savenay on Saturday afteruoon, April 12. Miss Delano joyfully recognized her and talked with her for a few minutes before taking the anesthetic for the fourth operation. She recovered from the ether three lonurs later, again talked with Miss Kerr for a few minntes, and asked:

"Who is doing your work in Washington while you are away?"

Mies Kerr's answer satisfied her, but in a moment she aronsed herseit, and with a flash of her old encray exclalimed: 
"But what about my work? I must get back to my work." She did not speak again. All day Simday, Monday and Tuesday she sermed to rest quietly; abont eight o'cloek 'Tresday evening, April 15, she died.

To savenay during the following days went the thoughts of the nursing and lied Cross worlds. The funeral was military in character. A nurse spectator wrote:

On Friday morning at eight-thirty, the casket, borne by eight enlisted mon and guarded by six nurses, was taken to the Red ('ross auditorium. It was covered by a large American flag and was placed directly before the stage. Behind and around were placed... flowers in protusion, from the American Red Cross at Paris, the nurses of the various units and many groups at home.

By nine oclock, the nurses began coming and ... the service started promptly at half-past nine. Chaplain Gilbert (). Miller, of the 309 th Engineers, read the Episcopal burial service... After the address, the casket was carried by soldiers to a flag-draped eaisson. A company of soldiers lining the roarl presented arms as the borly was borne to the gunarriage. The procesion then formed: the band of the 309th Engineers, the military escort, the caison with the ten pallbearers, the four honorary pall-bearers, the nurses representing the American lied ('ross and the Army Nurse Corps, both in France and America, and Army nurses from nine base hospitals. ...

The line of marret was up the road, throngh the grounds past the main hospital building and over a small incline to the mortuary. 'The hand played ('hopin's Mareh and as the long line passed slowly hy, every man in khaki-and there were hundreds of them-stood at attention; small French bors in their hack sehool pinafores doffed their capse and stoon at the salute: a French officer saluted and a poilu put down his heary bundle hefore la did likewise.

The thag before the main hospital building was at half-mast. Beneath it in the gateways and windows were crowds of womberl soldiers and convalesent patients. As we womd out of the arate and turned up the hill between high stone walls, we passol a typical Fereheh serene, a row of small stone homsen with thatehed roofs, before whe he som two oled Breton peasints, in white head-dresses, and some boys and grirls.

IIarel as it was to lose Miss lotano in this way. it sonemed

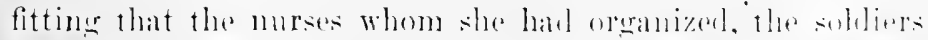

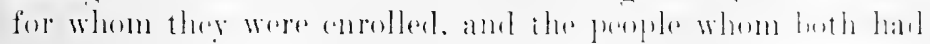




\section{HISTORY OF AMERICAN RED CROSS NLRSING}

erossed the ocean to help, should have surrounded her at the last. ${ }^{6}$

Even the enemy for whom Miss Delano had labored in the dars before the United States entered the European War was present. The account of the funeral continued:

As the procession wound up the hill, it passed groups of German prisoners, who saluted. When it reached the mortuary, the guard presented arms and the band played "Nearer My God to Thee," as the nurses filed up to form a crescentshaped group, just je-yond the main building. As the casket was carried inside, the chaplain read part of the Committal Service and the brief rites were over. Soldiers will guard the house until word is received to send the body home for final burial in Arlington. ... .

The whole service was singularly beautiful. The sun shone and the blue sky, the soft green of the trees and the brown, freshly turned earth of the plowed fields, seemed a part of our last tribute. . . The rows and rows of one-story barracks and the canvas tents of the huge cantonments lie in the midst of peasant cottages and small farms. There are hills in the distance but for the most part. the landscape rolls with here and there trim gardens, walled-in fruit orchards or a short, lazily revolving Brittany wind-mill. The strictly American camp. lying in the midst of this peaceful French countryside, emphasized to us again the reason why we had the French Tricolor and the American Stars and Stripes side by side in our Red Cross anditorium. ${ }^{7}$

On May 2 Miss Delano's body was temporarily interred in the American military cemetery at Savenay. Four or five nurses, three Army officers and two Army chaplains stood by as "taps" were somnded over this the grave of an Ameriean war nurse. The white wooden eross which stood for many months at the head differed in no wise from the three hundred odd arosses which marked the other graves in this one section of Savenay military cemetery.

"The dead," wrote Macterlinek, "are dead only when we stop thinking abont them." The American Red Cross appointed May 7,1919 , as a national menorial day for Jane lolano and at Sational Ifeadpuarters in Washington and at Division head-

" "Last Honours," Edna Foley, The American Journal of Nursing, Vol. 19, pp. 6s:9-69.2.

Ibid. 
quarters thronghout the United States, nurses and civilians gathered in thonsinds to paly tribute to the murse who, in the words of the editor of the fourmal, "wask, at the time of her death, the most "onspicuous woman of the war." Of the many words s spoken on these occasions, perhaps none better fit, in their simplicity and stremgth, her character and work than do those of an Army surgeon:

To the tanse of the sound eduration of the murse and the extension of her sphere of activity $m$ relation not only to hospitals and to private practice but to the broader fields of public hygiene and sanitary instruction, II iss Detano gale much of her lite.

She lived to see nursing generally recognized as an indispensable complement to the practice of medicine, as it must one day be recognized as an integral part of the art of therapy; she lived to see the trained nurse miversally regarded and employed as a vital agent in measures of public sanitation throughout the civilized world.

To the affiliation and coördination of the important nursing arencies of the country, to the end that under the Anerican Red (ross there miglit be established a force of murses properly selecten and organized, adequate not only for the demands of peace, but for the emergencies of war, she gave the latter years of her life. It was work well done.

She lived to see the standards of nursing for which she stood recognized by the (iovermment. She lived to sce the nurving agencies of America united and coopperating with the Army and the Red ('ross. She lived to know that the hed C'ross was ready and to realize that it had griven to the Army a contingent serond to none in the service, in character. in morale, in organization and in efliciency. She lived to sere that the American Army nurse hat stock the test. She rave her lifre freely and intererved]y to a moble service. She alscomplished that which she mulertosk. She dien at the heright of her powers, at work. She was a fine figure. the figure of an American murse."

Serenteren months after here death in Brittany. (ommitment

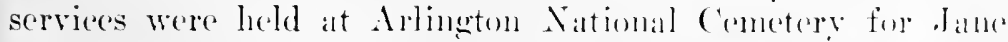

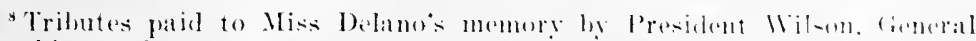

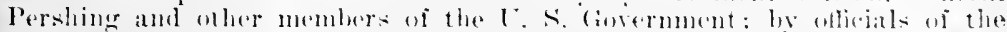

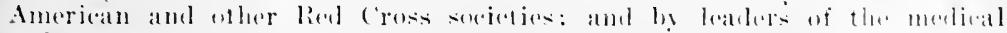
and mursing professons are on file at National ileadquarters.

o.. Vursine and the Art of Medieine." II. S. Thasur, the lmorian

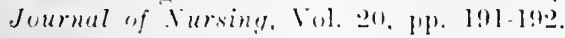




\section{HISTORY OF AMERICAN RED CROSS NLRSING}

Delano and at last her body rested among the nation's soldier dead on a wooded hillside slope overlooking the white, eypressshader amphitheater, the gleaming stretch of the Potomac beyond and in the distance Washington, the city in which had been enacted the crowning events of her high and lonely destiny.

To the student of history, no phase of study is more engaging or more productive of speculation than the rise of leaders to fit the ehanging needs of the changing times. For each specific need, cirenmstances (for want of a better word) appear to bring forward men and women temperamentally attmed to each speeifie need, and for the moment the new leader rides on the crest of the wave. Then the need changes, the wave recedes, the old leader sinks back into the turbulent seas of human effort and a new wave, bearing on its crest a new leader, comes crashing in upon the shores of time.

In 1616 Miss Noyes had been Miss Delano's own ehoice as a co-worker, and upon her poised and unobtrusive strength Miss Delano had relied to her last conscions moments of life. Thus, in the period of demolilization and reconstruction, it was a natural consequence that Miss Noves should follow Miss Delano. Miss Noyes was as admirably fitted for leadership in the new era as Miss Delano had been in the old. War is a spectacular cataclysm, incredibly dramatie, and Miss Delano, in her life and death and personality, had matehod it. Demobilization with its unrest and reconstruction, with its meertainty and indecision, called for sanity and an merring sense of proportion, by means of which the displaced social order might be neatly rearranged again into the normal conditions of peace. In temperament and methods of work Miss Noves matehed the newer need. On Angust 8, 1915, the general manager at National Headquartors amomerd her appointment as director of the Department of Nursine : sinee the previns ldecember she had been serving as areting director. At its first mecting after the Armistice, a meeting held December 9. 1919, the National Committee on Red Cross Nursing Servioe manimonsly nominated Miss Noyes as its rhaiman and the Executive Committee on January 2, 1920, ratified the nomination.

In the midwinter of 1918-1919 National Hearquarters en-

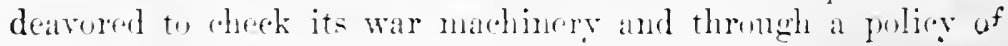


contraction and economy to assume peace-time dimensions. On February 15, 1919, an adjourned session of the anmal meeting of the American Red Cross was held at National IIeadquarters and the officers and committees which were to carry on the activities of the organization were elected. The members of the War Comncil had anmonneed their intention to resien on March 1, so the responsibility for the leadership of the Anerian hed Cross would, on that date, revert to the Central Committee.

1)r. Livingston Farrand had been appointed by President Wilson as the new (hairman. Dr. Farrand was graduated from Princeton University in 18ss, had there taken his master's degree, had been graduated from the College of Phrsicians and Surgeons of Columbia Lniversity and had studied at Cambridge and Berlin. He was for nine rears execntive secretary of the National Association for the Study and Prevention of Tuberenlosis and had served in France during the war as director of the Rockefeller Commission for the Prevention of Tuberenlosis in France. This organization was later merged into the International Health Board. From 1914 until 1917 he had been president of the University of Colorado. His point of view thus embraced that of the administrator, the social service worker and the edueator.

The Central Committee had as its new vice-chairman, Willoughby Walling, of Chicago. Robert Lansing represented the Department of State, John Skelton Williams the L. S. Treasurr, General Ireland and Admiral Braisted the War and Navy lepartments, Alexinder King the Department of Justice. The new members elected by the Board of Ineorporators were Mrs. Frank V. Mimmar and Charles E. Seott, former general manager at Tational Headquarters.

The newlyppointed Executive Committee, of which I)r. Falrand was dhairman ex-officio, was made up of those who represented beth the old and new orders. Four members had served on the War ('onneil: they were Mr. I)avison. Mr. Wadsworth. Mr. Bliss and Mr. Secott. The new members of the Committare wore Goneral I reland, Admiral Braisted and Sineretary of the Interior Lane.

To till valeanceies wallsed by death, three women were elected members of the Board of Incorporators. They were Mrs. Lentand Wood, Mrs. Joseph Cudahy and Mrs. Angust Pelmont. Mrs. Belmont had sorved as an assistant to the War Cimneil 
and in her the Nursing Service found a powerful and sympathetic ally.

On the eve of demobilization the Ameriean Red Cross had an adult and junior membership of over thirty millions. "Almost immediately following the Armistice," stated the Annual Report of the Society for the year 1919, "thoughtful Ameriean Red Cross leaders began to study the problem of utilizing the great Red Cross machinery developed by the war and the rich Red Cross experience aequired in the war, for peace-time needs, primarily in the Lnited States; seeondly for the welfare of humanity at large." 10 Out of this study grew the League of Red Cross Soeicties and in the United States, the Red Cross peace program in the interests of public health, a field in which Dr. Farrand was an acknowledged leader. The development of rural nursing and elass instruction to women formed perhaps the most important and lasting phase of this program and accounts of these projects may be found in subsequent chapters.

As to the American Red Cross foreign program of emergeney relief, the personnel of the Commission for Franee had their fingers, during 1918 and 1919, on the pulse of European public opinion. On December 17, 1918, Miss Hall wrote Miss Noyes:

I wish I could make you understand how little the French either want or need us at the present time. In spite of the cordiality of their weleome to President IVilson, it is macte apparent to ns that they will be glad to have ns leave their country. It is not that they do not appreciate what we have tried to do for them: but if you could see this comntry as it is orerrmn eren to the remotest corners with Americans who are buying ont the food, usurping the places on street-rars. trains and theaters everywhere in France, you would appreciate their desire to have their comntry to themselves. I think that all members of the Red ('ross organization have more and more the feeling that the sooner we can wind up affairsdoing this in the spirit in which we began work-the better it will be. 'The work of the Children's Burean and the Burean of Tubermlosis will be hrought to a conclusion by the first of April. The commissioner tells me that the work in Italy is being rosed as rapidly as that in France.

It would appear that at the present time, the Army is not returning large numbers of its nurses home. so it is. therefore.

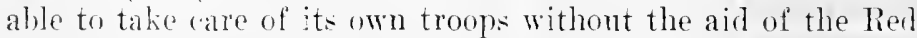
Cross to any extent. This means that our military program ${ }^{10}$ Annual Report, 1919. p. 13. 
is very rapidly being brought to a conclusion. Croups of nurses ranging from thirty to fifty are being released every week and I an sending a good many home. There is no doubt but that at the present time you need nurses more at home than we do here. We have forty-nine murses in Ciermany; they were sent up to are for American prisoners but will probably be returned to us in about six werks.

During the winter and spring of 1918 and 1919 the Commission for France mantained eleven convaleseent homes for members of the Ameriean Expeditionary Forees. A list of these institutions may be found in the Appendix.

The exodus of the American Armies from France during the first five months of 1919 was as rapid as had been their advent and the "transportation miracle" of May, June and July, 1918, was repeated in March, April and Ilay of 1919. In the official summary of the War Department Colonel Ayres wrote:

As soon as the Armistice was signed, preparations were made for returning the troops to the Inited States in the shortest possible time. 'This was renciered difficult by the fact that for the eastward novement, we had relied largely on the British, who arried approximately half of the troops. After the signing of the Armistice, the British needed these ships for the return of their own colonial troops to Canda, Anstralia and South Africa. This situation was met by the Army 'Transport Service, which immediately began the conversion of one large (argo ship) into tromp-arrying resseks. By means of these converted (argo ships. by the assigmment of German liners and also by the ereat aid rendered by the Nary. which put at the Army disposal eruisers and battleships, the diny is being bronght back home even more rapidly than it was taken to France. ${ }^{11}$

During Feloruary 181,751 men sailed for the Tnited States; during March, 212.699: during April, 290,87\%, and during

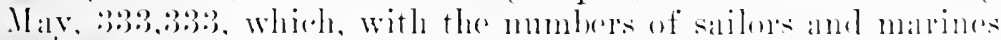
also returued that same month, bromght the month's total to well over ono-third of a million mone. ${ }^{1: 2}$

As the movement of Ameriande seldiers from the Wraterm Front to the ports of embarkition beam the Aneriean Red "Whe War with remany." pp. 4i-4s.

13 llikl., lp. $37-38$. 


\section{HISTORY OF AMERICAN RED CROSS NURSING}

Cross in France established a chain of infirmaries and dispensaries which were located along the line of communication and at the docks. ${ }^{13}$ In connection with this work Miss Fitzgerald's name reappears, for to her was delegated the supervision of Ameriean Red Cross murses assigned to this phase of demobilization service. She wrote:

Another activity for which I have been made responsible has been the supervision of the American Red Cross infirmaries. . . The following extracts from a report will give an idea of these activities:

At Xantes, the infirmary seems to more than justify its existence. There are anywhere from 20 to 25 dispensary cases daily. In the infirmary of eight beds, patients can be placed until the ambulances are secured to take them to the hospital. If the beds are not used for this purpose, oflicers are allowed to sleep there at night, being charged a small fee to cover the laundrying of the bed linen. While I was there, an officer came in who had eridently just left the hospital. He was chilly and rery miserable. He was at once told to lie down on the bed nearest the stove and was corered with blankets. Probably a couple of hours of rest would be sufficient to enable him to continue his jommey. A corpsman is on duty at this infirmary every night, so that any aceident case is cared for at any time during the twenty-four hours. The nurse in charge of the infirmary also looks after the dormitory where about seventy enlisted men may sleep either by day or night. Perhaps twenty-five exhausted men were sleeping there as I went throngh.

The Red Cross infirmary at Dijon, which was loeated in one of the main railroad stations, was a busy place during the early months of 1919. Miss Fitzgerald wrote of it:

This particular station has practically been given over for the use of Americans. The American special train from Toul to ('laumont stops here, so a large number of our men are always to be fombl either just arriving or just departing from 1)ijon. The slightly injured fiml their way to the Red Cross infirmary and there receive First $\mathrm{Aid}$ care. Besiles these men, the district surgeon s office sends to this infirmary for observation, all the nen who are not fit to be on dutr. but who are not ill enough to be admitted to a base hospital. often a comple of lays in bed will enable these men to go

${ }^{23}$ For a list of these infermaries and dispensaries, see the Appendix. 
back to duty without being transferred to the hospital at all. The nurses in "harge of the infirmaries are all most enthusiastie about their work. They get very near to the men and are able to help them in many smail ways.

At the doek infirmaries the nurses found perhaps the happiest work which they experieneed during the European War. "Here," wrote Miss Fitzgerald, "they come in contact with men, sone of them still ill, others convalescent, but all of them radiant at the thought of going home."

Brest, St. Nazaire and Bordeaux were the three principal ports of embarkation. Miss Fitzgerald wrote of the infirmary at Brest:

Its position could not be improved upon. It is on the doek from which the tugs leave to carry the patients to the transports lying at anchor outside the breakwater. The Army has put up a new shed abont four times as large as the one housing the original infirmary which is still used to take eare of the overflow. They have erected a new building also for the canteen departnent; it is next door to the infirmary and hot drinks can now be served much more easily.

I saw the loading of one boat. Sereral hundred, sick and wounded, passed through the infirmary in good order and without confusion. They are classed in groups such as "tubercular," "wounded," "(asuals" and other types. The port authorities have their officers present checking them up and the sistem works well and quickly.

Ambulances and ambulance trains mload the men right on the lock. If the weather is bad or there is much delay in loading the tug, all stretcher cases are kept in the infirmary hut, are given warm drinks and are made comfortable in every possible way. If the weather is rough, the patients are here transferrel to the "snow-shoe stretcher," which is better suited for embarkation purposes. Extra blankets are provided for the patients (luring their trip in the tugs to the transjorts and one or two nurses accompany each hoatloal.

The patients are then settled (omfortahly on the ship. the extra blankets are removerl to be kept for future use, the patients are given what they need in the way of comforts and the lied ('rosi nurses: and other workers finally leave them. Several times, on aceonnt of rough weather or late hours. the patients hase not been allowed to come ahoard the steamer and have had to be someght back be tue to the deck. In such cases, they have been kept in the lied ('ross hut until arrange- 


\section{HIS'IORY OF AMERICAN RED CROSS NURSING}

ments could be made for their return to hospitals in the neighborhood. Meals are served them by the Red Cross Canteen.

Navy Base Hospital No. 5 had received most of the "Class D" men who were returned to the United States during the early months of 1918, but in April of that year Kehuron Center was dereloped and later Camp Pontason. During 1919 the "Class D" men were evacuated almost entirely through the hospitals of these eamps to the doeks.

South of Brest was St. Nazaire, and here the American Red Cross established another large infirmary. A special dock was given over entirely for the sick and wounded. Near it was an enormous shed which had been divided into two unequal sections. The larger seetion was turned over to the Y. M. C. A., which looked after the welfare of well troops. The smaller seetion was assigned to the Ameriean Red Cross. Here Red Cross canteen workers set up counters, installed a doughnut-baker and provided facilities for feeding large numbers of men. At the farther end several eots were set up and here the Red Cross nurses held sway. Miss Fitzgerald wrote: "I was much struck by the activities which were going on at Embarkation Camp No. 7, at St. Nazaire, where over three thousand men are daily bathed, deloused and entertained in Red Cross huts...."

South of St. Nazaire was the busy port of Bordeanx. Here the Red Cross dock infirmary was loeated in a large warehouse. Four nurses, Amarita Heath, Ida K. Neville, Emma Wilson and Ella Robinson, were assigned to duty there; Evelyn Walker was chief nurse of the Bordeaux zone and had gensral supervision of the work. Miss Robinson wrote:

We took rare of alont 30.000 sick and wounded men on the dorks at Bordeaux letween December and May. Early in 1919, we hat the severely wombled men. To these we gave every posible attention we could. adjusting their helpless borlies or limbs to a more comfortable position on the stretehers. reinforeing a dresing, assisting them to eat. for many of them were jaw or arm fractures and were not able to raise themserses to swallow.

T'o cath mann on the stretchers. we gave pajamas, handker-

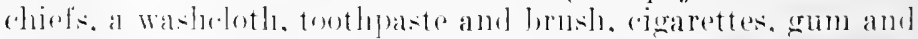
rookifes and we tried to fulfill any request he might make such as forwarding a cablecram or mailing a letter or card. 
To the walking eases, we gave small packages containing handkerchief's, digarettes and cookies. In themselves these gifts seemed trifling and we sometimes questioned whether it was worth while. but they were gradly areperted and many times the boys would say as they took them, "Here's the Red Cross to the end!" 'The men were wonderfully appreciative and I think we received more than we gave.

Emma Wilson wrote that "they are too happy to need much, these boys who are going home, but they are always ready to shont for the lied Cross."

A nurse always stood at the gang-plank to see the wounded and sick safely aboard. "Thus the last thing they see as they are earried upon the boats," wrote Miss Fitzgerald, "is the American Red Cross nurse."

The first mits of the American Medieal Department to return home were the original six American Red Cross base hospitals, which as mits of the Ameriean Army had been serving with the British Expeditionary Forees. The Presbyterian Enit, No. 2, sailed on .Jannary 25 and on March 13 the Peter Bent Brigham Lnit, No. 5, embarked for home. The other forr followed in quick snecession; the Lakeside Unit, No. 4, sailed on Marel 2.2; the Pennsylvania Unit, No. 10, on April 2; the St. Lonis Lnit, No. 21, on April 13, and the Northwestern Lnit, No. 12, three days later. ${ }^{14}$ One by one during the spring of 1919 the persomnel of American base hospitals and other sanitary columms in France were returned thromen the port of New York to Army eamps and eantomments in the Cnited States and subsequently were mustered ont of the Army.

The home-eoming murses were not met with the popular aerain with which the home-eoming troops were hailed. They were not greeted at the docks with waving thase, were not anked (1) mareh in the parades. In the editurial colmmes of the Journal Miss Paluer wrote:

We reently spent some time in New York, where the arrival of transperts bringing onr troops from france was a daily ocenreme which was marle much of ly the press. . . Practically all these incoming transports haid murses aboald.

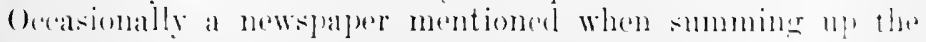

16..llistory of Nursing Activities, A. F. F.. on the Watern Fromt during

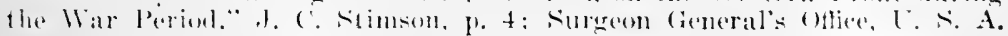




\section{HISTORY OF AMERICAN RED CROSS NURSING}

personnel of officers and men, "five or twenty or fifty women nurses" but none of them by name.

A few days ago, we saw a group of our nurses come off a big transport, earrying their heary suitcases, wraps and bags, go down the gang plank that looked to be at an angle of forty-five degrees, and walk the whole length of the Hoboken pier, between rows of soldiers lined up on either side. There was not the slightest attention paid to them by any of the official groups who were there to weicome the men or by the public in general.

Almost eleven thousand American nurses were in Europe during the early months of 1919 ; ten thousand were serving in the American Expeditionary Forces and some seven hundred others directly under the American Red Cross. In the military hospitals, in camps and cantonments in the United States, eleven thousand others were on duty. The return of these twenty-three thousand nurses to civilian life offered difficulties of adjustment of a nature which the Red Cross, which had ealled them into military service, was well able to anticipate and understand. And, too, sinee the Nursing Service had mobilized the great proportion of these nurses into military service, Miss Noyes and Miss Delano felt a responsibility for facilitating their return to the types of nursing which had previously most interested them.

On Decenber 10, 1918, Miss Noyes, as president of the Ameriean Nurses' Association, had written to Miss Delano:

In view of the fact that large numbers of nurses are about to be released from service in the antomment hospitals of this country and returned from duty overseas, it seems important that a burean of information should be established in New York ('ity, as the majority of the nurses will be returned through this port.

The purpose of this burean will be to serve as a sort of clearing-house through which the nurses may be directed towarl opportunities for service now existing and also adrised as to their future. Such a burean would, l fecl sure, be of inestimable value to the Public Health Nursing Burean of the Anerian lied Cross in recruiting nurses for the servive. It will be expally valuable to the Tisiting Nurse Associations and other forms of public health service. hospitals, training schools and other institutions which now appear to be in great need of nursing personnel. 
As president of the American Nurses' Association, it was first my idea that this work should be done under the auspices of the three national nurses' organizations, as it secmed to be a professional problem. . . The fact that the Red Cross has assigned the majority of these nurses to the Army and Navy and is in a measure obligater to continue its interest in them and render such assistance to them as seems possible, marle your sugrestion that the Red Cross assume the immediate control of such a bureau, most opportune and desirable. It would lurther appear that such an agency would be of great value in helping secure nurses for the publie health service of the lied Cross.

On Monday, December 2, I presented the plan informally at a joint meeting of the Boards of I)irectors of the three national organizations of nurses. They were decply interested and all expressed their ceneral approval and appreciation of the tentative plan and their willingness to present it to their respective Boards of I)irectors.

It was understood that the plan presented was about as follows (no notes being taken):

1. That the lied Cross was prepared to open a burean of information in New York City for nurses released from war service and that the three national nursing organizations were invited to place representatives in this office to assist and advise upon matters affecting the branches of service represented by the three assoriations.

?. It was understood that the Red C'ross assume the expense of rental, equipment, clerical assistance and management.

3. It was also understood that the Red Cross would in all probability assume the management and expense during the perion of demobilization. If upon the completion of this perionl. the Red cross decided to withdraw. that the three national organizations ontinue the Bureau under their auspires if strch an oftice secms necessary.

4. That a small Alrisory ('om in representative of the three organizations be asted to serve in a purely advisory capacity until such time as the lied cross should withow then this lwisory Comncil might form the nucleus of at Board of lipertors.

On Deermber 10 Miss Inlano secured Red Cons approval for the developuent of this plan and the further dotails of organization were turmed over to M Iss Soyes.

() ll lerember 1:; Misi l)elano wrote to the presidents of the three national nursing associations. She ontlined the gen- 


\section{HISTORY OF AMERICAN RED CROSS NURSING}

eral purposes and organization of the Bureau of Information and then continued:

.. . It seems desirable to have the coöperation of the three national organizations of nurses, giving them the opportunity to place in the Bureau a representative who conld advise the returning nurses in regard to available opportunities. ... The Red Cross will be responsible for all expenses, except the salaries of the representatives selected by the national organizations.

It will of course be necessary to secure all possible information from training schools, hospitals, public health nursing organizations and other nursing activities in regard to available positions and it is desirable that wide publicity be given to the establishment of such a burean, so that the organizations will naturally turn there for advice.

May I request, therefore, that you place the matter before your Board of Directors, asking for their coöperation and giving them opportunity to place a representative in the office.

It would also seem desirable to have a small arlvisory committee which could assist in the development of the work. I would, therefore, suggest that in addition to the President of your organization, two additional members be selected to serve on the committee.

The Joint National Committee of the Bureau of Information was appointed early in January, 1919, and was composed of Miss Nutting, Miss Francis and Miss Nores as representatives of the American Nurses' Association; Miss Goodrich, Miss Clayton and Miss Hilliard as representatives of the National Leagne of Nursing Education, and Miss Wald, Miss Beard and Miss Crandall as representatives of the National Organization of Public Hoalth Nursing. Florence .Johnson was the office manager of the Bureau. She served also as a member of the Conmitter. Miss Noves was chairman. During the forlowing montlis the Joint National Advisory Committee stood sponsor for the development of the Burean of Information for Ninrses.

Florencer Johnenon was office manager, as it has been stated bofore, and she bromeht to this as to here other tasks in ronnection with the mobilization and demobilization of nurses, the poise and rich personal rharm which rharacterized her preArmistire and post-Armistiece service. Miss Johnson had had 
opportunity to go overseas, first uas aassistant to Miss Stimson and later as chicf nurse of the American Red ('ross in Europe, but she elected to remain in New York. When the homing transports canne in she met the murses at the doeks with the same warn enthusiasm with which she had bade them Godspeed for France eighteen months before. "She still lives on the docks," wrote a personal friend to Miss Noyes in the spring of 1919, "and every night she comes home 'a dead dog.' Can't you use your influence to make her go a bit slower or at least to take part of Sunday ?"

As the development of the Burean progrossed two divisions were created, one the Division of Institutional and Student Assignment and the other the Division of Public Health Nursing.

Rachel Independence Albangh was chief of the first-named division. She was a Maryland woman and had received her nurses' training at the Homeopathic Hospital at Baltimore. Executive experience in varions Naryland institutions followed and later she was superintendent of the Grace Hospital at New Inaren, Connecticut. For the next fourteen years she served as secretary of the Connectient State Board of Nurse Examiners and from 1915 to 1919 as Inspector of Training Schools. In these capacities she conducted the valuable Connecticut State surver of nursing activities which was a precursor of the lied Cross nursing survers. Previous to her Red Cross appointment she had been one of Miss Goodrieh's staff in the Army Sichool of Nursing.

To Miss Mlbaugh was delegated all detail in commection with the placement of nurses in hospitals, schools of mursing, sanatoria and otler institutional positions. The Burean of Information had on Jannary 1 taken over the work of student enrollment from the Committee on Nursing of the Comncil of National l)ofense and also of the Army School, so the placement of these students in rivilian hospitals also fell to Miss Mlbangh.

Yssabella ciertrude Waters volunteced her sorviess for

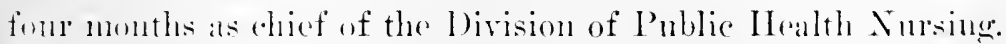
lossessed of independent means and many adrantages of birth and aluation, she had, like other women of heregenelation, fomml in nursing an ontlet to her desire for altruistic sorvioe and wals thronghout her long career a volunterer. In 1 s.t the was graduated from the dohus Ilopkins Sehool and som afterwards went to Ilenry Street to assist Miss Wald. Inring the 


\section{HISTORY OF AMERICAN RED CROSS NURSING}

Spanish-American War she did military nursing in the United States and Cuba. In 1899 she returned to Henry Street and remained there for thirteen years. In 1912 she undertook statistical work for the National Organization for Public Health Nursing. Her volume on Visiting Nursing in the United States ${ }^{15}$ ranks as a leading source-book on the subject. Patrician in appearance and winning in personality, she brought to the Bureau of Information keen intelligence and a knowledge of publie health organizations and resources perhaps unsurpassed by any woman in the United States.

After four months' organization work Miss Waters resigned and Jane Elizabeth Hiteheock followed her as chief of the Division of Public Health Nursing. Miss Hitcheock had attended Mount Holyoke College for two years and had taken special work for three years at Cornell University. She was graduated in 1891 from the New York Hospital and was for two years a head nurse of the Newton (Massachusetts) Hospital. She then went to Henry Street Settlement and for twelve years before her appointment to the Bureau of Information was superintendent of the Henry Street staff of visiting nurses.

During the early perior of 1919 the day's work at the Burean of Information eonsisted largely in interviewing nurses returning from France; often Miss Hitcheock and Miss Albaugh talked to thirty or more nurses each, listed their previous experiences and future interests and catalogued the cards for future reference.

Like the soldiers, the nurses were coming back phrsically and nerrously exhausted and their one desire was to go home and rest. This attitude and the growing dissatisfaction to return to the comparatively narrow fields of private duty nursing was expressed by Laura Hartwell:

The state of mind of some ex-members of the Amerian Expeditionary Forces resembles somewhat the forlorn desolation of a homeless (at. While this is true of both men and women, it applies especially to the returned orerseas nurse, not so much to those who return to the arms of admiring families to be pettei and spoiled and urged to take a long rest. but to those who live in a trunk, as it were. and who make their homes wherever their hat happens to be. . . .

${ }^{15}$ Published in 1909 under the auspiees of the Ruscell Silge Foundation, by the ('harities Publication Committee. Niw York City. 
But at any rate, they were at home. Aud the first private duty ase, when one returned to the white uniform, brought a rertain sutisfaction, but soon one's thoughts turned wistlully back to the days when slithering around in the mul, wearing rubber boots, was the msual netherl of going on duty.

As the days passed and the patient became convalescent, the honging for a wider sphere became more acute. . . The present somehow does not seem to fit with the past and the future of useful and remunerative work seems very distant. 'This attitude is of course. to a great extent the reflection of the world's unrest, but the people who stayed at home have adrancel along different lines from those who went orerseas and they cannot see why the daily round cannot easily be taken up again.

And then how one misses the comradeship of the life over there, where the English language was sufficient introduction, the comraleship which by force of eontrast makes the bustling life at home where each one is intent on his or her own business, seem cold and unfriently. . . . ${ }^{16}$

To nurses suffering from this natural psychologieal reaction, the Burcau of Information offered a chamel of recintry into civilian life. By September, 1919, it had proven unequivocally its value. In the Division of Institutional Assignment the names of 2333 nurses had been registered for placement. On the other hand, hospitals and schools of mursing had registered 1716 vacancies in positions ranging from superintendents of hospitals, superintendents of schools of nursing, night supervisors, instructors, charge nurses, anesthetists, laboratory and X-ray technicians, dietitians and general ward and pupil nurses. The total number of eraduate nurses placed in positions by Miss Mlbangh's division numbered 805 ; this figure, however, includes only the placements regarding which Miss Alhangh had detinite knowledge that the nurse had acepted the position to which she had been referred. Creat difficulty wals experienced to get the nurses to report back to the limean after they had areepered a position.

The second major aretivity of Miss Albangh's division was student assignment. () 477 appliations recoived from romng women formerly combled in the Army sehool and desiring placement in aivilian hespitals, 398 were referred to aceredited schools of nursing. In this connertion Miss Mlhangh gave ralualule information to Miss Wheeler in her revision of the

"1 1 merican Journal uf 1 ursing. Vol. 211. Ip. 294.2!5. 


\section{HISTORY OF AMERICAN RED CROSS NURSING}

list of accredited training schools, as published by the American Nurses' Association and assisted with much of the elerical details of compilation.

The activities of the Division of Public Health Nursing consisted in collecting and disseminating information regarding the general ficld of public health nursing; in collecting and disscminating information regarding public health uursing education, especially with reference to post-graduate scholarships; and in referring qualified public health nurses to agencies desir ing their services. From February 10 to September 15, 1919, three hundred and sixty-six different public health mursing organizations applied to this division for assistance in sceuring nurses. "Many of the requests," wrote Miss Hiteheock, "come in wholesale. North Carolina wants twenty-one nurses for town and country work; the Tubereulosis Association, of Springficld, Illinois, wants fifty; the State department of health in a middle-western state puts in a modest request for one hundred and fifty public health nurses."

During the first seven months of its existence this division had registered the names of 1274 publie health nurses or nurses interested in taking up this specialized phase of the profession and had referred 1255 of them to organizations desiring their services.

Miss Hitchcock gathered some interesting data regarding the preliminary education of nurses enrolled in her division. Eleven per cent had had only a grammar school education, 20 per ecnt had had college, normal or private sehool cducation, 69 per cent had had high school training. As to their preparatory work in public health nursing, 117 had had public health nursing courses while attending a general sehool of nursing; 75 had had post-graduate courses in public health mursing; 524 had had practical experience. The requirements of this division for registry were the same as those of the Red cross Burcau of Public Health Nursing Service.

As the end of the demobilization period approached and the Red Cross prepared to close the Burean of Information, the opportunity for lamehing a lone-cherished project seemed ripe. "Almost from the beginning of our organization life." declared the editorial columms of the Journal. "the need for central leadguarters has been talked of, first by one group of members and then by another, but there has never seemed to be al tine when all the conditions were farorable." 
In Oetober, 1919, Miss Noyes made the first move toward the transfer of the Bureau of Information for Nurses from the Red Cross to the three organizations of nursing. At a meeting of the joint boards of directors of the three national organizations, Miss Noyes, as president of the Amerien Nurses' Association, was authorized to appoint a committee to consider ways and means by which the Red Cross Bureau of Information could be transferred from the Department of Nursing to the three national organizations and used as the nucleus for central headquarters for the nursing associations. Miss Nutting was the chairman and Elsie M. Lawler, Mary S. Gardner, Katherine Tucker, Mimnie H. Ahrens and Miss Noyes (exofticio) were the members of this committee. They set to work and drew up a plan which was presented to the Board of Directors of the American Nurses' Association at a meeting held on January 15 to 16,1920 , in New York City. The report of this Committee on Transfer and of the new plan was, in part, as follows:

The Burean of Information for Nurses was established by the Red Cross in February, 1919, largely for the purpose of assisting nurses who have been in Army or Red Cross service. In this, it has been of notable service. . . The time approaches when the Red Cross will no longer feel justified in continuing it. It would seem inadrisable to continue it in its present form. It woukl, however, talke it: phace in a larger plan-the establishment of national nursing healdquarters as a center for the work of our national asonciations. . . The committec believes that the conditions are farorable for the establishment of such headquarters and that steps should now be taken toward that enel.

'The tefinite work to be carried on in such a center would be limited at first to that most urgently needed. There should be: (1) otlices for the seeretaries of each of the three national creanizations: (*) a burean of appointment and atvice: (3) a division of publieity: ( $t$ ) an ollice for the Americun fourmul of lursing: (.) a library and reating rooms; (6) the combined clerienl fores of all these departments.

The expensere of maintaining such a heallguarters will un-

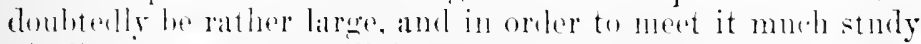
of all our resoureses will be needed. It is our opinion that

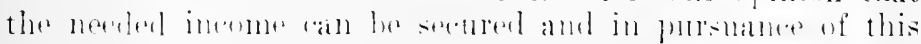

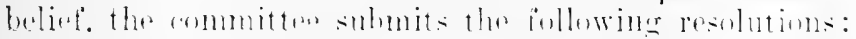




\section{HIS'TORY OF AMERICAN RED CROSS NURSING}

A. That the three national associations of nurses take orer from the Red Cross the activities of the Bureau of Advice and Information.

B. That this transfer be made as soon as suitable headquarters can be obtained (if possible, be the building now housing the National Organization for Public Health Nursing) and the necessary financial and other arrangements made to conduct the work.

C. That the Bureau be taken orer as a branch of a national nursing headquarters to be established in New York City, looking forward to decentralization at the earliest possible date.

D. That national headquarters include the three nursing organizations with the coöperation of the Department of Nursing of the American Red Cross.

Three ways are presented for the administration of the headquarters: (1) pooling the resources and personuel and resting responsibility in a committee with proportionate representation; (?) A federation of the bodies concerned with a central committee which shall be advisory; (3) A combination of these two plans by which certain interests and expenses shall be shared, others handled by each association. under the direction of a committee which shall act as a board of trustees. This is the plan recommended. . . . ${ }^{17}$

The plan was immediately hailed with enthusiasm by the majority of nurses. It would effeet great saving of time and money, as under the old order duplieation in the work of the three organizations had been mavoidable. As New York was the mursing and hospital center of the United States, it seemed the logical eity for a headquarters.

The American Nurses' Association met at Atlanta, Georgia, April 12-17, 1920, for its Twentr-Seeond Convention, and the new plan for central headquarters was presented on April 15. Miss Nutting, as chairman of the Committee on Transfer, read the report. The names of Miss Coodrich and Miss Clarton were added to the Committee on Transfer, which was later authorized to continue as the Committee on National Nursing Headquarters. After some discussion Miss Mac.Millan, of Chicago, moved that "the Association accept the report of the Committee on Sational IIcadpuarters and anthorize the organization of the headquarters." The motion was carried.

${ }^{17}$ For further details, see the Ameriem Joumal of Nursing, Vol. 20, pp. 503-50.5. 
By August, 1920, the details of transfer had been completed and the Central Headquarters established in New York City. Miss Albaugh was appointed office dircetor representing the American Nurses' Association and the National League of Nursing Education. The Red Cross financed the project during its first year. At the joint convention of the three national organizations of nursing, which was held in Seattle between June 26 and July 1, 1922, Miss Noyes retired from office as president of the American Nurses' Association with the satisfaction of knowing that the National Nursing Headquarters would be maintained; the revision of dues which provided for an increase from fifteen to fifty eents per capita for membership in the American Nurses' Association, aceomplished at this merting, made adequate finaneial provision.

'The establishment of a eentral headquarters marked the realization of a need long felt by nursing leaders; it ranked as one of the signal aceomplishments of the nursing profession during the life of the Association.

A seeond major development of the demobilization period was the organization of a third govermment nurse eorps, that of the Lnited States Public Health Serviee. In this development the Red Cross Nursing Service played an important part by giving its interest and support to the program of the Publie Ilealth serviee for the proper establishment of a rorps of qualified nurses and rendered valuable assistance in recruiting these murses for the new eorps.

The Inited States P'ublic IIralth Service had been established in the year 17 as as the Marine Hospital Service. Under a rooreanization act of .July $1,19(02$, this service was colarged and its name rhanged to that of the Public Health and Marine Inspital Service. Again in 1912 different divisions which were still in operation in 1!1! wore established, and its name again changed to that of the Lnitod States Public Health Sirviere.

Two of the nine divisions of the Public II alth Service were the Bureatu of Sirentific Leseareh and the Bureall of Marine

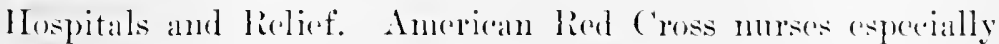
interested in the "atre of tratehomat pellatgrat and othere discasces had been assigned duringe 1918 to the special hospitals eon-

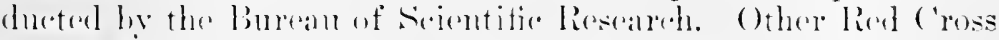
murses had bern assiened to general institutional numsing in the 


\section{2+ HISTORY OF AMERICAN RED CROSS NLRSING}

hospitals maintained by the Bureau of Marine Hospitals and Relief. Among these was the large base hospital at Nitro, West Virginia, which maintained an average nursing staff of some ninety Red Cross nurses.

The Burean of Marine Hospitals and Relief was charged particularly with responsibility for furnishing hospital care to civilian sailors, both native and foreign. During the fiseal year ending Jume 30, 1918, this burean operated 20 such marine hospitals and maintainer? 119 other relief stations where hospital and out-patient relief was furnished to 71,806 patients. ${ }^{18}$

Red Cross public health nurses were assigned to the sanitary zones maintained by the Public Health Service around Army cantonments. The type of duty these nurses rendered has already been deseribed.

Previous to the post-Armistice period Miss Noyes had seleeted nurses for these various types of service and had herself sent the nurses' papers direetly to Dr. Rupert Blue, then Surgeon General of the Public Nealth Service. This arrangement was not satisfactory, howerer, beeause there was no executive nurse in the Public Health Service to whom these nurses might turn for adrice and aid.

"With the signing of the armistice and the cessation of hostilities," wrote General Blue in the Anmual Report of the U. S. Publie Health Service for the rear 1919, "arose the problem of taking eare of the injured sailor and soldier after discharge from the military forees." The Burean of Marine Hospitals and Relief was selected as the most promising machinery already in existence, and plans for an increase of one hundred per cent in the capacity of the marine hospitals and the establishment and maintenance of additional hospitals were formulated.

One of the major phases of this expansion was the provision of an adequate foree to statf these hospitals. Cimeral Blue appealed to the Red Cross Nursing Serviee in locember, 1918, for additional nurses. An rarly step in developing the nursing forec lay in the appointment of an exerentive nurse to derelop and supervise the work and here the Reed cross provided salary and traveling expenses mutil the peminent appointment of a superintendent of murses to drevelep this servioe wals madr:

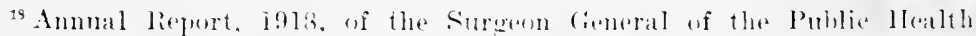

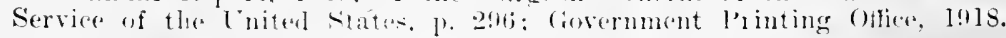


Luey Minnigerode was chosen to undertake a tour of inspection of the marine hospitals. On January 10, 1919, Miss Noyes explained to the general manager at National Headquarters her recommendation that Miss Minmigerode's salary be carried on the Nursing Service budget:

Some weeks ago, Surgeon (ieneral Blue asked the Department of Nursing to appoint a nurse as inspector of the marine hospitals. In view of the fan that we have been providing nurses for these institutions, we folt very anxious to to this, in order that we might serence unifornity and improve the standard of nursing rare of the sirk in these hospitals. I think Miss Delano spoke to yon about this before she left.

We engaged Miss Minnigerode who had previonsly been in charge at National Ileadquarters of the preparation of nursing persomel for special overseas duty, for this purpose. . . .

During .Jamnary, 1919, Miss Minnigerode visited the marine hospitals at Baltimore, Savanuh, New Orleans, Mobile, Memphis and Wilmington, North Carolina. She found that with the exeeption of the hospital at the Emigration Station at Ellis Island and the special hospitals such as the Pellagra Ilospital at Spartanbure, North Carolina, few murses had been employed in the past in these institutions. There were no adequate murses' quarters and the nursing eare of the patients was given entirely by orderlies.

Miss Mimigerode returned in February to Washington, was

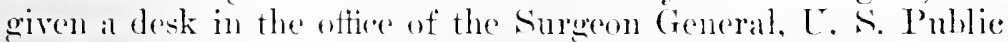
Health serviee, and there she began to study the problems attendant mon the development of a murse eorps.

On March 3, 1919, P’ublic Let 320 was passed ly Congress, which authorized the seretary of the Treasury to "provide immediate additional hospital and samatorim fareilities for the rarre and treatment of dischareed sick and disalbled soldiers, sailors and marines, Army and Nay Nurses (male and female), patients of the War likk Insuranee Burean, and the following persons only: merehant marine samen, seamen on

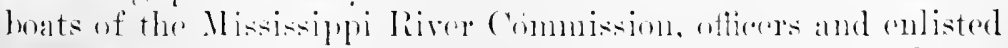

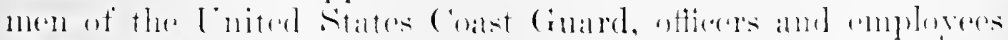

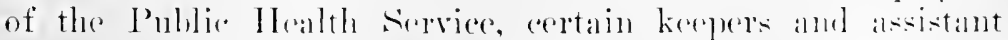

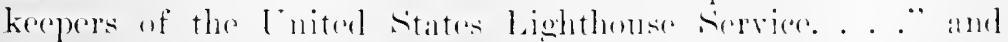
othere specially namenl glomps. "It will be seen," wrote Generil 


\section{HISTORY OF AMERICAN RED CROSS NURSING}

Blue in his Annual Report for 1919, "that Congress thus designated the Public Health Service as the medical agency of the Government through which beneficiaries of the War Risk Insurance were to be given the necessary hospital and sanatoria treatment. This legislative action is in line with the administrative practice of the Public Health Service in endeavoring to have utilized by other Government Departments and Bureaus the sanitary and medical machinery which it has perfected."

In a letter written on March 14, 1918, General Blue announced to Miss Noyes that Miss Minnigerode had been selected as superintendent of the United States Public Health nursing service. In this position she immediately began to build up an office and field force. Obstacles attendant upon such pioneering were naturally encountered in the following months, but with the fearlessness and outspoken resolution which characterized her methods of work and with the firm support of the Surgeon General and the Red Cross, Miss Minnigerode cut her way through prejudice and conservatism and established a nursing service which employed the largest number of nurses utilized by the Government during the demobilization period.

Hospital facilities to be used for the care of personncl enumerated in Public Act 326 were to be provided through the expansion of the marine hospitals; through the maintenance by the Public Health Service of several former Army base hospitals, and through the establishment of new hospitals. The United States was divided into fourteen districts and offices for the examination and assignment to hospitals of beneficiaries of the War Risk Insurance Bureau were established in each district.

Early in 191!) arrangements were effected by which the Nursing Service at National Headquarters undertook to assign nurses to Miss Minnigerode's division. This arrangement was outlined in the otticial bulletin issued in April, 1919, by the Public Health Sorrice:

The Nurse Corps of the U. S. Publie Health Service consists of a superintendent of nurses, chief nurses, nurses and reserve nurses.

Ascignment to duty as chief nurse is made by the surgeon Generat upon recommentation of the -uperintendent and after the canclitate has furnished satisfactory evidence that she meets the requirements of such service. 
The position of chief nurse in a hospital of the U. S. Public Health service, so far as conditions permit, is equivalent to that of superintendent of nurses in a civilian hospital. She will have general supervision under the medical officer in charge, of all the n!msing service in the hospital and is expected to instruct the murses assigned to that hospital in the duties peculiar to the Marine Hospital Service.

\section{Nurses}

Application for the appointment of nurse in the Nurse Corps of the I. S. l'ublic Health Service should be made to the Surgeon General I. S. Public Health Service, who will direct that the necessary information be sent to her. For the present and until the Nurse Corps is established, the Nursing Department of the American Red Cross has becn requested to assign the nurses to these hospitals, and the applicants must therefore meet the requirements for enrolment in the Red Cross. 'The Red C'ross assigns the nurses for a perion of six months, after which time the appointment may be made permanent. . . .

\section{Appointments}

Applicants who meet the requirements of this service will be placed on the cligible list for appointment as their services may be required. . .

The first six months after appointment shall be considered as probationary period. to observe the fitness of the nurse for this service and here alaptability to comblitions in marine losspitals. If during the six months, a murse has given satisfartory sorvice and has met the requirements of the Marine Hospital service, she mily then become a permanent nember of the Vurse ('orps. if she so desires. She must then, however. conform to the regulations of the Civil servien Commission. . . .

Prior to only 1, 1919, murses in the Public Health Service received $\$ 70$ a month for the first two rears of service. with proportionate increales for longer terms of serviee. Ifter July 1, 1919, the salary was increased to $\$ 80$ a month. ('hief

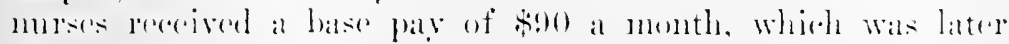
increased to $\$$ tol). Qualters, subsistence and lanndering of uniforms were furmished and the murses recoived thipte dars'

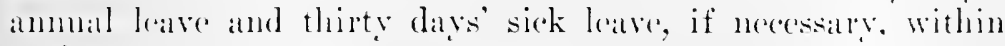
a given your. 


\section{HISTORY OF AMERICAN RED CROSS NURSING}

The uniform to be worn in the wards was a white cotton, one-piece dress, with white shoes and stockings. Nurses assigned to the Public Health Nurse Corps who were members of the Red Cross Nursing Service were permitted to wear the Red Cross indoor uniform and the Red Cross cape. However, if they were aceepted as permanent members of the corps, they were expected to secure the regulation uniform of the corps. Later an outdoor uniform, which was forest green in color and which consisted of oxford coat and skirt, was authorized. The insignia of the Public Health Service was a bronze design consisting of the coiled serpent of Esculapius with a bronze anchor superimposed upon it.

Perhaps because the work in the marine and other hospitals of the Public Health Service dealt with the ex-service men, or because the arrangement effected by the Red Cross offered temporary employment until the nurses could make up their minds regarding the type of permanent civilian work they wished to enter, the Publie Health Service was for a time very popular with the demobilized nurses. By July 1, 1922, the American Red Cross Nursing Service had directly assigned 625 of its nurses to the Public Health Nurse Corps and had recommended for appointment the names of approximately fifteen hundred others. During February, 1920, the Nursing Service at National Headquarters sent the papers of an average of twenty nurses a day to Miss Mimnigerode"s division.

By the end of the fiscal vear 1920 the Nurse Corps of the Public Health Service had a strength of 1100 nurses. Miss Minnigerode had as her assistant Clare Gaffner, a graduate of the Maryland General Hospital School, of Baltimore. Miss Gaffney had served in Sanitary Zone No. 9 for twenty-two months, and in November, 1919, had been assigned to Washington as assistant superintendent. Miss Minnigerode's staff also included a cecond atssistant, Mary Ruth Swan, who was detailed partially to the Washington headquarters and partially to field supervision. Meta ('. Brooke and Mabel K. Adams were also assistants to Miss Mimigerode and were assigned to duty langely in the fichl. "Cö̈perative relationships had also been established," stated the Ammal Report of the Public Health Service for the rear 1920. "with the Federal Iboard for Vocational Edueation with regard to a small nursing force which had boen fomd necessury for the prosecution of medical catre for trainees of that Boiard." These nurses did 
general medical and soeial service "follow-up" work. They were under the supervision of $\mathrm{Mrs}$. Katherine C. Hough, who was on duty in the office of the Chief Medical Officer of the Federal Board.

The Anmul Report of the Public Health Service for the year 1920 continued:

. The greatest problem with which the nursing scetion has been confronted is the inability to secure an adequate number of well-trained nurses suitable for the work. ... In addition to this the rapid organization of a female nursing corps has thrown new burdens on the Public Health Service in the matter of securing adequate quarters and perfecting an organization for the discipline of so large a corps. These problems are being met gradually but the question of quarters still remains a difficult one. . .

$I_{n}$ the discipline of the nursing corps there has been found to exist a certain spirit of unrest which is by no means confund to any one group of persons, and this has resulted in a very large turnover, which it is hoped may be avoided during the roming year because it loes much to militate against the efficieney of the Corps and renders more difficult the establishment of a high morale. . . .

During the period between June 30, 1920, and July 1, 1921, the coipleration with the Ameriean Red Cross entinued indirectly, but the nurses were referred to the Public Health Service Nurse Corps witl reeommendation for appointment rather than assigned direetly, as had been the procedure under the initial agreement. Of the 1350 nurses apointed during this fiscal year, only 2 fig were reommended thromgh the Red Cross; the other 10si were recruited through Miss Minnigerode's offiee. Howerer, the publicity giren to the needs of the Public Incilth Nurse (orps ly the Ried Cross and the efforts of Red Cross I)ivision Direetors of Nursing were instrunental in seanring these murses. During this period the further development of the Nurse (arpes progeressede educational projects were launched and a far more satisfactory esprit de corps was huilt up ammenge the nurs. One-fourth of the nurses who resigned

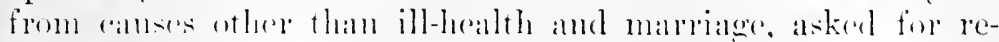
instatenent.

By order at the Seceretary of the 'Treasury, on April 19, 1921 , all the andivities of the Public IInlth serviec which 


\section{HISTORY OF AMERICAN RED CROSS NURSING}

related to the beneficiaries of the Bureau of War Risk Insurance, except those activities relating to the operation of hospitals and dispensaries, were transferred from the Public Health Service to the Bureau of War Risk Insurance. The Sweet Bill, which was approved by Congress on August 9, 1921, legalized this order and created the Veterans' Bureau. By an Executive Order of May 1, 1922, all hospitals earing for ex-service men and women were transferred on that date from the Public Health Service to the Veterans' Bureau and on July 1 all dispensaries, with the result that some thousand nurses of the Public Health Nurse Corps were automatically shifted from Miss Mimnigerode's division to that of the superintendent of the Nurse Corps, Neterans' Bureau. The Nurse Corps of the Public Health Service eontinued, however, to be maintained to staff the hospitals and dispensaries of the former Bureau of Marine Hospitals and Relief and Reconstruetion aides and dietitians were placed in Miss Mimnigerode's division when the hospitals were transferred. On July 1, 1922, this division had a total strength of 450 nurses, dietitians and aides.

The Nurse Corps of the Veterans' Bureau numbered in the summer of 1922 some fonteen hundred nurses-those of the former Public IIealth hospitals, those of new hospitals of the Veterans' Bureau and those of the Federal Board of Voeational Re-erncation. Mary Agnes Ilickey was the newly appointed superintendent. Mrs. Hickey was born in Ireland and was graduated in 1900 from St. Mary's Hospital, Brooklyn, New York. Whe had extensive experience as a murse instructor and as a school nurse. She went overseas in 1918 for service with the Red Cross Children's Bureau but in the military shortage was assigned to the Service ile Santé to nurse Ameriean wounded in French hospitals. She was transferred to the Army Nurse Corps late in 1918, returned to this comntry during the following rear and in August entered the Publie Health Nurse Corps. where she later served as Miss Minnigerode's assistant.

At the presont date of writing the organization of the Nurse Copps. Vorterans' Burean, has not heen entirely perfocted. Howerer, the first indication that the Veterans' Burean would look to the lied cross Nursing service as its reserve, as had the Publir. Inealth Serviee, was contained in a letter addressed to Miss Johuson on July 5, 1922, by Colonel Robert L. Paltterson, assistant director of the Veterans' Burean and formerly 
ehief of the Red Cross Bureau of Medical Service in 1914. Colonel Patterson said in part that "the Bureau desires to call your attention to the existing shortage of nurses for duty in the U. S. Veterans' hospitals and to recunest that you do whatever you are able toward recruiting nurses for this service. . . . To be cligible for appointment to this service," he added, "nurses must be citizens of the United States, graduates of recognized training schools for nurses, registered and able to qualify under the regulations of the Civil Service Commission. The salaries of nurses inchde quarters, subsistence and lanndry, and are as follows: staff nurses, $\$ 960$ per annum; head nurses, $\$ 1020$; assistant chief nurses and acting chief nurses in hospitals of less than 200 beds, $\$ 1200$, and chief nurses in hospitals of 200 beds or more, $\$ 158+$ per anmum. Vacancies in the higher grades are tilled by promotion from a lower rank, rather than by new appointments."

During the European War the casualty rate among Ameriean nurses in military service secmed high. The principal cause was disease. No murses were killed in action. Four were wounded in eneny air raids. In view of the fact that nurses belong to the sanitary service and that the sanitary service is a non-eombatant branch of the Jlilitary Establishment, a branch protected in previous modern wars by international agreement and commonly aceepted prineiples of humanitarianism, this tigure is minge in the history of Ameriean war mursing. The American nurses wounded in line of duty were Beatriec Mary MacI lonald, a nurse nember of Batse Hospital No. 2, who was wounded Angust 17, 1917, while on detached duty at Casualty Clearing Station No. 61, British Expeditionary Fores: Eva Jean Parmelee, of Base IIospital No. 5, who was womnded september 4, 1917, while on dut? at her base, No. 11 Cieneral IEspital, British Expeditionary Forees. Damnes ('amiers, France; Isabelle stambangle, of base Hospital No. 11, who was wounded March 2:), 1!1 $\mathrm{s}$, while on detached duty at So. 42 Stationary IJospital, British Expedi-

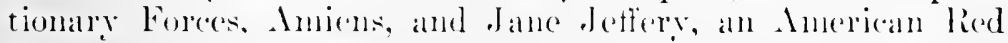
C'ross ehild weltare nurse assigneel to military servioe. who was wounded on July 1.i. 1915, at Anerican lied ('ross Hospital No. 107, Jour-sur-. Morin, France.

Of the 2:30)(10 American murses in military serviee from April di, 1917, to Nosember 11, 191!) (this figure dees net inrhole those assigned to intluenza relied nor these worloing at 


\section{HISTORY OF AMERICAN RED CROSS NURSING}

Red Cross Chapter, Division or National Headquarters or serving upon Red Cross eurollment committees), over three huncled died from diseases contracted in line of duty, and $4+9$ others suffered total or partial disability-a total of some 749 nurses. Thus three out of every hundred nurses either died or suffered temporary or permanent disability from war nursing service.

The number of Army nurses who died during the participation of the United States in the European War was 268; of this number 218 were reserve members and 50 were regular members. The number of Nary nurses who died during the same period was 28; of this number 24 were Ameriean Red Cross nurses, one was a reserve nurse but not assigned through the Red Cross and three were regular members. Thus the number of American Red Cross nurses who died in line of duty with the Army and Navy was 242. Forty other Red Cross nurses died in other types of war nursing, so the total of American Red Cross nurses who died in line of duty in the European War was 282.

Four American Red Cross nurses died in line of duty with American Red Cross commissions or allied relief organizations orerseas. The first of these was Nina Louise Sermonr, who died from pnemonia on Oetober 10, 1918, at Ameriean Red Cross Hospital No. 114, at Poule, France; the second was Nettie Grater MreBride, who sucemubed to trphus ferer on December 23, 1915, at an Ameriean Red Cross hospital at Thmen, Siberia. Jane Delano was the next murse to die under the Red Cross flag, and on May 17, 1919, Edith May Winchester died from trphus at Erivan, Amenia, while on duty with the Armenian and Srrian Relief Committee. Three others of the 282 nurses were killed by aceidents; one when the airplane in which she had been taken for a flight erashed, and the other two in the ancident on the S. S. Mongolin. I full list of the Red Cross nurses who died in military service may be found in the Appendix.

()f the $4+9$ nurses partially or permanently disabled, some twenty-five per eent suffered from tubereulosis. ${ }^{19}$ 'The high

\footnotetext{
${ }^{90}$ This figure was taken from information fumished by American Red Cross nurses who filled ont the questionnares issued hy bivision bepartments of Xursiug to all ex-service American lied cross nurses. Acording to a compilation prepared in the statistieal division of the surgeon General's oflice, the pereentage of tubereulosis among nurses adnitted as paticnts in Army hospitals was much lower.
} 
rate of tuberculosis eame, it is thought, from general lowered vitality due to the lack of proper heating facilities and the long hours of duty. On questionnaires later sent out by the Red Cross, disabled nurses stated that they had first suffered from heary colds but had not stopped to report them and take the needed rest because they appreciated that their inactivity would place the burden of their work on the shoulders of their already overburdened sister nurses. While the Red Cross made every effort to secure a thorough physical examination before the nurse was admitted to the Red Cross and military services, this was not always possible; some of the examining physicians were thorongh but some were lax. Upon reëxamination after they had seen service in the Army, there were nurses who were found phrsieally unfit and discharged. Yet even with every effort on the part of the Army to sift ont these nurses, it is quite possible that many murses whose vitality was not suffieient were retalined in Army service because of the acute shortage of nurses and the brief time within which the Army and the Red Cross was called upon to mobilize.

Public Act 3:6, which, it will be remembered, was the Congressional authorization for the hospital care and treatment of heneficiarics of the Bureau of War Risk Insurance, had especially named Army and Nary nurses as eligible for its benefits. American Red Cross nurses on duty with the Army or the Nary in this comntry or overseas were eared for in special infirmaries maintained for sick nurses by the base hospital to which they were attached. As reserve nembers of the Army and Navy Nurse Corps, they were eligible to all benefits of Federal care, compensation and rëducation. During 1918 Army nurses convalescent in this country were sent to recuperate at Seabright, the comntry estate of Mr. and Mrs. Jacob Schiff, which the New York plilanthropist and his wife had turned over to the Aruy. Seabright was loeated at Redbank, New derser, and "was not merely a house but just a big, heautiful sunshing. home, with evervthing in it that the family had loved and enjoyed," wrote Xi. E. IIines, an Army nurse. "It offers every confort one could inawine," she ronitinued. "It is more like a fairy tale than real life. for it is actually true that we folt the atmosphere of the hominess, the hospitality, the peatere and rest as soon as we entered . . and although we were sent by the (iovernment, and some came reholuntly and alnost in tears becanse they didn't know or couldn't conceive what kind 


\section{3+ HISTORY OF AMERICAN RED CROSS NURSING}

of a place it was, we left more reluctantly, because nowhere is there another place like it." 20 Seabright was maintained entirely by the generosity of its owners, althongh the Army Nurse Corps had supervisory authority over the nurses sent there. The length of stay ranged from two weeks to three months, depending on the needs of each patient, and the nurses were entertained at no eost whatsoever to themselves. Mr. and Mrs. Schiff also gave much of their time and interest to the nurses. Seabright was elosed during the last days of October, as the leating facilities were inadequate for the winter months.

Early in Jamuary, 1919, a rest honse for nurses was opened at Riverdale, New York, the former homestead of Grace Dodge, the New York woman philanthropist who did mueh for the establishment of the Young Women's Christian Association and the Central Club for Nurses in New York City. Mr. and Mrs. Cleveland Dodge offered the nse of the Riverdale estate to the Army Nurse Corps and continued its maintenance until the spring of 1920 . The interior of the house was charming and the grounds sloped down to the Hudson River.

The mamner in which sick Army nurses were eared for overseas was described by Miss Stimson in her "History of the Nursing Aetivities, Ameriean Expeditionary Forees, during the War Period on the Western Front:"

Sick nurses have been eared for in various ways. In some hospitals, such murses were kept in quarters. This method is minatisfactory and should be followed only when no other provision is available. Some hospitals have made a special part of the nurses' quarters into an infirmary and have assigned nurses to duty there as though on regular duty in the hospital wards. This plan is second best. The most satisfactory scheme is to have a ward or part of a ward of special room in the hospital proper set apart as a nurses' infirmary, to which all nurses unible to go on duty for any physical reason whatioever are sent at once and where they receive regular care as patients.

In some centers. it has heen found advisable to have a center infirmary in one of the hospitals, to which all the sick murses of all the hospitals of the center are sent. While this plan of concentration made for economy of supplies and nursing stall". it has not worked out satisfactorily in every instance, owing to the prejudice which existed in the minds of

s. Imerican Journal of rursing, Vol. 18, p. 172. 


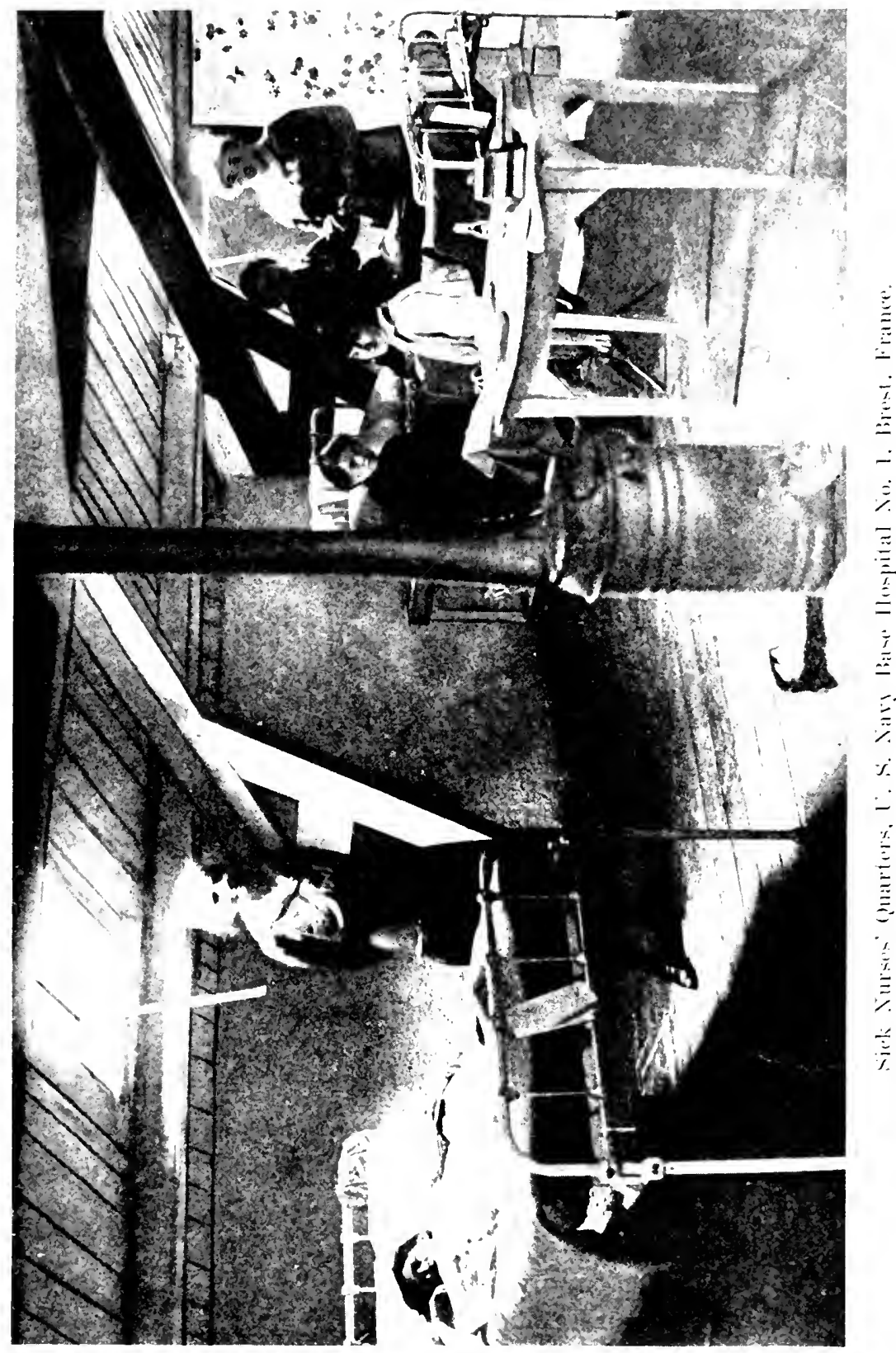



most sick nurses to being cared for in a hospital not their own and by nurses and doctors who were strangers to them.

Miss Stimson deseribed the method by which sick and disabled Army nurses were returned to the United States from foreign service:

The eracuation of sick nurses, after the usual classification by a meelical board, wals throngh Base Hospital No. s at Savenay up to February, 1919, when Base Ilospital No. 113 was made the place of collection for patient nurses.

The following paragraph in a leter dated Iarch 3, 1919, from the superintendent of the Arny Nurse corps to the Director of Nursing. A. E. F., stated the plan for the disposition of sick nurses upon their arrival in the Lnited states: "Those who arrive in the Lnited states as patients may go home if they themselves desire to do so, provided they make an oflicial request for relief from service, stating at the same time that they desire to forego further treatment at government expense. The Medical I)epartment is most desirous of giving all nurses every opportunity to regain so far as possible their normal health, so mless the nurses themselves desire to go home, they will in all cases be furnished with proper care as long as it is needed.

When acutely sick and disabled nurses arrived in New York they were, if they so desired, sent directly to Army base hospitals in this comintry for further care. Yet among the many home-(oning nurses were women whose sickness and disability had not ret become acute enough for them to have requested hospitalization. They retumed to New York, got their discharge from the Army and plunged into civilian mursing again, only to find that their health had been undermined and that they were mable to work. The nurses suffering from tuberenlosis offered examples of this type of ineipient disability. They were, hewerer, still eligible for Federal aid, but there was no provision for their treatment and care during the period when they were establishing their chans or during eonvaleseence, after they hated been discharged from hospitals of the Public Health service. For nurses siek or disabled in Red cross foreign serviee, there wats no provision whatsocerer.

The fonr women whose position best enabled then to befriend anel ald siek and disilnled murses were Florenees. Johnsent and Christine Numo, at Atlantic Division Ileadyuater's; Miss 


\section{HISTORY OF AMERICAN RED CROSS NURSING}

Noyes, at National Meadquarters, and Miss Minnigerode, in the Public Health Service. Miss Johnson and Miss Nuno met the sick nurses on the docks and their interest and sturdy labors did not cease until each nurse had claimed and received the care and compensation provided by Federal law for Army and Navy nurses or by National Headquarters for nurses under special Red Cross service overseas.

Christine Nuno was Miss Johnscn's assistant. She had been graduated in 1914 from the School of Nursing at St. Luke's Hospital, New York City. She was for some months ehief nurse of the base hospital at Camp Meade, Maryland, and was then transferred to New York and served as chief nurse of Debarkation Hospital No. 5. In June, 1919, she was discharged from the Army and went to Atlantic Division Headquarters to assist Miss Johnson in locating and caring for sick nurses, a task for which her unfailingly happy disposition made her admirably fitted. Beneath a manner bubbling over with sheer exuberance of spirits, she possessed a very real and deep sympathy for each and every one of the sick murses whom she piloted through the mazes of Federal adjustment. Her good cheer seemed limitless, her enthusiasm could not be cooled by any amount of red tape and delay, and in her eompany the sick nurses took heart and langhed with her.

Through the Red Cross Burean of Information for Nurses, Miss Johnson and Miss Nuno eame in eontact with many sick and disabled nurses who were being held in New York pending investigation and hospitalization by the Public Health Service. These nurses needed good aecommodations and supervisory aid in presenting their claims; however, the prices existing in New York hotels were beyond their resourees, especially since the majority of them had not yet begun to reecive compensation from the Veterans' Bureau. 'The Atlantic Division accordingly engaged aceommodations for ten murses at an exeellent hotel on Madison Square, and sick and disabled nurses were cared for there without charge until their claims were settled and they could leave New York. As soon as the numbers of sick nurses passing through New York decreased, these ronms were relinquished. At the same hotel were quartered the students of the Army School of Nursing who were taking their public health training at IIenry Street Settlenent. The Sureon Creneral of the Army had requesterl assistanee from the lied crose to enahle these students to secure instruction in public health nurs- 
ing, and the Executive Committee on Jamuary 13, 1921, appropriated a fund of $\$ 40,000$ for their maintenance while they were at 'Teachers' ('ollege and Henry strect.

The lotel on Madison Simare provided eomfortable quarters for siek murses detained in New York City but did not meet the need for a convalesent home where nurses might live several weeks in the country at reasonable expense and in attractive surroundings. On "July 1, 1920, "The Evergreens," a twelve-alcre enuntry estate at Bay shore overlooking Great Sonth Bay on the sonthern shore of Long lsland, New York, was leased and opened as a convaleseent home. In the Amnual lieport for the year ending June 30, 1921, Miss Noyes wrote of the Bay Shore Convalesecnt Home:

Its use was not restricted to Red Cross nurses alone and it has heen patronized by the Tnited States Public Ilealth Serrice, the War Risk and the Federal Boards. During the past twelve months, 294 murses have sojourned there and have derived sreat benefit from the opportunities for relaxation and ronvalescent care. Mabel Fletcher, a Red Cross nurse, is the hostess. Lp to June 30, 19:1, the expenses of ruming the house had amounted to $\$ 12,917$ but it is felt that the value of this convalescent home to the nurses and to the Red Cross cannot be easily measured in money. . . The majority of the nurses not only pay their way but frequently supplement their board bills with money donations of appreciation. In this way, much of the expense has been met.

Throughout the period of demobilization, murses were slow to report their disability to the field representatives of the Burcau of War Risk Insurance and to claim hospitalization and vocational reiducation. The following arrangement, as reported by Miss Mimnigerode, was finally effected:

It should be a matter of common knowletge, from the wire publicity given this Art, that nurses also are eligible for treatment under the Burean of War Risk Insurance. The Publie Health service in eöperation with the Ameriann Reer ('ross. has agreed that the liod (ross Division Directors of Nursing may refer ases of nurses requiring treatment to the district superviser of the Public Mealth service. Who will give instructions as to the procedure requirerl to obtain treatment and who will alon makesarrangements for the hospitalization of mirses meding are. 


\section{HISTORY OF AMERICAN RED CROSS NURSING}

In order to facilitate action, four Division Directors of Nursing in different parts of the country have been appointed as consulting officers in the Public Health Service, with anthority to confer with district supervisors concerning treatment for nurses. These nurses are: Florence M. Johnson, New York; Jane Van de Vrede, Atlanta; Lyda Anderson, St. Louis; and Lillian L. White, San Francisco.

Nurses are also eligible under the Federal Board of Tocational Education and can take any training they desire, in just the same way as do soldiers. . . Any nurse physically unable to pursue her nursing work, as a result of her military service, should be eligible. Application for this training should also be made to the Red Cross Division Director of Nursing, who understands how to reach the Federal Board and how arrangements for rocational education should be made. ${ }^{21}$

Still the nurses continued to hold back from claiming Federal aid. Now and then word of an unusually unfortunate case would percolate to the office of one of the four Division directors and she would investigate the case, but this system was highly unsatisfactory. In 1921 Miss Johnson sent ont a questionnaire to every ex-service nurse in the Atlantic Division and the information received proved of such value in locating disabled nurses that Miss Noyes authorized all the Division directors to send out similar questionnaires. The following is an example of the questionnaire nsed; as filled in, it is typieal of the answers received from many nurses:

Division: Pacific Questionnaire Date: April s0, 19.2

1. Name: H-_, Lucic $M$.

2. Address, Temporary:

$$
\text { Permanent: } 1215 \text { 1sth St., Sacramento, Calif. }
$$

3. Red Cross Badge Number: 2i4z (Joined lied Cross in 191?).

4. Date of appointment to service: December 22. $191 \%$.

5. Date of discharge from service: March 2: 1918.

6. Service with Army: Yes

Nary

Red Cross: Tes

T. S. Public Tealth Service Sanitary Zone

Emergency. Influenza Epidemic, Disaster, etc.

7. Condition of health on discharge: physically exhausted. 21 A mrrienn Journal of Tursing. Vol. 20, p. sol. 
8. Condition of health at present time: good.

9. Approximate date of illness, if any and where: October 1, 1915, in Now lork (ity. It was this illness of nervous erhaustion which rendered me unfit for extensive Army service.

10. Have you notified the Veterans' Bureau or the Red Cross Nursing Service: No.

11. Are you drawing compensation from the Veterans' Bureau: No.

Date granted.

Number.

Hospitalization, if any.

Name and address of dortor by whom examined.

12. Remarks: See abore.

13. Vocational training: Yes, at my oun expense.

Number.

Where: Simmons College, Boston, Mass.

What kind: Public health mursing course.

Length of course: nine months.

14. Remarks: Il ale nerer asked benefits for myself from the American Red Cross.

15. Date granted.

16. Present occupation: Public heallh nursing covering Sacramento County under direction of American Red Cross, sacramento ('hapter.

As an example of the further interest which the Red Cross took in the ex-service nurse, when the questionnaire came into Pacific Division leadpuarters, Miss White, Division Director of Nursing, referred it to the Red Cross Burean of Post-War Service, whirh was a contimuation of Red Cross Home Service for ex-servies men, and the director wrote the following reply to Miss $\mathrm{IV}$

Miss Lillian I. White . . has handed me your questionmaire of April ?0 for acknowledgment and reply. We note that vour present phrsical condition is fair, but that rou were in poor health at the time of your discharge. probathy camsed hy an ageravation of an illness suffered prior to enlishment. In order that vour future interests may be safoguarded. may wre state that the sub-distriot office of the Teterans Burean. Yorehants Vational Bank Builline. Siaramente-that hraneh of the Government responsible for the arministration of the War liisk . L.t-js anthorizol to extend medial (are, lospitalization, eompensation and borational 


\section{HISTORY OF AMIRICAN RED CROSS NURSING}

training to former reserve members of the Army Nurse Corps, who may now be incapacitated with disabilities which are a result of military service. We are offering this information, should a relapse of the illness you suffered prior to your service with the Army Nurse Corps occur, which might make you eligible to the benefits of the War Risk Insurance Act.

If you have any unadjusted claims against the Government such as liberty loan allotment, adjustment of back pay, this office is available to serve you.

Of the $4+9$ disabled nurses, twenty-two were nurses who had incurred their disability while in active service under the American Red Cross. 'To care for them and for other members of its overseas personnel who became ill in line of duty, the Commission for France established a special hospital, American Red Cross Hospital No. 101, at Neuilly, near Paris; it was arranged that sick members of other American welfare organizations could also be sent to No. 101.

Owing to the exorbitant prices which prevailed in France in 1918, need arose for a convalesent home where nurses on Army, Navy and Red Cross service might go to recuperate when they no longer needed hospitalization. The Nurses' Bureau at Paris Headquarters in July, 1918, opened a convalescent home at Le Croisic, a quaint little fishing village on the Brittany coast. The house was located on a streteh of sandy beach overlooking the ocean and had aceommodations for one hundred murses on convalescence or on leave. "The good food, the fresh, bracing air, the fine bathing and the picturesque Breton peasant life," wrote Miss Hall, "combined to make La Croisic an ideal resting place for nurses and workers worn with the strain of war service. The rates of ten franes a day were most reasonable and bronght the home within the means of all."

In November, 1918, the lome at Le Croisic was closed on areomit of the elimate, and the IIotel du Cap at the ('ap of Antihes, near Cammes, in the Riviera, was opened January 6, 1919, as a substitute. Areommodations were dereloped to reeeire some two hundred convalesecnt Red Cross women personuel there. Five public health nurses were sent down to do visiting and general numsing. Kate C. Hough was the supervising nurse. Mrs. Homgh was a craduate of the Newark City Ilospital sebool of Nursing and had done private duty, hospital, district and industrial nursing prior to her assigmment 
in March, 1918, to the Red Cross Children's Bureau. For some six weeks during the military crisis of the summer of 1918, Mrs. Howwh cared for Ameriean wounded in French hospitals under the special arrangement effected by the American Red Cross and the s'ervice de Sunté. With this wide experience and with native executive ability and intiative, she developed at the Hotel du Cap at Cannes a convaleseent home which the nurses who visited her described as ideal. 'The location was one of rare beanty, the food was exeellent and the atmosphere which permeated the hotel one of kindly interest and solicitude.

Many of the nurses who served overseas with the Ameriean Red Cross were returned to the United States on Army transports. When those who had been taken sick or had been disabled in Red Cross service arrived in New York they were temporarily cared for at the hotel on Madison square or at Bay Shore until settlement of their Red Cross insuranee could be effected. The provision made for them by National Headquarters was the same as that made for all Red Cross workers in foreign service. As this arrangement was mique in the history of insurance, a brief accomt of it will be given.

Previous to 1917 the Executive Committee had individually considered every case of sickness, disability or death of a Red Cross worker and had made specific reconmendations on each, but with the large mumbers of Red Cross personnel who were being sent overseas in 1917 it was seen that a more standardized arrangement would have to be effeeted. At a meeting held September 28, 1917, the Executive Committee instructed the War Comncil "to make an investigation of plans for providing insurance for persons engaged in Red Cross work in foreign countries . . . and to report to the Executive Committee for action."

The War Comeil immediately appointed a National Adrisory ('onmittes on Insuranee, the members of which were the actuaries of the foremost insurance companies in the lonited States. Arthur Hunter, dhef alotuary of the New York Life Insurance ('ompany, was the ehaimian; Ilendon ('hulb, aldviser to the Bureau of War Risk lusuramee and an anthority on marine insuranee, was one of the members. Anomgethere members were R. Henderson, actuary of the Equitalle life: A. L.

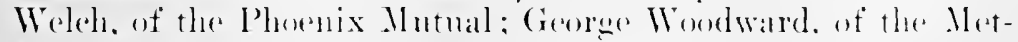

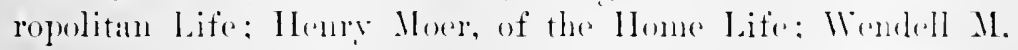




\section{HISTORY OF AMERICAN REI CROSS NURSING}

Strong, of the Mutual Life; B. D. Flynn, of the Travelers Insurance Company, and J. H. Woodward, actuary of the New York State Industrial Commission.

The Insurance Committee immediately began to investigate the possibility of having Red Cross overseas personnel included under the War Risk insuranee laws as Federal liabilities, in that the Red Cross was a semi-governmental organization. Congress was approached on the subject but it was decided that if the benefits of the War Risk Insurance and disability laws were extended to Red Cross workers, they would have to be extended also to the workers of all welfare organizations, a procedure manifestly impossible. Moreover, commercial companies refused to insure Red Cross personnel going into foreign service; they felt the risk to be too great beeause Red Cross foreign service called for the assignment of nurses, ambulanee drivers, ontpost and line of communication eanteen workers to points second only in danger to that of the front line. Henee with the doors of Federal and commereial aid closed to its overseas personnel, the majority of whom were men and women of moderate means with one or more dependents, the War Council felt that the Red Cross must devise its own insuranee.

Aceordingly, the Committee prepared several plans and submitted them to the War Conncil, which reeommended to the Executive Committee that the so-called "second plan," with various modifications from time to time, be accepted. The Executive Committee at a meeting held on Deeember 6, 1917, approved the following plan, which was without cost to the workers:

The Red Cross has procured life, health and accident insurance for its workers abroad. . . The insurance granted is substantially as follows:

1. A policy of life insurance on the term plan in the sum of $\$ 1000$ for each worker-payalse in event of death or in erent of total anc permanent disability from any cause, payment for total and permanent disability to be inale at the cul of two years from date of disability. and, in the meantime, the worker rereices the weekly indemuity lescribed in the next paragraph.

2. A policy of accillent and health insurance which provides for the parment of weokly indemnities of $\$: 0$ per week in the rase of total disability resulting from bodily injury or disareand, $n$ addition, provides for the payment of 
$\$ 500$ in the event of certain permanent injuries as mentioned in the policy.

'The weokly indemnity payments are to commence four weeks from the date of disability and continue until disability ceases. not exeecling a total period of two years f'rom date of disability. Inring the first four weets necessary medical care and attention will be furnished by the Red Cross without cost.

In alopting this plan the Red Cross appreciated that this smim of $\$ 1000$ would not be adequate to provide for a bencficiary totally disabled in Red Cross foreign service. Such a provision lay whlly beyond the powers of the soeiety. However, National Headquarters felt that this health and aceident insurance and this sum of $\$ 1000$ in case of total disability lay within lied Cross resonres and would prove of some real assistance to a disabled worker or to his or her benefieiary.

In developing this plan the Red Cross set up at National Headquarters in April, 1918, a Burean of Insurance, of which Robert C. Rathbone, of New York City, was the director. He was followed in Oetober of the same year by Winfield $A$. Wilson. Mr. Wilson had been engaged previously in insurance work in Washington and he had charge of the seven phases of insurance which were used by National Headquarters to protect the Red Cross in its many activities.

The plan for life, health and aceident insurance included the utilization of large commercial insurance companies to which the Red Cross paid premiums, so that the Red Cross might profit by the field organization of the large companies. In the matter of the parment of preminms the Red Cross encountered the first "snalg." State and Federal law declared that insurance premimms must be a fixed premium; the Red ('ross, howerer, was loath to have any profits acerne from contracts which they were obliged to place, so the Advisory Committer appealed to the Insurance Commission of the State of New York (the hul of the insurance world) to have an exeeption made to embrale the lied c'ross plan, which presided that all preminms, minus artual losers. taxation and a small charge

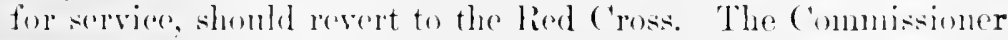
retered the appeal hut the Advisory ('ommitter atreded it to the Lexplature of the state of Xew York, where the existing laws were amended, making possible the lied C'ross insuranee on a non-protit basis, 


\section{HIS'TORY OF AMERICAN RED CROSS NURSING}

The result of this ruling was seen when on December 1 , 1919, the Red Cross by vote of the Executive Committee deeided to self-assume the life insurance and permanent disability clauses of its insurance. This decision brought an accounting whereby the sum of actual losses, taxation and a small charge for service were dedueted from the total amount of premiums paid from time to time by the Red Cross to the insurance companies, and the balance was returned to the Red Cross. This sum amounted to $\$ 264,000$.

Several months after the Red Cross had assumed this phase of its insurance, the Executive Committee, upon Mr. Wilson's recommendation, voted a change in the plan of payment of the $\$ 1000$ due under the total disability clause of the life contract, to the disabled worker. The original provision ealled for payment of the face of the contract amounting to $\$ 1000$ if at the end of two years the disability was adjudged to be of a permanent and total eharacter. This clause was changed so that at the end of the two-rear period the worker having received the indemnity under the health and accident policy paid only for total disability, would, if disabled, be considered totally disabled within the definition of the provision, whereby the $\$ 1000$ would be paid in weekly installments of twenty dollars each instead of in a lump sum. This change was made because of the obvious difficulty of determining, even by medical examination, what constituted permanent disability. The new contraci insured to the disabled worker a steady income for practically another year. After the expiration of this fifty weeks' allotment the case was elosed. In the ease of drath of the insured, the sum was paid in a lump sum to the beneficiary.

Tational Headquarters continued, however, to handle its health and accident insurance through the 'Travellers' Insurance (ompany that it might be benefited by the assistance of the field staff of that eompany in prevernting malingering.

The provisions drescribed above protered Armv, Navy and Red cross nurses assigned to duty with lied Cross foreign commissions. No protection was, howerer, available for Red Cross nurses who heremene siek or disabled while temporarily assigned by the Red ( ross to influenza relief in eantomment hospitals or in rmerenerey hospitals establisher for the rivilian sirk. Cases of this type were monteroms and finally in 1920 Miss Noyes

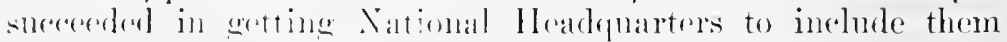
amone lied chos reponsibilities. Int they were never in- 
cluded in the insurance plan, which was purely for the benefit of Red Cross workers in foreign service for the society.

Such were the goverument and Red Cross provisions for siek and disal)led murses. Yot even in the best regulated and equipped hospitals of the Public Itealth Service, or in the luxurions and sympathetic enviromment at Bay Shore, the plight of the disabled ex-service nurse was as pitiable as that of the disaliled ex-service man. Mental cases conld not be adnitted to Bay Shore, and perhaps some of the bitterest agomy of the war was endured by nurses in govermment hospitals-murses who were trying to regain their mental and nervous poise; like the shell-shoeked ex-soldiers, nothing seemed worth while and they often ate their hearts ont in long periods of extreme melancholia.

Not the care given or not given to exceptional cases but that given to the rank and file will have determined whether or not the Government and the Red Cross net their obligations toward the women who saerificed health and means of livelihood in order that American men might have skilled mursing eare in their hour of need. Cases of negleet may have ocenred just as likely as eases of "goldbricking," that term applied to soldiers and murses pauperized by too much help. That the Government and the Red Cross did its duty generonsly and in kindly spirit to at least one sick and disabled nurse and that this aid was truly appreciated, is shown in the following letter written to a Red Cross Division Direetor of Nursing by a disabled exservice murse:

Your very kind letter... eame on Monday, and in reply I would like to say that I have been receiving full compensation since my discharge from the Army. I must say. too, that mothing rould exceed the kindness and consideration and grool rare with which I have been treated since 1 first took ill in Octuber. 191\%. I was in five different hospitals in France and three in the Lnited states and in every one of them I was treated with the greatest kindness and I know I owe my life to the are I received. I wish I combl make von muderstand how much I apprexiated it all. My long illnes, pnemmonia. followed by empremia. Was mate bearable ame. betweres the

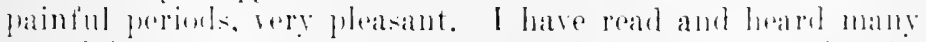
complatiots from nurses regalding theip treatment in the

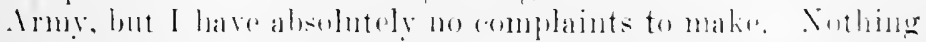

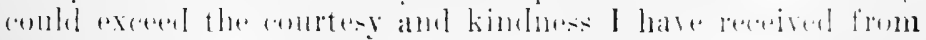




\section{HISTORY OF AMERICAN RED CROSS NURSING}

every one with whom I came in contact. I am afraid my nursing days are over, but I am glai to be home. The climate here is dry and cold and seems to be the only one that agrees with me. I have har several abscesses in my lung since the incision healed. Apart from that I feel fairly well.

Thank you so much for your kind offer of service. The only thing I find any need of is reading matter. We are twenty miles from a town of any size and you may be sure I make the trip rery seldom. I should be very glad indeed for books or magazines.

One of the projects of the nursing profession during the demobilization period was the establishment of a memorial to American murses who had died in military service. This was not a Red Cross nursing project; it was undertaken by nurses and friends of nurses. However, the labors of Miss Noyes, in her position as president of the American Nurses' Association, and those of Red Cross nurses who supported the memorial, and also the numbers of deceased Red Cross nurses whose sacrifice the memorial perpetuated, make necessary brief mention of the project in this history.

In January, 1919, Dr. Ama Hamilton, the founder of the Nightingale School for Nurses at Bordeanx, France, visited the Lnited States for the purpose of raising funds for the Nightingale School. The Maison de Santé Protestante, the hospital in comection with which the school was maintained, dated back to 1861 and had long since outgrown its buildings and equipment. Owing to its location in a closely built quarter of the city, the homsing facilities of the hospital and school could be expanded only by removal to a new site. In 1914 Mlle. Elizabeth Bose, of Bordeaux, had presented to the Maison de santé thromgh I)r. Hamilton, her home, Bagatelle, an watate of sixteen acres, located just ontside the eitr, to be nsed as the site for the new hospital. Funds for eroeting the building were. howerer, not avalalle, and the war held up the project until the ressation of hostilities.

When J)r. Hamiltom arrived in New York City in Jannary, 1919, she interviewed many nursing leaders; one of these was Miss IIilliard, then superintendent of the Schools of Nursing at Bellevere and Mllied Hospitals. Miss Hilliard later stated to Mise Maxwell that she believed that the American Nurses'

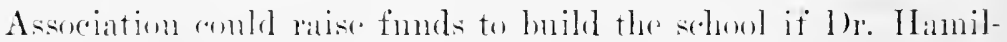
ton could raise the funds to binild the hospital. 
At a meeting of the Joint Boards of I)ireetors of the American Nurses' Association and the National League of Nursing Education, Miss Maxwell proposed that the Anerican Nurses' Associntion provide a fund for a building which would house the Nightingale School, this building to be a memorial to Ameriean murses who had died in war service, and especially to the hunderd Amerian murses who lay horied in French soil. The othere members of the Joint Boards felt that such a memorial would be in keeping with the spirit and work of Florcure Nightingale, the founder of professional nursing, who had said: "Let crery founder train als many in her spirit as she ean ; then the pupils will in their turn be founders also." The Nightingale school was, it will be remembered, the only sehool in France giving training to murses on the modern professional basis known as the "Nightingale Srstem."

The question was then referred for action to the newly appointed Joint National Committee (of the Burean of Information for Nurses), the committee which represented the three national organizations of mursing from which had developed the Joint National Committee of National Nursing IIandyuarters. At a meeting of this committee it was roted that the Amoriman Nurwes" Association slould undertake to raise by December 1, 1919, a fund of fifty thousand dollars $(\$ 50,000)$ to be nsed in ereeting and expipping a murses' home and classrooms for the Nightingale. Sichool, this sum to be known as "the Ilemorial finm to American nurses who hatd died in military service in the Enropein Wiar."

Immediately throngh letters, personal solicitation and editorials in the Jourmul. efforts were malle to raise the smm. The Joint National ('ommittere was particularly alatreed with responsibility for ralsing the amomet this committec, it will be remembered, wats compesed of Miss Nutting. Miss Nosess and

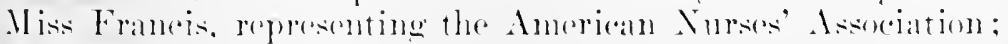

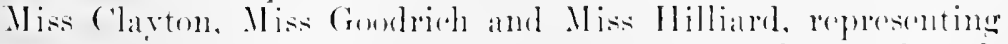

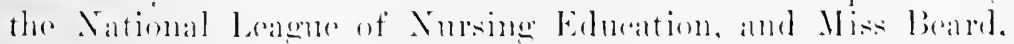

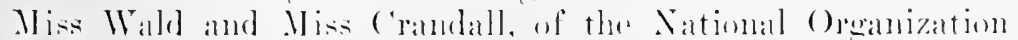

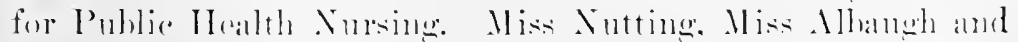

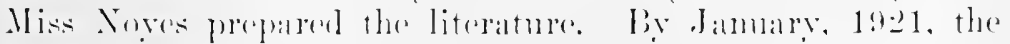

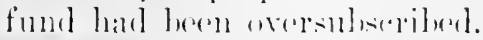

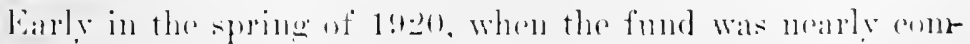

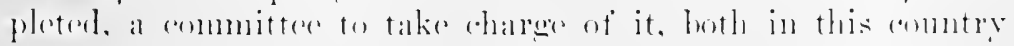

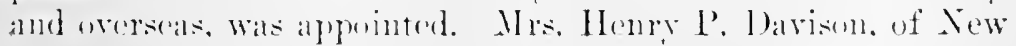




\section{HIS'TORY OF AMERICAN RED CROSS NURSING}

York, was chairman, and Mr. Robert Bacon treasurer. Miss Fitzgerald, who was then in Geneva, Switzerland, Mrs. Charles Tiffany, Miss Nutting, Miss Maxwell, Miss Ruth Morgan, Miss Noyes, Mr. Ethan Allen and Mr. C. A. Coffin were members. This committee was later enlarged to include Miss Hay, then chief nurse of the Ameriean Red Cross in Europe, Mr. Nelson D. Jay, of the Morgan-Harjes Company, Paris, and Dr. Kendall Emerson, of the Commission for Europe. As soon as the fund was transferred to the Morgan-Harjes Company in Paris the large New York eommittee went out of existence and disbursement of the fund was earried on through the smaller Paris committee.

In September, 1920, Miss Noyes went to Europe to inspect American Red Cross nursing activities, and while in France visited Bordeaux and conferred with the Trustees of the sehool and with Dr. Hamilton regarding the terms of gift. The plans for the school were gone over and building immediately began.

The Charter and By-Laws of the Nightingale Sehool as finally drawn up included the following paragraphs:

\section{Article 3. Organization.}

In 1921, American nurses, desiring to perpetuate the memory of their fellow-nurses of the American Army, Nary and Red Cross who died while in active service during the great war, subscribed a sum of $7 \% 5,000$ francs, known as the Ameriean Nurses' Memorial Fund.

The Joint Committee of the three great associations of nurses in the United States (1. American Nurses' Association, president Clara Noyes; 2. National League of Nursing Education. president Lillian Clayton: 3. National Orcanization for Public Health Nursing, president Mary Beard) decider to derote this sum to the construction of a boarding establishment for the Florence Nightingale School, for the sole purpose of facilitating better education for French nurses and the training of a larger number of superior nurses for France.

An Advisory Committee, created with the approval of the Administrative Board, will act as a Board of Arvisors in the managenent of the school. Its members will he chosen by the Joint ('ommittee of the three great associations of American nurses. This drvisnry ('ommitte shall publish reports on the operation of the sohool. These reports will allow the nurses who collerted the Memorial Fund to follow the progress of the Florence Nigntingale school. 
In response to the desire of the women who donated the Ameriuan Nurses's Memorial Fund, the school shall conform more ant more to the precepts of Fiorence Nightingale and consequently will always be directed by a hospital nurse who shall herself hold a "first-class diploma" preferably from this school.

The teaching of the school shall be constantly improved, and shall endeavor to approximate more and more dosely the program published by the League of Nursing Education in the United States... .

The members of the Advisory Committee of the Nightingale School were Miss Jammé, representing the National Leagne of Nursing Edueation; Miss Anne H. Strong, of the National Organization for Public Health Nursing, and Miss Noyes, of the American Nurses' Association.

The entire memorial fund amomnted to 850,000 franes, of which 755,000 were expended for the erection of the building and the remainder for equipment and furnishings. In the central hall of the building a bronze tablet was placed, a tablet bearing the inseription:

\section{'To the Florence Nightingale School \\ In memory \\ Of our comrades who died in service $\mathrm{He}$ \\ The Nurses of America \\ Indiente this Menorial \\ To the Hiwher Eduation \\ of Nurses: \\ For Humanity and For France.}

During the late aftermoen of .June 5, 1921, the laving of the corner-stone of the Florenee Nightingale school took place. After sereral aldresens. Miss IIay, acting as Miss Noyes representative. placed in the aromer-stone a bex containing the stat-

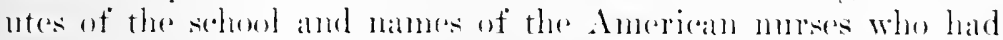
died in serviee; then the first stone was laid. A year later, on May 1.2, 19:2.2, the one hundred and second amiversary of Miss Nightingale's birthe the Amerion Norses Memerial buildiug. them ampleted. was dediented.

The question of al suitalde memorial to Miss Dedann was first raised immediately atter her death and Ameriean lied cross murses in France subseribed a sulall find of abunt six hundred 


\section{HIS'TORY OF AMERICAN RED CROSS NURSING}

dollars for the purpose. National Headquarters authorized Miss Noyes to act as trustee of this sum until a decision had been resehed regarding the form which such a memorial should take.

At a meeting of the National Committee held Deeember 9, 1919, the chairman appointed a committee to study and report upon plans for the memorial. This committee was made up of Miss Maxwell, Miss Kerr, Miss Gladwin, Mrs. Gretter, Miss Jammé, Miss Van de Vrede, and Miss Palmer as ehairman.

At the meeting of the National Committee held on April 14, 1920, at Atlanta, Miss Gladwin, in the absence of Miss Palmer, read the report of the Delano Memorial Committee. The subjeet had been disenssed with Mr. Powell Minnigerode, director of the Coreoran Gallery of Art in Washington, and he had suggested that a mural decoration srmbolizing Miss Delano's work be placed in the interior of the National Headquarters building. Other suggestions had been made that the memorial take the form of a building to honse the Nursing Service and to be erected on the Red Cross grounds; a scholarship fund, with a tablet at National Headquarters commemorating Miss Delano's life and work; a life-size figure in bronze representing a Red Cross murse, to be erected on the grounds of National Headquarters; a life-size statue of Miss Delano herself in bronze, to be ererted on the grounds at National Headquarters, and a chullowse for nurses.

Two weeks after the Atlanta meeting, on April 27, death removed from her many activities the chairman of the Delano Memorial Committee, Sophia F. Palmer. Miss Noves then appointed Miss Minnigerode as chairman; she added two more mombers to the ammitter. Miss Buardman and Mr. Powell Minnigerode, and developed extensive plans for raising a Mcmorial Fund.

At a mecting of the National Committee held April 23, 1921, Miss Mimnigerode moved that the Delano Memorial Committee be enlared to include the Division Directors of Nursing and certain of her nurses and members of the baity in soveral parts of the Eniterl States: that the members of the Sational Delano Memorial Committer be anthorized to form sub-committees in their own localities, and that a general treasurer be appointerd. The motion was ampred.

The reoremingel bolano Momorial Commitee had as its 
members Mrs. William Church Osborn, Mrs. Henry P. Davison, Mrs. August Belmont, Mrs. Frank N. Hammar, Mrs. L. E. Gretter, Miss Boardman, Miss Amy Alexander, Mrs. John Lyneh, Miss Kerr, Miss Nevins, Miss Janmó, Miss Ghadwin, Miss Maxwell, Miss Stimson, Miss Hay, Miss Foley, Miss Albangh, Miss Johnson, and Miss Minnigerode, chairman. At the present date of writing, subseription to the fund is in process.

Miss Delano herself had established a fund under which public liealth nurses were to be assigned in remote commmities to ronduct a service in memory of her father and mother. Of the twenty-two items of Miss Delano's will, nine of them contained legacies to murses or mursing organizations. Four of these items named nurse friends as beneticiaries; the other five were in favor of nursing organizations as follows: the Alumne Association of Bellevue Training School for Nurses, the Alumne Association of the Training School for Nurses, Hospital of the University of Pemsylvania; the New York Eye and Ear Infirmary, and the following bequest to the American Red Cross :

Item XXI: I give and bequeath the sum of Twenty-Five Thousand Dollars $(\$ 25,000)$, unto the American Red Cross in trust, the principal of said fund to be kept intact perpetually and the income only arising therefrom to be used for the support of one or nore visiting nurses, under the supervision of that organization, in loving memory of my father and mother, such nurse or nurses to be known as the "Delano Red Cross Nuse, or Nurses." In addition and for the same purpose. I give and bequeath unto the said American Red Cross the entire right and interest in and to any royalties to which I may be entitled at the time of my death. unto any book or books written or published by me. and I direct that such royalties. als paid to the said American lied ('ross. shall be adled to the income from the aforesail trust fund and used for the same purpose as hereinbelore provided therefor.

At a meeting of the National Committee held on December 6, 1!21, a plan eontaining the details of selection of the Delano Rod cross murses and the metheds by which their work was to br supervised and the fund administered, was submitted by Miss Fox and apperoed he the National Commitere The tirst 


\section{HISTORY OF AMERICAN RED CROSS NURSING}

Delano Red Cross nurse was Stella Fuller and she was assigned to duty in Alaska.

Among the unsettled war problems which claimed the attention of nurses during the demobilization period was the training and utilization of Red Cross nurses' aides. Early in 1919 Miss Boardman, always a staunch advocate of the volunteer aspeet of Red Cross nursing service, as well as the first friend of the professional service, brought forward a plan for utilizing Red Cross aides in commection with the care of the sick in communities where there was an insufficient number of nurses. In the plan it was specified that the service of these aides should be purely volunteer; that the aides themselves should be required to have taken the prescribed course of training for Red Cross aides: and that they should work under professional direction and should wear a distinctive uniform and badge.

At the meeting of the National Committee on Red Cross Nursing Service, which was held at National Headquarters on December 9, 1919, Miss Boardman presented her plan; it was informally discussed. At an adjourned meeting held the following day Miss Nevins, the chairman of a small committee which had been appointed to consider the plan, read a recommendation that the "National Committee on Red Cross Nursing Serviee recommend that such Chapters as so desire may organize those who have taken the required courses (Home Hygiene and Care of the Sick, Food Selection and, if possible, First Aid) and are ready to rolunteer their services for the sick . . . in coupperation and with the supervision of the Chapter Committee." Miss Gladwin recommended that the plan be developed in the District of Columbia Chapter as an experiment and the resolution, with this and other minor amendments, was passed.

The next mention of Miss Boardman's plan appeared in the Minutes of the National committee of a meeting held April 16 , 1920, at Atlanta, Georgia. Again the plan was discussed, and a report of the successful demonstration in the l)istrict of Columbia Chapter was read. Miss Condrich, Miss Van de Vrede, Miss Johnson, Miss Maxwell and Miss Francis spoke of good work done by laywomen with which they were personally familiar. Niss Noyes emphasized the fact that the point of contacet in carrying ont the plan would be from the National Committer to I)ivision I)irectors of Nursing to Chapter Committers on Nursing Artivities.

Mist Fancis moved that they approve the plan and recom- 
mend that it be extended to such Chapters as were prepared to develop it, this extension to be decided by the Division Director of Nursing in coipperation with the Division manager. The motion was carried.

As the Nursing. Sorvice swung toward normality again, a detinite Red C'ross peace-time program in the development of publie laralth nursing, class instruction to women in Home II yeiene and care of the siek and in nutrition was undertaken. liall of these subjects will be treated in subsequent sections. I tinal general nursing project of considerable importance during the demobilization period was of an erlucational tye and included two clearly defined phases: the dissemination of propaganda regarding exeneral and public health nursing and class instruction, and the dissemination of propaganda regarding student nurse recruiting.

The first of these projects, which was as picturesque and droll an modertaking as any in which the Red Cross nurses had hitherto participated, first embraced the utilization of Chantauqua platforms as a medium through which to reach the American public. Early in April, 1917, the Radelifte Chantanquas had asked Miss I) cirenits to speak on the eneral Red Cross military and health program. Florenee M. Besley, a former Red Cross Town and comintry nurse, was chosen and was the pioncer Red Cross troubadour of health. So sucessful was she in interesting her andiences in Red ('ross class instruction and general mursing activities that Mr. Ladeliẗ̈e a year later asked Miss I)elano to reassign Miss Busley and to provide three other murses for similar work. Flora Bradford, (Mrs.) Margaret R. Cooper and Iolly" 'lwitchell took the road as itinerant murse-lecturers and instructors.

Immerliately alter the signing of the Ambitice, public interest in the Enited States regarding overseas servier ran high. National Headyuarters was already swinging toward a broad heilth program and was zeilons to tind ways in which this pro-

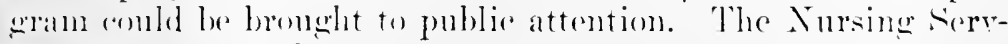
iene sugerested to the Department of Publicity that lied ('ross murse spealeres, nurses who had had orerseas experience. shomld be assigned to the ('hantampur platforms and shomld well the war and prare story of the Nursing Serviere.

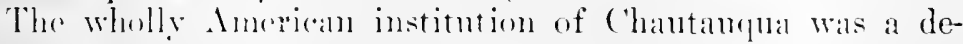
velpment of the Inirersity Extension idea and was a com- 


\section{5: HISTORY OF AMERICAN RED CROSS NURSING}

munity project by which American cities and espeeially towns and villages too small or remote to attract lecturers and entertainers of national prominence held a series of leetures and entertainments, usually for a week's duration, which combined edueational and entertainment features. The method by which a community held Chautauqua was simple: the mayor and town council voted to hold Chautauqua Week, and signed a contract with a commercial Chantauqua company whereby the company provided lecturers on eivie and literary subjects, musicians and other types of theatrical entertainers, in return for a pereentage of the gate receipts. Chautauqua Week was usually held under eanvas at the loeal county fair grounds and was attended by young and old alike.

The financial basis of the Chautauqua campaign was a happy one for the Red Cross. The commereial companies paid National Headquarters a weekly salary rate for each nurse speaker and provided maintenance and traveling expenses. National Headquarters in turn reimbursed the nurses and furnished posters, newspaper plates, material for publication in the loeal press, and copies of two pamphlets, one promoting the Red Cross public health program and the other urging young women to take up nursing, for distribution to the nurses' andience. The contact between the Chautauqua eompanies was made by Dr. Thomas E. Green, then director of the National Red Cross Speakers' Bureau. Details of the publicity material were handled through the coöperation of the Nursing and Publicity departments and loeal interest in the nurse's leeture was aroused by Red Cross Division and Chapter efforts.

The nurse speakers themselves had little idea, when they came to National Headquarters for a preliminary conference in May, 1919, of the viearious and nomalic summer which lay ahead of them, nor for that matter had Miss Noyes and her associates, else the Red Cross troubadours of health might not have taken the road with such ferror. The majority of the speakers had just roturned from one to three vears of foreign service; many of them had been "up the line," but surely no Red Cross nurses were more brave than the thirty-one Chantanqua speakers who started ont to try to hold their own against artists who had spent their lives in public speaking and entertamment. And the diftienIties of living at the front were often no harder than these experieneed by these nurses, who spoke one day at a giren town, then traveled during the night or the 
following morning to the next town, there acepted what local hotel accommodations they could find, spoke again in the afternoon and traveled again at night.

The list of ('hautaupua speakers held many names of nurses who had rendered gallant war service. Mary K. Nelson, of Evrenx, was one of the most eloquent. Nurses prëminently sucecsful as Chautanqua speakers were Edith Benn, Frances Maltby, Edith Ambrose, Ida F. Butler, Stella Fuller, Elizabeth IImut, Josephine Mulville, and Elizabeth Walsh. Florence Bullard, tho first nurse whom Miss Russell had sent to care for American boys in French hospitals, had lived through the eapture of Soissons in 1918 and her dramatic accounts of war nursing, followed by an appeal for guardianship of the public health, held andiences of from three to five thousand people tensely interested until she left the platform. Daisy P. Beyea was one of the nurses of Evacuation Hospital No. 6, and beeame so suceessful as a "spellbinder" that she continued as a speaker after her Red Cross assignment was finished. Gertrude Bowling, the young Hopkins nurse whose aeeounts of "shoek" work at the front have been quoted in an earlier (hapter, was another nurse who by reason of her experienees overseas and her great sineerity was able to speak amazingly well.

In addition to the nurses already mentioned, the list of Chantangua nurses included Lyedia Breanx, Jane T. Dahlman, Anne Dailey, Mabel Fleteher, Eleanor Grege, Mary Herring, Bree S. Kolley, Mary Momoe, Lamra Phillips, Lamra Roser, and Mary Sodlacek. To murses drilled since their probation days to atroid publicity and sensationalism, the Chantanqua atmosphere must have been at least an innovation. Miss Amhrose wrote Miss Noyes:

Fou'd be quite entertained at the dramatic introduction I have. Our progran is worked out so that my speech is always precerled by music and our baritone. quite a womber. gret: "up alter the rest of the talent bave left the stane and sings a rerse of "The Rose of No Man's Land." When he rameses the lines.

"Mid the war's dark curse itands the Red Cross nurse."

the cortains. which are covered on one sile hy an American flage amb on the other by a Red ('ross one, aro drawn a part amb] 


\section{HISTORY OF AMERICAN RED CROSS NURSING}

there I stand, in white uniform, cap and scarlet-lined cape. Then without further parley after the applause has died down, I begin.

To some of the nurses assigned to Chautanqua circuits, the sea of upturned faces which confrented them as they stepped forward to plead their cause was a paralyzing sight, far more terrifying than had been nursing service in an evacuation hospital or a bombed base. A nurse wrote:

I used to come wabbling out on the stage so scared I'd hang onto the tent poles, until I looked around my audience and saw those sickly babies and their tired, gaunt mothers; those undernourished children, many of whom have rickets; those hard-working mountain fathers. Then I seemed to forget everything else in the world-my stage fright and fatigue, that breathlessly hot, crowded tent, the hotel where my bed gets up and walks. All I remembered was that I am bringing to these people a message which may mean their future happiness and freedom.

The unexpeeted formed a potent factor with which the nurses on the road and the executives at National Headquarters had to be constantly prepared to meet. Just before their first speech, three of the nurses assigned to large and important eircuits suffered nervous breakdown as a result of their foreign service. To keep faith with their contract the Nursing Service had to find and prepare substitutes almost orernight. Another nurse kept several speaking appointments, then found the itinerant life and the uncertain hotel accommodations too wearing, and resigned. Another nurse suffered personal bereavement and was forced to leave her circuit. Two nurses found themselves temperamentally unfitted for the work. Substitutes had to be found immediately for all these speakers.

The twenty-five Chantanqua circuits to which the Nursing Service assigned speakers, looped the United States. Massachusetts, Rhode Island, Connectient, New Jerser, North I)akota and Nevada were the only states where nurses did not speak. The majority of the circuits took the nurses into isolatrd rural communities where the barren soil yielded only a neriger return for gruelling laber. In these regions living conditions were primitive and the people themselves of stoie and somber temperament; nsually they sat motionless through the 
nurse's leeture and when it was ended left the tent without reaction of any kind. Now and then the nurse's words fell on fruitful soil. Miss Butler wrote:

I give my leeture in the afternoon, always making the plea for the employment of a community nurse, the great need for more public: health nurses and the need for young women to enter training schools. I make as strong an attack as I dare on the awful conditions I see with my own eyes all through this comtry,-rile :lrainage and sanitation; filthy stalls and pig-pens quite often only a few feet from a dug well. I plead for a revival of interest through the Red Cross as a vital memorial to the men and women who died in France. Lsually the small Red Cross Branch or Auxiliary is the only organization in these communities outside a church and a school in the Paleozoic stage of education. But oh, it is such a forlorn country! I never dreamed of people in these Uniterl States of ours living with so little knowledge of health and of decent and comfortable living. They fairly eat dirt and God knows they drink it! But they are touchingly eager for a community uurse,- "some one to show us how." One woman eame to me with tears streaming lown her face. "I never dreamed." sle said. "that consumption could be eured; what you've said to-day is life to me."

The day's work on a Chautauqua eireuit held mueh of drollery as well as of hardship and pathos. One afternoon Miss Maltby found her andience partienlarly diffienlt; the ehildren on the fromt seat tittered and squirmed and pointed. Finally she stopped and said sternly: "If the child under the platform will come ont I will finish my lecture." A youngster jumped up and answered : "l"aint a child, muss, it's a hawg."

Miss Butler's assigmment took her to the mining districts of southern lllinois. "I got caught last night in a little town," she wrote, "where my experieneed ere told me at one glance that here was a hotel where I should do little sleeping. I told the manager, however, that I simply must have clean sheets; any one could see that the ones on my bed had heen slept on.

"Siure ther lave? he replied, 'but the travelin' man in that room last night was such a nice clean man them sheets aint noware real dirtr!"

()ne slepey smmmer aftermoon Miss Mulville was sitting on the colge ot an lowa ralload station platform wating for the local ancommodation train to wheeze in when a bageage man 


\section{HISTORY OF AMERICAN RED CROSS NURSING}

in worn-out khakis spied her and came over to talk. The conversation developed the fact that both of them had had service in France.

"I got mine in July an' was shipped back to Bordeaux," said the ex-service man. "I come to in a surgical ward of No. 6 an' there was a big red-headed nurse bossin' that shebang. Gosh, she was a bird! She was usually too tired to talk much, but, Iord, how she conld nurse! She wasn't much of a looker though; she was thin an' wore an ole gray sweater that hung down to her knees an' her skirt sagged an'

Suddenly he looked at Miss Mulville's smartly-tailored outdoor uniform, then up to her already twinkling gray eyes.

"Gosh, lady!" he gasped, "You're her!"

When the Chantauqua season closed in November, more than a million and a half people in all parts of the United States had heard the story of the Red Cross Nursing Service in war and peace from the lips of a participant. Two thousand four hundred and two Chantanqua andicnces, averaging from thirty to five thousand persons each, had listened to the nurses' lectures since the preceding Jamuary. In Nebraska, Red ('ross nurses had addressed 199, and in Ohio, 179 andiences. Miss Besley and Miss Maltby held the season's record; they had each delivered over two humdred and fifty specehes, six speeches weekly covering a period of nearly forty weeks.

The Chantanqua campaign, as it was called at National Ifeadquarters, gave marked impetus to the Red Cross public health mursing and class instruction program and offered a striking example of nurses' versatility.

The Chantanqua campaign, with its posters, pamphlets and newspaper plate matcrial, was the most ambitions publicity project which the Nursing Service had hitherto undertaken largely under its own auspices. 'True, Dr. Green of the Speakers' Burean and John Mumford and Marion G. Scheitlin, in turn Red ('ross Directors of Publicity, had guided Miss Noyes and her own publicity representative, Elizabeth Pickett, in the initiation of the campaign, but during the late spring and summer the Nursing Service itself carried the larger proportion of the work. The suecess which greeted the campaign instilled in $M$ iss Noyes and the members of the National Committee considerable confidenee in eneneral publicity methods and made them zealous to aequaint the public with the need existing from 1920 on, for young women to enter schools of nursing. 
One of the pamphlets which nurses had distributed from the Chautaucua platforms was a small folder, "How May I Become a Nurse?" written in popular vein and with the intent to interest girls among the rural and small town andienees to enter schools of nursing. The distribution of this pamphlet formed the first special effort of the Red Cross in this field.

$A$ seroud experinent in publicity of this type was modertaken in 1920 in the Delaware-Pennsylvania Division. Miss Francis wrote:

Upon the completion of the Roll C'all last year, we realized that the interest of our Chapters in public health nursing was far greater than our ability to secure publie health nurses who were prepared to establish these services. At the same time, the number of students in a large majority of the training shools for murses was seriously below normal. Appreciating that we could never meet the demands of our chapters for public health nurses if the supply at its source was so seriously cripleded, we decided to bring to the attention of the people of this division the need for puhlie health nurses; to educate them to an appreciation of the opportunities offered to students through almission to a training school of nursing; and also to develop a better understanding of the principles constituting somd nurse education.

With the endorscment of the Pennsylvania State Board of Examiners, Miss Francis worked ont an itinerary based on the numbers and geographieal divisions of Red ('ross ('hapters, Branclues and Auxiliaries and assigned Elizabeth Walsh to speak at cach town listed on the itinerary. Miss Walshis suceess on a Redpath Chantauqua eirenit the previons summer had already won her cager listeners in the lievstone state.

During o omuary end February, 1920, Miss Walsh addressed soren thomsand two hundred and sixty-nine persons in thiptyone towns in Pennsylvania. Her andiences assembled in "hurrhes, busines colliges, public and private secondary sebools and factories. Through herefforts, thirty girls were definitely known to have interviewed superientendents of schools of mursing with a viow toward cutering training.

The experiment undertaken ly Miss Walsh attracted considerable attention in nursing ranks and in the late spring of 1920 , the Joint National (ommittere on Norsing Iteadquarters appointed a sperial anmitter which was charged with respon- 


\section{HISTORY OF AMERICAN RED CROSS NURSING}

sibility for dereloping and conducting a nation-wide movement to recruit student nurses. Major Julia Stimson was ehairman and Miss Albaugh a particularly zealous member of this committee. Plans were drawn up and Miss Noyes, herself a member ex-officio of the committee, secured from the Red Cross Executive Committee an appropriation of thirty-five thousand dollars $(\$ 35,000)$ "of which so much as may be necessary shall be expended by the Director of the Department of Nursing during the six months ending December 31, 1920, to provide for all expenses at National Headquarters and in the Dirisions, in eonnection with the recruiting campaign for student nurses, as outlined in the plan developed by a special committee representing the American Red Cross, the American Nurses' Association, the National League of Nursing Education and the National Organization for Public Health Nursing." 22

The plan referred to above called for the organization in local communities of a student nurse recruiting committee, to be eomposed of representatives of such local groups as the Red Cross Chapter or Branch; the governing and auxiliary boards of the hospitals; hospital and training school superintendents; medical and nursing organizations, phrsicians; the board of education; the press; the chamber of commerce; and women's clubs. The duties of the committee were outlined in full and included the slow and steady dissemination through a number of years, of propaganda directed toward interesting the general public, and young women especially, in the nursing profession.

The publicity material included the distribution of an effective poster, a pampllet and application forms to be filled out and sent by interested roung women to superintendents of schools of nursing. Four motion pictures on nursing subjects had been produced by National Headquarters and they were used also in the recruiting morement, especially one which was called "In Florence Nightingale's Footsteps" and which visualized the training of a nurse. Newspaper "feature" stories were prepared and sent out to the local committees which were charged with the responsibility of having these appear in the local press.

One of the aims of the movement was to bring to the general public hetter appreciation of sound nurse education and the special leaflet, which was called "A Challenge to the Young

as Aer Arvice of Appropriation No. 263, Angust 3, 1920, National lleadquarters, Washingtom, l). C. 
Women of Ameriea," had this aim in view. On one side of the four-page leaflet was printed a list of punstions which every prospective student was urged to ask the superintendent of the school which she expected to enter; on the opposite page were the answers which should be given by the superintendent of any well-organized training sehool. The student was thus equipped with knowledge which wonld enable her to diseriminate to some extent between a school of low or high edueational standards.

Copies of the "plan" and full publieity material were sent, with appropriate letters requesting coöperation, to all presidents of State Nursing Associations; to the editors of medical and nursing publications; to the presidents of American national medieal and nursing associations; and to Red Cross I)ivision managers for distribution to Chapters and Branches. The following letter written July 20, 1920, by Frederiek C. Monroe, then general manager at National Headquarters, to all Red Cross Division managers, is illustrative of these letters of transmittal:

As you are aware, we are facing a critical shortage of graduate nurses for all types of work, particularly public health. 'The increasing demands of morlern medicine, the continuing needs of the late war and epirlemics of disease consequent upon the war are taxing the nursing resources of the nation to the limit. In one nursing bureau alone, there were recently five hundred more requests for nurses to fill positions in institutional and public health fiedds than there were murses avalahle. This condition will probably grow worse instead of better. . . .

The lied Cross is reeply concerned in this situation and has the traditional duty to help in every way possible to meet it. Not only is this true, but if the Red ('ross is to surceed in the public health field, it must have a constant and ever increasing supply of well-trained nurses to carry on its nursing activities. The nurse training solhool is the only sonre from which qualified nurses may be oldained. We must, therefore. stimnlate recruiting tor these shools. Yet the extrandinary ronditions now prevaling are a serions handicap. ('ommercial and industrial life, be offering great and immediate rewards, is drawing heavily upon the gommer womanhood of the country.

Rralizing the serionsness of the situation, grompe of nurse:

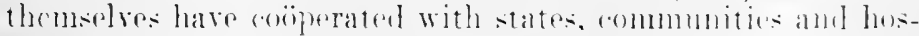
pitals in local mulearors to stimulate the enrollument of stu- 
dent murses. Recently also the three national organizations of nursing . . . have joined with the Red Cross in developing a national morement for the enrollment of student nurses. It is this national movement which you are now called upon to assist in every way possible. . . .

Then followed detailed administrative instructions. The Division Directors of Nursing took hold of the movement with interest and developed it extensively. In the following months, several ideas of eonsiderable originality were put into use. Miss $\mathrm{V}$ an de Vrede of the Southern Division appointed Miss Maltby to initiate the movement in her office. On Mareh 21, 1921, Miss Maltby wrote Miss Noyes of the work accomplished:

We first sent each active chapter a letter with sample leaflets and one poster. 'To this there was some response. We are now approaching them through "Briefs" [the Division bulletin]

To all our public health nurses and local committees, we have sent two newspaper articles, with the request that they be published in the high-school papers through the efforts of the local publicity chairmen, or failing that, that they receive space in the local newspaper. These two articles have gone to ninety publications in the division.

To college presidents and to Y. IV. C. A. presidents in colleges in the division, we have written and enclosed a poster and a recruiting article, asking that it be published in the college papers. We have also offered to send a personal representative to address the colleges on nursing as a profession. The colleges are responding well to the suggestion and a representative will probably start in April. . . .

In the Lake Division, Pearl Kamerer was appointed to develop student murse recruiting; she organized committees in Kentucky, Indiana and Ohio in commection with the state gradwate nurses' association. On April 8, 1921, she wrote Miss Albangh:

.. The Ohio State Recruiting Committee engaged Miss Mary E. Ciladwin to speak for a period of three months, beginning $M$ arch 1 , to the young women in the different Ohio colleges and to as many high schools and groups of men and women as possible. To finance the speaker, the accredited school of nursing were asked to contribute one dollar for each pupil in training. A few of the larger lied Cross chap- 
ters were aiso askel to assist. There was hearty response from the schools and the chapters . . . and most of the districts feel that their committees will be interested in doing something definite towards recruiting each year.

A novel idea was developed in Sanilac County, Miehigan, by Elba L. Morse, Red Cross supervising nurse for Michigan. Three "mother and daughter banquets" were held with a total attendance of eight hundred and fifty mothers and daughters, and on these oceasions the traditions and advantages of nursing were presented. Miss Morse deseribed the type of program:

The county nurse outlined the program and twenty-six highschool girls took part. The teachers assisted in choosing the girls and in rehearsing them, so it took very little time. The play was called The scope of Nursing and was given by twenty girls dressed in white, each girl representing a phase of nursing such as hospital superintendent, Army nurse, Nary nurse, Red Cross murse. As each appeared, she told the pleasant duties of the branch she represented. When the twenty lined up, each with their carls telling what phase they represented, so the mothers saw plainly the wide scope of the profession.

Next "ame human pietures,_- "the greatest mother in the world," the public health nurse as "the foster-mother of the race"; "the lady with the Lamp." . . .

other phases of the banquets were music and addresses by prominent nurse lealers. In one town the bancuet was freo; the committee solicited funds mostly from the wartime worker and invited every mother and daughter in the town. Fonr humbrel and fifty attended and the Methodist ('hurch was rrowded as it had not been since the war. One other town sold tickets at fifty cents and the third at seventy-five cents. Both towns had to restrict the number of tickets to two hundred, but could have sold many more. In one place it was roted that a similar banquet he held as an anmual affair each year to different nurses from that locality who had died ofereseas, the extra proceeds of the banquet to be nsed as a scholarship for a local high school girl entering training. . . .

Twenty girls entered schools of nursing in the fall of 1921 as a result of the "mother and danghter banquets." The indirect results of such educational effort, however, went on, for the idal of altruistie nursing serviee had herm planted in the impressionable minds of yommgeris and was not to be wholly forgotten. 


\section{HISTORY OF AMERICAN RED CROSS NURSING}

The movement to recruit student nurses was not confined to definite time limits but was intended to be a steady constructive upbuilding of public interest and judgment of nursing education. At the present writing, it is too early to estimate the effect of the movement upon the profession.

Throughout the period of demobilization, an acute shortage of nurses in all phases of service was experienced. Schools of nursing reported to the Red Cross Bureau of Information and later to National Nursing Headquarters special diffieulty in securing adequately-trained nurse instructors. The dearth of this type of personnel was particularly serious because such a condition, if not remedied, would check the supply of properlytrained nurses at the very source, the sehool; so at Miss Noyes' request, National Headquarters appropriated funds to be used as scholarships for nurses desiring to take post-graduate courses to fit themselves to teach in sehools of nursing. Twelve such scholarships and four loans were granted in 1921 to enable nurses to take courses at the department of nursing and health at 'Teachers' Colleges.

Perhaps the outstanding aceomplishment of the nursing profession during the period of demobilization was the winning of assimilated rank of Army nurses. This aecomplishment was brought about by the persistent efforts of nurses and friends of nurses in the face of strong opposition from the War Department. While the American Red Cross officially took no part in this legislative struggle, individual leaders of the Rerl Cross Nursing Service were staunch sponsors of the movement. For this reason and also because the new law materially affected the Red Cross in that its nurses are the reserve of the Army Nurse Corps, a brief aecount of this movement belongs in a history of the Anerican Red Cross Nursing Service.

An arly request which the nursing profession made to the War l lepartment for definite status and authority for Army mulses was as follows:

The American Nurses' Association, in convention assembled in Philadelphia on this first day of Hay, 191\%, wonld offer the following resolnition:

Whereas. it is true that nurses who are responsible for the actual nursing of the patients in the military hospitals have no anthority to regulate hyorenio conditions therein: and 
Whereas, this situation tends to discourage nurses from undertaking the work; and

Whereas, this is a danger to the hospitals' population; ant

Whereas, it has been found essential in representative eivil hospitals to place upon the unrses the responsibility for the are of the patients, the wards and operating room and the (reanliness and order pertaining thereto:

Therefore, be it resolved: that it is the sense of this meeting that the proper military authorities should be requested to specifically define the status of the nurse and confer upon her the anthority necessary to eontrol the situation, to the end that the general welfare of the sick may be promoted and a very grave danger to the well averted.

Early in the summer of 1917, the War Department issued the following regulation defining the status of Army nurses:

As regards medical and sanitary matters in eonnection with the sick, members of the Army Nurse Corps and Army Nurso Corps Reserve are to be regarded as having anthority in matters pertaining to their professional duties (the care of the sick and wounded) in and about military hospitals next after the oflicers of the Medical Department and are at all times to be obeyed accordingly and to receive the respect due their position.

The phrase "in matters pertaining to their professional duties (the care of the sick and wounded)" permitted individnal interpretation on the part of commanding officers of military hospitals as to whether the murse's anthority did or did not extend beyond the person of the patient. Thus the anthority over ward matters such as ventilation, light, temperature, sanitary conditions, supplies and other questions was not definitely granted Army murses and the regulation, nurses felt, did not meet their demands for definite authoritative status. Their struggle, therofore, continued.

One of the first organized moves to secure rank for Army nurses came in the summer of 1917 from a group of prominent New York women who formed a committe later known as the New York Committee to Secure lank for Army Nurses. Mrs. Harriot Stanton blatel was dhaimuan and Mrs. H. (). Mavemeyer an enthusiastic member. 'This committee had the active support of leading nurses in New York ('ity, among whom Miss Maxwell Was perhaps the most ardent. Holen Hoy 


\section{HISTORY OF AMERICAN RED CROSS NURSING}

Greeler, a graduate of Vassar College and a member of the New York Bar, first volunteered her services as comnel and later, when nation-wide organization was secured, was retained by the nursing profession to represent them.

Early in 1918, bills were introduced into both houses of Congress, in the Senate by Mr. Chamberlain and in the House of Representatives by Mr. Dent, which purposed the general reorganization of the Army Nurse Corps. These bills called for an increase in the number of exeeutive officers in the Nurse Corps, the raising of compensation of Army nurses and the collecting in one plaee of all regulations regarding Army nurses.

The disenssion in Congress regarding the reorganization of the Army Nurse Corps offered opportunity for the advocates of rank for nurses to press their elaims. Two bills proposing absolute rank for Army nurses were introduced into the House of Representatives; the first one was introdueed by Congressman Iufkin on March 27 and proposed commissioned rank with the rates of pay proposed by the War Department reorganization bill; the second bill was introduced by Congressman Raker on April 5 and proposed the pay incident to the rank.

On April 16, the Honse Committee on Military Affairs, of which Representative S. Hubert Dent, of Alabama, was chairman, held the first meeting on the question of rank for Army nurses. Mrs. Greeley stated that the object of the committee was to secure rank

... in order to promote the efficiency of the nursing service of our boys by conferring upon the nurses some outward, risible sign of the authority which is supposed to be in them, a sign by rirtue of which their instructions may be promptly carried out in the wards. For at present their authority to give orders is continually disputed by the cnisted men who serve as orderlies and friction and dangerous delays in the execution of orders result. We believe that the insignia of rank will gire conchusive notice to all that nurses are officers and are to be obeyed.

Mrs. Greeley then summarized the action following the introduction of the Lufkin and Raker bills; she stated that after conference with each other and with General Gorgas. the advocates of the two bills had agreed to abandon their bills and support a proposition for relative rank in the form of an amendment to the War Department's reorganization bill. This anculnont read: 
Seetion 3. (a) That the members of said corps shall have relative rank as follows: The superintendent shall have the relative rauk of major; the assistant superintendents, director and assistant directors the relative rank of cajtain; chief nurses the relative rank of first lientenant; and nurses the relative rank of second lieutenant ; and as regards mediral and sanitary matters and all other work within the line of their professional duties sinall have and shall be regarded as having authority in and about military hospitals next after the medi(al oflicers of the Army and shall wear the insignia of the rank in the army to which their rank corresponds.

The meaning of the term "relative rank" was next defined by Mrs. Greeley:

You will notice that this amendment differs from the Lufkin and Raker bills in asking for relative rank instead of absolute rank. The term "relative rank" has two meanings. It may mean simply relative position, or it may mean a kind of rank which lacks one or more of the escential elements of absolute rank and so is quasi instead of actual, relative instean of absolute. We are using the term in this second sense. 'The relative rank here conferred is only quasi rank. It lacks several of the essential elements of absolute rank-it does not eall for a commission; it does not carry the pay, the allowances or the cmoluments of absolute rank; and it makes no attempt to confer the power of command incident to a line ollice of similar grate. The only incidents of absolute rank which the relative rank contemplated in this amendment will coufer are:

1. 'The dignity incident to the name of the rank.

2. The right to wear the insignia thereof.

3. The eligibility to exercise authority within the limits set forth in the law, which are as follows:

As recards medical and sanitary matters and all work in the line of their duties. they shall have and shall be regarded as having authority in and about military hospitals next after the medical oflicers of the Army. ...

Among the nurses present at the hearing was Miss Delano, and Mrs. Grecley alled upon her to testify. Miss I)

Mr. Chairman, for a number of years I was superintendent of the Army Nurse ('orps when siug. (ien. Torney was surgeon General of the Army. As the superinterdent of thes Army Nurse Corps I inspected all of the military hospitals in 


\section{HISTORY OF AMERICAN RED CROSS NURSING}

this country, Honolulu and the Philippines, and had ample opportunity to watch the working out of this plan in times of peace. Now, I believe that what was true under conditions which obtained then would hold true to a greatly increased degree now in time of war. I had a basis of comparison, because before I came into the Army Nurse Corps I was for a number of years superintendent of what was at that time the largest training school in the United States, that at Bellevue Hospital.

II hen I went into the military hospitals I found an absolute lack of coördination of the activities in the wards. I found division of responsibilities and more or less friction; a tremendous amount of adjustment necessary on the part of the nurse; a tremendous amount of yielding of things they considered important for the sake of peace. I found this adjustment constantly necessary, and, even in time of peace, great difficulties. ...

I will cite one instance. ... We had notice from the tuberculosis hospital at Fort Bayard that a number of the nurses were reported as having incipient tuberculosis. I was sent to Fort Bayard to look into the matter. . . . I found the head nurses of the wards absolutely without responsibility for the cleanliness of the wards. I had again a basis of comparison, because we had a large tuberculosis service at Bellevue, and I was cntirely familiar with the methods necessary to prevent the spread of tuberculosis or the reinfection of patients. I found, so far as I could determine, no systematic plan for preventing the spread of contagion in the hospital at Fort Barard because the cleanliness of the ward rested absolutely in the hands of the corps men.

Miss Delano next discussed the regulation given above which defined the status of the Army nurse:

Efficient organization in any hospital, civilian or military, is in my opinion to be secured only by placing definite responsibility upon one person in the ward.

In the matter before us I do not believe that any regulation will effect the purpose we desire. First, because we have bark of us the traditions of years. We have the corpsmen, we have even the officers themselves and perhaps the nurses. with these traditions of divided responsibility. and we have this tradition of the Hospital Corps man. who in the past has not been placed definitely under the nurse. Now, a new regulation is made, but, as II rs. Greeley said, the interpretation of that regulation depends entirely upon the temperament of the 
conmanding offier or of the person to whom he delegates the duties regarding it. . . .

Mrs. Greeley then called Julia Lathrop, chicf of the Children's Bureau, who spoke in favor of the proposed amendment. Mrs. Highbee was the next speaker. She brought forth the comparative powerlessness of the nurse to deal with an insubordinate orderly. Miss Goodrich was the next speaker. She printed out among other things, that in the view of the falet that personnel of the Hospital Corps was constantly changing, it was highly important that the authority of the head nurse should be so elear to all with whom she eame in contact that no loss of time should result in teaching the new men her real status. Rank wonld immediately establish this authority without words or written regulations. Mrs. Greeley then read letters supporting rank from nurses in foreign service, and ealled upon additional speakers. Among these were Colonel Vietor C. Vaunghan, Medieal Corps, National Army; Major Martin, then a member of the Advisory Commission of the Couneil of National 1)efense; Miss Thompson of the Army Nurse Corps; Major W. J. Mayo; Dr. William M. Geer, Viear of St. Paul's Chapel, New York City; Mrs. Harriot S. Blatch, representative the New York Committee to Seeure Rank for Nurses; and Mrs. Harriot Blaine Beale, of the District of Colmmbia. The hearing was then adjonrned.

On April 20, the Military Affairs Committee heard General Gorgas opinion regarding the proposed anendment to the medieal reorganization bill; the Surgeon General stated that he "did not see the neressity or the advisability for commissioning the great number of nurses,-it would be over $\$ 30.000$ als seenend lieutenants. I do not see," he said, "that it is necessary for their functioning. We ean give them all the anthority" they walnt in the war now.

The reorganization of the Army Nurse Corps, which was finally contained and passed in the Arme appropriation bill for 1919, became law on oluly 9, 191s, but rank for nurses was net ineluded therein. The failure of the proposed aneme-

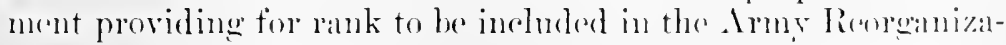
tion bill, was largely due to the opposition of the War lepartment.

The nursing profession was resolute in their claims for rank

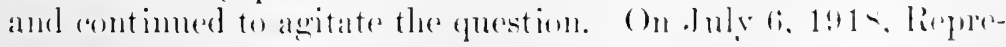




\section{HISTORY OF AMERICAN RED CROSS NURSING}

sentative Raker introduced a bill into the House, H. R. 12698, which read as follows:

Be it enacted by the Senate and House of Representatives of the United States of America assembled, that the members of the Army Nurse Corps shall have relative rank as follows: The superintendent have the relative rank of major; the assistant smperintenrlent, director and assistant directors the relative rank of captain; chief nurses the relative rank of second lientenant; and nurses the relative rank of second lieutenants; and as regards medical and sanitary matters and all other work within the line of their professional duties shall have and shall be regarded as having authority in and about military hospitals next after the medical officers of the Army and shall wear the insignia of the rank in the Army to which their rank corresponds.

This bill was referred to the House Committee on Military Affairs. In the pressure of the times, the bill was lost sight of until late in 1918 when the subject of rank for Army nurses again began to claim interest.

With the return of nurses from foreign service early in 1919, rank for Army nurses became the foremost nursing issue of the demobilization period. A National Committee to Secure Rank for Army Nurses was formed by the addition of new members to the old New York City Committee of which Mrs. Blateh had been ehairman. Among these new members were the presidents of the national organizations of nursing, the nembers of the former Committee on Nursing of the Comeil of National loefense and influential lay men and women. Mr. Taft was the honorary chairnan, Miss Noyes vice-chairman and Mrs. Greeley was secretary and commsel.

At its midyear conference in New York in 1919, the Board of 1)irectors of the American Nurses' Association voted to support the movement to secure rank, drew up with the aid of the National (Taft) Committee a plan for state organization and instructed their seeretary, Katharine Dellitt, to write to all State Nurses' Associations asking their coöperation. (On .January 2s, 1919, Miss DeWitt wrote in part as follows to the offiecrs of all State associations, asking their active support to the following plan:

1. That the State-wide committeen to be formerl should be the State Branches of the National ('Taft) Committee to Serure Rank for Nurses. 
2. That these state (ommunities should be composed about twenty of lay persons and nurses, the chairman preferably a lay person, either a man or a woman.

3. That the State Committee raise enough money through voluntary subseription to finance its own work and to contribute a quota of $\$ 250$ for the 1919) (ampaign, to the National Iealquarters in Washington, payable as soon after March 1, 1919 , as possible.

By April, 1919, only twelve state committees had been organized. In the April issue of the Journal, Miss Noyes, as president of the American Nurses' Association and vice-ehairman of the National Committee to secure rank, addressed the presidents, other officers and members of state associations, outlined again the plan of organization and elosed her letter with a strong plea for coöperation. In the same issue, the Journal spoke in the editorial columns for rank and from then until the passage of the Lewis-Raker bill, was a persistent and eloquent advocate.

On June 6, 1919, a bill similar in wording to that of the second Raker bill, was introduced in the Senate by Senator Jones, was referred to the Senate Committee on Military Affairs and was published as Senate bill No. 17:37. From then until the end of the legislative struggle, the bills proposing rank were referred to as the Jones-Raker bills.

'Throughout the summer and fall of 1919, the nurses organized their forces in the ficld. At Washington, Mrs. Greeley organized extensive office headquarters and from there directed the work in the ficld and "on the Hill" with persistent checrfulness and vigor. Sara E. Parsons, veteran nurse educator and war leader, volunteered her services at Mrs. Greeley's office and during the fall and winter of 1919 and 1920 spent much time in bringing to the attention of Congressmen the vexations, experiences and privations to which murses had been needlessly subjected orerseas on account of lack of rank. Expert publieity advice was seenred and a news service established at Mrs. Greeley's oftice which issued bullotins periodically to the press and to State (ommittees to secure liank for Army Nurses. Hundreds of nurses who had had foreign service sent in affidavits recounting the diffienlties which they had experioneced in the performanee of their duties, in traveling, in questions of quarters and even in recreational matters, due to their lack of dignitied and anthoritative status in the Army. These letters 


\section{HISTORY OF AMERICAN RED CROSS NURSING}

and affidavits were published in the Journal throughout the eampaign and eopies of them were sent to Congressmen with urgent letters asking for rank. "Ever sinee April," stated the editorial columns of the (November, 1919) Journal, "a stream of letters, resolutions and petitions has been triekling into Congressmen's offices from nurses, lay persons and organizations, recently from doctors, too. . . Not only has a pleasing proportion of the whole Congress promised to vote for rank when it reaches the floor, but a goodly number of influential men on both Committees [on Military Affairs] are pledged to its support in committee. Both chairmen, Senator Wadsworth, of New York, and Representative Kahn, of California, have beeome avowedly sympathetic."

Early in the fall of 1919 , Congress undertook a general reorganization of the Army. The Senate Committee on Military Affairs took up for consideration the Jones bill proposing rank and submitted it at the War Department. The following letter was written on August 28, 1919, by the Seeretary of War to the chairman of the Committee:

In reply to your memorandum of August 20, 1919, in which you request to be furnished with the riews of the War Department relative to the bill (S. 1737) "To grant rank to the Army Nurse Corps and for other purposes," I beg to inform you that the War Department is opposed to the provisions of the proposed bill.

The bestowal of the relative rank upon Army nurses as provided for in the bill, while not actually providing them with commissions. would in effect result in placing a considerable number of Army nurses above a large number of Army officers, including medical officers under whom they are serving in hospitals. Tnder regulations issued by the War Department, members of the Army Nurse Corps live been given rank above all enlisted men in the Army and as regards medical and sanitary matters and work in connection with the sick have anthority in and about hospitals next after the officers of the Medical Department anrl are at all times to be obeyed accordingly, and to receive the respect due to their positions.

The enartment of the proposed legislation would not, in my opinion, serve any useful purpose.

On Liptember t, Creneral Ireland appeared before the Senate Commitere on Military Iffairs to disenss the reorganization w the Medical Department and expressed hinself as opposed 
to rank. Hitherto, General Ireland had been a staunch advoeate of all projects which seemed to better the condition of nurses in the Army; in fact he was perhaps the first advoeate of the Army Nurse Corps, for he had gone down to the beach at Siboney during the Spanish-American War and had asked the nurses on the lied Cross ship Texas to come ashore and help in the eare of the sick. This request of his had been a very radieal departure from Army precedence and the services of the nurses from the Texas had formed one of the entering wedges of professional nursing service in the Military Establishment. But at the hearing on September 4, 1919, General Ireland stated that he felt the nurses" "idea in seeuring rank to better their position would be altogether wrong." Even if General Ireland had himself believed in rank for Army nurses, it would have been highly embarrassing for him to have advocated it, beeause he could not well have opposed the Chief of Staff and the Secretary of War, both of whom were vigorously opposed to granting rank to Army nurses.

On Oetober 31, the Senate and the House Committees on Militury Affairs met jointly to hear General Pershing express his views on Army reorganization. General Pershing stated that he farored the bestowal of rank upon nurses "up to and including the rank of second lientenant." His indorsement and that of the American Legion, gave much encouragement to advorates of rank and the campaign went on spiritedly.

Officially, the American Red Cross took no part in the struggle. It the first meeting of the National Committee on Red ('ress Nursing service after the signing of the Armistice Miss P'almer read the following resolution:

Whereas-From humdreds of nurses and doctors of all grades of rank and ability returning from Army service to rivil life we have heard of the distressing handicaps put upon the Army nurses in the late war by her lack of suitable officer"s rank; anid

Wherea-'That handicap not only apprexiably lowered the efficiency of the mursing service rendered but also premitted discomfort. disconrtes and dispespect to result to the nures in all her relations, profesional, recreational and social : and

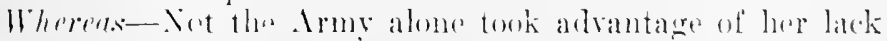
of rank but public institutions malopuainted with her position and function and even lied ('ross arencies themselses at times discriminated against her for the arewed reanen that she was 


\section{0 + HIS'TORY OF AMERICAN RED CR̈OSS NÜRSING}

not an officer, Red Cross liotels having some of them denied her shelter and comfort on that ground; and

Whereas-The lack of standard treatment by the Army, which she so valiantly served in no conscript capacity, and the failure on the part of the great organization, the American Red Cross, to support her in her great need for rank and a clearly defined position, have altogether bred in far too many of our Army Nurse Reserve a deep-seated discontent; and

Whereas-The hardships and humiliations complained of seem upon analysis to have resulted in no wise from the exigencies of war, but from purely aroidable causes; now therefore be it

Resolved: That we, the National Committee on Red Cross Nursing Service in annual conference assembled this 9 th day of December, 1919, do hereby deeply deplore not only the unfortmate conditions that have existed and the feelings they have aroused, but also the hitherto omission of the American Red Cross to lead or participate in any effort to correct these difficulties, or a recurrence of them by the elimination of their causes and the establishment of rank for nurses; and further

Resolved: That we express to the Central Committee of the American Red Cross our deep concern that in the absence of coöperation by the American Red Cross in the nurses' present struggle to establish a suitable and dignified officers' status for themselves in the American Army comparable with that of other English-speaking nurses, there may be little heart in the nurses of Ameria for continned enrollment in the Red C'ross for service in the Army Reserve; and finally be it

Resoled: That we therefore invite and urge the Central Committee to a most serious and earnest consideration of the obligations of the American Red Cross to American nurses in these premises.

This resolution had been drawn up and signed by Miss Maxwell, Miss cintting, Miss Palmer and Miss Crandall. After Miss Palner had finished reading it Miss Noves stated that the Red cross had nevere taken any aetive part in legislative work, but she brelieved that it was srmpathetic with the movement. Miss Minnigerede moved that the resolution be adopted and presented to the Central Committee of the Red Cross for consideration. This notion was carried.

On 1)ecentuer 2., Miss Noyes transmitted a copy of these resolutions to I)r. Farrand, chatirman of the Executive Committee, and on of anmary 2,1920 , he acknowledged receipt of them 
and asked Miss Noyes to discuss them in detail with him at her convenience. Some day's later, she and Mrs. Greeley had a eonferenee with Dr. Farrand, at which he stated that the Red Cross was in sympathy with any movement which would better the condition of Army Nurses in that the Red Cross Nursing Service was the reserve of the Army Nurse Corps, but that its polieies did not permit it to take part in any legislative struggle. He stated also that while he appreciated that grave consideration was due to formal resolutions passed by a committee as powerful and representative as the National Committee, yet he did not think it advisable to present these resolutions to the Exeentive Committee for action, becanse General Ireland was a member of the Executive Committee and was also one of the chicf opponents to bestowing rank on $\Lambda \mathrm{rmy}$ Nurses. Dr. Farrand said that he felt that if these resolutions were submitted to the Executive Committee, the members wonld naturally seek the advice of General Ireland, the highest medical officer in the Army, and after hearing his views which were known to be distinetly hostile to rank, would in all probability refuse the aid petitioned by the National Committee. This, he felt, would result in embarrassment to the Red Cross and in harm to the eause of rank for numses. However, he.advised Miss Noves to continue her individual efforts to secure rank and the conference was then elesed. To recordoof these resolutions appear on the Minntes of the ('entral and Executive Committees.

The legislative struggle was, however, nearing an end. The clause proposing rink for A rmy nurses was ineluded among the provisions of the lill for Army reorganization and was introduced as such in the Senate on Junuary !), 1920. by Senator Wadsworth. It was also included in the House bill on Army reorganization, Ifter five weeks, during which nurses interviewed congressmen "on the llill" while other nurses and friends of nursing bronght pressure to bear on the committee men from the field, the conferenee committer on Army re-

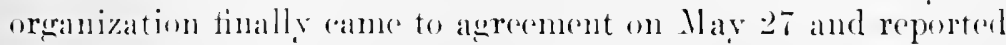
that "the provisen for the relative rank of numseses was agreed to, it being andatined in hoth hills." The Honse of Representatives atopted the conferenee repert on llar 20 , the semate adopted it on the next day and the bill for Army reorganizat-

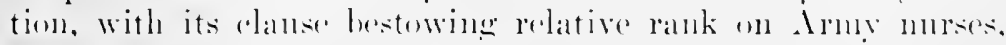
was signed fone + be President Wrilsent and breane law.

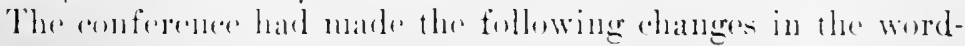




\section{$10 \tau 6$ HISTORY OF AMERICAN RED CROSS NURSING}

ing of the original Lewis-Jones-Raker bill: Head nurses were added to the elass having the rank of second lientenant; the clause "and shall wear the insignia of the rank of the Army to which their rank corresponds," was omitted and in its place were inserted the words "The Secretary of War shall make the neeessary regulations prescribing the rights and privileges conferred by such relative rank."

On August 10, 1920, the Surgeon General was notified by the Secretary of War regarding these regulations and he immediately placed the gold leaves of a major on the shoulders of the Superintendent of the Army Nurse Corps. Other nurses in the corps donned the insignia as soon as orders to that effect could be disseminated through American Army hospitals. Thus was ended the second most important legislative struggle regarding American military nursing service which had arisen in the United States.

In retrospeet, it will be seen that at no stage of its development did the Red Cross Nursing Service take a more important place in mursing activities than during the period of demobilization. Miss Noyes' dual position as president of the Ameriean Nurses' Association and direetor of the Red Cross Nursing Service may have been one of the reasons for this; another and perhaps more vital cause was the fact that the American Red Cross from 1919 to 1922 , in its forcign program, its public health nursing and educational activities, was the organization emploving the largest numbers of nurses in the world, and therefore, with its previons war responsibilities and its newer peace activities, it was an organization heavily charged with professional adjustment and advance.

The dual projects undertaken by the Red Cross Nursing Service and outside organizations were the establishment of the Burean of Information and its subsequent metamorphosis into National Nursing IIeadeuarters : the creation of the Nurse ('orps of the Public Health Service, with the Red ('ross Nursing service as its rescrve: the hospitalization and reëdueation of sick and disabled nurres: memorials to nurses: and the student nurse reeruiting movement. The purely Red Cross nursing projects were pullic liealth mursing, class instruction, and edu"atimal work thromgh the ('hautaugna. The one major project of Armolilization in which the Nursing Service had no official part was the struggle for rank. 


\section{CHAPTER XII}

THE CIOSE OF TIE FOREIGX EMERGENCY RELIEF PlROGRAM

The ('ommission for Europe-The Commission for PolandThe Commission for the Balkan States-MontenegroAlbania-(irece-North and South Serbia-Roumania - Contraction of IIar Organization

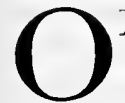

N November 11, 1918, the Ameriean Red Cross had nine commissions conducting medical and general relief activities in Europe and Asia; these commissions were operating in England, France, Belgium, Italy, Palestine, North Russial, Siberia, Serbia and (irece. Accounts of the mursing serviee rendered by these commissions have already been given, with the exception of those to Serbia and Greece. The Commission for Rommania, it will be remembered, had been withdrawn previous to the cessation of active hostilities.

During the post-Armistice period, the immediate task before the Amorion lied cross was to bring about as swift a retrenchment of foreign activities as was compatible with the ideals and obligations previously assumed by the society. The nations of western Europe were well able and eager to undertake their own reconstruction and by the begimning of the vear 1920 the Americun Red Cross had recalled its commissions from England, France, Belgium and Italy.

The need for medical and general relief in Poland and the Balkan States, however, was only just beginning. The war clond which had previonsly shronded true eonditions in these comitries wats gradually rolling back and the poverty and discalse which existed there began to reecive cognizance in the minds and press of western Enrope and America. In June,

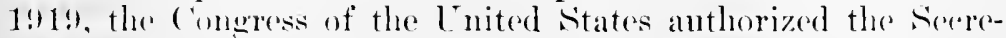
tary of War to transfer to the American lied Cross such medical and surgical supplies and dietary foodstuffs in kurope as should not be needed he the Ameriean Army abroad or at heme, "to be nesd by the Ameriean Red ('ross to relieve the pressing needs of the eomintries involved in the late war." 


\section{HISTORY OF AMERICAN RED CROSS NURSING}

Thus a two-fold foreign problem confronted the American Red Cross: First, to terminate its activities in the countries where a continuation of such service was no longer needed; second, to develop a constructive program in countries where such service was needed and desired.

Under the régime of the War Council, the form of organization for Amcrican Red Cross activities overseas first contemplated, had been a Commission for Europe, with headquarters at Paris and branches operating in different eountries of the European field. Major Murphy's title, it will be remembered, was that of Commissioner for Europe. As the need for American Red Cross relief activities developed in 1917 and 1918 in different countries and was presented to the War Couneil, new commissions with complete quotas of personnel and supplies, were organized at National Headquarters and sent into the field. If the area of their assignment was geographically so situated that the Paris office, the headquarters both for the Commission for Europe and for the Commission for France, was the logical line of communication with National Headquarters, the War Conneil linked up their organization with that of the Commission for Europe; if not, as was the ease with North Russia and Siberia, they operated independently of the Commission for Europe and reported only to National Headquarters.

On January 29, 1918, President Wilson notified the War Comncil of the resignation of Major Murphy from membership on that body. Major Murphy's services were desired by the Army. On February 5, Major Perkins was appointed Commissioner for Europe. The Nursing Service at National Headquarters and that overseas, however, was not accorled direct representation on the staff of the Commission for Europe. Miss Delano had thought that Miss Russell would oceupy such a position but she had been assigned, instead, to duty in the Department of Military Affairs of the Commission for France and there she had stayed until her resignation and the subsequent reoromization of the Nurses' Burean under the Bureau of Women's Hospital Serviee. In lien of other representation, the Chief Nurse of the Commission for France had also served as the modimm of commmication between the executives of the Nursing Serviee at National Headquarters and the varions ehief nurses of commissions in the European field and the records of duty of nurses assigned to Belgium, Italy and Palestine were 


\section{CLOSE OF' THE FOREIGN RELIEF PROGRAM 1079}

kept in the Nurses' IBurean of the Commission for France. Miss Delano and Miss Noyes kncw that this form of organization was not perfect but it had been uphill work to get even that, as has been stated before.

When the $\mathrm{I}$ ar ('ouncil went out of office on February 28, 191!), the Execntive Committee was confronted with the need for new governing machinery. The post-A rmistice reorganization at National II adquarters las already been described. As a form of organization through which to conduct the postArmistice program overseas, the Executive Committee voted a continuation of the form of organization first adopted by the War Council,-a Commission for Europe, with lucadquarters of the conmission at P'aris and the varions commissions in different comtries lacading up through the European Commissionce to National Headquarters. I)r. Farrand, it will be remembered, was the new chairnan of the Central Committee. Dr. Frederick Panl Keppel, one time Dean of Columbia Lniversity and during the participation of the United States in the European War, third assistant Secretary of State, eame to National Headquarters on July 1, 1919, to aet as vice-chairman in charge of foreign operations, in which eapacity he assumed the direction of all American lied Cross work overseas. The new Commissioner for Europe was Lientenant Colonel Robert E. Olds, a lawyer from st. Paul, Minuesota, who had formerly served as combelor to the Anerican Red Cross Commission for France. He took up his new duties early in 1919.

In May, 1!1!, the. Exerentive C'ommittee formally appointed a Commitfer for the Readjustment and Liquidation of European Activitios. This committee was charged with the responsibility of selling all hed Cross supplies no honger needed in Enrope and of reducing all activities to a minimm. The rommittee was composed of L. J. HImter, comptroller of the Anerican Red C'ross, and. . H. Gregg, director of the former l ceartment of Foreigu Aflairs at National IFeadquarters. Both of these men had heen in France working on the problems of retrenchunent sinere arly in April and among other duties, they took orer the aftalies of the ('ommission for Franee.

Ameriean lied cross nursing serviee in Franee in onneetion

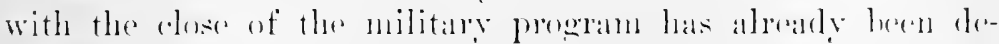

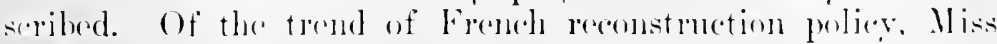
IIall, then rhice numse of the Aneriean hed ('ross in Fiance, wrote Miss Nires on March 14, 1919: 


\section{HIS'TORY OF AMERICAN RED CROSS NURSING}

It appears that the French Government has not asked the American Red Cross to assist in reconstruction work in France; furthermore, it welcomes instead small groups working directly under its own direction, rather than the work of a large organization like ours, which wishes to formulate its own policies and to carry on the work according to its own methods. An illustration of this is given in the fact that both the Smith and Vassar College Units have now been severed from the American Red Cross and are engaged in reconstruction work under the French Government. There is every evidence here that an effort is being made to bring the affairs by the Red Cross in France to a conclusion as rapidly as is consistent with the size of the organization and the varied work it has done.

As far as the nurses themselves are concerned, it has seemed the wiser policy to return as many as possible to the United States, owing to the need for murses at home. We have kept the number needed for other European commissions and also a small reserve for emergencies here in France.

On December 1, 1918, there had been approximately six hundred American Red Cross murses on duty with the various commissions in Europe and all administrative details in connection with their service had been carried on through the Burean of Nursing of the American Red Cross Commission for France. As the nursing activities of these commissions were bronght to a conclusion in the spring and summer of 1919, the majority of the nurses then in Europe reported back to the Nurses' Burean at Paris and were returned to the United States. On March 24, Miss Hall wrote Miss Noyes:

... The work of the Nurses Burean is being brought to a close and the major part of it will be finished this month. I few activities, however, will continue to be maintained and it will take perhaps two or three months to wind up these projects. 'T'o carry these and the new constructive program, it has been suggested that a Bureau of Nursing be attached to the Commission for Europe which is now under organization and which will have its headquarters at Paris. As long as there are nurses on duty with other commissions in Europe. there will be neel for a Nurses' Bureau in Paris.

In this letter, Miss Hall asked that her resignation as chief murse of the Ameriean Red Cross in France be areepted: she had been overseas for two vears and desired to return to her 


\section{CLOSE OF THE FOREIGN RELIEF PROGRAM 1081}

former work in the United States. "May I suggest," wrote Miss Hall in the letter" of March 24, "that Aliee Fitzgerald would make a most admirable candidate for the position of chief nurse of the new Bureau?"

A month later, Miss Hall wrote Miss Noyes of the further contraction of American Red Cross activities in France:

Great pressure is being brought to bear on the Medical and Surgical Defartment, including the Xurses Bureau, of the American Red Cross in France, to bring our affairs to a close and to get our personnel started for the states. May 1 has been named as the date for the nominal closing of the 'Nurses' Bureau. I have pointed ont the demands which may be made upon us for nurses and I have been toid that the Commissioner for France can no longer lue responsible for the further assignments of nurses to duty; if any nucleus of this bureau is retained. it will have to be attached to the office of the Commissioner for Europe.

Fifty-nine nurses were released and sailed for the Cnited States in April: fifty-eight others left in May and in June and July one hundred and fifty additional ones returned home. Miss Hall left Brest late in IIay, but before her departure from Paris, she made reeommendations to the new Commissioner for Europe regarding the organization of the nursing staffs of future Red cross commissions and these recommendations became the basis of future Anerican Red Cross nursing organization overseas. The release of nurses continued until there remained in Europe and in Paris only suel nurses as were needed for the so-called "constructive" program.

On May s, 1!19!, C'olonel Olds transmitted Miss Hall's reeommendations as follows to all departments and Bureaus of the Commission for Europe:

The Burean of Nursing. formerly reporting to the Commissioner for France, will be transferred to the Commisioner for Europe about May 10. the time when the operating tasks whing it has been conducting in France will have been substantially (ompleted.

Becalle of the altered work of the American lienl Cross in Euroge. the alctivities of this Burean will be substantially different hereafter than they have been heretofore. Its responsibilitics will induce: 


\section{HISTORY OF AMERICAN RED CROSS NURSING}

1. Aid to each operating commission in securing a chief nurse and in assisting chief nurses in obtaining an adequate force of workers.

2. General advisory service to the chief nurse reporting to each commissioner.

3. Direction of any nursing operations remaining under the Conmissioner for France.

4. Continuance of the nursing records already established and of the present personal service to all nurses in Europe.

In all this work, the Chief Nurse, in direet charge of the Bureau of Nursing, will work in close coopperation with the Department of Nursing at National Headquarters and will apply the general rules laid down by that Department to meet the above responsibilities, she shall maintain such a reserve force of nurses as may be required to meet the policies of the Commission for Europe and this question shall be given consideration in arranging the release of nurses now engaged.

The Chief Nurse shall report to that member of the Commissioner's staff who is in charge of medical service, at present Lieutenant Colonel Taylor.

Upon Miss Noyes' recommendation, Colonel Olds on May 10 appointed Miss Fitzgerald chief nurse of the American Red Cross in Europe and, as such, director of the Burean of Nursing, and suggested that she immediately get in touch with the chief murses of the varions commissions then in Europe.

This reoreanization of American Red Cross nursing service in Europe marked the suceessful culmination, on paper, at least, of the struggle begum by Miss Delano in 1914 and carried on by her, hy Miss Noves and the majority of chief nurses in the ficld during the ensuing rears, for a dignified and professional status of American Red Cross nurses on aetive duty.

On May 22, one hundred and ninety-seven nurses and twentyone murses' aides were on duty in Enrope, making a total of two hundred and eighteen. Thirty of these nurses were still serving in France, some at American Red Cross Hospital No. 10: , the mantenaner of which was continned for the benetit of the personnel of American welfare organizations still in Franer ; somo at various dispensaries; others in the Nurses' Equipment Shop) and the Salvage lepartment; and still others on duty at the herd cross dock intirnaries. Fight null'ses hald beren linaned to the liockefoller lonudation; rightern to the

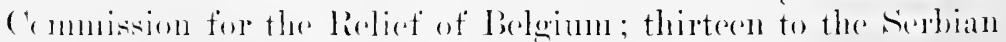




\section{CLOSE OF 'THE FOREIGN RELIEF PROGRAM 1083}

Tuberenlosis IIospital; two to Montenegro; and one to the French Army als a radiographer.

The murses on duty on 11 ay $2 \cdot 2$ with the varions foreign eommissions numbered one hundred and thirty-one. Nincty of these wereserving in the Balkan States. Late in Oetoher, 1918, Nattimal II aldeparters had organized a Commission for the Bilkins, of which Henry W. Anderson was rhairman and II len Seott IIay rhief inurse. Iliss Hay arrived in Paris heitlyuarters in I)ecember and recruited from among the mur.ses heing released by the Army Nurse Corps in France and the Nurses' Burean of the former ('ommission for France, a large statf of experionered and able public health and institutional murses for duty in the Baltic States. An aceount of these aetivities will be given later.

In May, twolve nurses wore still on duty in Italy, moder Miss Foley's direction. Nincteen were in Palestine lnt had no whief murse and as the atfairs of the Commission for Palestine were then being conchnded, no suecessor to Miss Madiera was appointed. Eight other nurses were on duty in Poland and two in Prague, ('zeohn-slovakia. The affairs of the Commission for Great Britain were being brought swiftly to a conelusion and by July 1, all Amrrican Red Cross murses on Major Endi(")tt's staft, had saled for the States or accepted assigmments under the ommissions remaining in Europe.

Annong the muscttled problems of the former Commission for France wias that of nurses" afuipment. On August 5, Miss Fitzgerald wrote Miss Noyes:

As long as we had supplies here in Paris, it seemed proper to continute to equip nurses, but the time is coming very shortly when we will not have enough supplies left to lo so. I have dischised the question thoroughly with Miss liherles and we asree that sereral or eren one depet for equijunent wonld he vere expensive and would not begin to give satisfatetion to all: for instance, an Equipment burean in l'aris could bardy reach some parts of the Balkans and an equipment depet in the Balkans eonlel not reateh Poland or Siberial. 'Transportation is hieluly unecrtain and much loss of time and equipment would inevitahly ensue.

()wing to this. I have slugereted that a dress allowane he mate to eateh nurse assigned under the lied cress. with whish

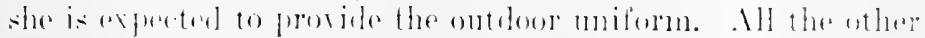
articles she will provide at her own expense. In alluwanet of 


\section{8\$ HISTORY OF AMERICAN RED CROSS NURSING}

one hundred dollars would cover the expense of a suit each year. a straw and felt hat, two waists and perhaps an ulster one year and a raincoat the next. What are your wishes in this matter?

This recommendation was approved by Miss Noyes and the Commissioner for Europe. The Nurses' Equipment Shop was closed and the supplies distributed or returned to the Burean of Nurses' Equipment of the Atlantic Division.

The close of the Nurses' Equipment Shop and the return of nurses from Great Britain, Belginm, Italy, Palestine and Siberia marked the termination of the pre-Armistice nursing program. The true post-Armistice nursing program embraced three distinet types of nursing service: First, emergency nursing to alleviate suffering ineident to the war in Poland and the Balkan States; second, a constructive program which consisted in the establishment of schools of nursing under American standards in foreign comntries and the development of nursing service in connection with health units; and third. indirect stimulation to the development of an international advisory nursing service in the League of Red Cross Societies. These last two phases of the post-Amistice nursing program will be treated in subsequent sections. This section of this chapter will deal only with the emergency nursing relief given in Poland and the Balkan States.

On November 9, 1918, the Independence of Poland had been solemnized and on June 2S, 1919, the treaty of Versailles had recognized the Republic. When Poland was opened to the Allies in December, 1915, she was found to be withont adequate food, machinery and textiles of all kinds. Her lands in the East had been the arena for much of the heariest fighting between Germany and Russia in the early days of the war, and reconstruction there had not yet been initiated. The political and military situation was a secthing one and the entire population had since 1916 been the prey of typhus, cholera, smallpox, trachoma and the skin disfases due to inadequate freding and unsanitary housing eonditions.

Some insight into the enditions of poverty and misery which hat existed in Poland since the collapse of liussia were known to relicf organizations in the Tuited States during 191s, lut the bristling Teutonic front did not permit the sending of 


\section{CLOSE OF 'THE FOREIGN RELIEF PROGRAM 1085}

Allied relief persommel. However, the Polish Reconstruction Committee and the War Work Comneil of the National Board of the Young Women's Christian Association had organized and given short eourses in elementary nursing and social service teehnigue to a group of young Polish-Ameriean women then in the Inited States, with a view toward assigning them to relief work in Poland as soon as that nation wonld be opened to the Allies. These young wonten were to be known as Polish Grey Simaritans. Reeruiting and training was under the direction of a joint committee; Madane Laura de Gozdawa Turezynowicz, Madame Marya Przybylowska and Misses Elizabeth Packard and Alice Preston represented the Polish Reconstruction Committee; Mrs. John R. Mott, Miss Sarah S. Lyon, Mrs. Henry P. Davison and Mrs. Harry M. Bremer represented the Yomig Women's Christian Association; Mrs. Mott was chairman. The committec had at its disposal the sum of fifty thousand dollars with which to finance the training of the Samaritans and their assignment overseas. Contact between the committee and the American Red Cross had been established in June, 191s; Madame Turernowicz had written Miss Delano regarding the placement of Polish Grey Samaritans in hospitals where they might assist in the care of the 200,000 Poles then in the American Army and Miss Delano had referred her to Miss Goodrich and the Army School of Nursing.

The first contingent of Polish Grey Samaritans went to France in September, 1918, under the direction of Madame Paderewski, wife of the distinguished Polish pianist who later became president of the Polish Republic. With them was an American-trained Polish nurse, Josephine Jokaitis, who had done public health nursing under the Chicago Infant Welfare Society. Mrs. Jokaitis was enrolled in the American Red Cross Nursing Service through the Paris Committee early in 1919 and afterwards played an important part in Ameriean Red ('ross nursing service to Poland.

A second group of one hundred Grey Samaritans sailed from Tew York on April 1!, 1!19, for serviee in Poland. 'The Joint Commite of the Polish Cirey Simaritans had intended to assign a murse to take ehatrese of the mit and broached the subjeet to Jliss Albangh, but arrangenents were finally madde between the Ioint ('ommittee and Miss Noves and Miss Hall whereby the mit would be linked up in l'oland, if opportunity developed there for their serviees muder the Ameriean lied ('ress, with the 


\section{HISTORY OF AMERICAN RED CROSS NURSING}

Chief Nurse of the American Red Cross Commission for Poland.

In February, 1919, at Paris Headquarters, an American Red Cross Commission for Poland was organized, of which Dr. W. C. Bailey, of Boston, was the director. The nursing personnel was composed of four American Red Cross nurses and thirteen Polish Grey Samaritans of Madame Paderewski's group. Emma Wilson, a Hopkins nurse who had done medical social service work at Bellevue Hospital, public health nursing at Henry Street and had served under the Commission for France in the Service de Santé and at the Bordeaux dock infirmary, was chief nurse; Mrs. Jokaitis was her assistant. A second Polish nurse, Marie Suchowska, who had also been trained in the United States, accompanied the unit. The two other American Red Cross nurses were Mary Bartley and Martha S. Clarke. A trainload of supplies had already been sent up to Poland in January and the commission took another trainload with it when it left Paris for Warsaw, in two sections, on February 20 and 21.

In a report of the Nursing Service in Poland from Mareh to June, 1919, Miss Wilson wrote:

On March 3. our band of five nurses and thirteen aides reached Warsaw, and on April 26 three more Red Cross nurses arrived. We immediately began to set up headquarters and a personnel house. . . .

Calls for nurses for special duty came early and have since been constant. . . The uncertainty of our plans, the difficulties of transportation and the extent of the territory to be covered made it seem undesirable to establish a hospital at Warsaw to care for ill members of the commission. On June 3, we had given twenty-six weeks of private duty nursing to our own personnel. We also furnisher nursing care to British offirers of the Inter-Allied Commission and to a C'aptain of the Hoover Food Commision.

Since the plans of the Polish Commission were in a formulative state. we were invited to hely at the large military hospital at Warsaw, the Ljazlowski śpital. On March 10, one half of our murses and addes went on duty there. A.t first the conditions seemed unholievable. but we have seen much worse since. The native nurses were of course. untrained and their hours of duty seemerl very short to us. but in view of their insufirient food and uncomfortable quarters, little more could have been expected of them. 


\section{CLOSE OF THE FOREIGN RELIEF PROGRAM 1087}

There was no soap, no bed linen . . no suitable food for patients on liquid or light diet and practically no medicines or nursing appliances. The day's rations of hard black bread was placed each morning on the bedside table of the convalescent and the dying alike. To Red ('ross supplies even were available for our nurses or their patients during their three weeks' assignment here, but the American nurses' work won for them many friends.

Late in Mareh, the commission deeided to undertake general relief work in the Iepartment of the East and the coöperation of the Polish Red Cross was sought. 'Twenty-two young Polish women were seeured to act as interpreters and were attached to Miss Wilson's staff as nurses' aides. Of their assignment to duty, Miss Wilson wrote:

We divided our forty nurses into four units, each with American Red Cross nurses in charge of numerous aides, and on April 3 we left Warsaw on the Commissioner's supply. train.

On April 26, nine more Polish aides and on May 14, thirteen others were sent from Warsaw into the field, so that the nursing staff finally numbered seven American Red Cross nurses, thirteen Grev Samaritans and forty-four Polish aides. The plan for relief work cmbraced the assienment of American Red Cross persomel to the Kored district from whenee they were to work north thronerh the regions of Brest-Litovs and IBialystok. Major II. IV. Taylor took charese of the work in the Department of the East with IIajor 1. J. Chesley as his ehief of staff.

One of the mits went to Maciejow, a village with a popnlation of $20(0)$, of whom the majority were Iews, and established a small hospital and dispensary in an old building formerly used as a Ciorman hospital and bathhomse. Food and supplies and a small amomut of nursing and dispensaly sorvier were distributed from this base to the surrounding andentreside.

A second mot went to l bolsk and estallished a dispunsary and canteren in buildings formery belonging to an old Polish estate. Miss bartley was in rharege of the nursing antivities here and IIrs. Inkaitis did publir hralth nursing.

The third wuit went to Pruzalla, a villace localted a few hours' travel north of Pirest-l.iforsk. The nurses and aides went into an wh palace which was half ocouped hy the military 


\section{HISTORY OF AMERICAN RED CROSS NURSING}

authorities but found conditions such that little medical or nursing service conld be rendered. Instead, Mrs. Clarke, the nurse in charge, and her aides did the honsekeeping for the American personmel and ran a canteen which daily fed eighteen hundred people.

North of Pruzana was located Bereza Kartusa and the mit assigned there established an orphanage for sixty Polish children and a dispensary from which medical service, public health nursing and general relief was extended into the surrounding country.

Early in June, 1919, Miss Wilson returned to Paris headquarters. Conditions in Poland were chaotic. The nurses had had no voice in the determination of nursing policies and the executives of the commission seemed to possess little idea of the possibilities for the broad and varied service which nurses might render. The leaders of the commission felt that a speak. ing knowledge of the Polish language was of paramount im. portance, without which the American nurses conld do little and they appeared to prefer the services of poorly-trained Polish-speaking aides to that of American Red Cross nurses working with interpreters. Miss Wilson had stood out for the development of dispensaries and public health nursing service muder the direction of the well-trained American nurses; but the Commissioner did not agree with her in this poliey and ordered her to return to Paris Headquarters. She understood that the inursing program in Poland was diseontinued and ex. peeted that the American nurses and Polish aides would follow her within a few days, if not on the next train. The days passed and no murses made their appearance. Miss Fitzgerald. anxions lest the undirected group should come to grief, sent a cable of protest to the Commissioner for Poland regarding the treatment given Miss Wilson and requested that an acting chief nurse be appointed at onee who would communieate with the Nurses' Burean at Paris Headquarter's and send in reports of the nurses' enduct and welfare. In response, Colonel Bailey appointed Mrs. Jokaitis as acting chice murse and hold the nurses in Poland, where they continned to do eivilian relief work.

I) ning the summer of 1919 , all the affairs of the Conmission for Poland were in a somewhat fluid state. On Lugust 11. Colonel ('hesley was appointed to sureced Colonel Bailey and he inmediately drew up plans for the derelopment of an extensive 


\section{CLOSE OF THE FOREIGN REIIEF PROGRAM 1089}

medical and nursing program in Poland. Early in September, he called upon the Chicf Nurse of the European Commission to seeure ten Polish-speaking Ameriean nurses for service in Poland but several days later had eomtermanded the order, authorizing instead a social serviee worker to go to the Enited States and recruit all persomel, professional and otherwise, for the reorganized Polish Commission. In place of the usual salary of $\$ 70$ a month for Red Cross nurses in foreign service, Major Chesley anthorized the sum of $\$ 10$; ; he also stated in his letter of instruction to his new representative that "it is not rssential for our work that the nurses have the regular nurses' minforms, as those issned to social workers will be satisfactory." Major Chesley wrote on the same day to Miss Noyes, that he felt that "it would be better, not only for the workers but for the Red Cross, to have Miss - personally superintend the recruiting of the nurses and to convoy them to Warsaw to us," rather than to have it done through Miss Fitzgerald's office.

The situation which ensmed possessed eertain elements of humor which Miss Noves and Miss Fitzgerald would have been better able to appreciate if their paticnee had not already been overtaxed by the seemingly complete ignorance, on the part of Red Cross foreign eommissioners, of the standards and regulations of the Nursing Sorvice. To offer murses a higher salary for service in P'oland than that which was heing given to those working under other lied Cross foreign commissions was manifestly mufair. To delegate to a larwoman the choiese and supervision of hed Cuoss nurses and to sugerest that when so chosen they wear the muform of social serviere workers, was a proeedure which flew in the very face of nursing traditions. Months were consmued in the adjustment of this irregularity. Finally, the ten Polish-speaking nurses were recruited throngh the Nursing Servier at National IIradquarters and in the various l)ivisions, particularly that in ('hieago, and set sail from New York in Derember, under the leadership of Edith Morle Bemm, one of the former nurse lecturers on the Rarleliffe (hautanquas.

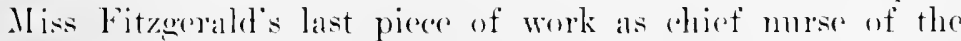
Ameriean lied e ross in kinrope consisted of a tomr of inspeetion which she made in Poland between ()otober 2 to Oetober 17. Of the activities of the "ommission in Bialrstok, she wrote:

The visited two very larew warehonses. nne of which was particularly well stodierl with dothing. medial supplies and 


\section{HISTORY OF AMERICAN RED CROSS NURSIN(x}

general equipment. We visited a refugee camp to which the returning natives are brought for cleansing, are kept on an average of three days and supplied with some clothing by the American Red Cross. Some of the soldiers stationed nearby have also received clothing from the organization. We also risited a typhus hospital of five hundred beds which has been vastly improved through the guidance and advice of our physicians and to which some equipment has been given. No American Red Cross personnel, however, is assigned there.

Next we went to an Army hospital of one thousand beds to which the commission had giren equipment, and also the laboratory, of which Dr. Placila Gardner is in charge. . . . Apart from the equipment given to the hospitals, no American Red Cross medical work of any sort is being done in Bialystok. . . .

On their way east, Miss Fitzgerald's party visited the village of Slonim to which the commission had previously given equipment. Miss Fitzgerald wrote:

The hospital was in a rery bad condition and the only person who seemed to be at all responsible was one nativ woman who took us around. The patients were not cared for. the building was dirty and nothing seemed to be in place. I have never seen a more striking example of the uselessness of giving equipment to a hospital without providing at least a temporary loan of personnel to teach the natives how to use that equipment. . . A very elaborate bathing arrangement which has been put up was naturally out of order and all the water which should have been in the boiler or in the tub was on the floor.

1 remarked on the fact that a nurse or nursing aide could do a great deal eren in a short time in such a hospital, but it seems that that kind of work has not entered into the scheme outlined in Poland in the past.

From Slonim, Miss Fitzgerald went to Baranovicei and found there a hospital attached to a military camp and a large distributing center. Miss Fitzgerald wrote:

The hospital is in hetter shape than any I had previonsly seen. . . I Polish aide was on duty there and others were busily distributing rothing and food, going in rarts from one village to another. . . This distribution represents a great deal of work and requires a considerable number of people. In the month of september alone the unit stationed 


\section{CIOSE OF THE FOREIGN RELIEF PROGRA.I 1091}

at Baranovicei reached 148 villages and distributed elothing to about 40,000 people. . . When sick people are found in the homes no attempt is male to give them merlical attention at that time, but if rery ill the family is alvived to take the patient to the nearest hospital, which in many cases is a long distance away.

From Baranovicei, Miss Fitzgerald went to Kobryn and found similar work being carried on. From there she proceeded to Brest-Litorsk and themere back to Warsaw. She then made the following recommendations:

There is practically no medical work being done by the American Red ('ross in Poland and I feel that we are missing a great opportunity by not placing nurses and nurses' aides in the Polish hospitals. "There is no reason to think that when this method has sueceeded so well in other countries it would not be equally successful in Poland. . . . Hitherto, the policy of the Amerian Red Cross in Poland has placed the question of langmage before any other factor. This is plainly shown by the very large Polish persomel composing the commission. In units like those at Baranovicei and Kobryn, the only American people are the doctor and one stenographer ; the rest of the tifteen or twenty women are Poles, some of whom were enrolled in America bint many of whom do not even speak English.

I have been tolil on excellent authority, and I can remlily believe it, that the Polish people thenselves wonld prefer American workers and molombedly these wonld carry with them a prestige which no native can obtain. It is not always easy to determine the spirit in which the native distributes assistance and there is always the danger of crippling one's gift through a patronizing attiturle.

The military situation in Poland early in 1920 was favorable to the development of an Ameriean Red cross program. In April, 1920, the Republic had an army of 700,000 mem in the fielel. An active spring offensive was expected on the part

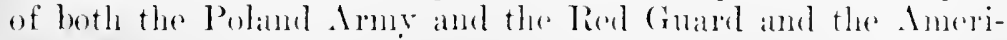
can lod Cross anmmission in Poland nulde extensive plans to furnish medieal, nursing and geeneral reliet to Polanel doring the ansuing months.

lu adelition to the muit of ten Polish-speaking numses Xat tional II 


\section{HISTORY OF AMERICAN RED CROSS NURSING}

of 1920, so that by June, 1920, the nursing staff of the Polish Commission numbered eighty-one murses and twelve nurses' aides.

On May 19, Miss Hay left Paris to make an inspection trip in Poland and during the following weeks she visited the chief centers of American Red Cross mursing activities and found that the Commission for Poland had developed a broad program of melical relief in the regions dominated by Warsaw in central Poland; by Vilna and Minsk in northeast Poland; by Bialystok and Brest-Litorsk in eentral-eastern Poland and by Lemberg and Cracow in southern Poland. The résumé of nursing activities which follows is based largely on Miss Hay's report of her tour of inspection made in May and June, a report submitted to Miss Noyes on July 15, 1920.

In Warsaw, American Red Cross medical and nursing relief included the maintenance of a typhus research hospital and a small hospital for the care of American Red Cross personnel in Poland.

The Typhus Research Hospital had been established in March miner the direction of the League of Red Cross Societies. ${ }^{1}$ 'The patients consisted of especially typical and critical cases of typhns, which were chosen from anong patients of hospitals in the field, particularly that at Stanislau, and sent to Warsaw for obscrvation and treatment. The capacity of the hospital was twenty-eight beels. The nursing staff was maintained at an average strengtl of about twelve nurses of the Commission for Poland. The commanding officer was Dr. F. E. Palfiey and the head nurse, Stella Mathews. Miss Mathews was a Milwanke nurse who hat organized the nursing persomel and served as chief nurse of Base Hospital No. 22 and Eracuation Iospital No. 20 at Bean Desert Center, A. E. F., France.

The hospital established for the care of American Red Cross persomuce in Poland was located in Praga, a suburb of Warsaw, and was callerl the Praga Hospital. Lenua II. Denny was heald murse.

Northeast of Warsaw was situated the Russian-Polish eity of Vilua, where the Polish Arny opened on March 1!), 1:20, a military sureical hospital. The American lied Cross Commission for Poland furnished expipment for this hospital and

For a complete acrount of the campaign against typhus in Poland, see the linlletins of the Lenagle of lied Cross Sociedies, 1919-1920, Vol. 1. 


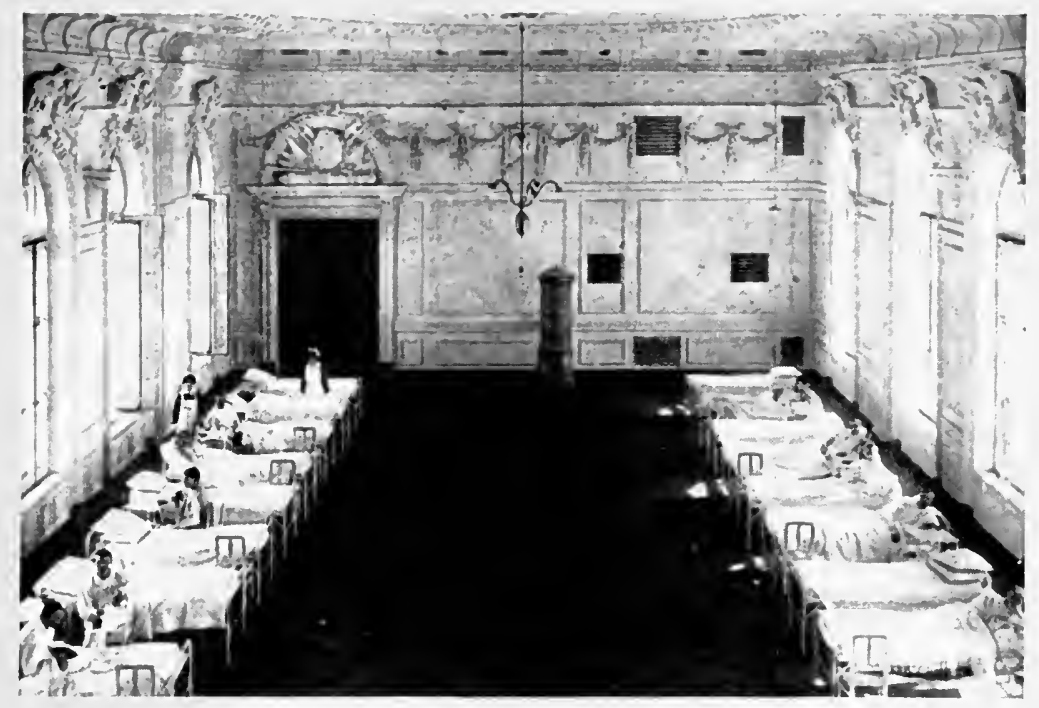

A ward of the Vilna Military Surgical Hospital, Vilna, Poland.

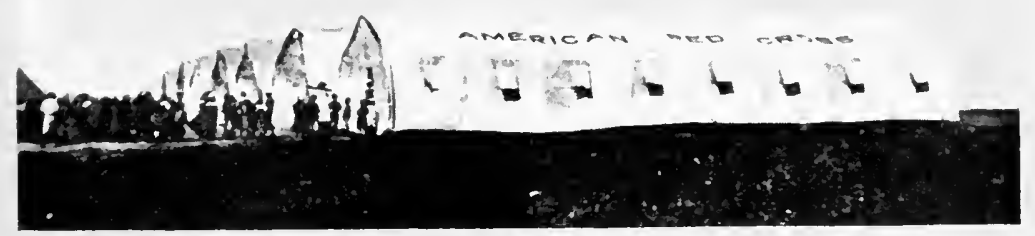

The American Red Cross Orphanage at Liskow, Poland. 


\section{CLOSE OF 'THE FOREIGN RELIEF PROGRAM 1093}

assigned twenty-seven nurses to duty there with Edith Clendenning as head nurse. The hospital was housed in tents, barracks and a laree and attractive building which had formerly been ocoupied by the Russian Military School. The capacity was three hundred and fifty patients, with an emergener expansion to six lundred.

On the outskirts of Vilna in a large pine forest the Vilna Railroad had maintained (prior to the outhreak of the European $\mathrm{War}$ ) a hospital for the benefit of its employees. The large main building had been subsequently wrecked and was not usable, but the hospital establishment ineluded detached cottages wherein infeetions eases had been treated. The commission took over and repaired seven of these, assigned an Amerian Red Cross surgeon and seven nurses to duty there and assisted the Vilna Railroad in the maintenance in these cottages of a hospital of fifty beds. Like the Vilna Military Surgical Hospital, this institution was rom under dual management, with 1)r. Machersky, the head phrsician of the Railroad of the Vilna District, coöperating with the American Red Cross offieer, C'aptain J. J. Donovan. Louise M. Water was the head nurse.

Southeast of Vilua was the former Russian province of Minsk and in it was loeated the eity, Minsk. Tlere during the spring and summer of 1920 Field Unit No. III operated; Marie Suchowska was the nurse in eharge of several Polish aides and muler lore direction they earried on a eertain amount of district nursing and distributed food and elothing in the Minsk district.

Sonthwest of Minsk was Bialystok, headquarters of the American Rerl cross in the Department of the East. Here the commission had established early in Jannary, 1920, an orphanawe in the main barracks of a former post of the Russian drmy and by July 1 had collected $7 \times 3$ children there. The ehildrents foud was largely supplied by the Polish Governmont and the Anerican Relief Association, with supplementary rations from the warehouses of the rommission. (lasses in carpentry, plumbing. coobhling and sewing for hoys and girls were oreanized and school gardening was encouraged umler the anspiens of the Ameriean olmior Red Cross.

In eommection with the Bialystok (Opphanage, a lospital of

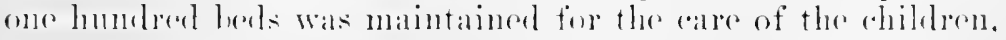
"who ane always below stamblard upon admission," wrote Miss 


\section{HIS'TORY OF AMERICAN RED CROSS NURSING}

Hay, "and suffer from tubereulosis, pink-eye, measles, mumps, whooping cough and malaria." On June 25, 361 children had been eared for in the hospital, while at the dispensary 2224 treatments had been given. The nursing staff consisted of fifteen American Red Cross nurses and the head nurse, May L. White. In addition thirty-five Polish aides were on duty in the orphanage. Twenty-seren of them were employed by the eommission and nine by the Refugee Bureau of the Polish Gorermment, which coïperated with the Ameriean Red Cross in the maintenance of the orphanage.

At the Orphanage Hospital, instruction was given to Polish aides in elementary mursing. The textbook in Hone Hygiene and Care of the sick was translated into the Polish language and was used as a basis for theoretical teaching. Dr. Laleski, assistant medical chief, supplemented this text by lectures and one of the Polish-speaking Ameriean Red Cross nurses, Doris Wartosky, condueted practical work for the aides in the wards of the Orphanage IIospital.

South of Bialystok on the Bug River was located the eity of Brest-Litorsk. Ameriean Red Cross Field Unit No. II were assigned to duty there early in 1920 and made it the headquarters for medieal and general relief without the district. Eleanor Nettel, an American Red Cross public health nurse, was in eharge of several Polish airles. The work, like that of Unit No. III, consisted largely in the distribution of relief supplies, but Miss Mettel made a constructive step forward by interesting and training her staff of Polish aides and the local midwives in more adequate care of mother and child.

American Red Cross Field Unit No. IT was assigned to the town of Tarnopol, situated soutleast of Brest-Litorsk in Galicia among the foothills of the Carpathian Mountains. Tarnopol was in 1!20 a city of some ten thonsand inhabitants and harl suffered considerable destruction and consequent demoralization cluring the war. Fichl Tnit No. IT was engaged in distributing relief supplies there. Alice A. Tanguay, an Anerican lied ('ross nurse, wals on duty and hat in charge the three Polish adeles. Two hospitals were maintained at

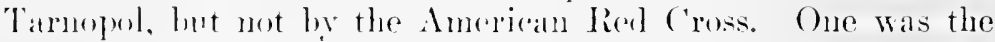
Infertions Ilospital. which "in eleanliness and care of the

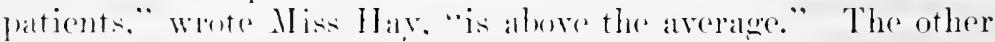
Wals the Mmineipal II sepital, which was muler the direction of Sisters of Sit. Vineenent de P'anl. 


\section{CLOSE OF THE FORFIGN RELIEF PROGRAM 1095}

Southwest of Tarnopol and situated among the Carpathian ranges was Stanislau, to which Field Unit No. VI was assigned. A large typlus hospital was maintained here by the local govermment and sent cases northwest to the Typhus Research IIospital at Warsaw. 'The services of the American Red Cross nurse and Polish aides of Unit No. VI were utilized, however, for civilian relief work.

The Galacian eity of lemberg (Lwow), which was northwest of Stanislan, was the headquarters for the Anerican Red Cross in sonthern Poland and the warehouse base for activities in Stanislan and Tarnopol. Here Panline H. Wilkonski, an American Red Cross Polish-speaking murse, was on duty but her work was chictly in the field of eivilian rather than medical relief.

West of Lemberg was located Kakopane, near which the Countess Zamorska had established some twenty-five years before the war, a School of lonestic Science for Polish Girls. In her report of a tour of inspection made in Poland in May, 1920, Miss Hay wrote:

This school is located about four kilometers from Zakopane, among the beantiful foothills of the Carpathian Mountains. The main building is a three-story one and there are also detached rottiges. The houselieeping is that of the thriftiest housewife.-serupulous reanliness, thoroughness and thrift are apharent everywhere. Dairving, poultry raising, gardening and agriculture are included in the three years' course of training.

"One must wit and rooking is necessary" the Countess Zamoysta neer to saly, "therefore every woman should know how to rook. One must have rean surromulings, therufore one nust be taught how to make the home dean and orderly and to kere it so. ()ne must have rean (lothes, so one must learn to wask and iron.'

With practionl idlals such as these, the Comntess and her daughter have wathlisherl a conrese of training of great benedit

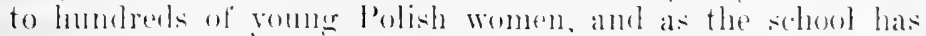
always been truly lorish in spirit. it has herome a fosteringe center for ardent patriotiom and leser for Poland.

On May 1, 1920, Fuily Skorupa, one of the ton murses of

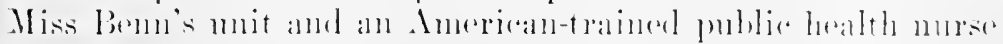

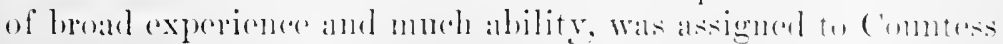




\section{HISTORY OF AMERICAN RED CROSS NURSING}

Zamoyska's Sehool to organize and conduct classes in Home Hyriene and Care of the Siek. Miss Skorupa had herself been graduated from the school before she had come to the United States, so her assignment there was a particularly happy one.

Miss Skorupa translated the Delano textbook on Home Hygiene and Care of the Sick into Polish and nsed it as the basis for her instruction at the school. The course was eagerly received by teachers and pupils alike. Two of the teachers received special instruction, with the view of preparing themseives to give the course in the event that the Ameriean Red Cross nurses might be withdrawn from Poland.

West of Zakopane was located Cracow, a Galacian city which boasted a municipal hospital of fifteen hundred beds. In connection with this institution, a group of Polish women, among them Miss Epstein, had endeavored ycars before the war to establish a sehool for murses, but the plan had met with scant success, if judged by Anglo-American standards of nurse education. Early in the spring of 1920 , Stella Tylski, another Polish American-trained public health nurse of Miss Benu's unit, had been loaned to the Municipal Hospital; she had gone on duty in the School for Nurses and tried to do what she conld. Of the conditions of porerty and misery which existed there in May, 1920, Miss Hay wrote:

We visited the medical, gynecological, obstetrical, children's and eve and ear departments. The medieal and surgical warls are large and light, but in them exist frightful conditions of overerowding.--two adults to every bed even in the most morean eases. There is space for more beds, but there is no money with which to purchase them, or, for that matter. any other supplies. One likes to picture the heavenly transformation that could he brought about here with a minimum of supplies and an arlequate nursing personnel.

The grvecological department is located in one of the oldest parts of the indinling. clirectly under the dormer root. Crowled as it is with pationts in intense suffering. dirty. with uo mursing ale one wonders how any benefit could ever be found here or how any surgeon rould daily face such desperate conditions.

The obstetrical department is in a higger and lighter room. but is so rewded and so destitute of supplies as to be truly tragie. "Clean" obstetries would seem an imposibility. One shuddered with stmpathy when they weinherl the naked little habies. one after another, in flue colid motal sale pan! The 


\section{CLOSE OF' THE FOREIGN RELIEF' PROGRAM 1097}

nursing service is under the Sisters of St. Vincent de Paul,good and patient women but powerless to cope with the many difficulties. The nursing care, except for that coming from the Nursing Solool, is given by domestics of the most slatternly and indifferent type. Miss Tylski states that the patients and beds throughout swarm with vermin, that when handages are removed unspeakably bad conditions are rerealed. ...

In these departments and under such conditions, the student nurses browse alout in seareh of whatever seraps of nursing knowledge they may chance to find. Miss Tylski has done what she could to help them, but any good influence or careful lessons from her are likely to be lost in the objectionable conditions abounding everywhere.

On .June 15, 1920, Miss Benn resigned as chief nurse of the Ameriean Red Cross Commission for Poland and was sueceeded by Miss Mathews, formerly head nurse of the Typhus Research Hospital.

Such were the nursing activities of the American Red Cross in Poland during the spring and summer of 1919. National Inadpuarters and the Commission for Europe were turning their attention from the widespread distribution of emergency relief to the development of a more permanent and constructive program. One of the major phases of this constructive program included plans leading toward a better appreciation in foreign countries of the value of the professionally-trained nurse, and a pioneer attempt along these lines was lanuched in July, 1920, at Warsaw. The Polish Red Cross Society maintained there a hospital wherein it gave, after the eustom of other eontinental Red Cross socedices, a three months' course in the theory of militury nursing to yomg women who were ealled Polish Red Cross "walr aides" and who were subsequently assigned to service with the Polish Army. In July the eliss under instruetion at the Polish Red cross Hospital in Warsaw mmbered 10:3 students. Madame Ioljukorska, the director of Nurses of the Polish Red cross Hospital, ealled on the Chief Nurse of the Commission to assist her in giving more thorough preparation to these aliles. Mrs. Jokaitis and Praxeda Franczak, a Polish-spoaking Anerion lied Cross nurse who had gone overseas in Miss Benn's mut, were assigned to duty there and tried to develop an elementary rourse similar to that in Home Hrgiene and Care of the siek. The attempt was not an unquali- 


\section{HISTORY OF AMERICAN RED CROSS NURSING}

fied suecess. The American nurses went into the wards of the Polish Red Cross Hospital, cleaned them and gave bedside care to the patients, but this service resulted in loss of prestige for the Amerieans in the eyes of Polish aides and patients alike. While the actual eare of the sick was regarded by the American nurses as dignified and altruistic the Poles regarded it as degrading menial labor fit only for domesties. Thus the American nurses could maintain little diseipline and their endeavors to provide instruetion through theory and actual demonstrations of nursing technique were received with seant enthusiasm.

Early in August, 1920, the Polish Armies met with military reverses. The Soriet Army of Rnssia invaded Poland from the north. On August (;, Colonel Olds eabled National Headquarters that "owing to the critical situation in Poland, thirtyseven nurses were immediately released. . . Thirty-five others are being lield in Poland for any emergency. Future nursing service in Poland," conchnled the cablegram, "is stationary." On August 11, the Red Guard ent the DanzigWarsaw Railroad and three days later began to elose in about Warsaw.

The military crisis wiped out Ameriean Red Cross medical and nursing relief in northeastern and central-eastern Poland and cansed the evacuation of personnel and supplies from Warsaw to Cracow. One of the picturesque ineidents of this withdrawal was the removal of the orphans from Bialrstok. The orter for immediate evacmation allowed Miss Mathews scant time for preparation. She applied at once to the military authorities for transportation and in spite of the traffic eongestion and the great need for rolling stock, they allotted her fifty-one freight cars. Into these all equipment which conld be moverl. rlothes. fond. eots and medical supplies, were placed and lid ty the thomsand ehildren. Two nurses were assigned to earh rar full of rhillren. During the four days' trip southward throngh the panir-stricken enmtry-side food was sroved from an Ameriean Red Cross eanteen car attached to the long (ralcollation train.

Their destination was the village of Liskow, near the sonthwestern border. When the romgsters arrived, there were not honses enomeh in Liskow to shelter them all. It was a warm midrummer night, so Miss Mathews had the eots set up in the fields, and the young Poles rolled up in their Anerican 


\section{CLOSE OF TIIE FOREIGN RELIEF PROGRAM 1099}

Wankets and slept in the open. The next day temporary billets for them were foumd in Liskow and in adjoining hamiets until the ereetion of a new orphanage andel be completed.

The Soriet Army, howerer, hat loess mable to hold their gatins in the face of the salvare l'olish romntereffensive. By Alugust 19 the Poles hatel romted the lied Ginard from the Warsaw I bistrict, had taken 10,000 prisoners (atecording to news dispatches) and recovered territory in east rentral Poland inchuling Brest-Litorsk. Huring the late days of Angust, the victorions Polish Amy drove the Soviot Army completely ont of Poland.

Early in Angust, the Ameriean Red Cross commission pansed in their evalenation to recommoiter in Cracow and there the nurses begeded so hatrd to be allowed to remain in Poland rather than to be sent on to Paris with the rest of the American women personnel that thirty of them, with Miss Mathews as their chict, were permitted to stay. When Warsaw had leeen threatened, vast anantities of Ameriean Red Cross supplies in the Warsaw and Bialpestok distriets had been moved to Cracow. Five railsoal trains were seconred ly the eommission then in Cracow and were loaded with food and elothing. Canteen and dispensary ears to which doctors, nurses and other persomel had been assigned, were attached to the trains and aich train was started back from Cracow at different tangents into Poland. The trains stopped at towns and rillages and fod and clothed the refugees and native population and gave first ald to many who had been womded in the sovet advanee. "The reports of these railond mits." stated the Ammal Report for the vear 1921. "show that they ared for more than 1000 sureical cases weekly and fed a maximum of 750.000 persons in a single month."

The eraenation of hespitals and the subsequent withdrawal of Ameriean Red Cross persomnel from Poland to Cracow marked the elese of the plan for nation-wide medical relief for Peland whidh had heen contemplated ly the commission. The nurses and representatives of other types of personnel were not returned, howerere to Paris. but were kept in (raleow and

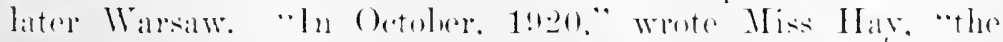
numses aletivities in Polamel were largely restricted to clals-work in hone morsing in ('ranow, Poson, Kornik and Warsaw. In

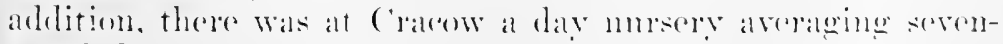

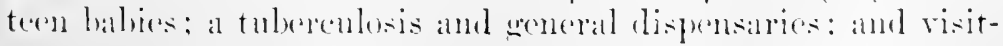




\section{HISTORY OF AMERICAN RED CROSS NURSING}

ing nursing among the families of dispensary patients." The development of the child health program which later took place in Poland will be described in a subsequent section.

The second verdant field for American Red Cross emergency relief during the post-Armistice period was, it will be remembered, to be found in the Balkan States. In October, 1918, Miss Hay had been released from her work as director of the Bureau of Instruction at National Headquarters and with two nurses, Marietta Wilsey and Caroline E. Robinson, had sailed early in December for France. In London, Rachel Torrance had joined the group as Miss Hay's assistant and the four had proceeded to Paris. Miss Hay there organized a unit of some fifty-three murses who were then being released from duty with the Army and the Commission for France and with them had gone to Rome. Colonel Anderson, the commissioner for the Balkan States, had succeeded in recruiting persomnel for his staff and in bringing into the Balkan States approximately $25,000,000$ pounds of supplies which consisted largely of food, hospital supplies, clothing and agrieultural implenents.

In January, February and March, Headquarter's for the Commission for the Balkans was located at Rome; in April, they were transferred temporarily to Salonika, Greece, and later to Belgrade.

Previous to the arrival of Colonel Anderson and his staff at Rome, two American Red Cross commissions were already operating in the Balkans but were engaged chiefly in civiliain rather than medical relief. The first of these, the Commission for Serbia, of which Dr. Edward W. Ryan was in command, had been engaged in distributing supplies there since the spring of 1917. The second, the Commission for Greece, of which Lieutenant Colonel Edward Capps was in command, had arrived in Athens on October 23, 1918, with large supplies of food and elothing. No American Red Cross murses, however, were on professional duty with either of these eommissions: Miss Gladwin had assisted Dr. Ryan in the distribution of material relief in Serbia but returned to the United States (arly in 1919.

The organization of the Commission for the Balkans followed in miniature that of the Commission for Europe: Colonel Anderson and the heads of varions departments who formed his staff had charge of the "enrolhnent of personnel, the aeduisition 


\section{CLOSE OF THE FOREIGN RELIEF PROGRAM 1101}

and movement of supplies to the varions ports and similar service outside the several countries . . . but on arrival of persomnel and supplies at the ports, they eame under the control of the eommissioner or mit for that territory, which had dirent charge of the work in its given state." 2 'The line of communication between the varions commissioners to the Paris Oflice and National Hcanlpuarters was throngh Colonel Anderson and for the Nursing Service, through Miss Ilay.

Miss Lay and her morses arrived in Rome in Jamury and immodiately the tiftr-the murses were divided into units, each with its hearl nurse, and were sent into the Balkan field. Additional nurses wore assiened to service in the Balkans early. in 191! by Miss IIall and Miss Fitzgerald and on Jume :30, 1919, the inmsing staff numbered ninety-eight nurses who were working moler six mits assigned to Montenegro, Mlbania, Greece, North and Sonth Serbia and Rommania. These muts were attached earle to the staff of the commissioner of the country to which ther were assigned and the head nurse worked in as close coöperation with the commissioner as conld be established.

Such, in Innary, 1919, were the organization, the persomel and the facilities for development of an extensive American Red Cross relief program, both medical and general, in the Balkan States. Ot the standards of mursing eare which existed there, Miss Ilay wrote her report of the Nursing service of the Balkan Commission, Novenber 1, 1918, to September 30,1919 :

The trained murse and good nursing have scarcely been known in the Balkans mutil the recent wars and the influx of foreign mursing missions so splendidly demonstrated their value. ${ }^{3}$

Conditions in Balkan hospitals have been mo:t inarequate and the care of patients deplorable. . . The murwing service, always tritling and incidental. has derenerated still further from the ine reased anomut of work an! the sureity of helpers. Where with fifty patients one nerer planned to grive a bed bath or do onglit to prevent a bedsore. how comld any such

see Annual Repert, 1919, p. 124.

${ }^{3}$ For an aceonut of the foreign units sent between 1914 and 1918 to

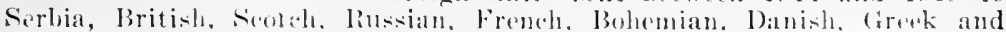

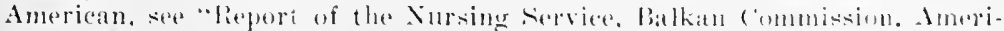

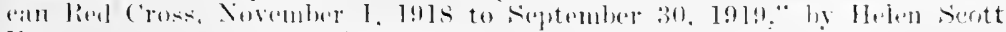

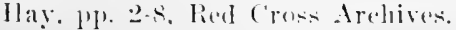


extraordinary activity be expected with five hundred patients? Medical students, both men and women, feldchers (men with a limited amount of medical and hospital training) and midwives were able to assist with operations and dressings, to preseribe simple remedies and to taie temperatures, but none of these had any mind for nursing tasks themselves. Neither did they know or desire good nursing from the helpers in the wards, who were men and women of the lower elasses and who clattered about their hospital duties without training or supervision of any kind. . . .

For the ills of the neighborhood, the boils and malaria and rheumatism, there are the old babas, or grandmothers who incline to squash poultices. No one in the average Balkan village ever bothers himself or his neighbors with questions of prevention or any public health propaganda.

The big task, therefore, in our medical relief work is far less one of dressing so many wounds and washing so many babies, and caring for so many tuberculosis patients, as it is to ereate among the people a real appreciation and desire for an improved order of living: for the sanitary hospital, for the skilled care of the typhoid sufferer, for the right eare of well babies and the like. Neighborly assistance and foreign skilled supervision may be desirable for some time to come. But when the people themselves have been educated, through the example of doctors and nurses, to the point of wanting this improved order of living, on that day they will be able themselves to carry on admirably the desired activities.

In all health projects, the trained nurse or trained woman worker is essential. . . .

This accomt of American Red Cross nursing service in the Balkans during the period previous to the adoption of the policy of child health mits, a period lasting from In Inuary to Norember, 1920, will begin, for geographical reasons, with a brief account of the mursing service in Montenegro and wil! continue with aceomts of that developed in Albania, Greece, North and South Serbia and Rommania.

The Commission for Montenegro arrived late in Jannary in Podgoritzal, the largest city in Montenegro and one which had a population of about fourteen thousand, and established its headquarters there. The first Ameriean Red Cross commissioner for Montenegro was Major Elliot G. Dexter' he resigned on April 2s, 1!19, and was suceeded by a Californian, Major Henry R. Fairelomgh. The first heal nume of the mit of fome- 


\section{CLOSE OF THE FOREIGN RELIEF PROGRAM 1103}

teen nurses in Montenegro was Georgia B. Greene. She was suececeled on April 15 by Lena Margaret Johnson.

In: working in a country as isolated as Montenegro, where supplices had to be brought in ly camion or on the backs of mules or porters when the roads grew impassable, the Ameriean Red cross personnel naturally met with primitive living conditions. The plan adopted by the commissioner of such a group was to establish upon arrival in the field of future activities an Amerian Red Cross persomel house, equip it with hed Cross supplies and charge one of the personnel witl the luty of maintaning the household in eleanliness and providing adrequate meals. Sometimes this housekeeper was a nurse, sometimes a social service worker, but the fate which had overtaken the Geveli Units in 1915 in Serbia had made National Headquarters especially charge each commissioner with the responsibility of safeguarding the health and welfare of his persommel. Another plan used in the Balkans was the rstablishment of Red Cross central mess and recreation rooms. The difforent nembers of the personnel were then furnished, nsually throngh arrangements by the Govermment of the comtry to which they were sent, lodgings elose at hand. They then lived in these lodgings and went to the Red Cross headquarter's for meals and diversion. Snch a plan was established at Polgoritza and was more or less satisfactory. "Two of the nurses," wrote Miss Hay, "were quartered in honses where a pig wals also a denizen. The others were very comfortable."

The American Red Cross established in Poderitza a hospital of sixty-bed capacity. This was first located in an old military barracks. hut was moved in April to the former residenee of Prince Mirko, just outside the city. The lower floor wats used for persommel, the secome one for operative and sick medical cases reguiping nursing care and the third for conval-

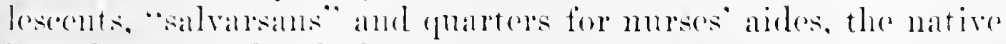
housckecpere and oderlies. The house was lighted by kerosene lamps and wats heated by wood stoves but had no pumbing water. ()f the native aldes, Miss Johnson, the chief murse in Montenegro, wrote:

Wreserest three young intelligent-looking girls of ahout cighteren and tow them into the hospital. They learned some

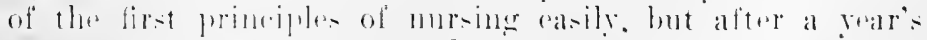

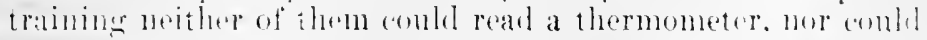




\section{0+ HISTORY OF AMERICAN RED CROSS NLRSING}

we trust them to carry out orders unless we were there to see that they did it. One reason for this is that the word of a man is a command, so when a man patient insists on getting up immediately following a laparotomy, the aides in fear and trembling let him, aud when an hour previous to an operation he madly calls for food, they dutifully get it. Now both they and the patients, however, are gradually beginning to learn that an American woman's word, if she is head of the ward in which he happens to be, is as good as that of a man.

In connection with the hospital the commission maintained a lively dispensary where from fifty to ninety patients were daily treated. A dental department was an active phase of this service. One murse was on duty at the dispensary and two others. Mabel Nelson and Sara MeCarron, did risiting mursing among the families of dispensary patients. The eity of Podgoritza was bisected by a small river into the "old" and the "new" towns. The "old" town inchuled a large Turkish settlement and there the murses found conditions which seemed unbelievably wretehed to the Oeeidental relief worker. Miss McCarron wrote:

When we arrived in Podgoritza on January 26, 1919, it was very cold. There was no coal and little wood. . . . Six days later I started out to do district work and $m y$ first patient was a barl nephritis ase. I found her almost on top of the stove; they do this to keep warm. The family was in fairly affluent circumstances and could provide the nourishment she needed.

We visited from twenty to thirty families each day. My district was in the "old town." the Turkish section, or "Turkey-town," as we called it. It was five hundred year: old. When we first arrived. the spirit of the people was at low ebh and they were slow to gran the idea that we were there to help, but when they did, every door was open to us, ('hristian and Turish alike. The poverty was stark and terrible, no fires in some of the lomes, the people santily dad: dirty: no soap; hungry. Many had no beds and those who harl mattreses to lay on the dirt floors were considered well off. ()thers. desperately poor. had only a slip of burlap to lie on. () h. it was heart-rending:

One case, a wilow with an cightt-year-old girl. was suffering from an infecterl foot. and I got there at twilisht. After I had rosed the boor. Which was the only means of light they had. I could not sere the patient hubled in a corner on a 


\section{CLOSE OF 'THE FOREIGN RELIEF PROGRAM 1105}

bundle of filthy rags, reeking with pus from the infeeted foot. The wound had been discharging for two years, the patient told me. We sent her to our hospital for two months. When she rame home, she found that the walls hall been whitewashed, a small hole opened in the ceiling above the fireplace for the smoke to exrape, an army cot, sheets, blankets and food daily until she could get work.

Early in March, the two public health nurses in Podgoritza started school mursing. Miss MeCarron wrote:

The five hundred children in the prinary school were barefooted, illy clad and tonely. The school was not heated in any way and they sat there and shiverenl, too cold to study. I inspected them every month and on my first inspection found over two humbed ases of pediculosis; numerous ones of scabies; some impetigo and nephritis; no trachoma; one case of aente conjunctivitis and on a later inspection two of farus. I succeded in having thirty-one bad head cases shaved at once, more than I could ever accomplish at home in ten months. The principal and teacher were splendid in their cooperation.

Spine and eye cases went to the dispensary for treatment. also pediculosis victims for petrol and lard. Talks on care of the teeth and month were given by Dr. Wolf, our dentist, and tooth brushes, handkerchiefs, covers for drinking glasses and soup were distributed.

All tuherculosis, mahnutrition, scurry, convalescent pueumonia, bonchitis and influenza cases in the district were referred to the dispensary every morning at nine oclock and reseived evaporated milk, jam, eggs and any other article of diet the doctor ordered.

A large somp kitchen was maintained at Podgoritza and "feeds nearly one thousand people daily," wrote Miss May, "with a very palatalle thick somp prepared with vegetalles and flavored with harem. For Mohammedans a similar soup is furnished which contains regetable oil instead of bacon. 'The daily foos ration is a liberal half pint of sonp and one-sixth of a kilo of breand and nuany of the recipients sit down on the sirlewalk and at it immorliately. One lay Mr. Turekerman,

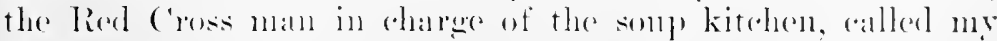
attention to two rhildren who, while waiting for their sollp, hat pieked me a bone from the gatter and were voracionsly guawing at it." 


\section{HIS'TORY OF AMERICAN RED CROSS NURSING}

North of Podgoritza was located Niksie, a city of some fire thousand population. There the commission established a hospital of thirty beds and maintained a dispensary and visiting nurse service; Emily Chaney, Emma Robbins and Edith Burgess were on duty. Two of these nurses also assisted in conducting the somp kitchen "where we saw the same ragged and underfed people," wrote Miss IIay, "and many children shivering in the cold wind which comes down from the snowy mountains."

The Podgoritza unit endeavored to extend its work to Kolashin, a mountain town northeast of Podgoritza, and nurses and other Red C'ross personnel were sent up duriug the spring of 1919. Thronghont Montenegro, the American Red Cross hospitals and dispensaries treated many peasant farmers and in Kolaskin the murses tried to do rural visiting nursing. Local bandits made such work unsafe, however, and finally the unit was recalled to Podgoritza.

South of Podgoritza was Cetinje, capital city of Montenegro. It also had a population of five thousand. The American Red Cross IIospital which was established there was located in a building known as the Prince's Palace. Elizabeth Mitchell, the nurse in charge, finally transformed the Palace from a dirty and inadequately equipped hospital into one which wats attractive and at least sanitary. In comnection with the hospital, a day nursery for children of working mothers and another for tuberenlons rhildren was developed.

At Cetinje a Montenegrin women's club had organized the only orplanage which existed early in 1919 in the small principality. Miss Mitehell berame interested in it and the commission furnished food, rothing, bedding and tooth brushes (and considerable arlviee in the use of these articles) to the rageged yet lapply vomngsters.

One of the American Reel Cross nurses at Cetinje was Bernice Brady, a public health nurse. She wrote:

Cetinje dons not lork as if it had five thonsand inhahitants, but practically every room houser an entire family. Naturally. sanitary conditions wore impossible. We often ejacoulaterl, "What a hardy race." hut we only saw those able to survive the crowerl homsing. the sarcity of fuel, the lark of dothing and fool in winter snows and cold spring rains and hot dry months when water is of necesity rationed. The 


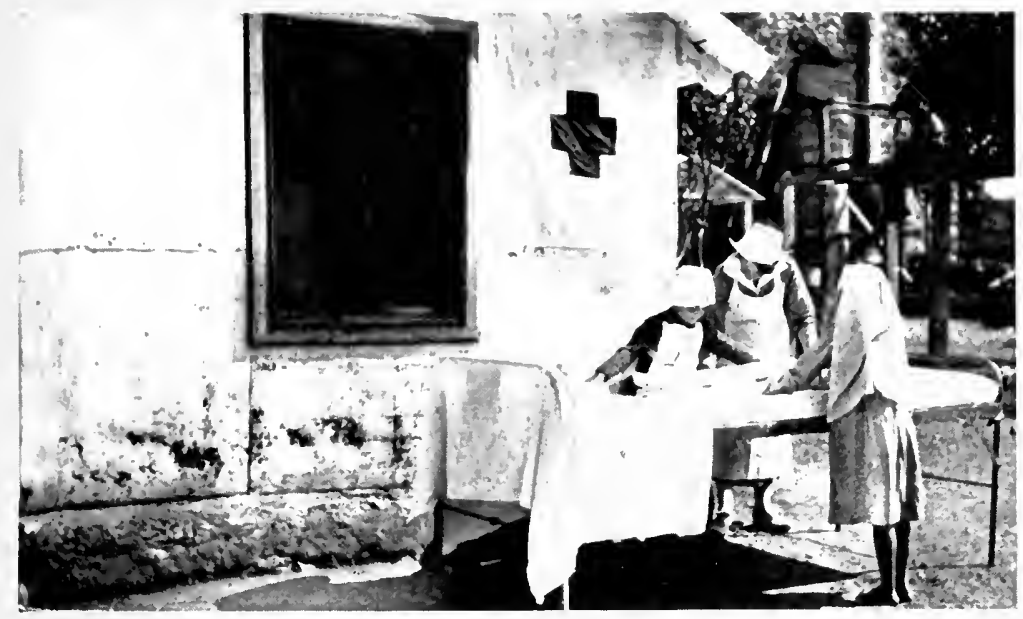

An American Red Cross murse. Teannie Frasier, instrueting two pupils of a Little llothers" (dass in elementary nursing procedure, Podgoritza, Montenegro.

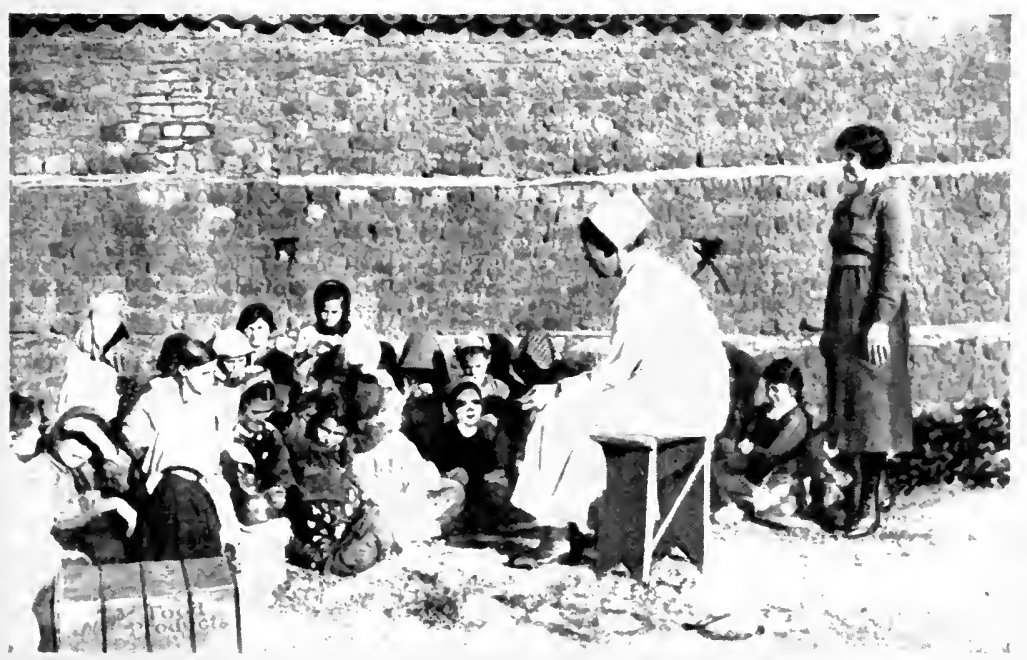

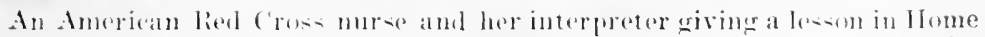
Hygiene and Care of the sick to a group of refugetes in Tirana, Alinania. 



\section{CLOSE OF THE FOREIGN RELIEF PROGRAM 1107}

country is monntainous and unproductive, rich in only one thing,-history and tradition. (The Albanians say that St. Poter was born in a waysile hovel between ('etinje and Podgoritza, but do not explain his sulwequent change of residence.) 'The story of Montenegro is one of constant fighting to retain their freedom and they boast that they have never been ronquerest.

The men are used for the Army and the women do practically all the manual haloor. The birthrate is low and the infant mortality high, to judge from observations. Practically no records are kept and birth registration has yet to be introducel. Aside from a few of the upper class, wonen have little or no eduation. Willows predominate and, as there are no industries and they usually have several small children to care for, they carn a meager living by buying and selling in a pedsler faslion. journeying over the mountains on foot and returning with supplies on their backs. They are often alsent for fonl days and in that time the children at home fond for themselves.

Many of the poorer people live in stone hovels. When they have wood. they build their fire on the dirt floor and huddle about it in rags such as one camot inagine in ones wildest dreams of porerty. Even with all the patches, many are sarcely covered.

Whereser Miss II ay and leer nurses went, they earried with them the ideas of sanitation and orderly living, which are the fonndation stones of somul nurse edueation, and they strove to pass these principles on to the natives with whom they worked. Jontenegro in 1919, however, was not a fertile ficld for such ideas to talio root. At Niksie, Miss Chaney and Miss Robbins were allo to instruet their native aides with considerable success, lut the brave plans for introdueing the elass-work in Jome llyegrene and ('are of the siek which were initiated by Miss Ilay and the "Kole soreicty" a women's organization at Porlenoritza, diel not dovelop.

The Amerian lied Cross Commission for . Mlbania, of whide

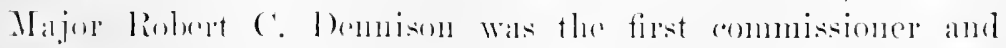

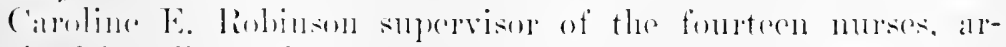

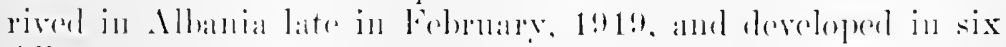
Alhanian aties the hospital, dispensare, visiting nume and civilian roline servioe which formed the chief phases of Americam Red cross peliof ihrough the ballians. 


\section{HISTORY OF AMERICAN RED CROSS NURSING}

To Sentari, the most northerly and the largest city in Albania, one of which had a population of about thirty-two thousand, the eommission sent a nnit of eleven Ameriean Red Cross workers. Four of these were nurses, with Ella McGovern as head murse. The eity boasted of the only hospital in $\mathrm{Al}-$ bania and to it the commission gave supplies and raised its eapacity to one hundred and thirty-five beds, instead of dereloping a separate institntion. Need existed, however, for a dispensary, so the commission established one which by July 1 had treated 2606 cases.

The visiting nursing at Sentari which was first developed by Viola Nohr and Leslie Wentzel was comparatively suceessful. By July 1, the murses had made 1349 calls. Scitari maintained an orphanage for thirty girls and to it the eommission gare food and elothing. Mfiss MeGovern leetured there on simple questions of hygiene. Similar health talks were given by her in the eity sehools and in the American Red Cross sewing rooms, established to give training and employment to women.

Sonth of Sentari the Mati River flowed to the Adriatie Sea and the early spring rains swelled it into a torrent. During the Anstrian invasion in 1915, the only bridge spanning it had been destroved and in 191! had not been rebuilt. Travel was possible only by motor, earts or on foot and the roads were poor. When travelers came to rivers such as the Mati, they had to eajole the native ferrymen to convey them across at cost of many words and numerons coins. Tevertheless. the commission strove to establish dispensaries in small and isolated Albanian towns and with true zeal, the murses and other workers started out over the rongh but always picturesque and often beantiful momtain $z$ salds. Sueh a town was Kroyal, where Marion Echternach and Sarah Buchamnan clid risiting nursing and were on duty in the Ameriean Red Cross dispensaly. Mis: Buchannan's report eontaned an interesting description of the quaint life:

On April s. 1919. after three hours of mountain (limbing, we fomml muredres on the silfe of one, in the little village of Kroya, the home of the Mllanian hero. Nkender bey. The streets were ton narrow and rocky to allow our camion to come into the town. so we walked. . .

Onr house was a typical rural Albanian one: although it was new. it was made of old material. When we arrived, men 


\section{CLOSE OF THE FOREIGN RELIEF PROGRAM 1109}

were laying a concrete floor in a large room on the ground floor, but it never dried. We had two small rooms above for the four of us, the doctor, the interpreter and the two nurses. Miss lichternach and I shared the same room and used it also for kitchen and dining room.

We rooked with charcoal on a three-legred affair called a mongal. We followed the Mhanian enstom of sending our meat and pudking out to be haked. One day I attempted a pie: in lieu of a board, I used a large sheet of paper and my lolling pin was a milk bottle. Marvelons to say, the pie was voted a success.

In a fair-sized room in the next house, we established our dispensary, and during six weeks treated thirteen hundred. Many skin diseases, tuberrulosis of the hone and gastric conditions were prevalent. The stomach trouble we attributed to the almost exelusive diet of pooriy baked corn bread and sour milk.

Lnfortunately our supply of drugs was limited, but we had quinine, phenacetine and epsom salts. We made cough sirup, nsing as a basis sugar and lemon juice. 'The people in the village were aboolutely drug famished; the Lustrians had taken everything and nothing hat been imported. Some came and sail they were not sick lut wanted medicine for the time when they would be. Others reported having been ill five or ten years ago as a pretext for hegging medicine now.

In another town where there was a pharmacy, the doctor gave a written prescription to a man and explained that in return for the paper, if presented at the pharmacy, he would recove six pills and that he must take one of these every day. On the sixth day, the doctor was much surprised when the pationt presented himself with a small scrap of the presoription, and the reguest that he might receive another. On questioning him, the doctor found that he had taken one-sixth of the palper each day. Iost of our droges were in powelered form and we foum that the patients invariably took paper container as well as the powder.

Taken as a whole, the people of Kroya were appreciative amel self-respecting. "Wr have no legerars," wrote Miss Burhannin.

Somth of Kroya was Tirana, an inacessible hill-town of twelve hundred inhahitants. "The only mole of travel to this

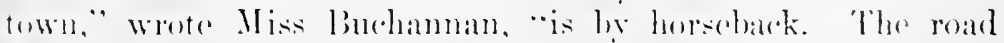
wats in many places the merest trail, stere and rowk, with a 


\section{HISTORY OF AMERICAN RED CROSS NURSING}

precipice on either side, so that one false step of your horse would be fatal."

Six Ameriean Red Cross nurses, including Miss Robinson, the head nurse in Albania, were on duty at Tirana, some of them in an Ameriean Red Cross hospital of thirty beds. Miss Buchamman at one time was among these and she wrote:

We had four native women of the gipsy class for assistants and we were able to teach them quite a bit. The women of the upper classes cannot be induced to come out of their sechusion.

The majority of our patients were men, many of them gunshot cases. These mountaineers are constantly fighting over some ancient family feud.

At Tirana, the American Red Cross maintained an aetive dispensary service. 'Two of the nurses did distriet work. An interesting development of the Tirana dispensary was a mobile unit which operated in the hill-towns in the vicinity. At Singere, this mit treated $3 i t$ patients in four days. Lney Joaquim was the publie health nurse who aceompanied the mobile dispensary on its journering. The unit at Tirana also furnished supplies and medical and nursing service to a loeal orphanage.

Westward from Tirana and located on the Adriatic shore. was the capital eity of Mlbania, Durazzo. Two nurses, Barbara Sandmaier and Ėmily Chaney, did some temporary nursing there but were transferred in May to Tirana. Sarah Buchannan assisted there in distributing supplies in March to sixty ehildren who attended a school which was located on a hill above the bomb-wrecked town. "We redressed all the small children," wrote Miss Buchamnan, "but had nothing for the larger ones. The childern were very modest in being. reclothed: some of them showed extreme embarrassment. This modesty in children I have found everywhere in Albania and it is chamming to sece"

Sonthwest from lourazzo and Tirana was the hill-village of Elbasan and there two murses, Annio Slatek and Margaret (rarretsem, did dispensary duty and visited anonge the needy and appreciative Mlbanian peasiants.

From Elbisan, Miss buchamnan went out with a mobile dispensaly to Kavaja and huring the four dars the mut was on duty there, they treated albont there hmolred patients. "Many, 

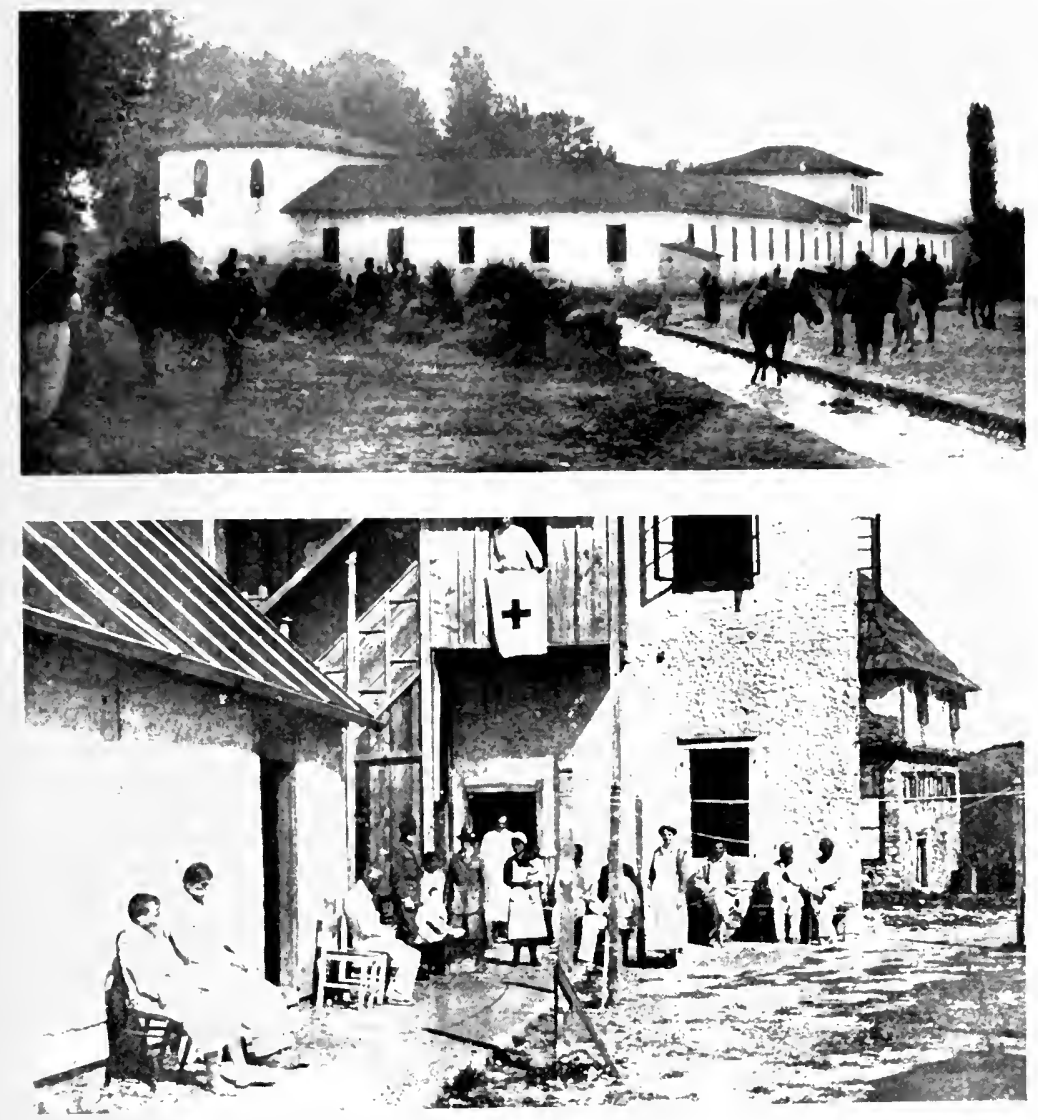

(Above) The open sewers of Tirana, Allania.

(Center) An Imerican lies C'rose dispentary in Albmial.

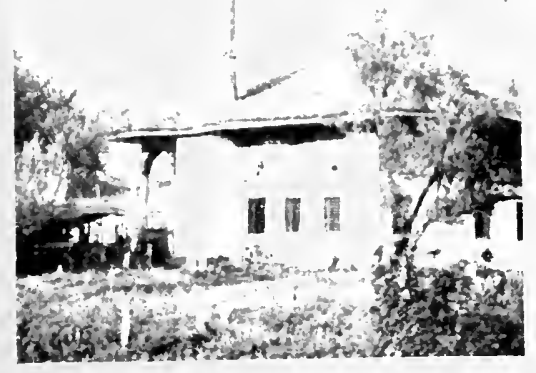

(Lower) A mowifue of Tirana. 



\section{CLOSE OF THE FOREIGN RELIEF PROGRAM 1111}

we felt," wrote Miss Buchamman, "came out of euriosity. We saw the usual amount of tubereulosis and the syphilitic conditions which existed in other towns."

Koritza was the farthest south eity in Albania wherein the commission developed a hospital dispensary and visiting nurse service. Anong its right thonsand residents were many Christians and muncrous Americans and Albanians who had been in the United States. Accorlingly, the American Red Cross work met with suceess.

Ameriean Red ('ross nursing service in Greece was marred by organization diftienlties which rendered the work of the nurses incffective and after some nine months' endeavor, all emergency musing service was discontinued. The Commission for Greece, of which Major Capps was in command, had arrived in Athens in ().tober. 1918. The mursing staff of the commission, as oreanized in the United States, numbered scren murses. Three of them were American Red Cross nurses: Lena Margaret Johnson, chief nurse, Marie Clare Glanber and Mary Margaret Trmon: the other four were Greek murses who had been trained in Ameriea: Marie Zacea, Elene Inglisaki, Marie Kompren and Margaret Chryakis. These Greek women had been sent to America by the Greek Government and were muler contract to render five vears of service to the Greek lied Cross on completion of their training. In the sumner of 191s, arranerements were effereded between Miss Delano, Commissioner ('apls and the Greek Minister whereby the Ameriean lied cross acreed to enroll threse four women as nembers of the Nursing service and send them to Greece with the ermmission. L Fon theil arrival there, they were to remain in service with the commission as long as they were needed and were tinally to be transfored to the Greek Govermment for the fulfillunent of their contract.

The murses arrioed in Atloens in November, 1!19. On De-

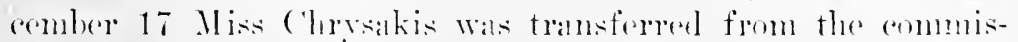

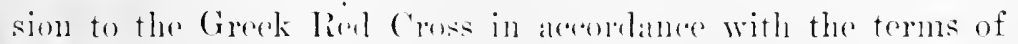
her contrate. The remanining six nurses were assigned to temporary duty, half of them in a cirenk military hepital in

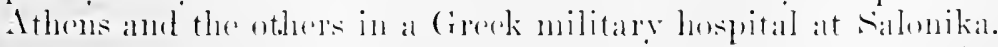

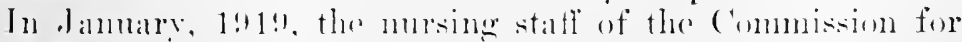
Greene was angmented by the arrival of two additional mits of the Amerienn hed cross nurses. The first unit, which 


\section{HISTORY OF AMERICAN RED CROSS NURSING}

consisted of six of the nurses of the original Balkan unit, with Miss Phelan as head nurse, had been sent to Athens by Miss Hay in Rome. The second unit arrived in Greece ten days after Miss Phelan's group; it consisted of three nurses with Sarah Addison as head. Thus the total nursing strength of the Greek Commission numbered eighteen enrolled nurses.

$\mathrm{By}$ the middle of Norember, 1918, the executices of the commission had outlined a program of general and medical relief work throughout Greece, so the nurses were recalled and assigned to different posts of duty under various members of the Commissioner's staff. The work which they accomplished falls into three prineipal groups; first, eivilian relief among the Greek refugees in Bulgaria and on the Aegean Isles of Samos, Mitylene and Chios; seeond, medical relief in Macedonia, Athens and Crete; and third, health and social survers made on Samos and Mitylene. The eivilian relief rendered by American Red Cross nurses will first be described, beginning with that given to Greek refugees in Bulgaria.

During the last two years of hostilities, the Central Powers had deported many Greeks and held them in Bulgaria. These unfortunates were beginning to come home late in 1918, so the commission established relief stations along the railroad leading from eastern Macedonia into Bulgaria. At these relief stations, dispensary service, food and clothing were furnished to the rapatries. Miss Johnson was assigned to the station at Tirnovo-Sienieu and held the position of chief nurse of the eastern Macedonian district. Miss Zacea went to the station at Dedeagatch and Miss Kouroven to that at Xanthi.

The three nurses left Athens on December 5 bound for Drama, where the British forces gave them rations for two days. Miss Hay wrote:

From Drama, they went on their way in a freight ear, quite empty. Through the ingenuity of one of the Aneriean men, a modicum of comfort was acquired; beds were made from boxes, blankets were tacked up to give some privary. In this (ar, Miss Johnson and two men lived for six weeks and hare they entertained en passant the Bulgarian Minister of War, the commander of the French armies in Greece. the faculty of Rohert College. ('onstantinople, and French, Greek, English and Bulgarian offirens galore.

At each of the three raibroad renters. Tirnova-tiemen, Dedeagatch and Ianthe, quarters were arranged in a house or 


\section{CLOSE OF THE FOREIGN RELIEF PROGRAM 1113}

freight car for a cook-house, a dispensary and living places for the American Red Cross personnel. Needed supplies for the daily distributions were arranged for in cars alongside. Hot somp and bread, or rice and bread were ready when the trains of rapatriés arrived. The task was to get to every person in that sorry crowd that needed food, clothing and medical care. To make sure that no one would be overlooked meant quick and systematic work. All were in a sal state, emaciated, ragged and dirty. With no food for two or three days, sick, weak and cold, they had been huddled together sixty to seventy-five in a car.

In this miserable and destitute company, births and deaths were frequent oreurrences, and one given duty of the Ameri(an Red Cross at each station was the burial of the dead. 'To the new mother were given extra food and such wonderful baby clothes as were not to be hoped for in those days of bitter want.

From Tirnova, Miss Johnson sent a list of patients who had received special treatment or needed further care to Miss Zacea at the next American Red C'ross station, Dedeagatch. After gool food and kindly treatment there, the rapatries went on to Xanthe, where Miss Kouroyen and her helpers gave them needed final assistance before their arrival in Greece, just over the border

By January 11, 1919, all Greek refugees were reported to be out of Bulgaria and the American Red Cross relief stations were closed, with a record of having cared for 49,000 refugees.

The storied isles of the Aegean Sra, Samos, Chios and MityIne were the other scenes where American Red cross nurses did notable civilian relief work. 'To Samos on Felmuary 1, 1!19, a submarine chaser of the Ameriean Navy brought the two nurses, Lanra Bunting and Mary Frances Mingane, and two social service workers. The murses assisted in the direction of a larese workrom and in the distribution of supplies. When the American Red Cross workroom was closed on May 16, 1519, 5.25 refugees and poor on the isles of Samos and Nicaria laul been aided and 11,70t garments distributed.

North of Simos liy the Isle of Chios. Miss Johnson, the chief murse of the commission, was assigned to duty there by ('ommissionere ('apps on February 17 and with l)r. Harriet Clark, established a dispensary which daily trated sisty ases. lt was clesed. however, in two weeks on aceount of a larek of medical supplies, so Miss Johnson assisted in the distribution 


\section{HIS'TORY OF AMERICAN RED CROSS NURSING}

of food and clothing until Mareh 21, a date on which all supplies were exhausted. "A total of 3120 families (11,000 persons)," reported Miss Johnson, "reeeived both food and clothing. One thousand and fifty families (7000 persons) received only food."

North of Chios was situated the Isle of Mitylene and there two Ameriean nurses, Blanche Gilbert and Mary Fleming, condncted a work room in which $30,3 \pm 7$ garments were made in six weeks and later distributed with food, to refugees and the poor of Mitylene, Tenedos, Embros, Samothrace, Lemmos and Nudros. "There was nothing done in this group of islands," wrote Miss Gilbert, "of a medical or nursing nature. The condition of the refugees is fairly good. There is little sickness. 'The honsing is impossible but the homes for the most part are elean, but with very poor sanitary facilities. The unfortmiate people have received so mneh aid that many of them seem to have lost their self-respect and will willingly beg."

The program of American lied Cross medical reliof, as was previously stated, contemplated the establishment of dispensary and risiting nurse service in Macedonia, Greece and the large isles in the Aegean Sea. Four mreses, with Miss $A d d$ ison as head nurse, were ordered to Macedonia late in January. Miss Addison established leadquarters in Kavala and with her nurses, cleaned and equipped a small civil hospital there and assisted the Ameriean Red Cross doctor in establishing and maintaining a dispensary there which in four months treated 3598 patients. The public health murses made 270 visits during the same periods to lomes of dispensary paticnts.

To Rodolivas, a village near Kavala, were assigned two nurses, Emily Porter and Mary Franees Mingane. In addition to "specialing" one of the Americau Red Cross persomenel who had typhoid fever, the two nurses assisted in the treatment of 11.50 patients at the American lied Cress dispensary, made 25 lome visits and gave instruction and distributed clothing to 5830 school childeren, all in a period of three months. In addition, Miss Porter oreanized and directed a small workroom which emplored right women.

It Irava, in the Kavala district, Miss Zaeca devoloped a disperusary service which treated between February 10 and 11 ay

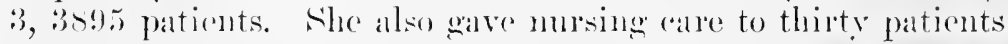
in their homest and superevised the mursing of the children of a locill orphianiger. 


\section{CLOSE OF THE FOREIGN RELIEF PROGRAM 1115.}

North of Kavala, was the village of 1)rama. Four Ameriean lied Cross nurses were assigned to duty there; they gave nursing care to sixteen homdred patients in a Greek hospital, in the American led Cross dispensary and in their homes. The work at l)rama had been interrupted by the assignment of two of the nurses to "speeial" an American Red Cross social worker who had a severe case of typlus. They had no sooner returned to Drama than they were recalled again to Kavala to murse an American Red Cross physician, also stricken with typhus.

Serres was a small momtain town northwest of Kivala and to dispensary and nursing service there, three murses were assigned at various times.

Even though the mursing service in the Kavala distriet was interrupted by the nursing care given to the American Red Cross personnel, its accomplishment was eommendable and, wrote Miss Hay, "was the only piece of general medieal relief work attempted in Greece. Nurses should not, however, be left alone in such work in any stations as were Miss Zacea and Miss Porter, although the attitude of the murses themsclyes, in such lonely assignments as in the eare of the typhus cases, was soldierly."

The nursing service in the Greek Peninsula centered at Athens and eonsisted in baby welfare work and in the establishment of a sehool of nursine, to be treated later hy Miss Noves in ithens. The infant welfare program inchuderl a bi-weekly baby elinie and instruetion to mothers at the elinic and in their homes. Margaret Tymon, the nurse in charge, also conducted classes, the first of tem and the second of fifteen, to train romng Greek women to assist in infant-welfare work.

When the time approached for Miss Tymon to return to the Enited States. the Ameriean Red Cross phrsician adrised the l'atriotic Losene, the Greek oreanization which was to take oxer the mamiarement of the elinies, that an untraned womm womld moet the American Red Cross requirements as Miss

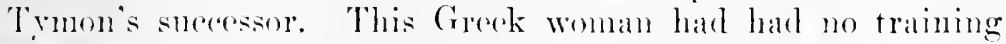
either as a nurse or an infant welfare worker. Miss Hay tinally prevaled on the eommission and the Patriotic ladene to refor the matter to Miss Noyes at Xational Ifealquarters.

()pposite Athens, on the western shore of the Peninsula of

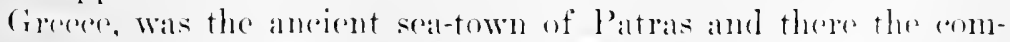
mision on Marele 7 sent Blanche Kalernal to opent an infant

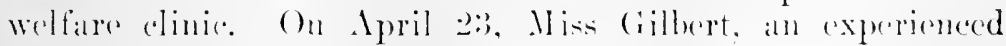


infant welfare nurse, arrived and subsequently developed an active center. The prospect for a permanent station at Patras was, however, not bright "because," wrote Miss Torrance to Miss Hay, "the poor have little means and desire on account of the more spectacular demands, resulting from the war, to improve their own living conditions and the more edueated and responsible class have yet to feel that such living conditions among the poor ought not to be tolerated."

The only other infant welfare station which was developed by the commission was located at the Isle of Crete. Miss Phelan and Miss Fleming arrived on April $\tau$ at Canea, the second largest city on the island, and developed baby clinics there in coöperation with the local branch of the Patriotic League. Miss Phelan left Canea early in June to return to the United States; Miss Fleming took over the direction of the station and another nurse, Alma Hartz, was assigned to duty there. The station was turned over on July 1 to the Patriotic League and the American Red Cross nurses withdrawn.

The two health survers conducted by the commission were made by Miss Phelan on the Isle of Mitylene and by Miss Bunting and Miss Mingane on the Isle of Samos.

Such were the activities and accomplishments of the nursing service of the Commission for Greece. The efficiency of the nurses, as it was said before, was marred by administrative difficulties. Miss Hay wrote:

The nurses of the Greek Commission were a fine body of women, representing a high order of ability, experience and devotion. They have good reason to resent the treatment accorded them and to deplore the fact that their accomplishment in actual nursing service was so pitiably small. To one resents the fact that they were used so largely for civilian relief work; that may have been necessary. What seemed deplorable was that the advice and special services that they as nurses were so well qualified to render were never asked and rarely accepted. . . .

In the summer of 1919 , Miss Hay recommended that the American Red Cross nurses assigned to duty with the Creek Commission, be withdrawn at the end of their six months' term of service and that they be returned to the L'nited States. The recommendation was aceepted, but a subsequent change of plans later permitted the development of a child-welfare program. 


\section{CLOSE OF 'THE FOREIGN RELIEF PROGRAM 1117}

In Serbia, the nursing service was more extensive than that rendered by the commission in any of the Balkan States. The headpuarters of the Anerican Red Cross Commission for Serbia were lowated in Bolgrade. Rachel Torranee, Miss Ilay's assistant, was chinef nurse. In northern Serbia, twenty-two nurses were assigned to duty and they nsed as bases for activities extemding into numerous villages, the two cities of Kragujevatz and Pozalreatz, and four towns, Cuprija, Kraljevo, Palanka and l'etrovatz.

Kragujeratz was located south of Belgrade, a city of some eigliteen thousand population. To it the commission assigned 1)r. Marriet Gervais, a physician, Dr. Marion Stevens, a dentist, and Mary B. Ross, a nurse who had had much experience in social service work in New York City. 'The three women established sewing-ronms where Serbian women were given employment in making garments to be distributed among the needy when completed. They gave professional care and many supplies to alunt one hundred and thirty orphaned children who were being eared for by a local Serbian welfare organization. The orphans were homsed in one of the former roval residences.

Sontheast of Kragujeratz was the village of Cuprya and here two American physicians, Captains John Voor and Thomas Lowe, and thres nurses, Kathryn Willians, Inez Gilliland and IIry Snow, established a hospital and a dispensary. "The mit is, to my mind," wrote Miss Hay, "one of the strongest in Serbia."

In Kraljero, a village somthwest of Kragujeratz, the commission established a dispensary and a chalin of sewing rooms. The clinies were small chough to require the attention of only the Amorican lied Cross phrsician, I)r, Mary Elliott, so the two nurses, Marietta Wilsey and Sybella Haviland, gave their entire time to supervising the mamufacture of garments in sewing rooms at Kraljeve, Milamovatz, Chachak, Terzmik and Kroshevatz and distributing food supplies and the finished garments to the destitute in these and neighboring villages. Groeroms supplies of linen and hospital carments were made and given to the local Sorbian Hospital.

Nolth of Kragujeratz was situater the village of Palanka and there the American lied rooss numeses removated a hospital where anditions existed similan to those enementerest by the murses of the (ropereli lonts of 1914 and in derepere if not in extent, he Miss Nightingale herselt at Sintari. Harriet Lente 


\section{HISTORY OF AMERICAN RED CROSS NURSING}

and Lieutenant MeNabb of the Balkan Commission inspected the Palanka Hospital on March 11, through the courtesy of the one over-worked Serbian physician who alone was trying to meet the medical needs of the hospital and a district of some hundred thousand residents. Miss Leete wrote:

In front of the Palanka Hospital, the yard was filled with mud and filth. In the rear were trenches which were used as toilets. Sanitary! Yes, there were toilets, but they were in an impossible condition.

All refuse and excreta from the hospital was thrown into a ditch which emptied near the open well. The condition of the surrounding fields was even more dangerous. . . .

The hospital was a military one and was filled with Serbs and prisoners. When we arrived, there were 297 patients and thirty beds. The main corridors were fairly clean, but leading from each wing were outside entrances and one of these hallways was used as a toilet-room, no conveniences, just the floor, part of which was tiling, with the doorway of earth. From the hallway the stench penetrated throughout the long corridors.

In the hallway adjoining the other wing, Lieutenant MeNabb and I discovered, apparently thrown in and piled one upon another, at least twenty bodies of patients who had died in the hospital. The daily death rate at that time was from ten to twenty and frequently the bodies were allowed to remain there for sevoral days. It was a ghastly sirht.

In the wards where the thirty beds were, the patients were lying on the few mattresses or on the boarls. The cots han no springs. In the other wards they lay elose together on the floor, sometimes with dirty straw for berlding. 'Tubereulosis, dysentery and pneumonia cases all in the same ward. White faces! White as the ones in the morgne. Many conghing. many more too weak to move and apparently, from the odors in the ward, they were going without any care.

'The doctor said that there were orderlies. It took some time to discover them, as they were soldiers who spent most of their time in the office or in the kitchen. . . .

On March 14, Miss Leete returned to Belgrande and asked that she be reassigned to Palanka with supplies and a suffieient number of murses to clean up the hospital and train the orderlies. Fonr dars later, she and another nurse, Faith Donison, reported to Lientenant Mr Nabb, who had remained at Palanka, and they began the renoration of the hospital. Two more American 
nurses, Eleanor Blackstone and Marie MeDowell, arrived on: March 2 in and the Serbians sent ten soldier-orderlies and some Serbian murses from Belgrade. By $A$ pril 3, Miss lecte and her nurses had changed conditions to such an extent that the death rate hatd eatsed. Miss Denison came down with typhus on April 11 and some twelve days later, Miss Lecte. The two other Ameriean nurses cared for them and they returned in the summer of 1919 to the United States. All American Red Cross activities in Palanka were discontinued late in May.

'To Petrovatz, a village east of Palanka, the Commission for the Balkans sent two phirsicians, Alberta Greene and Marjorie Burnham, and two nurses, Anme O'Hara and Laura Lowe Kreigh. They developed a large dispensary service at Petrovatz which treated aloont one hundred eases a day, and onee a week held clinies in the neighboring villages of Seotonje, Meleniea, Pashanatz and Runoviteh. A small hospital was opened during the smmere in an old building ontside the village.

North of Petrovatz was sitmated Pozarevatz, a city of thirteen thousand inhabitants, and here the eommission developed a genaral hospital, and dispensary, a tubermosis hospital and a bomeing orphanage. Two physicians, Egbert Borgeson and David Kadrsky and three murses, Jemie Hoagland, head nurse, liftie Swayze and Ilary Ricketts, were on duty there. The hospital was of thirty-fom-bed capacity and in it an active operative serviee was maintained. At the dispensary connected with it, clinies avoraging forty patients daily were held. Miss May described the tripe of eases treated:

An Albanian woman with inoperable carcinoma, who entreaterl the doctors to operate if there was a single chance, stating that she would oladly take all responsibility: a mumber of women with fente clisorders; ex\%ma of the breast; murh bone tubereulosis: an aceident wase, a vomer man who laal fallen from a hay wagon on to a hay lork, dying semen afterwalds from a ruptured spleen; a bally emaciated whik with tencler abdomen who wailingly refused hospital treatment. . . .

On the outskirts of the town, set amone a grove of trees on a slight rise of land was the attractive and well-equipped Tuberrolosis IInspital. There were areommodations for thirty odd

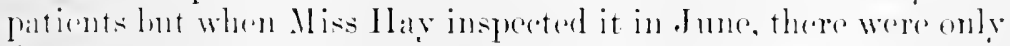

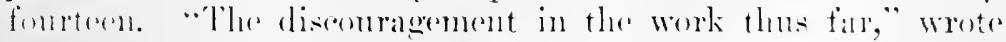




\section{HIS'TORY OF AMERICAN RED CROSS NURSING}

Miss Hay, "has been the unwillingness of the patients to stay long enough to get benefit from the treatment."

To a loeal orphanage where thirty youmg Serbs were being cared for, the unit at Pozarevatz gave food, clothing, linen and medical attention.

South Serbia was honey-combed with relief activities of the American Red Cross. In nine towns and their outlying villages, the commission conducted general and medical relief. Thirty Ameriean Red Cross nurses were assigned to duty there.

Southwest of the eity of $\mathrm{Nish}$ in eentral-eastern Serbia was Pirot, an inaccessible town of eleven thousand inhabitants lncated near the Bulgarian frontier. Five Americans were on duty there, the phrsician, Captain Herman Hundling, two nurses, Eva Ferris and Mrs. Maud Metealf, the nurse who had served in Belgrade in 1915, and two civilian relief workers, Alida Bigelow and Françoise de Bacourt. Pirot had a clean and well-run civil hospital and to it the commission gave many supplies. Captain Hundling maintained a dispensary which treated a daily average of fifty patients and the nurses aided him there and did district-risiting. The murses also assisted in the distribution of food and elothing throughout the Pirot district.

Leskovac was a town of fourteen thousand population and was located southwest of Pirot. On duty at Leskovac were two nurses of the commission, Sara Crosley and Esther Rose, and an enrolled American Red Cross nurse, Phebie Whedon, who had gone to Serbia in 1!1t as a member of the Franco-Serbian Relief Association and had later worked under Dr. Rvan after he had taken over the activities of the Franco-Serbian Relief Association. Miss Whedon had charge of the distribution of supplies and Miss Crosley and Miss Rose were on duty in a military hospital where two hundred and fifty Bulgarian prisoners had been receiving the medical and numsing care typical of Serbian hospitals. Althongl the advent of the Amerian nurses was not hailed with enthusiasm, they did good work in elearing up the building, requisitioning American Red Cross supplies and instrueting the orderlies in the use of them and giving the pationts the needed surgical nursing eare. The majurity of the Bulgars were invalided home in May and the two nurves wore transferred to Vranja.

This town of eloren thomsand sonls was situated sonth of Torkovale, on the single railroal which bisecterl serbial hongi- 


\section{CLOSE OF 'THE FOREIGN REIIEF PROGRAM 11:1}

tudinally from Gergeli, on the Greek border, to Belgrade, on the Austro-Humgarian frontier. Medical relief work at Vranja centered about the Scottish Wonen's Hospital and Miss Crosley and Miss liose eonducted an extensive dispensary service in connection with it. The Seottish Women's llospital Lnit on dute at Vranja ju 1919) had come to Serbia in Septemlere 1916, had heen assigined to duty at Ostrovo and after an active service there had been transferred in October, 1918, to Vranja to care for typhus patients.

There were many orphans in Vranja and the commission maintained there soup kitchens, an orphanage, and sewing rooms for girls. Helen King, a gradnate of the Massachusetts General Ilospital School but not an enrolled American Red Cross nurse, was in charge of this work and was assisted by a young Seoteh woman, Vida Matheson.

Sonthwest of Vranja and near the Albanian frontier was Prizren, the fifth largest eity in Serbia. Here the commission assigned two surgeons and a physician and four nurses, including Mildred Williamson, the supervising nurse, and they developed a hospital of seventy-seven beds, an orphanage where eichty-four vomng serbs were eared for, and a soup kitehen which daily fed five hundred people. Captain II. R. Bradner was in charge of these activities.

The hospital was pieturesquely located on the banks of a switt monntain stream. It maintained an active operating room, surgical walds and two isolation tents for the treatment of tuberenlosis patients, and aleross the turbulent water-comrse and reached by a small foot bridge, a two-story building which housed the medical wards. "The entire hespital at P'rizren,." concluded Miss Hay, "in the care given the patients both we dectors and nurses and the eleanliness and thrifty managenent apparent on erery side, is pleasingly Imerican."

In all the Balkin States, the Ameriean nurses and surgeons did the work closest at hand and most deserving of inmediate attention. In some towns, this means the estallishment of somp kitchens and dispensaries for the civilian population. In other towns were native military hospitals where, like fostering sores of war, the wounded were still, even as late as the mielsmmmer of 1919 . being ared for in the haphazard mothods which rharareterized the troatment of the sick and womeded thromehont

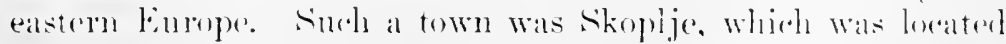
solutheast of Prizren and to it in Fehruary, 1!19. Went a muit 


\section{HISTORY OF AMERICAN RED CROSS NURSING}

of six American Red Cross nurses, with Eleanor Wilson as supervisor. They were first on duty in the Vardar Hospital but in April, all the patients there were transferred to the big Half Moon Serbian Military Hospital in the western section of the town. Miss Hay wrote:

In such a report, it is not possible to portray the sweeping changes that were made in the departments given over to our nurses in both the Vardar and Half Moon Hospitals. But they worked such seeming miracles in order, cleanliness and efficient care that even the most indifferent of the officials took notice and begged for the continuance of their services. The infinitely greater comfort and the more kindly treatment which their services meant for the patients themselves is also a thing which cannot be told.

Gostivar was a town loeated south of Prizren and southwest of Skoplje. A unit of six American Red Cross workers were assigned to duty there; Lieutenant Theodore Reed was the phrsieian, Eugenia Bogart was supervisor of the three other nurses and Genera Bateman was in charge of civilian relief work. They established a hospital of twenty-five beds, a dispensary with a daily average attendance of one hundred and twenty-five patients and conducted risiting nursing and general relief in the adjoining momtain villages.

The hospital was a trim and thoronghly model little American institution set down among the Serbian foothills. Even the American Red Cross personnel house reflected ingenuity and high standards of cleanliness. "Althongh there is no kitchen," wrote Miss Hay, "and the meals are prepared on the porch, regardless of wind and weather, they are good. Miss Bogart acts as housekeeper. One chief distinetion of this mit is the possession of a big, tin-lined serviceable bath-tub, improvised from a tin-lined tobaceo ase and large enotgh to acoonmodate (with careful arjustment) even a full grown man. This tub. like other conveniene's at Gostivar, is due to Dr. Reed's inventive gifts."

MIonastir, second largest aity in Serbia, was situated sonth of Costivar in the sonthwestern corner of the small principality. Tho gromes of American lied crose persomel were on duty there. The first eloup comsisted of four nurses, with Elsie Jessup as hearl, and they served in the American Woments Hospital; the second group consisted of one nurse as supervisor, 


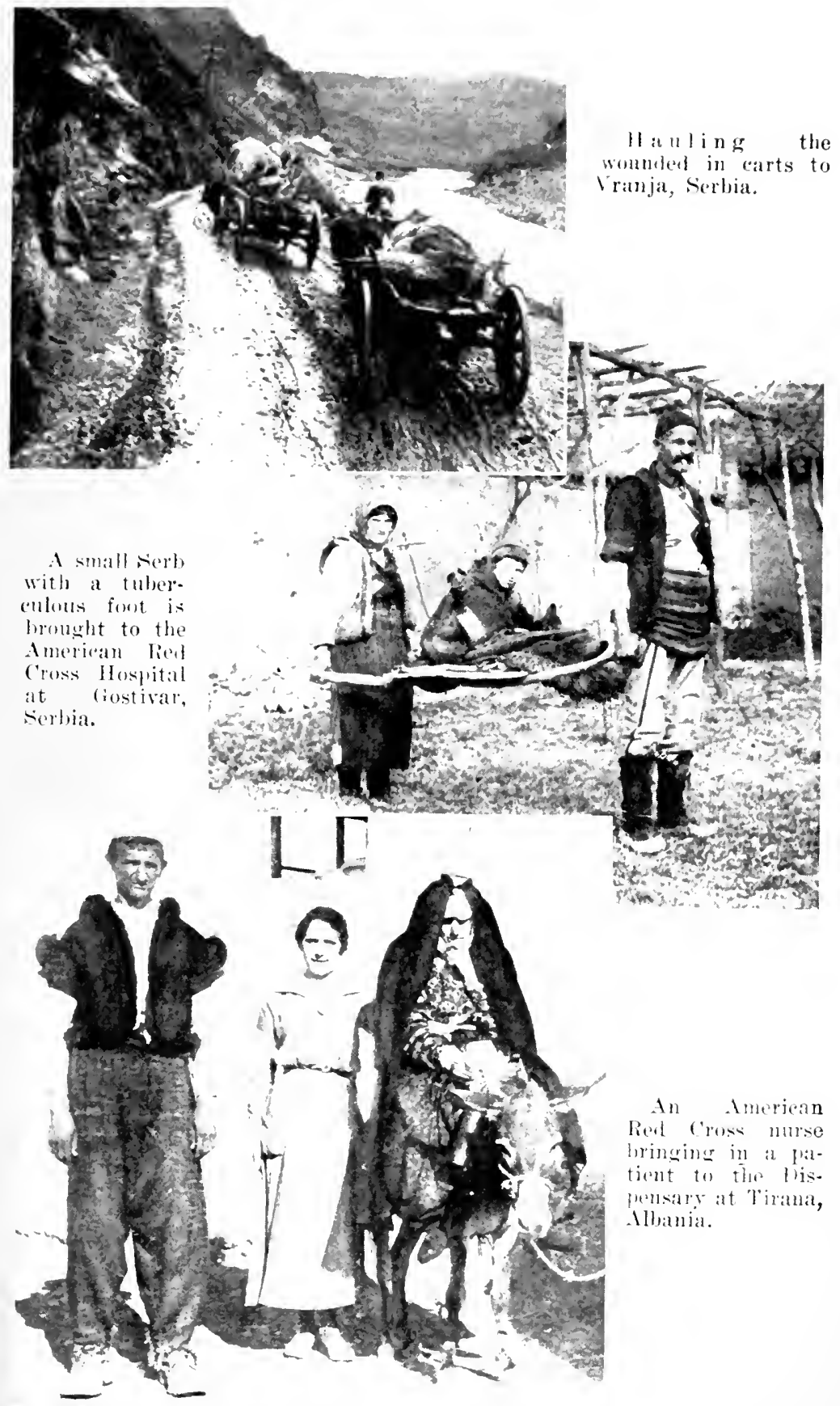

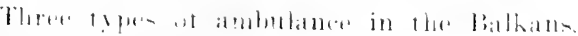




$$
\text { - }
$$


Emma Hart Rogers, and two civilian relief workers and they conducted a sewing-room and distributed material relief among the destitute in the eity.

The American Wonen's Hospital was of fifty-bed eapacity and was under the direction of two American physicians who hat been in Serbia since Jannary, 1918,-l)r. Regina Keyes and 1)r. Mabel F. Flood. The Ameriean Red Cross nurses went on duty in the hospital in Jammary, 1919. An aletive dispensary service, averaging 150 patients daily except on market dars, when the numbers ran as high as 230 , was maintained in connertion with the American Women's IIospital, but the nurses of the Balkan Commission were not on duty there.

American Red Cross civilian relief in Monastir consisted in the maintenance of a sewing-room, where garments were made, and of a bathhouse which the Serbians were required to use before they were given the Red Cross clothing. Two nurses were in charge of these projects, Kate Maefadden of the bathhouse and Miss Rogers of the sewing-room and persomnel house.

Kavadar was a village which lay north and east of Monastir. There the commission developed an active dispensary and an orphanage and conducted general district, tubereulosis and infant welfare nursing service. The persomel consisted of Captain R. M. Blakely, the physician; four nurses with Mand II ath as head murse; and one civilian relief worker.

The dispensary was located in three large rooms of one of the municipal buildings. The attendance averaged over a humdred, with two hundred on market days. The patients were nsually aises suffering from the explosions of "duds"; bone tuberrolosis in advaneed stages: tubereulosis of the eyes; pellagra and the like. 1 branch dispensary was maintained at Negotin, a neighboring village.

In the Kavadar district were some four hundred orphans and anome them were stray waifs melaimed by relatives or friends. For these the Ameriean Red Cross representatives astallished an orphanage which in .June hall twenty-eight chareges. ()ue of them was a semingly timorous lourkish lad who "wats afraid," wrote Miss May, "that the Sorbian buys wonld whip him so came protected with a dagger concealed in his hlonso."

'The public health musing service at Kavadar was perhaps the must interesting phase of Amorican lied cross endeavor there. From the dispensary, the nurses followed their pationts 


\section{HISTORY OF AMERICAN RED CROSS NURSING}

home and brought into many south Serbian houses, soap, light, air and general order. This union of old-world eustoms of living and new-world methods (for public health nursing was primarily an American development) was often full of uneonscious pathos. Miss Hay wrote:

In a Turkish family where the mother had died of tuberculosis, learing a two-year-old tubereulous baby, the father did his best to earry out the nurse's instructions and on the morning we called we found him gone to his work but the baby well wrapped up and sitting out of doors in the sunshine, getting strong and well.

During the month of April, 1919, one thousand six hundred and fifty-three patients were treated at the Kavadar dispensary and twenty per cent of them were suffering from tubereulosis. These eases inchuded all types of the disease, eye, bone, glandular, pulmonary and that of other internal organs. The vietims made no effort, previous to the advent of the American Red Cross nurses, to treat the disease aceording to modern methods. "One woman," wrote Miss Hay, "brought from a village fifty kilometers distant, her two daughters, both of whom had tubereulosis of the left hand. The wounds had never been dressed with anything other than leaves."

The infant welfare work at Kavadar was very appealing to the American murses. Ursula Tibbels was the nurse in eharge of it at Kavadar and Miss Heath at Negotin and they held baby clinics and distributed American Red Cross lavettes. Miss Hay wrote:

Such pitiful rags as were taken off the wee Serbian babies, -rags such as an American mother conld never imacrine as any baby's best tothes. And in place of these, we gave the Red Cross layettes, line knit shirts, downy flannelette shirts and dress and a warm baby eape and lood; soap. talcum powder, wash cloths, towels, and a parkagre of twenty-four diapers, so clean and new that we could only with difficulty persuade the mothers to put them to their intended use. if the baby was in the least dirty. or if the clothes or rags abont the baliy were not clean, then the iavette was withlehl until the mother had remedied these faults. Each mother was required to put the new elothes on the baby to.show us that she harl really profited by our instrmetion and it was a racliant and wondering baby and a very prond mother which soon 


\section{CLOSE OF 'THE FOREIGN RELIEF PROGRAM 1125}

confronted us. It was a fine gift to the patient and denying Serbian mother, that lasette from Amerixan women's hands, but lest of all it meant al elean and romfortable and therefore a hallyy baby. In the month of May eighty-five layettes were given ont.

South of Kavadar and the ninth town in southern Serbia where the commission developed emergency reliet activities in 1919, was the border-town of Gevereli. Of the plight of the village and district in 1919, Miss Ilay wrote:

Situated in the midst of an important fighting center, Gergeli is now little more than a pile of stone and rrumpled mud walls. Whatever eseaped shot and shell was licked up by the flames of the retreating Army or has long since grone to cook the soldier's soup or to warn a shivering family. Such a burned-out ruin is the big tohace factory in which was located in 1914 the Military Hospital wherein the American Red cross murses and boctoris fomght typhus. In the cemetery nearby is Dr. lommelly's grave. . .

The Gevereli distrixt consists of seren townships and twenty-one villages, with a total of e000 families and 10,000 population. . . Helen Lyilia Bailey was the nurse in charge of all work there and was for a month the only American Red Cross representative. In this time, she treated, quite alone, some five humbred patients: she was altogrether without a doctor's adrice, a state of affairs which should not be, as the responsibility of lifo is too great. On April 18. Whth L. Wood, a mirse, arrived and took over the dispensary work and some of the visiting nursing. and on llay 13, Fileanor Wilson was sent down and took (harge of the sewing-room in Gevgeli and the orwanization of similar ones in adjoining villagess. Ir. Smith arrived about May 1 and Dr. Frost also stayel in cievgeli for a few weeks.

Stark poverty presailed thromghont the Crevgeli district. The Ameriean Red cross persomel there distributed latre fuantities of tlomr, pork, beans, riee, lard, soap, and elothing and later even leoes, spades, shovels and grindstomes.

In addition to Montenegron. Allomia, Creece and serbia, the other state in the balkan gromp in which the Amerientered

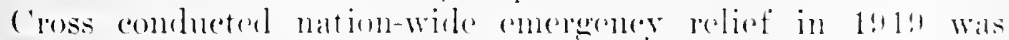
Rommania. The fomr-fold military ocempation, hy (iementm.

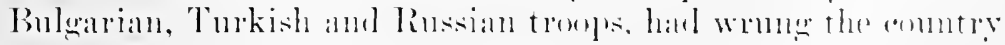
dry. When the serend American lied ('ross commiston ar- 


\section{HIS'TORY OF AMERICAN RED CROSS NURSING}

rived in Bucharest on February 25, with Lieutenant Colonel H. Girleon Wells, of Chieago, in command, they found horses dead from starvation on the streets, children and adults alike in rags and gannt with hunger, going barefoot in the snow, and typhus, pellagra, war dropsy, eve troubles and tubereulosis pandemic. Only the iron constitution of the Roumanian peasant prevented a much further decimation of the Roumanian population than has been deseribed in a previous section.

When an entire nation is hungry, the people want food, not toothbrush drills or other devices of health education. Thus the American Red Cross program in Rommania was a feeding and clothing program on a national scale and a subsidy, on equally large proportions, of drugs, linen and food to Roumanian hospitals.

In any emergency relief program, a public health murse is an able instrument, because a good public health nurse is trained to estimate both the social and medical needs of those whom she is endearoring to aid. Sereral of the fifteen Amerian Red Cross murses of the second Commission for Rommania were women highly skilled in public health nursing and medieal social service, such as Florence Patterson, the chief nurse, Katharine Holmes and Evelyn Obear. The others were institutional murses who were well fitted to go into a Rommanian hospital and prepare the requisition lists of drugs, blankets, linen and food which were necessary to put that hospital again into operation. Thus while the American nurses in Rommania established no Ameriean Red Cross hospitals per se, and operated fow dispensaries on a scale comparalle to that which prevailed in the other Balkan States and did practically no visiting nursing, their selviees eertainly may be said to have been utilized in a professional eapacity. They were not tueked away in isolated sewing-rooms and civilian relief stations in Roumania "to keep them ont of mischief" as in Greece, lunt were given anthority and a field to eover which was almost unbelievally broal. Niss Patterson, in addition to her duties as chief inurse, was the assistant director of eivilian relief of the commission.

The method in which the second Rommanian Commission attacked its tasks is woll illustrated loy a brief deseription of the work of sereral mits. In Bucharest. Miss Palterson and I). Biyne worked out a rivilian rolief program which supplied food, dothing, drugs, and opuipment during the spring and 
I

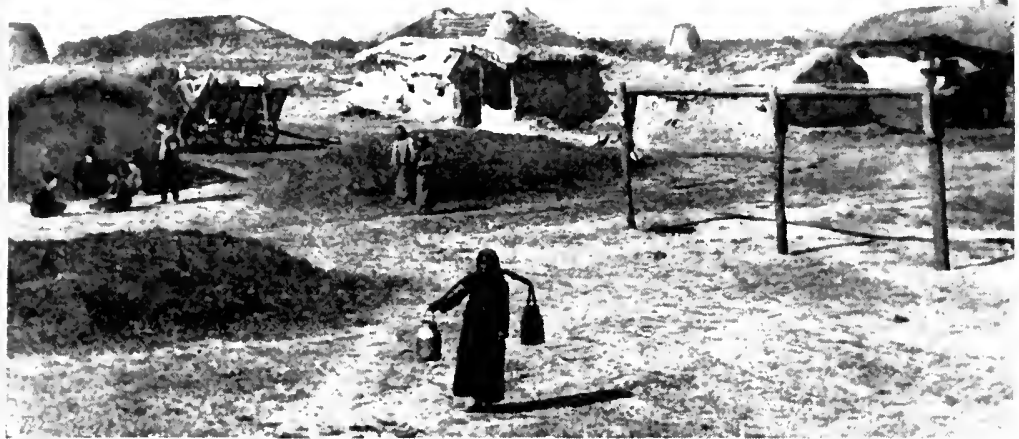

Rommanian refugees living in mud dug-onts in the devastated war zones.

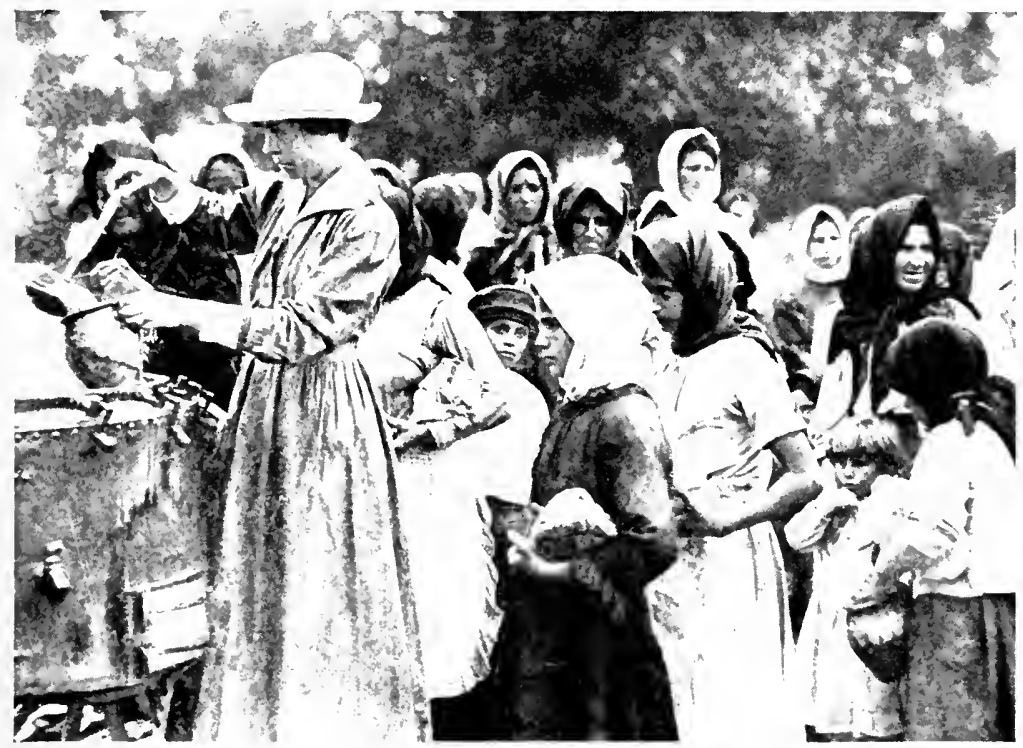

An American lied cros nurse serving somp to Rommanian refugees. 

early summer of 1919 to eleven Roumanian hospitals; sixteen schools and children's aid socicties; twonty-four orphanages; and fourtern asylums and sanatoria. Three special canterns were estiblished and by the end of July, 1919), had served 168,118 portions of thick sonp and bread, and had been aided, cither with this food or by gifts of clothing, 5.),146 persons who were not included in the above list of institutions aided.

'To develop the program in rural sections of Rommania, mits were organized and sent ont into the field each with its quetia of villages to cover. Such a mit was the Foesani Unit which estahlished its headquarters at Focsini, a eity of some twentyfive thonsand population which was located in sonth-central Moldavia near the boundary line of Wallachia. Captain Arthur I). Fulton, Katharine Iolmes and Josephine Ellett composed the persomnel of the unit and their territory consisted of eighty-five villages, fifty-seven of which had been bomber. The two murses and Captain Fulton established canteens in each one of these fifty-seven villages. From these canteens a daily ration of thick sonp and white bread was served to an average of one humbled people.

An example of the offeet which resulted from the distribution of sanitary supplies and a judicions amount of advice by the Ameriean Red Cross representatives, was found in the village of Odobesti. During their oceupaney there the Germans had built a good bathhouse but in the alosence of soalp and towels the Rommanians in 1919 were not $n \operatorname{sing}$ it, thomgh typhus was epirlenic in the community. Captain Fultom ured the local anthorities to put the baths into operation and Miss IIolnes and Miss Ellett distributed soalp and tolel the recipients to go and use it at the public baths. Within due season the efferets of an aldepuate diet, as partially supplied hy the canteens, and the use of the soap began to bear fruit in a dimimution of typhus ares.

'Jhe distribution of supplies and druge to aldearly established but imporerished Rommanian lospitals was deseribed in a report covering the artivities of the Ilfor Tuit: Ruth Woire a gratduate of the Ronserelt Ilospital and a nurse who hatel serverl at American Reel Cross lospital No. 1, was a member of this group. The official report was in part als follows:

We found at Budesti (a village in the Bucharet distriet) a Rommanian hospital with oighty-two cases of typhus. The 


\section{HISTORY OF AMERICAN RED CROSS NURSING}

hospital had nothing in the way of equipment but some iron bed frames, with boards laid across them. In many cases, we saw as many as five people trying to lie on one bed; they were wrapped in bits of carpet and in rags. Men, women and chililren were all crowded together. One old woman lay dying while her three bedfellows shrank as far from her as possible to remain on the bed.

The doctor in charge, a capable appearing young man, showed us the linen which had been turned over to him; it consisted of shapeless bundles of rags. He had no medicines, no means of transportation to visit outside cases and practically no food for his hospital patients. They were trying to make sugar from some old beets to add to the diet. We left him pajamas, convalescent robes, blankets, soap, food supplies, a little medicine and some advice.

The general relief administered by the Ilfov Unit consisted, by the first week in July, of forty-one eanteens which were serving food to $\$ 18,030$ people in 114 villages. "Our elothing distributions," stated the writer of the Ilfov report, "ran nerk to neck with the aid given through eanteens and hospitals and we finally covered the people before they died of sunlmm. No matter how well conducted our distributions were at the begiming they always ended in a riot when our most numerous clients, the Tiganes, begun to think there would be nothing left for them. When the last shirt was gone, we dashed for the car, guarded by gentarmes and special constables who love the opportmity of wielding the big stick." In this respect, Miss IIolmes was much horrified during her early werks of service to see the local authorities trying to keep the Rommanian peasant women from stampeding the piles of layettes, by lashing them with ox-whips, treatment which had little effect upon the somewhat over-eager mothers.

Early in June, 1919, Colonel Wells resigned as rommissioner for Rommania and returned to the Enited States. Coloned Anderson then moved the headquarters of the Balkan Commission from belerade to Bucharest to be able to keep general orersight of the work in Rommania.

The summer of 1919 saw the complete reorganization, in policy at leatst. of the Commission for the Balkans. By that date the paralysis of trarlo with the Balkan States, due to the enrmy's subnalrine aretivities in the Mrediterranean, was arrled and after an interval of four years, ships were again bringing 


\section{CLOSE OF 'THE FOREIGN REIIEF PROGRAM 1129}

supplies into the Balkan ports. Moreover, the crops of 1919 were being harvested by the women and a time of comparative plenty was again at hand. The national temperament of the various Balkan principalities was one of great physical stamina. Aceustomed as they were to almost constant warfare and quick to feel its ravages, the peoples of the different countries and especially Ronmania were equally swift in responding to the piping times of peace and with their hereditary enemy crushed, they attacked reconstruction with hope.

The autumn of 1919 seemed an anspicious time for the close of the emergeney relief as undertaken by the Ameriean Red Cross in the Balkans and throughont Europe and for the initiation of a eonstructive program limited to the field of health. Many of the nurses and surgeons of the Balkan Commission had been overseas sinee 1917 and desired to return to the United States. Even more important was the fact that the large quantities of the Red Cross general and American Army medieal supplies which Colonel Anderson had brought to the Balkan States in Jannary had been distributed and the finanees of the soeiety, in the estimation of the executives at National Headquarters, did not permit the purehase of new supplies with which to continue emergeney relief of an international scale. Thus the persomnel was slowly withdrawn, leaving only a nucleus in various dispensaries and welfare stations aromel which was soon to be built the constructive program in the field of child health.

During the summer of 1919 , the development of the League of Red Cross socicties progressed rapidly and on November 17, 1919, Miss Fitzgerald resigned her duties as chief nurse of the American Red Cross in Europe to assume those of the Director of Nursing of the Leame. Florence M. Waters served for some months as acting chief nurse of the European Commission, but in Jammary, 1920, came to the United States for a short vacation preparatory to returning to Europe as Miss Fitzgerald's assistant in Geneva.

1 happy serpuence of events followed. The Minntes of a meeting held l lecember $2: 3,1919$, of the Commission for Europe recorded statements that

Coloned Olds annomeed that Colomel bimerson is about to wo to serhia with authority to make arranerenents

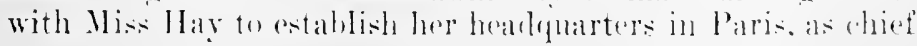




\section{HIS'TORY OF AMERICAN RED CROSS NURSING}

nurse of the commission. So far as the work in the Balkans is concerned, it has seemed that she could handle these details fully as well from Paris as from Belgrade.

Miss May's experience in the Balkans subsequently proved to be of invaluable assistance in working out the details of American Red Cross nursing service in connection with the child health units and the establishment of schools of nursing in foreign countries. Her powers of administration, always considerable, had increased with her years of Red Cross service; in faet, a Red Cross colonel had once said: "Miss Hay" is the biggest man in the Balkans." Her detailed knowledge of local conditions often seemed truly amazing to those with whom she worked, but the reasons for this were simple: She land assisted her nurses in dispensaries and hospitals in isolated Balkan villages, she had gone with them into dark and poverty-stricken homes, she had struggled alike with arrogant commissioner and insubordinate murse, with avaricious native politicians and easy-going public officials, and she actually knew whether the initiation of a permanent welfare program would not be practicable. Thus she was able to render, in her new office, service of a broad and high order.

Of the six American nurses who received the Florence Nightingale Medal of the International Red Cross, four of them had had service at some time during the European War in the Balkan States. It a meeting held December 10, 1919, the National Committee had passed a motion that the chairman appoint a sulb-rommittee to consider eandidates for this meilal and submit its recommendations to the National Committee. This sub-eommittee nominated Mrelen Seott May, Martha Russell, Florence Jolnson, Mhna Foerster and Linda K. Meirs, and renominated Mary E. Gladwin, whose name had been previonsly bronght forward by the National Committee. Isr. Farraind forwarded these nominations on March 26, 1920, to the International Committee at Genera and the medals were subsequently conforred on these nurses.

The last montlis of 1919 saw the close of the American Red

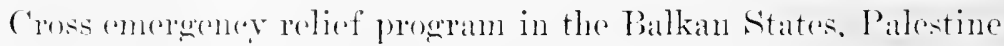
and Silurial. Comblitions in the Balkin States had realehed the stage farcoralite to the intiation of a constructive health prorgram. In Palestine and Syria the American Committee for 


\section{CLOSE OF 'THE FOREIGN RELIEF PROGRA.M 1131}

Relief in the Near East assumed major responsibility for the alleviation of suffering. Political conditions in North Russia had alrealy made necessary the withdrawal from Arehangel carly in 1 !1 19 of the American Red Cross representatives. In Sileria, Bolshevik vietories also cansed the withdrawal of allied forces and the Ameriean Red Cross late in 1!1!) and early in 1920. The only emmissions remaining overseas and operating on the old pre-Armistice policies of nation-wide general and nedical relief was that in Poland and the close of this phase of service has already been described. The Enropean ('ommission, with its headquarters at Paris, was serving chiefly as the elearing homse thromgh which were being atministered the details coincident to the elose of the energeney relief and the initiation of the new elild health program.

With the termination of the emereney relief program and the withdrawal of the commissions per se from Great Britain, France, Belgimm, Italy, Montenegro, Albania, Greece, Serbia, Rommania, Palestine, North Russia and Siberia, the overseas service of the American Red Cross immodiately incident to the European War may be said to have been ended. On June 30, 1!20, only one humdred and sixteen American Red Cross nurses were on dnty orerseas.

In the sixteen months which had passed after the resignation of the War Comncil on February 25,1919 , an appreceible contraction in American Red Cross war oreanization harl taken place. On Fobruary 28, 1919, the number of persons in Reel Cross employ in the Enited States and overseas totalled 1t,625. 1921 of whom were volmuteers (mupaid workers). On Jume 30,1920 , the number of persons totalled 5.517, of whom thirty were volunters. The American Red Cross administrative, elerical and field staff had thus heen redured hy the resignations of !108 individuals, 18 ! 1 of whom had been volunters. As to the chapter and membership strength of the sereietry on

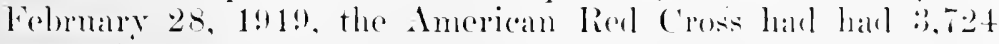
active (hapters and an adult membership of $20,00(0.0010)$ per-

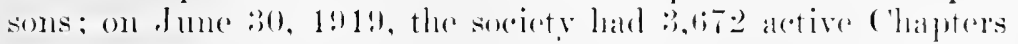

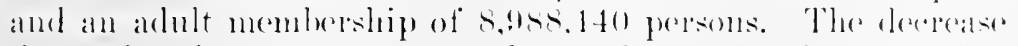

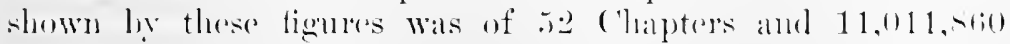
ardult memlerses.

lu this figure whiele gives the loss of aleven million members.

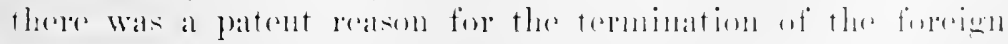

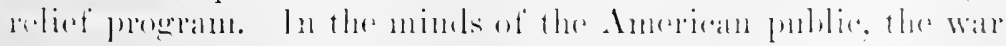




\section{HIS'TORY OF AMERICAN RED CROSS NURSING}

was over and the need for American Red Cross activity accordingly ended. To the average American, the Red Cross was primarily a war organization, so defined by the main clauses of its Congressional Charter, so understood by the man on the street. Some eight millions in 1919 had caught the idea of the need for eontinued support of an American Red Cross foreign and domestie program, but eleven millions had not.

Lnepestioning and universal public support from the Ameriean people is perhaps the most powerful genie in the world and with it the Ameriean Red Cross had, indeed, accomplished wonders. The society in some respects may be compared to the lamp of Aladdin. Near the elose of the nineteenth century, Clara Barton had found the lamp in Switzerland and had bronght it to the United States. From 1905 to 1914, it had been held tenderly in the hands of Miss Boardman and a few influential friends and had then possessed but comparatively meager financial resourees with which to perform its services, ehietly in domestic disaster relief. Then the European War had burst upon a startled eivilization and Miss Boardman had prevailed upon the still comparatively feeble genii of the lamp to organize and finance the Merey Ship Expedition. A brief period of comparative rest followed. In 1917, however, the national emergeney brought about a ehanged aspect of the Anerican Red Cross and it beeame an organization deserving the mqualitied and miversal support of the Ameriean public. President Wilson appointed the War Comeil. Mr. Davison as chaimin vigoronsly rubbed the lamp and lo, the American publie responded in twenty months with a total contribution of four humbled million dollars. The society was reorganized on the basis of a Rockefeller corporation and expended in foreign and domestic relief two humdred and serenty-three of these millions. Then in turn the emergency subsided, the fiekle genie of Ameriean publie support turined its attention to other matter's and the lanup was handed back to the Execntive Committere still possessed of many lesser genii who eould be commanded to bo usoful things, to be sure, but with the all-powerful genie of universal, unquestioning public support gone until amother national emergency would again automatically command its service. 


\section{CHAPTER XIII}

PARTICIPATION IN INTERNATIONAL NIRSING EDICATION

Trunsition-League of Red ('ross Societies-SChools of Nursing-Miss Noyes' Trip Overseas-Child Health C'enters- Nursing ictivities in Insular and Foreign Possessions of the United States

$\mathrm{F}$

OLLOWING the Armistice the general impression that the Ameriean Red Cross had fulfilled its mission in Enrope seemed to have prevailed. The commissions which had been established in practically all the conntries of the Allies were gradually withdrawn until earty in 1920, with the exeeption of the Conmission for Poland, there were none left.

These commissions had been largely oceupied with questions of general relief and medical nursing (are of both the civilian and military sick. General relief activities predominated and included the distribution of supplies of all kinds,- - clething, food, hospital furnishings, linen, surgical instruments, drugs, ete. : also raw materials of all kinds, sewing madhines, sewing materials-needles, thread, thimbles, buttons, tape-in order that emplorment might be given to the women of the comutry. IIospitals and dispensaries were opened, child welfare work established, also visiting mursing: mother rlubs were started and lied ('ross elasses in Home Hygriene and Care of the Sick were conducted guite widely.

Inte all this work the Red Cross murse was intredueded. With the une ertainty attendant upon the development of at elealle-ent program, nurses frequently found themselves assigned to work in which their professional training seemed partially wasted, such as supervising work rooms and soup kitchens, the distribution of supplies and the hensekerping in persomed homses. Sot infrequently did the nurse do her day so work in al nurrery or

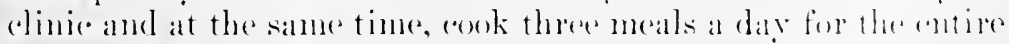
persomele attend to all the buying and look after the eleanliness 


\section{3+ HISTORY OF AMERICAN RED CROSS NURSING}

of the house, for mless the doctors, nurses and other personnel had confortable living quarters, with well-cooked food, they ran serious dangers from infection; and native cooks unless trained by some one were ignorant of the Anerican method of preparing and cooking food. When members of the personmel fell ill, the nurse assumed, in addition to her regular duties, their mursing care. Instances of hours of night work, added to an already overerowded day, were so common as to excite no comment. Good sports as they were, the murses assumed these extra responsibilities without faultinding and with a checrfulness truly commendable. It was part of the service, they were the ones prepared and, beeause of their special preparation, they accepted the responsibilities without question or complaint.

That advantage was taken of them goes without saying. Instances where guests in large numbers were brought in without warning by the members of the unit were, alas, only too frequent. Lnder these eireumstances, the nurses did not shine as social lights at such simple festivities as occurred in the evening. 'They were, moreover, painfully conscious of the fact that they suffered in this respect, by eomparison with the other women members of the mit, social and clerical workers and teachers. In spite of their philosophy as a group, there were some heartbreaks on this account and indiriduals here and there found it difficult to maintain their equanimity and poise.

Following the withdrawal of the conmissions, a stream of workers, nurses, doctors and others poured back from Europe to Ameriea, learing here and there a worker or two, to supervise specitic pieces of work, to guard warehouses filled with Red Cross supplies, including those turned over by the Medical Department of the Army, and to develop Junior Red Cross activities.

Red Cross officials at headquarters both in Paris and in Washington were deeply conscions of the fact that the war-torn comntries of central and eastern Europe were still in dire need. They were practically without the necessities essential to support and maintain life. Medical and nursing assistance were needer fully as much, if not more, during the reconstruction preser than during the period of active hostilities. The discomragement of the people facing this sitnation almost withont supplies of erery kind and with so depreciated a enrency that it was practically impossible to go outside of Europe to 
buy them, was quite understood by the Ameriean Red Cross. This condition was greatly complicated by the overwhelming problem of the refugees; each country had its own and the enormous numbers from liussia increased their difticulties. Further than that, the problem of war orphans in large numbers in each comntry seened almost manswerable.

With full and intimate understanding of the situation, executives at National Ileadquarters were, nevertheless, obliged to listen to questions raised by menubers of the Aneriean Red Cross throughont the country, who had been working at considerable tension even before the Lnited states became one of the combatant nations and at high spoed from then on. "The war is over," they said, "so why should we continue? We want to go back to our own affairs." Although there were still large quantities of supplies in European warehouses of the American Red cross and money left from the war budget for European work, a strong feeling existed on the part of many individuals in the Lnited States, even though they were sympathetic, that the countries of Europe should assume the question of rehabilitation for themselves.

To Red Cross officials, the question was a perplexing one. An operation of such proportions as that being conducted by the American Red Cross in Europe could not be stopped immediately. The warehomses which were filled with Red Cross supplies in various parts of Europe and to which the War Department in 1:1!) turned over large eonsigmments of supplies and dietary foodstuff's as anthorized by Congress, ${ }^{1}$ had to be guarded and plans devoloped for a svetematic and efficient method of distribution, while particular activities such as the Junior lied cross work, whild welfare activities in Greece, and the raried phases of service in Poland could not be immediately discontinued without destructive results to the comntries concerned. However, the executives at National Headquarters knew that they must take cognizanee of the trend of American publice opinion. Forerned largely by the factor of the supplies in European warehouses, they finally decided on a restricted and clearly defined program of a construetive character. The nursing service of this program embraced four distinct phases: lndireet stimulus to the nursing service of the latague of Red Cross Soredeties: schools of nursing: nursing service in

${ }^{2}$ Bulletin No. 23, War Department, July 19, 1919. Army Appropriation, Act of Congress. 


\section{HISTORY OF AMERICAN RED CROSS NURSING}

comnection with child health centers; and nursing activities in the insular and foreign possessions of the United States.

Sentiment at National Headquarters ${ }^{2}$ after the Armistice was pointing toward the participation by the American Red Cross in a broad and general program in which all the Red Cross societies of the world might become participants. On December 3, 1918, President Wilson wrote as follows to Mr. Davison:

Pursuant to our conference of yesterday, I am writing to ask you if you will not be kinil enough to make arrangements, if possible, to come to France at an early date for the purpose of conferring with me and others there as to the international relations and coopperations of the Red Cross. I sincerely hope that you will give the most serions consideration to this and that you will arrange to come, if it is at all possible.

When Mr. Davison arrived in Franee in December, 1918, he endeavored to develop a league which included in its membership the Red Cross societies of the world and had as its aim the betterment of humanity. He was appointed by the American Red Cross as chairman of an Ameriean Red Cross International Commission and resigned on Mareh 1, 1919, as chairman of the War Couneil. A large sum of money was appropriated by the American Red Cross for this International Commission. Mrr. Davison endeavored to get the Peace Conference at Versailles definitely to endorse the plan for a League of Red Cross Societies. They declined to do so, but with the assistance of President Wilson, it was possible to seeure the insertion of Article XXV in the Corenant of the League of Nations. It is to be notieed that this article does not refer at all to the League of the Red Cross Societies but to National Red Cross societies throughout the world:

The members of the League agrec to encourage and promote the establishment and coöperation of duly authorized roluntary mational hed ('ross organizations having as jurposes improvement of health. the prevention of disase and the mitiration of suffering throughout the world.

${ }^{2}$ On Novimber 27. 1918, a confidential personal letter was addressed to President Wikon by a high oflicial at National Heardquarters which struck a prophetir note. infortunately the earbon of this letter is unsigned and manus mon then in high anthority at National Ieadquarters have since cisclaimed anthorship of it. Hence it is not quoted. 
Shortly after Mr. Davison's appointment representatives for the Red ('ross societies of Great Britain, Franee, Italy, Japan, and the United States formed a committee, which established headyuarters at cannes for the purpose of studying the situation. The committee fillally decided to call for conference, experts in health, medieine, economies, and nursing from all parts of the world, in order to prepare an extended program of Red ('ross aetivities, in the interest of hmmanity, to be presented at a meeting of the International Red Cross Committee at Genera to be held thirty dars after Peace was declared.

This conference finally took place from April 1-11, 1919 at Camnes. Miss Delano had fallen ill some weeks before this, but it was expeeted that she would make an early recovery and be able to represent the American Red Cross Nursing Service when the meeting was ealled. In fact she did attend one preliminary enference held at Mr. Davison's house at Cannes for the purpose of advising on mursing questions to be presented at the conference, and also on nursing representation from other countries. As the time for the conference approached, however, the possibility of Miss Delano's attendance was dissipated and it beeame necessary to provide for a suitable substitute. The American Red ('ross had been requested by IIr. Havison's committee to send Miss Lillian Wald to represent the Federal Children's Bureau, lepartment of Labor, U. S. A. As Miss Wald had been a member of the National Committee on Red Cross Nursing Service since its early days, it was determined that she should represent as well the American Red Cross Nursing Service.

While arrangements to this effect were being made at National IIeadquarters, Mr. Davison, appreciating Miss Delano's condition and not waiting for adviee from Washington, asked $M$ iss Stimson, then director of the Army Nurse Corps in France and formerly chief nurse of the American Red Cross in Franee, to attend. Miss Hall, who had followed Miss Stimson as chief of the Nurses Burean at Paris headquarters. Wils present. Miss Fitzgerald was also in attendancer. not. lownever, as a nursing delegate, but because of her linguistic ability as an interpreter and translator.

Great Britain was represented by Miss A. M. Gill, then superintendent of nurses, Royal Infirmary, Edinburehe and president of the Sucottish Matrons, and by Miss Mlicia LleydStill, the head Matron of St. 'Thomas' Hospital, London. 


\section{HISTORY OF AMERICAN RED CROSS NURSING}

Countess de Roussy de Sales, of the French Red Cross, was the representative of France. Italy was represented by Professor Emilia Malatesta Anselmi and the Countess Nerina Gigliucei, both of whom were volunteer murses of the Italian Red Cross. Miss Stimson acted as chairman of the nursing representatives.

The Report prepared on lines suggested by the Exeeutive Committee of the Cannes Conference is in the main as follows:

A. More important existing nursing organizations: In recrard to interuational and national organizations, both official and volnntary, the field is so vast ant available information so inadequate that it is thought best that the preparation of surh a survey of the position be postponed, subject to the consideration of a larger and more representative gathering.

B. Indiations for international Red Cross action: 'The proposed ('entral luternational Red Cross Bureau should include a Nursing Department. The chief objects of this Department should be:

1. To act as an intelligence center, to collect, analyze and distribute information regarding all matters pertaining to mursing, and to women's work in public health, such as inlant welfare, honsing, social service, etc.

2. To nudertake propagancla in countries where trained sick nursing and public health work are not at present fully dereloped.

3. To seek out in these countries (Par. 2) suitable personnel for training both in sick nursing and in public. health work, to advise and assist them to obtain the necessary training, and to return them to their own (omutries as pionecrs.

4. 'To arrange for conferences of representative nurses am health workirs from all comntries for the interchange of irleas.

C. Ttilization of existing Red (ross assets: It is recogr. nized that the Rexl cross at the present time is in possession of a vory valuable asset in existing personnel. This personnel inclutus:

1. Fully trained pofescional numes.

2. In France and Italy. volunterer trained nurses.

3. Tutrainer and partially trained workers. known in Ameriea as morse' aisls (nuder the lied ('ross). and social workers: and in Fongland as V. A. D)'s (under the Ped ('rose). Suredial Mlititary P'robationers, and health visitors: and in france and Italy, anxiliary nurses.

D. P'rmanent liorl Cross nursing organizations: 
1. International-lt is recommended that in connection with the proposed Intermational Red C'ross Bureau there be a Department of Nursing, with a resident secretary, who shall be a representative of the nursing profession. 'The probable duties of such a secretary are indicated under paragraph 13.

2. National-It is recommended that in addition to their present duties, national Rerl ('ross organizations beep) permanent registers of trained murses arailable for any national or local emereney, and that they atso kecp registers of Red Cross workers, with data of their experience, for similar service.

The Report concluded with the statement that "we fecl that many of the subjerts under discussion are very far-reaching and must necessarily affecet large lodies of workers and that, therefore, no decisions shonld be arrived at by a few individuals, but that these subjects should be referred to a larger and more representative body of professional women and should be considered preferably after the Committee of Rind Cross Societies has coneluded its deliberations and outlined the future activities of the International Bureau. ..." The mursing delegates then suggested the following subjects for discussion:

1. The utility of the trained nurse for public health work.

2. The possible shortage of nurses for this rlass of work, and how the shortace can be made good.

3. Whether it is necessiry for all health workers to be fully trained nurses.

4. Special courses of training in public health work for nurses and others.

5. Scholarships and other forms of assistance.

To the Report of the nursing delegates was appended the following set of liesolutions :

1. Resolved. That the Ifealth Bureaur colleret. analyze publish and distribute information pertainger to nursing and

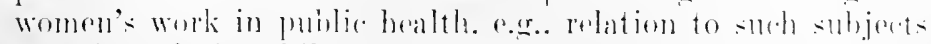
as tubereulosis, rhild welfare the presention of hlindues, pre-natal calre. serejal service. este.

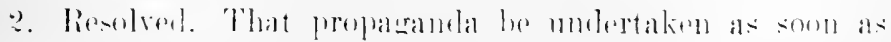

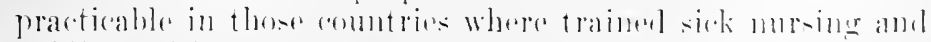

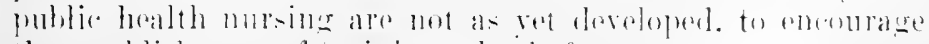
the establishment of training selowhls for nomses. 


\section{1 to HISTORY OF AMERICAN RED CROSS NURSING}

3. Resolved. That suitable personnel for instruction, both in the care of the sick and public health nursing, be sought and trained so that such personnel may return subscquently to their own countries, qualified to inaugurate and direct movements for the establishment of training schools and for the training of nurses.

t. Resolved. That a system of scholarship be established to make it possible for trained nurses to receive the necessary supplementary education to qualify them as public health nurses and as teachers.

5. Resolver. That information in regard to the importance of public health nurses and the lack of adequate facilities for their training be widely disseminated; that there be widespread information so that the courses of training in existing schools may be adjusted to meet the requirements of public health nursing; and that spccial schools may be established to qualify women for the great opportunity for service open to them in this field.

It was significant that while the importance of public health mursing was stressed, the emphasis was placed on the establishment of schools of nursing.

Out of the Camnes Conference grew the League of Red Cross Societics. The relation of the League to the International Red Cross Committee at Geneva, with special reference to duplication, was explained br Mr. Davison at the first meeting of the General Council of the League, which was held in Mareh, 1920. The two fundamental prineiples of the Constitution of the International Committee were neutrality and universality and these principles made it impossible for the International Committee to assume in 1919 the program proposed for the League.

The spring of 1919 was a busy one for the newborn League. Its first venture in the mursing field took place in June, 1919. Ten nurses, with Emma Wilson as head nurse, were released from service muder the Nurses' Burean of the Commission for Europe at the request of the medical director of the League and were assigned under the Burean of Hygiene and Public Health of the Polish Crovernment, to work in typhus hospitals in Poland. In a letter written Jume 30 to Miss Nores. ${ }^{3}$ Miss Fitzecrald, then ehief nurse of the Ameriean Red Cross in Emrope, describer the plan:

"Disliking the nse of the personal pronomn $I$ and findiner the term "National Director of the Red Cros Nursing Service" awkward beause of its length, the writer of this chapter has decided to use the phraseology "Miss Noyes." 
The nurses' salaries are to be paid by the League and transportation from Paris to l'oland and back again will be the responsibility of the Polish Government. 'The length of contract is for four months and the plan of work involves the assignment of one American Red Cross murse and an Englishspeaking l'olish aide to a Polish hospital. where our nurse will act as rhief and will train native nurses to do the work there. Of the eleven murses who are going, eight of them have already seen service with foreign commissions and two others in the service de santé.

The ten nurses were assigned to various Polish typhus hospitals and did the best they conld for the four months' term of their contract. Late in November, 1919, they returned to Paris headquarters, and of the work aceomplished by them, Miss Fitzgerald wrote in her report of a tour made by her in Poland, October, 1919:

The Polish hospital which I risited showed the effect of the gool work done here by two of our American Red Cross nurses assigned to the Polish Govermment. Neither of them spoke Polish and no interpreter had been secured for them, but they had been able to clean up the hospital; to obtain equipment for it from (olonel Gilchrist; to train native women and put them in a neat uniform; and, above all, to secure the full confidence and coopperation of the Polish doctor in charue. The same can be said of all the units where these nurses have been placed. . . .

'The Polish Government eited the nurses' work as "devoted and fruitful."

The League had not yet appointed, as recommended in the nursing resolution adopted at the Camnes Conference, a director of nursing. Ineh concern because of this delay was felt by loth $\mathrm{Miss}$ Noves and Miss Fitzgerald, as will be secn by reading the correspondenee that passed between them at this time. 1 letter of .July 22 from Miss Fitzerald emphasized this loint:

I assure you that I have not been idle alont trying to have a mursing representative attahed to the Leange of low ( ros sorieties. I think that the (ommission for Furope as a buely is keenly anxious to have this dome and the departure of the muit for loband was nsed as a sperial argument in faror of

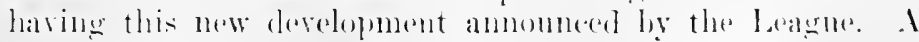




\section{$11+2$ HISTORY OF AMERICAN RED CROSS NURSING}

nursing unit, such as the one to Poland, which does not actually come under our jurisdiction, must necessarily be cast quite adrift, unless the League of Red Cross Societies assumes the responsibility of supervising this mit and other unit: which we may lave in the field.

This crossed a letter from Miss Noyes which indieated that she too was anxious and was even then preparing a communication to the League upon this question. Because of this lack of proper preliminary investigation and centralized direetion, the unit sent to Poland was not able to render serviee of as farreaching a type as had been hoped. The reeall of the unit ended further joint enterprises of this nature in Poland.

In the appointment of a Director of Nursing of the League, the National Committee on American Red Cross Nursing Service took an indirect part. As the plans for an extensive nursing program were developed by the League, Miss Noyes became anxious lest a person of inadequate preparation be selected as director. This, she felt, would not only create very definite difficulties, should the American Red Cross withdraw, which then scemed possible, leaving eertain undertakings under the supervision of the League, but would tend to break down the standards already established. As the Ameriean Red Cross had standardized its Nursing Service and had supplied approximately 20,000 graduates for actual service during the war, it seemed quite proper that it should take the initiative in advising the league upon as important a matter as the seleetion of a Director of Nursing of the Leagne.

A merting of the Advisory Committee of the National Committee was called and a special letter was prepared and sent throngh the chairman, Dr. Farrand, offering the facilities of the National Committee to the Leagne. This letter was sent hy him, with a letter of transmittal, to Mr. Davison, the chairman of the League. The ofler was quickly aecepted and a cable soon followed from the Leagne asking the National Committee to sulmit names of nurses suitable for appointment as Nursing l)irector. It is interesting to note that practically erery one of the National ('ommittee gave in recommendation the name of Miss Fitzererald. Thuns, Miss Fitzgerald's name in recentmenclation was transunited to the Latague by eable. In a letter of Oetober 27,1919 , 1)r. Richard P. Strome, then nedie; director of the langue, expressed his appreciation of the sop. vien of the National ('ommittere. It is of interest to mote low 
far the inlluence of the National Committee had been extruded since its ereation in 1909 and the appointment of a Director of Nursing of the League of Red Cross Societies ten years later.

On November 17, 1919, Miss Fitzgerald resigned as ehief murse of the Anerican Red Cross Commission for Europe to become lirecter of the l)ivision of Nursing of the Leagne. Of the early organization of the League, Miss Fitzgerald wrote:

In the summer of 1919, the Leagne of Red Cross Societies hall othicially established itself in an historical old house in cieneva, switzerland, under the protective wing of the (athedral. By this time. Sir I)avid IIenderson had been appointed as I)irector General and Dr. Richard strong as (ieneral Medial I)irector. The dillerent sections of the Medi(al tepartment were the divisions of Tuberonlosis, Merlical Information, library of l'ublic llealth, Sanitary Engineering and Nursing, ('hild Welfare. Vital Statisties and Malaria.

(On Norember 1\%, I reported for service with the Jeanue and I donbt if any one ever aceepted a position with so slight a knowledge of what it cotaled, with leser opportunities for following any establisbed precodents and with less data on which to build a program. Most of us felt very new and mequal to the task which had been set before us by the lievolutions passed by the Cannes (onference, but we mate up in enthusians, exprit de corps and loyalty to our ideals our lack of experience in international service and the absence of any helplul gridance or precerlent.

In planning for the work of the Ilvision of Nursing. my first step was to try and secure as much information on mursing as I could gather from the dillerent ountries. One dominant fact impresed itself on mo mind through these monthe of preliminary work in anticipation of our first aseconbly was the dibliculty of molerstanding and heing unelerstoml. internatimally sueaking. Worts were nsed by many nations with entirely dillerent meaning in early aroe comparative studies of reports were therefore of no salue and l folt that 1 Wais not erettine on the right roall to "internationalize nursinge" aceording to the neesls and resourees of ditherent combtries. I therefore prepared a report for the Lementy whide

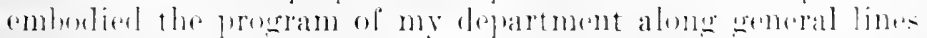

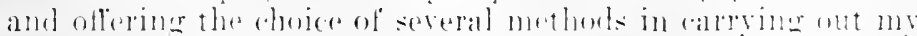

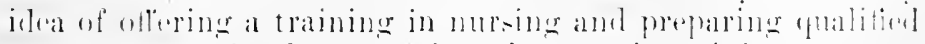
yomer women in the ountries where such training was not illear!y arailable. 


\section{HISTORY OF AMERICAN RED CROSS NURSING}

Early in March, 1920, the League held at Geneva its first General Assembly, and representatives of twenty-seven national Red Cross societies were present. At a meeting of the medical section, Miss Fitzgerald's Report on Nursing was read and the following resolution was voted:

Resolved: That the League of Red Cross Societies urge the establishment in Europe of one or more model training schools for public health nurses, but that until this can be realized there be founded under the superrision of the League nursing scholarships for the national Red Cross Societies of those countries where no such facilities exist, in a eity chosen as being most appropriate.

Of the development of this scholarship project, Miss Fitzgerald wrote:

... I went to London and arranged for a course in practical and theoretical public health nursing which was given at King's College for Women with affiliations with the different child welfare centers, tuberculosis dispensaries, school nursing and other associations for rural nursing, district nursing, etr. The League of Red Cross Societies offered ten scholarships and asked National Red Cross societies to offer others to enable nurses to go to London and study public health nursing as a post-graduate course. Twenty nurses representing the following eighteen countries answered the first call: The Lnited States of America (two nurses), Canada, Venezuela, Peru. England. France. Italy, Portugal, Belgium, Denmark, Swerlen, Switzerland, Poland, Czecho-Slovakia, Serbia, Roumania, Greece, Russia. These nurses were most carefully selected by the different hed Cros: societies according to directions issued from Geneva:

Age: Twenty-thrce to forty years of age.

Education: Exidence must be produced showing continuous education up to the age of cighteen years.

Training: The student must possess a diploma or certificate as regulater by the highest nurrsing standards of the country which she represents.

Health: A medical certificate of general good health must be prorluced.

Reference: Should be given in evidence of good charater and efficiconcy. In selecting stulcuts particular attention must be paid to the necessity for unnsual intelligence to enable them to profit by a course which is necessarily intensive. 
Language: The students must be sufficiently familiar with the English language to follow lectures and take notes.

Form of Application: Must he filleel in and returned to the Direetor of the Department of Nursing of the League of Red ('ross siocieties.

It was felt that this method of training in public health was, for the present at least, our best way for keeping to standarlized nursing in its branches and the course in London is being repeated with thirteen nurses present from the following countries: England, Canada, Mexico, Japan, New Zealand, Austria, Hungary, Bulgaria, Latria, Lithuania, Iceland and ('zedo-s'lovakia. This course, like the first one, is under the direction of Miss F. M. Waters.

The general program of the Department of Nursing of the Leagne included as one of the duties of its director careful "follow-up" supervision of nursing activities developed by national branches of the League. Miss Fitzgerald also supervised some chilel welfare activities which had been developed and finanerel by local agencies in Rommania and Czcoho-Slovakia bnt the medical direction of which had been placed under the Medical I epartment of the League. Of the development of schools of mursing, Miss Fitzgerald wrote:

A training sohool for nurses in Belgrade, Serbia, was orcanizel under a special committee comprised of representatives of the Serbian Red Cross, the Serbian ('hild Welfare ('ommittee of Americat the Serbian Minister of War. Minister of lloalth, military hospital and rivil hospital. I was privilexperl in meeting sereral times with this committee and I assigned 11 is: Enil Vewton. a British trained nurse of extemeled experiencere to he director of the new shool in answer to the reefuest that the league of Reri C'ross sucieties take an active part in its administration.

The derelopulent of this international advisory nursing service was framght with many diftionlties and considerable disromberment. Miss Fitzocrald wrote:

- Perhaps the greatest ohstarle to quick artion and rapid result - will continue to be the distances which separate

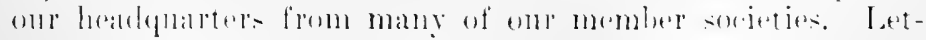




\section{HISTORY OF AMERICAN RED CROSS NURSING}

ters travel slowly, wires are expensive and unsatisfactory, and personal visits prohibitive in many cases. ${ }^{4}$

The Department of Nursing of the League of Red Cross Societies finds some encouragement in the fact that it has established a personal contact with nurses from thirty different countries, many of whom will act as pioneers in nursing uncler the flag of their own Red Cross society and with what help we of the League of Red Cross Societies can give them.

The League of Red Cross Soeieties lost the services of Miss Fitzgerald in the autumn of 1921. After an absence of six vears from the United States, she had returned for a muchneeded rest, and also with the hope of aronsing some interest on the part of philanthropic individuals and "fonndations" in the nursing service of the Leagne. While she was in the comntry some changes in Leagne policies influenced Miss Fitzgerald's resignation. She was suceeded by her assistant, Miss Katherine M. Olmsted, an American Red Cross nurse who had shortly before been appointed to advise in publie health nursing matters of the League program.

At the second meeting of the General Comneil, held in Genera, March 28-31, 1922, the nursing program of the League was discussed. In this discussion emphasis appeared to be laid on public health mursing at the expense of murse education, which is necessary as a sound fundamental basis to any nursing service. This eaused some anxiety to those who were interested in the development of the minsing program of the League. The change of nane of the Burean from that of "Department of Nursing" to "Department of Public Health Nursing" seemed a clear evidence of misplaced cmphasis, and appeared to suggest a drawing away from the resolution adopted at the Cames Conference.

By the date of the seeond meeting of the General Conncil of the League, the "experimental period" " of its existence may be said to have been ended. In the light of past experienee, it became possible in 1922 to define "with relative contidenes" "

* The fact that rach Rod Cross society was promitted to interpret the qualifications of the students led to lack of uniformity. The canadian or American nurse fomnd herself a member of a class which contaimel women with lied Cross cortificates it is true, but who could hardly be regarded als graduate murses. liecent reports show that an offort has been minl. to alopt a minimum standard, but so far withoht sneeses.

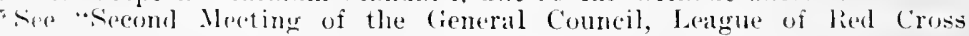
surieties., Vol. 11. p. 15.

"Ifill., p. 19. 
the type of service which the League could most effectively render. This service was thought to be chiefly in an advisory apacity rather than in the development, as first contemplated by the Camnes Conference, of the leagne as an international healtl organization or of an extensive program in the field of medical researeh. This change of policy involved a substantial reduction in the entire program of the League, and in this reduction the l)ivision of Nursing shared.

Miss IIay attended the Comeil meeting as a representative of the American Red Cross Nursing Service, and in a speech made at that tine emphasized the necessity of nurse schools as the only safe basis for a general or special public health service:

It seems to me we shoukd lose an musual opportmity, even nerglect a very important duty, if this boly did not put itsolf on record as making most conspicuous this idea, that for public health nursing and for the best development of public: hoilth nursing in any country we must have the assistance of thoroughly trained nurses. . .

The nursing delegates had under consideration the publication of a panphlet which would set forth the activities that might be undertaken by the League, and Miss Hay suggested that a statement such as the following be introduced into it:

In the more essential nursing activities which the Leagne can condurt, it is recommended that the League shall undertake to stimulate the organization of nursing sehools of the lighest standards in countries where these do not now exist.

This recemmendation of Miss Hay's was in line with the efforts of the American Red Cross to introduce into European comntries the Nightingale System of nurse education. An accomnt of the selools of nursing subsidized by the American lied C'ross follows.

In Prague, Czecho-Slovakia; in Posen and Warsaw. Poland: in Constantimple, Turkey, and in Port-an-Prince, IIaiti, the American lied cross estahlished sehools of nursing. In Athens, Greece and Sofia, Bulgaria, similar attempts were male but, at the date of writing of this history, were msurenserinl.

At the reequest of Dr. Mlie Masaryk, the danghtere of the president of the new repmblic of C'zecho-slowakia, Miss Fitz- 


\section{$11+8$ HIS'TORY OF AMERICAN RED CROSS NURSING}

gerald visited Prague on July 3, 1919, for the purpose of conferring with I)r. Masaryk on the subject of a school of nursing. 1)r. Masaryk placed an interpreter at Miss Fitzgerald's disposal and she visited the general, maternity and ehildren's hospitals in Prague. In the report of her trip Miss Fitzgerald wrote:

... I then had a final interview with Dr. Masaryk. The question in my mind at the time was as to the advisability of taking over the present training school / the State school which was finally selected], where some students are now awaiting their graduation, and reorganizing it, or whether to start an entirely new organization. The former plan apjealed to me becanse it would avoid duplication of elforts and the fact that pioneer work had been done might make it easier for the new people coming in. Dr. Masaryk anreed with me in this matter and I mate it very plain to her that the suecess of the scheme wonld depend entirely upon two things-first, the possibility of enrolling the projer class of students, i.e. girls of fair eduation and of high moral gualifications: and secondly the matter of oltaining not only the full coopperation of the medical profession, but of seeing a thorongh (hange in their present point of view, so that they would themselves see the necessity for a training school. . . .

Dr. Masaryk scemed willing to guarantee that all these above conditions would be complied with and seemed to have no doubt in her mind that this could be done at an early date.

The plan as finally drawn up was stated as follows by Miss Fitzgerald in a letter written July 18, 1919, to Miss Noyes:

We are to send two trained nurses to Prague for a periori of three years to start a training school for nurses in that city. At the same time Miss Masaryk is to pick out two weHeducated. well-qualified and representative youmer women of the (zecho-slovak race, able to speak English, to rome to America to take the nurses' training there. When they finally receive their diplomas, they will then be ready to return to Prague and carry on the work, when we are ready to withelraw our two nurses from there. The soheme has been approved by the Commission for Europe, and is now awating final endorsement from Washington to become a definite Han. As I told you in my last letter, I think that Miss Marian Parons would he a rery good person for this piece of work, would she be willing to molertake it. One thing which makes me very oftemistic about the final outeome of this plan is the fare that the medical profession in l'rague is of a very high standing. 
Miss Fitzuerald presented a budget, which included the salaries for three years of a head nurse and one assistant, with a maintenanee appropriation of twenty franes a day and traveling expenses. It also ineluded a monthly allowance of $\$ 25$ for each of the two students for two years, with traveling expenses. The total appropriation called for something over twenty thousand dollars. It afterwards developed that two murses were not suffieient to develop the school, so two additional were assigned, one to develop a public health course which formed part of the student course, the other as supervisor of the prartical work in the wards. A copy of the communication was sent to Red Cross Headquarters, Washington, D. C. The plan was immediately considered and a cable of approval was transmitted on July 29, 1919, by I). Farrand.

As the Red ('ross was expecting to terminate its general relief work in Europe, Dr. Farrand felt that a commitment covering general supervision for longer than one year might place the Red Cross in an awkward position shonld it decide to close its Paris oftiec. The question of some other organization acting as the liaison between National Headquarters and the school was discussed and suggested in the cable. The necessity for this was remote, as direct communication and direction from National Headquarters in Washington was quite practicable.

After returning to this comntry for a brief rest. Miss Parsons, accompanied by her assistant, Ahtta Lontell, went back to Enrope and assumed the responsibility of organizing and direeting the School of Nursing at Prague. Miss Parsons was horn in Maine and was a graduate of the School of Nursing of the Boston City IIospital. After several years of executive experience in varions $\mathrm{Now}$ England institutions. she took a two years' conrse at Teachers College in training school administration. She joined the drmy Nurse Corps ats a member of Base Hospital No. 7 . She served aloroad with this nuit and wals reldalsed Oetober, 1919. Miss Parsons' experience and thorengh preparation eminently qualified her for this exeectingly difficonlt and arduons mulertaking.

Thus the first steps were taken lie the Aneriean Red Cross toward a more constructive pust-wat program in Eurepe. one

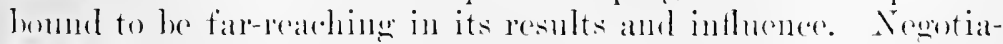
tions were also immediately opened with the Malsinchusetts (ieneral sichool of Nursing and alrangenents manle with it to 


\section{HISTORY OF AMERICAN RED CROSS NURSING}

receive the two graduates, Bozena Brezinova and Franciski Ruzickora of the State School, for instruction covering a period of two years, a credit of one vear to be given them for the time spent in the State School at Prague. ${ }^{\top}$ The two young women arrived in this country in August, 1920. But their knowledge of English was found inadequate and special tutoring became necessary; thus their admission to the school was delayed until January 1, 1921. Unfortmately Miss Brezinova suffered a nervous breakilown almost immediately and was sent to the MeLean Hospital for treatment, where she remained until the autumn of 1921 , when she was returned, unimproved, to her own country. In the early summer of 1921, Vilma Cerna, who had graduated that spring from the State School, partially trained under Miss Parsons, replaced Miss Brezinova. She spent the summer in the wards at the Presbyterian Hospital, New York, acquiring American methods and entered Teachers' College at Columbia University in the autumn as a special sturlent in administration of schools of nursing. Here again the handicap of imperfect English made special tutoring almost imperative, which Wiss Nutting, through private means, supplied. The summer of 1922 was spent by Miss Cerna in the wards at the Massachusetts General Hospital, in order to secure further practical experience. She returned September 16 to Czecho-Slovakia to serre as assistant to Miss Parsons until the termination of the contract. At the time of writing this chapter, Miss Ruzickova had not yet finished her course; all reports indicated that she was a good student and interested in her work.

Miss Nores on her tour of inspertion in the antumn of 1920 visited the School of Nursing at Prague. The two most serions defects at that time were inadequate facilities for teaching practical nursing in such wards of the hospital as had agreed to admit the students, and an insuftieient dietary for the nurses. In making romels through the hospital. Miss Joyes was struck hy the lack of proper equipment. The linen and clothing sipply was most inadequate, and in the tuberculosis wards particonlarly pationts shivered moler but one blanket. This marde it almost impossible to keep the windows open and to whtain fresh air.

7. Yajor Herbert S. Johnoun of lioston, former Amorican Red Cros; Commisioner to cordostovalia. Was not only interester in the project but was responsible for its origin. 
In the wards a corner was usually set off with a half-partition to make a so-called reom in whieh the nurses had formerly slept; here at the time of Miss Noves inspection they were ocenpied by the ward maids or attendants. The murses' hone wis a fairly good building. The sleeping rooms hatel beren remfortably furnished; usually there were two or four students in each room. The historic porcelain stove ocenpied a mrmer of each. The seareity of coal, however, male it imposible to have fires except in the living room. Miss Parsons had tited up this room in a very attractive manner and hateserenred ofpually pleasing elass rooms and a library.

The dining room, however, was a cheerless place. ('onnected with it was a geod kitchen where the food from the hospital, provided for the murses, was served. As Miss Hay and Miss Soves lonlged in the sehoul, they were given ample opportmity to sample the food. I lay's menu, more or less typical, was about as follows: A larere piece of heary, black bread, withont butter'; sulstitute eoffee, withont milk, but with sugar, provided to the murses before they went on duty in the morning. Upon this meacer diet they were expected to work until noon. For the mid-rlay dimer usmally thin somp, cabbage, bread withont buter. and for deseret a larege, heary bum, made of comparatively white flour. which eontained in the eenter some som rheese and a seanty sprinkling of sugar. For supper tea, bologma samsage oreatsinally and bead or plain boiled potatoes, generomsly sprinkled with caraway seeds, or by way of variety, sour rherse. If putatoes were given no bread was provided. Twier a week meat was served for elimner. Thus with little or no variety the wearisome rontine wats followed day after day. The stmdents and graduate nurses looked pale and anemic and it sermed marvelons that 11 pon so meager a dieet they wore able to deag throngh a day s work on the wards where anything but hrenienic and santary anditions prevaled.

Two recommendations were made to the Paris office:

1. That an allowance of 18.000 franc: be given to Miss

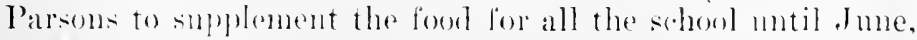

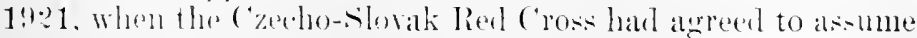
this responsibilits.

$\because$ That instade of provintine cooked food from the hospital, the equivalent in money he griven Mis- Parsens to huy

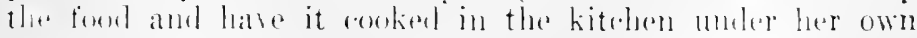
birentions. 


\section{HISTORY OF AMERICAN RED CROSS NURSING}

The recommendation requesting an appropriation for food was granted by the American Red Cross and the second recommendation later became effective. The result was that a more gericrous diet, palatably cooked and served, was procured for the nurses, with a corresponding increase in their physical well-being.

Another observation of Miss Noyes was that only two pieces of soap, two inches square and filled with irritating alkali, due to scarcity of raw material and cost, was issued to the wards weekly. This served all purposes, for the hands of doctors and nurses, for bathing the patients and for general cleaning purposes. Despite these limited supplies the wards, sumny and bright, looked exceedingly tidy and elean, with white well-serubbed floors and polished bits of brass here and there; and even though the linen was scanty, permitting only of a weekly change, the beds looked fairly comfortable and clean.

The faenlty of the selool at that time consisted of Miss Parsons, Miss Lentell and Blanche Kacena, a BohemianAmerican nurse, who had been prepared at Teachers College, and who spoke the Czech language. Miss Kacena was detailed to the supervision of the instruction in the hospital. Pansy Besom, a public health nurse, formerly with the New England Division of the Amerien Rerl Cross, was assigned to develop a pullic health nursing course, and was at that time making a survey of the resoures of the city. May lonise White was acting as an assistant. Mary H. Bethel was instructing in Home IIrgiene and Care of the Sick in comnection with the Czech Red cross.

The organization of the sehool consisted of a Board of Managers of nine members, upon which the Czecho-Slovak Red Cross, the Ministry of Hyeine, the faculty of the University of Prague and the military gromp were iepresented; the superintementent of the State Ilospital and the Aneriean Nurse direcetor were also menulers.

The curriculum consisterl of a two vears' and four months course which had been arranged by the director, and the majority of the subjects, becanse of the language difficulties, hat to be given by physicians, members of the medical department of the Tniversity of Plagene or of the hospital statf. lustrucetion by the Amerian lired Cross muses, exerpt that hy Miss

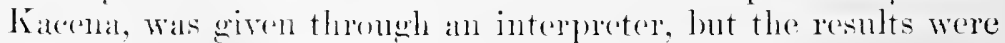


surprisingly good. Gradually Miss Parsons was able to add to the currieulum a thorough course in invalid cookery and nutrition, a course in bactoriology ; and finally to grive the students the advantages of Amcrican textbooks; because of the lack of mursing textbooks written in Czech language, she introluced a comrse in English.

Attiliations that would enable the students to olitain added experience were gradually developed with the University (State) Hospital. Here pratetical mursing experience in four

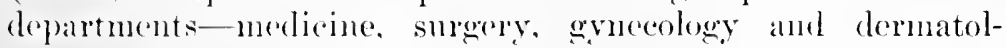
anc-wats given. The Chiletren's IIospital, a private institution, afforded training in pediatries and field work in public health nursing in connection with the child health centers developed by the Ameriean Red Cross, was arranged.

An important step in the history of hospitals and the education of nurses in ('zecho-Slovakia consisted in the placement of wards of the State Inospital under the direction of the Americam murses of the Prague School. Previous to 1920 the School of Nursing had hat no nursing control of any department of the State Hospital and many of the duties eommonly assigned to nurses, such ats taking pulses and temperatures and giving hyporlermines, had been assmued by the young plysicians. A leading internist connected with the State IIospital, impressed by Miss larsons arements and the better methods and results, offered the school two of his wards as a teaching ficld. As the type of nurwing which was done in these two wards became known, the sehool was gradually repuested to assume chare of the nursing in sureical and grnecologieal wards ats well.

Is to the students, it was observed that they appeared to be drawn from the millle elasses. A tuition of serenty kronen pere month was repuired from the ontsot from all student murses. 'The prejudier against nursing as a protession for gentlewomen still prevaliled in (zoeho-slovilkia. The attitule of the merlical profession in many instaness was discomragine; they appeared quite willing to areept nurses of the poorest errate, and some were indined to show some antagonism to the plan of a molern sebonl. With the haleking. howerer, of President Masalrek.

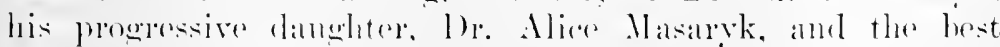

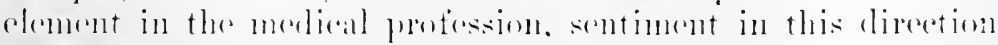

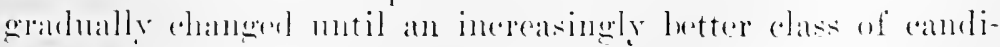
dites were aldmitted. 


\section{4 HISTORY OF AMERICAN RED CROSS NURSING}

The American Red Cross contract with the State School at Prague called for gradual withdrawal of the American nurses from the school. Two nurses were prepared in the schools of the United States to succeed them. 'The foundation was carefully built and the school at Prague bade fair to compare favorably with any modern school in America. The American nurses were prepared to pass the torch to their Czech sisters who had been taught under their auspices and to give them the courage as has been the case in the history of all such movements, to "carry on" as pioneers in a country where a system of modern nursing was still a matter of wonder to the large part of the population. That the school was maintained at all was an accomplishment of no mean proportions. During the years following the European War, Czccho-Slovakia was making a mighty effort towards reconstruction and improvement of its economic conditions. Surrounded as it had been by enemy countries, over-rum by armies which had lived upon it, stripping it bare of everything, was it a cause for wonder that its hospitals were destitute of the bare necessities? The Czechs, a proud people with umbroken spirit, were well aware of the situation and were making a desperate and apparently highly successful effort to improve conditions.

Although the idea of introducing the Nightingale Srstem of nurse education in Poland was conceived at an early date following the signing of the Armistice, the development of a school was slow. In her first commmication from the Leagne headquarters under date of November 20, 1918, Miss Fitzgerald wrote to Miss Noyes: "I believe that the American Red Cross Commission for Poland is planning to start a training school for nurses. The comntry is not yet ready for it, and I tried to persuade Colonel Chesley [then commissioner] that they should not undertake such a picee of work until they at least had the advice and coipperation of a nurse of experience." This was the first hint that a school for murses was ocenpying the thought of the Commission for Poland. From time to time during the winter and spring of 1920 , letters first from Miss Waters, who served as arting loirector of Nursing at the Paris heatquarters during the interval succeeding Miss Fitzererald's resignation and Miss Hay's appointment, then from Miss Hay and Wiss Bemn, contained reforenoes to such a project.

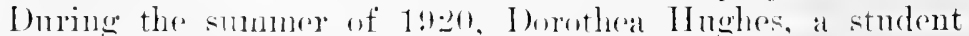
nurse in the Army sedool of Sursing at Waltor heed Hoppital, 
wrote to the Red cross office that throngh friends she had become greatly interested in Poland and desired to be of help to it; that as she had entered a training sehool for patriotie reasons she wonld like to assist with the organization of a school in Poland, and was ready to subseribe $\$ 10,000$ a year through the American Red ('ross for three yoars for that purpose. Miss Noyes, knowing that Poland was asking for assistanee in this direction, assured Miss Ilughes that she had written at an opportune time. Adviee of the offer was transmitted to Miss Ilay, and upon the assurance that the money was available, she submitted on . Iuly 1, 1920, a careful plan for a school in Warsaw, lased upon her survey of mursing activities and needs in Poland made in .June to Major IJoneij of the Medical Staff, American Red Cross Commission for Poland. This plan was to be presented with a detailed letter of transmittal from Miss Hay to Madame de Bisping, then president of the Polish Red Cross. The best laid plans dependent upon members of the human race to exerute often misearry, as will be seen from the following extract in a letter from Miss Hay to Miss Noyes dated July :30, 1!20:

Miss Fitzgerald returned this week from her trip to Poland and Prague. and lorings back valuable reports. She may write you direct on the question of the training school in Warsaw, but the faets in the ase are these: That 10r. Honeij insteal of giving Mme. de Bisping my letter to her regarding the school, sent it without further explanation or conference. quite contrary to what he had said he would do. Miss litzgerald reports that IIme. de Bisping was somewhat consternated at the higness of the plan. and the fact that the Polide lied Cross was little prepared to give any material as sistance to such a plan regartless of how nuch they wanted the sehoul.

This may lave been one reason for the fact that but little was heard on the subjeret of the Warsaw school for a time, althongh the bolsheviki drive in the summer of 1920 alamed the full attention of the Polish Red ('ross. The guestion, howerer. was not allowed to die.

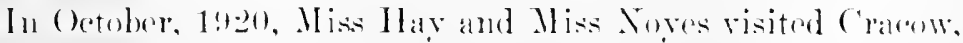
where the lowal antherities had experesond a desime that the

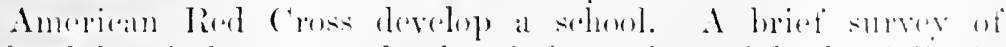
local hespitals was made that information might lue fully in

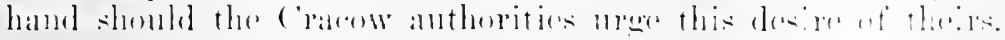




\section{HISTORY OF AMERICAN RED CROSS NURSING}

Miss Hay and Miss Noyes left, after two days, for Warsaw, where in addition to making a fairly comprehensive study of the general conditions, specifie eonsideration was given to the question of the development of the school of nursing, toward which Miss Fitzgerald and Miss Hay had been working in operation with the Polish Red Cross.

Conferences were held with representatives from the Ministry of Health, the University of Warsaw, the Municipal Government, with Miss Zlenkier, a nurse who had built in Warsaw a complete and modern hospital for ehildren and who had taken a partial course of training at St. Thomas Hospital, London. Various hospitals were visited; among them a ehildren's clinic, where an unusual opportunity seemed to be presented for the development of a central sehool; the Infant Jesus Hospital, a large institution which had been under the direction of Russian authorities and from which, upon their evacuation, they had removed all the furnishings. This hospital, unlike others which had been visited, was quite modern in its equipment, with lavatories and diet kitehen well furnished. The hospital was under the direction of Sisters who were good housekeepers and possessed comparatively modern ideas of nursing, as the eleanliness of the wards, beds and bed linen clearly indicated.

The local authorities interested in the development of the sehool presented a plan which had been prepared by the special committee, which included the individuals already mentioned as well as others. This plan was formulated from suggestions apparently made by Miss Fitzgerald and Miss Hay, combined with loeal ideas. Ineluded was the Prussian system of keeping a hand upon the graduates after the completion of their course; for a given space of ten years they were to be under the control of the institution. The plan also earried with it insurance for invalidism and old age; it ineluded a Congregation of Sisters, every nurse to be a member of this Congregation, ete. The merits of the plan were discussed at a conference and a connter one was prepared, which with modifications was used as the basis of understanding and eontract with all the schools sponsored by the American Red Cross. The six main points of the plan were as follows:

1. A corps of instructors of broad experience and unquestioned ability. At least four trained nurses are necessary for the class and practical instruction and supervision. A fifth 
nurse is also desired to organize and arry on some public health activity, so that preparation for this jumportant field of usefubess may be made a part of the solbol's program.

2. A murses lome allequately furnished and maintained. Such a home must be large enough to take care eomfortably of the total pupils acided on ... besides rooms for the farculty. for classes, study, recreation, houschold menage, etc. It should be attractive, comfortable, sanitary, well heated and lichted, and with sulfieient service to keep it immaculate. Berause pupil murses have large demands male of them. phrivical and mental, the food should be ample and of the best quality. Ample lamblry and bathing arrangements are also neresiary.

3. I informs, texthooks and translation of same, equipment for class work, as charts, models, ete. It is possible that in order to attract a sufficient number of pupils, a small monthly allowinere also be providerl.

4. Ifospital atfiliation. Such hospital aftiliations should be secoured as will ensure the thorough practical training of the pupils in the varions rlases of disorlers, as medical, surorical, transmissible, gynecolonical, pecliatrie, ete. It is important that the livertress of the school, with her assistants, be given the mursiug control of such hospital divisions as are secured for this practical training.

It is understood that rules and regulations governing the admis-ion of pupils, their supervision and general direction, may safely be left to the director of the training school to develop after hor arrival. Also rules governing the activities of graluate unrses should primarily be left with the graduates themselves.

In this ronnection, it is important to state that any rules binding the graduates of such a school to extended service or control after graduation are contrary to American method. and principles and are, we believe, certain to reart unfarorably un the school itself and to reduce materially the number of desirable cambidates available for the training. It is expertesl that the direstor of the sehool and an interested school committe will lend every assistance in securing proper recognition and alfequate salaries for the members of this new-born profesion, either through suitahle Surse l'ractice Arts. rexistration bie the forermment, or in such ways as would proted the porplo and the nurse graduate.

5. Coriperation of the medical fraternits. or leading memhers of it. who would asist in se'onring the fesired hosplat

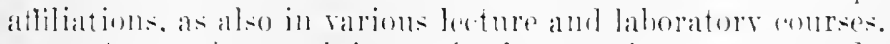

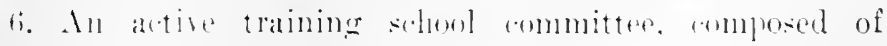




\section{HISTORY OF AMERICAN RED CROSS NURSING}

representatives from the various interested groups, leading physicians and others, who would give of their whole-hearted sympathy and support toward the creation and maintenance of such a school of the first class.

'The help and influence of the larger body is needed, but that the work might le vigorously pushed forward, such a larger committee shonld be stibdivided into smaller working committees, as. for example, a Committee on Nurses' Home, Committce on Curriculum, on Hospital Affiliation, etc. It is recommended that to this larger committee be appointed two nurses residing in Warsaw. who have had training in two of the best London hospitals, Miss Szlenkier and Miss Zarzycka; also that the Commissioner for Poland, American Red Cross, the Chicf of the Medical Staff, and the Director. Department of Nursing of the Commission for Poland, A. R. C., be exofficio members of the committee. ${ }^{8}$

No doubt the suggestions which had already been made, in addition to the plan submitted by Miss Noyes and her associates, seemed a radical one. Time was needed for the Polish committee to digest it.

Miss Nores risited Posen for the purpose of interviewing a committee who were interested in the development of a school of nursing, and also to review the work of a small group of nurses located at Kornik and two who were giving instruction in Home Hrgiene and Care of the Sick in Posen itself. Lpon her arrival a conferenee was held which had been arranged for by Dr. Zniniewicz, president of the Posen branch of the Polish Red Cross, an able woman phrsician vitally interested in the establishment of a school in that city. There were representatives present from the Municipality, the Department of Health, the Division of Military Hospitals and the Posen Lniversity; also Miss Hay and Miss Mathews were there. The Posen representatives stated their sinecre desire to help in every way possible in the organization of a school of nursing with Aneriean nurses in charee. They sugesesed a building formerly used by a German phrsician as a private sanitarimm, which was at that time under consideration as a hospital for the Government railroar amplorees and their familics. In order that a better understanding of the American standards and requirements might he had, a copy of the plan which had been prepared for the Warsaw Committer was given to the Posen group.

"For further details. see "Outliue of School for Nurses in Poland, October 2.5, 1920," Ried Cross Arehives. 
Out of the plans for a school of nursing for Poland, two schools instead of one emerged. The Posen Committee lost no time in putting their plan into shape and presented it on December 12, 1920, through two important railroad officials, to Miss Mathews. On Deeember 25 Miss Mathews, Miss Skorupa and Mr. Barge, then commissioner for Poland, made a visit to Posen, and at a meeting held the following day, the "Direetors of Railways" offered their newly-furnished Hospital of sixty beds and a dispensary as a practical field for the School. The Department of Ilealth offered the coöperation of other hospitals and the lean of the University offered their newlyopened clinies and traehing equipment. The direetion and execution of the plan was placed in the hands of the Polish Red Cross, which in turn was expeeted to contribute furnishings. The city agreed to furnish light, and the railway director, coal.

On December 30, 1920, Miss Mathews in a letter to Miss Hay reeommonded that two Ameriean Red Cross murses then in Poland and a third murse be sent to the prospective school in Posen; these nurses were Lonise Walter, who spoke German fluently; Stella Tylski, a Polish-American, and Miss Suchowska, whose enrollment in the American Red Cross Nursing Service was then pending. The approval of the Commissioner for Enrope was finally secured and the murses sent to Posen.

The subsequent months were difficult ones for the little group of muses. The promises of the Committee, while unquestionably made in good faith, did not always materialize. Apparently" there was some talking at ross purposes. "Ihiving quarters" to an Anerican nurse meant one thing, a good home or good rooms, heated: to members of the Polish Committee it might have meant a corner of a ward. The first diffieulty was suitalle living guarters.

The promised aftiliation for obstetries was at that time not available. The Railsoad Hospital, which was offered as a tearhing field, had alroady a nursing staft of Catholir Sisters, and they hat to be enendiated. Then rertain members of the medical profession, true to American form, hexame conerned lest the graduates might puretien medieine after graduation. and sont a formal commonieations to the ('ommitter which

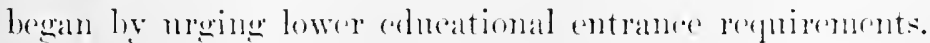

- Letter by Drs. Adamski and Miklasinski, Angm-t 14. 1!21. 


\section{HISTORY OF AMERICAN RED CROSS NURSING}

Miss Ita MaeDonnell, a Red Cross nurse who had been sent as director of the sehool, and who had been accustomed to working with Sisters in America, gradually effected an arrangement whereby the Sisters were given the housekceping, purchasing of supplies, supervision of help, and laundry. This meant, however, that the small group of American murses with the assistance of ten probationers were obliged to assume, both day and night, the actual nursing work in the wards. The diffienlties, met and overeome, would have discouraged a less enthusiastic group. Such handicaps as bedbugs, lack of water, shortage of linen and utensils, low beds, poor mattresses, laundry only every two weeks, were met and conquered; gradually order and cleanliness were secured. The type of student admitted was excellent, and a two-year course was arranged to the best advantage. The school was formally opened on November $10,1921$.

A request for an appropriation of $\$ 11,500$ was approved by the Executive Committee of the Ameriean Red Cross in 1921, with the expectation that it would take eare of the teaching faculty for two years and six months. It was further expeeted that graduates from the school or from among the Polish students brought to this conntry on Rockefeller Foundation Seholarships and placed in the Massachusetts General Sehool of Nursing would at the end of that time be available for this work. In April, 1922, Dr. Hill, then vice-ehairman in eharge of foreign operations at National Headquarter's was able to increase the fund to $\$ 15,000$ in order that an additional instructor, inereasing the faenlty to four, might be provided, and Lena Johnson was added to the staft.

In $A$ pril, 1921, plans for the development of the Warsaw School had reached such a stage that Helen Bridge, whose work with the Siberian Commission has already been described, sailed from New York as direetor. The project was financed by Miss Dorothea Hughes. On Miss Bridge's arrival in Poland, she began organization of the committee, selection of buildings, repairs and equipment, preparation and printing of cirenlars and application blanks, publieity, interviewing candidates, sclection of statf and the countless details incident to a project of this nature, difficult in a well-organized country like Aneriea, but doully so in a comtry wasted ly war and hampered by a thomsand economie and traditional obstades. A less optinistic persen than Mliss Bridge might have lost heart, but 
she believed in the enterprise and so did her committee, and she forged ahead.

In a letter to Miss Noyes under date of August 2, 1921, Miss Bridge wrote:

You will be delighted to know that up to the present we have had sixty-four inquiries concerning the school. I have ancepted four candidates and lave forty-five applications pending. We are quite pleased to have a quality of applicant superior to that which I anticipated. The first applicant was the daughter of a Polish Countess, a splendid girl, but too young. She has withdrawn until next year. The first applieation to be completed was that of IIary Pawlowiczowna. She is a splendid young woman who has had one year at the University of Warsaw. Is it not significant that our first accepted candidate should come to us so well prepared? ... Of the four accepted there is another who has had two years at the university, one who is quite ready for the university, and the fourth falls short of having a certificate from the eighth (laks (the equivalent or more than our high school) becalnse she failed in French. Almost every candidate I have interviewed speaks French and a number of them also speak Finglish. . . .

The attitude of the physicians on the Council and others in Warsaw towarl the school seems rery good.

Each suceeding report recorded the growth of interest and the betterment of conditions. Finally October 19, 1921, was deeided upon as a snitable date for the formal opening, which included the ancient Polish enstom, the Blessing of the House by the Cardinal. "American nurses," stated an address of welcome written ly. Miss Noyes, "extend their hands across the sea and woleme this new school as they would a new relation."

The adtless by I)r. W. Meezkowski, a friend of the school, slowed the attitude of the best element in the medical profession toward this project:

Poland is now like a bad housekeeper who, having an abundance of eversthing, wastes: many children are born, but the nation does not exert itself to keep them alive. Death takes them away as in no other country in the world, and the general mortality is much greater in Poland than anywhere else.

There must come a time for us 10 open our eres and see where we are groing. We must begin a wise and flamned war 


\section{HISTORY OF AMERICAN RED CROSS NURSING}

against illness. We must visit our ill people and examine the conditions of life of the healthy; we must enter the homes of the peasants and the town dwellers, we must render popular the idlea of real nursing, we must increase the means of prerenting disease, we must take care of women during pregnancy and after childbirth, and we must provide the proper care for sick people in their homes and in the Hospitals.

This task can be carried out only by an intelligent and devoted nurse, such a nurse as graduates from the schools of North America and England. Our school has as its object the production of such nurses who must be pioneers. Its task is to produce the first nurse instructors for the medical institutions, and that is why, in accepting our first candidates, we have been so exacting in regard to their moral and educational qualifications.

After thanking the Polish Committee members, the Americans and others who had made the school possible, he continued:

Before I finish I wish to speak to the pupils of the School of Nursing. to those pioneers who on graduation from this school will go the first into Polish society, taking to the villages and towns the rules of hygiene, cleanliness and orler, and who will give to the patients in the hospital and in the home honest and wise care. Nursing-as stated in our regulations-is not an ordinary profession. For us it is like an Order which demands a special vocation. Here hard work does not suffice, there must be sacrifice, a row to give oneself with one's whole heart. This high task of giving help to the poor and suflering, of preventing disease, will be your reward, and the rommon service to this high idea will create among you links. sincere sisterly relations. This school will aid you in educating your heart and brain and in developing your love of mankind.

The report for Jannary, 1922, amouneed the sad death of T). Nerzkowski, whose last office for the school had been to secure the balance of $4.000,0(00$ marks due on the 1921 appropriation to be given by the Polish participants. The report as well indieated the completion of the plan for hospital affiliations. The ecomonic situation, affected as it was by the rapid depreciation of the enrener. bromert financial anxieties and compliations that ereatly increased the problem for Miss

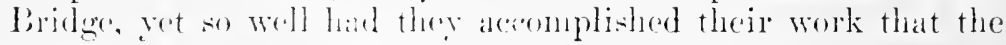




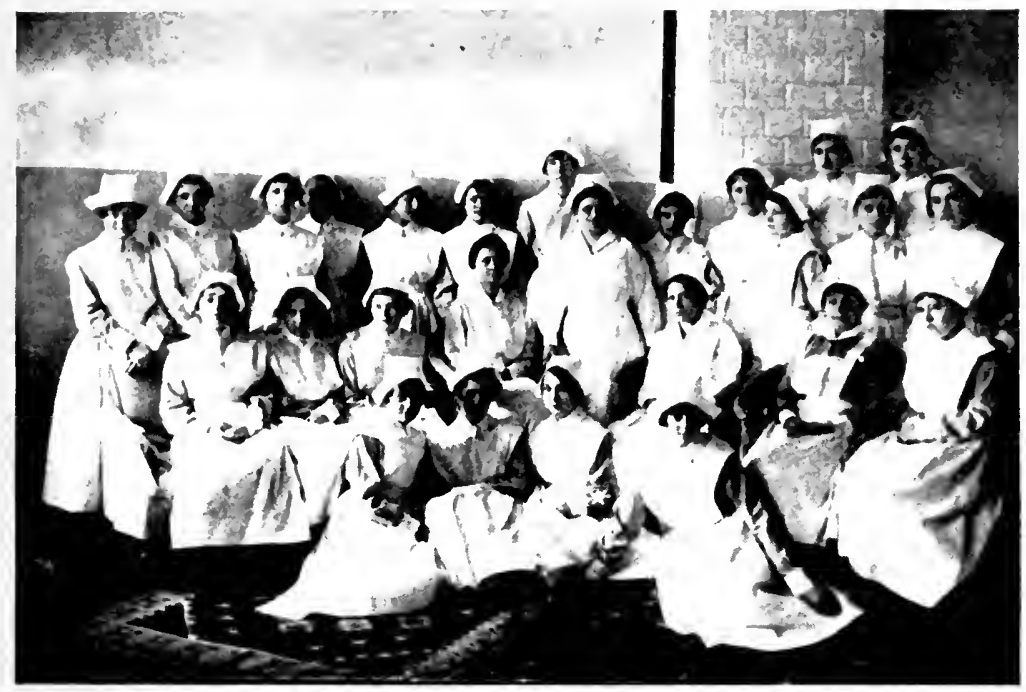

First clasis of the School of Nursing. Warsaw, Poland, established by the Ancrican Red Cross.

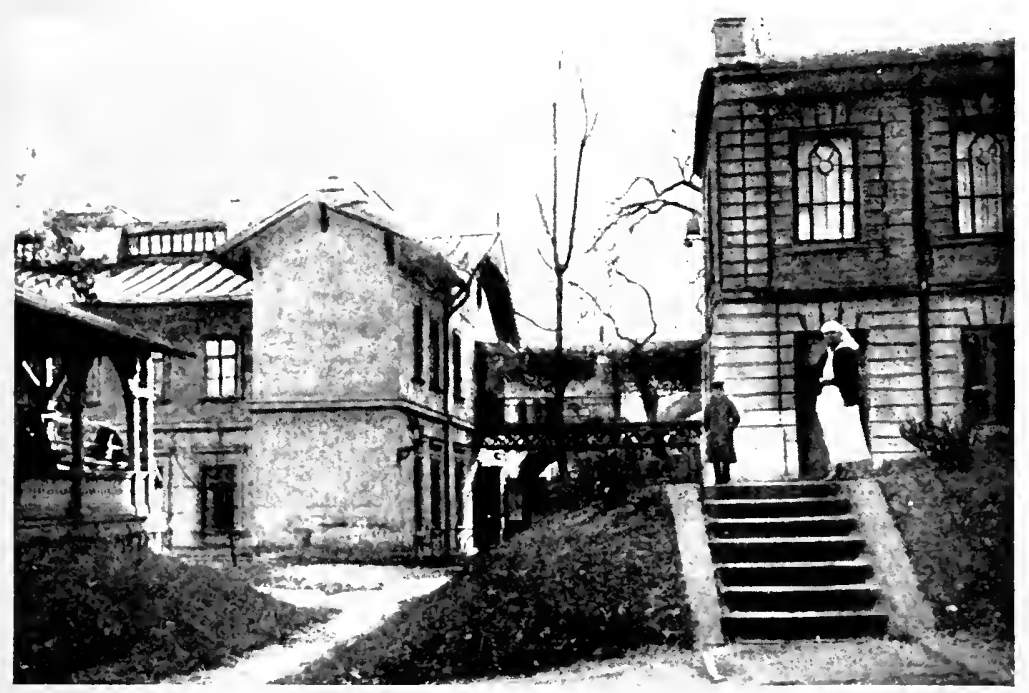

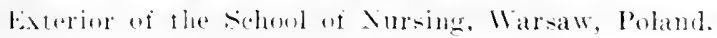



Administrative Comeil at a meeting in Deember asked the sehool to assume responsibility for the housckeeping, kitchen, and dietary for pationts and the lamelry. I Hospital Committee was also suggested. 'That Miss Bridge, supported by Miss Mathews, appreciated the practionl difticulties as well as the advantages of taking eharee of the honsekereping was shown in a letter to Miss 11ay under date of 1)ee(muber 20, 1921:

I talked the whole thing over with Miss Mathews and she agrees with me that, while it is a large orler. that we will probalbly be able to bring up the standard of the nursing much more quirckly it the bousckeeping is under our control.

This same letter recommended a dictitian, qualified to assume the instruction to student nurses not only in invalid cookery and mutrition, but in household administration, including the laundry; to arrange the dietaries and to take charge of the buving of food. Furthermore, she should be able to speak either 'Polish, Freneh or German. The Paris oftice approved this repuest, and a cable to this effect was sent to National Hoadquarters. On May o B Bortha Holman, an enrolled Red Cross dietitian, left the Cuited States for Warsaw. That she was needed and was facing heary responsibilities was plainly vident, as shown in a letter from Miss Bridge of April 17:

The hospital is in a perfectly wretched condition, very dirty and whout signs of anything you combl call real organization. . . It is the same ohl story of preceding slowly mutil you hase won local confidence. We went into the hospital with eighty-five patients to are for, but this number was quickly inceased to one humdred and twenty. . . .

Ifter the preliminary conrse, our twenty-two student nurses went into the wards. I shall never forget the picture they made on that first morning in their erisp new nniforms and their fares bright with anticipation. 'Two of the stments. whe had never been in a hospital hefore were so frightended that we hatel to stay with them in the wards for a time nutil the first sharp elge of their fear had worn off. I still remember the flushed frightened face of one of them.

After the first day. the patiente lexered the studente to stay with them all nieght. for, they said, "wo hatse been talsen care

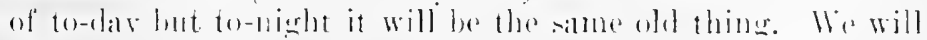
ring and ringa and no one will answer." 


\section{4 HISTORY OF AMERICAN RED CROSS NURSING}

Fortunately for the school, three of Miss Bridge's assistants were Polish as well as Roman Catholies, this being the prevailing religion. Consequently, when questions arose concerning attendamee at mass at eleven o'clock in the morning by all the students, they were able to satisfactorily explain why this was not possible.

The night nursing in the nospital was still left to the Polish Red Cross nurses. There was little or no system and no discipline. Such nursing attention as the patients required was largely left to the sanitars (orderlies), who waited on men and women alike, even performing such delicate attention as giving: bedpans to women patients. This eondition troubled the American nurses, as they were aceustomed to seeing patients receive the same careful mursing at night as was griven during the day. Miss Bridge expected to place the student nurses upon night duty as soon as they were sufficiently experienced, but in order to do so many internal changes were necessary. However, at the time of the completion of this history these changes had not yet been made. The conditions that prevailed in the operating room made it impossible to give student nurses training in surgieal technique and operating room procedure. Here the felcher (operating room orderly) had reigned supreme regardless of sex and nature of operation. It became erident that student murses eould not be assigned to service in that department until a qualified Ameriean nurse had been seeured to reorganize the work, direet the mursing and instruct the sturlents in surgical technique. A request was sent to Ameriea for a nurse qualified for this work, which would increase the teaching personnel in the sehool to six. This, however, was to be regarded as temporary.

In $n$ war, however, were the American nurses discouraged. In the period of shently over a rear during which they had been at work they aceomplished marvelous things. "Their staff included four graduate murses, one dietitian and thirty sturlent nurses. They harl an attractive residence, woill furnished, with suitable class rooms and geod teaching equipment. Seroral well equipped wards offered a satisfactery tiedd for practical instruction. Control of the housekerping lammery and dietary department romeded out the facilities as a teatrhing fielel. Ther had a representative sehool committere ralled "The

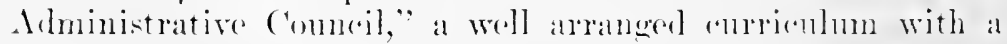

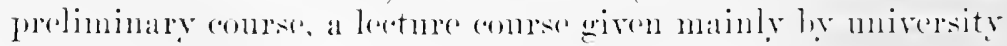


teachers, and a gromp of students exceptionally intelligent, well edueated and retined. This aecomplishment demonstrated good and efficient management, and a receptive and coöperative sehool committee. When the time shall arrive for the withdrawal of the American nurses the futere of the selool would seem to be assured. History repeats itself, for as it has been the nurse in America who has been the instrument through which nurse education and institutions for the eare of the sick have been brought to their present state of excellence, so it will probably be in Poland, if edneated and cultured young women enter the schools.

The school at Posen differed in some respects from that at Warsaw, the latter being organized on a basis that would conpare farorably with the most nodern school in America; the former, excellent in character, and run on somel principles, was mable beanse of eertain inherent conditions, such as living quarters, to develop on as progressive a basis.

The July, 192.2, Report of the Posen School showed a faculty of fom American Red Cross nurses, two of them of Polish nationality; fifteen students; a two years' regular course and a three montlis preliminary conrse; arrangements perfected for practical experience in medicine, surgery. gynecology, children; affiliations in obstetries and communieable diseases; a corps of instructors, doctors and nurses.

In both schools a tuition fee was required; an eight-hour working day prevailed in each; the eharacter and edncational qualifieations of the students were excellent.

A school of nursing had been discussed by the American Red Cross Commission for Greece, and a plan had been prepared ly Jajor Carl E. Black in July, 1919, and presented by him to Colonel Capps. This plan was based upon Major Black's survey of Greck hospitals and a study of Greek methods of preparing nurses. Major Black disenssed his plan with the Greck Red Cross, Colonel Capps, physieians, hospital authoritios and others, but althongh Miss IIclen Scott IIay, a recognized nurse odncator, was directing all Red Cross nursing activitios in the balkan States, inchuding Greece, she was not ralled into any of these anferences or shown the plan until after it had beens submitted to Amerian and Gresk Red Cros:

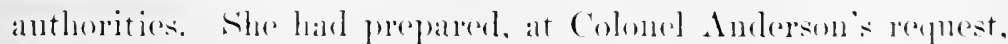

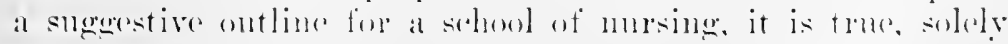

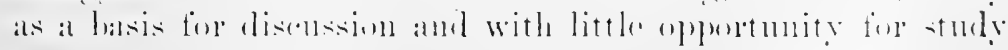




\section{HISTORY OF AMERICAN RED CROSS NURSING}

of local conditions, and with the understanding that it would not be regarded as a complete plan.

Fortunately Major Black's somdness of views on the question of educational entrance requirements, as well as on the social and professional status of the graduate murse, enabled him to present recommendations of a sound and dignified character. His plan, which was an ambitious one, called for an operation covering five years at an estimated cost of about $\$ 12,000$ per year, or about $\$ 60,000$. Matters had proceeded even so far as to discussion of a hospital upon which to graft the school, a point of great moment to such American nurses as might be sent to carry the plan throngh, and a matter upon which the advice of Miss Hay would have been of great value. The concluding paragraph of Major Black's report stated:

At the time of leaving $A$ thens for America, we have received no answer from the Hospital Board, and do not know their final decision when confronted by the terms in detail. The matter is left in the hands of Major Dewing for final consummation with either the Evangelismos Hospital or some other hospital in Greece.

Little was heard of the project of the Greek school of nursing during the early months of 1920. During the summer of that year President Venizelos had a conference with Commissioner Olds in Paris, at which the Commissioner again offered on behalf of the Ameriean Red Cross to assist in developing a school of nursing in Athens. One of the conditions of the offer was that the Greek Red Cross should provide suitable buildings. The finanees of the Greek Red Cross did not permit them to assume this item in the summer of 1920 . In October, however, President Venizelos wrote Commissioner Olds that a member of the Greek Red Cross had presented a million drachmas to the Society for such purposes; that in his estimation the Greek Red Cross was prepared to alecept the offer of the American Red Cross; and that he had placed the matter in the hands of Mr. J. Athanasakis, then president of the Greek Red Cross. Tu November, 1920, Mr. Athanasakis wrote Commissioner Olds that the Greek Red Cross had decided, however, to place the direction of the school in the hands of two of its volunteer lied Cross murses. This artion amomnted practically to a rejection of the Mureriean lied crosse offere, as 
in its training school contracts the American Red Cross had reservel the privilege of appointing Aueriean nurses trained under the Nightingale System to direet the sehools, and this clause was clearly understood by the officers of the Greek Fied Cross.

Such was the state of affairs when Miss Hay and Miss Noves arriver in Athens late in November. Great excitement then prevailed throughout Greece. Political changes had deposed the "Commoner" and brought back King Constantine. Miss Hay and Miss Noyes tried to see the president of the Greek Red Cross but did not succeed. Thurs a final settlement other than that described above regarding Ameriean Red Cross coiperation in the establishment of the $\Lambda$ thens School was not effected.

Bulgaria was again in 1920 urging the reorganization of the selool started in 1915 under the direction of Miss Hay at the Alexandra Fospital in Sofia, which was deseribed in Chapter IV. As the plan presented was incomplete and somewhat unsatisfactory, it was felt that a conferenee with the Bulgarian anthorities would be of great value. When Miss Hay and Miss Noyes reached Bulgaria they found that the situation had changed since overtures had been made a few weeks previous. The Bulgarian Red Cross, which had for some years conducted a so-called school of mursing, had requested the Government to lay aside the plans for the Alexandra Hospital School, and to pay to it any moneys available for this latter project. The bill covering this change in plan had already had two readings in Parliament, althongh the nurses from the Alexandra Hospital Sehool, who had been under Miss Har, and many physicians and other prominent people had done all they could to delay a decision. The situation was eritical. Throngh the American Chargi d'Affaires a conference was secured for Miss IIay and Iliss Noyes with the Aeting Prime Minister Dimitroff. Prior to this, howerer, they had beon invited to visit King Boris and had laid the reoranization plan before him. He manifested the greatest interest, and gave assurances of his support. The attitule of the Primo Minister was wholly non-eommittal, but an early derision was pronised. Howerer, such other reassurances were given to the effeet that the reorcanization of the sehool would ge througin with the passing of the hudget that it seemed a foregone conclusion. Miss Noyes waited soreral dats at Softia with the hope that a detinite decision 


\section{HISTORY OF AMERICAN RED CROSS NURSING}

would be reached. She was finally obliged to leave, but before doing so submitted the following recommendation:

That we assist the Bulgarian gorernment as far as possible in the resumption of a school of nurses, providing the Bulgarian government itself is ready to do its full part, financially and otherwise, by stating that it would seem but fair under the circumstances that we should select and provide salaries for not less than two American nurses, and at least partial maintenance for not less than two years. In the event of failure to establish the school, that at least one scholarship might be given to the best qualified nurse of the Queen's School, so that she might complete her course in America and be better prepared to assist her country in developing nurse education.

It seemed highly desirable that there be a modern school in Sofia, not only to perpetuate the plans so dear to the heart of Queen Eleanora, but because it was greatly desired by a large number of Bulgaria's most thoughtful people. The Bulgarian Red Cross, however, produced one argument which apparently was most convincing to the Bulgarian government, and that was economy. The cost of maintaining a school of the first order necessarily represented more ontlay than people of many foreign countries were accustomed to think necessary. It that time the lev was selling ninety to a dollar, and failure to secure an enthusiastic acceptance of the assistance which the Bulgarians had roluntarily sought might be ascribed to this cause.

From time to time, however, the question of the school was again raised by those most interested. In the early summer of 1922 a final coüperative plan based on the preceding recommendation seemed a foregone conelusion, and an appropriation to cover it was establisher at National Hearlquarters. The Bulgarian authorities were notified and asked to submit their reassurances. It the time this history goes to press these have not been received. A leading citizen of Bulgaria when diseussing with Miss Soyes the project and the tendeney to procrastinate said, "It is the East." This may explain the present delay.

It Constantinople a sehool of nursing was established with which the Amprican Rerl Cross was affiliaterl. Mrs. Anna Rothrock, who harl borm assigned as rhief umrse to the mit of fifty-four nurses which had heen oreanized ly the American 
Red Cross for service with the Near East Relief, was detached from that organization in the spring of 1920 , and asked to undertake the development of a sehoel of mursing and a hospital in Constantinople, moler the anspices of a local committee. This committee ind luded representatives from the Amerien Red Cross, American ('ollege for Women, Roberts College and Ameriean interests snch as the Standard Oil and the Near East Relief. Substantial assistance was given them by the Near East Relief in gifts of equipment; also by the American Red Cross Commission and the Ameriean Red Cross Clapter at Constantinople, of which Admiral Mark L. Bristol, United States Nary, high commissioner to Constantinople, was the chairman. The institution was developed in "Old Stamboul," in a building formerly the home of a rich pasha, a large three-story honse with two distinct divisions, the Iaremlik and the Saremlik. The building was in very poor repair with deep rooms with windows only upon one side. Rongh wooden floors and total absence of heating facilities and plumbing made the question of proper organization of the hospital a difficult one. Nevertheless, with the supplies which had been given, the building was put in good shape. Hundreds of fect of stove pipe were used in setting up stoves, the only means of heating the wards and the living quarters of the nurses. While marvels were accomplished in making the place habitable, nevertheless it was far from being an ideal building for either a hospital or a school. The dangers of fire, with no means of control should one oceur, the long steep stairs and the general unsuitability as far as arrangement was coneerned. make the building far from satisfactory for the purpose.

The hospital proper consisted of wards with from six to twelve beds, and five private rooms of one or two beds, a total of eirhty beds: two large halls for convalescents. an operating room, a pharmatey supply room and dispensary. There was one kitchen for the hospital and the staff, with a single Creek cook. An Ameriean Red ('ross tietitian, Vellie Malliday. Was in eharge and was accomplishing astenishingly good results with the facilities at her disposition. The water supply was m"wrtain: there was no lannelry exopt an outside rom which hat originally acemmotated the lanmery work for a privite family. The toilets were of the Turkish variety. marble and in erend repair. In the equipment wis a Turkish hath, white

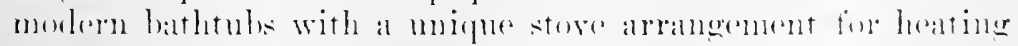




\section{HISTORY OF AMERICAN RED CROSS NURSING}

the water were installed in some of the smaller rooms. The Dispensary was on the ground floor under the part of the building used for the graduate nurse staff. Linen and dressing rooms and sewing rooms adjoined. The home for the student nurses was arranged in what was formerly the servants' quarters. The rooms were clean and sufficiently large for two or three students. A combination sitting room and study was provided, the pupils taking their meals in the personnel house. The faculty consisted at that time of six Ameriean nurses, all of whom had been recently engaged in the care of refugees on the Island of Proti. They had been temporarily loaned to the American Hospital upon the closing of work on Proti. In November, 1920, five of them were permanently engaged on the regular hospital staff.

The school course was finally arranged to require a period of twenty-eight months. The minimum educational requirement for admission was that the applieant should have completed a full high school course or its equivalent. Anatomy, physiology, bacteriology and chemistry were taught by an instructor of the Constantinople Women's College. Praetieal and theoretieal nursing were taught by members of the nursing staff. While this school was not strictly speaking a Red Cross enterprise, American Red Cross nurses, some of whom were partially or entirely paid by the American Red Cross, had effected the organization, and had brought this school into line with other schools in Europe which the American Red Cross had subsidized. In the course of time the staff was decreased and a gradual change in personnel resulted.

Upon the resignation of Mrs. Rothrock in the fall of 1921 . Miss Lyda Anderson, who was acting als assistant to Miss Hay in the Paris office, was appointed to replace her. Under Miss Anderson's administration some changes gradualiy took place, the course of instruction was reduced from three to two vears, and a definite affiliation was being songht with the American College, similar to university affiliations which exist in Ameriea. The type of student admitted to the sehool gradually improved and inchded representatives from many coumtries. The question of langlage was a serions one. and as interpreters were ont of the question alasses in English were griven in order that the students might not only arail themselves of the hest textbooks written in Enelish, but profit by the instruction given by the American murses. 
There were in 1922 no other molern sehools of nursing in that part of the world. The future usefuluess and importance of this selool not only to ('onstantinople but to a large surromuding area is self evident. A new hospital and school building of gool type of construetion was imperative, while many inprovements had heen made to facilitate the work the inlerent defeets of ronstruction were of such a nature that it would have been uscless to try to overeome them by temporary repairs.

From the beantiful tropical island, ealled indiseriminately Inati or San Domingo, depending entirely upon whether one refers to the western one-third, Haiti, or to the eastern twothirds. Santo Domingo, there came early in 1920 from the (Everument a repuest for four Red cross murses. In 1918 a school of nursing had been organized moder the direction of commander X. T. Ile Lean of the Medieal Corps of the Inited Sitates Naly in eonnection with the City General Hospital in Port-all-P'rince. The protecting arm of the United Sitates Government had been extended under the treaty of 1915 to the "Blatek Repliblic" and representatives of the Medical Jepartment of the United States Xary had been assigned to direct the sanitary development of the island. Lucia D. Jordan, assisted by .Iosephine T'. Ray, members of the Nay Nirse Corps, muder difficult conditions. had laid a substantial fomuclation for the first modern school of nursing on the island, but in 1920 were withdrawn. Hence the request of the island government.

Miss Butler, then director of the Nursing Service of the lnsular and Foreign loivision, secured as director of the Srehool of Nursing at Port-an-Prinee Vashti R. Bartlett. whose name and record has appeared in previous chapters, and two whers, Anna M. Hamsherry and Mary Griffith. These nurses were paid, transported and maintained by the Hatian Government. Mliss bartlett. with her training school experience, morey and enthusiasm and ability to speak thent Erench, was aperailly well yualified for the talsk.

The little eproup of three saliled in July, 1921. Olive M. simens followed later. They fomml sisters in charge of the warels. Later. lowerer, the sisters withelew from this work

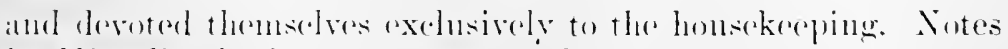

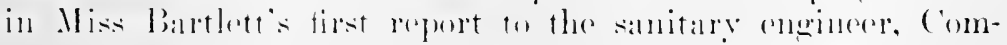
minder Neleam, indieated some discomraging features: 


\section{HISTORY OF AMERICAN RED CROSS NURSING}

There are at present 31 student nurses and about 400 patients. . . The school having started with a two years' course, the seniors should have graduated in October, but the date . . is still unsettled pending the result of all examinations and a policy to aid nurses in starting their outside work.

Special duty was considered for the unemployed graduates and at first a salary of $\$ 10.00$ a week was offered. Opportunities for practical experience in the wards were limited, but facilities for additional experience was secured in a special ward where Sisters had been in control. Suitable class rooms and better sleeping accommodations were secured and lesson plans, the translation of textbooks and the preparation of lectures in French occupied the attention of all the nurses. The future of the graduates continued to trouble Miss Bartlett, as the poverty of the people seemed to preclude any extensive use of qualified nurses. Sot the least of the diffienties was a distressing epidemic of smallpox described by Miss Bartlett in a letter, January 28, 1921 :

I am discouraged about the school. The smallpox has almost disrupted the hospital. From 60 to 70 patients are admitted each day and so many nurses are needed for this work that the other branches of nursing are neglected. We do no operating except emergency ases because the patient may break out with smallpox the next day. Some of the cases are awful; those that we lo not find for several days come in in had shape. This morning, for example, three nurses worked for several hours picking worms out of the sores of one patient, and this happens every day. Many times we have to take them out of their eyes. In one ward two days ago, where onr illest patients are. we had 14 deaths in 24 hours. I think we have about 600 smallpox patients and, with 1 t nurses leaving. it is a question how to give them the (are they need. and I fear new nurses will not come with combitions as they are. I few minutes ago they telephoned and asked for two speeial nurses and I hardly know how to spare them.

Tet Miss bartlett with eharacteristic reserve said nothing of the heroic work dome by the Ameriean Red Cross nurses who worked clay and night to relieve the suffering of the poor unfortunates.

After a vear of rapuec work, Miss Bartlett and Miss 
Griftith resigned. Miss Hansberry was appointed director. Olive Sinnons with Grace Ihlite and Sara S. Smith, who had been assigned in November, 1921, completed the Red Cross mursing fanily.

Early in 1920 the American Red Cross appropriated through the Insular and Foreign Division $\$ 10,000$ for the purpose of crecting a suitable building as a house and school for murses in aceordanee with the sugerestion of the Medieal l)epartment of the Nary. Plans were submitted to Sational IIeallpuarters and, with eertain minor changes sugerested by lliss Noyes, were approved. As a Red Cross Chapter existed in Ilaiti, a committee from this ('hapter was appointed to supervise the construetion of the building and the expenditures. This ammitten inchuded Commanter J. M. Minter, M. C., U. S. Nary; Commanuler A. I. Parson, .1. C., U. S. Navy, as well as representatives from the (hapter. The money was mate avalable in the antumn of 1921 and work was immediately hegun. The school building gerew rapidly and soon the old and tottering building was torn down.

In order to appreciate the discouragements encountered in attempting a project of this nature one must understand the character of the people and the country as well as the historical hackeround. Il're C'olumbus first landed, finding Indians and grold. which the Spaniards coveted and ganined. Contact with the white man exterminated the Indian. The negro from Africa was introdued, the beginnings of slavery in the new world. The French oecupied the island with reforms and eneral improvement. In time they disappeared, leaving only their languane, mutil to-day tle people are mainly negroes, with some mixed blool. Revolution followed revolution, delte, poverty, nisery, bandity and discase existed, accompanied by inevitably low standards of morality. The invited and aceepted intervention by the Enited States in 1915 bronght many improvenents, among others the School of Nursing, the tirst of its kind in the islanel. In 1922 it was but four years old, a mere infant, but wrowing stronger as indicated by the reports.

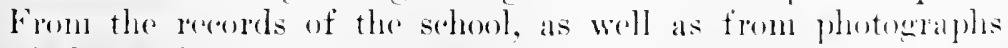
of the student nurese in their trim miforms, all neegroes. at comelusion may he drawn that in spite of many diftionlties and

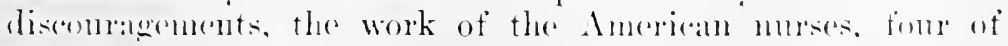

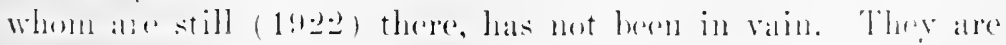
slowly dereloping an edurational system that will ultimately 


\section{HISTORY OF AMERICAN RED CROSS NURSING}

give to the island what they greatly need, a well-trained native nursing personnel.

These were steps in an educational program of the American Red Cross. They indieated that the peoples of European and other countries, perhaps throngh observation of the work done by graduate nurses from other countries during the war, or because of the work of American Red Cross murses with children and refugees following the war, were intelligently seeking assistance for the purpose of developing their own supply of nurses. And the American Red Cross was becoming painfully conscious of the fact that it conld not continue to provide nurses and supplies indefinitely to the stricken countries of Europe. Furthermore, the Red Cross appreeiated that its health work, especially for the children, would not be constructive if native nurses were not ready to "carry on" when the Ameriean Red Cross nurses had to be withdrawn. 'Tlec League of Red Cross Societies was also stimulating interest in schools of nursing wherever its Director of Nursing saw and felt that it was practicable. For these reasons the American Red Cross was deeply interested in the organization in these comntries of modern schools of nursing. But three years of study through direct participation it realized that educational work of another type must go on.

Quite generally in the comtries of Europe and in Haiti, where American Red Cross nurses had conducted classes in Home Hygiene and Care of the Sick, or had established schools, the feeling quite generally existed that routine bedside nursing procedures, the performance of such lousekeeping details as scrubbing and seouring, sweeping and dusting should be delegated to servants. The war and the example of graduate nurses did a great deal, however, to change this attitule of mind. In Poland partienlarly the students eaught the idea, and began setting an example that will inevitably break down many ageold tralitions. Quite generally the feeling prevaled that the work of the murse enderl with the application of a few surerieal dressings; the bathing of the patient, and the making of his bed belong to a servant. Even in Maiti it was noticed that an orderly sent on an errand where a basket or bundle must be earred would press into service for a few permies a mam or woman tottering with age, or a half-starved child, to relieve him of this hurlen. Ameriean nurses "who rolled up their slecres" and with soap and water and plenty of enerey deaned 
up a partieularly had situation not infrequently lost prestige thereby. Until the principle that actual work with one's hands is dignified and honorable and uplifting can be implanted in the minds of the peoples of countries where antocratic forms of government prevaling for eenturies have developed sharp class lines, modern seloools of mursing or other democratic systems of elucation will make but slow progress.

In line with other edneational work special scholarships were given hy the Aneriean Red ('ross to three members of the committees organized in Italy under the guidance and direction of Miss Gardner. One of these was given to Contessa Balzani of the Rome Committee, one to Siguorina Bosio of the Florence Committee, and one to Marchesa Firmaturi of the Palermo Committee. This group reached Ameriea in the late summer of 1921 . After visiting schools of mursing, publie health nursing organizations in Boston, New York, Chicago, Pitsburgh. Washington and Baltimore, they returned to Italy. Scholarships of this nature were developed not only to strengthen the work started under the direction of the Red Cross in Italy, but with the hopes that special efforts would be made toward the establishment of sehools of nursing to supply. a qualified group of murses in Italy to supervise. direct and cxtend the work so well started in that cominy. Italy, as was the ease with many other comntries where the Red Cross had operated, was in great need of a qualified nursing personnel in order to continue public health and other nursing activities.

Seholarships had also been given in the year 1920 to two French mures from the eity of Lille, France, to Mlle. Matter and Durrleman, both gradiuates of the Nightingale School at Bordeanx, for the purpose of studring school administration at Teachers College, New York City. It was their expectation to return to Lille to assist with the organization of a school in that city.

Three additional American Red Cross scholarships had been granted to chable two [talian nurses and one Freneh nurse to attend the conrse at King's College, lendon, which was developed by the League of Red Cross Societies.

Although the Ameriean lied cross had bern conducting extensive nursing ate ivities orerseas since 1914, no representative of the Nursing servien who possessed a knowledge of the entire

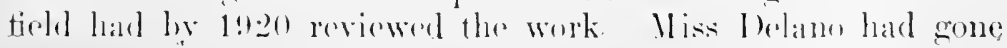




\section{HIS'TORY OF AMERICAN RED CROSS NURSING}

overseas for this purpose but her illness and death interrupted the plan before it had been begun. In 1920, requests asking that Miss Noyes come overseas were reaching National Headquarters and it was finally decided that she leave in September. Three partieular reasons existed for this tour of inspection; first, to inspect existing American Red Cross nursing activities; second, to confer on the nursing aspects of the proposed child health work; third, to advise on the foreign schools of nursing subsidized by the American Red Cross. As president of the American Nurses' Association, Miss Noyes took with her to deliver to the Trustees of the Florence Nightingale School of Nursing the terms of the deed of gift money for the American Nurses' Memorial. Miss Ida F. Butler, then assistant to the director of the Nursing Service, was left in charge of nursing activities at National Headquarters and Miss Noyes sailed on the Aquitania on September 21, landing in Cherbourg, France.

After a few dars spent in Paris in conference with officials of the European Commission, Miss Noyes and Miss Hay left Paris Oetober 4 for Prague, having arranged an itinerary which included in Poland the cities of Cracow, Warsaw, Bialystok and Posen; in Austria, Viemna; in Serbia, Belgrade; in Bulgaria, Sofia; in Turker, Constantinople; in Greece, Saloniki and Athens; in Albania, Valona, Durazzo, Tirana and Scutari; in Montenegro, Podgoritza, Danilograd, Ragusa and Zelenika, and in Italy, Florence. The Leagne of Red Cross Societies had, through Miss Fitzgerald, invited Miss Noves to visit Geneva, to confer on the International League of Red Cross nursing aftairs. She wished as well to visit King's College, London, but these visits were later found to be impossible.

During the summer of 1919 the policies which were to govern the future program overseas of the American Red Cross were, as it has been said before, being formulated. Several of the commissioners for foreign service favored the continuation of general and medical relief on national proportions: some few officials desired to narrow the progam to one which embraeed only preventive health measures and which utilized the dispensary as the prineipal operating unit in the field rather than the large surcicil hospital. On Jume 10, 1919, Miss Hay prepared and submitted to Colonel Olds the following memorandum of nursing activities in Poland which clearly shows that an extension of lwth an cmeregeney medical program, 
as evineed in the reference to two thousand beds for Poland alone, and of constructive work of a remedial and edncational nature, as evinced by the reference to the establishment of dispensaries and the organization of classes for women, was still being considered by American lied ('ross ofticials overseas:

Hosprital Work: With the eontemplated establishment of approximately 2000 hospital beds throughout Poland by the American Reel ('ross. American nurses would of neessity be used only in a supervisory capacity,-one nurse to every fifty patients or more and Polish ajeles to assist in the actual care of the patients.

Dispensary and Public IIealth Work: These to be established in outlying Polish towns and to consist of one or more physicians and two or three murses whose duties would be to assist in the dispensary and develop various public health artivities as visiting nursing, bahy welfare, school visiting and courses in Home Hygiene and Care of the sick. In such centers, the emphasis would be placed on (a) the thorongh grounding of Polish aides in their duties so that they can carry on under Polish physicians; (b) such awakening of local interest in health problems as is possible through various local organizations and through popular instruction of women in Home Ilyriene and care of the sick.

Health lifuculion: The organization of short courses in nursing seems to appear as an important and immediate duty. This elucational work falls into three elasses: (1) an intensive rourse for Polish War aides; () a course for Polish aides now working moler the American fied C'ross; (3) a popular eroure for edncated Polish women in Ilome Hyoiene and ('are of the siek: (4) the establishment of schools of nurving along Amerion lines in Poland. to be treated in a later rhapter. . .

It the present time. there are in Poland seventy-eight nurses. It is estimated that a total of one humber nurses could be well chaged in carrying ont satisfactorily the program recommoniled above.

The neessity for the shifting of the emphasis from a program of general medical and material reljef in Enrope to a more constructive one of preventive health measmpes with special emphasis npon the wolfaro of ehildren, began to be felt

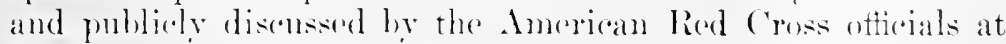
Sational Il'addpuarter's in the antmom of 1919. Commissioner'

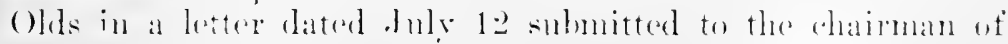




\section{HISTORY OF AMERICAN RED CROSS NURSING}

the Central Committee certain general considerations relating to the future work of the organization in Europe. In this communieation he emphasized the gravity of the problem of the children in Europe. In a cable of August 23 to Commissioner Olds, Dr. Farrand recommended a definite plan for the establishment at available points in Europe of "ehild saving centers," with necessary dispensaries and medical and nursing persomel. The recommendation recognized that the American Red Cross shonld coöperate with other organizations operating in the field; it further set forth that it would concentrate upon the field of undernourished and neglected children and the prevention of epidemic and disease. In a masterly brief presented October 30 , Colonel Olds made the following statement:

We rest under no illusions concerning our capacity to handle such a situation. It is plain that the American lied Cross cannot possibly assume to take up more than a small part of the burden. In the first plare we have never accepted any responsibility for fceding any large groups, even children. and do not propose to do so now. That operation, basie as it is. must continue to be an obligation of governments and of other organizations. On the other hand, we believe the Ameriran Red ('ross may well undertake a health service for rhildren at various critical points on a sale commensurate with the resources at its disposal. We do not foresee any difliculty in confining our responsibility within any reasonable limit.s which may be imposed. If permiscion to proceed is given we are ready to go ahead with a definite plan. It involved the setting up of field units, orqanized on the simplest and most effective lines, to furnish health service for children.

While some delays must be expected when there is a shift from one progran to another, the child health program seened slow in getting under way. There were doctors, nurses, executives and other workers still in the various eomntries of Europe. asperially in Poland, who were more or less inatetive. Mredical men, including children's specialists, were being sent to Enome and requests for additional nurses were being receiverl at National Headquarters. Conference followed conference at the Paris office, ables came and went, but still the "curtain did not go np." althomgh the program was there and the actors waiting. A relear-cut plan of derailed oreanization and operation serenced to low lateking. and what was more significant, the 
motive power and force to swing a plan into action in the field was either not there or if there was without authority.

Miss Noyes ${ }^{10}$ was greatly coneerned by the inaction, especially when she found a group of twenty nurses waiting in Paris for assigmment. Having drawn hearily upon the nursing resources of Ameriea, where nurses at that time were greatly needed, it was disappointing to her to find so many in Europe still unassigned. This was still more distressing when it conld be appreciated that a great opportunity for their services existed; indeed instanees were later noted where initiative was actually discouraged on the part of publie health nurses because of the lack of knowledge and experience on the part of the individual medieal directors and other offieials.

In Poland Miss Hay and Miss Noyes found many sore spots. Here again were unassigned nurses; in Cracow but sixteen out of twonty-eight were at work. An effort was being made to use murses in Warsaw, but here again the announced program was not moving. The need for a well-trained public health nursing supervisor was apparent and a recommendation made to that effect. Miss Mathews had been appointed chief nurse in Poland, but because of a lack of understanding and experience in nursing affairs on the part of the commissioner her position as chief nurse was not only uncertain, but at times mrecognized. It was neeessary, therefore, to prepare and present to the eommissioner a definite statement defining her relationship to the commissioner, murses, phrsicians and other persomel. The idleness of the nurses in Poland was in a measure due to the Bolsheviki Advance in the summer of 1920 , which retarded the subsequent derelopment of the child welfare program. The disturbing factor was that in spite of this situation additional nurses were still being requested for Poland.

In Belgrade but one Red Cross nurse was found, Miss Rhobie Whedon, who was then in elarge of the Belgrade Orphanage, which was being run under the anspices of the Covcrmment. Conferences with Dr. Reeder inspired a recommendation to Colomel Olds that the American Red Cross assist the American Child Welfare Association as far as possible in

${ }^{10}$ Neither Miss Noyes nor Miss Hay recarded themselves as experts in publie health nursing. yet their familiarity with the general field of nursing and their experienee as administrators had given them preparation as observers and advisors. 


\section{HISTORY OF AMERICAN RED CROSS NURSING}

seeuring and maintaining an adequate staff. Later, a generous appropriation was given this organization by the American Red Cross, and Red Cross nurses were selected and sent from Ameriea to assist in the development of the child welfare program.

In Constantinople the question of the relationship of the American Red Cross nurses assigned to the Near East Relief to that commission was adjusted. Also as there seemed some probability that the Near East Relief might withdraw from child welfare work and as so fine a begimning had been made by Frances MeQuaide and Emma Wood, the former through child welfare stations, the latter through a hospital for tubereulons children and as chief nurse of all nursing activities, the following recommendation was made:

With the withdrawal of the Near East Commission from child welfare work in Constantinople, it is recommended that the American Red C'ross, through its Chapter and commission. should coöperate to have this important work carried on. This child welfare work is in keeping with the European program for 1921, and, already well begun, is proving of great ralue in the conmmity. Such work also would provide a field for the public health instruction of the pupil nurses of the American Training sichool, a plan which is most heartily approved by Admiral Bristol and Commissioner Davis, as well as by the hospital authorities.

At that time 120,000 Russian refugees had just arrived on various types of boats, having been driven out of the Crimea by the advance of the Bolsheviki. Among the Russian refugees were a large number of Wrangel's Army. The condition of these unfortmates on board the steamers, with little food and water and almost no shelter, during a period when there was mueh rain and chilly antumn weather, can well be imagined. They were packed in the boats in such great numbers that it was impossilile to relax or eren to lie down and rest. The addition of sueh a large number of people, almost without supplies of any sort, taxed the resources of an already orererowded eity. The utmost effort and good will was displayed by the relief oreanizations located there and he governmental agencies, but despite that, much suffering ensued. For the sick who were in need of hospital attention the old Russian Embassy, completely expipped with Anorican Ied Coss supplies, was hatily 
utilized. An adrouate supply of Russian nurses and doctors were available to staff the iustitution, bnt its support and maintenance had to be provided for from local sources. The American Hospital opened its doors to the Ameriean Red Cross persomel who had evacuated Sebastopol, and Russian sick, both soldiers and rivilians, were admitted to its wards to the very limit of its eapacity. This was but one page in the sad history of the refugee situation in Europe, an aspect of war which brought problems and suffering immeasurable in extent.

Leaving C'onstantinople, Miss Hay and Miss Noyes proceeded to Grece, stopping first at Saloniki for a day, where quantities of Ameriean lied Cross supplies were located. Three Ameriean murses were still in that city, Emily Simonds, Tessa d'Alberti, and Mary L. Boyle, but the American Red Cross rolief station there was rapidly being closed and the nurses were soon withdrawn.

Proceeding from Saloniki, Miss Hay and Miss Noyes next visited Athens. It will be recalled that ehild welfare work had been started in varions localities in Greee under the commission but with imperfeet suceess. That modertaken in Athens under Miss Tymon was probably the most enduring in character.

With the elosing of the commission in the summer of 1919 , the ehild welfare work was left moder the direetion of the Patriotic League and with the exception of oceasional advice from Miss Zaeca in Athens, whose salary was being paid by the Govermment, was entirely without professional direction. Requests, however, trinsmitted throngh Major Dewing, who had suceeded Colonel Capps, were received at National Headquarters, asking for a qualified director for the ehild wolfare work in Creece. The Jumior Red Cross had also planned to develop its program, and by special arrangement Kathleen I) Olier, a ked ('ross public health nurse and a graduate of the Rochester Cieneral Hospital, Rochester, New York, was sceured, and acted as the representative of both the Junior Red ('ross and the Nursing serviee.

Epon leer arrival II iss Dolier beam the reorganization of the child weltare work. The Patriotic league was still intercated, acting as the internodiary between the gorermunent and the work. A gromp of pomeng women from the best families were trabed to act as assistants in the relinies and for home visting. The city was divided into distriots and ahout serou 


\section{HISTORY OF AMERICAN RED CROSS NURSING}

hundred well babies were admitted to the clinic. Layettes were provided for the newborn. School nursing was gradually started under the direction of Ellen Inglesaki, a Greek-Ameriean Red Cross nurse; Charlotte Heilman, a former member of the Italian Commission, was appointed as her assistant, and Miss Zacea was secured for clinic work. Miss D'Olier resigned in Deeember, 1920, after a year's service, leaving Mrs. Heilinan in charge. At the time of the arrival of Miss Hay and Miss Nores the ehange in government was causing great concern, and the continuation of American Red Cross child welfare work seemed to hinge entirely upon the attitude of the new Government toward the program. Members of the Patriotic League and the home visitors, sympathizing with Venizelos, were about to resign, feeling that inless they did so, they would be asked to anvhow. The daily supply of milk which had been furnished to the babies had not been provided for two weeks.

A conference with Prime Minister Rhallis was secured. After expressing his deep appreciation of the work he gave assurances that the assistance of the Government would be continued. He expressed his desire that the American nurses deal directly with the Government. Miss Noyes then recommended to Commissioner Olds that the American Red Cross contimue its support of the infant welfare station at Athens for six months longer, with the understanding that at the elose of this period the salaries of the nurses would be assumed by the Committee of the Patriotic League and the station contimued. The recommendation was approved and on July 1, 1922 , Mrs. Heilman's salary was assumed by the Patriotic League and she remained in Athens in eharge of the station.

During an enforced stop at Vallona, Albania, Miss Hay and Miss Noyes had an opportunity to make some partieular obserrations on health eonditions. They were entertained at the Hospital Civile, the only livable place; here only men were in evidenee, except in the laundry, where a few native women with but few facilities managed to take "off the rough" and send the sheets and clothing back to the wards sadder and duller in hue than they were when sent. But there seemed to be great possibilities for good work in Albania as well as in Montenegro. ln the former at Durazzo, at Tirana and Sentari, nurses were already developing school mursing and hone visiting in cooperation with .Junior Red Cross sehool activities, and were giving considerable attention to the ever-present refugee. In 
Montenegro, at Podgoritza and at Danilograd, the same type of work was progressing. At Ragusa and Zelonika on the Dalmatian Coast, abont 15,000 Russian refugees from Constantinople were gradually being disembarked and were claiming the attention of a relief unit of doctors and seven murses, three at Ragusa and four at Zelenika. This unit had been temporarily diverted from Montenegro, where they were being sent to develop health work.

The opportmities for child health work in both Albania and Montenegro were evident, and as a number of Red Cross nurses were working in varions places in those conntries, the following recommendation seemed practical to submit:

1. The poverty of this country and erying need of more assistance is everywhere emphatic. Valona, with a good hospital cottage plant. built by the ltalians, would seem to be an excellent field for a health unit, carrying out the general policies of the $19: 1$ program.

At I)urazzo, 'Tirana. S'utari, our nurses are doing most useful work. If more health units, however, could be sent to Albania, each of these centers would be a desirable field for the revelopment of various public health artivities, at least two nurses being assigned to earh mit. The nurses woull then have no comnection with the Junior Red Cross, except that, as a part of their activities, wonid be included the care of any school children, or other coöperation desired.

¿. That" a rhief nurse be appointed, to include in her artivities both Montenegro and Albania.

While travel is somewhat difficult. it is believed that this could be quite satisfactorily arranged as a whole.

3. In the development of the work of any public health units sent there, as also in the present school nursing program. that the public health field orcanizer, comnerted with the laris oftice. should ascist in stanclardizing the work and raising this to its highest degree of efficiency.

From Ragusa, Miss Hay and Miss Noyes went to Florence, where a conference was held with members of the speeial eommittee organized by . Iiss Gardner for the purpose of arranging that there members be chosen from these committees to visit the Inited States as gnests of the Aureriean Red ('rose to study mursing education and public health mosing notheds. One of the clinies oreanized moder the anspies of the Italian Commission was risited and found to be in an active and efficient stilte. 


\section{HISTORY OF AMERICAN RED CROSS NURSING}

Upon the completion of the tour of inspection in late Deeember, 1920, some definite recommendations were presented to Colonel Olds. These were based upon observation of conditions as found in each country by Miss Hay and Miss Noyes. As a full report of the schools has already been given, this section will only treat of observations in general and of child welfare work.

It was urged that nurses not needed for work in connection with the training schools be withdrawn from Czecho-Slovakia. As an instance of the wisdom of this, the case was presented of a group of ten nurses who had been requested for typhus work but who had found upon their arrival that they were not needed. Some of them, indeed, had been given temporary work, most of it excellent in character, but none of it related to the announced program; and two of the nurses were unassigned.

It was a keen disappointment to Miss Noyes that she had to leave Europe without completing final arrangements for the organization of all the proposed schools of nursing. That her visit to Poland probably gave an impetus to the plan is demonstrated by the rapidity with which the project materialized. At the date of writing this history, Bulgaria is still considering the proposition and Greece has not yet replied to the communication of December 1, 1920.

Miss Noyes left the child welfare work, with the exception of Greece, and places here and there where the murses in a more or less detached manner were doing some good public health work, in much the same condition as she found it. Little progress had been made.

At the close of her tour of inspection Miss Noyes made the following general recommendations to Commissioner Olds:

Recommended that a supervising nurse for all public health activities in Europe be appointed, who shall be a woman of broad experience and training in all branches of public health, and who shall act as field organizer of all public health activities.

'That it is important that personnel houses be arranged in which all American Red Cross persomel should be required to live. It is only fair that if some are requires to live in a house, all shonil be, and people with the right lied cross spirit have no good arsument for holding ont against such a roquirement. These houses should in every case be made attractive. 
Every house shonld have, as a house mother, a woman of the highest qualifications, who would not only be a good chaperone for the women personmel but who would have the ability to make a most attractive home and to give a diet in which economy and adequacy are satisfactorily combined.

Recommended that the term "health units" be used instead of "medical units."

That salary rates and all perquisites, as, for example, maintenance, uniforms, vacations, etc., should be made as uniform as possible for all women of equal experience and capabilities.

In addition to these general recommendations, Miss Noyes prepared some special suggestions regarding the small health unit, which, under date of January 4, 1921, were presented to Colonel Olds. Extracts are given:

I had begun long before I left America to think in terms of simple working groups. . . . Small nursing groups without elaborate offices or other personnel are in a better position to do constructive public health nursing work than can be done in connertion with a big organization. It is the old story of not being able "to see the forest for the trees." I can only say that my riews have been strengthened since my tour.

While a health unit of any character may need supplies of food and clothing in order to make the work effective, this should usually be distributed as secondary, and a supply in accordance with local needs be made available. . . .

It is also necessary to recognize that health units may be of several varieties, the character of each depending upon local conditions and facilities. The following types, modified as occasion demands, have occurred to me as practical and possible:

1. Composite unit, such as that suggested for Montenegro, where doctors, nurses, Junior lied Cross and "feeding" personnel work out a joint program with the simplest "overhead organization."

2. A health unit with dortors and nurses which may work out a simple health program of a preventive ats well as curative nature.- - leveloping the work through dispensaries that may exist or he developed by the unit.

3. A public health nursing unit without any Imerican Red ('ross doctors or oflice personnel. The heal nurse of the mit acting as the manager. financial agent, "tc.. such as the child welfare wnit in Ithens. 
$N$. B. This unit is, I believe, securing better results with less expenditure of Red Cross money than any that I have seen.

4. A unit of nurses, possibly Red Cross doctors, although not absolutely necessary as local physicians might be available, supplementing the working of other organizations such as the Hoover Feeding Program; nurses attached to a food station, selecting delicate children, following them to their homes, arranging for treatment if necessary, supplying food, looking into home conditions and general health of family. This was suggested for the Whiting feeding work in Montenegro and seems to offer wonderful possibilities at little expense.

5. The relief unit, such as that at Vienna and Budapest: while not health units, the relief units are so closely related that they can be included in the list.

In any plan, but most particularly the fourth, local facilities, doctors, nurse assistants, dispensaries and coöperation of other organizations should be utilized and sought, and established promptly. Chief nurses, field supervisors and consultant American Red Cross doctors will probably be required.

I am firmly convinced that our work is incomplete and not constructive if we do not make every possible effort for its perpetuation,-building up local interest and initiative, by means of local committees or through organizations already in existence, utilizing local physicians and nurse assistants, urging governmental help such as appropriations, buildings, supplies, etc.

I appreciate the fact that this idea is not new and has been carried out in many places. For example, the three hospitals, Tirana, Scutari, Podgoritza, organized and equipped by the American Red Cross, are being continued in a fairly efficient mauner by local authorities. The child welfare work at Athens can, I believe, be entirely carried locally in six months or a year, tapering off gradually.

As I am assuming that you are in sympathy with these views, it seems therefore quite unecessary to add further arguments. I believe, however, that the simplicity of the small unit resulting in financial saving by reduction of personnel and complicater overhead management, is the strongest argument in their favor.

One last thought: It is quite possible to conduct a health unit withont a Red Cross doctor. Athens and Kornik, near Posen, are two good illustrations of this type in Europe. Ife have some in other countries, and many in America, (noperating with loral roctors where indicated. . . . 
Upon Miss Noves's return to National Headquarters the latter part of Ianuary, 1921, she found that soeial workers had bern authorized for the child health work in Europe and that Mr. Homer Folks of New York, a reeognized authority on social questions, and Miss Margaret Curtis of Boston were to proceed to Europe to advise as to how they might be utilized. Some difference of opinion existed as to the wistom of introducing social workers into a child health program, limited to a fairly short period. Many of the medical men connected with the Red Cross in Europe had expressed themselves as opposed. They argued that in the general dearth of local agencies through which the social worker is accustomed to function they might not fit into the plan, and that this might prove a somree of embarrassment rather than a help. Nevertheless, a group of forty-one social workers was selected and arrived in Europe during the spring and summer of 1921.

After making an official report to Dr. Farrand. Miss Noyes recommented that a public health nurse, recognized as an authority on public health mursing, be sent to Europe to study public health nursing in comection with the child welfare units. She felt that the same type of specialized advice for the nursing service was required as had been deemed necessary for the social service. This request was granted, and Mary $\dot{s}$. Gardner was seenred and left early in May. 1921, arriving in Paris May 24 and retuming September 21. Miss Gardner visited (zecho-Slovakia, Poland, the Baltic States, Austria. Serlia and France; also the eities of London and Constantinople.

At a meeting of the Central Committee held at National IFeadquarter's. January 2!), 1921, Dr. A. Ross IIill had been clected vice-chaimun in charge of forcign operations. I)r. IIill was a Nova Scotian by birth, had studied in Germany in $18: 13$ and 1s!1, and the following year had taken his Ph.l). from Cormell. Subsequently he taught in varions Anerion miversities. the subjects claiming his special attention being pspehology and education. In 1907t he was dean of the Collegere of Arts and Scienees at Comell, and the followine rear became president of the Luiversity of Missonri, a post in which his

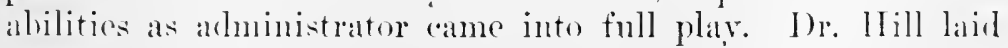
down his presidential robes after twenty-tive years of muiversity scrviore to enme to the Ameriean Red Cross. He is a trustee of the carnegie Fonndation, was formerly a member of the 


\section{HISTORY OF AMERICAN RED CROSS NURSING}

National Research Council, and one time president of the Western Philosophical Association.

On March 12 Dr. Hill, aceompanied by Mr. H. S. Bird and Mr. James K. MeClintock, left the United States for Europe; Mr. Charles Scott, Jr., followed on a later steamer. They were all members of a body known as the European Inquiry Committee, which had been appointed some months before for the purpose of studying and advising upon the operations of the Ameriean Red Cross in Europe. Dr. Hill, with characteristic thoroughness and singleness of purpose, began a study of the existing organizations at the Paris office before he attempted to study that of the separate Bureaus or the field work in connection with this proposed child health program. The result of his study was a report which restated the program of the American Red Cross in Europe and grouped the future operations under two distinet projects:

1. The carrying on of the child health program.

2. The definite liquidation of the general relief program.

After thus establishing a definite working basis, Dr. Hill returned on May 6, 1921, to the United States to preseut his report to the Central Committee for their eonsideration. The recommendations were approved and he returned to Europe the first of June to make a study of field work and to install the child health program. Colonel Olds and Colonel Emerson resigned from the European Commission June 30, 1921. Entil a new eommissioner was selected in August, 1921, Dr. Hill discharged the duties of that offiee. In Angust, however, Mr. Ernest Bicknell was appointed as acting commissioner and in November, the Exeentive Committee appointed him as eommissioner.

Miss Gardner eompleted her tour by September, but did not see Dr. Hill until he also returned to Paris from his survey of the field operations, when they, together with Miss Hay, conferred. This was unfortunate, but under the circumstances could not be helped.

At that time the date for terminating the health work of the Red Cross, while under consileration, had not been fixed. Miss Gardner's observations, however, were marle with the knowledge that the work was temporary in character. Intolligent evaluation moler these eircomstances was very difficult. 
As Miss Gardner's report eovered the plan of the activities, much of it will he incorporated. In every country she met the majority of the staff nurses both in conference and as individuals. She saw the other American Red Cross personnel and local men and women interested in the work. $\Lambda$ that time ninety-eiglit American Red Cross nurses were in Europe, exclusive of those with the Near East Relief. Miss Gardner's report follows:

There is a certain similarity in the child health progranıs of the three more northern countries visited, the Baltic Provinces. Poland and Crecho-Slovakia. Serbia will also be considered with this group because thongh work in Serbia is carried on by the Serbian Child Welfare Association, the stations are supported by Red Cross subsidy, and the nurses are Red Cross nurses. In all these countries child health stations have been established where American nurses are at work with native doctors, and, in all, attempt is being made to train in a short period of time native young women to carry on the work, after the withdrawal of the American personnel, pending the graduation of nurses from the newly established nurses' training schools. Details differ somewhat. In the Baltic provinces over a hundred child health stations were already established before the arrival of the American nurses. "Swesters," native women possessing varying degrees of nursing experience, are employed for dispensary work (sick and well baby clinics) and home visiting. The work of the American nurses, therefore in the Baltic provinces will consist not in establishing health stations but largely in teaching this existing group of women the American technique of their work. The American nurses had arrived in the Baltic provinces but a few days previous to my visit, and actual work har not yet begun, though all was in readiness for it.

In Poland the plan is one of demonstration, a nurse and a social worker going to a town for the primary purpose of establishing a dispensary and milk station (possibly also a small hospital if such is needed) and moving on as soon as these needs are obtained, subsequent risits supplying the necessary stimulation to further effort.

In ('zecho-slovakin the program implies the establishment of twenty-two centers (Government geographical units) of a model type, a number of woll equipperl rooms with laboratory facilities, babies' hathtubs, ete. in addition to the nsual dispensary equipment. As in Poland a nurse and sorial worker work together in the establishment of these enenters. but: unlike lolind, the American persomel remains to run the 


\section{HISTORY OF AMERICAN RED CROSS NURSING}

centers after establishment. In the latter part of June, the time of my visit, none of the centers were in actual operation owing to delays in securing rooms, equipment, etc. The nurses and social workers were, however, for the most part, in their conters, busy about the necessary preliminaries. ${ }^{11}$

In Serbia the problem presented is somewhat different, in that Scrbia is essentially an agricultural conntry. The stations, ten in number, are all located in small villages and serve a large surrounding rural area. At each station are two nurses, one working in the dispensary and one doing the school work and home visiting. Home visits are made by kola (ox cart) or on horseback and often involve many hours of travel for a single patient. In Serbia, adults, both men and women, are cared for at the dispensaries and by the visiting nurse.

In all four countries classes are held for mothers and expcetant mothers, also for little girls ("little mothers").

The question of governmental support has been variously met. In the Baltic provinees the govermments have been asked to make no immediate promises, but to study for themselves the workings of the centers with a view to a later takeover. As the American Red Cross commission to these countries has been peculiarly happy in its relation to the governments and has succeeded in interesting them greatly in its health work, later government support seems exceedingly probable.

In Poland, governmental support has not been sought for varions well considered reasons. The work in Poland is carried on largely through a Polish national society, the P. A. K. P. D. (Polski Amerykanski Komitet Polocy Dzieciom-Polish-American Society for the Promotion of Children), which has branches throughout all of Poland. It is through the P. A. K. P. D. that the American Relief Association has worked in its big task of feeding the children of Poland.

In Czecho-Slovakia governmental support was assured before launching the program.

In Serbia an intercsting situation exists peculiar to the country. The first start of the commission was through local committees of the National Public Health Society, a body which fortunately proved too weak both centrally and locally for the purpose. About the time of my visit it was decided to work instear through the Peasants' Coöperative socicty, a strong national organjation which has been in existence for twenty-five rears for the purpose of coöperative buying, and "Eight centers open Sept. 1. 
on which it seems possible to graft a health program, so making use of a familiary organization which has already gained the confidence of the people it serves. Its loeal eommittees are composed of the peasants themselres. 'Though non-governmental, this society is closely allied to the Government.

Austria presents a problem quite different from the four countries already spoken of. Austrians are excellent organizers, and before the war their child health work was of a high standard. The work of the American Red Cross in Austria has been larelely confined to subsidy and the supply of hospital and dispensary equipment and the child health stations are alrealy served by women of superior type. The Austrian doctor in charge of the child health stations subsidized ly the American lied ('ros: has, however, asked for the services of an American public health nurse to demonstrate American methods of home risiting. At the time of my visit to Vienna the American nurse had very recently arrived, but the prospect of eflective work of this type scemed hopeful.

The effort to train in a short period of time young women to replace the American nurse, pending the time when native graduate nurses will be available, has been in every country the most diflicult part of the health programs, and quite naturally so, because the work required of such an individual does not differ from that at present being done by the American nurse who has required years of preparation for the task. Two methorls have been nsed, individual, teaching in the actual field of work, and the opening of eourses, four to six months in duration, which are attended by gromps of students who live at a central headquarters, and learn through both field and rlass work the ruliments of health visiting. The girls available have for the most part been somewhat bolow the gratle desirable for the nurses training schools. Whether this type of woman wan, after a short period of training, even partially and temporarily fill the place required of her can only be proved by a longer period of actual experience.

It present, evidence from different localities is conflicting. . . .

Miss Gardner visited the five sehools of nursing, all of which, with the exerption of the one at belgrade, had been organized by Anerican Ried c ross nurses.

In commenting upon them she stated:

I will first speak briofly of the training school . . . though not primarily my oinject of stuly. hut as all puhlice health 


\section{HISTORY OF AMERICAN RED CROSS NURSING}

work is dependent upon the production of qualified nurses and the present child welfare programs of the various countries all imply some form of trained native personnel for their continuance seemed desirable. ...

There are many difficulties involved in the starting of a training school in a foreign country, some fundamental and common to all the schools, others more peculiarly local. I feel though that none of these difficulties are insurmountable and that the American nurses engaged in this work are performing a task in the highest degree useful and constructive....

The establishment of training schools would seem in this sense to be in the highest degree constructive, for it is planned to train women who when graduated will take over the responsibility of future development in their own countries. Expenses are already shared or met by the local communities. and the work is everywhere being done with a minimum of American personnel. . . .

Miss Gardner concluded her report with some specific recommendations which, in view of the time consumed in her trip and the peculiar conditions which governed the undertaking, were exceedingly comprehensive and helpful:

The public health programs present a far more complicated problem than the schools. A number of inhibitions to successful accomplishment naturally present themselves.

1. The new programs replace the former infinitely simpler and naturally more popular programs of relief. Such a change is fraught with difficulties in countries brought by war and suffering to the easy acceptance of material assistance.

?. The persomel for the new programs have in many instances not been (hanged, and men and women engaged for quite other work are now involved in a most difficult form of specialized health work without previous preparation for it.

3. Nost of the efforts toward constructive work have been built on the American ronception of a local committee. and its assumed fecling of responsibility for community welfare. In some of the comntries altruism seems to take other forms,the military conception of patriotic service. for instance, and a conmittee composed of the so-called representative people of a community. who themserves derive nothing from the proposed subject. is a less familiar vehicle for sustained hetpfulness than . Imericans alwars realize.

4. A trpe of health work which in America and England is of exceedingly slow growth is in Europe being molertaken 
within a time limit which would at home be considered prohibitive.

5. Most of the programs are based on the American public health nurse as a vital factor in its accomplishment. None of the countries except perhaps dustria possess her prototypeyears of education, training, and disenpline late gone into the making of an American nurse, and she cannot be reproduced in any short period of preparation.

(i. P'ossibly most important of all is the different estimate placed in some of the countries upon human life, and especially child life. When all is said and done the saving of an individual child's life is not always considered a matter of great importance, an attitule of mind difficult for Americans to understand but one having a vast influence upon the whole situation.

That these difficulties and inhibitions have been met and overcome as successfully as they have, speaks well for the American workers. 'The degree of artificial stimulation enployed, however, should be a matter for serious consideration. Stimulation has its place, but is only of any permanent value if it can ultimately be withdrawn with safety.

'The realiness of the countries to receive the kind of help offered is of course the crux of the whole matter. The fact that such a desire has had to be artificially stimulated in every country but Austria does not necessarily militate against the plan, but clear analysis is made difficult by the fact that a certain amount of material benefit in the way of supplies, subsidy, etc., has necessarily formed a part of the educational effort.

A big piece of demonstration work has been carried on over a wide area of European territory. Many of the demonstrations have been good. some have served their purpose in that they have been closely and intelligently watched by those likely to profit by the object lessons. . . .

For the future, Hiss Gardner felt that several courses were open :

1. A complete withdrawal of all American peronnel and money within the next ten or twelse months. This conle! probably be acomplished without loss of Red Cross diensty or prestige if plans were inangurated at once.

?. A prolonged stay of a number of years with less stimmlation and less intensive effort. This would imply a wholly lifferent point of view on the part of the persumbel. an att $j$ tule more nearly aphroaching that of the misionaries who 


\section{9+ HISTORY OF AMERICAN RED CROSS NURSING}

neither seek nor expect immediate results, but who measure success by decades, and who expect to give years of continuous service.

Between these two extremes were two others:

A. After the retirement of the Ameriean commissions a limited subsidy could be left to be administered by native groups under certain stipulated conditions.

B. In addition to such subsidy or withont it, a tiny American persomel conld be left, not more than two or three pcople, one of whom should be a well equipped public health nurse who would aet in an advisory capacity either to the subsidized bodies or to those desiring such assistance.

The last plan, though possessing many adrantages, should not. I believe, be unreservedly recommended for all countries. I think the time wiil soon have come when a cessation of outside stimulation is to be desired. If at the end of another eight, ten or twelve months such an American advisory service is not very generally and sincerely wanted and asked for, it should not, in my opinion. be offered, certainly not for the mere object of tying a string to a subsidy.

The task which confronted the Red Cross administrative workers in Paris, medieal direetors, murses and soeial workers in the field, was monumental. It meant not only the organization of loeal committees and the building up of local interest, but the physieal task of organizing and openiug up child health eenters. Then there was the work of selecting and training loeal nurses and health visitors. This entailed special courses for the latter at Cracow, Prague and elsewhere, for the former a preparation by special courses in eonneetion with the new schools of nursing at universities, of which, for eximple, the school at Dorpat, Esthonia, under the direetion of Mrs. Vaughan, was one.

While the child health work had heen diseussed since early 1920 , and its development anthorized, a final plan of organization had not been formulated until 1921. Howerer, with the simplifieation of central alministration and with the knowledge that to the American Reel cross, as a member of the European Reliof ('omncil and because of survers made by Red Cross doctors and nurses. had been allocated the neelieal and social care of the (hildren, gradually the activities seemed to group themselves into two elasses: 
First. Child II ealth Centers.

Which might be ambulatoria, children's hospitals or chilfren's wards, milk stations, (linic's for the examination, weighing and measuring of ehildren, also special areas for intensive pre-natal work, as a community demonstration were included.

Second. Educational Hork.

Pre-natal and post-natal instruction for mothers, instruction in Home Hygiene and care of the Sirk, are of rhildren, whild health propatranda for the general public, and instruetion in public health nursing to grathate nurses as in Austria, Baltic States and ('zecho-slovakia, as well as on health visitors at Cracow, in order that personnel shonld be developed to "carry on" after the withdrawal of the American Red Cross.

Modifications of the general plan were used in each country where the American Red Cross operated. In the main, the field supervision included one or two American doetors, a supervising nurse and a social worker; to the centers were assignel local doctors, an American nurse, also a local nurse where one existed and from two to four student health visitors. From the eentral oftice medical, nursing and social direction was given by American personnel, which included well-known specialists such as l)r. J. II. Mason Knox and Dr. Phillip Jeans and also I)r. IIngh IIaming for general medical supervision. General nursing direction wats given by qualitied public health nurses. Mrs. Elsbeth Vamgham for Czecho-Slovakial, Poland and the Baltic States: Miss Sophie C. Nolson for the Balkan Ntates, Austria, Ilmoary and Serbia. Both of these nurses had been assigned as assistants to Miss IIay in 1921. With this oranization a elearer understanding of the work was gratually acequired.

In Anstria one humbled and one centers were established. Inere, als well as in Ilumary, the nurses, with the exception of the supervisors, were natives. In the Baltic states there were by July of $1: 1: 21$ sixty-six eenters, in september one humberel and forty, this rapid expansion oecmuring bofore the arrival of the Ameriean lied ('ross nurses. These arenters

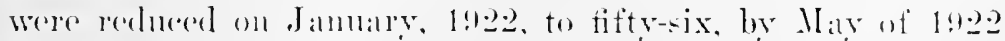

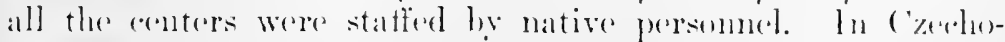
Slovakia twenty-one anters were established. ln llungary

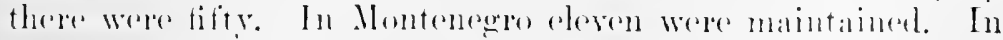




\section{HISTORY OF AMERICAN RED CROSS NURSING}

Poland one hundred and fifty-six ambulatoria and sixty-nine centers were organized and when the Red Cross withdrew over twenty thousand children were registered and under supervision and two thousand expectant mothers were receiving practical instruction. In. Rommania the Ameriean Red Cross work passed through varions stages: First, the Ameriean Red Cross commission had developed general and medical relief until 1920. Then, upon the withdrawal of the commission, six American Red Cross nurses had been left with Lady Paget's Mission, but were finally withdrawn. Later one American Red Cross nurse, Miss Agnes Von Kurowsky, was assigned to Roumania and worked with the Junior Red Cross until November, 1921. Later the Government assumed the responsibility for the baby clinic at Breaza, which she had supervised. In Serbia the Ameriean Child Welfare Association, subsidized by the American Red Cross and supplied with American Red Cross nurses, developed ten stations and conducted a health workers' course. In comnection with the work loeal committees were formed, contracts were made with local ageneies and loeal personnel were trained. In some instances clothing was supplied and layettes in large numbers were distributed. Food was usually distributed, however, through the local or State representatives of the American Relief Association, such as the P. S. K. P. D. of Poland or other agencies.

That Dr. Hill had his mind fixed upon a given date as an objective toward which to work is best told in his own words:

In organizing the rhild health centers of the American Red Cross in Europe, it was my notion in July, 19.21, that in some countries at least a period of two rears would be necessary for effective operation. But by October, after I had traveled over the field and visited the centers already in operation. I rearhed the conclusion that. while it would probably take more than two years for the American Red ('ross to carry the program to a thoroughly satisfartory demonstration, yet in one vear it would probably be posible to convince local agencies of the possibility and desirability of their taking responsibility for the continnation of the work. This opinion was anfirmed by a conference with Miss (iardner just before her return from Europe.

Acordingly, throughout the year an effort was male to enconrage loxal participation in the program and to develop local aremedes and local personnel. From corresponlence with the Commissioner for Europe and from the reports of 
the directors of field operations, it became clear that the transfer to local agencies by July 1, 1!2:2, was not only feasible but wise, even if that involved the granting of sulssidies in some instances to these local agencies for the first year of their operation. Ac'ordingly, the ('ontral Committee at a meeting held iebruary $1 \%$, 1922, took the following action:

That it is the sense of the Central Committee that the Red ('ross shonld conclude its work in Europe, with the exception of certain activities of the Junior Red ('ross, on Jume 30, 19:2, this resolution being subject to the following conditions:

I. It is recognized in order to secure the transfer of Red Cross activities to other agencies with the least possible loss of value that the Red Cross may continue a certain amomnt of superrision and in special cases render temporary assistance of an incidental nature to the arencies taking over these activities, etc.

Of course the action referred to had reference to the child health program only. and did not mean the discontinuance of the work of training nurses, nor of the relief to Russian refugees in Constantinople, nor of the furnishing of medieal and hospital supplies to Soviet Russia.

That the personnel worked as a team is demonstrated by the fact that by July 1,1922 , nearly all the field workers wore released. The exceptions were certain nurses whose services wore in eomnection with the sehools and Mrs. Heihnan in Greece. The American Red Cross made provision for Mrs. Ifrilman's salary until July 1, 1922 , a dite on which it was assumed locally. The serviees of Miss Elizabeth Marshall were retainel until October, 1922, in Constantinople, where she had been assigned to develop publie health nursing for the school of nursing there. Also here and there in Eastern Europe was left a murse alvisor-Mrs. Vaughan for the Baltic States and Poland: Miss Nelson for general supervision of the Balkans, Austria and Jungary: Miss Sehaub in Hungary, and $\mathrm{Xiss}$ Torrance in Czecho-slovakia. Thus the nurses who had been first in the field wore the last to leave. Miss II Ir,

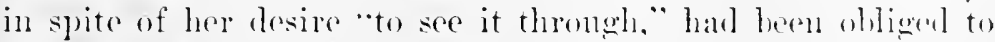
roturn to Ameriea .June t, 192.2, becanse of the illnese of a

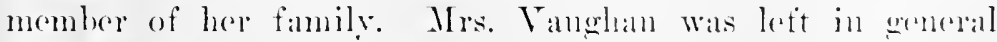
rharee. She however, was also obligerel for similar reasums to leare in Sepomber, 19.2.2. Miss Nolsom thus remained ats 


\section{HISTORY OF AMERICAN RED CROSS NURSING}

the representative of the Nursing Service until such time as it was deemed wise to leave the committees without special advice, and until the last of the field nurses were withdrawn.

The organization of the child health work under the American Red Cross appeared to be slow in getting under way, but the rapidity which characterized its later development and the final withdrawal of the majority of the American workers by July 1, 1922, may well lead to speenlation as to its real value and permaneney. As a demonstration, even though there may be some criticism of the American Red Cross for trying to develop in a short time under most difficult conditions a type of work that usually required a longer period even in Ameriea, we believe it was valuable. The minds of the people were directed towards positive health as an objective. The instruetion of thousands of women and girls in personal hygiene, in the care and feeding and proper elothing of children and the emphasis placed by the American nurses by precept and example upon the importance of good nursing service to the sick as well as health nursing eannot have been entirely lost.

The island possessions of the United States also profited by the skill and devotion of Ameriean Red Cross nurses. Their services were first ealled for in 1919 and at the closing date of this history, June 30, 1922, numerous types of nursing activities were in process of active development. Arministrative details in comnection with this insular nursing service were conducted through the Department of Nursing of the Insular and Foreign Division of the American Red ('ross of which Miss Ida F. Butler was director. The islands in the Atlantic Oeean to which American Red Cross nurses were assigned were Santo Domingo and Porto Rico of the West Indian Group and the Virgin Islands, which were located cast of the West Indies; those in the Paeifie were the Hawaiian and the Plilippine Islands.

When the United States Marines were sent in 1919 to molice the Island of Santo Domingo, the Medical Corps of the Thited States Nary sent a complement of Nary surgeons. sanitary officers and enlisted men with them, and these medical men of the Nary served as sanitary officers of the island. Through them the Dominiean Republic ealled upon the Amerian Red Cross to assign nurses to service there, the Republic to provide salaries, transportation and maintenanee. the Nursing serviee 
to select the murses, to act as the intermediary for the Government and to advise and direet the nurses' work. From 1919, and up to .June, 1922, ten Ameriean Red Cross nurses, Mary Muriel Cameron, Marie F. Falconer, Mabel Dershem, Elizabeth Wricht, Innrietta Wiltzius, Clara J. Farnsworth, Elizabeth IIunt, Mary E. Slaneman, Agnes Meyer and Elizabeth Miller, were on duty on the island.

The type of service which these nurses met included the reorganization and direetion of hospitals, the establishment of dispensaries and the orranization of elasses of instruetion. In addition there was the actual routine of nursing work, in which, nuder conditions next to impossible, they performed almost superhuman nursing tasks. Some attempt was made to train young women in the principles and practice of nursing, but the chicf aecomplishment in this field lay in the practical phase's and little was done toward the organization of sehools or the standardization of mursing education. In the majority of Dominican hospitals the nursing service was under the management of religious Sisterhoods.

The experiences of the nurses were more or less the same, and an extract from a letter written by Miss Wiltzius to Miss Noyes on August 5, 1922 , will serve as an illustration of the difficulties under which they all worked. Miss Miltzius was on duty at the hospital at Santiago. She wrote:

When I tell you that it is the dirtiest, most neglected place I have ever been in, you can guess that it is terrible, for I have seen and helped "clean up" a few unsightly so-called hospitals before this.

Not one room is in any kind of order. The bedside tables serve as individual medicine cases, clothes lockers and food containers. . . The sanitary arrangements are unspeakable. . . . . ioiled linen, garbage and used gauze are thrown out of the windows or in some corner. When a new bed is needed, it is set up. There is no such thing as spacing the beds at regular intervals in the wards. . . .

'The buildings themselves are very niee and when they are painted and connected by covered corridors I think this can bo male the prettiest hospital on the island. lorated as it is on the outskirts of the town, with the mountains behind it. the situation is ideal.

Miss Wiltzius" arlvent had not been greeted with onthusiasm by the native doctor in charge of the hospital at siantiago, but 


\section{HISTORY OF AMERICAN RED CROSS NURSING}

after some weeks "he seems to have ceased," wrote Miss Wiltzius, "to regard the American nurse as a necessary evil and the air is not as frigid as on the first day."

Miss Wiltzius' living quarters were almost as primitive as were conditions in the hospital. She wrote:

I am living with a rery nice native family downtown because the hospital is in an undesirable neighborhood. 'This family, howerer, lives at some distance from the hospital but I have a "sea-going hack" which takes me back and forth. The arrangement is satisfactory when it comes, but it is discouraging to have to wait and then walk. The two rooms I occupy are on the street with only one door for ventilation and light. I did feel very "shut in." after serbo but now that I have a cot and sleep on a balcony, it seems wonderful. Down here on the street I had no air and the dust just pours in. The Marines were very good about getting me "fixed."

Commander I. S. K. Reeves, Marine Corps, United States Navy, whose effort to improve health and sanitary eonditions hat borne such fine fruit, spoke appreciatively in a letter of June 27, 1922, of the nurses and their work:

You have sent me nurses of the most superior type. They are a credit to your organization and a pride and joy to mine. I cannot say too much in praise of your choice and take this opportunity to thank you again.

Under the direction of the United States Nary doctors, who acted as sanitary officers, and because of the energetic and devoted work of the Red Cross nurses the hospitals were gradually developed into first-class institutions. Great improvement took place in the nursing eare of the sick, and through dispensaries a better knowledge of personal hygiene and health conditions was rlisseminated.

This last phase of the sanitary program in Santo Domingo was greatly assisted by classes in Home Hygiene and Care of the Sirk, which was given ly Isabel Hall Basken. Mrs. Basken was a native of the Dominican Republic and a grarluate of Lineoln Inopital Sirhool of Nursing in New York. In April, 1920 . she was appointed as an instructor of this entrse and was eneretic in organizing classes among the women and rome girls of that country. In a period of two rears tifty were 
instructed; forty-one received certificates. Mrs. Basken also translated sections of the texthook on Home Hygiene and Care of the Sick into Spanish.

Another island possession, Porto Rico, asked in the early months of 1921 for a public health nurse. Ilere there was a well organized Chapter which had been excectingly ative during the war, with Mr. Knowlton Mixer as executive secretary. Kathleen l)'Olier, whose fine work in developing the child welfare work in Greece has already been deseribed and who had resigned from that field in l)ecember, 1920, was secured. She sailed $A_{\text {pril }} 23,1921$, and in her first report wrote:

The Nursing Center of the Porto Rico Chapter, American Red Cross, opened its oflice May 31. The stafl consisted of the supervising murse [Miss I) Olier], two statf nurses and two part time doctors. . . . The aim of our work is the reduction of the infant death rate. . . The death rate among infants under one year in Porto Rico is 146 per 1000 births. ... The need for the pre-natal clinic is demonstrated by the death of a large number of children before reaching the age of one month, or even one week. . . While we are chiefly interested in the mother and baby, once we enter a home we make the family the mit of our work.

Miss D'Olier found a virgin field with but few nurses, graduates from the local schools, that might be secured to assist her. The stamblards of nursing were low. While a registration law existed, its provisions were not maintained or enforeed. Miss D'Olier ureel Red Cross participation in the organization of a school of nursing at San Juan similar to those sponsored by the Red Cross in Europe. A plan and recommendations were prepared and presented. but these were, at the time of writing, still awaiting confirmatory assmances from the local anthorities upon certain points regarded as essential to a rö̈perative enterprise. After a yearls service. Miss I) Olier returned to the Enited States for conference and a vacation. The climatice enditions and the differulties incodent to a field where soon aretive eases of tuberemlesis al lone needed attention, the eharer of a sanatorimm arenmmodating ST, with a wating list of 400 , malle a change and rest anlvisable. Ifter a month in this anutry she peturner? to sinn .Jum. Two Porto Rican muses, crinduites of st. Luke's Memurial 


\section{HISTORY OF AMERICAN RED CROSS NURSING}

Hospital School at Ponce, were brought to the United States on Red Cross scholarships. They returned in Jume, 1922, and were assigned to duty as assistants to Miss D'Olier. This increase of staff relieved in a measure the strain. Miss D'Olier and her staff helped to develop elinies of various types, home visiting and courses of instruction, three phases of the Red Cross program which will unquestionably help to develop a higher sense of community responsibility and a better understanding of good health requirements.

Located some forty miles east of Porto Rico were the Virgin Islands, which the United States had purchased from Denmark on March 31, 1917, with a United States Treasury warrant for $\$ 25,000,000 .^{12}$ This transaction closed a question which had been an open one for fifty years. Wireless messages were sent on that day to the Danish and Ameriean anthoritics to lower the Danish flags and raise the Stars and Stripes. A representative of the Navy Department was assigned by Secretary Daniels to assmme governmental responsibilities until the permanent govermment had been determined upon br Cruze. The total area of the islands amomnted to one hundred and thirty-eight square miles and the total population, according to a census taken in 1911 , was 27,086 persons, of whom a large number were negroes. The chief islands of the group were st. Thomas, St. Croix and St. John.

Less than a month after Secretary Lansing had consummated the purchase of the Virgin Islands, the United States declared war upon Germany. Through its Insular and Foreign 1)ivision, the American Red Cross subsequently organized Chapters for war work in the newly-aequired territory. When $\mathrm{Mr}$. Frederick A. Moran, a field representative of the Insular and Foreign Division, marle a visit in June, 1920, to the Virgin Islands, he found that the Chapters at St. Thomas and St. Croix were still active and were interested in the peace program of the Red Cross. His first report to National Headquarters urged the assignment of two nurses, one to St. Thomas and St. John, the other to St. Croix.

When the sanitary oftieers of the Lnited States Nary had first eome to the Virgin Islands, they hat anthorized the cstablishment of schools of nursing. The work incident thereto had not, however, progressed rery far and but two native

w "The European War," New York Times Current History, Vol. XI, 1917. 
nurses had heen graduated. With the support of the other physicians, D)r. Mink, (hiof Modieal Airl, Navy Department, urged the assignument of Ameriean Red Cross public health nurses to inamgurate health work in the public schools. Thus the serviers of the two murses requested by Mr. Moran were to be ntilized in school nursing, which was to serve as an entering werlge mitil the training school project could be taken up again.

Miss Butler sceured Florence C. Freeman and Ruth C. Waterbury to develop the nursing program in the Virgin Islands. Miss Waterbury was a graduate of the Hopkins School and was a highly qualified public health nurse. She was, moreover, familiar with the American Red Cross Nursing Scrvice, because she had served as a nurse member of the Commission for Poland.

The two nurses arrived at St. Thomas on November 4, 1920. Miss Waterbury had been instrueted to act as supervisor of all the mursing work in the islands, so she set up headquarters at St. Thomas. Miss Freeman proceceded to St. Croix. Both nurses began immediately the development of the school nursing program.

Their work met with appreciation and suceess. The St. Thomas Mail Notes for June 5, 1921, contained the following statements.

I would further call your attention to the splendid work in the line of school nursing acomplished in the past year. Of the 199.? (hildren enrolled in ail the sthools, publie, private and parochial, 1701 have been carefully examined and in the cases fomml infective appropriate action was taken to correct such defects.

For this noble work we are indebted to the Red Cross and most especially to Yiss Waterbury of that service, backed most corilially by the Gorernment and melical officers and all school oflicials.

Ineritably there were many diseouragements eneountered in a new renture of this tye in a recenty acquired possession where many of the "lefterer" offieials from the previous rérine wore artainly not enthusiastie, if not openly hostile to new metheds and the introluetion of new systems. Haphazarl, easy-uning aministrations do not constitute the 


\section{0\& HIS'TORY OF AMERICAN RED CROSS NURSING}

happiest foundation upon which to build a more rigid, thorough and progressive system.

In the late summer of 1921 Miss Waterbury began to feel the strain and went back to the United States for a rest and conference with National Headquarters. Miss Freeman had resigned the previous May. Miss Waterbury returned to St. Thomas on September 15 and took with her an assistant nurse, Elizabeth S. Robinson, who was assigned to school nursing at St. Croix and Frederiksted. The work at Frederiksted developed so rapidly that another American Red Cross nurse, Alice F. Stenholm, was assigned on January 4, 1922, solely for duty there. $\Lambda$ s the months passed health eenters were established both at Frederiksted and Christiansted in addition to school mursing. Classes were held and native nurse assistants were seeured and trained. That the work had local governmental support is shown by the speeial order issued by the governor, which, under date of September 25, 1921, supported the public health nursing program, announced the appointment of Miss Waterbury as the supervising Red Cross school murse of all school nursing in the islands and indicated the centers of development as St. Thomas, Christiansted and St. Croix. Some months later Miss Waterbury was asked to serve, in addition to her work as supervisory nurse, as the general field representative of the Ameriean Red Cross in the Virgin Islands, an ardnous program for one person to carry, but one for which her training and enthusiasm made her well fitted. From time to time the murses of her staff returned to the United States, for any nursing service in the tropies is a severe one, and new nurses were sent to fill their places.

From the date of Miss Waterbury's return to the Virgin Islanels in September, 1921, the mursing activities there developod steadily and by June of the year 1922 the improved condition of the school children well rewarded the nurses for their hard work.

The two gromps of islands in the Pacific Ocean in which the Ameriean Red Cross developed varions nursing activities were the Hawaian and Philippine lshands.

In IIawaii a local Committere on Red Cross Nursing Service had been oreanized prior to the war and an active Red Cross Chapter hat also rendered conspicuous servien during the peried of hostilitios. When the post-war program in public health morsing was annomened the Itilo Branch of the IIawai 
Chapter voted to support it and secured a California public health nurse, ('atherine $S$. Bastin, to develop a community nursing service. Miss Bastin hat seen service overseas at Dr. Blake's hospital in Paris and later in the Army Nurse Corps in France.

In a letter written December 20, 1921, Miss Bastin gave an interesting accomut of her work:

The work here is of a peruliar nature. Think of twelve nationalities and add to them all the possible mixtures, and what a motley arowl it becomes! Japanese are the predominating people. They are an industrious, quict, law-abiding race. They have their own ('nstoms of long standing and, although very polite to the white nurse, they selfom let me do anything. I am always ushered in and made welcome, but when I suguest a bath or some other treatment for the patient, they only smile and bow and say, "I too much thank you" hut I am not allowed to give the bath. 'The Chinese and Koreans 1 find most amenable. 'The Portuguese are dirty and indifferent, as a rule. The Hawaiians do not like to put forth an effort. They have lived very contentedly with their fishing, sweet potato and tarrow patches, and a few fruit trees. Life has always been very simple to them, so why make it complicated ly a lot of "newfangled" ideas about food, (lothes, and sanitation?

Much of my work has been in the schools as there is no s(hool nurse and that is where the greatest need lies. . . . The infant death rate is very high in these islands, and so I lave started a well haby conference, which I hope in time will help to reduce it.

This is too larere a field for one nurse, but I can see no immediate prospect for another one coming. . . .

In a communication a few days later, Miss Bastin wrote that she expereted to start within a month two elasses in Home Hyereme and (ane of the Sick. One eourse was to he given to Hawaidan women and the other, a moditied conrse, was to be eomblueted in the high sehool.

Miss bastin was also mude interested in the student nurse recruting movenutent and distributod the recruiting literature and posters throughout her territory. By May 1!2.2, she had ilereloped a woll organized and varied program of community serviece.

In the philippine lstands prior to the Eurupean War, the

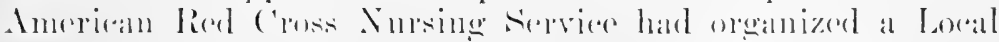




\section{HISTORY OF AMERICAN RED CROSS NURSING}

Committee for enrollment. The large numbers of American nurses then resident on the islands and the several schools for training native nurses, which had as their superintendents well-trained American nurses, constituted a supply from which the Nursing Service hoped to draw members. An active Chapter has also been organized and previous to 1917 had rendered good service in the field of disaster relief. During the European War both the Local Committee on Red Cross Nursing Service and the Chapter were aetive participants in the various types of nursing activities and ehapter production and when the post-war program was launched the Chapter took up the development of public health nursing and of class instruction to women in Home Hygiene and Care of the Sick.

In December, 1920, Emmet W. White, who as manager of the Insular and Foreign Division, was then on a tour of inspection in the Philippines, eabled National Headquarters, requesting the appointment of a Director of Nursing for the Philippine Chapter. This eable was followed by others from him which suggested various individuals, some of whom were not nurses, others not enrolled nurses. Before Miss Butler and Miss Noves had succeeded in securing a suitable appointee. Mr. White on February 28, 1921, eabled that he had selected a director. It was found that she had been in the Philippines many vears, but was not enrolled in the Red Cross Nursing Service; neither did she meet all the present requirements, and furthermore she was without public health experience or training. Her preliminary training, received many years ago, was good, her knowlerlge of the Philippines and the people was a decided asset and her spirit and interest were musual. On the other hand, she lacked a background of Red Cross nursing experience and knowlerge of Red Cross organization.

The issue at hand between Mr. White and the Philippine Chapter and Miss Butler and the Nursing Service at National Ileadquarters then became the old issue of "maintaining standards." Possession in $\mathbf{1 9 2 2}$ of the coveted badge and appointment card of the American Red Cross Nursing Service was a definite guarantee to whomsoever it might eoneern that the owner thereof had successfully met requirements of training, experience and character which placed her among the representative women of her profession. In justice to the many nurses whose applications for enrollment hal been rejereted, the Nursing Service could not, on the whim of im- 
petuous Chapter and Division officials, set aside these definite requirements and enroll any nurse the latter might choose to select. An ironclad regulation of the Nursing Service, a regulation of the greatest protection both to the Chapter and the Nursing Service itself, was that every nurse engaged in American Red Cross nursing service should be an enrolled murse. Thus the Local Committee at Manila conld not recommend nor could the National Committee at National Headquarters ratify the enrollment of $\mathrm{Mr}$. White's appointee as I)irector of Nursing of the Manila Chapter and the nurse herself was faced with the embarrassing task of trying to develop a mursing service withont the aid or supervision of National Headquarters.

The situation which resulted was chaotic. Graduates of sehools of nursing in the Philippines which did not meet the requirements for enrollment were employed by the Chapter and called Ameriean Red Cross nurses. Courses of instruction for Red Cross aides were given which were not anthorized Red Cross courses. These irregularities were not only contrary to all instructions, but in some instances constituted an actual infringement of the law established to safeguard the use of the Red Cross emblem.

The nursing situation in the Manila Chapter was, indeed, little more than the old struggle which had seemingly to be fonght over and over again between the leaders of the Tursing Service at National Headquarters and each new commissioner or Chapter official in the field, struggles as wearisome to Miss Delano and Miss Noves as the repeated aceomits of them must be to readers of this history. Commissioners and officials of remote chapters, who had been in Red Cross service eomparatively overnight and who did not choose to acquaint themsclves with the long-established methods of organization and procedure which had prevailed for many years at National Headquarters, took up their duties with inderstandable enthusiasm and as a first gesture of their new anthority reorganized or initiated anew mursing activities in line with their own and local ideas; as a result they set awry the well-oiled machinery of a long-established professional service. Becanse nurses were women. each new enmmissioner or official seemed to think that he could do with them anything he wished. It is seriously to be questioned if the medieal phases of American Red ('ross serriee, a fair professional comparison. were so dragend about by the ears als was the Nursing serrice. The 


\section{HISTORY OF AMERICAN RED CROSS NURSING}

executives of the Nursing Service at National Headquarters were answerable to the American Nurses' Association, which had accepted affiliation with the American Red Cross on certain definitely defined "professional prerogatives," and Miss Delano and Miss Noyes strove to defend these prerogatives at cost of much labor and weariness of spirit. Certes, they grew as tired of "fighting for standards" as their opponents must have grown of having them fight! The most discouraging aspect of the whole situation was that it seemed as if every step of the struggle for professional status had, like the embryonic steps in the evolution of the race, to be lived through before a new nursing serrice could be brought into being.

To return to the Manila Chapter: As the irregularities increased, it finally became evident even to Chapter officials that the services of a well qualified and enrolled nurse should be sent to supervise their nursing activities with as little delay as possible. Accordingly, Virginia Mason Gibbes, a graduate of the Roper Hospital School of Nursing, Charleston, South Carolina, sailed on March 26, 1922, to assume the responsibilities of Director of Nursing for the Manila Chapter. As a member of an enrollment committee, as an instructor in Home Hygiene and Care of the Sick, as a Town and Comntry public health nurse and as a member of the Southern Division nursing staff, Miss Gibbes had gained a rich and varied background of Red Cross nursing experience. The affairs of the Chapter were also put into more satisfactory aligmment with the organization at National Headquarters by the appointment of Mr. Knowlton Mixer some months previously as manager of the Manila Chapter. Like Miss Gibbes, he was experienced in Red Cross organization and polieies, and together they began to study the situation and bring the Red Cross activities into line. Miss Gibbes began a study of local affairs, nursing schools, resourees and organization as a necessary basis for all Chapter nursing activities.

One of the outstanding diffienlties in the Philippines was that the Chapter, by utilizing the services of poorly trained nurses' aides, was depriving the professionally trained uurses on the islands of enployment. Miss Gibbes sonn reported an apparent over-supply of gradnate nurses. She wrote: "Of one hundred and two recent grarluates of the ......... School, twenty have no prospect of immediate emplorment. As far as I can learn, there is no registry for nurses." This lack 
of employment was one of the chicf inhibitions to the development of professional mursing in the Philippines, and professional nursing serviee was one of the vital needs there. Miss Gibhes immediately "advised the development of murses and not nurses' aides," as stated in the Minutes of a meeting held May 12, 1922, of the Excentive Committec of the Manila Chapter. In a letter addressed on June 8 to Miss Noyes at National IIearlquarters, Mr. Mixer annomeed an important change of policy:

\begin{abstract}
... The Chapter has abandoned its plan of training Red Cross aidles. . . We are using only graduate nurses. . . . I believe our present program is quite in line with your ideas and I an fully convinced that we will obtain better results and cover a wider field of usefulness.
\end{abstract}

It is true that a few aides were still used in the provinees, but their activities were to be supervised by graduate murses. In connection with the development of public health mursing in the Philippines, sereral native murses came to the United States in 1921 and 1922 for post-graduate courses in public health nursing. Two of them were given Red Cross scholarships and entered the courses at the University of California in San Francisco. 'Two entered Teachers' College and were prepared to return to Manila to engage in Red Cross work.

While Miss Gibhes and Mr. Mixer were laboring to bring about these changes, an appointment of international interest to nurses had been made in the Philippines. It will he remermbered that late in 1921 Miss Fitzoerald had resiened as Inircetor of Nursing of the Leagne of Red Cross Societies. In Maich, 1922. she was appointed through the Rockefeller Foundition to membership on the staff of General Leonard Wood, then erovermor general of the Philippine Islands, for the purpose of making a study of nursing resourees, schools of nursing and public health mursing in the Philippines amb alon to aret as general adviser to General Wood on all nursing questions. That a nurse should have been appointed as an adviser on nursing atfairs to the eovernor of a state or provinee was a progressive step forward in the canse of profersomal mursing

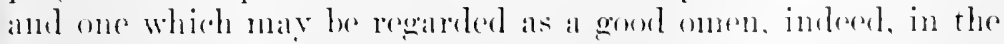
develogment of somul nurse education and the hetterment of nursing "are of the sick. 


\section{HIS'TORY OF AMERICAN RED CROSS NURSING}

With the close of the emergency relief and child health programs, the American Red Cross Nursing Service, as it has been said before, withdrew its nurses from the foreign field and left, with the exceptions already mentioned, only the nurses who were conducting schools of nursing in Europe and the Island Possessions of the United States. During the four transitional years in which this elose of foreign activities and withdrawal of personnel had taken place, contraction of the organization created to meet the military needs had taken place in the United States. The number of Red Cross Divisions had been reduced from fourteen to five. This contraction was one of administrative machinery alone and was not, in any sense, a lessening of American Red Cross nursing activities in the United States, for the "peace-time" nursing program of public health nursing and elass instruction to women was being developed to unpreeedented proportions, as may be seen in subsequent chapters.

Death alone had broken the ranks. Jane Delano and Henry P. Davison, outstanding war leaders, had died during this period, both of them from practically the same malady and both of them in their prime. Ida M. Tice, a charter member of the National Committee on Red Cross Nursing Service, and Sophie F. Palmer, a woman whose keen mind had piloted the nursing profession through the stormy waters of registration, one of the first nurses to sponsor affiliation with the American Red Cross and the first adrocate, and for fifteen years the guiding spirit of the Journal, had died and from among the rank and file, as a direet result of service in the European War, two hundred and eighty Ameriean Red Cross nurses.

But the vanguard of the Nursing Service remained and was on July 1,1922 , serenely and powerfully moving on to the fulfillment of its destiny, with an enrollment of thirty-nine thousand nurses and a National, State and Local Committee srstem of over fifteen hundred nurse volunteers. "It seems," wrote one of these forty thousand nurses pledged to respond upon call for altruistic service, "that when we have onee heard and answered the call of the Red Cross, we ever wait and listen, ready to come when needed." 


\section{CHAPTER XIV}

FROM RLRAL NLRSING TO THE PLBLIC IIEALTII NCRSING SERVICE

Outline of Eirly (irowth-Requirements for ApplicantsAffiliation P'rinciples Adopted-Grouth of Central and Branch Units-Early Affiliations-The Interruption of Ilar-scholarships.

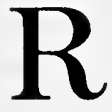

URAL mursing, so called, or the extension of the visiting nurse's service to the people of isolated districts, has long been carried on in many countries-in Great Britain and Ireland by the staff of the Queen Victoria Jubilee Institute; in Norway and Sweden by Red Cross nurses; in Australia ("bush mursing") by a nationally organized association: in Canada by the nurses of the Vietorian Order, and to some extent by various groups in other foreign lands. In this comntry a pioneer rural mursing association was founded in 1896 ly Ellen M. Wood, a Johns Hopkins nurse, in Westchester County, New York, where she volunteered mursing aid to the country people in her home community. Suecessful from the heginning. it grew nutil (by 1920) it had extended over some twenty villages. Miss Wood died abroad (1900) of trphoid fever, contracted on board ship while mursing a sailor smitten with the discase. After her death her name was giren to the association.

Another pioneer was Lxdia Holman, a Philadelphia nurse, who, having visited the Kentucky monntains, matle her home there for some vatrs and carried on an individual serviese to the Southern Highlanders. Iiving in a little cabin and being supporter mainly by the voluntary gifts of food materials brought by her patients. She was later able to develop the Lydla II. Holman Association (1911). her chief assistants being medieal members of the Johns Hopkins Lniversity and Medieal sidenel. This assoeiation wats, however, nut permanemt and harl been dissolved before Red Cross plans for Rural Nursing hatd beren mate public. ${ }^{1}$

-Reports of the llolman Association. 


\section{HISTORY OF AMERICAN RED CROSS NURSING}

In 1905, when the Peace Conference following the RussoJapanese War was held in Portsmonth, New Hampshire, the envoys of those countries made a gift of $\$ 20,000$ to the State to be used for eharitable purposes. Several persons then tried to have this gift used in establishing a State-wide system of rural nursing, but their efforts failed. ${ }^{2}$

The service earried on under the Ameriean Red Cross, first called The Rural Nursing Service, afterwards renamed "Town and Country Nursing Service," and still later the "Bureau of Public Health Nursing," had its inception in the mind of a woman especially distinguished for a combination of nursing talents with soeial gifts and ereative energy. This was Lillian D. Wald, founder and leader of the well-known Henry Street Settlement in New York City, first ealled the Nurses' Settlement. A New York State woman, graduated from the New York Hospital Training School under Irene Sutliffe, Miss Wall's venture into a mode of life which eombined visiting nursing with all the other interests of an ardent lover of humankind and a progressive citizen, has been made widely familiar through her beok, "The House on Henry Street." In her long and remarkable service she has done more, perhaps, than any other one Ameriean woman to ehange the eonventional form of visiting nursing into those varied civic and community efforts which she was the first to eall "Public Health Nursing," thus enlarging Miss Nightingale's phrase "Health Nursing."

Miss Wald has already been mentioned as one of the Red Cross members in New York State before the reorganization of 1904-1905. It has been shown that she gave assistance to the New York Anxiliary during the Spanish-American War, and afterwards remained faithful to the work of enrollment, ret she felt, and expressed, strong dissatisfaction at secing so popnlar and potent an organization as the Red Cross limited to the uncertain and irregnlar service of relief in war or calamity. She reflected that both must in their nature be sporadic, and that if, in time of peace, there were no absorlying interests to hold the enthusiasm of members, they would fall away, and ouch emerenener would need fresh reorganization. Mereovere it seremed to her wasteful to have a national. woll-organized society periodically inactive. Foreign Red

2"History of Rural Nirsing”: Fannie F. Clement, American Journal of lursing, April, 1913 . 


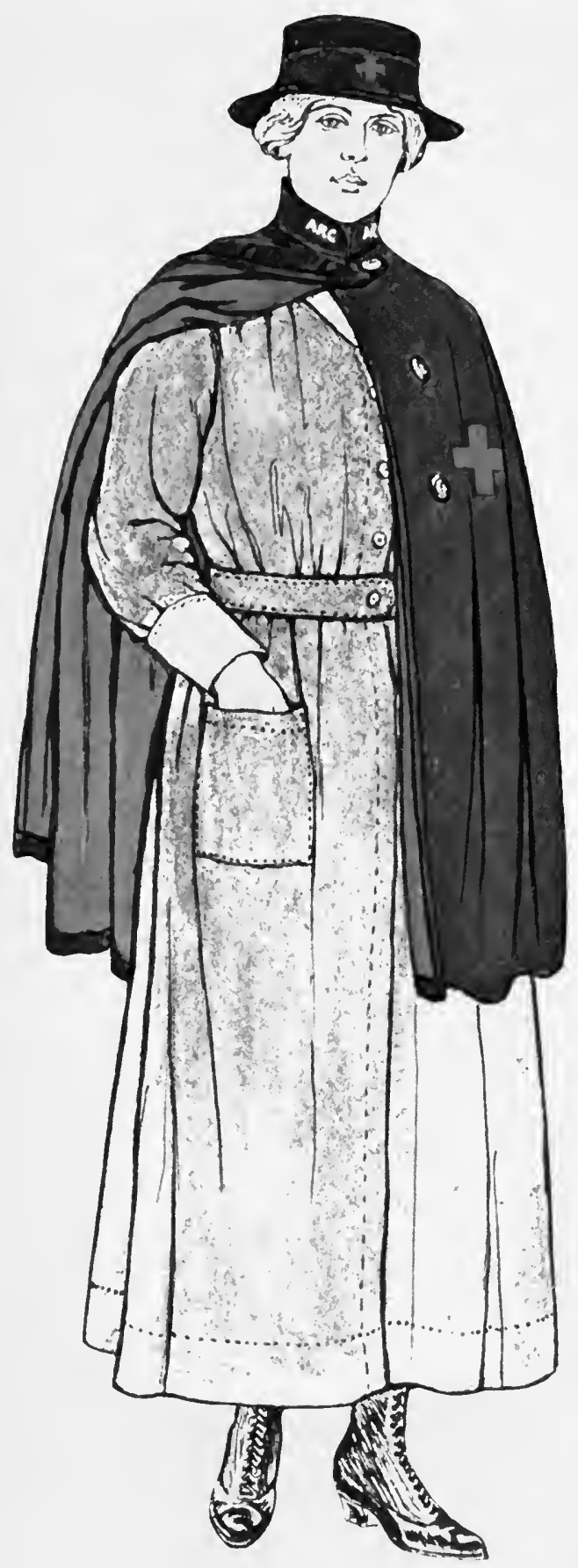

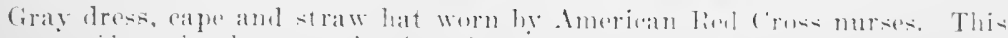

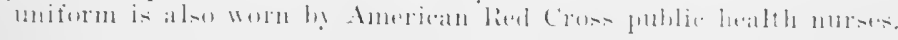



Cross societies had to train and maintain their own nurses in time of peace, but in this eomtry it was different. She conceived the idlea that the Red ('ross would be the logieal association to promote visiting nursing in rural distriets and small seattered towns on a national scale. and carly in 1900 she had an opportunity to bring her idea forward. 'There was in that year a meeting at Mayor George McClellan's honse in New York City to promote tubereulosis eamp work, which, following the International Red cross resolntion at the Convention held in England in 1907, was being taken up by the Red Cross societies of the different comntries and states. Miss Wald spoke at that meeting and though she kept no eopy of what she said, her plea was along the lines here indieated. It linked well with the anti-tuberenlosis campaign in which the Red Cross soeieties were then ready to take a part, and though no immediate result followed from her address that day, she, herself, waited only for another opportunity to press her point. An influential and generous nember of the Board of Ineorporators of the Ameriean Red Cross was Jacob H. Schiff, one of Miss Wald's family's frients, and through him the following letter from her reached the annual Red Cross meeting in Washington in December, 1910:

\section{Mr de.AR Mr. SCHIFF:}

... It seems to me particularly appropriate for the Red Cross society to undertake ultimately in Ameria, an extensive and systematically organized service of nursing for the scattered dwellers in rural regions. such as we now find well dereloped in Great Britain and in Canada. In the older countries armies of trained nurses are sent into remote country regions to nurse, to educate, to bring scientific, alvanced humanitarian and sanitary messages to the public. In Amevica in a few sporadic instances only. are nursing are and protection agalust infection posible to the sick country person. After developing the day (amp). why should not the lied cross soedety molertake the orcanization of a rast. farreaching soheme of country nursing. getting such support and coöperation as may he posible from the dwellers in mountan, farming or lonely ilesert regions. coördinating and guiding all, and bringing the help of the nurse to satterod. isolated families... .

There rondel be no lareer or nobler work posible to the Red

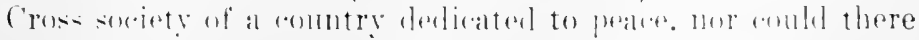

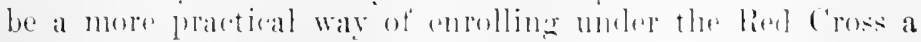




\section{HISTORY OF AMERICAN RED CROSS NURSING}

band of faithful and deroted workers held together between disasters for a universal need, an army ready to be enlisted for an extraordinary disaster. I very ardently hope that the National hed Cross society will take up in serious manner the organization of a rural nursing system, that it be national in its scope. . . .

I believe that it would not be diffieult to administer a service of this kind even on so large a scale. Headquarters might well be maintained in Washington and a traveling supervisor, a trained nurse [be employed],

In addition to this traveling supervisor, there should be local supervisors and possibly county local chapters to supplement and keep in touch with the nurse or nurses. Support of the nursing organizations should come from the central organizations but money would be obtained from the bodies to be sent into the general treasury. . . .

[There should be] affiliation ... perhaps federation with all existing societies. This I think would not be difficult to accomplish as the country nursing associations now in existence feel isolated and need the fellowship of similar bodies.

At first it would seem a most difficult matter to obtain suitable women for this work. I believe this is not insurmountable. The very existence of the association on so great a scale wonld stimulate the nurses in the training sehool. . . . It would probably develop that scholarships could be given to send specially fitted young women to the post-graduate eourse at Teachers ('ollege. ${ }^{3}$ This course was established largely for the purpose of equipping women to do work of this kind. . . .

In my opinion, it would be much more desirable for the Red Cross soriety to take up this work than it would be to organize another national society, for reasons that are so obrious. I do not think the Lnited States would need much stimulus, for I believe that the eause carries its own appeal.

$$
\text { (signed) LildaA D. WaLD. }
$$

The members present when this letter was read naturally could not decide so large a plan off-hand. The majority opinion was that enrollment and organization should be the ehief olject of concentration for sone time longer, but a subeommittee was appointed to talk the matter over with Miss Wald. No records were kept of its informal and intimate

${ }^{3}$ The post-graduate work at Teachers College here mentionel had developed broally from its first plan "Institutional Management," hut it had not yet underiaken preparation for "Rural Nursing."-ED. 
conferences, but the results are evident in later papers. At the annmal meeting in Decenber (1911) letters were read indieating that $\mathrm{Mr}$. Jaeob Sehiff and Mrs. Whitelaw Reid offered generous gifts to establish a fund for a rural health nursing service. Mr. Sehiff ultimately promised that if rural nursing was practicable he would give the Red Cross an endowment in securities amounting to $\$ 100,000$, the income to be used for the service. Until permanently established, he would give $\$ 5000$ yearly. Mrs. Reid promised an amnuty of $\$ 1000$ and later increased this sum to $\$ 2000$. At the Executive Committee meeting on December 14, Miss Boardman proposed a special committee with Miss Delano as chairman to make a study of the subject and report. On February 6, Miss Delano made her report and the projeet for rural nursing was approved in prineiple and referred to the National Relief Board. A trial year was agreed npon. On November 1, 1912, Miss Fannie F. Clement was appointed superintendent. The year's work was suecessful. At its end a meeting was held in New York at Mrs. Whitelaw Reil's honse, where the continuation of the Servire wis advised. The endowment was finally accepted, and the Rural Nursing Service renamed and inade perminent. ${ }^{4}$

Iliss Delano made publie mention of the new field at the American Nurses' Association meeting in Chicago, June, 1912. She then said:

There is one phase of the Red Cross work which scarcely comes in here, but ! would cak especially to present to you the possibility or the fact of our rural nursing service. which is soon to be organized and the possibility of the need of many nurses for positions in this serviee. Nlay I urge upon those of yeu who may tontemplate taking up this work that at the earliest moment vou place vourselves in line for some form of experience in mursing of this kind. If this movement is established, we shall need humbreds of nurses throughout the conntry. I cannot injpress upon you too much the importance of arrving this work into the neglected communities: it is work that I am sure will be near the hearts of all of us. Those of you who may (onsider taking this up. please make arlanements as soon as possible to rommmuicate with the

- Red Cross Report, 1913. See letter from the Secretary of War. transmittiner this lieport to Congress. Document No. 1028, House of Representatives. 


\section{HIS'TORY OF AMERICAN RED CROSS NURSING}

Red Cross and place yourselves in line for experience and instruction. ${ }^{5}$

The Committee on Rural Nursing for the trial year stood thus: Mabel T. Boardman, chairman; Jane A. Delano, vice chairman; Lillian D. Wald, Mrs. Whitelaw Reid, Mrs. William K. Draper, Annie W. Goodrich, John M. Glenn, Wickliffe Rose. Dr. Winford Smith, Surgeon J. W. Schereschewsky, Public Health Service. Miss Clement, the ehosen superintendent of Rural Nursing, was, of eourse, always present as an exofficio member of the committee, and acted as its seeretary, at first informally, then after a year or more by official appointment.

The first meeting of the eommittee was held November 14, 1912, in Mr. Glenn's oftice in the Russell Sage Foundation Building, New York City, Miss Boardman in the ehair. There were present: Mr. Rose, Miss Wald. Miss Delano, Miss Goodrich, Miss Clement, to whom the direction of the work was confided, and Mr. Glenn. The four nurses present were appointed a sub-committce, of which Jiss Delano was chairman, to draw up recommendations, and the next day they proposed as suitable qualifications for applicant nurses:

1. The existing requirements of the Red Cross for enrollment, omitting reference to age.

2. A rourse of four months (one-half an arademic year) under supervision of a recognizerl Visiting Nurse Association.

3. Recommendation by such association.

The sub-committee also considered the finaneial basis, and for this they advised the development of seholarships and loan funds, suggesting that loans be marle sufficient to cover the expenses of the special training, to be reajaid on farorable terms and that a limited number of scholarships be offered. Their suggestions were adouted and the details, as will be set forth later, were agreed upon.

At the annual Red ( ross meeting (1912) Miss Delano said:

Following a resolution pased at the last anmual mecting. measures lase heen taken for the extablishment of a Rural Nursine surviere. The oreanization of this work has been placed unrler a spereial sub-committer of the National Relief

"Procerdings American Nurecs' Asociation. 1912. 


\section{FROM RURAL, 'TO PUBLIC HEAL'TH NURSING 1217}

Board, but it is hoped that the Nursing Service committecs already in existence will render valnable assistance in securing a personnel for Rural Nursing. A more extended report of this work will be given loy llise Fammie F. Clement, who has recently been appointed superintendent of Rural Nursing."

With such brevity of words and simple, direct action, a service was legun which led the way to a revolution in health conditions in our neglected country areas.

In lee first report Miss Clement ontlined the activities to be looked for as a result of the initial year's work, and emphasized the stimulant effect upon edncational standards that might be expected. She said in part:

The Red Cross Rural Nursing Service is to be concerned with mursing the sick in rural communities, carrying instruction alone sanitary and humanitarian lines into the homes, and dealing with enviromment in a way to improve living conditions. It hopes to coöperate with all agencies dealing with questions of individual and public health and the many organizations that in the final analysis have a common object in view.

The unlimited opportunities for humanitarian and educational work to be fount in rural communities will appeal to murses who understand and enjoy country life and people, and who are interested in public health movements and social work.

It is reasonable to expect that the result of such a standard of qualifications will not only assure the best prepared women for rural inursing, but will also influence the cotablishment of courses in public health work and social service in hospital training sebools where such courses properly beloug. Women who anticipate rural nursing will eventually look for their training to schools qualified to prepare them to meet the requirements of the Red Cross for this work.

The superintemdent began at onee to make a survey of all the nursing associations and edncational institutions of the comntry to ascertain where subtable smpplementary training and experience in visiting mursing and related work might he elitained.

This surver showed that of all visitime murse asociations in the United states rmpleying there or more muses (there were

- The Rod rosss Bulletin. January. 1913. 


\section{HISTORY OF AMERICAN RED CROSS NURSING}

then about forty associations of that size), training centers where nurses could obtain preparation in public health nursing as deemed necessary by the Red Cross for rural work were few and far between. Only about six visiting nurse associations offered a so-called course, and in most of those there was little elass instruction.

Cireulars of information were prepared and widely distributed, giving the scope and aims of the venture, and the organized nursing profession was directly appealed to. Miss Clement wrote:

The Red Cross is dependent largely upon hospital training school superintendents to induce the right kind of women to enter the rural nursing field. Presidents of alumnæ associations, officers of state. county and local nursing associations, nurses' clubs and registries, and the members of Red Cross committees are in a position to lend their influence to aid the Red Cross in its endeavor to build up its Rural Nursing service. It is important also that they do so if it is to succeed in fulfilling the purpose for which it has been organized.

The call for public health workers must be sounded in every hospital training school, among nursing organizations, and educational institutions, and much remains to be accomplished in providing special training for these workers, opportunities for which are far too inadequate. . .

The Red Cross will meet the expense of organization and general supervision. In order to maintain a uniform standard of nursing, all Red Cross rural nurses will be under the general direction and superrision of the superintendent. . . .

For rural communities already alive to the adrantages of visiting nursing which are looking for a nurse, for those which realize these adrantages but need advice as to wars and means of support of a nurse. and for those regions where it will doubtles: apnear necessary to demonstrate more fully the need of one. the Red C'ross Rural Nursing Service stands ready to furnish all possible assistance.

At the end of the trial year (1913) the name "Rural Nursing Service" was changed to "The Town and Country Nursing Service" for reasons to be specified presently. The subcommittee on nursing then hecame the Town and Country Nursing Committee, and was enlarged to allow representation

'Red Cross Magazine, July, 1913. 
upon it to the three national nursing associations, whose seope and titles have been mentioned in a former chapter.

To the sub-eommittee as origrinally formed there were now added Miss Krueger (American Nurses' Association). Miss Nutting (National League of Nursing Education), and Miss (randall (National Organization for Publie Health Nursing). Thus complete coïrdination of these societies was bronght about, as was essential for the solution of such pressing questions as the establishment of new training centers and the adjustment of relations with publie health organizations and related bodies. Finally several valued members were added to the committee from the laity. The complete list follows:

Town and Country Nursing Committee:

Mrs. Whitelaw Reid, chairman

Jane A. Delano, vice-chairman

Mabel T. Boardman

Lillian D. Wald

Mrs. William K. Draper

Annie W. Goodrich

M. Adelaide Nutting

Ella P. Crandall
Prof. Thomas X. Carver

Mathile Krueger

Eina Foley

Mrs. Larz Andersoll

Mrs. Willard Straight

John X. Glenn

Wickliffe Rose

Dr. Winford Smith

Dr. J. II. Schereschewsy, P.H.S.

To consider the conditions of affiliation with Yoeal organizations, with power to act. there was a committee consisting of:
Miss Boardman, chairman
Miss Wald
Miss Delano
Miss Goodrich

Finally, there was the Committee on Education:

$\begin{array}{ll}\text { Miss Goodrich, rhairman } & \text { Miss Clement } \\ \text { Mrs. Hraper } & \text { Miss Crandall Miss Wald }\end{array}$

The conperation thus arrived at was of great significance, for the stealy and unbroken growth of mursing organization had made American murses a real power. It will be recalled that at the eonvention of 1911 , the Associated Alumule hat lroalenerl into the Ameriam Nurses Assoxiation, in 1912 the Superintendent's Soropty had reorganizerl on ampler lines to berome the National Leagne of Nursing belucation. and within its membership and that of the Anerican Nursos Association 


\section{HISTORY OF AMERICAN RED CROSS NURSING}

there had been formed the new and potential National Organization for Public Health Nursing, with Miss Wald and Miss C'randall as its first president and secretary. This new body necessarily included many nembers of the laity, and because of its own vital energy and the demands of the times, promised to have a future of wide seope, while the League of Nursing Education now took the key position of being the one united force responsible for guiding the adequate training of the nurse in manifold new lines. The delicate questions of coördination opening before them were dealt with by Miss Wald in. a letter to Mrs. Whitelaw Reid:

December 2, 1913.

We are in the position of which we have dreamed for years, of promoting and actually establishing nursing for the people throughout the country. I presume all of us are too experienced in the organization of great movements not to expect to make some mistakes, but I have the loope that this great morement for hitherto neglected people will be phenomenally: free in this respect. I am tremendously interested in the two organizations recently established, this one and the National Organization for Public Health Nursing. Each has, in my judgment, a distinctive place and shonld interlock without overlapping. But there seems to have arisen some question of the latter and since the same people are interested in both organizations. that would appear to be avoidable. May I suggest that at the meeting in Washington, so far as possible, the soope of earh may be refinitely ontlined.

In my judgment, the National Organization for Public Health Nursing sheuld maintain the purposes of its constitution. It is in some measure a mutual benefit society, wherein nurses and individuals and organizations that promote the work of nurses may meet together for combined effort. The methods whereby their efforts may lead to mutual benefit are written into the constitution. . . .

It is my hope that the supervision and the central control of the lied ('ross socicty will be so obviously adrantageous that gradially crery rural and small community nurse will be enroller under it: organization.

I believe that it would he practical and statesmanlike for our committee of the Red rrose to limit its work during its constructive period to the first olject that it has set out to acomplish, namoly. the promotion of interest in country nursing, and the establishment and supervision of nurses in 


\section{FROM RURAL 'TO PUBLIC HEALTH NURSING 1221}

country communities and small towns. The difference between the two societies, as I see it, is that the one is for edneation and mutual benefit, a mion of workers and those interested in their work, and the other administrative and supervisory. In my judgment it would seem that our lied Cross committee ought not to establish educational centers, but that it should send nurses who are to be enrolled in Red Cross work to the educational centers provided by other organizations. It onght to be the business of 'Teachers College and the National Organization for Publie Health Nursing to promote these elucational centers in the interest of public liealth nursing throughout the country. Should these agencies fail to provicle proper educational facilities for the Red Cross nurses, our society may eventually be obliged to organize such, but it seems to me that we are llissipating some of our strength by assuming functions which as yet we are not in a position to carry out efficiently.

(Signed) Lillian D. WaLd.

The relationship between the National Organization for Public Health Nursing and the Town and Country Service was defind at a committee meeting in Narch, 1914, in the following statement :

The National Organization for Public Health Nursing is a general bouy, including in its membership persons engaged in all forms of public health nursing. It is concerned with developing standards of ethies and technique, maintaining a central bureau of information and issuing regular and orcasional publications. . . On the other hand the Red Cross has undertaken a sperialized piece of work, namely, the organization and administration of visiting nursing in towns and (omntry districts. its efforts being directed toward the estahlishment of a personnel of visiting nurses especially qualified for this work. To this end it assists in the organization of local mursing associations and on the basis of affiliation assigns Red Cross visiting nurses to local organizations wishing to employ a Red Cross visiting nurse. The Red Cross Town and country Nursing service represents an effort to standardize visiting nursing in the towns and rural districts and to correlate the work of jolated nurses and nursing organizations muler a central body as a means of strenerthening to the fullest possible degree their powers to moet most adequately the health needs of their communities. Br mutual agrement. the promotion of interest and alvioe on all visiting nursing questions in small towns and rural (ommunities 


\section{HISTORY OF AMERICAN RED CROSS NURSING}

is deflected as far as possible by the National Organization for Public Health Nursing to the Red Cross. . . . The National Organization for Public Health Nursing does not maintain a nursing personnel as does the Red Cross, nor does it assume responsibility in the supervision of the work of visiting nurses. ... By reciproeal representation, it is made possible for either organization to hold intimate knowledge of the other's activities, and for the two to work together consistently to develop and maintain standards of visiting nursing technique to the ultimate benefit of both the nursing profession and the publie at large.

The energy with which Miss Clement and her small staff worked in those first months may be judged by lines taken from the brief records of May, 1913:

Nearly seren hundred letters enclosing bulletins on rural nursing have been sent to superintendents of all hospitals in the Lnited States of fifty beds and over, asking them to interest pupils in rural nursing.

A request has been sent to one hospital in every large eity asking for addresses of local registries, and by this means one hundred and thirty-six nurses' clubs and registries have been informed upon the work.

Circulars have been sent to over four hundred Red Cross nurses enrolled since 1912, to one hundred and sixty-seren members of state committees, and to the chairman of local committees, with the request to interest nurses.

About four thousand, five hundred circulars all told have been distributed.

Several articles on rural nursing have been published in the mursing journals and in one a course of instruction in visiting nursing has been advertised. ${ }^{8}$

The records of Jamuary 1, 1914, show the following figures aud give the action of conmittees on points coming before them:

No. of asocriations affiliated............... 14

Applications from nurses received........... 1:0

No. of nurses appointed...... ......... 16

Applications rejerted ..............?

Preparatory courses arranged for nurses....... 15

Minutes uf Town and Comentry Nursing Servire Commitee, May 5, 1913. 
Courses completed ................ 8

Courses discontinued before completion....... 2

Nurses still in training, Jan. 1, 1914.......... 5

Applications pending ................ 10

Eligible for appointment (not including those ap-

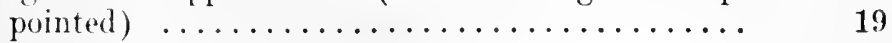

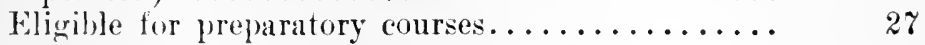

Sicholarships granted .................. 3

Amount of money expended in scholarships. .\$350.00

Loans made to nurses................. 4

Amount of money loaned........... 199.00

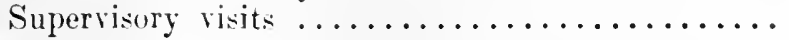

By that time the question of affiliation with State boards of health had come up twice. It was talked over at the January meeting of the Town and Country Nursing Committee (1914) and it was agreed that the demands which would inevitably eome through such extensive affiliation could not ret be met. The Committee on Education then framed the following resolution:

This committee recommends that the Town and Country Nursing Fervite concentrate its effort for the present within a comparatively small area, rather than to undertake work in wilely satteren clistricts, where proper supervision and development are practically impossible.

On March 2, 1911, increased scope was given to the Committee on Elucation by enlarging its functions to include questions of (1) Organization, (2) Administration, Attiliation. The committer thereupon handed in on March ?) 1914, these recommendations:

1. That for the present, women of high school education be given preforence, and that two years of high school be requirel.

2. That as soon as possible, full high school education be made a prerequisite.

3. That for the present every candidate he obliged to take at least four menthe training, except in eases of exeeptional women. who might be required to take only tharery. allowing their former experience to serve as equivalent for field work incluted in such course. 


\section{HISTORY OF AMERICAN RED CROSS NURSING}

The end of 1914 showed figures and statisties of a work as ret only in its incipieney. Alone, these figures express little, but are striking in comparison with later statisties and are valuable as showing the very beginnings, always the reeords most easily lost in historical files:

December 8, 1914

Loans

No. Amount

Loans granted prerious to December $1,1913 \quad 3 \quad \$ 199.00$

Loans granted Dec. 1, 1913, to Dec. 1, 191413 1,900.00

Total

$\$ 2,099.00$

Scholarships

Scholarships granted previous to Dec. 1, $1913 \quad 3 \quad \$ 350.00$

Scholarships granted Dec. 1, 1913, to Dec. 1,

1911

1200.00

Total

$\$ 550.00$

Exhibit

Requests for exhibit............ 10

Granted ....................6

Nurses

Total number of nurses appointed Dec. 1, 191313

Nurses appointed 1)ec. 1, 1913, to Dec. 1, 191433

Total appointments since organizations of service ................. 46

Appointed nurses receiving preparation under direction of lied Cross............. 7

The exhibit referred to in this report was the first one prepared for use by the Town and Conntry Nursing Serrice, and after being shown at the International Dry-Farming Congress in 'Tulsa, Oklahoma, it was taken to the nurses' convention at St. Lonis. It was intended for use at conventions and in small communities that were considering public health nursing, as it portraved in a simple way, by charts and photographs, the daily work of the Red Cross visiting nurse.

A special exhibit on Town and Comntry Nursing Service was next prepared for the World's Fair in San Francisco (1915). For this a eretificate and bronze medal were awarded. Another form of educational work of that year was the traveling library put into circulation on Anguist 3, 1!14. Four months after its foundation it had fiftr-five books with an aver- 
age daily eireulation of fourteen. It grew in usefulness and in dimensions until early in April, 1920, when it was discontimued by reason of the very extensive and thorough plans of the National Organization for Public Health Nursing for providing special sourees of reference in at least one public library in every state.

The comnittee work of 1914 was full of planning and preparation; the results of much of this will be met in detail in subsequent pages.

The pressing need for more centers which would offer courses in preparation for the Town and Country Nursing Service was continually dealt with, and a great part of the labor of those early months consisted in correspondence with sehools and training leaders all over the country. Several visiting nurse associations were opening their fields of work for practical use, but it was essential that theory, properly presented, should be combined with the practical work. How this problem was met will be told presently.

For the help and interest of affiliated groups as well as for communication letween the nurses, the first leaflet, ealled "The Red Cross Visiting Nurse," was issued on April 12, 1915. "In order" [it saicl editorially] "that members of the Town and Conntry Nursing Service as well as affiliated organizations may beeme aequainted . . to keep the nurse and affiliated organizations informed . . every member . . . and every affiliated organization is invited to become a contributing Editor . . ." It was issued-several times in multigraphed form, and in September, 1915, it expanded into a printed leaflet, published at the discretion of the superintendent, not at fixed periods. This little bulletin was presently named "The Town and Country Nursing Service" and appeared at intervals until 1)ecember, 1918, when it was discontimed. The National Red (ross and the varions Divisions had meanwhile adopted a similar form for their Bulletins. In January, 1920, the servioe began pulblishing a department in "The Public II ailth Nurse," organ of the X. O. P. H. X.. under the title "Rorl ( "rosis P'ublic Ilealth Nursing."

By $1: 1+$ the oramizations affiliating with Red Cross Rural Nursing were of a varied niture-lied cross ('hapters, women's rhubs, health and welfare soriceties, Associated ('harities, visiting nume associations and erporations. while their locations hrought the lied ('ross Town and comery unre into 


\section{HISTORY OF AMERICAN RED CROSS NURSING}

Alabama, Arizona, Conneetieut, Illinois, Kentueky, Maryland, Massachusetts, Miehigan, New Jersey, New York, Ohio, Pennsylvania, South Carolina, Virginia, West Virginia and Wisconsin. thirty-eight in all, the first nurse having received her appointment in $\mathrm{July}, 1913$, to an Ohio village, Cuyahoga Falls. The seeond one went to Warrenton, Virginia.

The human side, which, after organization has been perfected is ever the all-important side of the work, may be best shown in the graphie reports, narratives and appeals of the nurses engaged in the serviee. For a comprehensive impression of the ehief events as they oceurred in the early years the following material has been seleeted from the reports made by Miss Clement to her eommittee:

... The effort to begin rural nursing in Laurel, Maryland, first brought up the question of Red Cross coöperation with the Metropolitan Life Insurance Company. This corporation had on the suggestion of Miss Wald already developed an extensive visiting nurse service for its industrial poliey holders. An agreement was finally concluded with it by the Red Cross in May, 1913, of which the most essential provision was this:

"The Red Cross is prepared to make an arrangement with the Metropolitan Life Insurance Company in proriding nursing care for its industrial policy holders through the Red Cross Rural Nursing Service, this arrangement to include the official endorsement by the Metropolitan Life Insurance Company of regulations for rural nurses authorized by the Red Cross."

The Russell Sage Foundation, through its Southern Highlands Department, was instrumental in bringing ahout (n) öperation with the Red Cross in the southern mountains, and early in 1913 hefore any affiliations with the new Service were made, the superintendent of nurses under the auspices of that department risited five counties in the Kentucky mountains. stopping at the various denominational schools and learning of opportunities for introdueing Red Cross nursing.

The Rural Organization Service of the Department of Agriculture roöperated with the Red Cross in 1914. lt was among the early organizations to appreciate the part public health nursing was to play in the development of rural life, and in its loeal demonstration work a group was organized in Chilton C'ounty, Alabama, to have charge of a county nursing 
system, the first in the state. The committee, constituting as it dirl one of the very earliest examples of coüperation between pullic and private interests, is worthy of special note. The Red Cross nurse appointed in March, 1914, was responsible to a county health committee on which served the county health officer, the county superintendent of schools, the rounty arent of the Farmers' Union and a representative of a leading woman's club. Expenses were met by an appropriation of $\$ 500$ from the county board, $\$ 500$ from the school board, and $\$ 500$ from private sources.

... In Alabama there are "beats,"-territorial divisions which inchule several school districts.'A county improvement association with branches in each leat, under a "beat manager," has been oryanized, each beat subdivided into school districts where a superintendent is head of a small group. . . .

Industrial mursing early came within the scope of the Town and Country Nursing Service. While a number of the nurses worked in manufacturing towns or villages they were not invariably employed by an industrial concern.

The New Jersey Zinc Company as early as April, 191t, sought Red Cross affiliation. This company for many years has arried on welfare work successfully and when its work extended, a Red Cross murse was assigned to Palmerton, Pennsylvania. Franklin, New Jersey, where the smelter of this company was located. employed a hed Cross nurse in June of the sime year and a nurse was sent to its mining section in Gilman, Colorado, in 191\%.

In $1918 ;$, through tire generosity of a member of the Committee of the liural Nursing Service, a nurse was appointed to organize a nursing association in Hazard, a rapidly growing railroal town in the kentucky mountains. This first effort did not stimulate local support as was anticipated. but when the work was started again in May, 1914, the town contriluted toward the nurse's salary and the work continued for a rear. during which time a raluable demonstration was male as to what public health nursing may mean to this and other momtain sortions. In six months time the nurse examined all the whoul whildren, and found in one small village that seren pere "ent of the whildren had trachoma. . . Through her efforts the state law exchuding such raves from the schools becane for the first time effective in that part of the state.

The Rureau of Rural Sanitation of the Virginia sitate Board of Hoalth, alministering funds of the liockefellar 
Foundation, employed a Red Cross nurse to work in the Ragged Mountain section of the Virginia mountains. The physicians who had made the initial survey and administered treatment for hookworm discase had left, and it was the plan to put nurses in the field for follow-up work, teaching practical sanitation from home to home and working under the county health officer in giving further treatment for hookworm. This was a new departure in public health nursing and a promising one, but the funds were withdrawn by the Rockefeller Commission for other purposes, and after several successful months this work was discontinued.

In a South Carolina community a unique phase of the work of one of the Red Cross visiting nurses has resulted from her appointment, amongst rarious other duties, as sanitary inspector of washerwomen. Since last March, such workers have been required by law to hold permits. Over seren hundred have applied for permits, and the living and working conditions of over half of them have already been investigated, and permits granted by the nurse.

The first appointment west of the Mississippi was made in Oetober, 191t, to a typical mining community in Arizona. This represents a pioneer work, for the nurse was the first in the state who had had special training in public health nursing. To the credit of the group responsible for this work in Jerome, it may be said that in order to obtain a nurse thus qualified they volunteered to pay her traveling expenses across the continent. Success in developing her school nursing and general community service played an important part in the extension of public health nursing in Arizona as was frequently attested by the State board of health and State medical authorities.

The Red Cross visiting nurse in Wisconsin is developing school work particularly. inspecting children in public and parorhial schools. After examining several hundrerl rhildren she found that many had spinal curvature. This condition was reporter to the school authorities, who will remerly the faulty seating and desk arrangcments. The defertive eyesight and hearing. throat troubles, skin and teeth ronditions brought to light give convinaing evirlence of the need of close supervision of the physical well-being of chililren. Wherever school nurses are employed rommunities are pretty generally aroused to this fart. Teachers, and parents appreciative of results, are usually most grateful for the attention given the 
children by the nurse. She has also been asked to give talks on hygiene in the continuation shools and at the tearhers' training school in her community. graduates of which will soon be going out inte the rural sehools of Wisconsin.

The State Tuberculosis: Committee has been active here [Fulton, Kenturky. Surh assoriations have always emphasized the importance of the visiting nurse. Indeed, it was

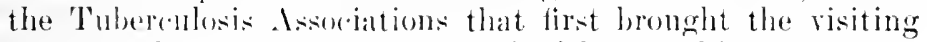
nurse to the forefront and recognized her teaching powers.

The first connty school nursing in Michigan started in Mar(h, 1915, muler the kent ('ounty Board of Supervisors and the nursing in an aljacent county became aftiliated in December of that rear. Kent ('onnty was the first in the country to apply the illea of health leagres for school children on a comnty basis and among its several pioneer eflorts a dental traveling elinic for county schools was instituted.

The three county murses in Michigan are employed by Boards of supervisirs, aftiliated with the Red Cross. The area in these sereral comnties ranges from forty to nine hundrel square miles. Two of the nurses are known as county school nurses. having supervision of eight thomsand to twelve thousand rhildren. While most of the time of the other county nurses is devotel to school work, anti-tuberculosis and infant welfare nursing, and sometimes bedside nursing, are included.

The two murses appointed to DeKall, County, Illinois. by the Red (ross (1915) were the first county nurses in that state.

The Consolidated Coal Company, through its Welfare Department, contracted lied ('ress alfiliation (1916) and the first nurse was appointed in Jenkins. Kentucky.

The Inti-Tuberculosis Committe of Greenville. Misissippi, was the first gromp in that state to seek lied Cross atrilia-

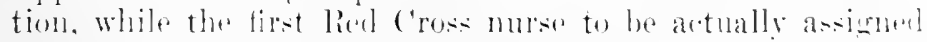

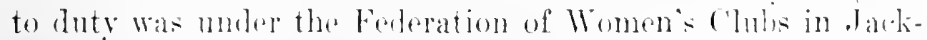
son. Throngh beveingment of the work in these aenters the state tuberenlesis authorities wrote to the Toul crose in re-

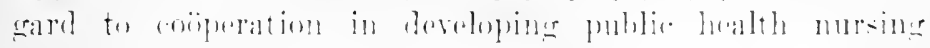


throughout the state. Circulars issued by this association adrocated the employment of Red Cross nurses and of a state nurse who also would be of the Red Cross staff.

North Dakota made rapid advance in its derelopment of county nursing. The Red Cross nurse appointed to LaMoure County (October, 1916) was a pioneer and her work stimulated others as a letter written by her (July, 191\%) indicates. She said: "I am indeed pleased over the prospect of a nurse in Stutsman County. That is our neighboring comnty to the north. . . . I have just had a letter from the superintendent of schools of Dicky County, our neighbor to the south. In Sargent County, east of Dicky, they are circulating their petition for a Red Cross nurse. . . . Barnes County is employing a domestic science teacher. They promised that if our nurse was a success they would get one too."

Appointment of nurses for county work is a practice rapidly spreading. Wisconsin has its State law authorizing counties to employ nurses for combined school nursing and anti-tuberculosis work, while a number of other states are about to enact such laws. To be a county school nurse means, nsulally, that one must be a tuberculosis and infant welfare nurse, an attendance officer, a sanitary inspector, a teacher of lygiene, family adviser and more or less of a general visiting nurse, as well, for the various school districts within the area.

Dental clinics have been established by several affiliated organizations, and one rural commnnity has started school lunches, which have met with much favor. Xursing in the schools is generally introduced roluntarily on the part of the nursing association. Boards of education soon appreciate its value, ant the number of appropriations from school boarls made to nursing organizations for services of the nurse in the schools is increasing from day to day.

Owing to the risk of contracting typhoid fever in country districts, where it is much more prevalent than in cities, anil in order to safeguard rural nurses from this disease. the Conmittee on Town and County Nursing Serrice now (1914) requires that andidates submit a rertifiate of immunity from typhoid before appointments are granted. A rertifieat of immunity from smallpox and a health certificate are allon required. 


\section{FROM RLRAL TO PLBLIC HEAL'TH NURSING 1231}

Infant welfare work is a prominent feature in several of the communities, where mothers' conferences are held regularly. Prenatal visiting, making periodical risits to new mothers and babies, teaching in the home in regard to the care and freding of infants, discouraging the employment of untrained midwives, all are artivities which claim the attention of the lied ('ross visiting nurse. In a southern monntain community one of the murses has organized mothers' helpers' classes, similar to those carried on in some of our large cities. She is also griving weekly lectures on health topies in the schoolhouse of over five villages. to which young and old are welcome. Nurses are sending articles regarding their work to their rounty or local newspapers. while a number have responded to wills to speak at meetings of parent-teachers' associations, church societies, women's clubs and country life conferences.

Miss Florence Besley has been with the Radeliffe Chautauqua, representing the Reel cross. This plan of including such representation was an! innoration. but has proved so successful that the ('hantanqua ('ompany las asked the Red Cross $(1916-191 \%)$ to appoint nurses for several circuits.

Miss Kuhn, in the mountains of Kentudey. has originated an idca new to pmblic health nuring (1916). She has been holding a health clinic at a sumblay school in her county. It has been so surcessful that she expects to start another in another section.

Baby welfare stations were molertaken in several places by Red f'ross nurses. Palmerton, Pennsylvania, and Franklin, Now Jersey, were the first among Red Cross attiliations to start permanent baby welfare stations, as they are known in (citics.

The second traveling exhibit was arranged during the vear 1915 and many requests to lied Cooss Hearlyuarters trestitied to its usofulness. The Bulletin (september 1:3, 1!15) gives this description of it :

The exhithit consists of thirten frames. dimensions two hy two and a halt foret eath. which tell by means of hictures and lecremels of the aletivities of the visiting nurse in rural communities and small towns. 


\section{HISTORY OF AMERICAN RED CROSS NLRSING}

Frames one, two and three picture the nurse preparing for her daily rounds and at work in the homes caring for the sick; four, five and six show the nurse at work in the school; seven and eight are deroted to infant welfare work; nine to sanitary inspection; ten and eleven to tuberculosis work; twelve and thirteen to club and class work as it is frequently organized by the nurse.

The first lantern slide exhibit was prepared in 1914 and circulated widely for two years with excellent results. It had a set of about one hundred views. The later striking amplification of education through the eve in the elaborate moring picture department of the Red Cross Nursing Service was initiated by a two-reel film illustrating its work, which was used by the Govermment at the San Franciseo Exposition (1915) up to December of that year. Duplicates were made and used over the country by the Red Cross. This was one of the first moving pictures for furthering health nursing propaganda. By 1920, the Bureau of Motion Pietures of the Red Cross had three distinct films of the Nursing Department, namely: "Wimning Her Way," "In Florence Nightingale's Footsteps" and "Every Woman's Problem."

It the end of this brief ontline of the early vears of the service, it is appropriate to emphasize the part of the Red Cross in strengthening and multiplying public health nursing center's. Wiss Clement's article, "Five Years in Retrospect" (1)(tober 31, 1917, ended the five-year period). brings ont incidentally this great service of the health organizations of 1912 . but few were concerned with rural commmities. In training schools and among nurses themselves there was little realization of eountry health problems, nor. incleed, had the hospitals vet felt keenly the obligation to send ont women equipped to carry on the trachings of health preservation.

The visiting nurse associations of the large cities hatd been the first to realize that more training was needed to cope suecessfully with the health problems of the home and industry, as ther were also the first to endeavor, to the best of their ability. to provide opportunities for such further training.

Miss Clement wrote of the Red Cross intluence:

It was at a time when puhlic health nursing was new alike to the nursine profosion, to those re-ponsible for the training of nures and in rural conmmutites gonerally. that the Town 


\section{FROM RURAL, TO PLBLIC HEAL'TH NURSING 1233}

and Country Nursing Service was organized. Adopting as its premise that training or experience in public health nursing was necessary for rural health work, the greatest eflort during the past fire years has been directed toward the supply of adequately prepared nurses. With almost no propaganda among communities, the number of reguests for nurses comling to the Red cross inas always exceeded the supply. Numerous organizations, national and local, lave been actively disclosing the presalence of sickness and disease in rural districts and the possibility of better living conditions through the teachings of healih nurses. With one or two exceptions, however, none until lately have concerned thenselves with increasing the supply of nurses to fill the demand thus created, which is quite another problem and a far more ditrieult one.

'To what extent the Red Cross has been instrumental in stimulating a desire among nurses for rural work, would be hard to tell. Every possible opportunity to reach nursethrougl the traininis sehools, through nurses organizations and at nurses' meetings, has been utilized. Thousands of pamphlets dealing with rural nursing have been distributed among the aftiliated communities. Many of the Town and Country nurses have written papers or spoken before grouls of nurses. Figures showing how many nurses have entered post-graduate training in publie health nursing subsequent to correspondence with the Town and country Nursing Serviee during the past five years would indiate most concretely, perhaps, the results of this endeavor. ('overing this period there have bean one hundred and serenteen appliants to the Town and Country Cursing Service who have entered conrses in public health nursing, thirty-four of them taking an eight months' rourse. Since Derember 1, 1916, twentynine applicants have entered courses, thirteen for an eight months' term. The total number represents an increase of ten over last vear.

P'rimarily through the influene of the national sorieties of nurses, a change in the hospital training sehool curriculum is gradually taking place in many rities."

The response made to the pamplulets and letters here spoken of incluled many repluests for "alfiliation" from small coities which, though not strictly "rumal". wished to be included within the seope of the servere. It was in order that slleh towns might he consistrently ineluded that the name "Roural Sursinge"

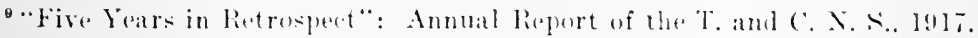




\section{HISTORY OF AMERICAN RED CROSS NURSING}

was changed to "Town and Country Nursing Service" within the first experimental year. By this change the original purpose and policy of the Rural Nursing Service remained unchanged, but with broadened scope, to include affiliations with nursing organizations in cities that were carrying on country or rural nursing work. At first the limits of a "Town" were not defined, but in March, 1915, it was agreed that a population of 25,000 should be regarded as the maximum sized town with which aftiliation be undertaken, and that the service should aim to reach the strictly rural commmnities first. ${ }^{10}$

This limitation remained in force until 1918.

At the end of the five first years Miss Clement resigned her position of superintendent of the service, having built up her work strongly and well, from its tentative inception. Her resignation, reluctantly accepted, was delayed for some months by the committee. Of the essential quality of her influence and spirit, Mary S. Gardner wrote:

Because the war brought about such unprecedented development of all American public health nursing work and because the new fields of action so frequently appealed to the dramatic sense, students of the public health nursing movement sometimes fail to give sufficient acknowledoment to those pre-war efforts which alone made possible the later expansion.

During Miss Clement's directorship of the Town and Country Nursing Bureau, all local matters were dealt with directly from Washington. decentralization mot having at that time simplified the difficult problems of alministration. To deal wisely with the details of a hundred raried sitnations in as many parts of the Cnited states demancls unusual powers of understanding. Every worl of Miss C'lement's filed correspondence breatles not only a spirit of intense personal interest, and that srmpatletic unferstanding of widely diverse local conditions leading to wise decisions, lunt also a love of the work which made it for her a true vocation. Her sucesisur feels that the subsequent sucess of this hurean of the lied Cross was in large measure due to Miss clement's quict and nuobtrusive preliminary work. In any estimate of the final achievement of the P'ublic. Ifealth Nursing Burean of the Ameriean Red cross, Miss C'lement's pioneer contribution shonld be recognized to the full degree as important and valuable.

${ }^{30}$ Minutes, March 18, 1915. 
Fannie F. Clement was born in boston and inherited the stanch and conscientions virtues of the pioneer New Englander. Sle was a Smith ("ollege woman (class of 1903); a graduate of the Boston ('ity Hospital School for Nurses and of the Boston Lying-In IIospital; then after three years of private and elistrict nursing she spent the year 1910 in the Social Service lopartment of the Boston I)ispensary, and had also a conrse at the School for Social Workers in Boston. She enrolled in the Red Cross Nursing Service on April 10, 1910. I) reports and articles form a complete history of the Rural and Town and Comntry Nursing service during her direction of it.

The rest of this (hapter will go back, in point of time, to talke up the special features of the work as they developed, in sufficient detail for students and serions readers, who may desire to follow each topic throngh to the date of reorganization.

In the small bonklet of printed "Regulations" adopted by the Exerutive ('ommittee of the Red Cross, Deember 30, $1 ! 12$, the rules and requirenents for nurses desirous of entering the Rural Nursing Service were given. Their essential paragraphs were these:

The Red Cross Nursing Serrice includes a section on rural mursing. established to provide visiting nurses for rural commmities.

A two rears' course of training received in a general hospital with a chily arrage of at least fifty patients during the applicant s traning is required. Subsequent hospital experience. or a pust-grailuate course, may be judged as an equivalent where there is delicieney of previons training. Graduates of state luspitals for the insane are eligible if their experience inchules nine monthe" training in a general hospital either duriner their romlse of training or subsegnent thereto.

An applicant must be a member of an organization affiliated with the American Nurss Asociation, and must have the oticial entorsement of this organization and of the training showl from whith she graduated.

In states where regi-tration is prosided for by law, rural

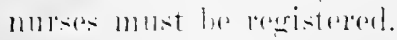

Traninger oxperiene in visiting mursing or some other form of sicial servier is repuitrest.

Exeptions to the ahwe qualitiontions may be made with

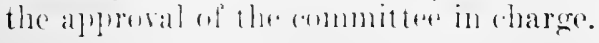




\section{HISTORY OF AMERICAN RED CROSS NURSING}

A four months' course with selected risiting nursing associations is arranged by the Red Cross for nurses who have not had this preliminary training. Where possible, one month of this period will be spent with a visiting nursing association in the country.

These requirements had been agreed upon at a meeting of the Committee on Rural Nursing Serviee, held on December 10, 1912. One year later (December 9, 1913) they were reissued with the added proviso, moved by Miss Delano and roted affirmatively by the committee, that enrollment with the Red Cross Nursing Service should be made one of the requirements for appointment to the Rural, by that time renamed the Town and Country, Nursing Service.

A number of exceptions to the regulations for general enrollment were then found to be necessary for the admission of nurses to the Town and Country Nursing Service. Snch were allowed as to the age limit, uniform, and other details

In 1914 some stiffening of the requirements was agreed upon. To the general hospital regulation it was now stipulated, as already speeified in the regulations for enrollment, that such training must have inehuded the eare of men. 'The applieants' sehool record was taken up for discussion, and the subcommittee on education recommended (Oetober 13,1914 ) that two years of high school or its equivalent be required for appointment to the Town and Country Nursing Service until October, 1916, after which a high school diploma or an equivalent to a full high sehool course, be required. ${ }^{11}$

The standard thus set seemed feasible in view of the academie ratings of the thirty-five nurses in active service, namely:

$\begin{array}{ll}\text { Common srhool } & 8 \\ \text { High school, one year } & 3 \\ \text { High school, two years } & 2 \\ \text { High school, graduate } & 7 \text { (generally } 3 \text { yr. course) } \\ \text { High school, equivalent } & 3 \\ \text { In doulst } & 8 \\ \text { Collegre, two years } & 2 \\ \text { Collegre, graduate } & 1\end{array}$

Having these figness and the manimons recommendation in favor of high school repulperment of the supervising nurses of

${ }^{11}$ Minutes T. \& C. X. S.: Dre. 8, 1914. 
the Metropolitan Iife Insurance Company, with which the service was coöperating, the Committee on Elueation voted manimonsly to establish this standard as rocommended, and at a meeting of the whole committee (March 1s, 1915) the step was endorsed, one vote only being ant in the negative. At the same meeting the committee diseussed the possibility that the special training might cone to be inchuded in the training school period, and with this in mind it was moved by Mrs. Mraper and seconded by Miss Wald that the following resolution be sent to the Committee on Education of the League of Nursing Edncation:

Tnasmuch as the Town and Country Nursing Service cannot meet the increasing demands of communities for nurses, the committee calls to the attention of the National League of Nursing Eduration the advisability of including in the training school curriculum a special course fitting the nurses for this publie healtin service, the Red Cross recognizing that evell to require a minimum of four months postgraduate work is asking a great deal of the nurse after a regular three years' course. ${ }^{12}$

In the meantine, while waiting and hoping for the training sehools for nurses to act on the resolution, thomgh the regulation for four montlis special posteraduate training still obtained, the committee recommended that student nurses be enconraged to take the more thorough preparation offered in the several right months courses then developing. This policy was followed, even though its adoption by reducing the number of training centers to which applieants for the serviec conld bo referred, made more difficult the work at Headquarters in trying to meet the demands upon it. In 1916, with the pressure of war problems then arising, the decision regarding high selool was reconsidered, and temporarily diseontinued as shown iis the following record:

Of the sixty-nine murses in the service. twelve have hat a grammar sefrool enlueation only. twenty-three one year hish school or lese than two. twenty-one have lan two or threse pears of high shool in adrance of srammar sobool. and thir-

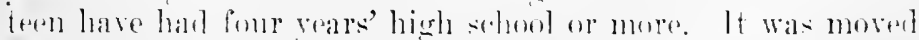

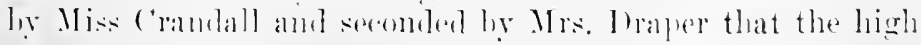
12. Minutes T. \& C. X. s.: Marrh 18, 1915. 


\section{HISTORY OF AMERICAN RED CROSS NURSING}

school requirement be suspended, but that the question come up for action a year hence. This was voted. ${ }^{13}$

The leaflet of information for applicants, published March 21, 1917, announced the final action on the high school requirement:

A minimum of two years' high school education or its equivalent is required. Study and experience subsequent to schooling will be taken into consideration when determining an equivalent. ${ }^{14}$

In the same leaflet, candidates for the Town and Country Nursing Service were required to have "attended schools of nursing which included in their courses both theory and practice in obstetries and the care of children." This, as all nurses know, meant post-graduate training for many, as it was then by no means universal, even in general hospitals, to find these two branches provided. This new requirement of the Red Cross undoubtedly stimulated greatly that process of "affiliation" between hospital nursing schools which was designed to afford every pupil training in these and other important specialties. Another requirement of a different kind met with in 1917 was this:

A knowledge of driving or riding horses, and more frequently the use of an automobile is necessary.

In 1918 attention was drawn to the personal equation:

The fact that a nurse meets the educational qualifications and the professional requirements as well, is not sufficient to secure her acceptance and assignment by the Burean of Publir. Health Nursing. Personality and the ability to manage difficult situations and to carry responsibilities will also be considered.

Regulations of 1917 and 1918 said:

Certain visiting nurse ascociations and educational institutions accept as students for a four or eight months' course nurses who wish to prepare for the Town and Country Nursing Service, and who, though otherwise eligible have not had w Minutes T. \& C. N. S.: December 12, 1916.

14 A. R. C. 150, March, 1917. 
training or experience in public health nursing. It is expected that their preparation will include several weeks with a rural nurse in order that they may come in direct contact with rural social problems before assuming responsibility in work of their own.

The requirements of 1920 for general enrollment were these:

Nursing Education.

The applicant must be a graduate of a school for nurses giving at least a two-years' course of training in a general hospital which includes the eare of men and has a daily average of at least fifty patients during the applicant's training period. Ciraduates of hospitals for the insane are not eligible for enrollment unless their experience includes at least nine months' training in a general hospital, either during their course of training or subsequent thereto. Subsequent postgraduate training or hospital expericnce which supplements deficiencies of training may be accepted as an equivalent by the National Committee upon recommendation of a Local Committee on Red Cross Nursing Service.

Registration.

In states where registration is provided for by law, the murse applying for enrollment in the Red Cross must be registered.

Age Limit.

Applicants must be at least twenty-one and not over fortyfive years of age. Exceptions to this requirement may he maile by the Red cross for those enrolling for public health nursing and other special Red Cross service.

Physical Examination.

A physical examination eertificate must be filed with the enrollment application. Immunization against typhoid, paratyphois and smallpox is also required when an applicant is enrolling for services of a nature which remers such prerautionary measures desirable. Blank forms will be supplied for this purpose and the physical examination and immunization treatment will be given without expense to nurses by a physician designated or provided by the Nursing Serrice.

Enmllment for public health nursing carried these requirements $(1920)$ : 


\section{HISTORY OF AMERICAN RED CROSS NURSING}

Applicants must have had at least two years' high school education or its equivalent and must have attended schools of nursing which include in their courses both theory and practice in obstetrics and the care of children. Special training or experience in public health nursing may be accepted by the Red Cross to supplement deficiencies in hospital training. In addition, applicants must have had not less than eight months' experience on the staff of a recognized public health nursing association under a supervising nurse, or not less than a four months' course in public health nursing in a school acceptable to the Red Cross Bureau of Public Health Nursing. Exceptions to these requirements should be taken up with the Division Director of Public Health Nursing and such applications will be considered on their merits. The fact that a nurse meets the educational qualifications and the professional requirements as well is not sufficient to secure her acceptance and assignment by the Burcan of Public Health Nursing. Personality and the ability to manage difficult situations and to carry responsibilities will also be considered.

While the minimum rcquirement of the Red Cross for preparatory training is a four months' course, including both theoretical and practical work, experience in the past few years has demonstrated the advantages of nurses haring even longer preparation for public health nursing in the smaller communities, where the responsibilities derolving upon the nurse working alone are considerable. There is, in addition, a great domand for nurses who have had a more thorough preparation. The four months' course may be supplemented by theoretical work, such as given in the six weeks' summer course at Trachers College, Columbia Lniversity, New York City, and by other special courses offered by this and other educational institutions.

In addition to academic training, eight months' courses. including experience in school mursing, pre-natal and infant welfare work, tubereulosis and industrial nursing. and other branches of public health nursing may be obtamed in Boston, New York, Cleveland, and other sections of the country. There are a number of miversities or schools offering postgraduate courses in public health nursing which are acceptable to the Rerl Cross. ${ }^{15}$

A later and hriofer statement shows that the hope of having public health training included in the regular hospital had not been realized. It is, in fact, often not practicable, and still oftener even impossible.

${ }^{15}$ A. R. C. 703, Revised, July 15, 1920. 
Public health nursing is a highly developed form of nursing, preparation for which is not included ordinarily in the training school curriculum. It is necessary, therefore, for the murse who wishes to be successful in this field to undertake a postgraluate course or to secure her training through supervised experience under the direction of a publie health nurse instructor. ${ }^{16}$

During the winter of 1912 and 1913 letters of inquiry were sent by Miss Clement to forty Visiting Nurse Associations to learn what course of post-graduate instruction might be offered by then, and what possibility of eöperation there might be iin the special training of rural nurses. Replies were received from twenty-six, and arrangements were made by the Red Cross with several, next to be mentioned, whereby applicants who had not yet had suitable experience and who in other respects were qualified, should receive a short eourse in public health nursing. None of these associations charged tuition. Three of them gave a salary during the special training. Outlines of the available courses were typed by the Red Cross for distribution, and their important details are given below. Many minor points covering uniform, expenses, ete, have been omitted as messential.

\section{The Instructive 1)istriet Nursing Association, Boston. ${ }^{\mathbf{1 7}}$}

In response to the increasing demand of the public for nurses qualified for positions in public health work this association offers to nurses of recognized hospitals a post-graluate conrse of four monthe in public health nursing. This eourse is designed to erive a basis for any fiedd or social work where nurses are in demand. The variety of fied work. lectures and class discussion, shows the relation of nursiner to other social artivities. Find work onsists in mersing the patients under the are of the Instructive l)istrict Nursing Asocintion, in preventive work for babies, in work with the Boston Assoriated charities. anst in the observation of the work of several Boston rharities. Three (ourses deal with the following subjects for which realliner is repuired:

I. IIistory, principles and adninistration of public health nursillg.

This inchudes the origin of district nursine. its purposes.

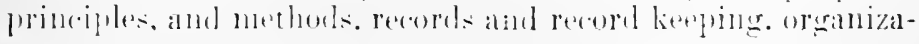

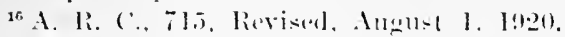

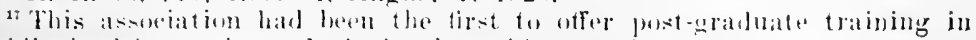

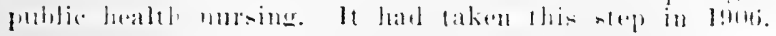


tion, administration and reports; the development of school nursing, preventive work for babies, tuberculosis nursing, welfare work in shops and factories, hospital social service and rural nursing. Opportunity is given to observe these various branches of riursing.

II. Medical and social relations of disease.

What can be done towards prevention as well as treatment of infant mortality, tuberculosis, alcoholism, venereal disease, neurasthenia and occupational diseases. Proper nutrition of families is considered.

III. Elements of sociology and social progress.

a. Introduction to the social field with special reference to the life of the industrial city family, to get a sympathetic understanding of their lives, their health, education, recreation, labor, politics, religion, ethics, and ideals.

b. Social progress as to health, education, recreation, etc., considering what other agencies are doing and low nurses can best coöperate with them.

\section{Henry Street Settlement, New York City.}

The Henry Street Settlement offers a three months' course in public health nursing. . . Each nurse is assigned to one of the regular Settlement districts, for which she becomes directly responsible. She is expected to assume the nursing of the patients in her district with the same care and enthusiasm that would be shown if she were to remain permanently. In her district or field work, she is under the careful guidance and instruction of her head nurse and supervisor.

Class instruction is given once a wcek. A talk upon a given subject on one week is followed on the next by a visit of inspertion to some institution, this visit being intended to illustrate the talk.

The following outlines represent one of the courses covering three months.

Lesson I. Observation. Inspection of Ellis Island.

Lesson II. Talk, Public Health Nursing in New York City.

Jesson III. 'Talk. Babies' Welfare Associations. After the lecture, class visits the Sottlement Milk Room.

Lesson IV. Talk. Social Service Bureau of MIt. Sinai Hospital.

Lesson V. Staff Meeting. (a) Welcome, by Lillian D. Wald. (b) Organization of the Public Health Nursine lssociation in the Enited States, Ella P. Crandall, secretary. 
Lesson VI. The Publie School Nurse.

Lesson VII. Observation. School nursing in one of the Public Schools.

Lesson VIII. Symposium on Settlements by members of the staff living in various Settlements in the city.

Lesson IX. Staff Meeting. Talk: New York's Milk Supply. (Lantern Illustrations.)

Lesson X. Observation. (a) 79th St. Branch of the Henry Street Settlement; (b) East Side House Settlemen'.

Lesson XI. Talk. (a) Institutions for the care of tuberculosis patients; (b) Convaleseent eare.

Lesson XlI. Observations. The Rest; Grand View on the Hudson (Convalescent Home of the Settlement).

Visiting Nurse Association, Chicago, Illinois.

The Chieago Visiting Nurse Assoeiation gives a three months' course, covering the various branehes of public health nursing. Personal attention is given by the supervisor. Weekly meetings are held at tine office and daily meetings at the sub-stations.

Detroit Visiting Nurse Association, Detroit, Michigan.

The Distriet Association provides a course of three months, giving the advantage of observation in the several districts with various types of populations, in five dispensaries where Association nurses serve, in the baby welfare field, in tuberculosis work including an open air school, one county and two rity sanatoria and in the summer home for mothers and ehildren at Bay Court. Through the Board of Health nurses get in touch with the work of the school nurses.

l'ractical teaching in the homes will be given chiefly by the senior nurse. Nurses are expected to do general nursing, giving half time to field work.

Richmond Instructive Visiting Nurse Association, Richmond, Virginia.

The Richmond Association provides a three months' course or longer with field work under supervision of the Asociation. Experience will be given with the staff of nurses doing instruetive work in the infant mortality and tuberculosis field, also experience with the medical and sanitary inspectors of the city. 


\section{4t HISTORY OF AMERICAN RED CROSS NURSING}

District Nursing Association, Buffalo, New York.

A six months' course for graduate nurses is provided by the District Nursing Association of Buffalo, New York, giving the first months' training in office experience, followed by practical field work under a supervisor for four months, changing districts and nationalities. A three months' course is also given. Through coöperation with the Board of Health experience with the school nurses and tuberculosis nurses is provided. The baby welfare nurses are under the Nursing Association, and experience in this field will be included in a course. Nurses will be given opportunity to attend weekly conferences by the Associated Charities.

Weekly lectures are given on such subjects as the following: Friendly Tisiting; Principles of Organized Charity; County Poor Department; Children's Aid and Care; Health l)epartment; School Nursing and Child Hygiene, Children's Court; Truant School; Probation System; Crippled Children's Guild; Settlement Work; District Nursing and Social Service Work.

\section{Visiting Nurses' Settlement, Orange, New Jersey.}

This association provides a three months' course to include lectures on social and nursing work, classes in cooking and general instruction in visiting nursing. In classes for the baby clinic instruction is given by a physician.

District Nursing Association, Concord, New Hampshire.

The association provides a three months course. Experience is provided in connection with courses taken in Chicago, Ill. Concord. New Hampshire, and Richmond, Tirginia. It is the intention of the Red Cross to provide at least one month's experience in rural nursing for all nurses who have completel a three months" course with a city organization. Experience in rural work will be provided by the J)istrict Nursiner Asociation of Northern Westchester County, New York, and the Nursing Ascociation in Hagrerstown. Maryland.

As other associations will be utilized by the Red Cross as training centers for its rural nurses, the foregoing outline is subject to additions at any time. It is hoped that at least one association in erery state may hecome a training center for Red cross nurses in rity and comtry.

These schedules have been repeated in detail because as pinneer reflorts of errat sincerity and altuism they deserve 
recognition, and also beeanse historieally they will serve to measure progress. Even a few vears atter their origin, the broadening and enriching of their teaching work was marked, in the rase of those associations that rontinued to teach. The Henry Street Settlement, for example, in afliliation with 'Teach. ers college, grew to the stature of an eminent educational center. None wonld now, at time of writing, nse the term "course" in comnection with their carefully planned field work and instruction, but however they may expand no finer spirit of service an they show than that of their early and eager serviec. As other opportmities were opened some of the pioneers felt relieved of responsibility.

Soon after these schedules had been published twenty-four nurses had been assigned; twelve to Henry Strect Settlement, New York: five to the Richmond Association, five to Boston, and one to Chicago.

This trpe of preparation through apprenticeships continued for several years (1912-1915), gradually giving way to "courses" of a more gemuinely educational character given by universities and colleges.

Not content with simply recommending the existing special courses to its applicants, the Committee on Education, at an early moment, liat gone thoronghly into the subject of preparing its own minimim standardized schedules of post-graduate work for the help of training centers. As early as $191+$ requests had come from several eolleges in the South and West for outlines of courses for Rural Nurses, and tentative suggestions had been submited in reply. The demand for schedules for suitable courses grew to be insistent, and this at a time when it was difficult eren for the leaders in nursing edueation to formulate the minimum requirements of postegraduate study to fit nurses for this new and rapidly developing field of serviee. The fielel itself seomed taily to dischose broader horizons, reaching far beroud those that the ordinary training of murses had equipped them to neert. To erowd speedalized instruetion into a four months post-graduate rourse soon proved unsatisfactory to the eenters tryine this mothod, as well as a serere tax upoin the student, and ret while the Town and Country Nursine

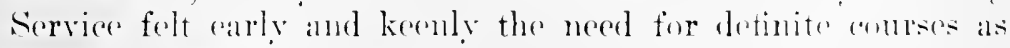
the only sure fomblation for the propere deselopment of its work, its recommendations were, of combers subject to the decision of educaters. Therefore, while tentative ontlines were 


\section{HISTORY OF AMERICAN RED CROSS NURSING}

sent out by the Red Cross previous to 1915 , it was not until March of that year that it definitely sanetioned an outline, and that was for an eight months' eourse only.

The early outlines, always tentative, were agreed upon by the Committee on Nursing, in two forms: one, the minimum for a four months' course; the second, for an eight months' course. ${ }^{18}$ They were sent, always with emphasis laid upon the longer one, to the various groups of institutions which subsequently established training eenters. In active correspondence was eondueted from Headquarters on the proposed eourses, and a general propaganda was carried on, including personal visits to a number of cities. The propaganda was of eonsiderable magnitude, and it may be justly held that the influence of the Red Cross in thus promoting opportunities for advanced training in public health work was very great and ecnstituted the first efforts at standardizing such courses. Miss Clement said of that period:

The education of the rural nurse was of such vital importance in the early days of the service, that our struggle to locate opportunities for obtaining it never ceased. Our outline of the four months' course was prepared at the time when we first began to insist that a "course" must inclurle academic training and not experience alone. The proposal of a training center to be established by the Red Cross itself, eame up before the committees on Town and Comntry Nursing Service, but it was generally agreed that teaching was the duty of strictly educational institutions and should be left to them.

The outlines of those earliest tentative schedules drawn up by the Committee on Education are here given:

The minimum training period in preparation for Red Cross visiting nursing is four months, approximately eighteen weeks. It should include class instruction. lectures and visits for observation, together with practical work in connection with well organized public health nursing agencies in city and country.

The acarlemic work of a four or eiglit months' course given in comeetion with a university or other educational institution must he in charge of a teacher nurse well grounded in the principles and technique of public health nursing. 'This part of the rourse. consisting of class justruction and lectures, should oceupy five or six hours woekly. Additional time should be allowed for visits of ohservation.

"Annual Meeting. Committee on Nursing, December, 1913. 


\section{Four Montlss' Course}

I. Public health nursing (three hours weekly) to be giren by nurse. Ilistory, derclopment, principles, equipment, technique, nursing care, surgical nursing, medical nursing, nursing of chronices, nursing of children, nursing of infants. maternities, insurance and industrial nursing, emergencies, frec medical service, relief and coöperation, fees, gifts and other related subjects, household hygiene and dietaries. clerical work.

II. Hygicne and sanitation. ('Two hours weekly.)

A general survey of principal health problems of a modern municipality and rural elistrict.

The fundamental principles of sanitary science, their application to water supply and milk supply and to the disposal of sewage and garbange.

Air sipply, probloms of tenement and factory sanitation. functions and methork of hoards of lealth.

The use of vital statistics as an index of lealth conditions.

III. l'rartical sociology (one hour weekly).

This course sloukl be designed to snggest. with snch class diseussion as the limited time permits, the important and significant plases of the social treatment of families and individuals. It shenld include the making of an investigation. kecping of records, recognition of the normal standard of living. enforcement of orlinary family and social obligations. utilization of one's experience with individuals and families: in distress as a (ontribution to movements for prevention and sorial protection, and other common elements in these various kinds of social work. Reading and special topies for sturly might be inclusted.

Finll Instruction....

The field nursing in its various branches must be muler close supervision of experienced risiting nurses. It is imperative that general visiting nursiug. school nursing. tuberrulosis and infant welfare work shomld he well organized in the aity where the course is offered. During the innrse student nimrses slomld be given opportmity to learn of board of health activities, what public institutions exist for relief. and the laws rolating to health, eflucation and emplorment of men. women and ehildren. They honld attent Sisorebitent charities anferences. where the relied work is well organized and learn of the ollice rontine. methods of fandle treatument.

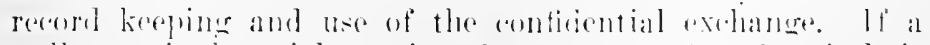

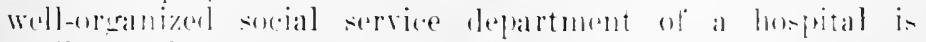

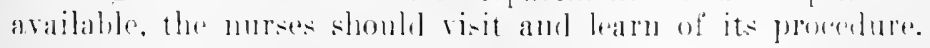




\section{HISTORY OF AMERICAN RED CROSS NURSING}

Visits for observation to various other social agencies might be included.

Of the fifteen weeks' work spent in the city, eleven might be given to general visiting nursing of surgical, medical, maternity and infectious cases, special attention being given to asepsis, use of household utensils, disposal of used dressings, ventilation, care of room, diet, medication, provision for care between nurses' visits, disinfeetion, sick room comforts, baths, provision for care of family during illness of a parent, isolation and quarantine precaution, treatment of family problems, coöperation with other agencies, special branches, two weeks in the schools, one week in tuberculosis and contagious nursing, and one in infant welfare work. Record keeping in the various branches of public health nursing should be a subject of special study. If experience in these branches is includerl in the general work of a risiting murse association, ('ol'responding allowance should be made in the amount of time devoted for special work in each branch.

The last three weeks should be spent in a rural community, if possible where school nursing is carried on, and where the nurse has developed classes or clubs for young persons, organized mothers' conferences or has been instrumental in developing other forms of social work. It would be well for the nurse to attend a meeting of the local visiting nurse assor.iation and to have explained to her the form of organization. duties of committee and methods of financing the work, that she might understand the problems from that side.

\section{Eight Months' Course}

I. Public health nursing (see I under four months' conrse)-Three hours weekly.

II. Nutrition-Two hours weekly.

A non-technical study of the functions and nutritive values of foods, the feeding of families and larger gromps with particular reference to nutritive requirements and the cost of food in relation to the family budget.

1II. Elements of pychology and their application to nursing problems-Two hours weekly.

IV. Preventive Medicine-Two hour: weekly.

Methorls of application by nurses of modern scientifie molial knowledge in the prevention of disease: the "auses of infant mortality. tuberoulosis and the more prevalent (ommuni-

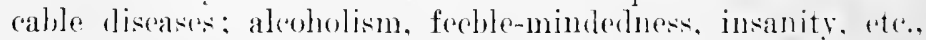
and araibable measures for presention and methods of eare.

V. llyerene and sintation-'Two hours wrekly. (see 11 under "Four moiths' course.") 


\section{FROM RURAL 'TO PUBLIC HEAL'TH NURSING 1249}

VI. Modern Social Problems-Two hours weekly.

An introduction to the study of modern social problems and their relations. Such topies as the following:

Adjustmonts made necessary hy changes affecting the family. property and frecelom of contract; the demands for better protection of persomal rights in contrast to property rights, emplasized by the wrowth of the democratic movement; the tendency toward direct antion in the affairs of government; the cont rol of industrial conclitions in the interest of the common wolfure; the aljustment of the educational sistem to modern needs; the public health movement in its relation to other social problems; the movement through labor organizations and other voluntary associations, or through sorial lecrislation and social insurance, to raise and maintain the standard of living: finally the emphasis upon coöperation in contrast to individualism.

VIl. Practical Sociology-One hour weekly. (See III under "Four Montlis' ('ourse.")

VIll. Riural Sociology-One hour weekly.

In March, 1915, the schedule given above was revised in certain details as follows. The new material only is shown:

III. A Study of Mental Processes Involved in the Work of a Nurse with Individuals and ('ommunities-Two hours weekly. (('ompare IIl. Elements of Psprhology.)

This courue will include detinitions and dass exercises illustrating certain common mental processes. These will be considered in thoir comnertion with the bedside and educational work of a murse and appliation mate with reference to her apporath to individuals, families, classes and other group moetings, as well as to the entire community. Foreign and native populations in their old and new environments will be sturied with reference to (ustoms, superstitions and other racial characteristics. Practice in construction of leson plans and presentation of subject material will be required. Concrete plans for conmunity service will be developed.

111. Practical sociology (slimhtly modified)-One hour weekly.

This andro should be designed to sugrest, with surh rlass discussons as the limited time permits. the impertant and sirnificant phases of the social treatment of families and individuals. It slould indelude the making of an in we-tigation. the

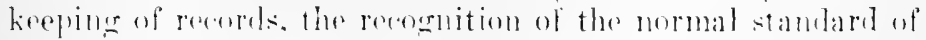
living. the enforcement of ordinary family and social obli- 


\section{HISTORY OF AMERICAN RED CROSS NURSING}

gations and other elements of social work. Reading and special topies for study might be included.

VIII. Rural Sociology (new)-One hour weekly.

This course is descriptive and socrological in character with a purpose of directing students into practical forms of service. It includes lectures, recitations and a limited number of special papers presented by numbers of the class. The material used is the Country Life Bibliography on the topics, Church, School, Public Health, Good Roads, Coöperation, etc. A study is made of the history of rural society, its extent, the rural population, size, composition, sources, regional populations; the rural community, types and organization, peculiar communities and peoples, contrasting types, as the individualist and the highly socialized communities, principles of social service. methods and results, specific prolslems such as porerty, rural health, rural education, the comntry church, coöperative organization and the method and principle of rural survey for finding the basis of country social service.

To this suggested outline, several training centers having by that time been opened, as we shall see later, the Committee on Nursing added:

Your committee expects to present for your consideration during the current year a resolution to the effect that only training centers offering eight months' courses shall be accepted as giving satisfactory preparation for Red Cross Town and Country Nursing Service; that a suggestive outline for an eight months' course as herewith presented be endorsed and your Superintendent be anthorized to use it.

No sooner had the needs of the Rural Service become evident than Miss Nutting, at the head of the Department of Nursing and Health at Teachers College, Columbia University, took artion to meet them.

A special four montlus' course was established there in the winter of 1913-1914. The practical instruction was worked out in coöperation with the Henry Street Settlement and the District Nursing Association of Westchester County, New York.

Two months were spent in the Settlement, in visiting nursing in the homes; one in the Division of Child Hregene and Contagious I)iseases of the New York Board of Health: one with the public school nurses and in the Tuberculosis Service and 
Milk Stations, and one in the rural nursing work. Instruction by means of lectures, conferences and excursions was given twice weekly by 'Teachers College, as grouped under the three heads: 1, Public Health Nursing; 2, Rural Life Problems; 3, The Applieation of Prerentive Medieine in Nursing.

Teachers College, said Miss Clement, was thus the first educational institution in the country to offer a course by which graduate nurses could receive academie instruction in rural problems in connection with a short course in public health nursing.

The Boston Visiting Nurse Association (formerly the Instructive District Nursing Association of Boston), followed next to Teachers College in framing a course meeting the special needs of the Red Cross Town and Country Nursing Service. It gave its practical teaching in a "model distriet" under a competent supervisor. Two months spent in this way were followed by two in preventive work with mothers and babies, and the field work of the Associated Charities, under the guidance of the respective secretaries of those associations. Special provision was made for aetual service in rural communities, and special classes and reading on rural problems provided. The lectures and class work eovered:

1. Iistory, principles, and administration of public health mursing;

2. Melico-social relations of diseases;

3. Elements of sociology and social progress.

Exeursions were arranged weekly to institutions and charitable agencies in Boston. Opportunities were given for observation of industrial welfare work, public school nursing and tuberculesis nursing and prevention.

Cimilar steps were taken in a number of other localities so that the liod ('ross Report eovering the year ending November 30,1911 , said:

Fonr and eight monthe' courses have been openod this rear in Cimcinnati. ('olumbus and ('hicago). The estahlishment of such courses chesly conerns the derelopment of the Town and country Nuring service. . . St. Lonis. Baltimore and

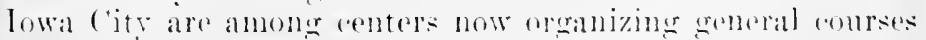
in pubice hralth nursing. Nilwankere has a three monthe 


\section{HIS'TORY OF AMERICAN RED CROSS NURSING}

course and sereral cities, among them Pittsburgh and Detroit. are offering lecture courses for nurses on public health topics. Serenteen nurses have entered upon courses this year. The increased number of nurses desiring to qualify for Red Cross service in the eight months' courses in preference to the shorter periods of training, is a particularly encouraging feature in the development of rural nursing. Ten nurses now taking eight months' postgraduate courses in Boston, New York, Philadelphia and Chicago, will be available for appointment in June.

The results of improved opportunity were shown in the following record:

Out of sixty-six nurses in service in 1916, thirty-three had had special courses including academic training, fourteen having had eight months' courses. Of the total number of thirty-three, fourteen were prepared at Teachers College in conjunction with Henry Street Settlement, four months' course; two were prepared at Teachers College, eight months' course; eight were prepared at Phipps Institute, eight months' course; three were prepared at Boston Instructive Distriet Association in conjunction with Boston School for Social Work, eight months' course; four were prepared at Boston Instructive Iistrict Nursing Association, four months course; one at New York School for Social Work, eight months' course; and one at the Chicago Visiting Nurse Association, four months' course.

'Two of these taking the Summer Course, four and eight months' course, and seventeen the four' and six months' course given in conjunction with Henry street Settlement.

Covering about this same period, twenty-two candidates for the Town and Country Nursing Service entered the Boston Instrnctive Inistrict Nursing Association courses given in conjunction with other local agrencies. Of these five took the eight months' and serenteen the four months' course.

A year later Columbia University took another advaneed step by preparing Teachers College to give special public lealth instruction to undereraduate nurses during their lospital training.

While it was true that public health nursing in general was beroming more and nore seriously developed, yet the concrete sperialty of rural work was not always thoroughly dealt with. On this point Miss (lement wrote: 
With one or two exceptions the courses in public health nursing to not include study or experience in rural health and sanitation or practical experience in rural liursing. 'There is need for such a course for while knowledge of city conditions serves as a good foundation for rural work, some knowledge of rural sociology and familiarity with country life will forestall lessons otherwise to be learned by sad experionce. Any one of the present schools of public: health nursing, were financial assistance from the lied Cross forthcoming, might willingly provide for specialization in rural nursing.

In 1919, of thirteen educational institutions giving public health nursing courses, two were recorded as giving cight months', four giving four months', and two nine months'. The others gave summer or evening courses.

With the development of the Educational Committe of the National Organization for Public Health Nursing (1917-1918) it was no longer necessary for the Red Cross to give time and labor toward stimulating the establishment of courses in public health mursing, or advising upon the form and contents of their curricula. For then a new conmittee of the N. O. P. H. N. took over these responsibilities, and employed an educational secretary to arry on its work. Nuch of the time of this secretary was given to field work, visits to schools already conducting or preparing to open public health nursing courses. The committee made a study of existing centers with the aim of arriving at a satisfactory basis, and presently amounced a minimm standard based largely on the previous models set up by the Red Cross Town and Comntry Nursing Service. It then gradually compiled a list of schools which maintained this standard and which it endorsed. In 1918 the Town and ('omntry Nursing Serviee definitely placed the responsibility of endorsement upon the National Organization for Public Health Nursing. By. July, 1!21, there were ten pmblie Isealth nursing courses fully endorsed by the Educational committee of the National ()romization for Publie I Iralth Nursing and nime tentatively endorsed, neaning that full endorsoment was to be given when rertain qualifioations had luen mot. 111 of these compes were used by the Red cross for the training of

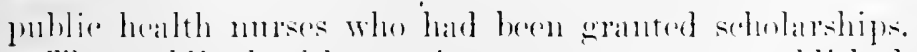

The publie health nursing andeses were estalblished on a sommd edueational hasis. In most adses they were a part of 


\section{5: HISTORY OF AMERICAN RED CROSS NURSING}

the curriculum of a leading university and in a few they were developed within a school for social service or social economy. Lectures and instruction of a high order in the theory of public health nursing were thus assured.

The length of the courses was usually one academic year, with the possibility of further specialized or advanced study. A course of four mouths was also offered for nurses unable to take the longer one.

The work of the courses was divided about evenly into theory, obtained in the university or school, and field work, where the theory was applied. To this end, practice fields were developed or existing facilities utilized to provide supervised experience in the different forms of public health nursing. Thus for four months of study and class room instruction in the principles of public liealth nursing, medical inspection and school mursing, nutrition, communicable disease control, sanitary science, educational and industrial hygiene, educational psychology and sociology and principles of modern social work, the student spent the full four months in the field putting into practice what the course had taught her. Perlaps the greater part of the time would be spent on the staff of a good risiting nurse association which offered experience in the care of all kinds of illness in the home and in teaching the principles of healthful living, home hygiene and sanitation. Some time would be spent on the staff or at least in observing the work of the school nurses; with the board of health nursing staff, olserving methods of eommunicable disease control and other activities. A definite period of actual family ease work would be afforded with a charity organization socief y so that the nurse might become acenstomed to treating the fanily as a unit and also might gain an insight into social problems and their solntion. Experience in metlods of infant and child welfare, nutrition, are of delinguents, dependents and other special chasees was includerl either throuch participation or observation. Some courses provided also a rural field where conditions pecouliar to comntry life might he met.

This inconplete list serves to show how public health nursing education had progressed since the short time when the pioneer distriet nursing associations provided the only means for public health mursing training.

The process of efterting a working nuion with local groups prepared to assist in taking np rural work preceded and gave 


\section{FROM RURAL 'TO PUBLIC HEAL'TH NURSING 125:}

rise to the present organization of the Town and Country Nursing Service as perfected in its central and related associations, and therefore logieally comes next in our text.

As already pointed ont, there were few Red Cross Chapters before the Virld War, nor did these ocenpy themselves especially with questions of health. It was, therefore, to groups of a different character that the Rural Nursing Committee first turned.

To reach and inform such groups a pamphlet was issued (1913) giving a statement of the aims of the Rural Nursing Service and offering suggestions on low to organize a local nursing association. Loeal groups were asked to write to Headquarters, and upon request suitable by-laws for lheir necds and an outline of suggested duties would be forwarded to them. A year later (1!1t) a revised pamphlet ealled "Ameriean lied Cross Town and Country Nursing Service, General Outline, Form No. 2" contained full information on every point. From those first leaflets only the earliest and later seetions historically interesting will be quoted, in order that ehanges may be traced and the general continnity on main lines made clear.

It is the purpose of the Red Cross, through its Town and Country Nursing Serrice, to further the establishment of local nursing asociations in order that the services of the visiting nurse may he brought within reach of small town and conntry districts of the Tnited States, and through affiliation with local organizations to assist them in promoting the interests of public health nursing. In aceorlance with this purpose the Red C'ross emleavor's:

1. To assist local groups in the organization and administration of nursing associations within its sope when called upon to do so.

$\because$ 'To derelop a persomnel of ellicient risiting nurses well equiped by tribing and experience for risiting nursing in the smaller communities. such murses to be emplosed by locial oranizations alliliated with the Tuwn and Comntry Xursing Servire.

3. To asist affiliated orenuizations in maintaining approved stanclares of public health nomsinge and in rarions wase to help the nurses meet the health needs of their communities more alderpately.

The acentanee of a fow regulations on the part of hocal

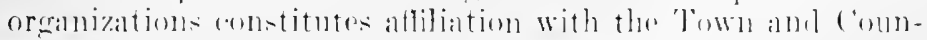

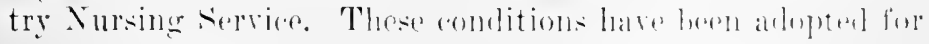




\section{HISTORY OF AMERICAN RED CROSS NURSING}

the purpose of establishing some degree of uniformity in the adninistration of risiting nursing. They consist of standard regulations deemed essential by the Red Cross to conserve the best interests of local nursing associations and the community at large. All other regulations or recommendations contained in this "Outline" are suggested, not prescribed.

1. An affiliated organization shall regularly employ such visiting nurses as fulfill the requirements of the Red Cross and are appointed to its Town and Country Nursing Service.

(Although the assignment and dismissal of these risiting nurses is made by the Red Cross, whether they retain their position or not depends upon the recommendation of the affiliated organization by which they are employed, and to which they are directly responsible.)

2. Temporary or substitute visiting nurses employed by an affiliated organization shall be approved by the Red Cross.

3. At least six months' salary shall be assured before a visiting nurse is assigned to duty by the Red Cross.

4. I'hen on duty Red Cross visiting nurses shall wear the uniform and pendant of the Town and Country Nursing Service.

5. The constitution, by-laws, rules and regulations that concern the visiting nursing of affiliated organizations shall be approved by the Red Cross (and before adoption any subsequent alterations or amendments thereto).

6. The designation "in affiliation with the American Red Cross Town and Country Nursing Service" shall always follow titles of an affiliated organization when appearing on publications, record blanks, etc.

7. For each year's service a Red Cross risiting nurse shall be entitled to one month's racation with pay, during which time a substitute nurse shall be employed. (The lied Cross will endeavor to supply substitutes.)

8. In order to guarantee maintenance of nursing standards, the work of lied Cross risiting murses shall at all times be subject to inspection by the Red Cross.

9. The nursing of patients by Red Cross visiting nurses shall always be carried on under the direction of a physician.

10. When two or more visiting nurses are emplored in one community by an afliliated organization. one shall be designated by the Rod ('ross as head nurse or superintendent. In such instances it is so adrised that provision be made for the nurses to live together. exceptions to which custom shall be approved by the Red c'ross.

11. Red C'ross visiting uurses shall keep areful records of their pationts on renort ards provided or approved by the 
Red Cross, and an afliliated organizaton shall sulmit to the Red Cross iluplicates of the monthly rejorts made by the nurse or report sheet 3 for this purpose.

12. Red ('ross visiting nurses shail not attend infectious: diseases unless due provision an be made for the care of other patients. ('They give instruction in mursing and erery possible assistance to families in which such eases oecur.)

1:). Red (ross visiting murses shall not act as midwives when merlical attendance is a railable.

14. Wherever an affiliated organization assumes the responsibility of nursing are of industrial policy-holders for the lletropolitan life lnsurance Company, the monthly reports of such risits sent to the ollice of the company in alecordance with an arrangenent previonsly effected, shall be aceompaniod by bills for the amount to be paid by the company to the Red ('ross for the service rendered, the full amount of said bills to be remitted by the Red Cross to the Afliliaterl organization.

15. An ammal report of the work of an affiliated nursing organization made to the lied Cross on special forms furnished for this purpose shall be submitted in January of each year.

16. In affiliated organization shall agree to employ a Red Cross visiting nurse for a period of not less than a year, and to notify the Red cross in writing of any intention thereafter to withdraw from affiliation one month before it may be discontinued. This agreenent is male with the unclerstanding that should the Red Cross deem it artisable to discontinue aftiliation it will do so br giving a month's notice of its intention to the affiliated organization.

In 1914 hut two changes were made in the "Conditions of Aftiliation," namely:

2. If at any time an affiliated organization desires a changre of nursis at least one month's notice thereof shall be grisen to the Red ( ross and the nurse employed.

And this proviso was added:

(conditions of Aflibation are suhject to amentment by the

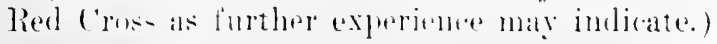

The somend artide of "( indditions of Aftiliation" of 1913 was amplition $(1 ! 1+1)$ to rad : 


\section{HISTORY OF AMERICAN RED CROSS NURSING}

When temporary nursing assistanee is necessary, affiliated organizations will engage a nurse who is a grarluate of a hospital training school giving at least two years of general medieal, surgical and obstetrical training in a hospital having a minimum daily average of fifty patients. An effort will always be made by the Red Cross to supply qualified substitutes.

Of the advantages to local nursing associations of affiliation with the Red Cross, the first circular said:

Upon the affiliation of a local nursing organization with the Town and Country Nursing Service, the latter assumes no financial or other local responsibility. or does it impose any fee. On the contrary, certain benefits are extended to aftiliated organizations, made possible by a large endowment fund to be used by the Red C'ross for this special purpose.

1. A distinct advantage lies in the assurance that Red Cross risiting nurses have met a definite standard as to character and as to preparation for visiting nursing.

$\because$. The Red ('ross meets the expense of a general superrision of its visiting nurses, maintained by occasional risits of the superintendent of nurses and supervisors, and throngh monthly and annual reports kept by the nurses and submitted by local committees to the Town and Country Nurving Service. This supervision in no way interferes with the responsibility of a nurse to the local organization under which her work is ronducted. On the other hand, through these visits, it is made posible for affiliated organizations to obtain helpful suggestions as to methods of administration that have proved of rahe in other sections of the country.

3. Py various forms of assistance riven to its nurses, the Red (ross can best scrve its affiliated organizations. I trairding library is maintained for their nse, including standard works on economic and social probleins.

4. In most rural sections nurses are cut off from helpf:ul ascoriation with others doing similar work. Both they and their rommittees often realize that they are handicapied by this ionlation. whereas irlentification with an extensirely organized pullic health agency. as the Town and country Nursiner Service. wolid give them an added stimulus toward the establishment and maintenance oi high standards of visiting nursing. . . .

๘. The Red C'ross supplies affiliated organizaltions. withont tharee. with reererd ards. receipt books. betside notes. and monthly report sheets userl in connection with the local work 
of the murse. These cards are adapted to the nse of small (ommunuties. A set of forms to be lised in seherol work has been prepared, and may be purchased by aftiliated organizations. Alfiliated or nanizations are not requiped to use the lied cross forms whe they have preforence for others.

8. A supply of risiting murses hags and equipment is kept on land by the lied ('ross in Washington. They may be purchased by aftiliated organizations.

For the guidance of affiliated societies these rules for the nursing serviee were sent out:

1. Appointment to the Rural Nursing Service will be for a period of one year, and reappointment may be made for anch year subsequent thereto. I murse may leave during the first three months in the service, but after that time she is expected to remain throughout the year, except in anse of serions illness, or when the lowal commitee rexommends otherwise.

$\therefore$ A rural nurse will be given a certificate of appointment and furnished with a hed ('ross pendant bearing her appointment nmmber. 'The latter is to be worn only when she is in recrulation uniform of a hed Cross rural inurse, which she shoud wear while on duty. The pendant remains the property of the Red cross and must be returned when her connection with the society has ceased.

3. Rural nures will receive thirty days' vacation annually with gay and this racation is to be devoted to rest.

t. It is not expected that under ordinary riremustances nurses will be alled upon for night duty, but in rase of emerwency where this is necessary provision should be marde for the care of their patients during the day. Patients will be visited on holidays and sundars when special or immediate attention is required. Exceut in emergenceses the nurse is experced to make visits at night only at the request of a phivician.

$\therefore$ It is alvisable that calls for a unrse be accepterl from

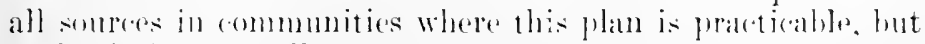

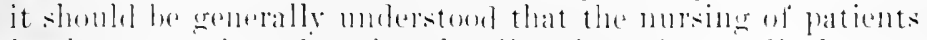
is alwals combluted muler the direction of a medical pracetitionere.

6. I murse is experted to ohtalu the ensent of her commitere before answering the all of a physician outsile her district and this should only he given when the nures's other (ases permit.

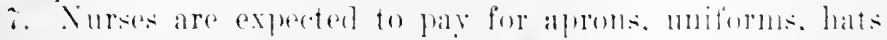

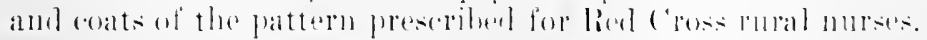


8. Nurses are not allowed to attend infectious diseases unless due provision can be made for the eare of the other patients. They may give instruction in mursing and every possible assistance to families in which such cases oceur.

9. 'They should not act as midwives when medical aid is arailable, nor under ordinary circumstances be expected to attend normal deliveries. They may answer calls to patients reported any time after confinement.

10. Where two or more nurses are employed in a community, one will be designated head nurse.

11. Nurses should not accept personal presents of money from patients or friends of patients.

12. They should not attempt to influence the religious or political opinion of patients, to influence patients in the choice of a physician, or prescribe for patients or dispense drugs except under directions of a physician.

13. Nurses are not allowed to solicit in any way for commercial interests with which the Red Cross through local organizations coöperate in the eare of the sick.

14. Giving of material relief is outside the sphere of the visiting nurse, and cases requiring such aid should be reported to the committee or directly to an agency in the community whose province it is to provide for such needs. The nurse. however, should be provided with means for relieving emergency need until such time as her committee or the relief agencies can act. This "emergency fund" might also be increased to include extraordinary expenses such as a night nurse, or a relief nurse, or the transportation of a patient when necessary.

15. liural nurses are expected to keep careful records of their patients on report cards provided by the Red Cross for this purpose.

16. To avoid leaving verbal messages with patients or their friculs when not able to communicate directly with the physician, the nurse should do so in writing, and in order to protect both patient and the nurse it is hoped that under similar circumstances the physician will observe the same rule.

1\%. Nurses should be held responsible for property loaned by the local board of patients, and they should take a receipt for the same, seeing that it is returned in good condition.

18. Nurses are expected to share in the responsibility of local committees in rery way, to protect their property and practice economy in the use of supplies.

19. Nurses will be under the general supervision of the Red Cross, which will be maintained by occasional visits of 
the superintendent of rural nurses and through their monthly and annual reports submitted by local rommittees. 'This supervision will in no way interfere with the respensibility of the nurse to the local board under which her work is conducted.

20. Enrolled hed Cross nurses form the nursingr reserve of the Army and Nary. 'They are called upon for cluty only in time of war and for emergency work fluring alamities or national disasters. Enrolled Red Cross nurses may be appointed as rumal nurses, in which case they will not be sulject to call for emereney work ontside their own community.

21. Rural nurses, although primarily responsible for the efficient care of patients, are expected to take an artive interest in families, teaching by instruction and demonstration the principles of hygiene as applied to their homes and surroundings as well as of person. They should know the health laws and what opportunities exist in their community for the improvement of unsanitary and other unfavorable conditions in which the patients live. They should be informed upon social matters and arail themselves of educational adrantages within their rearlb to cnable them to meet more adequately the needs of their people. With the support of an able and enthusiastie (ommitte, they have unlimited opportunities for constructive work through the homes. interested individuals. private societies. country schools and other public institutions.

The foregoing conditions and regulations are snbject to amemlment as Red ('ross rural nursing develops.

Affiliation with societies organized on the state-wide plan was a question of frepuent recurrenee. It had been eonsidered presuature in 1914. In 1915 it still seemed so, but a beginuing was then made. The Bulletin of November 17, 1915, said:

It would be impracticable for the laed cross to contract affiliation with state organizations in which arese it would be impersible to meet its obligations therehy astumed to supply.

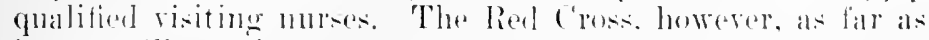
it rall, will appoint nurses for lowal work at the instigation of

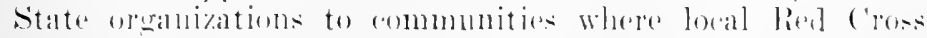

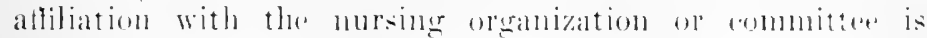
acromplisherl.

In important reservation made in 19th was upen the rela-

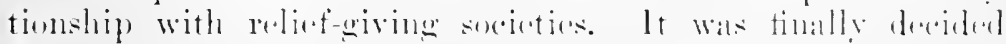
that such aftiliation shomld not he chtoped into, als if wals held

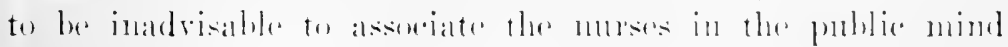




\section{HISTORY OF AMERICAN RED CROSS NLRSING}

with ageneies for giving material relief or charitable aid. $\mathrm{C}_{\mathrm{p}}$ to that time, affiliation with such bodies had not been entirely. ruled out, although, as the regulations show, emphasis had been laid on the importance of separating the nurse's work from that of the charity worker. Snch separation, however, for practical purposes, was difficult and from the popular point of view impossible, if affiliation actually existed between charitable bodies and Red Cross nurses.

The ofticial record on this point was:

The attitude among the leading nursing associations today being against material relief giving. the question as to whether or not Red Cross aftiliation with Associated Charities should be contracted was discussed at lengtl. Miss Wald movel that the sense of this committee be recorded as against affiliation with organizations of relief, or those known as relief giving agencies. Mr. Bicknell seconded the motion, which wa: carried. ${ }^{19}$

On the matter of finaneing visiting nursing the earliest suggestions made to loeal associations for their guidanee were:

1. The chief item of expense in rural nursing is the salary of the nurse. The cost of livery will be an important item in some communities. This may be lessener by surgesting to families requiring the services of the nurse that they send a conveyance for her when possible. The use of a hicrele or horseback riding may often be practicalble. Where there is no telephone in the house where a nurse resides one should he provided where possible. A fully equipled hag for professional use should be loaned her by the lowal Boari. It will he necessary to maintain a supply doset from which art ielw ma be loaned or rented to patients. Teedle llork culdh anil other societies may be expected to contribute some of the necessary supplies.

2. Various wass of raising money are in anderal noe. Members of the board should inprovise dimitiol mothonls adaptable to local conditions. Is many peroo.. : in the com munity as possible should be uraed to contribute tumaril the

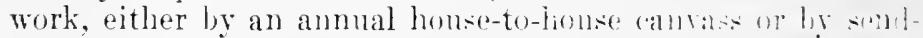
ing out written requests. As all persons without an lines of distinction enjoy the benefits of improred anditions hromeh

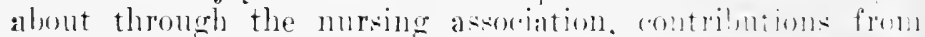
all should be solicited. Those who aln well alforml lal'

20. Minutes: Town and Country Nursing Swrice, I)e. 12. I9Iti. 
subseriptions should be encouraged to make them, and every contribution, no matter how small, should be welcome.

3. Fees collerted from patients should add considerably to the income. It is a generally accepted principle anong learing nursing associations that patients should pay for the services of the nurse. Her field of usefulness is greatly extended by working as far as possible on a business hasis. Many will thus utilize her services who on other terms would resent the idea of employing a "charity nurse." Patients are experted to pay for professional visits aceording to their means and nurses and local committees should encourage patients to do so. Where it is practicable a nominal fee should be designated, regulation of which is a matter for local boards to discuss. If a patient is unable to meet the full charge, the amount to be collected should be left to the discretion of the nurse. Sick persons who should receive nursing care and are unable to pay for it should not for this reason be denied the services of the nurse. Patients who are able to engage a private nurse are not expected to utilize the services of a rural nurse except in cases of emergency.

4. Sometimes several small villages which alone cannot raise funds sufficient to carry on rural nursing may unite in this work and share the necessary expenses.

5. Through coöperation between the Metropolitan Life Insurance Company and the Red Cross, the nurse's visits to industrial policy holders will be paid for by the Insurance Company, and fumds thus collected will be used to increase the income to local nursing associations.

f. Churches, women's clubs and various local societies will often contribute toward the work. Boards of education, health departments, local and county, may appropriate an annual amount toward the eare of school chillren or for sanitary measures carried on by the nurse. Local nursing associations should appeal to their county and state tuberculosis societies and other ageneies working along public health lines. large organizations interested in special diseases, or those interested in improving general living conditions, may lend financial assistance to communities within their field of artivity. If only a few month's salary is available. the work should be put under way. This is the hest method of eduating a community to the need and nsefulness of a visiting nurse.

C'crtain minor changes in the rules of affiliation were made from time to time. In 191 s a somewhat eomplicated procedure for parment ly the Metropolitan Life Insurance Company for 


\section{6* HIS'TORY OF AMERICAN RED CROSS NURSING}

services to its policy holders was simplified by authorizing affiliated societies to negotiate matters of payment directly with the company. At some time in the summer of 1917 the pendant worn by the murse was given up and from then on the Red Cross public health nurse wore the regular pin.

In 1919 the privilege of using the Red Cross emblem was withdrawn from affiliated organizations, although they might continue to use the words "In affiliation with the Red Cross Bureau of Public Health Nursing." This became necessary, as the war growth of chapters was so great that every county had its Red Cross Chapter, and where affiliated nursing organizations also were formed, bearing the emblem and collecting funds under its sanction, confusion resulted and difficult situations arose.

Although the granting of scholarships and loans was a very important feature in the early development of the service, it became so much more complex as related to the later growth that it has seened best to deal first with the progress of organization:

In the initial work of organizing the Rural Nursing Service following the preliminaries of 1910 and 1911, the special committec in charge of this, with Miss Boardman as first chairman, was organized under the National Relief Board. This differentiated, at the ontset, the nurses of the Rural Nursing Service from those who had, from the time of the reorganization of the Red Cross (1904), enrolled for war service or emergency call under the War Relief Board.

In 1915 the Committee on Town and Country Nursing Service lost the immediate and personal association with Mrs. Whitelaw Reid which it had had from its foundation, for her prolonged absence from the country decided her to resign as rhairman of the committee. Her place was filled by Mrs. Harriet Blaine Beale, for many rears closely associated with the Visiting Nurse Society of the District of Columbia.

In the following year Mr. Eruest P. Bicknell, Miss Blanche E. Mazard, Mrs. William C. Osborn, and Miss Ruth Morgan lereame member's of the committee. At the annual meeting of the ('entral ('ommittee in December, 1!16, the war pressure making a nore complete amalgamation necessary, mification was brought about. All hed cross nursing, of whatever 
variety, was then composed into one general service, ${ }^{20}$ with ordered subdivisions, as has been described muder Mobilization. Hitherto there had been no formal relation between the Town and Country Nursing Service under the National Relief Board, and the Nursing service operating under the War Relief Board. But now (1916) all lied Cross murses were placed in one "Red Cross Nursing Service." of which the component parts were defined thus.

The term "Red Cross Nursmg vervice" includes (a) the National Committee: (b) State and Local ('ommittees on Nursing Service and such other committees as it may deem necessary to appoint: ((') all enrolled Rerl ('ross nurses, including member's of the 'Town and comntry Nursing Service; (d) enrolled dietitians, Sisterhoods and other orders, when assigned to duty under the Red C'ross; and (e) women volumteers selerted for hospital service or other duties relating to the ware of the sick.

All nurses employed by Chapters, other Red Cross organizations. or affiliated rocjeties authorized to use the Red Cross insignia. must be enrolled Red Cross nurses and subject to the regulations of the Nursing Service.

All Red Cross courses of instruction, except those in First Aid and Areident Prevention, are under the control of the Red Cross Xursing service.

This National Committee was empowered to create speeial sub-eommittees. The Town and Comntry Nursing Service next (1917) became one of the two bureans operating under the National Committee on Nursing Service, the other being the Burean of Nursing Service. The title of the superintendent was altered to "I)irestor of the Burean" and certain danges of policy for the nursing staff were aldopted, which will he dealt with in a later paragraph. The position given to organized murses on the National Committee was mique among international Red c'ross soeveties, and cmphasized both the reeognition of and the grave responsibility devolving npon the American nursing profession as a self-eontrolled hody of oreanized workers. In Julv, 1917, a third hurealu, that of Instruction,

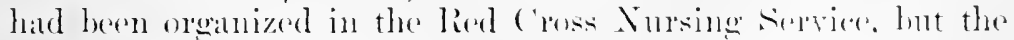

20 The Minutes of the Central Committee. Desember 1:3. 191ti. read:

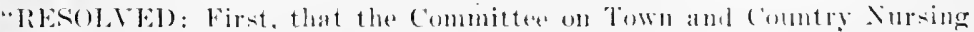

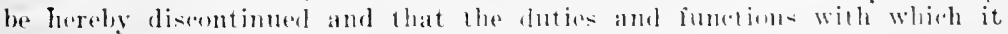

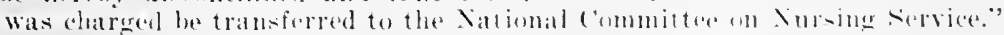




\section{HIS'TORY OF AMERICAN RED CROSS NURSING}

functioning of the Bureau of Town and Country Nursing was nualtered.

In December, 1915, when the three governing boards of the Red Cross were made advisory, the executive powers which they had formerly had were placed in newly ereated Departments.

The Department of Civilian Relief then functioned as had the former "National Relief Board" and the 'Town and Comtry Nursing Service bore the same relation to it as it had borne toward the older body. This arrangement, however, resulting as it did in a division of responsibility between the "Nursing Service" and the "Department of Civilian Relief," was not permanent, and on December 7, 1917, the Red Cross Nursing Service was made a Department, and thenceforth the Town and Country Nursing Service functioned as one of its bureans. The general extension of branches and Division headquarters that took place during the war has been outlined (see Mobilization), and the reorganization after the war will be described in a final chapter.

No special form or name was required of local organizations wishing to affiliate, but simply that they should have the purpose of promoting rural visiting nursing by the help of the lied Cross organization and equipment. However, when aftiliation was effected with a society not primarily organized for community nursing, an effort was always made to have a special group ereated to be directly responsible for this branch work:

It is expected that in the development of Red Cross rural nursing, local committees will be created, meeting standards of salary and other regulations which are deemed necessary to insure the best interests of a commmity. The locality benefited by the work of a nurse is expected to meet the expenses connected with it. Fees collected from patients are not sufficient for this, as all sick persons are not able to pay for the services of the nurse. As a rule, patients are expected to pay for professional visits, arcording to their means, but those mable to make any payments should not so meared for. The responsibility for laising the necessary funds rests with the local committee, which also superintends the work of the nurse.

How necessary and valuable the influence of the Red Cross was and is locally in mantaining good nursing standards, is well illustrated by the following incident. Al local association 
afliliated in the carly days with the Red Cross formed a secondary, informal relation with another loeal group not comnected with the Red c'ross. This seeond group employed mutrained women, whom it alled "attendant nurses." The Red Cross then, through its affiliated associations, requested the secondary group to use only the term "attendant" and to discontinue calling untrained women "attendant nurses." It is preeisely" by such easy steps as the above that local standards may be lowered in the absence of some strong, central, mifying body. The carly work of the Red Cross in eneouraging local pioneer efforts was tireless and painstaking. No beginning was too small to reccive its fostering eare. $A$ s a result, it created an atmosphere that stimulated and encouraged. An advantage of a strong central body is found in the inspiration of the feeling communicated to its membership, of belonging to something large, something national. The personal visits, the national correspondenee, the definite standards, convey a sense of support and encouragement.

While supervisors soon eome to be a necessity in any large organization, they were also definitely useful in the early work as organizers. This was recognized from the first, and in the Report of 1913 we read:

To reach the most neglerted communities, it is necessary for an orcanization to spend mueh time in the field, and the demand for this work will in future be more adequately met hy the appointment of another nurse, whose salary will be paid by the Red ('ross. With this addition to the staff, it will be possible to make regular and systematic visits of inspection to atfiliated organizations, and more opportunity will be available to respond to many ralls asking for someone to present the work at varions (inlss and mass meetings, which has been possihle thus far only to a limited degree.

In 1914 the Report said:

Mis: Whis lioberts, formerly superintendent of the Visiting Nurse Asociation of ('incinnati. and who has recently completed a course in the I) (partment of Sursing and Health

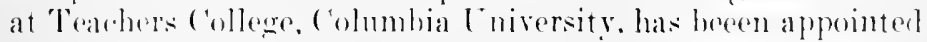
supervisor of hed croses risiting morses.

Fifty-one supervisory visits to afliliated organizations have ben male hy the superintemlent and supervion thring 1911 . and. with the purpose of placing before nurses the public. 


\section{HIS'TORY OF AMERICAN RED CROSS NURSING}

health needs of the smaller communities, they have presented the work of the 'Town and Country Nursing Service in seventyfive hospital training schools.

In 1914 the field supervising nurses of the Metropolitan Insurance Company, four in number, who were appointed to the Town and Country Nursing Service, were requested by the Red Cross to make a speeial study of the demands made upon rural nurses and the preparation needed by members of the Town and Country Nursing Service. At an informal meeting in St. Louis, held later that year (1914), these field nurses, whose work took them from coast to coast, met with the Committee of the Town and Country Nursing Service of the Red Cross to diseuss their findings. An arrangement had lasted for a year (1913-1914) by which these supervisors, paid by the Company, made reports to the Red Cross of organizations affiliated with the Rural Nursing Service. In the matter of a uniform standard the Red Cross visiting nurses were under the general supervision of the superintendent or her supervisors. But in matters relating to their local work their responsibility to the loeal group was eomplete.

In 1915 the supervisory visits numbered sixty-seven with eighteen more for organizing work. In 1916, sixty-nine, with many additional meetings with committees and public otficials, and to address organizations and mass meetings.

The Ammual Report of the service for 1917 said:

A second supervising nurse was employed for several months early in the year. This has made more visits to communities possible than during 1916. One hundred and eight supervisory visits and fifteen visits of organization were marle. To do justice to a most important function of the Town and Comntry Nursing Service. additional supervisors are needed. Many affiliated organizations are seeking more frequent supervisory visits than the present limited number permits.

To help the local applicants it was agreed that memhers of the Town anl Country Nursing Service Committee should. whenever possible, art as advisers and organizers in their own envirouments, and the superintendent recommended that annmal conferences for lied ('ross visiting nurses anu affiliated local gromps be arranged for varly at the time of the ammal Rell cross meeting in Washington. 
To assist in the formation of lowal mits the Red Cross Nursing serviee prepared and distributed leaflets of advice on how to organize. The "arliest form of this adviee was inchaded in the first panphlet issued by the service in 1913.

In any work the initial efforts have a special interest, and are, moreover, too easily lost sight of, and so it is befitting to record the aftiliations of 1913 and 1914 that they may not be forgottens.

Location

Name of Organization

Date of Affiliation

Cuyahoga Falls, Ohio
Warrenten, Va.
Hot Springs, Va.
Bloomfield, N. J.
Winchester, Va.
East Islip, N. Y.
Clarksburg, W. Va.
Lamrel, Md.

Spartanburg, S. C.

Dorset. Vermont Boucester, Mass.

Greenwood, Va.

Piurehase, X. Y.

Manchester, Mass.

Grenville, S. C.

(')hasset. Mass.

chilton County, Ala.

Palmerton, Pa.
Visiting Nurse Association

Distriet Nurse Association

llot Siprings Valley Nursing As. sociation

League for Friendly Service (Community Nursing Serviee taken over by R. C. Clapter)

District Nurses' Association (Community Nursing Service)

Visiting Nurse Committee of R. C. C'latpter (Community Nursing Service)

Women's Civic Club (community Nursing Service)

Visiting Nursing Committee (Temporary Community Nursing)

Spartanburg llealth League (Community nursing service eotton mills)

Dorset Nursing Association

Glutleester District Nursing Association. Ine.

Greenwood Visiting Nurse Assoeiation

Purchase Nursing Association

Manchester Visiting Nurse Committee of the Women's Club (Community Nursing Sirvice)

Children's Charity Circle, later known as Public Ilealti Nursing Association

District Nursing Commites of

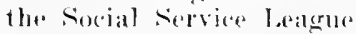

Chilton county lealtl ('ommit tee (Primarily lualth alueational work with 3 comuty schools

Visitimg Nurse ('ommittere of Now Jarsey Zine ('o.
July 1. 1913

Ang. 1, “

Sept. 1, “

، 15, .

" 30 , “

Noy. 1, “

“ $8, \cdots$

" 21,6

Dee. 13, “

* $23, \quad$,

Feh. 1, 1914

$\because 6, .$,

Mar. 24, “

Apr. 16, “ 


\section{$12 \% 0$ HIS'TORY OF AMERICAN RED CROSS NURSING}

\begin{tabular}{|c|c|c|c|c|}
\hline Location & Name of Organization & \multicolumn{3}{|c|}{$\begin{array}{l}\text { Date of } \\
\text { Affiliation }\end{array}$} \\
\hline Hazard, Ky. & $\begin{array}{l}\text { Perry County Nursing Assoeia- } \\
\text { tion (Mining seetion of moun- } \\
\text { tain and general work) }\end{array}$ & May & 4 , & \\
\hline Albemarle County, Va. & $\begin{array}{l}\text { Commmity Work of Bureau of } \\
\text { Rura] Sanitation, Va. State } \\
\text { Board of Health (Educational } \\
\text { Health Service) }\end{array}$ & June & 1 , & “ \\
\hline Franklin, N. J. & $\begin{array}{l}\text { Visiting Nurse Committee of } \\
\text { New Jersey Zine Co. (Indus- } \\
\text { trial Nursing on Community } \\
\text { basis) }\end{array}$ & “ & 13, & “ \\
\hline Canaan, Conn. & $\begin{array}{l}\text { North Canaan Visiting Nurse } \\
\text { Association }\end{array}$ & Aug. & 1 , & " \\
\hline Chippewa Falls, Wis. & $\begin{array}{l}\text { Assoeiated Charities (Community } \\
\text { Nursing Service) }\end{array}$ & “ & 5 , & “ \\
\hline Cambridge, Md. & $\begin{array}{l}\text { Cambridge Visiting Nurse Asso- } \\
\text { ciation }\end{array}$ & Sept. & 12 & “ \\
\hline Grosse Pointe, Mich. & $\begin{array}{l}\text { Mutual Aid Soeiety and Neigh- } \\
\text { borhood Club (Community } \\
\text { Nursing Serviee) }\end{array}$ & Oct. & 1 , & “ \\
\hline Morgantown, W. Va. & $\begin{array}{l}\text { Child Welfare Committee of As- } \\
\text { soeiated Charities (taken over } \\
\text { by Morgantown Chapter, A. } \\
\text { R. C., Nov. 1, 1919) }\end{array}$ & " & " & “ \\
\hline Nt. Carmel, Ill. & $\begin{array}{l}\text { Women's Club (Community } \\
\text { Nursing Service) }\end{array}$ & $" 6$ & 7, & “ \\
\hline Bridgeton, N. J. & $\begin{array}{l}\text { City Nurse Committee of Bridge- } \\
\text { ton Civic Club (taken over by } \\
\text { Cumberland County Chapter- } \\
\text { Community Nursing Serviee) }\end{array}$ & " & S & “ \\
\hline Jerome, Arizona & $\begin{array}{l}\text { Visiting Nurse Association (Re- } \\
\text { opened under Board of Health) }\end{array}$ & “" & 21 & “ \\
\hline Litchfiełd, Conn. & $\begin{array}{l}\text { Litehfield District Nursing Asso- } \\
\text { eiation }\end{array}$ & Nov. & 20 & “ \\
\hline Fulton, Ky. & $\begin{array}{l}\text { R. C. Public Health Nursing } \\
\text { Service (formerly known as } \\
\text { City Health and Welfare } \\
\text { League until Nov. 18, } 1918 \text { ) }\end{array}$ & Dec. & 3 & “ \\
\hline
\end{tabular}

If space permitteil, credit should be given in the case of every association listed above to some one or more specially devoted women to whose ability and influence success was largely due. It would be a fitting tribute to them to mention sperial phases of their work, but one which would require another volume.

So wrote the first superintendent of the service, and she added:

Then, too, if anyone connested with the Town and Country Nursing Service deserves special mention. it is that gromp of nurses who labored with such faithfulness and courace in (o) untry distriets from the beginning. 


\section{FROA RURAL TO PUBLIC HEALTH NURSING 1271}

'They were superior women, the heart and soul of the public health mursing, and after all is said the greatest benefit of affiliation resulted from their attraction to the Red Cross and the appointment of women of their type.

Before the ontbreak of the World War the organization of the Red Cross by Chapters was but slightly dereloped. 'Those that were strongest were in large eities where the rural nursing idea was not felt, and as a rule the Chapters did not then take up activities along lines of health eonservation. It was only after the entrance of the United States into the war that rural seetions generally organized into Chapters, and not until after the armistice did these Chapters turn to the activity of the public health service.

The influence of the war on both general organization and the Town and Country Nursing Service was profound. As to the nursing service, a completely new policy was formulated, and in organization generally new forms developed. 'The nursing staff' will be considered first.

It is to be remembered, at this point, that while any regularly enrolled Red Cross nurse with additional requirements for public health nursing might enter the Town and Country Nursing Serviee, and many did, not all Town and Country nurses were neeessarily "enrolled." For them enrollment for war service had not at first been required, and in place of the Red Cross badge of the enrolled nurse the 'lown and Country Nursing Service staff wore a pendant, but under the exeitement of the war menace a new situation arose, partly brought about by the inclination of nurses to volunteer for the war: partly from the desire on the part of the leaders in Public Health Nursing to keep their forees intact in this country. The situation offered these altermatives: Either the Public Health Nurse was to be put in a separate group, of which the members should be given eredit for military service, or all murses should be allowed to decide freely whether to take active service under the War lopartment, or home service in their own comitry. A combination of these alternatives eventually brought about a kind of rassifiation enrollment for the Red Cross. In 1:17 Miss Clement wrote:

When the two Services were hrought together under the one administration, definite provison was marle by the Xational committee on lied ('russ Nursing service regularly to 


\section{$12 \% 2$ HIS'TORY OF AMERICAN RED CROSS NURSING}

enroll nurses who were available for the Town and Country Nursing Serrice solely. Thus all nurses assigned to duty under this Service are now enrolled Red Cross nurses. They are enrolled as any other Red Cross nurse by the National Committee on Nursing Service, but with the understanding that response to a call for war service is not compulsory, or any other Red Cross duty outside the community to which they already are assigned under the Town and Country Nursing Service.

\section{The Bulletin of April 15, 1917, said:}

While one of the most important duties of the Red Cross is to maintain at all times an adequate enrollment of nurses for service in the event of war, the rapid development of various peace activities under the Nursing Service has mate it desirable to enroll nurses with special qualifications who might be available for war duty.

Certain exceptions to the usual requirements for enrollment will therefore be made, as in the ease of nurses selecterl for committee work, those willing to act as Instructors of Red Cross classes. and candidates for public health nursing under the Town and Country Nursing Service.

Many inquiries regarding the calling out of enrolled Red Cross nurses in the Town and Country Nursing Service for war relief work have been received of late, both from nurses and their nursing organization. There being over eight thousand enrolled Red Cross nurses, those assigned to duty under the Town and Country Nursing Service will not be called out by the Red Cross for war service. Although the latter would not be debarred from volunteering for war service, the Rerl Cross considers the public health work in which they are at present engaged as most important. and only if urgent needs of this comntry require it would the Red Cross consider calling them for other duty.

The following letter from Miss Delano to the nurses belongs to this period:

$$
\text { April ?6. } 1918 .
$$

In these days of mprecedented demand upon the nursing profession. decision as to the relative usefulness of individual effort is often a matter of great dinliculty. The call for murses for military service both here and abroad must rightly and of necessity draw heavily upon the nursing resondes of the country, but we feel that the public health nurse is also an 
important factor in the preservation of national health. It is therefore the policy of the Red C'ross to leare molisturbed as long as posible the nurses of its 'Town and Country Nursing Service.

Should a (hange of this policy (which now seems unlikely) ever become necessary you will be personally notifiel. Meanwhile, I hope you will continue at your present work with the assurance that the Red Cross fully appreciates its importance and value to the country.

We are plaming to supply an insignia to be worn on the arm by all Red C'ross nurses who at our request are remaining at their present post of duty.

Very sincerely yours,

(signed) JANE A. DeLaxo, Director, Department of Nursing.

This attitude of the Red Cross, strongly supported by public health bodies generally, was quickly justified by events, for while on the one hand war demands broke through the routine of peace, on the other, the calls for nurses for health conservation were immensely increased, and the nurses who stood at their posts in this field were elassified as the Special Service Gromp. This group has already been deseribed with snffieient detail. In the Pulletin of October, 1918, Mary S. Gardner wrote:

Soon after the declaration of war the National Committee on lied ('ross Nursing Service provided for an enrollment of public health nurses to be held available for public health work under the Real ('ross either in this country or abroal. later it secmerl necessary to safecruarl the training of our pupil nurses and the maintenance of our national health by creating a sperial eroup for all nurses holding important pesitions in training sehools or in public health nursing. This gromp was called the sperial Service Group. As seon as this flan was

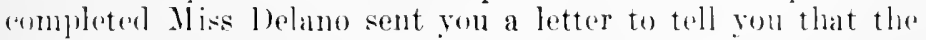
Red ('ruse recognizes the important part pour are playing in the preteretion of the health of the nation and astis all of you to remain at your posts as member of this speecial servien (irolip).

To many public health nurses the decision to stand by an innortant pioce of home work has been a dithicult one. It is

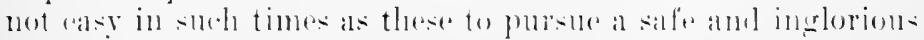
way, even thomgh the sign-posts be very phanly marked "jath of tuty." 


\section{4 HIS'TORY OF AMERICAN RED CROSS NURSING}

The public health group, however, is not a large one, if all the nursing resources in the country are taken into account. It would seem. therefore, wise that though all nurses should enroll in the Red Cross, those trained or experienced in publie health work should for the present at least use that training and experience where it will be most effectixe, namely, in doing the work for which they alone are prepared and which so sadly needs them.

A further extension of the service resulted from the need of special lealth protection in the military cantonments at home. Miss Gardner wrote:

We had been at war but a short time, when the Red Cross added a new actirity to its countless forms of helpfulness and one involving public health nurses. Zones were formed by the United States Public Health Service around the big cantonments and in these zones public hcalth nurses were placed working under the medical director. For this service experienced nurses are needed. At first, part of the nurses were Red Cross nurses, and on the Red Cross payroll, part were engaged and paid by the United States Public Health Service. It has been decided that all the zone nurses should be enrolled Red Cross nurses, thus setting a single standard for all, and that on the recommendation of the Red Cross all chief nurses should enter the Enited States Public Health Service.

When this zone work carried on by the Red Cross in cooperation with Lnited States Public Health Service erentually found its way into the Town and Country Nursing Serrice it seemerl only out of place becanse the name of the burean was not sufficiently inclusive to be descriptive of such an activity. It was therefore decirled to change the Bureau's name to the Bureau of P'ublic Health Nursing. ${ }^{21}$

The change in name and scope of the service went into effect on May 18, 1918. Miss Gardner had then suceceded Miss Clement for a temporary period only, with Miss Fox as assoeiate dircetor. Both were exceptionally well fitted to direct the enlarging service.

Mary Sewell Gardner was a Connecticut woman, of a representative Now England family. One of her aneestors on the maternal side had been president of the first Provincial Congress of New Hampshire and later a signer of the Declaration of lndependence. On the paternal side her family had in-

${ }^{21}$ Bulletin No. 3, Vol. 4, October, 1918. 
eluded many lawyers and judges and her father served on the Suprene bench of Massachusetts. Miss Gardner's early edncation had been entrusted to tutors and later she attended a girls' school in Farmington, Connecticut, then traveled extensively abroad. She was given the position of superintendent of the Providence (Rhode Island) District Nursing Association inmediately after her graduation from the Newport Hospital. 'To enable her to help in the development of the Red Cross Town and Comntry Nursing Service the trustees of the Providence Association generonsly gave her leave of absence for that purpose. Miss Gardner was recognized throughout the comutry as an authority on all phases of public health work, and she had had numsual experience in rural unrsing while extending visiting nursing throughont Rhode Island. She was the second president of the National Organization for Public Health Nursing and a permanent nember of its board. She wrote "Public Health Nursing," the first book on that subject and a standard one. In 1918 Brown University gave her its II. A. as a "pioneer in making the eare of the sick an honored profession. . a gentlewoman whose writings and example have brought us healing of the body and inspiration of the spirit."

Very charming, feminine and attractive with a rich sense of humor and a balanced mind, so upright that she commanded aeneral confidence, Miss Gardner threw all her gifts into the Red Cross work, but in the midst of her administration she wis dispatched on a special mission to Italy to organize public health nursing there, and then after the war she returned to her position in Rhode Island.

Elizabeth Gordon Fox then became the director of the Burean. Born in Milwaukee, she took howors at the Lniversitr of Wisconsin (Phi Beta Kappa) and graduated with distinction from the Johns Hopkins Hospital. She served on the statf of the Chieago Visiting Nurse Assoeiation for four rears, then berame superintendent of the Visiting Nurse Association of Diyton, (ohio, and from there went to a similar position in the eity of Washington, where she also served as president of the board of Nurse Examiners. She had been enrolled in the lied Cross Nursing Cervice since 1913. In 1921 she was chusen as vice-president of the Xational (Organization for P'nblic II aalth Nursing, and npon the resignation of Edna Folery then puesident, sureeded her and was elected as president to a seromel 


\section{HISTORY OF AMERICAN RED CROSS NURSING}

term of office in 1922. Her largest achievement after becoming director of the Red Cross work was in knitting up the relations between the Red Cross national organization and its branches and State health boards. This important stage of progress will be deseribed in the next ehapter. Foreeful, direet and unaffected, a keen and analytical thinker and a remarkable organizer, Miss Fox held her burean in strong hands.

At first the war worked injuriously upon the service. Miss Fox wrote:

The Town and Country Nursing Service experienced a check in its growth during the war brought about by the transfer of national and local attention from peace activities to war work, and by the serions shortage both in qualified public health nurses and in candidates for post-graduate preparation occasioned by the withdrawal of many thousands of nurses for military service.

The secondary effect of the war and its accompanying calamity, the epidemic of influenza, was to heighten the interest of Red Cross Chapters and the general public in health and nursing matters.

The first finaneing of a Rural Nursing Service was made possible, as has been told, by the gifts of Mr. Jacob Sehiff and IIrs. Whitelaw Reid. But not all could be used for loans and scholarships, as the general administration of the Service had to be eovered as well. In $1912 \$ 1000$ was set aside for loans, a maximum of $\$ 250$ being agreed upon for one loan, and seven scholarships were ammonnced, three of $\$ 200$ each and four of $\$ 100$ each. Previons to December 1, 1913, three scholarships were granted and three loans made. Between that date and December 1, 1914, one scholarship and thirteen loans were granted.

In $1915 \mathrm{Mr}$. and Mrs. Schiff gave $\$ 5,000$ more to be nsed expressly for the Loan Fund and the Scholarship Fund was thereafter abolished for a time. Between December 1, 1914, and leeember 1, 1915, eleven loans were granted. By 1)eember 1, 1916, eight more had been made.

At the ammal merting of that rear it was agreed that, as murses were taking the eight months' course in larger numbers, the maximm loan should be inereased from $\$ 250$ to $\$ 300$ and, in special cases, to $\$ 400$.

It was mever contemplated that the Red Cross would entirely 
support the cost of a local rural nursing service. Its poliey was against this practice from the very start even though appeals for financial aid were numerous and although lack of local funds became a frequent cause for the discontinuance of affiliations one after another. It was not long, however, before the finaneial helplessness of certain communities became appealingly elear:

Before the end of the first year of the service, and before any outside eflort to meet partieular financial appeals was contemplated, a member of the Committee on the Town and Country Nursing Service had volunteered to meet the expenses of placing a nurse in the Kentueky mountains. Contributions from private sources for particular communities were later administered by the Red Cross in a number of instances, primarily to encourage the introduetion of visiting nurses in the Southern Highlands. These donations were used to pay the salaries of unrses temporarily in whole or in part with the idea always in mind that the work would eventually be supported loeally.

In 1914 the possibility of creating a sustaining fund was discussed. The records say (December 8, 1914):

The desirability of the Red Cross establishing a fund whereby the salary of nurses might be supplenented who were to be employed in sections of the country that could not at present provide the salary of a Rei Cross visiting nurse in full, was favorably considered. Miss I) lano offered to supplement the salary of a nurse to be sent to the mountains of North Carolina under the Presbyterian Board for one year.

The report of December, 1915, returned to this theme, dwelling especially on the needs of the momtain regions:

In many mountain commmities loral financial resources are such that the salary of the nurse cannot be raised either by private subseription or public appropriation. The church mission loards and educational orranizations which have been active in the mountain conntry for vears lave inchuded visiting nursing in their artivities in twelve or thirteen instances, but there are three million persons living in the Southern Highlands.

The Town and Country Nursing Service was orcanized to help just surh communities as this section represents and yet they cannot procure Red Cross vi-iting nurses unless some 


\section{2\%8 HISTORY OF AMERICAN RED CROSS NURSING}

provision can be made to aid them financially. Three Red Cross visiting nurses have been appointed to mountain communities, one in each of the States of Virginia, Kentucky and North Carolina. One was employed by a visiting murse association supported by private sulsscription from the mountain people and summer visitors, one by a denominational mission board, and one by local funds supplemented by outside individuals.

Within the past few months inquiries have been received from several mountain schools asking if the Red Cross could aid in financing the work of a visiting nurse. A broad field for rural nursing lies open in this section and study of its resources reveals the fact that unless some provision is made by the Red Cross or other organization whereby such communities may be aidcd financially, there is little prospect of nurses who have met the standards of hospital training and post-graduate preparation in public health nursing required by the Red Cross being employed in this part of the country.

The meeting of the committee (March 18, 1915) had taken steps to meet this need. The Department of Agriculture under the smith-Lever Act had aided numerous rural localities throughout the country by contributing toward the support of county agents. There was a close connection between the work of these agents and health work being done by the county nurse. One middle western state had even written to the Red Cross to ask if nurses could he supplied to fill county agents' positions with the aid of State and Federal support. Other instances were known too where Federal money was being used for local educational healtin work by nurses. Thus the idea of direct financial aid from the Federal Department of Agriculture in the extension of rural nursing was not entirely novel when the committee appointed its chairman, Mrs. Beale, and Miss Lathrop. head of the Children's Burean, a committee to interriew Secretary Houston upon this subject. The interview took place, however, with negative results.

Within a short time, however. public support by contributions to loral funds had grown rapidly along lines indicated as the original plan of the Red Cross. ${ }^{22}$

A committee report (November 30, 1916) said:

In twenty-seven communities public funds are now paid toward the support of the work. There is little uniformity in the amounts of appropriations, ranging as they do all the way ${ }^{22}$ Report by Miss Clement. Dec. 1915. 
from $\$ 200$ to $\$ 300$ anmully, the amount received by six communities, to $\$ 1200$ and orer received by six other communities. The entire salary is paid in six communities from public funds.

By 1917 gifts from individuals and from Red Cross Chapters had begun to swell the funds for mursing edueation. In that year the Chapters of New York County, Boston Metropolitan, Chicago and Cincinnati cach gave $\$ 500$, and Mr. Harvey Gibson and Mrs. William Draper each gave $\$ 500$, making $\$ 3000$. In the autum scholarships for visiting murses were again announced. More than one hundred direct inquiries came from nurses, giving clear evidence of the value of the scholarship plau. Nine seholarships of $\$ 250$ each, for eight months' courses, were distributed, and the Superintendent's report said:

It is to be hoped that a permanent scholarship fund may be provided by the Rod ('ross whereby an eight months' course will be brought within reach of many nurses, otherwise unable to obtain it.

During the formation of plans for the rapid extension of public health nursing under the Chapters immediately after the Arnistice in 1918, the need for increasing greatly the number of nurses prepared for public health nursing stood out clearly. The cartier scholarship fund of $\$ 3000$ was nearly exlanisted. The opportmity to secure many recruits for public health nursing from anong the thousands of nurses returning from war service seemed good, providing some means were available to help them pay the cost of preparation.

Just before suling for Europe (.Imury 1, 1919) Miss Delano presented a reepuest to the general manager that the War commeil of the lied C'ross appropriate $\$ 50,000$ for a scholarship and loan fund for murses needing instruction in publie houlth mursing letere being avaliable for assignment to duty under the lied Cross:

In the develumment of our Red C'ross public healuh program, I do not feed that it will be nexesiary to alsk for any larege expenditure of funds for administrative propeses. The organization which we new have glught to be sutlicient. It will, however, be necesary. in my opinime to have funds 


\section{HISTORY OF AMERICAN RED CROSS NURSING}

available for other phases of the work, the most important of which are as follows:

1. A loan or scholarship for nurses who need instruction in public health nursing before being available for assignment to cluty under the Red Cross. May I recommend that $\$ 50,000$ or so much of this fund as may be necessary be set aside as a loan or scholarship fund for the coming year.

2. A fund arailable for the maintenance of a publie health nurse during a period of demonstration in rural or mountain districts which are unfamiliar with the value of such a service. The communities most in need of public health work are often absolutely ignorant of the advantages to be gained, and, while perhaps entirely able to support a nurse, can be convinced of their needs only by an actual demonstration of at least a few months. Time and again we have found in the development of our Town and Country Nursing Service that communities were entirely able and willing to support a public health nurse after such actual proof.

In contrast to communities of this character, remote and scattered settlements may never be able to provide the entire salary of a public health nurse. For such communities the Red Cross might be justified in supplementing the salary which such a community might be able to pay by an amount sufficient to secure the scrvices of a craduate nurse.

I have no donlut that the Red Cross Chapters can be interested in assuming the responsibility for the salary of nurses during this period of demonstration. and I believe that every effort should be made to secure the funds locally, if possible, but there should also. I believe, be a fund at Headquarters which could be used in an emergency until other arrangements could be made.

3. A fund for the establishment of a teaching renter where nurses ran receive definite instruction and experience in the management of a rural rommunity. For several years I have hoped for the establishment of such a center in a typical rural community-preferably a county with a small eity or village as headquarters. Such an organization conld no roubt be established in coopperation with the commmnity, but it would sarcely seem fair to ask a connty to meet the entire expense, as this project would he rondured as a trring-ont place and instruction center for nurses who would be cmployed in other (ommunities.

4. A fund for the extemsion of hed Cross courses of instruetion to inchude all the women of the eountrye esperially those who are livines in remote and roral districts. Our plan 
of instruetion in Home Iygiene and Care of the Sick and in Home I)ietetics has so far been available only for women living in large cities or where graduate nurses and dietitians are easily available to give the instruction. It has not been possible to extend the work to isolated commmnities where the need is far grater than in the rities and larger towns. These courses of instruction-especially in rural communitiesmight often give us the opportunity to convince the community of the neessity of establishing a public health nursing servire, and woud be our easiest and most natural point of approach. These courses would secure for the murse serving such a community the intelligent coöperation of the women and would greatly facilitate and increase the usefulness of her work. I believe that some plan should be worked out to provide instruction for all classes of women, recardless of their ability to pay for such instruction. Funds for this purpose should, I believe, be secured through the Chapters, but may I recommend that a letter be sent to the Chapters, authorizing them to use Chapter funds for the extension of our educational program. I sulmit in connection with this a recommendation adopted at a recent meeting of the Division Directors of Nursing. ${ }^{23}$

On December 31, 1918, the War Council authorized an appropriation of $\$ 30,000$ as a Scholarship and Loan Fund for nurses needing instruction in public health nursing. Later it was decided to allot $\$ 25,000$ for scholarships and $\$ 5,000$ for loans. ${ }^{24}$

This fund was appropriated for the exclusive use of nurses preparing to do public health nursing nuder the Red Cross, since its purpose was to make possible the plan for the expansion of such work.

In February, 1919, a group of representatives of the National Organization for Public Ilealth Nursing, headed by Miss Wald, conferred with I)r. Farrand, the chairman of the Central Committee, for the purpose of asking the Ameriean Red cross to make an additional appropriation for scholarships which would not he restricted to nurses promising to enter Red ('ross service, but would le arailable also to nurses preparing for pullide hoalth nursing morter other anspices. This projecet was stated in a letter to Dr. Farrand from 1 liss Wald, February 14, 1919. as follows:

Letter from Miss Delano to Mr. Sentt, Deember 14. 1918.

"Jetter from yiss Xuges to Mr. Seott. Jamuary \&. l!l!?. 
Just prior to the entrance of the United States into the war there were estimated to be about six thousand public health nurses, and the demand was already greatly in exces: of the supply. While the war increased this demand and created an enormously increased need for such nurses, the supply became even less, and with the coming of peace this momentum, already great, has become overwhelming.

Municipal, county and state departments of health, public schools, child saving agencies, industrial establishments, visiting nurse associations and other public and private agencies are unable to develop their public health plans because of inability to secure a sufficient nursing personnel, and are making demands for nurses, which cannot be filled except in very small measure.

The introduction of two federal bills, one by the Children's Bureau of the Department of Labor and the other by the United States Public Health Service, both projecting plans which will demand many hundreds of public health nurses, also emphasize the need.

The Bureau of Public Health Nursing of the Red Cross proposes to develop rural and small town public health nursing and will need several hundred nurses for this purpose. The appropriation of $\$ 30,000$ made by the Red Cross for the preparation of public health nurses for the service of this bureau will provide from seventy-five to one hundred nurses. The Chapters, through Chapter scholarsinips, it is expected, will provide possibly one or two hundred more. The rest of the nurses needed by the bureau must be secured through other means. While the work the Bureau of Public Health Nursing expects to do will meet a great need, it can care for only a small part of the whole field. Therefore, there is a great need for an added appropriation of $\$ 150,000$ to prepare several hundred nurses for public health work outside of the Red Cross.

With a fund of $\$ 150,000, \$ 300$ scholarships could be giveri to five hundred nurses for a four months course in publie health nursing. However, as there is a special and immediate need for executives and teachers, it is the feeling of those primarily interested in public health nursing education that a more desirable distribution would be to offer scholarships of $\$ 600$ for an eight months' course to $1: 5$ nurses especially adapted by preparation. experience and temperament for the larger executive and elurational positions. The remaining fund of $\$ 75,000$ would then be available as $\$ 300$ scholarships for :50) nurses for a four months course.

There are at present thirteen centers scattered throughout 
the country already organized and conducting such courses, which coulil admit and most satisfactorily train these nurses for publie health work.

Such a group of 375 women esperially equipped for rural, town and eity work requiring executive and teaching ability, combined with sorial knowledge and vision, while not completely mecting the constantly increasing need, would serve as a tremendons impetus to public health nursing throughout the whole country.

The lied ('ross nurse appeals strongly to the heart of the American public, and the public would unquestionably approve the expenditure of Red Cross money in any plan to bring help to hed ('ross nurses in the difficult period of readjustment. esperially when such help might be given hor as a recognition of her fine service and as an expression of the conviction of the American Red Cross that the country still needs her in a raluable public service here.

Public health nursing caunot continue to meet the greatly stimmlated denand without a scholarship fund sufficiently large to show appreviable results. It is more fitting and less confusing to have such a fund come from one source, not several sources.

Such a Red Cross scholarship fund might well be administered by the special committee of the Red Cross, now in existence, which has in its membership representatives of the three national mursing associations, and which is now acting in an ahrisory caparity to the Red Cross Bureau of Information for returning nurses.

$$
\text { (signed) Taluiax D. Wald, }
$$

Honorary President of the National Organization for Public Ilealth Nursing for the Officers and Nembers of the Adrisory Council.

On Fobruary 27, 1!19, the Mar Council acting upon this petition, anthorized the appropriation of seventy-five thousand dollars $(\$ 5,000)$ as an additional Socholarship Fund for murses needing instruetion in pulblic health nursing but not necessirily promising to serve in the lied Cross Public Health Nursing Serviee.

This mate a total of $\$ 100,000$ for scholarships and $\$ .5000$ for loans authorizod on loeember :31, 1918, and Fobruary 27, 1919. The general terms moder which this fond was to be administred were stated in a letter to Miss Wall from the germeral manager as follows: 


\section{HISTORY OF AMERICAN RED CROSS NURSING}

1. These scholarships are open to Red Cross nurses or those eligible for enrollment on the recommendation of the Division Directors of Public Health Nursing and the Joint Committee representing the three national organizations of nursing through their representation at the Red Cross Bureau of Information. These recommendations are subject to the approval of the director of Public Health Nursing Bureau and the director of the Department of Nursing at National Headquarters.

2. While the appropriation is mainly intended for those who are being released from military service, other nurses who meet the general requirements are also eligible.

3. While the War Council stipulated the purpose for which this fund should be used, they did not wish to establish hard and fast regulations, but preferred to leave the matter of spending it subject to alterations within the diseretion of the general manager and the director of the Department of Nursing.

4. In addition to the scholarship fund of $\$ 110,000$ ( $\$ 25,000$ of which was appropriated for preparation of nurses for service under the Bureau of Public Health Nursing of the Red Cross) there is a loan fund available of $\$ 5,000$. The maximum loan shall be $\$ 350$. Rerommendations for loans from this fund are received through the same channels as indicated above for scholarships. It is definitely understood that loans should be awarded by the Department of Nursing for the purpose of elucating nurses for Publie Health Nursing under the Red Cross Bureau of P'ublic Health Nursing. ${ }^{25}$

The specific conditions governing the distribution of scholarships and loans were set forth in a memorandum of instructions, July 15, 1919, as follows:

There are now two scholarship funds arailable for Red Cross nurses who contemplate preparing themselves for public health nursing ly taking post-yraduate courses. Scholarships from the first of these funls are known as "restricted scholarships," meaning that they are restricted to nurses who are pledered to serve in the Red Cross Public Health Nursing Service for one year.

There are three types of scholarships awarded from this fund. These sholarships are awarded for post-graduate courses of eight months', four monthe' and six weeks' duration. The maximmm scholarship for the eight months' course

zetter from Mr. Monroe to Miss Wald, Fobruary 26, 1919. Sere Divisions of File Records, National lleadquarters American Red Cross. 
is $\$(100)$; for the four months' rourse $\$ 300$; and for the six weeks' course \$i5. The scholarship carrying the maximum of $\$ 75$ is designed only for nurses who have hat a considerable amount of public health nursing experience under supervision and who feel the need of additional theoretical preparation before undertaking independent work. This seholarship is to enable them to take the six weeks' summer course in theory. 'There are two or three such courses which are approved by the l)epartment of Nursing. Nurses who have had vory little experience or experience of doubtful value should take one of the longer courses.

Scholarships may be awarded to nurses who have had no experience in pullic health nursing, who have had a limited or considerable anount of public health nursing experience withont supervision or who have had eonsiderable experience under supervision and give promise of further development. It is not thought wise to grant scholarships to nurses who have hat considerable experience in public health nursing under supervision, but who have shown no evidence of ability to work withont supervision. Candidates should meet the training school requirements necessary for enrollment in the Red Cross. Preference should be given to high school graduates or those who can show a substantial equivalent. Registration should be required in accordance with the ruling of the Red Cross.

In states where registration is provided for by law the nurse applying for curollment in the Red Cross must be registered:

Preference should be given to nurses who are enrolled or who are eligible for enrollment and will become enrolled, although exceptions may be made where deemed necessary. $I_{n}$ general, scholarships will he awarded to nurses between the ages of twenty-three and forty years. Exceptions may be made where candidates possess unusual ability. The candidate shall present a doctor's certificate of her physical condition.

Murh more than good education and good physique is required to make a good publir health nurse. The candidate must possess grood jumlgment, self-reliance, the ability to work in harmony with all kinds of peenple, good nature and common sense. In order to be rertain of this a request for information should be sent to the superintendent of her training sobool, two or more recent amployers, and posibly a sebool teateher who lad known her for some sears. Where the candidate has been engagenl in private duty this request should be sent to at 


\section{HISTORY OF AMERICAN RED CROSS NURSING}

least two people who have known her intimately, in addition to the superintendent of her training school. If the candidate has been engaged in war service, National Headquarters will secure her efficiency record.

In February, 1919, the director of the Department of Nursing received the following letter from Dr. Taliaferro Clark, of the United States Public Health Service, chicf of the Bureau of Sanitary Service of the Red Cross:

I am in receipt of communication from the Surgeon General of the U. S. Public Health Service under date of January 25, 1919 , in which he states that the service desires to inaugurate a system of social service and follow-up work as a part of its program for the prevention and control of renereal diseases so that infected persons may be kept under observation with strict supervision of their homes and places of employment until they have been cured.

The services of qualified public health nurses who have had additional training in social service work are required to do this important public health work effectively. After a canvass of the field the Surgeon General advises that no registered public health nurses having special qualifications for follow-up work in connection with renereal disease control work are arailable at the present time, although the Public Health Serrice is prepared to give immediate employment to ten nurses qualified for this particular form of public health work and to continue the employment of such nurses in increasing number for an indefinite period of time provided the appropriations asked of Congress for this purpose are granted. Furthermore, it is the plan of the Service to transfer this special form of activity to State and Local Borards of Health as rapidly as this can be arranged, thereby creating an increased demand for nurses with the sperial qualifications mentioned.

The surgeon Ceneral states that so far as it is known to him no funds are arailable for this purpose from any source and recommends that, if such request be consistent with the Rerl Cross program for publie nursing and not at variance with the lied C'ross program for post-war work, the sum of $\$ 6.000$ be appropliated to be expender in the trainine of not less than ten public health nurses for a period of four months each at the . Johns Hopkins Hospital. Baltimore. Marrlant.

In riew of the wide prevalence of renereal infertions in the general population an the motential langer of these infertions: to national efficiencer. the desirability of arlopting all fruitful 
measures for their control and the lack of public health nurses with the special training desired by the Public Health Service available for duty in connection with its program for the control of these diseases, I wish to recommend that the War Council be requested to appropriate the sum of $\$ 6,000$ to be expended by the director of the Bureau of P'ublie IIealth Nursing for the training of not less than ten public health nurses in accordance with the plan proposed by the United States Public Health Service.

In response to this letter the Department of Nursing made reeommendations to Mr. Munroe which were approved by him, and certain funds were appropriated for the coopperation songht by the United States Public Health Service.

With the exhanstion of the first large scholarship and loan fund the need for another such fund stood out sharply as stated in a memorandum sent by the director of the Department of Nursing to the Central Committee in December, 1919, as follows:

After careful consideration and conference with the Division directors of the Departments of Nursing and the direetor of Public Health Nursing at National Headquarters, it seemed highly desirable to present a request for an additional appropriation for scholarships and loan funds to the Executive Committee.

At the meeting of the National Committee on Red Cross Nursing Service on December 9, 1919, the matter was presented for their consideration and it was a manimons rote that the request be prepared. The recommendations for this appropriation are based upon the following arguments:

1. The Division directors of Public Health Nursing have estimated that they can readily use sixteen hundred public. health nurses and will aeutely need at least one thousaml public health murses during the coming six months. From present resources there is very little possibility of meeting eren a small part of this personnel.

?. It will be necessary, therefore, to look to the graduates of courses in public health nursing to fill this need. The rourses can admit during the next six months somewhere between 4.50 and 500 students. There are undoubtedly as many more nurses who are ready for post-graduate courses. but the larere majority will be unable to do so unless they are given liberal financial assistance. The high ast of liviner contimuse to make it practically impossible f $\mathrm{r}$ them to forego 


\section{HISTORY OF AMERICAN RED CROSS NURSING}

a salary and in addition meet the cost of a course from their own resources.

3. Chapter scholarships will undoubtedly be available in considerable number, but they can by no means be relied upon to meet the whole need and they are limited to a comparatively small group of nurses who are in a position to return to the Chapter which grants the scholarsinip. There will be many occasions when the Division directors would like to grant scholarships to nurses but will not find the Chapter scholarships suitable. There are also Divisions where Chapter scholarships will be scarce.

4. The original scholarship fund of $\$ 100,000$ is exhausted. The results achieved from it would seem to justify us in seeking another such fund. It helped materially in meeting the need; by this means, 247 nurses liave already been prepared for this branch of work; it greatly increased the popular appreciation of the need of adequate preparation for publie health nursing; and it undoubtedly stmmlated the opening of several new courses.

Following the granting of this appropriation new instructions were issued governing its disbursements indicating certain changes in policy from that governing the distribution of the first fund :

A second national fund of $\$ 100,000$ is now available for Red Cross nurses who contemplate preparing themselves for public bealth nursing by taking a post-graduate course. This fund is divided into two smms, $\$(60,000$ being for scholarships and $\$ 40,(000$ for loans. No part of this fund is "restricted" and no recipients will be required to serve in the lied Cross Public Health Nursing Servire although all recipients must promise to engage in public health nursing for one year.

In addition a special loan fund of $\$ 10.0(10)$ has been approsriated to be distributed among the Divisions for the purpose of defraying traveling and other incidental expenses incured by nurses taking the post-graduate comrses in public bealth nursing. Where such Ioans are ronsidered necessary in addition to a Sational or Chapter scholarship or lom. they may be made from this fund by the Invision bepartment of Nursing direct to the nurse.

It is desired that only those andidates shall be recommended for scholarships who are well edlucated, academically and profeswionally, and whoce records show more than ordinary ability and personality. 
Furthermore, it has been deemed unwise to set any stated amount either for the scholarships or tle loans. In making announcement of this second fund no amounts will be specified and no maximum and minimum stated. Funds are arailable for partial scholarships supplemented by loans to be added to the nurses' own resources, the amounts to be determined individually for each candidate. It is desired that in the future the majority of candidates shall receive smaller scholarships than in the past and that deficiencies shall be met by loans. Scholarships covering the entire cost of the course, no part being in the form of a loan, shall be granted hereafier only under exceptional circumstances.

Scholarships and loans from the national fund may be awarded for one or both semesters of a post-graduate course of eight months; for a post-graduate course of four months or for one of six weeks. The scholarship or loan for the six weeks' summer course should be granted only to nurses who have had a considerable amount of public health experience under supervision and who feel the need of additional theoretical preparation before undertaking independent work. Nurses who have had experience of less than six months, or without supervision, or of doubtful value, should take one of the longer courses.

It should be explained to applicants that scholarships and loans are not awarded to nurses who are able to meet the expenses of a course themselves. Candidates should apply for the minimum amount which will enable them to meet the cost of the course. Nurses who can take the conrse with the assistance of a loan shat] be grantel a loan rather than a scholarship and where possible partial scholarships, supplemented by loans, should be eneouraged. ${ }^{26}$

With the decentralization of the Burean of Public Health Nursing earlier methods of administration beeame obsolete and a different sustem was set up. New instructions were issued to the Chapters, whose great increase in numbers has been mentioned. Seetions relating to finance are quoted below:

15. Where no Public. II alth Nursing Service exists or none is immodiately projected it is rery desirable that a

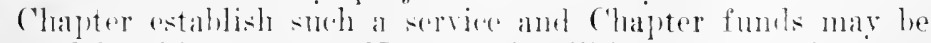
used for this purposn. IIewewer. it will he proferahle in many cases not to wa ('hapter funds wholy. but to enlist the suppert of the community hy seaking the money needed from

${ }^{20}$ Instructions for Divisions, March 15, 1920, from general manager. 


\section{HISTORY OF AMERICAN RED CROSS NURSING}

sources such as munieipal or county funds, private contributions, or special campaigns.

18. Where a nursing service is being condueted by a municipality or county at publie expense, but is affiliated with the Red Cross Bureau of Public Health Nursing, the Chapter should be permitted to contribute money from Chapter funds to cover certain necessary expenditures not provided by law to be paid from public funds. The Chapter, howerer, should not take over the entire financial responsibility for a nursing service which is now being conducted by the city or county and supported by public funds.

20. The desirability of establishing a Chapter public health nursing service having been deeided upon, the Chapter shoukd adopt in advance some plan for financing it. The financing of the public health nursing service shall be done by the Chapter Committee on Nursing Activities, subject to and with the advice of the Chapter Exeeutive Committee.

21. It will be well to have arailable at the time of starting the service an amount sufficient to finance it for a period of at least three months.

22. 'The various items of expense which may be expected are:

The salary of the publie health nurse or nurses.

The salary of a possible substitute for either the period of a nurse s racation or illness.

The rent of an office for the nursing service, where necessary.

The purchase or rental of a conveyance.

Street car or train fare.

The cost of a telephone in the nurse's home.

The rost of loan rloset supplies. ${ }^{2 i}$

The cost of the nurse's bag with equipment.

With the prommlgation of the above reorganization plans the final policy of the Red Cross was thus stated:

The Ped cross would prefer to have communities organize and finance their own public health nursing service, when possible, under the supervision of the state authorities.

Where the community is unable or not rearly to bear the entire burden of funancing a public health nursing service, the ${ }^{n}$ In effect March 1, 1919. 
Red Cross will undertake to organize the service, and finance it, with the aid of the community, or from its own funds, until such time as the state or Municipality will take over the direction and supervision of the service.

It was well known that when the Red Cross launehed its Rural Nursing Service large seetions of the eountry had no visiting nurses.

In 1909, in seventeen states of the Union, only seven visiting nurses were reported, or one to every 230,000 square miles. Throughout Great Britain and Irelaud in 1909 there was one Quecu's Nurse to every seventy-two square miles. On the basis of population there was (1909) an average of one murse to 614,634 persons in the seventeen states under eonsideration, while in Great Britain and Ireland there was one nurse to every 27,246 persons.

The sixteen Red Cross nurses appointed in 1913 were a veritable grain of mustard seed. Nearly twelve months later the variety of groups emploving Red Cross visiting nurses included :

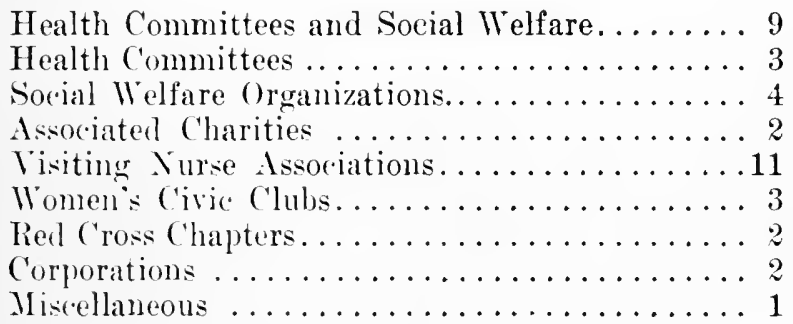

One year more, and the demand far outran the supply. In that year 21 new affiliations were accomplished, but 8 old ones were diseontinued for lack of funds. By 1917, 85 atfiliated assuciations were employing 97 murses in small towns and rural commmuties. In that vear it was estimated that all the nurses sile one were at work in communities nmmbering trom 500 to 10,000 people. the early limit of 5000 inhabitants per tow having eradually risen to 25,oot). Xineteen tields of work had populations ruming from 1000 to .8000 : thirtern other fielels vilried between 5000 to 10.000 . The visiting aroas ranged from two square miles in the smallest tield of $\delta$ on persens to from two to cight seguare miles in these having 
1000 to 5000 persons, and from one to seven square miles in those having populations between 5000 to 10,000 . By February 1, 1917, there were sixty-one communities where Red Cross visiting nurses were stationed. Twenty-two states entered into this list, New Jersey and Michigan each having eight, Massachusetts seven, Kentucky and Pennsylvania each five, California, Arizona, North Dakota, Missouri, Ohio and Iowa each one. During the previous year (1916) the cases having received nursing care numbered 10,286 ; the total number of visits made were 112,836. These visits fell, approximately, into elasses as follows:

Public school visits, eight per cent; infant welfare, seven per cent; prenatal care, two per cent; tuberculosis cases, three per cent; visits of sanitary inspection, four per cent; nursing care, forty-seven per cent; while business and unclassified calls completed the list.

In other words, bedside nursing eame first with 47 per cent of visits made. Instructive visits came next, with 17 per cent, business calls, with 13 per cent; social service calls, with 11 per cent, and unclassified, 10 to 12 per cent. Inquiries from communities eager to learn of visiting nursing or to establish it now increased by nearly 100 per cent, while applications from nurses also increased. The status of public health nursing generally after the Armistice is described in the next chapter, and the statistical chart there shown gives a complete picture of the statistical side of ou material. 


\title{
CILAPTER XV
}

\author{
RED CROSS PLBLIC IIEALTII XIRSING AFTER TIIE WAR
}

A

MONTH after the Armistice the general manager (Frederick IInnroe) wrote to the Division managers the following: "With the declaration of poace the further development of our public health mursing and of our courses in Home Hygiene and Care of the Sick and Home Dietetics, which have been temporarily interrupted by the more insistent needs of the war, will now be annong the foremost activities of the Red Cross." "It is planned," he wrote, "that each chapter will have a Committee on Nursing Activities through which all matters relating to this work may function," and stated that one of the activities to be assumed by this committee would be "to develop and aid the organization of public health mursing orer the entire territory of the Chapter." Thus the first official step was taken toward the initiation of the expanded public health nursing program of the Red Cross after the war.

The reasons given by the Burean of Public IIealth Nursing in recommending this expansion were set forth as follows:

Public health nursing, like many social derelopments of recent years, had its origin in the large city. spreading slowly from one city to another and from city to town. but not expanding to any extent at first to small towns, villages and the open country. Only in the years immediately precelling the war had there begun to be an active appreciation of the need of extending the advantages of public health nursing berond the larger centers. The attention of many students and leaders of American aftairs shifted its forms to the stuly of the development of country life. They were quick to discover that among other elements of neglect one of the most serious was the lack of provision for the preservation of health and care of the sick. It the same time national and state agencies, both public and private. wencerned with health proh-

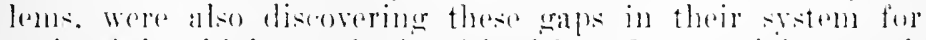

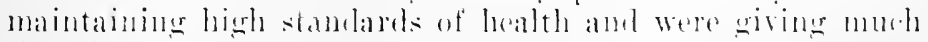
thonght to walys and means of tilling them. Sitate tuberect- 


\section{9+ HIS'TORY OF AMERICAN RED CROSS NURSING}

losis associations in many states, and state departments of health in a few, began to extend public health nursing to the people in the smaller towns and the country, and were making fair headway. And then the war came and a large part of the trained personnel necessary for the execution of these plans was drawn into war work, thereby seriously crippling their fulfilment for the time being. At the same time the need for extending healtl machinery and increasing the number of health workers all over the country was greatly accentuated by war conditions, and so soon as possible emergency plans to fill these needs were set going.

For five years before the war the Red Cross also was engaged in promoting rural nursing through its Town and Country Nursing Service. Having for the most part a quite uncultivated field in which to labor, this service progressed but slowly. Though the number of services under its direction never exceeded one linndred at any one time and the work consequently never reached impressive proportions, its influence was much in excess of its size and it played a valuable part in the early days of rural nursing. During the war a number of new activities came under its direction. Since the old title, the Town and Comntry Nursing Service, did not fit these new phases of work, it was changed to the more appropriate one of the Bureau of Public Health Nursing.

Ont of the experience of the war and of the country during the war grew certain great primary leswons of more universal and convineing value than could perhass have been taught by all the educational work of all the health agencies together before the war. It is unnecessary here to recite these lessons, since they are known to all. As the result of them at the close of the war there existed throughout the country a lively awareness of the present inadequate distribution of pulslic: health nursing, an aroute ronscionsness of the miversal need for it and a widespread remand for public health nurses.

A year after the armistice, we found in taking stork of the situation that there were two states. ()hio and Wisconsin, in which there was a mandatory law compelling every romuty to have a public health morse (in Wisconsin the law provides the alternative of a public: health instructor); that in sixtren states there were permissive laws enabling the connties to use county funds for pullic health muring, if they rhoose so to do; that in fiftren states there were state supervising murses employed by the state department of health as directors of burathe divisions or sub-divisions of public health nursing, whose functions were to promote puislie health nursing in the counties and to get county officials, (onnty funds and county 


\section{PUBLIC HEAL'TH NURSING AFTER THE WAR 1295}

interest back of a public program for public health nursing. Arcording to Miss Yssabella IVaters' figures there were four states, Massachusetts, Connecticut, Rhode lsland and New York, in which there was one publie health nurse to every four or five thonsand people. I)r. C. E. A. Winslow says the ideal is one to exery two thousand. From the high standard of these states the ratio decreased rapidly, the lowest being one public health nurse to one hundred and eighty thousand people in Mississippi. Wyoming had only two public health nurses; Nevala, three: Ttah, outside of Salt Lake ('ity, none. So rapidly in the last few months, however, has rural nursing progressed that no doubt these figures are airealy out of date.

At the same time the country was corered with "realymade" groups of workers in Red Cross chapters. These workers were disciplined by continnous and exacting war duties; they had learned to get together for a common purpose; they had shared in the respomsibilities of the nurse and had felt the exhilaration of serving others in a big eanse. 'Their war duties were drawing to a rlose, but for many of them the spirit of service remained and conkl be put to use in community activities.

With this machinery and this spirit ready at hand and a great need existing throughout the rural parts of our country for public health nursing. the Red Cross was in a position to make a great contribution to the welfare of the people of the nation by setting the chapters to work to promote this aetivity in territories which otherwise might not be able to introduce it for some time to come. In so loing the Red Cross would simply be extending its traditional duties of saving life, mitigating suffering, preventing unnecessary disease and fortifying physical stamina. ${ }^{1}$

The Red C'ross was convineed that the Chapters in rural and semi-rural communities would find an execellent opportunity to perform a service of great value through the establishment of public health nursing since there were many counties, towns and rillages having no such serviee, where the need was great and where the installation of such a servien by the chapter would be warmly woleomed. It was planned, therefore, to encomrage Chapter's in such localities to develop a public health mursing service.

The seope of the Town and Comutry Serviee had been linited to towns having a population lese than 25,000 and to rusal

${ }^{1}$ Fehruary 1920. issue of the Pullie Health rurse: "The development of the Red cross Public Health Nursing service." 


\section{HISTORY OF AMERICAN RED CROSS NURSING}

communities. In the spring of 1918 the National Committee on Red Cross Nursing Service removed this limitation and set no restriction in its place on the basis of population. It was henceforth permissible to establish a uursing service in communities of any size when so desired. The Red Cross did not propose, however, to enter communities where the work was well established and the people well informed in public health nursing prineiples and procedures. Such communities were already meeting the situation in this field and were not in need of assistance and supervision. The concern of the Red Cross was for those communities in which public health nursing was just being established, where the people had yet to learn how to develop and manage this new undertaking, where advice and trained supervision were needed, or where the backing sceured by being a part of the Red Cross service was a source of moral support and strength.

It was recognized that public health nursing was a public function which depended for its suceess on its understanding and willing aceeptance by the people of the community. For this reason, it was agreed that it would be much more sound and permanent in eharaeter and wider in seope if it were built slowly and if the general public had a share in the local responsibility for and management of this fundamentally public enterprise. As public health nursing was considered to be a community service, it was to be developed in harmony and coöperation with other community activities. Furthermore, as any loeal accomplishment formed an organie part of the work of the state, it was agreed that the Chapter should plan its service in line with the state program for publie health nursing and should always be responsive to suggestions from the state. The Red Cross was to be considered an educational ageney, not neecsarily the permanent direeting ageney, and assumption of financial responsibility by the municipal or state authorities was to be woleomed.

Moreover, as reported later: "In working out the plans for the conduct of this work, eonsideration was immediately given to the fact that the Red Cross was not alone in the field: that many other ageneies, national, state and local, public and private, were engaged in promoting some one or more branches of public health nursing: and that much good work was already under way. These andueies wrere attareking the need from various angles, none of them with complete programs or with any 


\section{PUBLIC HEALTH NURSING AF'TER THE WAR 1297}

immediate expectation of mecting the whole need. There seemed to be no probability that all of them working together would be able to meet more than part of the great need of rural communities for some time to come. The Red Cross merely proposed to supplement the work of these agencies by bringing assistance to rural people until governmental agencies could more nearly take care of them." 2

When this general plan had been aecepted by the Central Committee of the Red Cross, instructions were issued which set forth the following poliey:

Chapter nursing activities shall always be conducted with the thought that in so far as they affect the public kealth they constitute one phase of a very broad public problem. With this thought in mind the chapter mursing actirities shall be carried on in a manner that will assure coöperation with medical or social welfare work existing or to be introduced in the community. It is equally important that the spirit in which the work is conducted shall be one that will enlist the interest and aid of the entire commmnity. With that end in view the activities shall be developed as a public service and not as a charity and the personnel conclucting such activities shall make an especial effort to popularize them. It is not proposed to initiate public health nursing activities in commmities where agencies exist for this purpose, unless to cooperate with or aid the established agencies. The American Red ('ross secks only to develop the public interest in public health nursing activities. It does not seek to retain permanent. supervision of these artivities and will welcome state or municipal assumption of supervision and control of all pulblic. health nursing services. The lied Cross proposes to initiate public health nursing services only in localities where there are no existing agencies for that purpose and where none is immediately projected hy any other state or national organization. The Red ('rose also desires to cooperate with other organizations already in the field and to render the fullest measure of such coüperative service. It loes not seek to supplant or compete with any existing service or organization, or to initiate any program which will conflict with the plans: of other oreanizations. The lied c'rose rather secks to aid other anemedes with the ultimate purpose of securing the wisest possible development of the publie health nulsing stroice thromeh the properly anstituted state and howl oreaniza-

".The Red Cross Public Health Nursing Service. A llistory and Fore. cast." liti cross Bulletin, . Jutury $26,1920$. 


\section{HIS'TORY OF AMERICAN RED CROSS NURSING}

tions. Because of its extensive Chapter organization, the Red Cross feels that it is able to promote the establishment of these activities in territories which otherwise might not be able to introduce such a service for some time to come. By this development the Red Cross may make a distinct eontribution to the progress of publie health nursing throughout the country. ${ }^{3}$

Participation in and the organization of public health nursing by the American Red Cross was described as follows:

The American Red Cross is anxions to promote this work in small towns and in the comntry, but would prefer to have commmities /public authority) organize and finance them own public health narsing service, where possible, under the supervision of the State authorities. Where the community | public anthority | is mable, or not ready to bear the entire burden of financing a public health morsing service, the lied Cross may undertake to organize the service and finance it, with the aid of the commmity or from its own funds, until such time as the state or mimicipaity will take over the direction and support of the service.

The ways in which the Red ('ross may proceed in developing public health mursing may roughly be classified under four headings:

(a) It has authorized its Chapters to develop public health nursing services and to use chapter funds for this purpose. The work may therefore be started by the Red ('ross Chapter.

(b) There one or more other local agencies, public or private, are desirous of combining in a joint nursing service and are ready to share in its cost, the Chapter may participate and contribute its share of the funcls if it is proportionately represented on the committee in charee of the service and if its standards of personnel and work are maintained.

(c) Occasionally an organization which is conducting a local public health nursing service desires the assistance of the lied ('ross in securing a nurse and its advice and help in regard to and supervision of the mursing service. It mav secure this continuous and systematic assistance by affiliating with the Red ('ross P'ublic Health Nursingr service. In so doing it must agree to maintain

3"The Organization and Administration of a Public Health Nursing Service. lnstruction for Chapters," March 1, 1919. 
certain standards of sorrice set forth in the ... statement alled the "Alliliation Agrement" and must sirn this statement as an evidence of its intention to olserve these romelitions.

(d) Where there is an existing organization condurting a public hailth nursing service which might greatly extend the devetopment of its work through the finame ial assistance of a ('bajoter, the ('hapter may contribute a sum sufficient to aid in this development. No domations from ('hapter funck in exors of ome-tenth of the yearly expense of conducting the public health mursing service maly bo made. however, exrept molder special riremstances and with sperial permission from the Division. ${ }^{4}$

The old Town and Comntry Nursing Service had consisted larecely, as set forth in the proeding section, of a sorios of affiliations with local oreanizations, quite independent of the lied ('ross ('hapter, such as women's elubs, Visiting Nurse Associations, Civice Lagues, town and school boards and similar groups. While the plan was now changed to extend the service hereafter thromel the chapters, the old mothod of reating affiliations with local organizations ontside of the chapter was not abandoned, althongh limited by the new poliey that such affiliations shonld not be made in states having a well developed sestem of State supervision of mursing molder the State department of health. It was felt that the State supervising nurse was prepared to give the neessary direction, assistance and supervision to independent public health mursing oreanizations and that eonseguently any attiliations which the lied cross might form with them would only result in necdless duplication.

As stated in the first paragraph of this chapter, all nursing activities condurted hy the (hapter including public health nursing were to be alministered hy a Committer on Nursing Letivitios. The mothod of appointing this onmitter and suernestions anorming its mombership were set forth in the instructions to (hapter's as follows:

The members of this committer shall be appointerl he and

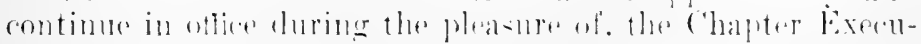

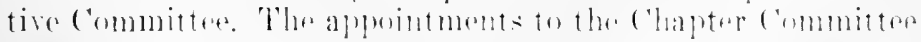

- Information for communities concerning the liod cross Public Health Nursing Service. 
on Nursing Activities shall be approved by the Division Director of Nursing before they are confirmed. The committee should consist of as many workers as, in the judgment of the Chapter, may be neccssary to carry on the work effectively and should include both men and women. It will usually be found desirable to limit the committee to fifteen members and there should not be less than five members.

The chairman of the committec shall be appointed by the chapter Executive Committee and should be a person having a positive interest in all the activities under the jurisdiction of the committee. A rice-chairman should also be appointed to carry on the work of the committee in the absence of the chairman.

The chapter Committee on Nursing Activities should include among its members one or more representatives of each of the following:

(a) The Board of Health.

(b) The Board of Education (or representative teacher).

(c) The Medical Association.

(d) The Chamber of Commerce or Board of Trade.

(e) The Clergy.

(f) Such other active local organizations as the Civic Club, Woman's Club, etc.

(g) The Chapter Home Service Section. It may be of advantage also to have a representative of the Committee on Nursing Activities on the Home Service Committee, and it is suggested that this be arranged for when practicable.

(h) The Local Committee of the Red Cross Nursing Service, where convenient; or, if not, then a representative Red Cross nurse qualified as a general representative of the Red Cross Nursing Service should be appointed with the approval of the Division Director of Xursing.

(i) Other local public health nursing agencies, if any.

(j) Chapter s.hool Committee.

(k) Inited States Department of Agriculture (usually a Itome Demonstration agent). ${ }^{5}$

Certain regulations were male concerning the nurse's servire to the Chapter. The first three months were to be eonsidered probationary and a month's vacation with pay allowed anmally. It was reommended that after six months' service one half the traveling expenses incurred by a nurse in reporting

s“"The Develepment and Administration of Chapter Nursing Activities; Instruction for Chapters," March 1, 1919. 


\section{PUBLIC HEdITH NURSING AFTER THE WAR 1301}

for duty be refunded. One half day a weck, exclusive of Sundays and holidays, was assigned for rest and recreation and sick leave with pay arranged for. If night duty were necessary in emergencies, the nurse was to have sutficicut rest the following day. Private practice by the nurse was absolutely forbidders.

In addition, definite instrutions were issued conecrning certain aspects of the work, such as the professional relationship of the nurse to the medical profession, the inadvisability of material relief given by the murse and the placing of the work on a business rather than on a charity basis, allowance being made, however, for those mable to pay the full cost of the nurse's risit and for the maintenance of a free serviee for Army and $\mathrm{Nay}$ men and their families and for disabled exservice men.

In regard to appointments the instruetions read:

The public health nurses must be appointed to the Chapter by the Bureau of Public Health Nursing at lied Cross Division healquarter's. ...

Nurses desiring to serve as Red C'ross public health nurses must meet all the requirements of the Ret C'ross Burean of Public Ilealth Nursiug and must be enrolled Red C'ross nurses or must make appliantion for enrolment. . .

Requirements for appointment in the Red Cross Public Health Nursing Service were detined as follows:

A graduate nurse who has had no experience or training in public health nursing cannot conduct a pulblic health nursing servie satisfactorily. The varied respensibilities demand a person who is an organizer, teacher and demonstrator as well as a nures and one who is familiar with puhlic health problems and precedures. Thase qualifications and this knowledge are only securest by experience under direction or by spectial training.

public health mursing is a highly developed form of nursing. preparation for wheh is net inchuled orlinarily in the

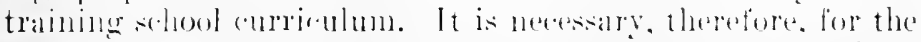
nurse who wishes to be sucesestul in this field to umelertake a

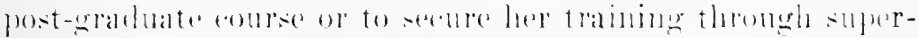

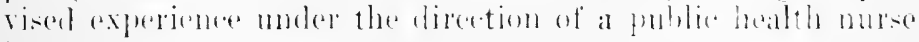
instrutetur.

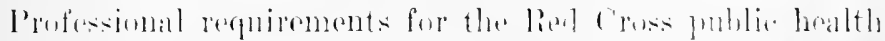

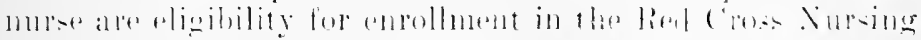




\section{HISTORY OF AMERICAN RED CROSS NURSING}

Service and a four or eight months' eourse in public health nursing, either post-graduate or taken during training, or its equivalent in supervised practical work.

In addition. such personal qualifieations as good health, education, publie spirit, ability to manage difficult situations and to carry responsibility, must be considered. In many services a nurse is granted two weeh's sick leave with salary, though a more generous arrangement may be made where the nurse has beeome of proved value and where the illness has been contracted through the performance of her duties.

Under ordinary cireumstances, nurses should not be called for night duty, but in ease of emergency, when this is done, the chapter shonld provide for the care of her patients during the day. The chapter should forbid any attempts made by the nurse to practice privately after hours. ${ }^{6}$

The instructions also included recommendations that an office, telephone, loan closet, filing cabinet, mursing equipment and suitable transportation be provided and that an aceurate and adequate record system be maintained. So salary conld be prescribed and only a general guide was attempted and issued. ${ }^{7}$

As was reported later:

The old Town and Country Nursing Service was managed entirely from Headquarters. as it had its begimning long before the Red Cross decentralized. But with this greatly enlarged program it was necessary immediately to set up a Burean of Public Health Nursing in each of the thirteen Red Crose Divisions and to secure public health nurse directors for these bureaus. ${ }^{8}$

The staff of the Bureau of Pnblic Health Nursing at National Headquarters included the director, Elizabeth G. Fox, and an assistant, ('harlotte E. VanL)uzer, a public health umre of wide experience as eity visiting nurse, rural comity school nurse and as medical social serviee worker at Bollevene llospital, New York City. As school nurse she oremized school mursing in Watertown, New York, and later in Líent Cominty, Michigan, under the Town and Comntry Nursing Service of the Red Cross, did an ontstanding piece of work which is still a model to be followed by rumal school murses.

-"The Development and Administration of Chapter Nursing Activities."

"Ilid.

".."The Red Cross public llealth Xirsine service. A llistory and Forecast," lied cross Bulletin, Janumry 2ti. 19:20. 


\section{PUBLIC HEALTH NURSING AFTER THE WAR 1303}

In Jamuary, 1920, Katharine W. Holmes, whose work in Europe has been described, was aulded. Siteps were immediately taken to appoint public health murses as directors to organize and operate the newly ereated Bureaus of Public Health Nursing in the I)ivisions.

In several of the Divisions, the already appointed director of the lepartment of Nursing was a public hoalth murse and was therefore appointed director of the Burcan of Public Health Nursing also. These were Elizabeth Ross, later sucreeded by Bernier Billings; Jane Van de Vrede; V. Lota Lorimer, suceeded by Grace Bentley and later by I. Malinde Ihavey: Nimie Alrens, and Eva Anderson. Grace Harrington and Ethel Pinder, the first appointed in May of 1920 and the second in July, 1920, to fill valcancies in the Northwestern and Southwestern Divisions respertively, were also appointed as directors of Nursing and Public Health Nursing. Three murses, Mary K. Nelson, Nellie F. Oxley, and Olive Chapman, who were appointed Directors of Public Health Nursing in the New England, Potomae and Mountain Divisions respectively, later beeame Direetors of Nursing as well. Most of these nurses have been spoken of earlier in the history.

Fonr murses, Anna 1 . Ewing, Madeline Oldfield, Mrs. Ethel S. Parsons and Mls. Grace Engblad, all of whom had served as chief nurses in the extra cantonment zones during the war, were appointed directors of Bureaus of Public II aalth Nursing in fomr of the l)ivisions. Having had several years' experience of public health mursing in the cast, west and sonth and a postgraduate conrse at Teachers College, Anna A. Ewing was appointed to the Atlantic Division and filled the position with painstaking zeal mutil the Atlantic Division was merged in the Waslingtom l)ivision in June, 192.2. Madeline Oldfield, who hat had ten vears' experienee in public health mursing larecely in or aromind New York ("ity, was appointed to the Potemare lovision and was later sureereded by Nellic F. Oxler. Mrs. Grate Engliad, an English weman, trained and with rears of experienes in this comntry, undertook the work in the Gulf division. where she served until her hoalth made a change

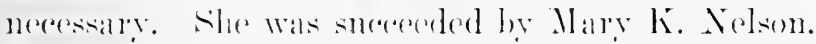

Mrs. Eithel s. Palroms. a eraduate of the publie health mors-

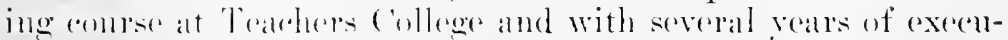

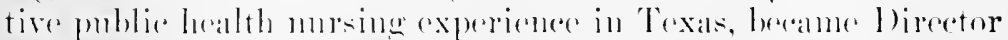
of Pullie Iloalth Nursing in the sonthwestern l)ivision. After 


\section{HISTORY OF AMERICAN RED CROSS NURSING}

a year of service she resigned to become Director of Public Health Nursing in the Texas State Board of Health and was succeeded by Anna L. Stanley.

One of the leading school nurses in the country, Miss Stanley could not long be satisfied in a general executive position and in July of 1920 gave up the Division directorship to become special supervisor of sehool nursing for the Red Cross, in which position she did much to work out a standard school nursing technique for Red Cross nurses. She was succeeded by Ethel Pinder.

'Two years' experience in industrial nursing gave Mrs. Florence Downing, who was appointed director in the Pennsylvania-Delaware Division, an added advantage in handling the public health nursing problems in Pennsylvania, a state of many industries.

Coming from the East originally but with ten years of public health nursing experience on the Pacific Coast, Emma Grittinger, as director of the Bureau of Public Health Nursing in the Northwestern Division, was no "ontsider." Leaving for the East in February, 1920, to take up public health nursing work at Teachers College, she was succeeded by Grace Harrington.

Also with an eastern training, but a western exxperience, Mary L. Cole was taken over from the superintendeney of the Visiting Nurse Association of Santa Barbara, Califormia, to become Director of Public Health Nursing in the Pacific Division and later director of the Nursing Service as well.

Each Division Burean was a part of the Division l)epartment of Nursing. It remained the function of the National Burean to determine gencral policies and plans, set uniform standards, outline uniform administrative procedures, make contact and work ont agreements with other national agencies and to guide and help the Division Bureaus. It beeame the function of the I)ivision Bureans as projections of the National Burean to interest the Chapters in and to help them to organize and administer public health nursing serviees, to secure for them trained public health nurses and to guide and assist them by visits of the l)ivision staff to the Chapters and of ('hapter officials and workers to the I)ivision oftice, by regional and state meetings, thromgh correspondence and a sistem of monthly reports and he other methods. The loivision Bureau was responsible for the maintenanee in the Chapters of stanclards of 


\section{PUBLIC HEALTH NURSING AF'TER THE WAR 1305}

nursing work and personnel set by the Ameriean Red Cross as previously deseribed.

'The operating unit was the Chapter, which was usually countrywide, or the afthliated organization. The plaming, direction and exerention of the work was left entirely to these local units with national standards for their guidanee and with the supervision described alvove, which always had as its primary consideration the peculiar needs and possibilities of the individual Chapter. The line of communication was from Chapter to Division and from loivision to National Hradpuarters. The latter did not negotiate direetly with the Chapters.

In March, 1!1!), soon after the work was decentralized, the general manager issued two sets of instructions to be distributed by the lovision managers to the Chapters. These were called "The l)evelopment and Administration of Chapter Nursing Aetivities" and "The Organization and Idministration of a lublic Health Nursing service" and were designated as "A-700" and "A-701." Many extracts from these Instructions have been given in the preceding pages. Two pamphlets called "Information for Communities Conceming the lied Cross Public Inealth Nursing Service" and "Information for Nurses Coneerning the Red C'ross Public. Ilealth Nursing Serviee" were issued by the bureau, as was also a popular pamphlot for propaganda purposes called "Have you a Community Nurse!"

The trpical methods used by the Divisions to introduce publie health nursing to the Chapters were described by one of the Division directors of Public Inalth Nursing as follows:

The progress of the work in the chapters may be indicated through the followine methols which have been pursued. The work had its first introduction through the medium of a cir(male letter from the I)ivision Manager to all ('hajuters. an-

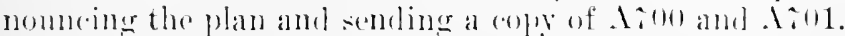

'The nest step was to make the eromeral fiehl representatives thommbly familiar with the plans and jurposes of the Bu-

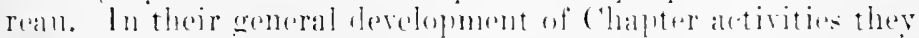

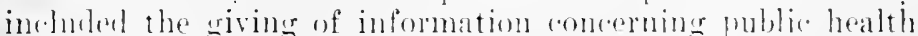

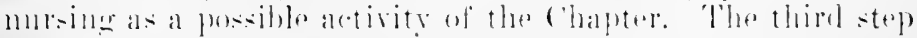

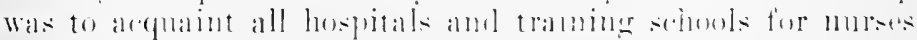

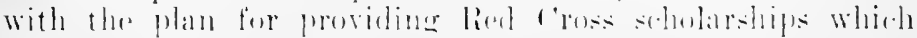

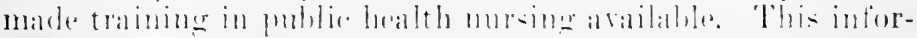

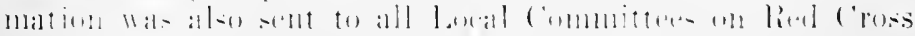




\section{HISTORY OF AMERICAN RED CROSS NURSING}

Nursing Service and to all Home Service secretaries. In addition, the Department of Publicity gave full information regarding the Red Cross plans for public health mursing to the publicity chairmen of the different Chapters and also to press officials. The Inivision publication, "lied Cross Briefs," also carried regular articles on the subject and in order to make this information available to nurses abont to be graduated, every hospital in the accredited class was asked to furnish a list of the senior nurses in their training schools and these nurses were put on the regular mailing list for "Briefs," thus giving them each week eurrent information regarding the progress of the work of the burean and other information which might be of value to these prospective nurses in planning their work after grarluation.

Efforts were made by the Division Dirertors to visit in person or to send a nurse assistant to visit as many of the Chapters as possible both to introdnce the work and to holp the Chapters which were interested to take the right steps toward its organization. Some of them commented as follows:

Only those Chapters were visited by us who requested us to do so, saying they were interested or could be interestal.

Every (hapter and most of the larger brandese in the Jivision bave been visited by the lovision birector of Nursing and the health progran presented.

The Division Inire tor made personal visits to ('hapters,

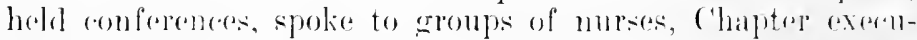

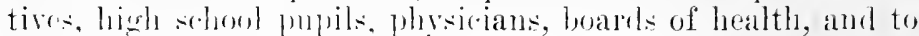
various other wroups of people.

While this was going on in the Dirisions, muel publicity was being eiven the public loralth nursing progran ly the Rerd Cross in newejapers, popular magazines, nursing jommals, thr Red Coross Marguzine and from the platform.

The response from the Chapters to the sugesestion that they might cngage in public health monsing was so inmodiate that the Division directors were soon roverwhelmod by its volume.

As an inmediate corollary, it was reported, they had to find public health zumses to fill the positime which immerliatrels brean to spring up, or to interest other morses in secouring the noessary preparation to fill these pusitions. 


\section{PUBLIC HEALTH NURSING AFTER THE WAR 1307}

The second proposition was much harder than the first. Hundreds of Chapters received with great interest and zest the information that moder certain eonditions they might engage in public health nursing and were eager to get under way at once. Theip demands speedily ontran the supply, and the I ivision directors hat to turn from stimulation to restraint.

They described the methods used to reach and interest nurses as follows:

Interviews and correspondence with nurses in Division offiece; addresses to nurses at state and local organization meetings and to pupils in training schools; circularization of nurses and superintendents of training sohools; distribution of the booklet "Information for Nurses" and Division bulletins to senior "lassess of training sehools; personal talks to nlurses who were to take state recistration examinations; influencing ('hapters to interest senior nurses in training selools by inviting them to sorial functions at which public health nursing was presented : alvertisements and write-ups in newspapers, magrazines and The Public Health Nurse and the American Journal of Nurwing. ${ }^{9}$

They ascribed their inability to keep up with the demand to a variety of eauses, the most common being: the lack of properly qualified public health murses; the lack of eonvenient post-gradnate schools and their orercrowded condition; the inability of many murses to take post-graduate training because of insufficient education or lack of funds; the difieulty in getting nurses to modertake rural work, and the searcity of aceredited training schools in several states.

In Jume, 1920, the national director of Public Health Nursing reported:

During the year nearly 800 nurses have been added to our fiold staff and : lammeh a public health nursing sorvice. a truly remarkable adrivement. The secoring of so larese an additional personnel in so short a time was due principally to three things:

1. The return of thousands of antrese from orerseas. many of them with a new interes in mblic health mursing. While humlerels of these ame into our service. loundreds also went

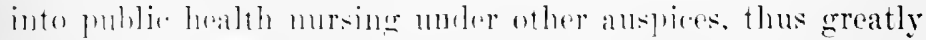
inceralsing the total number of workers in this field.

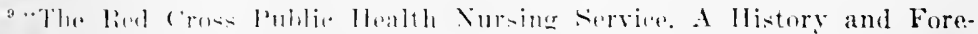

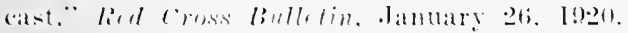




\section{HISTORY OF AMERICAN RED CROSS NURSING}

2. The active campaign carried on by the Divisions in all nursing centers, such as training schools and state and local nursing associations, and the broadcast adrertising given rural nursing. The Red Cross has made rural nursing popular among nurses. Formerly interest was largely directed toward city work, and only a few nurses had caught the vision of the great opportunities awaiting them outside the large centers. To-day rural nursing occupies the limelight, and nurses by the hundreds are flocking into it. They have had their imagination fired by the infinite possibilities for original, effective and very human service in the smaller towns and the country.

3. During the past year 278 scholarships and 69 loans have been awarded from the National Fund of the Red Cross to graduate murses to enable them to secure public health nursing training at one of the accredited schools or universities giving a public health nursing course. The Chapters also have shown great interest in assisting nurses to become fully prepared for their public health nursing work, and have giren approximately 2 (it scholarships for this purpose. The Metropolitan Chapter of Boston alone has furnished 60 scholarships to graduate nurses, leaving them free to take up their public health work in whatever part of the country they desire. [This was also true for other Chapters.]

Both the National lied Crow and the large city Chapters have been most generous too in aiding schools and universities giving a public liealth nursing course to nerfect either their theoretical or practical work. Peabody College has been helped to carry on its course through a large subsidy from the Red Cross and at the Lniversity of Lonisville. Kentucky the salary of a director for the course is contributed by the Red cross. .. . I practice field is being provided for the course at the Tniversity of California, and the Richmond shool of social Service and Simmons College, Boston, have been aided with appropriations. The Minncapolis Chapter is financing the practice field in Hennelin County for the course in public health nursing given by the Tniversity of Minnesota. The St. Lonis Chapter is contributing not only the entire cost of the practice field for the mublic hadth nursing course criven by the Missouri School of Social Economy, but the salary of the director of the course and three superrisors as well. 'The New York County ('hapter has male a large appropriation toward the preparation of public health nurses at the Henry Street settlement, New York City. ${ }^{10}$

1) The Eniversity of Michigan and the School for Social Service at Philadelphia were given financial assistance later by the National Red ('ross. 
Berause of the tremendous demand for nurses trained especially for public health nursing, becanse of the popularizing of rural nursing which demands special preparation, and berallse of the num needed assistance rendered humbleds of nurses through Red Cross scholarships, there has been a remarkable hoom in all the schools giving courses in public halth nursing. Formal training in public health mursiner throngh definite educational channels has been given tremendous impetus, and nurses generally a re becoming convinced of the need for such training before undertaking pulblic: health nursing. Attenclance at the various schools for public health nursing increased during the sohool year $1919-20$ from 100 to 1000 per cent. Three new courses were opened and there are definite prospects of three more beng opened in the fall of 1920 .

At the eonference of the staff of the Department of Nursing at National IIeadquarters in the fall of 1919 , it was estimated that the Divisions would need over 1000 public lealth nurses in the next rear. The great question was how to seenre them. The number of nurses returning from overseas service who had had training in public health nursing and whom it was hoped to recruit for chapter service was far too few. The scholarship find of $\$ 100,000.00$ was a great help toward obtaining a trained persomel, but meant delay while the nurses were recenving their public health nursing training. In the meantine the ('hapters were clamoring for public health nurses.

ln the discussion at the conference, the directors spoke again and again of the cagerness of the Chapters to help their communities throngh establishing a public health mursing service and the pity of losing the opportunity. Various methods of adding to the supply of public health nurses withont serionsly lowering the standard established by the hed Cross were disconsiod: the sending of nurses to a good visiting nurse asso- iation for a fer months experienee and then plareing them in : C'hapter service with the understanding that their theorotical training shomld be geoten at the first opportmuty: or the planding

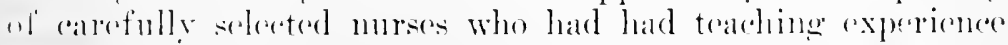
but no pulilir health mursing experience in positions nudere comtinnons supervision for a few wooks with fropurnt follow up visits on that they might leam while ganing experiones in the tord and delay the taking of the conrse motil the opportmity arose. 


\section{HISTORY OF AMERICAN RED CROSS NURSING}

It was the growing sentiment of the conference, however, that a four months' public health nursing course was little enongh training to require and Miss Gardner erystallized this feeling in words which met with overwhelming agreement:

Before we put in inexperienced nurses why couldn't we frankly say that we haven't the goods to deliver? This is not a proposition that we can go at by leaps and bounds. It is slow moving. We are going to lose a certain amount of enthusiasm. but we wan afford to. We should educate the Chapters more and stimulate them less. Let us frankly say we cannot meet the demands with trained people ail at once and must wait until we can, rather than resort to all sorts of makeshifts.

In view of the stand taken by the directors that the Red Cross should not attempt to meet the needs of the Chapters with unprepared nurses, another way of securing a few experieneed public health murses was bronght up for discussion. It was suggested that Visiting Nurse Associations should be looked upon as recruiting and training eenters for public health nurses, giving them, through actual experience on the statt' under supervision, sufficient preparation for independent work in the country. Ways of accomplishing this withont making it difficult for the already overburdened Visiting Nurse Associations were diseussed. The conclusion seemed to be that two methods might be followed. 'The first, suggested by Miss Garduer, was to send nurses from a given locality to a Visiting Nurse Associaltion to become a member of its staff for a sutficient period to gain necessary experience, probably not less than eight months, and then to return to the community from which she ame, to take an independent position. The Visiting Nurse Association would probably be able to take such a nurse on the usual salary basis. The seeond, that already in rogue, was for the llivision directors to make personal or written repuests to specifie Visiting Nurse Associations for candidates to fill specific vacancies, since the murses with the Visiting Nurse Associations were more likely to be interested in a eoncrete offering of a definite position than in a general appeal for interest. l)irectors in Divisions far removed from the larger Visiting Nurse Associations might, he this mothod, interest some of the murses on such staffs to eome to their l)ivisions to definite positions.

The loivision rlipectors concluded by nuanimonsly recommondinge the contimanee of a national fund for scholarships 


\section{PUBLIC HEAL'TH NURSING AFTER TIHE WAR 1311}

and loans to prepare murses for public health nursing in the regular post-graduate courses.

Several months later the problem of meeting the needs of the Chapters for public health nurses having continned acute, the subject of some temporary measure to meet the need was again considered. A plan was laid before the l)ivisions for the emplegnent of morse's not fully qualified beeanse of a lack of sultivent training or experience in public health morsing. It wats proposed that these nurses shonld be appointed as substitutes, be given two months' preliminary preparation on the staff of a recognized public health musing organization muder supervision and then be plared in chapters under mnch closer supervision than that given the regular staft.

It was further proposed that these substitutes should carry on a process of self-education throngh preseribed reading and be enconraged to complete their preparation as soon as pessible thromgh taking a full standard course, or at least a summer (o)

This plan was decided upon with much reluctance and apprehension, becanse it was forared that murses with so inadequate a preparation would not be alle to neet the many responsihilitir's of a public health nurse, since those with far better preparation were finding that their knowledge was scarcely rpual to their tasks and that they had to draw on every resonree to handle the problems daily confronting them.

It was a pleasant surprise therefore to discover that the chapter's on the whole had so far progeresed in understanding the range and importance of public health morsing that they were not willing to aceept this opportunity to lamede a service withent finther delay, but preferred to wait for a fully qualifind public health mise. In the words of one state supervisor's r'epolt:

Ilere I fombl the Committee on Nursing dretivities composed of seren buen and two women, and the most wille-alwake committere we hase. They ware well organized. seeting information, stmlying the proposition from all angles ame willing to wait matil a very competent nurse can be located.

Nurses were no nore interested in this substitute plan than were ('hapter's, and it was unt possible to find many willing to

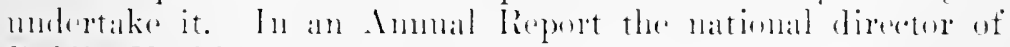
Publir Iloalth Nursing stated: 


\section{HISTORY OF AMERICAN RED CROSS NURSING}

The plan for the use of substitutes has not met with much enthusiasm so far. The five Dirisions which are able to fill their positions have no need of it. In many states the State standard has now been elevated and a return to a more elementary form of training would not be acceptable to the state, as in California, for instance. A very practical obstacle has been that the Chapters themselres, and eren many public officials, are not willing to start their nursing serrice with a nurse who is not sufficiently trained to do a big constructive piece of work. They demur when it is suggested that they accept a substitute and frequently say they would rather wit until a fully equipped public health nurse can be had. Erery division reports this same response. Substitutes are not going to be popular. Furthermore, the nurses themselves have passed the stage of makeshifts and are daily becoming more impressed with the need for further preparation. Few nurses of the right sort are willing to accept the status and preparation of substitutes. Tevertheless, the plan will be tried in perhaps a half dozen states where the need is pressing and the supply small.11

As a result the plan soon fell into disuse and was abandoned. Not more than thirty substitute nurses were employed.

It must not be construed, however, that all the Chapters were so enlightened that they recognized the value of employing only a qualified public health murse. Every now and then the Division dirctors found that some Chapter lad employed a local nurse with no training or experience in public health nursing without consultation with the Division. In the course of time, however, it frequently turned out that the Chapter regretted its action and later came to the Division sceking a nurse with adequate preparation. It also happened even more frequently that the nurse engaged by a Chapter without any public health nursing experience or training soon discovered that she was beyond her depth and roluntarily decided to seek further training. This tendeney was mentioned in several of the monthly reports :

One of the healthy signs of growth is that the nurses who have gone on duty withont sufficient training have in every instance reeomized their need and have applied for assistance in plaming for post-graduate courses.

In the lake Ilvision no less than four nurses insufliciently prepared and phared hy Chapters withont dace ansultation

${ }^{11}$ Ammal lieport, July 1, 1919 to June 30, 1920. 


\section{I'UBLIC HEALTH NURSING AF'TER TIE WAR 1313}

with Division headquarters have themselves now felt the inadequacy of their own training and are seeking to supplement it by a course in public health nursing.

On the whole, the effect of Red Cross public health mursing has been to elevate the standard. Some of the State department of health men still say quite openly that they think the Red Cross is clemanding too high a standard, but many of them are coming to feel that we have been wise in maintaining a high standard and a good many people in the Chapters are beginning to realize the necessity of demanding nurses with better preparation.

There is much more definite recognition of the need for special training for public health nurses among all groups employing such nurses. Appreciation of the necessity of special training is constantly increasing among the nurses themselves with the sudden prominence given to publie health nursing.

We feel that our program has had a stimulating effeet and aroused the interest not only of the nurses but of county boards of supervisors. In a recent conference with a member of a board of supervicors we were told that the board realized the neerl for qualified women and was especially anxions to have the supervision of the Red ('ross. Chapters who have put on unqualitied nurves without the kuowledge of the I)ivision oftice have almost invariably come to realize that the nurse is not able to arry the program and have asked us to assist them to secure proper preparation for the nurse. Whem such nurses have resigned and the ('hapters have asked for another nurse they have stated they would prefer to wait indefinitely in order to have a qualified public lealth nurse.

It must be eonfessed that now and then one of these unqualified murses did surprisingly woll, rombining valualle experiener in wther mursing ficlds with personality and geod semse. ()ne State director reported the work of a nurse with no public health anrsing training:

Miss - deserves special mention. The technique of her work semms ideal, and her acomplishments hate tern

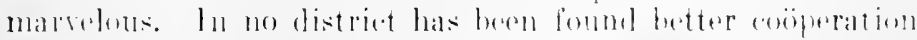

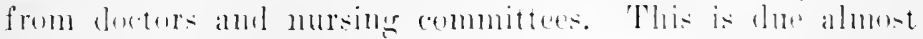




\section{HISTORY OF AMERICAN RED CROSS NURSING}

entirely to the personality of the nurse. Her marked success and the failure of some of the young graduates of the four months' public health courses gives rise to the question as to whether an older nurse with experience as a hospital executive, even without public health training, is not preferable. As the State is now districted, the district supervisor is able to give close supervision to all nurses, and certainly in this one instance the experiment has been successful. In almost every instance do we find that the older women are doing better work than younger nurses.

With the rapid growth in the number of public health nursing services the necessity arose for securing assistance by building up a field staff, each department in the Red Cross having its own specialists in the field. Before decentralization eight Division Directors of Public Health Nursing had been appointed who in turn had appointed fifteen assistants and field supervisors. As even this expansion was inadequate the national director in the summer of 1919 sent this memorandum to the general manager recommending that the staff be donbled:

The American Red Cross in undertaking the promotion of rural public health nursing throughout the country has taken upon itself the responsibility for a very far-reaching and important public activity. This undertaking will be either a widespread, superficial, comparatively umproductive and poor piece of work, or else it will be an intelligent, thoroughgoing, permanently productive enterprise.

With almost no exceptions the Chapter people know very little about public health administration in general and in particular of the activities carried on under the name of public health nursing or rommunity nursing. The suggestion that they should undertake to derelop public healt le ativities within their jurisdiction usually is a new itlea to them.

There is very definite and immediate need for the enlargement of the Iivision staffs. In response to our stimulation many of them are onueciving original plans for arrying on public health mursing. which very frequently are not onmel nor well adapted to loral needs. inasmueh as they lave little knowledge of the sope. functions, principles and management of public health muring. it is quite natural that their plans frequently should be mwise and imperfect. 


\section{PUBLIC HEALTH NURSING AF'TER THE IVAR 1315}

The overwhelming demand for public health nurses has made it necessary for us to appoint to independent and responsible positions many nurses who are young in years, lacking both in general experience in the world and special experience in public health nursing. We are requiring only a minimum of preparation.

For all of these reasons it is absolutely essential to the surcess of our work that there should be very ("lose contact between the ('hapters and the Divisions; that there shoult be personal visitation at frequent intervals; and that guidaneo and assistance should be at all times available to the ('hapters without mudue delay. This necessitates adequate and welltrained statls at Division healquarters permitting constant field supervision. It seems essential that there showhl be provision on the statts of the I)ivision Bureaus of Publit: Ilealth Nursing for at least one public health nurse for each state to atet as field organizer and supervisor.

By fall, that is six montlis after decentralization was completed, the I)ivision and field staff numbered 42 . In this same time the number of loeal nurses liad grown from 99 on . March 1, 1919 , to :316 Oetober 1 of the same year. A paragraph in the Anmal Report for the fiscal year ending June 30, 1921, reads as follows:

In adlition to the Division Director of Nursing local Red Cross nurses are receiving help and supervision from fifty-five supervising nurses. which is an average of twenty-four local nurses to one supervisor. Of these fifty-five supervising nurses, thirty-reven are employed wholly hy the lied ('ross and dighteen are shared with the state department of health or the state 'Tuberenlosis Issociation or both. It is our hope that our supervisory staff an be increased sufficiently to give more assistance to the young nurses who are taking up their first piece of exerutive work. All of us need help and alvice and inspiration. but especially when we are starting out abone inte a new tield. and it is a serious obligation on the part of the lienl ('rosis to give full measure of support and assistance to these young pioneers in our serrice.

At the meeting of the National and Vivision staffs of the Departulent of Nursing at National Headenarters in the fall of 1:19!, referent to previonsly, a discussion of the need of the chapter numse for assistance hromeht ont many interesting

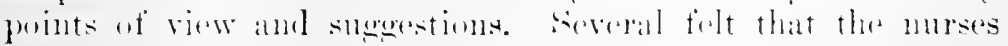




\section{HISTORY OF AMERICAN RED CROSS NURSING}

needed much help in the first few months of their service and should be visited frequently. Others thought that a supervising or organizing nurse should go with the newly appointed nurse to her new territory and assist and guide her in making her contacts. Still others felt that organizing nurses should go into a county, before the coming of the Chapter nurse to prepare the ground for her reeption and insure the right working relations between the nurse, the committee and the community.

The concensus of opinion in regard to supervision was that it should be primarily for the purpose of consultation and encouragement; frequency and length of visits depended largely upon the nurse; the nurse should if possible be given a chance to spend a few dars at the Division office before taking up her work with the Chapter in order that she might learn something of her Chapter and of general Red Cross organization and procedures. It was felt that if a nurse was well prepared for her work she should be given the chance to make her own contacts and to develop her own initiative.

It was also suggested that the nurses would learn much from each other and from the Division staff if they could come together oceasionally in state meetings or in smaller meetings of those in a group of counties. This plan was followed with good results in a number of Divisions. Meetings were arranged of Chapter nurses from perhaps eight or ten adjacent counties at the most central point. Often the nurses drove to these meetings on a Saturday. They were usually the guests of the Chapter of the county in which they were entertained. The Division director or a field supervisor usually met with them and many practieal problems were discussed. Another way of comparing experiences and passing on ideas, of forwarding helpful suggestions and of keeping the nurses in tonch with what was going on in the Red Cross was through the issuing of periodical Division bulletins to the nurses. The bulletins were informal, newsy, personal doements, not pretending to be dignitied literary achievements but partaking more of the character of a family letter. This method proved so popular, stimulating and helpful that it became the regular practice in nearly all of the Divisions.

A larese volume of correspondenee passed between the murses or menbers of their committer and the I hivision oftice. Throngh the receipt of the murses montluly statistical and narrative 


\section{PUBLIC HEALTH NURSING AFTER 'THE WAR 1317}

reports the Division directors were able to keep in pretty elose touch with the work of the nurses and with their problems and to offer many suggestions.

In many Chapters where a public health nurse was employed there was already a Hone Service secretary in charge of the social work of the Chapter. It happened occasionally that a difficulty arose in determining what should be the division of work between these two. As a guide to a solution of this difficulty, Miss Margaret Byington of the National Department of Civilian Relicf and later director of Field Service prepared in collaboration with Miss Fox a statement which defined the respective functions of both murse and social worker so that there should be no duplication but rather a dovetailing of each other's activities to insure a mified piece of family health and social work. Matters of health were thus the responsibility of the nurse, and social and cconomic problems that of the social worker, both being alike responsible to the Chapter Executive Committee and neither undertaking to direct the work of the other.

A better understanding also grew ont of State and Division conferences attended by Home Service secretaries and public health nurses. A report of one such eonference stated:

Temmesse was well represented at the conference held the last week in August at l)ivision headquarters for Home Service secretaries and nurses. This conforence was particularly necessary and proved to be most valuable in making it dear to secretary and murse just what their respective duties were and how they were related very closely to each other. It also gave a vision of what cordial team work could arcomplish, as the reports from ammunities where Home Service secretary ant nurse were working together were a real inspiration. I am quite sure that each llome service secretary and nurse who was working alone went away with a desire to so organize their community that a co-worker would he employed.

The tendeney on the part of the Chapters to use the Home

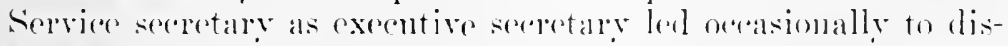
rord which repuired a visit from the supervising nurse or fiold representative to adjust. Sines cxperience had prowen the wisdom of kepping the line of respomsibility from the murse to

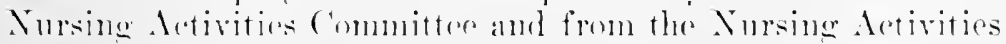

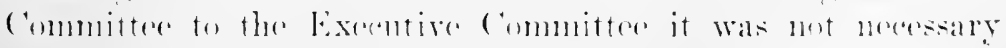




\section{HISTORY OF AMERICAN RED CROSS NURSING}

for the exeentive secretary to assume any responsibility for the nursing service other than that of helping to coördinate its undertakings with other activities of the Chapter.

The instruction that public health nurses should not engage in relief giving was found to be too rigid to be followed at all times in Chapters having no Hon.e Service worker and communities having no social worker. In such localities, in order to accomplish her primary purpose of alleviating and preventing disease, the nurse was confronted in many homes with the necessity of first removing the social or economic difficulty which was causing the ill health. The safest and wisest procedure seemed to be for the nurse to report her problem to her Excentive Committee and to place the responsibility for action with it. In such situations as these the Division was prepared to give attention to each individual family problem and to advise the Chapter Executive Committee.

A matter of important concern to the Red Cross was its initiation into State departments of health and other State agencies, such as the State Tubereulosis Association, from a standpoint of eoüperation and the maintaining and upholding of the authority of the State department and the good work of all while developing public health nursing in the Chapters as a part of the Chapter organization and program. The Red Cross believed that the State departments of health should have the moral if not the legal authority and responsibility for outlining a State-wide, gencral program for the development of public health nursing throughont the State, and for establishing and maintaining at least a minimm standard of personnel and service. It believed that the programs of public and private lecal organizations should fit in as far as possible to the general program for the Sitate as a whole and should be under the gencral oversight of the State in regard to standards of persommel and practice. The Red Cross also believed that the State would have no reasom nor desire to interfere with the internal oreanization and alministration of local private agencies or their relation to their central bodies, as long as the State standard was maintained as a minimmm and as long as the actirities of the private agencies did not conflict with the general plan ontlined by the State.

There was at first in several states an attitude on the part of some of the state departments of health of doubt and eren disapproval of the Red c'rose purposes in expanding public 


\section{PUBLIC HEALTH NURSING AFTER THE WAR 1319}

health nursing through its Chapters. This was due largely to the fact that it was a slow and difficult task to bring about working agreements, owing to the rapidity with which the work expanded, the diversity of conditions in each state, and the differences in program and development of the various State departments of health. Thus in order that there might be some generally aceepted prineiples of coöperation, representatives of the Exeentive Committee of the Conference of State and Provineial Health Authorities, the National Tuberenlosis Association and the American Red Cross earried on a series of consultations. These resulted in Deeember, 191!), in a mutually accepted statement of principles as follows:

I. In undertaking to develop public health nursing the Rer Cross does not seek to supplant or compete with state and local departments of health or other organizations.national, state or local, public or private, engaged in the same work. It seeks rather to supplement their activities by assisting legitimate public health mursing agencies and by establishing itself or working with other ageneies to establish community mursing services. It plans to interest its Chapters thronghout the country in public health nursing with this purpose and policy in view.

II. The Red Cross believes that in time public health nursing should and will become a pullic service conducted by the state, county or municipality, through their official health agencies. Red ('ross Division officers will seek consultation with the State health anthorities in eards state where this has not already been done, for the purpose of learning what plans the state Department of Health may have for developing public health nursing. and of determining in what way the Red ('ross may (ooperate and make lied ('ross plans for the development of this work by it: ('hapters thronghout the state conform to the plans of the state department of health. In this mndertaking the Red ('ross will have as its object the ultimate assumption by the state. counties and municipalities of public health services initiated by its ('hapters.

III. Following this principle the Red Cross will ancourage the reation of a Burean. Division or sub-l)ivinim of Public llealth Nursing within the state department of health. which should assume such suphrvision of public lealth nursing als mal be assigned to it he the chicet health executive oflicere of the state. 


\section{HISTORY OF AMERICAN RED CROSS NURSING}

IV. (a) Looking towards the establishment of a bureau, division or sub-division, a State supervising nurse might be appointed to serve the State department of health, who would study the publie health nursing needs of the State, would work out a plan to cover them, assume supervision of local services, as indicated in paragraph III, and correlate so far as possible the nursing activities of other agencies within the state such as the Red Cross and the State Tuberculosis Association.

(b) In states where these two ageneies are working extensively it is suggested that the State supervising nurse should have assistant supervising murses. one in charge of the nursing activities of the Red Cross and one in charge of these activities for the State Tuberculosis Association. These two agencies would provide the salaries for the assistants in charge of their respective activities. The assistants would be responsible both to their respective agencies and to the State supervising nurse and would submit their plans to her for adjustment and endorsement.

V. In each State a Committee on Coördination of Public Health Nursing Services might be ereated representing the State Department of Health, the Red Cross, the State Tuberenlosis Association and other appropriate agencies to advise with the State Department of Health at frequent intervals concerning the best alignment and cooperation of the varions nursing activities.

VI. Where State supervising nurses, assistant supervising nurses and other publie health nurses attached to the State health organization and supported by funds contributed jointly by the State health organization and other agencies or are contributed wholly by such agencies, appointment should be made by the State health exeeutive with the approval of the participating agencies. Such appointment should not be in conflict with existing laws of the state. Public health nurses supported wholly by funds contributed by the American Red Cross or other extra-governmental agencies should be free from Civil Service restrictions.

VII. Where the State Department of Health is unable to provide the salary for a state nurse and where some mutually satisfactory plan of coöperation (such as that outlined above) has been agreed upon by the State Department of Health, the Red Cross and State Tuberoulosis Association, the salary might be pais in part or in whole by any 
or all of these and other agencies. This should be a temporary measure, the State to assume the salary as soon as possible and the nurse regardless of the source of her salary should be state supervising nurse for the State Department of Health.

VIII. Where the Red ('ross pays in whole or in part for any nursing service. Red ('ross stantards of appointment of nurse and service should be observed.

IX. Public health nursing as carried on by the Red Cross may cover any of the following activities:

Prenatal or infant welfare work,

Maternity service,

School nursing,

Control of communicable diseases, including tubercu losis and venereal diseases,

Industrial nursing,

Mental Hygiene nursing,

Care of the sick on the visit basis.

Which one or ones of these branches is to be undertaken by the Red Cross Chapter in any given commmity would be determined hy the need, by the adequacy of any existing services, ly the practical factors of territory to be covered and population to be served and by the plan alopted by the Red Cross after consultation with the State Department of Health for the development of public health nursing by the Red Cross in that state.

While this statement was in process of preparation there ose a need for a supplementary statement to cover the prineiples to be followed in states where there was no State bureau of public health nursing and no State nurse, but where both the Red Cross and the State Tuberenlosis Association were engaged in promoting public health nursing. The gist of the plan which was suggestel to meet this situation was contained in the first two paragraphs of a supplementary statement drawn up by the Red Cross and Tational Tubereulosis Association :

I. It is highly desirable that a public health murse should

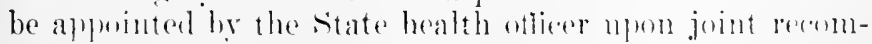
mentation of the Red ('ross and the state Thluepentosis Assoriation to have tharee of public health nursing within the state. Herexpenses might he shated hy the state los

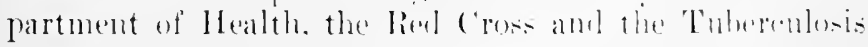




\section{HISTORY OF AMERICAN RED CROSS NURSING}

Association, or by the latter two, until such time as the State Department of Health is able to assume part or all of her salary.

II. This State Director of Public Health Nursing shall be made the official representative of the Division Burean of Public Health Nursing of the Red Cross, and of the State Tuberculosis Association, and shall be charged with the responsibility for the development of their public health nursing artivities in conformity with the plan of organization, methods of procedure and standards of each. Through the State health officer she shall be responsible to the State Tuberculosis Association for its part of her work and shall be responsible to the Division Director of Public Health Nursing for nursing activities in which the Red Cross Chapters participate.

The prineiples set forth in these two statements were followed in the working plans that were subsequently agreed upon in a number of states. The efforts made to work out coïperative plans in the varions states were described in these words:

The formulation of working arrangements in the states, howerer, on the basis of these principles has been a slow and difficnlt task. No two state agreements have been just alike. In 22 states a definite written agreement has been made with the State Department of Health. In 7 more, an agreement will soon be in written form. In 6 states, there is a definite understanding but no formal agreement, and in 13 , the final plan of coöperation has not yet been determined, in a few of which we have been unable to reach any common ground. In these few, however, we are slowly overcoming antagonism and approaching the day when peaceful coopperation will be possible.

The majority of these efforts at coöperation are working out very woll. There are at present 11 states in which the State wholly finances its state program of public health nursing. In these states the Red Cross has done one of three things:

1. It has made the State nurse, already appointed by the State Department of 1 Iealth, the official representative of the Red Cross I)epartment of Nursing as well.

?. It hils supplied an assistant state nurse in charge of Red croses mursing.

3. It has maintained its own State nurse, who worts in 
close consultation and coöperation with the State Department of Ilealth, though independent of it.

In 7 more states the State pays the larger part of the State nursing budget, the lied cross contributing the remainder under a coöperative arrangement similar to one or the other of the first two plans given above. In 7 states in which there has been no State mursing serviee, the lied Cross is developing such a service mider the auspices of the state health oflicer but at Red Cross expense. In 7 states the State mursing budget is financed jointly by the State, the Tuberculosis Association and the Red ('ross. In the remaining states the Red cross is working independently in antieipation of joining hands with the state within the next few months.

Our eflorts have been directed primarily toward findine a methor of coöperation with the State departments of health, and secondarily, wherever possible, of including coöperation with the State 'Tubereulosis Association at the same time. In 15 states this joint agreement has been effected. In several states we are working amicably by the side of the State 'lubereulosis Asociation, although there is no formal agreement. In some states its program does not include the orwanization of local public health nursing service. At present the Red ('ross is responsible for the salaries of approximately a) State and assistant State supervising nurses.

The activity of the lied Cross in organizing town and county' publie health nursing services, in developing supervision on a state basis, and in providing or contributing toward the provision of the personnel for state bureans of public health nursing has done mueh toward alvanding state public health nursing programs. State bureaus wholly or partially maintained by state funds have been created in more than a dozen states during the past year. Legrislation will be mushed in a number of states to provide public funds for state bureaus of nursing now financed by private contribution, or to incerasc the state budget alreaily provided for this purpose. 'The ehalater and standards of state work have aleo been notioeahly improved and elevated. The superior quality and better resilts of work done according to high standards has heen se convineing that many pullie officials. who at first thought our

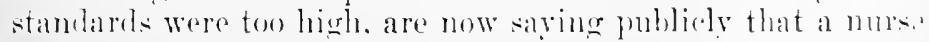
without sperial training or experience in public health nursing rarely acomplishes any constructive work. ${ }^{12}$

In the comrse of time, as the Chapters eontiumed to undertake publie health nursing services and as these sorviens leceime

:Amual Report, In!y 1, 191!, to .7ume 30, 19!20. 


\section{HISTORY OF AMERICAN RED CROSS NURSING}

more elosely integrated with the other activities of the Chapter, the neol became elearer for maintaining a elose connection between Chapter public health nursing and the whole Red Cross organization as directed and supervised from the Division. It did not seem appropriate or desirable to require the State or assistant State supervising nurse of the State Department of Health to give as much of her time, energy and thought to Red Cross inatters as was necessary to maintain the necessary internal relationship between the Chapter public health mirsing services and other Chapter work, and to take part in the general administrative obligations of the Red Cross under the direction of the I)ivision Staff Comeil (the need for which will be explained later in this chapter).

In order to accomplish these Red Cross objects and at the same time to adhere to the principles agreed upon with the Exeentive Committee of the Conference of State Health Authorities, it was neessary merely for the Division to arrange to assign a member of the Division nursing staff to act as an assistant superrising murse in states in which the State Department of Health had a State nurse, with the understanding that this nurse in her eapaeity as assistant would have eomplete charge in all matters of internal organization of the Red Cross public health nursing services in the state under the guidance of the Division.

To the end that this procedure might have the understanding and approval of the State health anthorities the Executive Committee of the Conference of State Health Authorities was invited to meet with the Red Cross national officials and Division managers at Washington on April 20, 1921. The report of this meeting was as follows:

In response to the request of Mr. Persons (vice chairman), Miss Fox put before the meeting the problems with reference to the public health nursing services now being arried on by the chapters of the American Red Cross in accorlance with agreements male by the Red Cross with the varions State health authorities.

These problems are:

1. The intense homand for public health nurses hals forced the platement in ('hapters of murses who are inexperienced and inadequately trained in eommunty organization, in the nse of voluntere assistants and in the stimulation of general ('hapter 
development. It is not so much a question of adding work to the well recognized forms of public health nursing as it is the adaptation and correlation of the nurses' service to other aspects of the (hapter's program in the local community. Chapters find it imposible to have their nursing service divorced from their ounior Red ('ross work, their IIome Service and several of the other reenguzed lied cross aretivities.

?. Fnder the present form of anreement with the health authorities in several states, in acorrlance with which the murse who supervises the Red Cross murses is the State superrising nurse, it has been foumd that she ramot give sufticient time and attention to the peculiar phases of Red Cross public health nursing to meet the needs of the nurses employed by Chapters, to detect weaknesses in Chapter machinery, to develop other kinds of Chapter service and to organize community interest.

Miss Fox pointed out how the newer forms of agreement and understanding which have been worked out in the State of Michigan, where there are more than 6.5 Red Cross nurses, are proving satisfactory and effective in solving the problems of the Red Cross. Dr. Olin (Commissioner of Health for Mirhigan) and Miss Ahrens (I)irector of Nursing in the Central Division) explained in detail the present arrangements.

Both the State supervising nurse and the Red Cross supervising murse were appointed upon the joint approval of the State health commissioner and of the Division othice of the Ret Cross.

Earh time before the Red Cross supervisor goes into the field she consults with the State supervisor of nursing about the local situation of each place which she plans to visit. In this way the local Red ('ross murse receives a direct message as to state plans and is liept cosely in tomch with the state bureau of nursing. The state report forms are used by the Rell ('ross nurses and dupliate reports are filed with the state bureaus. Thu lied ('ross nurses write clirectly to the state lopartment of Ifealth on all oflicial health matters. They

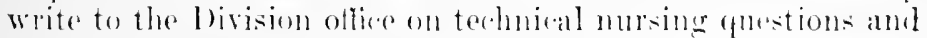
on matters relatine to ('halpter lusiness.

It was the grencral opinion. expresed by lor. ('rumbine

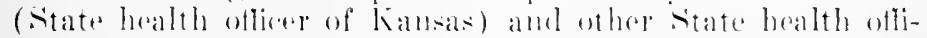
cers. that the public luealth prouram of the American lied ('ross has heren well alticolated with the state nursing programs and that, with the exeeption of an oretsenal mis-

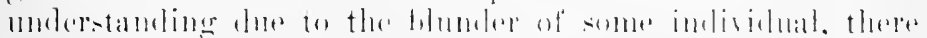
was less trenthe in aremelating these aletivities than there was

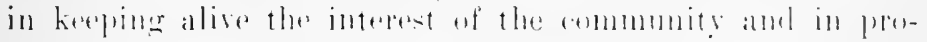




\section{HISTORY OF AMERICAN RED CROSS NURSING}

moting the idea of rural public health nursing. Dr. Crumbine was convinced that the necessity for keeping Red Cross Chapter activities entirely moler the Red Cross, if Chapter interest is to be maintained, had been taken too lightly. It was also generally agrced that it is to the interest of the State to have Red Cross Chapters attain permanency, stability and continuity. These, better than the official agencies, can edncate communities to want public health nursing and to appreciate standards in nursing. Wientually all the Red Cross nurses should be taken over by public local health authorities, but it is anticipated that it will require a long time to bring this about in some communities. The Red C'ross must, therefore. pursue a policy that will both raise its nursing standards and insure Clapter understanding and support.

In reply to a question from Dr. Williams (State health officer of Virginia) Mr. Persons assured the health oflicers that new forms of coöperation in the varions states would be effected only as both the Red Cross and the State health authorities had reached a full and complete agreement. The Red Cross is not approaching this situation with preconceived ideas to be rigidly applied in all sitnations. . . .

There was general agreement that better mutual understanding wonld be achieved if the Division managers and the State health officers met more frequently in friendly, informal visits, when things are ruming smoothly, and not, as now, when, usually, contacts are limited to the occasions on which there is some question at issue.

Because of the partial identity of goals and problems, even thongh there was distinct divergence of method and app:oach, the need arose for an understanding between the Red Cross Public Health Nursing, the National Tuberculosis Association and the National Organization for Public Health Nursing. The successful accomplishment of this moderstanding was reported as follows:

Tast December the National Organization for Pubic Health Dursing, the National 'Tuberoulosis Association and the Red C'ross came together to discuss their respective mursing programs for the purpose of deciding upon a division of labor, methods of coöperation and rhannels of consultation. Is a result. the lunctions of each in the fieht of mursing were defined, moasures for the use of each other's facilities were adopted, the mulertaking of rertain projects jointly was determined upon and a permanent conference committee ap- 
pointer. This action shut the door on the possibility of misunderstanding, wasteful duplication and dividerl interest among publie health nurses and opened up great opportmities for joint effort, intelligent team work and united support.

\section{The agrement follows:}

Foreword:

The Red Cross and the National Tubereulosis Association, through their Division and state organizations, being the organizations probahly administering the largest number of public health nursing services, and the Sational Organization for Public Health Nursing, as the voluntary borly representing all types of public health nursing, necessarily have many interests and problems in common. Therefore, they seek to supplement each other by utilizing the facilities of each in common as far as possible and by joining forces in undertakings in which it is advantageous to do so. To accomplish this it is necessary that the functions of each organization and the lines of eooperation be clearly defined and future lines of coöperation be, so far as possible, anticipated. These three organizations, through their accredited representatives in conference assembled in Washington, D. C., December 5th, 1919, hereby define what each organization considers to he its functions in the ficld of public health nursing, and enter into an agreement as to methods of performing its functions by means of coördination and coöperation. . . .

Ways and Means of Coöperation.

\section{Educutional}

\section{Courses}

The Red Cross and the National Tuberculosis: Ascociation look to the National Oreanization for Publir. Health Nursing to take the leall in matters pertaining to the edueation of publie health nurses. Before granting either finandial subsidy or sclololapships to a post-graluate course for public loalth nurses the lied Cross will require that the course he endorser by the National Oronization for Public. Ilealth Nursiner. The National Tuberenlosis . Lsociation will make the same requirement, hut will insistently urere through its representative on the Euluational ('ommittere of the National Oreranizat ion

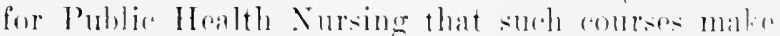
provision for a sulable proportion of taaching of 
tubereulosis and is ready to coöperate in establishing standards of teaching for tuberculosis nursing based upon the judgment of the leaders in this field, medical nursing and sociologieal. It further urges similar consideration for the advice of other specialized health organizations.

\section{Forum}

The Educational Committee of the National Organization for Public Health Nursing will act as a form for the discussion of all questions pertaining to the education of public health nurses. The director of the Red Cross Bureau of Public Health Nursing and the National Tuberculosis Association Secretary for Nursing, and possibly later representatives of other national organizations interested in public health nursing, will sit on this committee as members. These organizations will undertake jointly or separately, l,ut under the general direction of the Elucational Committee, to prepare series of monographs on practical methods of conducting various public health nursing activities, and also pamphlets on other special subjects as needed.

3. Institutes

Believing strongly in the need for annual and widely distributed institutes for public health nurses of considerable experience or training, the Red Cross and the National 'Tuberculosis Association will join with the National Organization for Public Iealth Nursing in recommending that such institutes (to cover two weeks or more) be organized and ('onducted by suitable establisher agencies within the states with the assistance of the National Organization for Public Health Nursing, in consultation with these other national bodies. The latter will offer the assistance of their Division and State staffs in conducting the institutes and will encourage their local staffs to attend. These three orsanizations acree that these institutes should be general in character; including tubercubsis, child hygiene, venereal diseases and other special subjects. The Rer C'ross stands rearly to sugrest subjects and tearhers in the rural nursing field and the National 'Tuberonlosis Assoriation to furnish outlines of lectures and teachers in tuberculosis subjects. 


\section{Library}

In view of the fact that the National Organization for Public Health Nursing has a library department with an appropriation for adequate expansion, and has a circulating package library operating through 4t state library centers, which has been endorsed by the American Library Association, the Red Cross and the National Tuberculosis Association will not endeavor to develop duplicate library facilities but will recommend that their field staffs make the fullest possible use of the facilities offered by the National Organization for Public Health Nursing. The latter organization will undertake to develop its library resources to meet the speeial needs of these staffs, particularly as their work affects the rural nurses.

\section{Magazines}

The Public IIealth Nurse las granted a section to the Red Cross Bureau of Public Health Nursing under the editorship of the director of the bureau, to be deroted to the activities and developments of that bureau.

The National Tubereulosis Association does not at this time suggrest a department in the magazine devoted exclusively to tubereulosis, but suggests that a reasonable amount of space be given to the consideration of tuberculosis nursing and other phases of the tuberculosis movement.

\section{Recruiting}

The Red C'ross hopes to join with the three national nursing organizations in a program for recruiting student nurses. The National Tuber ulosis Association reconnizes that this is distinctly a function of the nursing organizations.

III. Employment

Believing that there are many adrantages to be secured through a mational dearing house of employment which would also serve ats a theretory of information, the National Oroanization for Public Ilealth Nursing will endeator to anemplish this for public health morses as a part of the aretivities of the proposed joint nursing healquartors. It is moderstoorl that while all credentials womld he ototaned by such a clearing homse. placoments would contimue to be 
made through the various existing agencies. The Red Cross, because of its great demand on the supply, will appoint its own representative to the executive staff of the clearing house.

IV. All three organizations are free to conduct analytical studies of rarious typical and atypical pieces of machinery for the purpose of determining standaril methods of organization, practice and technique, but will consult each other in planning these studies in order to avoid duplication and to take advantage to the fullest extent of the facilities and fields each can offer for this purpose.

\section{Legislation}

The National Organization for Public Health Nursing and the National 'Tuberculosis Association will seck to create public opinion in favor of, and assist in, the enactment of suitable public health nursing legislation, such as the appropriation of public funds for public health nursing and the creation of divisions of public health nursing within State departments of health. The Red Cross endorses this broad endeavor but prefers not to take part in efforts involving legislation.

VI. Machinery for Coördination

\section{Joint Consultation Committee}

The execntive secretary of the National Organization for Public Ilealtl Nursing, the director of the Burean of Public Ilealth Nursing of the Red Cross and the secretary for nursing of the National Tuberculosis Association will form a joint consultation committee. This committee will meet frequently for conferences relative to problems and projects confronting or contemplated by any one of the three.

2. Exchanges of memoranda regarding new programs or changes in policy before putting the same into action.

3. Stute Committees on Public II ealth Nursing

'The Red Cross, the National Organization for Public Health Nursing and National Tuber'ulosis Association favor and will endeavor to reate State committees on public health nursing representing generally the three organizations and the state be- 
partment of Health and may include other State nursing organizations and State agencies engaged in, or responsible for, promoting public health nursing artivities. Such a committee will have no administrative responsibility for, but will concern itself with, the advancement of publie health mursing in the state through the stimulation of public opinion, through interpretation and adrice and through the promotion of coördination.

It is mutually understood that no ehanges will he made in the procedure outlined in this agreement without the full consideration of the three partieipating ageneies.

While the joint consultation committee deseribed in the paragraph on Machinery for Coürdination was not made use of, the methods of working together deseribed under Ways and Means of Coöperation were earried out with regularity and mutual satisfaction and the reciprocal relations of the three organizations were minterrupted and cordial.

\section{REORGANIZATION}

The Red Cross during the war and for two years after the Armistice was organized in departments, each one of which had its own fickl staff for the purpose of promoting and supervising its special work in the Chapters. There soon developed a tendency, however, to concentrate much of the immediate guidance of Chapter work in the hands of a general tield staff who were responsible for the organization and administration of Chapter affairs, hut not for the professional activities of the Chapters. In July, 1920, a "Joint 11 entorandum on the Relation of State supervising Nurses to Field Representatives" was prepared by the directors of the Burean of Publie Health Nursing and Fichl service. This read in part:

We think it is pretty generally understood that the new plan of lovision organization plates upon the general tient represmatives the responsibility for advising the chapter (oncerning its organization, adminstration, general program and apportionment of funds. It is their task under the guidame of department heals to deselop in the ('hapter a coherent, balaneed and unifer plan of work, appropriate to the nerels of the ammmity and on response to the gemuine interest and wishes of the people. It is their task to see that the ('haptr ofluals and the committes are representative. 
well selected and on the job; that rarious committees work together and that their activities doretail; and, in general, representing department heads, to assist Chapters to carry on these activities successfully. The directors of various departments are responsible for seeing that the activities which the Chapter undertakes are carried on according to Red Cross standards. In the case of the Publie Health Nursing Service, the State nurse has a special responsibility for the supervision of the nursing service in the Chapter, including the selection and appointment of the nurse, advice as to the type of nursing work to be carried on and its relationship to other nursing service in the county and the supervision of the professional aspects of the nurses work.

From this it is evident that the field representatives and the department representatives must have a genuine understanding of each other's work based on constant consultation and interchange of information and opinions. Such team work is only possible where the two groups of workers meet for regular and frequent conferences.

Much of the work of preparing the Chapters to undertake public health nursing was delegated to these field representatives by the Division Bureaus of Public Health Nursing.

The reorganization of the Red Cross in the spring of 1921 brought about a much closer relation between the general ficld staff and the nursing field staff. The change in administration was described in The Public IIealth Nurse, May, 1921, in an article entitled "Remodeling the Red Cross," from which the following extract is taken:

In order to meet the needs of the Chapters in their local expression of Red Cross service the war organization of the Red Cross has been revised. An organization designed to do a national war task obriously was not suited to the present commmity work of the Red Cross. . . .

The resilt of this change in the needs of the Chapters has been the doing away with departments in the national and livisional organization and the erection in their place of staff rouncils of sperialists, meeting in consultation with the managers, concerning the problems of the ('hapters. with the resulting harmonizing of the professional recommendations of cach specialist into a single unified scheme for the guidance of the (haptors.

This changre in orcanization which has just come about in the Ilivision and in the national oreanization does not in any 


\section{PUBLIC HEALTH NURSING AFTER THE WAR 1333}

way mean that the professional and technical phases of the work arried on by the chapters will be severed from professional and technical standards of work or from the alvice and gruidane of professional leaders in the division and national organization. Professional standards will be observed just as jealously in the luture as in the past and the means of upholding them will be maintained and carefully guarded. In all professional matters ('hapter murses will be supervised as heretolore by nurses. The field staft will include public: health nurse supervisors as formerly in order that the local public localth murses may continue to follow and uphold the best professional standards and technical practice under the guidance of supervisors thoroughly familiar by training and experience with such standards and practice.

The reorganization also changed somewhat the status of the Bureau of Public Health Nursing:

"When the elimination of departmental organization in the Red Cross took place on April 1st," the Ammual Report of $19: 0()-: 1$ states, "the Burcan of Public Health Nursing became the lublice Health Nursing Service, with its director a member of the National Staff Council. Its administrative charactor was converted into an advisory character and its interrelationship to other Red Cross activities became more firmly estallisherl. While the Public Heaith Nursing Service has equal standing and representation on the National staff ('oun(il with other services, there is a doser relation to the Nursing service than to any other because of the almost inseparable connection between public health nursing and nursing as a whole. It, therefore, continnes to be a part of the Nursing service. although it has direct representation on the National statf comole and its director is responsible directly to the rice-chairman."

The inquiry preceling the reorganization brought ont the falet that it was neeresiary for the public health murse, in those C'hapter's in which she was the only trained workere, to take a

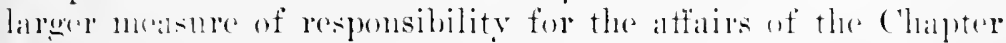
in general. and in all chalpters to relate her work elosely to the other ('hapter aletivities. This meint she must have a more intimate knowledge of all phases of lied Cross work and in aldition to her terohnical duties must berome something of an orwatuizer and leador. 
"In looking over the work of our nurses during the past year or two," the director commented in her Annual Report, "we find that though usually skilled technicians they are not always good organizers. When one stops to consider that many of them have just completed their preparation for public health mursing and have had no executive experience, and moreover that many of them are eity bred and city trained, it is not surprising that they do not at first show qualities of leadership and organizing ability. The task which they confront is a complicated one and diffieult even for older and wiser heads. We wish that there were enough public health nurses so that we need not place responsibility for the organization of new work on the shoulders of inexperienced young public health nurses. Their courage and enthusiasm are abundant and admirable, but their ability as creators, executives and leaders is not yet developed. Often a publie health nurse is the first and only trained worker with whom the Red Cross Chapter officials and the community have ever had dealings. She may be the only person in the "hole county trained in public health work and thinking in terms of broad social endeavor. Upon her shoulders falls the responsibility for making her work a part of the life of the county, for drawing the people throughout the county into it as individuals or organized groups, for developing ways of multiplying her service through the help of untrained volunteers, for making public bealth mursing understood, believed in and userl and its responsibilities shared by people throughout the county. She also has the responsibility of developing public bealth mursing in harmony with the other activities of the Red C'ross Chapter and of making it serve the purposes of the Chapter to the fullest possible extent. Her task is a big one and a most interesting one but requires very definite qualities of leadership which usually come only with experience.

'The majority of our Red C'ross publir health nurses are recent graduates of public health nursing courses or have not been in public health nursing work very long. Many of them are young and unused to taking their part in public work. That they need a great deal of help from their state and Inivision supervisors is natural and justifiable. 'That many of them develop into real leaders in their counties where given enough help at the beginning is being proven by our experience.

The process undertaken late in the year of knitting the field stafl together and making it more general and therefore more nsoful in character will help to strengthen the ('hapter public health nursing services. Not only will the Public Ilealth 
Nurses have behind them the supervisoly nurses but the general representatives of the field staff as well. ${ }^{13}$

Rural and small town nursing were of such recent development that no standard methods of procedure had been formulated and no plan for a complete rural community nursing service was amnouncel. Because of the widely raried conditions existing in different parts of the comintry, no stereotyped plan eould ever be universally applicable. it number of experiments, it was felt, would have to be conducted and their results analyzed and measured before any working models could be endorsed as thoroughly tested and satisfactory.

In the summer of 1921 Virginia Gibbes, who had had sereral years' experience in the Red Cross, both in commmity and i)ivision positions, made a study of the Chapter services which had been suecessful in meeting eertain organization problems. Several hundred of the Chapter murses also wrote an account of the methods used to develop their work in their Chapters. A pamphlet based on this material, which representerl the results of widespread and varied experience, was nearing completion as this book went to press.

As approximately 80 per eent of the lied Cross public health nurses in mal districts were giving all or part of their time to school nursing, for which no recognized standard technique and practice had been evolved. Miss Anna S. Stanley, formerly director of Public Health Nursing in the Southwestern Division and an expert in school mursing by reason of years spent first as school nurse, then as supervisor of school murses and later as teacher of school mursing in one of the aceredited public health musing comrses, was asked to conduct a serices of conferences on school nursing in six of the Divisions of the Fed cross. As a result of these conferenees a standard pratetice of technique for sehool nursing was acreed upon and embodied in a mineographed outline of school nursing procedure. This proved to he of the greatest help to murses and met with an increasing demand.

The effort to bring about a closer articulation of the varions activities of the Chapter was strengthemed by the temeleney to do away with the multipliation of Chapter committeses thes coneentrating the general management of all its affairs in the hamels of the lixerutive Committere. There was firepuent ditti-

${ }^{13}$ Annual Report, July 1, 19:0) to June 30, 19!21. 


\section{HISTORY OF AMERICAN RED CROSS NURSING}

culty in securing suitable personnel for the Executive Committee, the Home Service Section, the Committee on Nursing Activities and the Chapter School Committee, without using the same people for all of them. The great need for closest coïperation between the various committees was apparent. In many Chapters it was felt that the various activities conld be developed more intelligently and harmoniously if the Chapter program was conducted by the Executive Committee, with subcommittees to deal with the details of different undertakings. The comment of one director represented the experience of them all.

We are finding it somewhat difficult to secure sufficient number of people willing to serve on a Nursing Cominittee as outlined in A-700 and A-701. In several Chapters we have found it adrisable to use the Executive Committee, adding to it the several people who would be helpful and necessary to carry on the work. We believe this latter method will be generally used in the smaller Chapters.

In the light of this general tendency to unify the hitherto independent activities of the Chapter, a review of the various methods of engaging in public health nursing by the Chapters was made.

The Red Cross had previously agreed that no one activity of the Chapter should be operated independently of the others and that Chapter funds should only be used for work in the operittion of which the Chapter shared directly and for which it possessed an administrative responsibility commensurate with its financial responsibility. Is a result it beeame clear that Chapters thereafter should engage in public health nursing only when they could share in its operation and when they could have a conncetion with other Chapter work, such as the servire for ex-service men and the activitios of the Junior Red Cross. It was also felt that siner the fiold staff was more than orenpied with the superrision of Chapter public health nursing serviess, affiliations with independent oreanizations shonld be disconraered exeept when the public anthorities, having taken orer a Chapter sorviere, desired the eontinuance of the assistance and supervision of the lied ('ross. 
TYPES OF RED CROSS PUBLIC IIEATII NURSING

Red Cross public health mursing had as its object the saving of life, the upbuilding of family health, and the promotion of commmnity sanitation and hygiene. It dealt with individuals and families in its efforts to restore the sick to health; to find and correct phrsical imperfoctions; and to teach the practice of healthful living and establish hygienic habits. It dealt with the community in its efforts to assist in ehecking and eliminating communicable and preventable discases; in discovering and correcting unsanitary conditions; and in edncating the public in phrsical hygiene and public sanitation. No phase of publie health mursing was omitted, the nurses engaging in bedside nursing. prenatal and maternity musing, infant and ehild welfare and school nursing, tuberculosis nursing, communicable discase control and health edncation of many kinds. Seldom was a public health nurse able to carry on all of them. Usually, when working alone in a large territory, she confined herself to one or two aetivities, the choice being deternined by the need, the desires of those she served and the possibility of aeeomplishment.

The ereat majority of the Red Cross Chapter public health nurses worked in rural districts and most of them harl as their territory an cutire comnty. In the more highly organized seetions there were sometimes sereral health muses working in the same comutr, ableh murse having a certain commmity within the eomuty for her speedial field, but in general the murses were called num to cover a large area. Some of the western comnties in particollar were no less than enomums, covering as larege a territory as certain of the small castern states.

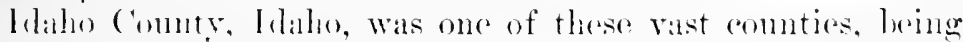

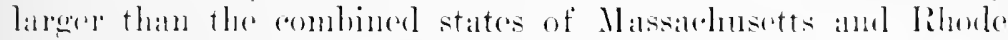
Islamel. The ('hapter public health muse for this county wrote:

My hagrage has to he desirned to parek on the saldile. A

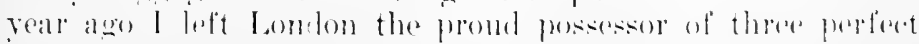

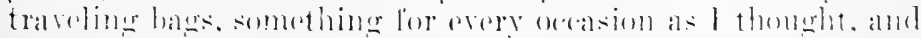
mow I anm epeseing the mountains with all my immoliate

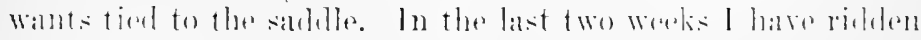

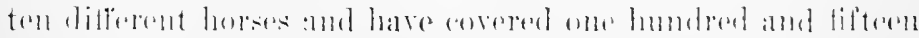

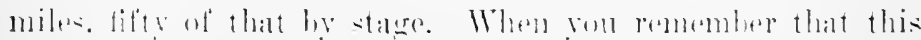

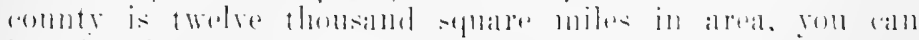

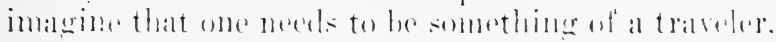




\section{HISTORY OF AMERICAN RED CROSS NURSING}

The Red Cross publie health nurse in Alaska, whose work of health instruction took her from place to place often widely separated, used whatever means of transportation were at hand. At the end of an Aretic winter, she wrote:

I had quite a trip. One place I went by dog team over a hundred miles, then to another place by train. There is only one, which runs to suit the company. I was four days coming one hundred and thirty miles, but the scenery was sublime.

This same nurse was not deterred when trains and other methods of transportation failed. Of her trip over the broad pass from Anchorage to the interior, she wrote:

We (the nurse and two teachers) left Anchorage July 5th and got to Dead Horse that night. Stayed all night and left next morning for Hurricane Gulch, arriving there at two P.M. That is the end of the railway on that side. From there we had to walk seventy-two miles to Healy, the beginning of the railway into the interior. We took it slowly the first day so as to get used to walking. The walking was very bad in some places, the ground being wet and swampy and the heat and mosquitoes were dreadful! The third day out one of the teachers met with an accident, so they had to turn back and I continued my journey alone, but every one along the way was so kind and I got horseback and "way-on" rides for about twenty miles, so I just walked fifty miles in all.

In another of the big counties of Idaho, Lemhi County, the nurse reached her most isolated schools by means of a typieal eoach of pioneer days. She said:

We got in a covered stage drawn by four and six horses. If you ever saw Buffalo Bill's show, the "Deadwood" coach, you see my picture. We hold our breath as we go up nine thousand feet straight up like a ladder and then over the mountain; the road is spiral but we go up all the time; ninety miles and four days' trip. 'There are only seven children in the school, but they are four hundred miles from a hospital and our visit is worth while.

Another pioneer nursing service of the Red Cross was that which was established among the lumber camps along the Pemigawasett River in the New Hampshire wilderness. 'The nurse had her headquarters in the little town of Limmoln. the center of the lmmbering operations, where she tanght the 
mothers Home Hygiene and (are of the Sick. Her "district" was the whole Pemigawasett wilderness. She assisted the doctor, accompanying him to the distant lumber camps often into the very heart of the mountains. Here she fomml great need of presentive work as well as actual nursing. The men were humbled together in large numbers in almost murentilated bunk houses. Many of the men were unvardinated and no care was taken in regard to communicable and other discases. In their work of felling trees and getting them to the stations in the dead of winter, accident and frostbite were common, ${ }^{14}$

A great majority of our nurses being employed by Red Cross ('hapters whose jurisdiction covers a whole county, are engaged in county-wide work. A lew are employed by hed Cross branches and their service is limited to the town in which the branch is located. The nurses engaged in town work have foumd it possible to develop a fairly well rounded public health nursing program. Those who are attempting to cover a whole county without assistance have found it manifestly impossible to develop more than one or two of the several phases of public health nursing. Usually the nurse and the Chapter together have decided that the best way to open a new service is offered by undertaking school nursing. It is obvious that if there are from 60 to 90 rural schools scattered over a large county, in all of which the nurse wishes to render some serviee. she will not have much time to develop other phases of public health nursing. There is a dauger, however, that the people of the county may come to think that sehool nursing represents the whole of the public health nursing program when the nurse makes this her primary work. In order to avoid this mismderstanding we present the program of public health nursing in terms of family health work rather than in terms of a number of independent specialties. We say that we want to help to secure and maintain gomel health among all the families in our county and that our first sten towards attaining this object will be taken through the aremue of the sohook. It is. of course. our object to builil erentually a complete and adequate county nursing service proviling all the different forms of public health mursing. inchuding the eare of the sick. ${ }^{15}$

Especially in the ereat comnties of the West, school nursing secmed to be the mest pratetical and result producing program.

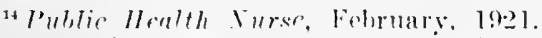

1. Annual liepurt, June, l!201, to July, l!21. 


\section{HISTORY OF AMERICAN RED CROSS NURSING}

A typical winter day's work of a school nurse was described by Miss F. B. Palmer, public health nurse for Martin County, Minnesota, and published in the October, 1920, issue of the Public Health Nurse.

I had come to the county for a few weeks as a public health nurse with the hope of impressing upon the people the need of and the benefits to be derived from a continuous county nursing service.

It was in December, when the snow was many inches deep and the thermometer below zero. The superintendent of schools, an active and intelligent woman of fifty-five years, had mapped out the schools and districts that were most isolaterl and in need of a nurse. We took the $4: 10$ A.M. train to a little town twenty-five miles away. Here we searched for something that looked like a hotel. Finding it at last, we walked in and, seeing no one around, we took possession of the stove and chairs and curled up and slept until 7 A.M., when the "proprietor" came thumping down stairs. He was is: surprised to see us as we were glad to see him. In a short time we had breakfast-coffee, bread without butter, and some boiled meat. Breakfast being over, we started forth in an anto for a school ten miles north, but half way there we ran up against so much snow that we had to dig our way out.

The school wasn't reached until about $10: 30$, but as there Fere only four pupils in this sehool we hat plenty of time. All the children were from one family and were born in a foreign land. They had had nearly all of the contagious diseases and were left with some of their complications and were still abiding by a few old enstoms. An annul bath and clothes sewed on for the winter was their one law. One child had eye trouble and was deaf, due to poor care during the measles. Another had enlarged tonsils and adenoids. All four had defective teeth and pediculosis.

We decided to take the children home and explain their condition to their parents. The fatier was not home and the mother was in bed with a new baby. While the nurse was earing for the mother and baby, the county superintendent started on the rhildren and it wasn't long before a great change had taken place. The superintendent informed the mother that the would keep in ('lose touch with her and hal? her to make healthy ritizens ont of her children and that in the spring she would all and take the children to the doxtor, and when spring ame sha did hring the eluiblen in to the doetor, hut she has to do it only once, for the parents have heon doing it ever since. 

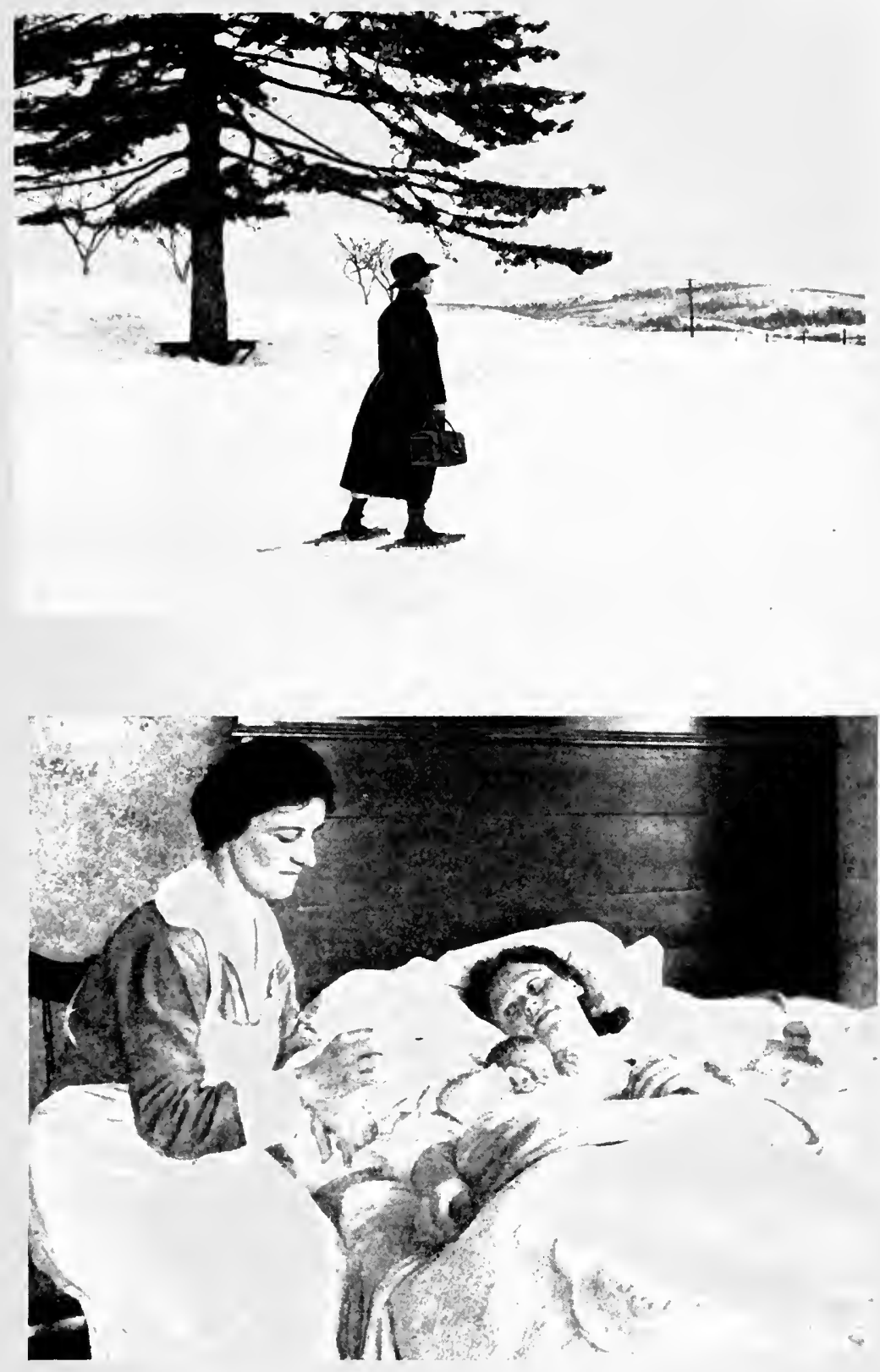

An American Red Cros public health nurse on her rounds 



\section{PUBLIC HEAL'TH NURSING AF'TER 'THE WAR $13+1$}

From this home we drove our ar six miles, got out, hired a team of horses and huggy and slowly womnd onr way for four miles throngh the tall evergreen trees. (Only a rabbit or deer jumping through the trees helped to break the silence of the wooks. It indeed seemed like the "forest primeval." At the end of the narrow passage we reached a lake which we crossed with a little more speed. As we drove up to the school, which was in the eenter of a group of small houses, every loor was opened and interested people peered ont. The larger number of them were half-breed lndians. The parents (ame up to the school to see what was going on. They saw the children inspected and listened to a short talk on the "Health of the school Child." Sereral cases of trachoma were found. The parents were told of these and urged to have every member in their family examined. A friendly old squaw asked us to supper at her house, and we didn thave to be urged, as we were hungry, having come without lunch. A well-cooked meal of soup, boiled potatoes, rice, beans and renison was set before us and we ate with a rengeance.

Eight o'rlock found us on our way to a little town eight miles north. Once there it didn't take long to warm up aromed the stove and then (limb upstairs to our cots, which looked pretty good but felt mighty cold. "Well, to-morrow will find us up early and ready for another day that is really worth while," said the indomitable smperintendent, "and if earh school and each family could have a nurse to visit them, what a healthy, haply place we could have to live in, and wouldn't I he proud to have a public health nurse in the office with me! What a help we would be to each other!"

Frequently school nursing included the organization and operation of clinies for the correction of defects of sehool children. One of the Chapters reported a clinic held in coöperation with the local doctors for the exrision of adenoids and tonsils. The work of the public health nurse had brought to light the need of four hmuled children for this operation. A throat speeialist was bronght from the eity and for an entire week a daily operative clinic was held with the eoiperation of all the hocal doctors, morses and Clatapter people. One hundred and ninetrethree rhildren were operiated ujow in that one week and a valuable piece of correcetive work aneenuplished.

clinies of many kinds were oramized ly the Red cross public lealth murses not only in the larerer towns amd anteres. lut in isolated rubal distriets where medieal and dental atten- 


\section{HISTORY OF AMERICAN RED CROSS NURSING}

tion were most needed. One of the Red Cross scholarship nurses in the Southern mountains wrote:

Our dental clinic held in September was a success, more than seventy-five people attended; many came from remote sections, miles away. One woman sixty-eight years old walked twelve miles across mountains to see the "tooth-doctor." She sat down in the dental chair and in a moment arose and said "I want yer all ter know I done prepared myself ter die before coming liere en if I never git ont a this chair alive jest know I wuz prepared ter go." She sat down and had eight snags extracted (by painless extraction) and when the dentist hact finished, she "praised the Lord for the strength" and went out and brought her friend in, who had a number of extractions done. I asked the good woman where she came from and how she happened to come. She said "I heard that bad teeth wuz bad fer the system and $I$ is been a ailin' fast lately en I thought hit might be my old rotten teeth a damagin' me." Her friend was a widow with no ehildren and no means of support; she was aged too. The dentist and the Chapter took care of her bill.

In many counties of lesser size, prenatal and infant hygiene aetivities were given great emphasis, and inchnded the conduct of hundreds of baby conferences. One of the Division directors of Public Health Nursing reported:

Summer seems to lave been the time to sow the seed for bahy health stations or clinics. They are springing up in the most mexpected places, and thriving beyond the expectations and hopes of those who are responsible. We have twenty-five in active operation, with six in process of organization. One county has been practically covered this summer by a trave]ing clinic.

The supervising nurse for northern California wrote:

The Mothers' Edheational Center, located in Red Cros headquarters, is the most ambitions attempt that has been marle along these lines by any of our ('hapters, for here we have not only two full time nurses, but a paid mediaal man. He is the rity physidian and is on duty at the Center two days a week fom 10 i.u. until noon, and on Saturday at the same hours at a branch which has been organizol in a kinderearten of a school, where there is a large attendance of foreigners of many mationalities. liecords of all first borms are secured 


\section{PUBIIC HEALTH NURSING AF'TER THE WAR 1343}

each day and a letter sent immediately to the parents, inviting them to make use of the Ilealth c'enter. This is followed by a monthty risit and letter throughont the entire first year; the result is shown in the attenlance at conferences.

\section{Another Division director wrote:}

Some of the methods by which the interest was gained (in baby conferences) in the different communities were very interesting. One nurse canvassed the town and put a little flag in the window of each house that claimed a baby under two years old as a nember of the family. She secured the cooperation of the physicians by speaking individually to them of the bahy stations and asking them to get together, and decirle among themselves what time each one would give, which they did.

She offered a prize to the high-school girl who made the best poster for the baby stations. One of the newsjapers donated a good quality of white paper and the painting class in the high school donated the paint. This resulted in active interest among the girls, and some very nice posters.

A little publicity in which the townspeople were given a chance to participate often proved an auspicious beginning for "babe health station.

T'revious to the establishment of regular conferences a "Baby" ('ampaign" was often held as a preliminary measure to arouse interest. An Aneriean lied Cross supervising nurse sent the following report:

The Parkershurg, Ta., Chapter of the Red Cross arranged for a Baby Week (ampaign. The publicity and proliminary work was unusually well hambled but. in their zeal to rath all. tor many appointmats were made for the same hour, crowting us somewhat.

The bulding griven to the Red cross for their activities was make rearly for the work. Being an old residence. it would have been an admirable arrangement if the hables had not come in suld "Jroves." A front room upstairs was arranged with displays of proper elothing, proper and improper foods for dhililren, the usual posters and the like. I supply of literature on the health of the dhild was provided for distrihution. More than five thousand preces were griven out.

Wr met with splemelid aöpration from the duetors and nurses. in fact. of many doctors (ame that we titted rup two

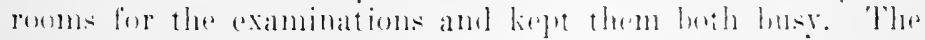




\section{$13+4$ HISTORY OF AMERICAN RED CROSS NURSING}

Red Cross had employed one nurse full time for the week and the various public health nurses from the schools, Metropolitan Life Insurance ('ompany and Red ('ross, besides several married nurses volunteered their services on the various days.

It was somewhat hurried and crowled but with all a real success, I think. Four hundred and thirty-six pre-school children were examined during the weck and Mrs. l'rice wrote me that since they did not finish with all who had registered, they had continued the clinic for two days the following week. Their public health nurse will do the follow-up work. Dereloping from the campaign is their plan for a demonstration in modifying milk in the near future and for baby clinics twice a week this summer.

The films "Birth Registration" and "Infant Clinics" were shown at the rarious morie houses during the week and pictures were taken of a great many of the babies. Slides will be made of these pictures and they will be shown later on.

That the nurses did much bedside nursing was shown in many of their reports as follows:

One day during the influenza epidemic I risited one large town in my territory and, as I always do on arriving in a town, I called on the three doctors and obtained from them a list of people they wanted me to visit. The people whom I saw and their circumstances rary so widely that I an going to enumerate them.

The first was not an influenza but a maternity rase. The baby three dars old was wrapper in a blanket and placed at the foot of the mother's bed. When I entered the door I stepped on sereral pieces of coal which harl rolled down from the pile of coal against the wall on the floor on one side. One

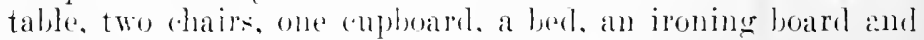
small stose completed the furnishing of the two rooms in which this young married (ouple lived and brought their first child into the world. With little to do with ontside of the equipment in my nurse" bas, l bathed the babs, demonstrating to the mother and father who wore watrhing the different steps and inperesing upon them the importance of beginning right with their first balky and feeding here at regulan intervals

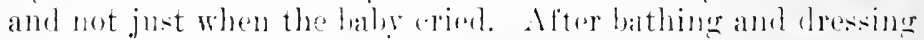
the baby 1 gave the remilar routine are to the mother, and then lof with final brief repetition of important points in the (are of lier bibs.

My next rall was on a premature babe two montls old and

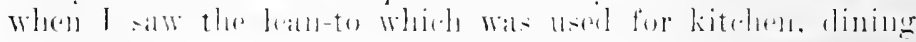


room and sitting room for a family of five, including the baby which was bundled up in old quilts behind a red-hot stove, I didn't wonder the doctor haul sent me. When I looked at the baby I thomght it must have been shoveling coal along with the dirty-faced uncle who "ame in. The bahy was almost the color of a pirkaninny from soft coal soot, and his little shirt I'm confident had not been changed for a week at least, but he was ganining even with such treatment although still very thin. I asked for materials for a bath and before the indifferent mmarried nother and interested young annt, and skeptical granchother demonstrated a bath and urged that the baby have one every day. On seeing the baby's bottle I decided to suggest how it should be cared for, which I did. The mother grew more interested in time and promised to bathe the haby regularly, but she will need frequent instruction and encouragement for to all appearances she has the mentality of a child of about ten years.

My last call late in the afternoon was in a home with four small children three of whom were coming down with the measles, and one boy had hat measle: and now had pneumonia. He was irrational and had a high temperature so the mother quickly assembled the materials for a warm sponge ordered by the doctor and while I was giring the bath she frantically finished making him a new nightgown to be put on alter the bath. I had been there the day before and had advised that the children be put to bed so of the three prospective cases one was in a crib and the other two crosswas on a divan-bed, making the living room resemble a hospital. The sick pneumonia boy was in a room by himself as directed with a wintow open and was receiving are just as I had demonstrated the day before. The mother watehed every movement I made and althongh she said she knew nothing about caring for the sick, she appeared to have learned more in two hours from the looks of her patient and bedroom than most people would learn in many days.

I'll explain my long silence by telling you of my experience during an epictemice of typhoid which hroke ont at (iilmore, 18 miles from salmon and 10.000 feet in the air. One would naturally think that altiture womld purify most anything. but we harl 18 ases. Ire hos only one, but as we had her in our ware not more than eighteen hours you can inagine she was a pretty sick woman when we gent her.

Fortmately this mining (amp) had a litth howital of eight

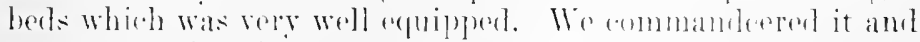
started moring in the worst asos. I tomk with me from 


\section{HISTORY OF AMERICAN RED CROSS NURSING}

Salmon a young girl, an undergraduate who had had four months' training in a hospital in St. Louis and who was most helpful. As soon as their temperatures were normal the patients were sent home. Three were kept all of the time. It was necessary to melt snow for water, split wood and shovel trails. I made regular visits to the homes, instructing the people how to take care of themselves and of those dependent upon them, so as to prevent further cases developing. The snow was between four and five feet deep and I was serenty miles from a physician.

This last week I was asked to investigate a T. B. case, a man living with his four children all in one room-living, cooking, eating and sleeping in the same tiny space. One son 17 had a very suspicious cough. A girl of fourteen did the washing and cooking for the family besides going to school. She washed the father's handkerchiefs, advised the girl about disinfecting and the general care of her father. The Red Cross has furnished a tent, and the neighbors have put up the frame. The happy man is now in it, away from the cooking, and he feels so much better in the fresh air. The house has been scrubbed and cleaned generally and the children are to be examined next week.

An average day's work of a nurse in one of the larger counties was given by one of the Red Cross public health nurses in a Minnesota county:

A ride of thirty-five miles in a tin Lizzie brought me to my destination-a schoolhonse of one room, poorly lighted and dirty, to teach the first lesson of a series of twelve two-hour lessons in Home Hygiene and Care of the Sick. Twenty mothers of different races-Polish, French, Irish and American were assembled.

A bed had been installed with a straw tick, sheets, pillow cases and blankets borrowed from the pupils. Each mother was taught how to make a bed, turn a helpless patient, change draw-shects, lift and make comfortable paralyzed patients. The position and quantity of furniture and the temperature and ventilation of a sick room were also explained. There were discussions on this lesson and preparations were made for a second meeting the following week.

Good-bys were said and I left for another thirty-five mile ride over a sandy, rough road when I was hailed by a farmer, "Be you that comty nurse?" "Yes." "Well, come and see my colt, it's got hurt." Another drive of three miles to find 


\section{PUBLIC HEAL'TH NURSING AF'TER THE WAR 1347}

a beautiful animal six weeks old torn by wire on the left shoulder straight across the chest to the right leg. The depth of the wound was fully two inches, the length over sixteen. The famer had done some veterinary work two days before, lut his lands, needle and cotton were dirty. Infection and high fever had set in and a bad condition was the result.

A large sheet was sprearl on the gromul, the patient laid out on it, hind and forefeet tied together and flexed, the master of the house sat on its head, while the young son did likewise on its flank. I sterilized my hands thoronghly and proceeded to business and for one hour steadily cleaned and removed infected tissue, cut away the old stitches, washing with hot water and lysol, tied two arteries and poured tincture of iodine into the wound-the patient resting peaceably and quietly as if it knew the comnty nurse was doing her best to help it. A few days later I found the animal doing well and the wound healing.

Another start was made towards home when a woman emerged from the woods. "Please come and see my twins, one is dying." I found two baby boys, aged three and onehalf months, weighing seven and one-half pomds each, in a very serious condition, being fed every half hour on condensed milk, wrapped up in blankets, lying on a feather bed behind an immense stove. There was no fresh ajr in the room and this was August! There was a history of tuberculosis in the family and the mother wondered why the children didn't grow! She couldn't see any reason for it. With the proper care and with the instruction eagerly followed by the mother, within a week a marked improvement in babies and mother. honse and surroundings, could be seen, and all lived happily ever after.

We have an average enrollment of two hundred pupils in the Home Hyriene and Care of Sick rlasses. Five hour? daily teaching, and in addition, the weighing of varions babies, the changing of formula, the removal of incipient tuberculosis cases to sanitaria, and to make a life a little more interesting the taking of a mental case to a State institution finishes an average day's work. ${ }^{16}$

The class work in Home Irgiene and Care of the Siek stimulated the demand for permanent public health musing serviees. One l)ivision director said:

From actual work in the field we have come to the conchsion that all comoty public health work should be prefared by ${ }^{10} .1$ meriean ofournal of Vursing. June, 19:00. 


\section{$13+8$ HISTORY OF AMERICAN RED CROSS NURSING}

classes in Home Hygiene and Care of the Sick. As one of the Red Cross chairmen has written in, "You will see that the nursing elasses act as trumps in this game of demonstrating to the people the necessity of county-wide publie health work." In this partieular community the instruction work has brought about the demand for two public health nurses.

One of the most constructive activities of the public health nurse which was always attended with encouraging results was mutrition and growth work, one aspect of which was health and growth elasses and another hot luneh and milk in the schools. One Division director wrote:

Many of our nurses have started hot lunches in the rural schools, and have been able to interest the mothers in deroting some of their time to preparing the lunches: thereby reliering the nurse of this extra responsibility. Also, in some of the high schools, the older girls are assuming this responsibility, one group preparing and serving the lunches, and another putting the kitchen in order, under the supervision either of one of the teachers or some member of the Red Cross Nursing Activities Committee.

\section{Another Division director said:}

A splendid coöperative work is being done by Miss Mayer, public health nurse for Miscogee Comnty. and Miss Jessie Fortson, county demonstration agent. Miss Fortson attended 1)r. Emerson's lectures at the Division office and has returned to her county, and is putting her knowledge into practice. She goes with Miss Mayer into the schools and weighs and measures the pupils. While Miss Mayer is doing phrsial inspertion of the pupils Miss Fortson keeps a list of each pupil's name, weight, ete. and checks up those of normal weight. Then she chasifies the underweight children and gives them sperial adrice about the selection of food and how to increase their weight. In this way contact is mare with the pupils. and much interest is show by them in trying to bring their weight up to normal. The pupils also have exhilited much interest in the phrsical inspertions. Miss Mayer sents a report slip to the parents of normal children as well as to the parents of those needing correction of deferts. as parents not getting a slip have been sending their child back for his or her report of inspertion. These workers are really making their efforts count for something. 
That the Red Cross public health nurses were called upon to do muth teaching and organizing was evident from a narrative report from the supervising nurse for Tennessee:

On a recent trip through Tennessee, we found the most extraordinary enthusiasm for the public health nurse manifested by the chapters which have nurses employet. The nurses have done excellent work, inspecting school children, giving nursing eare, instructing mothers in the hygiene of pregnancy, organizing little Jothers' Leagues, conclucting health elasses, opening health centers, infant welfare stations and rest rooms for farmers' wives.

'They are condurting classes in Home Hygiene and Home Care of the sick, and giving other health instruction to pupils in grammar, high and Normal schools and colleges.

They are giving nursing care and instruction in hygiene to patients ill with tuberculosis and instructing families how to prevent the spread of tuberculosis and other dangerous communicable diseases. In fact, their activities are so many and their work so well received that at the Farmers' Convention a great real of time was given by the Home Makers' Section to the telling of the activities of the nurses in the rarious chapters.

The work of the nurses knew no color line. Not only was much bedside uursing undertaken among the eolored population, but school inspection, special dental clinies, baby conferences and health centers were established in colored sections. Mary Quinn, Red Cross public health nurse for Wichita County, Texas, wrote:

On Friday, we had a health conference for the colored. The basement of the Baptist Church was fixed up, and Doctor Wolch and Doctor Means, prominent church workers over in the district. lined up the mothers and babies. There were twenty-two babies wejerbel and measured and examined. Talks were given after the examination and a committee appointed to continut with the lowalth conference erery month. 'The last Thursilay of the month has beend dereded oil. I must say the colored folks are rery cuthusiastic over the public health center work. There are three atos who. I know, have had tonsillectomies since the conference in september.

Seores of eolored midwives in the somth, some of them living on islands which could only be ratehed hy rowhoats on a cortain 


\section{HISTORY OF AMERICAN RED CROSS NURSING}

set of the tide, were instructed and advised by public health nurses of their own race.

The unrses found exeellent opportunity for health publicity in eonnection with the State and eounty fairs, particularly in the Sonth and West. Interest aroused in this way was made the basis for future intensive work. An example of this activity was found in a report from San Joaquin County Chapter, California :

The Public Health Nursing Service of San Joaquin County Chapter held a very successful Children's Health Conference, in comnection with the County Fair, the week of September 13th-18th. As the fair committee had very few permanent buildings, the conference was housed in a tent. The space allotted us was $30 \times 50$ feet or one-half of the tent. At first glance it looker hopeless, but after a carpenter had erected beams for dividing into smaller booths, we felt more hopeful. By the use of sheets and mosquito netting, we were able to arrange a dressing room, weighing and measuring room, examination room, booth for the dental hygiene department and a large space for demonstration and exhibit material.

One hundred and sixty children, ranging in age from six weeks to six years, were examined during the week. The examinations were made by physicians of stockton and san Joaquin ('ounty, volunteering for three hours each. The dental exhibit from the Lniversity of California proved of great interest to both mothers and children. A Stockton dentist was in attendance each afternoon. Demonstrations on the are of the infant were given each afternoon, by pupil nurses from the local hospitals. In the evening Red C'ross films were shown. "American Junior," "Wimning her Way," "In Florence Nightingale's Footsteps." "In Equal Chance," the Nittional Organization for Public Health Nursing film and the Federal Children's Burean film, "Our Children." were also shown.

A separate tent with a cot and First-Aid appliances was provided and a number of minor cases were ared for.

Although the Health Conference meant a week of toil for the public health nurses. we feel that it has been rery much worth while, dne to the interest shown by mothers of children of all ages and also by a great number of prenatal cases. Ife also feel that it gave the people throughout the county a better understanding of the work undertaken by the Amerian lierl ('ross.

An interesting fenture of the exhibit was a booth main- 


\section{PUBLIC HEAL'TH NURSING AF'TER THE IVAR 1351}

tained by the publie library, featuring books on child care, and emphasizing the excellent coöperation they give the public health nurses in our work throughout the county.

The County Farm Bureau gave valual,e help throughout the conference, and ? isplayed in their booth was an excellent poster stating the coopperation of the Red ('ross with the Farm Burean in giving the classes in Home Hygiene and Care of the sich.

The foregoing examples written for the most part in the nurses' own words gave some idea of the scope of Red Cross public health nursing. It was by no means the whole story, however, but rather a glimpse here and there of undertakings and accomplishments. Underlying every activity and an inseparable part of every public health nurse's program was the constant, persistent teaching of hygiene and health habits, better eare of the siek and better living through practice and preeept, through demonstration, illustration and personal advice. The following paragraph which closed the annual report for the fiscal year, 1920-21, epitomized the service rendered by the Red Cross public health nurses:

All orer the country in the most out-of-the-way places, as well as in the thriving agricultural centers. our nurses are at work. In the tiny settlements in the high sierras, among Indian tepees, in the heart of the Appalachians, on the loneiy islands off the New England coast, on the wind-swept plains of Montana, in the villages along the Mexican border, in the heart of the forest of northern Ilichigan and in the mining camps of Kenturky and Wost Vircinia, the rhance to live, the message of health and the good will of the lied cross are being arried by those brave, and often lonely workers, in the uniform of the nurse and of the Red Cross. 


\section{CHAPTER XVI}

\section{CLASS INSTRUCTION FOR WOMEN}

7 HE system of class instruction for women under the Red Cross Nursing Service, now so extensive and so 1 carefully worked out, took its rise in a suggestion made by Miss Boardman to the District of Columbia Branch in 1908 . The January Bulletin for that year said:

The District of Columbia Branch at its annual meeting took up the subject of special Red Cross courses in First Aid (for men) and Home Nursing (for women). Committees were appointed to arrange for such courses.

In the April following the Bulletin reported:

Lectures on First Aid for men and Home Nursing for women, instituted by the Distriet Red ('ross Branch, have proved most successful. Especially the latter were largely attended. Inquiries have been received as to arrangements being made another year for nursing courses to be provided at small expense for women's clubs, etc.

These first chasses in home nursing were given in St. John's Parish Hall, Washington, I). C. ; the First Aid lectures, to men, were held in the Y. M. C. A. anditorium. Botle halls were given withont (harge for their use, but the l)istrict (hapter paid the lecturers ten dollars for each class. The murses who eondureded the classes for wonen were, lily kimely (Connecticut Training Sohool); (Coorgial Nevins (. lohns Hopkins); and Mrs. ('harrles Young (Rochester Homeopathic). They taught largely by demonstrations of practical nursing procedures.

The preamble and schedule of this early home nursing course follow. I'nfortunately the precise anthorship eamnot be stated ; very probably the thire nurses mentioned collaborated in arranging the printed material. 


\section{HOME NURSING COURSE FOR WOMEN}

There are thousands of families in which sickness occurs yearly, when the services of a trained nurse, either because of the question of experise or for some other reason, cannot be obtained. To provide a simple conrse in llome Nursing for those who will hare the care in such rases of illness, the Red Cross has arranged ior the following lectures to be given and demonstrated by trained murses. It is suggested that those taking this course bring paper and pencil or blank book for the purpose of retaining notes of these valuable instructions.

I. Ilygiene of sick-room: Location of room. Ventilation. Demonstration of bel-making. Clothing of patient. General care of patient.

II. Dietetics: Food in health. Preparation of food for the sick, surh as beef-tea, milk, egrss, ete., with illustrations.

IIl. Tuberculosis with Exhibit: Mortality. Modes of infection. Destruction of sputum. Disinlection of rooms. Open-air treatment. Diet of consumptives.

IV. Contagious Diseases: Obligation to prevent spread of infection. (compliance with health laws. Protection of attendants. Preparation of room. Disinfection. Scarlet fever. Diphtheria. Ileasles. Pnemonia. Typhoid. Whooping cough. Influenza. Disinfection and fumigation after disease.

V. Wother and Baby: Care of expectant mother. Care of new mother. Care of baby. Clothing, feeding and habits of baby. Artificial feeding. 1)iet of (hild until six years old.

†. Emergencies: Merfical, surgical: Fainting. Apoplexy. Epilepsy. Hysteria. Drowning. Heat exhaustion. Sunstroke. Burns. Scalek. Concussion of brain. Foreign bodies in eye, car, throat, ete. Cuts. Bruises. Sprains. Fractures. Hemorrhages. Bandages. Antiseptics.

Where plans have been perfecterl for the lelivery of this conrse, the tickets for six lectures are $\$ 1.00$; or for Red Cross members, 50 cents.

How the example of the District of Colmmbia inspired Red Cross members in Brooklyu, and served to lring IIome Nursing forward in the disenssion of local nursing associations, has already been told. Still more inportant was the action of the Society of Superintendents of 'l'mining Sehools for Nurses. This influential body, at its session in 1!ons, directed its standingr committee on Eduration to prepare an outline of class 


\section{4 HISTORY OF AMERICAN RED CROSS NURSING}

work in Home Nursing "suitable for the use of the Red Cross, or any other organization wishing to provide in a satisfactory mammer for such instruction to women in their homes." This step was taken on the soeiety's own initiative. M. Adelaide Nutting was then chairman of the Edneation Committee, and to assist her in this special task, a subeommittee of five was selected by the society. They were Sister Amy, of the Boston Children`s Hospital; Ada Carr, of the Johns Hopkins; Annie Damar, president of the Associated Alumna; Sara Cabaniss, then head of the Riehmond Nurses' Settlement; and Helen Seott Hay, superintendent of the Illinois Training Sehool for Nurses. Miss Hay made her first appearanee in Red Cross Nursing history in this committee work.

A year went by with work and correspondence in the Nursing Outline, but the pressure of the details of early organization and expansion temporarily hindered the Red Cross from pursuing systematically the elass work it had begmn. A few extracts from letters of that time will give a pieture of tentative effort, and of the somewhat sporadie, yet encouraging attempts at teaching.

To Miss Boardman from Isabel Hampton Robb:

Cleveland, Ohio,

October $4,1908$.

I went up to New York and talked over our conversation with the rest of my committee. 'The Committee on Home Lectures is at work on the courses and will have a course ready to send you between now and Jamury. If I may suggest, would it not be well not to offer any Home Nursing courses before January, 1909. and to make that generally known? In the meantime, this course can be prepared, the cards printed and the various associations of nurses written to in each eity to seeure suitable lecturers.

1 can take it up here with our local associations, or for the state society, if you like. . .

To Miss Boardman from M. Adelaide Nutting:

February 18. 1909.

At the meeting of the Superintendent's Society last year the Committee on Edneation was asked to consider the matter of classes in IIome Nursing, with a view to preparing simple outlines which would be useful to the lied ('ross and other societies desiring to carry on work of this lind. 
It $i$ : the belief of the committee that, inasmuch as a good many diseases arise in the home through ignorance, it is inportant to begin the classes with a short preliminary talk upon the causes of disease, and the measures with which the mother or home-maker should be familiar m order to exercise proper methods of prevention. As I understand from Mrs. Robl that you maly be anxions to arry on some of these classes this winter, I an sending the outline, which must be accepterl as preliminary ratler than as a final statement of the committee's recommendation.

I am sure that Mrs. Robb has discussed with you her irleas which are shared by the members of the committee, as to the advisability of arranging lor these talks throngh onr murses: association and depending upon them to select from their body such trained murses (and probably other assistants) as are best prepared to carry on this teaching. . . .

\section{To Miss Nutting from Miss Boardman:}

Thank you for your letter of February 18 th with its outline for Home Nursing courses. The plan to have these courses under the nurses' assoriations is exactly what I should like to see. I hope a little later in the year to take up this matter. ...

To Miss Boardman from Miss Richardson:

California, Jamuary 20, 1909.

On Sumby last while addressing the Y. II. C. A. of this (ity I spoke of the alvisability of organizing llome Nursing dasses after the plan of the st. John's Ambulance ('orps. The dua was enthusiastically taken up by that oramization and several uther societies have spoken to me about it.

I brought the matter before our meeting to-lay and was (ylad to learn that rou had begun this work in Viashington some time agro. I woukl bike, if possible, to have the benetit of yonr experience along this line before definitely starting a

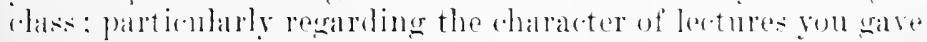

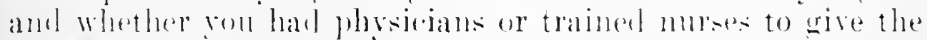
lectures. I hat thonght of having our Nureces Auxiliary take up the matter as it would rive them something to an. i sultmit herewith a synopsis of what I have ylamed to grive them.

$$
\begin{aligned}
& \text { (signed) C. H. lismolatex. } \\
& \text { sian frandeison lienl (ross. }
\end{aligned}
$$




\section{HISTORY OF AMERICAN RED CROSS NURSING}

\section{To Miss Boardman from Miss Pierson:}

New Jersey.

Will you kindly send me information of Red Cross Home Nursing courses? As a similar course is now given in a Nurses' Settlement in which I am interested, it might be desirable to incorporate it under the Red Cross auspices.

(signed) Margaret H. Pikison, ${ }^{1}$

Orange, New Jersey.

To Mr. MeClure (California) from Miss Boardman:

April 7, 1909.

Many thanks for your notices in regard to the meetings of the Chinese Detachment of the California Red Cross. I think it is a most excellent idea to bring such education in amongst its people. I wonder if it would be possible, in time, to have some simplified Home Nursing courses for Chinese women provided? Most of them must be very ignorant of modern hygienic laws, and quite as ignorant of modern ideas in regard to the nursing of the sick.

(signed) Mabel Bolrdalax.

The California Red Cross, then one of the most active of the branches, having developed by reason of the demands made upon it during the Spanish-American War, had a Nurses' Auxiliary which gave class teaching, not only to home women in Home Nursing but also to women in industry. Its pioneer work in that direction is the earliest instance of the kind in Red Cross ammals. The Bulletin (July, 1909) said of it:

The Aurses' Auxiliary, a very valuable adjunct of the Califormia Branch, has indertaken to start factory lectures and demonstrations at the noon hour beginning in April... Sereral factories. laundries and department stores are interested in these methods. and consider them of practical value to working women. The women's auxiliary of the relief column has inangurated a series of talks on Home Nursing and Prevention of Disease.

After affiliation had been brought about in 1909. Miss Delano and her committee at once revived the project of organizing IIome Nursing elasses on a national seale, as Mrs. Rohb had

"Miss Richardson and Miss Pierson were nurses. 
thought it possible to do. With the execption of an interesting letter written by Miss Delano to Mrs. Draper suggesting the idlea and asking Mrs. Draper's opinion (Ilarch 15, 1:10), little record was made of preliminary steps in this direction, but eally in 1911 the full plan was completed and published as follows:

\section{The American Red Cross Bulletin} Jannary, 1911.

Second Anmul Report of National Committee on Red Cross Nursing Service.

Home Nursing and First Aid Instruction for Women.

It has been demonstrated that the instruction of men in First Aid will reduee deaths and serious results from injuries about one-half. Simular instruction, inchuling Hyogene and Home Nursing, is no less important for women, but has never been undertaken on a national sale.

The American Red Cross has decided to organize such classes and has placed them under the greneral direction of the National committee on Red ('ross Nursing Service. We hope for the coöperation of state and local Committees and all enrolled lied ('ross Nurses. The course of instruction will include: ten lesons in First Aid; fifteen lessons in Hygiene and Home Nursing: fifteen lessons in Dietetics and Honsehold Eonomy.

All instruction will be very practical and pupils will, as far as possible, be required actually to do everything described in the traching.

It must be distinety moderstood that the instruction is only intended to prepare women to render emergency assistance in "as of arridents. to give more intelligent (are to their own families under ampetent direction and, in exceptional (ases, to assist in relief work under the supervision of the Nursing service of the American Red Cross.

The First did courses must be wiven by a physician and other instruction by a hed cross nurse, miless otherwise anthorized by the anmittee in (hatrese.

Mism Marion L. Oliver, of Washington, D). C., will have chatree of the oreanization of the latios. Forther information may be obtained be aldresing llome Nursing and loirst Airl mitrurtion for Women, American lided cross. Washington. 1). (

The Home Nursing rlasses were then for a time uppermost

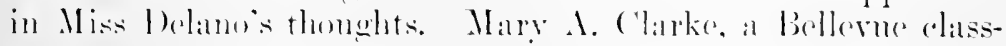
mate who assisted here during that period wrote: 


\section{HISTORY OF AMERICAN RED CROSS NURSING}

During all the busy days of 1911 Miss Delano did not forget a little pigeon-hole compartment of the big steel filing cabinet, said drawer being marked "Home Care of the Sick." Into this from time to time she tossed some little scrap from her pen, or gleaned from the nursing magazine, or any other source. She explained to me that sile was collecting these for a book on Home Xursing, that she did not know when she would ever have time to write such a book, but it was in her mind to do so, for she eandidly thought it was urgently needed, trained nurses being then, as they always would be, beyond the purse of the great majority; and moreover, any intelligent woman was capable of putting into practice the principles of nursing. . . .

Some months after this when I was asked to take charge of the first Home Nursing elass formed in Philadelphia, conposed of the Girls' Friendly Society of the Parish of St. John, Kensington, Miss Delano furmished me with chapter headings of the book-to be-as arranged by herself and Mis: MeIsaac, the famous little book not having yet reached the stage of proof sheets. For two classes I gleaned my subject material whence I could, but for the third I was supplied with proof sheets which were my pride until the book was published.

Miss McIsaac had then come to Washington as superintendent of the Army Nurse Corps. She was already a well-known anthor of nursing text-books and her collaboration made possible the speedy conclusion of the book Miss Delano had begun.

The Red Cross Magazine annomeed the publication of this text-book by saying in the issue of October, 1913:

So valuable and successful have the Red Cross Textlooks on First Aid proved that the Committee on Nursing Serrice decided to provide an equally valuable text-book on Elementary Hycriene and Home Care of the Sick.

This new textbook has been prepared by two of the best known nurses in this conntry. Miss Jane $\mathrm{A}$. Delano, R.X.. was superintendent of nurses at the I'niversity of l'ennsylvania IIospital, of the great Belleve Training shool in New York, and of the [nited States Army Nurse Corps.

II er collaborator in the texthook is one of onl equally prominent and able nurses-Miss lsabel Melsade, R.... formerly superintendent of the Illinois Training sichool for Nurses and at present superintendent of the Army Nurse Corps. 


\title{
CLASS INSTRUCTION FOR WOMEN
}

The title page of the textbook read:

\author{
AMERICAN RED CROSS TEXT BOOK ON ELEMENTARY \\ HYGIENE ANI IIOAL CARE OF THE SICK \\ l) $y$ \\ Jane A. Delano, R. N. and \\ Isabel IleIsaac, R. N. \\ Prepared for and indorsed by the \\ American Red Cross.
}

It was published by P. Blakiston's Sons and Company, Philadelphia, and had a preface written by Miss Boardnan, in which she said:

One of the most significant facts in the march of human progress during the last decade is the great awakening of public interest to the questions of health. Work as hard as they might, neither the medical nor nursing profession could alone accomplish much along sanitary lines until the people in general became aroused to the importance of such matters. Knowledge that personal heaith depends largely upon the health conditions of the community brings home to each individual a serions personal interest and sense of responsibility. But in spite of the strongest barricrs yet devised, disease cannot always be kept out. To the gentle hands of women belongs the eare of the sick and every woman should realize that the time may come when such a care will be hers.

It was hardly to be expected that courses in elementary nursing procedures conld be launched by the Red Cross witlout considerable discussion and some opposition. Especially. was this true of graduate nurses, who brought forward the eriticism that individuals completing the conrse would praetice nursing as nurses. So decp was this feeling on the part of individuals here and there, that ther refused to act as instructors. Miss I) lano and Miss MeIsiac were so determined to safeomard nursing standards, and ret to give the people at larese some instruction in mursing technigue. that they decided not even to nse the word "mursing" in the title of the book. substituting the term "C "are of the Siek" in place of "Ilome Nursing." These words convered at onee the intent of the comrse and its nso in the home for hregienic betterment and for the care of the sick. 


\section{HIS'TORY OF AMERICAN RED CROSS NURSING}

Before the textbook was printed much of it was submitted to superintendents of training schools for suggestions and eritieism. The National Committee on Red Cross Nursing Service was also called upon to review the manuscript before it was finally published. "The Home Nursing elasses," stated the Minutes of a meeting of the National Committee held on December 10, 1912, "were then considered and the National Committee approved of this undertaking."

Every effort was then made to place the emphasis upon the course as one, not to prepare women for nursing as a livelihood, but as a means of preparing them to look after their own health and that of the family with more intelligenee. Instruetors were urged to make this most clear to each class.

The first year's work in Home Nursing elasses, summed up at the end of 1912 , seems quaintly simple as compared with the statistics shown in another part of this chapter. Miss Delano wrote:

The object of this instruction for women is not to fit them for professional service, but to make it possible for them to render such service to the sick in their own homes as may safely be intrusted to them.

The following classes have completed a course in Elementary Hygiene and Home Care of the Sick under the direction of the Red Cross; South Manchester, Comn., two classes; Washington, D. C., two classes; Philadelphia, one class.

Several dasses are now receiving instruction in Philadelphia. Cincinnati, El Paso and Paterson, N. J., and other classes are being organized.

In a class largely made up of factory girls, recently examined in Elementary Hygiene and Home Care of the Sick. by one of our Local Committees on Red Cross Nursing Service, the general average for the class of ten. for both written and practical examinations, was over 85 per cent; the highest average being 90 per cent, with only one member of the class below 80 , her standing being 79.5 per cent, on a scale of 100 .

In the same report Miss Delano spoke of the possibility of beginning courses in dieteties and household economy. 'This was the first mention made of the desirability of instituting class instruction in these subjects, now so largely dereloped under Red Cross anspices in its teaching centers. The enemmaing popular response to the classwork decided the Red Cross 
to augment its efforts by enlarging the list of subjects taught. Early in 1913 the following circular was issued:

The American Red Cross has decided to organize classes of instruction for women in First Aid, home nursing, hygiene and allied subjects, to be given under the supervision of the National Committee on Red Cross Nursing service.

1. To afford women the opportunity to learn first aid to the injured and to provide simple instruction in the home care of the sick.

2. 'To afford women the opportunity to learn how to prepare food for the sick and well.

3. To afford women the opportunity to learn how to prepare rooms and other places for the reception of the ill and injured.

4. To afford women the opportmity to learn how to protect their own health and that of their families.

It must be distinctly understood that this course of instruction for women is only intended to prepare them to render emergency assistance in case of accident, to give more intelligent care to their own families under competent direction and in exceptional ases, to assist in relief work under the supervision of the Nursing Service of the American Red Cross.

Much needless suffering is now caused the ill and injured on account of the ignorance of unskilled persons. It has been sairl that the fate of the injured is dependent on the care which their injuries first receive. It is therefore necessary for everybody to learn what to do first in an emergency, and what not to do. This is easy to learn, but the subject must be learned. Sobody an be expected to know this without instrution. The number of people injured in the Cnited States is rapilly mounting and is now in the hundreds of thominnds anmally. Knowledge of first aid to the injured cannot, it is true. prerent the consequent suffering entirely, but it an be male an important factor in this result.

The health of the family depends largely unon the home maker, and it jo most esential that she have a definite knowl-

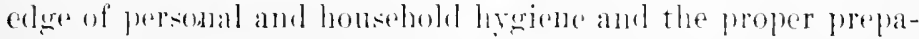
ration of foosl. Sperial diet for the sick is no less escential. Scareely a woman is mancquanted with the siek room in her own family and some simple instrution in the are of the sick should be a part of arery woman's edueation. It is the

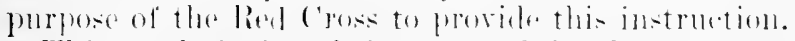

Thlis work is jut heoing started in this country. so that

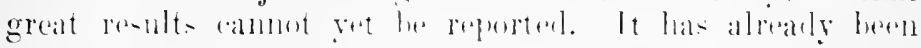




\section{HISTORY OF AMERICAN RED CROSS NURSING}

demonstrated here, however, that instruction in first aid will reduce deaths and serious results from injuries about one-half. On railroads and everywhere else that the American Red Cross has carried first aid instruction, all interested are enthusiastic in praise of the benefits derived.

The list of classes conducted during the year 1914 is historically interesting, as that fateful year made a dividing line in all fields of work.

1914. Fifth Report, National Committee Nursing Service; Completed Classes: Washington, D. C., nine classes; Sonth Manchester, Connecticut, two classes; Manchester, Massachusetts, one class; Danville, Illinois, one class; Paterson, N. J., two classes; Providence, I. I., one class; Philadelplia, Pa., six classes; Elyria, Olıio, one class; Cincimati, Ohio, seven classes ; total number of classes, thirty ; total number of pupils, five hundred seven; total number of eertificates issued, two hundred serenty-five. Current and Incomplete Classes: Clinton, N. Y., one class; Basking Ridge, N. J., one class; Gladstone and Peacock, one class; Bernardsville, N. J., one class; Amesbury, Massachusetts, one class; El Paso, Texas, one class; Cincinmati, Ohio, nine classes; Paterson, N. J., two classes; Ltica, N. Y., one class; Cleveland, Ohio, one class; Norfolk, Va., one class; 'Troy, N. Y., two classes; total number of rlasses, twenty-two; total number of pupils, three hundred forty-four. Grand total, fifty-two classes; grand total, eight hundred fifty-one pupils.

The war stimnlated the nursing activitios of women to an intense degree, and this stimulus was heightened in 1916 by the threat of tronble on the Mexican border. Miss Delano wrote (Decemloer, 1916): $:^{2}$

The interest in preparedness excited in this country by the European War, intensified in the early summer by the possibility of war between the Initerl states and Ilexico rasulted in an extrasdinary incresce in the interest in the courses of instruction given under the auspices of the lient Ćross.

The demand by women anxions and eager to be of service to their (onutry, for some form of instrution that would in a measure be preparatery. resulted in the recommendation by the Cational Committee on Nurving service at the last anmul meting, that a combined course of ten lesoms in

${ }^{2}$ Seventl Aunual Report, 1916. 
Elementary Iy yoine and IIome Care of the Sick and five in First did le arranged and put into practical operation. 'This was done. but as the demand for which this course was especially provided was no longer urgent, the special course was finally withdrawn september 1, 1916. after which the aourse of tifteen lesons in Elementary Jyeriene and Home C'are of the sick was allopted as the hasis of preparation and selection of women for service as nurses' aides.

The lessened urgeney to which Miss Delano here refers did not last long, for although the menace of war with Mexico receded in the latter part of 1916 , the next spring bronght its own catastrophe, and the teaching of nurses' aides was resumed. This has already been deseribed under its own heading. We return now to Miss Delano's interupted report, (1916) in which she describes the "teaching renter."

Red C'ross (lasses for instruction have developed so rapidly that ('hapters have been urged to form educational committers for the purpose of supervising some of the details of chass organization and tedrhing. I loser coöperation has been urired between the ('hapters and the Local committees on Rerl Cross Xursing service. This is heing aceomplished by mombership upon the eluational committees of the (hapter he one or in some aties. two or more nurses from the Local C'ommittees on Red ross Nursing service.

One of the practical outerowthe of this interest by the ('hapters in the educational work of the Red Cross has been the derelopment of the "Tearhing Center" with a nurse director. Class oreanization and in many ases, instruction maly he comblueterl hey the direetor. Howses have heen loaned or rented, adequate tearhing equipment secured and by this

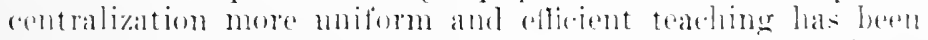
the result. In some instances, all the chapter artivities-

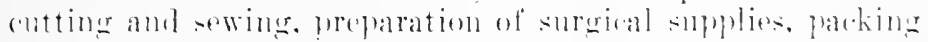
and aistribution as well as the instruction-hase heen enell-

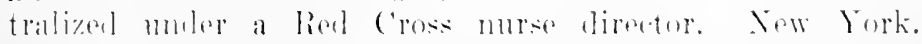

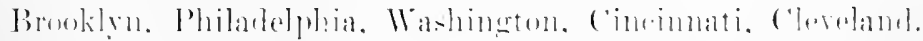

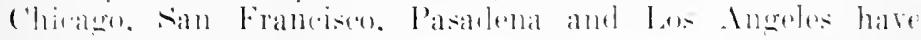
estalliti-henl =lleh.

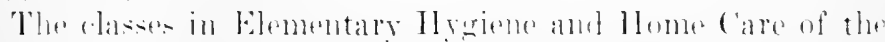

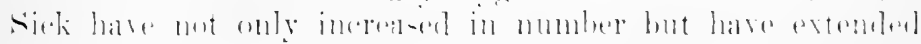

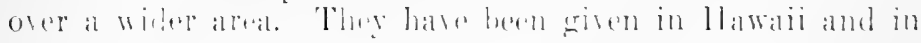




\section{HISTORY OF AMERICAN RED CROSS NURSING}

nearly all the states in the country, while larger cities and small towns display equal interest. The classes are given under the anspices of Chapters, clubs, churches, schoolspublic and private-individuals, stores, and industrial concerns. In many instances, where pupils cannot pay the class fees, these have been provided by persons interested in extending this instruction.

The widespread interest in the courses of instruction given under the Red Cross has been revealed by an unprecedented demand for qualified Instructors. Every effort is being made by the Burean of Nursing to secure, through Local Committees and the Nationa! and Local Leagues of Nursing Education, the names of nurses qualified and available for this work.

Classes in Home Dietetics were systematically lamnehed with the publication of a textbook in 1917. The first were organized in February of that vear. They rapidly became very popular. With the great expansion of interest in these courses due to the war, they were placed under the Bureau of Instruction.

The many groups acting as sponsors for class instruction gave decided color to the whole field of work, so varied were their forms and characters. They included Young Women's Christian Associations and Girls' Friendly Societies, Red Cross Chapters, women's clubs, church circles, public and private schools, shops, factories and individuals. The war period added semi-military groups, such as the eneampment schools of the Women's Section of the Nary League.

Early in 1918, still muder the pressure of a vastly augmented bulk of administrative work of all kinds, the decentralizing system of organization already deseribed was effected by the Red Cross and the work of elass instruction became more and more clearly defined as a growing, special branch of actirity.

In the earliest work of fonnling rlasses, either for First Aid or Home Hrgiene the Red Cross published simple suggestions on the following lines to guide its members: Organizers of elasswork were to be eertain of a suitable number of pupils who would agree to be regular in attendance, and who were then to select some one from the number to act as president of the class. The president so seleceter was to communicate with the bepartment of Instruction for Women at National Headquarters. A roll was then to be supplind to the class president, on which names of elass members were to be inseribed and answers given, 
in respeet to certain essentials. Pupils under sixteen years of age were not to be aceepted. The proper size of a class was between ten and twenty. The class president was expected to find a local physician or murse to toach the respective classes. The name and address of each phrsician or nurse was to aceompany the roll of pupils' names. Before the elasswork was actually begun all instructors were to be approved by the Red Cross and a card of anthorization issued from National Headquarters. Thus simply organized, the class teaching ran along easily for sereral vears until the inereasing stimulus of war efforts made itself felt. By 1916 elasses for instruction had developed so rapidly that the Red Cross Chapters were urged by Headquarters to form Educational Committees to supervise the details of class organization teaching. The Chapters were also encouraged to coopperate elosely with the Local Committees on Red Cross Nursing Service, which have been spoken of in a previous chapter, by placing one or more of the nurses from such committees on the educational committees of the Chapters. The Chapter's responded so well and so intelligently to these suggestions that, from their coördinated educational efforts there dereloped the Teaching Center with a nurse direetor deseribed by Miss l)elano on a previous page.

'To facilitate the organization of classes as thoroughly as possible cither under the auspices of Chapters or other agencies, it was necessary to develop careful plans and procedmres. These were worked out by the Nursing Service at National Headguarters. The instructions were very simple at first, and as the carliost classes wore infrequent, each one was practically supervised from Sational Headquarters. Finally, however, many pamphlets and separate forms were required to explain the procedure. comprising as it did the qualifications and appointment of instruetors; finaneing the elasses; foes; equipment for tearhing: the methods of sending in reports: conduct of examinations; marking papers; certitiates: sulject matter of the varions types of instruction; guides for instructors and billiegraphies for students and instructors. So complete was all this material that it forms a valuable part of the records in the arehives of the Ameriean Red ('ross at Washington. 1). ('.

The early phases incident to the oreanization of any project are often natred by difticulties and interruptions. Soon after the courses of instruntion were set in metion, Marion ()liver,

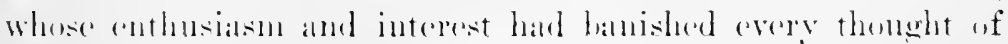




\section{HISTORY OF AMERICAN RED CROSS NURSING}

difficulty, was obliged to leave Washington and sever her connection with these courses.

The effect of the war, however, was to stimulate greatly the public interest in all Red Cross work, and the organization of the Nursing Service in all its branches went swiftly on.

Miss Delano, as ehairman of the National Committee on Nursing Service had assumed, from 1914 to 1916 , the entire responsibility of these classes. Upon the appointment of Clara D. Noyes as director of the Burean of Nursing Service in 1916, the classes were transferred to her general direction until they were placed under the Bureau of Instruction in April, 1917, with Helen Seott Hay in charge.

The decision of the Red Cross at the request of the War Department, early in 1916, to prepare twenty-five nurses' aides to form an anxiliary group to the nurses of each base hospital then under process of organization by the Red Cross for the War Department, gave a great impetus to the course of Elementary Hygiene and Home Care of the Sick. The course in itself was not considered as adecuate preparation for this group, but hospitals acting as the parent institution to a base lospital were asked to give each individual seleeted for this group a month's course in the institution. Nevertheless hundreds of women who had finished the eourse felt that it might qualify them for service in military hospitals should the Cnited States becone engaged in war. "The idea became more widespread and the demand for classes inereased. Particularly was this true immediately after the declaration of war in April, 1917, and during the months that followed. The demand for instruetion increased beyond the ability of the Nursing Service to provide facilities for it. The textbook on Home loieteties which had been issued during the early winter of 1916 , also attracted much interest. The demand for dietitians for service in military hospitals, as well as to act as instruetors, became almost as great as that for nurse teachers. Cntil June, 1917. Miss Noyes worked alone with these activities. She was at the oftice early and late. Sumdays and holidars. The pressure was so enormous that work increased beyond the space apacity to "are for it. The third floor of the Headquarters building, inclubling the gallery, was crowded with desks, and from approximately ten workers, inchding Miss Delano and Miss Noyes. the number grew nutil there were eighty, and still the work

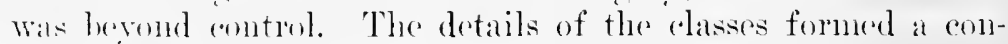


siderable part of the work with which this office force was bust. Drring the summer of 1917 , the pressure for instructors was very great. There wore as yet no Division oftierers to whom the selection of these nurses might be referred. Therefore, the Local lied Cross Nursing Committees, of which each state had one or more, were asked to recommonel instructors.

Many times during the arowed smmmer of 1917 several baskets of palpers of enrolled nurses would repuire examination in order to dotermine the qualitications for teaching the eomrse before the instruetors' appointment eard conld be issued. Before the eard was sent out the approval of the Local Committee was secured. With the offices so crowded, and the celiek of typewriters and constant interruption making sustained, delibcrative thomght almost impossible, Miss Noyes frequently used the attic in wheh to serutinize these eredentials. Evon the gravest oceasions may have their hmmorous aspect and evidently this impressed one woll-known writer-Gelett Burgess-who, in Collier's Weelly, August 1, 1917, wrote:

"But here is the director of the Burean of Nursing Service, come for a necessary conference. Crowded into a narrow space between tables, with women pushing, "exrouse me.' excuse me!" past them every minute the conversition goos on until- Miss Noyes, Miss Noyes'-the head of the Bureau of Nursing service is ealled to the long distme phone. where a lady in another rity. who had taken the examination in IIome Care of the sick, wilily wants to know: "Where is my certifieate?' Miss Noyes promises to send it by special inlivery. does send it immediately. Her tormentor, howerer. without waiting the necessary time. continnes to write. phone and teicegraph, as if she expected the certificate to arrowe instantaneonsly by wireless. Poor Miss Noyes! In order to do al little writing she has to forsake her comfortable office and tlee for refinge to the attic."

This pressure entinued mutil relieved by the appointment

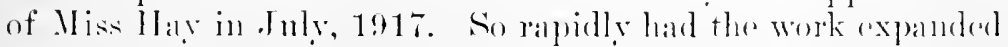

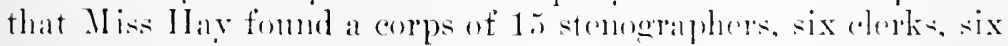
trpists and one messenger, who were attemline to the detalib of this one aldivity. After decentralization was anupleted, the

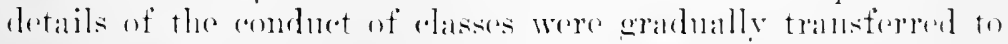

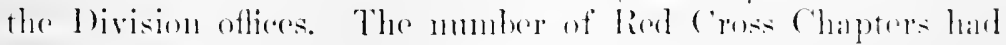

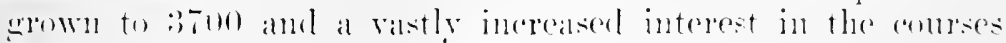




\section{HISTORY OF AMERICAN RED CROSS NURSING}

was spread throughout their jurisdiction. As interest in the classes of Elementary Hygiene widened some dissatisfaction with the textbook was expressed, and revision seemed neeessary. Miss Delano appointed a committee during the summer of 1917 to work out a suggested plan, of whieh Anna C. Jammé, of California, was the chairman. Two other nurses formed the committee of three; one of these was a Washington (D. C.) nurse whose name cannot be secured and the other was Amy Hilliard, who for the moment put aside her duties as general superintendent of Bellevue and Allied Sehools of Nursing to eome to National Headquarters and work ont this plan.

Aune Hervey Strong, graduate of Bryn Mawr College, of the Albany Training School for Nurses and also of Teachers College, at that time professor of Public Health Nursing, Simmons College, Boston, was asked to undertake the revision, using the plan developed by the smaller committee and later approved by the National Committee. This she eonsented to do. After some delars, the book was ready for eireulation early in 1918; the name was ehanged to "Home Hrgiene and Care of the Sick"; the text revised and brought up to date with several other ehanges, such as a rearrangement of eontents and the addition of a bibliography. At this time an interest in the book held by Miss MeIsaac's sister was bought by Miss Delano. By the terms of Miss Delano's will the textbook with all author's royalties became the sole property of the Ameriean Red Cross.

Within the Division Departments of Nursing, the work in comection with the two courses of instruetion, Elementary II rgiene and Home Care of the Siek and Home Dieteties, was systematized on the following plan:

a. Adrice to and supervision of, Chapters on matters of general policy and practice prescribed by National Healquarters.

b. Supervision of instruction personnel; appointment of Chapter supervisors of the courses in Elementary Hygiene and Home Care of the sick, and in Home Dietetics: appointment of instructors for Elementary Hrgiese and Home Care of the Sick: "oöperation with Tational Headquarters in the enrolment of Red ('ross Dietitians and the appointment of instructors for Home Diptetics.

c. Adrice to Chapters on matters concerning compensation of instructors and class fees. 
d. Maintenance of records of instruction personnel, and forwarling of this information to Chapters.

e. Study and reconmendations as to methods of promoting enrollment of students.

f. Advice to and coöperation with, Chapters on matters relating to classrooms and classroom equipment.

g. Sinmmarization for the Division manager of reports of class instruction work received monthly from chapters and preparation of Division summaries for transmittal by the Division manager to National Headquarters.

With the newly decentralized system, the work of the Bureau of Class Instruction at National Headquarters was divided and placed under the supervision of two bureaus known respectively as (1) Burean of Elementary Hygiene and Home Care of the Sick, with Miss Hay as director, and (2) the Bureau of Dietitian Service, with Miss George as director. As the volume of work increased, it became necessary to appoint $\mathrm{Di}$ vision directors of the Bureau of Elementary Hygiene and Home Care of the Sick.

In Jamuary, 1918, the Surgeon General of the Army requested that Miss Hay be released from the Red Cross to do sone special work in his office in connection with the Army School of Nursing. Following Miss Hay's resignation, Harriette Sheldon I)onglas, whose name and interesting background have already been given in a previous chapter, became director of the Burean of Nurses Aides and Instruction. She contimued in that office until Deecmber 31, 1921, when she resigned becallse of pressing personal elaims upon her time.

IIrs. lsabelle Wilbur Baker suceeeded Miss Douglas, coming to National Hoadquarters on .January 1, 1922, from the New Eingland I)ivision, where she had served suecessively as an instructor, director of a Chapter teaching center and Division l)irecter of Instruction in Home Hreiene and Care of the Siek. This practical training and experience was a valuable contrilution to the develepunent of the work at Nitional IIeaderarter's. Mrs. Batker was a graduate of the Rhode lsknd Sidend of Nursing and purevions to her marriage, had been superintemlent of the Johuson Memorial IIospital, stattord Springes. (onnecticut.

I) nring the period which elapsed between the rear 1!9t and the real 19.2.2. rlass instruetion for woment increalsed to an

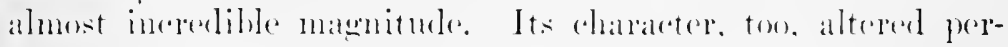




\section{HISTORY OF AMERICAN RED CROSS NURSING}

eeptibly and a marked difference in the class of students, during wartime and after, beeame evident. The war brought out many women who had visions of war nursing, but afterwards the extent of class teaching among factory workers, the young women of humble homes and, most strikingly, among rural families, momntain and farm dwellers, and little country villages, gave gratifying proof that a solid and enduring work of education had been built np. The number of certificates issued from 1914 to 1921 follow: 1914, 273 eertifieates; 1915,250 certificates; 1916,3927 certificates ; 1917, 31,188 certificates; 1918, 27,942 certificates; $1919,49,072$ certificates; $1920,89,748$ certificates; 1921, 61,304 certificates.

These figures do not include thousands of women and girls who took the instruction but who for various reasons did not complete the course and receive the certificate.

The peak of enrollment was reached in 1920 when 117,908 pupils took the course. That the enthusiasm in this phase of health education should have reached its height at this particular period was a natural result of the alarm ereated by the influenza epidemics of the two preceding years. Never had the necessity for prepareduess by every wonan against the onslanghts of disease been more graphieally and tragieally emphasized.

When this instruction was first given there was but one anthorized form-the Standard course. This consisted of lessons totaling twenty-two and one-half hours as a minimum; it was conducted by an authorized Red Cross nurse instruetor. Examinations, both practical and theoretical, were given at the end. of the lessons, and certifieates were granted to those whose markings were satisfactory. In 1920 an adaptation and modification of the Standard course were anthorized. The Adaptation of the course consisted of the same inumber of hours, followed by examinations and eertificates as in the Standard eourse, but trachers of physiology, biology, physical training, and lome erenomies and others specially qualified were allowed to give the theoretical instruction. It was designed for use in schools and remote communities. Authorized Red Cross nurse instruretors in every instance were made responsible for the conrse and fur giving the practical lessons. A plan was worked out by National ITeadquarters indiating those chapters in the Red crosis texthook that might be tameht by the lay teacher and those that shomld be taught by the nurse instructor. By this 
arrangenent the nurse instruetor's time was ronserved, thins making it possible for a greater number of students to have the advantiages of the instruetion.

The Modification was anthorized for the benefit of those women who would find it diffienlt to take a written test, for women lacking a knowledge of English and for girls too immiture to take cither Standard comrse. It covered the same number as the other two of the lessons to be given entirely by a Red Cross nurse instructor. No written examination was to be required, but practieal tests were to be given, and at the completion of the lessons a eertifieate granted to those eligible.

In order to secure a standardized, efficient method of instruetion and to give some special training in teaching to instructors, institutes were leeld in every Division under the supervision of the l)ivision Inectors of Jome Hreiene and ('are of the sick, whose experienee in teaching and administration had been demonstrated. The educational benetits of these institutes were invaluable, they not only enabled the I)ivision Lireetors to eome into personil eontact with the instructors in their Divisions, but served to improve tle methods and technique of the instructors thenselves. A still further step lading to the better preparation of nurses as instruetors in Hone Hygiene and Care of the Sick was the inanguration in several muiversities and colleges of a short course in methods of tealling.

The "Guide for Instructors" was revised in the spring of 1921 , with the expectation that it would help to secure eqeater uniformity of method in presenting the information entained in the textbook. It was compiled to assist especially the instructors who lacked rexperienee in tealehing or who hald not learned to apply teaching methods to the earre of the sick in the home. This Givide as revised eontaned outlines of the comres, an exerellent explanatory text, illustrations of nursing terlnivine intended to standardize demomstrations, sugegested lists of equipment for tealeding aenters and traveling explupment, and lists of

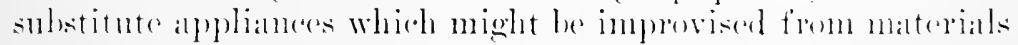
arailable in the simplest home. The substitute appliances were not alumse deviess, but ship-shape and trig. The pamplulet was

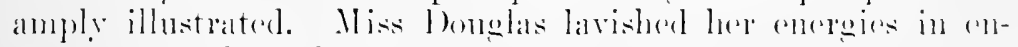

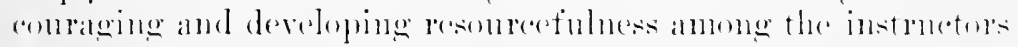
and in this she met with response and cuthusiasm from the Division directors. 


\section{HISTORY OF AMERICAN RED CROSS NURSING}

Beeause of the increased demand in rural communities for these classes, itinerant or field instructors were appointed in many of the Divisions. These instructors were supplied with traveling equipment which could be transported very easily no matter into what remote distriets they traveled, or by what methods they were carried. Thus was simplified in a great measure the problem of earrying the message of Home Hygiene to isolated regions where it was impossible to set up teaching centers. The instruetors in the insular possessions of the United States and in the foreign field were objeets of special interest at Headquarters and their work was aided in every way by Miss Noyes and Miss Douglas. A complete miniature equipment for demonstrations in elass was made up and sent to Alaska for the use of the instructor who conducted classes there.

Miss Douglas wrote (1921):

I cannot praise too highly the splendid work many of our nurse instructors have done. They have been missionaries in the true sense of the word, overcoming many seemingly insurmountable obstacles and never sparing themselves in order to give various groups this necessary instruction.

Classes have been held in all types of schools: grade, high, parochial and private sehools; vocational, Americanization and Continuation schools; universities, colleges and normal schools. They have been held in industrial plants, church and commercial organizations; for groups of Camp Fire Girls and Girl Scouts and for groups in Red Cross Teaching Centers. The work has been earried on in Alaska, the Dominican Republic, Hawaii, the Canal Zone, Porto Rico, Siberia, Poland, Czecho-Slovakia, China and the Philippine Islands. The classes have includied missionaries, Indians, foreigners, deaf mutes and the blind; classes have been conducted for the Chinese women of Chinattown, N. Y. C., for the girls in the Crittenden Homes and other correctional institutions, for women and girls in practically all occupations, and as well those of the leisure class.

The instruction has been related more and more closely with the daily life and acts of service of those who have eomploterl it. The desire to put the knowledge gained in these courses to practical nse in the community has been revident. In several places where this work has been going on "Il alth Chubs" have been organized which participate in community projects, especially those: which aid in public health. 


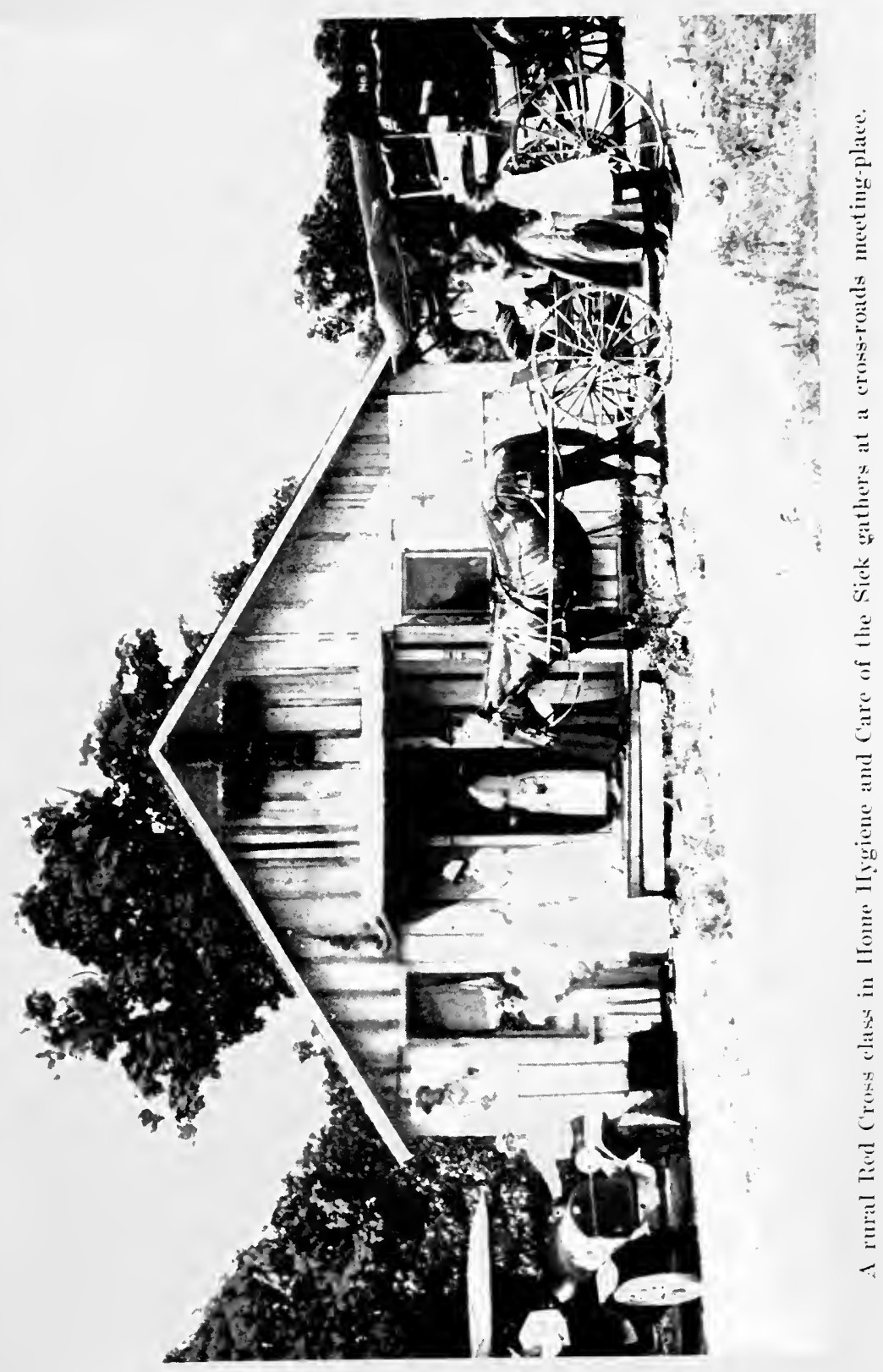



The public health nurses recognize the value of this instruction as an introduction to their work in rural communities and as a means of developing civic pride. In one community a new school house and in another a loospital was established.

The vocational value of this course has been incalculable. Many a young girl, hesitating as to the choice of a vocation, has caught a glimpse, through the course in Home Hygiene and Care of the Sick, not only of the opportmities for service and success that lie in the mursing field but of the realization of any innate capacity she might possess for this career. Schools of nursing have already seen the truth of this statement and many of their applicants have been reeruited as the direct result of the interest aroused by this instruction.

From every Red Cross Division instances have been reported where young women, having developed an interest in nursing from these classes, were encouraged to enter a school of nursing. From one Division alone it was reported that 125 young women had entered schools of nursing in one year. Many were from isolated homes in remote country or mountain regions where their opportunities were few and their future most limited, and who from their Home Hygiene classwork were led into wider lives of action and interest.

A certain Division Director of Home Hygiene was interviewing a candidate instructor:

"Are you familiar with our course?" she asked.

"Yes," was the reply. "Probably my desire to become a nurse would never have been stimulated but for this Red Cross course."

"This is most interesting!" exclaimed the Division director, "and goes to show the importance of presenting the instruction to young girls as well as to older women."

"All throngh my training," went on the cancliclate. "my" ardent desire was to instruct classes in Home Hygiene under the Red Cross."

Needless to say she receired the appointment as an instructor. All over the comntry during the influenza epiclemies of $191 \mathrm{~s}$ and 1919 the groups who had completed this course and many who had taken the andese in preparation for the national emer'geney, gave woluntarily of their strength, time and serviec. Lnder the sulpervision of nurses and physietans they took ware of children, the aged and the chronically discased, thereby reloas- 


\section{3ॅt HISTORY OF AMERICAN RED CROSS NLRSING}

ing the graduate nurses for the care of the influenza patients. The majority of these women could not have rendered this service had it not been for the Red Cross instruction in Home Hrgiene and Care of the Sick.

Motion pietures have been utilized for class instruction. "Every Woman's Problem," produeed in 1920, was of such simple universal appeal and genuine educational value that it met with a never-failing popular welcome. It told the story of Mrs. Helpless and how she learned, throngh her course in Home Hrgiene and Care of the Sick, efficient methods of caring for invalid Aunt Mary.

For the scliools and rural sections where the motion pieture could not be used lantern slides were prepared. The slides with eaptions, depicted the practical work of the course.

The wide extent and popularity of the classes in forcign fields as well as at home created a demand for the translation of the text-book on Home Hrgiene and Care of the Sick in whole or in part into Czccho-Slorakian, Korean, Russian, Polish and Spanish. Perhaps no other book of its kind has been so widely. translated.

Among the interesting exhibits placed in the musenm at National Headquarters was a miniature reproduction designed to show how a class may be suceessfully conducted in an ordinary bedroom in an arerage home, using home equipment. The room contained two windows and a fireplace, providing almost perferet rentilation. The painted floor was bare except for a few rag rugs. Extra chairs were added for the accommodation of the class members, but otherwise the bedroom furnishings consisted only of two single beds, a dresser. Washstand, a bedside table and a comfortalle chair. A hlackboard stood at one side of the room, and models and charts were suitably arranged. A hot water bag was in evidence. In one of the beds a member of the rlass acted as a patient and reclined against pillows supported hy a suitrase which was ntilized as a head rest. The instructor in full lied cross miform instructed the member: of the rlass, one of whom made the empty bed, another earried a tray to the patient, while the "model" "infant was seen in the foregronnd safoly confined within his "kiddic coop" improvised from an inverted table. 


\section{CHAP'TER XVII}

\section{TIE IIETITIAN SERVICE}

DHE history of Red Cross work in "IIome Dieteties," the "Bureau of Dietitians" Service" or the "Nutrition Service" as it has been variously called, falls easily into three periods.

The first of these covers the time from the inception by the lied Cross Nursing Service of work in dietetics to the time when the nation began to make definite moves towards casting in its lot with the Allies in the World War.

The second period extends, practically, from the time of the planning and organization of the first base hospital units to the signing of the armistice.

The thirel period is the period of transition from the acute sitnations of war to the more normal problems of peace, and closes, in so far as this history is concerned, with the date on which the burcan was made into an independent Red Cross serviee.

The Led Cross Nutrition Sierviee, as it has eome to be called, had its beginning in a conrse of instruction in "dietetics and homschold erone my" which was offered by the National Committer on lied couss Nursing Service along with eourses in "First Aid" and "Hrgiene and Home Nursing." The following statement of the purposes of these comrses and the plans for them appeared in the ammal report for the rear 1!12:

It has been demonstrated that the instruction of men in first aisl will reduce deaths and serions results from injuries about onte-lalf. Similar instrution, including hreiene and home nursing. is no les: important tor women. lut has never beren molertaken on a national siale.

The Amerian lied ('ross hals deredeled to orwanize such rlatses and has wated them muler the eqeneral direetion of

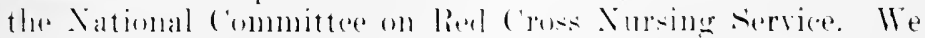
hepe for the reijperation of state and lenal rommitters and all enrolled lied ( rosis nurses.

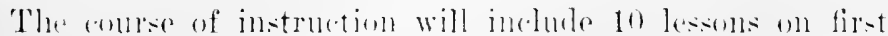




\section{HISTORY OF AMERICAN RED CROSS NURSING}

aid, 15 lessons in hygiene and home nursing and 15 lessons in dietetios and houselold eromony. . . .

The first aid (o)urses must be given by a physician, and other instructions hy a hed Cross nurse unless otherwise authorized by the committee in charge.

Miss Marion L. Oliver, of Washington, was placed in rharge of the organization of these classes. The reports for 191:3 and 1914 showed that no regular work in home dieteties was undertaken during these two yars:

191.3-The instruction includes first airl, clementary hygiene and home rare of the sick, with possibly later courses in dietetic:s and household economy.

1914- Soon after the arloption of the general plan for the instrurtion of women, Miss Marion ()liver who was plared in charese of the organization of these (lasese, was obliged to leave I"ashington and give up temporarily the work in which she was of much interesterl. The musial demands made upon the ehairman of the National (ommittee during the past year have marle it difficult to (lo much comstructive work in connection with these rasses lor wonen. but we have been gratified at the evidrifes of interest and often surprised at requests for information from unexperted sources.

A little instruction in "diretretios" was sometimes inchuded in the contrses in home care of the sick given by nurses to alasses

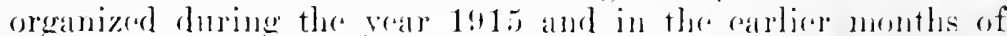
the vear following. In a lattor writtan to Miss ( C. E. Masom

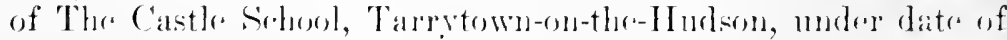
May 4, 1916, Miss Poardinan stated that "egor woment in the

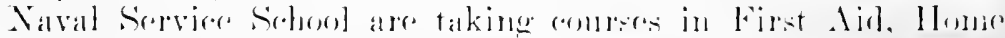

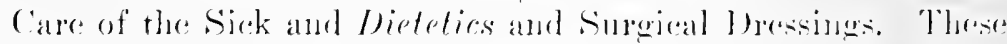

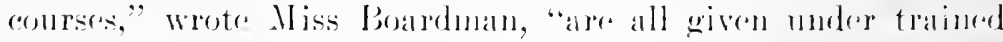
nurses."

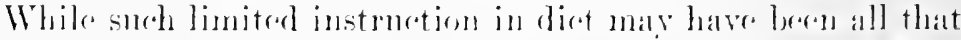

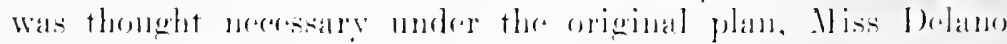

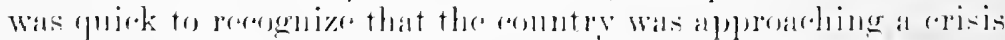

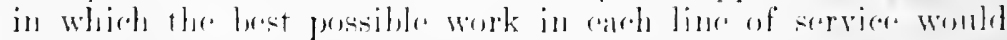

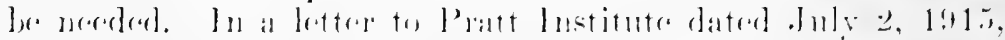

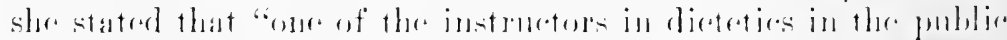

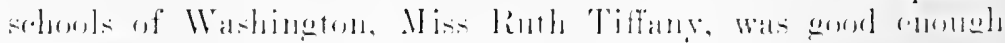


last year to give a course of lessons in Dieteties which was organized muder the anspices of the Ameriean Red Cross."

This was the beginning of a correspondence with a mumber of lome economies people in regard to the preparation of a textbook on the subject of "Food Values and Hone I)ietetics" for use in similar classes. As a result, such a book was prepared by Miss Ada \%. Fish, head of the department of art and home reonomies of the William Pem High Sehool for Girls, Philadelphia.

The aim and scope of this first text-book was given in the anthor's introduction:

'This book is designed for general use in classes to be taught under the supervision of the American Red Cross Nursing Service. The aim of the course is to give in a simple way the underlying principles of cookery. These are presented in fifteen lessons. There are also directions for fourteen lessons in practical cookery."

The book was not ready for eirenlation until in February, 1917; meanwile little classwork was attempted. The Annual Report for 1916 said:

1)uring the year four experimental classes in dietetics were hell, with a total enrolhment of 43 pupits, and 36 certificates in this conrse were issued.

These rlasses were organized under the direction of Miss Noyes and were tanght by dietitians.

The new aspects of the work were voiced in the same report:

A great interest in this course in home dietetios has been evineed and the necessity for qualified instruetors as woll as for dietitians for base hospitals has resulted in the organization of a national committere on dietitians, of which lliss

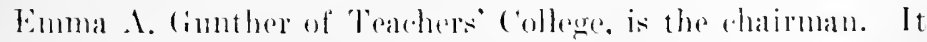
is hopect nltimately to organize local (o)mmitters to alsist with the work of enrolling dictitians for this purpese.

At a meeting of the National Committee on lied Cross Nurs-

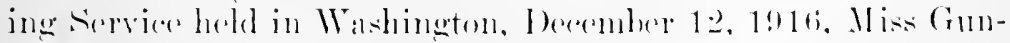
ther's appointment was approved. The other members of the

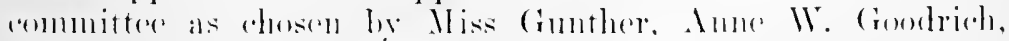

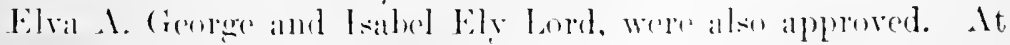




\section{HISTORY OF AMERICAN RED CROSS NURSING}

an adjourned meeting on the same date the chairman of the Committee on Dietitians was made an ex-officio member of the National Committee on Red Cross Nursing Service.

At this meeting Miss Gunther outlined very briefly the work that had been done and such plans for organization as had been formulated. She spoke of the opportunities for dietitians in connection with the Red Cross, not only as instructors in the course in Home Dietetics, but as dietitians for base hospitals and for such other opportunities as might eventually present themselves.

Even while this committee was being approved in the routine of business of the Deember meeting, Miss Delano was anticipating the need for a larger and more representative committee in order to compensate for the laek of State and Local Committees on Dietitians' Service. In a letter to Miss Fish under date of August 30, 1916, she wrote:

We are planning to inerease the Committee on Dietitians securing a representative woman in each of the large cities who will help us in securing instructors for the classes. Miss Gunther of 'Teachers College is chairman of this committee and you will no donbt hear from her soon in regard to menbership on her committee, and I do hope that you will feel that you can accept the position. I am quite sure that we shall have difficulty in securing suitable instructors and shall rely upon your interest and coöperation.

The committee, as enlarged during the early months of 1917, was eomposed of the following members:

COMMITTEE ON RED CROSS DIETITIAN SERVICE

\section{Ex-olficio Nember}

Miss Jane A. Delano, ('hairman, National Committee on Red Cross Nursing Service.

Miss Edna White, Chairman, Ohio State Lniversity, Columbus. Ohio.

Miss Emma Gunther, Tearhers College, Columbia University, New York C'ity.

Miss Isabel Ely Lord. Pratt Institute. Brooklyn, X. Y.

I)r. Ruth Wheeler. Goucher ('ollege, Baltimore, Ma.

Miss Jenna Coofer, Battle Creek Sanitarium, Battle Creek, Mirh.

Miss Catherine J. Machay, lowa State College, Ames, Iowa. 
Dr. Agnes F. Morgan, Cniversity of California, Berkeley, Cal. Miss Ciace E. MICCullough, Peter Bent Brigham IIospital. Boston, Mass.

Miss Ala \%. Fish, William Penn Jigh Shool, Philatelphia, l'a.

Miss Enle Raitt, Iniversity of Washington, Seattle, Wash.

Miss Amuie IV. Goodrich. Army Shool of Nursing, Surgeon (ieneral's (oflice, Waslington, 1). (C.

Miss Elva A. George, Red Cross Ileadequrters, Washington, I). (

Miss Lmma smedley, Philatelphia, Pa.

Miss Helen M. Pope. ('arnegie Institute, Pittsburg, Pa.

Miss Lulu (iraves, (are Modern Hospital, ('hicago, Ill.

Miss Flora Rose, cornell Iniversity, Ithaca, New York.

Miss Violet Ryley, Invaliel sollters Commisson, Toronto, C'anarla.

Miss Alice Loomis, Iniversity of Nebraska, Lincoln, Nebr.

Miss Clara Colburn, Cniversity of Chicago, Chicago, 111.

Later, at the suggestion of the chairman, Miss White, Miss Emma Conley, who was in Washington temporarily, acted as chairman of the committee during her stay in order to facilitate the work.

In May, 1917, Miss George, a member of the committee, a graduate of Pratt Institute, Brooklyn, and loug associated with It. Ninai Hospital. New York City, was brought to Red Cross Headeruarters to take charge of the enrollment of dietitians and the organization of classes in Home Dietetics.

In the fare of the prospect of war which overshadowed the eomintry, no better statement of the organization aims and obligations of the new I)ietitian serviee of the Red Cross conld have been formulated than that contained in Miss Noyes' cireulatr letter to detitians, issued in January, 1917:

The development of the elucational work and the organization of base luspital mits uncler the auspices of the Ameriean lied cross has created a demamel for qualitied and experienterd dietitians.

'The opportmities for dietitians in this service may be gromped for the present unfer two main divisions.

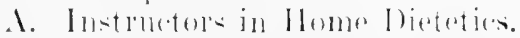

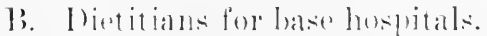

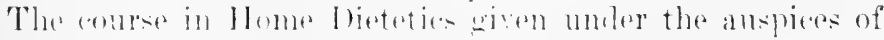

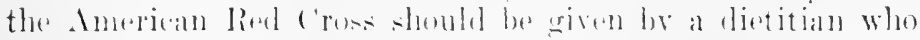


meets the requirements as established by the Central Committee on Dietitians of the American Red Cross. 'This committec passes upon the credentials of applicants and recommends to the Bureau of Nursing Service such dietitians as appear to meet all the requirements for instructors.

Classes in Home Dietetics are now being organized in all parts of the Lnited States, and it is the desire of the Red Cross to keep on file at the National Headquarters as complete a list as possible of qualified dietitians who are ready to serve as instructors. A textbook has been prepared by Miss A. Z. Fish, William Pem High s'chool, Philadelphia, and may be secured from the Red Cross at a cost of one dollar $(\$ 1.00)$.

The course in Home Dietetics consists of fifteen lessons of three hours each. Full particulars explaining the management of the dlasses will be forwarded upon request.

Dietitians are also needed to take care of the special diets in comnection with the base hospitals now being organized by the Red Cross. Base hospitals are organized around civil institutions in time of peace in order that we may be prepared in event of war to send out groups of nurses, doctors and other persommel who are accustomed to working together. The dietitians are enrolled with the nursing staff and at the same salary, $\$ 50$ per month.

It is also desired to keep lists of dietitians who will be available for dictetic work in convalescent hospitals, refreshment rooms, ete. If it is your desire to enroll for any one of these services, kindly fill out the inclosed application blanks and return to the Bureau of Nursing Service, Washington, D. C.

The rear 1917 showed a rapid development of this service. Professional home economies workers, although already busy with tests, experiments and the preparation of literature for the solving of some of the problems which the country would be called upon to face in the conservation of food and other materials and in the safeguarding of health, were stirred loy this added opportmity for service under the standard of the Red Cross. The first dietitian was curolled Fobruary :3, 1917; by the end of the rear six hundred and forty-five dietitians had been enrolled as instructors and an additionial two humdered and eleven for lied cross serviee in military hospitals. The tirst rlasses in IIome Dieteties were oreanized in February and by

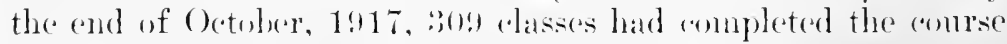
of instruction, and 2s:11 cortiticates had heren issued. At the 
time of making the annual report classes in Home Dietetics were being held in one hundred and forty-nine teaching centers. How successful this bureau was in enrolling and assigning dietitians for war service was summarized in Miss Delano's statement before the Twenty-first Ammal Convention of the Ancriean Nurses' Association in 1918 in which she stated that S.) Red cross dietitians were then in service in cantonment and naval hospitals while 48 others had been assigned to base hospital units and 3 to French military hospitals under Red Cross supervision, making a total of 133.

"We were fortunate," concluded Miss Delano, "in developing this scrvice just before the needs of war eame upon us, and so we have been able to meet the demands of the Army, the Navy, and special divisions of our own work."

Although the reeord of the total enrollment of dietitians by the Red C'ross during the year 1917 was gratifying, on April 6 but twenty had been listed as qualified for service with base hospital mits. By the end of June the enrollment had reached sixty-nine. Of these, nine had been assigned to units which sailed for France during May and June. Later in the year Miss Inlano reported that seventeen were on aetive duty with base hospitals in France and that eighteen had been assigned to eantomment hospitals in this country.

As is stated in another chapter the first six base hospital units to be sent to France frem this eomtry, May and June, 1917, were loaned to the British Goverument and assigned to work with the British Expeditionary Forees. These were followed almost immediately by assigmments to the Ameriean Expeditimary Fores, to eamps and cantonments in this country, and to the Nisr.

The distinetion of being the first dietitian to enter active scrvice orersats may be claimed by Florenee Bettman ${ }^{1}$ of Base Ilespital Lnit No. 10, Pemssylyuia Hospital, Philadelphia, or hy Inne T. Cpham,2 Base Itospital Enit No. 4, Lakeside

${ }^{1}$ Florener Bettman was born in Jersey (ity. X. T.. attended school at Plantelel chminary. and received her terehnieal training in Boston and as papil dietitian in Jefferson Inopital. Philadelphia. Iater she held positions as dietitian in the Vantion lhuse of the l'ennsybania Hospital for the Insane. and in the Preshyterian Herpital. Philirlelphia.

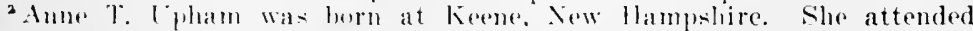
schenl at Theaton sominary and completed the iull course in home

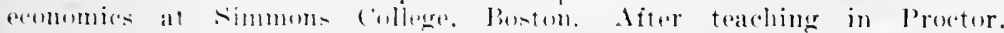

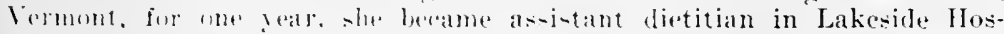
pital. Cleveland. 


\section{HISTORY OF AMERICAN RED CROSS NURSING}

\section{Hospital, Cleveland, for the reason that May 8 was the date on which both of these minits sailed.}

A report made by Miss Upham stated:

I was attached to Base Hospital No. 4, which was located at General Hospital No. 9, British Expeditionary Forces, at Rouen, France. As dictitian, I lived with the nurses. I was under the chief nurse, and was governed by the sane rules and regulations as the Army nurses. My duties from May 25 , 1917 , to september 14, 1917, consisted of the management of the nurses' mess and the housekeeping duties of the nurses' quarters. From September 14, 191\%, until June 10, 1918, my dutios were to plan, prepare and serve food for special patients. I had no oflice and no special diet kitchen. All the work was done in the big hospital kitchen with British Army rations. I also planned and prepared the meals for the fow sick officer patients who were in the hospital. I)uring this time, the special diets had increased from two on the first day to 10 per cent of the total number of patients in the hospital by June 10, 1918. On this date, I was given the complete charge of the plamning, preparing and serving of the food to all patients, as well as plamning and smpervising the special diets and the officer patients' diets. From ouly 1, 1918, I also had charge of the cooks and kitchen police, as there was no mess sergeant in the patients' kitchen. I continued with these duties mutil January 25th, 1919, when the hospital was closed. By this time, I had obtained the coöperation of the nurses, officers, and especially of the enlisted men who worked for me. I was in a British hospital where there had nerer been a dietitian, comsequently I had to prose to the British officials that we could be of service. I was not hampered, as many dictitians were, by a mess officer who knew nothmg about feeding a large number of people, and yet thought he knew it all. To me, it was very interesting to see how much (ould ba done wilin very little equipment and limited rations. ...

It first the general opinion seemed to bo that dietitians knew only how to serve ice rream and tainty foods, which were imposible in France. Therefore, the ronchusion wis drawn that they were neeless members of a war-time organiration.

For any one with a semse of homor, there ware many fumby happentings. On one oreasion when the British eommanding ofliere read the loster of onr mit, and saw the word "dietitiall" after my bame. he sail, "What kind of a reature is that :" 1 s it happened, he did not remain long enough to 
find out that "that creature" was of some use. One day a British ollicial was inspecting the kitchen, and I was introduced to him by the British quartermaster as "our lady cook." At first I seemed to be considered as merely a cook by the English, and of tentimes, much to my discrust, by the Americans, who it seemed to me should have known better.

The Peter Bent Brigham Hospital Unit sailed May 11. The dietitian with this unit was Marjorie Hulsizer, ${ }^{3}$ of Vinchester, Malss., Hospital.

The duties which fell to Miss Hulsizer, while she remained with the British Expeditionary Forees, served as a good illustration of the lack of standardization of the work of dietitians of which II iss Lpham wrote. However, this condition was not peculiar to the British military organization.

In a letter to Red Cross IIeadquarter's the chief nurse of the unit spoke of Miss Hulsizer's assigmment:

Of course her work is nothing like she har expected or hoped, and I do not linow whether she will slump professionally or not. I hope not. But the diet system of the hospitals of the British lixpeditionary Forces is so firmly established that it would require an Act of Parliament to sanction the introduction of a trained dietitian, neither wonld they know what it means. So she is the "lome sister." She looks alter our quarters, runs the mess, does the marketing, engineers the latumley women and is admired by everyone. . . down to the rook in the hitchen.

Miss Ilulsizer herself wrote a breezy account of her duties at this time:

Wr draw rations every morning of bacon, rice. onions. potatoes, timned meat, milk, conar, jam, oleomargarine, pork

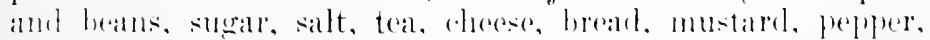
pirkles, and roal and ice when they hawe it. I foed about one homeled and twenty people. We draw rations for eighty and sine we are allowed there shilings for ach person, we take the pemainder lor the one hundreel and twenty in moner which grives me what is alled mess moner. With it I huy fresh recetables. frubt and other things not procurable in the

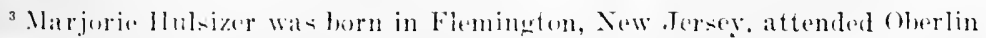
collene and later praduated from timmons college. She wats a pupil

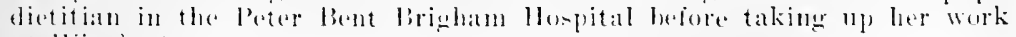
at IIinchester. 
rations or from the canteens near camp. The old market women shake hands with me, tell me that before the war is over I shall speak excellent French, and they complete the occasion by handing me a bunch of flowers, a "sourenir." some days we get enough flowers to make the mess hall a regular bower. For marketing I am allowed a Red Cross ambulance. One of my P. B. men goes with me to carry the baskets and the ofticers' mess cook goes in at the same time to do his buying.

These ambulances are driven by girls from England. I get a different one detailed to me each tme and 1 so enjoy talking to them. Their regular work consists in carrying the wounded from the trains to the hospitals.

The other part of my work is to keep the Sisters' quarters, seven huts, nine tents and seren alwrus, or portables, and the bathhouses dean. For that I had three P. B. men, but they have recently gone and all $I$ have now is one patient detailed to my work full time and two patients two hours a day who can do no scrubbing or hard work, but we rub along somehow.

That things did turn out well at last for this particular dietitian, was chronicled in a letter which Miss Hulsizer wrote to the Director of Red Cross Nutrition Service at Washington after her return from France:

After I left the B. F. F. in December. 1918. I went to an American Hospital. Base 53. in Paris, for as soon as 1 learned that my unit, the Peter Bent Brigham. was to be sent home. I asked II iss Hall, chief nurse of the Red Cross in Paris, to find out if l could be transferred to the A. E. F. I felt that 1 couldnt go home without having the experience of feeding the patients themselves. She immediately arranged it for me with $M$ liss stimson.

The hospital in Paris. No. s. had been a large one. There were nearly a thomsand patients when l arrived. In my diet kitchen we prepared food for four hundred and on down to fifty, and for one on the day l left. The work was interesting and I enjoged working with the American soldiers. They are the most considerate thonghtful. intelligent and easily tanght hors I have ever seen. With the B. L. F. I had heen rumbing things absolutely on my own. 1 (e)tain sum of money was griven me each week by the chief nurse and I disl the bigying

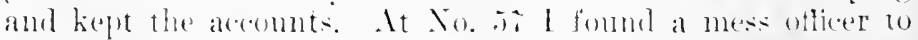

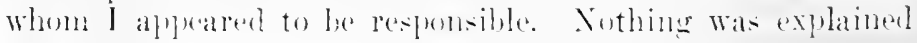


to me. I was left to "fall into things," and I fell. The mess oflicer was a most diffieult one to get along with, but he was really very eflicient and I respected his ability if not his personality. Finally, one day, I had a little talk with him "man to man" and after that we got along splendidly. He allowed me to buy, or to have bought, nearly everything that I neederl. Ocrasionally I had to do a little explaining, but usually my orders were unquestioned.

On the whole, my experience in France was free from friction. I wanted to tell you this, as I have heard so many dietitians say that they have had most uncomfortable times. I never have had to do any of the rooking myself. I was always given plenty of cooks and K. P.'s. But I liked to have the boys feel that i actually could do things myself, so I often spent a good deal of time in the diet kitehen preparing food.

On June 10 Base Hospital Unit No. 2 from the Presbyterian IIospital of New York City assumed elarge of British Military Hospital No. 1 at Le Tréport, France. Mary Radford Harold, a graduate of the Mctropolitan Hospital School of Nursing, of New York City, and special student at Columbia University, acted as a dictitian with this unit, although she was enrolled as a reserve murse. Miss Harold did not sail with the unit but took up her work later in the summer.

The fifth mit in the assigmment to the British, Base Hospital No. 12, from the Northwestern University Medical Sehool and Cook Comuty Hospital, sailed May 19, on the S. S. Mongolia. (On accomint of the tragie aceident happening a few days out, which is described in another chapter, the Mongolia returued to Now York, but on May 22 again sailed for France. With this nnit were two dietitians, Nary Lindsler, ${ }^{4}$ house director and business manager of the Illinois Training School for Nursing, and Margaret Knight," lead resident of Willard Inall, Northwestern Eniversity. Althongh Miss Knight's ap-

- Mary Jindsley was horn in Green Village, New Jersey. She attended school at Lasteri Seminary and later graduated from lratt lnstitute, Brooklyn. She was dietitian for the Harrishurer foncral IIospital for two vears. Was with the Woman's Ilospital of Northwestern L niversity Medieal Selool for two years and a balf, and had been with the lllinois Training Shoul for Nursiug for fomr years at the time of receiving her appointment to military service.

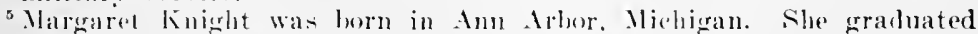

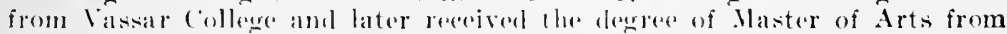

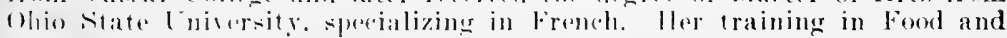
Nutrition was receiven in the Department of llome Economies of the latter institution. 


\section{HISTORY OF AMERICAN RED CROSS NURSING}

pointment was primarily as an interpreter, she was later assigned to duty on the hospital staff.

All throngh the report submitted by Miss Lindsley there radiated an optimism seemingly untonched either by the hardships which were beyond any one's control, or by entrenched British enstom, (including tea for breakfast, which was beyond "Act of Parliament"). Her description of the bath accommodations gave evidence of her disposition to see the best side of things:

The bathhouses were in reality long huts with a fire in the middle for heating the water. No other heat was available. Finding one's bath day posted meant, at the appointed time, putting on a trencin coat and rubber boots and tramping through rain and shush to find icicles on the edge of the bathtub. And yet I know of no one who took cold, or who was otherwise marle ill, by the tramps through the wet, or from taking a bath in the cold place.

Perhaps the most trying thing in the whole sitnation was the "long arm" method which she was called upon to use in doing her work. The British military mess system was well organized and no woman, dictitian or otherwise, was allowed access to the mess kitchen. In spite of the fact that Colonel Collins, commanding officer of the unit, made an earuest plea to the Division Director of Military Serrice that Miss Lindsley be allowed a diet kitchen, the thing simply conld not be done. Her sugestions and orders were all formulated in consultation on the ontside and reached the kitelen throngh the top sergeants. Nerertheless, she reported as among the things which marle the work pleasant and interesting, the "working with the sergeants to secure greater variety in their messes, makine" substitutions for the regular army ration and formulating new recipes for using the limited materials to lie had." The value of such a service as this following the not infrepuent oceasions wheri the German submarines had "beaten them to" the food transports, an well be imagined.

Another paragraph of Miss Lindsley's report showed that war has its playtine as well as its more serions business:

Porhap one of the most interesting experiences we had was our Find I hy. July 4. 1918. As the British hat entritained 11: at lifferent times with their fleld sports. the oflicers and 
men of our unit decided it was up to us to entertain them with some real Imeriean sports. 'The Fourth of July was the day set, aud invitations were sent out to all the surrounding camps. Back of our camp was a plain between two sloping hills and this was selected as our natural amphitheater. 'The day was perferet and it was a beantiful sight to see the miform of earch of the Allied Forces against the backerromul of green hills and bhe sky. The "silver (queem," a large British dirigible, which patrolled our coast on the lookout for submarines, came in and floaterl over the amphitheater. Farther out in the (hamnel vere "submarine chasers" ready for any action that might be clemanded of them.

While the sperts were in progres: a fleet of German observation planes flew over, dropping some of their light bombs, which burst, making little eurly clouds in the air. but not one of the three thonsand spectators left his place, so interested was every one in the sports and so sure that nothing more than an observation fleet would he passing so early in the afternoon. TOne would be wlat to believe that the Germans purposely selected their jightest bombs as a concession due to the ocrasion. El.

'The tea and sandwiches which were served after the sports were finished represented work to which the camp kitchen crews had contributed alt their spare time.

In concluding lier report Miss Lindsley stated:

May I summarize my experience by saying that to me the dificulties of the situation never seemed to he very great, but the ofyertmities of it were so trememlous that there was not time enongh in the day to encompass them. Imagination was repuired and alaptability was required. and when these two were put together the difliculties were never insurmountable.

Miss Knight's arcomt of her experiences in the same hospital read in part as follows:

We reached Camiers Tume 11, 191\% late at night. What we could see of the hosplital seemenl to be only huge tent wark with a fow frane and metal huldinge for administration whies. operating rooms. wok homses, ote. There were

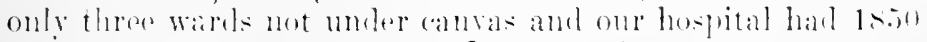

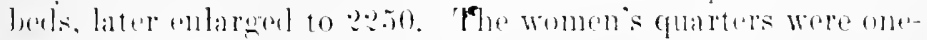
story huts with rooms for two: the hathome in a sepalate

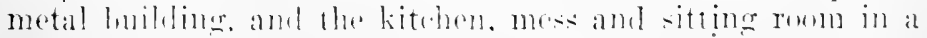

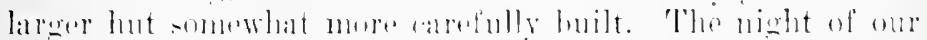

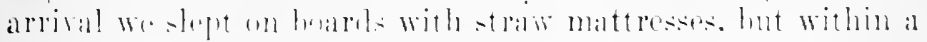




\section{HISTORY OF AMERICAN RED CROSS NURSING}

few days our army cots had arrived, and with the addition of some essentials, such as a basin and piteher, a table, an improvised chiffonier and curtains, a room became fairly comfortable for the warm months of the year. But in the winter the cold was almost unendurable; four pounds of coal per person per day is a pretty small ration and we always saved it until we could both be in the room, when our little stove did its best for us.

When, during the war, Miss Knight's parents received a letter from her in which she gave an account of the fuel allowance, they proceeded to weigh out four pounds of coal in order to visualize more clearly just what the possibilities of such an amount of fuel might be, and as Mrs. Knight reported, "We looked at that little heap of coal and then looked at each other."

\section{Miss Knight's report continued:}

The work given the dietitians was different in each hospital. Sometimes they cared for the nurses' home, with perhaps occasional assistance given to the officers' mess. In other places the dietitian prepared food for especially sick patients: still elsewhere she would have charge of the general hospital diet kitchen or the general walking patients' dining hall. This last was my special assignment.

The dining tent seated $3: 0$, eight at a table. Our serving was done cafeteria style and all the food carried across an open lot from the cook house. We had an improvised dish warmer, a huge box lined with pieces of tin that were cracker boxes flattened out. The shelves were of woven wire fencing and the heat was furnished by a little oil stove on the bottom shelf. When the meal was finished, the soldiers took their dishes to the exit and deposited them in boxes from which they were taken by the dish-washers, washed and sterilizel. The washing was done out of doors; only a canvas stretehed over tent poles protected the dish-washers. Te had six army stores each holding a huge pot which was kept constantly filled with water. It took nearly all of one man's time to keep these six fires going and the "ontainers filled with water. Sometimes we fed 1450 earh meal: that meant dishes were washer and returnerl to the serving table constantly. The best we could do was to serwe 7.5 jer hour and the sight of that long line of wombled and sick men standing patiently in the mud and rain waiting for their meals will always stay in my nemory. We had a waiting tent for them, where they 
could sit till a rhance came to get into the dining tent, but nothing wonld induce them to use it no matter what the weather. 'The herding instinct was too great or else the army habit of a cue was too strong to orercome.

In the afternoons and erenings the dining tent was used as a club room. We always manageil to keep one of the three stoves going and the men would gather in groups around the warm oasis on a wintor night to write, play cards or read.

The two Christmases were the bright spots, the rest of the nearly two years of overseas work was mate up of hart work, air raids, cold, rain, uncertainty of supplies, wounded, sick and complaining men. As professional dictitians, we hat little chance to put into practice the training we had received; as women we had the chance of a lifetime to use as best we conld what was given us of equipment and supplies and, best of all, to give to hundreds of men a bit of cheer and kindness. To see the lines smooth out of a nerve-worn face, the gruffer traits of human beings slip into the background under your efforts, those are the things that should remain in our minds as in a measure offectting the horrors and the weariness and the anxieties of those months.

The last mit to assmue charge of a British hospital during the year 1917 was Base Hospital [nit No. 21, of the Washington Lniversity Medical School of St. Lonis. Ratehel Watkins of Barnes Hospital, St. Lonis, was the dietitian.

Athongh the dietitians in the British area carried on their work under the distinet limitations of an old and rigid military srstem, they sueceded in making their usefulness folt and five of the numler were decorated by the British Government.

The splendid enthusiasm show by the dietitians at this time, both at home and orerseas, was equalled only he the anomalons nature of their status when once they were alsigned to active duty. Although the Military lepartment had repuested the Red ('rose to maintain an corrollunent of women professionally tratined as dietitians, nothing was done in the way of defining the dutice, rights and privileges of these dietitians after their serviecs were aneepted. The Mammal for the Medieal Department of the Luiterd states Army for 1916, stated:

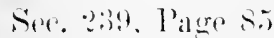

$11 h_{1}+1$ the number of sick requiring special diet is large, the commandinge oflicer of the hu-pital may wablish one or more 


\section{HISTORY OF AMERICAN RED CROSS NURSING}

diet kitchens for the preparation of their food, under the immediate direction of such skilled dietists as are available. Competent dietists belonging to the Nurse Corps may be assigned to this duty. Rules for the management of diet kitchens will be prescribed by the commanding officer of the hospital according to the particular needs of each case.

And in Section 760, page 227, the enumeration of personnel allowed a base hospital concluded with the following:

46 nurses, female (1 chief nurse, 1 assistant to chief nurse, 41 in wards, 2 in operating room, 1 dietist).

There appeared in all this little more than a rather vague idea that some competent nurse might be intrusted with special dietary work.

The information given out by the Red Cross under date of August 5, 1916, did not go much farther in the matter of status. In a cireular letter to the chief nurse, "in re to dietitians for base hospital units," Miss Delano said:

It has been decided that if a dietitian is appointed as a member of the unit she shall be counted as one of the fifty nurses and will probably receive the same salary allowed to nurses. I think it important that there should be no misunderstanding in regard to the dietitian being under the direction of the chief nurse of the unit, as otherwise there might be friction and difticulties. . . .

It was evident that Miss Delano was proceeding along the line indicated in the Mamual of the Medical Department in thus rating the dietitians as "ompetent dietists belonging to the Nurse Corps." But, aceording to regulations, members of the Army" Nurse Corps "shall be graduates of hospital training schools." Since dictitians received their training from quite another souree they could not be included and no provision for military rating for a woman outside the Army Nurse Corps hat beem made by the Military Department-al situation which conld not then ion remedied exeept by Aret of Congress. As such action was almost beyond the possibility of securing at the time, nothing remaned for the dietitian but a position as a civilian employer, and the following corronlar was sent ont

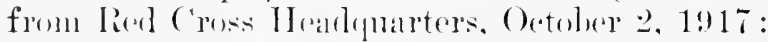


When a dietitian is not a nurse she comes under the heading of a civilian employee and should be included in the civilian list. Each rhief nurse shoule communicate with the medical director in order to reserve a vacancy for the dietitian in this group. If this is not done, there will be no oppo:tunity to secure salary and transportation. When the dietitian is a civilian employee a base hospital may take out 6i5 nurses. When the dietitian is a iso an enrolled Red C'ross nurse she may be included as one of the 6.5 nurses.

The led Cross provides a uniform for lietitians consisting of a gray worsted dress, (ape, long nister and black velour hat. This should be worn with gray gloves and high black boots with low heels.

The result was that the dietitian found herself still in the Nurse Corps, but "not of it," a civilian employee "with a difference," and also without rank in a situation where authority" was the first requisite in getting things aceomplished. Added to this, complications in connection with the Nursing Scrvice itself overseas were requiring strict attention from Red Cross Headquarters, the American Dieteties Association had not ret been organized, and the American Home Eeonomies Association, deeply engrossed as it was with the work of food conservation, was giving little thought to dietitians beyond eneouraging them to euroll for service under the Red Cross.

Manifestly, so far as the dietitians were coneerned, the situation conld be summed up in Kipling's lines deseriptive of a ecrtain military faux pas. "It got beyond all orders." That it did not also get "beyond all ope" was due to several reasons. First, the Ameriean Expeditionary Forees were guiltless of much of the tradition that belongs to an old and crrstallized military organization, and the "civilian" dietitians were reerived with a fair degree of composure if not alwas with positive enthusiasm. Perhaps a second reason why the dietitians "muddled thromgh" as well as they did was that they were in a sense nudisciplined; their training had given them some knowledge of subjeret matter, along with a gerneral desire to put this to practical use, but they were, themselves, hittle used to the discipline of either the solelier or the mise and, as a eonsequence. they went into the work "on their own," little tronbled by notions of precedent. proceeding as fast and als far as the onmmanding officer or the mess efficer wombl permit. Surely a third reatson for whatever suceess the dietitians may have to 


\section{IISTORY OF AMERICAN RED CROSS NURSING}

their credit is due to the fact that, given the opportunity, they were able, in most instances, to demonstrate the value of their service; recognition was sometimes slow in coming but it usually came.

Following the Circular of October 2, 1917, already quoted, no formal aetion in regard to dietitians was taken during the remainder of the vear, but a few excerpts from the report of a dietitian, Mrs. MacPhadyen ${ }^{6}$ who was with one of the first base hospital units of the American Expeditionary Forces illustrated well some of the points which have just been made. In her report she said:

We sailed from New York August 7th, 191\%, arriring in St. Nazaire August 20th, 1917. On arrival we found that all Red Cross nurses and dietitians were transferred to the Army. We did not feel rery happy about this, but of course there was nothing to do but make the best of it.

However, the Red Cross did not forsake us. After we arrived at our destination we received many things which added to our comfort,-blankets, sweaters and warm clothes, which were greatly needed, as our first winter was very colk.

I found that no provision had been made by the Army for special diets or diet kitchens. It was a case of using my own initiative and doing what I thought best in my own department. I was allowed to have sereral chests of cooking utensils and equipment sent by the Red Cross, and I began my work by taking a corner of the main kitchen and making special diets for the sick, which after two weeks numbered about fifty. My first patients fared well. I assure voul. . . . Finally, our commanding officer, seeing I was determined to have a diet kitchen. came to my rescue and provided suitable quarters, also furnishing all extra equipment needed, such as a gas range and cooking utensils. The Red Cross ranges were put into the main kitchen for cooking light diets, of which I also had supervision.

Everything moved along smoothly. I soon hard a well-

- Mrs. Margaret MacPhadyen was born in Ivernie. Aberdeenshire, Scotland. She was gratuated from MacDonald Ontario Agricultural College in 1913. and the following rear was instructor in domestic seience and food value for the Agricultural Department of Toronto. Her hospital work previous to her entering military service was done in Harlem llos. pital. in ballevese and in the Ontario Ladies Hospital. On Octoler 10, 19ls. Mrs. MacPhallen resigned from the Yledical Department of the Enited states Army and anepted a gosition as dietitian with the Bureatu of Hospital Amministration, Ameriean Red Cross Headquarters. IIotel Regina, Paris. Mrs. Mareluatyen was assigued to L. S. Base Hospital Unit No. 9, New York Hospital Lnit. 
equipped and up-to-date diet kitehen, one that would compare favorably with those of many $\mathrm{New}$ York hospitals. Our patients increased rapidly. I rarely had less than three hundred light and special diets, and during the drive five or six hundred. I did my best to represent the Red Cross and to do the work I knew they would wish me to do.

In a letter to Miss George, under date of January 31, 1918, Mrs. MacPhadyen stated:

There are some things in regard to the work here which I would like to tell you about. 'To berin with, there seems to be a rague idea of what we are really here for.

I have had to do all my own planning. Fortunately, I have a splendid commanding oflicer, who has done everything in his power to aid the work. The chief murse, I am sorry to say. has not been of much assistance, thinking at first, apparently, that I did not "belong" because I was a "civilian." This going as a "civiiian" is is strange arrangement and very disagreeable. . . I I was able to take my place and to hold my own after I came here, but a younger and less experienced person would have been completely discouraged. . . . There is another matter I wish to know about,- - they are asking oflicers, enlisted men and nurses to take out insurance. I wished to do so but was told that I could not, as I was a "civilian."

In Mar, 1917, Congress authorized the establishment of thirtr-two (amps and cantomments in this country, and in Septemuler the leed ('ross was called upon to furnish dietitians for this serviee. Here the served as administrative dietitians, as diet supervisors or as instructors in dieteties in the Army School of Nursing.

As might be expected, conditions mader which the dietitian worked raried ats widely in the different aintemnents as in the lase hunitals orerseas. 'Thus, from one dietitian:

The three monthe I frent at camp Wadsworth were not as

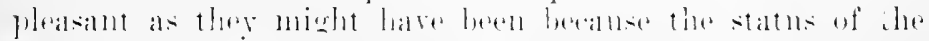

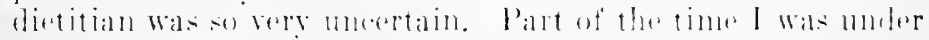
the whet unrese and part of the time under the mess ollicer. There were no rules or regulations cone erning me.

And this from a dietitian at ('amp shollye: 


\section{HISTORY OF AMERICAN RED CROSS NURSING}

I am directly responsible to the mess officer and the commanding officers, and am rated with the officers.

Judging from the following report from a dietitian at Camp Greene, North Carolina, things were not so bad-merely a trifle confused :

The mess officer under whom I work is very progressive and is getting things into fine shape, improving all the time. ... Are there any special rules for the dietitians, especially as to hours, or do they keep the same hours as the nurses, and, if so, what hours are the nurses supposed to hare?

Notwithstanding the fact that work in the cantonment hospitals did not afford the inspiration which accompanied service overseas, something of the spirit of the "trenches" was usually evident whenever things got a bit thick. To quote a report from Camp Travis :

I have been here two weeks as dietitian, and I find my position a peculiar one.... I supposed that when we were sworn in that, for the period of the war, we were members of the Arny Nurse Corps. . . . Now I find that we are listed as civilian employees and have no military standing . . but, whatever my standing. it will make no difference with my work which I am trying to do as well as I can.

"Carrving ou" in the face of more serions difficulties was indieated in this report from a dietitian at Letterman Hospital:

I have been assignerl to the diet kitchen in the olficers' ward. am? have been disappointed in finding much manual work to be done by dietitian. . . Heretofore. as you know, nurses have had (harge, the last one having been in this diet kitchen for more than two years. She was a harr-working German woman. Willing to stay on duty all hours, and who did much of the artual cooking herself. . . I I took the matter up with Miss Keener. the chief nurse, who sees the situation as 1 do, and she in turn took it to the rommanding officer. Ile was rery kind hut said he could grive me no extra help. He sail to simplify the menus and to cut out all specral diets. giving the somi-solid. light and full diets practically the same. . . This very morning, after the order harl been siven to retrench on sperials, the wrath of the ward medical rhicf came down upon my hearl. for he wished to test a four- 
day diabetic diet. When I explained the situation he saw things my way and returned to his duties-but, I did the diets for him, as I know I always will do if it is at all possible.

The work of giving instruction in the Army School of Nursing was attractive to most of the dietitians assigned to this duty. The extracts quoted below from the report of I rma Latzer (now Mrs. (iamble), a gralduate of the l'niversity of Illimois, give a pieture of this phase of the work of dietitians, and, at the sance time, throw a side light upon the confusion wrought everwwhere by the never-to-be-forgotten epidemic of influenza. She stated:

I was at the Base Hospital at Camp Grant from themiddle of sicptember, 1918, to the middle of the following April. Because of my previous experience I was assigned the duty of giving instruction in dictetics to the students in the Army School of Nursing.

Three days after 1 arrived at camp the "flu" epidemic reached us and classes could not be started until the epidemice hat passed. During that time every one served where most neerled in caring for the sick as they were brought to the hospital by the humireds.

I was given (harge of the nurses' mess. The meals were not harl to plan or prepare, for the allowance per person was liberal and the detail holp was plentiful. (of course the "flu" dicl not pass up reols and waitresses, but with rolunteer help from herkford we all managed to be fed.

When the time cane for chaswes fo hegin it was not a difficult problem to equip) the diet kitchen. Lieutenant colonel D. ('. Michie. commanding officer of the Bise Hospital, was deeply interested in the wolfare of the student nurses and throngh him and Miss Imla Williamson, dhiof nurse, the purchiaing of grood and arlequate equipment was rompara-

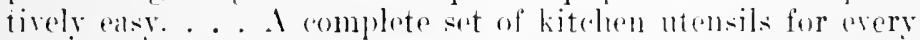
desk and one laree electric range male it as bals to teach dieteties in the army as in any morern miversty elassroom.

The stulents wore an interesting aroup to work with.

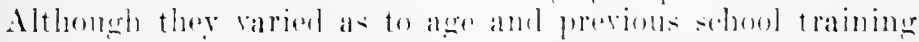
all were there for a definite purpose and easer to make the best une of their time and opportunitin.

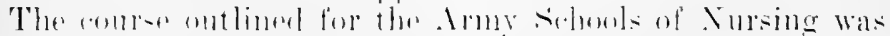

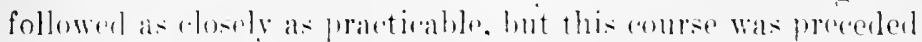
by fomer femonstration losins to aid the stulents in their prartial work on the warkls. The sturlent group hat to be 


\section{HIS'TORY OF AMERICAN RED CROSS NURSING}

divided into four sections because of the large number and their different times of arrival at eamp. Every section upon the completion of its course gave a dimner to which were invited the various commanding officers of Camp Grant and members of the faculty of the Army Sehool of Nursing.

The course in dietetics was followed by a lecture course in diet in disease, in which the students were also keenly interested.

Of course, overseas service was the hoped-for goal of many of the dietitians who entered service here, and it can be believed that the following note which reached Miss George was intended to carry a hint:

I have been on duty at Camp _since Jamuary 10th, and I find that the experience in an army diet kitchen here . . . would certainly be very valuable by way of introduction to hospital work abroad.

In no ealling or profession does each individual measure up to standard in matters of training, experience, executive ability, personality or tact. Dietitians were no exception to the rule, and in riew of the responsibility which came to the individual dietitian, the wisdom of the requirement made by the War Department that, before being assigned to duty overseas, the dietitian must serve in a cantonment hospital in this conntry may be appreciated. The following letter from Dr. Ruth Wheeler to Miss George of the date of May 2, 1918, gave an indication of the sifting-ont process.

When ron can, will you have some one look into conditions in onr side of the work at Camp ____? Reports have come to me that there are four dietitians there. no one of whom has sufficient training herself to enable her to train the others or to direct the whole scheme really well. One of our alumne who is there says she is loing nothing that any maid servant could not do. . . I have written her that her jol, just now is to be thankinl that she is in such a fortmuate position for getting the linomlerke and experience she needs. . . She is probably doing as important work as she is capable of right now.

Two dietitians ried while in the service in eantomment hospitals in this comotry. Olive Will Noreross, of Worester, Massalehnedts, at erarhate of the State Normal Sehool at Fram- 
ingham, Massachusetts, died September 26, 1918, at Camp Dix, New Jersey. Meda Morse, of Foxloro, Massachusetts, also a graduate of Framingham Normal School, died December 24. 1918, at Camp 'Taylor, Kentucky.

By the end of June, 1918, eighty-two dietitians were on duty in the cantonment hospitals in this eountry. This number was greatly angmented during the following months and at the close of the fiseal year Jume 30,1919 , one hundred and forty-three were on duty in the Lnited States and Hawaii.

As dietitians were not named in the cmumeration of positions open to enlistment in the Navy, the one dietitian, Henrietta I. French, ${ }^{7}$ who saw Naval service abroad, enlisted as a yeoman (f) and later functioned as a dietitian. Miss French entered the service in October, 1917, and was assigned to Naval Base Hospital No. 2 at Strathpeffer, Scotland.

Fifteen dietitians served in Naval hospitals in this comtry, five being assigned to the Great Lakes Naval Training Station Base Hospital with Mildred G. Stiles ${ }^{8}$ as head dietitian. Miss Stiles was assigned to duty February 8, 1918, and resigned from the service in June, 1920, on aceount of ill-health. During this time sle served in the hospital at the Norfolk Naval Base, with the Naval Hospital at Anmapolis and New York Naval Hospital.

Taken in cross-section, the Navy seems to have regarded the innoration of the dietitian strictly from the point of view of the "special interest" involved. This statement from a Naral officer :

With all this difleculty of getting food, I want a dietitian who can toll me what to use if l haven't the particular article of food which I should have.

And this from "before the mast:"

"We got another one o" them."

"()ne o" what :"

"One o" them as wants to take our beans."

F Henrietta l. French eranduated in Home Fenomies at Iewis Institute.

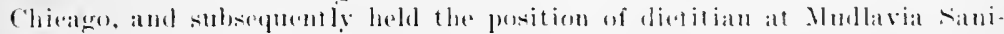

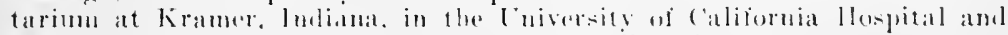
in the Xaval Batse lla-pilal at Stanford. Californiat.

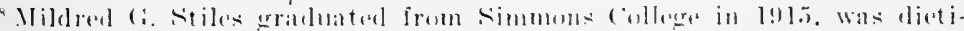

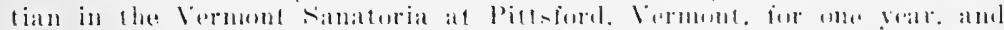

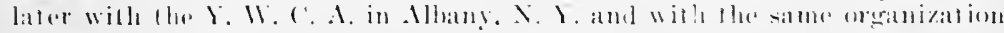
at formgrawn. (H)io. 


\section{HISTORY OF AMERICAN RED CROSS NURSING}

The Nary being, perforce, a more or less self-sufficient institution early made arrangements with several universities to have instruction in dieteties given to their Hospital Corps men. Of this work, Gertrude Thomas of the University Hospital, Minneapolis, Minnesota, wrote to Miss George in March, 1918:

At present, besides the hospital work, I am engaged in teaching dieteties to Hospital Corps men for the Nary. This work is very interesting and we have begun classes for the second group of one hundred men.

Of the little group of fifteen dietitians who served with the Navy, two made the supreme sacrifice. These were Irene I. Jury of Washington, D. C., a graduate of the Lney Webb Haves National Training School of Washington, who died at the Naval Hospital at Pelham Bay Park, N. Y., December 9, 191S, and Hortense Elizabeth Wind, of Ann Arbor, Michigan, a graduate of Iowa State College, who died December 10, 1918, at Norfolk, Virginia.

Subsequent to the issuance of the eirenlar letter of Angust 5,1917 , already quoted, the matter of the status of dictitians received little attention until the following spring. At a special meeting of the National Committee on Red Cross Nursing Service hold at National Headquarters March 14, 1918, Miss George, who was present by invitation, reported the assigmment of 130 dictitians to duty in the Army, Navy and Red Cross. Quoting from the Minutes of the meeting:

A discussion followed on the duties and responsibilities of dietitians in military hospitals, inchuding relation of dietitian to commanding officer. Miss Nutting stated that the distitians felt that they could do more eflicient work if they were under the direct anthority of the commanding officer rather than the divided responsibility to the mes: sergeant and to the chief nurse.

The committee adjonrned, however, withont taking any formal action in the matter.

Naturally the American Dieteties Association which had been oremized in ('leveland the previous October with Lulu Graves, head dietitian of Cleveland Lakeside Hospital, as president, and Lema F. Cooper, head of the Battle Creek

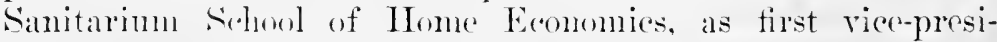


dent, was interesting itself in plans to simplify the situation for the dietitians in active service. Also the Division of Food and Nutrition of the Sanitary Corps of the Army gave promise of being able to muderstand to some extent the difficulties of the dietitians. A brief statement of the organization and initial antivities of this division is copied from the report of the Surgeon General tume 30, 1!) 1:), Vol. 11:

In August. 1917, there was organized in the otlice of the Surgeon (ieneral a Division of Food and Nutrition and its oflicers were anthorized by letter of the Secretary of War dated O(tol)er $16,191 i$, to inspect food supplics in camps, to endeavor to improve the mess conditions and to study the ration suitability and food requirements of the troops. Otficers of this division were sent to camps in the linited states and while in camp gave instruction to cooks, mess officers and unit commanders and also made extensive studies of ration requirements and suitability. In March, 1918, it was decided to send a group of these officers to the American Expeditionary Forces to organize similar work in France. To this end, on March $\pi$, six officers left the States for that purpose. This party proceded first to England and remained there from Iarch 16 to April :... One officer was left in England to contime the work there and on April 3 the other five officers proceederl to France. reporting to the chice surgeon at Tours on April 1:. . . karch officer visited and inspected organizations in his sector (assigned him) and reported his observations. Later the group came together at Bijon. The following extract from the report of the director of the section summarizes the results of this preliminary survey:

The results of this preliminary inquiry and of the reports and (onferencess led to the ronclusion that although the garrison ration being istued generally to troops was adequilte as to total food material and the quality of the articles as a rule grood, in many places the feeding of the men was poor. Hue in large part to the mnfaniliarits of the meseserereants and cooks with the ration in kind and to their weneral inefficiency under the conditions existing in France. in a lack of interest in or

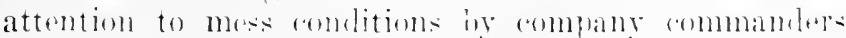
and higher ofliess. and in the allanes seetion. where

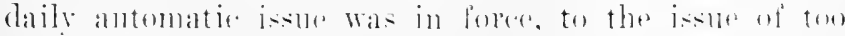

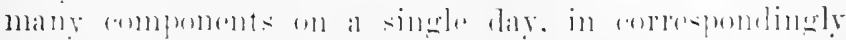

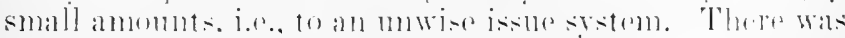

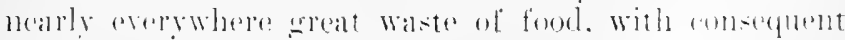
underfeeding. . . . 


\section{HISTORY OF AMERICAN RED CROSS NURSING}

As a result of this conference it was decided by the director of laboratories to establish, with the consent of the chief surgeon, a section of food and nutrition in that office.

Meanwhile, under date of March 15, Miss Cooper wrote to Major Murlin of the Food and Nutrition Division reporting to him a conference which she had had with Colonel Furbush of the Surgeon General's office. Major Murlin's reply dated Mareh 25 , was in part as follows:

Owing to the fact that I have been absent from the office for a week your letter of March 15th has just come to my attention.

I am, of course, interested in what you tell me about your conference with Colonel Furbush. My own impression is an agreement with what Colonel Furbush told you, viz., that the proposed arrangement could scarcely be aceomplished at the present time. I am not at all sure but that the Surgeon General would take an altogether dilierent view of the matter, particularly if your president and yourself, or some other committee, should wait upon him in person and lay the matter before him.

Whatever you do along this line, you should be careful to make it clear that the matter has not originated with myself. In other words, I am not requesting that the lietitians be brought under this division, where I think they belong. I feel with you that matters are not satisfactory either to the dietitians or to the Army officials. ...

As indicated by this letter it was hoped that the Dietitian Service might be made a part of the Food and Nutrition Division, but on account of other demands made upon both Miss Graves and Miss Cooper the plan was not put forward officially. Somewhat aside from this, however, the rather exhaustive set of suggestions quoted below and formulated in part by the New York Dictitians Association was sent informally to the Surgeon General's office:

SLGGESTIONS FOR THE GUIDANCE OF DIETITIANS IN SERVICE UNDER TIIE WAR AND NAVY DEPARTMENTS

\section{Respoxsibilities axi Detirs}

It should be molerstood by the officer of the hospital to which a lietitian is assigned, whether she comes in the 
capacity of an administrative dietitian or as a special diet supervisor.

Administrative Dietitians shall be under the supervision of the Commanding Officer, to whom they will make all complaints, critieisms an!l suggestions. Their responsibilities and duties should be outlined by the Commanding Officer and facilities for desk work supplied. Power to report workers to the Commanding Officer.

They will coöperate with the medical staff, the Chief Xurse and the Quartermaster's department.

They will be under the social supervision of the Chief Nurse.

The duties of administrative dietitians will be the making of menus, regulating of dietaries, the supervision of preparation of food, and the control of sanitary conditions under which food is prepared, direction of transportation of food to serving kitehens, requisitioning on Quartermaster's department, supervision of cafeteria service in mess halls.

special diet superisors shall be under the supervision of the Commanding Officer, but shall be directly responsible to the chief medical officer. They shall be responsible to the Commanding Ofticer in all matters pertaining to coöperation with other departments. Shall have proper kitchens and equipment.

They will be under the social supervision of the Chief Nurse.

The duties of special diet supervisors shall be supervision of the preparation of soft, light and liquid diets, and special diets. Transportation of same to ward serving rooms, requisitioning for diet kitchen needs to Quartermaster's department, have complete control of the liet kitchen working force, subject to the Commanding Officer's direction.

\section{UNiforiss}

The duty uniform should be plain white. made like the nurses" No. too. The Red C'ross dity uniform of blue erepe, with white collars and culls and apron, may he purchased after assigmment to buty. The lied ('ross (al) may be worn, if the dietitian is enrolled in the lied ('ross servide.

A gray uniform may be purchased after assignment to duty. made in the style of the Army, or the Xary, nurses muiforms. duty.

A gray cape is issued by the Red ('ross after assignment to

\section{INSIGNIT}

The Dietitian may wear a Rod C'ross dietitian's batge if she is entolled under the lied ('ross. 


\section{HISTORY OF AMERICAN RED CROSS NURSING}

She should be permitted the use of the letters U.S. and the caducei with the letter I) added. (Note that the Sanitary Corps wear (aducei with the letters S.C. added.)

\section{ENLISTMENT}

The dietitian should either be enlisted for three years' service, or be counted as a reserve.

\section{RANK}

Where responsibility entitles, the dietitians, like the nurses, should be considered for a ranking position.

\section{S.ALARIES}

Administrative dietitians, as for chief nurse.

Special Diet Supervisor, $\$(; 0$ a month, with traveling expenses and maintenance, as for enlisted and reserve nurses.

\section{LEAVE}

As for nurses.

\section{ReLease}

For illness or other serious causes, only.

\section{Transeris to Otiner Services}

At the discretion of the Surgeon Cieneral's office, dietitians may be transferred from one service to another.

In discussing the above suggestions with Miss George, Miss Noves nucrely expressed donbt as to their having any weight with the Surgeon (ieneral. As a matter of fact Circular No. 27, famons among dietitians, and issuced by the Surgeon General May 1:3, 1918, showed the influence, not of the "suggestions," but of the report made by the l)ivision of Food and Nutrition. The circular in full was as follows:

\section{AMLRICAN EXPLUITIONARY FORCES}

C'inclear No. $2 \%$

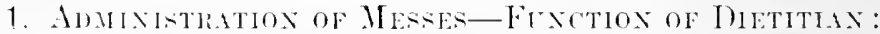
The reports of medisal inspertors and oflicer's of the Food and

Xutrition sietion show that the administration of messes is, 
as a rule, the least efficient and satisfactory part of hospital administration. The defects noted are a monotonous and illbalancel dietary, poor service, and lack of cleanliness in the kitchen and the kitchen porsonnel. 'These inspertions show that the ('ommanding Officers have not mate the proper use of the agency which is esperially intended to correct these deferts, that is, to make the proper use of the dietitians who have been assigned to the base hospitals to we their expert knowledge for the correction of these defects and to exercise the constant rigilance and attention to detail which is necessary to successful administration of mess.

Dietitians are trained experts in nutrition and food preparation. If not trained nurses, they are civilian employes having a status analogons to a trained nurse. The function of the dietitians is to supervise the preparation not only of the special diets, but to make ont the bills of fare and supervise the preparation of all food furnished by the government. 'The dietitian has expert knowledge of which the Commandins Officer should make the fullest use for the benefit of his rommancl. She should be ahle to relieve the mess officer from the burden of details required to secure a well balanced ration. proper variety and preparation and a good service. The mess officer should make a daily inspection, accompanjed by the dietitian and the mess sergeant, to see that the details of a good service are earried out fully and completely.

Like all other women of the personnel of a hase hospital. the dietitian is under the disciplinary authority of the Chief Nurse.

While "scraps" of official paper are always rahned as things to conjure by, it is doubtful if the issuanee of this order had the offect of modifving directly the situation of the dietitian in any particular hospital. As has heen previously sugesested, the dietitian made her way in the military servie laredy by the fore of her personality. As late as becember 9, 1918, in an address ${ }^{9}$ given hefore the American Public Health Association in (hicago, Major Hoskins, of the Division of Food and Nutrition said:

At times it is differult to secure the nice adjustments demanded when a woman dietitian withont military status. a

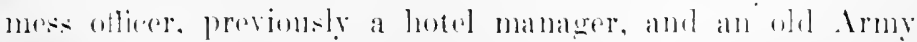

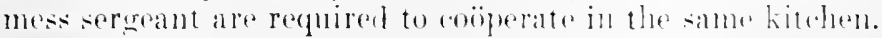

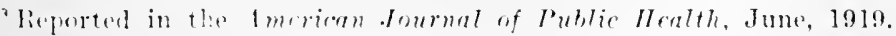




\section{HIS'TORY OF AMERICAN RED CROSS NURSING}

Mary Pascoe, of the Unirersity of Nebraska, and dietitian in Base Hospitals No. 8, No. 117 and No. 214, June, 1918, to July, 1919, said:

No changes having been made in the duties of mess officers or sergeants at the time the above duties of army dietitians were formulated, the immediate earrying out of these duties would have been absolutely impossible untess one could have suceceded in having these individuals remain more or less in a comatose condition. A perusal of the Army Cooks' Manual will show definitely that a striet adherence to these duties on the part of the dietitian would result in immediate friction with those persons with whom it was absolutely necessary to coöperate - the mess officer and the mess sergeant.

However, in time I did find it possible to justify to myself my presence in France, even though the results I was able to obtain fell short of what I had hoped to do when I reached France. ... At all times I had the sympathy and the backing of the commanding officer.

Again in contrast, quoting from the report of another dietitian : ${ }^{10}$

I was allowed none of the many other duties ascribed to the dietitian by "Ford" 11 and by Paragraph 1 in the Circular No. 27 issued by the Chief Surgeon of A. E. F. May 13. 1918. When the commanding officer refused to allow me even the administration of the diet kitrhen numolested by the mess officer. I asked on O(t. :99, 1918, through proper chanmels, for transfer, but heard nothing of it.

That "Cirenlar 27 " could and did work "overtime" in some instances may be gleaned from a quotation from the report of Sara Sellers, ${ }^{12}$ dietitian, Base Hospital No. 22 :

${ }^{30}$ Gertrude Palmer, dietitian, Base Hospital No. 46. Complete report on tile in the ollice of Nutrition Service, Red Cross National Headquarters.

${ }^{11}$ "Details of Medioal Military Arministration." Jy . Joseph H. Ford, B.S., A.M., M.1). Col. Mediol Corps. I+. S. Army. July. 19ls.

12 Sara Sellers (110w Mrs. Arthur T. Schunck) was born at Lebanou, Ohio. She was graduated in Home Economios from Olso state Lnirersity in 191:3, and later entered St. Luke's Hospital, New lork City as pupil dietitian. Following this she was dietitian at Fllis llospital. Schenectady, $\mathrm{X}$. After aiglat monthe work at lliclatel Reese Ilospital, Chicago, slie returned to Si. Cuke's as leatd dictitian. Which pusition she held until she was assigned to base lospital Xo. 22. During lee stay in New York she taught classes in cantern work under the $\mathrm{Y}$. W. C. A. 
I maintained the position of chief executive of the kitchen and the kitchen personnel. Both the mess sergeant and kitchen sergeant were responsible to my orders. Natters of discipline were attended to by the mess sergeant. 'The mess officer acted as my superior officer in name only-or in such instances as sending requests through channels, ete., aceording to Almy routine. In all matters of menu, diet, sanitation of the litchens and mess halls 1 was responsible. My position was maintained ly the orders, support and cooperation of the commanding officer and by the loyalty of the mess sergeant.

The kitchen of our original mit was entirely inadequate and impossible. I submitted plans for its reconstruction and personally supervised a group of arpenters who made the desired changes. My plans met with the approval of the camp commandant, also of Major Gore. The kitchens assigned to ['nit ?:2 and supervised by the mess department of fo. 2:) were constructed by the engineers according to $\mathrm{my}$ plans. The origina! plans contained $2+$-incll sinks in a kitchen which was designed to serve 1000 patients besides other inalequate fittings. The maximmm number served from the reconstructed kitchen was $3: 00$ patients.

Between $J$ une 15th and 30 th I was on temporary duty with Base Ilospital Xo. 6 at Talance, Bordeanx. I was ordered to make a surver of the kitchens, mess halls, service. waste. sanitation and organization. This I did, and submitted a formal report to the eommanding officer, Colonel Babcock.

The following graphie and altogether hmman deseription of some of her experiences as given by Miss Hungate. ${ }^{13}$ will be of interest just here. It will be noted that Miss Humgate did not sail for orerseas mutil Augnst, 191s, some time after the Military lopartment had issued the order referred to above. Miss IIungate's report read in part as follows:

After a session of several months at Camp Wheeler. Georuria. I became the one hundred and oneth feninine mem-

${ }^{13}$ Mary Tilylur Ilumate. (now Mrs. W. F. Bemett of Outantico, Vir-

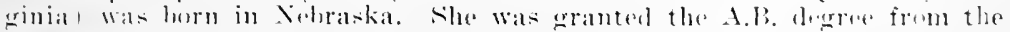
Folversity of Xehraska in I915. and following this received a vear of

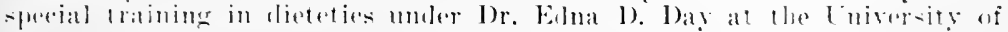

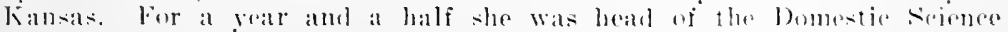

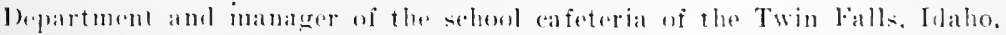

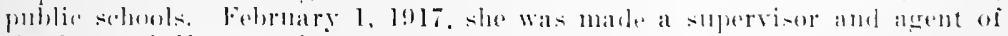

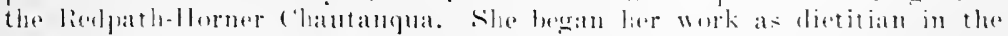

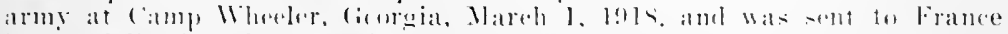

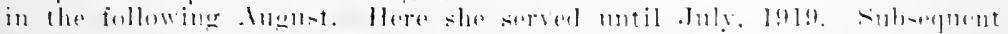

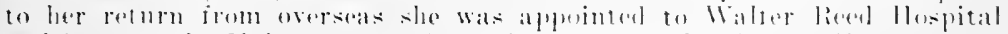

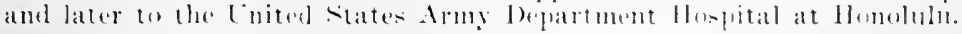




\section{HISTORY OF AMERICAN RED CROSS NURSING}

ber of Base Hospital No. 51, an organization which originated in Boston, but whieh contained abont thirty others who, like myself, well remember their first trip east to Chicago. The doetors and hospital corpsmen of the unit were sent overseas first, while the nurses were retained in New York, being outfitted with uniforms and schooled in military drill. The hundred nurses all wore street uniforms of blue serge, blue velour hats and tan shoes; while $I$, the dietitian, the one hundred and oneth, was duly fitted out in a similar suit of gray, a black hat and black shoes. There was no question about it, I was the odd member of the family; my clothes served only to indicate that I was with, but not of the unit. Furthermore, no one seemed to know just what I was there for, or just what to do with me after 1 arrived. But during those long hours of drill in the hot Armory, I was in my glory, because the officer in charge divided us into squads aceording to our heights, and my gray uniform was permitted to blend inconspicuously with the bine ones. At last our flag was dedieated, our trunks and suitrases locked, our days of drill were over and we were to embark for "overseas." We had spent hours in that sweltering Armory practieing the process of embarking. with military preeision, on an imaginary boat, and when the great day arrived we were all ready to swing into formation and march up the gangplank like a group of reterans. But how different was the reality! We stood for hours down at the pier at Hoboken. (I remember that I perspired entirely through the back of my only gray silk blonse, which turned it a brilliant hemna, but nevertheless I dressed up in said blonse for the ensuing six months). Finally, they armitted us to the boat. Oh, the tragedy of it all! Those hours of rehearsal were forever wasterl, because, instead of forming into squads and marching double-file up the gang-plank, we scurried in through a coal-hole down in the bowels of the ship, and I, with my gray suit and black hat, trailed in the rear as pleased as Punch over heing allowed to go along. even though no one. mrself included, had any definite ideas about just what I was going to do.

Miss Hungate's story as it proceeded showed that once mors the "one hundred and oneth" was found mingling inconspienously with the "hundred."

My chronicle must include a sketch of the welcome we received when wo arrived at Brest, in Angust, 1918. It that time Brest was mot comsidered the most attractive place in France, and I am positive that it was nerer slandered. We 
left the Ship La France in "lighters" and soon had parked our suitcases on the pier, used same for convenient seats and settled down in the drizzle awaiting the appearanee of Army trucks to carry us up to Pontanezan Barracks, where we were to be quartered. Our number's were now 303, as units No. 55 and No. 50 were in our convoy. Finally a train of huge trucks put in an appearance and I think that most of us received a real thril! as we bumped along over the cobblestones to our destination. From every house and shop were excited groups of French waving the 'Tricolor or the Stars and Stripes and shonting a welcome to the American women. We waved our flagr: and shonted ourselves hoarse in return. By the time we reached lontanezan Barracks we were all supremely pleased with ourselves and camped on our suitcases in front of Xapoleon's old headquarters, indifferent to the drizzle overhead and mnconscious of the consternation we were causing within the historie old building. But when three hours had elapsed withont any disposition being made of us we becan to notice that our "dress up" uniforms were becoming slightly damp and that mess call would not be unwelcome. Finally a second lieutenant stepped out from headquarters and looked us over: three hundred and three women dejectedly sitting on suitcases awaiting their fate. He did not seem pleased with our appearance, for aiter an audible "Ny God! Three hundred women!" he turned his back and went inside. It seemed that we were not expected; in fact, previous to this time but one group of women had landed at Brest, the other detachments having gone by way of Southampton and Le IIavre. Ioreover, at that particular instant one lundred thonsand Amerian troops were wallowing in the Brittany mut and under such circumstances, the problem of finding shelter for three hundred women extra was a serions one indeed. But the impossible was accomplished and we were quartered in some partly constructed hospital wards which furnished us with beds and shelter even though they did not provide so necessary a convenience as a water supply for the first twelve hours.

lase Inospital No. 51 was one of the eight hospitals which comprised the Iustien Iospital group just outsile the eity of Toul. . . Our unit arrived here at three oclock in the morning of sept. 11, 1918. The memorable sian Mihied Irive began on the 1:th and before we had time to get our bearings we were fairly inmulated by the stream of patients which poured in almost incessantly for four days and nights. . . . I had no time to draw up a jlan. to perfect an organizaltion or to do anything except the work that crowled me at the 


\section{HIS'TORY OF AMERICAN RED CROSS NURSING}

moment. I was given a range in one corner of the main kitchen. At first my only helper was a walking patient, a lad who had been gassed and who was notoriously slow both in thought and in action. Later he was reinforced by two French women who gave very good assistance though they were not cooks nor could they understand English. There was one thing that we did accomplish all through this busy time and that was to always have a boiler of hot cocoa or soup available in the receiving ward. The condition of the patients as they were admitted was most pitiable, all were hungry and had been without hot food for days. The physicians decreed that the hot drink was advisable even for those that went direct to the operating room and for those cases which did not demand immediate surgical attention we supplied bread and jam in addition.

Miss Hungate's report also indicated a rather free interpretation of the prerogatives of a "eivilian" employee in the Army:

On October the sixth I was given two rery small rooms on the first floor of the main hospital building for a diet kitchen and with my gassed cook and two French women I moved in. This moving was a very simple process, as I was given no utensils to work with, and it was with difficulty that we borrowed (?) a few necessary articles from the already inadequate supply of the main kitchen. . . To add to the difficulties was the omnipresent lack of water. The French always retained the control of the water supply and the only hours that it could be drawn were from seven to ten in the morning and from three to five in the afternoon. Often the water wonld be shut off before we had even filled the G. I. (ans, which never seemed to hold enough eren when full. I adkled to my meager store of kitchen utensils by making a personal trip to the group supply warehouse and persuading the ofticer in rharge to give me what he had. I harl no anthority for drawing these precions articles, so dis not trust them to our own supply sergeant for delivery (he had too many equally insistont demands for them and would have assuredly divided them among the three other kitchens). so I had them borne to my kitchen on a litter and settled with the Quartermaster later.

Miss Hungate's story of the Thanksgiving dinner of Base Hoppital No.51 is full of luman interest:

"Thanksciving day, 1918, will always be a "red-letter" day in my memory. The war was at last over ; Thanksgiving had 
attained a new significance. Base Hospital 51 planned to celebrate with food, and every delicary that wonld add to our dimner was purchasel, regarlless of cost. 'The kitchen forces worked overtime, cooks labored all night in order to insure a quarter-section of pumpkin pie to every patient that could eat same with even a semblance of impmity. The wards took on a most festive appearance as the "up patients" lecorated them lavishly with greens, ornaments male from Hershey wrappers or other bright materials, and the frames that supported those poor wrecks of crippled bolies were festooned like carnival booths. But on 'Thanksgiving eve, we girls received a shoek that almost brought tears. A hospital train was due in the early morning and three hundred of our patients were to leave for a port of embarkation. It seemed hard to send those lads away without their feast. Some of them had been in the hospital for weeks and had not grumbled even when the fare was both meager and monotonous. 'The goody box which the nurses had packed in New York had been set aside for Thanksgiving, and, on hasty consultation, we decided to devote its contents 11 preparing a treat for those patients. Some of the girls made fudge and the Red Cross provided cigarettes and matches, so when those men lined up for evacuation the next morning the nurses were there with cornucopias of goodies and each patient was sent away with the "bon royage" of his floor nurse ringing in his ears. The hand of fate seemed mysteriously to evacuate those patients on that particular morning. for by the time that dinner was to be served their number was almost replaced by the ragredest, most forlorn bunch of stragglers I have ever seen. They were for the most part British soldiers, filthy, humery and fontione. Some had spent four years of hard labor in the salt mines of Met\%, and when the Germans gave them their freedom they set forth withont rations, proper shoes or transportation. Our hospital sheltered over two hundred of these exprisoners. gave them baths, clean elothing and heds. amb, best of all. was able to share the turkey and goose and pumpkin pic. Inad it not been for the timely evaruation of the moruing we would have been fored to feed them the "orned willie," the haritacts and colfee of an emrerency meal. I have never seen a more cosmopolitan gathering soated arouml a single board than the one which gramed the tahle after the "chow" had heen sent out and the kitrhen fores sat down to its foast. Beside the student from ('olgate. who had enlisted in the hospital (orps in order to drive an ambulances, sat an ex-ilerobat

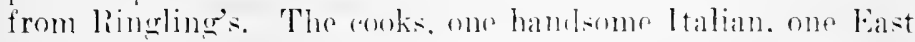

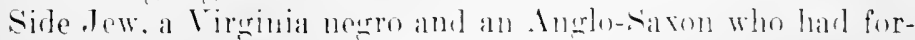




\section{HISTORY OF AMERICAN RED CROSS NURSING}

merly labored in a Kentucky brewery, oceupied the seats of honor. The three "Hinies," prisoners of war, whom we all liked and respected in spite of race prejudice; one Russian, a lad whom we had adopted after his daily pilfer of our garbage cans and who never did learn to savry the strange tongues which surrounded him; and three volatile, ehattering French women.

Miss Hungate quoted a stock query from mess sergeants, with her equally stock responses; also a few other amusing notes are included :

"Now, Lady, would you mind explaining to me, just what is a 'dietitian?' You see, you are the first one of your kind I have ever met, and I would really like to know what you do?"

"Certainly. A dietitian is a 'lady mess sergeant.' The female of the species is more deadly than the male-that's why they invited us to come to war."

A mess officer, evidently not speaking under instructions from the chief nurse, said to a dietitian who reported to him for duty: "We have enough 'diet cooks.' Hadn't you rather do nursing on the wards?" But it is to be assumed that here, again, the function, if not the status, of the dietitian was presented convineingly, in view of the fact that the hearty cooperation of the mess officer was soon aceorded to this dietitian in her work.

Mrs. Thurman, of Base Hospital No. 41, reported:

Many funny things happened, but one thing stays in $m y$ mind most. I was relieving a nurse in one of the wards, taking care of a patient, a dear bor, just eighteen. who was coming out from mder ether. He was making a lot of noise. and I said, "Oh, Earl, do be quiet: just remember the boy next to you, whose back is almost blown away, and he is not screaming." He replied, "Yes! but that's !im, and this is me." . . .

This from Ruth Shott, of Eracuation Hospital No. 19:

One mess officer insisted on serving tripe to all patients because it was cheap and he had purchased an oversupply.

And this from Miss Palmer:

There was Aimee, our gay, cheery little French helper, who hat lost everything in the war. The boys all stmlied Freneh 
in order to talk with her and wrote ont little notes from their French books for her. She promised to go back to Ameriea with me. but she married the mess sergeant and came home with him instead.

In passing, a brief quotation from Bertha Baldwin, whose report follows, is respectfully referred to whom it may concern:

Just as I was learing one hospitai, the commanding officer. in obedience to a general order just gone out from Headquarters. asked me to assist with the general mess. The mess oflicer was a doctor, a specialist in nose and throat, but knew nothing abont foods and kitchens. The acting mess sergeant was an ex-butcher, and he it was who made out the menus.

An account of the work of the dietitians who served directly under the Red Cross overseas would constitute an entire chapter in itself. A formal report of the Diet Kitehen Service was submitted to the Red Cross by Bertha Baldwin, ${ }^{14}$ Red Cross dietitian; also Miss Baldwin furnished the Bureau at National Headquarters with a more personal account of her sixteen months of service. In the interest of brevity excerpts are made in order from these reports:

The Diet Kitchen Section was organized in September. 191\%, as a part of the Ifelieal and Surgical Division of the Department of Military Aflairs. with Miss Ruth Worgan ak chief. The personnel, American Red C'ross registered dietitians sent from the Cnited States and anxiliary dietitians recruited in France, were attached directly to the section registering with the main Bureau of Persomel. When the Womenःs Bureau of Hospital Service was established in July. 1918 . the Diet Kitchen Section still remained a part of the Medical and Surgical Division.

On August : tth, 1918, in the reorganization of the Ameri(an Red Cross the Service of Diet Kitchens remained under

"Bertha $x$. baldwin was born in Cloverdale. Cowley County. Kansas. She was graluated from Milwanker-Downer College. Milwankere" Wis.. and in 1!u!n received the B.S. dearre at Teachers College. Colmmbia I niversity,

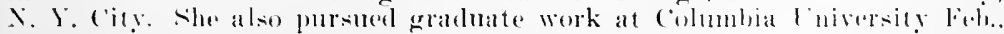

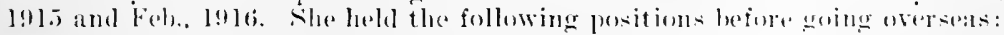

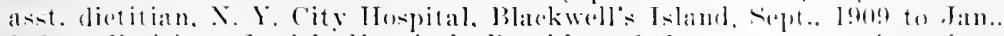
1910: dietitian. Jewish llospital. Brocklyn, 1910: asst. suprintendent.

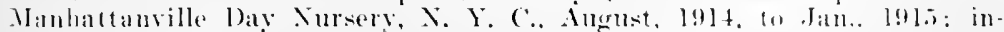

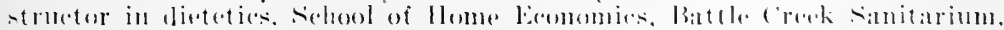

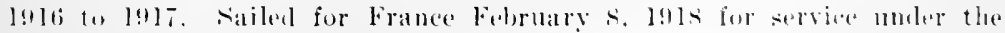
Americian lied cross. 
the Bureau of Hospital Administration of the Medical and Surgical Department, but the dietitians were placed under the Bureau of Nurses.

On January 14, 1919, by order of the director of the Medical and Surgical Department, the Serrice of Diet Kitchens was placed under the Bureau of Nurses in order to have the work more elosely comnected with the personnel of dietitians.

On February 1, 1919, the Dietitian and Diet Kitchen Service were a part of the Bureau of Nurses.

The serrice totaled 20 dietitians, assistant dietitians and auxiliary dietitians.

The demands for dietitians far outnumbered the personnel available. Although most base hospitals had brought over dietitians on the staff, all new hospitals, base, camp and American Red Cross, did not have them. 'The dietitian's work justified itself sufficiently to create a demand for larger personnel of trained professional workers.

\section{ACTIVITIES}

The work of the service started by coopperating with other organizations and individuals for diet kitchens in French hospitals. At the same time plans for the work with the A. E. F. were formed.

The first activity of the diet kitchen section was its coöperation with the Bien-être du. Blessé in installing diet kitehens in French hospitals. This was suggested as early as Anggust, 191\%, and on December 21, 191\%, the formal agreement was signed between Madame la Marquise d'Andigne for the Bien-ître du Blessé and Miss Ruth Morgan for the Anerican Red Cross.

In February, 1918, an American Red Cross dictitian (Miss Baldwin herself) was assigned to the Bien-être du Blessé to supervise the American Red Cross interests in the kitchens. She was made chief dietitian of the Bien-ître du Blesié (dietitian en (hef) and organized and supervised the work of all the kitchens on American dictary lines adapted to the French military hospital conditions.

From a general point of riew the work was most satisfactory and nseful for the rery siek and wounded. altheugh it neser reached the soientitic basis fomm in the states. The Ameriean lied cross coased its coüpration in maintaining 
these kitchens on February 1, 1919, and considered it a privilege to hand over the equipment and remaining food stuff to the service de sinté for further use.

Throngh the service, 15 dietitians or anxiliary dietitians were supplied to the hospitals of the A. E. F. and if the persomel had permitted many more requests would have been fillerl.

Diet kitchens were installed in several hospitals, and dietitians or anxiliary dietitians assigned for the work. 'Two dietitians were assigned to organization work of American Red ('ross diet kitchens in A. E. F. hospitals.

At st. Nazaire the dietitian ${ }^{15}$ advised in the building of a big main kitcluen, organized a cafeteria mess for 1000 convalesent patients, orcanized a complete diet kitchen and serving room which served from 400 to 500 individual diets. She also standardized diets in hospitals and did advisory work for neighboring camp hospitals.

... in the hospital at Romorantin and the ofticers' hospital in Paris, the auxiliary dietitians did splendid wort in (atering to the very sick men, cooking and serving American delieacies.

'Throngh the Burean of Hospital Administration the dietitians commenced coipperating in the food and mutritive problems of all hospitals muder the American Red Cross. Plans for standardizing rations and menus, for administering the foul, departments in the hospitals and for regulating the reqnisitions and purchases of foods were under way in November at the time of signing of the Armistice. . .

In .Tune, 1918, the commissioner received a request from the Army that the Ameriean Red Cross purchase equipment for 100 diet kitchens to be donated to the Army on the requisitions approved hy the Chief surgeon's office, Tours. The list for such equipment was immediately make by an American Red Cross dietitian and the equipment ordered.

One of the Amerion Red Cross representatives attached to

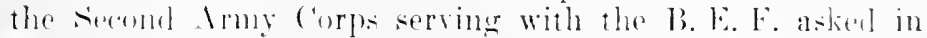

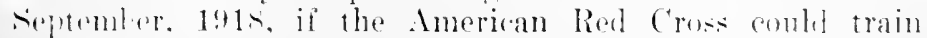
soldier cooks in sperial aoking for the sick. so that mon

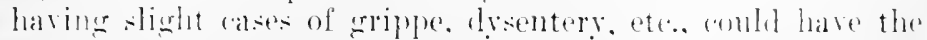
proper fowds in their reciments and thes aroil heing ofut lark to the hase hospital. Plans were worked ont between the 


\section{HISTORY OF AMERICAN RED CROSS NURSING}

chief surgeon of the Second Army Corps and the chief of the Diet Kitchen Service, and an American Red Cross dietitian arranged a two weeks' course.

\section{GENERAL WORK AT G. H. Q.-A. R. C.}

To this service was referred the many questions and demands of a dietetic nature that came in to General Headquarters. I dietitian was practically always attached to the office or available through the courtesy of the chief of the Bureau of Hospital Administration. The requirements of food per month of the American Red Cross hospitals and of nurses homes were estimated, the menus of various hospitals looked up and sent out on request.

In spite of limited personnel and difficulties of obtaining food and equipment, the dietitian and Diet Kitchen Service thoroughly justified itself and was of inestimable value to the Army. The appreciation of the French Govermment encourages the Scrvice to hope that the work thus started will be of lasting value.

Some idea of the operation by the American Red Cross of diet kitchens in Army hospitals may be gleaned from the following excerpts from General Instruction, 50\%, issued ly the approval of C. C. Burlingame, Director, Nedical and Surgical Department, and included in Miss Baldwin's official report:

In certain instances the American Red Cross furnishes equipment for the diet kitchens in the American Army hospitals, and in addition may furnish special diet materials for their operation: and may also assign persomel. When operated by the American Red Cross in Arny hospitals diet kitchens shall be under the Bureau of Nurses, Medical and Surgical lepartment.

Equimment for diet kitrhens should be issued only upon the request of the commanding officer with the further approval of the ('hinf sureon of the Army, or the chief surgeon of the sertion in which the hospital is located.

The persomed for operating these diet kitchens consists either of dietitians, nurses or nurses" aifles, with dietary experienere. Ill personnel for this morpese will be supplied throush the Burean of Xirses. The personnel so assigned to the commanding oflicer will necessarily conform to all regu- 
lations concerning conduet and hours of duty of nurses, as laid lown by the eommanding officer and chief nurse of that hospital.

The American Red Cross in placing these speeial diet kitchens in Army hospitals is not attempting to operate within the hospitals independently of the commanding officer. It must, therefore, be remembered that the American Red Cross is operating the diet kitchens as a part of the hospital, entirely under the established hospital administration.

The purpose of establishing these diet kitchens functioning exclusively under the Meelical and Surgical lepartment is to provide special foods for the sick. They shonld not be diverted from this purpose and become canteens. The liet kitrhen becomes an official part of the hospital and in serving ford to the siek must be elosely supervised by the officials of the hospitals.

In her personal account Miss Baldwin says:

The fall of 1917, when the American Red Cross began preparing for the year's work, plans were male for special foods for the future sick and wounded, and through the Bienêtre du. Blessé-a Franco-American society-diet kitchens were subsidized for French hospitals. The needs of the American hospitals when our Army wonld be needing their services were arranged for. In December, 191\%, trained registered dictitians were cabled for.

... I was the first to be sent over for American Red Cross work, arriving February 19. 1918.

I was loaned to the Bien-être du Blessé to look after the American Red Cross interests, under Miss Rutil Moram, whiuf of the diet kitchen section, under Ir. Burlingame. 'The' Bien-être du Blessé mate me chief dietitian to install amu organize and supervise all their diet kitchens, to standardize the equipment. the liets, the menus and the recipes. . . I I was transferred temporarily to American service- Imerican Red Cross Hospital No. 101. The men who had robunteered for the trench ferer experiment had just heen sent out. about fo in number, and I assisted in the food part of the work.

. . . The ereater part of June and July, I was at Amerian Red Cross Military Hospital Xo. 3 (oflicer's). Parts. I went over to install and organize a liet kitchen, hut toxt chalden of the main kitchen with soldier cooks when the Foneth chef and

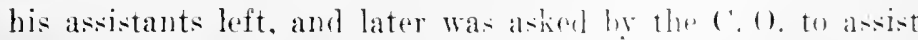
the mess ofticer for the general mese in the main kitehen.

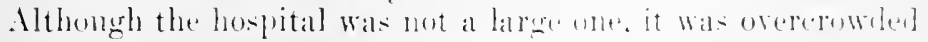




\section{HISTORY OF AMERICAN RED CROSS NURSING}

for the cooking facilities. I was acting chef for a couple of weeks until permanent arrangements could be made.

In September, Dr. Burlingame, ehief of the Bureau of Hospital Administration of the Medical and Surgical Department, asked for my assignment as dietitian for the bureau to aid in the food situation in all American Red Cross hospitals. I continued the work I had begun on rations and menus. As this work was entirely organized, it was stopped by the Armistice.

Since all work in the military line was practically finished, in February I was assigned to the Social Center of the children's work in the 19th Arrondissement. The food elinic for the three dispensaries was held there, with food consultations for mothers, and a feeding elass for undernourished children, and conferences with mothers and teachers were to be developed. The middle of April the organization of the work was entirely ehanged and my work finished. At this time a Frencliman, executive secretary of a large society interested in nutrition and hygiene, asked for my services to give leetures at the Acadeny of Medieine on the work of the dietitians at home. The American Red Cross did not feel that this conld be arranged, as the bureaus were elosing so soon.

Miss Baldwin's coneluding paragraph is of interest as it expressed the opinion of a woman of broad general training as well as speeial training in her profession :

Dietitians were needed very badly in every American Red Cross department and bureau which had to do with food, as well as in the hospitals. Food was too scarce to waste, and those untrained in food lines cannot appreciate the ralue and possibilities of foods. If there could have been a Food Burean which liandled and supervised food stuffs for all departments - buying, standardizing of recipes. menus, rations, etc. with people trained scientifically and practically. it would have been quite worth while. In the hospitals dietitians are indispensable. hecanto neither soldier cooks nor Frenth chefs (no matter how good their eooking) (an appreciate what sick men need or want. Even in the staff mess for dortors, nurses and men, the dietitian has proved herself invaluable. There were continuous demands from the Army for dietitians. If the American Red Cross could have developed the Dietitian servire. a most vital part of war work wolid have been rearherl. 
Personally I have enjoyed immensely my service in France. All $\mathrm{my}$ work has been professional, which only a dietitian could have done. Because of that I felt as if I were really of use.

Sprightly echoes of Miss Baldwin's report may be traced in the following extracts from a letter written by Laura J. Hawley ${ }^{16}$ to Miss George, under date of September 9, 1918, Paris:

I told you of the joyful welcome I received at Red Cross healquarters when 1 arrised-because I was to work with the French-and how in the twinkling of an eye they mysterionsly changed their attitude and asked me to go into a base hospital.

I was very much disappointed. For that reason, I investigated the situation as thoroughly as I could. I spent some time with Miss Baldwin and found out just what she had done. ... to go back a long way-the original eable for six dietitians cane abont in this way: Mme. d'Andigne found her work growing rapidly and was mable to get suitable assistants. She therefore came to an agrcement with the Red Cross by which they supplied the dietitians and a certain amount of equipment, I believe-and she supplied the food-for the diet kitchens and paid the dietitians. Shortly afterward she decided to use volunteers and a seeond cable was sent asking for rolunteers.

There was more or less friction and a good deal of feeling on the part of the Red C'ross that Inme. d'Andigne's work was ton slow in beiner organized. Miss Baldwin in the meantime. fitted in very happily. pleasing both factions. thongh Miss ILorgan felt things went pretty slowly-through no fault of Miss B.'s of course.

Then I appeared. Miss Morgan and Mme. d'Andigne got together. (Both of these women are exceedingly erratie and altogether charming.) 'The outene of the interview wis that for the time the lied ('rosis decided to open no more kitrhens under the bien-êter du blessé. Mne. d'. oftered to pay me a salary and put me at once at the front in al liet kitchen if I would leave the lied cross. rather if l rould leare. She was not asking me to leave. She told me the was anxious to have graduate lietitians and tould pay them herself.

${ }^{19}$ Tanra hay Ilawler was horn in Salt Lake (ity. She studied at Rockford (Illinois) ('ollowe and at stout lnstitute. Menomenie. Wis. She acted as dietitian for the rigton sohool at Winnetka. Ill. and also for the

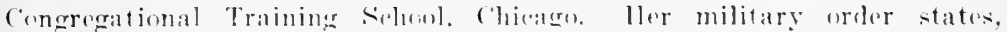

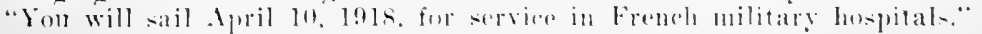




\section{$1+18$ HISTORY OF AMERICAN RED CROSS NURSING}

Through her wide soeial aequaintance she has the entrée into many French hospitals where the American Red Cross camnot go at all-that is why the Ameriean Red Cross has eooperated with her.

All this sounds very mixed up and is mixed up-but so is the whole situation.

I was sent to St. Nazaire, where the Army has a regular Army hospital-not a Red Cross one. The C. O. had asked frantically for a Red Cross dietitian-and I was loaned. Dr. Burlingame said I could make the job as big as I wanted to, for the proposition was probably the worst in France. All i can say is that $I$ hope it was the worst.

Quite mofficially I'll tell you the sewer was backed up 4 inches in the basement kitchen, where the cooking was done in garbage cans. The food was frightfully prepared. The officer's' trays were impossible.

Everything is wretchedly slow over here-but this is what I have done. I am afraid you will not think it is very much.

1. Built new kitchen for enlisted men's mess (convalescent), introducing (afeteria system of service.

2. Had new diet slips printed.

3. Built and equipped diet kitchen and serving rooms.

4. Standardized liquid and soft diets.

5. Invented system for serving soft diets directly from diet kitchen to patients in outlying shacks. (Official report has been made on this to A. E. F. Headquarters as suggestive to other hospitals.)

In the meantime I have rum the original diet kitchen.

I have gone all around France. more or less, seeking sundry neceswaries-breaking all the rules in the army, but getting away with it.

'This week I am in Paris seeking a lot of new equipment for our nain kitchen. The mess sergeant has been up and found nothing-—o I am particularly delighted to have located the impossible myself.

I British dietitian and a volnuteer worker have been offered to me as understudies but I would rather wait a little longer and have an honest to goodnoss dietitian.

This is a stupid letter, sticking to facts. Some day I'll try to write you an interesting one. My address is care American liorl ('ross. Paris.

I don't know of any two dietitians over here doing the same thing. But rarh prohlom is mique.

I have been very thankful to have no rank. T do not like lavinu onr uniforms like the nurses' aides-absolutely unproferimblal women. 
Space permits of 110 more than a passing notice of the work done by the dietitians in the Red Cross huts. Miss Hazenis: ${ }^{17}$ report quoted below contained three interesting tonedes: 1 tribute to the splendid work of the many practically mitrained "hut" workers; an evidently imnerent "ontrasting of the attiisules of mind of two conmunding offieers, and an entirely naire statement that the real interest of a dietitian is the feeding of the sick:

My work in France was rather urique becanse, while I had had more theoretical diet work, having talught the three years. and as moth practical work as many of the girls, I did less artual diet work than most of the dietitians.

The few weeks I spent at American Red ('ross No. 5 at Autenil, Paris, was as dietitian. When the hospital was closed there I was sent to Vichy to take charge of the kitchen of the lied ('ross recreation hut. . . .

'The girls in tharge were loing splendid work, but they were not aceustomed to working with the huge cuantities of material necessarily handled, which were almost berond them. and they welcomed my arrival. At that time we were serving rocoa in the afternoon between one-thirts and three: the time had to be limited because there were such swarms of boys that the line often reached (lear throngh the hall and down the street for a block.

Not only did we serve the cocoa in the hut, lut at the suggestion of Colone] Webh, the commanling ofticer of the center. roroa and sandwithes were served to wery bor after he anme

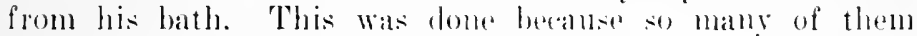
secmed weak and hungry following the bath.

At that time we were serving from !n to $1: 01$ gallons of

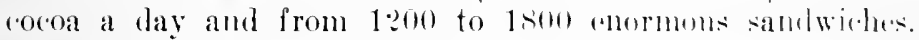
I did none of the serving lout simply hat warge of the kitchers.

After Christmas as the work grew easier, we started the

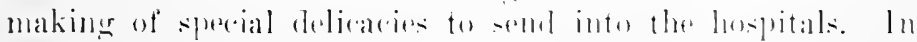

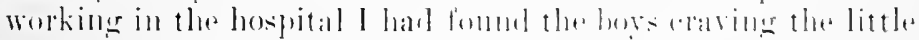

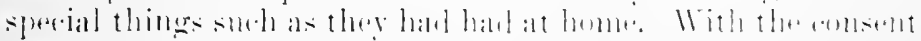

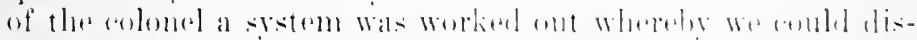

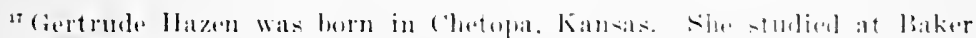

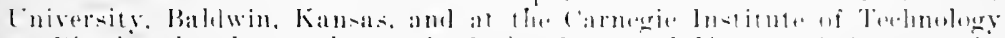

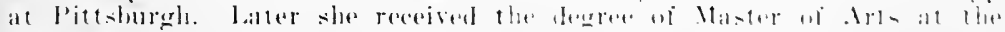

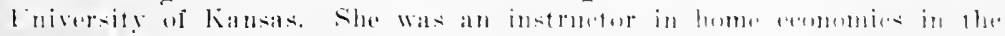

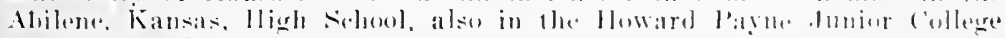
nt Jạtete. Missumri. 


\section{HISTORY OF AMERICAN RED CROSS NURSING}

cover the things the boy was craving so much and get that thing to him. I did a great deal of that work myself, because I liked to keep in tonch with the hospital life, but I went into the hospital only after the day's work was orer because I did not have a minute of spare time during the day.

... The doctor and the nurses were loud in the praises of onr work, because most of the cases were building cases and food was the main thing. We found it was necessary to appeal to the boy's whims to get him started eating, but once started he would eat not only the things we sent up but also his regular mess.

When I was sent to Savenay in March there was no food served in any of the huts outside of the candies and Red Cross cookies. I started right in, trying to find what was needed and the most economical way of getting it done. Within ten days after my arrival we were serving cocoa in each of nine huts. I secured the coöperation of the Army mess sergeants there, so that they made the cocoa for us in the Army mess kitchens while we furnished the materials.

We sent some food into the hospitals there but the request of Colonel Cooper was obeyed, for he felt that it would result in a dissatisfaction with the army food. However the doctor told me that I pulled two boys through who never would have lived had it not been for that catering to their appetites.

... I thought perhaps you would enjoy knowing just what one dietitian in France did when she was sent out of the beaten path. You see I was accustomed to the college women as we had them in the huts, and I knew nurses. I had had a thorough grounding in the seientine principles of nutrition and food preparation, and I declare $I$ used everything I knew.

It is rather a far cry from the gallons of cocoa and the hundreds of sandwiches mentioned in Miss Hazen's report to the more or less domestic atmosphere of Miss Domelas' 18 work as directror of the persomnel houses of the South Serbian unit in raloniki. It must be mentioned, howerer, that Miss I oonglas (njoyed a bricef sway in a military hospital. She wrote Miss George muler date of June 6, 191: :

${ }^{19}$ E. Constance Donglas was born in Bradley, California. Sle grad. wated from the Cniversity of California in 1!nt and later did post-grate nate work at Cohmbia Cniversity, $X$. Y. ('ity. She tamght domestio

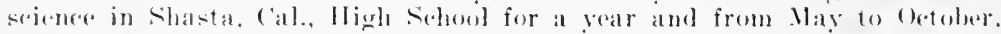

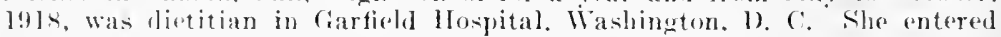
Red crost sorvice in octoher. 1919. It is interesting to note that the

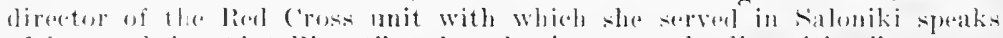
of her as lexing "intrlligent" and as having a good "disposition." 
I believe I wrote you from Paris-or rather from Anerixan Red ('ross IIospital No. 101 in Neuilly, about the first of January. I was a patient there for wer two weeks, and as soon as 1 recorered was asked to take the place of dictitian. That meant transferring to the French Commission which at first disappointed me, but seemed the thing to do, and turned out very happily. The work was no joke als I hat to be housekeeper also, the previous one having suecumbed to the flu. but I enjoyed it all, from marketing days twice a week to training the french maid to prepare special diets, keeping my accounts, and risiting the employment bureaus. . . .

Miss Delano was at the hospital about a week while I was first there, and seemed so well and fit when she left that it seemed incredible to hear of her death.

I came down to Saloniki in Mareh via Rome, Tarento, Itea and Bralo, the last three towns lesignating the British route of transportation into the Balkans. The British certainly provided for us most carefully all along their line and it was quite fun staying in their (ampls and morting the "Sister." Also they represent sanitation and deanliness which is more than I can say for the native inhahitants. I think it would annse our people at home to see the members of our group starting up country with canteens of boiled water, large pieces of mbleached muslin to cover the railway chairs, and other precautions against sickness and "cooties."

IJere at Saloniki I have charge of the housing and feeling of the south serbian unit personnel and such of the general staff as are still stationed here. We expected to do relief work with the refugees here in which aase I plamed to establish food clinies in commertion with the medical clinise. hut nume of it has materialized to date. We have three two-story houses and a flat, in the better part of the town ame right down near the water front.

The greater part of our supplies rome from onr cum ware-

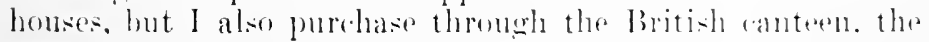
Fremeh bazaar and gret some fow thinge from the Italian warehonse. I have a perferetle ceoul litte ford three afternoons a week, one time of which I go ont to the Amerian Farm lor fres milk. orean and hutter, and wallally stay to tea with lowetol and ilrs. Homse. . . .

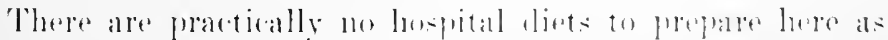
our persumel are rery shlom a

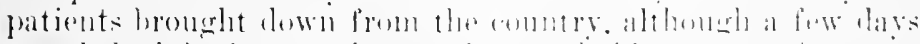

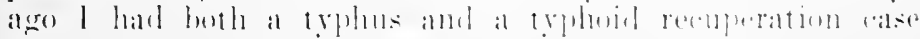

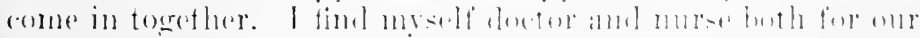

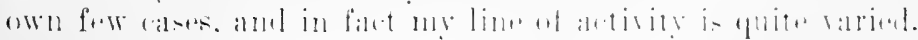




\section{HISTORY OF AMERICAN RED CROSS NURSING}

I am sure I shall graduate with a Ph.D. in something when I get through here.

.. . The r.hief maladies we have to guard against are malaria, dysentery, typhus and typhoid, and cholera possibly. i keep our drinking water boiled and all food from the open market carefully washed and well cooked. I have both Greek and Serbian help besides some Bulgarian prisoners, so conversation is carried on by "signs and wonders."

This may not be technically dietetic work but it is interesting and worth while. Anyway, amost no one over here is doing what he planned when he started.

For two of the dietitians who served overseas there was to be no home coming. Cara Mea Keech, of Santa Ana, California, a graduate of Milwaukee-Downer College, and serving with Base Hospital No. 68, died October 18, 1918, and was buried in England. Marian Helen Peek, of Green Spring, Ohio, a graduate of the Boston School of I omestic Science, died February 17, 1919, at Base Hospital No. 44 and was buried at Suresnes, France.

A report of some homely "peacetime" work came from the Red Cross Commission for Albania in 1920, in a letter from the chief nurse, Miss Caroline Robinson, to Miss Hay. It read in part as follows:

In Koritza, Miss Palmer is taking charge of the house. As she has a good rook it does not require much of her time si) she and Miss Brown have a chiddren's clinic in the morning and give instruction in practical work in the afternoon, Mis Brown visiting the homes.

Miss Oades is holding sewing classes, which make chothing for the chillren. She is also supervising the orphanage ani] has a small school for child ren who do not attenel the public schools. I hope they will be able to chothe theer children and turn them over to the public schools as there are at least 13 schools in Loritza.

Early in the vear 1919 the question of the duties and status of dietitians in military hospitals again recoined attention. On March s, Circubar lecter No. 191 wals issued by the oflice

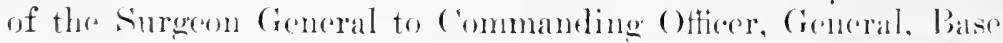
and Port of Embarkation Hospitals, lepartmont Surgeons and ('anp Sureonens, ('ertain P'ost Hospitals, Surgeons, lndependent Posts, dir Sirvice: 
1. A consideration of the duties and status of dietitians in a number of military hospitals indicates the necessity for a general statement defining rather exactly the dietitian's place and duties. It is realized that any such general statement will be subject to modification when applied to individual hospitals.

\section{RELATION OF DIETITIAN TO IIOSPITAI STAFF.}

The dietitian is responsible as far as her professional work is concerned to the commanting oliicer of the bospital. As assistant to the mess officer, she coopperates with him and the rhief nurse. The chief nurse of the hospital will send in a separate efficiency report of dietitians, monthly, basing this report not only on her own observations, but on those of the mess officer as well. Socially, the status of the dietitian should be that of nurses, and in matters of conduct she is under the authority of the chief nurse.

\section{STATUS.}

The dictitian is a civil employee of the Medical Department, but to place a competent dictitian on the same basis with rooks and maids is an injustice to her and a disadvantage to the hospital in which she is working. Dietitians designated as head dietitians receive an additional $\$ 5.00$ per month. Inetitians performing the duties of head dietitians but not so designated should be recommended for such appointment.

\section{DETIES.}

(a) Of the head dietitian.

lieports to the wief nurse, or ward surgeon, deficiencies of service found in wards in order that these may he corrected through proper chamnels. Reports deficiencies of preparation and serviee found in the mess hall and kitehens, to the mess oflicer. Insperts serving of food in all the wards and has the responsibility of seeing that it is properly preparel. Sinpervises and asigns the work of her asistants. Is responsible for the planuing of all patients monus hut confers with mess ofliner concerning market conditions before approving menus.

\section{(b) Of the dietitian.}

Tave immediate supervision of the preparation of fool in

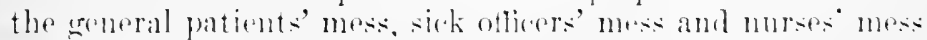
(if tesired be commanding ofticer). They also have tharese of the filling of the food arts. Have immediate supertision

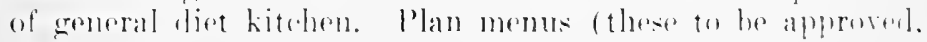
howeser. lefore use by the heart dietitian). Ilave direct re- 


\section{HISTORY OF AMERICAN RED CROSS NURSING}

sponsibility for the preparation of diets and should be supplied with sufficient help to relieve them of the details of this preparation. Visit wards to confer with ward surgeons, nurses and in suitable eases with patients regarding special diets.

\section{EQLIPMENT.}

'The head dietitian should have an office provided with a desk, the office to be located in a quiet place near the mess department or diet kitchen.

6 . The value of the dietitian to the hospital is largely determined by the degree to which coopperative relations are established. Conferences at regular intervals, in which the conmanding officer meets with the head dietitian, chief nurse and mess oflicer, are recommended.

By direction of the Surgeon General:

C. R. DARNall,

Colonel Medical Corps, U. S. A.

Executive Officer.

In June, 1919, the United States Public Health Service issued Bureau Cireular Letter No. 173 to the "Medical Officer in Charge, United States Marine and Publie Health Service Hospitals," in regard to dietitians' service. The instructions and specifieations contained in this eirenlar are practically identical with those issued by the office of the Surgeon General, but a few rather interesting variations are noted nnder their special headings (the italies are the author's):

Retation of Dietitian to IIospital Staff.

... She is experted to work in coördination with such other officials including the chief nurse as may be designated by the oflicer in charere. The efficiency of the dietitians serrices will be determined from reports of ward surgeons who are directly responsible for the prescribing of diets. "The chief nurse will also remler a monthly statement of the efficiency of the service of foods. The dietitian has social status equil to that of the chief nurse, but subject at all times to surbl regulations and restrictions as may be in foree governing all nurses in the service of the hospital.

r. Stralus.

The dietitian is a civil scientific employee of the hurean, and is not to be plased on the seme basis uilh cooks and maids. 'To do so is an injustice to her and a disalvantage to the hospital. ... 
While perhaps $f$ 'w persons eould have been found sordid enough to have desired the prolongation of the war, the fact remains that the sudden ternination of actual hostilities eame as a distinct shock to numbers of persons engaged in absorbing war activities, and elerishing equally absorbing plans for future accomplishment. The vicissitudes of the dietitians offer a case in point. Since the earlier months of the war, Miss Thompson had felt the need for a supervising dietitian to eare for the business of the serviee in the oftice of the Surgeon Gencral. No funds being avaliable for the salary, she at last hit upon the plan of placing such a person upon the pay-roll as a clerk in the Army Nurse Corps. Miss Cooper, who had volunteered for the service, was appointed by Miss Thompson, but only in time to take the oath of ottice on the day of the signing of the Armistiee, a little late to bring much in the way of aid and enconragenent to the dietitians in the overseas service.

The method of the appointment was a makeshift, but it indieated a willingmess on the part of Miss Thompson to see the afficirs of the Dietitian service direeted by a person of that profession. The duties assigned to $\mathrm{M}$ iss Cooper included the general supervision of the work of all dietitians, responsibility for the recruiting, assignment, transfer and diseipline. In the course of her work IIiss Cooper inspected the dietary departments of thirty Army hospitals. The portion of Miss Cooper's report which was published in the Repurt of the Surgeon (ieneral, I. S. Army, to the Secretary of War, 1919, Vol. Il, Page 1127 is given below:

The I) ietitian Service although a comparatively new branch of the Medical Department has grown considerably in size and importance since the begimning of the war. at which time there were no dietitialls attached to army hospitals. It the the of the fiscal vear. June 30, 1918, there wore 1 tit dietitians in the servie. At the time of the simninge of the Armistire. Norember 11, 1918, there were 3ist dietitians. Of this number $x$ t served overests: the remaining sid were distributed among gr hase. greneral and post lowitals of the Initel states. Since the signing of the Armisties the num-

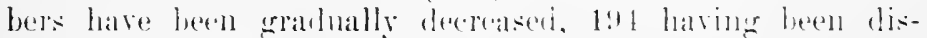

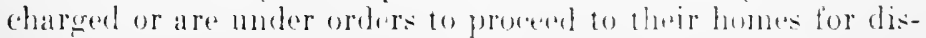

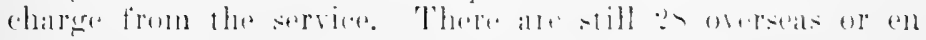

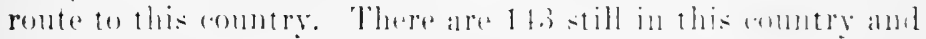

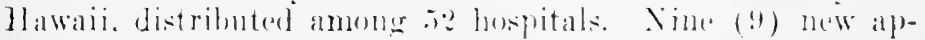

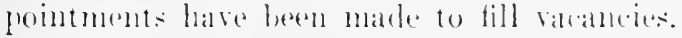




\section{HISTORY OF AMERICAN RED CROSS NURSING}

Early in November, 1918, a supervising dietitian was appointed and assigned to duty in the Surgeon General's office.

The increasing demand on the part of hospitals for additional dietitians and complimentary verbal reports from commanding officers are evidences of the popularity of this branch of the service. Some of the larger hospitals have had as many as ten dietitians. During the epidemic of influenza the dietitians proved themselves of inestimable ralue in organizing forces for the feeding of the sick and well. Three dietitians lost their lives during the epidemic and several others were seriously ill from it. It seems unfortmate that these professional women, who worked side by side with nurses, doctors and enlisted men, should not have the privilege of War Risk Insurance.

The value of food and nutrition for both sick and well has come to be recognized as such an important factor in army life that it is believed that the dietitians have come to be a permanent factor in all well regulated Army hospitals as well as civilian hospitals.

Unfortunately for the development of the office, Miss Cooper's leave of absence from her work in the Battle Creek. School of Home Economies eould not be extended and she relinquished her position in the Surgeon General's office in July, 1919. To succeed Miss Cooper it was not easy to find a dietitian possessed of the degree of training, discrimination and executive ability which the situation demanded, and who would be willing to accept the position, or who could be spared from whatever position she might he filling. However, previons to her departure, Miss Cooper had written to Josephine IIapper, a gradnate of the University of Illinos, who was then dictitian at Jefferson Parracks, asking her to undertake the work. This Miss Happer consented to do. lnt was transfored to Walter Reed Hospital, presmably for the reason that the budgets of all the departments were lowing redured to such an extent that the Army Nurse Corps no longer had suffivient funts to allow for the salary of a supervising dietitian. She remained on the par-roll at Walter Reed Inospital but was sent to the Surgeon Gencral's office on temporary duty. From this tine on the office becane an empty title. In reporting her experience Miss Happer wrote:

My duties while at the Surceon General's office were chiefly the transforing of dirtitians from one hospital to another. 
keeping recorels, answering letters from dietitians, in fact all letters eoncerning lietitians. During the time l worked in the Surgeon General's office I worked at Walter Reed for two woeks when a number of the dictitians were sick. Most of the work was done unter the supervision of Major Stimson, or of some of her assistants.

With the passing ont of the rule permitting field employees to oecupy a bureau or office position, Miss Happer was transfered to Camp I)ix in the early part of Fobruary, 1920, and Major Stimson took over the work of the office. 'The following letter from Major Stimson to Miss Cooper, nuder date of Fobruary 10,1920 , is self-explanatory as to subject matter, but in passing it might be said that possibly any dietitian with sufficient training and experience to make her acerptable to the profession would have hesitated to acept as predetermined a position as the one liere suggested. Major Stimson wrote:

It is not at all my desire to take over the Dietitian Service, but for the time being it is necessary for me to flo so. I have been searching diligently for some accredited, grathate dietitian who is also a graduate nurse, into whose hands I can put the Dietitian sorrice. Such a person conld be appointed into the Army Nurse Corps, and there would be no difliculty about the payment of her salary.

Such in briof is the story of the supervising dietitian under the Army Nurse ('orps. To say that it was here an empty name is not to eritieize the Nurse ('orps as sureh. A sinular maladjustment would have persisted had the dietitians been placed under anv alien service. The problem of suitable food for the army retended berond the hospital and the dietitians should have been incluced in and answerable to the eneneral foud and Sutrition Division of the military oreanization.

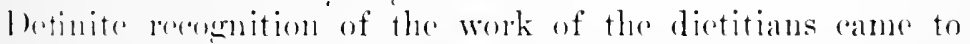
them in varions wars. The bestowing of decorations by the

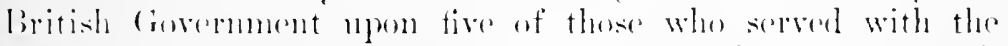

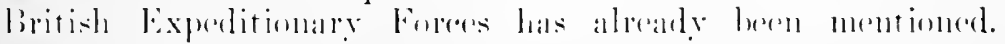
'That the Aneriean Fixpeditionary Forese has approwal, if ant "decentations," to offer was related hy Miss Humgate in the

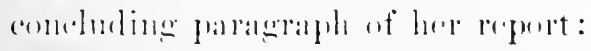

In July, 1919. I found myelf ome of all the remaining

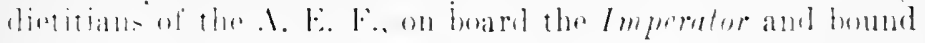




\section{IISTORY OF AMERICAN RED CROSS NURSING}

for home. Of course we exchanged experiences and found no two had faced parallel conditions. We had all gotten so far from our training, from our ideal of a dietitian and her work, that most of us were inclined to be dirappointed in our results. A brigarlier general who was a fellow passenger did much to hearten us and reëstablish our morale. He wanted to personally meet and thank some dietitians for their good work. He saik that his only experience in an Army hospital, some years before the war, had branded them in his consciousness as places of badly selected food, poorly prepared, and utterly unfit for the sick. To his surprise, when he became a patient in an A. E. F. hospital he was served.trays of palatable, well chosen food, and upon inquiry, learned that a college trained dietitian was responsible. He was so enthusiastic over our work that he thought it should not be confined to hospitals alone. but should be extended to the feeding of the entire Army, where cooks and mess sergeants could be given traininc ant supervision in the preparation of food and the balancing of menus.

And Major Hoskins, who visited nearly every camp and cantomment hospital in this country, had this to say :

When the dietitians first came into the Army, they encountered many difficulties incident to the introduction of women into what had previously been in the military experience a strictly masculine pursuit. I hase much admiration for the skill with which they met these tactical difficulties, and the valuable service they rendered to the army.

Nore to be appreciated than any of the foregoing was the approval voiced by Surgen General Ireland when he stated ${ }^{19}$ that the dietitians land proved themselves of such value to the Army that the oreanization of an Army general hospital staff which did not include them conld scarcely be contemplated any more than one which did not include nurses.

The home work of the Nursing Servire and with it the Inetitian Siervie paralleded the work abroad thromghout the war period. In Mareh, 1915, the Burean of Instruction was divided into a Burean of Instruction and Nurses' Aides and a

12 Testimonial offered by the Surereon General at a special meeting of the National rommitter on lied Cros Nursing Serviee called at Red Cross Hearlquarters. January (;, 1! 2 . to consider a proposal to eliminate the Nutrition Service of ile Red Cross. 
Bureau of Dietitian Service. Miss George assumed responsibility for the latter under the guidance of the Committee on Dietitian Service.

At this time the United States faced the possibility of several vals of war. The course in Home Dicteties was supplemented in June, 1918, by the publication of a mamual on "Emereney Cooking for Lare Croups of l'eople," a pamphlet intended "as a guide for instruction in cooking for larege gromps of people in emeremeneses, such as fires, floods, the movement of troops, ete, which Red C'ross Chapters are frepuently ealled upon to meet." Several months later material for a course in "War Diet in the Home" was issued. Instruction in Home I)ieteties, as in Iome Hygiene and Care of the Sick, was first carried on entirely by National Headquarters dealing directly with the local organizations griving the courses. But following the decentralization in March, 1918, Division I)irectors of Nursing were made responsible for all details pertaining to these classes. The plan was, however, to appoint special direetors of this service monder the mursing service in each Division, and during the year following directors were appointed in the Atlantic Inivision and in the Central llivision. The appointment of instruetors continued to be made from National Headquarters.

As has been shown earlier in this dhapter, the original course in Home lleteties was plamed to "give in a simple war the molerlying principles of cookery" but this was som found to be inadepuate to the needs of the tine. The limitations and restrictions of the food supply were putting upon the people the task of making substitutions for this or that food material which rlaneed to be at the time either mobtainable or needed for the tighting forecs. The hardships consegurent to the use of muarenstonsed fords was found to be more than a puestion of forecoing onces preferenees. As a matter of fanct, certain "substitutes." so called, were in manv ases not substitutes. no matter in what form they wore sorved. It heramuse evident that a knowledere of what fouds to seleset in ordere to smpply the varied motritional needs of the body was, broally speaking. of mere importane than the ability to prepare four well. The home ceomomices workers of the anntry had beren molifying their tearehing to make it ansistent with results of observations

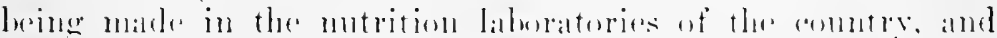

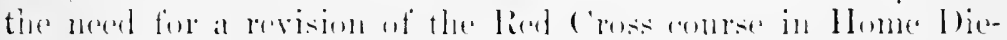




\section{HISTORY OF AMERICAN RED CROSS NURSING}

tetics beeame apparent. Accordingly, in the spring of 1918, Mabel Wellman, Head of the Department of Home Economics of the University of Indiana, was asked by the bureau to prepare a course which should be based upon the principles underlying the selection of adequate food and emphasize the importance of these as compared with mere skill in food preparation.

While Miss Wellman prepared the bulk of the course, Dr. Dorothy Reed Mendenhall, of the University of Wisconsin, furmished the material for the lessons on infant feeding and food for the child, and Caroline Hunt, of the U. S. Department of Agriculture, States Relations Service, wrote the chapter on "Calculation of the Dietary." As rapidly as this material could be gotten in shape it was sent out to the classes by the bureau in typewritten form pending the time when the lessons could be unified and printed as a textbook.

Unfortmately for the class work in Home Dietetics the work of preparing the new course of lessons was retarded through pressure of other obligations which seemed of more importance at the time. In January, 1919, Miss George wrote Miss Delano, who was then in Paris:

We have gone very slowly with the Home Dietetics plans. . . . So many of our very good committees on dietitians are elusive these clays; they all seem to have an enormons lot to do under any number of different organizations.

The workers in the field were not slow in seeing that a new impetus had been given to the whole subject of food and nutrition and that the Red Cross was faced by an added responsibility concerning it. In a letter to Miss George, Miss Sells, director of IDietitian Service of the Atlantic Division, said:

Home Iieteties has no popularity because the arailable instructors have tried to teach according to the textbook.

A little later Mrs. Mchlig, director of the service for the Central l)ivision, wrote:

In one rase the texture of the custard interested the teacher more than its use in the diet. its digestibility or its empositions. There has heen so much ariticism of our text that I fecl the neml for holding our instructors up to a very high stanilaril. 
She added:

Miss Marlett, of Wisconsin, writes me that the Red Cross course will have to be sufficiently worth while, before the Extension teachers will be warranted in teaching it.

In August, Lettic (G. Weleh, director of the Nursing Service of the Mountain Division, wrote to National Headquarters:

It is very gratifying to know that a complete change of plan for Ilome IDictetics instruction has been made. I trust that the revised plan proves more feasible than the previous one. . .

It is my desire to assist in this activity to the fullest extent possible.

The widening seope of the Dietitian Service was suggested by Miss George, in a letter to Miss Noyes, requesting authorization to represent the Red Cross at the meeting of the American Home Economics Association to be held in Blue Ridge, North Carolina, in June, 1919:

It is desirable to present to the Ameriean IIome Economics Association the revised Red ('ross course in Ilome Dietetirs. Several members of the Committee on Dietitians will he present, and will present the matter and lead in disconsions that may arise. A rough draft of the outlines is being prepared by the lepartment of Agriculture in coïperation with the Reil Cross which will be ready by June ?lith.

Another object in having a Red ('ross representative at the meeting is to arrance for coopperation with the IJome Demonstration agents through the States Relations: representatives who will be present, in organizing Red Cross clisses.

It will also he pertinent to the extalblishment of this edincational work in the South to confer with the large representation of householil economics people from the southern states who will be present.

In granting the authorization requested Miss Noyes said:

I shall he very glad, indeed, to have you attem the comrention which meets at Blue Ridge. $X$. (C., and fect sure that it will be greatly to the advantage of the Ilietitian service of the Red Cross.

On July 15, 1919, Miss Georee resimned her position as director of the Burean of I)ietitian Serviee: Marsaret 


\section{HISTORY OF AMERICAN RED CROSS NURSING}

Sawyer, a graduate of the University of Illinois, suceeded her at National Headquarters.

The year following her graduation Miss Sawyer studied at Cornell Medical School and Russell Sage Institute of Pathology in New York City. Following this she was made instructor of applied nutrition in the State University of Iowa, where she remained for three vears. Because of the service she was able to render when the medical staff of the University was depleted by war time demands, Miss Sawyer was not ealled into active war service until it was deeided to make some test observations upon the diet of aviators. In October, 1918, she was ordered to report for duty at Ellington Field, Houston, Texas, but she was shortly transferred to Rockwell Field, San Diego, California. Later she was assigned to Walter Reed Hospital on detached duty, remaining there until July, 1919, when she was made director of the Bureau of Dietitian Service.

Beeause of Miss Sawyer's special training and interest in the subject of applied mutrition the date which saw her assumption of the position would seem to constitute a natural dividing point between the work which the bureau found at hand during the war and which Miss George had so faithfully directed, and the new field which was opening up before it.

With the prospect of being able to place a director of the service in each of the Divisions, the need for the very large Committee on Dietitian Service was no longer apparent. At a meeting held in Cineinnati on Septenber 11, 1!1!), the Committee on Red Cross Dietitian Service made the following recommendations to the National Committee on Red Cross Nursing Service:

I. That the present committee of nineteen members be reduced to fire members.

11. That the national director of the Burean of Dietitian Serrice act as the serretary of the National Committee on Red ('ross J)ietitian Service.

III. That a director of the Bureau of I)ietitian Service be placerl in earh of the Division offices.

IV. That the nembers of the rommittee he Dr. liuth Wheeler. hearl of Department of Home E(wnomies, Goucher College. Baltimore. Md.; Miss Edna X. White, hearl of leepartment of l]one E(onomirs, (Ohio state Lniversitr. ('olumbus, (Dhio; Mise lena F. Cooper, director. School of IJome

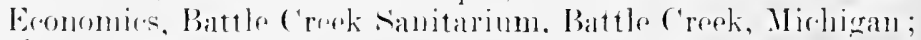
Mlis Elva A. Cieorere, former director of the lied cross 
Bureau of Dietitian Service, and Miss Margaret Sawyer, present director, Burean of Dietitian Service.

Ijy manimous rote, Dr. Wheeler was elected chairman of the Sational Committee on lied Cross Dietitian Service.

It a merting of the National Committee on Ried Cross Nursing Survienat Washington, D. C., December !), 1!)19, these recommendations were approved.

At this sane noeting the chairman announced that the textbook on dieteties wonld be diseontimed and a new eomrse, of a lesson plan type, which was then under preparation, wonld be used.

Also, it was moved by Miss Palmer that the director of the I) which nurses were entitled in the War lisk Insurance and report back to the Adrisory Committee.

Mrs. Higbee moved to amend by inserting "and dietitians" after nurses. The motion as amended was carried.

The secretary of the Committee on Dietitian Service expressod a wish that the name of the burean be ehanged. It was decided that this be referred back to the director of the Department of Nursing and the seeretary of the Committee on Dietitian sorvice for adjustment. (The ehange of name to Burean of Nutrition service was noted in the Ammal Report, Jume:30, $1 ! 200$.

Athomgh the impetus which the war had given this burean hasd beren vere eonsiderable, anch montle of the transitional period of 191!-1920 nutred a further demand for development in the ficld of nutrition. At a later meeting of the National

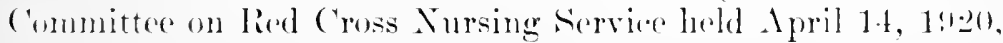
in Atlanta, Cooregia, a very interesting and extensive progran was rexommended by the Committee on loctitians and was in vallt as follows:

The qualifications for enrollment in the bietitian sirvien of the Inericall lied cross shall be graduation from all all-

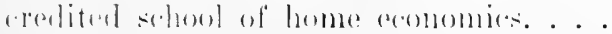

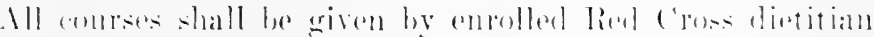
intrinters.

statr Committres on lied ('rose l)intitian survine shall be forment in eath statte. . .

The oreanization of the National and state Cummiteres on

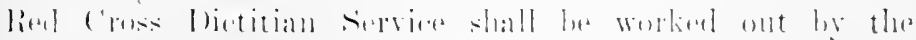




\section{3* HIS'TORY OF AMERICAN RED CROSS NURSING}

director, Department of Nursing and the director, Bureau of Dietitian Service, and shall include the following points:

A. The National Committee on Red Cross Dietitian Service,

1. The National Committee on Red Cross Dietitian Service shall be composed of five members, three of whom shall be nominated by the American Home Economies Association and two by the American Dietetic Association.

2. The members of the National Committee on Red Cross Dietitian Service shall be members of the National Committee on Red Cross Nursing Service.

3. All members shall be enrolled Red Cross dietitians. bers.

4. A quorum of this committee shall consist of three mem-

The method of appointment of members of the State Committee on Red Cross Dietitian Service, their qualifications and the functions of these committees were also outlined.

It was also recommended that the program of the Dietitian Service showing activities already undertaken and the suggested extension be worked out by the Department of Nursing.

"Any one nutrition center," the report continued, "may include all or part of the following adaptations."

I. A center where nutrition clinies for children who are suffering from malnutrition may be held. These children are followed into their homes where the mothers are given instruction and help.

I1. A renter to which any individual or agency may refer its nutrition problems.

IIl. A center where food for the sick may be prepared and distributed upon request from any agency, physician, dispensary. hespital. or public health nurse, and where individuals may be sent for instruction in the preparation of food for special diseases.

Miss Sawrer presented the report to the National Committee. It was moved by Miss Gladwin that the recommendations made in the repert as read be incorporated in the material to be prefared by the rhairman and later referred to the nembers of thre Natinnal commitere on hed Cross Nursing Service. This was "arried. The chaiman explained that it would be necessarry to include the five nembers of the Committee on lied Cross 
Dietitian Service in the National Committee on Red Cross Nursing Service.

The report of the Bureau of Dietitian Service for the year ending June 30,1920 , told its own story:

The fiscal year may be considered the transitional year in the development of the Bureau of Dietitian Service. The responsibilities assumed during the war necessarily had to be continned and at the same tine a definite, constructive, workable program had to be developed in harmony with the general peace program.

As the Army had no supervising dietitian since January 1 , $19: 0$, this bureau has acted as a recruiting agency for the Army as well as for the Navy and l'nited States I'ublic Health service. It has also acted in an advisory (apacity to the dietitians being discharged from the service and has been the means of putting many of them in touch with openings, as well as aiding many hospitals in secoming dictitians.

The Bureau of Dietitian Service has :2,38\% enrolled dietitians. These women are all trained in home exonomies. Forty-four members were enrolled during the fircal year, 1 if as hospital dietitians and 30 as instructors in Food relection, making a total enrollment of 509 hospital dietitians and 1.8 is instrucetors.

The supplying of dietitians to the Army, Nary and Inited States Public Health Service hospitals and the extension of its course in Iome Dietetios were the main artivities of this bureau on July 1, 1919. In developingr the health program of the American Red Cross it soon became apparent that the artivities in the field of nutrition would have to be extendend to meet the health needs of the commmities. This roncolption necessitated the complete reoranization of the bureau and its artivities.

A definite poliey of roopperation was worked out with the States Relations Service of the Itepartment of Anriculture and in each of the four I)ivisions in which a director of the hureau has been placed, a definite plan of coöperation has: heen effected with earh state Extension servien.

It was decided that the most effective contribution this buran could make to the houlth program wat the development of nutrition abses for undernomrished ehildren. the estahlishment of hot sohool hunches, and the patemsing of it: andret in Fond sialextion.

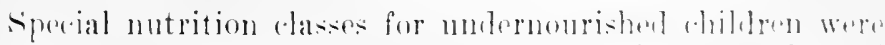

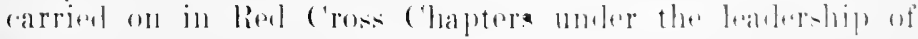
mutrition experts. The nutrition worker organized and ant- 


\section{HISTORY OF AMERICAN RED CROSS NUIRSING}

ducted these classes, followed the children into their homes, where she assisted the mother in solving the food problems relative to the diet of the entire family, and also coopperater with the social worker and the pubiic health nurse in special cases wherein they needed adrice and assistance. Three nutrition centers were established during the fiscal year, while 138 nutrition clinics were conducted in the Atlantic and Southern Divisions.

Because the development of nutrition classes for undernourished children promises to be the most important activity of the bureau and because there is great need of standardizing the conduct of them, a plan whereby there will be at least one center in each Division for the training of nutrition workers has been begun. An effort is being marle to establish these centers in coöperation with a Department of Home Economics. Such a coöperative plan is being worked out between Tearhers College and the New York County Chapter, and Peabody College and the Nashville Chapter.

The course in Food Selection, replacing the former course in Home Dietetics, comprises a study of foods and the factors which determine the selection of an adequate diet for the family. During the fiscal year, 162 classes were held and 1,497 students certified in this course.

The Burean of Dietitian Service stimulated an interest in hot school lunches and assisted in their establishment through chapter Committees on Nursing Artivities, or the Chapter School Committee of the Junior Rerl Cross in commties not served by a Home Demonstration agent, and in localities where the request came from the Extension Service.

The administrative work of the burean had demanded almost the entire attention of the director and the need for assistanee became apparent. In November, 1920, Amma R. Van Meter, a graduate of the Lniversity of Illinois, and for several years a member of its faculty, also later professor of Home Exeonomies at (Ohio State Lniversitr, was nade assistant direcotor of the burean. Miss Van Meter's first work after eoming to Cational Headquarters was the making of necessary revisions in the lessons in Fond sereretion. Within a few months the long-promised textbook was published and ready for distribution.

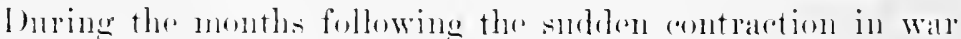
arotivities the led crosi passed through many transitional and tratative phases in matters of organization and administration, 
and the Nutrition Service had its full share of these experiences.

A special meeting of the nutrition members of the National Committee was called for August 17, 1920. Miss Noyes, chairman, Miss Edna White, Miss Ruth Wheeler, Miss Elva A. George and Miss Margaret Sawyer were present.

The chairman explained that the meeting had been called to diseuss the transfer of the Nutrition Servive from the Nursing to the Health Service, aceording to a proposal made to Dr. Farrand by Mr. Munroe and 1)r. Peterson, director of Health Service. She stated that inasmuch as the program of the service had ehanged with the development of the health program of the Red Cross she felt willing to see the serviee developed on an independent basis, partienlarly as a profession other than the mursing profession was involved; but she saw no reason for it to be changed from its present position and placed nnder medical direction in Health Service, and she felt that no good argument had been offered to eonvinee her of the advantages of such a change. She stated further, however, that if the Nutritional Committee agreed that such a change seemed desirable, she would offer no further objection.

The members of the committee expressed themselves as in harmony in general with Miss Noyes' point of riew.

Miss Sawyer stated that she thought that a service which reeruited its personnel from a distinat professional group should not be administered under any different gromp, and for that reason recommended that the Sintrition Service be made an independent service. Howerer, if the Health service were made to include all of the health activities of the lied Cross, nutrition, as one of the activities, would necessarily have to be ineluded.

The meeting then adjourned to Mr. Munroe's office.

Mr. Mmmore stated that he felt that it was an administrative matter and that for such reasoms he wished to sere the transfer of the Nutrition Service to the Ilealth Servier. The Nutrition (ommittere expressed their desire to sere an independent service hut finally agreed to acept the deeision of the general manager that mutritional work should be transferred to the Ihealth sirviter.

Notwithstanding the apparent tinality of Mr. Munroe's ruling, no formal steps were taken to effect the transfer and the matter was lost sight of follewing the appointmont by Dr. 


\section{HISTORY OF AMERICAN RED CROSS NURSING}

Farrand of a committee (later known as "The Chairman's Committee of Inquiry") to eonduct a study of the entire Red Cross organization. The results of the findings of this committee in so far as they affected the Nutrition Service were shown by the following excerpts from the committee's report submitted January 12, 1921 :

Nutrition Service: Nutrition Sirvice should have distinctive recognition as a part of the program and shonld inelude:

A. Development at National Headquarters of gencral policies and national contacts and, in each division, of state contacts, with assistance to the chapters in developing their local contacts.

B. Information and advice for the benefit of personnel in each division and of executive seeretaries and paid workers as well as officers and volunteers in the chapters, concerning nutrition service and ways of enlisting and using trained local rolunteer personncl in this service.

C. Development of a suitable text for elasses in Food Selection and of a procedure for organizing and conducting such rlasses.

D. Arrangements for enrollment and training of workers in nutrition service who will be available for employment by Army and Navy and other government hospitals and by chapter committees and civilian hospitals.

The Minutes of the meeting of the Central Committee, January 29, 1921 (page 1821), ineluded the following:

TOTED: That the Central Committee approves in general the report of the Chairman's Special Committee of Inquiry, more particularly the fundamental change from a departmental organization to a line and staff organization, ete. . . and that it is the hope of the Central Committee that the transformation can be completed by July 1, 1921.

The Ammal Report of the Red Cross Nutrition Serviee for the vear conded Inne 30,1921 , told the remainder of the story, in so far as it is connected with this history, and was in itself both a reapitulation and a forecast of the Red Cross Nutrition Service.

Nutrition Service operated as the Bureau of Nutrition Sertice in the lepartment of Nursing until the general re- 
organization plan of the Amerian Red cross went into effert, April 1, 1921. Since then it has operated as a separate service. It has continned the work of enrolling women trained in home efonomic's to act as dietitians in hospitals of the Army, Navy and Lnited States Public IIealth Service, or as instructors in the conrse in Food Selection. 'The standards for enrollment are being raised through a more critical consideration of the qualifications of eacli candidate than was possible under the pressure of war conditions. Twenty-two hospital dietitians and 101 instructors were enrolled during the year. The total enrollment at the end of the fiscal year was 2,514.

'The line of activities of the service determined upon last year in conformity with the general plan of permanent operations of the Amerioan Red Cross has been contimued. Cooperation with the states Relations Service of the Cnited States Department of Agriculture has been strengthened, and in those divisions in which the service has a director the work in coöperating with the State Extcusion service is progressing satisfactorily.

The prevalence of maluntrition among children of the nation, rieh and poor alike, as shown by inspections made by physicians, is a menace to the health of the nation and as such (onstitutes an emergency which calis for help from the lied Cross. Such aid is being given by the Nutrition Service as rapinly as its resources will allow, along the following lines:

1. Nutrition dasses for undernourished dhildren.

In schools in coöperation with the sehool physician and the solhool nurse.

In community centers allied with social organizations.

In rö̈peration with Ilome Demonstration agents.

In cooperation with the Public Ilealth Service.

Reports for the year show 1.114 nutrition rlasses condurted with an enrollment of : : og) children. Four thousand, seren hundred and thirty-two visits were made to the homes of these rhildren.

I training center. to give the mutrition specialist the tedhnique for the condurt of untrition ciason's, is now in operation in New York ('ity through the rö̈peration of "Teachers" College. Columbia Fniversty, ant the Xew York County (hapter. A similar training enure of six weeks was begun in olume at the state Tniversity of Iowa. the Department of llome Eeo-

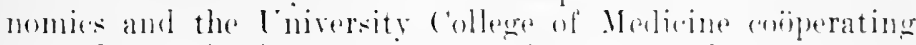
with the sperial instructer in mutrition from the lied ('ross. several other universities hase shown erreat interest in this plan and have asked that they be allowed to estallish similar relations with the lied cross. 


\section{$14+0$ HISTORY OF AMERICAN RED CROSS NURSING}

2. Classes in Food Selection.

Organized among the mothers of ehildren in nutrition classes.

Organized among other groups as an independent Chapter activity.

Organized in eoöperation with Home Demonstration agents.

These classes are conducted by instructors selected from the list of enrolled dietitians. The textlook, "The Red Cross Course in Food Selection," has been revised and published recently.

During the year reports were received from 163 classes in Food Selection and 1,587 certificates were issued.

3. Hot lunches for school.

Nutrition Sersice has worked in coöperation with the Junior Red Cross Service and with the Home Demonstration agents and teachers in stimulating an interest in providing hot lunches in schools. Two hundred and twenty-seven such activities were reported.

4. Nutrition training courses for Red Cross personnel.

In the special training courses for Chapter executive secretaries, which are being developed by a mumber of educational institutions in coöperation with the Red Cross, varying amounts and plases of home economics are included, depending entirely upon the point of view and experience of the instructors. In some cases the material included has ben arlequate, in others not. To meet this situation the Nutrition Service is preparing a suggestive outline of material to be included in the training course for hed Cross seretaries and ficld representatives.

Inasmurb as most of the (hapter Executive Seretaries and Public llealth Nurses receive their field training in urban communities, rather than in rural, it is the desire of the Nutrition sorvere to plan a course which will deal with the problems of the rural lome in distinetion from those of the rity home.

In conchuding this chapter it may be said that history dofines its own limits both as to suljowet mattor and cmphasis, and it has in this rase claimed the greater spaler for the war work of the dietitians.

But with this part of the story redded, the major interest of the Nutrition Sorreve is soen to hark barek to the original ideal

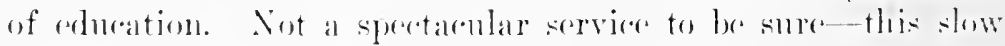
and fainstaking work of helping astablished agenedes in the 
none too easy task of readjusting their programs to meet the demonstrated need for more rational and consistent education in regard to adequate food. Nevertheless, it has been a service which has embodied to a high degree the spirit of the Red Cross, which impels to the lending of aid wherever needed. 


\section{APPENDIX}

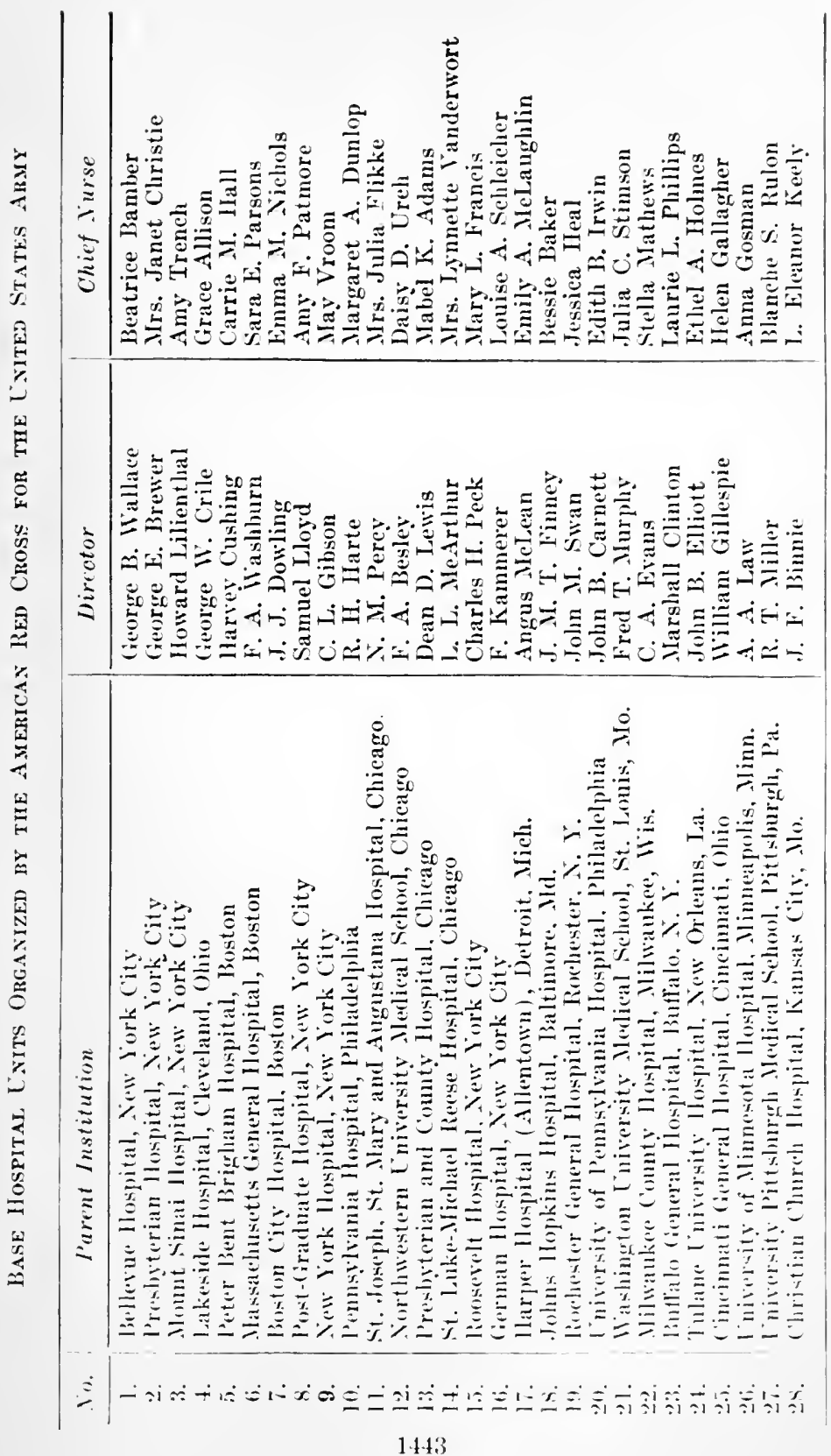




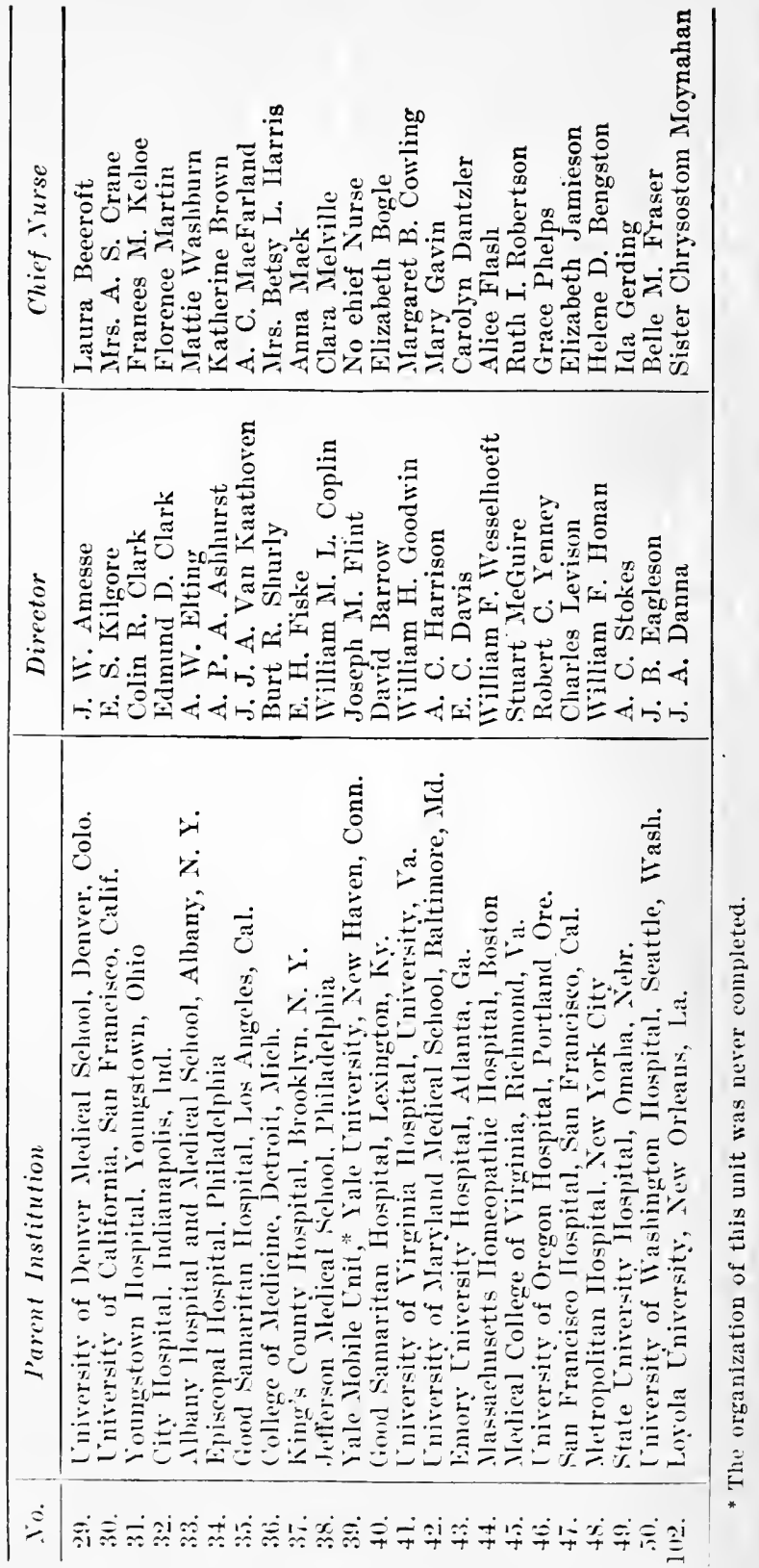




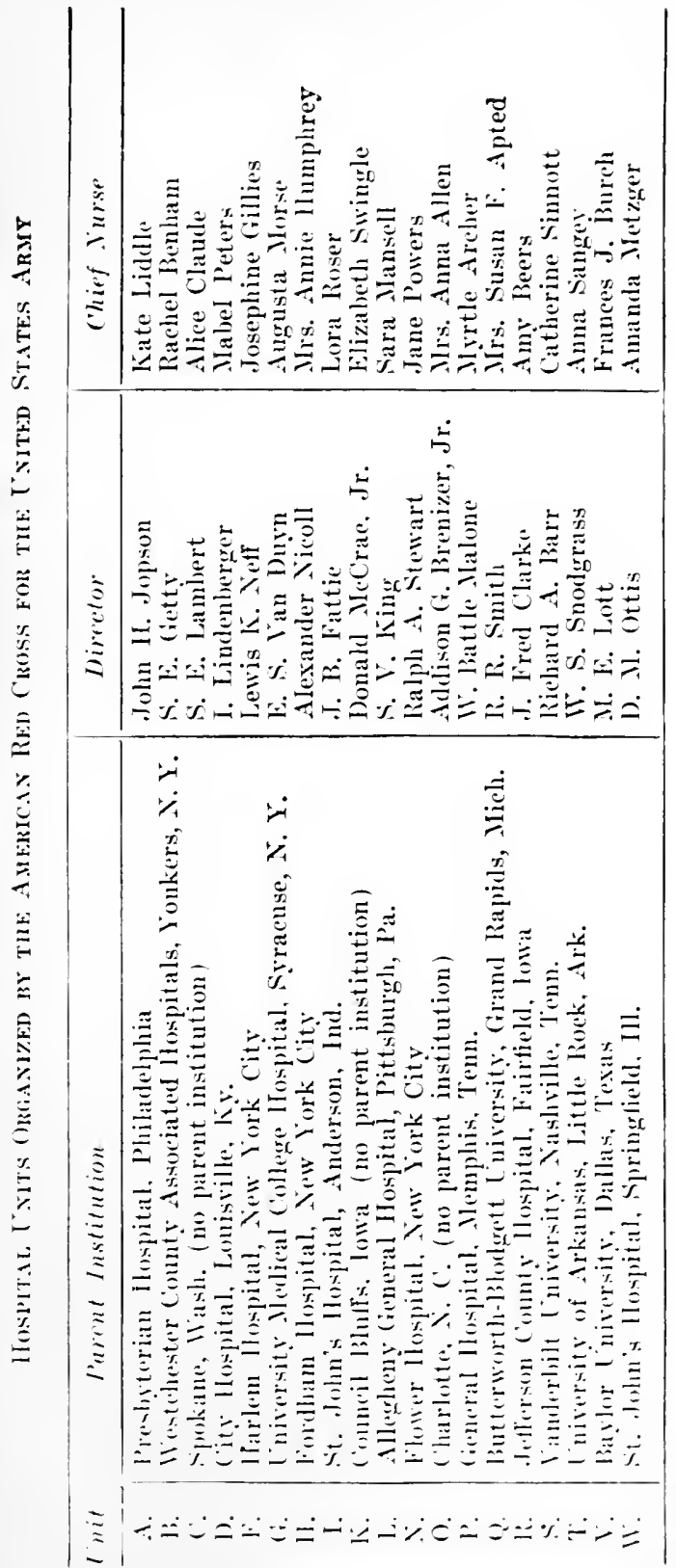




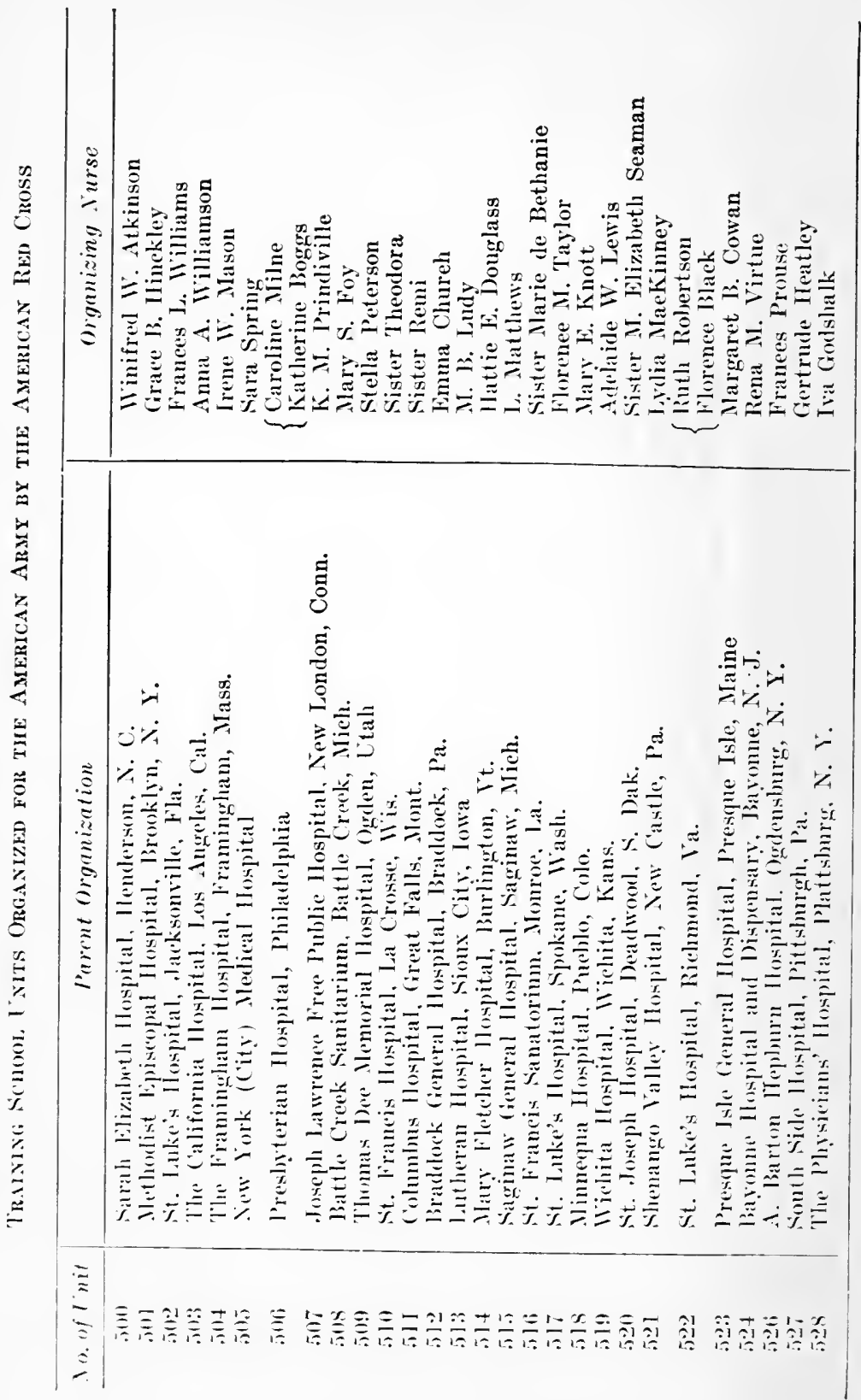




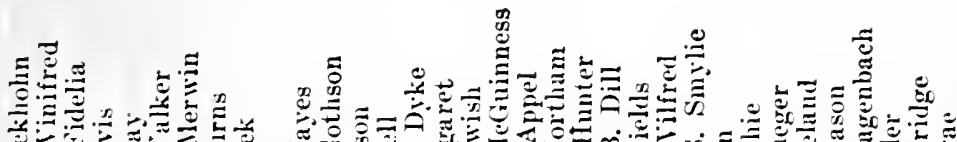

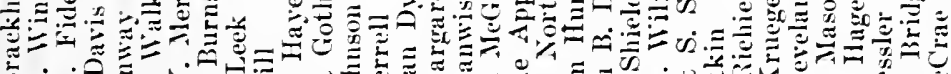

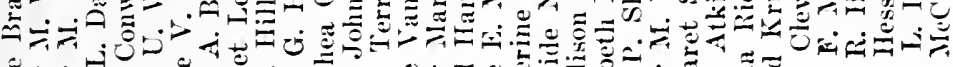

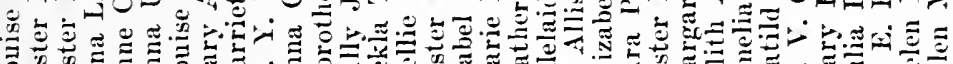

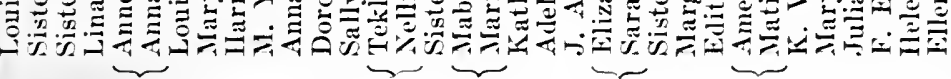

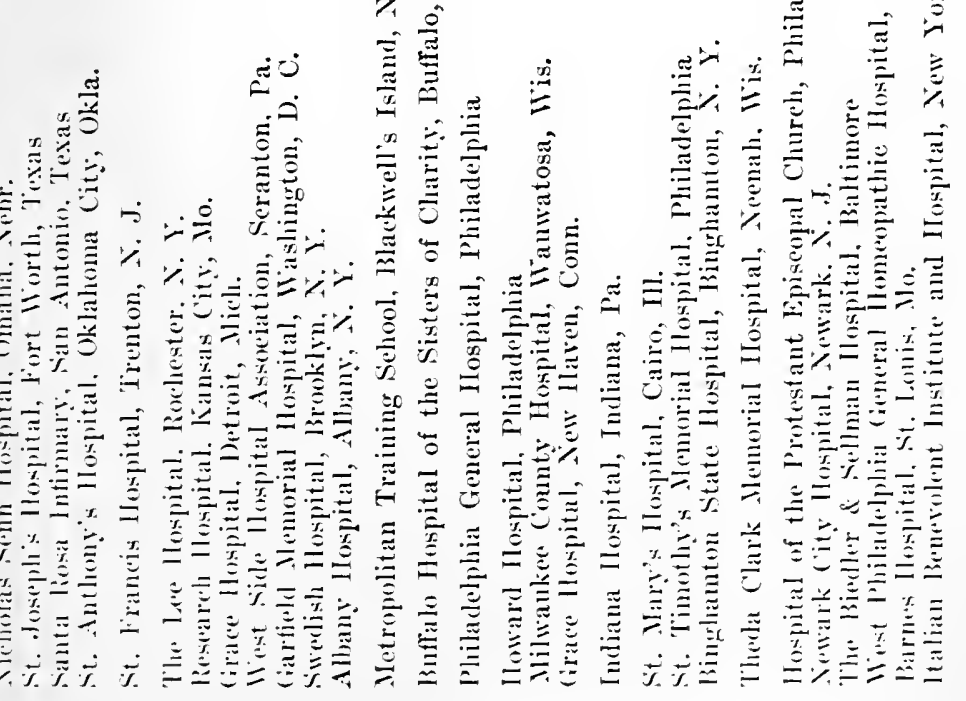

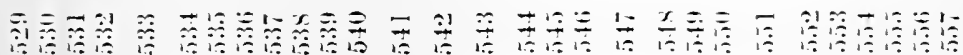




\section{8}

\section{APPENDIX}

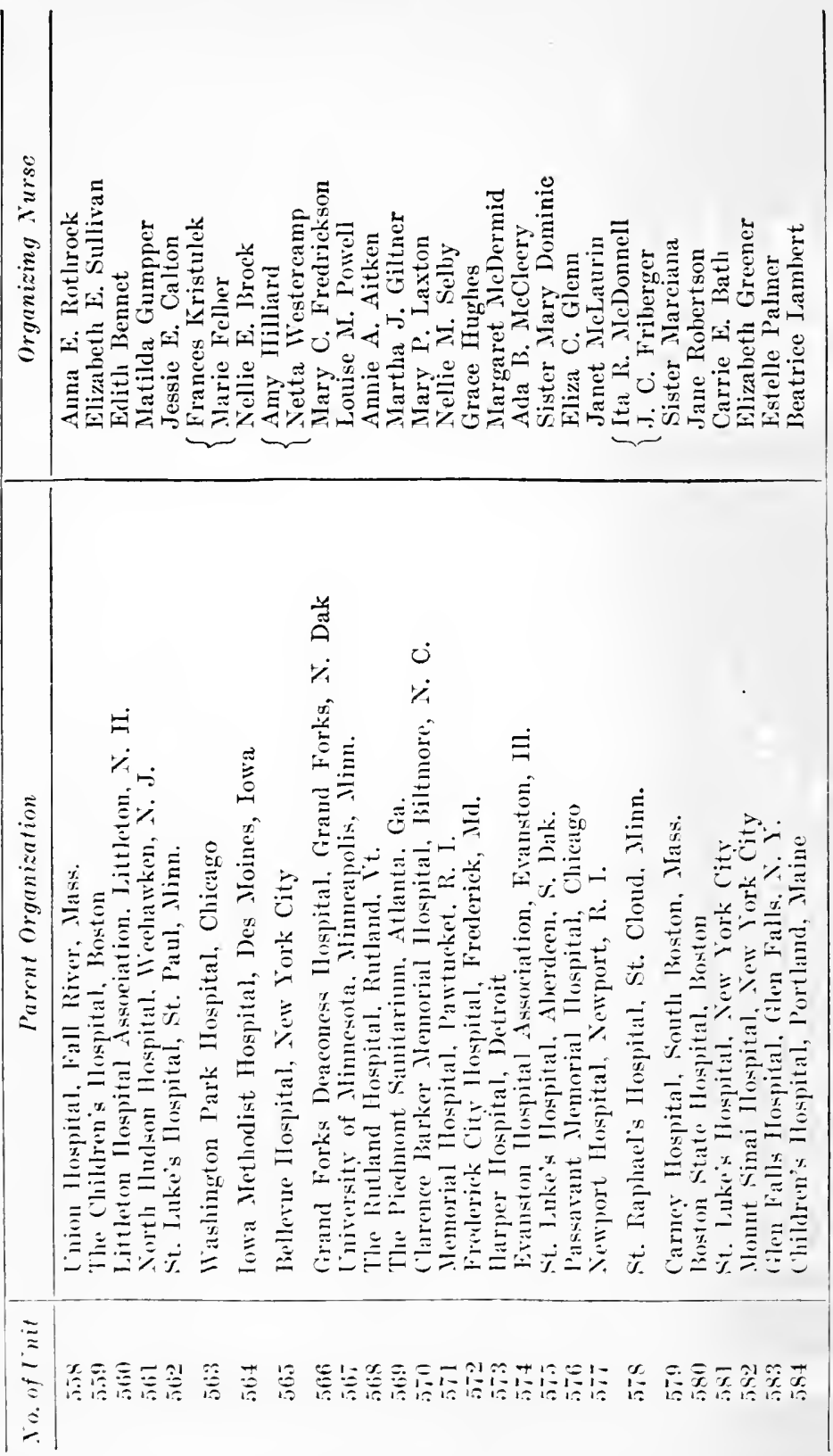




\section{APPENDIX}

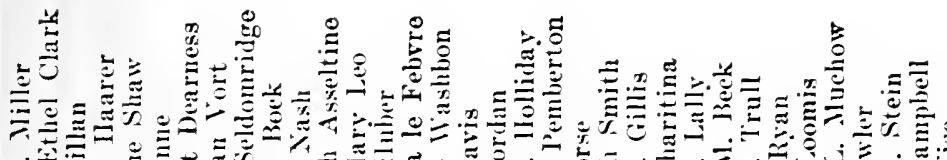

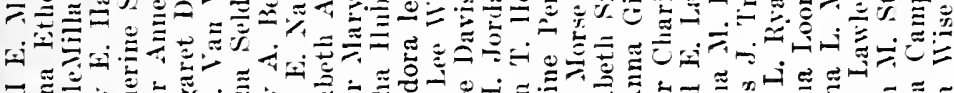

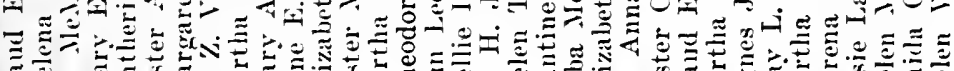

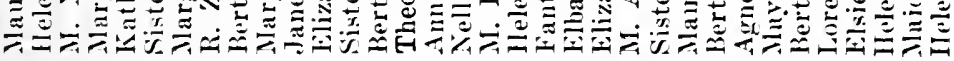

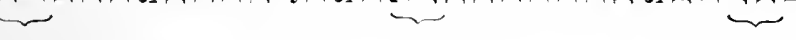

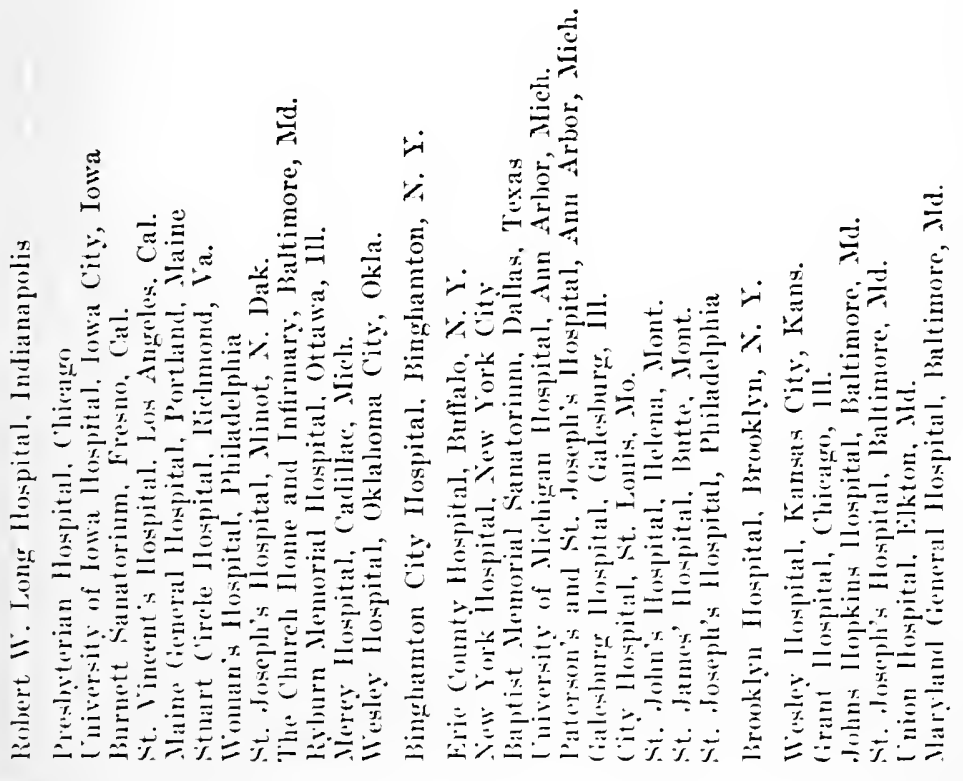

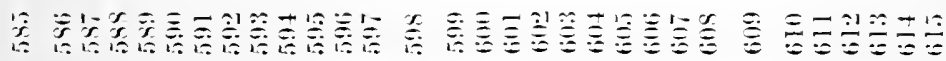




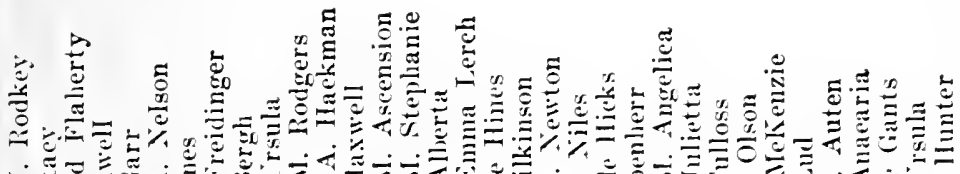

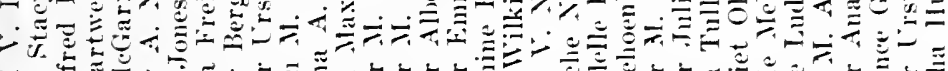

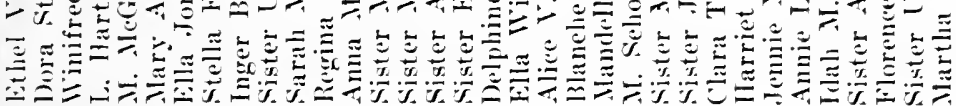

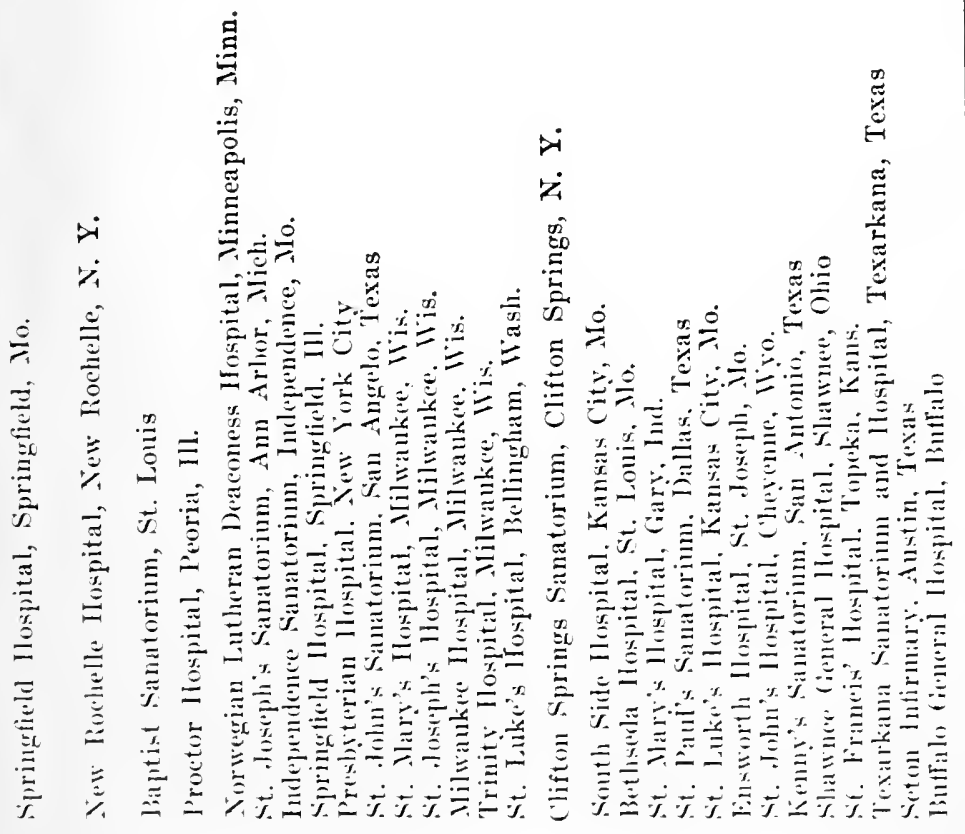

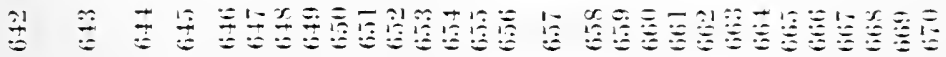




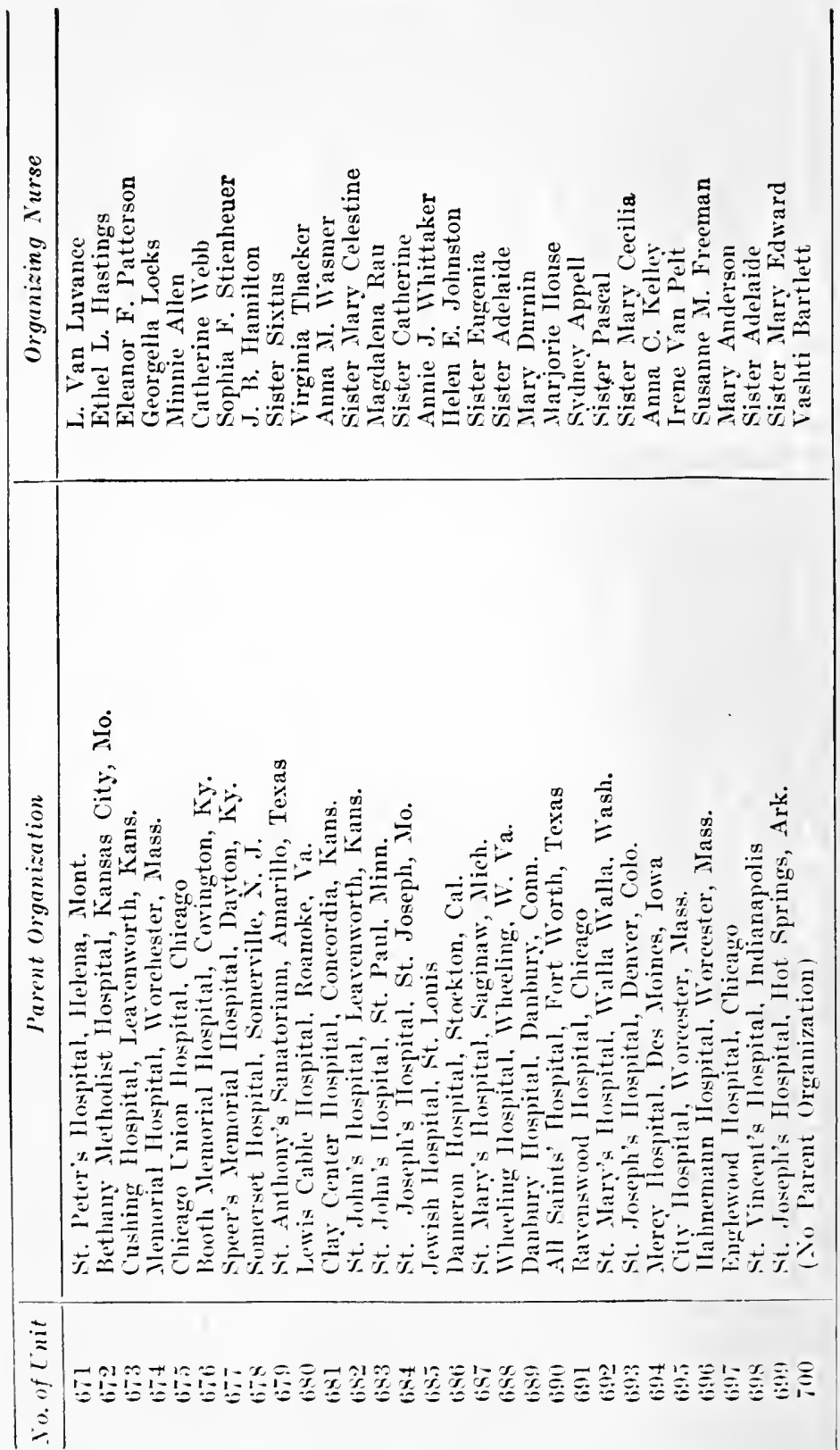




\section{APPENDIX}

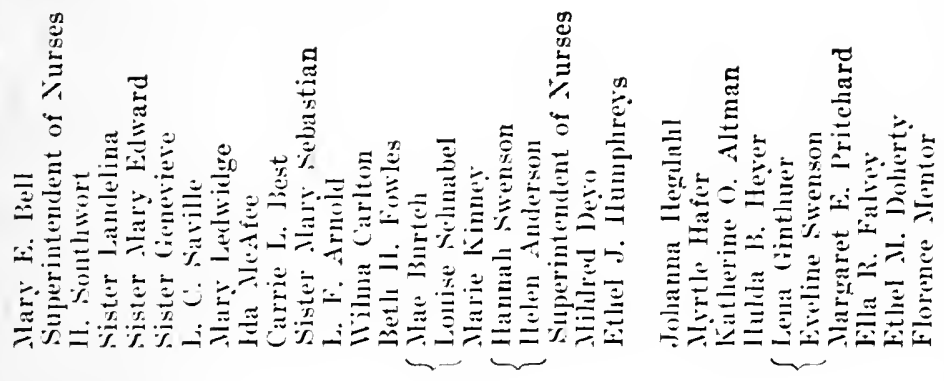

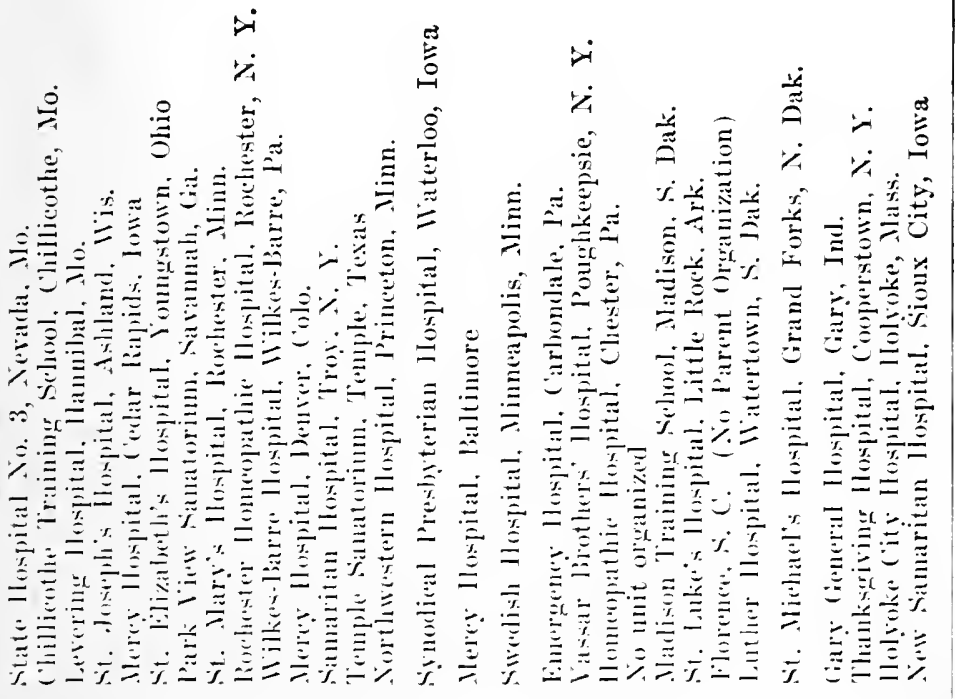

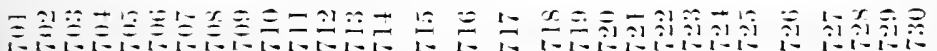




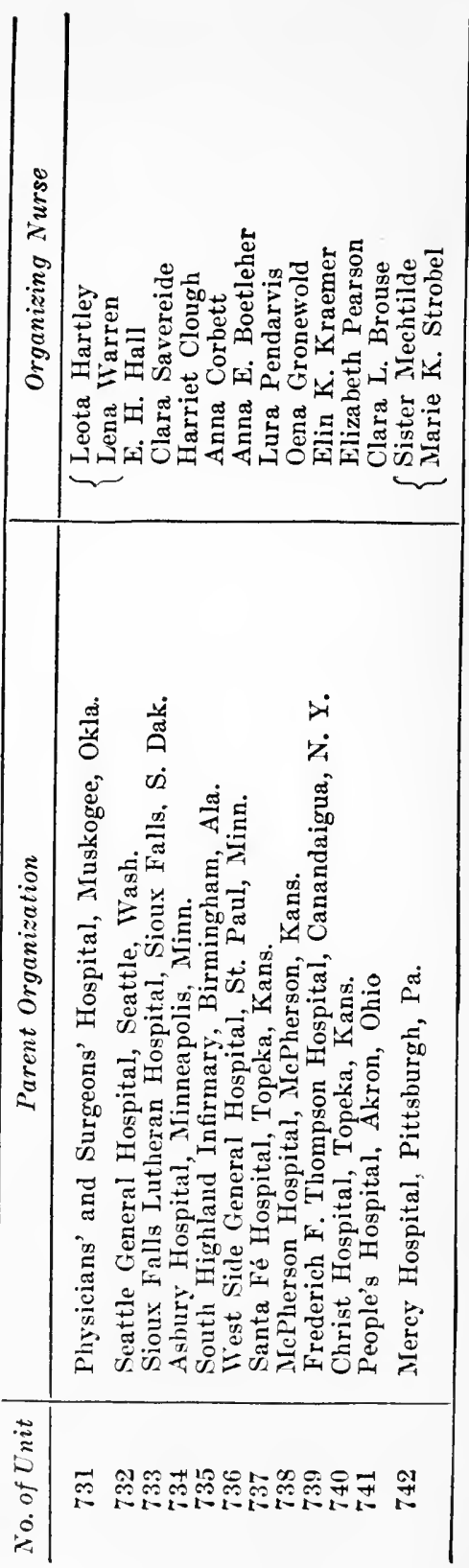


Base IJospitals Organized by the American Red Cross for the United STATES NAYY

\begin{tabular}{|c|c|c|c|}
\hline & I'arent Institution & Dircetor & Chief Nurse \\
\hline & $\begin{array}{l}\text { Brooklyn. N. Y. } \\
\text { San Franeisco, Calif. } \\
\text { (Iane llospital) }\end{array}$ & $\begin{array}{l}\text { Dr. W. B. Brinsmale } \\
\text { Dr. Stanley Stillman }\end{array}$ & $\begin{array}{l}\text { Frances Vun Ingen } \\
\text { C. Elizabeth Ilogue }\end{array}$ \\
\hline 3. & Los Angeles, Calif. & Dr. Rea Smith & Sue Dauser \\
\hline 4. & $\begin{array}{l}\text { P'rovidence, IR. I. } \\
\text { (lhodle Island Ilospital) }\end{array}$ & 1)r. George A. Mattingly & (irace Mclntyre \\
\hline 5. & $\begin{array}{l}\text { Pliladelphia, Pa. } \\
\text { ( Mothorlist Episcopal } \\
\text { llospital }\end{array}$ & Dr. Robert LeConta & Alice Garret \\
\hline $\begin{array}{l}6 . \\
7 . \\
8 .\end{array}$ & $\begin{array}{l}\text { Seattle, Wash. } \\
\text { Homston. Texas } \\
\text { Riclimond, Va. }\end{array}$ & $\begin{array}{l}\text { Dr. Milton f. Sturgis } \\
\text { Dr. Julsen I. Taylor } \\
\text { Dr. A. W. Willis }\end{array}$ & $\begin{array}{l}\text { Mlanehe Fairweather } \\
\text { Magrie E. Ilouse } \\
\text { Bernice Hall }\end{array}$ \\
\hline
\end{tabular}

Naval Station Hospital Units Organized by tile American Red Crogs For the LNited States Navy

\begin{tabular}{|c|c|c|c|}
\hline & $\begin{array}{c}\text { Loeation of Parent } \\
\text { Institution }\end{array}$ & Director & Chief Nursc \\
\hline 1. & $\begin{array}{l}\text { Pittslurgh, l'a. } \\
\text { (Nt. Margaret's Ilospital) }\end{array}$ & Dr. Nelson I1. Clark & (irace Anthony \\
\hline 2 . & $\begin{array}{l}\text { Philadelphiar, Pa. } \\
\text { (St. Agnes' Hospital) }\end{array}$ & Dr. John A. McGlinn & Catherine Moran \\
\hline 3. & $\begin{array}{l}\text { Montelair. N. J. } \\
\text { (Nonntainside IIospital) }\end{array}$ & Dr. James IIanan & Blanclie Konnedy \\
\hline 4. & $\begin{array}{l}\text { Brooklyn, N. Y. } \\
\text { (St. Mary's llospital) }\end{array}$ & Dr. John A. Less & IIelen Grady \\
\hline 5. & $\begin{array}{l}\text { Colmmbus, Ohio } \\
\text { (Grant Hospital) }\end{array}$ & Dr. V.A. Dodd & Carrie E. Churchill \\
\hline 6. & $\begin{array}{l}\text { Austin, Texas } \\
\text { (Noton Infirmary) }\end{array}$ & Dr. Z. T. Scott & Nell Freund \\
\hline 7 & Toledo, Ohio & Dr. Charles W. Moots & Daisy Mapes \\
\hline$\because$. & lioston, Mass. & Dr. L. R. G. Crandon & $\begin{array}{l}\text { Emily l'ine } \\
\text { (organizing nurse) }\end{array}$ \\
\hline 10. & Minneapolis, Minn. & Dr. Clifford llenry & Crecentia Diedericks \\
\hline 11. & San Francisco, Calif. & 1)r. Carl l'. Tones' & Myrtle (i. Chandler \\
\hline 13. & Mimneapolis, Minn. & Dr. William l: lioherts & Sadie Murpluy \\
\hline 14. & St. Loulis, Mo. & Dr. I. C. Jlatmis & Grace lienanace \\
\hline 15. & Dubuqpue, Iowa & I)r. Jolnn ('. llancock & Frances Pedersen \\
\hline 16. & Philarlelplia, Pa. & I)r. M. B. Miller & Winifred Prown \\
\hline 17 & Sieattle. IVasls. & Dr. John S. Mrelirile & Edna 1.. Rohinson \\
\hline 18. & Buluth, Minn. & 1)r. Arthur Collins & II. ()live Graham \\
\hline 20. & $\begin{array}{l}\text { S. Mons, Mo. } \\
\text { st. Paul. Minn. }\end{array}$ & 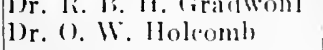 & 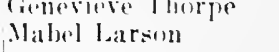 \\
\hline
\end{tabular}




\section{Nayy Detachmests Organized by the American Red Cross for the U.ited States Navy}

\section{Training School}

Organizing Nurse

Newton Hospital, Newton Lower Falls, Mass...... Mary M. Riddle St. Luke's llospital, New Bedford, Mass.......... Susan E. Emmott Enion Ilospital, Fall River, Mass............. Anna E. Rothrock St. Luke's Hospjtal, New York City........... Carrie E. Bath Orange Memorial Hospital, Orange, N. J........ Bessie Millman Protestant Episcopal Hospital, Philadelphia..... Katherine Brown Allegheny General Hospital, Pittshurgl, Pa..... Lettie Draling Columbia Hospital. Washington, D. C.......... Lacy Minnigerode I'rovilence llospital, Washington, D. C......... Sister Flavia Cniversity Hospital, Charlottesville, Va.........Margaret B. Cowling l'asadena llospital, l'asadena, Cal............ Lila Piekhardt St. Luke's Ilospital, San Franeisco, Cal......... Esther A. Brown Seattle (General Ilospital, Seattle, Wash.........thelyn Ilall sit. Luke's IIospital, Seattle, Wash...........Johanna Burns San Franciseo Hospital, San Francisco, Cal...... Katherine Flynn Anna Jaques llospital, Newburyport, Mass. . . . . Jessie (irant Butler Ilospital, Providence, R. I........... Evelyn C. Jehan C'lildren's IIospital. Boston, Mass............ Elizabeth E. Sullivan

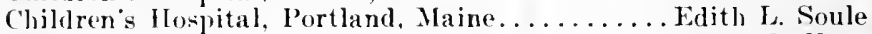
Garfield Memorial Hospital, Washington, D. C... Agnes G. Hayes Eastern Maine (ieneral Hospital, Bangor, Maine.. Ida Washburne Georgetown Hospital, Washington, D. C....... Barbara Sandmaier German Hospital, New York City........... Charlotte Grim Hartford IIospital, Hartford, Conn........... Lauder Sutherland House of Merey Ilospital, Pittsfield, Mass......... Mary Marey .John Sealy Hospital, Galveston, Texas.......... L. Shackford Maine General Hospital, Portland, Maine........... Margaret M. Dearness Malden Hospital, Malden, Mass............. Charlotte M. Perry Boston, Mass., Loeal Committee on Red Cross

Nursing Service .................Julia E. Reed, Sec'y

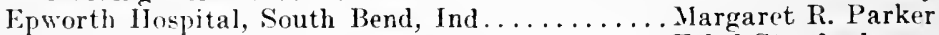

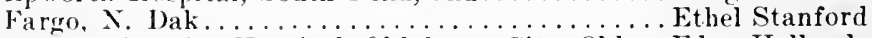
State Lniversity Hospital, Oklahoma City, Okla.. Edna Holland Loral Committee on Red Cross Nursing Service,

Salt Lak. City, Itah.................. Damaris A. Breman, Sec City and County ILospital, St. Paul, Minn....... Frances D. Campbell St. Vineent's llospital Alumna Association...... Bertha A. Thompson St. Joscph's Hlospital, St. Paul, Minn.......... Sister Mary Charles

\section{Americay Rem Cross Military Hospitals w Great Britaiy}

Ameriean Fed Cross Vilitary Hospital No. 4-Mossley Hill, liverpool American Rorl Cross Military IIospital No. 21-l'aignton, South Devon American lied Cross Military Hospital No. 22-Lancaster Gate, London American Red Cross Military llospital No. 23-St. Katharine's Lodge, Iondon Amprican Red cross Vilitary IIospital No. 24-Baroda IJouse, London

An American lied cross Military Iospital of wenty-eight heds was opencel near buhlin. Ireland, October I.), I!!18, to s' e American mechanjes from four ä̈rorlromes. 


\section{Amprican Rei Cross Convalescent IIospitals}

Ameriean Red Cross Convalescent Hospital No. 101-lingfiell, London Amerienn Red Cross Convaleseent Hospital No. 102-Wimbledon, London American Red Cross Convalescent Jome for Surses-l'utney, London

\section{Americay Army llospitals in Great britain}

Cnited States Army Base Hospital No. 204-IIursley Park

Cnited States Army Base llospital No. 33-l'ortsmintl

Cnited States Army Base llospital No. 37-bartford

United States Army lase llospital No. 2!-Tottrnham

United States Army Base Hospital No. 40-Sarislury Court

[nited States Army Camp Hospital No. 35-Wincliestor

Enited Stutes Army Camp Hospital No. 40-knotty Ash, Liverpool

[nited States Army (amp lespital No. 34-Romscy

United States Army Camp Hospital No. 36-Southampton

\section{American Rej Cross Military Iospitals ix Fraxce}

No. 1-Neuilly-sur-Seine

No. 2-5 Rue Puceini, Jaris

No. 3-4 Rue do Clhevreuse, Paris

No. 5-Auteuil. Paris

No. 6-bellevue, laris

No. 7-Jonilly-Seine-ct-Marne

No. 8-Malaliry

No. 9-32 Bonlevard des latignolles (for skin diseases)

\section{Anerican lien Cross hospitals in France}

No. 10I-2 Boulevard de Châtean, Neuilly (for personmel of lied Cross and other welfare arganizat ionsi

No. 102-Neufehâtean (for contagious discasess)

No. 103-44 Rue Chanveau. Nenilly (overtlow hospital for A.R.C. Military llospital No. l)

No. 104-Beauvais, L'seole Professionelle

No. 105-Jonily, maintained for French wounded after the withdrawal of Amerieans

No. $107-$ Jo1y-sur- Murin

No. log-Firilu, Dr. Fitelis Iospital

No, 110 - Coincy, Aisne

No. 111-chitean'Jhierry, Aisne

No. ll2-Auteuil, laris (under eonstruction)

No. 11:3-Connac, for the Czecho-slovak Army

No. 114 -'Toul

L'Mopital des dllics, at the Chateau d'Anmel, near Compeigne: Ambulance chirurerieal St. Paul: the temporary formation at chantilly: the

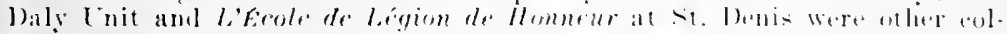

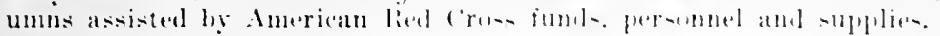




\section{American Red Cross Infirmaries in France}

No. 1-Dijon

No. 2-Bourges

No. 3-Angers

No. 4-Nantes

No. 5-Tours (St. Pierre du Corps)
No. 6-Limoges

No. 7-Brest

No. 8-Bordeaux

No. 9-St. Nazaire

\section{Ayerican Red Cross Dispexsaries in Fraxce}

No. of Dis-

pensary Tisits Made

No. $\quad 1 \ldots \ldots \ldots \ldots \ldots \ldots \ldots 28,000$

No. $2 \ldots \ldots \ldots \ldots \ldots \ldots \ldots 12,435$

No. $\quad 3 \ldots \ldots \ldots \ldots \ldots \ldots \ldots, 3,397$

No. $\quad 4 \ldots \ldots \ldots \ldots \ldots \ldots \ldots \ldots, 433$

No. $5 \ldots \ldots \ldots \ldots \ldots \ldots \ldots, 3,748$

No. $\quad 6 \ldots \ldots \ldots \ldots \ldots \ldots \ldots, 1,715$

No. $\quad 7 \ldots \ldots \ldots \ldots \ldots \ldots \ldots .5,999$

No. $\quad 8 \ldots \ldots \ldots \ldots \ldots \ldots \ldots, 1,804$

No. 9 -A.R.C. Military Hosp. 24,500 (Out-patient elinic)

No. 102-A.R.C. Hospital..... 15,316 (Dispensary connected with No. 102)

Total ........ $\overline{97,347}$

American Red Cross Conpalescent Homes for the American ExpedTIONARY Forces ix Frayce

No. 1-St. Julien, Gironde

No. 2-Hotel Regina, Biarritz

No. 3-Norgat

No. 4-St. Cloud, Paris

No. 5-Vatan-Indre, Issoudun

No. 6-Le Croisic

No. 7-kochefort-en-Terre-Morbihan

No. 8-Château de Villegenis, near Paris

No. 9-Chateau de Samery, Huisseau-s-Cosson

No. 10-Alvignae

No. 11-Hotel du Cap d'Antibes

Location of Americay Red Choss Nurses' Homes in Fraxce

Paris, 41 rue Galiler

Passy, 5 and 7 me Louls Boilly

Neuilly, 17 Avenue St. Foy

Paris, 118 rue de la Faisanderie

Paris, 4 rute ('hevrense, A.R.C. M.II. No. 3

St. Denis, Base Jospital No. 41

Paris, 17 rue Allguste-Comtr. liase Hospital No. 57

Dijon, Ilotel du .Jura

Talence, Base Iropital No. 6

Bordeaux. 2 Cours du Jullet

Le Croisie

Cannes, Hotel Biarritz 
Nurses' Recreation Clubs Bulut by the Americin Red Cross for Rediular and Reserve Members, Army Nurse Corps, A.E.F., France

Angers, Base IIospital No. 27

Allerey, Base Hospital No. 26

Bazoilles, Base Hospital No. 18

Bazoilles, Base Hospital No. 48

Baccarat

Beaune, Base Iospital No. 61

Beaune. Base Hospital No. 80

Brest, C Ilospitul No. 33

Brest, Hase Hospital No. 65

Chnteauroux, Base Hospital No. 9

Donjenx, Military Hospital No. 11

Limoges, Base Hospital No. 24

Le Valdahon, C. H. No. 12
Nantes, Army

Nantes, Base Ilospital No. 11

Neufchatean, liase Ilospital No. 66

Rimaucourt, Base llospital No. 58

Rimaucourt, Base Hospital No. 64

Rimalleourt, Base IIospital No. 52

Rimaueourt, Base llospital No. 59

Savenay, Base IIospital No. 8

Tours, Base llospital No. 7

Toul, Evencution Hospital No. 1

Vittel, Base Hospital No. 23

Vertuzey, lase Ilospital No. I

Bazoilles, Base IIospital No. 60

\section{Hospitals, Dispensaries, and Convalescent Homes of the American} Red Cross Cuildores's Bureau is Fraxce

Toul :

Asile Caserne de Iuxembourg, an orphanage.

Children's Ilospital.

Maternity Hospital.

Dispensary Service:

Toul.

Nancy.

Lunéville.

Nellve Maison.

Gerbéviller.

Epinal.

Foug.

Dinard:

Children's colony, dispensary and infirmary.

Damarie-les-lys, near Melun:

Cluildren's colony.

Nesle:

Chillren's hospital.

Dispensaries.

Amiens:

Dispensiry and public liealth nursing service.

Fian-les-bains:

Chatelet llospital for Children.

Medical examination for every rapatrié chilel entering France.

Lyoms:

Chateau des IIalles, St. Fuy lMarentière, a convalescent lome for chil. iren, orjogially a hospital.

llospital Violet, for ehildren suffering from eontagions diseases.

Hospital lloltzman, for elildren suffering from ncute diseases.

La challs, an orphanagra.

Chilel Wolfare Exposition.

St. Fitionne:

1)ispensary.

('hantalorieter Ilospital for Children.

('hild Wolfare Enpositios. 
Marseilles:

Dispensary and milk station.

'Temporary ehildren's hospital and preventorium.

Child Welfare Exposition.

Tonlouse:

Child Welfare Exposition.

Bordean:

Dispensary and visiting nursing.

Child Welfare Exposition.

Blois:

Dispensary and risiting nursing.

Corbeil :

Dispensary and risiting nursing.

Paris :

Levallois Dispensary, 38 rue de Gide.

Grenelle Dispeusary, 17 rue de L'Arre.

Censier Dispensary, 20 rue de Censier.

Ja Conrneuve Dispensary, 58 rue de la Convention

Mignottes Dispensary, rues des Solitaires ot des Mignottes.

Dispensaire Marie-lannolongue, 129 rue de Tolbiac.

Edoward Pailleron Dispensary, a rlie Edouard Pailleron.

Poteau Dispensaly. 41 rue de l'oteau.

Assistance Publique, 40 rue du Pre-Saint-Gervais.

L'Argonne l)ispensaly. 21 bis. rue de l'Algomne.

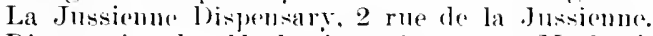

Dispensaire des Mathurius, 32 rue des Nathurins.

Patronage- Fanco-American pour la Premicre Enfance, 35 rue Dareau.

Bobigny Dispensary.

Paris: rither institutions:

Hôpital Mariolléline. 75 rue Arago.

Bicetre llospital. Je rue du P'astelur.

La l'ouponniere de Porehefontaine, V'ersailles.

lionell :

Dispensary and social servier.

Dijon:

Crecle at Camouflage C'amp, Ameriean Expeditionary Forees.

Dix'ly"

Mledical examination (staff from Evian-les.lains) for rapatrié eliblelren.

L. Cilandier:

Contagious hospital and dispensary for Prelgian refugee children.

Le llavre:

Dispensary and small children's hospital.

Prixchpar llospltas axi lospexsines Amen or Estabisiled by tile

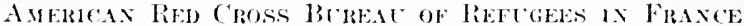

The British and Ameriean Friends" Malernity Hespital. Châlons-sur-Marne. ITo-pital for cieck babies. British and Amorican.

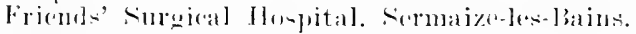

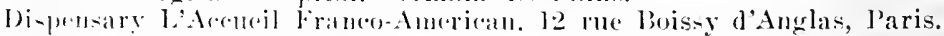

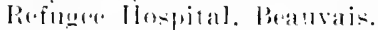

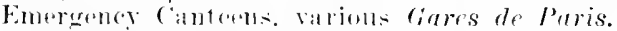

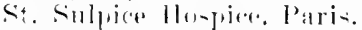

Ilespital and hispensary. Limeges.

llo-pital and bi-punary. Antomlime.

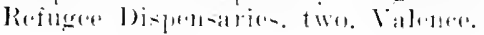




\section{Hospitals ayi Dispensaries of the Ayericax Red Cross bureau of} TUHroviosis is Fmaxce

Tuberculosis pavilions at Bligny, Briis-sons-Forges, near Paris.

Juberculosis pavilioms, L'Hopital st. Joseph, Paris.

Barrucks of the Assistance l'ublique, Paris.

L’lloppital Bénóvole lobis. P’aris.

Edith Wharton Sinatorinm, Yerres.

Asile Ste. Eugrinie, Lyons.

Tuberculosis Dispensiary, Cours Ganhetta, Lyons.

Ellward T. Trudean Salnitorium, at Plessis-liobinson, near Paris.

Women's l'uberonlosis llospital, Blois.

Tuberculosis Dispensary, Blois.

Joixt Dispexsarifs of the Rockeffiler Commission for tily Prevextion

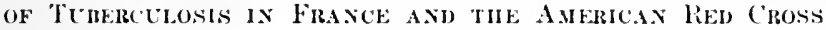

Pnris:

Dispensary de l'Argome, 19th Arrondissement.

Dispensary des .lienottes, lath Arrondiscement.

Dispensary do la Glaciòre, l3th Arrondissement.

Dispentary des Mathurins.

Department Eure-et-Loir:

Chartres.

('hât coaludun.

I)reux.

St. Rimy-sur-Avre.

Nograt-le-Rotrou.

\section{Nortit Ressia}

American Red Cross Ilospital, Archangel, Russia.

ITAIY

AMERICAN REH CROSS IIOSPITALS

Rimini Refugur IIospital.

Refugere llowpital. Canicattini bague, Sicily.

Amerian Red ('ross Naval llospital, Genoa.

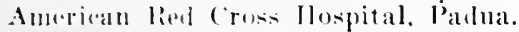

Amerian lied Cruss llospital, Rome.

Cimvalescent Iluspital for Tubereulosis Children. Taormina.

AMERICAN RED CROSS DISPENSARIES

Cesinatico.

limllaria.

('hioureria.

limose

Jilurence.
Naples.

Avellino.

Villa Siln Giovanni.

Tatormina.

\section{AMERICAN RED CROST TEACHISG CENTERS}

Nurses' Conter, Milan.

Rome (comrse of training for public health visitors).

Gienoa

Finerence

rillermo 


\section{Palestine}

\section{AMERICAN RED CROSS HOSPITALS}

American Red Cross Surgical Hospital, Jerusalem.

Turkish Municipal Hospital, Jerusalem.

Children's Hospital \& Dispensary, Jerusalem.

Tent Hospital, Wadi Surar Refugee Camp.

Infectious Disease Hospital, Jaffa.

American Red Cross Hospital, Ramleh.

American Red Cross Civilian Hospital, Haifa.

American Red Cross Hospital, Aere.

American Red Cross Cholera Hospital, Tiberias.

American Red Cross Hospital and Dispensary, Es Salt.

\section{AMERICAN RED CROSS DISPENSARIES}

Carmelite Convent, Mount of Olives.

Francisean Monastery, Bethany Road.

Bucharlea, Jerusalem Distriet.

Dispensary in conneetion with the Greek Hospital, Jerusalem District.

Convent of the Holy Cross, Jerusalem District.

Russian Convent, Jerusalem District.

Bishop Gobat's School. Jerusalem District.

David's Tower, Jerusalem District.

Ludd.

\section{ROUMANIA}

American Red Cross Hospital, Roman.

American Red Cross Dispensary, Roman.

Ameriean Red Cross Dispensary, Jassy.

Child Health and Feeding Units in 1919-1922.

\section{Podgoritza:}

\section{Montenegro}

American Red Cross hospital, dispensary and public health nursing service.

Niksic:

American Red Cross hospital, dispensary, soup kitchen and public liealth Kolaskin : nursing.

Anerican Red Cross dispensary. ('etinje:

American Red Cross hospital, day nursery, orphanage, public health nursing.

\section{Seutari :}

\section{AlBANIA}

Auterican Red Cross dispensary, pulblic health nursing and orplanage. Kroya:

American Red Cross dispensary and public health nursing.

\section{Tirana:}

American Ped Cross hospital, dispensary, public lealth nursing, health instruction. 


\section{Durazzo:}

Public health nursing (to a small extent).

Elbasan:

American Red Cross dispensary and publie health nursing.

Kavaja:

Mobile dispensary service.

Koritza :

Anerican Red Cross hospital, dispensary and public health nursing service.

\section{Greece}

Refugee Relief Stations at Tyrnovo-Sieniew, Dedeagatch and Xanthi, Macedonia.

Civilian Rolief Stations (uurses assigned there) on Samos, Chios and Mitylene.

Kavala :

American Red Cross dispensary and public health nursing.

Rodolivas:

Ameriean Red Cross dispensary and publie health nursing.

Prava:

American Red Cross dispensary and public health nursing.

Drama :

American Red Cross dispensary and public health nursing.

Serres:

American Red Cross dispensary and public healtl nursing.

Athens:

Child welfare clinic, classes for training native health visitors.

Patras:

Child Welfare station.

Crete:

Child Welfare station.

Kragujavatz:

North SErbia

Sewing rooms and public health nursing.

Ciuprya:

Anerican Red Cross lospital, dispensary and public health nursing.

Kraljevo:

Amerian Red Cross dispensary and chain of sewing room at liraljevo, Milanovatz, Chachak. Terznik and Kushevatz.

Yalatnka:

Serbian military hospital aided by nurses, other personnel and supplies. Petresatz:

American Red Cross hospital (summor only) and dispensary and mohile di-pensary serviee in neighboring villages of scotonye, Mlelenica. l'ashanatz and Rumoritch.

Pozarevatz:

Ameriean Red Crose general hospital dispensary, tubereulons hospital and an orplonage.

Pirot:

\section{SotTII SkRBIA}

American Ped Cross dispensary, public health nursing and distribution of slpplies.

Leskovac:

Asigmment of nurses and smplies to a Serbian Military llospital. 
Vranja:

Assignment of nurses to the Seottisl Women's IIospital Unit, establish. ment of American Red Cross soup kitehens, sewing rooms and orphanage.

Prizren:

American Red Cross hospital, orphanage and soup kitchen.

Skoplji :

Assignment of nurses to Vardar and Ilalf Moon (Serbian) Military hospitals.

Gostivar:

Ameriean Red Cross hospital, dispensary, public health nursing and Monastir: general relief.

Assignment of nurses to the Ameriean Women's Hospital, establishment of Ameriean lied Cross sewing rooms and distribution of general

Kavadar: relief.

Ameriean Red Cross dispensary, orphanage and general district, tubereuGevgeli : losis and infant welfare nursing service.

Publie health nursing and publie distribution of general relief.

\section{Siberia}

\section{AMIERICAN RED CROSS IIOSPITARS}

Russian Island IIospital, Vladivostok.

Assistance to Fortress Jlospital. Vladirostok ITarbor.

Assistance to Coech Naval Hospital, Vladivostok.

Tladirostok Rofugere Ilospital.

Morskol (Jritish Xaral) Hospital. Vladivostok.

Emergency Hespital American liel cross Barracks No. 7 . Thalivostok.

Teaching Conter. No. Io St. Peter the cireat Street, Vladivostok.

St. Lnki = To-pital. Tokro. Jajan.

Surgical Pavilon, llarlin Military Ilospital, Iarbin, Manchuria.

Buclaluo llowital. Mane!nuria.

C'holera work in Chinese City llospital and Jinssian City Jospital, IIarbin, Manclunriat.

Assistance to Jlospital of the Rinscian Railway Service Corps, IJarbin, Manthuria.

Government Immigration station Jospital, Cleliabinsk.

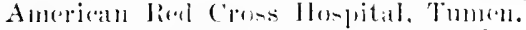

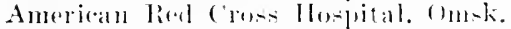

Ameriean lied Cross Ilospital. Tomok.

Assistance in cpuipment and slpplie's to c\%ech Invalid Ilospital, Petroparlork.

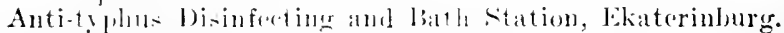

Anti-typher llo-pital. Petrejarlork

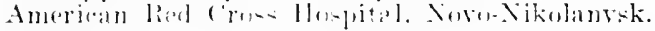

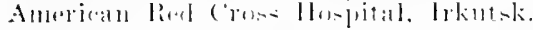

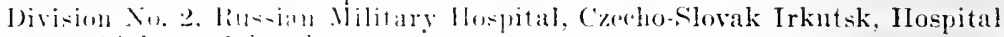
(. A.i., lokint-k.

Militatre ('ity llapital. mear trkilt-k.

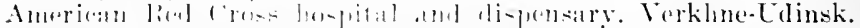

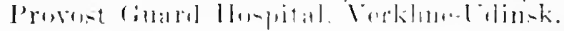

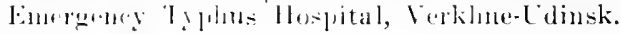


DISPEXSAIRES ANU INYTAL, CIIYICS

Railroad Dispensary, Irkutsk.

Fmergency Iressing Car, liailroad Station, Irkutsk.

Dental clinic, likaterinburg.

Dental Clinic, Cheliabinsk.

\section{MISCFLI.ANFOIS}

Iospital train built and supplied by Ameriean Red Cross for czechoSlovak Army. 1:2 atrs.

Conplete Anti-Typhus train buile and supplied ly American lied corosis for Allimd Experlitionary forer.

Five relief trains sent out to midsle and wostom siberia. arerage value

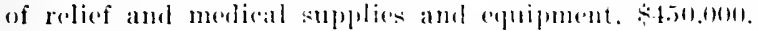

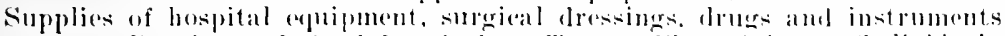

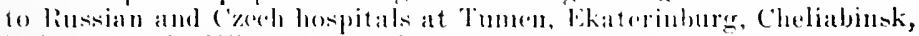
laimar. (Honsk. Nikolsk and Vladirostuk.

Chilelren's Colony, Russian Island, Vladivostok llarbor. 


\title{
AMERICAN RED CROSS CHILD HEALTH UNITS
}

\author{
January-A pril, 1922
}

(564 ambulatoria and milk stations established; 68 local hospitals aided.)

\section{Albania}

Durazzo

Tirana

Amsteltin
Badeno
Bischof shofen
Brixlegg
Bruck
Brunnau
D. Landsberg
Ebensee
Fggenberg
Feld Kirchen
Freistadt
Frolmleiten
Gmunlen
Gras Furstenfeld (4 stations)
Hallein
Hall Innsbruck (2 stations)
Itzling-Gniol
Judenburg
Kirclidorf
Kitzbunel
Klagenfurt (2 stations)
Kleinmunchen
Kroms
Landeck
leilnitz
Leolen

Scutari

\section{Austria}

Leising

Linz (2 stations)

Mistelback

Murau

Murzzuschlag

Neunkirchen

Okufstem

Reid

Reutte

Rottenman

Saalfelden

Salzburg

Scharding

Spittal

Stanis

Steyr

Stockirau

St. Polten

St. Veit

Vienna (4I stations)

Villach

Voitsberg

Wills

Weiz

Wiener Neustadt

Volfsberg

Czecho-Slovakia

\begin{tabular}{|c|}
\hline 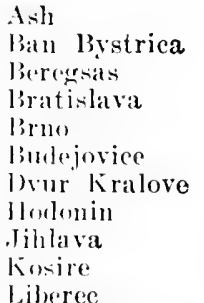 \\
\hline
\end{tabular}

Ash

liercersats

liratislava

lirme

limbejovice

l)vur Kralove

liosire

Liberee

\author{
Morarska Ostrava \\ Most \\ Munkacevo (with 2 rural branches) \\ Otomoue \\ ()riskor \\ Parlubice \\ P'lzen \\ l'rague \\ Pribram (with 2 rural branclese) \\ susiee (with a rural hramches)
}




\section{Greece}

Athens ( 6 stations)
Salonika (in and about Salonika, 7 stations)

\section{HUNGARY}

\author{
Baja \\ Balassagyarmat \\ Bekesesaba \\ Budapest (2I stations) \\ Debrecze \\ Eger \\ Esztfrgom \\ Gyula \\ Gyor \\ Hodmezovasarhely \\ Jaszbereny \\ Kaposvar \\ Keeskemet \\ Kiskunfelegyhaza \\ Mako
}

\author{
Miskolez \\ Nagykanizaa \\ Nyireerlaza \\ Papa \\ Pees \\ Satoraljaujlueli \\ Szegged \\ Szegled \\ Szeklsfolorvar \\ Szekszar \\ Szolnok \\ Szomitallely \\ Cjpes \\ Veszprem \\ Zalaegerszec
}

\section{Montenegro}

Cetinje (since January 1, 1922, maintained hy local doctors)

Kolashin (since Mareh 1, 1922, maintained by a local (loctor)

Niksie

Podgoritza (one loeal health station formed in Minreh, 1922, heing a combination of American Refl Cross and two local organizations. On Mareh 31, transferred entirely to local authorities)

Vir-Pazar (since January 1, I922, running under local doctors)

\section{Polaxd}

Alexandrow (near Torun), I ambulatorium.

Alexandrow (near Sciers), l ambulatorimm.

Augustow, l ambulatorium and a hospital aided.

laranowicze, 2 ambulatoria, a milk station and a hospital aided.

lexlzin, l ambulatorium and a milk station.

liala (near Warsaw), l ambulatorium.

Biala (near lirakow), l ambulatorium and milk station.

Bielsk, 2 ambulaturia.

Blas\%ki, l ambulaterium.

Bobkra. 1 ambulatorium and a hospital aided.

Borszozow, l ambulatorium and a huspital aided.

Brodniea, l ambulatorimm and a milk station.

lirody, 1 ambulatorium and a milk station.

Brzese-Litewiski, l ambulatorimm and a milk station. 
Brzezany (near Lwow), 1 ambulatorium.

Brzeziny (near Warsaw), l ambulatorium, a milk station and a hospital aided.

Brdgoszez, 2 ambulatoria, a milk station and a hospital aided.

Chajny, 1 ambulatorium, a milk station and a hospital aided.

Chelm, 1 ambulatorium, a milk station and a hospital aided.

Chelmno, 1 ambulatorium and a milk station.

Cliodziez, a hospital aided.

Clirzanow, l ambulatorium and a milk station.

Ciechanow, l ambulatorium and a hospital aided.

Cieszyn, l ambulatorium.

Crolno, 1 ambulatorium and a hospital aided.

Czeladz, l ambulatorium and a milk station.

Czestrochowa, l ambulatorium, a milk station and a hospital aided.

Czortkow, l ambulatorium.

Dabrowa, l ambulatorium.

Dawidgrodek, 2 ambulatoria.

Domaezewo, 1 ambulatorium.

Elogzow, l ambulatorium and a milk station.

Garwolin, l ambulatorium.

Gostynin, 1 ambulatorium and a milk station.

Grajewo, 1 ambulatorium.

Grodekjac, l ambulatorium and a hospital aided.

Grudziadz, 1 ambulatorium and a milk station.

Halicz, l ambulatorium.

Jaroslaw, 1 ambulatorium, a milk station and a hospital aided.

Jaworow, 1 ambulatorium and 2 hospitals aided.

Kalisz, l ambulatorium and a milk station.

Kalusz, l ambilatorium and a milk station.

Kielee, 1 ambulatorium, a milk station and a hospital aided.

Kolo, l ambulatorium.

Kolomyja, l ambulatorium and a milk station.

Konstinty, l ambulatorium.

Kovel, 1 ambulatorium and a milk station.

Korzee, l ambulatorium.

Krakow, 4 ambulatoria, a milk station and a hospital aided.

Krasnostaw, l ambulatorium.

Krokowiee, a hospital aided.

Krzemieniee. 1 ambulatorium and a hospital aided.

Kintno, l ambulatorium and a milk station.

Lenino, l ambulatorimm and a hospital aided.

Leczyca, 1 ambulatorium, a milk station and a hospital aided.

Liela, 2 ambulatoria.

Lodz, 3 ambulatoria and 6 milk stations.

lomza, 2 ambulatoria, a milk station, and a hospital aided.

Lublin. 2 amlulatoria, a milk station and 2 hospitals aided.

L,uboml, 1 ambulatorinm.

Lack, l ambulatorimm and a milk station.

Lminiex. l ambulatorium.

I.wow, 2 ambulatoria, a milk station and 2 hospitals aided.

Mierlayzoe, l ambulatorium.

Mikdlajow, 1 ambulatorium.

Minsk-. Iazowiecki. 1 ambulatorium and a milk station.

Mlawa, l ambulatorium and a hospital aided.

Nieswie\%, 1 ambulatorium and a hospital aided.

Yovogrodek, 1 ambulatorim, a milk station and a hospital aided.

Nowy Siac, l ambulatorimm and a milk station. 
Nowy Tare, 1 ambulatorium, a milk station and a hospital aided. Olyka, 1 ambulatorium.

()patowrek, 2 nmbulatoria.

Ostrow, l ambulatorium, a milk station and a hospital aided.

(lltynia, I ambulatorium.

Pabianice, l ambulatorium.

Pecenizym, 1 ambulatorium and a hospital aided.

Piotrkow, l nmbulatorium and 2 milk stations.

Pinsk, 1 ambulatorium, a milk station and 2 lospitals aided.

Plock. 3 ambulatoria, a milk station and a hospital aided.

lonsk, l ambulatorium and a milk station.

lolhaice, 1 ambulatorium and a lospital aided.

Poznan, 3 ambulatoria.

Pruzany, l ambulatorium and a hospital aided.

Przasnyisz, l ambulatorium and a hospital aided.

Przemorsk, 2 ambulatoria.

l'rzemuslany, l ambulatorium.

l'romysl, l ambulatorium and a milk station.

lulawy, l ambulatorium.

l'ultusk. I ambulatorium and a hospital airled.

Rarlom, l ambulatorimm, a milk station and a hospital aided.

liawa Ruska, l ambulatorimm.

liosyszoze, l ambulatorium.

liowne, l ambulatorimm and a milk station.

lizeszow, l ambulatorium, a milk station and 2 hospitals aided. lizgow, 1 ambulatorium.

liypin, l ambulatorim and a milk station.

Simbor, 2 ambulatoria and a milk station.

Simolomierz, a hospital aided.

Saruy, l ambulatorimu aud a losipital aided.

Sejuy, l ambulatorimm and a hospital aided.

Siedice, 2 ambulatoria and a hospital aided.

Sierpe. 1 ambulatorim and a milk station.

Skierniewice. I ambulatorium and a milk station.

Slonim. 1 ambulatorium.

Simllaceowe, a lospital aided.

susuowice, l ambulatorium. a milk station and a hospital aided.

Stawiszyn, l ambulatorimm.

st. lol. lialowie\%al. 1 ambulatorium.

Stollwe. l ambulatorimm and a hospital aided.

stolin. l ambulatorium.

stryi. I ambulatorium and a milk station.

strikiow, l ambulatorimm.

sukjourk, 1 ambulatorium.

swimbiany, I ambulatorimm.

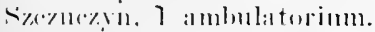

seior\% I ambulatorium. a milk station amd 2 hospitals aided.

Tarmolurzer. I ambulaturium.

Tarmopol. 3 ambulaturia, a milk station and a hoppital aided.

Tarnow. I ambulatorium. I milk station and a lospital alded.

Tozew, l ambulatorimm and i hospital addod.

Prelenlany. I ambulatorimu and at hompital ablesl.

Tlumac\%. ] ambulatorium.

Tuma-zow, 1 ambulaturimm and a milk station.

lormn, I ambulatorimm and a miik station.

Tus\%n. 1 ambulaturimm.

IVagrowiere a lowpital ailled. 
Warsaw, 6 ambulatoria, 8 milk stations and 2 hospitals aided.

Wegrow. I ambulatorium.

Wieleezka, 1 ambulatorium.

Wielun, 1 ambulatorium and a hospital aicled.

Wilno, 3 ambulatoria, 2 milk stations and 3 hospitals aided.

Wloclawek, l ambulatorium and a milk station.

Wlodzimierz Wolynski, l ambulatorium, a milk station and a hospital aided.

Wolomin, a hospital aided.

Zakopane, 2 ambulatoria and a hospital aided.

Zbaraz, 1 ambulatorium.

Zdunska-Wola, 1 ambulatorium and a milk station.

Zolkiev, 1 ambulatorium.

Zydaczow, 2 ambulatoria, a milk station and a hospital.

\section{SERBiA}

Alelexandrovatz
Bajna Baslita
Belgrade
Blace
Chiliegovatz
Kosjerici

Krupanj

Lazarevac

Pozega

Razanj

Trstenik

West Russia ayd Baltic States

December, 1921-A pril, 1922

ESTHONIA

Arensburg (Kuresaare)

Azeri

Baltisch-Port

Dorpat (Tartu), 3 stations

Harku

Johvi

Kimarovka

Krila

Kose

Kullamaa

Kunda

Kuresaar

Iihula

Iotisal

Inganuse

Mois

Miraste

Narva, 3 ftations

Nomme
Paide

Pernau, 3 stations

Petseri

Pihla

Rakvere

Rapiva

Reval, 4 stations

Riisipere

Sindi

Slobodka

Sunr Miltsi

Tapa

Torgu

Vairara District

Warbla

Wigala

Wilijandi (Fellin)

Worn

Wrangelstein 
LATVIA

Aiskrauklo

Allaseh

lirsehe

Boldera

Chuussee

Digna ja

Dvinsk, 3 stations

Eglaine

Friedrichstadt

Goldingen

Giriva

Hasenpoth

Jacohstadt

Je'ahmiesta

Kraslawa

Kreslavka

Kreusherg

Libau, 3 stations

ludsen

Martini

Mazeikiai

\author{
Milgrarvis \\ Mitau \\ Mitauer \\ Muhlen \\ Muhlgraben \\ Ogre \\ Plavinas \\ Puspkin \\ Reshiza. 2 stations \\ Riga, 7 stations \\ Ritter \\ Rueava \\ Salus \\ Scliaulen (Shavli) \\ Serrene \\ Sintasehi \\ Talsen \\ Tomes \\ Tiekum \\ Wendal \\ Wenden
}

\section{LITHUANLA}

Alexota

Alytos

Ainhulatory No. 7

Kermolitis

Kozeikai

lovno, 4 stations

\author{
Mazeikai \\ Meriampol \\ Sehaulen \\ Slaboda \\ Vilkoviski \\ Wilkowisehi
}

\section{Americax Red Cross Nurses Cited avi Decorated Durixg the EURopeay WAR *}

Aaron, Marjorie......... Medaille d'Honneur des Epidemies, French Addison. Sara.......... Medal of Mlilitary Merit, Greek

Allison, Grace E........ liogal Red Cross, lst Class, British

Allison, liuth Hovey (Mrs.). Croix de Guerre, bronze star, French

Anderson. Anna W....... \{ lied Cross (silver medal). Serbian

Inderom. Ixda W........ Anstrian Red Crosis

Armstromer Graed E....... Me Maille d'llomnelur des Epidemies (bronze)

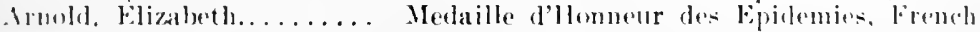

Arvin. Mary W.......... Royal Red ('ross. 2ud alass, British

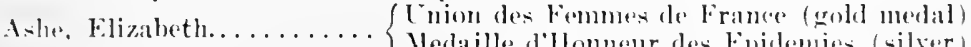

lialey, llelen........... Cross of Merey, Serhian

baker. Aurel........... Medaille d'llomente de Epildemies

* From newspaper clippings and correspondence. a list of nurses whe have

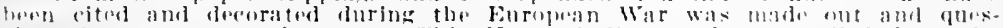
lonnaires sont to each nurse. This lionor koll was then enmpibd from the

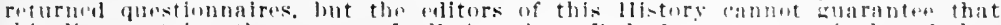

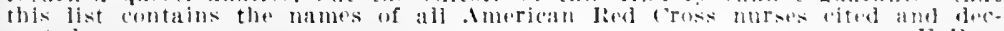
oraterl. 
Baker, Bessie.............

Baker. Katlerine Volk.....

Balen, Anna.............

Bartlett, Kathryn........

Bauer, Caroline...........

Bedell, Ruth E............

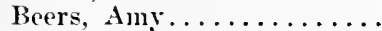

Bender, Liilu G............

Bentley, Grace............

Berry, Nettie Josephine....

Beulshausen, Mary........

Bigelow, Helen...........

Blackstone, Eleanor........

Bogart, Eugenia...........

Bonneson, Harriet M.......

Borg. I la A ..............

Boyle, Sara Jane..........

Bowes, Mary M.........

Brady, Bernice..........

Brendell, Mrrtle L. . . . . . . .

Broaddus, Emma.........

Broussard. Eunice.........

Brownell. Mary A.........

Bullard, Florence.........

Burgess, Edith.........

Briggs, JIelen May. . . . . . .

Burcham. Daisy..........

Burky. Florence.............

Butler, Rose Kate........

Cairns, Jelen W..........

Camblos, Jacqueline.........

Carothers. Dora C........

Carmuthers, Isabelle.......

Carson, Anno J...........

Cassidy, liosa A . . . . . . .

Chaney, Emily D.........

Christie, Mrs. Janet B......

Claiborne. Estelle D.......

Clark. Sisanne..........

Clay. Josephine A........

Commelly. lietty Clara.....

Cormier. Bernadette........

Corning, Alice..........

Cornwall, Bertla........

Cox, Katherine

Cromwell. R. Jeer.

Cromeg. Sara II.

('up)aidere. ('onstance.....
Medaille d'Honneur des Epidemies (silver)

Silver Red Cross Medal, Hungary

Roval Red Cross, 2nd class, British

Gold Cross of St. Anne, Russian

Red Cross Medal, 3rd class, German

Medaille d'Honneur des Epidemies

Medaille d'Honneur des Epidemies (silver)

Cross of Merey, Serbian

Red Cross Silver MedaI, Austrian

Royal Red Cross, 2nd elass, British

Cross of Merey, Montenegrin

Medaille d'Honneur des Epidemies (silver)

Red Cross. Serbian

Cross of Mercy, Serbian

Cross of Merey, Serbian

Medaille d'Honneur des Epidemies

Medaille d'Honneur des Epidemies

Medaille d'llonneur des Epidemies

Red Cross, Serbian

Cross of Merey, Montenegrin

Medaille d'Itonneur des Epidemies

Medaille d'Honneur des Epidemies

Croix de Guerre with bronze star

Regina Maria, Queen Marie of Roumania

Croix de Guerre with bronze star

Red Cross, Serbian

Cross of Merey, Montenegrin

Royal Red Cross, 2nd class, British

Royal Red Cross, 2nd class, British

Royal Red Cross, 2nd class, British

Royal Red Cross, 1st class

Cross of Mercy, Montenegrin

Medaille d'Ilonmeur des Epidemies

Medaille d'Honneur des Epidemies

Royal Red Cross, 2nd class, British

Royal Red Cross, 2nd elass, British

Medaille d'Honneur des Epidemies

Ted Cross. Serbian

Roval Red Cross, lst class, British

Citation, U. S. Base Ilospital No. 2, January, J918

Royal Red Cross. 1st class, British

Citation by the British

Medaille d'IIonnour des Epidemies (silver)

Pilmes Acalemiques, French

(rojx de Guerre. bronze star

british Royal Red Cross, 2nd class

Medaille d'llomneur des Epidemies (silver)

Medaille d'Honneur des Epidemies

Croix de Guerre

Medaille de la Reconnaissance (French

Army )

Order of Elizabeth, Belgian

S Merlailfe de la Reine (with eross), Belgian

cross of st. Anne, Russian

('ross of Meroy, Serbian

Royal Ried Cross, 2nd elass, British 


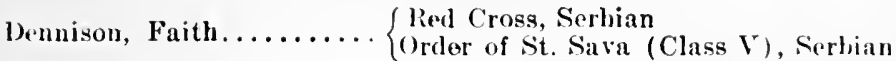

Distinguished Service Medal, Lnited States, posthumously awarined

bistinguished Service Mlodal (golll)

American Red Cross, posthmmensly awarded

Medal awarded by the Austrian Govermuent for aid remdered in time of war

American Reel Cross Medal of Merit

Medal awarded by l'an-American lexposition, $\bar{T}(\tilde{y}) 1$

Dolano, Jane A...........

Medal awarded by American National Red Cross in grateful memory of her clevoted and distinguished service, 1908-1919

Medal awardecl by the National Institute of Social Sceiences for serviec of high and inestimable value to her eomintry

Order of the Japanese Red Cross

lanama-Pacifie Exposition Medal conferred upon Miss belano as eoljaburator in the exhibit prepared by the Cuited States Government

DeLozier, Mary M.......

Diamond, Nary Anna.....

Dingley, Nellie.........

Driver, A. Madere.........

Dunlop, Margaret A......

Dyer. (ienevieve E.........

Fib. IJelen Tane. . . . . .

Eisconhard, Nettie.........

Ellett, Insephine S........

Elliutt, Mrs. Helen Briggs.

Elworl. Bessic J.ydia...... .

Emereon, Martha F.......

Eunley Lydia Evangeline...

Fingel, Mre. Austa IVhite...

Fians. labed Ilakomaln...

Evers, Bimma Elise.......

Furrusin, Eilna Allison....

Forernson, da M.........

Ferriess, Era ...........

Finuell, Frances a foress of Mereve serbian

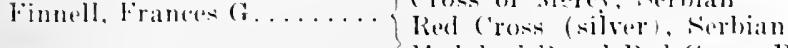

Fithererald, Mlier..........

Medaille d'Honneur des Epielemies (silver)

Medaille d'IIonneur des Epidemies (silver)

Medaille d'Jlonneur des Epidemies (.ledailles de Vermeil)

Medaille d'Flonneur des Epidemies (silver)

Royal Red Cross. Ist elass. Britisl

Citation, by Sir Domelas Hain

War Decoration, 3rol denree, Anstrian

Royal Red Cross, 2nd class, British

loyal lied Cross, end elass, british

Regrina Maria (Class I a), Rommanian

lingal lied Cross. 2nd class, British

citation. ly Sir Donglas laigr

Roval Red Cross, 2nd class, Pritish

Silver Medal. lst class, with War Decoration, llumgarian lied Cross

lioval lied cross

lioval lied Cross, 2nd elass, British

lioval Red Cross, end rlass, British

Cierman Red Crose. brouze metal. Bral class

liowal Rerd Cross. 2nel relass, British

britisle certificate of Herit

C'roix de (inerre, bromze star

Medaille de la liecommaisisance

('rose of Merey. Serbian

Merlal of lingal lical cross, liritish

Italian Decoiration

Forence Nirhtingale Madal

Foerster, Aluma......... International liesl ('ross

(Nt. Anmo- Molirl. limai:m

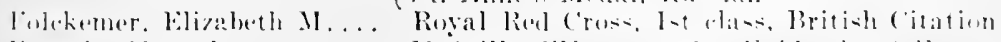

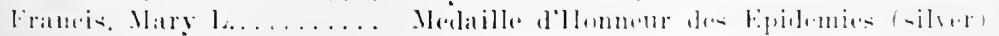


Francy, Luella......... $\begin{aligned} & \text { Cross of Mercy, Serbian } \\ & \text { Red Cross (silver), Serbian }\end{aligned}$

Frasius, Ruth......... $\left\{\begin{array}{l}\text { Red Cross Medal } \\ \text { Citation, Germany }\end{array}\right.$

Frederick, te Rue........ lioyal Red Cross, 2nd elass, British

Garther, Agnes J.........

Gavin. Jary C............

Gerhard, Eva...........

Gerrard, Gertrude $\mathrm{M} \ldots \ldots\}$

Gibson, Matilda M.......

Gilborne, Alice......... Regina Maria, 3rd class (Queen of Rou-

Medaille d'Honneur des Epidemies (silver)

Medaille d'Honneur des Epidemies (silver)

Royal Red Cross, 2nd class, Britislı

Royal Red Cross, 2nd elass, Britisl

Citation, by Sir Douglas Haig

Croix de Guerre, bronze star

Citation, signed by General Petain mania)

Giles, Bertrice......... $\left\{\begin{array}{l}\text { Red Cross (silver), Serbian } \\ \text { Cross of Merey, Serbian }\end{array}\right.$

Gilliland, Inez......... Cross of Mercy, Serbian

Gladwin, Mary E........ \{ $\begin{aligned} & \text { Florence Nightingale Medal } \\ & \text { International Red Cross }\end{aligned}$

Glauber, Marie C........ Medal of Military Merit, Greek, 4th class

Gould, Elspeth Anna...... Royal•Red Cross, 2nd elass, Britisl

Hadsall. Edith L......... Medaille d'Honneur des Epidemies (silver)

Hagadorn, Aliee.......... Medaille d'Honneur des Epidemies (silver)

Haile, Elizabeth........ Cross of Merey, Serbian

Hall, Carrie M......... Royal Red Cross, lst elass, British

Hamilton, Olivia E....... $\left\{\begin{array}{l}\text { Citation, by Sir Douglas Haig } \\ \text { Medaille d'Honneur des Epidemies (silver) } \\ \text { Cross of Mercy, Ilontenegrin }\end{array}\right.$

Hanehette, Lou S........ Medaille d'Honneur des Epidemies (silver)

Harold, Mary R........ Royal Red Cross, 2nd class, British

Hartwell, Jennie $\mathrm{V} . \ldots \ldots \ldots$..... Medaille d'Honneur des Epidemies (silver)

Hartz, Alma Elizabeth.... Medal of Military Merit, 4th class, Greek

Havey, Malinde $\ldots \ldots \ldots \ldots .\left\{\begin{array}{l}\text { Cross of Mercy, Montenegrin } \\ \text { Royal Red Cross, 1st elass, British }\end{array}\right.$

Hasson, Estler Voorhees.... Medaille d'Honneur des Epidemies

Haviland, Sybella........ Cross of Mercy, Serbian

Hay, Helen Seott......... $\begin{aligned} & \text { Florenee Nightingale Medal } \\ & \text { International Red Cross } \\ & \text { Regina Maria (Class IIa), Roumanian }\end{aligned}$

Hayes, Myrtle Elizabeth.... Royal Red Cross, 2nd class, British

Heath, Maud.......... Cross of Merey, Serbian

Henry, Ethel............ Medaille d'Honneur des Epidemies

Hill, Ada............ Medaille d'Honneur des Epidemis's

Hoaglaud. Jennie P...... Medaille d'Honneur des Epidemies, bronze

Holmes, Katharine $\dddot{W} \ldots \ldots$ Q.... Queen Maria Cross, Roumania

Horn, Matilda H......... Croix de Guerre

Horner, Blanche........... Medaille d'Honneur des Epidemies

Izen, Clara .J.......... Medaille d'Honneur des Epidemies

Jaffray, Madeleine F..... $\begin{aligned} & \text { Croix de Cucre } \\ & \text { "Insigne en Bronze," French }\end{aligned}$

James, Agnes F......... Medaille d'Ifonneur des Fpidemies (silver)

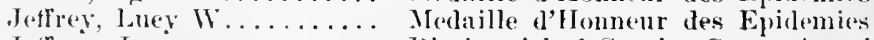

Jeffery, Jane..............

Jessup. Elsie.............

Joluson, Florenee M......

Distinguisled Serviee Cross, Ameriean

C'ross of Merey, Montenegrin

Florenee Nighitingale Medal, Internationa] Red Cross 
Jolunson, Helen

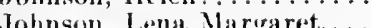

Johnson, Lillian. . .

Johnston, Margaret $11 . . .$.

. Jordan, Pauline..........

Jorgensen, Sigrid.........

Katena, Blanche..........

Kehoe, Frunces M........

Kennedy, Mary...........

Kerrigan, IJelen.........

Kiol, Soplia V.........

Kipp, Lorraine

Kirk, Mrs. Emily Jolland..

Knapp, (irace If..........

Kochert, WV. Louise.......

Krans, Flla M..........

Kreigh, Laura J..........

lauridsen, Karen..........

Leete, llarriet I. . . . . . . .

Lester, Minnie A.........

Lewis, Lydin . . . . . . . . .

lew is, Mary Elizabeth.....

Lister, Hannah...........

lombard, Arabella A......

Loughran, Nellie..........

Lyon, Elizabeth C.........

MeCarron, Sarah.........

McClelland, Itelen Grace...

MeClosking, Louise IIelenne.

Maclonald, Beatrice M....

Matelonalel, Irene

Melowell, Marie L........

Macfadilen, Kate.

Meriece. Mary Gertrude....

Mac(illivray, Fditl........

Marefirengr, Filora........

Meruire, Margalet ('.......

Moliornan. Inzal G........

Mrkiniglt, Lillian $\$$........

Meket. Ine\% . . . . . . .

Molamman, Veral.........

Whemblin. Fmili.........

Mo Manigrill. Villa . . . . . . . .

Mlar. Ne'al, Jane' ('........
Union des Femmes de France (silver)

Cross of Merey, Montenegrin

Croix de Guerre with bronze star

Rad Cross (silver), Serbian

Cross of Merey, Serbian

Regina Maria, Roumanian

Croix de Guerre with gold star

Medal of Military Merit, Greek

Medaille d'llonneur des Epidemies (silver)

Royal Red Cross, 2nd elass, British

palmes Academiques, French

St. Anne's Silver Mledal, Russian

St. Anne's Goll Medal, Russian

Queen Elizabeth Medal, Red Cross, Belgrian

Red Cross (silver), Serbian

Cross of Merey, Serbian

Medaille d'IIonneur des Epidemies (silver)

Medaille d'llonneur des Epidemies (silver)

Silver Medal of Ilonor, with War Decoration, Austrian Red Cross

Medaille d'Honneur des Epidemies (silver)

Cross of Merey, Serbian

Medaille d'Ionneur des Epidemies (silver)

Red Cross, Serbian

Royal Red Cross, 2nd class, British

Roval Red Cross, 2nd elass, British

Royal Red Cross, 2nd class. Britiph

Cruix de Guerre, bronze star

Medaille d'Jlonneur des Epiclemies (silver)

Medaille d'Honneur des Epidemies (silver)

Royal Red Cross, 2nd class, British

Red Cross, Serbian

Cross of Merey, Serbian

Distinguished Service Cross, American

lioval lied Cross. Ist elass, British

Citation, by Sir Douglas Ilaig.

Roval Red Cross, British

Distinguisleed Service Cross. Ameriean

Croix de Guerre, bronze star

Roval Red Cross, 2nd elass, British

British Military Medal

Cross of Merey, Serbian

S Red Cross. Serbian

Order of St. Sava (Class V), Serbian

lied Cross Medal, Serbian

Mrelal of Merey, Serbian

Modaille d'Therneur des Lejdemies (silver)

Royal Red Cross, 2ud class, Britisle

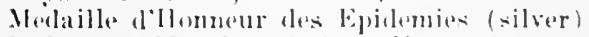

Red Cross Medal, 2nd dass. Hungarian

Medaille delonmenr des Epidemies (silver)

Royal lied Cross, British

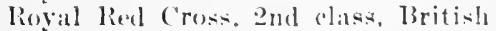

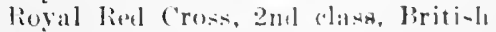

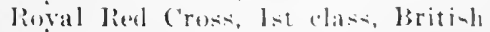

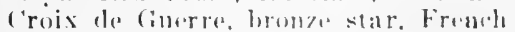

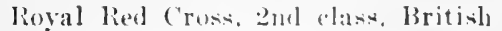


MacNulty, Carolyn........ Croix de Guerre, bronze star, Freneh

Martin, Florence J.........

Martin, Isabelle..........

Mauffray, Helena..........

Meirs, Linda K.........

Medaille d'Honneur des Epidemies (silver)

Military Degree, 4th elass, Greek

Medaille d'llonneur des Epidenies

Florence Nightingale Medal

International Red Cross

Croix de Guerre, bronze star

Cross of St. Anne, Russian

Metcalf, Mrs. Maud H.... Cross of Mercy, Serbian

Cross of St. Sava, Serbian

Miller, Elsie L......... Royal Red Cross, 2nd class, British

Miller, Mrs. Lena B....... Royal Red Cross, 2nd elass, British

Minnigerode, Luey........ Gold Cross of St. Anne, Russian

Mitchell, Elizabeth....... Cross of Merey, Montenegrin

Monroe, Edith.......... Medaille d'Honneur des Epidemies

Morrison, Edna M........ Medaille d'Honneur des Epidemies (silver)

Morton, Ruth......... Royal Red Cross, 2nd class, British

Nelson, Mabel $\mathrm{V}$.

Croix de Guerre, bronze star

Red Cross, Serbian

Nelson, Mary K......... Palmes Acadeniques

Nicholson, Ann Estella..... Royal Red Cross, 2nd class, British

Norwich, Margaret........ Cross of Mercy, Serloian

Noyes, Clara Dutton...... Medal awarded by the National Institute of

xye, Sylvene A.................

Obear, Evelyn E.......... Regrina Maria (Class J Ja), Roumanian

O'Brien, Agnes V........ Roval Red Cross, 2nd elass, British

O'Hara, Anne M......... Cross of Merey. Serluan

O'Leary, Margaret......... Regina Maria (Class IIa), Rommanian

Olsen, Lydia Josephine..... Nedaille d'Ilonneur des Epidemies (silver)

O'Neill, Mrs. Mary Agnes... Cross of Merey, Serbian

Parmelee, Eva Jean...... $\left\{\begin{array}{l}\text { Roval Red Cross, 2nd class, British } \\ \text { Military Medal, British }\end{array}\right.$

Parrish, Minnie........ Cross of Merey, Montenegrin

Parsons, Marion G....... Royal Red Cross, lst class. Mritish

Patmore, Amy F......... Medaille d'llonnewr des Epidemies

(Regina Maria Cross, Roumanian

Melaille d'Jlonneur des Epidemies (silver)

Decorated by the Japanese lied Cross with a

Patterson, Florence M...... Florence Nightingale medal. this being a special medal of that organization and not to be confused with the Florence Nightingale Medal of the International lied Cross

Perry, Edith V.........

Perry, Jennie E..........

l'eterson, llanna $\$ . . . \ldots \ldots$

Jliblips, Mrs. Julia $\$$.......

Phillips, Eawrie L. . ......

Porter. Enily............

Jotts, Susan 1)..........

Jowers, Margaret iI . . . . . .

I'ructor, Elizabetl ........

(')anmen, Sina M.......

Medaille d'Ilonneur des Epirlemies (silver)

Croix de Guere, bronze star

liegril Red Crosic, 2ull class, British

Order of St. Silva (Clas- V) Serlian

hoyal Red Cross, Ist class, l3ritish

Mrelailla dellonneur des lepidemies (silver)

Medal of Military Merit. Creek

Gress of Merey. Serbian

lioyal lied ('rost. end class, British

lied Crose (silver). Serbian

(rowes of Wereys serbian

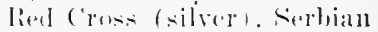

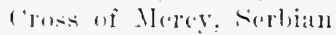


Quinsler, Mrs. Edna

McCoughlin ........ Distinguished Service Medal, American

Radelif, Lillian......... Metaille d'llemuenr des Fpidemies

(Croix de Guerre. gilt star

Ranney, Susan.......... Regina Maria (Class Ila1). Remmanian

Reid, Agnes............. Medaille d'llonnelur des Epidemies (silver)

Rice, Marion H........ Palmes Academigues

Richardson, Agnes H...... (roix de Guerre, bronze star

Rieker, Frunces E....... Mefaille d'Ilonneur des Epidemies (silver)

licketts, Mary II ........ C'ross of Merey, Serbian

Reynolds. Clara P....... Red C'ross Ifonor Medal, Austrian

Rebbins, Emma G........ Red Cross, Serbian

Rebertson, Kutharine M... Re Regina Maria (Class IIa). Roumanian

Robertson, Ruth I....... Medaille d'IIonneur des Epidenies (silver)

Roche, Mary Jane........ Roval Red Cross, End class, British

Rogers, Emma Hart...... Gross of Merey, Serbian

Rose, Esther M......... Cross of Merey, Serbian

Ross, Marion J......... \{ross of Merey, Surbian

Ross, Mary B......... Cross of Nerey, Serbian

Rowe, Anna E.......... Cross of Mercy, Serbian

lied Cross (silver), Serbian

Florence Nightingale Medal

International Red Cross

Medaille d'Hlomeur des Epidemies (silver)

Ryan, Lulu B.......... Medaille d'Hlomeur des Ep

Sahol, Elina P......... Croix de Guere, bronze star

St. John, Mrs. Jane Rignel.. \{ Croix de Guerre, bronze star

Royal Red Cross, 2nd class. British

Sands, Tyldesley L...... Royal Red Cross, 2nd class, British

Schmitt, Dolly belle...... Ro koyal Red Cross, 2nd elass. British

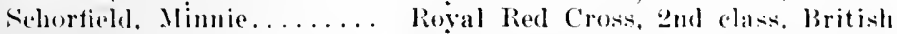

Scott, Eleanor M. ....... Roval Red Cross, lst class. British

Siralini. Olive E......... Royal Red Cross, 2nd elass. British

Sliarpe, Anna M. ......... C'roix de Guerre, bronze star

Siemed, Louisa E......... (iorman Medal

Simith, Alice O.......... Croix de Guerre, bronze star

Smith, Molly Bawn ...... \{ Red Cross (silver), Serbian

Speneer, lintl Helen...... Royal Red C'ross. lst rlass. British

Suow. Mary l.......... C'ross of Merey Serbian

Stambaugh, J. Isabel.... . Distinguished Service Cross. American

\{ Rogal lied Cross, 2ull class. British

liojal lied ('moss. end rlas.. British

Distinguished Sirvice Madal. Ameriean

Royal lied ('ross. lst dass. liritish

Merlaille de la Recomnassance (French Army)

Citation, by sir loomglas Hain

Merlaille d'llenneme les Eijlemies (silver

(ross of Merey. Serbian

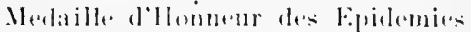

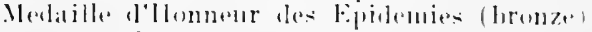

lingat lied cross. list alass. liritish

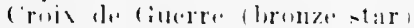

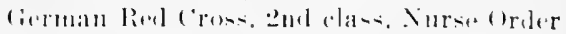


Thompson, Dora E...... $\left\{\begin{array}{l}\text { Distinguished Service Medal, American } \\ \text { Companion of British Empire }\end{array}\right.$

Thompeon, Sarah R...... Croix de Guerre

Tibbells, Ersula.......... Cross of Mercy, Serbian

Tittman, Anna L........ Gold Medal on the Ribbon of St. Anne, Russian

Todd, Louise M........ Croix de Guerre, bronze star

Torrance, Rachel C........ Regina Maria (Class IIa), Roumanian

Turner, Lila B.......... Croix de Guerre, gilt star

Tymon, Margaret........... Medal of Military Merit, Greek

Geh, Daisy D........... Royal Red Cross, Ist class, British

Vuagniaux, Emily........ Croix de Guerre, bronze star

Walkinshaw, Arvilla...... Royal Red Cross, 2nd elass, British

Wallace, Olive S.......... Royal Red Cross, 2nd class, British

Warwick, Bessie Mae....... Medaille d'Honneur des Epidemies

Watkins, Jeannette........ Medaille d'Honneur des Epidemies

Watson, Helen R........ Cross of Mercy, Montenegrin

Watson, Isabel.......... Medaille d'Honneur des Epidemies

Weir, Ruth........... Regina Maria (Class Ila), Roumanian

Whedon, Rhobie......... Cross of Mercy, Serbian

Wilcox, Mabel.......... Order of Elizabeth, Belgium

Wilday, Grace............ German Red Cross Medal, 3rd class

Wilkins, Maud........... Medaille d'Honneur des Epidemies

Williams, Kathryn....... Cross of Mercy, Serbian

Williamson, Mildred....... Red Cross (silver), Serbian

Wilsey, Marrietta........ Order of St. Sava (Class V), Serbian

Wilson, Eleanor.......... Cross of Mercy, Serbian

Wiltzius, Henrietta...... $\left\{\begin{array}{l}\text { Cross of Mercy, Montenegrin } \\ \text { Red }\end{array}\right.$

Wood, Edith I......... Cross of Mercy, Serbian

Worley, Pearl M.......... Medaille d'Honneur des Epidemies 
American Rep Cross Nurses Who Died in Walk Shenice or as a Rescet

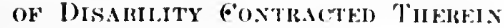

War Serrice-1 pril 6,1917 , to Normber 11,1919

\begin{tabular}{|c|c|c|c|}
\hline Nurse & Date of & of 1 eath & I'lace of linath \\
\hline Allen, Phoebe ..... & oet. & $2: 3,1918$ & Ft. Slocum, N. Y. \\
\hline Amundson, Esther ........ & Oet. & 20,1918 & $\begin{array}{l}\text { Base Ilospital No. 3.;, } \\
\text { A. E. F. }\end{array}$ \\
\hline Anderson, Nora Emelie.. & Jan. & 16,1919 & $\begin{array}{l}\text { Base } 11 \text { ospital No. } 68, \\
\text { A. E. l. }\end{array}$ \\
\hline Athay, Florence .. & Nov. & 12,1918 & $\begin{array}{l}\text { Base IIospital No. 67, } \\
\text { A. E. F. }\end{array}$ \\
\hline Aubert, Lillian ... & Oct. & 6,1918 & $\begin{array}{l}\text { Walter Reed Gen. Hospital, } \\
\text { Washington, J). (C. }\end{array}$ \\
\hline Ayres, Mrs. Edith. & May & 20,1917 & $\begin{array}{l}\text { On board S.s. Mongolia, } \\
\text { base llospital, No. le }\end{array}$ \\
\hline liabcock, IIazel F.. & March & 12,1919 & $\begin{array}{l}\text { Camp Iospital No. } 33 \text {, } \\
\text { A. E. F. }\end{array}$ \\
\hline 13ailey, Margaret S. & Oet. & 16,1918 & $\begin{array}{l}\text { Jlospital Train No. } 58, \\
\text { A. E. F. }\end{array}$ \\
\hline Baird, Laura A. & Oet. & $1(i, 19] 8$ & Coup Merritt, N. J. \\
\hline Baldwin, Jessie P'. & Fets. & 6,1919 & $\begin{array}{l}\text { Evaenation Hospital No. } 4 . \\
\text { A. E. F., Coblenz, (A.rmany }\end{array}$ \\
\hline Bartlett, Frances. & Oet. & 27,1918 & $\begin{array}{l}\text { Base Hospital No. llis. } \\
\text { A. E. F., Vichy, Franep }\end{array}$ \\
\hline Berker, Edith G & Dec. & 21,1918 & Ft. Benjamin, Ilarrisen, Ind. \\
\hline B.llman, Jeanette & Nov. & 12,1918 & $\begin{array}{l}\text { Base llospital No. } 18 \text {, } \\
\text { A. E. F. }\end{array}$ \\
\hline Berry, May & Dec. & 30,1917 & $\begin{array}{l}\text { Base llospital No. 32, } \\
\text { A. E. F., France }\end{array}$ \\
\hline Bishop, Amy I,......... & Oet. & 15,1918 & Ft. Riley, Kans. \\
\hline Bradtield, Edith & May & 5,1918 & Ft. Sill, ()kla. \\
\hline . Laura Bulle. & (let. & 24,1918 & Camp Dodge, Iowa \\
\hline Brandon, Hazel ... & (tet. & 30,1918 & Camp Kearney. ('al. \\
\hline Breen, Amme M. ('. & Nov. & 17,1918 & $\begin{array}{l}\text { Batse Hospital Xo. 48, } \\
\text { A. E. F. }\end{array}$ \\
\hline Prock, Monica & Nov. & 29,1918 & $\begin{array}{l}\text { St. Elizabeth's Mospital, } \\
\text { Washington, l). ( }\end{array}$ \\
\hline Buck, lỵdia Muriol. & Dec. & 15,1918 & Ft. Logan Roots. Ark. \\
\hline Butll, (irace (r... & Oct. & 8,1918 & $\begin{array}{l}\text { liase Hospital Xo. Ds. } \\
\text { A. E. F. }\end{array}$ \\
\hline Buman, Roser E. & Oet. & 13,1918 & Camp l'ike. Ark. \\
\hline rk. Etheel Marion. & oet. & 18. I918 & ('amp Fremont. ('al. \\
\hline Butler, Iimma M...... & April & 8,1918 & ('amp) Doulue. lowa \\
\hline liygrne, lomice E..... & (lit. & 14,1918 & $\begin{array}{l}\text { Gen. llospital No. 1, Now } \\
\text { York city. }\end{array}$ \\
\hline Byren, l'atricia Irene. & Marcli: & 26.1918 & (amp Me. Irthur. Tevas \\
\hline (Girns, Mary Kity & Sept. & $20,191 \mathrm{~s}$ & 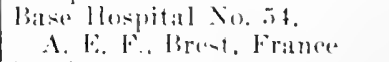 \\
\hline Campledl, Flerence Ib. & Nov. & 18.1918 & 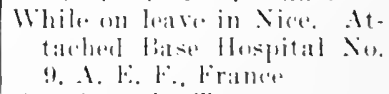 \\
\hline ('arils & ()$_{1} \cdot 1$. & $4,1 ! 1 \mathrm{~S}$ & Sin Antunio, Tisis \\
\hline
\end{tabular}


Americax Rei Cross Nurses Who Dien ix War Service or as a Result

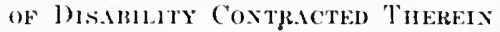

\begin{tabular}{|c|c|c|c|}
\hline \multirow{2}{*}{$\frac{\text { Surse }}{\text { Casstevens. Geneva } \ldots \ldots \ldots}$} & \multicolumn{2}{|c|}{ Date of Death } & \multirow{2}{*}{ 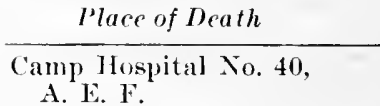 } \\
\hline & Uct. & 14,1918 & \\
\hline Casterline, Drusilla Marie... & Dee. & 31,1918 & $\begin{array}{l}\text { Naval Hospital, Mare } \\
\text { Island. Cal. }\end{array}$ \\
\hline Cattles, Edith Jume........ & Oet. & 27,1918 & Ft. Domglas, Ctah \\
\hline eil. Mrs. Katherine W. & April & 18,1918 & Camp Whecler, Ga. \\
\hline Chandler. Florence ......... & oct. & 13,1918 & Ft. Riley, Kans. \\
\hline ('hristellsom, Mabel ('... & Oct. & 22,1918 & Camp lewis, Wash. \\
\hline Christman, Caroline 11. & Oct. & 6,1918 & $\begin{array}{l}\text { Evacuation Hospital No. } 6 \text {, } \\
\text { A. E. F. }\end{array}$ \\
\hline Clements, Anna Gertrude... & $\begin{array}{l}\text { Jan. } \\
\text { (aft }\end{array}$ & $\begin{array}{l}31,1919 \\
\text { er war) }\end{array}$ & $\begin{array}{l}\text { General IIospital No. } 12, \\
\text { Nortl Carolina }\end{array}$ \\
\hline Cochran, Cecil J. & Oet. & 15,1918 & $\begin{array}{l}\text { L. S. P. H. S. Hospital, } \\
\text { IIuntsville, Ala. }\end{array}$ \\
\hline Collins. Theresa V...... & Oct. & 7,1918 & Camp Dix, X. J. \\
\hline Comnelly. Katherine R. & Oct. & 16,1918 & Camp Gordon, Ga. \\
\hline Coover, Etta . . . . . . & Oct. & $16,191 \mathrm{~s}$ & Ft. Riley, Kans. \\
\hline Cosgrore, Amna M....... & June & 1,1919 & $\begin{array}{l}\text { U. S. Army Embarkation, } \\
\text { Hospital No. 4, New York } \\
\text { City }\end{array}$ \\
\hline Courtney, Helena J.. & Oct. & 7,1918 & Gronp "D", A. E. F. \\
\hline Cox, Cliarlotte A... & Sept. & 28,1918 & $\begin{array}{l}\text { Base I[ospital No. } 42, \\
\text { A. E. F. }\end{array}$ \\
\hline Cummings, Mary H. . & Oet. & 22,1918 & Ft. Sam Houston, Texas \\
\hline (upp). Lillian F...... & oct. & 7. 1918 & Camp Gorton, Ga. \\
\hline Dalliby, Anna Marie.. & Nor. & 26,1918 & Naval Hospital. Norfolk. Va. \\
\hline Dalton, Ella ........ & May & $25,19 \leq 9$ & $\begin{array}{l}\text { Camp llopital No. 4, } \\
\text { A.E. F., chatean-Thierry, } \\
\text { France }\end{array}$ \\
\hline Daris, Cora Belle. & Oct. & 6.1918 & Camp Fordon, Cia. \\
\hline 1)elano. Jane $A \ldots$ & April & 15,1919 & Savenay. France \\
\hline 1)ent, Katlierine. & June & 16.1918 & $\begin{array}{l}\text { Base Hospital No. 24, } \\
\text { A. E. l⿳亠丷厂 }\end{array}$ \\
\hline Dingley, Xellir M. & Aug. & 28,1918 & $\begin{array}{l}\text { Mobile Oper. Enit No. } 1 \text {, } \\
\text { A. E. F. }\end{array}$ \\
\hline 1)odson. Kato ..... & . Tan. & 21.1919 & (amp) Travis. Texas \\
\hline Donovan. IIelen Frances & Sept. & 30.1918 & ('amp, 1)ix, X. .J. \\
\hline J)owrl. Holen Frances... & Jall. & 2.1921 & $\begin{array}{l}\text { loitzsimmons General IIos- } \\
\text { pital, Denver. Coln. }\end{array}$ \\
\hline Drummoncl. Ilourietta I. & Oet. & 10.1918 & Neviers, France. A. L. F. \\
\hline Eastuan. lizzie $F \ldots \ldots$ & (Het. & 14.1918 & ('amp) Mills. L. l.. New York \\
\hline Fisfelde. Thelma T..... & Jan. & 20,1919 & $\begin{array}{l}(\text { amp llospital Yo. .2. } \\
\text { A. E. k. }\end{array}$ \\
\hline Fmery, Mary Frances. & May & 1,1919 & $\begin{array}{l}\text { remeral Hospital No. } 2, \\
\text { Ft. Mcllenry. Mll. }\end{array}$ \\
\hline Fritkson. Alma $11 .$. & ()$\cdot t^{2}$ & 28,1919 & lit. Loman. Colo. \\
\hline Frirkiom. Fannio il. & (1).t. & (j. la is & (amp, Fherman. ohio \\
\hline Fvans, Mand ..... & Feh. & 13,1919 & $\begin{array}{l}\text { liase llospital No. lo3, } \\
\text { A. V. l. }\end{array}$ \\
\hline Fairchild. Heln . & . Tan. & 18.1918 & $\begin{array}{l}\text { liasollepital No. lo, } \\
\text { limaner. A. F. F. }\end{array}$ \\
\hline
\end{tabular}




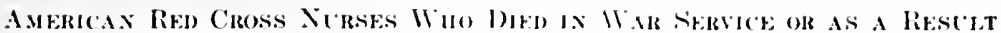

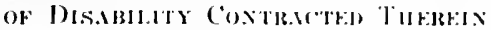

\begin{tabular}{|c|}
\hline limsir \\
\hline 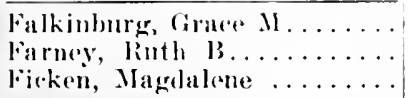 \\
\hline
\end{tabular}

Fleteloer, Iancy N.......... May

Furrest, Filerin L.......... oct.

Foster. Ilaze] ............ Get.

Franklin, Eimma M........ Get.

Firr. Alma $.1 . \ldots \ldots \ldots \ldots$ Ang.

Gallihar, Nellie G......... (bet.

Girvin, Ilester Jlaria....... Oct.

Golden, Katherine V........ Fib.

Food, Mottie

Good. Vietoria

(ioman, Beatrice M....... (). (1)

Goshorn, Ehol May........ Sos.

Graham, lelorence Beatrice.. May

Grant, Myrtle E

March 10,1919

Grepe. Katheryne li....... Oet.

firimes, Mal igaret . . . . . . . O.t.

(iroves, libua Irene....... (Get.

Hagratorn, Alice B........ May

llankiusom. Flurence (........ Oct.

11:anley, Elma ........... Sov.

Ilarely. Salıra R........... Inet.

Heali. Mary ........... Het.

Ilechit. Mrs. Felicital....... Fol.

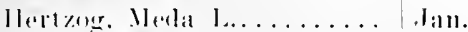

llidell. Marie 1............ Srept.

Hill. Flina Milon ........ Jan.

llinton. Flormese A...... ran.

Jutrumn. Katherine.
22, 1918 lias lluspital No. S. A. l. F.

9. 191s camp Lee. Va.

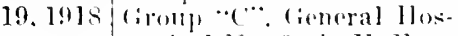
pital No. 9. A. E. F.

25, 1919 (camp llospital No. 4 , A. E. F.. Chatua-Therry, Firancer

2.). 191s (amp) (uster. Mich.

14, 1918 (icorial llompital No. 1 . Vow Jork ( ity

4,19186 (

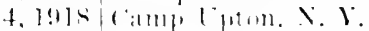

s. 191!? lias. llo-pital Xo. 10.5.

1. F. 1.

万. 1919 ( :amp Mle( lollan. Mlı.

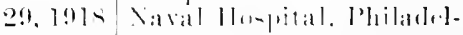
flitil. Pil.

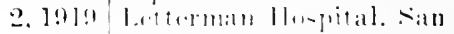
limmoison. ( ill.

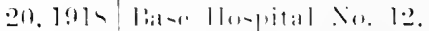

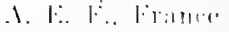

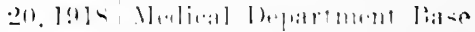

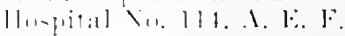


Americax Red Cross Nurses Who Died ix War Service or as a Result of Disability Coxtracted Therein

\begin{tabular}{|c|c|c|c|}
\hline Nurse & Dateo & of Death & Place of Death \\
\hline Hogan, Agnes . . . . . . . . . . & Sept. & 17,1919 & $\begin{array}{l}\text { Naval Hospital, Washing- } \\
\text { ton, J). C. }\end{array}$ \\
\hline Hokanson, Edith B.. & March & 8,1919 & $\begin{array}{l}\text { Naval Hospital, Great } \\
\text { Lakes, Ill. }\end{array}$ \\
\hline Iollenback, Lottie & Jan. & 3,1918 & Ft. Riley, Kans. \\
\hline Hurley, Nell ..... & Oet. & 18,1918 & Camp Bowie, Texas \\
\hline lreland, Alice $\mathrm{A}$.. & Fob. & 3,1918 & $\begin{array}{l}\text { Base Hospital No. } 34 \text {, } \\
\text { France }\end{array}$ \\
\hline Irwin, Katherine P...... & June & 24,1918 & $\begin{array}{l}\text { Evacuation Hospital No. } 2 \text {, } \\
\text { A. E. F. }\end{array}$ \\
\hline Jacobs, Gertrude E... & April & 22,1922 & $\begin{array}{l}\text { St. Josepl's Hospital, } \\
\text { Phoenix, Ariz. }\end{array}$ \\
\hline Jennings. Lucy Eunice....... & Sept. & 30,1918 & Camp Sherman, Ohio \\
\hline Jessen, Anna iV......... & Aug. & 22,1922 & New York, N. Y. \\
\hline Jolınson, Inez E............. & Jan. & 30,1921 & Albany, N. Y. \\
\hline Jones, Mamie . . . . . . . . . . & Dec. & 31,1918 & Camp Logan, Texas \\
\hline Joyce, Katlıryne & Sept. & 27,1918 & $\begin{array}{l}\text { Evaeuation Hospital No. 4, } \\
\text { A. E. F. }\end{array}$ \\
\hline Keirn, Margaret Eleanor..... & Oct. & 13,1918 & $\begin{array}{l}\text { Base Hospital No. 58, } \\
\text { A. F. F. }\end{array}$ \\
\hline Kemper, Anna E. . & Sept. & 25,1918 & Camp Jaekson, S. C. \\
\hline Kimball, Florence. & Oet. & 20,1918 & $\begin{array}{l}\text { Base Hospital No. 22, } \\
\text { A. E. F., France }\end{array}$ \\
\hline Kirketerp, Daisy M........ & Oct. & 20,1918 & $\begin{array}{l}\text { U. S. Embarkation Hospital } \\
\text { No. l, Hoboken. N. J. }\end{array}$ \\
\hline Klinfelter, Ina E. & Oct. & 2,1918 & $\begin{array}{l}\text { General Hospital No. 1, New } \\
\text { York City }\end{array}$ \\
\hline Knapp, Estelle A... & Oct. & 7,1918 & Camp Meade, Mrl. \\
\hline Knowles, Miriam E. & Nov. & 11,1917 & $\begin{array}{l}\text { Base Hospital No. } 18, \\
\text { A. E. F., France }\end{array}$ \\
\hline Kotte, Emma & March & 15,1919 & $\begin{array}{l}\text { Naval IIospital, Great } \\
\text { Lakes, Ill. }\end{array}$ \\
\hline Kuhlman, Nargaret . & Oct. & 23,1918 & Camp Sherman. Ohio \\
\hline Kulp, IJarriet I,. & Dec. & 26,1918 & $\begin{array}{l}\text { Camp IIospital No. 12, } \\
\text { A. F. l. }\end{array}$ \\
\hline Larsen, Anna E. & Oct. & 25,1918 & Camp Sherman, Ohio \\
\hline Tarsen, Effie A. & Dec. & 14.1918 & Camp Dodge. Iowa \\
\hline Lea, Alice ..... & Dec. & 21,1918 & $\begin{array}{l}\text { Naval 1Iospital. Great } \\
\text { Lates. Ill. }\end{array}$ \\
\hline I.each, Ethel O. & Oct. & 1,1918 & $\begin{array}{l}\text { Edgewood Arsenal, Edge- } \\
\text { wood, Md. }\end{array}$ \\
\hline Jeclaire. Florence .. & Oct. & 8. 1918 & Camp Devens, Mass. \\
\hline Ledden. Claire Agnes & May & 31,1919 & $\begin{array}{l}\text { Base IIospital No. 94, } \\
\text { A. E. l., France }\end{array}$ \\
\hline Jedford, Ima I. & Oet. & 7,1918 & $\begin{array}{l}\text { Base 1Iospital No. 116, } \\
\text { A. F. F. }\end{array}$ \\
\hline Icee, Elizaleth Francess. & Oet. & 6,1918 & $\begin{array}{l}\text { Base IIospital No. } 47 \text {, } \\
\text { A. F. F. }\end{array}$ \\
\hline Jide, Julia & Fels. & 24,1919 & $\begin{array}{l}\text { Base Hospital No. } 17 \text {, } \\
\text { A. E. F. }\end{array}$ \\
\hline Jinb, Mario L... & May & 12,1921 & Vonkers. X. Y. \\
\hline
\end{tabular}


American Red Cboss Nurses Who Dien in War Service or as a Restet of DISAHILITY CONTRACTFI) 'THEREIN

\begin{tabular}{|c|c|}
\hline Nurge & Date of Death \\
\hline $\begin{array}{l}\text { Linn, lois } \ldots \ldots \ldots \ldots \\
\text { Lippolı, Antoinette } W \ldots \ldots \ldots\end{array}$ & $\begin{array}{ll}\text { Oet. } & 1,1918 \\
\text { Nov. } & 5,1918\end{array}$ \\
\hline $\begin{array}{l}\text { Lowe, Grace Mahel......... } \\
\text { L.undholm, Ruth V........ }\end{array}$ & $\begin{array}{ll}\text { Oct. } & 24,1918 \\
\text { Oct. } & 17,1918\end{array}$ \\
\hline $\begin{array}{l}\text { Lundholm, Viola } \ldots \ldots \ldots \ldots \ldots \\
\text { Lynch, Esther } 12 \ldots \ldots \ldots \ldots \ldots\end{array}$ & $\begin{array}{ll}\text { Oct. } & 11,1918 \\
\text { Aug. } & 10,1920\end{array}$ \\
\hline
\end{tabular}

lyon, Gladys Nancy........ Dec. 19, 1918

MelBride, Nettie Grace....... Dec. 23, 1918

MeCord, Crystal E......... Dee. 18, 1918

MaeDonald, Flizabeth I..... Oct. 20,1918

MeDowell, .Jessie R........ Oet.

Mefirath, Laura O......... Oct.

MeGuire, Catherine J.......

Meciurty, Catherine .........

MeIntosh, Jennie ...........

Mackay, Lillias

MoKittrick, Marguerite R... McVullen, Anna M......... ()et.

MeNerney. Elizabeth M......

Mateher, Ella ...........

Malloch, Grace Iee..........

Mariner. Jessie $13 \ldots \ldots \ldots \ldots$.

Marshali, Harlan ...........

Martin, Constance ......... Sept. 17, 191s

Martin, Sylvia Elizaheth.... Aug. 10,1921

Mrreer, Jane R.......... Get.

Metcalf. Flizabeth il ........ onct.

Hetcalf, Mildred Anna....... ( )et.

Micheau, Grace Bell........ Oct.

Miller. Cecelia E............ oct.

Millman, Dorothy Beth...... Oet.

Ninick. Mary E......... Oet.

Moakley, Holen A........ Aner.
Iace of Derith

(amp Sherman, Ohio

lase Hospital No. 6], A. F. F.

Ft. Mclherson. (ia.

lase Hospital No. 58 , A. E. F.

(iroup "I)", A. F. F.

Temple Baptist Mem. San., Dallas. 'Pexas

Base Ilospital No. 68, A. E. F.

American Ilospital Tumen, Western Siberia

Evacuation Hospital No. I, A. F. F.

Base IIospital No. 35,

A. F. F.

11, 1918 (amp MeArthur, Texas

3, 1918 ('amp Grant, 111.

10, 1918 ('amp lee, la.

Base llospital No.54, A. F. F.

Rock lsland Arsenal, III.

Etlgewood Arsenal. Eilgewool. Mal.

Saginaw, Miels.

Emergency llospital No. 2, A. E. F.

(amp Dix, N. J.

Base llospital No. 25,

A. E. F.

Base Ilospital No. j.5.

A. E. l'.. Toul. France

10, 1918 Camp IIancock, Ciat.

18, 1919 Cincral IIospital No. 40, sit. Inouis, Mo.

Naval Hospital, (helsea. Mass.

I. S. P. H. s., Ft. Thomas. $\mathrm{kr}$.

9. 191s Naval Hospital. New York

20. 191S Ft. MePlirrson, (ia.

8, 1918 Naval Hospital, Newport. Ii. 1.

28. 1918 base Hospital No. GR. A. F. F.

6. I91s (amp Sinerman. Whio

10, I9] Base lloplatal Xo, 31. A. F.. F.

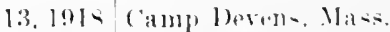

2.2, lols fort Blic. Treats 
American Red Cross Nurses Who Died in War Service or as a Result of Disability CoNTracted Thereis

\begin{tabular}{|c|c|c|c|}
\hline Nurse & Date & of Death & Place of Death \\
\hline Moeschen, Frances W........ & Sept. & 7,1918 & Base Hospital No. 42, A. E.F. \\
\hline Morrison, Sophia Ellen...... & Feb. & 10,1919 & Minot, N. D. \\
\hline Morton, Hazel E. . . . . . . . & Oct. & 28,1918 & Camp Cody, N. Mex. \\
\hline Moss, Marie Antoinette..... & Oet. & 9,1918 & $\begin{array}{l}\text { U. S. Base Hospital, Edge- } \\
\text { wood, Md. }\end{array}$ \\
\hline Munn, Maud Amelia........ & Dec. & 1,1918 & Camp Mills, L. I., New York \\
\hline Mırphy, Alice V.... & Oct. & 7,1918 & $\begin{array}{l}\text { Base Hospital No. } 68 \text {, } \\
\text { A. E. F. }\end{array}$ \\
\hline Murphy, Anne M.. & Sept. & 28,1918 & Camp Lee, Va. \\
\hline Murphy, Lillian $\mathrm{H}$ & Oet. & 10,1918 & $\begin{array}{l}\text { Naval Hospital, Hampton } \\
\text { Roads, Va. }\end{array}$ \\
\hline Murphy, Teresa M. & Nov. & 9,1918 & $\begin{array}{l}\text { Headquarters 13ase Section } \\
\text { No. 3, S. O. S., A. E. F. }\end{array}$ \\
\hline Newkirk, Hattic M.. & April & 2,1918 & $\begin{array}{l}\text { On way to Camp Beauregard, } \\
\text { La. }\end{array}$ \\
\hline Noring, Ella M. & Oct. & 10,1918 & Camp Merritt, N. J. \\
\hline Norton, Mary ... & Sept. & 28,1918 & Camp Jackson. S. C. \\
\hline Nurney, Mary C. & oct. & 8,1918 & $\begin{array}{l}\text { C. S. Hospital No. } 10 \text {, } \\
\text { Boston. Mlass. }\end{array}$ \\
\hline O'Brien, Camille Louise. & April & 18,1919 & $\begin{array}{l}\text { Camp Hospital No. } 25, \\
\text { A. E. F.. France }\end{array}$ \\
\hline O'Conner, Carmilite. & Feb. & 13,1919 & $\begin{array}{l}\text { Base Hospital No. 113. } \\
\text { A. E. F., Savenay, France }\end{array}$ \\
\hline O'Conner, Gertrude & Feb. & 9,1919 & l3ase IJospital No. 7 A. E. F. \\
\hline $\mathrm{O}^{\circ}$ Connor, Mary E.. & Oct. & 3,1918 & $\begin{array}{l}\text { U. S. Hospital No. 19, } \\
\text { Axalia, N. C. }\end{array}$ \\
\hline Ophaug, Helga .J.. & July & 1,1918 & Ft. Sheridan, Ill. \\
\hline Oreliard, Helen & Nareh & 20,1918 & $\begin{array}{l}\text { C. S. Naval Hospital, } \\
\text { Charleston. S. C. }\end{array}$ \\
\hline Orgren, Clara M. & Oct. & 6,1918 & $\begin{array}{l}\text { Base Hospital No. 29, } \\
\text { A. E. F., London. Fngland }\end{array}$ \\
\hline Orerend, Marion L. . & June & 16,1918 & $\begin{array}{l}\text { Base Hospital No. 3, A. E. F., } \\
\text { France }\end{array}$ \\
\hline (wens, Lillie May. & Oet. & 10,1918 & Camp Jee, Va. \\
\hline Parr. Hargaret I.. & Oct. & 17,1918 & (amp) Grant, 111. \\
\hline Parry. Aisrora E... & ()et. & 7,1918 & C'amp Taylor, Ky. \\
\hline lerek, Garnett ()live: & ().t. & $6.191 \mathrm{~s}$ & Great Lakes Naval Hospital \\
\hline Pennington, Pearl W & June & $2.5,1918$ & $\begin{array}{l}\text { Camp Jackson, Columbia, } \\
\text { S. C. }\end{array}$ \\
\hline l'ooples, Mary I. & fet. & 16,1918 & $\begin{array}{l}\text { Naval 1Iospital, l'uget } \\
\text { Sommd, Wash. }\end{array}$ \\
\hline Pepoon, Lucile & Nov. & 24,1918 & $\begin{array}{l}\text { Base Hospital No. 12, } \\
\text { A. F. F. }\end{array}$ \\
\hline ins, Ettir M & Oct. & 4,1918 & Camp Mearle, Md. \\
\hline Pretrie, Evelyn V... & May & $26 i .1918$ & lit. Ogletlorpe, tha. \\
\hline Phillips, Meryl G.. & May & 19.1918 & $\begin{array}{l}\text { Cinneral llospital No. } 1, \\
\text { New York City }\end{array}$ \\
\hline Plare, Eilna E. & Sept. & 29,1918 & $\begin{array}{l}\text { Naval Hospital, l'liballu- } \\
\text { plia. la. }\end{array}$ \\
\hline Forele. Frances & Oct. & 8.1918 & Fort (lntario, X. Y. \\
\hline
\end{tabular}


American Red Cross Nirses Who Dien ix Wak Service or as a Restit

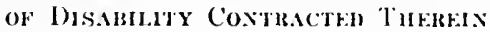

\begin{tabular}{|c|c|c|c|}
\hline Nurse & \multicolumn{2}{|c|}{ Date of Death } & \multirow{2}{*}{$\frac{\text { Place of Death }}{\substack{\text { Alamp. Mcclellan, Anniston, } \\
\text { Ala. }}}$} \\
\hline P'rice, Cornelia I.......... & Oet. & $9,19] \mathrm{s}$ & \\
\hline Quigley, I'auline A........ & (oct. & $18,19] \mathrm{s}$ & ('amp Custer, Mich. \\
\hline Ragan, Mabel A............ & ()et. & 1,1918 & $\begin{array}{l}\text { Biso llospital No. 17, } \\
\text { A. E. I. }\end{array}$ \\
\hline Raithel, Hattic II. . & Nov. & 2,1918 & $\begin{array}{l}\text { liase Hospital No. } 29 \text {, } \\
\text { A. E. F., london, England }\end{array}$ \\
\hline Rered, Inez E............. & March & 7,1919 & Ft. Riley, Kans. \\
\hline Regan, Mary Josephine.. & (oct. & 23,1920 & $\begin{array}{l}\text { (iluckner Sunatorium, Colo- } \\
\text { rado siprings, Colo. }\end{array}$ \\
\hline Reveley, Annie Dade....... & Oct. & 18,1918 & $\begin{array}{l}\text { Facenation Hospital No. } 4 \text {, } \\
\text { A. E. F. }\end{array}$ \\
\hline Roberts, Annabel S.... & Jan. & 17,1918 & $\begin{array}{l}\text { Base llosprital No. 2, A. E. F., } \\
\text { France }\end{array}$ \\
\hline Robinson, Genevra. & Oct. & 22,1918 & $\begin{array}{l}\text { liase Hospital No. } 68 \\
\text { A. E. I.. France }\end{array}$ \\
\hline Robinson, Violet E... & Nov. & 2,1918 & $\begin{array}{l}\text { Gardiner (ieneral llospital, } \\
\text { (iardiner, Maine }\end{array}$ \\
\hline Rockwell, Vera Marie. & Sept. & 21,1918 & $\begin{array}{l}\text { Naval llospital, C'helsea, } \\
\text { Mlass. }\end{array}$ \\
\hline Rodgers, Teresa Elizabeth... & Oet. & 28,1918 & March Firld, Riversisle, Cal. \\
\hline Rose, Lovie Lucinda......... & Oct. & $.10,1918$ & $\begin{array}{l}\text { Base Ilospital No. 68, } \\
\text { A. E. F., Engrland }\end{array}$ \\
\hline Royer, Norene M. . & Sept. & 17,1918 & $\begin{array}{l}\text { liase llospital No. } 46 \text {, } \\
\text { A. W. F. }\end{array}$ \\
\hline Russ, Freda . & Oct. & 21,1918 & (amu) Fremont. Cal. \\
\hline Sagre, llelen C..; & ()et. & 5,1918 & (amp) laylor, Ky. \\
\hline Siargent, Ilelen MI. & Oct. & $20,191 \mathrm{~s}$ & Fort Sloeim, X. Y. \\
\hline Sintor, Clara II... & Nov. & $14,1 ! 18$ & ('anp) Inodge, lowa \\
\hline Sebleirer, Mary J.... & Oct. & $6,191 \mathrm{~s}$ & l:Ilis lstand, N. Y. \\
\hline Fichomheit, Charlote & Dee. & $6,1 ! 1 s$ & $\begin{array}{l}\text { Mohile llospital No. } 3 \text {, } \\
\text { A. E. F.. Jiance }\end{array}$ \\
\hline Sichreiber, Orma A. & ()e.t. & $9,19 \mathrm{IS}$ & $\begin{array}{l}\text { Jatse llospital No. } 49 \text {, } \\
\text { A. E. l. }\end{array}$ \\
\hline Suhureman, Olive & O).t. & 11,1918 & ('amp Mearle. Ml. \\
\hline Sinvery, linth . ........ & ()et. & 16,1918 & (amp laylor. ky. \\
\hline Sebastian, Mrs. Mary McF. & ()ct. & 23,1918 & $\begin{array}{l}\text { National Mlilitary IIome, } \\
\text { Ind. }\end{array}$ \\
\hline Suler. liarbara L....... & $(1) \cdot \mathrm{t}$ & 21.1918 & ('amp l)orlge, Iowa \\
\hline Seymour, Nina louise... & ().t. & $10,1 !)]$ & $\begin{array}{l}\text { 1. li. ('. llospital No. } 2 \text {, } \\
\text { Flature }\end{array}$ \\
\hline Shrope, Lyodia D. ....... & July & 14,1917 & Ft. Mayart. N. Mex. \\
\hline Simm, Mrs. Lera siott. & Het. & 19.1919 & Fe. likley. Kans. \\
\hline 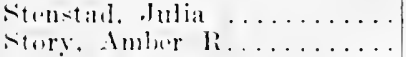 & $\begin{array}{l}\text { Nuv. } \\
\text { Sus. }\end{array}$ & $\begin{aligned} 5.1 ! 11 \\
20.1 ! 15\end{aligned}$ & 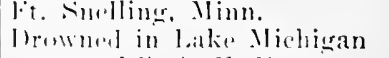 \\
\hline Symmos. Kathleon $\mathrm{l}$. & int. & $4.191 \mathrm{~s}$ & 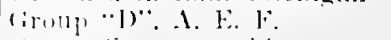 \\
\hline Taylor. Fva $\ldots \ldots \ldots$ & $F(b)$. & $20.191 ! 3$ & (amp, Slurman, ()hin \\
\hline J'muplin. Ninmi ... & (b.t. & 1i. 1!1 - & li1. Sturiolinn. lll. \\
\hline Thomians. Matry ......... & $(1,1$. & $3: 3.191$ - & 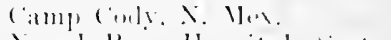 \\
\hline lhompison, Alive l. $\ldots$. & $1) \cdot t$ & $2+.1 \div 15$ & $\begin{array}{l}\text { Navial liane llanpital, fint- } \\
\text { land }\end{array}$ \\
\hline
\end{tabular}


Americax Red Cross Nurses Who Died ix War Service or as a Result of Dis.ability Costracted Thereis

\begin{tabular}{|c|c|c|c|}
\hline Iurse & \multicolumn{2}{|c|}{ Date of Death } & I'lace' of Death \\
\hline Thorsen, Emma .......... & Nov. & 24,1915 & Camp Dodge, lowa \\
\hline Tompkins, Agnes ........... & J:III. & 6,1920 & $\begin{array}{l}\text { C. S. A. General Ifospital } \\
\text { No. } 28 \text {, lt. Sheridan, Ill. }\end{array}$ \\
\hline Trank, Florence M.. & Oet. & 8,1918 & $\begin{array}{l}\text { Base Hospital No. } 58 \text {, } \\
\text { A. E. F. }\end{array}$ \\
\hline Travis, Goldie X. & Oet. & 6.1918 & Fort Snelling, Minn. \\
\hline Treichler, Amy ... & Feb. & $14,191 \mathrm{~s}$ & $\begin{array}{l}\text { Naval Ilospital, Charleston, } \\
\text { S. C. }\end{array}$ \\
\hline Trimble, Marie E... & Sirpt. & 13,1918 & Chelsea, Mass. \\
\hline Turner, Marion Pearl. & O.t. & 21,1918 & $\begin{array}{l}\text { Taval Ilospital, Mare } \\
\text { Island, Cal. }\end{array}$ \\
\hline Turner, Phyllis M. & Sept. & 28,1918 & $\begin{array}{l}\text { C. S. General Hospital No. } \\
\text { 1. New York }\end{array}$ \\
\hline Viberg. Judith S... & Oet. & $14,19] 8$ & Camp Lee, Va. \\
\hline Vietmeier, Ida IIenriet & Jan. & 8,1919 & $\begin{array}{l}\text { Camp Iospital No. } 71 \text {, } \\
\text { A. E. F., France }\end{array}$ \\
\hline Volland, Magdelena M.. & Sept. & 22,1918 & $\begin{array}{l}\text { Base llospital No. 23, } \\
\text { A. E. F., France }\end{array}$ \\
\hline Walch, Caroline Prose. & Oet. & 18,1918 & $\begin{array}{l}\text { Camp Travis. Ft. Sam } \\
\text { Houston, Texas }\end{array}$ \\
\hline Walker, Anna A. & June & 15,1919 & $\begin{array}{l}\text { Base Ilospital No. 55, } \\
\text { A. F. F. }\end{array}$ \\
\hline Ward. Lillian .. & Oet. & 22,1918 & Camp Greene, X. C: \\
\hline Ward, Nellie J. & $\left.\mathrm{J}_{11}\right]_{y}$ & 12,1918 & $\begin{array}{l}\text { Base Ilospital No. 15, } \\
\text { A. E. } 1 .\end{array}$ \\
\hline Watkins, Gladys . & Oct. & 16,1918 & $\begin{array}{l}\text { Base IIospital No. } 56, \\
\text { A. E. F., France }\end{array}$ \\
\hline Wrigner, Allerta I.. & Jan. & 20,1919 & let. Riley Kans. \\
\hline Weimann, Elizabeth 1 & Nov. & 6,1918 & $\begin{array}{l}\text { l3ase Ilospital No. } 62 \text {, } \\
\text { A. E. l. }\end{array}$ \\
\hline Weise, Rose.. & May & 20,1922 & $\begin{array}{l}\text { Fitzsimmons General Hos- } \\
\text { pital, Denver, Colo. }\end{array}$ \\
\hline Wellman, Maybelle & Oct. & 15,1918 & $\begin{array}{l}\text { General IIospital No. 1, New } \\
\text { York }\end{array}$ \\
\hline Wulls. Matilda $\mathrm{F} \ldots$... & oct. & 1.5. 1918 & Camp Eustis, Va. \\
\hline Wolsh, Georuiana Mary & $\cdot J_{i \gtrless n}$ & 29.1919 & Vancouver Barracks, Wash. \\
\hline Wencl. Dorothy II. . & June & $4.1 ! 19$ & $\begin{array}{l}\text { St. John's Hospital, Spring- } \\
\text { field, Ill. }\end{array}$ \\
\hline Wost Anna Pelle l'.. & oct. & 21,1919 & $\begin{array}{l}\text { Walter Reed ILospital, } \\
\text { Washington. J). C. }\end{array}$ \\
\hline Whaley, Ena $M \ldots . . . . .$. & Oct. & 15.1920 & $\begin{array}{l}\text { Fitzsimmons General Hos- } \\
\text { pital. Denver. Colo. }\end{array}$ \\
\hline Whereler, Jaella Matilla. & Jan. & 14.1919 & $\begin{array}{l}\text { Can1 Ilospital Xo. 12, } \\
\text { A. E. F.. Franer }\end{array}$ \\
\hline Whiteside. Lydia $V$. & ()et. & 21.1915 & $\begin{array}{l}\text { Base IIospital Xo. } 26 \text {, } \\
\text { A. l. I: }\end{array}$ \\
\hline llierens. 1)aisy $\mathrm{l}$. & (). a.t. & $2 \cdot 2.1 ! 1 \mathrm{~s}$ & Comp ('orly. X. Mex. \\
\hline Williams. Anuir M. & $(1) \cdot 1$ & $1 . \overline{1} .1 ! 1 s$ & 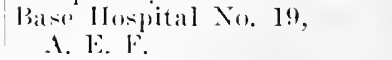 \\
\hline Winche-ter. Jolith May..... & May & $17.191 !$ & Armonia \\
\hline
\end{tabular}


American Red Cross Nurses Who Died ix War Semtce or as a Restelt

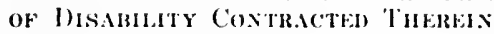

\begin{tabular}{|c|c|c|c|}
\hline Intrse' & \multicolumn{2}{|c|}{ Wate of Death } & I'lare' of Itath \\
\hline Mood, Helen Burnett. & M:ly & 20,1917 & $\begin{array}{l}\text { (In loard i.t. Itongolia en } \\
\text { ronte to Frances }\end{array}$ \\
\hline Worth, Margaret W. & & $23,191 \mathrm{~s}$ & $\begin{array}{l}\text { Base llowpital No. 48, } \\
\text { A. W. F. Fance? }\end{array}$ \\
\hline Wriglat, Mayne L & ()et. & 5,1918 & Camp (iraut, 111. \\
\hline Voung, Alice M.... & ()$\cdot \mathrm{t}$. & $4.1 ! 118$ & ('amp) Sevier. S. ('. \\
\hline Youme, Florence $\mathrm{Ml}$. & Oct. & $23,191 \mathrm{~s}$ & ('amp Derens, Mnsis. \\
\hline Young. Rose A......... & Nov. & 28,1917 & ('am]) Shelly, Mliss. \\
\hline lonng, Mrs. Rose lirkwood. & Inute & $2: 3,1 ! 1 !$ & $\begin{array}{l}\text { it. lukes llowpital, New } \\
\text { lork }\end{array}$ \\
\hline
\end{tabular}

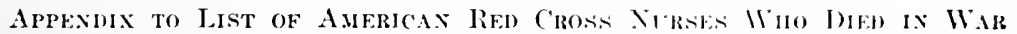

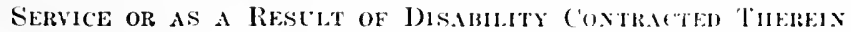

After consideration and by a speeial anthorization from lliss Noyes, the following nurses were posthumously awarded lied cross medals aud eitations, along with the other nurses on this list who died in war service, or as the resint of elisability contracted theroin.

In almost every ease the nurse died of influenza, or prommia following influenza, during the 1918 epidemie. just after travel orelers for military service ladel been issued to her, hut before she had oplertunity to execute the oath. Nith hut prebably two or three exceptions, all theis murses had been assisting the Red (ross in caring for influenza patients while wating for their travel oreters for military service.

\begin{tabular}{|c|c|c|}
\hline Iurse & Date of Death & Ilace of Irath \\
\hline lireen, Margineet M.. & ().t. 20,1918 & $\begin{array}{l}\text { it. Yincent's llespital, Nelv } \\
\text { York ('its. }\end{array}$ \\
\hline 1)avis, Elsie $11 \ldots \ldots \ldots \ldots$ & $2: 3.1918$ & Ship Iards, Philatelphoia \\
\hline M,wns, Mayme T. & 2.5 .1918 & $1:$ s. \\
\hline 1)mbar, liamona ('anti & $(3 \cdot \mathrm{t} . \quad 10.19) 18$ & $\begin{array}{l}\text { Presbyturian llospital, Sew } \\
\text { Jork ('ity }\end{array}$ \\
\hline limnoms, Fia. & Norember. 1918 & 1.5 \\
\hline linglambl, Margaret & ()et. 1.5.19)s & $\begin{array}{l}\text { Mashington Park llospital, } \\
\text { (hisand lll. }\end{array}$ \\
\hline (ine-t. Mabuel l'... & 30.1914 & 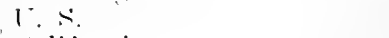 \\
\hline llonghtom. Ilalen $(1 \ldots \ldots$ & Sor. 2. 21!1s & Galifornia \\
\hline lluliness. Hanna Priseilla. & (1, toblere lals & $1 .<$ \\
\hline hordatene lyolia $\ldots \ldots \ldots$ & Sov. 14.1919 & $1: \therefore$ \\
\hline fowers, Mlliertia MePlarsan. & $5.1 ! 11 \mathrm{H}$ & $\begin{array}{c}\text { South llighlanel Intirmary, } \\
\text { liamineham. Alat. }\end{array}$ \\
\hline Millar, Emmiere ...... & 30.1911 & $1 \therefore$ \\
\hline 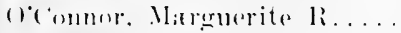 & $11.1: 14$ & ('hicitan \\
\hline 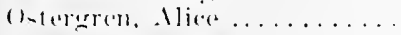 & !. 1914 & 1.2 \\
\hline Statgendr. (hatrottes. & $\therefore .1917$ & \\
\hline Whaloy. Mbimal W. & $11.1 ! 1] ! 1$ & tharle-tom. $<$ \\
\hline Whitely. Mrs. Anna l: & Ipril. & Rritioh lis Fomere lirmes \\
\hline
\end{tabular}


Americay Red Cross Dietitiaxs Who Died in War Service or as a ResLlet of DisABILITY CoNTRACTED TIIEREIN

\begin{tabular}{|c|c|c|c|}
\hline Dietitian & \multicolumn{2}{|c|}{ Date of Death } & Plaee of Death \\
\hline Jury, Irene I. & Dec. & 9,1918 & $\begin{array}{l}\text { Naval Hospital, Pelham Bay } \\
\text { Park, New York }\end{array}$ \\
\hline Keech, Cara Mea........... & Oct. & 18,1918 & $\begin{array}{l}\text { Base Hospital No. } 68, \\
\text { France }\end{array}$ \\
\hline Morse, Meda ... & Dec. & 24,1918 & Camp Taylor, Louisville, Ky. \\
\hline Noreross, Olive ... & Sept. & 26,1918 & Camp Dix, N.J. \\
\hline Peck, Narian IIelen. & Feb. & 17,1919 & France \\
\hline Wind. Hortense Elizabeth.. & Dec. & 10,1918 & Norfolk, Va. \\
\hline
\end{tabular}




\section{INDEX}

Abramson, Mrs. Jennie A., on conditions at Vittel, Franee, 501

Palestine Commission, 8!92

Accueil Franco-Americain, 830

Aceredo, Eugenia L., Children's Bureau at Toul, 766

Acre, Palestine, Red Cross lospital at, 903

Alams, Mabel K., assistant on Nurse Corps of the Public Health Serviee, 1028

chief nurse, laase Hospital No. 13,508

Addison, Sara R., at National Headquarters, 240

relief work in firecee, 1112

relief work in Maedonia, 1114

with service de sianté, 586

Agramonti, Dr. Aristide, yellow fever work by, 14

Alrens, Minnie H.. Committee of Transfer, 1021

director Central Division of American lied Cross, 247

on mobilization of nurses, Chicago, 404

public health nursing, 1303

Aidles, lied ('ross, 9ĩj)

Alaska, public licalth mursing in, 1335

Alhania, relief work in, $1107-1110$, $11 \% 2$

Alhawh, Raehael Independence, $1(12: 3$

assignment of nurses, 1019

campaign for nurses, 1060

(hitef of l)ivision of Institutional and Situlent Assiemment, 1017

Drlano Memorial committer, losi in intluenzal epidemice. 975

Albright. Josepline, in charge of puhlic health nursing at Faclirostok, 9:33

Aliford llouse, hod as hospital, $7: 21$

Alexamer. Amy. Delano Memorial committer, 10.5)
Alexander, Mrs. Charles B., Committee on Nurses for the Philippines, 62

Allan, Ida .J., ehief nurse of U. S. Army Camp llospital 35, 428

Allen, Ethan, Committer, Memorial Fund to American Nurses, 1048

Allen, Mary Shermun, president, Texas lied Cross State Nursing Committee, 130

Allen, Dr. May, medieal direetor at Dinard, France, 769

Allenby, General, 893

Alliance IIospital, Ivetot, France, 195

personnel of, 196

work of, 196

Allison, Grater, ehief nurse of U. S. base Hospital No, 4, 339, 443

on embarkation of unit of Base Iospital No. 4, 414

superintemlent of murses of liakeside llospital, Cleveland, Ohio, 328

Altman, Henriettal, visit to devastated France. 9s?

Alumma soriaties of fraduate Nurnes, orcanization of, 20)

"Amberine" treatment for lourns, (i) 1

Ambroser, Elith, as Chautamqua nurse, ]10.5.)

at emorgency hospital at Jouy-surMorin, bis

American ambulanexe, at Nenilly, France. 53.5

American committer for Armenian and sirian lieliof. ss?

Amerian Evpeditionary foreses in France. 4tis. (i:32)

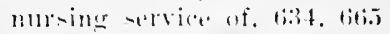

shortater of nurses for. ils

Amerialu Felleation of Sursese aftiliation with National lied (rom Som soly, 71, 74. 14

organization of. 7 
American Journal of Xursing, on civic obligations of nurses for Red Cross enrollment, 82

on Red Cross reorganization and hope of alliliation with nurses, 74

publicizing Red Cross events, $7 \tau$ report from, on Red Cross aftiliation, 71

reprint of Red Cross Central Committee circular on recruiting murses, 75

special military number, May, 1918, on extra-cantonment service, $394,395,399,400,402,415$

American Medical Association, cooperation with American Red Cross, 126

American llission hospitals, volunteer work in Siberia, 914

American National Red Cross, neutral character of, 22

non-sectarian elaracter of, 22

organization of, $\mathbf{2 5}$

Rielief C'ommittee, 26

reorganized, aim and purpose, 75

American Nurses' Association, 1022, $1: 219$

aflitiation of American Red Cross. nurses with, 71, 74, 123

Twentictl Anmual Convention, $387-358$

American Nurses' Club, London, 425

American lied Cross, coöperation of, with U. S. Medical Corps, 631

foreign program of, closed, 19141915. Sce Mercy Ship Expedition.

gencral reorganization of, 1909, 101

in France, establishment of, 532 plan of nurses' enrollment for, 105

proclamation relating to, issued ly Presilent Taft, 1911, 120

American lierl C'ross Commission for Europe, 4int, 612

American Rerl cross Commission to Fance. 379

American Real C'ross hospital servicer, (j;3), (i3)

Amerian hed cross hospitals:

Comaleserent llospital No. 10l, Lingreckl. Engrland. 434

Comvaleseont IInspital No. 102, Wimblerlon. Enerland, 438

llospital No. 万. Paris, it7
American Red Cross hospitals:

Hospital No. 100, 731

Jlospital No. 101, Neuilly, France, 611

IIospital No. 103, Neuilly, France, (i)

Iospital No. 104, at Beauvais, 596

Ilospital No. 105, 604

Hospital No. 109, at Evreux, France, 6(09-610

Hospital No. 110, at Coincy, France, 616

moved to Villers-Dancourt, 617

Hospital No. 111, at ClâteauThierry, 617

Hospital No. 114, Luxembourg, 622,770

transforred to Fleury-sur-Aire, 6:2:3

hospital in North Russia, 680, 684

hospitals in war zone, 612

hospitals, two types of, 532, 533

Military Hospital No. 1, 535

Military llospital No. 3,748

Military IIospital No. 4, Liverpool, 427

Military Mospital No. 5, at Auteuil, France, 599

recreation luit of, 601

Military IIospital No. 6, at St. Clond, 610

Military Ilospital No. 21 ("Oldway IIotuse"), 429

Military IIospital No. 22, London, 430

Military IIospital No. 23, London, 430

Military IIospital No. 24, London, 430

Military IOspital No. 107, at Jouy-sur-llorin, 6. (i0).5

bombed by (nemy aviators, 608

military liospital, at Jonilly, France, 60:3

military lospitals, operation of, 5:3:3

American Tier] Cross Motor Corps, and extra-cantonment zones, 404

Ancrican lied cross Nursing Service. Sere Nursing Siervice.

Executive Committere of National ('ommitter on, 2.59, 2060

relation of, to Army Nurse Corps, 313 
American Red Cross officials subject to military jurisdiction of United States, 534

Ameriean Real Cross Burean of Pernomel, $37: 3$

Ameriean lied Cross Ilealquarters, 23.5, 230

American lied Cross Town and Comntry Nursing Service, name elanged to liurean of public llealth Nursing Service, 345

Amerienn Rolief Clearing House, $5: 31$

Ameriean troops, Irigaled with Frencl and Britisli, 579

sent to Siberia, 911

Ameriean Women's War Relief Fund, Committee of, 146

Amiens, air raid on, 465)

conditions at evacuation of, Mareh, 1918, 831

work of Children's Bureau at. 774

Anderson, Colonel IIenry IV., Commissioner for lialkan States, 1083,1100

melical director in lioumania, 1128

organization of American Rod ('ross commission for Rommanja, 882

Anlersom, Eva, public lealth nursinge. $1: 303$

Anderson, Frimees, 361, 362

Amderson, Mrs. Larz, Jiwn and Comntry Nitrsiner Committer. 1219

Anderson, Lyda, at National llealyuarters. 240

directer, Sonthwestern Division of Amoriean lied cross, :2t6, ] $0: 3 \mathrm{~s}$

mursing school in Constantinople, 11711

on Austrian solulier, 170

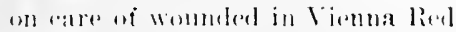

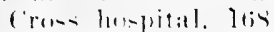

on ditlienlties with individuals of mits-. 171

on Cierman examination of traver

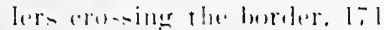

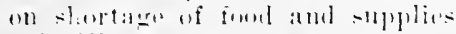
in liesnax, loi?

supervine of Marey ship Fyuditinn lni K. dis

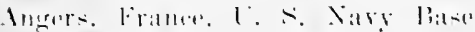
H1mplat Io. 1, at, 7.24, 73.5
Angliean order, nursing serviees of, in ('ivil llar, 8

Angunleme, France, lied Cross dispellsary at, 8:3s

"Annex," tirst Amorican lied Cross hospital in North Russial (jso, (isit

Anselmi, Emilia Malatesta, Jalian representative at Canmes Conforence, 1138

Apterl, Mrs. Sinsan, at Amerion Red Cress Military Hospital No. 5, at Autenil, 6in

Iquilania, collision with s.t. shan, 727

Archere, Francess 13., Châtean des llalles hospital, 781

Arehere, lieatrice, Palestine Commission, $8 ! 2$

Arizena, pural nursing in, 122s

Arkwriglit, Mrs. Proston S., IVoman's Alvisory (ommitere, 300

Armonia, Amorican lied crosis funds for, $8 ! 1$

Armenia Proper, 858

Armenian and Syrian Relief. Amorican committer of, sis?

Armories, lied Coross emererency mursts supplind to, 6:2

Armstromgr. Dr. li. K., medical chiei, Chatelet hospital. 7z!

Armstrong, Mrs. IV. N., in Army Nurse corps legislative efforts, (is

Army, relation of nursing service to. 3111-38s. xien also under Numiner Servien.

Army and Dayy Nurse (iorps, in(roase of salary. 37t

domestic servios:37

were-1at = duty. 374

reculations regarding uniforms, 374

Army Nurse liill. defent aí. bi!

aflorts for bit. lis. ti!l

Army Nurse (ioper appointment to, $4: 3$

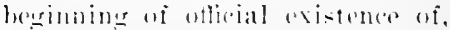
42

libll rolatine to rank in. logo

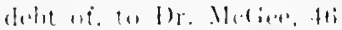

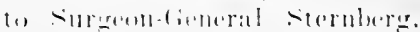
tri

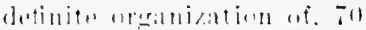

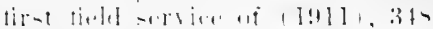

in puntise eperlition t." Vira (rus (19)]1,.31 
Army Nurse Corps, made permanent part of Army, 47

legislation for, 67

numbers of, during War service, Spanish-American War, 43

organization of, 42

origin of, 35-35

qualifications for appointment to, 39

regulations, 715

improved, 101

relationship of, to American Red

Cross Nursing Service, 313

reorganization of, 1066,1069

requirements for membership in, 38

salaries of, 697

status of, 356

war services of, Spanish-Ameriean llar period, 43

Army nurses, appointment of first six, 41

assigned to Red Cross, $62 \mathrm{I}$

bill to secure rank for, 1069-1072 passage of, by Congress, 10751076

Congressional Committee report on value of, 65

coöperation of Red Cross with, 628

question of rank of. 1061-1066, 1069-1072, 1074-1076

Army rank for Nurses, efforts for, 70, 1064 et scq. Sce also Rank for nurses.

Army Sehool of Nursing, 283, 284, 286.257

Alvisory Committec, 285, 286 enception of idea, by Sarah Eilson, 11

grifts toward, 286. 287

11)an submitted, 294. 285

Arnett, 1)r. Lillie A.. on dispensary at Angouleme. France. 838

(n) work at le Cilandior. 820

Am-tein. leos, direcerer of Military Reclief of Xew York County ('latpter, $36(i 3)$

Arthur. Major. commendation of male nurses on Missouri, bo

Artillery training centre, at ('amp) Contenidath, 73 is

Ashe, Filizaluede ll.e chief murse of

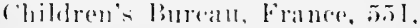
ind

of (ommision for lielgium, $\$ 18$
Ashe, Elizabeth H., work in Children's Bureau, France and Belgimm, 760

tuberculosis prevention work in France, 846

Asher, Blanche, on trip of Base Hospital No. 102 unit to Genoa, 670

Asile Caserne, Laxembourg, 622. 766

converted into military hospital, 770

Asile Ste. Eugénie, Lyons, France, 853

tuberculosis hospital, 850

Associated Alumne, as part of The American Federation of Nurses, 71

efforts of, towards Red Cross affiliation, 71

misunderstanding between War Department and, 41

offer from, for Spanish-American war nursing service, 40

Astor, Mrs. John, Committee of American Women's War Relief Fund, 146

Athanasakis, Mr., president. of Greek Red Cross, 1166

Athens, infant welfare work in, 1116

relief work in, 1111

Atlanta, Ga., eall for Red Cross nursing service at, 1917,136

meeting of lied Cross Nursing Service, $1920,1+33$

recommendations of, 1434

Atlantic Division of American Red Cross, 244, 24.5

Atlantic llighlands, Red Cross nurses at. 61

Auerbach, Joseph A., New York homo of, nsed for nurses, 422

Austin Dam, breaking of, 1911, 132

Anstrian solulier, 170

Anstrial, chilal welfare in, 1191

Autelit\%. France, emergoncy eanteen at. $8: 37$

Autenil, France, emorgeney hospital :11.

Amxiliary No. 3, Spanisla-Amorican IV:ar. membersilip romposition of. 47

report of. March 1, 1s99, 5.5

Ariragnet. Wr, child welfare work, I'arisis, 815 
Ayers, Colonel Leonarel P., chicf of Statistics Branch, General Stafr, U. S. Army, 404

on campaign of 1918,578

on exolns of American Army from France, 1009

on fourth great German offensive, 605)

on hospital eapacity in United States, during European War, 404-40.5

on need of nurses in inlluenza epidemic, $97 \mathrm{l}$

on third great German offensive, 602

Ayres, Edith, killed at sea, 470

Babl, Sara M. F., on work in Italian hospitals, 671

on Italian drive, 673

Babbitt, Ellen C., Children's Bureau, welfare expositions, France, 1918,783

at Marseilles, Franee, 792

Babhitt, Frank L., on nursing (ourse at Vassar, 268

Baeon, liobert, treasurer of Committere, Memorial Find to American Nurses, 1048

baconrt. Francoise de, relief work in Serbiat, 1120

bailey, 1)r. Fillhert A., director of ilerey ship [nit G, 167

Bailey, 1)r. W. C.. director of Red Cross Commission for I'olant. 1080

Bailey. Ilelen Lydia, relief work in Serluia, 1125

bailey, llary li., eliild welfare work, Finnee, s1:

baker, Aurel, 1.59

liaker, liernard X.. on committee to secure lied Cross ship for IVorlel IVar, 140

Baker, Bersien dhiof nurse, Base Mospital No. ls. 4 sti

on eonditions at bazoilles, Franee, 4 (9)

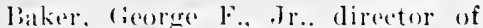
(ommission to laly, sis!)

baker, Newton bient. Sercetary of War. amel Red crosis hospital minits. $: 3+1$

an furnisling miforms for Army Nirso (orpers, iti?
Baker, N. D., on regulations governing the employment of American lied (rosis in time of war (1916), 320

Baker, Mrs. Isaluelle IVilbar, director of Flementary Hygiene and llome Care of Sick, 1369

Balch, Dr., organization of Base Ilospital No. 55 by, 338

balcom, Helen, State Committee, lowa, 112

Baldwin, Bertha, dietitian; Report of eliet kitchen service overseas, 1411-1417

baldwin, Jorotlea, child welfare exposition at Marseilles, France, 7 ().

Baldwin, l)r. John C., director, Cluiluren's liureau at Nesle, France, 772

member of children's Bureau, France, 7.58

on conditions at Nesle, Franee, 772

Balfour Mission, 442

Balkan States, relief work in, 1077 , $1083,1084,1100,1102$

sanitary conditions in, at outbreak of World War. 1st

Balzani, Contessa. scliolarship to stuly nursing, 117.j

Bamher. licatrice, dhief nurse, Base llospital No. 1.50.5

Bancroft. 1)r. Mabel H., (lispensary at Levallois. France, 803

on work for refugees in l'aris, 834

Bapaume, France, eaptured by Germans, 1918, 464

Baranoviaci. Poland, condition of hospital at. 1090

Barher. Eelith A., director Northern Division of Ameriean Red cross. 247

report on intluenza work, 977-979 Barbour, James li., Ameriean Relief ('learing llomere. 531

Barbusise an the prilu, 1.52

Barow, Jlr. ommui-ioner for Po. litul. at mursing scheol in Polimal. 11,is?

larrow, Amolia, ('juil War nursing service of. 1:3

Jiarlow, Ma jur firmeral. 236

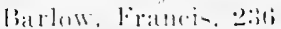

liarmarl. Helenis. ntfierer of Asso-

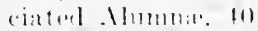

barmbllar, ( latra, 1.59 
Barnett, Edith, death of, from typhus in Siberia, 942-943

work of, in Siberia, 939

Baroda Ilouse, London, used as hospital. 430

Bartlett, Major General George T., command of U. S. Army Base Section No. 3, 426

Bartlett, Vashti R., ehief nurse of American Red Cross detachment at Harbin, 937

in hospital supplies work, 298

in Nursing Service headquarters, 237

nursing in Haiti, 1171-1172

on eholera epidemic at Harbin, 937, 938

on conditions in Haiti, 1172

on homage to dead soldiers at Pau, France, 153

on the poilu, 153

supervisor of La Panne Hospital, 203

Bartles, Mary, ehief nurse, relief work in Pruzana, Poland, 1086, 1087

Barton, Clara Harlowe, first president. Ameriean Association of the Red Cross, 13

in Cuba, 25

in War of 1870,21

nursing services of, at Johnstown flood, 18

organizer of volunteer field nursing, in Civil War, 9

plans for relief of concentrados, 25

president, Ameriean National Red Cross, 22, 25

share in organization of Red Cross Iospital and Training School for Sisters. 2I

Barton, ])r. Stephen E., Executive Committee. Ameriean National Red Cross. 1898, 25

in relation to the Lampasas expedition, 32-333

Base hospitals. See U. S. Army Base Ilospitals.

Basken, Isabel IIall, lome hygiene clasis in Santo Domingo, i2no

Bassot, Mlle.. rhilel welfare work, Frances, Sl2. S1.)

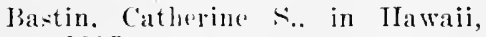
1.20:5

liateman. Cinnevat, relief work in S(robia, 1122
Bauer, Caroline, 167

Baurle, Marie, ehild welfare work, Franee, 813, 814

Bayne, Dr., in Roumania, 1126

Baylies, Mrs. Edmund L., member of Committee on nurses for the Philippines, 62

Bazoilles, France, conditions at, 490

U. S. Army Base Ilospital No. 18 at, 488

U. S. Army Base Hospital No. 46 at, 508

Beal, Boylston A., London Chapter, Ameriean Red Cross, 425

Beal, Dr. Howard IV., direetor of Unit F, Mercy Ship Expedition, 146

Beale, Mrs. Harriet Blaine Committee on Town and Country Nursing Service, 1264

in Army Nurse Corps legislative efforts, 68, 70

on rank for army nurses, 1069

Beard. Mary F., committee on settling war nursing policy, 254

conference to consider nursing problems, 254

Joint National Committee, 1047

Joint National Committee of Bureau of Information, 1016

Tational Committee on Red Cross Nursing Service, 249

on plan for special enrollment of nurses, 2.57

on status of public health nurses and Special Service group, $27 \mathrm{~s}$

Bears. Elmira W., at Chateau des II alles hospital, 781

in charge of child welfare work at Lille, 822

Beatle, Alicr. in Meres Ship Relief Expedition, 390

on passage of troops through Budapest. 175

on relief work in Burlapest. 174

on work at Burlapest. American Rerl Cross hospital. 173

supervisor of Merey Ship Lnit E, 173

Beatiy, II. O., director general, Ameritan Relief Clearing llowse, 5:31

Beauvais, France, Aneriean Red Crosi llospital No. 104 at, 596 energency lospital at. 5 !nc

refuger liespital at, $8: 32$ 
Beauvais area, conditions, 5\$

Becher, Dame Ftleel T.. Queen Alexundru's lnperial Nlilitary Nursing Service, 474

bedloe's Island, Red Cross services on, 61

Beecroft, Lamra A., chief nurse, U. S. Army Base Ilespital No. 29, Tottenliam. England, 438

Belgian refugees, $1(i)$

Belgium Red ('ross, 1999

Belgium Luit No. 1, 200

Bolgium Cnit No. 2, 200

Belgrade, bombardment of, 177 condition of wounded at, 178 evacuation of, by Rerlos, 178 military hospital at, 17 \%

American Red Cross units at, recalleel but retained at request of King leter, 185

difliculties of. $17 \%$

taken over lig Ameriean Red Cross Lnit 1, 17\%

turned over to Austrian military authorities, Nov. 28, $191 \%, 187$

on eve of second Austrian offensive, 18.5-18i

re-capture of, ly dustro-Germans, ()etoleer, 19) 1 .). 186

recovery hy Serlss. Dee. 15, 1914, $17 !$

Bell. Bessie S., chief murse of A. E. F.. in France. 48.2. 501:3

direstor of nursing service, ('lât eallu-Tlicery. 6334

Bell. Surgeon II. L.. Satiomal Committere on hed Crosis Nursing Service. 9.)

Bellevue lluspital. Nurses Traininge ribleol established at. $1: 3$

Bellis. Ma jor li. L... lirector of .1 sile

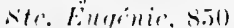

bellows. Mr.. on women's work in the (ivil llatr. lo)

president of lnited States Sanitary commisiom, s

Pelmont. Mre. Anerlest, linarel of lowerporators of American lied ('ross. 10167

Dalame Mrmorial (inmmitter. 10.51

Woman's Alvisory commitier. 300

linum, Elith Merle, Chantanipua nurse, 105.
Benn. Edith Merle, chief nurse of Ameriean Real Cross Commission for loblatul, los? resignatien of. 1097

Bemnete, lomise, on eruelty of war, 149

supervisor of Merey Ship (nit I), 148

Bentinck, Mrs. Carondish, opened suite for nursese in lomelon, 425

Bentley. Graee, public health nursing. 130:3

Benton, Dr. Fred G.. 167

Bereza Kartuza, loland. Red Cross relief work in, 1088

Besley, Florence M., Chautauqua nurse, 10;3

Chautauqua work for rural nursing. 1231

Besles, 1)r. Frederick, director, Biase Ilospital No. 12. 469

Besom, Pansy, mursing sehool in Prague. 1152

Besson, Dr., rhild welfare work, France. 812. 81.5

Bethel. Mary H.. chief nurse of Vlarlivestok Refuger Ilospital, 933

nursing scluool in Prague, 1152

Bettman, Florence, first dietitian overseas, lissl

Butts. Miss, appeinted for Plikiplpine sorriere, 6 i3

loyea. Mrs. Dalisy l'irie, Chantanqua mur:o. loi.s.

on comelitions at Evaenation Hospital No. is. (j45)

Bialystok, Amerian Red Cross relief work :1t, 10!9:3

Biertre llopital. SOT

Bieknell, Ernest P., committee on lecture course for liad cross nitrsis, 1:2:2

Commiter on Town and comntry Nur-ing service, 1:20t

direntor-inderal of civilian Relief, 2:31

Eureperal commissioner, 530. llis

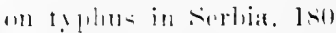

on Mniforms of Army Nurse (iurpe. Bist)

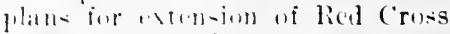
for retiof work, 24.2

Biselow. Nlifa, relini work in Serbia, $11: 0$ 
Bigelow, Glenna F., on preparation for overseas duty, 418

Bigelow, Helen Amy, in charge, Children's Ilospital at Evianles-Bains, 778

Biggs, Dr. Ilerman M., committee on settling war nursing policy, 254

conference to consider nursing problems, 254

report on tuberculosis conditions in France, 844

Billings, Bernice, public health nursing, 1303

Billings, Dr. Frank, in efforts for Army Nurse Bill, 69

Bingham, Laura Blanche, on work at Children's Hospital for tuberculosis prevention, Paris, 852

Bird, General Charles, Central Committee, 230

Birmingluam, Colonel, acting surgeon-general, U. S. Army, 349

on requirements for enrollment of reserve nurses for IIexican Border service, 352-353

on uniforms of reserve nurses, Army Nurse Corps, 365, 369

Birtles, Agnes C., lrospital work at Liverpool, 428

reception of, in London, 425

Black. Najor Carl E., plans for nursing seliool in Greece, 11651166

Black, Niss, delegate to ninth International Red Cross Conference, 1912, 124

Blackstone, Eleanor, relief work in Serlia, 111!)

Blackwell, Surgeon E. M., 126

Blackwell, Dr. Elizalsetl, helpful intimaey with lilorence Niglitingale. 6

share in organizing United States Sanitary Commission, 6

training of nurses in C'ivil War, 5

Blackwell. Dr. Emily, training of nurses by, in Civil War, 5

Blake, Dr. Iosepll A.. establislied Ameriean lied Crose thilitary Ilospital No. 2, France, 5:39

blakoly, l)r. 12. M., relief work in Sirbia, 1123

Blatch, Mrs. Marriet S., work of, to secure rank for army nurses, $106 \bar{i}, \quad] 069$
Bliss, Mr. Robert W., on Executive Committee of American Red Cross, 1007

Bliss, Mr. and Mrs. Robert W., organization of American Distriluting Service by, 531

Blodgett, Mirs. John WVood, on nursing course at Vassar, 268

Blois, France, American Red Cross dispensary at, 797

children's hospital at, 798

tuberculosis hospital at, 853

Blue, Admiral, sceuring of officers for Mercy Ship, 140

Blue, Surgeon General Rupert, 1024 creator of Committce of Public Health Nursing, 266

gives Red Cross responsibilities in influenza epidemic, 973

National Committee on Ped Cross Nursing Service, 248

on Red Cross public health nurse, 403

Boardman, Mabel T., Central Committee, 230

committee, lecture course for Red Cross nurses, 122

Committee on Rural Nursing, 1216

Delano Memorial Committee, 1050,1051

Executive Committee, rcorganized Red Cross, 74

National Committee on Red Cross Nursing Service, 95, 127, 249

on appointment of Red Cross nurses, 84

on class instruction for women, 1352

on dietitian classes, 1376

on enrollnent in the Nursing Service, 357

on home nursing courses, 1355, 1356

on importance of Nursing Service (lied Cross Bullotin), 75

on plin for affiliating organized nursess, 88,89

on Red Cross nursing standards, 83

on "The Rerl Cross Nurse," address before Anerican Society of Superintemdents of Training S.bhools. 75

on lierl Cross Nursing Service, 327 
Boardman, Mabel T., on serviees of Mrs. Whiteluw Reid, 47.48 organizing Rural Nursing serviee, 1264

plan for lied Cross aides, 10.52 preface to hed Cross text look, 13:5!)

Town and Country Nursing Committ(' $e^{2}, 1219$

"Cuder the lied crosis lelage," necount of sanitary rommission of Rockefoller foumblation and Anterican fied Cross in Serbian typhus epidemie, 1915, 184

Woman's Advisory Committee, 300

Bohigny, France, American Red Cross dispensary at, 810

Bogart, Engenia, relief work in Serbia, II 22

Bogle. Elizalleth M(C., chief nurse, Hase Hospital No, 40, 439

Boligny, Miss, nursing services at Ponce, 33

Bordeatux, France, ehildren's hospital at, 79:5

dock infirmary of American Red ('rosis at, 1012

L. S. Base Hospital No. 6 at, 493

Borgesom, 1)r. Eghert, relief work in Sirloia, 1119

Bosio, Nignorina, scholarship to stuly mursing. 1175

Boston listructive Distriet Nursing Association, training for public health nurvine. 1241

Boston Visiting Furso Association Training for publie liealth mursiner. 1:0.51

Bomlevard lielleville dispensary, 809

bouleguesur-Mer. hase llospital So. 5 at 4.53

lowling, fiortrule, Chantanequa nIIr:0. T(1.).

(1) Alerome victory bits

on comblitions at chatealu-Thierry, (itit)

lownant. I. Jatriace. Iti

on llas-ar llospital. $1+6$

on naval horpital at Gireat Lakes, III.. - (11!)

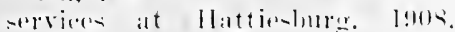
$1: 30$

supervisor of Merey ship, (uit l): $1+t i$

on Tommy Atkins, 1 is
Boyle, Sara Jane, child welfare work at te Glandier, 818

on work at Je Glamdier, 818

Bradbury, 1)r. Bial F., director of Mercy Ship Lnit G, 166

general eonsulting surgeon of German military hospital at Kosel, 166 ;

return of, to United States, 167

Bralforul. Flora, Chautauqua nurse, 10.53

Bradley, Colonel A. S., 484

Bradley, Dr. Frances Sage, on tuberculosis prevention work in France, 8.):3

Bradner, Capt. M. R., relief work in Sorbia, IIel

Brady, Bernice, relief work in Montenecrro, 1106,1107

Braisted, Rear Arlmiral William C., 686,692

Central Committee, 230, 1007

Executive Committee, 1007

National Committee on Red Cross Nursing Service, 248

on eommittee to secenre Red Cross slipe for Worlel War, 140

Bramion, Mrs. Gertrude C., work of, at Ilarlin, !38

Braun, Frederien, on Naval Hospital in fillam, 7:32

Breamx, Lyilia, Clantauqua nurse, 10.5

Bremer. Mrs. Ilatry M., recruiting rolice nurses for loland, Jos.

lirenuin. Agmes. supurintemlent at bellevar, during Sipanish-American War period, $4 !$

Brest, Fance. lowel infirmary of Anorican liod ('poss at. joll

I. S. Army hase ho-pitals near, 996

L. S. Nary Balso IIospital at, 728, 7:3ij

Brent-litorsk. Rod Cross reliof work at. $111 ! 14$

Rerest-litor-k Troits, thit

Herewer, Charletter, at National

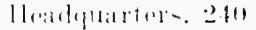

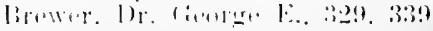

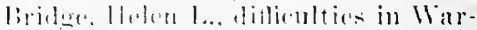
sills. Ilis,

(n entmoltional nur-iller work in

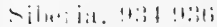

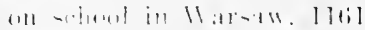

lolief surk in l'ulaml. I lear

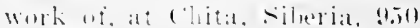


Brigham, Peter Brent, Unit, U. S. Army Base Hlospital No. 5, 452

Brinsmade, Dr. W. C., director of U. S. Navy Base Hospital No. $1,734,996$

British Nursing Service, 472-482 rules for nurses, 476

status of nurses in, 483

Brogan, Mary A., Children's Bureau at Nesle, France, 772

Brookbanks, Nellie V., chief nurse, American Red Cross Military Hospital No. 4, 435

hospital work in England, 429, 431

Brooke, Meta C., assistant on Nurse Corps of the Public Ilealth Service, 1028

Brown, Eleanor Beatrice, visit to devastated area, France, 989

Brown, Mary Magoun, 361, 362, 37 I, $373-374,383-384$

Brown, Miss, relief work in Albania, 1422

Brown, Mrs. Edgar, volunteer lielper, 241

Brown, Mrs. Leonard, 154

Brownell, Mary, Rounianian Commission, 882

Bryan, Dr. Robert C., Roumanian Commission, 882

Bryant, Sallie J., work of, at Berosoka, Siberia, 947

Buchaloo llospital, Siberia, 915

Buchamman, Sarals, relief work in Albania, 1108-1110

Buckler, IV. II., london Cliapter, American Red Cross, 425

Bucklin, George A., Jr., 155

Budapest, establishment of Red Cross hospital at, 172

Budapest, passage of troops through, 175

Budapest hospital. elosing of, 175

relief work at, 173-174

wounded at, thoughtfulness of, 175

Budin, Madame, eliild welfare work, l'aris, s15

Buffalo Distriet Norsiner Assuciation, training for public health nursing. 1244

Bukcley, (apt. Rudolple, on autityphus work in Siluria, 918, (i)!

on couditions in Omsk, 925

on conditions in Silueria, 920
Bukeley, Capt. Rudolph, on Siberian prison trains, 921-922

Bulgaria, mobilization of, 221

plans for nursing school in, 1167, 1168

relief work among Greeks in, 1192

Bull, Mrs. Lanmau, Committee on Nurses of Aluxiliary No. 3, Spanish-American War, 47, 55

nursing services on the Oregon, 32

Bullard, Florence, Chautauqua nurse, 1055

Bunting, Laura, relief work in Samos, 1113

Bureau of Equipment at the Atlantic Division, 371, 384

Bureau of Information for Nurses, $1014-1016$

Bureall of Nurses and Medical Attention, Florida yellow fever epidemic services from, 16

Bureau of Nurses' Equipment, 371

establishment of, 363

Bureau of Sanitary Service under the Department of Military Relief, 346

Burgar, Donna G., on Tiktoria Theater hospital at Gleiwitz, 162

Burges, Anne, at Orleans, France, 1918,740

hear nurse at Camp Coctquidan, 738

Burgess, Clarlotte, supervisor of Merey Slip Lnit C. 156

Burgess, Gelett, on work of Miss Noyes, 1367

Burgess, Edith, relief work in Montenegro, 1106

Burgess, Elizabeth, 95:)

conferences of medical and army ollicer's and nurses, 284

League of Nursing Education, aidles course at Vasiar, 268

Burgess, Mary A., clief nurse of avaluation hospital in Chantilly, 61.5

Burke, Ilrs. E. S., head of Cleveland workroom for hospital supplies, 299

Burlingame, 1)r. C. C.. 531, 619 director. llospital service. Ameriean Rerl cross in France, 531 on American Red C'ross Mlilitary llospital No. 6, (il I 
Burlingame, Jr. C. C., on Americau lial ('ross military hospital at Joully, (io.t

on American lierl Cross Ilospital No. 110 at coimey, 616

on emergency hospital at Auteuil, 5!?

on emergency hospital at Jouysur-Norin, (30).

report of hospital work, 630

Burnap, Dr. Sidney R., 339

Burnes, Oolalı, 49l

Burnham, Dr, Marjurie, relief work in Sicrlia, Ill!

burns. "amberine" treatment for, (i) 1

Bums. Sophia M., conference with Miss Rhodes, itio

Molike llospital No. 9, 649

linrex, llelen T.. on lospital train service, 500, 6i3ti, ti3!), (it42

Burrill, Mrs. 1larve 1)., Sitate Committre of New York. Ilo

Bush, living. 14n

Bushnell, Colonel (ieorge li. Acting surecon General. Merdical Corps, on expenser of appiplnient of Army Nurse (orpes. 370

Butler, Edward D., (onterence to eonsider mursing problems. 2.5t

Butler. Dr. Ethan liatere. director of Serhian lnit No. 2. lso. 18

in charese of sureical parjlions at American lied Cross hospital at Belgrade. 1s.

biatler, Ina li.. Chantaunqua nurse, 10.5 .5

(hiof murse of Jospital Violet, 784

in eharge at Natiomal Jeadquarters during lliss Noyes tour. 1176

(o) results of clatutaurpula talks. 10.5

Butler, Minnette. on ares of eom-

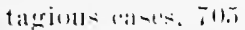

livbere lamios. al chritenu des Hallas humplital. Thl

livingtem. Margaret. on functions of murse and social worker, 1317

Cahanis., silrat nursing in-truction for womlm, lint

(abut. 1)r. libebarel r'.. dirmetor of

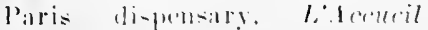
rranen-1 merionin. s:30 ('abot, Najor Richard $A ., 774$

C'adel. Inc\% loritise, chicef nurse of Trudeau fianatorium, France, (.). 2

(ackmus, Nalley, recold of, 64

C'allin, Freda, it lo (ilandier, 819

Callin. liredia 11. on dispensary at line Censier. l'aris. so.)

on dispensary at linlence, France, S 42

Caldwell, Mary, on work at Ameriain liod ('ross Military Hogpital No. 3. $7+8$

California, arly work toward replaceing lied cross State Nursing (ommitter by the State Nirrses Assoriation. sid

Nursese Auxiliary (1!(0!)), 13.56;

puhlic health nursing in, 1342, 1343

(islibits. 1330)

Cambrai, sclood of mursing at, 822

Camerom, Mary Muriel, nursing

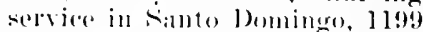

Cammuflage (amp. at Dijon, France, s] 6

('amoullage of ships, 42:3

Camp Blatek, Red C'ross services at, (i)

Camp Coetpuican, artillery training rentre. T3s

('amp lerry yollow ferey guarantine (amp) 15

Cimploul, Fitolle, and cantonment dativ. 3900

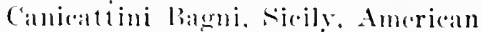
lied ('ross hospital at sti.s

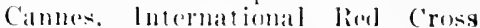
fonference, April. i!l!s, 11:37 report of. 113 sill 111

Canterns. emorenency at railroald stations in fintores. $\$ 3$.

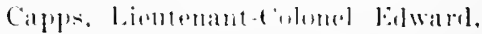
in commintel of commission for

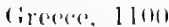

relief work in lireere. 1111

Carditl. Matres. American coaling later. 7.21

lomital at. 721

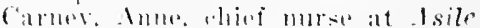
ste. Enetide sin

Carpenter. Mro. Marr li.. on state fommontare of lien Virginial. 1111

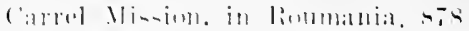

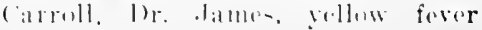
wrikl lw, 11 
Carson, Isabelle F., ehief nurse of American lied Cross Military Hospital No. 23, 430

Carter, A. Maury, at National Headquarters, 240

Carter, Gertrude P., clief nurse of Red Cross unit at Omsk, 925

work of, in Siberia, 914

Carter, J. Ridgely, American Relief Clearing Ilouse, 531

Carver, Prof. Thomas N., Town and Country Nursing Committee, 1219

Casa dei Convalescenti, 866

Casualty Clearing Station No. 6l, 462

Casualty Clearing Stations, 461

Catholie orders, offers from, for Spanish-American War nursing service, 40

Catholic Sisters, nursing services of, in Civil War, 7

Cazalet, Colonel Charles, publie healtlı work at Bordeaux, France, 796

Census of nurses, 301, 304, 305

need for, 306-30s

Central IDivision of American Red Cross, 247

Cerna, Vilma, training for work in I'rague, 1150

Cetinje, Montenegro, relief work in, 1106

Chalons-sur-Marne, babies' hospital at, 828

Chamberlain, Senator, bill for reorganization of Army Nurse Corps, 1066

Chambers, lirank R., recommends nursine course at Vassar, 268

Chandler, Ilyrtle Gilmore, on Naval Ifospital at Parris Island. 708

Chaney, Emily, relief work in Albania, 1110

in Montenegro, 1106

Chanler's llospital, Miss, Red Cross nurse at, 61

Chanler. Margaret L. (Mrs. Richard Aldriehs, in Army Nurse Corps lecistative efforts. 6s, 70

investigation hy, of Philippine nursing anditions. fi?

nursing services at lonce, 33

servides of lit

Chantilly, France, evacuation hos. pital at, 614
Chapin, Dr., conference to consider nursing problems, 254

Chapman, Olive, director of public health nursing, Mountain Division, 1303

"Chapters," or loeal branches of American Red Cross adopted, 1909,102

Charleston, demand from, for nurses, Spanish-American War, 58

Red Cross nurses at, 60

Charlton, Amua, State Committee of New York, 110

Chateau de la Fontaine Bude, 848

Château des Halles, hospital for eliildren, 780

Châtean IIospital, at Sermaize-les. Bains, 829

Chateauroux, France, Base Hospital No. 9 at, 499

Château-Thierry, American Red Cross Ilospital No. 111 at, 617

Châtedguyon, France, Base Hospital No. 20 at, 506,507

Chaumont, France, Base Hospital No. 15 at, 493

Chautalonette Hospital, opened at St. Etienne, France, 1919, 789

Chautaupua coöperation for rural nursing. 1231

Chautauqua nurses, 1053-1059

Cheliabinsk, Siberia, evacuation of, 942

Red Cross hospital at, 940

Chelsea, naval hospital at, 706

Cherry, Elizabeth E., on evacuation hospital at Chantilly, 615

Cherry lline disaster, 131

Chesley, Major A. J.. clicef of staff of relief work in Department of the East, 1087

director of American Red Cross Commission for Poland, 1088, 108!

Chester. Pa.. nursing service at, 1917,136

Chicago Visiting Nurses' Association, trainine for l'ublic Ilealth Nursing. 1243

Chickamanga lark, hospital needs at. 58,59

('hicf nurse (American Red Cross), duties of . j6s-5jo

position after reorganization. 573

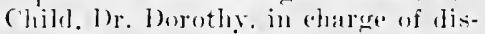
pensary and laboratory, Chate. let hospital, 779 
Child, Dr. Florence, resident physi(ian at Chatelet hospital, 7i!)

Child saving etenters, Dr. Farrund's plan for, 1178

Child welfare, Albania and Montenegro, recommendation for, 1183

child health work in, 1198

Constantinople, 1180

Dr. llill's work for ehild health centers, 1196

expositions. France, 783

at St. Etioune, France, 790

at Toulouse, France, 1918, 795

Europe report of Miss Gardner, 118!-1191

France, 1918, 812

Greece, 1181

Poland, 1179, 1180

program for, 1195

rural nursing, 1231

Children's Bureau in

activitius of $7(55,824$

France,

at Aniens, Tit

at Bloise, 797

nt Corbeil, 798

at Dieppe, 779

at Evian-les-Bains, 777

at Lxons, 783

at Mitarscilles. 7!)

discontiuucel, 1919, 795

at Nesle, $7 \%$

at Paris, sil!

dis(ountinued, 1919, 809

fereling of rhilluen hy, 808

training of visiteuse's d'enfants h. Sll

childrens Bureau of Civil Affairs Department, 757

('hilklen's Bureau. Work of, 760

(hildren's Jlospital, at Evian-lesBains. it

(limere city Hospital at Ilarbin, 937

('lins, relief work in, 1113

(hital, Siherial. American Red cross work at, !1,iu

('hryalkis, Mararet, relief work in Greoce. 1111

chubh, Honclon, National Alvisors (immittere on Instlrince. loit]

('hubh, Perer, estate of, at Wim.

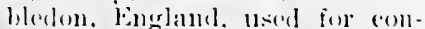
valescent hospital, 43 s

('humbh, Mrs. Margaret l'., rhilil wolfare work. Fance, 19ls, wl:;

Chilelens bureall at jibia. France. $70 \pi$
Churchill, Ladely landolph, Cimmmit. tree of American Women's llar Rerlief Find, itti

Cincinnati mereting of Red ('ross Dietitian Serviere, 1432, 14:3i3

Civil Alfairs Department of Americau lied ('ross, 7.5

Civil IIar, lack of trained nurses in, 5

mursing services of sisterhoods iin, 7

relief work in, by U. S. Samitary Cimministion, 6

Women of, memorial to, proposed, $1: 2: 3$

Civil IVar nurses, roster of, 12

Civilian lielicf. 231

Clark, Alma A.. child welfare work, Francer, 1!1]s, st?

Clark, Dr. Harriet. on Chios, 1113

Clark, Lillian Craig, work of, at Irkutsk, !14

Clark. I)r. lisliaforro, director of Red Cross limealu of sanitary Servicererert of, 346

on fumds for public lealth nursing. 1:2si

surgeon, luited Sitates Health Siervices. $34 t$

Clarke. Major IVilliam E.. Commission for france. 5ti:2

Clarke, Marthal S... at .Isile C'aseme.

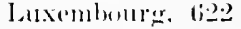

chiof murse of rolief work in Pruzana, Polatmel. Justi. losis

Clarke. Mary A. on Mlis | Malands plan for lome morsing. l:3is. $13.5 \mathrm{~s}$

on Mlins I delancios fitmess for lind Crosis organization struice. T-2

on Red cross enrolhenent of

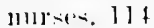

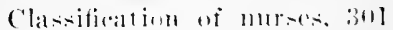

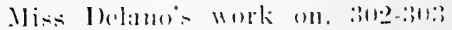
:31t

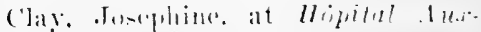
ilinr. \1, :3!. 1!!!

volunterer sorviee at St. Valery. $\therefore: 39$

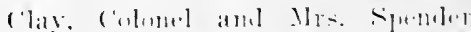

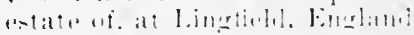

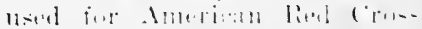

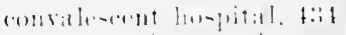

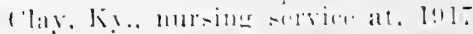
$1: 3 i$

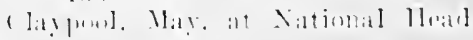
17nteture. 211 
C'layton, S. Lillian, Committee of Transfer, 1022

committee to get hospitals to aid in training army nurses, 286

conference of medical and army oflicers and nurses, 284

conference to consider nursing problems, 254

enrollment of nurses, 290

plan for special enrollment, 258

Joint National Committee, 1047

Joint National Committee of

Bureatl of Information, 1016

National Committee on Red Cross

Nursing Service, 248, 249

Clement, Fannie F., Committee of

Rural Nursing, 1216

eonference to consider mursing problems, 253

director of Town and Country Nursing Service, 240

head murse, Red Cross Town and

Country Nursing Service, 206

National Committee on Red Cross

Nursing Service, 249

on elassitication of nurses, 1271 , 1272

on plan for rural nursing, 1218 on public health nursing, 1253

on Red Cross influence, 1232, 1233

on training for public health nurs. ing, 1246

outlime of activities for rural nursing, 1217

report on work in rural nursing, $12 \div 6-1231$

resignation from rural nursing, 1234,1235

superintendent for rural nursing, 1215

work for public health nursing, report. 1913. 12222-122.24

(')endenning. Editl, head nurse of l'olish army hospital at Vilna, 10933

('lothing and supplies, purveyed by lilorence Nightingale, 3

('lube for nuraes. Ameriean Ninses (lub, lomolon, 4.2.)

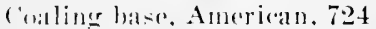

(ubh, Davirl J... commer American Dational Recl ('ross, ls98. 25)

(i,blenz. occupied by Anurican lied ('ross, 994, 99.5
Coetquidan Camp, artillery training centre, 738

Ooffey, Anma E., assistant chief nurse, A. E. F., in France, 503 nursing service at ChâteauThierry, 634

Coffin, C. A., Committee for Memorial Fund to American Nurses, 1048

Cohan, France, conditions at, 753

Coincy, France, Ameriean Red Cross Hospital No. 110 at, 616

Colburn, Clara, Committee on Red Cross Dietitian Service, 1379

Cole, Aileen B., on reception of colored nurses at Camp Sherman (Dec., 1918), 406-407

Cole, Mary L., director of Public Health Nursing, 1304

Collin, Dr., clild welfare work, Paris, 815

Collins, Dr. Joseph, tuberculosis prevention work in Italy, 867

Colon, Annie L., work during influenza epidemic in Michigan, 978979

Colony Club, mobilization station for nurses, 420

Colnmbia University, training for public health nursing, 1252

Concord, N. 1I., District Nursing Association, 1244

Conley, Enma, chairman, Committee on Red Cross Dietitian Service, 1379

Connecticnt Training Sehool, offer of, for Spanish-American War service, 40

Connelly, Betty, chicf nurse, Mobile Unit No. 5, 451

Connely, Willard, on training of hospital corpsinen, 712

Connor, Major C. II., National Committee on Rad Cross Nursing Service, 249

Constantinople, conditions in, 1180 mursing school in, 1168, 1169, 1170

"Contract doctor," 350

"Contract nurse," 350

Contrexerille. France, U. S. Army Base llospital No. 32, 503

Convalescent Bureau, 614

Convalescent home, la Chaur, at Lyons. France, 7s.j

Convaleserent homes, Ameriean Red Cross, 732 
Convalescent homes for nurses, 1033 . $1035,1037,1040$

at Rowaton, Conn., SpanishAmerican War, (6l

Comvoy system of transportation, its

Coolidge, Mrs. J, Raudolph, Jr., Woman's Advisory Committee, 300

Cooper, Edna, hospital train service, inot, 6336

Coopere, lemal li., Committee on Red ('ross Dietitian Sorvice, 1378

letter of Major Murlin, 1400

snpervision of dietitians' report, $14 \cdot 25,1426$

vice-president, American Dietetie's Association, 13998

Cooper, Mrs. Margaret li, Cliautauqua murse. 1053

Copelin, liessie A., on trip to Flenry-sur-Aire, 623

Copp, A. IV., on Commission for Europe, 5:30

Corbeil, France, playgromel at, Sol

Red Cross dispensary at, soo

work of Children's Bureatu at, lo1s, 7!s

Corbet.t, Mliss, work for dietitians' entolhunt for Red Cross hospital service, s.5

Corbin, Aljutant-fieneral, letter from, aluthorizing lied Cross nurses for the Philippines, (i)

Corps insignia, Navy Nurse Corps, (i) 9.5 . (j9)

Correspontence courses for nurses' training. 20

Connty larm Bureau, cö̈peration with public health nursing. 13.) 1

Covor, 1)r. Ellen, rhateau des Hallest llospital, 7so

(owelin, Mrs. Minthrop, ts

active menrlore commitese on nuirime. Susiliary. Xo. 3. Span-

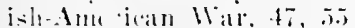

first relatiman, (ommitter to Reranre be det of fonereese the kmplesment of 11 inmen Norses

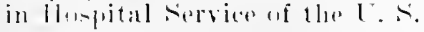
Army. lit

(1) sperial remmitter for cluser

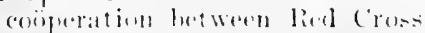
amd Emoremment, jti, is
Cowles, Mrs, William L., Committre on Nurses for the Philippilues, 62

in Army Nurse corps legislative etfort, 70

pioneer momber of Auxiliary No. 3, Spanish-Amerian Mar, $t 7$

Cowman, 1)r. lsabel billiot, vioepresident, Suciety of FinalishAmerican llar Ninrses, ti

Cox, Dorothy, child welfare work at lyoms, Franeo, 786

Cox, Mary l), ill with typhus. 1!)

Cramdall, Ella lhillips, aicl in gectting curollument of murses, 2yon committer to get hospitals to atid in training army nurses, est;

Joint National (ommittere, 1047

Joint Xitional Committee of Balrean of luformation, lolf;

National committer on lied cross Nursing Sorviare. 24!

on National (Orgatuization for P'ublic Ilealth Nursing, loge esecutive secretary, 347

resolution for rank for army nurses, 1074

Town and Comuty Nursing Committr(a, l:2)!

work at bayton, Olito, Hood, 1!13, 134

Crawford, Malude s., on romdilions

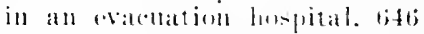

Crawford. Salrah Alam- -npervisjug nurse of linrean we linber-

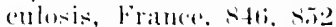

Crodick, klisaleth. on Amerian lied croms Military llospital No. .7, $1 ; 01.2$

crete. infiat weliage in. 1116

Crigliten, lily li., alicef nurses in Amerian lial cross llilitary lloipital So. if alt St. ('loul, (i)!

(rile. 1)r. Aicorere 15 .. direnter of l. . Army liate Horpital No. 1. 1.3k+rithe :3:34, 413

oreaniation wi hase lomplatals for

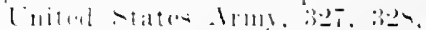

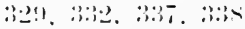

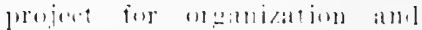

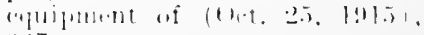

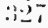

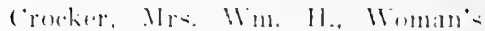

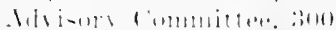

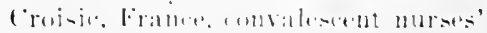
lonme at, luth 
Cromelien. Maud, visiting agent of Auxiliary No. 3, Spanish-American War, 51

tour of field hospitals, 58

Cromwell, R. Lee, 159

Croslev. Sara, relief work in Serbia, 1120

Cross, lliss, roluntecr helper, 241

Crowell. Elizabeth, tuberculosis prevention work in France. 845

Cuban eivil hospitals, American nurses' work at, 64

Cuban Red Cross nursing contingent. first. 30

Cudahy, Mrs. Joseph, Board of Incorporator's of American Red Cross, 1007

Wonan's Advisory Committee, 300

Cullen, Mrs. Thomas S., head of Baltimore workroom for hos. pital supplies, 299

Curley, Teresa, ill with typhus, 191

Curtis, Margaret, child welfare work, 1187

director of Bureau of Refugees and Relief, Paris, 825

Curtis, Mrs. Namah, mursing organization services of, 38-39

Cushing, Dr. ILarvey. 32!

director. liase IIospital No. 5, 452 organization of base lospitals, 332,333

Cushman, liuth, on bombing of Châlons. 6.54

Cuthlert, Eugenie J., volunteer helper, 241

Cutler. I. Otis. manager of Fourteentl, Division, 912

Cutting, Mrs. Bavarl. in Army Nurse Corps legislative efforts, (is

pionepr member of Auxiliary No. 3.47

Croch naval hospital. 913

Czechorlerak army, activities of, in siberian. 9 I0

Cacho-sonkia child welfure in, $11 s !, 11 !+6$

relior nurses in, los.

schoml for nur-es at l'rague, 115011.54

1)illman, Janr T.. C'hantaufua nurste. 10.5.j

Mailay. Ann" Chautancua nurse, (1).5.
Dallas floods, 1908, 130

Dallyn, Capt. F. A., director of Inter-Allied Commission, expedition in Siberia, 918

Daly, R. J., Commission for Europe, 531

Damar, Annie, instruction for women, 1354

Damer, Miss, Alumnæ representative, Committee for affiliating organized nurses with Red Cross, 73, 87

on need that state nursing asso. ciations act directly for Red Cross, 86

on nurses' enrollment with Red Cross, 81

Daniels, Josephus, on hospital expansion at Norfolk, 700

Danna, Dr. Joseph A., director U. S. Base Hospital No. I02, 665

Dannes Camiers, France, air raids at, 453,472

U. S. Army Base Hospital No. 5 at, 452

U. S. Army Base Hospital No. 12 at. 469

D. A. R. IIospital Corps, and Society for the Maintenance of Trained Nurses, coöperation between, 60

Darche, Louise, early nursing superintondent, 19

Darrach, Major, at British front, 4.54

Darst. Lieutenant Gilford, 140

J)artiord, England. C. S. Base Hospital No. 37 at, 4.37

Daspit, L. Agnes, director Gulf Division of Red Cross, 246

Danser. Stle Sophia, chice nurse of I. S. Nary Base Itospital No. 3. 72.2

on L. S. Navy Base IIospital No. 3,723

Davis, Major-General George IV., chairman, Central Committee, 206

Davis. Rer. Robert, Commission for Europe. 5:31

1)aris, 1)r. linbert. wor: with children in 'Toul, 76.5

1)avis. John W., Central Committee, 230

Davison. II'pry l'., aceepts aicl of National Committee to Leagne, 1142 
Davison, Henry P., and nurses' equipment, 364

at International Conference at Cannes, 1919, 1137

chairman on War Council, 25̃3

conferenee to consider nursing problems, 254

Excentive Committee of American Red Cross, 1007

opinion of Miss Delano's services, 967

Work of, for Red Cross, 1136

Davison, Mrs. Henry P., elatirman of Committee for Memorial Fund to American Nurses, 1047, 1048

Delano Memorial Committee, 1051 recruting relief nurses for Poland, 1085

Day, William R., action toward fixing official status of the Red Cross, 26

Dayton, Ohio, floods, 1913. 132

Dean, Mrs., efforts for Red Cross affiliation, 71

superintendent at Mt. Sinai, 49

Deans. Agness G.. National Committee on Red Cross Nursing Service, 249

conference to consider nursing problems, 253

Nursing Service Headquarters, 238

De Arizeun. Madame. 154

Deaths of mirses during war, 1032

De Cabrole, Maslame, 1.54

Deeentralization plan, 242

1) Forest, liobert W., Central Committee. 230)

Dehelley, Dr.. work of, in Rommania, $8 \rightarrow \dot{S}$

Delano. Tane Archer, activities of, during Spanish-American War period. 72

address to (onvention on Nursing Edheation, 9:7-962

Ameriean lied cross parade, New York, 420

appeal to graduating nurses, 343

assigmment of reserve nurses to

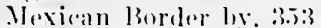

at Twentioth Annuil Comvention.

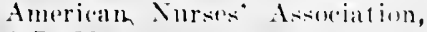
35i-3iss

burial of, temporary, at Savenay. 1004
Delano, Jane Arcluer, cantonment nonrsing, during apitemic of

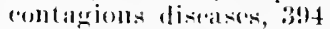

censils of murses, 301

chairman of conference to consirler nursing problems, 25:3

chairman of National ('ommittee, 320

chairman of National committee on lied Cross Nursing Service, $9 ;, 96,127,248$

Christmas boxes to nurses overseas, 207

committere lexture comrse for Red C'rosis murses, 122

Commitlee on Rod C'ross Dietitian Serviere 1378

Committee on Rural Nursing, 1.216

committe on settling war nursing policy. 2.jt

committee to gret hospitals to aid training army nurses, 2S6, 287

committees for inmses' enrollment, $10 \mathrm{~S}$

Conference of Medial and Army (oflicers and Nurses, est

correspondener with reserve nurses on Mlexican lingrder, 353. $351 ;$

death and funcral of, at Savenay, $10013,1001.161322$

delerate to Nintlo Intromational hed Cross comference. I!12, 124

development of American Red ('resses muler, :3:30

directions to murees' aides (let(ar), 274.27 .5

director of Ninrsinger ets

early lifo story of. li, li

editur lied ciose Deplatement of Imrrican fournal of lursing. 115

offorts for Rad cross atliliation. it

embalkation for trip orersats. 99.

Emercuney committe on linsinc. 21 i

fonal reting platw ai, at Arliner-

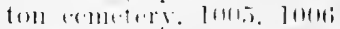

le:thl uf Initul stille nur-ine

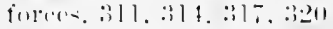

in Florila yellow forer eppidemie, $1+i$

$l_{a=1}$ limblutaly of lom

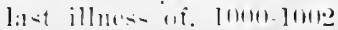


Delano, Jane Archer, letter of introluction from Walter D. McCan. Chief Surgeon, A.E.F., Paris, 999

letter to nurses, at time of war, 1272,1273

memorial for, 1049, 1050

National Committee on Red Cross Nursing Service, first meeting, 102

National Relief Board, 1912, 125

Nursing Staff, 1916, 235

on afliliation of Red Cross and state societies of nurses. I12

on Army Sehool for Nursing, 963, 96.5

on assignment of colored nurses, 406

on Base Hospital No. 57, 999

on elassification of nurses (report) 300

on Committees of Red Cross Nurs-

ing Service (report), $2.52,2.53$

on Dietitian Serviee, 1381

on dictitians' classes, 1378

on enrollment in the Nursing Ser-

vice. $35 \overline{7}, 391,392$

on enrollment of nurses (report), 289, 290

on expipment of Army Nurse Corps, $374-383$

on first lay at Brest (diary), 996

on home nursing, 1360

on incerest in nursing after war,

1362. 1363

on Navr units in Schools. 693

on Nurses' Drive (report). 291

on nursing (ensus (letter). 308

on nursing groups coöperating $(\mathrm{repos}) \mathrm{t}), 26 \mathrm{t}$

on offer to send Redl Cross nurses

to Mrican horder. 35)

on public health nursing (report), 1.27 .5

on routine work (letter), 236, 237

on rumors of treatment of nurses

aleroad (form lotter). 263

on roral nursing, l2]k, 1217

on scholarship and loan fund for

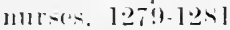

on statlis of Army nurse. 1067lofi?

on status of public health nurses and special service groule (lot$(\sin ), 2-2 \mathrm{~s}$

on traching centrers for home nursing, $1363: 3,1364$.
Delano, Jane Archer, on trip across Atlantic (diary), 996 on uniforms for Red Cross Nursing Service, 358-360, 366, 369, $377,378,380$

on work in first making surgical dressings, 296. 297

on visits to hospitals around Brest (diary), 996-998

on volunteer Nurses' Aides (letter ), 275,276

considering advisability (letter ), 269,270

status defined, 2$\rceil 1,272$

on work in Red Cross (letters to Miss Noyes), 232, 233, 234

on work of volunteer helpers (letter), 241

organization of base hospitals by, with Colonel J. R. Kean, 333 organization of Red Cross Nursing Service by, 139. 230

plan for Army Sehool of Nursing, 286

plan for demobilization and aid to nurses, 1015. 1016

plan for home nursing books, 1358 plan of division directors and relation to Headquarters, 243, 244

purpose of emergency detacliments defined by, 341

Red Cross enrollment, services in, 76

relationship between Army Nurse Corps and Ameriean Red Cross Nursing Service, defined hy, $31: 3$

selection of nurses for Merey Ship Expedition hy, 140

superintendent of Army Nurse Corps, 96

resignation of. 98

talk to nurses at Xay Base Hospital No. 1. 99s

trext bork of, 1368

Town and country Nursing Committee. 121 ?

tributes to, 100.5

twent y-year nursing service period before Red cross atliliation, 17 will of, lo.il

work during influenza epidemic, 980

work for home nursing courses. 1366

work in consus and rlasifieation of nurses (letters), 30:-304 
Delano, Jane Archer, work in nurses' drive (Miss Noyes' report), 292,293

Welano . Memorial Committee, 1050, 1051

Delano Red Cross Nurse, 105l

Dwany, Commander E. II., 140

De Lassenee. Mayor Alfred, 154

De Long. Katherine C., work of, in Italy, 863

De Luze, M. Charles, public health work at Bordeaux, France, 796

Denio, Oregion, work during influenza epidemic, 978

Denisom, Dr. Walcott, 168

Denison. Faith, at Palanka hospital, Serloia, 1118

ill with typhus, 1119

Dennison, Maj. Robert C., relief work in Albania, 1107

Denny, Lenna Il., head nurse of I'raga hospital, l'oland, 1092

Dent, Congressman S. IInbert, bill for reorganization of Army Nurse Corps, 1066

Dental clinies, rural nursing, 1230

De l'age, Antoine, organization of Belgrian Red Cross hospitals by, 200

De Page, Madame Marie, death of, on Lusitania, 201

in Enited States to raise funds for Belgian Red Cross, 200

Dershem, Mabel, nurse in Santo Domingro, 119!

1) Wha, Mary, work on IIospital Corps Committee, 36

Detroit Visiting Nurse Association, training for public health nurses. 1243

Dovagne. Mrs.. child wolfare work, Paris, sls

Drvine, Dre Eelward T., chief of licfuncess and Relief Bureatu, France. 8:6

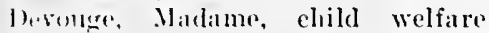
work, l'aris. S15

Devainte, Dr., child welfare work, Fiance, 19]s. 812

D) Witt, Katharine, editor. Red (rose Nursing brpartment, 1 merionn Journal of Jursing, sti enrollment of murses, work for, $296)$

Sireretary of Natiomal Committere letter tu secure rauk for nurses 11170,1071
Dewar, Janet, chief nurse at Vhulirostok liefugee llospital, 927 on mursing efmeation at Vhadivostok kofuger IIospital, 9.2

Dewey, Elizabetlo, commendation of work of, 751

on work at liedel llospital No. 7, 7is 1

on work at Field llospital No. 12, $748-750$

State Committee of New York, 110,112

Dexter, Major Elliot G,. relief work in Montenegro. 110:2

Diemer, Mlle., ehild welfare work, France. 19]8. 812, 815

on visitruses denfonts. 816

Dieple, France, work of Cliildren's Bureau at, 779

Diet Kitchen Serviee Oversoas (report). 1411-1417

Diet kitclens, organization of by Florence Nightingale, 3

Dicteties, home, 1364

Dietitian, classification, 1390, 1391

Dietitian Service, 137.1-1398, 13991441

report for year 1919-1920, 143.5, 1436

Dietitians, enrollment of, for hospital serviee. 85)

Miss Noyes' eireular letter to, $1379, \mathrm{3} 3 \mathrm{SO}$

insignia of, 1401

rank of. 1402

silary of, 1402

uniform of, 1401

Dijom. France. Bise Hospital No. 17 at. 494

Ilospital Init "s." at. 4 !)

Dinat. Fance. Work with ehilenen at. $76 !)$

Disability fuestiomalire for ex-ser-

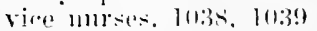

bisease, prerentage of deat he due to, !sti

Dispensaries, etablishel by American lied crow in lourope. Jits

taken were by wher oreanizal tions. 71

location off. at valuins points in Fiallur. Tris

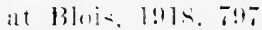

at Buhiens?. Sintes 411

at curlwil. care of American -rideliers.

at Girinclle. sols 
Dispensaries, location of, at various points in France, at Levallois, $19 \mathrm{I} T, 803$

at Lyons, 785

at Marseilles, 792

at Paris, 802,810

Bonlevard Belleville, 1919, 809

at Rue Censier, 80.5

at Rue de l'Argonne, 808

at Rue de Pre-Saint Gervais, 808

Dispensaire Marie-Lannelongue, 807

Dispensaire des Mignoties, 807

La. Courneure, at Paris, 806

Mutualité IIaternelle. 807

Poteaul Dispensary, 808

at Toul, 768

travoling, at .Jorusalem, $8 \Omega 5$

District Nursing Association of Troy, X. Y., group affiliation witli lierl Cross, 85

District of Columbia, first enrolled lied Cross hranch, 76

District of Columbia Red Cross Branch, pioneer in home care nursing organization work, 80

Division directors of nursing, 242

Division of Institutional and Student Assignment, 1017

Division of Public Tealth Nursing, 1017,1020

Dix, Dorother L., and accomplishmont of. 9

leacl of Inited States nursing forces, 311

Doane, Marion. Jeard nurse of $\mathrm{St}$. Luke's JIospital, Tokyo, 917

Dock, Lavinia J.. nursing services of at Johnstown floorl, 18

in Florida yellow fever epidemic, 16

Dodrlridge. Commander J. S.. 140

Dodere, Mr. and Mrs., loan of estate for convalescing nurses, 1034 , 1035:

Bowlger. Perter. Browing Company's trucks. :373

Dololior, kathlern, relief work in

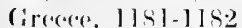

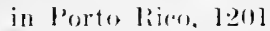

Dollinger. l'mofesor onlins, contres of. te American lied Cross Staff, 173
Dominican Republic Red Cross relief, 1199

Donald, Jennie, Roumanian Commission, 882

Donnelly, Dr. James F., illness and death of, 191, 193

Donnelly, Katherine, 349

sent to Vera Cruz, 1914, 128

Donet, Dr., child welfare work, Paris, 815

Donovan, Capt. J. J., relief officer at Vilna, Poland, 1093

Doub, Mabel E., work of, at Harbin, 938

Douglas, Arizona, nursing aid given at, 1911, 131

Douglas, Constance, work in Personnel Houses, Saloniki (report), 1420,1422

Douglas, Harriette Sheldon, director of elementary hygiene and lome eare of sick, 1369

Nursing Service Headquarters, 239

on work on instructors, 1372

Downer, Dr. Earl B., assistant surgeon at Belgrade American Red Cross hospital, 183

on capture of Belgrade in second Austro-German offensive, October, I915, I86

Dowling, Miss, appointed for Philippine service, 63

Downing, Mrs. Florence, director of I'ublic Health Nursing, 1304

Doyle, Jennie V., State Committee, Oregon, 112

Jrama, Macedonia relief work in, 1115

Draper, Helen F., on committces for nurses' eurollment, $\mathrm{I} 07$

Draper, Martha L., work of, at Cliarleston, S. C., 58

Draper, Mrs. Amos G., member Army Nurse Corps legislation comnittece, 67,70

work on IIospital Corps Committee, 36

1) raper. Mrs. William K., ehairman Woman's Adviwory Committer, 300

Committes on Rural Nursing, 1216

conference to consider nursing problems, 253 
1)raper, Mrs. W. K., embarkation of unit, L. S. Army Base llospital No. 4 (Lakeside), 4l:)

first meeting of National Commit. tee on Red Cross Nursing Service, 102

National ('ommittee on Red Cross Nursing Service, 95, 127, 249

on enrolment of colored nurses, 405

services for Red Cross enrollment, 76

Town and Country Nursing Committere, 1219

work toward securing superintendents' eligibility for Red Cross work, 84

Drever, Mlary E., vice-president, Soeicty of Spanish-American War Nurses, 46

Drown, Luey, early nursing superintendent, 19

Drunkenness, efforts to combat, by Florence Niglitingale, 4

1)uensing, Fmma, death of, German Army service, 65

Dumaut, Henri. inspired by Florence Nightingale, 2

organization efforts of, for relief society, 1863,5

Dunbar, Irs. I. I., cluaiman, Nurses' Committee. 129

Dunlıp. Margaret A.. elice nurse, American Ambulance, at Nenilly, France, 226, 536

chief nurse, Base Hospital No. 10 , 459

Durand. Dr. .T. I., member of Children's Burean, France, 758

Durazzo, Albania, relief work at, 1110

Durrleman, Mlle., scholarship to stucir nursing, 1175

l)wer. Elizabeth H., on hospital ships. 700

on Norfolk Naval IIospital, 700

lakins, Martlua St. John, clijef nurse. Nenilly hospital, 538

Fast fit. lonis, nursine service at, 1917. 1:30

Fastern Division, American Red ('ross, mursing alctivities of 93!)

Enstland disistur, 1915, 135
Wehols, Miss, delegate to Ninth International Red Cross Conference, 19)12, 124

Echtermacle, Marion, rolief work in Albania, 108

Ecole de $\therefore$. I. La Reine, at Le Glanlier, France, 818

Fenry, France, Evacuation llospital No. 6 at, 64.5

Eddy, Ruth, lalestine Commission, 892

Eden, Marie, at Le Tríport hospital, 463

Fdith Wharton Sanatorium at Yerres, France, 853

Edson, Mrs. Sarah, Civil War nursing services of, 11

Education, nursing, international, 1145

Red Cross plan of schools in Warsaw, $1156-1158$

convention for, 95.5-962

requirements for, 1237

Educational facilities. arranged by Florence Niglitingale. 4

Educational Committee of National Organization for Public Iloalth Nursing, 1253

Edward Trudeau Sanatorium, at Plessis-Rohinson. 853

Egbert, Dr. Elwarl, director of Merey Ship Lnit C, 1.56

Fl Paso, Texas, nursing aid given in, 1911,131

Elderkins, Mary, on armistier day in France. 98?

member of operating team sent to line, 741

on conditions at Cohan, France, 753

on work at Fvacuation Ilospital No. 8. 754

on work at Jonilly. 742

on work with Ficld Hospital No. 112.752

Eldom. Miss, chief nurse. Nursing Burean, dmericin lied ('rons, 618

Eldredge. Adlat ahairmiur. Stata

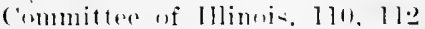

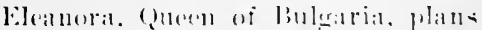
of. for etablishinter tratuing selonol for norres in sophlial, It?

Ellot. Tusphline. (hildren's liureall, it Tull. 7ti

relief work in liotmmania, 1120

Elliott. Dr. Mary, in Sirlial, 1117 
Ellis, Maude, ill with typhus, 191

Ellis Island, mobilization centre at, 416

Ells, Marie C., child welfare work, France, 1918, 813

Embarkation of nurses, 423

Emergency Committce, Red Cross, 264

Emergency Hospitals established in France, 595

at Beaurais, 596

at Chantilly. France, 614

at Jouilly, France, 603

at Jouy-sur-Morin, 605

in war zone, 612

nurses assigned to, 617

Emerson, Dr. KendaII, Committee Memorial Fund to American nurses, 1048

Emerson, Ilajor, acting medical director at Vladivostok Refugee Hospital, 927

Endicott, William, Commission for Europe, 1917, 427, 530

Engblad, Mrs. Grace, director of Bureau of Public Health Nursing, 1303

England, American Red Cross Commission work in, 441

American Red Cross hospitals in, 431

changes in American hospitalization policies in, 440

Enright, Miss, Graduate Nurses' Protective Association of New York State, 40

Enrollment of nurses, Miss Delano's report, 289,290

plan of National Commitiee on Red Cross Nursing Service, 96, 102

Enrollment of Red Cross nurses, 114

Epstein, Miss, work in Poland, 1096

Equipment of nurses for overseas duty, 575

Equipment Slop, Nurses', Paris, 万is

Es Salt. Palestine, conclitions at, 90.)

Escort duty. ocean. ill

Etretat, France, Hase IIospital To. 2 at. 4.54

Europeat Inquiry Commission, 1188

Furopean systemi of Red Cross nursing, idcals of, 21

European War, 387-fist

building of embarkation camps in, 389
European War:

camps in organization of, 389-391 need for nurses, 390-393

cantonment lıospitals, establishing in, 389-393

cantonments in, organization of, 389-391

need for nurses, 390-391

entry of United States, date of, 387

'Red Cross base hospitaIs in, mobilization for, 389

training schools in, establishing of, for artillery, 389

for aviation, 389

for chemical warfare, 389

for engineers, 389

for tank and quartermaster corps, 389

Evacuation Hospital No. 4, Écury, France, 645

Evacuation Hospital No. 6, Écury, France, 645

Evacuation IIospital No. 8, Souilly, France, 754

Evacuation Hospital No. 9, 648

Evacuation Hospital No. 114, Fleury-sur-Aire, taken over by Medical Corps, 624

Evans, Charles, chief of Bureau of Friends, on American Friends Serrice Committee, 828

Evans, Madelaine, chief nurse at A sile Site. Eugónic, 8.̃o

Evian-les-Bains, children's hospital at, 777

return of French to, 775

work of Children's Bureau at, 777

Évreux, France, American Red Cross Hospital No. 109 at, 609-610

Ewing, Anna A., director of Bureau of Public IJealth Nursing, 1303

Ewing, Mary C., organization of tuhereulosis sanatorium at Yerres, 848

Exton, Katharine D., child welfare work, France, 1918, 809

Fairchild, Blair, seeretary of $T u h r r$ culeraur de la Guerre, France, 844

Fairchild, llelen, at liritisl easualty de:aring stations, 461

Fairclomgh, Il'ney R., relief work in Nontenegro, 1102 
Faleoner. Marje F., in Santo Domillego, l19!

Firmer. Floremee, 159

at Tumen Ilospital, Siberia, 924

work of, in Siberia, ! lt

asisistant to Dr. Conlter in Siberia, 9.20

Farnsworth, Clara (a., in Santo Domingro, 1199

Firrand, 1)r. Livingston, appointed chatrman of American Red ('ross, 1007

attitude of, on rank for Army murses, 1075

eareer of, $] 007$

('outril Committe for European ('ummission, 1079

director of the Rockefeller Commission for tha Prevention of Tulereulosis in France, 844

Executive Committe of American lied Cross, 1007

uffers aid of National Committee to League, Il 42

recommenils plan for "child saving e(n)ters," 1178

tulereulosis prevention work in lialy. 567

work for soholarship and loan fund for nurses, 1.281-1283

Farrambl, Mrs. l.. child welfare work at corlesil, France, 799

Farwell, Dr. Margaret W., dispensary at Corboil, France, 799

Fiverweather. Dr. Roades, director of Merey ship [nit B, 150)

fearn, Miss, elijlal welfare work, Framer, 19]8, som

Fecleral Pululic Ilealth Serviee, 973974

Fenlerittion of Nurses Committee on lienl cross Nursing, work of, 87 !.2

Federation of Nurses, desire of, for lind ('ross nursing, $87,88,89$, (1)

Ferres. Dorethy M., sllperviser of lingrinm [nits Xos. ] and 2 , 231]

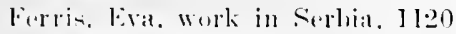

Field lloppital No. 7, Coulommiers, France, 流

Finll llospital So. I:2, Pierrefonds, Frathere Tt!

Findel Ilu-pital No. 10!9. iti

Find lluplital No. 11: it7
Ficlu Ilospitals, manned by Red ('rosis nurses, 5]

Fife, Major J. I)., Base llospital Xo. 21,467

Finamees, plans for visiting nurses, $12(i)$

Finlay, l)r. Charles, yellow fever work of. $1: 3$

Finley, 1)r. John 11., Commissioner for l'alestime, s!le

Finney, 1)r. lolun W. T., director, liase Ilospital No. Is. 486

Firmaturi, Marchesa, Seloblarship \& Stuly Nursing. 1]73

First Aiti Departurent, organization of 1910,1$] 1 ;$

Fish, Ada $Z$.. autlior of "linod Values antl Home Dieteties," $1: 377$

Committee on Red Cross Dietitian Service. 1379

Fiteh, Dr. Ralph, director of Alliance llospital at rietot, lirance, 195

director of llopital romplimen-

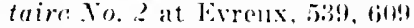

in elarge of French military hospital at st. Valory-en-Catux, 198. 539

Fitzerald, Alice Lonise Florence, carcer of, .js.3

chief nurse of Amerion lied Cross in Europe, si2, 1082 resignation of, 1]:2!

Committer for llemorial Fund to Amerienu Nerses, 1048

development of Reloosls of Nursincr, 1145,1146

director of Division of Nursing of League, 1143

resinnation of, 1146

explains lobignte of licd Cross $S_{0}$ ijetiks, 11\%]

in rharese of work with serrioe de sentr. .853

Intermational tonierence at ('annes, 11:37

on doek intirmaldes for soldiers

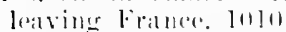

on derek infirmars at lipest, 1011

on enuipment for nures in Enrole, l112:3

on linn. Mimel's statf in lhilipline?, 1:31!!

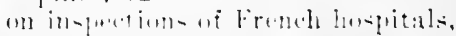
is is int

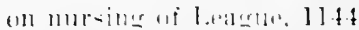


Fitzgerald, Alice Louise Florence, on opening Rimini Refugee Hospital, Italy, 860

on public health nursing in Italy, 872

recommeudation on relief work in Poland, 1091

relief in Europe, Polish, 10881091

on visit to Prague, 1148

tour of inspection in Poland, 1089

work in Sicily earthquake, 1908, 131

Flanagan, Katluyn, children's convalescent home, La Chaux, 785

Fleming. Mary, relief work in Crete, 1116

relief work on Mitylene, 1114

Fleteher, Gertrude, matron of "Oldway House," 147

on expected sickness at beginning of World War, 148

on psychology of war nursing, $147-148$

Fleteher, Mabel, Chautauqua nurse, 1055

hostess of Bay Shore Convalescent Ilome for nurses, 1037

Fletcher, Mary M., chief nurse, Evreux hospital, 539

delegate to Ninti International Red Cross Conference, 1912, 124 on English Tommies, 197

supervisor of Alliance Ilospital, at Yretot, France, 195 resignation, 197

Fleteher, Nori. British Nursing Service, 476

Fleury-sur-Airr, Evacuation IIospital No. 114 at, $(624$

Flexwer, Bernard, Roumanian Commission, 882

Flexner, Dr. Simon. Chairman Red Cross Medical Advisory Committere, 2.)3

committee (dhairman) on scttling war mursing joli( $y, 254$

conforence to amsider nursing problems, 254

Flowel, Dr. Mabel F., in Serbia, 1123

florence $/ 1$. . s.... (xplosion on, 730

Florence Nightingale Fomblation, I.24

Florence Nightingale Madal, 1130

Florilat vellow forer apdemic, nursing history of, $13-18$

[iod ('rosis a id in, 13
Floyd, Lulu T., sent to Vera Cruz, 1914,128

Flynn, B. D., National Advisory Committee on Insurance, $10+2$

Foch, Marshal, commander-in-chief of Allied Forces in France, 580

Foerster, Alma E., Commission to North Russia, 677

committee on choosing candidates for medal, 1130

on trip to North Russia, 678

on work in North Russia, 680-683

Roumanian Commission, 882

Foley, Edna, chief nurse of American Red Cross Tuberculosis Commission in Italy, 871

Delano Memorial Committee, 1051

Town and Country Nursing Committee, 1219

Folks, Homer, child welfare work, 1187

director of Civil Affairs Department, American Red Cross, 757

on work for refugees at St. Sulpice, 8.37

Food and Nutrition Division of Sanitary Corps of Army, aid to dietitians, 1399

work of dietitians, 1402, 1403

Foodstuffs, to Nortl Russia, 677

Ford, George B., Commission for Europe, 530

Foreign activities, American Red Cross, development of, 536

Foreign relief work of the American Red Cross, 1077 et seq.

Fort IIamilton, Red Cross services at, 61

Fort Wadsworth, authorization of Red Cross nurses for. 57

Red Cross nurses at, 60

Fortress Hospital, in Vladivostok, 913

Fortress Monroe. Red Cross service at, Spanisti-American War, 61

Fortson, Mis, public health nursince, 1348

Foshurgh, Major James B. A., on emereney lospital at Beanvais, 596

on position of American Red Cross supply units, second battle of Picarly, 579

on sanitary situation of Second Division. (60)3

or work of American Red Cross overseas, (ils? 
Foscani Unit, Roumania, 1126

Foteenoff Ilospital, Sofia, Bulgaria, 221

Foundution to Florence Niglitingale, 124

Fox, Elizabeth Gordon, director of Burean of Public llealth Nursing, $1275,1276,1302$

director Town and Country Nursing Service, 240

functions of nurse and social worker, 1317

meeting of heol Cross anthorities with state oflicials: results and problems. 1324-1326

National Committee on Red Cross Nursing Service, 249

on Town and Country Nursing Serviee, 1276

France, division into nine zones by Commissioner (iihson, 612

nurses in, shortace of. 514

German activities in, 464

physicians in, 1917, 758

refugees in, American Red Cross' work for, 826,843

relief work in, 1080, 1081

C. S. naval hospitals in, 728

Franeis, Mary L., chicf nurse, L. S. Army Base lIospital No. 15, 493

Francis, Susan C.. director Pennsylvania Division of Red Cross, 245,246

Joint National Committee, 1047

Joint National Committee of Bureau of Information. 1016

National Committer on Red Cross Nursing Service, 249

on mursing and public health work, I0.59

on Red C'ross Aide plan. 10.52

Franczat, Praxerla, aide in Poland, 1097

lirankel, I. K.. eonference to consiler nursing problems. 2.j4

Frederiksted, Virgin lslands, nursiner work at, l:014

Fromaln, Florence C'.. nursing ser. viee in Virgin Islands, l:203

resignation. 12014

Freneh. llenrietta L., dietitian over. seac. $139 \%$

French. Dr. William .J., director uf dispensaries, France, lols, son!

frenelh lied Cross, mobilization of. i2) 4

liriends. Society of, 826 liuller, Stella, Chautauqua nurse, 105:)

first Delano Red Cross nurse, 10.52

Fulton, (apt. Artluur D., in Rou. mania, 1127

Furbush, Colonel C. I., Advisory Committere of Army Sichool of Nursing, 2sis

Furse, Dinme Katherine, Britisl, Nursing Service in France, 478

Gaffney, Clare, Assistant on Nurse Corp of the l'ublie llealth Ser. vice, 1028

Gardner, Mary S., (ehiof of Public lealth Nursing in Italy, 867

on mursing system in Italy, 8.5.5. 857

on training of Italian nurses, 868 Gardner, Mary Siewell, Committee of Transfer, 102]

director Town and Country Nurs. ing Service, 240

enlarging of Public llealth Nursing, 1274, 1275

on ittitude of nurses, on Public Health grouping, 1273, 1274

on training of publie health nurses, 1310

report of tour of liurope on eliild health and mursing school, 1189. 1194

report on work of Niss ('lement in town and country nursing. 1234. 1235

sent to stucly public health nursing in Europe, 11si-11sis

Gare de l'kist. Paris, emoraney can. teen at. 837

Gare du Nord, Paris, s.35

emererency canteren at. sist;

Garretson, Jarmaret, relief work in Allania, lila

Garrett, Aliee $\mathrm{ll}$. elifer nurse of [. S. Nar Base Hospital No. $\therefore$.

on L. S. Nayy lase 1lospital No. $\therefore$ i.

Garrian, charlute, at Natienal

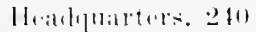

fiecer. [)r. Willian M., on rank for

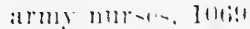

(ielston, 1)r. ('latir li.e member of chilibens linleati, France. ins

work at Evian-les-balins, 7T 
Gencral Hospital No. 1, B.E.F., U. S. Armr Base Hospital No. 2 unit at, 4.54

General Hospital No. 9, B.E.F., Ronen, France, unit of Base Hospital No. 4 at, $444-452$

General Hospital No. 11, B.E.F., Base Hospital No. 5 unit at, 452 General Hospital No. 12, B.E.F., Rouen, France, unit of $\mathrm{C}$. S. Army Base Hospital No. 21 at, 467

General Hospital No. 12, B.E.F., under American Red Cross, service at. 468

General Hospital No. 16, B.E.F., Le Tréport, France, 459

General Hospital No. 18, B.E.F., personnel of U. S. Army Base Hospital No. 12 assigned to, 469

General Hospital, Montauk Point, Ret Cross services at. 61

General Medical Board, 264

Genera, General Assembly of League, 1144

Genoa, Italy, American Red Cross Naval hospital at, 865

George, Elva Anne, Bureau of Dietitian Service, 1429

resignation from, 1431

charge of dietitians for base hospitals. 238, 239

Committee on Red Cross Dietitian Service, 1379

desires to widen scope of lome dictetics, 1431

director of Dietitian Service. 1369

National Committee on Dietitians, 1377

nutrition member of, 1437

on slowness of lome dictetics, 1430

German Government. Ameriean Red Cross work in Russia and Serlia at request of, 22.)

German military discipline, 163

(ierman women, as early volunteer military nurses. 2. 163, 16.5

German woinded. I6t;

eondition and care of. 162-163

mental attitude of, 164

Gervais. Dr. 1Harriet. in Serbia, 1117

(ievereli. Sorlia. 1st

acconmodations for American nursing wuits at, liss

Amorican lied Cross hospital at, 187
Gergeli, Serbia, conditions in, 1125 Serbian Units No. 2 and No. 3 assigned to, 180

typhus among American Red Cross units at, 181

typhus enidemic at, 209

Gibbes, Virgulia Yason, nursing service in Philippines, 1208

study of ehapter.serviees, 1335

Giberson, Miss, delegate to Ninth International Red Cross Conference, 1912, 124

Gibson, Harver D.. ehairman, Executive Committee of New York County Chapter, 363

general manager at National Headquarters of the Red Cross, 371

gift for nursing education fund, 1279

Gigliueci, Countess Nerina, Italian representative at Cannes Confer ence, 1138

Gilbert, Bianche, at Amertcan Red Cross Military Hospital No. 5, at Anteuil, 601

nursing service in Greece, 1116

nursing serviee in Mitylene. 1114

Gilbourne, Alice, Roumanian Commission, 882

Gilder, Rosamond, on Children's Bureau in France, 824

secretary of Children's Bureau, France, 758

Gill, Mliss A. M., Great Britain`s representative at Cannes Conferenee. $113 i$

Gill, Helen Z.. liead nurse of surgical ward at Tonl hospital. 767

work with Children's Bureau at Toul. 766

Gill, Laura Drake. Auxiliary No. 3 aide. services of, Spanish-Anerjean War, 50

in Army Nurse Corps legislative efforts. 68

in charge of Cuban mursing party, $32,5.5$

on Lema Potter Cowdin, 48

services of 6.4

(iill. 1)r., director of Rnssian 1sland IJospital. 913

Gillet-Monte. Maclame. 782

rilliland. Ine\%, nursing service in Serloia. 1117

Gilmonr. Mary S.. efforts for Red Cross afliliation, il 
Gilmour, Mary S., superintendent at New York City Sclool, during Spanish-Ameriean War period, 50

Gilson, Ilclen Ionise, mursing service of, in Civil War, 10

Givenwilson, lrenc M., on European lonspitals. 480

on Revigny llospital, 525

on tome of Prouch, British and Buluian military lospitals, 520

Givson, IIarvey 1)., American lied Cross Comminsioner for France, 612

Gladwin. Mary E., appointed for Philippine service, 63

eareer of $176-177$

committee, lecture course for Red ('ross nurses, 122

committee on rhoosing candidates for medil, $11: 30$

defense of home nursing teaching, 81

Delano Memorial Committee, 10.50, 10.51

delegate to Ninth International liod Cross Conference. 1912. 124

dietctic work on the Lampasas (xpedition. 33

National Committee on Red Cross Nursing Service. 127, 24 !)

on arrival of merlical "roïnforcements" during typluss siege at Belerate. ISI-18:2

on bumbarimmit of Belgrade. 177 on rondition of womnded at $\left.133^{3}\right]$ grade, 17 !)

on improvel eomlitions at $[B]$ graule hospital aftor typhus epidemire. list

on monotomy in Serhia, ISI

on limel crosis aidr plan. 10:52

services for liod c'ross enrollment, 7

supervisor of Sorbian mits, $1+1$, 17,6

work at louton flowds. 1913, 133

Glaseme. Arthur fi., liommaniam

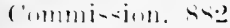

(ila11 ler. Narie ('Iare. relief work in (iperede. 1711

Glowitz liermamy, arrival of Morey Hoip l nit I al, loi

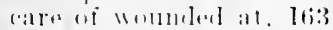

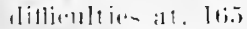

private hlinilien ios oflierses at, Iii:
Gleiwitz, Germany, shifting move. ments of liusiatin and German armies aloont, lo:3

Enit I assigmed to, I60

liktoria Theoter lospital at, 162 ('Iosinge of, 166

Glenn, John .11.. ('ommittee on Rural Nursing, 12l6

Town and ('omntry Nursing Committer. 121!

Glass, Mrs. John, head of Chicagn workroom for hospital supplies, $2 ! 9$

Godard. Stella, reserve nurse, Camp Stuart, Newport News, Virginia. 410

Godot, Mlle. A. M., child welfare work, France. 19]8, son

Golden, Ruth, elief nurse, Evacuation Ilospital No. 9, fits

Goldwater. Dr. S. S.. at Convention of Teagrue of Nursing Education. 9.5.5, 9.56

committere to get hospitals to aid in training army nurses, 286 , 287

Golzar, Rachel, reserve nurse, A.X.C., on establishing of cantonment hospitals, 3933

Good Samaritan. as rarly example of Red cross characteristies, 1

Goodman, 1)r. Albert R. director of Belgian Luits Nos. 1 and 2 . 20ul

Goolriclt. Annie Warburton, 5y?, 544

committer to sereme luspital aid in army murses' training, $2 \mathrm{S6}$, $2)^{2}$

Commites of Transfer. lowe

Committor on lierl (ross l)iet it ian Sorvice. 1:37?

Commiter om limal Nursing, $12] 6$

conforener of menlial and army ofliers and nurces on plan for army selowel of nursing. 204. 25.)

eonference to (onl-inler nur-ing prolilems. 2.5.2. 2.5t

dean of Army Subul of Nursing, siti

Toint Sational rommittor. lot:

.roint Cat innal committere of line reall wi laformation. lobli

Xatienal (iommiten of Americall

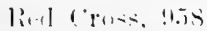


Goodrich, Annic ITarburton, National Committee on Diefitians, $137 \pi$

Tational Committee on Red Cross Nursing Service, 248

on overscas duty, 553, 554, 555, 559

on plan for special enrollment of nurses, $25 \%$

on rank for army nurses, 1069

on Red Cross ajde plan, 1052

originator of Arriy School of Nursing, 283. 284

plans for Army School of Nursing, 286. $962^{\circ}$

resigns as Dean of Army Nursing School, 289

Surgeon-General's office, $\mathbf{9 5 4}$

Town and Country Nursing Committee, 1219

work for nurses' census, 304, 305

Goodwillie. Mary, vice-chairman Woman's Adrisory Committee, 300

Goodwin, Sir John, Balfour MIission, 442

Goodwin, Phillip, Commission for Europe, 531

Gorgas, Surgeon-General William C., 338. 344

appeal by (Aug. 1, 1918), for increase of enrollment of nurses, 319

Central Committee, 230

letter to aid drive for nurses, 290 , 291

National Committee on Red Cross Nursing Service, 248

on rommittere to secure Red Cross slip for Worlel War, 140

on Army School for Nursing; statistics. 963. 964

on need of nurses, $9 \tilde{5} 4$

on nered for murses' census, 306 , 307

on organization of lase lospital units by Indical Reserve Corps vernus American lied Cross, 3:31

Cosling, Batrien M.. Commission to North Rinsiate bit

Tommanian (ommision, s,82

Gounonilhou. Markame. public lealth work at Bordeatux, Franer, 796;

Gourlay, Mres liohere (Adoline H. liowland), at National Iteadquarters 210
Government directed routine nursing, as evolved in Civil War, 9

Governor's Island, Red Cross nurses at, 61

Graduate Nurses' Protective Association of New York State, offer of Spanish-American War services, 40

Graham, Flora A., on recreation on Ellis Island, 419

Grant, Jessie, clijef nurse, Base Hospital No. 55 (Boston, Mass.), 338

Grant, Robert. Jr., London Chapter, American Red Cross, 425

Graves, Lulu, Committee on Red Cross Dietitian Service, 137?

President American Dietetics Association, 1398

Gray's Ferry Road, Naval hospital at, 701

Great Britain, American Red Cross hospitals in, 431

changes in American hospitalization policies in, 440

Naval hospitals in. 720

work of American Red Cross Commission in, 441

Great Lakes. Ill., Naval hospital at, 709

Greece, conditions in. inspected by Miss Noyes and Miss Hay, 1181

Sursing School plans, 1165-1166

relief work of American Red Cross in, $1100,1111-1116$

Gregg. A. II., Committee on Readjustment aud Liquidation of European Aetivities, 1079

Gregg. Eleanor, Cliautauqua nurse, 10.5

Greeley, Mrs. Helen Hay, National Committee to Secure Rank for Army Nurses, 1070

plan to serure rank for army nurses. 1066, 1067, 107 1

work of, to secure rank for a rmy nurse's. 1066 , 1067

Green, Dr. Thomas E., Aill in securing lome dofonse nurses, 283

director of National Red Cross Sipeaker's Bureau. 10.54

Greens. 1)r. Allerta. relief work in Serbia, 1119

Grene. Feorgia B., nursing service in Montenegro, 1703

Greene, Marion P.. on rhild weltare work at Corbeil, France, 800 
Greene, Marion P., on dispensary at Corbeil, France. 799

on playground at Corbeil, France, So1

(imenlenf, Dr. Charles R., on nursine services of Lampasas nursinc eroup, 34

on sirvites of Lampasas group, is 6 on value of Miss Rutty, 34

report of. on conduct of the war with Sipain, 31

suggestion, as to land service for Rid] ('moss. 29

Freenlox:s, Anma J., State Committex. District of Columbia, 112

Greenwood, Miss, death of, at Sternherge [*. S. Finld lfospital, 53

work at Dayton tlools, 1913, $1: 33$

Frenclle, Franee, dispensary at, 804

Gretter. Mrs. I. E., Delano Nemorial Committee, 1050, 1051

delegate to Ninth International Red Cross Conference, 1912, 1.24

Statu Committee. Michigan, 112

Cirettor. Lystra, early nursing superintendent. 19

Criffin, Major R. E., to Mrs. Whitelaw Reid, on nursing service at ('lickimmauga Park, 59

Griflith, Mary, nursing. in Haiti, 1171.1173

Grittingere, Enma, director of public lieiltll mursing. 1304

Gromitch, Imu. Slavko, baby hospital at Nish. Serhia, 2l:5

(irulee. 1)r. Clifford. Children's Burealu, Framere 1918, 782

Gillest, Mrs. Freteriek, 72]

(iuimun. Dr., elible welfare work. Franee, 1918, 812. 815

(iulf Division ut leel Cross, 246

fimm, J)r. Solskar II. associate director of the Rockefollor Commi-ion for the Presention of Tulnerenlasis in Fianee. St4Sit.

Fumning. Lieutenant Colouel R. $\mathrm{C}$., 1119

Gouther. Fimma A., dietotios olatsos. Sitional (ommision on biatiti:lu=. 1:3:

('ommitter an lited Cross Dietitian Sirvier. 1:37s

National fommitter on lied f'rose Nursin! Sirvite, 204!)
Haas, Miss, volunteer helper, 241

Hagler, 1)r., in charge of pavilion at l3lerade American lied Cross hospital, 183

Inaifa, Palestine, hospital at, 901

llaija, l'alestine, out-pationt clinie at, ! $11 \% 2$

IIaigitt, Ethel, reserve nurse, near Junction City, Kansas, on enntomment muring, 394

IIaiti, conditions in, 1173, 1174

lied Cross nursing in, llil

smallpos in. 1172

Inldora, fortrunner of Florence Nightingale, 2

IIalifax, munition explosion, 1917, 136

IIall, Carrie M., chief nurse of American Red Cross in Franco, 613

chief nurse of Ameriean Red Cross in Great Britain. 434

chief nurse, American Rou Cross in (it. Britain, transferred to l'aris, 629

chicf nurse, Base Ilospital No. 5 , 452

National Committeo on Red Cross Nursing sicroice. 24!)

on American lied (ross activities in Finnee, ]07!-1081

on foreign relief. loos

on Miss Delano's hialth, 1001, 100.2

on Mliss Delano's illness, 1000 , 1001

on nursing situation in England, 4.3.)

recommendations of, for foreign relief, losl, lose

tramsfrered to Paris leadquarters. Siptember. 1!9]s. 411

ITall. Eleimur. Army Nurse Corps. (amp) Taylor. lomisville, Ky.. on aintominent nursing. 394-3!5.5. $3: 96$

on . Melical Corps men. 397

Iall. Maria M. C.. and sister, ('ivil IV a r nursing sovioes of $1 \mathrm{i}$

llalrorson, Idilat, at Amerian Real frosillo-pital No. 10!?, Erreus. (i) 11

(in work at Evian-les-liatins.

Ilamaldall. Persiat. lind Crose huspital a-tabliohed at, for linsiatus. ] 6111 
IIamburg, S.S., selection of, as Red Cross ship, 140

Hamiltom, Dr.. opposition from, to first Red Cross nurses' unit, 15 public liealth work at Bordeaux, liranee, 795, 796

Hamitton, Dr. Anna, funds for School for Nurses in France, $10+6, \quad 1047$

Ilamilton. Ellen M., Palestine Com. mission, 892

traveling dispensary service at Jerusalem, 895

Hammar, Mrs. Frank V., Central Committee of American Red Cross, 1007

Delano Hemorial Committee, 1051

Woman's Adrisory Committee, 300

Hampton, Caroline, early nursing superintendent, 19

II ampton, Isabel, early nursing superintendent, 19

Hankins, Harriet, reserve nurse serving on Mexican border, 35̃

Hannan, Katherine C.. chief nurse at U. S: Army Evacuation Hospital No. 17, 947

Hansherry, Anna M., nursing service in Ilaiti, 1171,1173

Happer, Miss, supervision of dietitians, 1426,1427

Harbin, Chinese City Hospital at, 937

cholera epidemic at, 1919,936

Harbin Military IIospital, 915

Hareourt, Viseountess, Committee of American Women's War Relief Find 146

London Chapter, American Red Cross, 42\%

Hardy, Nannie 13.. 349

sent to Vera Cruz. 1914, 128

Harjes, Herman, Anerican Relief Clearingr House. 531

Ilarolı, Mary Radford, dietitian overseas, 1385

Iassan, Esther V., superintendent, Navy Nurse Corps, 5.37

Harrimain, Mrs. E. II., Woman's Alvisory Committee, 300

Harrington, Grace, acting chief nurse of silorian Commission, 930

chicf nurse of Western Division, Amorican lierl ('ross, !3!!

pullice health nursing. 1303

sail from Vladivostok home, $\mathbf{9 . 2}$
Harris, Mrs. Betsey Long, chief nurse, Base Hospital No. 36, 501

Harriss, Dr., donator of yacht Surf, 701

IIarte, Dr. Richard H., director, U. S. Army Base Hospital No. 10, 366, 459

Hartrigge, Mrs. A. C., State Committee, Georgia, 112

IIartwell, Laura, on attitude of returning nurses, 1018

Hartz, Alma, relief work in Crete, 1116

Harvard Lnit, first, sailing of, 167

Harvard Lnit, second, U. S. Army Base Hospital No. 5, 452

Harvey, Miss, volunteer helper, 241

Harvey, Alice B., 349

sent to Vera Cruz, 1914, 128

Harvey, I. Malinde, public health nursing, 1303

Haslam, Edith M., Palestine Commission, 892

Haslar Royal Naval Hospital, England, 146, 147

Unit D at, 146

Hassan, Esther Voorhees, first superintendent of Navy Nurse Corps, 686

services of, 64

Havemeyer, Mrs. H. O., work of, to secure rank to army nurses, 1065

Haviland, Sybella, in Serbia, 1117

ITave, Red Cross dispensary at, 822

II awaii, nursing work in, 1204, 1205

llawley, Laura J., dietitian overseas, 1417,1418

Hawley, Mrs. Joseph R. (Miss Horner), in Army Nurse Corps legislative efforts. 68,70

offierr. Associaterl Alumnæ, 40

Ilay, Holon Srott, 141

aid in Balkins, report. 1102

at Commeil meeting of League, 1147

at National lleadquarters, 239

charge of home nursing courses, 1366

Committee for Memorial Fund to American Nurses, 1048

Committer on "loosing candidates for melals, 1130

Conferemes to eonsider nursing prohlems, 2.53

D.lano Mfemorial Committee, I05I 
Hay. IIclen Seott, Director of Elemontary hygiene and home rare of sick, 1369 ?

established murses' training school in Bulgarin, 142

enemeral stuperintendent of murses on Merey Ship expedition, 140 inspection in Albania, 1182

inspection in Florence, 1183

inspertion in Greece, 1183

inspection in Mlontenegro: recommendation, l IS:3

insperction in Poland, I179

instruction for women, 13.j4

memorandum of nursing activitie's, 1177

nurse, Commission for Balkans, 1083

on American Red Cross activities in Polamd, lo!99, 1100

on conditions at Municipal Ilospital, Cracow, 1096, 1097

on conditions in Poland in 1920, $10 ! 3-1094$

on conditions in Serbia, 1119 , 1124.112 .5

on Countesis Zamboya's selinol of Domestir Seinee in Poland, 109.5

on relief work in Greece, 1112 . 1110

on work in Serbia, 1122

organization of Nurses' Training School at Softa, Bulgaria, l!) ì, 219

plan for mursing school in Bulgaria. Il6i

plan for school in Warsaw, ll.ss

retiring of, from Kief, for Bulgal rial. lis

snior supervisor of Inits $\mathrm{C}$ and 11. 1.5 .7

stuly of llarsale eomlitions. 11.20;

-mperintmalent of murses. Merey

- Jip "xpelition, 140. 14

tomer of inspertion in Poland. Iots tome of in-pertion with Miss Jispe. 1170

work for corsing sidenel for ['olindul, 11.5.)

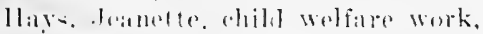
France, I!)] s, sog

Haytom. Aral. of the Washington,

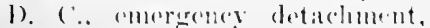
3.53

llaywarel. Mrome on lorpital work in Pirtis. .ti
Iazard, Miss Blanche E., Committee on 'Tow'n and Country Nursing Siervicer, 126it

llazen. Miss, report of dietitian wrik. $1+19,1+20$

Hazlott, Dr. 'T'. Lyle, lis9

llraly, Tamar, ollicer Associated Alumme, 41

IIciale, Susan, and cantonment duty, 390

Heath, Amarita, at dock infirmary in Bordeaux, 1012

nurse in Serbia, 1123

Hebherd, liobert IV.. coöperation with led Cross in oliminating promiscrlous use of amblem, 8.j

Hickry, Blary Agnes, Work with letorans' liuream, 1030

leilman. ('harlotte, school nursing, (irceece, 1182

work in Grence. 1197

Helforimnin in German hospitals, 163,165

IIenderson, Alice, on inspection of tourists at ['au. France. 152

on Pali, France, 1.50

oll wombled at l'au. France, 151

supervisor of Lnit R, lio

Hendersom. Buma 11. S State Committre of lllinois. 110

Hendersom. Sir Datrid, director-generat of ledague. 1143

Ifendersom. R., Xitional Advisory Committe on Instrance. I04l

Henry. Laty. Committed of Ameri(an Women's War Rolief Fund, $141 ;$

Jlenry, Sarah S.. work in Cuba, (it

llenry, Major William 1l.. at Amerion lien cross lonspital in North linsiat. Gis]

IIemry Stront Sentement. 1212

aid in traning publie health nurses. 12.50. 12.51

Army seluewl of Nursinte. 2os

trainine for pallie health nursing. $1212.1 \cdot 2+3$

Hom-latl. Marjorio. appointed for Plalippine service. ti:3

apprintment lo Masnilis. is

work at l'ot llospital. Furt

IV:al-wortla, is

llerpick. Hon, liohert. on the puiln. 1.i.

Herring. Mary, (hamanuma nurse, 111.5 
Hertzer, Katrina, nursing staff, 235 Navy Nurse Corps representative at National Headquarters, 689

on condition of patients at Budapest Military Reserve Hospital No. 4,173

on Miss Hassan's work, 686

Hertzog, Dr., military commander of Budapest hospitals, 173

Hewitt, Elizabeth M., services at Hattiesburg, 1908, 130

llibbard, M. Engénie, work in Cuba, 64

Hiekman, Ky., nursing service at, 1917,136

Higbee, Mrs., 384

Higbee, Mrs. Lena S., Ameriean Red Cross parade, New York, 420

approves plan for special enrollment of nurses, 2.58

Conference to consider nursing problems, $2 \tilde{4} 4$

National Committee on Nursing Service, 127, 249

on rank for Army nurses, 1069

second superintendent, of Navy Nurse Corps, 687

Hill, Dr., Inspeetion in Europe, 1188

Ilill, Dr. A. Ross, vice-chairman of foreign operations, 1187

Hill, Anne P., on armistice time in France, !81

Hill, Dr. Howard Kennedy, on L'Hospicrs Cirils de Lyon, France, 780

on submarine attaek, 718

work for child health centers, 1196

IIill, Marỵ, 159?

Hill, Mrs. William II., on hospital train service, tito

work for refugees, in France, 83.

Hilliard, Amy, approves plan for special inrollment of nurses, 2.58

Committee on revision of text book, li3es

eonference to eonsider nursing problems, 2.54

co-operation with 1)r. Hamilton for funcls for nurses' sehool, 10.4ti. 1047

Joint Xitional committer, $104 \bar{i}$

Joint Satiomal committere of Buredul of Information, lolo;

Sational committore on lied cross Nursing Service. 249
Hindenberg Line, breaking of, 509, 510

Hinds, Dr. Robert W., director of Mcrey Slip Unit D, 146

direetor of Belgian Units Nos. 1 and 2,200

IIine, M. Estelle, Spanish-Ameriean and World War service, 65

deseription of Seabriglit, estate of Mr. and Mrs. Schiff, loaned to nurses, 1033

Hitcheock, Jane Elizabeth, ehief of Division of Public Health Nursing, 1018

work on Division of Public Healt lı Nursing, 1020

IIoag, Elizabeth, on mursing service in naval hospitals, 704

1Ioagland, Jennie, in Serbia, 1119

Hobson, Mrs. Joseph, efforts for Army Nurse Bill, 69, 70

member Army Nurse Corps lerislation committee, $67,69,70$

Hodenpyl, A. D., eonference to consider nursing problems, 254

Hodge, Capt. Edward B., on air raid at Amiens, 465

Hodson, Jane, 65

value of book by, to the trained nurse, 39

Hoff, Colonel J. V. R., eommendation of women for field hospital work, 59

tribute of, to Miss Maxwell, 53

Hoffman. Frederick. on Commission for Europe, 531

ITofker-Lesser, Bettina A., sisterin-chief, Red Cross Ilospital. 23

Ilogue, E. Elizalueth, elief nurse of [. S. Naral Base Hospital No. 2,721

Holman. liertha, dietitian in Warsaw, 1163

llolman, Lydia, pioncer in rural nursing. (is)

rural nursing. I211

Holnes. Ethel A., chief nurse. Rase IIospital No. 24 , 50-4

llolnes. latharine. relief work in Roumania. 1126;, 1127

llolmes. Katherine W.. burean of pullic lealth nursing. 1:30:3

on wurk for refuerees, in l'aris, $8: 3.5,8+0$

appointed for l'hilippine sorvice, (i:) 
Holtzman, Mrs. Florence L., in charge of finances, ('hiteau de's Halles, hospital, 781

Iloltzinan, Ilospital at Lyons, France, 7s:3, ist

lloly Cross sisters, nursing services of, in C'ivil 11 ar, 8

llome Care Nursing Course, diseussions concerning, 80.81

Home Care Nursing Course, origin of, sll

llome defense nurses, 2S2, 283

Home dieterties, courses, 1430

Home hagiene, Hontenegro, 1107 Santo Domingo, 1200

llome Nursing Committer, work of, 265

llome nursing comse circular, 1361

Ilone nursing cothse for women, outline, work, 13533-137t

report of National committere on Real Couss Nursily, 13:5

Isme mursing courses, organization of, $13664,1364.5$

Home Xinrsing Teaching Centers, 1363,1364

Homesickness. 169

llomrigle, leatriee von, servieds on lompasess experlition of. :3:3

llood, Mary, rilei murse in Iladirostok liefugee llospital. 917

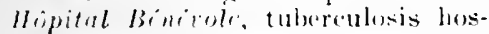
pital. sits

lliprital duriliare lo. 3'i, 199

Mlipital Ben role, 1!) bis, Paris, 8.53

llipital ('omplimentaim lo. 2, turnerl oner to l)r. litch, 609

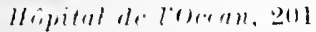

Mapital sit. Jeseph. l'aris. Sti

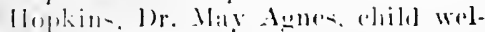
fare Work at Narseilles. Finance, $79: 3$

Jlophins. Jan A., otlienr Associated Alummit" 411

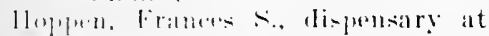

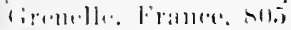

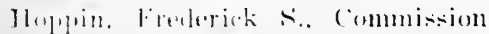
firr linronn, $5: 31$

Mr-hin-. Majur. on dirtitian's ditli(niltien. $1: 11: 3$

(1) work of lisetitians. 14:3

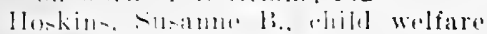

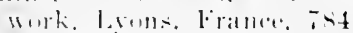

(o)

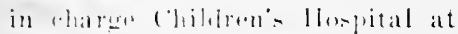

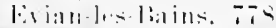

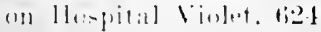

llospital ears, lied Cross service on, Spanish-Ameriean llar, 6l

Ilospital conditions in the latter l!)th eentiry, is

lluspital Corps Committee, neceptances of services by Government, $36 ;$

origin of, 36

llospital conomies, class in, at lorachers collegr, efforts for Red Cross atliliation, 71

llospital lloltzman, at Lyons, lirallee, isto

llospital nurse's, for lield work, desirability of. St

llospital ship .l/issouri, 60

llospital slips, C'ivil $\|$ ar origin of, 12

llospital stall, relation of dietitians to, 14:3, 14:24

llompital standards, in Civil War, 12

Ilospital silppliex, 20!15

llospital Suppies, country divisions, $2 ! ! ! 9$

Work startinl. 2!)(i, 297

Hospital training selools for nursom, establishment of, 13

Ilospital train sorvece. qualifieations of nlurses for, 643

llospital trains. (i:34. 643

instructions regarding nurses, 635

women on duty, 500

llospital liolet, at Lyons, France, 78:3, 784

llospitals, Amerion Red cross, esstablished in France, (ji30

two types of, 53:2, 53:3

in France, bombel by enemy aviators. 5is! - it! 2

in Nosember, 1!1s, 5ll

mantained ly L. S. Nary, 7.20

maternity at lonl. France tis

naval. in France. Fes

naval. in Gireat Britain. T:0

of lle A. F. F.. Buration of. 4ho

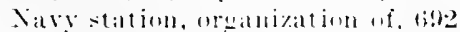

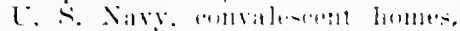

Ameriean lied l'rom. $7: 32$

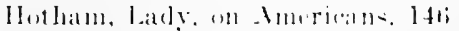

llouph. Mrs. Kintlerine ('.. superviare of entralenent homm for

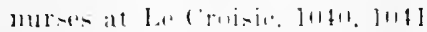

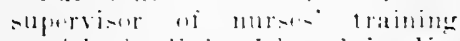
with the finderal buard fur bi-

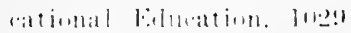

Howarel. Garrie 1... Pani-h-.1meri-

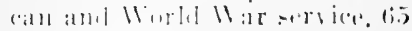


Hower, Martha, child welfare work at Le Glandier, 818

IIughes, Dorothea, finances school in Warsaw, 1160

interest in nursing school for Poland, $1154,115 \overline{5}$

IIuglies, Dr. Laura A., vice-president, Society of Spanish-American IIar Nurses, 46

Hughes, Major, Sixth Division of Marines, 734

Hughes, l'riscilla J., on camouflage of ships, 423

on conditions back of the lines, Lorraine liront, 643

on conditions of German trenches, 957

on conditions of imprisoned British soldiers, 9s's

on country about Trèves, valley of Moselle, 993

on hospital at Coblenz, 99j

on reception of American Red Cruss at Guile, 994

IIull, Mrs. Jolın S. 'T., in Army Nurse Corps legislative efforts, 68,70

Inulsizer, Marjorie, dietitian overseas duties, 1363

on dietitian duties overseas, 1384, 1385

IIundling, Capt. Ilerman, in Serbia, $11 \geq 0$

Ilungato, Miss, dietitian overseas, $140.5 \cdot 1410$

Report on dietitian work, 1427, 1428

Ilunt, Caroline, dietary lessons, 1.330

llunt, Elizabeth, Chautauqua nurse, 10i5)

in Santo Domingo, 1199

llunt, liev. (iocliney P., chaplain of Base Hosputal No, 102, fitis

IIunt, Ilarriet, work oi, at Irkutsk, 944

IInter, Arthur, National Advisory Committer on fusurance, l11.t

Hunter. L. J., Committef onl hearl. ju-turent and liquinlation of European Artivities, lot?

Ilunter's I-land, cimbalescent Jlome for sth lieerinent in, Red Cross services at, die

IIuntiugtom, Henry S., on work at llatiol, P'alestime, (m)l

llurst, olice. Work at Ficld llospital ‥ 1.2. T5l
Hutton, Mrs. Henry, 154

IIutton, Colonel Paul C., 606

Idaho, public health nursing in, $133 \%, 1338$

Idjukovska, Madame, director of nurses of l'olish Red Cross Hospital, 1097

Ilfov Unit, Roumania, 1127, 1128

Illinois, nursing service in, 19I7, 136

rural nursing in, 1229

Immune nurses, requirements, during Spanish-American War, 38

Infant welfare, in Crete, 1116

in Greece, 1115

in Patras, 1115, 1116

in Serbia, 1124

Infirmaries, at docks, 1010.1012

for American troops in France, 548

Influenza epitlemic, 972,976

aid of classes in hygiene in, 1373, 1374

need for nurses in, 971-975

Information, liurean of, 1019

Information Bureau for Nurses, 1014-1016

Information for Nurses Called upon for Active Service (A. R. C. $702,1917), 372$

Inglesaki, Ellen, at sehool nursing, Greece, 1182

nursing service in Greece, 1111

Inquiry Commission, European, 1188

Insurance, for nurses, 1042-1045

Insurance, National Advisory Committere on, 1041

plan of, 1042,1043

International Nurse Education, 1145

International Red cross Conference, Cannes, 1919. 1137

International lied C'ross Conference, Ninth, 1912. 124

International Reel cross Treaty, accesion to. Jy Lnited States. 6

Irceland. Cieneral Merritte W., 331 , 355,454

appointment as surgeon general. 万人 I. as I

letter to Mliss Dolamo telling of tine work of nurses. !s 4

on Contral Commitlese of Ameriean lied crosis, lout

on lixentive (ommitter of Ameri(a) linel ('ross, lont 
lreland, Gon. Merritte 11 ., on rank for army morses, 1072-107:3

Jrkutsk, silueria, Ameriena lierl ('ross losplutals at, 94:3

withelrawal from, of Amritan foreses and Amorican liond cross persommel, 94s

Isalublla of spain, lirst queen to further scientific military mursing, 2

Italian drive, 673

Italy, aldivitios of Aluterican Rod Cross in, s.is

dispellsalies in, sobi

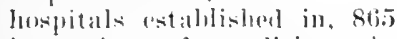

inspertion of eonditions in, hy Miss Noyes and Miss Ilay, Ils3 nursing sytem in, 8.54

plans for nursing in. 1175

schools of fullic health nursing in. sil

training of pullic health nurses in. sis

war conditions in, Sis

Jackonville. Fla., authorization of Chief surgom to contract for mursise for, :3s-83!

Jackenvill, Marine Hospital, oppen-

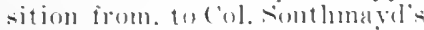
tirst mit of lied (rosis murses, 1.5

Jaequith. Lueia. National commitee

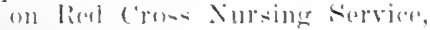
249

Jaffa. Paldetinn. infortions disease lomelital at, ! (t)

taken by British, 1917. s!!?

James. Armes F.. chien numse, Amorian Rerl C'rosis Military Haspital Xir. 11:3, .82

Jamme. Amma ('a deloisory (onmit. tore of Nightingrale soluesel. lolt!

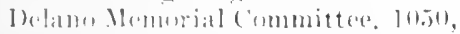
10.1

National limmitero on liad ('ross

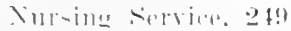

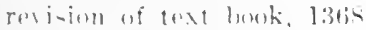

. Tarhat. ('altitin. 140

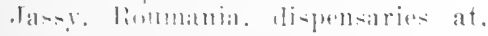
ins?

Jay. Xelonen 1). ( rial Fumel to Amuriean Nurne. lolit

Joanc. 1)r. Phillip. molical smpurvi-ion. 1 1!b.j
Jefrory, lame, at emergency hospital al . Jolly-sur-.1/orill, biit

woumded in line of donty. I0.3]

Jenkins, Mrs. Melon Martloy, 415

Jommines, lrene. on work at le: (ilamlior, sing

Jorusalem, rhildren's luspital at, $\mathrm{s} 9 \mathrm{ti}$

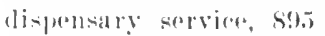

rolief work of American Red ('rosis in. !n!)

Romsian hespital at. 89:3

taken loy liritish, ]917, s!l

Turkish muniripal hospital at, 894

Jasup, Elsieservion in sterbial. 1922

Jomplim, Lane, rolief work in $\mathrm{Al}$. bania, 1 lio

Johnsom, Anna J., on conditions at Evaluation llospital So. :, 648

on experiences at A. R. C. Mlospital Jo. 104, at Buarais.

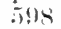

on A. R. C. military hospital at Jomilly, toist

Johnson, Elizabeth, Sinte committre. Indiana, 11]. 11:

Jolmsun, Florente Merriam. aisl to sick nurses, 1033, 10.36

Commitues en choosiner randidates for moslal, 1]:30

Delano Memorial committer. 10,5l

direneter Atantite division of Red (1018s. 24.3. $372-374,37 !, 343$, 344.10134

Joint Citional (ommitten of 13nrabe of Information, lolti. Jol7

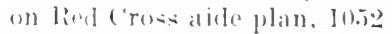

sopice in France, 1928

Julnsom. Jusphine, at National lleadipartar- 240

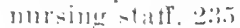

Juhm-un, lemal Varearet, nursing sorvie in (hion. 1113

in 1irence. 1111. 111:2

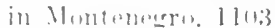

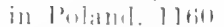

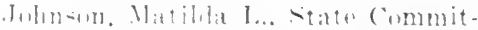

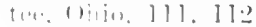

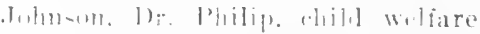

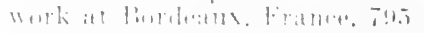

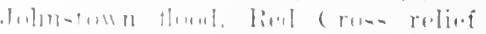
and nur-ing wort ins. 13. In

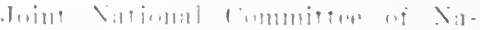
timal Nursiner Hablyuarturs. 1114 
Jokaitis, Madame Josepline, acting chief nurse in l'oland, 1088, I097

pulhlic service nursing in Poland, 1085-1087

Jones, Major Harold W., 339

Jones, Dr. Louise Taylor, director, Mabel Gronitel Baby IIospital, $2 \mathrm{I} 6$

Jones. Miss, clijef nurse of Camp l'ontanazen lospital, 997

Jones-Raker Bills, for rank for army nurses, I071

Jordan, Lueia D., nursing service in IIaiti, 1171

Jordan. Pauline, on nursing in Italy, 860

with Carrel Mission in Roumania, 878-881

Jordian, J. H., operating manager, American Relief Clearing House, 53I

Jorgensen, Mary C., mobilization of nurses in New York. 421

Jorgenson, Sigrid H., 652, 655, 658

Jouilly. France, emergency hospital at, 603

Jouilly, navy operating team at, 741,745

Jouy-sur-Morin, France, emergency lospital at, 605

Junior Red Cross, Greece, IISI

Jury, Irene I., death of, I39S

Justis, Iulu J., at National Headquarters, 240

Kacena, Blanche, nursing service in Greece, 1115. 1116

nursing school in Prague, 1149

Karlesky. Dr. David, in Serbia, 1119

Kaisermann, Sara, Palestine Commission. 892

Kamerer. learl. work of, in recruiting nurses, 1062

Kanely. Lily at National Committee headlunarters, 206;

instruction for women. 1352

Kaplan. Rose. death of, at Jerusalem hospital, (6.)

Kastin. Pexsia, Red Cross lospital established at, for linssians. 159

kavala. reljof work in, 1114. 1115

Kean, colonel .Jeflerson li., antiner chaipman, (entral committere. Amoricin lied Cross, 349, 3.50, $351-352$
Kean, Col. Jefferson R., defines status of volunteer nurses' aides, 271

direetor general of military relief, 231,331

director of Ambulance Service of A. E. F., 364, 541

National Committee on Red Cross Nursing Service, 249

on mobilization of base hospitals and American Red Cross, 338, 339

on organization of base lospitals, $332,333,337$

on Red Cross Nursing Service, $331-333,339,340$

on requirements for enrollment of reserve nurses, 352

on outline of medical service of zones, 324-325

on uniforms and equipnient of Army Nurse Corps, 360, 364

organization of hase lospitals, $333,337,338,340$

Keech, Cara Mea, dietitian, death of, 1422

Kellerhouse, Grace, at American Red Cross Military .IIospital No. 5, at Auteuil, 601

Keller, Bree S., Chantauqua nurse, i055

chief nurse of Kerhoun Ilospital ecruter, 996

Kelly, Alice A., on conditions during the St. Mihiel Drive, in Franee, 6033

Kelly, Mary Irene, visit to devastated area, 989

Keenan, Mina, work at Ellis Island, 416

Kemp, Cliristine, work of, at Irkutsk, 943

Kennan, George, Vice-President, American National Red Cross, I $8 ! 9,2.5$

Kenny, Thomas II., commission for Europo, 531

Kentucky, rural nursing in, 1227

Koogh. Sir Alfrofl, Merdical Department, British Army, ti.t

Keppel, br. Frederick Paul, vicechairman of foreign operations of liod cross poris

Korhomul Hospital centor, 996

Kormallshalı. Persia, 160

Lerr. Amma K., arrival of. in France for Miss Delilno. 1002 
Kerr, Anna K., Delano Memorial Committee, 1050, 1051

Nursing Service Ileadpuarters, $2: 38$

Kerr, J)r., conference to consider nursing problems, 254

Kerrigun, Telen, 183

ut IIOpital iluxiliare. No. 3.', 1!!?

transferred to Yvetot, linance, 184

volunteer service at $S t$. Valery, 539

Kerrigan, Mrs. John, Connecticut 'Training School, 40

Keyes, 1)r. Regrina, in Serbia, 1123

Khoi, l'ersia, Red Cross hospital rstallished at, for Russians, 1.)9

Kiof, Russia; Polyteclnic Institute llospital of the American Red Cross at, 155

assignment of lnits C and If to, $15 \overline{5}$

character of Russian patients received at, 156,157

Christmas at, 157

closing of, 1.79

equipment for, 155

recort of , 158

routine at, 157

selection and preparation of, 156

visiturs at, $15 i$

Kiol. Sophia, 383

supervisor of Merey Slip L'nit II, 158

with lils:sian Red Crosis. lis?

King, 1)r.. ill with typlums, 190

Kingr. F. R., Commission for Vurope, 5.31

Kine. Helen, in charere. Children's IIospital at Evian-les-Bains, 7 s

in Sorbia. 1121

Kinney, Cora, on dispensary at Bobigme. Sine, 810

Kinney. Dita 11.. appointment of, as 1)r. Mereer's sheressor in Army Nirso Corpes, 47

heat of fovornment nursing forces. 311

work of, in Army Nurse Corps, !?!

Kirbsimth, 1)r. Revnold M., arrival uf. with liul murses, at Salntîk:1, 1s!

on contration of typhus hy per. sommel of Americin lind (jous minits, 1s:

direntor wi l nit 1. 1.in

Kirkpatriek, 1)r. 11. 1). direstor of the liommanian (ommisionon and
Kirkpatrick, Dr. W. 1), in charge of pavilion at Ameriean Red Cross lonspital at Beloralo, 1s:3

1) puty Commissioner for Russia, (i7 8

Kitchen, Derothy Iawis, on recras. tion hut at $A$. R. C. Nilitary Hospital Xo. 5, 601

Klex, lodwin, 159

Kiline, (irace, Naval Training Camp at Charleston, 713

Knight, Margaret, dietitian oversois, 1385

report on eonditions and duties in France, 1387-13s!)

Knights llospitallers. 2

Knott chain of lootels, New York, tuken over hy IVar Department, for murses, 42l

Kinox, 1)r. .J. H. Mason. 1195

associate chief of Children's 13ureaula at l'aris headquartors, slz

pullic lealth work in France, ifi2

Kisher, Dr. Giorge M.. leg;

Liosel, (iermany, assignment of Lnit G to. 160

arrival of 161,$166 ;$

changes in units at, lifi

military lospital at, loti, l6t

cosing of, liti

jublie scloos liazret at, lofi

Komroyen, Marie, nursing sorvice in Girence. 1111

rolief work in Grece. 1112

Kraguyerats, sanitary conditions at, 187

Kramer, Lalura E.. work with Childreñ Bureau at Toul, itit

Kruirlı. laura Jowe, nurse in Serbia. $111 !$

Kreshs.laty, Madame Elumard, on training selowels for nurses, in France. i:?

Froya. Albania. reliet work in, $110 \mathrm{~s}$, $110 ?$

Krueger. Mathilil. at revgreli, ill "ith typhus. $1 ! n$

Xitional ('ommitton an lied cross

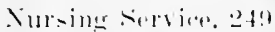

on spirit of Americun lnits at (ieveleli. 1s!)

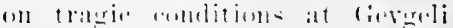
he-pit:il. 1-!)

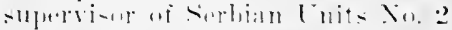

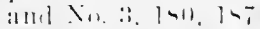

Tum an and rimutry Norsing ('omnitten, 1.21! 
Kuhn, Miss, work in rural mursing, 1231

Kurdistan, Red Cross work in, SSS

Kurowsky, Agmes von, mursing service in Rumania, 1196

La Bonte. Dr., at Je Glandier, 819

La Cournewre, dispensary at Paris, 806

Ladel, Dr. Marmird, in charge of work with Children's Burean in Meurthe-et-Moselle, 766

Ladies' Relief Committee. work of, in or ramizing eivilian war relief, 6

La Garle, Major, request from for Red Cross nurses, 2S-3I

lake Division of Red Cross, 246, 247

lalenki, 1)r., assistant medieal clief in Poland. public health leetures, 1094

Lambert. 1)r. Alexander, 329

Commission for Europe, 531

conference ou chief nurse's position, 567

director. Rell Cross Medieal and Surcical Service, 532

I.amprsis nursing expedition, 31, 32. 33

services of, 56

Lancer. Dr. John, director of Red Cross hospital in public sehool at liosel. 167

Ianctrit. Domalda, ehild welfare work. France, 1918. 809

Iane. 1)r., ill with typhus in Serbia, 190

Jane, Secretary of Interior, Exeeutive committee of American Red Cross, 10007

lansing, Riolert. ('entral Committee of Americin lied Couss, 1007

La Palme, Beluimm, hospital at. 201

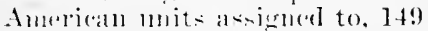

Lappe. 1)r. E. .J. medical director of chatelet llosicital. 7-s

lathrop. Mre. 1-illwi, work with rhildren in Toul. T(j)

lathrop, lulia, Emrorency Committow on Nur-ing. 20it

on rauk for army nurses, loben

latimur. Fianeers li., at Xeuilly llos. pital. iss

batrer. I rmal (Mrs, ramble) on diotitian in-tmution in Army fichool of Xursing, 7395,13946
Laughlin, Mrs. Irwin, London Chapter, American Red Cross, 425

Laundry service, organization of, by Florence Nightingale, 3

Lawler, Elsie M., Committee of Transfer, 1021

Laws, Annie, 117

work at Dayton floods, 1913, 133

Lazaret Konzerthaus of the American Red Cross, 165-166

Lazear. Dr. Jesse W., yellow fever work by, 14

League of Red Cross Societies, 1140 work of, explained, $11+1$

Leary, Catherine L., chief nurse at Camp Sherman, on assignment of eolored nurses, 406

Lease, M. Agnes, one of first six army nurses, 41

Le Comit, Dr. Robert, direetor of U. S. Navy Base Hospital No. 5. 728

Le Croisic, Franee, nurses's convaleseent lome at, 613

Lecture course for American Red Cross nurses, 122

Leete, IIarriet L., ehief nurse at Anteuil American Red Cross Military Hospital No. 5, 600

iuspection of hospital in Serbia, 1117,1118

National Committee on Red Cross Nursing Service, 249

tuberculusis prevention work in France. 845

typhus epiclemic in Serbia, 1119

work in Clildren's Bureau, Paris, 1917.761

Le Giaudier. France, colony of Belgian children at, 818

Lehmann. . Margaret. supervisor of Merey Slipe Lnit A. 150.183

Leiter lospital. Red Cross nurses at. 57. 58,60

Ienihan, Ames: R., child welfare work at Blois. France. 798

Lent. Mary E.. supervising nurse, U. S. Public IIealth Service, 400

J.entell, Miss, nursing sehool in Pranne. 1152

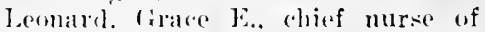
bias Section No. 3. France. 4:3t

dieector of Nursing Service in Fiance. 442

Leserere, I)r., rhild welfare work, France. 812. 815 
Lesser, Bettina Uofker, association with Red cross llospital and Training sichool for sistors, p.op

chief of hospital work, Amerion National lied ('ross (1s!s), 2.5 on comban experieners, 34, 3.5

Lesser, Dr. A. Womae, eseentive surgeon, Amerian National lierl Cross ( 1 s!) 5$), 25$

expentive smegem. Rexl ross lluspital and Training ficlool for Sisturs, 21, 2.2

return of. to New York, 30

work with Auxiliary No. 3,47

letterman llospital, San lianciseo, army sehool of nursing, 2 sis

dietitians at, 1394

Levallois, France, dispensary at, 1917,803

Leven, M. Enile, child welfare work, Franee. 1!18. \$12, \$15

Leverman, Kathery $A$., on sanitary formations, at Chatom-lhiorry, 6.56

Tewis, Miriam, at elillern's colony on, linssian $[s]_{10 m 1}$ !32

L'llospires rivils dr Lyon, France, is

Library, Pullic ITealth Nursiug, 12.24. 12.2.5

Iidalle. Katherine. Hospital Enit "A." 491

l.ien. Dr., joins Dr. Snotly y group for linsia. 167

lihom. Franes. aptured by rerma111- 19!1s. $41 ; 4$

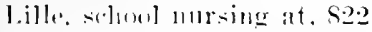

limores, France. Amerione find Crowe children's lfoppital at. $\sin$

liator llowital Xo. 13 at. Jons

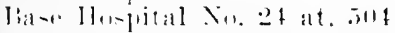

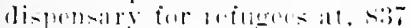

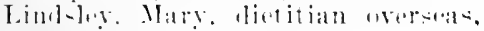
$1: 39 . ;$

repurt un comlitions in Francer, I:3iti, 1:3-?

I.inenteler. Mre. Y., State ('om-

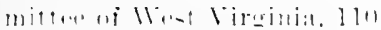

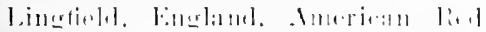

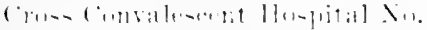
[11] $: 11.4: 34$

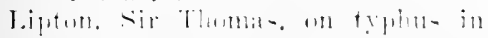
Sinlina 1!1

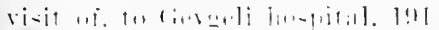

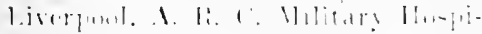
tal Xi1. 1 in 1.29 l.iverponl, I. S. Camp IIospital No. (i1) it 4.32

l.heyil, L.nlu T.. 241, 349

l.higl-sill. Mi-s Alicial, representative of rimat liritain at Cammes conforemere. 1133

local cimmitters on linel Cross morsing servite, 3:90

l.ocal linits, formation of, 1269) 1070

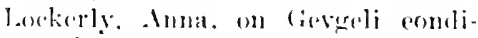
timils. $1 ! 102$

on illums uf lieveredi stalf, lon, $19 \mathrm{I}$

l.niviug. Mis.. Is:i

lometer, Ameriann lined croso Mili. tary llowpitil Do. D.2 ia, $4: 30$

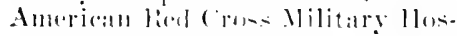
pital Xo. 2:3 in. $4: 31$

Amerian lind (rone Military IJospital No. 20 t in. $4: 30$

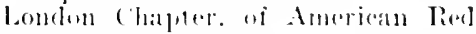

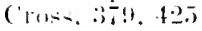

loner. Ir. John II. memter of opere

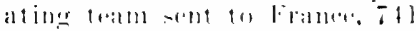

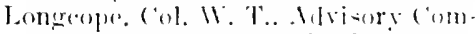

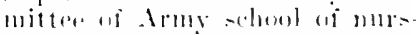
ing. ens.;

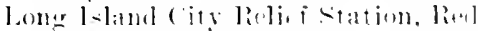

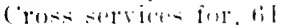

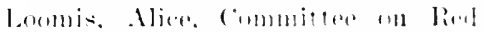

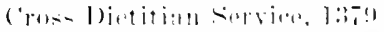

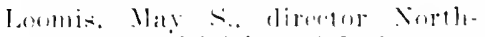

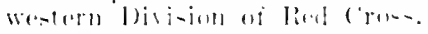
24.20 is

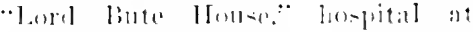

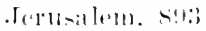

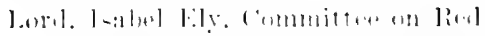

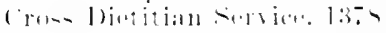

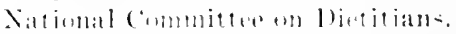
1:3:-

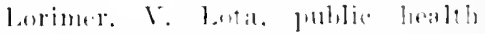
n111-ing. 1:31:3

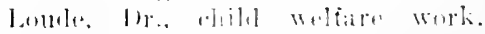

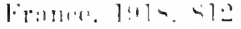

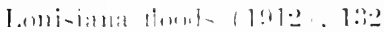

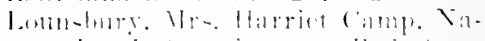

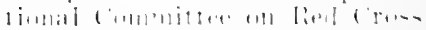

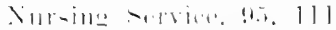

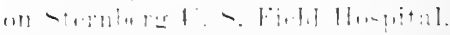

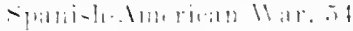

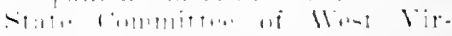
zini:1. 110. 11:2

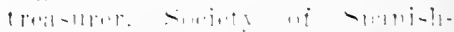

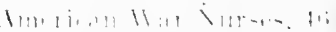

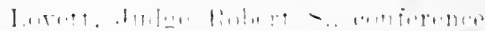

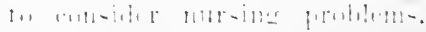

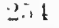


Lowe, Amy F., child welfare work at Corbeil, France, 799

Lowe, Dr. Thomas, in Serbia, 1117

Lucas, Dr. William P., director of

Chilelren's Burean, France, 758 on child welfare legislation in France, 759

on ehild welfare work, France, 1918,794

on risiteuses d'enfants, 811

work at Evian-les-Bains, 777

work at Marseilles, 791

Lucas, Mrs. IV. P., member of Children's Bureau, France, 758

work at Marseilles, 791

Ludd, Palestine, dispensary at, reorganized by Palestine commission, 901

Lufkin, Congressman, bill to secure rank of army nurses, 1066

Jusk, Ila, ill with typhus, 182

Inxembourg, Asile Caserne at, 622

l.ydia 1l. Tolman Association, $12^{\prime} 1$

Lynch, Colonel Charles, and First Aid of Ameriean Red Cross, 332 committee, lecture course for Red Cross nurses, 122

National Committee on Red Cross Nursing Service, 95

on enrollment in Nursing Service, 357

on making Red Cross members active participants in social responsibility, 81

Lrnch, Mrs. John. Delano Memorial Committee, $105 \mathrm{I}$

Jyon, Alice l', one of first six army nurses, appointment of, 41

lyon, Sarah S.. reeruiting relief nurses for l'oland, 1085

Lyons. France. dispensaries at. 785

llospital Violet at, 624

work of Children's Burean at, 783

tuberculosis prevention at, 850

Taas, Clara I... voluntary self-sacrifice to vellow fever investigation. 6.5

Mabel Cirouitele Bahy IIospital at Nisl. Sorhia, 215

as ficld ambulance. 1915. 217

Melsirle. Nellie Grace, Ieatle of, 929, $10: 32$

Y.e 'ammon, Ablie R.. dereloping of lield cross workroum. 296

Mecammon, Edith . V.. developing of lied crosis workroom, 296
McCan, Walter D., letter of introduction of, for Miss Delano, 999

MeCandlish, Mary P., Châtcau des Halles hospital, 781

MeCarron, Miss, on conditions in Montenegro, 1104, 1105

McCarthy, Dame E. Maud, matron. in-chief, B. E. F., 474

McCarthy, Katherine, member of operating team sent to line, 741

MrClellan, George B., on conditions in Italy, 854

McClelland, Helen Grace, at British casualty elearing stations, 456 , 461

McClintic, Dr. Brown, 159, 160

NeClintic, Eleanor Soukup. Sce Soukup, Eleanor.

McClintock, Mr. James K., Inquiry Commission, 1188

Mrcloud, Mary J., vice-president, Society of Spanish-American War Jurses, 46

work at Mexico City, 64

MeCoy, Jieutenant-Colonel J. C., 619 commanding officer of A. R. C. Hospital No. III at ChateauThierry, 617

director of American Red Cross Hospital No. 114, 770

MeCullough, Ernest, Commission for Europe, 530

McCullough, Grace T., Committce on Red Cross Dietitian Service, 1379

MeCume. M. Virginia, State Committee of IIest Virginia, 110

MacDonald, Beatrice Mary, at No. 61 Casualty Clearing Station, 456

womnded in line of duty, 1031

MacDonald. Dr. Cliarles, director of Merey Ship Unit E, 173

NacDonnell, Ita, relief work in Poland. 1159

MeDowell. Marie, nursing service in Serbia, 111!)

MeEroy, Anna Elizahetl, vice-president, Society of Sipanisli-American War Nirses, 46

Maefadden, Kate. nursing service in Srrolia, 1123

Mereer. Dr. Anita $\mathrm{N}$.. appointment as acting assistant surgeon, $U$. S. Army, 38, 42

efforts for army rank for nurses, 70 
McGee, Dr. Anita N., maintenance of high standards by, 3!)

organization of llospital Corps Committee by, 36

presidem of Society of SpanishAmerienu War Nurses, 46

report of, on Army Nurse Corps' war service, 43

resignation from Army Nurse Corps, 47

summary of value of services to nursing hody, 46

MeGovern. Eilla, relief work in $\mathrm{Al}$ hania, 1108

MeGovern, Nellie E., chief nurse, Romsey Hospital, 434

chief nurse, U. S. Camp Iospital No. 34,434

work in England, 431

Machevsky, Dr.. head plyysician of railroad, of Vilna district, Poland, 1093

Maciejow, l'oland, Red Cross relief work at. 1087

Mclntire, Mary, arrival in England with Roumanian units, 1918, 887

Rommanian Commission, 882

MeIntyre, Grace L., chief murse of U. S. Navy Base llospital No. 4. 725

on trip to Fngland on S.S. Briton, 72.5

work at Halifax explosion, 1917, 136

work at Verklnme-[rolinsk, 947

Melsaac, lsahel, in Army Nurse Corps legislative offort, fis

berok for home care of sick. 1358

deatle of. September 21. 1914. 101

delexate to Xintle lntermational Red Cross Conference, 1!)l:2, $1 \cdot 2+$

lowal of [nited States nursing forces. 311

National ('ommittee of American Red ('ross, !):s

National committere on Nursing Survice. 127

l'resident. 1 merioan .Journal of I Irsintl (o.. 7l

supurintendent of Army Nurse (impis. 1111,35 !)

superintendent of lllinuis Traning followl for Nurners. 3!

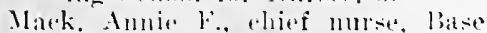
Ilospital No. 37, 437
Mackay, Catherine J., Committes on Racl Cross Dintitian Service, 1378

Mrkere. Adelaide, chairman of (leveland bocal ('ommittere on Red crows Nursing Service, 328

Mackenzie, Katherine L.. ehild wel. fare work, lirance, l!) 1 s. Sol!

Mrkinley. l'resilent, commenclation of 'lhilippines' Nurses' Committore finaneial statement, (i3)

reception of special rommitter for cleser eopipuration lutwren led Cress and Govermment, st;

MaKinnom. Mrs.. rhâteru des Malles lospital. 750

MeLaughlin. Emily A., chief nurse, lase llospital No. 17, 49.

work at bayton, Ohio, floods, 1913. 134

McLean. Commander N. T., at Ilaiti, 1171,1172

MoLeod. Margaret Frances, at Beauvais hospital, sis

dispensary at liur Censier, Paris, 806

on child wolfare work at St. litienne. France. 7ou

Macklin. Katherine. Palestine Commissiom. s:20

MrMillan, Ilelena M.. State Committee of lllimois, 110

McNalbb. Lientenant, work in Serbia, 111s. 111 !

MeNelis. Mary C.. on Naval Jaspital. (iray"s lorry limal. T(1)

on nursing service in the Nary, 702

Maclplayden, Mrs.. on eomditions for dieditians in Framee. l:39:2. 1393

MeQuale. Nora M.. on Naval Hospi-

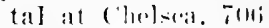

om Naval llospital at larris Islamel. F119)

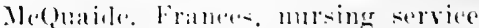

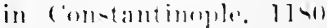

l'alrstine (inmmini-ion, s!!?

Marefoniar. reliof work in. 1114

Malloira. Folith. Pale-tine Commissinn, s!!?

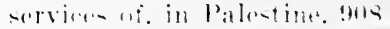

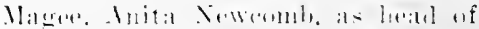
[nitel stalde erobromment murs. ine cirrese 311

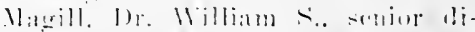
reeter of llows slipe luits an! 11. 1.5. 
Magill, Dr. IVilliam S., resignation as, 158

Magruder. Dr. Ernest Pendleton, direetor of Merey Ship Unit No. 3. 180,187

illuess and death of, through typhus, 182-183, 193

Malain, Miss, volunteer helper, 241

IIaison d:linfance, at Marseilles, France, $7 ! 92$

Iale nurses, commendations of, by Major Arthur. 60

Mallory, 1lazel. at Le Glandier, 819

Maltby, Frances, Chautanqua nurse, 1055

recruiting of nurses, 1062

Manget, Major F. P., aeting commissioner and manager of Western Division, American Red Cross, 939

Manget, Felieice dispensary at Boulevard linlevilla. 809

Manning. Dr. Mlugl, Medieal Supervisionl. 1195

Manning. 1)r. John P., dispensary work at Paris. 802

at Disponsure Maric-Lanneloncue, soi

at llutualite Juternelle, 806

Mansficld. Burnice 1)., at Naval Hospital at Grat Lakes, 11l., 710, 711

Mantoms, Dr. Dora. child welfare work. Hince. 1918. 812

Marcle. Fencral Peytom C'. Chief of Stafl. on regulations regarding (1)uipment of Army Nurse (or pis. $381-302$

Marer. Inory. rlijef nurse of Russian Islaml Hospital. 931

Mare Island. Naval Ilo:pital at. 713

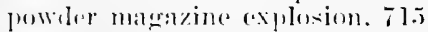

Mario Feorlorovola. Dowager Empress of limsita l.75

Marirllotome Hopital. partly finamonl by American lied Cross, Silici

Wari-lannelomgne. Dispenstive. sot

Marine Howital and Relisf, liureau rif. 11024

Marlborougl, J)meluss of. (ommitee of Amerienn Moments War lielief Funde 1 th;

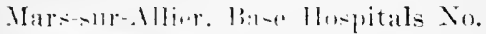

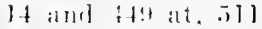

Mareilles, Franere, rhild welfare "lerk at, $791-79.5$
Marseilles, France, dispensary at, 792

Marshall, Miss Elizabeth, nursing service in Constantinople, 1197

Marshall, Florence M., director I'oman's Bureau, 300

Martla Waslington Hospital, Sicily, 865

Martin, Florence J., chief nurse, Base Ilospital No. 32, 504

Martin, Dr. Frankliu, organizer of General Medical Board, 7

student nurse campaign, 293, 294

Martin, Major, on rank for army nurses, 1069

Marye, Hon. George T., I55

Mason, Adm. M. C., ehairman of Distriet of Columbia Red Cross; advocates Red Cross workroom, 296

Míassacluusetts General Mospital, Nurses' Training School established at, 13

Massage and physio-therapy, 344345

Masseuses, demand for, through derelopment of physio-therapy, 344-345

regulations concerving enrollment of, 345

Maternity llospital, at Toul, France, 768

Mather, Mary E., on child welfare work at Dijon. 817

Mather. Samuel. president. Lakeside Hospital, Cleveland, Ohio, 337, 415

Matleson. Virla, in Serbia, 1121

Nathews. Stella R. l]6:3

chief nurse, Ameriean Rel Cross Commission for Poland. ]097

chice nurse. Typhus lieseareh IIospital at Warsaw, Poland, 1092

mursing school in Poland, II58, $115 ! ?$

rofuger chilel care, in Poland, 1098

State Committer. Wiscomsin, 112

Matter, Mademoiselle. sclublarship to study wursing, 1175

Mattlew, Margaret L... work of, at ('litit. Sibmeria. !)on

Mattingly, Dr. (ieorge A. dirertor of $\dot{P} . S$ Nary l3ase llospital No. +. 7.2 .5

Mat\%(n) Eumma, wounderl at stat, $+70$

Maude, Ciencral, at Bagdad, 892 
Maxwell, Miss Anna C., 362

Advisory Committe of

Sichool of Nursing. 285

aidl in nurses' memorial, 1047

Army Nurse curps, tis

Assuciated Alummio Committer to affect alliliation of nurses and Red ('ross, 73

at Steroubery Ilospital. (aimp Thomas, Chiekamatigal Park, report of $19.51-52-53$

Committere for alliliating orranized nurses with lied Cross, si, 88

Committe for Memorial find to Ameriean Nurses, 1048

Delano Menorial Committee, 1050,1051

delagate to Nintl Internatiomal lied Cross Conference, 1!1]2, 124 efforts for lied Cross alliliation, 71

Natimal Committer of American lied (ross. !) 5 s

Nitional Committee on Red cross Nursing Sirrice. 95, 111, 127. $24 !$

on Rirl ( ross atile plan, 10.i2

resolution for rank for Army mollises. $107 t$

services of, in recrutiting nurses, .i)

superintemelent, Jresluterian Hospital, 48

tribute to, from 1)r. Iloff. sis

vinit to Europeran lonspitals. 4so

work for Rerl Cross emrollment, iT

Work to serolue rank for Army nur:es. 1060.5

Mayer. Miss. publie halth nursing, 1349

Mayo, Mai. W. ., on rank for Army murses. loti!n

Merkowski, Dr. Wh. address at showel for nurses in Warsaw. 11til. $116 i^{2}$

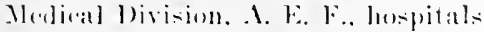
in lirance. ill

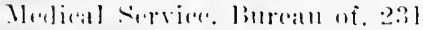

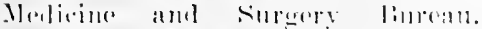

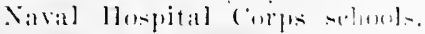
$7 ! 2$

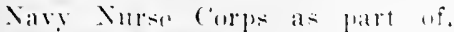
lisiti

Mehlier. Mrs.e on lome divetide. $14: 30,1431$
Meirs, Linda K., chief nurse, Amerioan lind croses llowpital Xo. 1]4, (i2.3.2, 770

chitef nurse of emereneney hospital at Joly-sur-.lnorin, tivi;

(ommittere on C'loweinge ('andidittes for Merlal, 11:30

Rommitnian (iommismion, Stre

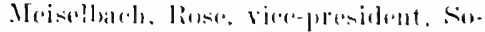
riety of Spani-h-American IV ar Nurses, 46

Meloy. Mrs. (i. S., volunteer hinger, 241

Menurial to nurses, Nirhtingale Sellomel. $1117-1049$

Memorial to muraen Who have died in sorvice. ]1041. 1017

Memorial to womlen of (ivil Mar proprosel. 1:11:2, 1:2:3

Mendenhall, Dr. Denothy liend, lessons on infant forelitie. 14:30

Mercer. Vindetta ('., anl molsile hospitals. 8.30

Morry ship kxpedition, atoption of

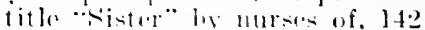
arrival ot. in Enfitand, 14.)

cargu of, lill

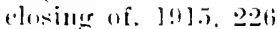

datily rontinte of. on shiphoard. 144

di-tribution of mols of. 141

ocoan vorise of. $1+4$

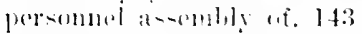

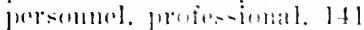

sleection uf lanile for. 14:2

sentiment of. 142

servior moiform and apuipment of

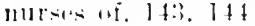

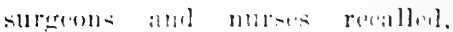
191.5 .215

[nit lo. ]. alrival of, at Salonical. 17is

dishambiner of lat

military lomplitel at linlerrale

talien isme lis lit

per-omul wi. iti

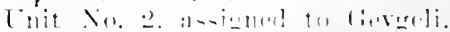
] 511

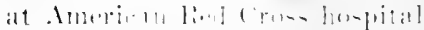

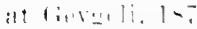

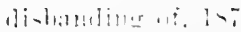

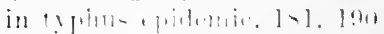

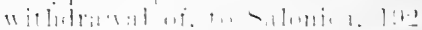

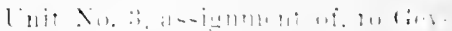
$\because 1 \mathrm{i}, 1-11$

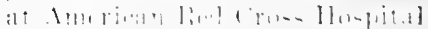

a 1 (a)

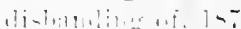


Merey Ship Expedition, Unit No. 3, in typhus epidemic, 181

withilrawal of, to Salonica, 192

Unit $A$, assignment to Pau, France, 150

volunteers for Scrbian typhus epidemic, 154

Cnit B, assigned to Pau, France, 150

volunteers for Serbian typhus epidemic, 154

Unit C, assignment of, to Kief, Russia, 155

changes in, 158

Unit $\mathrm{D}$, assignment of, to Paignton, England, 147

at Haslar Hospital, England. See Haslar Royal Naval Hospital

officers of, 146

withdrawal of, from Paignton, 149

Unit E, establishment of Red Cross hospital at Budapest by, 172

Unit F, officers of, 146

at Paiguton. England, 145. See also Paignton. England

withdrawal of, from Paignton, 149

Unit G, at Kosel, Germany, 166

Lnit H, assignment to Kief, Rus. sia, 155

clanges in, 158

Unit I, changes in, 165

members assigned for Russian prison work, 166

Lnit $K$, arrival of, in Tienna, 167

transferred for German prison work in Russia, 171

Meredith. Mrs. C. K.. in Army Nurse Corps legislative efforts. 68

Merriman. Mrs. A. N.. Commission to Nortle Russia. 67s

Méry. Or.. child welfare work, Paris, S1.)

Metcalf, Mrs. Maurl, at Mabel (irmiteh liaby llospital, 216

in Norbia, 11:0

on conditions at $\mathrm{Nish}$. Serbia, 219

Men ropelitan Nurses' ('lub. offer of services. for sianish-American ilar. 40

Metfel, Eleauor, public health work in Poland, 1094
Metzger, Amanda, chief nurse of U. S. Camp Hospital No. 40 , Liverpool, 432

Meusc-Argonne campaign, 633

Mexican border, American Red Cross nurses, first field service of, 348 , 349,351

disturbances on, 1911, 131

nursing service conditions at, 348 . 357,385

U. S. Army base hospital establishment at, 349

U. S. Army camp hospital establishment at, 349

U. S. Army cantonment lospital establishment at, 349

U. S. troops mobilized on, 1911, 117

Meyer, Agnes, in Santo Domingo, 1199

Mever, Frances H., joins Dr. Snoddy's group for Red Cross nursing among German prisoners in Russia, 167

supervisor of Mercy Ship Unit G, 167

Michigan, rural nursing in, 1229

Miel, Rev. E. D., Commission for Europe, 531

Miles, Emogene E., on Pau, France, as recruiting station, 151

work at La Panne Hospital, 203

Military probationers, British Nursing Service, 475

Military relief, 231

Mill, Anne P., on hospital train service, 638

Miller, Anastasia, on work at Refngee Hospital at Beauvais, France, 833

Miller, Annie, at Naval IIospital at Mare Island, 713

on types of nurses' service in Eu. ropean War, 714

service at poweler magazine explosion on Mare Island. 715

Miller, Elizabetl, in Santo Domingo, 1199

Miller, Clıaplain Gilbert O., funeral scrvice for Miss Delano, 1003

Miller, Dr. James A., assoriate director of the liockefeller commission for the Prerention of Tubereulesis in France. St4

Milliken, Sayres L., on Army Nurse (orpes miforms, 359, 360

on nursing service at Camp Serier, South Carolina, 409 
Mingane, Mary Frances, nursing service in Creece, 1114

in Samos, 1113

Mink, Dr., at Virgin Islands, 120.3

Minnosota, sehool nursing in, 1:340, $13+1$

work of pulylie health nurse in, $1: 346,134 \pi$

Minnigerode, lucy, aid to sick nurses. 1036

claarge of special units of nurses, 239,240

on character of Russians received at Kicf, $156,15 \%$

on confidence of Russian patients toward Americans, 157

Delano Nemorial Committee, 10.50, 1051

in inlluenza epidemic, 975

iuspection of Marine lospitals by, 1025

on rank for Army nurses, 1074

on Russian wounded, lis

on war risk insurance for nurses, 1037,1038

public health nursing service, 1026

return of, to Lnited States, 1.j8

supervisor of Merey Slip Lnit H, 156

volunteer helper. 241

Ninnigerode, Powell, committee on memorial for Miss Delano. ]05t)

Minsk. loland. Red Cross roliof work at, lo!!:3

Minter, Commander .J. Ml., Committer in llaiti. 1173

Mirman, M., work with eluldren in Toul, 76.5

Missimer, Florener. member of operating team sont to line. Tt5

on eonditions at .Jonilly, 74.5

on lielel hospitals. T47

Misisipipli. rural nursing in. 1229, $1: 301$

Mississippi llood disasters, s6, l2?? $1: 32$

Mi-souri, nursing service in, 1917, $1: 36$

Missomri, liod Cross serviees mo til

Mitele?l. Filizheth G... rhilel welfarm

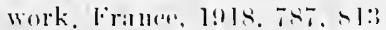

nursing serviec in 11 ontonemoro. $1101 ;$

Mitchell, 1)r. Sullice. serviens wf. in Floriala yollow fover epillemia. 16

Mitylene, relief work in. $111 \mathrm{t}$
Mixur, Knowlton, in Philippines, 1209

in P'mertor Rico, 120]

Mixiell, Mr. liaymond, medicin-chef, r'hitelef llospital, 77!

Mobile llospital No. 4, organized from personucl of lase IIrospital No. 21, 4199

Mobile Ilospital No. 9, Belginm, 649

Molitar [nit No. 1, 650)

Molbile Luit No. in, service near front line.450)

Mobilization entre for nurses at lillis Island, 416

Moer. Henry, National Adrisory Committee on Insurance, 1041

Molnun, libluard D). L., $1+0$

Molloy. Jane $r_{\text {.., }}$ on cantonment nursing. 394

recreition at ('amp Dovens, 396

Mongazon, France, base Ifospital Xo. 27 at. 500

Ifongolin, nurses killed on, 469

Money. Cicneral Sir Arthur, 893

Monroe, Frederick C., on recruiting of nurses, lofil

Monroe, Mary, Chautaupua nurse, 10.5 .5

Montauk. contract for nurses for, $38-39$

organization of hospital services at. (i)

tents for lied cross contribution toward nursing sorvice, 61

Montenergo, relief work in, 11021107.1183

Montparnasio, emergency canteen at, $8: 37$

Moody, Mrs. Matude G.. 3ti2. 366, 371. 372. 374. 379. 38.3. 354

at children's colony on liusian Islamel. 932

Mrome. John liasutt. Contral Cummittere. 2031

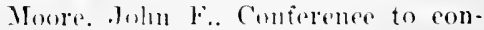
sider nursing ponlems, 2.54

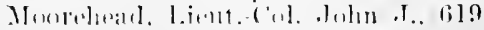
at Amorian lienl ('rose Ilospital

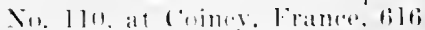

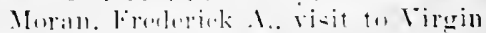
$1+1: 1111 \%, 1: 2+12$

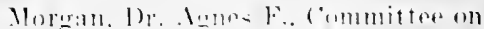
linel (rom l)intitian sorvices. $1: 3: 9$

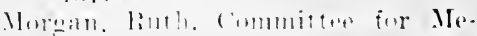
imorial find lo Ameriean Dnt? 
Morgan, Ruth, Committee on Town and Country Nursing Service, 1264

director of Nursing Service, 564

establislment of nurses' club, at Paris, 563

on position of nursing profession, 564

Morrow, Colonel, chief surgeon of Second Dirision, in France, 604

Morrow, Judge W. W., Central Committee, 230

president. Red Cross in San Francisco, 1905,129

Morse, Elba L., plan for recruiting nurses, 1063

Morse, Meda, death of, 1397

Morton, Ruth, chief nurse, Mobile Hospital No. 4, 469

Moselle Valley, 993

Mosher, Dr. C. D., clild welfare work at Corbeil. France, 799

Mother Angela of Mound Citr, nursing services of, in Civil iTar. 7

"Mother" Bickerdyke, Civil War nursing services of. 12

Mother Franeis of Chicago, nursing services of, in Ciril War. 7

Mother Gonzaga of Philadelphia, nursing services of, in Civil War, 7

Mother Anthony O'Connell, nursing services of, in Civil War, 7

Mott, Mrs. Joln R.. recruiting relief murses for Polantl. 1085

Mloufflard. Mllle.. tuberculusis prereution work in Paris, St7

Mount, Miss. appointed for I'lilippine service. 63

Mountain Division of Red Cross. 247

Monssean, Dr.. public health work at Bordeaux, France. 796

Mulville. Josepline. Chautauqua nurse. 105.). 10.57. 10.5s

Mumford, John. aid in Chautangua campaion, loses

Munro, Mr.. on transfer of mutrition service to leasle hervice. 1437

Mumroe. Mrs. Gererese. sprinsor for Amerian Ambulanoe il Nenilly, France. 53,5

Murlin. Major. Fond and Nutrition Division of Army. 1400

Murplyy. Colomel Find T., direstor, Batec llopplal No, 21, 46it
Murphy, Colonel Fred T., director of Medieal and Surgical Department, American Red Cross in France, 824

Murplyy, Major Grayson, American Red Cross War Council, 612

appointed to Gencral Pershing's staff, 531

Conmmissioner to Europe, 1917,427

head of commission for Europe, 530

resignation of, as Commissioner for Europe, 1078

Nurply, Mary, elief nurse at "Oldway House." Paignton, 429

Murray, General Arthur, actingchairman of the Central Com. mittee, 360

ehairman of Red Cross Central Committee, 337

Murray. Virginia, opened dispensary at Lyons, France. 785

Mury, Edith Agnes, chicf nurse of Fillis Island. 416

on work at Ellis Island, 416

Muscle Shoals, Alabama. manufacture of nitrate at. 347 .

Muscle Shoals Sanitary District. Surgeon General Riupert Blue, on duties of Reá Cross public health nurse, 403-404

Intualite Maternelle. taken over by Children's Bureau, 1918, sot

Napolconic Wars, relief work of Sisters of St. Vineent de Paul in. 2

Nash, Jane E.. National Committee on Red Cross Nursing Service, 249

Nassau Ilospital. Red Cross services at. $6 \mathrm{I}$

Tational Advisory Committee on Insurance. $104^{\circ}$

Nationil Committec on Nursing Serviece, 102

National Commitere on Red Cross Nursing Sirvice, 9.), 245, 249

duties of . 3.57. 376

evolution of "Mrs. Roblis Committers I'lan," (9)

mext ing Thene 16, 1977. $40.5,406$ action taken recardiner enoullment uf colered nurses. fol.). 4illi;

mexting 1)re. 5. 1911. 40.5 action taken regarling enrollment of coloresl nurses, 405 
National Committee on Red Cross Nursing Service, meeting held . Ju110 20, 1917, 40.5 enrollment of colored nurses, 40.5

nurses' ('nrollment plan, 102

National Emeremen Association of Women Physicians, olfer of Spanish-Ameriean War services from, 40

National Reel Cross IIearlquarters, building of. by Capt. James Servmser, 12

Natiomal Red Corss illeals, origrinal conception of, for Lnited States, 13

Sational Red Cross Society, affiliation with American Federation of Nurses. 94

Naval Affairs linreau, American Red (ross. (i9)

Naval llospital Corps schools, 712

Naval training mits, in schools, (i)!?

Nary hase hospitals, equipping of, (i!)

oreanization of, (69)

Nary, in European War. 68.

Xay leagur. Wuments Saction, 269

Nave Nurse Corpos testi

assigmment of lied Cross nurses (1). (i)? 4

(x)

Estluer V. llasion, tirst superinfondent. (isti

incignia of. 149.5. 699

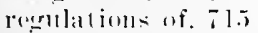

relations with Ameriean Red

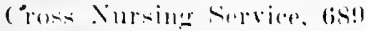

rewpirements of. tist

-alarien of $6: 97$

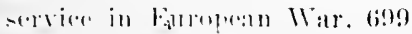

miform- of. tigt timti

Xavelperating Tiam Xo. 1. Tt1

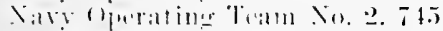

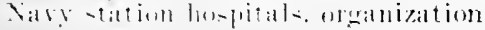
1if. tis:

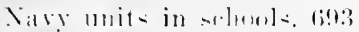

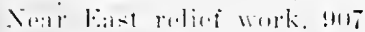

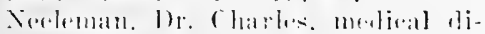

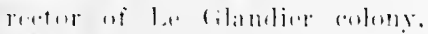
414

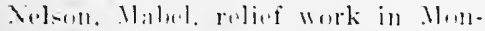
tomenere. 1104

wnk in liallatm- 11:4

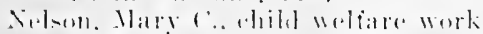

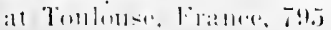

Nilson, Mary C., supervisor, work with rhildren at binard, France, 769

Nolson, Mary K., Chautauqua nurse, 10.5.5

dirretor of public health nursing, 1:30:3

on work at Ameriean Red Cross lospital at st. Valeryoen-('aux, l!s

sulpervisor of Alliance IIospital, Yvetot. Franee. 197

supervisor, Ameriean Red Cross Hespital No. lo!, at Evromx, 539,609

volunterer service at St. Valery, 539

work at Hopital duxiliare, No. 3', 199

work of, in linance. 5.59, 560

Nelson. Sophic ('., ehicef nurse, rhat teau des llalles hospital. Tsl

mursing director. 119.)

Nesle, liance, captured by ciermans, 1918,464

(dilil werare work at, iil

Nenfohiteau, France. dispensary amd lowitill at, 4!2

traveling dispensaries at. 548

Neully, France, American Ambulance at. 53.5

American Red ('ross Iospital No. liil at, (i)l

Neville. lila K.. work at dork infirmary at Borklatux. 1012

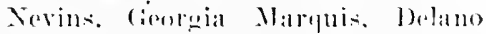
Wrmorial (

delexale lo Ninth lnternational lind (rons comferemere 1912. 129

director Ponanace Divi-ion of linel ( rosis. $24 t i$

tirst meet iner of Xational cimmit -

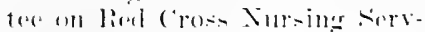
ira. $101+2$

head ui liartidd] Jlo-pital, Mashingturl. :3!

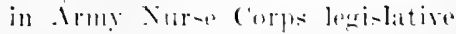
eflint. lis. in

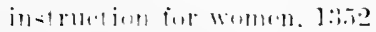

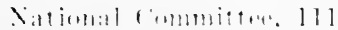

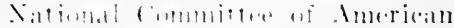
linel 1 ron. 1, in

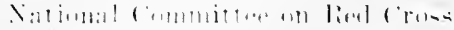

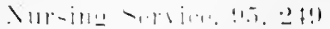

on entribuent in the Pursing $-1.1010 .2 .5$ 
Nevins, Georgia Marquis, superintendents' society representative, committee for affiliating organized nurses with Red Cross, $8 i$

New Albany, Indiana, nursing service at, 1917,136

New Castle. Indiana, nursing service at, 1917,136

New England Division of the American Red Cross. 244

New Haven Hospital. Nurses' Training School established at, 13

New York Auxiliary No. 3, duties of, 27

New York Burean of Nurses' Equipment, 367, 37?, 3S2

New York City Branch of American Red Cross. organization of, 21

New York City Training School for Nurses Alumne, desire of, for Red Cross affiliation. 80

New York County Nurses' Association, discussion by, of relations with Red Cross. so

New York Red Cross Branch, additional stipulations regarling nursing service with Red Cross, 79

New York State Nurse Registration Act. 79

Newell, Lavinia H., Moman's Advisory Committee, 300

Newmin, 1)r. R. 1I., director of Nerey Ship Lnit G. $16 \pi$

general operator of fierman military hospital at Kosel, 166

joins Dr. Snokldy's group for Russia. 167

Newsom, Mrs. Ella K., Civil War nursing services of, 11

Newton. Dr. Plitip. director of Merey Ship lnit If. 1.5;

in rharese of flying field hospital in lin-xian army, 1.s!

Nichols. Emma if.. National Committer of Amorican lierl Cross, 111. 9.5

Natiomal Committor on Rial Cross Nursing Service. 95. 127, 249

Niener, John. :36i:

Niglitingale. Florenere 414

and sanitary rngineering in lospitals, superiutrulenes of 3

attiturle of. toward soleliers' rereration, $t$
Nightingale, Florence, educational facilities arranged for by, 4 effort of, to combat drunkenness, 4 efforts of, for soldiers' wives, 4 help of, to foes, 4 help of, to soldiers' families, 4 help of, to Dr. Blackwell, 6 inspiration to Ifenri Dunant, 2 laundry service organized by, 2 organization of diet kitchens by, 3 organization of emergency nursing service, 2

purveying of clothing and supplies, 3

Nightingale, Florence, Foundation, 124

Nightingale School, France, 1047

Advisory Committee of, 1049

charter and hy-laws of, 1048, 1049

Nightingale Training School for Nurses, establishment of, 5

Nikic. Montenegro, relief work in, 1106

Nish. Serbia, haby hospital at, 215

conditions in, hefore Bulgarian oc(upation, 217

Noble. Colonel Robert E., on uniforms for American Red Cross Nursing Service, 366

on organization of base hospital units by Medical Reserve Corps versus American Red Cross, 3.31

Nohr. Viola, relief work in Albania, 1108

Noreross. Olive Ward, death of. 1390

Norfolk, Ya.. Naval Hospital, 19171918. 700

North Dakota, rural nursing in, 1230

North Rissia. Allied forese in, 67.5

American Red Cross Commision to. 675

military situation in, European War. 678

North Sea. L. S. Nary's actirities in, $71 !$

Northern Division of Rerl Cross, 247

Northwestern l)ivision of Red Cross. 2.47

Norton. ('harles 1)., Central Committor. $2: 30$

Tott. Dr. Iosial, yollow forer work of, 13

Voyes. (lina D.. aceompanies Miss D) lano to New York. 99.5 
Noyes, Clara D., Advisory (ommittre of Nightingale Sichool, 1049) aid to secure rank for Army nurses, 1071

aidl to sick nurses, 1036

American Red Cross parade, New York, 420

and embarkation of unit, U. S. Army Base llospital No. 4 (Lakeside), 414.415)

appeal to members of graduating classies of hospital scliools of nursing, 343

uppointment of. as director of Department of Niursing, 1006

at Twentieth Anmual Convention, American Nurses' Association, $387-388$

chief nurse of Base Hospital No. I, 360-362, 374, 379, 383, 3!13

circular letter to dietitians, 1379 , 1380

Committee, Menorial Fund to Ameriean Nurses, 1048

Conference to consider nursing problems, 253

coopperation of, with Army Nurse Corps and American Red Cross Nursing Service, 314, 315, 316, 317

director of Burcau of Nursing Service. 231

Director of Field Nursing. 248

gruide to instruction of volunteer nursis aides. 272.273

hist ory of calerer. 232

lospital smpplies' work. 298

in rharese of nursing service, 23.5

in influenza epidemic, 972 socoring nurses for. 9773

in l'osen. 11.is

incpertion in Alhania, 1182

in-pertiun in Florence, 1183

in-peretion in Gereere, 1181-1182

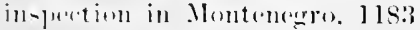

inspertion in lonlumele 1]79

Juint Sitional fimmittere Iots

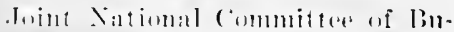
ratu of lnformattion. lolti

letper comereruiner axplusion of

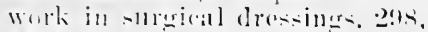
$29 ! 9$

loltere of Mi-s Malmo anking her 16 join work of lied crost. 23:3, 231
Noyes, Clara D., letter of protest against decision unfavorable to nurstis. gas

letter on conditions in Washingtoll, Sopt., 1918, 969

lettrer to Miss Delano coneerning roleasing of murses, 1014, I015

letter to nursis organizing units for the Army (f)et. 12, 1917), 323

National Committee on Red Cross Nursing service, 249

National ('ommittere to Secure lank for Army Nurses, 1070

nursing staff. 23.5

Nutrition Nomber of National Committee, 1437

on cantonment service, 390

on eantonment zone work, 346

on murses' repuipment. 360-366, $37(0,371,374,379,383$

on murses' salaries, 380

on mursing personnel of base hospital on embarkation, 41.j

on organization of nursing serviee in France, 5id

organization of mursing staff of first fifty base hospitals, 339, 342,344

plans for nursing school in Bulgarial. l]tio

plin of transfor of Bureau of Information. 1021, 1022

plan to recruit nurses. 1060

recipient of letter from Miss

Loulisi Lee Schuyler.

recommendation for nursing selheol in Bulgaria, 1168

recommendations to Colonel Odes after inspertion, 11s4, 1185, 1180

reports on work of nurses' drive, 292,293

responsilility for hospital supplice. 297

refires ats greselent of American

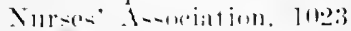

speiking trip to murses. through

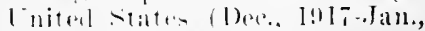

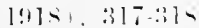

stmly of Wirsilw anditions, liniti

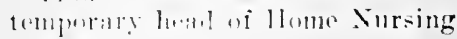

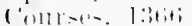

tour of in-1ntion. 11.50. 117ti

work during inturnzal epidemic, :1) 
Noyes, Clara D., work for home nursing courses, 1366, 1367 work for nursing school for Poland, 1155

work for rank for Army nurses, $1074-1075$

work to recruit nurses, 969

Noyon, France, captured by Germans, 1918, 464

Nuno, Christine, aid to sick nurses, 1035,1036

Nurse Corps, Narr, 686

Nurse Corps of the P'ublic Health Service, development of, 348

Nurse Corps of the Veterans' Bureau, 1030

Nurse Education, International, 1145

Nurses, affiliation between Army Nurse Corps and Red Cross, 96

American Red Cross affiliated with American Nurses' Association. 123

assigned to Nary Nurse Corps, 694

assigned to Navy bace hospitals, 692

"brother ruling," 763

colored, enrollment of, during European War. $405-409$

convalescent home for, at Le Croisic, France, 613

distribution of. in France, 763

enrollment of. in Red Cross, discussion of. 80

Miss Delano's reports on, 28?, 290

Nary Corps requirements for, $6 s \bar{T}$, 691

public health. shortage of. Tol

rumors concerning treatment alsroatl. $26 j 1.262$

school for, Constantinople, ll6s, 1169

state societies of nurses, entitled to Red Cross memberslip. 112

teaching molor Red Cross banner, discussion of, sol

types of service of, in European IVar. 714

type of work of, list4-1346

visiteuses d'enfonts, so!

war mursing program, 2.74-2.js

Nurces a ickes. Reed remst. Ttit

astigned to forejont service, 5t6

question of, 269
Nurses' aides, Red Cross, status, duties, requirements, $273-276$

Nurses' Associated Alumnæe of the United States and Canada, organization of, 20

first convention of, 20

work of, for maintenance of standards, 20

Nurses' Bureau, American Red Cross, 613

Nurses' club, Pension Galilee, at Paris, 562

Nurses' drive, 291

Miss Noyes' report, 292, 293

Nurses' equipment shop, establishment and maintenance of, 380381

at Paris 698

Nurses' training schools, growth of numbers of, 20

Nursing, Army School for, 963, 964, 965

Miss Delano's opinion on, 960

Nursing. Department of, at Red Cross Central Division Headquarters. Chicago, 404

Nursing, National Committee on. of

National Council of Defense, 265

Nursing Amendment, Army Reorganization Bill, 70

Nursing Department, organization of, 1910.116

Nursing Education, aid of Women's Section of Nary League. 269

at Vassar, 268

Convention, 955.962

Nursing leaders, personality of, in latter 19 th century, 1S-19

Nursing needs, 9.54

Nursing sehorils:

Buigaria, plans. 1167-1168

Constantinople. 1170

Greece. plans. 116.5-1166

Nursing schools. Miss Gardner's report. $1191-1193$

Poland, 1159-1160

Prague. 1149

program for. 1195

Warsaw, 1159-1161 conclitions. 1163-1164

plans. $11.56-1158$

Nursingr Sirvice. at layton, 19l3, 132

at laris, 5on

Briti-h. 435. 472-482

rules for murses, t76;

status of nuroes in, 483 
Nursing Service, budgret syistum for, in England, 435

lumreall of, 2:31

contract form for Philippines, $6: 3$ emererency, organization of, by

Florenere Niglitiorale, 2 enrollment in (ireit Britain, 435

in Eistland disister. 1915, 135

i.1 France. $.502,50.5,510$

need of, $1 ; 20$

staludards of. 527

proposed lamdling of, 94

Nursing Siervice, Ameriean Red ('loss. alditional elrollment (l!) is) in. 510

Amerian Expeditionary Forees, (ii) 4

asionments to Nary base hospi1 als. 6992

discipline in overseas service, 210 duties of 251,252

wlucational work of in siberia, $9: 34$

Fiecultive Committee, 25:3

foreign program closed. 1915, $2 \cdot 26$

forcl supply in France, 513

head of, qualifications for, 562

lleathularters, 236, 237

in France. 518

cranazation of, 572

in lialy. sclusols of, 871

in Nour Ealst. 907

in Siluria. !) (1., 92?

meining of. 12(i.j)

Citionill ('ommittee on, 95, 127 duties of. :24!)-2.51

nursese enrollment plan. 102

relations with Xary Xurse Corps, (is!)

relation of. to the Army, 310 $3 \rightarrow$ i

al timn of Armistice. 631

hase lowsitals, 310, 314, 327

al-inmunt af nurses for, sperial alisuasise to, 34.5

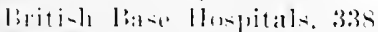

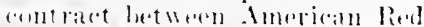
('ross alld Lalkeside Ilespital. ("leveratud. ()hio. :336

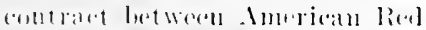
frows and partent institutions mulertaking oreanization of, $3: 36 ;$

(4)

mtahlishment wf. 335

molilization ai, :3:s
Nurwing Service, Amorican Red Cross. hatse hompitals, inusterrolls of , 335., 33:36;

nul'se' a indes, 33.5

nurming statf of, 334,335

perionmel of, 334-335

supplementary and replacement horpitils. 3:3s

Bureal of Sanitary Sorvice under the Department of Military Relief. organization of, 346

cantonucht zonc service, 345-348, 390

assignment to Camp Sherman, $4111 ;$

assignment of colored murses at (amp) Slerman, Ohio, 40.5)

assignment of individuals to, $411-41 \cdot 2$

at Muscle Shoals Sinutary Distric.t. $403-404$

courtexies shown to nurses. 397

recreation lonses for murses, $3997-3918.4114$

spirit inperesed by reserve tutrse oll, 412

derelopment of physio-therapy, $34+-34.5$

disension between Miss lioardman and Dr. (reosere Wr. Crile, 327

(mbarkation of nurses, 413

emereney detachments, 310, 316, $: 341$

duties of , :34:

orwantation of 341,342

fersimnel of. :34

valur af. :34:

(2mrollment of nur:es, 3200-323

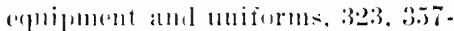
inti

Burean of Nursen Eifuipment, :3i;3

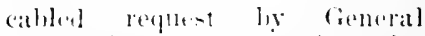
Pror-hing ior nurses rquipn116nt. BS

explipulent of nurre by Amor-

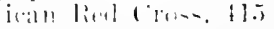

unifinm of Amminan Army

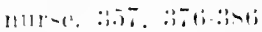

cxtra-antumment \%one service, $\because 1.5 .: 1$ in

alpheptation of funt for mi-

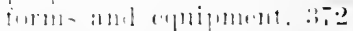

anountion of l \& Puhlia

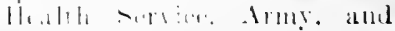

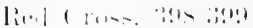


Nursing Service, American Red Cross, extra-cantonment zone service, duties of nurses, 399, 403

in infectious and communicable diseases, 400-405

in pandemic of Spanish influenza (1918-1919), 403

hospital units, $310,316,327$

equipment of, $340,341,344$

establislment of, 340,344

medical sections, 344

organization of, 340,344

personnel of, $340,341,344$

purpose of, 340

Red Cross Chapters and, 340, 344

Red Cross nurses and, 344

surgical sections, $340,341,344$

insignia, 357,356

laundry allowanee, 385

local Red Cross Chapter and base hospital unit, relation of, 334 , 336

marine hospitals, 348

Mexiean border service, $348-357$

organization of units, 310,315 , 320-321

Red Cross Commission for France, insignia of, 374

Red Cross division offices, establishment of, 342

Red Cross public health nurses, 399-400

regulations governing the employment of American Red Cross in time of war, 334-335, 341

reserve nurses, for Mexican border service, insignia of, 352

requirements for enrollment, $351-3.52$

removal of Red Cross from cap of, 376

uniform of, $368-369$

wearing of brassard by, 368

responsililities of American Red Cross, 415-416

Roman Catholic Sisterhoods, uniforms and insignia. $376-37 \mathrm{~s}$

"safety suits," appropriation for, 384

salaries, 380

special mits, $344-345$

status of nurses, $33 . \bar{t}$;

subsistence of, provision for, 384 . 385
Nursing Service, American Red Cross, supplementary and replacement hospitals, 338

training school units, 342-344 types of assignment elaracterizing war nursing service, 410

Nursing Service, American Red Cross, reorganization of, 564 report, anmual, 1917, 136, 138 report of committees, $252,253^{\circ}$

resolution on rank for Army nurses, 1073, 1074

Rutl Morgan, director of, 564

sub-bureau of Women's Bureau of Hospital Serviee, 564

Nutall, Mrs., in charge of Nueces nursing party, 33

Nutting, M. Adelaide, Advisory Committee of Army school of nursing, 285

aid to rural service, 1251

and embarkation of unit, U. S. Army Base Hospital No. 4 (Lakeside), 415

Chairman National Committee on Nursing of Council of National Defense, 264

Committee, Memorial Fund to Ameriean Nurses, 1048 .

Committee of Transfer, 1021

committee on settling war nursing policy, 254

eonference to consider nursing problems, 253

efforts towards Red Cross affiliation, 71

Federation representative, Committee for affiliating Organized Nurses with Red Cross, 87

in Army Nurse Corps legislative effort, 68,69

Instruction for women, 1354

Joint National Committee. 1047

Joint National Committee of Burcan of Information, 1016

letter on home nursing, 13541355

letter to Miss Delano entlorsing war nursing poliey, 258, 259

National Conmittee of American Red Cross, 9.28

National Committee on Red Cross Nursing Serviee, 249

organizes Emergency Committee on Nursing, 264

publicity work in Sturlent Nurse Reserve Campaign, 294 
Nutting, M. Adelaide, president, Amerieun Federntion of Nurses, 71 .

report on ontput of nurses from training scheols, 255

resolution for rank of Aruy nurses, 10it

Superintendents' Socioty Commit. tee to refeed nurses' and Red Cross alliliation, 74

Town and Country Nursing Committeo. $1 \geq 19$

Town and Country Nursing Servic ( 2,1219

Work of Committee on Nursing, 2(i.)

Sutrition Serviee, meeting of members: transfer planno(d, 1437 report of, 1438

()'Donnell, Graee, hospital trair dut $y, 500 .(6336$

()'Domell, Mary A., work in Cuba, 64

()'llara. Anne, nursing service in Ferhia, 1119

o'kefe, Elizalheth $k$., reserve nurse orl Mexiean horder. 354-35.)

W'laughlin, Mrs. C'allan, volunteer nitrse, 24l

W'Malley. Anmo l... Palestine Commisiom. S!!?

W. Neill, l)r. Frances, director. chitean des Malles hospital, Tsl

Mades, Miss, relief work in Alluania, $14: 22$

()henr, Evelyn, nursing sorvice in Remmania, 1120 (i

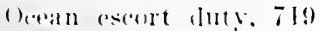

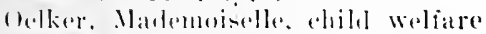
werk. Puris. si.j

1hio, arly shlistitution hy, of state Nur-iner Acomelations for lied

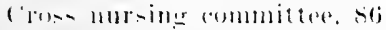

Howers. 191:3, 1:32

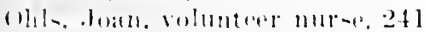

[1] [oluny ('luh. mohilization stal-

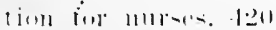

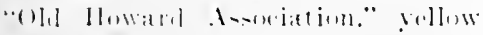

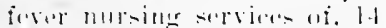

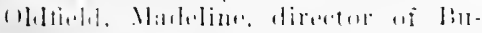

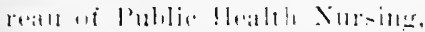
$1: 311: ;$

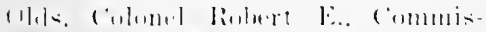

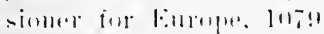

bn eare of rhibluen ithrabl, 117s ()ls, Col. Robert E., resignation from linropean Commission, IIs's

"Ohlway Ilonse," Paignton, longland, 14.5, 146, 424. Siec also latignton, linglaul.

taken over by Ameriean lied ('loss, lols, "as Military Ilospital $\times 1,21,42 !$

Oliver, Narion l., lome narsing (ourser. 1365)

organization of dietitian classes, 1376

orranization of nursos' aides groups at National lleadguarters, $2016 ;$

Olmstead. Katherine .1., liommanian Commission, 882

Director of Nirrsillg of Leigute, $11+6$

Onathat relone, 1913, 13:2

Omsk, Niberia, (Narluted because of bolsleviki, 94l

Omak (Silweria) llowpital, 9206

Orange, X. J., Visiting Nurses' Settlonent. training for public health mursing. 1:244

Orlains, France, emergency cantern at. $8: 37$

Ormeston. Hôpital, tuberculosis hospital, s4s

Orr. Dr., operation on Miss Delano, lonel

Oshorn, Mrs. William ('., Army Nurse (onple, legistation comimittra. is

(ommittee on Town and combtry Norr-ing Fervice, letit

1)enane Memorial Commitere. 10.51

National committer on lied crens Nursingr sirvices, $24 !$

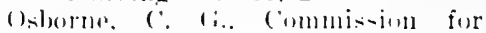
linrope. $5: 31$

Msler. Sir William, an-ulting ply-ireian to (innmitere of the. Amerinan Miment- Ilar linlief Fimml. Itij

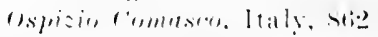

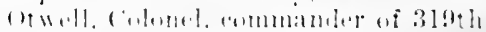
linginter 720

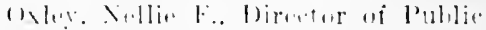

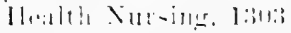

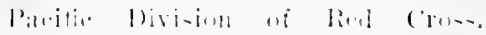
217

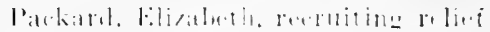

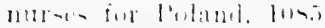


Packard, Mary C., State Committee, Maryland, $11:$

Paderewsi, Madame, relief work in loland, 108.5, 1086

Padua, ltaly, American Red Cross hospital at, 86.)

Page, Mr. Walter H., honorary president of London chapter, Ameriean Red Cross, +25

Paget, Lady Artlur, Committee of American Women's War Relief Fund, 146

Paid nurse, form of Red Cross agreement for, 78

Paignton, England, analysis of cases treated at, 147

assignment of Mercy Ship Unit D to, 147

assigmment of Mercy Ship Unit F to, 145

arrival of Unit $\mathrm{F}$ at, 145

withdrawal of American units from, 149

Palais d'Hiver, at Pau, France, 150

Palanka Hospital, Serbia. 1118

Palestine, American Red Cross Consmission to. 891

Rerl Cross relief work in, 1130

relief nurses in, 1083

Palfrey, Dr. F. E., director of Typlius Research IIospital at Warsaw, Poland, 1092

Palmer, F. B., school nurse in Minnesota, 1340, 1341

l'ilmer, Miss, dietitian overseas, 1410.1411

work in Albania, 1422

l'almer. Sophia F., 94

Chairman of American Revolution ('ommittee in Ruchester, and -merintending nurse. 40

(i)mmittee on momorial for Miss [).]:mo, 10.50

"riticism of attitude of public toward lome coming nurses, lol3, 1014

dwith of , 10.50, 12io

nilor. 1 merione . ournal of Tursint? 71.391

"fforts towards Rerl (Crose aftiliation, 71

Xitional committere of Amprian

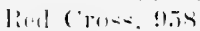

Cational fommittere on liorl croms Xirr-iner sorvice. 9.)

in mon-entorllment of roluntere nurnes, 100
Palmer, Sophia F., resolution for rank for Army nurses, 1074

services for nurses' enrollment in Red Cross, 76

State Committee of New York, 110

Paris, dispensaries at, 802,810

work for refugees in, 834

work of Children's Bureau at, 801

Park Hospital, origin of, 35

Parkhill, Clayton, demand of, for nurses, $5 \mathrm{~S}$

Parmelee, Eva Jean, on air raid at Dannes Camiers, France, 453

wouncled in line of duty, 1031

Parris Islant, Naval hospital at, 708

Parrish, Major Robert E., in command of C.S. Army Evacuation Hospital No. 17, 948

Parson, Commander A. L., Committee in Iaiti, 1173

Parsons. Ellen, State Committee of Illinois. 110

Parsons, Emily E., Civil War nursing record of. 10

Parsons, Louisa, death of, in British Army service, 65

Parsons. Maud, chief nurse of Base Hospital No. 105, 996

Parsons, Mrs. Ethel S., director of Burean of Public Health Nursing, 1303

director of Public Health Nursing in Southwest. 1304

National Committee on Red Cross Nursing Sorvice, 249

Parsons, Silra E., clief nurse, Base Ilospital No. 6. 493

work of. to secure rank for Army nurses. 1071

Parsons. Miss, nursing scloool in Pragle. 114?. 1152

Paseoe, Mary, dictitian overseas, $14(14$

Pateroun. Jesise G., Palestine Commi-ion. s!re

latmore. Amy Florence. Whef nurse, Base Hospital No. S. 4!te;

Patras. tireece. infant werfare werk at. 1115. 1110

Patten, M: S.. Ilirector, Department of Ililitary Aflates. jos

Patteror). lisie. State Committere of lin Vork. 110

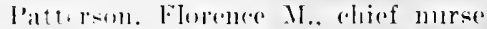
wi the lioumanian Commission, si:2 
'atterson, Florence M., at National llealquarters, 240

mursing service in Roumunia, 1126 on departure from Rommania, 1918,887

on Roman ILospital, Roumania, $883-585$

work with Service de Sunte, ist

work on Student Nurse Campaigm, 293

Patterson, Colonel Robert U., assistant director Veterans' Bureati, 1031

Base llospital No. 5, 452

elicef of Bureatu of Medical Serv. icco, enti

director of Bureau of Medical sorvice, 231

National Committee on Nursing Service, 127

seluetion of sturgeons for Merey Shlip expedition by, 140

Pau, lirance, arrival of American units at, Jijo

as reeruting station, 151

assignment of Nerey Ship Lnits $A$ and 13 to. 150

lurial of soldiers at, 153

rases received at, 152

closing of Ameriean Red Cross lospital at, list

inspertion of hospital by tourists at. 1.52

recorel of work of American units at. 154

volunterering of American mnits from, for serbian typhus epidemice. 1.it

P'arillen Bellever, St. Clomd, hospital. ti]n

lealselly. 1)r. Francis, lioumanian (inmmission, sise

Pearer. I)r. li. M.. chairman, Natimal Mordical board at Red ('rosis lleadeluaters. 5.5l

(onference to eomsillor nursing prollems. 254

Peilres. I)r. N. O.. member of childrent- Bureau, France, ijs

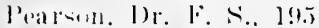

l'sk, Malrion llelen, diotitian, death (i) 14.2 .2

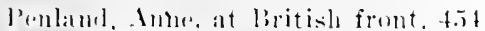

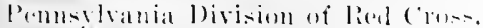
$2+.3,24 t i$

l'mun-yania, on lied cross nursing -tamblatris si:3 l'ension Cialilee, Paris, nurses' club, $5(62$

Pepoon, Nargaret A., National Committere, 111

National ('ommitter on lierd Cross Nursing Simicen, !95

l'epper, George Wharton, conference to consider nursing problems, 25.

Pepper, Mrs. Goo. Wlatton, Woman's Advisory (ommmitter, 300

Pepper, Marearet, lis!

Perey, Dr. Kitrlton (i,, chicef of Ameriean lied Cross dispensary, 7 (i)?

Perkins, Major James II., Commission for Europe. 530, (j) $107 \mathrm{~s}$

on qualifications of licat of Nursing serviere. itie

Perkins, colonel liobert P'., disector of (ommision to laty, sis!)

Perkins, 1)r. lioger (B., liomnanian (ommission, is2

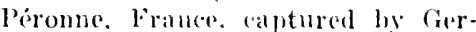
mans. 1918. 4tit

Perry, Mliss, deleurate to Nintli International lied Crosi Confer. (nee, 1!) 12, 124

l'ershing, lineral, 345, 381

attitude on rank for Army murses, 1073

Persoms, IV. Frank, Nitional ('ummitter on lied cross Nursing Sicrices, 2t?

Petor Bent lirjoham linit. I: S. Army liane llospital so. $\bar{x}$. $4.2 \cdot$

Peters. Florence M.e rhilil wellare work, Fance, l!)ls, stl!

Petrograll, reception of American

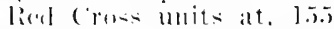

letrola. Doris, on comblitions at Everax lon-pital. 5is!

Pettit, Cienowevit, on werk at

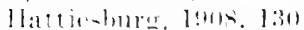

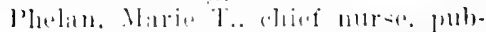

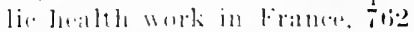

di-pen-atry work at l'aris. - 113

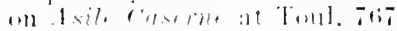

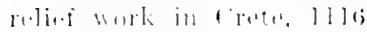

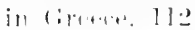

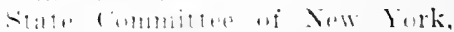
1111

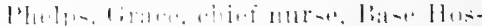
bitial \1, His ind

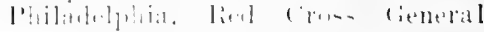

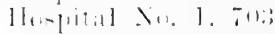


Philadelphia Red Cross Society, work of, in Johustown flood, is

Philippine Islands, nursing service, 120.5, $1206-1209$

Philippine nursing service, contract form for. 63

Philippine war nursing, conditions in. 69

Phillips. Lawrie L., chief nurse, Base llospital No. 23, 503

Phillips. Lilura. Chautauqua nurse, 10.5 .5

Physicians in France, 1917, 758

Physio-therapy. development of, due to the war. $344-345$

Plessis-Robinson, tuberculosis hospital at, 8.51

Picardy, seend hattle of, 466,578

Pickett. Flizabeth, aid in Chautauqua eampaign, 10.5s

Pieree, Katherine N., head of Samaritan Hospital in Troy, nurses' recruiting work of, 50

Pierson. Miss, letter on Home Nursing course, 1356

Pinarel. l'rofessor, child welfare work. Paris. 815

Pindell. Miss, efforts for Red Cross afliliation. 71

Pinder. Ethel, assistant to Miss Harrington on work in Siberia, 930

director of Public Health Nursing in Sonthwe-t. 1304

public lealth nursing service, 1303

Platt. Philip S.. director of Educational Surre. 783

Plavground, at Corbeil. France. 801

l'lummer. Simantla C., SpanishAmorican and World War service. (i.)

Pollerrit\%a. Montenegro, Red Cross ald at t. $110: 3-110.3$

Pohle. Strphanie, work of, at lrkiut-k. 944

Poilu. 1.5-1.5:3

Poland. rhild welfare work in, 118911! 10

("omlitions in. 1179

nur-ing showel for, 11.j4. 1155

lied rose relien work in, 1077, lombiet sere.

(a)mlitions in .June. 1919. 1085

redirf nur-ist in. 10s3

Poland Sillowl for Nursos, 1160

Poliund Scluol of Nur-ine. 1159)

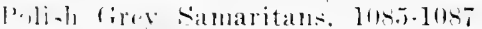

Ponta Delgada, American Naval base, 720

Pontanazen, Camp, hospital, 997, 998

Pope, Amy E., work in Cuba, 64

P'ope. Helen M.. Committee on Red Cross Dietitian Service, 1379

Popper, Baron Armin. military commander of Red Cross hospital at Budapest. 173

Porchefontaine, teaching center of Children's Bureau, 814-816

Porteous, Elizaheth, vice president, Society of Spanish-American War Nurses, 46

Porter, Annie C., Base Section No. 3 , France, 434

Porter, Annie G.. chicf nurse, American Forces in England, 442

Porter, Emily, relief work in Grecee, 1114

Porter, Gladys H., on A sile Caserne, Luxembourg, 623

work with Cliildren's Bureau at Toul, 767

Porter. Dr. J. Y., services in Florida vellow fever epidemic, 16

Porter, Margaret, 154

Porto Rican Civil Hospitals, American nurses' work at, 64

Porto Rican expedition, of Red Cross nurses, 31

Porto Rico. Reel Cross nursing service in. 1201

Portsmoutl, England, U. S. Army Base IInspital No. 33. 436

Portsmonth. N. 11.. Red C'ross services at. 61

Poteau Dispensary, opened, 1918, sos

Potomac Division of Red Cross. 246

Potter. Bishop. Chairman. American National lieel Cross Relief Committer. 26

Potts. Amy, report on fear of inHuenza, 979, 980

Potts. Sisan 1). on (itrman invasion of Nosle. France. Ti:3

with (hildrents Bureau at Nesle. France. $7: 2$

Poupennie se sanatorium. 814

Powell. Lenise M., National Commit. tere on Riefl cross Nursing Sirrsice. 249

Power, Amuir, developing Red Cross workroom, :296; 
Prague, nurses' school, 1150-1152 nursing sehool at, 1149

Pratt, IClen, on conlitions at Evaclation llospital No. 4, 645

l'reston. Alice, (iI!) reeruiting relief nurses for Polant, I08:)

l'reston, Ralph, American Relief Clearing IIouse, 531

Commission for Europe, 531

l'rince dlercea llospital, Roman, Rommania, 883

Prison trains, in silueria, 921-922

l'ritchard, Mary, on cantonment serviee at Charlote, North Carolina, 400-402

(m) (ommunicable diseases, 402

Pruzana. Poland. Red Cross relief work in, 1085

Praybylowska. Mme. Marya, recruiting relief nurses for Poland, l(18.)

Psychiatrie and Orthopedic Base llospital L'nits, 372

Irublic llealth Nurse, I22.5

Publie health nurses, appointments as, 1301,1302

status of, 278

Pullic Inath Nursing, 1028, 12401.292

after war: expansion: poliey: reorganization, 1293-1351

aims of Rural Nursing Service, $1.2 .5 .5-120.3$

Division uf. 1020

education for, 124.)-1251

1)r. ('lark on funds for, 12861298

extension of, 1279

fumb for. disbursiments of, 12SSl.25!)

nexpls for. 12s7-12s8

history of, l-2]l-12:39

in Itily. 868

Miis C'loment's report for 1913. 1.2.2.2-1224

Misis (iardner's studies and visits. twins in Enope. Ilst

namer rlatuged from Red Crom Town and Conntry Nursing Service to. 347

Satimal orgmization for: relattinus with Red Cross. 1:30ti1:3:341

menel to rularge ficld staff for. 1314

furpuses of, -26ti
Publie Ilealtl Nursing, report of . Ju11e. 19:20, 110:9, 1307-130!) repluirements for, 1238.1240

saliary for, 1020

sclools for, 1241-1244

training for. 12.53-1.254

uniform of. lo: 2 S

United States, 1023

Putnoy, Lomlon, eonvaleseent home for Amerieans, $4: 38$

Quain, Dr. E. II., Bismarck, North Dikuta, organization of Siurgical Section No. l. Ameriean Rial Crosis l[ospitill ['nit. 34]

Quinm, lotetta C.. clibla welfare work, Frallere. 1918. Sol9

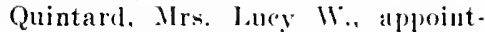
nent of, to Camip Wikoff, Montauk Point. 5l

in Army Nurse Corps legislative effort, os

St. Luke's Ilospital, service record of. 49

work at Montauk, 60

work in Cuba, 6t

Raee, Ethel V.. dispensary at Boulevard liwlleville, so!

Rainey, Paul, Commision for Euroje. 531

Raitt. Lithe. ('ommitter on Red Cross Diectitian Sirvice. 1379

Raker, (omgresinan, hill to secure rank for Army nurses; lo6t, 1070

Ramleh. Palostine, hospital at, reorganized by latestine Commi-oion, !nl

Randolph. Mary, deroluping Red (ros- workrowm. 2 ! 4 i

Ranger. Olive. Paletine ('ommission, s!? 2

Wali Furar llospital. Palestine. s!s

liank for Army nur-es. lills to seflure. lotiti, t in

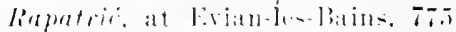

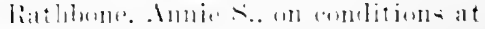
"Nalluation of Aminus. Marrh. [19] 19.31

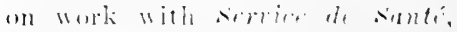
in:

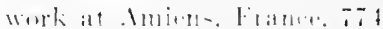

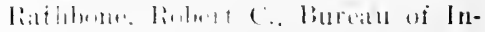
surallete. lot:s 
Raub, Mademoiselle, child welfare work, Paris, S15

Raumo, Finland, reception of American Red Cross units at, 155

Readjustment and Liquidation of European Activities, Committee of, 1079

Reconcentrados, plans for relief of, 25

Reconstruction aides, 277

Recreation luts, established in France, 514

Recreational facilities arranged by Florence Niglitingale, 4

Recruiting of nurses, 969

Red Cross, origin of idea, 1 reorganization by Congress, 74

Red Cross, steamship. See Mercy Ship expedition.

navai personnel of, 140

sailing of, for World War, 139

"Red Cross Bulletins," article by Mahel Boardman, 75

Red Cross Bulletins, report of lectures. 79

Red Cross class-work plans, 82

Red Cross emblem, protective resolutions concerning use, 85

Red Cross expedition on S.S. Lampasas, 32

Red Cross Hospital, metamorphosis of. into lark Hospital, 35

Red Cross IIospital and Training School for Sisters, 21, 22

Red Cross: Hospitals, defects in service, 23, 24

final history of, 35

loss of prestige, 30

male attendants in, 23

Red Cross Nurses, appointment of, 84

field linspital service, 5]

first unit in Enited States, 15

Red Cross Nursing Reserve, in Missisippi floods. Sti

Red Cross Nursing Service, anticipation of survices. 26

intensive organization of, 139. sere also Nirrsing Serrvice.

Tational Commitee of, 95

Red Cross nursing standards. S:3

lied rrose (orranization, first unit in [niter] Sitates. 13]

in 1 s!s 25

lied frosis lieliof ship, state of Texas. 2.j
Red Cross Sisters, requirements, 22 work with American forces, 28

Red Cross Society for Maintenance of Trained Nurses, 27

Red Cross Society of New Orleans, yellow fever regulations, 14

"Red Cross visiting nurse," 1225

Red Cross workroom, first, 296

Reed, Dr., on work at La Courneuve, 806

Reed, Elizabeth, chief nurse at Vera Cruz, 1914, 128

Reed, Henrietta R., at Asile Caserne, Luxembourg, 622, 623

at dispensary at Grenelle, France, 804

head nurse in dispensaries, France, 1918, 809

Reed, Dr. Theodore, in Serbia, 1122

Reed, Major Waiter, head of Yellow Fever Commission, 13

Reëducation of Mutilćs, Bureau of Civil Affairs Department, 757, 854

Reeves, Anna, 127

Nursing Staff, 235

Reeves, Commander I. S. K., on work of murses at Santo $\mathrm{Do}_{\mathrm{O}}$ mingo, 1200

Refugees and Relief Burean of Civil Affairs Department, 757

work of, in France, 825

Refugees in France, provision for, 839

work among, 830

Reid, Mrs. Whitelaw, Army Nurse Corps legislation, $67,68^{\circ}$

article by Mabel Boardman, 47

chairman. Committee on Nurses for Philippines, 62

chairman, Committee on Nursing, Auxiliary No. 3, 47. 55

Committee of Ameriean Women's War Relief Fund, 146

established hospital in France. 53S interview with l'resident MeKinley, 56,57

Jondon Chapter. A. R. C., 425

Sational Committee on Real Cross Nursing Sorvice, 9:5, 127

Town and country Nursing Committee. 1215. 1216. 1219 resionation from. logt

Rinecke, Miss, work at bayton flonds. 1!13, 133

Rivlief in the Near Fast, American Committer for, 907 
Relief work, of Red Cross type, early "xnmples of, 2

Sisters of Clarity of Sit. Vineent de laul, 2

volunteer for, early German, 2

Religioms Orolers, in Simanish-Amerietun Win mursing, 44

Revalult, Dr., child welfare work, Paris, 81:5

lienrganization of Red Cross, 13:31-6

Rentinger, Amma L., National Com. mitter on Red Cross Nursing Sirvile, 249

on Bulgian refugees, 161

on Gioman Helferinner, 165

on German woumled, 166 at Gleiwitz, 162

on mental attitnde of German wommded, 164

on Russian and German militiry moviments about Gleiwit\% lis supervisor of Merey Ship Lnit I, 162

Reviguy, France, hospital at, 52.5

Hhoads, Major T. L., work at Dayton floods, 1913. 134

Rhodes, Nari* I3., in charge of murses' equipment, 575, 577

lice, Captain A. A.. 619

lice, Marion M., at IIopital Auxiliare, . No. 3\%, 199

volunteer service at St. Valery, 5.3.?

lich, Mabel, supervisor of Merey Ship [nit C. 1.5

Ridharts. lintal in Army Nurse (arpe legishative oflort, 68

lidehatrds. Dr. Theolore 11 .. aitl in oreanizing work on hospital supplies, $2 ! 97$

(anferencer to eonsider nursing jublims. 2.54

Dhpartment of Military Rolief, (is!)

lirestor of Supplies Bureaur. 23]

Vitional cimmenter on lied cross

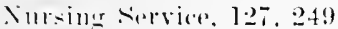

on expipping Nary base hospitals. (i)

Richarels. Mre. Theolore W., aid in

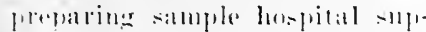
p.litis. 29 s

heall of 11 ashimertom, H. ('.. Work

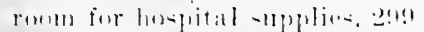

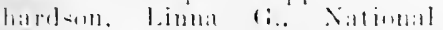
fommitten on lied cross Nurs itse Sirvice, 95,111 lichardson, Linna $G_{\text {., }}$ on Home Nursing (oursos, 1355)

lichier, Wreselles, State ('ommittere, ('alifornia, 112

liehmond Instructive Visitiner Nurse Asoreciation. training for publir laralth nursing, le4:3

lickiets, Mary, mursing service in Serlia, lila

liddle, Mary M., efforts towards lied ('roses alliliation. 71,73

president of the Associated Alumn:m. iI

State Committee, Massachusetts, 112

Ridley. Miss, apprinted for Philippine service. $6 ; 3$

Rignel, Jane, Mobile Ilospital No. 2, 4.5 .5

Rimini Rofugere Inospital, Italy, 860

liohb. Mrs. Isalud IIamptom. fo, 9:3, 014

alliliation of oroanized nurses with Reel Crosss, si- -9.2

appointment to War Relief Board, 89. 911

in Army Nurse Corps legislative iffort, 65

death of. 109

Sational committer on Red Cross Nursing Surviru, !5j

president. Ascoeiatol Alumne. 40

Robly, Isalul Nutting, on home nursinde corltrsos, 13.54

Robhins. Annic A. vierpresident. Sucietr of spanish-Ameriman Wiar Nollows. $41 \%$

Pinhints. Fmma. relief work in Montomegro. Illoti

Roherts. Ahhie. slpervisor of lisit. ing Nulsers. 1:2107

work at batem tloods, ]9?:3. 134t

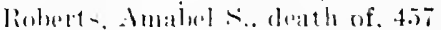

liohert-. Iary M.. "antomment buty, 8901

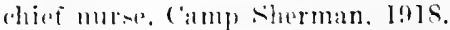
H11. 112

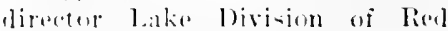
( rem. 246.278

liwhinn. Varkatret. Work at ("halum-

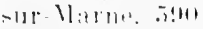

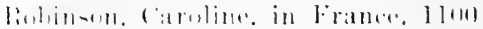
pliof work in Alhania. 1110. 1 +3.2

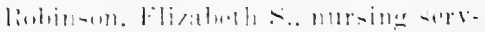

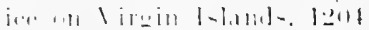

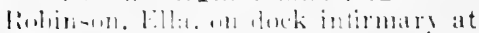
limerasu. 1112 
Robinson, Miss, delegate to Ninth International Red Cross conference, 1912,124

Rockefeller Fomdation, coöperation in Rural Nursing work, 1228

tubereulosis prevention in France, $8+4$

typhus commission, in Serbia, 183, 184

Roder, Maric, at National Headquarters. 240

Rogers, Emma Hart, relicf work in Serlia, 1123

Rogers, Mrs. Wadsworth, 154

Rollins, Clara A. reserve nurse, on colored nurses, $40 \bar{T}-408$

Romall, Roumania, Prince Mercea Hospital at. 883

Roman Catholic Sisterhoods, uniform and insignia, 376, 377, 378

Rome, American Red Cross hospital at. 866

Rommell. Miss, delegrate to Ninth International Red Cross Conference, 1912, 124

Romsey, England, American Army camp at, 432

L. S. Camp llospital No. 34 at, 433

Rose, Dr.. conference to consider nursing problems, 254

Rose, Estler, nursing service in Serbia, 1120

Rose, Flora, Committec on Red Cross Dietitian Sirvice, 1379

Rose. Wickliffe. ('ommittee on Rural Nursing, 1216

Town and (omutry Nursing Committer. 1:21!

Rosenalu, 1)r.. comference to consider nursing problems. 2.54

Roser, Laura, Chautauqua nurse, 110.5

Roser, Lora B., chiof murse L. S. Arny Base Hospital No. 204, Winchestor. England, 432

Ross, Elizaleth, division elirector, Amerian herl cross in New Enolimel. 244

public health morse. 1:303

Rosis, Mary li.. in serbia. 111 on whliare work at Paris. Sile

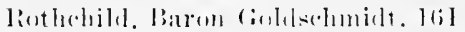

Rothroek. Mrs. Anna E... (hitef nurese. Nuar last lioliof for Asia Minor, 907
Rothrock, Mrs. Anna E., resignation in Constantinople, 1170 school for nurses in Constantinople, 1168, 1169

Romen, France, air raicls at, 449

General Hospital No. 12, British Expeditionary Forces, 467

Red Cross dispensary at, 816

U. S. Aruy Base Hospital No. 4 at, $442-452$

U. S. Army Base Hospital No. 21 at, 467

Roumania, American Red Cross Commission for, 882

in Balkan War, 876

effect of European War on, 875

entrance of, into European War, 1916,877

nursing service in, 878

relief work in, $1126-1130$

treaty with Russia, 1918, 856

Roussy de Sales, Countess de, French representative at Cannes Conference (1919), 1138

Rowland, Adeline H. (Mrs. Robert Gourlay), at National Headquarters. 240

Roumanian Commission, . 882

work in French lospital, 589

Roye, France, captured by Germans (1918), 464

Rue Censier dispensary, Paris, 805

Rulon. Blanche S., chief nurse, U.S. Army Base Hospital No, 27, 500.636

Rural Nursing Service, 1211, 1235, 1239. $1255-1263$

Russell, Martha M., chief nurse. American Red Cross Commission for France, 379, 350, 492. 540. 671

committee on choosing candidates for merlal, 1130

tulereulosis prevention work in France. 845

Russell. Martha, work in France. 547.574

liussell Silgr Fonndation aid in coöperation with Rural Nursing. $12: 26$

Russia, Anerian Red Cross (ommission, 1 iT

American lied cross work amony prisomers ins. at repuest of (iel man (iovermment, 2.2.)

nuries of , y.eti

Russian llospital, Jorusalem, 893 
Russian Island, children's colony on, 932

Russiun Island Hospital, 913 reorganized, 931

Russian wounded, 157-158

Rust, Captain Armistead, in command of S.s. Red ('ross, 140

Rutley, Edith, Spanisl-American and World War service, 65

Rutley, Sophia, cantomment duty, 380

Rutty, lsahelle E., work on the Lampasas expedition, 31-32-333

Ruzickova, Franeiska, Ameriean training as nurse, 1150

Ryan. Jr. Edward W.. in command of commission for Serbia, 1100

conference to consider mursing prollems. 2:4

director of Serbian unit, 141, 176

on evacuation of Belgrade hy Serhs, 178

ill with typhus, 181

investigates condition of Red Cross units at Cievgeli. 181

on retaking of Belgrade by Serbs, 179

Ryan, Jolun D., director general of Military Relief, 364, 541

estate of, at Putney, England, used for convalescent home. 43s

Rykert. Miss. superintendent at Post-Graduate during SpanishAmerican War periol, 4!

Ryley, Violet, committee on Rod Cross Dietitian Service, 137?

Sag Harbor. Home for Convaleseent Soldiers, Red Cross services at, (i)

St. Barnabas Guild Clul of Nurses, offer of Spanish-Ameriean IV services from, 40

$\therefore$. Crois, lied Cross work at. 1203

st. Etienne. Fance, Chautalonette hospital, 19)19, -

dispensary opened, 1918, 7ss

st. John, lírs. Alioe, dhief nurso of Siburian ('ommision. 912. 913:3

closing program at lablivastok. $9 .+2$

on onnditions in Vladirotuk, !nt

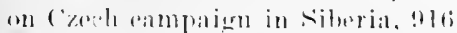
on epuigment of Tumen lisispital, 9.2:3

on withlrawal from Verkhne. lolins. Siberia. 9.80
St. John, Mrs. Alice, work of, at Chita, Siberia, 950

St. Nazaire, France, diet kitehen service at, 1413

dork infirmary nt, 1012

C. S. Arny lase llospital No. 1 at, 487

U.S. Army Base Hospitnl No. 101 at, 487

St. Sulpice, Paris, work for refugees, s.36

St. Thomas, V̈irgin Islands, Red Cross llork at, 1203

St. Valery-en-Caux, American Red C'ross volunteor nurses at, 539

hospital at. 199

French Military Jospital No. 43 his, Amorican Red Cross unit in cluares of, 198

Salaries of murses, $697,1027,1031$

Silem fire. 135\%

Salomon, Mrs. William, offered Ionlon home for hospital, 430

Samos, reliof work in, 1113

Samuel, Mary, superintendent at Rooserelt, during SpanishAmerican War period, 49

San Francisco County Nurses' Association, opening of Red Cross State Branelu by. 8.5

San Francisco eartiquake and fire $(1906), 129$

rolunterer nulesing service in, 82

S'matorium lege, tuberculosis hospital. 849

Sanborn. Miss, efforts for Red Cross atliliation. Il

Sanders. 1)r. ('larles M., director of Morey shij, lonit I. l62

Samblhills llospital, in Florida rellow ferer eplidemice 16

Sandmaier. Barbara. 240. 1110

Sanger. Jolunetta B., one of first six army nurses appeintment of, 4

Santitation, 3,8

Sinto Jumingu, Iied Cross relief work in. $119 ! 9$

Sarisbury cisurt. England. C. S. Army Base llospital No. 40 at, 433

samblers, duppline. appointrd to develuge reconstrution aides. 278

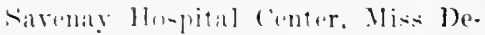
lano" oferation-at, lonl

I. S. Army Bane lospital No. 8 in, $4 ! 1,-490$ 
Savenay Hospital Center, U. S. Army Base Hospital No. 18 in, 486

Sawyer, Margaret, Bureau of Dictitian Service, 1432

nutrition nember of National Committee, 1437

Seattergood, J. Henry, director, American Friends, France, 827

Schaffer, Margaret E., one of first six Army nurses, appointment of. 41

Schaub, Miss, work in IIungary, $119 \pi$

Seheitlin, Marion G., aid in Chautauqua campaign, 10.8

Schenck, Mrs. E. G. II., State Committee of New York. 110

Schereschewsky, J. W.. Committee on Pural Nursing, 1216

Schiff, Jacob H., Board of Incorporators of American Red Cross. 1213-1214

Schiff, Mr. and Mrs. Jacob H., loan of estate for convalescing nurses. 1033

Rural Nursing Service, 1215, 1276

Schneider, Anne E., at Field Hospital No. 2i, Château-Thierry, 6.56

Scholarship and loan fund for nurse's. 1279-1281, 1283, 1284, 1288,1290

Schools for Nursing. Army, 960, 963965

in Europe, 1191-1193

in France. $521-523$

in Greece, 1182

in Poland. 17.5?. 1160

in Warsaw, Poland, 1163, 1164

Naval llospital Corps, 712

nary units. 6993

Schuyler, Louisa Lee. on Civil War lack of trained nurses, 5

executive. "Women": Central Association of lielief,"

member of Army Nurse Corps, legislation committere 6 i

Scott, Charles E.. C'entral ('mmmit.

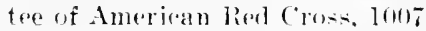

European Inquiry Commission, 1188

Exerutive committer Amerian Ritel cross, loriti

Serrmer, (apt. lames. gift of National Rerl Cross llearquarters by, 12
Scutari, Red Cross aid at, 1108

Sedgwick, Dr. John P., member of Children's Bureau, France, 758 work of Children's Burean at Toul, 766

Sedlacek, Mary, Chautauqua nurse, 1055

Selective draft, 390

Selective Service Law, 389

Sellenings, Dr. Osear H., ehild welfare work at Marseilles, France, 791

Sellier, Henri, work for tuberculosis prevention in France, 851

Semenoff, General, 919

Sennott, Katherine G., Hospital L'nit "S." 496

Serbia, American Refl Cross work in, at request of German govern. ment, 225

child welfare in, 1190, 1191

conditions in military hospitals, 188

entry into World War, 176

relief work of American Red Cross, 1100,1117

typhus epidemie in, 154, 179, 18.3

Serbian patients at Beigraile Red Cross hospital, 18.3

Service de Santé, A. L. F. Fitzgerald in elharge of work with, 583

nurses assigned to, 579-59.5

Sewny, Mrs, L. C., Palestine Comnission, 892

Seymour, Nina Louise, death of, in line of duty, 1032

Shackford, Clara L., supervising nurse, Bureau of Tubereulosis, France, 846

Shaneman, Mary E., nursing service in Santo Domingo, 1199

Shaw. Agnes, appointed for Philippine service, 63

Shaw. Sara E.. appointed for Philippine service, 63

on nursing system in Italy, s.58, S62-S64

story of Lampasas experienees, 33.34

shaw, steamship. collision with Iquitunia. 727

Shoplan, Mary E., chief nurse at OI] Colony Ciub, 420

Shelton, Nina, nursing serviee, A. E. F., at Chatcau-Thierry, 634 
Sherman, Elizaheth F., work at IIalifax explosion, 1917,130

Shipe, convoy system of transporta. tion, 718

"Showek teams," 658

Slott. Ruth, dietitian overseas, 1410

siliraly, Mrs. (Beorge ll., pioneer niemher of Auxiliary No. 3,47

Sliurley, Dr. Burt F., arector, Base Ilospital No, 36, 50)

Siheria. American Red Cross relief work, 910, 929. 1130

Ameriean troops sent to, 911 conditions in, $920-922$

elucational nursing service in, 934 typhus repiclemic in, 1918, 918

Silomer, refusal of Miss Barton's aid at, 27

Sicily, earthquake in, 1908, 131

Martha Washington lospital in, 86i.j

Sick murses, care of, 1034. 1035

Sichrs, Mary, ill with trphus, 191

Sigras, Comintess, 173

Silliman, Mrs. Chas., aitl in preparing sample hospital supplix's. 298

Simmoncls, Enily lanise. un sanitary conditions in military hospitals in. 187

Simom. Margaret B., work in Philadelphia buthliner disaster. 190?. 131

Simons. Olive N.. elijly welfare work, France, 1918, 809

nursing sorvies in IJaiti, 117

Sims. liear Arlmiral IV. S.. eommancler of Ameriean naval oper. ations oversoas, ils

Singer. Paris. loanine of "Oldway Jomse" by. for hospital purposies. $7+6$

Sister Adeline Taylor. nursing sersincesof. in Civil War. 8

cister (lirsisstom. 665

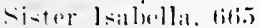

"ister." as title of nurses on Merey Ship experlition, 14:

sinterbouls. mursing serviefs of. in ('ivil Wir, $i$

Sisters, licid Cross, 2.2. 23

Sister of Sit. Vincent de Paul, in >apoleming Wars. 2

skinner, Mre. lieshert l'., london (hapter. A. R. ('.. 4.2.)

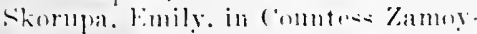

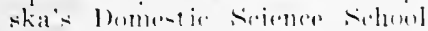
in Poland, 109.5. lo!?6
Skorupa, Emily, nursing school in Poland, 1159

Slack, Annit*, relief work in Albania, $1] 10$

Slemons, 1)r. and Mrs. .J. M., members of Clibldren's Buranu, Franere, 58

Slocum, (olomel s. L. D., 140

Slonim. [oland, hospital comblitions, $10 ! 90$

Slusher, ('lara, ill with typhus, I90

Smallpox in Haiti. 1172

Smedlry, Emma. Committer on Red C'roses d)ietitian Service, 1379

Smith, J)r., in Sorbia, ]12.5

Simith, Emily Ilammunel. child wol. fare work at Marseilles, France, 791

Smith, 1)r. H. S. B., dispensary at st. Etirnme, Franee, 1918, iss

Smith. llelen. Is?

transfurrel to St. Valery-en-Caux, 798

trausferred to lvetot, France, lst

Smith. Molly B., on dispensary at Corbeil, Franere, 799

on work at Ilopital Betz, 594

Smitl, l)r. lima, direetor of $[S . S$. Nary Balse IIospital Xo. 3. 722

Smith, Sara S., nursiner service in Ilaiti, 1173

Smith. Colonel W. M.. Chatirman, Aldvisory Committee of Army s.hool of nursing. 29.5

conference to consider nursing problems. 2.i4

Smith. Dr. Winford II.. Committee on linral Nursing, 1216

director ereneral of Military Re. liof. 3rit. 374. 541

on emergeney letachments $(1919) .316$

on expensin of nurses' equipment, 351

oreanizel Base Jlospital No. 19. H. Sii

Town and (omntry Norring Commitere. $1201 ! 1$

Smith, columel Winford II.. training uf Army mur-te. :2-1;

(1) Iniform= of Roman Catholio

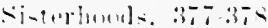

Wat nur-int puling. 2.it

smith follege foit, anteren of, for

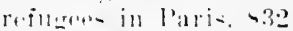

smithis, 1)r. I'. A., los 
Snythe, Eva Louise, dispensary at St. Etienne, France, 1918, 788

Snively, Emily C., Sanitary Unit No. $5,402,403$

Snively, Mary, early nursing superintendent. 19

Snively. Dr. H. H., senior director of Units $\mathrm{C}$ and $\mathrm{H}, 15 \mathrm{~S}$

Snoddy, Dr. Cary A., director of Red Cross hospital at Vienna, 167

on arrival of Austrian wounded at Tienna, 168

on effectiveness of projectiles, 170

German prison work in Russia, 166

senior direetor of American Red Cross Units, 166

Snow, Mary, in Serbia, 1117

Snyder, Juliet, child welfare work, France, 1918, 809

in clispensary at Rue de Pre-Saint Gervais. sing

Societé de Secours aux Blesses Militaires, 848

Societé de Secours aux Rapatriés, at Lyons, 782

Society for Maintenance of Trained Niurses. 60

Society of Public Ctility of Genera, 6

Society of Spanish-American War Nurses, 46

Society of Superintendents of Train. inig Sehools for Nurses, 20

Sofia, Bulgaria, nurses' training school at, 219

Soldier-orderlies. 961

Soldiers' families, assisted by Florence Nightingale. 4

Soukup. Eleanor, on Persian sanitation and eustoms, 159-160

South Carolina, rural nursing in, 1228

Southampton. England. U. S. Army Camp Hospital No. 36, 436

Southmayd, Col. F. R., work in yellow fever epidemies. 14

Southwestern Division of Red Cross, 246

Spanisi-American War, Red Cross services in. 2.5

Spaulding. Holen M.. child welfare work. Jrance. l!ls, son

IIrpital A uriliare, lo. .3', 199

volunteer service at St. Valery, 539
Special Service Group, 278, 279, 281, 282

Spelman, Lillian M., Palestine Commission, 892

Vadi Surar Hospital, Palestine, 898

Speyer, Mrs. James, ex-officio member of Committee on Nurses for the Philippines, 62

pioneer nember of Auxiliary No. 3,47

"Splint teams," 658

Springport, Mich., nursing service at, 1917,136

Stack, Elizabetl, work at Angel Island, 64

Stambaugh, Isabelle, on casualty clearing station team, 465

wounded at Amiens, 465, 1031

Stanley, Anna S., conferences on school nursing, 1335

director of Publie Health Nursing in Southwest, 1304

Starr, Lida G., appointment to Manila, 59

appointment to Philippine service, 63

work of, at General Hospital, Fortress Monroe, 59

State Associations of Nurses, suggestion for substitution of for State Nursing Committees, 86

State Committees, for enrollment of nurses, 106

organization of, 110

State Health Departments, relation to Red Cross, 1318-1321. 1326

State Nursing Committees, in effectiveness of, 86

State Soeieties of Nurses, entitled to Red Cross membersiip, 112

state of Texas, as Red Cross Relief Ship, plans for, 25

Statistics, deatl toll of various countries, $98 \tilde{j}$

numbers serving in American Red Cross. 1919. 1131

numbers of soldiers sent home after Armistice, 1009

nurses neederl (1918), 967

percentage of deaths due to disrase, 986

Steelman. Katherine, volunteer work in Siberia. 915

work at lrkutsk, 915

Stenlunlm. Alice $F$, service on Virgin Islands, 1204 


\section{INDEX}

Stern, Frances, social service work, Franee, 1918, 809)

Sternbure, Surgeon General Georere Miller, and the Rid Cross, 2!)

demand that Cuban nurses le inmune to yollow fever, 31

first action from, towarl reegnition of Army Nurse Corps, $46^{\circ}$

on origin of Army Nurse corps, $36 ;-38$

to Mrs. Whitolnw Reid, on plan to use Red cross nurses in base hespitals, 57

Sternberg Ilospital. Chickamanga, lied Cross serviees at, il

Stevens. Dr. Marion, in Serbia, 1117

Sterenson, Mrs. Beatrieo $V_{\text {.. in de }}$ fense of Ilome nursing teaching, 81

on Red Cross health erlucation, 81 sirvices for Red Cross enrollment, $7 i$

State Committee of New York. 110 work in Brooklyn for Home Care Nilrsiller. so

Stovensom, ח. ('.. in charge of administration. ('hatelet hospital, $77 !$

work at levian-les-Jiains. 77

Steward, Lewha member of operating triblu sent to linte. T4.

Stewart, lsibel Il., Lealente of Nurs. ine Ealuration Ailes course at latsitr. 2 tis

work for National rommittor on Nursilug. 2(6.)

Strwart. Mlisess, voluntere helpers. $2+1$

Stiles. Milelred G., elene dietitian at litat lakes Nilval Trainingr siation lialone llospital. 13997

Stilluman, Mike ('harlutt'. 36i2

ctillman. I)r. Stamley. direcetor of 1. S. Nalaal liase llospital No. $\therefore .721$

Stimsıl, Julia C'.. eareer of. $312-313$, 3titi, til!!

Stimnn. Inlia. rampaim for $r+$. erolitiller morsese greill

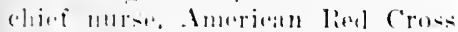
in Fralne. ittit ititi

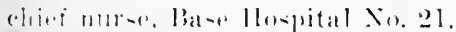
thit

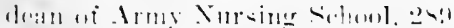

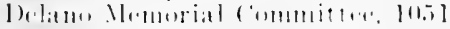

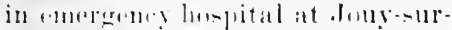
Ilorin, bin;
Stimson, Julia, International Conforence at (ammes (1919), 1137

National committere on Nursing Sirvicer, 127

National committer on Red Cross Nursing Sirvice, 24!

on eare of sick Army nurses, 1034 on eonditions at Anorican Red Cross Ilospital No, 104, Beauvais, France, 5!66, 599

on hospital train service, 642

on nurses nssigned to emergency hospitals, 617

on murses' explipment for military nursing service, 575

on position of elipef murse of Anerican Reel Cross, 567,568 on qualitications for hospital train service, 6it3

on tour of Bealuvais area, 581

on work witl, Army nurses, 628

superintrinclent of Army Nurse Corps. 311. 312

work at Dayton floods, 1913, 134

Stimson, Majur. takes over dietitian serviee 1427

Stirk. Miss, Ihilippine service, 63

Sitork. l'auline I., on "shock" work, (i.)!)

Stome, Frances A., appointment of, as Assistant superintendent at the Sternbere l'. S. Field Hospital. 52

service of git

Storrs. Cobonel Ronald, military forermor of Jermialem, 893

Straiglit. Mrs. Willard, Town and (i)untry Nursing Committee, I:2]!

Stroule. Elizalueth Coombs, on "sluerek" work. 6i.s

Strong. Amma 11.. Alvisory Commit. tere of Nightingal. Sichos, lot?

Jabere of Niscing Education atils preparing course at Vassilr. 当is

Xittimal ('ommitter an limel Cross Nursinge sinvion. 204!

ctrong. Annt llorvere revision of

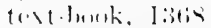

Stroller. Malor .I. N.. heard of Vladi. butrh lowplital. !3!!

ctrone. I)r. liachatril l'.. head of typhns anmmis-iun of lineke. fillor Fommlation atmel Ameri. rin litel ('ros in Sirbia, 133 . $1>1$ 
Strong, Dr. Richard P., medical director of League, 1143

Strong, Wendel M., National Advisory Committee on Insurance, 1042

Stuart, Dr. Bertha B., Children's Bureau at Blois, France, 797 on work at Blois, France, 797

Stuck, Archdeacon Hudson, letter concerning nurse at Ft. Yukon, 282

Student Nurse Reserve Campaign, 293-296

Stuff, Lillian B., delerate to Ninth International Red Cross Conference, 1912, 124

public health work at Lyons, France, 850

work after Omaha cyclone, 1913, 132

Subcommittee on Red Cross Nursing Service, organization of, 94

Submarine attack, 1918, 718

Subnarine chasers, base at Queenstown, 719

Suchowski, Marie, in charge of relief work at Minsk, Poland, $1086,1093,1159$

Sundberg, Anna M., child welfare work, France, 1918, 809

Superintendents, eligibility of, for Red Cross service, 84

Superintendents, murses, Army Nurse Corps legislation, 68

women as pioneers, 19

Superintendents' Society, 71

Supervising nurses, authority of, 210

Supplies, Bureau of, 231

Surf, as amlumlanec ship, 70$\}$.

Surgical teams, at easualty clearing stations, $4(j 1$

Sutliffe, Irene II.. Army Nurse Corps legislative offorts, 68

at (amp Black, 5l

rarly nursing superintendent, 19

New York lluspital, sorviere recorrl of. 49

Swan, 1)r., of Rochester, Minn.. on organization of lase lospitals, 3332,333

Swan, Mary Ruth, assistant to Miss Mimmicurode. ]02s

Swayze. Effice, in Sorloia, 1119

Siwift, Bame Sarah, British Nursing Sirvicer, 47t;

Swope, Ethel, at IIopital Auffredi, 5.98
Syria, 888

Turkish massaere of Armenians in, 1914,889

Syrian and Armenian Relief, American Committee for, 889

American Red Cross funds appropriated for, 891

Széchényi, Countess, presentation of $\mathrm{X}$-ray apparatus to Unit $\mathrm{E}$ by, 173

Taft, President Wm. H., Chairman Central Committee, 230

issue of proclamation relating to Red Cross service, 1911, 120

National Committee to Secure Rank for Army Nurses, 1070

president of reorganized Red Cross, 74

Talleyrand-Perigord, Count Helie de, 161

Tampa, Red Cross nurses at, 61

Tanguay, Alice A., at Tarnopol, Poland, 1094

Tanner, James, Central Committee, 230

Taormina. Italy, convalescent home for children at, 866

Tarnowsky, Dr., 619

Taylor, Carl, Commission for Europe. 530

Taylor, Catherine, chief murse of, Oldford lIouse hospital, 722

Taylor, Major II. W', lieal of Relief in Department of the East, 1057

Tennant, Arlelairle, at National Theallyuarters, 240

Tennessee, public lealth nursing in, 1349

Terni de Grecory, Winifred, on training of mirses, 870

Tensler, I)r. R. 13. appeals of, to Ameriean Mission hospitals for aid in Siberia, Angust, 1918, 914-9]5

investigations of, in rladivostok, 912

Texas, pullic health mursing in, 1349

Thather, Mrs. Tolen S., 36il, 362

rhaiman, Uniform Committere, resignation of. 38$]$

Thaver, William S., on nursing ('omditions in Franee. 518

tribute to Miss Delano. 1005

'lomas, Ellen, reserve murse sorving on Mrxican border, 3.)4 
Thomas, Gertrude, on dietetie instruction to Navy IIospital Corpes Men, lis!s

Thompson, Dora 1E, 311, 312, 34t

American Red cross parade, Xew York, 420

approves plian for special curollment of nurses. 2.is

conference of merlical and Army ofleers and murses, 28 't

conferenee on nursing problems, $25+4$

National Committee on Red Cross Nursing Service, 24!

need for supervising dietitian, 1425

nurses' eantomment service, 393

murses' training after armistice, 984

nursing service elanges, 316

Thompson, Nliss, on rank for army nurses, lotis

on uniforms and insignia of Ro. man Catholic Sisterhoods. 37ti$37 \pi$

on tuniforms of reserve murses, Army Nurse corps, 362, 36!?, 372

plans for army school of nursing, 2 siti

superintentent of Army Nurse (orps. 311-312. 314

Thompens. Margaret li., ehief nurse,

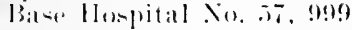

Thompsom. Olive I.. on conditions at

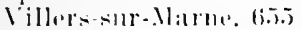

Thoruton. Miss llars li... Sereretary uf the Ascoriated Alumma. ed $\dot{f}$ forts for lind crosis alliliation. 71

Thurman, Mrs., dietitian orersos, $1+111$

Tibleds, Irsula, in Sorliai, 112-4

liborias, lablostino, hospital at. (11)!

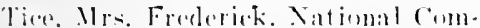
mittere ton lind ('ron Nursing

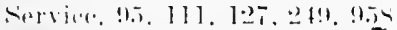

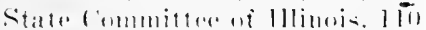

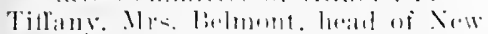
lint fits watkrmm for sur

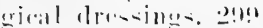

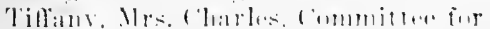
liemorial Fome 10 Amerisall

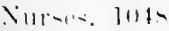

Titrins. linth, chasses in dietedicts. 1370
Tirana, Alhania, relief work in, 1109,1110

Tittulum. Anna l., in charge of third Silwerian unrsing unit, 9:30

(hief nurse of Wistern Divisiorb, (1):3:3

chicf murse at Vlarlivostok lospital. $9: 39$

sails for home from Siberia, 9.52

Tomsk, Siheria, Ameriean Rind ('ross an!ivitios at, 942

Torney, l)r. (ionrgo H., appreciation of Mis- [Daluos work in Army Nurse Corpens

surgeon gencral of Lnited States Army, 32.), 326

Torranei2, Rachel. 1100

chice murse. Ameriean Red Cross, in Cirat Britain, +41

in Norbia, 1117

organization of Nursese Training School at Solia, Bulgaria, 19li, 219

Rommanian Commission. 892

visit to devastated area, 9s? work in C'erho-Slovakia, 1197

Tottenham. Fingland. I'. S. Base llospital No. 29. 438

Toul, France, dispensalries established at. itis

maintenance of project. 7 I

work of chilleren's Burean in. 76.5

Toulume, Framer, rhild welfare ex. position. 191s. 795

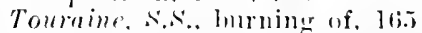

Town and comntry Nursing Serviar.

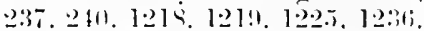

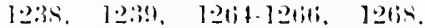
1.27]. 1272, 127\%, 107s

Towne. Mi-s. alpointer for Philippinceserviere ti:3

Townsend. Hewarel. on spereial

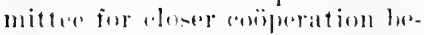

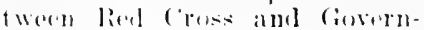
nincint . is

Tratued malore, lank of. in rivil II ar. is

Tram-ior. fommittan af. 10?21

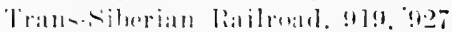

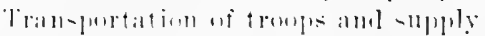
-lifie. Holl. Tls

Trantere. (apte. operattion on Miss

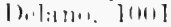

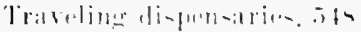

Travis, lre catherimes. at wintant,

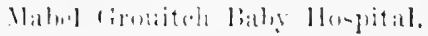
-2lit 
Treport, France, evaeuation of, 466

U. S. Army Base Hospital No. 10 at, 459

Treves, Sir Frederick, on organized volunteer aid for Red Cross, 324

Triage, 664

Trippett, Josephine, Pelham Bay Training Station, 717

Trudeau, Edward T., Sanatorium, 851

Tuberculeux de la Guerre, 844, 848

Tuberculosis, work of the American Red Cross to comhat, 843 et seq.

Tuberculosis Association. National, coöperation with Red Cross, 1326-1330

relation with Red Cross, 13211323

Tuberculosis Burean of Civil Affairs Department, 757 . 843

Tuberculosis, Commission for Prevention of, in France. 844

Tuberculosis hospitals aided by American Red Cross, 848

Tuck, Mrs. Edward, president, Tuberculeux de la Guerre, 844

Tucker, Katherine, Committee of Transfer, 1021

Tulloss, Clara, ill with typhus, 190

Tumen, Siberia, evacuated because of Bolsheviki, 942

Tumen Ilospital. Siberia, 923

Tupman, Mrs., delegate to Ninth International Red Cross Conference, 1912, 124

Turczynowicz, Ime. Laura de Gozlawa, recruiting relief nurses for Poland, 1085

Turkey, 889

Turkish Municipal Hospital at Jerusalem. 894

Turnbull, Dorotlıy, chicf murse of American lied C'ross llospital No. 104, at lieaurais, 598

Turnure. Major P. R.. 345

Tuscania. Steanship, torpedoed, 1918. 720

Tuttle. Jennie L.. work at Dayton flookls. 1913, 134

Twiss, Mrs. C. V.. State Committee of New York. 110

Twitchell, Dolly, Cliautaupua nurse, 10.53

Tye. Menia S. National Committee on lied Cross Nursing Service, 249
Tylski, Stella, Municipal Hospital at Cracow, Poland, 1096, 1159

Tymon, Mary Margaret, nursing service in Greece, 1111, 1115

Typlus epidemic in Serbia, 154, 179, 918,1119

work of sanitary commission of Rockefeller Foundation and American Red Cross in, 183-184

Typlus Research Hospital at Warsaw, Poland, 1092

Umbria, Steamship, carried unit of Base Hospital No. 102 to Genoa, 668

Uniforms, of Navy Nurse Corps, 694-696

of Public Health Service, 1028

United States, in European War, 485 et seq.

U. S. Army Base Hospitals:

Hospital No. 1, St. Nazaire, France, 487

Vichy. France, 505

Hospital No. 2, Etretat, France, 454

Hospital No. 4, 442-452

unit of, at Rouen, France, 442 452

Hospital No. 5, Dannes Camiers, France. 452

transferred to Boulogne-surMer, 4.53

Hospital No. 6, Bordeaux, France, $4 ! 3$

Hospital No. 8, Savenay, France, $496-499$

Hospital No. 9, Chateauroux, France, 499

IIospital No. 10, Le Tréport, France, 45?

Hospital No. 12. Dannes Camiers, France, 469

IIospital To. 13, limoges, France, 508

IIospital No. 14, Mars-sur-Allier, Fince, 5ll

IIospital No. 15, Claumont, France, 493

IIospital No. 17, Dijon, France, $4 ! 4$

Jlospital No. 18. Bazoilles. Franee. $4 \$ 8$

temporarily assigned to Savenay. France, 45.5-486;

ILospital No. 19, Vichy, France, 509 
U. S. Army Base Hospitals:

Hospital No. 20, Chntedguyon, France, 506, 507

Hospital No. 21, Rouen, Franee, 467

Hospital No. 23, Vittel, Franee, 503

Ilospital No. 24, Limoges, Franee, 504

Hospital No. 27, Mongazon, France, 500

Hospital No, 29, Tottenham, Englnull, 438

Hospital No. 32, Contréxeville, France, 503

Iospital No. 33, Portsmouth, England, 436

Ilospital No. 36, Vittel, Franee, 501

Hospital No. 37, Dartford, England, $4: 37$

Hospital No. 40, Sarisbury Court, England, 4:38

Ilospital No. 46, Bazoilles, France, 508

Hospital No. 82, Luxembourg, 623

Hospital No. 10l, St. Nazaire, France, 487

IIospital No. 102, on Italian Front, 665

Hospital No. 202, 741

Hospital No. 204, Winchester, lingland, 432

Hospital No. 449, Mars-sur-Allier, lirance, 511

L. S. Army Base Section No. 3, kngland, 420;

['. S. Army Camp Hospital No. 34, fiomsey, England, 433

Howital $x_{0.35}$, Winchester, England. 428

Ilospital No. 30, Southampton, kingland, 436

Iloipital Xo. 40, Liverpool, Engr. land, 432

I. S. Army Medical Corps, coüperation with American Red cross. (6:31

in France, 1917, 494

[nited States General Hospital, lirtrens Monrone. it

L. S. Nary atetivities of, at Gibraltar. 7 i!)

hospitals of. equipped by Ameri(ain Riel ('ross. 7:20)

Nirre compo bisti

overseas service of, $7 \mathrm{IS}$
U. S. Navy, participation in North Siea activities, 719

persomiel of, 1917,698

training of personnel for Furopean IVar, 698

training units in sehools, 699

U. S. Nayy Hase Hospital No. l, $694,728,733$

Hospital No. 2, Strathpeffor, Scotland, 721

Hospital No. 3, Edlinburgh, Scotlund, 722

Hospital No. 4, Whitepoint, Ireland, 725

Hospital No. 5, 728

U. S. Navy Hospital, at (iuam, 732

United States Public Ifealth Service, $398,3999,1023$

United States Sanitary Commission, 6i-9)

Civil War relief work of, 6

Cpham, Anne 'T., first dietitian overseas, 1381,1382

Upjoln. Anna lliles, child welfare work. Lyons, France, 784

C'rch, Dais: D), chicé nurse, Base Itospitil No. 12. 469

['skub, sanitary conditions at, 188

Etley, Grace, at llabel Grouitch Baby Hospital, 216

Valence, France, dispensary at, 842 playgromel estahlished at, 842

Van BIarcom, ('arolyn C., American Red Cross parade, Now lork. 400

Army Nurso Corps miforms, 3til, 363

Sursing Serviee, Atlantic J)ivision, American lied ('russ, 244, $245,362,345.5,371,353$

resignation of, 372

Van de Vreme, Jane. Committer on memorial for Mise lonano. I0.50

division director of nursing. lo3s for North and South carolinat.

Florida, (ienreia and Tennensine. $24 t i$

public lealth mur-ing arvies, 130:3 on lied ('rosis alile platu. loi.2

Van longer, ('harlotte k... Burean of Puliar llarlth Nursing. l:31:2

van Drke. Dr. llenry. lal

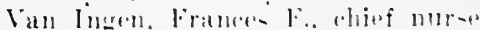
of 1 . S Naty Base llowital No. l. 734 
Van Ingen, Frances F., on conditions at Brest, France, $738-740$

on Miss Delano's talk to nurses of Nary Base Hospital No. 1, 998 on orcanization of staff of $\mathbf{U}$. $\mathrm{S}$. Nary l3ase llospital No. 1, 734 on L. S. Navy Base Hospital No. 1 at Brest, 736

reception to Miss Delano at Brest, 996

Van Meter, Anna R., Bureau of Dietitian Service, 1436

Van Schaick, Dr. John, Commission for Europe, 531

Commissioner to Belgium. 817

Vanderbilt, Mrs. William K., sponsor for American Ambulance at Nenilly, France, 536

Tassar College nursing course, 268

Vaudling, Marjory, at Le Glandier, 819

Vaughan, Mrs. Elsbeth H., at National Headquarters, 240

nursing direction, 1195

school at Dorpat, 1194

work in Baltic States, 1197

Vaughan. Victor C., on rank for Army nurses. 1069

Verkhne-Ldinsk, provost guard hospital under American Red ('ross. 947

withdrawal of American Red Cross from, 949

Vernon, Miss, State Committee of West Virginia, 110

Veterans' Bureau, Nurse Corps of the, 1030

Venille-les-Roses, convalescent home at, 195

Vichy, France, Base Hospital No. 1 at. 50.5

Base Hospital No. 19 at, 509

Vickery, Dr., in charge U. S. Navy liase Hospital No. 1, 734

Viemna, established Red Cross hos. pital at, by Tercy Ship Unit $\mathrm{K}, 167$

(losing of , 171

recorel of, 171

shortage of food and supplies in, $16 ! 9$

treatment of Red Cross unit at, 169

wrilome of herl Cross unit at, I73

Vilitoria Theater lospital. See Gleiwitz.
Vilna, Poland, equipment of Polish Army lospital at, by American Red Cross, 1092

Violet, Hospital, at Lyons, 624

Tirgin Islands, nursing service in, 1202-1204

Visiteuses d'enfants, training of, 811

Visiting nurse, Albania, 1108

Visiting Nurse Association, 1310

Vittel, France, U. S. Army Base Hospital No. 23 at, 503

U. S. Army Base Hospital No. 36 at, 501

Vladivostók, American Red Cross activities in, 917, 939

American Red Cross emergency service in, 912

closing of nursing program at, 952

Fortress Hospital in, 913

Morskoi (Naval) Hospital at, 933

Refugee Hospital in, 927 reorganization of, 932 revolution of Nov. 18, 1920, at, 933

Voluntary Aid Detachments. British Nursing Service, 478, 480

Volunteer nurses, in Red Cross service, 21,78

L. S. Army regulations for, 99

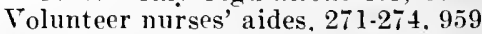

Von Wedikind, Dr. I. S., in charge U. S. Navy Base Hospital No. 1, 734

Voor. Dr. John, in Serbia, 1117

Wadhams, Colonel Sanford H., on buildings for hospitalization in France, 511

Wadi Surar, Palestine, hospital at, 898

refugrees at. 898

Wadley, Mary F., Arny Nurse Corps legislative effort, 68

murses' reeruiting work of. 50

Nadsworth, Eliot, acting chairman.

Rel Cross Central Committee, $337,387,358,389$

conference to consider nursing prublems, 254

equipment of Army Nurse Corps. 364

Executive Committce of American lied Cross. 1007

Wald. Lillian D., Arlvisory Committre of Army school of rursing, 28.5 
Wald, Lillian D., ehairman, Committere on llome Nursing, 26 (i)

conference on nursing problems, 254

Committes ou liural Nursing, 1216

Emergeney Committee on Nursing, $26 ;$

Joint National Committee of Bureall of Information, 1016,1047

National committere on Red Cross Nursing Service, 249, 958

public liealth nursing service, 1.212-1215, 1220

Rerl Cross enrollment, 77

Representative in Conference at Cannes (1919), 1137

scholarship and loan fund for murses, 1281.1283

Town and Country Nursing Gommittee. 1219

Walker, Evelyn, on dock infirmary at Bordeaux, 1012

pullic health work at Bordeaux, liance, 796

Walker. Dr. May F., in charge of dispensary for refugees at limoges. France, 837

director of American Red Cross chilhren's hospital at Limoges, France, 837

Wall, Emma L., National Committee on Red Cross Nursing Service, 249

State Committee, Lonisiana, 112

Wallace, lilizaheth, ehilil wolfare work at Vlarseilles. France. 79l

Walling. Willonghloy, Contral Com. mittee of Ameriean Red Cross, 101617

Walsh. Arelaisle M.. State Committow of lllinois. 110

II:als, Elizabeth. Cliautauqua nurse, 10.5 .5

talks on mursing. 1059

Wilter. Lomi-e M., lead nurae of Vilma lialroad hospital in Julamil. 10!3:3, 115?

Wiltom. Isabel Toan. publie health nursing work. ti.i

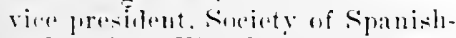
Amereican Wis Nurses. 16

Wiar fommeil. Amerian lial Cross, 2:34. 4113

War lmpartmont, appropriation for recom-tratetion atese. 27

at itulde on rank for Army nurese, $111-2$
War Department, Red Cross serviees

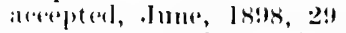

ropert on services of colored nurses, 408

llar mursing, policy of Roul Cross, $254-2.55$

War Relief Board, handling of Nursine Service. !4

War Risk Insurance, linreau of, 1030, 1033, 1037, 1033

War wounded, agresment in Socioty of Public latity of Cieneva, i

War Zone Burrall of ('ivil Affairs Department, 7.7, 8.74

Ward, Admiral Aaron. in elarge of Mercy Ship expedition, 140

Ward, Dr. Elwir Sit. John, surver of conditions for 'lenrkish government. Ss!)

Ward, Virginia. at Natiomal Ifearlquarters. 240

Wardwell, William T., Amerioan National lied C'ross Relief ('ommittee. 26

president, lied Cross Hospital and Training sichool for sisters, 22

Warner, Iona A., State Committer, Tennesier, 112

IVarsaw, conditions for lospital, 1150

Nurses' Solowel at, ll61. 1l63. 11tit

Wartowsy. Doris. mblie health work in Poland, logt

Washburn. Mattie if.. rhiof murat. I. S. Army liase Hospital No. ?.3. 436

Washington, D. C., instruction for women. 13.72

organization against influenza. 976

Watcrbury, liuth C., work in Virgin Islands, 12013. 1204

Waters, Florence If.. 11:2!)

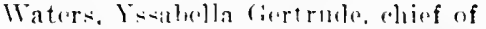
division of Public Health Norsing. 1017. $101 \mathrm{~s}$

compilation of pullid lealth nurs. iner anemedes lise tit

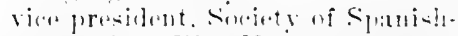
Amoriman War Nurase thi

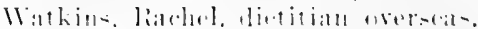
$1: 3-1$

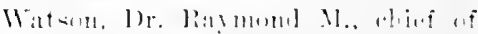
dental depationent at Juspital linlet - - i

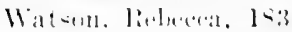


Watt, Dr. James, member of operating team sent to line, 745

Watt. Richard M., on committee to secure Red Cross ship for World Wiar, 140

Weber, Elizabetl, appointed supervisor of Mercy Ship Lnit F, 148

Weeks, Mrs. Robert Wolcott, volunteer lielper, 241

Weill-1lalle. Dr., child welfare work, l'aris, 812,815

Weill-Raynal, Madame, child welfare work, France, 19]8, 812

Weir, Ruth, nursing service in Roumania, 1127

on work at Neufchateau, 492

Weir, Wilhelmina, nursing services of, in Florida yellow fever epidemic, 16

Weleh, A. A., National Advisory Committee on Insurance, 104l

Welch. Lettie G.. director Mountain Division of Red Cross, 247

lome lieterties. 1+31

Weleh, Dr. William H., conmittee on settling war nursing policy, 2.74

in Army Nurse Corps legislative effort. 69

National Committee on Nursing Servier. 127

Woller, Marion. ehief nurse at A. R. C. Military IJospital No. 4, liverpool, 428

Wellington. Fertrude F.. National Emergeney Association of Women Physicians, 40

Wollman. IIabel, home dieteties, 1430

Wells. Edrar II., Commission for Croat Britain, 427

Wolls. Mrs. F. N., volunteer helpor, 241

Wolls, Colonel II. Gideon, command in Rucharest. Red Cross service, 1126

revirnation in Roumania, 1128

lommanian Commission. 882

Wekh, Mabelle S.. 147

supervisor of Merey ship Lnit F, 146

Wontzel. Teslie. in Albania. 1108

Westoner. steimship. torpedoesl, July. 1918, 730

Wotherill. Mrs. lichard, volunteer helper. 241
Wharton, Mrs. Edith, vice-president Tuberculeaux de la Guerre, France, 844

Whedon, Rhobie, service in Belgrade, 1120,1179

Wheeler, Hary C., National Committee on Red Cross Nursing Service, 249

State Committee of 1llinois, 110

work at Dayton floods, 1913, 134

Wheeler, Dr. Ruth, chairman, National Committee on Red Cross Dietitian Service, 1433

Committee on Red Cross dietitian service, 1378

nutrition member of National Committee, 1437

on nceds for dietitian "sifting out," 1396

White, Edna, Gommittee on Red Cross Dietitian Service, 1378

nutrition member of National Committee, 1437

White, Eleanor R., chief nurse, Officers' Hospital in France, 538

White, Emmet W., Philippine Islands, 1206

White, Grace, nursing service in Haiti, 1173

White, Lillian I., director Pacific Division of Red Cross, 247, 1038

White. May Louise, head nurse. Bialystok Orphanage Ifospital in Poland, 1094

nursing sehool in Pragne, 1152

White, Dr. William C., chief of Tubereulosis Bureau of Ameriean Red Cross, 845

tubereulosis prevention work in Italy, 867

Wigovin, 1)r. William F., chief of Nose and Throat Department, Hospital Violet, 785

chile wolfare work at I. Glandier, 820

Wiggin, Mrs. Laura, at IIospital Violet. 785

child welfare work at Le Glandier, s:0

Wileox, Mabel I., chiof nurse of wel. fare work with Bolgian children at Havre, 822

Wilkes-Barre, Pennsylvania, work against influen\%a, 175

Wilkinsen, Miss. delegate to Ninth Intermational Reel Cross Confer('nce, 1912, 124 
Wilkonski, Pauline II., relief work in Poland, 1095

Willari, Mrs, Mary Iatch, Mretropolitan Nurses (lub, 40

Williams, Major Chas. T., Commissioner for Russia, 678

on military situation in North Russia, lits

Williams, John Skelton, Central Committer, Ameriean Red Cross, 230, 1007

Williams, Kathryn, service in Sorhia. 1117

Williams, Katherine, on work in last ereat German offensive, $589-5 !) 2$

Williamson. Anne A., chief nurse at Camp) (irant. 408

on colored nurses at Camp Grant, $405-40 !)$

organized lospital staff, 722

Williamson. itrs. Gertrude, work in influenza epidemie. 977

Williamson. Mildred, service in Serbial, $11: 21$

Wilsey. Marietta, in France, 1100 in Serbia. 1117

Wilson, Eleanor, nurso in Serbia, $11 \cdot 2 \cdot 2,112.5$

Wilson, Emma, chief nurse of relief commixion in Polanil, 1086

dock infirmary at Borleanx, 1012

nursing servies in Poland, 10\$6, 1140

on administrative conditions in relief werk in loland. Jume, 19)! 1058

return to laris of, from Poland. lose

Wilsom. Iola, afforts for Rorl Crose atliliation, 7 ]

recording serertary. Sinciets of Spanish-American War Nirses. 46

Wilson, Mary B.. work at Darton tlond-, 1913, 134

Wilson, 1)r. Warren P.. 3s7. 3se

IVilsm. Winfield A. Puresu of Insmramere. 7043

Wilsun, President Wondrow, on 1. 1 . F. in Siberial. 011

on Vorian-itmition, 318

on Trans Sibrian railway onditim!1 . 927

Wiltzills. Mlempetta, nursiner servian in S Santo Dominmo, 11!n!. 1200
Wimbledon, England, American Red ('ross ('omvitescent llospital No. $102: 11,435$

Winchester, Elitl May. death of, in line of duty, 10332

Winclester, Fongluml, I․ S. Army liase Ilospital No. 201 at, 432

Vind, llortense Eliznbeth, death of, 1398

Winship, Mr., 15:5

IIinslow, Minnie, chiof nurse at old ('olony ('lisb, 420)

Winter, Brigalier cieneral Francis, chief surereon of Ameriean Armies in Great Britain, 126, $4: 26,484$

Wisconsin, rural nursing in, 1228

Wiseman, Dr. (i. R., on enmelitions in devatated areas. (ss?)

Witler, likabeth, diet kitehen. Evacuation Howpital No. ". Iits

Whitepoint, Ireland, I". S. Navy liase llospital No. 4. 727

Whitney, Mrs. ll. P., hospital of, at Jouilly taken over by American lied (ross, 603

Woleott. Wm. Preseott. 491

Woman's Adrisory Committe. 300

Wemen's Bureal of IInspital Serv. ice, Nursiner Service as subbureall, sit

Women's Contral Asseciation of Relief, importance of, in Civil War. 6

Women's Commitec on Anxiliaries, 26

Women's tetachments, 26R, 26!

Women, as murses on lonspital trains. 6i.s.

Women's Work in Civil War. Dr. lipllow: on. 10

Tood. Alebide A.e chief nurse of Allianere llowital. Yvetert. Franke. Int

Wont. Eilith l... nursing serviee in Surhiar. 112.i

on piasiane through ocean war zone. lti.

reorve nures serving on Mexican

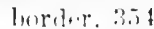

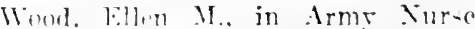

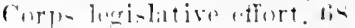

Winul. Emmi VI. Xiar rant roliof work, $31 \%$

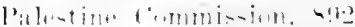

work al ('unstantimble. 11 lon

work at litmleh, Pale-tine, ant 
Wood, IIelen B., killed at sea, 470

Wood, Major General Leonard, appreciation of Miss Delano's work in Arny Nurse Corps, 98

Wood, Mrs. Leonard, Board of Incorporators of Ameriean Red Cross, 1007

Woman's Advisory Committee, 300

Wood. M. E., work of, at Fort I Iamilton, 60

Wood, Margaret, on ehild welfare work in France, 825

Woods, Vena M., on American Red Cross Children's Hospital at Limoges, France, 837

Woodward, George, National Advisory Committee on Insurance, 1041

Woorlward, .T. H., National Advisory Committee on Insurance, 1042

Wormeley, Katherine P., book by, on "Sanitary Commission," 8

Wright. Dr. Dudley D'Avergne, ehief medieal officer of Alliance Hospital, Yvetot, Franee, 196

Wright, Elizabeth, in Santo Domingo, 1199

Wrigley, Alma E., National Committce ou Red Cross Nursing Service, 127,249
Wyckoff, Lieutenant H. M., Commission to North Russia, 678

Wyman, Surgeon General, member Executive Committec reorganized Red Cross, 74

Yellow fever, in Cuban Red Cross Hospital, 30

medieal history of, in U. S., 13, $14,15,16,17$

Yellow Fever Commission, appointment of, 13

Yerres, Tuberculosis Sanatorium at, 848

Young, Miss, work at the Detention ITospital, Camp Wikoff, 60

Young, Mrs. Charles, instruetion for women, 1352

Young, Edith, ehild welfare work, France, 1918, 809

Yvetot, France, Alliance Hospital at, 195,196

Zaeca, Miss, relief work in Greece, 1111,1112

Zamovska, Countess, Sehool of Domestic Science in Poland, 1095

Zichy, Countess, 173

Zlenkier, Miss, service in Warsaw, 1156 





\title{
THE LIBRARY
}

\author{
University of California \\ SOUTHERN REGIONAL LIBRARY FACILITY \\ 405 Hilgard Avenue, Los Angeles, CA 90024-1388 \\ Return this material to the llbrary \\ from which it was borrowed.
}




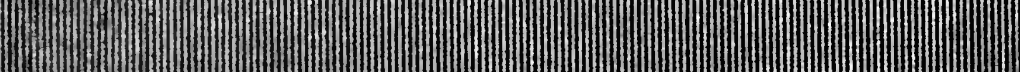

m.

man

$$
\text { (1) }
$$

$$
\text { (1) }
$$

$$
\text { (1) }
$$
m

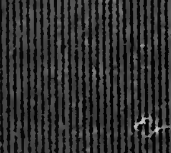

